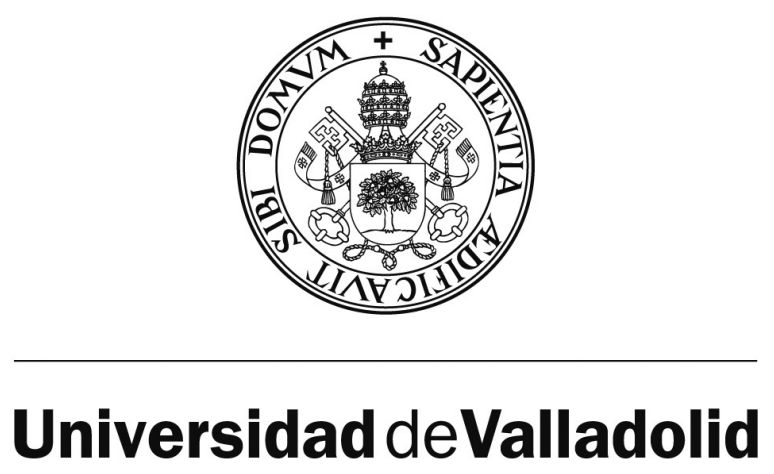

ESCUELA TÉCNICA SUPERIOR DE ARQUITECTURA

DEPARTAMENTO DE CONSTRUCCIONES ARQUITECTÓNICAS, INGENIERÍA DEL TERRENO, MECÁNICA DE LOS MEDIOS CONTINUOS Y TEORÍA DE ESTRUCTURAS

TESIS DOCTORAL:

\title{
EL PAPEL DEL ZUNCHO EN LA RESTAURACIÓN MONUMENTAL: ATADO PERIMETRAL DE ESTRUCTURAS DE CUBIERTA EN IGLESIAS DE VALLADOLID
}

TOMO I

Presentada por Rosa Bellido Pla para optar al grado de doctor por la Universidad de Valladolid

Dirigida por:

María Soledad Camino Olea

Francisco Javier León Vallejo 



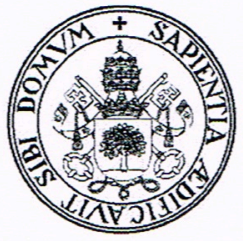

\section{Universidad deValladolid}

Impreso $2 \mathrm{~T}$

\section{AUTORIZACIÓN DEL DIRECTOR DE TESIS}

(Art. 2.1. c de la Normativa para la presentación y defensa de la Tesis Doctoral en la UVa)

Dra. Da María Soledad Camino Olea, con D.N.I. n 12233077K, Profesora Titular de Universidad del Departamento de Construcciones Arquitectónicas, Ingeniería del Terreno y Mecánica de los Medios Continuos y Teoría de Estructuras de la E.T.S. de Arquitectura de la Universidad de Valladolid y D. Fco. Javier León Vallejo, con D.N.I. $n^{\circ}$ 12350651L, Profesor Titular de Universidad (Profesor prejubilado) como Directores de la Tesis Doctoral titulada EL PAPEL DEL ZUNCHO EN LA RESTAURACIÓN MONUMENTAL: ATADO PERIMETRAL DE ESTRUCTURAS DE CUBIERTA EN IGLESIAS DE VALLADOLID, presentada por Da Rosa Bellido Pla, alumna del programa de doctorado de Tecnologías Constructivas, impartido por el Departamento de Construcciones Arquitectónicas, Ingeniería del Terreno y Mecánica de los Medios Continuos y Teoría de Estructuras, autorizan la presentación de la misma, considerando que dicha investigación reúne los requisitos propios de una tesis doctoral en cuanto a la condición de tema inédito, así como al rigor y profundidad con la que ha sido elaborada y por su conformación.

Valladolid, 18 de septiembre de 2015

Los Directores de la Tesis,

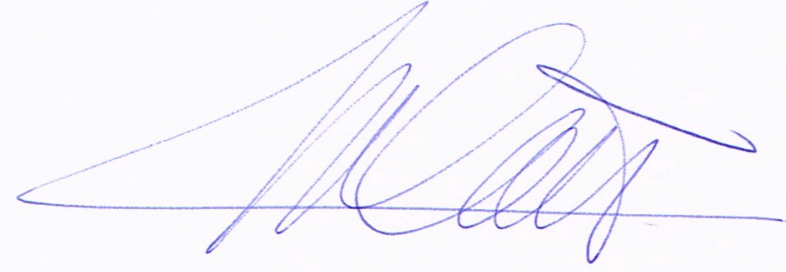

Fdo.: María Soledad Camino Olea

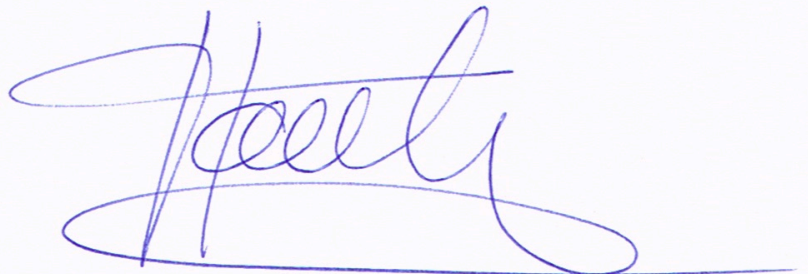

Fdo.: Fco. Javier León Vallejo 

Dedicatoria:

A mi familia. 

Agradecimientos:

En primer lugar debo agradecer al arquitecto del Servicio de Restauración de la Junta de Castilla y León, Marco Antonio Garcés, el planteamiento hace cinco años de la cuestión central de la Tesis: qué sabemos del empleo de zunchos en la restauración monumental. También su paciencia para atender mis consultas durante estos años.

Agradezco especialmente a Ana Iglesias, responsable de la mayor parte de las obras realizadas en los años 70 que se analizan en la Tesis, cómo me ayudó a comprender su labor a partir de los medios y criterios disponibles en ese momento.

A todos mis profesores, que en algún momento han compartido sus conocimientos, especialmente a José Luis de Miguel por su apoyo incondicional en mis primeros pasos como calculista. También quiero recordar en estos momentos a aquellos que, sin ellos saberlo, me contagiaron su pasión por el Patrimonio edificado y la inquietud por su conservación: Pedro Navascués y Santiago Huerta.

A los arquitectos que han aportado su valiosa documentación: Alfonso Basterra, Joaquín García, Elesio Gatón, Marcelino Hurtado, Lorenzo Jurina, Vicente López Bernal, Miguel Malheiro, Salvador Mata, Eduardo Pedruelo, y Antonio Sánchez del Barrio.

A todo el personal de las instituciones que han colaborado con las búsquedas: IPCE, AGA, AMVA y Fundación del Patrimonio Histórico Santa María la Real. Beatriz García desde la Biblioteca de la ETSAV. Ana Belén camarero y Raquel Blanco en el Archivo Central de Cultura de la Junta de Castilla y León. Y a Virtudes Azorín, del IETCC, por sus libros.

A los párrocos y personas de vida consagrada por haberme permitido merodear por sus iglesias, y al responsable de la Delegación de Patrimonio del Arzobispado de Valladolid, José Luis Velasco, por su paciencia.

A los vecinos de los templos que me han permitido entrar en sus casas para tomar fotografías desde sus ventanas y azoteas.

A todas las personas que desinteresadamente me han guiado en las visitas a los edificios, acompañándome cuando era posible al espacio bajo cubierta de iglesias, en muchas ocasiones casi intransitable: María en Nava del Rey, Elena en Serrada, José Antonio en Tordesillas, Fidel en la Catedral, el párroco de San Antolín, la Priora de la Concepción, Alfonso en San Gregorio, Jaime en las Angustias, Alaejos, Luis en La Pasión, Ma José en Santa Cruz, los miembros de la Asociación Pro Restauración de Templos de Medina de Rioseco en Santiago, Antonio en el Museo de las Ferias, Mayorga, Mariví en Cuenca, los Padres Pasionistas en Peñafiel, Villaverde, el padre Teófanes Egido en San Benito, el Prior Salus en San Pablo, el Hermano Satur y el profesor Sigüenza en la Santa Espina.

Y, por último, gracias por su guía a los co-directores del trabajo: $\mathrm{M}^{\mathrm{a}}$ Soledad Camino Olea y Francisco Javier León Vallejo. 



\section{INTRODUCCIÓN}

I. 1. Presentación del objetivo........................................................................... I.01

I. 2. Justificación del interés de la cuestión ................................................... I.02

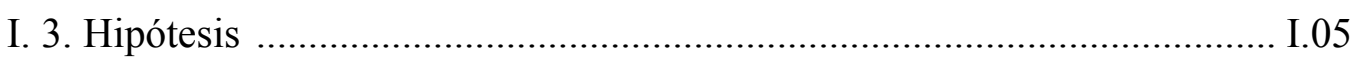

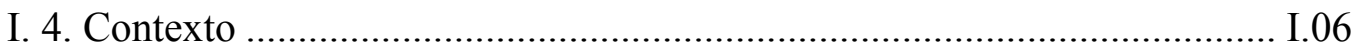

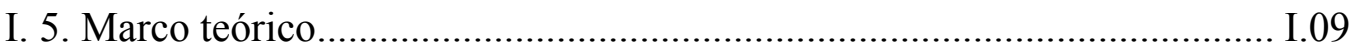

I. 6. Organización del documento .............................................................. I.11

I.6.1. Metodología y fuentes de la investigación...................................... I.11

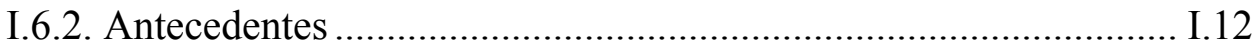

I.6.3. Análisis y discusión ................................................................... I.14

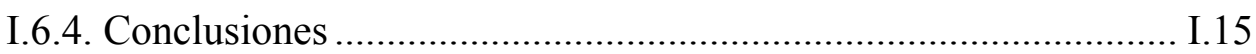

I.6.5. Bibliografía y lista de ilustraciones............................................ I.15

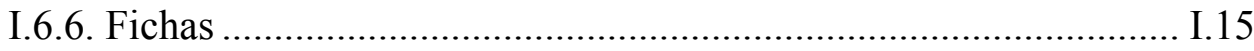

\section{METODOLOGÍA Y FUENTES DE LA INVESTIGACIÓN}

II. 1. Establecimiento de un protocolo ......................................................... II.02

II.1.1. Diseño metodológico del proceso de investigación...................... II.02

II.1.2. Selección de los casos de estudio ............................................ II.02

II.1.3. Elección de las fuentes documentales .......................................... II.03

II. 2. Recopilación documental para establecer el estado del arte .................... II.03

II.2.1. Fuentes documentales ............................................................ II.04

II.2.1.1. Bibliografía especializada sobre el Patrimonio ............... II.04

II.2.1.2. Tratados de construcción............................................... II.04

II.2.1.3. Proyectos de investigación de otras universidades ......... II.04

II.2.2. Recorrido lingüístico. .............................................................. II.05

II.2.3. Recorrido constructivo............................................................... II.05

II. 3. Desarrollo del estudio de los 40 casos ................................................ II.05

II.3.1. Recopilación documental de fuentes indirectas: bibliografía...... II.05

II.3.2. Fuentes directas: proyectos de ejecución..................................... II.06

II.3.3. Trabajo de campo …………….......................................... II.08

II.3.4. Elaboración de fichas descriptivas............................................ II.10

II. 4. Procesamiento de los datos .............................................................. II.11

II.5. Resultado de la investigación ................................................................ II.13 


\section{ANTECEDENTES}

III. 1. Terminología: elemento de atado, encadenado, zuncho ........................III.01

III. 2. Marco histórico del atado estructural ..................................................III.09

III.2.1. Los primeros encadenados ......................................................III.09

III.2.2. El encadenado en los Tratados de construcción históricos ..........III.13

III. 3. Marco conceptual para el uso del zuncho en restauración ....................III.29

III.3.1. Criterios de intervención ..........................................................III.29

III.3.1.1. Cartas y leyes .............................................................III.29

III.3.1.2. La formación de los técnicos ......................................III.33

III.3.1.3. Generalización en el siglo XX........................................III.40

III.3.2. El zuncho en la restauración en otras regiones ...........................III.45

III.3.2.1. Badajoz .................................................................III.45

III.3.2.2. Galicia....................................................................III.47

III.3.2.3. El zuncho en Portugal ..................................................III.49

III.3.3. Relación del zunchado con el problema del sismo ......................III.63

III.3.3.1. El terremoto de Lisboa...................................................III.63

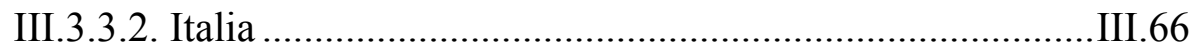

III.3.3.3. América latina..............................................................III.71

III.3.3.4. Terremoto de Lorca, Murcia.........................................III.74

III.3.3.5. Estrategias actuales frente al riesgo sísmico...................III.80

III.3.4. Últimas tendencias en restauración monumental ........................III.83

III.3.4.1. Conservación preventiva ...........................................III.83

III.3.4.2. Des-restauración .........................................................III.85

III.3.4.3. La fascinación por la tecnología ...................................III.88

III.3.4.4. El punto de vista práctico ..............................................III.94

III.3.4.5. Los nuevos conceptos de refuerzo estructural .................III.101

III.3.4.6. Resumen de las últimas tendencias.................................III.103

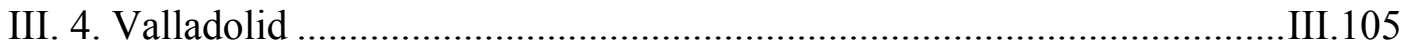

III.4.1. El foco clasicista ....................................................................III.105

III.4.1.1. El sistema de talleres ..................................................III.108

III.4.1.2. Los Tratados: Palladio .....................................................III.109

III.4.1.3. El método de Cartabones ................................................III.110

III.4.1.4. Condiciones y trazas ........................................................III.111

III.4.1.5. La pendiente de cubierta en las iglesias del foco.............III.115

III.4.2. Las actuaciones del siglo XIX...................................................III.116

III.4.3. División administrativa en el siglo XX.....................................III.122 


\section{ANÁLISIS Y DISCUSIÓN}

IV. 1. Análisis de los proyectos de restauración............................................ IV.01

IV.1.1. La documentación escrita...................................................... IV.02

IV.1.1.1. Necesidad de la intervención ....................................... IV.03

IV.1.1.2. Justificación del zuncho............................................... IV.18

IV.1.1.3. Definición de dimensiones de los zunchos ................... IV.30

IV.1.2. La documentación gráfica ..................................................... IV.37

IV.1.2.1. Las trazas .................................................................. IV.37

IV.1.2.2. La documentación de los proyectos mediados del XX.. IV.39

IV.1.2.3. Las herramientas de los arquitectos mediados del XX.. IV.40

IV.1.2.4. Los levantamientos recientes ....................................... IV.41

IV.1.2.5. Definición del zuncho en los planos ............................. IV.42

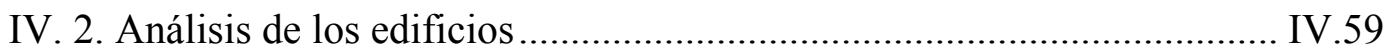

IV.2.1. Descripción y tipologías.......................................................... IV.59

IV.2.1.1. La Geometría ............................................................. IV.60

IV.2.1.2. Clasificación básica de los templos estudiados ............. IV.62

IV.2.1.3. La utilización de los edificios ..................................... IV.70

IV.2.1.4. Ermitas románicas ...................................................... IV.74

IV 2.2. Aspectos estructurales ......................................................... IV.77

IV.2.2.1. La Cimentación......................................................... IV.77

IV.2.2.2. Los Muros ................................................................... IV.90

IV.2.2.3. La estructura de cubierta............................................ IV.96

IV.2.3. Los tejados .................................................................. IV.101

IV.2.3.1. La tipología de cubierta original................................... IV.103

IV.2.3.2. Dimensiones ............................................................ IV.110

IV.2.3.3. Pendiente y material de cobertura de los faldones......... IV.112

IV.2.3.4. El refreno ............................................................... IV.116

IV .2.3.5. La cornisa............................................................... IV.119

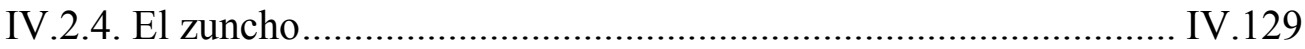

IV.2.4.1. Conclusiones parciales del análisis previo desarrollado

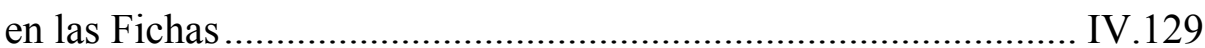

IV.2.4.2. Los zunchos comprobados in situ................................ IV.135

IV.2.4.3. Zunchos demolidos en la siguiente actuación ............... IV.141

IV.2.4.4. Zunchos y patología relacionada con su incorporación. IV.142

IV.2.4.5. Clasificación básica de los zunchos observados en la labor de campo 
IV.3. Discusión IV.153

IV.3.1. Incorporación del zuncho. IV.153

IV.3.1.1. La fecha IV.153

IV.3.1.2. El detalle. IV.155

IV.3.1.3. El anillo IV.157

IV.3.2. Relación del empleo de zuncho con la solución estructural ........IV.159 IV.3.3. Comportamiento del zuncho IV.160

IV.3.4. Síntesis de los conceptos desarrollados IV.162

\section{CONCLUSIONES}

Conclusiones V.01

\section{RECOMENDACIONES Y FUTURAS LÍNEAS DE INVESTIGACIÓN}

VI.1. Recomendaciones . VI.01

VI.2. Futuras líneas de investigación VI.02

VI.2.1. El problema del acceso ...............................................................03

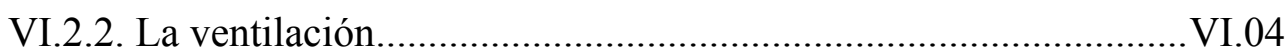

VI.2.3. La evacuación de aguas en los edificios históricos.....................VI.06

VI.2.4. El material de cubrición cerámico ............................................VI.09

VI.2.5. El cinchado de torres y cúpulas ...............................................VI.10

\section{BIBLIOGRAFÍA}

VII.1. Referencias bibliográficas VII.01

VII.2. Listado de ilustraciones. VII.13 
VIII. FICHAS: RESUMEN, DOCUMENTACIÓN Y VISITAS

\begin{tabular}{|c|c|c|}
\hline FZ-01 & Catedral & Valladolid \\
\hline FZ-02 & Concepción & Valladolid \\
\hline FZ-03 & San Gregorio & Valladolid \\
\hline FZ-04 & Pasión & Valladolid \\
\hline FZ-05 & Asunción-PortaCoeli & Valladolid \\
\hline FZ-06 & Angustias & Valladolid \\
\hline FZ-07 & San Agustín & Valladolid \\
\hline FZ-08 & San Benito & Valladolid \\
\hline FZ-09 & San Lorenzo & Valladolid \\
\hline FZ-10 & San Pablo & Valladolid \\
\hline FZ-11 & Antigua & Valladolid \\
\hline FZ-12 & Rosarillo & Valladolid \\
\hline FZ-13 & Salvador & Valladolid \\
\hline FZ-14 & Descalzas Reales & Valladolid \\
\hline FZ-15 & San Joaquin y Santa Ana & Valladolid \\
\hline FZ-16 & Huelgas & Valladolid \\
\hline FZ-17 & Santa María & Alaejos \\
\hline FZ-18 & San Juan & Arroyo \\
\hline FZ-19 & La Santa Espina & Castromonte \\
\hline FZ-20 & Santa María del Castillo & Castronuño \\
\hline FZ-21 & Santos Justo y Pastor & Cuenca \\
\hline FZ-22 & San Juan & Fresno \\
\hline FZ-23 & Santa María & Iscar \\
\hline FZ-24 & Santa María & Mayorga \\
\hline FZ-25 & San Francisco & Medina de Rioseco \\
\hline FZ-26 & Santa Cruz & Medina de Rioseco \\
\hline FZ-27 & Santiago & Medina de Rioseco \\
\hline FZ-28 & San Antolín & Medina del Campo \\
\hline FZ-29 & San Martín & Medina del Campo \\
\hline FZ-30 & Santos Juanes & Nava del Rey \\
\hline FZ-31 & San Juan & Olmedo \\
\hline FZ-32 & Santa María & Palazuelo \\
\hline FZ-33 & San Pablo & Peñafiel \\
\hline FZ-34 & San Cebrián de Mazote & San Cebrián de Mazote \\
\hline FZ-35 & Santa María & Tordesillas \\
\hline FZ-36 & La Anunciada & Urueña \\
\hline FZ-37 & Santa María & Valbuena \\
\hline FZ-38 & Santa María del Castillo & Villaverde \\
\hline FZ-39 & Santa María & Wamba \\
\hline FZ-40 & San Pedro & Serrada \\
\hline
\end{tabular}





\section{Introducción}

\section{I.1. Presentación del objetivo}

La investigación se centra en el empleo de elementos de atado o zunchos como una de las soluciones más habituales de refuerzo en las intervenciones sobre edificios del Patrimonio construido. Dichas piezas se disponen en la coronación de los muros de fábrica, precisamente en su encuentro con el tejado, en uno de los puntos más delicados de los edificios históricos desde el punto de vista constructivo, donde coinciden además el apoyo de la estructura de cubierta, el arranque de las bóvedas y el engarce de tirantes de madera o metal. Entran en conflicto aspectos tanto mecánicos como estéticos, ya que debe asegurarse el contrarresto de los empujes horizontales que puedan producirse $\mathrm{y}$, al mismo tiempo, buscar la máxima eficacia en la evacuación de las aguas. Cornisa y alero están especialmente expuestos a la degradación debida a factores climáticos y ambientales, que se suma al envejecimiento de los materiales producido por el simple paso del tiempo. La configuración geométrica de los apoyos, además, condiciona el comportamiento estructural de toda la cubierta, y todo esto se produce justo en el punto donde en las restauraciones monumentales se incorpora habitualmente el zuncho.

Muchos profesionales siguen considerando hoy necesario incorporar zunchos en coronación cuando acometen obras de restauración monumental, mientras otros lo desaconsejan expresamente. Esta investigación pretende contribuir con datos reales a la comprensión del comportamiento de las cubiertas de los edificios históricos, desentrañando el papel que desempeñan en ellas estos elementos.

Se ha llevado a cabo el análisis del atado perimetral de estructuras de cubierta en una muestra representativa de iglesias en la provincia de Valladolid sobre las que se han producido actuaciones de forma más o menos reiterada a lo largo de los años. A partir de la información obtenida sobre estas obras se escudriñan las reglas subyacentes y la evolución de las soluciones constructivas empleadas en diferentes momentos de nuestra historia. Partiendo de las intervenciones llevadas a cabo por iniciativa del Ministerio en los años 60 y 70, se recorre el hilo conductor que mantiene vigentes algunos criterios incluso tras el traspaso de competencias a la 
Administración Autonómica y su maduración tras el cambio de siglo hasta desembocar en la situación actual.

El trabajo se ha realizado dentro del Departamento de Construcciones Arquitectónicas de la Universidad de Valladolid, dado su objetivo fundamental de aportar conocimientos técnicos relativos a la construcción de los edificios históricos y a las obras de restauración que se realizan sobre los mismos. Se elude así en el texto, de forma intencionada, cualquier apreciación estética o artística.

\section{I.2. Justificación del interés de la cuestión}

Es evidente la importancia del Patrimonio histórico como legado que una generación deja a sus sucesoras, clave de la identidad y factor fundamental de cohesión social. El Patrimonio cultural no es un mero conjunto de posesiones, sino una construcción social y simbólica. Es un elemento clave para la sociedad y uno de los aspectos fundamentales de su gestión es la salvaguarda de los edificios protegidos que forman su soporte físico.

Toda construcción sufre un deterioro con el paso del tiempo y las actuaciones de cada generación para afrontarlo son cuestionadas por las siguientes. Los criterios aplicados en cada época van evolucionando y sólo la revisión científica de las soluciones adoptadas en cada caso, pasado un periodo de tiempo suficiente, puede confirmar su eficacia real. Esta Tesis pretende aportar conocimientos sobre cómo se han comportado a medio plazo ciertas medidas aplicadas en algunos momentos de forma casi sistemática a la hora de restaurar los edificios monumentales en España. Los técnicos que acometan obras en el futuro podrán contar con esta información a la hora de valorar si incorporan o no elementos de atado perimetral y las características más adecuadas para los mismos.

Podemos encontrar numerosos estudios de las intervenciones sobre los edificios del Patrimonio enfocados desde el ámbito de la teoría arquitectónica. Polémicas históricas en cuanto a los términos más adecuados para aplicar a las intervenciones: restauración frente a rehabilitación, conservación o el último vocablo de moda, el reuso. Debate entre partidarios y detractores de las reconstrucciones historicistas y la anastilosis. 
Los términos empleados en el título de la Tesis han sido expresamente elegidos, ya que se trata de palabras muy utilizadas en los proyectos de restauración de edificios históricos durante décadas que en la actualidad están experimentando cierto rechazo por parte de los arquitectos. El catedrático Javier Rivera afirma que "Monumento ha sido sustituido por Bien Cultural o por Patrimonio, que tienen acepciones distintas, sujetos mucho más amplios y puntos de partida más diversos para afrontar su conservación" ${ }^{1}$. Al tratar el papel del zuncho en la restauración monumental se pretende, por un lado, emplear las mismas expresiones que se utilizaban en la época a la que pertenece el grueso de los documentos revisados, y por otra hacer hincapié en la consideración de los edificios históricos desde un punto de vista puramente constructivo, sin otras connotaciones adicionales.

Los técnicos dedicados a Conservar y restaurar el Patrimonio han debatido generación tras generación cómo afrontar la salvaguarda del mismo. Parece asimilada por fin la Conservación preventiva como actuación de referencia frente a las grandes restauraciones, convertidas en último recurso y llevadas a cabo sólo si resultan inevitables. También se ha conseguido volver a valorar el entorno de los monumentos, vencida la moda de retirar adherencias y considerar "pólipos"2 las construcciones adosadas. A pesar de los numerosos debates siempre se producen recaídas, estas últimas sobre todo a raíz de la incorporación a los procesos de gestión del patrimonio del público de masas a través de las redes sociales para las que un monumento es "una joya" que debería mantenerse exenta, como un relicario. Y eso que han pasado casi cien años desde que se publicara el encendido alegato de Torres Balbás contra el derribo de adherencias, en defensa de la autenticidad de las catedrales ${ }^{3}$.

Los textos de carácter técnico se centran con frecuencia en el análisis de los materiales que forman el edificio desde un punto de vista físico y químico. Ensayos de dureza, composición o porosidad de la piedra. Pruebas con nuevos materiales y

\footnotetext{
${ }^{1}$ Rivera Blanco, J. (2013). Nuevas tendencias de la restauración monumental. De la Carta de Venecia a la Carta de Cracovia. En Seminario: La doctrina de la restauración a través de las cartas internacionales. Universidad Politécnica de Valencia. Obtenido en http://riunet.upv.es/handle/10251/28161\#. Pág.387.

${ }^{2}$ Así denomina el arquitecto Salvador Mata en la memoria del proyecto de la iglesia de las Angustias a anexos como la sacristía (ver Ficha FZ-06)

3 "No concibiéronse las catedrales para estar aisladas, sino para armonizar con los edificios destinados a sus servicios... y con las casas que por todas partes las rodeaban. Suprimir las construcciones adosadas es adulterar por completo la creación de los artistas medievales que las labraron" (Torres Balbás 1919,p. 359)
} 
tratamientos para reparar, reconstruir o consolidar. Afortunadamente, ha surgido en los últimos años una tendencia clara hacia la recuperación de técnicas tradicionales, abandonando poco a poco, por ejemplo, el uso de cemento en las construcciones históricas para recuperar las ventajas inherentes al mortero de cal. También vuelven a emplearse la madera, el ladrillo y la piedra para reponer las piezas malogradas.

El abandono del estudio de los sistemas tradicionales de construcción en los planes de estudio de varias generaciones de técnicos, centrados únicamente en profundizar en el manejo de los criterios surgidos del Movimiento Moderno, según se describirá en el apartado II.3.2., ha desembocado en un desconocimiento de los citados sistemas tradicionales. El avance en la investigación sobre las construcciones históricas formará parte de la base de conocimientos necesaria para actuar sobre las mismas con más eficacia y en el mejor de los casos interrumpir procesos de alteración que están dañando, a veces de forma irreversible, nuestro Patrimonio edificado.

El interés por la conservación de techumbres de madera históricas bajo criterios de mínima intervención es muy reciente, por ejemplo las recomendaciones al respecto del IPCE son de $2011^{4}$. Y debemos reconocer que aún encontramos muchos arquitectos que optan por desmontar las armaduras de cubierta y reemplazarlas por estructuras nuevas cuyas prestaciones y seguridad les resultan más fáciles de controlar.

Aunque en la actualidad podemos encontrar estudios de posgrado dirigidos a formar especialistas en restauración de edificios históricos, aún podemos detectar carencias a la hora de localizar una documentación técnica rigurosa. Cada profesional interviene según su propio criterio y en muchos casos sin conocer actuaciones previas en el edificio, o incluso estrategias fallidas empleadas en sus propias obras que, como decíamos, pueden no manifestarse hasta varios años después de su terminación.

Uno de los aspectos más descuidados en las citadas intervenciones sobre edificios protegidos es el seguimiento a posteriori de las actuaciones, el control de sus efectos a lo largo del tiempo. Con frecuencia se adopta una técnica que en algún momento "se pone de moda" sin comprobar sus efectos a medio y largo plazo. En algunas

\footnotetext{
${ }^{4}$ IPCE. (2011). Recomendaciones para la conservación de techumbres de madera. Instituto del Patrimonio Cultural de España IPCE. Obtenido en http://ipce.mcu.es/pdfs/recomendacionestechumbres2011.pdf
} 
obras recientes se está reparando deterioros incrementados tras la aplicación de determinados supuestos consolidantes o incluso provocados por ellos. Es por eso muy recomendable efectuar a medio plazo un seguimiento de las obras de restauración o rehabilitación realizadas sobre los monumentos históricos.

\section{I.3. Hipótesis}

La ejecución de un zuncho de hormigón armado en el remate de los muros de iglesias de Valladolid, incluso en las declaradas BIC (Bien de Interés Cultural), ha sido, según decíamos, una práctica habitual en las obras de restauración de cubiertas acometidas durante décadas. Se plantean así las primeras cuestiones: cuándo se empiezan a incorporar estos elementos y por qué se colocan. Se pretende averiguar si se trata de una pieza estructuralmente favorable o perjudicial, si incluso en algún caso resulta necesaria, y si se siguen empleando estas soluciones en la actualidad.

Se han considerado, como punto de partida, las siguientes preguntas de investigación, que se plantean para cada uno de los casos analizados:

- A qué se está denominando zuncho en los proyectos.

- Cuándo se incorpora este elemento.

- Por qué se coloca y cuál es su misión según el autor del proyecto.

- Qué había antes en ese lugar y qué encontramos ahora.

- Cómo es su geometría: desarrollo, dimensiones, ubicación.

- Cómo trabaja, cuál es su cometido y si es estructural.

- Si está desempeñando alguna función en la actualidad y cómo se comporta.

Estas cuestiones conducen a la formulación de ciertas hipótesis:

- El empleo de zunchos en restauración monumental surge en un momento determinado de la segunda mitad del siglo XX.

- Los zunchos se incorporan cuando se sustituye armaduras de madera por nuevas estructuras de cubierta realizadas con hormigón o acero.

- Los arquitectos asignan al zuncho, en sus proyectos de restauración, funciones diferentes según las necesidades. 


\section{I.4. Contexto}

La delimitación del objeto de estudio abarca diversos ámbitos: geográfico, temporal y tipológico. En el campo de la Restauración monumental es posible obtener abundante documentación sobre conceptos teóricos mientras que son verdaderamente escasos los textos orientados al análisis de aspectos constructivos abordados desde un punto de vista específicamente tecnológico. Según se explica en los epígrafes anteriores, el objetivo de este trabajo es precisamente profundizar en cuestiones puramente constructivas, dejando de lado juicios de valor y cuestiones de forma. La investigación se acomete desde dos frentes, según se ha explicado: el análisis de las copias de proyectos de restauración que se conservan en diversos archivos y el testimonio material que proporcionan los propios edificios.

El catálogo Fuentes Documentales para el estudio de la Restauración de Monumentos en España, publicado en 1989 por el Ministerio de Cultura, recoge un listado de las intervenciones llevadas a cabo por la Dirección General de Bellas Artes antes de la transferencia de competencias a las Comunidades Autónomas. Se indica cada monumento, o conjunto urbano indexado, la fecha en que se acometen obras en el mismo, su descripción básica, el nombre de los arquitectos que las realizan y la signatura de las cajas en que se encuentra archivado.

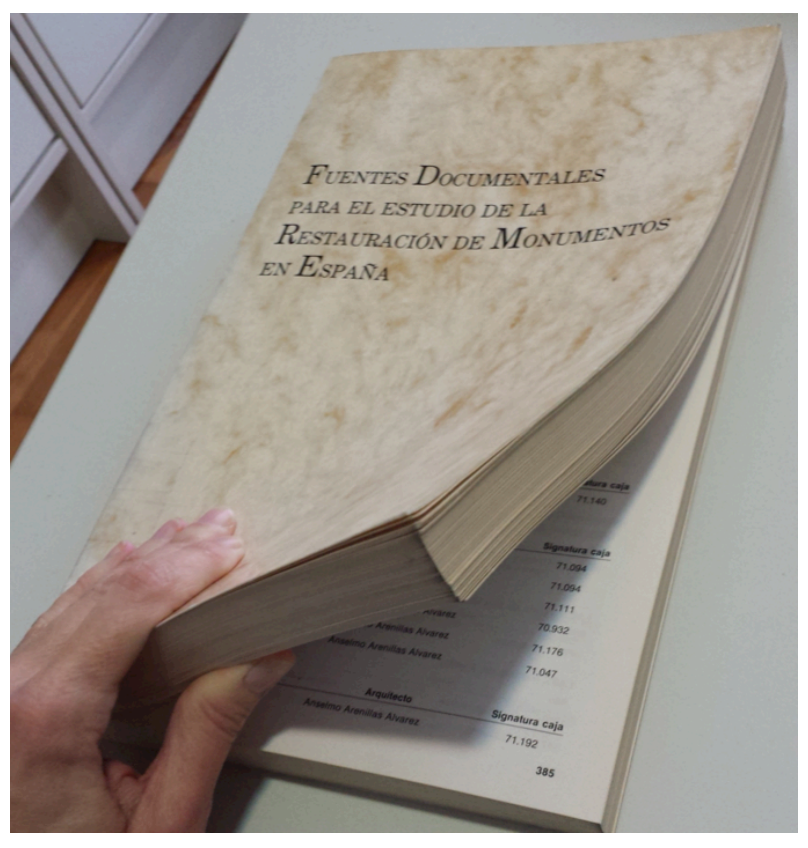

Fig.I.1. Portada del libro Fuentes Documentales

Desde simple limpieza de un templo hasta recalce de cimientos, sustitución de cubiertas o restauración general, se incluye todo tipo de actuaciones realizadas desde la década de los cuarenta hasta mediados de los ochenta ${ }^{5}$.

\footnotetext{
${ }^{5}$ Otro libro editado por la Dirección General de Bellas Artes y Archivos del Ministerio de Cultura, "Intervenciones en el Patrimonio arquitectónico (1980-1985)", cierra el ciclo histórico en que la custodia del patrimonio arquitectónico se realizaba desde la Administración central, según afirma en el prólogo del mismo Dionisio Hernández Gil.
} 
El arquitecto Alfonso Muñoz Cosme reconoce en el prólogo de la obra que la documentación referida puede emplearse para distintos fines. Se trata de unos datos valiosos tanto para el investigador como para los técnicos encargados de llevar a cabo las intervenciones futuras. Cada proyecto de restauración realizado refleja el estado del edificio en un momento preciso y a través de un enfoque dado. El material disponible es heterogéneo pero de gran valor para la sociedad.

La introducción del libro, a cargo de Soledad Cases, resume las características del fondo documental que denomina "Proyectos de restauración de bienes inmuebles del Archivo Central del Ministerio de Cultura". Describe cómo los expedientes suelen constar de memoria, planos, presupuesto económico, mediciones y pliego de condiciones técnicas, aunque reconoce que muchos documentos se repiten al programarse las obras con anualidades y efectuarse intervenciones no programadas. También hay expedientes incompletos en los que falta alguno de los documentos. Las referencias se agrupan ordenadas por comunidades autónomas.

Al comienzo de la investigación se adopta el índice del citado catálogo Fuentes para llevar a cabo la selección preliminar del conjunto de edificios objeto de estudio. Se trata de todos los monumentos de la provincia de Valladolid que se recogen en el libro. En cada uno de ellos se cuenta con al menos una intervención documentada en el Archivo General de la Administración llevada a cabo en la época en que, según la investigación preliminar de esta Tesis, se empezó a generalizar el empleo de zunchos en la restauración del Patrimonio.

La elección de estos edificios sobre los que se intervino desde el Ministerio, y en muchos casos se ha vuelto a actuar ya bajo control de la Comunidad autónoma, permite generar datos sobre la evolución de los criterios restauradores en el proceso de traspaso de competencias. La recopilación de datos para la Tesis abarca tanto los proyectos de restauración acometidos por la Administración central como los documentos generados años más tarde para las obras acometidas sobre esos mismos inmuebles, tras el traspaso de competencias, que se custodian en la Administración autonómica. Como veremos en el análisis y las conclusiones de la investigación, en los primeros años tras este traspaso se mantienen algunos de los criterios del Ministerio, pero poco a poco se pone en crisis el modelo y se lleva a cabo un análisis profundo de los métodos llegándose a desarrollar pautas propias. 
Según el arquitecto Marco Antonio Garcés, técnico del Servicio de Restauración de la Junta especializado en el patrimonio monumental, aunque Castilla y León es una de las comunidades que alberga más Patrimonio histórico construido, la lista de bienes oficialmente reconocidos como BIC no lo representa de forma razonable, ni por distribución ni en cuanto a tipos arquitectónicos. La asignación de tareas otorga además competencias sobre BIC a la Consejería de Cultura y sobre los edificios no catalogados a la de Fomento ${ }^{6}$.

\begin{tabular}{|c|c|c|c|c|c|c|}
\hline \multicolumn{7}{|c|}{ La Conservación del Patrimonio Monumental dedicado al Culto en Castilla y León } \\
\hline \multicolumn{7}{|c|}{ RELACION ENTRE MONUMENTOS Y EDIFICIOS DEDICADOS AL CULTO } \\
\hline Provincia & $\mid \begin{array}{l}\text { Total } \\
\text { Monumentos }\end{array}$ & $\begin{array}{l}\text { Iglesias en la } \\
\text { categoria } \\
\text { Monumento }\end{array}$ & $\begin{array}{l}\text { Relación } \\
\text { Iglesias/ } \\
\text { Monumento }\end{array}$ & $\begin{array}{l}\text { Iglesias } \\
\text { Monumento } \\
\text { dedicadas al } \\
\text { culto }\end{array}$ & $\begin{array}{l}\text { Relación } \\
\text { Iglesias } \\
\text { dedicadas } \\
\text { culto/total } \\
\text { Monumentos }\end{array}$ & $\begin{array}{l}\text { Iglesias } \\
\text { Monumento } \\
\text { no dedicadas } \\
\text { al culto }\end{array}$ \\
\hline Avila & 67 & 47 & 70,15 & 40 & 0,60 & 7 \\
\hline Burgos & 122 & 94 & 77,05 & 86 & 0,70 & 8 \\
\hline León & 79 & 55 & 69,62 & 47 & 0,59 & 8 \\
\hline Palencia & 106 & 92 & 86,79 & 81 & 0,76 & 11 \\
\hline Salamanca & 83 & 57 & 68,67 & 52 & 0,63 & 5 \\
\hline Segovia & 97 & 72 & 74,23 & 62 & 0,64 & 10 \\
\hline Soria & 69 & 51 & 73,91 & 44 & 0,64 & 7 \\
\hline Valladolid & 113 & 86 & 76,11 & 74 & 0,65 & 12 \\
\hline Zamora & 40 & 34 & 85,00 & 26 & 0,65 & 8 \\
\hline Totales & 776 & 588 & 75,77 & 512 & 0,66 & 76 \\
\hline \multicolumn{3}{|c|}{$\begin{array}{l}\text { Total BIC incoados y declarados } \\
\text { Iglesias en relación con Monumentos } \\
\text { Iglesias Culto/Monumentos } \\
\text { Edificios eclesiásticos/BIC } \\
\text { Iglesias dedicadas al culto/ BIC } \\
\text { Iglesias no dedicados culto/BIC }\end{array}$} & \multicolumn{4}{|c|}{$\begin{array}{l}2.201 \\
0,76 \text { ( } 3 \text { de cada } 4 \text { son edificios eclesiásticos) } \\
0,66 \text { ( } 2 \text { de cada } 3 \text { están dedicados al culto) }\end{array}$} \\
\hline
\end{tabular}

Fig.I.2. Tabla del libro "Conservación preventiva en lugares de culto". (Garcés 2009)

Según el cuadro anterior, tres de cada cuatro monumentos declarados en la región están dedicados al culto, es decir, el 76\% de los BIC son iglesias. Dado que para el análisis debe compararse un número de casos representativo de similares características, se acota la muestra sobre la tipología más abundante en la región: las iglesias.

La lista de templos de partida queda entonces ajustada a cuarenta casos objeto de estudio, diecisiete en la ciudad de Valladolid y veintitrés en la provincia. A los 39 templos citados en el libro se añade una iglesia parroquial a la que ha sido posible acceder que permitirá además servir de contraste para controlar determinados parámetros.

\footnotetext{
${ }^{6}$ Garcés Desmaison, M. A. (2009). La conservación preventiva de los monumentos destinados al culto en Castilla y León. En Conservación preventiva en lugares de culto. Madrid: IPCE.
} 


\section{I.5. Marco teórico}

Como veremos a lo largo del texto que forma el cuerpo de la Tesis, los edificios de fábrica han contado en muchos casos con sistemas de atado estructural, incorporados tanto desde el origen de su construcción como en las distintas transformaciones sufridas a lo largo del tiempo. Entre las primeras piezas de madera embebidas en los muros o adosadas a éstos de la Antigüedad y los más modernos cinchados con acero o textiles, encontramos los abundantes elementos de hormigón armado cuya ejecución se generalizó desde mediados del siglo XX hasta casi nuestros días.

Muchos profesionales aún consideran hoy necesario incorporar un zuncho perimetral de hormigón armado sobre la coronación de los muros cuando realizan una obra de restauración de cubiertas de una construcción histórica ${ }^{7}$. Otros lo desaconsejan expresamente pero ¿tenemos datos reales del comportamiento de estos elementos, las razones por las que se colocan o incluso se retiran? Este estudio pretende aportar luz a estas cuestiones, según se ha decrito, a partir del análisis de un conjunto de iglesias monumentales de la provincia de Valladolid a las que se incorporó en algún momento un elemento al que en su proyecto de restauración se denominó "zuncho".

En España se ha aplicado a lo largo del tiempo dicha designación "zuncho" para hacer referencia a piezas de distinta naturaleza, con materiales y comportamientos estructurales heterogéneos. Es habitual denominar zunchos a elementos tanto de hormigón armado como de madera o metálicos, mientras que en Italia, por ejemplo, se referirían a cada uno de esos casos con una expresión específica: cordolo in cemento armato, catene in legno y cerchiature di ferro.

Se están llevando a cabo en los últimos años diversos estudios sobre obras de restauración monumental estructurados a partir de periodos históricos, con el fin de analizarlas dentro de un determinado contexto político y social: la Guerra Civil, la Posguerra, los años centrales del franquismo, el Desarrollismo hasta 1975. En el presente trabajo no se limita el ámbito de las actuaciones en función de las fechas en que éstas se hayan acometido, abarcándose para cada templo todas las obras documentadas desde el momento de su construcción hasta nuestros días.

\footnotetext{
${ }^{7}$ Benedicto Salas, R. (2012). De las sustituciones de cubiertas en las iglesias del patrimonio monumental. Zaragoza: Institución Fernando el Católico.
} 
En la investigación se aborda el análisis de los edificios en su ciclo de vida completo, desde su génesis hasta la actualidad. Se rastrean todas las obras y reparaciones realizadas a lo largo del tiempo de las que pueda accederse a documentación, aunque el grueso de datos y el hecho preciso de incorporarse zunchos se ha producido básicamente en la segunda mitad del siglo XX.

La transferencia de competencias a las Comunidades Autónomas supone un hito fundamental para la transformación de los criterios de intervención sobre el Patrimonio. Según se explica en el apartado III.4 sobre Valladolid, a finales de los 80, las jóvenes Administraciones locales tienen necesidades específicas de autoafirmarse y ocupar espacios de representación, a ser posible que reflejen la relevancia de la región desde tiempos antiguos, por lo que acometen importantes restauraciones y sobre todo rehabilitaciones de inmuebles asociados a acontecimientos históricos.

El área bajo influencia de Valladolid cuenta con un repertorio monumental imponente y muy numeroso. La época de mayor esplendor arquitectónico en la región corresponde al llamado foco clasicista $^{8}$, en torno al año 1600. En algunos casos se trata de templos proyectados anteriormente que se rematan en este periodo, en otros se conciben y arrancan en ese momento. Su construcción estuvo a cargo de un reducido número de maestros, autores de las trazas, que incluso se alternaban en el cargo durante la ejecución.

La investigación sobre el estado previo a las modernas intervenciones analizadas pasa por establecer similitudes y diferencias entre ellas. La mayor parte de las construcciones estudiadas presenta soluciones comunes, como la cubierta dual: con bóvedas de ladrillo hacia el interior y cubrición mediante faldones a dos aguas recubiertos de teja árabe.

Durante la fase de documentación se han localizado datos hasta ahora inéditos relativos a las intervenciones del siglo XIX. La tesis doctoral de Domínguez Burrieza sobre la figura del arquitecto Jerónimo Ortiz de Urbina, los artículos que van emanando de la misma y el libro editado por el Ayuntamiento de Valladolid, confirman la actuación contundente de los arquitectos decimonónicos sobre muchas de estas iglesias.

\footnotetext{
${ }^{8}$ Se trata de un término acuñado en los años ochenta por el historiador Agustín Bustamante para referirse a la arquitectura de la escuela vallisoletana en la etapa 1561-1640 a la que pertenecen algunas de las iglesias estudiadas en la Tesis.
} 


\section{I.6. Organización del documento.}

Según se aprecia en el índice, el documento se ha dividido en dos bloques, en el primero se encuentra el cuerpo base de la Tesis y el segundo contiene la documentación recopilada sobre los edificios. En primer lugar se describe la Metodología empleada, a continuación se establece el estado del Arte y posteriormente el Análisis y discusión de los datos. Finalmente se desarrollan las conclusiones.

\section{I.6.1. Metodología y fuentes de la investigación}

La investigación llevada a cabo es de tipo mixto. Se ha empleado como fuentes directas los proyectos de ejecución originales, complementados con la inspección de algunos edificios como labor de campo. Una parte importante de la investigación se ha centrado en el estudio de casos a partir de una muestra seleccionada de iglesias de la provincia de Valladolid.

El proceso se ha dividido en tres fases. En la primera, desarrollada entre $2011 \mathrm{y}$ 2012, se abordó el estudio de los Antecedentes, necesario para establecer el Estado del arte de la cuestión y el Marco conceptual. A continuación se estableció un protocolo articulado en varias etapas para sistematizar cada Estudio de caso: recopilación documental, trabajo de campo, análisis e interpretación de los datos y obtención de conclusiones. Simultáneamente a estas actividades, con el fin de adelantar hipótesis que permitieran reorientar y perfeccionar las pautas de la investigación, se dio comienzo a la tercera fase centrada en el análisis y discusión.

Para responder a la cuestión científica planteada se emplean además dos instrumentos auxiliares de procesamiento de la información.

- El primero de ellos es el uso de fichas en las que se recogen los datos más importantes de cada monumento, tanto documentados como obtenidos de forma directa mediante las visitas.

- Para organizar y clasificar los datos comunes o distintivos entre los diferentes casos se han elaborado tablas mediante la herramienta informática Excel.

A partir de la sistematización anterior se han extraído unas conclusiones. Se ha tratado también de identificar aspectos no resueltos y posibles frentes abiertos, así como de elaborar una serie de recomendaciones. Finalmente se reflexiona sobre las implicaciones de la Tesis tanto a nivel teórico como práctico. 
El fundamento metodológico y las fuentes de la investigación desarrollada se exponen en el capítulo II, que incluye un esquema de flujo de las etapas del proceso.

\section{I.6.2. Antecedentes}

La primera parte del trabajo trata de esclarecer el estado actual del arte en que se asienta la investigación: su marco teórico, conceptual, histórico y referencial.

En el primer apartado del capítulo III se aborda el problema lingüístico tanto del origen del término como de su empleo a lo largo de los siglos en el ámbito de la construcción arquitectónica. La palabra zuncho cuenta con una amplia difusión en nuestra lengua, pero su empleo está casi completamente restringido al ámbito peninsular. Es además un término cuya acepción generalizada no se recoge en los diccionarios al uso, que lo consideran casi en exclusiva un simple sinónimo de anillo o banda metálicos. Se ha elegido la palabra zuncho frente a posibles alternativas como las expresiones atado estructural o encadenado para confirmar la intencionalidad de los autores de los proyectos analizados que empleaban precisamente ese término en contextos diferentes.

Como veremos en las conclusiones del trabajo, la palabra zuncho se ha aplicado para designar desde elementos de simple reparto lineal de tensiones puntuales a lo largo de los muros de fábrica, hasta anillos perimetrales cerrados que tratan de confinar un conjunto de piezas estructurales para asegurar su estabilidad.

En el segundo apartado del marco histórico se realiza un compendio de alusiones a encadenados en muros de fábrica extraídas de Tratados de construcción, desde el siglo XVI hasta principios del XX. Esta parte del texto fue difundida en diciembre de 2012 en la publicación electrónica $\operatorname{ReCoPar}^{9}$ de la Universidad Politécnica de Madrid.

El análisis del marco conceptual que propició el uso de zunchos en restauración monumental se acomete desde varios frentes, que se desarrollan a su vez en apartados distintos. En primer lugar se revisa la evolución de los criterios de intervención sobre el Patrimonio a lo largo del tiempo. Dada la abundancia de documentación existente relativa a la Teoría de la Restauración monumental se evita

\footnotetext{
${ }^{9}$ Bellido Pla, R. (2012) El zuncho en la Tratadística. En revista electrónica Red Temática de Conservación, Restauración y Rehabilitación del Patrimonio Arquitectónico $n^{\circ}$ 9. Madrid: UPM.
} 
incluir la explicación de las distintas Cartas y Leyes que ocupa habitualmente gran parte del volumen de los trabajos de investigación relacionados con el tema, incluyéndose una reseña básica del tema.

Otro factor que determina los criterios de intervención es la formación de los arquitectos, en especial la falta de ella en historia de la construcción de algunos técnicos responsables de las intervenciones. Se señala cómo determinados cambios en los planes de estudios de la carrera de arquitectura causaron la incorporación a la profesión de varias generaciones de técnicos versados en hormigón armado y acero pero sin nociones básicas del comportamiento de un muro de fábrica o una cercha de madera. Como veremos, la falta tanto de material docente relativo a construcción histórica como de experiencia en edificación con materiales y sistemas tradicionales, convirtió una única publicación en el manual por excelencia para los restauradores de varias generaciones y determinó su forma de actuar ${ }^{10}$.

Un aspecto importante para establecer el marco teórico en que se desarrollaron estas intervenciones consiste en descubrir qué se estaba haciendo en esos momentos en otras regiones de España. Se han seleccionado como muestra datos de Badajoz y Galicia, zonas que cuentan con estudios muy recientes rigurosos y con menor difusión hasta este momento que los correspondientes a Cataluña o Madrid. Se incluye también un apartado sobre el zuncho en la restauración monumental portuguesa.

Durante la investigación se ha puesto de manifiesto la íntima relación entre el zunchado y la preocupación frente al comportamiento estructural en zonas de actividad sísmica. Se manifiesta cómo el origen del atado en la Antigüedad se produce en regiones secularmente enfrentadas a terremotos. El desarrollo de técnicas específicas de atado en muros de fábrica en Centroamérica e Italia se ha transmitido a la península en procesos de ida y vuelta. Además, aunque Valladolid queda fuera de los mapas de riesgo, las reiteradas alusiones al terremoto de Lisboa en muchos proyectos han obligado a obtener datos fiables sobre la incidencia del mismo, que se incorporan a los antecedentes. También se incluyen algunas referencias a las reparaciones mediante zunchado realizadas tras el reciente terremoto de Lorca en mayo de 2011, experiencias que están repercutiendo sobre los criterios con los cuales se están llevando a cabo las intervenciones actuales en el resto del país.

\footnotetext{
${ }^{10}$ López Collado, G. L. (1982). Ruinas en construcciones antiguas. Causas, consolidaciones y traslados. Madrid: Servicio de publicaciones MOPU.
} 
El apartado relativo al marco conceptual se cierra con una reflexión sobre las últimas tendencias en restauración monumental. A pesar de la amplia documentación en contra de la incorporación indiscriminada de zunchos de hormigón armado a los edificios del Patrimonio publicada a lo largo de las últimas décadas, éstos se siguen incluyendo en numerosas obras.

El capitulo de Antecedentes se cierra con la información específica sobre Valladolid, que se divide en tres grandes apartados: En primer lugar se incluye un epígrafe sobre el citado "foco clasicista"; a continuación se repasan las intervenciones realizadas en el siglo XIX, y por último se tratan las actuaciones del siglo XX. Estas últimas se enmarcan en el sistema de Zonas establecido desde 1929, sucesivamente reordenadas hasta su configuración definitiva de 1940 a 1958. Salvo escasas excepciones, fueron los dos arquitectos a cargo de Valladolid como centro de la Segunda zona quienes dirigieron las obras de restauración en este periodo, especialmente Luis Cervera Vera y Anselmo Arenillas.

\subsubsection{Análisis y discusión}

En el capítulo IV se lleva a cabo el análisis de los datos recopilados en las fichas. Se organizan y relacionan entre sí los diferentes aspectos de las mismas, tratando de establecer unos indicadores oportunos. Parámetros en cierto modo mensurables, como la justificación con que se incorpora a los proyectos de restauración, la definición aportada, si se han ejecutado realmente los zunchos, posición sobre el muro y otros aspectos que haya sido posible confirmar en la visita.

En primer lugar se analizan los proyectos revisados. Se revisa cómo se justifica y describe en las memorias y presupuestos el empleo del zuncho, y a continuación se trata la documentación gráfica de los proyectos, cómo aparece el zuncho reflejado en los planos.

En segundo lugar se aborda el análisis de los edificios, clasificando las iglesias según su geometría, materiales y uso. Los aspectos estructurales relacionados con la incorporación de zunchos se dividen en tres grandes apartados: las actuaciones sobre cimentación, los muros de fábrica y las estructuras de cubierta. Se revisa la documentación obtenida sobre los tejados y la relación de los elementos que lo forman con el zuncho. Se incluyen los datos sobre la cubierta original de los edificios. 
Dentro del análisis de los edificios se desarrolla un apartado sobre el zuncho donde se recogen las conclusiones previas del análisis llevado a cabo para elaborar las Fichas. Se describen las características de los zunchos observados en las visitas.

El análisis se cierra con la Discusión de los datos. Se plantean hipótesis sobre las fechas en que se incorporan los zunchos, su forma y el comportamiento de los mismos. A partir del análisis descriptivo y relacional y su discusión se trata de establecer unos resultados y se debate su idoneidad.

\section{I.6.4. Conclusiones}

En el último capítulo se exponen los resultados de la investigación desarrollada en los apartados anteriores que dan forma a las conclusiones.

\section{I.6.5. Bibliografía y lista de ilustraciones}

Para comodidad del lector se ha optado por incluir todas las referencias citadas en el texto como notas a pie de página. En la bibliografía final se recopilan todas las referencias anteriores por orden alfabético.

Se incluye también una lista de ilustraciones que recoge el pie de foto y la página en la que ésta se encuentra insertada. Se ha tratado de incluir preferentemente fotografías propias, que aparecen referenciadas como "visita" indicándose en cada caso la fecha de su obtención.

\section{I.6.6. Fichas}

En el segundo tomo se incluye la documentación más relevante de los monumentos analizados como Estudios de caso. En cada formato de Ficha resumen se incluye:

- Una imagen del alzado lateral a la cota del posible zuncho de atado sobre coronación de los muros y otra que representa el aspecto más característico de cada edificio.

- La descripción esencial del monumento, materiales que lo conforman y aspectos singulares del mismo. 
- Dimensiones grosso modo de ancho y altura de naves en metros, sólo con el objetivo de marcar el orden de magnitud ${ }^{11}$.

- Breve memoria histórica constructiva con una hipótesis de las etapas en que se va ejecutando cada edificio.

- Listado de intervenciones modernas, ordenadas cronológicamente, con una breve descripción de las actuaciones resumida a partir de la documentación completa aportada al final de la ficha.

- Planos: Se ha incorporado una selección de imágenes de planos obtenidas a partir de fuentes diversas, desde archivos hasta proyectos de restauración originales conservados en el Servicio de Restauración de la Junta de Castilla y León.

- Ilustraciones: Aunque se incluyen imágenes de libros, revistas y páginas web, en general las fotografías han sido obtenidas personalmente durante las visitas a los edificios. No se pretende elaborar un catálogo sino proporcionar información gráfica suficiente para comprender la geometría básica de cada templo.

- Solución constructiva de la cubierta: Se ha tratado de averiguar en lo posible, ya que en muchos casos no queda vestigio alguno de la misma, cómo era la solución constructiva original. Tras la visita a los monumentos se confirma también su estado actual.

- Zunchos: Se confirma en qué momento pudo producirse la incorporación de un zuncho al edificio, si se mantiene en la actualidad y, si ha podido verse, en qué condiciones se encuentra.

- Se incluye un análisis y reflexión básicos sobre los datos sobre el zuncho obtenidos en cada edificio, con hipótesis que avanzan los posibles resultados.

- A continuación de cada Ficha resumen aparece para cada edificio la transcripción de la información obtenida en los archivos, a partir de los proyectos de restauración conservados en los mismos. Se indica en cada caso el archivo en que se custodia, signatura de la caja y proyectos que ésta efectivamente contiene. En muchos casos se

\footnotetext{
${ }^{11}$ Debe tenerse en cuenta que se trata de edificios de grandes dimensiones que fueron concebidos con sus medidas no expresadas en metros sino en pies de Castilla, por ejemplo ancho de nave 50 pies.
} 
han localizado copias repetidas de un mismo proyecto en distintas cajas mientras para algunas de las intervenciones no ha sido posible localizar los datos previstos.

- Al final de cada estudio de caso se dispone el resumen de la visitas realizada al edificio, con una selección de imágenes representativas. En muchas ocasiones se tomaron estas fotografías en condiciones ambientales muy adversas, ya que se trata de recintos interiores de difícil acceso, sin iluminación, poco ventilados y con abundante polvo en suspensión y excrementos de palomas, lo que imposibilita obtener imágenes de buena calidad. En algunos casos no ha sido posible recorrer toda la superficie de los recintos bajo cubierta por no contar con un acceso practicable. 



\section{Metodología y fuentes de la investigación}

El diseño de la metodología se ha realizado a partir del planteamiento del problema concreto de investigación. Tras detectarse una generalización del empleo de zunchos de hormigón armado en las restauraciones monumentales de los últimos cincuenta años, se plantean diversas cuestiones sobre la incorporación de dichos zunchos a las que esta Tesis pretende responder. Para ello se considera necesario analizar un número representativo de edificios en los que en algún momento de la historia se ha considerado conveniente incorporar esta pieza. Para llevar a cabo la investigación se han seguido los pasos siguientes:

\section{Etapas del proceso}

1. Establecimiento de un protocolo.

Diseño metodológico del proceso de investigación.

Selección de los casos de estudio.

Elección de las fuentes documentales.

2. Recopilación documental general para establecer el estado del arte.

Fuentes documentales

Recorrido lingüístico

Recorrido constructivo

3. Desarrollo del estudio de los 40 casos.

Recopilación documental de fuentes indirectas: bibliografía.

Recopilación documental de fuentes directas: proyectos de ejecución.

Trabajo de campo: programación de visitas a los edificios y entrevistas.

Elaboración de fichas descriptivas.

4. Procesamiento de los datos.

Determinación de variables

Búsqueda de relaciones entre las variables: elaboración de tablas.

Análisis evolutivo, cualitativo, cuantitativo y relacional.

Discusión de resultados.

5. Resultado de la investigación

Extracción de conclusiones.

Búsqueda de implicaciones teóricas y prácticas.

Planteamiento de cuestiones abiertas.

Posibles recomendaciones. 


\section{II.1. Establecimiento de un protocolo}

\section{II.1.1. Diseño metodológico del proceso de investigación}

La investigación realizada es de tipo mixto, y combina métodos descriptivos y analíticos. En ella se integra el análisis cualitativo de los estudios de caso con el posterior análisis cuantitativo de las variables elegidas a partir del citado proceso. Para la obtención de los datos se ha combinado el estudio de las fuentes documentales con el trabajo de campo basado principalmente en visitar las iglesias y, en algunos casos, realizar entrevistas. Algunas etapas del proceso se han llevado a cabo de forma consecutiva, mientras que otras tareas se han acometido simultáneamente

Se ha considerado que la estrategia mixta adoptada para esta investigación conduce a unos resultados más amplios y profundos que los que podrían obtenerse con un enfoque sólo cualitativo o estrictamente cuantitativo. Se trata del llamado enfoque integrado multimodal, cada vez más valorado como valiosa herramienta para generar conocimiento ${ }^{1}$.

\section{II.1.2. Selección de los casos de estudio}

Según se ha explicado en la Introducción, se delimita inicialmente la muestra al conjunto formado por las iglesias en la provincia de Valladolid indexadas en el libro "Fuentes documentales para el estudio de la restauración de monumentos en España", requisito que asegura que se cumplen determinadas condiciones ${ }^{2}$. A medida que avanza la investigación se aplican criterios de selección y exclusión para acotar los casos de especial interés, como la falta de documentación sobre obras realizadas o la posibilidad de acceder a los edificios, que en algún caso incluso han sido objeto de demolición o ruina.

\footnotetext{
${ }^{1}$ Hernández Sampieri, et al. (2010) Metodología de la investigación. México: McGraw-Hill

${ }^{2}$ Las iglesias indexadas en la publicación del Ministerio son monumentos reconocidos a nivel nacional y cuentan con al menos una obra ejecutada y documentada en la segunda mitad del siglo XX.
} 


\section{II.1.3. Elección de las fuentes documentales}

Cualquier descripción nunca es fruto de una acción mecánica, ya que para realizarla habrá sido necesario seleccionar unos datos determinados entre un sinnúmero de factores susceptibles de registro. Cuanto más somera y condensada se persiga mayor proceso de reflexión puede llevar aparejado.

La fuente de información básica sobre los edificios más eficaz a la que se hace continuamente referencia en la documentación de las Fichas es la del propio Catálogo monumental de la provincia editado por la Diputación, tanto relacionada con los contenidos de la versión más actualizada en DVD como de los ejemplares originales en papel.

Se ha tratado de sistematizar la recopilación de datos de los inmuebles, aunque al tratarse de monumentos únicos cualquier actuación sobre los mismos siempre va a resultar singular. Se organizan los distintos procesos siguiendo un método y buscando generalizaciones de índole científica. Según se ha mencionado más arriba, se ha optado intencionadamente en el análisis de los templos por eludir apreciaciones estilísticas para centrar el enfoque lo más posible en los sistemas constructivos empleados, descartando cualquier aspecto de distribución espacial, ornamentación o referencia a modelos artísticos.

\section{II.2. Recopilación documental general para establecer el estado del arte.}

La investigación comenzó con una búsqueda general de documentos en los que apareciese mencionado el término zuncho a lo largo de la historia. Una vez comprobado que su empleo en construcción se generaliza sólo en España y en épocas no muy lejanas, se rastrean sistemas de atado estructural equivalentes al mismo con otras posibles denominaciones, entre ellas la más frecuente: encadenado. En los antecedentes se rastrean los primeros atados desde el ámbito de la arqueología. Posteriormente se recopila documentación sobre empleo de zunchos en restauración monumental, empezando por las prescripciones y recomendaciones recogidas en textos legales, el uso de zunchos en distintas regiones de España, Portugal e Italia. Se hace un recorrido por las tendencias actuales en estos países y los condicionantes que supone la acción del sismo en determinadas zonas. Se trata además la importancia de la formación de los técnicos implicados y los recursos con los que han contado para realizar sus intervenciones en el uso del zuncho. 


\section{II.2.1. Fuentes documentales}

El análisis general del Estado del Arte, se ha llevado a cabo a partir del estudio de las fuentes documentales académicas más habituales:

\section{II.2.1.1. Bibliografía especializada sobre el Patrimonio y su restauración.}

Durante los cuatro años de investigación se han consultado gran cantidad de documentos. En la bibliografía se incluyen sólo aquellos que aportan información específica relevante y que son citados a lo largo del texto.

\section{II.2.1.2. Tratados de construcción}

La base de datos más completa actualmente en España es la que proporciona el Instituto Juan de Herrera a través de las digitalizaciones de tratados de construcción de los siglos XVI al XX realizadas por SEDHC (la Sociedad Española de Historia de la Construcción) $)^{3}$.

Otra fuente de material de libre acceso y alta calidad es la base de datos de la Biblioteca Nacional de Francia ${ }^{4}$.

Aunque en el desarrollo de la tesis no aparecen referencias de tratados ingleses, debe puntualizarse que se ha revisado la valiosa documentación que aporta el libro editado en 2008 a partir de la tesis doctoral defendida en esta misma Escuela por Almudena Herrero Rey ${ }^{5}$, en el que se incluye una transcripción de textos de tratados ingleses junto a su traducción a nuestro idioma.

\section{II.2.1.3. Proyectos de investigación de otras universidades.}

En el apartado III.3 se resumen las aportaciones de la tesis doctoral de 2003 elaborada por Mariana Esponda en la UPC (Universidad Politécnica de Catalunya), que analiza el uso de hormigón en restauraciones de España, Italia y Méjico.

\footnotetext{
${ }^{3}$ http://www.sedhc.es/biblioteca/tratados.php

${ }^{4}$ http://gallica.bnf.fr

${ }^{5}$ Herrero Rey, A. (2008). Tratados ingleses de arquitectura: 1563-1663. Valladolid: Universidad de Valladolid.
} 
Otras obras relacionadas con el enfoque del problema de la restauración monumental en España a lo largo del siglo XX son las editadas a partir de los proyectos de investigación coordinados por Pilar García Cuetos desde la Universidad de Oviedo, sobre los que se trata en el apartado III.4 sobre Valladolid.

\section{II.2.2. Recorrido lingüístico.}

La primera tarea ha sido terminológica, con la búsqueda del origen y primeros usos conocidos del vocablo zuncho y sus palabras asociadas: zunchado, cincho, suncho, cadena, encadenado, atado estructural.

\section{II.2.3. Recorrido constructivo.}

El siguiente paso ha sido la localización de documentación general referida al encadenado de muros de fábrica a lo largo de la Historia. Se incluyen los datos recogidos en Tratados históricos y Manuales de construcción, y a continuación en bibliografía técnica especializada: libros, actas de congresos, tesis y revistas.

\section{II.3. Desarrollo del estudio de los 40 casos}

Los edificios seleccionados se han estudiado a través de fuentes documentales tanto directas como indirectas. Una vez obtenida y organizada toda la información disponible sobre los mismos en relación con las obras de restauración llevadas a cabo en las que es posible que se haya ejecutado zunchos sobre la coronación de los muros, se han realizado las visitas. Al acceder a las iglesias se ha tratado principalmente de comprobar la veracidad de la documentación estudiada y su correspondencia con el estado real de la construcción.

\section{II.3.1. Recopilación documental de fuentes indirectas: bibliografía.}

Tras las obras sobre teoría de la restauración analizadas para desarrollar el estado del arte, en la fase de trabajo centrada en los estudios de caso se ha consultado catálogos y publicaciones centradas específicamente en los edificios del Patrimonio histórico de Castilla y León. Hay algunos estudios con información valiosa editados tanto por el Ayuntamiento como por la Diputación de Valladolid, sobre todo relativos a inmuebles catalogados como BIC, aunque gran parte de los datos que contienen son referencias de tipo histórico artístico. 


\section{Catálogo Monumental}

La obra de referencia citada constantemente en las Fichas de las iglesias estudiadas es el Catálogo monumental y artístico de la nación (1900-1961), ordenado por Real Decreto en 1900. Se trabajó en la catalogación de bienes de cuarenta y siete provincias, concluyéndose treinta y nueve de los que sólo fueron publicados diecisiete. Según se ha descrito en una anterior anotación al pie, digitalizado en la web del CSIC (Centro Superior de Investigaciones Científicas), organismo encargado de la investigación en España, podemos encontrar una copia del tomo de Valladolid inédito redactado por Francisco Antón Casaseca en 1916.

El primer tomo de la provincia, correspondiente a la localidad vallisoletana de Medina de Rioseco, fue publicado en 1956 por Esteban García Chico, que también editó el último de esa etapa, relativo a Nava del Rey, en 1972. La continuación corrió a cargo de Juan José Martín González, profesor de Historia del Arte en la Universidad de Valladolid, que redefine los contenidos y publica otros nueve ejemplares, entre ellos el de Monumentos religiosos de la ciudad. Jesús Urrea se ocupa de la gestión de los últimos cuatro volúmenes y del DVD, editado en 2006 por la Diputación de Valladolid, que contiene los quince volúmenes del VI al XX.

Para la revisión de las últimas tendencias en restauración monumental se recurre principalmente a revistas y Actas de congresos y jornadas.

\section{II.3.2. Recopilación documental de fuentes directas: proyectos de ejecución.}

Probablemente el soporte clave de esta investigación es el manejo de las copias de los proyectos de restauración conservadas en los distintos archivos, encontrándose información significativa principalmente en los siguientes:

\section{IPCE}

En el Instituto del Patrimonio Cultural de España, con sede en la Ciudad Universitaria de Madrid, se integraron diversos organismos ministeriales como ICROA, CECOMI, Subdirecciones Generales de Monumentos y Arqueología. Su cometido es investigar, conservar y restaurar los bienes que forman el Patrimonio Cultural de nuestro país. Se han consultado algunos ejemplares de proyectos, generalmente con firmas originales, que se conservan en el Instituto y por algún motivo no han sido traspasados al AGA (Archivo General de la Administración ubicado en Alcalá de Henares). 
También se han descargado todos los planos relativos a los templos seleccionados disponibles en la base de datos digitalizada denominada Planoteca. Muchos de estos planos se han empleado para ilustrar las Fichas resumen incluidas en el segundo tomo de la Tesis.

\section{AGA}

El Archivo General de la Administración se encuentra en Alcalá de Henares, en la provincia de Madrid, y alberga documentación procedente en su mayor parte de organismos públicos.

Se han revisado los proyectos relativos a las iglesias seleccionadas, en muchos casos duplicados, y la documentación administrativa de los mismos contenida en las cajas: certificaciones, contratos, ofertas, etc. En algunos casos se ha obtenido copia de determinados planos y fotografías.

\section{AMVA}

El Archivo Municipal de Valladolid conserva la documentación producida desde la Edad Media por los órganos de gobierno de la ciudad.

Las Licencias de obras mayores y menores que se custodian en el Archivo Municipal incorporan en algunos casos documentación de los proyectos. Se trata siempre de obras ubicadas en la propia ciudad.

La fototeca accesible digitalmente ofrece además imágenes de otras localidades y ha resultado de gran utilidad.

\section{JCYL}

Servicio de Restauración y Archivo Central de la Consejería de Cultura y Turismo de la Junta de Castilla y León, en Valladolid: Se conserva documentación administrativa y proyectos de intervención desde la transferencia. Ha sido la principal fuente de material para la investigación.

Se ha accedido también a otras instituciones pero sólo de forma puntual, ya que ofrecían otro tipo de documentación de menor relevancia para este estudio:

\section{BNE}

Se ha comprobado en las fichas de sala que no hay documentación de interés sobre iglesias de Valladolid que no esté referenciada en la base de datos de acceso online 
de la Biblioteca Nacional de España. Se han revisado las fotografías correspondientes a la provincia en la Biblioteca Digital Hispánica.

\section{AHPVA}

En el Archivo Histórico Provincial se han consultado, por ejemplo, algunas actas manuscritas de la Comisión de Monumentos.

\section{COAM}

En el Servicio Histórico del COAM hay sólo algunas postales sobre Valladolid, y el repertorio de imágenes de García Mercadal, que incluye unas quince fotografías relacionadas de las que se han adquirido copias proporcionadas con muy baja calidad.

\section{Archivos de arquitectos y empresas constructoras}

Se ha revisado la base de datos DOCURECOPARESPA por si contaba con alguna información de interés. Se trata de un inventario del fondo documental de la asociación de empresas constructoras especializadas en restauración monumental ARESPA y la red temática RECOPAR.

A raíz de la crisis económica de los últimos años, que ha azotado especialmente al sector de la construcción, algunas de estas empresas han desaparecido, por ejemplo CYM YAÑEZ, citada repetidamente en la documentación de varios de los templos estudiados. Esto ha supuesto una penosa pérdida del material que constituyeron sus copias de los proyectos, planos de obra, mediciones reales, etc.

\section{II.3.3. Trabajo de campo}

La labor de campo ha consistido en visitas a los monumentos. En algunos casos se ha considerado necesario entrevistar a los técnicos autores de los proyectos.

\section{Limitaciones de las visitas a los edificios.}

La tarea de concertar las visitas a algunas de las iglesias ha resultado muy laboriosa, aunque en otros se ha contado con la colaboración de los religiosos y personas a cargo de los edificios implicadas. En varios casos ha sido imposible obtener el permiso para acceder al trasdós de las bóvedas por considerar los responsables que se trataba de una actividad improcedente o peligrosa. 
La visita al espacio bajocubierta de una iglesia, en sí misma, puede presentar múltiples dificultades. En primer lugar se precisa penetrar en zonas poco ventiladas y de acceso difícil, en algunos casos ni siquiera posible en condiciones de seguridad sin disponer de medios auxiliares, como arneses o andamios. Algunas escaleras muestran deterioros importantes, incluso falta de peldaños. En algunos casos ni siquiera se cuenta con huecos practicables y, si los hay, son en muchos casos de pequeñas dimensiones y con frecuencia cuentan con abundantes desperdicios de palomas.

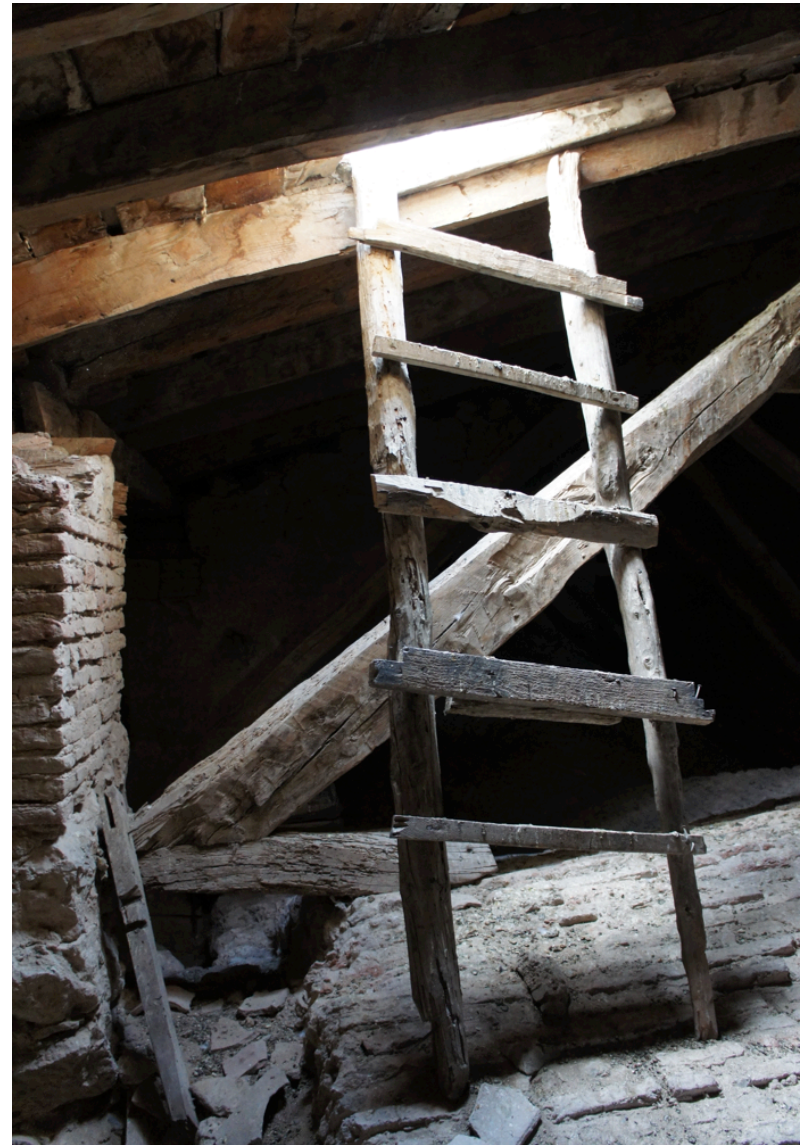

Fig.II.1. Escalera de mano en el espacio bajo cubierta de la iglesia de Peñafiel (visita 20/08/2015)

El espacio bajo cubierta empieza a contar con iluminación sólo en contadas ocasiones y tras intervenciones muy recientes, en las que suelen dejarse además tablones para facilitar el tránsito sobre las bóvedas o en algunos casos pasarelas.

El polvo en suspensión y la falta de luz dificultan además la obtención de fotografías de mínima calidad, según es posible apreciar en las ilustraciones.

Se trata de un tipo de inspección únicamente ocular. Se recorren las zonas a las que se puede acceder en un determinado momento para tratar de comprobar in situ qué solución constructiva conforma actualmente la cubierta, si coincide con alguna de las definidas en la documentación, si cuenta con zunchos y cómo se conforman.

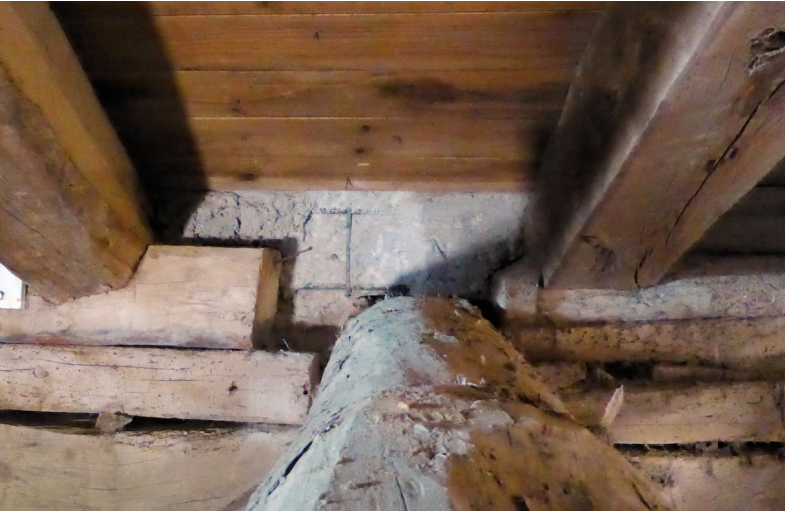

Fig.Il.2. Imagen de cata para comprobar la existencia de zuncho de hormigón tras el durmiente de madera en San Francisco, cortesía de A. Basterra 2015. 
Casi en ningún caso es posible efectuar mediciones, ni siquiera canto o ancho de estos elementos que, con frecuencia, se encuentran alejados, a considerable altura, semi-embebidos en los muros o incluso con sus remates completamente ocultos tras tabicas de fábrica, piedra o madera.

En este tipo de estudios es muy importante poder visitar los edificios, ya que los detalles representados en planos con frecuencia no concuerdan con la solución realmente ejecutada. En los archivos se custodian proyectos cuya consulta puede llevar a conclusiones erróneas, como los de Ana Iglesias en Castronuño y Santa Cruz cuyos planos son de libre acceso en la Planoteca del IPCE.

\section{Entrevistas}

Las conversaciones con los acompañantes, guías y feligreses de cierta edad presentes en los templos, han sido factores no previstos en la planificación inicial de los trabajos que han resultado de considerable interés. Algunos de ellos narran las impresiones que les produjeron las obras de mediados del XX, incluso confirmando si se efectuaron de una o otra manera, izando elementos con una gran grúa, o sin ejecutar una parte de lo previsto. Otros han podido describir incluso cómo era el estado del inmueble antes de las mismas, por ejemplo la subida a cubierta de Castronuño por el exterior que coincide con una imagen localizada en la obra inédita de Casaseca de $1916^{6}$.

Se ha localizado a algunos de los técnicos autores de las intervenciones para comentar con ellos las razones que les llevaron a incorporar estos zunchos y las condiciones en que se desarrollaron sus obras de restauración, resultando especialmente valiosa las aportaciones de Ana Iglesias.

\section{II.3.4. Elaboración de fichas descriptivas}

La información obtenida sobre cada una de las iglesias estudiadas se ha resumido en una ficha con un formato fijo. Se incluyen imágenes y planos generales, una breve memoria histórica constructiva, la lista de intervenciones realizadas en el siglo XX. En un apartado específico se describe la solución constructiva de la cubierta y

\footnotetext{
${ }^{6}$ La consulta del manuscrito inédito de Casaseca digitalizado está disponible en la página web: http://biblioteca.cchs.csic.es/digitalizacion_tnt/index_interior_valladolid.html
} 
finalmente se recogen los datos relativos a zunchos. Cada ficha lleva un avance de conclusiones parciales. A continuación se presentan textos extraídos de las memorias y presupuestos de los proyectos de restauración, con fecha, autor y signatura del archivo en el que han sido localizados. Por último se ha descrito brevemente la visita a determinados edificios, el estado en que se encuentran en ese momento, y si se ha podido acceder a un espacio bajo cubierta y comprobar la existencia de zunchos.

\section{II.4. Procesamiento de los datos}

Un parámetro clave para la organización de los datos obtenidos es sin duda la fecha de incorporación del zuncho. En muchos de los casos analizados se trata de un dato casi imposible de confirmar. En primer lugar los proyectos se contratan en una fecha, se elaboran los planos y redactan presupuesto y memorias en los que aparecerá otra fecha. Se adjudica la obra, a veces pasados varios años, y se ejecuta el zuncho, casi siempre además con ubicación y dimensiones diferentes a las previstas en el proyecto.

Las obras de restauración monumental son especialmente complejas y delicadas. En muchos casos no es posible realizar catas o siquiera acceder a los espacios bajo cubierta, que carecen de huecos de paso, lo que obliga a emprender las tareas sin conocer el estado real de la construcción. Con frecuencia el descubrimiento de las condiciones reales lleva a sobrecostes y reelaboración de los proyectos mediante documentos una vez más con fechas distintas: reformado, modificado, nuevo proyecto.

En varios de los casos analizados también se interrumpen las obras de forma tanto involuntaria, por problemas administrativos o malas condiciones atmosféricas, como voluntaria. Hay obras en las que el contratista abandona y debe proseguirse con un constructor diferente. En algunos casos también hemos visto cómo se cambia de arquitecto en pleno proceso.

Por fin se recibe la obra provisionalmente $y$, pasado el tiempo, de forma definitiva. En los últimos años se intenta desde la administración que los técnicos documenten lo realmente ejecutado mediante la redacción de una Memoria final, con planos y fotografías.

En la base de datos ANDREA con la que se gestionan las consultas de sala del Archivo General de la Administración, por ejemplo, aparece una fecha distinta a la 
contenida en memoria y planos de los proyectos que referencia. Según se ha comentado en la introducción, además, las restauraciones de los años 60 y 70 se programaban con anualidades, lo que llevó a fragmentar los proyectos en varias versiones de años sucesivos. También con el traspaso de competencias a las administraciones autonómicas se produjeron interrupciones y cambios de todo tipo.

\section{Determinación de variables}

En primer lugar se revisa la documentación de los proyectos de restauración, que se ha organizado en dos partes, por un lado memorias y presupuestos, por otro fotografías y planos. En el primer bloque se rastrean palabras clave asociadas a determinados conceptos: necesidad de la intervención, justificación del uso de zunchos y definición de características de los mismos. En el segundo apartado se analiza cómo se representan los zunchos en los planos.

En segundo lugar se acomete el análisis de los datos recopilados sobre los edificios, que se describen a partir de una clasificación a través de parámetros básicos de tipo geométrico, de estado y utilización. A continuación se consideran datos relativos a aspectos estructurales. En tercer lugar se analizan los elementos de cubierta y, por último, los zunchos observados en las visitas. Se determinan las variables que definen estos zunchos, aunque en la visita es muy difícil llegar a concretar los datos sin contar con medios auxiliares ${ }^{7}$ : material, dimensiones, ubicación, desarrollo lineal o en anillo cerrado, etc.

\section{Búsqueda de relaciones entre las variables: elaboración de tablas.}

Se ha elaborado una gran tabla de trabajo con todos los datos de las variables elegidas, a partir de la cual se van extractando los distintos cuadros.

\section{Análisis evolutivo, cualitativo, cuantitativo y relacional.}

El estudio de las variables se acomete desde varios focos. Una vez ordenados los parámetros se analizan las relaciones entre ellos, se valoran las coincidencias y los cambios de criterio que se van produciendo a través de los años. También se señalan los factores singulares.

\footnotetext{
${ }^{7}$ Incluso durante la realización de las obras con frecuencia no llegan a determinarse con precisión los sistemas constructivos de estos edificios, con áreas sin acceso y cambios imposibles de detectar aunque se realicen catas puntuales.
} 


\section{Discusión de resultados.}

Una vez revisadas las variables y las relaciones entre ellas se plantea cuáles son las cuestiones más relevantes de la incorporación de zunchos en la restauración monumental.

\section{II.5. Resultado de la investigación}

Tras la obtención de datos, su análisis y la discusión de los resultados del proceso investigador, se ofrecen respuestas a las preguntas planteadas.

Se buscarán las posibles implicaciones teóricas y prácticas de las conclusiones obtenidas, proponiendo recomendaciones de cara al futuro.

Por último se plantearán cuestiones abiertas y nuevas líneas de investigación. 
Tabla resumen etapas del proceso

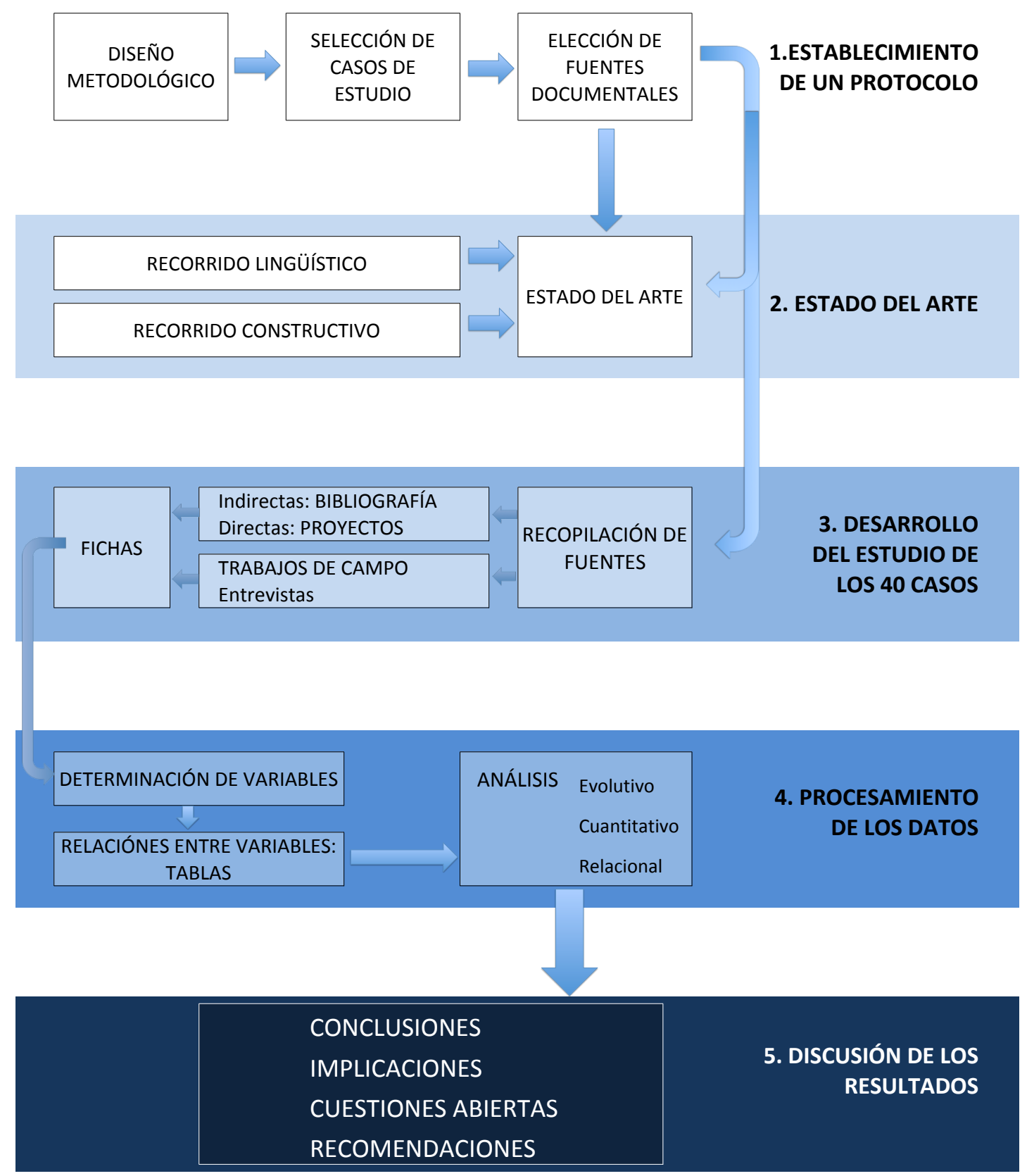




\section{Antecedentes}

Para establecer los antecedentes o estado del arte del tema elegido se organiza el estudio en tres frentes. En primer lugar se rastrea el uso del término zuncho y las expresiones equivalentes que podemos encontrar en el ámbito de la construcción. A continuación se concreta el marco histórico del atado estructural, con los primeros encadenados de la historia y cómo se trata el tema en los Tratados de construcción históricos. En tercer lugar se aborda el análisis de los distintos factores que conforman el marco conceptual del uso de zunchos en restauración monumental: los criterios, la formación y medios de los arquitectos, las cuestiones específicas relativas al comportamiento frente al sismo, el cinchado de cúpulas y las últimas tendencias que pueden observarse en las actuaciones de restauración del Patrimonio edificado. Por último se incluye un apartado que profundiza en los aspectos distintivos de Valladolid, la relevancia de sus edificios históricos y las particularidades de las intervenciones de los siglos XIX y XX en la provincia.

\section{III.1. Terminología: elemento de atado, encadenado, zuncho}

Desde los albores de la arquitectura se ha considerado oportuno dotar a los muros de fábrica de complementos que mejorasen su comportamiento estructural. La versión más simple de la búsqueda de cohesión longitudinal que podemos encontrar en las fábricas es el simple incremento de espesor de una o varias de las hiladas de piedra o ladrillo con el mismo material, formando una especie de faja o resalto a la altura de los forjados y en el borde superior. También se recurre tempranamente en la Historia de la arquitectura al cosido de sillares entre sí mediante grapas o lañas. Otra manera de reforzar los muros de fábrica más avanzada consistía en incorporar durmientes de madera adosados a los muros, o bien embebidos en éstos. La evolución de estas piezas lineales condujo más adelante al empleo de ganchos de hierro, enlazados a modo de eslabones de una cadena. Esta palabra, cadena, con su derivada encadenado, se convierten en la denominación más habitual, y prácticamente la única durante siglos, de un sistema de atado estructural.

La colocación de zunchos ha sido prácticamente omnipresente en las construcciones de la segunda mitad del siglo XX, tanto para obra nueva como en rehabilitación. El término se encuentra también ampliamente difundido en los países de habla hispana pero con acepciones muy distintas en cada región. Ni siquiera en 
los diccionarios María Moliner o RAE (de la Real Academia Española) se incluye una definición acorde con el concepto al que se aplica en España de forma habitual, según puntualiza el profesor Ignacio Paricio en su glosario de la construcción ${ }^{1}$ :

"A partir de los años treinta se empieza a usar en las estructuras de hormigón una voz de larga tradición en la construcción de cúpulas: el zuncho. Su objetivo es abrazar a un elemento constructivo para evitar que éste se abra. Se usa en muchos casos, y por eso la definición de María Moliner es tan genérica: «abrazadera de hierro o de cualquier otro material resistente con que se refuerza alguna cosa, por ejemplo un cañón, o se sujeta fuertemente algo, como los palos del barco o las duelas de los toneles». En las cúpulas clásicas los problemas eran de una escala tan grande que se resolvían con cadenas de hierro, y eso nos explica la voz encadenado que todavía se usa. Hoy, en la construcción de estructuras de hormigón, se debe entender como el elemento continuo y armado que recorre el perímetro del forjado para atar sus componentes y mejorar su capacidad para transmitir esfuerzos horizontales, significado que, sin embargo, no aparece en ningún diccionario".

Desde mediados del siglo XX se ha generalizado especialmente la incorporación de estos elementos de atado estructural, que en el argot básico de la construcción actual en España denominamos zunchos, en las intervenciones sobre edificios del Patrimonio. El término se aplica para designar piezas tan dispares como, por ejemplo, carreras adosadas o embebidas en los muros, conexiones dispuestas con el fin de enlazar otros elementos constructivos, refuerzos en bordes de forjado o conjuntos que conforman un anillo perimetral. En América latina, sin embargo, se emplean con estas acepciones los vocablos cadena y dala, este último sinónimo de viga no refrendado en el diccionario RAE ni en el amplio glosario de términos de construcción publicado en 2001 a partir de la base de datos BANTE $^{2}$ de la Universidad de Valladolid. Sólo en Argentina se utiliza habitualmente en el ámbito de la construcción la palabra zuncho, que aparece incluso recogida en su normativa del hormigón armado, pero únicamente para designar el "estribo helicoidal de armado de una columna", significado recogido también en el Léxico del Instituto Torroja $^{3}$, tanto en la versión de 1962 como en su reedición posterior.

\footnotetext{
${ }^{1}$ Paricio, I. (1999). Vocabulario de arquitectura y construcción. Barcelona: Bisagra.

${ }^{2}$ Camino Olea, M. S. (2001). Diccionario de arquitectura y construcción. Madrid: Munilla-Lería.

${ }^{3}$ Antuña, J. (2009). Léxico de la construcción. Madrid: IETCC (CSIC) e Instituto Juan de Herrera.
} 
En varios países de América latina el término zuncho se emplea habitualmente para designar lo flejes de embalaje. En Palomino, un pueblo de Colombia, se ha desarrollado un proyecto para fabricar un material tejido con zuncho trenzado de colores con el que producir diversos objetos que ya ha sido adoptado por algunos arquitectos españoles para realizar muebles, cuyo sistema podemos consultar en la página www.mecedorama.com.

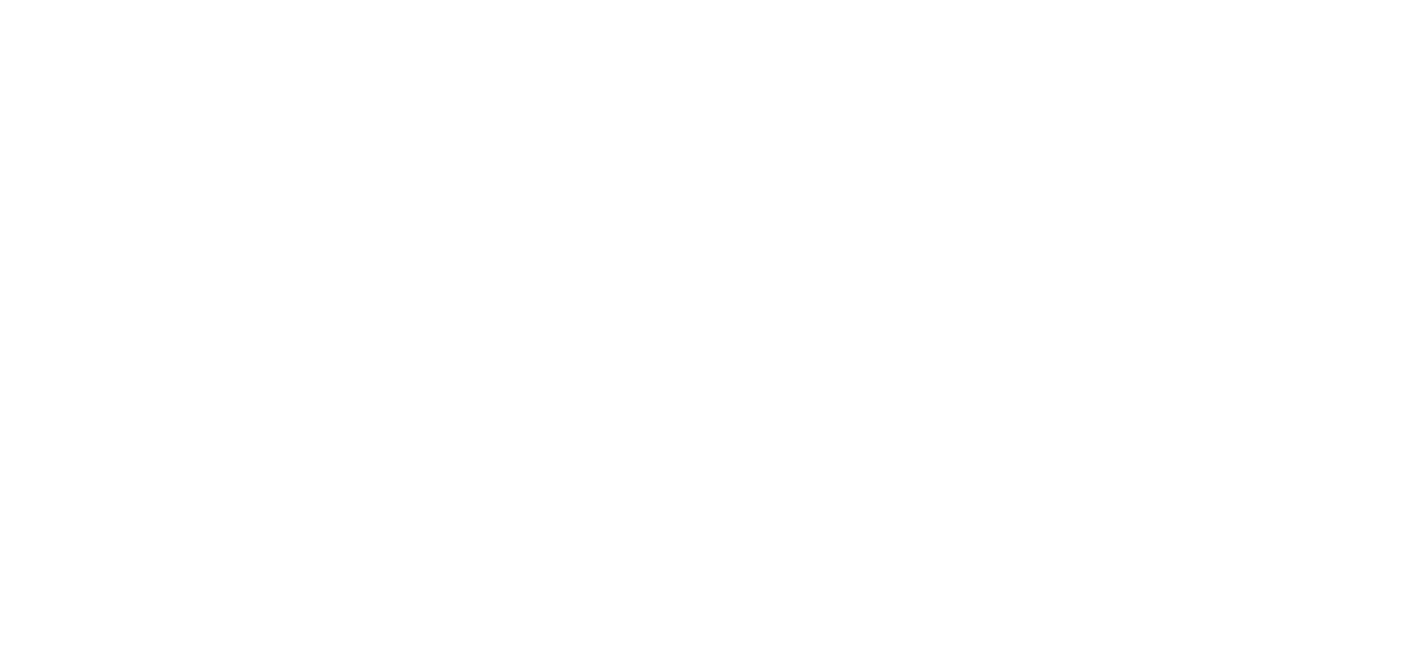

Fig.III.1: Elaboración de zuncho

http://palominocultural.files.wordpress.com/2011/05/zuncho.pdf (25/11/2014)

En diversos diccionarios aparecen definiciones de zuncho como refuerzo destinado a asegurar cañones, ruedas, barriles o edificios, casi todas ellas coincidentes en su consideración de pieza metálica, pero ninguna en concordancia con el uso mayoritariamente extendido. En muchos casos se destaca también como su función primordial juntar y atar elementos constructivos en edificios en ruinas.

No encontramos reproducido el vocablo zuncho en los Tratados de Arquitectura y Construcción hasta 1876. Los distintos refuerzos de atado descritos en estos documentos se resuelven en la mayor parte de los casos con piezas metálicas y con menos frecuencia en madera. Aparecen habitualmente bajo la denominación encadenado, que se mantiene en uso a lo largo del tiempo.

El Glosario de Arquitectura y de sus artes auxiliares de Mariátegui ${ }^{4}$ es un diccionario de términos de edificación en el cual se reproducen citas de documentos que contienen cada palabra para ejemplificar su contexto. Así define los siguientes vocablos relacionados con el atado estructural: Trabe como madero del suelo, lo

\footnotetext{
${ }^{4}$ Mariátegui, E. (1876). Glosario de algunos antiguos vocablos de Arquitectura y de sus artes auxiliares. Madrid: Imprenta de Memorial de Ingenieros.
} 
mismo que viga solera, del latín trabs, la viga; Cincho como faja o plinto que señala al exterior la altura de pisos de un edificio, o sinónimo de zemime, la llanta de hierro que afianza varias piezas de madera, con el origen árabe zamma (ligar, atar, sujetar); Asa, gafas o grapas para unir piedras de una hilada.

En este diccionario se incluye por fin el vocablo zuncho, aunque sin proporcionar una definición válida, ya que únicamente se puntualiza que es igual a suncho, otra palabra que ni siquiera figura en el mismo glosario. Nos proporciona, eso sí, una pista muy útil al remarcar que la voz la emplea ya en el siglo XVII Eugenio de Salazar $^{5}$ en sus Cartas.

Si revisamos la edición de 1866 del libro citado, en la misiva que Salazar dirige al Licenciado Miranda de Ron aparece sin contexto la expresión meté bien el zuncho, dentro de una lista de recopilación de ejemplos de "lenguaje marino". En el glosario incluido en esta edición se recoge el término zuncho sin aclarar tampoco su definición, indicando sólo que se trata de una "voz náutica de origen desconocido".

Según el lingüista José Manuel Briceño ${ }^{6}$, el uso de marinerismos (términos de marinería con significación ya no marinera, adaptados a objetos y actividades terrestres) fue muy difundido en América en esa época. La palabra zuncho empleada a bordo para referirse a los aros de hierro que reforzaban la unión de los palos del barco pudo dar nombre a nuevas formas mediante asociación de ideas. Tanto zuncho como suncho se incluyen habitualmente en los manuales náuticos y diccionarios marítimos clásicos españoles. Por ejemplo en la traducción de Vallarino ${ }^{7}$ de una obra en inglés de Darcy Lever editada en 1842 se repite más de veinte veces la palabra zuncho.

Parece claro que podríamos considerar todo el ámbito de la construcción arquitectónica independiente del naval, como en el caso de las bóvedas encamonadas, tan similares formalmente a las cuadernas de los barcos, pero resueltas siempre por diferentes gremios de carpinteros cuyo entorno laboral se protegía del

\footnotetext{
${ }^{5}$ Salazar, E. de. (1866). Cartas de Eugenio de Salazar, vecino y natural de Madrid, escritas a muy particulares amigos suyos; publicadas por la Sociedad de Bibliófilos españoles. Madrid: Imprenta y estereotipia de M. Rivadeneyra.

${ }^{6}$ Briceño, J. M. (1966). América latina en el mundo. Caracas, Venezuela: Arte.

${ }^{7}$ Vallarino, B. (1842). Arte de aparejar y maniobras de los buques. Madrid: Imprenta de José Félix Palacios.
} 
intrusismo con Ordenanzas específicas, según describe P. Hurtado-Valdez en su ponencia del Congreso CIMAD11. Desde el punto de vista lingüístico sin embargo, el origen del uso del término zuncho en construcción sí parece haber sido confirmado por los especialistas como una transmisión de la marinería al pasaje durante los viajes a ultramar.

En un artículo de la Revista de Filología Hispánica VI de 1944, el profesor Corominas $^{9}$ exponía que en ese momento la palabra zuncho sólo se aplicaba en España de forma general en Galicia, Asturias y oeste de Santander, encontrándose más difundida en América, con acepciones diversas según el país. En cuanto al origen etimológico, cita la opinión expuesta ya en 1925 por García de Diego en la Revista de Filología Española XII, quien la considera duplicado de cincho, a partir de la evolución de cingulum. Este último también considera posible un parentesco con la palabra que designa fleje en lengua euskera, zumitz.

En las hemerotecas sin embargo podemos localizar fácilmente artículos que emplean el término zuncho con naturalidad sobre todo en el primer tercio del siglo XX: en 1930 ABC para describir el cilicio metálico de la momia de Serapión o en una descripción poética como metáfora de los ríos que rodean una montaña.

Según una ponencia ${ }^{10}$ presentada en el III Congreso Nacional de Historia de la Construcción desarrollado en Sevilla, en el BOPI (Boletín oficial de la propiedad industrial) en los primeros años del siglo $\mathrm{XX}$ se registraron tres patentes que contenían el término "zunchado":

- 1903 Sociedad anónima de aplicaciones de ingeniería.

Sistema de cemento armado zunchado. Madrid. 30901

- 1905 Paul Habay.

Una traviesa de hormigón de cemento zunchado. Madrid. 36498

- 1911 Carmelo Castrillo y Olavarría.

Una aplicación de la armadura de vigas y pilares de hormigón zunchado en la construcción de postes de cemento armado. Madrid. 51837

\footnotetext{
${ }^{8}$ Hurtado-Valdez, P. (2011). Bóvedas de madera y construcción naval: Mitos y verdades de la construcción de bóvedas de madera castellanas entre los siglos XVII y XVIII. $1^{\circ}$ Congreso IberoLatino-Americano da Madeira na Construçao. Coimbra.

${ }^{9}$ Corominas, J. (1944). Indianoromanica. Revista de Filología Hispánica, 6, 156-157.

${ }^{10}$ Martín Nieva, H. (2000). La introducción del hormigón armado en España: las primeras patentes registradas en este país. En Actas del III CNHC. Sevilla.
} 
La primera patente está fechada en 1884 y se contabilizaron 159 hasta 1914, cuando se interrumpe el registro con el estallido de la Primera Guerra Mundial.

Aunque la palabra zuncho y sus derivadas se encuentran ampliamente difundidas hoy en España, especialmente en temas de restauración y refuerzo de edificaciones, su uso en la historia se restringió a ambientes náuticos y atados metálicos hasta mediados del siglo XX, empleándose tradicionalmente en construcción para designar este concepto, según se ha referido en párrafos anteriores, el término encadenado. Si bien es probable que desde el punto de vista lingüístico la voz zuncho y su derivada zunchado se transmitiesen como marinerismos en los viajes a ultramar, ya en el siglo XVI, debemos puntualizar que las soluciones empleadas entonces en edificación no están relacionadas del mismo modo con las empleadas en la construcción naval.

$\mathrm{Si}$ observamos las últimas tendencias en España en intervención sobre el Patrimonio, los zunchados se están resolviendo mediante bandas de acero y plástico. Esta nueva acepción recupera el sentido original de fleje o banda y concuerda con el uso del término en otros países que comparten el idioma, ya que en América latina se emplea el término zuncho casi exclusivamente en el ámbito de la industria. La voz zuncho designa el fleje metálico o de poliéster (en principio el nylon resulta demasiado caro y el polipropileno soporta esfuerzos menores) con el que se realizan los embalajes.

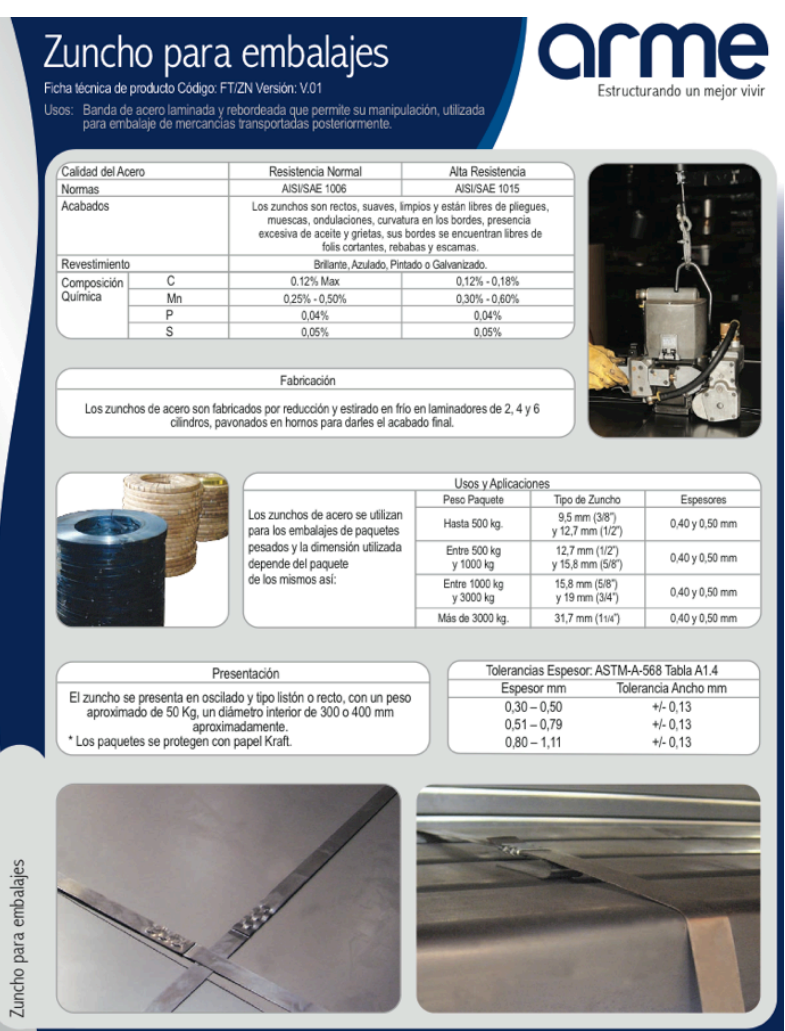

Fig.III.2: Folleto comercial zuncho embalajes "arme" http://www.arme.com.co/pdf/Zunchos_FichaTecnica.pdf

En resumen, en Argentina sí usan el término zuncho habitualmente (viene recogido incluso en su norma vigente del hormigón) pero refiriéndose al estribo helicoide de las columnas de hormigón armado. 
En el resto de América Latina no se emplea el término zuncho para las piezas de hormigón armado de sección rectangular dispuestas como atado o elemento de borde, sino cadenas de concreto o dalas. A las vigas las denominan trabes.

En el ámbito naval se emplea zuncho como sinónimo de brida en mástiles. También es una pieza habitual en armamento, tanto cañones como pistolas. Aparece alguna vez como llave especial para desenroscar el filtro del aceite en motos. En automóviles el zuncho refiere a una tira plana bajo la banda de rodadura.

Lo más habitual en la industria es emplearlo para embalajes, tratándose de una tira de material plástico o metálico que se coloca con un aparato de enzunchado.

Como curiosidad, en Vivero (Galicia) llaman zunchos a las castañas cocidas con cáscara y en Canarias se denomina así un sillín colgante para recolectar liquen.

En el epígrafe 59.2.1 de la Instrucción del Hormigón Estructural EHE-08 que recoge las condiciones geométricas de los forjados, y antes en la norma básica del ladrillo MV-201, denomina cadena de atado al elemento de borde de forjado sobre un muro sin emplear el término zuncho.

\section{Equivalencias}

En los textos clásicos en francés encontramos dos definiciones específicas. Por un lado para nombrar el método de encadenado se emplea la voz chaînage: Pour relier entre elles des portions de murs ou de constructions ayant tendance à s'écarter, on utilise le procédé du chaînage qui consiste à relier les parties divergentes au moyen de longrines en bois ou de fers à crampons noyés dans l'épaisseur du mur. (Para interconectar tramos de muros o construcciones con tendencia a abrirse, se emplea el método de encadenado que consiste en conectar por medio de zunchos de madera o metal embebidos en el espesor del muro). Y para designar un durmiente, riostra o solera de madera se emplea longrine: Pièce de charpente longue et continue posée horizontalement sur le haut d'un mur qui sert de base à un comble. (Pieza de la estructura de madera larga y continua colocada horizontalmente en la coronación de un muro que sirve de base a la cubierta), y longrine noyée para la pieza embebida.

Si el cincho es metálico podemos encontrar collier, y para la pieza de hormigón armado sobre muro de fábrica emplearíamos la expresión sommier en béton armé sur un mur en maçonnerie. 
En italiano, según se avanza en el epígrafe I.2 de la Introducción, se aplican expresiones distintas según el material, así podemos encontrar mencionado un zuncho de hormigón como cordolo in cemento armato, el durmiente de madera como catene in legno y los cinchados con acero cerchiature di ferro.

En inglés podríamos traducir directamente encadenado por chain bonding, y emplear una expresión equivalente a zuncho como viga de atado: tie beam. El zuncho en su acepción de banda para empaquetado equivaldría al término strap y las connotaciones de anillo perimetral nos llevan a ring anchor o ring beam.

En portugués a un zuncho de hormigón lo denominarían lintel de betão ${ }^{11}$. Como veremos más adelante, en los textos analizados en III.3.6, sin embargo, aparece con la misma frecuencia en las descripciones de obras de restauración monumental la expresión frechais de betão armado y, sobre todo, la palabra cinta.

\footnotetext{
${ }^{11}$ El profesor Lobo de Carvalho, experto en restauración monumental del Instituto Superior Técnico de Lisboa consultado en entrevista 18/03/2015, afirma que frechal (y su plural frechais) hace referencia a durmientes de madera de pequeña escuadría, no a zunchos. Según su criterio la expresión en portugués para nombrar un zuncho de hormigón es lintel de betão.
} 


\section{III.2. Marco histórico del atado estructural}

En este capítulo se revisa los antecedentes del zuncho moderno en los Tratados de construcción históricos. A partir de los Diez Libros de Vitruvio, considerados "texto fundacional de la teoría de la arquitectura occidental" ${ }^{12}$, se localiza alusiones a cadenas y sistemas de atado estructural en la mayor parte de los escritos consultados.

El uso de este tipo de soluciones arranca en la más remota antigüedad, por lo que la documentación más relevante para su estudio pertenece al ámbito de la arqueología, según se describe a continuación.

\section{III.2.1. Los primeros encadenados}

El arquitecto y arqueólogo Ignacio Arce, director de la misión española en Jordania, hace un análisis en uno de los CNHC de los sistemas de atado estructural más antiguos que conocemos desde la perspectiva de su eficacia como sistema de protección frente a las acciones sísmicas. Describe ejemplos de soluciones constructivas que, además de dar solidez y estabilidad a las estructuras, pueden contribuir a mejorar se comportamiento frente a las acciones sísmicas: En las construcciones de Babilonia intercalaban un estrato de hojas de palma cada varias hiladas para dotar de elasticidad a las fábricas ya en el siglo XIII aC.

Según el Libro I de Herodoto un estrato de caña trenzada, con betún caliente como mortero, se disponía cada trece hiladas. También explica como Koldeney confirma que en el Palacio los estratos con carrizo se disponían con un mínimo de cinco y un máximo de trece hiladas de separación. En el caso de Dawalib, época sasánida, se aplica en todas las hiladas ${ }^{13}$.

\footnotetext{
${ }^{12}$ González Moreno-Navarro, J. L. (1996). Los tratados históricos como documentos para la historia de la construcción. En Actas del Primer Congreso Nacional de Historia de la Construcción (pp. 255260).

${ }^{13}$ Arce, I. (1996). Elementos y sistemas constructivos antisísmicos en la antigüedad. Aplicación a la restauración de estructuras históricas. In Actas del CNHC VII (pp. 39-47). Madrid: I. Juan de Herrera, CEHOPU.
} 


\section{"Los ejemplos más antiguos de encadenados de que se tiene noticia se encuentran en Etiopía. La estela de Aksum representa un tipo de construcción de hiladas de mampostería alternándose con carreras longitudinales de madera, atadas a su vez transversalmente por piezas, también de madera, cuyas cabezas se manifiestan en fachada."}

Arce indica que el sistema aún se usa en iglesias rupestres etíopes y que fue el empleado en la construcción de la Kaaba en la Meca por un constructor abisinio.

Postula que los bizantinos usaron extensivamente tirantes de madera y hierro que pasaron a las arquitecturas islámica y occidental.

Cita encadenados y carreras de madera en las mezquitas catedral de las ciudades españolas Córdoba ${ }^{14}$ y Sevilla ${ }^{15}$.

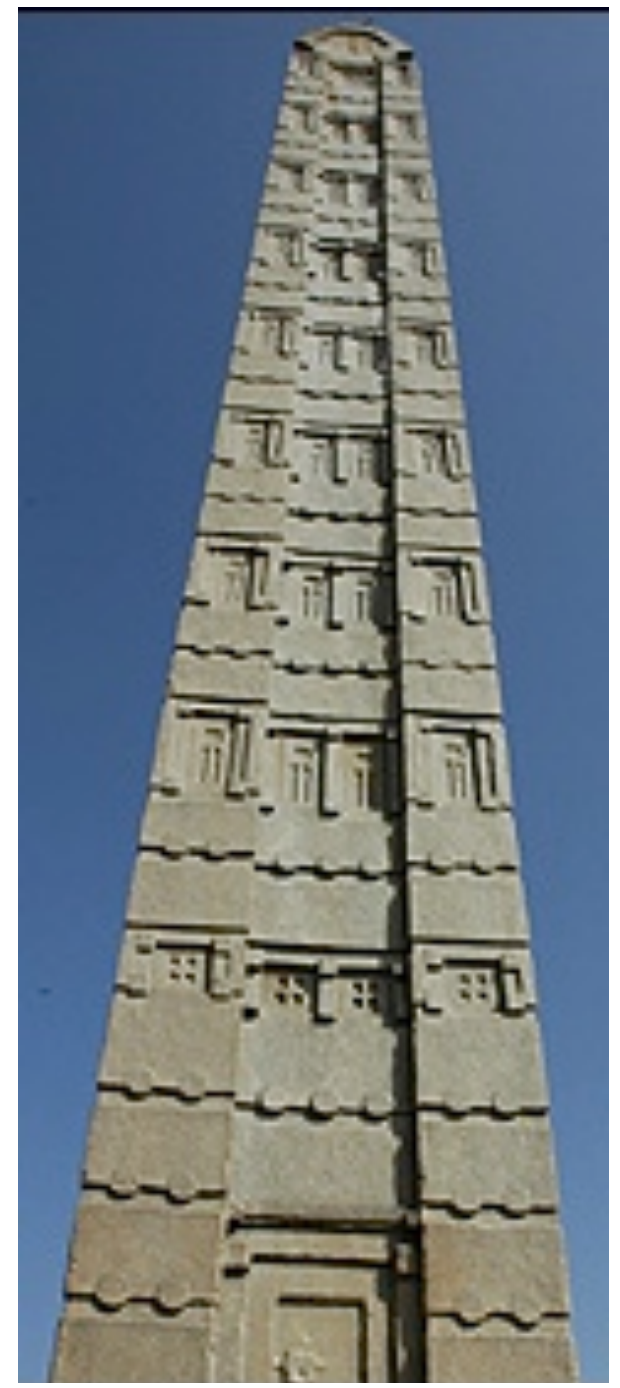

Fig.III.3. Estela de Aksum http://newsimg.bbc.co.uk/media/images/4 4715000/jpg (acceso 29/11/2013)

Se emplean carreras de madera tanto en Kashmir (India-Pakistán) como en Egipto.

En las imágenes siguientes, del templo Qasr El-Bint, en Petra (Jordania) podemos apreciar el buen estado de varios encadenamientos de madera embebidos en la fábrica.

\footnotetext{
${ }^{14}$ Jiménez, A., y Cabeza, J. M. (1988). Turris Fortissima. Documentos sobre la construcción, acrecentamiento y restauración de la Giralda. Sevilla: Colegio Oficial de Aparejadores y Arquitectos Técnicos de Sevilla.

${ }^{15}$ Hernández, F. (1975). El alminar de Abd Al-Rahman III en la Mezquita Mayor de Córdoba. Génesis y repercusiones. Granada: Patronato de la Alhambra.
} 

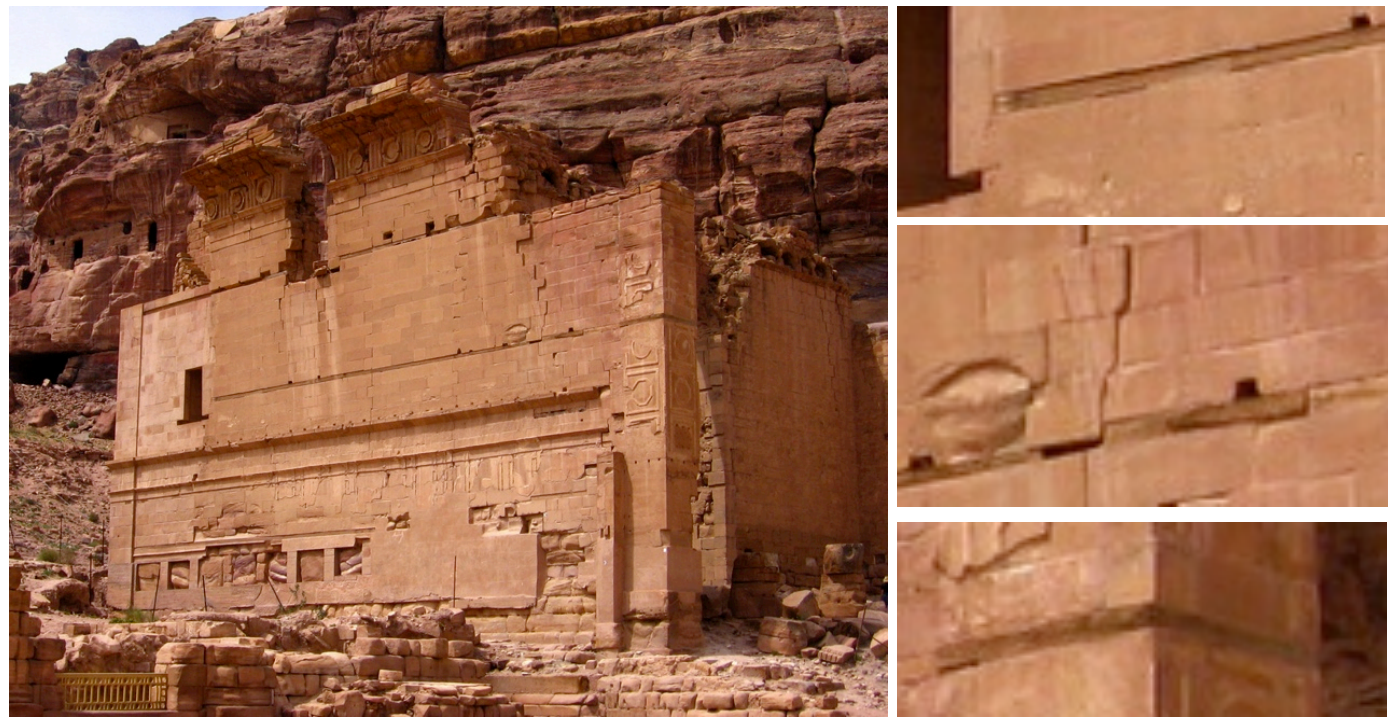

Fig.III.4. Templo Qasr El-Bint

http://www.travellingbackflip.com/typo3temp/pics/4021a23134.jpg (acceso 29/11/2013)

En regiones donde la madera escasea los encadenados se resuelven con piedra. Arce menciona piezas monolíticas de hasta $4 \mathrm{~m}$ con inscripciones talladas sobre las mismas en la torre del edificio barracks en la ciudad de Umm al Jimal (entre Siria y Jordania). En la fotografía podemos observar un detalle de empalme entre este sillares longitudinales de dicha ciudad resuelto en cola de milano.

Arce menciona cómo hoy en día se propone el uso de cable de acero en las juntas horizontales de las fábricas (o en otras abiertas ex profeso) para reforzar las estructuras contra los terremotos.

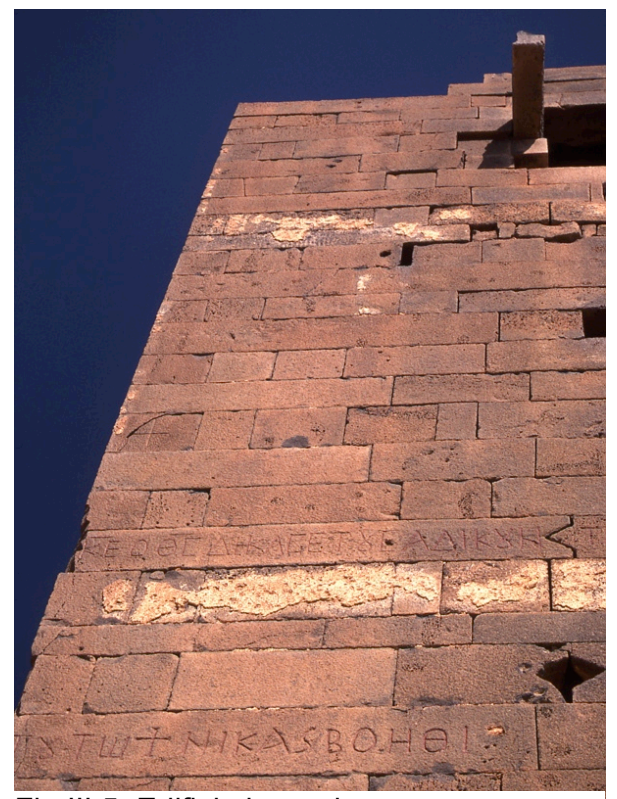

Fig.III.5. Edificio barracks http://www.jacobmetcalf.net

En la comunicación citada encontramos un único párrafo sobre la América precolombina, en el que se indica que también podemos encontrar soluciones basadas en el concepto de tierra armada babilónico, como la Quincha.

La citada quincha es una tecnología de construcción que emplea para conformar los muros unos entramados de madera, cañas o fibras vegetales revestidas con barro. 
Podemos encontrar la quincha, por ejemplo, en las plataformas superiores de la pirámide "La Galería" de Caral, en Perú, con troncos verticales de huarango de $15-30 \mathrm{~cm}$ de diámetro separados de 40 a $60 \mathrm{~cm}$ amarrados con atados de cañas.

En la imagen se aprecia la naturaleza del relleno de las pirámides de Caral, armado con "shicras de junco", unas bolsas de fibra vegetal rellenas de piedras, tecnología precursora de los actuales gaviones, que mejoraba el comportamiento frente a las acciones sísmicas.

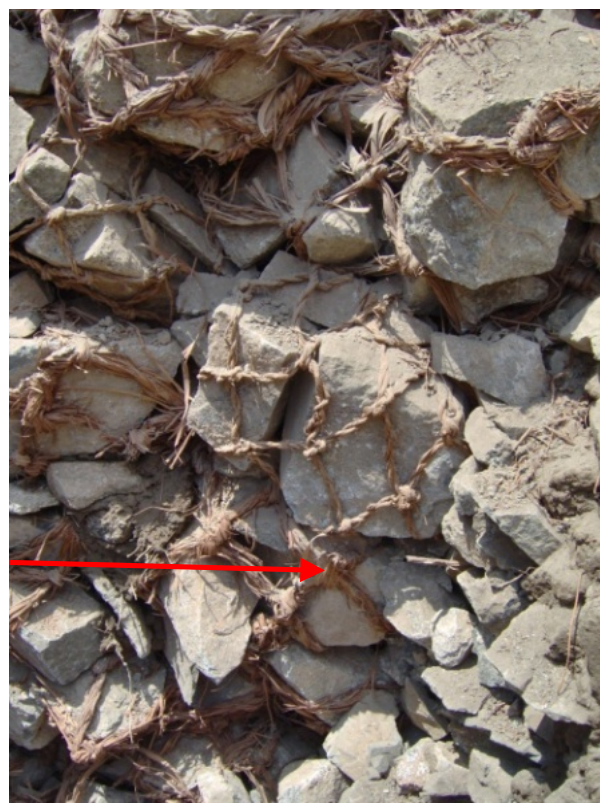

Fig.III.6. Shicras en Caral (VargasNeumann \& Iwaki 2014)

La ingeniería estructural sismo resistente presenta más dificultades que la aplicada en áreas sin actividad sísmica. "El mundo de la preservación patrimonial se debería dividir en dos: el de las áreas sísmicas y el de las áreas no sísmicas" ${ }^{16}$.

Podemos apreciar en la imagen siguiente (foto de la autora) un sistema de atado también empleado habitualmente en la Mesoamérica Prehispánica. Se trata de los tirantes de madera de una bóveda maya en Tikal, Guatemala. No aplicamos el término "falso arco", considerado por algunos estudiosos una herencia occidental erróneamente aplicada, al tratarse de "arcos cornisados, en saledizo, traducción de la expresión en inglés corbelled arch" $^{17}$.

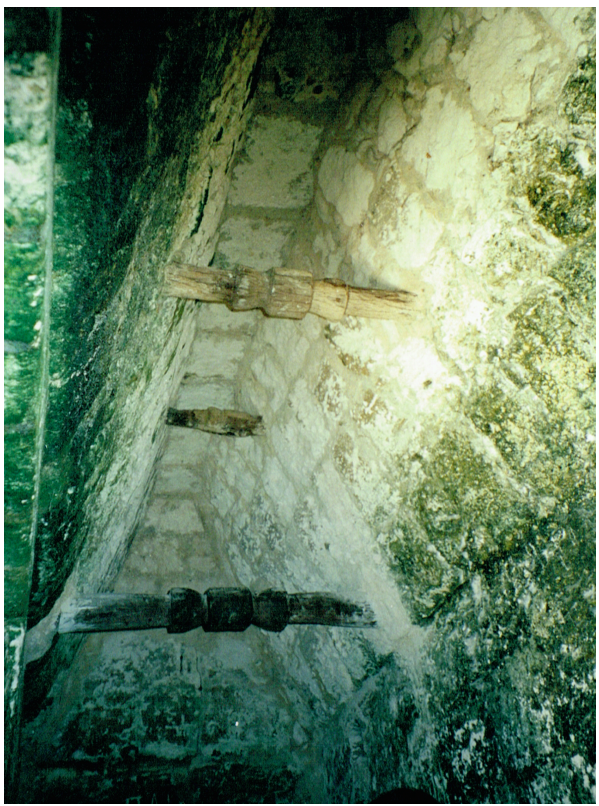

Fig.III.7. Falso arco maya en Tikal, visita marzo de 2002

\footnotetext{
${ }^{16}$ Vargas-Neumann, J. (2014). Propuesta de conservación: patrimonio edificado en tierra del mundo andino. En actas del congreso REHABEND (pp. 43-52). Santander.
}

${ }^{17}$ Villalobos, A. (2001). La falsedad del falso arco maya. Bitácora Arquitectura, (5), 4-13. 


\section{III.2.2. El encadenado en los Tratados de construcción históricos.}

El texto de este apartado sirvió de base a un artículo publicado en diciembre de 2012 en la revista electrónica $\operatorname{ReCoPaR}^{18}$ de la Universidad Politécnica de Madrid. En el mismo se recopila y expone, de forma cronológica, información de fuentes documentales sobre el origen y evolución de los sistemas de atado, considerados antecedentes directos del actual zuncho.

Desde las primeras traducciones de Tratados del siglo XVI hasta los Manuales de construcción de los albores del XX, se identifican y organizan referencias a encadenados. Se recoge tanto el simple incremento de espesor de la fábrica en forma de fajas o el engatillado de sillares mediante grapas, como sistemas más complejos, a base de cadenas metálicas embebidas en los muros de cerramiento para formar un anillo perimetral cerrado y atirantado.

El estudio del Patrimonio arquitectónico es una tarea casi detectivesca, ya que sobre cada monumento se superponen huellas de un sinfín de intervenciones llevadas a cabo a través de los siglos. El edificio deviene una especie de palimpsesto tridimensional.

A la hora de abordar el análisis de una solución constructiva determinada, uno de los primeros pasos es revisar los Tratados históricos en busca del origen de la misma y de su evolución a lo largo del tiempo, aunque en general no se pueda determinar de forma categórica si precisamente esa publicación influenció a la arquitectura de su época o a las posteriores. En las páginas siguientes se compendian, ordenadas de forma estrictamente cronológica, y por tanto sin jerarquizar, diversas alusiones documentadas a piezas de encadenamiento embebidas en muros de fábrica que podemos considerar el embrión de las actuales técnicas de zunchado.

\footnotetext{
${ }^{18}$ Bellido, R. (2012) El Zuncho en la Tratadística. Articulo en revista electrónica Red Temática de Conservación, Restauración y rehabilitación del Patrimonio Arquitectónico ReCoPar nº 9. Madrid: Universidad Politécnica de Madrid.
} 


\section{Antecedentes del zuncho en los Tratados}

A continuación se compendia de forma resumida alusiones a sistemas de atado localizadas en una selección de Tratados de Arquitectura e Ingeniería, en especial los disponibles en las páginas de la Sociedad Española de Historia de la Construcción y la Biblioteca Nacional de Francia, según se ha justificado en el capítulo de Metodología y Fuentes. La documentación se ordena de forma estrictamente cronológica, desde las primeras traducciones del siglo XVI hasta los Manuales de construcción de la primera mitad del XX. A partir del refuerzo más sencillo que podamos encontrar, como el aumento de grosor del material que constituye el propio muro formando fajas, o el cosido de sillares con lañas, llegamos a los más evolucionados, con bandas metálicas embebidas en el cerramiento para formar un anillo perimetral cerrado y atirantado. Se identifica una treintena de alusiones a atados, la mayor parte referidas como encadenado.

\section{SIGLO XVI}

Al analizar cualquier sistema de atado estructural podemos distinguir dos familias de elementos, que pueden disponerse en solitario o bien ser concebidas para trabajar conjuntamente. Por un lado los tirantes en sentido perpendicular a los muros de cerramiento, y por otro las piezas de reparto perimetral embebidas en éstos o adosadas a su superficie, tanto fragmentadas como continuas.

Un ejemplo del primer caso, con una única familia de piezas, lo encontramos en el libro IV de la traducción de Serlio ${ }^{19}$ realizada por Villalpando en 1552, donde se explican y representan los soportales con tirantes de hierro dispuestos de pared a columna para

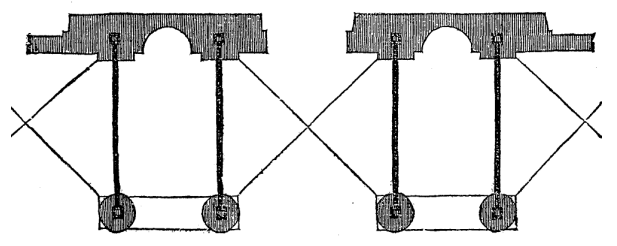
soportar los empujes de las bóvedas, pero sin Fig.III.8. Soportales, Serlio 1552 contar con ningún elemento de reparto transversal a éstos.

Las ilustraciones siguientes corresponderían también a una única familia, pero en este caso se trata de detalles de encamonados dispuestos sobre un durmiente lineal sin ataduras transversales. Se trata del Tratado de 1561 Nouvelles inventions pour

\footnotetext{
${ }^{19}$ Serlio, S. (1552). Tercero y cuarto libro de arquitectura de Sebastia Serlio Boloñés. Toledo: Casa de Iván de Ayala.
} 
bien bastir en el que Philibert de $1^{\prime}$ Orme $^{20}$, describe los espesores más adecuados para los muros de carga y recomienda no introducir en ellos refuerzos de hierro que al oxidarse puedan contribuir a su ruina.

En su remate se coloca la plataforma de madera $\mathrm{B}$, de un pie o diez pulgadas y ocho o nueve pulgadas de espesor con muescas cada dos pies que se representa en las figuras de planta y perspectiva, sobre la que apoya la cubierta de madera.

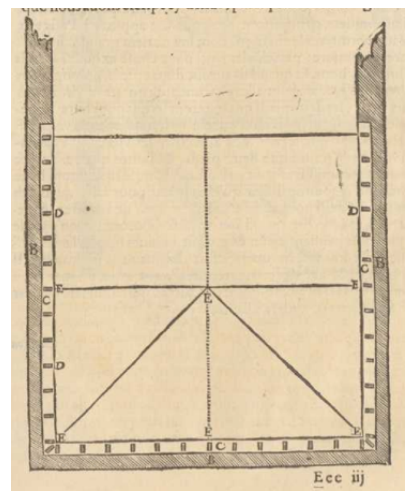

Fig.III.9. Encamonados, de L'Orme 1626

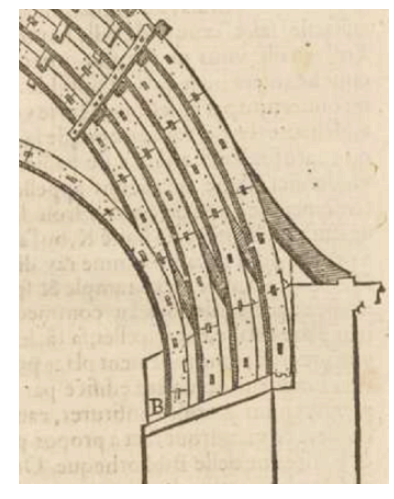

Para formar un atado perimetral, se repite desde antiguo la práctica consistente en incorporar conexiones puntuales que intenten dotar de cierta continuidad a los componentes de los muros de fábrica. Así, en el tercero de los Diez Libros de architectura de Alberti $^{21}$, en la edición de Espinosa en 1582, se describe sólo cómo las assas y clavillos de hierro que unen las hiladas de piedra superior e inferior no duran nada mientras que el alambre es casi eterno, indicando que las assas de madera untadas con cera pura y alpechín no se pudren. Parece claro que podían emplear en aquel momento, para la fabricación de grapas, tanto madera como hierro.

\section{SIGLO XVII}

Ya en este momento el concepto de atado incorpora la idea de refuerzo longitudinal en los muros de cerramiento. Así en 1639, en la primera parte del Arte y uso de arquitectura, Fray Lorenzo de San Nicolás ${ }^{22}$ describe cómo los muros de mampuesto deben llevar encima de cada altura dos hiladas de ladrillo o verdugos que hacen más fuerte la obra. Sobre los de sillería en seco, describe el uso de "drapas o rampones de yerro emplomados" para sujetar las piedras en los puentes romanos, y cita "las chapas de yerro como las alaba Vitrubio en su Libro 2".

\footnotetext{
${ }^{20}$ L'Orme, P. de. (1626). Oeuvres de Philibert de lOrme. Architecture. París: Chez Regnavld Chavdiere.

${ }^{21}$ Alberti, L. B. (1582). Los diez libros de Architectura de Leon Baptista Alberto. Traducidos del Latin en Romance [por Francisco Loçano]. Madrid: Casa de Alfonso Gómez.

${ }^{22}$ Fray Lorenzo de San Nicolás. (1639). Arte y Uso de Architectura.
} 


\section{SIGLO XVIII}

En la traducción de Castañeda en 1761 del Compendio de Vitruvio de Perrault ${ }^{23}$ encontramos la descripción del arquitrabe con vigas unidas o engatilladas con sus llaves a cola de milano pero distantes entre sí un dedo porque si se tocan se recalienta y pudre la madera. Aunque se trate de un elemento fragmentado podemos apreciar cómo se resuelve con cierta continuidad.

Será ya avanzado el siglo XVIII, con la traducción realizada por el P. Miguel Benavente en 1763 del original publicado en Viena en latín de los Elementos de arquitectura civil de Rieger $^{24}$, cuando encontremos una solución completa de encadenado definida al detalle.

Se describen tirantes de hierro A y madera B-D para atar transversalmente entre sí paredes maestras y el encadenado CCC de piezas de metal fijadas sobre los muros que se representan en la ilustración.

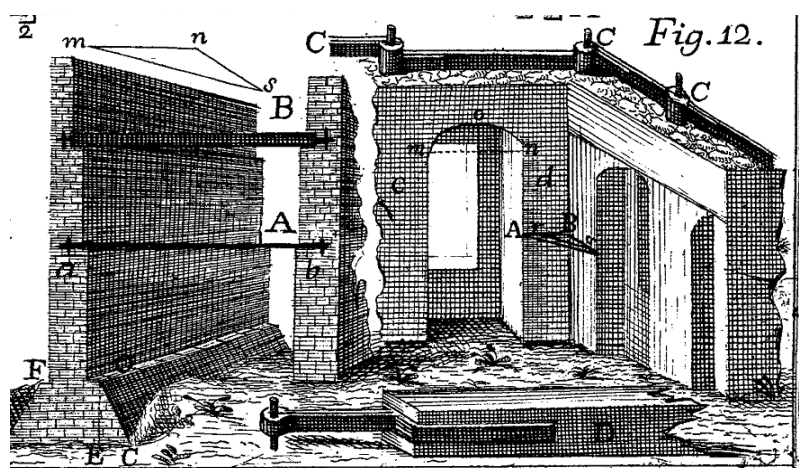

Fig.III.10. Tirantes, Rieger 1763

En el capítulo $3^{\circ}$ del manual de bóvedas tabicadas Modo de hacer incombustibles los edificios, de J. de Sotomayor ${ }^{25}$, se describe cómo se pueden armar estas estructuras de fábrica (que él denomina llanas) con gatillos de hierro, para evitar el uso de estribos donde sea caro el ladrillo. Es en la introducción de este libro redactada por Ventura Rodríguez, donde éste describe la ruina de la cúpula del colegio de Santa Victoria de Córdoba "de un arquitecto francés" (se refiere a su contemporáneo Dreveton) por falta de estribo en las bóvedas, indicando que tuvo que atar con cadenas en todos los pisos y que las bóvedas tabicadas deben atirantarse siempre.

\footnotetext{
${ }^{23}$ Perrault, C. (1761). Compendio de los Diez libros de arquitectura de Vitruvio. Madrid: Imprenta de D. Gabriel Ramírez.

${ }^{24}$ Rieger, C. (1763). Elementos de toda la arquitectura civil. Madrid: Impreso por Joachin Ibarra.

${ }^{25}$ Sotomayor. (1776). Modo de hacer incombustibles los edificios, sin aumentar el coste de construcción. Madrid: Oficina de Pantaleón Aznar.
} 
Debemos destacar que fue el mismo Ventura Rodríguez el que hizo disponer un zunchado a base de cadenas para reforzar la torre del Evangelio de la Catedral de Valladolid, que finalmente se desplomó. En el caso de la Catedral de Salamanca, por contra, había recomendado demoler la torre, que se encontraba gravemente agrietada, mientras que se ejecutó la solución diseñada por el ingeniero Baltasar Dreveton, consistente en un zunchado con seis cadenas a distintas alturas y un forro de piedra de gran espesor.

Aparece de forma muy temprana en la Historia la palabra trabes para designar vigas, tal como dijimos que se emplea actualmente de forma habitual en América Latina. En el capítulo III del Libro VI de Los diez libros de Arquitectura de Vitruvio $^{26}$, según la traducción de Ortiz y Sanz de 1787, se citan los trabes o maderas mayores, simples vigas que atraviesan en ancho y sostienen los otros dos en largo llamados interpensivos, que hoy denominaríamos brochales. Los vocablos "tirantes ó sean cadenas, transtra", designan desde entonces elementos de atado, identificando el traductor en nota al pie la voz transtris como origen del término tirantes.

Casi en los albores del siglo XIX aparecen ya de forma bastante reiterada soluciones de tirantes metálicos dispuestos en perpendicular a los muros, como en el siguiente detalle de alzado y sección de muro de fachada, tomado del Tratado Arquitectura civil de Benito Bails ${ }^{27}$ de 1796 , donde se representa en la moldura de la parte alta una cadena de hierro $\mathrm{S}$ embebida.

Esto no conlleva la desaparición de los atados concebidos como simples engrosamientos de la sillería. Por ejemplo, en la traducción de Ortiz y Sanz de los cuatro libros de Arquitectura de Palladio $^{28}$ de 1797 , se hace alusión al atado

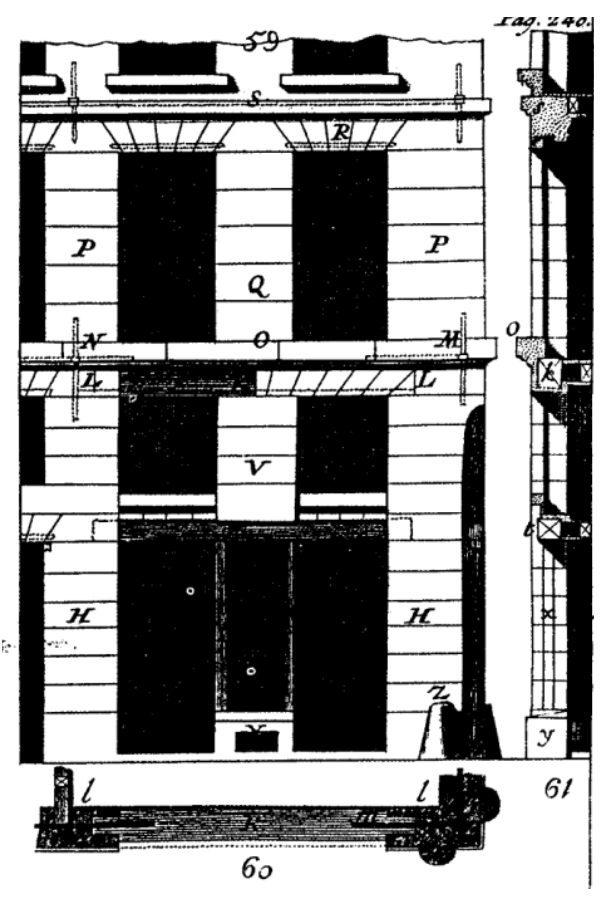
indicando que "en toda especie de paredes se Fig.lll.11. Fachada, Bails 1796

\footnotetext{
${ }^{26}$ Vitruvio, M. (1787). Los diez libros de Arquitectura. Madrid: Imprenta Real.

${ }^{27}$ Bails, B. (1796). Elementos de Matemáticas. Tom. IX. Parte I. Que trata de la Arquitectura civil. Madrid: Imprenta de la viuda de Ibarra.

${ }^{28}$ Palladio, A. (1797). Los Cuatro Libros de Arquitectura. Traducidos e ilustrados por Don Joseph Ortiz y Sanz. Madrid: Imprenta Real.
} 
deben poner algunas carreras de piedras o ladrillos mayores, que sirvan como de nervios que retengan atadas las otras partes. Al disminuir la sección de los muros de fachada se deberá mantener vertical la cara interna y en los escalonamientos se dispondrá un recinto, faxa o cornisa que circuya todo el edificio; lo cual le servirá de ornato, y será como un vínculo que lo tenga sujeto".

\section{SIGLO XIX}

En 1802 es también Benito Bails ${ }^{29}$ quien, en su Diccionario de Arquitectura civil, define cadena de hierro como la unión de muchas barras con clavetas o grafios que "se echan en el grueso de algunas paredes desde una cabeza a otra para enlazarlas mejor con las que se encuentran a escuadra. También se ciñen con ellas las paredes viejas o que amenazan ruina". En cuanto a esta última frase es importante destacar cómo el concepto de encadenado lleva implícito su uso como solución específica para refuerzo de fábricas antiguas o ruinas desde tiempo inmemorial.

Eck describe en 1841 chaînages (encadenamientos) en medio de los muros en su Traité de l'application du fer ${ }^{30}$, y en la figura III.12 vemos detalles del sistema denominado Didier para empalme en fundición de los tramos de cadena.

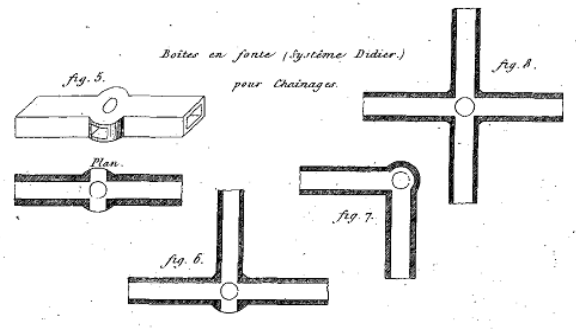

Fig.III.12. Detalles, Eck 1841

Sin embargo, este último autor incluye, en la misma publicación varios esquemas de forjados mixtos madera-metal y planos de consolidación de una iglesia con un rebuscado sistema de tirantes y bridas en los que no aparece reflejado ningún zuncho o carrera a modo de durmiente en la línea de los muros.

Sobre lo que acontece fuera de nuestras fronteras, encontramos una interesante afirmación en el tomo I de Elementos de arquitectura de Millington ${ }^{31}$, traducido en 1848 por Carrillo de Albornoz.

\footnotetext{
${ }^{29}$ Bails, B. (1802). Diccionario de Arquitectura civil. Madrid: Imprenta de la viuda de Ibarra.

${ }^{30}$ Eck, C. L. G. (1841). Traité de l'application du fer, de la fonte et de la tôle dans les constructions civiles, ...etc. París: Carilian-Goeury et Vor. Dalmont.

${ }^{31}$ Millington, J. (1848). Elementos de arquitectura, escritos en inglés por John Millington. Traducidos al castellano y aumentados con notas y apéndices por el mariscal de campo D. Mariano Carrillo de Albornoz, Director Subinspector del arma de Ingenieros en la Isla de Cuba (Vol. Tomo I). Madrid: Imprenta Nacional.
} 
Según éste, "en todas las casas de Londres hay enlaces o cadenas de madera (bond timber) embebidas en la fábrica por todo en rededor cada 4 o 5 pies de altura", lo que se representa en el detalle de sección reproducido junto a estas líneas.

También describe en el mismo texto un atado con dos grapas de cadena bajo el arranque de la cúpula de San Pablo y cita otras dos cadenas sin fin encastradas en la torre-fanal de Eddystone.

Se siguen editando obras, como el Manual de construcciones de albañilería de Espinosa ${ }^{32}$ de 1859 , en las que los encadenados o cadenas se describen como simples machones de refuerzo verticales de material de la propia fábrica. Este autor los desaconseja y recomienda que se dispongan sólo verdugadas horizontales.

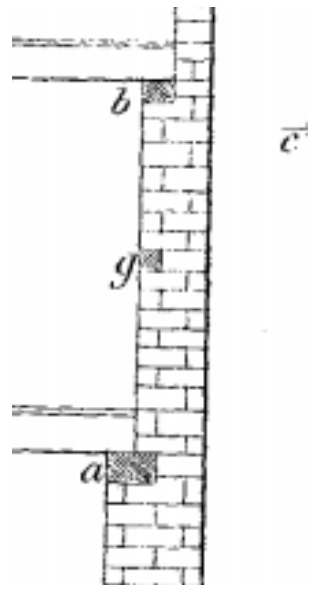

Fig.lll.13. Sección Millington 1848

Encontramos referencias a atados resueltos con madera principalmente en publicaciones francesas. Baudot, Viollet o Choisy describen ejemplos de durmientes destinados a encadenar fábricas medievales resueltos con este material.

La solución del campanario de la iglesia de Thiverval, de principios del s. XIII es descrita en 1867 por Baudot ${ }^{33}$, que la considera muy ingeniosa, en su obra Eglises de bourgs et villages.
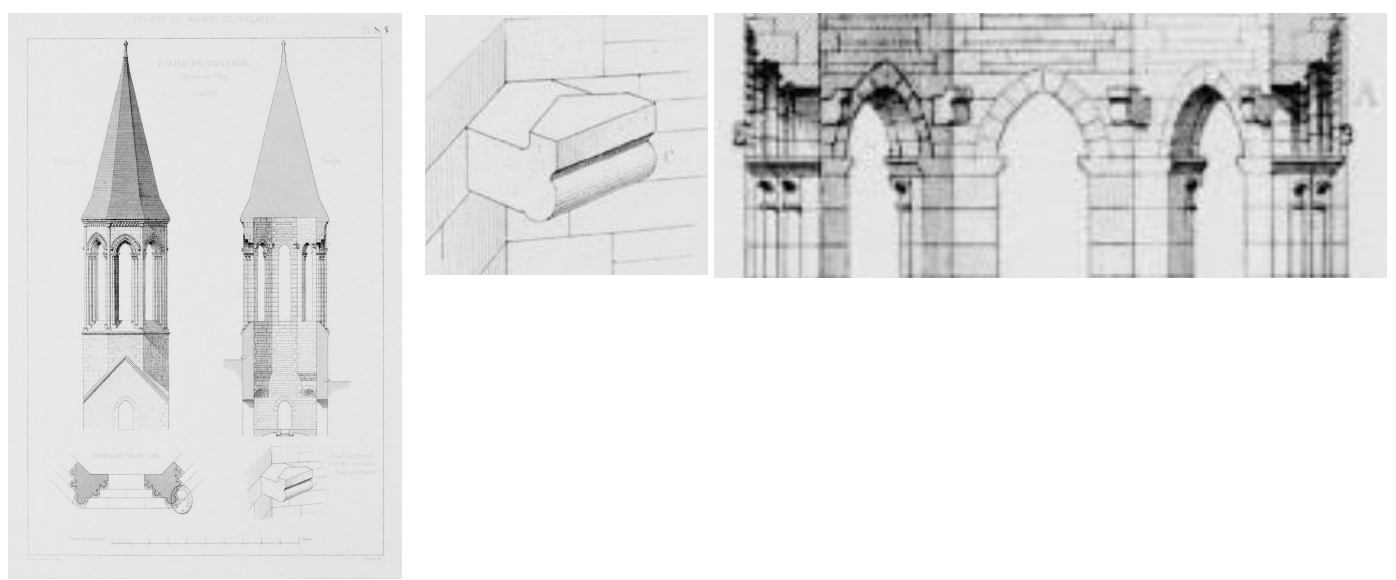

Fig.III.14. Campanario Thiverval, Baudot 1867

\footnotetext{
${ }^{32}$ Espinosa, P. C. (1859). Manual de construcciones de albañilería. Madrid: Imprenta a cargo de Severiano Baz.

${ }^{33}$ Baudot, A. de. (1867). Eglises de bourgs et villages. París: A. Morel, Libraire-Editeur.
} 
Se trataba de un encadenado de madera (chaînage en bois) dispuesto por la cara interior de los muros que apoyaba sobre unas ménsulas de piedra, empotradas en los ángulos, a la altura de la clave de los arcos. Estas piezas contaban con un cajeado para albergar el encuentro de las vigas de madera, según se aprecia con más detalle en la perspectiva central.

La conocida ilustración junto a estas líneas pertenece al tomo IV del Dictionnaire Raisonné de l'architecture française $\mathrm{du} \mathrm{XI}^{\mathrm{e}}$ au $\mathrm{XVI}^{\mathrm{e}}$ siècle, en el que Viollet-le-Duc ${ }^{34}$ explica en 1868 cómo los constructores románicos empotraron en los muros a diferentes alturas, bajo los antepechos de las ventanas, y debajo de las cornisas, piezas de madera longitudinales embebidas. Afirma incluso que se pueden encontrar restos de estas piezas en las murallas de fortificaciones galas ya en tiempos de César, con escuadrías cuadradas entre 12 y $20 \mathrm{~cm}$.

En la sección siguiente se marcan como C las vigas de reparto de madera embutidas también en los muros en el arranque de una bóveda de cañón románica. Explica que "estas piezas sin ventilar se pudrían rápidamente y dejaban huecos que aceleraban la destrucción, a finales del siglo XI, de unos edificios construidos sólo medio siglo antes".
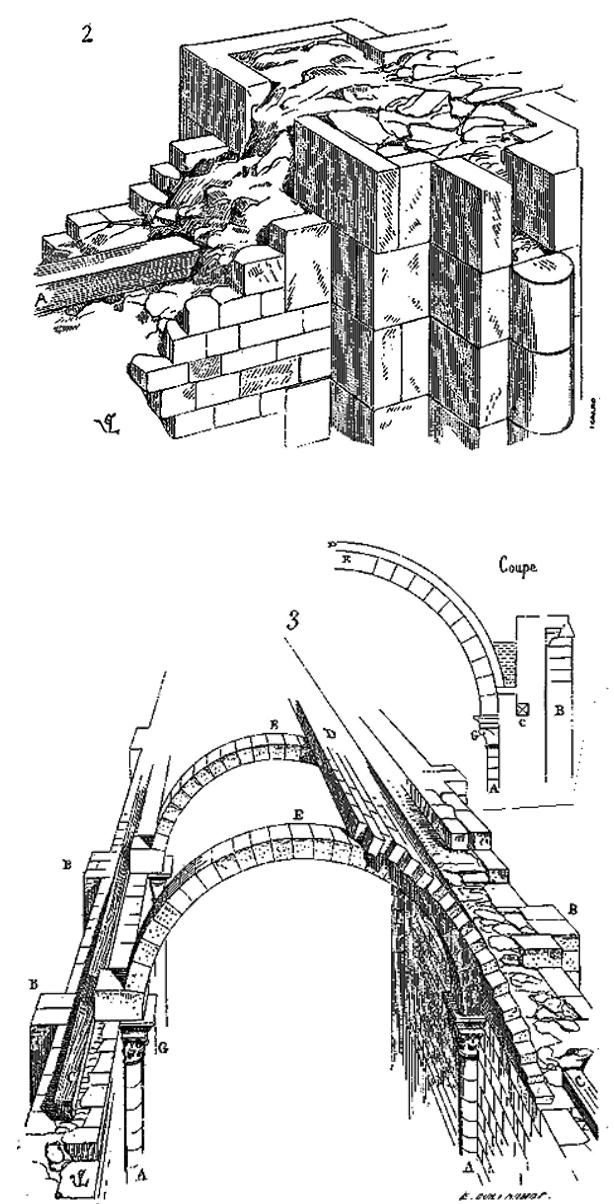

Fig.III.15. Detalles, Viollet le Duc 186

Según su extenso artículo sobre encadenado (chaînage) del tomo II "el término se aplica a durmientes de madera, sucesión de ganchos de hierro como eslabones de una cadena, o incluso barras de hierro embebidas en el espesor de los muros, horizontalmente, y destinadas a impedir la fragmentación de las construcciones de fábrica".

\footnotetext{
${ }^{34}$ Viollet-le-Duc, E. (n.d.). Dictionnaire Raisonné de l'architecture française du XIe au XVIe siècle (1867th ed.). París: A. Morel, Editeur.
} 
En el texto afirma que en sus restauraciones ha encontrado numerosos encadenados de madera: indicando los pisos, en el nacimiento de las bóvedas y bajo la coronación. Describe el doble encadenado en la nave de Vézelay, uno bajo las arquivoltas y otro bajo los capiteles de arranque de las bóvedas con unos ganchos para fijar unos anclajes transversales que supone empleados sólo durante la construcción del templo hasta

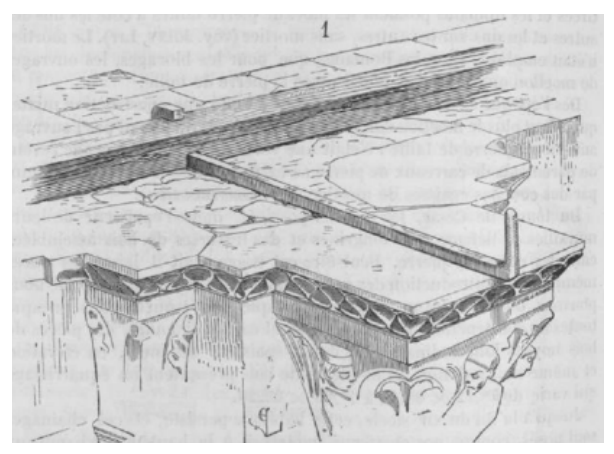

Fig.III.16. Ganchos en Vezelay, Viollet le Duc 1868 la entrada en carga de los muros.

Enumera diversos ejemplos de encadenados, embebidos en la fábrica a lo largo de los siglos XI a XIV, sueltos hacia el XV cuando se llega a la conclusión de que el hierro encastrado en la fábrica puede producir efectos funestos sobre la misma. Aunque se trabajaba la forja a mano se podía alcanzar importante longitud de piezas, más de $4 \mathrm{~m}$ en las ventanas de la Sainte Chapelle. Nombra atados de madera en las catedrales de Soissons, Laon, Tours y Amiens, y de forja en la de Reims.

En una nota explica que el detalle de empalme de barras de 2 a $6 \mathrm{~m}$ de longitud que representa está tomado del gran encadenado del suelo del triforio de la catedral de Amiens, dispuesto a finales del siglo XV para detener el movimiento de las cuatro pilas del crucero sobrecargadas por la torre central antes de su incendio. En las imágenes podemos apreciar el estado actual de estos elementos de atado que, según diversos autores se denominaban en la época "hierro de España" o forja de Toledo.
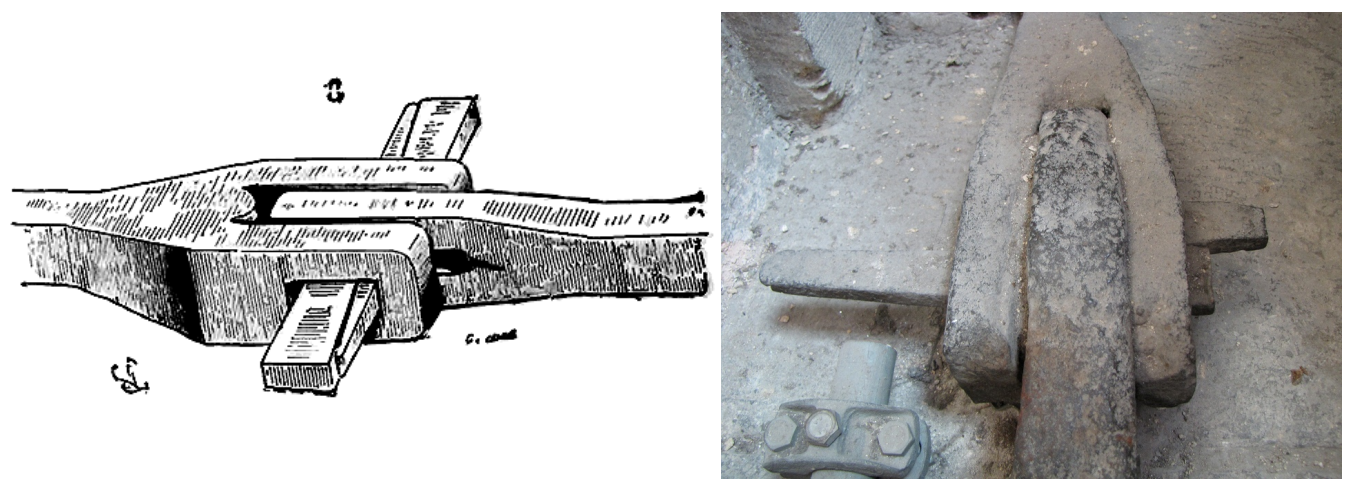

Fig.III.17. Tirantes Catedral de Amiens

http://cathedrale.gothique.free.fr/Cathedrale_Amiens_3.htm (21/10/2013) 


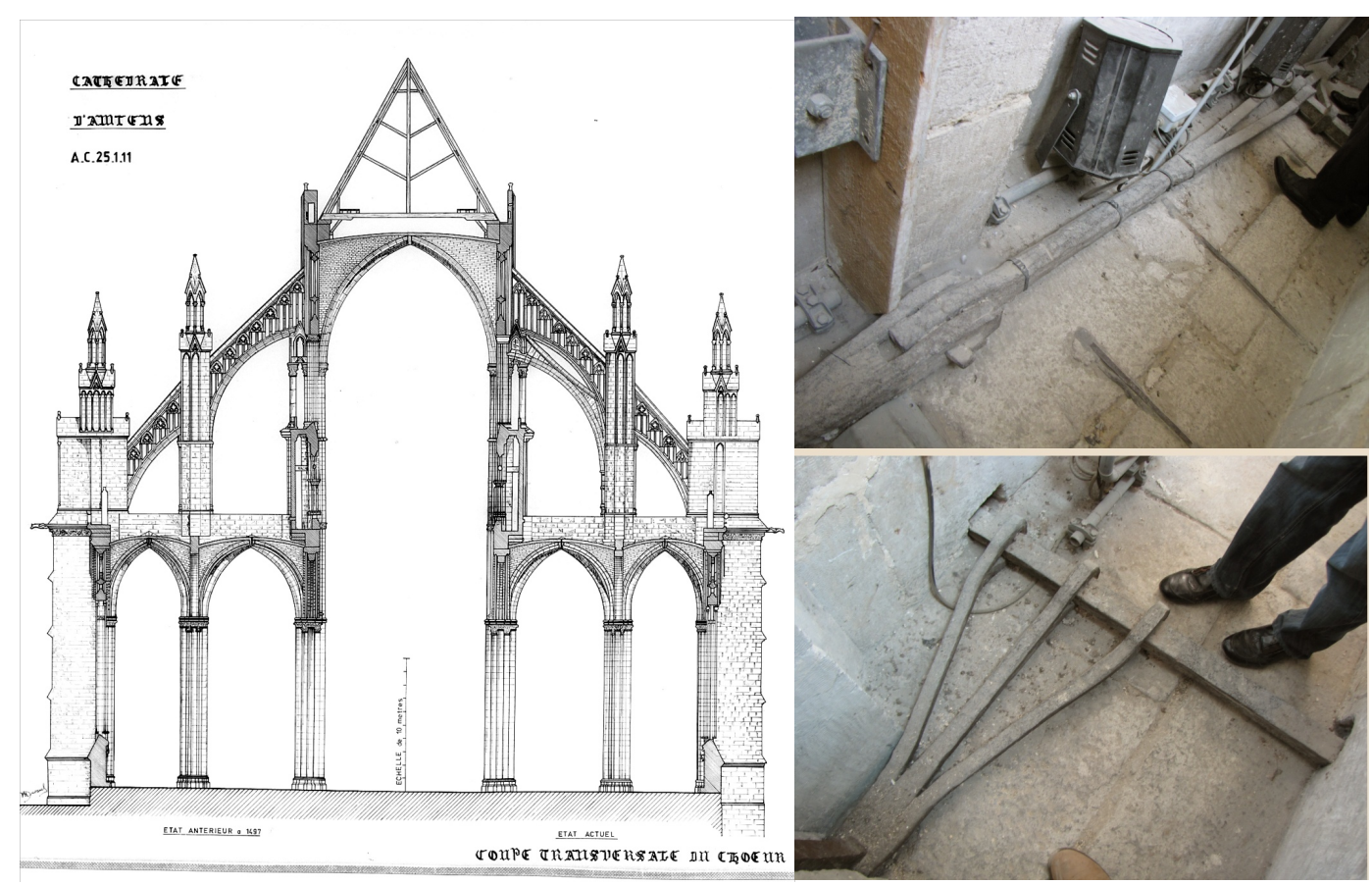

Fig.III.18. Tirantes Catedral de Amiens

http://cathedrale.gothique.free.fr/Cathedrale_Amiens_3.htm (21/10/2013)

Cita también los anillos de madera del castillo de Coucy y el progresivo abandono de la madera a favor del hierro, como en la Sainte Chapelle, en la que afirma se embebieron cadenas de grapas metálicas en rozas selladas con plomo, que se repetirían en las catedrales de Estrasburgo, Carcasona, Narbona y Rouen.

Sobre los entramados y suelos de madera, Valdés 35 explica en 1870 en su Manual del ingeniero y arquitecto que, "para preservar los empotramientos de las vigas de la humedad y dar más estabilidad a su asiento, se colocan éstas sobre soleras o cadenas" que corren a lo largo de las paredes, dejando una capa de aire alrededor de la cabeza empotrada. Se trata de otra solución en madera, con sólo dos líneas paralelas previstas únicamente como piezas de reparto, sin conformar un anillo arriostrante. En el mismo tomo encontramos otro término relacionado con el tema cuando afirma que "por medio de cinchos de hierro se puede anular el empuje de una cúpula".

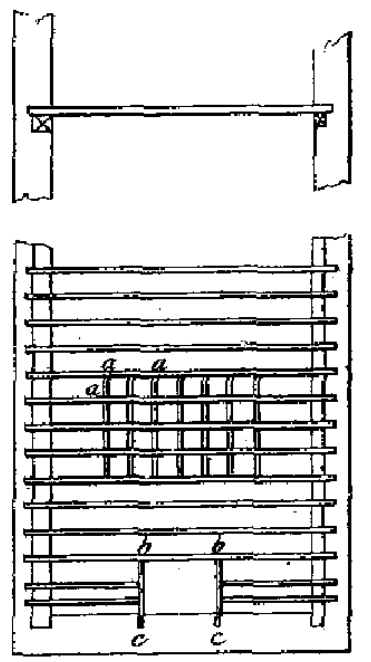

Fig.III.19. Cadenas, Valdés 1870

\footnotetext{
${ }^{35}$ Valdés, N. (1870). Manual del ingeniero y arquitecto. Madrid: Imprenta de Gabriel Alhambra.
} 
A finales del siglo XIX se mantienen también las corrientes menos evolucionadas, que consideran como atado el simple engrosamiento lineal de la propia fábrica, como podemos apreciar en los escritos de Rebolledo, Portuondo o Adeline.

El primero de ellos describe en 1875 como cadenas, en su obra Construcción general ${ }^{36}$, los refuerzos de sillería verticales en muros de mampostería, mientras que se refiere a los horizontales como simples fajas o bandas (verdugadas si se trata de ladrillo) que impiden el asiento diferencial de las fachadas.

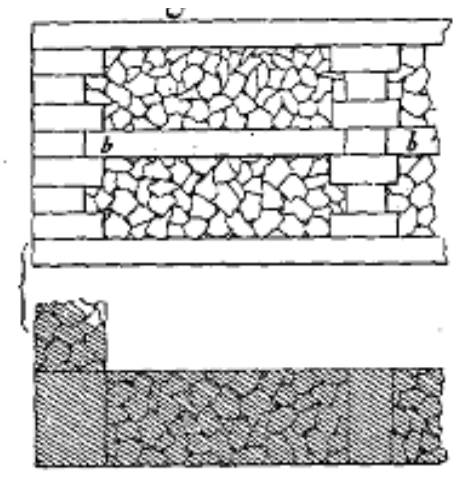

Fig.III.20. Cadenas, Rebolledo 1875

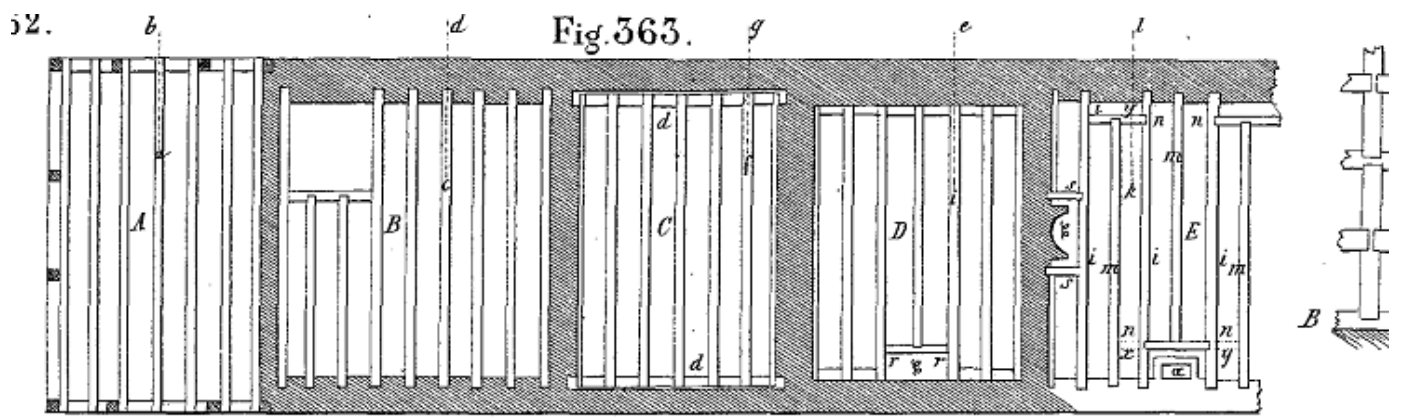

Fig.III.21. Planta de entramados, Rebolledo 1875

En el mismo manual Rebolledo representa de varias formas los cabios de los entramados que configuran los forjados de madera: $\mathrm{B}$ empotrados en los muros, $\mathrm{C}$ sobre carreras d empotradas en las paredes, o D con estas últimas no embebidas y sostenidas sobre canecillos. Se trata de elementos simples de reparto lineal, que en algunos casos ni siquiera se colocan.
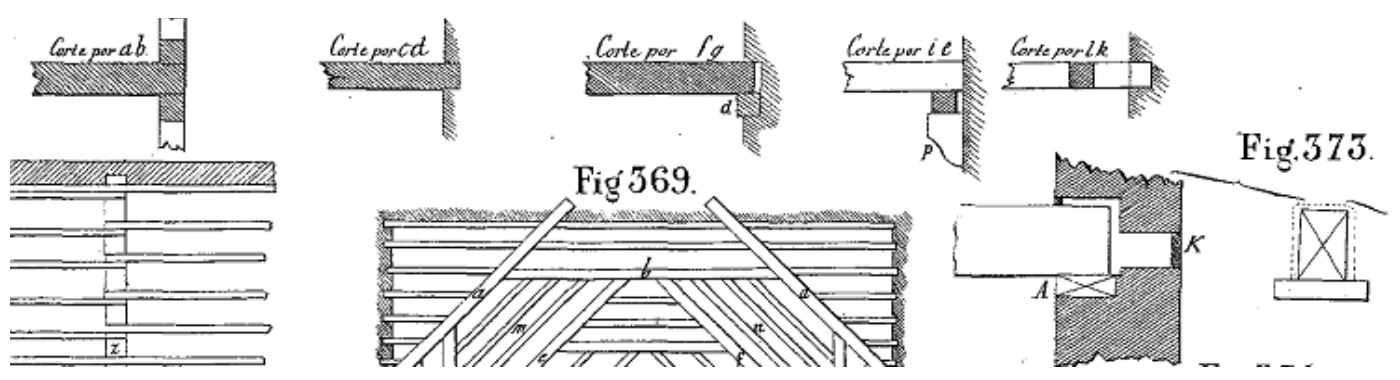

Fig.III.22. Detalles entramado, Rebolledo 1875

\footnotetext{
${ }^{36}$ Rebolledo, J. A. (1875). Construcción general. Madrid: Imprenta y fundición de J. Antonio García.
} 
Sólo dos años después Portuondo ${ }^{37}$ describe, en la primera de sus Lecciones de arquitectura, cómo en todas las épocas se ha considerado conveniente reforzar los muros con hiladas salientes horizontales y verticales, que también denomina cadenas.

Y en 1887 será Adeline ${ }^{38}$ quien recoja el vocablo cadena, sólo en su acepción de machón vertical, en su diccionario ilustrado Vocabulario de términos de arte. Cincho será para él la moldura a modo de faja o plinto corrido que acusa exteriormente las líneas de los pisos de un edificio.

En el manual de 1891 Architecture et constructions civiles de Denfer ${ }^{39}$ se incluye un capítulo entero sobre encadenados, en el que se describe cómo deben disponerse barras planas longitudinalmente atravesando todos los muros en cada planta a la altura del forjado: En una roza si es sillería, embebido en el mortero de la fábrica, o incluso en una de las hojas en las zonas donde haya chimeneas.
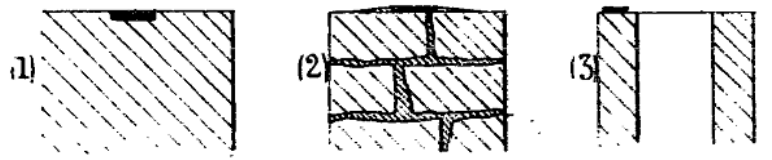

Para las uniones de estas pletinas cita el Art de bâtir de Rondelet.

Fig.III.23. Detalles Denfer 1891

También en La Histoire de l'Architecture de Choisy $^{40}$ de 1899 se alude en numerosas ocasiones al encadenado mediante durmientes embebidos en los muros: Los muros bizantinos se distinguen de los de la arquitectura occidental por una particularidad cuyo origen nos lleva a las edades más antiguas de la arquitectura: la mayoría presentan carreras y llaves de madera incorporadas en su sección, como los muros micénicos. En otro apartado de la misma obra se indica que esta costumbre conservada por los bizantinos se remonta a la época romana, con las carreras embebidas en el cuerpo de la fábrica formando una especie de encadenados longitudinales, aunque su duración era desafortunadamente la de la propia madera.

\footnotetext{
${ }^{37}$ Portuondo, B. (1877). Lecciones de arquitectura, explicadas por el profesor de la academia de ingenieros comandante del cuerpo D. Bernardo Portuondo y Barceló. Madrid: Imprenta del memorial de Ingenieros.

${ }^{38}$ Adeline, J. (1887). Vocabulario de términos de Arte, escrito en francés por J. Adeline. Traducido y aumentado con más de 600 voces y anotado por José Ramón Mélida. Madrid: Obra publicada por la empresa de La Ilustración Española y Americana.

${ }^{39}$ Denfer, J. (1891). Architecture \& constructions civiles. Charpenterie métallique 1. París: GauthierVillars et Fils.

${ }^{40}$ Choisy, A. (1899). Histoire de l'Architecture (Vol. Tome II). París: Gauthier-Villars.
} 
En la figura junto a estas líneas representa cómo las carreras embebidas a la altura de los riñones reciben el empuje que ejerce la bóveda de cañón en toda su longitud y permiten combatirlo

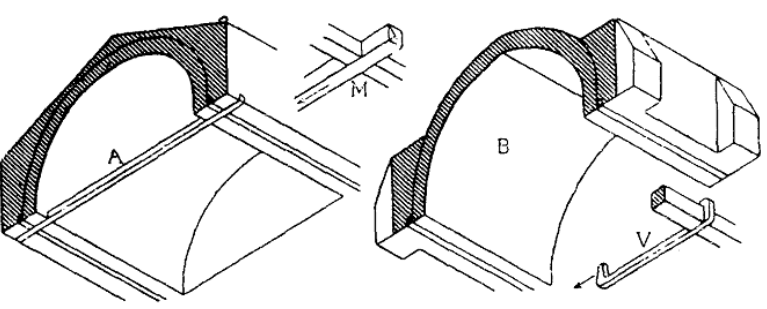
mediante contrafuertes $\mathrm{B}$ o bien tirantes A.

Fig.III.24. Bóvedas, Choisy 1899

En su capítulo de fortificaciones destaca el párrafo siguiente: "Generalmente las construcciones militares se encadenan por medio de carreras de madera. Las murallas de Coucy conservan la huella de estas piezas (...) servían para repartir el efecto de los impactos".

La descripción del encadenado de los muros del castillo citado mediante longrines noyées de 20x30cm de escuadría ya había aparecido en 1875 en el libro de Violletle-Duc ${ }^{41}$ Description du chateau de Coucy, por lo que consideramos muy probable que Choisy reprodujese sin más las ideas de su contemporáneo, coincidiendo con la hipótesis expuesta en 1999 por Kenneth Frampton ${ }^{42}$ en Estudios sobre cultura tectónica.

En 1898 aparece un apartado sobre trabazón y atirantado de paredes en el Tratado de construcción civil de Ger y Lóbez ${ }^{43}$ en el que indica que la trabazón de materiales no es bastante muchas veces y se establecen encadenamientos de hierro que enlazan unas paredes con otras y las partes de una pared con las inmediatas. Los encadenamientos se hacen con barras planas (...) tendidas en el centro de las paredes al enrasar cada piso, cuyas barras están atravesadas de trecho en trecho por otras cuadradas verticales llamadas llaves. Estos encadenamientos aparecen representados en las ilustraciones como tramos sueltos, en las esquinas y los puntos de acometida de tabiques perpendiculares, pero no como elementos continuos en toda la longitud de las fachadas.

\footnotetext{
${ }^{41}$ Viollet-le-Duc, E. (1875). Description du château de Coucy. París: Vve. A. Morel.

${ }^{42}$ Frampton, K. (1999). Estudios sobre cultura tectónica (Vol. 22). Ediciones AKAL.

${ }^{43}$ Ger y Lóbez, F. (1898). Tratado de construcción civil. Badajoz: Imprenta de Minerva Extremeña.
} 
En el artículo IV del citado Tratado de Ger y Lóbez se aborda también el tema obras de reparación y reforma de edificios, explicando actuaciones de recalzo y frente a desplomes. Se describe la manera de consolidar bóvedas vaídas con grietas verticales mediante cinchos de hierro forjado colocados horizontalmente por el trasdós "a la altura de los puntos de fractura en caliente" o, si la bóveda es grande, con cuñas y relleno de mortero.

Al describir los pisos de madera en su tratado Carpintería de armar, también en 1899, Gaztelu ${ }^{44}$ menciona las carreras (lambourde, que podemos traducir como rastrel) que sirven de apoyo a las viguetas, indicando que es una mala práctica empotrarlas en el muro, ya que se pudren, por lo que no deben soportar el peso de la fábrica superior. Dedica varias páginas al encadenado, que tiene por objeto ligar y mantener reunidos entre sí, por medio de cadenas horizontales fijadas por sus extremos, materiales diversos, muros, pisos, etc., impidiendo su separación. Indica que si el edificio es aislado se encadenan las fachadas de frente y laterales, pero si es de importancia se emplean tirantes en diagonal sobre los entramados de los pisos. Recomienda emplear barras planas y describe varios tipos de empalme para los eslabones, con ganchos y anillos, de charnela o en tablón, con clavija, perno o doble cuña, que representa gráficamente. La cadena se coloca en una acanaladura abierta en el sobrelecho de una hilada, que luego se rellena con plomo fundido. Se intuye en este texto el concepto del atado como sistema completo, con conexión de fachadas frontal y laterales, y atirantado incluso en diagonal.

En 1900 Rovira y Rabassa ${ }^{45}$ describe la evolución de los encadenados a través de la historia, en una nota desarrollada a pie de página, dentro del capítulo séptimo sobre empalmes de su obra El hierro sus cortes y enlaces. Explica cómo griegos y romanos enlazaban las distintas hiladas de sus sillares por medio de espigas de hierro, bronce o madera, y los sillares que pertenecían a una misma hilada mediante grapas en cola de milano. Indica que en la Edad Media hacían los encadenados con maderos embebidos longitudinalmente en el grueso de las paredes a la altura de los pisos, de los arranques de bóvedas y por encima de las coronaciones superiores, hasta el siglo XII, en que se cambia al hierro. En la misma nota expone cómo en principio se formaban los encadenados con grapas a modo de eslabones y, más tarde, mediante

\footnotetext{
${ }^{44}$ Gaztelu, L. (1899). Pequeña Enciclopedia práctica de construcción publicada bajo la dirección de L.-A. Barré. $\mathrm{N}^{\mathrm{o}} 4$. Carpintería de armar. Traducido y anotado por D. Luis Gaztelu. Madrid: Librería editorial de Bailly-Bailliere e hijos.

${ }^{45}$ Rovira y Rabassa, A. (1900). El hierro sus cortes y enlaces. Barcelona: Librería de Ribó y Marín.
} 
barras planas ensambladas en sus extremidades, incorporadas a lo largo de los muros y por encima de las bóvedas.

\section{SIGLO XX}

Kingsley Porter ${ }^{46}$, en The construction of Lombard and gothic vaults menciona en 1911 la inclusión de encadenados de madera al modo bizantino, indicando que su desintegración no causaba ruina en las iglesias lombardas por ocupar poca sección de los muros. Explica como ventaja que estas piezas prevenían la fisuración de la fábrica durante el fraguado del mortero, aunque puntualiza que el profesor Fernand de Dartein ya "había demostrado los efectos desastrosos que se podían llegar a producir". Ward ${ }^{47}$ cita a Porter en 1915 en Mediaeval church vaulting y afirma que en San Ambrosio de Milán hay encadenados de madera embutidos en la fábrica.

Se emplea por fin en 1927 la palabra zunchados, en el Tratado práctico de edificación de Barberot ${ }^{48}$, pero sólo para expresar cómo los tablones de un andamio provisional van unidos en sus extremos. Sobre el atado de las fachadas incluye un apartado completo relativo a encadenados dentro del capítulo de construcciones metálicas. En el mismo explica cómo deben hacerse solidarias, mediante su encadenado, unas partes del edificio con otras para que si una parte estuviese mal cimentada la sostengan las demás. Indica que en todo tiempo se ha hecho uso del encadenado, por ejemplo la alternancia de troncos con piedras en las construcciones primitivas, las grapas y piezas largas de madera ocultas en las fábricas antiguas o los encadenados compuestos de elementos pequeños o corchetes enlazados.

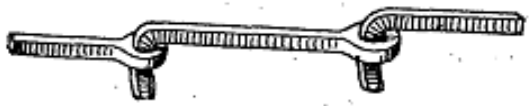

Fig.III.25. Detalle, Barberot 1927

En 1935 la Sociedad francesa de arqueología edita un documento que recoge los temas tratados en su $97^{\circ}$ Congreso e incluye el artículo de Paquet ${ }^{49}$ titulado Technique de la restauration des monuments historiques.

\footnotetext{
${ }^{46}$ Kingsley Porter, A. (1911). The construction of Lombard and gothic vaults. New Haven: Yale University Press.

${ }^{47}$ Ward, C. (1915). Mediaeval church vaulting. Princeton: Princeton University Press.

${ }^{48}$ Barberot, É. (1927). Tratado práctico de Edificación por E. Barberot. Traducido de la $5^{\text {a }}$ edición francesa por Lino Álvarez Valdés. Barcelona: Gustavo Gili Editor.

${ }^{49}$ Paquet, P. (1936). Technique de la restauration des monuments historiques. Societé française d'archéologie. En 97e Congrès archéologuique de France tenue a Paris en 1934 (pp. 411-424). París: A. Picard, Libraire.
} 
Se trata de una ponencia en la que se analizan las numerosas intervenciones realizadas durante los cien años transcurridos desde la creación del Servicio de monumentos históricos y la evolución de los criterios aplicados en ese tiempo. Paquet describe "la consolidación de fábricas fisuradas encastrando en ellas pórticos de cemento armado que no alteran el aspecto exterior de los muros", como en las catedrales de Arras y de Laon, y la colocación de cinchos de atado (ceintures), por ejemplo en la base del chapitel del campanario de Lampaul-Guimiliau donde sirve a la vez de canalón. Describe, entre otros aspectos relevantes, la sustitución de encadenados de madera embebidos en las fábricas, y consumidos por el tiempo, por piezas de hierro.

En conclusión, encontramos entre los atados descritos sistemas muy simples, tanto de piezas de reparto en paralelo a muros sin atirantar, como de tirantes sin elementos transversales a ellos. Destaca un caso bien documentado entre los tratados publicados en España, ya en el siglo XVIII, que supone un esquema completo bidimensional tanto con anillo perimetral como con atirantado interior, aunque se trata en realidad de la traducción de una obra de origen austriaco, Elementos de arquitectura civil de Rieger.

Las alusiones a sistemas de atado de muros de fábrica, embrión de las actuales técnicas de zunchado, se entremezclan prácticamente en todas las épocas. También los materiales, aunque podrían jerarquizarse evolutivamente desde el simple engrosado de la piedra, carreras de madera y piezas metálicas (lañas, ganchos y pletinas), se alternan hasta la llegada y preponderancia del zuncho de hormigón armado en el siglo XX y, como veremos en el capítulo sobre las tendencias actuales, su paulatino reemplazo por atados más ligeros y de carácter tecnológico. 


\section{III.3. Marco conceptual para el uso del zuncho en restauración monumental}

En este apartado se trata de establecer el marco conceptual en el que se desarrolla el empleo de zunchos en las obras de restauración de edificios históricos, el contexto en el que las actuaciones surgieron y se repitieron en el tiempo. Para discernir los factores que determinan la manera de actuar de varias generaciones de arquitectos, se estudian en primer lugar sus criterios de intervención.

Una vez establecidos estos factores, se ofrece una visión general del uso de zunchos en restauración monumental en otras regiones y países próximos, como Portugal e Italia. Se incluye dentro del contexto un apartado dedicado al sismo, un problema que, como se verá, incide de forma directa en el atado estructural.

Por último se incluye un breve apartado sobre el cinchado de cúpulas y las últimas tendencias actualmente en marcha en el ámbito del atado estructural en restauración del Patrimonio.

\section{III.3.1. Criterios de intervención}

Para llegar a comprender los criterios de intervención sobre los edificios históricos, es necesario tener presente la influencia sobre los mismos de las propuestas y leyes surgidas de los distintos congresos internacionales. Otro factor clave en la génesis de esos criterios es la formación académica de los arquitectos y los textos que manejan.

\section{III.3.1.1. Cartas y leyes}

Se ha escrito mucho sobre teoría e historia de la restauración monumental como disciplina. No está entre en los objetivos de esta Tesis emitir juicios formales ni entrar en el debate secular sobre la problemática "ontológica" de la restauración. Gran parte de los documentos que abordan cuestiones relacionadas con la intervención sobre el Patrimonio edificado dedican sus primeros capítulos a describir las teorías de la restauración y la evolución de criterios adoptados a lo largo del tiempo. Pretender resumir tal diversidad de posturas y sus sesudas fundamentaciones en pocas líneas sólo se justifica si recordamos el sinnúmero de publicaciones bien 
documentadas que ya abordan el tema que, además se mantiene abierto y sometido permanentemente a revisión.

Nos remontamos al Renacimiento para recordar que ya Alberti planteaba entonces tres posturas posibles frente al edificio preexistente: continuarlo en estilo antiguo, equilibrarlo con los elementos nuevos, o "recubrirlo".

A comienzos del siglo XIX se extiende por Francia y España la restauration stylistique codificada por Viollet-le-Duc, en la que se propugna la reintegración de los edificios a su unidad de estilo original, incluso a situaciones ideales en las que nunca estuvo: la repristinación. Mientras, en Italia se optó por lo que ha venido a denominarse el restauro archeologico, en el cual se trata de consolidar los edificios después de estudiarlos científicamente, empleando siempre que sea posible partes originales como anastilosis, o recomponiendo con elementos sutilmente diferenciados. En Inglaterra llegó a plantearse el mantenimiento de las obras del pasado intactas en el movimiento anti-restoration, definido por Ruskin en Las siete lámparas de la Arquitectura y recogido en el Manifiesto de la SPAB en 1877.

A finales del XIX se reacciona contra los excesos de todas estas tendencias, surgiendo de ese debate dos nuevas escuelas, el restauro storico, encabezada por Beltrami, en que se busca la realidad histórica original de los monumentos estudiando las fuentes documentales de cada caso concreto, y el restauro moderno definido por Camilo Boito. Este último recomienda en primer lugar realizar un adecuado mantenimiento, sólo si es necesario consolidar y en último extremo reparar, sin incluir añadidos ni renovaciones. Desde 1883 sus ocho principios han marcado la línea a seguir a las generaciones posteriores en toda Europa: diferencia de estilo entre lo antiguo y lo nuevo, diferencia de materiales en sus fábricas, supresión de molduras y decoración en las partes nuevas, exposición de las partes materiales que hayan sido eliminadas en un lugar continuo al monumento restaurado, incisión de la fecha de actuación o de un signo convencional en la parte nueva, epígrafe descriptivo de la actuación fijado al monumento, descripción y fotografias de las diversas fases de los trabajos depositadas en el propio monumento o en un lugar público próximo, o publicación de todo ello, y notoriedad visual de las acciones realizadas.

El primer documento internacional publicado para promover la protección del arte de los pueblos, considerado un bien universal a raíz de los postulados del restauro scientifico propugnados por Giovannoni, es la Carta de Atenas de 1931. Ésta recoge 
en sus diez puntos aspectos tan trascendentes como que los Estados deben salvaguardar los monumentos y difundir publicaciones sobre los mismos, la prevalencia del derecho colectivo frente al privado y que los materiales añadidos deben resultar reconocibles. Se incluye además consideraciones sobre el aspecto urbano de los monumentos, incluyendo su ambiente, las perspectivas y los jardines circundantes. Aspectos clave serán el empleo juicioso de los recursos de la técnica moderna, y más especialmente del cemento armado para consolidar y también la insistencia en formar equipos multidisciplinares.

Todos los métodos de restauración entraron en crisis tras las guerras mundiales, con centenares de monumentos y centros históricos prácticamente arrasados sobre los que se actuó de forma dispersa hasta prácticamente la firma de la Carta de Venecia de 1964, en la que se recogen axiomas básicos adicionales mayoritariamente aceptados hasta nuestros días, como la reversibilidad de las actuaciones, el respeto por los añadidos y el uso de medios científicos para el análisis. Otros documentos que han ido reconfigurando la disciplina han sido las Normas de Quito de 1967, la Carta de Ámsterdam de 1975, la Declaración de Bolonia, y las Cartas de Granada, Toledo, Washington, Machu Picchu en 1977, y Burra en 1979.

El año 2000 se firma la Carta de Cracovia, con una participación importante de España al haberse celebrado previamente en Valladolid una reunión internacional de expertos organizada por el Instituto Español de Arquitectura. En los primeros años del siglo XXI se mantiene abierto un debate que pide revisar procedimientos, metodología y conceptos sobre la restauración del Patrimonio, lo que se manifiesta, por ejemplo, en las Actas de los XII Cursos monográficos sobre el Patrimonio histórico impartidos en Reinosa en 2001.

En un artículo sobre las Cartas en una de las revistas del Instituto de Restauración del Patrimonio de la Politécnica de Valencia ${ }^{50}$, se compara el tratamiento de varios conceptos fundamentales en una selección de ellas (Atenas, Venecia, Cracovia y tres italianas de 1931, 1972 y 1987): anastilosis, mantenimiento, reversibilidad, etc. En cuanto al empleo de técnicas modernas, los primeros textos aceptan su empleo cuando los métodos tradicionales no alcancen los objetivos propuestos; en el 87 se recomiendan cadenas $\mathrm{y}$ zunchos frente a inserciones ocultas, pretensados $\mathrm{o}$

\footnotetext{
${ }^{50}$ Noguera, J. F. (2006). Cartas de restauración del patrimonio Arquitectónico. Historia y estudio comparativo. Arché, 283-296.
} 
inyecciones, y por fin en el 2000 se propugna la vuelta al conocimiento de las materiales tradicionales y al mantenimiento.

Muchos arquitectos y administraciones están acostumbrados a no explicar sus intervenciones, apareciendo únicamente algunas referencias en revistas, sin datos técnicos en unos textos meramente descriptivos. Las publicaciones de los Organismos centrales, hasta el traspaso de competencias a las Comunidades autónomas, consistieron prácticamente en meras catalogaciones. Posteriormente, desde los Servicios de restauración de la Comunidad de Madrid se editaron por ejemplo las series de Fichas de la colección Madrid Restaura en Comunidad, en las que ya se incluyen explicaciones de los criterios de intervención redactadas por los propios arquitectos responsables de las obras, y también se cuenta con publicaciones en la misma línea realizadas por la Junta de Castilla y León. En Cataluña, desde el Servicio de Patrimonio, se ha potenciado durante décadas la publicación de documentos divulgativos, además de organizarse Jornadas y seminarios.

En 2012 la revista Informes de la construcción publica un número extra monográfico sobre La integración de conocimientos en la Restauración del Patrimonio Arquitectónico, tema que no abordaba a fondo desde 1993. Antoni González Moreno-Navarro ${ }^{51}$, responsable durante décadas del Servicio de Patrimonio catalán y promotor de la metodología conocida como restauración objetivada o restauro crítico, expone su punto de vista sobre la evolución de la disciplina en nuestro país los últimos años.

Latorre $^{52}$ expone, en la misma publicación, la dificultad de estudiar por partes los problemas de una construcción histórica que forma un sistema holístico. Recomienda adoptar para definir cada proyecto de restauración arquitectónica la figura de un Plan Director elaborado por un equipo multidisciplinar minuciosamente coordinado.

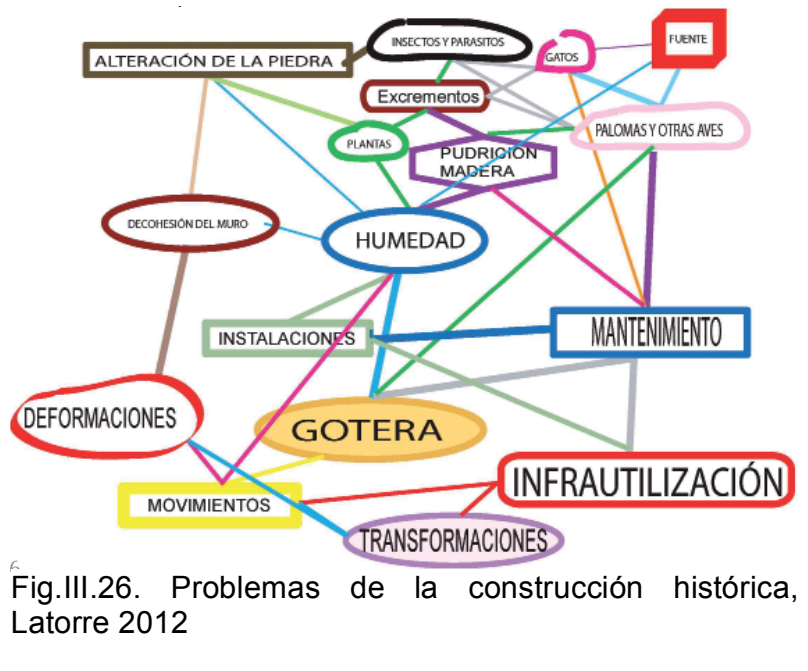

\footnotetext{
${ }^{51}$ Gonzalez Moreno-Navarro. (2012). Restauración monumental: ¿el método en crisis? Informes de La Construcción, 64(EXTRA).

${ }^{52}$ Latorre, P. (2012). El monumento como un todo. El plan director de restauración. Informes de La Construcción, 64(Extra), 45-56.
} 
Los criterios para intervenir sobre el Patrimonio van evolucionando a lo largo del tiempo. En cada época prevalecen unos conceptos sobre otros, homogeneizándose las actuaciones según tendencias más o menos homogéneas. Así en los años 50-60 se emplean masivamente refuerzos de hormigón armado y en los 70-80 se reemplazan las estructuras de madera de cubierta por cerchas metálicas. A partir de 2010 se trata de recuperar materiales tradicionales: se sustituye madera estropeada por madera (aserrada o laminada) empleándose siempre que resulta posible morteros de cal en lugar de cementosos.

Es importante la contribución de Heyman y sus seguidores para divulgar el cálculo plástico en comprobación de estructuras de fábrica, aunque seguimos considerando deslumbrantes las gráficas de elementos finitos. La Sociedad Española de Historia de la Construcción, desde su puesta en marcha en 1996, ha promovido la difusión del análisis de las estructuras de fábrica empleando sólo las ecuaciones del equilibrio. El profesor de estructuras Santiago Huerta en el prólogo de la primera edición en España del famoso libro de $\operatorname{Heyman}^{53}$, afirma que "para demostrar que una estructura de fábrica es segura basta con encontrar una situación posible de equilibrio compatible con las cargas, es decir, un posible camino de las fuerzas dentro de la fábrica...¿Cuántas intervenciones innecesarias, cuando no perjudiciales, se hubieran podido evitar con una adecuada comprensión del funcionamiento de las fábricas?".

\section{III.3.1.2. La formación de los técnicos}

El debate actual en torno a la enseñanza de la arquitectura en España no es un tópico reciente. El profesor García-Gutierrez, en la edición facsímil ${ }^{54}$ de los apuntes manuscritos de la asignatura de construcción de Luis Moya, describe cómo en su momento ya se criticó a fondo por su incoherencia el Plan de estudios de 1914. Así Anasagasti, entre otros, censura en 1923 la inclusión en los programas de una carga teórica que no se empleará en el ejercicio de la profesión. En la citada publicación se indica como "en tanto que la tecnicista enseñanza oficial tan sólo facilitaba la adquisición de conocimientos teóricos, tendiendo a la formación del arquitecto por

\footnotetext{
${ }^{53}$ Heyman, J. (1995). Teoría, historia y restauración de estructuras de fábrica: colección de ensayos. Instituto Juan de Herrera.

${ }^{54}$ Moya Blanco, Luis, \& Garcia-Gutierrez Mosteiro, Javier. (1993). Cuaderno de apuntes de construcción de Luis Moya (curso 1924-1925). Universidad Politécnica de Madrid.
} 
generación espontánea lanzándole a la profesión sin tener idea de ella, no se rompía definitivamente con el antiguo procedimiento de aprendizaje al lado de un maestro, procedimiento que para Moya se había mostrado como más eficaz a lo largo de la historia".

A través de los años los estudiantes de arquitectura han simultaneado la asistencia a clase con trabajos de colaboración, remunerados o no, en talleres de arquitectos veteranos. Estas prácticas que, generación tras generación dotaban a los neófitos de conocimientos prácticos mediante su participación en obras en curso, empiezan a presentar un serio inconveniente a lo largo del siglo XX: con la evolución en los procesos constructivos se abre una honda brecha entre obra nueva y construcción tradicional.

En los apuntes de Moya citados encontramos trazados y análisis de arcos y bóvedas de fábrica de piedra y ladrillo, esquemas de despiece en casos destacados de varios países, explicaciones de peculiaridades, requisitos, aclaraciones y comparativa entre soluciones. Se trata de un compendio de apuntes de Historia de la construcción en fábrica.

Es cierto que en la obra de Moya como arquitecto, si dejamos al margen consideraciones más profundas sobre su búsqueda inicial de una "arquitectura nacional" supuestamente defensora de la tradición, con el clasicismo como sistema formal más adecuado, encontramos sistemáticamente bóvedas tabicadas y muros de albañilería.

Sin duda un factor fundamental que condicionó la subsistencia de sistemas tradicionales fue la escasez de hierro y cemento durante posguerra y autarquía ${ }^{55}$.

Aún así para configurar su obra resultó fundamental el empleo del hormigón armado, tanto para resolver el alarde técnico que supuso la cruz del Valle de los Caídos como en el atado de los tambores y cúpulas de sus iglesias, como en San Agustín $^{56}$, mediante potentes zunchos.

\footnotetext{
${ }^{55}$ González Capitel, A. (1976). La arquitectura de Luis Moya Blanco. Arquitectura.

${ }^{56}$ Moya Blanco, L. (1998). Estudio del zuncho-estribo de la bóveda de planta elíptica y arcos entrecruzados de la iglesia de San Agustín, según el proyecto de Luis Moya Blanco. Informes de La Construcción, 50(456-457).
} 
Moya explica que los empujes de las bóvedas de la iglesia de San Agustín son muy importantes "debido a las grandes luces y rebajamientos". Se contrarrestan mediante zunchos empotrados en los muros, evitando atirantados vistos. Un zuncho general redondo de $40 \mathrm{~mm}$ rodea la elipse principal y otro secundario discontinuo de $30 \mathrm{~mm}$ transmiten al anillo los empujes de las bóvedas que cubren el salón mediante piezas de hormigón sobre los arcos fajones.

\section{III.3.1.2.1. Enseñanza de Historia de la} Construcción

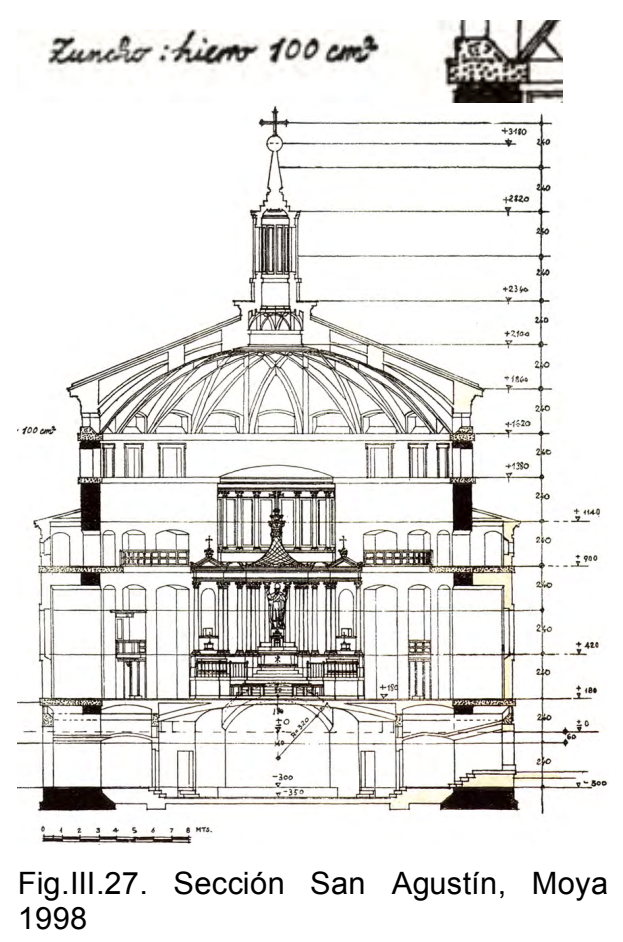

Encontramos los primeros intentos de recuperar la disciplina en las postrimerías del siglo XX con la introducción de cursos de posgrado. En la Escuela de Arquitectura de Madrid se incorporan las prácticas en taller de cantería como asignatura del Plan de 1996 y parte de un Master de Restauración. Ese mismo año nace la Sociedad Española de Historia de la Construcción promovida por el profesor de estructuras Santiago Huerta, desde la que se organizan los CNHC (Congreso Nacional de Historia de la Construcción) bienales. Desde 2007 la página de la Sociedad pone a disposición del público una amplia selección de Tratados históricos escaneados.
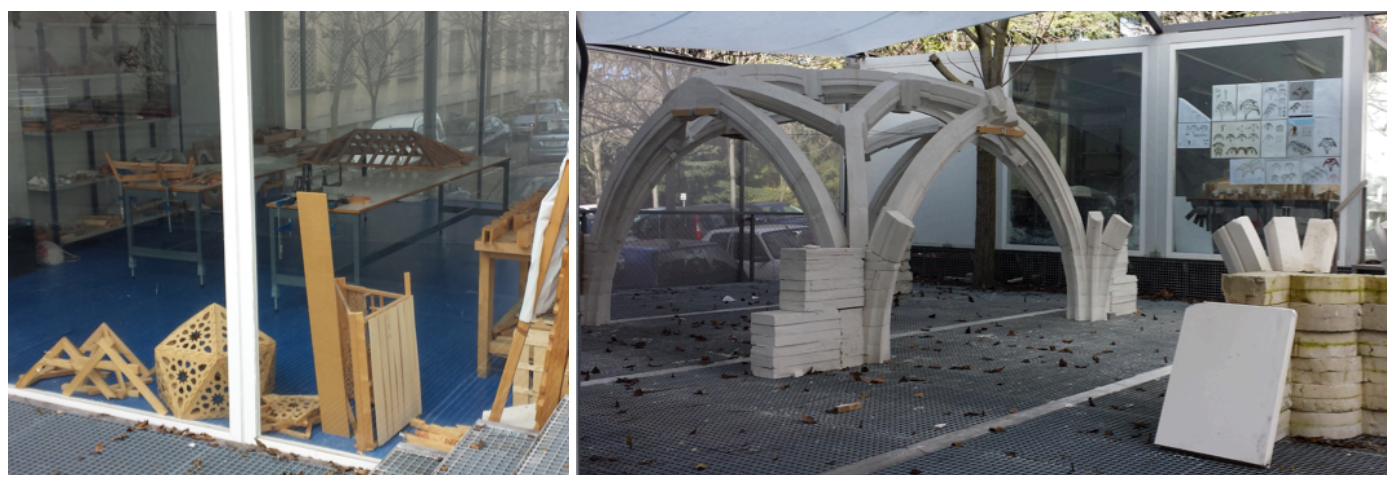

Fig.III.28. Talleres carpintería y cantería ETSAM, visita 30/01/2015

Actualmente se imparten enseñanzas de construcción histórica y tradicional dentro de numerosos programas Master que han ido materializándose con diversos nombres: Master en Conservación del Patrimonio (en 1989 como título propio en Valencia), Master de Restauración y Rehabilitación del Patrimonio (Valladolid), Restauración y Gestión Integral del Patrimonio Construido (País Vasco), etc. 
Durante algún tiempo en la Escuela de Madrid sí hubo opción en $5^{\circ}$ curso a la especialidad Restauración de Monumentos, hasta que las asignaturas pasaron impartirse sólo en estudios de Doctorado con el Plan de 1964. Teoría y Práctica de la Restauración estuvo a cargo de Menéndez Pidal y José Antonio Arenillas Asín ${ }^{57}$. En 1990 arranca un Master de Restauración Arquitectónica, que va evolucionando y desdoblándose, generando nuevos programas; Arqueología de la Arquitectura; Patología, Conservación y Rehabilitación; Conservación y Restauración del Patrimonio Arquitectónico.

El Departamento de Conservación y Restauración de Bienes Culturales de la Universitat Politècnica de València (creado en el año 1990) se postula como el único en la comunidad universitaria española que posee el área de conocimiento propia en Conservación y Restauración de Bienes Culturales.

\section{III.3.1.2.2. EI manual de López Collado}

Es conocida la influencia del libro Ruinas en construcciones antiguas en la generalización del uso de zunchos de hormigón armado en las intervenciones sobre el Patrimonio edificado. Obra del aparejador Gabriel López Collado ${ }^{58}$, este libro de texto en Escuelas de arquitectura técnica, se origina a partir de unos cursos de restauración celebrados anualmente desde 1973 para formar a los becarios del Servicio de Monumentos.

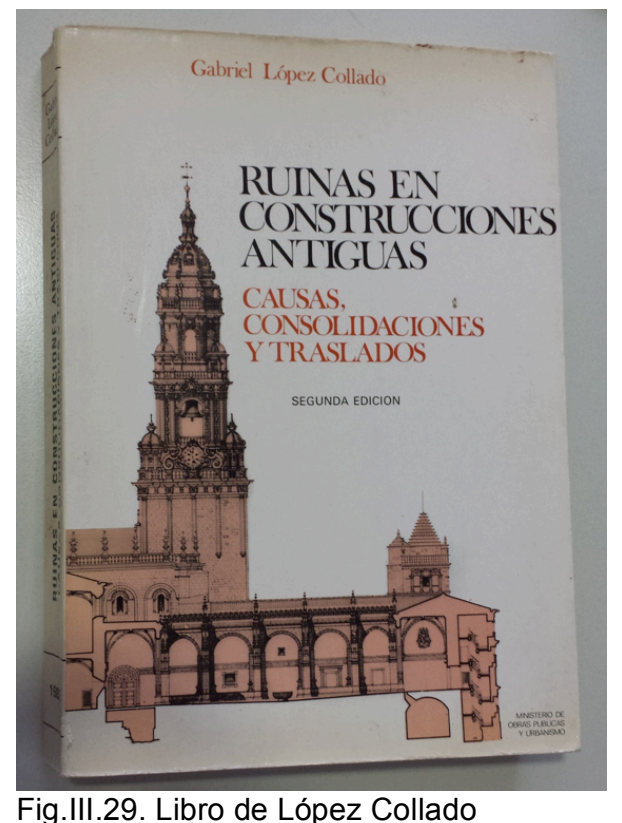

El propio autor explica en la introducción cómo su objetivo es resultar útil para todos los que intervienen en una obra de Restauración, para lo que adopta expresamente un lenguaje sencillo con explicaciones claras. $\mathrm{Su}$ experiencia profesional arranca en 1939 y el libro se reedita en 1982.

\footnotetext{
${ }^{57}$ Arenillas Asín colabora con su padre en varios proyectos en Valladolid, donde firma, por ejemplo, la sustitución de cubiertas de la Capilla de San Gregorio.

${ }^{58}$ López Collado, G. (1982). Ruinas en construcciones antiguas. Causas, consolidaciones y traslados. Servicio de publicaciones MOPU.
} 
En el Glosario final se recoge el término zuncho como abrazadera de hierro o de cualquier otro material resistente que sirve bien para fortalecer las cosas sometidas a gran presión. Aro de refuerzo que envuelve una pieza para aumentar su resistencia al pandeo.

"Los recalzos en cimientos no los haremos con mampuestos y morteros de cal, sino con hormigón de cemento. Con hormigón armado reforzaremos los arcos y bóvedas por zonas no vistas. Construiremos zunchos y tirantes, armaremos interiormente pilares de piedra en descomposición, acodalaremos cimentaciones, forjaremos cubiertas y pisos, reforzaremos interiormente los muros, etcétera. No debemos repetir una cubierta de madera como la de la fotografía número 21 , no vista y podrida, por otra también de madera, con vida limitada y riesgo de incendios; la sustituiremos por otra realizada con elementos y procedimientos actuales, de hormigón armado, metálica, de tabiquillos, etc."

En el apartado 29 acodalamientos y zunchados para recalce de cimientos analiza una gran viga cadena que circunda un edificio zunchándolo, en Teror. En el 40 comenta cómo el refuerzo de la cúpula de la plaza de toros de Málaga, con doble fila de cadenas en planta baja, se haría de distinta forma en ese momento: con un zuncho de hormigón armado cajeado por tramos detrás de la cornisa y unido a un forro del mismo material sobre todo el cascarón.

En las fotografías que se incluyen en el libro apreciamos zunchos en ejecución junto al forrado de bóvedas en numerosas obras: las catedrales de Tuy, Santiago, Gerona, la colegiata de Toro, iglesias en Yecla, Zaragoza, Moguer, Ribadavia, Jerez, Garachico...

En el epígrafe 48, Zunchos y tirantes de hormigón armado, afirma

"al estudiar una nueva cubierta pensaremos en un zuncho de hormigón armado (figura 80), atando la coronación de los muros, anclando cornisas y recibiendo las placas de anclaje para las cerchas de la cubierta. Cuando reforcemos forjados pondremos zunchos de hormigón armado. Si se trata de arquería, torres, etc., siempre zunchos y tirantes, en todos aquellos sitios en que sean fáciles de hacer, aunque de momento no los consideremos necesarios; con ello evitaremos nuevos movimientos que puedan acortar la estabilidad en un futuro más o menos próximo para el edificio" 


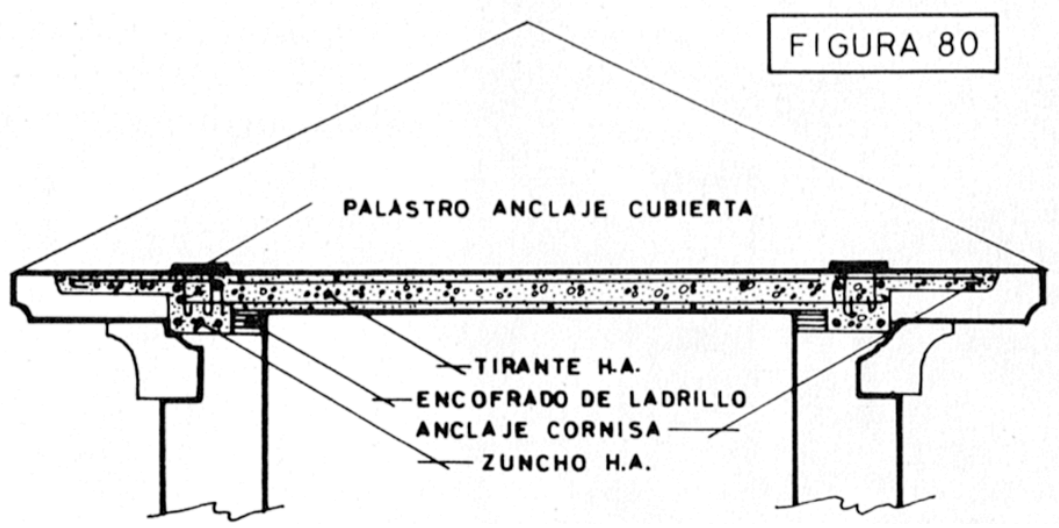

Fig.III.30. Ilustración del libro de López Collado

"Mucho insistimos sobre la forma de preparar y hacer las sustituciones en las viejas cubiertas de madera en nuestros edificios monumentales, por considerar que es la labor más importante de todas las que en ellos podemos realizar, no sólo por quitar el peligro que representa por su mal estado, sino también por ser el momento de reforzar, atirantar, acodalar y, en definitiva, mejorar el edificio para su mayor duración."

La falta de formación de los técnicos en la materia y el acceso a esta obra intencionadamente divulgativa la convierte en su manual de cabecera durante generaciones.

Aún en 1991 se edita un libro sobre las Jornadas sobre restauración y conservación de monumentos celebradas en Madrid en abril de 1989 en el que participa López Collado con una comunicación titulada "Actuaciones recomendables en Restauraciones de Edificios Antiguos" ${ }^{59}$. En el texto destaca que la Escuela de Arquitectura Técnica de la universidad politécnica de Valencia fue la primera del país en crear la cátedra Patología, Técnicas de Restauración y Rehabilitación de Edificios a partir del curso 78-79.

Describe dos etapas: reconocimiento de su estado actual y estudio de materiales. A continuación enumera los procedimientos a seguir para suspender y evitar los movimientos y desperfectos, aclarando que si se trata de zonas vistas deben repetirse los mismos materiales pero los no vistos podrán sustituirse o reforzarlos con materiales y procedimientos actuales. Defiende también dejar vistas las fábricas de

\footnotetext{
${ }^{59}$ López Collado, G. L. (1991). Actuaciones recomendables en restauraciones de edificios antiguos. In Jornadas sobre Restauración y Conservación de Monumentos: Madrid, 24 y 25 de abril de 1989 (pp. 177-182). Instituto de Conservación y Restauración de Bienes Culturales.
} 
piedra o ladrillo que nunca lo fueron pero que han perdido su revestimiento, sin cubrirlas con un revoco nuevo.

En las imágenes que acompañan al artículo que, según se ha mencionado, se publica en 1991, vemos la disposición de armaduras para reforzar con vigas, diagonales y revestimiento de trasdós de bóvedas en hormigón armado.
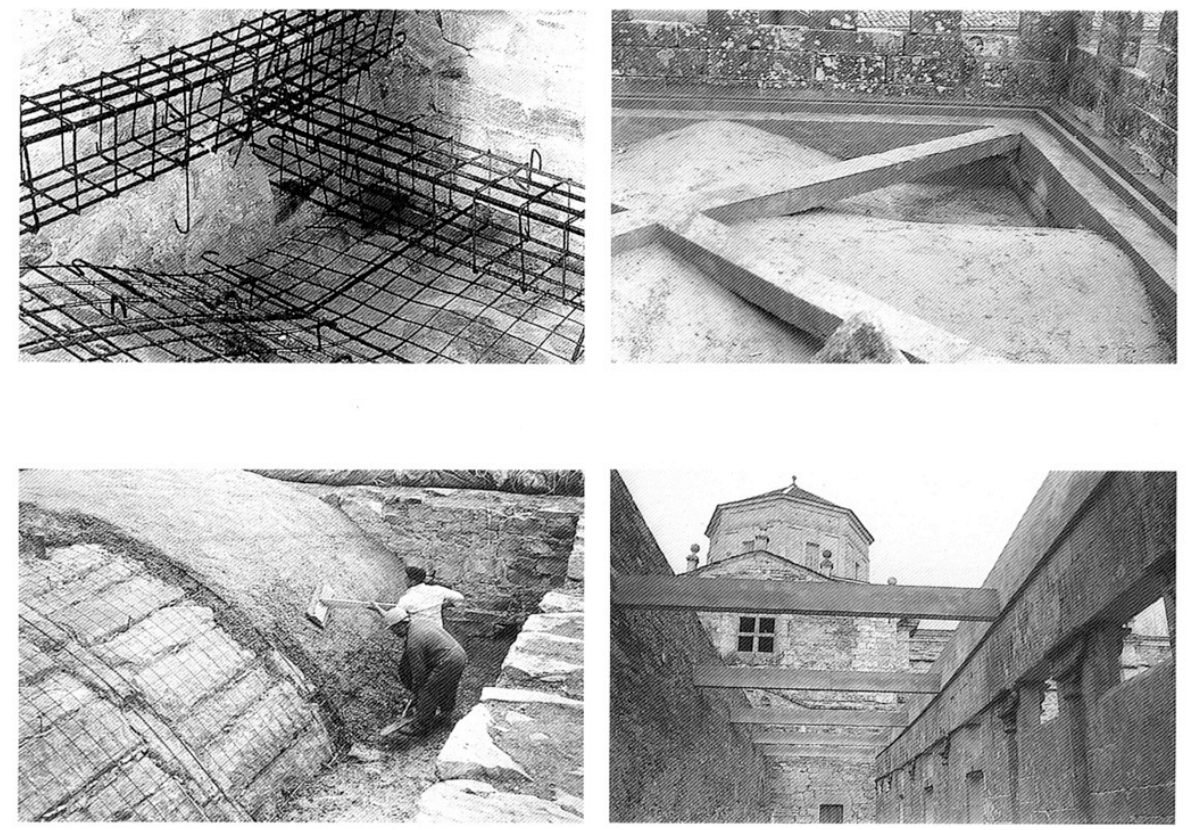

Fig.III.31. Fotografías del artículo de López Collado de 1991

Recomienda los siguientes "procedimientos:

- Recalzo de cimientos, o acodalándolos bajo los pavimentos con vigas de H.A.

- Zunchados exteriores de los cimientos, para anclarlos en el terreno, cortando su deslizamiento.

- Suspender las humedades por capilaridad en los muros, mediante zanjas de drenaje, taladros con rejillas, o siliconas que colmaten.

- Nuevos contrafuertes que suspendan el vuelco de los muros en mal estado y absorban los empujes que reciben.

- Fundir en el interior de los muros, vigas de H.A. para atar y suspender los movimientos.

- Rehacer, eliminando las desafortunadas obras.

- Eliminar las raíces de las plantas germinadas en los morteros de los muros, cubiertas y terrazas.

- Reforzar con H.A. los arcos y bóvedad que producen empujes o amenazan con hacerlo.

- Zunchar y atirantar con H.A. la coronación de los muros. 
- Suspender los empujes de cubiertas dañadas y suprimir los apeos de éstas sobre arcos y bóvedas.

- Sustitución de los elementos dañados en cubiertas vistas de madera, o sustitución de las no vistas por otras de H.A. o viguería metálica de los que se suspenderán los maderos de piso vistos en mal estado.

- Tratar la madera para suspender o evitar enfermedades".

\section{III.3.1.3. Generalización en el siglo XX}

En una tesis defendida en 2003 en la Universidad Politécnica de Catalunya por la arquitecta Mariana Esponda se recoge la evolución de los criterios de intervención con hormigón armado en la restauración de edificios históricos en México y en España. El trabajo es fruto de la evolución de los informes "after ten" vinculados al Método $\mathrm{SCCM}^{60}$ de restauración monumental (la Restauración objetiva, renombrada con las siglas del Servei de Catalogació i Conservació de Monuments creado en 1914) y la metodología de intervención sobre el Patrimonio de la Diputación de Barcelona en los últimos treinta años.

Según el enunciado de dicha tesis, las tecnologías históricas se caracterizan por el uso de materiales tradicionales que conforman obras de fábrica: adobe, ladrillo, piedra y mortero de cal. A principios del siglo XX se mantenían esos materiales de construcción. Desde mediados de siglo se generaliza el hormigón armado, al cambiar radicalmente la concepción estructural. Con el cambio de mentalidad los técnicos que intervienen sobre las construcciones de fábrica presuponen que las fisuras indican peligro en su estabilidad.

Analiza en diversas intervenciones los efectos sobre comportamiento estructural, vulnerabilidad del conjunto, durabilidad del material y compatibilidad con los materiales tradicionales. Afirma que las técnicas más utilizadas para consolidar estructuras de edificios históricos entre 1950 y los 90 son los refuerzos e inyecciones con hormigón armado. Distingue el fallo por incompatibilidad entre materiales de los debidos a errores de ejecución, de calidad, o de cantidad del material. No cita ni considera en ningún momento los añadidos de metal. Cuestiona que el tiempo que

\footnotetext{
${ }^{60}$ González Moreno-Navarro, A. (1992). La restauración objetiva (Método SCCM de restauración monumental): Memoria SPAL 1993-1998. Diputació de Barcelona. Servei del Patrimoni Arquitectònic Local.
} 
una técnica de intervención permanece en uso, aplicándose sobre el patrimonio, sea proporcional a su efectividad.

Describe cómo entre 1890 y 1930 se publicaron muchos manuales del hormigón armado. Los cursos de la Universidad no contemplaban el estudio de la mampostería y se pierden los oficios artesanales al considerarse obsoletos los morteros de cal.

Entusiasmados con el hormigón armado y su comportamiento elástico, la posibilidad de controlarlo científicamente, con verificaciones numéricas, lleva a desconfiar de los materiales tradicionales. Al valorar la seguridad de las estructuras históricas con normas nuevas se obtenían resultados desfavorables en cuanto a su resistencia, lo que llevaba a su sistemático refuerzo con hormigón.

En el aspecto económico, la mano de obra del hormigón era más barata, resultando las obras más rápidas y menor su coste. Las intervenciones son distinguibles de las preexistencias; en 1920 se considera que un añadido de hormigón resulta discreto, entonado y respetuoso (y cita como ejemplo a través de "Artes de la cal" de Gárate el criterio de Balanos sobre la restauración del arco de Tito en Roma por Stern y Valadier). En la Carta de Atenas de 1931 se incluye que "los expertos aprueban empleo de recursos de la técnica moderna... especialmente hormigón armado". Actualmente, tras la Carta del ICOMOS de 2002 se pretende retomar las técnicas tradicionales y emplear soluciones reversibles.

Nombra varias intervenciones, aunque en el documento accesible en internet no incluye fichas. Indica que en 1974 Luis Cervera Vera reemplaza madera por cerchas y chapa con zuncho de hormigón armado en la Catedral de Valladolid. Cita tres casos de zunchos en España recogidos en el libro de López Collado: Catedral de Tuy en Pontevedra 1971, Iglesia de San Pedro en Zaragoza 1974 y Monasterio Monfero en A Coruña 1971.

En el periodo de 1980 a 1995 las obras de restauración del Patrimonio más destacadas corren a cargo del Instituto de Conservación y restauración de bienes culturales de España y las Diputaciones de Barcelona y Girona. Afirma haber analizado 30 edificios correspondientes a esta fase de los que en el $8 \%$ se emplean materiales tradicionales. Detecta 19 zunchos perimetrales en muros y 4 en campanarios. 
Analiza las técnicas de intervención sobre cada tipo de elemento, muros, columnas, dinteles, arcos, bóvedas y cúpulas, diferenciando entre:

Tradicionales: reparación (sustitución, inyección, grapado)

Modernas: reestructuración (inyección armada, revestido de hormigón, entramados, atirantados, zunchado)

Concluye que el asunto es especialmente delicado en zonas sísmicas. En los últimos años, tras graves problemas, han cambiado los criterios de intervención, volviéndose al respeto por la concepción estructural original de los edificios históricos, después de intervenciones entre 1950-80 en Italia con empleo de cosidos armados, micropilotes, malla armada en bóvedas y encadenamientos o zunchos en muros y cubiertas.

Cita un informe de 1985 de la AITEC (Asociación Italiana del Cemento) que revisa 50 años de uso del hormigón armado en la conservación de monumentos. La catedral de Noto en Sicilia, sufre en 1950 el cambio del techo de madera por un forjado de hormigón armado de $48 \mathrm{~cm}$ de canto con zuncho perimetral y en los 80 inyecciones armadas. En 1996 cae parcialmente tras un terremoto.

En los años 60 se generaliza en México hacer refuerzos estructurales globales, confinando completamente con hormigón armado y en los 70 se debe volver a intervenir al producirse casos de agrietamientos generalizados. Tras el sismo de 1999 hay en Oaxaca 667 edificios afectados.

Afirma que el hormigón armado en restauración de edificios en Europa empieza en Francia e Italia. Más adelante, a finales de los años treinta, se utiliza en España, Portugal y Grecia. Por último en Alemania, Polonia, Hungría y Rumanía se aplica tras la segunda guerra mundial y de manera menos exhaustiva. No encuentra casi ejemplos en Inglaterra por su postura conservacionista y la preferencia por los materiales tradicionales.

Clasifica sus conclusiones sobre la evolución de los criterios de intervención con hormigón armado como técnica de restauración en tres grupos de razones:

I. Por qué se utilizó a partir de los años 50 en la restauración de edificios históricos.

II. Por qué se comienza a rechazar recientemente el hormigón armado, y propuestas alternativas que aparecen.

III. Por qué se sigue empleando a pesar de la constatación del balance negativo. 
I. Según la autora el éxito se originó por la pérdida de conocimientos sobre las técnicas tradicionales y la formación de los técnicos basada en los nuevos materiales, hormigón y acero, controlados a partir de su cálculo elástico, numérico. Se empezaron a calibrar las edificaciones históricas bajo el enfoque de los parámetros destinados a nueva construcción, lo que condujo a considerar necesario reforzarlos estructuralmente.

A partir de 1960 en España se generaliza el uso de hormigón armado "como una moda", incluso de forma preventiva, una especie de receta universal frente a posibles debilidades estructurales.

De 1970 a 1990 Esponda afirma que se restaura mayoritariamente con hormigón armado en casi toda Europa, Indonesia, Líbano, Egipto y también en países de América: Argentina, Colombia, El Salvador, Guatemala, México y Venezuela.

Enumera los usos más extendidos: recalce y nuevas cimentaciones, inyecciones en fábricas, arcos, torres, etc. Cita zunchos perimetrales colocados en bóvedas y cubiertas en las que se reemplaza la cubierta de madera por vigas de hormigón o acero.

El hormigón armado podía calcularse numéricamente (incluso con ordenador, lo que implícitamente se asocia a precisión y seguridad), someterse a control de calidad y resultaba práctico y económico.

La rapidez de ejecución de los refuerzos de hormigón favoreció su empleo tras conflictos bélicos y catástrofes naturales, para "reconstruir y consolidar", especialmente en zonas de actividad sísmica.

II. En 1982 el ICCROM dedica su Simposio Técnico Anual al estudio de los morteros y lechadas usados en la conservación de edificios históricos. Parte de los participantes critica el empleo indiscriminado de cemento (excesiva dureza, impermeabilidad, expansión, reacción ácido-álcalis...) y reclama una vuelta al uso de la cal.

El año 2000 tras el congreso de Bressanone "La prova del tempo. Verifiche degli interventi per la conservazione del costruito" se han ido demostrando los 
inconvenientes de las técnicas empleadas las últimas décadas del siglo XX. Falta de las oportunas durabilidad, reversibilidad y autenticidad.

Además de la incompatibilidad física y química entre los materiales tradicionales y los morteros de cemento, cita los problemas del distinto comportamiento estructural de los refuerzos y de las construcciones históricas. El "peligro de leer los edificios históricos bajo la base de la teoría de la elasticidad", de concebir la seguridad estructural de un modo que no corresponde al modo en que se creó esa edificación.

En el documento se describen los graves problemas que han sufrido las construcciones de fábrica reforzadas con hormigón en zonas sísmicas (México, Italia, El Salvador), con un aumento de rigidez que incrementaba su vulnerabilidad frente a solicitaciones dinámicas.

III. Se sigue utilizando el hormigón armado

Considera que se sigue utilizando por las mismas razones por las que se extendió su uso, porque aún se desconocen sus inconvenientes y no hay alternativas eficaces.

Es importante puntualizar que se trata de una investigación defendida en 2003 (han pasado más de diez años) en Cataluña, mientras que la Comunidad de Castilla y León donde se desarrolla nuestro estudio cuenta con características propias. Esponda recoge alternativas a la adición de cemento a los morteros de cal como el polvo de ladrillo y cita el posible uso de fibras reforzadas, de carbono o composite como sustitutos de los refuerzos con hormigón armado. 


\section{III.3.2. El zuncho en la restauración monumental en otras regiones}

Es evidente que el empleo del zuncho en restauración monumental no es un hecho aislado en la provincia de Valladolid que acota la investigación. En otras regiones también se ha utilizado, siempre dentro de las peculiaridades constructivas de cada una de ellas. Para situar el tema en su contexto se han seleccionado cuatro zonas sobre las que se cuenta con información especialmente contrastada, tanto gracias a la existencia de tesis doctorales específicas sobre restauración monumental en las mismas, como por la difusión de sus trabajos realizada por algunos arquitectos involucrados ${ }^{61}$.

Dentro de España se resumen las actuaciones más destacadas de Galicia y Badajoz, y como países extranjeros se analiza el estado de la cuestión en Portugal e Italia. El desarrollo del análisis en este último país se ha dividido en dos partes, incorporándose las intervenciones relacionadas con terremotos al siguiente capítulo sobre sismo y las más recientes al de últimas tendencias.

\section{III.3.2.1. Badajoz}

En su tesis doctoral en Historia del Arte, sobre restauración de monumentos en Badajoz, $\mathrm{M}^{\mathrm{a}}$ Antonia Pardo ${ }^{62}$ menciona numerosos zunchos al describir obras acometidas en los últimos cien años.

En la Iglesia de Nuestra Señora de la Granada se restauran las cubiertas en 1978: desmontaje de teja y estructura de madera, colocación de zuncho de hormigón sobre el coronamiento de los muros, para garantizar el atado de las fábricas.

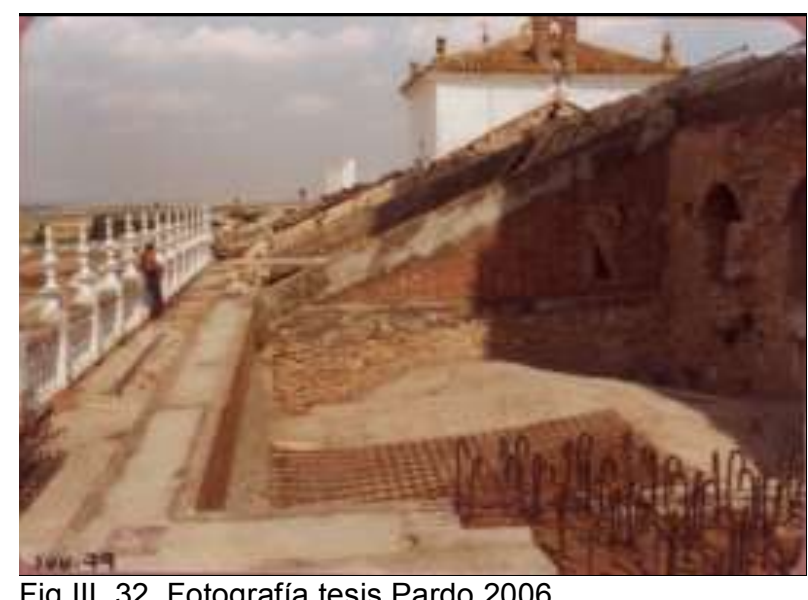

Fig.III. 32. Fotografía tesis Pardo 2006

\footnotetext{
${ }^{61}$ Ha sido posible contactar con los arquitectos citados en estos capítulos, como Vicente López Bernal, Miguel Malheiro y Lorenzo Jurina.

${ }^{62}$ Pardo, M. A. (2006). Un siglo de Restauración Monumental en los conjuntos históricos declarados de la provincia de Badajoz: 1900-2000. Universidad de Extremadura, Cáceres.
} 
El anclaje transversal se realizó con une especie de costillas de hormigón armado sobre los arcos fajones de las tres naves. Se cubre con cerchas metálicas con capa de compresión de hormigón armado, piezas cerámicas y teja curva recibida con mortero de cemento.

Pardo comenta que la intervención de Vicente López Bernal en el Convento de Santa Clara en 1991 es respetuosa porque intenta pasar desapercibida al visitante: al exterior se cubre con teja y al interior mantiene rollizos de madera y plementería de barro. En realidad la estructura portante se renueva y es de perfiles metálicos sobre zuncho perimetral.

La iglesia de Santa María del Castillo en Olivenza es reforzada por MenéndezPidal en 1968. Aparte de suspender el arco del coro de una viga de hormigón, coloca zunchos en cada piso y remate de la torre, tensores de acero e inyección de cemento en los muros.

La restauración de Santa María Magdalena, también en Olivenza, la acomete Manuel Fortea en 1992. Se recupera la supuesta pendiente original de las cubiertas de la nave central, con las laterales aterrazadas, que al parecer habían sido modificadas en una intervención anterior. Dispone paneles de chapa de acero y correas metálicas sobre zuncho de hormigón y tabicones de ladrillo.

En 1981 J. Manzano-Monís actúa sobre el Hospital de San Juan de Dios reemplazando las cubiertas una vez más por cerchas metálicas sobre un zuncho perimetral "que a su vez ejercía la acción de atado del coronamiento de los muros, algunos de ellos seriamente agrietados". Se disimulaba la cubrición de placas de fibrocemento con teja árabe vieja.

En Feria se cita el zunchado con hormigón y tirantes de acero de la torre agrietada de la iglesia de San Bartolomé también realizado por López Bernal en 1997.

Menéndez Pidal reemplaza otra armadura de madera por cerchas sobre zuncho perimetral en 1971 en la cubierta de la Iglesia de San Miguel en Jerez de los Caballeros. 


\section{III.3.2.2. Galicia}

En los últimos años se han desarrollado investigaciones de bastante calado sobre el Patrimonio gallego y las intervenciones producidas en el mismo. Encontramos varios artículos y comunicaciones acerca del arquitecto Pons Sorolla. En la tesis doctoral de Belén Castro ${ }^{63}$ se menciona cómo en 1978 éste coloca "zunchos y atirantados para reforzar la estructura" en la Real Colegiata de Roncesvalles. A mediados de los sesenta recalza la fachada principal y reconstruye el muro de la iglesia de Vilar de Donas en Lugo con zunchos de hormigón. También en el monasterio de San Rosendo de Celanova en Orense. La historiadora del arte afirma que

"el zunchado de hormigón es la otra operación que, junto al inyectado, califica una actuación de consolidación. Su instalación -normalmente oculta en las intervenciones de Pons-Sorolla- implica, a diferencia de las lechadas, trabajos previos de desmontaje más amplios para alojar con eficacia este sistema de refuerzo -por ejemplo, en la iglesia del Monasterio de Santa María de Acibeiro (Pontevedra) se establecen apeos con objeto de desmontar el muro frontal de cabecera en su parte alta (...) y alojar viga-zuncho de hormigón armado que ate por cabeza dicho muro, proceso realizado desde la cara exterior del muro utilizando la hoja interior de sillería como encofrado del hormigón. Por ello, el zunchado se asocia generalmente a la reposición de cubiertas con objeto de repartir mejor los empujes producidos por éstas"

También a mediados de los sesenta se combina inyección y zunchado en la iglesia de San Miguel de Eiré en Pantón (Lugo). A mediados de los setenta en San Martin Pinario (Santiago de Compostela) se instalan vigas-zuncho a lo largo del trasdós del cañón de la iglesia, en el nivel de apoyo de la cúpula y el cimborrio. Se combinan con un cascarón fino de hormigón armado con mallazo revistiendo las bóvedas.

Del mismo modo, el arquitecto citado refuerza las bóvedas e instala zunchos perimetrales en muros de la Catedral de Tui con atados transversales sobre bóvedas de naves y cabezas de muros exteriores a nivel de cornisas antes de renovar las cubiertas en la segunda mitad del siglo XX, ya que entiende que "la mejor solución para estabilizar el monumento consiste en construir nuevas cubiertas -previa consolidación de abovedamientos con cemento y zunchos de hormigón".

\footnotetext{
${ }^{63}$ Castro, B. (2007). Francisco Pons-Sorolla y Arnau, arquitecto restaurador. Universidad de Santiago de Compostela, Santiago de Compostela.
} 
Castro afirma que "la principal amenaza que afecta a la integridad de edificaciones antiguas es la conservación de sus cubiertas. La degradación del cierre superior acelera el proceso de ruina y desestabilización de las estructuras portantes".

Las tres décadas de intervenciones de Pons Sorolla director del Servicio en que trabaja como secretario técnico López Collado se legitiman, según Belén Castro, con la edición del famoso libro Ruinas en construcciones antiguas citado en el apartado anterior (III.36-40).

En una comunicación de Cristina González ${ }^{64}$ en el IV CNHC se describe cómo la cubierta del claustro de madera de la Catedral de Santiago de Compostela se reemplaza por otra "incombustible" de hormigón y las bóvedas se "consolidan" con 8-14cm de hormigón armado con mallazo anclado a los muros mediante mechinales.

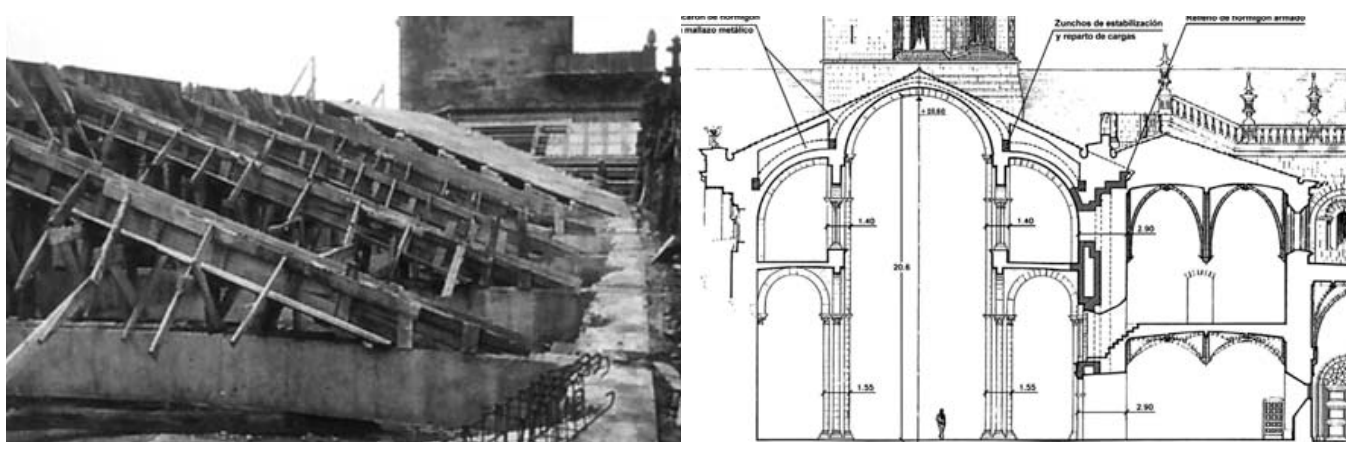

Fig.III. 33. Ilustraciones Catedral de Santiago, González Martín 2005

Explica cómo antes de recuperar la terminación pétrea de la cubierta de la nave mayor, que había sido ocultada en una intervención anterior, "se ejecutaron zunchos de hormigón armado de estabilización y reparto de cargas a lo largo de la cabeza de los muros extremos y sobre el muro de separación de naves" según se señala en la sección de 1969. Afirma también que se han acometido varias obras más de reparación de las cubiertas desde 1985.

\footnotetext{
${ }^{64}$ González Martín, C. (2005). Las intervenciones de Francisco Pons-Sorolla en la construcción de la Catedral de Santiago de Compostela entre 1962 y 1975. In Actas del Cuarto Congreso Nacional de Historia de la Construcción: Cádiz, 27-29 de enero de 2005 (pp. 499-510). Instituto Juan de Herrera.
} 


\section{III.3.2.3. El zuncho en Portugal}

Del mismo modo que encontramos grandes diferencias entre las expresiones empleadas en España y las habituales en otros países de habla hispana, el léxico utilizado en la construcción portuguesa no es el mismo que podemos encontrar en Brasil. Aunque en este último hay bastantes estudios de arquitectura colonial que contemplan las cuestiones relacionadas con la conservación de cubiertas tradicionales de madera sobre muros de fábrica, y las definiciones siguientes se han obtenido de un Glosario online brasileño ${ }^{65}$, la documentación del presente capítulo indaga en el uso de zunchos en restauraciones de iglesias realizadas en Portugal.

Cinta ou Cintamento Faixa, geralmente metálica, usada para envolver construções de alvenaria com a função de evitar possíveis desagregamentos.

Cadena o encadenado. Faja, generalmente metálica, usada para envolver construcciones de fábrica con el fin de evitar su posible disgregación.

Cinta de amarração é o nome que se dá à sucessão de vigas situadas nas paredes perimetrais das construções visando tornar mais solidárias entre si as paredes concorrentes.

Cadena de atado. Nombre que se da a la sucesión de vigas situadas en los muros perimetrales de los edificios con el fin de solidarizar los muros entre sí.

Frechal Componente do telhado. Viga que assenta sobre o topo da parede, recebe e distribui uniformemente as pressões exercidas por elementos equidistantes, como caibros de telhados, barrotes de sobrados, prumos etc. servindo de apoio dá sustentação à tesoura. Diferenciam-se dos baldrames devido ao modo de apoio: estes são ancorados somente nas extremidades, enquanto os frechais apoiam-se em toda a sua extensão na alvenaria, não trabalhando à flexão.

Zuncho. Componente del tejado. Viga que asienta sobre el remate del muro, recibe y distribuye uniformemente las presiones ejercidas por elementos equidistantes, como correas de cubierta, viguetas de forjados, apoyos, etc., que sirve de apoyo a las cerchas. Se distingue de las vigas riostras en su modo de apoyo: éstas se anclan solo en ambos extremos mientras que los zunchos apoyan sobre la fábrica en toda su longitud, sin trabajar a flexión.

\footnotetext{
${ }^{65} \mathrm{http}: / /$ www.iar.unicamp.br/lab/luz/ld/Arquitetural/Gloss\%E1rios/glossario_da_construcao.pdf consultado 20 de marzo de 2015
} 
Resulta interesante constatar que varios expertos lusos en restauración monumental consultados coinciden al afirmar que frechal (y su plural frechais) hace referencia a durmientes de madera de pequeña escuadría, no a zunchos. Según su criterio, por el contrario, a un zuncho de hormigón lo denominarían lintel de betão. Como veremos más adelante, en los textos analizados, sin embargo, aparece con la misma frecuencia en las descripciones de obras de restauración monumental la expresión frechais de betão armado y el término lintel, con un claro predominio de la palabra cinta.

La cubierta típica en Portugal presenta la asna (cercha) como principal elemento estructural, con una pendiente variable entre $20^{\circ}$ y $30^{\circ}$ y cuenta con tejas cerámicas sobre rastreles espaciados $40-50 \mathrm{~cm}$ que apoyan en frechal, madre y cumeeira.

Normalmente las cerchas son simples o tipo Palladio con luces medias entre 6 y $7 \mathrm{~m}$ y los empalmes, considerados articulaciones para el cálculo, suelen llevar refuerzos metálicos en prevención de viento, nieve $\mathrm{y}$, sobre todo, acciones sísmicas ${ }^{66}$.

Las especies de madera más usadas en las cubiertas tradicionales portuguesas son pino y eucalipto para construcciones industriales y castaño en edificios religiosos.

\section{III.3.2.3.1. Malheiro}

El profesor Miguel Malheiro es autor de una Tesis doctoral en portugués sobre la arquitectura románica en el valle del río Sousa defendida en la Escuela de Arquitectura de la Universidad de Valladolid en 2012. Su investigación se desarrolló dentro del Departamento de Urbanismo de la Universidad de Valladolid, por lo que el contenido es fundamentalmente gráfico y artístico, sin desarrollo de aspectos constructivos.

Entrevistado en la Universidad Lusíada de Porto el 26 de marzo de 2015, afirma que en Portugal se suelen reparar las piezas dañadas de las armaduras de cubierta de madera con el mismo material, reemplazándolas por completo sólo si es imprescindible y, en ese caso, también empleando la madera. No es habitual recurrir al acero en restauración monumental.

\footnotetext{
${ }^{66}$ Branco, J., Cruz, P., \& Piazza, M. (2006). Asnas de madeira. A importância da rigidez das ligaçoes. $4^{a}$ Jornadas Portuguesas de Engenarhia de Estruturas. Lisboa.
} 
En un artículo del Seminario Intervir em construçoes existentes de madeira ${ }^{67}$ analiza el caso de cinco iglesias románicas sobre las que ha realizado obras en los últimos diez años:

- San Mamede de Vila Verde en Felgueiras: no tenía cubierta y la hicieron completamente nueva, similar a las de edificios semejantes.

- San Nicolau en Marco de Canavezes: reforman la estructura pues era incoherente.

- Cabeça Santa en Penafiel: en los ochenta sustituyeron elementos degradados. Boletin en 1951.

- Tabuado en Marco de Canavezes: en los ochenta sustituyeron elementos degradados. Boletin en 1972

- Monteiro de Travanca en Amarante: madera de cubiertas y los muros en mal estado: colocan nueva estructura de madera y atados "ocultos". También publicado en un Boletin (en el texto posterior dice obra de 1958-1988)

En la primera parte del artículo describe la hipótesis de configuración original y cómo a mediados del siglo XX la DGEMIN (Direçao Geral de Edificios e Monumentos Nacionais) reemplaza algunas cubiertas. Las tres últimas, según lo publicado en boletines, mostraban techo de perfil curvo en la nave y asnas simples de dos pares con un tirante dispuesto a 1/3 de la altura. Madera de castaño de sección redonda, sin escuadrar. En la restauración se deja vista la madera donde antes había aparatosas bóvedas que simulaban mármol blanco.

Las primeras obras sobre las cubiertas de estos monumentos consistían en reparar sus armaduras. Más tarde también hubo que sustituir los elementos cerámicos, que duran unos 20 años.

En ese momento se incorporaron a estas tres iglesias zunchos de hormigón armado para reforzar la coronación de los muros y aumentar la resistencia frente a las sobrecargas del tejado ${ }^{68}$. La nueva estructura de cubierta sigue realizándose con madera de castaño.

\footnotetext{
${ }^{67}$ Malheiro, M. (2014). Intervençoes em coberturas medievais em madera: Tradiçao e contemporaneidade. En seminario Intervir em construçoes existentes de madeira.

68 "Nesta altura, as três igrejas receberam frechais em betão armado, para reforço do coroamento das paredes e maior resistência às sobrecargas do telhado".
} 
En las tres iglesias anteriores, se sustituyó el revestimiento cerámico deteriorado, los forros de madera de castaño y el aglomerado con lámina, por una subestructura de pino tratado y membrana de vapor. Mantienen las pendientes de los tejados. Rematan limas con zinc. El revestimiento de madera (forro) por el interior se sujeta a pares (pernas) y tirante (linha) a 1/3 en forma de artesa. Explica como "as pernas assentam sobre frechais em betão armado existentes, que se mantiveram" , es decir, las cerchas apoyan sobre los zunchos de hormigón armado, que se mantienen.

En San Mamede la cubierta se hizo nueva porque el edificio no la tenía, se encontraba arruinado. El autor de la restauración de este monumento explica ${ }^{69}$ que los sillares de la cara interior contaban con un resalte para impedir el desplazamiento hacia el exterior del durmiente de madera.

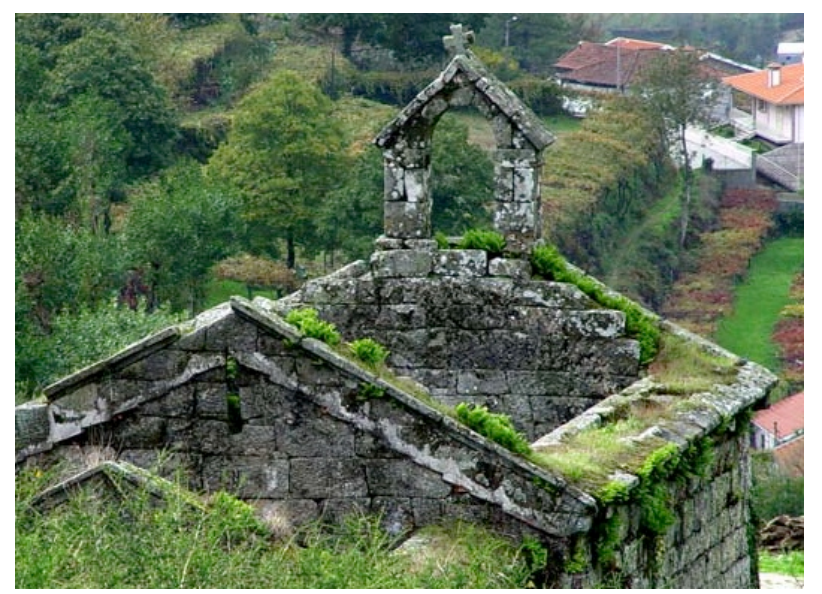

Fig.III.34. Fotografía de San Mamés antes de la intervención. www.todoromanico.pt (20/03/2015)

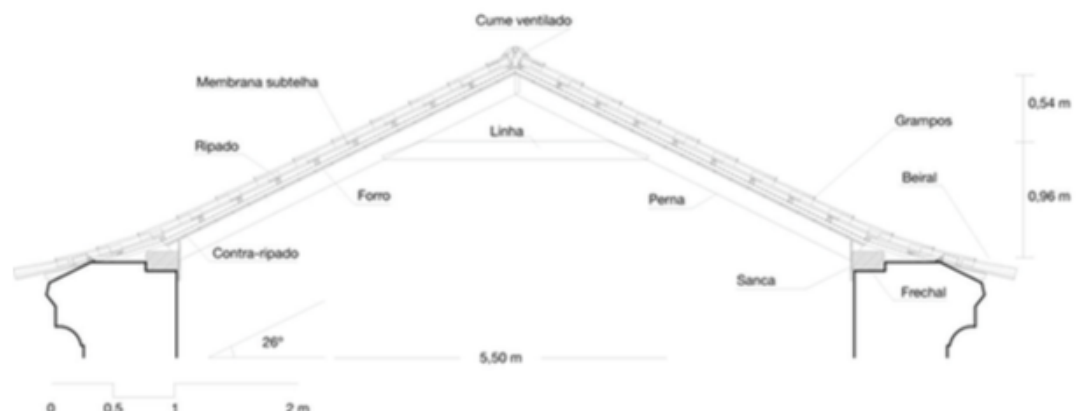

Fig.III.35. Sección transversal de San Mamés (Malheiro 2014)

En San Nicolás descubre una cubierta duplicada sobre la antigua de perfil interior curvo. Para resolver su apoyo se incorporó una hilada de sillares de granito sobre la cornisa. Han reemplazado todo con castaño, sección $6 \times 11 \mathrm{~cm}$, en pares y tirantes de cerchas, separadas cada $28 \mathrm{~cm}$ y eliminado la piedra añadida posiblemente en la intervención citada del 93.

Y por último, en la obra más reciente, la iglesia de Travanca, coloca un elemento metálico de conexión para reforzar el empalme de pares en cumbrera de nave central,

\footnotetext{
${ }^{69}$ Malheiro, en entrevista 26 de marzo de 2015, Porto.
} 
e incorpora conexiones ocultas de acero inoxidable en todos los encuentros de elementos de cubierta con los cerramientos para atar tanto cubierta como muros, que han sufrido movimientos, creando una solución de atado global del conjunto a partir de pequeñas interconexiones.

"Devido aos movimentos dos muros, que passaram pela separação de paredes em alguns tramos, houve a necessidade de realizar a amarração de todos os elementos à periferia dos tramos que compõem as três naves, através de ligações ocultas em aço inoxidável de todos os elementos aos muros, para uma interligação total do sistema de cobertura com as paredes que a suportam".

En este obra se hicieron sondeos, descubriendo que pilas y muros no tenían casi cimientos. Se aprovecharon sólo los barrotes mayores, las madres. Describe el sistema constructivo encontrado, la patente Patel que se empleaba en la zona en los años 70 , con ladrillos armados de $5 \mathrm{~cm}$ de grosor más capa de compresión de $5 \mathrm{~cm}$ apoyados sobre dos piezas de hormigón.

El profesor explica en la entrevista que el lintel de betão se coloca con el fin de regularizar la coronación del muro cosiendo transversalmente las hojas de caras y relleno, por eso es una pieza ancha de poco canto, mientras el frechal de madera es siempre un elemento de menores dimensiones. En todos los casos se dispone refreno porque, además de "bonito", evita recrecer en ese punto con una argamasa que "es una esponja para el agua".

La extinta DGEMN es responsable de las operaciones de valorización y salvaguarda de gran parte de los monumentos románicos (principalmente religiosos y militares, ya que hay pocos de carácter civil) que sobreviven a la expropiación de todos los bienes de la Iglesia llevada a cabo en Portugal el 28 de mayo de 1834. De la fusión de IPPAR e IPPA surge IGESPAR (Instituto de Gestão do Património Arquitectónico e Arqueológico). Hoy el organismo competente es la DGPC (Direção Geral do Património Cultural).

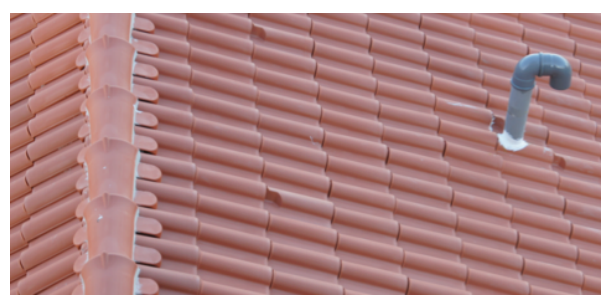

Fig.III.36. Tejado de la iglesia de los Canónigos en Porto.
En el país vecino se emplea frecuentemente el revestimiento de tejas tipo romano sobre doble familia de rastreles. En la imagen podemos ver la cubierta de la nave de la Iglesia de los Clérigos, recientemente restaurada 
En Oporto se forman los aleros con unas tejas curvas de grandes dimensiones, características de la zona, que vuelan exentas sobre las cornisas de fábrica.
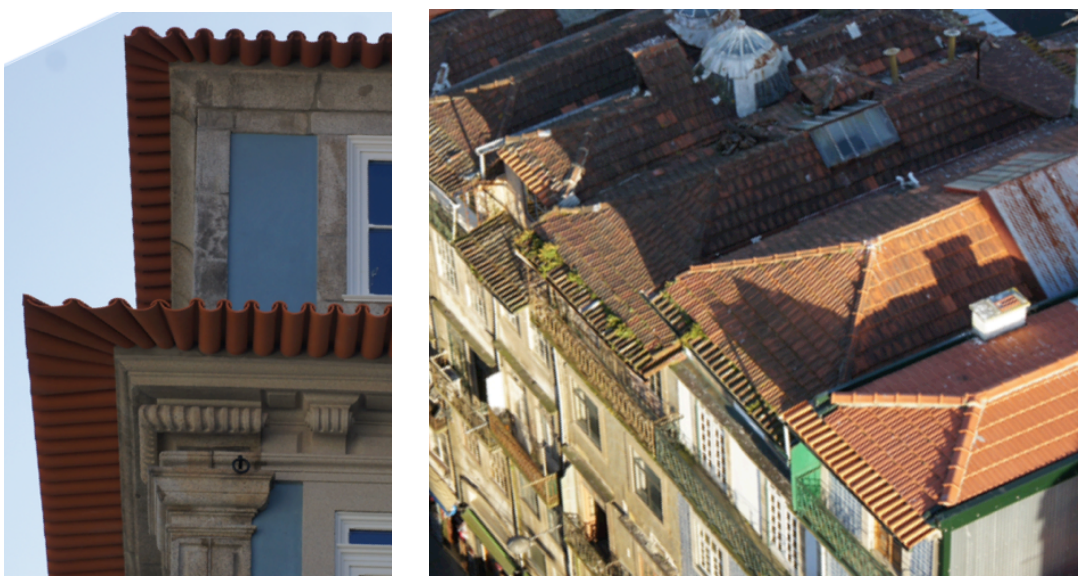

Fig.III.37. Vista general de tejados y aleros en la ciudad de Oporto

En muchos casos la doble familia de rastreles se dispone exenta, sin la tabla ripia imprescindible en Valladolid, aunque la solución empleada habitualmente por la DGEMN estaba constituida por forro sobre la perna, ripado, contra-ripado y telha. Sobre el contra-ripado se colocaba una sub-telha que durante algunos años fue sustituida por una lámina tipo Onduline.

En la actualidad se dispone una telha impermeabilizante pero que deja pasar el vapor para garantizar la ventilación del conjunto.
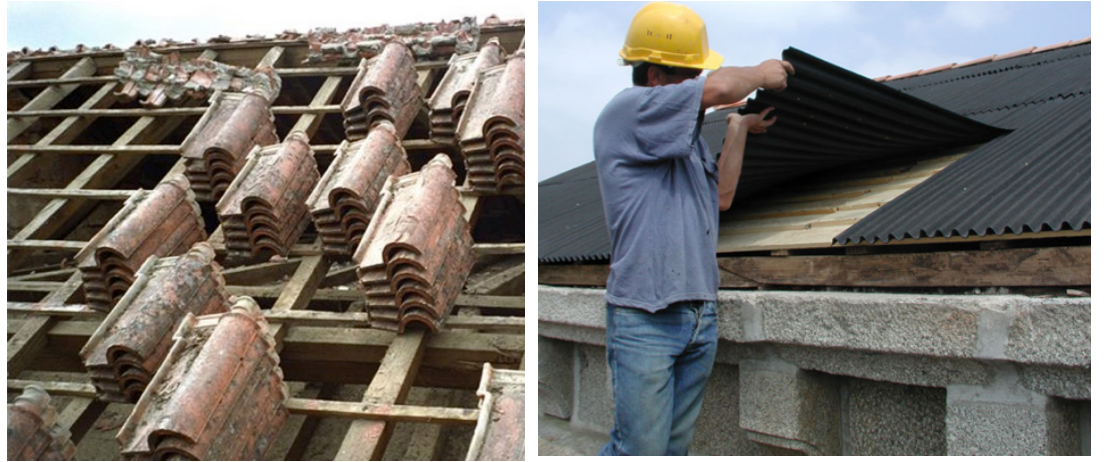

Fig.III.38. Obra de retejado en www.rotadoromanico.pt (20/03/2015) y telha airaes_recup

En la web www.monumentos.pt se puede acceder al sistema de información sobre patrimonio arquitectónico SIPA (Sistema de Informação para o Património Arquitectónico) gestionado por el ente gubernamental IHRU (Instituto de Habitação e da Reabilitação Urbana). En ella es posible descargar información general como inventarios o rutas temáticas y también documentación específica sobre cada uno de los monumentos catalogados. 
Se han seleccionado diez ejemplos documentados en la citada web repositorio www.monumentos.pt ${ }^{70}$ que, entre otras muchas actuaciones, describen la incorporación de atados empleando casi de forma indistinta los términos lintel, frechais y cintas de betão armado:

1. Colégio de Todos os Santos, Ilha de São Miguel (Açores)

1975 DGEMN Entre otras muchas actuaciones, levanta y renueva el tejado construyendo pilastras, cornisa y lintel de betão en las ventanas del coro alto.

2. Mosteiro de Santa Cruz, Coimbra.

1938 Se sustituye tejados a demoler por losa de hormigón, realizando la consolidação de paredes com anéis de betão armado.

1942 Betão armado em frechais.

1957 Reconstrucción de armadura y tejados sobre el ala del Refectorio, con cintagem de betão armado.

1970 Lintel em betão en sala anexa al piso superior del Claustro.

3. Igreja Paroquial de Ansiães, Bragança.

1967 Ejecución de frechais em betão armado para apoyo del tejado de la cabecera.

4. Igreja Paroquial, Vila do Conde.

1967 DGEMN Ejecución de frechais em betão armado.

1968 Ejecución de cinta ligeira de betão armado para amarração superior de las bóvedas.

1970 Ejecución de frechais em betão armado para travação de los muros.

1976 Reconstrucción de cubierta de la sacristía del lado Norte, aplicación de frechais de betão.

5. Santuário de Nossa Senhora do Cabo, Setúbal.

1965 Ejecución de cintas de travamento de betão armado; demolición de fábrica en entregas de los arcos para permitir se encastramiento.

1970 Recuperación de cubierta de iglesia con cinta e estrutura em betão armado

1974 Apertura de rozas constituyendo cajas para la construcción de cintas e pilares de betão armado.

6. Convento de Nossa Senhora da Penha de França, Lisboa.

1952 Ejecución de cintas de betão armado, sirviendo de fechal sobre los muros laterales, reparación general de cubiertas de iglesia.

\footnotetext{
${ }^{70}$ Acceso y consulta realizados el 30 de marzo de 2015.
} 
7. Ermida de Nossa Senhora de Guadalupe, Faro.

1960 Hormigonado de lintéis e cintas de travação, incluyendo demolición de fábricas.

1969 Reconstrucción de cubiertas, consolidación de nervaduras de bóvedas, hormigonado de lintéis e cintas de travação em pilares

1976 Reparación de tejados, limpieza de gárgolas, hormigonado de cintas de travação en muros de sacristía.

8. Convento de São Francisco de Estremoz, Évora.

1957 Reparación de cubiertas, cintas em betão

9. Convento de São Miguel, Gaeiras.

2000 Consolidación general del edificio con recalzo de cimientos en todo el perímetro y nivelación en la parte superior con un lintel de betão armado

10. Igreja de Santa Maria de Óbidos, Leiria.

1950 Lintéis de travação em betão armado;

1986 Sustitución de estructura de madera de cubierta por hormigón armado.

En el conjunto de descripciones seleccionado aparece 6 veces el término lintel; también se menciona en 6 ocasiones frechal y en 10 se hace referencia a cintas. Sólo en una ocasión se emplea la palabra anillo para referirse a un elemento destinado a consolidar los muros.

En la obra del arquitecto Pinho Borges se reemplaza la estructura de madera de la cúpula que cubre la Capilla del Santísimo Sacramento de la iglesia de Caminha, colocando una nueva en madera de castaño con un frechal perimetral también de $\operatorname{madera}^{71}$.
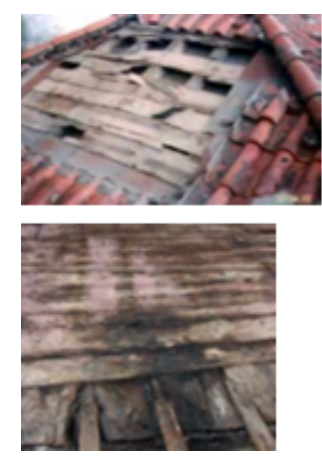

Fig.III.39. Iglesia de Carminha antes de la intervención, Ferreira 2012.

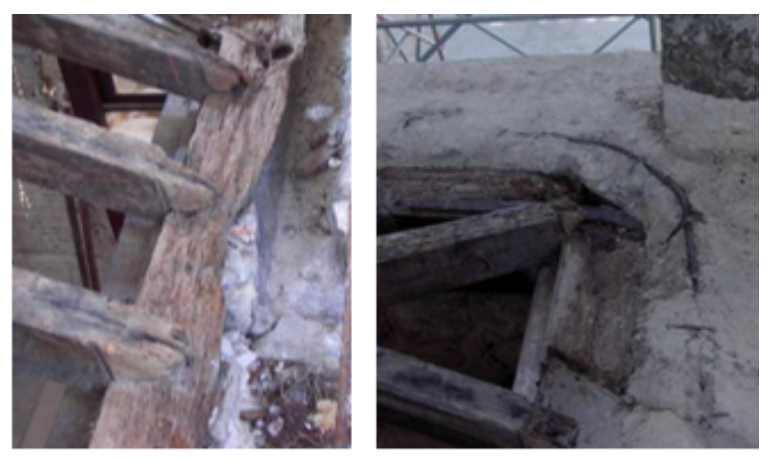

\footnotetext{
${ }^{71}$ Ferreira, F. (2012). Recuperação de estruturas de coberturas tradicionais de madeira - Análise de alguns exemplos. En Lourenço \& Branco (Eds.), en Seminário Coberturas de Madeira, Gimaraes: Universidade do Minho.
} 
La estructura de madera de cubierta de la nave de la citada iglesia de Caminha se encontraba podrida y con ataque de termitas. Portugal y Reis reemplazan los elementos de madera dañados por otros similares aplicando los oportunos tratamientos.
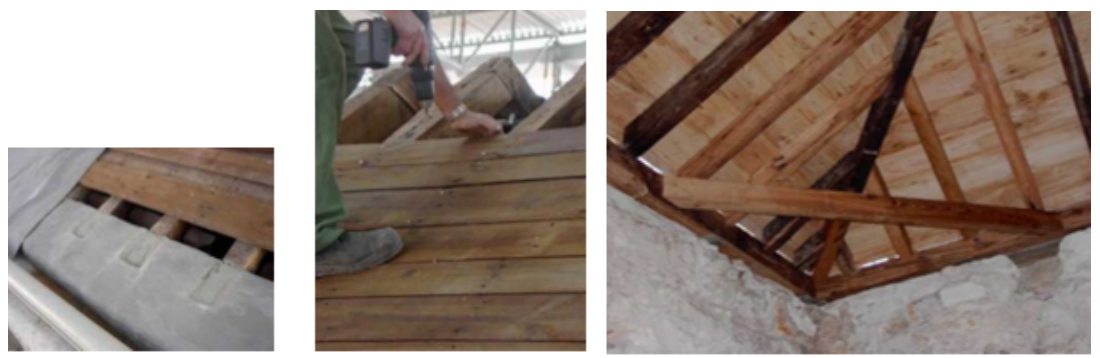

Fig.III.40. Caminha, prótesis de inoxidable y nuevo tablero, Ferreira 2012

Se mantienen la mayor parte de las piezas de hormigón armado, pues se considera que reemplazarlas por elementos de madera o piedra semejantes a los primitivos sería demasiado agresivo para el monumento, aunque algunas de ellas sí se sustituyen por secciones de madera.

\section{III.3.2.3.2. Refuerzos metálicos}

También según el citado Ferreira, los arquitectos Melo y Lourenço disponen un zunchado con anillo de acero inoxidable por el interior de la linterna del transepto de la Catedral de Porto. Sobre este anillo metálico se levanta la estructura de cubierta resuelta en madera.
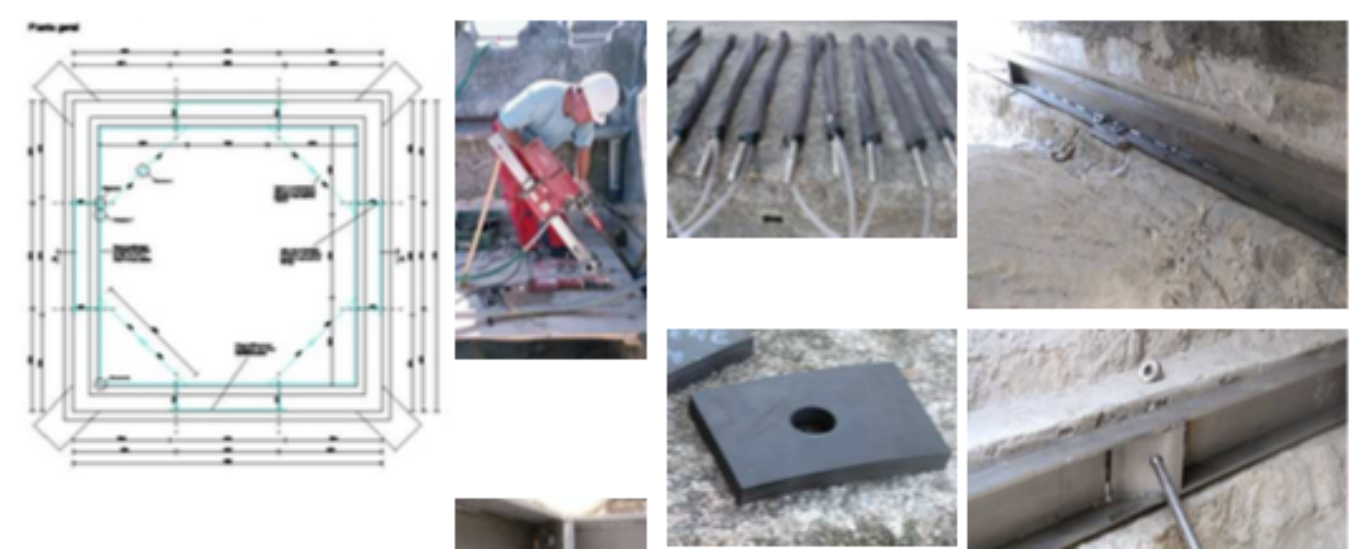

Fig.III.41. Zunchado con anillo metálico en catedral de Porto, Ferreira 2012

Aunque en Portugal es habitual emplear estructura de madera de castaño en cubiertas para reemplazar elementos originales en mal estado, según se ha explicado, 
en ocasiones podemos encontrar refuerzos más agresivos, incorporados sobre todo como elementos preventivos frente a esfuerzos sísmicos.

El refuerzo de muros de fábrica de una, o dos hojas con material de relleno en el interior, se encomienda en ocasiones a inyección de lechadas, resinas, encamisados con mallas de diferentes materiales (de acero, fibra de vidrio, polímeros, etc), anclajes transversales o postesados. Se incorporaron en varios casos estructuras adicionales de refuerzo resueltas con acero laminado, como las cerchas peraltadas de la iglesia de Vimioso ${ }^{72}$.
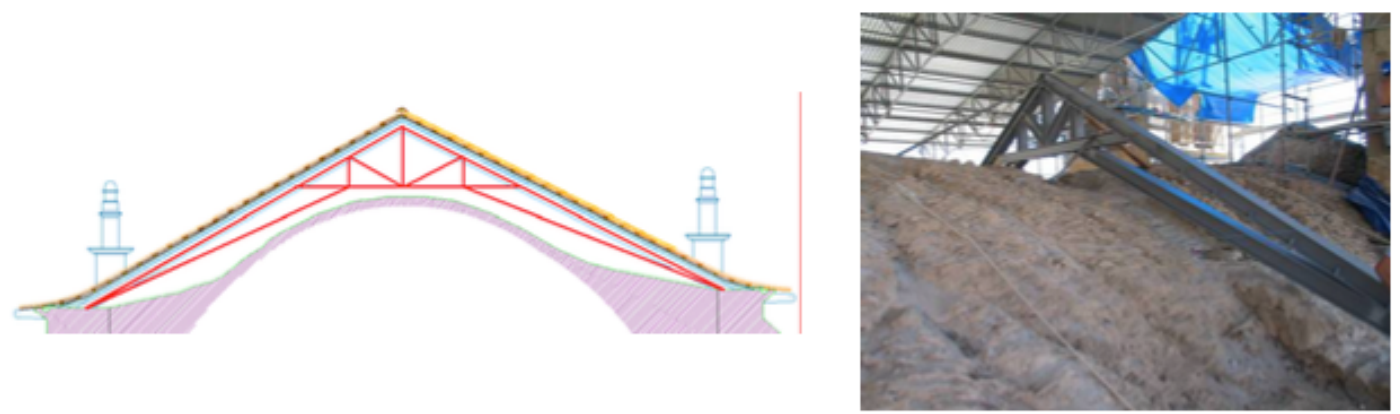

Fig.III.42. Cerchas metálicas de refuerzo en la iglesia de Vimede, Arede y otros 2008

Resulta interesante comprobar cómo la geometría del esquema de la ilustración siguiente, obtenida de un artículo de las $2^{\text {as }}$ Jornadas de Ingeniería de Aveiro, no coincide con la imagen de la fotografía junto al mismo, en la que aparece un tensor en vez del tirante de madera y el par apoya sobre la cara superior del zuncho de hormigón y no contra el frente.
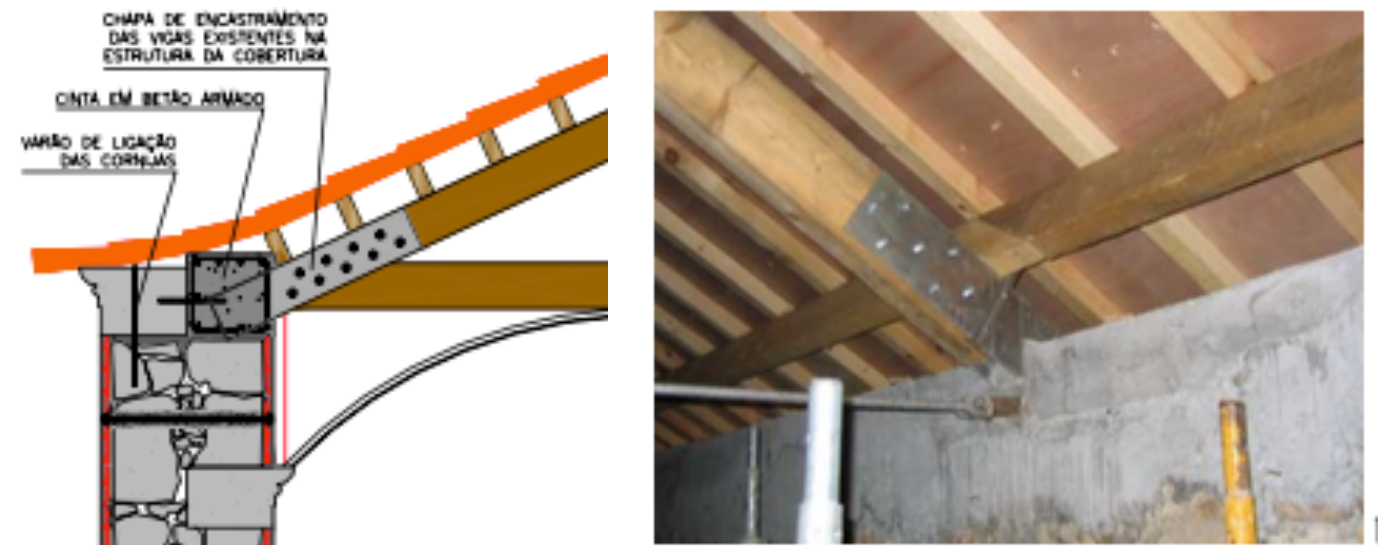

Fig.III.43. Enlace cubierta-muros, Arede y otros 2008

\footnotetext{
72 Arêde, A., Costa, A., Guedes, J. P. M., y Paupério, E. (2008). Reforço de Estruturas de Alvenaria de Pedra-Contribuições do NCREP-FEUP. Actas das II Jornadas de Engenharia Civil sobre Avaliação e Reabilitação das Construções Existentes.
} 
Aunque es posible que se trate de dos detalles correspondientes a zonas distintas de la intervención, como veremos más adelante es frecuente encontrar este tipo de discrepancias en los proyectos de restauración monumental, como en los esquemas de soluciones similares en la Iglesia de Santa María de Tordesillas realizados por Luis Mingo.

\section{III.3.2.3.3. Sinopsis del uso de zunchos en Portugal}

El origen de la degradación de los monumentos en Portugal fue la situación política y social del siglo XIX, tras las Invasiones Francesas y la fuga de la familia real a Brasil. El liberalismo condujo a la extinción de las órdenes religiosas y pérdida de privilegios del clero. El Estado se convierte así en propietario de los templos, se producen ventas masivas y un radical cambio de uso de los inmuebles perjudicial para su conservación.

A cambio, la titularidad pública de los edificios ha facilitado la gestión de su mantenimiento e intervenciones de conservación sin la necesidad de coordinar en cada caso a promotor (la Administración) y propiedad-usuario (el Clero) como sucede en España.

En 1901 se aprueba la primera lista de Monumentos Nacionales. Se organizan tres circunscripciones: Lisboa, Porto y Coimbra. En 1920 se crea el organismo AGEMN (Administração Geral dos edifícios e Monumentos Nacionais) y en 1929 la DGMEN, que edita sus Boletines desde 1935. (Tomé 2002) ${ }^{73}$ Esta entidad se ocupa de la gestión de los monumentos durante décadas y es responsable directa de sus obras de restauración.

En Portugal no se ha abandonado nunca el empleo de madera para reparar las armaduras de cubierta de sus iglesias monumentales, reparando las piezas deterioradas y reemplazando las estructuras completas únicamente si resultaba imprescindible y también con elementos de madera dispuestos con soluciones tradicionales. Para reforzar estas estructuras con frecuencia se incorporan conectores metálicos en los nudos.

${ }^{73}$ Tomé, M. (2002). Património e Restauro em Portugal (1920-1995). Porto: FAUP publicações. 
Techos $^{74}$ y bóvedas se resuelven en muchos casos con tablas de madera, habitualmente decoradas, que denominan forro.
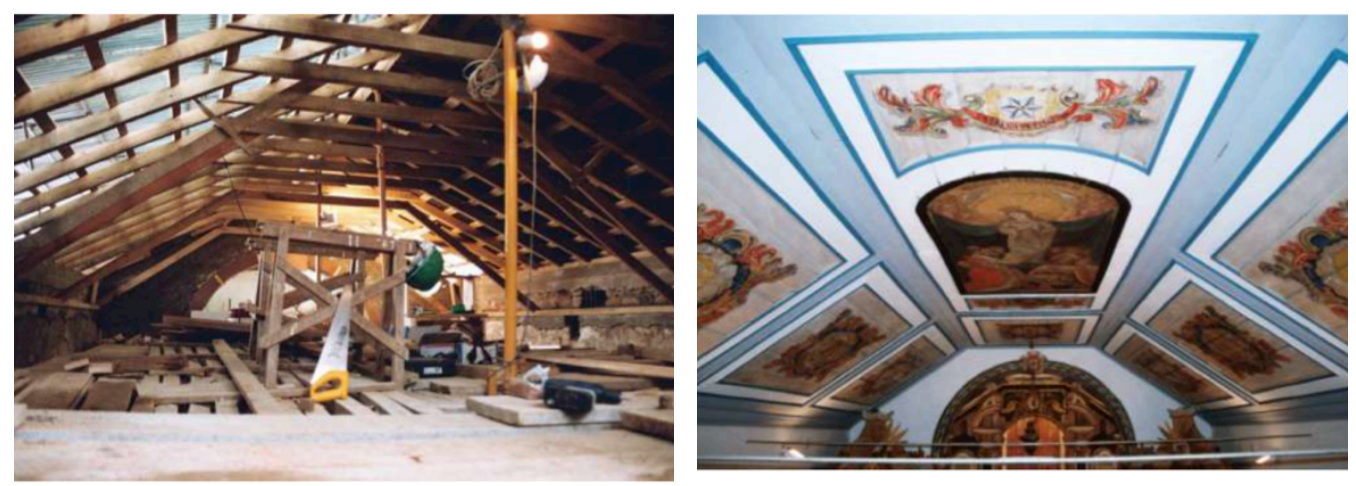

Fig.III.44. Techo reconstruido en iglesia de Vila do Rei, Sarrazola 2008

En las restauraciones de cubiertas se mantiene la geometría de los faldones con su refreno habitual, incorporando para formar el alero (beiral), una pieza de madera que en Brasil denominan contrafeito.

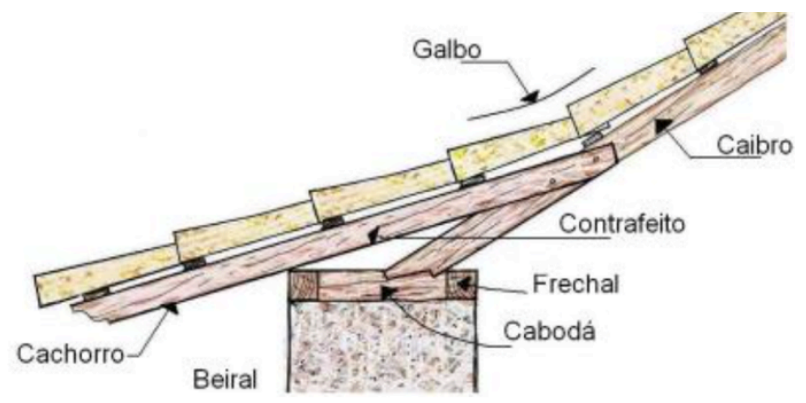

Fig.III.45. Imagen del blog

https://coisasdaarquitetura.wordpress.com/2010/09/06/te cnicas-construtivas-do-periodo-colonial-ii/

Si observamos el siguiente gráfico ${ }^{75}$ de patología de cubiertas de 700 edificios antiguos portugueses ubicados en Baixa de Coimbra entre 2004 y 2006, podemos darnos cuenta de que el debilitamiento de los muros de fábrica ocupa el último puesto entre las lesiones detectadas.

\footnotetext{
${ }^{74}$ Ilustración de Sarrazola, J. C. (2008). Tectos portugueses do sec.XV ao sec. XIX (Dissertação para obtenção do grau de Mestre em Recuperação e Conservação do Património Construído). Universidade Técnica de Lisboa, Lisboa.

${ }^{75}$ En Mendes da Silva, J. (2012) Telhados da cidade antiga: da expectativa ao desempenho. En Lourenço \& Branco (Eds.), en Seminário Coberturas de Madeira, Gimaraes: Universidade do Minho.
} 


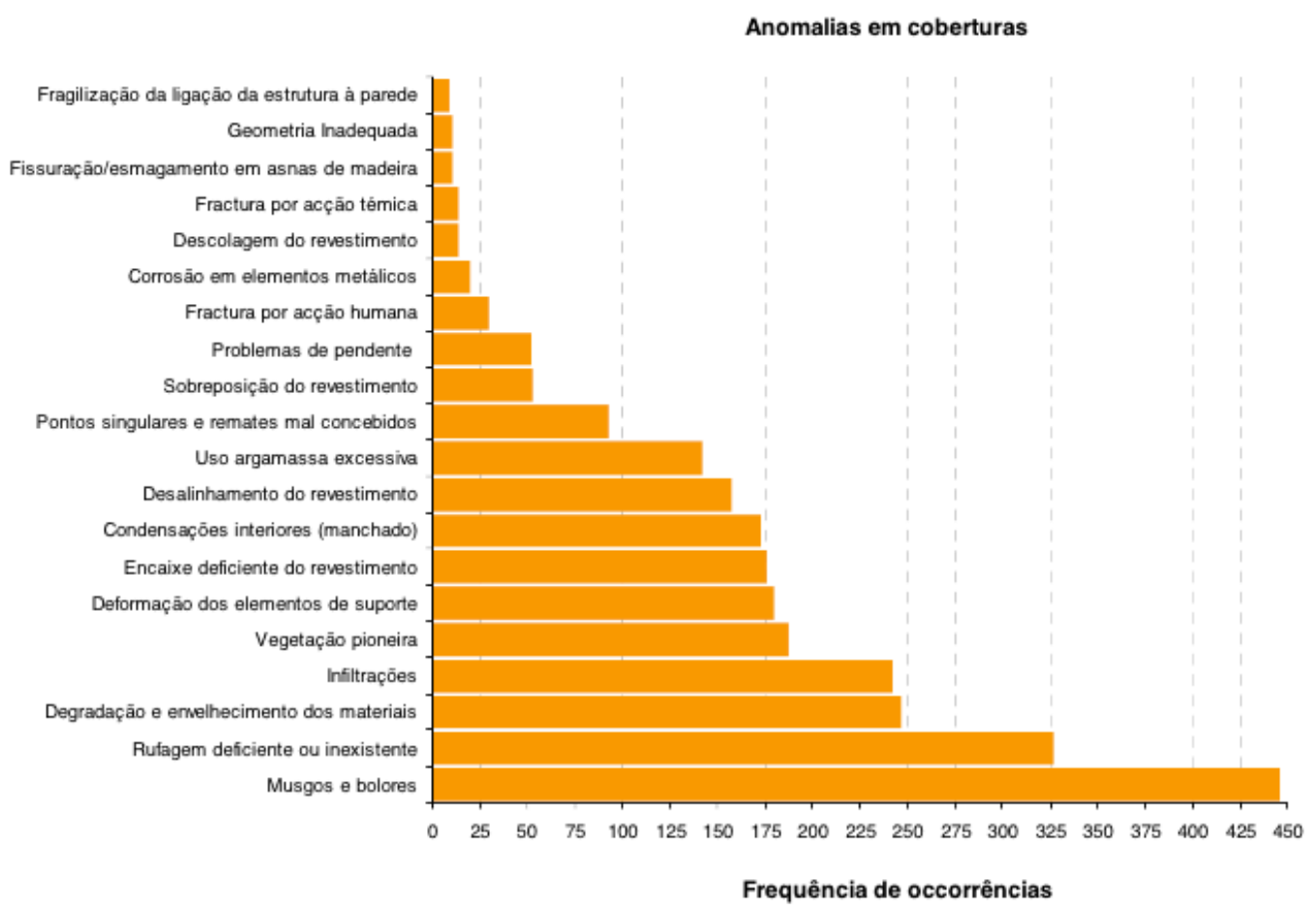

Fig.III.46. Gráfico de patología de cubiertas en 700 edificios antiguos portugueses entre 2004-2006, Mendes da Silva 2012

Aunque se hayan mantenido estas estructuras de madera sí se han ido incorporando sobre el remate de los muros de fábrica en muchos casos zunchos de atado de hormigón armado. Un objetivo primordial de estos elementos, para los arquitectos que lo colocan, es coser transversalmente las hojas que componen los muros para evitar su separación si se degrada el material de relleno; por eso se diseñan con secciones de anchura considerable, aunque en el anterior gráfico hayamos comprobado que en la práctica se trata precisamente de la patología menos habitual. 



\section{III.3.3. Relación del zunchado con el problema del sismo}

El uso de zunchos en restauración monumental es un asunto especialmente delicado en las áreas sometidas a riesgo sísmico, según se ha avanzado en II.3.1. En este apartado se expone el estado de dicha cuestión en Italia y América latina, donde los criterios de intervención han cambiado radicalmente tras los terremotos recientes.

En España también han evolucionado las actuaciones tras el terremoto de Lorca, que dañó especialmente el Patrimonio histórico de la zona.

En varios casos durante el estudio de documentación de las iglesias seleccionadas para la investigación aparecen referencias al llamado terremoto de Lisboa, al cual se atribuye sistemáticamente el origen de cualquier grieta o movimiento. A continuación se resumen los efectos reales recopilados en el Archivo Histórico Nacional reproducidos en una obra editada en 2001 por el Instituto Geográfico Nacional $^{76}$.

\section{III.3.3.1. EI terremoto de Lisboa}

El llamado terremoto de Lisboa se produjo en 1755, el día de Todos los Santos a la hora de la misa mayor (diez y cuarto de la mañana). Fue sentido en toda la península ibérica, llegando al sur de Francia y el norte de Italia. Intensidad máxima en España VIII (escala EMS-98). Las olas ocasionaron en España más muertes que el propio terremoto, que tuvo gran duración y numerosas réplicas.

El rey Fernando VI ordenó llevar a cabo una encuesta para documentar lo ocurrido pueblo a pueblo, recopilada por el Archivo Histórico Nacional. Contamos con información de 25 localidades de Valladolid (un valor medio si consideramos el máximo de 123 que corresponden a Segovia y sólo una referencia localizada en Asturias).

\footnotetext{
${ }^{76}$ Martínez Solares, J. M. M. (2001). Los efectos en España del terremoto de Lisboa (1 de noviembre de 1755). Madrid: Instituto Geográfico Nacional. Ministerio de Fomento.
} 
Se describen desde dos minutos hasta un cuarto de hora de temblores, un inquietante bamboleo de lámparas en las iglesias pero sin ruina de edificios en: Alaejos, Arenillas, Bercero, Berceruelo, Honcalada, Iscar, Lomoviejo, Marzales, Medina del Campo, Olmedo, Peñafiel, San Miguel del Pino, San Pablo de la Moraleja, Villalar de los Comuneros, Villamarciel, Villán de Tordesillas, Villavieja del Cerro,

En Matilla de los Caños explica cómo "en las bóvedas andaron un gran ruido como si anduviese mucha gente por ellas"

En Medina de Rioseco, además de mencionar que de la torre de la villa de Ampudia cayó una gran piedra sobre su iglesia, se cita cómo:

"En las Iglesias de San Francisco y de la Soledad quedaron abiertas algunas paredes y arcos de la media naranja, y separadas las piedras claves. Y en las Parroquiales de Santa Cruz, Santa María y Santiago, que padecieron el propio movimiento, cayeron de sus bóvedas diferentes yesones y se han reconocido algunas aberturas en las paredes y arcos, y todos se recelan de que sucedan grandes ruinas, aunque gracias al Altísimo hasta ahora no se ha experimentado alguna, ni más daño que el haber padecido un muchacho una corta herida."

Muriel de Zapardiel: "Y de una pared de las mayores de dicha Iglesia se cayó un pedazo de cal y se movieron todas las paredes de dicha Iglesia".

Tordesillas: "en el convento Real de Santa Clara se me ha testificado en el coro alto, en la hora de nona, se abrió una pared de dicho coro por donde percibieron mucha luz"

Torrecilla de la Abadesa: "Sí sólo en la Iglesia de la villa, se han reconocido unas aberturas en los arcos de las bóvedas, y mayor en la pared que hace coro, y no se ha experimentado otra cosa. Sí sólo, al parecer, se movía el suelo".

Valladolid: "los suelos, y paredes, Santos, arañas y lámparas de las Iglesias, todo se meneaba con bastante ímpetu, y aún en algunas, como en la Catedral, San Martín y Santiago, cayeron algunos pedazos de yeso, y tierra, lo que motivó a salirse cada uno aceleradamente de el edificio (...) ni se ha reconocido ruina, ni fractura en templo ni edificio, sin embargo que por Maestros se han registrado varios". 
La descripción de la localidad de Velilla es más extensa y narra la rotura de un tirante:

"Yo, Gabriel González, fiel de los fechos de este lugar de Velilla, Certifico en la forma que puedo: Como los Señores Manuel Moreno y Simón Blanco, Alcaldes de él, en virtud de Orden del Señor Corregidor de la villa de Tordesillas, en cumplimiento de el expedido por Nuestro Rey (que Dios guarde) pasaron a estar con los Señores Cura y Beneficiado de la Iglesia de este lugar, quienes llamaron a Santiago Tordesillas, Maestro de cantería, y juntos pasaron a dicha Iglesia el reconocimiento de las quiebras que ocasionó el temblor que se experimentó el día primero de noviembre de este año; y dijeron había comenzado como a las diez de la mañana, poco más o menos, y que duró como un cuarto de hora, y en el principio comenzó a moverse todo el encajonado del embaldose [sic] de la Iglesia, banco, y retablo, siendo tal el movimiento de la lámpara, que saltó fuera del vaso. Al medio de el temblor comenzó a restrallar [sic] toda la Iglesia con temeroso estruendo, y con gran violencia se movían todos los Santos del retablo, con ser su altura de tres varas, con igual simetría, tanto, que el sacerdote que estaba diciendo misa, echó por dos veces la mano a Nuestra Señora, temblando cayese sobre él, a cuya vista toda la gente salió de la Iglesia; y el arco toral de la Capilla mayor, con ser de medio punto, de veinticuatro pies de hueco, y sesenta y uno de macizos, hizo sentimiento por dos partes, hirió la bóveda, y por esta parte partió un tirante, y un quinzal del tejado, y los dos arcos del medio de la Iglesia padecieron igual sentimiento, hindiendo [sic] la bóveda como dos varas, y en la del Coro alto, con ser de piedra, esconchó [sic] algunos pedazos, y en la torre movió una piedra del arco de la campana, y abrió un poco el de un crucero, cayendo como una esportilla de tierra; y por dos hiendas antiguas que hay entre los dos arcos del medio de la Iglesia, y tirantes de su pared, salía el polvo con tanta fuerza, como si lo dispararan con una escopeta.

Y aunque por ahora no se reconoce especial peligro, se puede temer en adelante alguna ruina, naturalmente común en las casas por el especial temblor que padecieron, igual en las fuentes, que con no estar llenas, se levantaron hasta echar el agua fuera."

Resulta sorprendente que en la encuesta no encontramos mención a daños en la

Catedral de Valladolid, mientras que es un comentario habitual en la documentación sobre la misma que "la torre se derrumbó a causa de los daños del terremoto". Aunque éste ocurrió en 1755 y el colapso se produjo en 1841, prácticamente un siglo más tarde. 


\section{III.3.3.2. Italia}

Los terremotos han causado habitualmente en Italia miles de damnificados y gravísimos destrozos. En 1908 murieron 95.000 personas en el sur y en 1915 unas 30.000 en Los Abruzos. Los sismos de Asís en 1997, L'Aquila en 1009 y Emilia Romagna en 2012, resultaron especialmente devastadores para los monumentos en zonas tan significativas como Ferrara, ciudad declarada Patrimonio Mundial de la Humanidad.

En los últimos años han proliferado los estudios sobre el comportamiento frente a las acciones dinámicas de las estructuras históricas, tratando de adoptar consignas que optimicen las actuaciones en las obras de restauración. Un tema de debate fundamental es el peligro de anteponer seguridad frente a conservación.

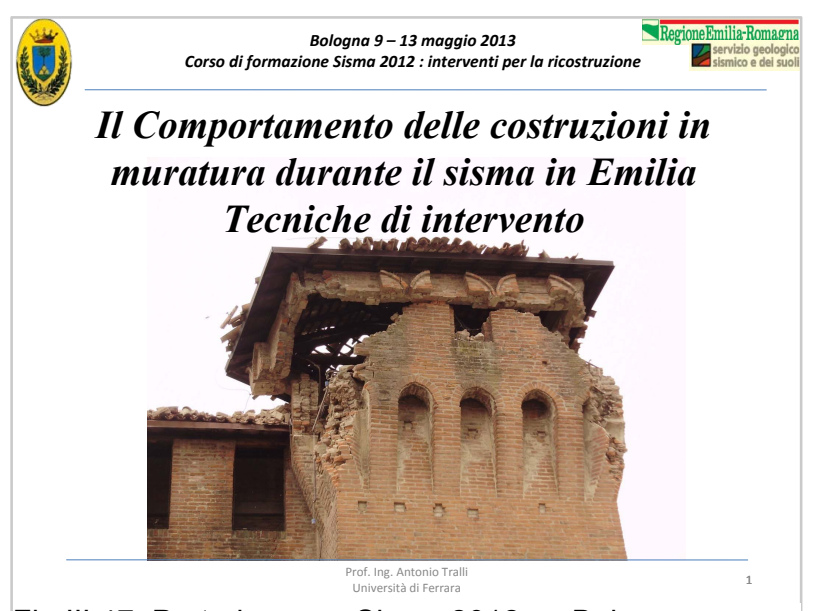

Fig.III.47. Portada curso Sisma 2012 en Bologna

Las técnicas no respetuosas con la naturaleza de las construcciones históricas presentan frecuentemente problemas de compatibilidad, por lo que deben conciliarse cuidadosamente ambos aspectos. En la mayor parte de la documentación generada actualmente por expertos italianos se describen los problemas ocasionados por realizar intervenciones innecesarias, o que incluso pueden resultar perjudiciales, sobre los monumentos de fábrica. Se impone el criterio de "intervento minimo" ${ }^{77}$.

En el caso concreto de las iglesias, es fundamental el valor simbólico y la tipología formal en cada caso. La característica más significativa de cara al comportamiento frente a las acciones sísmicas, cuenten con una o tres naves, será la definición espacial mediante muros de grandes dimensiones en planta y alzado sin arriostramiento transversal. Su funcionamiento como conjunto de planos independientes o como un prisma monolítico depende en gran medida del sistema de cubierta y de la conexión con la misma.

\footnotetext{
${ }^{77}$ ARX s.c.r.l. - Venzone (UD). (2003). Istruzioni Tecniche per l'interpretazione ed il rilievo per macroelementi del danno e della vulnerabilità sismica delle chiese. Regione Toscana - Area Servizio Sismico Regionale.
} 
La composición de la fábrica influye en su comportamiento dinámico: la respuesta de un muro con dos caras vistas y un relleno nunca será la misma que la de una única hoja de sillería bien aparejada. La cohesión de las membranas dependerá en gran medida de las llaves dispuestas.

También influye la historia constructiva del edificio, las fases y cambios, la conexión entre fábricas de distintas etapas. Y la patología estructural adicional que presente el templo, defectos y degradación de los materiales, problemas relativos al terreno o los cimientos, fisuras previas... La falta de mantenimiento es otra de las claves con que no solemos contar en el análisis de la respuesta estructural frente al sismo: disgregación o roturas debidas a humedades reiteradas.

El primer modo de colapso de un muro sometido a acciones horizontales corresponde al ribaltamento (vuelco). El segundo es la "rottura a taglio" (cizalladura), por acciones paralelas a su propio plano.
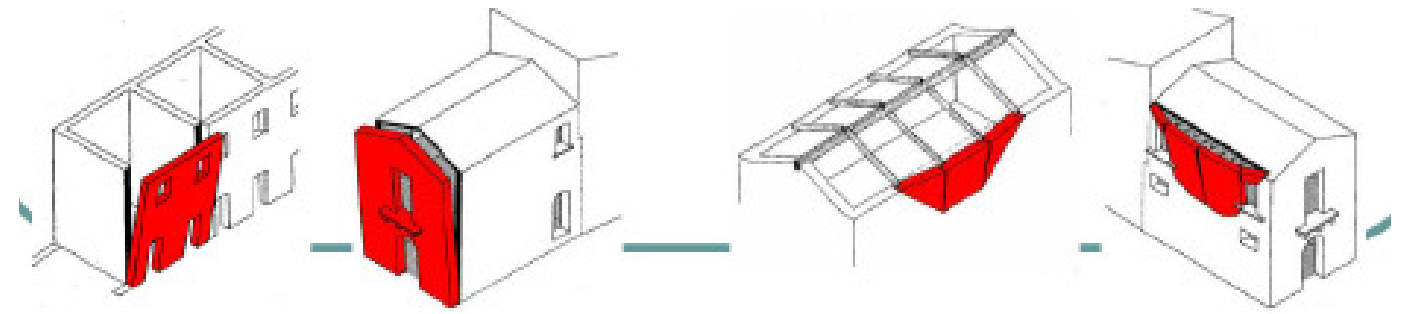

Fig.III.48. Esquemas de la presentación de la profesora Francesca Ceroni78

El profesor Emanuele Zamperini agrupa los mecanismos de colapso según tres modalidades:

Disgregación de la fábrica

Muro fuera del plano

Dislocaciones en el plano

En la presentación para las clases de Zamperini $^{79}$ en el Curso di restauro architettonico 2010-2011: Il comportamento sismico degli edifici in muratura tradizionale accesible en la web de la Universidad de Pavía encontramos el cuadro siguiente, que resume la "vulnerabilidad típica de las iglesias".

\footnotetext{
${ }^{78}$ Presentación en pdf original en www.ding.unisannio.it, a través de https://www.yumpu.com/s/Vg4DV7PIKhknFOdK (30/10/2013)

79 obtenido en http://www-3.unipv.it/ingegneria/copisteria_virtuale/valeriani/Restauro06Miglioramento\%20sismico\%20degli\%20edifici.pdf
} 


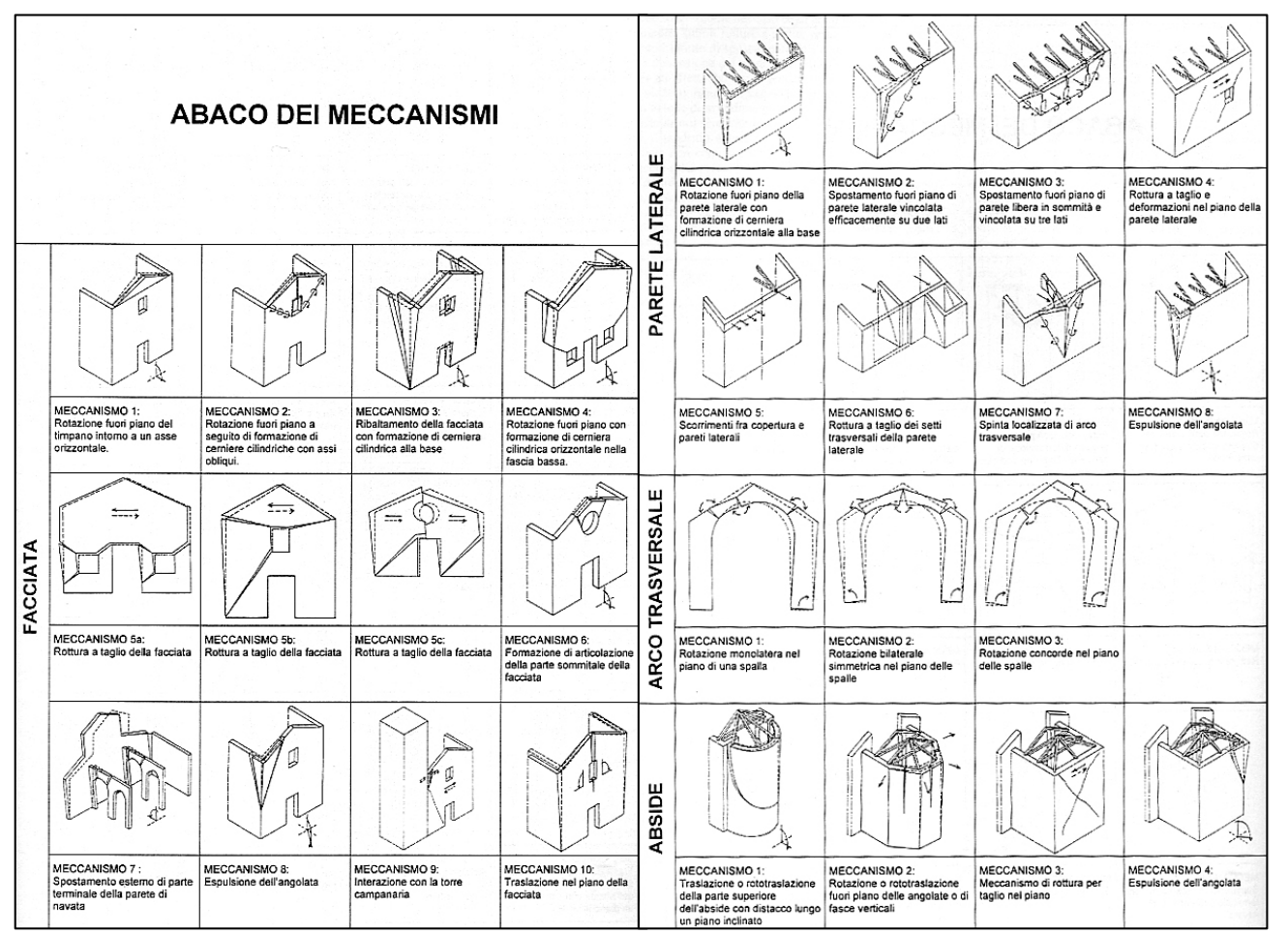

Abaco dei meccanismi di collasso delle chiese (da FRANCESCO DOGLIONI, Codice di pratica (linee guida) per la progettazione..., Bol. Uff. della Regione Marche, Ancona, 2000)

Fig.III.49. Cuadro de vulnerabilidad de iglesias, Zamperini 2010

Sugiere unas intervenciones determinadas sobre las cubiertas: conectar las armaduras a los muros con elementos metálicos, reforzar ese punto de encuentro con zunchos de madera o acero. Desaconseja expresamente la sustitución generalizada, las cubiertas de hormigón u otras soluciones muy rígidas y los zunchos de hormigón armado.
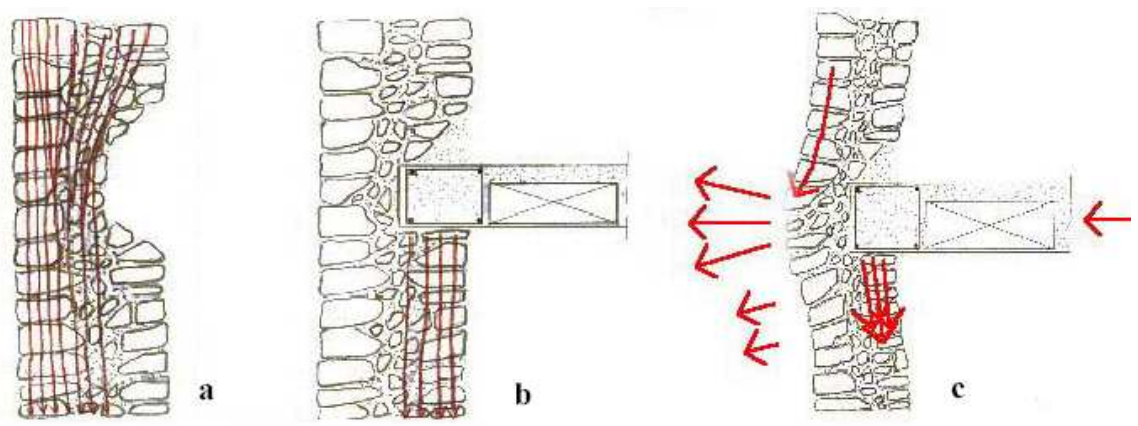

Corso di Restauro architettonico - A.A. 2010-2011

Fig.III.50. Patología de zuncho semi-encastrado, Zamperini 2010 
No deben practicarse rozas en muros tradicionales para semi-encastrar el zuncho de borde de un nuevo forjado intermedio, ya que esto debilita dichos muros. Ese nuevo forjado gravitará sólo sobre el paramento interior y en caso de acciones sísmicas el empuja a la hoja externa provocando su desprendimiento.

Desde el punto de vista del atado estructural hoy en Italia frente a la acción sísmica, podemos considerar que los expertos están adoptando los siguientes criterios $^{80}$ :

- La práctica tradicional de incorporar encadenados y tirantes metálicos se considera, en general, la solución más eficaz y recomendable como estrategia antisísmica.

- Se sugiere emplear barras redondas lisas dispuestas a ambos lados del muro.

- Existe además actualmente cierto consenso en Italia contra la incorporación de zunchos de hormigón armado tras los efectos de terremoto en 1997.

Minutuoli defiende el modelo didáctico de la Escuela de Florencia orientado al conocimiento del modelo estructural. Indica que "su fundador el profesor Piero Sanpaolesi pensaba ya a finales de los años cincuenta que un edificio estará tanto mejor restaurado cuanto más parecido de comporte estructuralmente a su comportamiento inicial".

Resulta casi sorprendente la descripción que en el mismo artículo se realiza de una intervención sobre los Uffizi, afirmando que "los planos horizontales fueron consolidados con losas armadas pero sin zunchos de hormigón armado, sino utilizando un cinturón de acero formado por perfiles en $\mathrm{C}^{\prime \prime}$. En cuanto a la catedral de Noto se señala la degradación de las pilas como desencadenante del colapso, casi medio siglo después del reemplazo de la estructura de madera de cubierta por hormigón, también citada en la tesis de Mariana Esponda, según lo descrito en el apartado III.3.1.

El caso de la Basílica de Asís tuvo gran difusión en los medios. Diversos autores acusan directamente del derrumbe de bóvedas a una intervención anterior en que se reemplaza la armadura de cubierta original de madera por una estructura de hormigón. Así lo hace el propio Minutuoli en el artículo citado cuando afirma:

\footnotetext{
${ }^{80}$ Minutuoli, G. (2012). Ciudad, arquitecturas y restauraciones, problemas de conservación de los cascos históricos. Informes de La Construcción, 64(EXTRA), 23-34.
} 
"Una mala restauración estructural puede ser más peligrosa que la falta de intervención. Ejemplos evidentes han sido el hundimiento de las bóvedas de la Basílica Superior de Asís, probablemente debido a la realización de un zuncho perimetral que rigidizaba la misma. Igualmente el hundimiento de la cubierta de la catedral de Noto. En esta, se creía que los pilares eran macizos, construidos en piedra de cantería, pero en realidad sólo la parte epidérmica del pilar, su perímetro, estaba formado por piedra maciza, mientras que su interior estaba constituido por un vertido a sacco, y con el paso de los años, la entrada de agua hizo colapsar los pilares provocando el hundimiento".

Según un artículo de $\mathrm{ABC}$ de la época el historiador del arte Federico Zeri clamó en La Stampa contra los locos que habían sustituido las vigas de madera por vigas de hormigón armado, más pesadas y que hacen más rígida la estructura:

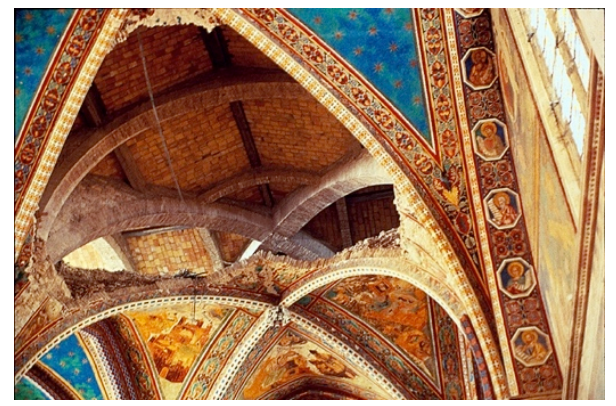

Fig.III.51. Bóvedas de Asís, Wikipedia $30 / 10 / 2013$

"Ecco l'effetto di scelte dissennate. Sono stati dei folli, ecco, dei folli. a sostituire le travi di legno del tetto della Basilica con travi di cemento armato che hanno appensantito e reso rigido il tutto."

Podemos considerar la expresión cordolo in cemento o calcestruzzo armato para referir en italiano el término zuncho (de hormigón armado). Incluso en la entrada cordolo de la wikipedia, en internet, encontramos afirmaciones tan rotundas contra el uso de zunchos de hormigón armado en la restauración de edificios de fábrica como la referencia siguiente ${ }^{81}$ :

"En los años ochenta y noventa se suelen consolidar edificios de fábrica incorporando un zuncho de hormigón armado en el remate de los muros. Se ha comprobado sin embargo que es un elemento excesivamente rígido respecto al muro tradicional, no beneficioso en el caso de solicitaciones dinámicas como las sísmicas y puede causar desprendimiento y colapso".

\footnotetext{
81 "Negli anni ottanta e novanta si è spesso consolidato gli edifici in muratura aggiungendo un cordolo in cemento armato alla sommità delle loro murature. Si è constatato però che esso è un elemento eccessivamente rigido, rispetto alla muratura tradizionale, non benefico nel caso di sollecitazioni dinamiche come quelle sismiche e può essere causa, anzi, in questi casi, di distacchi e crolli ".[1].

$\mathbf{1}^{\wedge}$ Sulla differenza tra l'efficacia del cordolo in c.a. e quello in muratura armata cfr. Giovanni Manieri Elia, Metodo e tecniche del restauro architettonico, Carocci, Roma 2010, pagg. 112-117.
} 
Sin embargo, con cierta frecuencia seguimos encontrando recomendaciones que contradicen esta postura cuasi unánime, divulgadas además desde la propia administración.

Por ejemplo, en la web de protección civil de la región de Umbría ${ }^{82}$ aparece una ficha en que se recogen mejoras a realizar en los edificios de fábrica para implementar su respuesta frente a las acciones sísmicas, consistentes en disponer zuncho de hormigón armado o bien encadenados metálicos en la coronación de los muros:

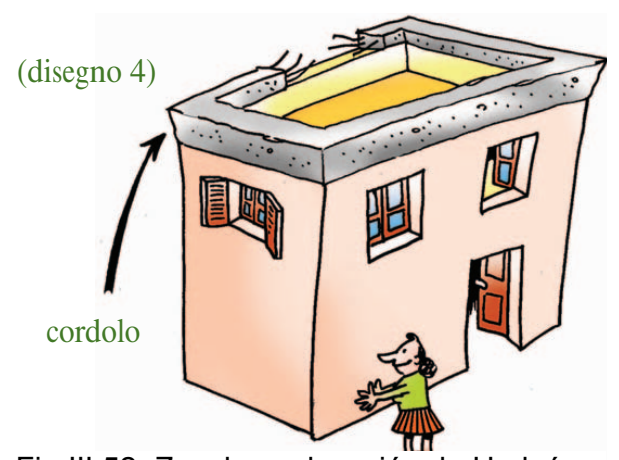

Fig.III.52. Zuncho web región de Umbría

\section{III.3.3.3. América latina}

Es incuestionable la recuperación de métodos tradicionales de construcción de probada resistencia frente al sismo (recordemos lo adelantado al principio del capítulo) que se está produciendo en América latina en la actualidad. Se emplean tanto en sencillas viviendas como en recuperación de estructuras históricas.

La catedral de Santiago en Cuba, por ejemplo, sufrió numerosas reconstrucciones desde su origen, resolviéndose en 1810 con "cinco naves separadas por pilares formados por haces de horcones de madera dura, con arcos y bóvedas encamonadas del mismo material, para que resistiese a los terremotos", empleando conocimientos del mundo de la carpintería. Los horcones son maderos hincados en el terreno, tanto en haces formando los pilares como en el resto del perímetro embebidos en el cerramiento de fábrica ${ }^{83}$.

El conjunto de horcones forma con la estructura de cubierta una estructura de madera autoportante, una especie de esqueleto eficaz frente al sismo, con la técnica constructiva llamada cuje. "El par y nudillo no está apoyado a los muros

\footnotetext{
${ }^{82}$ Ilustración (30/10/2013) en http://www.protezionecivile.regione.umbria.it/RESOURCES/NEWS/Scheda\%201\%20-\%20petit.pdf

${ }^{83}$ Perria, E., Sinicropi, D., y Paradiso, M. (2013). La Catedral de Santiago de Cuba como ejemplo emblemático de la difusión de saberes entre Europa y Latinoamérica. En Actas del VIII CNHC. Madrid.
} 
perimetrales, mediante un durmiente de base, sino que el estribo donde arrancan los pares está anclado a los horcones de madera".

El sistema constructivo de origen prehispánico mezcla de madera, cañas y tierra es denominado bahareque en Colombia y Venezuela, bajareque en Cuba, Guatemala y Honduras, quincha en Perú, Bolivia, Ecuador y Chile y fagina en Uruguay ${ }^{84}$.

En un manual de construcción sismo resistente de viviendas en "bahareque encementado", de la Asociación colombiana de ingeniería sísmica AIS ${ }^{85}$ se denomina zuncho a la brida de chapa metálica.

En otras publicaciones se emplea fibra plástica trenzada. Precisamente en una localidad de Colombia se emplea con la denominación zuncho una fibra de embalar sintética de colores con la que mediante trenzado fabrican paneles de cerramiento y mobiliario, según se ha explicado en el primer capítulo de esta investigación, sobre la etimología del término zuncho.

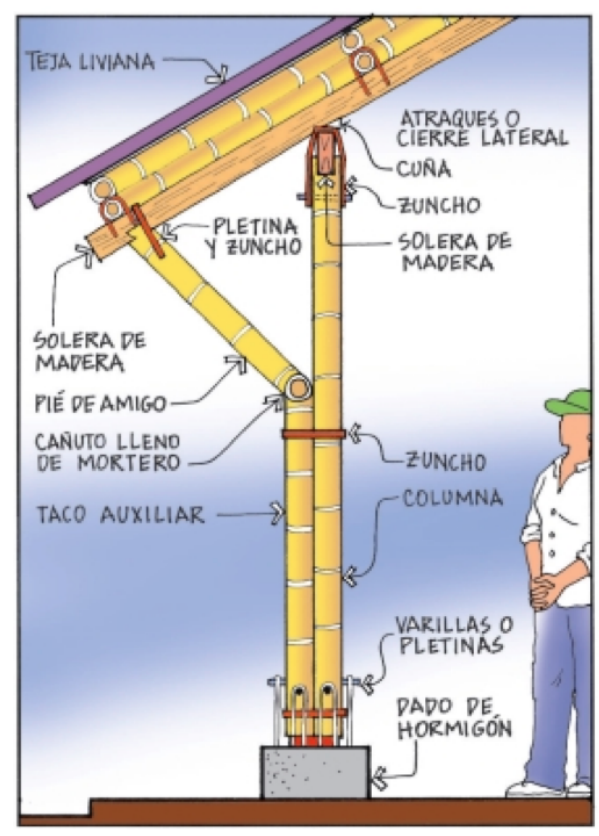

Fig.III.53. Ilustración AIS (30/10/2013)

En el sistema estructural descrito se constituyen los muros con entramado de madera y un tipo de bambú que denomina guadua. Las uniones zunchadas mediante estas pletinas metálicas se consideran articuladas a efectos de cálculo estructural.

En la línea de los estudios "after ten" en que se encuadra esta tesis, destaca un artículo de la Revista de Ingeniería sísmica mejicana sobre la evaluación estructural y comportamiento de reparaciones efectuadas a edificios históricos ${ }^{86}$.

\footnotetext{
${ }^{84}$ Pérez, C. L., \& Valencia, D. R. (2010). Bóvedas de madera y bahareque en iglesias coloniales bogotanas. Estudio de cuatro iglesias del siglo XVII. Apuntes, (23), 70-83.

${ }^{85}$ Asociación Colombiana de Ingeniería Sísmica. (2001). Manual de construcción sismo resistente de viviendas en bahareque encementado. Bogotá: AIS. Obtenido (24/10/2013) en http://cidbimena.desastres.hn/docum/lared/libros/guadua_lared.pdf

${ }^{86}$ Torre Rangel, O. de la, et Al. (2004). Evaluación estructural y comportamiento de las reparaciones efectuadas a edificaciones históricas. Revista de Ingeniería Sísmica, (70), 1-26.
} 
Los autores afirman que, tras analizar 150 restauraciones del último medio siglo en México "los zunchos con cable de acero localizados en el desplante de las cúpulas, aunque seguramente redujeron el nivel de daños ocurridos en eventos anteriores (cuando no existían dichos refuerzos) provocaron un degollamiento de la mampostería."

Sin embargo parece deducirse que los tirantes si han dado buen resultado: "El uso de tensores de acero en el arranque de bóvedas y arcos es ampliamente reconocido como una solución adecuada. En los casos observados en donde se aplicaron cables se tuvo buen comportamiento".

Las cúpulas se refuerzan en general con membrana de mortero y malla interior y exterior con conectores. Detectan que "cuando se realizaron reparaciones locales con viguetas y bovedillas, losa maciza o capas de concreto, se indujeron fuertes agrietamientos en la frontera con la mampostería existente no reforzada".

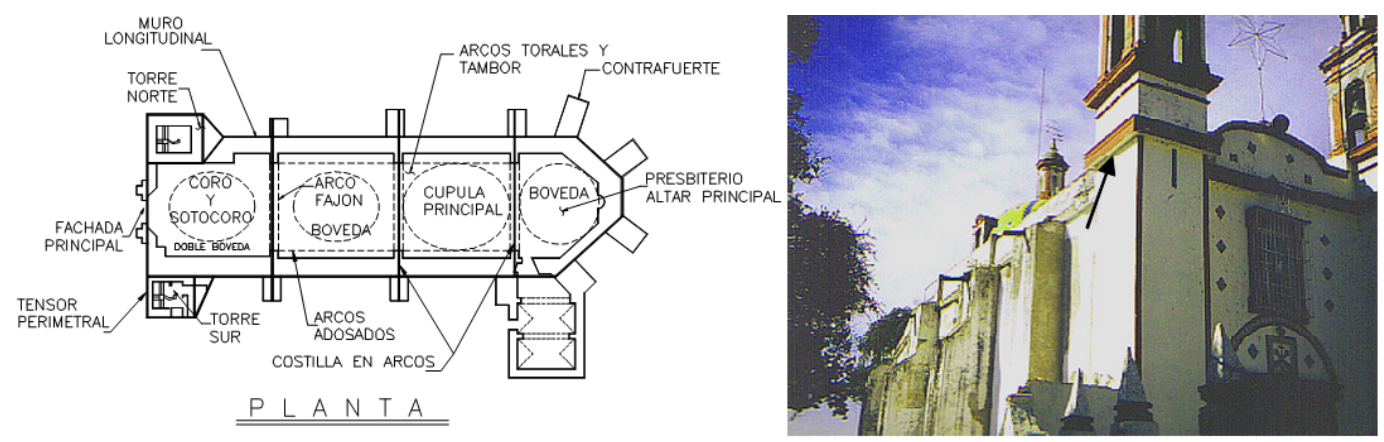

Fig.III.54. Iustración Torre Rangel y otros 2004

Llaman zunchos a los cables y placas de acero, mientras que a los elementos que en España denominamos zuncho los designan dala de concreto reforzado a manera de tensor por todo el perímetro exterior del edificio ubicado aproximadamente a la mitad de la altura de las bóvedas.

Indican que este sistema ha dado buenos resultados con un coste moderado. 


\section{III.3.3.4. Terremoto de Lorca, Murcia}

El 11 de mayo de 2011 dos terremotos sucesivos causaron gravísimos daños en la Lorca, destrozando gran número de viviendas, comercios y explotaciones agrícolas. Se trata de una ciudad con un pasado histórico importante desde el Neolítico: yacimientos arqueológicos, ciudad romana, mil años Lurqa musulmana de la Cora de Tudmir, ciudad fronteriza fortificada de la Corona de Castilla, cuna de esplendor barroco. El centro es un BIC declarado Conjunto Histórico-Artístico en 1964.

Sólo dos meses después de los movimientos, técnicos de varias instituciones (los institutos geográfico nacional y geológico y minero, las universidades complutense y politécnica de Madrid y la Asociación española de ingeniería sísmica) realizan un informe ${ }^{87}$ sobre el sismo de Lorca que incluye un capítulo sobre daños en las edificaciones. El texto de Cabañas cita los terremotos de Albolote (Granada) en 1956, el primero registrado en la zona, Vera (Almería) en 1406 (siglo XV), y cómo en 1579,1674 y 1818 ya hubo daños importantes en Lorca, con casas arruinadas.

El terremoto principal registrado tuvo magnitud 5,1 y dos horas antes hubo otro de 4,5 que debilitó las estructuras, con más de un centenar de réplicas menores posteriores. La dirección estimada de los movimientos fue NW-SE, lo que se pudo comprobar observando el mayor grado de agrietamiento en las fachadas este y oeste de los edificios.

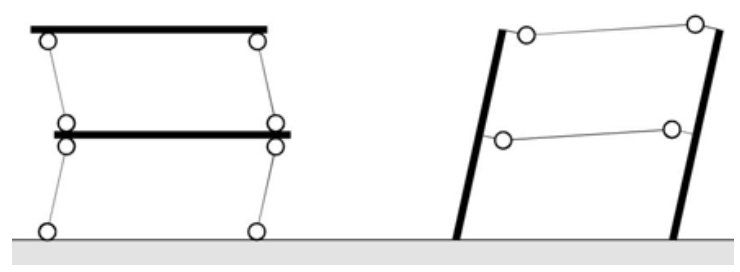

Figura 6.16. Esquema de mecanismo inestable (izquierda) y estable (derecha).

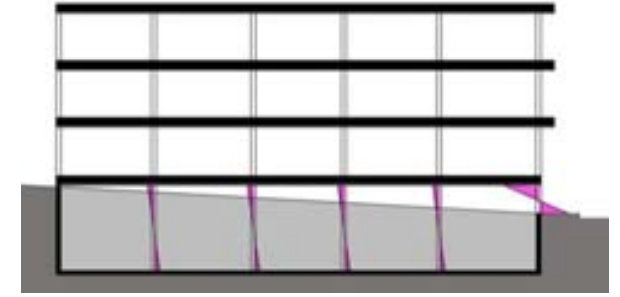

Fig.III.55. Esquema mecanismos inestables, informe Cabañas 2011

El informe describe la diferencia entre mecanismos inestables (losa masiva y pilar débil) y estables. Las alturas de planta variables también suponen una irregularidad de rigidez no deseable, así como los pilares cortos o enanos sobre muros de semisótano.

\footnotetext{
${ }^{87}$ Cabañas Rodríguez, L. et al. (2011). Informe del sismo de Lorca del 11 de mayo de 2011. Madrid: Instituto Geográfico Nacional.
} 
Daños en la edificación tradicional: fisuración característica en forma de aspa y pérdida de enlace con los muros arriostrantes transversales.
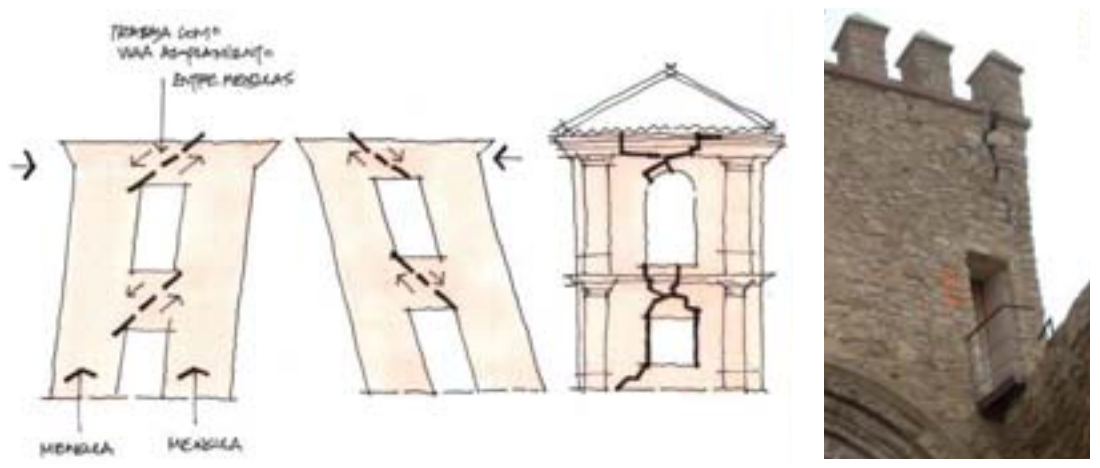

Fig.III.56. Fisuración, informe Cabañas 2011

Entre las conclusiones de ese informe se resalta que "los daños en el patrimonio histórico y cultural en terremotos relativamente moderados, que se dan con cierta frecuencia en España, hacen aconsejable acometer un plan especial de estudio y protección de monumentos histórico-artísticos susceptibles de ser dañados por terremotos".

Antes del terremoto de 2011 se había desarrollado, durante las últimas tres décadas, una política de restauración monumental cuyas técnicas más frecuentes fueron micropilotaje de cimentaciones, hormigonado de trasdós de bóvedas y cúpulas, vaciado de inmuebles con mantenimiento de fachadas y rehabilitación de cubiertas con hormigón armado. Según Martínez y Granados, en la iglesia del convento de las Clarisas la losa de hormigón que se incorpora sobre la cubierta de cerchas madera original era de $20 \mathrm{~cm}$ de espesor medio y fue causa de su colapso.

"Las estructuras de la arquitectura religiosa han sufrido daños moderados, con la aparición de grietas de separación entre hojas distintas de un mismo elemento, o bien mediante grietas de separación entre elementos distintos, con mayor gravedad en bóvedas y arcos sin llegar a colapsos parciales, a excepción de la iglesia de Santiago y la iglesia del convento de las Clarisas" ${ }^{88}$.

\footnotetext{
${ }^{88}$ Martínez Ríos, M. C., \& Granados González, J. (2013). Comportamiento estructural de las edificaciones históricas en el sismo del 11 de mayo de 2011 de Lorca. Alberca: Revista de La Asociación de Amigos Del Museo Arqueológico de Lorca, (11), 167-203.
} 


\section{III.3.3.4.1. Iglesia de San Francisco}

El arquitecto Ignacio Mendaro incorpora en 1983 zunchos de coronación en los muros de nave central de la iglesia de San Francisco y un nuevo tablero de madera con capa de compresión de hormigón.

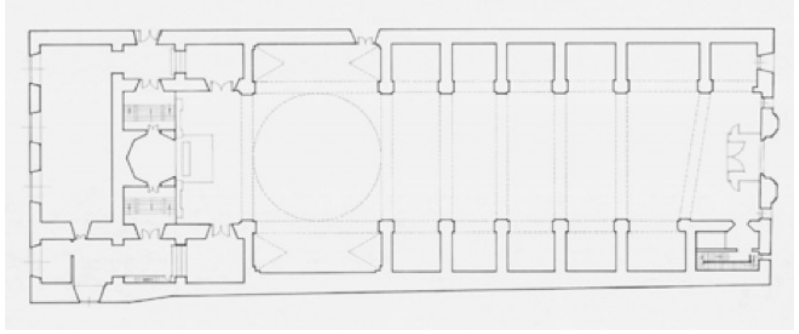

Fig.III.57. Planta San Francisco, Carazo 2012

La cubierta sobre capillas entre contrafuertes, de rollizos y cañas se reemplaza por un forjado de viguetas pretensadas y bovedillas cerámicas.

Tras el terremoto de 2011 aparecen numerosas fisuras en la bóveda de cañón que cubre la nave. Se acometen unas primeras obras de emergencia para reparar la torre, la cúpula y sellar con resinas las fisuras de la nave. Los muros se cosen con barras de acero y de fibra de vidrio. En una segunda intervención se repasa la cubierta y mejora la evacuación de pluviales con plancha de plomo ${ }^{89}$.

\section{III.3.3.4.2. Conjunto monumental de Santo Domingo}

Juan Carlos Cartagena ${ }^{90}$ analiza en un monográfico de la revista Alberca las actuaciones llevadas a cabo tras el terremoto, como traslado del claustro y apeo de capillas. Frente a los graves daños del crucero de la capilla del Rosario se colocó un apeo y cimbrado para la cúpula.

El cimborrio presentaba grandes grietas verticales en cada esquina, por lo que se realizó un zunchado temporal en su parte superior con cuatro anillos de cables de acero con tensores. Los cables se enlazaron a las esquinas mediante piezas de acero laminado ancladas con barras y resina.

\footnotetext{
${ }^{89}$ Carazo Díaz, N. (2012). Iglesia de San Francisco de Lorca (Murcia). Antes y después del 11 de mayo de 2011. Alberca: Revista de La Asociación de Amigos Del Museo Arqueológico de Lorca, (10), $107-142$.

${ }^{90}$ Cartagena Sevilla, J. C. (n.d.). Incidencia de los terremotos en el conjunto monumental de Santo Domingo (Lorca, Murcia). Alberca. Revista de La Asociación de Amigos Del Museo de Lorca, (10), 143-171.
} 
El campanario se cincha provisionalmente con eslingas textiles de nylon y ratchet (cintas planas de poliéster)

Restauración: Recolocación de elementos de la cúpula desprendidos o desplazados, saneado y refuerzo por el trasdós mediante malla de fibra tomada con mortero de cal y atado de la base al arranque en el tambor con cordones de fibra.

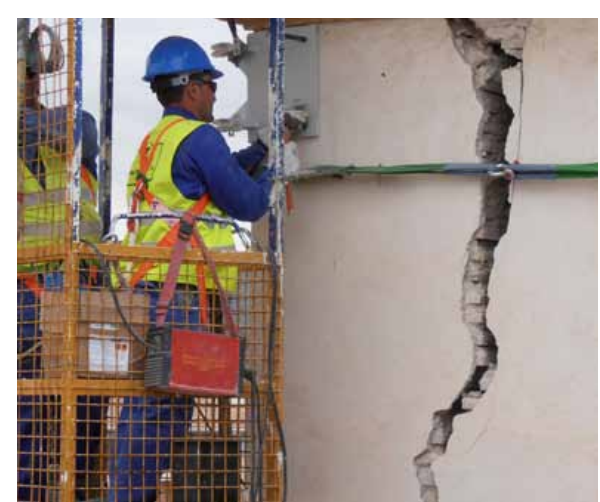

Fig.III.58. Trabajos, Cartagena

\section{III.3.3.4.3. Ex Colegiata de San Patricio}

Según otro artículo ${ }^{91}$ del monográfico de la revista Alberca, la iglesia de San Patricio fue capaz de resistir los movimientos sísmicos. El autor reflexiona sobre la doble vertiente de la magnificencia de un edificio, por un lado positiva según la relación entre mejor calidad constructiva y mayor vida útil, por contra precisará más medios para su mantenimiento, lo que a menudo provoca relajación y mayor deterioro. Resalta que, como es habitual en el Patrimonio, se trata de conjuntos donde se superponen de forma estratigráfica restos de edificios, épocas y culturas distintas. El templo cuenta con tres naves con girola y capillas entre contrafuertes, y sus obras comenzaron hacia 1570.

El arquitecto afirma que este monumento no colapsó pues sus estructuras no habían sido tan modificadas como en otros, lo que le permitió admitir ciertos movimientos y deformaciones.

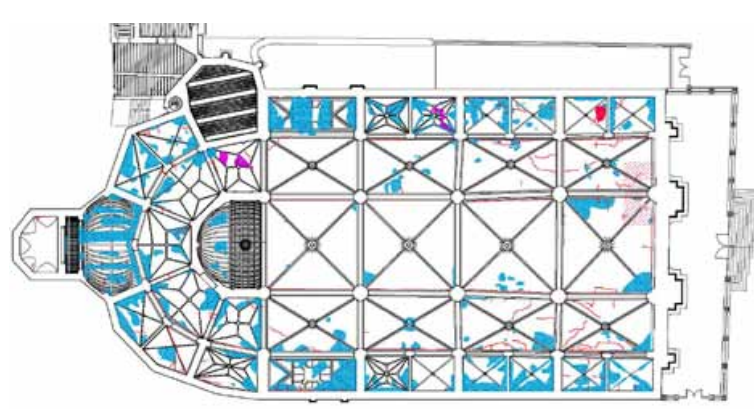

Fig.III.59. Planta San Patricio, de la Hoz 2012

Contaba con una losa que incrementaba su peso a la que culpan del vuelco de sillares e incremento de grietas en bóvedas y paramentos. En las obras de restauración tras la catástrofe se ha demolido dicha losa para colocar una solución constructiva ligera de tableros de madera con onduline. La girola sí había sufrido hace años el reemplazo completo de sus armaduras de cubierta leñosas por forjados

\footnotetext{
${ }^{91}$ Hoz Martínez, J. de D. de la. (2012b). Comportamiento de la ex colegiata de San Patricio en Lorca durante el terremoto de mayo de 2011. Actuaciones de emergencia y restauración. Alberca. Revista de La Asociación de Amigos Del Museo de Lorca, (10), 225-246.
} 
de vigueta de hormigón. Se ha retirado el hormigón en esa zona para disponer una cubierta más ligera, con durmientes y pares de madera.

\section{III.3.3.4.4. Iglesia de Santiago}

El mismo de la $\mathrm{Hoz}^{92}$ analiza también la iglesia de Santiago en Lorca tras el terremoto de mayo de 2011 y hace propuestas para su recuperación. El templo consta de tres naves, la central cubierta con bóveda de cañón con lunetos y las laterales de arista. Cúpula sobre pechinas con tambor y ocho ventanas. Se incendió en 1911 y de nuevo durante la guerra civil.

El autor considera que ha sido fundamental el llamado "síndrome de golpeo de edificios": debido a la diferencia de rigidez entre el tambor y las naves, que golpean durante el sismo como un bloque monolítico y provocan el colapso del primero. La secuencia del hundimiento con el giro se ha deducido observando los estratos de escombros en que los materiales de la cúpula aparecen bajo los restos del tambor.
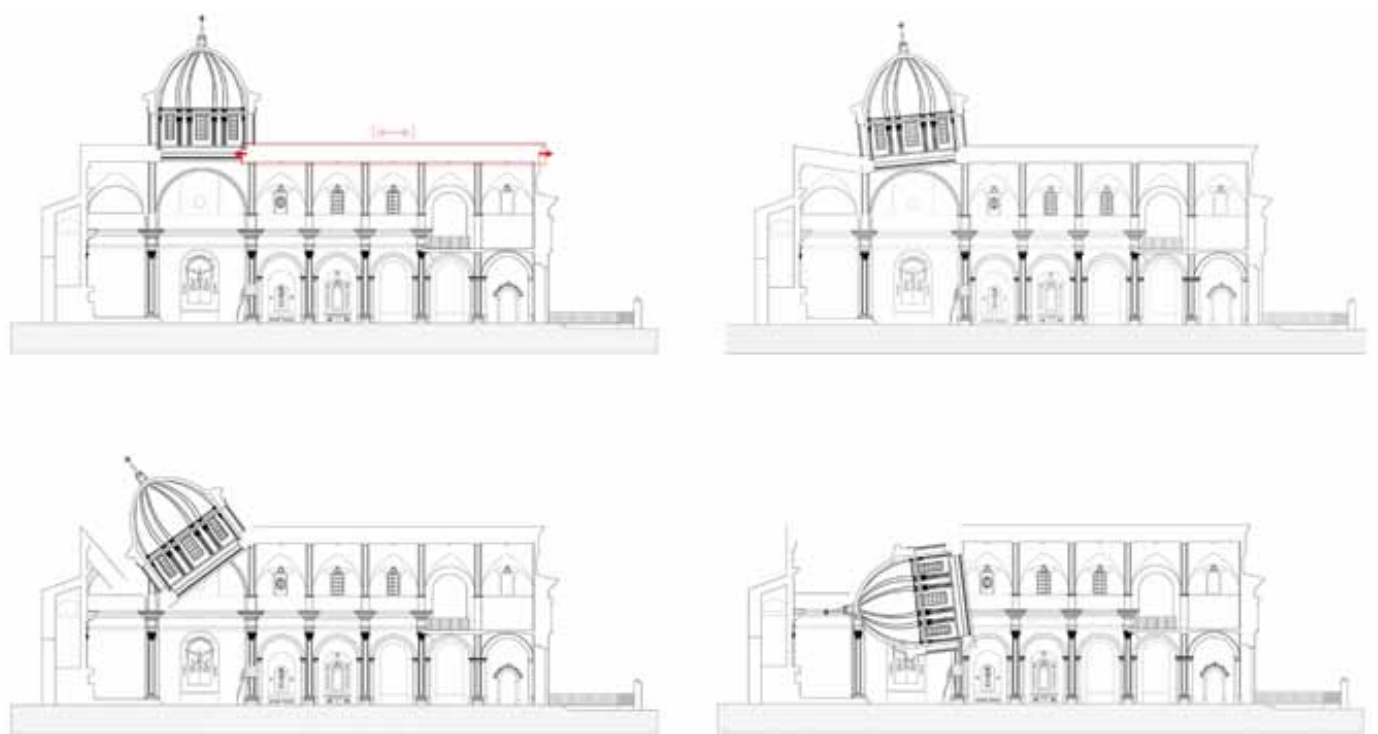

Fig.III.60. Proceso de colapso de la iglesia de Santiago, de la Hoz 2012

Afirma que es el edificio histórico que sufrió más daños y culpa al refuerzo introducido años atrás, la losa de hormigón sobre la cubierta de madera, que aumentó masa y rigidez de forma que se incrementó la aceleración sísmica. El resto de edificios religiosos han respondido frente al terremoto "de forma satisfactoria, probablemente por el tipo construcción a base de muros de mampostería, sillería o

\footnotetext{
${ }^{92}$ Hoz Martínez, J. de D. de la. (2012a). Análisis de la iglesia de Santiago en Lorca (Murcia) tras el terremoto de mayo de 2011 y propuestas para su recuperación. Alberca. Revista de La Asociación de Amigos Del Museo de Lorca, (10), 247-276.
} 
ladrillo (en varias hojas rellenas en su interior con perpiaños y morteros de cal) y cubiertos con bóvedas ligeras y simplemente apoyadas, lo que ha evitado los cambios bruscos de rigideces y, por tanto, los agrietamientos". En octubre de 2013 se ha instalado una estructura de madera laminada con doble casquete sobre el tambor de la cúpula.
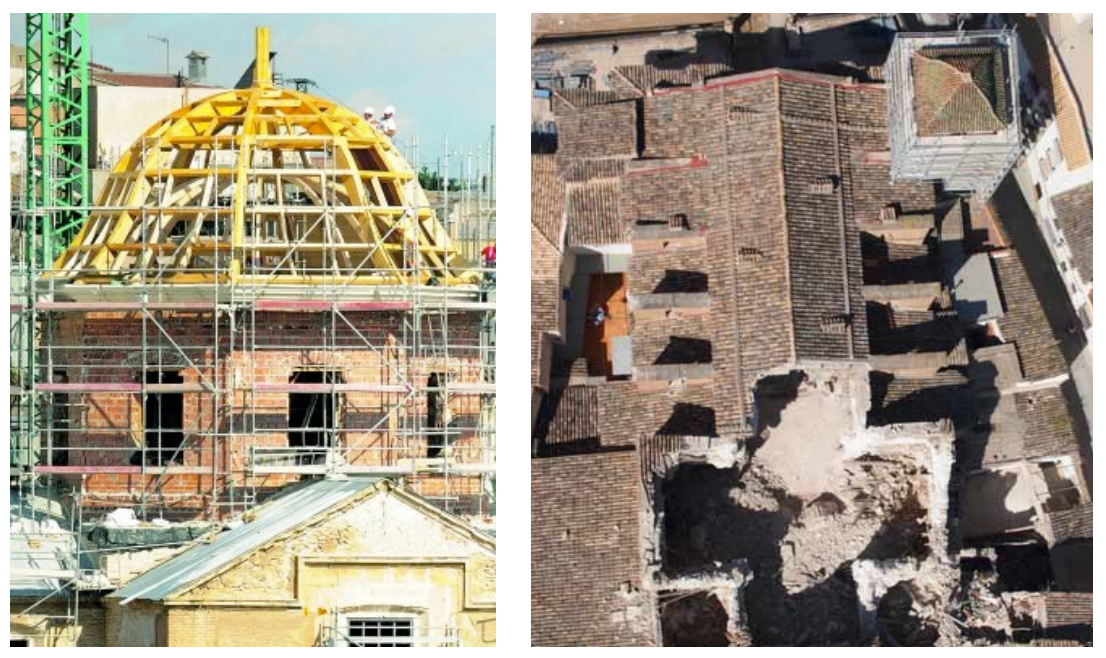

Fig.III.61. Nueva estructura de Santiago en Lorca. (http://patrimonioxlorca.org/wpcontent/uploads/2013/10/15266687.jpg 10/10/2013) e imagen de la ruina, de la Hoz 2012.

El arquitecto reflexiona además sobre las actuaciones generales que se están llevando a cabo sobre el Patrimonio de Lorca "de reparación basadas en fibras de carbono, Kevlar, aceros de alta resistencia, etc. (que no criticamos al desconocer las causas y las justificaciones de ello) pero, en nuestra modesta opinión y teniendo muy presente que un elevadísimo porcentaje del patrimonio de la ciudad ha conseguido resistir un terremoto muy destructivo por su elevada aceleración básica sin llegar a colapsar, consideramos que estos edificios no tienen un problema generalizado de esfuerzos".

En este sentido podemos encuadrar la reparación de la iglesia de San Cristóbal ${ }^{93}$ donde se emplea materiales compuestos FRP con el fin de no incrementar la masa ni introducir cambios bruscos de rigidez en la estructura. El comportamiento de la estructura del templo frente al seísmo fue bueno, sin colapsos parciales, presentando únicamente un cuadro de fisuración con preponderancia de las grietas a lo largo del eje de la bóveda de cañón, de vuelco y cuña en fachadas y remate del campanario.

\footnotetext{
${ }^{93}$ Yuste-Navarro, J. (2014). Reducción de vulnerabilidad y mejora sísmica de la iglesia de San Cristóbal de Lorca afectada por el terremoto de mayo de 2011 en Lorca (Murcia, España). In REHABEND (pp. 765-773). Santander.
} 


\section{III.3.3.5. Estrategias actuales frente al riesgo sísmico}

En el congreso Rehabend celebrado en Santander en abril de 2014, una de las conferencias Plenarias corrió a cargo del ingeniero peruano Julio Vargas-Neumann ${ }^{94}$ que, a lo largo de la misma, explicó la necesidad de revisar nuestros criterios de conservación del patrimonio vulnerable frente al riesgo sísmico y analizó cómo hacer compatible la autenticidad de los edificios históricos con las actuaciones de refuerzo preventivo. La Declaración de Lima en 2010 se incorporó a los "textos doctrinales" de ICOMOS tras una moción presentada por expertos de Japón y Perú.

Los criterios prioritarios son:

- Mínima intervención. Sólo actuaciones indispensables

- Refuerzo reversible. Reemplazable sin causar daño

- Materiales compatibles. Controlar desplazamientos sin complicar el comportamiento estructural original

Las intervenciones del siglo pasado han producido ciclos de daño-restauracióndaño que debe evitarse. Es recomendable adoptar una cultura preventiva y actuar antes de que se produzca un sismo, no una vez producido el daño. Vigilancia y mantenimiento continuos. Este criterio de actuación preventiva en áreas de riesgo sísmico conlleva la adopción de medidas para reforzar las estructuras de fábrica que presenten vulnerabilidad.

Implantada casi de forma general la premisa de mantener las condiciones originales de masa y rigidez sin cambios bruscos cuando se hace imprescindible intervenir las sobre un edificio histórico, los investigadores se están centrando en la comprobación de soluciones ligeras y tecnológicamente avanzadas.

Los terremotos son fenómenos recurrentes que producen daños acumulativos. Debemos tener en cuenta que las prestaciones del edificio van cambiando a lo largo del tiempo y como consecuencia de los esfuerzos. Por ejemplo bajo acciones horizontales se produce una fisuración que disminuye la capacidad resistente del muro.

\footnotetext{
${ }^{94}$ Vargas-Neumann, J. (2014). Propuesta de conservación: patrimonio edificado en tierra del mundo andino. In REHABEND (pp. 43-52). Santander.
} 
El siguiente esquema se ha obtenido de un libro ${ }^{95}$ que recoge los resultados de dos proyectos de investigación PRIN 2005-2007: "Innovative techniques and strategies for seismic upgrading of existing RC structures" y "Structural refurbishment and safeguarding of historical buildings by reversible mixed techniques".

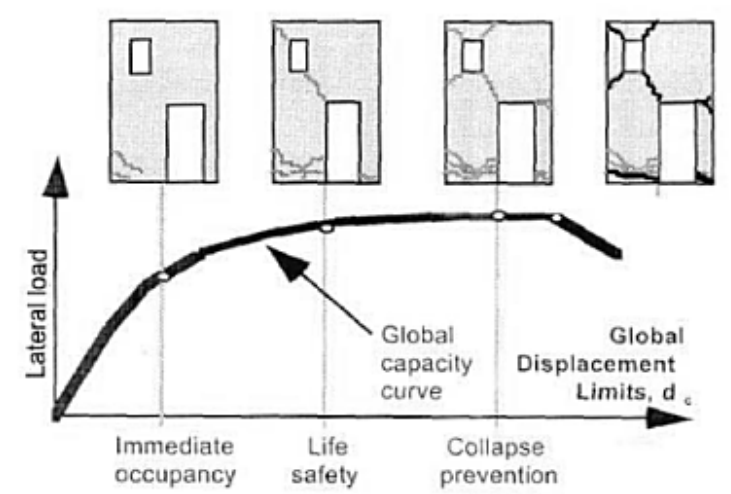

Figure 1. Pushover curve for a performance based evaluation of constructions (Rojan ct al., 1998).

Fig.III.62. Merma de resistencia acumulativa, Faenza y Mazzolani 2009

En la obra citada se puntualiza la distinción entre un edificio histórico y otro simplemente antiguo, y dentro de la primera familia pertenecerá o no a la categoría de monumento según sus valores culturales o artísticos intrínsecos.

Compara el comportamiento estructural de un muro URM (de mampostería sin refuerzo) y la mejora al ser reforzado con bandas horizontales y diagonales FRCM (fiber reinforced cement matrix) o con FRP (fiber reinforced plastic)

En el mercado encontramos ya diversos sistemas de refuerzo patentados para incrementar la resistencia de los muros de fábrica a flexión y cortante .

\footnotetext{
${ }^{95}$ Faenza, C., y Mazzolani, F. M. (2009). Innovative Strategies for Structural Protection of Built Heritage-PRIN 2005. Polimetrica sas.
} 



\section{III.3.4. Últimas tendencias en restauración monumental}

Se revisa a continuación qué está ocurriendo en el ámbito de la restauración de los edificios históricos en la actualidad. En primer lugar se introduce el concepto de conservación preventiva y a continuación se analizan las últimas actuaciones llevadas a cabo en Italia y Francia dentro de una corriente que algunos denominan des-restauración. También se resume otro tipo de intervenciones de tipo tecnológico, con especial hincapié en los proyectos de zunchados ligeros de Jurina en Italia.

\section{III.3.4.1. Conservación preventiva}

La conservación preventiva se está implantando poco a poco como estrategia fundamental frente a la costumbre establecida de acometer intervenciones urgentes de restauración tras procesos incontrolados de degradación. Consiste en realizar un seguimiento y control sistemático de los riesgos de deterioro que puedan afectar al inmueble.

Desde 2011 se ha puesto en marcha el Plan Nacional de Conservación Preventiva, que supone un importante cambio en la política de gestión del Patrimonio cultural. Este último ha pasado a considerarse un motor de generación de riqueza en vez de una carga.

El IPCE emprendió en 2009 un programa de autocrítica para analizar las soluciones adoptadas por la institución a lo largo de 25 años. De los 31 estudios 11 se centraron en inmuebles, en cinco casos defensivos, otros cinco monásticos y un archivo. De Castilla León sólo se incluye el claustro del Monasterio de Silos en Burgos. En un número monográfico sobre Conservación preventiva de la revista del IPCE de 2013 se recoge el resultado de estos análisis ${ }^{96}$.

Constatan que la causa más común de las lesiones son los daños asociados a la acción del agua y que se reproducen no sólo por ineficacia de los tratamientos o soluciones sino en la mayoría de los casos por la ausencia de aplicación de protocolos de mantenimiento. La aplicación de los mismos permite atajar a tiempo

\footnotetext{
${ }^{96}$ Cirujano, C., \& Sousa, A. L. de. (2013). Algunos datos y primeras conclusiones sobre el Programa de Control y Seguimiento de Intervenciones ejecutadas por el Instituto del Patrimonio Cultural de España. Conservación Preventiva: Revisión de Una Disciplina, (7), 147-157.
} 
los problemas, impidiendo un mayor deterioro. Sin ella harán falta intervenciones más costosas o incluso se producirán daños irreparables.

El 55\% de los bienes había sufrido humedades por capilaridad, y los drenajes perimetrales detenían el aporte pero el elevado porcentaje de sales en muros actuaba como captador de humedad y seguía el proceso de deterioro. El 55\% estuvo expuesto a filtraciones o escorrentías por deficiencias en cubiertas y aleros de poco vuelo. El $22 \%$ de elementos revisados carecía de protección y se encontraba en un estado similar al previo a la restauración.

Los morteros de cal y arena han tenido buen comportamiento, excepto los que sufrieron el añadido de una pequeña proporción de emulsión acrílica, que se contraen, agrietan o caen. Tampoco han funcionado los bastardos ni los preparados comerciales.

Las resinas epoxi han perdido color pero conservan su adherencia y propiedades resistentes. Los tratamientos de consolidación con silicato de etilo han sido inoperantes si se producía aporte de humedad, y perjudiciales frente al movimiento de sales en muros, formándose eflorescencias, exfoliación y disgregaciones. Los hidrofugantes siempre pierden eficacia con el paso del tiempo y no han tenido efectos perniciosos, por lo que es recomendable repetir su aplicación con asiduidad.

En dicho estudio se han identificado los agentes de deterioro más frecuentes:

1. Agua y sus procesos asociados: sales, heladicidad, erosión, disolución, oxidación, lavado, pudrición...

2. Aportación de materiales, técnicas o sistemas constructivos incompatibes con los originales (morteros cementosos, hormigón, resinas)

3. De origen antrópico asociado al uso

4. Derivado de la falta de mantenimiento

La superposición de etapas constructivas en algunos casos genera encuentros complejos que provocan problemas de falta de estanqueidad en los edificios. Por ejemplo, disponer una acera impermeable al impedir la evaporación a través del suelo puede propiciar la capilaridad.

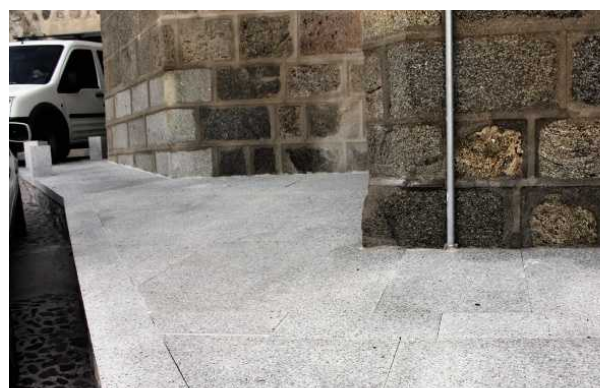

Fig.III.63. Ilustración Cirujano 2007 


\section{III.3.4.2. Des-restauración}

En los últimos años el concepto de des-restauración adopta más fuerza reabriéndose la cuestión a raíz de la supresión de las adiciones, realizadas por Viollet-le-Duc en 1860 en Saint-Sernin de Toulouse, llevada a cabo por Yves Boiret entre los años 1979 y 1997.

Tras décadas de simposios y Cartas parecía implantado como criterio general un cierto respeto a la permanencia de los estratos históricos, añadidos a lo largo del tiempo, independientemente de cuales fueran su época y estilo. La primera aparición del concepto des-restauración está documentada en un congreso en Munich en 1971, pero no se generaliza hasta el de Toulouse de 1980, con su acepción inicial de volver a un estado anterior eliminando las huellas de una intervención anterior.

Tollon establece en 1995 tres parámetros que condicionarán este tipo de actuaciones: histórico (las restauraciones anteriores como documentos de la historia), estético ( el restaurador permeable a las modas del momento) y técnicos ${ }^{97}$.

\section{III.3.4.2.1. Francia}

Varagnoli afirma que en Francia la des-restauración afecta a edificios fuertemente alterados en el siglo XIX, sobre todo a partir de los principios de la restauración estilística.

Según el profesor de la Universidad de Valladolid, Eduardo González Fraile, en Francia resulta extraordinaria la sensibilidad frente a la destrucción del Patrimonio, propiciada por los cataclismos de la revolución de 1789 y las distintas guerras. Distingue tres líneas básicas de actuación ${ }^{98}$ :

1. La corriente tradicional se basa en la refección, es decir, la reconstrucción "à l’identique" del estado original. Los edificios son hoy bienes de consumo sólidos.

\footnotetext{
${ }^{97}$ Varagnoli, C. (2008). Des-restauración en Italia, teoría y realizaciones. In Actas de la III Bienal de Restauración Monumental: sobre la des-Restauración (pp. 47-63). Instituto Andaluz del Patrimonio Histórico.

${ }^{98}$ González Fraile, E. (2004). La restauración de monumentos en Francia. Patrimonio Histórico, Monográfico(50), 87-95.
} 
2. La revisión crítica de la doctrina de Viollet-le-Duc

"La espléndida, sensible y rigurosamente técnica restauración de Notre Dame de París (Bernard Fonquernie, premio ARPA 2000), así como la controvertida (por los historiadores), documentada, valiente e igualmente rigurosa desrestauración de Saint-Sernin de Toulouse (Yves Boiret) son dos ejemplos disjuntos de la misma línea de trabajo, donde la investigación, el conocimiento, el método y el respeto, no tanto por la Historia, sino por la Arquitectura de la historia real, son claves para entender el resultado del proyecto".

3. La herencia creativa de los conceptos del Movimiento Moderno se mantiene como línea de actuación muy minoritaria de un grupo de arquitectos que introducen materiales y conceptos actuales en sus intervenciones.

\section{III.3.4.2.2. España}

En una comunicación del XI Congreso del CICOP en Cascais en 2012, Carrillo y Villafranca citan varios ejemplos de iglesias en las que se intenta suprimir bóvedas añadidas en el Barroco para recuperar techumbres mudéjares ocultas. Los autores del texto justifican el desmontaje de elementos no sólo por criterios tipológicos o estéticos, sino también estructurales, por ejemplo para eliminar refuerzos desafortunados ${ }^{99}$. Así en 1999, durante la fase de desmonte de las cubiertas de la Casa de Castril, sede del museo arqueológico de Granada, aprecian que las vigas principales de madera que sustentaban la galería este se encontraban prácticamente pulverizadas, y lo achacan al contacto con el hormigón de un refuerzo realizado décadas antes. El museo permanece cerrado desde 2010.

Describen como caso paradigmático del concepto de des-restauración las intervenciones sobre las cubiertas del Monasterio de Santa Isabel la Real en el Albaycín. Entre 1953 y 1982 Prieto-Moreno dispuso una sobrecubierta apoyada en un zuncho perimetral de gran canto y con enanos intermedios de apeo sobre los pares de la armadura histórica. Estas cargas puntuales estaban dañando la estructura original, según el arquitecto Carlos Sánchez Gómez, por lo que fueron eliminadas en 1995-98. En el proyecto se señalaba el rebaje del canto del zuncho al menos 2/3 aunque si las dificultades de dicha operación eran mayores se fijaba su completa extracción, obligando a la preparación de la coronación del muro con un tendido de

\footnotetext{
${ }^{99}$ Gutiérrez Carrillo, M. L., y Villafranca Jiménez, R. (2012). La des-restauración en el patrimonio histórico granadino. In Actas del XI Congreso Internacional de Rehabilitación del Patrimonio arquitectónico y edificación (pp. 441-421). Cascais: ICES CICOP.
} 
hormigón de espesor suficiente para que quedara enrasado con los faldones de cubierta de las galerías adyacentes". La estructura de madera se conserva, reforzándose mediante duplicación de los pares con piezas de igual escuadría unidas a las antiguas con tirafondos. Se coloca una carrera metálica en el alero a la que se anclan unos tirantes de cable de acero.
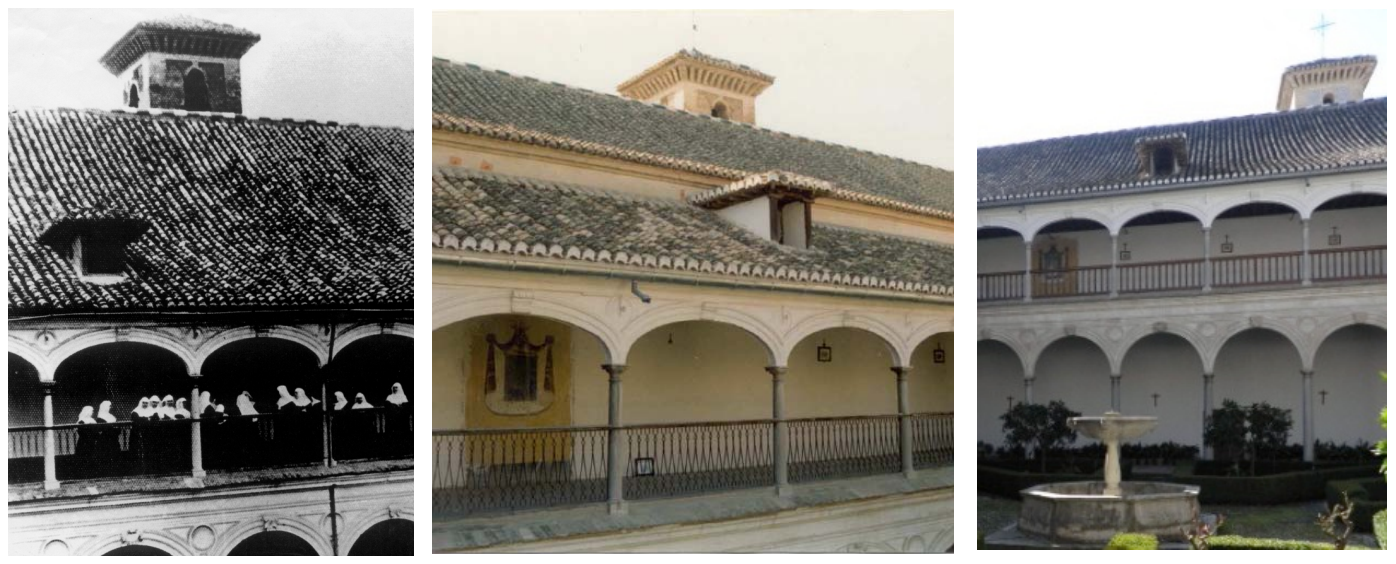

Fig.III.64. Cubierta de Santa Isabel, Gutierrez y Villafranca 2012.

En la revista electrónica de patrimonio histórico ${ }^{100}$ se cita también esta intervención incluyendo una imagen en blanco y negro del proceso de desmontaje del tablero original. En la imagen de la derecha se aprecia la des-restauración gradual de la cubierta del claustro realizada en $1999^{101}$.
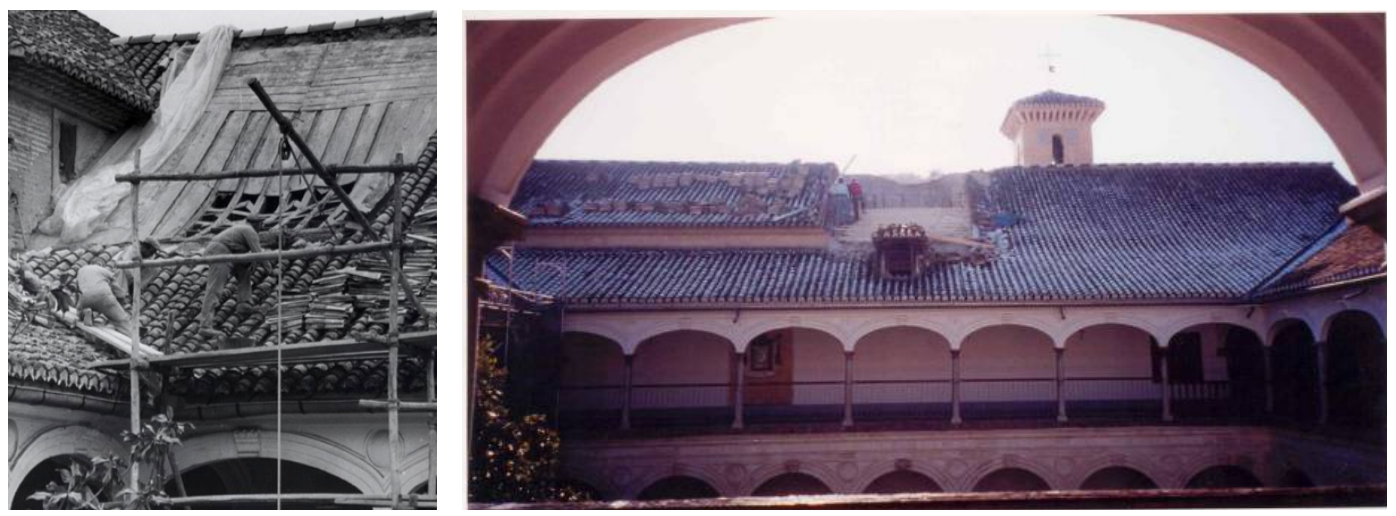

Fig.III.65. Desmontajes 1953 (Romero 2010) y 1999 (Caja Madrid 2008)

\footnotetext{
${ }^{100}$ Romero Gallardo, A. (2010). Apuntes y reflexiones en torno a la obra restauradora del arquitecto Francisco Prieto-Moreno y Pardo. Revista Electrónica Del Patrimonio Histórico, (7).

${ }^{101}$ Fundación Caja Madrid. (2008). Proyecto de restauración del presbiterio de la iglesia del monasterio de Santa Isabel la Real. Granada. Obtenido en http://www.fundacionmontemadrid.es/Ficheros/CMA/ficheros/F-patri-dossier-staisabel.PDF
} 


\section{III.3.4.2.3. Italia}

Mientras en Francia la des-restauración parece aplicada a minimizar intervenciones del XIX, en Italia afecta más a obras ejecutadas en el XX con materiales modernos, en especial a las realizadas por el arquitecto Franco Minissi a partir de 1950. Se trataba de restauraciones en que se empleaban materiales novedosos, como aluminio, perspex y plexiglás. Los intentos de cubrir con estos plásticos transparentes un teatro y una fortaleza fracasan por falta de mantenimiento, provocando problemas de incremento del deterioro de las fábricas por el efecto invernadero. Según el citado profesor Varagnoli, también han causado polémica obras en que se incorporan grandes vigas de hormigón armado, como el palacio papal de Viterbo o la restauración de la iglesia de San Clemente en Casauria.

\section{III.3.4.3. La fascinación por la tecnología.}

Según se resumía en el apartado III.3.1, los criterios adoptados en las intervenciones sobre el Patrimonio arquitectónico van evolucionando a lo largo del tiempo y periódicamente se forjan corrientes o escuelas de pensamiento que plasman sus ideales en las famosas Cartas.

El historiador Javier Rivera ${ }^{102}$ plantea en sus escritos interrogantes fundamentales de cara a la adopción de los criterios restauradores actuales. Cuestiona por qué es válida una postura y otra no, por ejemplo frente a la obra de Viollet, cuando en Saint Sernin se han destruido sus aportaciones y en Carcassone la ciudad inventada por él se ha declarado Patrimonio de la Humanidad.

Si analizamos el marco español, durante los últimos años del franquismo prevalecían los criterios marcados desde la Dirección General de Bellas Artes y por los grandes arquitectos de las siete zonas, González Valcárcel, los Arenillas, Chueca Goitia, Cervera, Prieto Moreno... Éstos entendían la restauración como una recuperación del sentido del monumento en sus características originarias, buscando la pureza del estilo, a veces mejorando el edificio hasta un grado ideal nunca

\footnotetext{
${ }^{102}$ Rivera Blanco, J. (2013). Nuevas tendencias de la restauración monumental. De la Carta de Venecia a la Carta de Cracovia. En Seminario: La doctrina de la restauración a través de las cartas internacionales. Universidad Politécnica de Valencia. Obtenido en http://riunet.upv.es/handle/10251/28161\#
} 
previsto, pretendiendo la recuperación de lo vernáculo. Tras ellos empieza un relevo generacional con Antonio Almagro, Alberto García Gil, Merino de Cáceres, Dionisio Hernández Gil, Peridis o Antón Capitel.

En 1982-84, al producirse el traspaso de competencias a las Comunidades Autónomas, los criterios de restauración se asumen desde nuevas oficinas o departamentos. "Eran momentos de aspiración colectiva por la defensa y protección del patrimonio". El profesor Rivera opina que hubo una disfunción debida tanto a la falta de profesionales específicamente preparados como de la exigencia masiva de sedes para una nueva administración con aspiraciones históricas.

Un grave problema que arranca entonces es la "sacralización de la tecnología" que hace caer a los arquitectos en manos de empresas y laboratorios, dispara los presupuestos y seduce a los promotores. También resulta fundamental la cuestión del uso: dotar de funcionalidad a construcciones obsoletas. Como historiador defiende la transmisión del monumento en sus valores históricos, incluso el arquitectónico (formal, espacial, de uso, significación) sin mantener el objeto congelado en el pasado. El conservacionismo a ultranza es un riesgo si es necesaria la intervención, por lo que aboga por la búsqueda de un equilibrio

Como valiosa fuente documental para el estudio de las actuaciones restauradoras en el cambio de siglo contamos con el Catálogo de la Exposición Conservar y restaurar, de 2003 que pretendía divulgar las obras realizadas esos años en la Comunidad de Madrid. Entre las intervenciones arquitectónicas descritas en la citada publicación encontramos ejemplos de soluciones completamente distintas que sin embargo tienen en común la radicalidad:

\section{Incorporación de zuncho}

Artesonado mudéjar del monasterio de las clarisas en Griñón. Edificio barroco del XVII muy castigado por la Guerra Civil y su uso como cuartel. Se desmonta, repara y recoloca la estructura de madera que cubre el presbiterio. Las estructuras de madera de la cubierta, sin embargo, que se consideran "en estado ruinoso se reemplazan por estructuras metálicas ligeras. También fue necesario atar la parte superior de los muros con un zuncho de hormigón, consolidando cornisas y aleros y colocando canalones y bajantes en los claustros".

2. Estructura nueva de madera laminada

Recuperación de artesonado oculto en la iglesia de San Andrés en Cubas de la Sagra. 
Se ha recuperado la posición primitiva de la cubierta que, en una restauración anterior, había sido sobreelevada al incorporar una estructura metálica superpuesta. La nueva es de madera laminada atirantada y se coloca sobre la antigua de par y nudillo reparada con prótesis. El artesonado cuelga de la nueva instalación.

Sobre la vigencia de los criterios adoptados en esta intervención, es revelador el hecho de que la restauración de 2001-2002 se haya divulgado en la web madrid.org seleccionada con otros doce monumentos que recomienda visitar en 2012.

La intervención de 1989-1993 del mismo arquitecto Ignacio de las Casas se recogió con todo detalle en una Ficha editada en la colección Madrid restaura en Comunidad. En aquella ocasión se recalzó la cimentación del ábside incorporando un zócalo, empotrando vigas sobre cada nivel de arcos y un alma en los contrafuertes, todo en hormigón armado. Se colocaron además tirantes sobre las bóvedas, demoliendo dos contrafuertes intermedios que se consideraron añadidos ya que no aparecían en un plano del XIX de Ibáñez Ibero. En la ficha se menciona que "no fue preciso desmontar la armadura de cubierta. Se colocaron refuerzos de acero galvanizado en las uniones de pares y durmientes".

\section{Estructura de cubierta nueva en madera aserrada}

Nueva cubierta para la iglesia de Nuestra Sra. de la Natividad en Valdetorres del Jarama. Reconstruida en los años 50 tras los daños de la Guerra Civil, en 1997-2000 el arquitecto Pablo Latorre dispone una nueva cubierta con una singular estructura de madera.

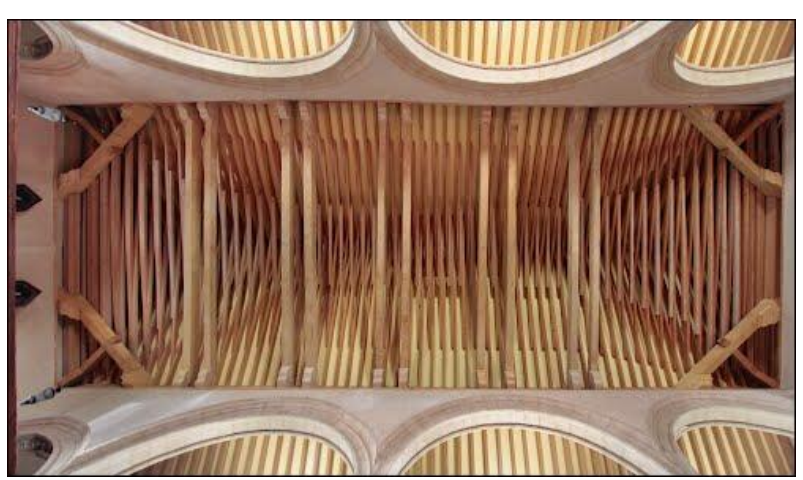

Fig.III.66. Ilustración del Catalogo 2003

4. Reemplazo de fábrica de ladrillo por muro de hormigón armado visto Linazasoro diseña en 2001 una nave de hormigón visto para sustituir la de ladrillo de 1961 engarzada con una cabecera gótica. También en el monasterio de El Paular interviene Barceló, según un Plan Director Integral que renueva los espacios. 
Podemos obtener también una perspectiva del estado del arte actual en la especialidad de la rehabilitación monumental a través, por ejemplo, de la documentación de un Proyecto de innovación para el Patrimonio liderado en 2009 por grandes constructoras: La iniciativa PATRAC Patrimonio Accesible: $I+D+i$ para una cultura sin barreras. En el estudio elaborado por técnicos de Geocisa y Acciona "Cirugía del Bien Cultural Técnicas de Rehabilitación/Refuerzos para edificios históricos del Patrimonio Cultural" ${ }^{103}$ se compendia desde las técnicas más tradicionales, como el simple rejuntado, hasta las más modernas.

En el texto de Acciona citado se denomina estructuras de URM a las construcciones con muros de fábrica, concepto adelantado en el epígrafe 5.6 (en que se describen someramente las estrategias tecnológicas actuales orientadas a afrontar el riesgo sísmico). Es fácil suponer que los autores de los documentos del proyecto son ingenieros que traducen del inglés términos como "masonry" por la voz "mampostería", en vez de como muro de fábrica en general, por lo que denominan con el acrónimo URM (walls unreinforced masonry) a todo tipo de muros de fábrica sin reforzar. En España el término mampostería debería emplearse con rigor sólo para designar muros de piedra sin labrar. Según el diccionario RAE se entiende por mampostería la "obra hecha con mampuestos colocados y ajustados unos con otros sin sujeción a determinado orden de hiladas o tamaños". En el documento se enumera diversos métodos para refuerzo de URM:

1. Inyección con lechadas de cemento o con resina epoxi.

2. Refuerzo externo URM mediante encamisado del muro con capas interconectadas de yeso reforzado en ambas caras y malla de acero. También se cita el recercado tradicional, con hormigón armado y pórticos de acero, para conseguir que el cerramiento actúe como fábrica confinada

3. Refuerzo interno, mediante barras o tendones pretensados de acero.

Los autores describen el refuerzo llevado a cabo en San Isidoro de Sevilla, Italia, consistente en micropilotaje y un esqueleto de hormigón armado embebido en muros, combinado con lechadas cementicias. Reconocen las críticas por tratarse de técnicas no reversibles pero alaban su "éxito técnico." También describen los sistemas de

\footnotetext{
${ }^{103}$ ACCIONA, \& LABEIN. (2008). Cirugía del Bien Cultural. Técnicas de Rehabilitación/ Refuerzos para edificios históricos del Patrimonio Cultural. Universitat Autònoma de Barcelona. Obtenido en http://www.recercat.net/bitstream/2072/88240/1/E2.26.pdf
} 
postesado, aunque asumiendo que no deben aplicarse a la mampostería histórica y el problema de la disminución de resistencia de los tendones a baja temperatura.

Las soluciones tecnológicamente más avanzadas conllevan el uso de materiales compuestos FRP (fibre reinforced plastic), con fibras de carbono (CFRP), vidrio (GFRP) o aramida (AFRP) adheridos a una matriz polimérica (epoxy, poliester o vini-lester). Según los técnicos de estas constructoras "Los FRP se ajustan a los principios de restauración de los edificios históricos. Se adaptan tanto a superficies curvas como rugosas, implican adiciones limitadas de material y no alteran la respuesta dinámica de la estructura. Las propiedades dinámicas de la estructura permanecen inalterables debido a que no se añade peso ni rigidez (....) La bibliografía al respecto muestra que el aumento de la actividad sísmica es una de las principales razones para la reciente expansión de la aplicación de laminados de FRP en muros URM. En todo el mundo."

Podemos encontrar numerosos programas de investigación centrados en métodos para refuerzo de muros de fábrica con FRP y sus ensayos correspondientes: a cortante, orientados a aumentar la ductilidad del conjunto y generar una distribución uniforme de fisuras en vez de agrietamiento: flexión fuera de plano, frente a cargas cíclicas, barras GFRP y CFRP cerca de la superficie. Incluso lo que denominan "rejuntado estructural" , con barras FRP embebidas en juntas ranuradas rellenas con mortero epoxy.

En resumen, el sistema actual más novedoso para de refuerzo de estructuras de fábrica es el uso de textiles. Por su ligereza tiene la ventaja de que no modifica la distribución de masas del edificio frente a los esfuerzos horizontales producidos por terremotos, inconveniente que sí presentaban por ejemplo los zunchados con hormigón armado de hace algunos años.

En los textos de PATRAC se recurre frecuentemente al empleo de cemento en inyecciones. Debemos suponer que se refieren a fábricas no históricas ejecutadas en origen con morteros de cemento o bastardos, pues el criterio actual ya es unánime en su apuesta por el uso de la cal para intervenir sobre el Patrimonio histórico. Así por ejemplo ya en 1998 en el II Congreso de Historia de la Construcción en A Coruña una ponencia ${ }^{104}$ describe cómo todo el exterior y grandes partes del interior de la

\footnotetext{
${ }^{104}$ Robador González, M. D., y Linares Díaz, J. F. (1998). El revestimiento de piedra en la catedral de Burgos. En Actas del II CNHC (pp. 417-429). A Coruña.
} 
catedral de Burgos estaban revestidos con mortero de cal, tanto para embellecer como por protección. Hasta el siglo pasado se realizaba mantenimiento reponiendo estas pieles periódicamente. Se trata de un material que tapa los poros y fisuras de la piedra soporte, y las partículas finas además penetran y lo refuerzan. El revestimiento cuenta con adherencia y plasticidad suficiente para deformarse, por lo que se adapta a los movimientos de la fábrica. El estuco proporciona aún mayor durabilidad. Con estos morteros se puede recomponer piedras deterioradas, ya que con el tiempo la cal se transforma en carbonato cálcico, el mismo material a reponer. Con la jabelga también se puede dotar de color si es necesario. Su falta es uno de los motivos de la degradación de muchos edificios.

En los últimos años se está tratando de justificar la efectividad del análisis del estado de los monumentos mediante profusos ensayos de laboratorio, cuyos resultados sólo podría interpretar un reducido número de investigadores científicos especializados.

Según explica Henriques ${ }^{105}$, de la Universidad de Lisboa, para el técnico ordinario esta abundancia de datos no suele resultar útil y se costea la obtención de los mismos sólo "por el marketing asociado a lo hipertecnológico". Cita la restauración del Palacio Nacional de Sintra en 1995, que supuso un cambio de paradigma. El edificio cuenta con dos grandes chimeneas cónicas que iban a ser revestidas con mortero de cemento, de uso habitual en la época. Finalmente se emplearon métodos tradicionales, retacando con un mortero de cal y arena, tras el cepillado de la capa biótica. El revoco final se hizo con "marmorino", una fina capa de mortero de cal y polvo de mármol, con terminación de lechada de cal. Describe problemas puntuales asociados a la ejecución de varios ensayos: La limpieza de la piedra con determinado tipo de aparatos láser puede dañarla. Tras un buen conocimiento de la geometría del edificio conviene determinar las propiedades de las fábricas. La termografía infrarroja señala las discontinuidades.

Tras consultar recortes de prensa y otras publicaciones posteriores a 2010 podemos apreciar que en muchos casos se siguen incorporando automáticamente zunchos de hormigón armado al restaurar cubiertas de iglesias monumentales.

\footnotetext{
${ }^{105}$ Henriques, F. (2003). The concept of acceptable technology in architectural conservation. In ITAM ARCCHIP ARIADNE Workshop.
} 
Algunos autores mencionan este zunchado como parte de trabajos respetuosos, llegando a afirmarse que el método "refuerza sin alterar ni modificar como prescribía Camilo Boito" en la descripción del zuncho sobre la cornisa de la iglesia de Nueva Tabarca $^{106}$.

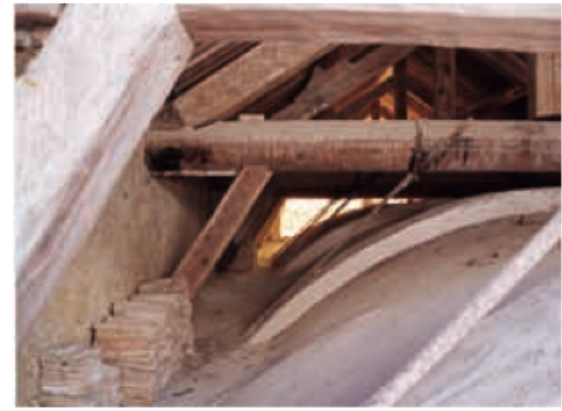

Camara del tradós una vez limpiada, 2004

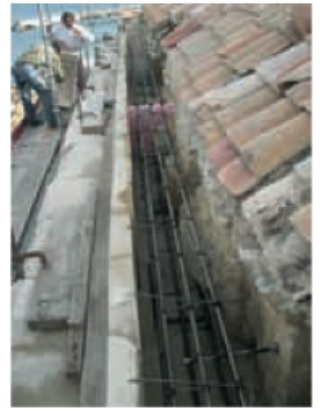

Armaduras zuncho de atado

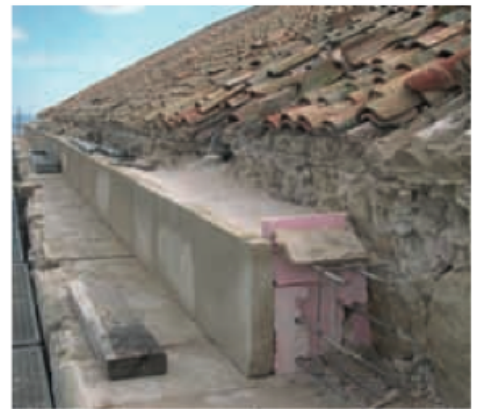

Hormigonado zuncho de atado y arriostramiento

Fig.III.67. Ilustraciones Nueva Tabarca, Martínez Medina 2012

Los técnicos que prescriben la incorporación de zunchos de hormigón armado en restauración de obras de fábrica histórica actualmente en España no consideran que se trate de una actuación contundente ni prácticamente irreversible.

\section{III.3.4.4. El punto de vista práctico. Manual de Roberto Benedicto ${ }^{107}$}

Según se va desgranando a lo largo de este trabajo, la documentación sobre restauración monumental es ingente desde el punto de vista académico. Cada día surgen nuevas aportaciones de universidades y centros de investigación, tanto desde el ámbito de la crítica conceptual, debatiendo reiteradamente los criterios formales, como técnico, con resultados de numerosos estudios y proyectos de investigación sobre materiales desde el punto de vista mecánico, físico y químico.

También la Administración publica informes divulgativos y edita revistas con imágenes y descripciones someras de las intervenciones que auspicia sobre el Patrimonio. Encontramos sin embargo menos estudios centrados en las obras de restauración con el enfoque práctico constructivo que guía por ejemplo esta Tesis.

\footnotetext{
${ }^{106}$ Martínez Medina, A. (2012). Los secretos de las piedras: El proceso de intervenciones en la iglesia de Nueva Tabarca. CANELOBRE, (60), 129-149.

${ }^{107}$ Benedicto Salas, R. (2012). De las sustituciones de cubiertas en las iglesias del patrimonio monumental. Zaragoza: Institución Fernando el Católico.
} 
Muchos técnicos siguen consultando en la actualidad los detalles constructivos de refuerzos y recomendaciones del libro de López Collado, analizado en el apartado III.3.1., que se publica en 1976 y es reeditado en 1982, con cuarenta años "en activo" como referente práctico. Un libro actual que sigue su estela de claridad y estilo accesible es la obra del arquitecto, académico y profesor de restauración monumental Roberto Benedicto "De las sustituciones de cubiertas en las iglesias del Patrimonio monumental". El texto cuenta con un dossier de fotografías al final de cada capítulo, aunque carece de los esquemas y detalles constructivos que confieren su carácter de auténtico manual a la obra de López Collado. El autor elude el compromiso de plasmar de forma gráfica los conceptos que expone, no materializa sus aportaciones.

Empieza evocando un refrán "quien no acude a la gota, acude a la casa tota" que ilustra sucintamente la importancia fundamental del mantenimiento de las cubiertas para la conservación del Patrimonio edificado, su auténtico talón de Aquiles. Aborda los problemas que presenta intervenir sobre las cubiertas de iglesias aragonesas, sin tratar la historia ni evolución de las mismas.

El paso del tiempo, con incendios, ruinas, abandono e intervenciones desafortunadas ha modificado sustancialmente las configuraciones de las cubiertas de los edificios históricos, provocando la casi total desaparición de las originales y en especial de sus sistemas estructurales. Constata los cambios sustanciales que afectan también a los muros de apoyo, con recrecidos que conllevan la desaparición de sus cornisas de coronación. El añadido de torres y espadañas, la reorganización de los faldones.

Hace la interesante reflexión de que analizando los escombros sobre relleno de senos de bóvedas podemos encontrar restos de tejas, lajas, losas que aporten información sobre revestimientos y soluciones constructivas anteriores. Otra forma de investigar sobre la evolución constructiva del edificio es localizar restos de antiguas soleras de apoyo empotradas en los muros, mechinales de empotramiento, improntas de aleros desaparecidos. También las alteraciones del aparejo deben documentarse.

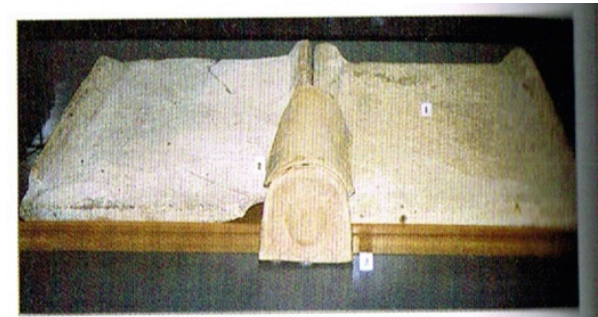

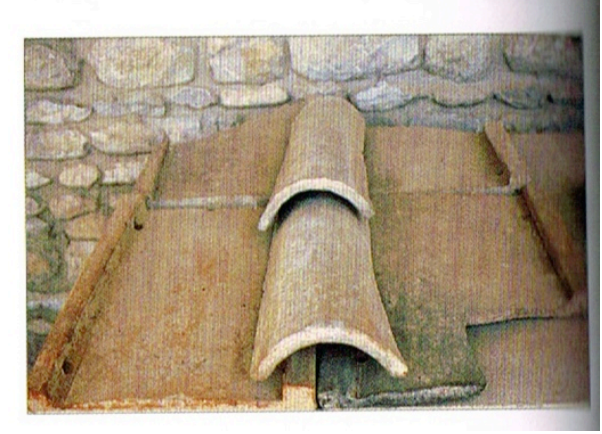

Fig.III.68. Ilustración tejas, Bendicto 2012 
En la imagen tomada del libro se observan tejas romanas planas tegula con las piezas curvas cubrejuntas imbrex.

Lamenta que nunca se ha profundizado en su estudio, "sobre las cubiertas alto y bajo medievales soportadas por armaduras de madera, nuestro desconocimiento es abrumador".

Divide el documento en varios capítulos según la tipología de las cubiertas:

- Con faldones sobre armaduras de madera vistas desde el interior

Naves laterales, pandas de claustros

Faldones sobre arcos diafragma

- Con faldones sobre armaduras de madera dispuestas por encima de las bóvedas

- Con faldones construidos sobre argamasas tendidas sobre bóvedas

- Planas sobre bóvedas

- Sobre cúpulas

- Chapiteles de torres

1. Con faldones sobre armaduras de madera vistas desde el interior:

Describe cómo las pendientes de faldones en el ámbito mediterráneo se presentan en torno al 35-40\%, incrementándose hacia el norte. La cercha es un elemento de geometría triangular construido con piezas de madera de tamaño razonable que salva luces mayores que una viga. "Si está correctamente diseñada, transmite a los muros que la reciben sólo cargas verticales y ningún empuje que los desestabilice. Es decir, los hacen trabajar exclusivamente a compresión, evitando la aparición de empujes precisamente en el punto más difícil de estribar, que es la coronación de los muros". Recalca que las tensiones de trabajo en la construcción antigua en general son muy bajas, y que sus materiales soportan bien las compresiones pero mal las tracciones (sólo madera o hierro). Describe los sistemas de armaduras más sencillos:

- De par e hilera: dos pares con una viga corrida superior en la cumbrera y otra inferior o solera en ambos apoyos.

- De par y nudillo: una pieza horizontal parte la luz de los pares.

- De par y nudillo con tirante: una viga horizontal enlaza la base de ambos pares en su entrega a la solera para equilibrar los empujes horizontales.

- Cercha con pendolón y dos jabalcones que reducen la luz de los pares trabajando a compresión. Incorpora un esquema que representa la forma de trabajo del sistema que denomina "cercha correctamente diseñada" 


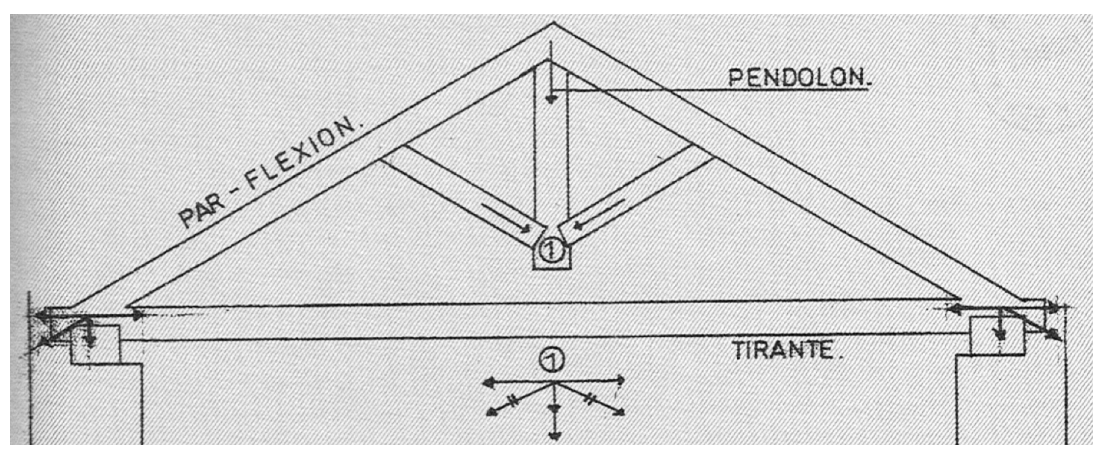

Fig.III.69. Cercha, ilustración Benedicto 2012

2. Con faldones sobre armaduras de madera, vistas desde el interior, sobre arcos diafragma:

Llama arcos diafragma a los que cuentan con un muro de igual anchura que el arco sobre el extradós del mismo que se rematan superiormente con las inclinaciones de los faldones de la cubierta a dos aguas para recibir las correas. Los arcos pueden articularse con el muro mediante ménsulas o machones hasta el suelo, también apoyar sobre pilares. Es una estructura que influye en la arquitectura civil. Sobre las intervenciones en este primer tipo de cubiertas recalca la importancia de sus valores históricos y artísticos, ya que suelen contar con policromías y relieves. "Su irreflexiva modificación podría alterar seriamente el funcionamiento estructural y la distribución de tensiones en aquella estructura, con las naturales consecuencias". Explica la manera de disponer andamios y sobrecubierta temporal para proteger la cubierta durante las obras. Recomienda no disponer impermeabilización sobre el tablero que impida la "transpiración" y cambie las condiciones de humedad de las piezas de madera.

3. Con faldones sobre armaduras de madera dispuestas por encima de las bóvedas:

Es la situación más habitual que ha encontrado. Para su explicación considera que "se trata de sustituir totalmente la cubierta existente sobre la nave central o única de una iglesia, no actuándose en otras cubiertas, como las de las naves laterales, capillas, etc... Antes de la intervención habrá que comprobar: que ningún elemento de la cubierta merece su conservación por no presentar aspectos históricos, tipológicos o artísticos que obliguen a otro tipo de intervenciones, que, en general, las bóvedas y sus estribos (muros, arcos, pilares, columnas, contrafuertes, etc) están en buen estado estructural y no se precisan apeos ni actuaciones previas".

\section{Las bóvedas:}

Recomienda averiguar el espesor y naturaleza de las bóvedas con perforaciones en los plementos, tras lo que se decidirá si hace falta apeos para garantizar la seguridad 
del personal sobre las mismas. Hace una serie de razonamientos básicos sobre las diversas rutinas que conforman las obras de rehabilitación: instalación de andamios homologados en coronación anclados al muro con bulones, escaleras, rampas de acceso, redes, suministro de agua, etc. Indica la necesidad de elaborar "un buen plano del estado actual de esas armaduras y faldones". Describe las condiciones más adecuadas para demoler y retirar escombros, siempre simétricamente y de manera gradual. A la hora de reponer rellenos de argamasa sobre los senos de las bóvedas puntualiza la conveniencia de emplear cal, nunca cemento.

\begin{abstract}
"De este modo intentar reforzar arcos y bóvedas con engruesamientos innecesarios no tiene ningún sentido y puede llagar a constituir una grave afección. En ningún caso ese refuerzo debe efectuarse tendiendo capas de hormigón armado con mallazos, en ocasiones de casi $10 \mathrm{~cm}$ de grosor, o construyendo vigas de hormigón armado adaptadas a las curvaturas del extradós de los arcos fajones y ancladas a ellos, como viene siendo repetidamente efectuado, con grave ignorancia".
\end{abstract}

Para las estructuras de cubierta con que se reemplazan las armaduras, puntualiza que se realizan con acero, a veces en madera laminada (aunque se trata de una opción más cara), por la dificultad de disponer piezas de madera seca o incluso de encontrar carpinteros especializados.

"Las obras de construcción de la nueva cubierta comenzarán por la consolidación, en su caso, de las partes superiores de los muros en que se van a apoyar las nuevas cerchas, que generalmente presentan afecciones por su exposición al agua de lluvia."

Menciona cómo también deben anclarse aleros y cornisas. Si éstos faltan deben reponerse sin emplear hormigón.

Una vez consolidadas y seguras las zonas en que se va a apoyar la nueva estructura, se procederá a la construcción de un zuncho perimetral en la cara interior de la cabeza de los muros. Este zuncho sustituirá a las soleras de madera que recibían las piezas de las armaduras, descompuestas, perdidas e incompatibles con cerchas de acero. En no pocos casos la retirada de estas soleras descompuestas dejarán el hueco que ocupaban. Si este no es suficiente para alojar el zuncho proyectado, normalmente de hormigón armado con sección $30 \times 30 \mathrm{~cm}$, será preciso cajear manualmente la fábrica del muro para conseguirlo. En ese cajeo hay que 
atender a la estabilidad de los aleros que pudieran verse afectados, adoptando las medidas de apeo provisional necesarias, que deben apoyarse en el andamio perimetral, al no existir otro lugar adecuado para ello y disponiendo los anclajes necesarios de sus piezas en el zuncho a construir.

Este zuncho debe presentar una superficie superior de apoyo perfectamente horizontal a la nueva estructura, por lo que su construcción se acompañará con los consiguientes controles de nivelación y precisará de un encofrado lateral inferior. Es un error, como frecuentemente se propone, que para evitar ese cajeo siempre dificultoso se construya el zuncho sobre el plano de coronación del muro, en lugar de empotrarse en él. En casi todos los casos esta sobre elevación implicará, en función del ancho total del muro y aleros, que las pendientes de la nueva cubierta, modificadas con este cambio y distintas de la anterior, no coincidan correctamente con el nivel superior de los aleros, con los consiguientes problemas de imposible solución. Es evidente que no se deben recrecer los aleros, porque eso comportaría una modificación injustificable de los mismos.

Conviene señalar que este zuncho, difícilmente zuncha o arriostra los muros, salvo en casos de plantas a cubrir de reducidas dimensiones. En casi todos los casos esas dimensiones alcanzan 10-13m de anchura por 25 o más metros. Es evidente que si los muros se han de mover lo harán con o sin ese zuncho. En cambio el zuncho es un elemento fundamental para obtener un plano perfectamente horizontal de entrega de las cerchas y un elemento conveniente para su anclaje. Como lo eran las soleras de madera retiradas."

Benedicto recomienda además disponer las cerchas sobre los ejes de arcos fajones, alineadas con los contrafuertes exteriores. Otras posibles configuraciones contemplan claves de bóvedas por encima del nivel de apoyo de las cerchas que obligarán a rediseñar ésta con el tirante a cota superior, o la posibilidad de recrecer muretes de ladrillo sobre los arcos a modo de diafragma rematados con un zunchito superior que siga las pendientes y reciba las correas. Describe cómo disponer cruces de San Andrés para arriostrar en el sentido de las cerchas.

Los tableros, al principio de ladrillo y más tarde de nervometal, se resuelven hoy (según Benedicto) con placas grecadas o paneles que permiten disponer las correas a $2 \mathrm{~m}$ de separación. Sobre ellas emplea mortero de agarre armado con un mallazo vinílico. 
En otro apartado aborda los problemas para reemplazar las cubiertas en el caso de contar con bóvedas encamonadas sobre las que no podemos transitar.

Mientras en el caso de cubiertas sobre armaduras este autor prescribe la incorporación sistemática de un zuncho de hormigón armado en la coronación de los muros, para el tipo de iglesia con cubiertas con revestimiento recibido directamente sobre el trasdós de las bóvedas lo rechaza con rotundidad. Afirma que no sólo no es necesario, sino que resulta perjudicial. "En ningún caso se proyectará ni permitirá la construcción de zunchos de hormigón armado, ajenos totalmente al artificio estructural de estos sistemas. Es frecuente que la contrata, con buena pero ignorante intención, proponga colocar un zuncho de hormigón armado sobre la coronación de los muros, o mallazos en las capas de argamasas a proveer." En el capítulo sobre cúpulas describe su intervención en un caso determinado con estructura metálica de principios del XX y revestimiento ligero de cinc. Finalmente expone sus reflexiones para tejados de torres, para las que reemplaza tramos de soleras de madera en mal estado por bataches, mientras que en el caso de emplear estructura metálica de reemplazo vuelve a considerar necesario colocar un zuncho de hormigón en cara interior de la coronación de los muros.

En resumen, este arquitecto aragonés clasifica sistemáticamente los tipos de cubierta de iglesias que podemos encontrar y reflexiona sobre los condicionantes que conlleva la intervención sobre las mismas, abordando especialmente los aspectos relativos a su reemplazo. Se trata de una obra de 2012 que sigue la estela marcada en su día por López Collado, pero sin la cualidad eminentemente práctica de la obra de aquel, que llegó a convertirse en una especie de vademécum de la restauración. En esta publicación se incluyen fotografías que muestran cubiertas desmontadas y vistas generales de iglesias, mientras que aquella contenía además un amplio surtido de detalles constructivos y aclaraciones gráficas de las que ésta carece.

Según el texto comentado, en la actualidad se mantiene la costumbre de reemplazar las cubiertas de armaduras sobre bóvedas por estructuras metálicas, disponiendo los apoyos de las cerchas de acero sobre un zuncho perimetral de hormigón armado que se cajea en la cara interior de la coronación de los muros de cerramiento. En otro tipo de cubiertas, sin embargo, como las que dejan a la vista su estructura, las trasdosadas directamente sobre las bóvedas con piedra recibida sobre argamasa o con terrazas, no se incorpora dicho zuncho, que se justifica sólo como pieza necesaria para regularizar el plano de apoyo y anclaje de las cerchas metálicas. 


\section{III.3.4.5. Los nuevos conceptos de refuerzo estructural. Lorenzo Jurina y el arco armado}

El profesor de Tecnica delle Costruzioni e di Riabilitazione e Consolidamento Strutturale de la Universidad Politécnica de Milán, Lorenzo Jurina, es autor de innumerables publicaciones sobre consolidación de edificios históricos desde los años 70 y participa de forma habitual en los congresos de nuestro país. Además de rastreando las Actas de los mismos, es posible acceder a sus numerosos escritos a través de la página web jurina.it. Según sus propias palabras "le gustan mucho las estructuras de acero ligeras, activas y reversibles" en sus obras de refuerzo estructural de construcciones de fábrica.

En sus explicaciones suele ilustrar el concepto de zunchado con imágenes de barriles (grupo de duelas sujetas por zunchos). En el ámbito de la construcción se emplea para confinar edificios o partes de éstos. Al confinar un elemento sometido a compresión axial incrementamos su carga límite, por ejemplo cuando colocamos un cincho metálico a una columna fisurada verticalmente. Podemos colocar el refuerzo por el exterior o en el interior del elemento, podemos emplear acero o fibras sintéticas, colocarlo de forma pasiva o forzar su funcionamiento activo poniéndolo en tensión.

Tras diversos ensayos de laboratorio, Jurina emplea en ocasiones manojos de finos cables de acero, que dispone contra las juntas horizontales de mortero en columnas de fabrica de ladrillo, para incrementar su ductilidad y resistencia. (fotografía de Techniche di cerchiatura di colonne in muratura,)

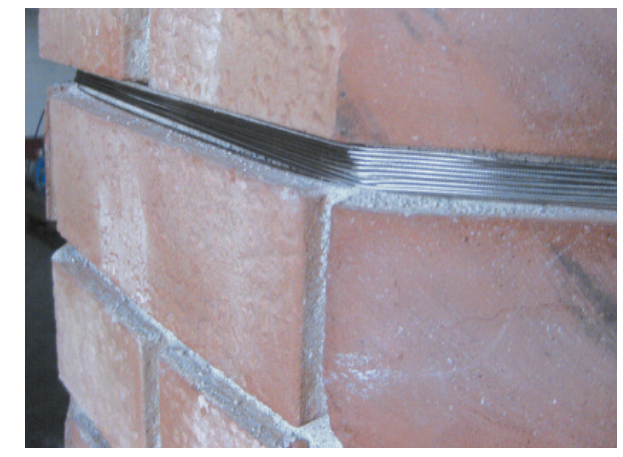

Fig.III.70. Ilustración Jurina

Otra de sus aportaciones es el "arco armado", RAM (reinforced arch method), una técnica de refuerzo basada en el mismo concepto estructural de asignar tracciones al metal y compresiones a la fábrica creando soluciones de tipo mixto. Al disponer cables tesados en el extradós de un arco e incrementar la compresión entre dovelas, se aumenta la ductilidad y resistencia a rotura de dicho arco. Cuenta con más de 400 modelos a escala con 6 geometrías distintas (tipo, peraltado, rebajado, apuntado y deformado), que ha sometido a cargas en varias posiciones para comprobar la eficacia del método. 
Imágenes que describen el comportamiento de un arco de dovelas comprimido: a la derecha las cuñas para repartir las tensiones en el contacto con la bóveda.
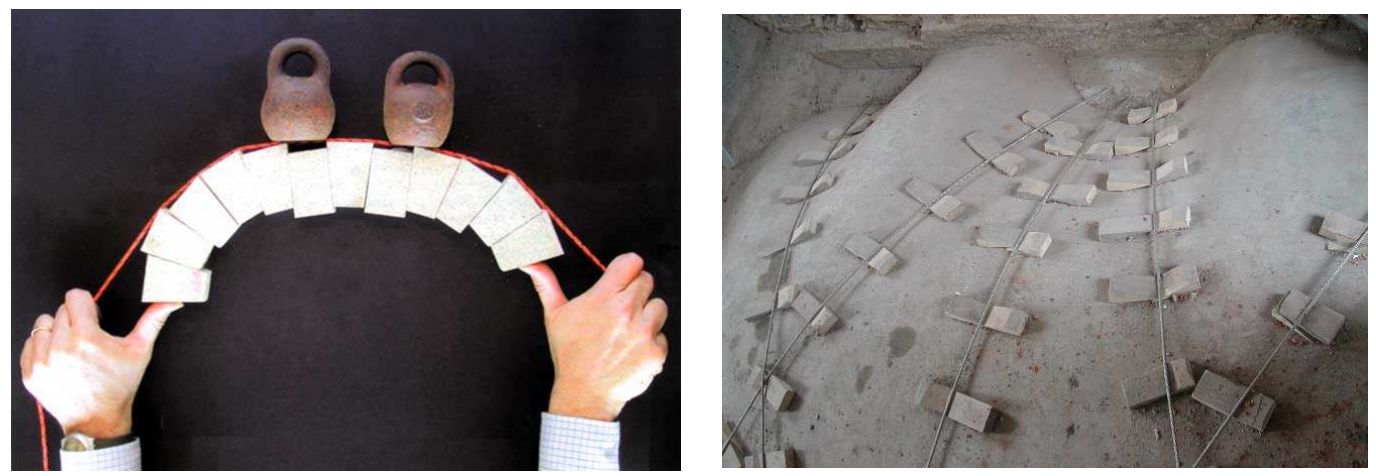

Fig.III.71. Ilustraciones arco armado y cuñas de reparto, Jurina y Bassoli 2010

Podemos reforzar un arco o una bóveda incorporando contrafuertes, colocando tirantes por el interior o el exterior o recreciendo con conectores. A veces se ejecuta un forjado en el bajo cubierta del que puede suspenderse la bóveda.

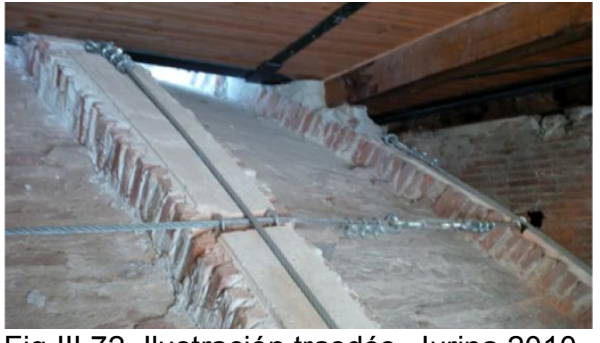

Fig.III.72. Ilustración trasdós, Jurina 2010
También se pueden adherir membranas de FRP por una de las caras. Al disponer cables postesados con la forma del arco que asuman las tracciones, se deja a la fábrica soportar únicamente esfuerzos de compresión ${ }^{108}$.

Para refuerzo de cúpulas el método propuesto por Jurina está basado en el mismo principio y propone disponer una retícula de cables activos formando paralelos y meridianos sobre el trasdós ${ }^{109}$.
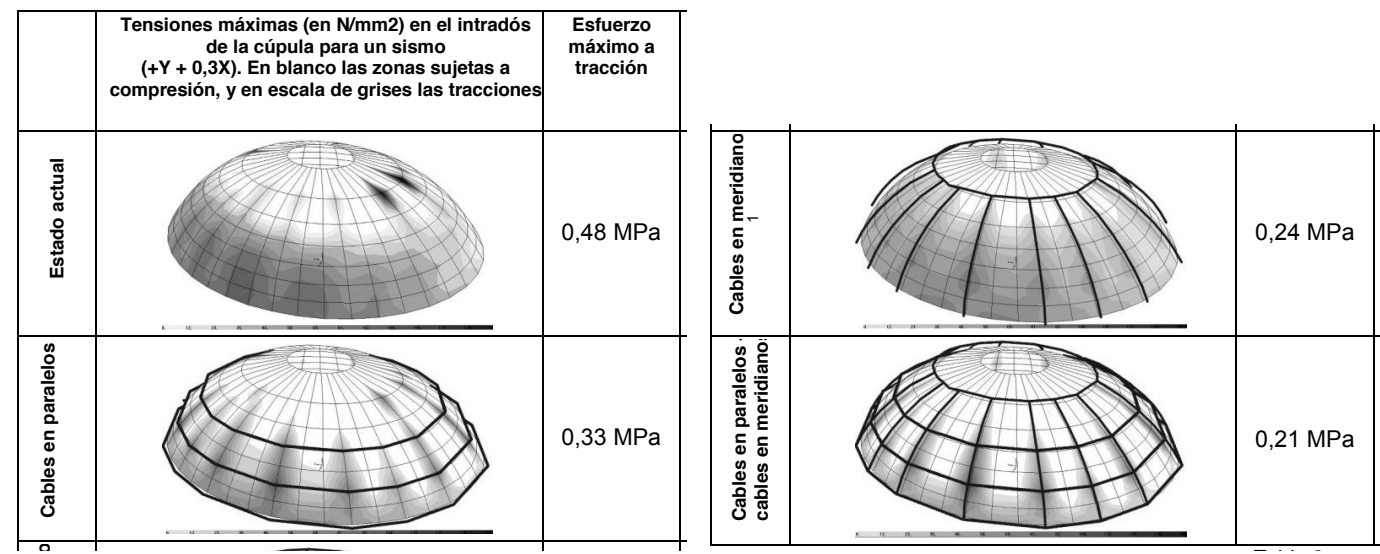

Fig.III.73. Tracciones máximas según el tipo de retícula de refuerzo, Jurina 2010.

${ }^{108}$ Jurina, L. (anno XVIII). Techniche di cerchiature di colonne in muratura. L'edilizia-Structural, (164), 38-49.

${ }^{109}$ Jurina, L. \& Bassoli, A. (2010). Cerchiature: tecniche tradizionali e innovative. Ingegneri, (5), 6-7. 


\section{III.3.4.6. Resumen de las últimas tendencias}

En general en los proyectos actuales de restauración de cubiertas de edificios del Patrimonio en España podemos distinguir unos criterios comunes o patrones imperantes:

En primer lugar se propone en los proyectos reparar las armaduras históricas de madera deterioradas que quedan en pie, aplicando refuerzos puntuales. Una vez han dado comienzo las obras, sin embargo, la mayor parte de los técnicos sigue optando por el reemplazo completo de las estructuras de cubierta existentes por otras nuevas, mímesis de lo ocurrido en los setenta con estructura metálica aunque ahora se resuelvan en madera laminada.

El zunchado se empieza a resolver con nuevos materiales más ligeros, acero o fibras trenzadas. Se adjunta como anejo al final de la Tesis un folleto comercial de la empresa BASF sobre la rehabilitación estructural de la iglesia del Salvador en Sevilla. $(2004-2006)^{110}$.

Se inyecta en los muros lechada de cal a baja presión. El refuerzo de arcos y bóvedas se resuelve adhiriendo bandas de aramida y fibra de vidrio con resina epoxy. El zunchado de la base de la cúpula se realiza con el mismo sistema. En algunos muros se encastran en rozas unas barras de fibra de carbono o también de aramida.

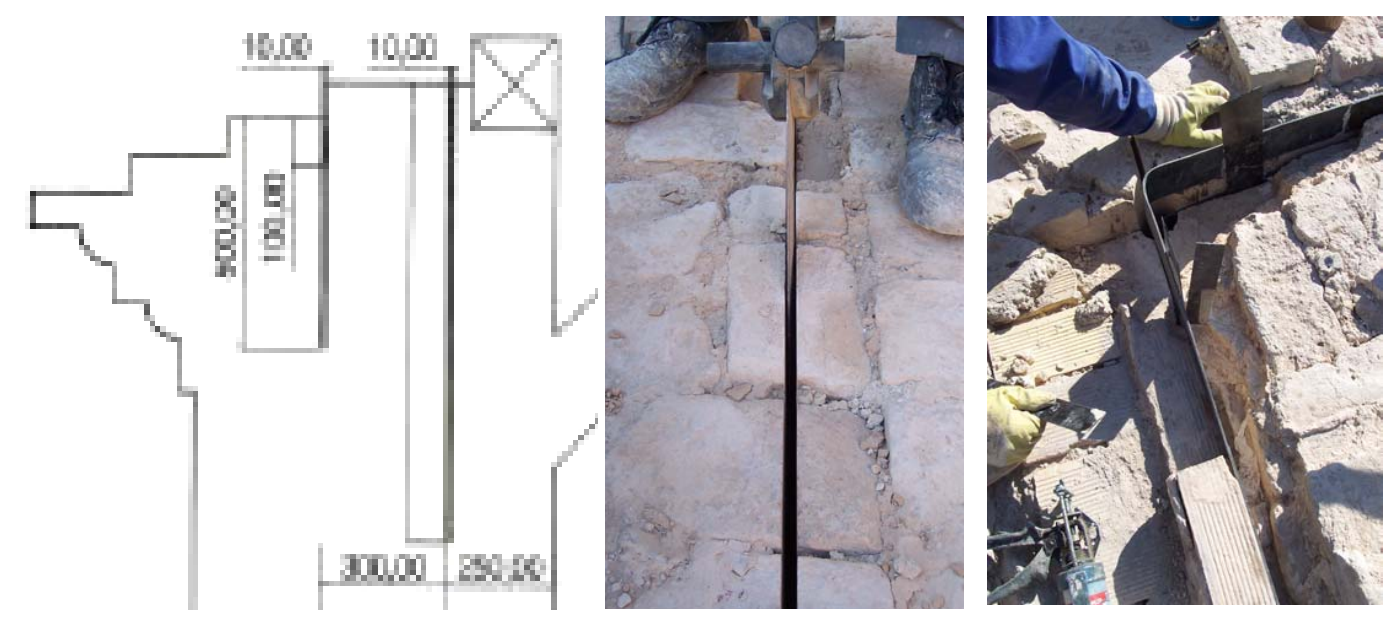

Fig.III.74. Zunchado con fibra de carbono, BASF 2006

\footnotetext{
${ }^{110}$ BASF. (n.d.). Obras iglesia del Salvador. Rehabilitación estructural. Obtenido en $\mathrm{ftp}: / / \mathrm{fb} .27 .354$ a.static.theplanet.com/documentaciontecnica/basf/basf_ob_igl_salvad.pdf
} 
Resulta especialmente interesante el apartado en que se describe "la instalación de un zunchado perimetral en la coronación de los muros, con láminas de fibra de carbono, mediante su inserción como armadura de tracción, en la cara externa". En una ranura de unos $35 \mathrm{~cm}$ de profundidad y $10 \mathrm{~mm}$ de espesor se embebe la lámina de fibra de carbono recibida con epoxi, en un sistema que recrea con materiales de última generación la actuación en hormigón más típica del siglo pasado.

A pesar de la amplia documentación en contra de la incorporación indiscriminada de zunchos de hormigón armado a los edificios del Patrimonio publicada a lo largo de las últimas décadas, éstos se siguen incluyendo en algunas obras de restauración que se acometen hoy en España. A veces incluso se recrea el "zuncho perimetral de coronación", si bien en algunos casos con materiales más modernos.

El zunchado en los países del entorno se ha redefinido debido sobre todo a la constatación de problemas en la redistribución de masas en zonas que han sufrido problemas de sismo, como Italia, al constatarse que los refuerzos masivos de hormigón armado actúan como ariete frente a las solicitaciones dinámicas. Las actuaciones más aceptadas se limitan a atirantar y coser los muros de fábrica mediante flejes de acero, pero sin recuperar el comportamiento tradicional de los sistemas resueltos con madera aserrada, que pasan a convertirse en elementos que trabajan dentro de sistemas mixtos más complejos. 


\section{III.4. Valladolid}

Una vez establecido el marco histórico y conceptual del empleo de zunchos en restauración monumental en España y países del entorno a lo largo de la historia, la última parte de los antecedentes centra la cuestión en el ámbito cultural y geográfico específico de Valladolid. El problema se trata de forma cronológica, describiéndose en primer lugar las condiciones que determinaron en los siglos XVI y XVII la construcción de numerosos edificios relevantes. A continuación se esboza el estado del arte en el ámbito de la restauración monumental en el siglo XIX y, por último, se describe el sistema administrativo por "zonas de actuación" organizado en el siglo XX para gestionar la conservación del Patrimonio.

\section{III.4.1. EI foco clasicista}

Entre 1561 y 1640 se desarrolla en Valladolid una actividad arquitectónica especialmente intensa, con el nacimiento del urbanismo moderno auspiciado por el monarca Felipe II, tras el incendio del centro de la ciudad y su consiguiente reconstrucción ${ }^{111}$. Tras edificarse la Colegiata de San Luis en Villagarcía de Campos, con trazas del aparejador partícipe en la obra de El Escorial Pedro de Tolosa, y la reanudación de las obras de la Catedral con diseños de Juan de Herrera, se sucede la construcción de un importante número de iglesias y palacios que podemos considerar "escuela", dado que responden a un lenguaje común.

Los distintos autores que abordan el estudio del contexto relacionado con este conjunto de edificios que englobamos bajo el epígrafe "foco clasicista", especialmente el profesor Agustín Bustamante, han localizado buena parte de su material en documentos legales, archivados en la Real Chancillería de Valladolid. La costumbre de incorporar trazas a las condiciones del contrato en la copia notarial han permitido redescubrir en los últimos años algunos diseños de gran interés que comentaremos más adelante.

\footnotetext{
${ }^{111}$ Bustamante, A. (1983). La arquitectura clasicista del foco vallisoletano (1561-1640). Valladolid: Institución cultural Simancas.
} 
A diferencia de las iglesias de Levante o Andalucía cuya estructura abovedada se manifiesta al exterior en forma de terrazas transitables, en Castilla se resuelven las cubiertas de forma dual, con una techumbre externa de faldones inclinados y techo abovedado independiente en el interior. Un ejemplo de caso extremo de la tipología de cubierta transitable trasdosada directamente sobre las bóvedas sería la iglesia de Santa Ana en Sevilla donde la azotea se empleó como plaza de armas ${ }^{112}$.

Según Bustamante, en el foco de Valladolid podemos encontrar edificios con muros de piedra tanto como de ladrillo y tapial, mientras que el abovedamiento es siempre de fábrica. La cubrición se resuelve con teja árabe dispuesta sobre armadura de madera, no empleándose la pizarra, y el plomo únicamente para revestir los chapiteles.

Hasta el desarrollo de este estilo, las iglesias parroquiales de la región fueron templos generalmente de tres naves, con planta salón de tradición gótica. Con el clasicismo se instaura un modelo de planta rectangular con cruz latina embebida, una nave única con capillas entre contrafuertes y testero plano, tanto en parroquias como en conventos, en estos últimos incorporándose tribunas y gradas. Las iglesias jesuíticas cuentan además con amplias sacristías anejas rectangulares y abovedadas.

En general, en el foco se emplean gruesos pilares cuadrados con pilastras adosadas en los frentes. En las iglesias de tres naves iniciadas con anterioridad que se concluyen en este periodo encontramos pilares cilíndricos, como en los Santos Juanes, donde excepcionalmente las bóvedas son de crucería, no de cañón. Desaparece la bóveda de crucería incluso en obras iniciadas con ella, empleándose por defecto la bóveda de cañón con lunetos.

Las iglesias que habían sido proyectadas con anterioridad y se rematan en este periodo mantienen la disposición original de tres naves, como los Santos Juanes de Nava del Rey, la iglesia de Santiago en Medina de Rioseco, la parroquial de Fuentelapeña y la de Santa María de Villabrágima.

Aunque Bustamante menciona, en la obra citada, la Catedral de Valladolid como único templo con tres naves concebido así por el arquitecto clasicista Juan de Herrera, en realidad su proyecto mantiene también los ejes de un templo gótico

\footnotetext{
${ }^{112}$ Gómez de Cózar, J. C., \& Benítez, R. M. (2008). Las soluciones inconclusas de las cubiertas de los templos medievales del Reino de Sevilla, España. Informes de La Construcción, 60(509), 57-67.
} 
previo, "la Colegiata de los cinco maestros"113: Juan de Álava, Francisco de Colonia, Juan Gil de Hontañón, Diego de Riaño y Rodrigo Gil.

Precisamente siguiendo las trazas de Herrera se embeben en la nueva fábrica elementos ya ejecutados según el diseño de Gil de Hontañón, incrementándose el grosor de muros y pilastras para reconfigurar los espacios, según se aprecia en la imagen siguiente del croquis enviado durante la obra por Diego de Praves a Juan de Herrera para explicarle una discrepancia en las medidas de replanteo.

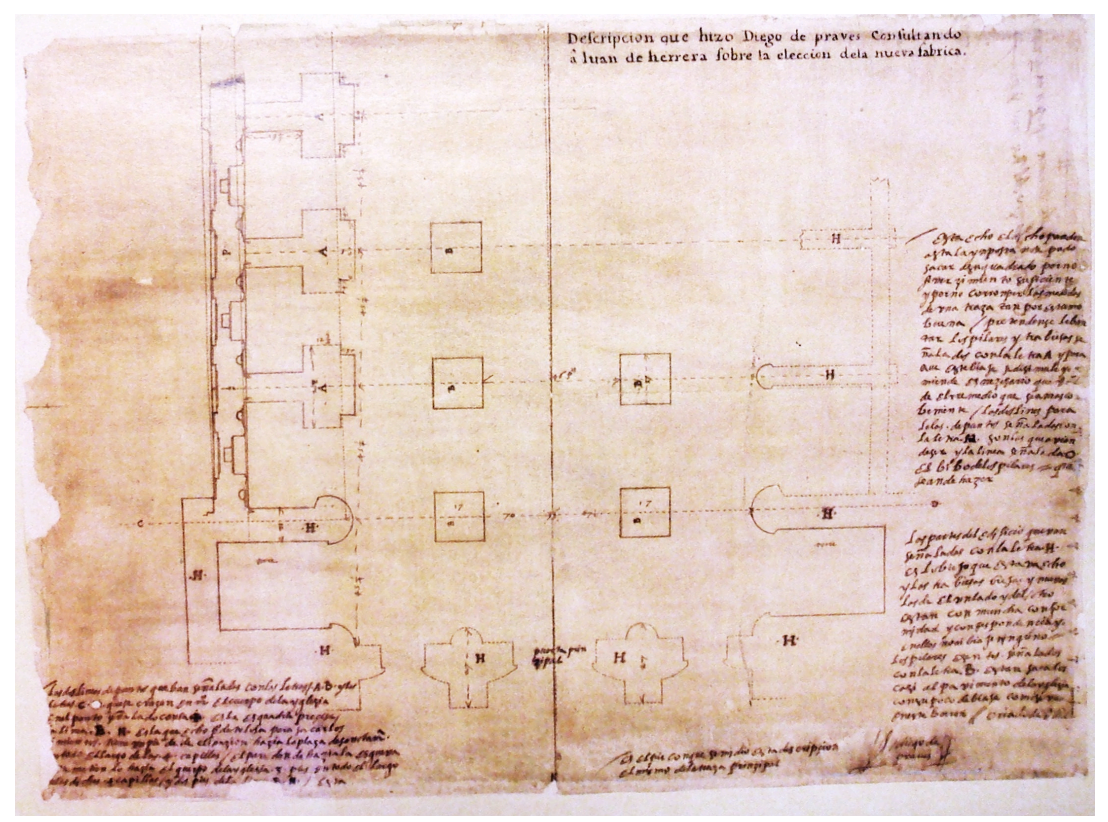

Fig.III.75. Croquis de Diego de Praves

Se trata del único documento de la época en que aparece representada la Cuarta Colegiata, al margen del famoso plano de Rivera Manescau, posterior y de fidelidad más discutible dado que refleja, entre otras cosas, el claustro herreriano que nunca llegó a ejecutarse.

Uno de los documentos más interesantes que podemos encontrar sobre la transición de la construcción gótica a la renacentista que se produjo en estos edificios se analiza en un artículo de Javier Castán Lanaspa ${ }^{114}$ a partir del hallazgo de un pleito en el archivo de Chancillería, interpuesto en 1596 por el mayordomo de la iglesia contra el arquitecto director de las obras Felipe de la Cajiga por

\footnotetext{
${ }^{113}$ Chueca, F. (1947). La catedral de Valladolid. Madrid: Instituto Juan de Herrera. Pág.24.

${ }^{114}$ Castán, J. (1990). La polémica entre Gótico y Renacimiento en el siglo XVI. La iglesia de los Santos Juanes de Nava del Rey (Valladolid). Boletín Del Seminario de Estudios de Arte Y Arqueología, 56, 384-403.
} 
incumplimiento de contrato, al rematar a la romana la iglesia de los Santos Juanes en Nava del Rey, concebida a la moderna con trazas góticas también de Rodrigo Gil de Hontañón. Las cubiertas previstas eran de terceletes y combados con 21 claves en los cuatro tramos de la nave mayor y 15 en los ocho de las laterales. Nervaduras y claves habían de ser de piedra de Salamanca y los cascos de ladrillo y yeso. Muros exteriores con contrafuertes rematados en pináculos.

Según el profesor Castán: "las bóvedas se voltearían todas a la vez, con el edificio cubierto. En julio de 1593 se contrataron treinta mil tejas cuya colocación estaba previsto comenzase en marzo del año siguiente, pero cambios introducidos en las cornisas de la nave", para utilizar material de mayor calidad en vez de la piedra local prevista, "y el retraso en la entrega de las trazas de los tejados" elaboradas por el mismo arquitecto trasmerano "dilataron las obras aún más. Estos no pudieron cerrarse conforme estaba previsto, y consecuentemente tampoco las bóvedas. En 1595 el edificio había por fin cubierto aguas y al año siguiente se hacían los abovedamientos".

Otro de los maestros del foco, Diego de Praves, en un informe pericial del citado proceso, manifiesta que son más firmes las bóvedas de ladrillo y yeso que las de crucería de piedra, por ser materiales más ligeros y que ligan mejor. Felipe de la Cajiga fue condenado a acabar la obra según su propia traza, tarea que remataron en 1602 sus hermanos, también canteros, tras su muerte en prisión.

\section{III.4.1.1. EI sistema de talleres}

En abril de 1585 se produjo, según Javier Gómez Martínez ${ }^{115}$, un curioso incidente relativo a la adjudicación de las obras de ampliación del monasterio de San Zoilo en Carrión de los Condes, Palencia, en el que participó un nutrido grupo de maestros canteros del foco, encabezados por Pedro de Nates. Se enfrentan a un colectivo local formado por carpinteros, albañiles y yeseros vecinos de la zona. Estos últimos son manipulados por los primeros para firmar con engaño unos documentos en blanco, de forma que ambos equipos acaban por ser detenidos.

Estos hechos tan peculiares confirman que el panorama de la organización de los oficios en el sector de la construcción en la Castilla y León del siglo XVI pudo

\footnotetext{
${ }^{115}$ Gómez Martínez, J. (1992). Obras en San Benito el Viejo de Valladolid y San Zoilo de Carrión (1583-1594). Buenas y malas artes en el foco clasicista. Boletín Del Seminario de Estudios de Arte Y Arqueología, 58, 333-348.
} 
articularse de la siguiente forma: un grupo de canteros unidos por lazos familiares, vecinales y de amistad, en este caso originarios de la Merindad de Trasmiera, en Cantabria, aprenden el oficio unos de otros y comparten tareas. Cuando uno de los maestros se hace cargo de una obra, redacta las condiciones y dibuja las trazas, en general una planta, alzado y sección.

Celestina Losada ${ }^{116}$ describe en La Arquitectura en el otoño del Renacimiento cómo Juan de Naveda entró al taller de su tío a los 11 años, llegó a oficial a los 14 y a los 17 ya como maestro obtuvo la "carta de aval" que le permitía contratar.

Se trabaja "en compañía", como alternativa al sistema gremial que se seguía aplicando en el resto de Europa, asociándose según el caso dos o más maestros que arrastran sus respectivos talleres, en los que los canteros se jerarquizan según su grado de especialización. Son estos maestros mayores que contratan las obras quienes a su vez subcontratan las tareas de carpintería y albañilería a trabajadores locales. Entre los principales artífices del foco encontramos a Pedro y Alonso de Tolosa, Diego y Francisco de Praves, Juan de Herrera, Juan del Ribero Rada, Juan de Nates, Pedro de Mazuecos el Mozo y Felipe de la Cajiga

\section{III.4.1.2. Los Tratados: Palladio}

Ya en los primeros textos sobre construcción editados en el siglo XVI se incluyen reglas relacionadas con la determinación de las pendientes ${ }^{117}$.

A la hora de abordar el estudio del foco vallisoletano un aspecto fundamental que debemos considerar es la influencia palladiana. Precisamente una de las primeras traducciones en Europa de I Quattro Libri, aunque parcial y manuscrita, la lleva a cabo el maestro del foco clasicista vallisoletano, Juan de Ribero Rada, en 1578, tan solo ocho años después de la edición veneciana ${ }^{118}$.

La primera traducción y edición de la obra completa corre a cargo del "Arquitecto del Rey" también maestro del foco, Francisco de Praves, en 1625.

\footnotetext{
${ }^{116}$ Losada, C. (2007). La arquitectura en el otoño del Renacimiento: Juan de Naveda 1590-1638. Santander: Servicio de publicaciones de la Universidad de Cantabria.

${ }^{117}$ Gómez, M. I. (2006). Las estructuras de madera en los Tratados de Arquitectura (1500-1810). Madrid: Asociación de investigación técnica de industrias de la madera y corcho AITIM.

${ }^{118}$ Navascués, P. (1980). Reflexiones sobre Palladio en España. En J. Ackerman, Palladio. Madrid: Xarait.
} 
En el apartado "De los cubiertos y tejados" del capítulo XXIX, Palladio expone cómo definir la pendiente óptima con $2 / 9$ de la luz, que equivale a unos $24^{\circ}$, pues con $1 / 4$ resulta demasiado empinada y no se sujeta bien la teja y con $1 / 5$ resulta demasiado tendida:

"Nosotros que vivimos en paises mas templados, debemos elegir la elevacion de caballete que haga mas agradable el cubierto por la bella proporcion y forma, y vierta las aguas expeditamente. Para conseguirlo se dividirá la anchura de lo que ha de ocupar el techo en nueve partes; dos de las quales se darán á la elevacion del caballete en su punta: pues si se hace por un quarto de su anchura, será el caballete y techo muy empinado, y las tejas ó ladrillos no podrán asegurarse bien; y si se hace por un quinto será muy llano, y los materiales y nieves los agravarán demasiado" $^{119}$.

En una comunicación del segundo Congreso Nacional de Historia de la Construcción, sin embargo, Angel Candelas ${ }^{120}$ puntualiza:

"Las comprobaciones que hemos efectuado sobre los diversos dibujos de la edición de 1570 arrojan como sorprendente resultado que Palladio no se atenía en general a esta regla que, por otra parte, tal como está enunciada haría suponer un exquisito control de la pendiente, dado el escaso margen existente entre la pendiente que toma como válida $\left(23,9^{\circ}\right)$, la muy empinada $\left(26,5^{\circ}\right)$ y la muy llana $\left(21,8^{\circ}\right)^{\prime \prime}$.

\section{III.4.1.3. EI método de Cartabones}

En el siglo XVII se emplea la "regla de trazado de cartabones" como método para determinar el perfil de las armaduras de cubierta.

Se trata de un sencillo proceso gráfico: en primer lugar se divide una circunferencia en un número entero de partes iguales $\mathbf{n}$ y se dibuja un triángulo rectángulo cuya hipotenusa es el diámetro de la circunferencia y uno de sus catetos un lado del polígono de $\mathrm{n}$ lados. La altura de armadura $\mathbf{h}$ será la intersección del otro cateto con el diámetro perpendicular. Según el esquema anterior, al cartabón de cuatro corresponde un ángulo de $45^{\circ}$, de $36^{\circ}$ al de cinco y de $30^{\circ}$ al de seis.

\footnotetext{
${ }^{119}$ Palladio, A. (1797). Los Cuatro Libros de Arquitectura. Traducidos e ilustrados por Don Joseph Ortiz y Sanz. Madrid: Imprenta Real. Pág.41.

${ }^{120}$ Candelas, Á. (1998). La carpintería de armar en los tratados europeos de los siglos XVI y XVII. En F. Bores et al, Actas del II CNHC. Madrid: Instituto Juan de Herrera, CEHOPU.
} 


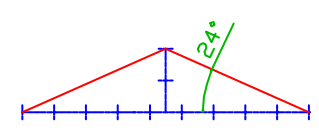

Palladio: $2 / 9$

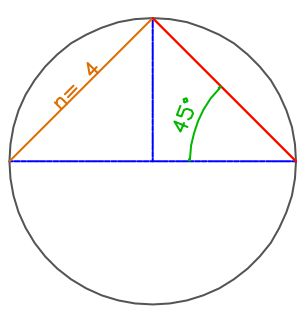

Cartabón de 4

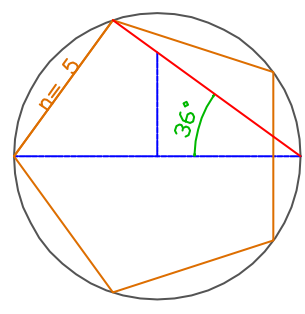

Cartabón de 5

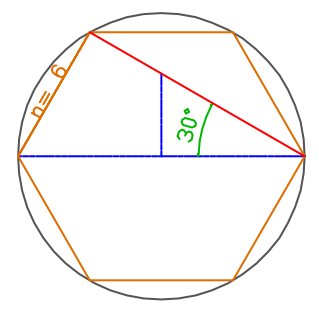

Cartabón de 6

Fig.III.76. Trazado de cartabones

Además de para trazar en obra el perfil general de las armaduras de cubierta, con las plantillas así obtenidas se definían las dimensiones y ángulos de corte de las piezas.

Fray Lorenzo de San Nicolás ${ }^{121}$ recomienda en su Tratado emplear la armadura de cinco para todo género de tejados, porque las maderas trabajan poco, y en menor medida la de seis, indicada sólo para tierras en las que no nieva. Según él, la de cuatro se aplicaría sólo a torrecillas cubiertas con emplomados o tejas clavadas.

Mientras que en los tratados franceses se recogen sobre todo pendientes muy empinadas y mansardas, con unos $55^{\circ}$ para teja y $60^{\circ}$ para pizarra, en los españoles se cita de forma bastante generalizada el cartabón de cinco que, según hemos comentado, implica $36^{\circ}$ de inclinación.

\section{III.4.1.4. Condiciones y trazas}

Precisamente en la segunda mitad del siglo XVI coincide en España la implantación del clasicismo con la recuperación del término arquitecto, empleado por el propio Juan de Herrera frente a la consideración de maestro mayor que había tenido su predecesor en la obra de El Escorial, Juan Bautista de Toledo, para la designación del autor que concibe un proyecto y lo plasma en forma de trazas sin que esto implique necesariamente su participación durante la ejecución de las obras ${ }^{122}$.

Las trazas de esta época que conocemos presentan características comunes, lo que nos muestra una sistematización en la forma de trabajo de sus autores. Se emplea planta, alzado y sección a escala con pitipié y anotaciones integradas, tanto numéricas como descriptivas. En general suelen llevar la rúbrica del arquitecto, y los

\footnotetext{
${ }^{121}$ Fray Lorenzo de San Nicolás. (1639). Arte y Uso de Architectura.

${ }^{122}$ Losada, C. (2007). La arquitectura en el otoño del Renacimiento: Juan de Naveda 1590-1638. Santander: Servicio de publicaciones de la Universidad de Cantabria.
} 
dibujos a línea, según el caso, se sombrean para potenciar la información. Sobre la cantidad de información que llegan a aportar este tipo de planos, Losada indica cómo sobre la planta de las trazas universales del convento de san Francisco de León aparece representada una curva que indica el recorrido solar.

Estos últimos años se han localizado algunas trazas de edificios del foco, conservadas gracias a su incorporación a las condiciones con el correspondiente registro notarial y su consiguiente protocolización y custodia, según describió la directora del Archivo Histórico Provincial $\mathrm{M}^{\mathrm{a}}$ Jesús Urquijo Urquijo en la introducción del catálogo de la exposición de planos, dibujos y maquetas celebrada en Valladolid en marzo de 1984:

"Cuando un artista se comprometía a realizar alguna obra, tenía que atar bien los cabos de su competencia para poder exigir posteriormente la puntual remuneración de su trabajo, por ello no es infrecuente encontrar junto a las condiciones de una obra el diseño de la misma, aceptado por el cliente y firmado por ambas partes. Son estos dibujos las piezas más cotizadas por los investigadores en sus rebuscas documentales" ${ }^{\prime 23}$.

\section{Convento de Santa Catalina}

En un breve articulo de Jesús Urrea ${ }^{124}$ se recoge una reflexión sobre el proceso constructivo de la iglesia del convento de Santa Catalina, dándose a conocer unas trazas contenidas en el protocolo notarial no publicadas por los autores que lo habían analizado previamente.

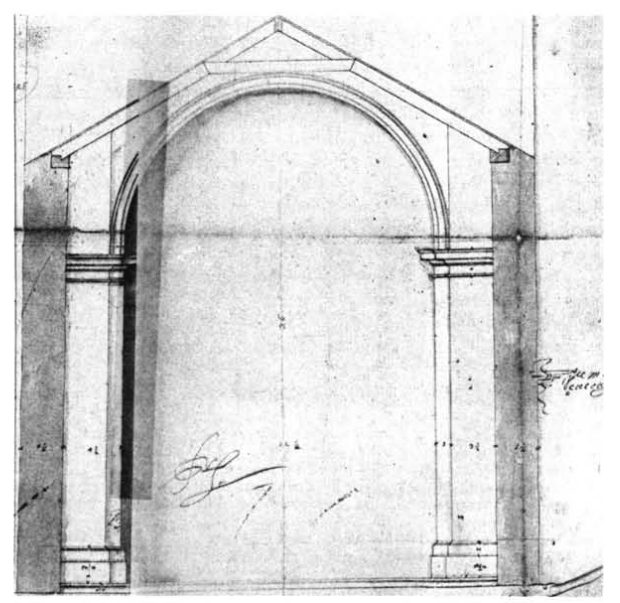

Fig.III.77. Ilustración Urrea 1986

Se trata de planta, alzado y sección de la capilla mayor en que se representa esta última rematada con un esquema de armadura de par y puente con una pendiente de unos $30^{\circ}$, sobre durmientes en la cara interior del remate de muros, para los que no se define cornisas voladas ni otras molduras. En el dibujo, que se reproduce junto a estas líneas, no se representa tampoco la cubrición de esa armadura.

\footnotetext{
${ }^{123}$ Urquijo, M. J. (1984). Introducción del catálogo de la exposición. In J. Urrea, Planos, dibujos y maquetas de Valladolid. Valladolid: Caja de Ahorros Popular.

${ }^{124}$ Urrea, J. (1986). Las trazas de Mazuecos y otros datos sobre el convento de Santa Catalina de Valladolid. Boletín Del Seminario de Estudios de Arte Y Arqueología, 52, 401-404.
} 
El protocolo de la Iglesia de Santa María de Cabezón corresponde a un contrato de ampliación del edificio, cuyas trazas habían sido encargadas inicialmente a Juan de Nates y posteriormente a Alonso de Tolosa ${ }^{125}$.
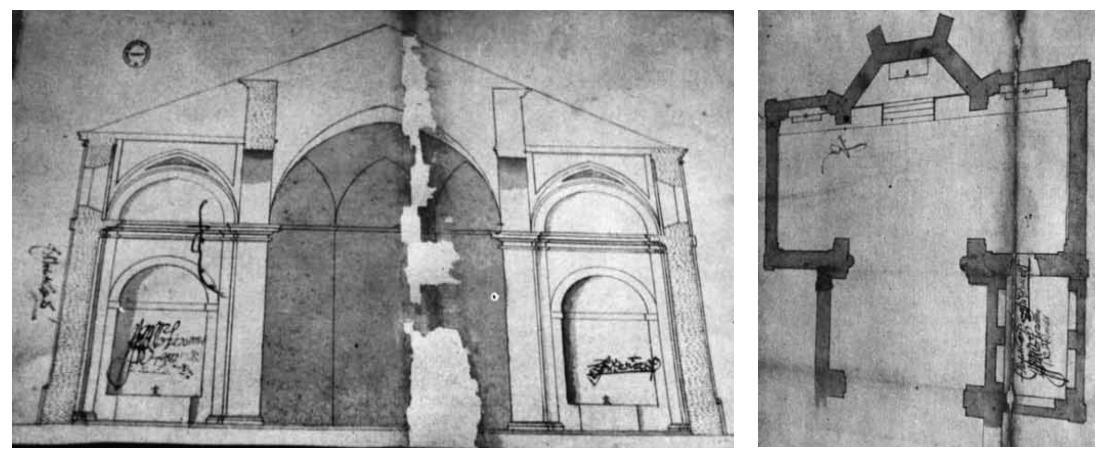

Fig.III.78. Trazas iglesia de Cabezón, Pérez 1984

La sección, rubricada por ambos, representa bóvedas y cerramientos, incluso con sombreados en las hornacinas, pero con una mera línea a dos aguas que parece indicar solo la envolvente geométrica del nivel de remate de los muros de la nave central por encima de las laterales. Los cuatro lienzos muestran cornisa en haces exteriores lo que demuestra que se trata de paramentos en fachada. Aunque al parecer el contrato afectaba únicamente a capillas laterales y sacristía, se representa en planta toda la cabecera.

Iglesia de San Pedro

Con documentación extraída de protocolos notariales conservados en el Archivo Histórico Provincial de Valladolid, se analizan en otro artículo dos etapas de la construcción de la iglesia de San Pedro en Valladolid ${ }^{126}$.

La primera consistió en labrar ocho estribos según trazas del bachiller Jerónimo de Nalda en 1571 y la segunda en desmontar la mitad de lo anterior, hacer la capilla mayor y terminar carpintería, albañilería y yesería conforme a una traza de autor desconocido. En las condiciones se describe (cursivas añadidas) "una armadura de

\footnotetext{
${ }^{125}$ Pérez Chinarro, J. M. (1984). Trazas para la iglesia de Santa María de Cabezón. Boletín Del Seminario de Estudios de Arte Y Arqueología, 50, 414-416.

${ }^{126}$ Fernández, L. (1987). Construcción de la iglesia de San Pedro. Boletín Del Seminario de Estudios de Arte Y Arqueología, 53, 327-330.
} 
madera tosca armada al cartabón de cinco y fundada sobre sus nudillos que tomen todo el grueso de las tapias a trechos convenientes y sobre sus soleras y trasoleras encima de ellas y sus tirantes y cuadrados y aguijones conforme a la traza ha de ser esta dicha armadura a par e hilera ... Se ha de tejar toda esta obra de teja nueva macizando por igual y los caballetes revocados de cal, barro y paja. En toda esta obra se ha de hacer a la redonda un tejaroz de ladrillo y cal".

\section{Iglesia de San Martín}

Las condiciones para la construcción de la capilla mayor de la iglesia de San Martín se recogen en seis folios autógrafos de Diego de Praves y "refieren en primer lugar a la obra de cantería y después a la albañilería y carpintería, en previsión de que distintos artífices se hiciesen cargo de ellas" ${ }^{127}$.

En dichas condiciones se especifican desde las proporciones de las mezclas de cal hasta el grosor de los elementos de ladrillo y tapiales, detallándose precios y plazos de entrega o pago. Las bóvedas se describen con ladrillo formando "vuelta de horno o media naranja de asta y media en los primeros tercios y acabarán en la clave en un asta ... sobre todo lo cual se echará su costra de cal y cascajo y yeso bien enlucido de cuatro dedos de grueso".

Para la carpintería se define cartabón de entre cinco y seis. Conforme a estas condiciones y trazas de Praves se contrata la obra al maestro de cantería Rodrigo de Holabe, aunque en el protocolo se indica que la traza se había mudado y hecho de más coste porque era necesario para fortaleza de la obra.

Hubo una segunda fase de obras bajo la dirección de Francisco de Praves, que culmina en 1621, y en 1965 se derrumba gran parte de la cubierta.

\section{Casa de Vallejo}

En otro artículo sobre el foco clasicista vallisoletano, esta vez centrado en la arquitectura doméstica, María Antonia Fernández del Hoyo ${ }^{128}$ explica cómo Diego de Praves valora la indemnización que corresponde al licenciado Vallejo por demoler

\footnotetext{
${ }^{127}$ Fernández del Hoyo, M. A. (2003). La iglesia parroquial de San Martín: su historia. Boletín Del Seminario de Estudios de Arte Y Arqueología, 38, 9-26.

${ }^{128}$ Fernández del Hoyo, M. A. (1990). Notas sobre arquitectura doméstica clasicista, 56, 415-432.
} 
soportales y rehacer la fachada de su casa cuando el Ayuntamiento decide ensanchar la calle. El propio Praves define y contrata la obra, apreciándose en la imagen siguiente la traza del alzado, con dintel y dos escudos.

Si medimos grosso modo, la inclinación de la cubierta está representada con unos $29^{\circ}$. Aunque se dibuja en este plano, en las condiciones se describe sólo la fábrica hasta la cornisa, "no obligándose el maestro a hacer el tejado".

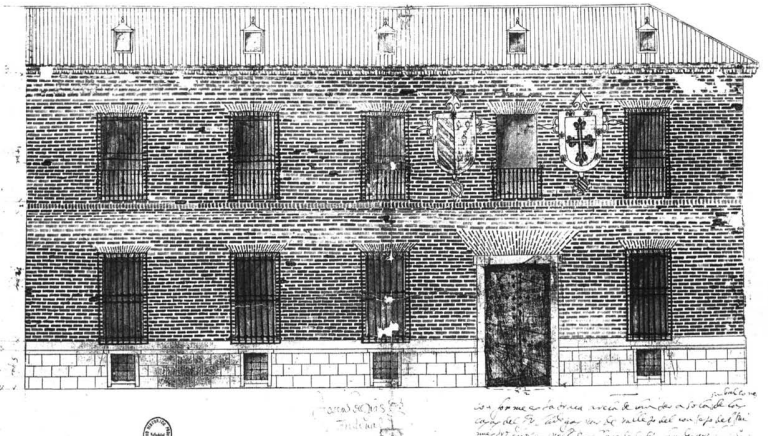

Fig.III.79. Fachada casa de Vallejo, Fernández del Hoyo 1990

\section{III.4.1.5. La pendiente de cubierta en las iglesias del foco}

Entre los distintos autores que escriben sobre el tema de las cubiertas de monumentos encontramos sobre la pendiente afirmaciones muy dispares, desde que "la mayoría de las cubiertas españolas tiene una inclinación entre $30^{\circ}$ y $45^{\circ}$, siendo la más común $36^{\circ}$, consecuencia de la frecuente utilización del cartabón de cinco" ${ }^{129}$, hasta otros que afirman exactamente lo contrario: "En cambio en España, Portugal e Italia las cubiertas son de pendiente menor, con valores que superan raramente los $30^{\circ}$. Los datos disponibles son sumamente escasos y los documentos de las restauraciones apenas prestan atención a estos sistemas, que parecen considerar carentes de valor artístico y por ello sustituibles sin consideraciones especiales" ${ }^{130}$.

Las cubiertas del foco clasicista vallisoletano se resuelven con estructura de madera, tablazón y recubrimiento de teja curva. Se suelen construir las bóvedas con rosca de ladrillo posteriormente, tras cubrir aguas. Encontramos citas que nos confirman que el maestro cantero daba trazas de la cubierta, pero también hay secciones en las que deja la techumbre sin definir, a veces como una simple línea a dos aguas.

Los edificios de traza gótica rematados en el periodo presentan grandes dimensiones de faldones al disponer las bóvedas de nave central y laterales a una

\footnotetext{
${ }^{129}$ Candelas, Á. (1998). La carpintería de armar en los tratados europeos de los siglos XVI y XVII. In F. Bores et al, Actas del II CNHC. Madrid: Instituto Juan de Herrera, CEHOPU. Pág.291

${ }^{130}$ Escrig, F., \& Pérez, J. (2004). La modernidad del Gótico. Seis puntos de vista sobre la arquitectura medieval. Sevilla: Secretariado de Publicaciones de la Universidad de Sevilla. Pág.194
} 
misma cota y unificar el volumen bajo-cubierta sobre las mismas. El nivel de intersección del tejado con los ejes de pilas se alcanza a veces disponiendo transversalmente estructuras tridimensionales de grandes escuadrías, pero con más frecuencia recreciendo muros de fábrica de ladrillo aligerados con grandes huecos a modo de ventanas. Hay casos en que el plano sufría un quiebro sobre esta arista de apoyo intermedio y adoptaba diferente pendiente a ambos lados, a veces más tendida sobre nave central que sobre lateral a veces al contrario. Tras las intervenciones del siglo XX suelen encontrarse faldones de pendiente constante desde la cumbrera hasta el alero.

En cuanto al ángulo preferido, aunque en toda la literatura se postula la conveniencia del cartabón de 5, que implica como hemos dicho $36^{\circ}$, en la realidad suelen adoptarse perfiles más tendidos, inferiores a $30^{\circ}$. El empleo preferente de teja cerámica y el sistema de fijación de la misma sin clavar sobre el tablero han sido factores determinantes a la hora de definir la pendiente de la cubierta.

\section{III.4.2. Las actuaciones del siglo XIX}

La investigación de las restauraciones de monumentos llevadas a cabo a lo largo de su historia ha conllevado una tarea adicional en el periodo decimonónico. Obras que hasta entonces se realizaban bajo la dirección de los maestros canteros pasan a proyectarse por arquitectos titulados en las Academias.

En el XIX surgen las figuras del Arquitecto Provincial y del Diocesano a las que se encomiendan las obras públicas y religiosas que, en el caso de Valladolid, son en la mayor parte de los casos asignadas al arquitecto municipal o Arquitecto de Ciudad.

Una documentación más profunda sobre las atribuciones y el ejercicio de estos profesionales en Valladolid se ha recogido en la comunicación aceptada para su presentación en el IX Congreso Nacional y I Internacional Hispanoamericano de Historia de la Construcción (Octubre de 2015, Segovia) bajo el título "El papel del arquitecto funcionario en la construcción decimonónica"131.

\footnotetext{
${ }^{131}$ Bellido y Hernández (2015) En la comunicación se analizan dos expedientes generados en la época del reinado de Isabel II y conservados en el Fondo Histórico del Archivo Municipal de Valladolid (AMVA). El primero corresponde al colapso en 1841 de la única torre de la Catedral y el segundo se refiere a unas obras de rehabilitación parcial llevadas a cabo en 1857 en la iglesia de Nuestra Señora de La Antigua.
} 
La aparición del ferrocarril, el telégrafo, la mejora de carreteras más los nuevos espacios edificables gracias a la Desamortización a la que se añaden los terrenos ganados por la cubrición con bóvedas de ambos cauces del río Esgueva, convierten la ciudad en un importante foco de desarrollo durante el periodo central del siglo. La actividad industrial cambia radicalmente, desaparecen las antiguas fábricas de telas y surgen otras nuevas con las que Valladolid pasa de ser una ciudad conventual y cortesana, a un enclave burgués. En esta época la ciudad de Valladolid experimenta un fuerte crecimiento llegando a duplicar su población a mediados de siglo.

La publicación en 2010 de un libro centrado en la figura del arquitecto Jerónimo Ortiz de Urbina (basado en la Tesis doctoral de Domínguez Burrieza) ha dado nueva luz a las restauraciones de edificios monumentales realizadas en Valladolid en la segunda mitad del siglo XIX. Como resultado de esta investigación se están publicando regularmente artículos y comunicaciones que complementan el conocimiento del tema desde diversos ámbitos: social, económico, artístico, etc.

La influencia del académico, arquitecto diocesano y miembro de la Comisión de monumentos Ortiz de Urbina no sólo se manifiesta en Valladolid; se extendió también por el norte del país a raíz de su labor docente en la Escuela Libre de Maestros de Obras, en la que se forma su propio hijo y numerosos estudiantes que eligen la Escuela de la Purísima Concepción en vez de la de la Academia de Bellas Artes de San Fernando ${ }^{132}$.

Ortiz de Urbina introdujo nuevos materiales y elementos estructurales y decorativos, con la funcionalidad del monumento como fin principal.

Podemos clasificar la obra de este arquitecto entre 1852 y 1936 en cuatro ámbitos:

1. Doméstica

2. Industrial (almacenes, fábricas)

3. Religiosa privada (congregaciones. Agustinos Filipinos con planos de Ventura Rodríguez, iglesia neogótica del Sagrado Corazón, de las hermanitas de los pobres, convento de las Salesas)

4. Religiosa gestionada por el Arzobispado (San Antolín, Santos Juanes, iglesias parroquiales de Villanueva de Duero, Velliza y Nueva Villa de las Torres)

5. Cementerios, peritajes (Mercado del Val), Teatro Calderón, Colegio San José, el Pasaje de Gutiérrez, frontón Fiesta Alegre.

\footnotetext{
${ }^{132}$ Domínguez Burrieza, F. J. (2011). El Valladolid de los Ortiz de Urbina (1852-1936). Valladolid: Ayuntamiento de Valladolid.
} 


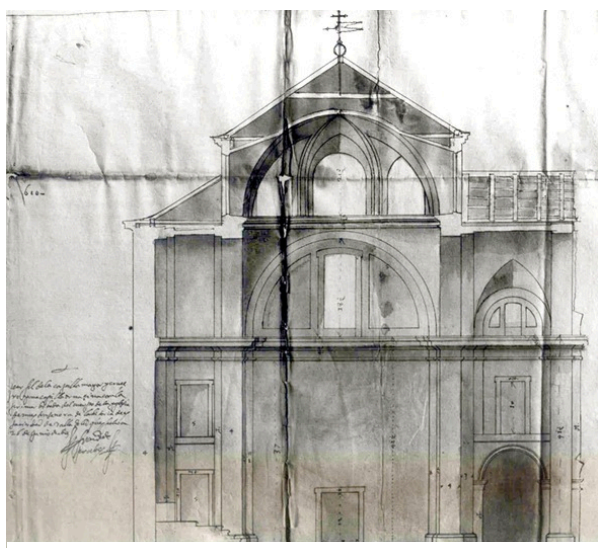

Fig.III.80. Ilustración de Praves,

Dominguez 2011
En 1897 muere el arquitecto diocesano Antonio Iturralde y Montiel "la personalidad más influyente de la Comisión Provincial de Monumentos durante toda la segunda mitad del siglo XIX". Jerónimo concluye sus trabajos, entre ellos la iglesia Nuestra Señora de la Victoria, cuyo plano original de Praves de 1613 vemos junto a estas líneas.

"El afán de reparación y restauración de la mayoría de los conjuntos arquitectónicos primaba por encima de todo, aun desposeyéndose a estos de ciertas cualidades que habían configurado su carácter estético original" ${ }^{133}$.

Burrieza afirma que en los archivos de la Catedral y de la Diócesis de Valladolid se conservan numerosos expedientes de obras inéditos. No ha localizado documentación sobre el estado de los edificios o las obras a ejecutar de las Reales Academias de San Fernando o de la Purísima Concepción. Alguno de la Comisión Provincial de Monumentos de Valladolid. Todos los expedientes se generaron bajo los auspicios de la Junta Diocesana de Obras y Reparaciones dependiente del Ministerio de Gracia y Justicia.

\section{Colegiata de San Antolín}

Uno de los primeros trabajos de Ortiz de Urbina fue como arquitecto director en la Colegiata de San Antolín de Medina del Campo, nombrado por la Diócesis en 1857.

El presupuesto que elaboró para la colegiata, elevándose a 67.502 reales, fue reducido a 56.156 reales gracias al aporte económico procedente de la feligresía. En todo caso, el pueblo siempre pagaba su iglesia. El inicio de las obras se retrasó. El informe es minucioso y proponía entre otras actuaciones:

- Cubrir el enlosado a medio metro de altura con un entarimado de madera para resolver la grave afección por humedad.

\footnotetext{
${ }^{133}$ Domínguez Burrieza, F. J. (2013). La Junta diocesana de obras y reparaciones, el pueblo y el estado durante la segunda mitad del siglo XIX: proyectos de conservación, restauración y de nueva planta en la arquitectura religiosa vallisoletana de Jerónimo Ortiz de Urbina. Arquitectura, Ciudad $Y$ Entorno, (21), 37-66.
} 
- Rebajar el pico del atrio y corrales del costado derecho para evacuar mejor las aguas vertidas desde cubierta.

- Repaso general de paramentos interiores, tapando las grietas.

- Reconstrucción total de tejado y armaduras de sacristía y antesacristía.

- Recalce de muros frente a la Plaza Mayor.

- Añadir columna.

- Reparaciones en la torre.

En el apéndice 23 de su Tesis Doctoral, Domínguez Burrieza ${ }^{134}$ incluye una transcripción del informe de Jerónimo de 1857 sobre San Antolín: "la bóveda construida de tabicado doble, excepto la de la capilla mayor que es de rosca, está pintada de un color aplomado figurando ladrillo".

Describe el edificio con sus medidas en pies. Indica que todos los muros precisan repaso general, esencialmente donde se introducen las cabezas de los tirantes que muchos están descarnados y sueltos, algunos sostenidos por tarugos de madera que acuñan sus cabezas.

Precisa qué tirantes renovar al encontrarlos podridos, carcomidos y rotos. Propone un recalce general a dos niveles, inferior y superior cerca del alero. En algunos puntos el inferior con 1 pie de grueso y más de 6 pies de altura. También se deben repasar los contrarrestos, descarnados debido a la mala solución de albardilla que los cubre.

Iglesia parroquial de Santa María del Castillo en Nueva Villa de las Torres. 1857

Recalce, reparaciones bóvedas, cubierta de la torre, retejar y "reconstruir ciertas partes de la armadura de la nave principal donde existía palo de vid y algunos muros donde esta estribaba."

Santos Juanes en Nava del Rey. 1857

El expediente se tramita casi a la vez que el de San Antolín. El Maestro de Obras de Cabildo declara inminente la ruina de la torre. Otro maestro de obras, Telesforo Martinez, certifica que la torre es estable pero recomienda reparar el primer cuerpo.

\footnotetext{
${ }^{134}$ Domínguez Burrieza. (2009). Jerónimo y Antonio Ortiz de Urbina: vida y obra. Universidad de Valladolid, Valladolid.
} 
En informe y presupuesto de Ortiz de Urbina se llama la atención al movimiento de dovelas de algunos arcos y problemas de la cubierta de madera. También advierte grandes grietas en la torre y culpa, aparte de caída de varios rayos, al uso de piedras areniscas de mala calidad. Propone variar el sistema de apoyo de la cubierta incorporando piezas nuevas a la armadura para no alterar el aspecto exterior pero mejorar la situación de la bóveda del crucero.

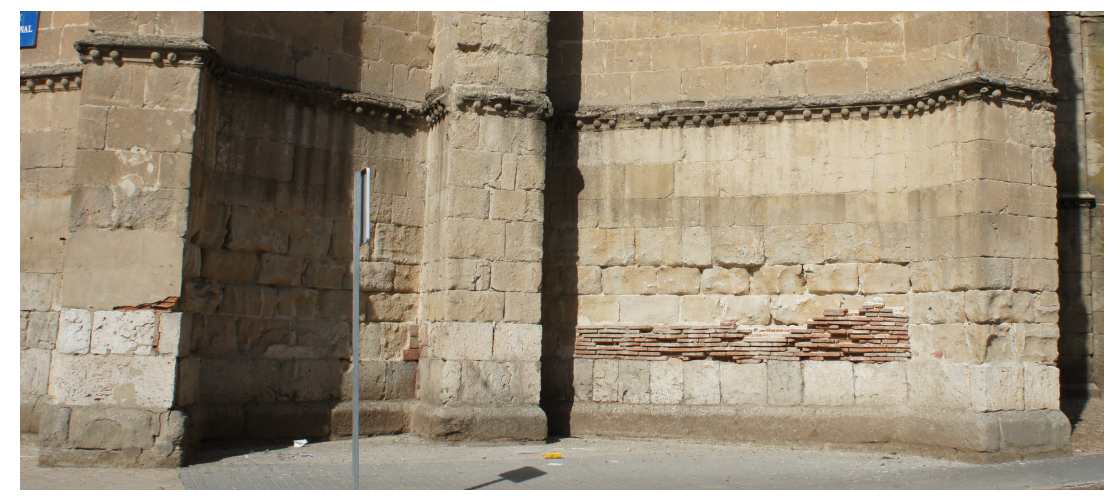

Fig.III.81. Reparación con ladrillo en Nava del rey, visita 20/06/2012

Interviene sobre la fachada a la plaza y "recalce" de los muros. En realidad parece que el historiador emplea en su artículo la expresión recalce para designar el retacado con ladrillo de la fotografía. En otras ocasiones hemos encontrado también la palabra "socalce" aplicada con esa acepción.

Iglesia parroquial de Nuestra Señora de la Visitación en Villanueva de Duero. 1858

Muros y torre se encontraban en buen estado. Las naves tenían su techumbre original oculta tras un entablado que Ortiz reemplaza por bóvedas tabicadas.

La estructura de cubierta también se sustituye por una nueva de madera. En 1874 se repiten los problemas, encontrándose en ruinas parte del tejado y el artesonado.

En el apéndice 25 de la Tesis citada se transcribe un informe de 1857 sobre los Santos Juanes, en el que se describen dovelas movidas en algunos arcos de sillería, y bóvedas de ladrillo con desperfectos, en especial la del primer crucero delante del presbiterio "cuya forma circular rebajada tiene depresiones notables debidas sin duda a la vez que a la causa ya indicada a la carga de las limas, que forman parte de la cubierta que sobre ellas descansan y que convendría reparar variando el sistema de los puntos de carga de dichas limas, e introduciendo piezas nuevas, pues de lo contrario será probable pongan en breve dicha bóveda en una próxima ruina". 
Iglesia parroquial de San Millán en Velliza. 1859

Necesita blanqueo y retejo. El arquitecto Julián Sánchez García desmonta la armadura de la capilla mayor llena de apoyos provisionales.

En 1897 se vuelve a intervenir sobre la bóveda al resultar dañada por el deterioro de hierros metálicos incorporados en el proyecto anterior para sujetarla a la estructura del tejado. Aunque Ortiz de Urbina ya ejercía las funciones de Arquitecto Diocesano, en ningún momento el expediente, eso sí, incompleto, cita su nombre.

Iglesia de San Pablo

Sufre la Desamortización, exclaustración y cambios de uso. Ortiz, Fuentes e Iturralde emiten un dictamen: parte de las fábricas y armaduras están en estado lamentable, en especial el costado izquierdo tras desmontarse una edificación adosada. Proponen recalce y contrarrestos, reparación de cubiertas y bóvedas del templo y retejo. Sólo hay ruina en una parte, el resto se encuentra en buen estado. Reparación general de la cubierta.

\section{La Antigua}

En 1867 el párroco en una carta describe goteras en la capilla mayor, con toda la tabla del tejado podrida y vigas rotas (seis años atrás reforzada con abrazadera de hierro); aleros podridos. Obras encomendadas al arquitecto Rezola, feligrés de la parroquia. El Ayuntamiento obligó a instalar bajantes.

\section{Las Angustias}

Según el párroco "ya por su antigüedad, ya por las crecidas y avenidas de la Esgueva", presenta señales evidentes de próxima ruina en 1862. En 1868 inspeccionan las obras y no se había ejecutado lo descrito en la memoria sino una casa de nueva planta para vivienda del sacristán en el actual c/Angustias nº 10 . Escalera desde la casa al coro pasando por la Cofradía. En 1897 Ortiz reconstruye cornisas y aleros de la iglesia.

Como arquitecto Diocesano, Ortiz de Urbina encara las obras de:

- Iglesia parroquial de San Juan Evangelista en Velascálvaro

- Iglesia parroquial de San Cristóbal en Boecillo. Nuevo (Se arruina el existente) 
- Iglesia parroquial de Nuestra Señora de la Asunción de Villabáñez

- Iglesia parroquial de la Anunciación de Nuestra Señora en Robladillo 1902

- Convento Santa María Magdalena en Medina del Campo. 1893. El arco toral que dividía el crucero del cuerpo de nave de la iglesia tenía un descenso de $15 \mathrm{~cm}$ debido a la rotura de su clave. Esto afectaba al tramo de bóveda en rincón de claustro que descansaba sobre el arco. Mencionaba grietas y deterioro en dos arcos continuos y sus bóvedas. Incluye un plano del cimbrado.

Torres

Proyecta nuevas para las catedrales de Orense y Valladolid, El Salvador de Simancas, San Juan Bautista en Portillo y los Santos Juanes de Nava. En un informe Ortiz recuerda cómo cuatro décadas antes, en 1859, había incorporado en el primer cuerpo de la torre de Nava dos contrafuertes, circulares en su sección horizontal.

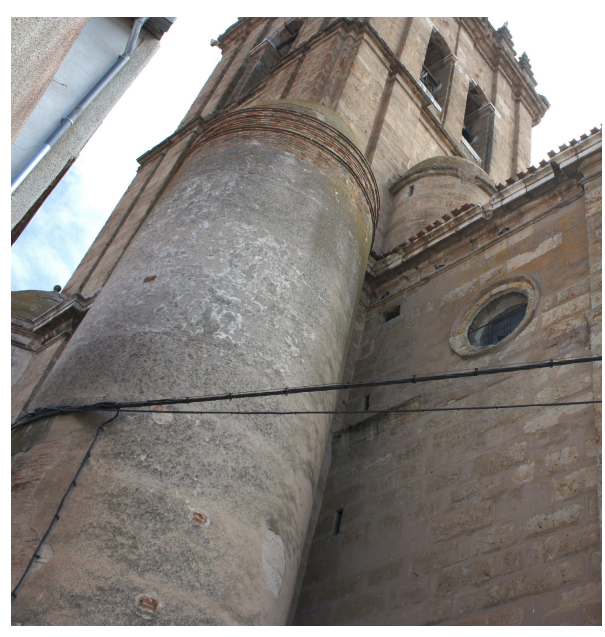

Fig.III.82. Contrafuertes cilíndricos Nava del Rey, visita 20/06/2012

"Obras que se llevaron a cabo en el templo durante el siglo XIX podrían haber sido bastante más numerosas de lo que se pudiera imaginar. De hecho, el propio Ortiz de Urbina señalaba en este último informe que junto a la entrada del campanario se habían instalado unos postes ó apoyos producto de un reconocimiento del edificio posterior al suyo de 1857 . De ahí la dificultad a la hora de precisar no solo la autoría de cada una de las obras de esta índole, sino también de su carácter y explicación originaria"(Dominguez Burrieza 2013, 62).

\section{III.4.3. División administrativa en el siglo $\mathrm{XX}$}

Durante el primer tercio del siglo pasado fue relevante la implantación en España de normativa específica para protección del Patrimonio. El Real Decreto de 26 de julio de 1929 por el que se crea un Servicio de arquitectos-conservadores constituye un auténtico "hito legislativo". Este organismo, con modificaciones posteriores, en la distribución de sus Zonas y en la designación de los Arquitectos-Jefe de cada una de ellas, se mantuvo vigente hasta prácticamente la entrada en vigor de la Constitución de 1978. 
Se puede considerar este Servicio

"La primera estructura profesional para la tutela patrimonial en España que nació con vocación de tal, organizada y dependiente del aparato del Estado, con criterios y directrices claramente establecidos desde un órgano rector como era la Junta del Patronato del Tesoro Artístico Nacional (...) De gran relevancia será la aparición en 1938, también en el seno del organigrama administrativo nacional, del Servicio de Defensa del Patrimonio Artístico Nacional que asumiría todas las funciones relativas a recuperación, protección y conservación del patrimonio desde esa fecha. Un organismo en el que, una vez finalizada la guerra, se integrarían los distintos Arquitectos de Zona encargados de la conservación de monumentos, sin olvidar que en la tarea de reconstrucción material del país también tendría un papel decisivo el Servicio Nacional de Regiones Devastadas y Reparaciones, creado por las mismas fechas"135.

El citado Servicio de Defensa del Patrimonio Artístico Nacional constituido en 1938 se distribuye por Zonas al mando de Comisarios. La Oficina Central corre a cargo de Pedro Muguruza, que también se encuentra al frente de la zona de Levante. La Zona Occidental comprende Coruña, Lugo, Orense, Pontevedra, León, Zamora, Salamanca, Valladolid y Palencia, comisariada por Manuel Cárdenas.

Tras la guerra se reorganiza el territorio según siete Zonas, pasando Oviedo a formar parte de la Primera y Salamanca, Valladolid y Palencia de la Segunda. En 1960 se modifican de nuevo las Zonas: Valladolid se adscribe a la Primera junto con Asturias, León y Salamanca. En la Segunda se incluyen Santander, Burgos, Palencia, Logroño y Soria.

La provincia de Valladolid cambia así de formar parte de la Zona Occidental en un principio, a pasar a Zona Segunda tras la guerra y ser considerada centro de la Zona Primera a partir de 1960.

Podemos encontrar documentación abundante sobre estos hechos en la página web de la Universidad de Oviedo, desde donde se lidera una investigación sobre Restauración Patrimonial:

http://www.unioviedo.es/restauracionyreconstruccion/documentacion.html

\footnotetext{
${ }^{135}$ Esteban Chapapría, J. (2007). La conservación del patrimonio español durante la II República (1931-1939). Barcelona: Fundación Caja de Arquitectos.
} 


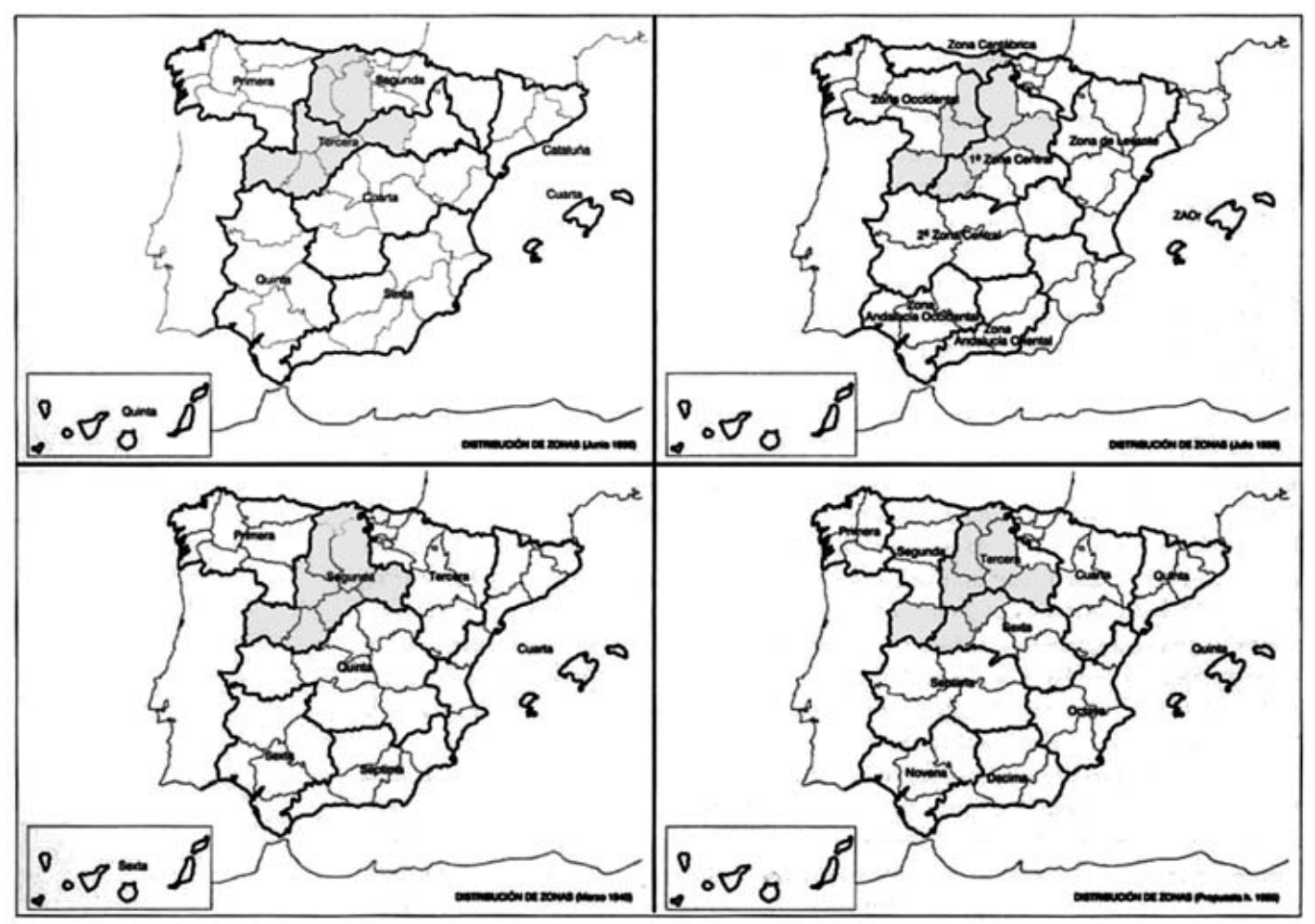

Figura 4. División de las áreas de reparto de los arquitectos de zona, en las fechas de junio de 1946 (arriba izquierda), julio de 1938 (arriba derecha), marzo de 1940 (abajo izquierda) y propuesta no aceptada de 1955 (abajo derecha) ${ }^{19}$

Fig.III.82. Organización en Zonas, Esteban 2007

La citada investigación acomete desde hace algunos años el estudio de la restauración monumental en España a lo largo del siglo XX de forma rigurosa, pero desde una perspectiva más orientada hacia el análisis político y de gestión del Patrimonio que técnica, por ejemplo dos proyectos del Plan de I+D+I:

A) 'Restauración y reconstrucción monumental en España 1938-1958. Las Direcciones Generales de Bellas Artes y Regiones Devastadas (2007-2009)'

La profesora de Arte de la Universidad de Oviedo Pilar García Cuetos lidera este Proyecto de ocho universidades centrado en la Gestión del Patrimonio en España durante el mandato de Franco.

Como resultado de la primera fase se ha editado el libro Restaurando la memoria, España e Italia ante la recuperación monumental de posguerra, en cuyo capítulo cinco se describen las actuaciones en la Segunda zona monumental de 1940 a 1958, a cargo de Anselmo Arenillas ${ }^{136}$.

\footnotetext{
${ }^{136}$ Martínez Monedero, M. (2010). Anselmo Arenillas y la segunda zona monumental (1940-1958). In Restaurando la memoria: España e Italia ante la recuperación monumental de posguerra (pp. 119154). Trea.
} 
B) 'Restauración monumental y desarrollismo en España 1959-1975 (2011-2014)' En una segunda fase desarrollada en 2012-2014 analiza el tema a lo largo de las décadas siguientes, del 58 a 1975, correspondientes al "desarrollismo".

Recientemente se ha publicado también libros basados en tesis doctorales sobre los arquitectos conservadores de las distintas Zonas: Alejandro Ferrant, Luis Menéndez Pidal o Francisco Pons-Sorolla. Sobre los responsable de las principales actuaciones de la época en Valladolid, hasta este momento sólo encontramos la documentación acerca de la obra de Arenillas en un capítulo del libro editado a partir del citado Proyecto de investigación.

Aunque Luis Cervera Vera, como investigador y académico erudito escribió más de un centenar de artículos y una treintena de libros, contamos con una única publicación centrada en su figura y se trata de un listado de su bibliografía ${ }^{137}$.

Tampoco se cuenta con estudios específicos sobre las restauraciones realizadas por la arquitecto Ana Iglesias, responsable de gran parte de las intervenciones realizadas en los años setenta, que trabajó desde 1972 hasta 1985 para la Dirección General de Bellas Artes, y posteriormente para el Gobierno regional y Empresa Municipal de la Vivienda en Madrid.

El citado Martínez Monedero puntualiza que el lapso elegido 1938-1958 corresponde a las dos primeras décadas tras la guerra civil conocidas como "etapa autárquica".

Una de las fuentes principales de su estudio es el catálogo de una exposición celebrada en Madrid en 1958: Veinte años de restauración monumental de España.

La precariedad económica de la época penaliza los proyectos en escala y tiempo: se acometen proyectos múltiples pero de escasa cuantía. El autor considera que las limitaciones mantuvieron a los monumentos aquellos años a salvo de actuaciones más ambiciosas y transformadoras, como las desarrolladas en los sesenta y setenta.

El vallisoletano Anselmo Arenillas fue arquitecto conservador de monumentos jefe de la segunda zona desde 1940 hasta su muerte en 1979. Durante la guerra actuó militarizado en protección, incautación y recuperación de monumentos. También su

\footnotetext{
${ }^{137}$ Yeves, Juan Antonio. (1996). Bibliografía de Luis Cervera Vera. Publicaciones desde 1943 a 1995. Madrid: Publicaciones de arquitectura y arte SL.
} 
hijo José Antonio Arenillas Asín fue arquitecto y colaboró en proyectos de la segunda zona. Según el autor citado, Arenillas no dejó escritos sus criterios de intervención, ni siquiera como memorias de las obras ejecutadas.

Arenillas actuó simultáneamente para Regiones Devastadas (desde 1939 hasta 1950. El servicio desapareció en 1957). Martinez Monedero critica la absoluta falta de rigor metodológico de las reconstrucciones, que llevó a la desfiguración del patrimonio, citando como ejemplo palpable las catedrales de Santander y Sigüenza.

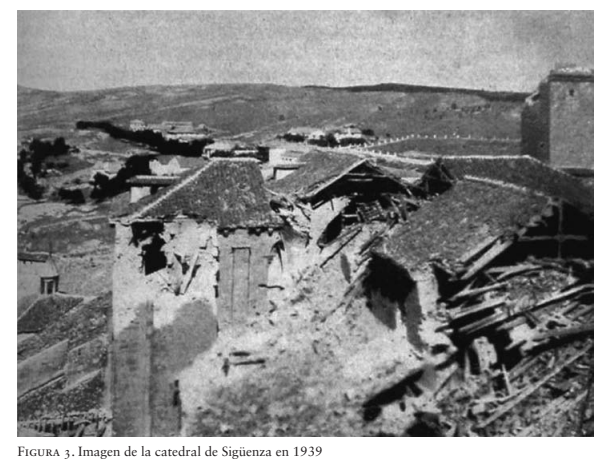

Fig.III.83. Catedral de Sigüenza en 1939, ilustración Martinez 2010

En el catálogo de la exposición figura Anselmo Arenillas como arquitecto jefe, Luis Cervera Vera arquitecto auxiliar y comisario José Luis Monteverde. De manera excepcional se hizo cargo de varios monumentos el comisario general Francisco Íñiguez Almech, como la catedral de Burgos, Santo Domingo de Silos y la iglesia de San Cebrián de Mazote en Valladolid.

"La mera conservación era una estrategia poco rentable formalmente; la intervención debía ser restauradora y dejar su huella a través de la transformación y la puesta en valor del edificio, aunque fuera por encima del rigor histórico. Lo habitual era que las intervenciones abordaran las patologías más acuciantes de los sistemas principales del edificio, es decir, cubiertas, seguridad constructiva y estructural". (Martinez 2010)

Martínez Monedero describe obras de Arenillas en esos años: Trabajos en la Plaza Mayor de Salamanca y varias en Ciudad Rodrigo. En Segovia: conjuntos urbanos, catedral e iglesias de San Juan de los Caballeros, San Martín, San Millán, San Nicolás, San Justo y Pastor, Vera Cruz, Monasterio de Santa María de Nieva, lienzos de muralla, alcázar y acueducto. Cómo recalza el arco de Medinaceli, las iglesias de Santa María de Caracena, San Miguel de Almazán y San Miguel Arcángel de Andaluz en la provincia de Soria. Iglesia de Santa María la Blanca y Monasterio de San Andrés del Arroyo en Palencia. Cita hasta 12 proyectos para restaurar "a fondo" la iglesia de Santiago en Salamanca. Con Fernando Población interviene sobre el Monasterio de la Purísima y el convento de las Dueñas en Salamanca. Varias campañas de actuaciones sobre la catedral de Ávila, recuperando la cabecera como bastión y huecos cegados en el XVIII. Restauración de las catedrales vieja y nueva 
de Salamanca rehaciendo la conexión entre ambas. En Santander además de en la catedral se opera sobre la colegiata de Santillana del Mar. Diversos castillos, entre ellos tres en Valladolid: Simancas, Fuensaldaña y Portillo. En Valladolid restaura también el Colegio de Santa Cruz, entre 1955 y 1957 con Íñiguez y, más tarde, en solitario.

La mayor parte de los arquitectos en Regiones Devastadas eran jóvenes de reciente titulación. Se les asignaron fondos importantes para la reconstrucción de enclaves monumentales, considerados dentro de un proceso más ambicioso de reconstrucción nacional.

De 1945 a 1985 es Luis Cervera Vera el responsable de restaurar las catedrales de Astorga y Valladolid, los Colegios de Santa Cruz y San Gregorio en Valladolid, las murallas de Madrigal de las Altas Torres, las iglesias de Frómista y Arévalo y las plazas de Arévalo y Lerma. Autor de más de numerosas publicaciones, sobre todo sobre Juan de Herrera, confiaba en los levantamientos minuciosos y documentos de época.

Otros arquitectos que intervinieron en monumentos de Valladolid antes del traspaso de las competencias a las Comunidades Autónomas, de forma puntual, fueron: Victor López Cotelo, Ignacio Gárate Rojas, Felipe Prieto Granda, Alberto García Gil, José Ángel Rodrigo García, José Luis Iñiguez de Onzoño, Luis Alberto Mingo Macías, Manuel Cuadrado Isasa y Javier López de Uribe. 



\section{1. Análisis de los proyectos de restauración}

El estudio de los proyectos para tratar de localizar y analizar el uso de zunchos en restauración monumental abarca dos frentes de distinta naturaleza. Por un lado la documentación escrita, que comprende tanto las memorias como los presupuestos, y por otro la documentación gráfica, en la que se pueden englobar tanto planos como bocetos y fotografías.

En el curso de la investigación se han revisado expedientes muy diversos, desde las simples solicitudes de licencia custodiadas en AMVA para abrir una zanja en San Benito de 1785 o revocar las fachadas de PortaCoeli en 1893, hasta los completos Planes Directores de San Antolín y la Catedral conservados en JCyL. Se han contabilizado en el estudio al menos 273 referencias datadas entre 1900 y 2000, de las cuales el mayor número se concentra entre la segunda mitad del siglo ${ }^{1}$.

Los proyectos realizados en los años 60 consisten en la mayor parte de los casos en una memoria que ocupa una o dos páginas mecanografiadas, acompañada de un plano que suele ser una planta de gran tamaño y poco nivel de detalle. Generalmente se incluyen mediciones y presupuesto aunque en algunos casos éste no se incorpora y sólo se describe brevemente las actuaciones en lo que denominan "memoria valorada".

Además de contar con memorias un poco más desarrolladas, el gran cambio de los 70 se produce en los planos, que adquieren mayor desarrollo y relevancia, según se explicará con más profundidad en el apartado IV.1.2.

En los 80 los proyectos aumentan su contenido y empiezan a incluir unas memorias extensas en las que se describen con más detalle el estado del edificio y las intervenciones previstas, incluyéndose en muchos casos fotografías. En los 90 se incluye en los proyectos anejos y estudios técnicos de todo tipo, desde análisis de la piedra, del terreno, informes arqueológicos o cálculos estructurales. A menudo el aumento de volumen no supone un incremento real de la información sobre los detalles de la obra prevista.

\footnotetext{
${ }^{1}$ En el apartado Discusión (pag IV.153) se incluye una gráfica que muestra la evolución anual del número de proyectos localizados.
} 
En ocasiones al incorporar un zuncho éste se menciona sólo en la memoria, o bien aparece reflejado únicamente en el presupuesto. Otras veces lo encontramos mejor definido en los planos, aunque como veremos más adelante no es habitual. En varios casos analizados ni siquiera concuerdan entre sí las dimensiones reflejadas en los documentos de un mismo proyecto, con un canto del zuncho mencionado en la memoria y otro diferente descrito en la medición o representado en un plano.

\section{IV.1.1. La documentación escrita: memorias y presupuestos}

A continuación vamos a analizar cómo se refleja la incorporación de zunchos en las memorias de los proyectos de restauración de los edificios estudiados, así como en sus presupuestos y otros documentos escritos conservados en los archivos como informes y cartas.

En primer lugar se revisa cómo se describen en los proyectos las condiciones en que se encontraba cada edificio en el momento en que se acometen las distintas obras de restauración del mismo, para tratar de precisar si éstas son consecuencia directa del mal estado de la estructura y hasta dónde influye el grado previo de deterioro en el empleo de zunchos.

A continuación se analiza cómo se justifica el uso de zunchos en esos proyectos, la descripción que cada arquitecto hace del elemento y su función, si se incorpora para repartir las cargas, apoyar las cerchas, consolidar los muros, etc.

Por último se comprueba cómo y donde se definen las dimensiones y ubicación de los distintos zunchos.

- Necesidad de la intervención

- Justificación del zuncho

- Definición de dimensiones de los zunchos 


\section{IV.1.1.1. Necesidad de la intervención}

Dentro de las preguntas de investigación formuladas al comienzo de los trabajos se plantea si en algún caso se incorpora el zuncho de hormigón en intervenciones parciales en las cuales se haya restaurado la estructura de cubierta sin llegar a desmontar completamente la misma. Se pretende verificar así si el empleo de zunchos está asociado indefectiblemente a una sustitución total de las cubiertas.

Uno de los puntos de partida que parecía confirmarse en una primera etapa de la investigación documental, fue que la sustitución de estructuras de cubierta de madera por cerchas metálicas y tableros con capa de compresión de hormigón se había convertido en una costumbre arbitraria en la segunda mitad del siglo XX y, por tanto, se realizaba de forma sistemática sin importar el estado en que se encontrase en ese momento la cubierta del edificio. Así encontramos la descripción que Mariana Esponda atribuye $^{2}$ a Javier Rivera sobre la sustitución de estructura de cubierta de madera de la nave central en la catedral de Valladolid por cerchas y correas metálicas en 1974 "aunque no se encontraban excesivamente mal, esto lo hizo como era la moda en todas las catedrales".

Es cierto, según se ha descrito en el epígrafe III.3, que la generalización del reemplazo de armaduras por estructuras modernas puede achacarse en gran medida, además de a "las modas", a la falta de conocimiento sobre el comportamiento de los materiales tradicionales, como la madera, de varias generaciones de arquitectos e ingenieros. Muchos técnicos modernos consideran que sólo el cálculo numérico de resistencia les proporciona suficiente seguridad, y no realizan comprobaciones de estabilidad por métodos plásticos, más acordes con la naturaleza de los edificios históricos.

Para analizar las soluciones adoptadas en los proyectos de restauración hay que tener en cuenta, además, que la ejecución por partes (generalmente por razones presupuestarias) de una obra de restitución y recomposición parcial, puede resultar en muchos casos más compleja, insegura y cara que la completa renovación de una cubierta. Y el factor económico es uno de los aspectos más importantes en la redacción de los proyectos.

\footnotetext{
${ }^{2}$ En las dos obras citadas por Esponda en su Tesis, Teoría e historia de la restauración publicada por Munilla-Lería y Patrimonio, restauración y nuevas tecnologías editada por la UVa en 1997 no se ha localizado la frase atribuida a Javier Rivera y supuestamente tomada de la página 153.
} 
A medida que se ha ido incrementando el volumen de datos sobre los casos documentados descubrimos, sin embargo, que las intervenciones se han efectuado en muchos casos inmediatamente después de producirse algún tipo de derrumbe parcial de los tejados. En los reportajes fotográficos que acompañan a los proyectos aparecen con frecuencia armaduras en muy mal estado, con secciones prácticamente desaparecidas, sobre todo en los extremos de las piezas de madera.

En el $\mathrm{AGA}^{3}$ hay una fotografía y en el AMVA tres que muestran vistas de la cubierta de la catedral de Valladolid tras desplomarse una zona del tejado, lo que prueba que la intervención de Cervera sobre su cubierta en 1974 respondió a un problema de estabilidad real. La mención de una "necesidad urgente" de intervenir no puede verse entonces como una simple excusa de los proyectistas para adoptar criterios provocados por la falta de preparación técnica o la simple conveniencia económica que parecía deducirse de los Antecedentes. El cambio de las armaduras en la segunda mitad del siglo XX pudo ser en muchos casos consecuencia del estado de degradación irrecuperable en que se encontraban los edificios.

En muchas ocasiones se aduce la falta de interés artístico de unos elementos ocultos como las armaduras de cubierta para justificar su sustitución. Algunos proyectistas tratan de justificar por qué mantienen la estructura en unos casos y no en otros basándose no sólo en el estado de degradación irreparable de la madera sino en cómo valoran ellos su coherencia e interés constructivo ${ }^{4}$ (Garabito López 2015).

La situación cambió a partir de las unas Jornadas sobre Conservación y Restauración de Techumbres en España organizadas en 2010 y 2011 por el IPCE. En el documento final se recogieron 18 recomendaciones de los ponentes, en las que se reclamaba la protección de las estructuras de madera, incluso de los clavos y telas que formen parte de las mismas. El texto promueve el conocimiento y documentación como requisitos cruciales para actuar, defiende el uso de soluciones no rígidas, compatibles con el comportamiento estructural de los sistemas, así como la necesidad de respetar los sistemas primitivos de ventilación y recuperar su capacidad sustentante.

\footnotetext{
${ }^{3}$ Las siglas AGA y AMVA refieren a sendos archivos descritos en el capítulo Metodología, pág. II.7.

${ }^{4}$ Así Javier Garabito y otros comparan sus intervenciones en la Colegiata de Roa y San Esteban de los Balbases empleando tablas con parámetros como el interés constructivo, el estado de las cornisas, las filtraciones, etc.
} 


\section{Recopilación de párrafos de los proyectos sobre la necesidad de intervenir}

Veamos a continuación en qué fecha se produce la sustitución de las armaduras en los casos estudiados y los argumentos que aducen los autores de los proyectos para justificar la necesidad de la intervención, describiendo derrumbamientos y empleando términos como "peligro". En ocasiones se describe también la existencia de codales y apuntalamientos provisionales previos que cargan sobre tirantes y bóvedas penalizando la capacidad resistente de los mismos.

En la memoria del proyecto de restauración de la iglesia del Convento de San Pablo en Valladolid se afirma que "debido a las goteras, se han podrido las cabezas de los tirantes y de los pares de sus grandes formas y también las soleras y parte de las correas. Para contener la ruina han ido poniendo puntales y codales que, a su vez, también se han descompuesto, y el conjunto perfectamente construido con maderas escuadradas amenaza una ruina rápida y pone en peligro, además, las bóvedas góticas de esta hermosa iglesia, Monumento Nacional. Se propone, con carácter de urgencia, desmontar la cubierta" (Arenillas 1964).

El citado arquitecto achaca los problemas al tipo de material de cobertura empleado en el tejado, de escamas de barro cocido teñidas con alquitrán. Al no fabricarse ya este tipo de piezas, eran imposibles de reponer y "por ese motivo se produjeron grandes y perpetuas goteras".

El mismo Arenillas describe en el proyecto de restauración cómo la iglesia de Santa María de Wamba "acusó una ruina progresiva por descomposición de los cuatro pilares del crucero y hubo de acudirse en años anteriores a su urgente reparación apeandolos sustituyendole algún pilar y enlechando con cemento su descompuesto nucleo que era de mala mamposteria" (Arenillas 1964). Sobre el mismo edificio se justifica treinta años más tarde la necesidad de llevar a cabo una nueva intervención explicando que "se produjo el derrumbe sobre la bóveda de la cubierta de la cabecera de la nave central... Bajo esta cubierta arruinada se encuentra la cabecera mozárabe de gran valor, que puede deteriorarse, por lo que es precisa una actuación de emergencia" (Quintana 1990).

La iglesia de la Pasión en Valladolid se encontraba en ruinas, y cerrada al culto desde 1926, cuando se reconstruye para su uso como museo en 1968 y se afirma: "ya cuando fue declarado Monumento Nacional se encontraba en franca ruina... Los muros de la iglesia son de tapial que debido al largo tiempo que han estado a la 
intemperie están descompuestos, no resisten reparación, salvo los del crucero y los de la capilla lateral" (Arenillas 1965) .

Y el mismo arquitecto indica en la memoria del proyecto de restauración de la iglesia de los Santos Justo y Pastor en Cuenca de Campos:

"Mas los muros de este templo son de tapial, que acaso estuvieron recubiertos de fábrica de ladrillo que los protegería contra la acción de los agentes atmosféricos; pero que hoy ha desaparecido y dejado indefensos los gruesos muros de tierra, y por ello amenazan ruina... En realidad se rehace toda la estructura portante y el tejado de la iglesia para lograr salvar el artesonado dejándolo en su emplazamiento. Los artesonados, origen de la clasificación de Monumento Histórico Artístico, corrían grave riesgo y no podían ser trasladados a otro lugar" (Arenillas 1967).

En la iglesia de San Martín en Medina del Campo afirma que "sus cubiertas llenas de goteras y roturas amenazan ruina en muchas partes, con lo que el artesonado morisco de su presbiterio y las bóvedas peligran" (Arenillas 1968). Y veinte años más tarde se interviene sobre el inmueble abandonado que se describe en los términos siguientes: "más que arruinado cabría afirmar que la iglesia y el palacio han sido saqueados... contexto de desolación... Pero es sin duda el arruinamiento de sus cubiertas lo que ha puesto definitivamente en peligro su estabilidad" (Fernández e Inglés 1989).

En la memoria del proyecto de intervención sobre el Real Monasterio de San Joaquín y Santa Ana en Valladolid se describe como "en el ángulo izquierdo del edificio, sobre la Plaza de Santa Ana, se ha producido el hundimiento de un entramado de madera originado por el pésimo estado de conservación de la cubierta, la cual es de construcción deficiente... la fachada lateral, falta de atado, se haya desplazado, empujada por la cubierta, produciendo grieta en la fachada principal... Se hace notar que una reparación del total de la cubierta se presenta como obra necesaria a realizar con urgencia, sobre todo en la zona de la iglesia" (García Gil 1969).

Y el mismo año vuelve a ser Arenillas quien se refiere al estado de las cubiertas de la Catedral de Valladolid de la siguiente forma: "hay tirantes de las formas que no apoyan en los muros, pares y piezas cuyas cabezas están descompuestas y en general todo el conjunto en peligro de que se repita el hundimiento actual en otros tramos. Por ello se juzga pertinente el cambio total de esta cubierta" (Arenillas 1969). 
En 1969 se había producido el hundimiento de dos cerchas de la nave central hacia los pies documentado en varias imágenes de la época.

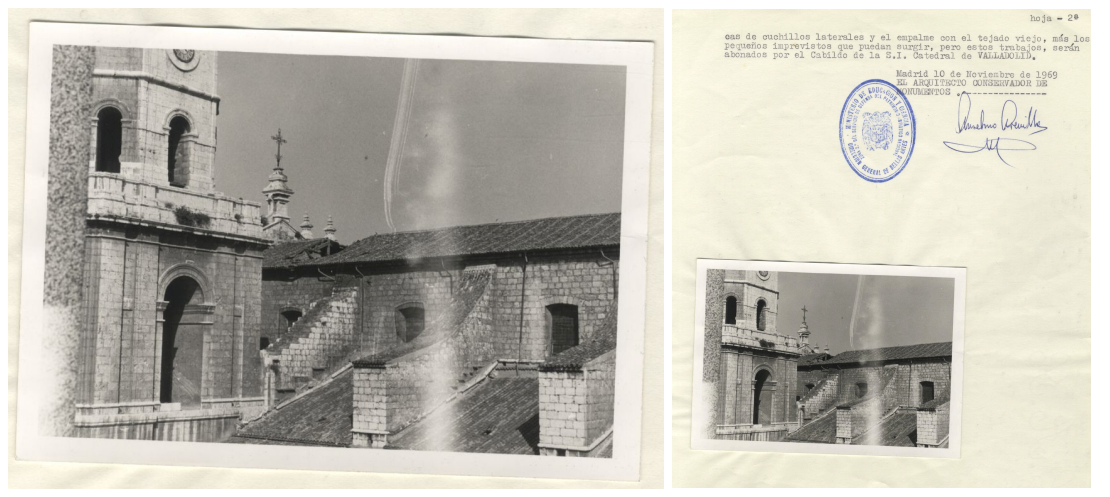

Fig.IV.1. Fotografía Catedral dossier (Arenillas 1969 AGA)

$\mathrm{Y}$ en el proyecto en que se define la sustitución de las armaduras por cerchas metálicas se afirma que "la catedral se encuentra con peligro de hundimiento de la cubierta de la nave central, lo que ocasionaría graves daños en las bóvedas y conjunto de las fábricas actuales" (Cervera 1974).

Este último arquitecto actúa en la Capilla de San Gregorio en Valladolid y justifica su proyecto afirmando: "para remediar el deficiente estado de las cubiertas del edificio que estudiamos, por el peligro que su actual situación representa, ... se pretende el desmontaje de las actuales armaduras con su cubrición, para su posterior sustitución por cubierta de Uralita, apoyada sobre tabiquillos de ladrillo" (Cervera 1974).

En la Memoria final del proyecto de restauración de la iglesia de San Juan en Fresno el Viejo se indica que "se ha considerado como etapa inicial acometer los trabajos de reposición de cubiertas, ya que su mal estado originaba grandes humedades que ponían en peligro la seguridad de sus bóvedas" (Rodrigo y Roldán 1974).

El proyecto de intervención ese mismo año sobre la iglesia de San Juan Evangelista en Arroyo de la Encomienda se denomina "Memoria de obras urgentes en la iglesia parroquial" (García Gil 1974).

En la iglesia de Monasterio de las Huelgas Reales en Valladolid se actúa varias veces a lo largo de los años 60 y 70, insistiendo en el mal estado de las cubiertas: "La iglesia ... tiene grandes goteras que perjudican a sus bóvedas y muros. El tejado presenta múltiples hundimientos y roturas denunciadas ya hace años y que han ido en aumento, los arreglos hechos por sus usuarios han sido apuntalar las piezas rotas 
con enanos que transmiten la carga a elementos débiles no preparado para ellos" (Arenillas 1959). "En general hay que levantar toda la teja, ya que se encuentra inservible más del $85 \%$ de la totalidad. Las formas están en muy mal estado, pudiéndose aprovechar muy pocos elementos, sin embargo como se proyecta dejar la cumbrera general a una misma altura, con madera suficiente nueva que se aporte y pudiendo sanear las cabezas de los elementos existentes se pueda formar una armadura suficiente para sanear toda la cubierta" (Arenillas 1960).

Años después Ana Iglesias afirma encontrar una cubierta en buen estado: "por conservarse bien su estructura principal de madera en su mayor parte, se conservará la misma y sobre ella y utilizando la tabla ripia como encofrado se formará una capa de compresión de hormigón ligeramente armada con mallazo" (Ana Iglesias 1975). Aunque poco después decide sustituir las armaduras por estructura metálica y hormigón sobre nervometal: "Se realiza la cubierta previo desmontado de la todavia de madera existente, sobre estructura metálica compuesta por cerchas y correas según figura en los planos adjuntos, sobre la que se crea la correspondiente capa de compresión formada sobre el nervometal que le sirve de soporte" (Ana Iglesias 1976).

Arenillas había lamentado la escasez de presupuesto, insuficiente para restaurar la cubierta en condiciones, tal vez por esa razón aporta madera nueva conservando la existente tras sanear las cabezas sin llegar a acometer obras de mayor envergadura.

Por fin será Ana Iglesias la que reemplace las armaduras por cerchas metálicas en 1976, a pesar de haber afirmado en la memoria del proyecto redactado un año antes que la estructura se conservaba bien.

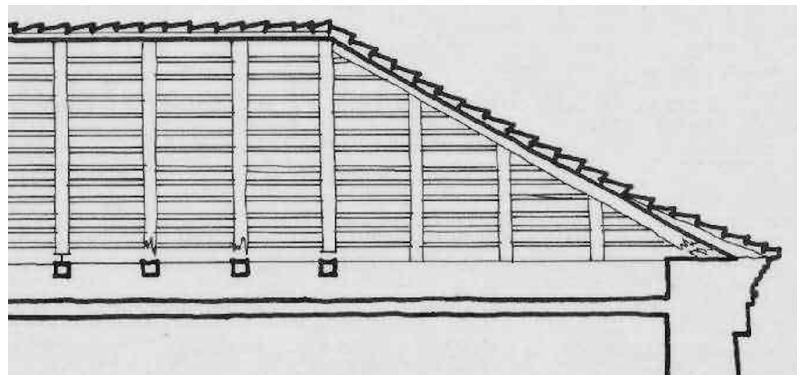

Fig.IV.2. Sección de estado actual 1975 con pares rotos representados en el plano, Iglesias IPCE

La obra de restauración de la iglesia de Santa María en Alaejos en los 70 se prolonga varios años y el reemplazo estructural previsto sólo para naves laterales se extiende a la cubierta completa. En la memoria se afirma: "El estado de los pares de las naves laterales es pésimo, con las cabezas empotradas en el muro sin ventilación totalmente inservibles y podridas, han sido reforzadas con anterioridad con puntales, troncos, bridas" (Ana Iglesias 1978). 
La iglesia de Santiago en Medina de Rioseco se encontraba cerrada al culto debido a su mal estado cuando se acometen obras en los 70. En la memoria se describe así las actuaciones a realizar: "Restauración de sus cubiertas previa demolición de las existentes en muy mal estado. La estructura principal de madera ha fallado en algunas zonas, produciéndose un hundimiento notable en las proximidades de la torre con el consabido arrastre de correas, tablas y tejas" (Ana Iglesias 1978).

La arquitecto Ana Iglesias también repara la iglesia de La Anunciada en Urueña y explica como "las cubiertas de la iglesia se encuentran en mal estado, siendo necesario por tanto la sustitución de todas ellas" (Ana Iglesias 1978).

En la iglesia del convento de las Descalzas Reales en Valladolid plantea sólo incorporar una capa de hormigón sobre la ripia: "Restauración de las cubiertas de la iglesia que dado su buen estado en cuanto a la estructura principal, deberán ser realizadas con la sustitución de la tabla necesaria existente para que sirva de encofrado para la formación de una capa de compresión de hormigón" (Iglesias 1979).

Y también describe en términos positivos el estado de la Iglesia de los Santos Juanes en Nava del Rey: "La armadura principal en sus cerchas y vigas, presenta un imponente aspecto debido a la gruesa escuadría de sus secciones y a la profusión de estos elementos. De la inspección realizada se ha llegado a la conclusión de que si bien, el estado de esta estructura es bueno, su interesante disposición y el hecho de la paulatina desaparición de estas estructuras por la sustitución inevitable por otras realizadas con medios más modernos, aconsejan la conservación de la misma aunque para ello haya que sustituir algunos elementos de los que la componen" (Ana Iglesias 1979).

La sustitución de la estructura de cubierta en los Santos Juanes fue un caso singular, ya que en una entrevista con la arquitecto responsable del mismo Ana Iglesias ésta confirmó que tenía intención de mantener las armaduras pero se desmontaron para construir una cubierta nueva con pendiente mucho menor porque lo había solicitado la propiedad alegando que "se mataban" cuando tenían que salir a mantenerla y retejar.

Diez años antes, sin embargo, Arenillas había querido rehacer toda la cubierta porque consideraba que una moderna sería más segura frente al fuego y si no lo hizo 
fue por falta de presupuesto: "Sería conveniente rehacer toda la cubierta en forma definitiva e incombustible pero esto sería operación costosa en exceso y por ello la Superioridad me ha dado orden de proceder a la reparación sustituyendo las maderas que ofrezcan peligro y retejando".

Ya en los 80 se sigue justificando la necesidad de acometer obras por el mal estado de los edificios, como en la Iglesia del Rosarillo en Valladolid: "La obra más urgente y necesaria es la reparación total de la cubierta por el estado de ruina en que se encuentra. La mayor parte de los elementos resistentes de madera están en condiciones muy precarias. Las armaduras de par, tirante y nudillo se encuentran rotas en un alto porcentaje y con reparaciones deficientes realizadas en diversas épocas (apeos con puntales de pares partidos, algunos pendolones metálicos, etc.) La rotura y salida de su sitio de los pares, ha provocado hundimientos de grandes zonas y caídas de escombros sobre las bóvedas de ladrillo" (Iñiguez de Onzoño 1980).

El arquitecto Luis Mingo describe en 1980 problemas de goteras producido por corrimiento de tejas, irregularidades en cubierta, fisuración en remates de cornisas y pudrición de armaduras de madera en la iglesia de Santa María en Tordesillas. En una hoja de Anexo explica que si durante el desmontaje se observa que se puede salvar parte de la armadura se hará para ahorrar formas metálicas y transferir esa cuantía a restaurar las capillas.

En los 70 se había actuado en la iglesia de la Asunción en el Convento de PortaCoeli en Valladolid de forma provisional: "Se han realizado en la cubierta obras provisionales de reparación que evitasen la total ruina de la cubierta... con carácter de urgencia, y de modo provisional hasta realizar un proyecto de renovación total de la cubierta, es necesario proceder a la inmediata reparación de la misma; sustituyendo ripia en diversas zonas, consolidando armaduras y efectuando un retejo general" (García Gil 1973) . Pero las dos cerchas de madera más próximas al cimborrio se hunden en 1982 y debe actuarse de nuevo: "Se ha podido observar la existencia de una zona próxima al cuerpo de la cúpula del crucero, en la que el deterioro de la cubierta es importante, ya que los pares del entramado estructural han cedido como consecuencia de que los durmientes de ambos lados están totalmente podridos por la humedad, a que han debido de estar sometidos durante años" (Roldán 1982).

Aunque en el edificio anejo del Cabildo de la Cofradía de las Angustias en Valladolid se incorpora zuncho, en el proyecto se describe el buen uso general de la 
estructura de cubierta del templo, que sólo necesita reparaciones (Pérez Medina y Bustamante 1982).

En la Colegiata de San Antolín en Medina del Campo se produjo un fenómeno interesante: se incorporan zunchos de hormigón armado en 1982 que son demolidos 14 años después para volver a ejecutarlos con una solución constructiva diferente. En la memoria de la primera intervención se afirma que las "formas de madera se encontraban en mal estado de conservación, o rotas o descompuestas las cabezas en su contacto con la fábrica de ladrillo. Una acción continuada del tiempo junto con otros agentes habían producido el efecto dominio sobre las estructuras de las naves laterales. ... La amenaza de ruina era evidente" (Gómez Santander 1982).

En un informe para la Junta de consejeros Paniagua (1999) puntualiza que hay que desmontar la cubierta ya que "un tirante de la nave central ha caído sobre la bóveda debido a la lluvia". En la primera intervención el arquitecto proyecta desmontar la cubierta, ejecutar los zunchos y volver a colocar la antigua estructura con reparaciones puntuales. En la segunda se reemplaza todo el conjunto con un diseño nuevo y distinto de madera laminada.

En la memoria del proyecto de restauración de la iglesia de San Francisco en Medina de Rioseco se explica como "se encuentra prevista la consolidación y saneado de los elementos leñosos en mal estado... Dentro del orden establecido con anterioridad, el proyecto contempla las acciones de mayor urgencia en su resolución como son las referentes a la estructura general y la cubierta del edificio... falta de resistencia en el sentido del eje del muro, generando unos agrietamientos en las zonas de mayor debilidad o de menor traba" (Gárate y Manzano 1988).

Al arquitecto Luis Tovar se le dan instrucciones precisas sobre el contenido que debe tener el proyecto para el que se le contrata de la iglesia de Santa María del Castillo en Villaverde de Medina, en un anexo firmado por Antonio de Meer como Jefe del servicio de Restauración en junio de 1989. En dicho documento se recogen, entre otras instrucciones, la consolidación de los arcos restaurando vigas y ménsulas para su permanencia como elementos decorativos y la reposición de cubiertas con una nueva estructura de madera. También se indica "actuaciones urgentes: se trata de renovar en su totalidad la cubierta dado que su concepción estructural está perjudicando visiblemente al edificio: en concreto, las cargas inciden puntualmente en los arcos que ceden y se agrietan" (Tovar 1989). 
La sustitución de la estructura de cubierta completa, en este caso, fue impuesta al arquitecto autor del proyecto por los técnicos de la Administración.

En el Monasterio de Santa María de Valbuena en Valbuena de Duero se reforma unas canaletas sobre los faldones de naves laterales. En el proyecto se explica la actuación: "Protección de los muros de la nave central de la Iglesia en cubiertas. Se programa esta actuación en el monumento, con caracter de urgencia máxima sobre la protección de los citados muros, para evitar que las aguas de lluvia y humedades y hielos penetren al interior de los mismos y se pasen a las bóvedas e interior de la iglesia " (López de Uribe 1981).

El arquitecto Pablo Puente reconoce en 1991 que la cubierta de tabiquillos de 1961 "dada por el INC en su momento, a base de faldones de ladrillo sobre tabiques que apoyan en las bóvedas, si bien ha preservado el monumento, evitando el deterioro de sus bóvedas, se considera inadecuado por desvirtuar el sistema constructivo tradicional de hacer trabajar a los muros perimetrales, concentrando las cargas en sus secciones ampliadas por pilastras interiores y contrafuertes exteriores, incrementando de esta forma la componente vertical y contrarrestar el empuje horizontal de las bóvedas. La propia ejecución de la cubierta actual, de poca inercia, su difícil acceso, y la ausencia de ventilación, ha dado como consecuencia la corrosión y disolución de los materiales"

En el caso de la iglesia de San Pedro en Serrada el reemplazo de estructura se justifica desde el punto de vista del coste: "El análisis económico de la posible reparación de las cerchas de la nave principal ha dado pie a plantear su sustitución por otras nuevas, realizadas a partir de escuadrías de tablón" (Areizaga y Corral 1992).

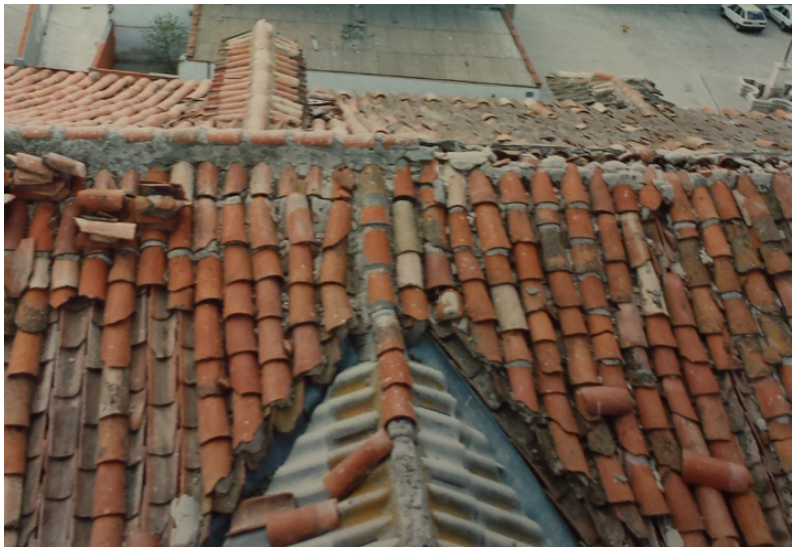

Fig.IV.3. Dossier 1992 Areizaga JCyL

El deterioro de dicha cubierta debía ser considerable ya que en las fotografías del dossier del proyecto se aprecia la falta de tejas en muchos puntos. En una Ficha de Diagnóstico, previa a la redacción del proyecto, Areizaga describe el desplazamiento horizontal de los muros de carga y cerramiento en su tercio superior, debido a la existencia de jabalcones en la cercha de madera de la cubierta que, modificando 
la reacción vertical de la carga de la misma y tras la pudrición de las cabezas de apoyo, producen la patología más generalizada y llamativa, grietas en arcos y bóvedas, etc.

Aunque el zuncho en la iglesia de Santa María de Arbás en Mayorga de Campos lo incorpora Espinosa en 1998, en dos intervenciones anteriores se describe el estado ruinoso del edificio y el colapso del ábside:

"Los artesonados de las capillas están en parte hundidos y en parte desprendidos, teniendo rotos los tejados de ellos y los de parte de la nave mayor y de la lateral. En el presbiterio también falta la teja y penetra el agua sobre el retablo. La sensación es de pleno desamparo y ruina... obras de urgente ejecución, precisas para salvar los restos de los artesonados y el retablo" (Arenillas 1965).

"Dado el estado de ruina del ábside que corona la Capilla Mayor los trabajos se iniciaron con su reconstrucción" (Rodrigo y Roldán 1974).

Sobre la nave lateral de Mayorga el citado arquitecto indica que "se prevé la demolición de la cubierta de rollizos existente y del muro arruinado". Todas las cubiertas "eran reparaciones de ínfima calidad, relativamente recientes, en estado de ruina o ya colapsadas, y apoyando directamente sobre los artesonados" (Espinosa 1998).

En la iglesia de El Salvador en Valladolid se desmonta íntegramente la cubierta y se coloca una estructura nueva de madera con secciones de mayor escuadría que las pre-existentes, reutilizando algunas piezas que se conservaban en mejor estado o restituyendo partes desaparecidas con prótesis. En la memoria del proyecto se afirma: "Al comenzar la ejecución de las estructuras de madera en cubierta se comprobó el pésimo estado de conservación de la madera, afectada por la acción de diversos insectos y hongos con el consiguiente peligro para la estabilidad de las estructuras. Esto provocó la reordenación de durmientes, cuchillos y correas de madera, colocándose un menor número de cuchillos pero con mayores escuadrías" (Abad 1997).

Los arquitectos autores de la última intervención llevada a cabo en la iglesia de Santa María en Iscar describen el mal estado de las cubiertas, con secciones desaparecidas a causa de la pudrición, sin el habitual alarmismo, aunque en el dossier fotográfico que acompaña al proyecto se aprecian daños de cierta envergadura: "Un punto particularmente dañado son los encuentros de los muros con la estructura, donde los durmientes, por las humedades, por carcomas, por el empuje de la 
estructura, por el mal apoyo de los muros, escasa sección, etc. presentan un grave deterioro, existiendo zonas en que se encuentran totalmente desplazados y girados sin apoyo en el muro, podridos, e incluso en alguna zona el deterioro es tal que han desaparecido" (Cembrero y Morante 2000).

La iglesia del Monasterio de Santa María de Palazuelos en Corcos del Valle se encontraba sin uso cuando se hundió parte de sus cubiertas. En el proyecto se describe una "intervención de emergencia en la cubierta de la iglesia ... la bóveda que cerraba en altura el crucero ha desaparecido al precipitarse la cubierta, arruinando pilares, muros, bóvedas del interior, y arrastrando capiteles... La iglesia está sin uso y cerrada. Su situación es preocupante" (Ana Montoya y José Manuel Horno 2000).

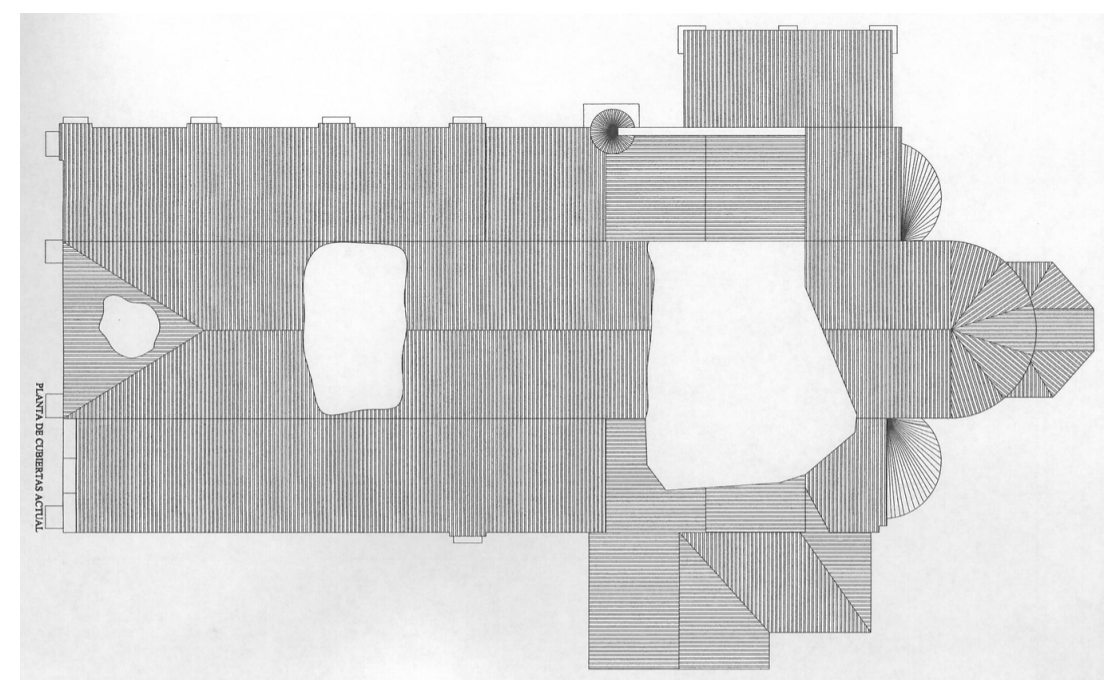

Fig.IV.4 Estado de las cubiertas 1999 Montoya y Horno JCyL

Encontramos también mencionados estos factores en otras iglesias que no se incluyen en la Tabla resumen final por carecer de datos precisos sobre la incorporación o no de zunchos. Por ejemplo la iglesia de San Cebrián en San Cebrián de Mazote en los 70 se repara tras indicar que: "La cubierta la que necesita más urgentemente una reparación, sobre todo en la parte correspondiente al supuesto coro, que se encuentra en estado de ruina por hundimiento de varios de los pares de madera, sin que hasta la fecha, afortunadamente hayan sufrido las bóvedas" (Manuel Cuadrado 1973).

Y en Olmedo "la iglesia de San Juan se encuentra en la actualidad en absoluto estado de ruina, conservando algunos elementos arquitectónicos de gran valor artístico, que de no ser trasladado a un lugar mejor acondicionado se destruirán como el resto de la iglesia" (Arenillas 1967). 
Las iglesias del convento de San Pablo en Peñafiel FZ-33 y San Benito el real en Valladolid conservan una estructura tradicional, completamente resuelta en madera, sobre la nave central, a pesar de las múltiples vicisitudes sufridas por ambos edificios durante siglos, que incluyeron recrecidos, cambios de uso, saqueo durante la Guerra de Independencia o Desamortización, pero en sus proyectos de restauración no se ha localizado los términos citados.

En varios casos se produjeron hundimientos y ruina que determinaron desde la reconstrucción del templo, como en San Agustín y Santa Cruz, hasta su demolición, en el caso de la iglesia de San Lorenzo, desaparecida en 1967. Cuando Linazasoro y Mata (1987) colocan la estructura de cubierta moderna que forma una gran bóveda y tejado a dos aguas sobre el cuerpo de la iglesia de Santa Cruz en Medina de Rioseco, se había derrumbado la cubierta, se encontraba en ruinas gran parte de los muros y la fachada a los pies había sido desmontada y reconstruida piedra a piedra años antes.

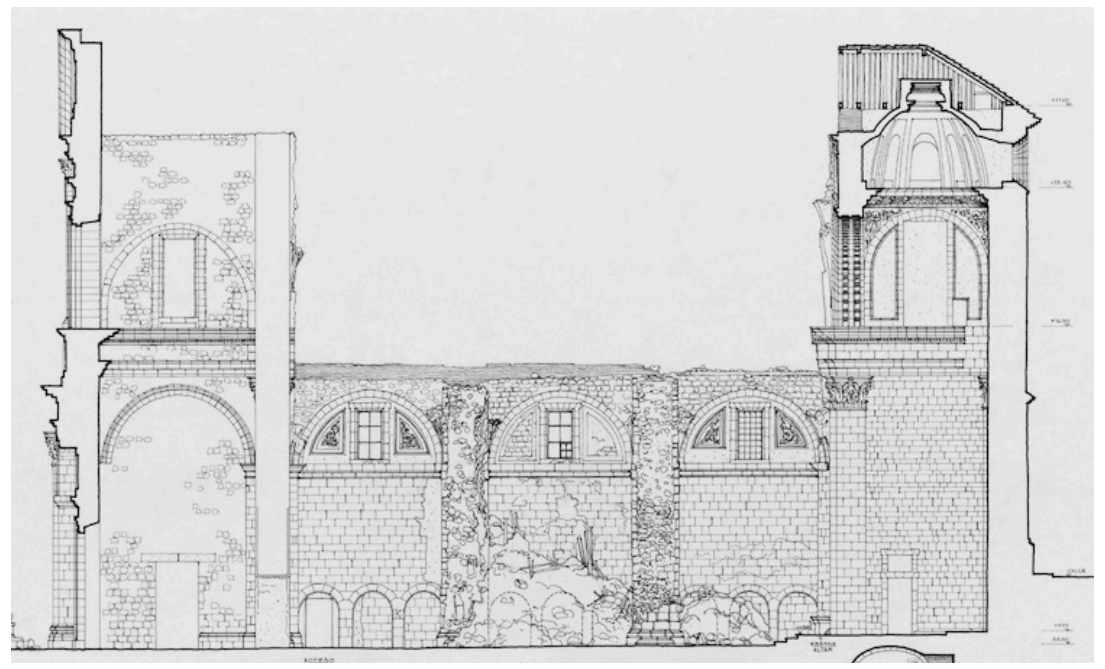

Fig.IV.5. Sección longitudinal 1979 Iglesias IPCE

La iglesia del Convento de San Agustín en Valladolid se encontraba en ruinas, y cerrada al culto desde 1835, cuando es reconstruida por Gallegos y González como archivo municipal en 1999.

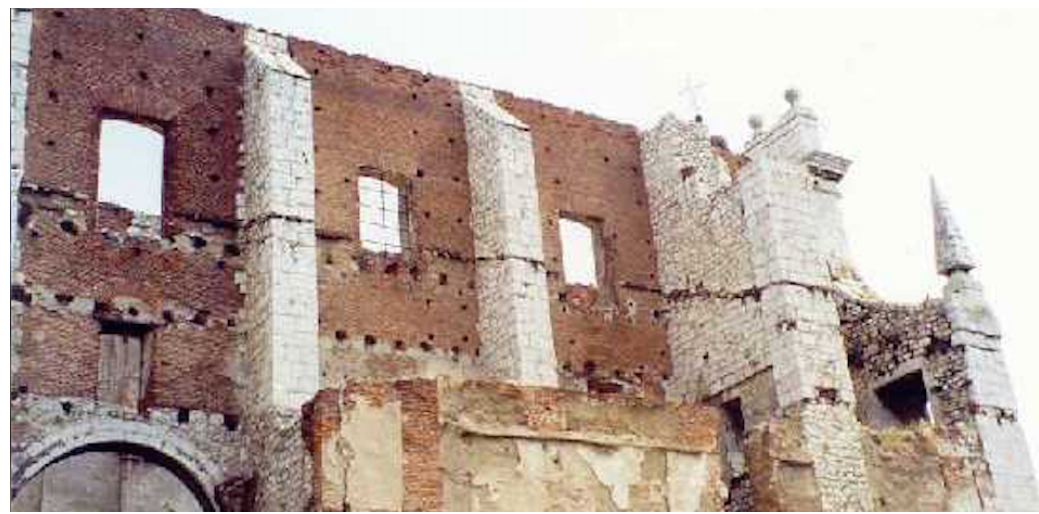

Fig.IV.6. Ruinas lateral sur San Agustín web AMVA 
Tabla 1: Justificación de la necesidad de intervenir

\begin{tabular}{|c|c|c|c|c|c|c|c|c|c|}
\hline \multicolumn{4}{|c|}{ JUSTIFICACIÓN DE LA NECESIDAD DE INTERVENIR } & \multirow[b]{2}{*}{$\begin{array}{l}\frac{\pi}{0} \\
\frac{\pi}{\pi} \\
\frac{\pi}{0} \\
\frac{8}{\pi}\end{array}$} & \multirow[b]{2}{*}{ 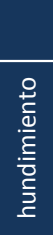 } & \multirow[b]{2}{*}{ 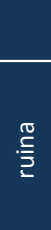 } & \multirow[b]{2}{*}{$\begin{array}{l}\frac{\pi}{U} \\
\frac{C}{0} \\
00 \\
\frac{0}{J}\end{array}$} & \multirow[b]{2}{*}{$\frac{\text { 음 }}{\frac{\text { don }}{\bar{d}}}$} & \multirow[b]{2}{*}{ 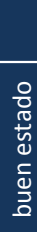 } \\
\hline FICHA & IGLESIA & FECHA & ARQUITECTO & & & & & & \\
\hline FZ-10 & San Pablo (Valladolid) & 1964 & Arenillas & $\mathrm{X}$ & & & $\mathrm{X}$ & $\mathrm{X}$ & \\
\hline FZ-39 & Santa María (Wamba) & 1964 & Arenillas & & $\mathrm{X}$ & $\mathrm{X}$ & $\mathrm{X}$ & & \\
\hline FZ-04 & La Pasion (Valladolid) & 1965 & Arenillas & & & $\mathrm{X}$ & & & \\
\hline FZ-21 & Santos Justo y Pastor (Cuenca de Campos) & 1967 & Arenillas & & & $\mathrm{X}$ & & $x$ & \\
\hline FZ-29 & San Martín (Medina del Campo) & 1968 & Arenillas & & & $\mathrm{X}$ & & $\mathrm{X}$ & \\
\hline $\mathrm{FZ}-15$ & San Joaquin y Santa Ana (Valladolid) & 1969 & García Gil & & $\mathrm{X}$ & & $\mathrm{X}$ & & \\
\hline FZ-01 & Catedral (Valladolid) & 1974 & Cervera & & 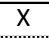 & & & 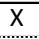 & \\
\hline FZ-03 & Capilla de San Gregorio (Valladolid) & 1974 & Cervera & & & & & $x$ & \\
\hline FZ-20 & Santa Maríadel Castillo (Castronuño) & 1974 & Iglesias & & & & & & \\
\hline $\mathrm{FZ}-22$ & San Juan (Fresno el Viejo) & 1974 & Rodrigo & & & & & $\mathrm{X}$ & \\
\hline FZ-16 & Las Huelgas Reales (Valladolid) & 1976 & Iglesias & $\mathrm{X}$ & $\mathrm{X}$ & & & & $\mathrm{x}$ \\
\hline$F Z-17$ & Santa María (Alaejos) & 1978 & Iglesias & $\mathrm{X}$ & & & & & \\
\hline $\mathrm{FZ}-27$ & Santiago (Medina de Rioseco) & 1978 & Iglesias & & $\mathrm{x}$ & & & & \\
\hline$F Z-36$ & La Anunciada (Urueña) & 1978 & Iglesias & & & & & & \\
\hline FZ-14 & Las Descalzas Reales (Valladolid) & 1979 & Iglesias & & & & & & $\mathrm{x}$ \\
\hline $\mathrm{FZ}-30$ & Los Santos Juanes (Nava del Rey) & 1979 & Iglesias & & & & & & $\mathrm{x}$ \\
\hline FZ-12 & El Rosarillo (Valladolid) & 1980 & Iñiguez & $\bar{X}$ & $\mathrm{X}$ & $\mathrm{X}$ & $\bar{X}$ & & \\
\hline FZ-35 & Santa María (Tordesillas) & 1980 & Luis Mingo & & & & & & \\
\hline$F Z-05$ & Convento de Portaceli (Valladolid) & 1982 & Roldán & & $\mathrm{X}$ & $\mathrm{X}$ & $\mathrm{X}$ & & \\
\hline $\mathrm{FZ}-06$ & Las Angustias (Valladolid) & 1982 & Pérez Medina & & & & & & $\mathrm{X}$ \\
\hline$F Z-28$ & San Antolín (Medina del Campo) & 1982 & Gómez Santander & & $\mathrm{X}$ & $\mathrm{X}$ & & & \\
\hline$F Z-26$ & Santa Cruz (Medina de Rioseco) & 1987 & Linazasoro & & & & & & \\
\hline $\mathrm{FZ}-25$ & San Francisco (Medina de Rioseco) & 1988 & Gárate & & & & $\mathrm{X}$ & & \\
\hline $\mathrm{FZ}-05$ & Convento de Portaceli (Valladolid) & 1989 & Roldán & & $\mathrm{X}$ & $\mathrm{X}$ & $\mathrm{x}$ & & \\
\hline $\mathrm{FZ}-38$ & Santa María del Castillo (Villaverde de Medina) & 1989 & Tovar & & & $\mathrm{X}$ & $\mathrm{X}$ & & \\
\hline FZ-37 & Santa María de Valbuena (Valbuena) & 1991 & Puente & & & & $\bar{x}$ & & \\
\hline$F Z-40$ & San Pedro (Serrada) & 1992 & Areizaga y Corral & $\mathrm{X}$ & & & & & \\
\hline $\mathrm{FZ}-08$ & San Benito el Real (Valladolid) & 1997 & Morán & & & & & & \\
\hline $\mathrm{FZ}-24$ & Santa María de Arbás (Mayorga) & 1998 & Espinosa & & $\mathrm{X}$ & $\mathrm{X}$ & $\mathrm{X}$ & & \\
\hline$F Z-07$ & San Agustín (Valladolid) & 1999 & Gallegos y González & & & & & & \\
\hline$F Z-13$ & El Salvador (Valladolid) & 1999 & Abad & & & & & $x$ & \\
\hline $\mathrm{FZ}-28$ & San Antolín (Medina del Campo) & 1999 & Paniagua & & $\mathrm{X}$ & & & & \\
\hline FZ-23 & Santa María (Iscar) & 2000 & Cembrero & & & $\bar{x}$ & & & \\
\hline$F Z-32$ & Santa María de Palazuelos (Corcos del Valle) & 2000 & Montoya & & & $\mathrm{x}$ & $\mathrm{X}$ & & \\
\hline $\mathrm{FZ}-02$ & Convento de la Concepcion (Valladolid) & & & & & & & & \\
\hline FZ-09 & San Lorenzo (Valladolid) & & & & & & & & \\
\hline FZ-11 & La Antigua (Valladolid) & & & & & & & & \\
\hline $\mathrm{FZ}-18$ & San Juan Evangelista (Arroyo de la Encomienda) & & & & & & $\mathrm{X}$ & & \\
\hline FZ-19 & La Santa Espina (Castromonte) & & & & & & & & \\
\hline $\mathrm{FZ}-31$ & San Juan (Olmedo) & & & & & $\mathrm{X}$ & & & \\
\hline $\mathrm{FZ}-33$ & San Pablo (Peñafiel) & & & $\mathrm{x}$ & & & & & \\
\hline $\mathrm{FZ}-34$ & San Cebrián (San Cebrián de Mazote) & & & & $\mathrm{x}$ & $\mathrm{x}$ & $\mathrm{x}$ & & \\
\hline
\end{tabular}

Una vez organizados los datos anteriores cronológicamente se observa que en las memorias de los proyectos de restauración de los años 70 no se cita la urgencia y ruina de los edificios para justificar la necesidad de intervenir sobre ellos, expresiones que se retoman en las décadas siguientes. 
Ana Iglesias menciona en varios casos el buen estado de las cubiertas y entre ellos se encuentra la iglesia de Nava del Rey donde precisamente acaba sustituyendo las armaduras por una estructura metálica con tablero de hormigón sobre nervometal, según se describe en la Ficha y el capítulo de Análisis de los aspectos estructurales.

Hacia 1975 dejamos de encontrar mencionado el peligro, que aparece sólo en el proyecto de Abad de 1999 para restaurar la iglesia de El Salvador, en la que no incorpora el clásico zuncho.

En San Pablo debe colocarse una estructura nueva en la parte de la cubierta, hacia la cabecera, que desaparece en el incendio de 1968.

En Valbuena se considera oportuno demoler las cubiertas existentes por estar resueltas con tabiquillos palomeros sobre las bóvedas cuyo estado es imposible de verificar por la inexistencia de acceso al bajo cubierta.

En Serrada se aducen razones de índole económica para sustituir la estructura de cubierta completa por una nueva.

En la mayor parte de los casos, sin embargo, se justifica la necesidad de intervenir en el templo tras producirse caída de cerchas o derrumbes parciales. Las obras se realizan porque las estructuras de cubierta de los edificios se encuentran en mal estado. 


\section{IV.1.1.2. Justificación del zuncho en las memorias y presupuestos de los proyectos}

Para llevar a cabo el análisis del empleo de zunchos en las obras de restauración de cubiertas de los monumentos seleccionados se recogen a continuación las expresiones con las que se justifican las características de los mismos y el objetivo con el que se incorporan. Se analiza qué términos se emplean exactamente para nombrar estos elementos, diferenciando además los casos en que un zuncho se describe en el texto de la memoria de aquellos en los que únicamente aparece reflejado en la definición de una partida del presupuesto. Se indica a pie de página el nombre con el que se titula cada proyecto, su autor y fecha con la referencia actual en el archivo que lo custodia. En las fichas al final del documento se aporta documentación más extensa de cada uno de los proyectos estudiados.

En primer lugar aparecen las intervenciones del arquitecto Anselmo Arenillas en los 60, que se refiere habitualmente al zuncho sin emplear el término, que describe como solera o solerón, excepto en la iglesia de la Pasión, donde lo denomina cadena:

En los proyectos de restauración de la iglesia del Convento de San Pablo en Valladolid describe: "Las formas de la cubierta se colocarán sobre una solera de hormigón armado que regularice la coronación de los muros, trasdose y consolide las cornisas y facilite con el atirantado de los cuchillos la contención del pequeño desplome de las fábricas de sillería" 5 .

"Como complemento se repararán las cabezas de los muros poniendo sobre ellos un solerón de hormigón armado de $40 \times 30 \mathrm{~cm}$, reparando los aleros y cornisas de ladrillo existentes" 6 .

En los proyectos de Arenillas de 1964 y Quintana y Boned de 1990 para la iglesia de Santa María de Wamba no se mencionan zunchos, aunque se reemplazan las cubiertas de naves bajas y cabecera. En una intervención de estos últimos sobre un edificio contiguo al templo llamado ala poniente sin embargo, sí se describe una partida con $88 \mathrm{ml}$ (metros lineales) de "saneado de coronación muro desmontando la

\footnotetext{
51964 - Sustitución de las cubiertas de San Pablo de Valladolid - Anselmo Arenillas - AGA 26/00370

${ }^{6} 1968$ - Proyecto de terminación de la restauración de las cubiertas - Anselmo Arenillas - AGA 26/00146
} 
mampostería suelta y el relleno cajeándolo para la realización de un zuncho perimetral".

En el proyecto de Arenillas para la iglesia de la Pasión en Valladolid explica como "los muros a conservar se les sanea con ladrillo y cadenas de hormigón armado en sus coronaciones"'?

Y en la iglesia de los Santos Justo y Pastor en Cuenca de Campos el citado arquitecto pretende "recrecer los muros de contorno para recibir la nueva cubierta, que como la anteriormente hecha sobre el cuerpo de la iglesia, quedará separada del artesonado permitiendo su aireación y visita... estas cubiertas se formarán con elementos prefabricados de hormigón y hierro en los pares y limas, con un solerón de hormigón armado con estribo, con sus tirantes de hierro que pasarán sobre los $\operatorname{artesonados"}^{8}$.

Arenillas plantea en la memoria del proyecto para la iglesia de San Martín en Medina del Campo que "las nuevas cubiertas se forjarán con tableros de hormigón aligerado "Ceramex" que apoyarán en un solerón de hormigón armado de 30x30cm y se atirantarán con redondos de acero de $20 \mathrm{~mm} \mathrm{D}$ colocados sobre los tirantes de madera" 9 . En el presupuesto figura una unidad de "regularización de coronación de muros con solerón de hormigón armado".

En 1969 el arquitecto Alberto García Gil coloca un zuncho en el Monasterio de San Joaquín y Santa Ana en Valladolid tras agrietarse la esquina: "La disposición de los forjados hace que la fachada lateral, falta de atado, se haya desplazado, empujada por la cubierta, produciendo grieta en la fachada principal. Zunchado de la esquina del edificio... en arriostramiento de muros de ángulo" ${ }^{10}$.

El arquitecto que interviene en la iglesia del Monasterio de las Huelgas Reales en Valladolid no justifica en la memoria la incorporación del zuncho perimetral de 30x40 que sí define en mediciones y planos, y lo denomina durmiente. Monta una nueva cubierta en la zona que cubre el coro a los pies. Incorpora dicho elemento: "a fin de conseguir un adecuado asiento de las nuevas armaduras de cubierta se

\footnotetext{
${ }^{7} 1965$ - Adaptación a museo local - Anselmo Arenillas - AGA 26/00206

${ }^{8} 1967$ - Reparación de la cubierta de la cabecera - Anselmo Arenillas - AGA 26/00120

91968 - Cubiertas - Anselmo Arenillas - AGA 26/00131

${ }^{10} 1969$ - Obras de restauración junto al coro alto - Alberto García Gil - AGA 26/00146
} 
proyecta un durmiente de hormigón armado que reparta sobre el muro continuo de tapial los esfuerzos y cargas de la cubierta"11.

En el plano 7 del proyecto de la iglesia de Santa María del Castillo en Villaverde de Medina se representa con una trama el área de ábside, sacristía y torre "a restaurar con perfiles metálicos, forjado, entablado de madera y cubierta con teja árabe" y con otra la zona "de consolidación en coronación de muros con zunchos de hormigón armado" $^{12}$.

Luis Cervera hace especial hincapié en las dos obras siguientes en el objeto de servir de apoyo para asentar la estructura de cubierta, mencionado también según hemos visto por Julio González en el coro de las Huelgas. El reparto de cargas no volverá a aparecer hasta el proyecto de Serrada de 1992.

En el proyecto para la Catedral de Valladolid afirma: "Las mencionadas cerchas se apoyarán en todos sus apoyos sobre un zuncho de hormigón armado, con objeto de repartir las cargas" ${ }^{13}$.

El proyecto de restauración de cubierta de la Catedral original del mismo año para el que se concedió licencia y en el que se basa probablemente el de Luis Cervera es del arquitecto vallisoletano Ángel Ríos Gómez, que en su memoria indica como "perimetralmente, por toda la coronación de los muros, correrá un zuncho de hormigón armado, sobre el que apoyarán las cerchas metálicas."

Y en la memoria de la intervención en la Capilla de San Gregorio en Valladolid: "Zuncho de hormigón armado en coronación de muros para asiento, previa demolición y enrasado" 14 .

En el proyecto de la iglesia de Santa María del Castillo en Castronuño se describe la incorporación de zuncho junto a otra serie de actuaciones que no llegaron a realizarse, como la demolición de coro y espadaña que aún hoy se mantienen en pie.

\footnotetext{
${ }^{11}$ Reforma coro - Julio González - 1972 - AGA 26/01573

121972 - Cubierta, fachada y vidrieras - José Ángel Rodrigo García y Joaquín Roldán Pascual - IPCE Carpeta $657-7$

13 1974-Proyecto de restauración de Cubierta. Catedral de Valladolid - Luis Cervera Vera - AGA 26/00088

${ }^{14} 1974$ - Restauración de cubiertas - Luis Cervera Vera - AGA 26/00065
} 
En este caso se le asignaba incluso la función de corregir el desplome superior de los muros: "Presenta el templo un desplome superior en sus paramentos, que tendrá que ser corregido con un zuncho de hormigón armado que ate perimetralmente todo el edificio, para lo cual habrá que desmontar esta parte de la cubierta de piedra y abrir una caja donde se sitúe dicho zuncho."15

También en los 70, los arquitectos Rodrigo y Roldán se refieren a una viga de atado que realiza la tarea de zunchar en la iglesia de Fresno. La obra de 1974 se lleva a cabo sobre una nave lateral: "La nueva cubierta se construyó en hormigón armado como elemento más eficaz ante posibles incendios y se zunchó con una viga de atado de este material" ${ }^{16}$. El resto de cubiertas sufre una restauración integral dirigida por Pedro Carreño en 2000 pero no se ha encontrado en la documentación revisada datos que hagan suponer la incorporación de más zunchos en este edificio:

En los 70 el grueso de las intervenciones corresponde principalmente a Ana Iglesias, que suele denominarlo zuncho de atado perimetral. En dos casos hace referencia también a su función de apoyo de una nueva estructura metálica. Según el proyecto de las Huelgas Reales, "se realiza la cubierta previo desmontado de la todavía de madera existente, sobre estructura metálica compuesta por cerchas y correas según figura en los planos adjuntos, sobre la que se crea la correspondiente capa de compresión formada sobre el nervometal que le sirve de soporte. Finalmente se coloca la teja pudiendo ser utilizada tan solo un $20 \%$ de la existente". En el presupuesto se define Hormigón de $350 \mathrm{kgs}$ de cemento, garbancillo y arena de rio, armado con $80 \mathrm{~kg}$ de hierro redondo en formación de zunchos de atado perimetral de muros, incluso el encofrado preciso $11,22^{17}$

En el presupuesto ${ }^{18}$ de la iglesia de Santa María en Alaejos se describe Hormigón de $350 \mathrm{~kg}$ de cemento, garbancillo y arena de río, armado con $80 \mathrm{~kg}$ de hierro al $\mathrm{m}^{3}$ incluso el encofrado preciso en formación de zuncho de atado perimetral de muros $17,34 \mathrm{~m}^{3}$.

\footnotetext{
${ }^{15} 1974$ - Proyecto de Restauración de cubierta y fachada Iglesia de Sta $M^{\text {a }}$ del Castillo - Ana Iglesias IPCE Carpeta 636-2

${ }^{16} 1974$ - Restauración de la cubierta - José A. Rodrigo y Joaquín Roldán - IPCE Carpeta 636-3

${ }^{17} 1976$ - Obras de restauración Iglesia de las Huelgas Reales -Ana Iglesias - AGA 26/01573

${ }^{18}$ 1974/78 - Restauración en la iglesia de Santa María de Alaejos - Ana Iglesias - IPCE Carpeta 6361; AGA 26/01573
} 
El proyecto de restauración de la iglesia de Santiago en Medina de Rioseco describe como "se creará un zuncho perimetral de atado en la coronación de los muros que servirá de apoyo de la estructura que será formada con cerchas metálicas"19. $^{19}$.

Para la iglesia de los Santos Juanes en Nava del Rey explica que "se procederá al levantamiento de las primitivas formas de madera y demolición de las fábricas que albergan los durmientes para proceder así a la formación del necesario zuncho de atado de hormigón armado, que a su vez sirva de apoyo y anclaje a la nueva estructura, esta se formará con perfiles metálicos y sobre las formas principales de ella se soldaran las correas sobre las que ira el nervometal que soportara la capa de compresión" $^{20}$. En la última carpeta hay una copia con la misma fecha 1979 en la tapa, idéntico dossier de fotos y sección transversal, pero en ésta se incluye una descripción de la obra diferente: "restauración de la parte de la cubierta que figura en los planos como en la fase anterior, levantar las primitivas formas de madera, demolición de fábricas que albergan los durmientes para necesario zuncho de atado de hormigón armado" ${ }^{21}$.

A partir de los 80 los proyectos son realizados por arquitectos distintos, lo que amplía el abanico de soluciones constructivas. Además del clásico zuncho de hormigón armado de sección rectangular encontramos en la coronación de los muros desde perfiles de acero laminado hasta dados de apoyo y zunchos-cornisa de hormigón armado. En la iglesia del Rosarillo en Valladolid se plantea: "Constituida por cerchas metálicas de perfiles normales laminados apoyadas en un zuncho perimetral de perfil Grey HEB 140 anclado al muro... regulación de paramentos con mortero de cemento para posterior asiento de viga GREY de zuncho perimetral" $^{22}$.

El arquitecto Luis Mingo sólo describe en el proyecto para la iglesia de Santa María en Tordesillas la "apertura de cajas para alojamiento de zunchos de atado con hormigón" ${ }^{23}$. Al reparar la sacristía Luis de la Riva define "en la coronación del

\footnotetext{
${ }^{19} 1978$ - Obras de restauración - Ana Iglesias - IPCE Carpeta 639-2

${ }^{20} 1979$ - Obras de restauración en la iglesia de los Santos Juanes - Ana Iglesias - AGA 26/01721 (1)

${ }^{21}$ IPCE Carpeta 642-6

${ }^{22} 1980$ - Restauración - Iñiguez de Onzoño - AGA 26/1574

${ }^{23} 1980$ - Obras de restauración en la iglesia de Santa María de Tordesillas - Luis Alberto Mingo IPCE Carpeta 643-7
} 
muro y, al objeto de atar todo su perímetro, se proyecta colocar un zuncho corrido de hormigón H-175 armado. Las armaduras se anclarán en los muros de la iglesia de tal forma y manera que permita una unión rígida... se proyecta un entramado de madera compuesto por cerchas sobre durmientes de madera ancladas éstas al zuncho de hormigón",24.

En el catálogo de monumentos de la provincia Mario Pírez describe en 1991 el edificio tordesillano con su "cubierta restaurada recientemente las tejas son de tipo árabe apoyadas sobre un tablero de nervo-metal, sustentado a su vez por unos perfiles IPE-140 dispuestos cada 1,20 y cuatro tirantes para todo el edificio, redondo del 20. Todo ello descansa sobre una viga de hormigón de coronación del muro. La cubierta de las naves laterales y sacristía son de madera"

Roldán no incorpora zunchos propiamente dichos en la iglesia de la Asunción en el Convento de PortaCoeli en Valladolid, sino unos "dados de hormigón para asiento de cercha" ${ }^{25}$.

En la cubierta del edificio del Cabildo de la Cofradía de las Angustias en Valladolid, se ejecutó en 1984 un zuncho-cornisa de hormigón armado que fue demolido en la intervención de 1992. En el proyecto se explicaba cómo se reemplazaba cornisa y alero de piezas de madera por una viga única de "hormigón armado imitando piedra caliza, que sirve para zunchar las cabezas de los pilares $\mathbf{y}$ apoyar las vigas de planta $2^{\text {a }}$ restauradas con el sistema Beta"26

En 1982 Gómez Santander sustituyó las cubiertas de nave central y laterales de la Colegiata de San Antolín en Medina del Campo, incorporando una nueva estructura de madera con tablero aglomerado y teja sobre un zuncho de atado de hormigón armado que será retirado por Paniagua en una intervención posterior. "Restaurar parte de las cubiertas, desmontando la zona a reparar en su totalidad, construyendo zunchos de hormigón en los apoyos, volviendo a montar la estructura... Consolidación mediante zunchos de hormigón del hastial trasero de la cubierta en la nave principal" ${ }^{27}$.

\footnotetext{
${ }^{24} 1989$ - Restauración de la sacristía - Luis de la Riva de la Peña - VA-64 Carpeta 5249

${ }^{25} 1989$ - Memoria de obras ejecutadas - F.P. Roldán - AGA 26/01815

${ }^{26} 1982$ - Obras generales - Diego Pérez Medina, Agustín Bustamante y Teresa Pérez - JCYL Carpeta 5202; AGA 26/00965; Archivo del Cabildo

${ }^{27} 1982$ - Restauración parcial - Gómez Santander - AGA 26/01512
} 
En los proyectos de Ana Iglesias en 1979 y Espejel en 1982 para reconstruir la iglesia de Santa Cruz en Medina de Rioseco, no ejecutados, sí se describían zunchos de hormigón armado, tanto en memoria como en planos de alzados y plantas. El autor final de su reconstrucción, Linazasoro, no representa zunchos sino vigas de hormigón armado de compleja geometría a dos niveles sobre las que apoya la nueva estructura de cubierta, moderna, de madera laminada: "La estructura del arco arranca de nervios de hormigón armado con la forma de la madera a modo de grandes salmeres, que más tarde se forrarán igualmente de madera" ${ }^{28}$.

Ignacio Gárate justifica el zunchado de la iglesia de San Francisco en Medina de Rioseco mediante la siguiente reflexión: "Otro tanto puede decirse en lo que se refiere al estado de la cornisa que adolece de una morfología constructiva común. Aquí la solución adoptada que la dota de continuidad es la construcción del ya clásico zuncho de apoyo perimetral que viene a sustituir parcialmente el trabajo de los antiguos durmientes" ${ }^{29}$. En el presupuesto describe la restauración de 40ml de cornisa de ladrillo aplantillado en coronación muros del Presbiterio; restauración de $65 \mathrm{ml}$ alero de ladrillo aplantillado en coronación de muros de nave central, con aportación de las piezas que sean precisas, de similares características y formas a las existentes. Incluso preparación de esta fábrica para ser trasdosada al zuncho perimetral, realizando mechinales y cajeados.

Por último, en la década de los 90, encontramos mencionadas todas las opciones anteriores, incluso arriostramiento y saneo de coronación de muros o reparto de cargas, que no se mencionaba desde los primeros 70 .

Tras el desmontaje de la cubierta de la iglesia de Santa María del Castillo en Villaverde de Medina, se ejecuta $21 \mathrm{~m}^{3}$ de zuncho de hormigón en coronación de muros "para su saneamiento" y 5 ménsulas también de hormigón. "Se contempla una nueva disposición de zunchos de atado que varían en cuanto a sección y colocación, y que es una consecuencia de observar in situ la obra que se está ejecutando. Se han previsto unos zunchos adicionales colocados en la coronación de los muros de fachada para unir de forma continua los zunchos transversales sobre los que se apoyan las vigas de madera. A la vez estos últimos han

\footnotetext{
${ }^{28} 1987$ - Restauración - José Ignacio Linazasoro y Salvador Mata - JCyL VA-019

${ }^{29} 1988$ - Proyecto de restauración - Ignacio Gárate Roja y Manuel Manzano-Monis - JCyL VA-062
} 
aumentado de sección ya que aunque esto supone un mayor volumen de hormigón, el acabado y ejecución de un solo zuncho en lugar de los dos previstos inicialmente, ofrece una mayor facilidad de ejecución así como un mejor acabado y remate" ${ }^{30}$.

Capilla Mayor y Sacristía de la Colegiata de San Antolín en Medina del Campo, se cubren con estructura de madera maciza sobre zunchos de atado, así como la capilla de las Angustias y Cuarto de Canónigos con madera laminada ${ }^{31}$.

Y en el proyecto de Pablo Puente para "revitalizar" el Monasterio de Santa María en Valbuena de Duero se describe cómo "se ejecutarán armaduras de madera de pino, apoyadas en zuncho perimetral... Ejecución de $76 \mathrm{ml}$ de zuncho de hormigón armado para atirantados y atados de fábricas de todo tipo. Previa labor de su cajeado cuidadoso en fábricas pétreas o de cualquier tipo" ${ }^{32}$.

Areizaga y Corral demuelen en 1992 los muros del crucero para disminuir la carga sobre los arcos torales de la iglesia de San Pedro en Serrada: "Aprovechando los desmantelamientos descritos a la altura de los arcos torales, se ejecutó un zuncho de atado en hormigón armado que rigidizará la traba de los muros, distribuirá más uniformemente la carga e impedirá el agravamiento de las grietas existentes en las claves de dichos arcos... De la misma manera se procedió a la demolición de las fábricas existentes a la altura de las cornisas, con el fin de proceder a la ejecución de un zuncho perimetral de hormigón armado que, mediante la armadura superior, consolide además las cornisas. Dicho zuncho perimetral tiene dos funciones fundamentales: redistribuir uniformemente las cargas que le trasladará la estructura y actuar como elemento de sobrecarga vertical que aplome los muros de cerramiento y corrija el desplazamiento horizontal al que han sido sometidos hasta el momento" ${ }^{33}$.

Al levantarse un muro nuevo en la iglesia de Santa María de Arbás en Mayorga de Campos, se plantea el zuncho como pieza de atado entre las hojas del mismo: "Se levantará un nuevo muro de cerramiento sobre los restos del anterior, con un asta de ladrillo por cada cara, para revocar posteriormente, y se rematará con un zuncho de

\footnotetext{
${ }^{30}$ Modificado de 1991. 1989 - Restauración de la Iglesia parroquial - Jesús Tovar Casales - VA-87 Carpeta 5273

311991 - Plan Director - Antonio García Paniagua - JCYL Carpeta 6297

321991 - Proyecto de revitalización - Pablo Puente Aparicio - Edades del Hombre (copia en JCyL)

331992 - Restauración de la iglesia de San Pedro en Serrada - Armando Areizaga Esteban y Juan Corral Fernández - VA-131 Carpeta 5324
} 


\section{hormigón para el atado de las hojas de ladrillo y el apoyo de la nueva cubierta...} Limpieza y consolidación de coronaciones de muros, con sustitución de canes y alero del muro sur y ejecución de zuncho corrido de hormigón en el muro norte... Zuncho de coronación en hormigón, para apoyo de la cubierta" ${ }^{34}$.

En la Memoria de la reconstrucción de la iglesia del convento de San Agustín en Valladolid no se menciona el zuncho que aparece definido en planos y presupuesto. Los autores del proyecto consideran que las vigas de cubierta de acero laminado peraltadas acodalan la coronación de los cerramientos: "la estructura de cubierta se realizará mediante vigas metálicas que servirán así mismo como elementos de arriostramiento de los esbeltos muros de las fábricas de la iglesia" ${ }^{35}$. En el presupuesto se define Zuncho en muro coronación. Hormigón armado HM-25 $\mathrm{N} / \mathrm{mm} 2$., Tmáx $20 \mathrm{~mm}$., consistencia plástica, elaborado en central, en zuncho de atado coronación de muro $\mathrm{i} / \mathrm{p}$.p. de armadura $(55 \mathrm{~kg} / \mathrm{m} 3$.), saneado de la coronación, cajeado fábricas de sillar, encofrado y desencofrado de madera, vertido con pluma-grúa, vibrado y colocado

En una Memoria final fechada en enero de 2001 tras el reemplazo total de la cubierta de la Colegiata de San Antolín en Medina del Campo, que modifica incluso altura de remate y pendientes, Paniagua describe el "reperfilado de las fábricas interiores entre naves con desmontaje de pilastras de ladrillo, ejecución de zuncho corrido para arriostramiento con cosido de fábricas verticales" ${ }^{36}$

Aunque no dispone zunchos, Abad demuele en 1999 la parte superior de los muros de la iglesia de El Salvador en Valladolid, ya recrecida con fábrica de ladrillo sobre la piedra, para reconstruirla aprovechando el material con el fin de "afianzar las hiladas superiores de los muros". Explica en la memoria cómo "la cubierta se deberá de desmontar progresivamente, se deberá de consolidar la fábrica de ladrillo en sus hiladas superiores, introduciendo unos nudillos que coincidan con los límites de los machones (situación que se aprecia en documento de estado reformado al efecto) para de esta forma asegurar un correcto apoyo y reparto de la carga que transmitirán los nuevos durmientes al muro" ${ }^{37}$.

\footnotetext{
341998 - Restauración - Luis Espinosa y José Ma Varona - JCyL VA-267

351999 - Rehabilitación de la iglesia para Archivo Municipal - Gabriel Gallegos y Primitivo González - AMVA C 30125-1

${ }^{36} 1999$ - Obras de emergencia de las bóvedas y cubiertas de la nave - Antonio García Paniagua JCYL Carpeta VA-398

${ }^{37} 1999$ - Restauración de la iglesia - Alvaro Abad - JCyL Carpeta 5378; AMVA 6007/1997
} 
A partir del año 2000 los proyectos revisados no mencionan zunchos, colocando generalmente durmientes de madera. La citada iglesia de El Salvador constituye un caso singular por el zunchado metálico que se lleva a cabo para atar la capilla adosada a la cabecera del templo: "Una estructura metálica rigidizadora, a modo de gran brida, atará el muro de fábrica de piedra del arco diafragma para que no transmita empujes a la capilla. A su vez, para zunchar todo el conjunto, se realizarán dos anillos perimetrales, uno interior en la coronación del muro de la capilla y otro exterior en el límite de la piedra y el ladrillo de los muros de la cabecera de la iglesia. El zuncho de coronación de la capilla consistirá en un perfil UPN colocado lo más bajo posible en el paramento interior del muro de piedra con anclajes mecánicos cruzados, a su vez estará triangulado espacial y horizontalmente, de tal forma que trabajará en el plano horizontal como una cercha. El zunchado de la cabecera se realizará por el exterior, puesto que, debido al estado del muro, con infinidad de grietas existentes, es difícil garantizar la eficacia de los anclajes y no parece conveniente hacerlo por el interior. El zuncho se realizará, a la altura del cambio de piedra a ladrillo, mediante una platabanda de acero inoxidable se sección 1000 x 400mm separada ligeramente de la superficie del muro por chapones o tacos para evitar escorrentías" ${ }^{38}$.

\footnotetext{
${ }^{38} 2006$ - Restauración capilla de San Juan Bautista - Eduardo González Fraile - AMVA 503/2006; Fundación del Patrimonio Histórico de Castilla y León.
} 
Tabla 2: Justificación del empleo de zunchos

\begin{tabular}{|c|c|c|c|c|c|c|c|c|c|c|}
\hline \multicolumn{11}{|c|}{ JUSTIFICACIÓN DEL EMPLEO DE ZUNCHOS } \\
\hline FICHA & IGLESIA & FECHA & ARQUITECTO & 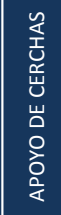 & 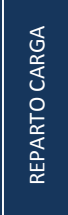 & $\frac{8}{\stackrel{8}{8}}$ & 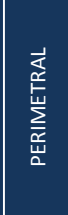 & 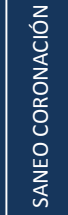 & 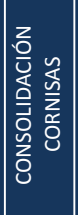 & 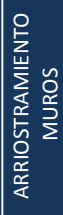 \\
\hline FZ-21 & Santos Justo y Pastor (Cuenca de Campos) & 1962 & Arenillas & & & & & & & \\
\hline $\mathrm{FZ}-10$ & San Pablo (Valladolid) & 1964 & Arenillas & & & $\mathrm{x}$ & & $\mathrm{x}$ & $x$ & $\mathrm{x}$ \\
\hline FZ-39 & Santa María (Wamba) & 1964 & Arenillas & & & & & & & \\
\hline FZ-04 & La Pasion (Valladolid) & 1965 & Arenillas & & & & & $\mathrm{x}$ & & \\
\hline FZ-21 & Santos Justo y Pastor (Cuenca de Campos) & 1967 & Arenillas & & & & & & & \\
\hline FZ-29 & San Martín (Medina del Campo) & 1968 & Arenillas & & & & & $\mathrm{x}$ & & \\
\hline $\mathrm{FZ}-15$ & San Joaquin y Santa Ana (Valladolid) & 1969 & García Gil & & & $\mathrm{X}$ & & & & $\mathrm{X}$ \\
\hline$F Z-16$ & Las Huelgas Reales (Valladolid) & 1972 & González & $X$ & $x$ & & & & & \\
\hline FZ-01 & Catedral (Valladolid) & 1974 & Cervera & $x$ & $\mathrm{X}$ & & $\mathrm{X}$ & & & \\
\hline FZ-03 & Capilla de San Gregorio (Valladolid) & 1974 & Cervera & $\mathrm{X}$ & & & & & & \\
\hline$F Z-20$ & Santa Maríadel Castillo (Castronuño) & 1974 & Iglesias & & & $\mathrm{X}$ & $\mathrm{x}$ & & & $x$ \\
\hline$F Z-22$ & San Juan (Fresno el Viejo) & 1974 & Rodrigo & & & $x$ & & & & \\
\hline$F Z-16$ & Las Huelgas Reales (Valladolid) & 1976 & Iglesias & & & $\mathrm{x}$ & $\mathrm{x}$ & & & \\
\hline FZ-17 & Santa María (Alaejos) & 1978 & Iglesias & & & $\mathrm{x}$ & $\mathrm{x}$ & & & \\
\hline$F Z-27$ & Santiago (Medina de Rioseco) & 1978 & Iglesias & $x$ & & $x$ & $\mathrm{x}$ & & & \\
\hline FZ-36 & La Anunciada (Urueña) & 1978 & Iglesias & & & & & & & \\
\hline FZ-14 & Las Descalzas Reales (Valladolid) & 1979 & Iglesias & & & & & & & \\
\hline FZ-30 & Los Santos Juanes (Nava del Rey) & 1979 & Iglesias & $\mathrm{X}$ & & $\mathrm{X}$ & & & & \\
\hline FZ-12 & El Rosarillo (Valladolid) & 1980 & Iñiguez & $\mathrm{X}$ & & & $x$ & $x$ & & \\
\hline FZ-35 & Santa María (Tordesillas) & 1980 & Mingo & $\mathrm{X}$ & & $\mathrm{x}$ & $\mathrm{x}$ & & & \\
\hline$F Z-05$ & Convento de Portaceli (Valladolid) & 1982 & Roldán & $\mathrm{x}$ & & & & & & \\
\hline FZ-06 & Las Angustias (Valladolid) & 1982 & Pérez Medina & $\mathrm{X}$ & & & & & & \\
\hline$F Z-28$ & San Antolín (Medina del Campo) & 1982 & Gómez Santander & & & $x$ & & $\mathrm{x}$ & & \\
\hline FZ-26 & Santa Cruz (Medina de Rioseco) & 1987 & Linazasoro & & & & & & & \\
\hline FZ-25 & San Francisco (Medina de Rioseco) & 1988 & Gárate & & & & & $\mathrm{x}$ & $\mathrm{X}$ & \\
\hline$F Z-38$ & Santa María del Castillo (Villaverde de Medina) & 1989 & Tovar & & & & & $\mathrm{X}$ & & \\
\hline$F Z-37$ & Santa María de Valbuena (Valbuena) & 1991 & Puente & $\mathrm{X}$ & & $x$ & $x$ & & & \\
\hline$F Z-40$ & San Pedro (Serrada) & 1992 & Areizaga y Corral & & $\mathrm{X}$ & $\mathrm{x}$ & & & $\mathrm{x}$ & $\mathrm{X}$ \\
\hline FZ-08 & San Benito el Real (Valladolid) & 1997 & Morán & & & & & & & \\
\hline FZ-24 & Santa María de Arbás (Mayorga) & 1998 & Espinosa & $\mathrm{X}$ & & $\mathrm{X}$ & & $\mathrm{x}$ & & \\
\hline FZ-07 & San Agustín (Valladolid) & 1999 & Gallegos y González & & & $x$ & & $\mathrm{x}$ & & \\
\hline FZ-13 & El Salvador (Valladolid) & 1999 & Abad & & & & & & & \\
\hline$F Z-28$ & San Antolín (Medina del Campo) & 1999 & Paniagua & & & & & & & \\
\hline$F Z-23$ & Santa María (Iscar) & 2000 & Cembrero & & & & & & & \\
\hline$F Z-32$ & Santa María de Palazuelos (Corcos del Valle) & 2000 & Montoya & & & & & & & \\
\hline FZ-02 & Convento de la Concepcion (Valladolid) & & & & & & & & & \\
\hline FZ-09 & San Lorenzo (Valladolid) & & & & & & & & & \\
\hline FZ-11 & La Antigua (Valladolid) & & & & & & & & & \\
\hline$F Z-18$ & San Juan Evangelista (Arroyo de la Encomienda) & & & & & & & & & \\
\hline$F Z-19$ & La Santa Espina (Castromonte) & & & & & & & & & \\
\hline$F Z-31$ & San Juan (Olmedo) & & & & & & & & & \\
\hline FZ-33 & San Pablo (Peñafiel) & & & & & & & & & \\
\hline FZ-34 & San Cebrián (San Cebrián de Mazote) & & & & & & & & & \\
\hline
\end{tabular}

Al ordenar los datos a partir de la fecha en que se incorpora un zuncho o "solera de hormigón" se observa que prácticamente todos los proyectos realizados en la década de los 60 fueron realizados por Anselmo Arenillas ${ }^{39}$ y gran parte de los correspondientes a los 70 por Ana Iglesias.

En las dos décadas siguientes cada proyecto se encarga a un arquitecto distinto, en los 80 radicados en Madrid y ya en los 90, pasados varios años de consolidación del traspaso de competencias a la Administración autonómica, se recurre preferentemente a técnicos castellano-leoneses.

\footnotetext{
${ }^{39}$ El papel de Anselmo Arenillas como arquitecto responsable de las obras en la Zona se ha tratado en el apartado correspondiente de los Antecedentes.
} 
La asignación al zuncho de una función de atado se repite de forma constante a lo largo de cuarenta años y es el término que con más frecuencia acompaña a la palabra zuncho en las memorias y presupuestos de los proyectos.

El objetivo de servir de apoyo de cerchas y vigas de cubierta es también bastante recurrente, aunque no aparece mencionado en los 60, época en los que tampoco se emplea aún el término perimetral.

La utilización del zuncho para sanear la coronación de los muros no se menciona en los años 70, mientras que sí aparece en varios proyectos de Arenillas de fechas anteriores y vuelve a ser una expresión recurrente en las intervenciones posteriores.

En varias ocasiones dispersas en el tiempo se coincide en que el zuncho es capaz de corregir el desplome de los muros y en dos de ellas se menciona además que el zuncho consolida la cornisa.

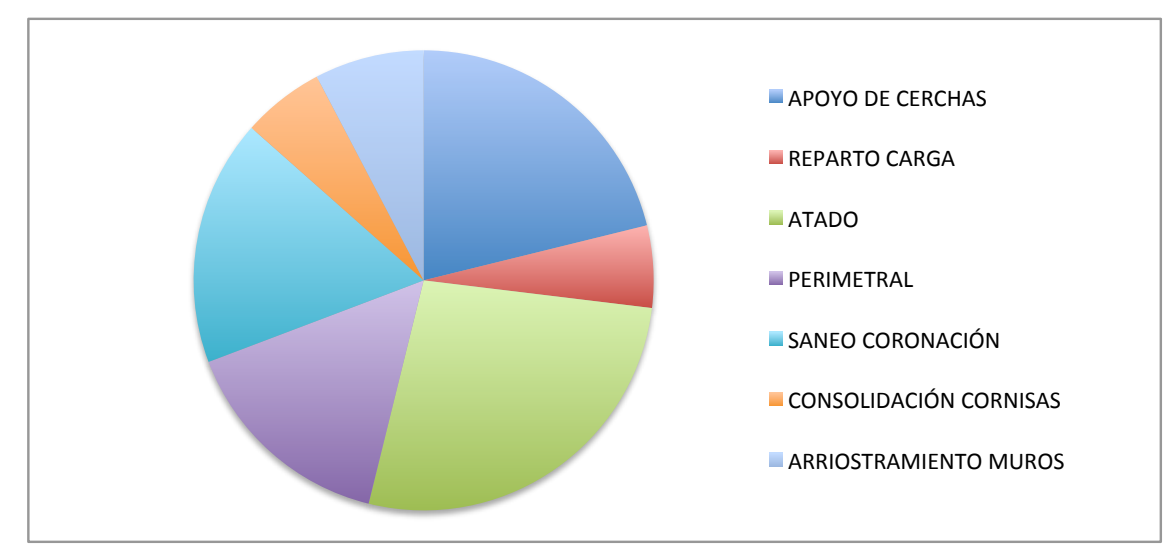

Se deduce así que la descripción más empleada, en los proyectos de la segunda mitad del siglo XX revisados, de la función del zuncho es de atado perimetral. 


\section{IV.1.1.3. Definición de dimensiones de los zunchos en las memorias y presupuestos de los proyectos}

A continuación se revisa cómo se definen en los proyectos las dimensiones del zuncho, diferenciando también las medidas señaladas en el cuerpo del texto de las contenidas en la descripción de partidas del presupuesto.

- En dos casos los zunchos se resuelven con perfiles de acero laminado:

La iglesia del Rosarillo en Valladolid ${ }^{40}$ se trata del único caso (aparte del refuerzo de la capilla de la iglesia del Salvador en Valladolid que se describe a continuación, donde se dispone una brida con zunchado de bandas metálicas) en el que se considera y denomina zuncho a un perfil de acero laminado HEB-140. Esta cualidad se señala tanto en la memoria como en los rótulos de planos.

El zuncho de coronación de la capilla de la iglesia de El Salvador en Valladolid ${ }^{41}$ consiste en un perfil UPN... El zunchado de la cabecera se realizará por el exterior... a la altura del cambio de piedra a ladrillo, mediante una platabanda de acero inoxidable se sección $1000 \times \mathbf{4 0 0 m m}{ }^{42}$ ". En el presupuesto se precisa $\mathrm{kg}$ de anillo perimetral A42b UPN $100 \mathrm{y} \mathrm{kg}$ de anillo perimetral de acero inoxidable con palastro 100.30 .

- Las dimensiones del zuncho aparecen descritas sólo en el texto de la memoria en dos proyectos de Anselmo Arenillas:

En la memoria de la iglesia del Convento de San Pablo en Valladolid ${ }^{43}$ indica que se pondrá un solerón de hormigón armado de 40x30cm, y en la de la iglesia de San Martín en Medina del Campo ${ }^{44}$ un solerón de hormigón armado de 30x30cm.

\footnotetext{
${ }^{40}$ FZ-12 - AGA 26/1574

${ }^{41}$ FZ-13 AMVA 503/2006; Fundación del Patrimonio histórico de Castilla y León

${ }^{42}$ En el documento final de la obra se recoge esta misma definición pero con unas dimensiones de platabanda inoxidable de $1000 \times 200 \mathrm{~mm}$, que no coinciden con la memoria del proyecto original ni con la partida del presupuesto.

${ }^{43}$ FZ-10 - AGA 26/00146

${ }^{44}$ FZ-29 AGA 26/00131
} 
- Se plantea la incorporación de zunchos pero no se llegan a definir sus dimensiones, sólo la cantidad total en el presupuesto, en los proyectos siguientes:

En el presupuesto de la Capilla de San Gregorio en Valladolid no se mencionan dimensiones de sección, sólo una longitud total de 72,40 ml.

No se mencionan zunchos, sólo cadenas, sin definirse en el proyecto para la iglesia de la Pasión ${ }^{45}$ sus dimensiones ni ubicación.

En el presupuesto de intervención Real Monasterio de San Joaquín y Santa Ana ${ }^{46}$ en Valladolid se define $0,855 \mathrm{~m} 3$ de zuncho de hormigón armado de $350 \mathrm{~kg}$ de cemento y $60 \mathrm{kgs}$. de hierro redondo, elaborado y colocado, incluso encofrado y desencofrado, en arriostramiento de muros de ángulo, sin precisar su sección.

No se definen las dimensiones en el detalle de sección donde se representa el zuncho de la iglesia del Monasterio de las Huelgas Reales ${ }^{47}$ en Valladolid.

En una partida del presupuesto para la iglesia de los Santos Justo y Pastor en Cuenca de Campos $^{48}$ se incluyen $252,80 \mathrm{~m}^{2}$ de faldón de cubierta en hormigón armado, incluidas soleras y tirantes, sin desglosar la parte proporcional de las soleras (zunchos) o sus dimensiones.

En el proyecto de la iglesia de San Juan en Fresno el Viejo ${ }^{49}$ hay dos plantas y un alzado, pero no aparecen definidos secciones ni detalles. En el presupuesto se recoge "1 ud regularización de muros de apoyo de cubierta incluso andamio y material necesario" pero no se mencionan los zunchos citados en la memoria.

En el presupuesto para la iglesia de los Santos Juanes en Nava del Rey ${ }^{50}$ se incluye $86,40 \mathrm{ml}$ de apertura de hueco para colocación de zuncho perimetral con diversas longitudes.

\footnotetext{
${ }^{45}$ FZ-04 - AGA 26/00206

${ }^{46}$ FZ-15 - AGA 26/00146

${ }^{47}$ FZ-16 - AMVA 161/1973; C1936-5

${ }^{48}$ FZ-21 - AGA 26/00120

${ }^{49}$ FZ-22 - IPCE Carpeta 636-3

${ }^{50}$ FZ-30 - AGA 26/01721 (1)
} 
En un informe de una página sobre la iglesia de Santa María en Tordesillas ${ }^{51}$ se indica bajo el epígrafe "descripción de obras ejecutadas", entre otras: "aperturas de cajas para alojamiento de zunchos de atado con hormigón de $350 \mathrm{~kg}$ ".

No se mencionan zunchos en el proyecto de sustitución de estructura de cubierta de la iglesia de La Anunciada en Urueña por tablero de rasilla sobre tabiquillos de 1978.

- Dimensiones del zuncho definidas en el presupuesto:

Es en el presupuesto de restauración de la Catedral de Valladolid ${ }^{52}$ donde se precisa 125,90 ml de zuncho de hormigón armado de sección 50x30cm incluso armadura, encofrado y placas de apoyo para cerchas.

El presupuesto de la iglesia de la Asunción en el Convento de PortaCoeli en Valladolid $^{53}$ contempla "4 ud dado de hormigón en masa de $\mathrm{H}=150 \mathrm{kp} / \mathrm{cm} 2$ de 0,80x0,50x0,40m i/asentado y recibido de placa de palastro de $8 \mathrm{~mm}$ de espesor y $0,50 \times 0,30$ con cuatro patillas D14 totalmente terminada para asentamiento de cerchas de madera, $\mathrm{i} /$ cajeado en muro existente".

Dentro del presupuesto para obras en la Cofradía de las Angustias en Valladolid ${ }^{54}$ se señalan $36 \mathrm{~m}$ de viga de hormigón armado alero-cornisa. El presupuesto de las obras siguientes contempla la demolición de esa pieza con compresor y retirada de $25,5 \mathrm{ml}$ de cornisa $0,90 \times 0,60 \mathrm{~m}$ de hormigón armado ${ }^{55}$.

En el presupuesto del modificado ${ }^{56}$ de la iglesia del convento de San Agustín en Valladolid se incluyen $51 \mathrm{~m}^{3}$ de zuncho en muro coronación, saneado de la coronación y cajeado fábricas de sillar. En el cuerpo de la nave de fábrica de ladrillo se diseña un zuncho de $1,10 \times 0,40 \mathrm{~m}$ corrido a ambos lados con encofrados de

\footnotetext{
${ }^{51}$ FZ-35 - IPCE Carpeta 643-7

${ }^{52}$ FZ-01 - AGA 26/00088

${ }^{53}$ FZ-05 - AGA 26/01581

${ }^{54}$ FZ-06 - JCYL Carpeta 5202

${ }^{55}$ FZ-06 - VA-91 Carpeta 5279

${ }^{56}$ FZ-07 - AMVA C30125-1 pieza 12
} 
madera y en la cabecera de sillería se cajean $0,35 \times 0,40 \mathrm{~m}$. Otro presupuesto ${ }^{57}$ recoge "11,22m3 de hormigón de 350kg de cemento, garbancillo y arena de río, armado con $80 \mathrm{~kg}$ de hierro redondo en formación de zunchos de atado perimetral de muros, incluso encofrado". Con las mismas mediciones define la partida de demolición de fábricas en apertura de caja para alojamiento de zunchos de atado perimetral de muros, diversas longitudes con $0,40 \mathrm{x} 0,30 \mathrm{~m}$.

Se especifica "17,34m 3 de hormigón de $350 \mathrm{~kg}$ de cemento, garbancillo y arena de río, armado con $80 \mathrm{~kg}$ de hierro al $\mathrm{m} 3$ incluso el encofrado preciso en formación de zuncho de atado perimetral de muros" en el presupuesto de restauración de la iglesia de Santa María en Alaejos ${ }^{58}$. Y, con las mismas mediciones, en la partida de demolición de fábricas pétreas en apertura de caja para alojamiento de zunchos de atado, diversas longitudes con $0,30 \times 0,40 \mathrm{~m}$.

Dentro del presupuesto del proyecto para la iglesia de Santa María del Castillo en Castronuño ${ }^{59}$ aparecen $16,20 \mathrm{~m} 3$ de hormigón de $350 \mathrm{~kg}$ de cemento, garbancillo y arena de río, armado con $80 \mathrm{~kg}$ de hierro redondo en atado de muros perimetrales. Con las mismas mediciones en la partida de demolición de fábricas pétreas en apertura de caja para alojamiento de zuncho, diversas longitudes con 0,50x0,40m.

En el presupuesto de la iglesia de Santa María de Arbás en Mayorga de Campos ${ }^{60}$ aparece "13,55 m3 Hormigón armado H-175kg/cm2 Tmax20mm elaborado en central en zunchos, i/p.p. de armadura $(75 \mathrm{~kg} / \mathrm{m} 3)$ y encofrado de madera, vertido con pluma-grúa: nave lateral 2x24x0,80x0,30; panera 1x8,50x0,50x0,30". En el plano de detalle nombra un zuncho "en L", pero no indica dimensiones de la pieza.

En el presupuesto de obras en la iglesia de San Francisco en Medina de Rioseco ${ }^{61}$ aparece " $51,55 \mathrm{~m} 3$ hormigón para armar de $175 \mathrm{~kg} / \mathrm{cm} 2$ de resistencia característica en zunchos perimetrales, incluso vertido y vibrado". Define muchas longitudes para la misma sección, siempre de $0,50 \times 0,35 \mathrm{~m}$, y en los planos se rotula:

4.01- Encofrado de madera a una cara para zunchado de muros en presbiterio, ábside y naves centrales y laterales.

\footnotetext{
${ }^{57}$ FZ-07 - AGA 26/01573

${ }^{58}$ FZ-17 - IPCE Carpeta 636-1, AGA 26/01573

${ }^{59}$ FZ-20 - IPCE Carpeta 636-2

${ }^{60}$ FZ-24 - JCyL VA-267

${ }^{61}$ FZ-25 - JCyL VA-062
} 
4.02- Armaduras de zuncho de acero $4200 \mathrm{Kgr} / \mathrm{cm} 2$ cuantía $50 \mathrm{Kgr} / \mathrm{m} 3$

4.03- Hormigón para armar de resistencia característica.. en zuncho de 50x35cms.

Se incluye en el de la iglesia de Santiago en Medina de Rioseco ${ }^{62}$ la demolición de fábricas en apertura de cajas para alojamiento de zunchos de atado $2 \times 20,00 \times 0,40 \times 0,30 ; 1 \times 28,00 \times 0,40 \times 0,30=8,16 \mathrm{~m} 3$. Ídem zuncho; y zuncho perimetral de hormigón de 40x50,350kg de cemento por m3 y $30 \mathrm{~kg}$ por $\mathrm{ml}$ de hierro 1 x61,88. Ídem hueco para zuncho ${ }^{63}$.

La partida de demolición con compresor de $24 \mathrm{~m} 3$ de zunchos de hormigón armado 40x30, 40x60 y 45x35 y ejecución de 93m3 de zuncho nuevo visto se incluye en el presupuesto de restauración de la Colegiata de San Antolín en Medina del Campo ${ }^{64}$. También aparece la apertura de $13 \mathrm{~m} 3$ de cajas para zuncho y vigas sobre muro de ladrillo con retirada de durmientes y desmontaje de $93 \mathrm{ml}$ de cornisas de ladrillo aplantillado en coronación de muros.

En el presupuesto de revitalización del Monasterio de Santa María de Valbuena en Valbuena de Duero ${ }^{65}$ se describe la ejecución de $76 \mathrm{ml}$ de zuncho de hormigón armado para atirantados y atados de fábricas de todo tipo. Previa labor de su cajeado cuidadoso en fábricas pétreas o de cualquier tipo, de sección aproximada de 0,30x0,40m., realizado con hormigón armado.

En el presupuesto para la iglesia de Santa María del Castillo en Villaverde de Medina $^{66}$ se desglosa $70 \mathrm{ml}$ de consolidación de muros con zuncho perimetral de hormigón armado de una sección media de 0,70x0,50 previa demolición y enrasado para su asiento. Se ejecuta $21,3 \mathrm{~m} 3$ de zuncho en coronación de muros.

$\mathrm{Y}$ en el presupuesto del proyecto de restauración de la iglesia de San Pedro en Serrada $^{67}$ encontramos $\mathrm{m} 3$ de hormigón $\mathrm{H}-175$ en zunchos en naves 0,50x0,45 y en crucero $0,25 \times 0,40$. También encofrado de pino para zunchos las longitudes correspondientes con las mismas alturas 0,45 y 0,40 .

\footnotetext{
${ }^{62}$ FZ-27 - IPCE Carpeta 639-2

${ }^{63}$ FZ-27 - IPCE Carpeta 640-1

${ }^{64}$ FZ-28 - JCYL Carpeta VA-398

${ }^{65}$ FZ-37 - Las Edades del Hombre JCyL

${ }^{66}$ FZ-38 IPCE Carpeta 657-7; VA-87 Carpeta 5273

${ }^{67}$ FZ-40 VA-131 Carpeta 5324
} 
Tabla 3: Dimensiones del zuncho definidas en los proyectos

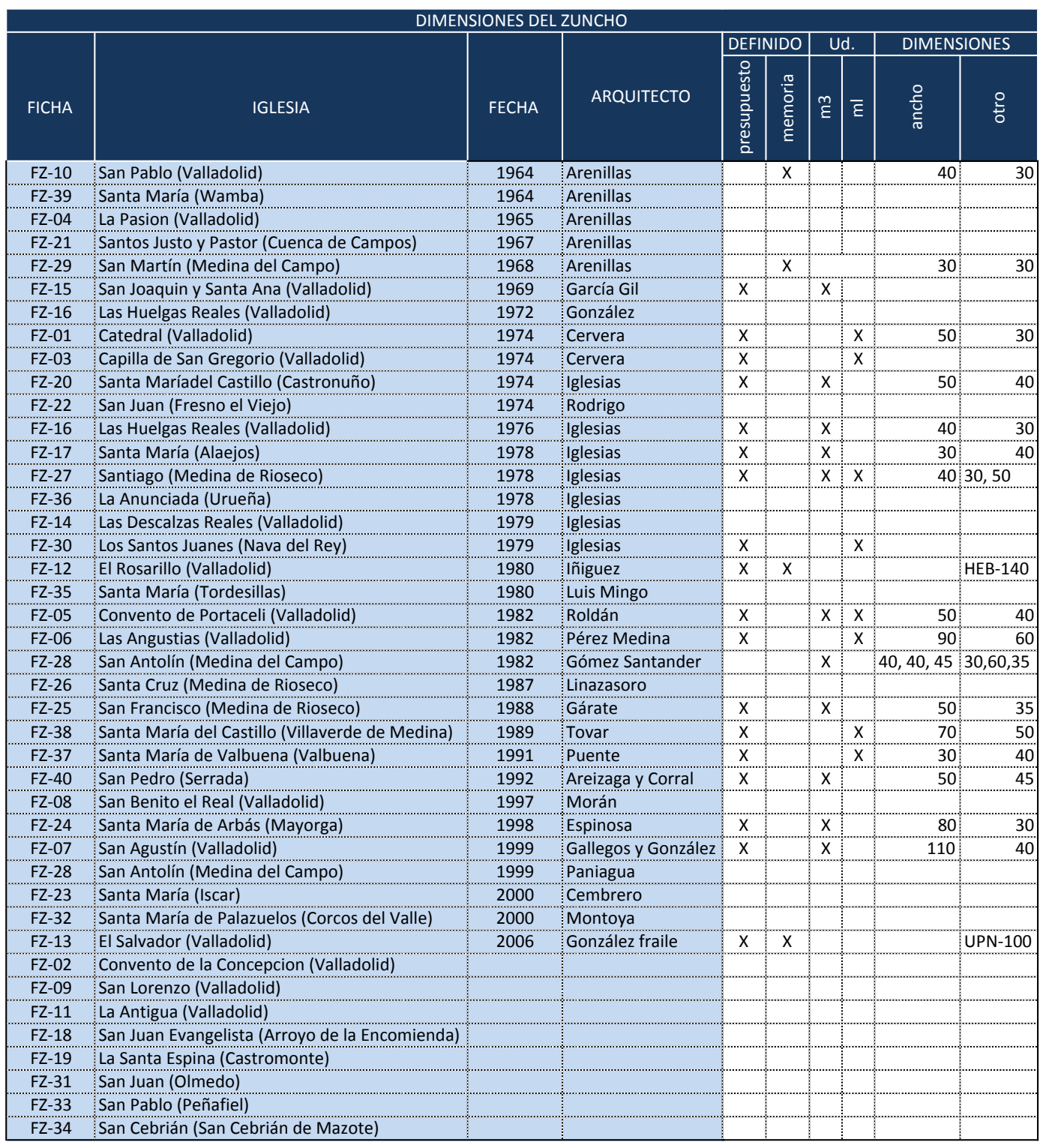

Hay un número considerable de proyectos en los que no se mencionan las dimensiones del zuncho. En algunos presupuestos aparece únicamente definida su longitud total o bien el volumen en $\mathrm{m} 3$, sin indicar dimensiones de sección o armaduras del elemento.

En casi todos los casos analizados la definición de dimensiones de zunchos está contenida en el presupuesto, sin que aparezcan ese tipo de datos en el texto descriptivo de las memorias, lo que sucede sólo en dos obras de Anselmo Arenillas, 
ya que en Rosarillo y Salvador dicha información se repite en memoria y presupuesto.

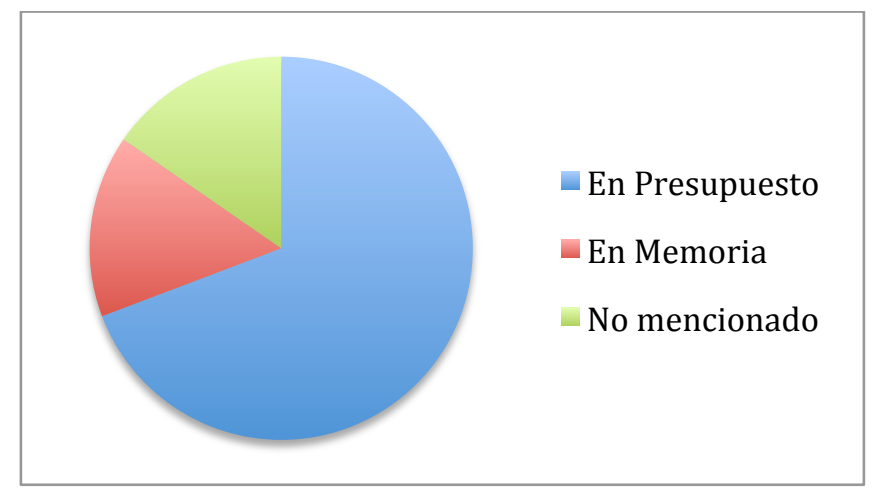

En una decena de casos se plantea la incorporación de zunchos pero no se llegan a definir sus dimensiones, sólo la cantidad total en el presupuesto. Casi la mitad de las partidas revisadas se cuantifican mediante la longitud en metros lineales mientras aparece la cantidad de zuncho expresada a partir del volumen de hormigón en metros cúbicos en aproximadamente un $60 \%$ de los casos.

En dos ocasiones se demuelen en la década de los noventa los zunchos incorporados en intervenciones anteriores bastante recientes, ambas de los ochenta: en la Cofradía de las Angustias en 1992 se demuele el potente zuncho-cornisa incorporado en 1984 y en la Colegiata de San Antolín en Medina del Campo en 1999 demuelen los zunchos ejecutados en 1982 sobre las fachadas y en la coronación de ambos muros interiores (piezas que según el proyecto estaba previsto encajar entre los durmientes de madera superior en inferior con que contaban estos muros).

En once intervenciones se define en el presupuesto la apertura de cajas en los muros de fábrica para alojar los nuevos zunchos de hormigón con las mismas dimensiones qué estos. 


\section{IV.1.2. La documentación gráfica}

A la hora de analizar el sistema constructivo tanto de las cubiertas originales como de las ejecutadas más tarde, encontramos la dificultad de que, si se cuenta con documentación gráfica, ésta casi nunca es fidedigna, ya que es habitual que las soluciones constructivas ejecutadas no coincidan con lo reflejado en planos del proyecto, si los hay, debido a cambios sin documentar producidos durante la obra.

Aunque la expresión gráfica de la arquitectura ha evolucionado con el paso del tiempo, en las intervenciones realizadas desde el siglo XVI hasta nuestros días los aspectos constructivos se definen mediante la sección, ya sea en forma de trazas o como resultado del diseño asistido por ordenador.

\section{IV.1.2.1. Las trazas}

Según Gentil Baldrich ${ }^{68}$ (1998), desde comienzos del siglo XVI comienza a ser relegado el método de emplear modelos o maquetas, para promoverse el uso de la sección constructiva como el procedimiento gráfico especialmente adecuado para la Arquitectura. Cita la Carta a León X escrita hacia 1514 y cómo el propio Miguel Angel realizaba sus maquetas seccionadas para mostrar el interior. En 1556 Daniel Barbaro, asesorado por Palladio escribe en su interpretación del texto de Vitrubio: La idea de la Disposición es esta: la Planta, el Alzado, el Perfil.

Las trazas originales de Juan de Herrera para la catedral de Valladolid muestran la maestría de su autor que incluso combina en un mismo dibujo el corte por claustro y crucero con la sección del cuerpo de la nave.

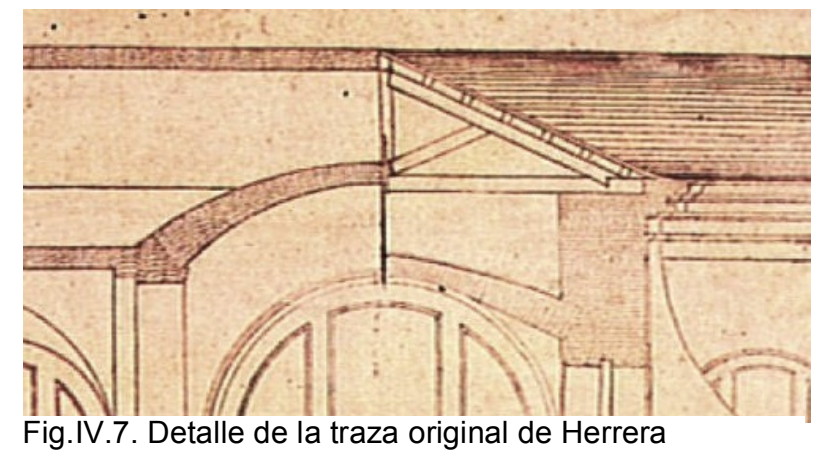

Herrera representa la cercha con su tirante prolongado apoyado sobre el muro sin durmiente.

\footnotetext{
${ }^{68}$ Gentil Baldrich, J. M. (1998). Traza y modelo en el Renacimiento. Sevilla: Universidad de Sevilla. El profesor José María Gentil es autor además de una tesis doctoral sobre la representación de la
} 


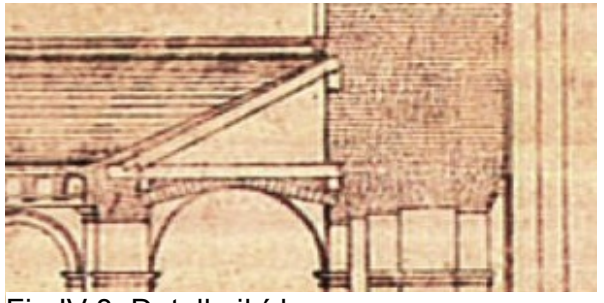

Fig.IV.8. Detalle ibídem

Aunque el claustro no llegó a ejecutarse, podemos apreciar la sección del mismo prevista en los planos. En este caso, la armadura que cubre las pandas sí muestra tres durmientes transversales de apoyo encastrados en la fábrica.

Algunas de las contadas trazas del siglo XVI que han llegado hasta nosotros son esquemas de carácter práctico que responden directamente a necesidades de obra. Así el croquis que Diego de Praves envió a Juan de Herrera para consultarle una discrepancia en el replanteo de los pies de la catedral (ya citado en el capítulo 6) o el siguiente, de Rodrigo Gil de Hontañón, que encontramos reproducido en el Catálogo de Jesús Urrea para la exposición Planos, dibujos y maquetas de Valladolid celebrada en $1984^{69}$.

\section{Rodrigo Gil de Hontañón} (1505-1577)

Planta y alzado del interior de Ntra. Sra. de la Antigua. Valladolid

$405 \times 300 \mathrm{~mm}$

Tinta. Papel blanco, reentelado.

Firmado: Ro Gil.

Archivo Histórico Provincial. Valladolid. Protocolo, no 70 , fol. 873 .

Aparece acompañando un informe emitido por el arquitecto el 20 de agosto de 1575 «para dar a entender como esta peligroso y con notable sentimientos y desplanos y bariga el pilar toral del coro de la higlesia de Nuestra Señora de la antigua», proponiendo al mismo tiempo el remedio "de no mucha costa y muy firme en arte y no parecera remiendo antes hedificio gracioso".

Bibliografía: E. García Chico, Arquitectos, Valla dolid, 1940, pp. 17-20

Fig.IV.9. Trazas de informe de Gil de Hontañón en la Antigua, Urrea 1984

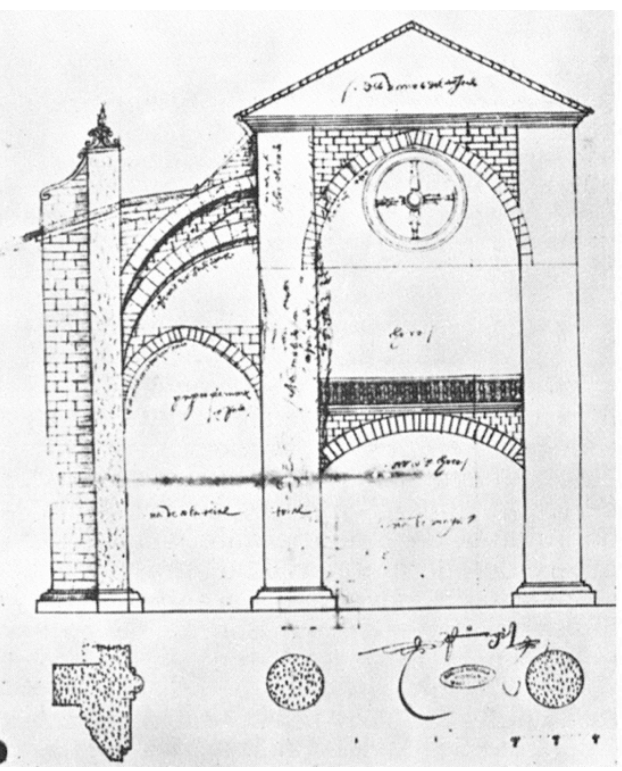

En estos rasguños ${ }^{70}$ se anotan directamente las explicaciones sobre el dibujo, que detalla únicamente aspectos relacionados con su objetivo. En la planta de la catedral, por ejemplo, aparecen sólo lo primeros tres tramos y en la sección de la Antigua la cubierta de la nave se representa como un simple triángulo, sin definir con detalle las armaduras que la conforman.

\footnotetext{
${ }^{69}$ Urrea, J. (1984). Planos, dibujos y maquetas de Valladolid. Valladolid: Caja de Ahorros Popular.

${ }^{70}$ Se denomina rasguños a los bosquejos menos definidos que una traza, por ejemplo el realizado por el propio Felipe II para su Palacio Real de El Pardo que se conserva en el Archivo de Simancas.
} 


\section{IV.1.2.2. La documentación de los proyectos de mediados del XX}

En los proyectos de restauración de Luis Cervera y Anselmo Arenillas encontramos una documentación muy parca. Los textos de las memorias se desarrollan en una única hoja en muchos casos, acompañados de las habituales mediciones $y$ presupuesto.

En ocasiones se complementa esta descripción con un único plano de planta que, aunque suele ser de grandes dimensiones, presenta un grado de definición muy somero. Habitualmente se representa sólo la geometría de las nuevas estructuras de cubierta con que se reemplazan las armaduras.

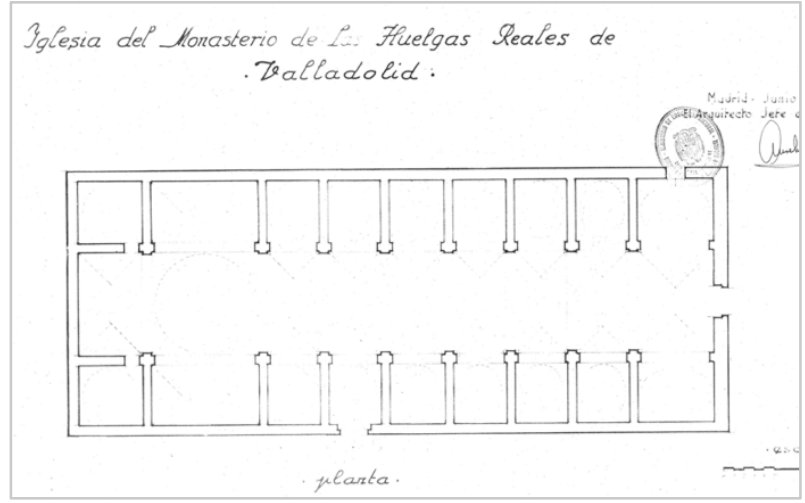

Fig.IV.10. Planta de la iglesia de las Huelgas Reales (Arenillas 1959 AGA 26/00262)

En la sección siguiente podemos ver el estado actual de la cubierta de la catedral de Valladolid antes de su reemplazo por cerchas metálicas en 1974. Se trata de un dibujo del arquitecto Angel Ríos (conservado en el archivo municipal), autor del proyecto con que se obtuvo la licencia y cuyas soluciones adopta sin cambio alguno meses después Luis Cervera que ya había reparado las cubiertas en 1960 y firma como autor de la reforma. En los dibujos se representa el apoyo de los tirantes de madera sobre el remate del muro de sillería (en los dibujos de Cervera toda la sección se cubre con trama homogénea) que cuenta con un tramo final de hiladas de ladrillo sin durmientes ni piezas interpuestas de madera de ningún tipo.

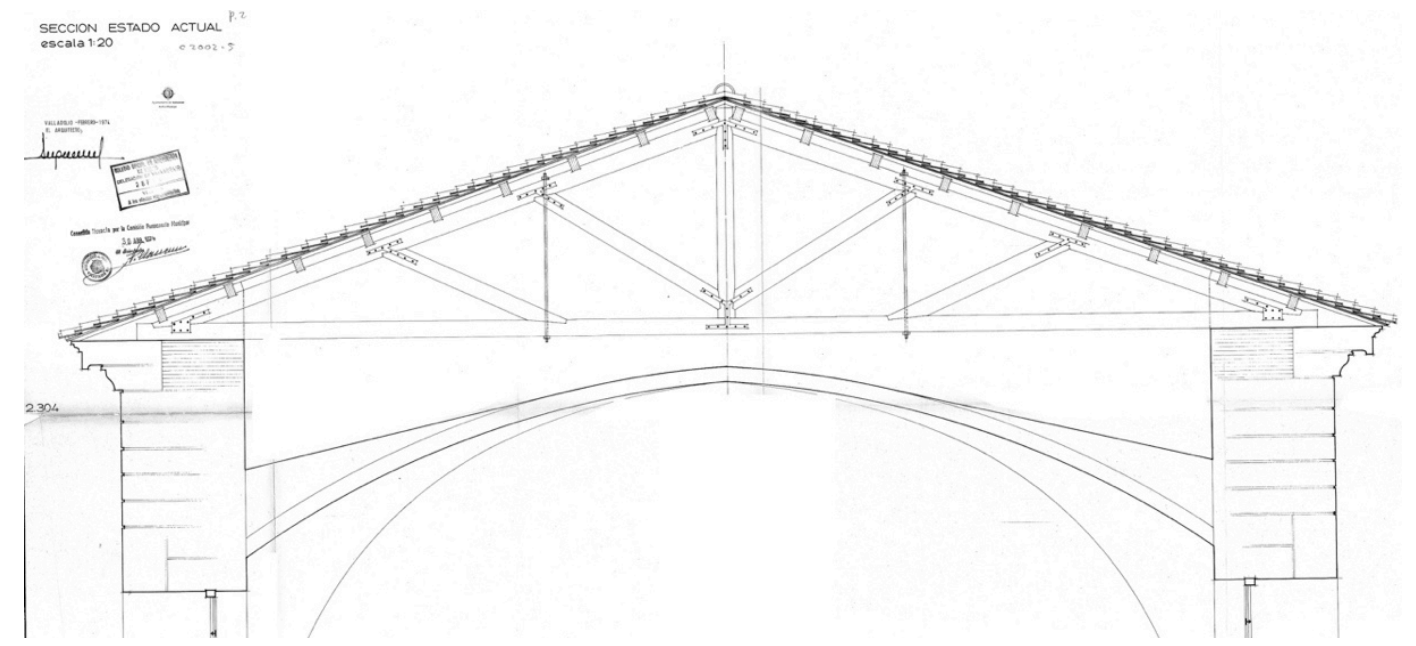

Fig.IV.11. Sección de la catedral antes de la reforma (Ríos 1974 AMVA 216) 


\section{IV.1.2.3. Las herramientas de los arquitectos de mediados del XX: la bicámara}

Los planos de los proyectos firmados por Ana Iglesias en la década de 1970-80 son de una calidad poco frecuente, delineados a mano con gran precisión. En la entrevista personal explica cómo Antonio Almagro les proporcionó en aquel momento una bicámara, aparato que permitía documentar la geometría de los edificios con gran precisión ${ }^{71}$.

En su capítulo del curso del Colegio Oficial de Arquitectos de Andalucía Occidental de 1988, Almagro explica como "generalmente, una sola perspectiva de un objeto no nos permite medirlo, sobre todo tridimensionalmente. Pero si utilizamos dos perspectivas, o dos fotografías tomadas desde dos puntos distintos, tendremos datos suficientes para poder determinar la posición espacial de todos aquellos puntos que sean visibles en las dos imágenes. Todo ello apoyándonos en las leyes geométricas y por tanto matemáticas..." Describe el origen de la fotogrametría, ya empleando pares de fotografías en 1858 para realizar el levantamiento de la catedral de Wetzlar.

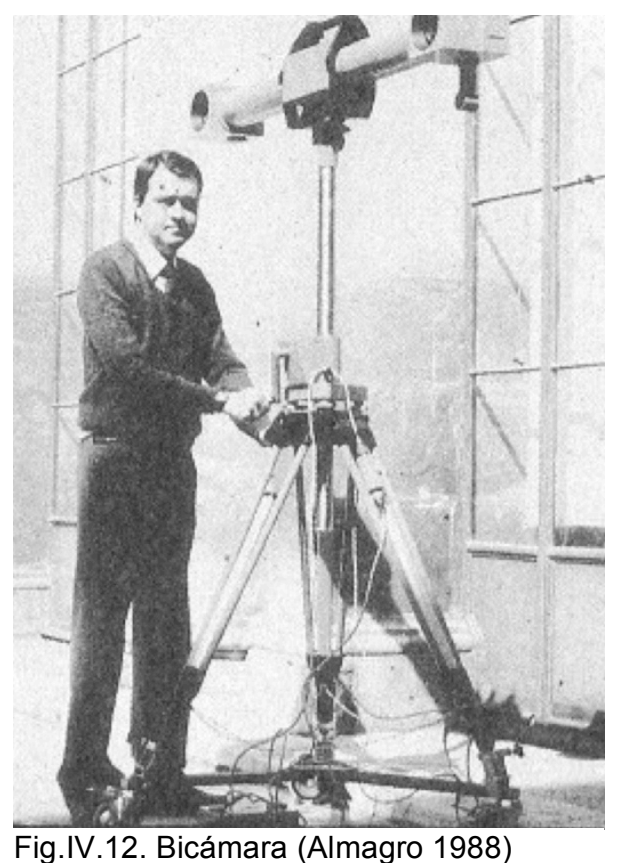

Estos aparatos ya no se fabrican.

La estereofotogrametría utiliza pares de fotografías obtenidas con ejes sensiblemente paralelos de tal manera que sea posible observar las fotos estereoscópicamente, como la combinación de imágenes de ambos ojos en la observación humana. La bicámara consiste en dos cámaras unidas rígidamente a una barra de determinada longitud.

Estos aparatos se utilizaban para fotografiar objetos situados a una distancia entre 5 y $15 \mathrm{~m}$, y su efectividad dependía de la pericia personal del técnico que la manejaba.

\footnotetext{
${ }^{71}$ Almagro, A. (1988). Planimetría y fotogrametría. In M. Alonso \& F. Mendoza, Rehabilitación y ciudad histórica. I Curso de Rehabilitación del COAAO en 1987 (pp. 201-219).
} 
A pesar de que como hemos dicho los planos que componen los proyectos de esa época son de una calidad excelente, en ellos encontramos siempre representada con falta de detalle la sección del encuentro cubierta-cornisa-muro. En algún caso podemos apreciar cómo quedan trazos inconclusos que, a veces, evidencian cómo no llegó a conocerse la naturaleza del muro en su remate y las soluciones constructivas del encuentro cerramiento-cubierta ni siquiera durante la ejecución de la obra.

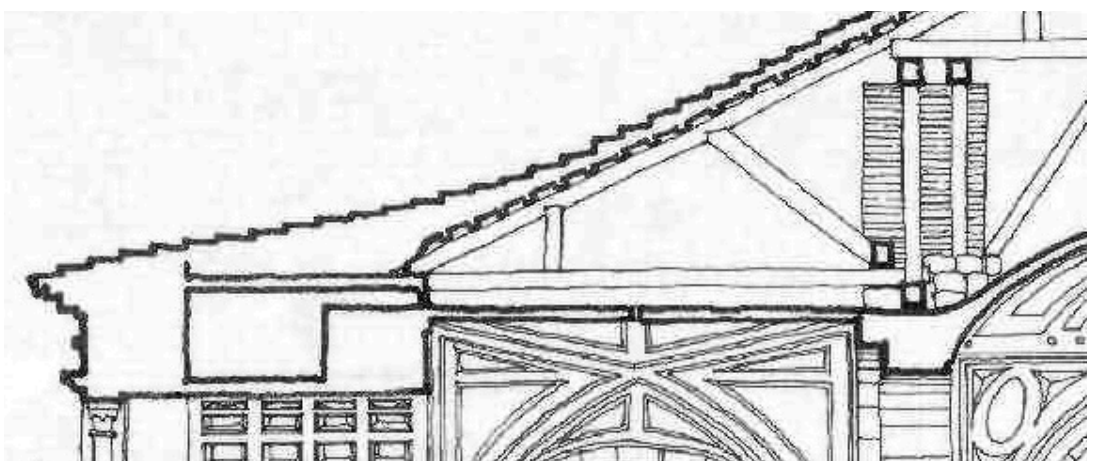

Fig.IV.13. Sección transversal Nava del Rey con líneas inconclusas en la zona del refreno (Ana Iglesias 1979 IPCE)

\section{IV.1.2.4. Los levantamientos recientes}

Desde del traspaso de competencias a las Comunidades Autónomas, las directrices para la elaboración de los proyectos se marcan desde el Servicio de Restauración de la Dirección General de Patrimonio de la Junta.

Los requisitos han ido evolucionando con el paso de los años, concediéndose cada vez más importancia a los estudios previos como herramienta que contribuye a mejorar todo el proceso constructivo. Desde los primeros proyectos en que empezó a solicitarse una breve memoria histórica, más adelante la elaboración de planos de patología, con croquis de las lesiones, hasta los alzados estratigráficos o "lectura de paramentos" con criterios tomados de la disciplina Arqueología de la arquitectura $^{72}$ de la actualidad.

En la Memoria del documento correspondiente a toma de datos y cartografía de la iglesia de Santa María en Alaejos en junio de 2011, por ejemplo, se describe de la siguiente forma los objetivos del trabajo:

"Uno de los objetivos fundamentales del presente trabajo consiste en documentar el edificio histórico mediante el levantamiento y cartografía del mismo,

${ }^{72}$ Caballero Zoreda, L. (1995). Método para el análisis estratigráfico de construcciones históricas o "lectura de paramentos." Informes de La Construcción. 
registrándose la realidad construida y su geometría real actual. De este modo, se pretende preservar sus valores culturales que como documento histórico posee.

Por otro lado, la cartografía del edificio se constituye como la herramienta básica para los posteriores trabajos tanto de investigación y conocimiento (lectura de paramentos, estudios histórico-artísticos, diagnóstico patológico, etc.), como de intervención (restauración) o de difusión y divulgación."

\section{IV.1.2.5. Definición del zuncho en los planos de los proyectos}

Muchos de los proyectos del siglo XX revisados en el proceso de investigación que se custodian en los archivos consisten en memorias de una o dos páginas, acompañadas por un presupuesto o incluso en ocasiones una simple valoración, y un plano de planta general. Hemos visto en el apartado anterior cómo el zuncho se describe a veces en las memorias, otras aparece definido por sus dimensiones en el presupuesto, y a veces se ejecuta aunque ni siquiera se mencione en el proyecto. A continuación vamos a revisar las ocasiones en que aparece este elemento en la documentación gráfica de los proyectos estudiados y cómo se representa en ellos.

El análisis de la documentación gráfica presenta unos requerimientos muy distintos a los del tipo cuantitativo desarrollados sobre los textos escritos en el apartado anterior. Se ha clasificado la información sobre el zuncho contenida en los planos de los distintos proyectos según los parámetros siguientes:

- Sí se representa el zuncho pero sin dimensiones ni ubicación.

- El zuncho se define mediante rótulos sobre la planta.

- El detalle no coincide con la solución realmente ejecutada.

- En las secciones no aparece el zuncho aunque se mencione en la memoria.

- Planos esquemáticos con escaso nivel de definición.

- Proyectos en los que se representa el zuncho con su detalle correspondiente.

Se detalla a continuación, según la clasificación anterior, los casos analizados. 
IV.1.2.5.1. En varios de los casos en los que se ejecuta un zuncho de hormigón se incluye en los planos una sección en la que aparece representado de forma reconocible este elemento, que incluso se señala y rotula como tal. Sin embargo, es habitual que no se acoten sus dimensiones ni la de su ubicación precisa dentro del muro.

Así lo hace Cervera en 1974 con la nueva estructura de cubierta para la Catedral, en un detalle sin dimensiones ni ubicación. En el plano describe un ligero cajeado de unos centímetros en el remate superior de la fábrica y el frente visto del zuncho enrasado con la cara interior del cerramiento.

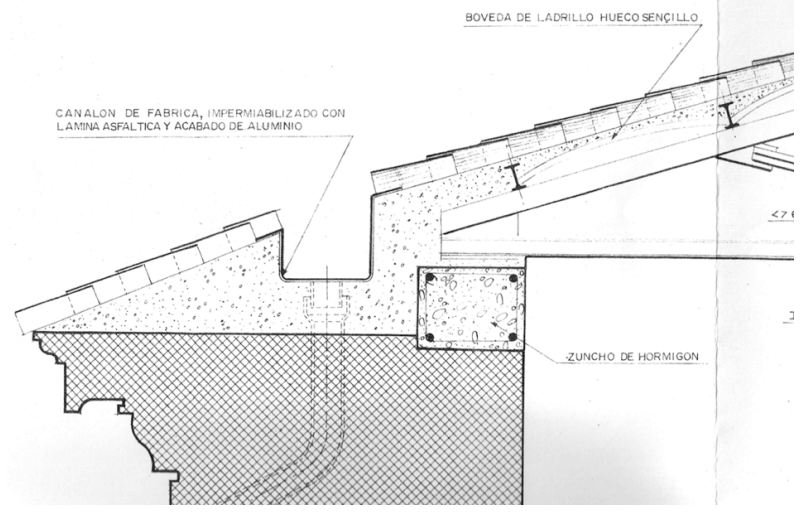

Fig.IV.14. Detalle Catedral 1974 Cervera AGA

En 1982 Gómez Santander interviene en San Antolín de Medina del Campo y coloca zunchos lineales sobre los cuatro ejes de muro. No se indican dimensiones de los mismos, aunque los interiores se representan con su anchura igual al grosor de los muros, solución que no coincide con la descripción de encajarlo entre dos durmientes que ofrece la memoria.

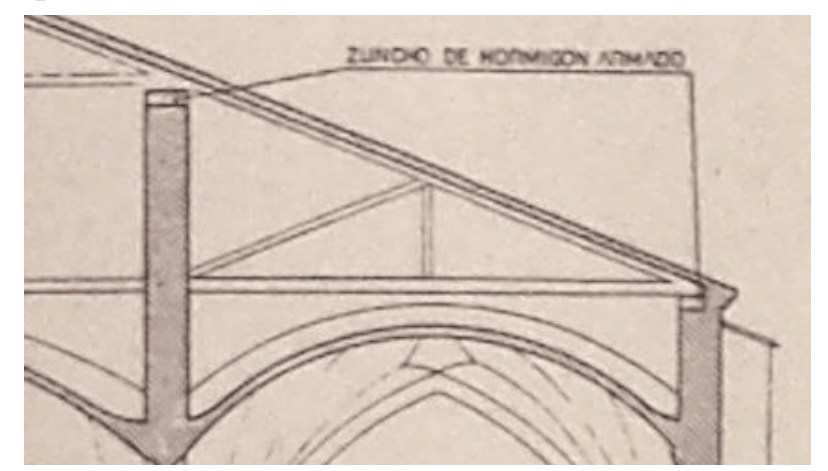

Fig.IV.15. Detalle San Antolín 1982 Gómez Santander IPCE

En los proyectos revisados de Ana Iglesias para los Santos Juanes no se documenta la sustitución de las cubiertas. En el dossier de 1991 de Navarro hay un dibujo que describe la prolongación del tablero de cubierta de hormigón con nervometal sobre las capillas laterales a partir del zuncho, que apoya como un pórtico de vigas continuas sobre los contrafuertes. 


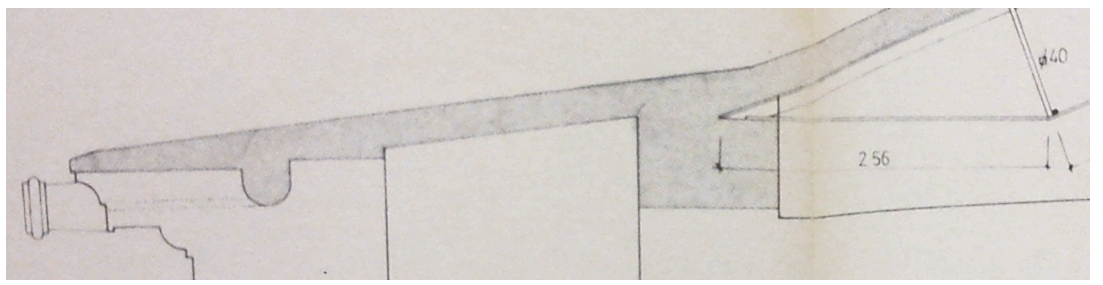

Fig.IV.16. Detalle Nava del Rey 1991 Navarro JCyL

Los planos de Espinosa para su restauración de Santa María de Mayorga en 1998 incluyen un detalle de zuncho en L, en el frente de la nave lateral, sin definir sus dimensiones ni su armadura. Sobre su ala inferior apoya una techumbre artesonada reconstruida y en un quiebro de la superior, mediante un apoyo pasante, los pares de madera laminada que forman el faldón de cubierta.
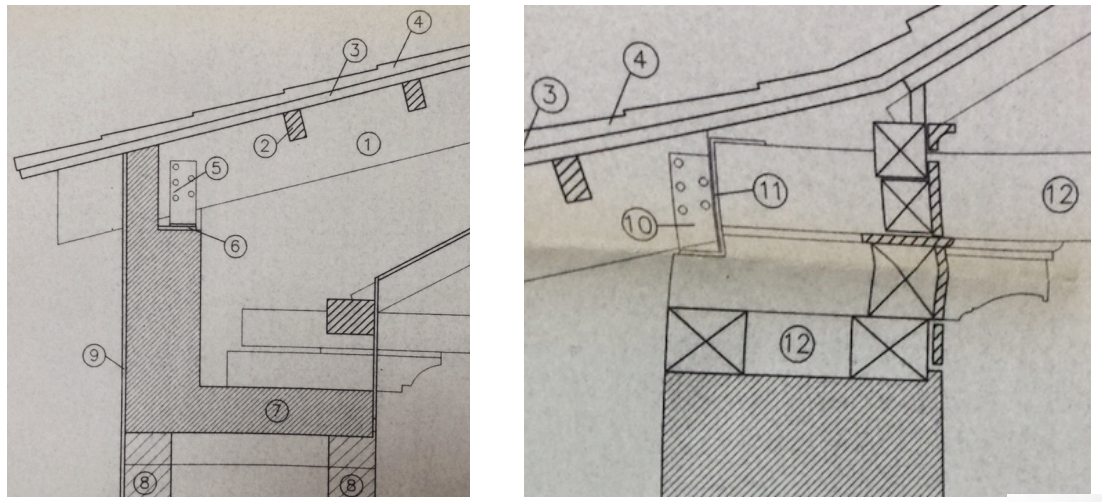

Fig.IV.17. Detalle Mayorga 1998 Espinosa JCyL

Montoya y Horno en 2000 restauran Santa María de Palazuelos con un proyecto en el que la cubierta aparece definida mediante una sección transversal general. El durmiente corrido sobre la coronación de ambos muros laterales, en este caso es de madera, atirantado con Montoya y Horno JCyL tensores metálicos.

En Villaverde de Medina, Jesus Tovar incorpora zunchos en 1989. Incluye unos detalles en cuya leyenda figura "zuncho de hormigón armado con redondos $\mathrm{D}=10 \mathrm{y}$ cercos $\mathrm{D}=8$ a 25 " pero no acota dimensiones ni ubicación del encajado sobre muros de fachada. El inclinado sobre los muros diafragma sí se define de 0,90x0,25 con 0,15 de fábrica a cada lado, aunque en la visita se aprecia cómo tanto éste como el otro se ejecutaron vistos, enrasados con el paramento.

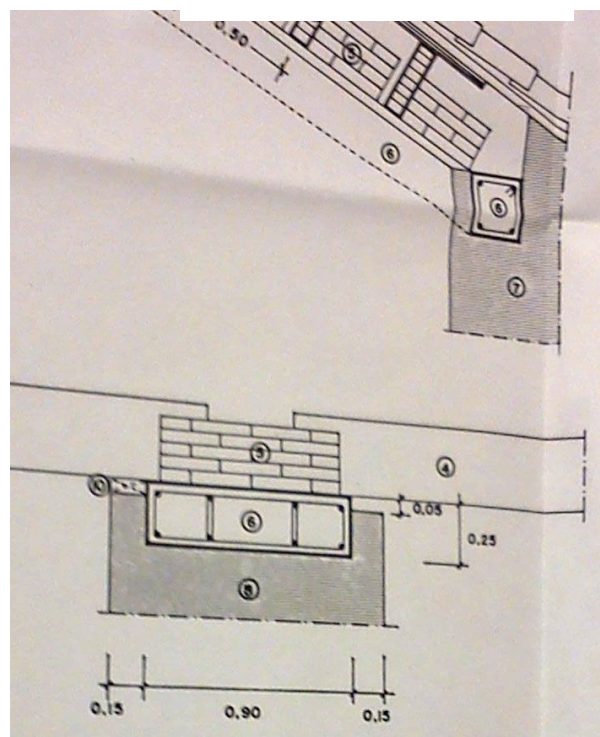

Fig.IV.19. Villaverde 1989 Tovar JCyL 
IV.1.2.5.2. La arquitecto Ana Iglesias fue responsable de muchas de las obras de restauración acometidas en los años 70 sobre el conjunto de iglesias analizado. Aunque en algunos casos no se han encontrado mencionados los zunchos en el proyecto, en la mayor parte se definen mediante un rótulo señalado sobre la planta de la nueva estructura de cubierta.

En 1974 escribe sobre la planta de Alaejos "zuncho interior perimetral de atado hormigón armado 40x40". También señala que el muro se recrece "hasta llegar a antigua línea vertical".

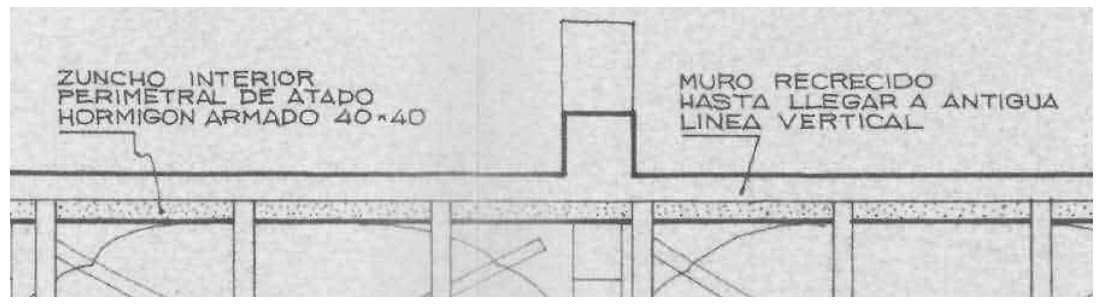

Fig.IV.20. Detalle Alaejos 1974 Iglesias IPCE

En 1976 incluye el detalle de sección de zuncho 30x40 sobre a una planta esquemática de las Huelgas Reales sin definir en este caso la ubicación exacta de la pieza sobre el muro, que se acota con una anchura de $40 \mathrm{~cm}$.

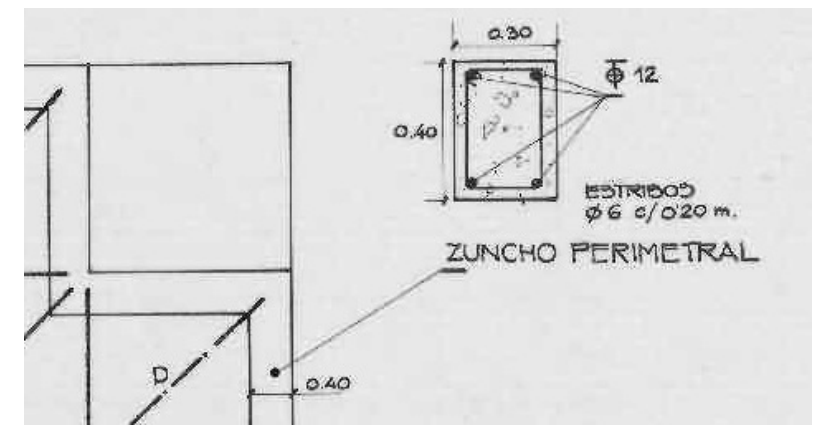

Fig.IV.21. Detalle Huelgas 1976 Iglesias IPCE

En la sección general de la iglesia de Santiago en Medina de Rioseco de 1978 no se aprecian los detalles del zuncho, cuyas dimensiones rotula de nuevo sobre la planta de estructura.

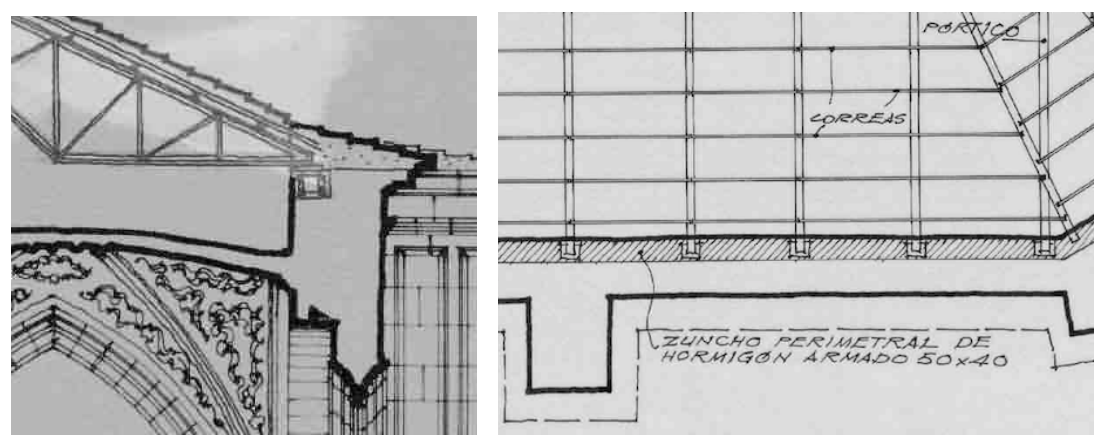

Fig.IV.22. Detalle Santiago 1978 Iglesias IPCE 
IV.1.2.5.3. Hemos visto que en varios casos entre los anteriores el detalle además no se corresponde con lo finalmente ejecutado. Este problema es bastante común.

Salvador Mata, en la entrevista, comentó que el peculiar detalle del plano de cornisa de su proyecto no se correspondía con la solución constructiva habitual de ladrillo que se llevó a cabo en las Angustias, cuando en 1991 demuele el zuncho-cornisa de hormigón armado fruto de una restauración anterior.

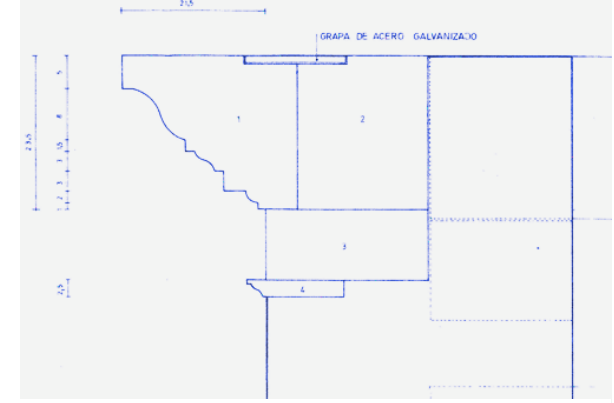

Fig.IV.23. Cornisa 1991 Mata JCyL

El caso de San Francisco en Medina de Rioseco es casi paradigmático. La obra arranca con planos de Ana Iglesias de 1979; tras el derrumbe final otro arquitecto, Espejel, rehace el proyecto diseñando una enorme cubierta abovedada, y finalmente en 1987 se contrata una tercera solución, con la bóveda al interior y cubierta a dos aguas, a Linazasoro.

Ana Iglesias incluye en sus planos su habitual definición de zuncho con leyendas rotuladas sobre la planta.
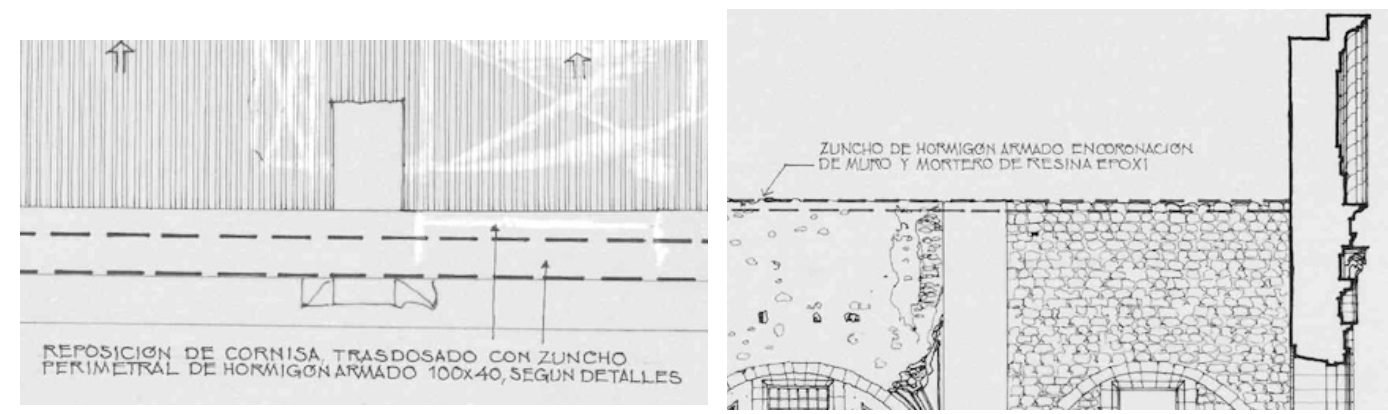

Fig.IV.24. Planta y sección 1979 Iglesias IPCE
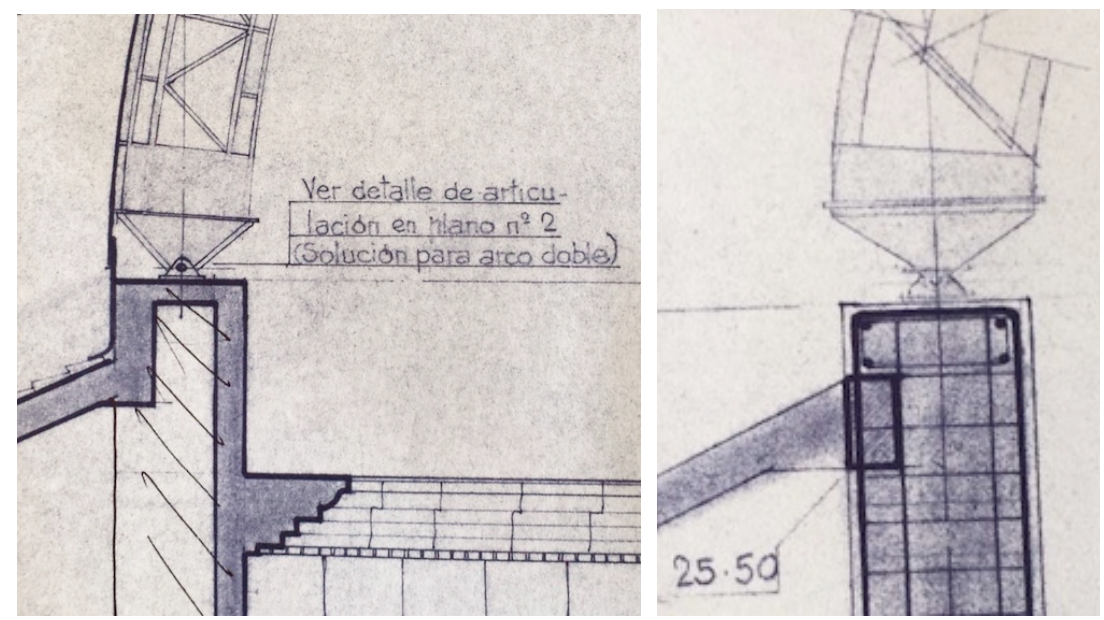

Fig.IV.25. Detalles 1982 Espejel IPCE 


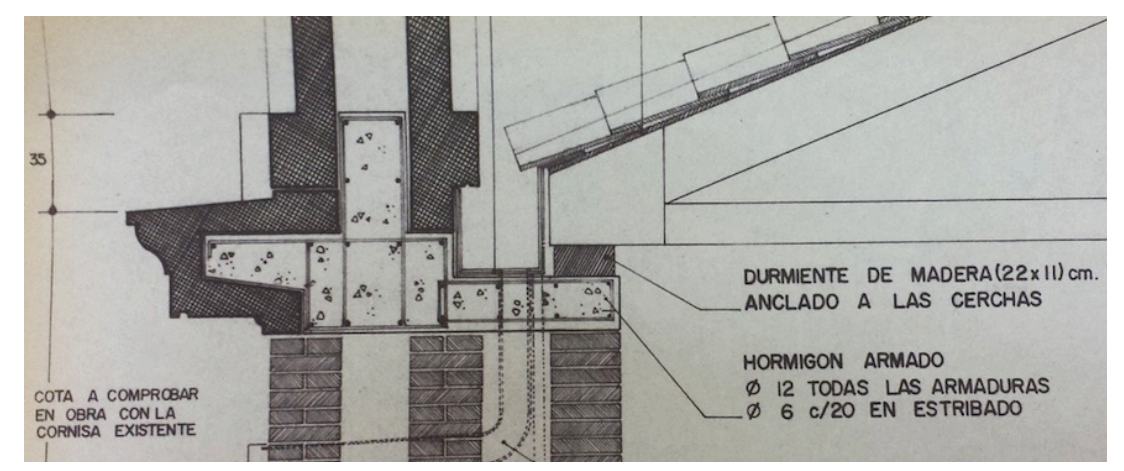

Fig.IV.26. Detalles 1987 Linazasoro JCyL

El detalle del tercer proyecto muestra una viga de perfil complicado en forma de yunque escalonado. Durante la visita se aprecia cómo el frente de la misma, bajo el apoyo del par, no es visto, sino que se encuentra oculto tras la fábrica de ladrillo, lo que indica que no se ejecutó conforme a dicho plano.

El detalle del proyecto de Luis Mingo para Santa María de Tordesillas en 1980 representa el zuncho centrado sobre el muro y con un tirante anclado a una cartela en el arranque de la cercha metálica. En el dossier se encontró un plano que debió realizarse para ejecutar la obra, ya que coincide con la solución observada durante la visita al bajo cubierta el 16/12/2013 y en el mismo se rotula "zuncho perimetral de 0,40 x 0,50 con 6 D16 y estribos D8/25", aunque como veremos en IV.2.4. no se llega a definir el anclaje del tirante.
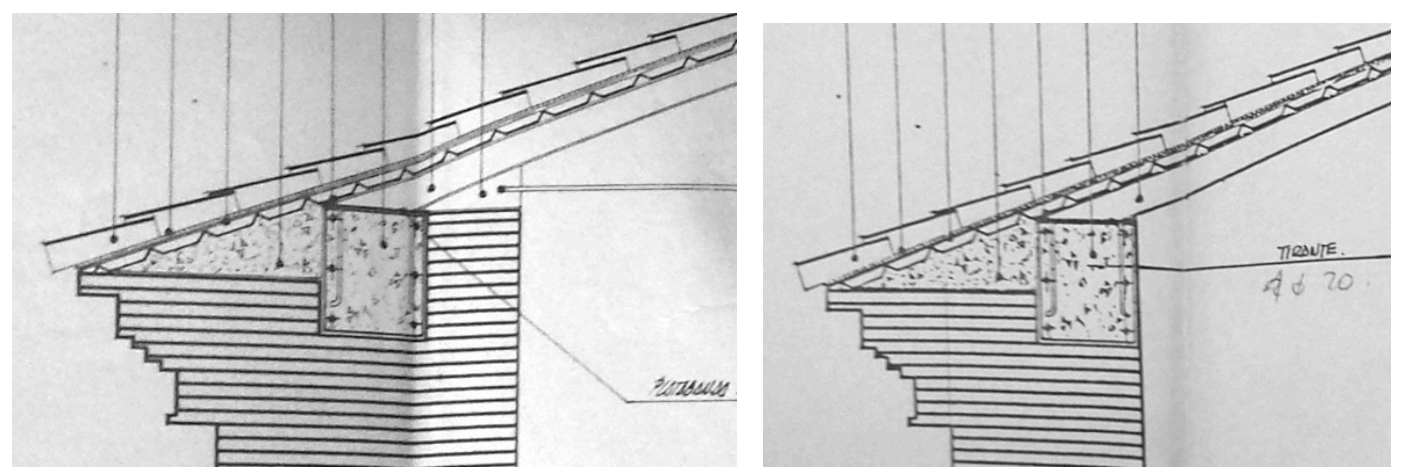

Fig.IV.27. Detalles proyecto y obra Tordesillas 1980 Mingo JCyL

Otro detalle en el que aparece el zuncho es el de Armando Areizaga para la iglesia de Serrada en 1992. En la leyenda se desglosa: teja curva cerámica, onduline, tablero fenólico de $19 \mathrm{~mm}$, correa, cercha, preformado de acero para anclaje a zuncho, D12 cada $35 \mathrm{~cm}$ en sujeción de alero, zuncho de hormigón H-175 de 60x25cm con 8D12 y cercos de D8 cada $10 \mathrm{~cm}$, recrecido con fábrica de LHD con mortero de cemento M40A, alero a consolidar. Pero, según se explica en la Ficha FZ-40 correspondiente, las proporciones del detalle no se corresponden con las dimensiones apreciadas en la visita realizada el 16/05/2014. 


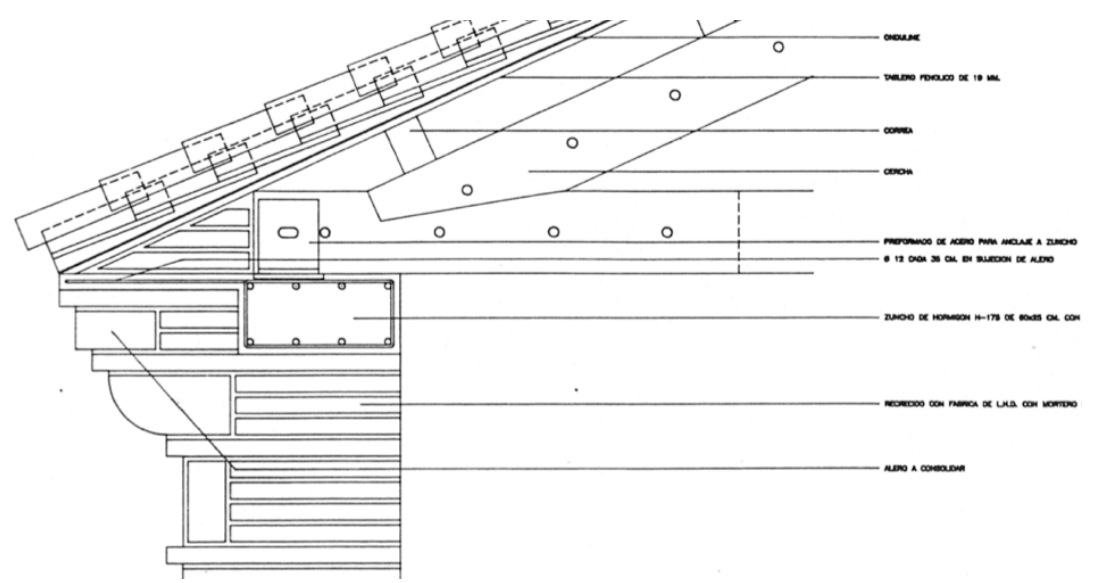

Fig.IV.28. Detalle Serrada 1992 Areizaga y Corral JCyL

IV.1.2.5.4. En muchos proyectos no aparece representado el zuncho en ninguno de los planos revisados.

En el plano de Arenillas del proyecto de 1965 en que se incorporan cadenas de hormigón armado en los muros de la iglesia de la Pasión transformada hoy en museo.

En la sección de 1994 de Gallegos y Salvador tampoco se representan detalles del apoyo de la estructura o la composición del muro. Aparece a trazos la prolongación dentro del mismo del perfil que soporta las placas de fibrocemento y una chimenea de ventilación de la cámara, que se prolonga hasta debajo del

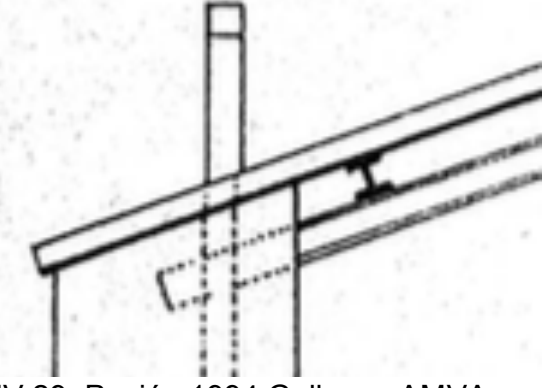

Fig.IV.29. Pasión 1994 Gallegos AMVA pavimento de planta baja.

En 1969 García Gil incorpora localmente un zuncho para arriostrar la esquina de la iglesia del convento de San Joaquín y Santa Ana pero en el dossier no se ha localizado documentación gráfica. En los planos de Ana Iglesias de una intervención posterior se representa el sistema constructivo definido en el proyecto de 1969 pero no se señala la existencia de zunchos. En 1993 Elesio Gatón dibuja la cornisa general (Fig.IV.30), en la que tampoco aparece, con el apoyo de la armadura

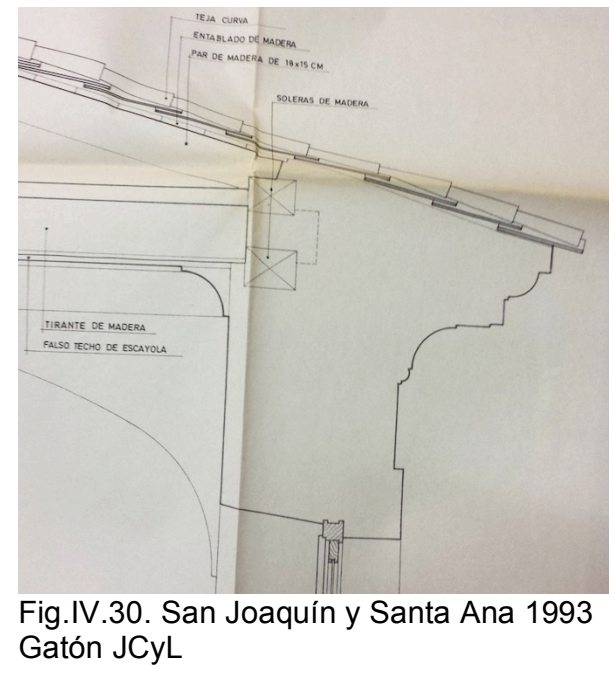
resuelto de forma tradicional. 
En 1974 Rodrigo y Roldán renuevan la cubierta de una nave lateral de San Juan en Fresno el Viejo mediante un forjado de hormigón armado con su correspondiente zuncho. Las copias de su proyecto conservadas en AGA e IPCE tienen un solo plano con dos plantas y un alzado, sin detalles de estructura.

En la última intervención llevada a cabo en la cubierta de la citada iglesia de Fresno el Viejo, Carreño desmonta, limpia y clasifica las piezas de la armadura en buen estado, reutilizándolas junto con elementos nuevos de madera de pino. $\mathrm{Su}$ detalle describe en 1997 la solución tradicional del apoyo sobre el muro resuelta con madera.

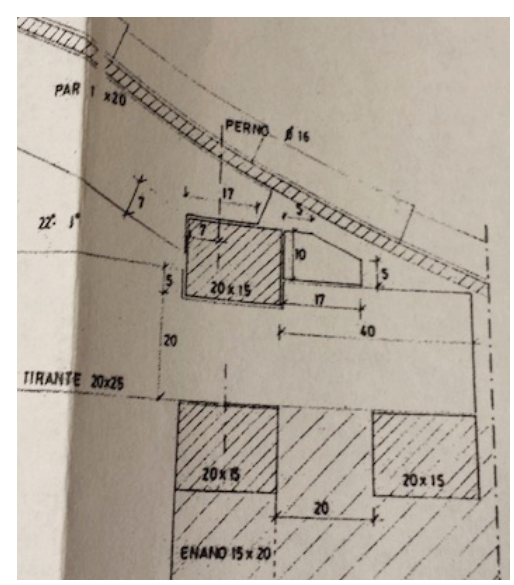

Fig.IV.31. Fresno 1997 Carreño

Tampoco aparecen zunchos en la sección de cubierta diseñada por Cervera en 1974 para la Capilla de San Gregorio con tabiquillos palomeros sobre el trasdós de las bóvedas.

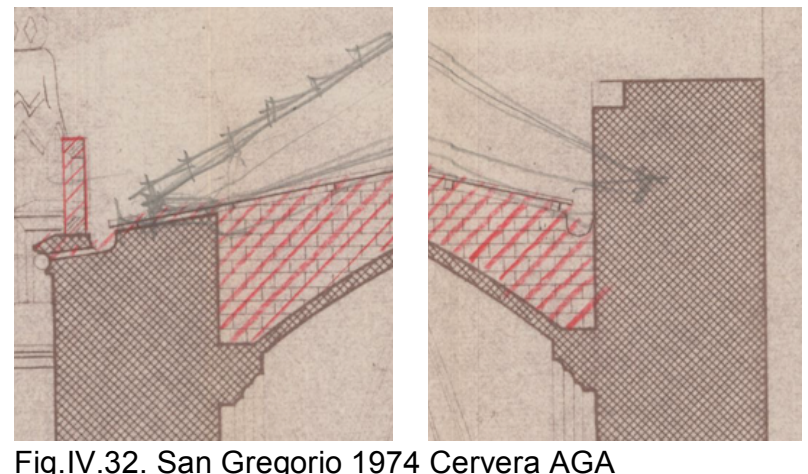

Fig.IV.32. San Gregorio 1974 Cervera AGA

En los detalles de Pablo Puente de 1991 no aparece representado ni se menciona el zuncho perimetral que se describe en la memoria del proyecto de Revitalización de Valbuena.

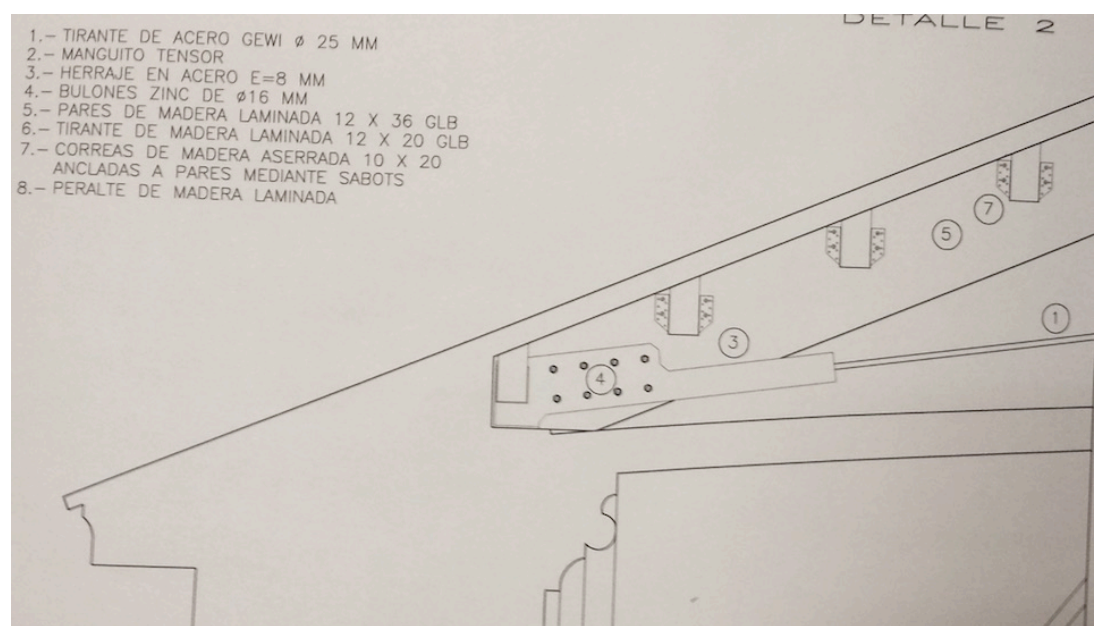

Fig.IV.33. Detalle Valbuena 1991 Puente JCyL 
En la última restauración de las cubiertas de Santa María de Íscar, Cembrero incorpora en 2000 madera laminada para reemplazar las piezas en mal estado, apoyadas sobre un durmiente de madera. No se mencionan zunchos en ninguna de las intervenciones analizadas. En el detalle de la cornisa se describe la prolongación del Onduline sobre el ancho del muro y el vuelo de ladrillos y bocatejas existentes. En el dibujo se coloca una rasilla sobre el remate del muro de piedra.

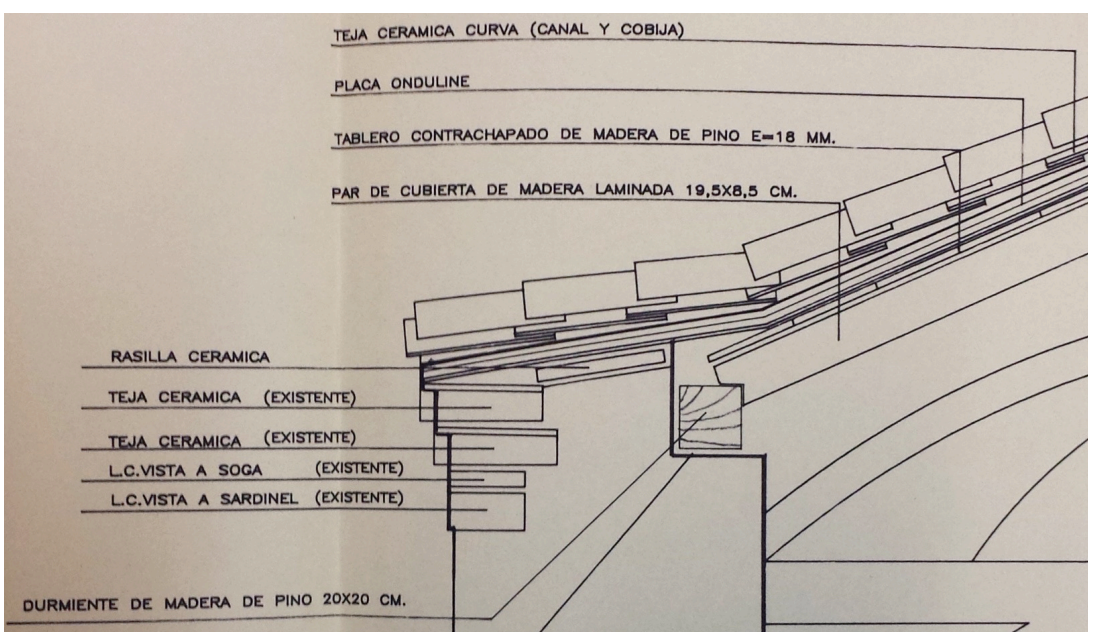

Fig.IV.34. Detalle Íscar 2000 Cembrero JCyL

En la sección transversal de la iglesia de Wamba de 1985 firmada por Quintana y Boned se representa una solución distinta en el muro del evangelio, más grueso, y en el de la epístola, donde se desarrolla la pasarela corrida de acceso a la cubierta, pero no se describe la composición de la fábrica.

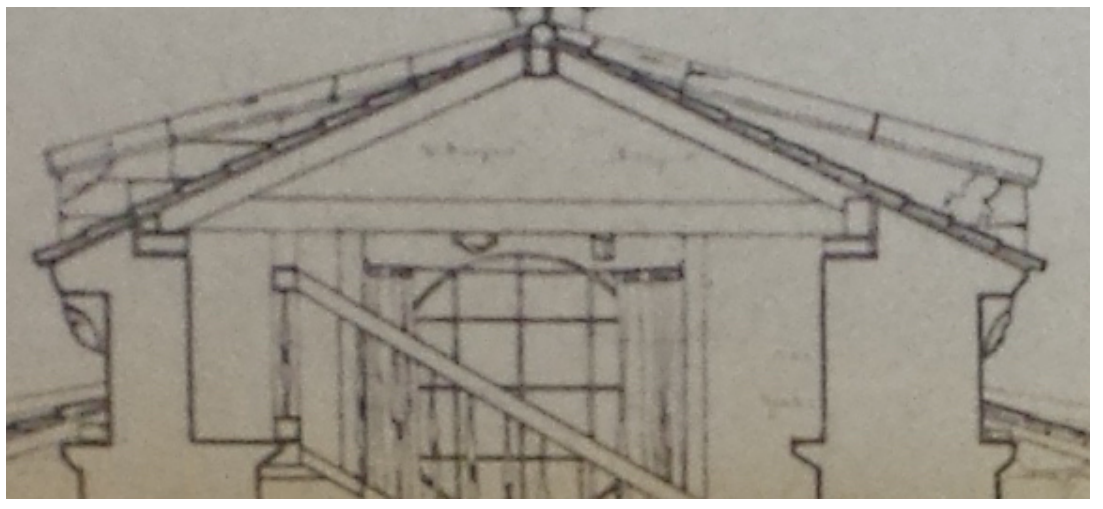

Fig.IV.35. Sección de Wamba 1985 Quintana y Boned JCyL

En 1962 había intervenido Arenillas, el cual afirma en la memoria del proyecto que pone sobre los artesonados unas "viguetas de hormigón armado a modo de par e hilera, estribando sobre los muros; forjar con bovedilla de rasilla o de cemento los faldones resultantes". No hay planos de esta intervención y la sección de 1985 muestra el artesonado como única estructura de cubierta pero, según se describe en la Ficha correspondiente, en algún punto se ha detectado la existencia de un zuncho de hormigón tras el durmiente de madera. 
IV.1.2.5.5. Como hemos visto, muchos proyectos no incluyen el zuncho en sus detalles. En algunos, además, los planos presentan un nivel de definición mínimo.

Por ejemplo, el detalle que da Arenillas para definir la estructura de cubierta metálica que coloca en San Pablo en 1964 es muy somero, con líneas sin rematar y a pequeña escala. Ni siquiera aparece representado el vuelo de la cornisa.

También en Cuenca de Campos diseña una estructura de vigas de hormigón que representa en color rojo sobre la sección sin indicar sus dimensiones.
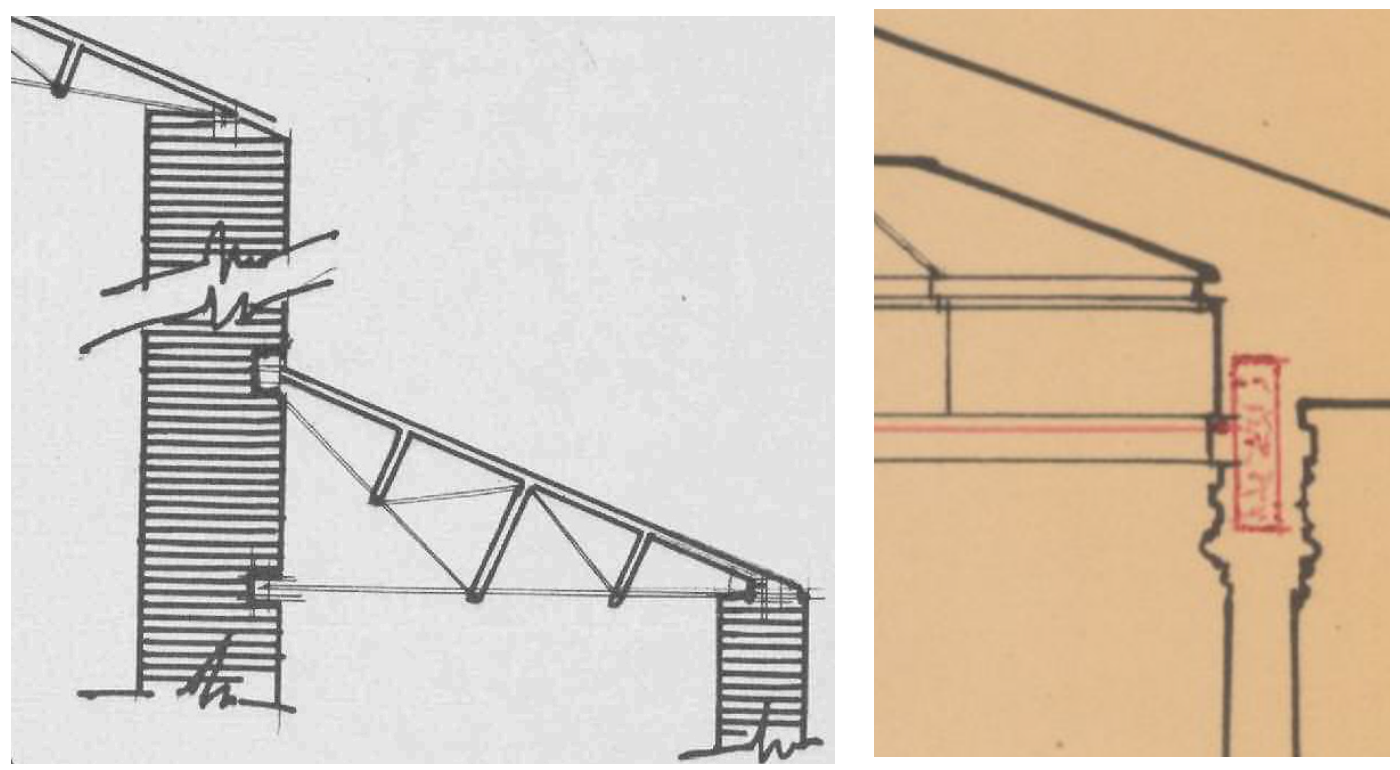

Fig.IV.36. Detalles San Pablo 1964 Arenillas IPCE; Cuenca de Campos 1967 Arenillas AGA

Otro claro ejemplo de diseño esquemático de Anselmo Arenillas es su sección transversal de 1968 para la iglesia de San Martín, en Medina del Campo, sobre la que dibuja a mano en rojo el conjunto zuncho, par y tirante que conforman la nueva estructura metálica que diseña para la cabecera.

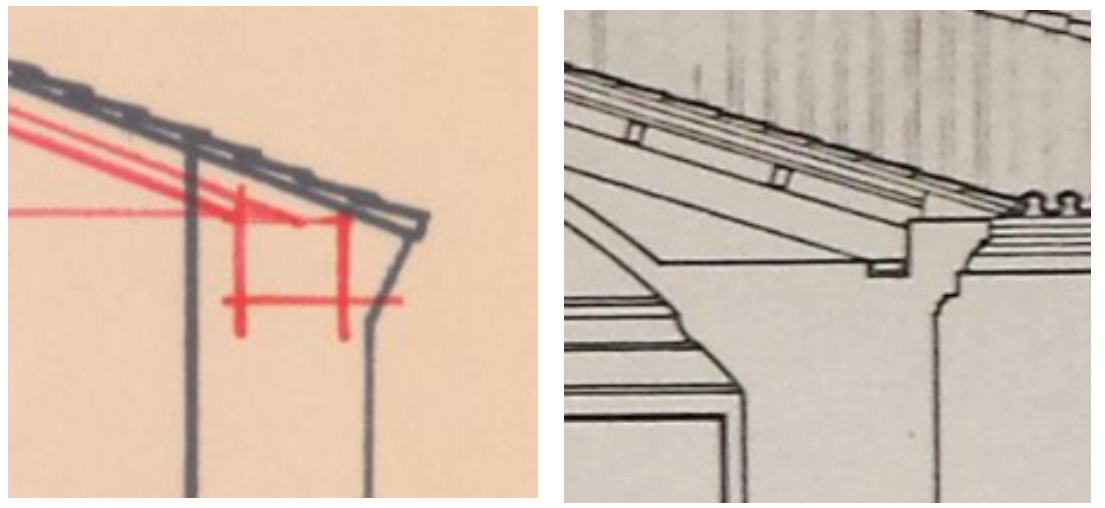

Fig.IV.37. Detalles San Martín 1968 Arenillas y SF. JCyL 
En la única sección transversal de la nave de la iglesia (plano sin autor ni fecha, puede ser de Fernández e Inglés 1989) también se representa de forma somera el apoyo del par de madera laminada sobre un pequeño durmiente, cajeado en la coronación sobre la que sobresale la cornisa, sin definir los materiales que forman la sección del muro.

También llama la atención, por su falta de detalle del apoyo de cubierta, el conjunto de planos de Ana Iglesias para la restauración de las Descalzas Reales en 1978 digitalizados en la Planoteca del IPCE ${ }^{73}$.

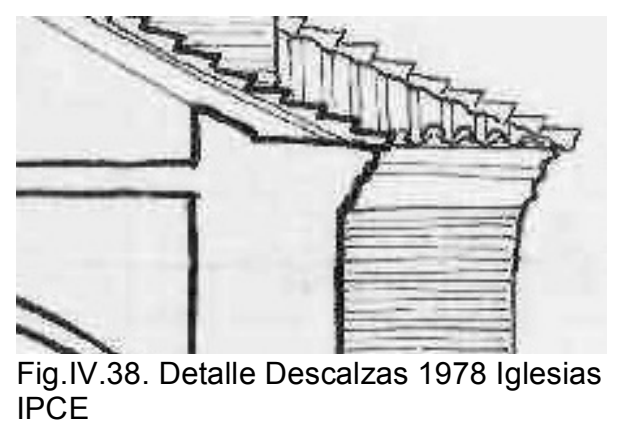

Según se ha comentado, en Castronuño no llega a ejecutarse la actuación proyectada en 1974 por Ana Iglesias. Los planos de su proyecto son generales y no ofrecen detalles de la sección de las fábricas. Es probable además que la estructura del tejado sobre el trasdós de las bóvedas la renovase años atrás Arenillas.

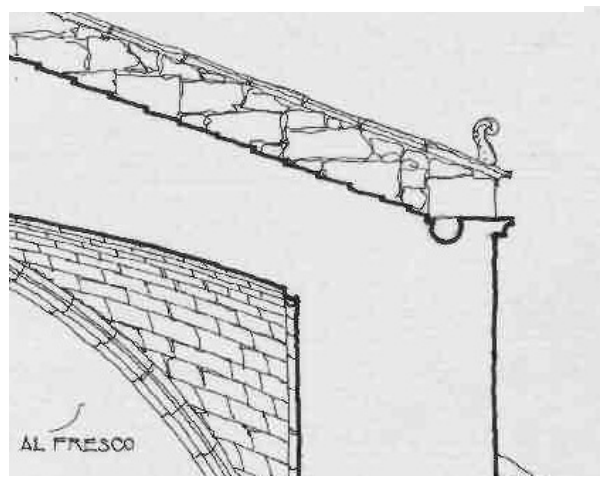

Fig.IV.39. Sección Castronuño 1974 Iglesias IPCE

En las copias del proyecto de Ana Iglesias en 1978 para la restauración de la Anunciada de Urueña no se han localizado detalles, y la sección de la Planoteca IPCE es un plano general con bajo nivel de definición aunque se señala la escala $1 / 50$ en la carátula.

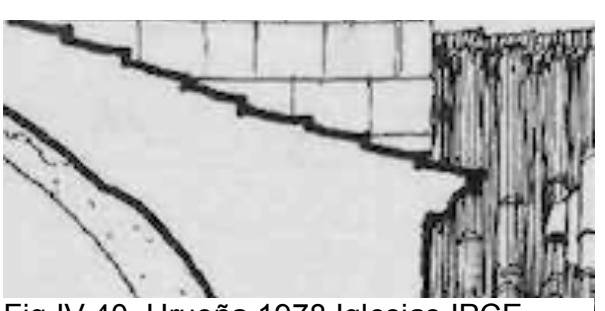

Fig.IV.40. Urueña 1978 Iglesias IPCE

No se cuenta con el proyecto de reemplazo de cubiertas de la Santa Espina. En el Plan Director de 2008 el nivel de detalle de los planos ${ }^{74}$ es muy bajo, apareciendo como un macizado homogéneo todo el espacio bajo cubierta, sin definir los sistemas constructivos, y el encuentro de faldones con el muro sin resalto alguno.

\footnotetext{
${ }^{73}$ Al principio del apartado se hace hincapié precisamente en la calidad de los planos de Ana Iglesias gracias al uso de la bicámara que emplea su delineante habitual Sandoval. Los planos de las Descalzas se atribuyen a otro dibujante, Luis Benito.

${ }^{74}$ Estos mismos planos se han utilizado además para ilustrar el libro La Santa Espina una morada luminosa, de Antonio Piedra, editado en 2014 por la Junta de Castilla y León.
} 
No es comprensible la baja definición y total ausencia de cotas en los planos citados cuando se cuenta con un preciso levantamiento $3 \mathrm{D}$ exterior general del Monasterio y del espacio interior del templo, según vemos en las perspectivas con líneas insertada en los planos.

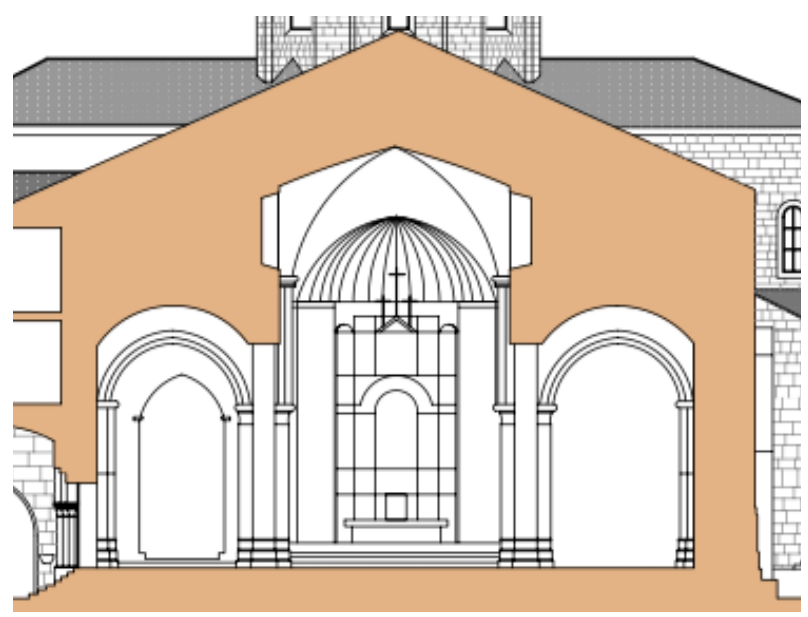

Fig.IV.41. Sección Plan Director la Santa Espina
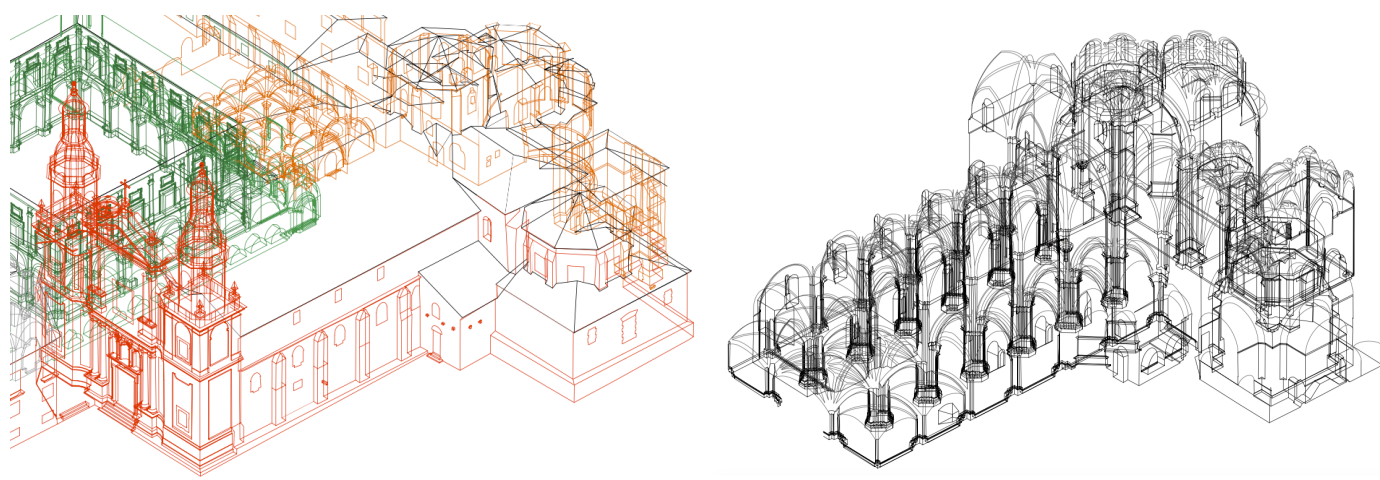

Fig.IV.42. Levantamiento Santa Espina

IV.1.2.5.6. Encontramos, por último, diversos proyectos en los que sí se incluyen detalles que describen las soluciones empleadas en las obras correspondientes.

Así, Ana Iglesias en 1974 incorpora un detalle a que describe el recrecido de ladrillo que pretende resolver la acumulación de agua tras la portada de Alaejos en la sección de estado reformado. En el mismo se detalla a escala 1:20, con un nivel de definición poco habitual en la época, la solución de anclaje de las cerchas sobre el zuncho.
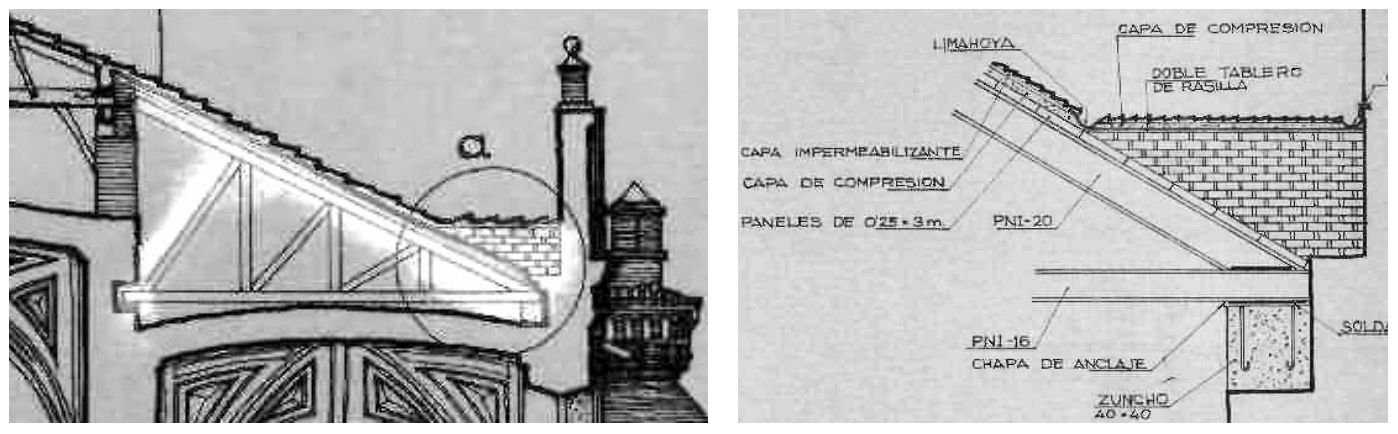

Fig.IV.43. Detalles Alaejos 1974 Iglesias IPCE 
Aunque el zuncho definido en el proyecto de 1982 realizado por Pérez Medina no se incorpora en el templo, sino en un bloque adyacente (la Sala del Cabildo), se trata de un elemento singular que puede resultar interesante tener en cuenta. En los planos se define la sección, acotada y con los diámetros de las armaduras especificados, como una singular pieza corrida que conforma el remate del muro incluyendo alero y canalón. Según Mata, el arquitecto que intervino diez años más tarde, el elemento llegó a deformarse y retorcerse, por lo que tuvo que demolerlo.

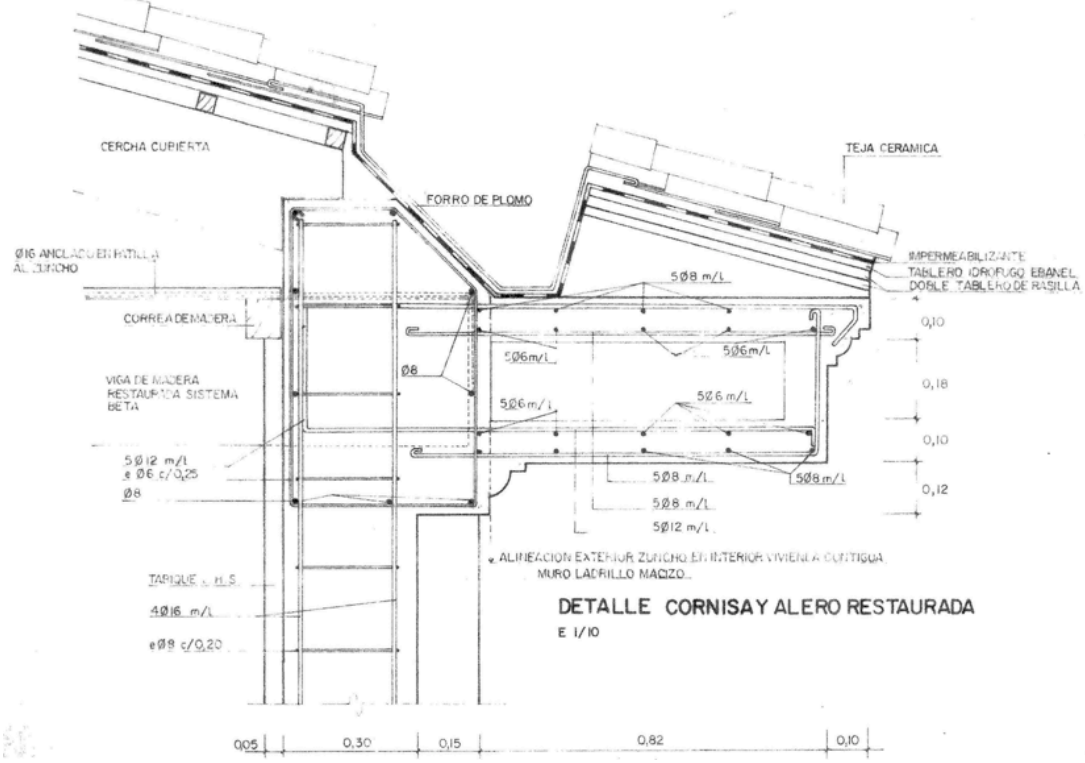

Fig.IV.44. Detalle zuncho-cornisa Angustias 1982 Pérez Medina JCyL

Iñiguez en la iglesia del Rosarillo coloca un HEB como zuncho perimetral.

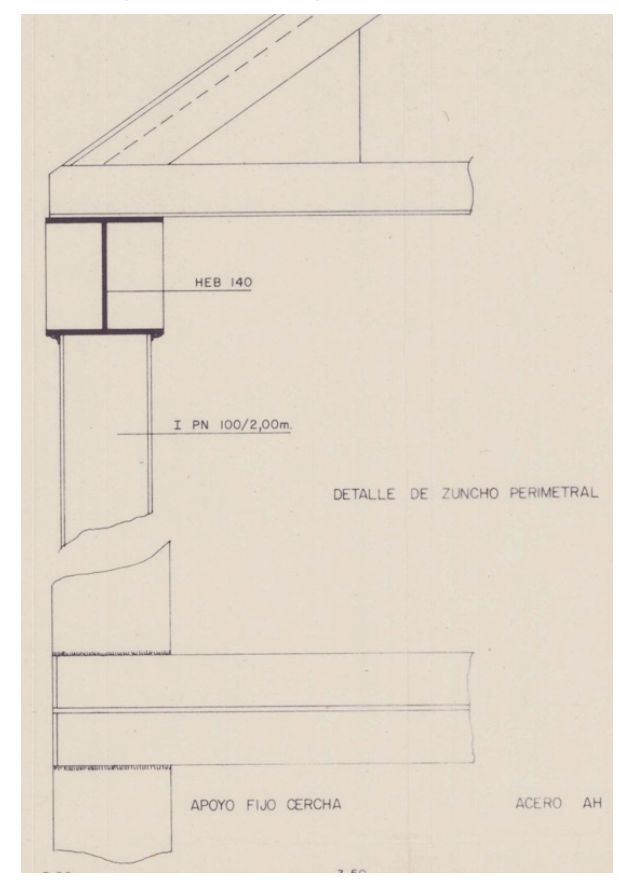

Fig.IV.45. Rosarillo 1980 Iñiguez AGA 
En PortaCoeli en 1983 se definen unos dados de hormigón para apoyar dos cerchas sin tirante que se reemplazan tras su hundimiento.

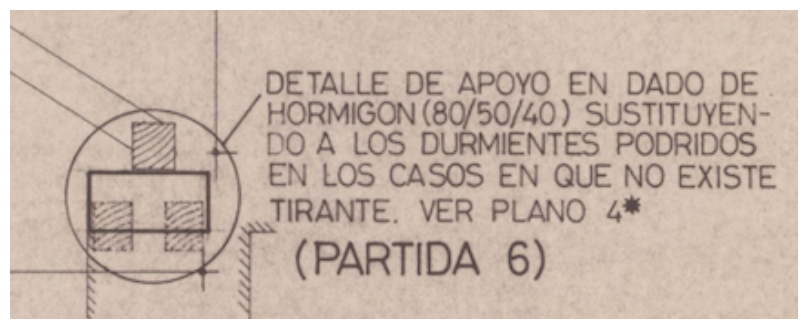

Fig.IV.46. Portaceli 4 dados 1983 Roldán AGA

En los detalles de Gárate para la cubierta de la iglesia de San Francisco en Medina de Rioseco se representa un zuncho genérico, sin acotar la ubicación, con las dimensiones definidas en una de las leyendas rotuladas en el plano.
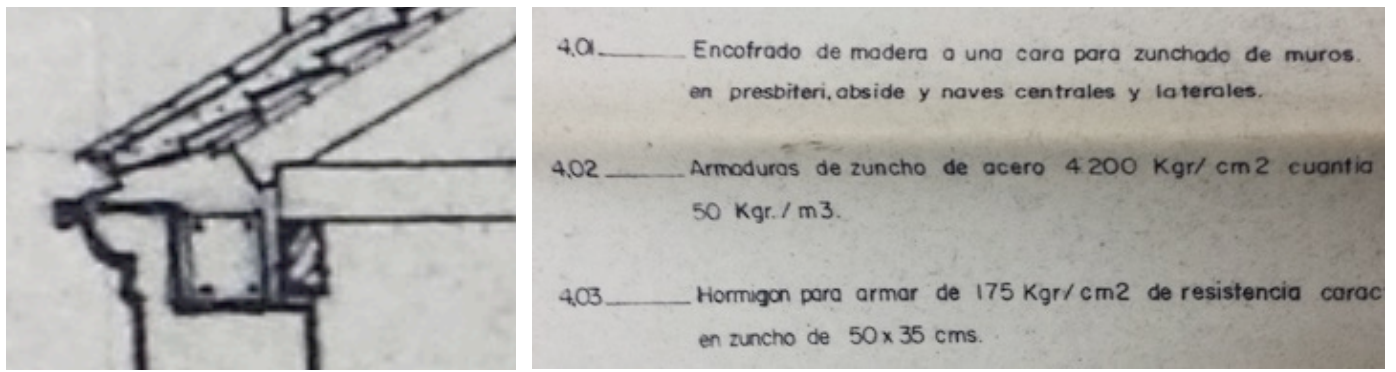

Fig.IV.47. Detalle San Francisco 1986 Gárate y Manzano JCyL

En 1998 Gallegos y González definen los detalles de la cubierta moderna del Archivo Municipal, antigua iglesia de San Agustín. El zuncho cubre la sección completa del muro, acotándose con anchura de 1,0 m aproximado y $0,35 \mathrm{~m}$ de canto en el detalle, aunque aparece en el presupuesto con una medición ligeramente mayor, de $1,10 \mathrm{x} 0,40 \mathrm{~m}$.

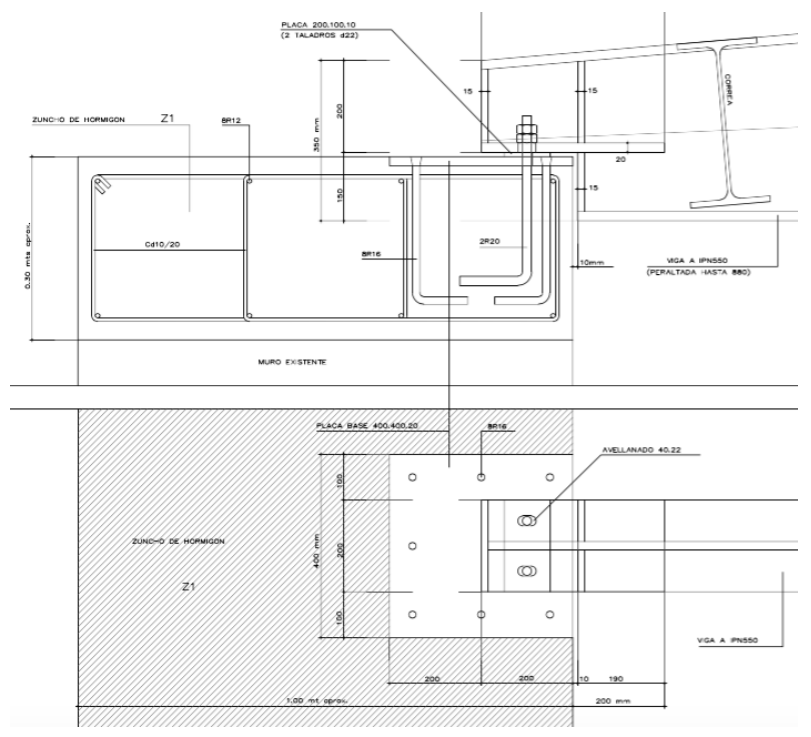

Fig.IV.48. San Agustín 1998 Gallegos y González AMVA 
Abad en 1999 restaura las cubiertas de la iglesia del Salvador sin incorporar zunchos de hormigón. El detalle de apoyo de cerchas sobre los muros se resuelve de forma tradicional, con dobles piezas de madera aseguradas con embridados metálicos.

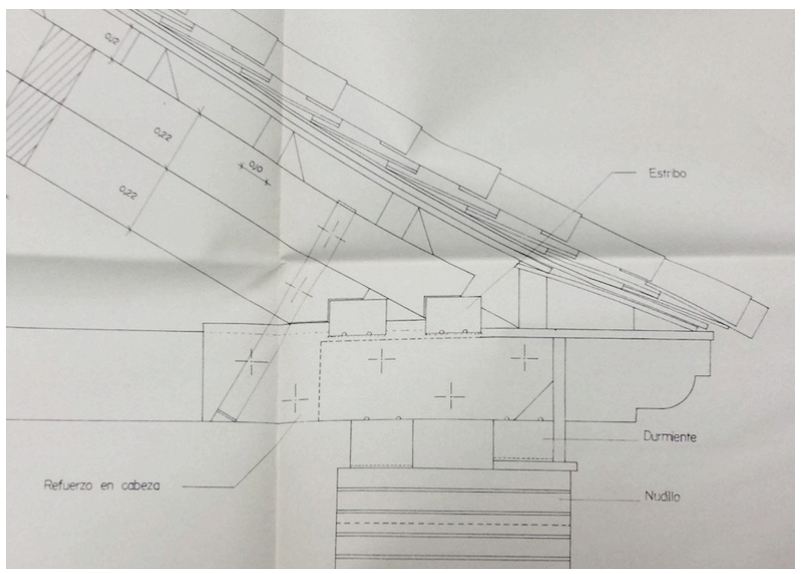

Fig.IV.49. El Salvador 1999 Abad JCyL

García Paniagua en 1999 define para la Colegiata de San Antolín una pieza de cornisa moldeada y supuestamente mantiene el zuncho existente sobre los muros de fachada desde el año 82. En algunas secciones representa un pequeño zuncho de hormigón entre dos durmientes de madera de los muros interiores con la pretensión de mantener la estructura de madera existente sobre la nave central y reemplazar sólo en crujías laterales, pero en otras aparece ya la solución que finalmente llevó a cabo con un zuncho más generoso y la sustitución total de las cubiertas.
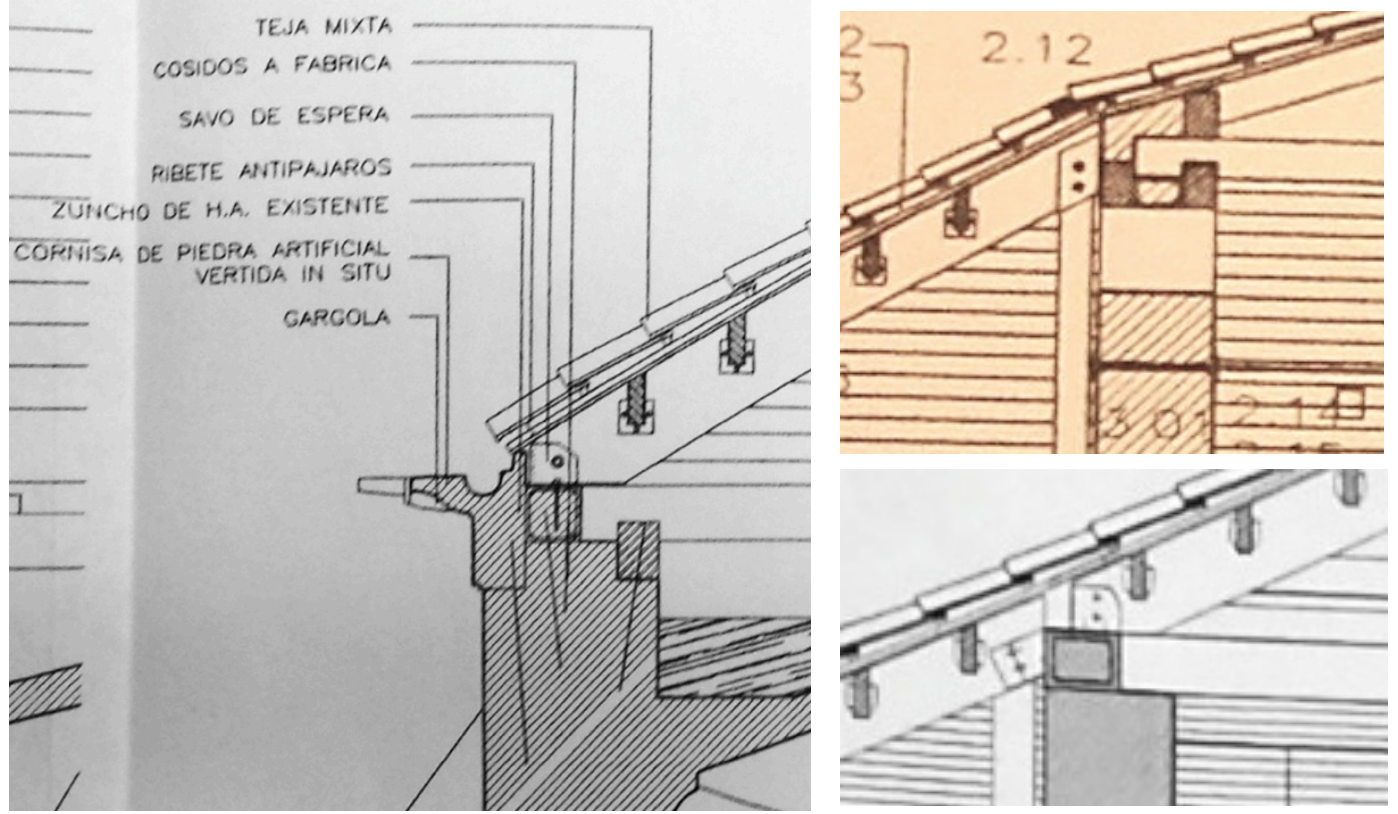

Fig.IV.50. Detalles San Antolín 1999 Paniagua JCyL 
En resumen, la documentación gráfica del conjunto de iglesias revisado comprende plantas, alzados y secciones que muestran características similares, desde los planos más antiguos hasta los levantamientos más modernos. La principal dificultad que ofrece su estudio es la falta de concordancia que se produce en muchos casos entre lo proyectado y la obra que se ejecuta. Otro aspecto que complica el manejo de los documentos es la escasez de cotas, ya que en la mayor parte de los planos ni siquiera se incorpora pitipié. La escala del dibujo suele determinarse únicamente en la cartela del plano, generalmente definida como 1:50 o 1:100, confiándose de la correspondencia con el dibujo por tratarse de documentos en papel. La consulta de esos planos sin escala gráfica se ha realizado en muchos casos mediante copias reducidas y fotografías de los mismos, con la consiguiente pérdida de información.

Aunque las técnicas modernas de levantamiento por puntos faciliten abundante documentación de la geometría del edificio al arquitecto que redacta un proyecto de restauración, los planos del mismo proporcionan a veces a los usuarios una información más escasa que la que obtendrían a partir de un simple croquis a mano acotado.

Se han clasificado en todas las épocas casos en que se representa correctamente el zuncho en los planos de proyecto, otros que lo incluyen pero sin precisar sus dimensiones ni ubicación sobre la fábrica, los que contienen detalles que no coinciden con la solución realmente ejecutada y algunos proyectos en los que es probable que se dispusiera zuncho pero éste no aparece representado. En los 60 el arquitecto Anselmo Arenillas suele proporcionar sólo una planta general y, si incluye detalles de la sección, éstos son muy esquemáticos. En los 70 las obras son realizadas habitualmente por Ana Iglesias que suele definir el zuncho mediante rótulos sobre la planta. 



\section{IV.2. Análisis de los edificios}

Hemos visto en el apartado anterior diversos aspectos relativos a los proyectos de intervención sobre el conjunto de iglesias elegido. A continuación vamos a tratar los factores directamente relacionados con los edificios construidos que se han podido contrastar mediante la labor de campo realizada. En primer lugar se incluye una breve descripción de los templos, tratando de clasificarlos a partir de una serie de parámetros básicos como su esquema geométrico, buscando una posible relación entre la tipología del edificio y la incorporación de zunchos en las actuaciones que se han llevado a cabo sobre el mismo a lo largo del tiempo.

A continuación se abordarán los aspectos estructurales, desde la cimentación hasta la cubierta, haciendo especial hincapié en la importancia de los muros de carga de distintas fábricas. En tercer lugar se plantea el análisis de los elementos que, además de la estructura, forman las cubiertas, como son el material de cobertura de faldones, los tableros y las cornisas. Por último se desarrollan las cuestiones específicamente relacionadas con los zunchos observados, como la fecha en que se incorporaron, sus dimensiones, ubicación y forma.

\section{IV.2.1. Descripción y tipologías}

El conjunto de edificios objeto de estudio comprende un amplio abanico de construcciones distintas, desde una pequeña ermita hasta una gran catedral, cinco antiguas iglesias convertidas en museos, otra arruinada y reconstruida como archivo y varios templos que forman actualmente parte de complejos monásticos o pertenecieron a ellos en algún momento de su historia. En algún caso la edificación se arruinó llegando prácticamente a desaparecer.

Según se ha justificado en los capítulos correspondientes a introducción y metodología, no se ha tratado de elaborar un catálogo y los monumentos tampoco aparecen ordenados cronológicamente en función de sus orígenes. Se mantiene, para clasificar las referencias, el orden establecido en el libro empleado como punto de partida para realizar la selección de los casos, que en cierto modo está organizado de forma alfabética por localidades. 
Empezamos el análisis de los edificios realizando una somera descripción de los mismos, en primer lugar geométrica, a continuación relativa a su uso y por último referida a su estado, tanto actual como a lo largo del tiempo, con especial énfasis en cómo se encontraba en el momento de incorporarse el zuncho.

En la última parte de la Tesis se recoge una documentación más completa de cada uno de los casos estudiados, estructurada en forma de Fichas con recopilación de transcripciones de la documentación manejada y el resumen con fotografías de las visitas de inspección que ha sido posible llevar a cabo.

\section{IV.2.1.1. La Geometría}

Todos los edificios de la muestra forman parte del Patrimonio histórico-artístico y cuentan con características espaciales y formales de interés aunque, según se ha comentado, algunos de ellos no estén actualmente catalogados como BIC. Estas construcciones han permanecido en activo durante siglos, sufriendo cambios dictados en cada caso por las necesidades del culto, los deseos de los benefactores o incluso para seguir las modas o adaptarse a los criterios estéticos imperantes en cada época.

Entre los casos estudiados, por ejemplo, encontramos el de San Antolín, que fue Colegiata en Medina del Campo, cubierta con bóvedas de crucería estrellada al mismo nivel, bajo la enorme cubierta a dos aguas.
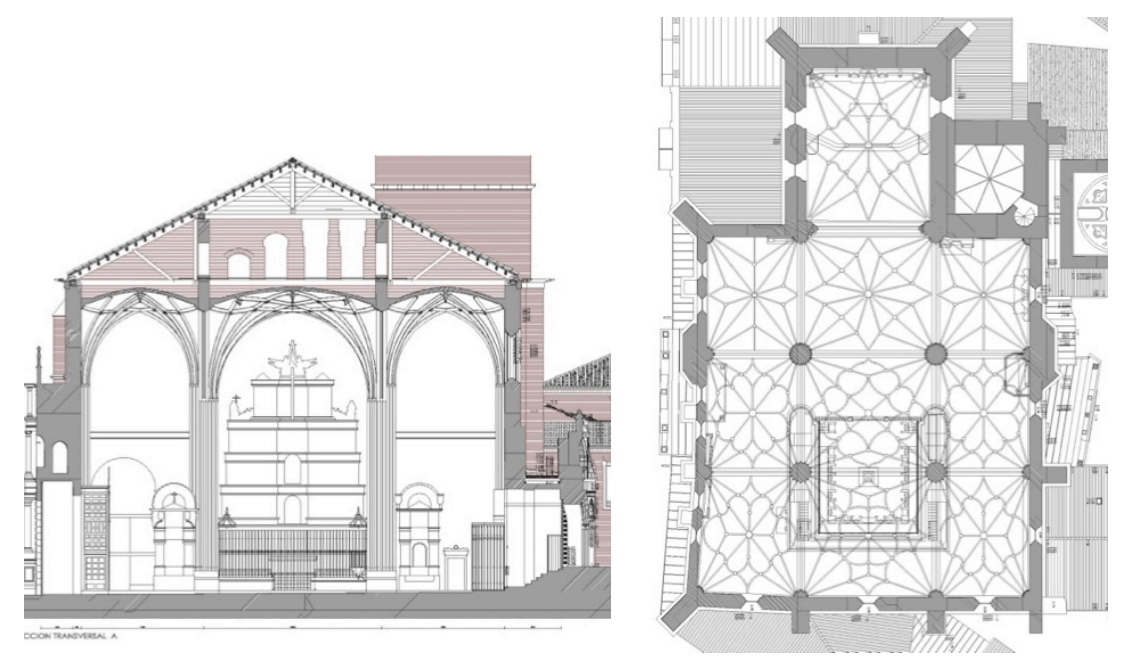

Fig. IV.51. Planta y sección San Antolín, Medina del Campo. 2003 Paniagua JCyL. 
La tipología de tres naves de similar altura bajo una única cubierta a dos aguas nos remitiría a la consideración de este templo como tipo salón ${ }^{1}$ :

- Las bóvedas de las tres naves arrancan a la misma altura, al ser de anchura similar las claves también quedan a un nivel semejante, se unifican los nervios sin compartimentar por tramos.

- No se cuenta con transepto marcado ni cimborrio; en el exterior se manifiesta una horizontalidad desornamentada.

- Unos pocos pilares exentos (góticos, cilíndricos o columnas) soportan el peso de las bóvedas en el interior.

Y en Nava del Rey, la iglesia de los Santos Juanes analizada, aunque esté ejecutada con un lenguaje "a la romana" ${ }^{2}$ cuenta con un esquema salón equivalente.
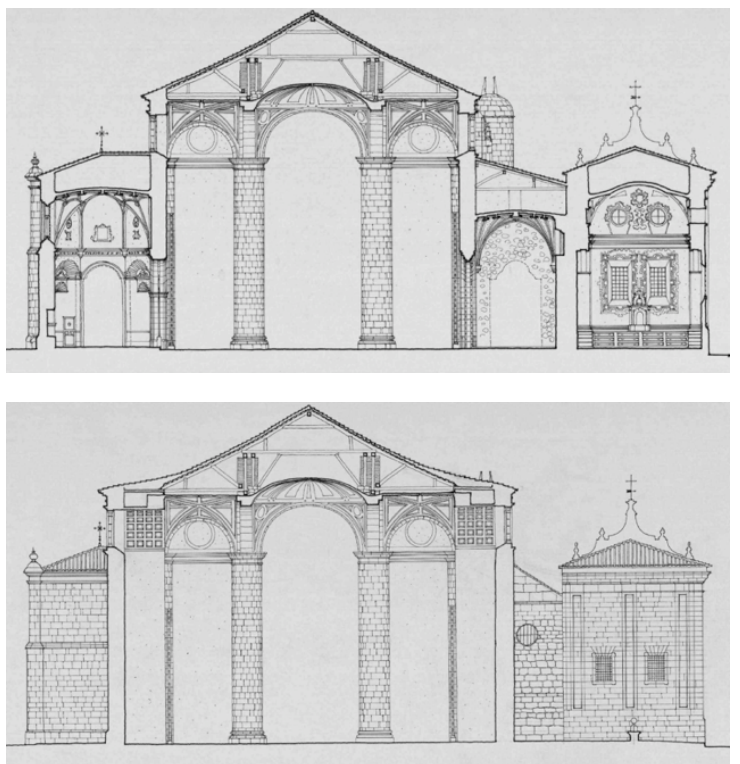

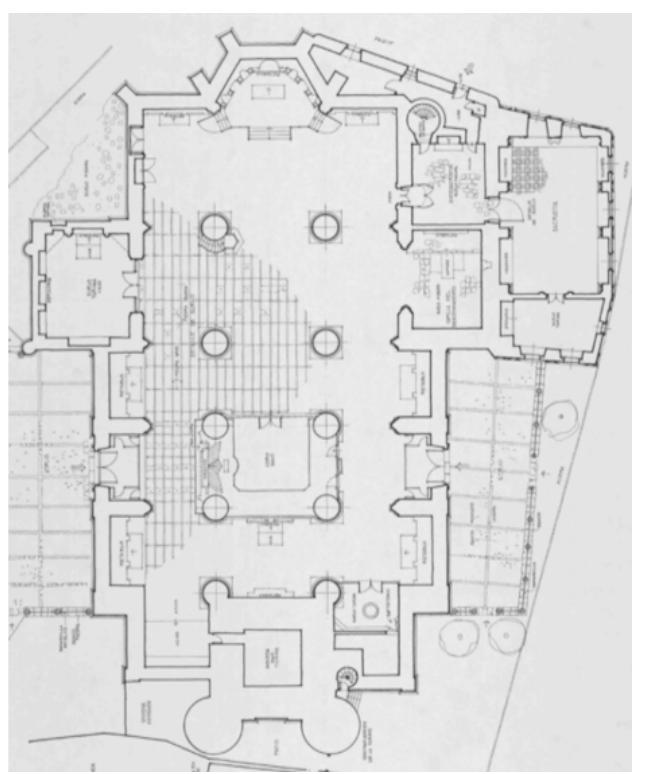

Fig. IV.52 Santos Juanes, Nava del Rey. 1978 Iglesias IPCE.

No es posible aislar estrictamente los aspectos constructivos de los estilísticos, pero dado que se pretende clasificar los casos de estudio a partir de la simplificación más básica posible, los dos ejemplos anteriores se considerarán, a efectos de su geometría, simplemente como iglesias de tres naves bajo dos faldones, San Antolín sin capillas laterales ${ }^{3}$ y los Santos Juanes con ellas.

\footnotetext{
${ }^{1}$ Se trata de qué entendemos hoy por iglesia salón columnaria, según Begoña Alonso (libro Arquitectura tardogótica en Castilla: los Rasines, a partir de su Tesis Doctoral pag108-115)

${ }^{2}$ En el apartado de los Antecedentes sobre El foco clasicista se describe el caso de este templo que fue objeto de un Pleito por incumplimiento de contrato al arrancar la obra bajo trazas góticas de Gil de Hontañón y ser rematado en estilo clasicista por Felipe de la Cajiga.

${ }^{3}$ Veremos en el análisis desde el punto de vista estructural cómo es posible que contar o no con capillas laterales puede llegar a incidir de forma directa en el comportamiento hasta nuestros días de un zuncho dispuesto en el siglo XX.
} 


\section{IV.2.1.2. Clasificación básica de los templos estudiados}

A continuación se clasifican las iglesias estudiadas en función de diversos parámetros, como la geometría básica de naves y cabeceras, la ubicación de las torres, el uso del inmueble y los procesos de ruina.

Tabla 4: Geometría del cuerpo del templo

\begin{tabular}{|c|c|c|c|c|c|}
\hline \multirow{3}{*}{$\mathrm{FICHA}$} & \multirow{3}{*}{ IGLESIA } & \multicolumn{4}{|c|}{ TIPOLOGÍA } \\
\hline & & & & & \\
\hline & & 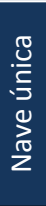 & $\frac{\frac{n}{0}}{\overline{\overline{0}}}$ & 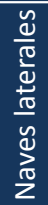 & $\frac{\frac{n}{0}}{\frac{\overline{0}}{\bar{D}}}$ \\
\hline FZ-01 & Catedral (Valladolid) & & & $\mathrm{X}$ & $\mathrm{X}$ \\
\hline FZ-02 & Convento de la Concepcion (Valladolid) & $\mathrm{X}$ & & & \\
\hline FZ-03 & Capilla de San Gregorio (Valladolid) & $\mathrm{X}$ & & & \\
\hline FZ-04 & La Pasion (Valladolid) & $\mathrm{X}$ & & & \\
\hline FZ-05 & Convento de Portaceli (Valladolid) & $\mathrm{X}$ & & & \\
\hline FZ-06 & Las Angustias (Valladolid) & $\mathrm{x}$ & $x$ & & \\
\hline FZ-07 & San Agustín (Valladolid) & $\mathrm{X}$ & $\mathrm{x}$ & & \\
\hline FZ-08 & San Benito el Real (Valladolid) & & & $\mathrm{X}$ & $\mathrm{X}$ \\
\hline FZ-09 & San Lorenzo (Valladolid) & & & & \\
\hline$F Z-10$ & San Pablo (Valladolid) & $\mathrm{X}$ & $\mathrm{x}$ & & \\
\hline FZ-11 & La Antigua (Valladolid) & & & $\mathrm{x}$ & \\
\hline FZ-12 & El Rosarillo (Valladolid) & $\mathrm{X}$ & & & \\
\hline FZ-13 & El Salvador (Valladolid) & $\mathrm{X}$ & $\mathrm{x}$ & & \\
\hline FZ-14 & Las Descalzas Reales (Valladolid) & $\mathrm{X}$ & $x$ & & \\
\hline FZ-15 & San Joaquin y Santa Ana (Valladolid) & $\mathrm{x}$ & & & \\
\hline FZ-16 & Las Huelgas Reales (Valladolid) & $\mathrm{X}$ & $\mathrm{x}$ & & \\
\hline FZ-17 & Santa María (Alaejos) & & & $\mathrm{X}$ & \\
\hline FZ-18 & San Juan Evangelista (Arroyo de la Encomienda) & $\mathrm{X}$ & & & \\
\hline FZ-19 & La Santa Espina (Castromonte) & & & $\mathrm{x}$ & \\
\hline FZ-20 & Santa Maríadel Castillo (Castronuño) & $\mathrm{X}$ & & & \\
\hline$F Z-21$ & Santos Justo y Pastor (Cuenca de Campos) & & & $\mathrm{X}$ & \\
\hline FZ-22 & San Juan (Fresno el Viejo) & & & $\mathrm{X}$ & \\
\hline FZ-23 & Santa María (Iscar) & & & $\mathrm{x}$ & \\
\hline FZ-24 & Santa María de Arbás (Mayorga) & & & $\mathrm{X}$ & \\
\hline$F Z-25$ & San Francisco (Medina de Rioseco) & $\mathrm{X}$ & $\mathrm{x}$ & & \\
\hline FZ-26 & Santa Cruz (Medina de Rioseco) & $\mathrm{X}$ & $\mathrm{X}$ & & \\
\hline FZ-27 & Santiago (Medina de Rioseco) & & & $\mathrm{x}$ & \\
\hline FZ-28 & San Antolín (Medina del Campo) & & & $\mathrm{X}$ & \\
\hline FZ-29 & San Martín (Medina del Campo) & $\mathrm{X}$ & & & \\
\hline FZ-30 & Los Santos Juanes (Nava del Rey) & & & $\mathrm{X}$ & $\mathrm{X}$ \\
\hline FZ-31 & San Juan (Olmedo) & & & & \\
\hline FZ-32 & Santa María de Palazuelos (Corcos del Valle) & & & $\mathrm{X}$ & \\
\hline FZ-33 & San Pablo (Peñafiel) & & & $\mathrm{X}$ & \\
\hline FZ-34 & San Cebrián (San Cebrián de Mazote) & & & $\mathrm{X}$ & \\
\hline FZ-35 & Santa María (Tordesillas) & $\mathrm{x}$ & $\mathrm{x}$ & & \\
\hline FZ-36 & La Anunciada (Urueña) & & & $\mathrm{X}$ & \\
\hline FZ-37 & Santa María de Valbuena (Valbuena) & & & $\mathrm{X}$ & \\
\hline FZ-38 & Santa María del Castillo (Villaverde de Medina) & & & $\mathrm{X}$ & \\
\hline FZ-39 & Santa María (Wamba) & & & $\mathrm{x}$ & \\
\hline FZ-40 & San Pedro (Serrada) & $x$ & & & \\
\hline
\end{tabular}


Un 50\% de los edificios estudiados se compone de una única nave mientras que el $50 \%$ restante cuenta con tres. La mitad de las iglesias de una sola nave tiene capillas laterales mientras que la otra mitad conforma un contenedor prismático rectangular a modo de caja. Sólo 3 de los templos que se desarrollan con tres naves cuenta además con capillas laterales.

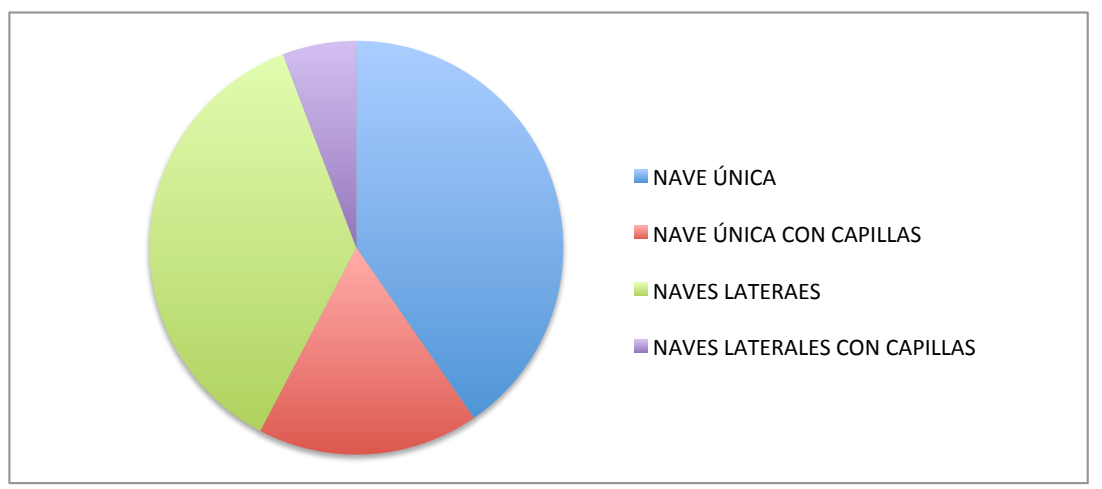

La cubierta, en el caso de poseer tres naves, puede desarrollarse, según hemos visto, a dos niveles independientes al modo basilical o bien cubrirse todo el espacio de forma continua bajo dos grandes faldones.

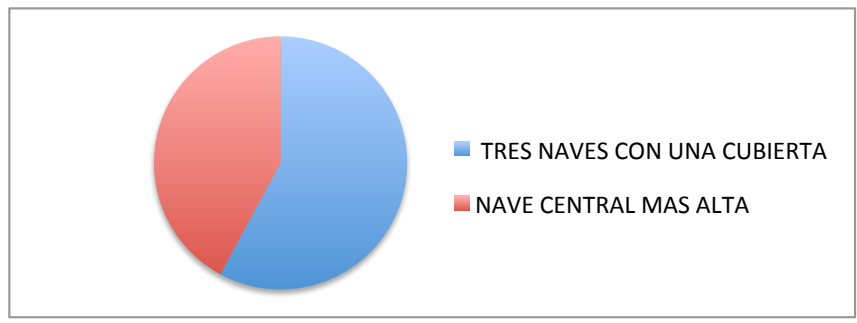

Todos los casos dentro de la muestra de iglesias de tres naves cuyos faldones de cubierta a dos aguas cubren también las naves laterales se encuentran en templos de localidades fuera de la capital. En varios casos la cubierta de la nave central se encontraba originalmente a cota más alta y fue modificada para adaptarse al citado esquema sin escalonamientos.
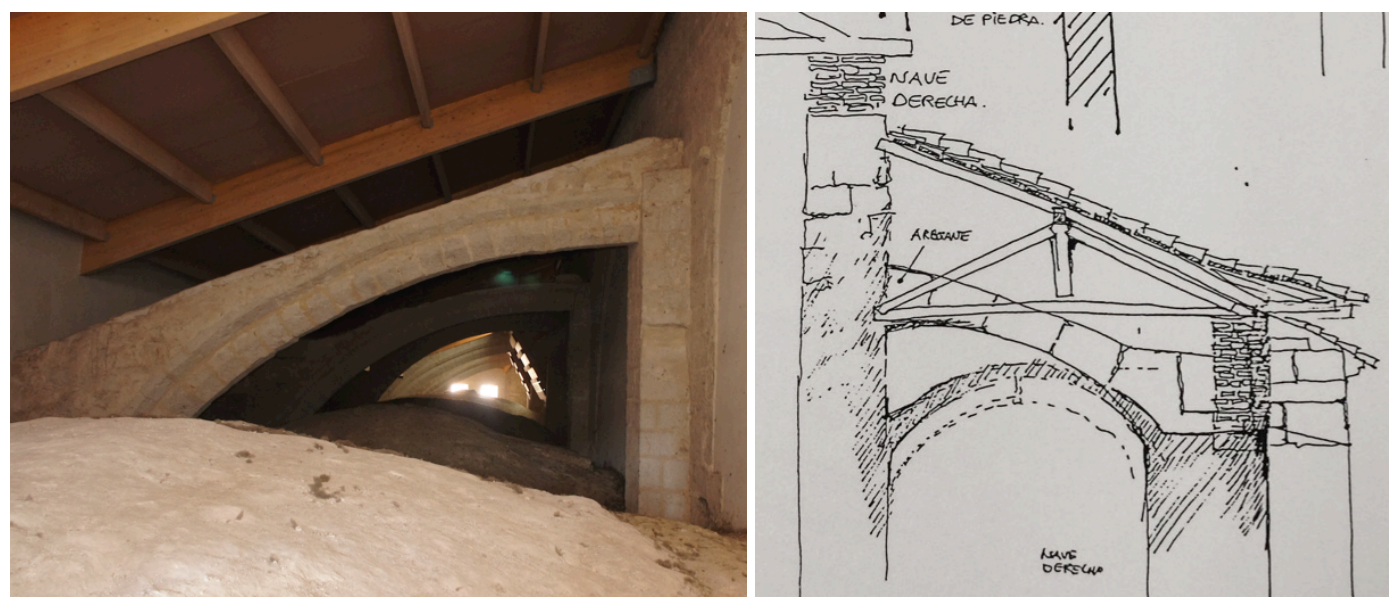

Fig. IV.53. Visita San Benito 23/04/2015 y croquis de nave lateral (Morán 1991 JCyL) 
Encontramos así varios templos con los ventanales de la nave central cegados o incluso arbotantes que han quedado inmersos en el espacio bajo cubierta, como en los cenobios San Benito el Real y San Pablo en Peñafiel.

A veces el faldón se prolonga más allá de la nave lateral y cubre la panda de un claustro adyacente, solución que encontramos repetida en el citado San Pablo de Peñafiel y en la Santa Espina.

En la fachada a los pies de Peñafiel se manifiesta el recrecido del espacio bajo cubierta de la nave lateral ejecutado con fábrica de ladrillo levantado directamente sobre el remate del muro de piedra.
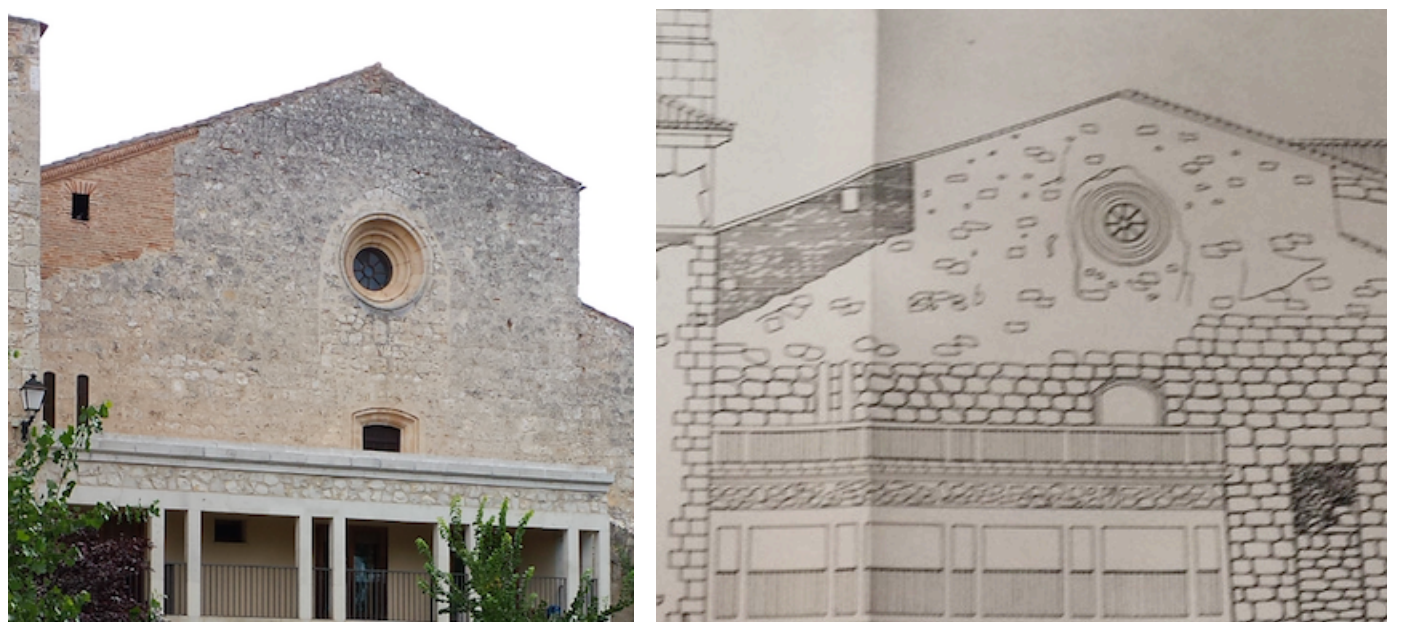

Fig. IV.54. Fachada a los pies Peñafiel, visita 21/08/2015; plano 1993 Abad JCyL

En la imagen siguiente, tomada del proyecto de restauración de Cembrero y Morante 2000 en la iglesia parroquial de Santa María en la localidad de Íscar, vemos dos fases de su hipótesis de proceso constructivo que constituyen un claro ejemplo de este tipo de transformaciones.

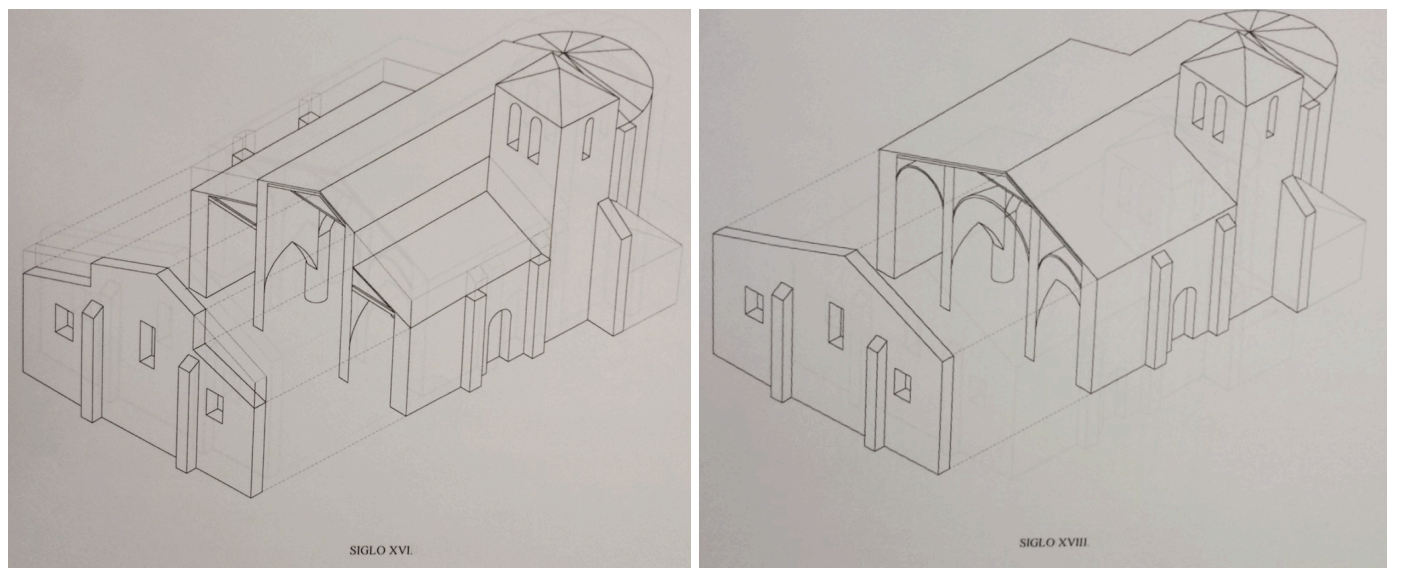

Fig. IV.55. Proceso constructivo Santa María en Íscar, 2000 Cembrero y Morante JCyL 
En esta iglesia de Íscar la nave central sobresalía originalmente por encima de las laterales, se recrece el muro testero a los pies para formar un piñón y se prolongan los faldones centrales hasta cubrir toda la planta. Podemos leer también claramente esta actuación en el cambio de aparejo de los muros, esta vez manteniendo el material, con el antiguo remate de las naves laterales remarcado además por la altura máxima de los contrafuertes.

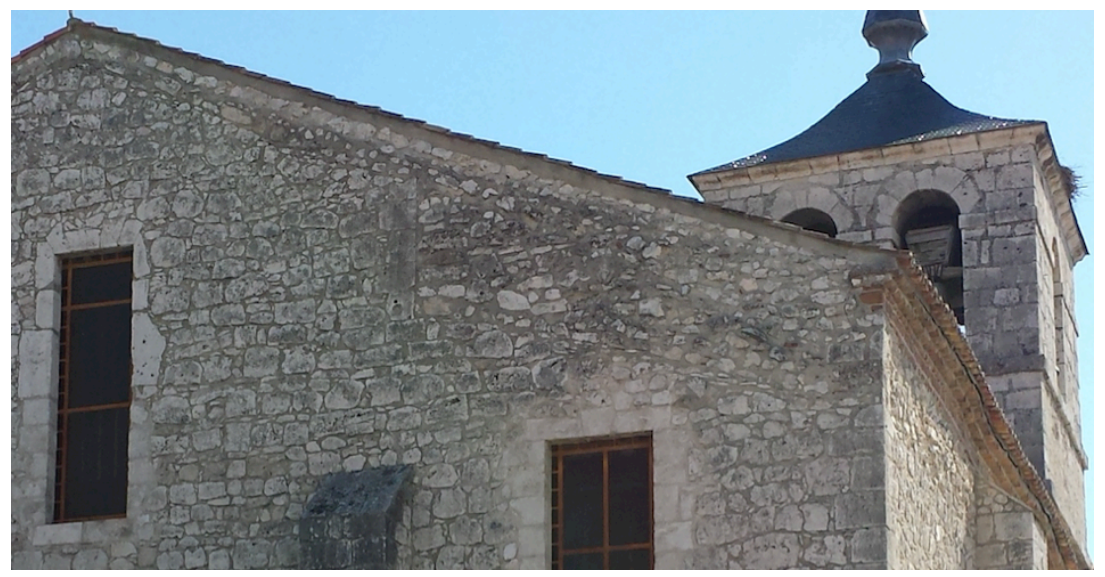

Fig. IV.56. Recrecido del muro a los pies en Íscar, visita 02/08/2015

\section{La cabecera}

La forma de la cabecera que predomina en el conjunto muestra es recta, hemos visto que gran parte de las iglesias son grandes contenedores a modo de caja, sobre todo en la capital, donde no aparece ningún ábside semicircular entre los edificios analizados.
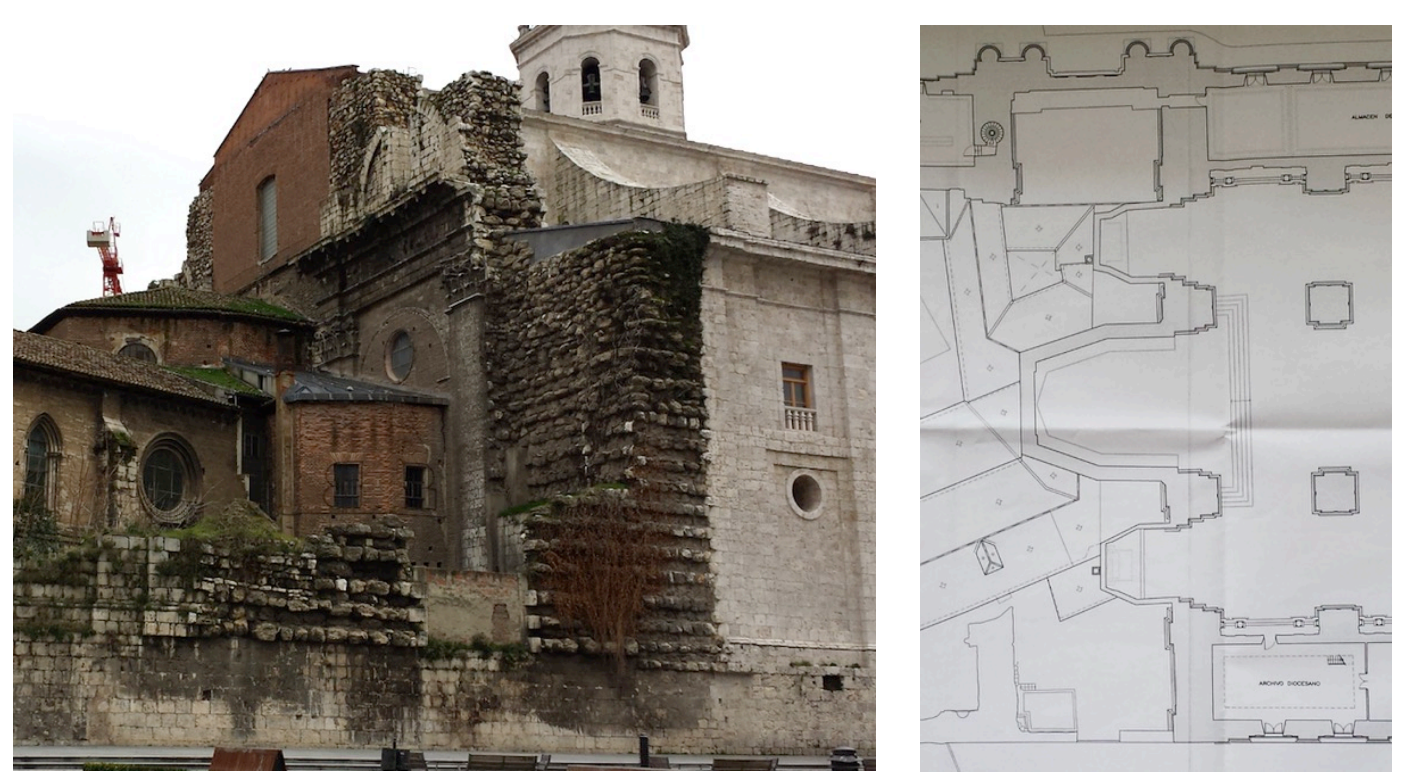

Fig. IV.57. Vista de los ábsides de la Catedral antes de su reparación (visita 31/01/2014) y detalle planta 1997 Gatón JCyL 
No podemos tener en cuenta el caso de la Catedral, con ábsides facetados, ya que como hemos visto se trata de un cierre concebido como temporal, resuelto con fábrica de ladrillo.

Tabla 5: Geometría de la cabecera

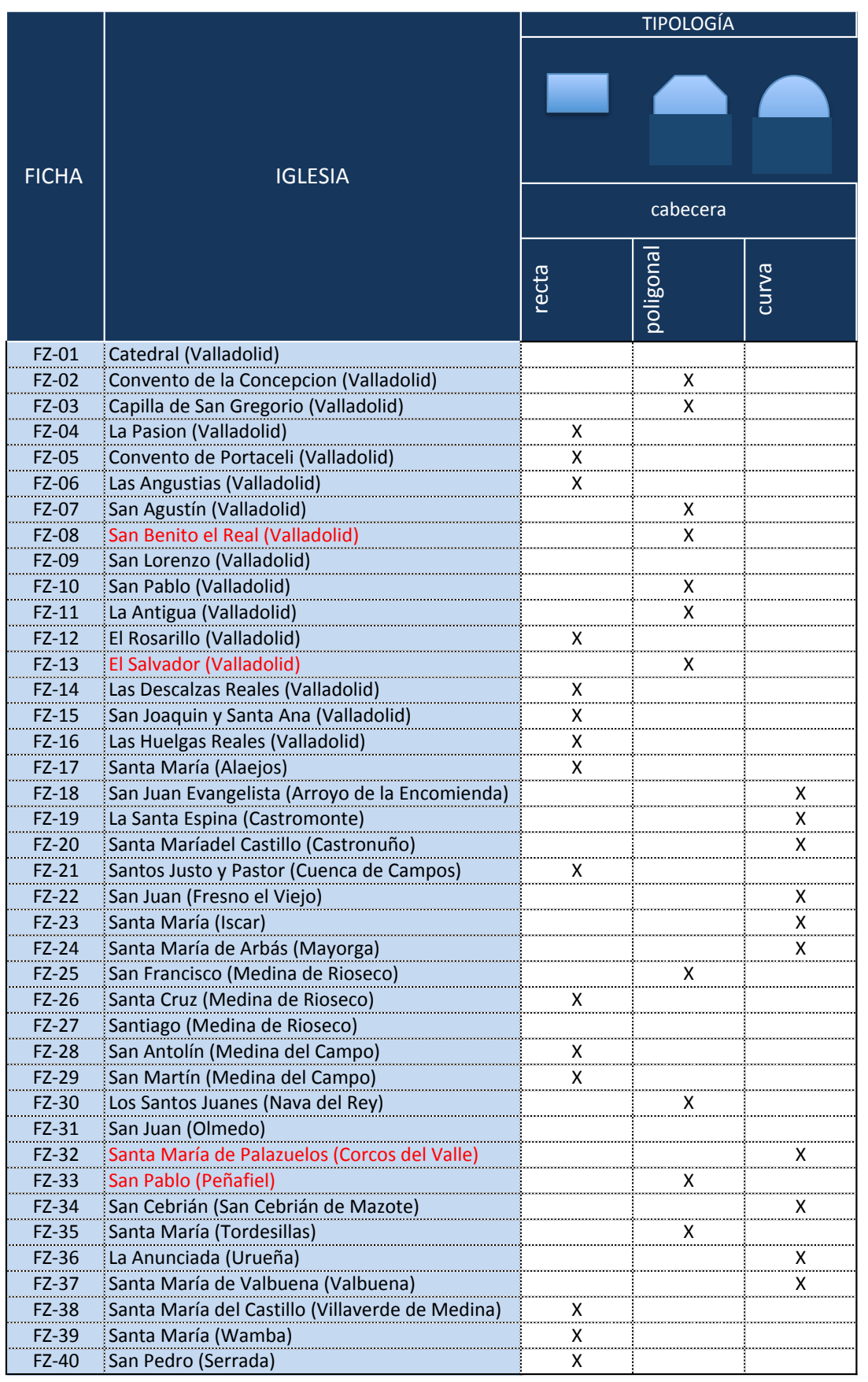


El contorno de las cabeceras también ha sufrido en muchos de los casos modificaciones a tener en cuenta. En la Santa espina, por ejemplo, encontramos hoy un ábside adosado escalonado pero la cabecera original ${ }^{4}$ estaba formada por cinco capillas de testero plano cubiertas con bóvedas de cañón, esquema representado en la planta sin fecha de la Planoteca IPCE aparece recta.

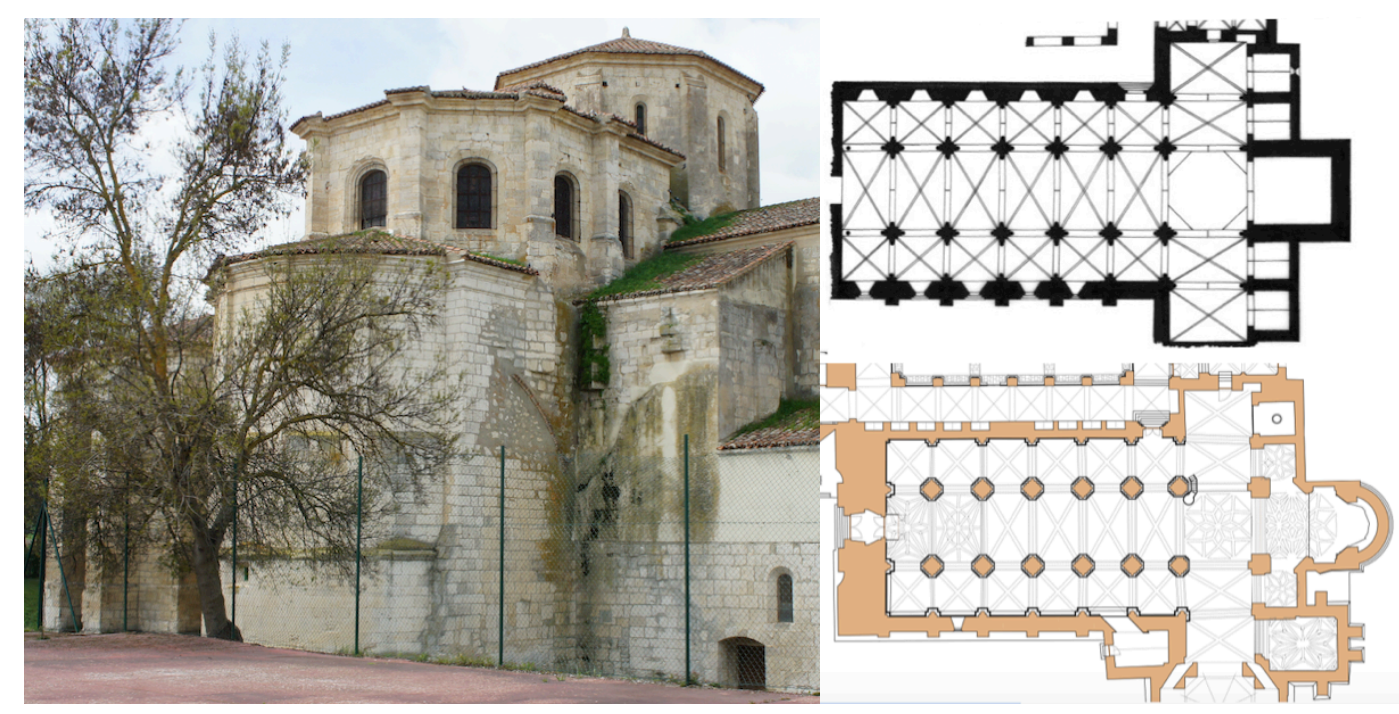

Fig. IV.58. Cabecera Santa Espina visita 28/04/2015; plantas SF IPCE y Plan Director 2008

La forma del ábside incidirá en la ejecución de posibles zunchos, que tendrán que ejecutarse por tramos o encofrados, como se verá en el apartado IV.2.4.

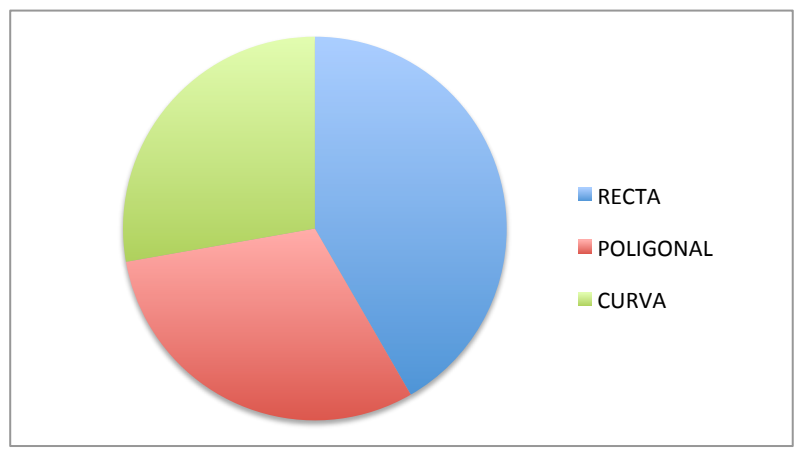

Otro aspecto diferenciador es la existencia de crucero, que puede manifestarse sólo en planta, sólo en alzado o a la vez en ambos. El cimborrio y la cúpula sobre el mismo son otros factores básicos que podemos señalar en cada uno de los templos.

\footnotetext{
${ }^{4}$ Fases constructivas descritas en el Plan Director de Alberto y Curro Arquitectos 2008 Tomo 2 Documentación y Diagnóstico Vol.2 pag. 18 y plano PDSE-ET1.
} 


\section{La torre}

La torre se levanta en distintas ubicaciones respecto al cuerpo de las iglesias: a veces en un costado, a los pies o junto a la cabecera, y en cada uno de estos casos puede colocarse por el lado del evangelio, centrada o en el lado de la epístola. La mitad de las iglesias de la muestra no cuentan con torre, disponiéndose las campanas directamente en una espadaña.

Tabla 6: Torres y cúpulas

\begin{tabular}{|c|c|c|c|c|c|c|}
\hline \multirow[b]{2}{*}{ FICHA } & \multirow[b]{2}{*}{ IGLESIA } & \multicolumn{4}{|c|}{ TORRE } & \multirow[b]{2}{*}{ 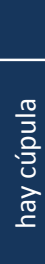 } \\
\hline & & $\frac{\tilde{w}}{\alpha}$ & 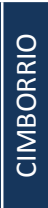 & 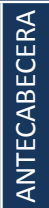 & 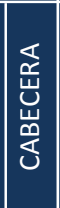 & \\
\hline FZ-01 & Catedral (Valladolid) & $\mathrm{X}$ & & & & \\
\hline FZ-02 & Convento de la Concepcion (Valladolid) & & & & & \\
\hline $\mathrm{FZ}-03$ & Capilla de San Gregorio (Valladolid) & & & & & \\
\hline $\mathrm{FZ}-04$ & La Pasion (Valladolid) & & & & & $\mathrm{x}$ \\
\hline FZ-05 & Convento de Portaceli (Valladolid) & & $\mathrm{X}$ & & & $\mathrm{X}$ \\
\hline FZ-06 & Las Angustias (Valladolid) & & $\mathrm{X}$ & & & $\mathrm{x}$ \\
\hline FZ-07 & San Agustín (Valladolid) & & & & & \\
\hline FZ-08 & San Benito el Real (Valladolid) & $\mathrm{x}$ & & & & \\
\hline FZ-09 & San Lorenzo (Valladolid) & & & & & \\
\hline FZ-10 & San Pablo (Valladolid) & & & & & \\
\hline FZ-11 & La Antigua (Valladolid) & $\mathrm{X}$ & & & & \\
\hline $\mathrm{FZ}-12$ & El Rosarillo (Valladolid) & & & & & $\mathrm{x}$ \\
\hline FZ-13 & El Salvador (Valladolid) & & & $\mathrm{x}$ & & \\
\hline FZ-14 & Las Descalzas Reales (Valladolid) & & $\mathrm{X}$ & & & $\mathrm{X}$ \\
\hline FZ-15 & San Joaquin y Santa Ana (Valladolid) & & & & & $\mathrm{X}$ \\
\hline FZ-16 & Las Huelgas Reales (Valladolid) & & & & & $\mathrm{x}$ \\
\hline $\mathrm{FZ}-17$ & Santa María (Alaejos) & $\mathrm{X}$ & & & & $\mathrm{X}$ \\
\hline FZ-18 & San Juan Evangelista (Arroyo de la Encomienda) & & & & & \\
\hline FZ-19 & La Santa Espina (Castromonte) & $\mathrm{X}$ & $\mathrm{X}$ & & & $\mathrm{X}$ \\
\hline $\mathrm{FZ}-20$ & Santa Maríadel Castillo (Castronuño) & & & & & \\
\hline $\mathrm{FZ}-21$ & Santos Justo y Pastor (Cuenca de Campos) & $\mathrm{X}$ & & & & \\
\hline $\mathrm{FZ}-22$ & San Juan (Fresno el Viejo) & & & $x$ & & \\
\hline FZ-23 & Santa María (Iscar) & & & $\mathrm{x}$ & & \\
\hline $\mathrm{FZ}-24$ & Santa María de Arbás (Mayorga) & $\mathrm{X}$ & & & & \\
\hline $\mathrm{FZ}-25$ & San Francisco (Medina de Rioseco) & $\mathrm{X}$ & $\mathrm{X}$ & & & $\mathrm{X}$ \\
\hline FZ-26 & Santa Cruz (Medina de Rioseco) & & & & $\mathrm{X}$ & $x$ \\
\hline $\mathrm{FZ}-27$ & Santiago (Medina de Rioseco) & $\mathrm{X}$ & & & & \\
\hline FZ-28 & San Antolín (Medina del Campo) & & & & $\mathrm{X}$ & \\
\hline FZ-29 & San Martín (Medina del Campo) & & & & & $\mathrm{X}$ \\
\hline $\mathrm{FZ}-30$ & Los Santos Juanes (Nava del Rey) & $\mathrm{X}$ & & & & $\mathrm{X}$ \\
\hline FZ-31 & San Juan (Olmedo) & & & & & \\
\hline $\mathrm{FZ}-32$ & Santa María de Palazuelos (Corcos del Valle) & & & & & \\
\hline FZ-33 & San Pablo (Peñafiel) & & & & & \\
\hline $\mathrm{FZ}-34$ & San Cebrián (San Cebrián de Mazote) & $\mathrm{x}$ & & & & $\mathrm{x}$ \\
\hline $\mathrm{FZ}-35$ & Santa María (Tordesillas) & & & $\mathrm{X}$ & & \\
\hline FZ-36 & La Anunciada (Urueña) & & $\mathrm{X}$ & & & $\mathrm{X}$ \\
\hline FZ-37 & Santa María de Valbuena (Valbuena) & & $x$ & & & $\mathrm{x}$ \\
\hline FZ-38 & Santa María del Castillo (Villaverde de Medina) & $\mathrm{x}$ & & & & \\
\hline FZ-39 & Santa María (Wamba) & & & & & \\
\hline $\mathrm{FZ}-40$ & San Pedro (Serrada) & & & & $\mathrm{X}$ & $\mathrm{x}$ \\
\hline
\end{tabular}


En rojo se señala las cuatro iglesias que mantienen sus armaduras sin zunchos en el cuerpo de la nave, dos de las cuales no cuentan con torre.

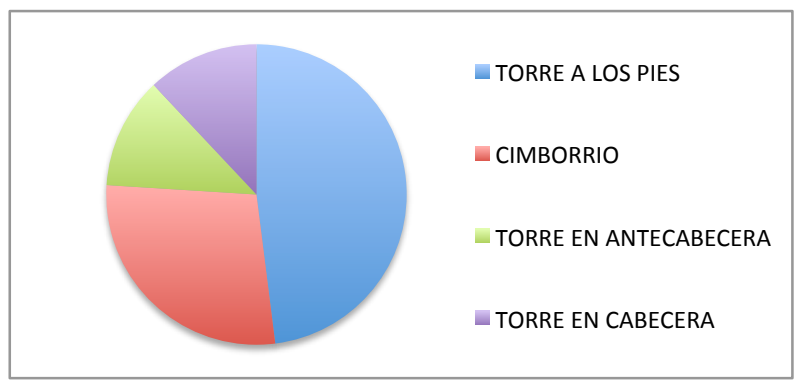

En Santa María de Tordesillas la torre de piedra se macla con el cuerpo del templo rematado con fábrica de ladrillo y el zuncho perimetral que recorre la coronación de los muros de la nave se corta en ese tramo y para cerrar el anillo resuelve el zuncho correspondiente con perfiles metálicos apoyados sobre ménsulas.

En Villaverde de Medina el zuncho de hormigón se prolonga sobre el testero a los pies rozando una mocheta que se formaba en el encuentro con la torre, girada unos $28^{\circ}$ respecto al eje de la nave.
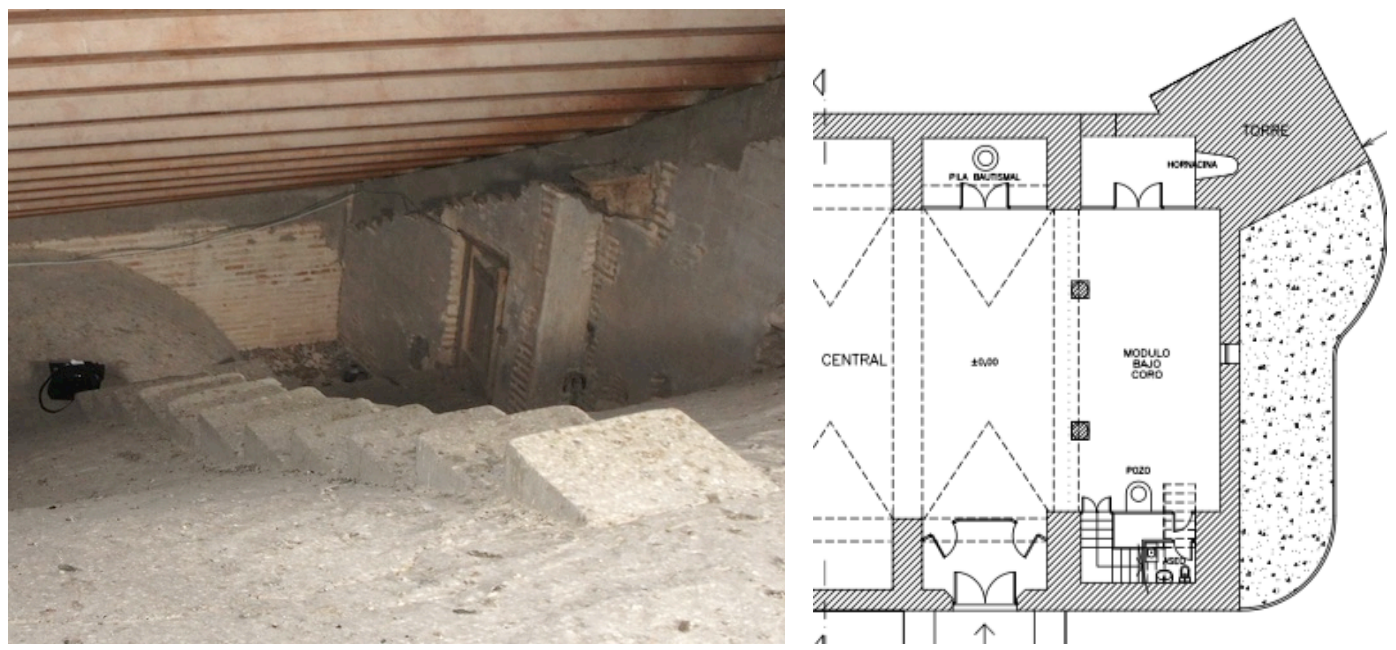

Fig. IV.59. Desembocadura escalera bajo cubierta Santa María en Villaverde visita 10/06/2012; planta 2007 Pardo JCyL

Una ubicación de torre singular la encontramos en la iglesia de San Juan en la localidad de Fresno el Viejo. La torre se levanta enrasada por el exterior en una de sus caras con el cerramiento lateral de la cabecera, con su cuerpo de campanas construido en 1834. El arranque de la torre sobre la cornisa que remata la fábrica de ladrillo del presbiterio presenta algunas hiladas de sillares que se prolongan con ladrillo visto en el resto del elemento. 

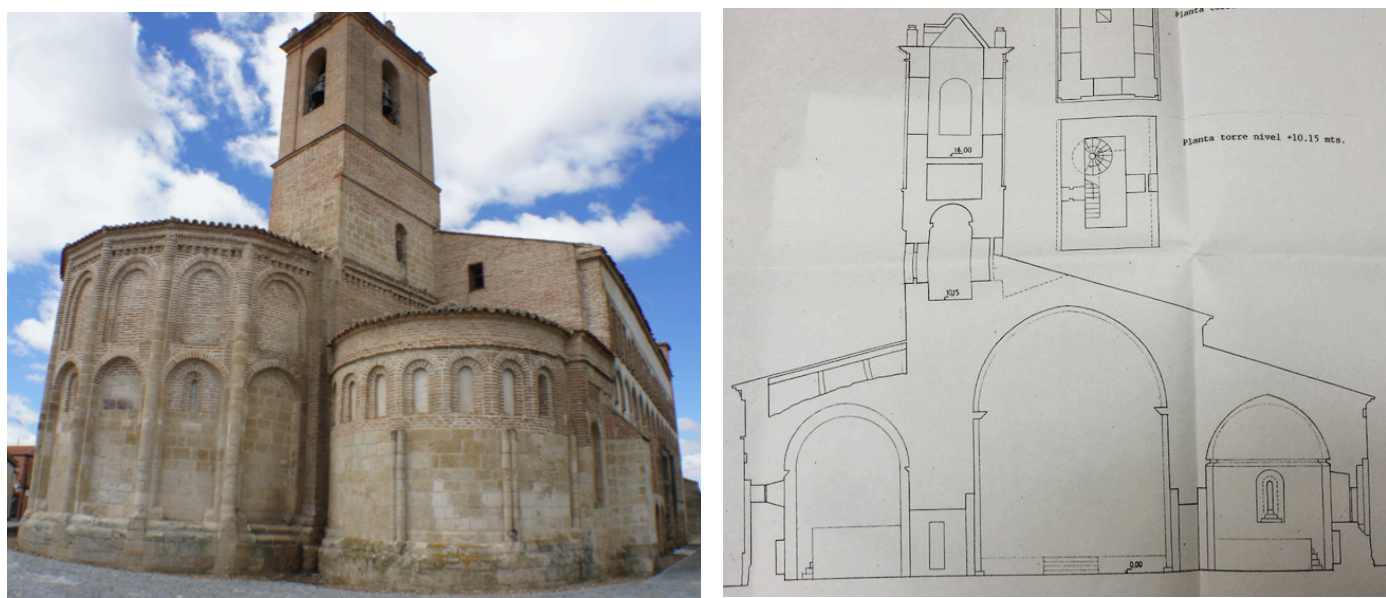

Fig. IV.60. Arranque de torre sobre la cabecera en Fresno el Viejo visita 13/08/2015; plano 1997 Carreño JCyL (imagen desde cabecera y sección desde los pies)

\section{IV.2.1.3. La utilización de los edificios}

Veremos cómo el uso de los inmuebles puede estar directamente relacionado con el funcionamiento del atado estructural. Un factor muy importante que distingue un museo de una iglesia, por ejemplo, son las condiciones higrotérmicas. En el museo se mantienen constantes de forma exhaustiva temperatura y humedad, manteniendo bajo control la entrada de luz natural. En los lugares de culto, sin embargo, es habitual encontrar excesiva humedad debida a la falta de ventilación, ya que suele tratarse de recintos cerrados con uso esporádico, además, durante una ceremonia pueden recibir puntualmente gran afluencia de personas.

En San Francisco de Medina de Rioseco, por ejemplo, se produjo una actuación de emergencia en 1990 por peligro de ruina del cimborrio tras detectarse deformación y rotura de dovelas del arco que separa la nave del crucero. En un informe $e^{5}$ se achaca la patología a que la falta de uso del templo, cerrado hasta su transformación en museo, había originado un notable aumento de la humedad relativa interior, transmitido lentamente a la piedra, que por esta causa había perdido rigidez.

En el caso de iglesias cerradas al culto durante décadas, o sometidas a alguna ruina parcial de su cubrición no reparadas con inmediatez, es habitual encontrar gran deterioro en la coronación de los muros que, como veremos a continuación,

\footnotetext{
${ }^{5}$ Informe encargado a Santiago Huerta y José Miguel Ávila, de la ETSAM, a través del Instituto Juan de Herrera. (Ver JCyL VA-093 en FZ-25-A)
} 
conlleva operaciones de saneado de los mismos directamente relacionadas con el empleo de zunchos de hormigón.

También podemos preguntarnos si se adopta con más frecuencia la opción de colocar zuncho al intervenir sobre un edificio que presenta un ligero deterioro o bien se convierte en la solución de referencia frente a inmuebles en muy mal estado.

Todos los edificios seleccionados son las iglesias que forman parte del Patrimonio histórico artístico de la provincia de Valladolid y sufrieron intervenciones a lo largo del siglo XX cuyos proyectos se conservaron en el Archivo Central del Ministerio de Cultura. Aunque gran parte de ellos están catalogados actualmente como BIC, dentro del conjunto hay ocho casos no catalogados. Se trata generalmente templos que han quedado sin uso, como Concepción, Rosarillo y San Juan de Olmedo, o que han sufrido drásticas remodelaciones tras arruinarse. Este caso corresponde por ejemplo a San Agustín, convertida hoy en Archivo Municipal de la ciudad de Valladolid o Santa Cruz en Medina de Rioseco. Más singular resulta la falta de incorporación al catálogo de la iglesia de Cofradía de las Angustias y de la ermita de San Juan en Arroyo de la Encomienda.

Según el profesor Castán ${ }^{6}$ el material del románico vallisoletano es una piedra caliza endeble de pobre apariencia, cortada en sillares, sillarejo o mampostería. En el curso de las obras con frecuencia se cambian los procesos constructivos o los materiales, rebajando la calidad del aparejo o empleando ladrillo para rematar, como en Fresno el Viejo. Achaca este problema a la falta de canteras y de medios económicos. San Juan, Fresno, Wamba y Castronuño fueron iglesias de órdenes militares (de la orden de los Hospitalarios de San Juan).

\section{Iglesias transformadas en espacios culturales}

La denominada Capilla del Colegio de San Gregorio tampoco puede considerarse tipológicamente una iglesia, no tanto por su uso actual convertida en sala del Museo Nacional de Escultura, como por tratarse de un volumen secundario adosado a la iglesia de San Pablo.

\footnotetext{
${ }^{6}$ Castán 2002 Panorama general del Románico en Valladolid.
} 


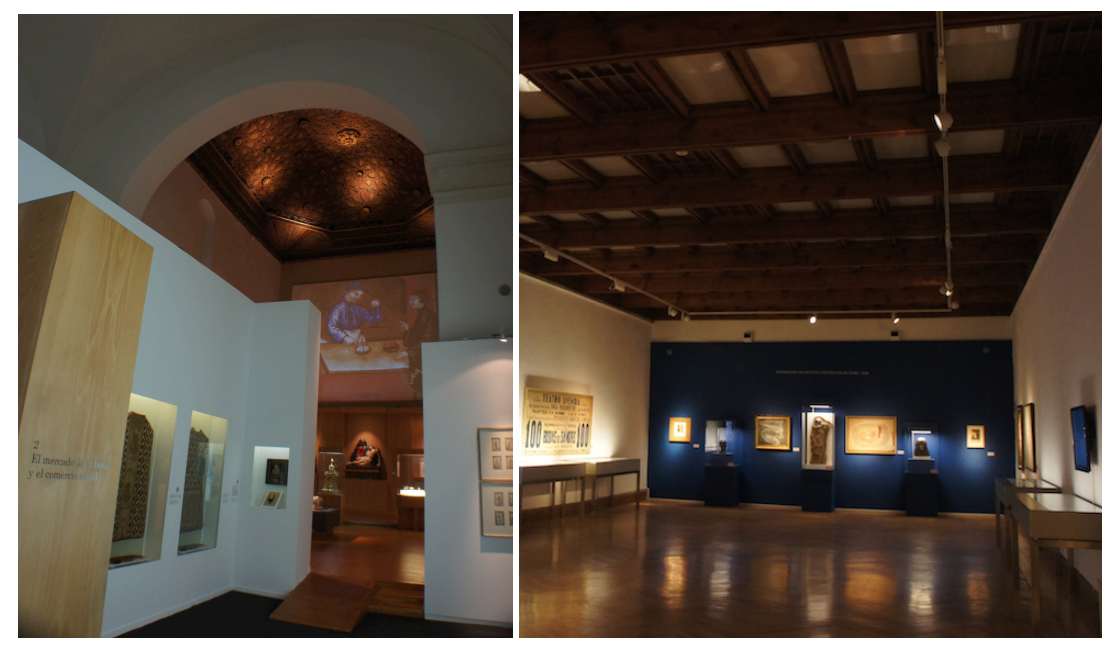

Fig. IV.61. Interior de los museos instalados en antiguas iglesias, de San Martín en Medina del Campo y planta alta de la Pasión, en Valladolid.

Tres de los cuatro templos convertidos en museos (todos ellos actualmente activos y con instalaciones de calidad), San Martin en Peñafiel, Santa Cruz en Medina de Rioseco y la Pasión en Valladolid fueron reconstruidos después de haberse producido la ruina de sus bóvedas. Esta circunstancia destaca la actitud respetuosa de la Administración actual de Castilla y León respecto a la reutilización de los lugares de culto como espacios de uso cultural sólo tras alcanzarse un estado prácticamente irrecuperable de los mismos.

Un caso similar lo constituye la iglesia de San Agustín, que se encontraba en ruinas cuando se aborda su reconstrucción para albergar el actual Archivo Municipal, uno de los centros que alberga fuentes consultadas para esta Tesis. En este edificio se incorpora una cubierta contemporánea de mínima pendiente y revestida de zinc.

El lenguaje arquitectónico empleado en las reconstrucciones de estos monumentos arruinados ha sido objeto de diversas publicaciones y estudios técnicos, citándose a menudo tanto San Agustín como Santa Cruz como proyectos modelo de recuperación, sobre todo durante los últimos años del siglo XX.

Otra iglesia víctima de un derrumbe sobre la que se realiza una reconstrucción moderna y redefine su uso como espacio cultural de la población más cercana es Santa María de Palazuelos. En la actualidad se llevan a cabo en el interior del recinto visitas guiadas y actividades públicas como exposiciones, bailes y conciertos. 


\section{Estado actual: monumentos arruinados}

El caso más radical de la lista corresponde a la iglesia de San Lorenzo, que fue demolida conservándose únicamente su torre y una portada. Ambos elementos se integran en un moderno edificio de viviendas que alberga una nueva iglesia de nueva planta en su interior. Aunque se ha consultado la documentación disponible en los archivos elaborándose la ficha resumen, ésta ha sido insuficiente, por lo que este caso ha quedado excluido del análisis.

Otro templo sin apenas documentación es San Juan en Olmedo, cuyos bienes muebles fueron trasladados en 1967 al Museo Nacional de Escultura ante la falta de seguridad de la construcción. El edificio se mantiene en pie y aparentemente en buenas condiciones, abriéndose esporádicamente para determinadas procesiones.

\section{Monumentos reconstruidos y modificados}

En el conjunto de casos estudiados encontramos también templos singulares que, tras sufrir grandes problemas estructurales, fueron reconstruidos con procesos que podríamos considerar de repristinación. A la hora de analizar el uso de zunchos en los mismos debemos tener en cuenta que las obras realizadas son más una reconstrucción que una restauración, por lo que las soluciones adoptadas pueden estar más en consonancia con las que se llevarían a cabo en una construcción de nueva planta que las propias de la mera intervención sobre un edificio histórico.

La iglesia de Nuestra Señora de la Antigua es un templo pequeño y oscuro, que sufrió durante siglos graves daños estructurales. La torre estuvo encamisada con un muro de piedra de grandes dimensiones hasta que a principios del siglo XX se libera y deja exenta tras demolerse el cuerpo del templo, conservándose con ella únicamente la cabecera y un atrio románico trasero. Se trata por tanto de un templo con su nave construida en pleno siglo XX en estilo gótico y, sin embargo, su imagen ha llegado a ser prácticamente la del monumento más conocido e identificado con la ciudad de Valladolid. No se ha podido comprobar si cuando se edificó se ejecutó un zuncho de hormigón bajo el apoyo de las cerchas de cubierta, ya que no se ha conseguido permiso del párroco para acceder al bajo cubierta. Se cuenta con fotografías de la última obra proporcionadas por la profesora Camino, pero en ellas no se aprecia más que una tabica de ladrillo que oculta el encuentro. 

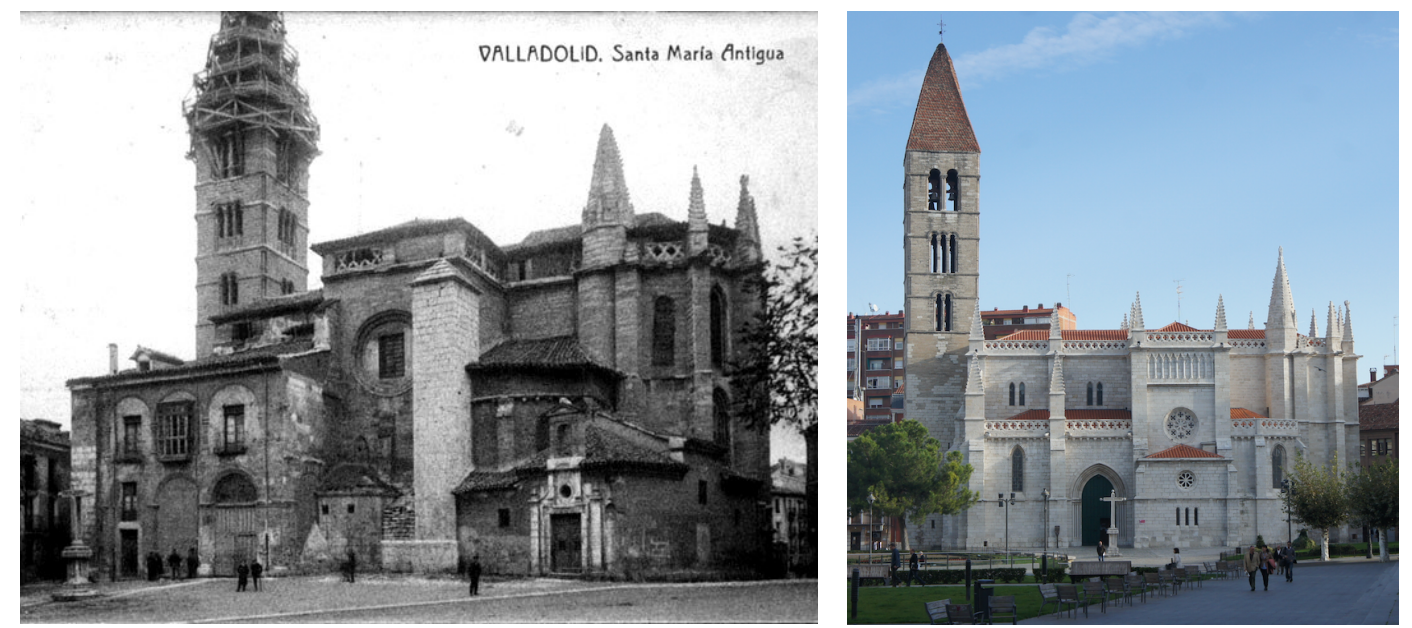

Fig. IV.62. Postal de la Antigua antes de la demolición y vista actual

Otro monumento que fue prácticamente reconstruido en la primera mitad del siglo XX es San Cebrián de Mazote. Con la última intervención en 1988, que Salvador Mata describe en su proyecto como "decoración escenográfica del interior con revestimientos en rojo y blanco con fingidos de ladrillo", se ha pretendido "recuperar el espacio interior primitivo".

En el conjunto de iglesias seleccionadas hay además varias de grandes dimensiones, monasterios, conventos e iglesias parroquiales. La iglesia del convento de San Joaquín y Santa Ana es la única de la muestra que no presenta un esquema de planta básicamente ortogonal. Se trata de un templo barroco de planta elíptica, con atrio y cabecera prismáticos, cubierto con una gran cúpula y linterna.

\section{IV.2.1.4. Ermitas románicas}

En la muestra analizada hay tres ermitas románicas, aunque en el caso de Castronuño ésta fue renombrada como "iglesia parroquial de Santa María del Castillo" tras la desaparición del edificio del mismo nombre. En ninguno de los tres casos, cubiertos con bóvedas de piedra que al exterior se rematan a dos aguas, se ha podido comprobar in situ si la solución de cubierta con la que cuentan en la actualidad coincide con la prevista a partir del estudio de la documentación consultada.

Tanto en Urueña como en Castronuño intervino Ana Iglesias en los años 70, elaborando proyectos que en alguno de los casos no llegó a ejecutarse. Es probable que en los tres edificios el tablero sea de ladrillo, ya que en Castronuño hay un proyecto de Arenillas de 1963 en el que lo describe así, apoyado sobre tabiquillos de hueco doble. Y en Arroyo, Alberto Gil en 1974 menciona un tablero de rasilla con hormigón sobre correas metálicas. En Urueña, Ana Iglesias diseña un tablero de 
doble rasilla sobre palomeros, aunque Paniagua, autor de una intervención posterior lo describe como nervometal ${ }^{7}$, una solución empleada por Ana Iglesias con mucha frecuencia.

San Juan Evangelista, en Arroyo de la Encomienda.
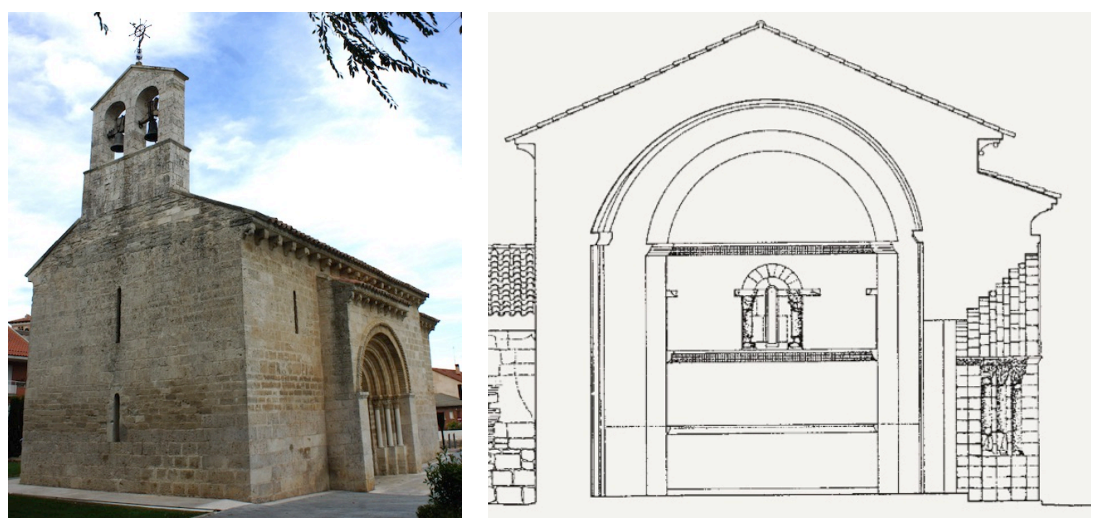

Fig. IV.63. Vista 30/07/2015; sección Enciclopedia del Románico

Santa María del Castillo, en Castronuño.
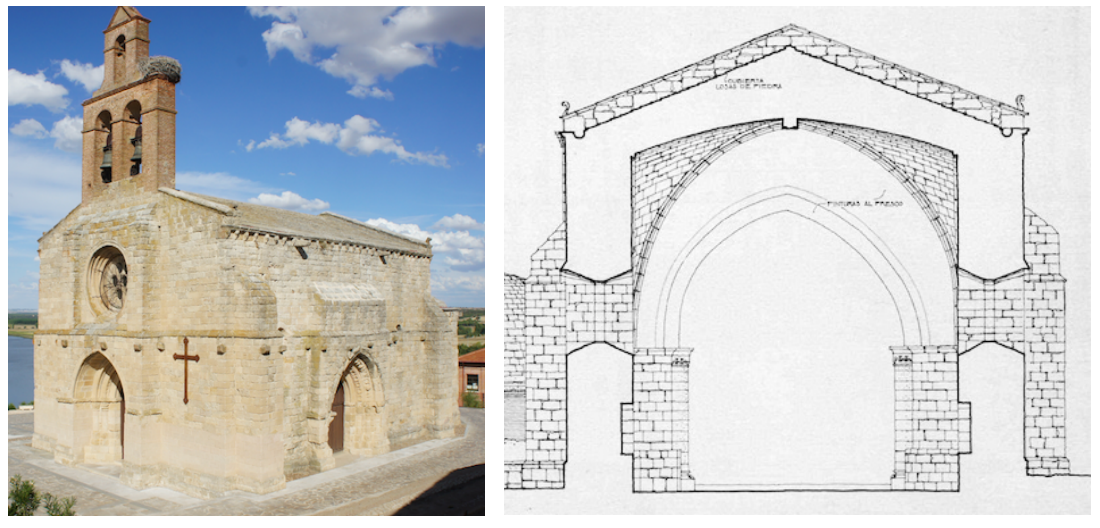

Fig. IV.64. Vista 13/09/2014; sección 1974 Iglesias IPCE

La Anunciada, en Urueña ${ }^{8}$.

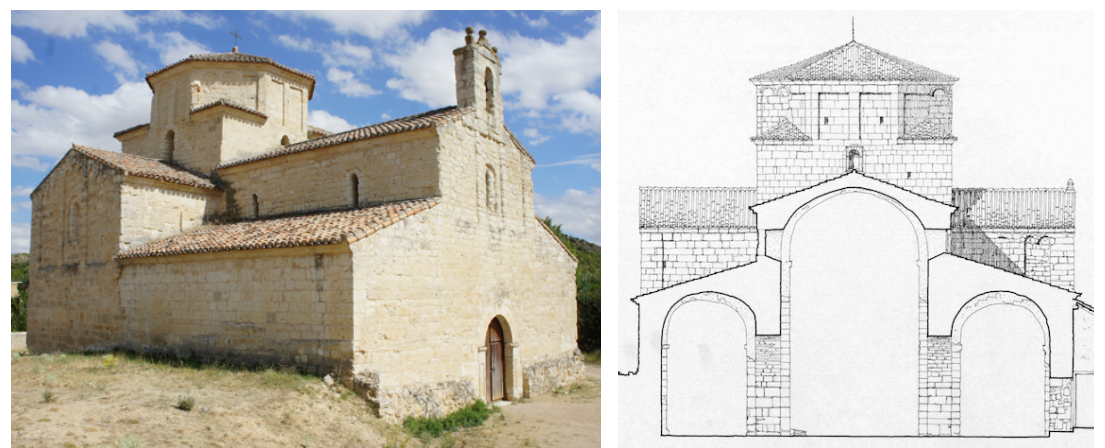

Fig. IV.65. Vista 30/07/2015; sección 1978 Iglesias IPCE

\footnotetext{
${ }^{7}$ Paniagua explica en la memoria del proyecto de 1993 que no hay acceso al bajo cubierta por lo que no ha podido ver en qué estado se encuentra la misma.

${ }^{8}$ Es el monumento más antiguo de la provincia, según Castán.
} 



\section{IV.2.2. Aspectos estructurales}

Las iglesias suelen construirse por fases, reemplazando elementos según los gustos y necesidades en cada momento. Se acometen periódicamente operaciones de mantenimiento, como encalados y retejos, y también obras de reparación de patología que va surgiendo con el paso del tiempo o debida a errores de diseño. Unas veces se reconstruyen bóvedas y torres que se derrumban, otras se añaden cuerpos de campanas o capillas adosadas. Se construyen bóvedas bajo artesonados de madera o se reemplazan volúmenes enteros de los templos. Las estructuras históricas se van alterando a través de los años, lo que dificulta su comprensión. La incorporación del zuncho como atado estructural modificará el comportamiento de todo el sistema de contrarrestos de los edificios.

A continuación se estudian las características resistentes del conjunto de iglesias, en especial las actuaciones destinadas a su reparación y refuerzo a lo largo del tiempo, entre las que se incluyen las operaciones de zunchado. Se analizan en primer lugar las actuaciones sobre la cimentación, a continuación las relacionadas con los muros y por último las llevadas a cabo sobre la estructura de cubierta.

\section{IV.2.2.1. La Cimentación}

Se han clasificado los aspectos relativos a las actuaciones sobre la cimentación a partir de los siguientes apartados:

- Edificios levantados sobre estructuras preexistentes

- Recalces de la cimentación

- Vaciados debidos a enterramientos

- Eliminación de recrecidos y rellenos

- Incorporación de contrafuertes

- Problemas estructurales desde el origen

- Instalación de drenajes

- Consolidación de ruinas 
IV.2.2.1.1. En muchos casos se levantan los volúmenes sobre preexistencias que conservan su impronta, por ejemplo la parte baja de muros de ladrillo que muestra los sillares bien labrados de una fortificación anterior en Villaverde de Medina. Otra indicación de anteriores construcciones en el emplazamiento de los templos es la denominación "del Castillo", que encontramos en varios de los casos de estudio.

Los muros de la iglesia de Santa María de Alaejos son de fábrica de ladrillo, excepto el del lado del Evangelio, que presenta tapiales encuadrados con ladrillo y tres tramos hacia los pies con sillería de piedra hasta media altura, tal vez restos de una construcción anterior. Sobre la piedra se levanta el cerramiento con fábrica de ladrillo y cajones de tapial.

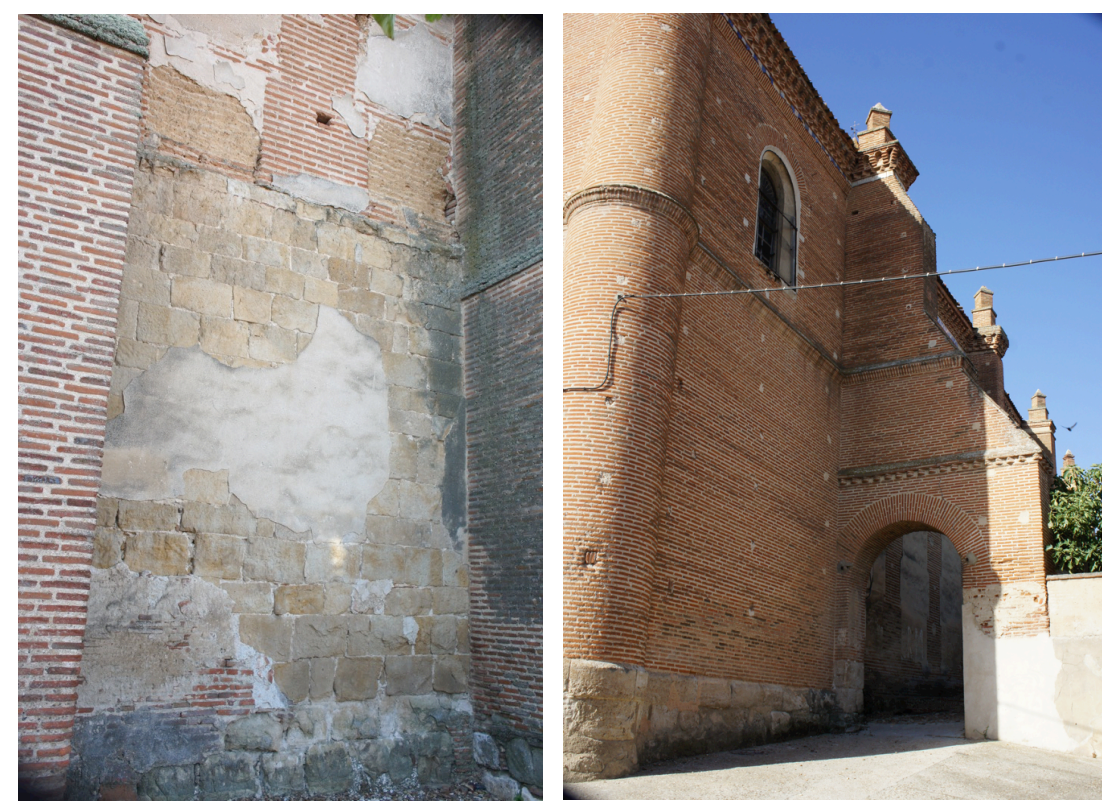

Fig. IV.77. Materiales y estribo fachada del evangelio Alaejos visita 02/09/2014

En la memoria de 1998 de Espinosa y Varona se describe un paño de construcción medieval de ladrillo y tapial integrado en la torre a los pies de la iglesia de Mayorga que, dado su grosor de metro y medio, parece de carácter defensivo.

IV.2.2.1.2. En otros casos se ejecutan recalces tras detectar terrenos poco competentes, sobre todo a raíz de la ejecución de volúmenes nuevos o la reconstrucción de zonas desaparecidas.

Diez años antes de que Cervera reemplace las cubiertas de la Catedral de Valladolid colocando el zuncho de hormigón, Arenillas, al tratar de reconstruir la 
portada sur en 1964, aprecia que "el terreno es echadizo" y aumenta la cimentación hasta profundizar $4,3 \mathrm{~m}^{83}$.

Tras la ruina del ábside de Santa María de Mayorga Rodrigo y Roldán ${ }^{84}$ levantan en 1974 uno nuevo de ladrillo, siguiendo su trazado primitivo original que, según los arquitectos, "precisó de nueva cimentación para garantizar su levantamiento en fábrica de ladrillo".

En 1961 Anselmo Arenillas ${ }^{85}$ proyecta recalzar por puntos la fachada a poniente de Santa María de Wamba con hormigón a fin de evitar movimientos de la fábrica y retacar la fábrica. En 1964 se prosiguen las obras de restauración que habían llevado a desmontar la torre, por riesgo de colapso de los pilares torales, en las que probablemente se colocó el zuncho ${ }^{86}$ :

"La iglesia acusó una ruina progresiva por descomposición de los cuatro pilares del crucero y hubo de acudirse en años anteriores a su urgente reparación apeándolos sustituyéndole algún pilar y enlechando con cemento su descompuesto núcleo que era de mala mampostería. Previamente se procedió a aligerar las cargas que sobre ellos actuaban demoliendo la gran torre o linterna por muros de mampostería de $0,80 \mathrm{~cm}$. de grueso que habían ido recreciendo en diversas etapas de su vida y alcanzaba una altura de unos $10 \mathrm{~m}$... una vez consolidados los pilares se proyecta rehacer sus cimentaciones que casi no existen, recalzándolos por puntos perimetrales y haciendo unas grandes vigas invertidas de hormigón armado... Una vez todo consolidado se proyecta levantar la linterna".

En el Informe arqueológico del proyecto de Quintana y Boned en 1987 se confirman estas actuaciones de refuerzo de Arenillas al afirmar que "pudimos apreciar un zuncho de hormigón que rodeaba toda la zona, atando los cuatro arcos torales".

IV.2.2.1.3. Los enterramientos dentro de las iglesias también condicionan el comportamiento de sus cimentaciones.

\footnotetext{
${ }^{83}$ Planos IPCE y cálculos AGA 26/00356

${ }^{84}$ IPCE 1379-2

${ }^{85}$ AGA 26/00357

${ }^{86}$ AGA 26/00370 ; AGA 26/00253
} 
Arenillas al llevar a cabo la reconstrucción de estructuras de la iglesia de la Pasión para adaptarla a museo, diseña (en 1962, al principio de las obras en cuyo contexto ejecuta los encadenados de hormigón hacia 1964) los nuevos cimientos más profundos de lo habitual por considerar que el terreno ha perdido capacidad portante a causa de la excavación de tumbas: "Se recalzarán los cimientos de la fachada con buen hormigón de cemento y se rejuntarán su cantería para consolidarla, sin restaurarla aún. Se harán cimientos nuevos en hormigón a las medianerías y muros a rehacer o hacer de nuevo, calculándose la profundidad de estos cimientos en dos metros, pues los enterramientos hechos antiguamente en la iglesia han removido el terreno" ${ }^{17}$.

González Fraile en su diagnóstico de la Capilla de la iglesia del Salvador afirma que "las criptas bajo la capilla a su vez sobreexcavadas por enterramientos amenazan la estabilidad del edificio. Las criptas han estado llenas de escombro, sin ventilar".

IV.2.2.1.4. En varios casos también vemos cómo se rebaja el nivel interior o la cota exterior cuando los edificios han sido objeto de recrecidos y rellenos a lo largo del tiempo. También se modifica en ocasiones la configuración existente para permitir la colocación de nuevos pavimentos, soleras o cámaras de ventilación bajo los mismos.

La iglesia de Castronuño también se encontraba semi-enterrada cuando interviene Arenillas en 1965: "El terreno alrededor del edificio va incrementando su cota con el paso del tiempo, dejándolo semienterrado a merced de las humedades".

"Se proyecta rebajar el terreno alrededor de la iglesia $25 \mathrm{~cm}$ con lo que quedará más bajo que el piso de la puerta... ${ }^{88}$ el terreno circundante que había llegado a tapar gran parte del conjunto por arrastres dejándolo como semisótano" ${ }^{89}$.

Los arquitectos que adaptan San Martín en Medina del Campo a su uso como Centro cultural, Fernández e Inglés, explican en la memoria del proyecto cómo en el edificio abandonado se había producido un relleno de espesor variable entre $60 \mathrm{y}$ $80 \mathrm{~cm}$ que debía retirarse.

\footnotetext{
${ }^{87}$ AGA 26/00253

${ }^{88}$ AGA 26/00356

${ }^{89}$ AGA 26/00206
} 
En 1965 Arenillas $^{90}$, que recientemente había intervenido sobre las cubiertas, deja al descubierto una zona semienterrada de San Cebrián de Mazote que en las anteriores restauraciones de Candeira e Iñiguez quedó sin excavar "parte del terreno, antiguo cementerio, al que por el lado norte está adosada la iglesia y que tiene una altura de tres ó cuatro metros de tierra sobre el nivel del piso de la misma. Esto produce grandes humedades en los muros de contorno y los guarnecidos de cal y yeso están desprendidos".

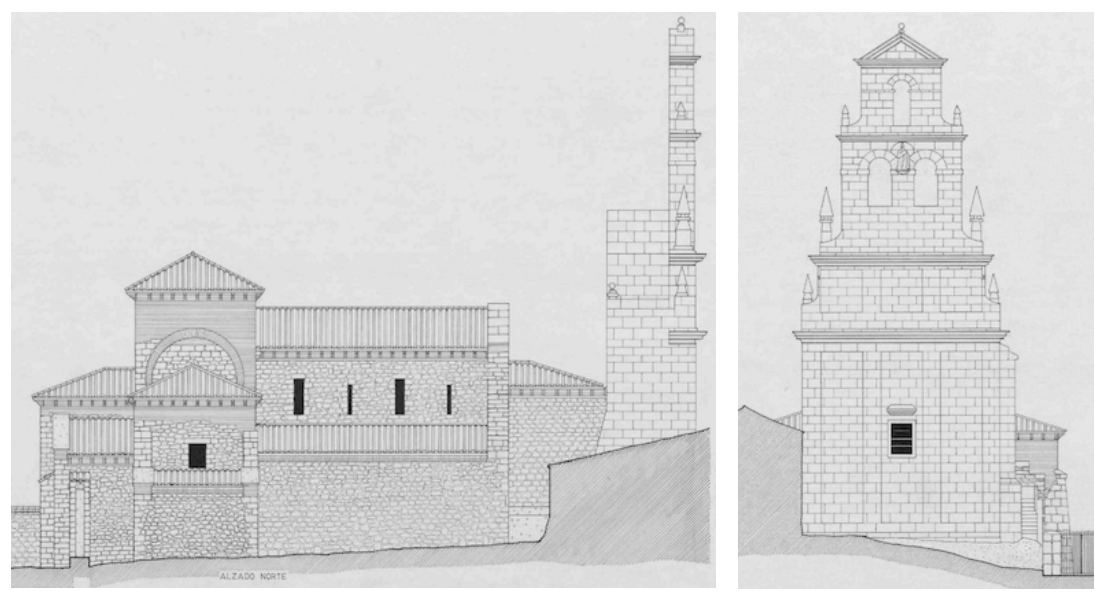

Fig. IV.78. Alzados norte y oeste San Cebrián, 1983 Benito JCyL

En las certificaciones abonadas del proyecto de Quintana y Boned de 1987 se recoge "demolición de zunchos para colocación del solado a la altura de la solera de hormigón" en la iglesia de Wamba. También aparece el encimbrado de arcos y zunchado con collarines de 4 pilares.

Se recupera la cota original del suelo, dejando al descubierto el arranque de los pilares, oculto entonces bajo un entarimado: "se rebajó con supervisión arqueológica el nivel del terreno de la nave románica hasta liberar las basas de los soportes medievales y el banco corrido perimetral. No fue posible esta operación en cabecera y transepto debido a la aparición de zunchos de hormigón ciclópeo bajo el crucero, que no se desmontaron... La cimentación románica, parcialmente fisurada, se consolidó mediante anillos de hormigón armado en torno a las zapatas dañadas".

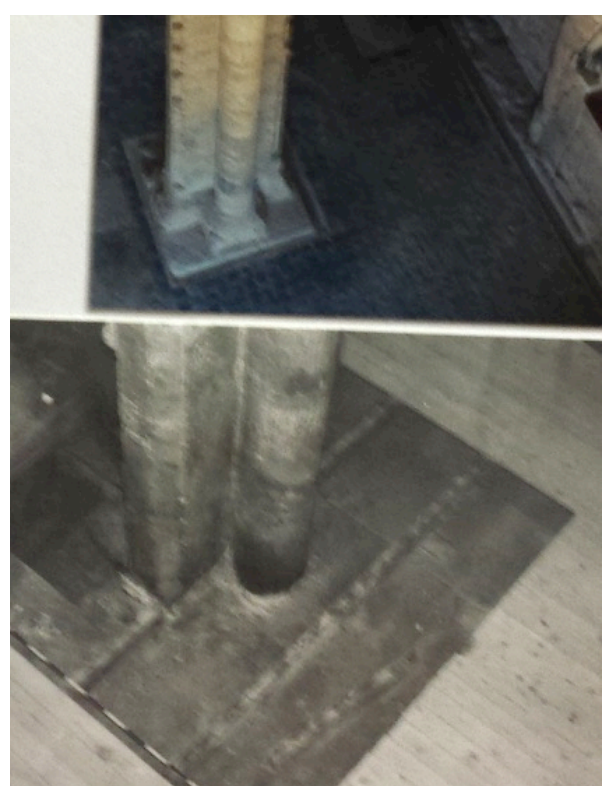

Fig. IV.79 Basas San Cebrián, dossier Quintana y Boned 1990 y 1985 JCyL

${ }^{90}$ AGA 26/00356 
IV.2.2.1.5. En varias ocasiones los proyectos, tras describir la necesidad de reforzar los cimientos, incorporan contrafuertes en los muros.

Varios de los edificios analizados cuentan con potentes contrafuertes ejecutados en el siglo $\mathrm{XIX}^{91}$, como los estribos de ladrillo del lateral del evangelio en San Pablo de Valladolid, o los cilindros en los Santos Juanes de Nava del Rey en 1857. En 1862 emiten un dictamen Ortiz de Urbina, Fuentes e Iturralde sobre el estado lamentable del costado izquierdo de la iglesia de San Pablo de Valladolid tras demolerse una edificación adosada. Proponen recalce ${ }^{92}$ y contrarrestos. Se adosan a las esquinas exentas de la torre dos contrafuertes cilíndricos de grandes dimensiones.
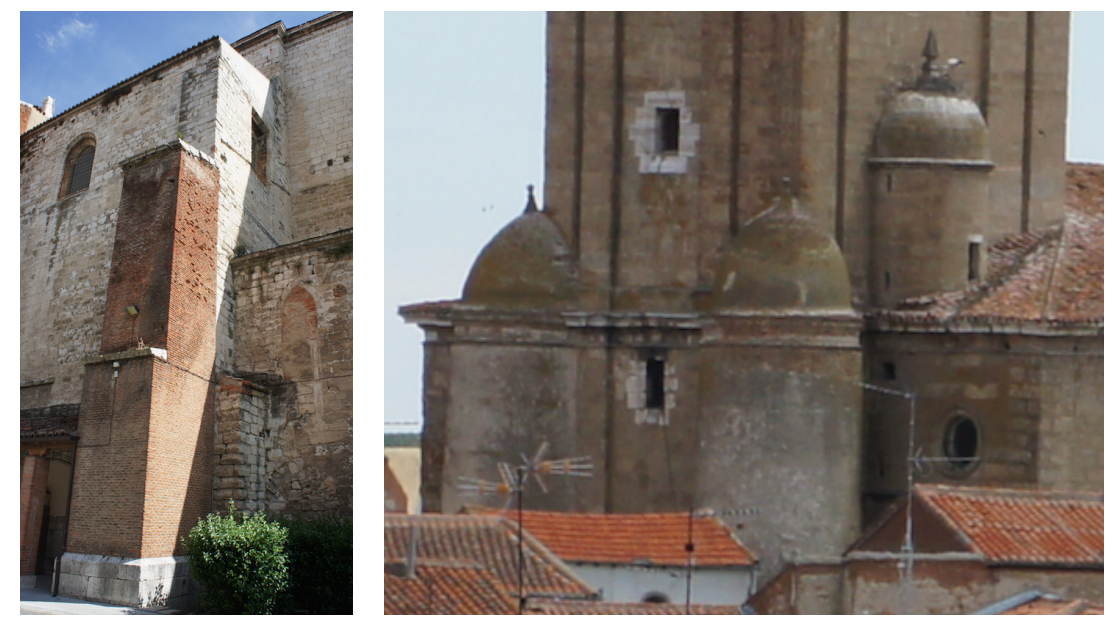

Fig. IV.80. Contrafuertes de San Pablo (visita 12/09/2014) y Santos Juanes (visita 12/09/2012) colocados por Ortiz de Urbina.

Ana Iglesias realiza en 1975 un recalce ${ }^{93}$ en el extremo del Monasterio de San Joaquín y Santa Ana que da a la calle Pedro Niño. "Trata el presente proyecto de las obras necesarias para consolidar parte del edificio que por falta de cimientos en esa zona, ha sufrido daños. Será por tanto necesario proceder a un recalce de cimientos en la misma, así como a la formación de un contrafuerte que asegure la estabilidad del muro que a él se encuentra trabado."

La sacristía de Santa María de Tordesillas se desploma $15 \mathrm{~cm}$ y se hunde un tercio de su cubierta. De la Riva, responsable del atirantado adicional del zuncho de la nave

\footnotetext{
${ }^{91}$ Domínguez Burrieza (2013) en artículos realizados a partir de su Tesis Doctoral recoge, entre otros, estos dos ejemplos de refuerzo estructural que lleva a cabo Jerónimo Ortiz de Urbina.

92 Aunque los historiadores emplean la palabra recalce parece que se refieren a un retacado de las zonas de zócalo de sillería desaparecidas que se rellenan con parches de fábrica de ladrillo, y no necesariamente a actuaciones de refuerzos de la cimentación.

93 AMVA 342/1975
} 
central ejecutado por Luis Mingo que había dado algunos problemas diez años antes, refuerza el muro en 1989 con un contrafuerte de hormigón armado en ménsula de $6,2 \mathrm{~m}$ de altura y $35 \times 70$ sobre una zapata de $3 \times 1 \times 1,5 \mathrm{~m}$.. Se reviste el contrafuerte con fábrica de ladrillo macizo.
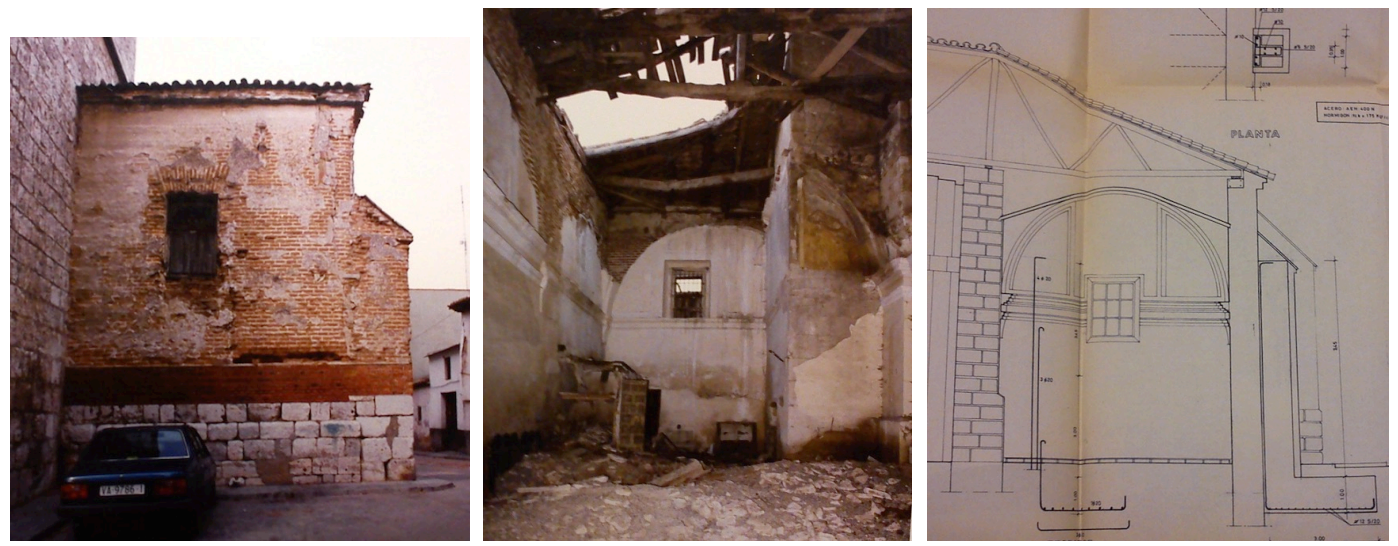

Fig. IV.81. Sacristía Tordesillas, dossier

IV.2.2.1.6. Los problemas estructurales detectados en varias de las iglesias arrancan desde antiguo, en algunos casos desde el inicio de la construcción.

La iglesia de Nuestra Señora de la Antigua es un caso singular desde el punto de vista de la estabilidad estructural, y encontramos documentados sus problemas desde la citada ${ }^{94}$ traza de Gil de Hontañón que ilustra su informe de 1575 en el cual ya propone un refuerzo del arco toral.

En la documentación que acompaña la Ficha FZ-11 se reproducen extractos del libro de Fernández Casanova impreso en 1911 donde explica los distintos problemas que presentaba la construcción a principios de siglo: "las fundaciones del edificio descansan en un banco de cascajo de mediana consistencia con alguna veta de arena, en que apareció el agua por bajo de la capilla absidial del Evangelio. Que se multiplicaron de tal suerte los enterramientos, que, a falta de extensión superficial, se aumentó la profundidad, vaciando el banco de cascajo hasta el plomo mismo de los cimientos a unos dos metros de profundidad por bajo de éstos, con lo cual dicho banco, no encajonado, se va corriendo y aplastando paulatinamente, ocasionando el consiguiente descenso y agrietamiento de los pilares y la descomposición de las fábricas que sustentan. Los cimientos de la torre aparecieron también completamente sueltos... En el siglo XVI la iglesia se encontraba ya en tan desfavorables condiciones de estabilidad, que según un escritor coetáneo, "parecía que quería

\footnotetext{
${ }^{94}$ En el análisis de los proyectos de restauración desde el punto de vista gráfico se ha incluido una reproducción de dicha traza.
} 
caerse". Entonces se aumentó la sección de algunos contrafuertes, se colocaron otros nuevos, se establecieron arbotantes".

Tras vaciar un relleno de la torre y eliminar el potente encamisado que la rodeaba desde el siglo XVI, García Guereta demuele en 1912 el cuerpo del templo y lo reedifica de nueva planta, conservando únicamente torre, cabecera y atrio. El propio atrio, que había sido restaurado antes de la reconstrucción del templo, vuelve a precisar actuaciones en 1948, cuando Arenillas afirma ${ }^{95}$ :

"Ha habido un desplome en el contrafuerte de la izquierda afectando también a la inmediación de toda la línea de fachada y los cinco contrafuertes... Primeramente se procederá a desmontar la cubierta en su totalidad y a continuación se saneará por puntos a todo lo largo de la fachada izquierda, previéndose alcanzar cotas de 2 a $2_{1 / 2}$ metros. Una vez consolidada la cimentación haciéndose un relleno con mampostería hidráulica, se levantará en fábrica de sillería con las mismas características que el actual hastial de la izquierda".

González Fraile realiza un potente refuerzo estructural en la iglesia del Salvador mediante una brida de perfilería metálica y zunchados perimetrales que conectan cabecera y capilla aneja. La estructura de la iglesia consta de una serie de muros diafragma que cuentan con contrafuertes laterales, excepto el que comunica con la cabecera, que carece de contrarresto y transmite empujes no compensados a la capilla. Durante la construcción se incrementa la altura de la iglesia, y también se levanta un muro de $80 \mathrm{~cm}$ de espesor sobre el muro de separación de la capilla para aumentar la altura del presbiterio. El citado arquitecto afirma que los defectos estructurales de la iglesia datan del siglo XV.

En el Catálogo se sugiere que la fachada del Evangelio de la citada iglesia de Alaejos debió presentar problemas de estabilidad desde el principio, por lo que se usaron sillares en la base y refuerzo en los contrafuertes; describe cómo "el estribo más desarrollado, junto a la cabecera, se construyó en 1786 y tuvo un hueco de paso cegado" que hoy encontramos practicable. Luis Cervera interviene en 1959 sobre muros y bóvedas y explica:

"se encuentra derruida la parte de bóveda correspondiente al tramo de nave lateral izquierda señalado en los planos que se adjuntan. Este derrumbamiento ha tenido su origen a causa del desplome de los muros de cerramiento, debido a una insuficiente cimentación. La cimentación de estos muros está situada sobre

\footnotetext{
${ }^{95}$ AGA 26/00294
} 
terrenos permeables; y la acción continua de lluvias han debido arrastrar tierras de asiento así como atacar los materiales constitutivos del propio cimiento. Se proyecta consolidar por pozos y zanjas el muro desplomado, para una vez consolidado proceder a la reconstrucción de la bóveda derruida. Los pozos y zanjas se rellenarán con hormigón una vez encontrado el firme. Se encuentra derruida la parte de bóveda correspondiente al tramo de nave lateral izquierda señalado en los planos que se adjuntan. Este derrumbamiento ha tenido su origen a causa del desplome de los muros de cerramiento, debido a una insuficiente cimentación. La cimentación de estos muros está situada sobre terrenos permeables; y la acción continua de lluvias han debido arrastrar tierras de asiento así como atacar los materiales constitutivos del propio cimiento. Se proyecta consolidar por pozos y zanjas el muro desplomado, para una vez consolidado proceder a la reconstrucción de la bóveda derruida. Los pozos y zanjas se rellenarán con hormigón una vez encontrado el firme".

Otro edificio que sufrió problemas de cimentación prácticamente desde su origen es la iglesia de San Francisco en Medina de Rioseco. En 1718 amenaza ruina el chapitel y se demuele. En 1726 ya se temía la ruina de la fachada: "maliziosa, desluzida y encanchada su piedra hasta una altura de siete pies", y se acomete el refuerzo de sus cimientos. Según García Chico el terremoto de Lisboa de 1755 provoca grandes hendiduras en las bóvedas e inclinación de la fachada. Se repara repetidamente la fachada en 1803, 1839, 1844, 1845 y 1874, hasta que se hunde el último tramo de la iglesia en 1954. En 1964 se incorporan unos enormes contrafuertes. La fachada a los pies se desmonta, cimenta con hormigón y reconstruye en el siglo XX pero el cuerpo de la nave, tras varios derrumbes parciales, acabará desplomándose en los años 70 .

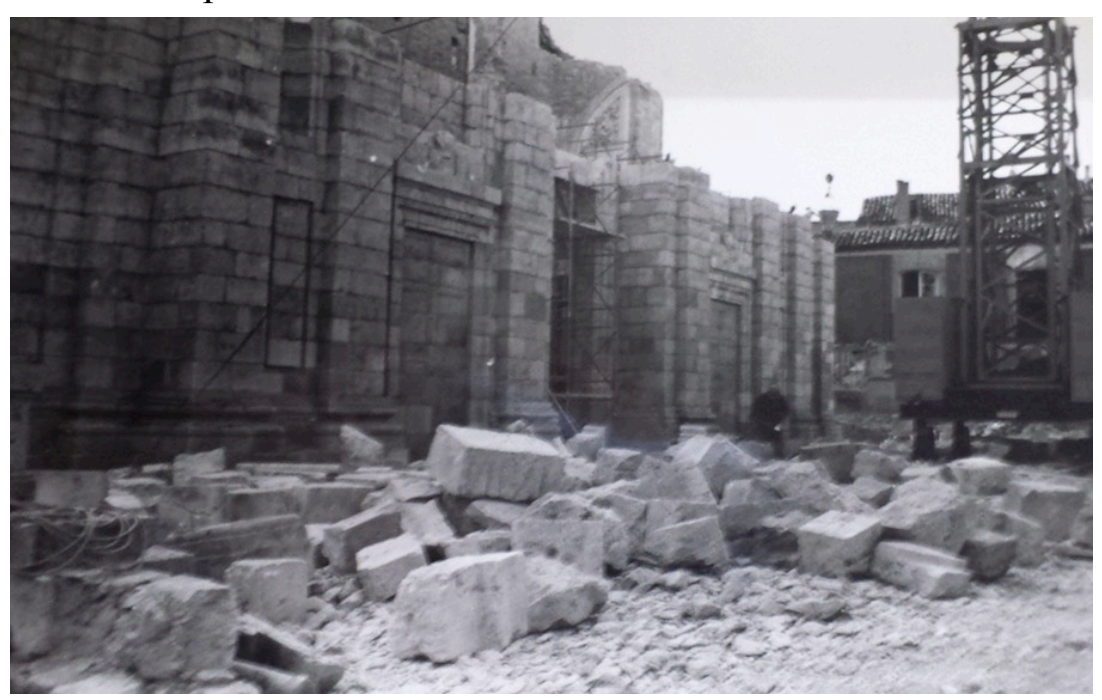

Fig. IV.82. Reconstrucción de fachada 1972 Roldán IPCE 637-3 
Arenillas explicaba en 1968 la necesidad de desmontar y hacer nueva cimentación de la fachada ${ }^{96}$

"En los años cuarenta se acusó un serio desplome de esta fachada, que alcanzó $1,20 \mathrm{~m}$ de desplazamiento de su vertical. Para contener esta ruina, la extinta Dirección General de Regiones Devastadas construyó unos inmensos contrafuertes de fábrica de ladrillo, cuya cimentación parece ser alcanzó $14 \mathrm{~m}$ de profundidad. Así logró inicialmente retardar el vuelco de la fachada, mas últimamente se ha apreciado que el movimiento prosigue, que este gran muro que tiene hasta $3 \mathrm{~m}$ de grueso se está separando del resto de la fábrica e incluso se separa de las bóvedas y esto se acusa sobre todo en la parte alta, allí donde no llegan los contrafuertes. De la observación de estos síntomas y de la información adquirida se deduce que el desplome no es debido a empujes de bóvedas ni cubierta, sino a fallo de cimentación que, en el templo no es profunda y en cambio al hacer los contrafuertes sólo encontraron terreno firme a las $14 \mathrm{~m}$ y antes el terreno estaba humedecido. Parece ser que la dársena del Canal de Castilla, situada en la parte alta del pueblo, tiene amplias filtraciones que actualmente discurren por la vaguada natural que constituye la calle Real y por debajo de ella; esta corriente es la que ha afectado a la cimentación. Contribuyó a su mal el relleno del cauce del río Sequillo, ahora ya dragado por la Confederación".

La cimentación de la capilla de las Angustias de la Colegiata de San Antolín tuvo que ser reforzada durante su construcción al aparecer bodegas antiguas y afloramiento de aguas. En esta zona no se localizaba un firme adecuado para cimentar ya desde el inicio de obras de la cabecera en $1738^{97}$. Tampoco en las Angustias funciona la cámara de ventilación del zócalo de la nave.

La iglesia de Serrada se reedifica íntegramente en varias ocasiones, demoliéndose en el siglo XVIII zonas mal ejecutadas y sufriendo diversos litigios por mala praxis. En su intervención de 1992, dentro de la cual se incorporó el zuncho de hormigón armado en el perímetro de la nueva cubierta, Areizaga y Corral $^{98}$ encargan un Estudio Geotécnico, realizado por la empresa GENOC SA que constó de 2 sondeos a 9 y $11 \mathrm{~m}$ de profundidad, con 8 ensayos de penetración estándar y dos calicatas. No se detecta nivel freático. Hay $1,1 \mathrm{~m}$ de rellenos antrópicos sobre arcillas arenosas

\footnotetext{
${ }^{96}$ AGA 26/00131

${ }^{97}$ Catálogo

${ }^{98}$ VA-131 JCyL
} 
firmes hasta $3 \mathrm{~m}$, arenas finas limpias compactas de 3 a $5 \mathrm{~m}$ y por debajo arcillas duras. En la memoria afirman que "el geotécnico libera de responsabilidad, tanto a la cimentación como a la naturaleza del suelo, en la apertura de grietas existentes en la bóveda del crucero así como en el primer tercio del muro lateral que limita aquel por el lado de la epístola".

IV.2.2.1.7. Con frecuencia se acometen grandes obras para configurar un sistema de drenaje perimetral, tanto exterior como interior, tratando de resolver problemas de humedades por capilaridad en el arranque de los cerramientos.

Anselmo Arenillas explica en $1959^{99}$, más de diez años antes de acometerse las obras que reemplazan las estructuras de cubierta, que el uso como depósitos militares del Monasterio de las Huelgas Reales durante la guerra deterioró pavimento y arranque de los muros: "Para evitar las humedades existentes se proyecta la construcción de un suplemento de la cimentación y zócalo en unos $25 \mathrm{~cm}$ de espesor en buen hormigón impermeable de cemento".

En 2000 Carreño restaura, más de veinticinco años después de la intervención de Rodrigo en las cubiertas, la iglesia de San Juan en Fresno el Viejo ${ }^{100}$ y diseña para el interior del templo una "sub-base de áridos compactados por capas en toda la zona de intervención donde se sustituyen los solados". Al parecer no llega a colocar el drenaje perimetral previsto en proyecto por un problema de falta de cota. Excava una zanja en la base de los muros hasta la cota originaria definida en arqueología, restaurando muros y pilastras hasta ese nivel. La zanja se cierra con áridos sueltos en espera de otra fase de intervención.
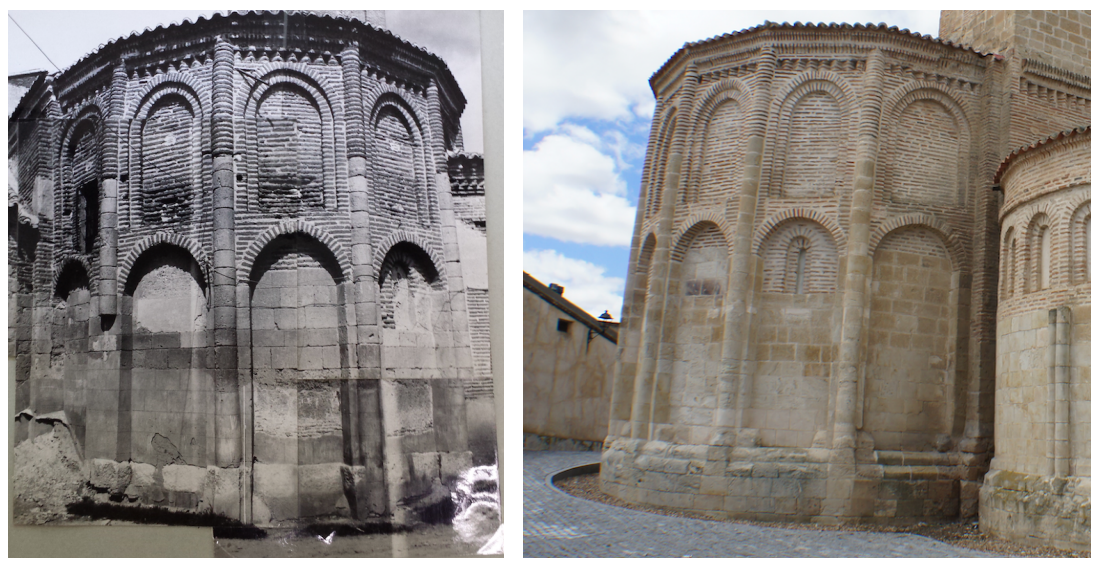

Fig. IV.83. Descarnado en base del ábside San Juan en Fresno el Viejo, dossier Carreño 2000 y actual visita 13/08/2015

\footnotetext{
${ }^{99}$ AGA 26/00294

${ }^{100}$ VA-256 JCyL
} 
Los zócalos de piedra de Santiago en Medina de Rioseco se degradaban debido a las humedades y se interviene sobre los mismos más de diez años después de la intervención de Ana Iglesias. En 1990 se restaura la cubierta semihundida de la sacristía, que muestra además apreciables grietas y deterioro en el zócalo. Se apea y reemplazan las faltas por sillares nuevos.
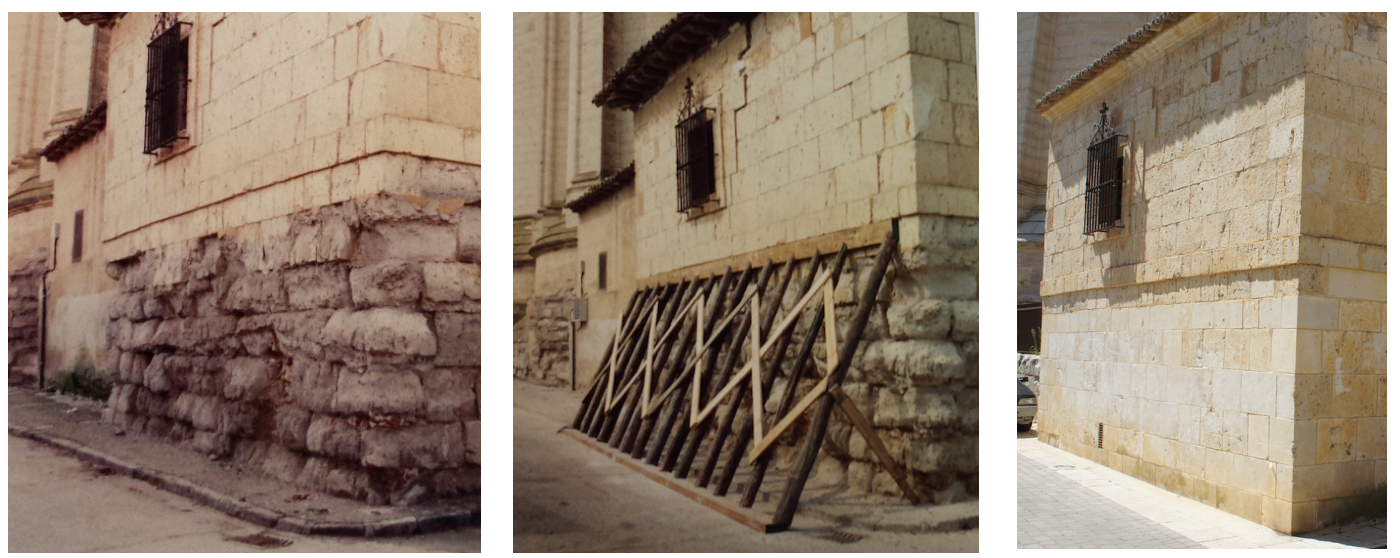

Fig. IV.84. Detalle de zócalo sacristía 1990 Pizarro VA-086 JCyL; actual visita 25/08/2015

También han pasado más de diez años de la intervención de Ana Iglesias sobre las cubiertas de la iglesia de Nava del Rey cuando en 1991 se encarga a CESECO un estudio de humedades para analizar el fuerte deterioro de los sillares de piedra arenisca. Se realiza también un estudio geotécnico con dos sondeos hasta 9,5 y $10 \mathrm{~m}$ de profundidad junto a la fachada principal (muro norte). El informe hidrogeológico no detecta presencia de agua en el subsuelo. Según una campaña de registro de humedades en muros se aprecian éstas hasta una altura de 2,5m tanto en exterior como por el interior. Recomiendan ejecutar una zanja de drenaje perimetral rellena de árido grueso (por bataches para no descalzar el muro) o preferiblemente disponer una malla de drenes verticales, en el interior y $5 \mathrm{~m}$ alrededor del edificio, con $15 \mathrm{~m}$ de profundidad. Aconsejan también practicar taladros de ventilación en los muros con pendiente hacia el exterior. El estudio de sillares distingue diferentes estados de arenización: la resistencia varía mucho entre la piedra sana, con más de $200 \mathrm{kp} / \mathrm{cm}^{2}$, y la alterada, menos de $50 \mathrm{kp} / \mathrm{cm}^{2}$.
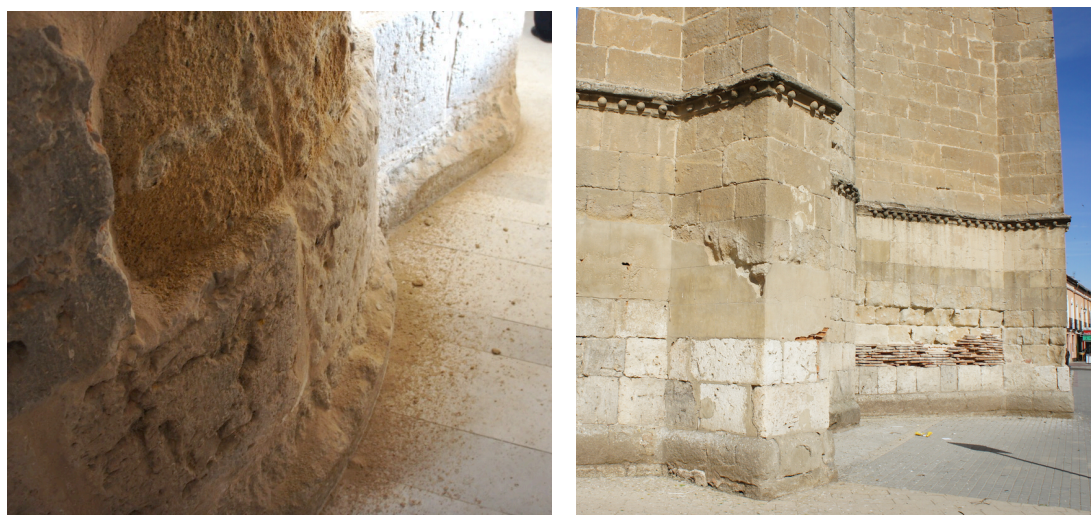

Fig. IV.85. Arenización interior y retacado exterior Santos Juanes, visita 20/06/2012 
En 1982, una década antes del inicio de la restauración integral de Puente, el arquitecto López de Uribe (VA-017) se propone en Valbuena la "eliminación de las humedades mediante la construcción de un concienzudo drenaje de circunvalación..."

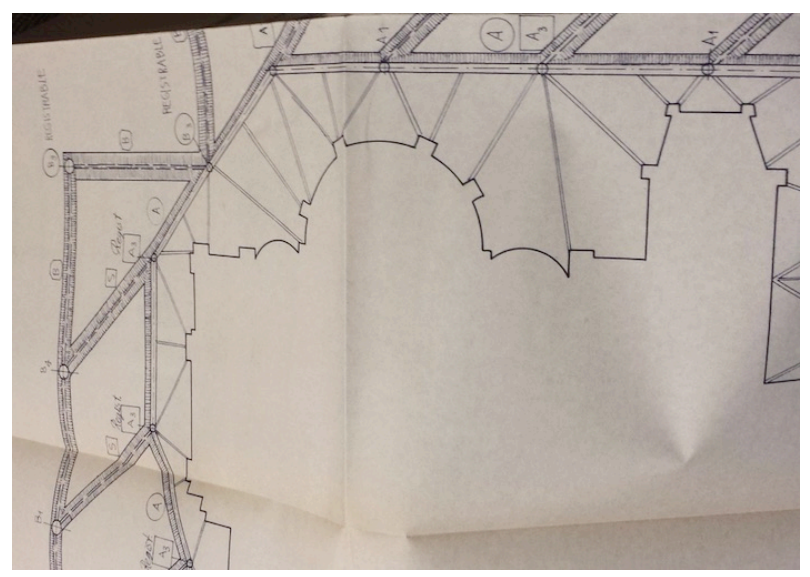

Fig. IV.86. Red de drenaje 1982 López de Uribe JCyL

La iglesia del convento de San Pablo en Peñafiel se localiza en el borde exterior de un meandro del río que ha ido erosionando la base del muro, a los pies. Aparecieron grietas en la parte superior de los muros y humedades ascendentes. En 1993 Abad (VA-162 JCyL) se proponía recalzar la cimentación, con el encauzamiento del río, para evitar la erosión en la base del edificio.
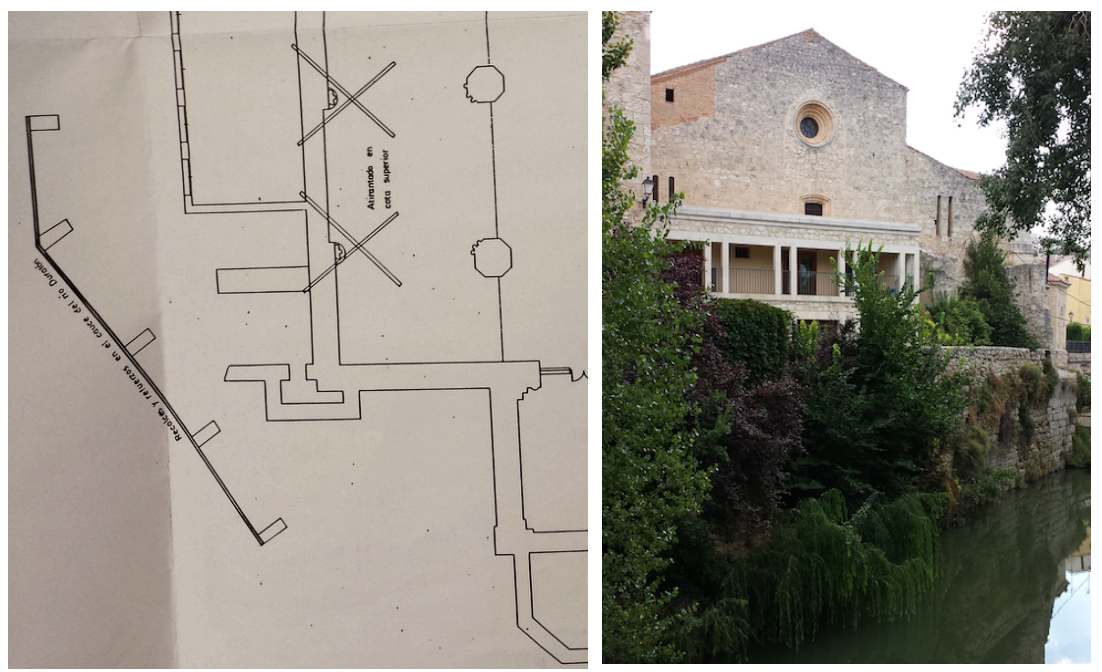

Fig. IV.87. Planta recauce del río y fachada a los pies Peñafiel 1993 Abad JCyL; visita 21/08/2015

IV.2.2.1.8. Los edificios sin uso o arruinados también son objeto de intervenciones de consolidación de las ruinas. Así, José Antonio Arenillas Asín consolida muros y portada de San Agustín en 1968, recalzando por puntos los muros perimetrales. 
En resumen, vemos así que prácticamente en sólo uno de los casos mencionados las actuaciones sobre la cimentación del edificio coinciden con una actuación en las cubiertas que conlleva la incorporación de zuncho de hormigón armado. En varios casos se actúa sobre la cimentación del edificio más de diez años después de haberse ejecutado zunchos y, en otros tantos, más de diez años antes. Un caso frecuente es que se realicen las actuaciones sobre la cimentación unos tres años antes de la intervención sobre las cubiertas, dentro de una misma serie de obras sucesivas que, según se ha comentado anteriormente, se desarrollaban por etapas mediante anualidades.

\section{IV.2.2.2. Los Muros}

Se analiza a continuación la posibilidad de encontrar una relación entre la existencia y el tipo de zuncho con la naturaleza del muro sobre el que éste se coloca.

Se ha hecho hincapié reiteradamente, en los antecedentes de la investigación, en la cualidad portante común a los muros que conforman los edificios históricos. Aunque se trata en todos los casos de muros de fábrica, ésta pueden resolverse con medios técnicos muy distintos según el caso. Podemos plantearnos las diferencias y similitudes del comportamiento de un cerramiento de sillería, por ejemplo, frente a otro de ladrillo, mampuesto encintado o cajones de tapia ${ }^{101}$.

El factor estructural más determinante será sin duda el esquema compositivo de la sección del muro, si se trata de un elemento macizo homogéneo o cuenta con dos hojas con material de relleno entre ellas. La solución de traba entre ambas hojas determinará no sólo la capacidad resistente, sino también su durabilidad.

Uno de los factores que han conducido a la incorporación del zuncho en la coronación de los muros responde sin duda a la búsqueda de traba del material heterogéneo que los conforma, tanto el encadenado en sentido longitudinal como el atirantado en dirección transversal y, en algunos casos además, el cosido de las distintas hojas o capas mediante la disposición de piezas anchas a modo de 1 lave ${ }^{102}$.

\footnotetext{
${ }^{101}$ En la introducción de la Tesis doctoral de Martínez Martínez (2003) se afirma que "Las diferencias entre sillería, mampostería, fábrica de ladrillo, adobe o tapial pueden ser comparables a las que se tendrían entre estructuras de madera y de acero, por ejemplo".

${ }^{102}$ Malheiro en San Mamede de Vila Verde coloca un zuncho ancho y de poco canto específicamente destinado a regularizar la coronación del muro y coser transversalmente las hojas de caras y relleno (entrevista 26/03/2015)
} 
Encontramos párrafos en los proyectos de restauración analizados donde se plantean, valoran y en muchos casos descartan defectos de cimentación como causa de patología, de la que se suele culpar a mala ejecución de los muros con rellenos:

Gatón en el Plan Director de la Catedral de Valladolid menciona que la cimentación de la torre desplomada se encontraba en buen estado, achacando su ruina a la mala ejecución de los muros de dos hojas de sillería sin enlazar correctamente y a la baja calidad del relleno empleado en los mismos.

Arenillas en la capilla de San Gregorio, al reparar la fachada en 1967, siete años antes de la intervención de Cervera sobre la cubierta, explica que "se ha previsto inyectar mortero rico de cemento en el interior del muro que es de dos caras de sillería y relleno de conglomerado de cal, que por las humedades está descompuesto, de este modo se consolidará todo el muro" (AGA 26/00120)

Los muros de tapial de tres astas y media de grosor que conforman la iglesia de Cuenca de Campos amenazan ruina y Arenillas los refuerza en 1962 rozando a ambos lados y chapando de ladrillo "a modo de emparedado". (AGA 26/00253) "En resumen, la operación consiste en lograr rehacer o consolidar el muro de tres y media astas que tiene ahora, convirtiéndole en un muro de ladrillo con un núcleo de tapial a modo de emparedado. Será operación delicada pero factible. Previamente se hará el recalce de las cimentaciones..." En una memoria de 1966 describe cómo ha chapado con ladrillo algunos de los muros, pero gran parte de ellos se han rehecho de nuevo con fábrica de ladrillo y zócalo de piedra.

Con cierta frecuencia la naturaleza de la fábrica que compone el cerramiento se modifica intencionadamente en su remate superior. Esta renovación del tramo superior del cerramiento obedece en algún caso al ajuste de cotas requerido por la geometría, pero en ocasiones también obedece al deseo de sanear la fábrica. Así en la catedral de Valladolid, por ejemplo, los muros de piedra se recrecen con ladrillo por el interior hasta alcanzar la cota de apoyo necesaria para las nuevas cerchas metálicas, manteniendo a la vista al mismo tiempo por el exterior la cornisa de piedra labrada. En el Salvador, sin embargo, al intervenir sobre la cubierta se "sanea" el remate de los muros demoliendo $75 \mathrm{~cm}$ y rehaciéndolo con ladrillo de tejar para "afianzar las hiladas superiores" ${ }^{103}$, pero no se coloca zuncho.

${ }^{103}$ Abad (1999) no incorpora zuncho pero demuele y reconstruye el remate de los cerramientos al sustituir la armadura por otra solución similar con distintas escuadrías y separación. 
La fábrica de la iglesia de Santa María de Tordesillas combina la cantería de cabecera y arranque de los muros del cuerpo del templo con la parte alta de nave central resuelta en ladrillo visto. Según se ha comentado al principio del análisis, el zuncho de hormigón incorporado por Mingo en la restauración de 1980 se interrumpe en el encuentro con la torre de piedra, prolongándose el atado perimetral sobre esta última mediante perfiles de acero laminado apoyados en ménsulas y enanos del mismo material.

Incluso durante la ejecución de las obras de restauración de un edificio histórico resulta muy difícil determinar la naturaleza exacta de los materiales empleados y las soluciones constructivas con las que éstos se aplican. En una investigación documental y con el trabajo de campo limitado, en el mejor de los casos, a inspecciones oculares, sin posibilidad de realizar catas, análisis, ni ensayos, resulta imposible garantizar la veracidad de las estimaciones.
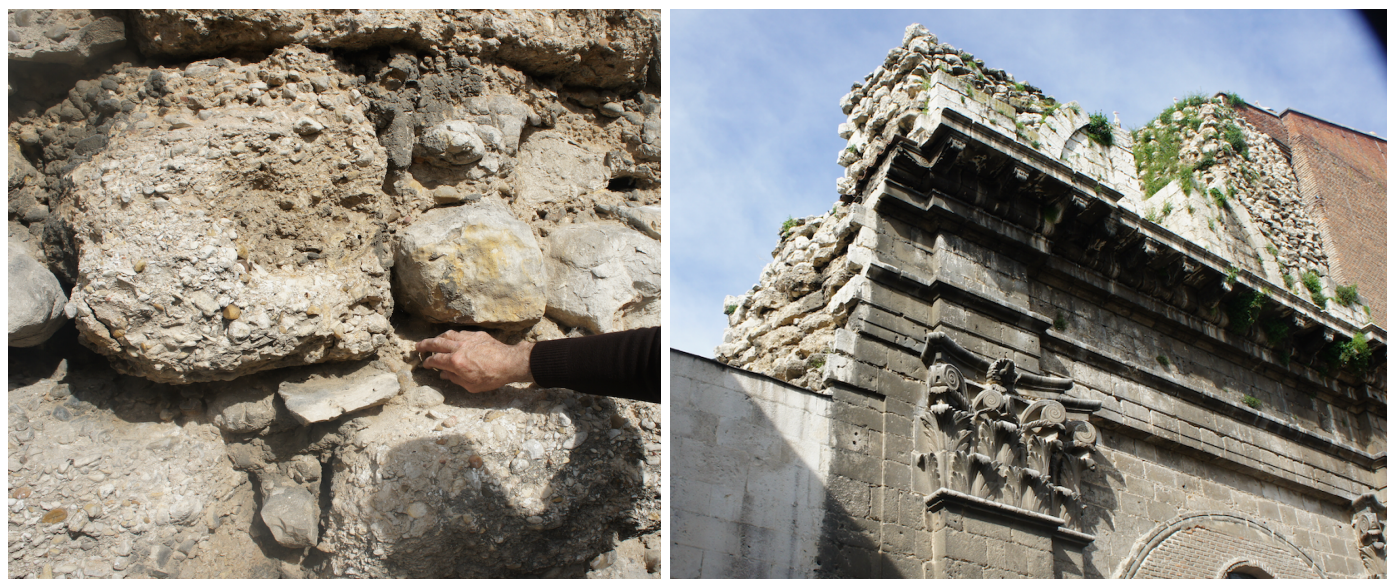

Fig. IV.88. Detalles del muro del crucero inconcluso catedral de Valladolid, visita 10/05/2012

Los muros del crucero interrumpido de la Catedral de Valladolid, por ejemplo, muestran el relleno ${ }^{104}$ tras los sillares labrados. El profesor Chueca Goitia en su monografía sobre el edificio describe los muros "un poco a la romana: una envolvente o revestimiento profundo de piedra de sillería y un núcleo de mampostería basta, que puede considerarse como un hormigón ciclópeo. La sillería de piedra caliza de Cabezón es de muy mala calidad; piedra desigual, de color blanquizco, llena de coqueras y pelos. El despiece de todos los elementos es muy menudo; seguramente la mala calidad de la piedra, ya en descomposición dentro de

\footnotetext{
${ }^{104}$ La sillería en la base de la torre se identifica como Facies Biomicrita: caliza micrítica con formas grumelares, englobando restos de gasterópodos y ostrácodos, algunos muy fragmentados. Análisis Petrológico UCM y CSIC incluido en el Plan Director (Gatón 1997)
} 
la cantera, impediría sin duda la extracción de grandes sillares. Esta pobreza de materiales se echa de ver en los fustes exteriores de las columnas dóricas de la fachada principal, que no están constituidas por tambores enteros" (Chueca facsímil 1998, 164).

Las variables que podemos encontrar en la composición de los muros históricos se multiplican: altura, espesor, materiales, componentes, escalonamientos, ataluzados, contrafuertes... Dentro de un mismo edificio, incluso en un mismo tramo de muro, podemos encontrar aplicadas varias soluciones distintas: sillares, dos hojas de piedra con relleno, mampostería, cajones de tapial, ladrillo visto y paramentos revestidos.

La imagen siguiente del hastial de la sacristía de San Pablo incluida en el proyecto realizado por Gatón en 1999 tras la caída de un entrepaño sobre una panda del Museo de Escultura, ilustra a la perfección la mezcla de soluciones que podemos llegar a encontrar cuando analizamos un muro histórico. El tapial entre machones de piedra se recrece en el piñón con adobe y fábrica de ladrillo. Las fábricas se superponen, sin enjarjes aparentes entre ellas, bajo unos faldones de teja de apariencia reciente.

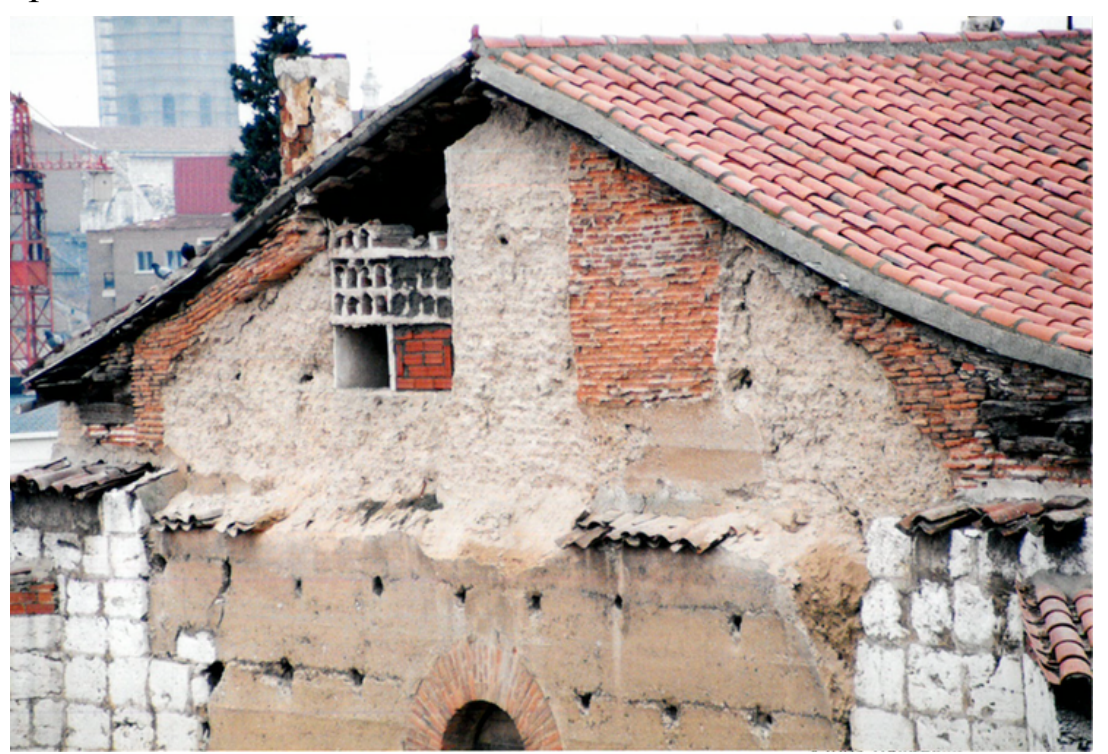

Fig. IV.89. Hastial de San Pablo desprendimiento en 1999 (C01936-005 AMVA)

Analizar el comportamiento constructivo y la capacidad estructural de un muro semejante no es tarea fácil. Este cerramiento, por ejemplo, se encuentra en la actualidad restaurado y homogéneamente revestido, sin que visualmente se pueda sospechar su verdadera naturaleza y los problemas que ha presentado a lo largo de su existencia. 
Tabla 7: Material de los muros

\begin{tabular}{|c|c|c|c|c|}
\hline \multicolumn{5}{|c|}{ MATERIAL DE LOS MUROS } \\
\hline $\mathrm{FICHA}$ & IGLESIA & $\begin{array}{l}\text { ष्ञ } \\
\text { 빰 }\end{array}$ & 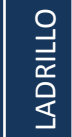 & $\frac{\overrightarrow{\frac{1}{a}}}{\frac{1}{1}}$ \\
\hline FZ-01 & Catedral (Valladolid) & $x$ & & \\
\hline FZ-02 & Convento de la Concepcion (Valladolid) & $\mathrm{X}$ & & \\
\hline FZ-03 & Capilla de San Gregorio (Valladolid) & $X$ & & \\
\hline FZ-04 & La Pasion (Valladolid) & & $\mathrm{X}$ & $\mathrm{x}$ \\
\hline FZ-05 & Convento de Portaceli (Valladolid) & & & \\
\hline FZ-06 & Las Angustias (Valladolid) & & $\mathrm{X}$ & \\
\hline FZ-07 & San Agustín (Valladolid) & 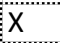 & $\mathrm{X}$ & \\
\hline FZ-08 & San Benito el Real (Valladolid) & $X$ & & \\
\hline FZ-09 & San Lorenzo (Valladolid) & & & \\
\hline FZ-10 & San Pablo (Valladolid) & $X$ & & \\
\hline FZ-11 & La Antigua (Valladolid) & $X$ & & \\
\hline FZ-12 & El Rosarillo (Valladolid) & & $\mathrm{X}$ & \\
\hline FZ-13 & El Salvador (Valladolid) & & $\mathrm{X}$ & \\
\hline FZ-14 & Las Descalzas Reales (Valladolid) & & & \\
\hline FZ-15 & San Joaquin y Santa Ana (Valladolid) & & $\mathrm{X}$ & \\
\hline FZ-16 & Las Huelgas Reales (Valladolid) & & $\mathrm{X}$ & $\mathrm{X}$ \\
\hline FZ-17 & Santa María (Alaejos) & $X$ & $\mathrm{X}$ & $\mathrm{X}$ \\
\hline FZ-18 & San Juan Evangelista (Arroyo de la Encomienda) & $X$ & & \\
\hline FZ-19 & La Santa Espina (Castromonte) & $X$ & & \\
\hline FZ-20 & Santa Maríadel Castillo (Castronuño) & $X$ & & \\
\hline FZ-21 & Santos Justo y Pastor (Cuenca de Campos) & & $\mathrm{X}$ & $\mathrm{X}$ \\
\hline FZ-22 & San Juan (Fresno el Viejo) & & $\mathrm{X}$ & \\
\hline FZ-23 & Santa María (Iscar) & $\mathrm{X}$ & & \\
\hline$F Z-24$ & Santa María de Arbás (Mayorga) & & $\mathrm{X}$ & $\mathrm{X}$ \\
\hline $\mathrm{FZ}-25$ & San Francisco (Medina de Rioseco) & $x$ & & \\
\hline FZ-26 & Santa Cruz (Medina de Rioseco) & $\mathrm{X}$ & $\mathrm{X}$ & \\
\hline FZ-27 & Santiago (Medina de Rioseco) & $X$ & & \\
\hline$F Z-28$ & San Antolín (Medina del Campo) & & $\mathrm{X}$ & \\
\hline FZ-29 & San Martín (Medina del Campo) & & $\mathrm{X}$ & \\
\hline FZ-30 & Los Santos Juanes (Nava del Rey) & $X$ & & \\
\hline FZ-31 & San Juan (Olmedo) & $X$ & $\mathrm{X}$ & \\
\hline FZ-32 & Santa María de Palazuelos (Corcos del Valle) & $X$ & & \\
\hline FZ-33 & San Pablo (Peñafiel) & $\mathrm{X}$ & $\mathrm{X}$ & \\
\hline FZ-34 & San Cebrián (San Cebrián de Mazote) & $X$ & & \\
\hline FZ-35 & Santa María (Tordesillas) & & $\mathrm{X}$ & \\
\hline FZ-36 & La Anunciada (Urueña) & $X$ & & \\
\hline FZ-37 & Santa María de Valbuena (Valbuena) & $X$ & & \\
\hline FZ-38 & Santa María del Castillo (Villaverde de Medina) & & $\mathrm{X}$ & \\
\hline FZ-39 & Santa María (Wamba) & $X$ & & \\
\hline FZ-40 & San Pedro (Serrada) & & $\mathrm{X}$ & $\mathrm{X}$ \\
\hline
\end{tabular}

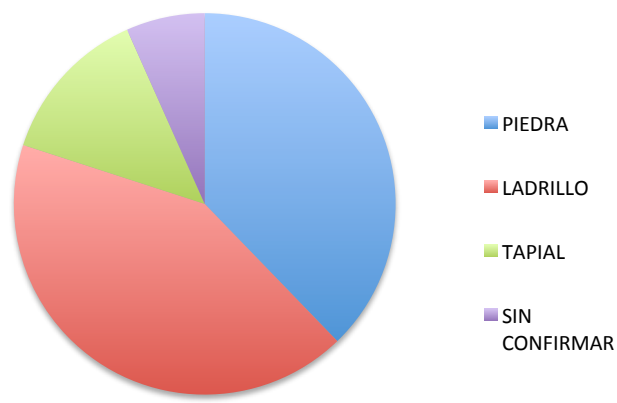


En la segunda mitad del siglo XX se extendió la costumbre de picar los revestimientos que protegían desde sus orígenes las fábricas históricas para dejar al descubierto el aparejo.

En la iglesia de Santa María de Íscar se descarnaron los revestimientos para dejar visto el aparejo de los muros. En 1978 Ana Iglesias (AGA 26/00397) describía así sus actuaciones: "además de suprimir los enfoscados que actualmente tapan la fábrica de ladrillo de tejar en los interiores de las arquerías ciegas y de proceder a las pequeñas reparaciones que sean precisas, se picarán además todos los enfoscados actuales de las fachadas... de manera que aparezcan las fábricas de piedra y mampostería originales".

Arenillas también explica cómo tratará los paramentos en la memoria del "adecentamiento" de los Santos Juanes en 1957: (AGA 26/00310)

"Siguiendo la moda del siglo XIX fue encalado su interior y luego no se limpió adecuadamente, por lo que ha llegado a nuestros días con un aspecto de suciedad impropio de un templo. Se proyecta levantar el encalado sin dañar la piedra allí donde esta presente buen aspecto, rejuntándola y lavándola con agua, y donde la fábrica sea de peor calidad se revocará con mortero de cal por paños o elementos completos y se tenderá luego en color casi blanco a tono con la piedra"

Además de reemplazar las cubiertas, en 1978 Ana Iglesias (AGA 26/00422) realiza otros trabajos complementarios en la Anunciada de Urueña: estudio arqueológico, picado de paramentos interiores descubiertos sólo hasta la mitad, rejuntado y tapado de grietas en bóvedas de los ábsides.

En 1987 Quintana y Boned pican los paramentos de Wamba "tras la confirmación por medio de catas supervisadas por arqueólogos y restauradores de pintura, de la no existencia de decoración mural a excepción de la de la cabecera mozárabe y del nicho del muro $\mathrm{N}$ de la iglesia, se eliminaron las empapadas capas de cal de los paramentos".

Paniagua en el Plan Director de San Antolín remarca cómo los enfoscados sucesivos de cemento han incrementado el deterioro de las fábricas. 


\section{IV.2.2.3. La estructura de cubierta}

Hemos adelantado en el apartado IV.2.2. sobre la documentación gráfica de los proyectos una recopilación de esquemas del estado de las cubiertas de las iglesias analizadas antes de las intervenciones clave. Excepto algún caso aislado en que se trasdosan directamente los faldones a dos aguas sobre las bóvedas, como en Castronuño, se trata de armaduras que cubren un espacio bajo cubierta sobre el trasdós de bóvedas de fábrica, generalmente de ladrillo.

Un estudio en profundidad de estas cubiertas históricas queda fuera del alcance de la Tesis, que pretende centrarse sólo en los aspectos más relevantes de las mismas relacionados con el uso de zunchos.

$\mathrm{Si}$ repasamos las secciones de estado actual anteriores, podemos observar armaduras resueltas con geometrías muy distintas. Algún cuchillo español, varias cerchas palladianas y otros ejemplos con pilarejos apoyados sobre los tirantes. La cercha $^{105}$ no sólo resuelve con su geometría la formación de faldones adecuada para evacuar eficazmente las aguas, el incremento de canto en el centro responde también al requerimiento estructural de un elemento biapoyado con un momento flector máximo en su centro. La pieza de atado horizontal, tanto si se trata de un tirante entre ambos apoyos como de un nudillo o puente dispuesto a más altura, minimiza el empuje horizontal proporcionando a la cercha un comportamiento mecánico acorde con el trabajo de los muros de carga.

La presencia de jabalcones que acodalan el tirante a cierta distancia de su entrega en el muro en varios de estos esquemas parecen fruto de actuaciones de respuesta a la pudrición de las cabezas realizadas a lo largo del tiempo y no parte de su diseño original.

Es evidente la necesidad de mejorar la ventilación de los extremos de los tirantes deteriorados, lo que nos lleva a reflexionar cómo la incorporación del zuncho de hormigón armado bajo el apoyo incide sobre este parámetro. Varios autores justifican el uso de cemento en las Memorias de sus proyectos de restauración por su cualidad de material impermeable ${ }^{106}$.

\footnotetext{
${ }^{105}$ Algunos autores prefieren el término cuchillo, como Paricio (1999) en su glosario.

${ }^{106}$ Arenillas describe para su actuación en la catedral de 1964 "el faldón de cubierta con doble tablero de rasilla y un tendido de mortero impermeable de cemento" (AGA 26/00370).
} 
Entre los escasos edificios de la muestra donde no se coloca zuncho de hormigón al restaurar sus cubiertas están aquellos en que se mantiene la solución constructiva original, como las Angustias en 1982, San Benito el Real en 1991 y San Pablo de Peñafiel. En San Benito, Morán no incorpora zuncho tampoco en las naves laterales, donde emplea una estructura de madera laminada fijada sobre tarugos de madera dispuestos en unos huecos cajeados en la fábrica. En la iglesia del Salvador en 1999 Abad rehace la armadura con madera nueva aprovechando las piezas reutilizables y no introduce zuncho de hormigón aunque diseñe una estructura con diferentes escuadrías y separación.

Tabla 8: Estructura de cubierta proyectada

\begin{tabular}{|c|c|c|c|c|c|c|c|c|c|c|}
\hline \multirow[b]{2}{*}{$\mathrm{FICHA}$} & \multirow[b]{2}{*}{ IGLESIA } & \multirow[b]{2}{*}{ FECHA } & \multirow[b]{2}{*}{ ARQUITECTO } & \multicolumn{7}{|c|}{ DECISIÓN DE PROYECTO } \\
\hline & & & & 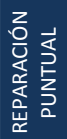 & $\underset{⿱ 乛 龰}{\stackrel{5}{z}}$ & 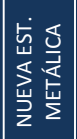 & 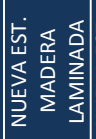 & 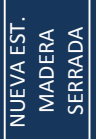 & 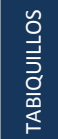 & 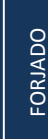 \\
\hline FZ-10 & San Pablo (Valladolid) & 1964 & Arenillas & & & $\mathrm{X}$ & & & & \\
\hline FZ-39 & Santa María (Wamba) & 1964 & Arenillas & & & & & & & $\mathrm{X}$ \\
\hline FZ-04 & La Pasion (Valladolid) & 1965 & Arenillas & & $\mathrm{X}$ & & & & & \\
\hline FZ-21 & Santos Justo y Pastor (Cuenca de Campos) & 1967 & Arenillas & & & $\mathrm{X}$ & & & & $x$ \\
\hline FZ-29 & San Martín (Medina del Campo) & 1968 & Arenillas & & & & & & & $\mathrm{x}$ \\
\hline $\mathrm{FZ}-15$ & San Joaquin y Santa Ana (Valladolid) & 1969 & García Gil & & & & & & $\mathrm{X}$ & $\mathrm{X}$ \\
\hline FZ-01 & Catedral (Valladolid) & 1974 & Cervera & & & $\mathrm{X}$ & & & & \\
\hline FZ-03 & Capilla de San Gregorio (Valladolid) & 1974 & Cervera & & & & & & $\mathrm{x}$ & \\
\hline $\mathrm{FZ}-20$ & Santa Maríadel Castillo (Castronuño) & 1974 & Iglesias & & & & & & $\mathrm{X}$ & \\
\hline $\mathrm{FZ}-22$ & San Juan (Fresno el Viejo) & 1974 & Rodrigo & & & & & & & $X$ \\
\hline $\mathrm{FZ}-16$ & Las Huelgas Reales (Valladolid) & 1976 & Iglesias & & & $X$ & & & & \\
\hline FZ-17 & Santa María (Alaejos) & 1978 & Iglesias & & & $\mathrm{X}$ & & & & \\
\hline FZ-27 & Santiago (Medina de Rioseco) & 1978 & Iglesias & & & $\mathrm{X}$ & & & & \\
\hline FZ-36 & La Anunciada (Urueña) & 1978 & Iglesias & & & & & & $x$ & \\
\hline FZ-14 & Las Descalzas Reales (Valladolid) & 1979 & Iglesias & $x$ & & & & & & \\
\hline FZ-30 & Los Santos Juanes (Nava del Rey) & 1979 & Iglesias & & & $x$ & & & & \\
\hline FZ-12 & El Rosarillo (Valladolid) & 1980 & Iñiguez & & & $\mathrm{X}$ & & & & \\
\hline FZ-35 & Santa María (Tordesillas) & 1980 & Luis Mingo & & & $\mathrm{X}$ & & & & \\
\hline FZ-05 & Convento de Portaceli (Valladolid) & 1982 & Roldán & $\mathrm{X}$ & & & & & & \\
\hline FZ-06 & Las Angustias (Valladolid) & 1982 & Pérez Medina & $x$ & & & & & & \\
\hline $\mathrm{FZ}-28$ & San Antolín (Medina del Campo) & 1982 & Gómez Santander & & & & & $x$ & & \\
\hline FZ-26 & Santa Cruz (Medina de Rioseco) & 1987 & Linazasoro & & $\mathrm{x}$ & & & & & \\
\hline FZ-25 & San Francisco (Medina de Rioseco) & 1988 & Gárate & & & & & $\mathrm{X}$ & & \\
\hline FZ-05 & Convento de Portaceli (Valladolid) & 1989 & Roldán & $\mathrm{x}$ & & & & & & \\
\hline FZ-38 & Santa María del Castillo (Villaverde de Medina) & 1989 & Tovar & & & & $x$ & & & \\
\hline FZ-37 & Santa María de Valbuena (Valbuena) & 1991 & Puente & & & & $x$ & & & \\
\hline $\mathrm{FZ}-40$ & San Pedro (Serrada) & 1992 & Areizaga y Corral & & & & & $\mathrm{X}$ & & \\
\hline FZ-08 & San Benito el Real (Valladolid) & 1997 & Morán & $\mathrm{X}$ & & & & & & \\
\hline FZ-24 & Santa María de Arbás (Mayorga) & 1998 & Espinosa & & & & $\mathrm{x}$ & & & \\
\hline FZ-07 & San Agustín (Valladolid) & 1999 & Gallegos y González & & $\mathrm{x}$ & & & & & \\
\hline FZ-13 & EI Salvador (Valladolid) & 1999 & Abad & & & & & $x$ & & \\
\hline FZ-28 & San Antolín (Medina del Campo) & 1999 & Paniagua & & & & $x$ & & & \\
\hline FZ-23 & Santa María (Iscar) & 2000 & Cembrero & & & & $x$ & & & \\
\hline FZ-32 & Santa María de Palazuelos (Corcos del Valle) & 2000 & Montoya & & $\mathrm{x}$ & & & & & \\
\hline FZ-02 & Convento de la Concepcion (Valladolid) & & & & & & & & & \\
\hline FZ-09 & San Lorenzo (Valladolid) & & & & & & & & & \\
\hline FZ-11 & La Antigua (Valladolid) & & & & $\mathrm{X}$ & & & & & \\
\hline FZ-18 & San Juan Evangelista (Arroyo de la Encomienda) & & & & & & & & $\mathrm{x}$ & \\
\hline FZ-19 & La Santa Espina (Castromonte) & & & & & & & & & $x$ \\
\hline FZ-31 & San Juan (Olmedo) & & & & & & & & & \\
\hline FZ-33 & San Pablo (Peñafiel) & & & $\mathrm{x}$ & & & & & & \\
\hline FZ-34 & San Cebrián (San Cebrián de Mazote) & & & & $\mathrm{x}$ & & & & & \\
\hline
\end{tabular}


En la tabla anterior podemos confirmar que dentro del conjunto de obras en las cuales se incorpora un zuncho de hormigón, la actuación más común es la sustitución de las armaduras por estructuras metálicas, que se lleva a cabo exclusivamente desde los años 60 hasta 1980.

Tabla 9: Fecha de actuación sobre estructuras de cubierta

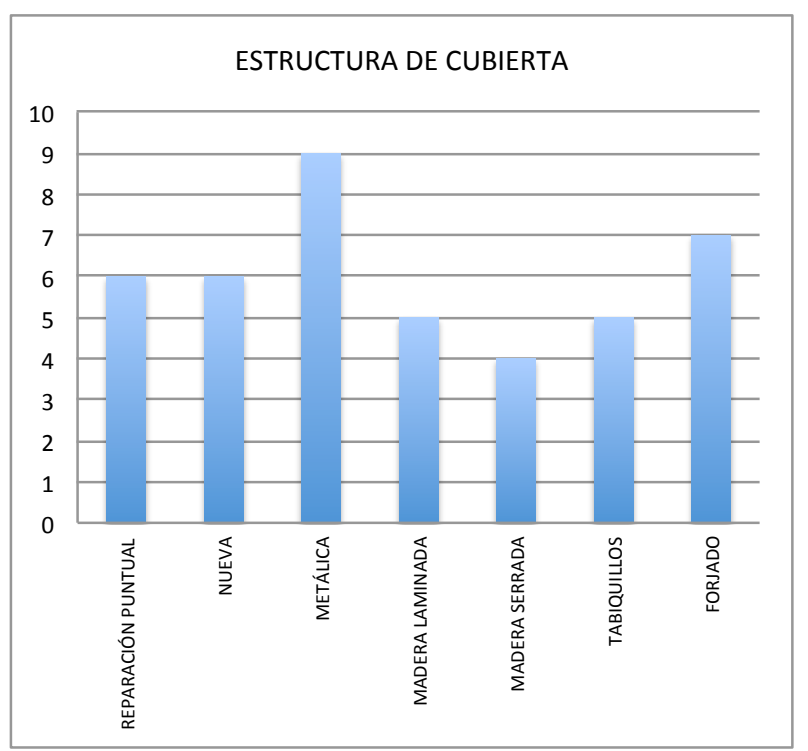

En la primera década analizada también encontramos los tableros de cubierta formados con forjados de vigueta y bovedilla, que no se vuelven a emplear salvo en la actuación puntual de Rodrigo en Fresno el Viejo hacia 1974.

En los 70 se llevan a cabo también intervenciones que resuelven los faldones de cubierta con tablero de rasillas sobre tabiquillos palomeros.

En los 80 y 90 se emplea madera aserrada y, también en los 90, laminada. Hay actuaciones puntuales en que tras arruinarse las cubiertas se coloca una estructura completamente nueva, la más moderna que corresponde a cada momento: cerchas con fibrocemento en 1965, en La Pasión, en el 87 madera laminada en Santa Cruz y cubierta plana metálica en San Agustín en el 99.

En Santa María de Tordesillas los pares metálicos apoyan sobre el zuncho de hormigón y se encomienda el atado transversal a unos tensores anclados contra el lateral del mismo. 
El apoyo de los pares se resuelve en todos los casos sobre la superficie horizontal de coronación del zuncho, mientras que en algunos casos los tirantes, de madera o metal, acometen contra su costado.

En la fotografía podemos apreciar el detalle diseñado por Paniagua en las naves laterales de la Colegiata de San Antolín, con los pares apoyados sobre la cara superior mientras los tirantes, también de madera laminada, acometen contra la superficie lateral del zuncho. Ambas piezas se fijan al hormigón mediante placas de conexión metálicas.

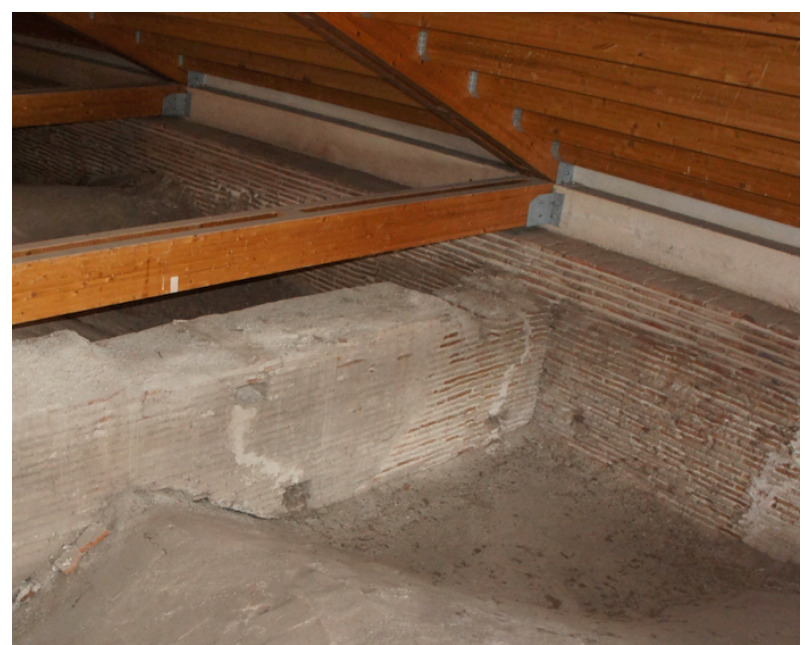

Fig. IV.90. Zuncho de hormigón en naves laterales de San Antolín (visita 05/05/2014)

En la visita a la iglesia de la Santa Espina se ha encontrado zuncho sólo en una nave lateral ${ }^{107}$, y las viguetas de hormigón que forman el forjado inclinado de cubierta penetran en un recrecido de ladrillo dispuesto sobre el zuncho de hormigón, enrasado a cara interior.

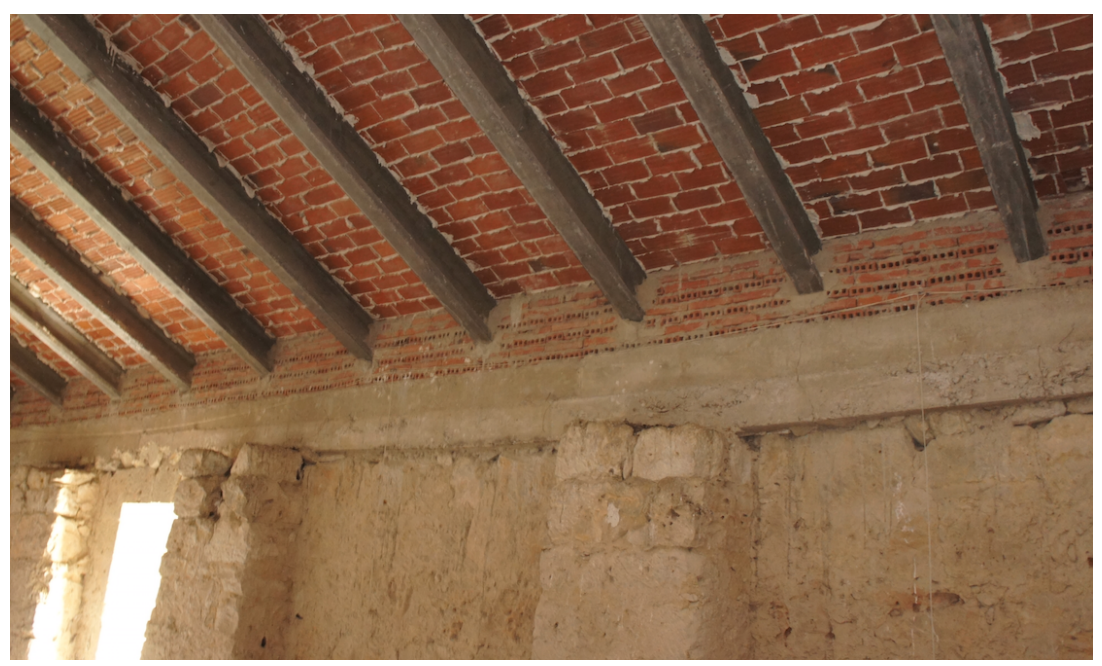

Fig. IV.91. Zuncho en nave lateral La Santa Espina, visita 28/04/2015

Varias de las sustituciones de cubierta con madera, tanto aserrada como laminada, recuperan las piezas de madera que puedan reaprovecharse, como Abad en El Salvador o Gómez en San Antolín.

\footnotetext{
${ }^{107}$ En el edificio de la iglesia sólo se aprecia zuncho en esa nave lateral, aunque hay múltiples elementos de hormigón en las cubiertas del resto de dependencias del Monasterio.
} 
Esta idea de desmontar y volver a armar una estructura de madera de cubierta reponiendo las piezas deterioradas no es nueva. En la documentación histórica de la iglesia de la Santa Espina podemos leer la siguiente transcripción del Libro de Obras recogida en el Plan Director ${ }^{108}$ :

(Fol 101v) Retejo.- Recorriose la Iglesia, quitando las goteras y para esto se compraron mil y quinientas tejas a noventa y seis reales el millar importan ciento y quarenta y quatro reales; y a un oficial por diez y seis dias a cinco reales cada dia llebo ochenta reales. Dos peones para llevar materiales a dos reales y medio cada uno por dia importan ochenta y todo 304.

(Fol 128v) Carpinteros.- Para deshacer los texados, hacerlos de nuevo, echar piso de madera a todos los lienzos del Claustro Reglar, desarmar los de la Yglesia, Sacristia y Dormitorio, y volverlo a armar, cortar las maderas de los Sotos para ello, y componerlas, y hacer andamios, estuvieron trabajando ocho carpinteros, y ocuparon en esto quatrocientos y veinte dias a seis reales de jornal uno con otro que ymportaron veinte mil ciento y sesenta reales. "

En resumen, aunque la incorporación de zunchos se ha realizado tanto en edificios con cerramientos de piedra como de tapial y ladrillo, se trata de un recurso al que se recurre especialmente cuando los muros se encuentran en mal estado. También parece que acompaña preferentemente a las nuevas estructuras metálicas de cubierta con que se sustituyen, en gran parte de los casos estudiados, las cerchas de madera.

${ }^{108}$ Libro de Obras 15-IV-1765 = 15-IV-1766 


\section{IV.2.3. Los tejados}

Si queremos remontarnos al origen de nuestras iglesias parroquiales tenemos que referirnos indefectiblemente al modelo de basílica paleocristiana. Se parte de una tipología civil romana de templos con tres o cinco naves separadas por columnas, con el presbiterio al fondo, y una cubierta a dos aguas soportada por una estructura de madera. Las basílicas paleocristianas que nos han llegado presentan las naves escalonadas y el espacio interior se cierra con un techo encasetonado plano. Si tomamos como ejemplo la basílica de San Pedro, levantada en el siglo IV y desaparecida tras su incendio en 1823, que podemos conocer a través de frescos vaticanos o de la obra de Tiberio Alfarano en el XVI, podemos apreciar cómo la nave central se cubría a dos aguas con una armadura de doble puente y pendolón.

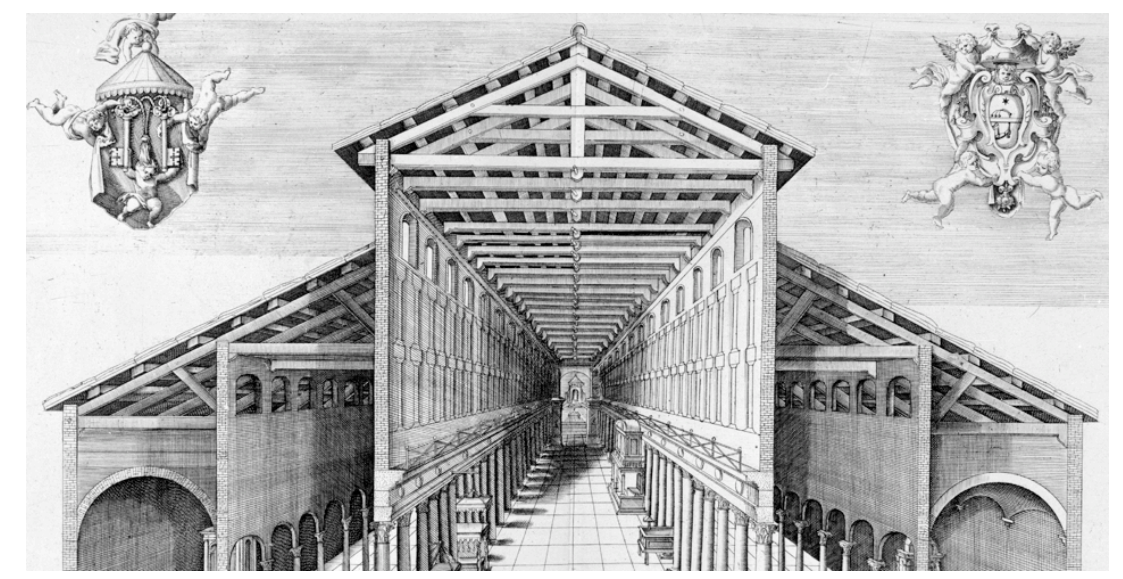

Fig.IV.92. Sección de la basílica de San Pedro (1576 Tiberio Alfarano) http://fotothek.biblhertz.it/ bh/c/bhpd23585-1c.jpg 10/12/2014

Este tipo de cubierta histórica a dos aguas recubierta de teja curva resuelve el problema de proporcionar unas superficies prácticamente continuas por las que deslizan las aguas y al mismo tiempo cuentan con la adaptabilidad necesaria para soportar las contracciones y dilataciones producidas por los cambios de temperatura efecto de la exposición a la intemperie. La relativa impermeabilidad la proporciona la yuxtaposición de las piezas cerámicas troncocónicas solapadas. En las iglesias analizadas en la investigación, las tejas se disponían sobre una tablazón de madera o ripia, clavadas o puntualmente recibidas con mortero. Tras las restauraciones modernas, en muchos casos el tablero de cubierta es un forjado o se ha rematado la antigua tablazón con una superficie de hormigón in situ.

Según se adelantaba en el primer párrafo de la introducción de la Tesis, uno de los factores que determinan la importancia de conocer a fondo el papel que desempeña el zuncho en la restauración monumental es la conflictividad del punto en que éste se ubica. La respuesta técnica al encuentro entre cubierta y fachada es un aspecto 
fundamental en el diseño de los edificios. La solución con que se engarza el alero, la "parte inferior del tejado, que sale fuera de la pared y sirve para desviar de ella las aguas llovedizas", con la cornisa "coronamiento compuesto de molduras, o cuerpo voladizo con molduras, que sirve de remate a otro" ${ }^{95}$, condiciona el comportamiento tanto estructural como higrotérmico de todo el tejado y repercute de forma directa sobre la durabilidad del mismo.

Según el diccionario RAE, armadura es el "conjunto de piezas de madera o de hierro que, ensambladas, sirve de soporte a la cubierta de un edificio". El vocabulario distingue entre durmiente y solera, ambos considerados maderos horizontales sobre los que descansan otros, por encontrarse esta última "asentada de plano sobre fábrica".

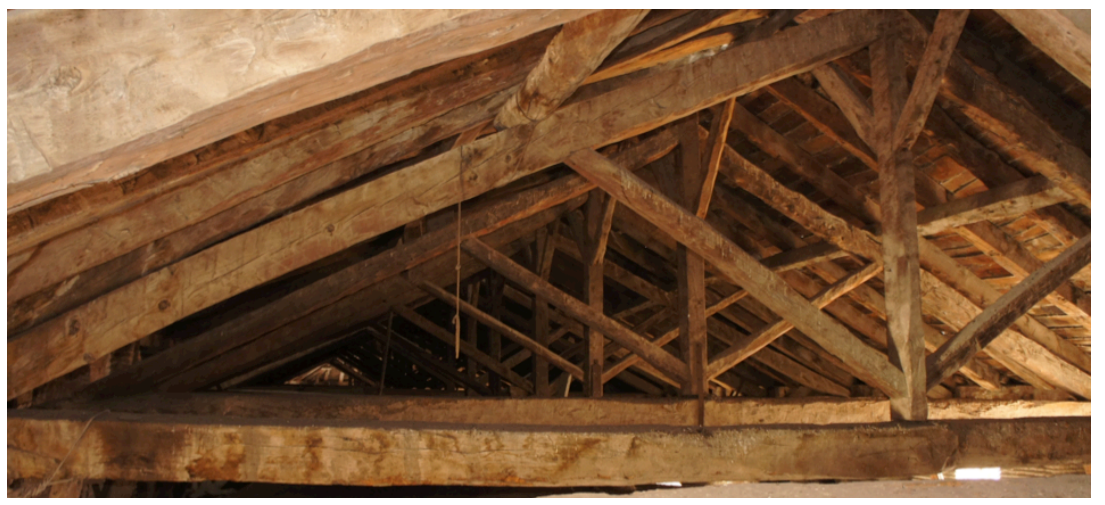

Fig.IV.93. Bajo cubierta FZ-08 San Benito el Real (visita 23/04/2015)

Aunque prácticamente todas las cubiertas del conjunto-muestra de iglesias estudiado se concibieron con cubierta a dos aguas soportada por estructura de madera, la formación de un espacio cerrado bajo la misma sobre el trasdós de unas bóvedas fue en no pocos casos, como las iglesias de Villaverde de Medina o El Salvador, una adición posterior ${ }^{96}$.

Revisando los planos de "estado actual antes de la intervención" de algunos proyectos podemos averiguar cómo estaba configurada la estructura de cubierta antes de esas obras, pero no confirmar si se trataba del esquema original o era fruto de otras actuaciones, sobre todo las decimonónicas de las que contamos con una documentación más escasa.

En estas secciones encontramos de forma reiterada la presencia de apeos y apuntalamientos puntuales tanto sobre las bóvedas como en forma de jabalcones o

\footnotetext{
${ }^{95}$ Las definiciones RAE distinguen con precisión el alero como parte del tejado de la cornisa como remate del muro.

${ }^{96}$ Ahora parece imposible imaginar San Cebrián de Mazote con un interior cubierto por bóvedas como se encontraba a principios del siglo XX antes de su repristinación. (Ver Ficha FZ-34)
} 
codales contra los muros. Se trata de refuerzos colocados tras la pudrición de las cabezas, frente a deformaciones excesivas o para empalmar piezas partidas.

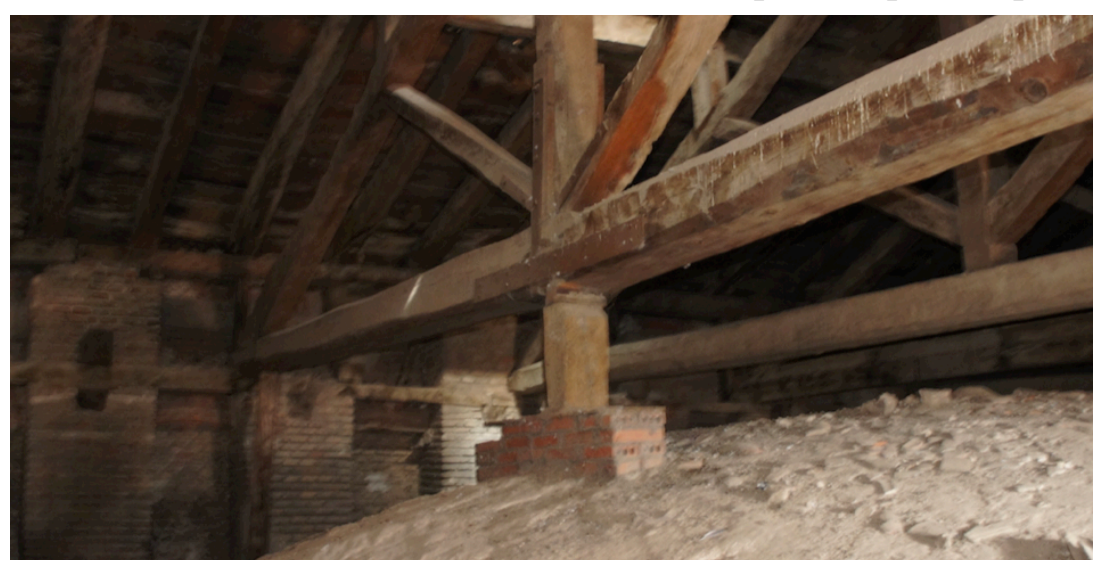

Fig.IV.94. Apeo sobre bóveda en San Benito (visita 23/04/2015)

\section{IV.2.3.1. La tipología de cubierta original}

A continuación vamos a buscar las posibles relaciones entre la incorporación del zuncho, el sistema de cubierta que se mantenía en el momento de la intervención, que en algún caso encontramos reproducido en los planos como "estado actual", y la tipología de cubierta original que podemos estimar en cada caso.

Tenemos edificios que conservan la armadura que tenían cuando se fueron acometiendo las habituales restauraciones con sustituciones puntuales de piezas en mal estado. En ocasiones se reparan pares y sobre todo tirantes con prótesis de las denominadas originalmente tipo "beta", con inserción de barras de fibra de vidrio recibidas con resinas epoxídicas para reponer los trozos podridos desaparecidos, generalmente las cabezas entregadas en los muros sin la oportuna ventilación. En el "estado actual" recogido en los proyectos solemos encontrar apuntalamientos de estas cabezas.

A continuación se reproduce el esquema de armaduras de algunos de estos casos que, como podemos ver, no muestra un patrón homogéneo. Aparecen desde cerchas españolas hasta de tipo palladiano, o incluso soluciones con varios niveles. También hay casos con armadura de pares y tirantes aislados, simples o dobles. Se distingue dos casos esenciales:

- Un volumen de cubierta sobre una sola nave.

- Un volumen de cubierta único sobre varias naves. 
IV.2.3.1.1. Se analizan en primer lugar las cubiertas que rematan una única nave, bien por tratarse de templos concebidos sin naves laterales, bien por resolverse la cubierta de éstas a una cota inferior, al modo basilical.

Las cerchas que cubren la nave central de la iglesia de San Benito el Real cuentan con unos codales a ambos lados que apean el tirante contra el muro sobre los arranques de las bóvedas de piedra. También hay pequeños tornapuntas, que acodalan en cumbrera a ambos lados, en dirección transversal al plano de la cercha.

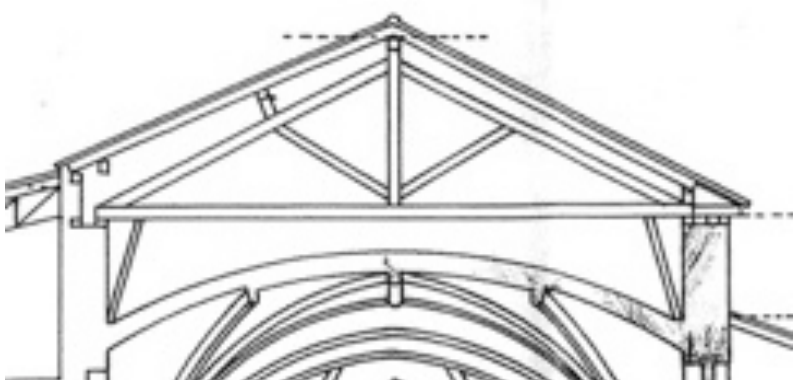

Fig.IV.95. Sección estado actual San Benito 1997 Morán JCyL
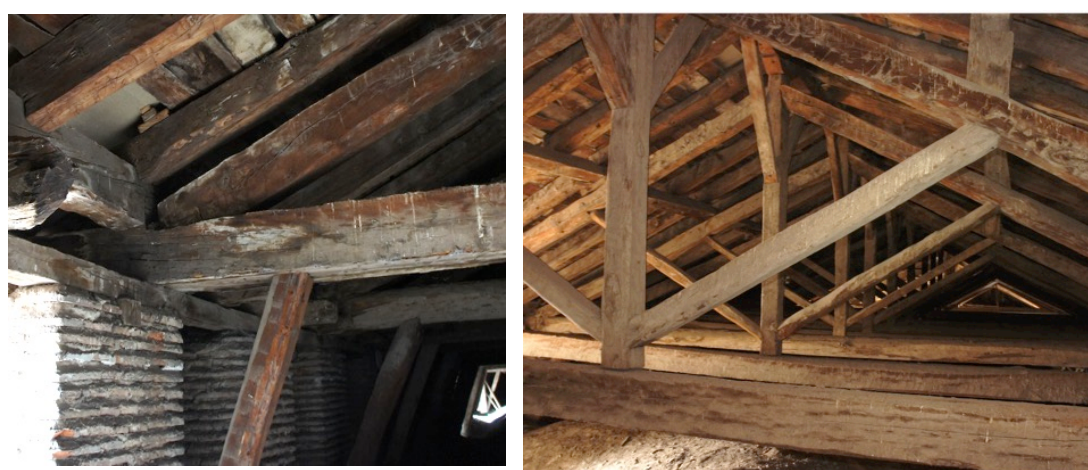

Fig.IV.96. Vistas del bajo cubierta San Benito, visita 23/04/2015

Los mismos apuntalamientos en ambos extremos pero dobles aparecen en la sección de Areizaga y Corral en Serrada.

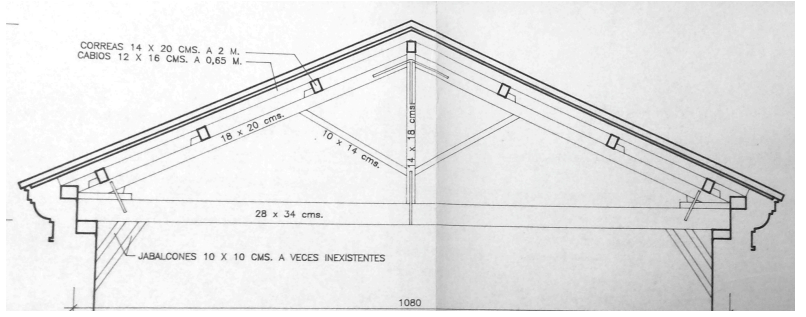

Fig.IV.97. Sección estado actual Serrada 1992 Areizaga y Corral JCyL
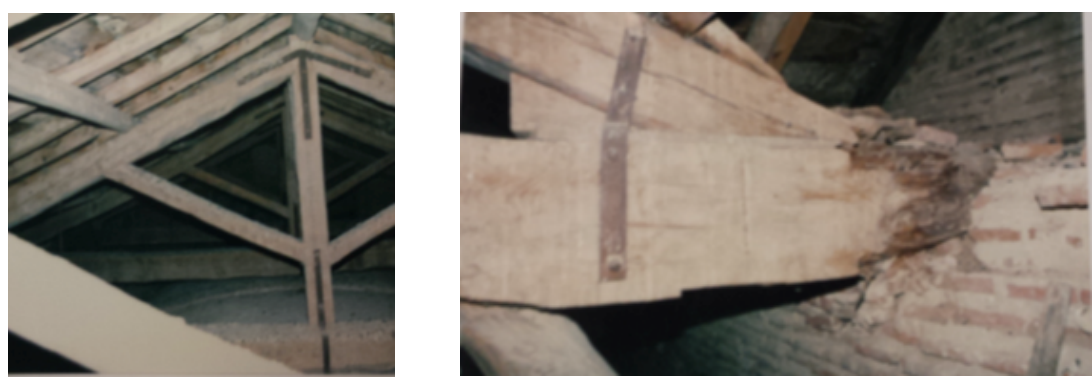

Fig.IV.98. Vistas dossier 1992 Areizaga y Corral JCyL 
En las fotografías del dossier de 1992 se aprecia cómo estas cerchas contaban con herrajes metálicos en los empalmes.

En el caso de San Benito se conserva la armadura con reparaciones puntuales, mientras que en la iglesia de Serrada se reemplazó por una nueva estructura de madera apoyada sobre zuncho de hormigón.

En Tordesillas la cercha representada por Mingo en 1980 también presenta un dado de apeo central sobre la clave de la bóveda.

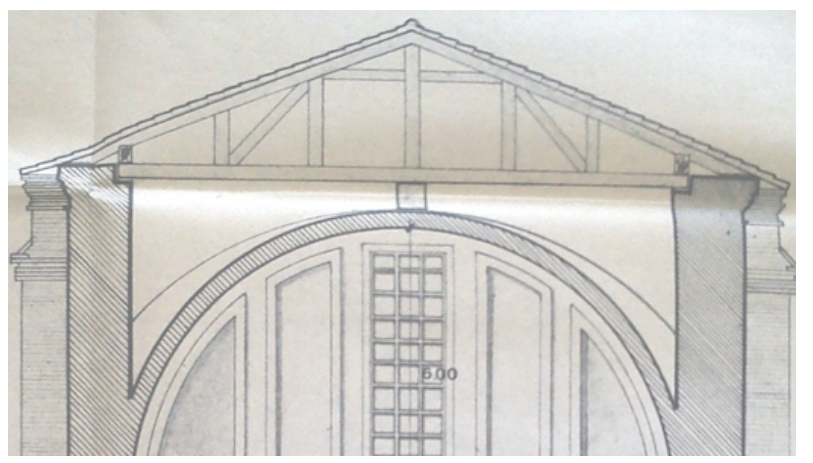

Fig.IV.99. Sección Tordesillas actual 1980 Mingo IPCE

En el Salvador se reemplaza por esquema similar de cercha palladiana con dos péndolas, pero con piezas duplicadas y mayor escuadría que no parece moderno. En la sección parece representarse un dado bajo el tirante, sobre la bóveda, similar al de Tordesillas.

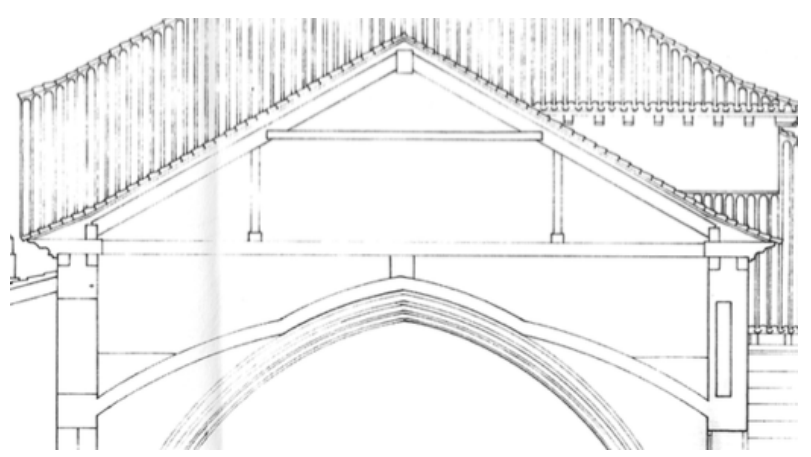

Fig.IV.100. Sección Salvador actual 1999 Abad JCyL

En estos dos casos como en los dos ejemplos anteriores, se incorpora zuncho en uno de los templos y se mantiene el apoyo sobre estribo de madera al modo tradicional en el otro. En Tordesillas se reemplaza la armadura por perfiles de acero y tensores con zuncho de hormigón y en el Salvador se reemplaza la armadura por una nueva similar reaprovechando las piezas en estado aceptable.

Se ha comentado ya en varias ocasiones cómo la iglesia de Santa Cruz en Medina de Rioseco constituye un caso singular por varios motivos. En primer lugar se trata de una iglesia cuya nave ha sido casi totalmente reconstruida tras derrumbarse en 
varias etapas. Contamos con un esquema de estado actual anterior al hundimiento final que corresponde al momento en que se estaba volviendo a levantar la fachada, faltaba el último tramo de bóveda a los pies y se encontraba apeado con ladrillo el arco fajón.

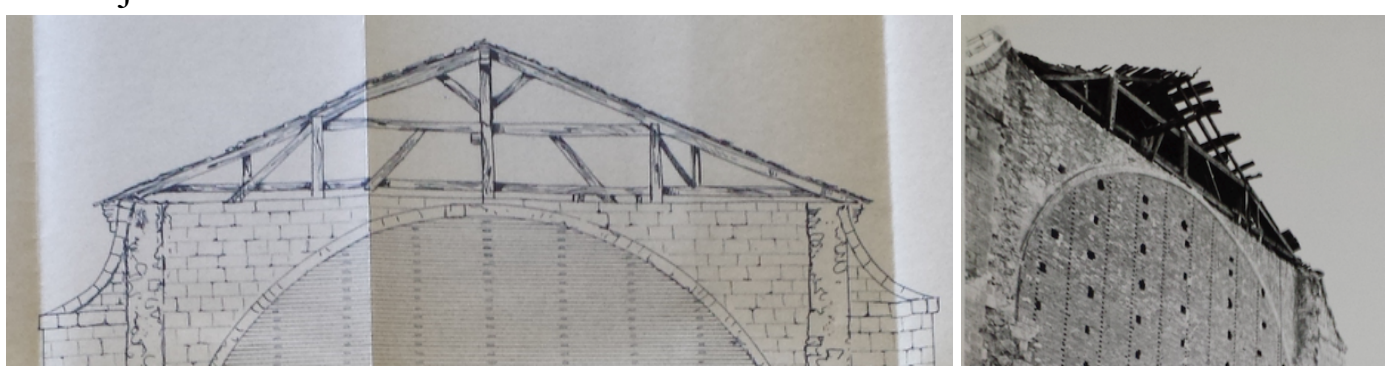

Fig.IV.101. Sección y fotografía dossier Santa Cruz 1972 Rodrigo y Roldán, archivo IPCE

La iglesia de la Cofradía de las Angustias muestra en la sección actual de 1982 de Pérez Medina una cubierta a dos aguas que cubre la única nave prolongándose sobre las capillas laterales formando dos cámaras. La armadura representada cuenta con tirante y puente. Este esquema avanza la solución de arquerías recrecidas sobre los ejes de pilares que veremos más adelante empleada por ejemplo en San Antolín.

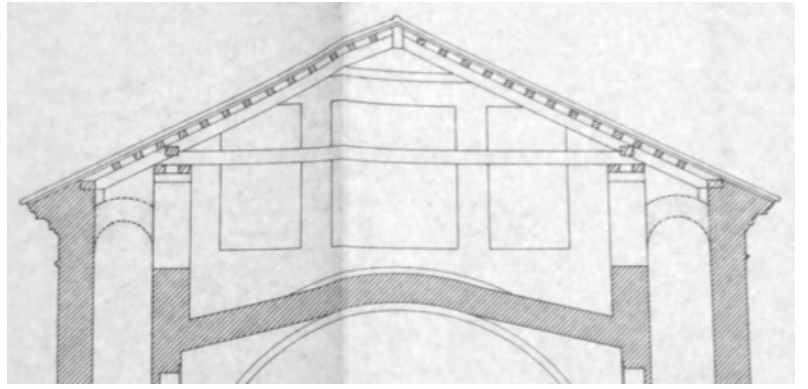

Fig.IV.102. Estado actual Angustias 1982 Pérez Medina archivo de la Cofradía

Otra iglesia con cubierta a dos aguas sobre nave única es la que encontramos en Villaverde de Medina. La estructura de cubierta original contaba con cinco vigas de madera por tramo, en el sentido longitudinal del templo, apoyadas sobre unas ménsulas labradas encastradas en unos muros del tipo arco diafragma. La evolución histórica, obras de restauración acometidas y patología de esta cubierta se describe en la Ficha resumen correspondiente FZ-38 ${ }^{97}$.

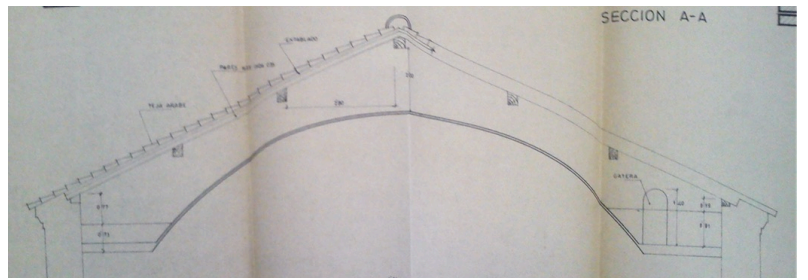

Fig.IV.103. Estado actual Villaverde de Medina 1989 Tovar JCyL

\footnotetext{
${ }^{97}$ En la comunicación firmada junto a $\mathrm{M}^{\mathrm{a}}$ Soledad Camino "La investigación documental. Factor importante para el análisis de la patología estructural de los edificios históricos" del Congreso PATORREB 2015 celebrado en Oporto se recoge una documentación más amplia sobre el comportamiento estructural de la cubierta de Villaverde.
} 
El esquema de las armaduras de la Catedral antes de su reemplazo en 1974 contaba, según el plano de estado actual firmado por Ángel Ríos para solicitar la Licencia de obras, muestra herrajes y tirantillas.

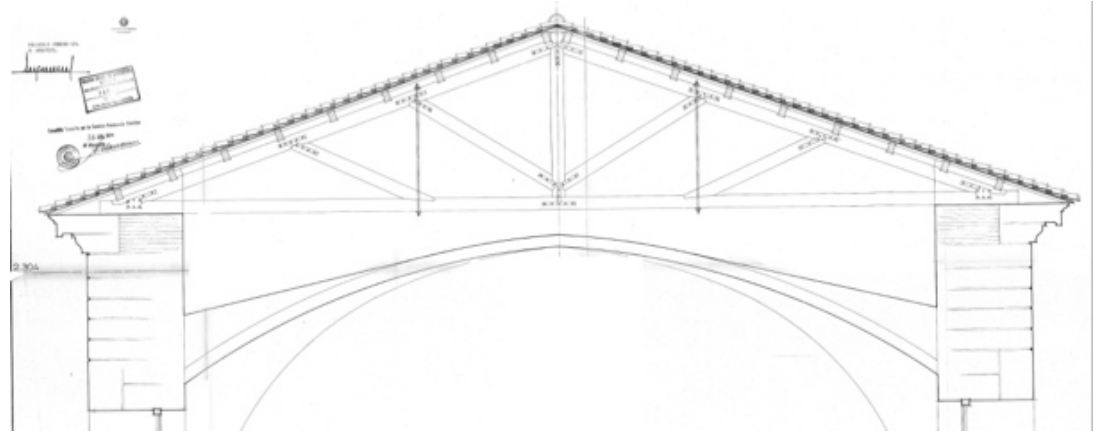

Fig.IV.104. Estado actual Catedral 1974 Ríos AMVA

IV.2.3.1.2. Hemos visto en el apartado IV.2.1. cómo más de la mitad de los casos estudiados de templos con tres naves cuentan con una única cubierta resuelta a dos aguas mediante dos grandes faldones.

La iglesia de Íscar muestra una solución constructiva de arcos muro diafragma equivalente a la ya mencionada de Villaverde de Medina. En ambos casos se levantó el templo con una estructura de cubierta de madera que dejaba su cara inferior vista como techumbre artesonada. Posteriormente se cierran unas bóvedas que la ocultan, en el primer caso cien años después de haberse acabado la construcción del edificio. Hemos visto también en el apartado IV.2.1. cómo en la iglesia de Íscar se transformó además la cubierta escalonada en un único volumen a dos aguas, recreciendo el muro piñón a los pies.

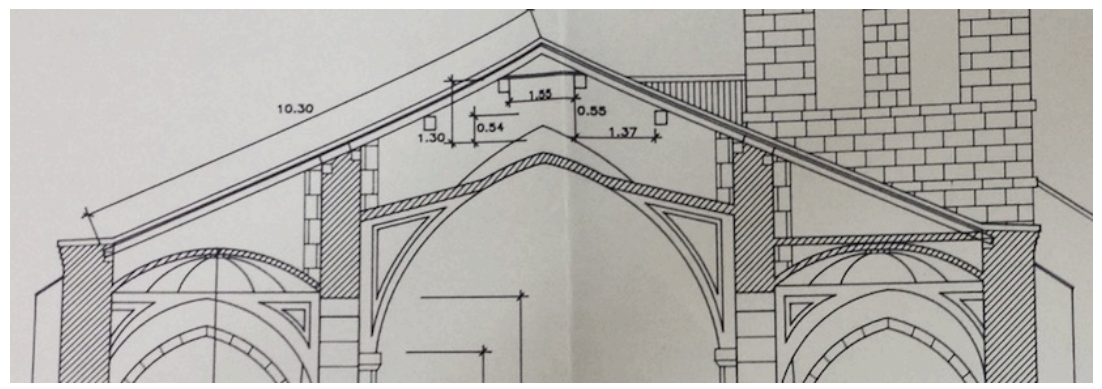

Fig.IV.105. Sección Íscar 2000 Cembrero y Morante JCyL

En Villaverde se ha comprobado que efectivamente se produjo la incorporación de zunchos al reemplazar las antiguas vigas por madera laminada, pero en Íscar el proyecto de Cembrero no menciona zunchos y no se ha podido acceder al bajo cubierta para comprobar si se colocaron o no. 
En Fresno el Viejo se prolonga sólo uno de los faldones, manteniéndose el tejado de la otra nave lateral a su cota original, solución que vemos también en San Pablo de Peñafiel, donde además de prolongarse un sólo faldón sobre una nave lateral se incluye bajo el mismo la panda del claustro adyacente. En la Santa Espina se prolongaron las cubiertas de la nave central, además de sobre ambas laterales, en la panda inmediata del claustro.

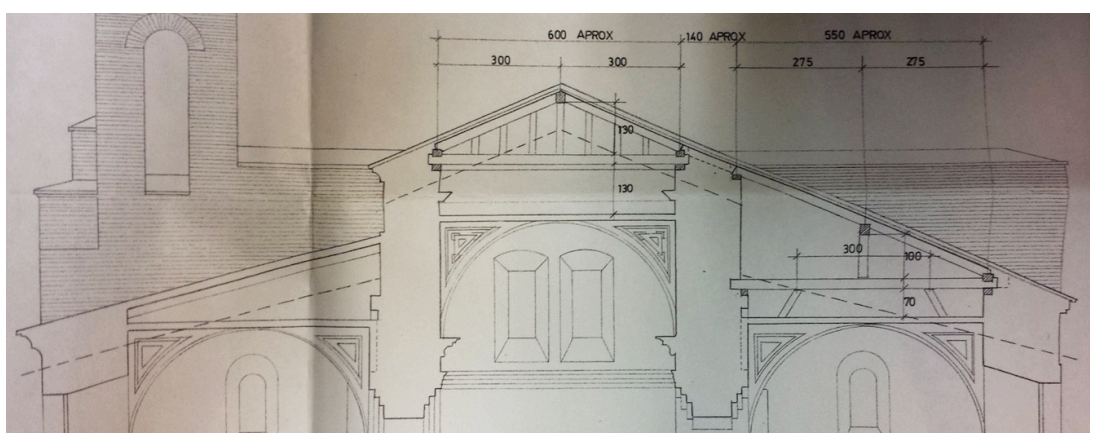

Fig.IV.106. Sección 1997 Carreño JCyL

En Peñafiel, según se ha mencionado con anterioridad, no se incorporaron zunchos en el cuerpo de la iglesia, pero tanto en Fresno como en la Santa Espina se ha comprobado la existencia de zuncho de hormigón sólo en una nave lateral, que parece no reproducirse en el resto del templo.

Según se adelantaba al describir las arcadas bajo cubierta de las Angustias, en San Antolín de Medina del Campo encontramos muros de considerable altura levantados sobre los ejes de pilares.

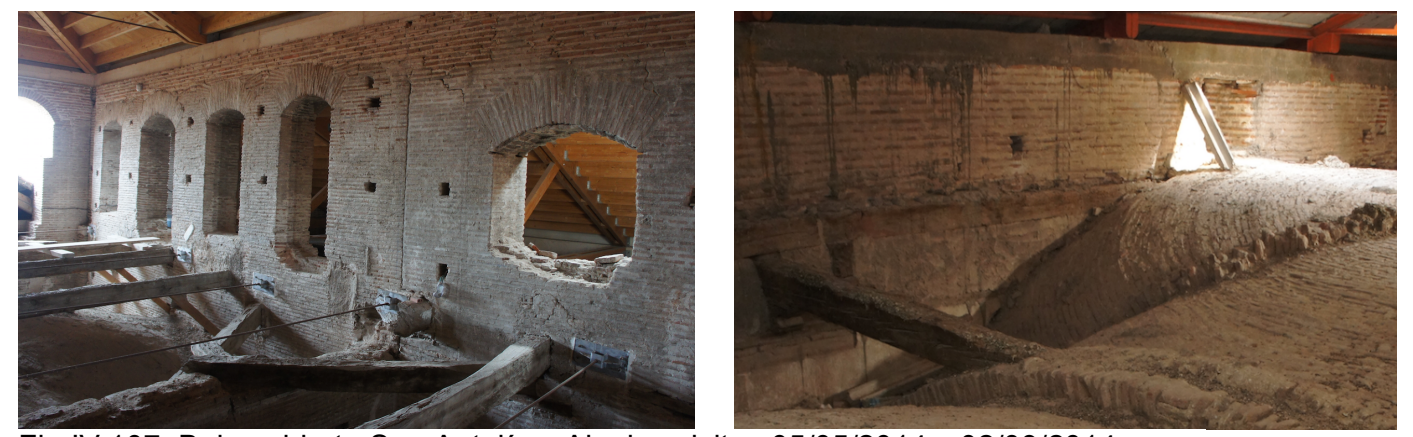

Fig.IV.107. Bajo cubierta San Antolín y Alaejos visitas 05/05/2014 y 02/09/2014

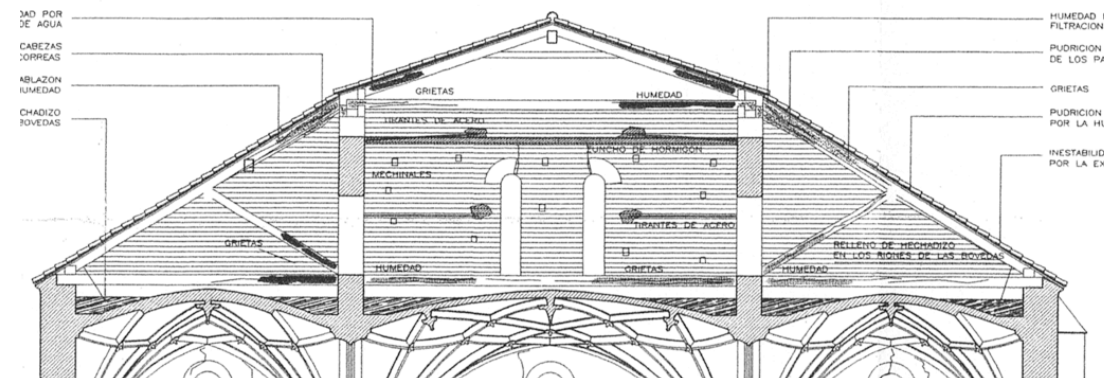

Fig.IV.108. Diagnóstico estado actual San Antolín 1999 Paniagua JCyL 


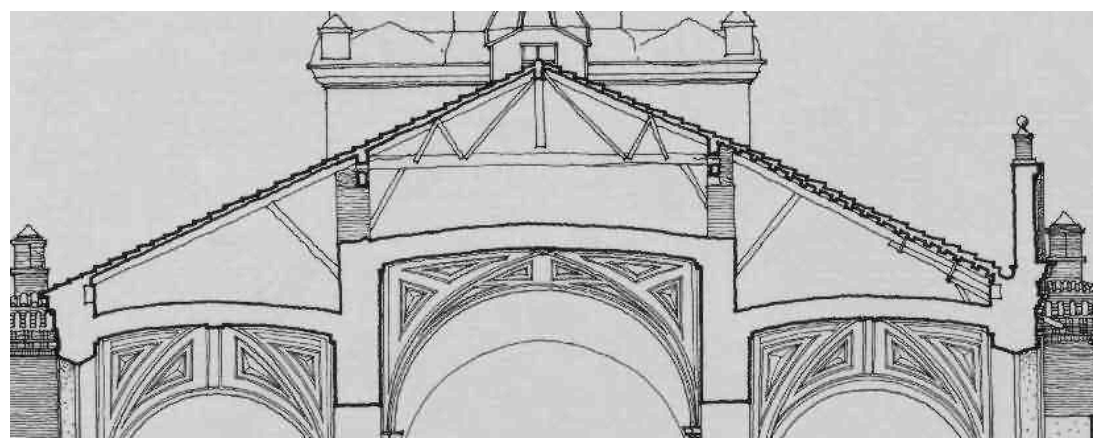

Fig.IV.109. Sección estado actual Alaejos 1974 Iglesias IPCE

Tanto en San Antolín como en Alaejos encontramos actualmente zunchos de hormigón que coronan en paralelo los cuatro muros bajo cubierta. En San Antolín se apoya sobre ellos una nueva estructura de madera laminada mientras que en Alaejos se trata de cerchas metálicas.

Otras iglesias de la muestra cuyas tres naves se rematan con una única cubierta son Santiago y los Santos Juanes.

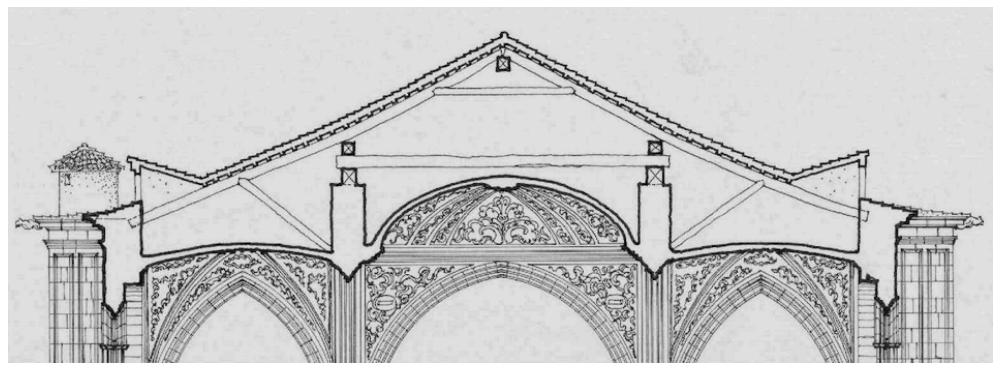

Fig.IV.110. Sección estado actual Santiago 1978 Iglesias IPCE

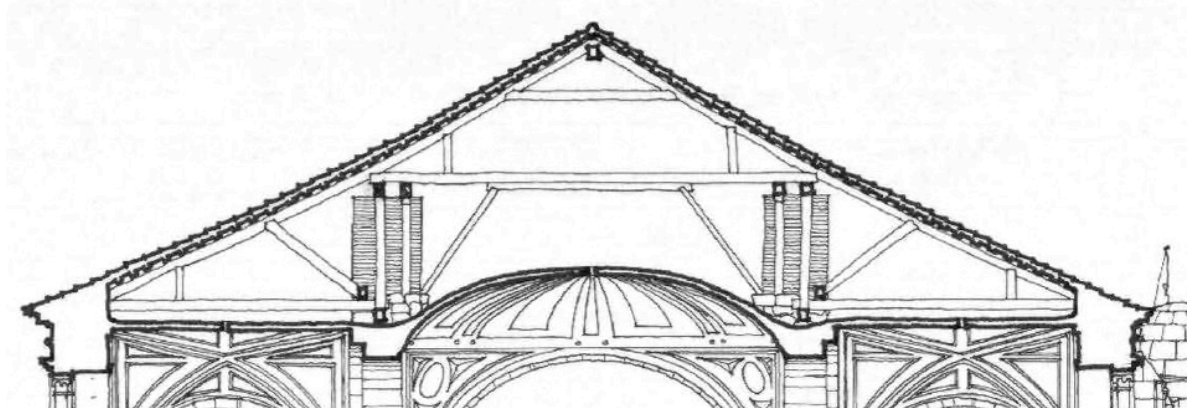

Fig.IV.111. Sección estado actual Santos Juanes 1978 Iglesias IPCE

En estos dos últimos templos intervino Ana Iglesias en 1978 y diseñó nuevas estructuras de cubierta, metálicas, en ambos casos apoyadas sobre zuncho de hormigón perimetral. En los Santos Juanes sobre los ejes de columnas no se levantaba un muro corrido, sino grandes machones de fábrica de ladrillo, y esos machones en Santiago son de sillares de piedra, excepto en la cabecera, donde se han resuelto con fábrica de ladrillo. 
Aunque el proyecto de Ana Iglesias define una estructura de cubierta completa de cerchas metálicas, en la visita al edificio se ha comprobado que se sustituyó únicamente la estructura de cubierta en ambas naves laterales, conservándose las armaduras sobre la nave central. Entre los machones en la dirección longitudinal se aprecian piezas de gran escuadría en buen estado.
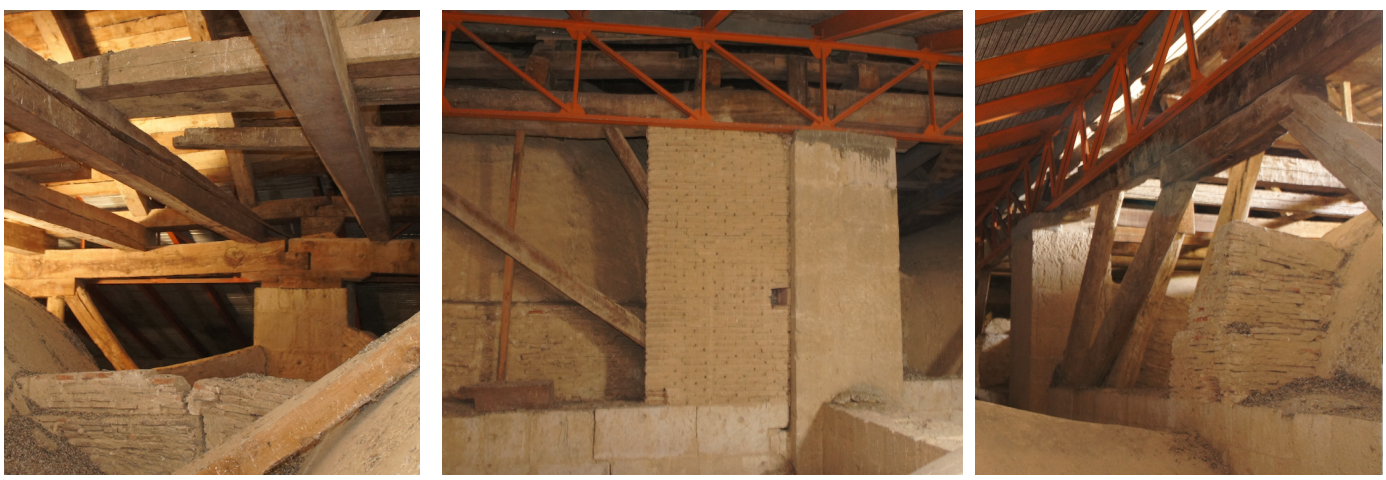

Fig.IV.112. Apoyo de armaduras en machones Santiago, visita 20/09/2015

\section{IV.2.3.2. Dimensiones}

Se ha tratado de establecer un orden de magnitud del ancho de nave de los templos, ya que en la mayor parte de los casos no se cuenta con sus medidas exactas. Muy pocos planos entre los consultados cuentan con una escala gráfica incorporada a los mismos, ya que se rotulan únicamente las escalas correspondientes en las cartelas, dando por sentado que se va a contar con planos originales cuando en la mayor parte de los casos sólo se dispone de reducciones y fotografías de los mismos, según se ha comentado en el apartado sobre la documentación gráfica de los proyectos. Hay muy pocos proyectos de restauración, además, que cuenten con un plano de planta acotado.

Recordemos que las dimensiones de estos edificios no se concibieron ${ }^{98}$ en metros, sino en las antiguas unidades lineales de medida, los pies. Un pie castellano ${ }^{99}$ equivale a $0,278635 \mathrm{~m}$ y tres de ellos forman una vara de $0,835905 \mathrm{~m}$.

\footnotetext{
${ }^{98}$ La iglesia del Monasterio de Palazuelos, por ejemplo, se diseña con 34 pies de ancho y 55 de alto en su nave lateral según el estudio histórico del proyecto de Montoya y Horno 1999, lo que equivale a $9,5 \mathrm{~m}$ y $15,3 \mathrm{~m}$.

${ }^{99}$ El pie visigodo es algo menor, de 0,3333m y el mozárabe 0,3327. Según explicaba Merino de Cáceres en sus clases de la ETSAM en 1993, en Segovia, por ejemplo, no se emplea la vara castellana o de Burgos, sino la misma que en Albacete o Logroño de $0,837 \mathrm{~m}$.
} 
Para establecer un orden de magnitud de las luces de cubierta del conjunto muestra de iglesias, en primer lugar se han diferenciado las que cubren una sola nave central, única o con mayor altura que las laterales y las capillas, que cuenten con su propia cubierta a cota inferior. En segundo lugar se consideran los templos en los cuales los faldones de la cubierta principal se prolongan sobre esas naves laterales, capillas, o incluso en ocasiones una panda del claustro adyacente.

Tabla 10: anchura aproximada de la nave central (luz libre a caras de apoyos)

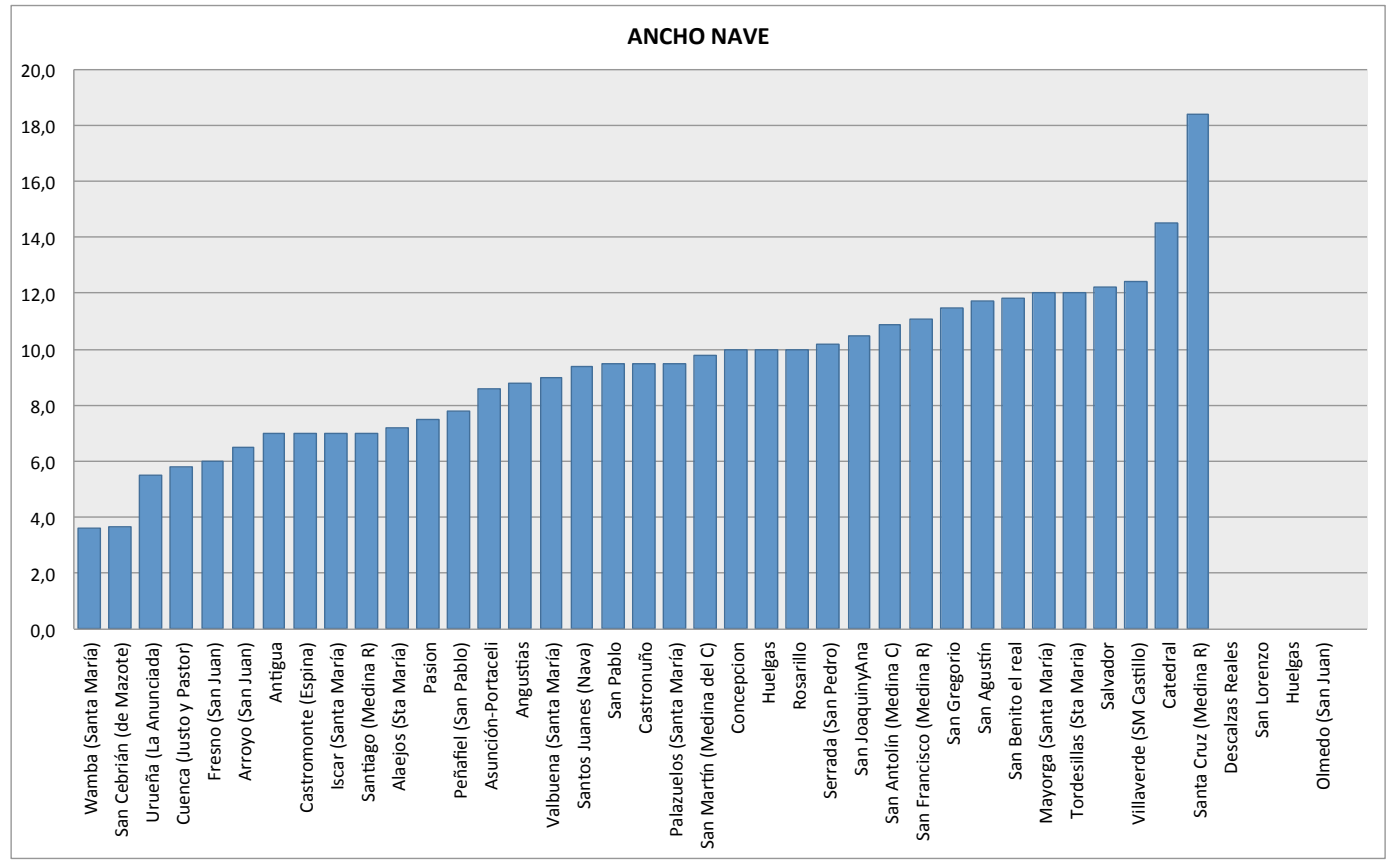

Tabla 11: anchura total aproximada bajo cubierta

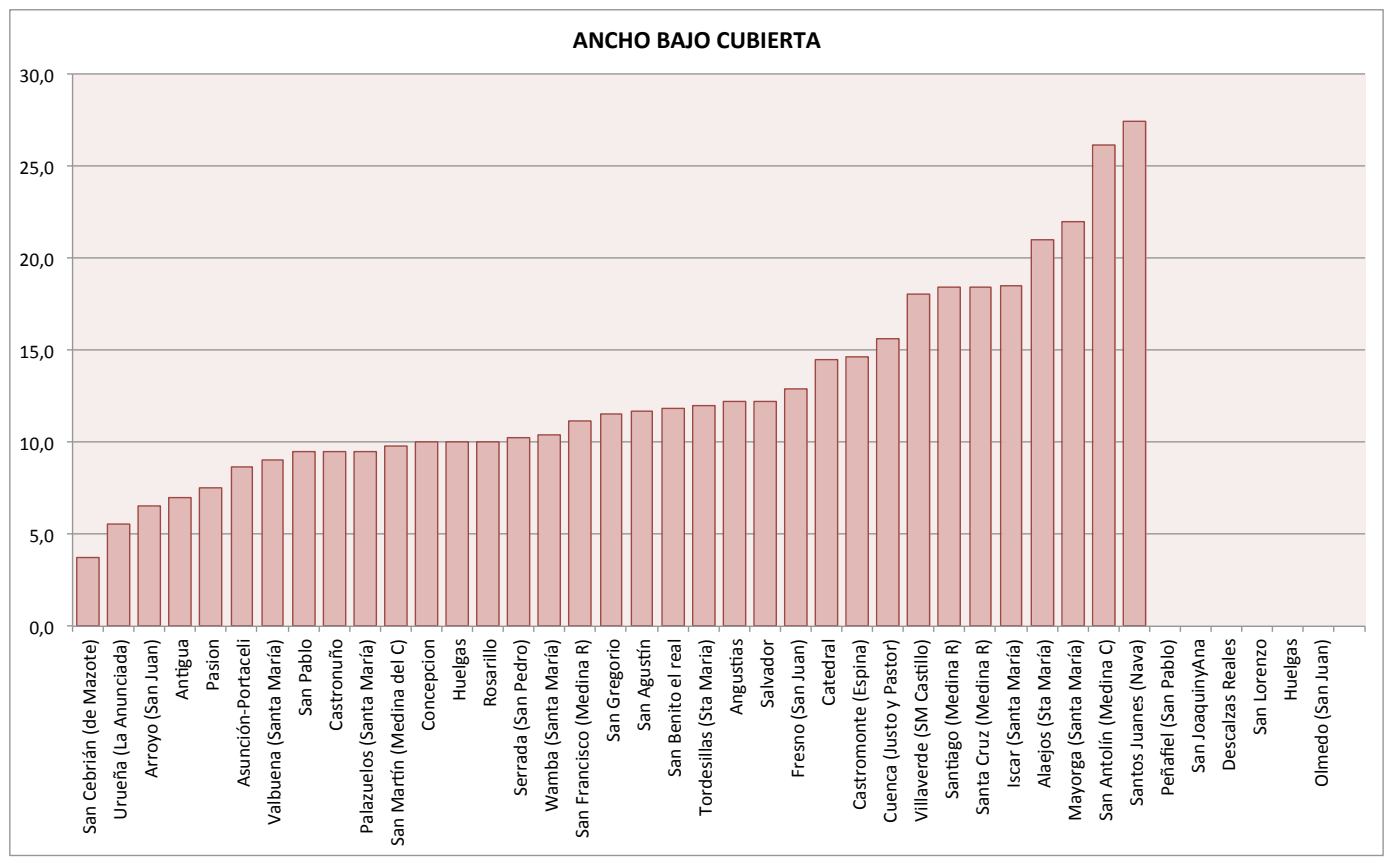


La luz mínima del vano en el primer caso es menos de cuatro metros y la máxima se estima en torno a doce o doce y medio, con la excepción de la Catedral, que alcanza hasta catorce metros y medio de anchura en la nave central. La iglesia de Santa Cruz de Medina de Rioseco tiene una anchura de nave de más de dieciocho metros, lo que la deja completamente fuera del rango del resto de los edificios analizados.

En el conjunto de iglesias que clasificamos como segundo caso, con las cubiertas prolongadas de las iglesias tipo salón, puede apreciarse en la tabla 11 cómo las estructuras que las sostienen llegan a desarrollar anchuras, con apoyos intermedios, de más de 26m en San Antolín y hasta 27,4m. en los Santos Juanes de Nava del Rey.

Si nos fijamos en los dos templos que encabezan las gráficas, llama la atención cómo en ambos casos se trata de iglesias que llegaron a presentar serios problemas estructurales. Las cubiertas de Santa Cruz se derrumbaron en los años 70 y en la iglesia de Nava del Rey se ha realizado una de las intervenciones más recientes para reforzar la estructura disponiendo celosías de acero laminado y tirantes que atraviesan de lado a lado el bajo cubierta.

\section{IV.2.3.3. Pendiente y material de cobertura de los faldones}

Son muy escasos los proyectos en que se define con precisión la pendiente de la cubierta. En algunos casos, si se indica en el texto el valor, éste no coincide con la inclinación representada en los planos. Debemos distinguir además la pendiente original de la actual, ya que es uno de los factores que suele modificarse radicalmente en las intervenciones. Para realizar este análisis se han valorado los ángulos de forma aproximada, en varios casos midiendo sobre copias y fotografías de planos sin acotar.

Según se ha explicado en el capítulo III.3, para determinar la pendiente, dimensiones y ángulos de corte de las piezas de las armaduras de cubierta en el siglo XVII se empleaba en España la "regla de trazado de cartabones", y en nuestros Tratados de construcción históricos se citaba habitualmente el cartabón de cinco, que equivale a $36^{\circ}$ de inclinación ${ }^{100}$.

\footnotetext{
${ }^{100} \mathrm{Al}$ cartabón de cuatro corresponde un ángulo de $45^{\circ}$, de $36^{\circ}$ al de cinco y de $30^{\circ}$ al de seis.(Ver gráfica en III.3)
} 
Aunque en la literatura se postula la conveniencia del citado cartabón de cinco, en los estudios de caso analizados en esta investigación se han encontrado siempre perfiles más tendidos, en la mayor parte de los casos entre $20^{\circ}$ y $30^{\circ}$.

Tabla 12: inclinación actual de las cubiertas

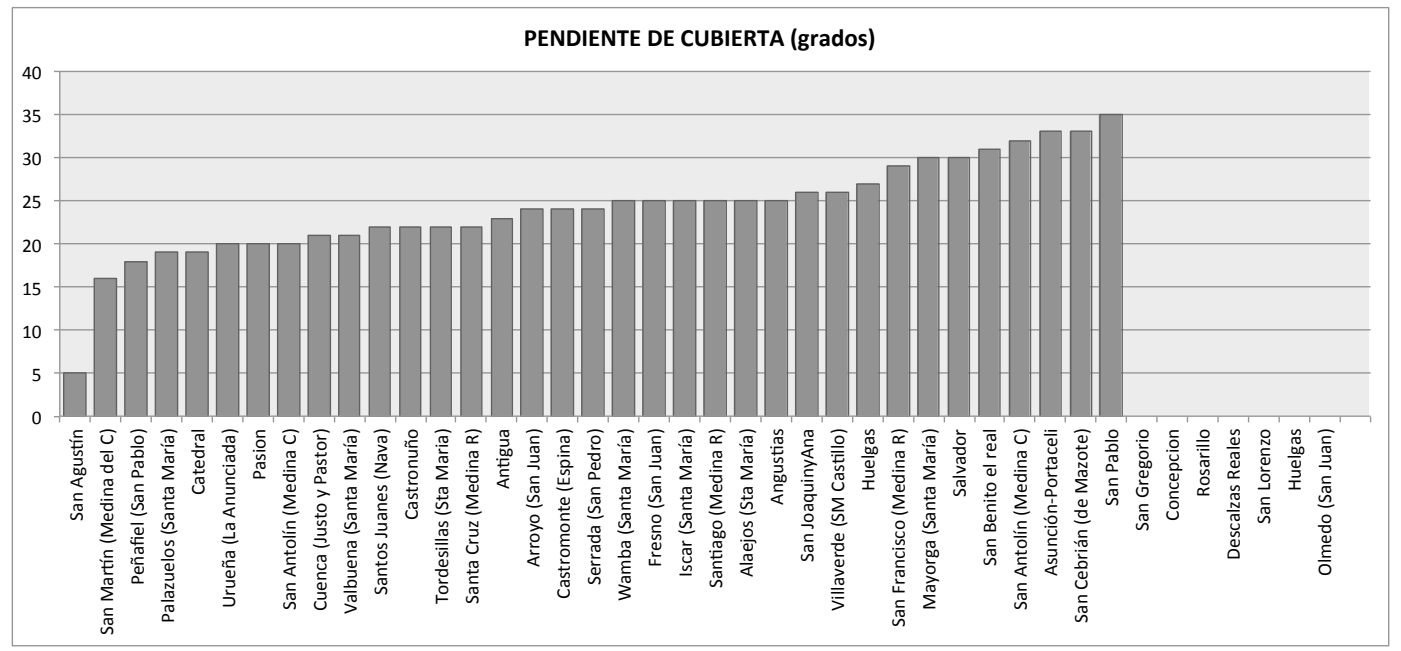

En las trazas originales de Juan de Herrera para la catedral la pendiente es aproximadamente de $24^{\circ}$ mientras que en el plano moderno las cerchas metálicas, colocadas por Luis Cervera Vera en 1974, presentan una inclinación de unos 19², que se encuentra entre las menores pendientes estimadas dentro del conjunto muestra.

El proyecto de 1982 de la Colegiata de San Antolín recoge un croquis de cálculo de la estructura de cubierta donde se rotula $14^{\circ}$ en naves laterales y $20^{\circ}$ en central sobre una línea con una única pendiente, cuando en la cubierta real quebrada, además, los laterales muestran unos $32^{\circ}$, mucho más inclinados que la zona central $^{101}$.

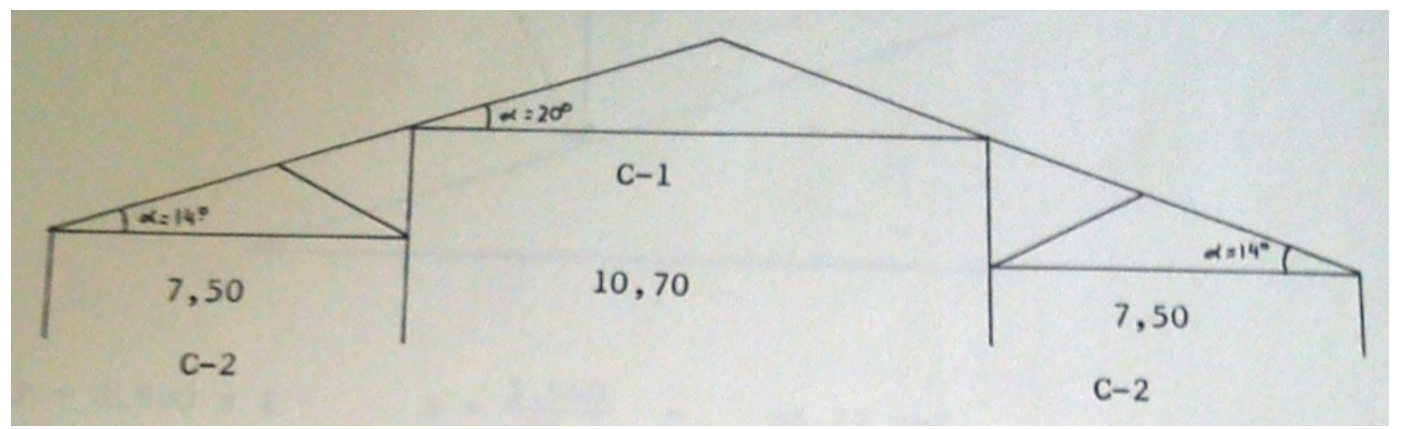

Fig.IV.113. Esquema de cálculo (Gómez Santander 1982 IPCE)

${ }^{101}$ En el gráfico anterior se han introducido los dos valores de pendiente correspondientes a San Antolín por tratarse de faldones quebrados pero continuos. En otros casos con distinta inclinación en nave central y laterales escalonadas se han desestimado los datos de estas últimas. 
En los Santos Juanes se reemplaza una cubierta quebrada con los faldones con $25^{\circ}$, más tendidos que el centro a unos $31^{\circ}$, por otra a dos aguas de perfil continuo a unos $22^{\circ}$.

Tras las intervenciones del siglo XX suelen encontrarse faldones de pendiente constante desde la cumbrera hasta el alero sustituyendo a aquellas en las cuales el plano sufría un quiebro sobre la arista de apoyo intermedio, sobre el eje de los pilares, y adoptaba diferente pendiente a ambos lados, a veces más tendida sobre nave central que en laterales, a veces al contrario.

Las iglesias estudiadas presentan una inclinación de sus faldones de cubierta comprendida, en general, entre $\mathbf{2 0}^{\mathbf{}} \mathbf{- 3 0 ^ { \circ }}$.

\section{Material de cobertura}

La mayor parte de los edificios estudiados se reviste con teja cerámica curva ${ }^{\mathbf{1 0 2}}$. Sólo en cinco de los casos aparecen otros materiales:

La cubierta de la iglesia de Castronuño se remata con lajas de piedra. Se trata de un edificio singular, no encuadrado en la tipología "parroquia", a la que podemos asignar la mayor parte de los templos de la muestra. Según se explica en la Ficha FZ20, la iglesia del mismo nombre se arruinó en 1919 y esta construcción románica de origen funerario, y anteriormente denominada Emita del Cristo, adaptó su uso y denominación.

La cubierta de la iglesia de San Pablo en Peñafiel cuenta con poca pendiente, de unos $18^{\circ}$. Se emplea teja de hormigón de la marca Uralita en todo el conjunto.

Y en el convento de San Pablo, en Valladolid, la pendiente de la cubierta es muy superior a la del resto de los edificios, alcanzando unos $35^{\circ}$. Anselmo Arenillas encuentra las cubiertas de San Pablo en los años 60 revestidas con escamas modernas de barro cocido teñidas con alquitrán. En sus intervenciones sustituye estas piezas por pizarra, que juzga más adecuada para la gran pendiente de los faldones, que mantiene aunque inicialmente había previsto su modificación para limitarla al 40\%.

\footnotetext{
${ }^{102}$ La Comisión de Patrimonio y las distintas Ordenanzas de los Cascos históricos generalmente no permiten emplear materiales de cobertura modernos en los edificios protegidos, que deben repararse con este material.
} 
Tabla 13: material de cobertura en la actualidad

\begin{tabular}{|c|c|c|c|c|c|c|}
\hline \multicolumn{7}{|c|}{ MATERIAL DE COBERTURA } \\
\hline FICHA & IGLESIA & $\frac{O}{\frac{O}{2}}$ & 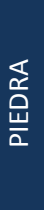 & $\underset{\mapsto}{\overleftrightarrow{\rightleftarrows}}$ & 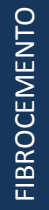 & $\begin{array}{l}\text { 으 } \\
\stackrel{\leftarrow}{0}\end{array}$ \\
\hline FZ-01 & Catedral (Valladolid) & $\mathrm{X}$ & & & & \\
\hline $\mathrm{FZ}-02$ & Convento de la Concepcion (Valladolid) & & & $\mathrm{X}$ & & \\
\hline FZ-03 & Capilla de San Gregorio (Valladolid) & & & $\mathrm{X}$ & & \\
\hline FZ-04 & La Pasion (Valladolid) & & & & $\mathrm{X}$ & \\
\hline $\mathrm{FZ}-05$ & Convento de Portaceli (Valladolid) & & & & & \\
\hline FZ-06 & Las Angustias (Valladolid) & & & $\mathrm{X}$ & & \\
\hline FZ-07 & San Agustín (Valladolid) & $\mathrm{x}$ & & & & \\
\hline$F Z-08$ & San Benito el Real (Valladolid) & & & $\mathrm{x}$ & & \\
\hline FZ-09 & San Lorenzo (Valladolid) & & & & & \\
\hline $\mathrm{FZ}-10$ & San Pablo (Valladolid) & & & & & $\mathrm{x}$ \\
\hline$F Z-11$ & La Antigua (Valladolid) & & & $\mathrm{X}$ & & \\
\hline $\mathrm{FZ}-12$ & El Rosarillo (Valladolid) & & & $\mathrm{x}$ & $\mathrm{x}$ & \\
\hline$F Z-13$ & El Salvador (Valladolid) & & & $\mathrm{X}$ & & \\
\hline $\mathrm{FZ}-14$ & Las Descalzas Reales (Valladolid) & & & & & \\
\hline$F Z-15$ & San Joaquin y Santa Ana (Valladolid) & & & $\mathrm{X}$ & & \\
\hline$F Z-16$ & Las Huelgas Reales (Valladolid) & & & $\mathrm{X}$ & & \\
\hline$F Z-17$ & Santa María (Alaejos) & & & $\mathrm{X}$ & & \\
\hline$F Z-18$ & San Juan Evangelista (Arroyo de la Encomienda) & & & $\mathrm{X}$ & & \\
\hline FZ-19 & La Santa Espina (Castromonte) & & & $\mathrm{X}$ & & \\
\hline$F Z-20$ & Santa Maríadel Castillo (Castronuño) & & $\mathrm{X}$ & & & \\
\hline $\mathrm{FZ}-21$ & Santos Justo y Pastor (Cuenca de Campos) & & & $\mathrm{X}$ & & \\
\hline FZ-22 & San Juan (Fresno el Viejo) & & & $\mathrm{X}$ & & \\
\hline $\mathrm{FZ}-23$ & Santa María (Iscar) & & & $\mathrm{X}$ & & \\
\hline$F Z-24$ & Santa María de Arbás (Mayorga) & & & $\mathrm{x}$ & & \\
\hline$F Z-25$ & San Francisco (Medina de Rioseco) & & & $\mathrm{X}$ & & \\
\hline $\mathrm{FZ}-26$ & Santa Cruz (Medina de Rioseco) & & & $\mathrm{x}$ & & \\
\hline$F Z-27$ & Santiago (Medina de Rioseco) & & & & & \\
\hline $\mathrm{FZ}-28$ & San Antolín (Medina del Campo) & & & $\mathrm{x}$ & & \\
\hline$F Z-29$ & San Martín (Medina del Campo) & & & $\mathrm{X}$ & & \\
\hline FZ-30 & Los Santos Juanes (Nava del Rey) & & & $\mathrm{x}$ & & \\
\hline $\mathrm{FZ}-31$ & San Juan (Olmedo) & & & & & \\
\hline FZ-32 & Santa María de Palazuelos (Corcos del Valle) & & & $\mathrm{x}$ & & \\
\hline FZ-33 & San Pablo (Peñafiel) & & & $\mathrm{X}$ & & \\
\hline FZ-34 & San Cebrián (San Cebrián de Mazote) & & & $\mathrm{X}$ & & \\
\hline FZ-35 & Santa María (Tordesillas) & & & $\mathrm{X}$ & & \\
\hline$F Z-36$ & La Anunciada (Urueña) & & & $\mathrm{X}$ & & \\
\hline$F Z-37$ & Santa María de Valbuena (Valbuena) & & & $\mathrm{X}$ & & \\
\hline $\mathrm{FZ}-38$ & Santa María del Castillo (Villaverde de Medina) & & & $\mathrm{X}$ & & \\
\hline FZ-39 & Santa María (Wamba) & & & $\mathrm{X}$ & & \\
\hline $\mathrm{FZ}-40$ & San Pedro (Serrada) & & & $x$ & & \\
\hline
\end{tabular}

En 1997, el arquitecto Elesio Gatón sustituye la teja curva que había revestido los tejados de las naves de la catedral durante siglos por láminas de plomo, material según él más adecuado a la pendiente que presentan los faldones y que admitiría pequeños impactos sin fracturarse. El problema de los impactos de piedras sobre las tejas es causado por la falta de terminación del edificio y sin duda se agravó tras la demolición de construcciones adosadas llevada a cabo bajo la dirección de este 
mismo arquitecto. El extremo sin remate de cerramientos de piedra con relleno a la intemperie sufre desprendimientos constantes con el paso del tiempo.

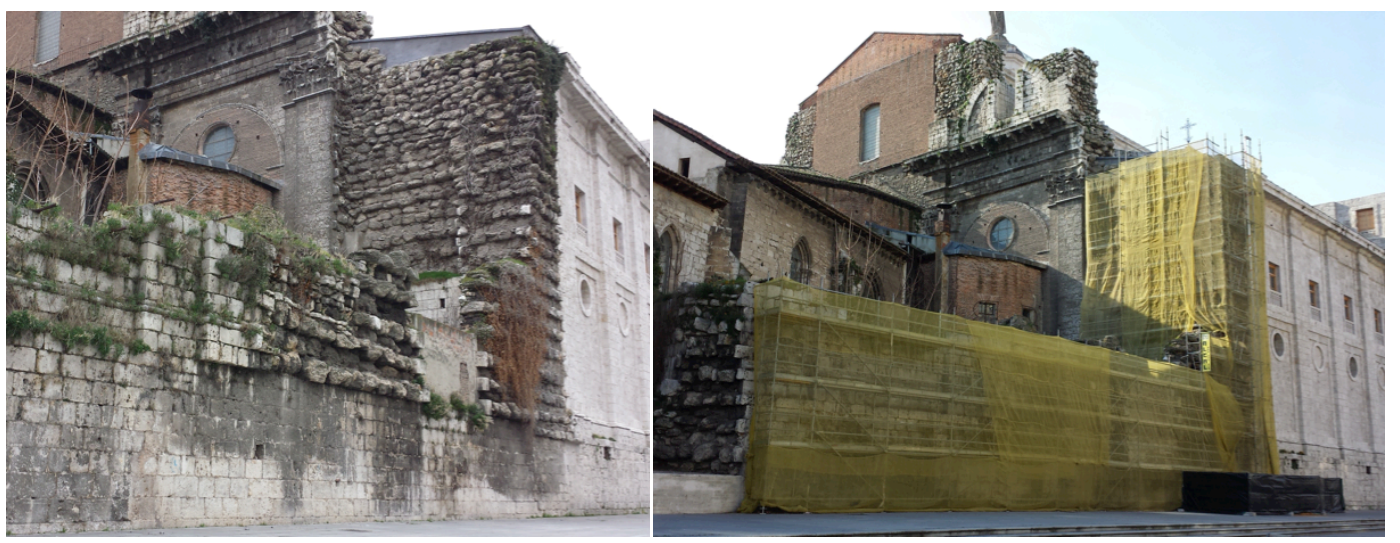

Fig.IV.114. Vista previa (visita 31/01/2014) y obras de saneado del muro (visita 19/03/2014)

Y la iglesia de la Pasión aún mantiene una cubierta de placas de fibrocemento incorporada en los años 60 por Anselmo Arenillas al adaptar el edificio a su uso como museo.

\section{IV.2.3.4. EI refreno}

En su página web albanécar ${ }^{103}$ el arquitecto Javier de Mingo avanza datos de la investigación sobre la carpintería de lo blanco para su Tesis doctoral. Sobre el cambio de pendiente de los faldones escribe:

"A lo largo y ancho de nuestra geografía abundan los edificios antiguos cuya cubierta muestra un cambio de pendiente en la parte más cercana al alero, haciéndose menos inclinada en dicha zona. Esta característica es indicativa de que se trata de una cubierta tradicional, y de hecho es uno de los síntomas que delatan que debajo pueda existir una armadura vista. Yo he llegado a oír que eso se hacía para que el agua, al discurrir, adquiera más velocidad y se aleje de los muros al caer al suelo. Desde luego, no se hacía por dicho motivo y dudo que pueda provocar ese efecto. Sin embargo sí que podía llegar a servir de "refreno" para las tejas impidiendo su deslizamiento generalizado hacia abajo, pero no obstante se trata de una cualidad secundaria. Lo cierto es que el cambio de pendiente, por lo menos en la arquitectura castellana, no tiene ningún fundamento estético ni funcional. Se debe exclusivamente a un problema constructivo que es muy fácil de entender si observamos los diversos componentes de una cubierta tradicional, sobre todo se si trata de un ejemplar de par y nudillo.

Los pares que forman los faldones acometen sobre el estribo, que siempre solía situarse -y aquí está la causa de la doble pendiente- en la cara interior del muro.

$\overline{103 \text { http://www.albanecar.es/cubiertas-de-doble-pendiente/ }}$ 
Entonces, si directamente se dejase el faldón tal y como está y se tejase, el agua iría a parar a las cabezas de los muros, con los devastadores efectos que ello supondría. Obviamente, la solución viene añadiendo otro faldón sobrepuesto al anterior, que permita llevar el agua hacia fuera. Los maderos que forman dicho faldón, llamados contrapares, al tener que partir de un punto intermedio de los pares originales y llegar más allá de la cara exterior de los muros, generan una pendiente menor que la original a la fuerza."

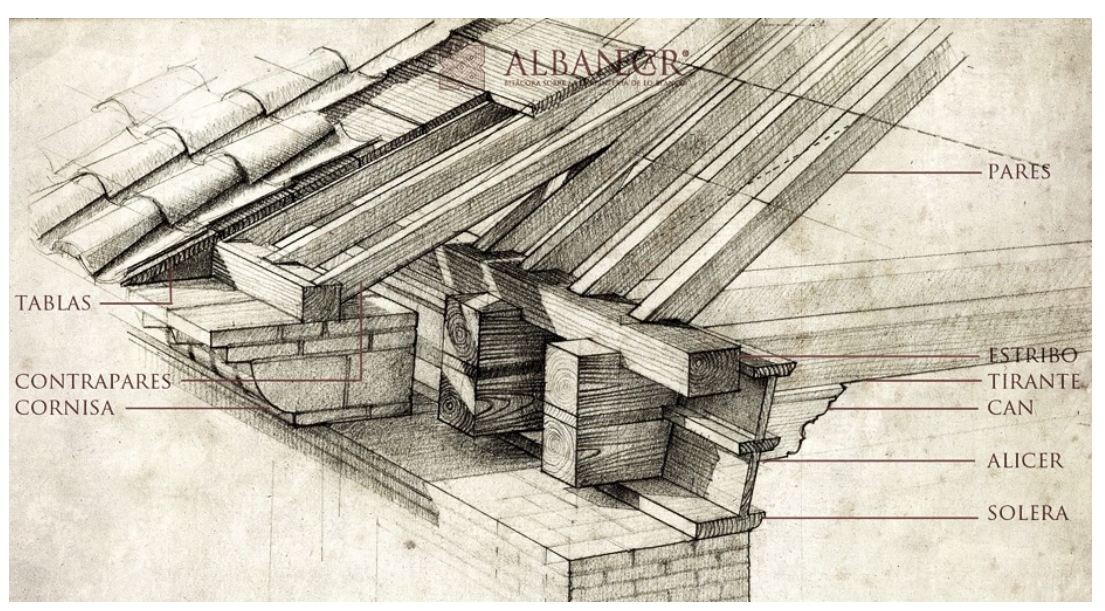

Fig.IV.115. Ilustración de la web Albanécar

Resulta curiosa una afirmación tan contundente en contra del refreno, que Mingo considera poco menos que una torpeza constructiva. Contrariamente a lo que afirma, el brusco cambio a una pendiente más tendida suavizaría la velocidad de las aguas en vez de acelerarlas, impidiendo por ejemplo el golpeteo contra el canalón si se cuenta con este elemento, o el incremento de desgaste de la superficie cerca del borde. En la construcción histórica, eminentemente pragmática, encontramos este recurso con la frecuencia suficiente para impedir una descalificación tan inmediata y asertiva.

En Castilla y León las instituciones tratan hoy de respetar esta característica de la arquitectura histórica. La Comisión Territorial de Patrimonio Cultural publicó, por ejemplo, el 20 de agosto de 2014 los acuerdos de una reunión, entre los cuales esta la autorización para rehabilitar la cubierta del Palacio de los Dávila, en Ávila. Encontramos en el texto la indicación siguiente: "No se cambiará la geometría de la cubierta, manteniéndose a dos aguas, con un refreno igual al existente para disminuir la superficie del hastial, que se ejecutará con mampostería de piedra como el actual; se realizará un control arqueológico".

En Portugal, según hemos visto, se mantiene la costumbre de quebrar los faldones de edificios históricos para conformar el refreno en sus restauraciones monumentales.

En Castilla y León, sin embargo, las cubiertas restauradas buscan a toda costa mantener la planeidad. Sólo en siete edificios de la muestra se adopta este sistema, y 
tal vez responde más a una falta de definición en los proyectos o a la deformación del relleno sobre el muro bajo el borde del tablero que a una intencionalidad real del proyectista.

En San Benito, Morán diseña cuidadosamente el detalle del alero con refreno en la nave lateral, solución propuesta también sobre la nave central en 1991 que no llegó a ejecutarse.

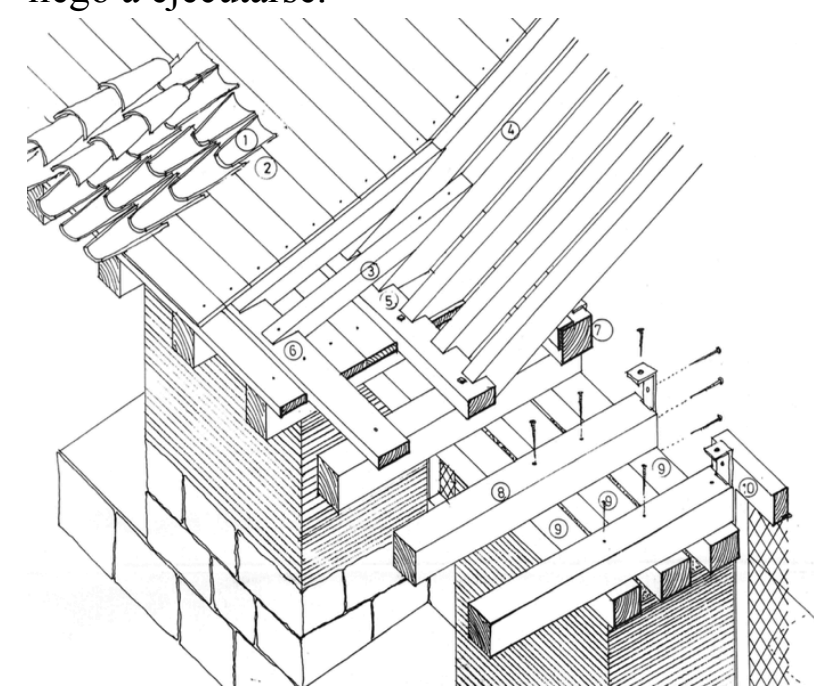

Fig.IV.116. Alero reformado (Morán $1991 \mathrm{JCyL}$ )

Salvador Mata, sin embargo, culpa al refreno de San Cebrián de Mazote de los problemas de la cubierta, afirmando en 1990 al describir las nuevas partidas en la Memoria del proyecto reformado:

"Modificación del perfil de la cubierta, que al ser descubierta su tablazón, se comprobó una patología producida al formar en la anterior restauración el nuevo alero, de manera que se producía un refreno excesivo. Se hace necesario el trazado de un nuevo perfil de cubierta que una el caballete con el extremo del alero, formándose con rastreles sobre la antigua tablazón, rastreles que han de ser progresivamente más altos, sobre los que posteriormente se clavará la placa de recubrimiento bituminoso, para el posterior recibido de la teja."

Diagnóstico que corrobora más tarde, en la Memoria final de la obra:

"los trabajos de restauración han resuelto los dos graves problemas que la iglesia tenía en aquel momento, como eran la entrada de agua por el refreno del tejado y la humedad por capilaridad de la cara norte y ábside de los pies. El desmontado de la tablazón del total de la cubierta y la rectificación del perfil de su plano mediante la aportación de rastreles graduales hasta el extremo del alero, para la posterior colocación de lámina bituminosa y teja, solucionaron definitivamente la patología de la cubierta anterior." 


\section{El acroterio}

Otras formas de rematar la coronación de los edificios históricos es el acroterio. Se trata de una elevación del plano de la fachada a modo de murete para disimular la altura del tejado que debe contar con algún sistema que permita la evacuación de las aguas, en el caso de la iglesia de la Antigua a través de las gárgolas.

En la Capilla de San Gregorio, al modificar la estructura de cubierta en 1974, Cervera desmonta y vuelve a colocar la crestería como remate a distinta cota.

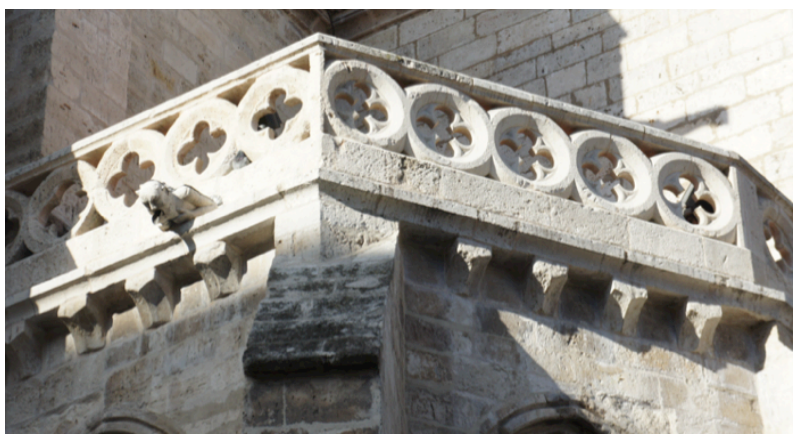

Fig.IV.117. Detalle de la Antigua 28/10/2014

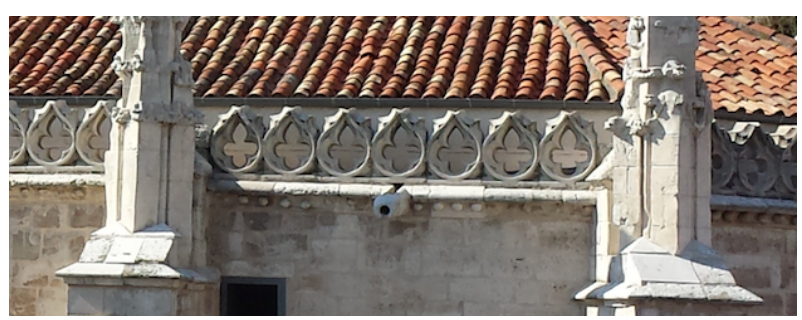

Fig.IV.118. Detalle San Gregorio 26/09/2014

\section{IV.2.3.5. La cornisa}

Algunos arquitectos mencionan entre las tareas encomendadas al zuncho su contribución a la estabilidad de las cornisas voladas. Hemos visto incluso cómo en el edificio del Cabildo anejo a la iglesia de las Angustias hubo un zuncho-cornisa de hormigón armado de grandes dimensiones, ejecutado en 1982 y demolido en 1991. Otro caso muy similar de zuncho-cornisa de hormigón armado en la ciudad de Valladolid que sí ha llegado hasta nosotros se encuentra en la iglesia de San Juan de Letrán. En la reciente restauración de esta singular fachada barroca se han incorporado para mejorar la escorrentía, sobre el citado zuncho-cornisa de hormigón existente, unas piezas de piedra obtenidas mediante corte con láser.
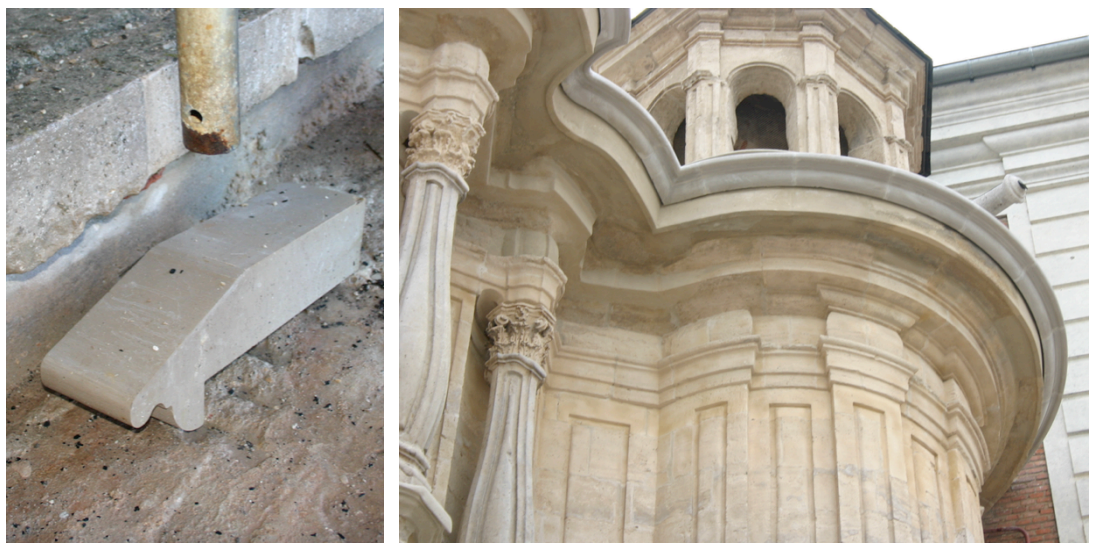

Fig.IV.119. Sobre-cornisa en San Juan de Letrán (cortesía Fundación del Patrimonio Histórico) 
En varios de los proyectos revisados, el arquitecto autor relaciona el mal estado del edificio con la falta de idoneidad de intervenciones anteriores. En especial se menciona el mal diseño de los aleros, o la falta de los mismos, como causa directa de patología en muros y cubiertas. En el Análisis del estado de conservación de la Colegiata de San Antolín del Plan Director, por ejemplo, Paniagua afirma que "en la cubierta restaurada en 1982 de naves central y laterales no se resolvió de forma definitiva los aleros, y la evacuación de aguas está provocando notables patologías en las fachadas".

En 1999 este arquitecto demuele los mil metros cuadrados de cubiertas de este templo y construye una cubierta con estructura de madera laminada apoyada sobre zunchos de hormigón. Para la cornisa diseña unas piezas prefabricadas de piedra artificial que sustituyen a las anteriores, tradicionales de ladrillo.

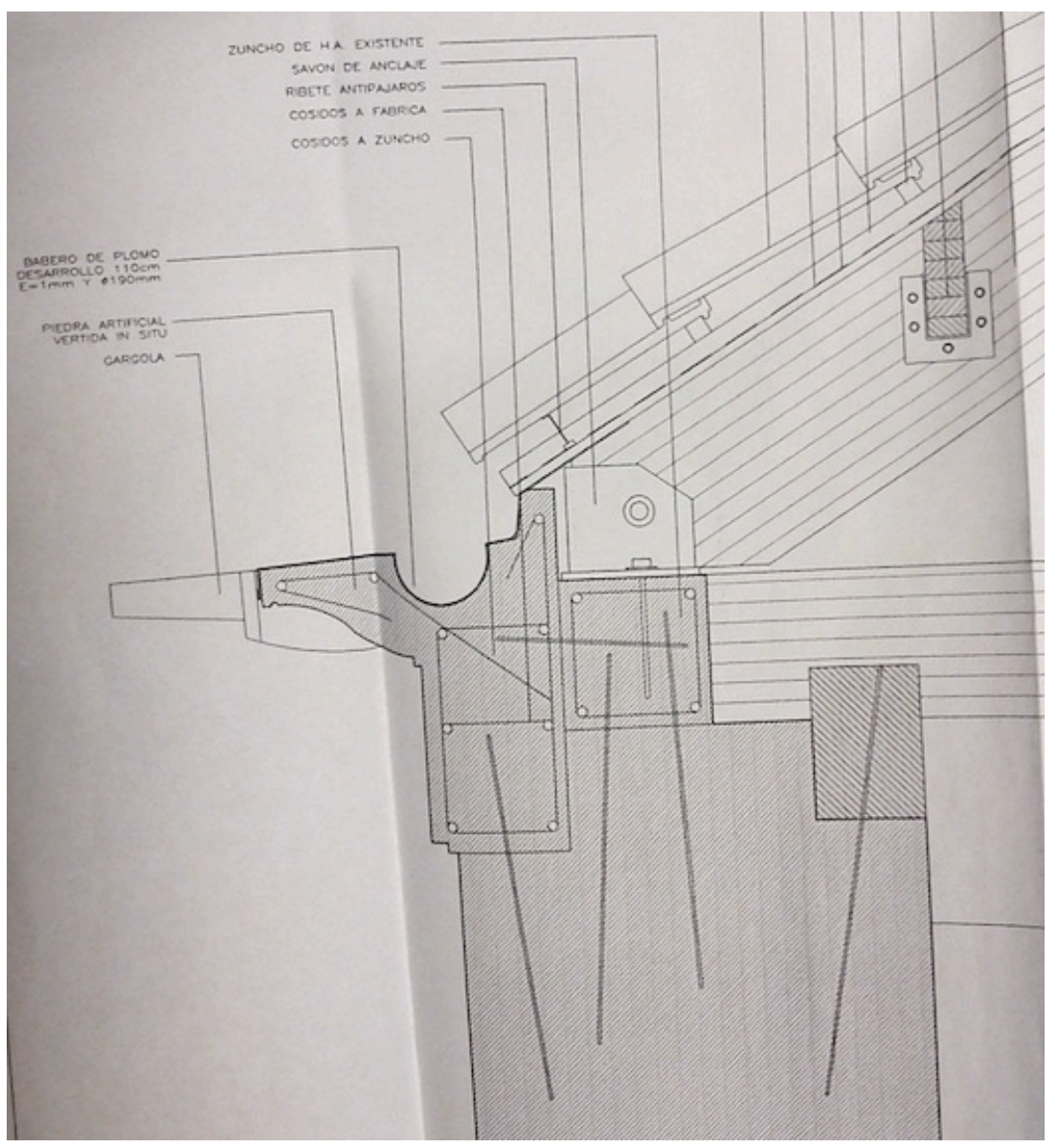

Fig.IV.120. Detalle cornisa San Antolín 1999 Paniagua JCyL

En el plano de detalle rotula "zuncho existente", para especificar que la nueva pieza de hormigón que forma el canalón y el vuelo de la cornisa se adosa a otra que se mantiene centrada sobre el muro fruto de la intervención anterior. Hay representado un cosido con barras que conectan estos elementos entre sí y con la fábrica. 

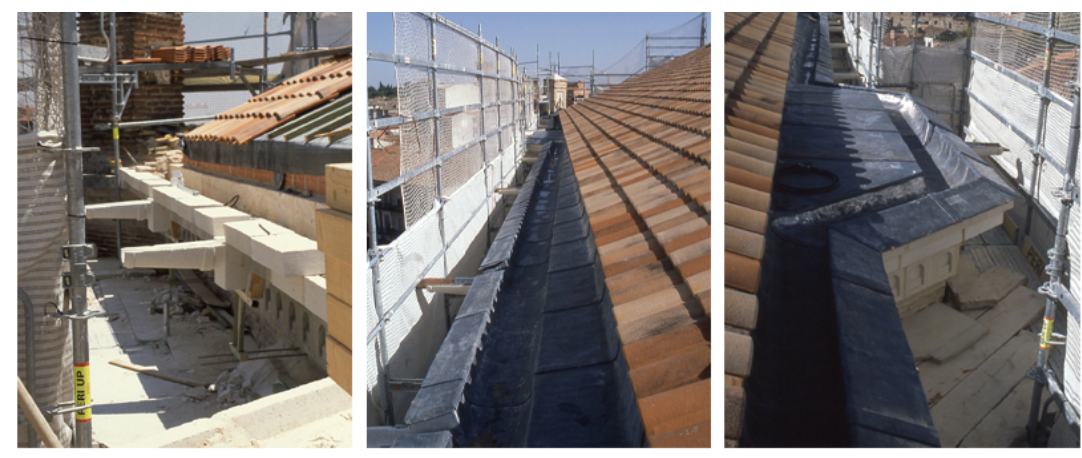

Fig.IV.121. Imágenes www.antoniopaniagua.com

(descargada 25/04/2014)

La reconstrucción de las cornisas erosionadas no es un tema tan fácil como suele suponerse. Los proyectistas dejan en muchas ocasiones sin definir cómo se construyen, delegando su resolución en cada caso al criterio del albañil que la ejecuta. Hemos visto por ejemplo cómo en las Angustias se cuenta con una de las secciones más detalladas del conjunto de casos estudiados y sin embargo el arquitecto en la entrevista comenta que en realidad no se emplearon las piezas representadas en el plano, sino fábrica de ladrillo revestida.

En el Departamento de Construcción donde se realiza esta investigación, se publicó hace unos años un breve compendio de esquemas de aleros de un conjunto de edificios tradicionales localizados en la capital y siete pueblos de la provincia de Valladolid ${ }^{104}$. En dicha obra se clasifican los ejemplos en función de sus materiales, formas, decoración, etc.

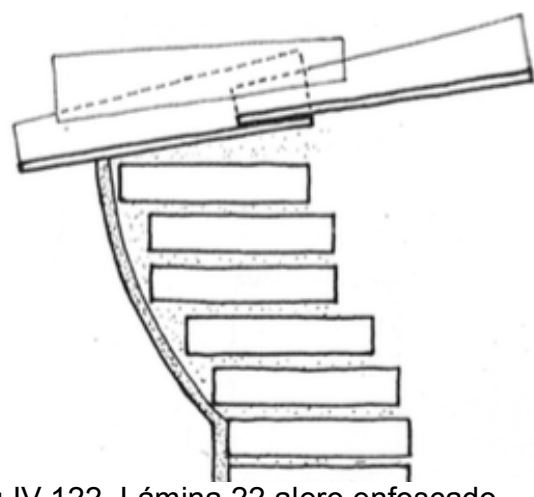

Fig.IV.122. Lámina 22 alero enfoscado
Se describe cómo los de fábrica de ladrillo suelen construirse simplemente volando las últimas hiladas, apareciendo en ocasiones ladrillos aplantillados aunque su empleo no es usual en arquitectura popular. Los ladrillos ordinarios suelen ir revocados tras retocar con alcotana y pasar la terraja.

La publicación confirma que las cubiertas habituales en la construcción tradicional de la zona son a dos aguas, con entramado de madera cuyos pares avanzan fuera del plano de la fachada como canecillos a veces tallados. En otros casos asoman las vigas del desván o bien canecillos sueltos apoyados en la coronación del muro.

\footnotetext{
${ }^{104}$ Departamento de Construcciones Arquitectónicas, Ingeniería del terreno y Mecánica de los Medios Continuos y Teoría de Estructuras (1984) Aleros en la Arquitectura popular de la provincia de Valladolid. Universidad de Valladolid
} 


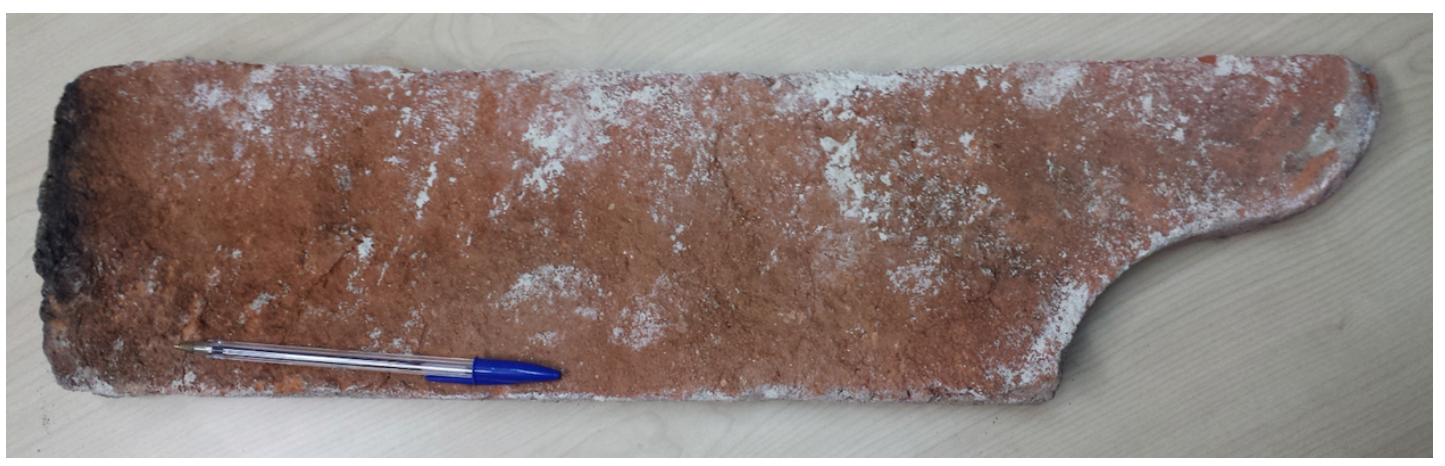

Fig.IV.123. Ladrillo pecho paloma gran formato para cornisa (colección Soledad Camino)

El peso de los sillares de cornisa, cuando ésta se resuelve con piedra, es un factor importante del diseño de la misma sobre el que han reflexionado algunos de los arquitectos autores de proyectos de restauración.

Anselmo Arenillas, por ejemplo, cuando estudia en 1965 cómo reponer los sillares de la torre izquierda desprendidos un año antes, decide sustituirlos por un núcleo de hormigón armado con un chapado de piedra. Justifica la solución por la falta de entrega de los sillares y la dificultad de ejecución que implica el manejo de tales bloques:
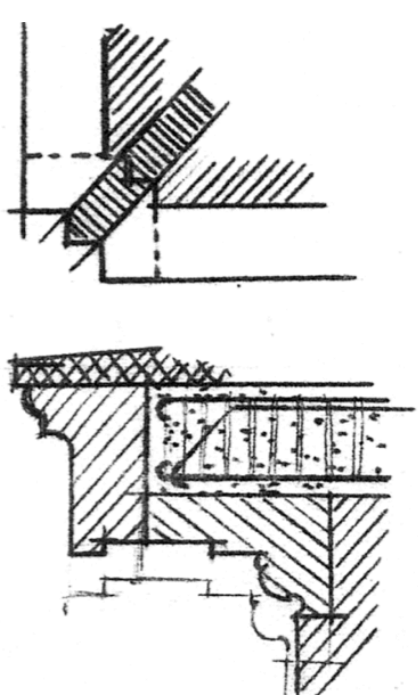

Fig.IV.124. Detalle croquis en memoria Arenillas 1965 (AGA 26/00356)
"Las piedras desprendidas son grandes y posiblemente estaban solo engrapadas a otras y muy mal sujetas, sin entrega casi en el muro... Como la altura de la cornisa viene a ser de 1,20, como su voladizo, y la entrega debería ser otro tanto, resultan sillares que pesarían, siendo solo de 0,50 $\mathrm{m}$ de largos, unas dos toneladas; serían muy dificiles de manejar y exigirian un andamio y gruas de elevación potentes. Convendrá por ello hacerlos segun se propone con nucleto de hormigon armado y revestimiento de piedra."

En 1983 López Cotelo interviene de emergencia tras la caída de otro sillar de unos mil kg desprendido en la misma fachada, que repone cosido con grapas metálicas.

En 1988 Ignacio Gárate afirma en la memoria del proyecto de restauración de la iglesia de San Francisco en Medina de Rioseco que el papel del zuncho es dotar de continuidad a la cornisa: "Otro tanto puede decirse en lo que se refiere al estado de la cornisa que adolece de una morfología constructiva común. Aquí la solución 
adoptada que la dota de continuidad es la construcción del ya clásico zuncho de apoyo perimetral que viene a sustituir parcialmente el trabajo de los antiguos durmientes".

Tabla 14: material de las cornisas

\begin{tabular}{|c|c|c|c|c|}
\hline \multicolumn{5}{|c|}{ MATERIAL DE LA CORNISA } \\
\hline $\mathrm{FICHA}$ & IGLESIA & 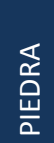 & $\begin{array}{l}\stackrel{0}{コ} \\
\stackrel{\bar{c}}{0} \\
\frac{1}{\triangleleft}\end{array}$ & $\begin{array}{l}\text { o } \\
\text { \& } \\
\text { o }\end{array}$ \\
\hline FZ-01 & Catedral (Valladolid) & $x$ & & \\
\hline FZ-02 & Convento de la Concepcion (Valladolid) & $\mathrm{X}$ & & \\
\hline FZ-03 & Capilla de San Gregorio (Valladolid) & $\mathrm{x}$ & & \\
\hline FZ-04 & La Pasion (Valladolid) & & & \\
\hline FZ-05 & Convento de Portaceli (Valladolid) & & & \\
\hline FZ-06 & Las Angustias (Valladolid) & & $\mathrm{X}$ & \\
\hline FZ-07 & San Agustín (Valladolid) & & & \\
\hline FZ-08 & San Benito el Real (Valladolid) & & & $\mathrm{x}$ \\
\hline FZ-09 & San Lorenzo (Valladolid) & & & \\
\hline FZ-10 & San Pablo (Valladolid) & $\mathrm{X}$ & & \\
\hline FZ-11 & La Antigua (Valladolid) & $\mathrm{x}$ & & \\
\hline FZ-12 & El Rosarillo (Valladolid) & & & \\
\hline FZ-13 & El Salvador (Valladolid) & & & $\mathrm{X}$ \\
\hline FZ-14 & Las Descalzas Reales (Valladolid) & & & \\
\hline FZ-15 & San Joaquin y Santa Ana (Valladolid) & & $\mathrm{X}$ & \\
\hline FZ-16 & Las Huelgas Reales (Valladolid) & & $\mathrm{x}$ & \\
\hline FZ-17 & Santa María (Alaejos) & & $\mathrm{X}$ & \\
\hline FZ-18 & San Juan Evangelista (Arroyo de la Encomienda) & $\mathrm{X}$ & & \\
\hline FZ-19 & La Santa Espina (Castromonte) & $x$ & & \\
\hline FZ-20 & Santa Maríadel Castillo (Castronuño) & $\mathrm{X}$ & & \\
\hline FZ-21 & Santos Justo y Pastor (Cuenca de Campos) & & $\mathrm{X}$ & \\
\hline FZ-22 & San Juan (Fresno el Viejo) & & $\mathrm{X}$ & \\
\hline FZ-23 & Santa María (Iscar) & & $\mathrm{X}$ & \\
\hline FZ-24 & Santa María de Arbás (Mayorga) & & $\mathrm{X}$ & \\
\hline FZ-25 & San Francisco (Medina de Rioseco) & & & \\
\hline FZ-26 & Santa Cruz (Medina de Rioseco) & $\mathrm{X}$ & & \\
\hline FZ-27 & Santiago (Medina de Rioseco) & $\mathrm{X}$ & & \\
\hline FZ-28 & San Antolín (Medina del Campo) & & & $\mathrm{X}$ \\
\hline FZ-29 & San Martín (Medina del Campo) & & $\mathrm{X}$ & $\mathrm{x}$ \\
\hline FZ-30 & Los Santos Juanes (Nava del Rey) & $\mathrm{X}$ & & \\
\hline FZ-31 & San Juan (Olmedo) & & $\mathrm{X}$ & \\
\hline FZ-32 & Santa María de Palazuelos (Corcos del Valle) & $\mathrm{x}$ & & $\mathrm{x}$ \\
\hline FZ-33 & San Pablo (Peñafiel) & $\mathrm{X}$ & $\mathrm{X}$ & $\mathrm{X}$ \\
\hline FZ-34 & San Cebrián (San Cebrián de Mazote) & & $\mathrm{X}$ & \\
\hline FZ-35 & Santa María (Tordesillas) & $\mathrm{X}$ & $\mathrm{X}$ & \\
\hline FZ-36 & La Anunciada (Urueña) & $\mathrm{X}$ & & \\
\hline FZ-37 & Santa María de Valbuena (Valbuena) & $\mathrm{X}$ & & \\
\hline FZ-38 & Santa María del Castillo (Villaverde de Medina) & & $\mathrm{X}$ & \\
\hline FZ-39 & Santa María (Wamba) & $\mathrm{X}$ & & \\
\hline $\mathrm{FZ}-40$ & San Pedro (Serrada) & & $\mathrm{x}$ & \\
\hline
\end{tabular}

En el apartado de aspectos estructurales se ha mostrado cómo la mitad de los casos analizados tienen muros de piedra y el otro 50\% de ladrillo, en algún caso combinado con tapial o bien revestido. 
Aunque lo habitual es que los edificios de muros de piedra se rematen con cornisas del mismo material, encontramos con frecuencia que fábricas de sillares y mampuesto se recrecen con algunas hiladas de ladrillo que se rematan con cornisas de ladrillo.

\section{MATERIALES DE LA CORNISA}

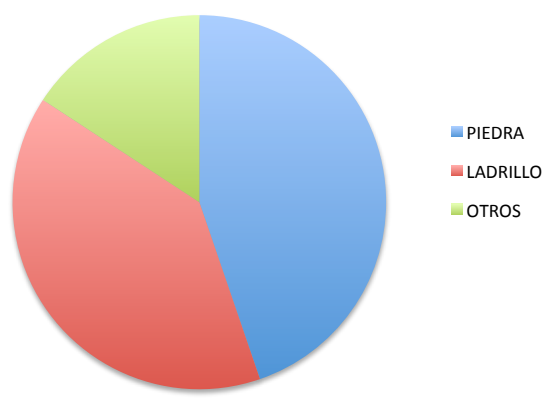

La cornisa de bocatejas sobre ladrillo que regulariza la coronación del mampuesto de piedra de la nave lateral en Santa María de Íscar muestra una grieta corrida bajo el vuelo de las tejas.

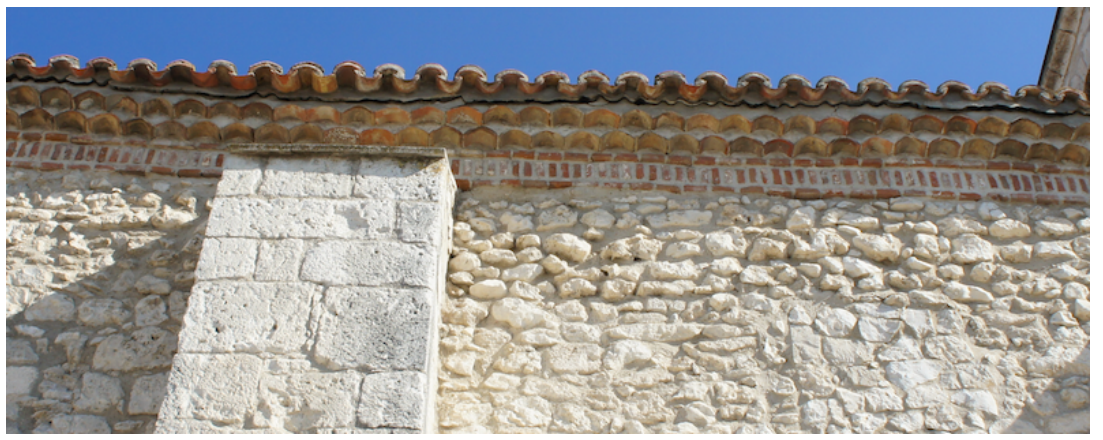

Fig.IV.125. Cornisa Íscar visita 02/08/2015

Incluso hay casos con vuelos sucesivos, como en la iglesia de Santa María de Tordesillas donde se ha dispuesto la cornisa de ladrillo sobre la existente de piedra en toda la cabecera y sobre un par de hiladas de ladrillo que rematan la sillería de la nave lateral.

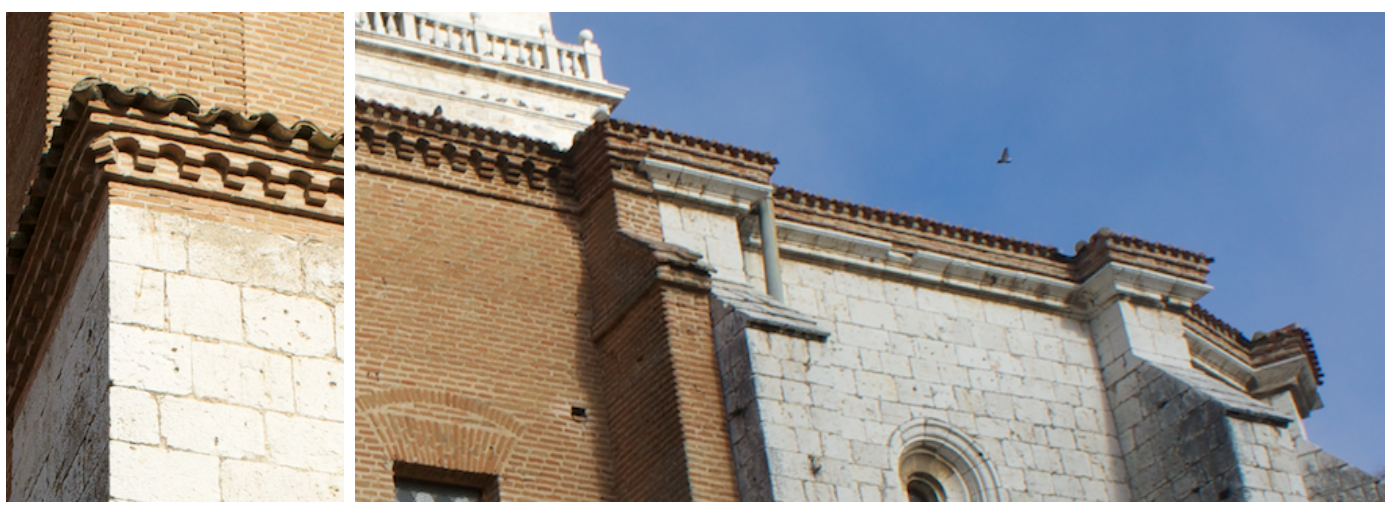

Fig.IV.126. Cornisas Tordesillas, visita 16/12/2013 
Un ejemplo de intervención sobre las cornisas de extraordinario interés es el caso de Santa María del Castillo en Villaverde de Medina. En 2008 el arquitecto José Luis Pardo interviene tras la caída de un considerable tramo de cornisa, patología que atribuye a la actuación realizada en 1989, cuando se reemplaza la estructura de cubierta por otra de madera laminada con zunchos de hormigón en perímetro y muros diafragma. Según Pardo,

"la inexistencia de elementos suficientes para el apoyo del tablero de madera en el encuentro con los aleros, produce pandeos tanto en el tablero como en el panel flexible onduline existente sobre el mismo, lo que provoca la rotura $y$ disgregación del mortero rígido de asiento de la teja, así como la correspondiente rotura de la misma en la zona en que termina el panel onduline. Igualmente se produce deslizamiento de los materiales indicados debido a la enorme pendiente que presenta la cubierta. Por otra parte, la deficiente ejecución y puesta en obra de ciertos elementos como el panel onduline, que no se prolongó hasta el exterior del alero sino que termina en el centro de la coronación de los muros de cerramiento, vertiendo en el mismo el agua que recoge, han motivado la existencia de patologías nefastas que finalmente han provocado el desplome de una zona del alero de ladrillo y agrietado buena parte del resto"

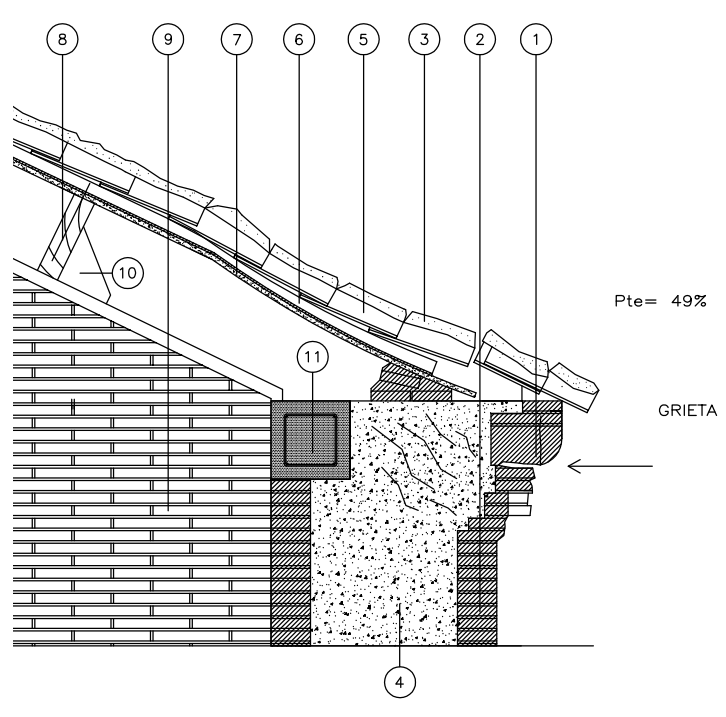

DETALLE CONSTRUCTIVO "2"

CUBIERTA Y ALERO ESTADO ACTUAL

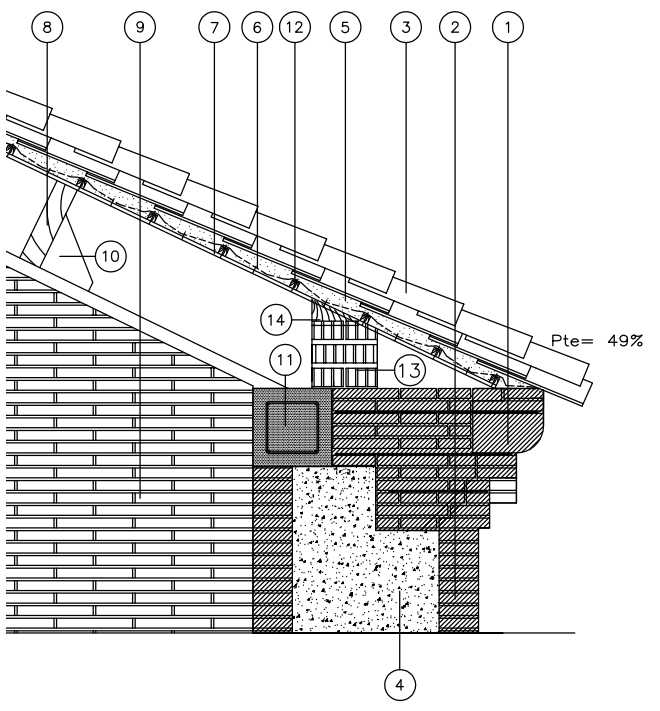

DETALLE CONSTRUCTIVO "2" CUBIERTA Y ALERO ESTADO REFORMADO

Fig.IV.127. Detalles de cornisa Pardo 2008 JCyL

Vemos así que la falta de la oportuna definición en el punto crucial donde se articulan muros y cubiertas es causa recurrente de patología en los edificios históricos. Al incorporar el zuncho perimetral suele o bien cajearse el remate de la fábrica existente o bien recrecer el paramento interior de la misma para resolver sin complicaciones la geometría del apoyo. 
En el diseño más simple posible con un muro macizo de sillares en que el alero lo conforma el propio vuelo de las tejas, entre el apoyo de los pares y el sillar de cornisa parece evidente que será imprescindible disponer sobre el muro un relleno donde apoyen esas últimas filas de tejas o el tablero ripia bajo las mismas.
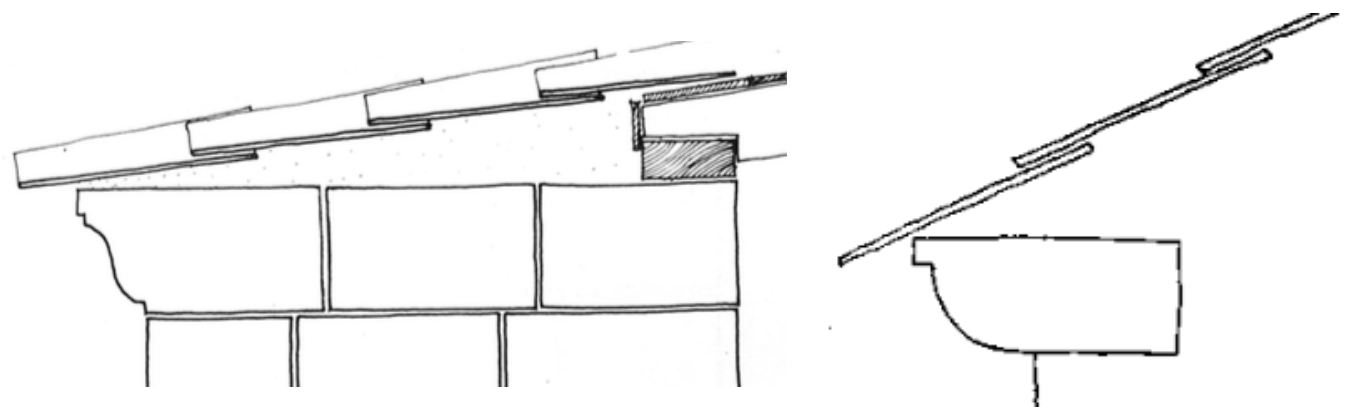

Fig.IV.128. Alero de piedra lamina 27 y cornisa en cuarto bocel Lám 24 Tesis Miguel Fernández Cabo

En un cerramiento de cierto porte, además, esa sección estará conformada por dos hojas careadas con un relleno de peor calidad entre ambas. Sin un remate superior a modo de albardilla, cualquier filtración de la cubierta penetrará en el interior del muro debilitándolo. Este problema se puede solventar disponiendo el perfil con el tradicional refreno sobre piezas de madera que permita la aireación del remate de muro.

La falta de conocimientos de la tradición constructiva, documentada en los antecedentes, hace imprescindible incluir en un proyecto de restauración un detalle de la configuración alero-cornisa lo más detallado posible, se incorpore o no el zuncho en ese punto.

En los dos dibujos que se exponen en una vitrina de la última planta del Museo de la Ciudad de Valladolid se representa el despiece de los sillares que forman la cornisa bajo el acroterio con un resalto para impedir la filtración horizontal del agua hacia el interior del muro. En uno de ellos, con los detalles de cornisa y acroterio para el Colegio de Santa Cruz de Valladolid, Ventura Rodríguez rotula la pieza E como "cornisa que debe correr en las tres fachadas de mediodía, levante y norte con la forma en que han de quedar las juntas de las piedras y sus trasdoses para que no se introduzcan las aguas en la fábrica, y los cañones de sus vaciaderos, que han de ser de plomo" 

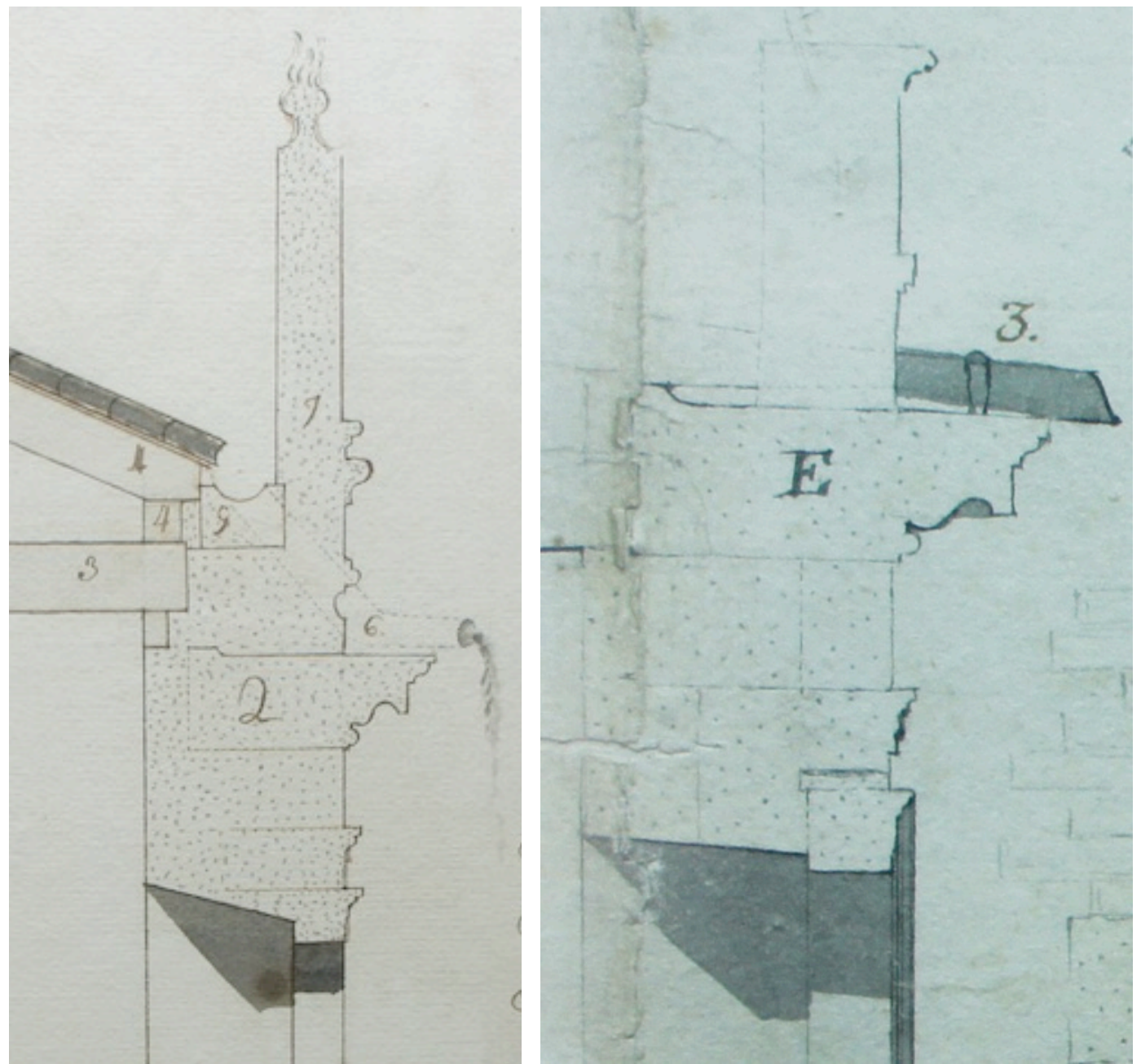

Fig.IV.129. Detalles de cornisas en vitrina del Museo Fabio Nelli de Valladolid 



\section{IV.2.4. El zuncho}

Una vez revisados los proyectos de restauración se ha reflexionado sobre los propios edificios, organizados por categorías, analizando los aspectos estructurales y estudiando cómo se han ido conformando sus cubiertas a lo largo del tiempo. En esta última parte del análisis vamos a abordar por fin las cuestiones directamente relacionadas con los zunchos observados en la labor de campo. En primer lugar se recopilan las conclusiones parciales obtenidas al elaborar las Fichas resumen de los datos, también contenidas en las mismas. A continuación se exponen con más detalle varios casos singulares de zunchos desaparecidos e involucrados en alguna patología estructural. Y finalmente se organiza una clasificación general para tratar de comprender el papel que desempeñan los zunchos en las obras de restauración de edificios históricos, objetivo fundamental de la investigación.

\section{IV.2.4.1. Conclusiones parciales del análisis previo desarrollado en las Fichas}

Tras el análisis de los datos recopilados en anejos y fichas podemos distinguir varios contextos:

- Casos sin documentación suficiente.

- Edificios sin posibilidad de acceso al espacio bajo cubierta.

- Zunchos mencionados en proyectos pero ocultos.

- Casos comprobados de restauración sin zuncho.

- Incorporación de otros elementos asimilados a zunchos.

- Zunchos ejecutados comprobados in situ.

- Zunchos demolidos

- Patología relacionada con la incorporación de zunchos. 
IV.2.4.1.1. En primer lugar podemos señalar los casos en que no ha sido posible obtener documentación suficiente relacionada con el empleo de zunchos, porque no se han localizado los proyectos o bien porque en éstos no se mencionan. No se ha concertado visitas al bajo cubierta de los mismos.

Aunque se cuente con datos de distintas intervenciones en el Convento de la Concepción, no se ha localizado documentación de las obras realizadas en las cubiertas de la iglesia.

El templo de San Lorenzo fue demolido y los proyectos revisados tampoco contienen información sobre el tema.

Tampoco se cuenta con documentación del proyecto bajo el que García Guereta llevó a cabo la obra de reconstrucción de la Antigua en la primera década del siglo $\mathrm{XX}$, no ha sido posible obtener permiso del párroco para acceder al espacio bajo cubierta y en las fotografías de catas practicadas durante la intervención de Gatón, suministradas por la profesora Camino, no se aprecia la existencia de zunchos en el muro.

En la iglesia de la Santa Espina no se ha constatado la existencia de zunchos en la cubierta de la nave central de la iglesia aunque, dado el grosor de los muros, estos podrían existir y encontrarse revestidos con la fábrica de ladrillo hueco. En la cubierta de la nave de la epístola sí hay un zuncho de hormigón armado visto que recorre el interior de la fachada sur del templo, pero no se cuenta con documentación del proyecto con el que se ejecutaron estas obras en los años 50 .

No se ha podido comprobar la existencia de zunchos en San Juan ante Portam Latina de Arroyo de la Encomienda.

No se ha encontrado mencionado ningún tipo de zuncho en la documentación analizada de las Descalzas. En la documentación analizada de Santa María de Íscar tampoco se ha localizado referencias a zunchos y los durmientes colocados en la restauración de cubiertas de la nave de Cembrero y Morante en 2000 se diseñaron con madera.

Y sobre la iglesia de Olmedo el único proyecto obtenido está firmado por Arenillas y trata de un traslado de bienes muebles, sin haberse podido localizar documentación de otras intervenciones. 
IV.2.4.1.2. Hay varios casos es que se cuenta con datos sobre zunchos obtenidos a partir de los proyectos de obras pero no ha sido posible acceder al bajo cubierta para comprobarlos.

No se ha conseguido permiso de la congregación para acceder al bajo cubierta de las Huelgas Reales, por lo que no es posible confirmar cómo se ejecutaron las obras correspondientes a los proyectos siguientes: En 1972 Julio González reforma el coro atirantando los arcos de la nave central en sus arranques y reemplazando la estructura de cubierta por una nueva, metálica, con entrevigado de bóvedas de rasilla. Incorpora un zuncho al que denomina durmiente. Ana Iglesias define en 1975 el zuncho con un detalle señalado sobre la planta cuando sustituye la estructura de madera de cubierta por cerchas metálicas, correas y capa de compresión de hormigón sobre nervometal.

Según la documentación analizada no se han incorporado zunchos en la coronación del cuerpo de la iglesia de la Cofradía de las Angustias, que conservaría así sus armaduras con reparaciones puntuales, aunque ha sido imposible confirmar este extremo por no haber conseguido acceder al espacio bajo cubierta de la nave central del templo. Se obtuvo permiso y llevó a cabo una visita al templo en la que se pudieron recorrer dependencias no visitables y revisar el exterior de algunas cubiertas pero no entrar en el bajo cubierta de la nave por falta de medios auxiliares.

En la iglesia del Rosarillo debió incorporarse un zuncho perimetral de acero laminado HEB-140 anclado al muro mediante perfiles IPN-100 cada dos metros, según se define en el proyecto de 1980 de Iñiguez de Onzoño, aunque no ha podido accederse para comprobarlo por encontrarse este templo cerrado y sin uso.

Según la documentación de los proyectos estudiados, en Fresno el Viejo, los arquitectos Rodrigo y Roldán incorporaron el típico zuncho perimetral rectangular en una nave lateral en 1974. En las últimas restauraciones Pedro Carreño ha reemplazado las armaduras restantes por estructuras similares de madera aserrada apoyadas sobre las tradicionales piezas de madera, sin incorporar ningún elemento de hormigón o acero coronando los muros del resto de las cubiertas.

El último proyecto ejecutado por Pablo Puente a partir de 1999, en la iglesia del Monasterio de Valbuena incorporaba zuncho de hormigón, aunque no se ha podido confirmar accediendo al espacio bajo cubierta si se llegó a colocar en la nave central o laterales, ya que no aparece reflejado en los planos. El diseño de la nueva estructura de cubierta de la nave central se resuelve con pares de madera laminada y 
tirantes con pendolón de acero Gewi cada 3m, y sobre estas cerchas se disponen correas de madera aserrada con tablero contrachapado hidrófugo.

IV.2.4.1.3. A veces se ha accedido hasta el lugar pero el zuncho no se manifiesta por encontrarse oculto, embebido en los muros de fábrica o revestido.

No se ha podido comprobar si el Museo de la Pasión cuenta con zuncho de remate en la coronación de los muros, ya que la superficie del paramento no manifiesta discontinuidades en el recinto de instalaciones bajo la cubierta de fibrocemento. Tampoco aparecen representados en los planos de 1993 ni mencionados en memoria o presupuesto. Sólo en el proyecto de Arenillas de 1965 se describe la incorporación de cadenas de hormigón armado en la coronación de los muros, pero la modificación posterior de Gallegos y Salvador elevó en 1993 la cota de remate de los mismos sin definir el remate de la nueva fábrica.

Los faldones a dos aguas revestidos de piedra que trasdosan las bóvedas de la iglesia parroquial de Castronuño tuvieron en origen un relleno de tierras que, según la memoria del proyecto de intervención de 1963, iba a ser reemplazado por tabiquillos palomeros de ladrillo con un tablero doble de rasilla aunque, según el testimonio de algunas vecinas de la localidad, nunca se realizó esta sustitución. En un proyecto de Ana Iglesias de 1974 se describe la incorporación de un zuncho de hormigón armado destinado a resolver el atado perimetral del templo, sin embargo en el mismo se definen entre otras actuaciones la demolición de la espadaña de ladrillo que aún podemos contemplar y la reconstrucción de la sacristía sin la actual cúpula. La propia Ana Iglesias en entrevista confirmó no haber llevado a cabo dicha obra. Resulta imposible corroborar o desestimar la existencia de zunchos en esta cubierta sin realizar catas.

En Mayorga parece que se incorporó zuncho de hormigón armado en la obra de Espinosa y Varona de 1989 en la cubierta de la única nave lateral al sustituir su estructura por una nueva de madera laminada, pero no se ha podido confirmar ocularmente ya que los pares apoyan sobre carreras de madera adosadas al muro de tapial. No consta que se haya dispuesto también sobre uno de los muros de nave central, aunque se menciona en su Memoria final de obra.

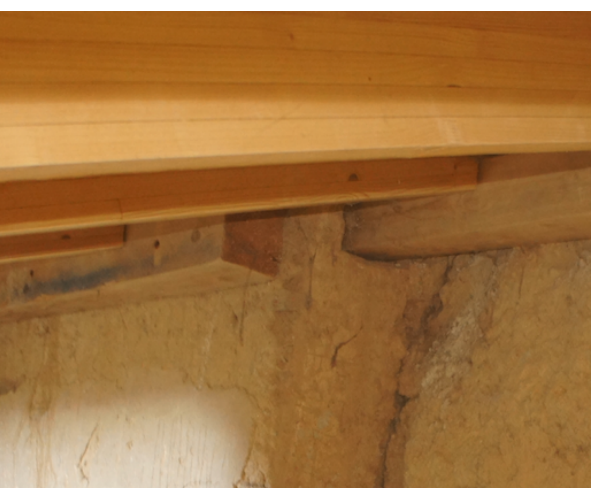

Fig.IV.130. Nave lateral Mayorga, visita 25/08/2015 
San Cebrián de Mazote ha sido visitada pero, según el responsable de la misma, no hay accesos a ningún espacio o cámara sobre la techumbre.

Se ha visitado la ermita de Urueña sin poder confirmarse tampoco la existencia de zunchos en la misma, aunque al parecer en 1978 Ana Iglesias debió colocar una estructura de cubierta nueva resuelta con tabiquillos de ladrillo y tableros de rasilla.

IV.2.4.1.4. Otras iglesias cuentan con cubiertas modernas tras producirse la ruina de las antiguas.

En el Archivo municipal se incorporó un zuncho rectangular de $110 \mathrm{x} 40 \mathrm{~cm}$ sobre los cerramientos laterales de fábrica de ladrillo de la nave central que no se prolonga sobre el testero a los pies. En la cabecera poligonal de piedra, aunque en el proyecto original estaba previsto colocar dados de hormigón cajeados en la fábrica, según el presupuesto del modificado final se dispuso un zuncho corrido quebrado de $35 \times 40 \mathrm{~cm}$. El inmueble se encontraba en ruinas ${ }^{104}$ y sin cubierta cuando Gallego y González lo reconstruyen en 1999 colocando una cubierta moderna de acero laminado y chapa colaborante.

IV.2.4.1.5. En cuatro ocasiones los edificios han sido restaurados sin incorporar zunchos y ha sido posible comprobarlo.

Se revisó las cubiertas de la iglesia de San Benito el Real y parece que no se ha incorporado el habitual zuncho perimetral de hormigón, ya que conserva gran parte de sus armaduras, apoyándose los distintos tipos de cerchas de madera sobre elementos también ejecutados con madera, algunos corridos y otros puntuales dispuestos sobre nichos cajeados en los muros, según se describe en el resumen de la visita.

La documentación de los proyectos de restauración de la iglesia del Salvador analizados muestra cómo en este edificio no se incorporaron los habituales zunchos de hormigón en las intervenciones de reemplazo de estructura de cubierta por madera aserrada. Se reutilizaron las piezas originales en buen estado, confiando la homogeneidad del apoyo a la reconstrucción de la banda de remate de fábrica de ladrillo disponiendo nudillos de madera embebidos y un doble durmiente sobre los

\footnotetext{
${ }^{104}$ En 1968 Arenillas Asín había recalzado y consolidado los muros en ruinas.
} 
mismos. En una obra de restauración de la capilla gótica adyacente a la cabecera, sin embargo, ya en 2006, sí se decide disponer una banda metálica perimetral para zunchar ambos volúmenes, que se arriostran mediante una gran estructura metálica de celosía insertada en el espacio bajo cubierta descarnando el relleno de los riñones de las bóvedas. Un zuncho metálico UPN está dispuesto por la cara interior del muro de la capilla y otro de platabanda inoxidable discurre por la cara exterior del cerramiento de la cabecera. Aunque no se ha visitado el bajo cubierta se cuenta con información suficiente y fotografías que confirman estos detalles, suministradas por el arquitecto de la Fundación del Patrimonio Histórico Joaquín García.

En la iglesia de San Pablo en Peñafiel se mantiene la cubierta de madera y no se ha detectado la incorporación de zunchos en el cuerpo del templo ${ }^{105}$.

La nueva estructura de cubierta incorporada por Montoya y Horno en el año 2000 en Palzuelos es de par e hilera de madera con un tirante metálico. Esta estructura se interrumpe en el crucero donde se ha instalado un sistema de jácenas, también de madera laminada, apoyadas sobre un nuevo soporte del mismo material, para salvar el gran hueco producido por un derrumbamiento. No se han incorporado los típicos zunchos perimetrales de hormigón armado, diseñándose en su lugar un durmiente de madera corrido para recibir la nueva estructura de madera. Ambos durmientes se atirantan mediante tensores metálicos. Aunque no se ha visitado el edificio se trata de una obra que cuenta con documentación suficiente, fotografías y un reciente levantamiento.

IV.2.4.1.6. Varios proyectos describen como zunchos elementos de hormigón armado de otra naturaleza: dados de apoyo o vigas.

Así ocurre en la iglesia del Convento de Portaceli, donde no parece que se haya incorporado zuncho perimetral sino algunos dados de hormigón cajeados en el muro de fábrica sobre los que se apoyaban varias cerchas que Roldán reemplazó en 1989, mientras refuerza el resto de cerchas de madera con un pequeño pendolón.

Los elementos incorporados en la intervención de Arenillas sobre ejes de pilares de la iglesia de los Santos Justo y Pastor en Cuenca de Campos eran vigas de hormigón armado.

\footnotetext{
${ }^{105}$ Durante la visita se aprecia como sí se ha incorporado zunchos de hormigón en zonas renovadas con estructura de madera laminada en otras zonas del conjunto monástico.
} 
En la iglesia de San Joaquín y Santa Ana hay soluciones constructivas diversas según las zonas. Parece que García Gil pudo incorporar en 1969 un zuncho de hormigón armado para atar la esquina, al incorporar un forjado de vigueta $y$ bovedilla, y una cubierta resuelta con tablero de una rosca de ladrillo con $2 \mathrm{~cm}$ de capa de compresión de hormigón apoyado sobre tabiquillos de ladrillo hueco. En la documentación de las intervenciones de Iglesias en 1978 y Gatón en 1993 sobre esa zona del templo no se representa ni menciona zunchos.

\section{IV.2.4.2. Los zunchos comprobados in situ}

La estructura de cubierta a dos aguas de la nave central de la Catedral de Valladolid fue reemplazada por cerchas metálicas en 1974 por Luis Cervera Vera, tras derrumbarse la parte central de la cubierta por el colapso de dos de las cerchas de madera. Las nuevas cerchas apoyan sobre un zuncho de hormigón armado embebido en un recrecido de ladrillo. Podemos considerar este zuncho de la nave central de la Catedral como pieza primordialmente de reparto, para distribuir el apoyo puntual de las cerchas metálicas sobre la coronación de los muros, ya que no se prolonga sobre el testero y por tanto no configura un anillo cerrado.

Es probable que en la nave de San Pablo fuera dispuesto un zuncho perimetral rectangular de 40x30 embebido en los muros de piedra, aunque no ha sido posible comprobar sus dimensiones al no estar expuesto a la vista su frente. La ejecución del reemplazo de estructura de cubierta en tres fases induce a pensar que este elemento no presentará continuidad en todo el perímetro, que muestra una zona con repisa de unos $95 \mathrm{~cm}$ con el intereje entre apoyos tabicado con ladrillo, otra sin resaltos en el paramento y en la cabecera unos tramos de perfil laminado sobre $40 \mathrm{~cm}$ de hormigón.. La estructura metálica incorporada en los años 60 por Arenillas es especialmente ligera, con cerchas separadas $1,45 \mathrm{~m}$ atirantadas una a una. Cuenta además con una familia de tensores adicionales que soportan la pasarela central dispuestos con una modulación transversal de $1,25 \mathrm{~m}$.

En Alaejos se colocaron zunchos de hormigón armado en 1974 que, en el presupuesto, la arquitecto Ana Iglesias denomina "de atado perimetral de muros". En los planos del proyecto se define un único elemento de sección 40x40 continuo por todo el perímetro exterior. Se ejecuta de $55 \times 30$ y cierra un anillo sobre la nave central de la iglesia, con otros dos zunchos lineales en muros de fachada sin continuidad con el testero a los pies. En este último hay una grieta vertical sin 
resolver (en rojo sobre el eje 1 del croquis) que ha sido mencionada en varios proyectos.

Entre los ejes 1 y 2 encontramos restos de tirantes metálicos. No se ha podido acceder a los tramos de fondo de la nave lateral A-B en 4-5-6. Las bóvedas C-D 2-34 presentan un perfil más apuntado y parecen resueltas con el ladrillo dispuesto de forma tabicada, mostrando por su trasdós un revestimiento de hormigón armado. El resto presenta los ladrillos a rosca con nervios resaltados. La estructura de cubierta de cerchas metálicas y forjado de vigueta y bovedilla de hormigón incorporada en el siglo XX apoya sobre los zunchos intermedios, prolongándose los cordones superiores en continuidad a ambos lados. En el eje de los zunchos hay además un atado de perfiles metálicos que acodalan entre sí transversalmente las celosías sobre el punto de apoyo de las mismas, tanto sobre los muros exteriores como sobre las fachadas.

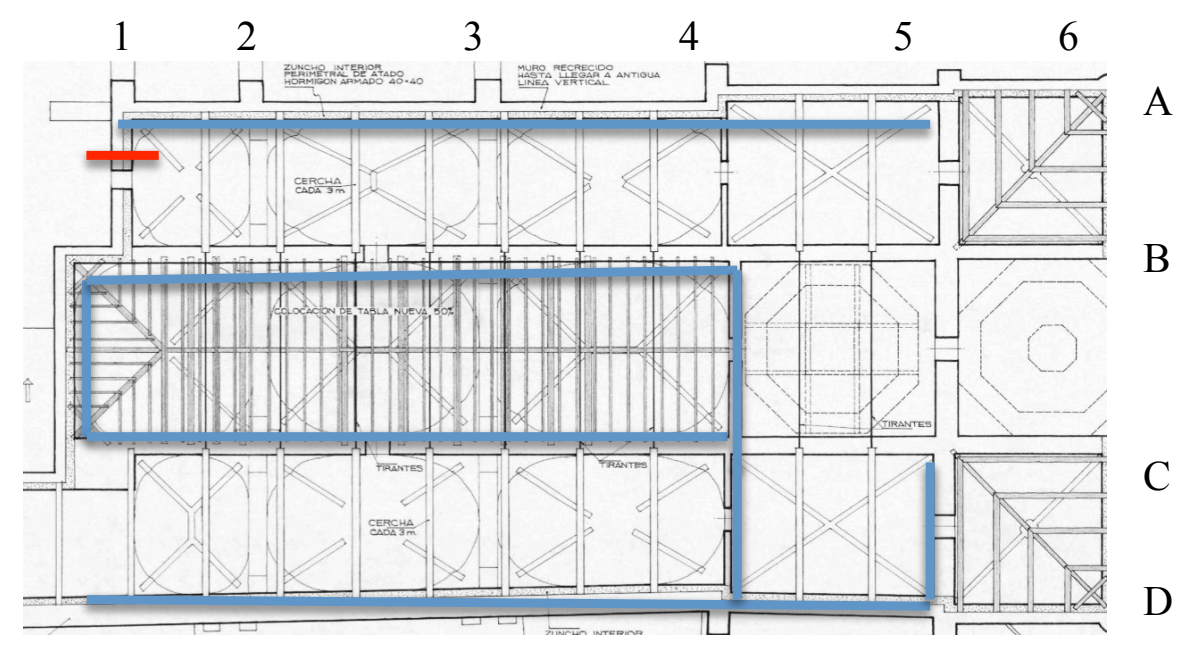

Fig.IV.131. Esquema de zunchos en la iglesia de Santa María de Alaejos

El Museo de San Francisco en Medina de Rioseco cuenta con un zuncho perimetral rectangular que discurre centrado sobre los muros en paralelo a un durmiente de madera que sirve de apoyo a los pares de cubierta. Según Gárate el zuncho ejecutado en 1986 no se emplea como apoyo de la estructura de cubierta, sino únicamente para reforzar la coronación de los muros y dotar de continuidad a la cornisa que los remata. Se cuenta con fotografías de una cata que lo muestra proporcionadas por Garcés y Basterra (2015).

La estructura observada en la visita al bajo cubierta del Museo de Santa Cruz coincide con la geometría definida en 1987 por Linazasoro en el proyecto 
reformado ${ }^{106}$, de madera laminada con cerchas y tirantillas sobre arcos también de madera laminada. El zuncho o viga, sin embargo, aparece semiembebido en la fábrica de ladrillo visto en vez de enrasado con la cara interior de paramento como aparece representado en los planos de detalle. En la misma visita se comprueba también que en la cabecera se ejecutó la estructura diseñada en 1979 por Ana Iglesias, con una cubierta de hormigón y nervometal sobre perfiles de acero laminado apoyados en un zuncho perimetral de hormigón armado

La nueva estructura de cubierta de acero laminado diseñada para Santiago, también en Medina de Rioseco, por Ana Iglesias en 1978 con cerchas metálicas no se realizó conforme al proyecto. Se incorporaron las dos vigas en celosía, de un metro de canto, dispuestas en sentido longitudinal y apoyadas sobre los ejes de pilares, pero se sustituyeron las armaduras únicamente sobre las naves laterales, disponiendo perfiles de alma llena y tablero de hormigón sobre nervometal, mientras que se conservaba la estructura de madera existente sobre la nave central. En los planos de planta de estructura se rotula "zuncho perimetral de hormigón armado 50x40" señalado sobre un anillo que rodea completamente el cuerpo del templo, mientras que en ambas torres y el espacio entre ellas se rotula zuncho 40x30. La solución final en los ejes de pilares quedó duplicada, con los elementos corridos de madera en sentido longitudinal y en paralelo, separados entre sí, un zuncho de hormigón y una celosía metálica de gran canto. Se trata de una solución singular, ya que las vigas de nave lateral parecen apoyar sobre la celosía y sostener en su extremo superior, tras un pequeño vuelo, al zuncho de hormigón.

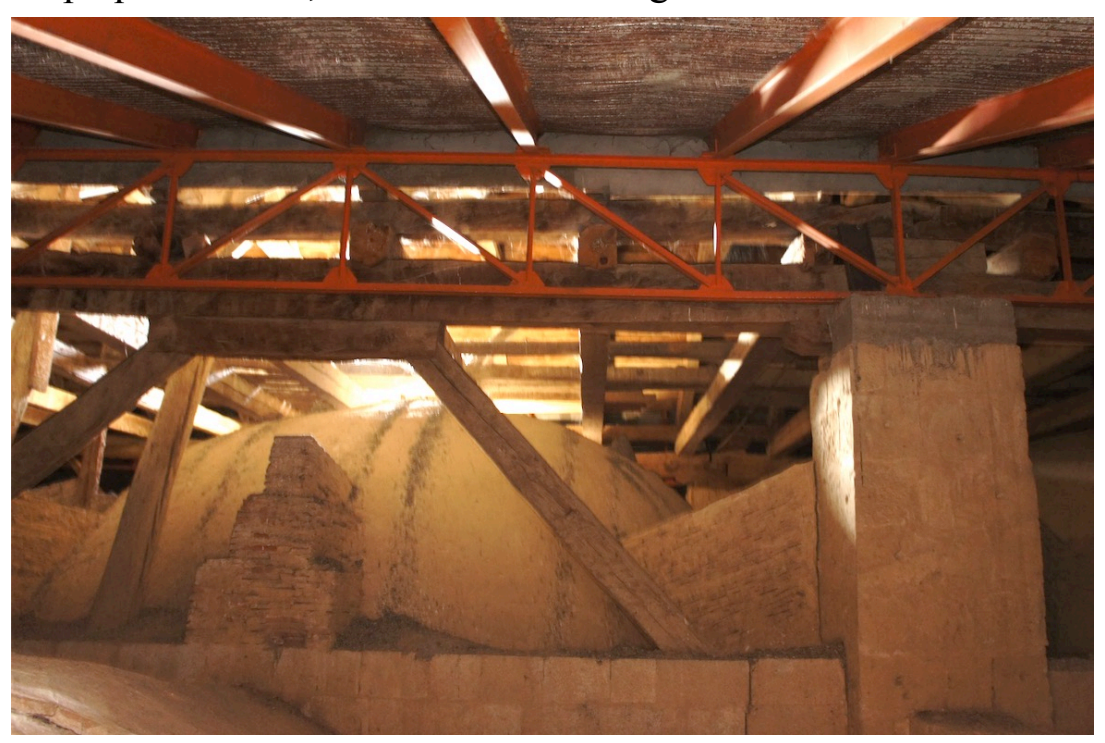

Fig.IV.132. Zuncho y celosía en Santiago, visita 20/09/2015

\footnotetext{
${ }^{106}$ En el proyecto inicial de Linazasoro aparecía una cercha diferente también de madera laminada pero con relleno de diagonales.
} 
En la imagen anterior se aprecia la complejidad constructiva de las cubiertas en la iglesia de Santiago, con su armadura original sobre nave central apoyada sobre los machones de sillería situados sobre los pilares del templo. Los dados de hormigón que recrecen ligeramente la mitad de los machones y sirven de apoyo a las celosías longitudinales corridas. El apoyo de los perfiles de alma llena que forman las cubiertas de naves laterales sobre dicha celosía y su remate mediante un zuncho de hormigón corrido. Incluso las bóvedas barrocas de nave central cuentan en su trasdós con unas costillas de fábrica que las refuerzan transversalmente y a $45^{\circ}$ contra los ejes de los machones.

En la Colegiata de San Antolín en Medina del Campo se incorporaron zunchos de hormigón armado en 1983 en unas obras dirigidas por Gómez Santander, pero fueron demolidos en 1999. En esta segunda intervención, Paniagua reemplaza la estructura de madera aserrada por una nueva de madera laminada dispuesta con un zuncho perimetral rectangular cerrado sobre la nave central y dos en las fachadas norte y sur engarzados con una pieza de cornisa-canalón también de hormigón. Todos estos elementos se cosen entre ellos y al muro de fábrica. En la cabecera la nueva estructura es de madera aserrada y sus cerchas también apoyan sobre un zuncho de hormigón armado.

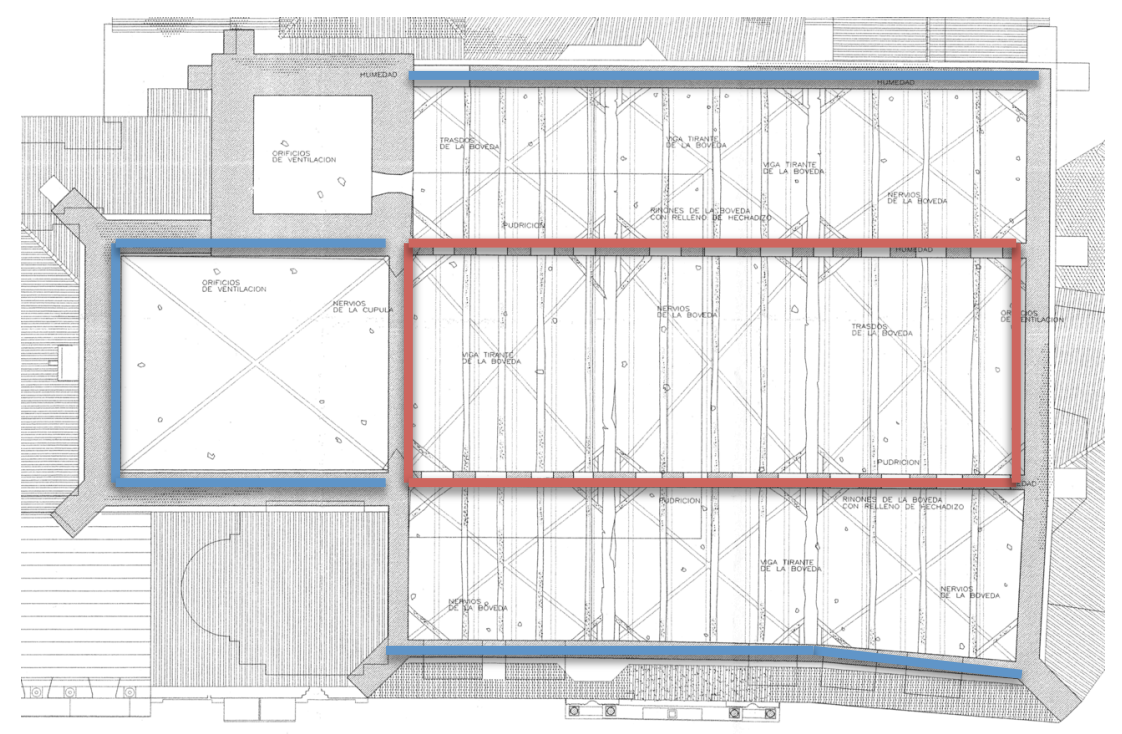

Fig.IV.133. Esquema de zunchos en la Colegiata de San Antolín de Medina del Campo

Tras el estado de abandono sufrido hasta 1989, Fernández e Inglés renovaron las cubiertas de la iglesia de San Martín, actual Museo de las Ferias, incorporando estructuras de madera laminada. Aunque en las secciones de 1989 se representan las vigas de cubierta apoyadas sobre un durmiente corrido, en las fotografías del trasdós 
de las armaduras de la cabecera tomadas durante un tratamiento de desinsectación y suministradas por el Director del museo se aprecia la existencia de un zuncho continuo de hormigón armado enrasado con el paramento interior de ladrillo.

En la cabecera de los Santos Juanes de Nava del Rey se sustituye la armadura de cubierta en 1978 por estructura metálica de IPN, atirantada con un perfil de sección circular roscado. En la nave, Ana Iglesias dispone cuchillos belgas sobre unas vigas en celosía tipo Warren compuesta y Howe, y resuelve su cubrición con una losa de hormigón y nervometal. Según se explica en el apartado siguiente, referido a patología inducida por restauraciones modernas, en una zona de este edificio el zuncho perimetral se ejecutó sobre las embocaduras de las capillas en vez de sobre el remate del cerramiento exterior de las mismas.

En la iglesia de Santa María de Tordesillas se incorporó un zuncho rectangular de hormigón armado 40x50 en la coronación de los muros de la nave central durante las obras de rehabilitación llevadas a cabo en 1980. En ellas, Luis Mingo reemplazó la estructura de madera original de la cubierta por una metálica formada por pórticos a dos aguas de acero laminado y tablero de nervometal con una capa de $7 \mathrm{~cm}$ de hormigón.

En dicha iglesia se trató de contrarrestar los empujes sobre el remate de los muros, debidos al diseño de los pórticos como simples vigas quebradas a dos aguas, mediante cuatro tirantes de acero anclados al zuncho en B, C y D. El cuarto se dispuso entre los muretes $\mathrm{E}$ y $\mathrm{F}$ que acodalan en el tramo de la torre, en cuyo encuentro se interrumpe el zuncho de hormigón. En el tramo corto A el canto del zuncho se reduce drásticamente, produciéndose además el encuentro con los zunchos a ambos lados con su remate a distinto nivel.

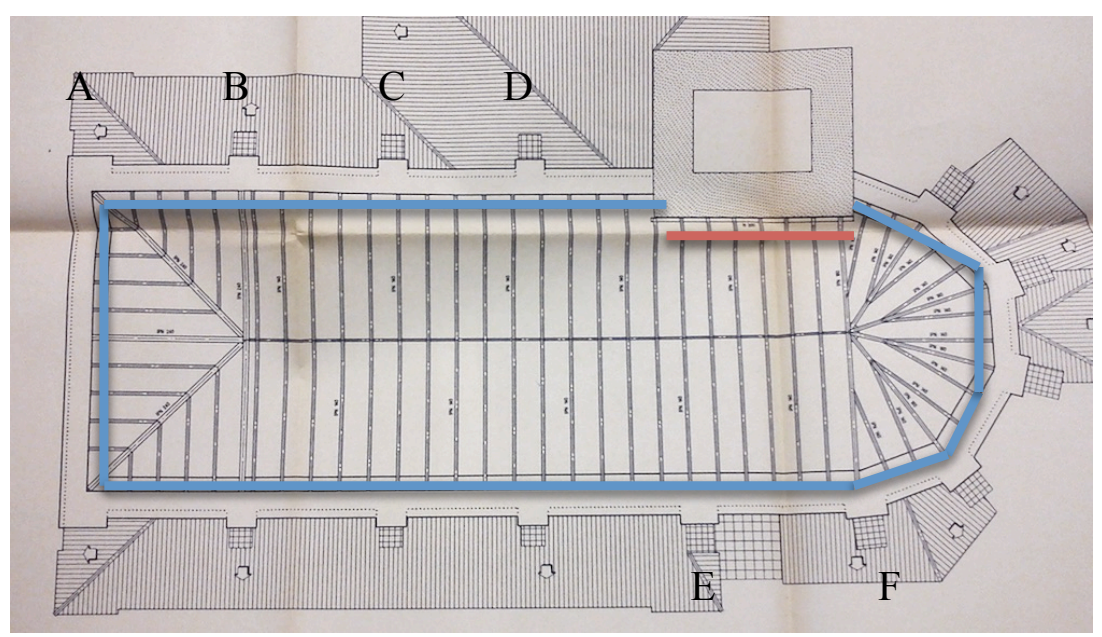

Fig.IV.134. Esquema de zunchos en la iglesia de Santa María de Tordesillas 
Se produjo el arrancamiento del anclaje extremo, correspondiente al eje B, que recibe los esfuerzos de las vigas diagonales que forman el frente a cuatro aguas sobre la fachada a los pies. En los apoyos A se manifiestan las grietas verticales a ambos lados de las aristas descritas.

En 1993 se realizó una intervención de refuerzo incorporando diez pares de tirantes adicionales. Los testigos colocados entonces se mantenían intactos en la visita realizada en diciembre de 2013.

En 1989 Jesús Tovar sustituye la estructura de madera existente en Villaverde de Medina, de cinco vigas por tramo apoyadas sobre ménsulas empotradas en los muros-diafragma originalmente a la vista y ocultas tras la ejecución de las bóvedas en 1703, por elementos de madera laminada. Sobre ambos muros laterales se dispone un zuncho perimetral de sección rectangular con su cara vista hacia el interior. Este elemento se prolonga con pendiente a dos aguas sobre ambos testeros de la nave, aunque interrumpe su recorrido en la parte central recrecida del piñón de la fachada a los pies. Sobre los tres muros-diafragma que forman los arcos fajones intermedios hay además zunchos de sección plana embebidos en el remate de la fábrica de ladrillo, sobre los que apoya la nueva estructura de cubierta. No se ha podido acceder al espacio bajo cubierta del presbiterio, cuya estructura se reemplazó en 1972, pero desde un hueco abierto en el muro sobre el arco triunfal también se confirma la existencia de un zuncho de hormigón.

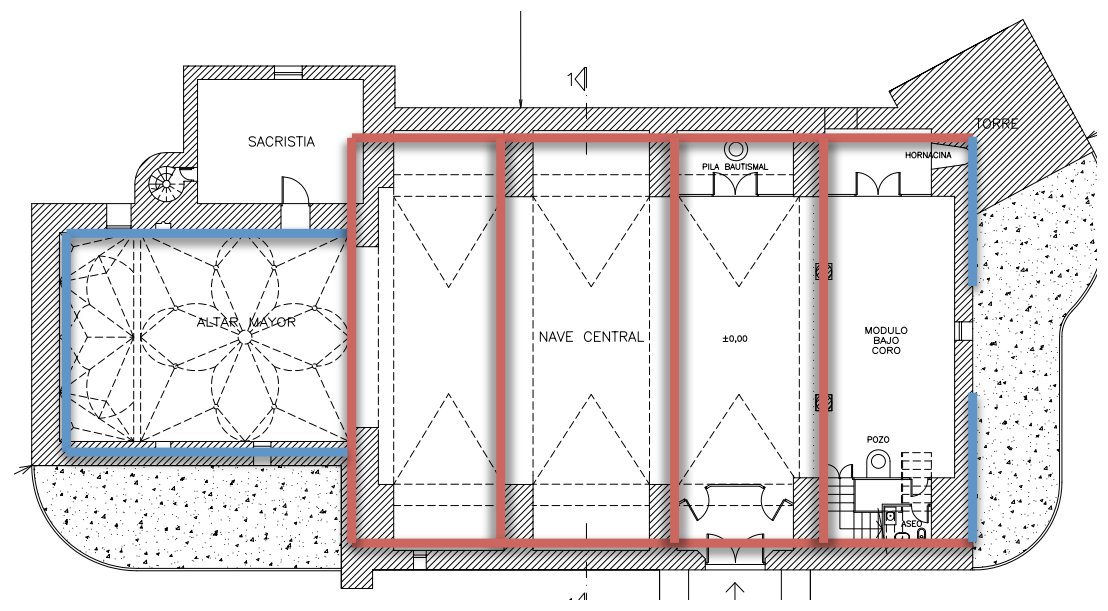

Fig.IV.135. Esquema de zunchos en la iglesia de Santa María del Castillo de Villaverde de Medina

No se cuenta con documentación que mencione zunchos en el caso de Wamba, aunque en la visita sí se ha detectado un tramo de este elemento sobre el hueco de acceso a la cubierta, por lo que es probable que se incorporase en la intervención de 
Arenillas que en los años 1962-1964 restaura las cubiertas con viguetas de hormigón armado a dos aguas con entrevigado de bovedillas y reconstruye la coronación de los muros.

En San pedro de Serrada se incorporó un zuncho de hormigón armado de unos $40 \mathrm{~cm}$ de canto en 1992. El zuncho A discurre enrasado a cara interior, sobre los cerramientos de la nave y testeros del crucero, sin continuidad en el muro a los pies.

No se ha comprobado su existencia en la cabecera. Según la Memoria del proyecto de Areizaga y Corral se trata de un zuncho perimetral con doble función: redistribuir uniformemente las cargas transmitidas por las cerchas y aplomar los muros con su peso propio. Se describe otro zuncho B que no se aprecia a simple vista, éste de atado, sobre los arcos torales, ejecutado para rigidizar los cerramientos nuevos sobre los mismos.

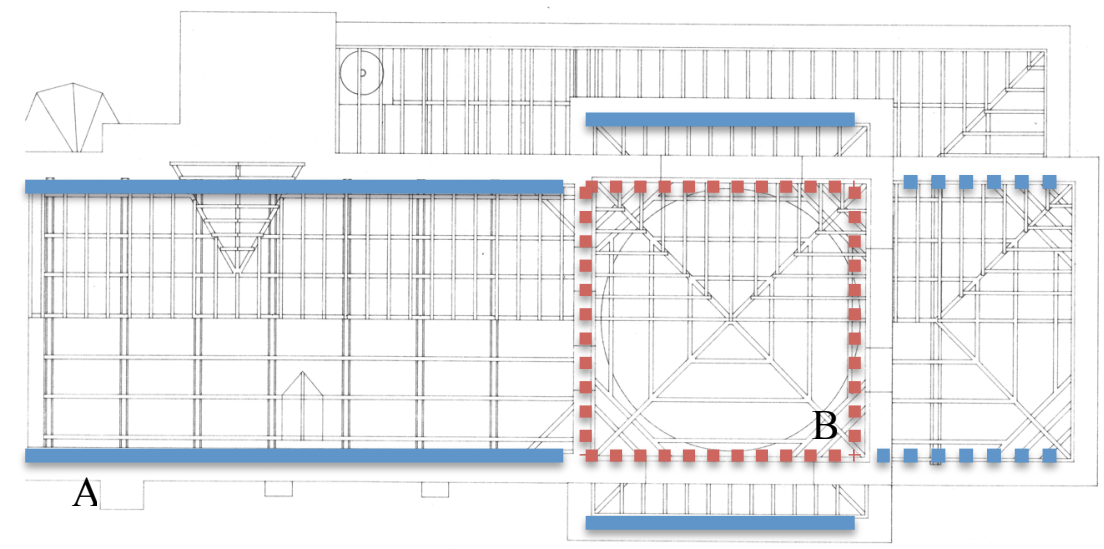

Fig.IV.136. Esquema de zunchos en la iglesia de San pedro de Serrada

\section{IV.2.4.3. Zunchos demolidos en la siguiente actuación}

Aunque para el análisis relacional entre los diferentes estudios de caso, según se ha descrito al inicio del capítulo IV, se han considerado de forma prioritaria los datos relativos al cuerpo de la nave central de los templos, resulta de gran interés para la investigación el ejemplo de la sala del Cabildo de la iglesia de las Angustias.

En 1982 los arquitectos Diego Pérez Medina, Agustín Bustamante y Teresa Pérez realizan la sustitución de cornisa y alero de piezas de madera del volumen adyacente a la iglesia destinado a reuniones y almacén de pasos de la cofradía por lo que en el proyecto denominan "una viga única de hormigón armado imitando piedra caliza que sirve para zunchar las cabezas de los pilares y apoyar las vigas de planta $2^{\text {a }}$ restauradas con el sistema Beta". 
En 1991 el arquitecto Salvador Mata hace demoler este elemento con martillo compresor y reconstruye la molduración de la cornisa con fábrica de ladrillo ${ }^{107}$. En la memoria del proyecto se describe cómo este zuncho había sufrido deformaciones intolerables con más de $15 \mathrm{~cm}$ de flecha, y $50 \mathrm{~cm}$ de desnivel, en una luz de sólo $7 \mathrm{~m}$. En la entrevista personal mantenida en octubre de 2013 Mata confirmó el reemplazo de esta pieza por una cornisa tradicional de fábrica de ladrillo volada.

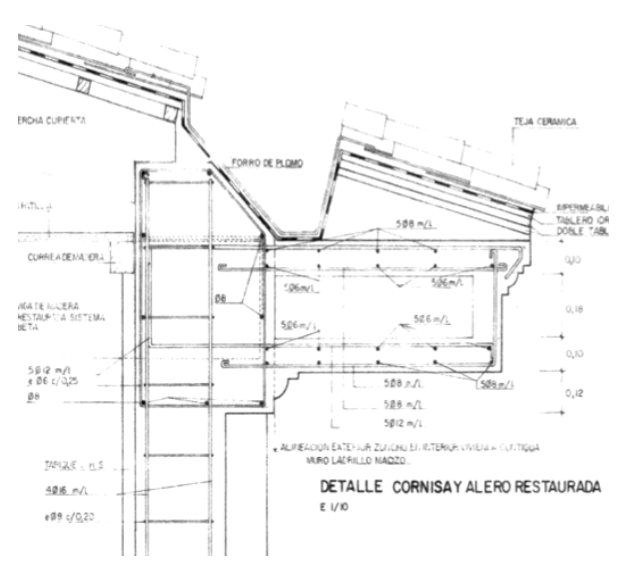

Fig.IV.137. Detalle zuncho-cornisa 1982 Pérez Medina JCyL

El otro caso detectado en el cual se eliminan los zunchos incorporados en la restauración anterior se produce en la Colegiata de San Antolín. En 1982 el arquitecto José María Gómez Santander desmonta la cubierta del templo recupera el $50 \%$ de los elementos de la estructura de madera para reconstruir una nueva armadura que apoya sobre cuatro líneas de zuncho de hormigón que, en la nave central, se encajan entre los antiguos durmientes superior e inferior. En 1999 se decide renovar toda la cubierta como obra de emergencia tras la caída accidental de dos tirantes. El arquitecto responsable del Plan Director, Antonio Paniagua, dispone una nueva cubierta a dos aguas con estructura de madera laminada sin el antiguo quiebro de cambio de pendiente entre la nave central y las laterales. Para ello reduce la altura de los muros laterales de la nave, demoliendo todos los zunchos del año 82.

\section{IV.2.4.4. Zunchos y patología relacionada con su incorporación}

Vamos a exponer a continuación dos casos en que se produce una patología tras obras en que se incorpora un zuncho de hormigón armado en la coronación.

En 1980, el arquitecto Luis Mingo desmantela la cubierta de la iglesia de Santa María de Tordesillas reemplazando la armadura de madera por una estructura de perfiles de acero laminado que forman simples pórticos a dos aguas. Cajea la coronación de los muros para disponer un zuncho de hormigón armado perimetral y

\footnotetext{
${ }^{107}$ En otros puntos del edificio, sin embargo, Mata extrae los durmientes de madera para colocar zunchos de hormigón, lo que demuestra que la demolición del zuncho-cornisa obedece a razones de índole técnica.
} 
dispone cuatro tensores de acero para atirantar el sistema. El tablero se resuelve con nervometal y capa de compresión de hormigón.

En 1993 se encarga una nueva intervención a Luis de la Riva de la Peña al detectarse la rotura localizada del hormigón del zuncho en varios puntos de anclaje de los citados tirantes de acero. El refuerzo consiste en la incorporación de diez pares de nuevos tensores, uno cada tres pórticos.

No es frecuente en rehabilitación monumental el diseño de este tipo de pórticos metálicos a dos aguas que hacen necesario el uso de tirantes añadidos para contrarrestar los empujes horizontales producidos por la propia geometría de los elementos. Habitualmente se reemplazan las armaduras de madera por cerchas trianguladas, precisamente con el fin de evitar empujes horizontales sobre la coronación de los muros de fábrica.

Según se describe en la Ficha FZ-35, es probable que el diseño del anclaje de los tirantes se modificase durante el transcurso de las obras
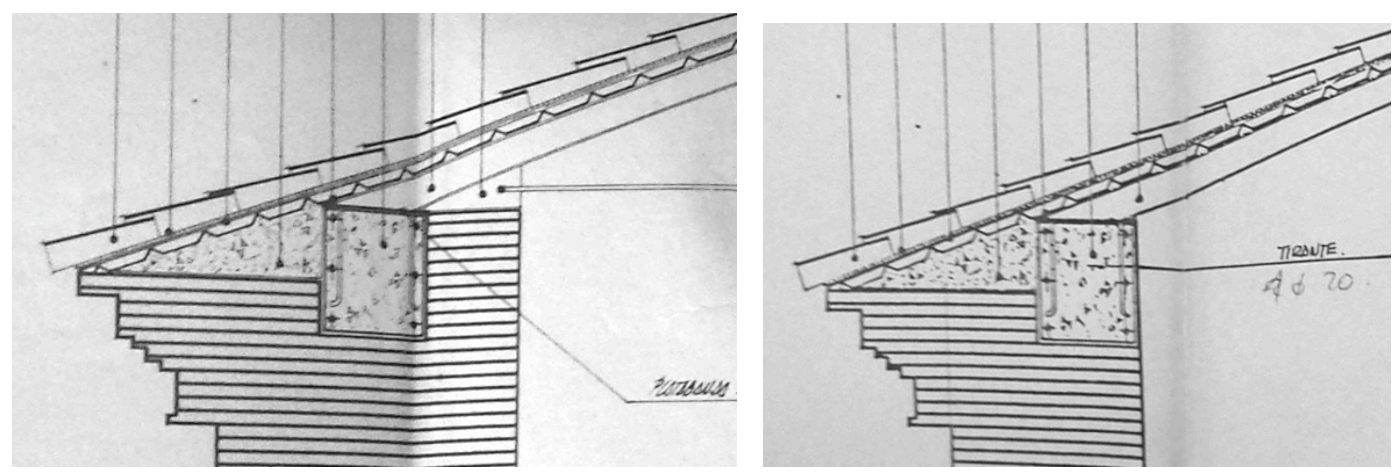

Fig.IV.138. Detalles de proyecto y obra Tordesillas (Mingo 1980)

En el detalle del plano 08 del Proyecto, conservado en el archivo del IPCE, a la izquierda de la ilustración anterior se representan los tirantes anclados a una cartela triangular soldada al ala inferior del perfil. En el de la derecha, sin embargo, tomado de un plano suelto con el mismo grafismo, localizado en la carpeta del proyecto de refuerzo llevado a cabo trece años después, el tirante acomete contra el zuncho de hormigón, detalle que concuerda con la solución realmente ejecutada que se observó en la visita al bajo cubierta. En el dibujo con la leyenda 4r20 señalada a mano, se representa el arranque del tirante embebido hasta aproximadamente el centro de la sección del zuncho, pero no se acota la longitud que debe profundizarse ni a qué altura colocarlo sobre la cara del zuncho. Años después se produjo la lesión, con arrancamiento de cuña del anclaje más próximo a los pies, que motivó la 
incorporación de tirantes adicionales, esta vez anclados a perfiles corridos y pletinas soldadas a ambos lados de las cartelas, sin duda propiciada por el cambio de solución y la falta de definición del detalle de obra.

El otro caso afecta a la iglesia de los Santos Juanes en Nava del Rey, donde la arquitecto Ana Iglesias incorpora hacia 1979 el típico zuncho perimetral rectangular de hormigón armado sobre el que apoya una nueva estructura metálica que reemplaza a la original de madera aserrada. La principal singularidad de este elemento es que, si bien en ambos testeros y crucero el templo cuenta con tres naves, en su zona central se incorporan unas capillas laterales, y el zuncho discurre sobra la embocadura B de las mismas en vez de sobre el muro A de fachada. El tablero de cubierta se prolonga así sobre dichas capillas con una solución constructiva anómala que, según los planos de 1978, ya se encontraba en la geometría original.

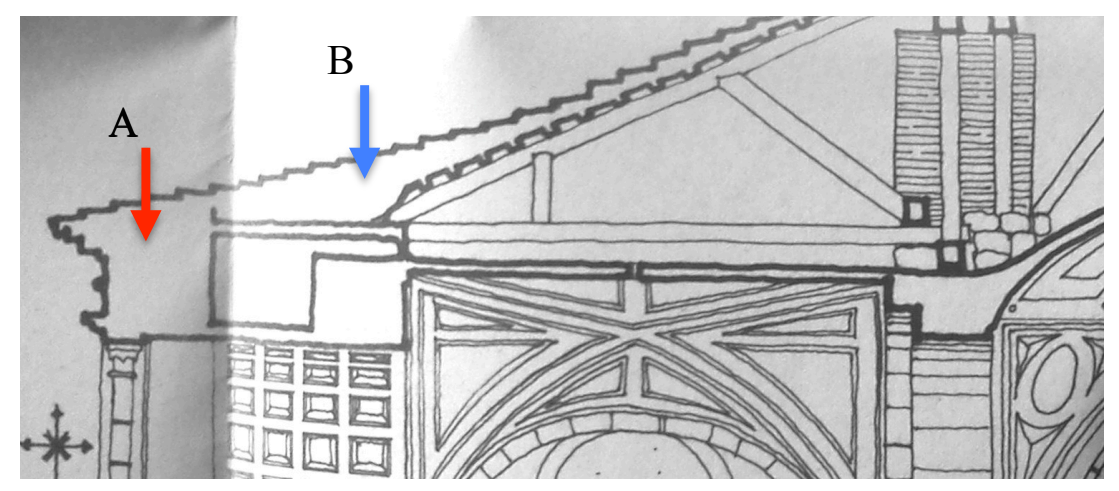

Fig.IV.139. Detalle de sección de los Santos Juanes

El zuncho perimetral de hormigón armado no llega así a conformar en este caso un anillo completo, interrumpido sólo por la macla de la torre a los pies. Tampoco ata en cabeza ambas fachadas laterales, ya que discurre como viga continua sobre apoyos puntuales en la línea de embocadura de las capillas. Ambas fachadas sólo cuentan para su atado transversal con la prolongación del tablero de hormigón sobre nervometal (de espesor variable entre 5 y $24 \mathrm{~cm}$ ).

Sobre el croquis de estructura de cubierta en el estado actual del proyecto de Hurtado se señala la zona de bóveda sobre el coro reconstruida en 1994 por Luis Navarro García con rosca de ladrillo y mortero de cal, y las grietas (marcadas a trazos) en el encuentro con los frentes de capillas de las bóvedas de naves laterales, que coinciden con el centro de los tramos en los cuales el zuncho no discurre sobre los muros de fachada C-D y E-F. 


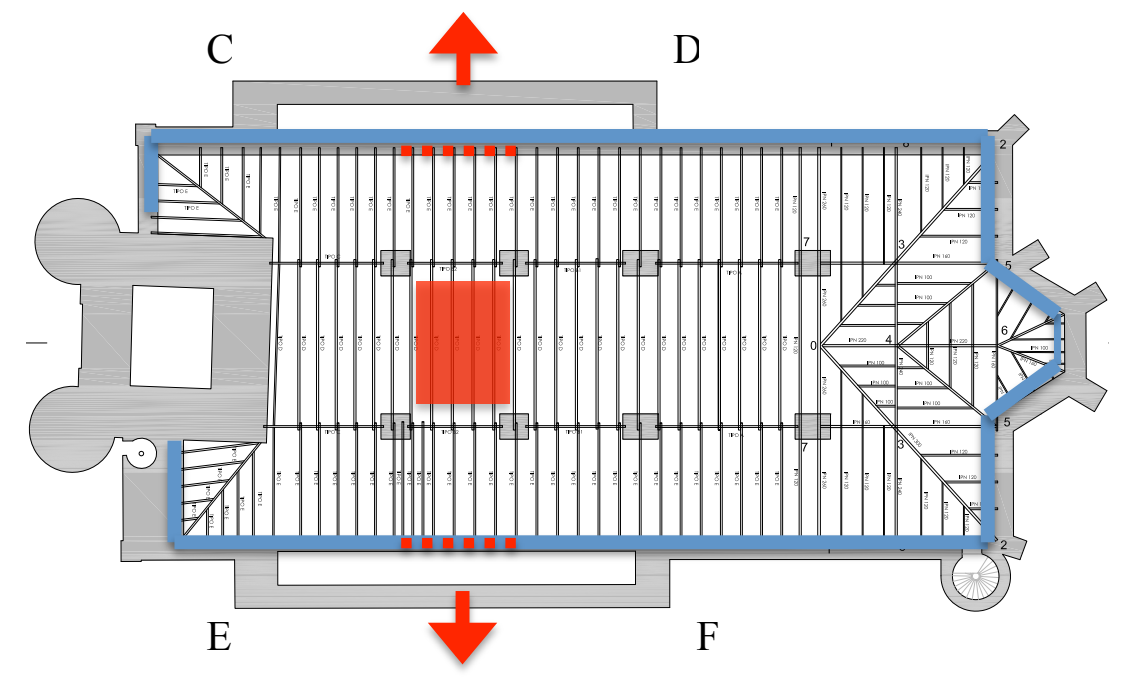

Fig.IV.140. Esquema de zunchos en los Santos Juanes de Nava del Rey

\section{IV.2.4.5. Clasificación de los zunchos observados en la labor de campo}

A la hora de clasificar la tipología de elementos estructurales que, como decíamos, se engloba bajo el concepto de zuncho, es posible adoptar distintas perspectivas.

El criterio más básico, relativo al material con que se conforman, permite diferenciar tres modelos fundamentales de atados: resueltos con madera, con hormigón armado o de metal. Es posible también encadenar con fábrica, según se ha descrito en los apartados de cinchado de cúpulas y condicionantes sísmicos. Hemos visto en el capítulo de Antecedentes ejemplos formidables, como las enormes piedras del conjunto arqueológico de Umm al Jimal (5.1. Arce, 1996). También hay sillares dentados que configuran algunos anillos de la cúpula de Santa Maria dei Fiore en Florencia $^{108}$.

En el ámbito acotado de las restauraciones realizadas sobre iglesias monumentales de la provincia de Valladolid elegidas como universo de muestra para la presente investigación, lo que encontramos incorporado en la coronación de los muros, de forma casi sistemática, son zunchos de hormigón armado. Se trata de piezas lineales de sección rectangular, ejecutadas in situ con diferentes dimensiones y ubicación en cada caso.

\footnotetext{
${ }^{108}$ Navas Gutiérrez, M. (1984). La cúpula de Santa María del Fiore. Informes de La Construcción, 36(359), 79-84.
} 
Según su esquema geométrico general se podría distinguir los casos siguientes:

- Segmentos: uno o varios tramos lineales aislados

- Continuo lateral: una única pieza longitudinal continua aislada

- Continuo paralelo: dos elementos lineales, a ambos lados de la nave $====$

- En L: ejecutados en continuidad sobre dos cerramientos en ángulo

- En U: ambos lados se prolongan sobre un testero en continuidad

- Anillo: los cuatro (o más) lados conforman un anillo cerrado

Aunque no se cuenta con el proyecto de ejecución de los años 50 en el que se definieron nuevas estructuras en La Santa Espina, en la visita se aprecia un zuncho lineal en una de las naves laterales.

En San Pablo los zunchos en paralelo de ambos laterales aparecen interrumpidos en el testero a los pies. En la cabecera hay tramos de perfil de acero laminado como piezas de reparto puntuales bajo los apoyos de las cerchas dispuestas de forma radial.

Las dos piezas lineales sobre muros de la nave central de la Catedral tampoco se prolongan sobre el testero.

En Serrada los zunchos de la nave central también se disponen en paralelo. En el proyecto se describe un zuncho en anillo sobre el tambor pero el muro se encuentra revestido por lo que no ha resultado posible verificar su existencia.

Se han señalado en el cuadro los zunchos en L observados en el bajo cubierta de San Antolín, pero debe puntualizarse que estas piezas de atado del testero son anteriores a la intervención de Paniagua.
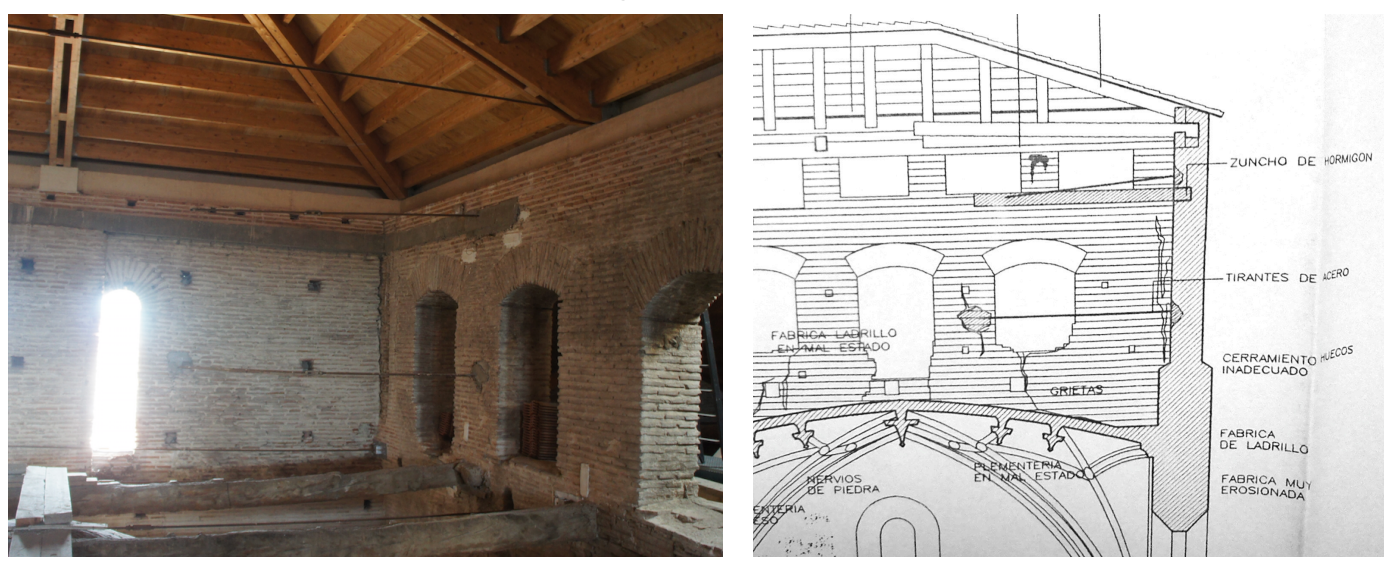

Fig.IV.141. Zuncho en L bajo el anillo posterior en San Antolín, visita 05/05/2014; plano de sección longitudinal 1999 Paniagua JCyL 
El anillo bajo cubierta de Nava del Rey se interrumpe con la macla de la torre a los pies, según se ha descrito en el apartado anterior, sobre los antecedentes estructurales.

En el resto de visitas los zunchos observados sí forman un anillo completo sobre la coronación de los muros, aunque por ejemplo en Alaejos se cierra el anillo en nave central pero no se prolonga sobre muro a los pies en los zunchos de las naves laterales.

El atado perimetral de la iglesia de Tordesillas se prolonga con perfiles de acero laminado en la macla de la torre para dar continuidad al anillo, aunque en el testero el zuncho presenta un canto mucho menor.

Y en Villaverde de Medina, aunque se interrumpe localmente la pieza sobre el muro a los pies, en la restauración se incorporó una auténtica red de zunchos, configurando hasta cuatro recintos con su anillo perimetral que se prolonga inclinado sobre los piñones de los muros diafragma interiores.

Tabla 15: Tipología del zuncho

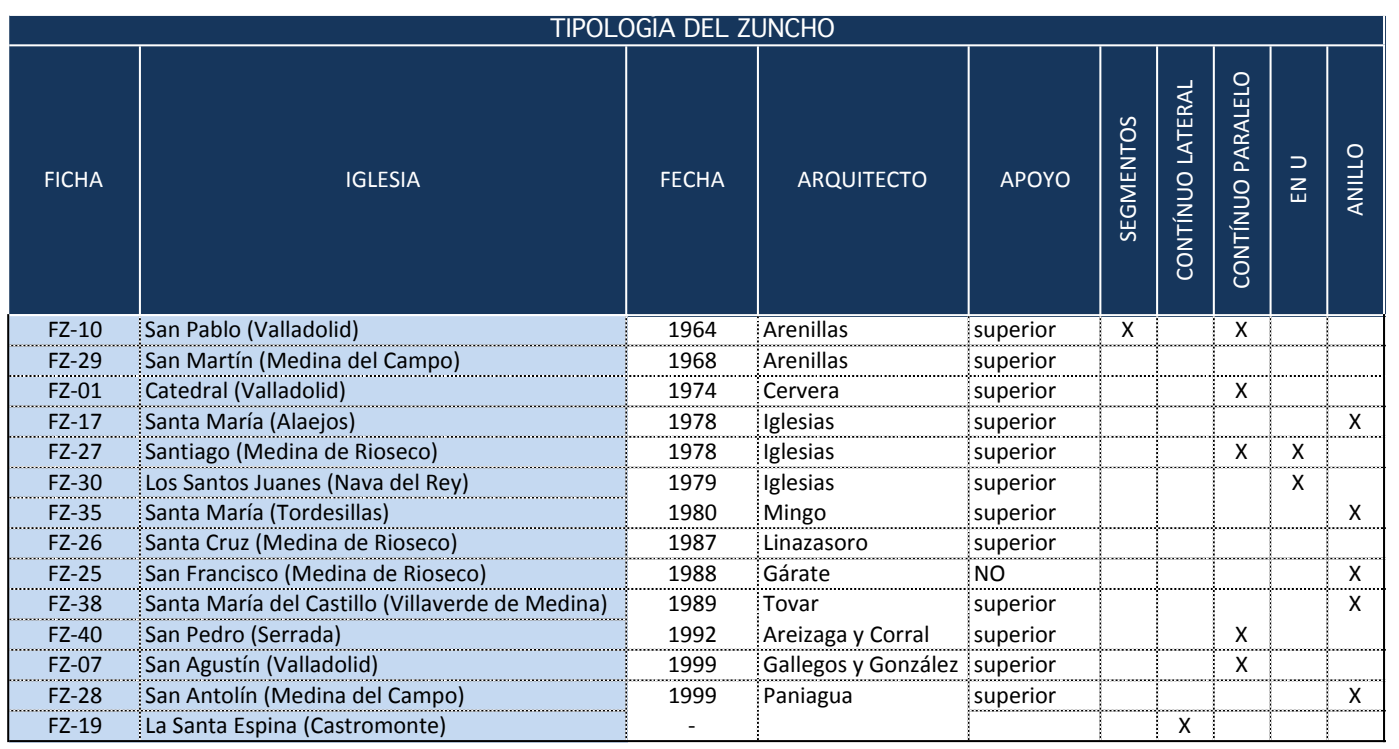

En resumen, prácticamente en la mitad de los casos estudiados, los zunchos se disponen en paralelo a ambos lados de las naves, y un porcentaje similar constituye anillos cerrados. Su descripción como elemento perimetral puede interpretarse entonces como "situado en el perímetro", sin que ello implique que se prolongue sobre el recinto completo. 


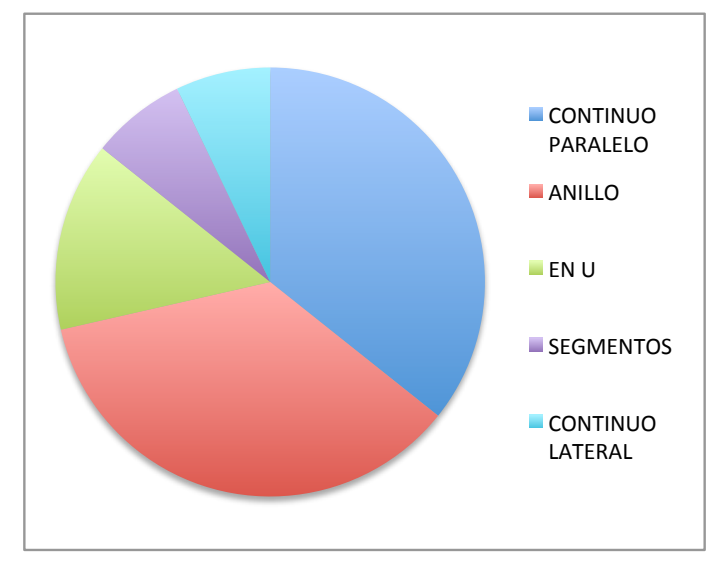

Si atendemos a cómo se percibe el zuncho desde el interior del bajo cubierta, en muchos casos la fábrica, de ladrillo o piedra, se recrece para enrasar el remate y se aprovecha como encofrado lateral perdido del zuncho. En otros se ha dispuesto un encofrado recuperable sólo durante la ejecución y el lateral del zuncho queda visto.

En cuanto a la ubicación sobre el remate del cerramiento, no se aprecia con nitidez si los zunchos tienen mayor o menor anchura y, en muchos casos, tampoco su canto real, por encontrarse embebidos o semi-encastrados en el muro. La mayor parte de las veces enrasado a cara interior o, en ocasiones, escalonado con un pequeño retranqueo.

Se recrece el remate irregular del cerramiento de piedra con un murete de fábrica de ladrillo que queda visto y actúa como encofrado lateral perdido del zuncho de hormigón sobre el que apoyan las cerchas metálicas de cubierta de la Catedral.

El remate de los muros de San Pablo es de sillares y también se emplea como encofrado perdido del zuncho.

En el resto de los casos que los zunchos quedan vistos, aparecen generalmente enrasados a cara interior.

Según se ha explicado con anterioridad, el zuncho quedaba oculto en la iglesia de San Francisco, donde sólo se ha confirmado su existencia gracias a catas practicadas a raíz de una nueva intervención.

Y en la iglesia de Santiago, por un lado aparece un típico zuncho enrasado en muros laterales y por otro un elemento lineal singular, exento, en los ejes interiores. 
Tabla 16: Situación del zuncho sobre el muro

\begin{tabular}{|c|c|c|c|c|c|}
\hline \multicolumn{6}{|c|}{ SITUACIÓN DEL ZUNCHO } \\
\hline $\mathrm{FICHA}$ & IGLESIA & FECHA & ARQUITECTO & frente & ubicación \\
\hline FZ-10 & San Pablo (Valladolid) & 1964 & Arenillas & piedra & \\
\hline$F Z-29$ & San Martín (Medina del Campo) & 1968 & Arenillas & visto & enrasado \\
\hline FZ-01 & Catedral (Valladolid) & 1974 & Cervera & ladrillo & \\
\hline$F Z-17$ & Santa María (Alaejos) & 1978 & Iglesias & visto & enrasado \\
\hline$F Z-27$ & Santiago (Medina de Rioseco) & 1978 & Iglesias & visto & enrasado \\
\hline $\mathrm{FZ}-30$ & Los Santos Juanes (Nava del Rey) & 1979 & Iglesias & visto & enrasado \\
\hline FZ-35 & Santa María (Tordesillas) & 1980 & Mingo & visto & enrasado \\
\hline FZ-26 & Santa Cruz (Medina de Rioseco) & 1987 & Linazasoro & ladrillo & \\
\hline$F Z-25$ & San Francisco (Medina de Rioseco) & 1988 & Gárate & madera & centrado \\
\hline FZ-38 & Santa María del Castillo (Villaverde de Medina) & 1989 & Tovar & visto & enrasado \\
\hline $\mathrm{FZ}-40$ & San Pedro (Serrada) & 1992 & Areizaga y Corral & visto & enrasado \\
\hline FZ-07 & San Agustín (Valladolid) & 1999 & Gallegos y González & visto & enrasado \\
\hline$F Z-28$ & San Antolín (Medina del Campo) & 1999 & Paniagua & visto & escalonado \\
\hline FZ-19 & La Santa Espina (Castromonte) & - & & visto & enrasado \\
\hline
\end{tabular}

Como se ha dicho, las dimensiones reales del zuncho no suelen coincidir con las definidas en los proyectos. Lamentablemente, en la mayor parte de los casos resulta imposible comprobar la anchura aunque se acceda al espacio bajo cubierta, por encontrarse tabicado el espacio entre apoyos. Tampoco es posible comprobar la dimensión exacta del canto en los elementos embebidos en la fábrica o si se encuentran a mucha altura sobre el trasdós de las bóvedas.

Sólo en tres de las visitas ha sido posible medir con precisión la sección del zuncho:

En San Antolín cuenta con unos 24x36.

En Tordesillas con 40x50.

En estos dos casos, precisamente, se trata de iglesias en cuyos proyectos se representa el zuncho sin proporcionar sus dimensiones.

$\mathrm{Y}$ en Alaejos se estima un ancho de $55 \mathrm{~cm}$ y $30 \mathrm{~cm}$ de canto, mientras que en proyecto se define con $30 \times 40$. 
En otros dos casos durante la visita sólo se ha podido confirmar el canto de a pieza que tampoco concuerda con el definido en los proyectos:

Así en Villaverde de Medina la pieza, diseñada en el proyecto como 70x50, presenta un canto de sólo $30 \mathrm{~cm}$, y en Serrada, donde se define de 50x45, el lateral observado no pasa de $40 \mathrm{~cm}$.

El paramento aparece recrecido con fábrica de ladrillo en la catedral, y en San Pablo con sillares de piedra, empleados como encofrado perdido de un zuncho que se embebe en el muro. La solución de Gárate en Santa Cruz donde lo centra sobre el muro y apoya la estructura en el estribo de madera que coloca delante en 1988 constituye un caso singular. En el resto de casos el zuncho suele quedar visto tras haberse ejecutado con encofrado recuperable, y sólo en una ocasión éste se centra sobre el muro, apreciándose cómo enrasa a cara interior de los paramentos interiores del bajo cubierta en todos los demás casos observados.

\section{AÑO DE ACTUACIÓN}

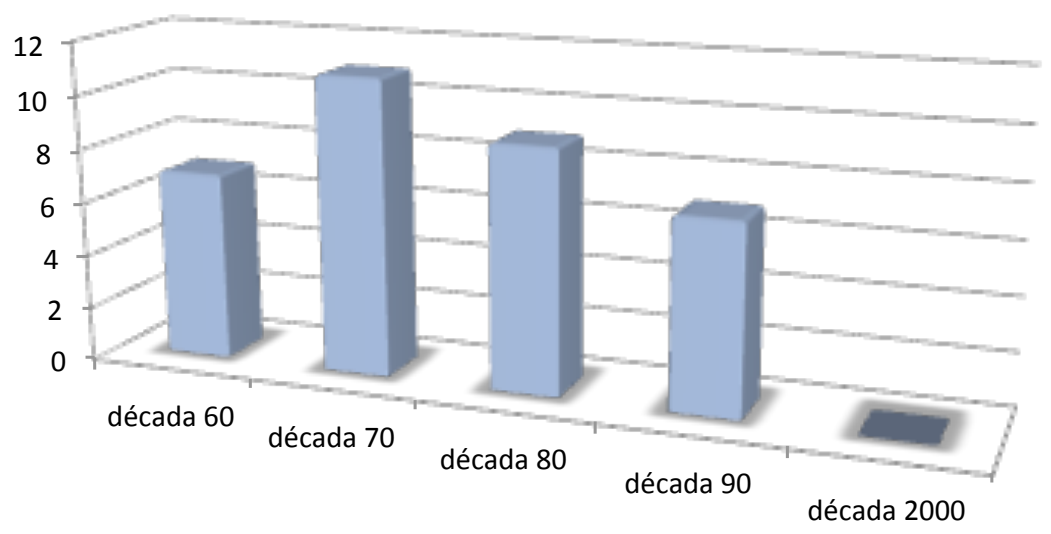

Las obras de restauración dentro del conjunto muestra seleccionado en las que se incorpora zuncho de hormigón armado se concentran en la segunda mitad del siglo XX, especialmente en los años 70. Prácticamente todas las llevadas a cabo en los 60 corrieron a cargo de Anselmo Arenillas y dos tercios de las ejecutadas en los 70, de Ana Iglesias. En los 80 y 90 cada zuncho corresponde a un arquitecto distinto.

Sólo en tres casos, de los 18 estudiados en los que se definen en el proyecto las dimensiones del zuncho previsto, se ha podido medir in situ con cierta con precisión ancho y canto del mismo. 
En cuanto al material, podemos concluir que en la mayor parte de los casos analizados en que encontramos zuncho, éste se resuelve con hormigón armado. En contadas ocasiones ${ }^{109}$ se incorporan piezas de acero laminado de forma local, como el tramo de macla con la torre de Tordesillas y los perfiles de apoyo en cabecera de San Pablo. Sólo en la obra de restauración de la Capilla en la iglesia del Salvador se emplea un complejo sistema de zunchado metálico.

En la mitad de las intervenciones comprobadas in situ el zuncho ejecutado conforma un polígono completo aunque es frecuente también encontrar nada mas dos elementos lineales dispuestos a ambos lados de la nave, sin prolongación por los testeros.

\footnotetext{
${ }^{109}$ No se ha podido visitar la iglesia del Rosarillo cuyo proyecto de restauración de 1980 incluía un zuncho de acero laminado HEB.
} 



\section{IV.3. Discusión}

Se plantean a continuación varios temas surgidos del análisis para tratar de correlacionar los datos obtenidos a partir de la revisión de los proyectos de restauración con los resultados del estudio de los propios edificios. En primer lugar se revisan aspectos relacionados con la incorporación del zuncho, en qué momento se produce ésta y cómo se define. A continuación se tratan cuestiones relacionadas con la vida útil del elemento, especialmente cómo se ha comportado a lo largo del tiempo. Por último se realiza una síntesis de todos los conceptos desarrollados.

\section{IV.3.1. Incorporación del zuncho}

Una vez confirmada la actuación precisa en que se incorporó cada zuncho a un edificio del conjunto muestra de iglesias de Valladolid, podemos estimar la fecha de las actuaciones, compararlas y evaluar la evolución de los proyectos de restauración monumental en la provincia lo largo del tiempo.

\section{IV.3.1.1. La fecha}

El estudio de los proyectos conservados en los distintos archivos desde principios del siglo XX que han sido localizados y revisados dentro de la investigación muestra un incremento de las obras a partir de mediados de los 50 que alcanza su máximo en los primeros años de la década de los 70.

Tabla 17: Fecha de los documentos revisados

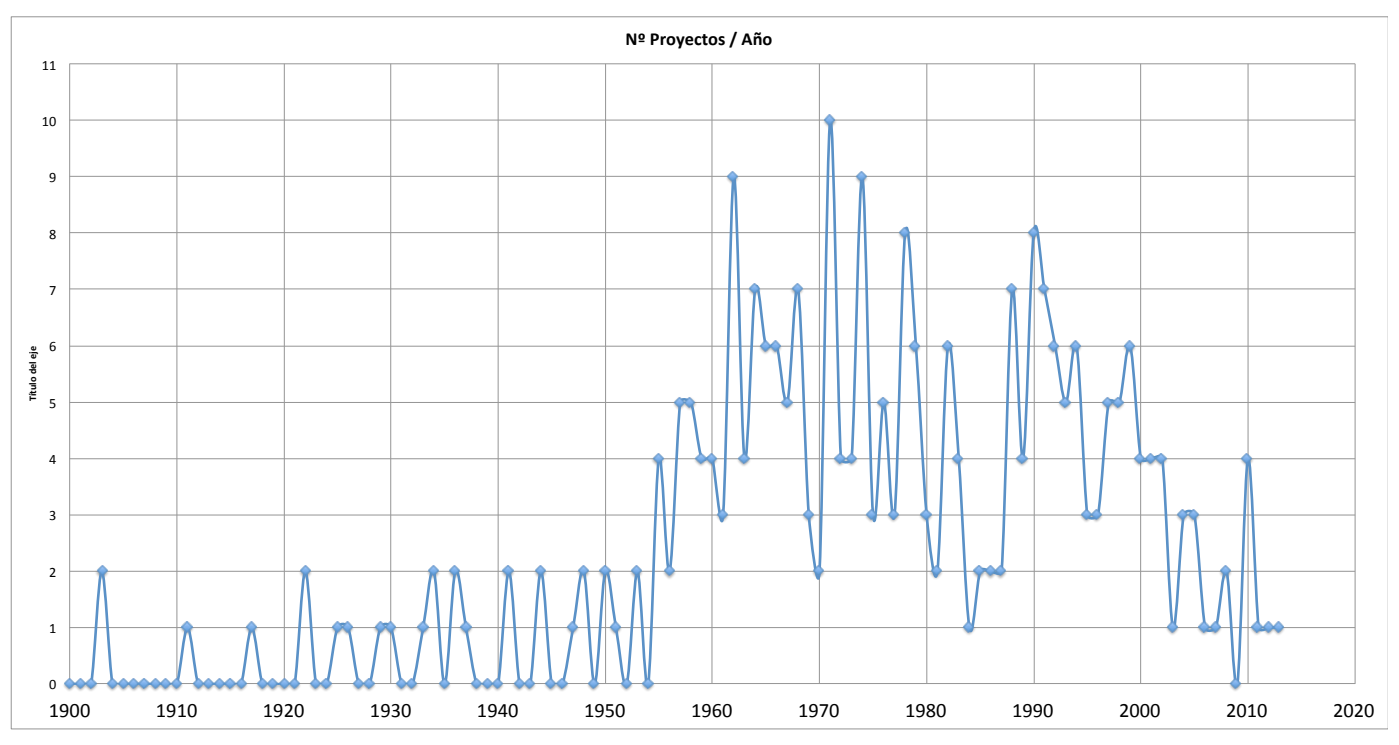


A mediados de los 80, coincidiendo con el traspaso de competencias en restauración monumental desde el Ministerio de Cultura hasta la Administración Autonómica, puede apreciarse cómo se reduce drásticamente y estanca el número de proyectos relacionados con los 40 edificios seleccionados, con sólo uno en 1984, hasta que vuelve a remontar y se alcanza otro pico en el número de intervenciones hacia 1990.

Si dentro del conjunto de proyectos revisados se considera sólo aquellos en que se incorpora zunchos en la coronación de los muros, puede apreciarse cómo sólo en el año 1974 se ejecutan en cuatro edificios, manteniéndose su uso hasta la interrupción en torno a 1984 para reanudarse en los años siguientes.

Tabla 18: Número de proyectos con zuncho por año

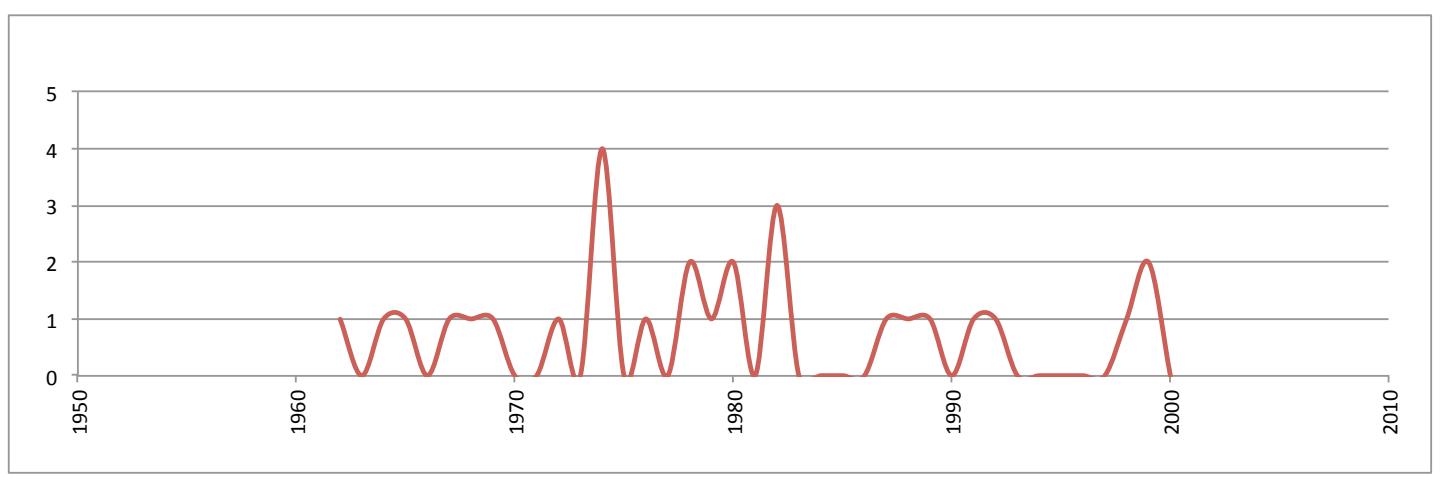

Parece entonces que, dentro de la muestra analizada, hay ejecución de zunchos tanto antes como después de la transferencia a las Comunidades Autónomas. Tanto los arquitectos contratados por la Administración central: Arenillas, Cervera e Iglesias como los que actúan en los años siguientes, con despacho también en Madrid: Pérez Medina, Gómez Santander, Linazasoro... Una vez consolidada la gestión de la Junta de Castilla y Leónlos proyectos corren a cargo de arquitectos afincados en Valladolid y profesores de la ETSAV: Gatón, González, Mingo, Tovar, Paniagua, etc.

Con el cambio de siglo, sin embargo, sólo aparece una incorporación de zunchado en uno de estos edificios. Se trata de la obra realizada por González Fraile en cabecera y capilla de la iglesia de El Salvador en 2006 y el refuerzo es metálico, con un singular esquema que denomina "brida". En ese templo ya se había llevado a cabo, además, una restauración de las cubiertas en 1999 a cargo de Álvaro Abad en la que reorganiza la estructura de cubierta colocando una similar a la existente pero 
con mayores escuadrías de madera aserrada y distinto inter-eje sin incorporar ningún elemento de hormigón.

¿Tendrá relación entonces la prácticamente repentina desaparición del zuncho en los proyectos de restauración de iglesias de Valladolid con el cambio teórico de los criterios de intervención resumido en el apartado III.3.1 de los antecedentes ${ }^{109}$ ?

Es posible que la participación directa de los técnicos locales en la elaboración de la Carta de Cracovia, con la reunión previa en la ciudad de un grupo de expertos internacionales organizada por el Instituto Español de Arquitectura, favoreciese su alineamiento con las teorías más avanzadas de la época, que precisamente el año 2000 planteaban la necesidad de recuperar el conocimiento y empleo en restauración de edificios históricos de los materiales y técnicas constructivas tradicionales con que se levantaron los mismos.

\section{IV.3.1.2. El detalle}

En el epígrafe sobre la cornisa del apartado Análisis se ha visto cómo la falta de definición en los proyectos de restauración de la zona donde se incorpora habitualmente el zuncho, precisamente en el encuentro alero-cornisa, incide en el deterioro de todo el conjunto. Veamos hasta qué punto la patología de las cubiertas que se rehabilitan en nuestro país está relacionada con la "dejación de funciones del proyectista".

Para analizar el deterioro de una cubierta se deben conocer (Galindo 1999) ${ }^{110}$ :

- Sus componentes constructivos, tanto aislados como en conjunto.

- Las acciones que actúan sobre ellos.

- El comportamiento de dichos componentes frente a las citadas acciones.

\footnotetext{
${ }^{109}$ En un artículo (Noguera, 2006) sobre las Cartas en una de las revistas del Instituto de Restauración del Patrimonio de la Politécnica de Valencia, se compara el tratamiento de varios conceptos fundamentales en una selección de ellas (Atenas, Venecia, Cracovia y tres italianas de 1931, 1972 y 1987): anastilosis, mantenimiento, reversibilidad, etc. En cuanto al empleo de técnicas modernas, los primeros textos aceptan su empleo cuando los métodos tradicionales no alcancen los objetivos propuestos, en el 87 se recomienda cadenas y zunchos frente a inserciones ocultas, pretensados o inyecciones, y por fin en el 2000 se propugna la vuelta al conocimiento de las materiales tradicionales y al mantenimiento (página III.31).

${ }^{110}$ Galindo, P. (1999) Comportamiento y diagnóstico de la cubierta. En Tratado de Rehabilitación, Vol.4 (331-339). Madrid: Munilla-Lería.
} 

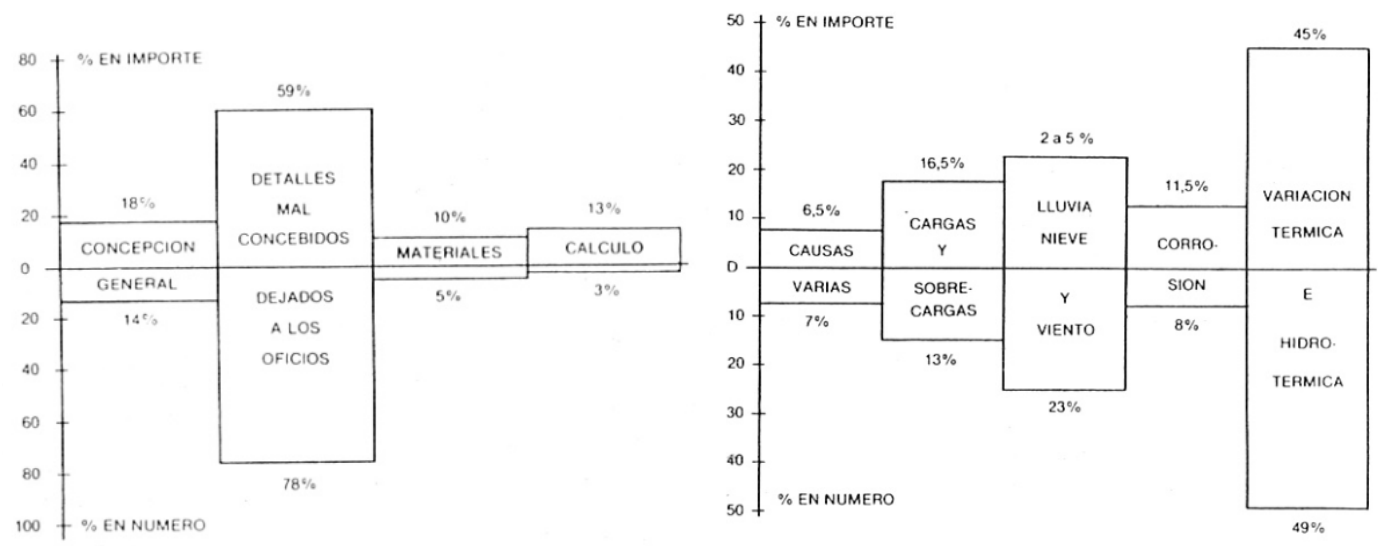

Fig.IV.142. Causas de siniestros de cubiertas (Galindo 1999, 331-332)

Si analizamos las causas de daños en las cubiertas de los edificios a través de su proceso constructivo empleando unas gráficas ${ }^{111}$ incluidas en el Tratado de Rehabilitación, vemos que la mayor parte se debe a "detalles mal concebidos dejados a los oficios". Este dato confirma la reflexión del apartado anterior según la cual los problemas ocasionados por algunos de los zunchos estudiados están originados por la mala definición de los mismos en los proyectos de restauración correspondientes.

En cuanto a la influencia de los agentes externos, prácticamente la mitad de los problemas detectados en su estudio proceden de variaciones térmicas e higrotérmicas y una cuarta parte de la falta de estanqueidad. Las variaciones de temperatura producen alargamientos y acortamientos del tablero, que presenta comportamiento distinto según su naturaleza, si está resuelto con madera, cerámica o chapa. La cobertura de teja exige para su buen funcionamiento una sujeción y solapes acordes con la pendiente, el reemplazo de piezas rotas y el correcto remate de los encuentros con las paredes.

Según el profesor Monjo ${ }^{112}$ las lesiones más destacadas sobre aleros y cornisas son las humedades, debidas a su alto nivel de exposición. Son determinantes además para estos elementos los cambios de temperatura, que provocan desprendimientos, grietas, fisuras y erosiones. Si el alero con caída libre del agua no tiene goterón, o bien su vuelo o inclinación son insuficientes, se produce la vuelta hacia atrás de la gota.

\footnotetext{
${ }^{111}$ Debemos puntualizar que los datos manejados por Galindo no se limitan a edificios monumentales, sino que más de la mitad de los mismos corresponden a edificios de viviendas.

${ }^{112}$ Monjo, J. (1999) Aleros y cornisas. En Tratado de Rehabilitación, Vol.4 (341-360). Madrid: Munilla-Lería.
} 


\section{IV.3.1.3. EI anillo}

En muchos de los ejemplos analizados los zunchos son elementos lineales que se colocan sólo en ambos laterales, sin prolongarse sobre los testeros a los pies del templo o en la cabecera.

Hemos visto en las conclusiones previas obtenidas en el caso de estudio de Santa María de Alaejos, por ejemplo, cómo en su proyecto de 1974 Ana Iglesias representa sobre la planta de estructura reformada un zuncho perimetral completo. En los rótulos se define además con gran precisión como "zuncho interior perimetral de atado hormigón 40x40".

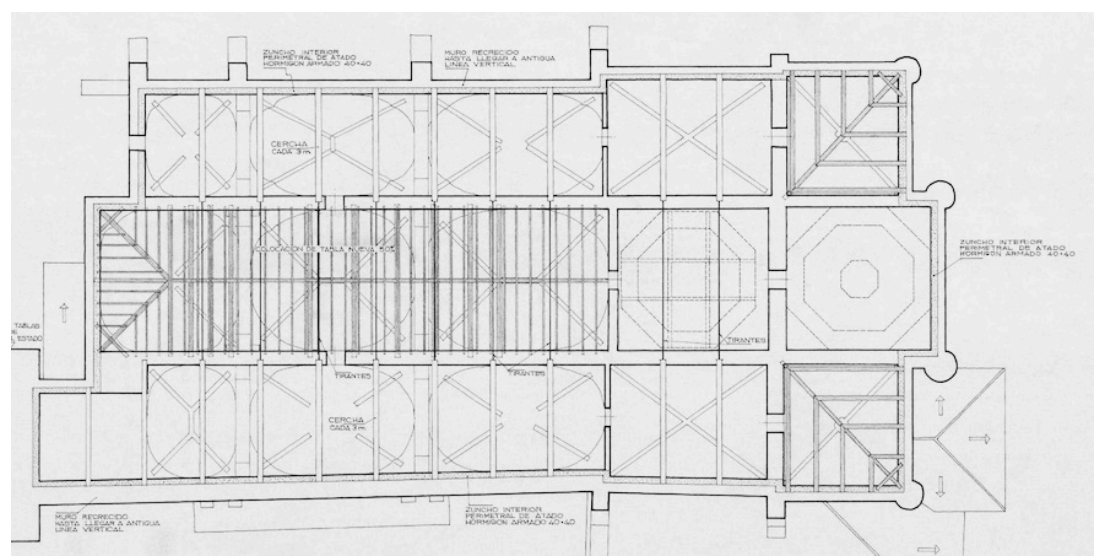

Fig.IV.143. Planta de estructura de cubierta 1974 Iglesias IPCE

En la visita al citado edificio, sin embargo, puede apreciarse que, aunque hay un zuncho 55x30 que sí cierra un anillo completo en el volumen de la nave central, en las naves laterales el zuncho que discurre por los muros laterales no se prolonga por los testeros a los pies.

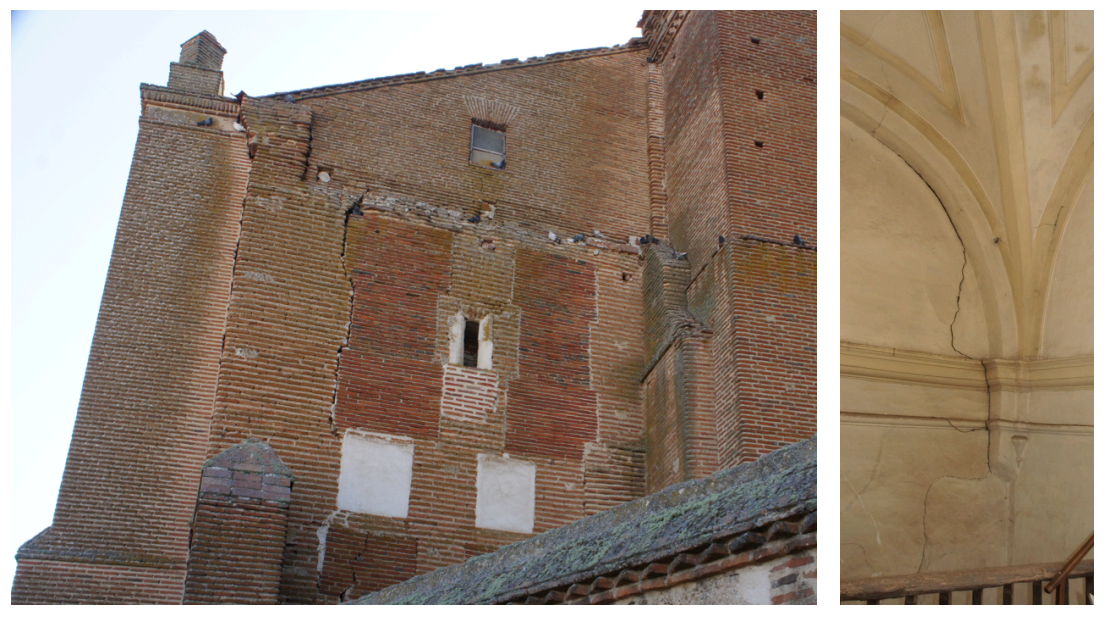

Fig.IV.144. Grieta en testero de Alaejos, visita 02/09/2014

En uno de estos testeros, cerca de la esquina opuesta a la torre, es precisamente donde encontramos una apreciable grieta que atraviesa la fábrica de arriba a abajo. 
En algunos casos el zuncho se dispone sobre la coronación de cerramientos de fábrica de ladrillo pero no se prolonga en los tramos de los mismos resueltos con piedra. En Santa María de Tordesillas el anillo perimetral se cierra empleando perfiles de acero laminado adosados al muro de la torre que forma una macla con el cuerpo de la nave. Estos perfiles se apoyan sobre ménsulas y enanos de acero sin alterar con cajeados el espesor de la sillería.

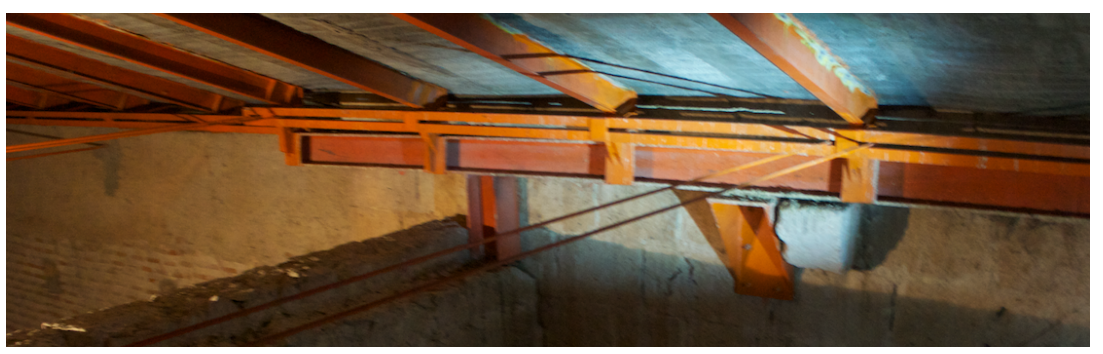

Fig.IV.145. Zuncho de acero adosado a torre Tordesillas, visita 16/12/2013

El material que conforma los muros influye efectivamente en la resolución de los zunchos que se incorporan sobre los mismos. Sin duda cajear un cerramiento de fábrica de ladrillo va a resultar más fácil y barato que adaptar un muro de cantería. Hemos visto cómo en varios de los casos se recrece con fábrica de ladrillo muros de piedra hasta alcanzar la cota deseada para disponer el zuncho. Así lo hace Luis Cervera en la Catedral.

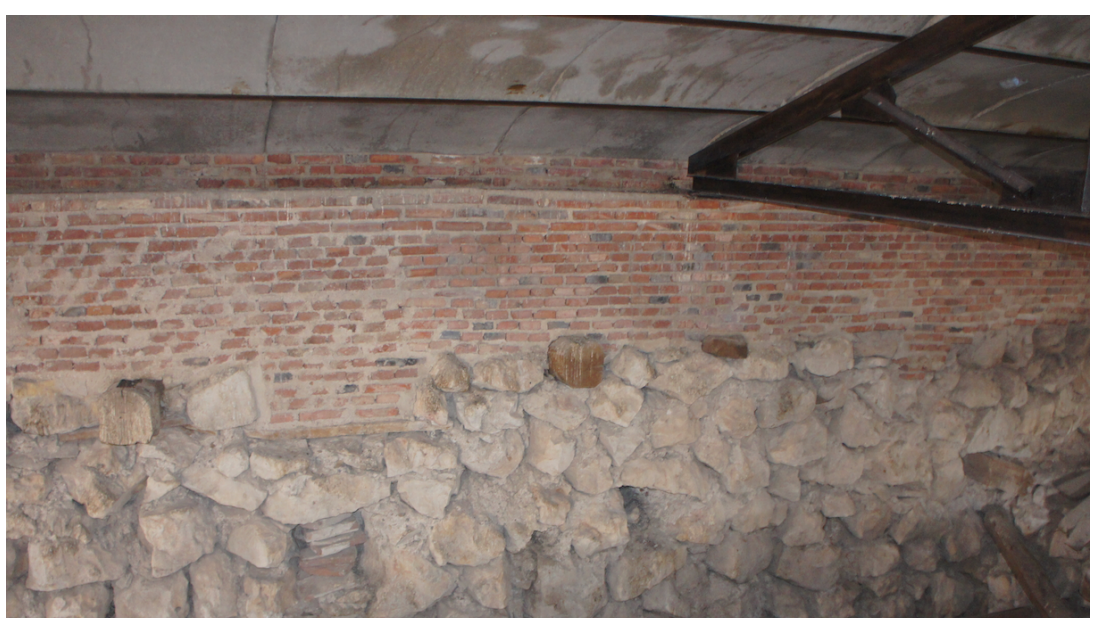

Fig.IV.146. Zuncho embebido en Catedral, visita 10/05/2012 


\section{IV.3.2. Relación del empleo de zuncho con la solución estructural elegida}

Cuando la arquitecto Ana Iglesias sustituye en 1979 las armaduras de los Santos Juanes en Nava del Rey por cerchas metálicas con tablero de nervometal con hormigón apoya éstas sobre el clásico zuncho perimetral de hormigón armado. Según hemos comentado en la página IV.12, este reemplazo se produce a solicitud de la Propiedad para aumentar la seguridad en caso de retejo, ya que la madera se encontraba en unas condiciones aceptables que no precisaban su retirada. Vemos así cómo el uso del zuncho de hormigón, en este caso, va ligado a la nueva solución de estructura metálica de cubierta y no aparece relacionado con necesidades de consolidación o remate de los muros.

En otras ocasiones, sin embargo, encontramos zunchos dispuestos específicamente para reforzar y dar continuidad al propio muro. Ignacio Gárate en la memoria de su proyecto de restauración de la iglesia de San Francisco en Medina de Rioseco de 1988 explica los problemas que observa en la cubierta:

"La patología de la cubierta de la iglesia responde al ya clásico problema de las estructuras insuficientemente atirantadas y en las que el esquema del recorrido de los empujes no se encuentra satisfactoriamente resuelto en su aspecto constructivo. Esto se debe fundamentalmente a dos causas: por una parte la falta de eficiencia de los tirantes de madera, a base de rollizos de sección excéntrica que hacen problemático el equilibrio de par y tirante, originándose una concentración de esfuerzos excesiva en la zona de borde del muro de apoyo. El segundo motivo que resulta complementario del anterior es el de la diversidad de materiales que configuran esta zona de apoyo, debida sin duda a las sucesivas obras de reforma sufridas a lo largo del tiempo. Esta situación produce una falta de resistencia en el sentido del eje del muro, generando unos agrietamientos en las zonas de mayor debilidad o de menor traba... Otro tanto puede decirse en lo que se refiere al estado de la cornisa que adolece de una morfología constructiva común. Aquí la solución adoptada que la dota de continuidad es la construcción del ya clásico zuncho de apoyo perimetral que viene a sustituir parcialmente el trabajo de los antiguos durmientes".

Vemos así en este proyecto cómo el zuncho se hormigona con la capa de compresión que cubre la tablazón de madera y se ubica en el eje del muro destinado a reforzar la continuidad de la fábrica, disponiendo en paralelo por la cara interior un durmiente de madera sobre el que apoya las cerchas. La concordancia de lo ejecutado 
con el detalle del proyecto ha podido comprobarse a través de las imágenes de catas realizadas por el profesor Alfonso Basterra ${ }^{113}$.
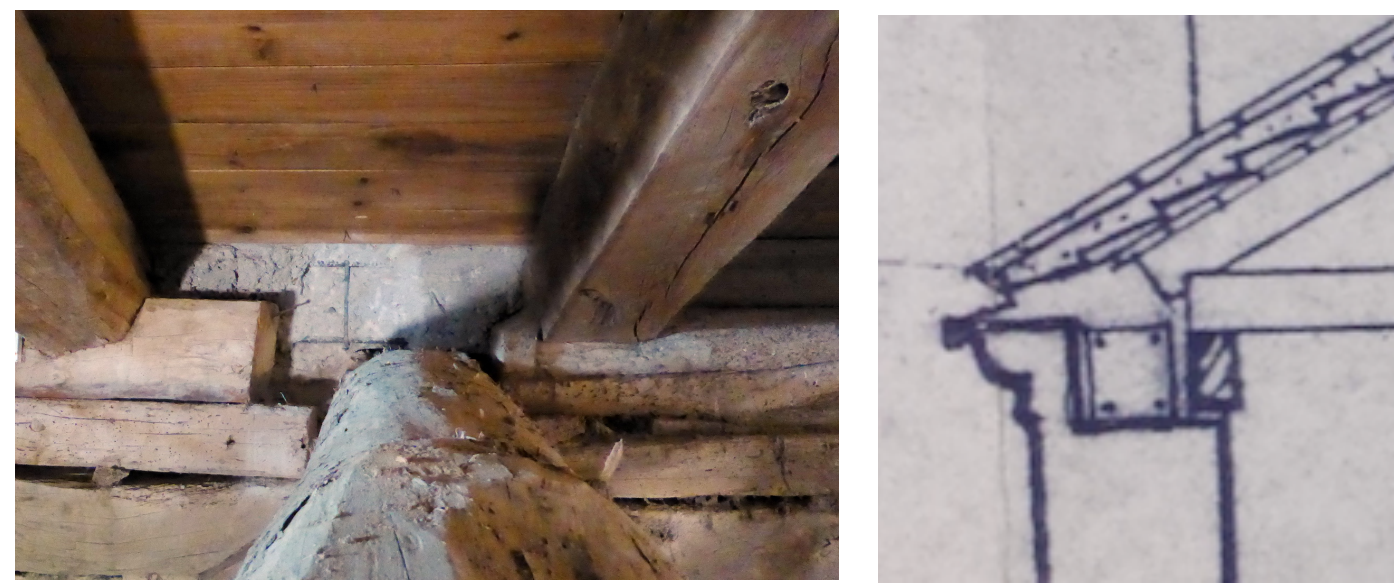

Fig.IV.147. Cata en San Francisco 2015 Basterra; detalle proyecto 1988 Gárate JCyL

\section{IV.3.3. Comportamiento del zuncho}

Tras analizar cuándo y cómo se han incorporado los zunchos en los edificios estudiados, falta comprobar cómo se han comportado éstos a lo largo del tiempo.

Al sustituir las armaduras por estructuras nuevas es frecuente disponer el zuncho como atado. Sin embargo en esas intervenciones suelen eliminarse tirantes de madera dejando restos de las cabezas embebidas en los muros, como los que se aprecian en la fotografía anterior del bajo cubierta de la Catedral.

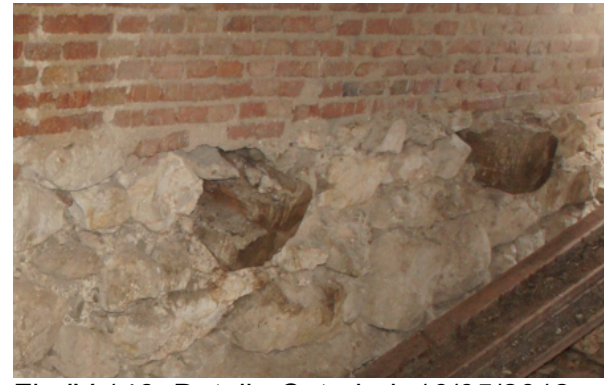

Fig.IV.148. Detalle Catedral, 10/05/2012

Entre el conjunto de actuaciones que acompañan a la ejecución del zuncho, suele encontrarse esta operación, que merma el atado transversal del edificio por encima del nivel de las bóvedas.

En algunos casos, como en las iglesias de San Antolín en Medina del Campo y Santos Juanes en Nava del Rey, pueden observarse piezas que se encuentran, en general, sanas.

\footnotetext{
${ }^{113}$ Catedrático director del Departamento de Construcción de la UVa
} 

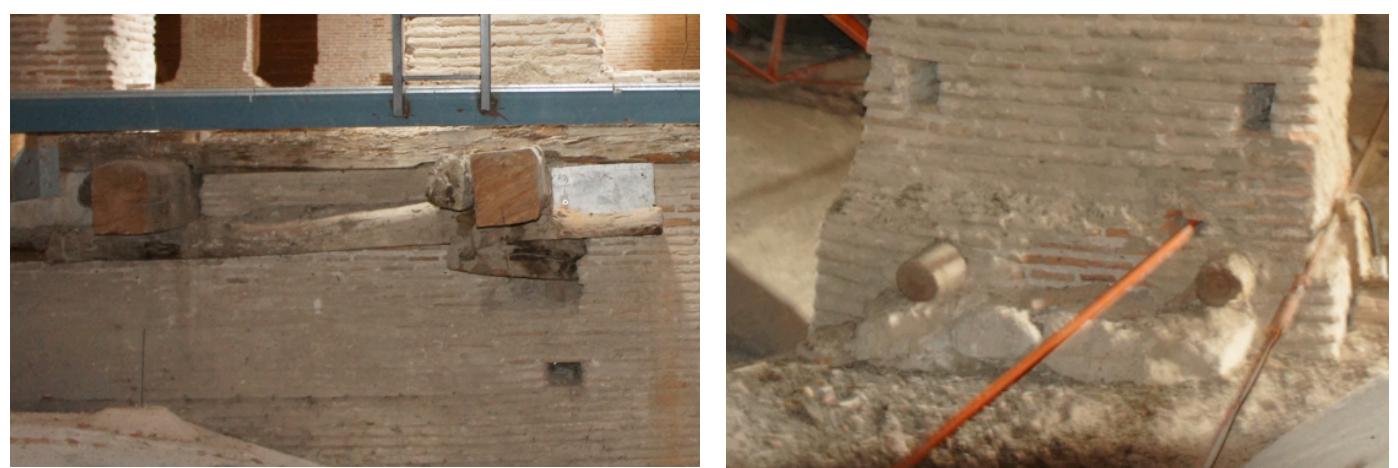

Fig.IV.149. Tirantes cortados en San Antolín y Santos Juanes, 05/05/2014 y 20/06/2012

La eliminación de los tirantes de madera afecta al comportamiento estructural del conjunto, ya que el arriostramiento transversal de los muros queda encomendado a la nueva estructura a nivel de cornisa. En las dos iglesias citadas se dispusieron tensores metálicos en la cota de los antiguos tirantes intermedios para resolver el problema.

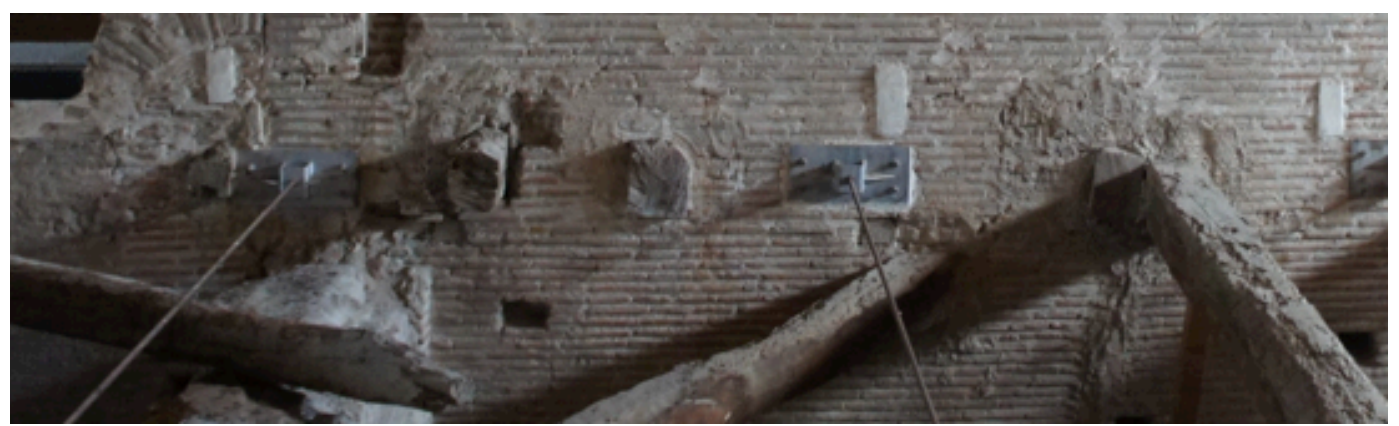

Fig.IV.150. Tensores en San Antolín 05/05/2014

En Alaejos quedan unas ménsulas pareadas y, en algunos casos, uno de los tirantes se conserva tras quedar encastrado en las bóvedas de ladrillo en el momento de voltearse éstas.
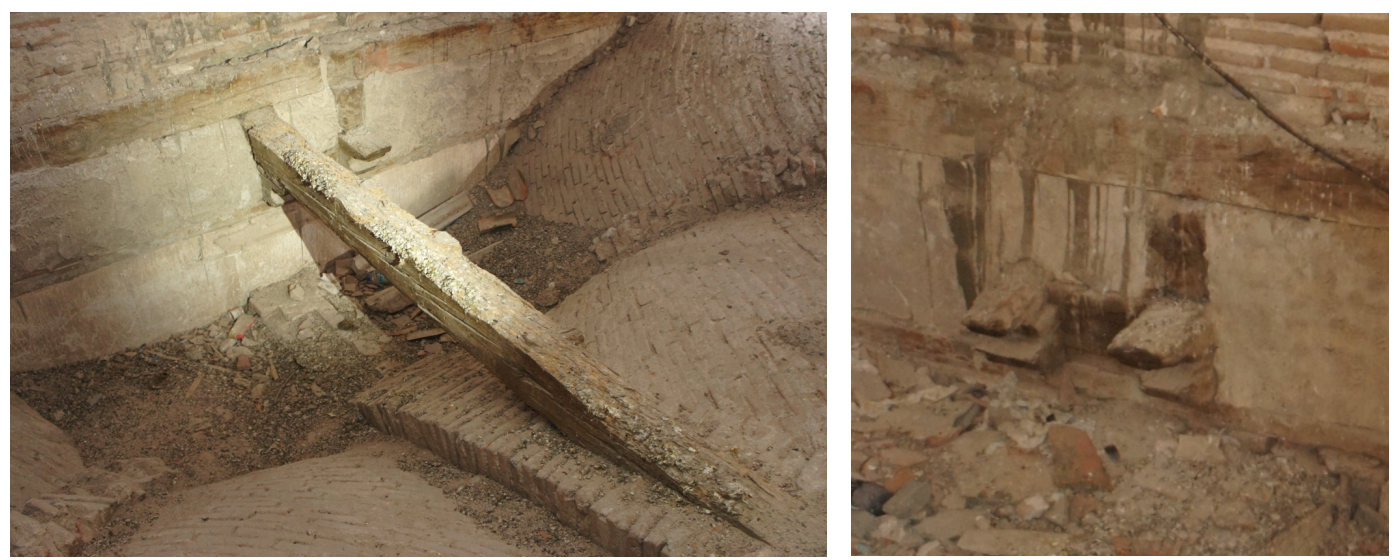

Fig.IV.151. Ménsulas en bajo cubierta de Alaejos, 02/09/2014 


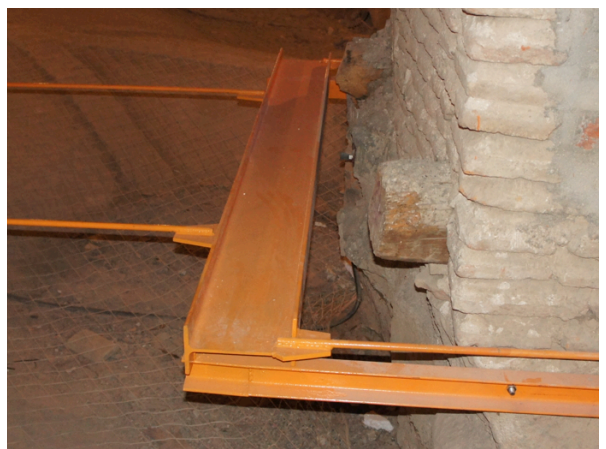

Fig.IV.152. Nava del Rey, 25/06/2013
En el caso de Nava del Rey, los tensores dispuestos en los 70 por Ana Iglesias a nivel inferior fueron suplementados en la última intervención reciente sobre el templo mediante unos aparatos de acero laminado que sorteaban los machones de fábrica del bajo cubierta.

A la vista de los ejemplos anteriores, puede concluirse que la sustitución de las armaduras por estructuras nuevas suele conllevar la desaparición de elementos adicionales de atado transversal intermedio entre los cerramientos de los edificios.

\section{IV.3.4. Síntesis de los conceptos desarrollados}

La palabra zuncho se emplea en España en las obras de restauración de edificios históricos para nombrar un elemento, generalmente de hormigón armado, que suele incorporarse sobre la coronación de los cerramientos cuando se actúa sobre las estructuras de cubierta de los mismos.

Tradicionalmente se han incorporado en ese punto piezas lineales de madera que formaban parte de la estructura de cubierta, como la solera y el estribo. El arquitecto Anselmo Arenillas dispuso en los años 60 estos elementos resueltos con hormigón armado en varios de los casos seleccionados para la investigación y los denominó en sus proyectos solera o solerón, sin emplear aún el término zuncho. En uno de los casos los describe también como cadenas, enlazando con la tradición que durante siglos empleaba esta palabra y su derivada encadenado para referirse a las piezas de atado embebidas en los cerramientos de fábrica para reforzar su continuidad.

Alrededor de 1970 se empiezan a incorporar estas piezas, descritas en la documentación de la mayor parte de los proyectos de restauración monumental como zunchos de atado perimetral.

En el estado del arte de la investigación se ha establecido que los criterios de intervención de los arquitectos desde mediados del siglo XX han sido determinados por tres aspectos: 
- Las Cartas y leyes, que han ido evolucionando hasta adoptar posturas cada vez más respetuosas hacia los edificios históricos

- La formación académica, que en un momento dado abandona el estudio de los sistemas constructivos tradicionales, especialmente los muros de fábrica y las armaduras de madera, para centrarse exclusivamente en el análisis de las estructuras de hormigón y acero.

- Las herramientas con que los profesionales apoyan su tarea, como el manual de López Collado, donde se recomienda la sustitución de las estructuras históricas por hormigón y acero.

En la actualidad aún se están publicando manuales que recomiendan emplear de forma sistemática determinadas soluciones constructivas que deberían aplicarse sólo tras un proceso previo de reflexión.

En Portugal no se ha abandonado nunca el empleo de madera para reparar las armaduras de cubierta de sus iglesias monumentales.

En Italia se ha mantenido la costumbre de atirantar con metal, adoptándose en los últimos años complejas soluciones de refuerzo de estructuras de fábrica con cables y tensores activos. Los graves daños causados por terremotos en sus edificios patrimoniales, con inercias alteradas por el uso de hormigón, ha llevado a los profesionales de la restauración a proscribir su empleo, favoreciendo el uso de materiales ligeros, incluso de tipo textil.

Entre las últimas tendencias del sector se encuentra la Des-restauración, que ha llevado incluso a demoler zunchos de hormigón incorporados en intervenciones anteriores.

En cuanto a los resultados de la investigación, se debe resaltar que han sido obtenidos a partir del análisis de 40 casos seleccionados, una muestra restringida a la provincia de Valladolid. Se trata de un grupo de iglesias en las que ya se había intervenido al menos una vez, antes de 1984, mediante un proyecto gestionado desde el Ministerio de Cultura, lo que ha permitido valorar la diferencia de criterios aplicados en ambos contextos. 
El hecho de contar con esa actuación previa, en muchos casos incorporando zunchos en los 70 y 80, condiciona los resultados posteriores, ya que las obras de los 90 llevadas a cabo desde el Servicio de Patrimonio de la Junta de Castilla y León no se enfrentaron a los mismos requerimientos que se pudieron producir en iglesias que no habían sido restauradas durante esos años.

Aunque el estudio se ha centrado en iglesias de Valladolid, según se ha dicho, en los antecedentes se han documentado problemas y soluciones similares en otras provincias.

El análisis de los edificios ha confirmado la gran dificultad que puede llegar a presentar la comprobación de la existencia de zunchos en el bajo cubierta. En primer lugar se encuentra en lugares a los que en algunos casos ni siquiera hay acceso o éste se produce en condiciones poco seguras.

El elemento a veces no se encuentra a la vista, está revestido o incluso embebido en los muros. En las tres ermitas románicas visitadas, por ejemplo, se supone que el relleno del trasdós de bóvedas fue reemplazado por tabiquillos o correas metálicas con tablero de rasilla pero es imposible comprobarlo mediante la simple observación.

El análisis de las memorias de los proyectos indica que prácticamente un tercio de las intervenciones se produjeron tras el hundimiento de elementos de la cubierta, debido a la pudrición de piezas de la estructura de madera, a raíz del deterioro causado por la entrada de agua. En general las obras se acometieron porque era necesario intervenir.

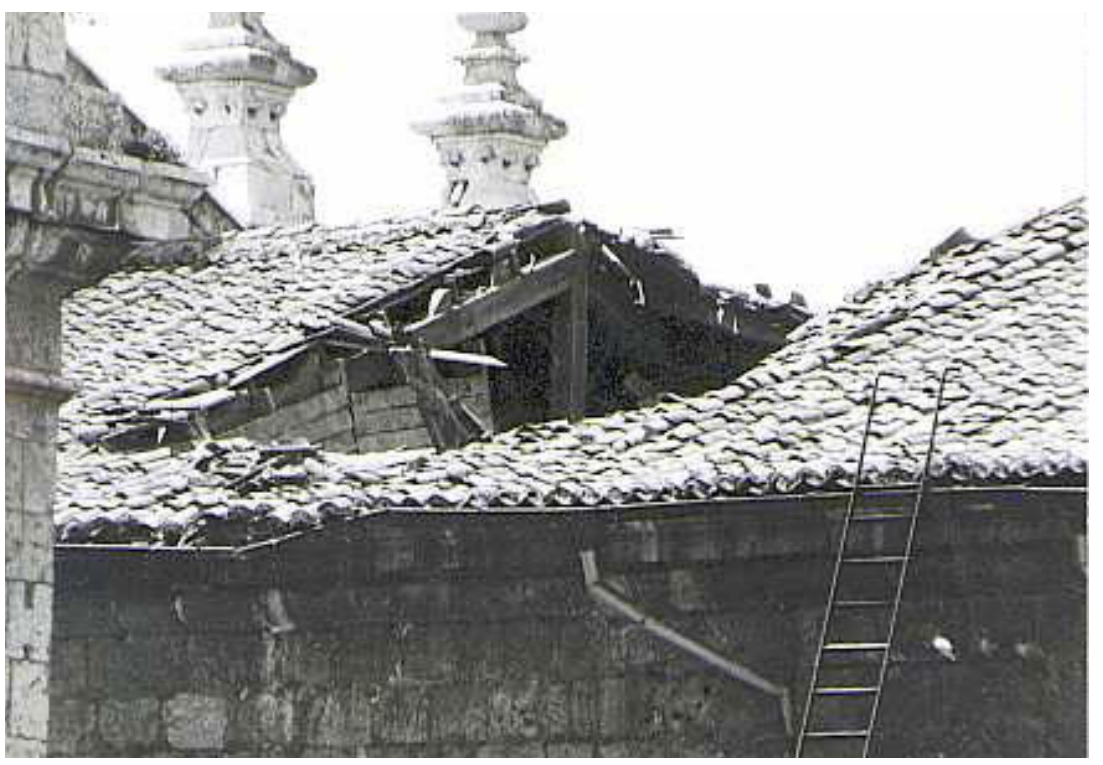

Fig.IV.153. Hundimiento de cerchas en la Catedral de Valladolid 4006 AMVA 
En muchos casos las armaduras se encontraban apeadas antes de la restauración con acodalamientos provisionales dispuestos entre las piezas de madera, contra los muros o sobre el trasdós de las bóvedas.

Para la arquitecto Ana Iglesias, responsable de la mayor parte de las intervenciones documentadas en los 70 , el zuncho de hormigón era un elemento necesario ${ }^{114}$ de atado perimetral que servía a la vez de apoyo y anclaje a la nueva estructura. Otros técnicos que intervienen en la misma época lo disponen sólo con el objetivo de apoyar las cerchas.

Es frecuente que no se especifiquen en los planos la ubicación y las dimensiones de los zunchos representados. Hay muchos proyectos donde ni siquiera aparecen en los planos los zunchos que se mencionan en las memorias o dimensionan en los presupuestos. Bastantes secciones son simples esquemas. Cuando se definen con cierta precisión, además, suelen no coincidir los datos con lo realmente ejecutado.

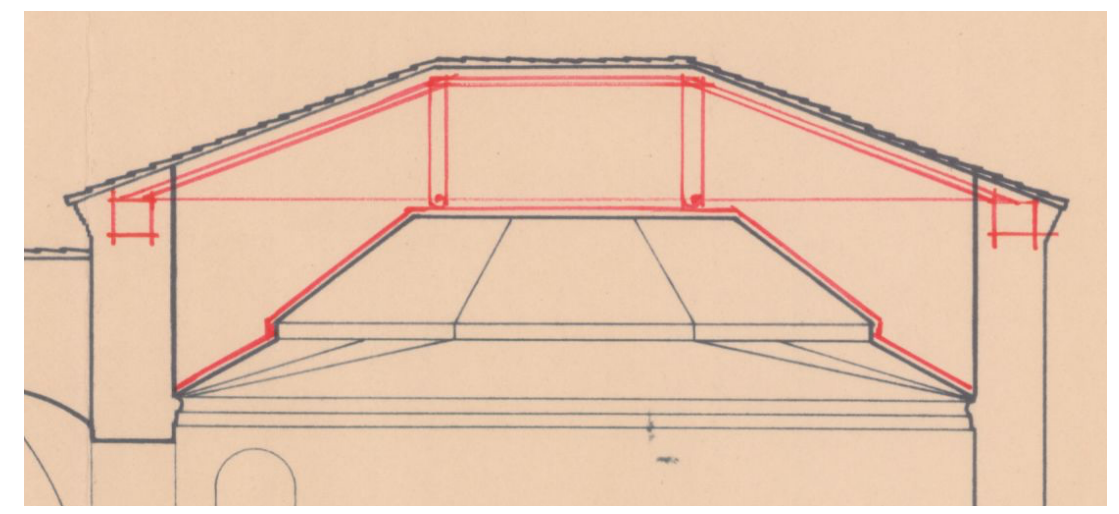

Fig.IV.154. Sección San Martín 1968 Arenillas AGA

La colocación de zunchos se plantea en proyectos de restauración de todo tipo de iglesias, desde ermitas hasta catedrales. La mayor parte de los edificios de la muestra situados en la capital son templos de una sola nave con capillas laterales, mientras que entre los del resto de la provincia abundan los que cuentan con naves laterales sin capillas. En varios casos una sección basilical con nave central más alta se ha modificado a lo largo del tiempo para incluir las tres naves bajo una única cubierta.

\footnotetext{
${ }^{114}$ En Nava del Rey se sustituye unas armaduras que se encontraban en buen estado por nueva estructura metálica, al parecer a solicitud de la propiedad que deseaba reducir una pendiente insegura para el retejo, y se coloca zuncho a pesar de no haberse producido problemas estructurales en la cubierta ni en los muros.
} 
En las restauraciones estudiadas se reconstruyen, añaden y retiran elementos añadidos, ya sean bóvedas de ladrillo, capillas adosadas, torres o sacristías.

El zuncho da continuidad al muro de fábrica ${ }^{115}$. Suele responder también a la necesidad de sanear la coronación de los muros, que a veces se resuelve demoliendo una cierta altura del remate de fábrica y levantándola de nuevo. La costumbre de descarnar los muros en la segunda mitad del siglo XX facilita la identificación de los materiales que los forman aunque, lamentablemente, éstos quedan desprotegidos.

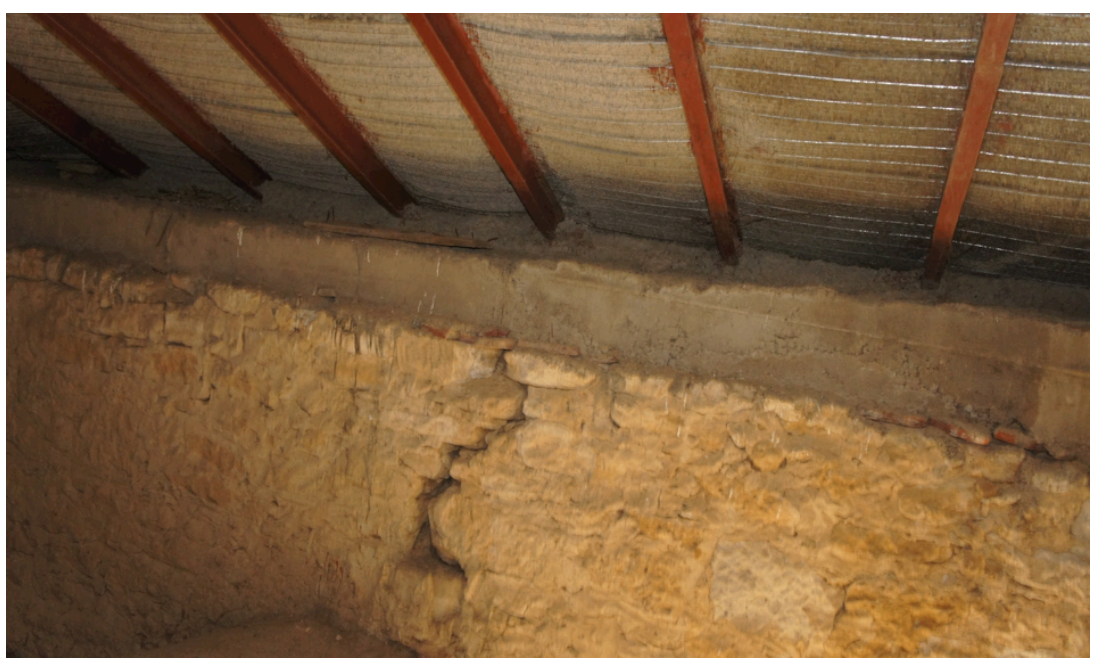

Fig.IV.155. Zunchado en la cabecera de Santa Cruz, Ana Iglesias 1979

La mayor parte de las iglesias revisadas cuentan con recubrimiento de los tableros resuelto con teja cerámica curva.

La pendiente de los faldones de la mayor parte de los casos estudiados ${ }^{116}$ se encuentra entre 20 y $30^{\circ}$, a pesar de las recomendaciones de los Tratados históricos sobre el uso de cartabón de cinco. Al colocar el zuncho se modifican con frecuencia las pendientes pero no se ha detectado un patrón, ya que a veces se incrementa y otras reduce.

El principal problema del delicado punto donde se inserta el zuncho es la falta de definición, que puede achacarse también al desconocimiento de los sistemas constructivos históricos por parte de los arquitectos modernos, expertos en el uso de hormigón y acero pero con falta de formación sobre piedra, ladrillo y madera. Con

\footnotetext{
${ }^{115}$ La mitad de los edificios estudiados tiene muros de piedra y el resto de ladrillo, frecuentemente combinado con tapial.

${ }^{116}$ La menor inclinación corresponde a San Agustín, actual Archivo Municipal con una cubierta prácticamente plana revestida con Cinc en torno a $5^{\circ}$, y la máxima a San Pablo, de unos $35^{\circ}$ y cubierta con pizarra.
} 
frecuencia se deja la resolución del detalle a criterio del albañil: "detalles mal concebidos dejados a los oficios" (pag. IV.156).

También un detalle mal definido ${ }^{117}$ como en Villaverde de Medina puede llegar a provocar considerables daños.

Un factor a tener en cuenta es el peso de los sillares de cornisa, que precisa medios auxiliares $\operatorname{costosos}^{118}$. En varios casos se recrece la coronación del edificio y construye una cornisa de fábrica de ladrillo incluso para rematar muros de piedra.

Algunos arquitectos asignan al zuncho de hormigón la función de coser y dotar de continuidad a la cornisa. Se potencia así el zunchado en la consolidación de las cornisas frente a agrietamiento ${ }^{119}$.

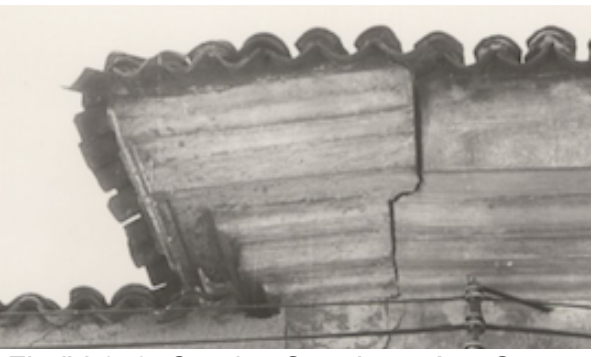

Fig.IV.156. Cornisa San Joaquín y Santa Ana dossier AGA

El zuncho perimetral se representa en los planos de planta cerrado formando un anillo, pero a veces se ejecutan dos elementos lineales paralelos sin prolongación en los testeros. El zuncho en la zona de cabecera se plantea a menudo configurado por tramos independientes, a modo de dados, debido a la dificultad para ejecutarlo en continuidad sobre una planta semicircular o poligonal quebrada.

Los zunchos se construyen habitualmente con encofrados de madera en la cara vista, aunque a veces se emplea una tabica de fábrica que se deja como encofrado perdido.

En el caso de Nava del Rey el muro estaba en buenas condiciones cuando se sustituyó la estructura de cubierta en los 70: el zuncho en este caso acompaña al diseño de la estructura metálica sin responder a un proceso patológico.

Algunos arquitectos mencionan en los proyectos la cualidad de impermeable del cemento y por tanto del hormigón. Sin embargo, el zuncho cornisa de San Juan de

\footnotetext{
${ }^{117}$ La caída de la cornisa de Villaverde se describe en la página IV.121 y en la ficha correspondiente. ${ }^{118}$ Arenillas, por ejemplo, emplea piezas menores e introduce hormigón armado en el detalle de 1965 de la Catedral.

${ }^{119}$ Por ejemplo en San Joaquín y Santa Ana sólo se define un tramo de zuncho en ángulo para reforzar la esquina.
} 
Letrán, como se ha visto en el análisis, tuvo que ser cubierto con piedra para impedir la penetración del agua. El dimensionado de la sección de las piezas con mayor canto que ancho en muchos casos, impide que funcione como traba entre las hojas del muro histórico y su relleno. También muestra que no está destinado a cubrir el remate del cerramiento a modo de albardilla.

La colocación del zuncho permite regular la geometría del encuentro murocubierta, en especial la prolongación del faldón hasta el alero sin refreno sobre el espesor del muro que se plantea en muchos de los casos.

Una vez colocado el zuncho, sólo a través de los planos de estado actual previos a esa obra es posible obtener datos de cómo se configuraba el encuentro muroscubierta, y siempre sujetos a posibles errores o falta de concordancia con la realidad.
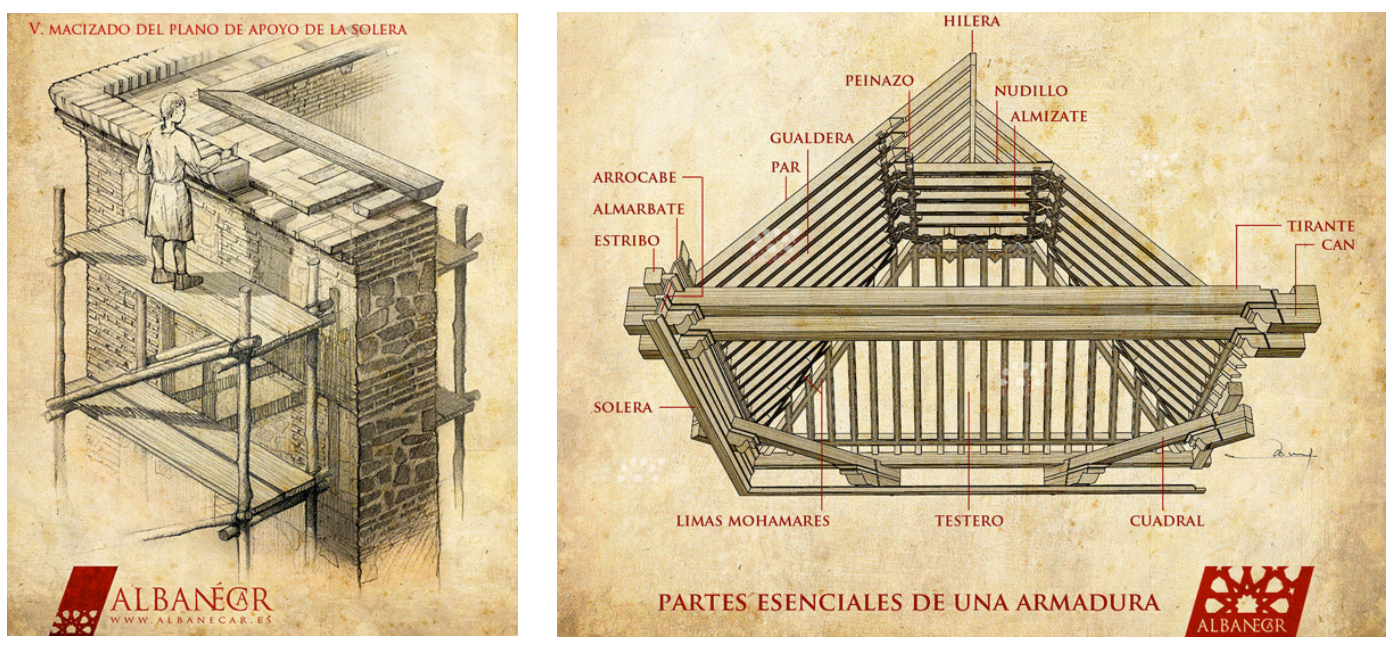

Fig.IV.157. Dibujos del arquitecto Javier de Mingo en su web albanécar 16/09/2015

Según se ha discutido en IV.3.2, al incorporar los zunchos se eliminaron en algunos casos tirantes de madera que ataban los muros a poca distancia sobre el trasdós de las bóvedas. Aparecen así unos tensores de acero anclados a dichos muros para suplir la labor de dichos tirantes.

Aunque no se ha detectado problemas de deterioro de las piezas de madera en contacto con zunchos en los casos estudiados, es posible que, en ocasiones, este elemento en contacto con la madera impida su oportuna aireación. En la iglesia de Fontiveros en la provincia de Ávila fue necesario, bajo la dirección de Nuere, romper el tablero de los años 70, sobre estructura metálica, para reparar el artesonado, que aún suspendido había revirado. El zuncho de hormigón no permitía realizar la reparación desde el interior del templo. 


\section{Conclusiones}

Tras el recorrido lingüístico efectuado se ha llegado a la conclusión de que el uso de la palabra zuncho en el ámbito de la construcción para denominar un elemento lineal de atado es relativamente reciente y se produce sólo en España a partir de 1970.

Históricamente las piezas de atado estructural se han denominado cadenas, desde los tratados históricos del XVI hasta las últimas normas de cálculo estructural vigentes.

La colocación de zunchos se plantea en proyectos de restauración de todo tipo de iglesias, desde ermitas hasta catedrales.

En los proyectos de los 40 edificios de Valladolid revisados, generalmente, se denomina zuncho a un elemento lineal de sección rectangular, ligeramente armado, que se dispone como remate en la coronación de los muros de fábrica que forman las naves.

Tras estudiar las soluciones constructivas que pueden observarse en las iglesias que han conservado sus armaduras, como San Benito el Real o San Pablo de Peñafiel, parece claro que en el lugar que actualmente ocupan los zunchos en la coronación de los cerramientos se disponía la solera sobre nudillos y el estribo de madera, sobre el apoyo del tirante, contra el que acometían los pares de la cubierta.

La colocación del zuncho permite regular la geometría del encuentro murocubierta, en especial la prolongación del faldón hasta el alero, sin el refreno sobre el espesor del muro que se plantea en muchos de los casos.

Al colocar el zuncho se modifican con frecuencia las pendientes pero no se ha detectado un patrón, ya que unas veces se incrementa y otras reduce.

El principal problema del delicado punto donde se inserta el zuncho es la falta de definición, que puede achacarse también al desconocimiento de los sistemas constructivos históricos por parte de los arquitectos modernos. Un detalle mal definido puede llegar a provocar considerables daños. 
La investigación ha confirmado que las dimensiones ejecutadas suelen ser diferentes a las que se definen originalmente en los proyectos. En bastantes casos los propios proyectos mencionan y representan zunchos genéricos sin precisar dimensiones ni ubicación.

Según se indica en el análisis, aunque se logre acceder al espacio bajo cubierta, en muchas ocasiones el zuncho no queda a la vista, ya sea por encontrarse revestido o embebido en la fábrica.

El zuncho de hormigón suele colocarse al reemplazar las armaduras de madera por estructuras nuevas, especialmente metálicas. La función que aparece asignada con más frecuencia en los proyectos es la de atado. A partir de los 70 se describe los zunchos empleando el adjetivo perimetral y asignándoles la tarea de servir de apoyo a las cerchas que forman las estructuras de cubierta. Varios arquitectos lo colocan con el fin de sanear o consolidar la coronación de los muros de fábrica y, en algunos casos, para reforzar la cornisa.

Algunos arquitectos asignan al zuncho de hormigón la función de coser y dotar de continuidad a la cornisa. Suele responder también a la necesidad de sanear la coronación de los muros

En varios proyectos se atribuye la patología de los edificios a la mala calidad de los muros con rellenos. Parece confirmarse, tras el análisis, que un cometido fundamental del zuncho en la restauración monumental es reforzar la cohesión de los muros de fábrica longitudinalmente en la dirección de los mismos. En sentido transversal, sólo en algún caso los zunchos cosen entre sí las hojas del propio cerramiento.

El zuncho perimetral se representa en los planos de planta cerrado formando un anillo, pero a veces se ejecutan dos elementos lineales paralelos sin prolongación en los testeros.

Cuando los zunchos se colocan en recintos de pequeñas dimensiones, puede considerarse que resuelven el atado transversal de los mismos, pero en las naves de grandes dimensiones visitadas se encomienda el atirantado a las propias cerchas o, en su caso, a nuevos tensores de acero. 
Los primeros zunchos de hormigón armado localizados los incorpora el arquitecto Anselmo Arenillas en los años 60 y en sus proyectos se describen como solera o solerón. Se siguen incorporando en los años 70 y 80 , con un breve intervalo, debido a los cambios administrativos, en torno a 1984. A finales de los 90 su uso repunta, hasta que prácticamente se abandona su empleo tras el cambio de milenio.

En los primeros años de gestión autonómica se continuó confiando los proyectos de restauración a arquitectos afincados en Madrid. Aunque no vuelve a emplearse estructura metálica o forjados de hormigón para sustituir las estructuras de cubierta en mal estado, en esa época se mantiene la incorporación de zunchos de hormigón en el remate de los muros de fábrica.

En los 90, aunque se emplea madera laminada y en ocasiones también aserrada, según criterio del autor del proyecto y las luces a cubrir, se recupera la costumbre de sustituir íntegramente las armaduras en mal estado en vez del criterio, más extendido a finales de los 80, de reemplazar sólo las piezas dañadas o consolidarlas con prótesis.

Tras el estudio de los Antecedentes se concluye que el empleo de estructuras de hormigón armado va desapareciendo poco a poco de los proyectos de restauración del Patrimonio. Especialmente en zonas de riesgo sísmico se tiende a emplear materiales ligeros cuando es necesario incrementar la cohesión de las fábricas.

Las soluciones de zunchado con materiales distintos del hormigón se adoptan también en muchos casos como medida provisional, así las cinchas textiles de Lorca, o al menos reversible (cables de Jurina en Italia).

Aunque en España se sigue empleando esporádicamente, en Valladolid el empleo de zunchos de hormigón en restauración de cubiertas monumentales se redujo drásticamente a partir del año 2000. 



\section{1. Recomendaciones}

La primera recomendación a tener en cuenta es que debería impulsarse en las escuelas de arquitectura la incorporación al tronco docente de asignaturas como Historia de la construcción, que actualmente queda relegada a seminarios y cursos de postgrado. Es importante conocer cómo se comportan los edificios históricos antes de acometer cualquier intervención sobre los mismos.

También deberían tomarse más precauciones antes de adoptar soluciones técnicas novedosas sin contrastar con el paso de los años. Una buena medida es supervisar cada cierto tiempo el comportamiento de los sistemas constructivos y materiales empleados, y difundir la información generada con dicho seguimiento entre los técnicos involucrados.

En las restauraciones modernas de las iglesias estudiadas, en general, no se ha prestado suficiente atención al detalle cornisa - alero. No se define con la precisión necesaria el encuentro de la coronación de los muros con la cubierta, lo cual ha sido un factor determinante en la patología de los edificios. Recordemos los magníficos planos de Ventura Rodríguez en que define en la sección del muro no sólo con el perfil exacto de la cornisa sino con el despiece de sillares con ligera pendiente y un resalto para evitar la penetración del agua en el interior de la fábrica. Los proyectos modernos representan la sección homogénea, sin indicar en muchos casos el aparejo o el material con que se va a construir la cornisa, y dejando la resolución del vuelo de la misma en manos de los operarios que la ejecutan ${ }^{1}$.

El zuncho casi en ningún caso aparecía correctamente representado dentro de la sección, dibujándose centrado para luego ejecutarse a ras del paramento interior o, por el contrario se representa enrasado y se construye semi-embebido con una tabica de fábrica empleada como encofrado perdido, tanto de ladrillo como de piedra.

Tras el sismo de Lorca también en España se debería adoptar medidas para no alterar la inercia de los edificios históricos con sustitución de cubiertas ligeras y adaptables por otras más pesadas y rígidas, como las losas y forjados de hormigón.

\footnotetext{
${ }^{1}$ El onduline corto que puede causar una patología tan importante como la que surge en Villaverde de Medina (Pág.IV.125). En otros casos la incorrecta fijación de la teja hace que ésta deslice sobre el onduline.
} 


\section{VI.2. Futuras líneas de investigación}

El acceso al espacio bajo cubierta de una iglesia BIC es siempre una experiencia enriquecedora ${ }^{2}$. Resolver técnicamente estructuras de semejantes dimensiones ha supuesto un reto constante a lo largo de la Historia, especialmente en los templos de tipo salón ${ }^{3}$. En este tipo de iglesia encontramos soluciones tan sofisticadas como las celosías de la parroquia de Simancas, los machones de ladrillo de los Santos Juanes en Nava del rey y las imponentes arcadas de la Colegiata de San Antolín en Medina del Campo.
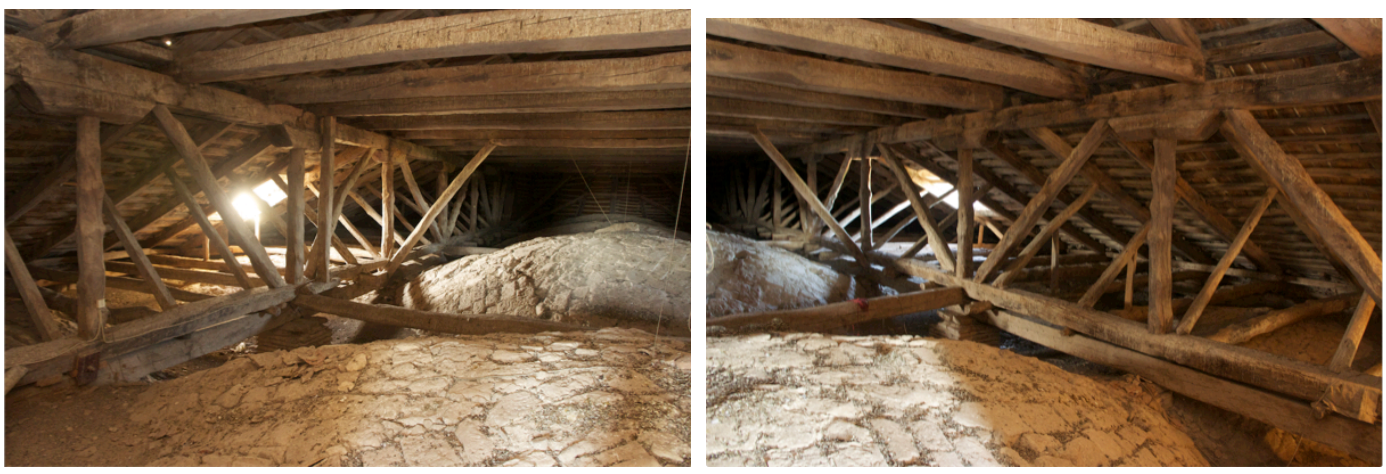

Fig.VI.1. Iglesia El Salvador de Simancas

En San Antolín hemos visto cómo el arquitecto autor de la restauración de 1982 llegó incluso a plantearse reemplazar los grandes faldones por un conjunto escalonado dejando a la vista las arcadas interiores de fábrica de ladrillo, solución afortunadamente descartada por su falta de coherencia tipológica. En el Plan Director de este edificio, además, Paniagua propone entre las actuaciones a medio plazo habilitar el espacio bajo cubierta para albergar una Exposición pública de los trabajos de restauración del conjunto monumental.

Se recogen a continuación diversos aspectos surgidos durante el trabajo de campo que pueden abrir nuevas vías de investigación dentro del ámbito de la restauración monumental.

\footnotetext{
${ }^{2}$ El arquitecto Eduardo González Fraile, autor de la restauración en 2006 de la Capilla de San Juan Bautista de la iglesia de El Salvador, desarrolla varios documentos sobre temas arqueológicos y de futuro uso del monumento. Entre ellos propone un plan de apertura al público del espacio bajo cubierta, ya que defiende que se trata de una visita de gran interés cultural.

${ }^{3}$ Consideramos también iglesias como tipo salón aquellas con altura de las tres naves distinta pero con una diferencia entre ellas que no permite abrir huecos para iluminar la nave central (Pano Gracia 2004, 39).
} 


\section{VI.2.1. El problema del acceso}

Según se adelanta en el Capítulo de Metodología, la labor de campo de esta investigación ha consistido básicamente en visitar el espacio bajo cubierta de algunas de las iglesias seleccionadas. En algunos casos no ha sido posible obtener el permiso por considerar los responsables, como el párroco de la Antigua o la abadesa de Las Huelgas que suponía un riesgo innecesario.

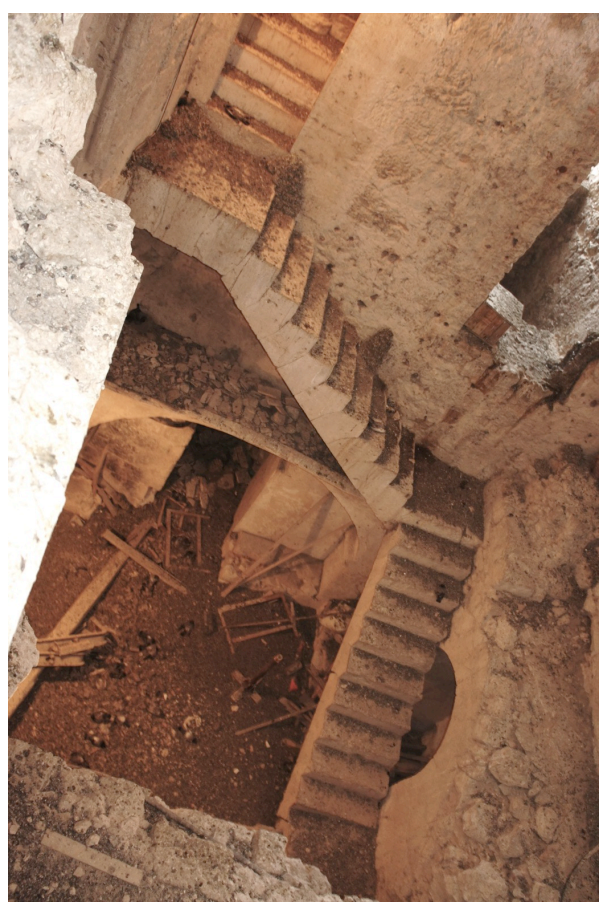

Aunque en muchos casos las dificultades han sido únicamente debidas a la falta de salubridad y confort, por la falta de limpieza de los espacios y sus accesos, en otros la subida al bajo cubierta se ha realizado en condiciones que sí deben ser objeto de reflexión. Cada arquitecto que actúa sobre una de estas iglesias debería promover la adopción de medidas permanentes para mejorar estos aspectos, no sólo durante el periodo de ejecución. Las imágenes junto a estas líneas pretenden ilustran estos aspectos, no denunciarlos, por lo que no se indica en el pie los edificios a los que pertenecen.

Algunos huecos de paso habían sido cegados tras determinadas intervenciones, otros presentaban dimensiones muy reducidas, a veces simples ventanas tipo velux que requerían recorrer tramos de faldón sin protecciones, en otros se contaba con escaleras rudimentarias de tablones o faltaban peldaños. En pocos casos se ha encontrado iluminación eléctrica.
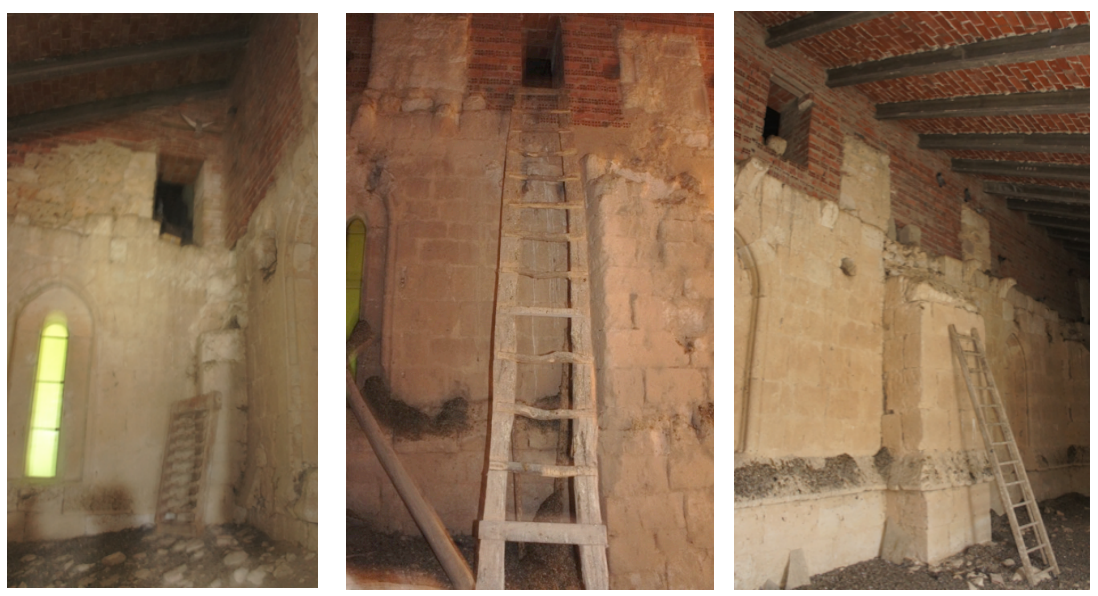
Si hay una relación directa entre la dificultad de acceder a la cubierta de un edificio y su mantenimiento, entonces muchas de las obras desarrolladas sobre las cubiertas a causa de su mal estado, de la pudrición por goteras o la degradación no atajada hasta una fase irreparable, también estarán relacionadas con este aspecto.

Por tratarse de un tema ajeno al objeto principal de la Tesis, las recomendaciones se han desarrollado en un texto aparte que se presentó en abril de 2014 en el Congreso REHABEND con el título El problema del acceso para el mantenimiento del Patrimonio. En dicha comunicación se avanza cómo las últimas tendencias en las obras de restauración monumental están empezando a contemplar estos aspectos, incorporando pasarelas sobre los tirantes, peldañeados y barandillas.

\section{VI.2.2. La ventilación}

A lo largo de las visitas se ha detectado que hay elementos de la cubierta, directamente relacionados con la problemática del difícil acceso a las mismas abordada en el apartado anterior, que han sido sistemáticamente eliminados en muchas de las intervenciones: las buhardillas. Según RAE, la buhardilla o buharda es "una ventana que se levanta por encima del tejado de una casa, con su caballete cubierto de tejas o pizarras, y sirve para dar luz a los desvanes o para salir por ella a los tejados".
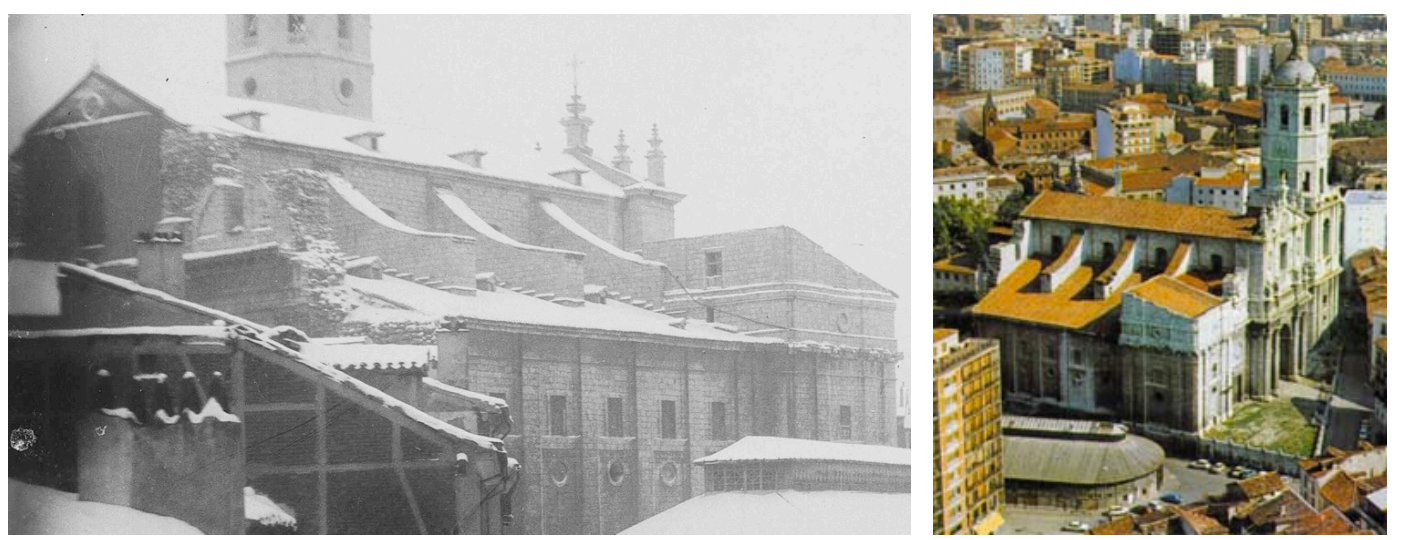

Fig.VI.2. Archivo Maso 009 y archivo UA 0296 (AMVA)

En el archivo digital del AMVA podemos encontrar imágenes de la Catedral de Valladolid antes de demolerse el mercado de Portugalete en las cuales pueden apreciarse los faldones de teja sin aberturas. En el mismo archivo, sin embargo, una fotografía en blanco y negro muestra el templo cubierto de nieve en el que destacan cuatro buhardillas en nave central y otras tantas sobre la nave lateral. 
En la actualidad, el revestimiento de teja cerámica de las cubiertas de la Catedral ha sido reemplazado por lámina de plomo, que cuenta con pequeñas ventilaciones en los faldones de naves laterales, muy escasas sobre nave central, y varias ventanas tipo velux, más incómodas e inseguras pero adaptadas a los criterios estéticos modernos.

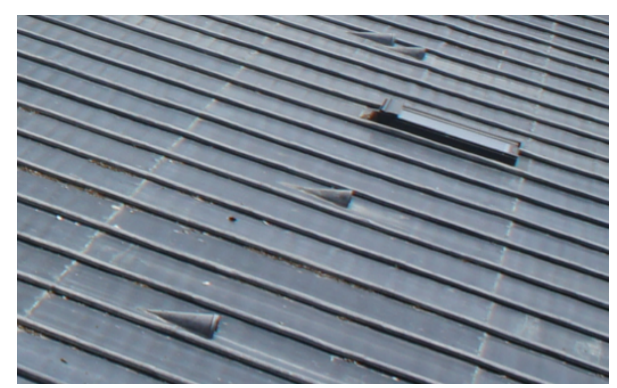

Fig.VI.3. Plomo visita 10/05/2012

En la iglesia de la Cofradía de las Angustias hubo también buhardillas, actualmente reemplazadas por ventanas inclinadas tipo velux, como podemos apreciar en la imagen a través del hueco de campanas de la espadaña.
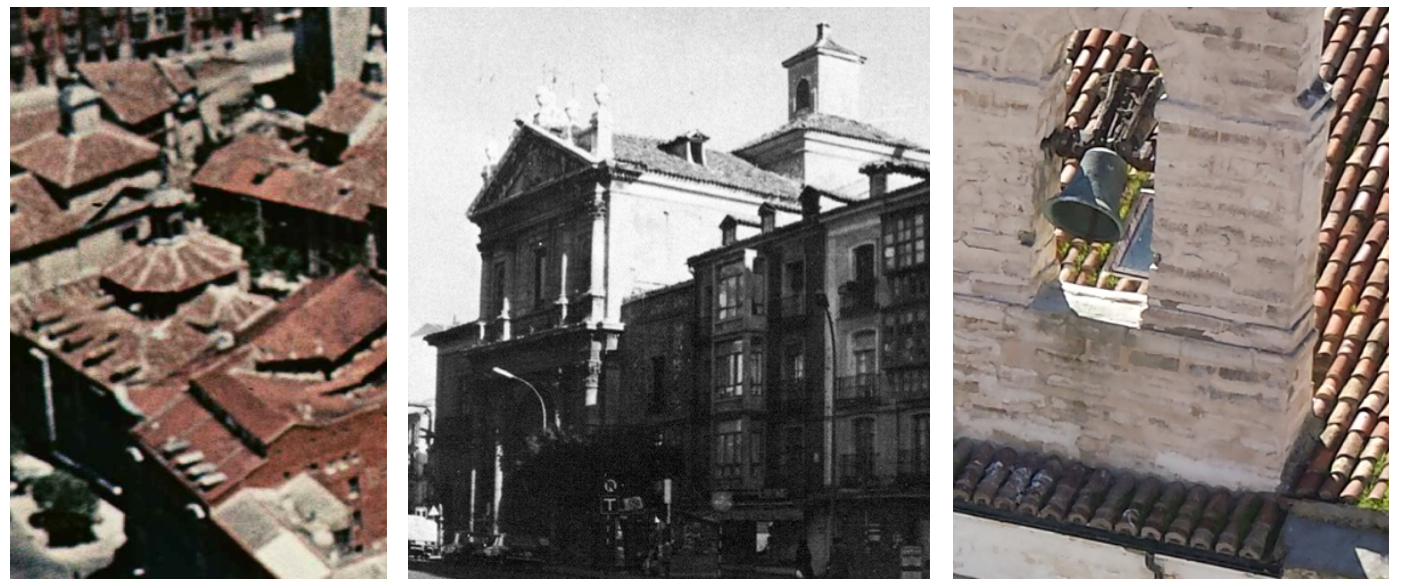

Fig.VI.4. Fondo Carvajal FC155-001/006, Lam.120 (Bustamante 1983) y visita 21/02/2014

En San Pablo hoy encontramos dos salidas abuhardilladas con carpintería de madera y vidrio, a los pies sobre la nave central, para acceder mediante pasarelas a las campanas También en cada faldón de naves laterales se dispone una. No se aprecian más huecos en el revestimiento de pizarra

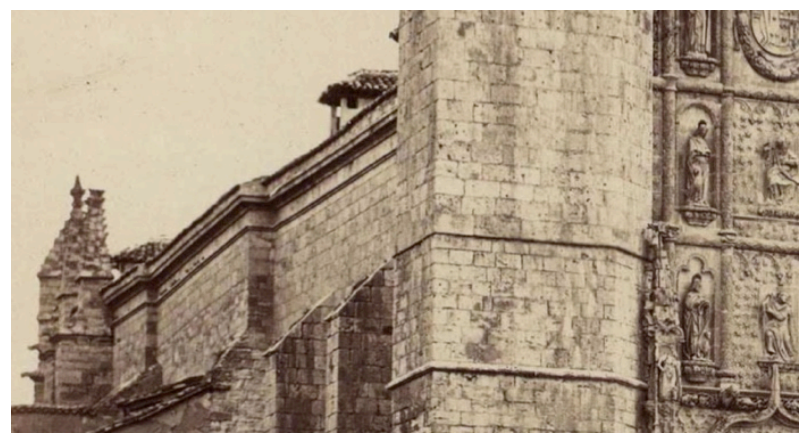

En una fotografía del archivo digital de la BNE podemos confirmar que había buhardillas en la cubierta de la nave central en 1864 , justo antes de la intervención del arquitecto Ortiz de Urbina sobre el templo.

Fig.VI.5. San Pablo BNE 0066233

También en la siguiente fotografía del incendio de 1968 vemos una buhardilla en la cabecera, que desaparece en la misma vista tras el reemplazo de la cubierta. 

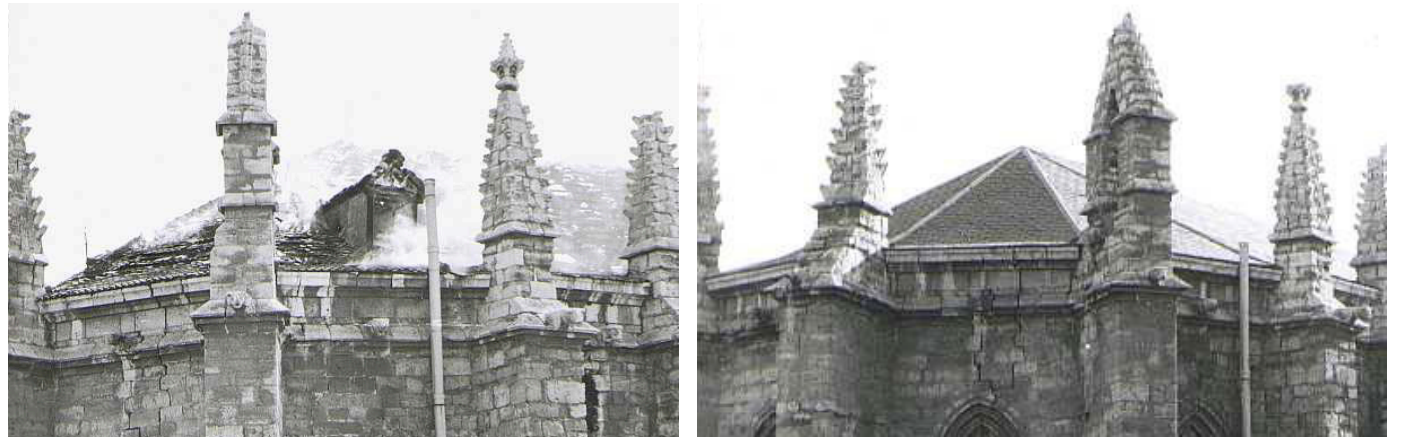

Fig.VI.6. San Pablo, archivo digitalizado AMVA 004091; 006451

Y en el último retejo de los Santos Juanes, llevado a cabo en el verano de 2014, se ha incorporado beatas cerámicas para ventilación del espacio bajo cubierta. En la cornisa que remata el muro se conservan encastradas una gárgolas con boca de cañón actualmente sin uso.

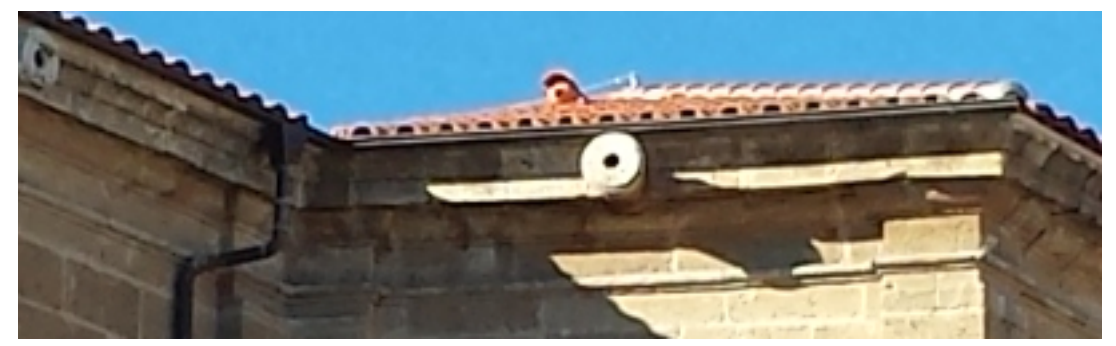

Fig.VI.7. Santos Juanes, visita 02/09/2014

\section{VI.2.3. La evacuación de aguas en los edificios históricos}

No es posible aplicar en restauración de inmuebles protegidos los sistemas de evacuación estandarizados para la obra nueva. La recogida del agua de lluvia de las grandes superficies que forman los faldones de estas iglesias exige cálculos precisos y un diseño cuidadoso de las instalaciones.

La colocación de canalones y bajantes en fachadas de edificios catalogados requiere el permiso de la administración competente en cada caso. Entre la documentación revisada aparecen solicitudes de licencia al Ayuntamiento para incorporar en los conventos de la ciudad, como las Descalzas en 1932, el "canalón que obliga la orden municipal" ${ }^{4}$. La Licencia de obras para la sustitución de estructura de la Catedral por cerchas metálicas que, como se ha explicado anteriormente, no se tramita para el proyecto de Luis Cervera sino a partir de unos

\footnotetext{
${ }^{4}$ AMVA 1049-53 1932
} 
planos similares de Ángel Ríos, es concedida con la condición de que se corrija un defecto apuntado por la Comisión de protección del Patrimonio Histórico-Artístico que el 16 de abril "no estima conveniente la solución de apoyo tanto de las cerchas metálicas como de la recogida y salida de aguas pluviales a través de bajantes que perforan la coronación del muro de fachada, afectando la cornisa incluida y su salida al exterior por fachada" 5 .
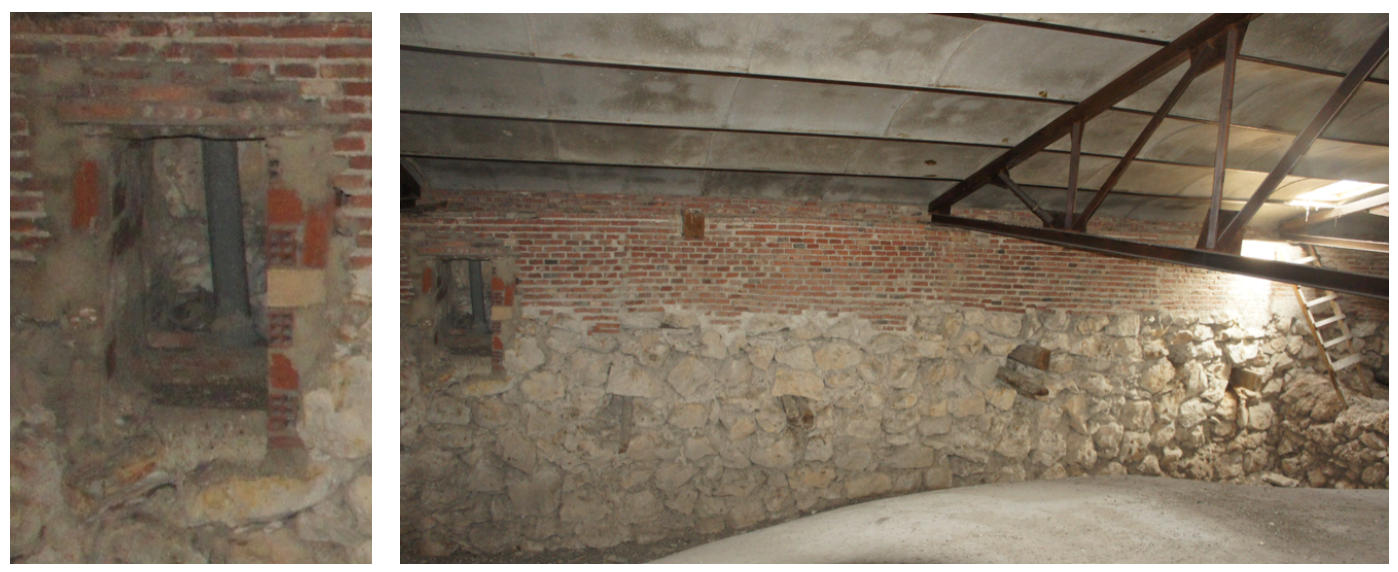

Fig.VI.8. Detalle bajante en muro y vista general en bajo cubierta Catedral, visita 10/05/2012

Actualmente la Catedral no cuenta con los canalones y bajantes que se aprecian en las imágenes tomadas antes de la sustitución de armaduras de 1974. En el bajo cubierta hay huecos de registro en los que se aprecian las bajantes que discurren dentro de la sección de los muros.
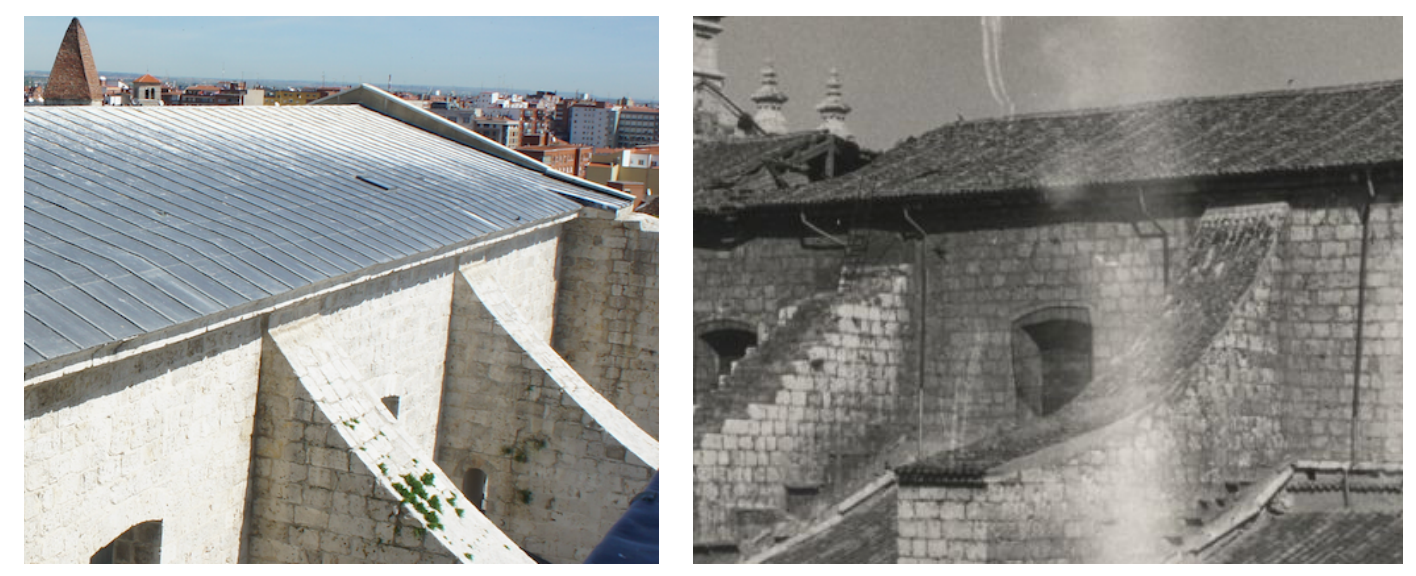

Fig.VI.9. Cubierta nave central actual Catedral visita 10/05/2015 y 1974 AGA 26-00146-002

Otro de los casos estudiados en que la recogida de pluviales también ha sido tratada por el arquitecto Elesio Gatón es Nuestra Señora de la Antigua. Según se describe en la documentación que acompaña a la Ficha FZ-11, Arenillas en 1965 había dispuesto las instalaciones bajo cubierta sobre el trasdós de las bóvedas.

\footnotetext{
${ }^{5}$ AMVA 216/1974 2002-5
} 


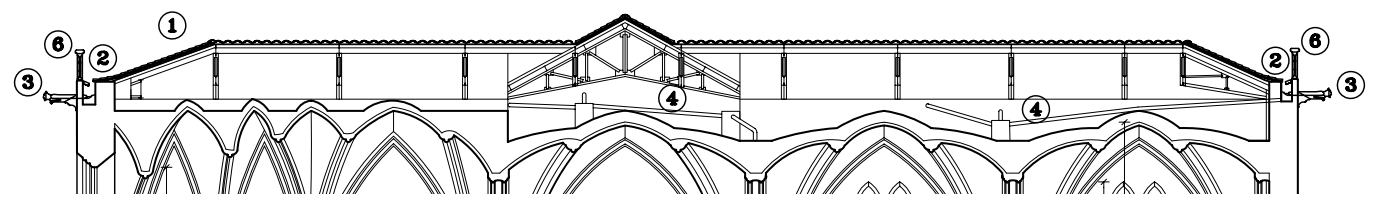

Fig.VI.10. Sección bajo cubierta la Antigua 2005 Gatón JCyL
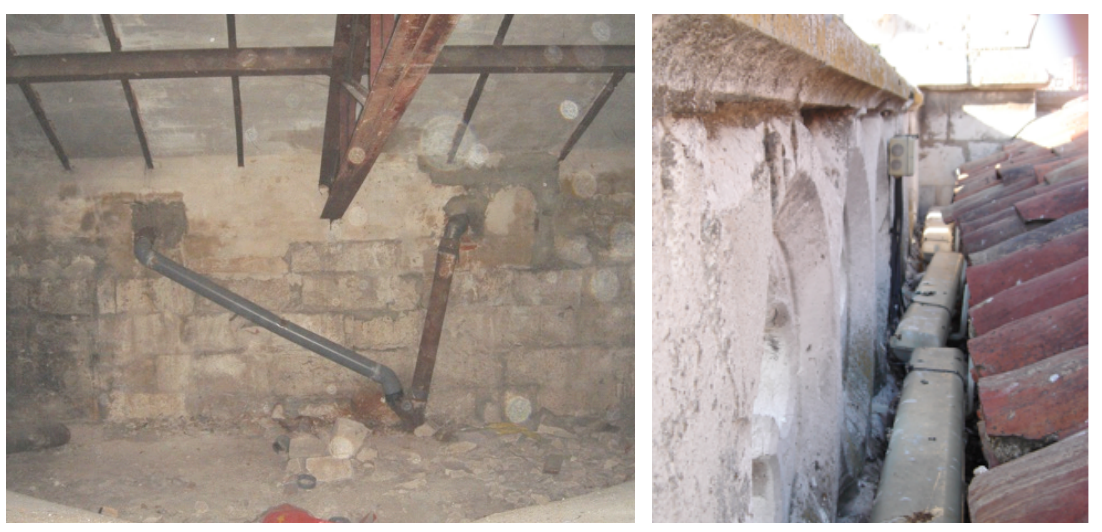

Fig.VI.11. Dossier la Antigua 2005 Gatón JCyL

Señala cómo numerosos canalones están prácticamente cegados tras la colocación en ellos de luminarias estancas, que se propone retirar, y la inutilidad de las gárgolas macizas existentes, colocadas como meros adornos, que propone perforar.
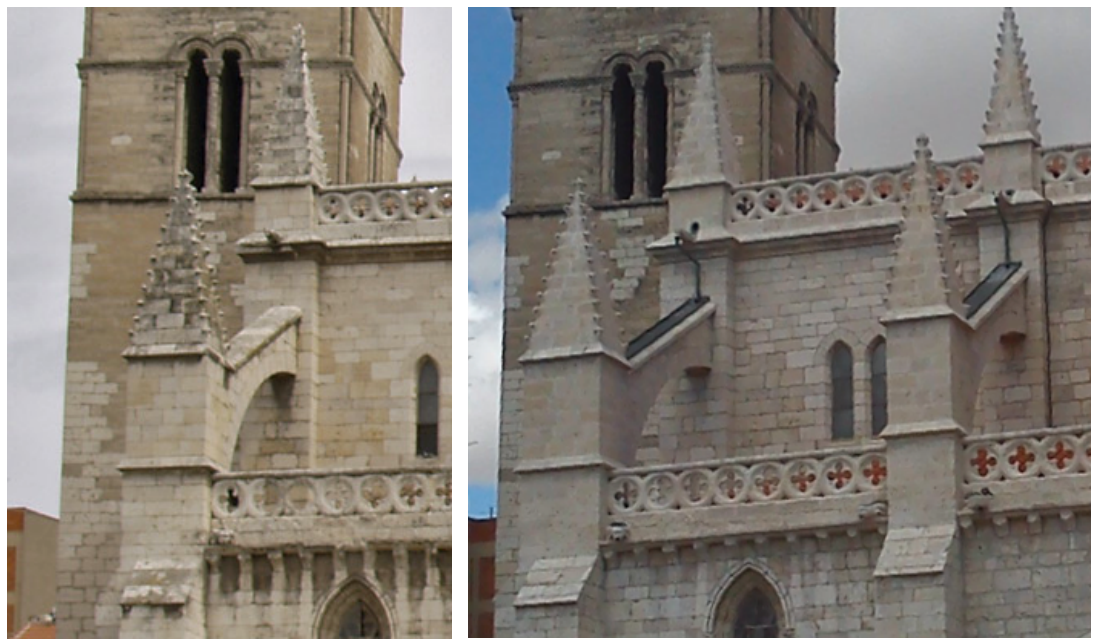

Fig.VI.12. Detalle arbotante 2008 wikipedia 20080816 ; visita 16/06/2012

Se dispusieron canales cubriendo los arbotantes con bajantes de cobre exentas que conducen hasta los mismos las aguas que atraviesan las gárgolas para evitar las salpicaduras.

En la investigación se han detectado varios casos más de problemas con la recogida de aguas de las grandes superficies de cubierta de los templos estudiados, cuya documentación se puede consultar en las Fichas correspondientes, por ejemplo la última reparación en la cubierta de la iglesia de Santa Cruz, que aún presenta problemas de humedad. 


\section{VI.2.4. El material de cubrición cerámico}

Una de las medidas más trascendentales que se están tomando en las obras acometidas en los últimos años es el cambio de material de revestimiento de los tejados. No es una decisión que se pueda tomar a la ligera aunque se cuente con la aprobación de la Administración competente en su caso, ya que, además de alterar estéticamente el monumento, se modificará drásticamente su comportamiento tanto higrotérmico como estructural.

Anselmo Arenillas encuentra las cubiertas de San Pablo en los años 60 revestidas con escamas modernas ${ }^{6}$. En sus intervenciones sustituye estas piezas por pizarra, que juzga más adecuada para la gran pendiente, unos $35^{\circ}$, de los faldones.
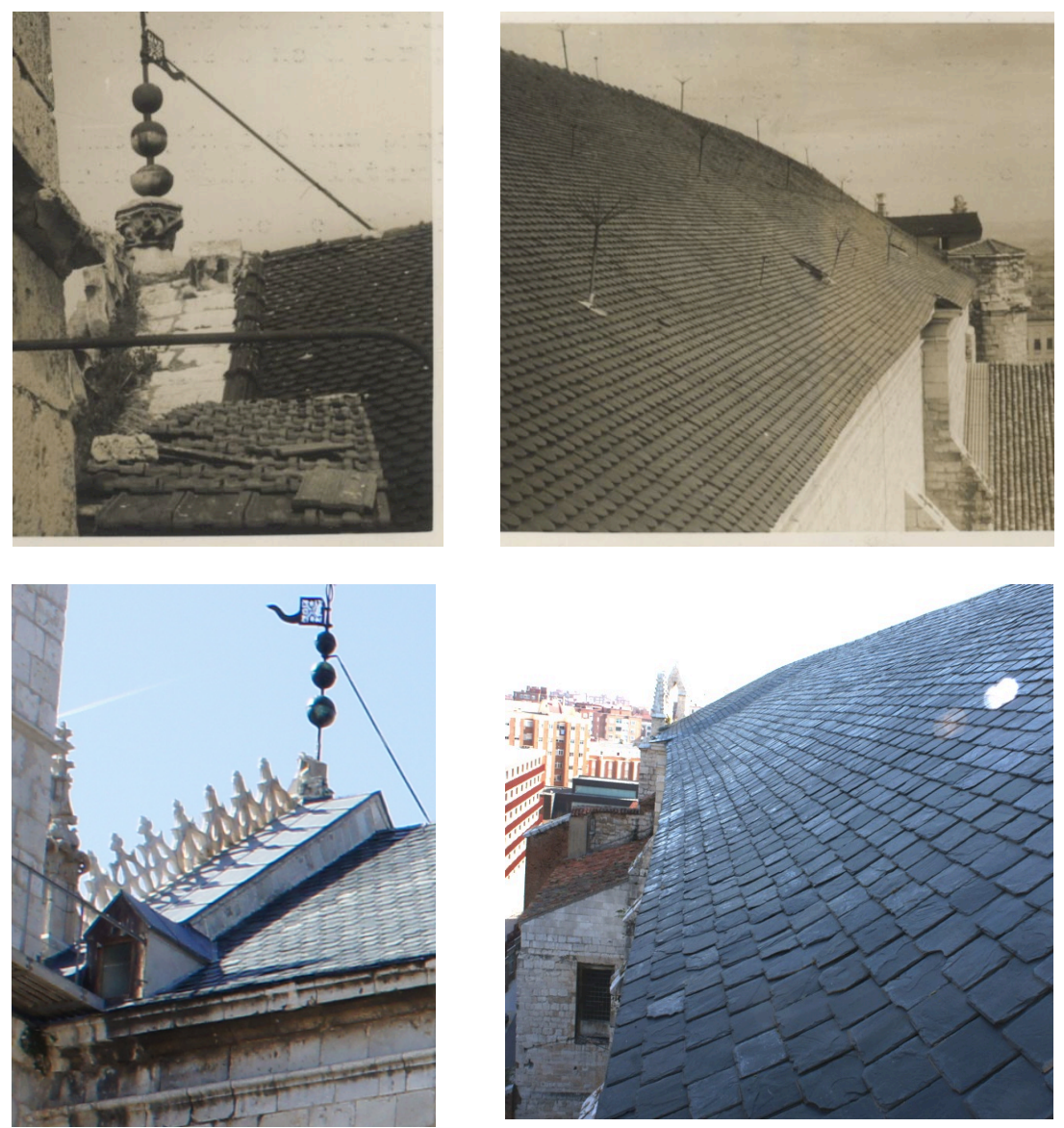

Fig.VI.13. San Pablo, digitalización (Arenillas 1962 AGA) y visita 26/09/2014

\footnotetext{
6 "Escamas de barro cocido, teñidas con alquitrán (fabricadas no hace cincuenta años) y clavadas sobre el enripiado. Estas escamas están rotas y faltan en muchos sitios, no siendo posible su reposición porque ya no se fabrican ni existen troqueles. Se han sustituido en parte con medios ocasionales y, como consecuencia, las goteras son grandes y perpetuas. (AGA 26/00370)
} 
Según define en el Plan Director de la Catedral de Valladolid aprobado en 1997, el arquitecto Elesio Gatón sustituye la teja curva que recubre los tejados de las naves por láminas de plomo, material según él más adecuado a la pendiente que presentan los faldones y que admitiría pequeños impactos sin fracturarse. En el Plan se incluye una extensa y documentada justificación histórica del empleo de este material desde el siglo XVI en diversos monumentos.

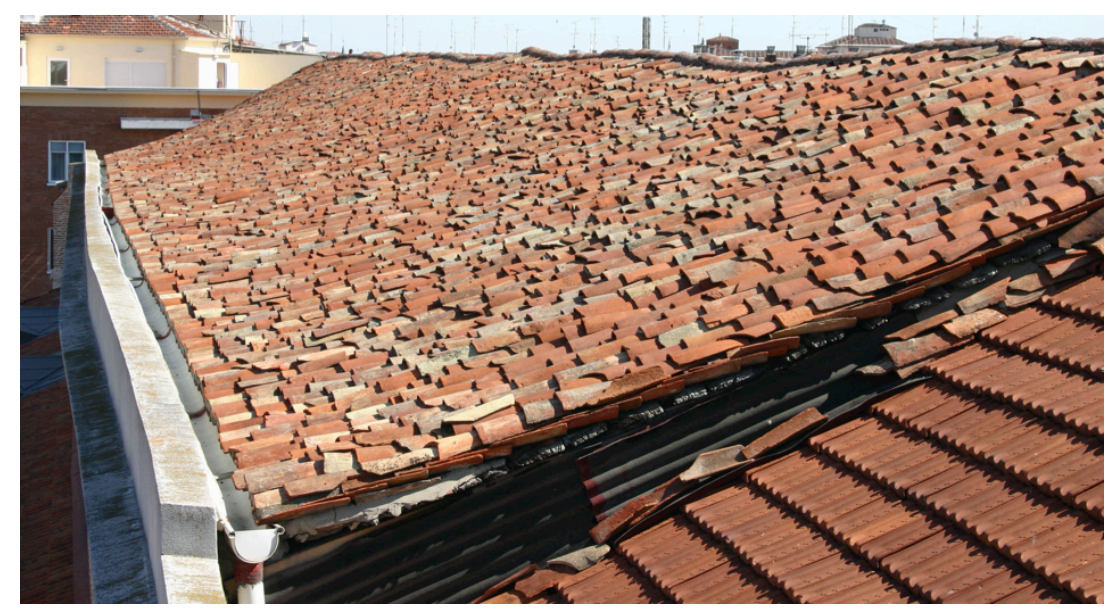

Fig.VI.14. San Benito el Real vista desde la torre-atrio (cortesía Fundación 3890)

El tipo de teja cerámica también incide directamente sobre la durabilidad de las cubiertas. Algunos usuarios de los templos han manifestado durante las visitas cómo en su opinión la teja curva conlleva un mantenimiento más complejo que la plana o mixta, por lo que su resultado es peor a efectos de conservación.

\section{VI.2.5. El cinchado de torres y cúpulas}

La investigación sobre el papel del zuncho en la restauración monumental ha tenido que acotarse en el espacio y el tiempo, dejando de lado aspectos tan interesantes como el atado de las cimentaciones o el refuerzo de torres y cúpulas.

Se resumen a continuación los aspectos básicos del cinchado de cúpulas como complemento adicional a la documentación contenida en los capítulos referidos a los marcos histórico y conceptual del zuncho que forman parte del cuerpo de la tesis. 


\section{VI.2.4.1. Marco teórico del refuerzo de cúpulas}

Las grandes cúpulas han marcado auténticos hitos en la historia de la construcción. El Panteón, San Pedro, San Pablo, Santa Sofía, El Capitolio... En el ideario colectivo tenemos asimilado el refuerzo perimetral de cúpulas como una constante a lo largo de la historia, con cadenas metálicas envolviendo el arranque de las mismas desde el su construcción o incorporadas en sucesivas intervenciones restauradoras.

$\mathrm{Si}$ asumimos las conclusiones de la tesis doctoral defendida en 1990 por Santiago Huerta $^{7}$, los antiguos constructores empleaban reglas empíricas ampliamente difundidas para dimensionar sus estructuras de fábrica. La condición más restrictiva para el diseño de las mismas no es la resistencia, sino la estabilidad. Se precisa determinadas dimensiones de los elementos que dependen de la forma geométrica de la estructura. Son reglas de proporción como las definidas por Gil de Hontañón en el XVI que recoge en su Tratado Simón García o las de Carlo Fontana en el XVII.

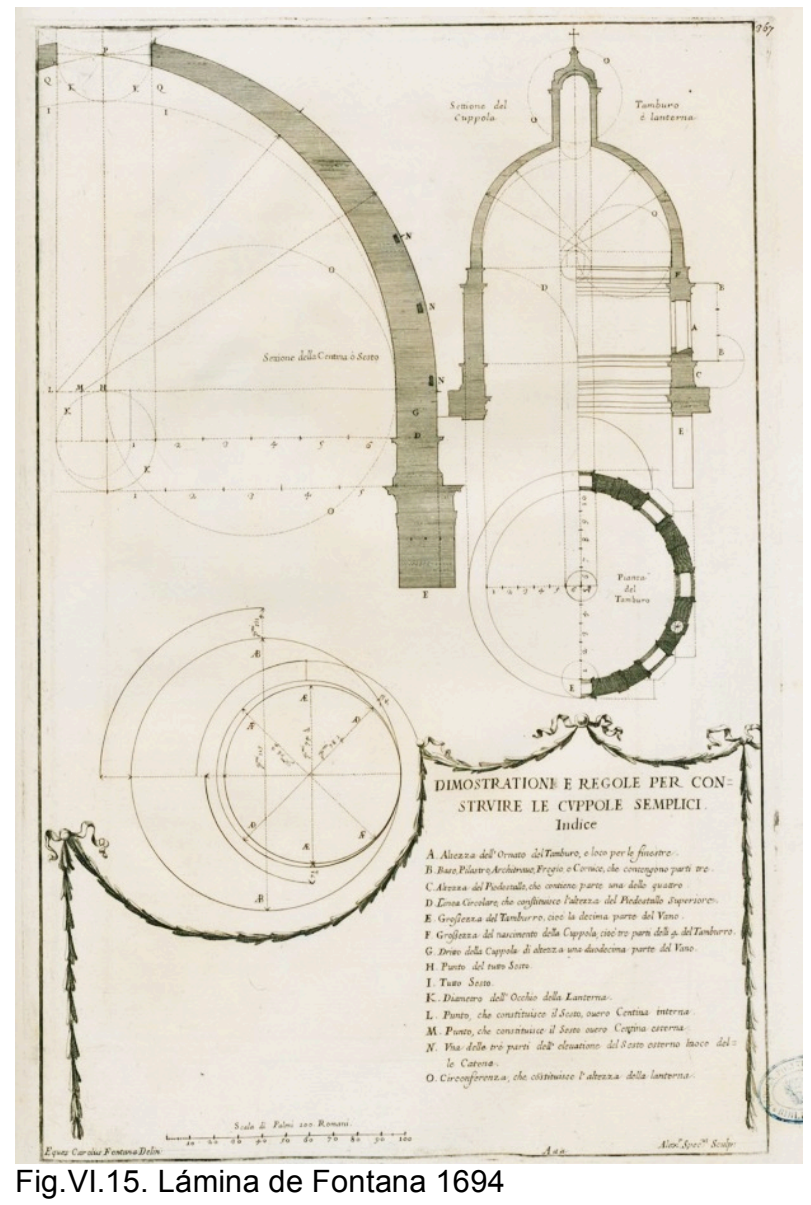

En algunos casos hizo falta formular reglas empíricas aritméticas, como en el diseño de contrafuertes y claves, en los que la estabilidad aumenta con el tamaño.

En la tesis citada se enumera las contribuciones del siglo XIX al análisis de bóvedas, citando un apartado sobre el cálculo de zunchados metálicos de cúpulas en el libro Résumé de Leçons donées a l'École des Ponts et Chaussées, de Navier en 1826.

\footnotetext{
${ }^{7}$ Huerta Fernández, S. (1990). Diseño estructural de arcos, bóvedas y cúpulas en España, ca. 1500-ca. 1800. Universidad Politécnica de Madrid.
} 
Las reglas de proporcionalidad de Fontana para dimensionamiento de cúpulas de doble cáscara incluyen la forma de colocar cadenas de hierro en su parte baja ${ }^{8}$, la zona con más propensión a abrirse.

En las Actas del I Congreso Internacional de Historia de la Construcción CNHC, celebrado en Madrid en 2003, encontramos una comunicación ${ }^{9}$ sobre cúpulas de Pietro da Cortona, como Ss Ambrogio e Carlo al Corso, terminada a su muerte. Se trata de una cúpula con el casquete construido en tevolezza (un material aligerado de ladrillo y mortero) y un anillo embebido de $1250 \mathrm{~kg}$ de hierro, que suponen próximo al arranque, al que denominan "cerchione di ferro".

Otros autores, sin embargo, rechazan la práctica de cinchar las cúpulas. Así en la traducción de Manuel Hijosa del Manual de Arquitectura de Juan Branca ${ }^{10}$, podemos leer "sabiendo bien la necesidad de tantos pobres jóvenes, que en los preceptos y obras de algunos que hacen de Maestros, no pueden aprender otra cosa en la construcción de bóvedas, que liarlas con cadenas de hierro, o fiarlas a la tenacidad de la puzolana; pero las fábricas bien entendidas (dice Viñola) quieren regirse por sí mismas, y no estar atadas con cabestros".

\section{Basílica de San Pedro}

En las Actas del II CNHC otra comunicación, presentada por Gema López ${ }^{11}$, incide en las peculiaridades de la estabilidad de una cúpula, la de S. Pedro en el Vaticano, a partir del análisis del famoso "informe de los tres matemáticos". Encargado en 1742 por Benedicto XIV a Francesco Jacquier, Tommaso Le Seur y Ruggiero Giuseppe Boscovich. Por encargo papal Giovanni Poleni recopila todos los documentos relativos a la obra y prescribe la colocación de más zunchos. La cúpula se construye en tres etapas, pilares y arcos torales de Bramante, tambor de Miguel Angel y conclusión con un perfil ligeramente más apuntado del previsto en el modelo de

\footnotetext{
${ }^{8}$ Cadenas señaladas como $\mathrm{N}$ en la lámina de Templum Vaticanum et ipsius origo "Dimostrationi e regole per construire le cuppole semplici" de la imagen Fig.VI.15

${ }^{9}$ Cerutti Fusco, A. C., \& Villani, M. (2003). Pietro da Cortona's domes between new experimentations and construction knowledge. En Proceedings of the First International Congress on Construction History: Madrid, 20th-24th january 2003 (pp. 579-591). Instituto Juan de Herrera.

${ }^{10}$ Branca, J. (1790). Manual de arquitectura, trad., comentários e acréscimos de D (Manuel Hijosa,[6 ${ }^{\text {a }}$ ed.]). Madrid: Viuda de D. Joachîn Ibarra. pag84

${ }^{11}$ López Manzanares, G. (1998). La estabilidad de la cúpula de S. Pedro: el informe de los tres matemáticos. En Actas del II CNHC. A Coruña.
} 
madera de éste por Giacomo della Porta y Domenico Fontana. La sección de $42 \mathrm{~m}$ de diámetro se desdobla a partir del primer tercio en dos cáscaras que van incrementando su separación con la altura. La interior cuenta con peldañeado para acceder a la linterna. Cuenta con 16 costillas y está coronada por una linterna.

Según Gema López, Poleni indica que "se colocaron tres zunchos de hierro, mediante barras enlazadas por cuñas o pestillos, durante el proceso constructivo, y no a posteriori. Pudieron tener el papel de ayudar a la fábrica en la retracción del mortero. Estaban colocados, uno en la linterna, y los otros dos en la zona de arranque de la cúpula, señalados con la letra L en la figura 1. Su función estructural es más dudosa, pero los tres matemáticos los tuvieron en cuenta". En el informe los matemáticos representan e identifican las grietas con letras. Estiman los pesos y analizan la estabilidad de la estructura. Como remedio a los problemas de la cúpula recomiendan colocar tres nuevos zunchos: en la imposta, cerca de la linterna y a media altura.

En una obra original del Massachusetts Institute of Technology de 1993, reeditada en español por Robert Mark ${ }^{12}$, se comenta como Poleni encontró rotas y reparó las cadenas originales durante la colocación de las cinco adicionales por él definidas.

El profesor Heyman ${ }^{13}$ en Teoría, historia y restauración de estructuras de fábrica explica cómo el informe de 1748 de Poleni da una muestra completa del estado de los conocimientos en construcción de fábrica de su época. Al observar la cúpula agrietada formando unos 50 gajos consideró el análisis de dos de ellos enfrentados como formando un arco bidimensional. Calculó el peso, lo dividió en tramos y ensayó con los pesos ensartados en una cadena. Superpuesta la línea de empujes obtenida experimentalmente al dibujo de la sección comprobó que se encontraba dentro, deduciendo que la estabilidad de la estructura estaba asegurada.

Con el mismo método, cortando en gajos y construyendo líneas de empuje, se puede resolver el análisis de una cúpula "incompleta", es decir, tanto con un óculo central como soportando una pesada linterna en coronación.

\footnotetext{
${ }^{12}$ Acosta, J. M. G., Martínez, D. L., \& Mark, R. (2002). Tecnología arquitectónica hasta la revolución científica (Vol. 5). Ediciones AKAL.

${ }^{13}$ Heyman, J. (1995). Teoría, historia y restauración de estructuras de fábrica: colección de ensayos. Instituto Juan de Herrera.
} 
Actualmente se ha recuperado los métodos del análisis a rotura para la comprobación de las estructuras de fábrica, tras su olvido durante gran parte del siglo $\mathrm{XX}$ en aras de la teoría de la elasticidad asociada al empleo del hormigón armado. El análisis a rotura difundido por Heyman, según se ha mencionado en la página III.33 de los Antecedentes, permite la comprobación de la estabilidad de un arco o bóveda visualmente a partir de un dibujo a escala. Recordemos que en los Tratados de construcción históricos aparecen de forma constante reglas que relacionas las proporciones de arcos, bóvedas y cúpulas. Teniendo en cuenta la posición de líneas o superficies "de confianza" la condición de estabilidad en estructuras de fábrica es la que determina la geometría. Los profesores Huerta y Aroca ${ }^{14}$ describen el problema en los siguientes términos:

"Mientras en el arco solamente consideramos los esfuerzos en dos secciones radiales, en las cúpulas las dovelas están sujetas a tensión en sus cuatro caras. esto hace a las cúpulas más estables y permite, por ejemplo, quitar la clave y abrir un ojo sin que colapse. Si todas las tensiones fuesen compresiones no existiría problema y es así en la mayor parte de las cúpulas. Pero en anillos de un cierto ángulo aparecen tracciones que la fábrica no está preparada para resistir. El ángulo depende de la forma de la cúpula y del sistema de cargas aplicado. En una cúpula semicircular de grueso constante aparecen tracciones en un ángulo $51,8^{\circ} \mathrm{de}$ la parte superior. La linterna o incluso un ojo hace que la zona de tracciones suba hacia la cumbre".

$\mathrm{Y}$ en El esqueleto de piedra ${ }^{15}$ podemos leer:

"La solución de membrana implica tracciones en el material en la base de la cúpula semiesférica; la solución de gajos conduce a una línea de empujes que es oblicua en el arranque y que por tanto, requiere una fuerza de contrarresto hacia el interior, quizá proporcionada por un zuncho o cadena de hierro. En cualquier caso, el problema aparece cerca de la base de la cúpula, donde es preciso un refuerzo externo. Para evitarse este problema debe cortarse la cúpula según un paralelo, para que deje de ser una semiesfera completa, o bien engrosarla cerca de la base, uniéndola progresivamente a otra parte de la estructura, para que en esa zona ya no sea una cáscara delgada. Nótese que el relleno de mampostería del seno de una bóveda gótica cumple un objetivo análogo."

\footnotetext{
${ }^{14}$ Huerta Fernández, S., y Aroca Hernández-Ros, R. (1990). Cúpulas de fábrica: un estudio de sus dimensiones y semejanzas. Ingeniería Civil, 75, 109-123.

${ }^{15}$ Heyman, J. (1999). El esqueleto de piedra: mecánica de la arquitectura de fábrica. Instituto Juan de Herrera, CEHOPU.
} 
Santa Maria del Fiore

La construcción de la cúpula de la catedral de Florencia en el siglo XV, sobre un esbelto cimborrio de grandes dimensiones preexistente, y sin cimbra, supuso un importante alarde técnico y creativo que ha sido analizado por numerosos especialistas a lo largo del tiempo.

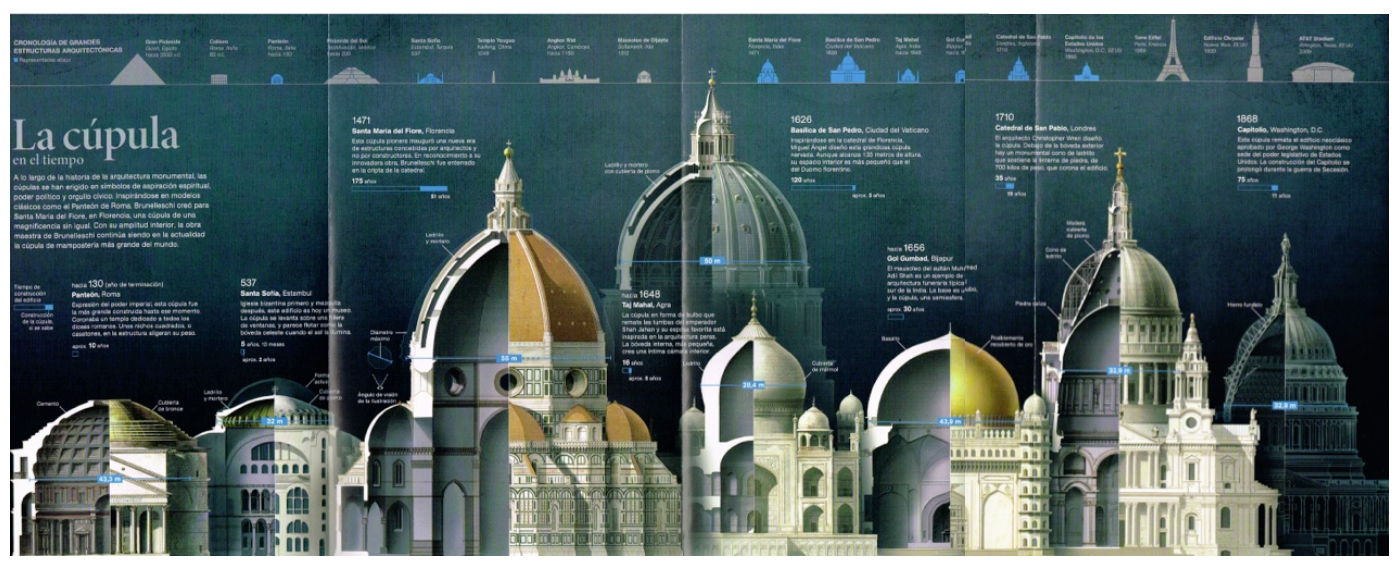

Fig.VI.16. Cúpulas, ilustración National Geographic 2014

En esta imagen del número de marzo de 2014 de la revista divulgativa National Geographic con una comparativa de cúpulas, se señala la de Florencia como la mayor del mundo.

Al parecer, en 1637 el arquitecto de la fábrica, ya propone incorporar un encadenado adicional para contener una fisura en la cúpula. Aunque otros técnicos consideraban que la lesión había surgido en fechas próximas a la construcción, en 1695 se empieza a fabricar la cadena. Se interrumpe cuando se habían recibido, según el Libro de Fábrica 186 piezas y nunca llega a colocarse ${ }^{16}$. Los numerosos estudios de la estructura de esta cúpula describen cómo se construye con dos láminas de espesor variable separadas por un espacio entre ambas (de 4 pies en la base), que aloja las escaleras.

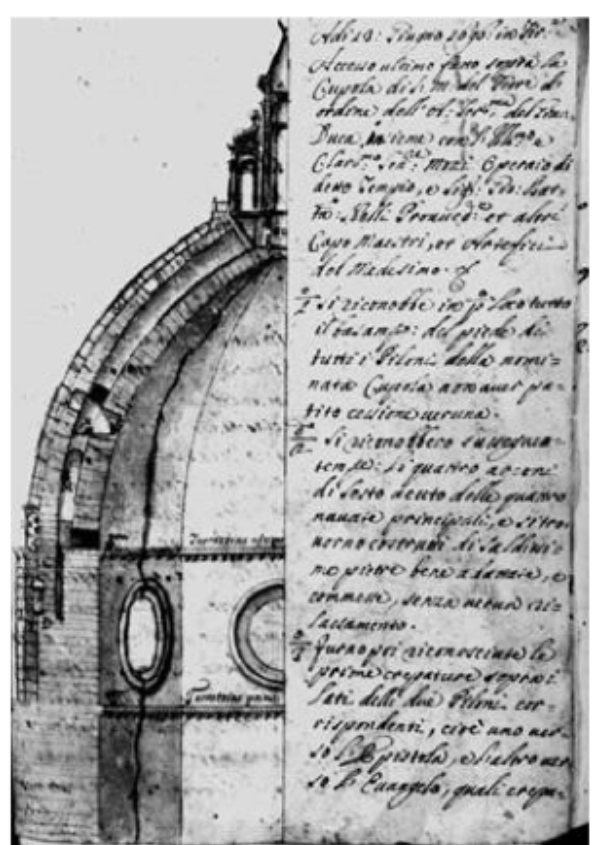

Fig.VI.17. Dibujo de Fontana, Biblioteca Nazionale Centrale.

\footnotetext{
${ }^{16}$ Di Teodoro, F. P. (2011). Giovanni Poleni, Domenico Maria Manni e le catene per la cupola di Santa Maria del Fiore: per la storia delle fratture e dei previsti risarcimenti alla" grande macchina" di Filippo Brunelleschi. Annali Di Architettura: Rivista Del Centro Internazionale Di Studi Di Architettura “ Andrea Palladio,” (23), 151-176.
} 
La lámina interior arranca con 7 pies en la base y se remata con 5 pies a la altura del óculo de coronación. La exterior, más delgada, se resuelve con $21 / 2$ a $11 / 4$ pies.

"El esquema estructural se basa en una serie de nervios verticales interconectados por varios tipos de elementos horizontales: anillos de atado de piedra, madera, hierro, así como los elementos en forma de bóvedas de cañón atando
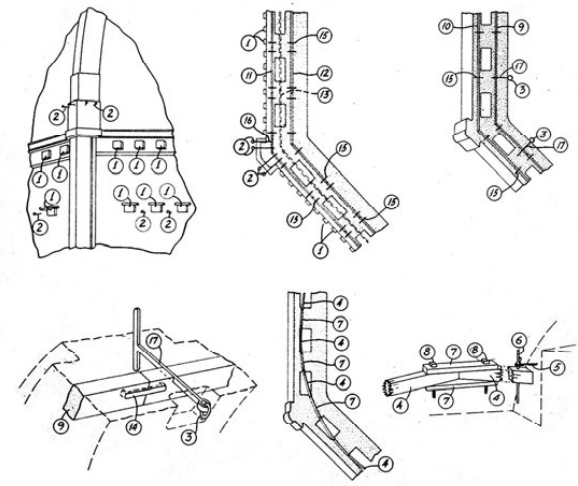

Fig.VI.18. Sistema de atado, Navas 1984 apud Rich 1969 los nervios de esquina con los adyacentes. Gran parte de los elementos de atado quedan embebidos en la mampostería y por consiguiente ocultos. ... se colocan vigas de madera de roble y cadenas de hierro que atan todos los nervios. Mediante grapas y eslabones se consigue unir las distintas piezas de piedra que forman las cadenas de atado y con platabandas y bulones se empalman los tramos de las cadenas de madera" ${ }^{17}$.

Podemos encontrar ingente documentación administrativa original digitalizada con la iniciativa "Gli anni della Cupola" ${ }^{18}$ con imágenes de contratos y pagos de materiales disponibles, transcripción de los textos y su análisis. Por ejemplo, el pago de una cadena de hierro para la tercera tribuna o la garantía de los proveedores de castaño para una cadena de madera en 1423.

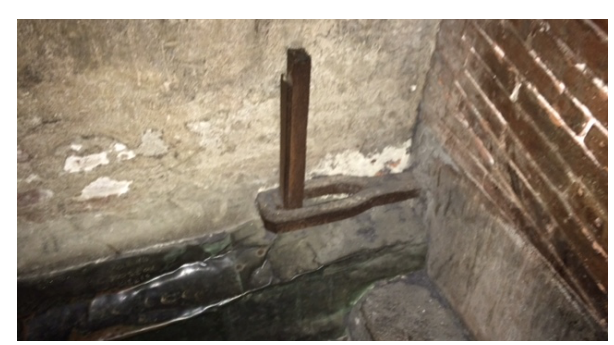

Fig.VI.19. Tirante, visita 28/03/2015

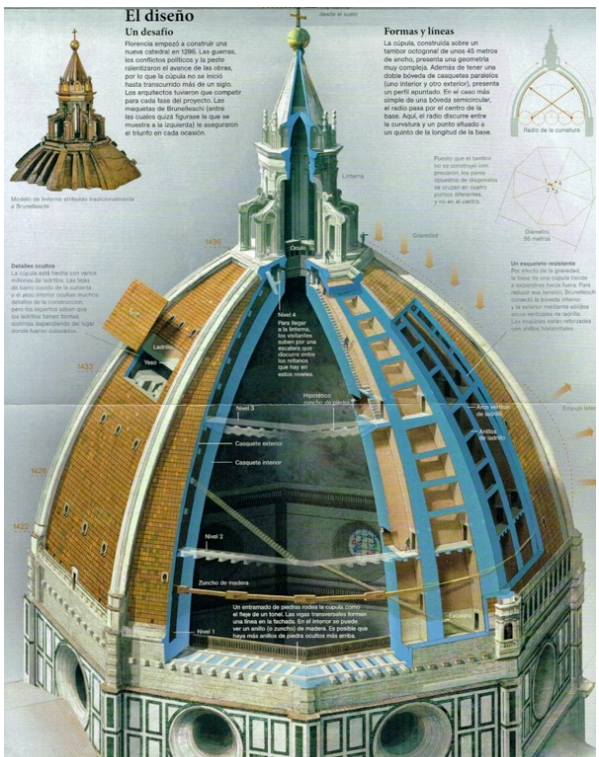

Fig.VI.20. Ilustracion National Geographic, Ricci 2014

Massimo Ricci, arquitecto estudioso del sistema constructivo de la cúpula de Brunelleschi, divulga de conclusiones en varios medios de comunicación,

\footnotetext{
${ }^{17}$ Navas Gutiérrez, M. (1984). La cúpula de Santa María del Fiore. Informes de La Construcción, 36(359), 79-84.

${ }^{18}$ En la página http://www.operaduomo.firenze.it/cupola
} 
describiendo la configuración geométrica espacial del aparejo de ladrillo de la lámina interna, dispuesto con una inclinación variable "en espina de pez".

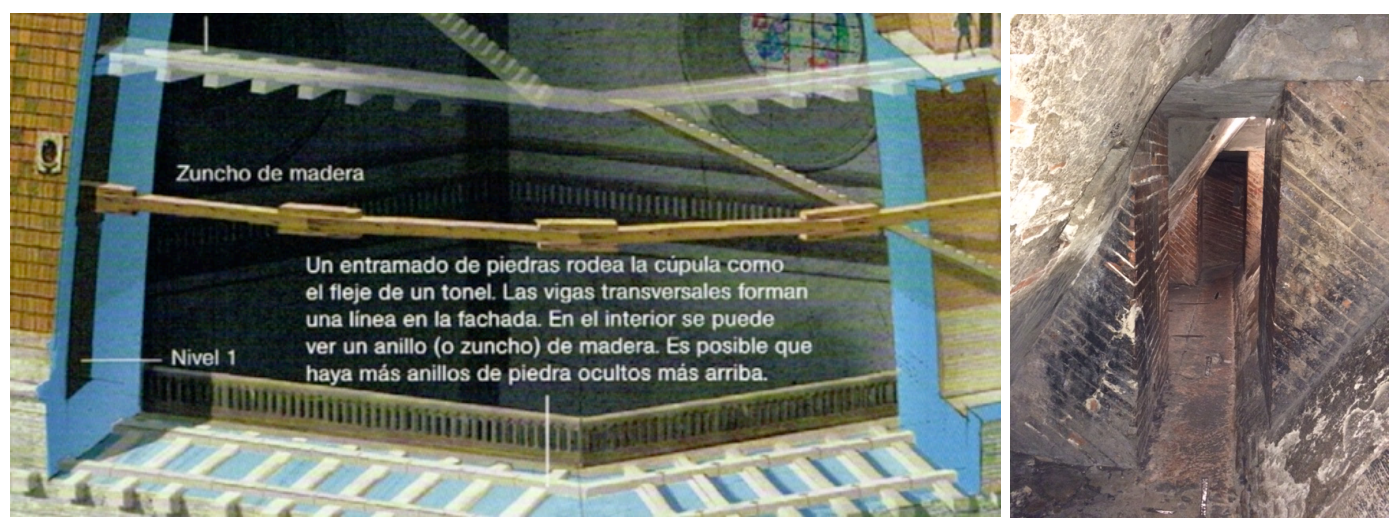

Fig.VI.21. Detalle de cinchas de piedra y madera, Ricci 2014 y ladrillos en espina, visita 28/03/2015

\section{VI.2.4.2. Algunos ejemplos en España}

Basílica de Loiola

En la revista de la Sociedad de Estudios Vascos Ondare se recogen varios artículos sobre el Anteproyecto de Restauración de la cúpula de la Basílica de Loyola, y en uno de ellos se analizan los aspectos estructurales ${ }^{19}$.

La cúpula, de unos $21 \mathrm{~m}$ de diámetro interior y doble cáscara de piedra, la exterior caliza y la interior arenisca, presentó un agrietamiento importante y bien documentado desde su construcción. En 1735 se colocó "dos arcos de yerro que ambos abrazasen toda la media naranja (...) en su anillo por la parte exterior". Las dos grietas principales de una pulgada, se rellenan constantemente con betún y aceite de linaza.

Según el texto, hacia 1990 algunas grietas presentan más de $6 \mathrm{~cm}$ de abertura y la Diputación encarga su análisis al profesor italiano Giorgio Croci. Este especialista considera necesario reforzar, primero con tensores provisionales y de forma definitiva con un haz de cables perimetrales y un anillo en la base exterior, todo de acero inoxidable.

\footnotetext{
${ }^{19}$ López-Amor, L. C. (2000). Anteproyecto de Restauración Interior de la cúpula de la Basílica de Loyola: aspectos estructurales. Ondare: Cuadernos de Artes Plásticas Y Monumentales, (19), 227234.
} 
El ingeniero analiza la geometría de la cúpula, deduciendo que la cáscara exterior cuenta con unos $60 \mathrm{~cm}$ de espesor por lo que la relación con el radio es superior a 0,05. Cita el estudio de Poleni sobre San Pedro y concluye que si la relación entre espesor $y$ radio de una cúpula semiesférica agrietada es superior a 0,042 , entonces ésta resulta estable. El proyecto se encargó a Carlo Fontana pero la estructura ejecutada presenta menos peralte y mayor linterna que el prototipo establecido por éste. Encuentra similitudes con la Cúpula de la Clerecía de San Marcos de Salamanca donde en 1667 se colocaron 6 tirantes.

Sobre este último ejemplo hay que destacar el comentario que recoge en 1982 la revista Materiales de construcción ${ }^{20}$ :

"Así en los problemas de la Cúpula de La Clerecía de Salamanca, ya los había detectado el conocido arquitecto Ventura Rodríguez, quien estimó que los materiales pétreos empleados no eran los adecuados para el enorme peso que tenía la cúpula y el cupulino o linterna. La enorme masa de ambos tiende a reventar el tambor de la cúpula. La reparación en aquella época consistió en zunchar mediante elementos metálicos o cadenas, que a lo largo del tiempo no ejercieron acción alguna."

\section{Otras actuaciones recientes}

El profesor Francisco Jurado ${ }^{21}$ expone en un artículo varias consideraciones interesantes sobre la restauración de una cúpula en una localidad de Castellón que realiza con Arturo Zaragozá. En primer lugar expone cómo realizaron en 1999 los cálculos estructurales con un programa desarrollado por ellos, especialmente para construcciones de fábrica, basado en métodos gráficos. La hipótesis de cálculo contemplaba un espesor (con su correspondiente peso propio) de $30 \mathrm{~cm}$, mientras que una vez comenzadas las obras se comprueba que el casco es mucho más ligero, con sólo $13 \mathrm{~cm}$ al estar formado por tres roscas de rasilla.

En el informe preliminar recomendaban incorporar un zuncho en la parte superior del tambor. Aunque esta pieza presentaba una importante grieta la cúpula se encontraba en buen estado. Al comenzar a sanear se descubre la existencia de un cinchado de forja embebido en la fábrica desde su origen en esa posición, lo que

\footnotetext{
${ }^{20}$ Fernández Paris, J. M. (1982). Valoración del estado de alteración de los materiales pétreos en los monumentos. Materiales de Construcción, 32(185), 43-59.

${ }^{21}$ Jurado Jiménez, F. (2003). Iglesia de San Miguel Arcángel (Canet Lo Roig, Castellón): restauración de la cúpula, bóvedas del crucero y cubiertas. Recuperem Patrimoni, (1), 100-105.
} 
resuelve la incógnita del buen estado del casco sobre un tambor con semejante patología.
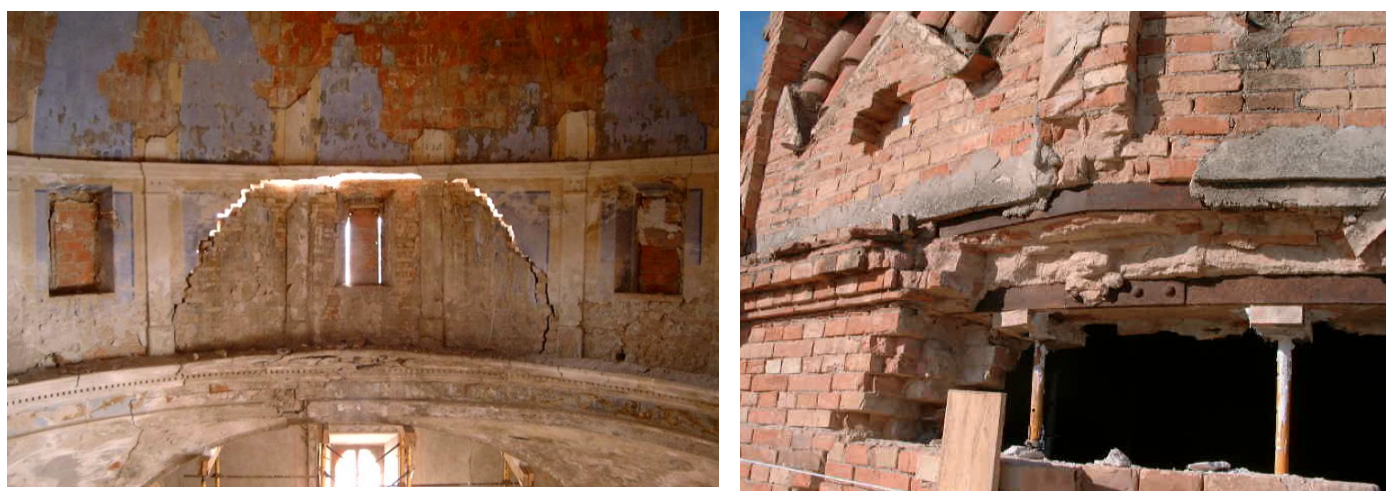

Fig.VI.22. Patología de cúpula, Jurado 2003

Otro caso del que podemos extraer interesantes conclusiones fue expuesto en una edición del congreso PATORREB por Silvia Spairani ${ }^{22}$.

Se trata del estudio constructivo de una iglesia construida en Elche a mediados del siglo XX. La cúpula es rebajada sobre una arquería y cuenta con un zuncho de hormigón en la base del tambor. Presenta grietas verticales y una horizontal que atraviesan el muro. Los autores afirman que aunque la cúpula es estable, se producen movimientos porque el zuncho perimetral esta colocado incorrectamente, en la base del tambor y no en la coronación del mismo.

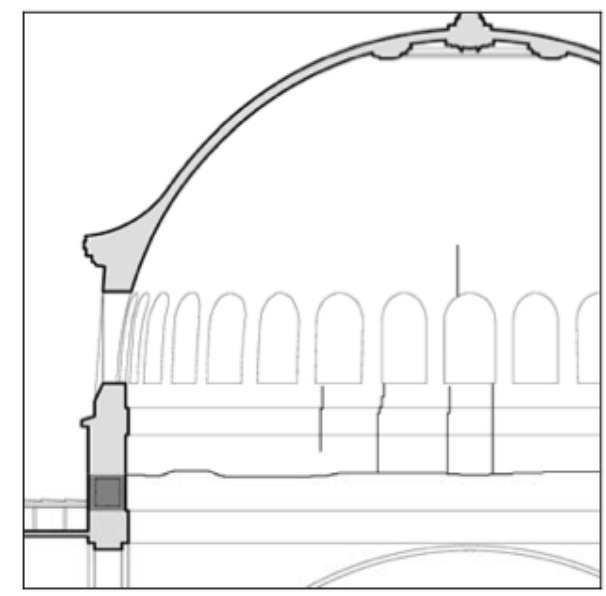

Fig.VI.23. Zuncho en iglesia de Elche, Spairani 2009

En la iglesia de San Pedro de Serrada (Ficha FZ-40) se dispuso en 1992 el refuerzo sobre el trasdós de la cúpula realizado con doble rosca de rasilla que aparece en la fotografía.

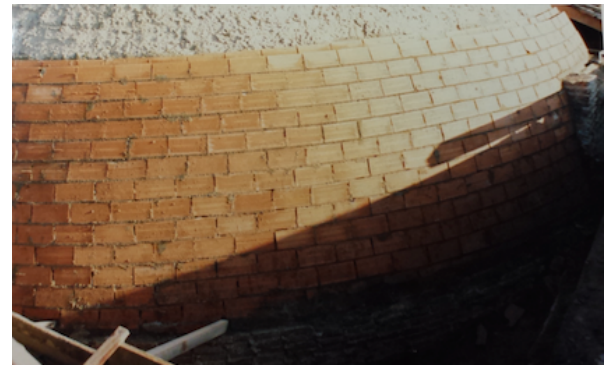

Fig.VI.24. Cinchado de cúpula con ladrillo en Serrada, Areizaga 1992 JCyL

${ }^{22}$ Spairani Berrio, S., Louis Cereceda, M., Spairani Berrio, Y., Mora García, R. T., Huesca Tortosa, J. A., Céspedes López, M. F., \& others. (2009). Estudio histórico y constructivo de la Iglesia del Sagrado Corazón de Jesús en Elche (Presentación). In PATORREB 2009 (pp. 793-798). 
Según se describe en los ejemplos anteriores, los cinchados se conforman con diferentes materiales, tanto cadenas de metal como vigas de madera empalmadas, incluso sillares de piedra formando una especie de parrillas perimetrales y revestido con hojas de ladrillo tabicado.

En conclusión, podemos afirmar que a lo largo de la historia se ha colocado frecuentemente encadenados para zunchar las cúpulas, tanto de forma simultánea a su construcción como posteriormente a raíz de la habitual fisuración de los cascos. Encontramos técnicos partidarios, que los incorporan casi como receta estándar, y fuertes detractores, que los consideran una adición estéril. 


\section{BIBLIOGRAFÍA}

\section{VII.1. Referencias bibliográficas}

ACCIONA, y LABEIN. (2008). Cirugía del Bien Cultural. Técnicas de Rehabilitación/ Refuerzos para edificios históricos del Patrimonio Cultural. Universitat Autònoma de Barcelona. Obtenido en http://www.recercat.net/bitstream/2072/88240/1/E2.26.pdf

Acosta, J. M. G., Martínez, D. L., y Mark, R. (2002). Tecnología arquitectónica hasta la revolución cientifica (Vol. 5). Ediciones AKAL.

Adeline, J. (1887). Vocabulario de términos de Arte, escrito en francés por J. Adeline. Traducido y aumentado con más de 600 voces y anotado por José Ramón Mélida. Madrid: Obra publicada por la empresa de La Ilustración Española y Americana.

Alberti, L. B. (1582). Los diez libros de Architectura de Leon Baptista Alberto. Traducidos del LatEn en Romance [por Francisco Loçano]. Madrid: Casa de Alfonso Gómez.

Almagro, A. (1988). Planimetría y fotogrametría. En M. Alonso y F. Mendoza, Rehabilitación y ciudad histórica. I Curso de Rehabilitación del COAAO en 1987 (pp. 201-219).

Antolinez de Burgos, J. (1722). Historia de Valladolid que dexó manuscrita Juan Antolinez de Burgos, vezino y natural de la misma ciudad. Valladolid. Obtenido en http://uvadoc.uva.es/handle/10324/482

Antuña, J. (2009). Léxico de la construcción. Madrid: IETCC (CSIC) e Instituto Juan de Herrera.

Ara Gil, C. J., y Parrado del Olmo, J. M. (1980). Partido judicial de Tordesillas (Vol. Tomo XI). Valladolid: Diputación provincial de Valladolid.

Arce, I. (1996). Elementos y sistemas constructivos antisísmicos en la antigüedad. Aplicación a la restauración de estructuras históricas. En Actas del CNHC VII (pp. 39-47). Madrid: I. Juan de Herrera, CEHOPU.

Arede, A., Costa, A., Guedes, J., y Paupério, E. (n.d.). Reforço de estruturas de alvenaria de pedra contribuçoes do NCREP-FEUP. En el $2^{\text {a }}$ Jornadas de Engenharia Civil da Universidade de Aveiro. Avaliação e Reabilitação das Construções Existentes.

Arêde, A., Costa, A., Guedes, J. P. M., y Paupério, E. (2008). Reforço de Estruturas de Alvenaria de Pedra-Contribuições do NCREP-FEUP. En Actas das II Jornadas de Engenharia Civil sobre Avaliação e Reabilitação das Construções Existentes.

Arias Martínez, M., Hernández Redondo, J. I., y Sánchez del Barrio, A. (2004). Catálogo monumental de Medina del Campo ( $2^{\mathrm{a}}$ ed., Vol. Tomo XIX). Valladolid: Diputación provincial de Valladolid.

arme. (n.d.). Zuncho para embalajes. Obtenido en http://www.arme.com.co/pdf/Zunchos_FichaTecnica.pdf 
Arnuncio Pastor, J. C. (1996). Guía de arquitectura de Valladolid. Valladolid: Consorcio IV Centenario de la Ciudad de Valladolid.

Arquitecturas restauradas. Una década de intervención en el patrimonio histórico de la Comunidad de Madrid: 1986-1995. (1995). Madrid: Consejería de Educación y Cultura, Comunidad de Madrid.

ARX s.c.r.l. - Venzone (UD). (2003). Istruzioni Tecniche per l'interpretazione ed il rilievo per macroelementi del danno e della vulnerabilità sismica delle chiese. Regione Toscana - Area Servizio Sismico Regionale.

Asociación Colombiana de Ingeniería Sísmica. (2001). Manual de construcción sismo resistente de viviendas en bahareque encementado. Bogotá: AIS. Obtenido en http://cidbimena.desastres.hn/docum/lared/libros/guadua_lared.pdf

Bails, B. (1796). Elementos de Matemáticas. Tom. IX. Parte I. Que trata de la Arquitectura civil. Madrid: Imprenta de la viuda de Ibarra.

Bails, B. (1802). Diccionario de Arquitectura civil. Madrid: Imprenta de la viuda de Ibarra.

Barberot, É. (1927). Tratado práctico de Edificación por E. Barberot. Traducido de la $5^{a}$ edición francesa por Lino Álvarez Valdés. Barcelona: Gustavo Gili Editor.

BASF. (n.d.). Obras iglesia del Salvador. Rehabilitación estructural. Obtenido en $\mathrm{ftp}: / / \mathrm{fb} .27 .354 \mathrm{a}$. static.theplanet.com/documentaciontecnica/basf/basf_ob_igl_salvad.pdf

Basterra, A., y et Al. (2005). Avance de propuestas metodológicas para el diagnóstico y análisis de estructuras de madera históricas. En Actas del Cuarto Congreso Nacional de Historia de la Construcción. Cádiz: I. Juan de Herrera, COAC, CAATC.

Baudot, A. de. (1867). Eglises de bourgs et villages. París: A. Morel, Libraire-Editeur.

Benedicto Salas, R. (2012). De las sustituciones de cubiertas en las iglesias del patrimonio monumental. Zaragoza: Institución Fernando el Católico.

Blanco y Caro, R. (1930, August 31). El Egipto de los anacoretas. $A B C$. Sevilla. Obtenido en http:/hemeroteca.abcdesevilla.es/nav/Navigate.exe/hemeroteca/sevilla/abc.sevilla/1930/08/3 1/007.html

Branca, G. (1790). Manual de arquitectura que escribió en italiano Juan Branca arquitecto de la santa casa de Loreto con adiciones y notas de Leonardo Vegni. Traducido al castellano por Don Manuel Hijosa. por la Viuda de D. JoachEn Ibarra.

Branca, J. (1790). Manual de arquitectura, trad., comentários e acréscimos de D (Manuel Hijosa,[6 ${ }^{\mathrm{a}}$ ed.]). Madrid: Viuda de D. Joachîn Ibarra.

Branco, J., Cruz, P., y Piazza, M. (2006). Asnas de madeira. A importância da rigidez das ligaçoes. En $4^{a}$ Jornadas Portuguesas de Engenarhia de Estruturas. Lisboa.

Brasas Egido, J. C. (2000). Antiguo partido judicial de Olmedo (facsímil 1977, Vol. Tomo X). Valladolid: Diputación provincial de Valladolid.

Briceño, J. M. (1966). América latina en el mundo. Caracas, Venezuela: Arte.

Burgos. (2007, November 16). Los expertos advierten de que hay que ver los templos en obras permanentes. ABC.es. 
Bustamante, A. (1983). La arquitectura clasicista del foco vallisoletano (1561-1640). Valladolid: Institución cultural Simancas.

Caballero Zoreda, L. (1995). Método para el análisis estratigráfico de construcciones históricas o "lectura de paramentos." Informes de La Construcción.

Cabañas Rodríguez, L., Carreño Herrero, E., Izquierdo Álvarez, A., Martínez Solares, J. M., Capote del Villar, R., Martínez-Díaz, J., ... y otros. (2011). Informe del sismo de Lorca del 11 de mayo de 2011. Madrid: Instituto Geográfico Nacional.

Camino Olea, M. S. (2001). Diccionario de arquitectura y construcción. Madrid: Munilla-Lería.

Candelas, Á. (1998). La carpintería de armar en los tratados europeos de los siglos XVI y XVII. En F. Bores et al, Actas del II CNHC. Madrid: Instituto Juan de Herrera, CEHOPU.

Candelas, Á. (2000). La carpintería de armar medieval. En A. Graciani, La técnica de la arquitectura medieval (pp. 271-296). Sevilla: Secretariado de Publicaciones de la Universidad de Sevilla.

Carazo Díaz, N. (2012). Iglesia de San Francisco de Lorca (Murcia). Antes y después del 11 de mayo de 2011. Alberca: Revista de La Asociación de Amigos Del Museo Arqueológico de Lorca, (10), 107-142.

Cartagena Sevilla, J. C. (n.d.). Incidencia de los terremotos en el conjunto monumental de Santo Domingo (Lorca, Murcia). Alberca. Revista de La Asociación de Amigos Del Museo de Lorca, (10), 143-171.

Castán, J. (1990). La polémica entre Gótico y Renacimiento en el siglo XVI. La iglesia de los Santos Juanes de Nava del Rey (Valladolid). Boletín Del Seminario de Estudios de Arte Y Arqueología, 56, 384-403.

Castán, J. (2006). El buen prior Fernán Rodriguez de Valbuena y la Iglesia funeraria de San Juan Bautista en Castronuño (Valladolid). Codex Aquilarensis, (22), 175-190.

Castán Lanaspa, J. (2002). Panorama general del Románico en Valladolid. En Enciclopedia del románico en Castilla y León: Valladolid (pp. 43-56). Fundación Santa María la Real.

Castán Lanaspa, J. (2006). Antiguo partido judicial de Nava del Rey (2a ed., Vol. Tomo XX). Valladolid: Diputación provincial de Valladolid.

Castro, B. (2007). Francisco Pons-Sorolla y Arnau, arquitecto restaurador. Universidad de Santiago de Compostela, Santiago de Compostela.

Center for History and New Media. (n.d.). Guía rápida. Obtenido en http://zotero.org/support/quick_start_guide

Cerutti Fusco, A. C., y Villani, M. (2003). Pietro da Cortona's domes between new experimentations and construction knowledge. En Proceedings of the First International Congress on Construction History: Madrid, 20th-24th january 2003 (pp. 579-591). Instituto Juan de Herrera.

Choisy, A. (1899). Histoire de l'Architecture (Vol. Tome II). París: Gauthier-Villars.

Chueca, F. (1947). La catedral de Valladolid. Madrid: Instituto Juan de Herrera. 
Cirujano, C., y Sousa, A. L. de. (2013). Algunos datos y primeras conclusiones sobre el Programa de Control y Seguimiento de Intervenciones ejecutadas por el Instituto del Patrimonio Cultural de España. Conservación Preventiva: Revisión de Una Disciplina, (7), 147-157.

Conservar y restaurar: cuatro años de actuaciones en el patrimonio histórico de la Comunidad de Madrid. (2003). Madrid: Consejería de Empleo, Turismo y Cultura. D.G. Patrimonio Histórico.

Corominas, J. (1944). Indianoromanica. Revista de Filología Hispánica, 6, 156-157.

Cuetos, M. P. G., Núñez-Herrador, M. E. A., y Martínez, A. H. (2010). Restaurando la memoria: España e Italia ante la recuperación monumental de posguerra. Trea.

De la Torre Yubero, A. (2009). San Juan y San Pablo en Peñafiel. ARGAYA Revista de Cultura, (39).

Denfer, J. (1891). Architecture y constructions civiles. Charpenterie métallique 1. París: GauthierVillars et Fils.

Departamento de Construcciones Arquitectónicas, Ingeniería del terreno y Mecánica de los Medios Continuos y Teoría de Estructuras. (1984). Aleros en la Arquitectura popular de la provincia de Valladolid. Universidad de Valladolid

Di Teodoro, F. P. (2011). Giovanni Poleni, Domenico Maria Manni e le catene per la cupola di Santa Maria del Fiore: per la storia delle fratture e dei previsti risarcimenti alla“ grande macchina" di Filippo Brunelleschi. Annali Di Architettura: Rivista Del Centro Internazionale Di Studi Di Architettura “ Andrea Palladio,” (23), 151-176.

Domínguez Burrieza. (2009). Jerónimo y Antonio Ortiz de Urbina: vida y obra. Universidad de Valladolid, Valladolid.

Domínguez Burrieza, F. J. (2011). El Valladolid de los Ortiz de Urbina (1852-1936). Valladolid: Ayuntamiento de Valladolid.

Domínguez Burrieza, F. J. (2013). La Junta diocesana de obras y reparaciones, el pueblo y el estado durante la segunda mitad del siglo XIX: proyectos de conservación, restauración y de nueva planta en la arquitectura religiosa vallisoletana de Jerónimo Ortiz de Urbina. Arquitectura, Ciudad Y Entorno, (21), 37-66.

Eck, C. L. G. (1841). Traité de l'application du fer, de la fonte et de la tôle dans les constructions civiles, ...etc. París: Carilian-Goeury et Vor. Dalmont.

Escrig, F., y Pérez, J. (2004). La modernidad del Gótico. Seis puntos de vista sobre la arquitectura medieval. Sevilla: Secretariado de Publicaciones de la Universidad de Sevilla.

Espinosa, P. C. (1859). Manual de construcciones de albañilería. Madrid: Imprenta a cargo de Severiano Baz.

Esponda Cascajares, M. (2004). Evolución de los criterios de intervención con hormigón armado en la restauración de edificios históricos en España y en México. Universidad Politécnica de Catalunya.

Esteban Chapapría, J. (2007). La conservación del patrimonio español durante la II República (19311939). Barcelona: Fundación Caja de Arquitectos. 
Faenza, C., y Mazzolani, F. M. (2009). Innovative Strategies for Structural Protection of Built Heritage-PREN 2005. Polimetrica sas.

Fernández del Hoyo, M. A. (1990). Notas sobre arquitectura doméstica clasicista, 56, 415-432.

Fernández del Hoyo, M. A. (2003). La iglesia parroquial de San Martín: su historia. Boletín Del Seminario de Estudios de Arte Y Arqueología, 38, 9-26.

Fernández, L. (1987). Construcción de la iglesia de San Pedro. Boletín Del Seminario de Estudios de Arte Y Arqueología, 53, 327-330.

Fernández Paris, J. M. (1982). Valoración del estado de alteración de los materiales pétreos en los monumentos. Materiales de Construcción, 32(185), 43-59.

Ferreira, F. (2012). Recuperação de estruturas de coberturas tradicionais de madeira - Análise de alguns exemplos. En Lourenço y Branco (Eds.), . En el Seminário Coberturas de Madeira, Gimaraes: Universidade do Minho.

Frampton, K. (1999). Estudios sobre cultura tectónica (Vol. 22). Ediciones AKAL.

Fray Lorenzo de San Nicolás. (1639). Arte y Uso de Architectura.

Fundación Caja Madrid. (2008). Proyecto de restauración del presbiterio de la iglesia del monasterio de Santa Isabel la Real. Granada. Obtenido en http://www.fundacionmontemadrid.es/Ficheros/CMA/ficheros/F-patri-dossier-staisabel.PDF

Galindo García, P. (1999). Comportamiento y diagnostico de la cubierta. En Tratado de Rehabilitación (Vol. IV, pp. 341-360). Madrid: Munilla-Lería.

Garabito López, J., Rodriguez, Junco, y Garabito. (2015). Intervenciones en cubiertas históricas de madera: ¿Restaurar o reconstruir? Anales de Edificación, 1(1), 16-22.

Garcés Desmaison, M. A. (2009). La conservación preventiva de los monumentos destinados al culto en Castilla y León. En Conservación preventiva en lugares de culto. Madrid: IPCE.

García Chico, E., y Bustamante García, A. (2000). Partido judicial de Nava del Rey (facsímil de 1972, Vol. Tomo V). Valladolid: Diputación provincial de Valladolid.

García de Wattenberg, E. (1991). Noticias para la historia de la Capilla del Museo Nacional de Escultura. Boletín de La Real Academia de Bellas Artes de San Fernando, (72), 287-310.

García López, A. (2008). Patrimonio cultural: diferentes perspectivas. Arqueoweb: Revista Sobre Arqueología En Internet. Universidad Complutense de Madrid, 9(2).

Gaztelu, L. (1899). Pequeña Enciclopedia práctica de construcción publicada bajo la dirección de L.A. Barré. $N^{\circ} 4$. Carpintería de armar. Traducido y anotado por D. Luis Gaztelu. Madrid: Librería editorial de Bailly-Bailliere e hijos.

Gentil Baldrich, J. M. (1998). Traza y modelo en el Renacimiento. Sevilla: Universidad de Sevilla.

Ger y Lóbez, F. (1898). Tratado de construcción civil. Badajoz: Imprenta de Minerva Extremeña.

Gil Muñoz, M. T., y Barrón del Pozo, A. (2013). Las humedades en edificios declarados BIC desde la perspectiva de la conservación preventiva. Desarrollo de una metodología de diagnosis y control. Conservación Preventiva: Revisión de Una Disciplina, (7), 119-128. 
Gómez de Cózar, J. C., y Benítez, R. M. (2008). Las soluciones inconclusas de las cubiertas de los templos medievales del Reino de Sevilla, España. Informes de La Construcción, 60(509), 57-67.

Gómez Martínez, J. (1992). Obras en San Benito el Viejo de Valladolid y San Zoilo de Carrión (15831594). Buenas y malas artes en el foco clasicista. Boletín Del Seminario de Estudios de Arte Y Arqueología, 58, 333-348.

Gómez, M. I. (2006). Las estructuras de madera en los Tratados de Arquitectura (1500-1810). Madrid: Asociación de investigación técnica de industrias de la madera y corcho AITIM.

González Capitel, A. (1976). La arquitectura de Luis Moya Blanco. Arquitectura.

González Capitel, A. (1983). El tapiz de Penélope. Apuntes sobre las ideas de restauración e intervención arquitectónica. Arquitectura, 24-34.

González Echegaray, M. C. (1991). Artistas cántabros de la Edad Moderna: su aportación al arte hispánico : (diccionario biográfico-artístico). Institución Mazarrasa. Obtenido en http://books.google.es/books?id=rhlMUy2iTeUC

González Fraile, E. (2004). La restauración de monumentos en Francia. Patrimonio Histórico, Monográfico(50), 87-95.

González Fraile, E. (2012). Innovación versus proyecto arquitectónico. El frontón y las fachadas de la Iglesia de San Pablo de Valladolid. En Actas VIII Congreso Internacional (pp. 255-267). Valladolid.

González Martín, C. (2005). Las intervenciones de Francisco Pons-Sorolla en la construcción de la Catedral de Santiago de Compostela entre 1962 y 1975. En Actas del Cuarto Congreso Nacional de Historia de la Construcción: Cádiz, 27-29 de enero de 2005 (pp. 499-510). Instituto Juan de Herrera.

Gonzalez Moreno-Navarro. (2012). Restauración monumental: ¿el método en crisis? Informes de La Construcción, 64(EXTRA).

González Moreno-Navarro, A. (1992). La restauración objetiva (Método SCCM de restauración monumental): Memoria SPAL 1993-1998. Diputació de Barcelona. Servei del Patrimoni Arquitectònic Local.

González Moreno-Navarro, J. L. (1996). Los tratados históricos como documentos para la historia de la construcción. En Actas del Primer Congreso Nacional de Historia de la Construcción (pp. 255-260).

Gutiérrez Carrillo, M. L., y Villafranca Jiménez, R. (2012). La des-restauración en el patrimonio histórico granadino. En Actas del XI Congreso Internacional de Rehabilitación del Patrimonio arquitectónico y edificación (pp. 441-421). Cascais: ICES CICOP.

Henriques, F. (2003). The concept of acceptable technology En architectural conservation. En ITAM ARCCHIP ARIADNE Workshop.

Hernández, F. (1975). El alminar de Abd Al-Rahman III en la Mezquita Mayor de Córdoba. Génesis y repercusiones. Granada: Patronato de la Alhambra.

Hernández Sampieri, R., Fernández Collado, C., y Baptista Lucio, P. (2010). Metodología de la investigación ( $5^{\mathrm{a}}$ ed.). México: McGraw-Hill. 
Herrero Rey, A. (2008). Tratados ingleses de arquitectura: 1563-1663. Valladolid: Universidad de Valladolid.

Heyman, J. (1995). Teoría, historia y restauración de estructuras de fábrica: colección de ensayos. Instituto Juan de Herrera.

Heyman, J. (1999). El esqueleto de piedra: mecánica de la arquitectura de fábrica. Instituto Juan de Herrera, CEHOPU.

Hoz Martínez, J. de D. de la. (2012a). Análisis de la iglesia de Santiago en Lorca (Murcia) tras el terremoto de mayo de 2011 y propuestas para su recuperación. Alberca. Revista de La Asociación de Amigos Del Museo de Lorca, (10), 247-276.

Hoz Martínez, J. de D. de la. (2012b). Comportamiento de la ex colegiata de San Patricio en Lorca durante el terremoto de mayo de 2011. Actuaciones de emergencia y restauración. Alberca. Revista de La Asociación de Amigos Del Museo de Lorca, (10), 225-246.

Huerta Fernández, S. (1990). Diseño estructural de arcos, bóvedas y cúpulas en España, ca. 1500-ca. 1800. Universidad Politécnica de Madrid.

Huerta Fernández, S., y Aroca Hernández-Ros, R. (1990). Cúpulas de fábrica: un estudio de sus dimensiones y semejanzas. Ingeniería Civil, 75, 109-123.

Hurtado Valdez, P. (2006). Los sismos y la restauración del patrimonio en tierra en Perú. En III Congreso de Tierra en Cuenca de Campos (pp. 91-98). Valladolid.

Hurtado Valdez, P. (2009). La restauración de edificios construidos con tierra en zonas sísmicas: La experiencia peruana. BIA, Revista Del Colegio Oficial de Aparejadores, Arquitectos Técnicos E Ingenieros de Edificación de Madrid, (259), 99-114.

Hurtado-Valdez, P. (2011). Bóvedas de madera y construcción naval: Mitos y verdades de la construcción de bóvedas de madera castellanas entre los siglos XVII y XVIII. En $1^{o}$ Congreso Ibero-Latino-Americano da Madeira na Construçao. Coimbra.

Iglesias Martínez, M. C. (1996). Análisis del doble papel de los morteros tradicionales de cal utilizados en los muros de fábrica tradicionales: su función decorativa y su función protectiva. En Actas del Primer Congreso Nacional de Historia de la Construcción. Madrid: Instituto Juan de Herrera, CEHOPU.

IPCE. (2011). Recomendaciones para la conservación de techumbres de madera. Instituto del Patrimonio Cultural de España IPCE. Obtenido en http://ipce.mcu.es/pdfs/recomendacionestechumbres2011.pdf

Jiménez, A., y Cabeza, J. M. (1988). Turris Fortissima. Documentos sobre la construcción, acrecentamiento y restauración de la Giralda. Sevilla: Colegio Oficial de Aparejadores y Arquitectos Técnicos de Sevilla.

Jurado Jiménez, F. (2003). Iglesia de San Miguel Arcángel (Canet Lo Roig, Castellón): restauración de la cúpula, bóvedas del crucero y cubiertas. Recuperem Patrimoni, (1), 100-105.

Jurina, L. (anno XVIII). Techniche di cerchiature di colonne En muratura. L'edilizia-Structural, (164), $38-49$.

Jurina, L., y Bassoli, A. (2010). Cerchiature: tecniche tradizionali e innovative. Ingegneri, (5), 6-7. 
Kingsley Porter, A. (1911). The construction of Lombard and gothic vaults. New Haven: Yale University Press.

Latorre, P. (2012). El monumento como un todo. El plan director de restauración. Informes de La Construcción, 64(Extra), 45-56.

López-Amor, L. C. (2000). Anteproyecto de Restauración Interior de la cúpula de la Basílica de Loyola: aspectos estructurales. Ondare: Cuadernos de Artes Plásticas Y Monumentales, (19), 227-234.

López Collado, G. (1982). Ruinas en construcciones antiguas. Causas, consolidaciones y traslados. Servicio de publicaciones MOPU.

López Collado, G. L. (1991). Actuaciones recomendables en restauraciones de edificios antiguos. En Jornadas sobre Restauración y Conservación de Monumentos: Madrid, 24 y 25 de abril de 1989 (pp. 177-182). Instituto de Conservación y Restauración de Bienes Culturales.

López Manzanares, G. (1998). La estabilidad de la cúpula de S. Pedro: el informe de los tres matemáticos. En Actas del II CNHC. A Coruña.

L’Orme, P. de. (1626). Oeuvres de Philibert de lOrme. Architecture. París: Chez Regnavld Chavdiere.

Losada, C. (2007). La arquitectura en el otoño del Renacimiento: Juan de Naveda 1590-1638. Santander: Servicio de publicaciones de la Universidad de Cantabria.

Luis Moya Blanco. (1998). Estudio del zuncho-estribo de la bóveda de planta elíptica y arcos entrecruzados de la iglesia de San Agustín, según el proyecto de Luis Moya Blanco. Informes de La Construcción, 50(456-457).

Malheiro, M. (Ed.). (2014). Intervençoes em coberturas medievais em madera: Tradiçao e contemporaneidade. En el Intervir em construçoes existentes de madeira.

Marcos Villán, M. Á., y Fraile Gómez, A. M. (2003). Antiguo partido judicial de Medina del Campo ( $2^{\text {a }}$ ed., Vol. Tomo XVIII). Valladolid: Diputación provincial de Valladolid.

Mariátegui, E. (1876). Glosario de algunos antiguos vocablos de Arquitectura y de sus artes auxiliares. Madrid: Imprenta de Memorial de Ingenieros.

Martínez Medina, A. (2012). Los secretos de las piedras: El proceso de intervenciones en la iglesia de Nueva Tabarca. CANELOBRE, (60), 129-149.

Martínez Monedero, M. (2010). Anselmo Arenillas y la segunda zona monumental (1940-1958). En Restaurando la memoria: España e Italia ante la recuperación monumental de posguerra (pp. 119-154). Trea.

Martínez Ríos, M. C., y Granados González, J. (2013). Comportamiento estructural de las edificaciones históricas en el sismo del 11 de mayo de 2011 de Lorca. Alberca: Revista de La Asociación de Amigos Del Museo Arqueológico de Lorca, (11), 167-203.

Martínez Solares, J. M. M. (2001). Los efectos en España del terremoto de Lisboa (1 de noviembre de 1755). Madrid: Instituto Geográfico Nacional. Ministerio de Fomento.

Martín González, J. J. (2000). Antiguo partido judicial de Valladolid (facsímil 1973, Vol. Tomo VI). Valladolid: Diputación provincial de Valladolid. 
Martín González, J. J., y Urrea Fernández, J. (2001). Monumentos religiosos de la ciudad de Valladolid I (facsímil de 1985, Vol. Tomo XIV). Valladolid: Diputación provincial de Valladolid.

Martín Nieva, H. (2000). La introducción del hormigón armado en España: las primeras patentes registradas en este país. En Actas del III CNHC. Sevilla.

Mendes de Silva, J. (2012). Telhados da cidade antiga: da expectativa ao desempenho. En Lourenço y Branco (Eds.), . En el Seminário Coberturas de Madeira, Gimaraes: Universidade do Minho.

Millington, J. (1848). Elementos de arquitectura, escritos en inglés por John Millington. Traducidos al castellano y aumentados con notas y apéndices por el mariscal de campo D. Mariano Carrillo de Albornoz, Director Subinspector del arma de Ingenieros en la Isla de Cuba (Vol. Tomo I). Madrid: Imprenta Nacional.

Minutuoli, G. (2012). Ciudad, arquitecturas y restauraciones, problemas de conservación de los cascos históricos. Informes de La Construcción, 64(EXTRA), 23-34.

Monjo Carrió, J. (1999). Aleros y cornisas. En Tratado de Rehabilitación (Vol. IV, pp. 341-360). Madrid: Munilla-Lería.

Moya Blanco, Luis, y Garcia-Gutierrez Mosteiro, Javier. (1993). Cuaderno de apuntes de construcción de Luis Moya (curso 1924-1925). Universidad Politécnica de Madrid.

Navascués, P. (1980). Reflexiones sobre Palladio en España. En J. Ackerman, Palladio. Madrid: Xarait.

Navascués Palacio, P. (1987). La restauración monumental como proceso histórico: el caso español, 1800-1950. En Curso de Mecánica y Tecnología de los edificios antiguos (pp. 285-329). Madrid: Colegio Oficial de Arquitectos de Madrid.

Navas Gutiérrez, M. (1984). La cúpula de Santa María del Fiore. Informes de La Construcción, 36(359), 79-84.

Noguera, J. F. (2006). Cartas de restauración del patrimonio Arquitectónico. Historia y estudio comparativo. Arché, 283-296.

Palladio, A. (1797). Los Cuatro Libros de Arquitectura. Traducidos e ilustrados por Don Joseph Ortiz y Sanz. Madrid: Imprenta Real.

Pano Gracia, J. L. (2004). El modelo de planta de salón: origen, difusión e implantación en América. En Arquitectura religiosa del siglo XVI. Zaragoza: Institución Fernando el Católico.

Paquet, P. (1936). Technique de la restauration des monuments historiques. Societé française d'archéologie. En 97e Congrès archéologuique de France tenue a Paris en 1934 (pp. 411424). París: A. Picard, Libraire.

Pardo, M. A. (2006). Un siglo de Restauración Monumental en los conjuntos históricos declarados de la provincia de Badajoz: 1900-2000. Universidad de Extremadura, Cáceres.

Paricio, I. (1999). Vocabulario de arquitectura y construcción. Barcelona: Bisagra.

Parrado del Olmo, J. (1990). Patronos y obras de arte en Santa María de Tordesillas. Boletín Del Seminario de Estudios de Arte Y Arqueología, (56), 518-541. 
Parrado del Olmo, J. M. (2000). Antiguo partido judicial de Mota del Marqués (facsímil de 1976, Vol. Tomo IX). Valladolid: Diputación provincial de Valladolid.

Parrado del Olmo, J. M. (2002). Antiguo partido judicial de Medina de Rioseco (2 ${ }^{\mathrm{a}}$ ed., Vol. Tomo XVI). Valladolid: Diputación provincial de Valladolid.

Pérez Chinarro, J. M. (1984). Trazas para la iglesia de Santa María de Cabezón. Boletín Del Seminario de Estudios de Arte Y Arqueología, 50, 414-416.

Pérez, C. L., y Valencia, D. R. (2010). Bóvedas de madera y bahareque en iglesias coloniales bogotanas. Estudio de cuatro iglesias del siglo XVII. Apuntes, (23), 70-83.

Perrault, C. (1761). Compendio de los Diez libros de arquitectura de Vitruvio. Madrid: Imprenta de D. Gabriel Ramírez.

Perria, E., Sinicropi, D., y Paradiso, M. (2013). La Catedral de Santiago de Cuba como ejemplo emblemático de la difusión de saberes entre Europa y Latinoamérica. En Actas del VIII CNHC. Madrid.

Peters, J. P. (1895). University of Pennsylvania Expedition to Babylonia. III. The Court of Columns at Nippur. American Journal of Archaeology and of the History of the Fine Arts, 439-468.

Plaza Santiago, F. de la, y Martín González, J. J. (2001). Monumentos religiosos de la ciudad de Valladolid II (facsímil de 1987, Vol. Tomo XV). Valladolid: Diputación provincial de Valladolid.

Portuondo, B. (1877). Lecciones de arquitectura, explicadas por el profesor de la academia de ingenieros comandante del cuerpo D. Bernardo Portuondo y Barceló. Madrid: Imprenta del memorial de Ingenieros.

Prats, L. (1997). Antropología y Patrimonio (Ariel SA). Barcelona.

Rebolledo, J. A. (1875). Construcción general. Madrid: Imprenta y fundición de J. Antonio García.

Rieger, C. (1763). Elementos de toda la arquitectura civil. Madrid: Impreso por JoachEn Ibarra.

Rivera Blanco, J. (2000). La restauración monumental en España en el umbral del siglo XXI, nuevas tendencias: de la Carta de Venecia a la Carta de Cracovia. Actas de Los Décimos Cursos Monográficos Sobre El Patrimonio Histórico, 6, 137-150.

Rivera Blanco, J. (2013). Nuevas tendencias de la restauración monumental. De la Carta de Venecia a la Carta de Cracovia. En Seminario: La doctrina de la restauración a través de las cartas internacionales. Universidad Politécnica de Valencia. Obtenido en http://riunet.upv.es/handle/10251/28161\#

Robador González, M. D., y Linares Díaz, J. F. (1998). El revestimiento de piedra en la catedral de Burgos. En Actas del II CNHC (pp. 417-429). A Coruña.

Romero Gallardo, A. (2010). Apuntes y reflexiones en torno a la obra restauradora del arquitecto Francisco Prieto-Moreno y Pardo. Revista Electrónica Del Patrimonio Histórico, (7).

Rovira y Rabassa, A. (1900). El hierro sus cortes y enlaces. Barcelona: Librería de Ribó y Marín.

Salazar, E. de. (1866). Cartas de Eugenio de Salazar, vecino y natural de Madrid, escritas a muy particulares amigos suyos; publicadas por la Sociedad de Bibliófilos españoles. Madrid: Imprenta y estereotipia de M. Rivadeneyra. 
San Nicolás, F. L. de. (1639). Arte y uso de arquitectura.

Sarrazola, J. C. (2008). Tectos portugueses do sec.XV ao sec. XIX (Dissertação para obtenção do grau de Mestre em Recuperação e Conservação do Património Construído). Universidade Técnica de Lisboa, Lisboa.

Serlio, S. (1552). Tercero y cuarto libro de arquitectura de Sebastia Serlio Boloñés. Toledo: Casa de Iván de Ayala.

Soraluce, J. R. (2008). Historia de la arquitectura restaurada. de la Antigüedad al Renacimiento. A Coruña: Universidade da Coruña.

Sotomayor. (1776). Modo de hacer incombustibles los edificios, sEn aumentar el coste de construcción. Madrid: Oficina de Pantaleón Aznar.

Spairani Berrio, S., Louis Cereceda, M., Spairani Berrio, Y., Mora García, R. T., Huesca Tortosa, J. A., Céspedes López, M. F., y y otros. (2009). Estudio histórico y constructivo de la Iglesia del Sagrado Corazón de Jesús en Elche (Presentación). En PATORREB 2009 (pp. 793-798).

Tellado, M. J. F. (2009). Cerchas tradicionales de madera en Galicia central: rasgos de comportamiento 3D. En Actas del Sexto Congreso Nacional de Historia de la Construcción: Valencia, 21-24 de octubre de 2009 (pp. 501-510). Instituto Juan de Herrera.

Tello, F. J. L., y Sanz, M. M. V. S. (1994). Estética y teoría de la arquitectura en los tratados españoles del siglo XVIII. Editorial CSIC-CSIC Press.

Tomé, M. (2002). Património e Restauro em Portugal (1920-1995). Porto: FAUP publicações.

Torre Rangel, O. de la, lopez vazquez, salazar hernández, y roldán cabrera. (2004). Evaluación estructural y comportamiento de las reparaciones efectuadas a edificaciones históricas. Revista de Ingeniería Sísmica, (70), 1-26.

Torres Balbás, L. (1919). El aislamiento de nuestras catedrales, 20.

Urquijo, M. J. (1984). Introducción del catálogo de la exposición. En J. Urrea, Planos, dibujos y maquetas de Valladolid. Valladolid: Caja de Ahorros Poplar.

Urrea Fernández, J. (2003). Partido judicial de Valoria la Buena (2 ${ }^{\mathrm{a}}$ ed., Vol. Tomo VII). Valladolid: Diputación provincial de Valladolid.

Urrea Fernández, J., y Brasas Egido, J. C. (2001). Partido judicial de Villalón (facsímil de 1981, Vol. Tomo XII). Valladolid: Diputación provincial de Valladolid.

Urrea, J. (1984). Planos, dibujos y maquetas de Valladolid. Valladolid: Caja de Ahorros Popular.

Urrea, J. (1986). Las trazas de Mazuecos y otros datos sobre el convento de Santa Catalina de Valladolid. Boletín Del Seminario de Estudios de Arte Y Arqueología, 52, 401-404.

Valdés, N. (1870). Manual del ingeniero y arquitecto. Madrid: Imprenta de Gabriel Alhambra.

Valdivieso González, E. (2000). Partido judicial de Peñafiel (facsímil de 1975, Vol. Tomo VIII). Valladolid: Diputación provincial de Valladolid.

Vallarino, B. (1842). Arte de aparejar y maniobras de los buques. Madrid: Imprenta de José Félix Palacios. 
Varagnoli, C. (2008). Des-restauración en Italia, teoría y realizaciones. En Actas de la III Bienal de Restauración Monumental: sobre la des-Restauración (pp. 47-63). Instituto Andaluz del Patrimonio Histórico.

Vargas-Neumann, J. (2014). Propuesta de conservación: patrimonio edificado en tierra del mundo andino. En REHABEND (pp. 43-52). Santander.

Vargas-Neumann, J., y Iwaki. (2014). Investigación sobre Caral, su valor científico y riesgo sísmico. En REHABEND (pp. 54-61). Santander.

Ventura Rodríguez. (1987). Informe que hizo el Arquitecto de S.M. D. Ventura Rodríguez, en el año de 1768, de la Santa Iglesia de Valladolid. Valladolid: Colegio Oficial de Arquitectos de Castilla y León Este.

Villalobos, A. (2001). La falsedad del falso arco maya. Bitácora Arquitectura, (5), 4-13.

Viollet-le-Duc, E. (1875). Description du château de Coucy. París: Vve. A. Morel.

Viollet-le-Duc, E. (n.d.). Dictionnaire Raisonné de l'architecture française du XIe au XVIe siècle (1867th ed.). París: A. Morel, Editeur.

Vitruvio, M. (1787). Los diez libros de Arquitectura. Madrid: Imprenta Real.

Ward, C. (1915). Mediaeval church vaulting. Princeton: Princeton University Press.

Wattenberg García, E. (2003). Catálogo monumental de Medina de Rioseco ( $4^{\text {a }}$ ed., Vol. Tomo XVII). Valladolid: Diputación provincial de Valladolid.

Yeves, J. A. (1996). Bibliografia de Luis Cervera Vera. Madrid: Publicaciones de arquitectura y arte SL.

Yuste-Navarro, J. (2014). Reducción de vulnerabilidad y mejora sísmica de la iglesia de San Cristóbal de Lorca afectada por el terremoto de mayo de 2011 en Lorca (Murcia, España). En REHABEND (pp. 765-773). Santander. 


\section{VII.2. Listado de ilustraciones}

\section{INTRODUCCIÓN}

Fig.I.1.

Portada del libro Fuentes Documentales

Fig.I.2. I.08

Tabla del libro "Conservación preventiva en lugares de culto". (Garcés 2009)

\section{METODOLOGÍA Y FUENTES}

Fig.II.1.

Escaleras de mano en el espacio bajo cubierta de la iglesia de Peñafiel

(visita 20/08/2015)

Fig.II.2. II.09

Imagen de cata para comprobar la existencia de zuncho de hormigón tras el durmiente de madera en San Francisco, cortesía Basterra 2015.

\section{ANTECEDENTES}

Terminología

Fig.III.1.

Elaboración de zuncho

http://palominocultural.files.wordpress.com/2011/05/zuncho.pdf (25/11/2014)

Fig.III.2. III.06

Folleto comercial zuncho embalajes "arme"

http://www.arme.com.co/pdf/Zunchos_FichaTecnica.pdf

Marco histórico

Fig.III.3.

Estela de Aksum

http://newsimg.bbc.co.uk/media/images/44715000/jpg (acceso 29/11/2013)

Fig.III4.

Templo Qasr El-Bint

http://www.travellingbackflip.com/typo3temp/pics/4021a23134.jpg(acceso 29/11/2013)

Fig.III.5.

Edificio barracks http://www.jacobmetcalf.net

Fig.III.6.

Shicras en Caral (Vargas-Neumann \& Iwaki 2014)

Fig.III.7.

Falso arco maya en Tikal, visita marzo de 2002

Fig.III.8.

Soportales, Serlio 1552

Fig.III.9.

Encamonados, de L'Orme 1626

Fig.III.10. 
Tirantes, Rieger 1763

Fig.III.11.

Fachada, Bails 1796

Fig.III.12.

Detalles, Eck 1841

Fig.III.13.

Sección Millington 1848

Fig.III.14.

Campanario Thiverval, Baudot 1867

Fig.III.15.

Detalles, Viollet le Duc 186

Fig.III.16.

Ganchos en Vezelay, Viollet le Duc 1868

Fig.III.17.

Tirantes Catedral de Amiens

http://cathedrale.gothique.free.fr/Cathedrale_Amiens_3.htm (21/10/2013)

Fig.III.18.

Tirantes Catedral de Amiens

http://cathedrale.gothique.free.fr/Cathedrale_Amiens_3.htm (21/10/2013)

Fig.III.19.

Cadenas, Valdés 1870

Fig.III.20,

Cadenas, Rebolledo 1875

Fig.III.21.

Planta de entramados, Rebolledo 1875

Fig.III.22.

Detalles entramado, Rebolledo 1875

Fig.III.23,

Detalles Denfer 1891

Fig.III.24.

Bóvedas, Choisy 1899

Fig.III.25.

Detalle, Barberot 1927

Marco conceptual

Fig.III.26:

Problemas de la construcción histórica, Latorre 2012

Fig.III.27:

Sección San Agustín, Moya 1998

Fig.III.28:

Talleres carpintería y cantería ETSAM, visita 30/01/2015

Fig.III.29:

Libro de López Collado

Fig.III.30:

Ilustración del libro de López Collado

Fig.III.31:

Fotografías del artículo de López Collado de 1991 
Otras regiones

Fig.III.32:

Fotografía tesis Pardo 2006

Fig.III.33:

Ilustraciones Catedral de Santiago, González Martín 2005

Portugal

Fig.III.34.

Fotografía de San Mamés antes de la intervención www.todoromanico.pt (20/03/2015)

Fig.III.35.

Sección transversal de San Mamés (Malheiro 2014)

Fig.III.36.

Tejado de la iglesia de los Canónigos en Porto

Fig.III.37.

Vista general de tejados y aleros en la ciudad de Porto

Fig.III.38

Obra de retejado en www.rotadoromanico.pt (20/03/2015) y telha airaes_recup

Fig.III.39.

Iglesia de Carminha antes de la intervención, Ferreira 2012

Fig.III.40.

Caminha, prótesis de inoxidable y nuevo tablero, Ferreira 2012

Fig.III.41.

Zunchado con anillo metálico en catedral de Porto, Ferreira 2012

Fig.III.42.

Cerchas metálicas de refuerzo en iglesia de Vimede, Arede y otros 2008

Fig.III.43.

Enlace cubierta-muros, Arede y otros 2008

Fig.III.44.

Techo reconstruido en iglesia de Vila do Rei, Sarrazola 2008

Fig.III.45

Imagen del blog

https://coisasdaarquitetura.wordpress.com/2010/09/06/tecnicas-construtivas-do-periodo-colonial-ii/

Fig.III.46. III.61

Gráfico de patología de cubiertas en 700 edificios antiguos portugueses entre 2004-2006,

Mendes da Silva 2012

Sismo

Fig.III.47.

Portada curso Sisma 2012 en Bologna

Fig.III.48.

Esquemas de la presentación de la profesora Francesca Ceroni

Fig.III.49.

Cuadro de vulnerabilidad de iglesias, Zamperini 2010

Fig.III.50.

Patología de zuncho semi-encastrado, Zamperini 2010

Fig.III.51.

Bóvedas de Asís, Wikipedia 30/10/2013 
Fig.III.52.

Zuncho web región de Umbría

Fig.III.53.

Ilustración AIS (30/10/2013)

Fig.III.54.

Ilustración Torre Rangel y otros 2004

Fig.III.55.

Esquema mecanismos inestables, informe Cabañas 2011

Fig.III.56.

Fisuración, informe Cabañas 2011

Fig.III.57.

Planta San Francisco, Carazo 2012

Fig.III.58.

Trabajos, Cartagena

Fig.III.59.

Planta San Patricio, de la Hoz 2012

Fig.III.60.

Proceso de colapso de la iglesia de Santiago, de la Hoz 2012

Fig.III.61.

Nueva estructura de Santiago en Lorca

(http://patrimonioxlorca.org/wp-content/uploads/2013/10/15266687.jpg 10/10/2013)

e imagen de la ruina, de la Hoz 2012

Fig.III.62.

Merma de resistencia acumulativa, Faenza y Mazzolani 2009

Últimas tendencias

Fig.III.63.

Ilustración Cirujano 2007

Fig.III.64.

Cubierta de Santa Isabel, Gutierrez y Villafranca 2012.

Fig.III.65

Desmontajes 1953 (Romero 2010) y 1999 (Caja Madrid 2008)

Fig.III.66.

Ilustración del Catalogo 2003

Fig.III.67.

Ilustraciones Nueva Tabarca, Martínez Medina 2012

Fig.III.68

Ilustración tejas, Bendicto 2012

Fig.III.69.

Cercha, ilustración Benedicto 2012

Fig.III.70.

Ilustración Jurina

Fig.III.71.

Ilustraciones arco armado y cuñas de reparto, Jurina y Bassoli 2010

Fig.III.72.

Ilustración trasdós, Jurina 2010 
Fig.III.73.

Tracciones máximas según el tipo de retícula de refuerzo, Jurina 2010

Fig.III.74.

Zunchado con fibra de carbono, BASF 2006

Valladolid

Fig.III.75.

Croquis de Diego de Praves

Fig.III.76,

Trazado de cartabones

Fig.III.77.

Ilustración Urrea 1986

Fig.III.78.

Trazas iglesia de Cabezón, Pérez 1984

Fig.III.79.

Fachada casa de Vallejo, Fernández del Hoyo 1990

Fig.III.80.

Ilustración de Praves, Dominguez 2011

Fig.III.81.

Reparación con ladrillo en Nava del rey, visita 20/06/2012

Fig.III.82.

Contrafuertes cilíndricos Nava del Rey, visita 20/06/2012

Fig.III.82.

Organización en Zonas, Esteban 2007

Fig.III.83.

Catedral de Sigüenza en 1939, ilustración Martinez 2010

\section{ANÁLISIS}

Memorias

Fig.IV.1.

Fotografía Catedral dossier (Arenillas 1969 AGA)

Fig.IV.2.

Sección de estado actual 1975 con pares rotos representados en el plano, Iglesias IPCE

Fig.IV.3.

Dossier 1992 Areizaga JCyL

Fig.IV.4.

Estado de las cubiertas 1999 Montoya y Horno JCyL

Fig.IV.5.

Sección longitudinal 1979 Iglesias IPCE

Fig.IV.6.

Ruinas lateral sur San Agustín web AMVA

Planos

Fig.IV.7.

Detalle de la traza original de Herrera

Fig.IV.8.

Detalle ibídem 
Fig.IV.9.

Trazas de informe de Gil de Hontañón en la Antigua, Urrea 1984

Fig.IV.10.

Planta de la iglesia de las Huelgas Reales (Arenillas 1959 AGA 26/00262)

Fig.IV.11.

Sección de la catedral antes de la reforma (Ríos 1974 AMVA 216)

Fig.IV.12.

Bicámara (Almagro 1988)

Fig.IV.13.

Sección transversal Nava del Rey con líneas inconclusas en la zona del refreno

(Ana Iglesias 1979 IPCE)

Fig.IV.14.

Detalle Catedral 1974 Cervera AGA

Fig.IV.15.

Detalle San Antolín 1982 Gómez Santander IPCE

Fig.IV.16.

Detalle Nava del Rey 1991 Navarro JCyL

Fig.IV.17.

Detalle Mayorga 1998 Espinosa JCyL

Fig.IV.18.

Palazuelos 2000 Montoya y Horno JCyL

Fig.IV.19.

Villaverde 1989 Tovar JCyL

Fig.IV.20

Detalle Alaejos 1974 Iglesias IPCE

Fig.IV.21.

Detalle Huelgas 1976 Iglesias IPCE

Fig.IV.22.

Detalle Santiago 1978 Iglesias IPCE

Fig.IV.23.

Cornisa 1991 Mata JCyL

Fig.IV.24. IV.46

Planta y sección 1979 Iglesias IPCE

Fig.IV.25.

Detalles 1982 Espejel IPCE

Fig.IV.26.

Detalles 1987 Linazasoro JCyL

Fig.IV.27.

Detalles proyecto y obra Tordesillas 1980 Mingo JCyL

Fig.IV.28.

Detalle Serrada 1992 Serrada JCyL

Fig.IV.29.

Pasión 1994 Gallegos AMVA

Fig.IV.30.

San Joaquín y Santa Ana 1993 Gatón JCyL 
Fig.IV.31.

Fresno 1997 Carreño

Fig.IV.32.

San Gregorio 1974 Cervera AGA

Fig.IV.33.

Detalle Valbuena 1991 Puente JCyL

Fig.IV.34.

Detalle Íscar 2000 Cembrero JCyL

Fig.IV.35. IV.50

Sección de Wamba 1985 Quintana y Boned JCyL

Fig.IV.36.

Detalles San Pablo 1964 Arenillas IPCE; Cuenca de Campos 1967 Arenillas AGA

Fig.IV.37.

Detalles San Martín 1968 Arenillas y SF. JCyL

Fig.IV.38

Detalle Descalzas 1978 Iglesias IPCE

Fig.IV.39.

Sección Castronuño 1974 Iglesias IPCE

Fig.IV.40.

Urueña 1978 Iglesias IPCE

Fig.IV.41.

Sección Plan Director la Santa Espina

Fig.IV.42.

Levantamiento Santa Espina

Fig.IV.43.

Detalles Alaejos 1974 Iglesias IPCE

Fig.IV.44.

Detalle zuncho-cornisa Angustias 1982 Pérez Medina JCyL

Fig.IV.45.

Rosarillo 1980 Iñiguez AGA

Fig.IV.46.

Portaceli 4 dados 1983 Roldán AGA

Fig.IV.47.

Detalle San Francisco 1986 Gárate y Manzano JCyL

Fig.IV.48.

San Agustín 1998 Gallegos y González AMVA

Fig.IV.49.

El Salvador 1999 Abad JCyL

Fig.IV.50.

Detalles San Antolín 1999 Paniagua JCyL

Descripción

Fig. IV.51.

Planta y sección San Antolín, Medina del Campo. 2003 Paniagua JCyL.

Fig. IV.52.

Santos Juanes, Nava del Rey. 1978 Iglesias IPCE.

Fig. IV.53. 
Visita San Benito 23/04/2015 y croquis de nave lateral (Morán 1991 JCyL)

Fig. IV.54.

Fachada a los pies Peñafiel, visita 21/08/2015; plano 1993 Abad JCyL

Fig. IV.55.

Proceso constructivo Santa María en Íscar, 2000 Cembrero y Morante JCyL

Fig. IV.56.

Recrecido del muro a los pies en Íscar, visita 02/08/2015

Fig. IV.57.

Vista de los ábsides de la Catedral antes de su reparación (visita 31/01/2014)

y detalle planta 1997 Gatón JCyL

Fig. IV.58.

Cabecera Santa Espina visita 28/04/2015; plantas SF IPCE y Plan Director 2008

Fig. IV.59.

Desembocadura escalera bajo cubierta Santa María en Villaverde visita 10/06/2012;

planta 2007 Pardo JCyL

Fig. IV.60.

Arranque de torre sobre la cabecera en Fresno el Viejo visita 13/08/2015;

plano 1997 Carreño JCyL

Fig. IV.61.

Interior de los museos instalados en antiguas iglesias, de San Martín en Medina del Campo y planta alta de la Pasión, en Valladolid.

Fig. IV.62.

Postal de la Antigua antes de la demolición y vista actual

Fig. IV.63.

Vista 30/07/2015; sección Enciclopedia del Románico

Fig. IV.64.

Vista 13/09/2014; sección 1974 Iglesias IPCE

Fig. IV.65.

Vista 30/07/2015; sección 1978 Iglesias IPCE

Aspectos estructurales

Fig. IV.77.

Materiales y estribo fachada del evangelio Alaejos visita 02/09/2014

Fig. IV.78.

Alzados norte y oeste San Cebrián, 1983 Benito JCyL

Fig. IV.79

Basas San Cebrián, dossier Quintana y Boned 1990 y 1985 JCyL

Fig. IV.80.

Contrafuertes de San Pablo (visita 12/09/2014) y Santos Juanes (visita 12/09/2012)

colocados por Ortiz de Urbina.

Fig. IV.81.

Sacristía Tordesillas, dossier

Fig. IV.82.

Reconstrucción de fachada 1972 Roldán IPCE 637-3

Fig. IV.83.

Descarnado en base del ábside San Juan en Fresno el Viejo, dossier Carreño 2000 y actual visita 13/08/2015 
Fig. IV.84.

Detalle de zócalo sacristía 1990 Pizarro VA-086 JCyL; actual visita 25/08/2015

Fig. IV.85.

Arenización interior y retacado exterior Santos Juanes, visita 20/06/2012

Fig. IV.86.

Red de drenaje 1982 López de Uribe JCyL

Fig. IV.87.

Planta recauce del río y fachada a los pies Peñafiel 1993 Abad JCyL; visita 21/08/2015

Fig. IV.88.

Detalles del muro del crucero inconcluso catedral de Valladolid, visita 10/05/2012

Fig. IV.89.

Hastial de San Pablo desprendimiento en 1999 (C01936-005 AMVA)

Fig. IV.90.

Zuncho de hormigón en naves laterales de San Antolín (visita 05/05/2014)

Fig. IV.91.

Zuncho en nave lateral La Santa Espina, visita 28/04/2015

Los tejados

Fig.IV.92.

Sección de la basílica de San Pedro (1576 Tiberio Alfarano)

http://fotothek.biblhertz.it/ bh/c/bhpd23585-1c.jpg 10/12/2014

Fig.IV.93.

Bajo cubierta FZ-08 San Benito el Real (visita 23/04/2015)

Fig.IV.94.

Apeo sobre bóveda en San Benito (visita 23/04/2015)

Fig.IV.95

Sección estado actual San Benito 1997 Morán JCyL

Fig.IV.96.

Vistas del bajo cubierta San Benito, visita 23/04/2015

Fig.IV.97.

Sección estado actual Serrada 1992 Areizaga y Corral JCyL

Fig.IV.98.

Vistas dossier 1992 Areizaga y Corral JCyL

Fig.IV.99.

Sección Tordesillas actual 1980 Mingo IPCE

Fig.IV.100.

Sección Salvador actual 1999 Abad JCyL

Fig.IV.101.

Sección y fotografía dossier Santa Cruz 1972 Rodrigo y Roldán, archivo IPCE

Fig.IV.102.

Estado actual Angustias 1982 Pérez Medina archivo de la Cofradía

Fig.IV.103.

Estado actual Villaverde de Medina 1989 Tovar JCyL

Fig.IV.104.

Estado actual Catedral 1974 Ríos AMVA

Fig.IV.105.

Sección Íscar 2000 Cembrero y Morante JCyL 
Fig.IV.106. IV.108

Sección 1997 Carreño JCyL

Fig.IV.107. IV.108

Bajo cubierta San Antolín y Alaejos visitas 05/05/2014 y 02/09/2014

Fig.IV.108. IV.108

Diagnóstico estado actual San Antolín 1999 Paniagua JCyL

Fig.IV.109.

Sección estado actual Alaejos 1974 Iglesias IPCE

Fig.IV.110. IV.109

Sección estado actual Santiago 1978 Iglesias IPCE

Fig.IV.111.

Sección estado actual Santos Juanes 1978 Iglesias IPCE

Fig.IV.112. IV.110

Apoyo de armaduras en machones Santiago, visita 20/09/2015

Fig.IV.113.

Esquema de cálculo (Gómez Santander 1982 IPCE)

Fig.IV.114.

Vista previa (visita 31/01/2014) y obras de saneado del muro (visita 19/03/2014)

Fig.IV.115.

Ilustración de la web Albanécar

Fig.IV.116.

Alero reformado (Morán 1991 JCyL)

Fig.IV.117.

Detalle de la Antigua 28/10/2014

Fig.IV.118.

Detalle San Gregorio 26/09/2014

Fig.IV.119.

Sobre-cornisa en San Juan de Letrán (cortesía Fundación del Patrimonio Histórico)

Fig.IV.120.

Detalle cornisa San Antolín 1999 Paniagua JCyL

Fig.IV.121.

Imágenes www.antoniopaniagua.com (descargada 25/04/2014)

Fig.IV.122.

Lámina 22 alero enfoscado

Fig.IV.123.

Ladrillo pecho paloma gran formato para cornisa (colección Soledad Camino)

Fig.IV.124.

Detalle croquis en memoria Arenillas 1965 (AGA 26/00356)

Fig.IV.125.

Cornisa Íscar visita 02/08/2015

Fig.IV.126.

Cornisas Tordesillas, visita 16/12/2013

Fig.IV.127.

Detalles de cornisa Pardo 2008 JCyL

Fig.IV.128.

Alero de piedra lamina 27 y cornisa en cuarto bocel Lám 24 Tesis Miguel Fernández Cabo 
Fig.IV.129.

Detalles de cornisas en vitrina del Museo Fabio Nelli de Valladolid

El zuncho

Fig.IV.130.

Nave lateral Mayorga, visita 25/08/2015

Fig.IV.131.

Esquema de zunchos en la iglesia de Santa María de Alaejos

Fig.IV.132.

Zuncho y celosía en Santiago, visita 20/09/2015

Fig.IV.133.

Esquema de zunchos en la Colegiata de San Antolín de Medina del Campo

Fig.IV.134.

Esquema de zunchos en la iglesia de Santa María de Tordesillas

Fig.IV.135.

Esquema de zunchos en la iglesia de Santa María del Castillo de Villaverde de Medina

Fig.IV.136.

Esquema de zunchos en la iglesia de San pedro de Serrada

Fig.IV.137.

Detalle zuncho-cornisa 1982 Pérez Medina JCyL

Fig.IV.138.

Detalles de proyecto y obra Tordesillas (Mingo 1980)

Fig.IV.139.

Detalle de sección de los Santos Juanes

Fig.IV.140.

Esquema de zunchos en los Santos Juanes de Nava del Rey

Fig.IV.141.

Zuncho en L bajo el anillo posterior en San Antolín, visita 05/05/2014;

plano de sección longitudinal 1999 Paniagua JCyL

Discusión

Fig.IV.142.

Causas de siniestros de cubiertas (Galindo 1999, 331-332)

Fig.IV.143.

Planta de estructura de cubierta 1974 Iglesias IPCE

Fig.IV.144.

Grieta en testero de Alaejos, visita 02/09/2014

Fig.IV.145.

Zuncho de acero adosado a torre Tordesillas, visita 16/12/2013

Fig.IV.146.

Zuncho embebido en Catedral, visita 10/05/2012

Fig.IV.147.

Cata en San Francisco 2015 Basterra; detalle proyecto 1988 Gárate JCyL

Fig.IV.148.

Detalle Catedral, 10/05/2012

Fig.IV.149.

Tirantes cortados en San Antolín y Santos Juanes, 05/05/2014 y 20/06/2012 
Fig.IV.150. IV.161

Tensores en San Antolín 05/05/2014

Fig.IV.151. IV.161

Ménsulas en bajo cubierta de Alaejos, 02/09/2014

Fig.IV.152. IV.162

Nava del Rey, 25/06/2013

Fig.IV.153.

Hundimiento de cerchas en la Catedral de Valladolid 4006 AMVA

Fig.IV.154.

Sección San Martín 1968 Arenillas AGA

Fig.IV.155

Zunchado en la cabecera de Santa Cruz, Ana Iglesias 1979

Fig.IV.156.

Cornisa San Joaquín y Santa Ana dossier AGA

Fig.IV.156.

Dibujos del arquitecto Javier de Mingo en su web albanécar 16/09/2015

Fig.IV.157.

Techumbre Fontiveros, web Fundación

\section{LÍNEAS DE INVESTIGACIÓN ABIERTAS}

Fig.VI.1.

Iglesia El Salvador de Simancas

Fig.VI.2

Archivo Maso 009 y archivo UA 0296 (AMVA)

Fig.VI.3

Plomo visita 10/05/2012

Fig.VI.04.

Fondo Carvajal FC155-001/006, Lam.120 (Bustamante 1983) y visita 21/02/2014

Fig.VI.5.

San Pablo BNE 0066233

Fig.VI.6. VI.06

San Pablo, archivo digitalizado AMVA 004091; 006451

Fig.VI.7.

Santos Juanes, visita 02/09/2014

Fig.VI.8

Detalle bajante en muro y vista general en bajo cubierta Catedral, visita 10/05/2012

Fig.VI.9.

Cubierta nave central actual Catedral visita 10/05/2015 y 1974 AGA 26-00146-002

Fig.VI.10.

Sección bajo cubierta la Antigua 2005 Gatón JCyL

Fig.VI.11.

Dossier la Antigua 2005 Gatón JCyL

Fig.VI.12.

Detalle arbotante 2008 wikipedia 20080816 ; visita 16/06/2012

Fig.VI.13. VI.09

San Pablo, digitalización (Arenillas 1962 AGA) y visita 26/09/2014 
Fig.VI.14.

San Benito el Real vista desde la torre-atrio (cortesía Fundación 3890)

Fig.VI.15.

Lámina de Fontana 1694

Fig.VI.16.

Cúpulas, ilustración National Geographic 2014

Fig.VI.17.

Dibujo de Fontana, Biblioteca Nazionale Centrale

Fig.VI.18.

Sistema de atado, Navas 1984 apud Rich 1969

Fig.VI.19.

Tirante, visita 28/03/2015

Fig.VI.20.

Ilustracion National Geographic, Ricci 2014

Fig.VI.21

Detalle de cinchas de piedra y madera, Ricci 2014 y ladrillos en espina, visita 28/03/2015.

Fig.VI.22.

Patología de cúpula, Jurado 2003

Fig.VI.23.

Zuncho en iglesia de Elche, Spairani 2009

Fig.VI.24.

Cinchado de cúpula con ladrillo en Serrada, Areizaga 1992 JCyL 



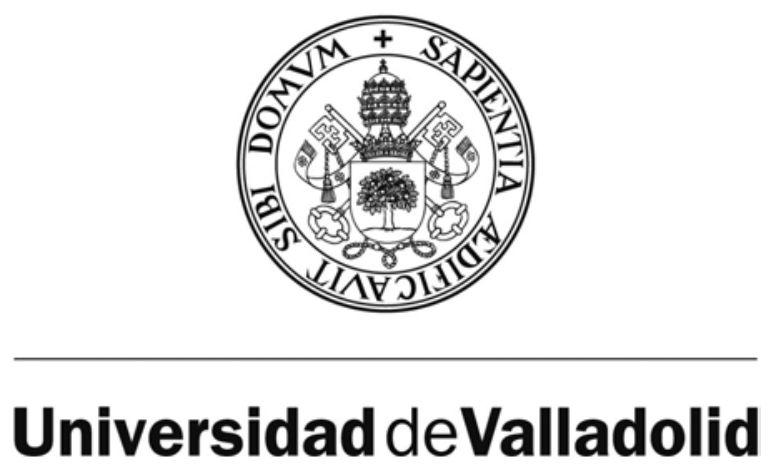

ESCUELA TÉCNICA SUPERIOR DE ARQUITECTURA

DEPARTAMENTO DE CONSTRUCCIONES ARQUITECTÓNICAS, INGENIERÍA DEL TERRENO, MECÁNICA DE LOS MEDIOS CONTINUOS Y TEORÍA DE ESTRUCTURAS

TESIS DOCTORAL:

\section{EL PAPEL DEL ZUNCHO EN LA RESTAURACIÓN MONUMENTAL: ATADO PERIMETRAL DE ESTRUCTURAS DE CUBIERTA EN IGLESIAS DE VALLADOLID}

TOMO II

Presentada por Rosa Bellido Pla para optar al grado de doctor por la Universidad de Valladolid

Dirigida por:

María Soledad Camino Olea

Francisco Javier León Vallejo 

VIII. FICHAS: RESUMEN, DOCUMENTACIÓN Y VISITAS

$\begin{array}{ll}\text { FZ-01 } & \text { Catedral } \\ \text { FZ-02 } & \text { Concepción } \\ \text { FZ-03 } & \text { San Gregorio } \\ \text { FZ-04 } & \text { Pasión } \\ \text { FZ-05 } & \text { Asunción-Portaceli } \\ \text { FZ-06 } & \text { Angustias } \\ \text { FZ-07 } & \text { San Agustín } \\ \text { FZ-08 } & \text { San Benito } \\ \text { FZ-09 } & \text { San Lorenzo } \\ \text { FZ-10 } & \text { San Pablo } \\ \text { FZ-11 } & \text { Antigua } \\ \text { FZ-12 } & \text { Rosarillo } \\ \text { FZ-13 } & \text { Salvador } \\ \text { FZ-14 } & \text { Descalzas Reales } \\ \text { FZ-15 } & \text { San Joaquin y Santa Ana } \\ \text { FZ-16 } & \text { Huelgas }\end{array}$

Valladolid

Valladolid

Valladolid

Valladolid

Valladolid

Valladolid

Valladolid

Valladolid

Valladolid

Valladolid

Valladolid

Valladolid

Valladolid

Valladolid

Valladolid

Valladolid 
- Mapas de la provincia descargados de "Municipios de Valladolid" en wikipedia el 22/07/2015

- Plano del centro de la ciudad de Valladolid digitalizado a partir del póster adquirido en Museo Fabio Nelli: Planta de la ciudad 1606-1738, elaborado por Daniel Villalobos en 1990.

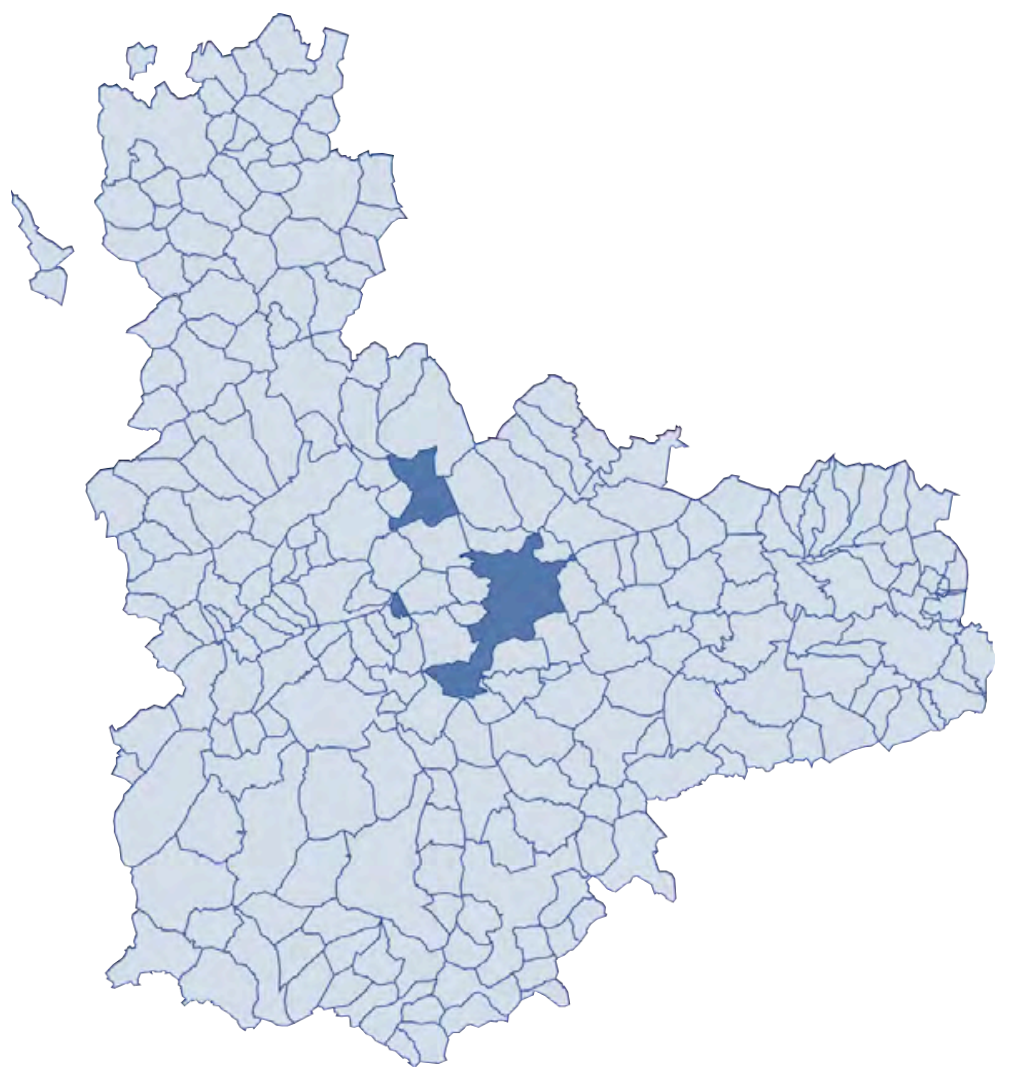




\section{Catedral de Nuestra Señora de la Asunción}

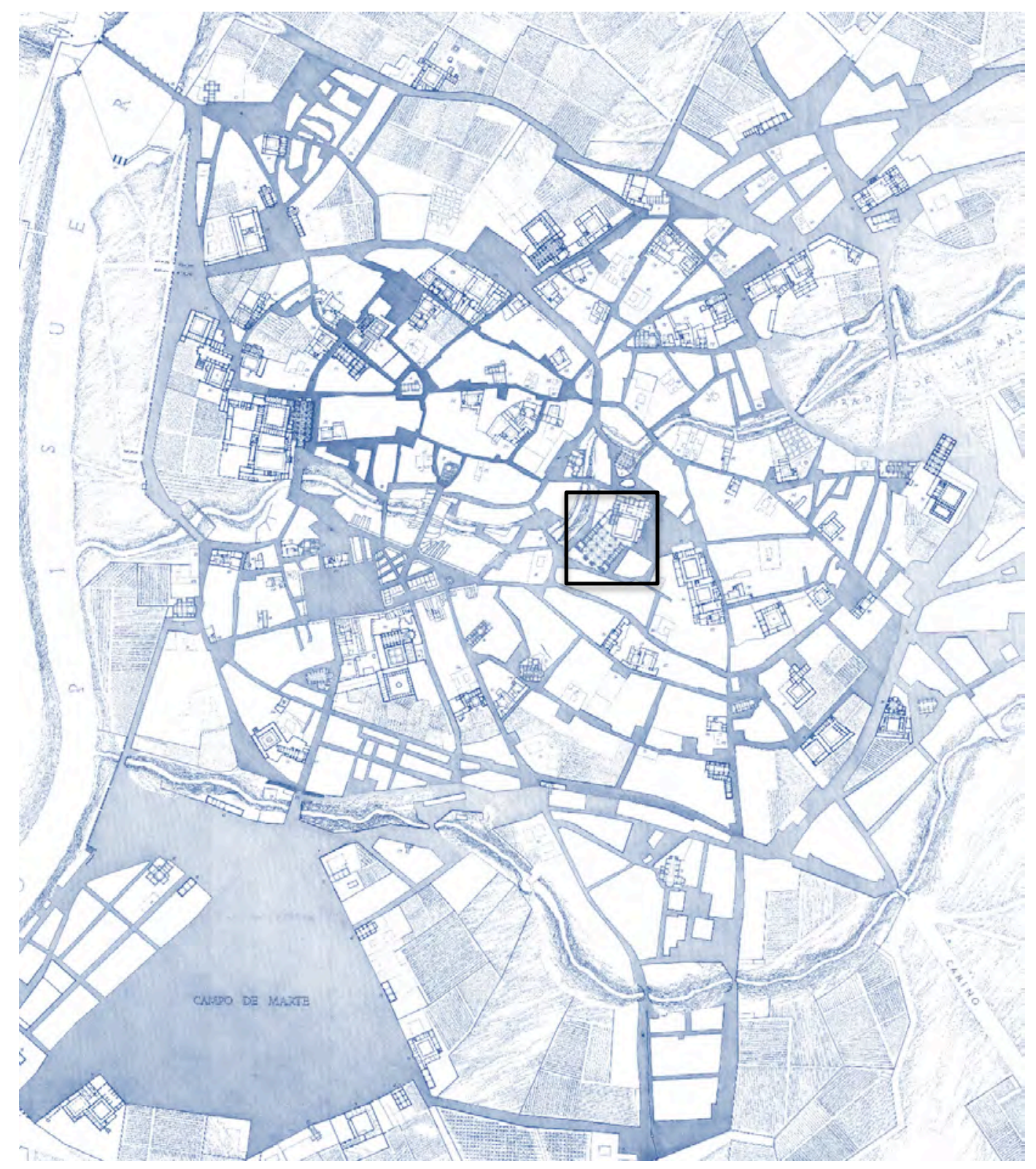



FICHA SÍNTESIS

Código de identificación: FZ-01

Denominación:

Catedral de Nuestra Señora de la Asunción.

Localidad: Valladolid

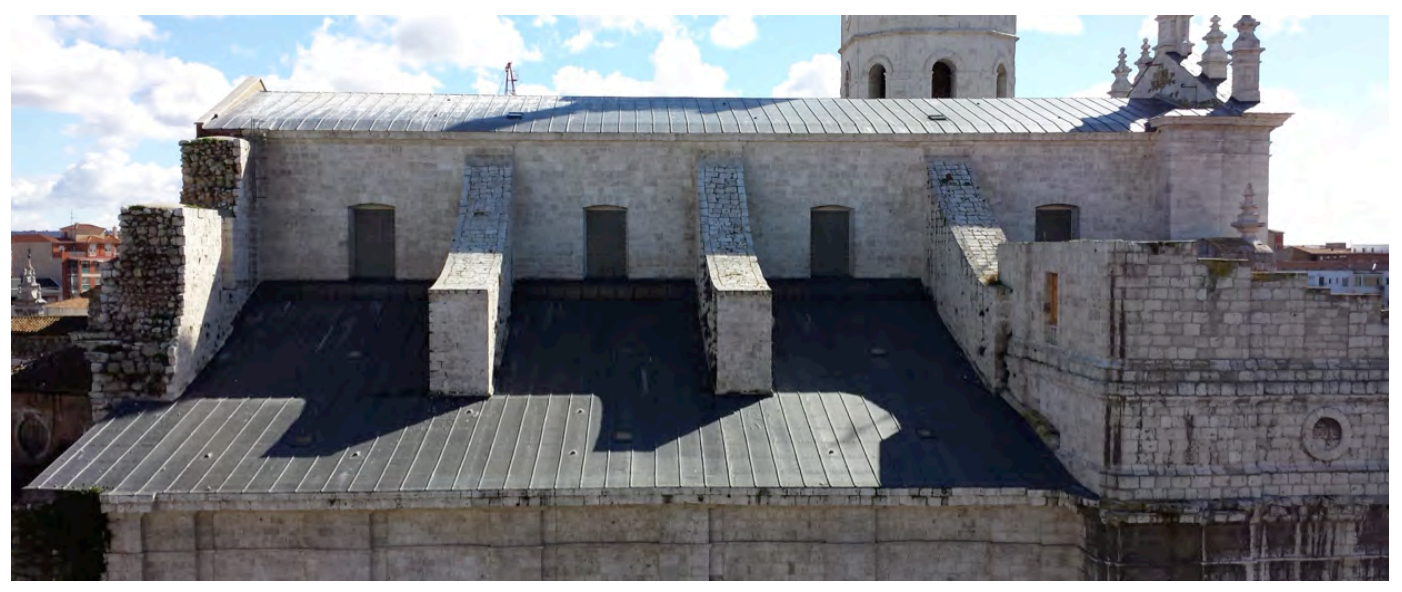

\section{Descripción}

Se trata de una iglesia clasicista de tres naves con capillas entre contrafuertes. La bóveda de la nave central, más alta, es de cañón con lunetos y las laterales de arista. Se encuentra ejecutada únicamente hasta la mitad la traza original de Juan de Herrera, rematándose las naves en forma de tres ábsides formando la cabecera en la zona que correspondería al crucero.

\section{Materiales}

Todos los muros son de piedra caliza, excepto el remate provisional de los ábsides y un murete recrecido por el interior en el bajo cubierta. Las cubiertas, rematadas inicialmente con teja curva, están revestidas con lámina de plomo desde finales del siglo $\mathrm{XX}$, salvo elementos puntuales como el remate de la torre semidesplomada en 1841.

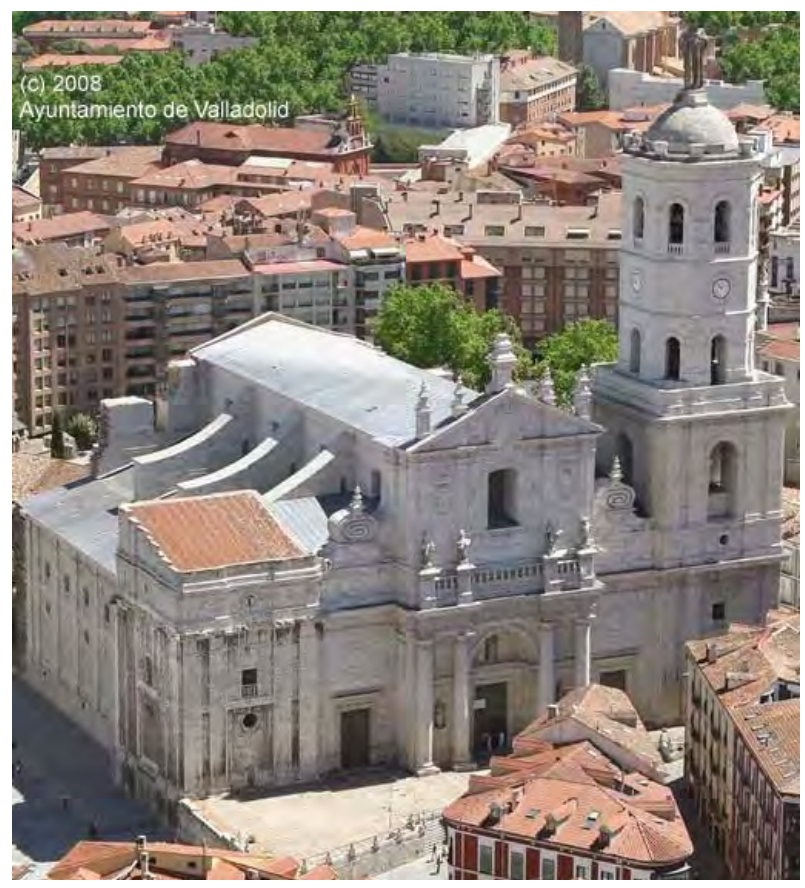

Ilustración 1: vista aérea (Ayuntamiento 2008) 


\section{Singularidades}

Las dimensiones en planta siguen el diseño original gótico llamado "de los cinco maestros" (Diego de Riaño, Juan de Álava, Francisco de Colonia, Juan y Rodrigo Gil de Hontañón) sobre el que arranca la fábrica, que pretendía, a su vez, ir reemplazando paulatinamente una colegiata anterior que incluía restos de otra, aún más antigua, de la que se conserva sólo la torre románica.

La torre izquierda truncada se desplomó en 1841 tras los daños del terremoto de Lisboa, a pesar del encadenamiento realizado por Ventura Rodríguez. Años más tarde se levantó la derecha, que se

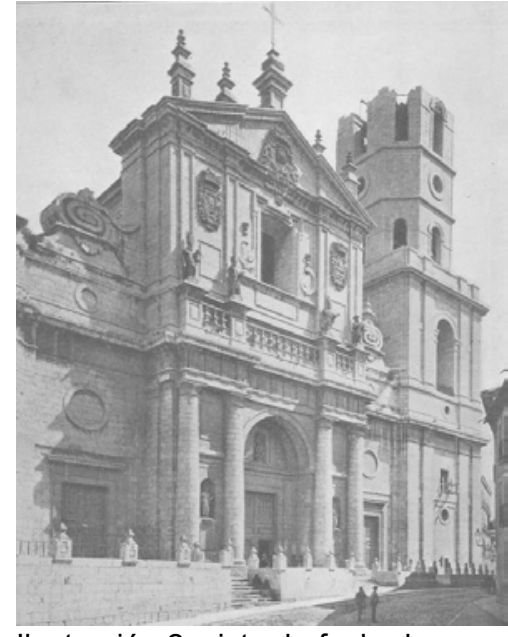

Ilustración 2: vista de fachada con torre en obras (AMVA 023) culmina con cúpula e incorpora la escultura en 1923.

\section{Dimensiones básicas del templo}

Ancho de nave central laterales capillas

Altura

$\begin{array}{rrr}14,5 & 9,2 & 7,0 \\ 31,2 & 18,2 & 9,0\end{array}$

La modulación con medidas en pies según Chueca (1947):

50 la nave central, 32 las laterales, capillas 20.

Anchura total del cuerpo entre paramentos 204 pies.

\section{Memoria histórica constructiva}

El monumento arranca en 1527 como Colegiata gótica que pretende reemplazar con una nueva orientación a la del siglo XIII, aunque ésta mantiene su uso hasta 1668. (Ver capítulo El foco clasicista)

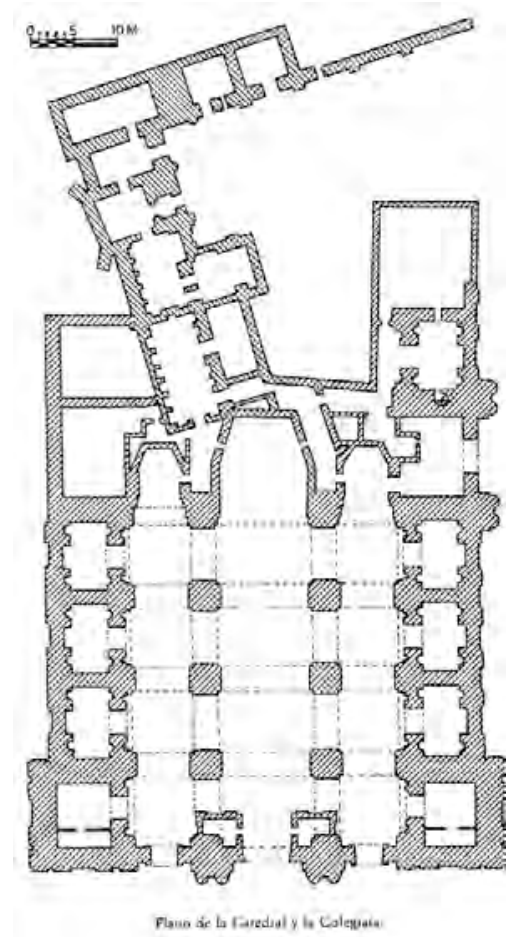

Ilustración 3: planta del Catálogo

Se aprovecha el arranque de muros para continuar la obra con un nuevo diseño proporcionado por Juan de Herrera, si bien éste nunca visita la misma, que dirige principalmente Diego de Praves. 
Bajo estas líneas vemos el croquis titulado "Descripción que hizo Diego de Praves a Juan de Herrera sobre la elección de la nueva fábrica". Según éste, las trazas no coincidían exactamente con los cimientos de la obra ejecutada, marcada con $\mathrm{H}$ : fachada principal, torres y primeras capillas de hornacinas.

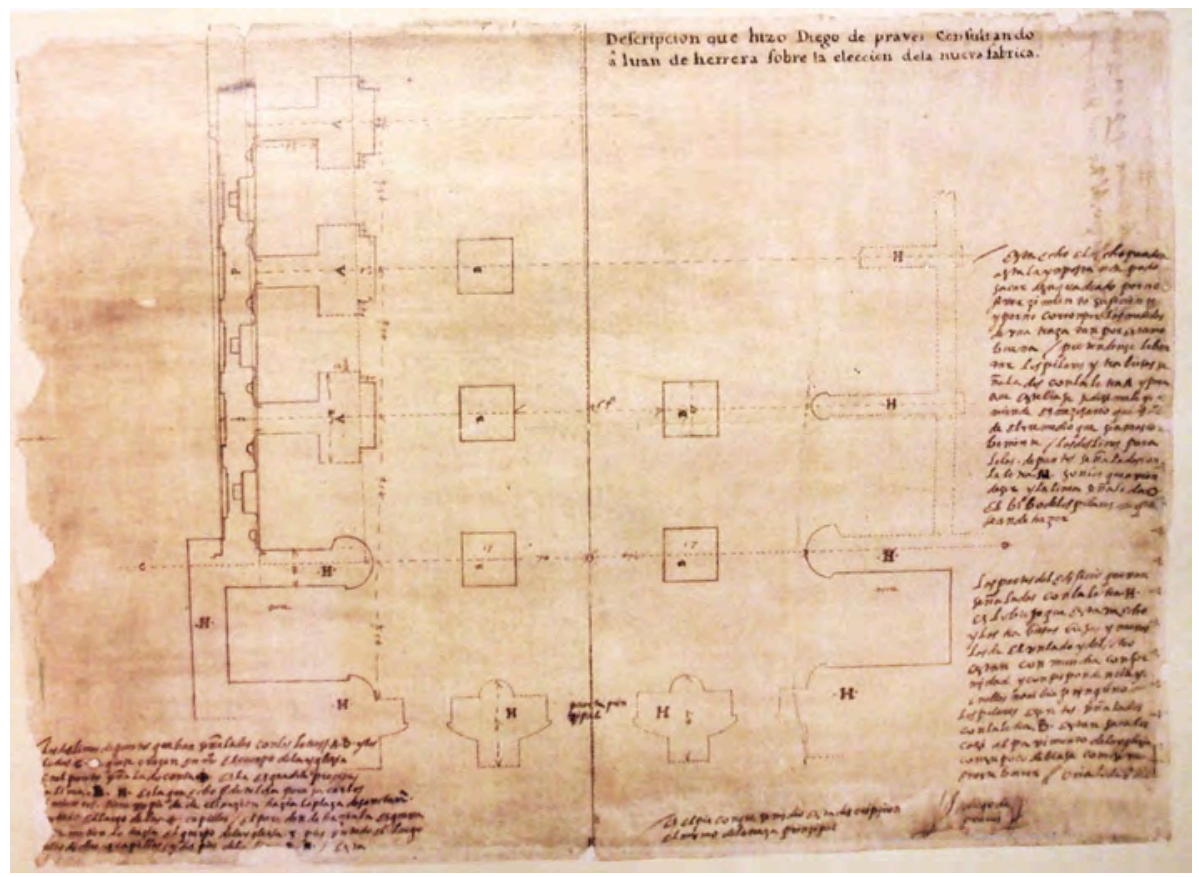

Ilustración 4: croquis de Diego de Praves para Juan de Herrera

Se trata de un documento de gran valor documental donde se indica que la altura de lo construido hasta ese momento llega a las impostas, quedando casi a ras de pavimento los pilares exentos. En el dibujo se puede apreciar de un vistazo el gran espesor con que se modelan los muros en el nuevo estilo frente a la esbeltez prevista en el modelo gótico. El punto de partida de las trazas sobre preexistencias es uno de los aspectos más frecuentes en el arranque del foco clasicista vallisoletano, y suele determinar la división del templo en tres naves, frente a la pastilla unitaria con capillas entre contrafuertes que encontramos en la fase final del estilo.

En un plano propiedad de RiveraManescau publicado por Juan Agapito y Revilla en 1943 en el Diario Regional aparecen estas construcciones en una fase más avanzada, aunque su fiabilidad es muy cuestionable, ya que también aparece representado el claustro diseñado por Herrera en sus trazas

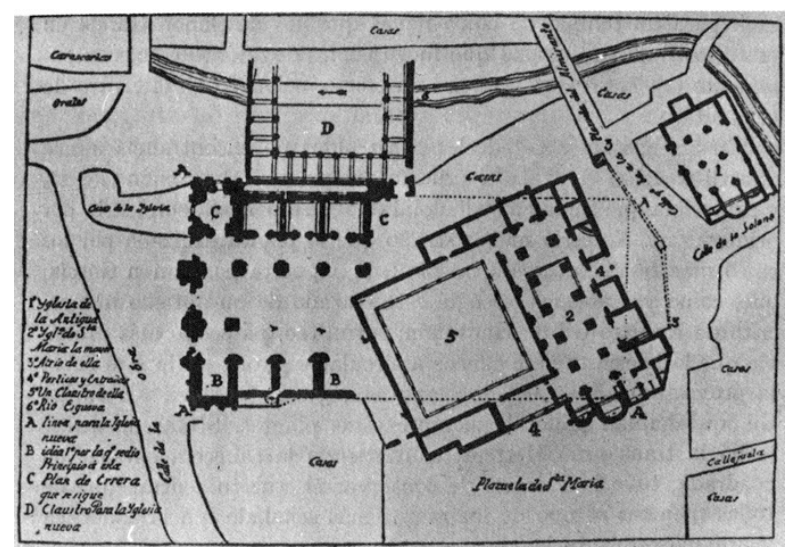
Ilustración 5: plano de Rivera-Manescau 
que nunca llegó a levantarse. En dicho plano se aprecia el contraste entre la orientación canónica de las cabeceras de la Antigua, y las dos primeras Colegiatas hacia el este, frente a la disposición de la definitiva.

"Durante el siglo XVI se abandona la antigua costumbre de comenzar las iglesias por la cabecera y capilla mayor (para que pudieran servir cuanto antes al culto) y, en cambio, se hace costumbre el empezarlas por la fachada principal y los pies"1.
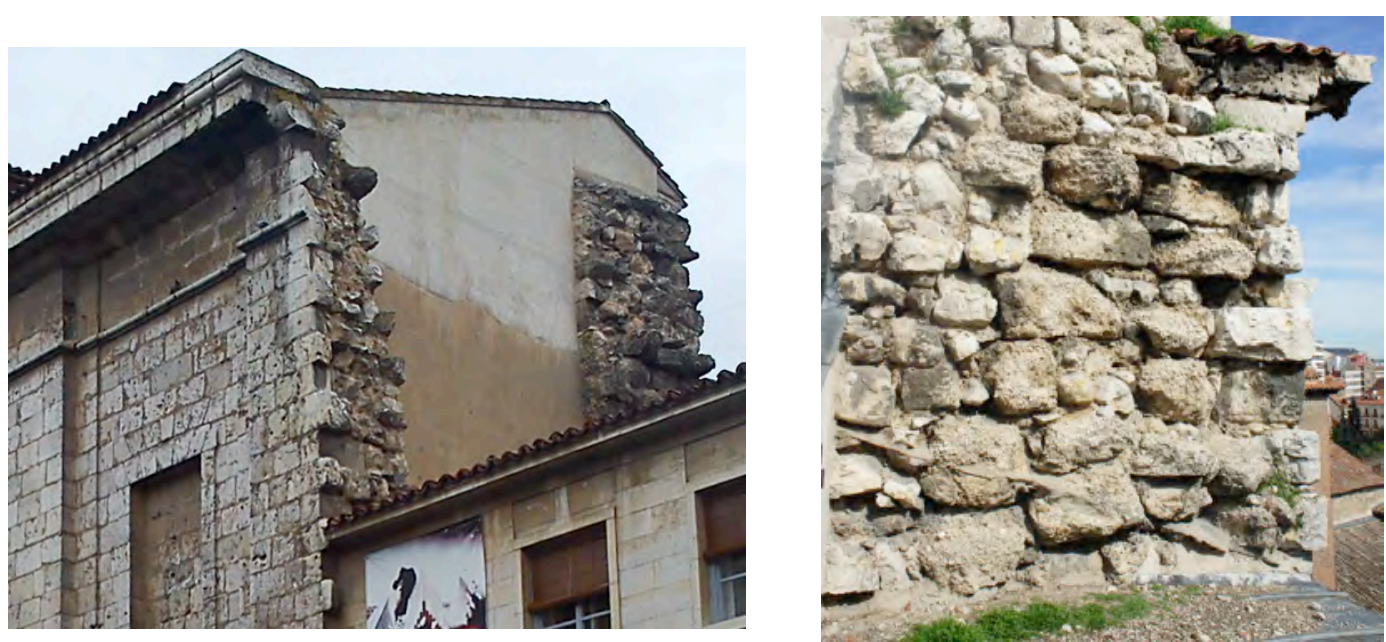

llustración 6: imágenes de los muros inacabados de la fachada sur (visita 10/05/2012)

Según Chueca, la sillería de piedra caliza de Cabezón empleada es de muy mala calidad, desigual, llena de coqueras y pelos. El núcleo de los muros se realiza con una mampostería basta entre ambas caras de sillería.

\section{Cronología. Fechas clave}

$1527-1974$

\section{Intervenciones}

1922 - Demolición parcial del crucero: reutilizan material para tribuna del órgano

1960 - Cubiertas - Luis Cervera Vera.

Reparación de formas, tamos de tablero y tejas deterioradas.

1961 - Arcos de capillas antigua Colegiata - Luis Cervera Vera

1962 - Restauración capilla de San Llorente - Luis Cervera Vera

\footnotetext{
${ }^{1}$ Chueca, F. (1947). La catedral de Valladolid. Madrid: Instituto Juan de Herrera. Pág. 36.
} 
1962 - Restauración fachada sur - Anselmo Arenillas Álvarez

Se continúa el muro de planta alta, a medias, sobre las capillas de la epístola.

1964 - Cubiertas y cantería - Anselmo Arenillas Álvarez

Reconstrucción de la cubierta sobre las capillas de la epístola, con jácenas de hormigón armado y forjado.

1964 - Recalce de la portada sur - Anselmo Arenillas Álvarez

Se recrece la profundidad de los cimientos de la portada.

1965 - Consolidación cornisas de torre izquierda - Anselmo Arenillas Álvarez

Se repone la cornisa, tras un desprendimiento de sillares, con un núcleo de hormigón armado revestido de piedra.

1966 - Acondicionamiento de nave sobre capillas laterales - Anselmo Arenillas

1967 - Restauración portada c/ General Cos - José Antonio Arenillas

1969 - Restauración urgente de cubierta nave central - Anselmo Arenillas

1973 - Consolidación de las ruinas - Ana Iglesias

Intervención urbanística sobre el entorno de la catedral

1974 - Reemplazo de cerchas nave central por metálicas - Luis Cervera Vera

\section{Incorporación de zuncho de hormigón armado}

Tras el hundimiento de dos formas se sustituye toda la estructura de madera que forma las cubiertas de la nave central por cerchas y correas metálicas con revoltón de ladrillo, capa de compresión y teja, colocando un zuncho perimetral de hormigón armado. También se incorpora una capa de $5 \mathrm{~cm}$ de hormigón sobre las bóvedas.

1982 - Reparación de atrio y tejados del archivo - Víctor López Cotelo

Retejo y remates interiores del archivo. Restauración de balaustrada y pavimento del atrio.

1984 - Grapado urgente de cornisa - Víctor López Cotelo

Obra de emergencia tras el desprendimiento de un sillar de cornisa durante la intervención en el atrio. 
1988 - Repaso de cubiertas y paredes para exposición - Elesio Gatón Se adecenta el inmueble para acoger Las Edades del Hombre

1994 - Restauración urgente de cubiertas - Elesio Gatón

Se mantiene la estructura de la nave central incorporada por Cervera en 1974, reemplazando el revestimiento de teja por chapa de plomo.

1997 - Restauración de cubiertas del lado de la Epístola - Elesio Gatón

Se van llevando a cabo diversas obras recogidas en el Plan Director de la Catedral.

Se reemplaza la teja sobre los contrafuertes por piedra.

En las naves laterales se sustituyen los forjados que forman los faldones por Ilustración 7: bajo cubierta sobre nave de la Epístola estructura de madera.

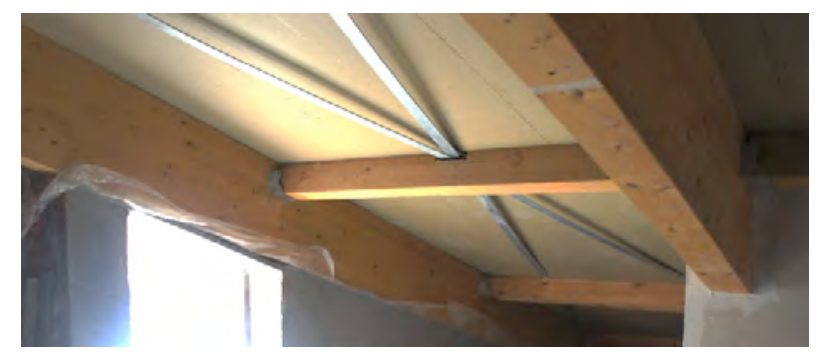

\section{Planos}

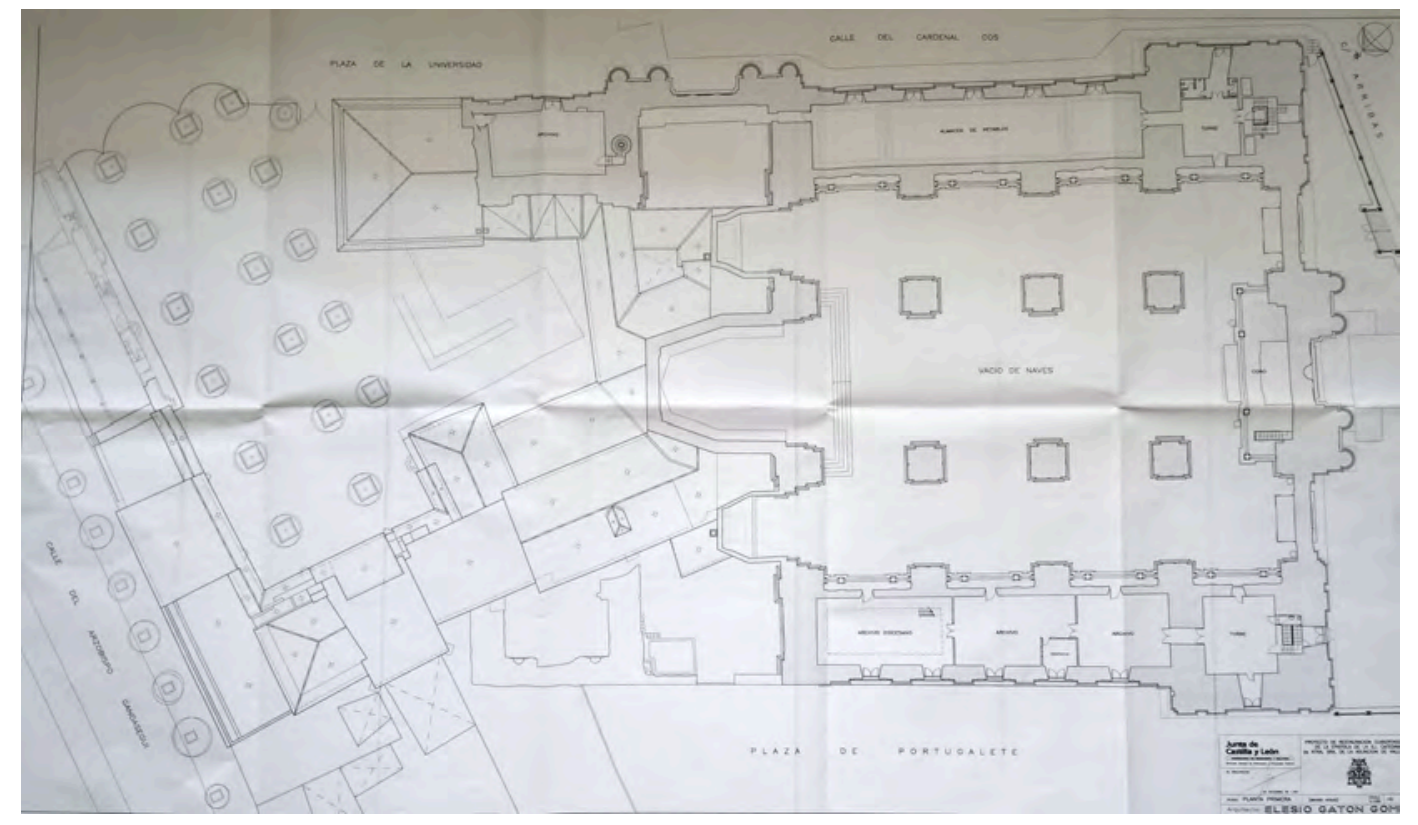

Ilustración 8: planta general. Plan Director (Gatón 1997) JCyL 


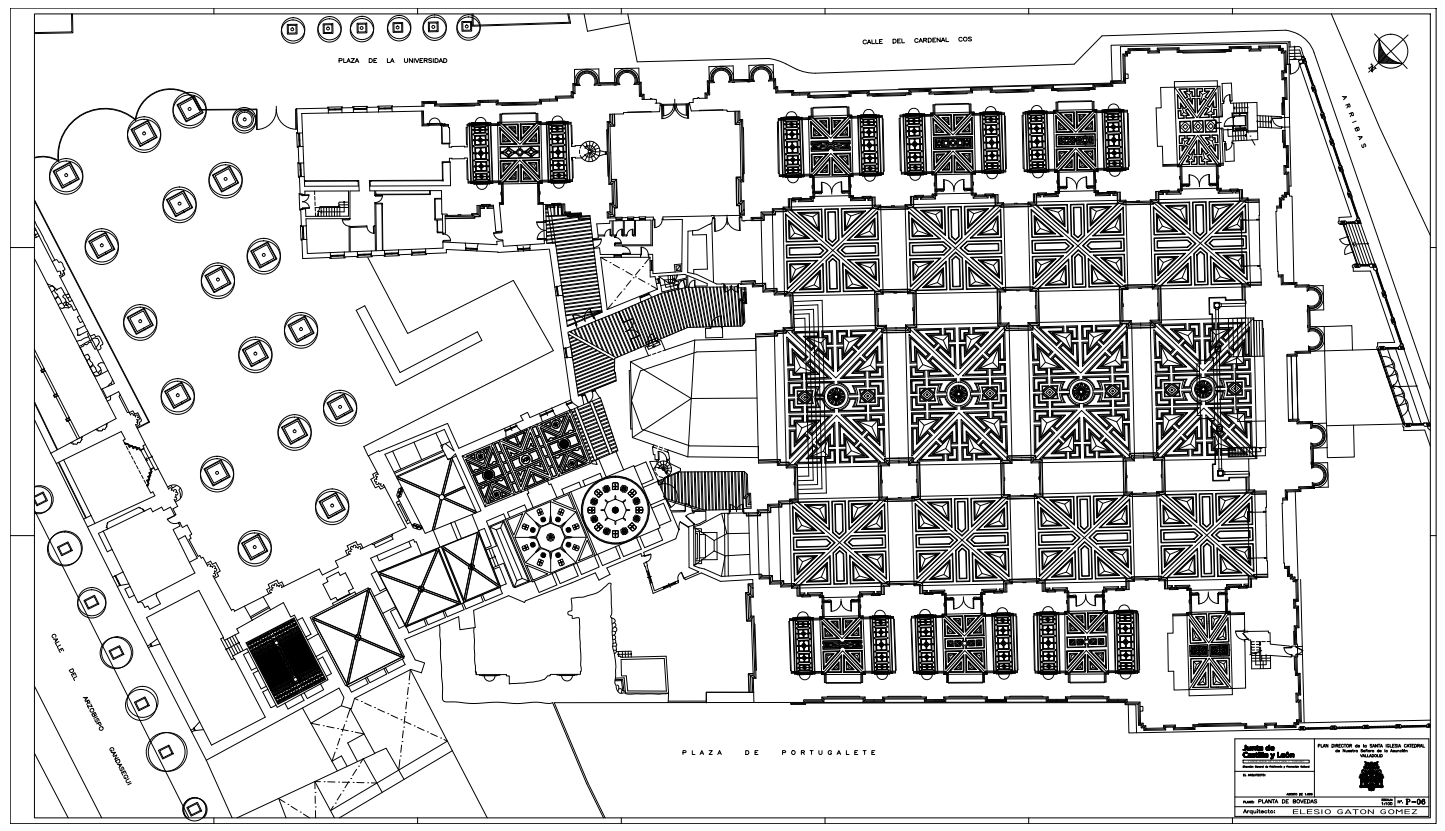

Ilustración 9: planta de bóvedas, Gatón Plan Director

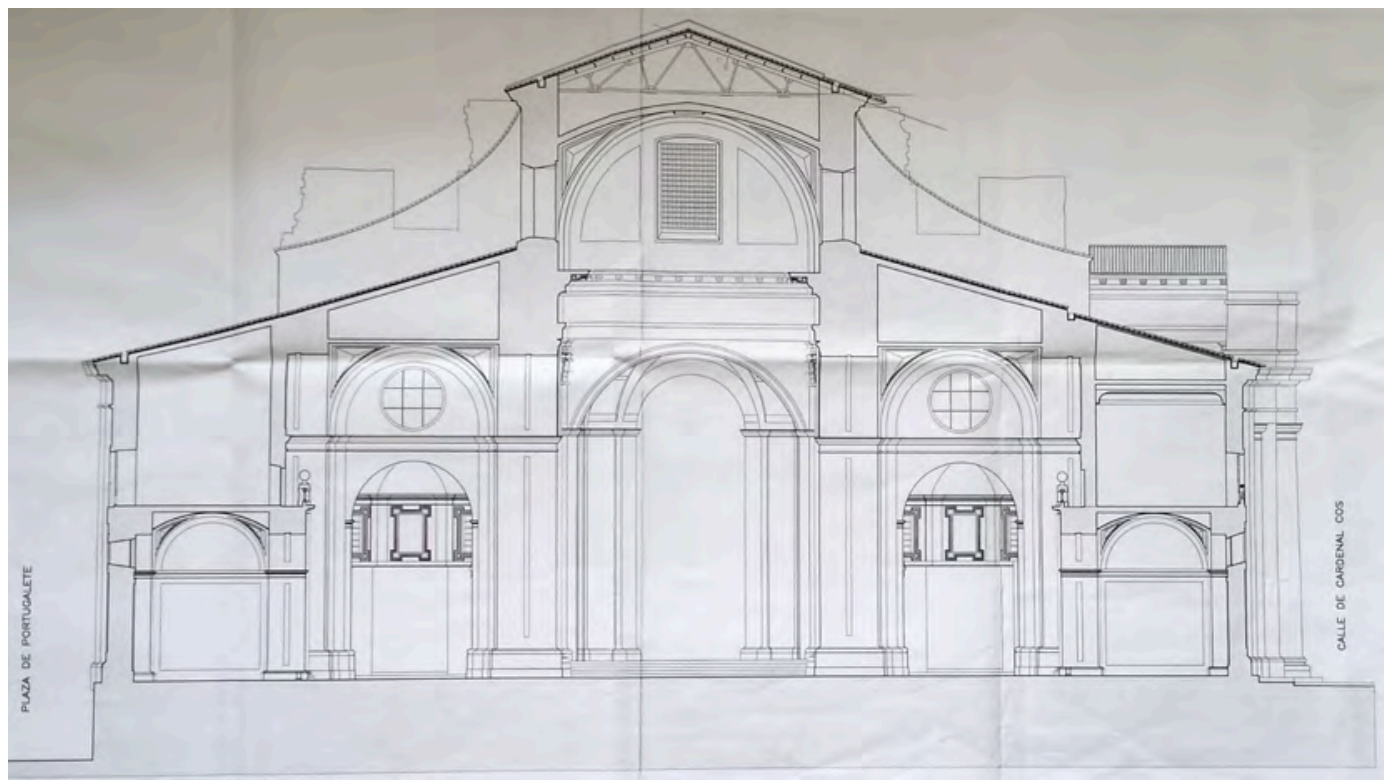

Ilustración 10: sección transversal estado actual. Plan Director (Gatón 1997) JCyL

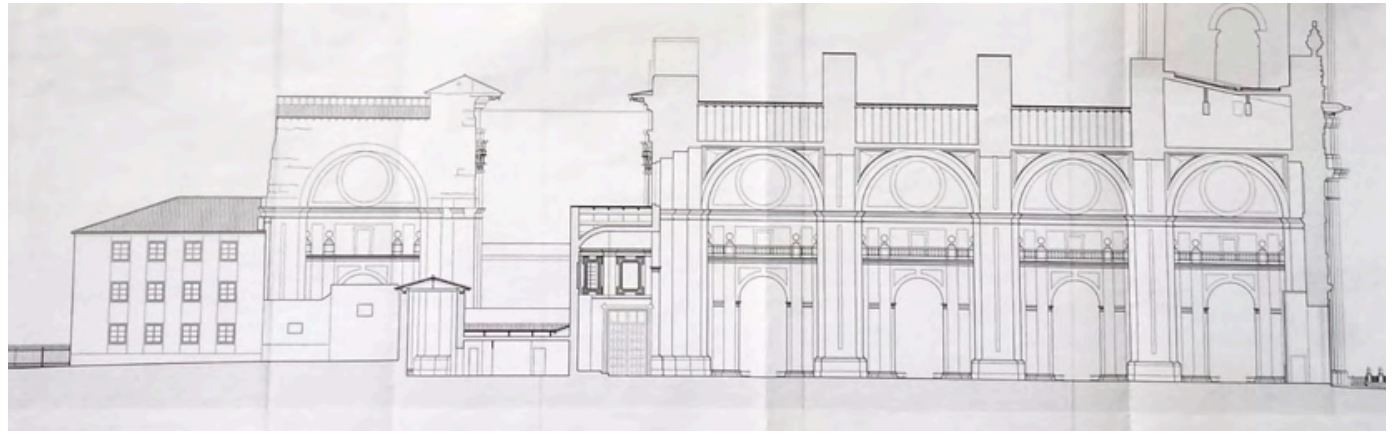

Ilustración 11: sección longitudinal. Plan Director (Gatón 1997) JCyL 


\section{Solución constructiva de la cubierta}

Según se ha indicado en el desglose de intervenciones, la estructura de cubierta a dos aguas de la nave central fue reemplazada por cerchas metálicas en 1974 por Luis Cervera Vera, tras derrumbarse la parte central de la cubierta por el colapso de dos de las cerchas de madera.

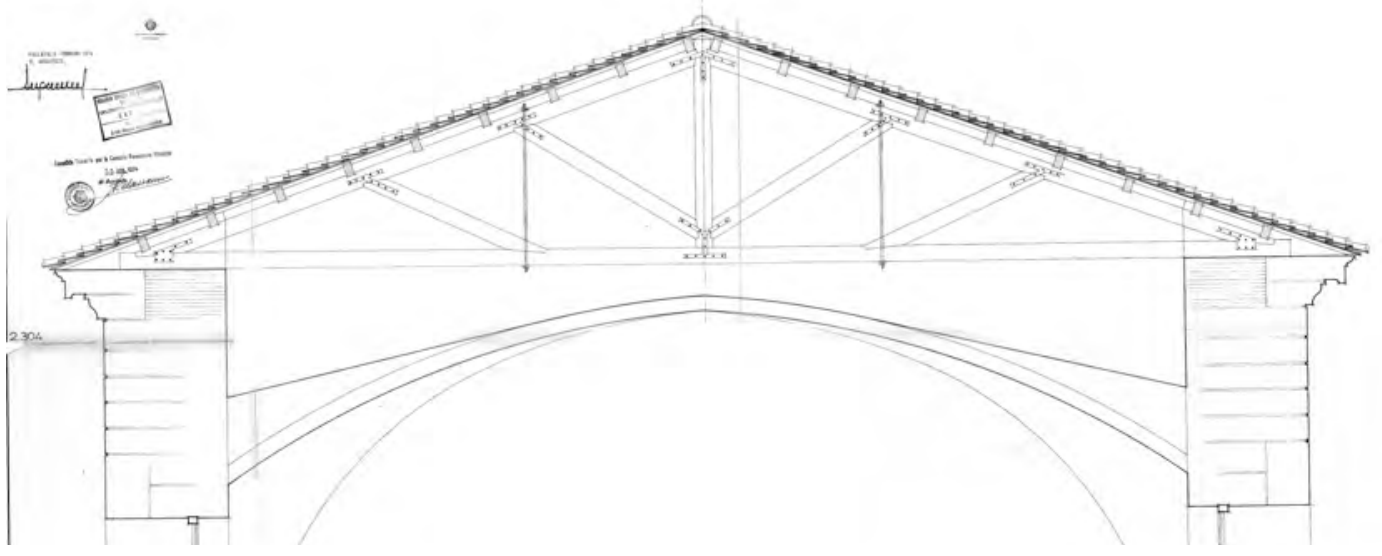

Ilustración 12: sección estado actual 1974. (Licencia Ángel Ríos AMVA 216)

En la fotografía siguiente se aprecian, sobresaliendo de la fábrica, los restos de piezas cortadas de la estructura de cubierta de madera original a media altura y un considerable recrecido de ladrillo sobre el remate irregular de la piedra. En el presupuesto del proyecto de 1974 se recoge una partida de $111,4 \mathrm{ml}$ de desmonte de coronación de muros, extracción de durmientes y cabezas de madera y $125,9 \mathrm{ml}$ de zuncho de hormigón armado incluso encofrado y placas de apoyo.

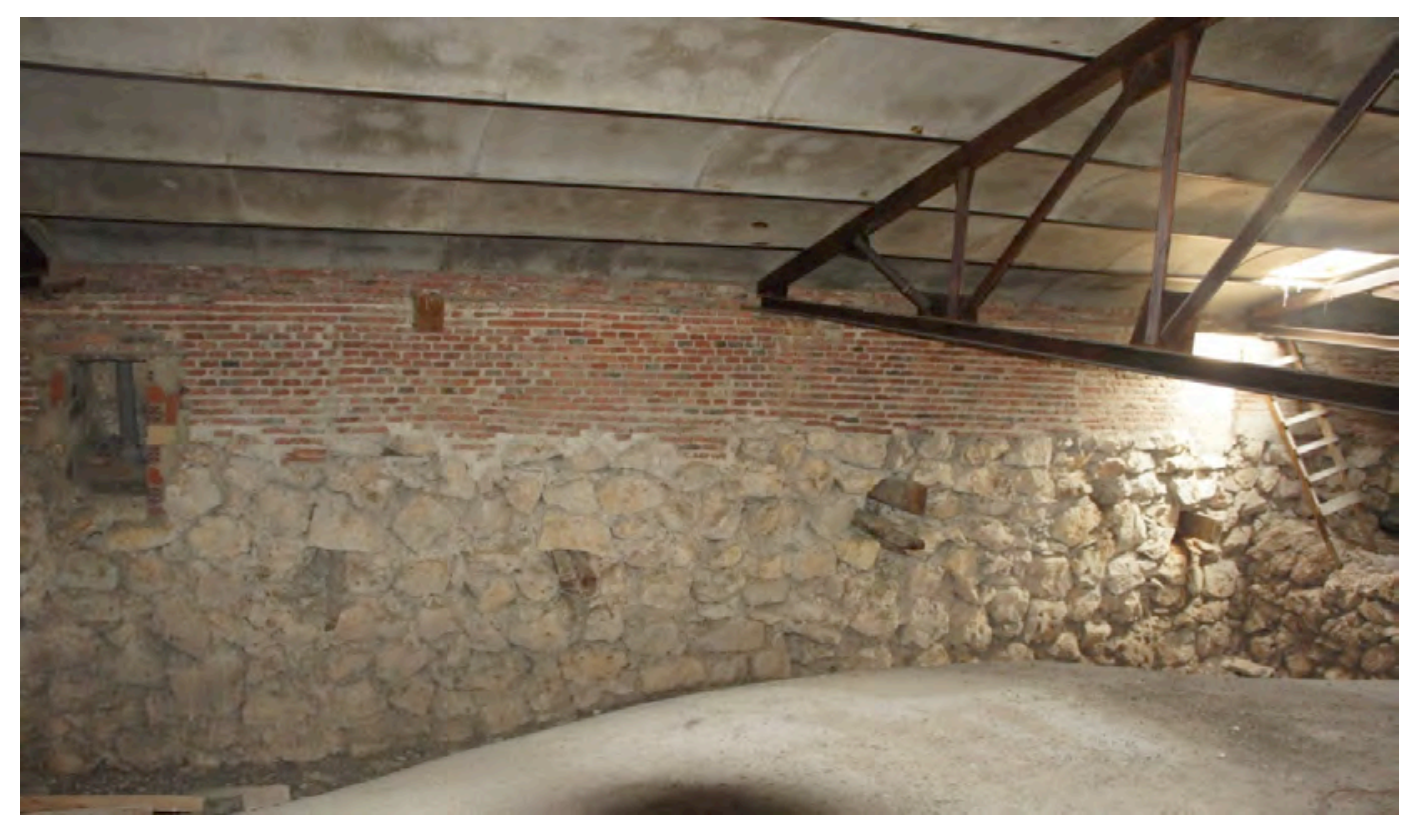

Ilustración 13: fotografía del espacio bajo cubierta de la Catedral (visita 10/05/2012) 
Sólo en las dos primeras crujías hacia la cabecera se empleó revoltón de ladrillo: en el resto, con el mismo perfil, placas curvas prefabricadas.

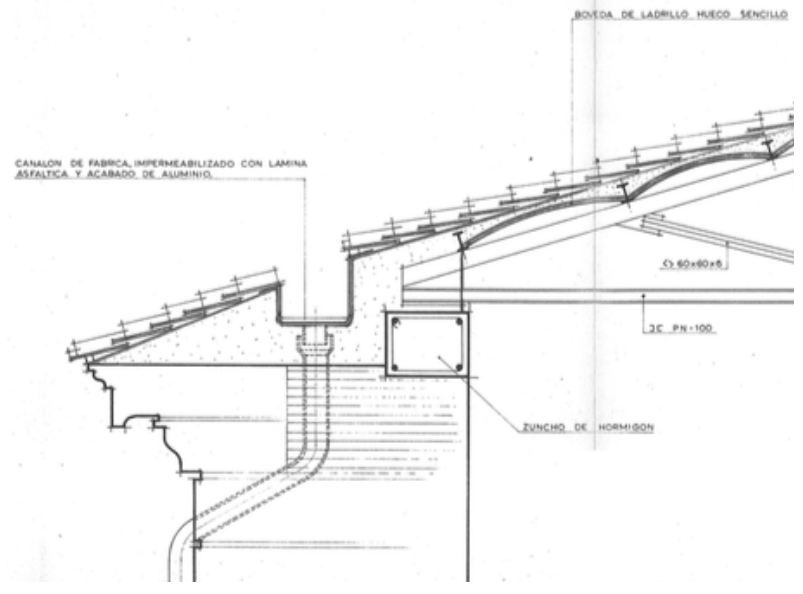

Ilustración 14: detalle cornisa proyecto Ángel Ríos (Licencia AMVA 216)
Tanto el proyecto de Ángel Ríos conservado en el AMVA para el que se concedió la Licencia de obras, como el prácticamente idéntico de Luis Cervera ejecutado, en los que se diseña la sustitución de la armadura por cerchas metálicas, recibieron objeciones de la Comisión de Patrimonio por el detalle de canalón y bajante embebidas en la coronación del muro.

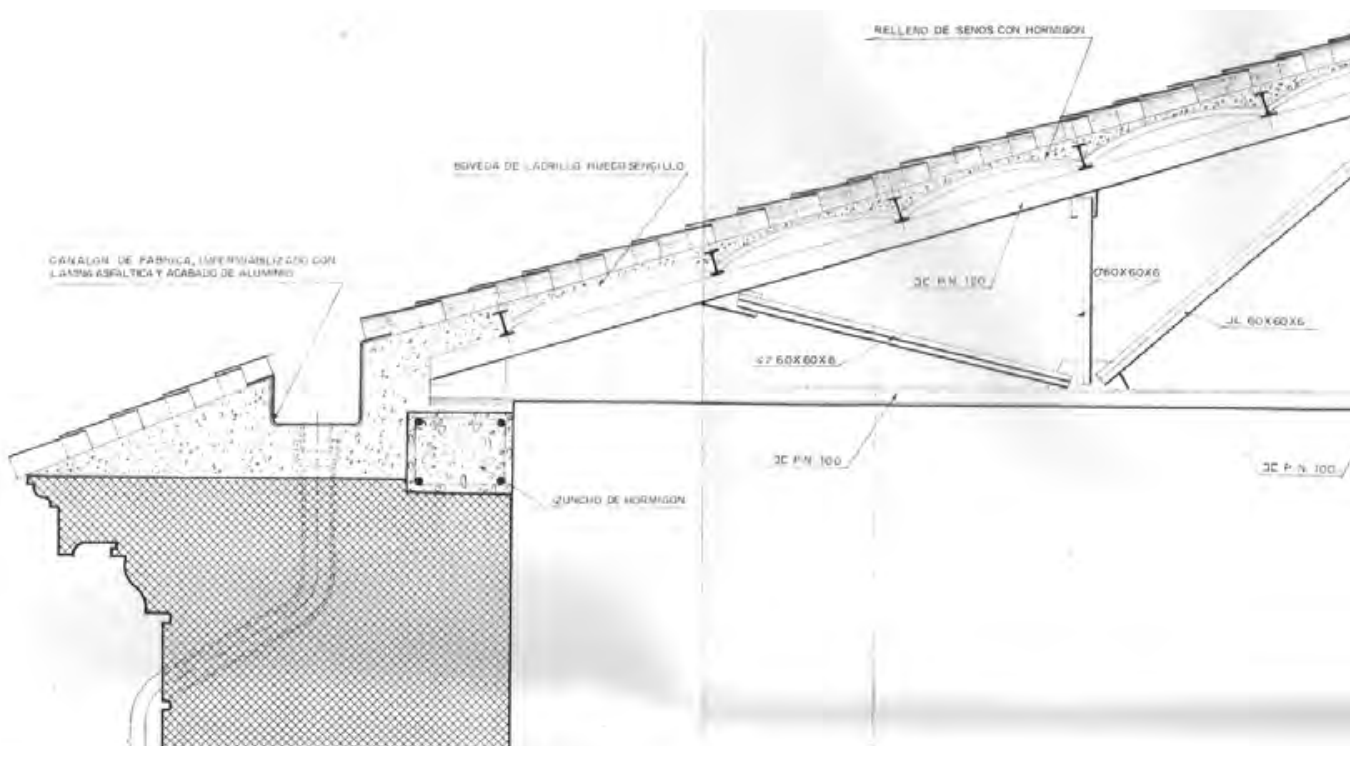

Ilustración 15: detalle del proyecto de Luis Cervera 1974

En las fotografías de antes de la sustitución de la estructura de cubierta se puede observar la existencia de un canalón y bajantes exteriores que quiebran para sortear la cornisa. 


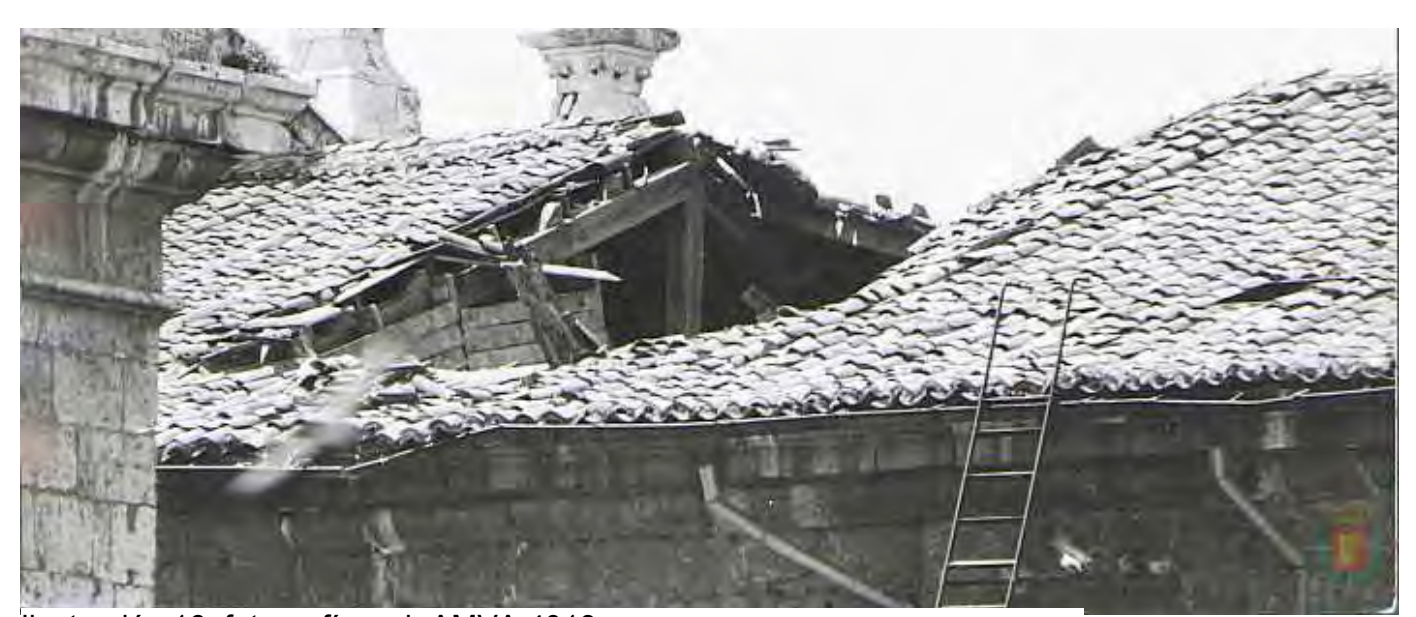

Ilustración 16: fotografía web AMVA 4013

En el Plan Director se describe cómo las naves laterales estaban cubiertas por forjados de hormigón armado inclinados, aunque en la sección del plano de Arenillas de 1964 aparecían representados en horizontal con recrecido de palomeros. En la fotografía se aprecian los restos de este tablero, efectivamente inclinado, bajo dados de hormigón armado (sin zuncho), incorporados para resolver el apoyo de las correas de madera laminada.

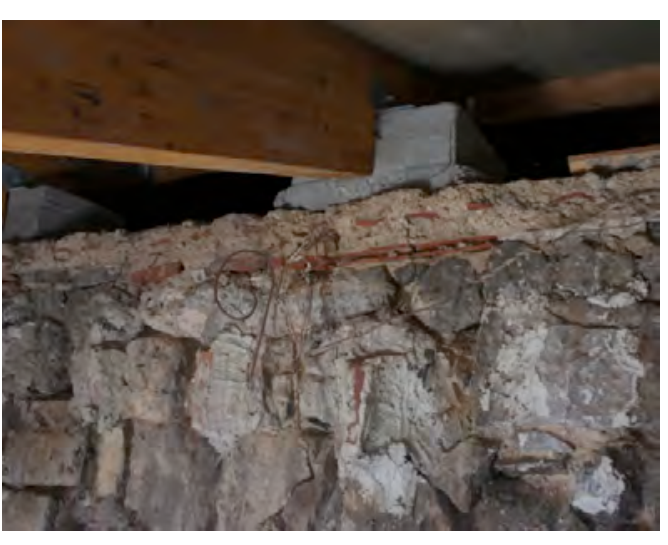

llustración 17: detalle apoyo de correas nave Epístola (visita 10/05/2012)

Esta nueva estructura en cubierta de naves laterales y capillas, de madera laminada con conectadores metálicos y correas de pino, tablero de madera y espuma de poliuretano, se coloca en 1997.

\section{Zunchos}

El zuncho de hormigón armado se introduce en 1974 sobre el mencionado recrecido de ladrillo. La pieza se embebe en la fábrica, confinada por tabicas de ladrillo que debieron aprovecharse para su ejecución como encofrado perdido, una solución que no se corresponde con el detalle representado en los planos del proyecto de Cervera reproducido en el epígrafe anterior. Sobre este zuncho apoyan las chapas de anclaje de las cerchas, formadas a su vez por perfiles de acero laminado tipo UPN, con diagonales de angulares soldadas mediante cartelas. 
En la fotografía se aprecia el encuentro del cerramiento de la nave central con el muro de ladrillo que cierra la obra inacabada sobre el altar mayor. La arista aparece reforzada por un peto de ladrillo hueco doble que forma un ángulo. El zuncho de hormigón armado no se prolonga en el testero, disponiéndose únicamente a ambos lados.
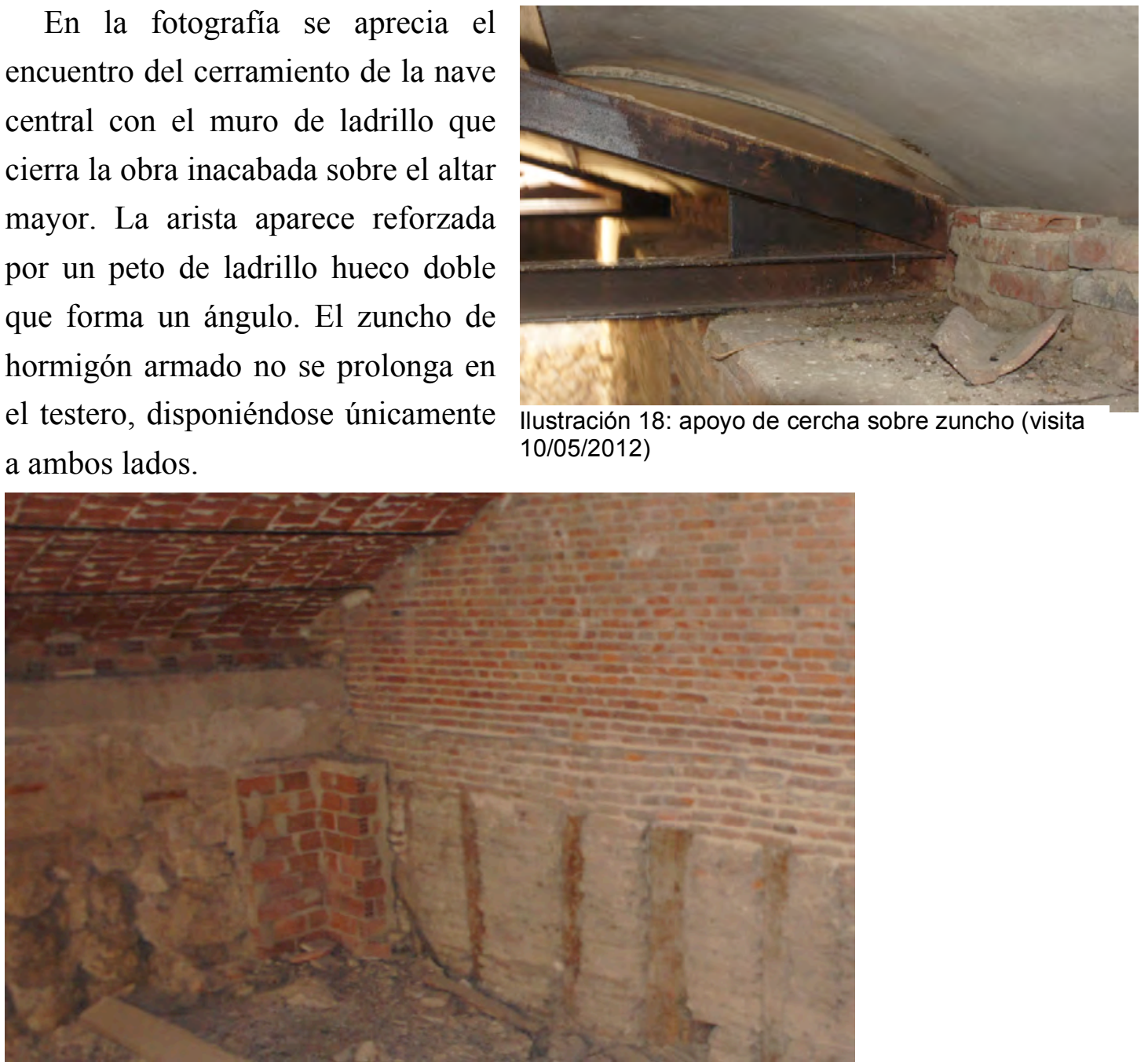

Ilustración 19: cerramiento bajo cubierta de la nave central hacia cabecera (visita 10/05/2012)

\section{Conclusiones}

En este caso podemos considerar el zuncho de hormigón armado primordialmente como pieza de reparto para distribuir el apoyo puntual de las cerchas metálicas sobre la coronación de los muros de la nave central, ya que no se prolonga sobre el testero y por tanto no configura un anillo cerrado. 



\section{Catedral de Nuestra Señora de la Asunción. Valladolid.}

Intervenciones citadas en la publicación del Ministerio:

1960 - Cubiertas - Luis Cervera Vera

1961 - Descubrir y limpiar arcos primitivos - Luis Cervera Vera

1962 - Restauración capilla de San Llorente de la antigua colegiata - Luis Cervera Vera

1962 - Restauración parte de la fachada sur - Anselmo Arenillas Álvarez

1964 - Recalce y restauración puerta sur - Anselmo Arenillas Álvarez

1964 - Restauración de cubiertas y cantería de la fachada sur - Anselmo Arenillas Álvarez

1965 - Cornisas de la torre izquierda - Anselmo Arenillas Álvarez

1966 - Habilitación de la nave alta de capillas para museo - Anselmo Arenillas Álvarez

1967 - Restauración de una capilla de la antigua colegiata - Anselmo Arenillas Álvarez

1967 - Restauración Puerta del Cardenal Cos - José Antonio Arenillas Asín

1969 - Obras urgentes cubierta de la nave central - Anselmo arenillas Álvarez

1974 - Entorno - Ana Iglesias González

1982 - Reparación de tejados y restauración del atrio de entrada - Victor López Cotelo

1984 - Obras urgentes: desprendimiento de un sillar de la cornisa - Victor López Cotelo

En la web del IPCE se facilitan 3 planos del proyecto de 1963 de Luis Cervera, de 1964 de Arenillas y 7 de 1967 de Arenillas.

\section{En el Archivo General de la Administración}

\section{AGA 26/00153}

1960 Luis Cervera

Proyecto de reparación de cubiertas de la catedral de Valladolid Memoria descriptiva (1 pág.)

"Se proyecta la reparación después de un detenido examen se ha visto que por rotura y desplazamiento de varias tejas ha ido filtrándose el agua y pudriendo con la humedad varios elementos de madera de la armadura. 
Procede en primer lugar desmontar las tejas en las partes afectadas y sanear los elementos de madera de las formas, sustituyéndolos por otros nuevos y aprovechando aquellos que puedan ser saneados.

Después de dejar en debidas condiciones la armadura se procederá a entablar con tabla de ripia nueva las partes afectadas, tejando a continuación, cambiando las tejas que estuvieren rotas y asegurando las que se encuentren sueltas".

Plano

Es una planta parcial muy burda, de pendientes.

Mediciones

AGA 26/0253

1962 Anselmo Arenillas

Proyecto de restauración de parte de la fachada sur de la catedral de Valladolid Memoria (2 pag)

Presentaba los huecos de $2^{\mathrm{a}}$ planta truncados . Ensayo de terminación de la Catedral.

Se trata de continuar el muro de fachada sobre las capillas, entre la torre y la portada, como estaba proyectado pero chapado con placa de piedra de $4 \mathrm{~cm}$ de espesor y dimensiones de los sillares existentes. Engrapada y recibida con cemento sobre un muro de hormigón en masa con tapas y cadenas de ladrillo en las zonas cargadas como pilares y contrafuertes y de ladrillo con cámara de aire en los entrepaños.

Se hace la puerta según Herrera pero menos saliente para no cortar el tráfico rodado. Planos (2)

Planta actual pinta en rojo sobre ella la portada y un croquis de alturas basamente, capitel y cornisa.

Un alzado con trama roja

AGA 26/00379

Proyecto de trabajos de mera conservación en parte románica de la catedral de Valladolid

Luis Cervera Vera mayo 1963

Memoria

"Después de un detenido examen de la parte Románica de la Catedral de Valladolid, se ha proyectado ejecutar diversos trabajos para su conservación.

Estando algunas de las piedras en mal estado, se proyecta sustituirlas por otras de las mismas características para conservar el mismo estilo del edificio.

También se proyecta sanear la cubierta, para eliminar las goteras existentes para lo cual se cambiarán algunas de las piezas de la armadura que están podridas. 
Así mismo se retejarán con teja curva la parte del tejado que se encuentra en mal estado, para la conservación del mismo.

Todos estos trabajos habrá que hacerlos con sumo cuidado y esmero, ya que tratandose de una obra de conservación habra de quedar con el mismo caracter que tiene sin variar para nada su constitución."

Mediciones:

Suministro y colocación de piedra de piña de Esgueva $\quad 12.283 \mathrm{~m} 3$

Suministro y colocación de piedra de Campaspero $124.772 \mathrm{~m} 3$

Rejuntado de piedras para la conservación de las mismas PA

Andamio PA

Saneamiento de la armadura de cubierta:

2 × $1,50 \times 2,00 ; 1 \times 3,00 \times 4,00 ; 2 \times 5,25 \times 6,30 ; 1 \times 2,85 \times 4,10 ; 1 \times 3,10 \times 1,40 ; 1 \times$ $2,80 \times 9,20 ; 3 \times 3,50 \times 4,80 ; 2 \times 2,90 \times 1,30 ; 1 \times 5,80 \times 3,00 ; 1 \times 2,20 \times 4,00 ; 2 \times$ $3,50 \times 2,10 ; 1 \times 2,90 \times 4,50 \quad 237,82 \mathrm{~m} 3$

Retejado de cubierta con teja curva $995,73 \mathrm{~m} 2$

Repaso de albañilería, limpieza y escombro a vertedero PA

Planos: una planta y tres secciones sólo de la zona de capillas y torre románica.

AGA 26/00370

Restauración de las cubiertas y cantería de la fachada mediodía de la catedral de Valladolid

Anselmo Arenillas Álvarez $\quad$ Enero de 1964

Memoria (2 pag +1pag anexo)

"Por orden del 5 de diciembre de 1.963 se redacto este proyecto que comprende la reconstruccion de la cubierta sobre la nave de las capillas del lado de la epistola de la Catedral de Valladolid. Y la de la cantería de la fachada correspondiente en la parte que es afectada por esta cubierta.

La fachada sur (a la calle del Cardenal Cos) tiene actualmente levantada, con su cantería, la parte de las naves centrales y lateral del lado de la epistola ...

falta colocar la gran cornisa de este cuerpo y la cubierta en segunda planta....

la cornisa será de cantería de gran vuelo; se sentará con mortero de cemento y engrapada al muro, mas sobre ella cargará el tejado para asegurarla y evitar el volteo. La cubierta se hará de fábrica a fín de evitar la descomposición y putrefacción de la madera ó hierro.

Siendo preciso hacer un cielo raso, se aprovecha para hacerle un poco más resistente y que sirva de soporte en la cubierta. Este cielo raso se formará con una placa de 
hormigón armado tipo antarquico "Ceramex" por considerarse el mejor de los del mercado. Para aligerar y aprovechando las maderas existentes en el muro de la fachada, se proyectarán unas jacenas de hormigón armado separadas entre sí 3,12m que dividirán el salón en zonas bien proporcionadas.

Estas jacenas atirantan la cubierta y solo exigen abrir machinales en el muro de la nave alta cada $3,12 \mathrm{~m}$ preferible a haber colocado viguetas (de $7,00 \mathrm{~m}$ de luz libre) cada $70 \mathrm{~cm}$.

Sobre el techo así formado con una placa uniforme, se levantará una cuadrícula de tabiques de panderete de 1,00 de separación y encima se hara el faldon de la cubierta (a un agua) con doble tablero de rasilla y un tendido de mortero impermeable de cemento.

La teja se colocará finalmente sobre este tablero recibiendo sus hiladas y cordone cada ocho tejas con mortero mixto de cal y cemento.

Como el agua de lluvia de las naves altas cae sobre la cubierta baja y supone más de $20 \mathrm{~m}$ de canal seguido es evidente que la teja canal no es capaz de recoger este agua y al rebosar da las eternas goteras en las iglesias en los dias de turbonada.

A fín de evitar esto se ha proyectado poner canalon en el final de la cubierta alta, recoger sus aguas con tubos cada $6,25 \mathrm{~m}$ y llevarlos por debajo de la cubierta alta de la nave baja hasta la fachada (siguiendo la pendiente del tejado)."

Cálculo del forjado.

2 Planos, terminación y portada, en web IPCE.

\section{AGA 26/00356}

Proyecto de obras de recalce y restauración de la puerta sur de la catedral Arenillas noviembre 1964

Al intentar reconstruir la portada sur se ha visto el terreno echadizo. Se aumenta la cimentación hasta profundizar $4,3 \mathrm{~m}$

Hay cálculos y los planos del IPCE

AGA 26/00356

Reconocimiento de las cornisas medias de la torre izquierda de la Catedral de Valladolid

Anselmo Arenillas Alvarez marzo 1965

Se redacta para reconocer las cornisas medias de la torre izquierda e intentar reponer el sillar o sillares de esquina desprendidos más de un año antes. 
Memoria 2pag con un detalle de planta y sección de núcleo de hormigón armado para sostener la esquina chapado de piedra. (pido copia)

"Por ser muy volada esta cornisa $(1,20 \mathrm{~m}$ aprox) y hallarse en mal estado, no es aconsejable andar sobre ella ni apoyar en ella ningún elemento y no hay huecos ni elementos próximos desde donde iniciar andamios... Las piedras desprendidas son grandes y posiblemente estaban solo engrapadas a otras y muy mal sujetas, sin entrega casi en el muro. Se piensa que reponerlas haciendolas con un nucleo de hormigon armado y chapado de piedra. Este nucleo de hormigon armado se insertará en un hueco practicao en el muro y con profundidad suficiente, para que trabaje como viga en voladizo.
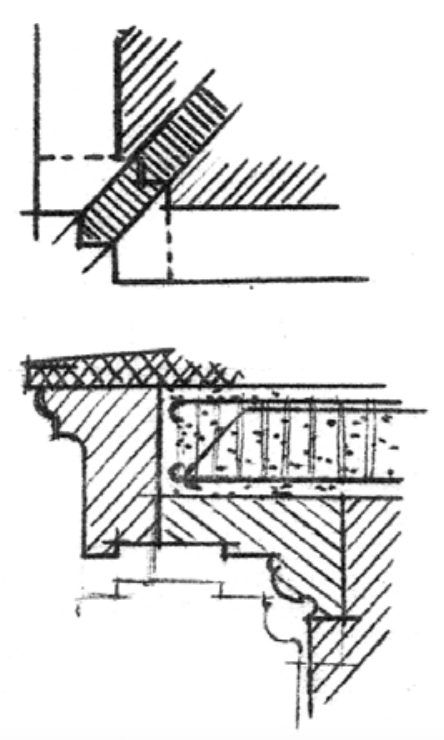

Ilustración 20: detalle del proyecto de Arenillas 1965

Esta operacion habrá de hacerse con toda probabilidad no solo en el sillar de esquina, sinó en los dos inmediatos de cada lado a causa de la forma de la esquina y de ser así habrá de hacerse de uno en uno, para evitar que quede descalzada la esquina de la torre y se produzca su derrumbamiento.

Como la altura de la cornisa viene a ser de 1,20, como su voladizo, y la entrega debería ser otro tanto, resultan sillares que pesarían, siendo solo de $0,50 \mathrm{~m}$ de largos, unas dos toneladas; serían muy dificiles de manejar y exigirian un andamio y gruas de elevación potentes. Convendrá por ello hacerlos segun se propone con nucleto de hormigon armado y revestimiento de piedra."

\section{AGA 26/00131}

1967 - Coronación del Remate de la Puerta del Cardenal Cos-Anselmo Arenillas Construye un zuncho de hormigón armado que sirva de soporte al forjado y a la fábrica de ladrillo.

AGA 26/00131

1968 - Habilitación para museo del salón de la nave de la fachada sur-Anselmo Arenillas

AGA 26/00146

1969 - Memoria-presupuesto de reparación urgente de la cubierta de la catedral de Valladolid para la reparación provisional del hundimiento de dos tramos de la cubierta de la nave central - Anselmo Arenillas 
Aunque hacía pocos años el cabildo había saneado la cubierta dejó maderas atacadas por xilófagos. "Hay tirantes de las formas que no apoyan en los muros, pares y piezas cuyas cabezas están descompuestas y en general todo el conjunto en peligro de que se repita el hundimiento actual en otros tramos. Por ello se juzga pertinente el cambio total de esta cubierta. De este estado no tenía conocimiento este Servicio porque el acceso a las cubiertas sólo es posible desde el exterior y mediante andamios o grandes escalas."

Propone los $8 \times 22 \mathrm{~m} 2$ derrumbados con Uralita gran onda roja sobre vigas doble $\mathrm{T}$ de

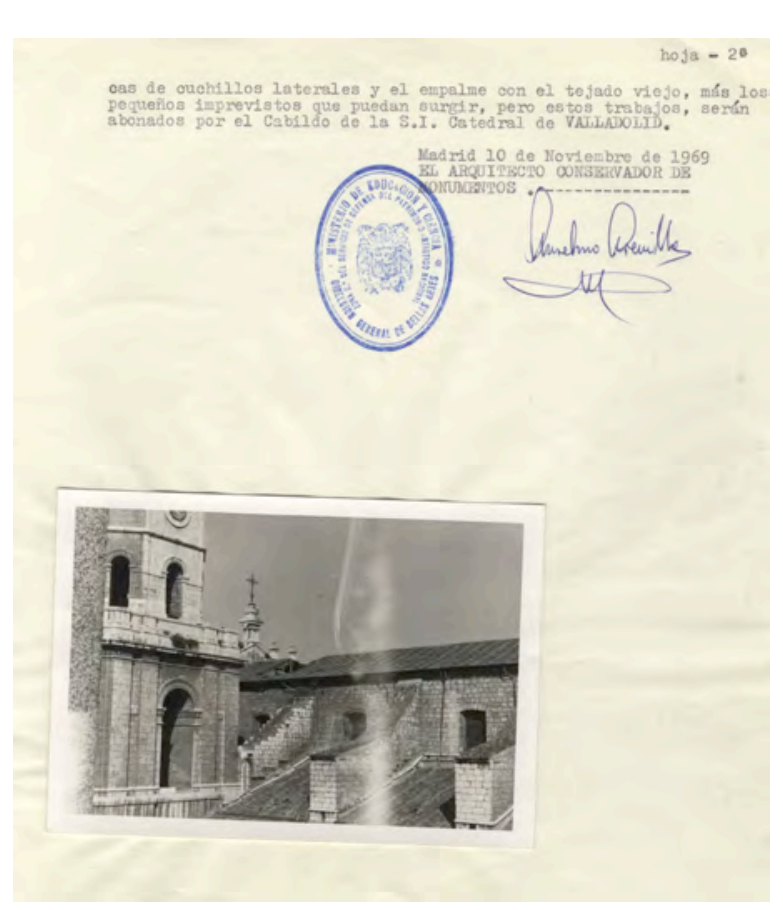
acero con $8 \mathrm{~m}$ de luz que descansen sobre los cuchillos paralelos. Describe cómo se colocarán estos $176 \mathrm{~m} 2$ de placas con una gran grúa.

En la fotografía blanco y negro incorporada al dossier se aprecia la existencia en aquel momento del peldañeado sobre el contrafuerte y escalerilla metálica para subir al faldón de la nave central, no así las ventanas practicables que completan el acceso hasta el bajo cubierta en la actualidad.

Ilustración 21: dossier Arenillas 1969

\section{AGA 26/00065}

1973-Obras de Ordenación del entorno de la catedral de Valladolid-Ana Iglesias

\section{AGA 26/00088}

1974-Proyecto de restauración de Cubierta. Catedral de Valladolid-Luis Cervera Vera

La memoria del proyecto se desarrolla en una página y media y se acompaña con dos planos de grandes dimensiones, uno con la sección de Estado actual a 1:20 y el otro con detalles de la restauración proyectada. 
"La catedral se encuentra con peligro de hundimiento de la cubierta de la nave central, lo que ocasionaría graves daños en las bóvedas y conjunto de las fábricas actuales."

Se encuentran en ese momento partidos los tirantes de dos cerchas, que se apuntalan provisionalmente.

Se proyecta sustituir la estructura. La teja se obtendrá de antiguas cubiertas desmontadas. "Las mencionadas cerchas se apoyarán en todos sus apoyos sobre un zuncho de hormigón armado, con objeto de repartir las cargas." Las limas se proyectan con el suficiente desarrollo, quedarán retranqueadas de la línea de fachada e irán provistas de bajantes situadas en el interior de la fábrica.

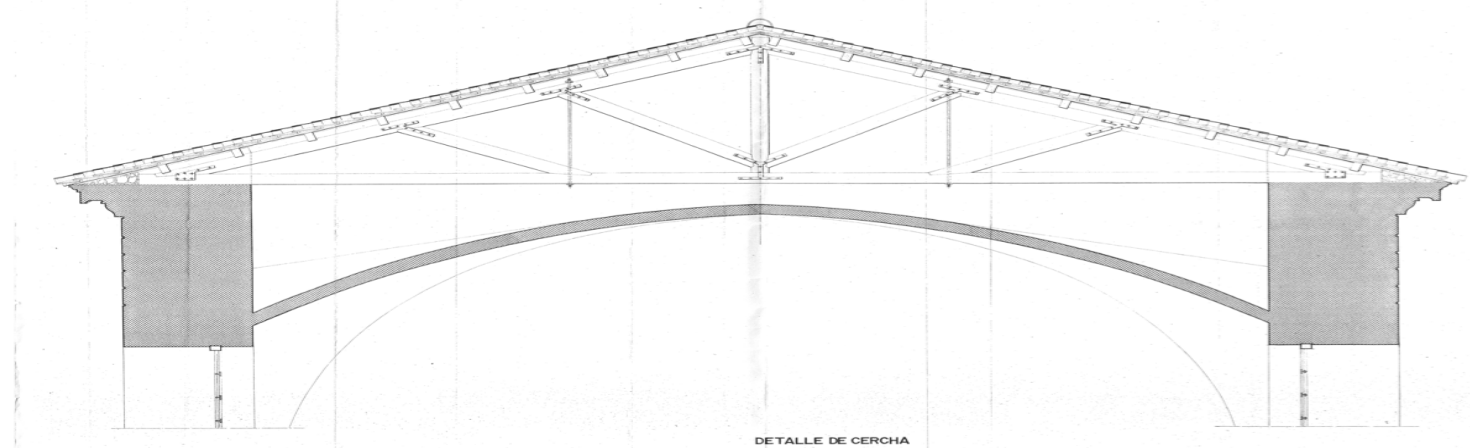

Ilustración 22: sección transversal de estado actual en 1974 (Cervera)

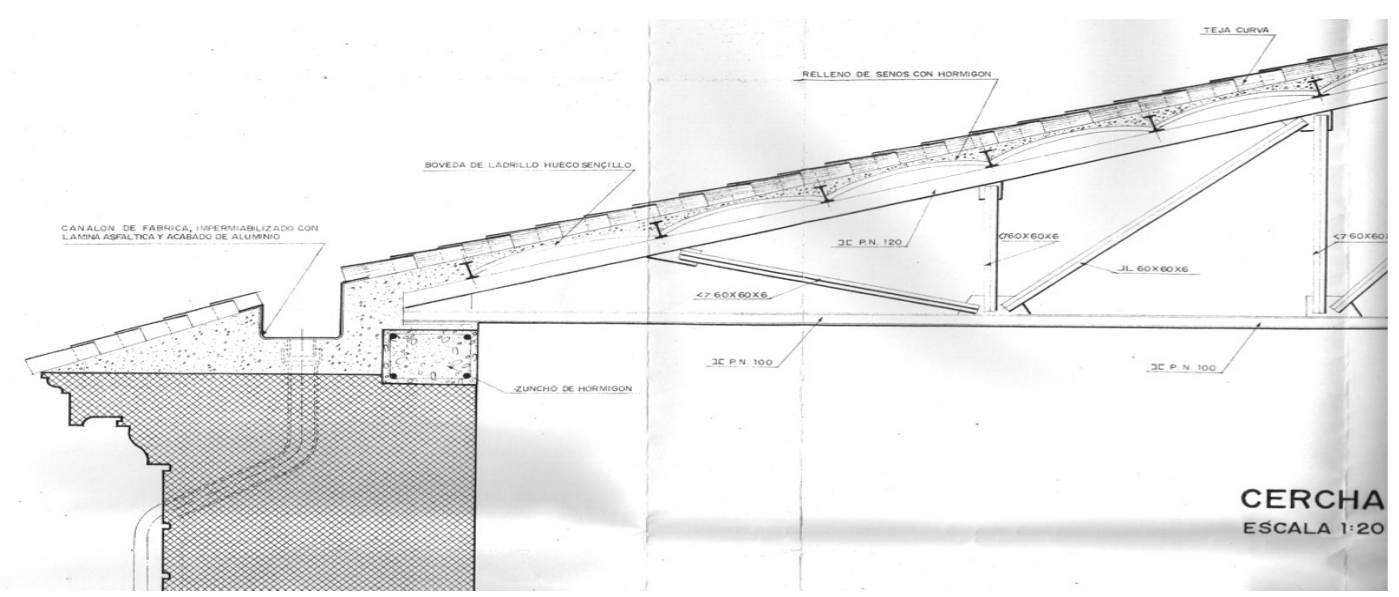

Ilustración 23: detalle sección transversal proyecto de Cervera 1974

En el presupuesto se define una intervención con

$1203 \mathrm{~m} 2$ desmonte de teja

$1203 \mathrm{~m} 2$ desmonte de estructura de cerchas, correas y ripia.

$111,40 \mathrm{ml}$ desmonte de coronación de muros extracción de durmientes y cabezas de madera

21,75m2 demolición de piñón de fábrica de ladrillo 
$21,75 \mathrm{~m} 2$ fábrica de ladrillo viejo con $25 \mathrm{~cm}$ de espesor

$125,90 \mathrm{ml}$ zuncho de hormigón armado de sección 50x30cm incluso armadura, encofrado y placas de apoyo para cerchas.

$44.097,69 \mathrm{~kg}$ de hierro en estructura metçalica de cerchas y correas

$1203,12 \mathrm{~m} 2$ placa de fibrocemento ondulado colocado entre correas metálicas, incluso enriñonado de senos con hormigón

retejado canal y cobija recibido con mortero de cal y arena cada 8 hileras

$944 \mathrm{~m} 2$ capa de compresión con hormigón sobre las bóvedas con espesor de $5 \mathrm{~cm}$

210,60 enfoscado con mortero de cemento en muros bajo cubierta

\section{AGA 26/01245}

Dos carpetas de documentación administrativa y un ejemplar del proyecto.

Proyecto de restauración de la catedral de Valladolid.

Victor López Cotelo enero 1982

En la Memoria explica que en la catedral hay dos tipos de problemas, ambientales y constructivos (deterioro por paso del tiempo) y su solución excede las posibilidades económicas acordadas.

La zona más afectada es el archivo. Propone colocar sobre el forjado de cubierta existente antes de retejar una base de Uralita minionda de fibrocemento con $3 \mathrm{~cm}$ de cemento armado con mallazo de alambre fijada por rastreles con aislamiento termico $3 \mathrm{~cm}$ de poliestireno.

Obras:

Retejado de cubiertas

Remates interiores de archivo y falso techo

Atrio: pavimento, consolidación de muro y restauración de balaustrada.

Planos. Muchos enormes con fotografías del atrio. Alzados del conjunto. Planta esquemática con faldones de cubierta sobre la que rotula el porcentaje de teja a reponer: $10 \%$ en ambos faldones de la iglesia, 100\% sobre estribos, torre y faldón hacia la plaza...

\section{AGA 26/01512}

Victor López Cotelo 1983

Obras de emergencia, por desprendimiento de un sillar de la cornisa, en zona de acceso público, con posibilidad de que se produzcan otros nuevos con peligro para personas y cosas.

Adjudicado a empresa ARROCABE SA 
Presupuesto:

Montaje de andamio, plataforma y valla

1 ud Apeo y acodalado de elementos de cantería con riesgo de desprendimiento inminente

ml Limpieza de vegetales y restos (fachada principal)

Tratamiento herbicida

Desmontaje y posterior montaje de piezas de sillería desprendidas

Rejuntado

Grapas metálicas

Saneado coronación de muro imprimación y capa de mortero epoxy

Todo impermeabiliza y repara grietas con resina Epoxy

En la memoria describe cómo los arbustos habían llegado a desplazar más de $10 \mathrm{~cm}$ las piezas de sillería contiguas

En la carpeta hay un presupuesto de liquidación que contempla la solera del atrio, con desmontaje de piedras, desbroce, compactación, drenaje y solera $7 \mathrm{~cm}$ de hormigón. Nuevo encintado de caliza. También algo de albañilería, 290m2 de falso techo y $1375 \mathrm{~m} 2$ de retejado: desmontaje de teja curva, limpieza del tablero, rastreles 40x30mm, planchas de poliestireno expandido de $30 \mathrm{~mm}$ de espesor, Uralita minionda clavada, rehenchido $3 \mathrm{~cm}$ mortero de cemento.

AGA 26/01313

Limpieza y restauración de cornisas en la catedral de Valladolid

Victor Lopez Cotelo julio 1983

Sólo memoria 1pag y presupuesto 1pag.

Durante las obras de restauración del Atrio se ha desprendido un sillar de cornisa de unos $100 \mathrm{~kg}$ de peso.

Se trata de limpiar y consolidar las cornisas e impostas para evitar nuevos desprendimientos.

Empresa ARROCABE SA 


\section{En el archivo de la Junta de Castilla y León}

\section{VA-163 (Plan Director)}

Carpeta 8235

En la documentación del Plan Director aparece una primera fase fechada en 1994 y otra en 1996. En la segunda se programan los planes de actuación a ejecutar en un plazo de ocho años. La aprobación definitiva del Plan es de 1997.

El arquitecto redactor es Elesio Gatón Gómez, con la colaboración del historiador Javier Rivera Blanco, el aparejador Pedro Julio Baz García, varios canónigos, delineantes y topógrafos.

En la Memoria del Plan Director se describe las siguientes Intervenciones modernas en la Catedral de Valladolid:

1922 Se desmonta parte del crucero herreriano con el fin de aprovechar el material para levantar la tribuna del órgano. (En esa época se obtiene fondos incluso vendiendo la reja de la Capilla Mayor, que se encuentra hoy en el museo Metropolitan de Nueva York)

1960 Luis Cervera Vera interviene sobre las cubiertas.

1961 El mismo arquitecto descubre arcos de las capillas de la antigua Colegiata.

1962 Y restaura la capilla de San Llorente. (3 planos fechados en 1963 en archivo IPCE)

1962 Bajo la dirección de Anselmo Arenillas Álvarez se acomete la obra de restauración de parte de la fachada sur, en realidad la del lado de la universidad.

1964 El mismo interviene en cubiertas y cantería

1964 Dirige el recalce de la portada sur.

1965 Consolida las cornisas de la torre izquierda 
1966 Y acondiciona la nave alta sobre las capillas laterales para museo, colocando en la cubierta de la misma un forjado ceramex que soporta el faldón de rasilla sobre tabiquillos palomeros.

Aunque en la Memoria del Plan de Gatón se indica que la fachada del crucero de Arenillas es de ladrillo con aplacado de piedra caliza, según el detalle bajo estas líneas extraído del plano archivado en el IPCE, este cerramiento se diseñó como un muro de hormigón trasdosado con medio pie de ladrillo al interior y aplacado de piedra en fachada.

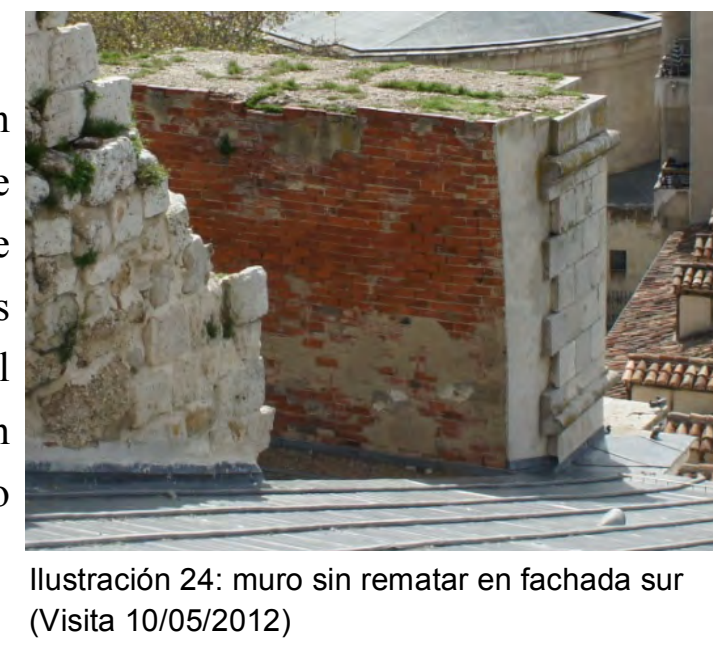

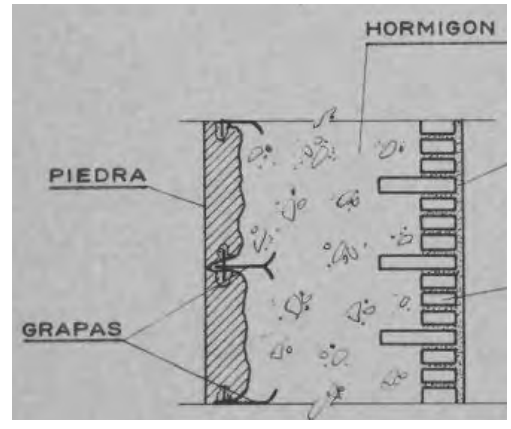

Ilustración 25: detalle de Arenillas 1967 (web IPCE)
En la fotografía se aprecia intradós y el borde superior de esta fachada sin remate.

1967 José Antonio Arenillas Asín restaura la puerta por la que se produce el acceso desde la calle General Cos. Se sigue la traza original de Juan de Herrera, pero retranqueada para ampliar el ancho de vía y facilitar el tránsito de vehículos.

1969 Anselmo Arenillas interviene de nuevo para llevar a cabo una restauración urgente de la cubierta de cerchas de madera de la nave central.

1973 Ana Iglesias ejecuta la ordenación del entorno y consolidación de las ruinas. Según Elesio Gatón, es una intervención pobre cuyo resultado duró sólo una década.

1974 Luis Cervera Vera sustituye la estructura de madera en las cubiertas de la nave central por cerchas y correas metálicas con revoltón de ladrillo, capa de compresión y teja colocando un zuncho perimetral de hormigón armado.

1982 Víctor López Cotelo repara el atrio de entrada y los tejados del archivo, en los que coloca placas de fibrocemento minionda.

1984 Víctor López Cotelo interviene de nuevo, como obra de emergencia tras el desprendimiento de un sillar de la cornisa, que repone con grapas y mortero epoxy. 
1988 Elesio Gatón Obras de adecentamiento de la Catedral de Valladolid: Repaso de estanqueidad de cubiertas y saneo de paramentos interiores para la exposición Las Edades del Hombre.

1994 Elesio Gatón Obras urgentes para la restauración de cubiertas en el Museo Diocesano y Catedral de Valladolid. Intervención profunda, incluso estructural, de las capillas de la antigua Colegiata. Se reconstruye el primer cuerpo de la torre románica.

1995 Propuesta de Informe de GEOCISA, que tomará muestras de los tipos de piedra caliza y elaborará un modelo de elementos finitos para estudiar la Patología estructural y de los materiales pétreos

En el avance y el propio Plan Director se incluye una descripción del estado de los distintos edificios del conjunto catedralicio en el momento de la redacción:

Archivo

Las cubiertas del mismo se encontraban en mal estado, a pesar de las diversas reparaciones de los últimos años

\section{Naves}

La nave central se cubre con cerchas metálicas, las laterales con forjados de hormigón armado. En el Plan Director se alude a estos últimos como inclinados, aunque en la sección del plano de Arenillas de 1964 aparecían representados en horizontal con recrecido de palomeros. Se menciona también que las bóvedas son de piedra revestidas interiormente con yeso y no presentaban problemas aparentes.

Los problemas de estanqueidad más acuciantes se debían a que la nave central vertía sobre las laterales. En el lado de la Epístola había canalones intermedios y una gran lima con bajantes en fachada pero en la del Evangelio, al rebosar las canales, se empapaba el forjado produciéndose penetración de las aguas en el archivo.

Aunque se retejó e impermeabilizó en 1988 las cubiertas de los tres ábsides de estructura de madera, continuaban con goteras, debido a la rotura de tejas por caída de material sobre las mismas desde los grandes hastiales de remate de las naves.

Describía también problemas en la nueva sala de la Colegiata, con dos capillas cerradas en ruina inminente. 


\section{Carpeta 8236}

En esta caja se archivan los documentos de campo elaborados para el levantamiento topográfico, realizado con estación total y nivel láser, en el marco de la primera fase del Plan Director.

\section{Carpeta 8237}

Planos del Plan, con plantas, alzados y secciones a 1:100 y detalles de bóvedas, cantería, carpinterías y esculturas a 1:50.

\section{Carpeta 8}

Memoria, planos y disquetes de la segunda fase.

En esta memoria se menciona que la cimentación de la torre desplomada se encontraba en buen estado, achacando su ruina a mala ejecución de los muros de dos hojas de sillería, sin enlazar correctamente, y a la baja calidad del relleno empleado en los mismos.

En la base de la torre moderna se detectó grietas con expulsión de piedra en equinas, por lo que se encarga a GEOCISA el estudio citado.

En esta segunda fase del Plan Director se incluye la reubicación de archivos en la planta superior de la nave de la Epístola, mediante el refuerzo de los forjados existentes y el añadido de otros ligeros (para soportar un archivo define $600 \mathrm{~m} 2$ de forjados de viga metálica aligerada, viguetas y revoltón de ladrillos con su capa de compresión y mallazo), conectándose estos recintos con las salas de investigadores y restauración ubicadas en la torre.

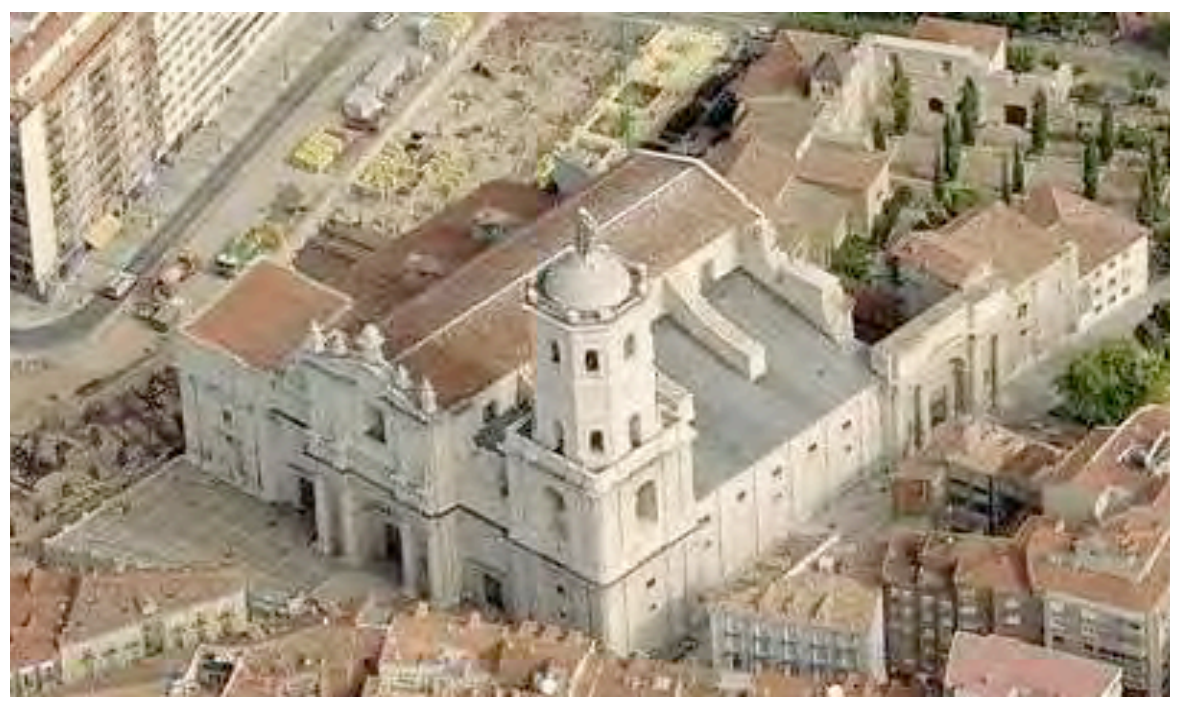

Ilustración 26: foto aérea aún con teja en gran parte de las cubiertas (www.foroxerbar.com 11/02/2014) 
En la Ficha de Diagnóstico se incluye la propuesta de sustituir el recubrimiento de las cubiertas de teja curva por láminas de plomo, material más adecuado a la pendiente que presentan los faldones y que admitiría pequeños impactos sin fracturarse. En el Plan se incluye una justificación histórica del empleo de este material desde el siglo XVI en diversos monumentos.

\section{VA-271}

1997-Proyecto de Restauración de cubiertas del lado de la Epístola de la SI Catedral de Valladolid. Elesio Gatón.

Se acomete la paulatina restauración de las cubiertas empezando por el balcón que da a la calle Cardenal Cos, donde Anselmo Arenillas había levantado una segunda planta en 1962. Gatón describe cómo se aprecian visualmente las etapas constructivas en la propia fábrica del muro. Incluye en la Memoria copia del capítulo del Plan Director en el que justificaba el reemplazo de la cubrición de teja por lámina de plomo, material más adecuado para una longitud de faldón de $35 \mathrm{~m}$ y poca pendiente.

\section{Análisis petrológico de la UCM y el CSIC.}

La sillería en la base de la torre se identifica como Facies Biomicrita: caliza micrítica con formas grumelares, englobando restos de gasterópodos y ostrácodos, algunos muy fragmentados. Pequeños procesos de arenización empiezan con la pérdida de pátinas que protegen la piedra, que se va empapando y disolviendo. Los cristales de yeso de las costras negras debidas al ensuciamiento, etc.

Además, restauraciones anteriores con empleo de mortero de cemento rico en sulfatos generan una aceleración en el proceso de degradación de los sillares de caliza.

Descripción de las obras:

Desmonte de tejas, revisión de estructura, minio, prueba de carga con sacos en forjado. Suplemento del zuncho actual conectado con barras y epoxy.

Nueva estructura de cubierta de naves laterales y capillas en madera laminada con conectadores metálicos y correas de pino, tablero de madera y espuma de poliuretano.

Cubrición con plancha de $3 \mathrm{~mm}$ de plomo en bandas de $675 \mathrm{~mm}$ en vertical y $2250 \mathrm{~mm}$ de desarrollo horizontal. Fieltro seco en contacto plomo-piedra. Ventanas Velux. 
Revestimiento superior de contrafuertes con planchas de piedra caliza y apertura de huecos de paso con roza y cargadero previos de hormigón armado a ambos lados.

Reemplazo de grapas de hierro por piezas de acero inoxidable en fachadas.

Limpieza con hidróxido sódico (Proliser), quince minutos y agua caliente a $90^{\circ} \mathrm{C}$ con pistola a presión 120 bares. Inyecciones con resinas epoxídicas, varilla de acero o fibra de vidrio.

Aplicación de consolidante e hidrofugante siloxano de la marca Wacker, tras comprobar respuesta de la piedra a estos y otros preparados (Cotelatex, Tegovakon y Tegosivin).

\section{En el Archivo Municipal de Valladolid}

\section{Fondo Histórico}

AMVA: CH 624-63 Licencia zanja desagüe 1785

(1 hoja) El Prior Simón Gómez Gayoso expone que "al abrir unos cimientos a la parte del Esgueva hay mucha agua que impide perfeccionarlos" y pide licencia para abrir una zanja y que se corte el tráfico con unos maderos en esa calle

AMVA: 433-13 Informe torre $1841 \quad$ J. Sánchez García Reconocimiento de la torre de la Catedral por D. Julián Sánchez García, Arquitecto titular de Ciudad, a demanda de la Sección de Policía Urbana. Mayo de 1841. Hace el reconocimiento con el Prior y el Penitenciario, hay una grieta en la torre en la fachada que da al Esgueva, se ha desprendido del trasdós parte de su revestido de sillería. No puede confirmar desplome por el furioso temporal de aguas y vientos que impide tirar plomos y niveles el día 8 de mayo. El día 12 continúa el temporal. Otro escrito del 18 dice que ha reconocido el interior de la torre pero sigue sin poder salir a las fachadas por los fuertes vientos y lluvias que impiden marchar por las cornisas. El 25 de mayo en otro escrito dice que había templado y lo iba a hacer pero volvió el mal tiempo.

AMVA: 437-2 Demolición torre hundida 1841

Expediente acerca del hundimiento de la torre de la Catedral.

Calamidad en el dia de hoy 31 de mayo con el desplome de parte de la torre. Se convoca una reunión de cuatro arquitectos para que informen.

Es un dossier amplio que incluye documentos muy variados, incluso informes de los médicos sobre el estado de salud y evolución de la afectada $\mathrm{D}^{\mathrm{a}}$ Valeriana Pérez. 
Hay un informe de Ingenieros Militares:

Explican que no se puede subir a la torre por encontrarse inutilizada la escalera, por lo que inspeccionan desde la calle, a 200 varas de distancia y mirando los objetos desde abajo. Describen cómo Churriguera se hace cargo de la obra y aligera demasiado la edificación de los dos cuerpos adicionales y el octógono que sostenía el cimborrio. Que empleó piedra y mezclas de mala calidad, lo que se advierte por la desunión.

"A los 112 o 114 años de construida hubo necesidad de echar tres cinchos o cadenas de hierro en los cuerpos altos que se notaron sentidos. hace 30 años se echó un punto de piedra de unos treinta pies de largo y unos diez de alto en el mismo ángulo que se desplomó ayer. Estas noticias históricas se han adquirido de un maestro de obras práctico en esta ciudad. Pasemos ahora a las observaciones que nosotros hemos hecho. En el primer cuerpo no se advierte ninguna grieta ni otro defecto, por lo que nos inclinamos a creer que los cimientos están buenos y seguros, solo si se ha advertido alguna otra piedra de su cornisa que ha sido desprendida a impulso del material que ha caido sobre ella. En el $2^{\circ}$ cuerpo y en el ángulo reparado hace treinta años, es donde sin duda estaba la parte más débil, pues a la altura de unas diez hiladas de piedras, cada una de unas quince pulgadas de alto principió el desplome de este edificio; habiendo dejado los paramentos inmediatos algo resentidos. En el tercer cuerpo solo han quedado dos lados y un tercio de uno de los contiguos; su estado de debilidad se deja conocer porque estribaban sobre un cimiento falso. De los lados del octogono que sostenía la bobeda de la cupula solo han quedado en pie cuatro de ellos y la cupula toda ha venido abajo si se exceptua un corto numero de piedras desunidas. Esto es lo que la grande y desventajosa distancia en que lo hemos observado nos ha permitido advertir. Sospechamos con bastante fundamento que la parte que ha quedado en pie del tercer cuerpo y del octógono no están muy seguras; a pesar que no hayamos advertido ninguna inclinación, ni grietas de tal consideración que amenacen una ruina tan proxima como se figura el miedo y terror que ha infundido este acontecimiento."

Recomiendan demoler esas dos partes, previo cercado del perímetro para evitar riesgo de daño a transeúntes.

Comisiones, escritos del Cabildo, de responsables políticos, expertos, etc. El último documento es del Alcalde Claudio Moyano, que confirma hasta dónde la Comisión que entiende la demolición recomienda llevar la obra al Cabildo y Ayuntamiento. 
AMVA: 751-13

Licencia cúpula torre

1922

Piden licencia libre de arbitrios para construir la cúpula sobre la torre y cerrar con verja los huecos de campana. El arquitecto municipal Juan Agapito y la Comisión de obras proponer acceder.

Agapito informa de que el andamio sobre la cubierta debería tener pasamanos. El Cabildo dice que lo pondrá, aunque las obras se han suspendido hasta la primavera.

\section{Fondo Administrativo}

AMVA: 216/1974 2002-5 Reconstrucción nave central 1974

1974 Sustitución de cubierta en la nave central de la catedral de Valladolid

Arq: Angel Ríos Gómez

Memoria (2 pag) Firma noviembre, visado 28 feb 1974

"Por encargo del Excmo. Sr. Arzobispo de Valladolid se redacta el presente proyecto de SUSTITUCIÓN DE CUBIERTAS DE LA NAVE CENTRAL DE LA CATEDRAL DE VALLADOLID, propiedad del Arzobispado de Valladolid.

La Catedral de Valladolid, edificio monumental de la época de Juan de Herrera, construida de piedra de sillería en sus muros, aras y columnas, y bóvedas de cañón de fábrica, es una construcción regia y en perfecto estado de conservación en cuanto a los materiales nobles que la forman.

Dispone de amplia nave central y dos cuerpos laterales. Su cubierta original es de cerchas de madera, correas, tabla ripia y teja, habiéndose reformado en algunas de sus zonas, a causa de hundimientos, por la Dirección General de Bellas Artes.

La urgencia en la redacción del presente proyecto, actualmente en ejecución, la motiva el inminente peligro de hundimiento de la cubierta de la nave central, con la correspondiente repercusión de daños en las bóvedas y conjunto del edificio. El transcurso de los años, así como la

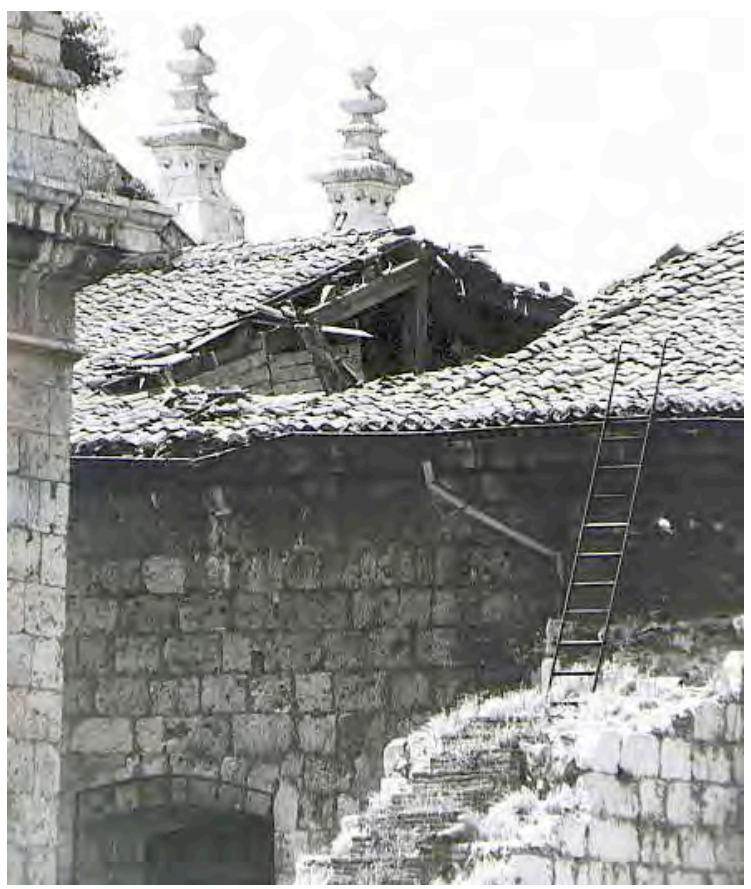
Ilustración 27: foto web AMVA 4006 calidad de la madera, ha menoscabado 
la resistencia de las cerchas que forman la cubierta de la mencionada nave central. Habiéndose partido los tirantes de dos cerchas, actualmente apuntaladas, y con peligro de arrastrar en su caída los piñones de fábricas $\mathrm{y}$ cerchas colindantes. lo que obliga a declarar en estado ruinoso toda la cubierta con la necesidad de sustituir los materiales actuales por perfiles metálicos.

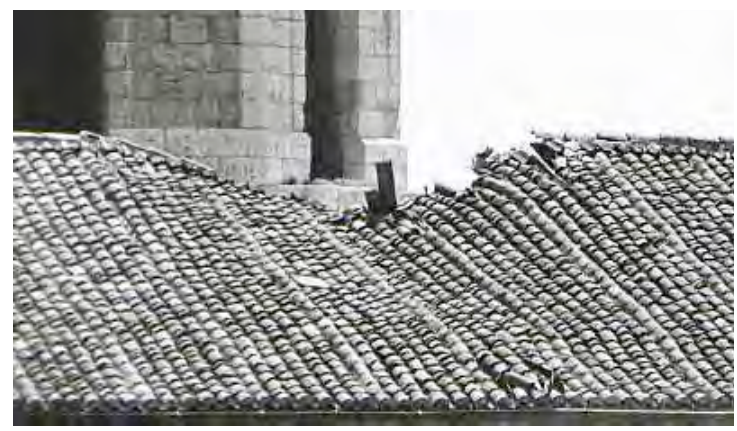

Ilustración 28: foto web AMVA 4010

La nueva estructura proyectada es a base de cerchas y correas metálicas, bóveda de fibrocemento, capa de compresión y teja a canal y cobija. La teja a reponer procederá de edificios desmontados, con objeto de conservar el carácter.

Perimetralmente, por toda la coronación de los muros, correrá un zuncho de hormigón armado, sobre el que apoyarán las cerchas metálicas.

Se proyectan amplias limas, retranqueadas de las líneas de fachada, con bajantes por el interior.

Se desescombrarán todas las bóvedas, procediéndose a su consolidación mediante solera de hormigón en masa.

Asimismo se desmontarán los servicios anejos a la Catedral cuyo estado deplorable impide su utilización.

Todas las obras se desarrollarán utilizando los medios de seguridad precisos con garantía para el personal y para la buena calidad de la obra.

La superficie a desmontar es de $1.130 \mathrm{~m} 2$ y el importe de la obra se estima en la cantidad de 4.107.444,74 pesetas. "

Planos (3): Fecha febrero 1974, visado 28 de febrero y sello "Concedida licencia por la Comisión Permanente Municipal" de 30 de abril. (pido copia de las secciones)

Planta 1:100 de cubierta con trama en faldones nave central.

Sección estado actual 1:20

Sección con nueva cercha metálica

Informe del Arquitecto Municipal 7 de marzo informa no hay inconveniente pero debe enviarse a la Comisión Provincial de Bellas Artes.

La Comisión de protección del Patrimonio Histórico-Artístico el 16 de abril no estima conveniente la solución de apoyo tanto de las cerchas metálicas como de la recogida y salida de aguas pluviales a través de bajantes que perforan la coronación del muro de fachada, afectando la cornisa incluida y su salida al exterior por fachada. 
La Comisión de obras y urbanismo propone a la Comisión permanente que se conceda la licencia con la condición de que se corrija el defecto apuntado.

La Comisión Permanente concede la licencia con esa condición. Concesión por duplicado.

AMVA: 2577-29 C2577-28 Cubiertas 1963

Hoja suelta con membrete del Ministerio de Educación Nacional, Dirección General de Bellas Artes, sección 28. Tesoro artístico

Visto el proyecto de obras formulado por Luis Cervera Vera que propone sustituir algunas piedras por otras de las mismas características para conservar el mismo estilo de su traza; sanear la cubierta y retejar con teja curva en las zonas que sea necesario importe 497.792,81 pesetas, se aprueba el proyecto.

Es la copia para el Alcalde de Valladolid, con sello de entrada al registro del Ayuntamiento 14 Nov 1963.

AMVA: 2577-26 leg.2577-27 Reconocimiento cornisas torre

Otra hoja suelta: Aprobadas obras de reconocimiento de las cornisas medias de la torre izquierda Anselmo Arenillas 100.000,00 ptas. Abril de 1965

En esa caja hay otras de San Gregorio y de Las Huelgas (la Abadesa informa un vecino excava cimientos junto a la iglesia. Le autorizan a rematarlos)

AMVA: 404/2006 C10923-2

Carpeta gruesa

Licencia de obras a la Junta para la Restauración de cubiertas de la nave central y lado del evangelio de la Santa Catedral de Nuestra Señora de la Asunción en Valladolid con exención de tasas municipales. Elesio Gatón.

Detalle constructivo 1:10. Apoyo de par de madera laminada sobre un pequeño durmiente de madera. Proyecto de diciembre de 2005. Pido copia plano P16 a 1/25

\section{AMVA: 5265/1998 C16098-3}

Restauración de cubiertas del lado de la Epístola de la SI Catedral de Valladolid. Elesio Gatón

Como el de nave central y Evangelio incluye Memoria con la misma documentación de cambio de teja por plomo del Plan Director. Pido copia de dos pag de cada memoria y de 1 plan. 



\section{Visitas realizadas}

10/Mayo/2012

El recorrido por el templo se ve facilitado por las últimas intervenciones realizadas bajo los criterios establecidos en el Plan Director, como la instalación de una trampilla tipo Velux en la desembocadura de la escalerilla metálica que apoya en el contrafuerte peldañeado $\mathrm{y}$, sobre todo, los huecos de paso abiertos a través de los contrafuertes inspirados en las trazas originales de Juan de Herrera que se conservan en el Archivo Diocesano.
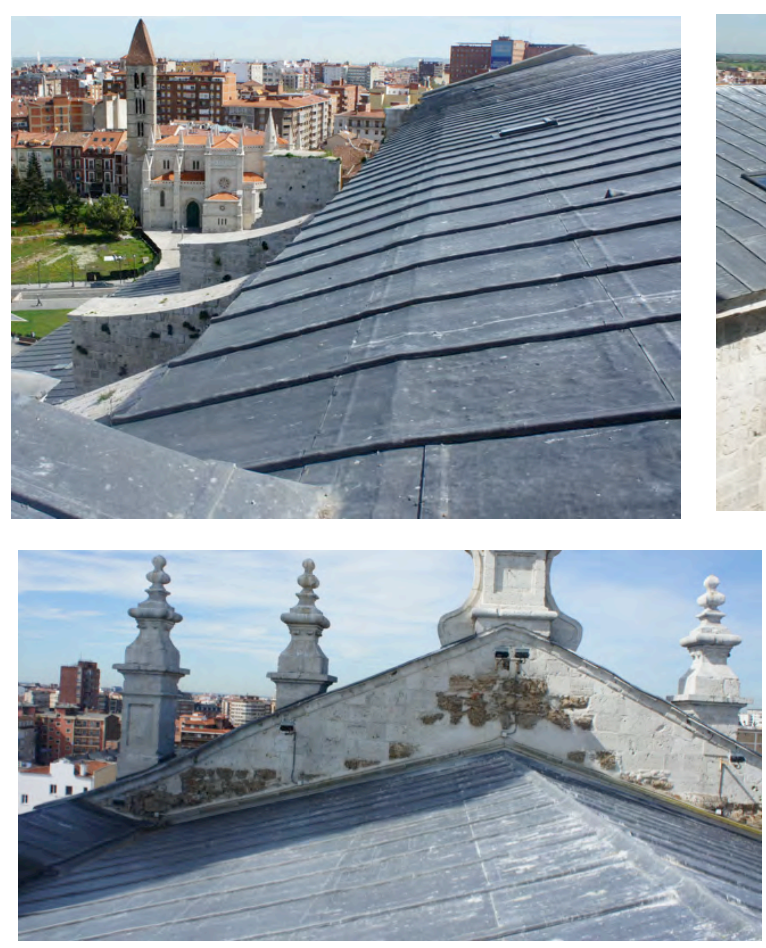
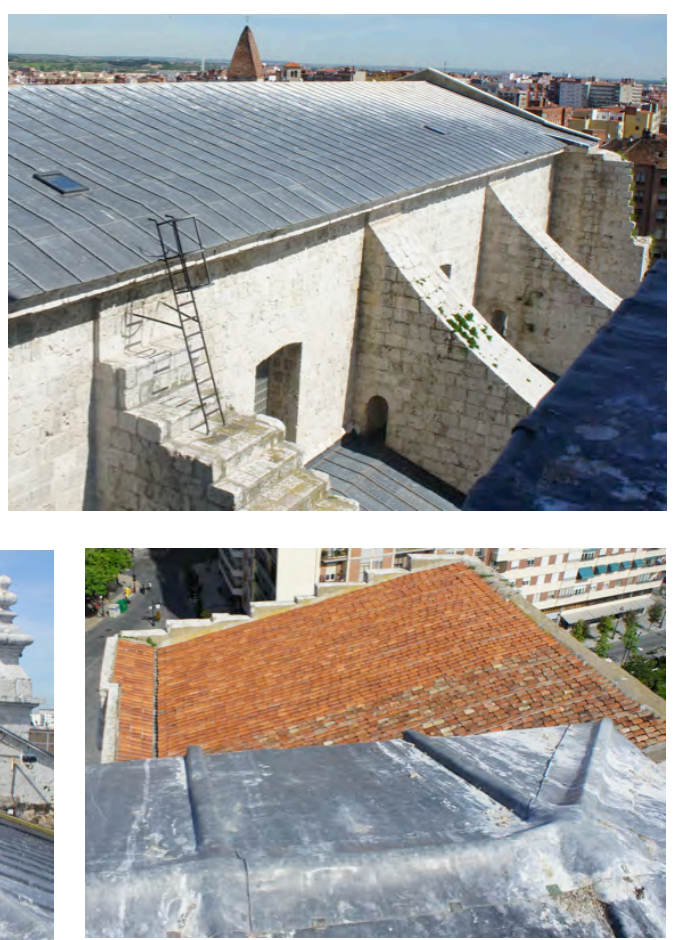

La cubierta de la nave central y ambas laterales están revestidas con lámina de plomo. Los contrafuertes presentan un remate superior de piedra vista, sin la teja con que contaban anteriormente, y ya encontramos un problema por crecimiento de vegetación en algunos de sus paramentos.

El remate a un agua de la torre truncada del Evangelio está revestido de teja curva, según se aprecia en la imagen correspondiente.

Una vez en el interior del espacio bajo cubierta de la nave central, se aprecia el estado en que se encuentran las cerchas metálicas incorporadas en 1974. 

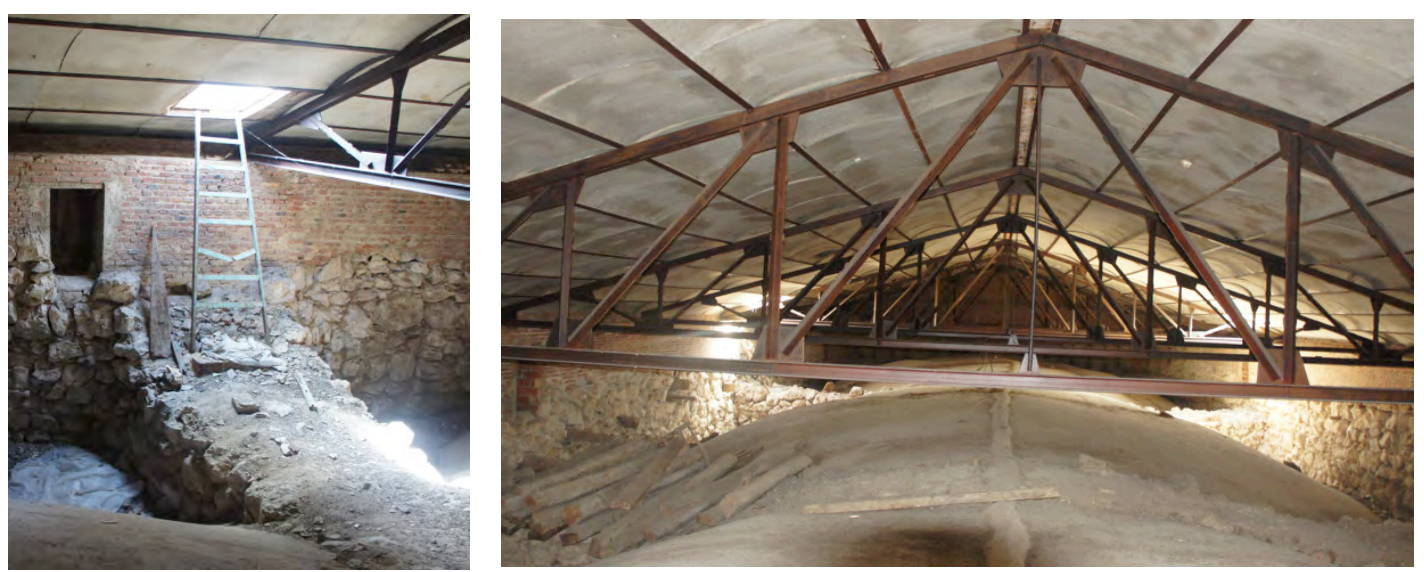

El revoltón de ladrillo se empleó sólo en las dos primeras crujías hacia la cabecera, utilizándose en el resto de la cubierta placas curvas prefabricadas con el mismo perfil.

En las fotografías podemos ver los restos de piezas de madera, con sus extremos embebidos en el muro de la estructura de cubierta de madera original, que fueron cortadas. Hacia los pies de la nave se mantienen algunos tirantes de madera sin desmontar junto a las nuevas cerchas.

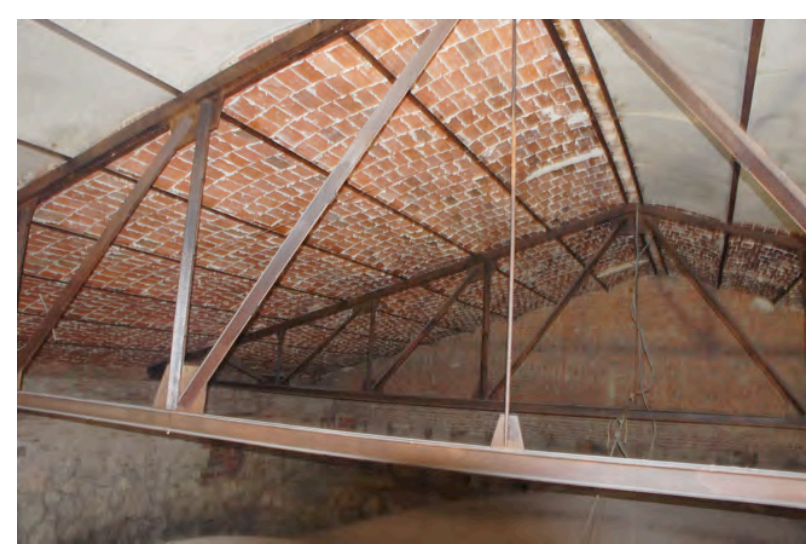

Hay un recrecido de ladrillo de altura considerable sobre el remate irregular de la fábrica de piedra. El zuncho de hormigón aparece confinado por estas paredes de ladrillo, que debieron aprovecharse durante la ejecución como encofrado perdido.

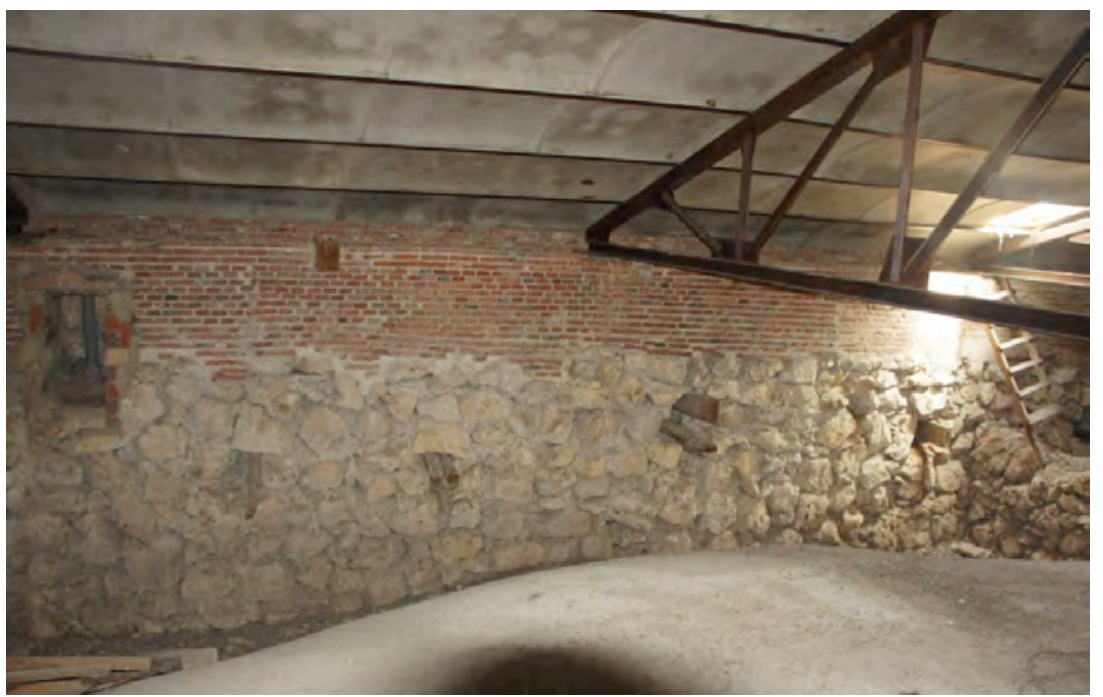


Sobre la cara superior del zuncho apoyan las chapas de anclaje de las cerchas, formadas por perfiles UPN con diagonales de angulares soldadas mediante cartelas.

La siguiente fotografía corresponde al cierre, concebido como provisional, de los ábsides al fondo del altar mayor. Se puede observar cómo la cubrición más reciente y flexible de plomo ya se encuentra deteriorada por la caída de materiales desprendidos de los muros inacabados que se han dejado al descubierto tras la demolición, estipulada en el Plan Director, de las edificaciones adosadas.

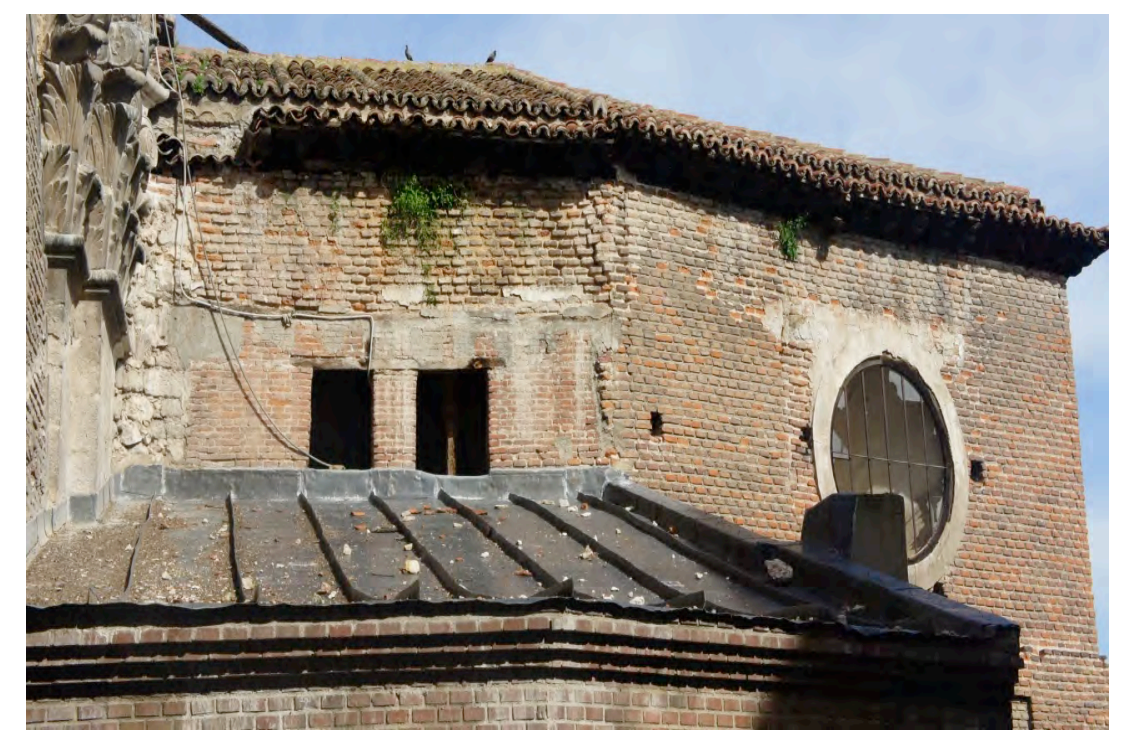

La imagen en blanco y negro del libro de Chueca sobre la catedral muestra el testero "provisional" sin dichas edificaciones adosadas y la siguiente del proyecto de Gatón la vista del conjunto con ellas años más tarde, poco antes de ser demolidas.
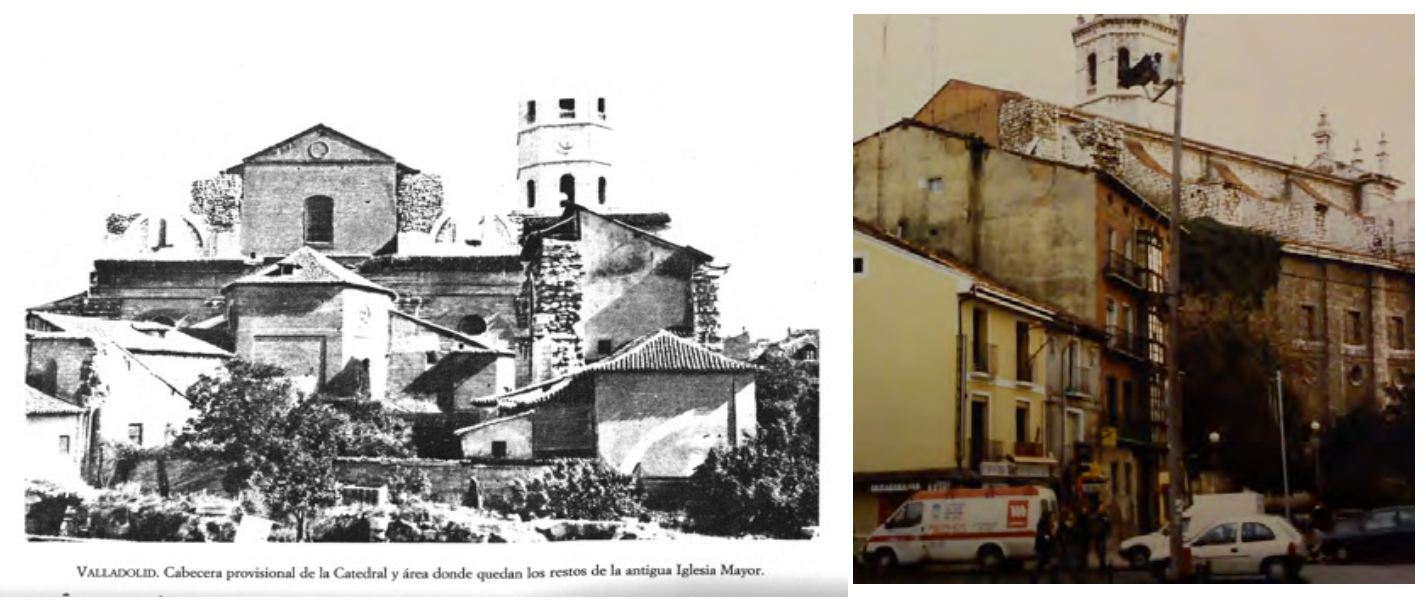

El muro de remate de la nave central, de fábrica de ladrillo visto, contaba con una moldura a modo de frontón y un adorno de óculo resaltado que no encontramos en la actualidad. 
Desde el espacio bajo cubierta se aprecia la configuración estructural de este cerramiento, que cuenta con un entramado de madera que se interrumpe a la cota de arranque del zuncho de hormigón.
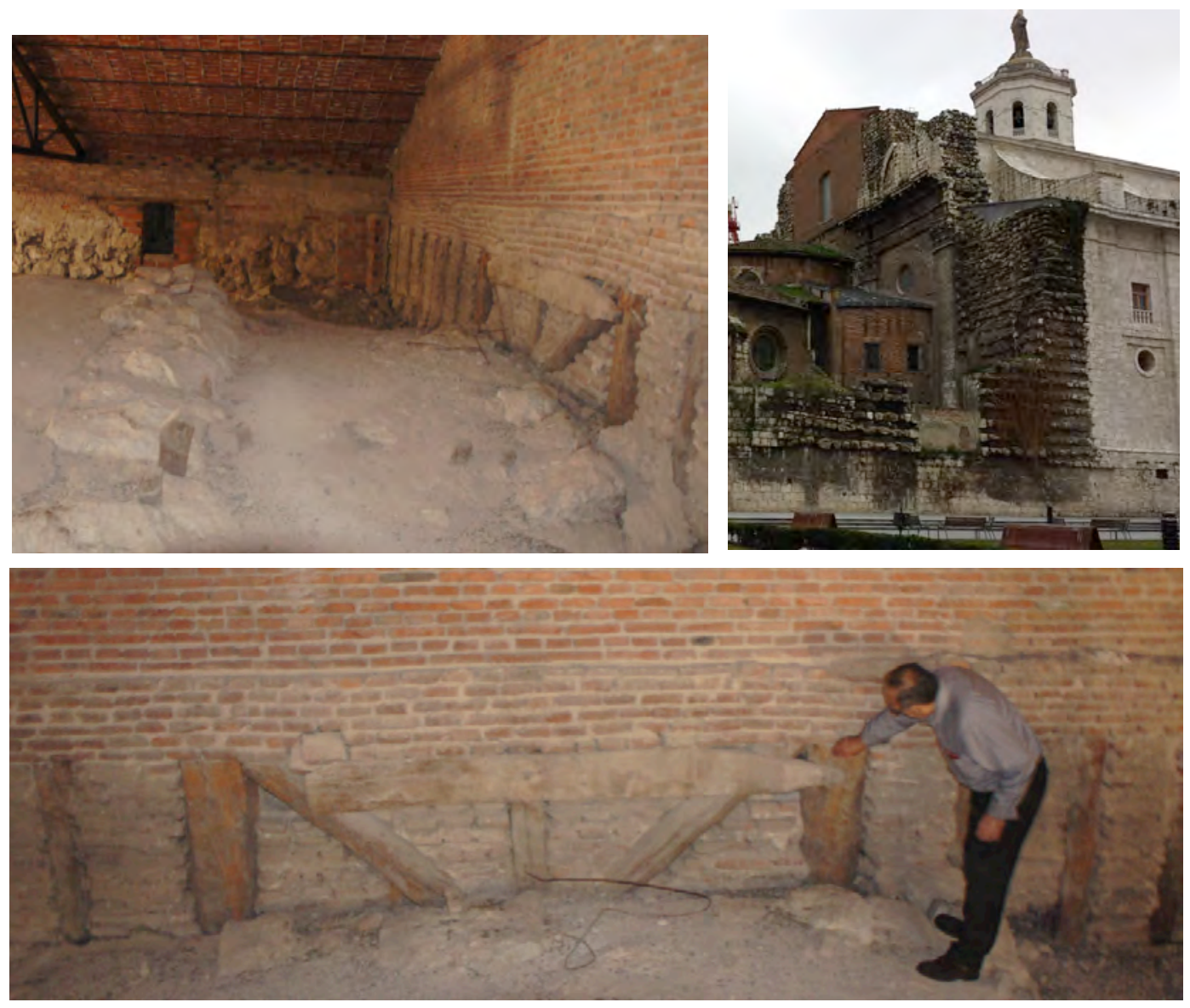

En la visita a los archivos se aprecia el gran canto de las vigas finalmente incorporadas, con bruscos desniveles y cajeados perimetrales para resolver el encuentro con la estructura previa de la nave.

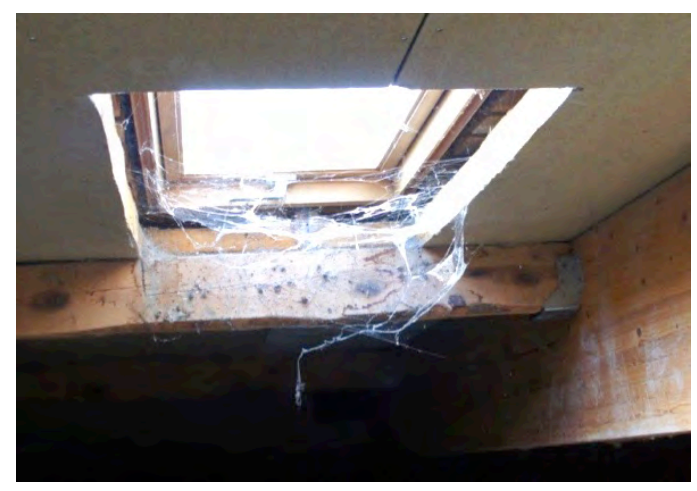

Hay indicios de degradación de los materiales alrededor de las ventanas de cubierta tipo Velux sobre las naves laterales, a pesar de lo reciente de su colocación 
Visitas posteriores

27 agosto de 2014

El remate del muro del crucero perpendicular a la fachada mediodía cuenta con un sencillo alero de madera.

21 febrero de 2014.

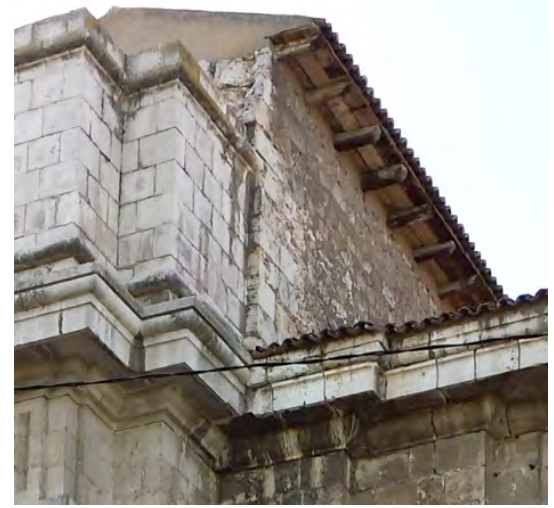

Desde una edificación colindante se aprecia los distintos tratamientos de las cubiertas: la de nave lateral sobre el archivo, con lámina de plomo (se trata del primer faldón del templo en que se incorporó este material a raíz del Plan Director) y teja curva sobre dependencias junto a la plaza de la Universidad.

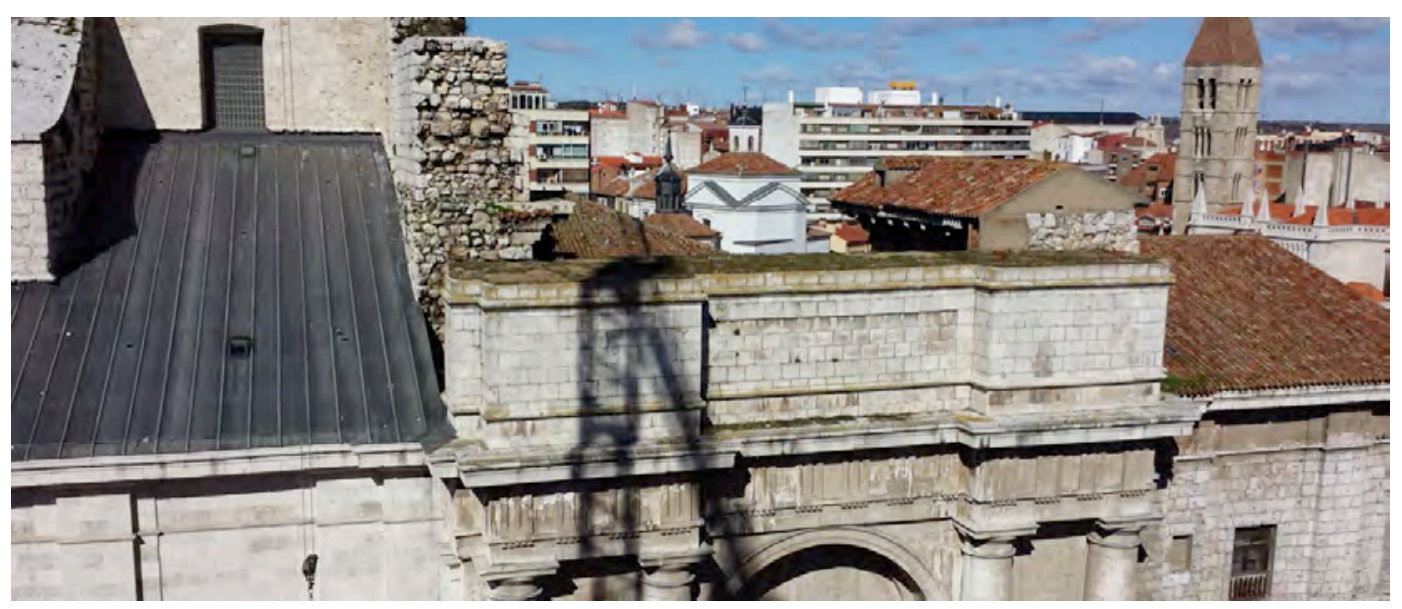

26 septiembre de 2014

Se ha realizado obras de reparación del remate de muro inconcluso, retacado después de producirse desprendimientos. Se aprecia cómo el ábside central, que contaba con teja en la visita de 2012, aparece ahora cubierto de chapa metálica.

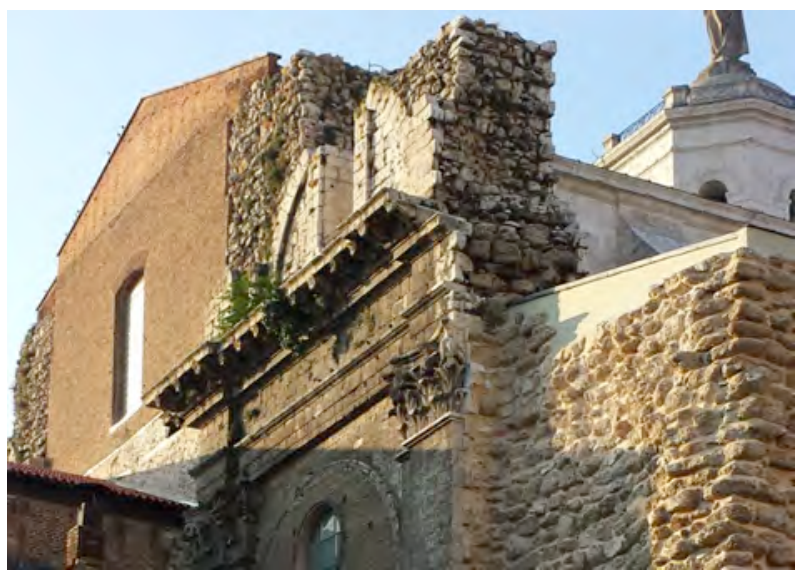





\section{Iglesia del Convento de la Concepción}

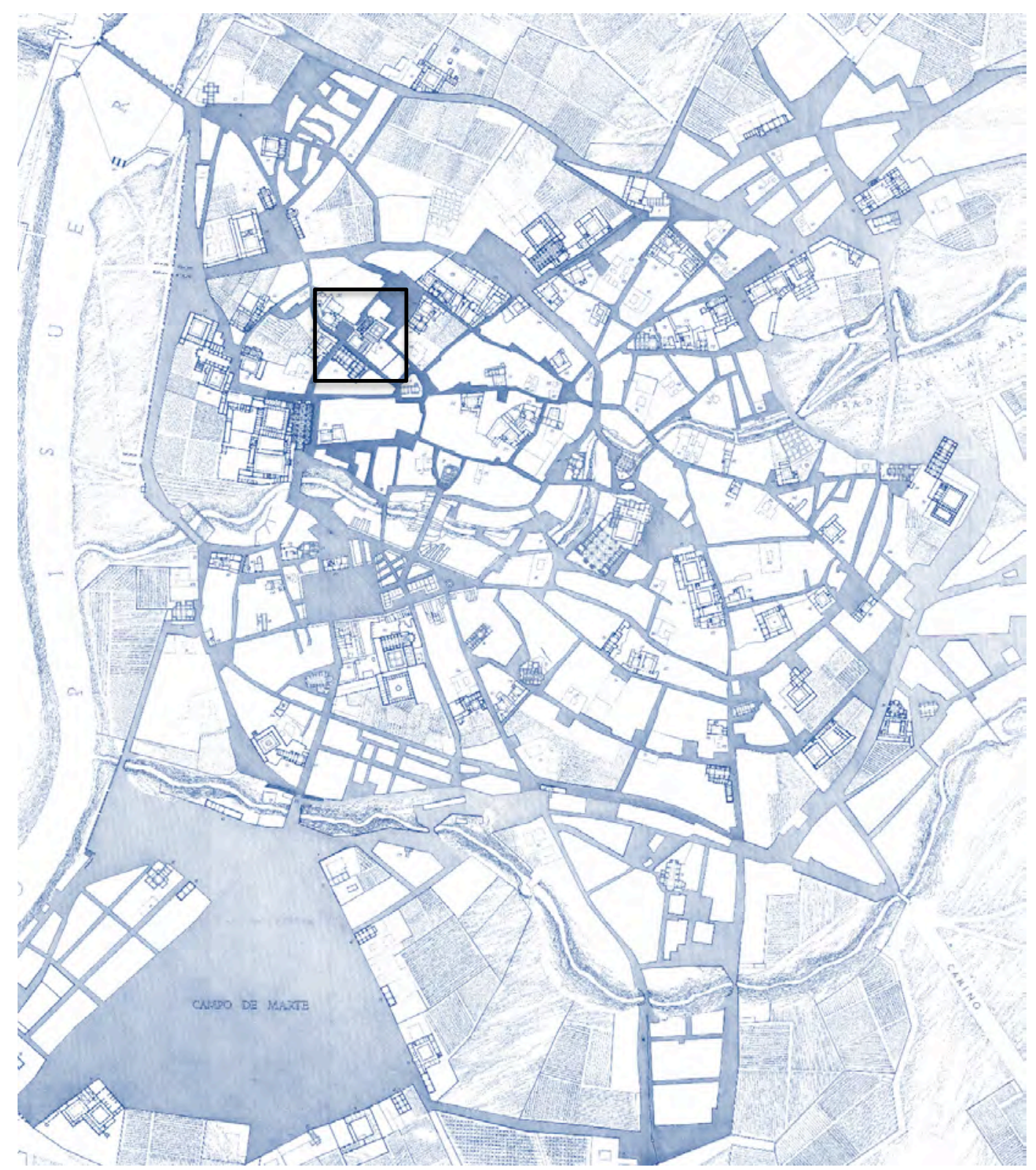



FICHA SÍNTESIS

Código de identificación: FZ-02

Denominación: $\quad$ Iglesia del Convento de la Concepción

Localidad: $\quad$ Valladolid
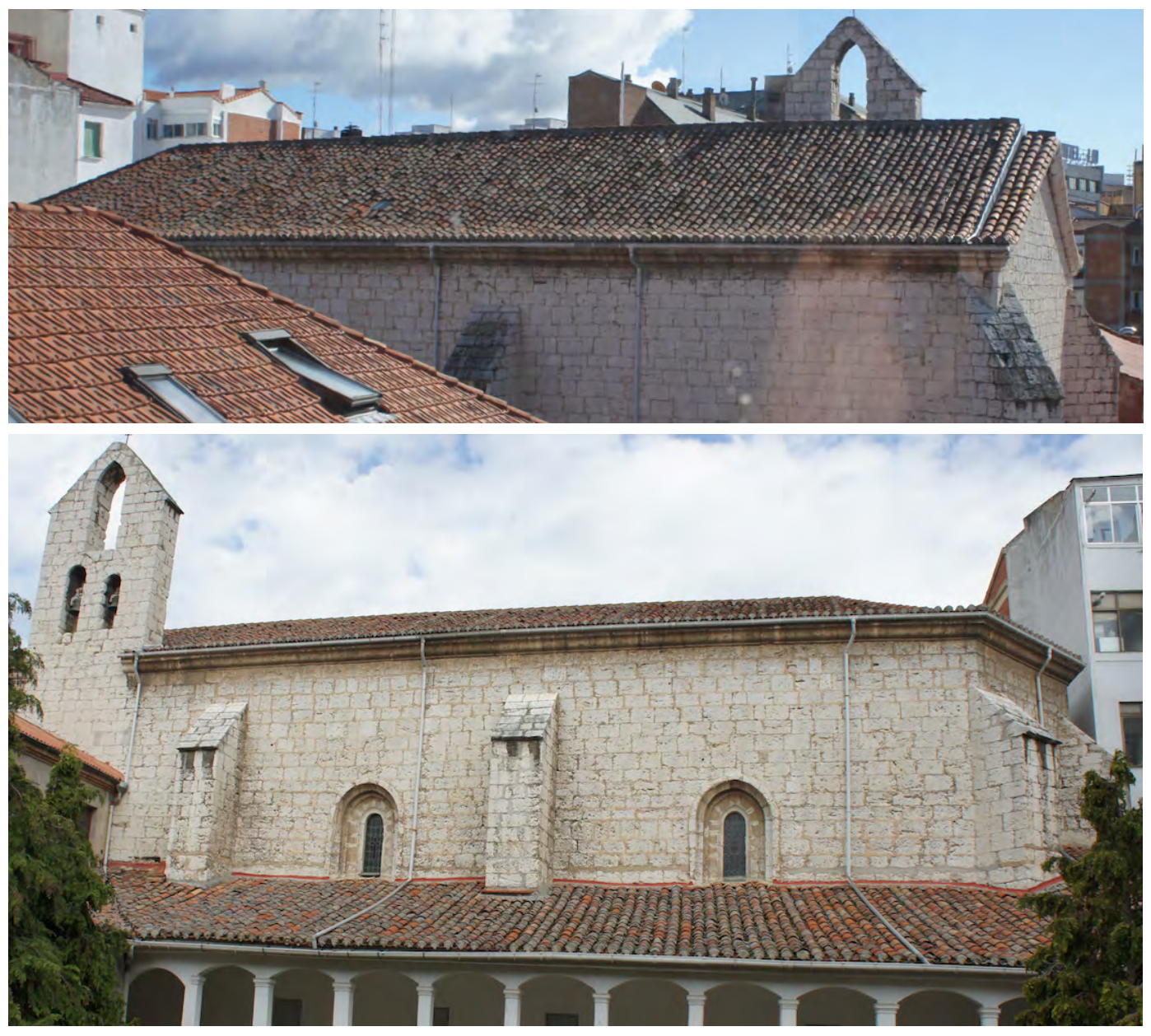

\section{Descripción}

Iglesia gótica de planta rectangular con una sola nave y contrafuertes hacia el exterior, sin capillas, de tres tramos desiguales cubiertos con bóvedas de crucería. La cabecera es un prisma facetado en tres lados.

\section{Materiales}

Los muros son de sillería de piedra con el arranque ataluzado. La cubierta está revestida de teja curva. 


\section{Singularidades}

La iglesia se encuentra vacía y cerrada al culto. El edificio se inserta bruscamente en el tejido urbano, con medianerías adosadas tanto a los pies como en el testero plano de la cabecera y la fachada del Evangelio respetando la alineación de la calle.

\section{Dimensiones básicas del templo} central

Ancho de nave 10

Altura

$\mathrm{x}$

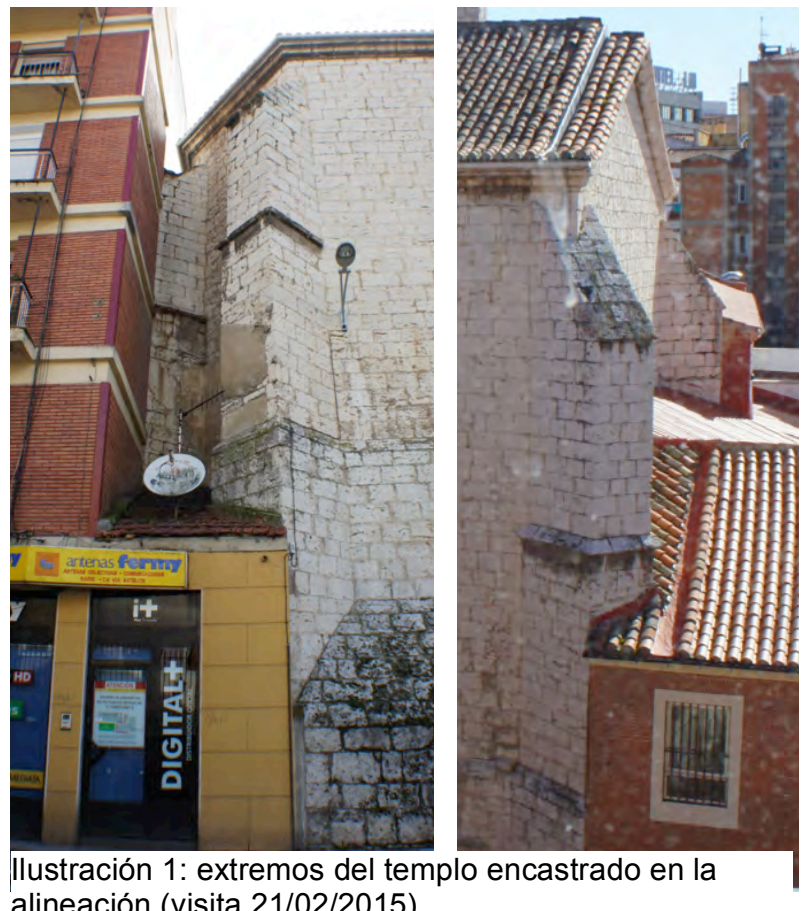

\section{Memoria histórica constructiva}

El convento se funda en 1521, según el Catálogo, que no incluye datos sobre el proceso constructivo del templo.

Algunas páginas web (www.valladolidweb.es; www.valladolidmonumental.blogs pot.com.es; consulta 06/04/2015) indican que la construye Jerónimo del Corral, también citado en la Guía por su posible intervención en las capillas funerarias.

\section{Cronología. Fechas clave}

1521 - 1981 - 1995

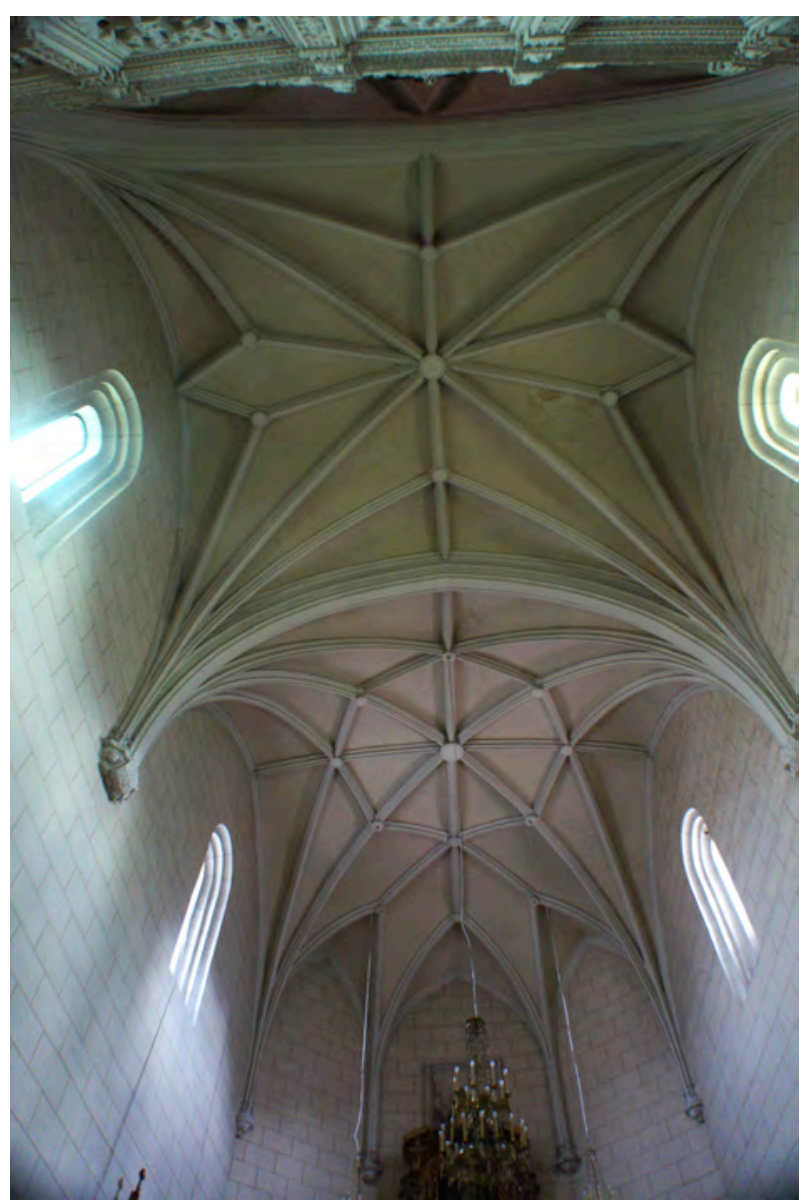

Ilustración 2: bóvedas (visita 22/04/2015) 


\section{Intervenciones}

1981 - Claustro y cubierta de la iglesia - Jesús Manuel Gómez Gaite

Retejo general de iglesia y claustro con sustitución de limas, canalones y bajantes.

\section{5 - Cubierta}

En el AMVA hay una licencia para instalación de grúa torre, aunque no se conserva documentación relativa a obras en las que se haya empleado esta estructura. No hay documentación de ningún proyecto realizado en esta iglesia en el Archivo municipal ni en el central de la Junta de Castilla y León.

\section{Planos}

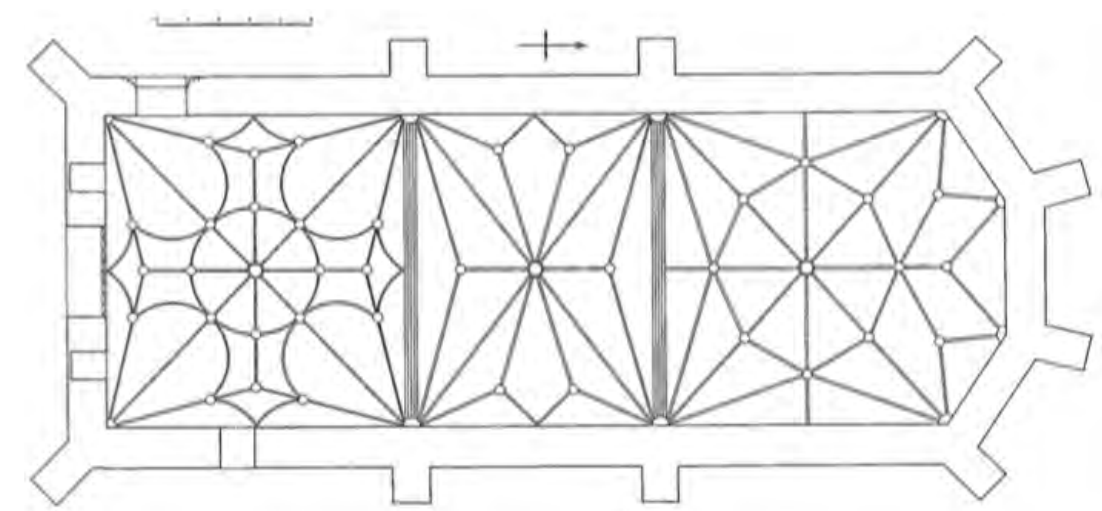

Ilustración 3: planta general (Catálogo)

\section{Solución constructiva de la cubierta}

Las pocas intervenciones documentadas llevadas a cabo en el Convento no aportan información gráfica del templo.

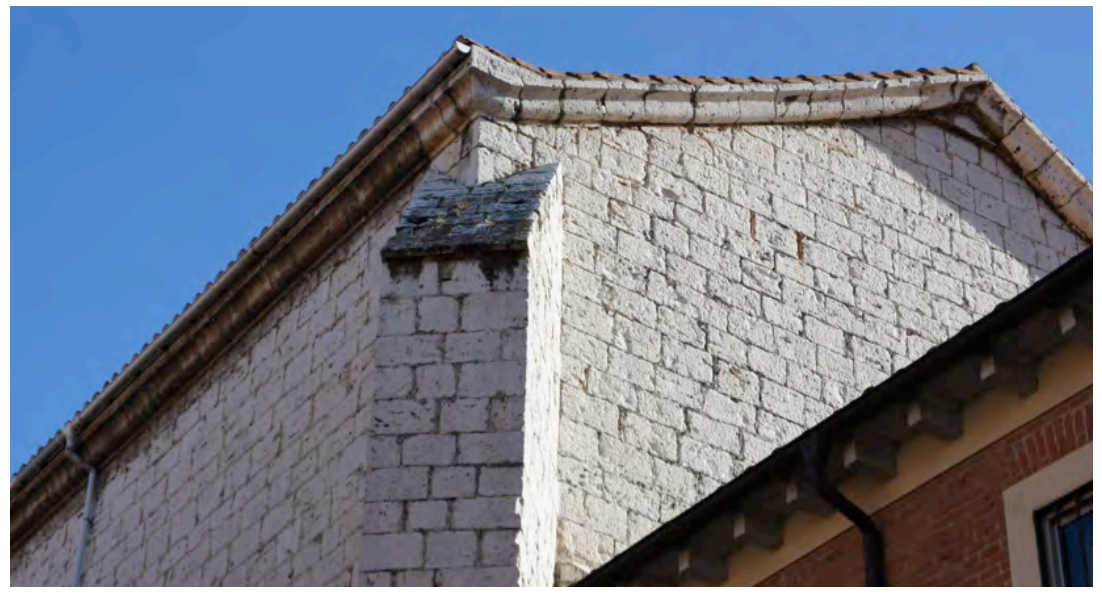

Ilustración 4: cornisa de piedra (visita 21/02/2015) 
Zunchos

La documentación revisada no aporta datos relativos a las intervenciones que hayan podido realizarse sobre la cubierta del templo.

\section{Conclusiones}

No se cuenta con documentación relativa a zunchos en la iglesia del convento de la Concepción. 


\section{Iglesia del Convento de la Concepción. Valladolid}

Intervenciones citadas en la publicación del Ministerio

1981 - Claustro y cubierta de la iglesia - Jesús Manuel Gómez Gaite

No hay planos en la web del IPCE

\section{En el Archivo Municipal de Valladolid}

\section{Fondo Histórico}

AMVA: CH-386-140 1857

Denuncia de las tapias de convento de la Concepción por ruinosas

El maestro de obras Pedro Alonso denuncia el estado de la medianera del corral con desplomes

AMVA: CH-322-172 1880

Licencia de obras solicitada por Hilario Martínez de la P. y Amigo, apoderado del Conde de Torrejón, patrono del Convento de la Purísima Concepción, para revocar un trozo de pared de dicho convento, sito en la calle Concepción

La Comisión concede la Licencia

AMVA: 1049-67 1911 Licencia de obras

Licencia concedida al convento de la Purísima Concepción para modificar huecos en plaza de Fabio Nelli.

Modificar los huecos abriendo los nuevos y cerrando los antiguos. Construir alcantarilla, nueva puerta a la calle de la Concepción. Plano de tela plastificada en colores con dos fachadas 1:00.

AMVA: 1049-52 1930

Licencia concedida a las religiosas Concepcionistas Franciscanas para abrir huecos en la fachada del convento en calle Concepción

Dos huecos de ventanas 160x130. Alzado de tela plastificada con colores.

AMVA: 874-35 1939-1940 Licencia de obras

Comunidad de Religiosas Concepcionistas, derribo, reconstrucción y elevación de piso en pabellón interior del Convento en calle Concepción (Contiene planos) (exp. 39/1939) 
La Superiora Sor Presentación Abad explica, en julio de 1939, que va a derribar un pabellón interior que amenaza ruina y volverlo a reconstruir con un proyecto. El Arquitecto Municipal Juan Agapito accede siempre que se respeten las Ordenanzas. En agosto Sor Presentación entrega memoria y planos.

Pabellón A derribar planta alta y tejado, construyendo de nuevo con ocho celdas, noviciado y cuarto para la Maestra de Novicias. Elevar un piso sobre el pabellón B con trece celdas, cuarto de baño y retrete. Los materiales a emplear son: ladrillo ordinario en muros, atirantado de pisos de vigueta metálica sin apoyos ni carreras, cubierta de teja común aprovechando la existente, tabiquería de ladrillo y adobe y escalera de madera.

3 Planos en papel vegetal con tinta negra y roja en lo nuevo: planta 1:100 y dos secciones. Una planta general en que se ubican los dos pabellones en el conjunto.

\section{AMVA: CH 371-95 1971}

Solicitud presentada por Alonso Martín, maestro de obras, para revocar la fachada del Convento de la Purísima Concepción [Hojas: 2 ; Planos: 1]

Solicitud de licencia: "Alonso Martin vecino de esta ciudad y maestro de obras en ella hace presente que en el Combento de la Purisima concepcion de Religiosas franciscas de esta otra ciudad se han metido unos puntos de ladrillo en la fachada y se ha socalzado el cimiento de Piedra Mampostería y Alero de madera nueba en el tejado; y otros Puntos ay que rebocarlos \# Cal y es lo que se demuestra en el Plano que presento"

Debajo se observa con otra letra firmado por Francisco Albarez que "en lo antiguo no obserbaron simetria alguna en la distribuzión de las ventanas y que en el día no se puso en remediar esos defectos" y se hacen diversas recomendaciones al respecto. El plano es un alzado con línea a mano.

\section{Fondo Administrativo}

AMVA: 6/1963 $1963 \quad 1189-6$

RUIPÉREZ, Inmaculada (CONVENTO DE LA PURÍSIMA CONCEPCIÓN). Reforma y ampliación Convento (Plano) (Exp. 6/1963)

La abadesa pide licencia para reforma y ampliación del edificio de la comunidad en noviembre de 1962. El proyecto es de Carlos José Balmori y define la ampliación de dos plantas más sobre un pabellón para clase de una sola altura. Entre otros materiales define "forjado de cubierta con tabiquillos y tablero plano". Un único plano con plantas, alzado y sección del bloque. En el croquis de ubicación parece 
uno de los dos de la obra anterior, en fachada calle Concepción

Lo aprueban aunque en proyecto figuran $10 \mathrm{~m}$ de altura y saldrán $14 \mathrm{~m}$ porque es una escuela singular.

AMVA: 606/92 1992

Expediente 606/92. Inmueble en mal estado en calle Concepción c/v San Ignacio (Convento de la concepción)

Parte de la Policía Municipal por la caída de cascotes de la iglesia Inmaculada Concepción en calle San Ignacio. La fachada es de piedra caliza con cornisa de una gola o papo de paloma corrido de la misma piedra y se remata con dos filas de bocatejas invertidas sobre las que se asienta un canalón y las tejas de borde del tejado. Ha caído un tramo de las bocatejas cerca de la puerta.

La Abadesa responde que han reparado lo imprescindible con grúa móvil pero están a la espera de subvención de la Junta de Castilla y León para proceder a la sustitución total de las cubiertas del templo.

\section{AMVA: 3366/1995 $1995 \quad 18452-5$}

URBICSA. Instalación de una grúa torre en el convento de la Concepción (Exp. 3366/1995)

Documentación de la grúa torre. Plano de ubicación de la grúa en la calle San Ignacio con su base frente a la puerta del templo, planta y alzado. Planos de la grúa y su cimentación.

AMVA: 6401/1999 1999 C178-3

MONASTERIO DE LA CONCEPCIÓN (TOMILLO MUÑOZ, Inmaculada Cándida). Reforma acceso al Convento (Exp. 6401/1999)

Proyecto del arquitecto Fernando Morán para pequeños cambios: ampliar dormitorio junto al acceso, colocar aseo en el patio reconstruir escaleras y habilitar locutorio. Según los planos corresponde a la zona del acceso más alejado a la nave del templo y no afecta a éste.

\section{En el Archivo de la Junta de Castilla y León}

No se localiza documentación 


\section{En el Archivo General de la Administración}

AGA 26/00930 (Una sola carpeta gruesa)

1983 - Liquidación - Jesús Manuel Gómez Gaite

Encargo del Ministerio de Cultura

Constructor: Jesús Yáñez Rodríguez

1982 - Restauración de claustro y cubierta - Jesús Manuel Gómez Gaite

Memoria: descripción tomada del inventario de Martin González y de su articulo con Felipe Heras "Inventario del Claustro de las concepcionistas Franciscanas" del BSAA.

Iglesia de una sola nave cubierta por bóvedas de crucería estrellada, dividida en tres tramos, por arcos ligeramente apuntados, que apoyan sobre ménsulas correspondientes al exterior a contrafuertes. La capilla mayor en el ábside es poligonal de tres lados. El coro se levanta en el último tramo sobre una bóveda de nervios combados curvos, que dibujan una circunferencia en el centro y una estrella. Bajo el coro se abre la puerta que comunica con el exterior. La portada es muy simple.

La piedra caliza de la fachada está bastante deteriorada, pues al hallarse los canalones y bajantes en muy mal estado, toda el agua de la cubierta escurre por la fachada, erosionando la piedra especialmente en los salientes, molduras y parte inferior del muro. En el interior los enlucidos que recubren bóvedas y muros presentan humedades de goteras y sobre todo la parte inferior del muro hasta la altura de un metro como mínimo. La sustitución de bajantes y canalones paliaría el problema en su mayor parte, aunque podrían subsistir humedades de absorción pues la acera de la calle se halla a cota ligeramente superior al pavimento de la iglesia.

Para subsanar el problema de las humedades de cubierta se ha previsto un retejo general de iglesia y claustro y la sustitución de limas, canalones y bajantes que se hallan totalmente destrozados. Superficie iglesia: $463,57 \mathrm{~m} 2$.

Drenaje en el patio del claustro y acera perimetral. Planos 1:100 esquemáticos del drenaje. Faldones de cubierta señalando con una línea retejo, canalón y bajantes.

Sección 1:50 del claustro se ve al fondo la fachada lateral de la nave con línea, en la transversal no corta la iglesia.

Detalle del alero muy basto no describe la sección, sólo canalón y bajante galvanizados y pintados. En el presupuesto incluye $70 \mathrm{ml}$ de restauración alero del claustro como limpieza y lijado de la madera, sustitución por semejante de la madera en mal estado, imprimación y barniz.

Inicio de obra abril de 1982. Recepción definitiva el 6/11/8. 


\section{Visitas realizadas}

$22 / 04 / 2015$

El estado de conservación del monumento es bueno, a pesar de tratarse de un templo desacralizado.

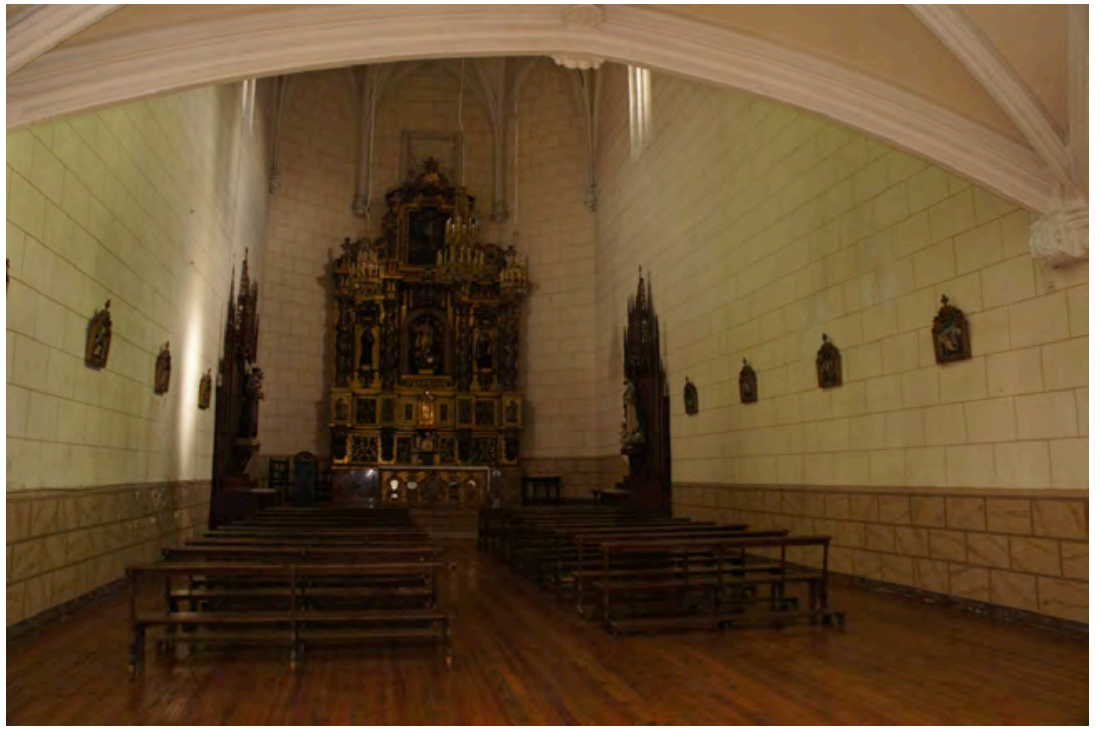

Aunque la madre superiora afirma que el interior del templo no ha sido pintado en décadas, sólo una zona de las bóvedas muestra ligeros desperfectos.
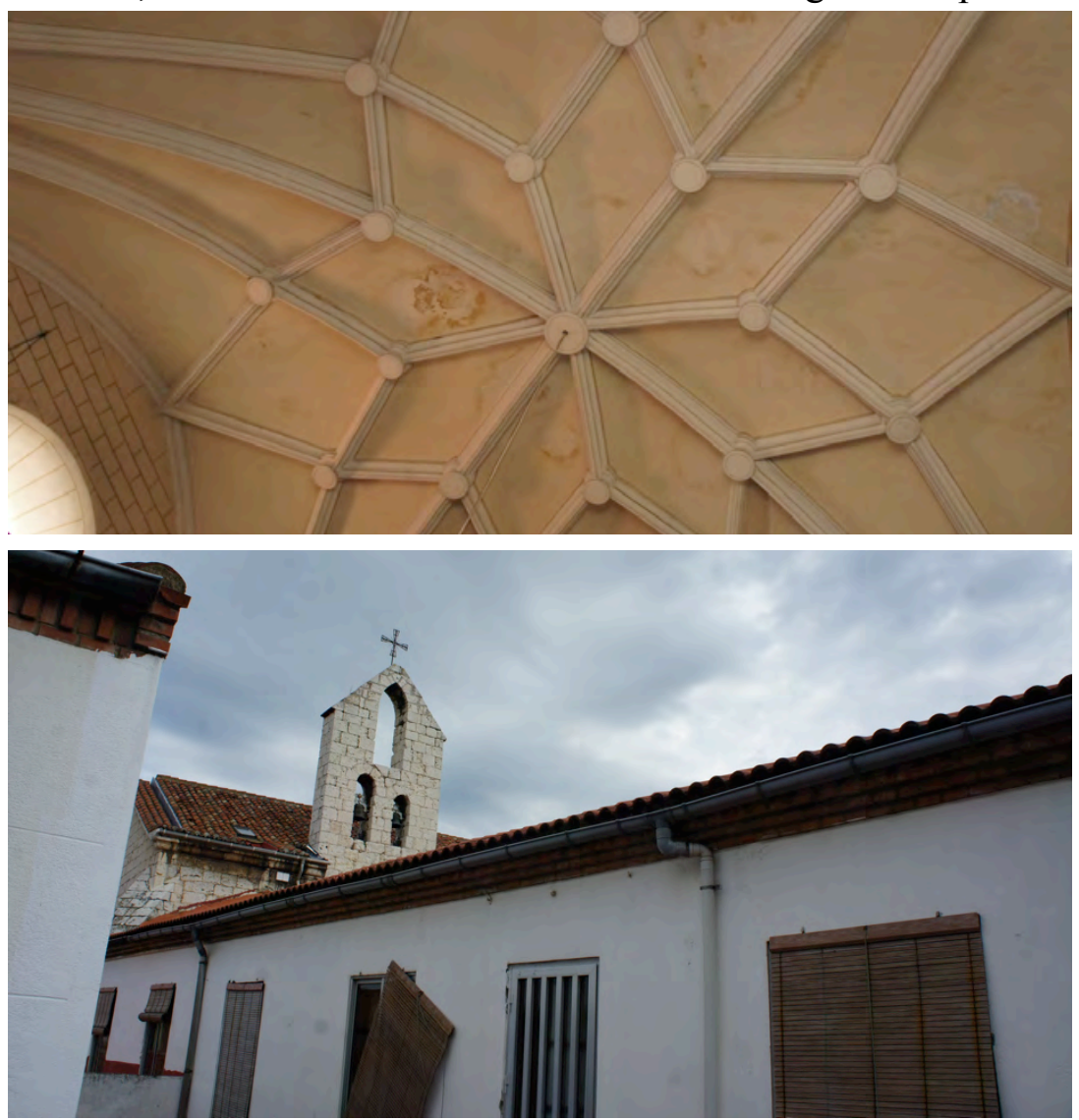

El acceso al bajo cubierta se realiza a través de una ventana tipo velux sobre el faldón, cerca de la espadaña. 
No se ha considerado oportuno recorrer la cubierta de las dependencias del convento que se aprecian en la imagen anterior llevando una escalera de mano, requisito imprescindible para alcanzar el hueco citado.

La cubierta del templo cuenta con canalones y bajantes que se prolongan sobre las tejas que cubren la panda del claustro adyacente.

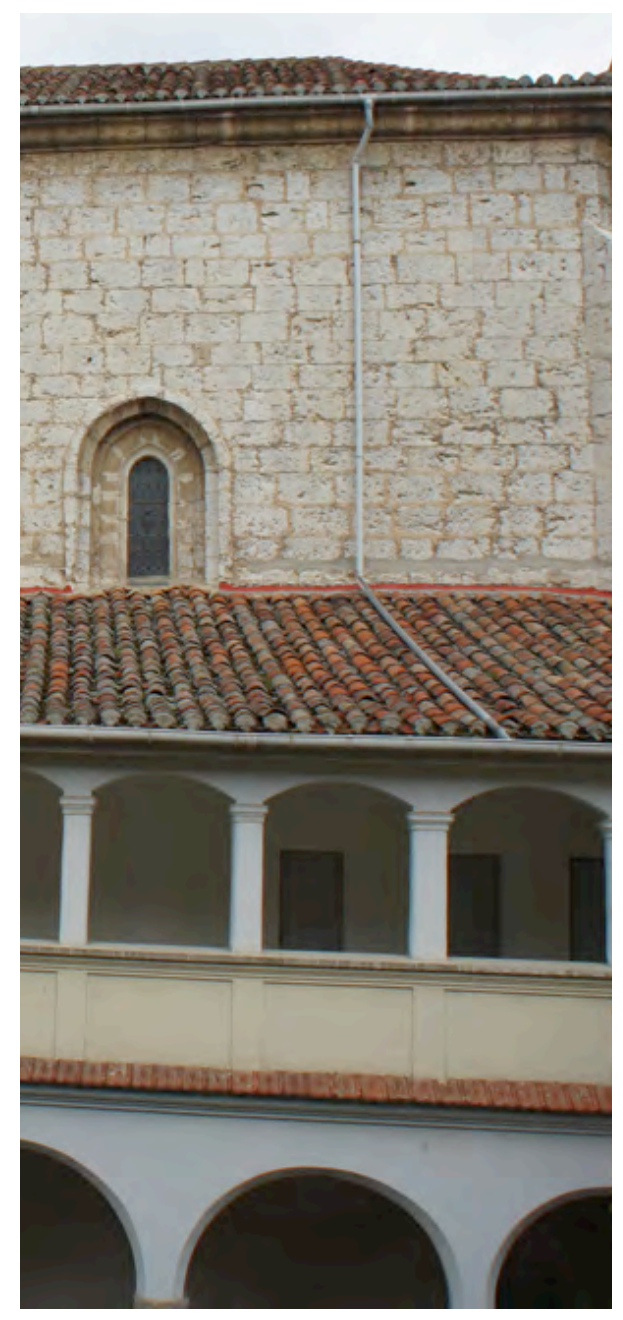




\section{Capilla del Convento de San Gregorio}

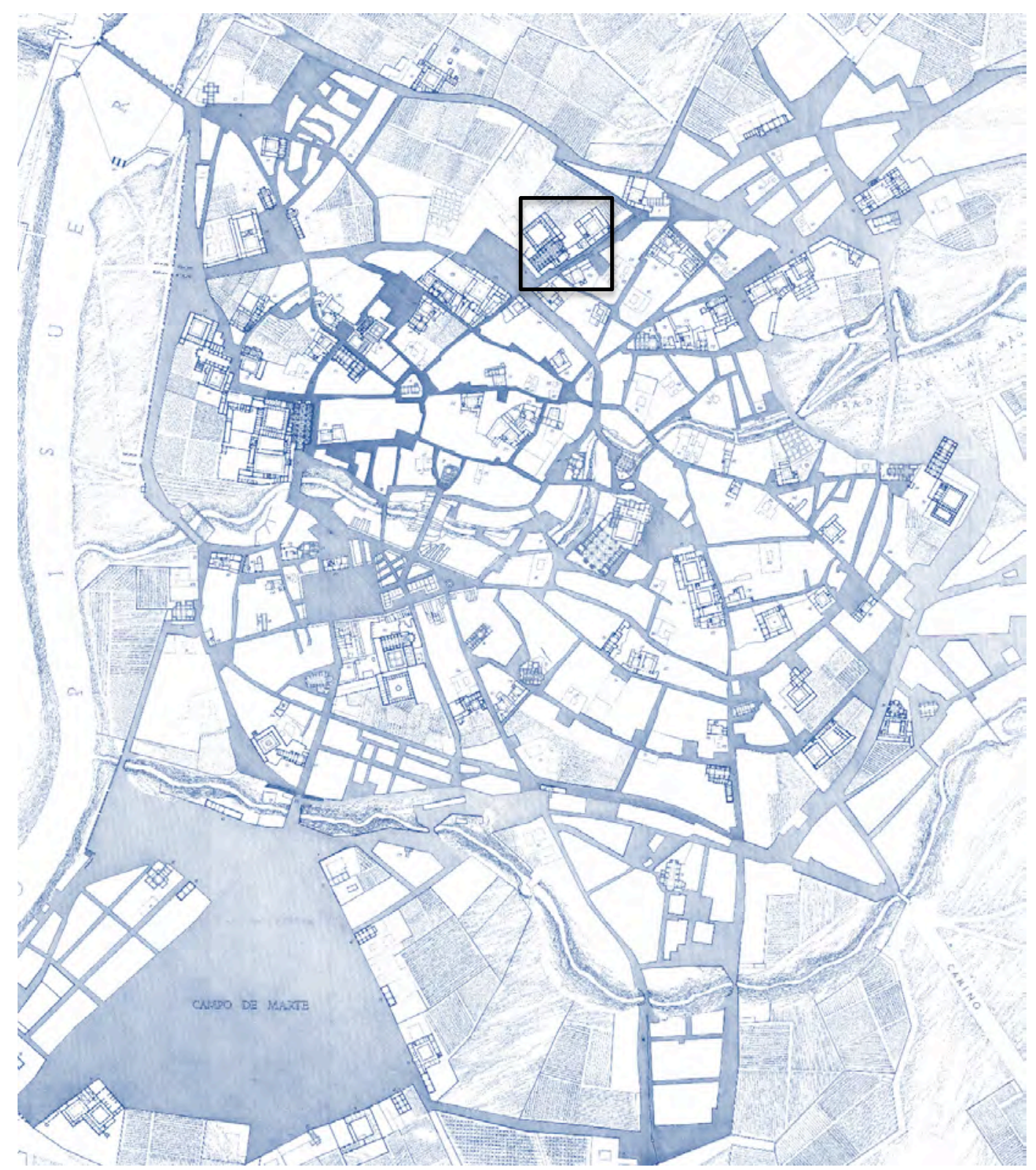



FICHA SÍNTESIS

Código de identificación: FZ-03

Denominación: Capilla del Convento de San Gregorio

Localidad: $\quad$ Valladolid

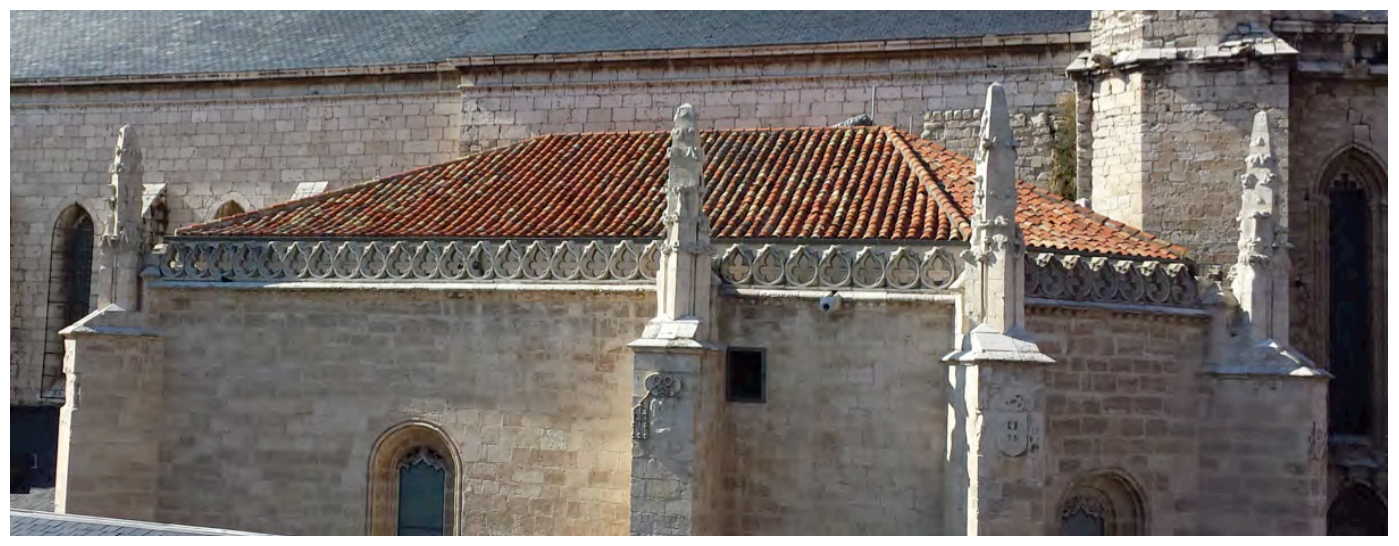

\section{Descripción}

Capilla gótica adosada a la cabecera de la iglesia de San Pablo, con el acceso entre ambas cegado. Se cubre con bóvedas de crucería y cuenta con un volumen más bajo de antecapilla, adosado a los pies, que alberga la escalera de subida al coro alto.

\section{Materiales}

Los muros son de sillería de piedra. La cubierta está revestida de teja curva.

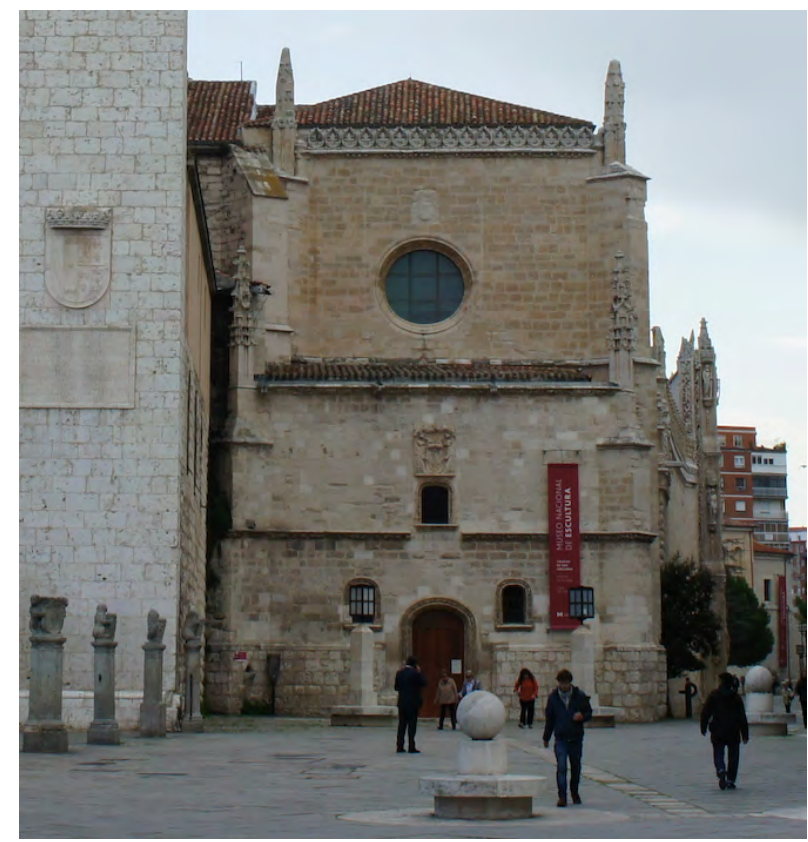

Ilustración 1: fachada a los pies, visita 13/04/2015

\section{Singularidades}

El edificio funciona en la actualidad como sala del Museo Nacional de Escultura. 


\section{Dimensiones básicas del templo}

central laterales capillas

Ancho de nave $\quad 11,5$

Altura $\quad 21,8$

\section{Memoria histórica constructiva}

Según Eloísa García de Wattemberg ${ }^{1}$ : La capilla, erigida para albergar un enterramiento, es obra de Juan Guas y Juan de Talavera.

Durante la ocupación francesa se independiza del Colegio, abriéndose una puerta provisional para introducir la paja. En 1822 se reabre al culto temporalmente y, en 1835 , se firma la orden de expulsión. Vuelve a abrirse entre 1861 y 1902, con una nueva puerta a mediodía y restaurada por Iturralde.

La cubierta del vestíbulo es reparada en 1889, tras hundirse la mitad por el deterioro producido por la caída de aguas del faldón de la iglesia de San Pablo. El proyecto inicial de Teodoro Torres planteaba no reconstruir las bóvedas, pero fue rechazado por la Academia, que recomendó reconstruir los nervios de piedra y los plementos con tabicado de ladrillo o sillarejos de toba ligera, aunque admitiendo el reemplazo por estructura metálica en faldones de cubierta.

La institución conventual de San Gregorio se funda en 1970 y se fusiona con el de San Pablo en 2009. La vivienda de frailes de San Pablo ocupa una antigua sacristía, tras demolerse los edificios, quedando en pie sólo la iglesia, en la exclaustración de 1835. Los espacios de lo que fue el Colegio de dominicos de San Gregorio, fundado en el siglo XV por el confesor de los Reyes Católicos Alonso de Burgos, son desde 1933 sede del Museo Nacional de Escultura y su capilla funeraria está cerrada al culto. Las obras se gestionan desde el Ministerio de Cultura.

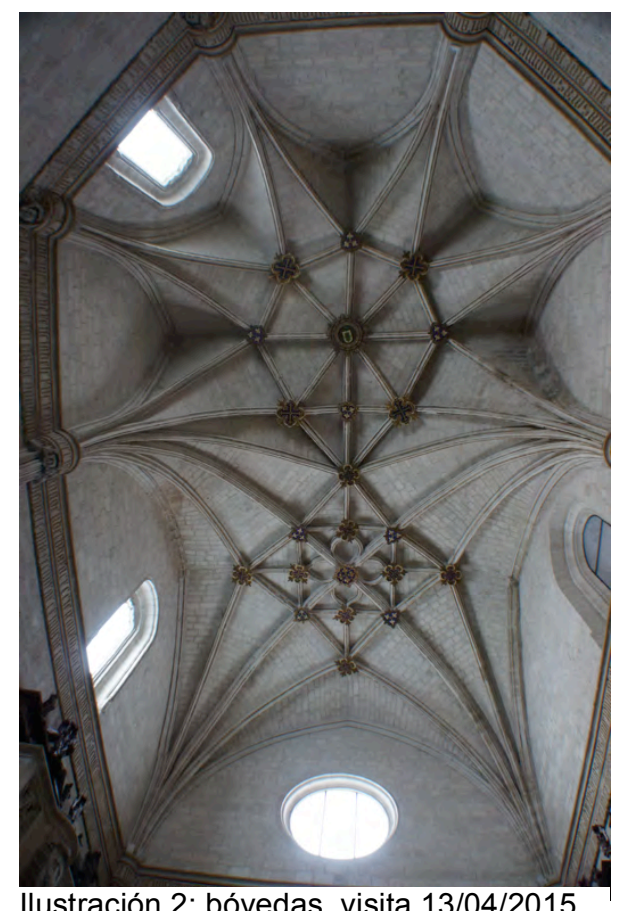

\footnotetext{
${ }^{1}$ García de Wattenberg, E. (1991). Noticias para la historia de la Capilla del Museo Nacional de Escultura. Boletín de La Real Academia de Bellas Artes de San Fernando, (72), 287-310.
} 


\section{Cronología. Fechas clave}

$1488-1889-1974$

\section{Intervenciones}

1932-33 - Emilio Moya

Adaptación a Museo: limpieza de muros, retejos, pavimentos...

1974 - Restauración de cubiertas - Luis Cervera Vera

\section{Incorporación de zuncho de hormigón armado}

Desmontaje y reemplazo de armaduras por cubierta de fibrocemento apoyada sobre correas metálicas y tabiquillos de ladrillo.

Consolidación de las bóvedas con una capa de hormigón.

1978 - Obras de restauración - Luis Cervera Vera

Restauración de la fachada. Se levanta la cubierta y rebaja la pendiente para liberar el óculo sobre el coro.

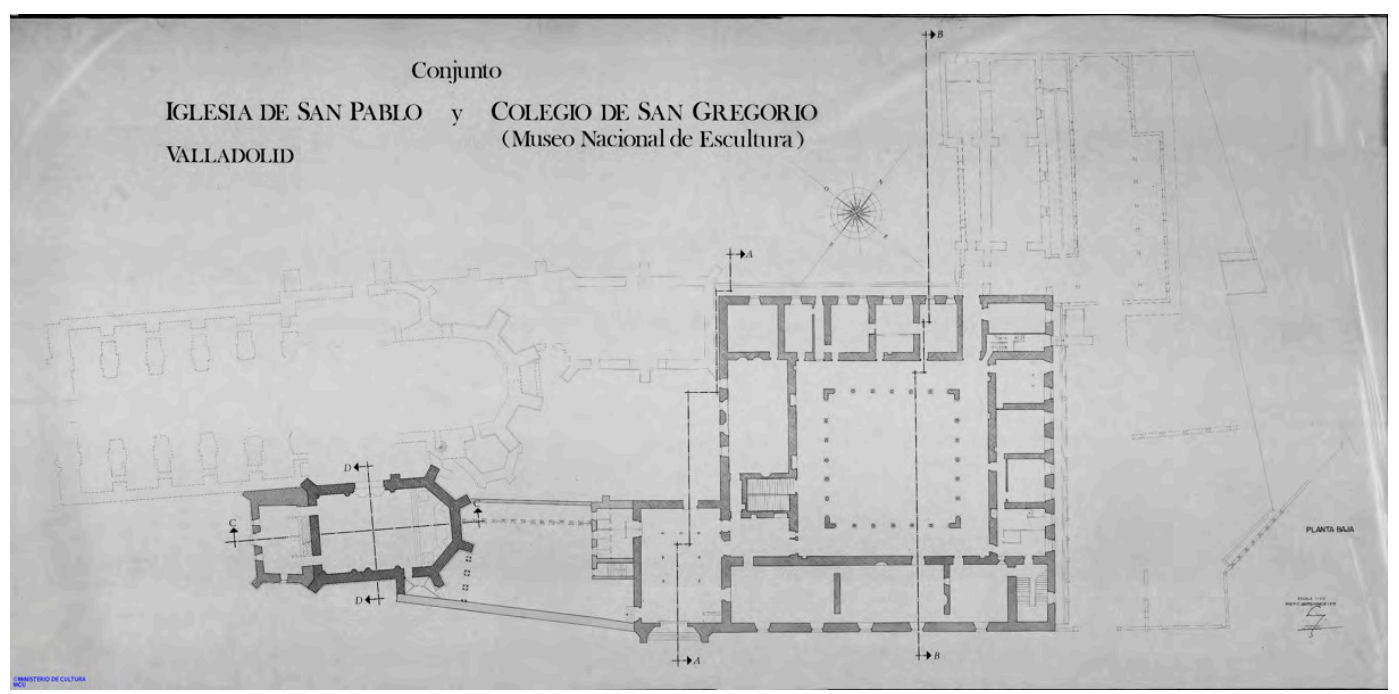

Ilustración 3: planta general del museo 1979 Cervera IPCE

1985 - Ignacio Represa

Cubre las rasillas vistas de la antecapilla con una bóveda de escayola.

Tras 6 años parada interviene Juan Pablo Rodríguez Frade. 


\section{Planos}

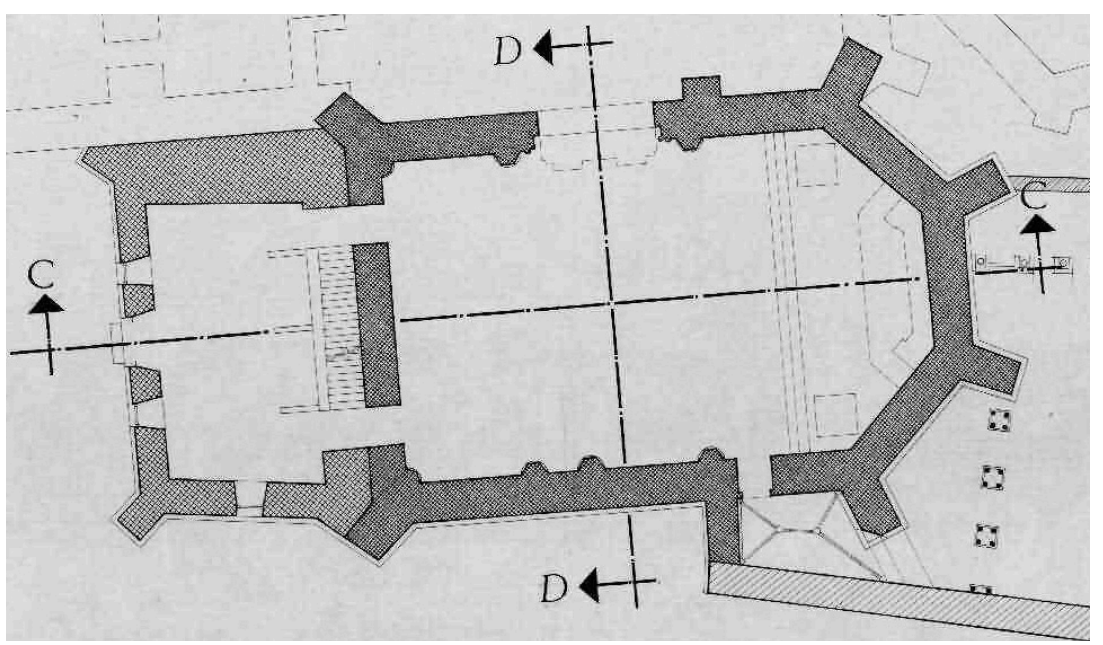

Ilustración 4: detalle plano planta baja 1979 Cervera IPCE

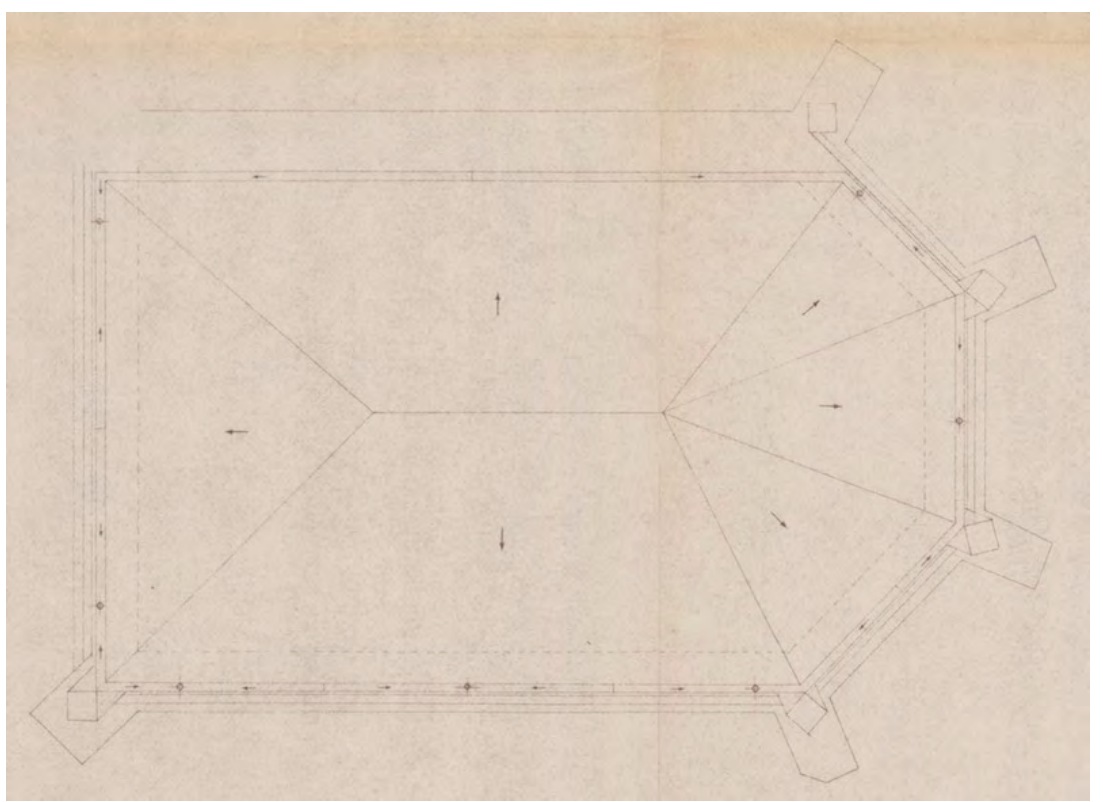

Ilustración 5: planta de cubiertas 1974 Cervera AGA

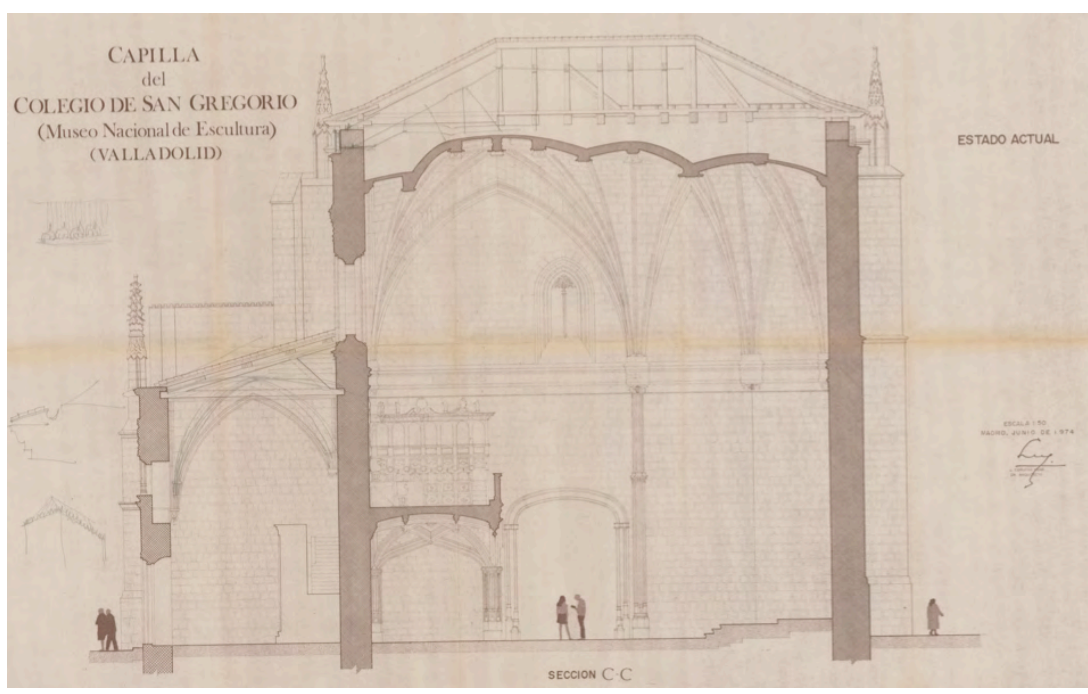




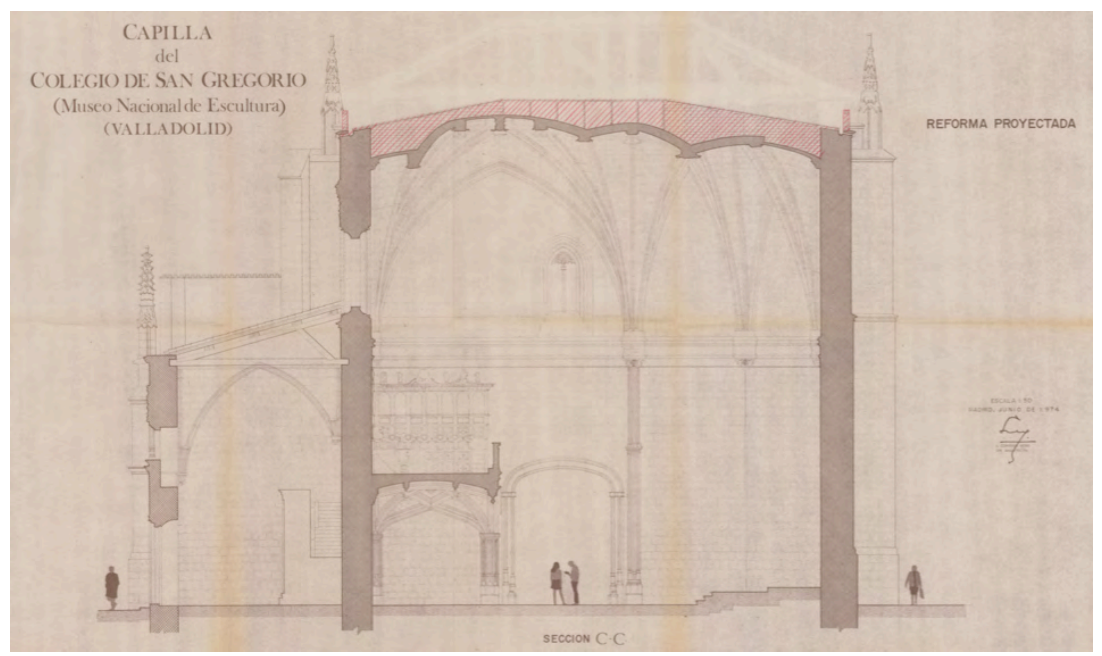

Ilustración 6: secciones longitudinales 1974 Cervera AGA
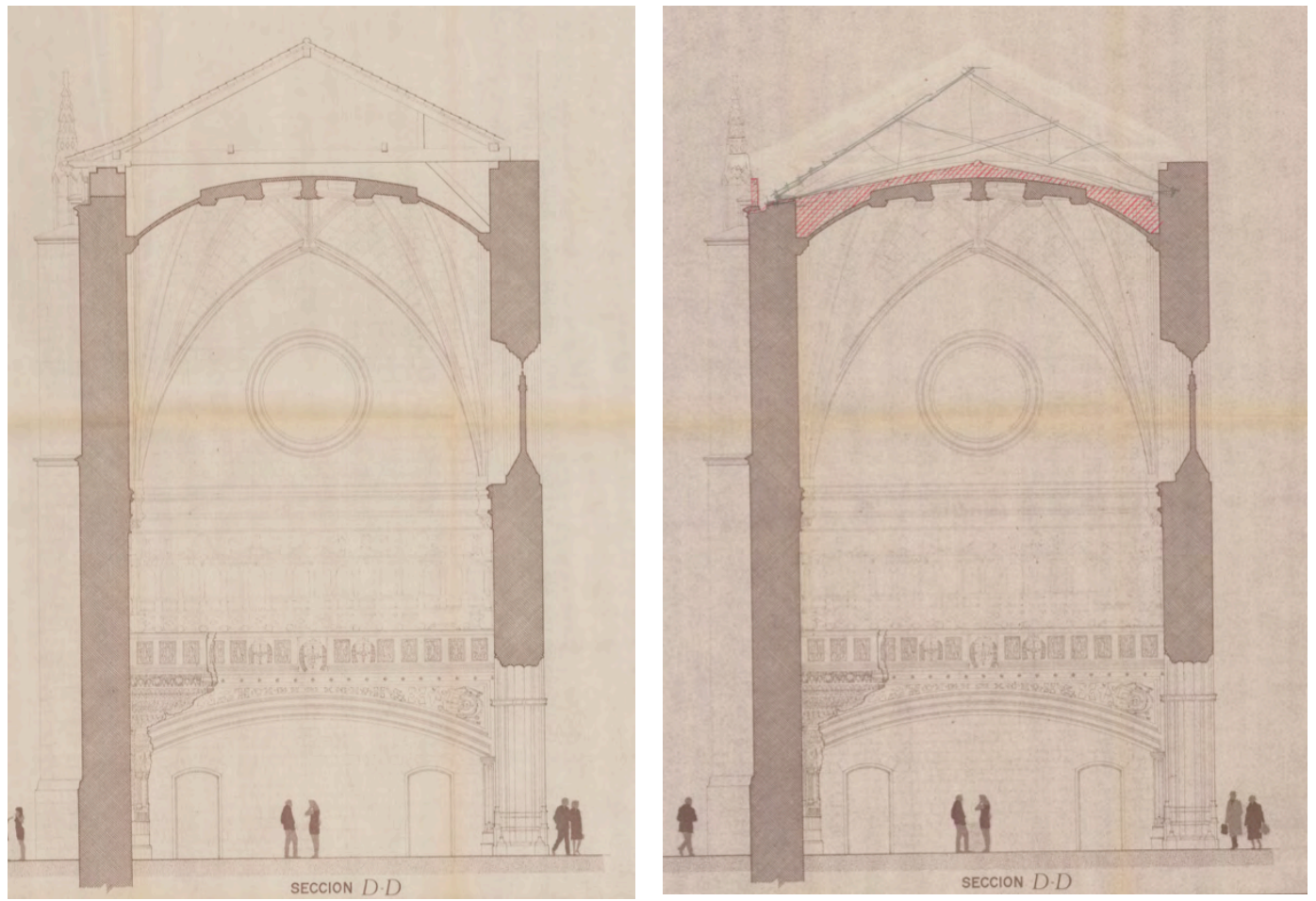

Ilustración 7: secciones transversales actual y proyectada 1974 Cervera AGA

\section{Solución constructiva de la cubierta}

En las secciones se aprecia cómo Luis Cervera modifica las pendientes en 1974. En el proyecto describe cómo se rebaja un metro la coronación del muro que da a la calle y levanta tabiquillos sobre las bóvedas, tras reforzar su trasdós con una capa de hormigón armado con mallazo, colocando sobre ellos planchas de fibrocemento. 
En el plano de sección transversal del proyecto conservado en el AGA aparecen, por encima del tablero sobre palomeros levantado sobre el trasdós de las bóvedas, líneas a lápiz que parecen representar cerchas metálicas con una pendiente mayor.

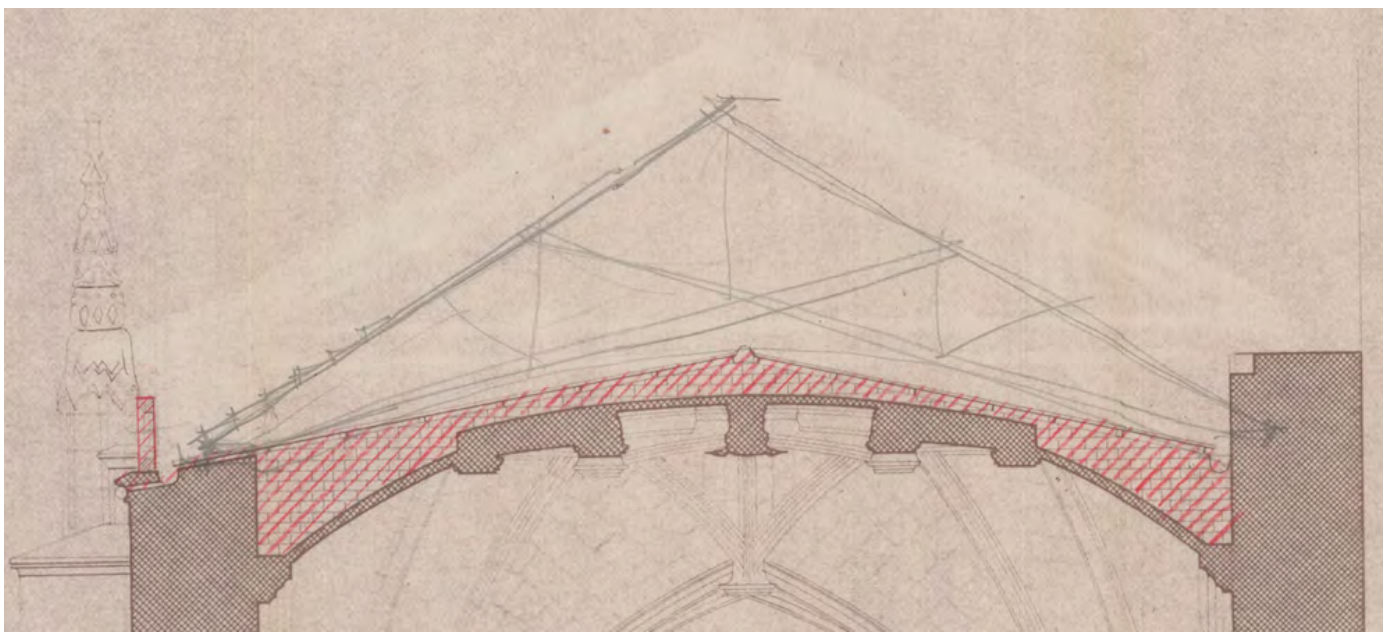

Ilustración 8: detalle sección 1974 Cervera AGA

Aunque no se ha podido acceder a la propia cubierta, desde la azotea del palacio de Villena se aprecia cómo los faldones, recubiertos de teja, muestran una pendiente intermedia.

El paramento de fábrica bajo los aleros se recrece por detrás del acroterio hasta la cota de molduras de pináculos, por lo que es plausible que, a pesar de la solución definida en el proyecto, finalmente se ejecutara una estructura una estructura metálica .

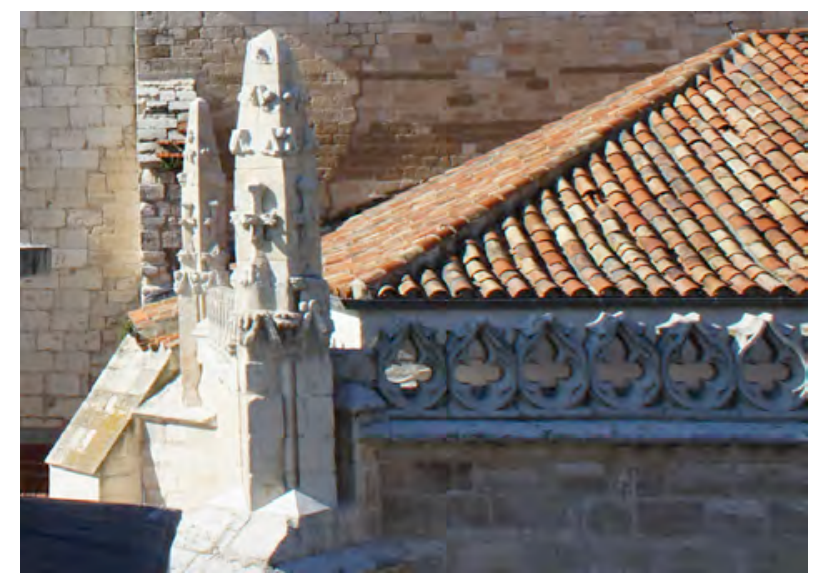

Ilustración 9: cubierta de la Capilla, visita 26/09/2014

\section{Zunchos}

En el presupuesto del proyecto se refleja 72,4ml de zuncho de hormigón armado incluso encofrado, pero no se ha podido acceder al bajo cubierta para confirmarlo.

\section{Conclusiones}

En 1974 Cervera sustituye las armaduras por una cubierta nueva con distinta pendiente y zuncho de hormigón, pero no ha sido posible confirmarlo en la visita. 


\section{Iglesia del Convento de San Gregorio}

Intervenciones citadas en la publicación del Ministerio:

1962 - Instalación del artesonado del coro de la iglesia de Villar de Fallames Anselmo Arenillas

1963 - Saneamiento de muros - Anselmo Arenillas

1964 - Restauración de portada y cresterías - Anselmo Arenillas

1965 - Construcción de un pabellón - Anselmo Arenillas

1966 - Restauración fachada principal - Anselmo Arenillas

1970 - Sustitución de cubiertas en zona de fachadas - Luis Cervera

1971 - Cubiertas - Luis Cervera

1974 - Mejora de distribución y ornato interior de las salas de exposición - Luis Cervera

1974 - Cubiertas - Luis Cervera

1978 - Obras generales en la capilla - Luis Cervera

1979 - Fachada oeste-sur - Luis Cervera

1981 - Obras urgentes restauración retablo del monasterio de la Mejorada - José María Cabrera Garrido

1983 - Restauración esculturas y relieves de la fachada - Ignacio Gárate Rojas

1984 - Obras urgentes en la portada - Ignacio Gárate Rojas

En la web del IPCE hay digitalizados dos planos de Luis Cervera: una planta de 1979 y una sección de 1974.

\section{En el Archivo Municipal de Valladolid}

\section{Fondo Histórico}

\section{AMVA: CH 269-21 1913}

Cesión de la capilla, anexa al ex-convento de San Gregorio, a la autoridad eclesiástica, con el fin de abrirla al culto.

Explican que la capilla aneja a San Pablo está utilizándose como archivo provincial y si sigue sin cuidarse caminará hacia la ruina. En un informe de marzo de 1914 se aconseja crear una Comisión de concejales pare que gestione el desalojo, y vuelta al culto de la capilla, con las autoridades. 
El Director general de bellas artes informa de la Real Orden por la que se trasladará el depósito al edificio de Pósitos y que las obras de reparación serán por cuenta de la Comunidad y bajo aprobación de Bellas Artes de San Fernando.

\section{Fondo Administrativo}

AMVA: 72112/2005 Exp. 72112/2005

Se trata de un edificio cercano de nueva construcción

Convento de San Gregorio Padres Dominicos. Centro de estudios de postgrado, dedicado a la enseñanza y la docencia, integrado en el Convento de San Gregorio y el Colegio Mayor Felipe II.

1964 Licencia de obras

Aprobación del proyecto de obras en el Convento de San Gregorio del arquitecto Anselmo Arenillas Álvarez. (Una cuartilla con sello sin copia del proyecto.)

\section{En el archivo de la Junta de Castilla y León}

No se localiza documentación relacionada

\section{En el Archivo General de la Administración}

\section{AGA 26/00253}

1962 - Instalación del artesonado de Villar de Fallemes - Anselmo Arenillas El sitio prefijado es algo escaso de tamaño y requiere que se desmonte en parte la cubierta, que no ha muchos años se había reformado para instalar las sillerías. Se colocan cinco jácenas y correas de acero con tablero doble de rasilla, tendido de cemento y teja.

Plano de planta y sección 1/100

\section{AGA 26/00370}

1964 - Saneamiento de humedades en el Monasterio de San Gregorio - Anselmo Arenillas

Julio de 1963

En este proyecto se incluyen 100 tubos Knapen y una atarjea 
AGA 26/00370

1964 - Restauración de la portada y crestería - Anselmo Arenillas

Abril de 1964

El pináculo izquierdo desplomado y el contrafuerte separado del resto de la portada gótico-plateresca.

AGA 26/00206

1966 - Construcción de un pabellón - Anselmo Arenillas

1965 Pabellón de nueva planta para exponer los Pasos.

Una nave de $8 \mathrm{~m}$ de luz. Se cuelga en ella el artesonado de Fallame a modo de coro.

AGA 26/00120

1967 Reparación de la fachada de San Gregorio - Anselmo Arenillas

En la carpeta pone 1966

Memoria: reparación del zócalo de piedra caliza: "se ha previsto inyectar mortero rico de cemento en el interior del muro que es de dos caras de sillería y relleno de conglomerado de cal, que por las humedades está descompuesto, de este modo se consolidará todo el muro.

La cubierta que dá las goteras de esta esquina, se encuentra en muy mal estado, con su armadura de madera podrida... rehacer con vigas de hormigón armado y doble tablero de rasilla, sobre el cual se hará un tendido de cemento impermeable."

AGA 26/00183

1979 - Restauración - Luis Cervera

Proyecto de restauración: sustitución de cubiertas en la zona de fachada del museo $441 \mathrm{~m} 2$ desmontado de cubiertas existentes, incluso...

$65,00 \mathrm{ml}$ zuncho de hormigón armado en coronación de muros, para asiento, previa demolición y enrasado para su asiento

$11572,00 \mathrm{kgs}$ hierro en estructura metálica de cubierta...

$441,00 \mathrm{~m} 2$ triple tablero de rasilla, sobre estructura metálica, para colocación de teja, incluso impermeabilización

En el detalle del plano se ve el tablero de rasilla formando bovedillas en el corte transversal sobre las cerchas, el zuncho de $25 \times 40$ con 4D14 centrado en el espesor del muro. Sobre el zuncho apoya la cercha de PNL y se levanta un peto de $1 / 2$ pie de ladrillo macizo enfoscado hacia el interior y cubierto con el muro moldurado al exterior, que bordea el canalón. 
AGA 26/00331

1971 - Restauración - Luis Cervera

Sustitución de armaduras por estructura nueva de cerchas metálicas apoyadas sobre zuncho en una zona del Museo. (NO afecta a la Capilla)

133,00 ml zuncho de hormigón armado en coronación de muros para asiento, previa demolición y enrasado para su asiento.

\section{AGA 26/00065}

1974 - Restauración de cubiertas en la Capilla del Colegio de San Gregorio (Museo Nacional de Escultura) - Luis Cervera

\section{Memoria}

El colegio fue fundado en 1487 por Fray Alonso de Burgos.

Las obras comenzaron el año 1488, siendo terminadas en el de 1496, y se atribuyen a Juan de Guas (Gomez Moreno), a Simón de Colonia (Mayer), y a Gil de Siloé (Torres Balbás).

La fábrica de la capilla estaba avanzada por el año 1489, posiblemente con la intervención de Juan de Guas; el claustro grande quedaba casi completo después de 1492; y, con él, la gran escalera de tres tramos...

Para remediar el deficiente estado de las cubiertas del edificio que estudiamos, por el peligro que su actual situación representa, se ha redactado el presente Proyecto.

Se pretende el desmontaje de las actuales armaduras con su cubrición, para su posterior sustitución por cubierta de Uralita, apoyada sobre tabiquillos de ladrillo, previa consolidación de las bóvedas, e impermeabilización de las mismas.

La zona que se proyecta restaurar queda señalada en el plano correspondiente.

Presupuesto

$428,99 \mathrm{~m} 2$ desmontado de cubiertas existentes incluso transporte de escombros a vertedero

$72,40 \mathrm{ml}$ desmontado de restos de cresterías de piedra caliza

72,40 ml desmontado de muros de fábrica de sillería en nivelación de muros con transporte a vertedero

$418 \mathrm{~m} 2$ limpieza de bóvedas hasta dejar vista la piedra, descarnado de juntas, incluso transporte de escombros a vertedero

418,00m2 capa de hormigón de $350 \mathrm{Kg}$. de cemento con malla metálica e impermeabilizante, incluso engrapado sobre bóvedas 
72,40 ml zuncho de hormigón armado de 350KGs. de cemento y $40 \mathrm{Kgs}$. de hierro incluso encofrado

428,99 m2 cubierta de fibrocemento gran onda incluso correas metálicas, material accesorio, pintura y colocación

98,90 $\mathrm{ml}$ limas en plancha de plomo de $2 \mathrm{~mm}$. incluso formación de pendientes, elementos de sujeción y colocación.

Planos: (pido copia)

Planta baja enorme 1:100 del Monasterio

Planta de cubiertas enorme, con los faldones de la capilla en trama roja.

Sección C-C 1:50 longitudinal de la capilla estado actual. Representa la armadura con vuelo de canes sobre doble durmiente, con refreno.

Sección C-C proyectada con palomeros. Desmocha el muro casi $1 \mathrm{~m}$

Sección D-D 1:50 transversal con la armadura. Traslada la crestería a otra cota como remate.

Las secciones tienen garabatos a lápiz encima de cerchas con aspecto de metálicas y más altura. En rojo se marcan los tabiquillos que soportan la Uralita.

\section{AGA 26/00065}

1974 - Obras de acomodación - Luis Cervera

Hoja de encargo, a la vez se ordena redactar este proyecto y el anterior de restauración de cubiertas. Ambos con importes iguales, de 5 millones.

Distribución y ornato de las salas del museo.

\section{AGA 26/00455}

1978 - Obras de restauración - Luis Cervera

Abundante documentación administrativa.

Se adjudicó a CONSTOSA en 1979, recepción provisional 1980 y definitiva en marzo de 1982.

El proyecto está desordenado e incompleto.

Tres planos:

Planta baja enorme general, alzado y sección estado actual de la capilla 1:50

Según las Mediciones parece una obra de restauración de la fachada de la Capilla: desmontado de elementos sueltos de sillería, pináculos de contrafuertes, apertura de cajas para llaves de hormigón 23,66m3, formación de zócalos con mampostería hormigonada. 
AGA 26/01076

1980 - Proyecto de Obras de restauración en la Portada - Luis Cervera

Abundante documentación administrativa.

Se adjudicó a CONSTOSA en 1980, recepción provisional 1981 y definitiva en marzo de 1983.

El proyecto afecta a la portada del Museo de escultura, lejos de la capilla. En los planos se define un sistema de drenaje.

AGA 26/01943

1985 - Proyecto básico y de ejecución de obras de restauración de antecapilla. Ignacio Represa

Anexo a memoria de 7 de enero de 1984

Recoge modificaciones informadas por la Junta Superior de Museos.

Respecto a la bóveda falsa de escayola se realizará una prueba de muestra que alcance a acotar suficientemente lo que esta pueda suponer en la definición del espacio e intrados toda vez que por las distancias existentes en la actualidad despues de la construcción de la nueva cubierta es físicamente imposible reponer el falso cielorraso de tablero machihembrado... decidir si se prodigue o se sustituye por un enfoscado sobre el forjado existente.

Barandillas, pavimento, peldaños...

La capilla (1487-1489) es obra principal de Juan Guas salvo el mutilado antepecho del coro de factura reciente.

Planos de gran formato pero que no definen más allá de la línea de bóvedas. 


\section{Visitas realizadas}

$13 / 04 / 2015$

El estado de conservación del monumento responde correctamente a su función actual como sala del Museo Nacional de Escultura.

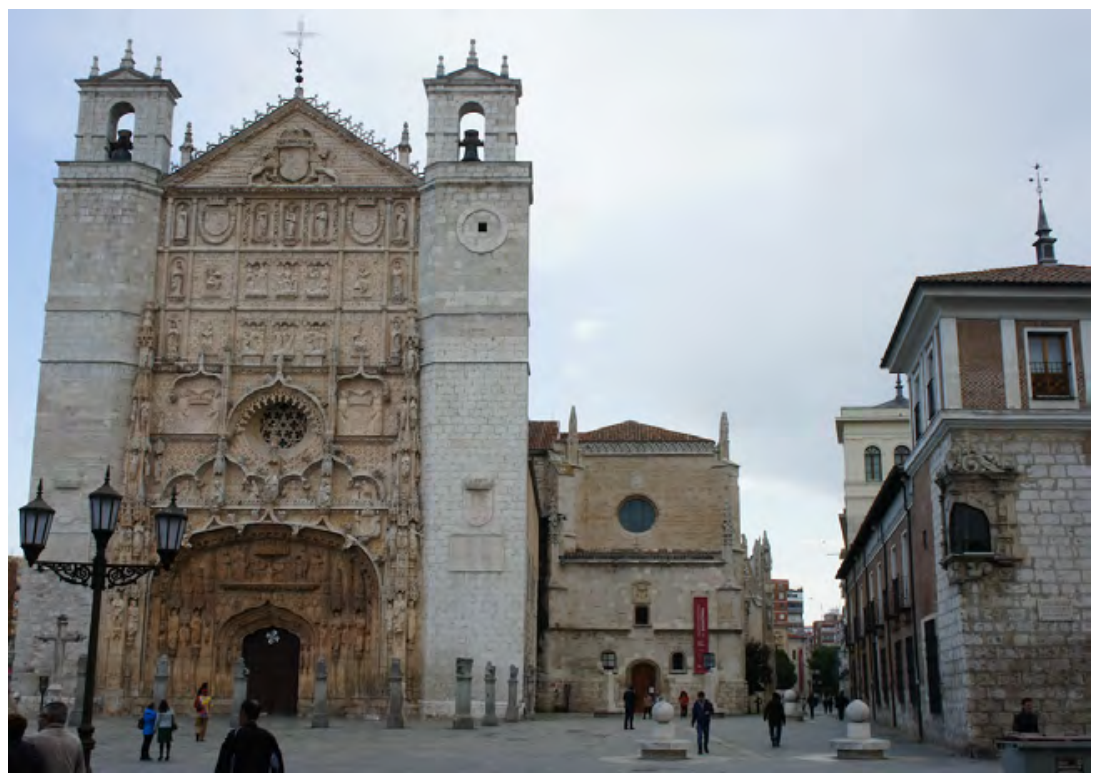

Ilustración 10: fachada de acceso a los pies por antecapilla

El edificio cuenta con dos accesos, uno desde la calle a través de la antecapilla a los pies y otro por la cabecera desde el patio del museo. Se aprecia un arco cegado que comunicaba con la iglesia adyacente de San Pablo.

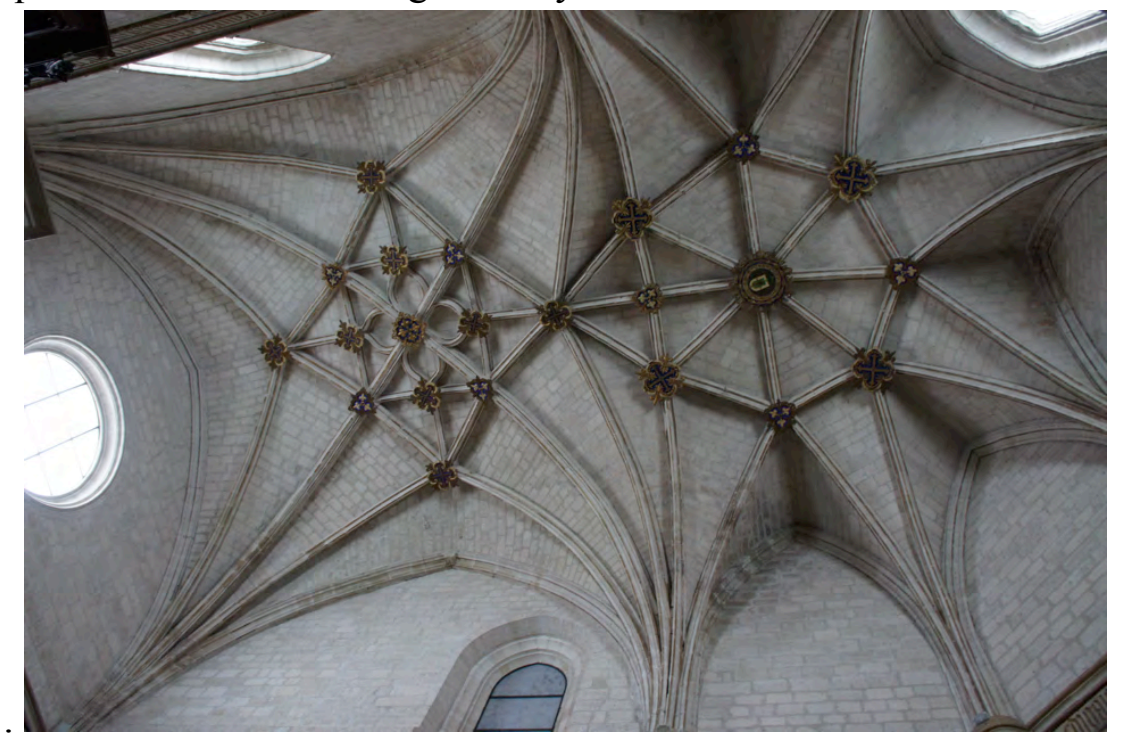

Ilustración 11: vista de las bóvedas

Hay una escalera de pates visible desde el patio que parece llegar a la cubierta pero no ha sido posible acceder a la misma. 


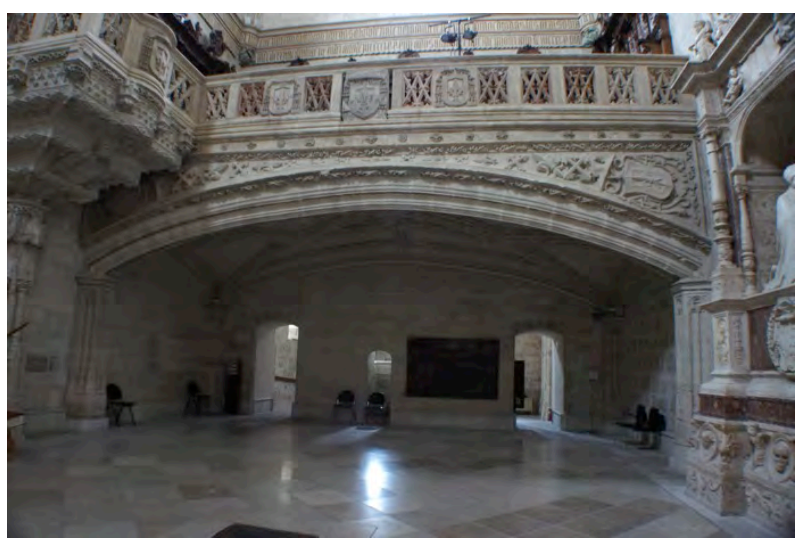

Ilustración 12: coro alto

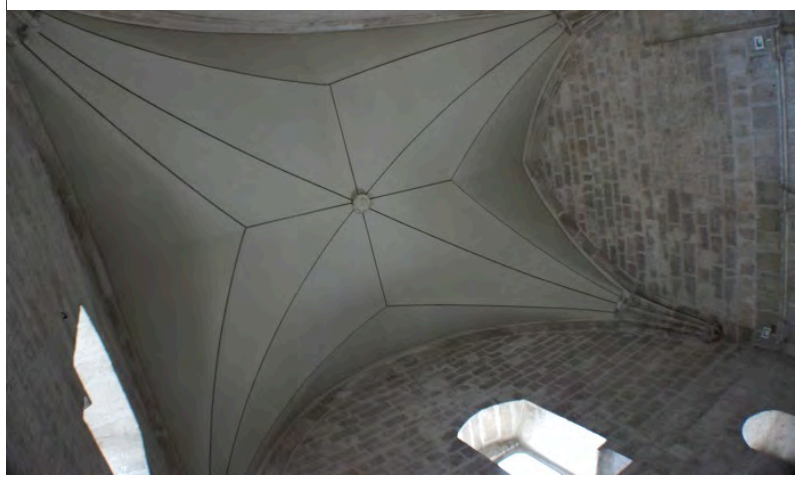

Ilustración 13: techo de la antecapilla 


\section{Iglesia de la Pasión (Museo Municipal)}

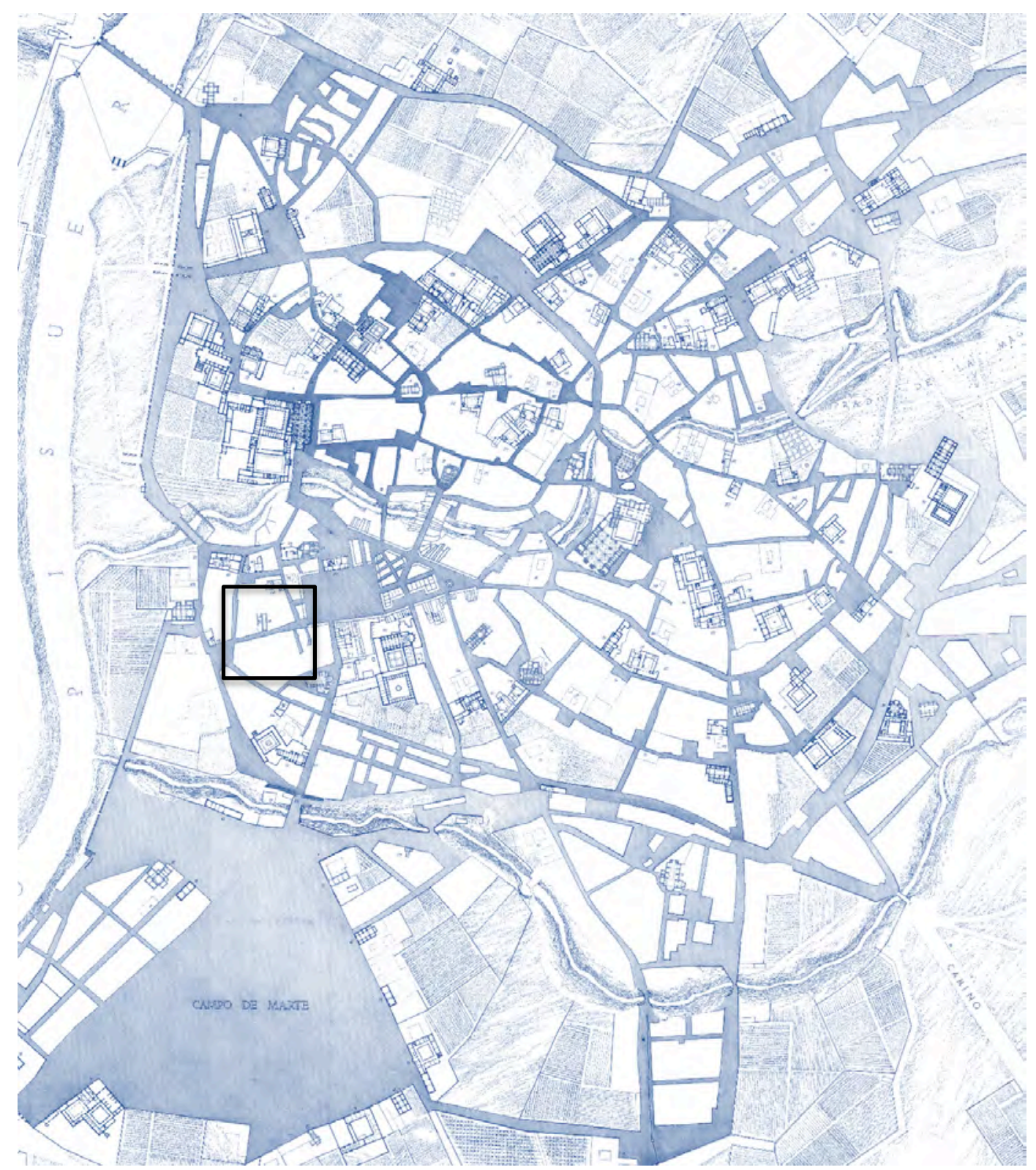



FICHA SÍNTESIS

Código de identificación: FZ-04

Denominación: $\quad$ Iglesia de la Pasión

Localidad: $\quad$ Valladolid

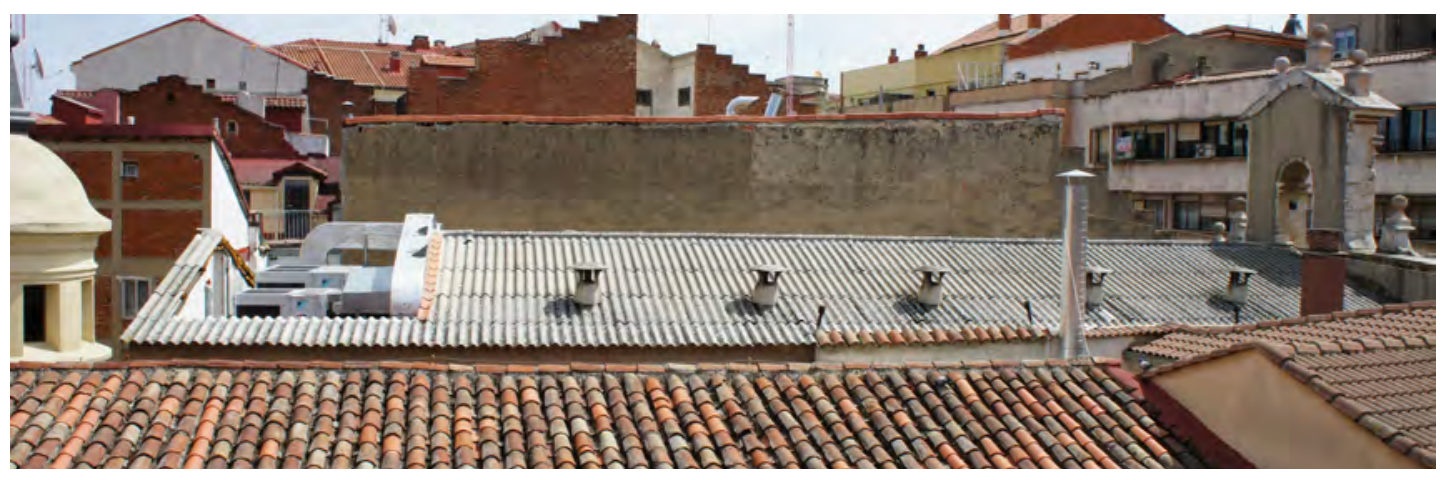

\section{Descripción}

Iglesia transformada en museo. Consta de una sola nave con techo plano, cúpula sobre pechinas y presbiterio poco profundo, y una planta superior también de techo plano. La antigua sacristía aneja se cubre con una cúpula elipsoidal.

\section{Materiales}

Los muros son medianerías que no se aprecian desde el exterior. Según la memoria de un proyecto del arquitecto Anselmo Arenillas de 1962, eran de adobe y tapial en planta baja y entramado de madera relleno de adobe y cascote en alta, que reforzó con entramado de soportes y carreras de hormigón armado. La fachada principal, a los pies, es de piedra. La cubierta del bloque anexo está revestida de teja curva, mientras que la del cuerpo principal se cubre con planchas onduladas de uralita.

\section{Singularidades}

El edificio pertenece al Ayuntamiento y se utiliza como Museo desde principios del siglo XX, tras arruinarse sus cubiertas.

Al tratarse de una Cofradía Penitencial la fachada cuenta con grandes puertas para salida de los pasos procesionales y un balcón corrido. 
Actualmente funciona como sala de exposiciones municipal, con dos plantas y un pequeño edificio anexo de comunicaciones.

\section{Dimensiones básicas del templo}

central laterales

Ancho de nave $\quad 7,5$

Altura

6,5

\section{Memoria histórica constructiva}

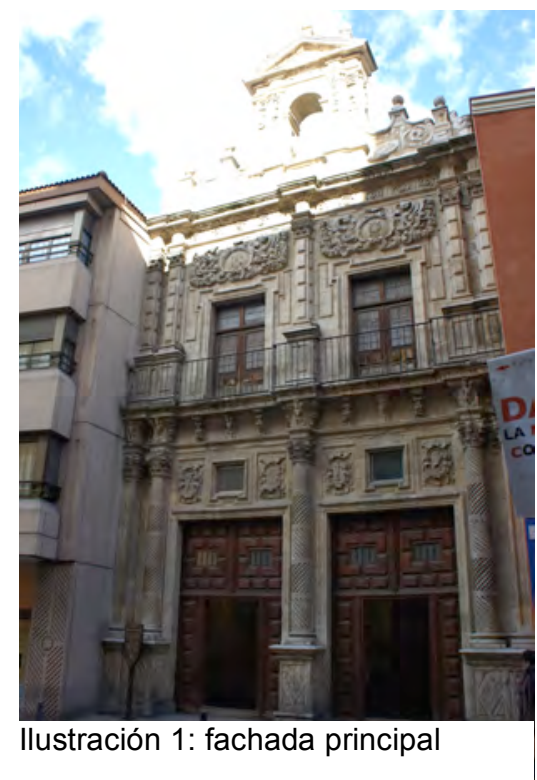

Según la Guía de Arquitectura ${ }^{1}$ :

Juan de Mazarredonda, Juan de Nates y Pedro del Río edifican la iglesia en 1579 y se inaugura en 1581. Felipe Cerrojo reemplaza el artesonado de madera por bóveda con yeserías barrocas en 1661. Pedro de Ezquerra y Antonio de la Iglesia sustituyen la fachada en 1672. En 1744 José Morante incorpora una cúpula con linterna sobre el crucero.

Se cerró al culto en 1926 por encontrarse arruinada. En 1968 se reconstruye y abre al público como museo. La obra entrañó dificultades adicionales por encontrarse las medianerías de tapial compartidas con los edificios de viviendas adyacentes. Uno de ellos fue expropiado. Los forjados son modernos con vigas metálicas revestidas con madera imitando un artesonado. Ambas bóvedas también son de nueva ejecución, con doble hoja de rasilla.

En 1991 vuelve a acondicionarse, incorporando una losa de hormigón, a nivel del falso techo de la sala de planta alta, para sostener maquinaria de aire acondicionado ubicada en el bajo cubierta.

\section{Cronología. Fechas clave}

$1579-1661-1926-1965$

\footnotetext{
${ }^{1}$ Arnuncio Pastor, J. C. (1996). Guía de arquitectura de Valladolid. Valladolid: Consorcio IV Centenario de la Ciudad de Valladolid.
} 


\section{Intervenciones}

1962- Consolidación muros y restauración de cubiertas - Anselmo Arenillas

1964 - Decorado - Anselmo Arenillas

1964 - Cubiertas y artesonado - Anselmo Arenillas

1965 - Adaptación a museo local - Anselmo Arenillas

\section{Incorporación de zuncho de hormigón armado.}

En el tapial se cajea un entramado de hormigón armado, se vacía el medio tapial resultante por zonas y se reemplaza por ladrillo en la medianera. Reconstruye ambas cúpulas, la del cimborrio no visitable con triple capa de rasilla. Las cubiertas anejas son forjados de rasilla sobre estructura metálica y la nave del templo se cubre con placa ondulada de fibrocemento.

Demuele la casa del sacristán y la colindante. Se reconstruyen con ladrillo visto similar al del testero de la sacristía. Sanea los muros a conservar con ladrillo y cadenas de hormigón armado en sus coronaciones.

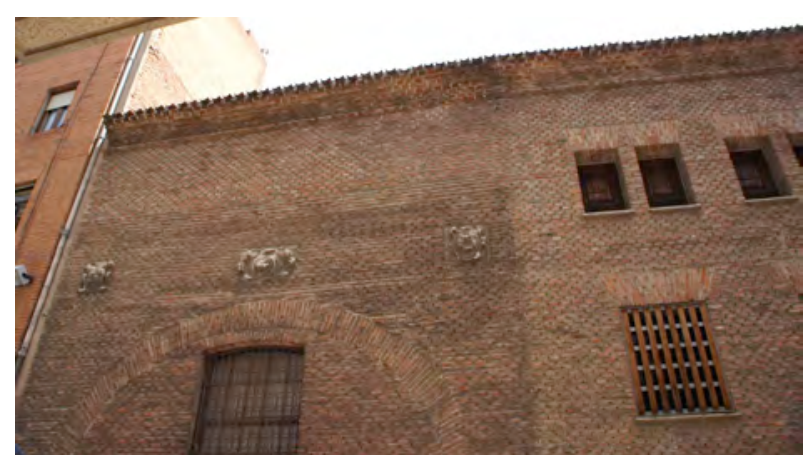

Ilustración 2: fachada lateral antiguas sacristía y vivienda, visita 14/04/2015

1992 - Restauración de la fachada - Ángel Luis Fernández Muñoz

1994 - Adecuación para sala cultural - Gabriel Gallegos y José Antonio Salvador Polo.

Actúa sobre naves, crucero y fachada. Se acondiciona un espacio sobre la cubierta para albergar la maquinaria de acondicionamiento de aire, sobre una losa de chapa nervada y $6 \mathrm{~cm}$ de hormigón. La cubierta de fibrocemento gran onda sobre perfiles de acero laminado IPN-200 se desmonta y vuelve a colocar con un perfil más peraltado para albergar las instalaciones.

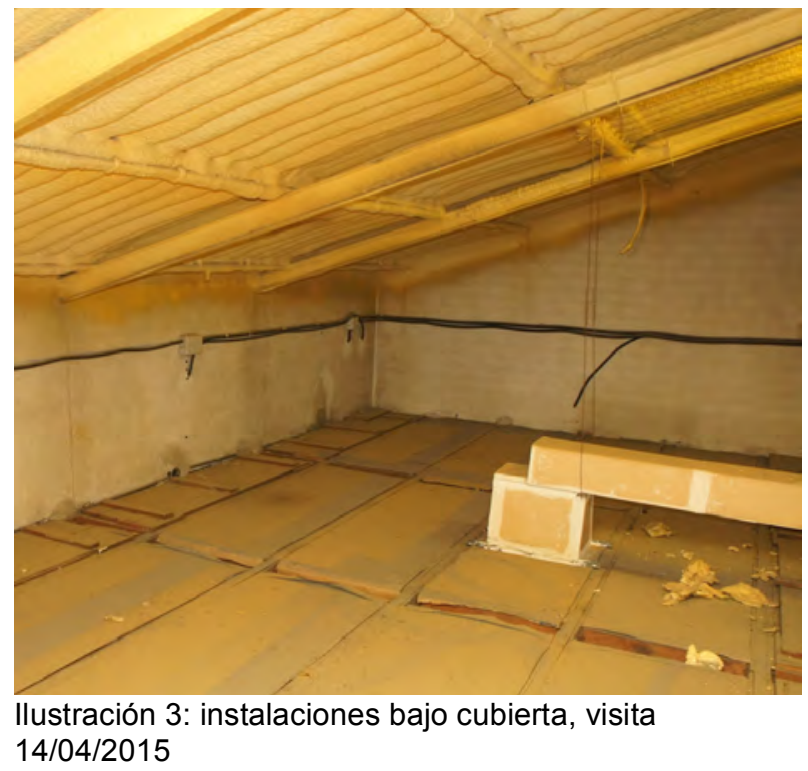




\section{Planos}

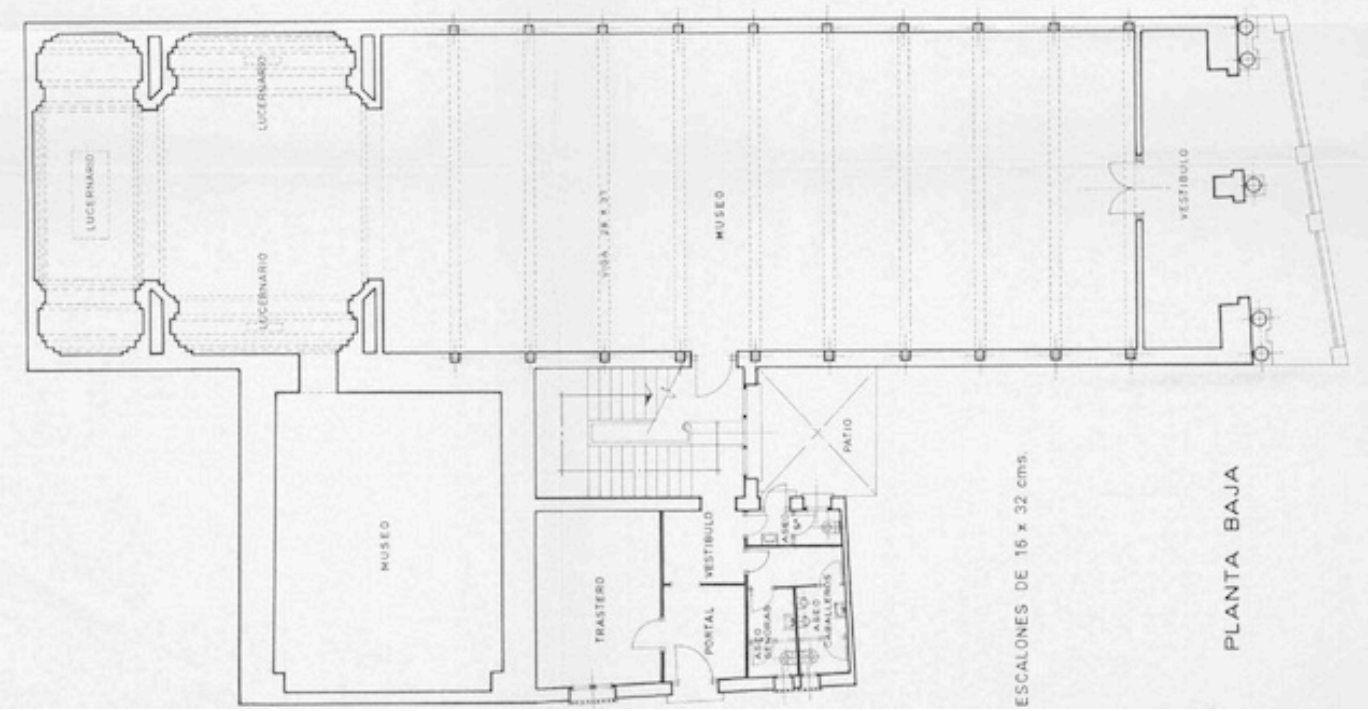

Ilustración 4: planta baja 1965 (Arenillas IPCE)

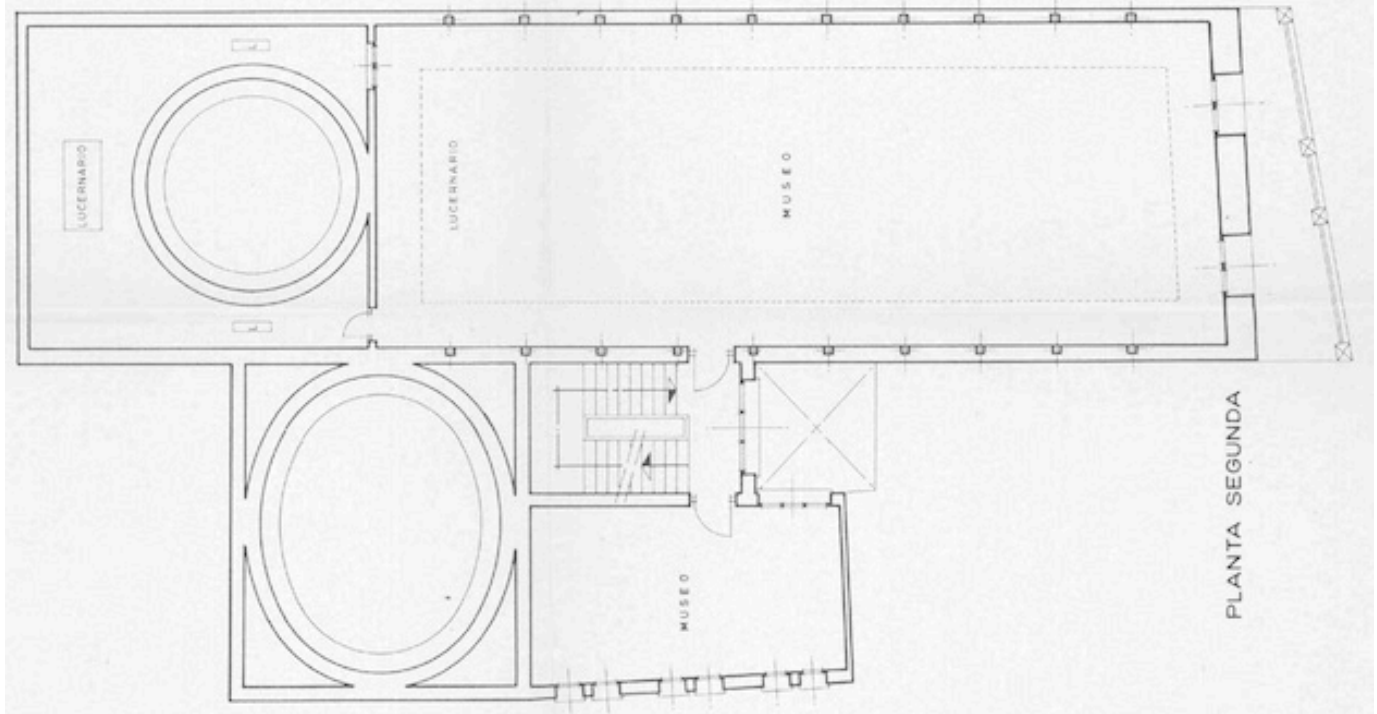

Ilustración 5: planta segunda 1965 (Arenillas IPCE)

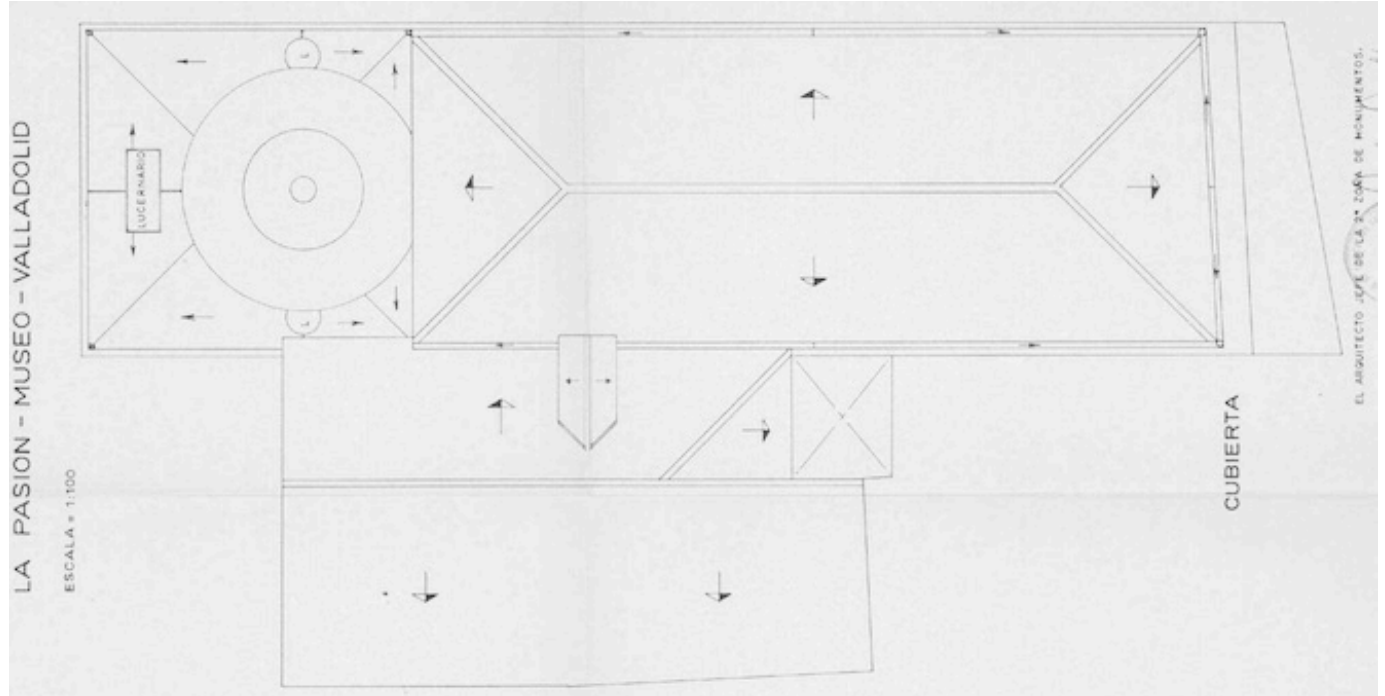

Ilustración 6: planta de cubiertas 1965 (Arenillas IPCE) 


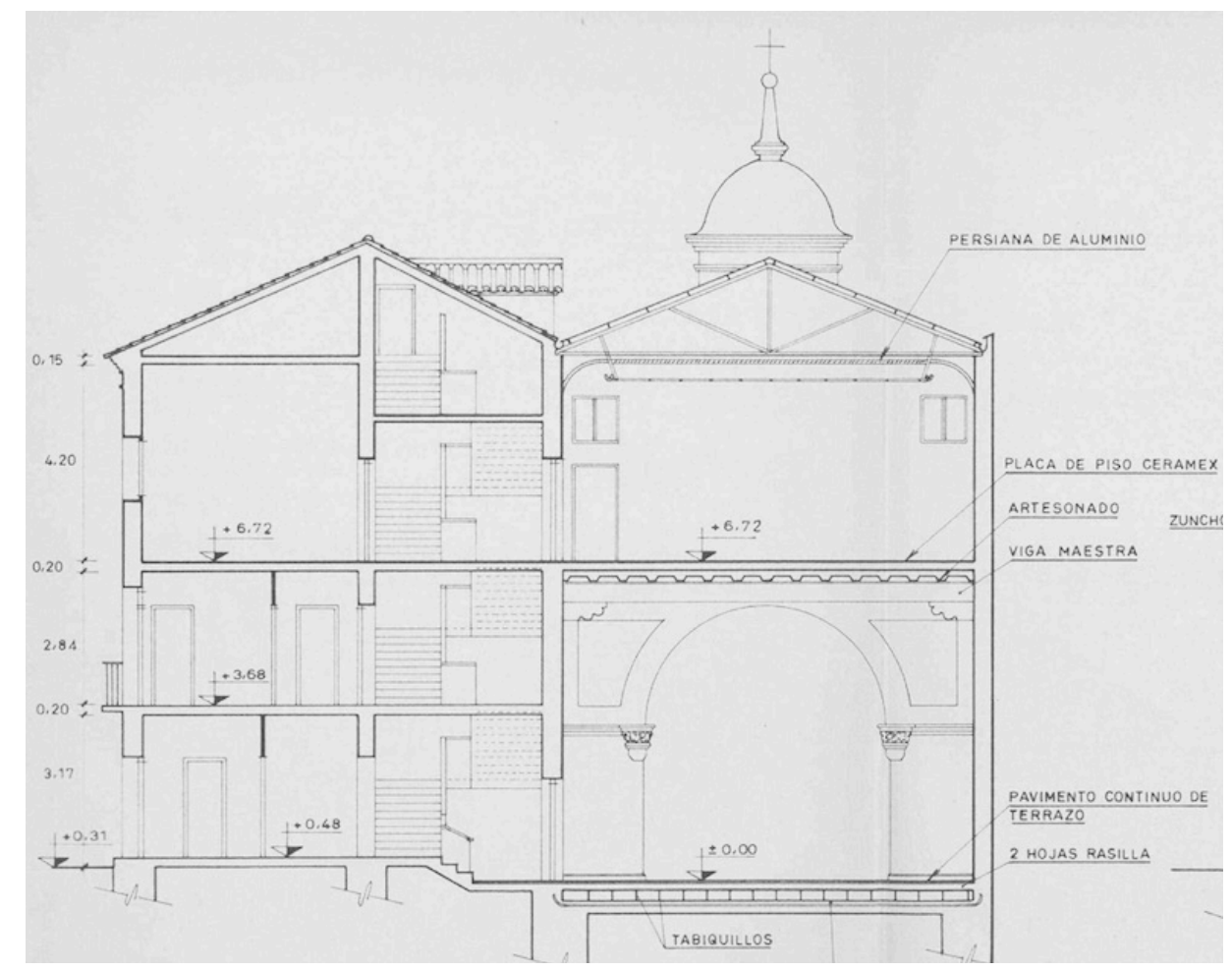

Ilustración 7: sección de la nave (Arenillas IPCE)

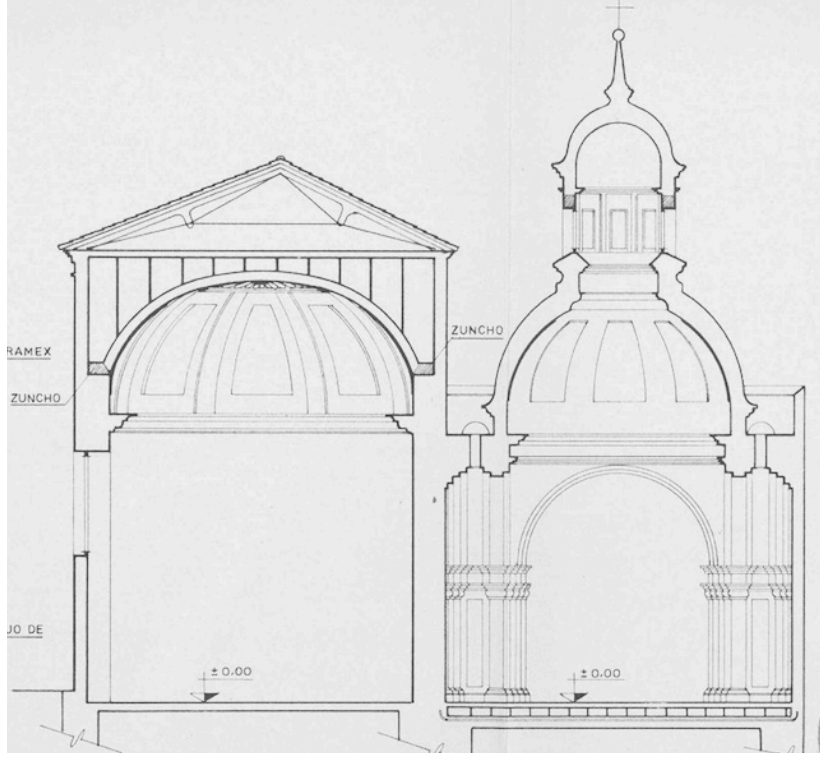

Ilustración 8: sección por cimborrio y antigua sacristía 1965 (Arenillas IPCE)

\section{Solución constructiva de la cubierta}

En la visita al bajo cubierta se comprueba que las secciones actuales no corresponden con los planos del proyecto de Arenillas, sino con el de Gallegos y Salvador, que intervienen en 1993 y modifican el remate del edificio para incorporar una potente maquinaria de acondicionamiento de aire. Se trata de una solución elemental de estructura metálica a dos aguas cubierta con planchas onduladas de fibrocemento. 


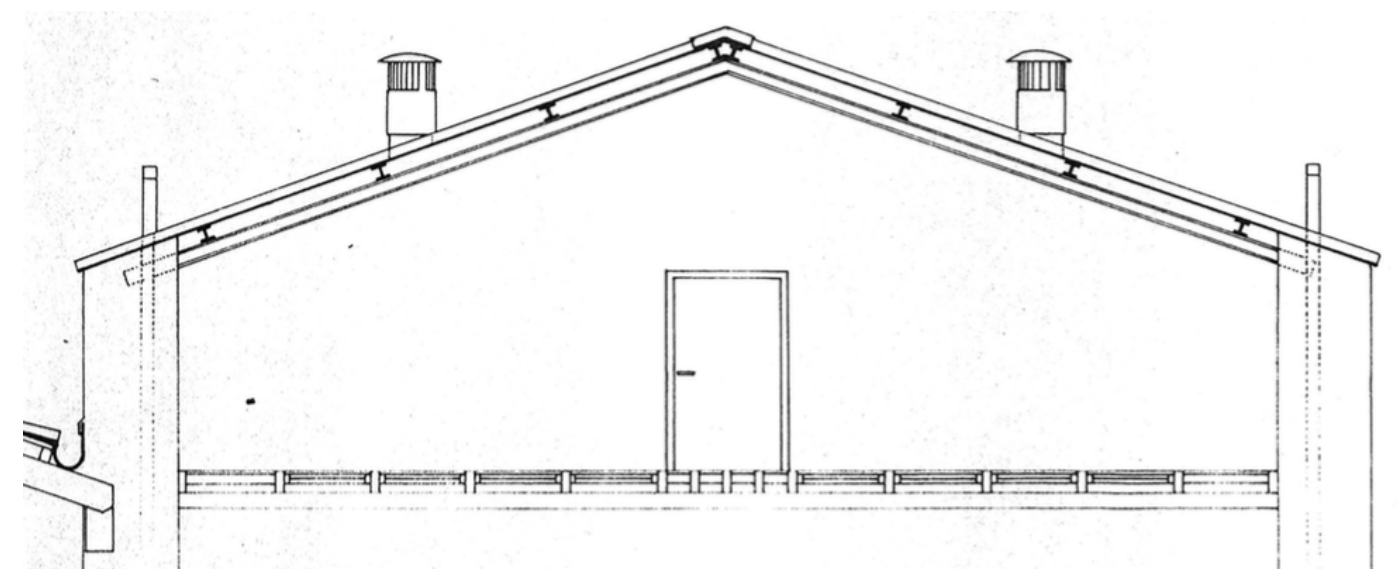

Ilustración 9: sección transversal 1993 Gallegos y Salvador AMVA

\section{Zunchos}

No ha sido posible confirmar la existencia de zunchos de remate en el edificio, ya que los paramentos no manifiestan discontinuidades en su superficie. Tampoco aparecen representados en los planos de 1993, ni mencionados en memoria o presupuesto.

Sólo en el proyecto de Arenillas de 1965 se describe la incorporación de cadenas de hormigón armado en la coronación de los muros, pero la modificación posterior de Gallegos y Salvador elevó la cota de remate de los mismos.

\section{Conclusiones}

No se ha podido comprobar si el edificio cuenta con zuncho de remate en la coronación de los muros. 


\section{Iglesia de la Pasión}

Intervenciones citadas en la publicación del Ministerio:

1962 - Consolidación muros y restauración de cubiertas - Anselmo Arenillas

1964 - Decorado - Anselmo Arenillas

1964 - Cubiertas y artesonado - Anselmo Arenillas

1965 - Adaptación a museo local - Anselmo Arenillas

En la web del IPCE hay 5 planos: plantas y secciones de 1964, plantas y secciones de 1965 y un detalle de estructura metálica del cimborrio sin fecha.

\section{En el Archivo Municipal de Valladolid}

\section{Fondo Histórico}

AMVA: 1053-85 1917

Expedientes relativos a la reclamación propuesta por vecinos de calle Pasión y calle Caridad, lindantes con la iglesia de la Pasión, sobre el mal estado de un muro de dicha iglesia. Licencia concedida para reparar la sacristía y derribar las partes ruinosas, y sobre reparación de la misma remitiéndose al Arzobispado

El Arquitecto municipal Emilio Baza expone que se trata de una pared de entramado con desplomes junto a la escalera de la iglesia. También encuentra en mala disposición tablazón y correas que apoyan sobre los pares de la armadura del tejado. La escalera se usa para acceder a dependencias sobre la iglesia y también se encuentra en mal estado.

El Vicario pide en 1926 licencia para derribar la parte en ruinas: parte superior de la Sacristía y escalera de subida a la Sala de Juntas de la Iglesia de la Pasión. Se le concede.

En 1932 el Alcalde ruega al Arzobispado que repare una valla de madera lamentable. Le responden que al ser Monumento nacional no puede, que compete al Ministerio. La Comisión de obras aclara que es monumento histórico-artístico dependiente del Arzobispado, no monumento nacional.

\section{AMVA: 766-6 1936}

Instalación de la Academia de Bellas Artes y de la Escuela de Música en la Iglesia de la Pasión 
Diversas cartas. Escrito del Alcalde en que confirma el proceso y acuerda encargar el proyecto de restauración y adaptación al Arquitecto provincial de construcciones civiles (según otros documentos el cargo lo ocupa Candeira)

AMVA: 2577-13 1958

Creación de un Museo Vallisoletano de Arte Contemporáneo. Se ubicó en el solar de la Iglesia de la Pasión.

Cesión de Eduardo García Benito de sus obras para ser expuestas en dicho Museo En el dossier encontramos numerosas cartas del propio García Benito, Bellas Artes, etc.

Entre ellas una de "Los vecinos de la Iglesia de la Pasión" en que ruegan que mientras se llevan a efecto las obras del museo se desmontaran "aquellas desplomadas paredes y enormes vigas que amenazan caer sobre las viviendas modestas que rodean el edificio de la citada Iglesia". Lamentan la basura y los roedores. Les responden que no porque no hay presupuesto asignado, se desescombrará cuando empiece la obra.

En una de las cartas de García Benito lamenta la falta de entendimiento con el Alcalde que no le brinda una celebración con autoridades.

\section{Fondo Administrativo}

AMVA: C.1358-8 1963-1968

Obras en la Iglesia de la Pasión para su destino como museo. Hojas: 62. Incluye:

- Expropiación de la casa número 2 de la calle Caridad, propiedad de la viuda de Pedro Presa Alonso, Ezequiela Asensio Domínguez, y su hijo, Félix Presa Asensio.

- Cerramiento de puerta de servidumbre de la casa número 8 de la calle Pasión, propiedad de Medardo Iglesias.

- Declaración de ruina de la casa número 12 de la calle Pasión, propiedad de María del Carmen Granja Serrano

Al ir a realizar las obras en mayo de 1963 Anselmo Arenillas encuentra que hay casas medianeras con habitaciones incrustadas en la casa que fue de la Sacristía e informa al Arquitecto Municipal Balmori para que las compren o expropien.

En junio de 1963 Construcciones Topesan SL para la obra al amenazar ruina la casa colindante. 
Informe del arquitecto Isaias Paredes. El muro lateral del $\mathrm{n}^{\circ} 12$ es de tapial de un metro de espesor que la demolición ha dejado en la mitad. Que no está en ruinas el ático y puede repararse.

Al final ordenan su desalojo y derribo.

AMVA: C.4278-4 1968

Adquisición y adaptación de la iglesia de la Pasión para museo de pintura (fotocopias)

Escritura de venta del Arzobispo Antonio García García al Alcalde José González Regueral y Jove del Solar de la derruida iglesia de la Pasión y las edificaciones que se mantenían en pie. Contiene planta 1:250 con trama en la pastilla alargada con frente a calle Pasión y un resalto con salida a calle de la Caridad.

Fotocopia de Actas del ayuntamiento, entre otras cosas recoge que se ha realizado obras a punto de acabar en colaboración con el Ministerio para reconstruir las ruinas de la iglesia como museo de pintura.

AMVA: e86-15434/91 1991

Restauración de la fachada de la Iglesia de la Pasión (Exp. 59/1991)

Convenio para financiación conjunta Ayuntamiento y JCyL de la restauración de fachada y pavimento de acceso.

AMVA: $1772 / 92 \quad 17808-3 \quad 1992$

Consejería de Cultura y Turismo. Restauración de la fachada de la iglesia de la Pasión (Exp. 1772/1992)

Arquitecto: Angel Luis Fernández Muñoz

Solicitud de licencia. Propietario: Ayuntamiento de Valladolid. Autor del Encargo: Junta de Castilla y León.

Memoria (cita de Luna Moreno, Luis. Gregorio Fernández y la Semana Santa de Valladolid): Juan de Mazarredonda y Pedro del Río la construyen entre 1579 y 1581. Felipe Berrojo renueva el interior de la nave y la cúpula. En 1968 se inaugura como mueso de pintura. No quedaban ya las bóvedas de yeserías y se rehízo el artesonado subyacente, resto quizá de la primitiva construcción de Mazarredonda y del Río. Se levantaron de nuevo las cúpulas del crucero y de la Sacristía, así como dependencias complementarias.

Confirma que en 1579 se empiezan a abrir los cimientos. En origen, la única nave debió cubrirse con techumbre plana de madera mantenida por gruesas vigas que se apoyan sobre canes tallados. Sobre la nave, sin pasar del crucero, se dispuso un gran salón, de idénticas proporciones, destinado a los Capítulos de la Cofradía, cubierto 
con techumbre plana también con grandes vigas.

Tras la intervención de Berrojo queda el espacio de una sola nave, al que sigue otro cubierto con cúpula, y la cabecera como ábside estrecho rectangular con un gran arco donde se abría el camarín para la imagen. Se recubrió la techumbre de madera primitiva con cinco tramos de bóvedas de ladrillo, recubiertas con yeserías, de medio cañón rebajadas, con lunetos.

Existió una linterna (hay referencias en los libros de la Cofradía de recomposiciones de la misma) pero no debió estar trazada como indica Schubert. Este último manifiesta que la cubierta exterior de la iglesia debió consistir en armadura a dos vertientes. (Coincide con dibujo de Martí y Monsó)

Hay restos de grandes maderos que hacen suponer un tejado más alto hacia el centro de la iglesia.

Hay discrepancias entre el dibujo del plano de Ventura Seco en 1738 que parece anterior a los cambios de Berrojo (cree que pudo copiarse de un plano anterior)

Planos de la fachada 1:25 estado actual y restaurado. Ubicación 1:5000.

AMVA: 1992-1993

Contratación de obras de adecuación de la antigua Iglesia de la Pasión para sala cultural (sala de exposiciones).

Pieza 1.- Expediente administrativo de contratación de las obras (Exp. 930.47660)

Contiene un folleto tríptico en que se explica las actuaciones y condiciones de la Sala. Explica que en 1575 la cofradía encargó a Juan de Mazarredonda, Juan de Nates y Pedro del Río levantar una iglesia. En 1579 comienzan las obras y en 1581 se celebra misa. En 1661 la cofradía encarga terminarla a Felipe Berruejo, en 1666 se propone modificar la capilla, en 1667 se acuerda levantar una portada nueva y en 1672 queda totalmente terminada la obra. En 1962 se ejecuta el proyecto de reconstrucción de estructuras, en 1964 la reposición de cubiertas y artesonado y la restauración del decorado. En 1965 se adapta a museo local.

Restos originales: fachada principal, parte de la fachada que corresponde a la sacristía, muros del crucero y sacristía, hasta arranque de bóvedas y restos de algunas zapatas de artesonado de madera.

Actuaciones:

Naves, cruceros y fachada principal. Construcción de un área para la maquinaria de aire acondicionado y facilitar el acceso a este espacio. Acondicionar la cubierta y crear un falso techo en la nave baja. En la fachada principal situada en la calle Pasión se proyectan dos banderolas independientes de las fachadas para ocultar las medianería, servir de soporte de información lejana y próxima y acoger las lámparas 
de iluminación.

Zona de servicios. En planta baja se creará un vestíbulo de acceso, con mobiliario para control e información. Se sitúan igualmente dos salas para almacén y cuarto para la maquinaria de ascensor. En la entreplanta se ubicarán los aseos...

Fecha de intervención febrero-julio de 1994. Arq: Gabriel Gallegos Borges y José Antonio Salvador Polo.

Pieza 2.- Modificación del proyecto de adecuación de la iglesia (Exp. 940.29530) Contratista: Julián Ortega SA

Modificado $\mathrm{n}^{\circ} 1$. Se cambian los solados que se iba a mantener por piedra Campaspero. Reparan cúpulas de escayola, dañadas al colocar iluminación.

Pieza 3.- Recepción provisional y definitiva de las obras.

Pieza 4.- Anexos I y II. Proyecto básico y de ejecución :Memoria; Pliego de condiciones; Mediciones y presupuestos; Planos. (Exp.920.48300)

Arq: Gabriel Gallegos Borges y José Antonio Salvador Polo

Memoria: remite a "Papeletas sobre arte barroco en Valladolid, la Iglesia Penitencial de la Pasión" de Concepción Álvarez Terán.

El edificio estuvo en ruinas, con restos de las bóvedas de la nave principal, de una hoja de ladrillo, y de las techumbres de madera. Había desaparecido la cúpula de la cabecera y con ella la linterna, la bóveda del ábside y la cúpula elipsoidal de la sacristía.

Cita párrafos de las obras de Anselmo Arenillas:

1962 "se observa que inicialmente la iglesia tenía un techo envigado y artesonado de madera que servía de piso a la planta superior, más la terminación con falsas bóvedas de ladrillo y yeso. Los muros son de adobe y tapial reforzado, con ladrillo, en la planta alta son de entramado de madera rellenos de adobe y cascote, pero por la larga exposición a la intemperie todo está descompuesto en esta segunda planta"

De 1964 Reposición de cubiertas y artesonado. Se pretende reconstruir la cubierta con estructura metálica y cristal impreso para conseguir luz cenital. Habían dejado vigas metálicas por debajo del forjado de hormigón que recubrieron con tablones de madera para simular un artesonado.

Para la reconstrucción de las bóvedas del cimborrio con dos hojas de rasilla para formar una bóveda peraltada con interior esférico y exterior elíptico peraltado 1964 Restauración del decorado. Techo de vigas metálicas en planta alta recubierto 
en madera.

1965 Adaptación a museo local. Demoler la casa del sacristán y la colindante. Se reconstruyen dejando ladrillo visto que armonice con el da la sacristía en la calle lateral.

Cita párrafos del proyecto de Arenillas:

"Los muros a conservar se les sanea con ladrillo y cadenas de hormigón armado en sus coronaciones. Los que por su mal estado no pueden mantenerse, se proyecta rehacerlos con doble tabicón de ladrillo y entramados con soportes y carreras de hormigón armado.

Se hace así porque es preciso, antes de demolerlo, meter el entramado de hormigón armado cajeando en el tapial y luego quitar este por zonas y meter el nuevo muro de ladrillo, solo así se evitará que las casas colindantes se derrumben, por su vejez y porque cargan en estos muros de tapial. Ahora quedará resuelta la medianería, siendo la del museo de ladrillo entramado de hormigón y la de los vecinos su medio tapial antiguo.

Se reconstruirán las bóvedas de la capilla lateral y la del cimborrio con su linterna, habiendose proyectado de acuerdo con los restos existentes, y se decorarán según dichos restos y según los croquis y fotografías viejas.

Las cubiertas en la casa son de teja curva sobre forjados de rasilla y armaduras metálicas. En la nave de la iglesia con armaduras metálicas y chapas onduladas translúcidas o de fibrocemento. La cúpula del cimborrio y su linterna, que no son visitables, se hacen con triple capa de rasilla revestida de mortero de cemento impermeable y rematada con doble capa de Gerfón."

Describe cuáles son los restos originales a partir de estos textos y del estudio visual de la obra:

La fachada principal ha sido recientemente restaurada

La parte que corresponde a sacristía del callejón lateral

Muros del crucero y sacristía hasta el arranque de bóvedas

Resto de algunas zapatas del artesonado de madera.

Y los nuevos:

Cancela, forjados y cubierta, pavimentos, encasetonados de techos, construcciones auxiliares con escaleras y patio, bóvedas de sacristía y crucero, linterna sobre cimborrio y algún arco fajón de dicho cimborrio.

Describe el edificio antigua iglesia penitencial reformada. Típica distribución interna con atrio cerrado de doble puerta, nave de planta rectangular y techo plano, y Altar 
Mayor con cúpula y linterna. A la izquierda la antigua sacristía cubierta con bóveda elipsoidal.

Sólo fachada y traza de planta poseen valor histórico.

Algunos párrafos sobre el estado constructivo actual:

"Fachada original de piedra natural. Muros de la nave reconstruidas con pilares y zunchos de hormigón, y cámara de ventilación interior. Cubrición a base de placas de fibrocemento ondulado y en el tramo central placas igualmente onduladas de poliester armado.

El ábside y sacristía tienen cimentación y muros originales, que sabemos de ladrillo macizo, complementados probablemente con tapial. Bóvedas y cúpula de doble pared de ladrillo. Estos dos elementos junto con la linterna no son originales."

Para mejorar el control ambiental decide cambiar las placas transparentes, que producen sobrecalentamiento con la entrada de sol. Proyecta instalar maquinaria en el bajo cubierta, para lo que ejecutará un forjado de losa de hormigón y cambiará escalera de pates por metálica. Las bandejas laterales, en techo de planta baja, ocultan el aire acondicionado. Recuerda que el artesonado actual es "falso". Colocará aislamiento térmico sobre estructura de techo de nave.

Dossier amplio con fotocopias de fotos:

Croquis de planta y alzado (trabajo del SEHA)

Fotos del SEAA de nave y bóvedas arruinadas.

Del estado del edificio, con cubierta de uralita recubierta de teja, estructura metálica bajo la misma, revestimiento de la cúpula, baberos, etc.

Pliego, mediciones.

Nave de planta baja $0,5 \times 7,7+24=181,85 \mathrm{~m} 2$ solado baldosa. Nave $1^{\text {a }}$ planta $180 \mathrm{~m} 2$ acuchillado de tarima.

Desmonta y vuelve a montar 9x4m2 de cubierta de fibrocemento con estructura de entramado de cerchas metálicas

$144 \mathrm{~m} 2$ de cubierta de fibrocemento granonda $(24 \times 6)$

$1259 \mathrm{~kg}$ acero laminado en perfiles IPN-200 y UPN-260

La losa de hormigón 7,5x4 con perfil tipo Lesaca (es una chapa nervada) de $1.25 \mathrm{~mm}$ y $6 \mathrm{~cm}$ de hormigón por encima del canto del perfil.

Planos

Plantas 1:50. Sección transversal. Es muy diferente de las del IPCE, el espacio bajo cubierta más alto, con una puerta. Por eso cabe la maquinaria. En el plano 23 
representa esa estructura a 1:20, con 5 IPN-200 como vigas.

Copia de las dos secciones:
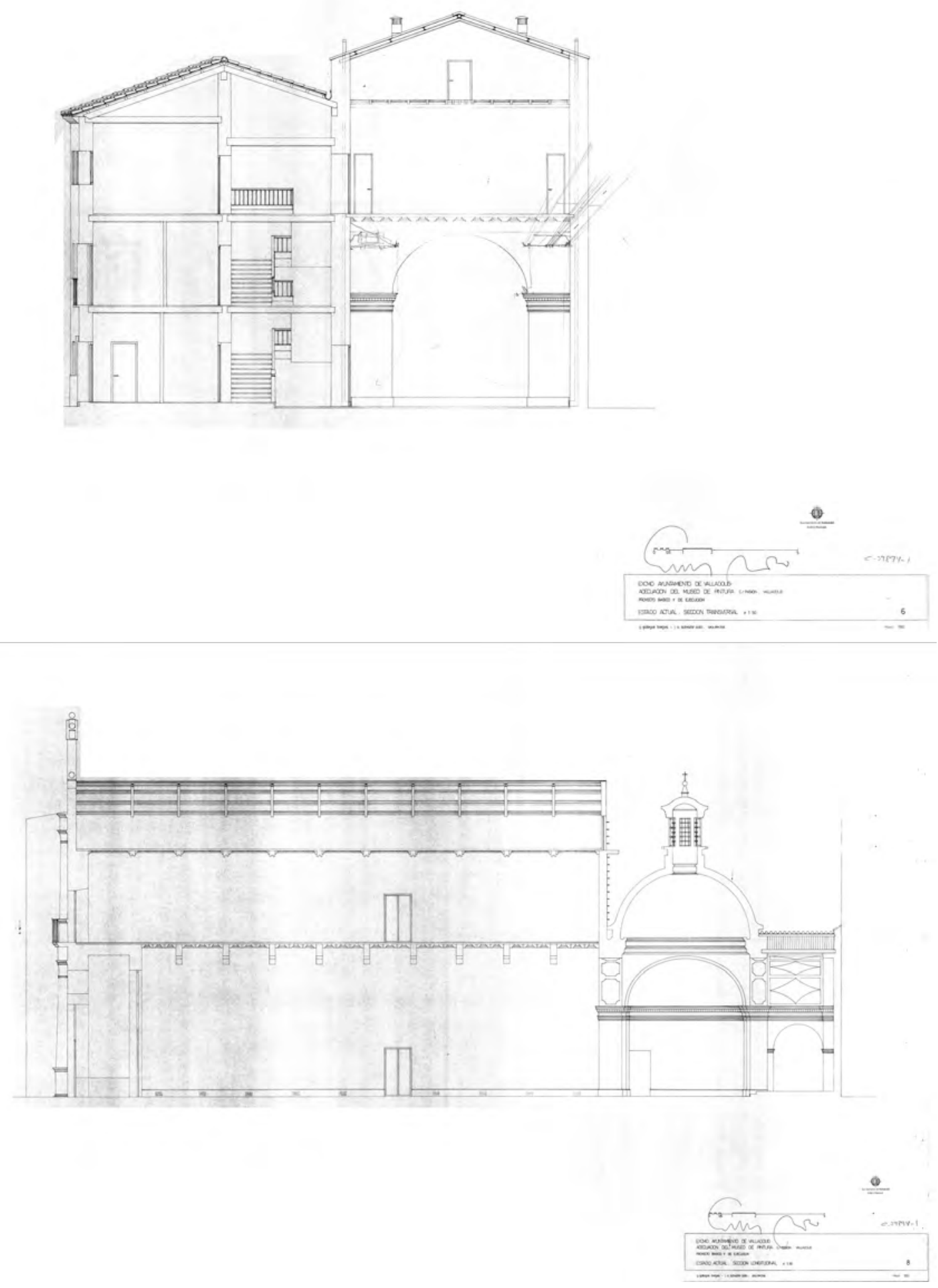

Pieza 5.- Proposición para tomar parte en la licitación del concurso adjudicatario de Construcciones Generales Julián Ortega S.A.

Justifica obras bien realizadas, no incompatibilidad, etc. 


\section{En el archivo de la Junta de Castilla y León}

VA-105

Carpeta 5338

Documentación administrativa: coincide con AMVA 1772 pero más abundante, con certificaciones, etc. Acta de recepción definitiva 29 de noviembre de 1994 (adjudicación 20/12/91)

Algunos apartados de la Ficha de Diagnóstico de Ángel Luis Fernández Muñoz:

Aspectos del entorno: Posición comprometida por pérdida de alineación, entre dos edificios del presente siglo (años 30 y años 80). Mínima dimensión del ámbito de acceso. Ocultación de su presencia en la perspectiva de la calle.

Estanqueidad de cerramientos: No parecen existir problemas de estanqueidad relacionados con la fachada, aunque si existen problemas de humedad por capilaridad.

Estanqueidad de cubiertas: Los elementos de piedra de fachada disgregados en parte alta por pérdida de la estanqueidad de la coronación.

\section{Cubierta de nave: fibrocemento con ventiladores industriales}

Cubierta de capilla: impermeabilización autoprotegida

Estabilidad de cimentación: No se aprecian problemas

Estabilidad fábricas: Tan solo comprometida por la degradación y pérdida de sección subsiguiente de parte de la fábrica de piedra de fachada.

En la Ficha de propuesta actuación se recoge: Tratamiento diferencial del ámbito de acceso a nivel de acera y calzada. Tratamiento de las medianeras antiguas. Formación de barrera antihumedad en planta baja. Andamiaje auxiliar. Mejora de la evacuación de pluviales en cabecera de muro y canalón de encuentro con el tejado. Mantenimiento, consolidación y restauración de los mismos (revestimientos) en figuraciones y bajo cornisas. Extracción de sales, neutralización de residuos, consolidación de descamaciones, limpieza de manchas y fijación de zonas arenizadas. Restauración de cornisas y vivos con piedra artificial sobre armadura de acero inoxidable. Desincrustación y eliminación de residuos adheridos. Limpieza y retacado de juntas. Microcosidos de refuerzo. Reposición de figura de coronación en cerrajería. Limpieza y protección de rejas y carpintería. Restauración de carpinterías.

Proyecto. El mismo consultado en AMVA

Ejemplar encuadernado con título "Memoria final" de marzo de 1993 
Adjudicatario "Conservación del Patrimonio Artístico SA"

La obra se inicia el 5 de mayo de 1992. Hay un proyecto modificado: el propietario del inmueble vecino no autoriza su tratamiento de medianería, no se trata el pavimento de la calzada, se han repuesto más piezas de las previstas.

Análisis petrográfico: toda la piedra es Campaspero, con dos variedades, una para fábrica y otra en molduras.

Dossier con las Fichas técnicas de morteros y otros productos empleados.

\section{En el Archivo General de la Administración}

\section{AGA 26/00253}

Reconstrucción de estructuras

1962 Anselmo Arenillas

"La iglesia está desafectada del culto desde hace muchos años. se conserva la fachada, parte de las bóvedas y decoración de escayola sobre los muros.

Es una iglesia construida entre medianerias sin mas luz que la del cimborrio pues sobre la nave de la iglesia en si tiene otro piso que se acusa en fachada con balcones. Se observa que inicialmente la iglesia tenia un techo envigado y artesonado de madera que servia de piso a la planta superior, mas lo terminaron con falsas bovedas de ladrillo y yeso.

Los muros son de adobe y tapial reforzados con ladrillo, en la planta alta son de entramado de madera rellenos de adobe y cascote, pero por la larga exposición a la intemperie todo está descompuesto en esta segunda planta.

Se hace preciso ante todo demoler todas las partes de los muros y bovedas que estan en mal estado, dejando limpio el solar de escombros y conservando bien la fachada de piedra.

Se recalzarán los cimientos de la fachada con buen hormigón de cemento y se rejuntarán su cantería para consolidarla, sin restaurarla aún. Se harán cimientos nuevos en hormigón a las medianerías y muros a rehacer o hacer de nuevo, calculandose la profundidad de estos cimientos en dos metros, pues los enterramientos hechos antiguamente en la iglesia han removido el terreno.

En la iglesia se consolidaran los muros careandoles con fabrica de ladrillo y mortero de cemento, conservando la linterna o lucernario y, según se indica en los planos de estado actual y futuro. Se gana en amplitud. En la planta alta estos muros conservan el mismo espesor que en la baja, pero se harán con cámara de aire para su mejor 
estabilidad. Se aprovecharán estas cámaras para poner chimeneas de autoventilación de la Iglesia.

Los pisos, que es forzoso rehacer, se forjarán con placa de hormigón armado aligerado con cerámica sin jácenas, cubriendo de una vez la luz total de la nave antigua de la Iglesia.

Las cubiertas se forjarán también con hormigón armado, encima se colocarán capas de cartón bituminoso cubierto con aluminio en placas de $2 \mathrm{~mm}$. Se considera esto una cubierta provisional, más pudiera ser que si su duración es aceptable en Valladolid, sirviese de cubierta definitiva".

Superficie de planta a cubrir 34,00x9,50x2 plantas

Un solo plano, con plantas y sección del edificio anejo.

\section{AGA 26/00370}

Proyecto de reposición de cubiertas y artesonado

Abril de 1964 Anselmo Arenillas

"Hace dos años se hicieron e este edificio obras de desescombro, consolidación de las fábricas existentes y reconstrucción de los muros y pisos, quedando paralizados interín el Ayuntamiento procedía a la expropiación de las casas colindantes que, por estar en periodo de ruina, impedían obras en las medianerías.

Comprende a este proyecto hacer la cubierta sobre la segunda planta, lo que supone construir las bóvedas del cimborrio y de los arcos que le sirven de arranque con su trasdós y poner la armadura y tejado de la nave y de los pasos alrededor del cimborrio.

Las bóvedas se proyectan tabicadas de cinco hojas de rasilla esférica en el cimborrio y cilíndrica en los arranques....

En la cubierta se colocarán ventiladores automáticos de chimenea de doble tubo a diferente nivel para permitir la ventilación del espacio entre cubiertas y evitar el recalentamiento del local bajo él.

Se incluye en el proyecto reponer el artesonado. Al hacer de hormigón armado la nueva estructura dejar elementos metálicos salientes de ella para recibirla".

Plano detalle jácena PN24 a 1/2 rotula "una jacena doble T perfil 24 cubierta con madera sobre los soportes hormigon"

No aparece ninguna alusión a zunchos en memoria, planos o presupuesto 


\section{AGA 26/00370}

Restauración del decorado (con cargo al Ayuntamiento de Valladolid)

Agosto de 1964 Anselmo Arenillas

"Cerrar el piso alto de la nave principal con un artesonado sencillo y decorativo en madera vista, sostenido con vigas de hierro para mayor economía y sobre el cual pueda ir la vidriera traslúcida, recordando el artesonado auténtico de la planta baja, pero algo modernizado para evitar que se considere una repetición o anacronismo.

Se proyecta también reparar la capilla lateral, cuya bóveda ha desaparecido, rehaciendo el muro desplomado de la fachada y el medianero con la casa colindante hundida, y también reforzar los otros dos lados.

...Toda la entrecubierta será así visitable y permitirá la limpieza de los cristales de cubrición y lucernario y de las persianas".

Dos planos; plantas sótano a cubierta y secciones AA y BB del IPCE.

No aparece ninguna alusión a zunchos en memoria, planos o presupuesto.

\section{AGA 26/00206}

Adaptación de la iglesia a museo local

Septiembre de 1965 Anselmo Arenillas

"Ya cuando fue declarado Monumento Nacional se encontraba en franca ruina. En los últimos años se contuvo ésta y se inició su restauración.

Respetando su disposición se ha previsto dejar la gran nave de la iglesia tal cual era, reparando su espléndido artesonado de madera del cual quedaban las ménsulas sanas, las grandes vigas maestras rotas y descompuestas y algunos maderos y molduras...

Una vez consolidadas las medianerías y demolidas las casas, se podrán elevar los muros de la iglesia en su segunda planta y rehacer la casa de la calle de la Comedia.

Los muros de la iglesia son de tapial que debido al largo tiempo que han estado a la intemperie están descompuestos, no resisten reparación, salvo los del crucero y los de la capilla lateral.

Los muros a conservar se les sanea con ladrillo y cadenas de hormigón armado en sus coronaciones. Los que por su mal estado no puedan mantenerse, se proyecta rehacerlos con doble tabicón de ladrillo y entramados con soportes y carreras de hormigón armado. se hace así porque es preciso, antes de demolerlos, meter el entramado de hormigón armado cajeando en el tapial y luego quitar este por zonas y 
meter el nuevo muro de ladrillo, sólo así se evitará que las casas colindantes se derrumben, por su vejez y porque cargan en estos muros de tapial. Ahora quedará resuelta la medianería, siendo la del museo de ladrillo entramado de hormigón y la de los vecinos su medio tapial antiguo...

(las cubiertas) en la nave de la iglesia con armaduras metálicas y chapadas onduladas traslucidas o de fibrocemento. La cúpula del cimborrio y su linterna, que no son visitables, se hacen con triple capa de rasilla ..."

Cálculos de calefacción

Planos (sólo uno que está en la Planoteca del IPCE)

Armadura del cimborrio

En el presupuesto no aparecen menciones a zunchos. Corrigen a mano 182,30ml de cornisas forjadas con ladrillo, de 1,00m de desarrollo, corridas de yeso. 



\section{Visitas realizadas}

$14 / 04 / 2015$

El estado de conservación del interior del monumento es adecuado a su uso como Sala de exposiciones Municipal.
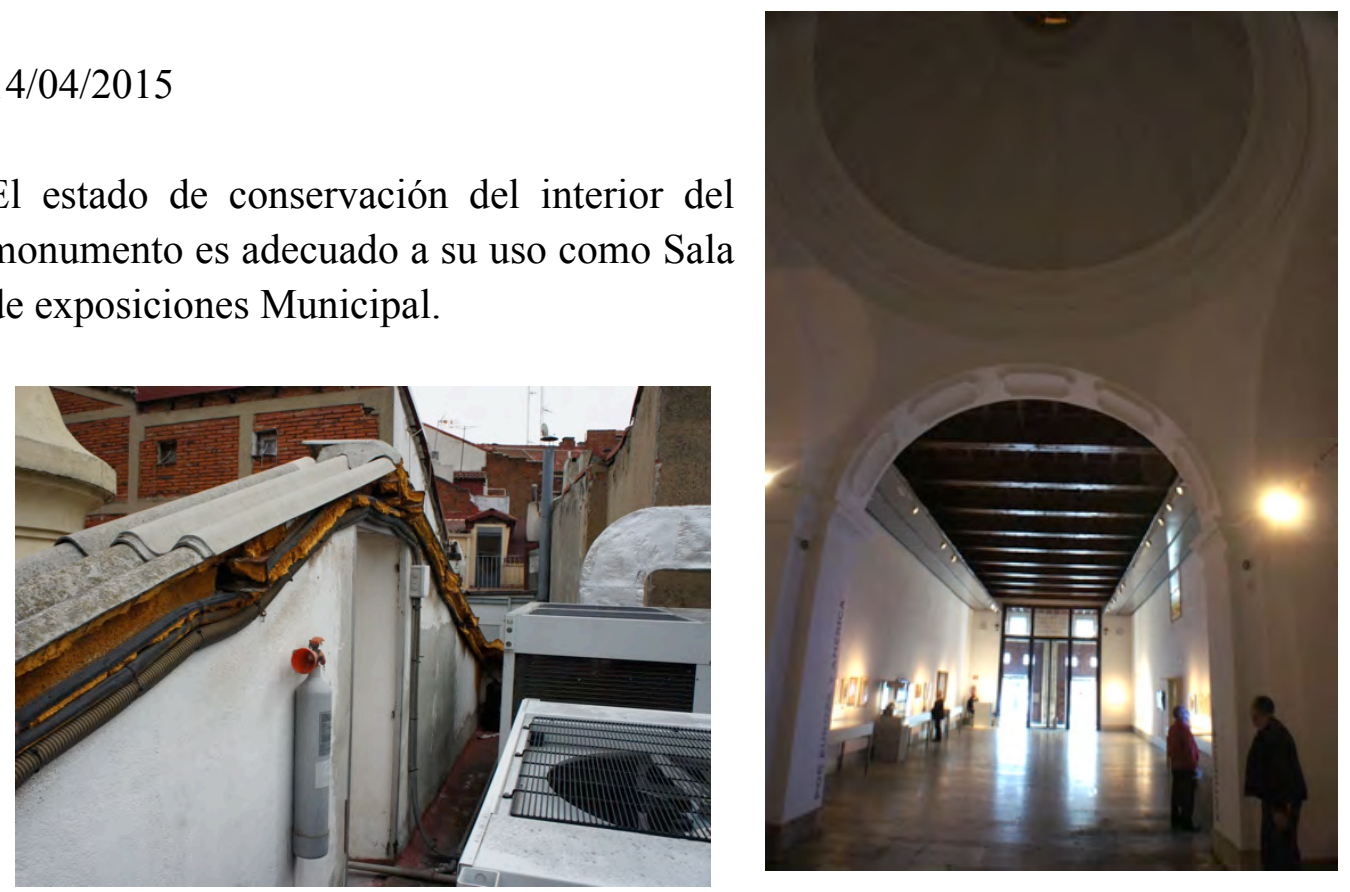

La cubierta, sin embargo, mantiene elementos constructivos de mediados del siglo XX poco frecuentes en restauración monumental, como la cubierta del cuerpo de la nave y el fondo del antiguo altar mayor, resueltos con placas de fibrocemento.

En las imágenes se aprecia cómo una zona de esta cubierta fue, en algún momento, recortada para dejar un espacio libre, a modo de terraza, donde albergar la maquinaria de acondicionamiento de aire. Los perfiles de acero laminado quedaron seccionados, sin aplicación de tratamientos protectores para prolongar la vida del acero a la intemperie, ni incorporar un mínimo remate al borde de las placas onduladas y al aislamiento térmico bajo las mismas.
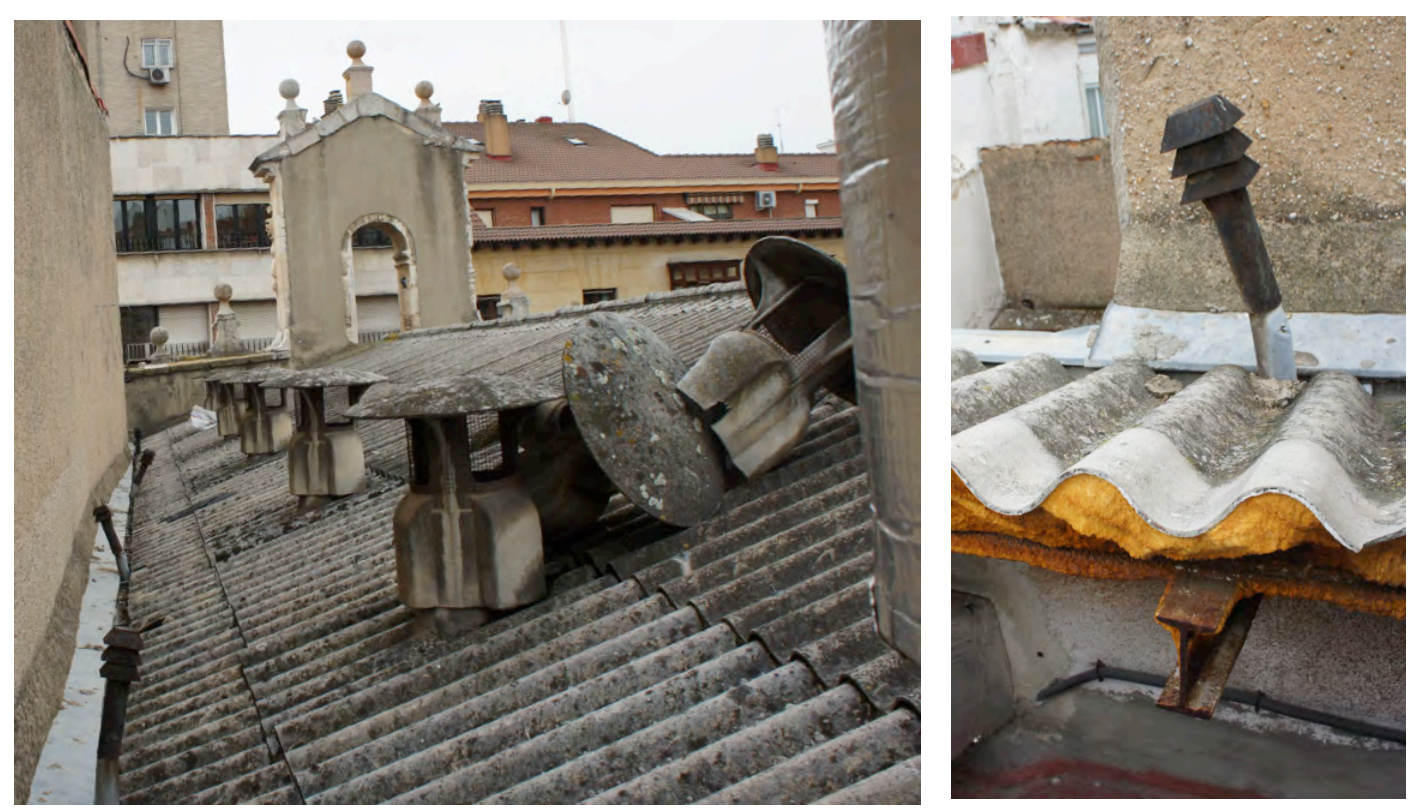
En las imágenes se aprecian dos familias de chimeneas para ventilación, las de mayor tamaño abiertas sobre el espacio bajo cubierta y unas más pequeñas en el encuentro del borde del faldón con muros de edificios medianeros, probablemente destinadas a garantizar la ventilación de las cámaras. La entrada al bajo cubierta se realiza desde esta terraza. Se encuentra cerrado, por lo que se concierta una visita posterior.

Aunque el acceso no resulta posible, por un hueco accesible desde el arranque de la cúpula de cabecera se aprecia el espacio bajo cubierta de la antigua sacristía. La estructura observada no coincide con la definida en los planos del proyecto de Arenillas, en los que aparecían cerchas ligeras de hormigón trianguladas con tensores. En el proyecto de 1993 conservado en el AMVA no se ha localizado planos que definan esta zona del edificio.

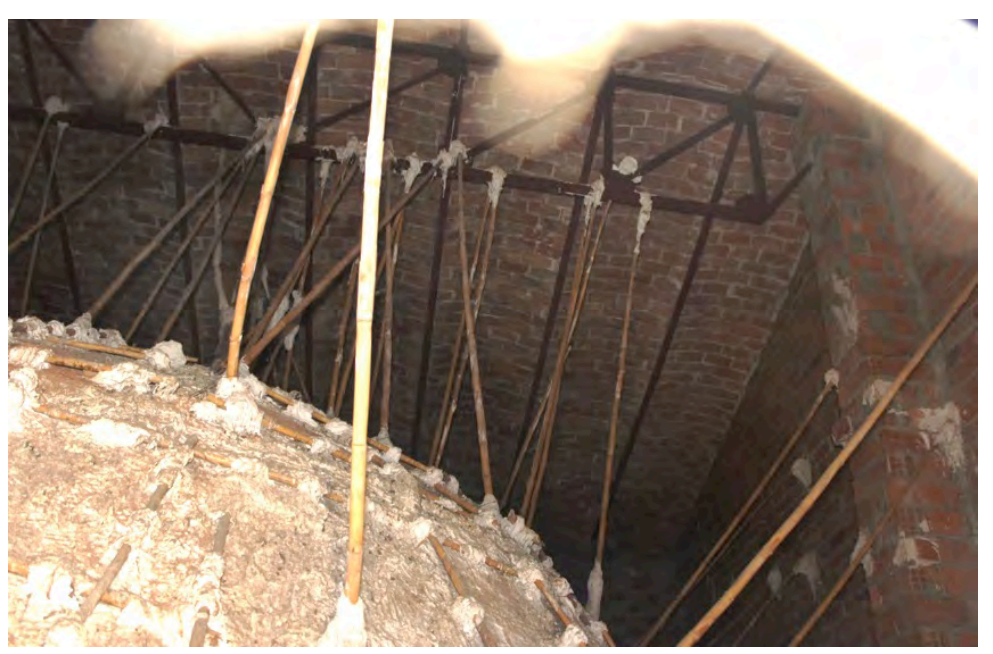

La cúpula elipsoidal cuenta con un soporte de cañizo colgado de una celosía metálica que forma la cumbrera de la cubierta a dos aguas sobre el edificio anejo de comunicaciones. $\quad \mathrm{La}$ estructura de ambos faldones está formada por perfiles metálicos con entrevigado de revoltones de ladrillo.

\section{$21 / 04 / 2015$}

Se accede al bajo cubierta por una puerta metálica desde la terraza de instalaciones. El forjado es un entramado ligero que forma el techo de la sala de exposiciones de planta primera. La estancia sólo alberga conductos de aire acondicionado.

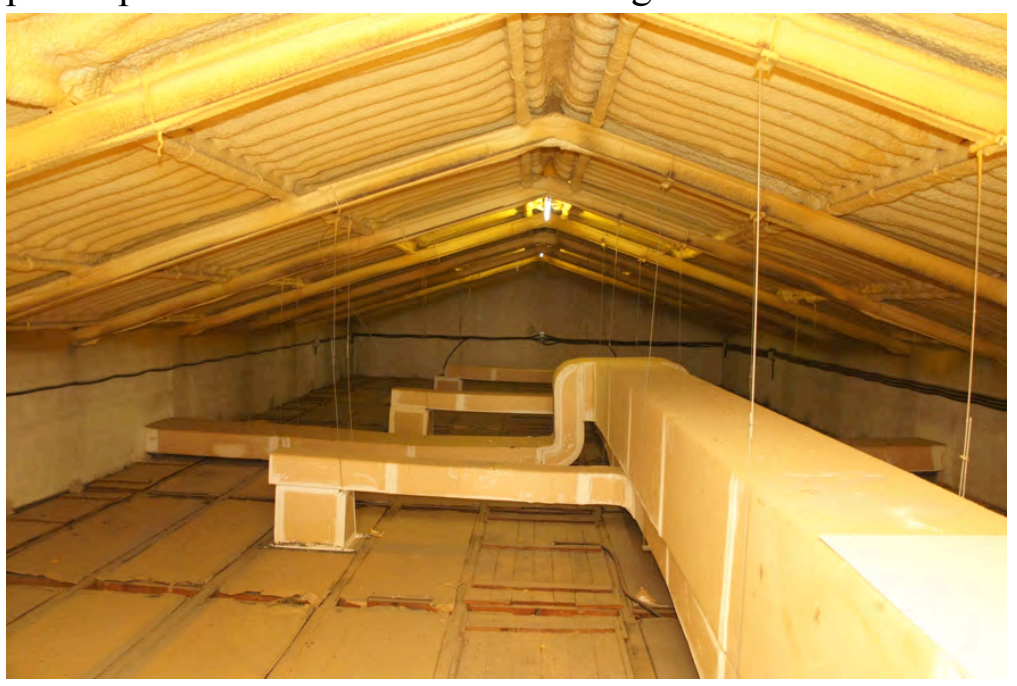




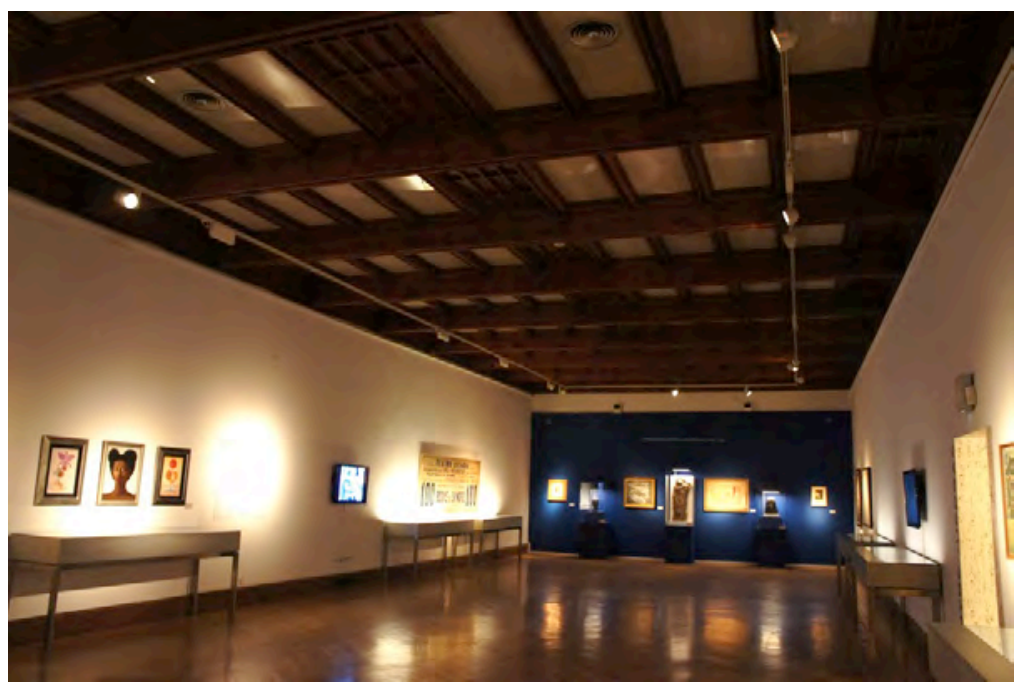

El tablero de cubierta se forma con placas onduladas de fibrocemento, que cuentan con un revestimiento proyectado por el interior.

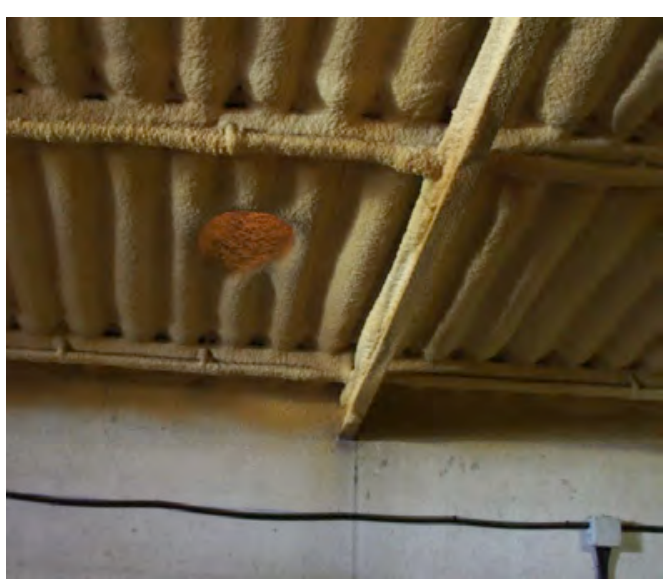

En la fotografía vemos el hueco bajo la chimenea de ventilación y el apoyo de los pares metálicos sobre el muro. No se aprecian los detalles de la solución empleada para el apoyo, si se cuenta o no con un zuncho o pieza de reparto bajo el mismo. El paramento no muestra discontinuidades en esta zona, y tampoco en el tramo descubierto de la terraza.

La solución constructiva de cubierta observada no coincide con la definida en los planos de sección del proyecto de Anselmo Arenillas de 1965 digitalizados en el IPCE. En ellos se representaba cerchas, mientras que la estructura dispuesta cuenta únicamente con pares. Sobre la cúpula elipsoidal de escayola de la antigua sacristía se representaba estructura mixta con cables de acero y hormigón, mientras que la observada en la visita al inmueble es una celosía metálica con cordones paralelos dispuesta en sentido perpendicular, bajo la cumbrera. En los planos se señala un elemento rotulado como "zuncho" a nivel de arranque de la cúpula elipsoidal, pero desde el ventanuco de la cubierta se aprecia que esta estructura es de escayola y cuelga de la celosía anteriormente citada por medio de cañas sujetas con pellones de escayola.

La construcción apreciada en la visita sí coincide con los planos de 1993 con carátula de Gallegos y Salvador conservados en el AMVA. En la sección se representa incluso la doble ventilación descrita, con conductos en ambos muros que se prolongan hasta debajo del solado de planta baja. 



\section{Iglesia de la Asunción en el Convento de Porta Coeli}

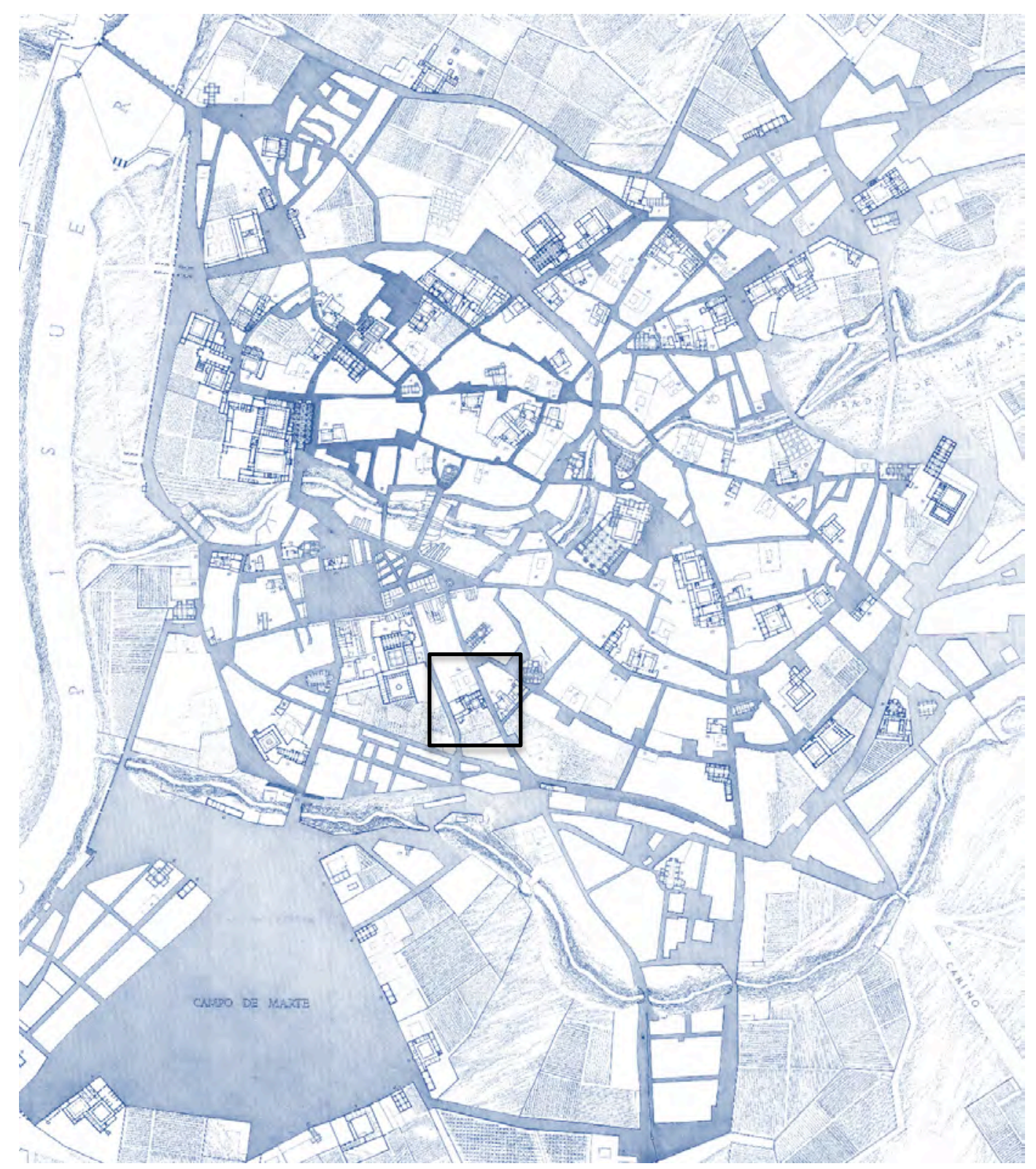



FICHA SÍNTESIS

\section{Código de identificación: FZ-05}

Denominación: $\quad$ Iglesia de la Asunción, Convento de Porta Coeli

Localidad: $\quad$ Valladolid

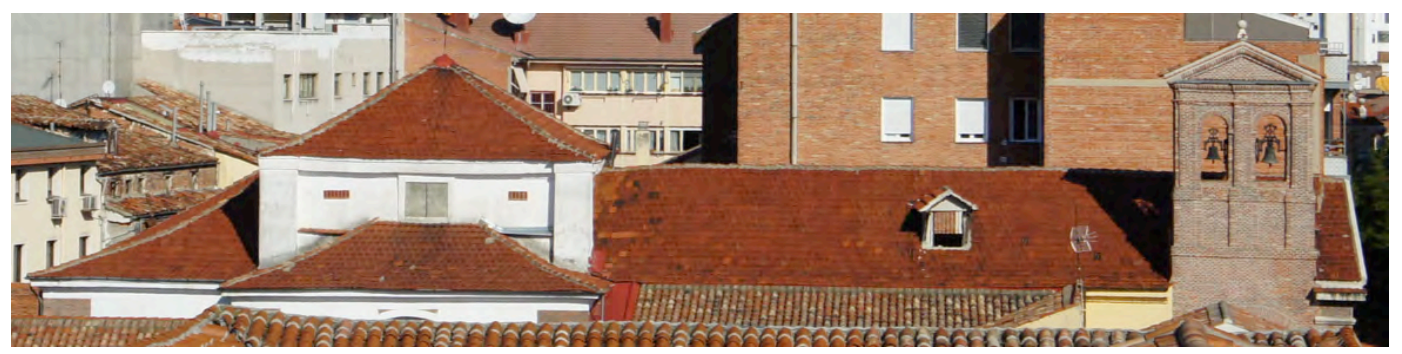

\section{Descripción}

Iglesia de una sola nave cubierta con bóveda de cañón con lunetos y testero plano. En el crucero se dispone una cúpula sobre pechinas.

\section{Materiales}

Los muros, revestidos, son de fábrica de ladrillo y tapial. Las cubiertas se recubren con teja plana.

\section{Singularidades}

La iglesia presenta la portada a los pies como única fachada exterior visible.
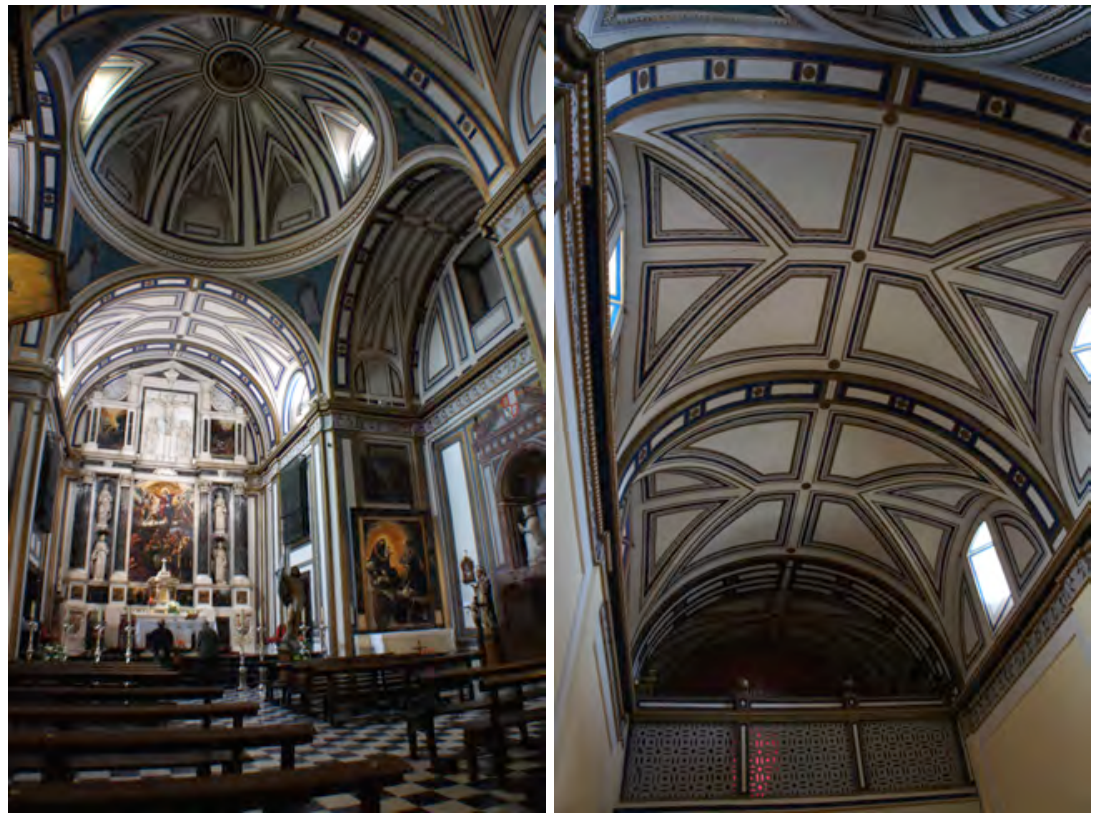

Ilustración 1: interior del templo, visita 03/05/2015 


\section{Dimensiones básicas del templo}

$\begin{array}{llll} & \text { central } & \text { laterales } & \text { capillas } \\ \text { Ancho de nave } & 8,6 & - & - \\ \text { Altura } & 13,7 & - & -\end{array}$

\section{Memoria histórica constructiva}

Según el Catálogo:

La construcción del edificio arranca en 1609 y se decora según trazas de Diego de Praves en 1613.

\section{Cronología. Fechas clave}

$1609-1989$

\section{Intervenciones}

1971 - Memoria de obras urgentes - Felipe Prieto

Se remoza la fachada.

1973 - Obras urgentes - Alberto García Gil

Reparación de armaduras mediante piezas metálicas, sustitución de entablado. Retejo

1989 - Consolidación de cubiertas - Pedro Roldán

Retejo. Reemplazo de tres cerchas de madera por otras equivalentes nuevas de pino apoyadas sobre dados de hormigón en masa $80 \times 50 \times 40 \mathrm{~cm}$ cajeados en el muro. Desmonta y reconstruye una buhardilla.

\section{Planos}

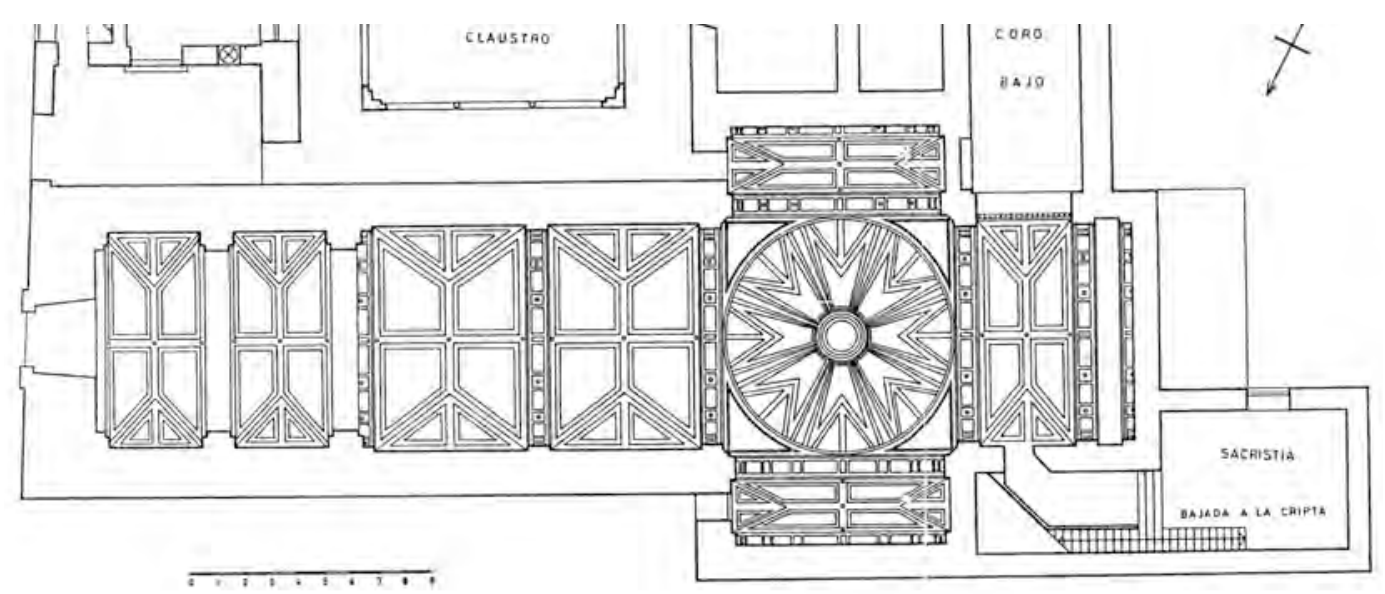

llustración 2: planta del Catálogo 


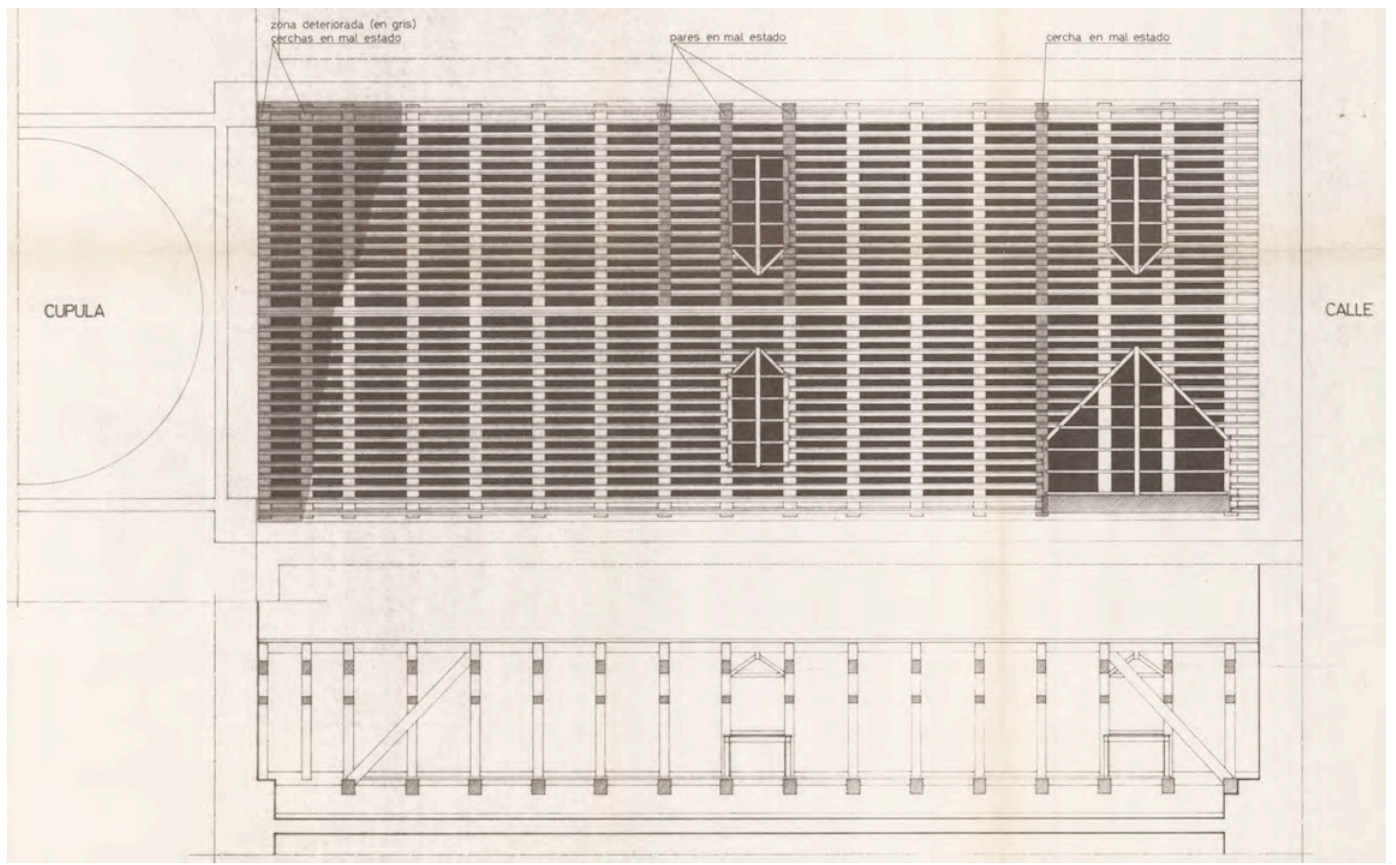

Ilustración 3: planta estructura de cubierta Portaceli actual 1982 Roldán AGA

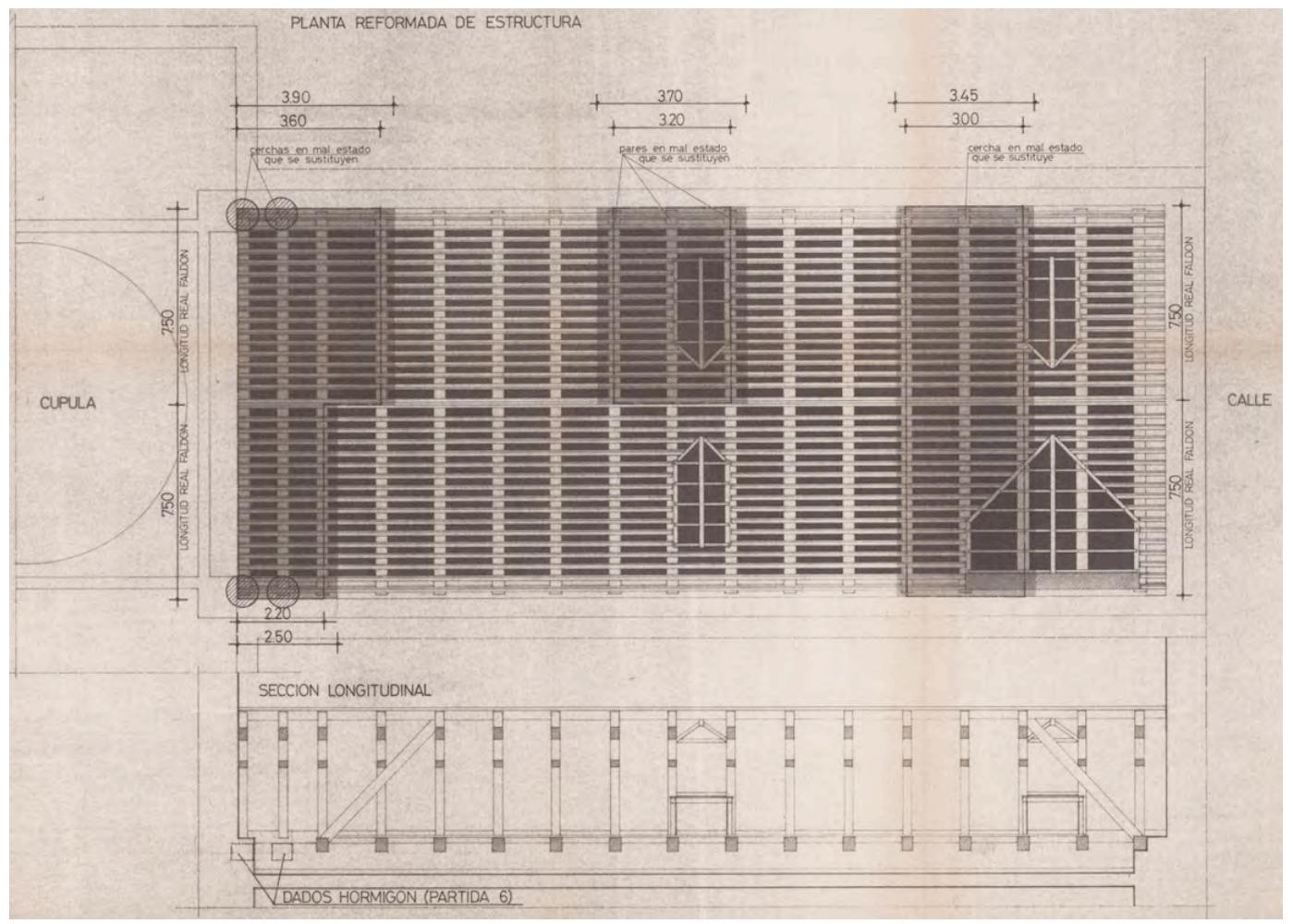

Ilustración 4: planta estructura de cubierta Portaceli reformada 1982 Roldán AGA 

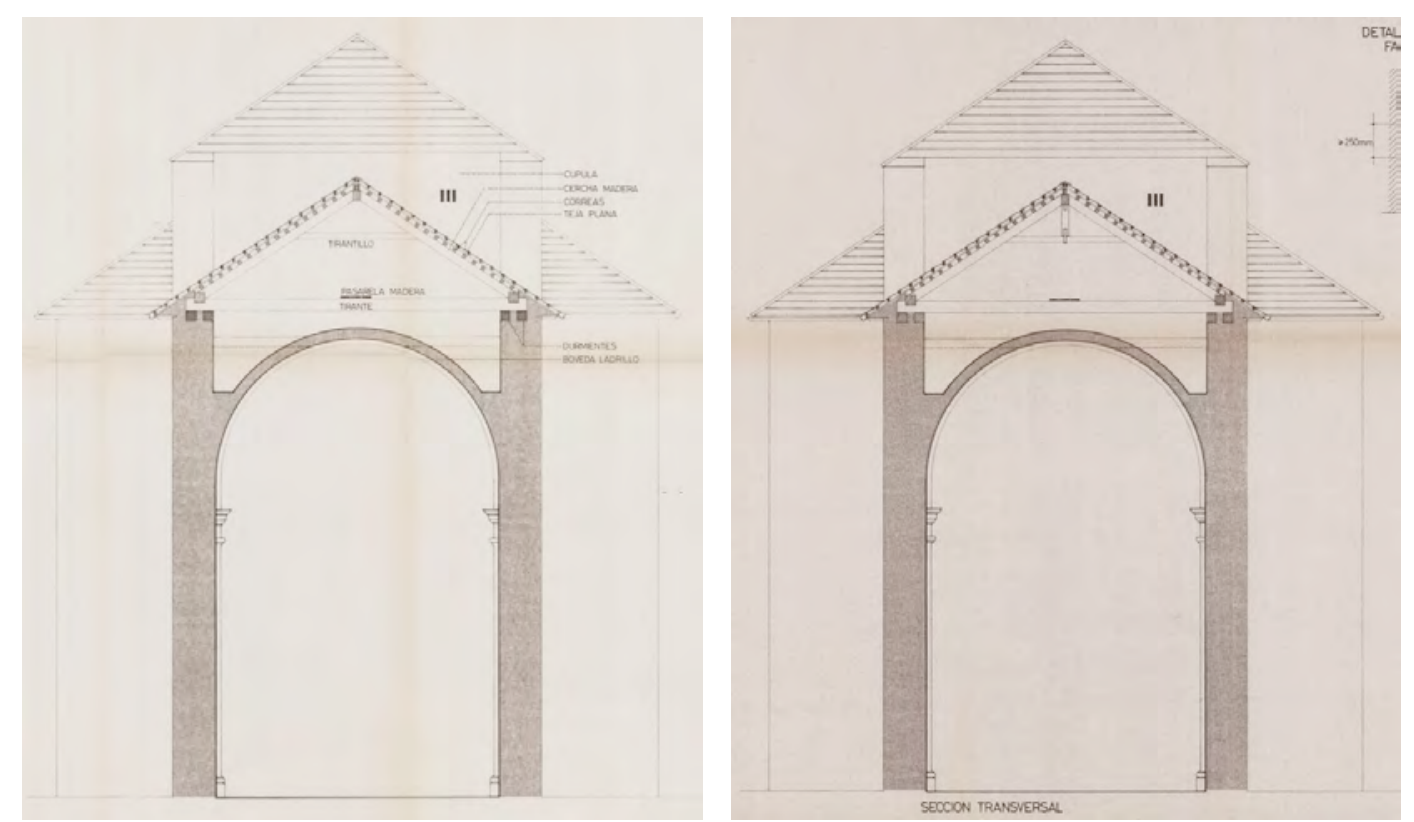

Ilustración 5: sección transversal actual y reformada 1982 Roldán AGA

\section{Solución constructiva de la cubierta}

En las secciones de Roldán de 1989 se aprecia cómo añade un pequeño pendolón hasta el tirantillo a $2 / 3$ de la altura de las cerchas de madera existentes para reforzarlas. Reemplaza varios pares dañados por otros de la misma sección y algunas cerchas completas, disponiendo el apoyo de las nuevas sobre unos dados de hormigón.

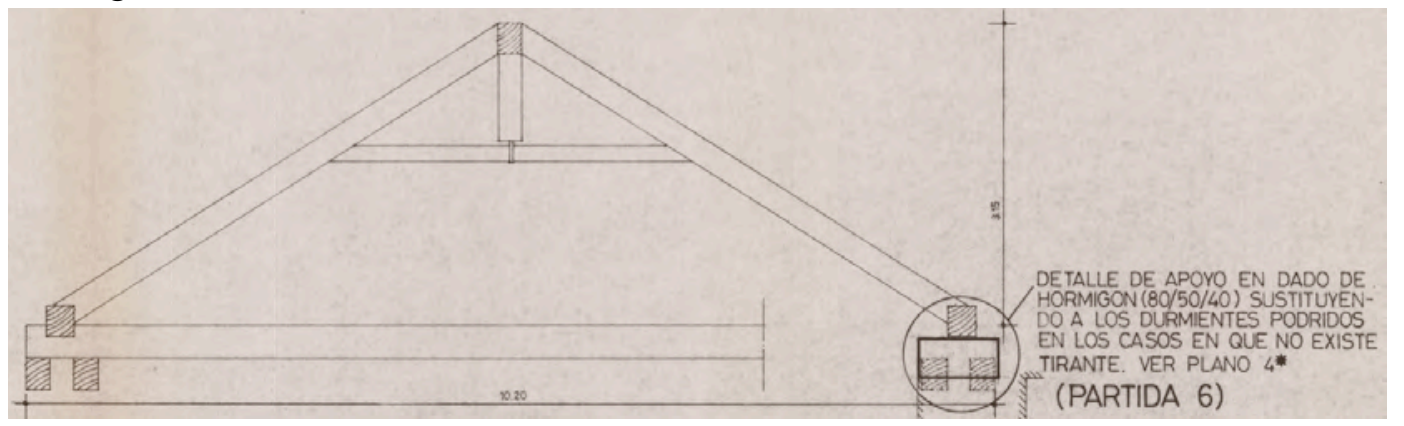

Ilustración 6: detalle cercha 1982 Roldán AGA

La pendiente de los faldones representada en los planos es de unos $33^{\circ}$.

En una de las cajas del AGA el proyecto contiene dos planos marcados como anulados, y en ellos aparece definida una cercha metálica de 10,2m de luz (longitud total a extremos del tirante) y 3,25 de altura compuesta por perfiles tipo PNL pareados. 


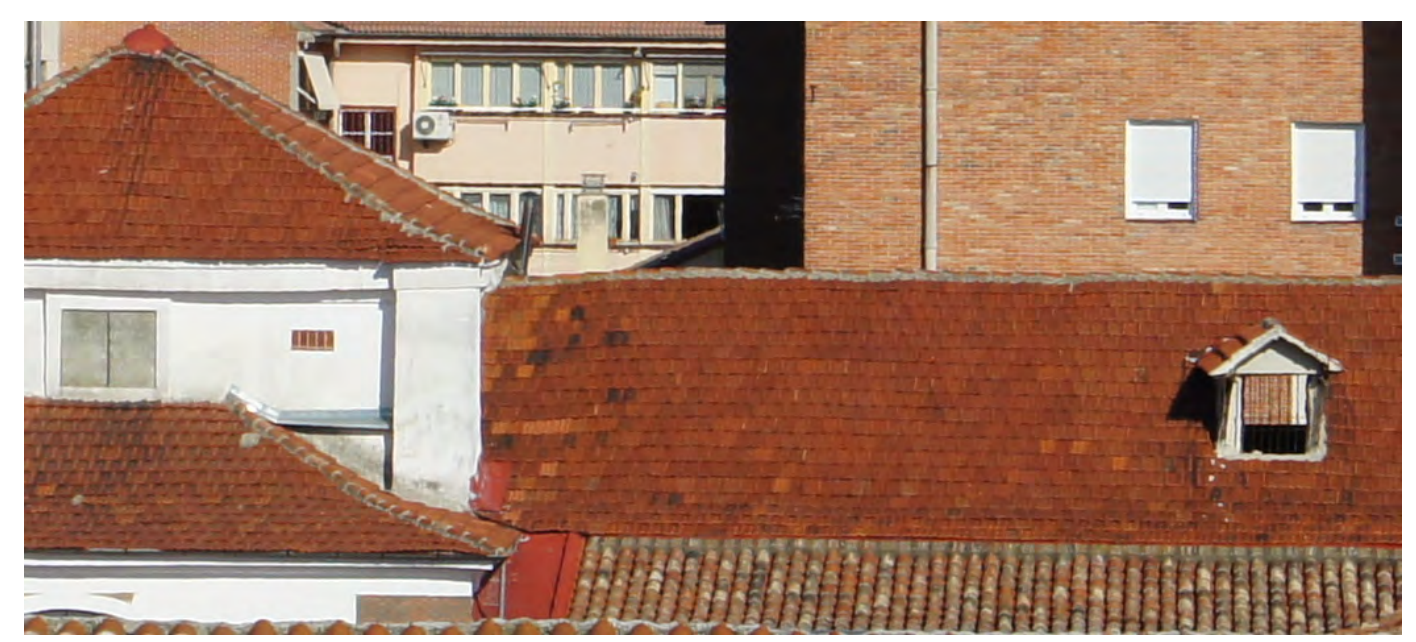

Ilustración 7: vista del encuentro de la cubierta de la nave con el cimborrio, visita 27/09/2015

\section{Zunchos}

En la intervención de 1989 se incorporan algunos dados de hormigón armado $80 \times 50 \times 40 \mathrm{~cm}$ para resolver el apoyo sobre los muros de dos, de las tres cerchas nuevas de madera, que no cuentan con tirante.

\section{Conclusiones}

En este edificio no parece que se haya se incorporado zuncho perimetral, sino algunos dados de hormigón cajeados en el muro de fábrica sobre los que se apoyan dos de las cerchas que se reemplazan en 1989.

La Comunidad no ha permitido acceder al recinto para comprobar el estado de la cubierta en la actualidad. 



\section{Iglesia de la Asunción, del Convento de Porta Coeli}

Intervenciones citadas en la publicación del Ministerio:

1971 - Obras urgentes en la fachada - Felipe Prieto Granda

1973 - Obras urgentes en la cubierta - Alberto García Gil

En la web del IPCE no se ha localizado documentación.

\section{En el Archivo Municipal de Valladolid}

\section{Fondo Histórico}

AMVA: CH 333-105 1893

Expediente de concesión de licencia a Eusebio Calvo Latorre para revocar fachadas del Convento de Religiosas de Nuestra Señora de Porta-Coeli sito en calle Teresa Gil números 26 al 30, accesorio a Duque de la Victoria números 29 y 31. (1 pag)

\section{AMVA: 1049-60 1925-1929}

Licencia concedida al convento de Porta Coeli para hacer las bajantes en las acometidas de la calle de Teresa Gil, aprovechando las obras de alcantarillas y asfaltado de la calle para hacer la acometida de aguas sucias

\section{AMVA: 9091950 Exp. 20/1950}

Convento de las Madres Dominicas de Porta-Coeli (Portaceli - Portacelli). Reforma planta baja para locales de tiendas y vivienda del capellán Proyecto de viviendas del arquitecto Julio González Martín Abre los huecos y quita un forjado intermedio para dejar cuatro amplios locales comerciales, rasga cinco ventanas nuevas en el muro existente de planta alta y redistribuye viviendas.

En otra solicitud proponen incorporar a los locales un tramo destinado a vía pública para comunicar Teresa Gil con Duque de la Victoria.

Escritura de renuncia de la Comunidad a indemnización por posible expropiación para alineamiento de calle.

\section{AMVA: 9381957 Licencia de obras Exp. 90/1957}

Sánchez Ramos, Ángel. Transformación de locales del Convento de Porta Coeli (Portacelli ó Portacaeli) en tienda. 
Planos de plantas y alzados de Confecciones Sanz, proyecto del mismo arquitecto que el expediente anterior Julio Gonzalez.

\section{AMVA: CH 388-304 1860}

Solicitud y concesión de licencia a Sor Juliana Gutiérrez, presidente del Convento de Santa María de Porta Coeli, para revocar parte de la fachada de dicho Convento, en la calle de Teresa Gil.

\section{Fondo Administrativo}

AMVA: 1978 Planeamiento de detalle C.2729-2

Plan Especial de Reforma Interior (PERI) en manzanas 709 y 710, calles Duque de la Victoria, Montero Calvo, Teresa Gil y Regalado para protección del Monasterio de Nuestra Señora de Porta Caeli. Se redacta por acuerdo de Pleno del Ayuntamiento. Contiene planos firmados por el arquitecto municipal Francisco Iturralde Falcón.

Hay edificios comerciales en baja y residenciales en plantas altas, oficinas y redacción e imprenta de un periódico. El Monasterio (cinco mil metros cuadrados de superficie) está en el centro de la manzana. Formado por casa-convento, claustro, iglesia, edificaciones anejas y huertas.

Se iba a crear una calle que afectaba al monasterio, se redacta el PERI para evitalo y preservarlo.

Carta de Sor Ma del Sagrario al Alcalde de 1978. Explica que se les negó la licencia para edificar porque había una calle Rodrigo Calderón proyectada desde hacía muchos años, aunque se oponía a la misma Bellas Artes, las dos instituciones no concordaban. Por eso acuerdan elaborar el PERI tras un montón de diligencias e informes.

AMVA: 391979 Licencia de obras menores C.2249-37

Fernández, María del Sagrario (Reverendas Madres Dominicas de Portaceli . Portacoelli - Portacelli). Licencia de obras. Contiene proyecto Exp. 39 (aparece tachado el 56)

Proyecto de restauración de fachada. Arquitectos Isaías Paredes Sanz y Ángel Ríos Gómez. Junio de 1970.

El muro con huecos anárquicos debe ser de tapial o adobe con entramados de madera, aunque aún no ha hecho calas. Remate de la cornisa con canecillos de madera. Se pretende consolidar el muro, reordenar los huecos, restaurar cornisa y 
canalones, nuevas carpinterías y rejas. Forrar el muro actual con $12 \mathrm{~cm}$ de fábrica de ladrillo macizo de tejar con pilastras hacia el interior, rozando el muro para mantener la alineación existente. Planos de alzados antes y después.

AMVA: 304/1979 Licencia de obras C.2962-1

Reverendas Madres Dominicas de Porta Coeli. Construcción edificio comercial en calle Teresa Gil 20. (Exp. 304/1979) proyecto y reformado del arquitecto Ángel Ríos Gómez.

Bloque de 39x13,3m más un apéndice de escaleras. Es un edificio de oficinas de ladrillo y trasladan el pórtico de ingreso de piedra para aprovecharlo. Las obras no afectan a la iglesia.

\section{AMVA: 14/1981 C.10073-1}

Procedimiento de declaración de ruina en zona de edificio con fachada a calle Teresa Gil. Madres Dominicas de Porta Caeli (Exp. 14/1981) (Incluye fotografías en blanco y negro) Inmueble con fachada de 38,35m y profundidad media de $14 \mathrm{~m}$. (Locales de La cocina moderna, almacenes Sánchez y Calzados el Toro)

Informe del aparejador municipal que disiente. Por eso debieron reformar sólo una parte en 1994.

No afecta a los edificios del convento y la iglesia.

AMVA: 1993 cédula C.27419-3

Cédula Urbanística 0053-6 ; Decreto 2391 ; Sagrario Fernández Campelo (Madres Dominicas del Monasterio de Nuestra Señora de Porta Coeli), calle Teresa Gil, 20

AMVA: 28195/53 1994 Licencia de vallas o andamios.

Calle Teresa Gil, 20. M.M. Dominicas Nuestra Señora de Porta Caeli

AMVA: 2897/1994 Licencia de obras

C.17769-1

Rehabilitación parcial del monasterio Nuestra Señora de Porta Coeli (Exp. 2897/1994)

Caja1) Proyecto de los arquitectos Ignacio y Miguel Paredes Peña y Juan Carlos Rivas San José. Abril 1993

Se recuperan antiguos huecos de balcones en fachada. Es el edificio de calle Teresa Gil, no afecta a la iglesia. Local entre La cocina moderna y una portada de arco apuntado.

Caja 2) Licencia sellada en febrero de 2000. Los mismos planos de 1993.

No afecta a la iglesia, aunque aparece representada en el alzado general. 


\section{En el archivo de la Junta de Castilla y León}

No se ha localizado información relativa

\section{En el Archivo General de la Administración}

AGA 26/00331

1971 - Memoria de obras urgentes en la iglesia del Convento de Portacoeli - Felipe Prieto

La iglesia es de una nave, de la primera mitad del siglo XVII, cubierta con bóveda de cañón con lunetos; los materiales empleados en su construcción son ladrillo y tapial. Tiene crucero cubierto con cúpula sobre pechinas decoradas. posiblemente fue trazada por Diego de Praves.

La fachada es un gran paramento liso. Sobre las jambas de la puerta descansa un frontón partido, con una ornacina...

Incluye dos fotografías blanco y negro de la fachada. No hay presupuesto ni planos, el proyecto sólo indica la cantidad total (cien mil pesetas) para adecentar y limpiar la fachada

\section{AGA 26/00045}

1973 - Memoria de obras urgentes - Alberto García Gil

Solicitud de Juan José Martín González explica al Director General de Bellas Artes que la conservación del edificio está seriamente comprometida, empezando por los tejados. es el momento de acometer una restauración en ellos, pues hecha a tiempo podrá evitar mayores males.

La techumbre es totalmente de madera, como la mayoría de éstos edificios, y presenta serios desperfectos en muchos de sus puntos. Según se aprecia en la fotografia $n^{\circ} 6$ que acompañan al informe, se han realizado en la cubierta obras provisionales de reparación que evitasen la total ruina de la cubierta. A pesar de todas estas obras, el agua penetra en el interior por diversos puntos, dejando manchas de humedad en las bóvedas de la Iglesia y levantando la pintura de las mismas.

Otra de las necesidades de mas urgente resolución que tiene planteada la Iglesia del edificio es la falta de vidrios en varios de sus ventanales... 
con caracter de urgencia, y de modo provisional hasta realizar un proyecto de renovación total de la cubierta, es necesario proceder a la inmediata reparación de la misma; sustituyendo ripia en diversas zonas, consolidando armaduras y efectuando un retejo general.

(En la fotografía $\mathrm{n}^{\mathrm{o}} 6$ del Dossier aparece un tabiquillo de alzado triangular como apeo dispuesto bajo un par de madera.)

Consolidación de armaduras de madera mediante piezas metálicas con sustitución de palos y ripia podrida y atirantado de formas en caso necesario $45 \times 12=540 \mathrm{~m} 2$

AGA 26/01581

1989 - Consolidación de cubiertas - Pedro Roldán Morales

Documentación administrativa

Recepción definitiva febrero de 1989. Construcción y mantenimiento de edificaciones SA

$112,50 \mathrm{~m} 2$ desmantelamiento cubierta de teja

1ud demolición de buhardilla

3ud desmonta, carga y transporte a vertedero de cerchas de madera actuales, en mal estado

4 ud dado de hormigón en masa de $\mathrm{H}=150 \mathrm{kp} / \mathrm{cm} 2$ de $0,80 \times 0,50 \times 0,40 \mathrm{~m}$ i/asentado y recibido de placa de palastro de $8 \mathrm{~mm}$ de espesor y $0,50 \mathrm{x} 0,30$ con cuatro patillas D14 totalmente terminada para asentamiento de cerchas de madera, i/cajeado en muro existente

3 ud cercha de madera formada por pares de madera de pino de $28 \times 25 \mathrm{~cm}$. tirante de $30 \times 35 \mathrm{~cm}$ y tirantillo de $15 \times 15$, ensamblado, según detalle totalmente colocado, para una luz de $10,20 \mathrm{~m}$ y clave de $3,25 \mathrm{~m}$.

$28,70 \mathrm{ml}$ correa de madera de pino de $25 \times 20 \mathrm{~cm}$ en parte superior de cercha, colocada según detalle.

\section{AGA 26/01815}

Documentación administrativa, honorarios, pagos.

Recepción definitiva febrero 1989.

Memoria de obras ejecutadas (F.P. Roldán 1984)

Desmantelamiento de la cubierta en aquellas zonas donde la estructura se encontraba en mal estado, tal como pares, correas, buhardilla, todo ello de acuerdo con plano $\mathrm{n}^{\circ} 4$ Demolición de buhardilla con recuperación de teja y carpintería exterior 
Dados de hormigón para asiento de cercha

Reposición de tres cerchas de madera y tres pares del mismo material, así como correas en pino

Reposición de buhardilla y pendolones de madera

Formación de cubierta con tabla machihembrada y colocación de teja

Reparación de canalón de cinz y remate de faldón con torreón central

Revoco, pintura y varios

Proyecto de consolidación de cubiertas en el monasterio. 1982

Fotocopia de fotografía encuentro faldón de nave cubierta de teja plana con cimborrio, semi-hundido.

Memoria

Efectuado un reconocimiento de la cubierta se ha podido observar que el trazado de su estructura responde a cerchas formadas por pares, tirantes u durmientes todo ello combinado con un falso tirante situado aproximadamente a $2 / 3$ de su altura (Ver plano 3).

Se ha podido observar la existencia de una zona próxima al cuerpo de la cúpula del crucero, en la que el deterioro de la cubierta es importante, ya que los pares del entramado estructural han cedido como consecuencia de que los durmientes de ambos lados están totalmente podridos por la humedad, a que han debido de estar sometidos durante años, esto se puede apreciar perfectamente en la fotografía de estado actual que se acompaña.

Por otra parte existen tambien varios pares, así como una cercha completa en mal estado que hacen necesaria su total sustitución.

Finalmente partes del entablado se encuentran en malas condiciones por la entrada de agua de lluvia ocasionada por la precaria colocación de la teja plana en grandes zonas.

En general se puede decir que la estructura de madera está en buenas condiciones a excepción de los defectos señalados... La solución que se propone consiste por tanto en la sustitución de las dos cerchas de madera más próximas a la cúpula por una de madera sobre unos apoyos o dados de hormigón, solucionando a la vez el encuentro de los faldones con el muro vertical a base de un babero de zinc que proteja la unión. Los tres pares del lateral derecho que se encuentran en mal estado (flechados y podridos) se sustituyen por otros de la misma sección, reconstruyendo la buhardilla que al estar estructurada encima de ellos se encuentra en mal estado lo que provoca la entrada de agua. 


\section{Descripción}

...La media naranja presenta corona de lunetos, para apertura de ventanas con todo lo cual resulta esta iglesia muy luminosa.

Planos (se solicita copia)

Planta de estructura de cubierta de la nave en estado actual 1/50

Sección actual 1/50. (Medidas: luz $17 \mathrm{~m}$ en el bajo cubierta, 16,8m en nave, pendiente $33^{\circ}$, altura unos $27 \mathrm{~m}$ )

Sección reformado: añade un pendolón al tirantillo.

Hay dos planos anulados, planta 4 y sección 5 a los que sustituyen los anteriores BIS. En ellos aparece una cercha metálica, de 10,20m de luz y 3,25 de flecha, con pares de perfiles PNL. 

Iglesia de la Cofradía de Nuestra Señora de las Angustias

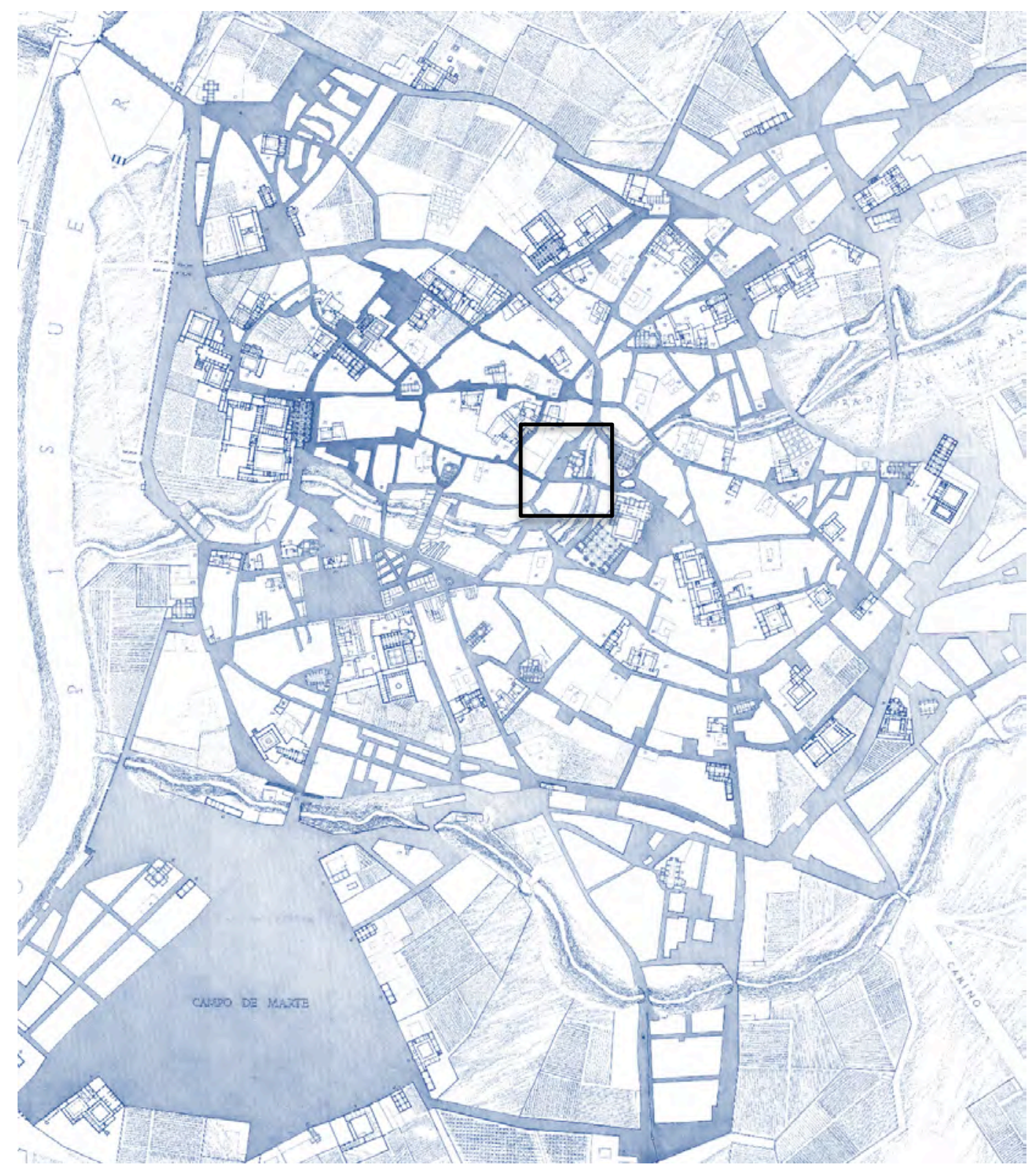





\section{FICHA SÍNTESIS}

\section{Código de identificación: FZ-06}

Denominación:

Iglesia de Nuestra Señora de las Angustias

Localidad: Valladolid

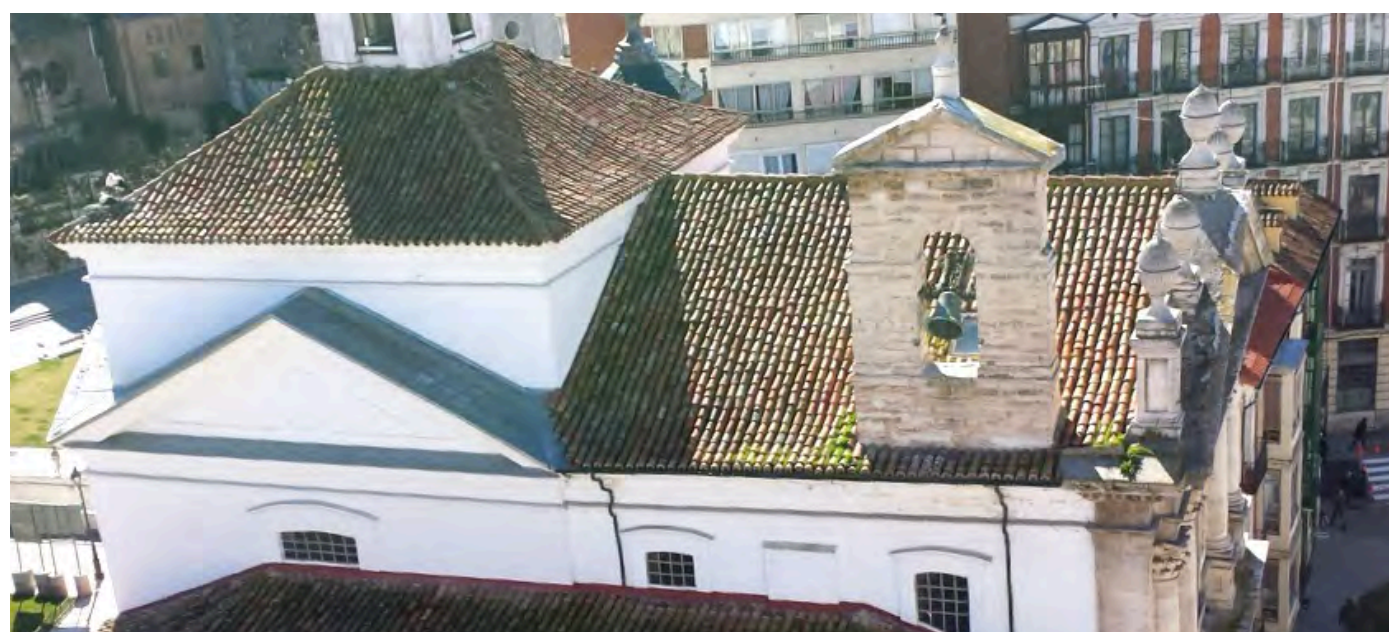

\section{Descripción}

Iglesia penitencial de estilo clasicista, con una sola nave y capillas hornacinas. Cuenta con dos tramos cubiertos mediante bóveda de cañón y un espacio centralizado bajo cúpula sobre pechinas, sin tambor. Estos espacios se concatenan con una capilla octogonal, con cúpula de cascos rematada con un linternón, y un camarín barrocos. Junto al cuerpo del templo se adosa un volumen prismático que alberga la sala del Cabildo.

\section{Materiales}

La fachada es de piedra caliza y el resto de muros de fábrica de ladrillo enfoscada y pintada. Las cubiertas están revestidas de teja curva, el linternón con pizarra.

\section{Singularidades}

Los volúmenes adosados a la nave original configuran una interesante construcción escalonada a modo de racimo: templo, dos capillas, camarín, sacristía triangular y sala del cabildo. 

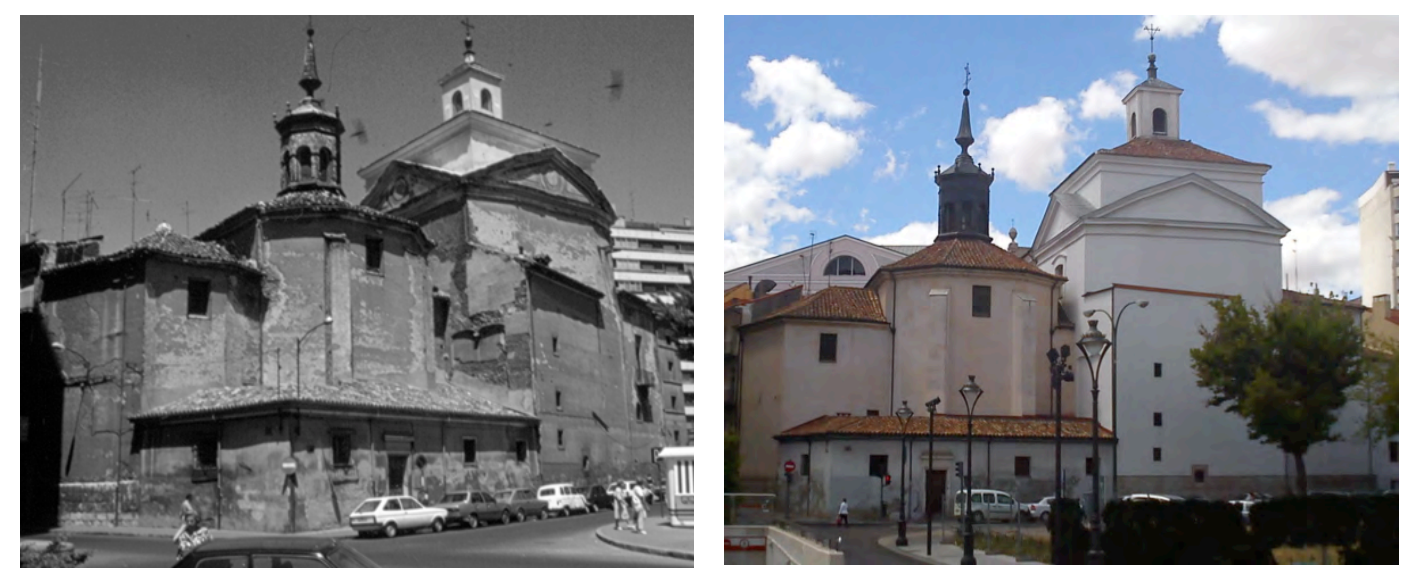

Ilustración 1: fotografía antigua dossier Mata y vista actual

\section{Dimensiones básicas del templo}

$\begin{array}{llll} & \text { central } & \text { laterales } & \text { capillas } \\ \text { Ancho de nave } & 8,8 & - & 1,7 \\ \text { Altura } & 16,9 & - & \end{array}$

\section{Memoria histórica constructiva}

El monumento arranca en 1579 y es obra del arquitecto Juan de Nates, que da las trazas y dirige la obra hasta el final. La construcción es generosamente financiada y organizada por el benefactor Sánchez de Aranzamendi, por lo que se termina el cuerpo principal en 1604, tras sólo 25 años de obra.

Según el Catálogo Monumental, brotó abundante agua que hubo que achicar durante la excavación de los cimientos, problema lógico dada la cercanía al cauce del Esgueva. La bóveda es ejecutada por el Bartolomé de la Calzada. Hacia 1710 se realiza la ampliación barroca de capilla y camarín, sacristía y vivienda del párroco.

\section{Cronología. Fechas clave}

$1579-1710-1982-1991$

\section{Intervenciones}

1970 - Obras urgentes: saneamiento de cubiertas - Juan José Martín González 
1982 - Obras generales - Diego Pérez Medina, Agustín Bustamante y Teresa Pérez. Según la memoria del proyecto, se realiza la sustitución de cornisa y alero de piezas de madera del edificio anejo del Cabildo por "una viga única de hormigón armado imitando piedra caliza que sirve para zunchar las cabezas de los pilares y apoyar las vigas de planta $2^{a}$ restauradas con el sistema Beta". Se renuevan teja y tablazón, así como las correas excepto las de nave central, de más escuadría, que se reparan con prótesis Beta. Sustituye la buhardilla de acceso por una ventana lucernario.

1991 - Restauración - Salvador Mata Pérez.

Demolición de la cornisa-zuncho de hormigón armado incorporada en la intervención anterior al edificio del Cabildo, anejo al cuerpo del templo, y reemplazo por elementos de ladrillo. Aunque el proyecto recoge la demolición de la caja de escaleras adosada al citado edificio y su reubicación por el interior del mismo, no llega a ejecutarse esta actuación. Tampoco la eliminación de un cuerpo triangular tras el altar.

En otros puntos del edificio se extraen durmientes de madera para colocar zunchos de hormigón.

\section{Planos}

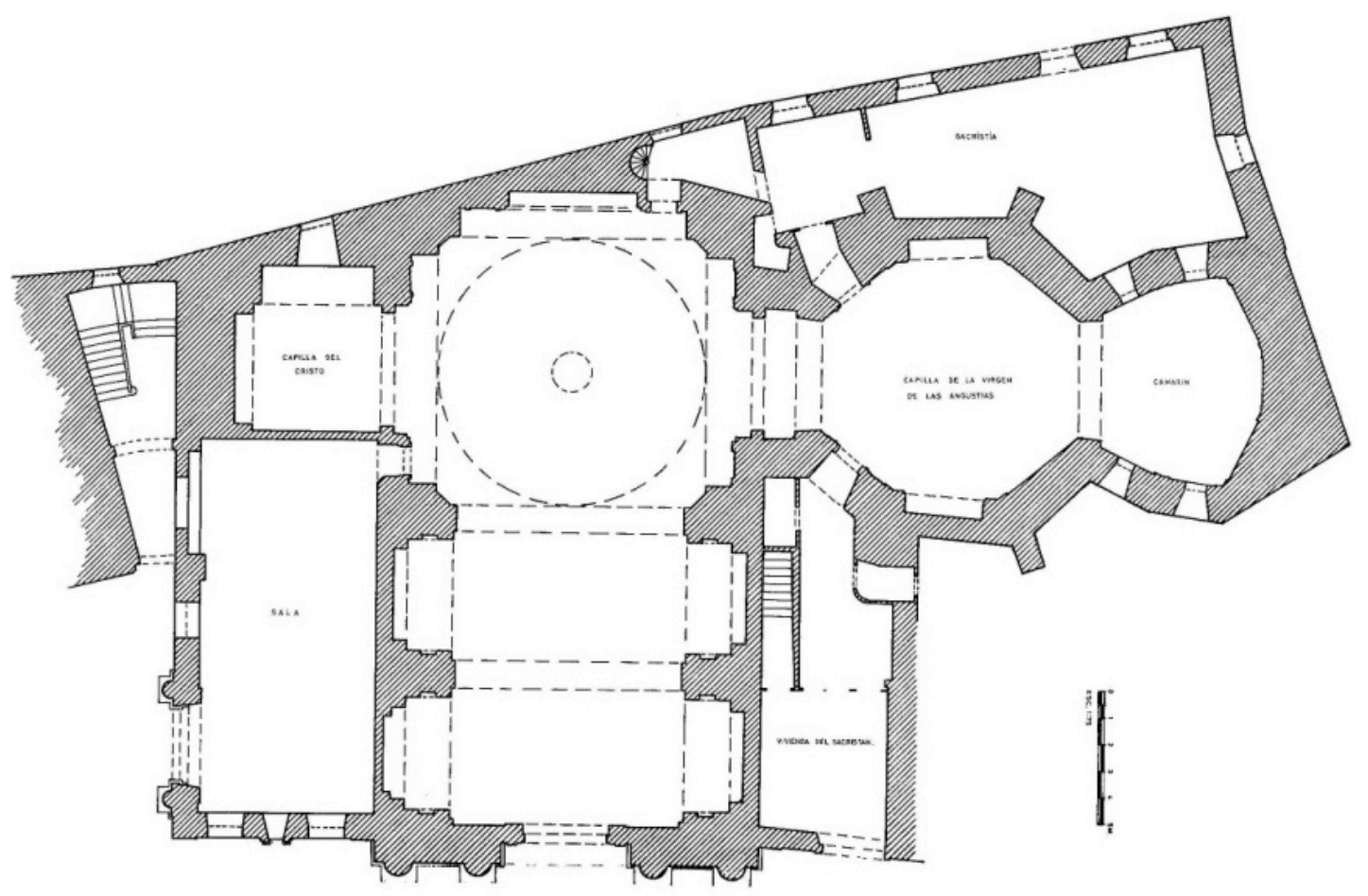




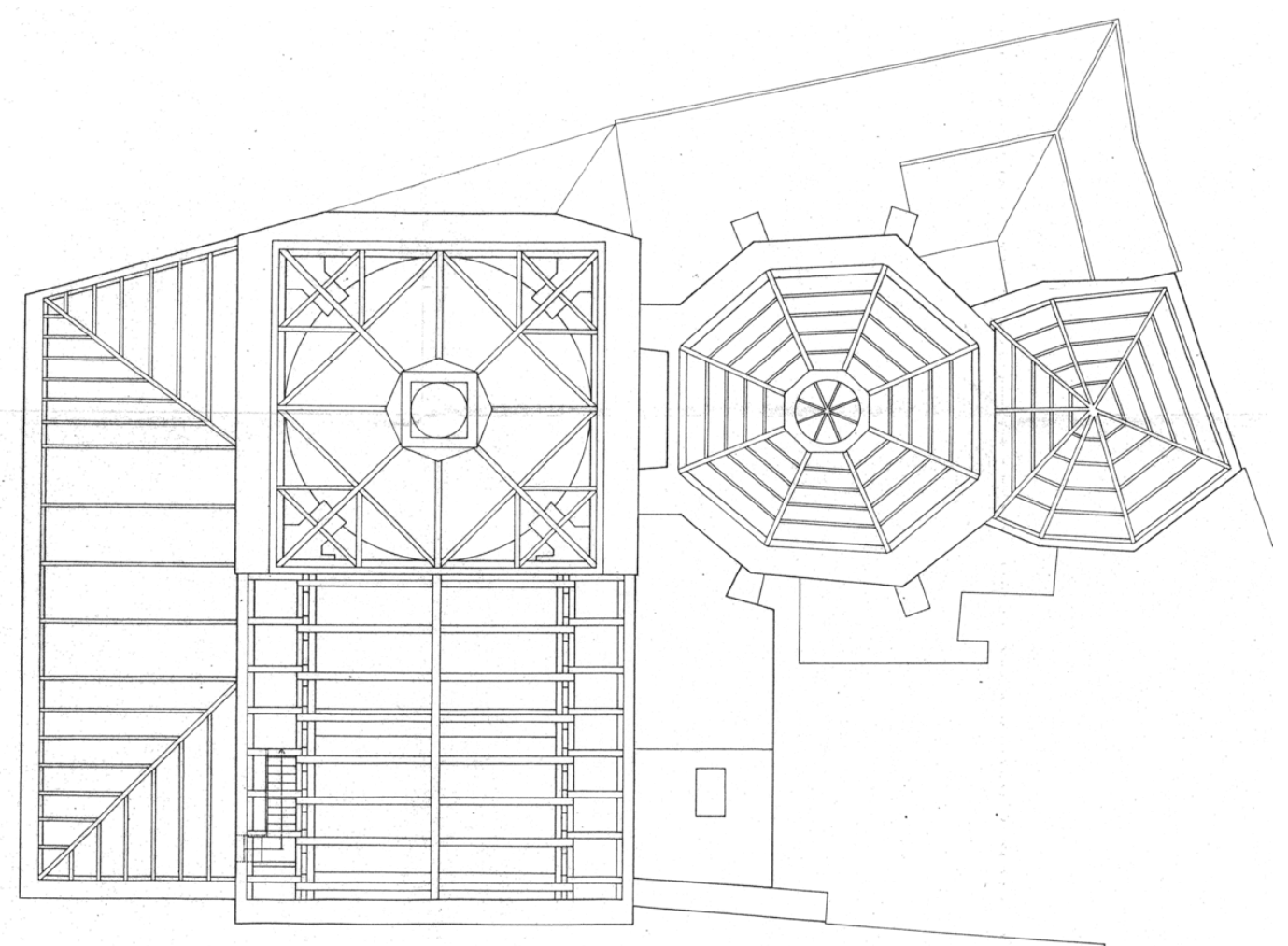

Ilustración 3: planta de estructura de cubierta (1991 Mata)

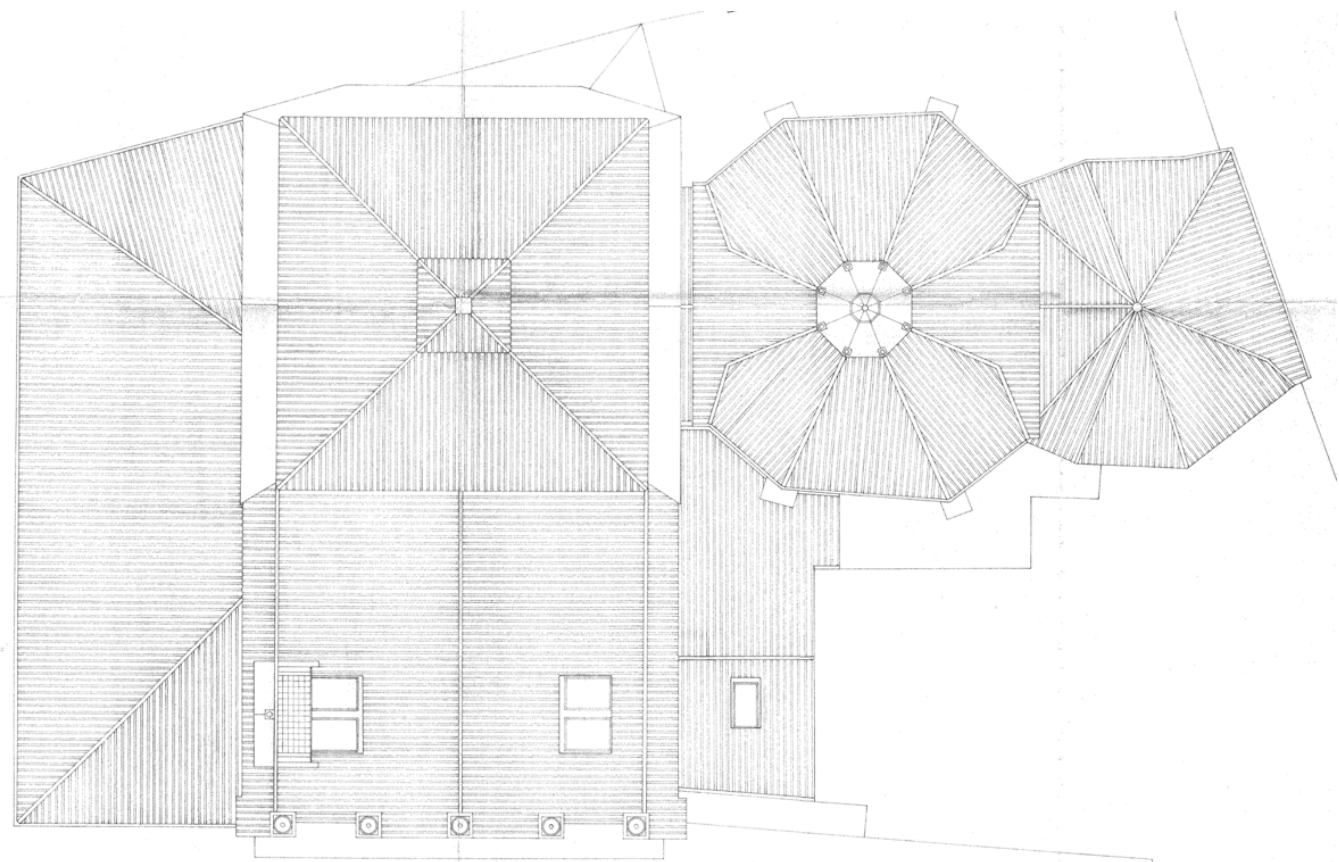

Ilustración 4: planta de cubiertas (1991 Mata) 


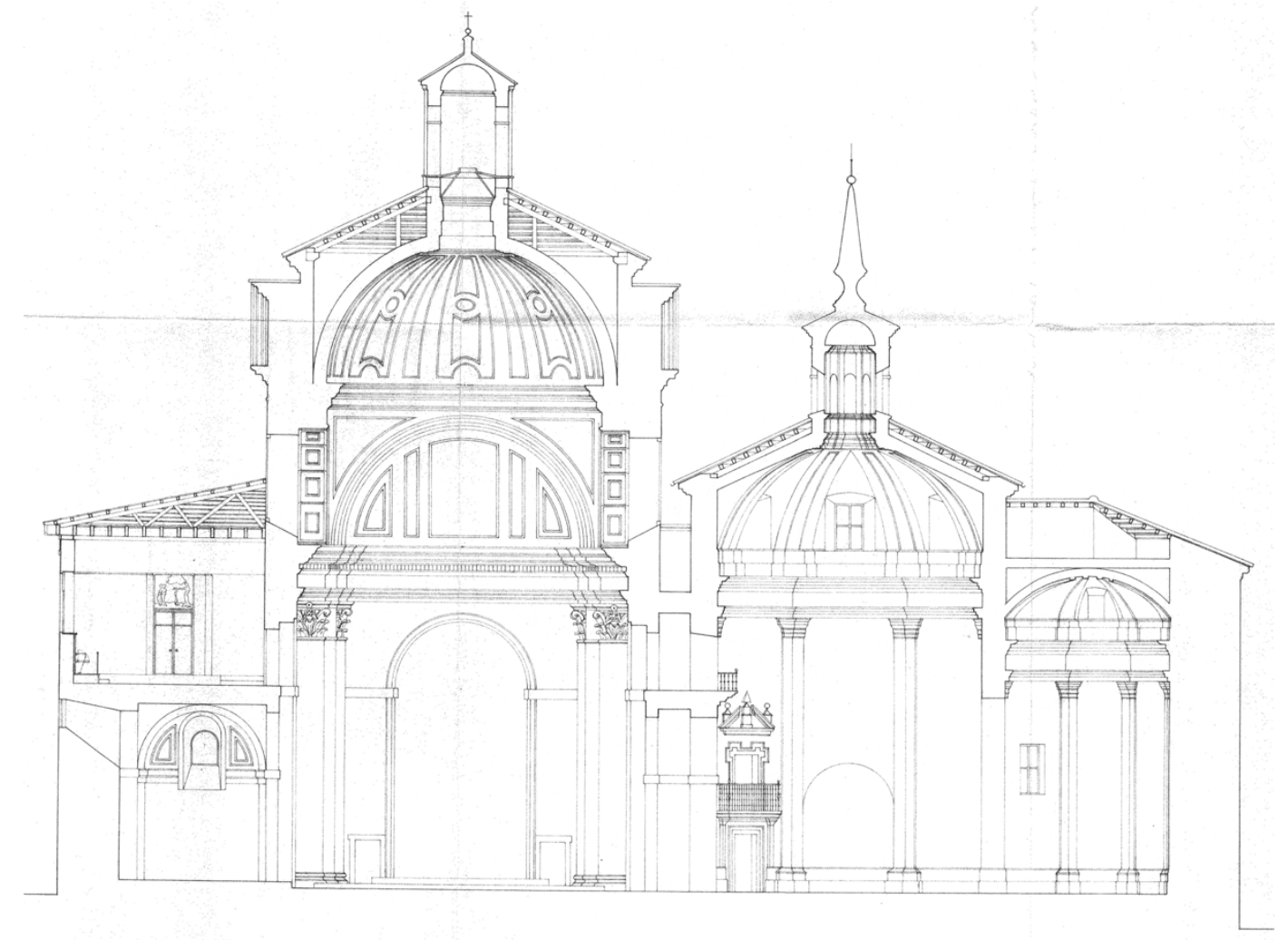

Ilustración 5: sección transversal del templo por crucero, capilla y camarín (1991 Mata)

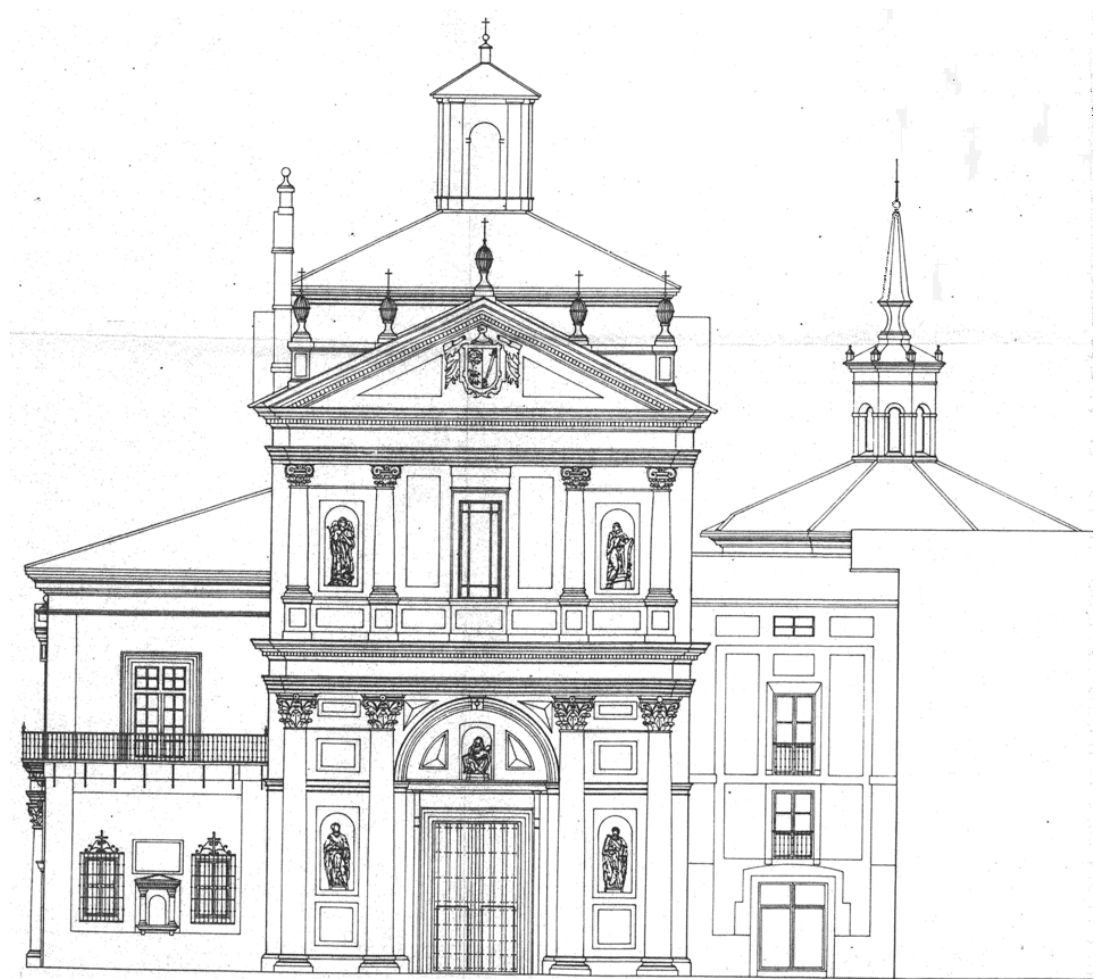

Ilustración 6: alzado principal (1991 Mata) 


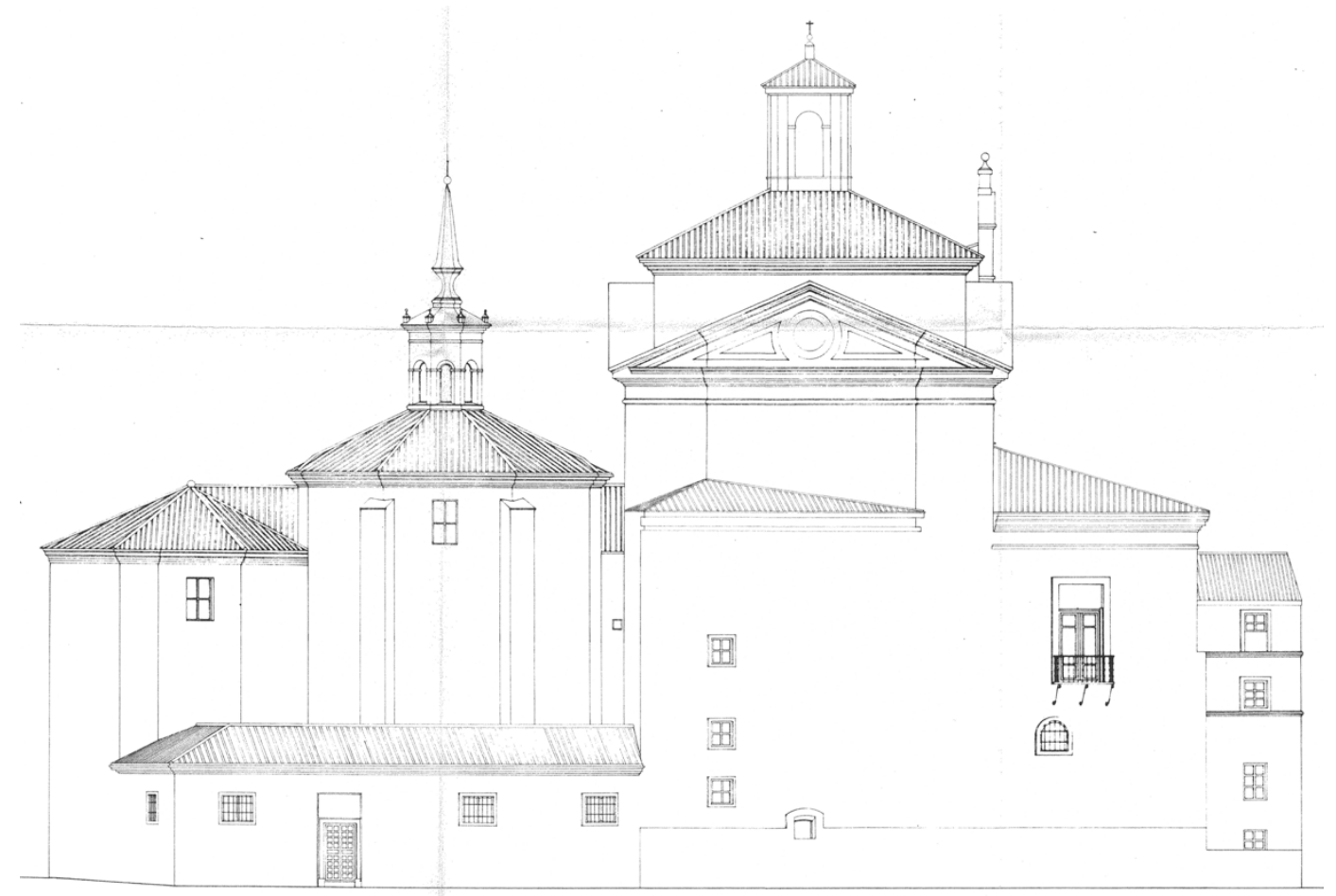

Ilustración 7: alzado posterior (1991 Mata)

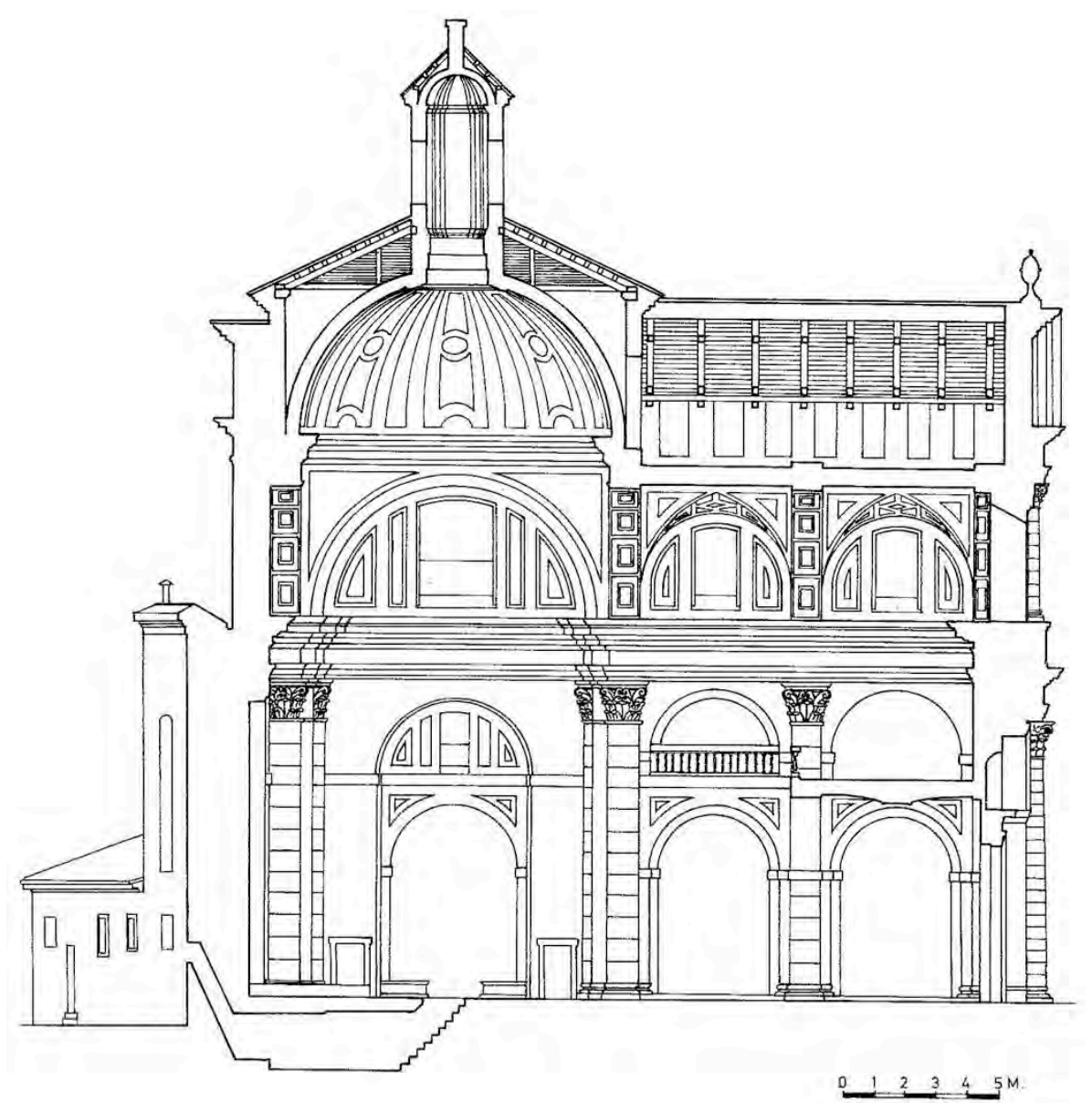

Ilustración 8: sección longitudinal del cuerpo del templo (Catálogo) 
Nueva estructura de cubierta del camarín radial en madera aserrada con pendolón central circular y tirantes metálicos embridados.

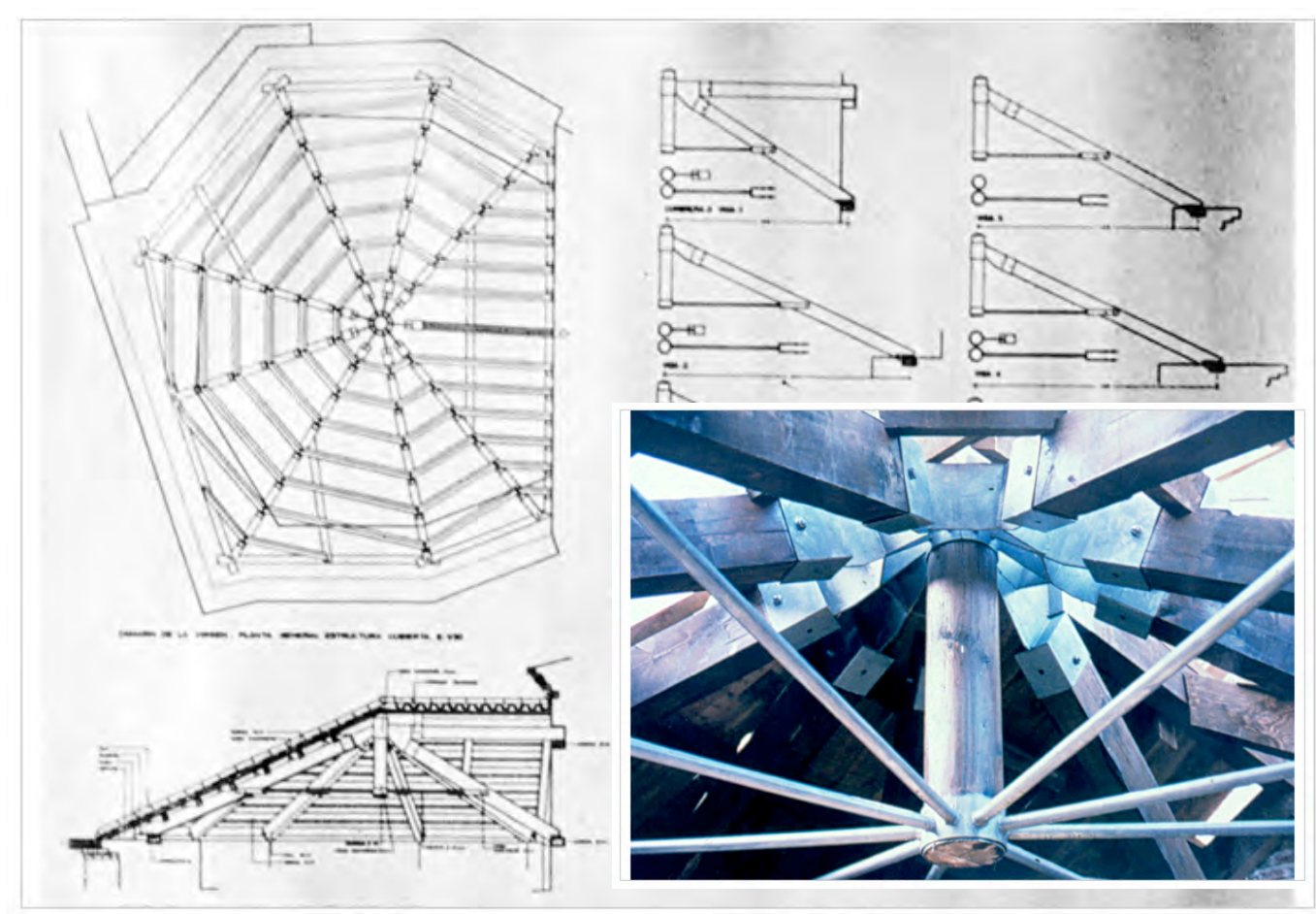

Ilustración 9: cubierta del camarín (1991 Mata)

\section{Solución constructiva de la cubierta}

Cada espacio presenta una configuración de estructura diferente en su cubierta:

\section{Cabildo}

En 1987 se cambiaron correas y tablero, reforzando los empalmes de los cuchillos existentes de madera con pletinas y bridas. Se ejecutó un zuncho-cornisa de hormigón armado con un vuelo de $92 \mathrm{~cm}$.

En 1992 se descubre que la solución anterior muestra un importante problema, oculto hasta entonces por el falso techo entablado: con $7 \mathrm{~m}$ de luz, las cerchas presentaban flechas de mas de $15 \mathrm{~cm}$, empotradas en el zuncho, retorcidas, y con más de medio metro de desnivel. Se demuele el zuncho y coloca una nueva estructura de madera, formada por cerchas con empalmes embridados y un tirantillo central D18 que apoya sobre carreras durmientes de madera. Se revisten los faldones a tres aguas con tablero y onduline bajo teja sobre correas $15 \times 19$. En los planos podemos medir $14^{\circ}$ de pendiente.

\section{Capilla y camarín}

Ambos espacios se cubren con estructuras radiales. 
Nave de la iglesia

Sólo en el proyecto íntegro de Pérez Medina de 1982 conservado en los archivos General de la Administración y del Cabildo encontramos secciones por el cuerpo de la nave. En los demás documentos se incluye solo el corte por el eje de la cúpula que describe el escalonamiento de capilla y camarín.

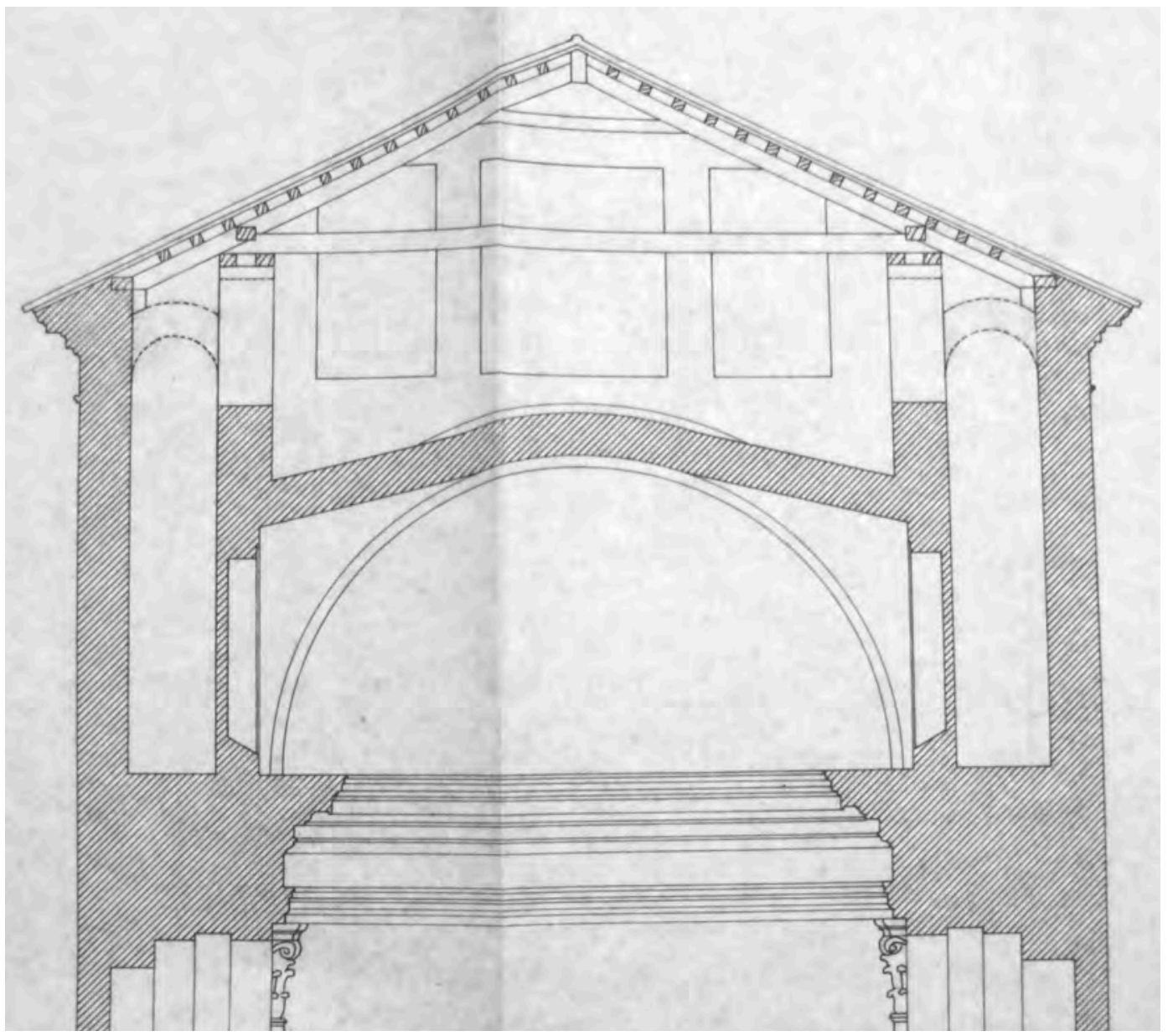

Ilustración 10: sección transversal (1982 Pérez Medina)

Según este plano y las dos fotografías siguientes, incorporadas al dossier del mismo arquitecto, la altura superior del cuerpo del templo se resuelve con los muros desdoblados en doble hoja con cámara.

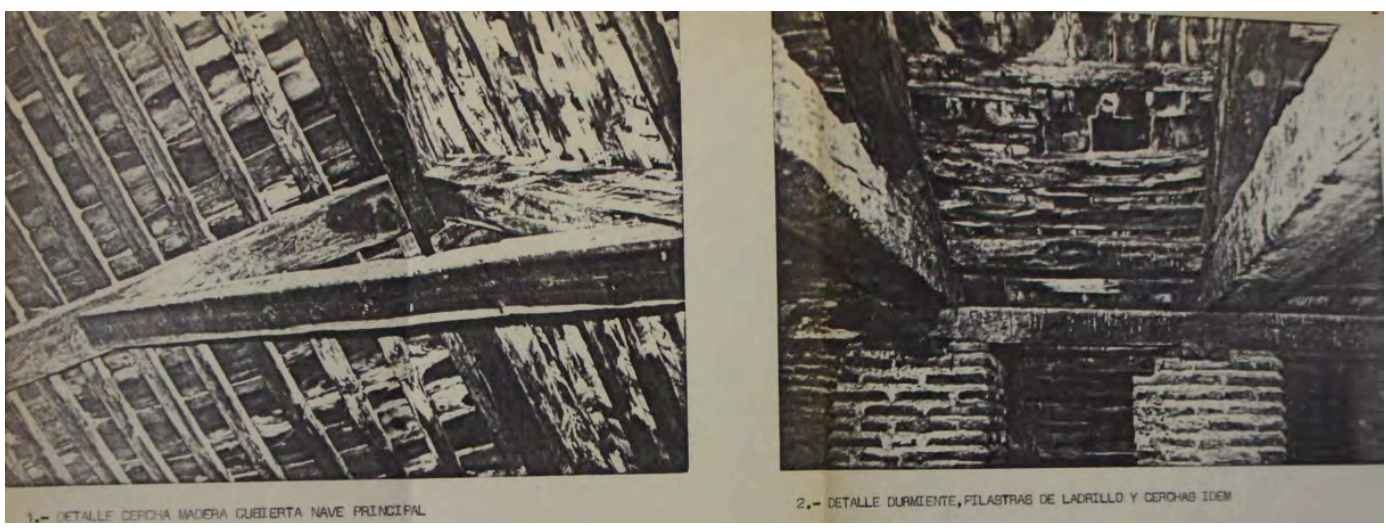

Ilustración 11: detalles cerchas 1982 dossier Pérez Medina 
Aunque no se ha podido acceder al espacio bajo cubierta, estos datos concuerdan con las secciones longitudinales del templo de la última intervención en 1991. Cada cercha apoya, a través de un doble durmiente de madera, en unos esbeltos machones de fábrica de ladrillo.

\section{Zunchos}

En la cubierta del edificio del Cabildo anejo al cuerpo del templo se ejecutó un zuncho-cornisa de hormigón armado en 1984 para reemplazar el alero existente de madera. Este elemento fue demolido en 1992 y se colocó una cornisa de fábrica de ladrillo revestido.
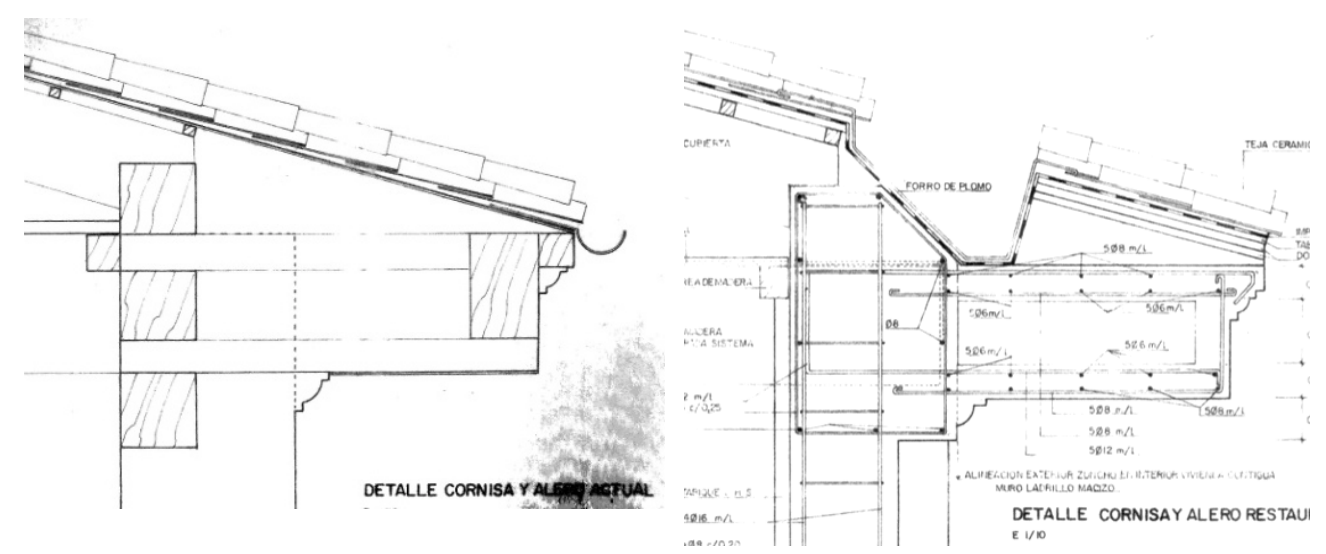

Ilustración 12: alero antes y después de la intervención de Pérez Medina en 1984 (JCyL)

En la cubierta del camarín barroco, el durmiente perimetral de madera semiencastrado en el remate de la fábrica configura un anillo octogonal. Este elemento fue reemplazado por otro similar de madera vieja, pero sana, procedente de derribo.
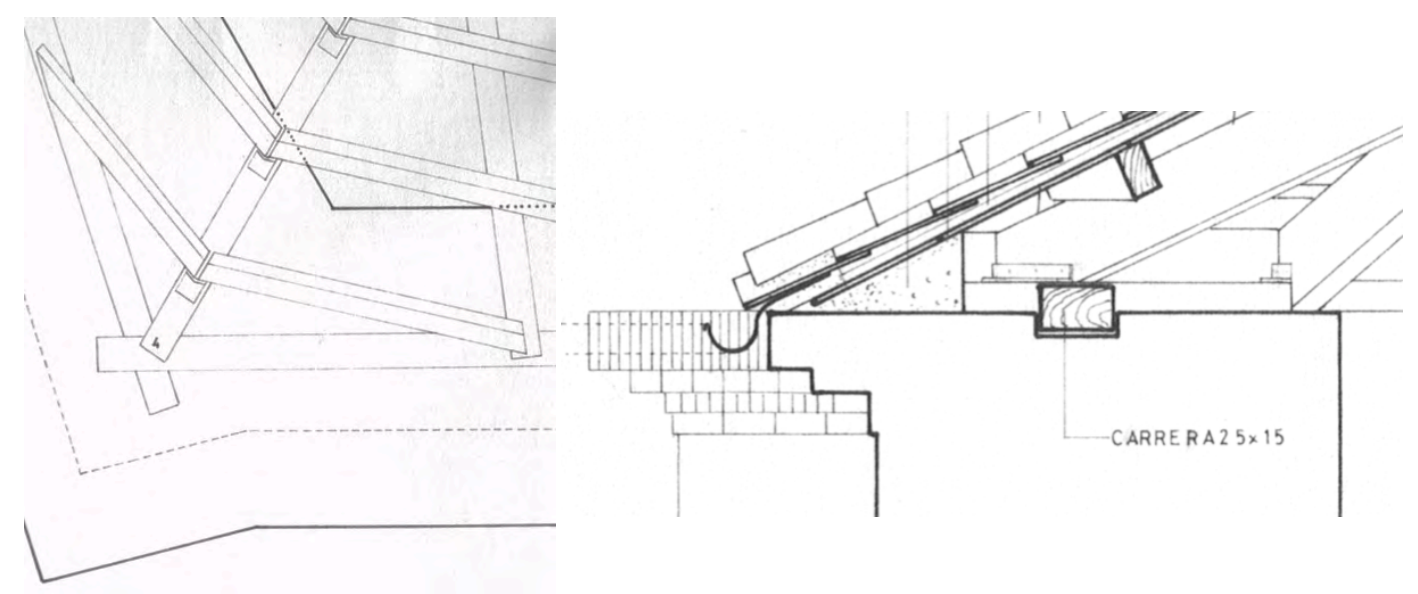

Ilustración 13: detalles durmiente camarín 1991 Mata JCyL 


\section{Conclusiones}

Según la documentación analizada, no se ha incorporado zunchos en la coronación del cuerpo de la iglesia, aunque ha sido imposible confirmar este extremo por no haber conseguido acceder al espacio bajo cubierta de la nave central del templo.

En un volumen anejo a la iglesia, correspondiente al Cabildo de la Cofradía, se incorporó en 1982 un atípico zuncho perimetral conformado con la sección de la cornisa que, según la Memoria del proyecto de intervención más reciente, sufrió deformaciones intolerables con más de $15 \mathrm{~cm}$ de flecha y $50 \mathrm{~cm}$ de desnivel. Este elemento fue demolido a los diez años y se reemplazó por una cornisa de ladrillo.

Al sustituir la cubierta del camarín barroco por una nueva estructura de madera, con diseño diferente pero inspirado en el original con pendolón central, se repuso en 1991, con madera sana, un durmiente perimetral de escuadrías semi-encastradas en la coronación de los muros y empalmadas formando un octógono. 


\section{Iglesia de Nuestra Señora de las Angustias}

Intervenciones citadas en la publicación del Ministerio:

1970 - Obras urgentes: saneamiento cubiertas - Juan José Martín González

1982 - Obras generales - Diego Pérez Medina, Agustín Bustamante y Teresa Pérez

No se ha localizado documentación en la web del IPCE.

\section{En el Archivo General de la Administración}

AGA 26/00183

1970 - Obras urgentes: saneamiento de cubiertas - Juan José Martín González

El arquitecto autor del proyecto firma como Consejero provincial de Bellas Artes. En la Memoria indica que es preciso acometer obras urgentes por filtraciones de las cubiertas. El documento consiste en una hoja mecanografiada y cuatro fotografías grandes, en blanco y negro, de desconchones en dos arquillos y goteras en dos bóvedas y una cúpula.

\section{AGA 26/00965}

1982 - Obras generales - Diego Pérez Medina, Agustín Bustamante y Teresa Pérez La caja contiene documentación administrativa relacionada con el traspaso de competencias del Ministerio de Cultura a la Junta de Castilla y León.

La Reseña Histórica contenida en el Proyecto es de Agustín Bustamante, especialista en el foco clasicista vallisoletano, escuela a la que pertenece la obra. En ella se describe cómo la fábrica de nueva planta se construyó con inusual rapidez, todo bajo dirección de Juan de Nates. Afirma que a lo largo del XVII no se realizan obras excepto conservación, como reparar tejas y cristales.

Se incorpora un Anexo I: Reconocimiento de la estructura de madera de la cubierta de la Iglesia de las Angustias. Destacan el ataque de insectos más concentrado en los tirantes inferiores de las cerchas, sobre todo en el de la segunda a contar desde la fachada principal, también ataque hongo de pudrición en las tres primeras cerchas y tablazón.

En el epígrafe 2.2 de la memoria se describe el estado de conservación de la iglesia. Se plantea la reparación puntual de secciones con el sistema Beta, de reconstrucción 
con varillas de fibra de vidrio y relleno con resina epoxy. Se justifica el empleo de estas prótesis en el buen estado general de la estructura de cubierta, que sólo precisa reparaciones locales. Las tres primeras cerchas están afectadas por hongo de pudrición. Toda la madera se trata con un producto de XilagelSA. Se remplaza una escalera de madera existente entre el suelo del bajo cubierta del cabildo y el extradós de la bóveda por una nueva de rejilla electro-soldada.

La cubrición, compuesta por correas, tablazón y tejas, se encuentra en muy mal estado de conservación, lo que ha dado lugar al hundimiento de la teja y entrada de agua, con la consiguiente pudrición de los elementos estructurales. Se prevé el cambio de tablazón y teja, así como el de todas las correas, excepto las de nave central que por su gran escuadría se consideran elementos estructurales de primer orden y se restaurarán con prótesis Beta y tratamiento antixilófagos.

Planea reemplazar las cubiertas de los frontones, retejar y restaurar sus molduras de piedra. También cambiar los canalones de recogida de aguas, que tapan parte de las molduras de las cornisas, por canalón oculto. Se pretende sustituir el casetón de salida a la espadaña por un lucernario practicable con salida a una pequeña cubierta plana.
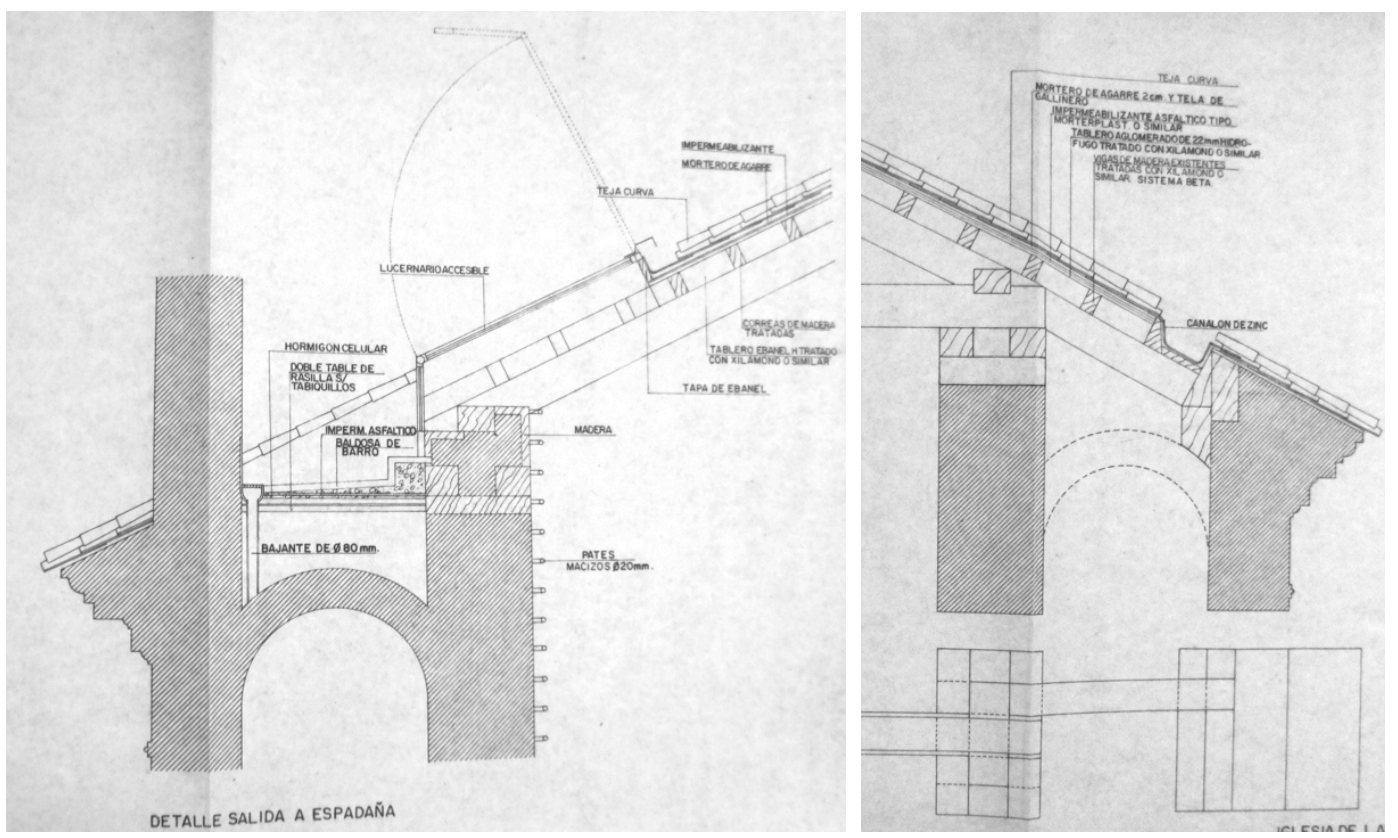

Ilustración 14: detalles nave central (1982 Pérez Medina AGA)

Otro lucernario simétrico se emplea para reemplazar una "mansarda lateral de iluminación y ventilación del bajo cubierta de la nave principal" que se encuentra en mal estado. 
En la actuación se rebaja el nivel de cubierta del balconcillo; que articula la iglesia, y la primera capilla octogonal, para "acentuar formalmente su carácter expresivo de rótula".

Se encontraban cegados tres de los cuatro huecos de la linterna, que se pretende reabrir y acristalar para recuperar su función lumínica.

En el epígrafe 2.3. se narra que la estructura de cubierta del cabildo debió realizarse sólo 50 años antes, por lo que la madera se encuentra en buen estado. Se reteja, sustituyendo correas y tablazón. Se modifica la geometría de una mansarda de acceso al bajo cubierta del cabildo situada sobre el faldón. Se diafanizan los espacios de ambas plantas, manteniendo piso y techo de madera de la primera.

Resume la envergadura de las operaciones: tratamiento de 54 grandes vigas y 150 correas sobre la nave principal de la iglesia, así como de 8 grandes vigas y 190 correas en la cúpula. En el cabildo 8 grandes vigas y 126 correas.

\section{Archivo del Cabildo de la Cofradía.}

(Consultado el 24 de marzo de 2014)

Se conservan en la propia Cofradía copias de diversos proyectos, retejos y dosieres de fotografías.

Entre ellos destaca una copia del proyecto completo de 1982 como la conservada en el AGA, y algunas partes que se describen a continuación de la carpeta 5202 del Archivo de la Junta.

\section{En el archivo de la Junta de Castilla y León}

\section{VA-06}

Carpeta 5202

1982 - Obras generales - Diego Pérez Medina, Agustín Bustamante y Teresa Pérez

Se lleva el expediente desde el Ministerio de Cultura, antes de la transferencia a las Comunidades autónomas. El Proyecto de Restauración $1^{\mathrm{a}}$ fase se adjudica a la constructora SILECA SA, que lo cede a COSERSA. En una carta del arquitecto Pérez Medina, dirigida a Ignacio Represa como Jefe de Servicio en funciones de los Servicios Técnicos de la Dirección General de Patrimonio de la Junta, se describe irregularidades graves de la obra en ejecución, como la falta del zuncho de atado en 
bases de pilares definido en el Proyecto Reformado o el descubrimiento de pilares mal armados hormigonados sin avisar a la DF con mala fe de la constructora.

Se redacta el proyecto Reformado, tras detectarse que los elementos del entramado de madera del muro del cabildo con plementos de fábrica de ladrillo y el de la fachada de la vivienda contigua estaban en muy mal estado, que había un muro medianero de $12 \mathrm{~cm}$ de espesor sobre el que estaba previsto apoyar un forjado, etc.

Se proyecta y ejecuta el reemplazo de 11 pilares de madera de $6 \mathrm{~m}$ de altura por hormigón armado, un muro medianero nuevo con zunchos en apoyo de forjado y zanca de escalera apoyado sobre zanja corrida de hormigón. También se realiza la sustitución de cornisa y alero de piezas de madera por una viga única de "hormigón armado imitando piedra caliza, que sirve para zunchar las cabezas de los pilares y apoyar las vigas de planta $2^{\text {a }}$ restauradas con el sistema Beta”

La solicitud de aprobación del reformado coincide con el proceso de transferencia de Competencias, en este caso a los Servicios Técnicos de la Dirección General de Patrimonio, por lo que la obra se paraliza durante un año. En 1986 la Cofradía lamenta que, por ejemplo, la vivienda del sacristán lleva dos inviernos sin tejado, cubierta con lonas, y en 1987, en otra misiva, advierte de que "el estado del templo con sus cubiertas sin terminar es muy preocupante".

Otra carta, esta vez del propio arquitecto director de la obra, insiste en que la paralización ha dejado ésta desprotegida, con la zona del cabildo sin teja, la linterna sin vidrio, etc.

Hay una nota de Ignacio Represa como Jefe en funciones de los Servicios Técnicos de 1986 en la que ordena desmontar la grúa de Yañez mal colocada ya que su contrapeso puede golpear la linterna del crucero. En algún documento de la Cofradía se confirma que este daño llegó realmente a producirse.

Carpeta 5278.

Una década después, se adjudican nuevamente obras de rehabilitación de este monumento a la constructora Restauración de edificaciones, asignándose al equipo redactor formado por el arquitecto Salvador Mata Pérez y el arquitecto técnico Belisario García Fiz. 
Encontramos en esta carpeta un interesante Dictamen sin acuerdo de la Comisión territorial de Patrimonio fechado en septiembre de 1990. Ocho integrantes no aceptan las actuaciones propuestas por el facultativo y proponen limitarlas a la consolidación de cubiertas y fachadas, otro sí lo considera adecuado y el Arquitecto Territorial defiende varios aspectos que en algún caso pasarían a una $2^{\mathrm{a}}$ fase, como la calefacción.

Se repite la denominación " 1 a fase", pero referida a un nuevo proyecto Modificado, en 1993. Hay varias cartas en las que el facultativo justifica sus actuaciones y describe las obras que se van realizando en 1991 y 92 . Se emprende la demolición de los $25 \mathrm{~m}$ de cornisa de hormigón incorporados en el proyecto de la década anterior.

Hay un cierto enfrentamiento entre la Cofradía y el arquitecto en cuanto a las demoliciones que pretende realizar éste para "quitar adherencias sin valor": la sacristía y el paso del chaflán, discutiéndose si son originales y datan del XVIII o fueron incorporadas con posterioridad.

En el documento de Liquidación aparecen además partidas como extracción de 94,8ml de durmiente de madera para alojar zuncho de hormigón y apertura de $15,17 \mathrm{~m} 3$ de cajas sobre fábricas para zuncho y vigas.

\section{VA-91}

\section{Carpeta 5279}

Proyecto fase I del 30/11/1990 y reformado del 28/12/1992. Acta de recepción definitiva datada el 30/03/1995.

Certificaciones: Se paga demolición de escalera, de capa de compresión en cubierta del Cabildo y 25,5ml de cornisa, todo de hormigón armado. Desmontado cuidadoso de $46 \mathrm{ml}$ de cornisa de ladrillo macizo para recuperar.

Se meten $165 \mathrm{~m} 2$ de forjado de vigueta y bovedilla aislante y otros $73 \mathrm{~m} 2$ del mismo pero inclinado.

\section{Carpeta 5280}

Contiene Proyecto, Estudio de Seguridad y Salud y Proyecto Modificado.

En la propuesta de eliminar "adherencias" (escalera y aseos junto al cabildo, sacristía y cuerpo triangular tras el ábside) se describe cómo dejar una especie de atrio trasero a modo de huella de dicho cuerpo, incorporando la sacristía en la cripta.

La Memoria del Proyecto incluye una descripción del monumento bastante extensa en la que se cita teorías de los profesores Martin González y Bustamante. Según ésta, la construcción del edificio clasicista más importante de Valladolid tras la Catedral se llevó a cabo en dos fases. Primero la iglesia, edificio del cabildo con su portada y cripta en 1579 gracias a la financiación del benefactor Sánchez de Aranzamendi, 
enterrado en la misma. Y hacia 1710, cuando la propia Cofradía compra las casas aledañas y levanta la ampliación barroca: capilla adyacente con el camarín de la Virgen de la Soledad, hasta ese momento ubicada en una pequeña capilla lateral. En esta segunda etapa debió incorporarse la casita contigua al Cabildo, el cuerpo triangular, sacristía y vivienda del párroco.

Salvador Mata cita los debates sobre la peculiar fachada en los que se considera como palladianismo adulterado lo que según él sería adecuación constructiva al solar y a la normativa de la reforma urbanística de Francisco de Salamanca.

En un plano con la evolución histórica de la zona se incluyen las versiones siguientes:

$1738 \quad$ Ventura Seco

1788 Diego Pérez

1890 Leonardo Miñón

1950 Propuesta de C. Cort

1968 PG Ordenación Comarcal

1990 Propuesta de Mata: abrir la calle paralela al cabildo para despejar la visual de la Antigua.

En la carpeta de precios contradictorios hay croquis esbozados a mano de la linterna y cerchas del cabildo.

Otra carta de la Cofradía fechada en 1992 lamenta el estado de la obra parada y sin lonas lo que produce más daños en el templo.

\section{Proyecto Modificado.}

Se reemplaza toda la estructura del camarín por encontrarse en mal estado vigas de madera, tablazón y teja.

Linterna y aguja de la capilla barroca se reparan in situ encolando con resorcina piezas de madera a un $60 \%$ de los elementos.

La estructura de cubierta del Cabildo, colocada en la obra de la década anterior, se encuentra retorcida, semiempotrada en la cornisa de hormigón armado con más de $15 \mathrm{~cm}$ de flecha y $50 \mathrm{~cm}$ de desnivel, por lo que debe demolerse.

El mal estado de los revocos exige su repicado al completo.

Finalmente se mantiene el cuerpo triangular, colocándose chapa ventilada en su cubierta.

Salvador Mata insiste en demoler la Sacristía o al menos disponer su cubierta de policarbonato. Remarca el riesgo de almacenar combustible líquido tras el Altar mayor. 
Los planos nuevos incluyen:

- Cubierta del camarín, una estructura radial de madera serrada con pendolón central circular y tirantes metálicos embridados.

- Linterna de la capilla.

- Vidriera.

- Forjados y cubierta del Cabildo con entablado sobre vigas de madera existentes. Sólo emplea hormigón armado en el anejo de escaleras, donde se dispone forjado unidireccional con zuncho perimetral.

- Cerchas del Cabildo. Incluye detalle de la cornisa volada $21 \mathrm{~cm}$ con cuatro piezas de ladrillo y una grapa superior de acero galvanizado.

- Vivienda del capellán, con forjados de semivigueta armada y bovedilla apoyados sobre zuncho semiembebido en fábrica de medio pie de ladrillo reforzada con pilarillos 2UPN-100 en cajón.

Si analizamos la documentación relativa a las actuaciones en la cubierta del cabildo, por ejemplo, contamos con la siguiente imagen del alero tal como se descubre en la intervención de 1984, aunque en este caso no sabemos con certeza si se trata de la solución constructiva original o del resultado de las obras indocumentadas que se llevaron a cabo en 1970.

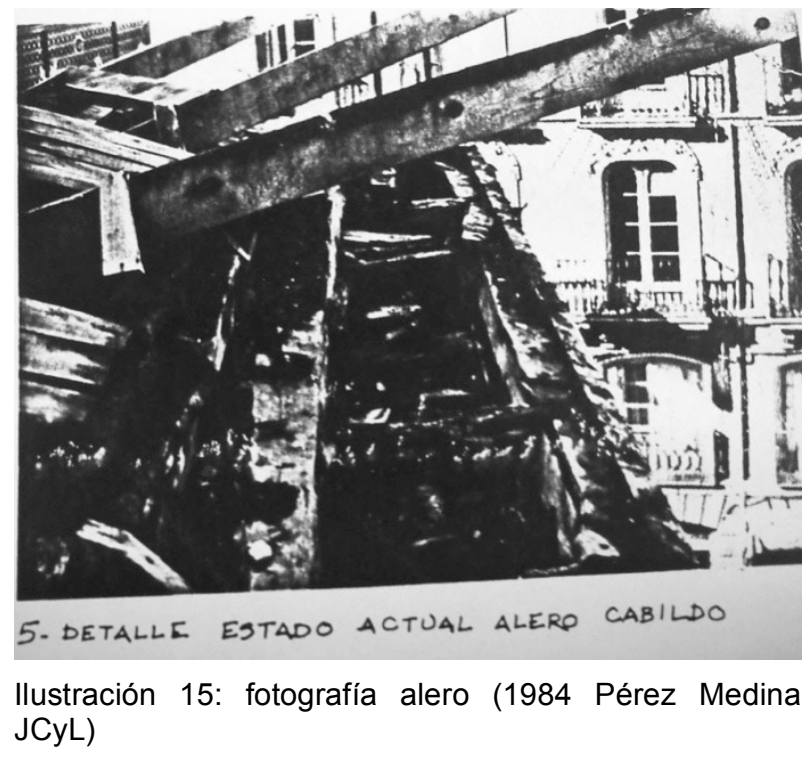

En el único plano de 1984 (la carpeta del Proyecto Modificado que se conserva en el Archivo no contiene los planos correspondientes del mismo) Pérez Medina representa la sección de estado actual en el detalle reproducido junto a estas líneas, con algunas piezas de madera $y$ otras $\sin$ identificar.

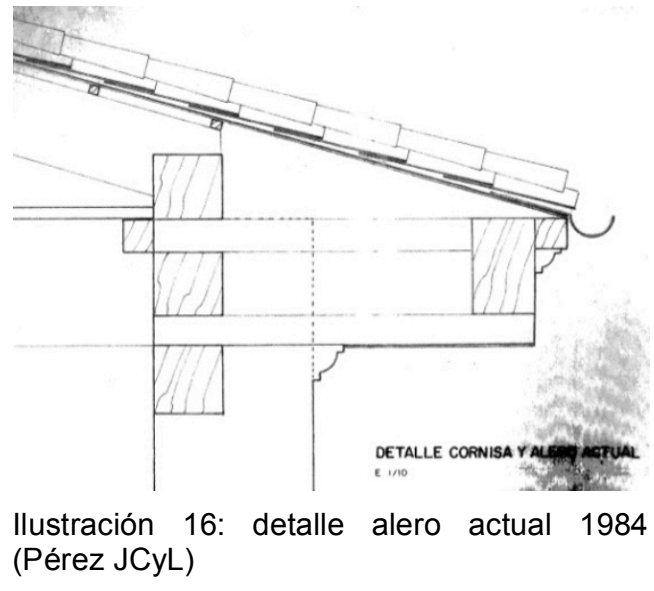


Según la solución propuesta en su proyecto, se reemplaza el conjunto alero-cornisa, a lo largo de 36m, por una viga de hormigón armado, elaborado con cemento blanco, que reproduce el mismo perfil.

El detalle de 1984 debió ejecutarse según lo previsto, puesto que en el reformado de 1992 se certifican las partidas para demolición con compresor y retirada de $25,5 \mathrm{ml}$ de cornisa 090x0,60m de hormigón armado, y 185,49m2 de capa de compresión en cubierta del cabildo. Aunque en la 1.26 de la misma certificación se abona también la “extracción de 94,8ml de durmiente de madera para alojar

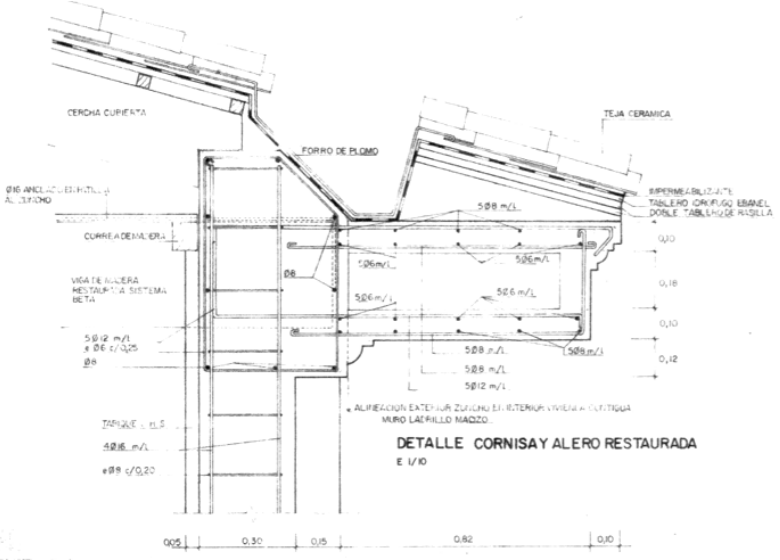

Ilustración 17: detalle zuncho-alero de hormigón armado (1984 Pérez Medina JCyL)

zuncho de hormigón".

En el presupuesto del proyecto de Mata se describe también el desmontado cuidadoso de $46 \mathrm{ml}$ de cornisa de ladrillo macizo con recuperación del material. En el plano $n^{\circ} 13$ se representa el despiece de la cornisa mediante cuatro elementos de los que no se indica el material, empleando una grapa de acero galvanizado para su Ilustración 18: detalle cornisa (1992 Mata JCyL) atado en cara superior.

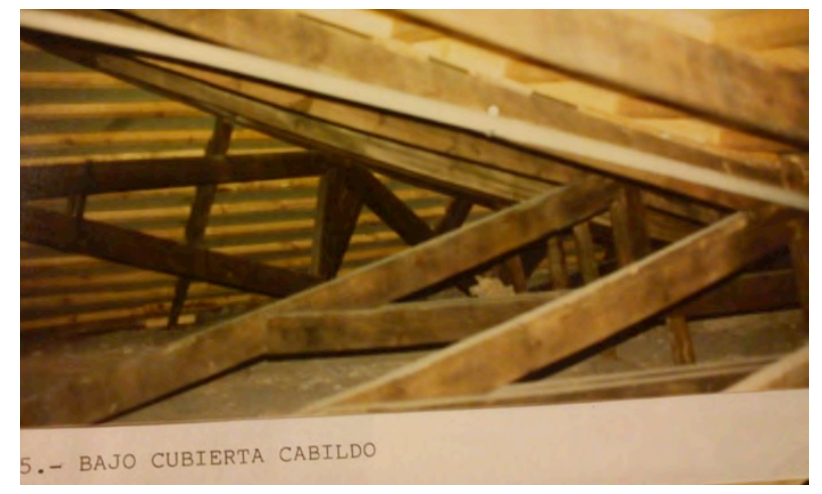

Ilustración 19: armadura Cabildo (1987 Pérez JCyL)

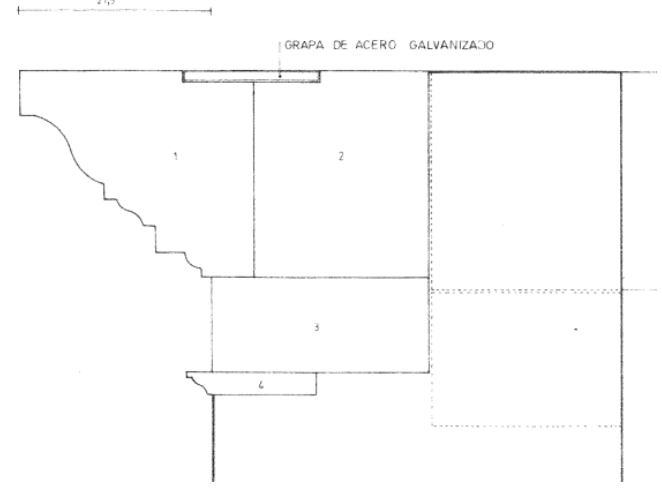

En cuanto a la estructura de la cubierta del cabildo, en esta fotografía del reportaje de 1987 se aprecia tras la colocación de nuevas correas de pino y tablero hidrófugo el empalme de elementos de los cuchillos existentes con pletinas y embridados. 

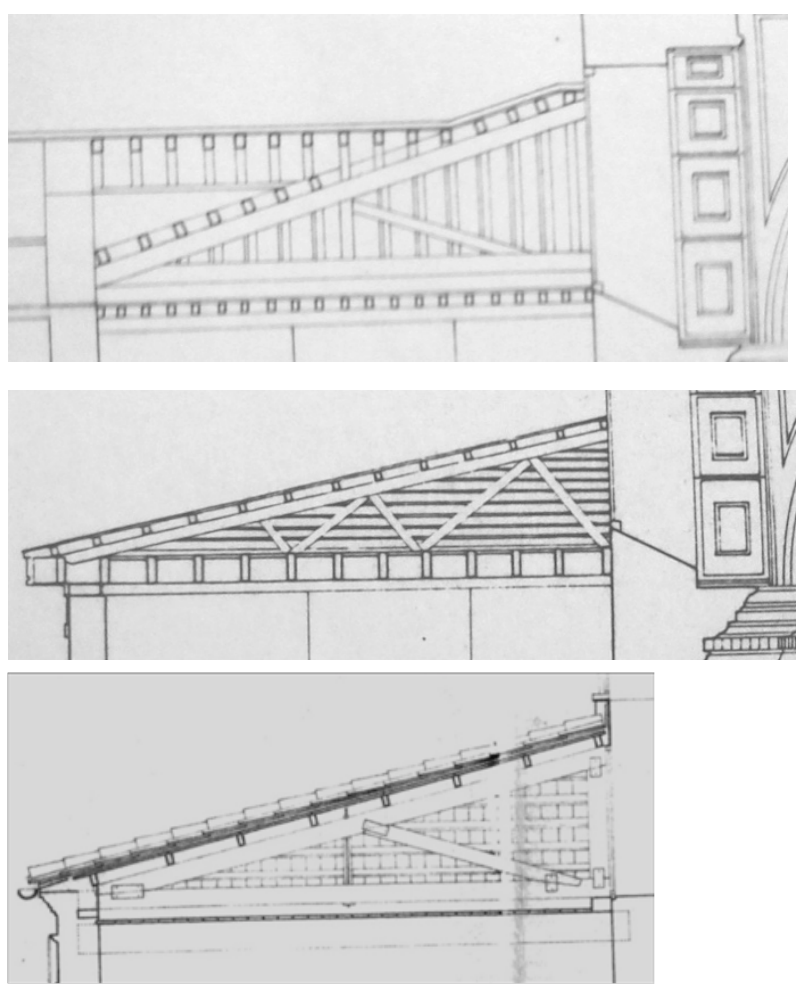

Ilustración 20: varios detalles estructura Cabildo
En el proyecto inicial de Mata se representa las cerchas del cabildo en el estado en que se encontraban (sección superior). Su diseño de dicho proyecto, como celosías probablemente metálicas según este detalle de la sección transversal del plano 17 (en el centro de la figura) es diferente de la solución finalmente ejecutada, (esquema inferior) con cerchas de madera similares a la encontrada, pero a las que se añade un montante vertical, tirantilla central y empalmes metálicos, diseñada con la colaboración de Alfonso Basterra.

En conclusión, durante la intervención de los 80 se reemplaza:

- Pies derechos y carreras de madera embebidos en fábrica por elementos de hormigón armado.

- Cornisa y alero por una gran viga de hormigón.

- Tablero y correas de madera por otras también de madera, manteniendo las cerchas.

Y en los 90 se demuele gran parte del hormigón añadido en la década anterior: en el caso del alero por un puzle de piezas de ladrillo y en el de las cerchas que cubren la nave del cabildo por otras, también de madera, con un diseño estructural completamente diferente, incorporando montante y tirantillo metálico verticales nuevos. Pero, incluso en los 90, se continúa retirando carreras de madera embebidas en la fábrica para rellenar con hormigón.

\section{Copia de los proyectos conservados por Salvador Mata.}

No se interviene sobre la nave de la iglesia, aunque se reteja el cimborrio e incorporan canalones.

Las cornisas se ejecutan al modo tradicional, volando las hiladas de ladrillo. (No según el croquis "puzle" de planos de proyecto). 


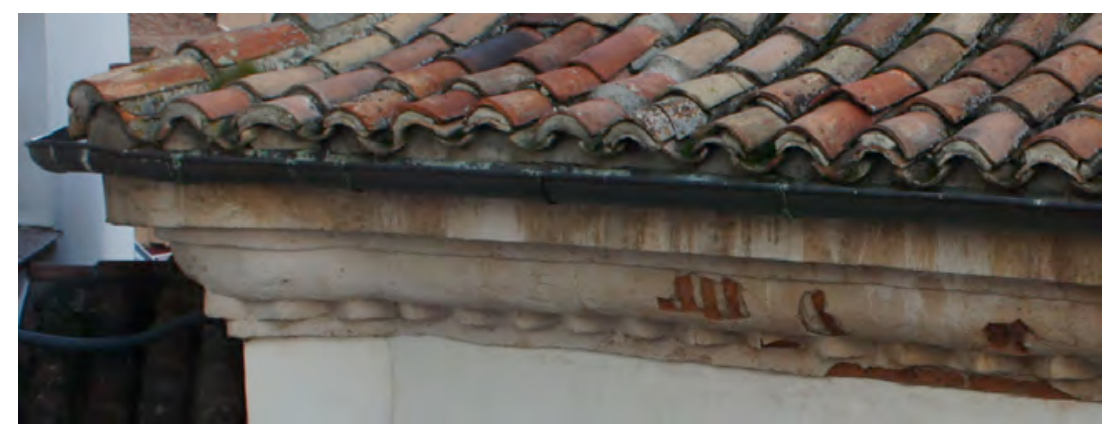

Ilustración 21: cornisa de ladrillo revestida (visita 24/03/2014)

Los planos del proyecto no reflejan fielmente la arquitectura realmente ejecutada, ya que tras desacuerdos con el Cabildo no se llegó a demoler la escalera adyacente para colocar una nueva en el centro de la Sala. La techumbre de madera se encuentra sobre las vigas, no suspendida bajo la cara inferior de las mismas de la forma representada en la sección longitudinal.

Tampoco se eliminan las adherencias, ya que se trata de espacios que resultan de gran utilidad para el desarrollo de actividades de los ocupantes. En algunos casos se ha llegado a soluciones extrañas, como la estrecha escalera que se desarrolla tras el altar mayor ascendiendo varias plantas sin desembocadura final.

\section{Cubierta del Cabildo}

Encuentra deformaciones de $15 \mathrm{~cm}$ en una luz de $7 \mathrm{~m}$ y más de $50 \mathrm{~cm}$ de desnivel. Demuele toda la cubierta, incluso el zuncho-cornisa de hormigón armado de 1982 para reconstruir el vuelo con fábrica de ladrillo.

\section{Cubierta del Camarín:}

Se reemplaza toda la estructura de cubierta por una nueva solución, también de madera aserrada, con un pendolón central que se inspira en la geometría existente.

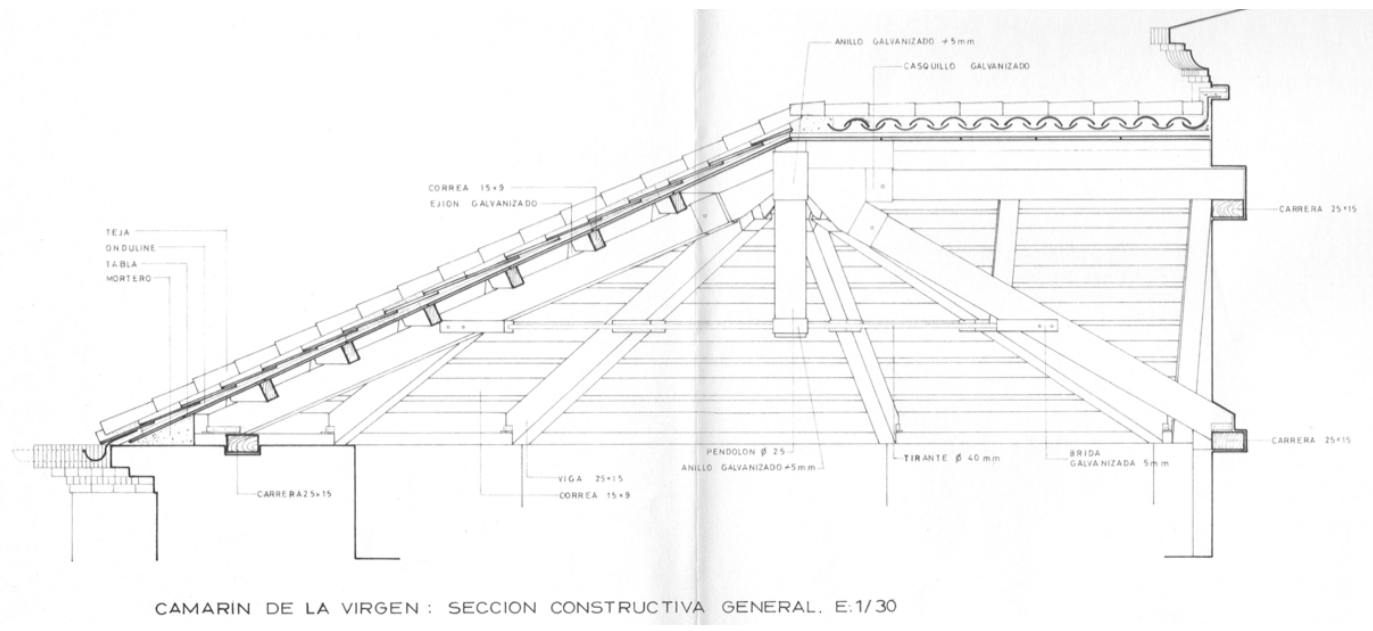

Ilustración 22: estructura Camarín 1991 Mata 
Repone un durmiente de atado perimetral:

Los antiguos pares acometían a un durmiente poligonal cerrado formado por escuadrías empalmadas y semi-encastradas en el remate de fábrica de ladrillo.

Se eliminan manualmente los restos de material descompuesto de dicho durmiente, y se coloca uno de madera recuperada de derribos con la misma sección $25 \times 15 \mathrm{~cm}$. Se practica con la azuela un cajeado similar para resolver las uniones entre los tramos.

Cubierta de la Capilla de la Virgen

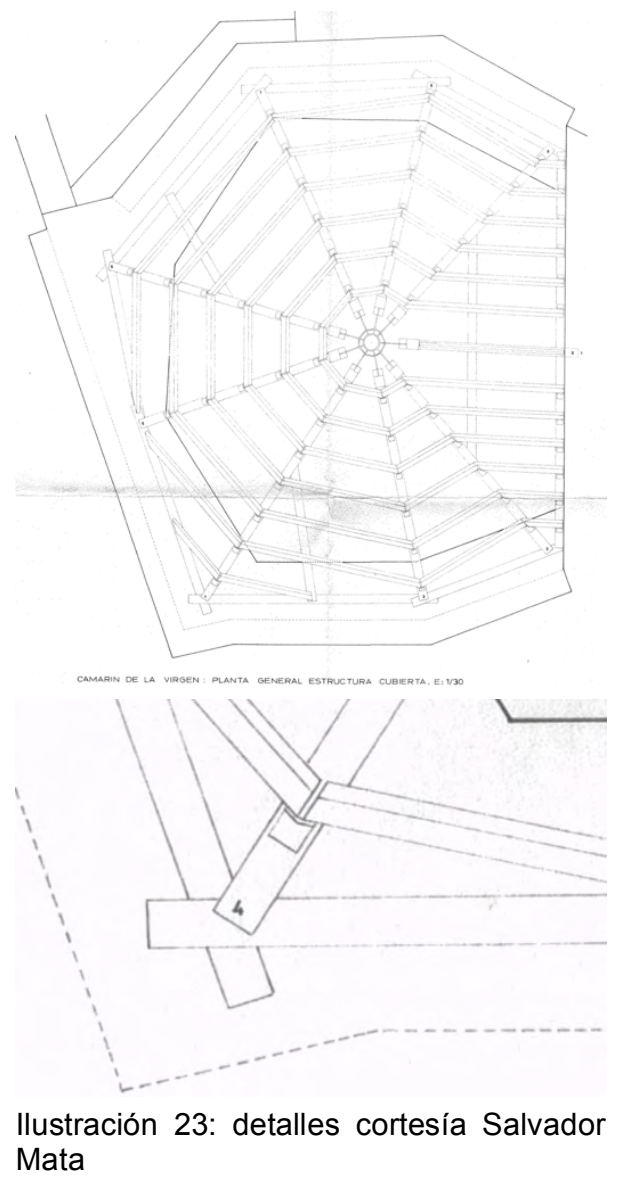

Aunque se encuentra degradada, se conserva la armadura de madera original, cuyas secciones (hasta un 60\%) se refuerzan localmente con trozos de tabla encolados con resorcina.

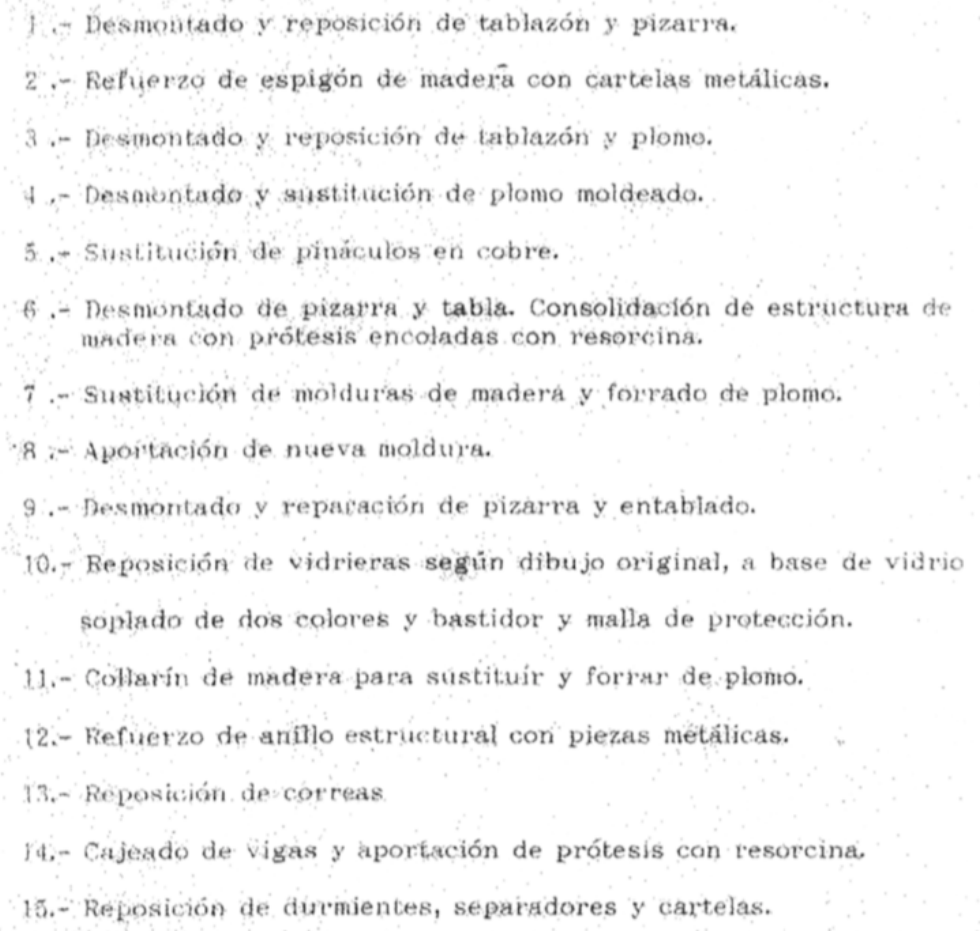


También se mantiene la linterna, de fábrica de ladrillo directamente apoyada sobre la carpintería.
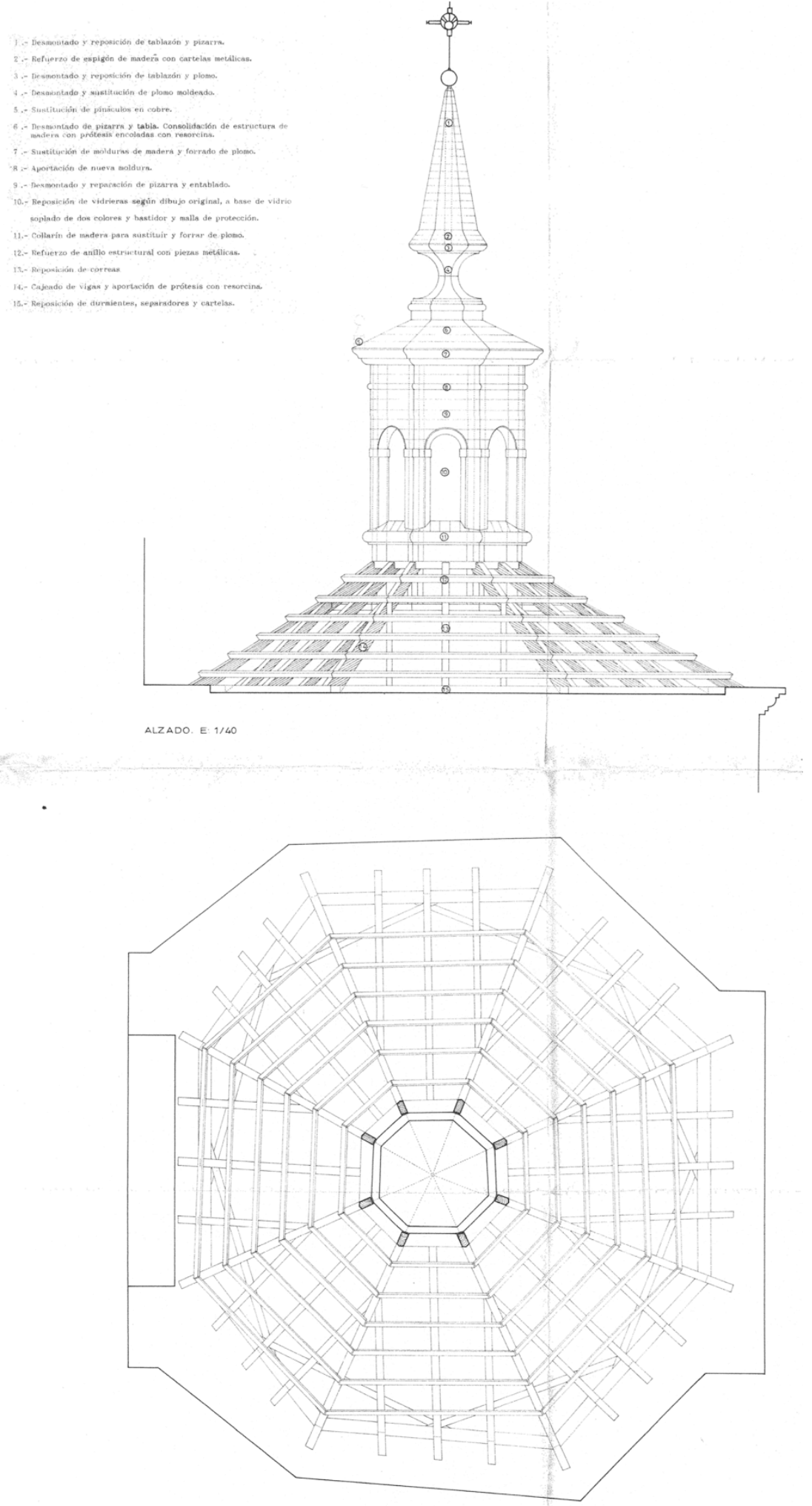

Ilustración 24: nueva estructura de madera Capilla de la Virgen (Mata 1991) 


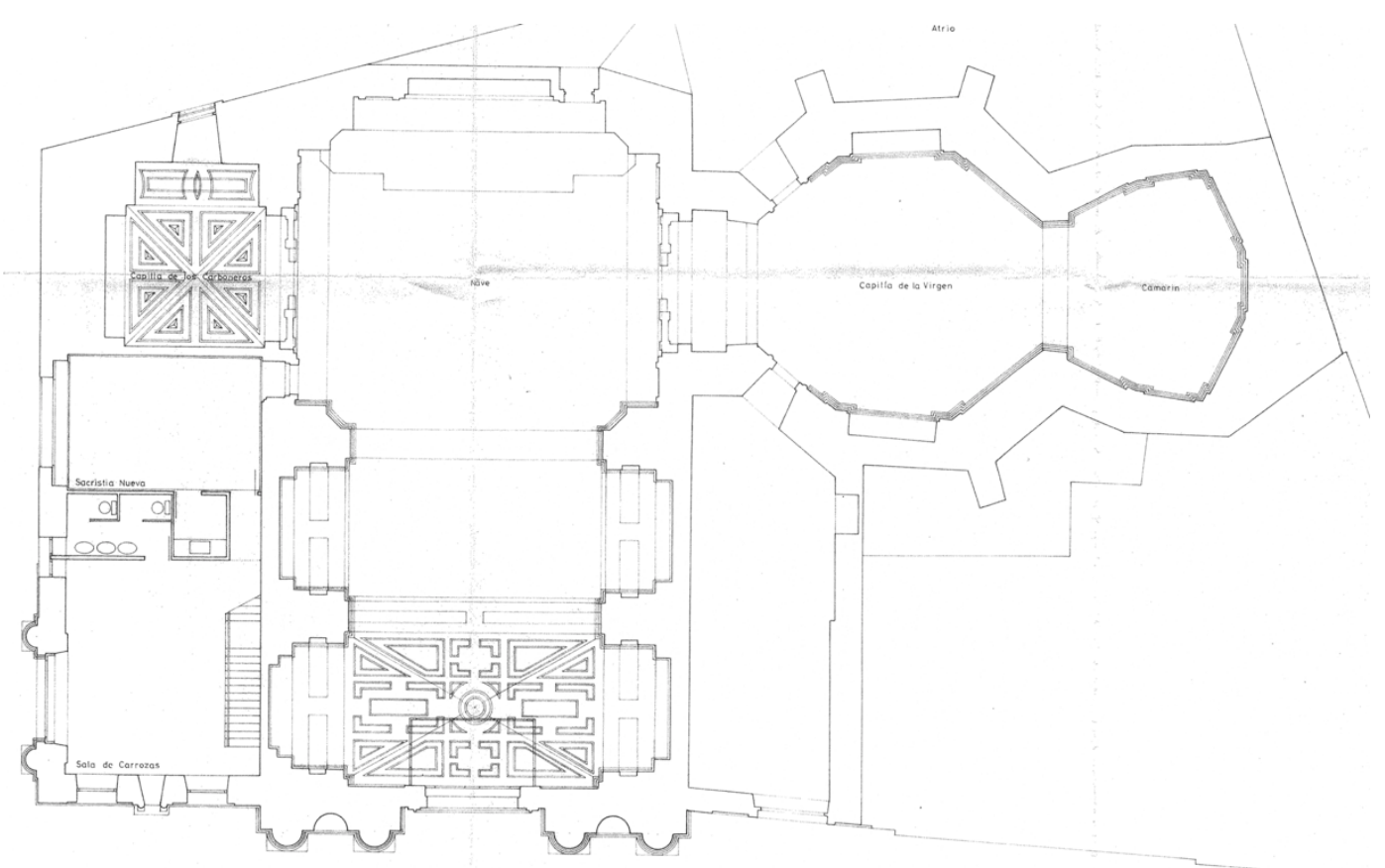

Ilustración 1: planta baja según proyecto de 1991 (Mata)

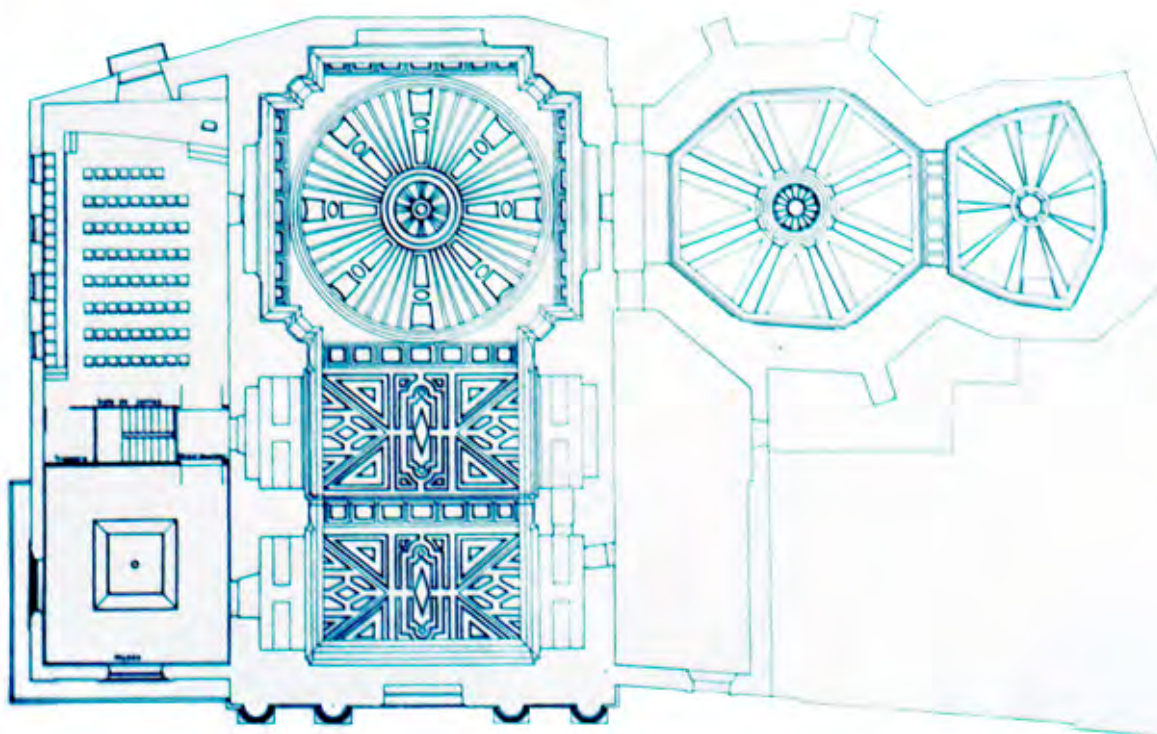

Ilustración 25: plano de bóvedas y planta alta (Mata) 


\section{En el Archivo Municipal de Valladolid}

\section{Fondo Histórico}

AMVA: 733-7 Informe fachada lateral 1864

Informe pedido a la Junta de Monumentos y Academia de Bellas Artes sobre el mérito artístico del arco y fachada lateral de la Iglesia de las Angustias

Que el arquitecto interino de ciudad examine las servidumbres.

El propietario del $n^{\circ} 18$ ha decidido reedificar de nueva planta según alineación que permite salir hasta plazuela. El problema es una servidumbre de paso de las Angustias por el balcón y una puerta que, según él, "no se usan" El informe dice que consideran que sí tienen mérito artístico y deben conservarse.

\section{AMVA: CH 340-137 Obras menores 1892}

La Cofradía quiere revocar el cuerpo de edificio a la izquierda de la fachada principal de la Iglesia que corresponde al salón y pide licencia gratuita.

La Comisión de obras condona la Licencia porque ceden gratuitamente el edificio para las elecciones
AMVA: $903 \exp 123$
Obras
1947

El 4 de noviembre de 1947 el Alcalde de la Cofradía pide licencia para habilitar una sala de reuniones y construir servicios sanitarios con proyecto del arquitecto Julio González Martín

Proyecto: una memoria 1pag explica que se trata de habilitar el patio que da a las calles Echegaray y Magaña. Sistema constructivo de cimentación con hormigón de $150 \mathrm{~kg}$ de cemento, fábricas de ladrillo con mortero de cemento en muros exteriores y de patio, cornisa corrida con mortero de cemento, cubierta de teja curva o plana sobre entramado de madera, tabique de panderete en los interiores, etc. Un plano con alzado, sección y planta.

AMVA: 906

Vivienda capellán

El Alcalde de la Cofradía pide licencia para reformar la vivienda del capellán según proyecto del arquitecto Julio González Martín.

Plano de plantas $1^{\mathrm{a}}$ y $2^{\mathrm{a}}$ actuales y reformadas visado en el COAM.

Se incorpora una escalera y cambia cocina y comedor de $2^{\mathrm{a}}$ a $1^{\mathrm{a}}$. 


\section{Fondo Administrativo}

Angustias 384/1986 C.3753-2

Restauración iglesia 1985

Es el proyecto reformado de vivienda continua al Cabildo y Cabildo en que se incorpora el zuncho-cornisa de hormigón armado.

Se desmontan 495,52m2 de teja curva para recuperar y tablero, de la cubierta de la iglesia. Las fotos son fotocopias blanco y negro (el detalle estado actual alero cabildo se ve igual de mal que en el dossier de la Junta)

\section{Angustias $320 / 90 \quad$ C.23-148-7}

Ruina Angustias 4

El vecino de la iglesia advierte del peligro de derrumbe de capilla y camarín, en muy mal estado, que acomete contra el lateral de su edificio.

Se archiva en 1992 tras las obras de rehabilitación

Angustias 266/1990 28057/54

Licencia cubierta terraza de edificio particular c/Angustias $4,1^{\circ}$ izda

Angustias 1580/1991

Restauración iglesia $1^{\text {a }}$ fase: junio de 1990

Documentación administrativa: Licencia de obras, informe de la Dirección General de Patrimonio Cultural.

ESTRECYM (Estudio de los sistemas técnicos de reparación, entretenimiento, conservación y mantenimiento) de urbanización, revestimientos, jardinería, etc.

Dossier fotocopias blanco y negro de las fotos. Se ve la cubierta de la nave bastante nueva con los velux. La espadaña y resto de cubiertas muy deterioradas, sobre todo linterna y camarín.

Angustias 3106/1995 18366-1

Obras complementarias iglesia. Salvador Mata

Se actúa sólo sobre el edificio de la Sacristía.

Angustias 66/2002 C.21436-3

Reparar cubierta Angustias 2

Obras en el edificio de viviendas de la esquina 



\section{Visitas realizadas}

24/03/2014

El estado de conservación del monumento es bastante bueno, ya que la Cofradía gestiona el mantenimiento habitual.

En la visita se recorre el edificio anejo, de despachos, desde el que se sale a la cubierta y se revisa el exterior de octógono y camarín. La cornisa muestra ya algún desconchado de la pintura que recubre la moldura.

Al lado contrario del templo, las salas del Cabildo no cuentan con la posibilidad de acceder a su cubierta. Tampoco es posible llegar a los espacios bajo cubierta ni tejado de la nave del templo, ya que la entrada se produce desde el coro alto de la iglesia, a través de una ventana sobre la cornisa, y para llegar a la misma sería necesario contar con una escalera de mano de más de $5 \mathrm{~m}$ de altura.

\section{$16 / 10 / 2013$}

En una reunión en su estudio de Zaratán, el arquitecto Salvador Mata confirma que en su intervención de 1991 reteja el cimborrio e incorpora canalones, pero no actúa sobre la nave de la iglesia.
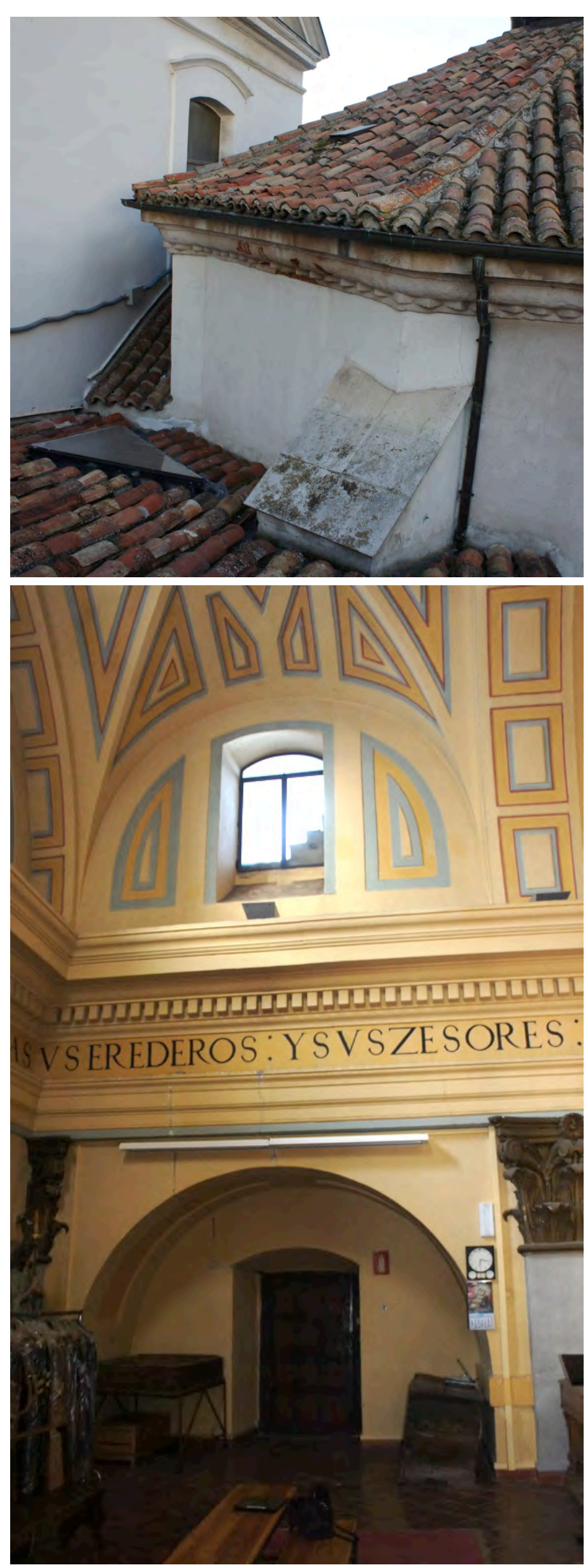



\section{Iglesia de San Agustín (Archivo Municipal)}

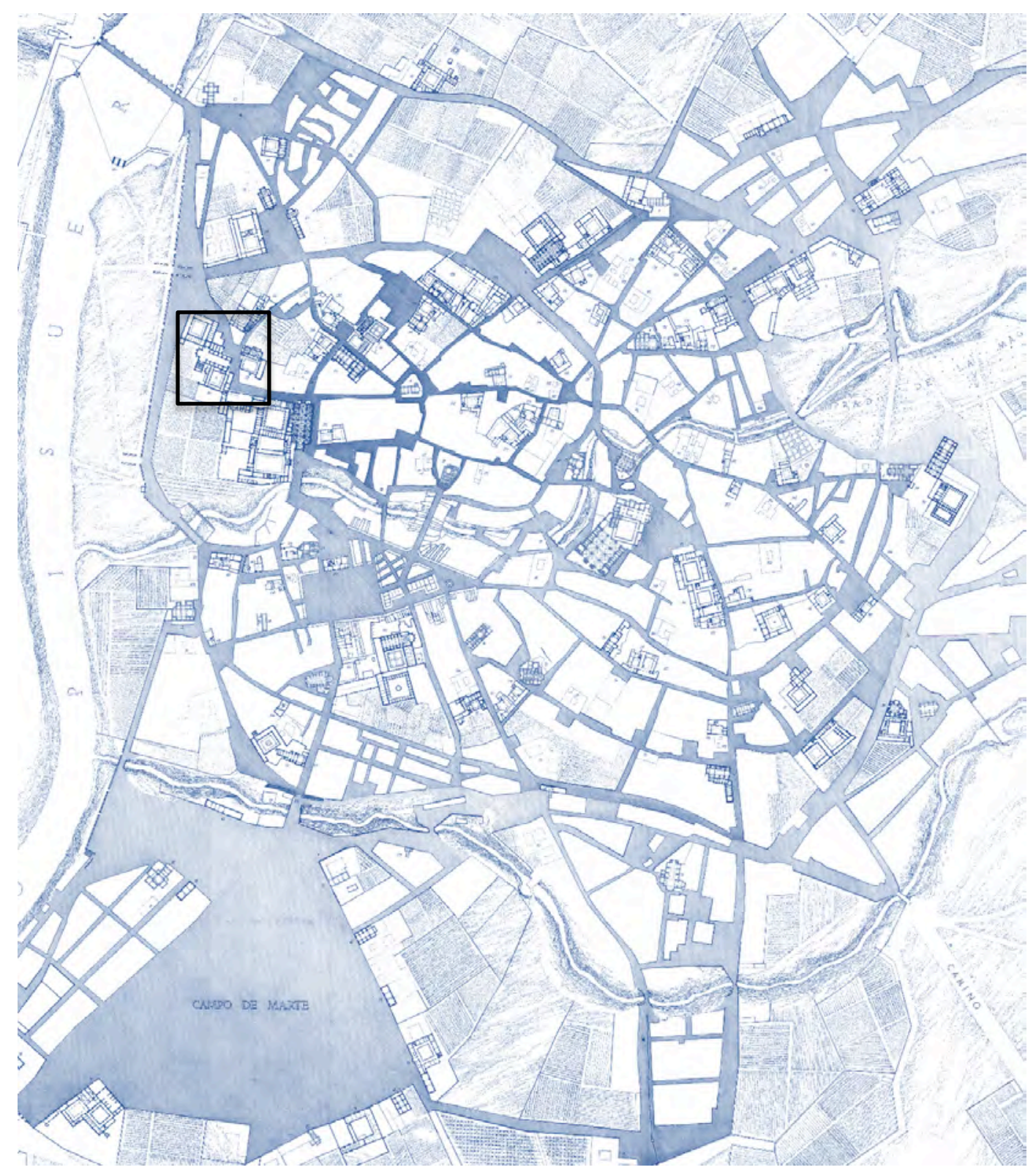



FICHA SÍNTESIS

\section{Código de identificación: FZ-07}

Denominación:

Iglesia de San Agustín

Localidad:

Valladolid

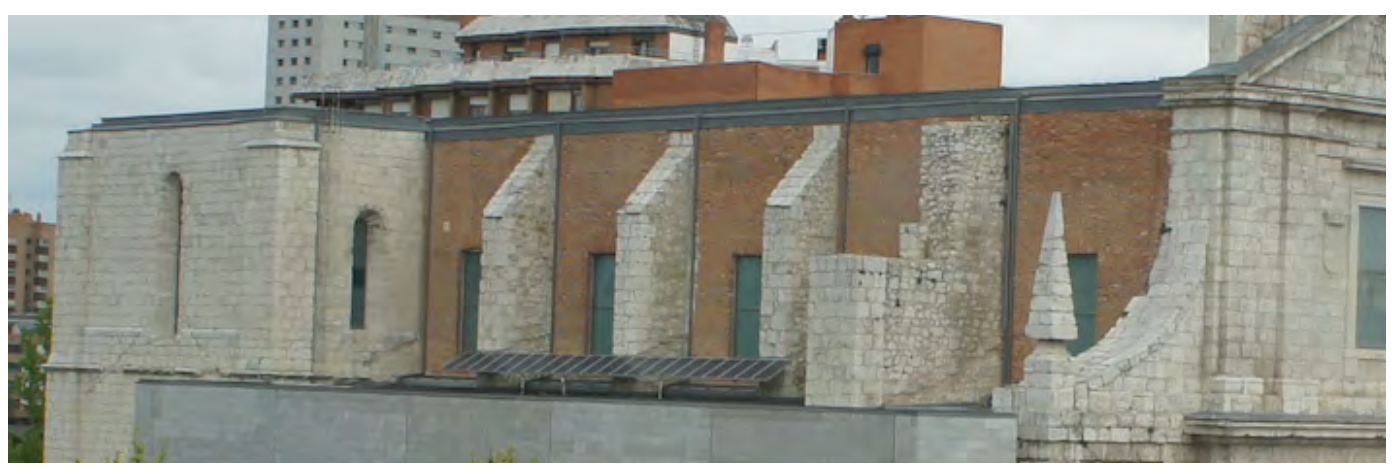

\section{Descripción}

Iglesia de una sola nave, con cinco capillas entre contrafuertes a ambos lados y cabecera poligonal. El espacio se cubre con un falso techo plano.

\section{Materiales}

Los muros de la nave son de ladrillo visto al exterior entre contrafuertes de sillería, mientras que portada y cabecera se resuelven con piedra Las capillas de la fachada norte son de tapial, con verdugadas de ladrillo, y el muro sur se compone de materiales diversos. La cubierta está revestida con lámina de zinc y una pendiente muy ligera.

\section{Singularidades}

El edificio se utiliza en la actualidad como Archivo Municipal.

En la rehabilitación de la iglesia arruinada, para adaptarla a su uso como archivo, se adosa un módulo por el exterior de la nave del evangelio que alberga los núcleos de comunicaciones. Junto al cuerpo del templo se recuperan unos restos del antiguo claustro, suspendidos sobre una estructura de perfiles de acero laminado.

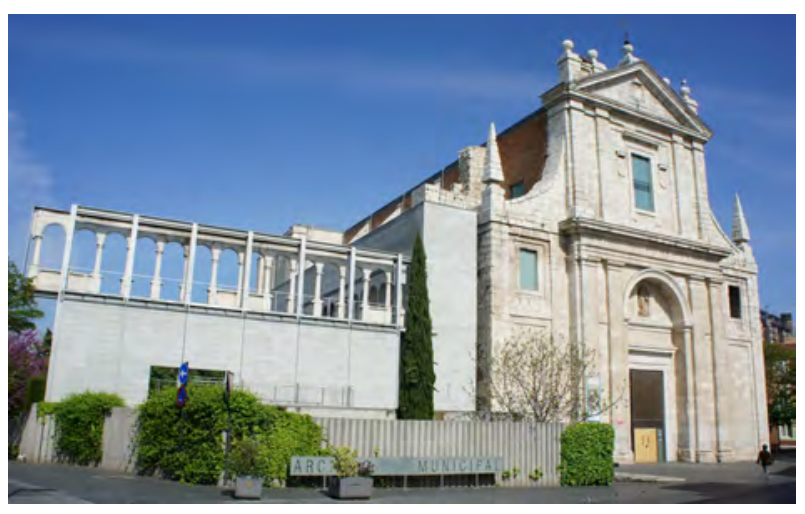

Ilustración 1: vista del exterior (visita 23/04/2015) 


\section{Dimensiones básicas del templo}

$\begin{array}{llll} & \text { central } & \text { laterales } & \text { capillas } \\ \text { Ancho de nave } & 11,7 & - & 5,6 \\ \text { Altura } & 22,9 & & 11,4\end{array}$

\section{Memoria histórica constructiva}

Según el informe arqueológico (Foramen SL 1998)

El convento estaba organizado en 1416. Su máximo esplendor viene en 1605 cuando se está construyendo la capilla mayor de la iglesia.

En 1619 se conciertan las tres capillas laterales restantes a los maestros Hernando del Hoyo y Rodrigo de la Cantera, con planos de Diego de Praves. Las bóvedas se hacen de ladrillo como los arcos (Catálogo)

Las tropas francesas lo usan como albergue, cuadra y pajar a principios del XIX, en 1814 cuatro monjes reanudan su actividad, con un desalojo temporal durante el trienio liberal, hasta su Desamortización en 1835. En 1864 la iglesia sirve como granero de paja para los caballos de la guarnición militar.

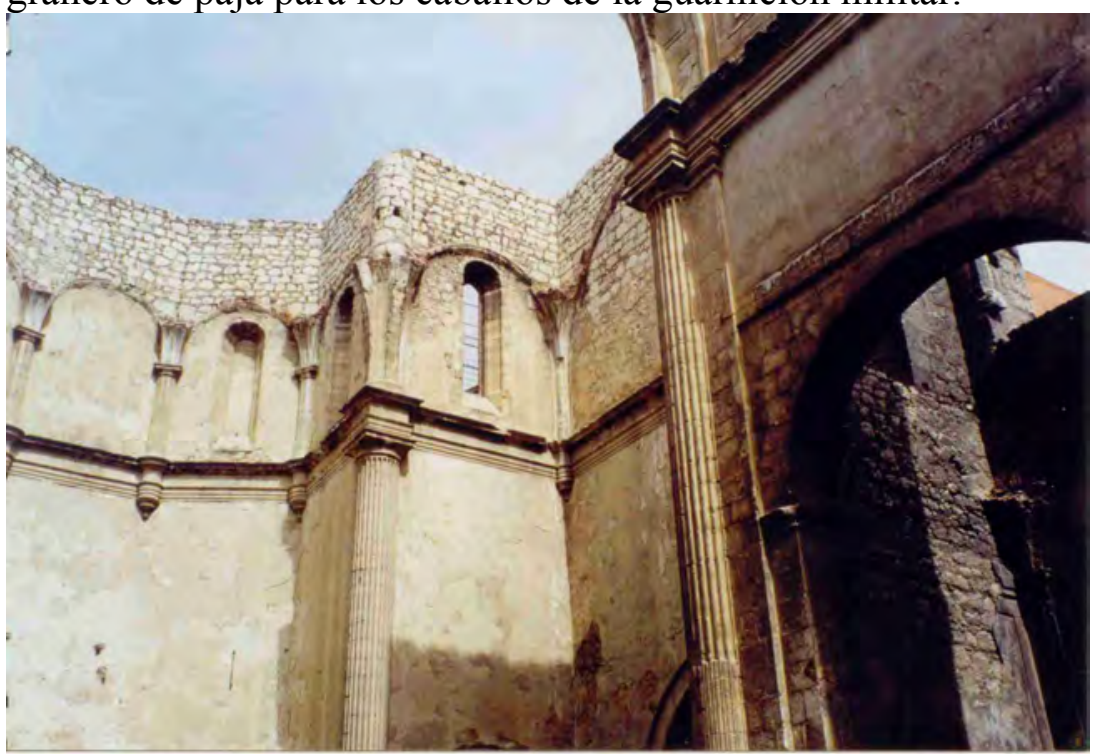

Ilustración 2: foto del interior de la cabecera en ruinas AMVA-000208826

En 1942 se concreta la permuta al Ayuntamiento, que se lleva a efecto en 1966. Las ruinas se consolidan, recalzándose y retacando las fábricas en 1968.

Entre 1998 y 2004 se rehabilita el edificio de la iglesia para su uso como Archivo municipal.

\section{Cronología. Fechas clave}

1605 - 1619 - 1814 - $1835-1966-2004$ 


\section{Intervenciones}

1968 - Recalzo y consolidación de muros y Portada - José Antonio Arenillas Asín Se consolidan y sanean las ruinas de la iglesia.

1998-2004 - Rehabilitación de la iglesia para Archivo Municipal Gabriel Gallegos y Primitivo González

Se excavan dos sótanos para albergar el almacén de documentos, habilitando la nave del templo como sala de investigadores y un espacio expositivo en la cabecera.

En las capillas de la epístola se instala la biblioteca y en las del evangelio, con tres niveles, se ubican los despachos. Escaleras y ascensores se desarrollan en un volumen prismático adosado a la fachada sur.

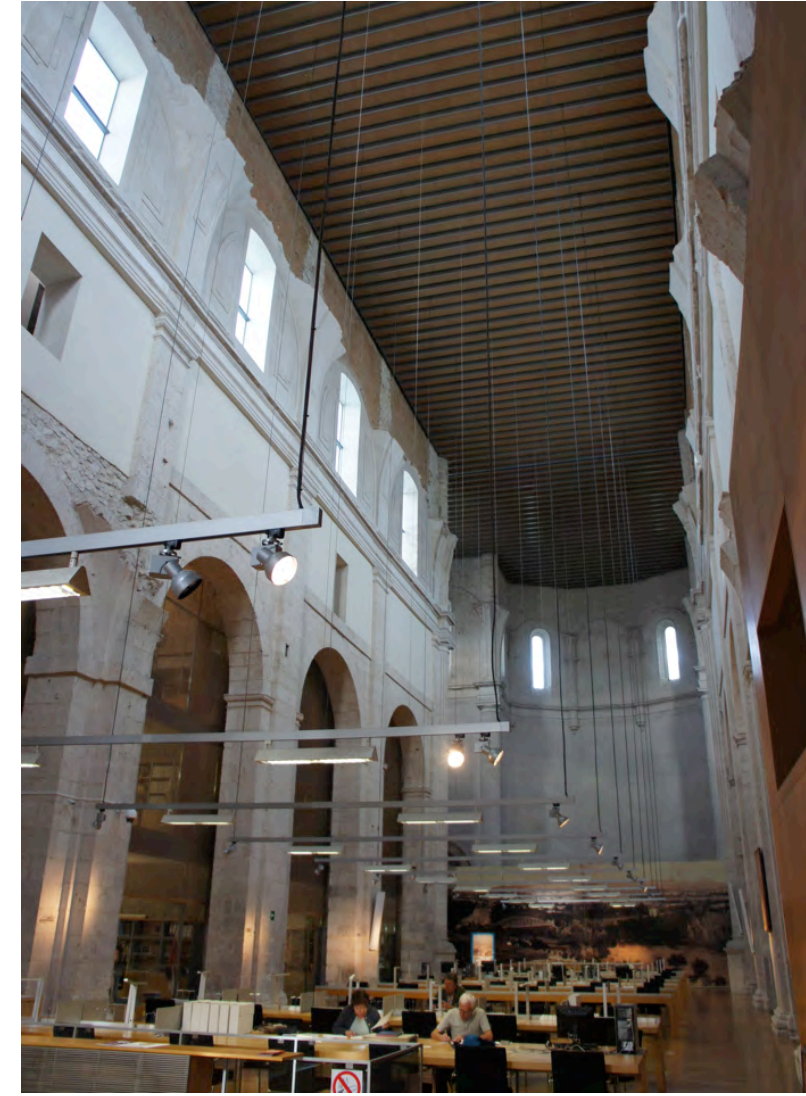

Ilustración 3: sala de lectura, visita 28/09/2015

\section{Planos}

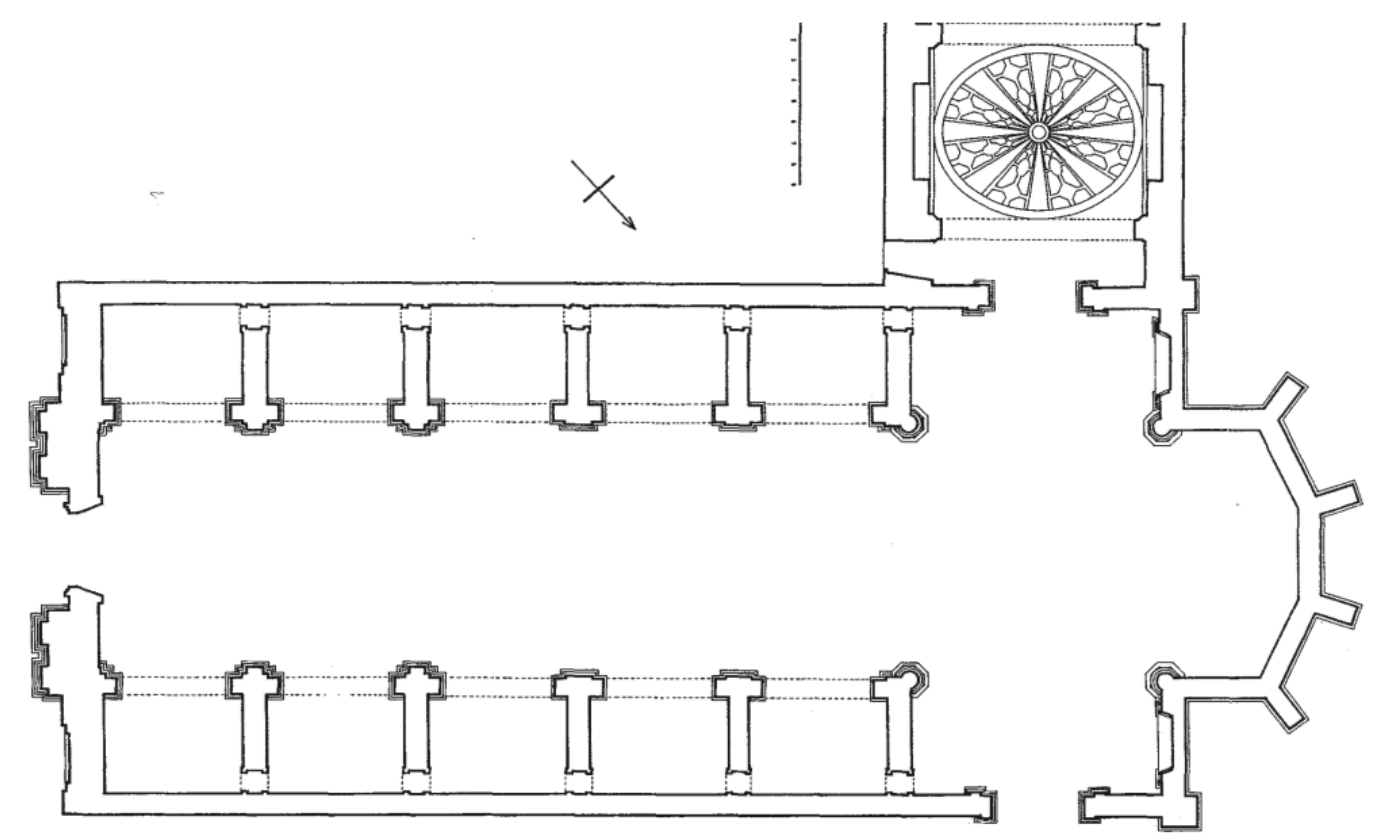

Ilustración 4: planta del Catálogo (edificio en ruinas) 


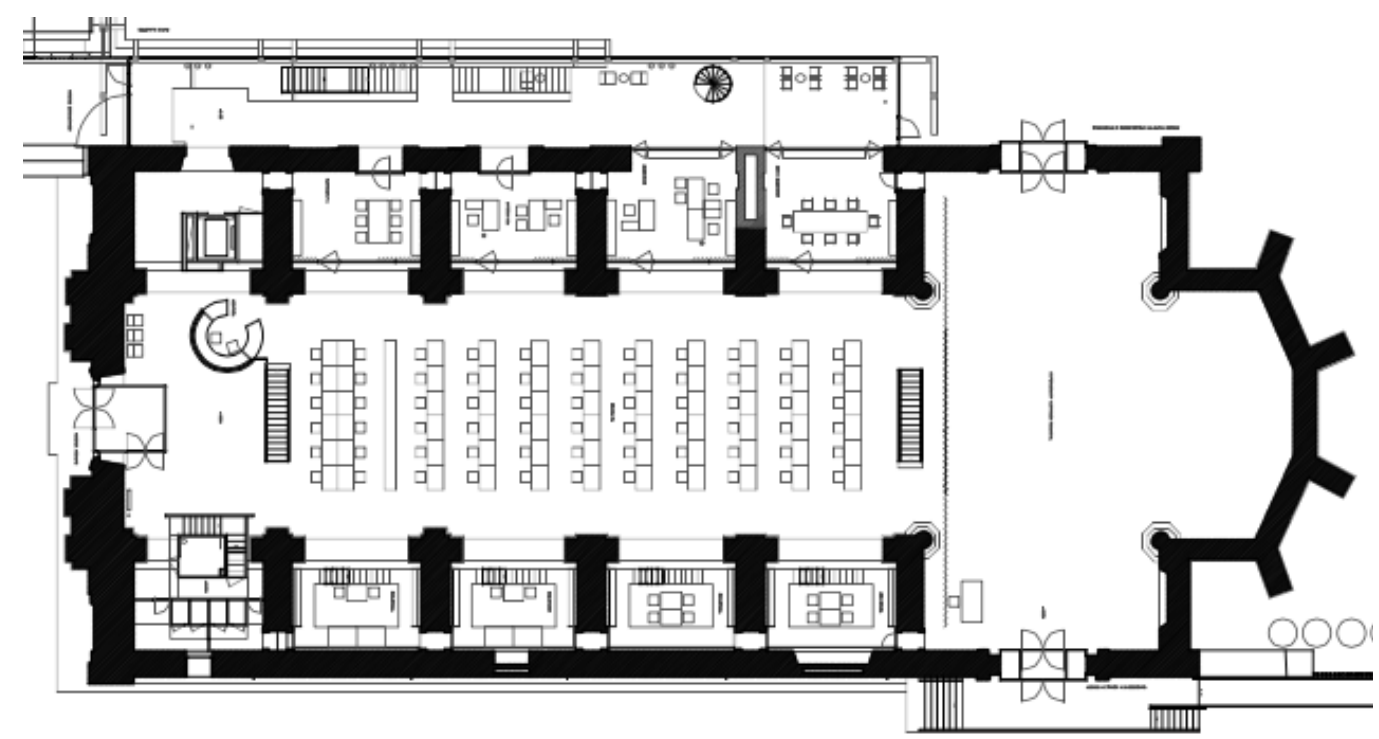

Ilustración 5: planta baja Gallegos y González 2004 AMVA

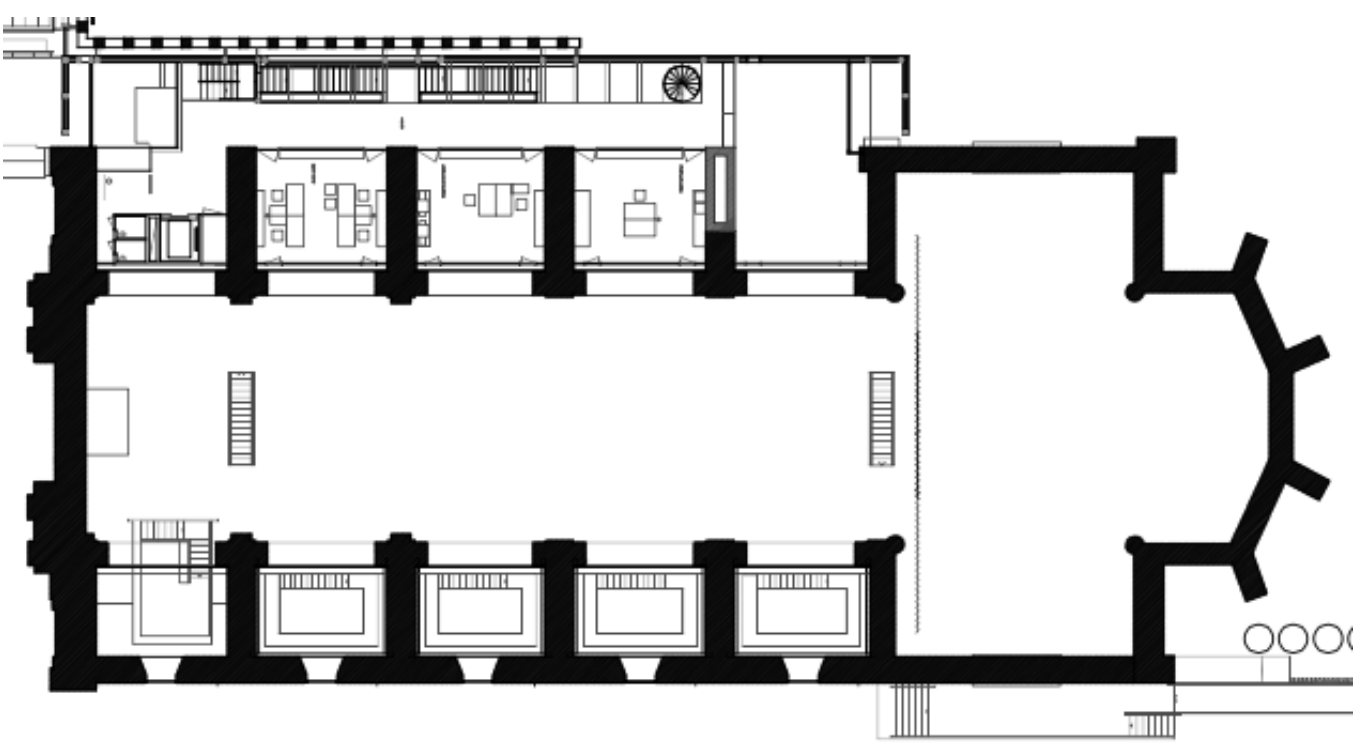

Ilustración 6: planta alta Gallegos y González 2004 AMVA

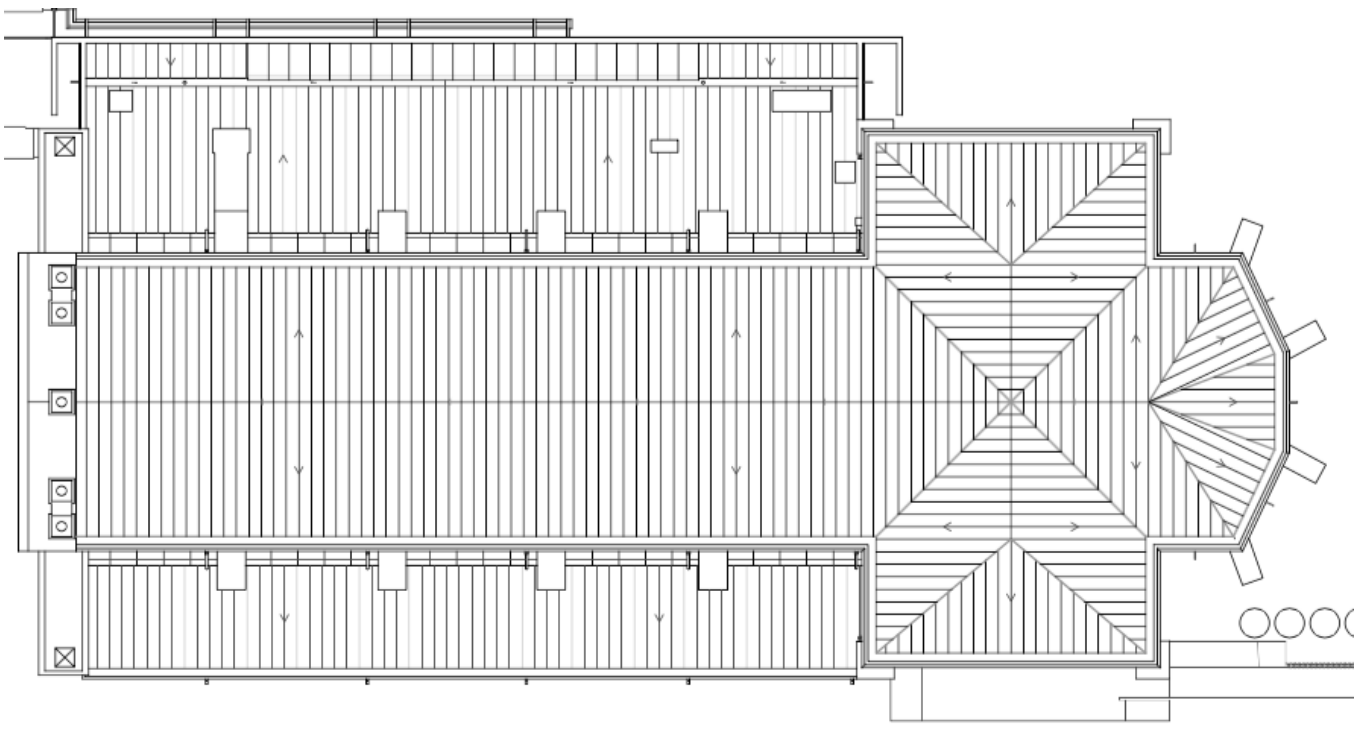

Ilustración 7: planta de cubiertas Gallegos y González 2004 AMVA 


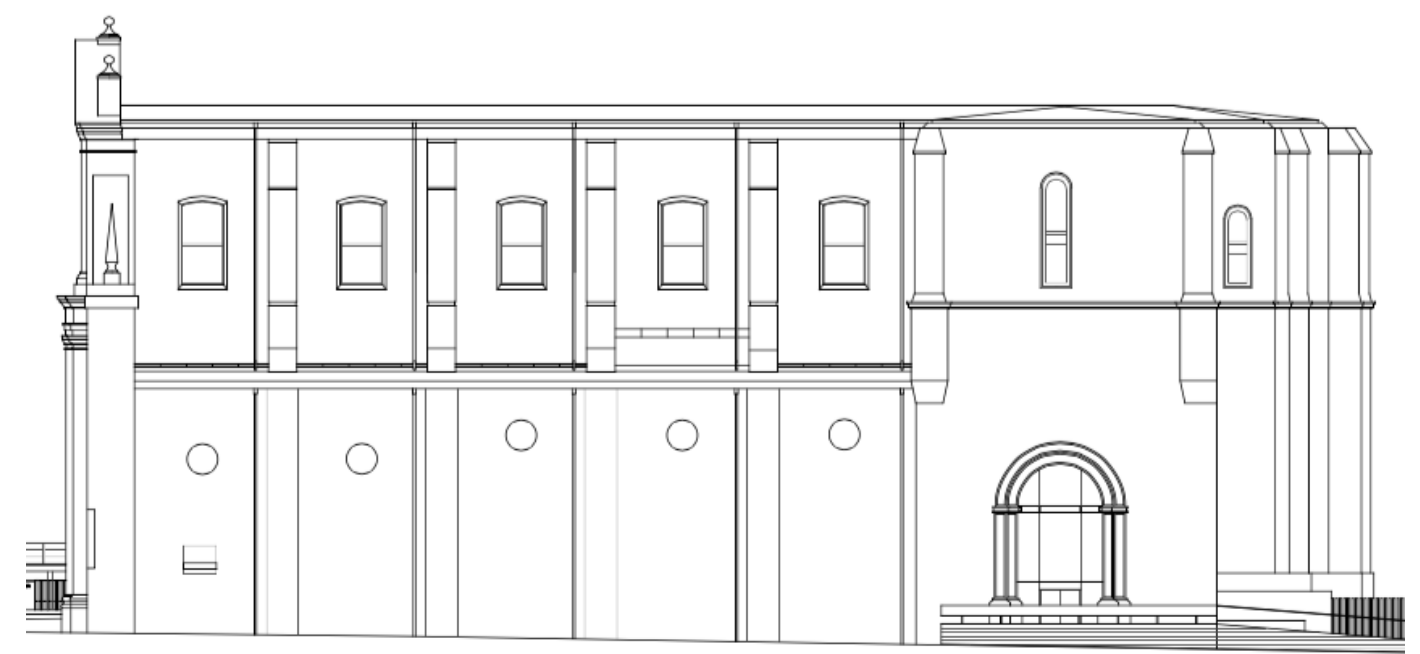

Ilustración 8: alzado norte Gallegos y González 2004 AMVA

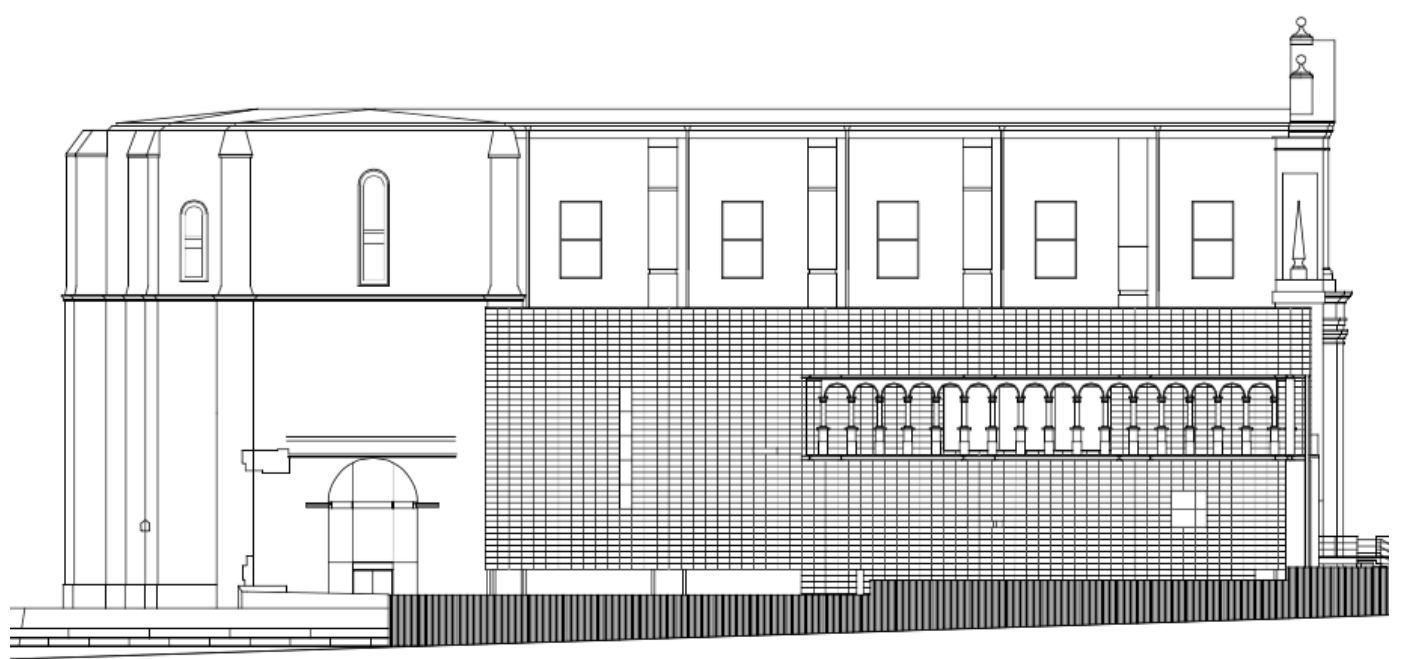

Ilustración 9: alzado sur

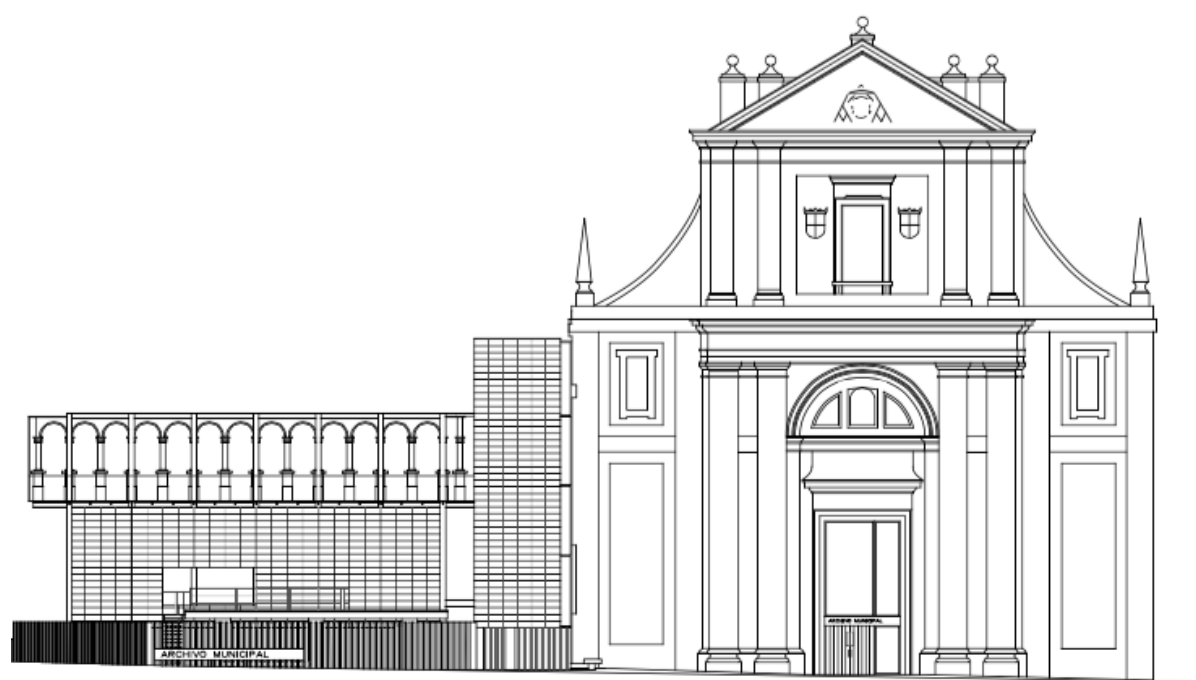

Ilustración 10: fachada a los pies Gallegos y González AMVA 


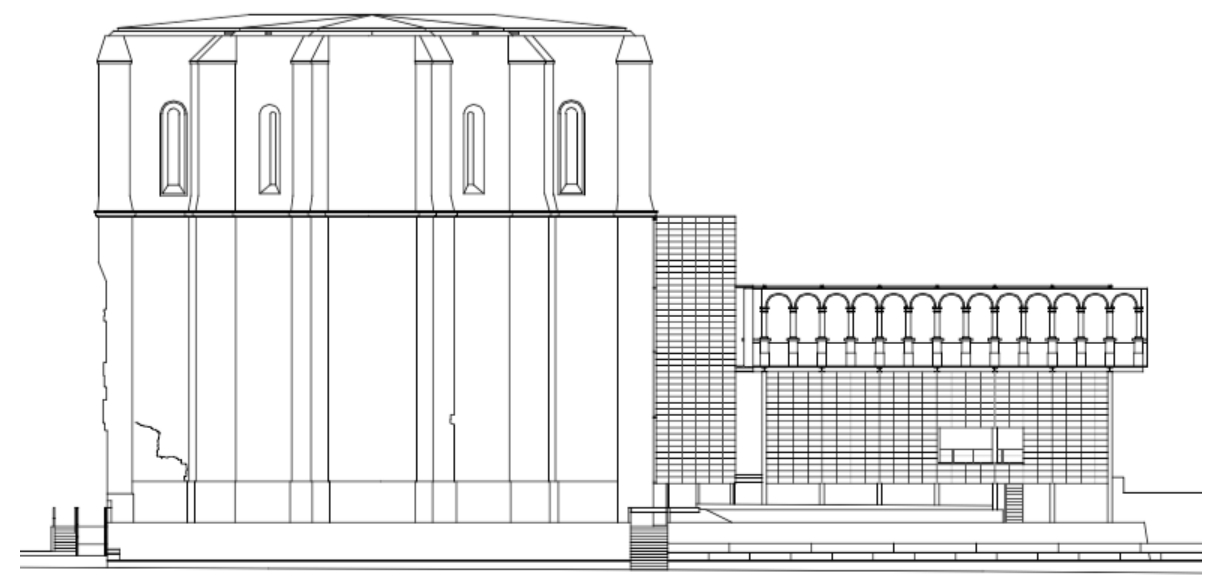

Ilustración 11: alzado de cabecera Gallegos y González AMVA

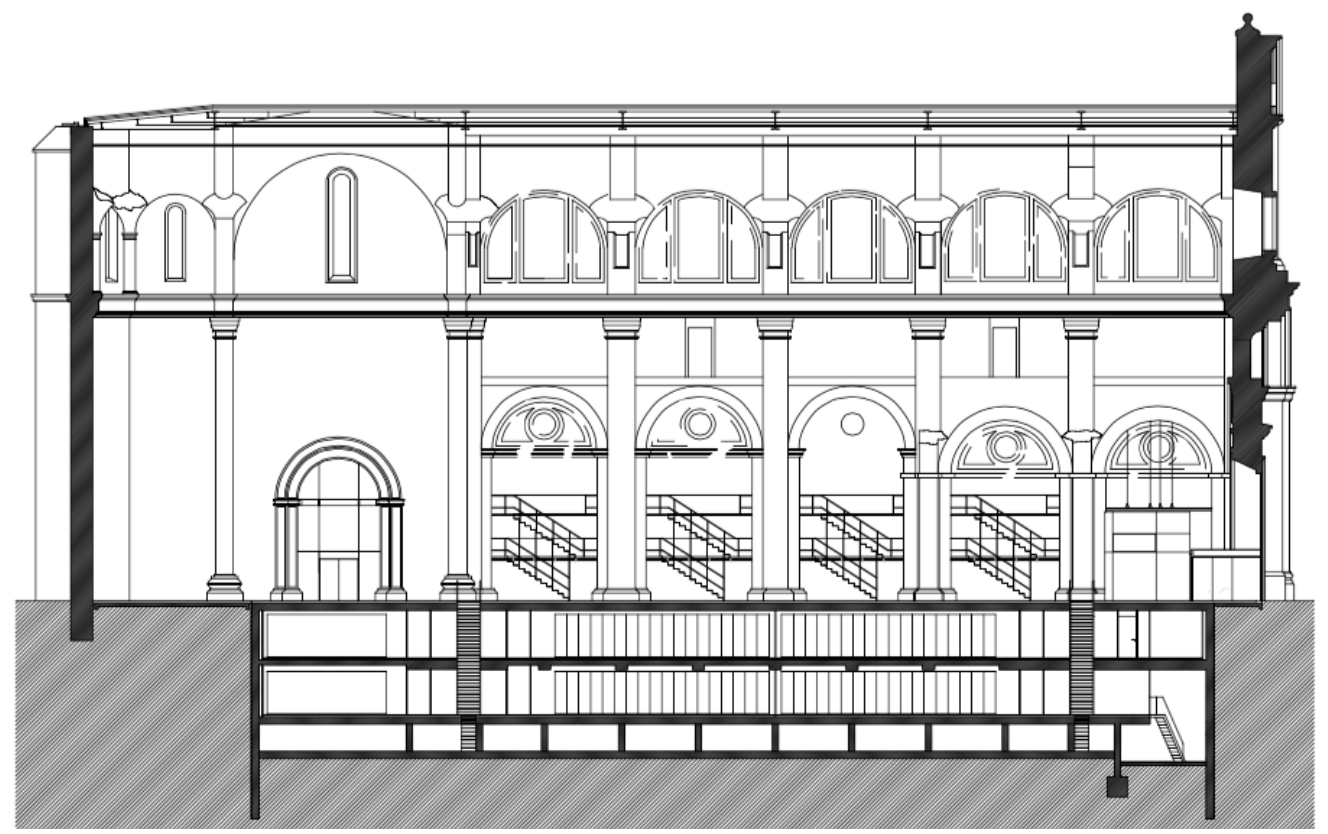

Ilustración 12: sección longitudinal Gallegos y González AMVA

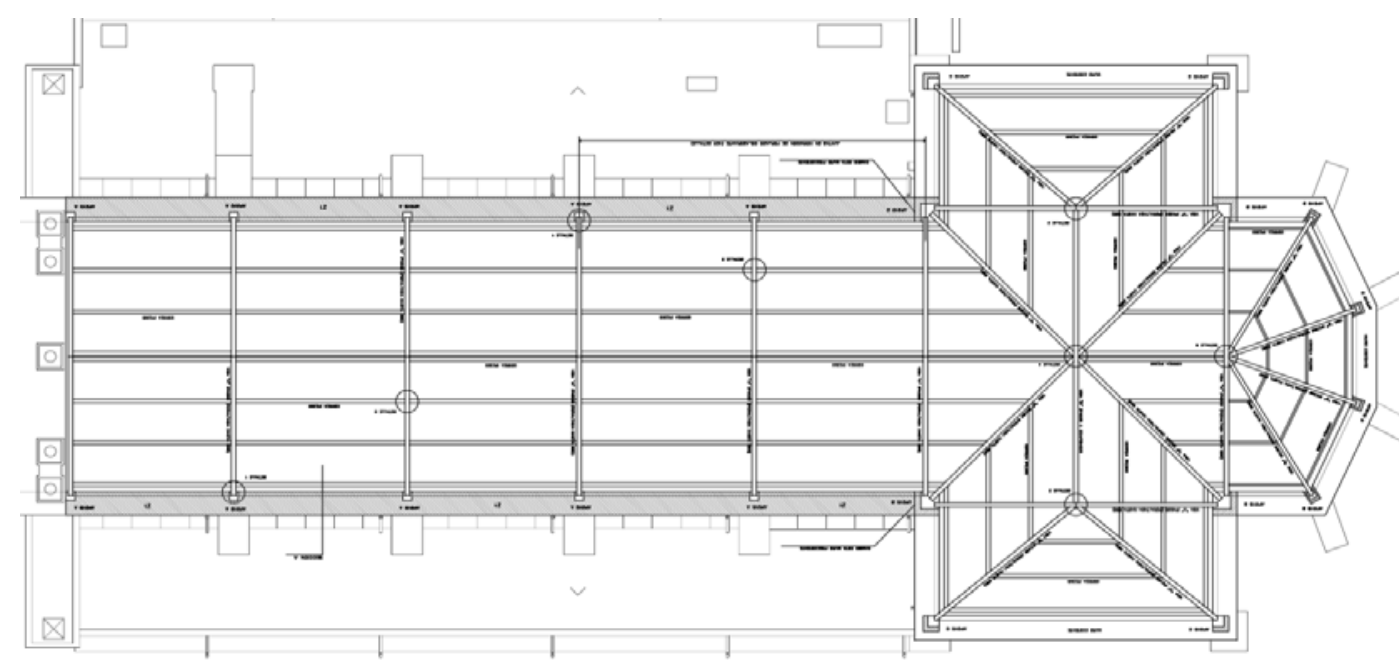

Ilustración 13: planta estructura de cubierta 1999 Gallegos y González AMVA 


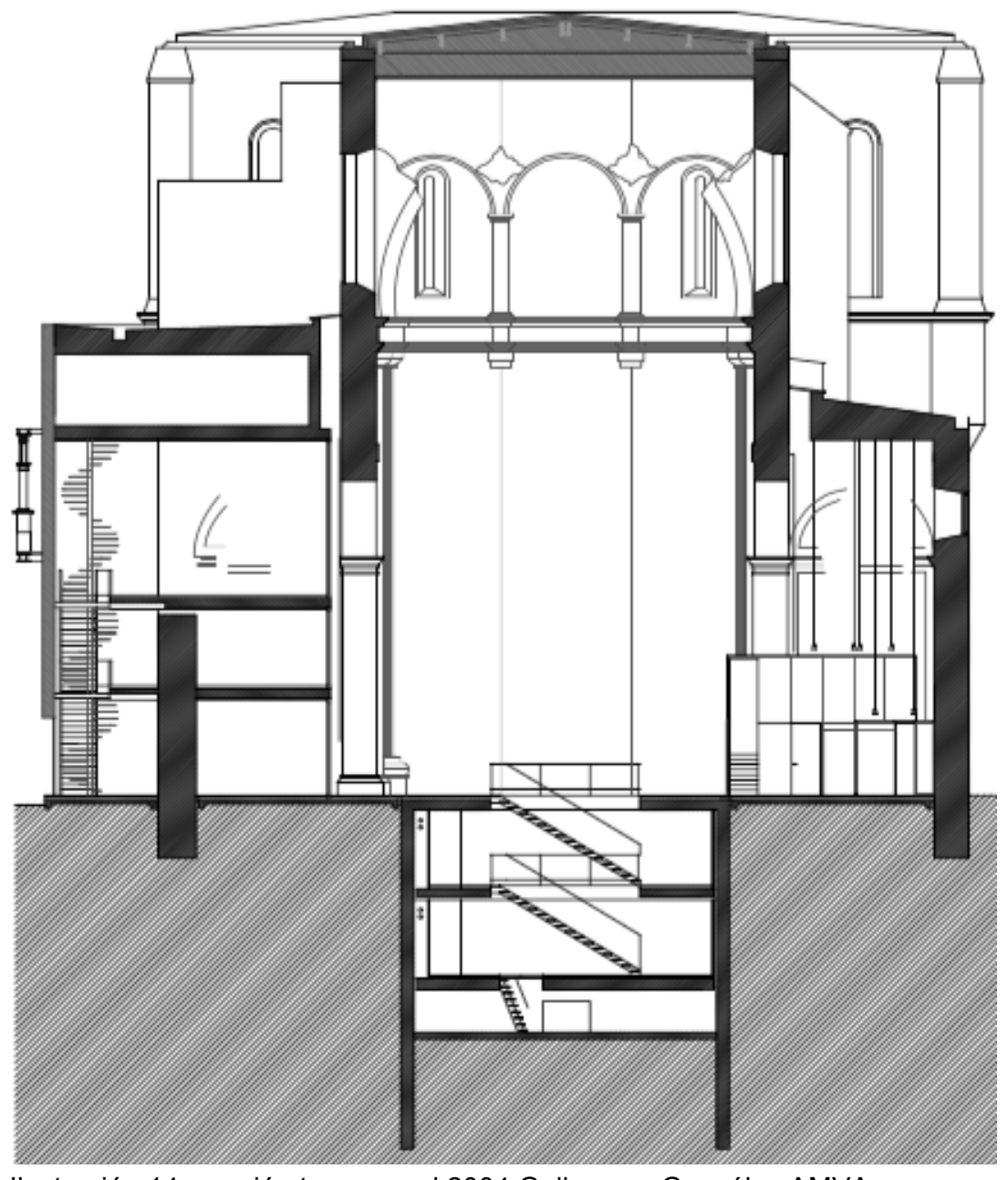

Ilustración 14: sección transversal 2004 Gallegos y González AMVA

\section{Solución constructiva de la cubierta}

En las secciones se aprecia la estructura metálica de cubierta, incorporada en 1999, formada por perfiles de acero IPN-550, peraltados hasta 880 , de $12,5 \mathrm{~m}$ de luz, biapoyados, con una losa superior de hormigón sobre chapa grecada colaborante. En la memoria se indica que estas vigas sirven además como elementos de arriostramiento de los muros de fábrica. La pendiente a dos aguas, determinada por la sección variable del IPN-550 peraltado hasta 880 , es de menos de $5^{\circ}$.

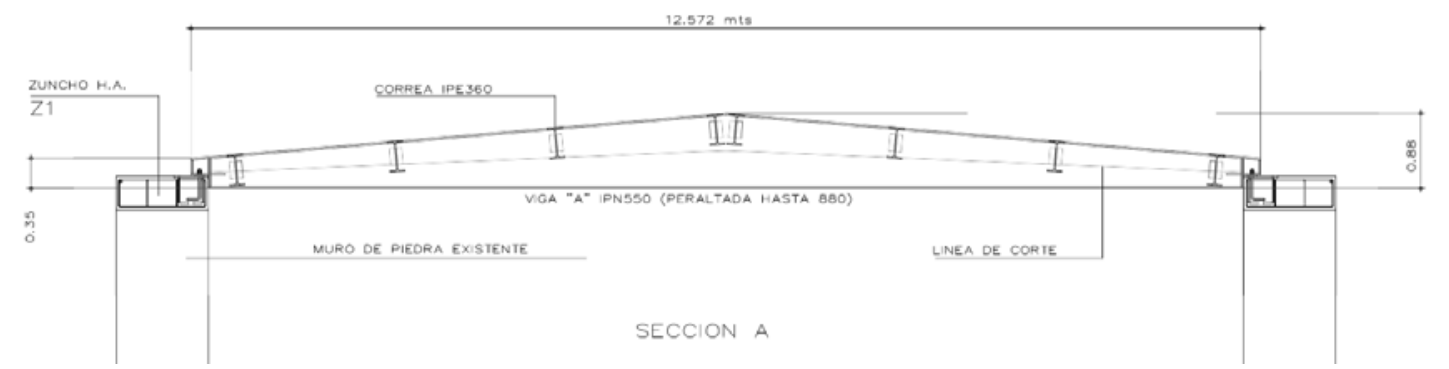

Ilustración 15: sección transversal estructura de cubierta 1999 Gallegos y González AMVA 


\section{Zunchos}

En el plano E7 estructura de cubierta, de mayo de 1999, hay un detalle del apoyo A de las vigas sobre un zuncho corrido de $30 \mathrm{~cm}$ de canto con el ancho del muro, en paralelo a ambos lados de la nave, que no se prolonga sobre el testero a los pies ni en la cabecera. Según el presupuesto del posterior modificado, sin embargo, el ancho de dicho zuncho figura de $1,10 \mathrm{~m}$ y su canto es de $40 \mathrm{~cm}$.

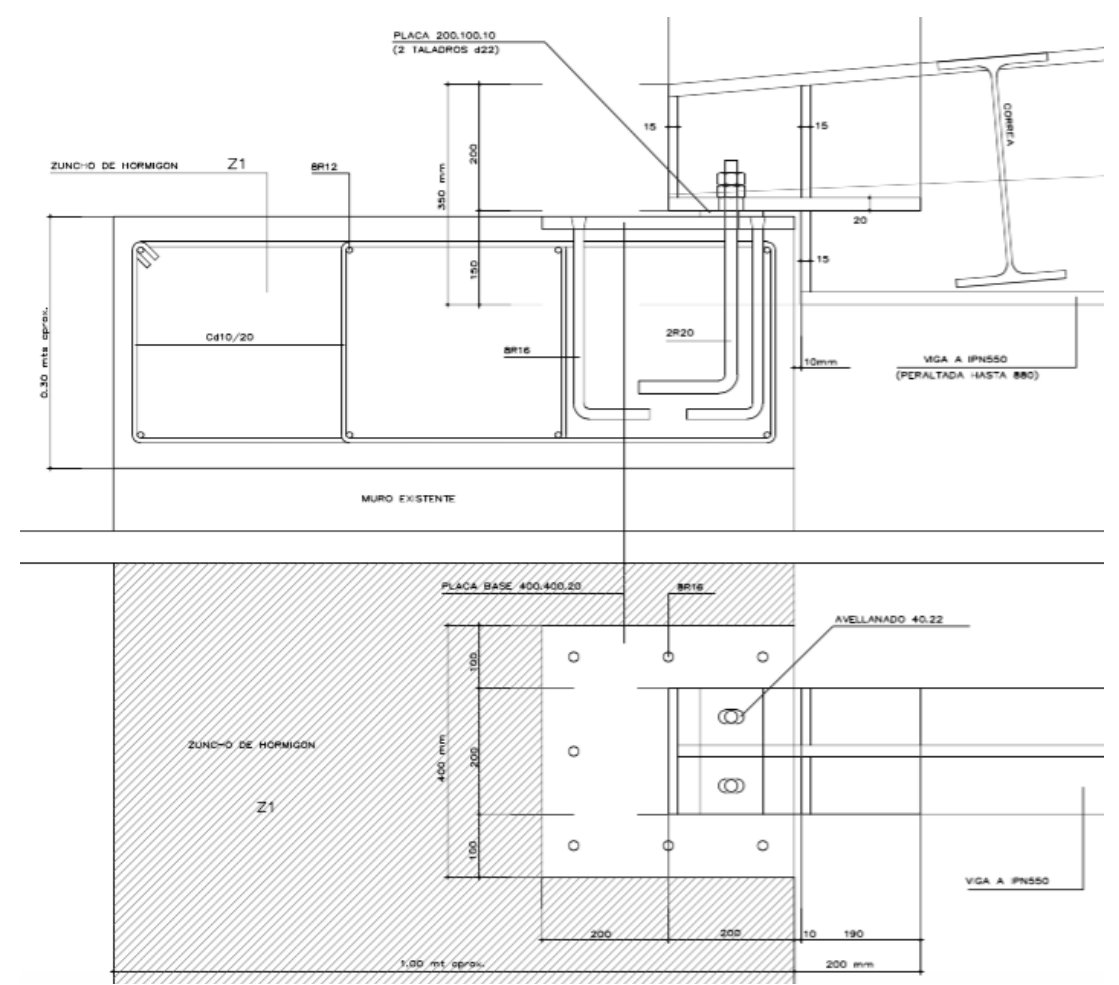

Ilustración 16: detalle del zuncho corrido Z1, plano E7 1999 Gallegos y González AMVA

En el plano E7 de 1999 se representa sobre el perímetro de la cabecera unos dados de hormigón, cajeados en el muro de piedra, de diferentes tamaños cuadrados con 50, 70 y $110 \mathrm{~cm}$ de lado, y canto $30 \mathrm{~cm}$ sobre los que apoyan las vigas metálicas diagonales.

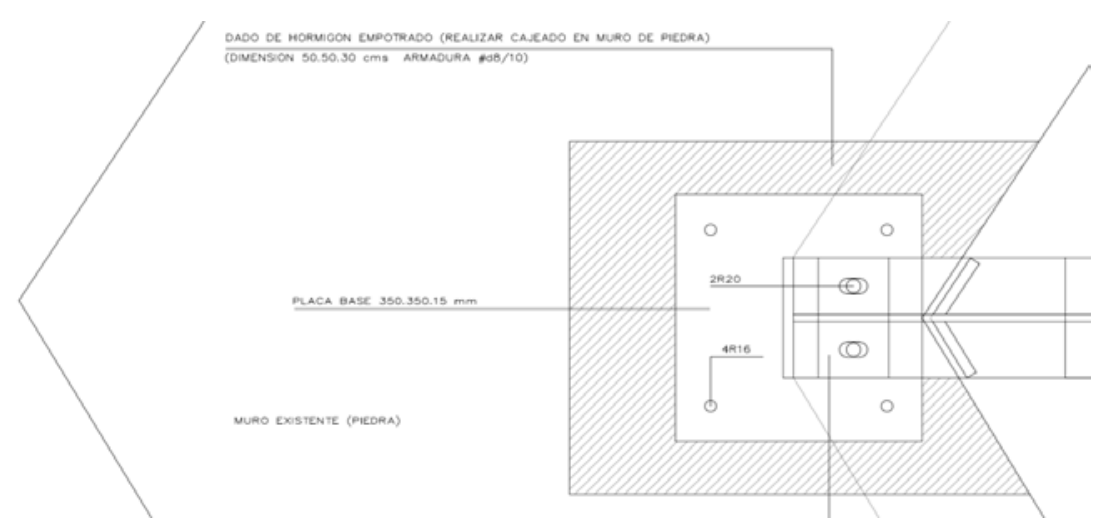

Ilustración 17: detalle de dado en vértices del ábside poligonal 
En el presupuesto del posterior modificado de 2001, sin embargo, se recogen 23 elementos de distintas longitudes entre 1,0 y $12,5 \mathrm{~m}$, que corresponden al perímetro completo quebrado que conforma cabecera y crucero, todos con $35 \mathrm{~cm}$ de ancho y 40 $\mathrm{cm}$ de canto, solución que no coincide con la representada en el plano citado de estructura del proyecto original.

\section{Conclusiones}

En este edificio se incorporó, según el proyecto de obras, un zuncho rectangular de $110 \times 40 \mathrm{~cm}$ sobre los cerramientos laterales de fábrica de ladrillo de la nave central, que no se prolonga sobre el testero a los pies. En la cabecera poligonal de piedra, aunque en el proyecto original estaba previsto colocar dados de hormigón cajeados en la fábrica, según el presupuesto del modificado final se dispuso un zuncho corrido quebrado de $35 \times 40 \mathrm{~cm}$.
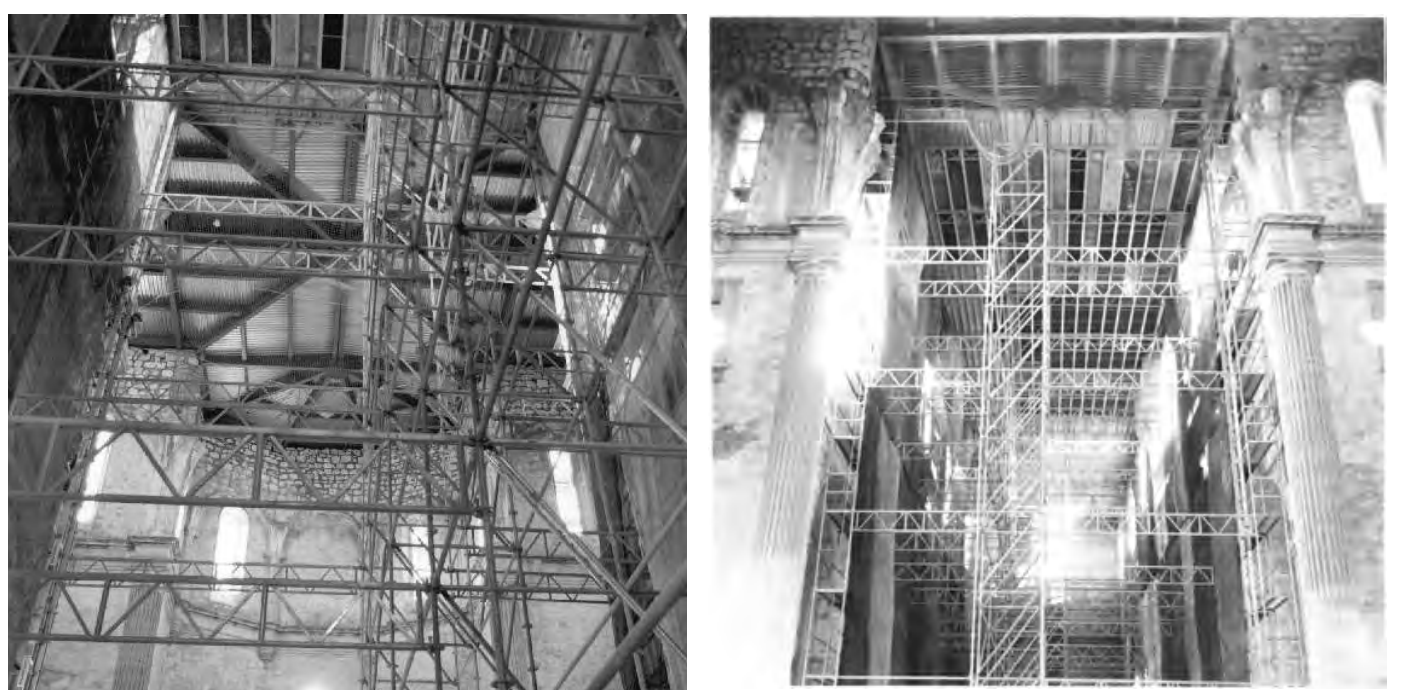

Ilustración 18: fotografías de obra, gentileza D. Eduardo Pedruelo (Director AMVA)

Aunque por falta de acceso no es posible comprobar in situ cómo se ejecutó la estructura de cubierta, en varias imágenes de la obra se aprecia la estructura metálica con chapa colaborante acorde con la geometría definida en los planos del proyecto. En el conjunto de imágenes, tomadas desde el suelo de planta baja, no se aprecian zunchos en la coronación de los muros. 



\section{Iglesia de San Agustín}

Intervenciones citadas en la publicación del Ministerio

1967 - Recalce y consolidación de muros y portada - José Antonio Arenillas Asín

No hay planos en la web del IPCE

\section{En el Archivo General de la Administración}

AGA 26/00131

1968 - Recalzo y consolidación de muros y portada - José Antonio Arenillas Asín Memoria: Proyecto de consolidación y saneado de las ruinas. Consiste en el recalzo de los muros perimetrales por puntos, y limpieza de escombros en el recinto de la iglesia. Restauración de la portada sustituyendo piedras en mal estado, rejuntando el resto con mortero mixto de cal y cemento.

Plano de planta 1:200 de julio de 1967 firmado Por Orden de Anselmo Arenillas, el presupuesto lo firma como Arquitecto ayudante de la segunda zona de monumentos.

\section{En el Archivo Municipal de Valladolid}

\section{Fondo Histórico}

AMVA: 1053-68 1929

Expediente relativo a permuta de la iglesia de San Agustín, donde se encuentra el Parque de Intendencia, por solar del Ayuntamiento donde se construirá dicho parque

\section{Fondo Administrativo}

AMVA: 1994 Expediente de obras municipales C.30124-2

Informe sobre el estado actual de la iglesia de San Agustín. Antecedentes.

Equipo Córbicu (exisa, del grupo texsa): informe de Antonio Gabaldón Carrizo

Portada y fábricas de piedra caliza: 65x26×29m; fábrica de sillares, sillarejo y mampostería revestida. Tramo de muro en fachada norte de tapial 39x8m Pruebas de limpieza, propuesta de tratamientos:

Eliminación de sales solubles con agua desionizada y pulpa de papel 
Consolidación con ésteres de silicio tipo Cotefilm endurecedor

Reintegración con morteros de tercera generación y epoxídicos, con carga de polvo de piedra, anclaje con varillas de fibra de vidrio y resinas epoxídicas Impermeabilización con Cotefilm HF, de Texsa

AMVA: 1998-2004 C.30125-1 (7 cajas)

Proyecto de las obras de rehabilitación de la iglesia de San Agustín para Archivo Municipal (Exp. 7/2000). Arquitectos: Gabriel Gallegos y Primitivo González.

Contratista: NECSO Entrecanales Cubiertas SA

Contiene :

Pieza 1.- Expediente administrativo

Pieza 2.- Informe arqueológico e intervención en la iglesia. FORAMEN SL

El convento estaba organizado en 1416. Su máximo esplendor viene en 1605 cuando se está construyendo la capilla mayor de la iglesia. (En 1591 hay 40 religiosos y en 1606 hay 79) Al pasar las tropas francesas en 1801 lo usan como albergue y poco después es cuadra y pajar.

En 1814 cuatro monjes reanudan su actividad, con un desalojo temporal durante el trienio liberal, hasta su Desamortización en 1835. En 1864 la iglesia sirve como granero de paja para los caballos de la guarnición militar.

EN 1942 se concreta la permuta al Ayuntamiento, que se lleva a efecto en 1966.

Cabecera renacentista, ábside de cantería, poligonal con contrafuertes en los ángulos rematados por un plano inclinado. La segunda fase de la construcción de la iglesia se inicia en 1589, rematando dos de las primeras capillas hornacinas, capilla mayor y crucero hacia 1594, con trazas de Alonso de Tolosa y Diego de Praves, firmadas por el segundo.

La última etapa constructiva del templo se inicia en 1619: cimientos, cuerpo principal de la iglesia, resto de capillas, coro y portada.

Mientras que al interior los muros son de ladrillo, por el exterior las capillas están realizadas en tapial en el que alternan algunas hiladas horizontales de ladrillo.

Encima de las capillas hornacinas del lado norte se construyó un cuarto para noviciado. 
Pieza 3.- Proyecto de ejecución de acondicionamiento de la iglesia de San Agustín para Archivo Municipal. Memoria y pliego (mayo de 1999)

Arquitectos: Gabriel Gallegos Borges y Primitivo González Estado actual

En la actualidad el edificio conserva los cerramientos exteriores, salvo las cubiertas de las naves central y laterales y el muro de cierre de las capillas a las que estuviera adosado el claustro.

La fachada y su ábside, así como los contrafuertes, están realizados en cantería. Los entrepaños de la nave central, en los que se abren huecos de dimensión rectangular, conservan la fábrica de ladrillo, vista hacia el exterior y guarnecida hacia el interior. En ellos se manifiestan diferentes mechinales provenientes de estructuras adosadas y posteriormente desmanteladas. El muro sur de las capillas nos presenta las mas variopintas texturas (...) el muro norte de las capillas está construido con tapial y verdugadas intermedias de ladrillo entre paños de mampostería correspondientes a los contrafuertes.

Actuación

La nueva cubierta, lejos de una recuperación mimética, trata de ser poco aparente, para así conseguir preservar la imagen actual de la iglesia, realizándose en zinc con una ligera pendiente.

\section{Demoliciones}

Se prevé demoler parcialmente el muro de cerramiento de la fachada sur, que se encuentra en mal estado. Pequeñas demoliciones para apertura de huecos existentes, actualmente cegados, nuevos huecos, limpieza de coronación de muros...

Se rebaja el nivel del interior de la iglesia para adecuarlo a la cota prevista de acabados. Muro pantalla para excavar los sótanos, micropilotes en la zona de ascensor y montacargas. Las pantallas se arriostran con vigas metálicas que conformarán el forjado de sótano, el de baja con placas alveolares. Zapatas aisladas bajo el cerramiento nuevo de estructura metálica en la fachada sur (que crea pasillo de comunicación entre niveles)

"La estructura de cubierta se realizará mediante vigas metálicas que servirán así mismo como elementos de arriostramiento de los esbeltos muros de las fábricas de la iglesia. Soportadas por las vigas se dispondrán correas formadas por perfiles de acero. Sobre ellos se colocará una losa de hormigón utilizando como encofrado perdido chapas de acero grecadas colaborantes. 
Cubierta inclinada

El tipo de cubierta será de junta alzada clavada sobre rastrel de madera. Esta cubierta verterá a un canalón, perimetral en la nave central, central en el lado sur y lateral en el lado norte, de lámina de plomo y bajantes de zinc. En el ábside se colocarán gárgolas de desagüe aunque el canalón está también conectado a dos bajantes que desaguarán a las cubiertas de las capillas.

Cálculo de estructuras: forjados, pantalla, vigas de cubierta de $12,5 \mathrm{~m}$ de luz biapoyadas.

Cédula urbanística.

Estudio geotécnico

Pliego

Control de calidad

Pieza 4.- Proyecto de ejecución. Planos (1999)

Altura acotada suelo baja hasta falso techo: 22,93m (capilla lateral 11,38)

En plano E7 estructura de cubierta de mayo de 1999 hay un detalle del apoyo A de las vigas IPN-550 peraltadas hasta 880 sobre zuncho corrido a ambos lados. Entre las vigas hay correas IPE-360.

En la cabecera no se prolonga el zuncho, sino que se diseñan tres tamaños de dado de hormigón empotrado cajeado en muro de piedra: en vértices de crucero apoyo $\mathrm{C}$ de 70.70 .30 con $\mathrm{D} 8 / 15$; en esquinas del crucero con nave y cabecera detalle $\mathrm{B}$ de 110.110 .30 con D10/15 y en vértices de ábside poligonal detalle apoyo D con dado 50.50 .30 armado con D8/10.

Pieza 11.- Proyecto modificado. Expediente administrativo y planos (2000-2002)

En la caja hay también documentación administrativa. Incremento de honorarios de los arquitectos acorde al modificado. Nota de prensa de aprobación del proyecto en mayo de 1999. (El modificado es de octubre de 2002) Un comparativo de presupuestos de otros archivos en Ávila, Toledo, Barcelona, Málaga...)

El modificado incluye revestimientos no medidos, la Biblioteca y el pórtico nuevo de perfiles laminados HEB para soportar el claustro que estaba en el Museo de Escultura. 
Pieza 12.- Proyecto modificado. Cuadro de precios y presupuesto (2001)

En presupuesto del modificado hay

$51 \mathrm{~m} 3$ de H.A. Zuncho en muro coronación.

Hormigón armado HM-25 N/mm2., Tmáx 20 mm., consistencia plástica, elaborado en central, en zuncho de atado coronación de muro i/p.p. de armadura $(55 \mathrm{~kg} / \mathrm{m} 3$.), saneado de la coronación, cajeado fábricas de sillar, encofrado y desencofrado de madera, vertido con pluma-grúa, vibrado y colocado. Según planos detalle de proyecto y normas NTE-EME y EHE.

$\begin{array}{llllll}\text { Nave central } & 2 & 38,00 & 1,10 & 0,40 & 33,44 \\ \text { Abside } & 12 & 1,00 & 1,50 & 0,40 & 7,20 \\ \text { " " } & 4 & 6,50 & 0,35 & 0,40 & 3,64 \\ \text { " " } & 2 & 12,50 & 0,35 & 0,40 & 3,50 \\ \text { " " } & 2 & 4,00 & 0,35 & 0,40 & 1,12 \\ \text { " " } & 3 & 5,00 & 0,35 & 0,40 & 2,10\end{array}$

El forjado de cubierta, $925,80 \mathrm{~m} 2$ de metal y chapa nervada Lesaca.S2 de $1 \mathrm{~mm}$, con capa de compresión de $5 \mathrm{~cm}$ de mortero de cemento y arena de río.

Pieza 18.- Proyecto final de obra y planos (2004)

Rehabilitación de la iglesia de San Agustín para Archivo Municipal Certificado final de la dirección de la obra de 24 de febrero de 2004.

Dos juegos de 16 planos "proyecto de ejecución final" con firmas originales de Gabriel Gallegos y Primitivo González.

Pieza 24.- Manuales y CD's (mantenimiento, proyecto)

Pido copia del CD con los planos de los tres proyectos de 1999, 2002 y 2004 en formato dwg.

\author{
En el archivo de la Junta de Castilla y León
}

No se ha localizado documentación (edificio de propiedad municipal) 



\section{Iglesia del Monasterio de San Benito el Real}

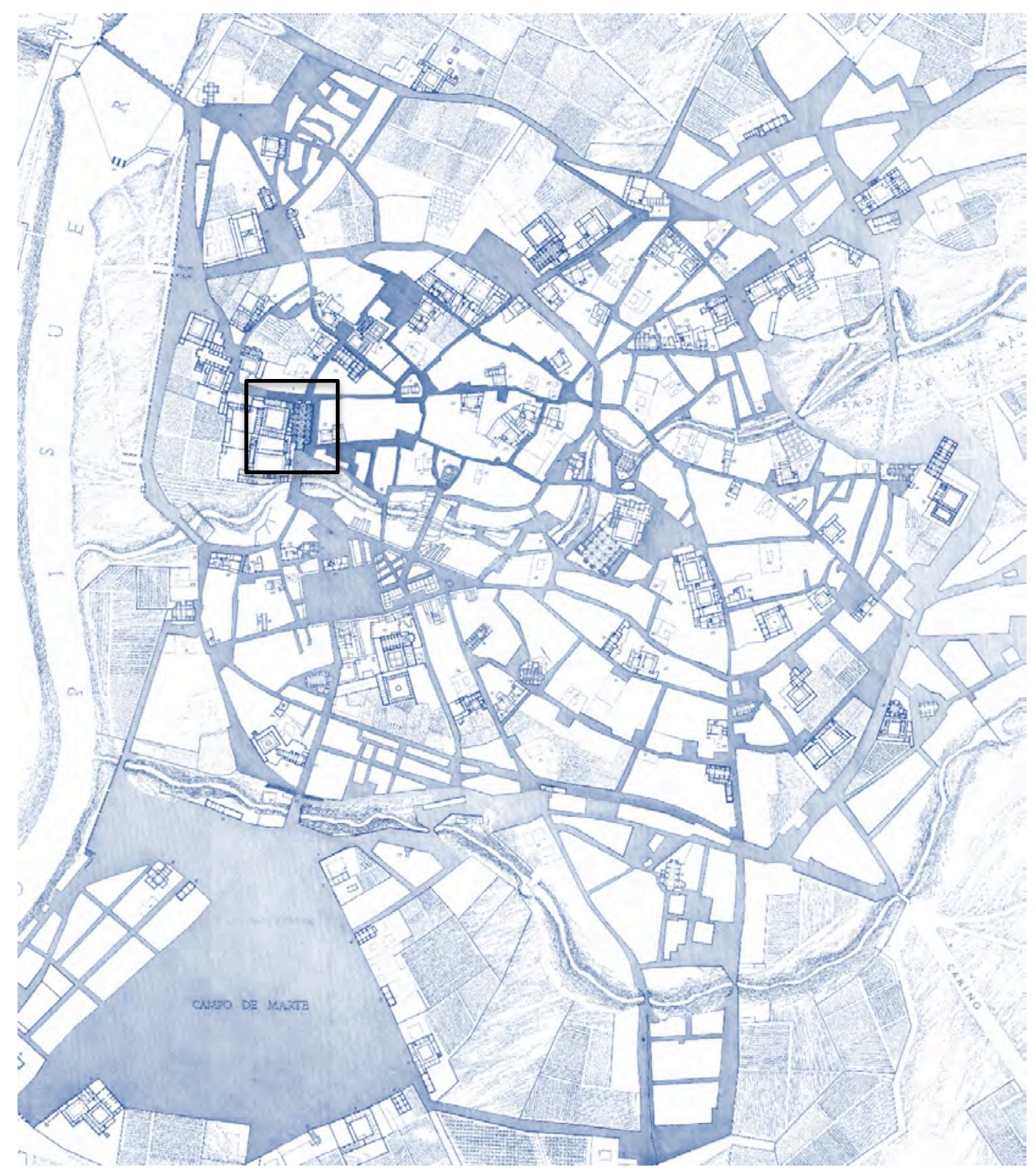



FICHA SÍNTESIS

\section{Código de identificación: FZ-08}

Denominación: $\quad$ Iglesia del monasterio de San Benito el Real

Localidad: $\quad$ Valladolid
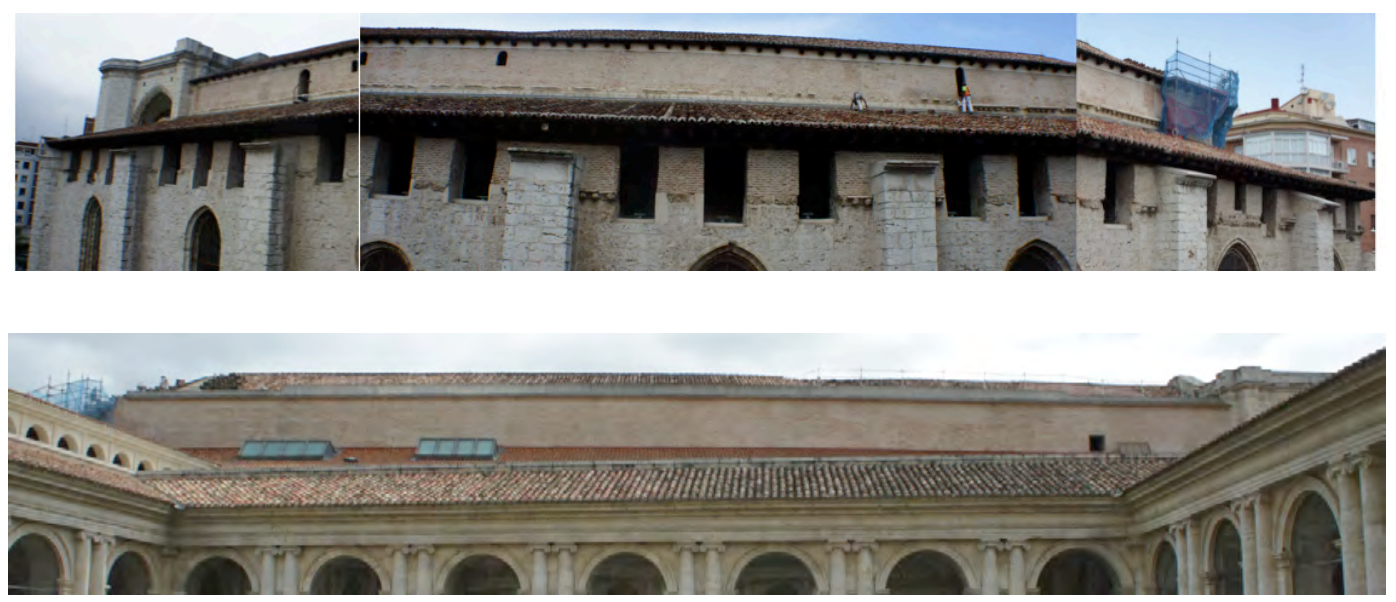

\section{Descripción}

Iglesia gótica de tres naves, distribuidas en seis tramos, con tres ábsides poligonales en la cabecera. Cuenta con potentes pilares de sección octogonal que soportan las bóvedas de crucería estrellada. A los pies se alza una original y robusta torre-atrio.

\section{Materiales}

Los muros son de sillería de piedra, con un recrecido de ladrillo en su coronación. Las cubiertas están revestidas de teja curva (excepto en alguna zona en que se ha incorporado teja mixta) y cuentan con aleros, sobre canes, resueltos en madera.

\section{Singularidades}

La torre-atrio de San Benito es uno de los iconos de la ciudad.

El conjunto monumental en que se inserta el templo es relevante desde el punto de vista de la museística: en el claustro adyacente se ubica el museo de arte contemporáneo español "Patio Herreriano" y en el espacio de la antigua hospedería se desarrollan exposiciones municipales de fotografía.

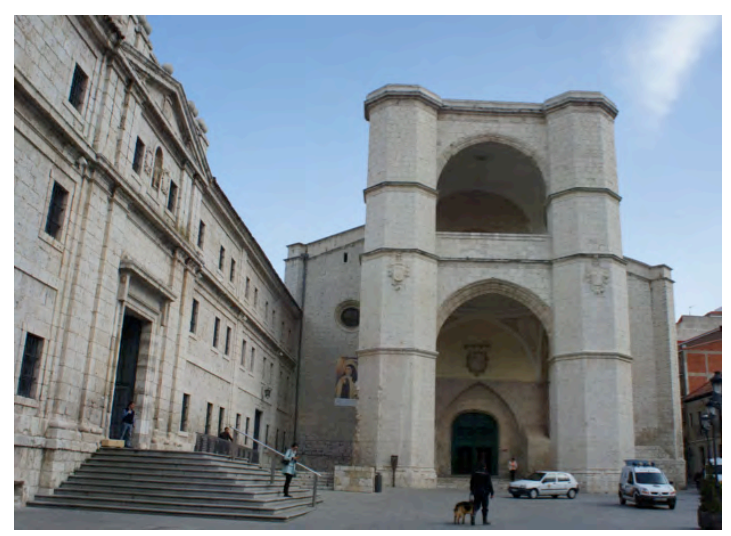

llustración 1: vista frontal de la torre-atrio y entrada al monasterio (visita 11/04/2015) 


\section{Dimensiones básicas del templo}

$\begin{array}{lccc} & \text { central } & \text { laterales } & \text { capillas } \\ \text { Ancho de nave } & 11,8 & 8,4 & \\ \text { Altura } & 21,5 & 15,8\end{array}$

\section{Memoria histórica constructiva}

Según la Memoria histórica de Teófanes Egido contenida en un proyecto de restauración de 1991 (Morán JCyL):

La construcción del templo es rápida, arranca por la cabecera, construida por Juan de Arandia y García de Olave entre 1499 y 1505, rematándose el cuerpo en 1515. Hacia 1540 se levanta el coro alto a los pies y entre 1569 y 1574 Rodrigo Gil de Ontañón y Francisco del río construyen la torre-pórtico que hoy conocemos. Tuvo un remate de ladrillo que doblaba su altura, añadido por Ribero Rada, que se demolió en el XIX. La cubierta original de 1515 descansaba sobre las bóvedas y fue modificada en 1572 colocándose vigas de 22 pinos sobre un recrecido de fábrica de ladrillo, nuevamente renovada en las tres naves entre 1588 y 1590.

Tras la Desamortización el templo se utiliza como almacén, fragua, fuerte... En 1837 se levanta el plano de cubierta para permitir la defensa con armas de fuego desde ventanas y plataformas.

En 1878 el Ministerio de Guerra lo transfiere al Ayuntamiento, que en 1892 lo cede, se restaura y reinaugura solemnemente en 1893 . En 1897 se incorpora la espadaña.

En 1914 se edifica una portería y escalera (luego caja de ascensor) adosadas al ábside de la nave del Evangelio, sobre cuyas bóvedas estuvo ubicada la vivienda de la Comunidad de Carmelitas hasta su desmantelamiento en 1988.

\section{Cronología. Fechas clave}

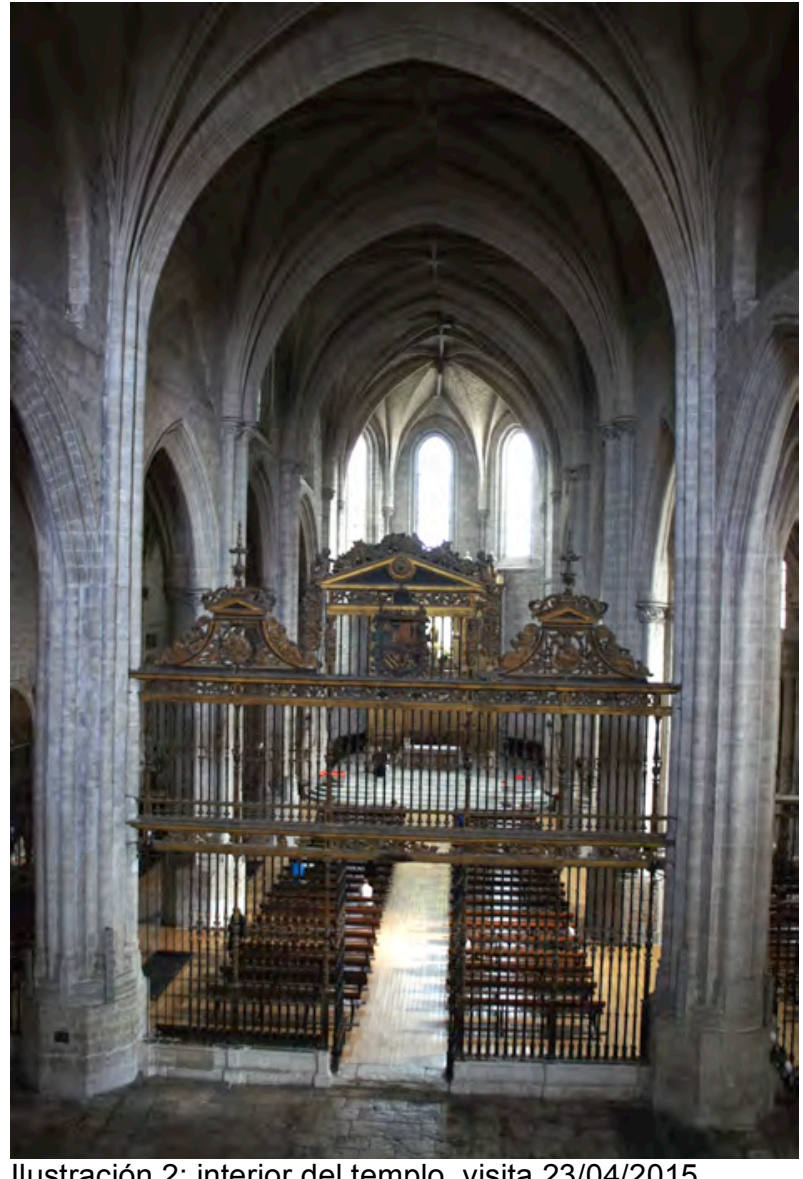

1499 - $1515-1572-1590-1893-1972-1996$ 


\section{Intervenciones}

En 1572 se recrecen los muros perimetrales de cantería con fábrica de ladrillo, colocando nuevas techumbres, con estructuras de madera, que se reemplazan sólo treinta años más tarde.

En el siglo XIX, tras la Desamortización, el templo se utiliza como fuerte y almacén, para lo que sufre de nuevo ciertas reformas.

En 1914 se incorpora un edificio de portería y escalera adosado al ábside.

1972 - Proyecto de obras de Conservación - Felipe Prieto Granda

Se cambia el sistema de calefacción. La limpieza del templo incluye un proceso de descarnado de los revestimientos interiores que deja los sillares al descubierto.

1997 - Restauración - Fernando morán

Limpieza de fachadas, restauración de bóvedas con estuco, demolición de cuerpos añadidos.

Se renueva la cubierta de la nave de la epístola con cerchas de madera laminada y otros elementos de pino. En el croquis, contenido en un dossier de Estudios previos, se describe la geometría de estado actual con los arbotantes ocultos en el bajo cubierta y las cerchas apoyadas sobre los machones recrecidos con ladrillo.

En el proyecto se propone demoler esta fábrica $\mathrm{y}$ reemplazarla por sillares de piedra similares a los del resto de la fachada.

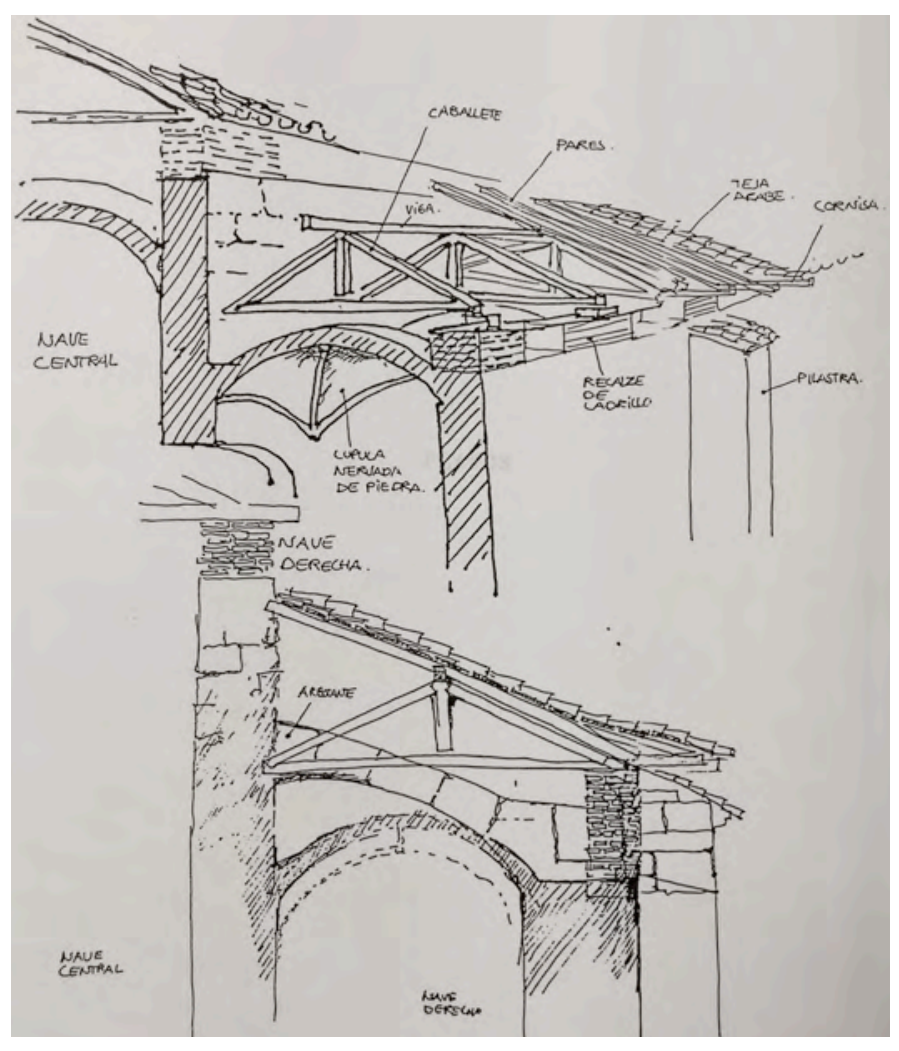

Ilustración 3: croquis de nave lateral (Morán 1991 JCyL)

2000 - Restauración del pórtico - Javier Blanco Matín

Sanea la torre-pórtico, rehaciendo el peto y reordenando los accesos desde la nave central. 


\section{Planos}

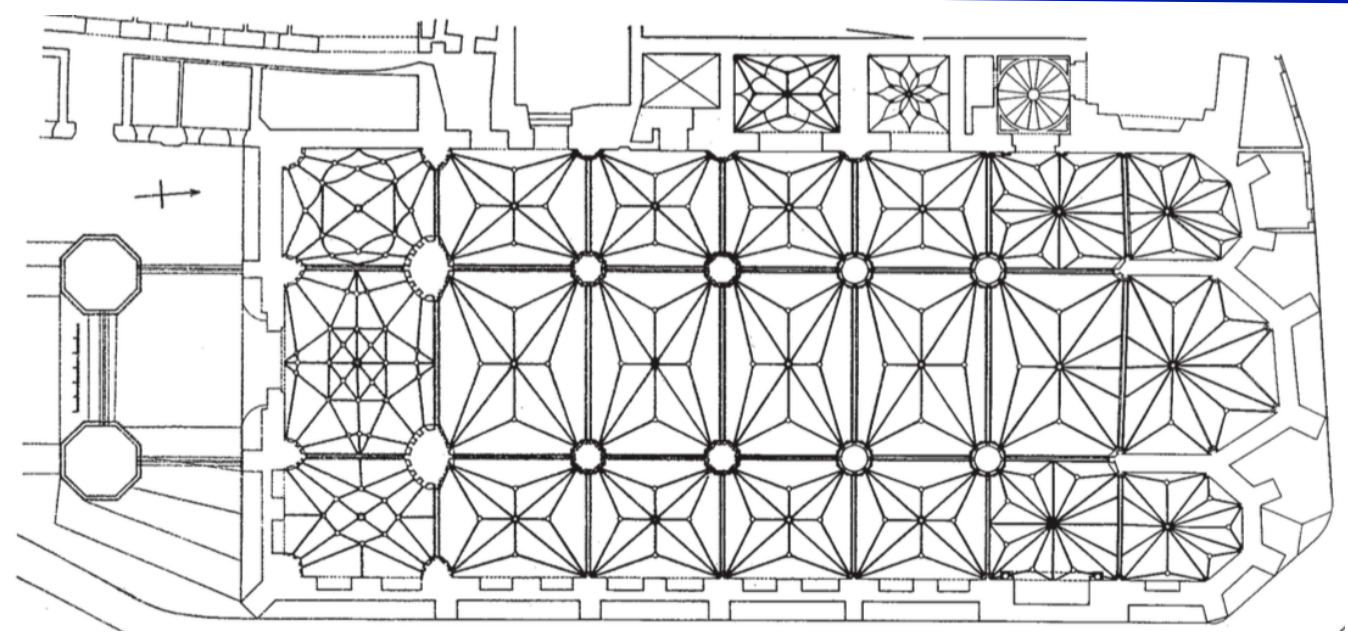

Ilustración 4: planta general del Catálogo

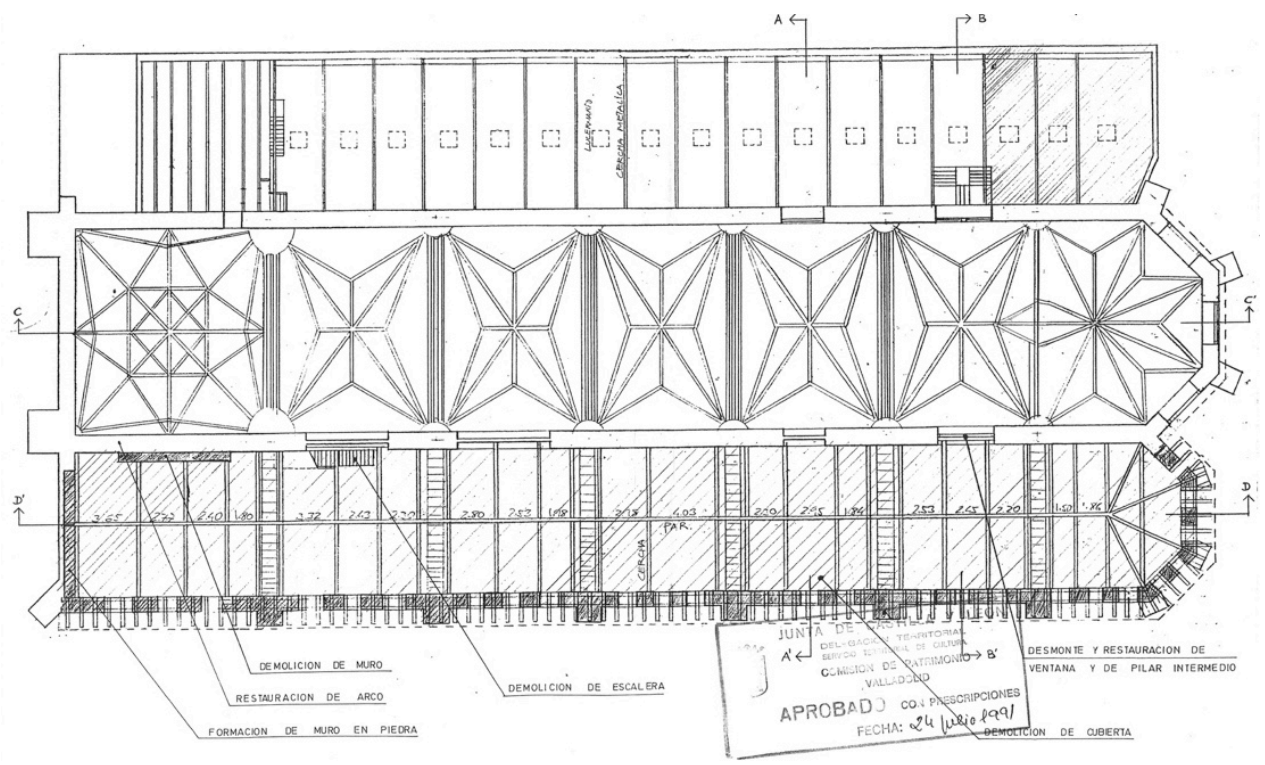

Ilustración 5: estructura de cubierta de nave de la epístola (Morán 1991 JCyL)

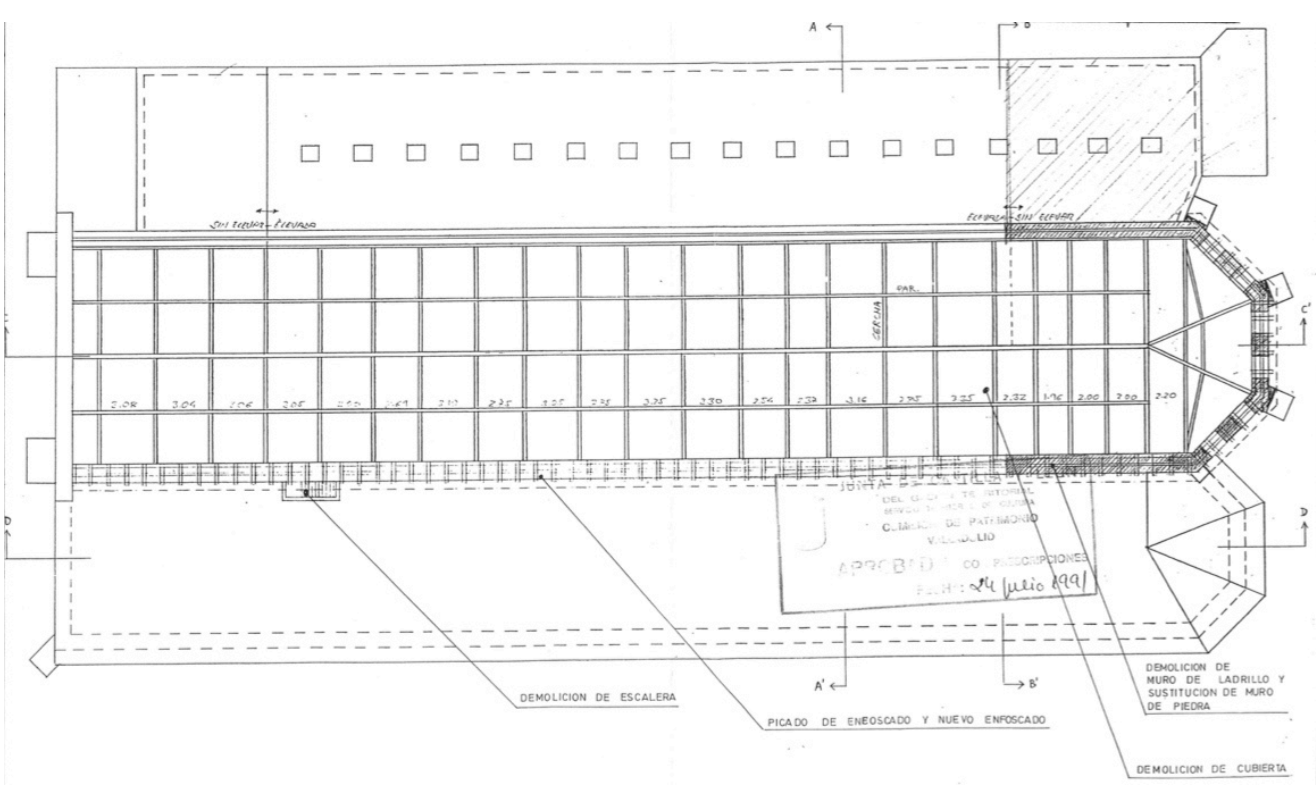

Ilustración 6: estructura de cubierta de nave central (Morán 1991 JCyL) 


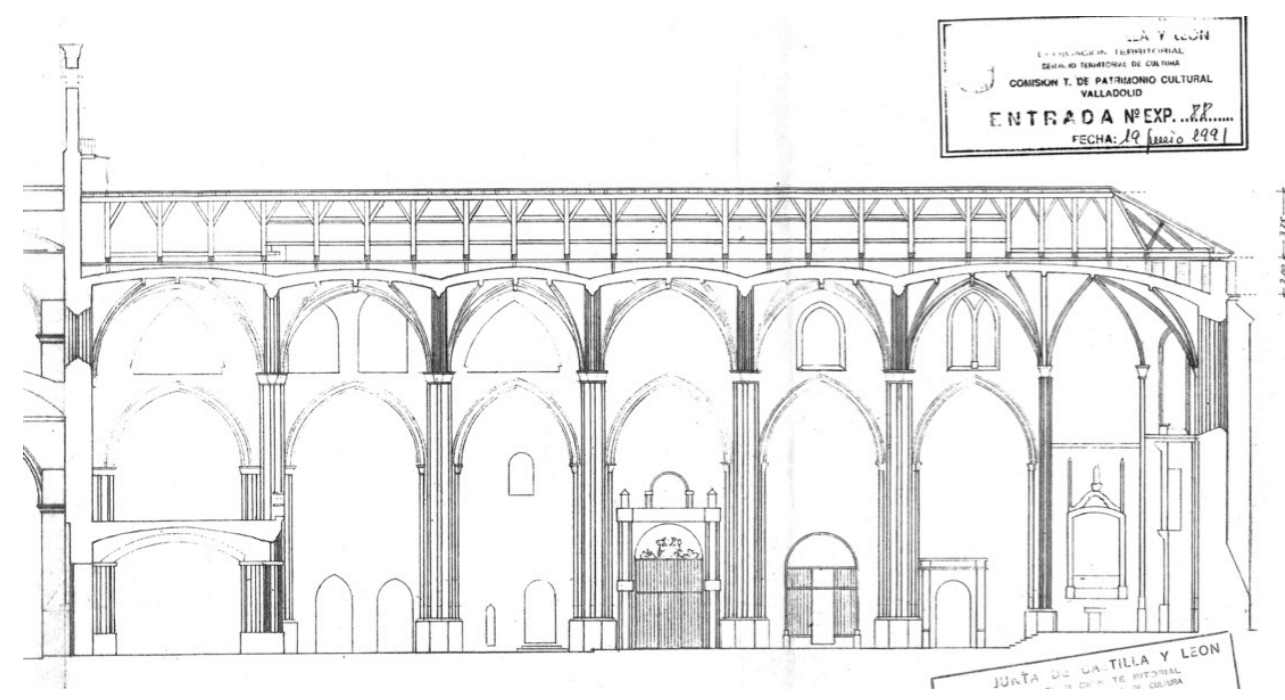

Ilustración 7: sección longitudinal de nave central (Morán 1991 JCyL)

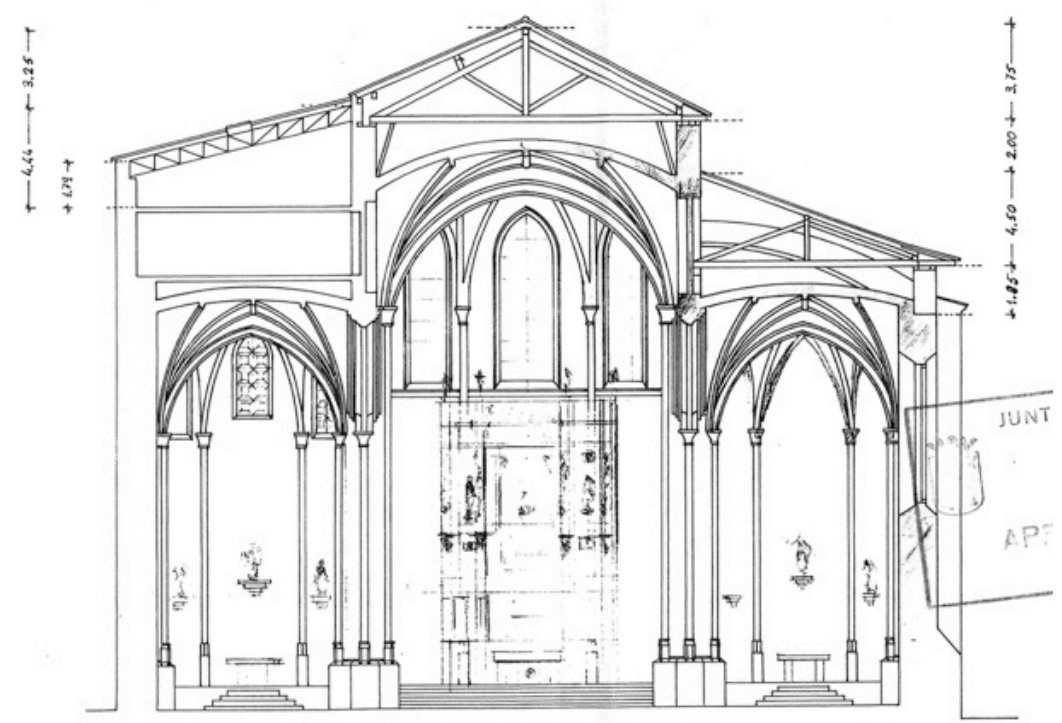

Ilustración 8: sección transversal estado actual en 1991 (Morán JCyL)

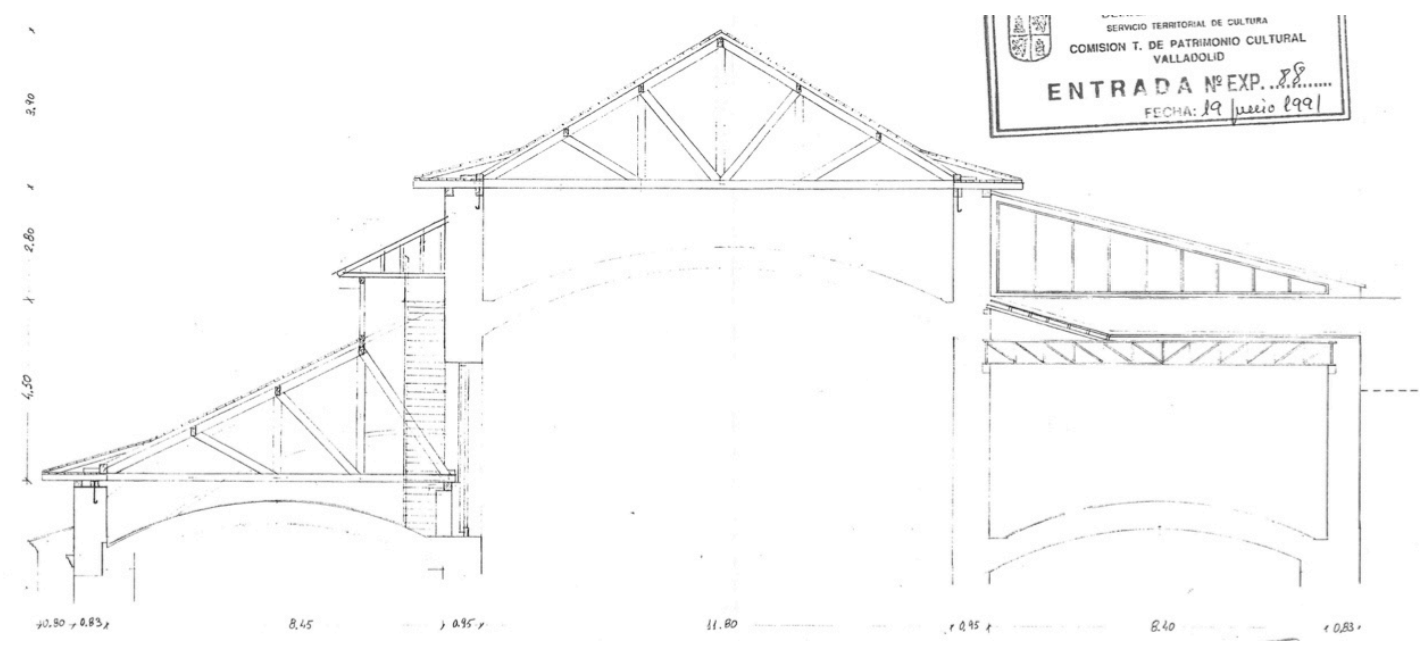

Ilustración 9: detalle de sección transversal propuesta (Morán 1991 JCyL) 


\section{Solución constructiva de la cubierta}

En las secciones se aprecian soluciones distintas en las cubiertas de cada una de las tres naves. La del evangelio cuenta con intervenciones modernas para habilitar la vivienda de los carmelitas. El lateral de la epístola se resuelve, tras la última restauración, con estructura de cerchas de madera laminada que apoyan sobre durmientes triples de madera aserrada de pino soria. El alero se resuelve también con estructura de madera.

Sobre la nave central se conserva la estructura histórica, de cerchas de madera aserrada de considerable escuadría, que corresponde al esquema representado en la sección de la nave incluida en el proyecto de restauración de la torre-pórtico, elaborado por Javier Blanco en 2000.

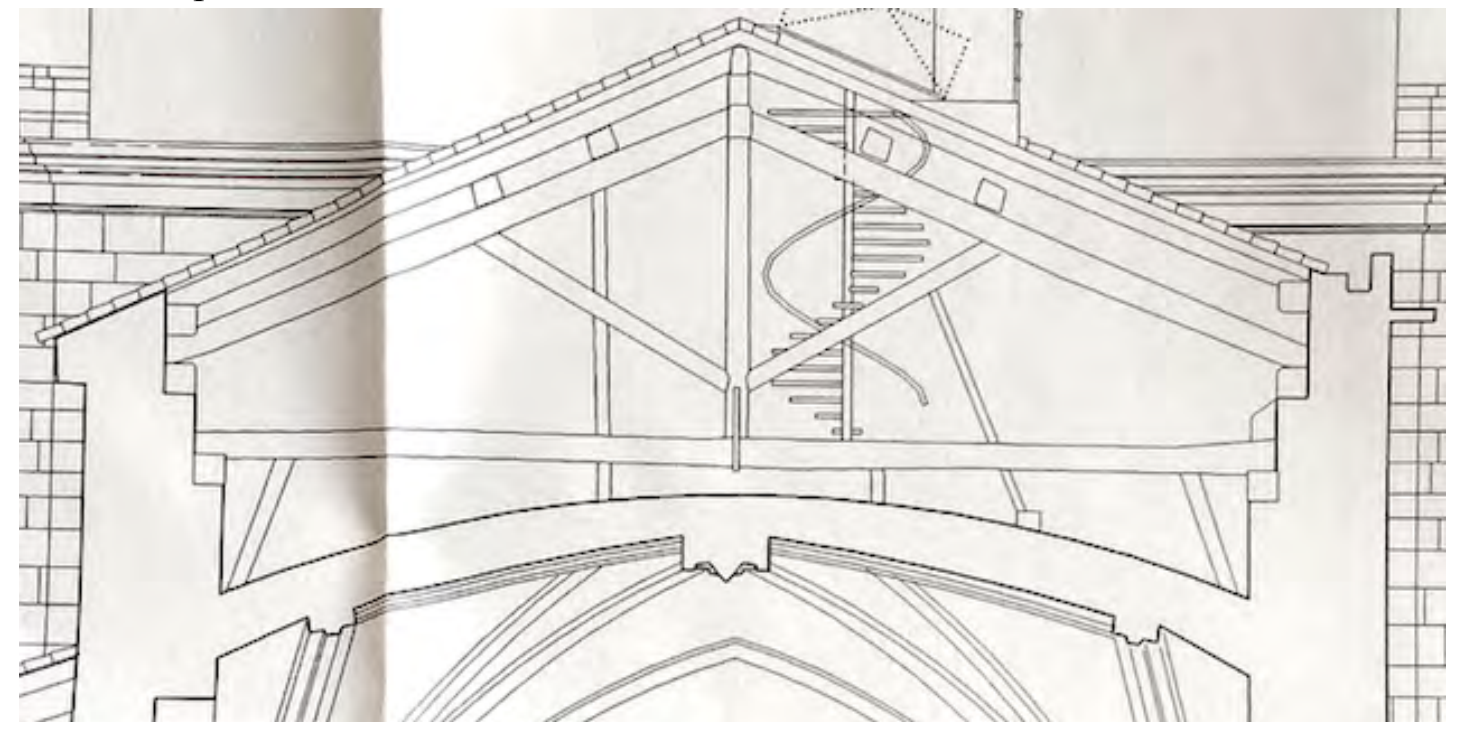

Ilustración 10: sección transversal 2000 Blanco, Fundación

La pendiente representada en los planos del proyecto de restauración de 1991 es de unos $26^{\circ}$ en nave lateral y $31^{\circ}$ sobre la nave central.

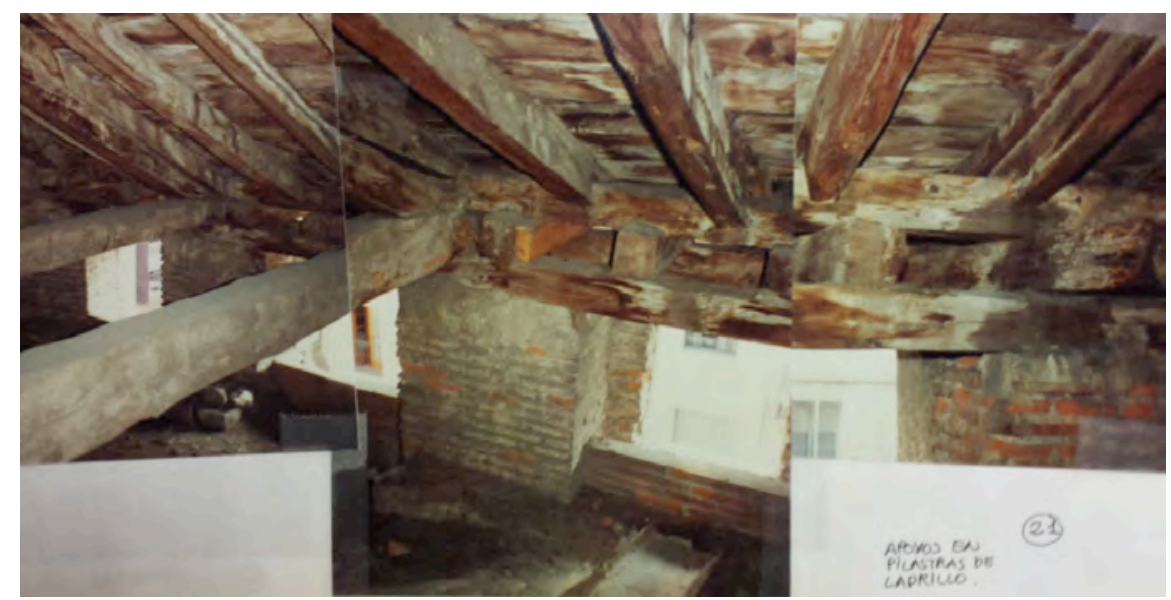

Ilustración 11: imagen del estado actual en 1991 (MOrán JCyL) 


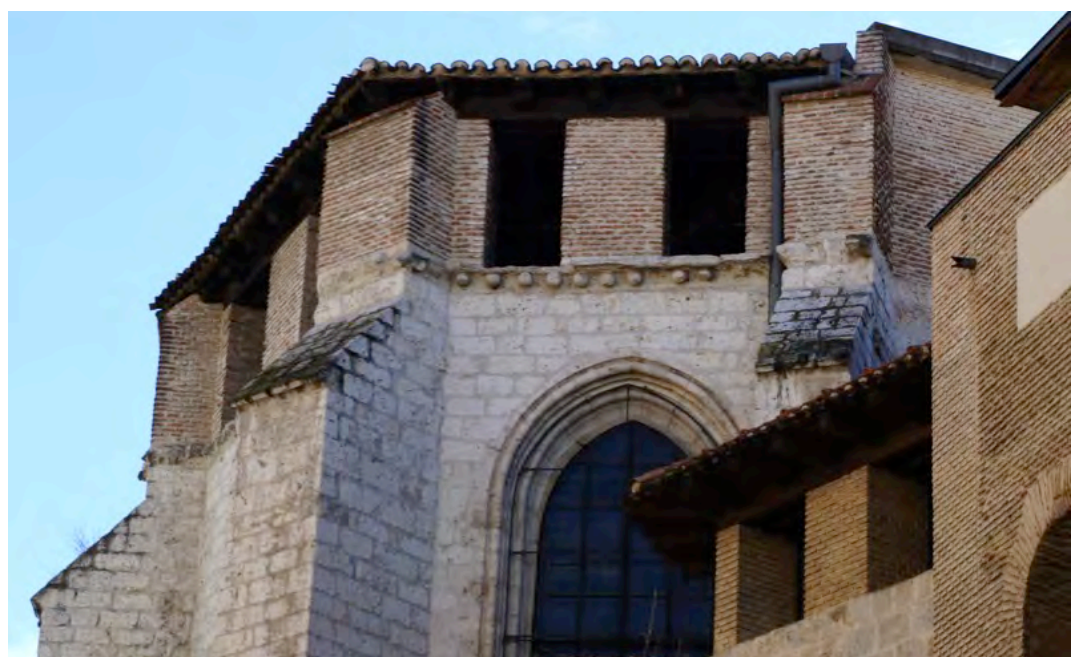

Ilustración 12: estado actual (visita marzo de 2015)

\section{Zunchos}

En las secciones y detalles de los distintos proyectos se representa el remate de los muros con durmientes de madera apoyados directamente sobre la fábrica de ladrillo, con dos barras de anclaje por cercha de $1 \mathrm{~m}$ de longitud de acero inoxidable.
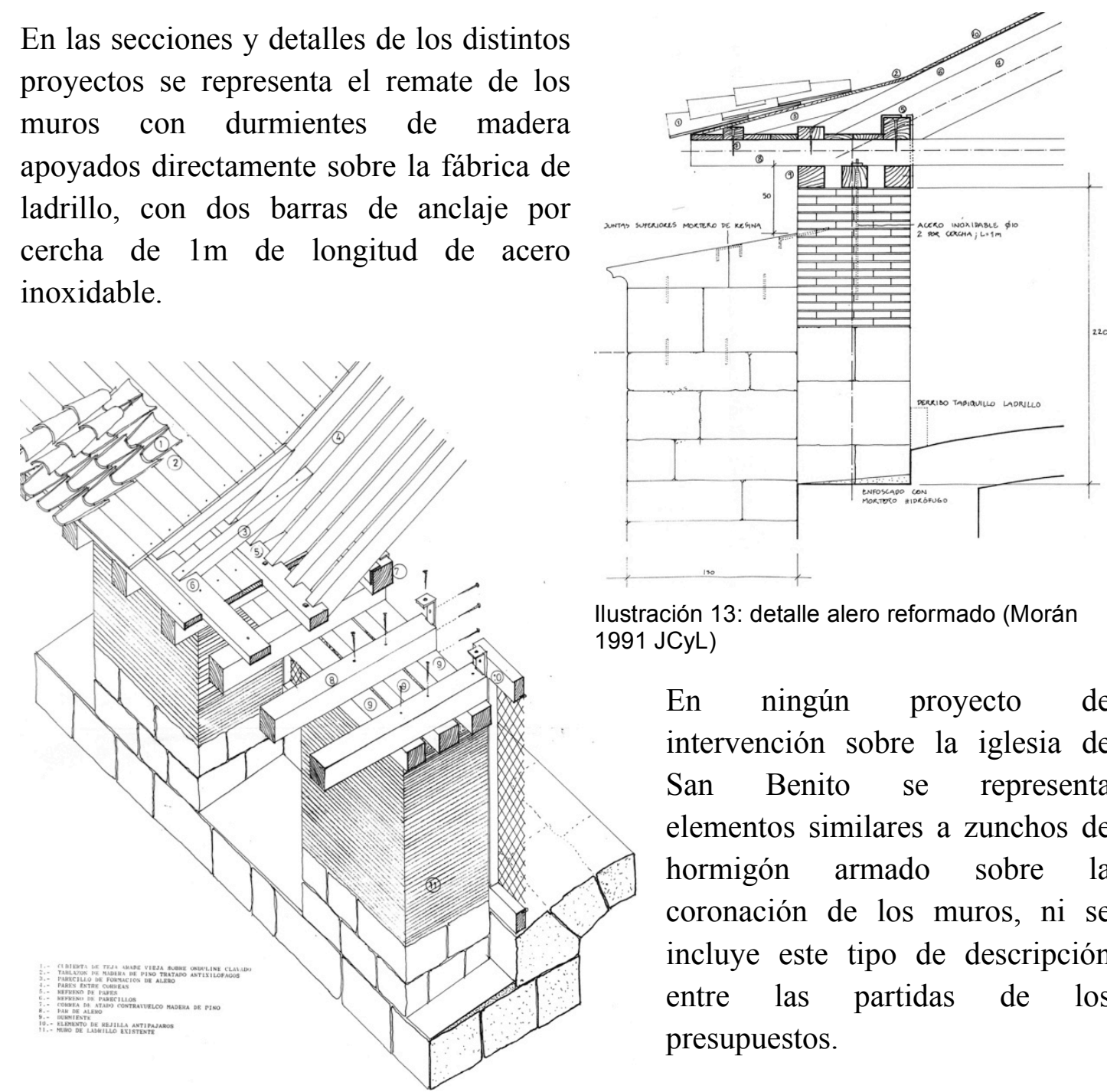

llustración 13: detalle alero reformado (Morán $1991 \mathrm{JCyL})$

En ningún proyecto de intervención sobre la iglesia de San Benito se representa elementos similares a zunchos de hormigón armado sobre la coronación de los muros, ni se incluye este tipo de descripción entre las partidas de los presupuestos.

Ilustración 14: axonometría alero reformado (Morán 1991 JCyL) 


\section{Conclusiones}

En este edificio parece que no se ha incorporado el habitual zuncho perimetral de hormigón, apoyándose los distintos tipos de cerchas de madera sobre elementos también ejecutados con madera, algunos corridos, otros puntuales sobre nichos cajeados en los muros. 


\section{Iglesia de San Benito el Real}

Intervenciones citadas en la publicación del Ministerio

1971 - Limpieza del templo - Felipe Prieto Granda y Manuel Cuadrado Isasa

En la página web del IPCE aparece un único plano de planta

\section{En el Archivo General de la Administración}

AGA 26/00024

1972 - Proyecto de obras de Conservación - Felipe Prieto Granda

Memoria: La iglesia se empezó a construir en el año de 1499. La fecha probable de terminación de las obras es el año 1515. Sus arquitectos fueron Juan de Arandia y Garcia de Olave. El pórtico es obra de Rodrigo Gil de Ontañón; se construyó entre los años 1569 y 1574. Poco más tarde entre los años 1577 y 1583 fueron añadidos otros dos cuerpos de ladrillo con dos ventanales (lo refiere a Parcerisa). Pocos años después de terminada la torre se produjo un incendio que destruyó los dos cuerpos y las bóvedas de Gil de Hontañón. Dentro del pórtico se encuentra la puerta de acceso al templo.

Iglesia de sillería con tres amplias naves y la cabecera formada por tres ábsides poligonales.

Hay dos tipos de pilares a) los cuatro comprendidos entre la reja y los ábsides a partir de la base octogonal constan de un núcleo circular con columnas adosadas, el núcleo de los restantes es en forma de estrella. Predominan las bóvedas de crucería con terceletes. Algunos ventanales góticos se encuentran cegados.

"A finales del siglo XVI se recrecen los muros con ladrillo para evitar que la estructura de las cubiertas descansara directamente sobre las bóvedas". También en esta época se recubrieron los muros en su parte interior con yeso y cal. El templo está ennegrecido por la calefacción a carbón.

Se va a cambiar el sistema de calefacción y limpiar el templo.

Planos: Planta de bóvedas 1:100. Sobre la carátula explica que es una "planta reducida del original propiedad del Seminario de Artes de la Facultad de Filosofía y Letras de Valladolid".

Planta general, sección longitudinal, fachadas lateral y frontal 1:100. 
El presupuesto es un capítulo único con picado de revocos y enlucidos para dejar las fábricas pétreas vistas. Incluye una partida alzada de ochenta mil pesetas para fotografías pero no hay ninguna en la carpeta.

\section{En el archivo de la Junta de Castilla y León}

\section{VA-106}

Carpeta 5302

Estudios previos de rehabilitación de la iglesia de San Benito el Real Arq: Fernando Morán Ortega. Marzo de 1991.

Iglesia gótica de tres naves con dos capillas anexas en su parte izquierda. El mantenimiento del templo lo realizan los Padres Carmelitas cuya residencia se ubica en el edificio anexo recién rehabilitado. Hasta hace pocos años la residencia estuvo ubicada sobre el templo, en una planta y el bajo cubierta sobre las bóvedas de la nave izquierda. Se accedía por un ascensor aún en funcionamiento instalado en un cuerpo de ladrillo añadido al ábside "que debe desaparecer".

La estructura de bóvedas nervadas en rincón de claustro ojivales sobre grandes pilares octogonales. El gran atrio con cúpulas sobre pecinas manifiesta gran solidez con su doble altura de grandes pilares octogonales.

Memoria histórica redactada con la ayuda de un Padre catedrático de Historia de la UVa, Teófanes Egido:

El templo se vincula al Monasterio, inaugurado en 1391, de estricta clausura con silencio riguroso y privaciones extremas. El origen fue la capilla del Alcázar Real, en el espacio ocupado por la actual sacristía. El Monasterio fue cabeza de toda la congregación benedictina.

1499 arranca la cabecera con los arquitectos Juan de Arandia y García de Olave. La obra está prácticamente acabada en 1515, en sólo 16 años.

El coro alto a los pies con sus tres bóvedas en el piso y antepecho de tracería delicada se construyó hacia 1540.

Los dos primeros cuerpos del pórtico-torre se levantaron entre 1569 y 1574 por Rodrigo Gil de Ontañón y Francisco del Río. Sobre ellos Juan Ribero de Rada añade dos cuerpos de ladrillo con ayudas municipales y de Felipe II. Este remate se ve afectado por el incendio de 1605 (desatado con las celebraciones del nacimiento de Felipe IV) y fue derribado en la primera mitad del XIX. 
"Preocupación por los tejados.

La cubrición del templo, como se ha visto, se realizó hacia 1515. Dadas las alturas de la nave central, el primer tejado descansó directamente sobre las bóvedas. Esto se consideraba entonces peligroso para la estructura por la presión de la cubierta y esto mismo explica la solución que se arbitró y que en aquel tiempo se pensó como imprescindible para la seguridad del templo. De nuevo es Floranes el que mejor resume la decisión, al hablar del abad Fray Plácido de Salinas: Prosiguió las obras de su antecesor, y una de las más costosas y provechosas fue el acabar de asegurar la iglesia, cuyo tejado hasta entonces descargaba sobre las bóvedas. Levantó sobre la cantería la pared de ladrillo que recibe el tejado. Por las cuentas de aquellos días se sabe que las obras del tejado comenzaron en febrero de 1572, que fueron muy rápidas, que los ladrillos los fabricó Pedro Alcalde, vecino de Cigales, y que las vigas empleadas fueron las de 22 pinos de Hontalvilla.

Los resultados de esta reestructuración están a la vista. La pared de ladrillo bordea la parte superior del muro de piedra produciendo una impresión escasamente estática y discutiblemente práctica. como resultado de la obra se ocultaron los arbotantes esbeltos de la nave central, cubiertos bajo el tejado.

Casi treinta años más tarde se tuvo que renovar el tejado, con sus estructuras, que seguramente son las actuales, en obra que duró entre 1588-1590. Fue durante el generalato de Fray Pedro Docampo, y la renovación afectó a la techumbre de las tres naves. Las obras fueron dirigidas por Juan Gil. Las vigas utilizadas eran las procedentes de pinos de Traspinedo. Las tejas se colocaron en el breve tiempo de tres días gracias a la actividad agitada de 54 obreros.

Después sólo se realizarían reparos parciales."

San Benito se salvó tras la desamortización al convertirse al uso militar, que perdura hasta los años sesenta del siglo XX. En la parte superior de ladrillo de la iglesia se ven restos de su conversión en fuerte. Más tarde se dedicó a almacenes y servicios: pajar, fragua con una chimenea incrustada en el coro... Se arrancaron losas del suelo para otras construcciones.

En 1878 el Ministerio de Guerra lo transfiere al Ayuntamiento con la condición de abrirlo al culto. Éste lo cede en 1892 y con suscripción popular se restaura y reinaugura solemnemente en 1893.

Restauración. Hubo propuestas no realizadas, como un proyecto de1899 de Ortiz de Urbina para dividir el atrio en cuatro niveles e instalar el convento. La restauración decisiva tuvo lugar en 1971-1972: "Se despojó a toda la iglesia de las numerosas 
capas de cal y yeso que cubrían todos sus muros y bóvedas y se dejó al descubierto la piedra de sillería".

En 1978 se firma una permuta para ceder al municipio locales sobre las capillas laterales para integrarlos en el "patio herreriano" a cambio de una parte derruida del monasterio que se restaura para los frailes. "En 1988 los responsables del plan de rehabilitación del monasterio demolieron la antigua vivienda sobre la nave del evangelio con criterios discutibles y sin contar con la comunidad, y la cubrieron. Aún no se ha procedido al derribo de las edificaciones que ocultan el ábside de la misma nave ni de la que corona el pórtico."

"Partes débiles:

Tejado de la nave lateral de la epístola. Es el sector más deteriorado, por ele stado de vigas sustentadoras, por el deterioro del tejado, porque está fallando progresiva y alarmantemente la soldadura de esta cubierta con el muro de la nave central. Hay peligro de desprendimiento y de hundimiento."

Explica que en 1837 se elevó más la cubierta con ventanas y plataformas bajo el alero para permitir fuego artillero.

Ábside exterior de la nave del evangelio. Está cubierto por la edificación de portería y escalera (luego ascensor) hacia 1914 para comunicar la vivienda de la comunidad con la calle Encarnación. "Este aditamento debe ser demolido".

El Ayuntamiento derribó en 1896 el cubo adosado resto de la antigua muralla y puso una caseta para reguladores de luz eléctrica sustituida a su vez por esta escalera.

Pórtico-torre. En el pilar próximo al monasterio se perciben restos del muro que fortificó el conjunto en el XIX. En 1897 se levantó una espadaña para las campanas. La baranda de ladrillo y cemento sobre el remate debió levantarse entre 1936-1939.

\section{Actuaciones a realizar:}

Cubierta de la nave derecha, en muy mal estado. Propone sustituir el recrecido de ladrillo por sillería, manteniendo las proporciones con un alero de canes de madera. "Patología: el desplazamiento horizontal de los paños de cubierta provocados por la flexión excesiva de los pares, junto con el deterioro generalizado de estos y el de la tarima de soporte, así como la ausencia de durmientes en apoyos de los pares y el desplome de algunos cuchillos añadido al incorrecto diseño estructural (apoyos sobre brochales colocados en huecos de ventanas) han provocado la imposibilidad de su mantenimiento y con ello es pertinente la ruina previsible a corto plazo. Esta situación implica la imposibilidad de realizar el mantenimiento mínimo de los paños, lo que produce que las tejas deterioradas no puedan ser sustituidas y por tanto se han producido goteras generalizadas en la nave con el consiguiente deterioro de la 
plementería de las bóvedas manifestado ya en el interior. Se han colocado plásticos y lonas para evitar filtraciones."

Proyecta desmontar la cubierta y colocar una estructura nueva de madera con alero idéntico al actual. Onduline bajo teja y reemplazo de ladrillo por sillería. Recuperar cornisa, formar troneras para iluminar ventanas y nueva escalera de acceso.

Cubierta del atrio. Proyecta sustituir remate de ladrillo por piedra y moldura, reemplazar la cubierta plana de lámina asfáltica por inclinada, retejar la del primer piso y remodelar bajantes exteriores.

Cubierta de la nave izquierda. (La que albergaba la residencia de monjes) Se encuentra restaurada con cerchas metálicas, forjado de bovedilla cerámica y viguetas de hormigón.

Proyecta su derribo parcial pues sobresale.

Cubierta central y bajantes. La estructura es de madera sobre el recrecido de ladrillo. Proyecta el desmonte total de la cubierta, colocación de nueva estructura de madera, alero idéntico, teja con onduline y reemplazo de recrecido de ladrillo por sillería. Proyecta la desaparición de las bajantes y su reorganización interior.

Limpieza de fachadas, restauración de molduras, reposición de piezas rotas. Restauración de bóvedas del atrio con estuco y reemplazo del remate de ladrillo por sillería con moldura.

Demolición del cuerpo de ascensor añadido, abriendo una ventana cegada colocando vidrieras.

Consolidación de arbotantes

Zunchado e inyección de pilar izquierdo junto al ábside, que presenta fisuras verticales: provisionalmente se tesará con cinturones metálicos ocho maderos, se coserá con 4 barras introducidas en taladros.

Reemplazo del pavimento, puertas, verjas, etc.

Planos y fotografías con anotaciones a mano y sobre papel vegetal.

Dossier de fotografías

Memoria de actuación de las obras a realizar.

Documento similar al anterior con las fichas de diagnóstico y propuesta de actuación. 
Proyecto básico y de ejecución de restauración de cubierta de la iglesia de San Benito el real. Planos con sello de la JCyL de junio y carátula de febrero de 1991. Estructura de madera con herrajes metálicos.

Copia del mismo proyecto básico y de ejecución más gruesa con anejo de cálculo de cerchas (listado de salida de programa de cálculo en francés), Pliego, planos, presupuesto. Partidas de demolición, estructura: $29 \mathrm{ml}$ en muro de planta baja durmiente $15 \times 20$ en madera pino soria incluso egones para apoyo de los pares; $63 \mathrm{ml}$ durmiente pino soria planta alta; $85 \mathrm{ml}$ de alero compuesto por 3 durmientes de pino de calidad estructural anclados al muro SDT de sección 20x15 y parte proporcional de can cada $0,5 \mathrm{~m}$ sec $20 \times 20,20 \times 10$ para refreno de pares y tabla $20 \times 3$ cepillada y clavada sobre el can, así como formación de refreno de pino soria de sección 7,5x15 cada $0,5 \mathrm{~m}$ terminado con madera pino soria 1 " en formación de cubierta.

$630 \mathrm{~m} 2$ de formación de cubierta de madera; $220 \mathrm{ml}$ de correas y $32 \mathrm{ud}$ de cerchas de madera laminada en nave derecha; 4 cerchas de MLE (madera laminada encolada) en ábside; 4 vigas riostras pino soria de $12,5 \mathrm{~m}$. En el presupuesto no se menciona ningún zuncho de hormigón armado.

\section{VA-106}

Carpeta 5303

Arq. Fernando Morán

Documentación administrativa, contratos, facturas, etc

Planos de estado actual de cubierta muy tenues.

Carta del prior de octubre de 1993 explicando que hace cinco años que se aprobó el proyecto y aún no se ha restaurado, que se va deteriorando.

Dossier de fotografías de Casariego. Se ve el arbotante oculto. Informe del arquitecto territorial de 1987: la intervención es necesaria.

Planos diversos. Detalles de cubierta (pido copia)

Proyecto Modificado de marzo de 1997.

Contratista: CABERO Edificaciones SA

Al desmontar la estructura de cubierta queda al descubierto la cornisa original, se considera conveniente su recuperación visual mediante el ajuste de la pendiente de la nueva cubierta. Se mantiene la vigencia de los planos del proyecto original.

Proyecto original en dos tomos, el de Memoria con fotos a color. 


\section{En el Archivo Municipal de Valladolid}

\section{Fondo Histórico}

AMVA: CH 375-111 1842

Expediente instruido con motivo de la denuncia hecha por Eufemio Martínez de Velasco, procurador síndico del Común, de la torre y fachada de la iglesia del monasterio de San Benito, por su estado ruinoso.

Se envía a reconocerla a los técnicos de la Academia de Nobles Artes de la Purísima Concepción. Desde el Cuerpo de Ingenieros se recomienda encomendarlo al Arquitecto de Ciudad.

Julián Sanchez Garcia certifica que los dos cuerpos superiores de la torre amenazan ruina, con la armadura carcomida, por lo que deben demolerse.

Se tramitan fondos para la intervención.

Finalmente en otro escrito se informa de que "sobre las diez y media poco mas de esta misma mañana se ha verificado el hundimiento de una parte de tejado de la torre del ex-convento de San Benito. Afortunadamente aquel se hizo por la parte interior y por semejante causa no tenemos que lamentarnos en estos momentos de males sin cuento..."

\section{AMVA: CH-385-89 1843-1854}

Expediente instruido con motivo del hundimiento del tejado de la torre de San Benito en diciembre de 1843 [Hojas: 24]

Se discute la preocupación general sobre la amenaza de ruina de la torre, la tranquilidad de los vecinos, si su reconocimiento corresponde al ejército por ser un cuartel. Se aprecian desniveles, grietas en enjutas y dovelas. Hay fondos para sanear "los sentimientos" y pasado el tiempo ver si progresan.

AMVA: CH 379-30 1849

Informe - y otros documentos - emitido por el Jefe de Ingenieros Militares sobre el estado que presenta la fachada de la iglesia del que fue Monasterio de San Benito, hoy Cuartel de Infantería, Caballería y Artillería. Incluye traslado de otro informe sobre el estado de la fachada y torre pertenecientes a dicha iglesia [Hojas: 7 pequeñas]

Tres documentos: presentación y dos informes, e solicitado y otro de 1842. 
Se redacta a solicitud de la Corporación que aprecia una grieta en la fachada. Ya estaba dos años atrás y no ha progresado. Se concluye lo mismo que en el anterior informe técnico, en el que se describía grietas verticales y oblicuas de poca anchura: no hay riesgo de ruina. Aconseja resanarla con buena mezcla para que no entre agua.

\section{AMVA: CH 384-91 1856}

Expediente relativo a la demolición del tejado y de los dos cuerpos superiores de la torre de San Benito [Hojas: 22]

Se deniega permiso para colocar piedra del desmonte de la torre en la plazuela inmediata, que se usará en las traseras de la cárcel.

Se está desmontando las piedras, se arrojan desde lo alto, con ese sistema se resienten los edificios inmediatos y corren riesgo los viandantes. Escrito de protesta de los vecinos.

Copia de las Condiciones del contrato: vallar el recinto, andamio se irá rebajando a la vez que la torre, desmonte por el frente, tierra en la zona de caída de materiales, retirada conforme vayan cayendo, tejado nuevo con alero de piedra, etc.

Escrito de Ortiz de Urbina explicando el problema para la Academia de Bellas Artes

\section{AMVA: CH-354-44 1881-1886 Subasta}

Reparaciones en la iglesia de San Benito y adjudicación a Canuto González Contreras [Hojas: 23]

Presupuesto y condiciones de las obras para la apertura al culto público. Pavimento de madera, de piedra y vidrieras.

Recepción provisional de la obra en que hacen constar que el enlosado de piedra de Villanubla presenta coqueras y grietas pero no son culpa del contratista.

\section{AMVA: CH 357-91 1883-1884}

Expediente de obras de reforma del Cuartel de San Benito, con el fin de instalar un Regimiento Montado de Artillería [Hojas: 8]

El Alcalde intentaba costear obras en la Casa Consistorial con una partida presupuestaria destinada a reformar San Benito porque el regimiento seguía en Alcalá de Henares, según la Comisión de Obras. Finalmente queda sin efecto este acuerdo tras recordar desde la Capitanía General el enunciado de una Real Orden en que se dispone alojar en San Benito al Regimiento montado de Artillería.

\section{AMVA: CH 361-210 1877-1880}

Reformas en los cuarteles de San Ambrosio y San Benito y construcción de un cuartel de Caballería 
Ventajas de aumentar la dotación de guarniciones militares en Valladolid y lo adecuado del terreno.

Se comenta que el Ayuntamiento podría, además de ceder gratuitamente el terreno, aportar fondos.

\section{AMVA: Legajo 1105 Caja1049-108 1911-1935}

Licencias concedidas a los cuarteles de Isabel II, San Benito y General Ordóñez para diversas obras

Desescombrar y reparar grietas y desplomes de un muro-cerca del cuartel Variación de rasantes de una tubería de desagüe.

Apertura de puerta de carros a la plaza de Ponente, ensanche del cuartes,

\section{AMVA: Caja 804-22 marzo de 1936}

Padres Carmelitas de San Benito solicitan licencia para construir terraza sobre la torre - pórtico de la iglesia de San Benito como ampliación de las obras que se están realizando desde el año anterior, tras el derrumbe de la cubierta. (Contiene planos) Se concede.

Dos planos en color sobre tela plastificada con detalles preciosos del armado de vigas del arquitecto Constantino Candeira.

Colocar paralelamente cuatro vigas armadas de 0,42x0,25m empotrándose en los muros de fábrica, sobre las que descansarán las losas de hormigón armado. El pretil o antepecho de ladrillo de un asta de espesor y $1,60 \mathrm{~m}$ de altura.

Fondo Administrativo (selección; hay 293 expedientes que hacen referencia a San Benito)

AMVA: C2351-3 31972

Padres Carmelitas (Iglesia de San Benito). Instalación depósito fuel oil de diez mil litros por instalador JAKSA. Dos copias con dos planos del esquema y detalles.

\section{AMVA: C23054-7 1215/1986}

Inmueble en mal estado Iglesia de San Benito (Exp. 1215/1986)

Denuncia de la Policía Municipal: el 17 de febrero cae un trozo del tejado de la iglesia frente al restaurante La Barraca. Es una parte de viga carcomida que causa destrozos sobre un coche aparcado.

El aparejador municipal informa que se trata de uno de los canecillos del brazo derecho del crucero que soportan el alero, de unos 70 a $80 \mathrm{~cm}$ de vuelo. Los 
canecillos están apoyados en una doble solera que corre sobre la coronación del muro. Por alguna gotera se habrá podrido. Es fácil reponerlos porque tienen sección prismática, sin labra. Es urgente intervenir porque las tablas que forman el alero han quedado sin apoyo.

Se subsana introduciendo unas piezas de madera. Se archiva el expediente.

\section{AMVA: C25175-1 1990 Expediente de contratación de obras}

Proyecto de consolidación del Monasterio de San Benito: zona aneja a la iglesia y alas de la calle Encarnación y patio de novicios. (Sólo planos)

Construcción triangular adosada al ábside a demoler. Nueva estructura de hormigón en edificios calle Encarnación uno con cubierta de madera arruinada y el otro de fibrocemento. En un detalle describe estructura sobre bóvedas anclada a los muros y sobre ella un zuncho HA existente en una panda del claustro.

\section{AMVA: C28596-7 769/96}

Expediente 769/96. Orden de ejecución en iglesia de San Benito. Propietario : Padres Carmelitas del Convento de San Benito

Sección de disciplina urbanística del Ayuntamiento: Se desprenden con cierta frecuencia fragmentos de piedra caliza de la fachada lateral derecha de la iglesia que pueden lesionar a los viandantes. Algunas bocatejas de remate de la cubierta pueden caer también, y se aprecia la degradación del maderamen del alero. Se incoa expediente de orden de ejecución en febrero.

La Consejería de Educación y Cultura tiene previsto intervenir en toda la cubierta y ha provisto fondos en 1996.

En septiembre se notifica que ha comenzado la ejecución de las obras.

AMVA: C16907-1 3825/1996

Junta de Castilla y León. Servicio Territorial de Educación y Cultura. (Montes Velasco, Eduardo). Restauración de la Iglesia de San Benito el Real (Exp. $3825 / 1996)$

Licencia exenta de pago.

Copia del Proyecto básico y de ejecución de Fernando Morán.

(Mismo proyecto consultado en $\mathrm{JCyL}$ )

AMVA: C20298-1 924/2000

CABERO EDIFICACIONES (Cabero Conde, Félix). Para la Fundación del Patrimonio Histórico de Castilla y León. Restauración pórtico de la iglesia de San 
Benito el Real (Exp. 924/2000)

Arq: Javier Blanco Martín

Rehace peto de la torre, recubre cúpula primer cuerpo con cinc, sanea paramentos, reordena el acceso, etc.

Hay una sección de la nave del templo hacia los pies en la que se aprecia el apoyo de cerchas sobre muro no parece que haya ningún tipo de zuncho.

En el proyecto hay un dossier con abundante documentación sobre San Benito, transcripción de numerosos documentos, incluso desglosa pagos de los Libros y otros documentos del AMVA.

En su presupuesto hay una partida con $5 \mathrm{~m} 3$ de zunchos de hormigón armado: $2 \times 16,8 \times 0,5 \times 0,3$ con encofrado de madera vista vertido con pluma-grua.

Dossier de fotografías, algunas a color. En una se aprecia la flamante cubierta de la nave central con dos zonas con distinto tipo de teja, plana y curva. En otra imagen se ve el interior del bajo cubierta de nave central con cerchas de madera y tablazón sin restaurar.

\section{En la Fundación del Patrimonio Histórico}

Proyecto de Restauración del pórtico de la iglesia de San Benito el Real Arq Javier Blanco

Modificado mayo 2001: nuevos precios descompuestos y presupuesto

Final de obra, que termina en agosto de 2001. Describe la intervención: derribo parte superior y cuerpos adosados de espadaña y colocación de campanas en terraza.

La salida a cubierta de nave central es provisional, hasta que se acometa la reforma integral de las cubiertas. El peto de la torre-pórtico de ladrillo se reemplaza por uno de sillería de menor altura.

Cubrición transitable en terraza y cinc en cúpula primer cuerpo en vez de la teja existente.

Limpieza, restauración de escudos y óculos.

Proyecto básico y de ejecución de la restauración.

Es el mismo que se conserva en AMVA 924.

En la memoria un plano de Rodrigo Gil de la torre. AHN Clero. Planos y dibujos num 91. El de Diego de Praves íd num 77. 



\section{Visitas realizadas}

23/04/2015

El monumento se encuentra en buen estado, sobre todo si tenemos en cuenta las vicisitudes que ha atravesado a lo largo de la Historia. Durante la visita el padre D. Teófanes Egido explica las distintas intervenciones y cómo en 1991 se intervino sólo sobre la nave de la Epístola, sin desmontar la cubierta de nave central como figura en algunos planos.

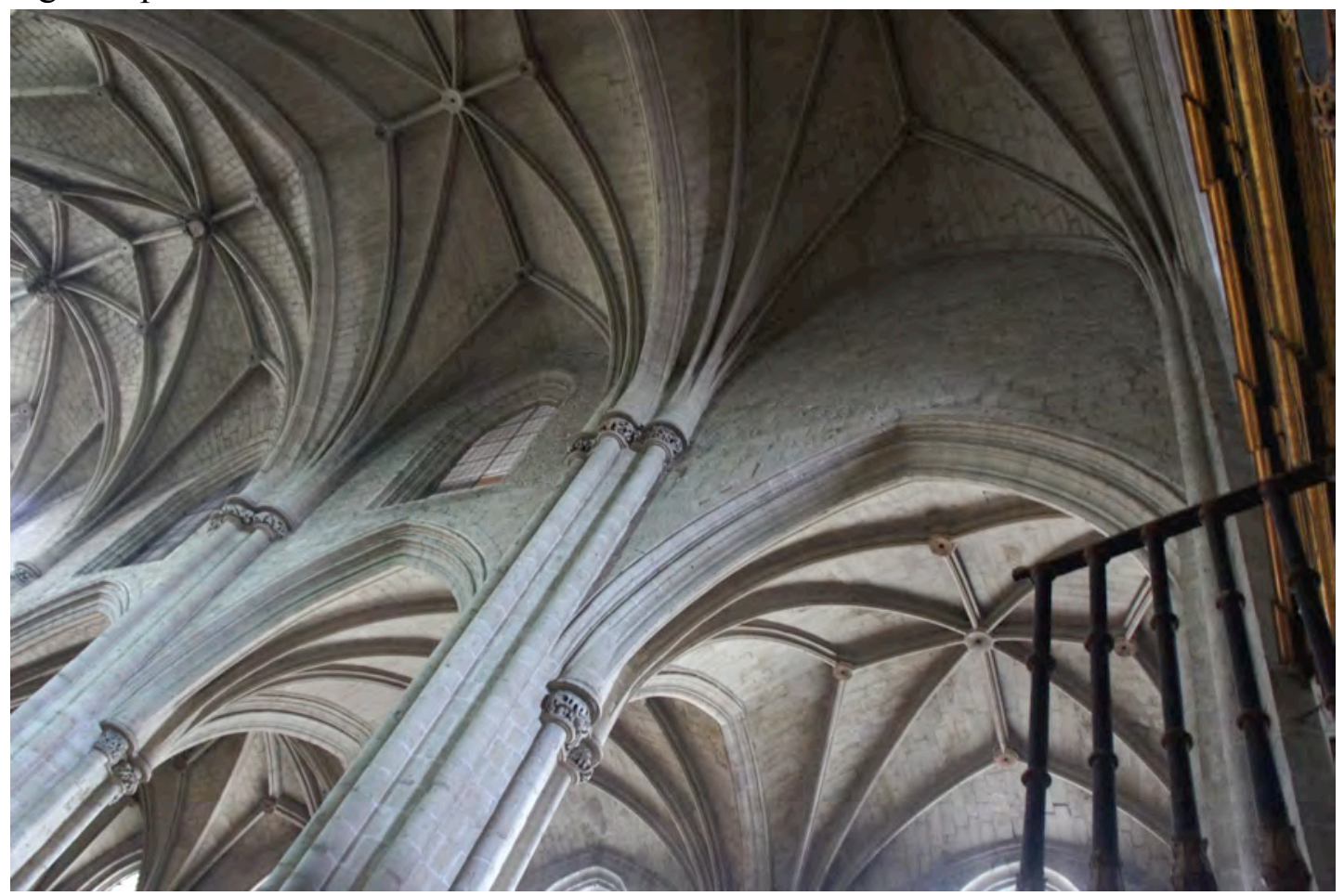

Muchos ventanales se encuentran cegados con fábrica.
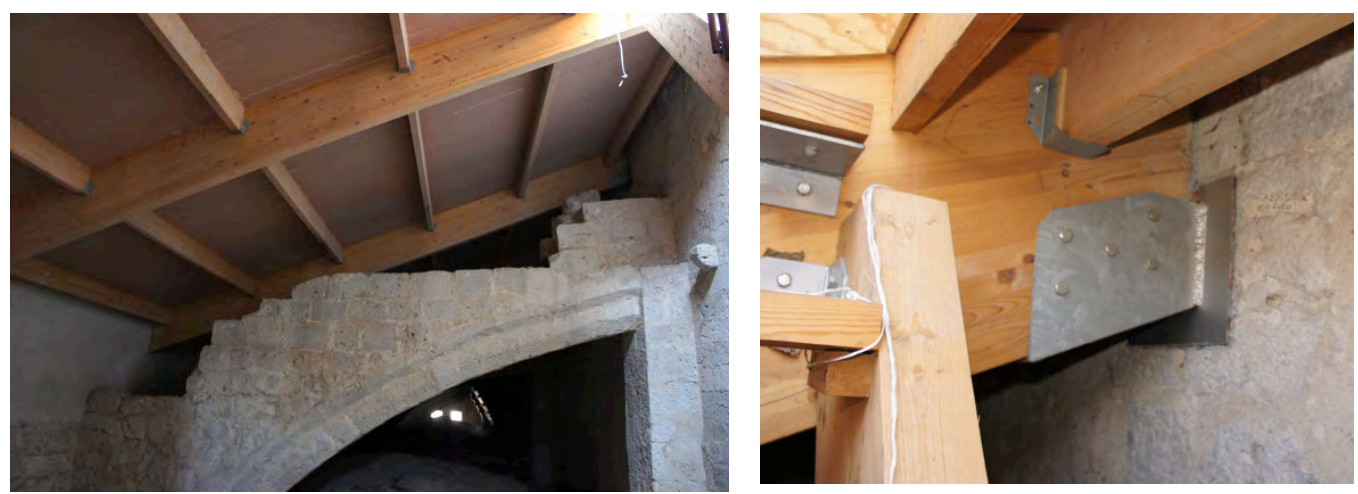

Desde el coro alto se accede al espacio bajo cubierta de la nave del evangelio por una escalera de caracol de madera. La cubrición de este espacio es de madera laminada a un agua. Las jácenas se fijan al muro mediante chapones verticales. En la imagen se aprecia el escalonamiento de los sillares sobre un contrafuerte, donde estuvo el pasillo de comunicación de la residencia de los carmelitas, hoy desmontada. 
Mediante una escalera recta de un solo tramo se accede a la superficie del faldón $\mathrm{y}$, a través de una compuerta, al bajo cubierta de nave central.

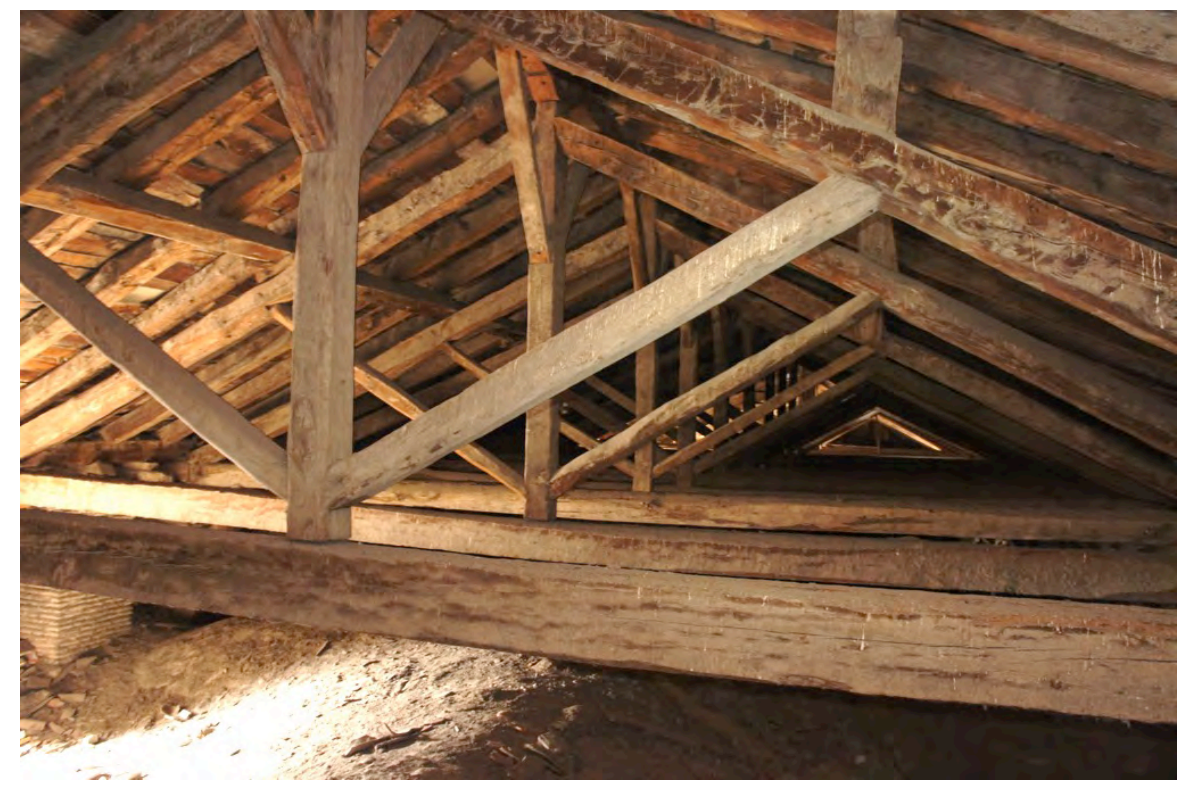

Sobre la nave central se conserva una estructura de madera tradicional, lo que no es frecuente en la mayor parte de las construcciones visitadas dentro del marco de esta investigación. Las formas coinciden con las secciones de estado actual del proyecto de Morán de 1991, por lo que no debió llevarse a cabo la propuesta del plano de estado reformado del mismo proyecto que se conserva en el archivo JCyL.

En el periodo que se realiza la visita se esta llevando a cabo el retejo de varias zonas con teja curva árabe. Los huecos entre algunas tablas ripias se cubren con tablero hidrófugo antes de recolocar la teja.
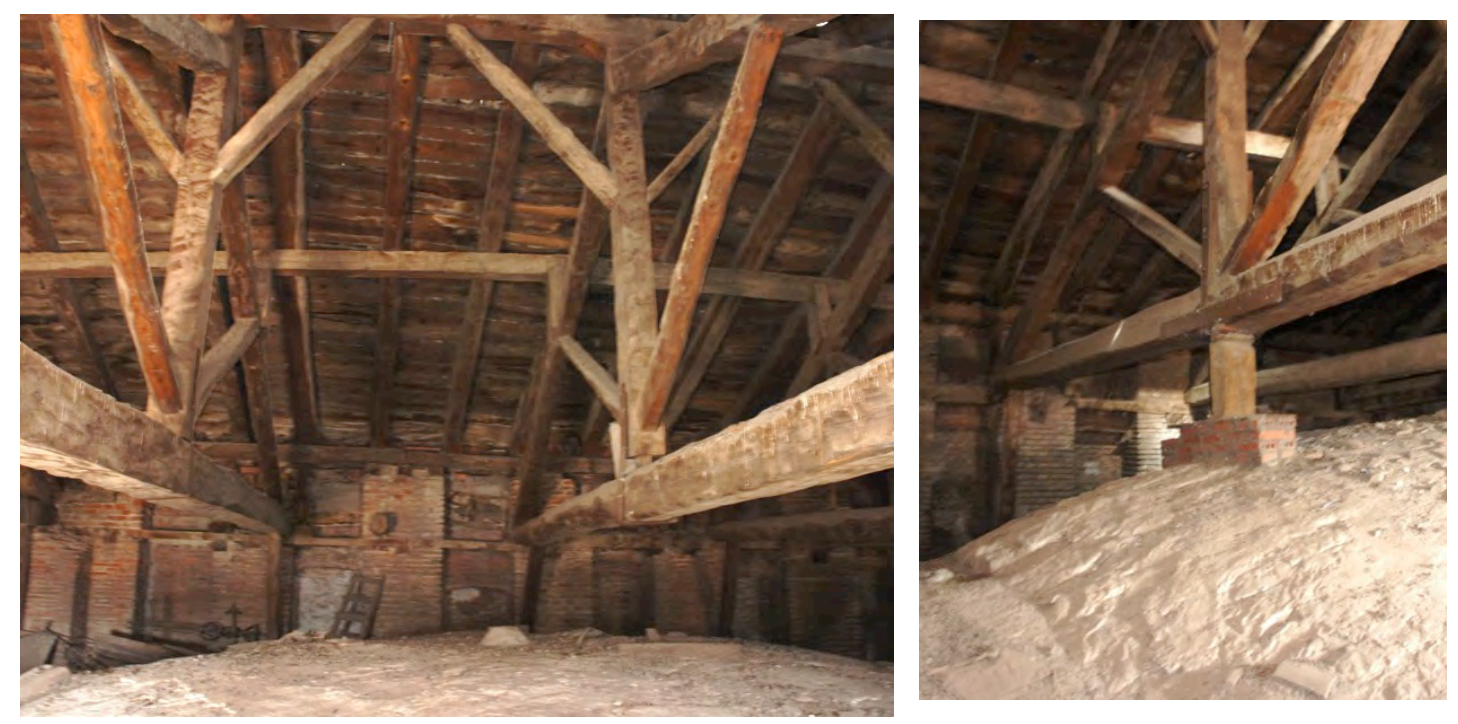
El trasdós de las bóvedas muestra la disposición de los sillares de piedra sin revestir, excepto alguna zona a los pies. Se observa el apeo puntual de un tirante sobre las bóvedas. En la cabecera éstas se desarrollan con mayor altura, según nuestro guía por tratarse de bóvedas demolidas para construir la escenografía de los actos organizados a raíz de la muerte del rey.

El apoyo de las cerchas se realiza sobre durmientes de madera, sin incorporar ningún zuncho. Los canes que forman el vuelo del alero se prolongan ligeramente hacia el interior del edificio.

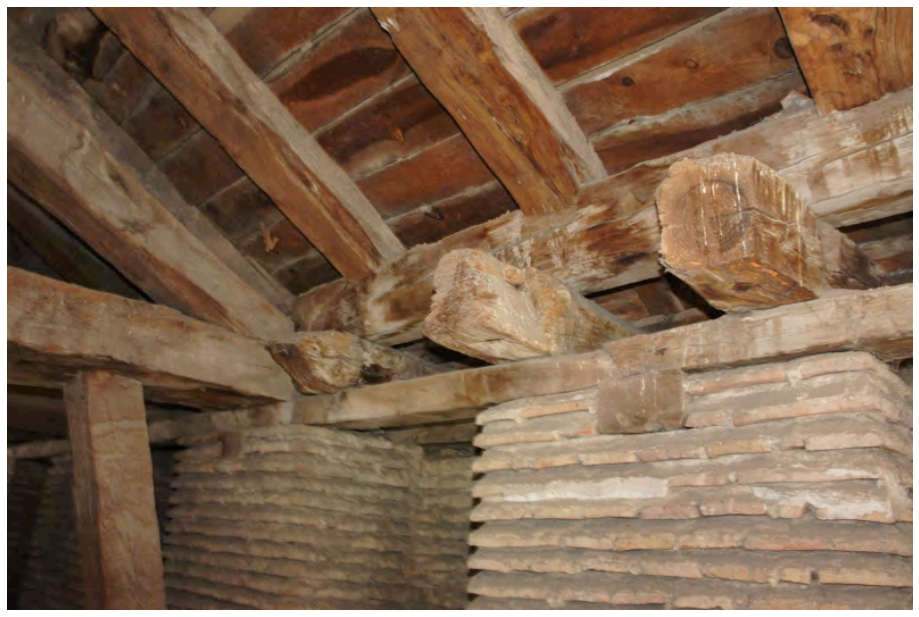

Hacia el exterior la madera queda vista, excepto en el frente bajo el alero donde cuenta con un revestimiento protector.

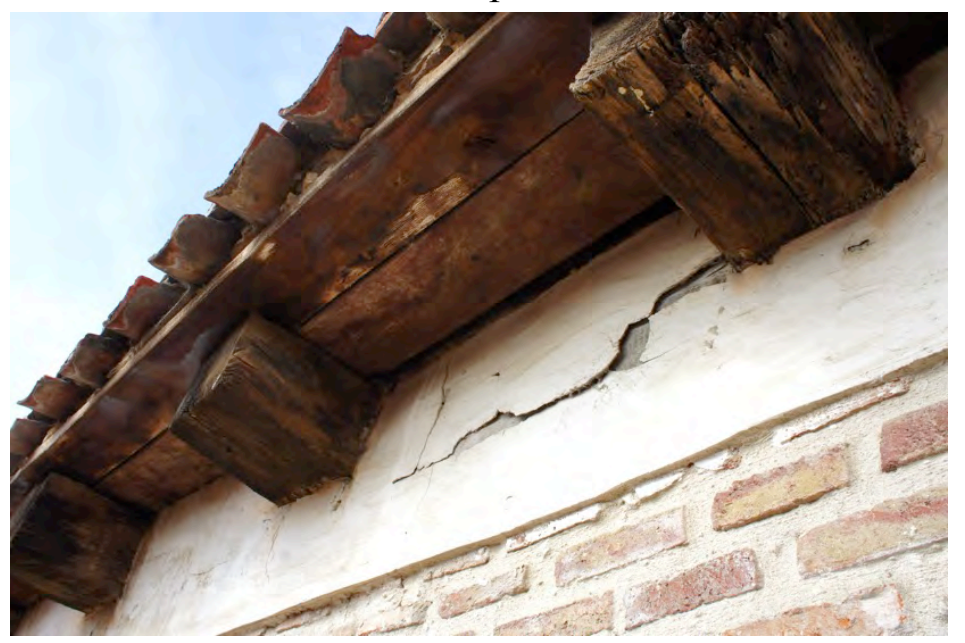

La nave de la epístola se cubre con una estructura de madera laminada encolada. El apoyo sobre el cerramiento de nave central se resuelve puntualmente con pequeños tarugos de madera dispuestos en cajeados de la fábrica. En otros casos sobre una extraña solución de dintel intermedio fijado con anclajes metálicos a las jambas de los ventanales. 

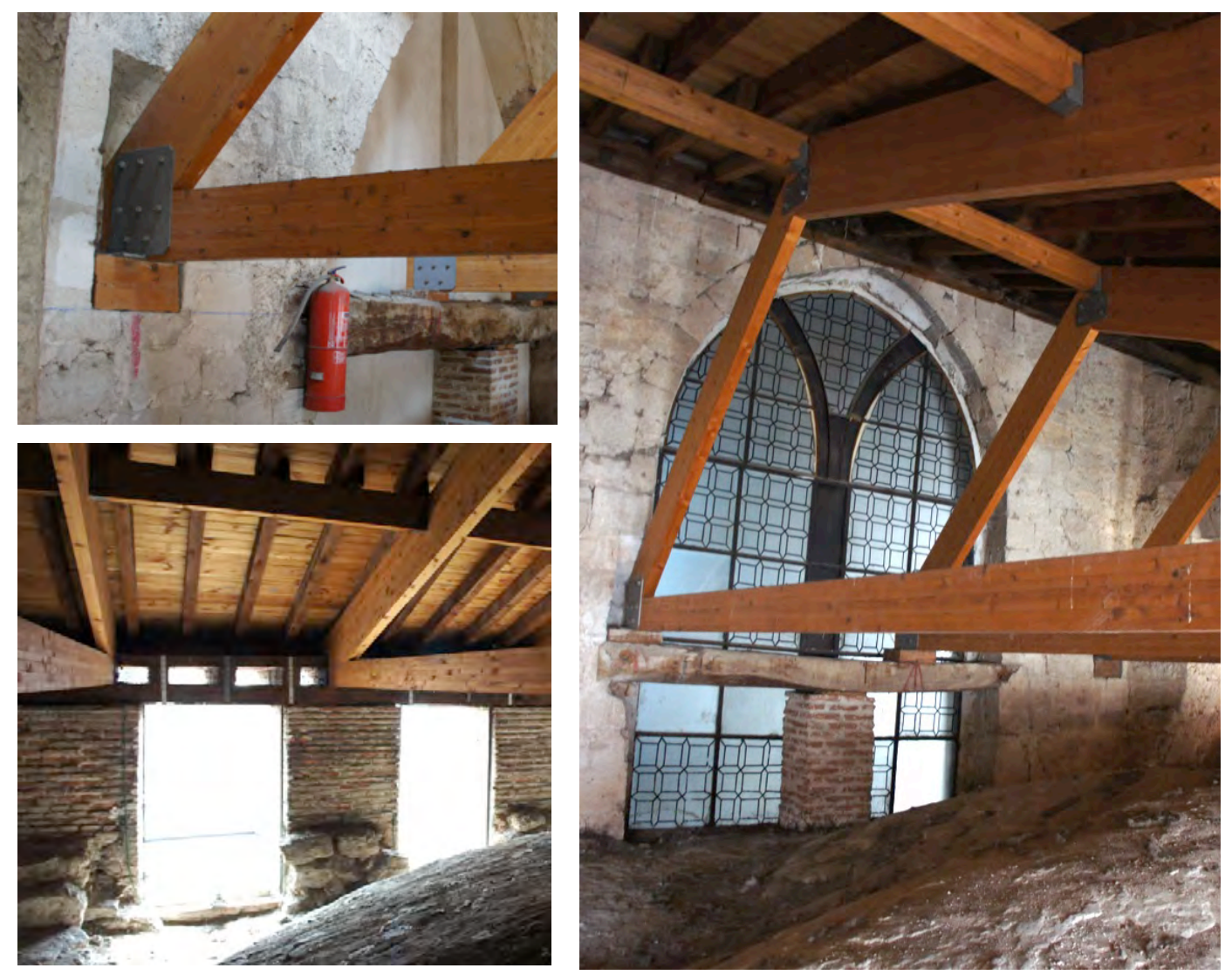

En la fachada lateral a la calle se observa la disposición definida en los detalles del proyecto de Morán.

El único vestigio de zuncho de hormigón aparece por detrás del apoyo de nave central hacia el oeste, y corresponde al recrecido que cerraba la antigua residencia de religiosos cuando estuvo ubicada sobre las bóvedas de la nave del evangelio.

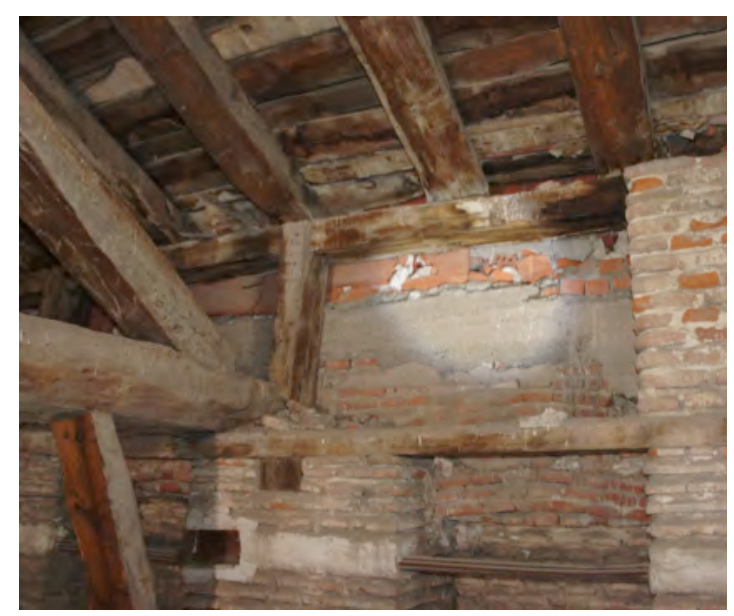

$\mathrm{Ni}$ sobre la nave central ni en la de la epístola aparecen elementos de atado de hormigón armado o acero que podamos considerar zunchos, disponiéndose las cerchas sobre varios tipos de durmientes, pero siempre de madera. 
$30 / 04 / 2015$

En las siguientes imágenes se observa el cerramiento oeste de la nave central desde el claustro del Museo Patio Herreriano adyacente. En una de ellas destaca, a los pies cerca de la torre-pórtico, el hueco de entrada al bajo cubierta desde el tejado de nave del evangelio. También una pequeña zona sobre el mismo donde la teja curva ha sido reemplazada por teja mixta.

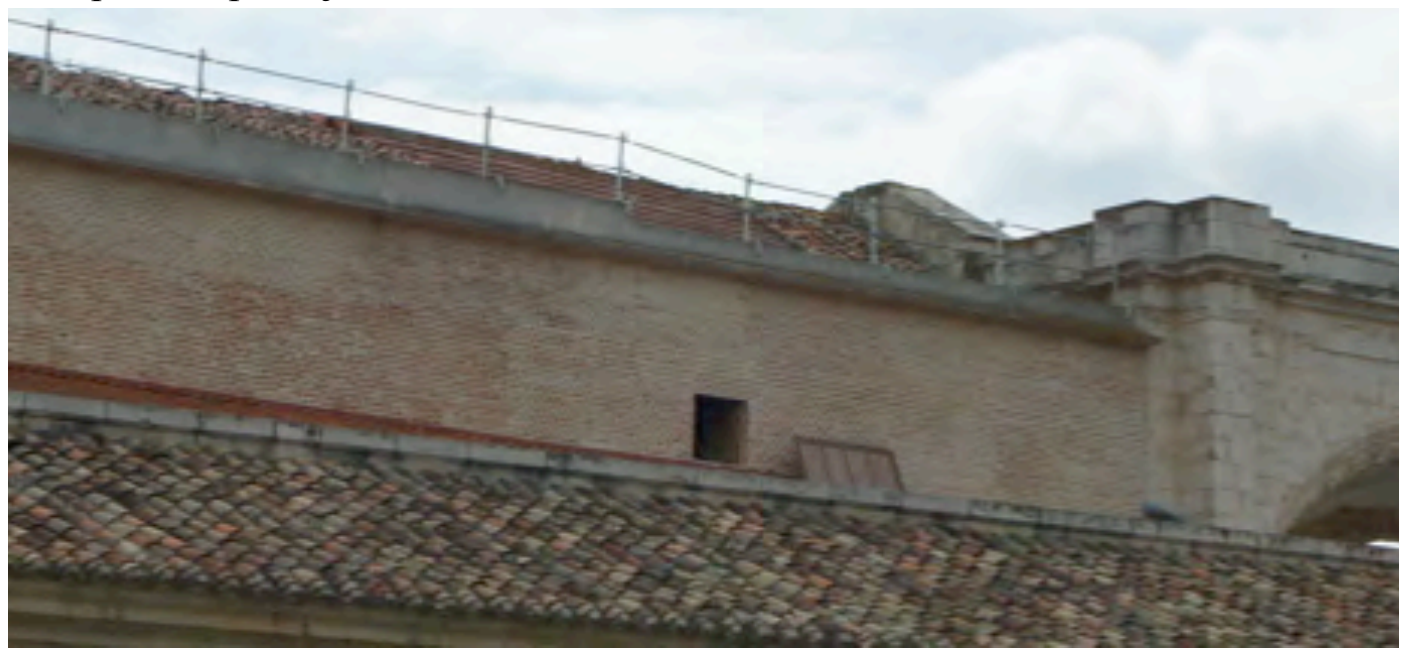

En la vista siguiente se aprecia el proceso de retejo de la cabecera sobre la tabla ripia existente.

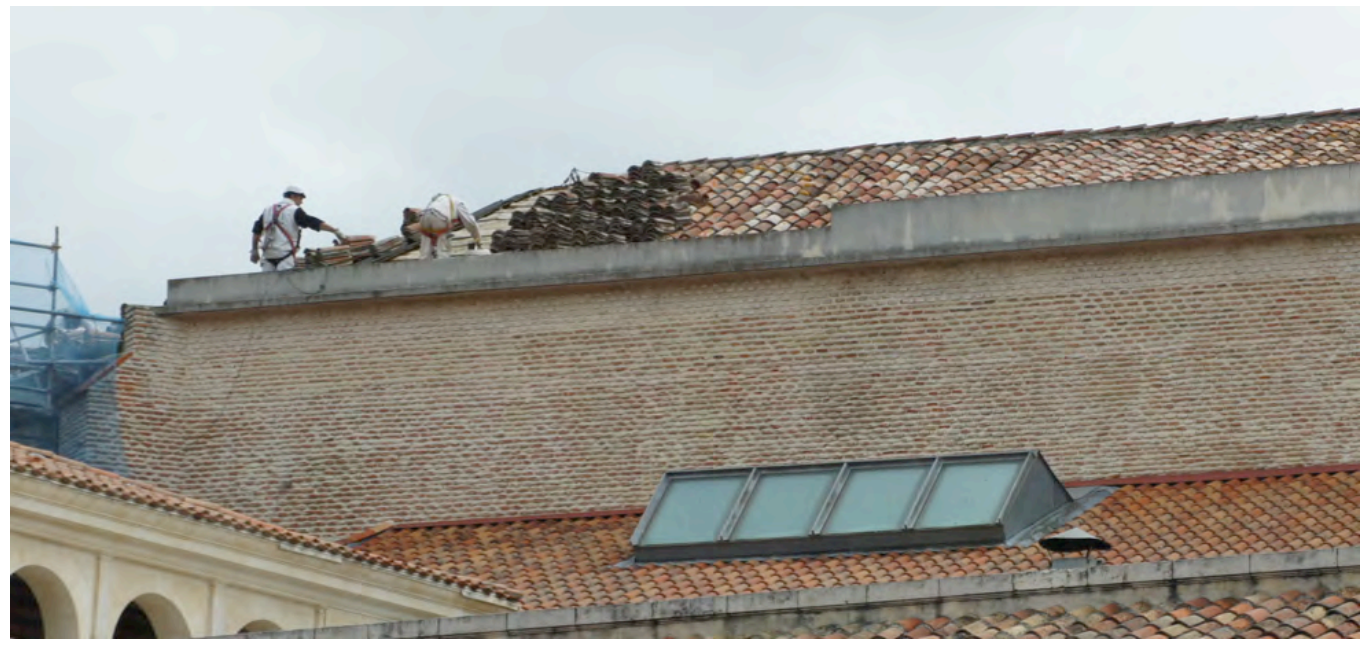

En ambas destaca la existencia de un elemento corrido que parece un peto de hormigón armado con un ligero vuelo sobre el paramento de fábrica de ladrillo. 



\section{Iglesia de San Lorenzo}

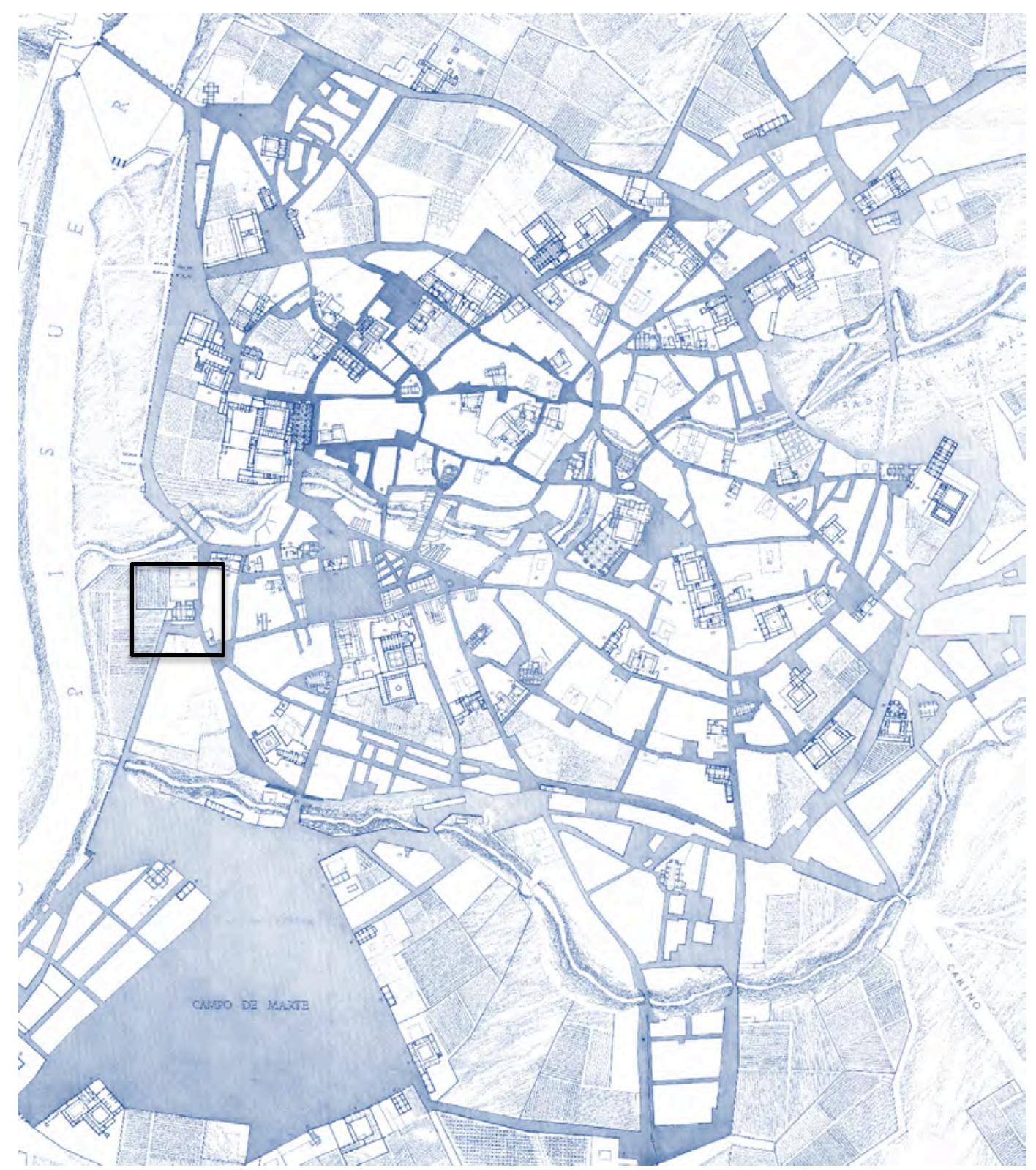



FICHA SÍNTESIS

$\begin{array}{ll}\text { Código de identificación: } & \text { FZ-09 } \\ \text { Denominación: } & \text { Iglesia de San Lorenzo } \\ \text { Localidad: } & \text { Valladolid }\end{array}$

\section{Descripción}

Iglesia original desaparecida. Sólo se conservan una portada y la torre, integradas en un moderno edificio de viviendas de ladrillo visto.

\section{Materiales}

Los muros de la iglesia original eran de ladrillo y tapial según el Catálogo, (pag82), aunque en un proyecto de 1958 (AMVA C943-92) se describe cómo son de tapial pero en ese momento se repican y revisten con media asta de ladrillo visto. Las cubiertas estaban revestidas de teja curva.

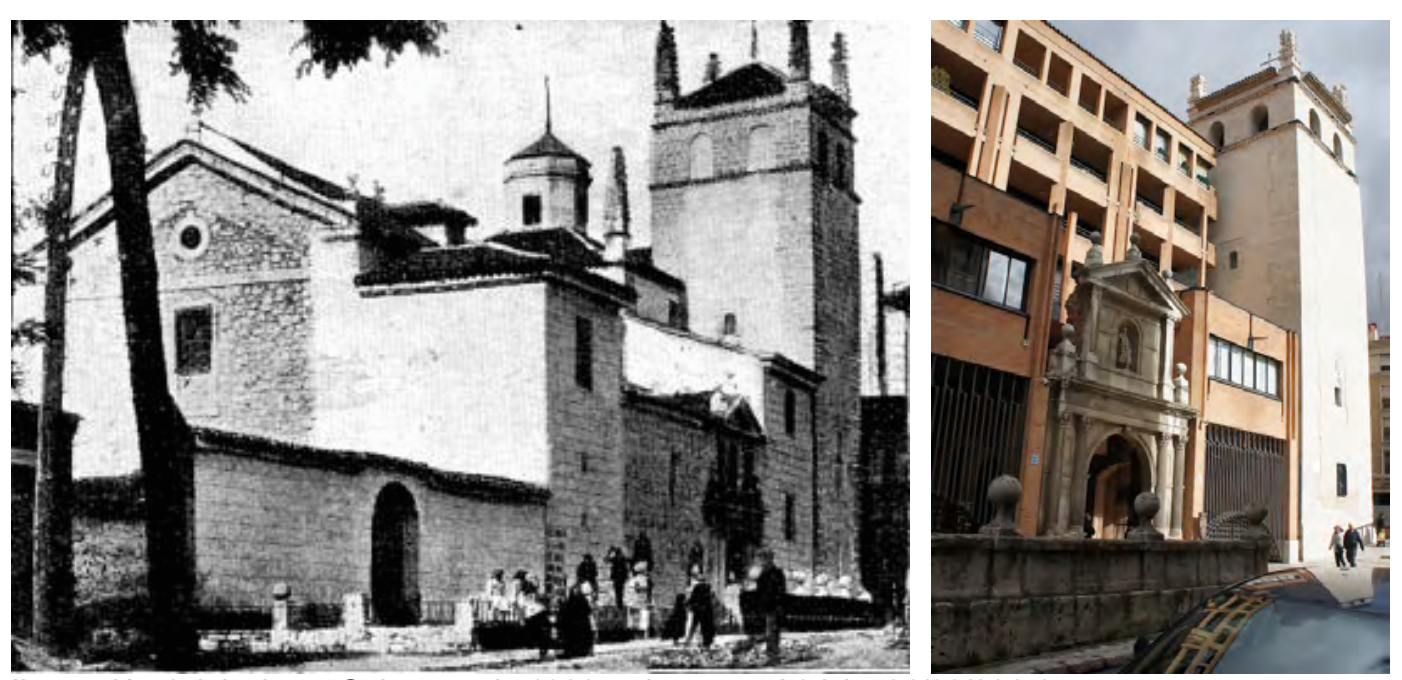

Ilustración 1: iglesia en Guia-anuario 1926 y vista actual (visita 21/02/2015)

\section{Singularidades}

Se trata de un monumento desaparecido, con una iglesia nueva, integrada en un edificio de viviendas moderno levantado por Luis Mingo en 1984.

\section{Dimensiones básicas del templo}

Ancho de nave

central laterales capillas

Altura 


\section{Memoria histórica constructiva}

Según el Catálogo:

Se arranca la construcción con trazas de Diego de Praves en 1596. Su hijo Francisco supervisa la ejecución de los tejados en 1616.

Reconstruida hacia finales del siglo XV y reparada en 1614. El cerramiento de las bóvedas y la cúpula sobre el presbiterio se realizan en la segunda mitad del siglo XVII. En 1825 se amplía el atrio, en 1855 el arquitecto Francisco Javier Berbén abre una puerta en el testero y en 1958 se reforma fachadas y cubiertas.

En 1967 se produce un hundimiento de la bóveda posterior tras el cual la iglesia es demolida.

En 1984 se edifica en el solar el bloque de viviendas actual.

\section{Cronología. Fechas clave}

$1596-1614-1967-1984$

\section{Intervenciones}

1958 - Reforma y reparación de cubiertas y fachadas - Miguel Baz

Se revisten con ladrillo los cerramientos de tapial, repicando la sillería perimetral con martillina. Se reteja y sustituyen por maderas nuevas los elementos del entramado que aparezcan en mal estado al descubrir.

\section{2 - Restauración - Alberto García Gil}

Se refuerza la torre, con nuevos forjados de vigueta metálica, y también la cubierta, con un zunchado de hormigón armado.

\section{4 - Demolición - Ángel Ríos Gómez}

Se demuele el edificio, que aún contaba con su armadura de madera en cubierta, según se indica en la memoria, tras la ruina de una bóveda.

Se mantienen en pie la torre de esquina y una portada.

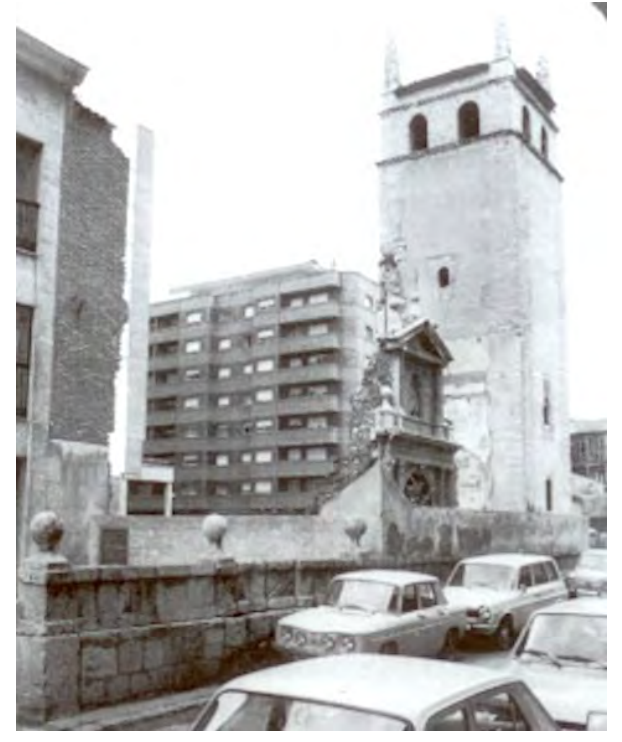

Ilustración 2: (05/06/2015) www.vallisoletum. blogspot.com 


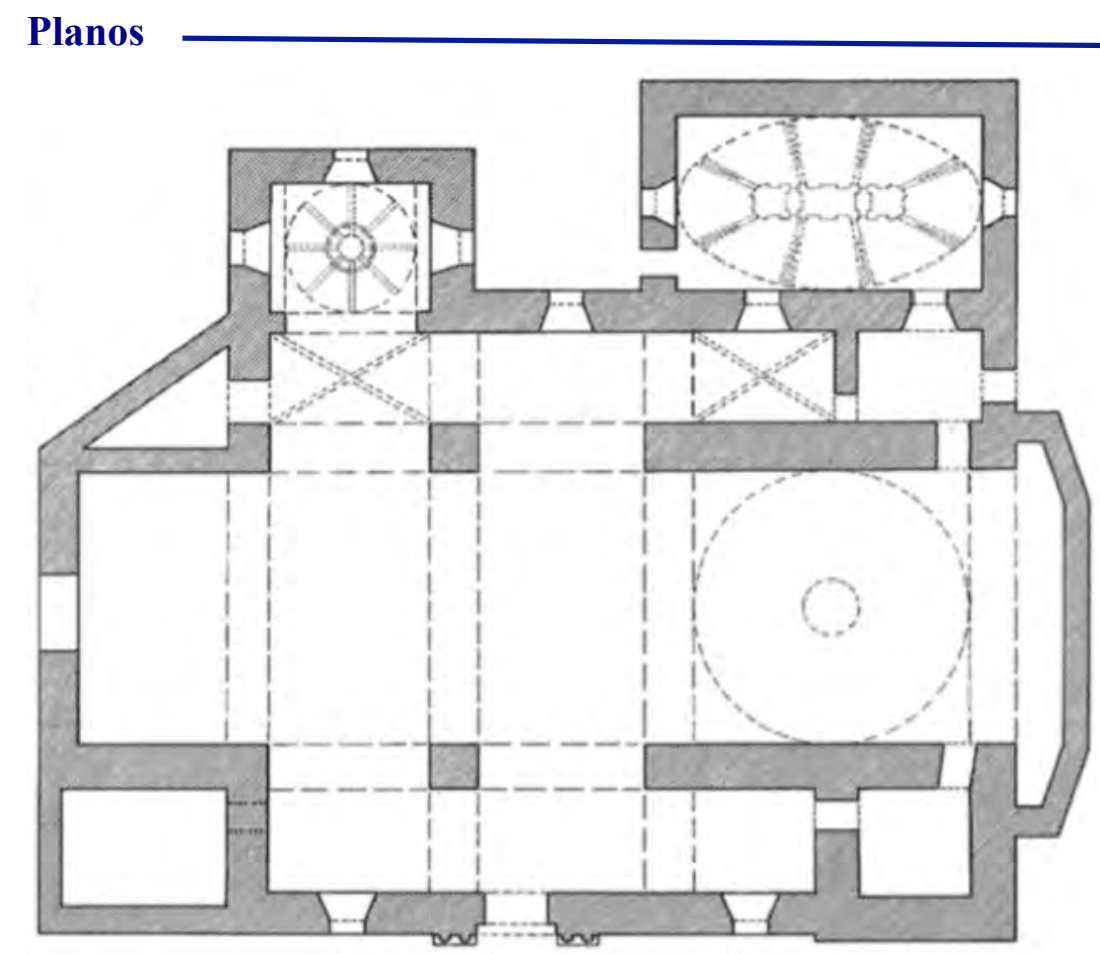

Ilustración 3: planta del Catálogo

\section{Solución constructiva de la cubierta}

En la memoria de la obra de 1958 se indica que "se desmontará toda la teja reponiendo las defectuosas e inservibles, cuyas limas y caballetes se recibirán con mortero de cemento, y si, al descubrir el entramado, aparecieren maderas no útiles para su función, se levantarán y sustituirán por otras en debidas condiciones", lo que nos indica que, hasta su demolición, la iglesia contaba con una estructura de cubierta tradicional de madera.

\section{Zunchos}

No hay datos que indiquen el empleo de zunchos en el edificio, excepto en el remate de la torre realizado por García Gil en 1970.

\section{Conclusiones}

Se trata de un edificio desaparecido. 



\section{Iglesia de San Lorenzo}

Intervenciones citadas en la publicación del Ministerio

1970 - Obras generales - Alberto García Gil

No se han localizado planos en la web del IPCE

\section{En el Archivo Municipal de Valladolid}

\section{Fondo Histórico}

AMVA: CH 374-50 1825

Concesión de terreno a José de Bassó, cura ecónomo, y otros, para ampliar el atrio de la iglesia de San Lorenzo y construir unas tapias hasta las huertas. Se aprueba la belleza de la propuesta.

\section{AMVA: CH 381-32 1855}

(Está en un legajo cosido en una vitrina de la exposición temporal)

Licencia a Francisco Javier Berben, arquitecto, para abrir un hueco de puerta en el testero de la iglesia de San Lorenzo, calle San Lorenzo, por encargo de la Junta de Fábrica

\section{AMVA: CH 387-82 1859}

Expediente en virtud del cual se concede una subvención para reparar el patio del templo de Nuestra Señora de San Lorenzo, a instancia de Eusebio Ortega, cura ecónomo [Hojas: 1]

\section{AMVA: CH 400-18 1876}

Concesión a Hipólito Luis Redondo, cura ecónomo de la parroquia de San Ildefonso, de las puertas verjas y la piedra procedentes del derribo de las antiguas Puertas del Carmen, con objeto de construir el cerramiento del pórtico de la Iglesia de San Lorenzo, en sustitución del que tiene de madera

AMVA: C943-92 1958

Sánchez del Caño, David (Párroco dela Iglesia de San Lorenzo). Reforma fachadas y cubierta del templo (Exp. 92/1958)

Proyecto de reforma y reparación de cubiertas y fachadas en la Iglesia de S. Lorenzo Arquitecto: Miguel Baz (Valladolid), julio de 1958. Aparejador Heraclio Vecino. 
Memoria-Pliego de condiciones

"Teniendo en cuenta que el aspecto exterior del templo en que se venera la imagen de la Patrona de esta Ciudad no responde a la importancia de la misma se pretende llevar a cabo unas obras de adecentamiento y conservación de sus fachadas al mismo tiempo que las de reparación de las cubiertas que tan necesitadas se encuentran de atenderlas. A tal efecto, en las gruesas paredes de tapial, se repicarán lo suficiente para revestirlas con media asta de ladrillo galletera a cara vista y llaves intercaladas de un asta, retundiendolas juntas a fin de conservar el caracter propio del edificio y contrastar con el tono calizo de la piedra silleria que limita aquellos paramentos, la cual se limpiará repicándola con martillina $\mathrm{y}$, tanto en las zonas que aparezcan deterioradas como en las cornisas que falten se repondrán con un enchapado de igual calidad o con mortero de cemento armado con redondos y su revoco de imitación a la natural, en lo que afecta a las cornisas.

Por lo que se refiere a las cubiertas, se desmontará toda la teja reponiendo las defectuosas e inservibles, cuyas limas y caballetes se recibirán con mortero de cemento, y si, al descubrir el entramado, aparecieren maderas no útiles para su función, se levantarán y sustituirán por otras en debidas condiciones".

Se concede la Licencia el 9 de agosto, por derechos para $995 \mathrm{~m} 2$ de retejo y $657 \mathrm{~m} 2$ de revoco.

Plano de alzado 1:100 (2 copias) en que señala faldones a retejar y paramentos a revestir.

\section{Fondo Administrativo}

AMVA: 99/1974 C.8534-8

Sánchez del Caño, David (Párroco dela Iglesia de San Lorenzo). Demolición edificio (Exp. 99/1974) (1 plano)

Proyecto de demolición de edificio en c/ Pedro Niño c/v a S.Lorenzo

Arquitecto: Angel Ríos Gomez

Aparejador: Pedro Julio Baz

Memoria

Ante el estado de ruina inminente de la bóveda posterior de la iglesia y el abandono total en que se encuentra desde su cierre al culto, se redacta el presente proyecto de demolición (...) se iniciará por la cubierta, desmontanto la teja, tabla y armadura de madera.

Plano de emplazamiento y un perímetro de planta con línea.

Solicitud de exención de tasa de Licencia

\section{En el archivo de la Junta de Castilla y León}

No se ha localizado documentación. 


\title{
En el Archivo General de la Administración
}

\author{
AGA 003321971
}

Restauración. Alberto García Gil (Segovia, diciembre de 1970).

"Iniciada su demolición fué detenida por la Dirección General a la vista del interés histórico-artístico de algunos elementos.

Posteriormente se ha decidido el mantenimiento de la torre y de una portada y la restauración del resto de la iglesia.

La iglesia, construida por Pedro Niño, siglo XV, fué inicialmente de una nave, probablemente cubierta con artesón, con cimborrio y esbelta e interesante torre.

La torre está construida en tapial reforzadas sus esquinas con sillería caliza y con madera en entramados horizontales y estructura de cubierta. Recientemente fué chapada de ladrillo".

El proyecto se concreta a la torre: construcción de nuevos entramados de vigueta de hierro, escalera. Reconstrucción de la cubierta con estructura de madera, zunchada con hormigón armado.

Revoco, etc. 



\section{Iglesia del Convento de San Pablo}

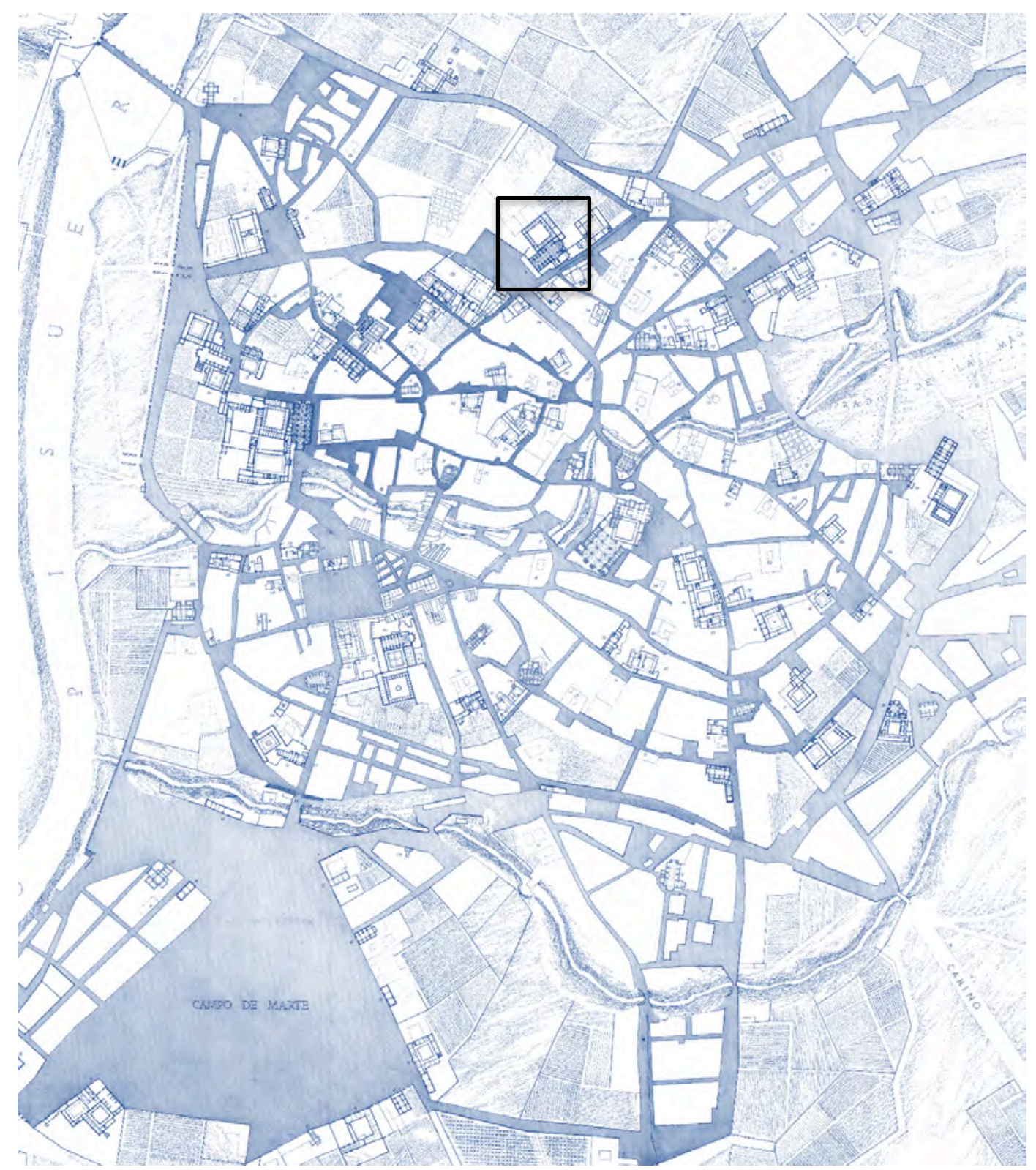



FICHA SÍNTESIS

Código de identificación: FZ-10

Denominación:

Iglesia de San Pablo

Localidad:

Valladolid

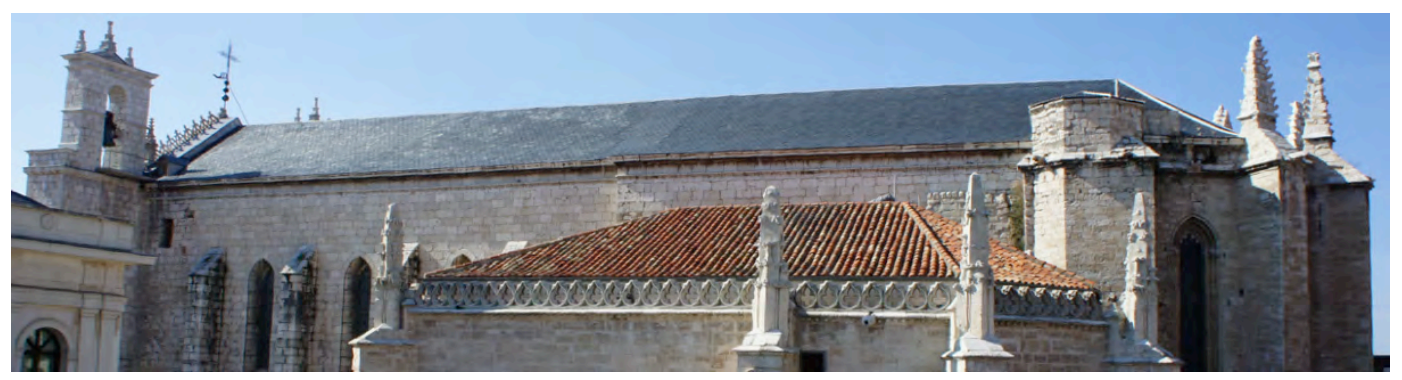

\section{Descripción}

Iglesia de una sola nave con cinco tramos y capillas entre contrafuertes interiores, crucero con brazos cortos y cabecera circular con dos capillas absidiales. Las bóvedas son de crucería, simple en capillas, excepto alguna estrellada, y de terceletes en los tramos de la nave central.

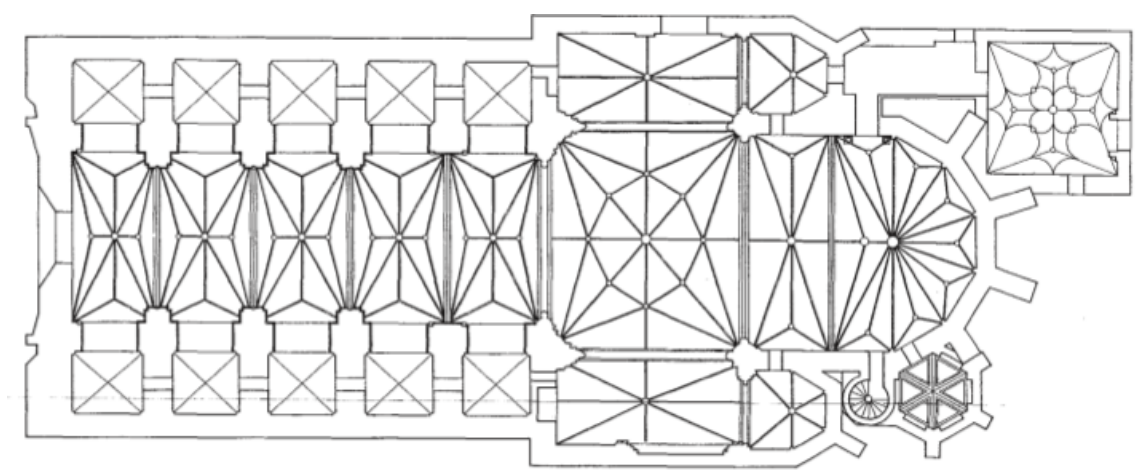

Ilustración 1: planta del Catálogo

\section{Materiales}

Los muros de nave central y fachada son de sillería de piedra, también encontramos sillarejo en naves laterales y algunos elementos con fábrica de ladrillo, como la planta alta recrecida sobre nave lateral y otras construcciones adheridas. También son de ladrillo dos grandes contrafuertes incorporados en el XIX. La cubierta de la nave central está revestida de pizarra, así como el faldón que cubre las capillas del lado del Evangelio. 
El faldón sobre las capillas del lado de la Epístola también cuenta con revestimiento de lajas de pizarra, menos la capilla de San José, la Sacristía y ambos brazos del crucero, que se cubren a distintos niveles con teja cerámica.

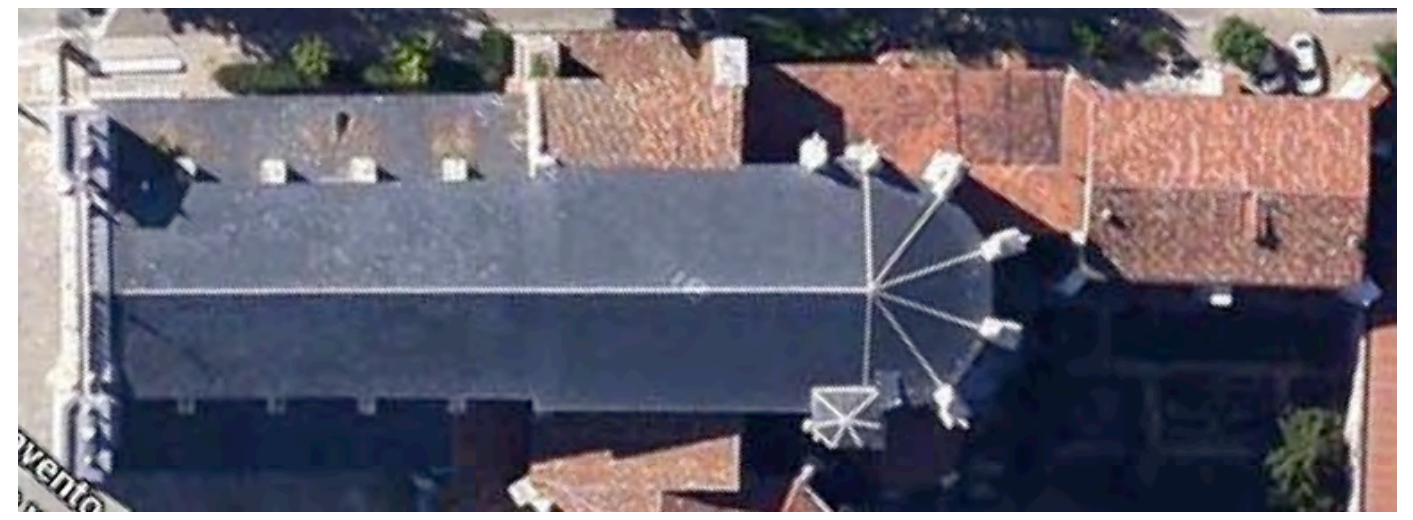

Ilustración 2: plano satélite google maps (28/09/2014)

\section{Singularidades}

La fachada es un auténtico retablo de piedra de iconografía abigarrada con un gran arco carpanel, un frontón con escamas, pináculos y remate de crestería. Se ha convertido en uno de los símbolos más importantes del Patrimonio de la ciudad.

\section{Dimensiones básicas del templo}

$\begin{array}{lccc} & \text { central } & \text { laterales } & \text { capillas } \\ \text { Ancho de nave } & 9,5-11,5 & 4,2 & \\ \text { Altura } & 25,5 & 9,3\end{array}$

\section{Memoria histórica constructiva}

Según el Catálogo el convento de San Pablo se funda en 1276. En el manuscrito de 1722 Historia de Valladolid, Juan Antolinez de Burgos describe cómo la reina María de Molina, esposa de Sancho el Bravo, edificó el Monasterio en 1286.

La intervención del cardenal Torquemada, a partir de 1445, impulsa las obras del cuerpo del templo, crucero y capilla mayor.

\section{Dela fundacion del conzento de san} حa Pablo Orden de Santo Domingo aa Yntroduxase la Relwion del señor Santo Domin

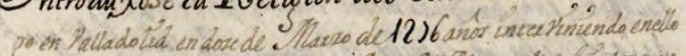

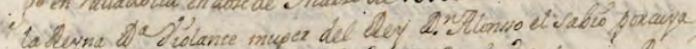

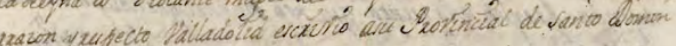
yo lasiquiente Cava.

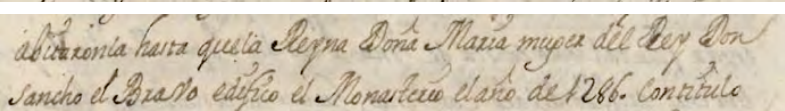
Ilustración 3: manuscrito de Antolínez (pp 264) 
Otros mecenas promueven las portadas, parte de la fachada principal de Simón de Colonia y la Sacristía, hasta la llegada del Duque de Lerma que modifica la fachada principal y construye el coro.

El convento sufrió a raíz de la ocupación francesa y las posteriores desamortización, exclaustración y cambios de uso, tras los que sólo la iglesia permanece en pie.

En el Congreso AR\&PA 2012 el arquitecto Eduardo González Fraile, tras analizar el despiece de sillares y molduras de la fachada, propone que la portada original de Simón de Colonia pudo tener un perfil quebrado, similar al que podemos encontrar en una portada adosada en un paramento interior, hipótesis que representa en la imagen siguiente.
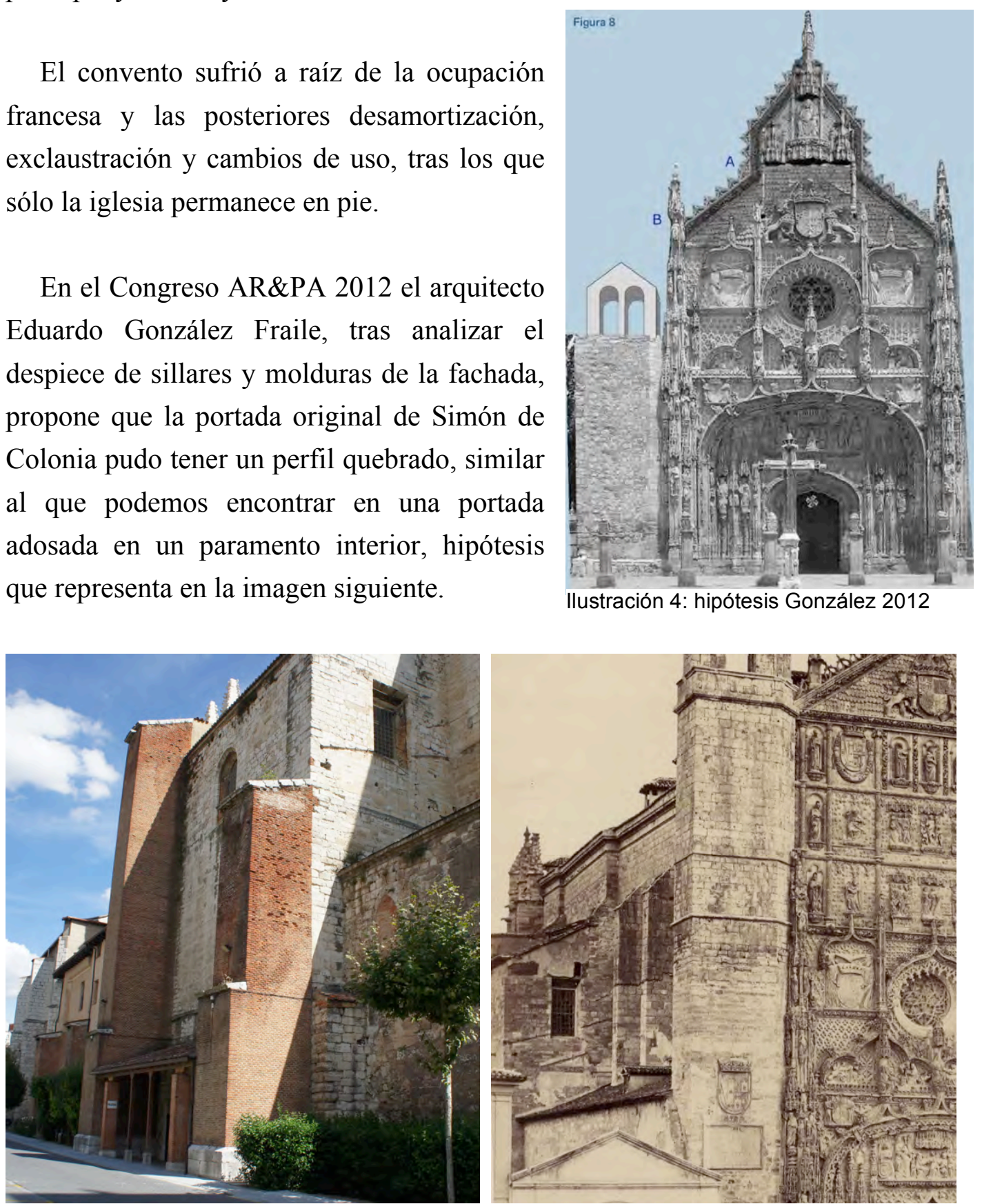

Ilustración 5: vista actual e imagen del siglo XIX sin los refuerzos BNE 66233 (Muriel 1864)

En 1862 Ortiz de Urbina, Fuentes e Iturralde emiten un dictamen: parte de las fábricas y armaduras están en estado lamentable, en especial el costado izquierdo tras desmontarse una edificación adosada. Proponen recalce y contrarrestos, reparación de cubiertas y bóvedas del templo y retejo. 
En los libros de actas de la Comisión de Monumentos que se conservan en el archivo histórico provincial de Valladolid encontramos citas reiteradas a actuaciones sobre el edificio a lo largo de esa década del XIX ${ }^{1}$.

El 9 de septiembre de 1968 un incendio destruye "la parte de cubierta del templo que se hallaba sin restaurar" y en enero de 1969 caen las bóvedas de capilla mayor y centro del crucero.
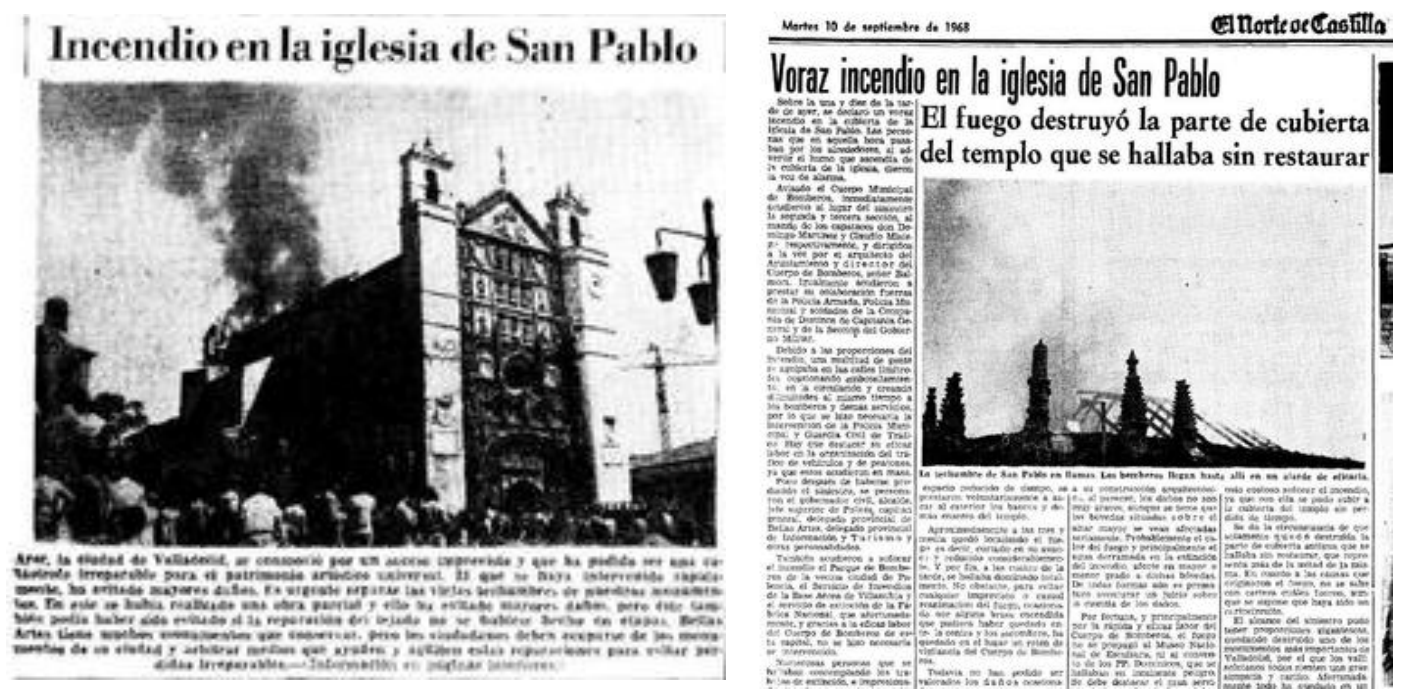

Ilustración 6: noticias en el diario El Norte de Castilla

En las fotografías de Berzal obtenidas en la hemeroteca de la página web del mismo periódico. En la visita al bajo-cubierta aún puede apreciarse la zona ennegrecida.
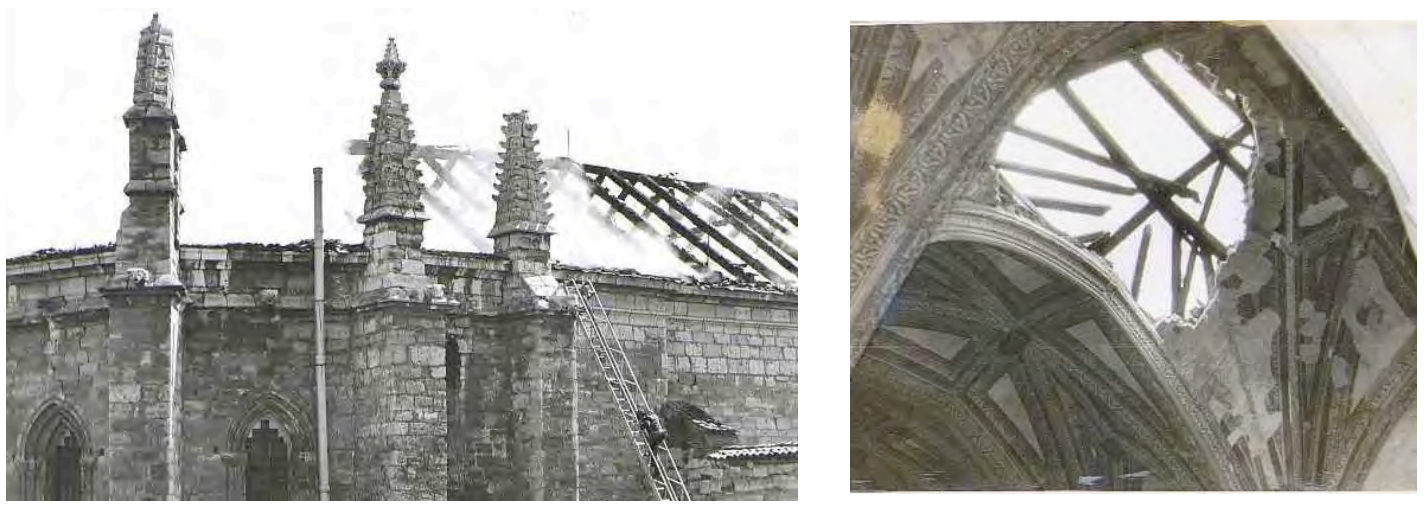

Ilustración 7: fotografías del incendio hemeroteca El Norte de Castilla

\footnotetext{
${ }^{1}$ Domínguez Burrieza, F. J. (2011). El Valladolid de los Ortiz de Urbina (1852-1936). Valladolid: Ayuntamiento de Valladolid.

${ }^{2}$ Aunque es una imagen sin datar, se incluye en un grupo de negativos en color en los que aún aparece
} 


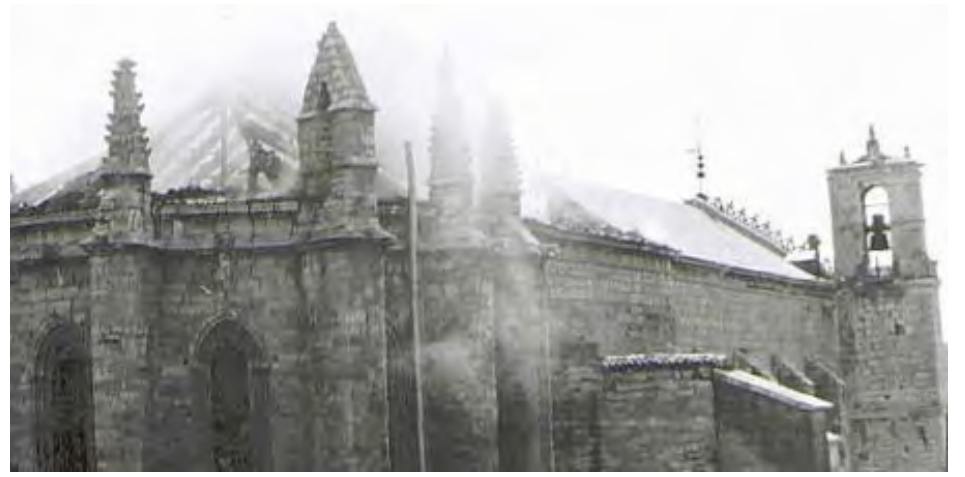

Ilustración 8: AMVA F00842-004

Estas imágenes se conservan también en el Archivo Municipal, donde encontramos además fotografías como la anterior (Ilustración 8), en que se aprecia claramente hasta dónde se extendió el incendio y cómo se conserva en pie la zona de cubierta ya reformada, revestida de pizarra, que corresponde al cuerpo de la nave hasta los pies.

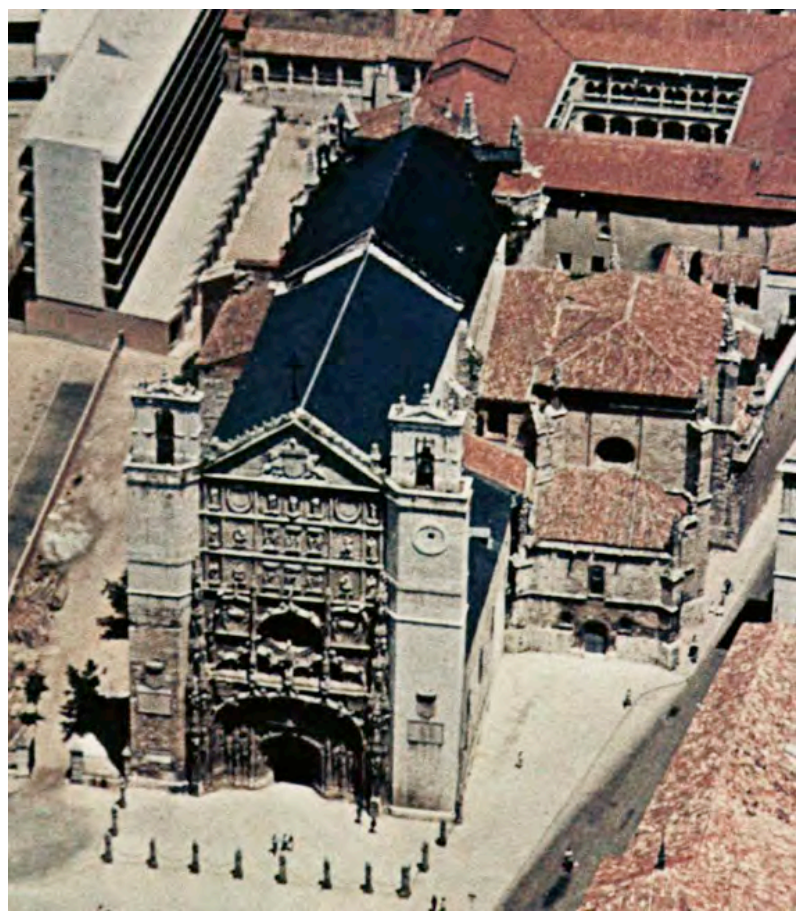

Aunque en la actualidad se encuentre resuelta con un único volumen a dos aguas, en algún momento ${ }^{2}$ la cubierta estuvo dividida en dos zonas escalonadas, según se aprecia en la vista aérea.

Ilustración 9: AMVA FC155

En la página web de la antigua Fundación Caja Madrid ${ }^{3}$ encontramos un video en que se describe brevemente una hipótesis de evolución constructiva que muestra, entre otros, los siguientes dibujos.

\footnotetext{
${ }^{2}$ Aunque es una imagen sin datar, se incluye en un grupo de negativos en color en los que aún aparece el mercado de Portugalete, demolido en 1974

${ }^{3}$ Página http://www.fundacionmontemadrid.es/Fundacion/Comunes/fun_cruce/ 0\%2c0\%2c72097_2747270_72098\%2c00.html (acceso 26/09/2014)
} 

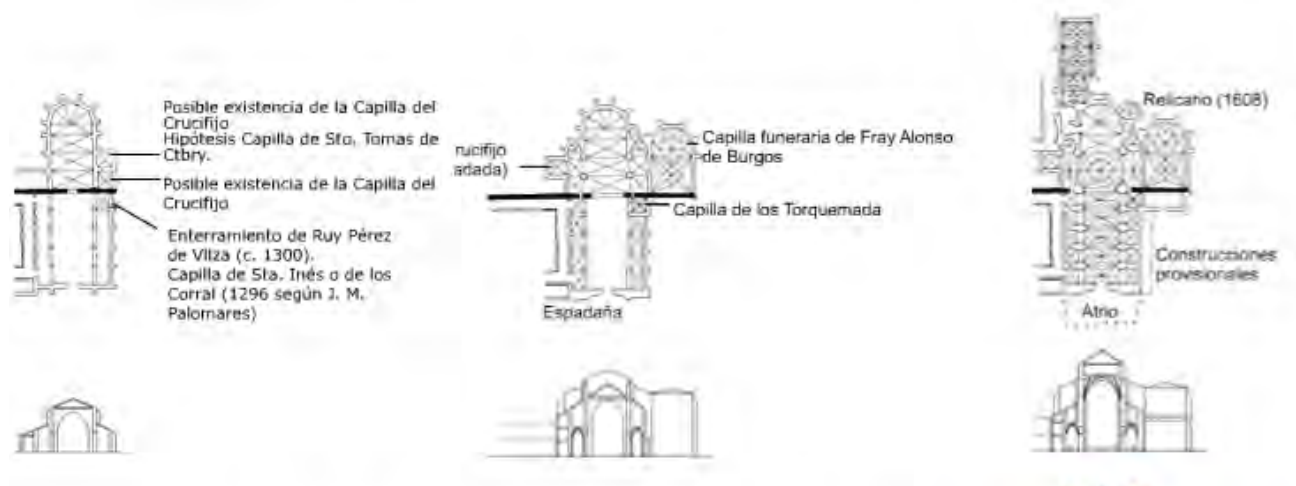

III. 1276-1321
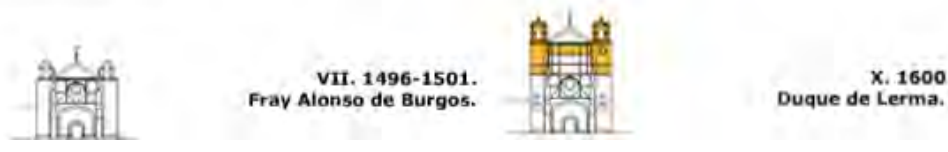

llustración 10: capturas de pantalla del video en la web de la Fundación Caja Madrid.

\section{Cronología. Fechas clave}

$1286-1445-1869-1968$

\section{Intervenciones}

1869 - Recalce con contrafuertes de fábrica de ladrillo, reparación de bóvedas y retejo - Jerónimo Ortiz de Urbina

1962 - Reparación de la crestería y cubierta - Anselmo Arenillas

Se prescribe el reemplazo de armaduras por cuchillos metálicos con tablero de rasilla en los dos primeros tramos a los pies.

1964 - Sustitución de las cubiertas - Anselmo Arenillas

\section{Incorporación de zuncho de hormigón armado}

Según la memoria la cubierta estaba revestida con escamas cerámicas modernas (con menos de 50 años) teñidas con alquitrán y presenta goteras generalizadas. Se propone reducir a máximo $40 \%$ la gran pendiente actual del tejado, que haría más apta la pizarra, reemplazando las armaduras por formas prefabricadas de hormigón armado, con doble tablero de rasilla y revestimiento de teja curva.

"Las formas de la cubierta se colocarán sobre una solera de hormigón armado que regularice la coronación de los muros, trasdose y consolide las cornisas y facilite con el atirantado de los cuchillos la contención del pequeño desplome de las fábricas de sillería". 
1968 - Proyecto de terminación de la restauración de las cubiertas - Anselmo Arenillas

Se decide completar el reemplazo de estructura de madera por cerchas metálicas con tablero de rasilla en crucero y cabecera, reparando las cabezas de los muros poniendo sobre ellos un solerón de hormigón armado de $40 \times 30 \mathrm{~cm}$, reparando aleros y cornisas existentes.

1969 - Restauración de bóvedas, cubiertas y pavimentos dañados por incendio - José Antonio Arenillas Asín

Tras el incendio se reconstruyeron con hormigón las bóvedas de ábside principal y crucero, sustituyéndose totalmente la cubierta de esa zona.

1971 - Obras de conservación - Felipe Prieto

Se renueva el pavimento dañado por la caída de bóvedas tras el incendio en crucero y ábsides, así como las paredes de la capilla mayor. Se renueva las cubiertas "de una pequeña zona correspondiente al brazo de la epístola del crucero y la de la primera capilla de la misma zona", obra que se realiza, según la memoria del proyecto, por cuenta de los padres dominicos bajo la dirección del mismo arquitecto.

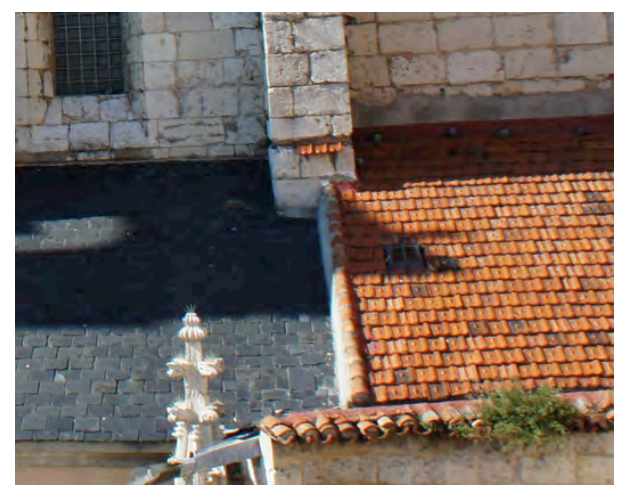

llustración 11: imagen actual de la zona reparada por Prieto en 1971

1982-1985 - Proyecto de restauración de la fachada y Reformado - Ignacio Gárate

2006 - Proyecto de restauración de fachada - Eduardo González Fraile

Durante cinco años se limpia la fachada y repone elementos de cantería desaparecidos o rotos.

El proyecto incluye un Libro del edificio que planifica el mantenimiento futuro del templo y posibles actuaciones a desarrollar

\section{Planos}

Hasta el levantamiento de González Fraile, encontramos en los archivos escasa documentación gráfica sobre este edificio. Tan sólo un mismo plano de Anselmo Arenillas con planta y esquema de faldones de cubierta, reproducido también por su hijo en 1969, que en ocasiones incorpora un detalle muy esquemático de sección con 
cerchas metálicas, que no se corresponden con la geometría realmente dispuesta con sólo dos montantes. Las plantas son bastante esquemáticas y no incluyen los grandes contrafuertes de ladrillo del XIX ni las zonas de Sacristía y capilla de cabecera.

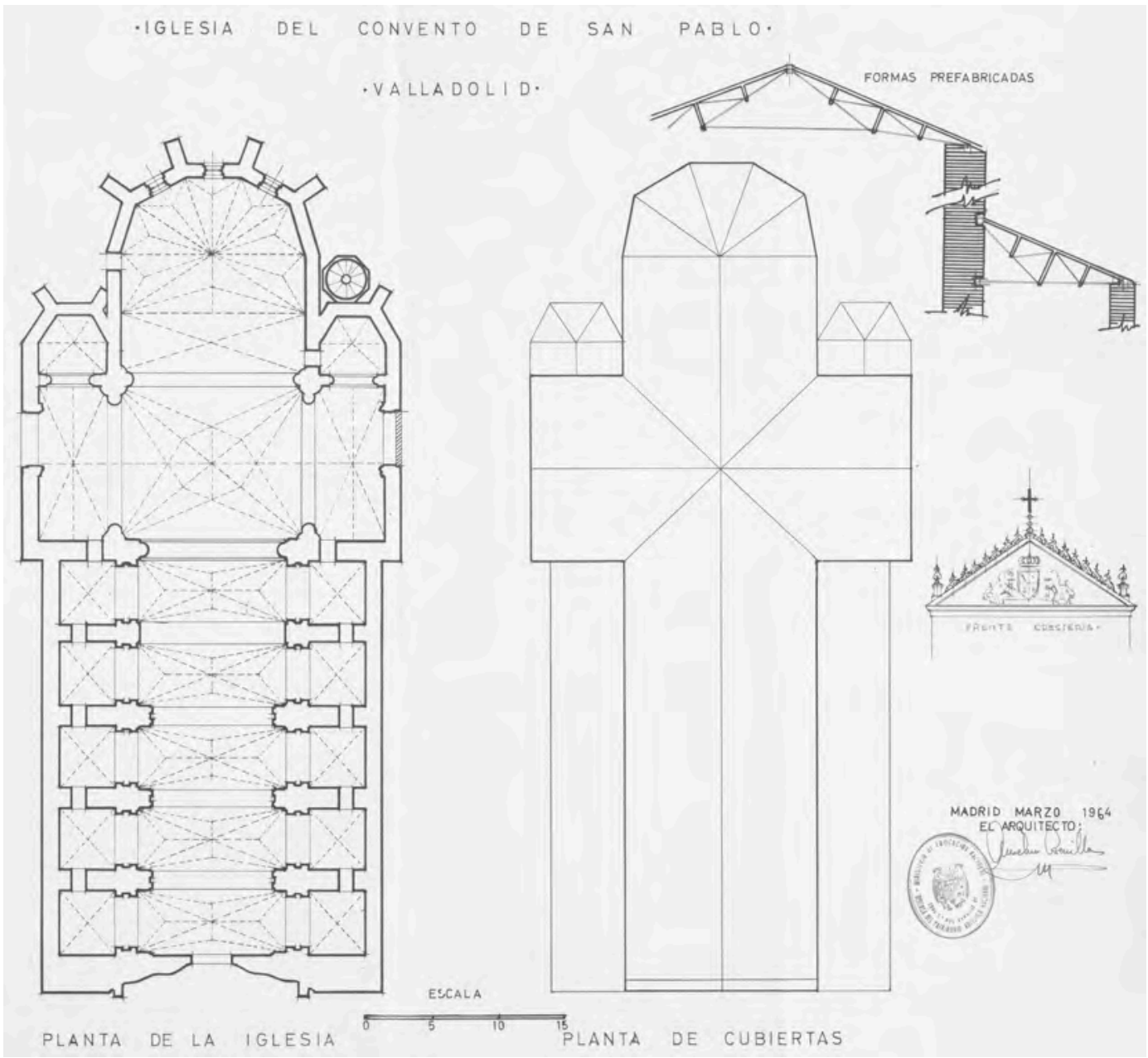

llustración 12: plantas y sección parcial de cubierta (Arenillas 1964 Planoteca IPCE)

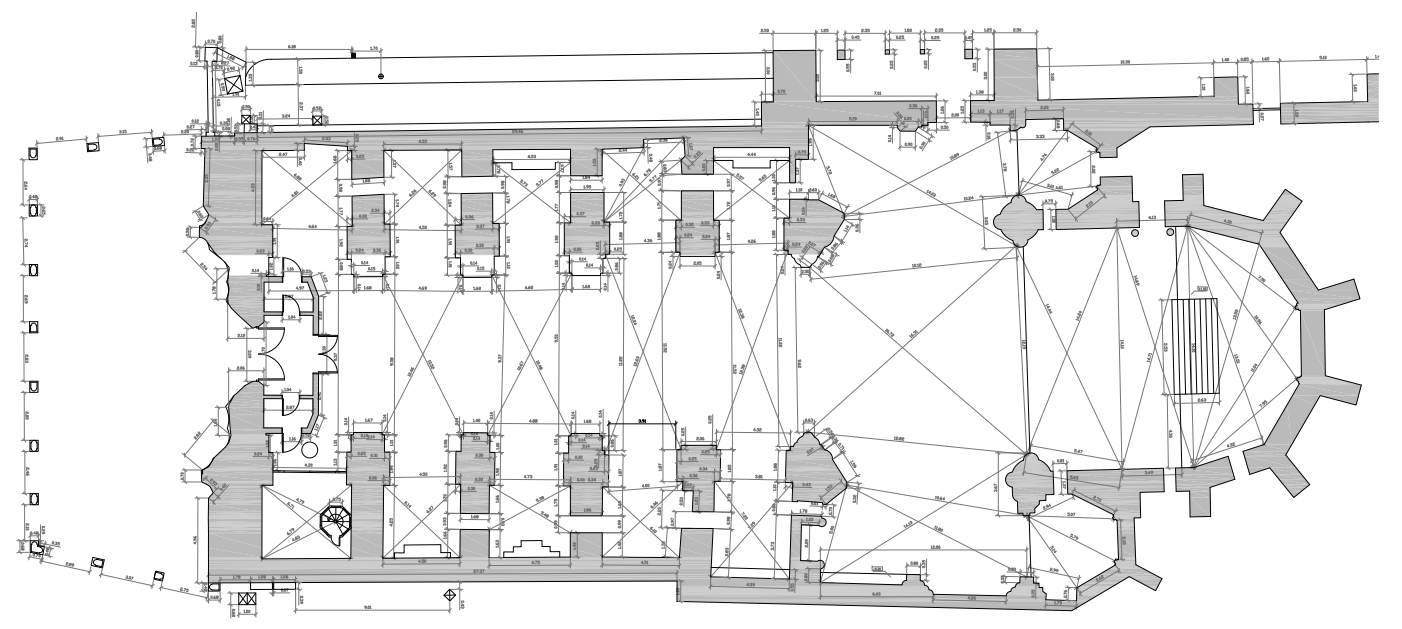

Ilustración 13: planta acotada (González Fraile 2006 JCyL) 


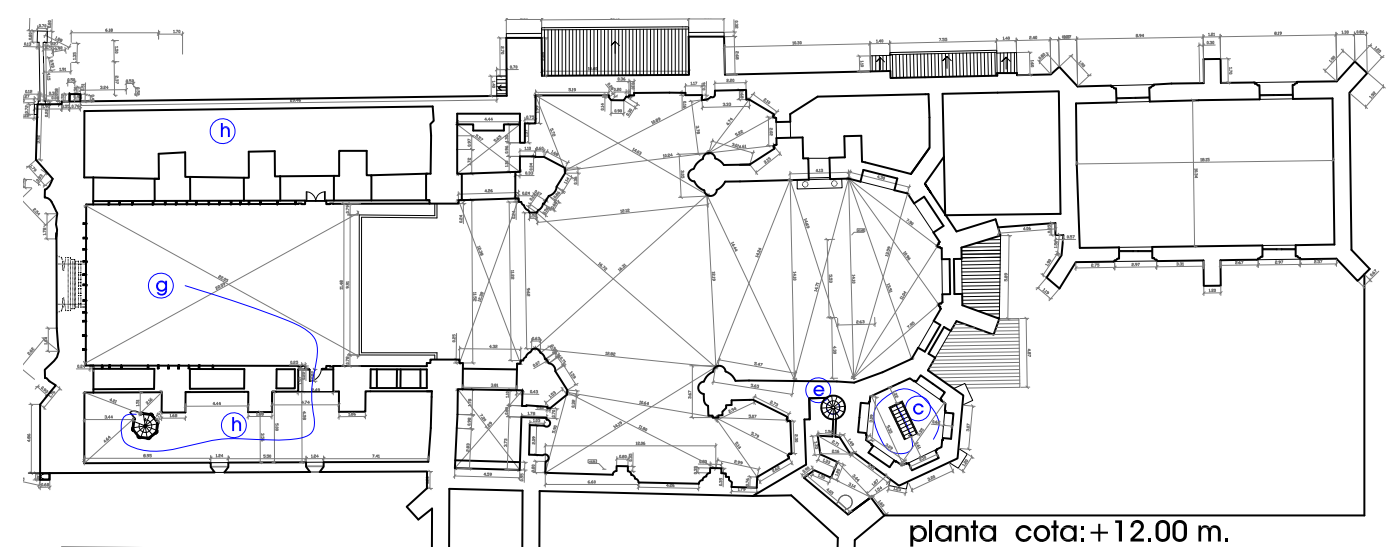

Ilustración 14: planta alta (González Fraile 2006 JCyL)

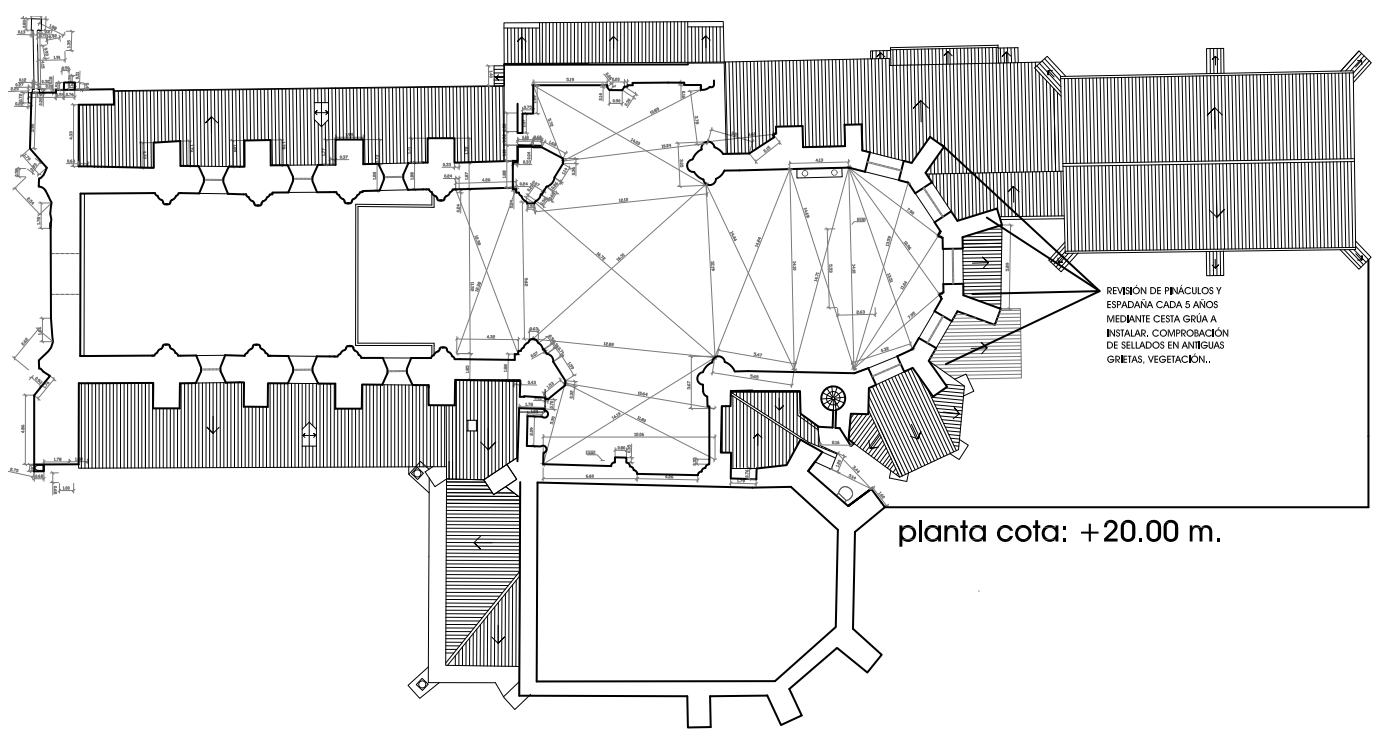

Ilustración 15: planta de cubiertas (González Fraile 2006 JCyL)

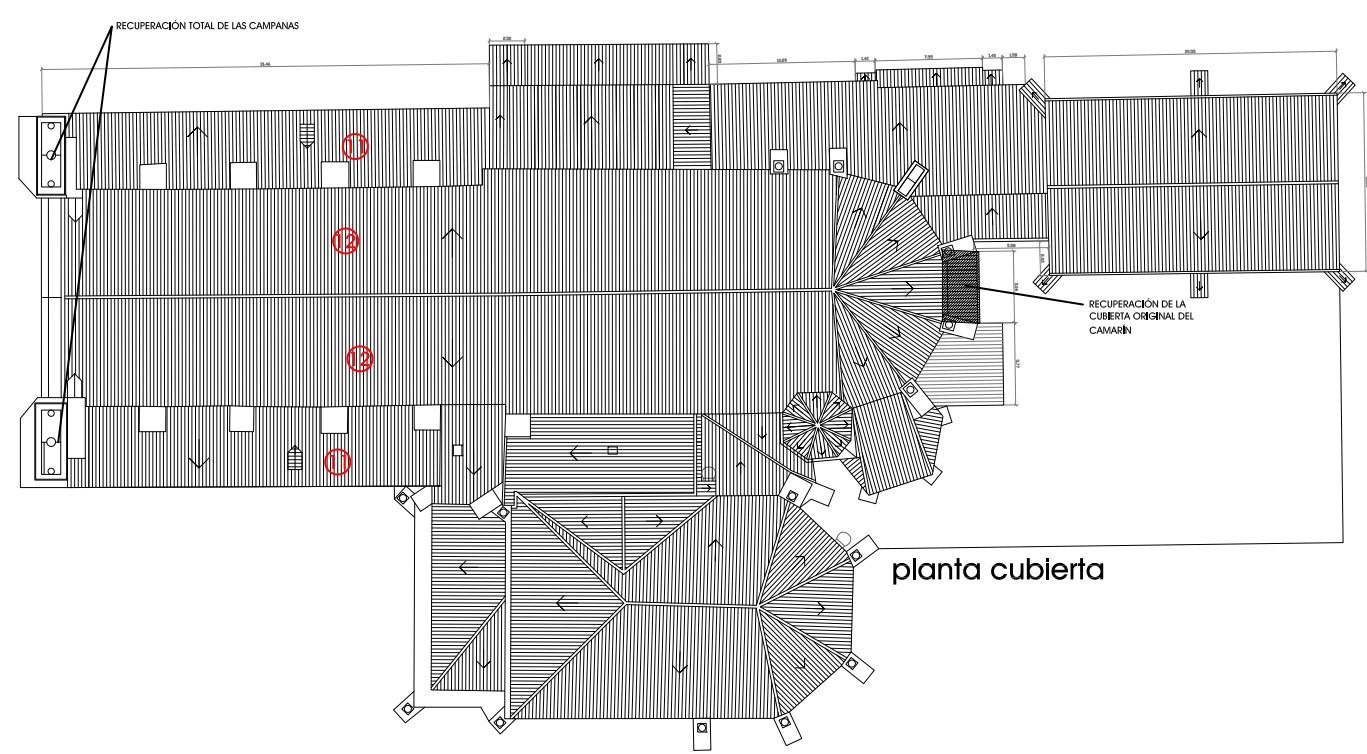

Ilustración 16: planta de cubiertas (González Fraile 2006 JCyL) 


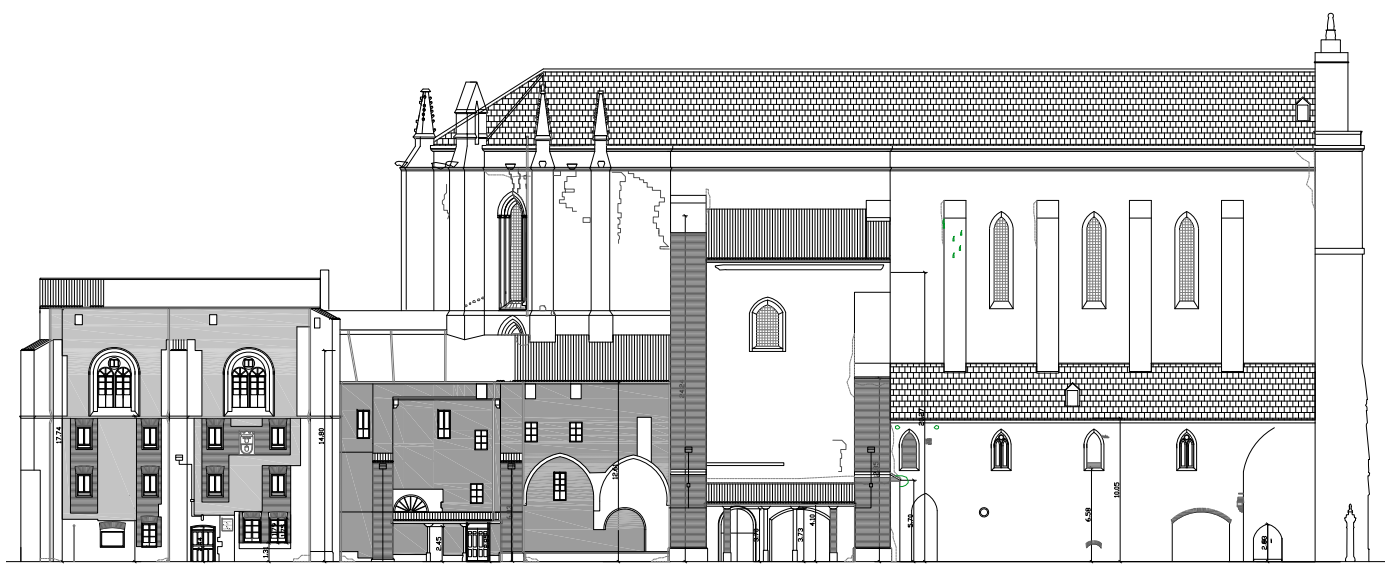

Ilustración 17: alzado lateral evangelio Futuras intervenciones (González Fraile 2006 JCyL)

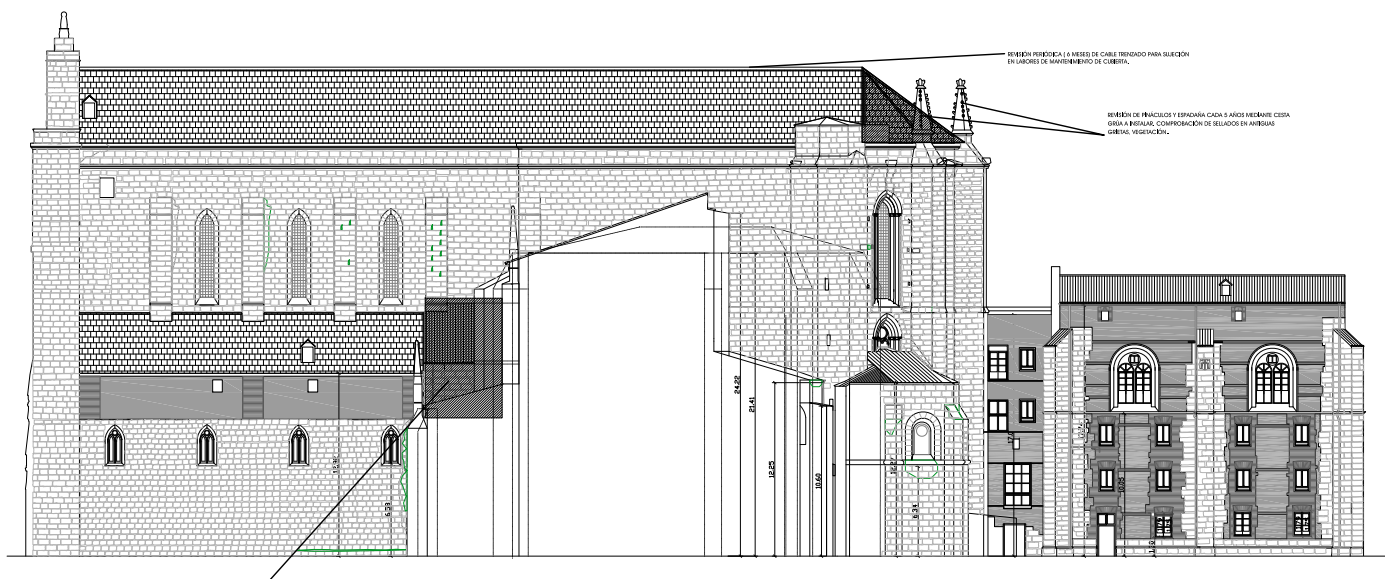

Ilustración 18: alzado lateral epístola del Plan de conservación (González Fraile 2006 JCyL)

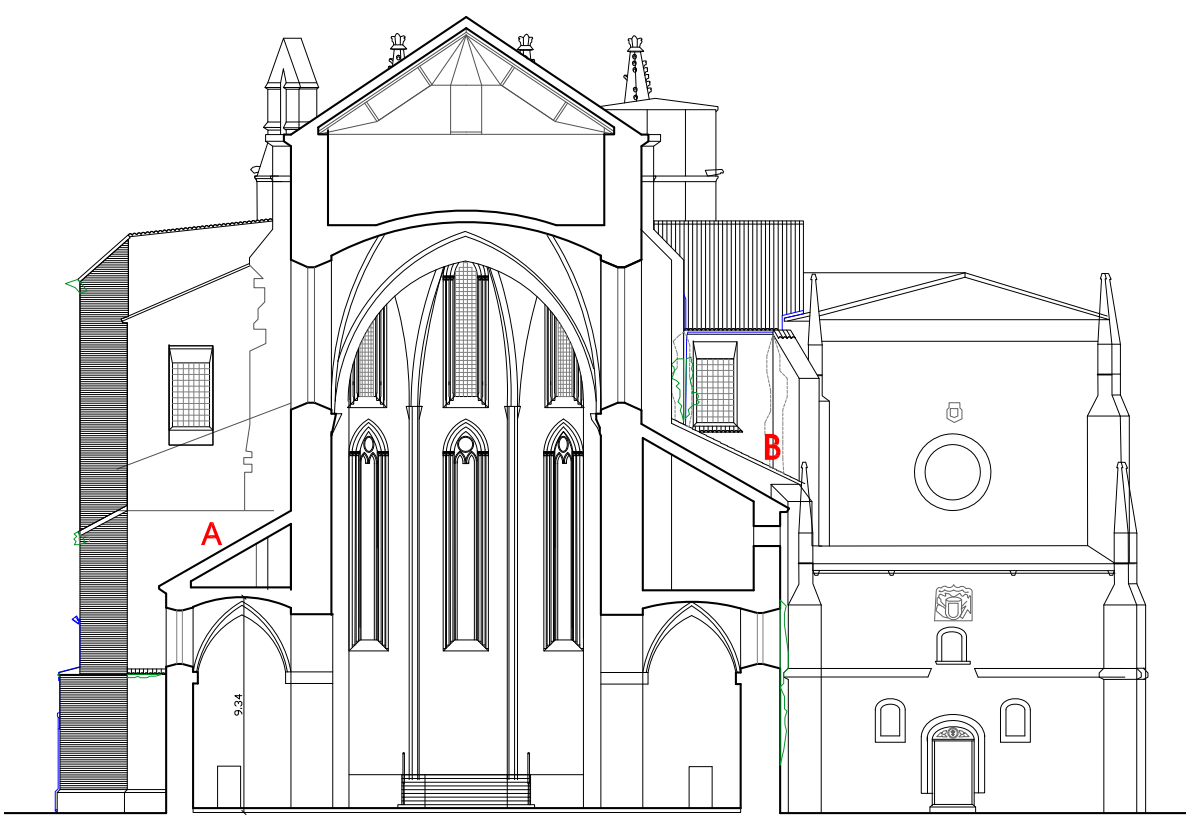

Ilustración 19: sección transversal. Futuras intervenciones (González Fraile 2006 JCyL) 

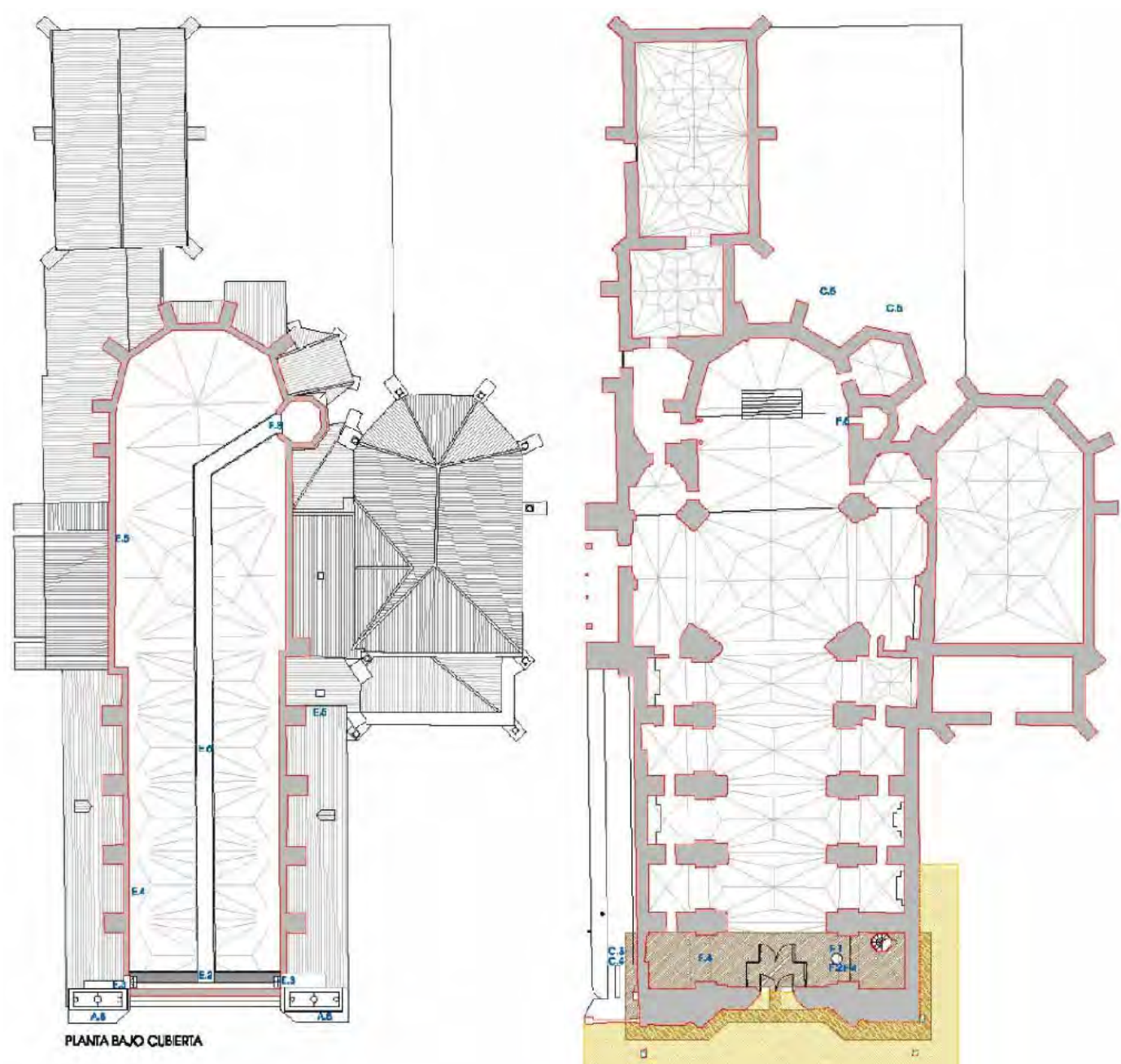

Ilustración 20: plantas de espacio bajo cubierta, plano Guia de intervenciones (González Fraile 2006) $\mathrm{http}: / /$ multimedia.fundacionmontemadrid.es/patrimonio/sanpablo

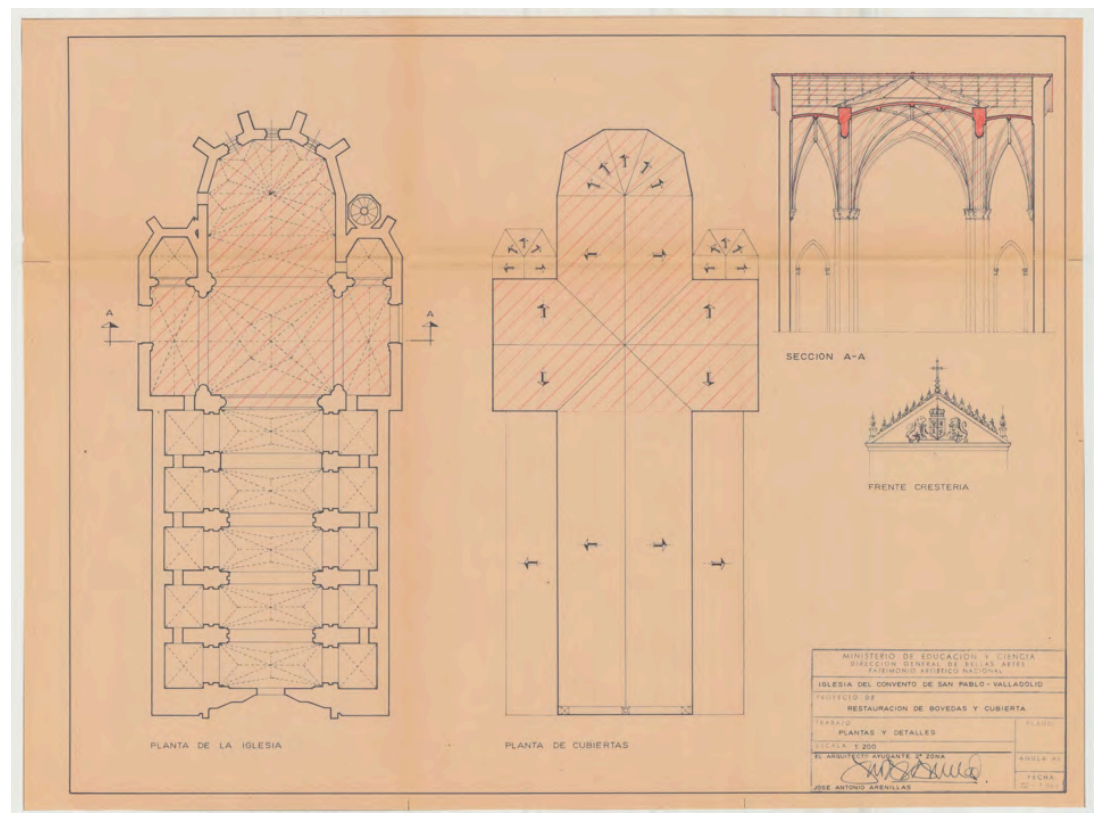

Ilustración 21: plantas y sección 1969 Arenillas Asín AGA 


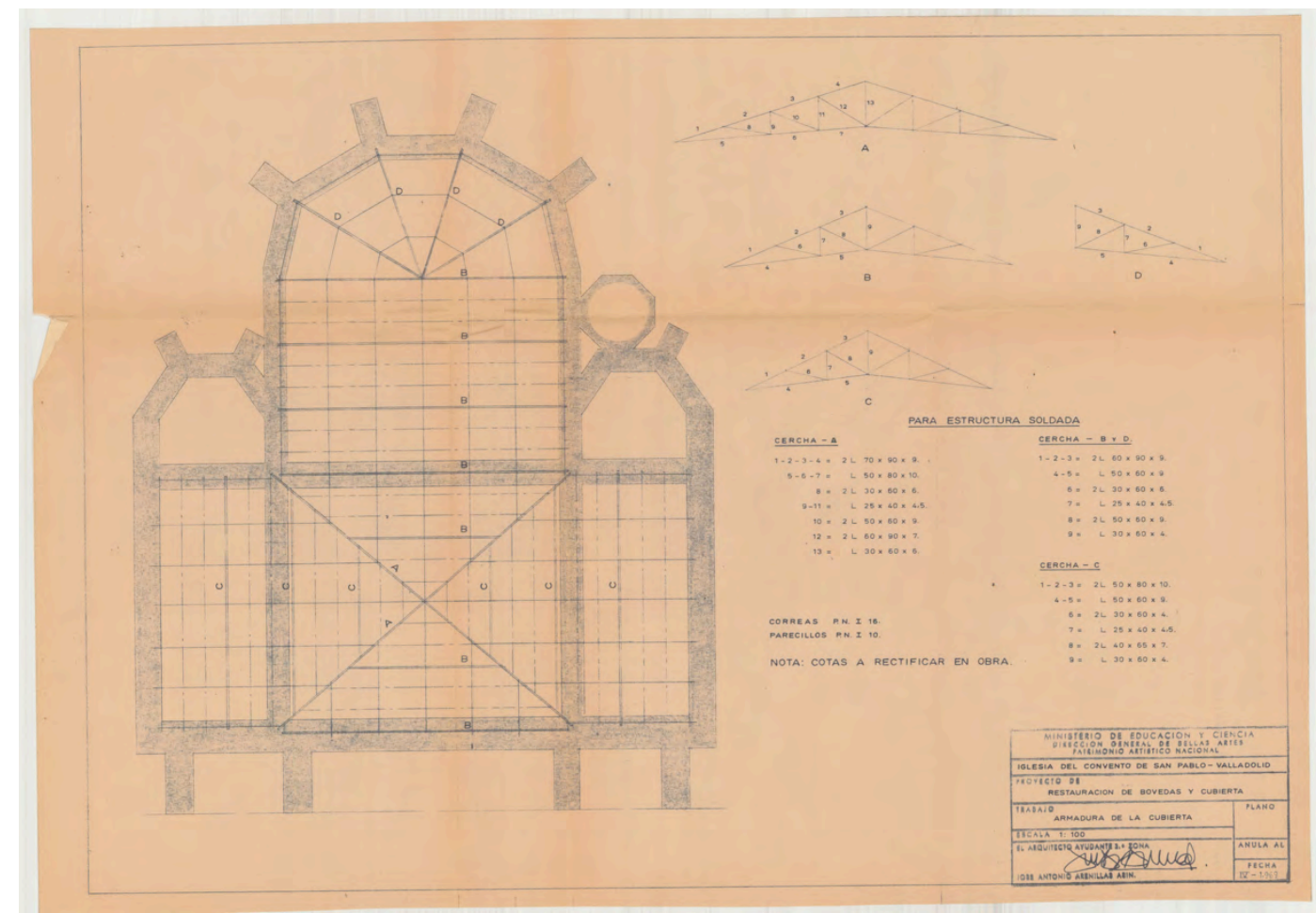

Ilustración 22: plano estructura de cubierta cabecera y crucero San Pablo 1969 Arenillas Asín AGA

\section{Solución constructiva de la cubierta}

Aunque según el Catálogo no está claro si las bóvedas de los cinco tramos hacia los pies se levantan en el siglo $\mathrm{XV}$, dadas sus características formales, o corresponden a la reforma de principios del XVII en la que se recrece el cuerpo superior de la fachada, en el manuscrito de 1722 Historia de Valladolid, Juan Antolinez de Burgos se afirma claramente que "levantó el Duque de Lerma el cuerpo de la iglesia para que quedase a igual altura con la Capilla mayor".

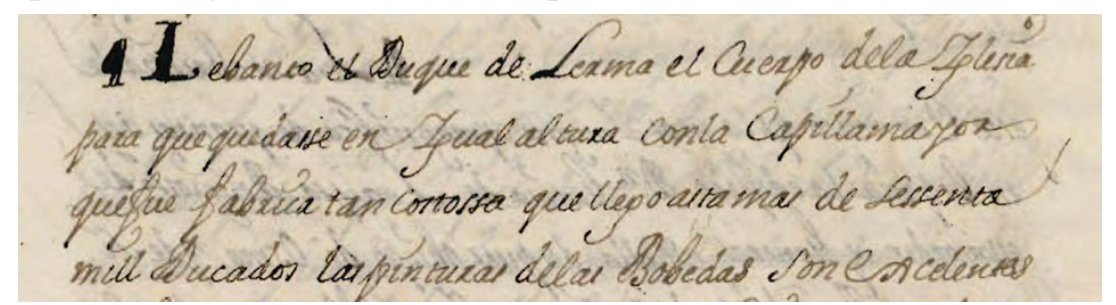

Ilustración 23: manuscrito de Antolínez (pp 264)

En los distintos planos de Arenillas se representaban los planos de cubierta dispuestos en forma de cruz, pero en realidad se configura en dos niveles, con el superior único, desde los pies hasta la cabecera a dos aguas, absorbiendo el sobreancho desde el crucero con un simple alabeo de los tableros. 
Los brazos del crucero cuentan así con sendas cubiertas independientes, a menor altura y revestidas con teja. La del lado del Evangelio presenta un único faldón, en sentido transversal y con poca pendiente, la de la Epístola en paralelo al eje del templo. También se cubre de teja plana el tramo de la capilla adyacente (se observa en la fotografía insertada junto a la descripción del proyecto de 1971).

El reemplazo de las armaduras de cubierta por estructura metálica se realizó por partes. Según lo observado en la visita, en 1964-5 se debieron colocar las nuevas cerchas atirantadas desde los pies hasta una crujía antes del crucero, realizadas en acero laminado, con un tablero de bovedillas de hormigón de perfil curvado.

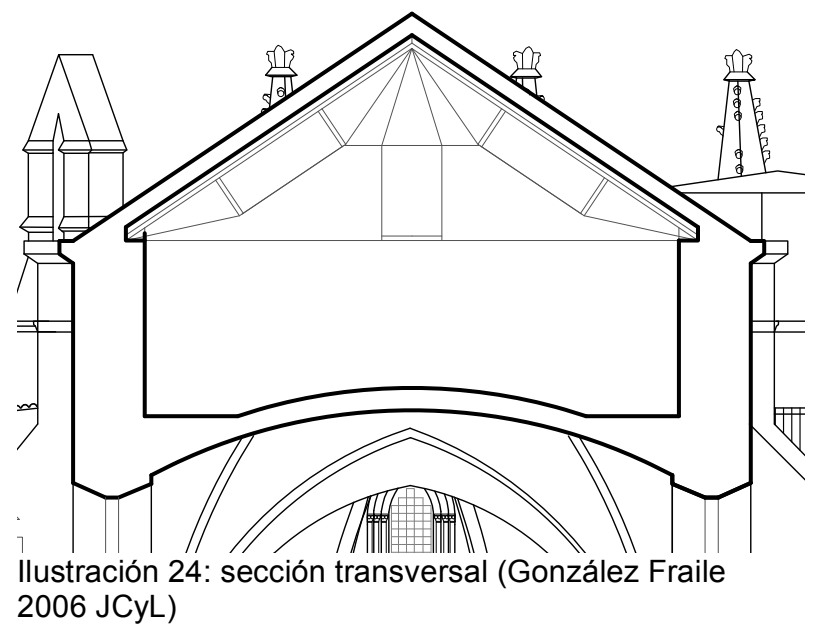

En 1969, tras el incendio del año anterior, se ejecuta el resto de la sustitución hacia la cabecera. Las cerchas de esta segunda fase presentan perfiles aún más ligeros y el entrevigado se resuelve con tabicado de rasillas. La geometría de las cerchas con dos montantes observadas en la visita al bajo cubierta no coincide con la descrita en la sección del proyecto de José Antonio Arenillas ni con el diseño de cerchas de diagonales y montantes incluido en su plano de estructuras.

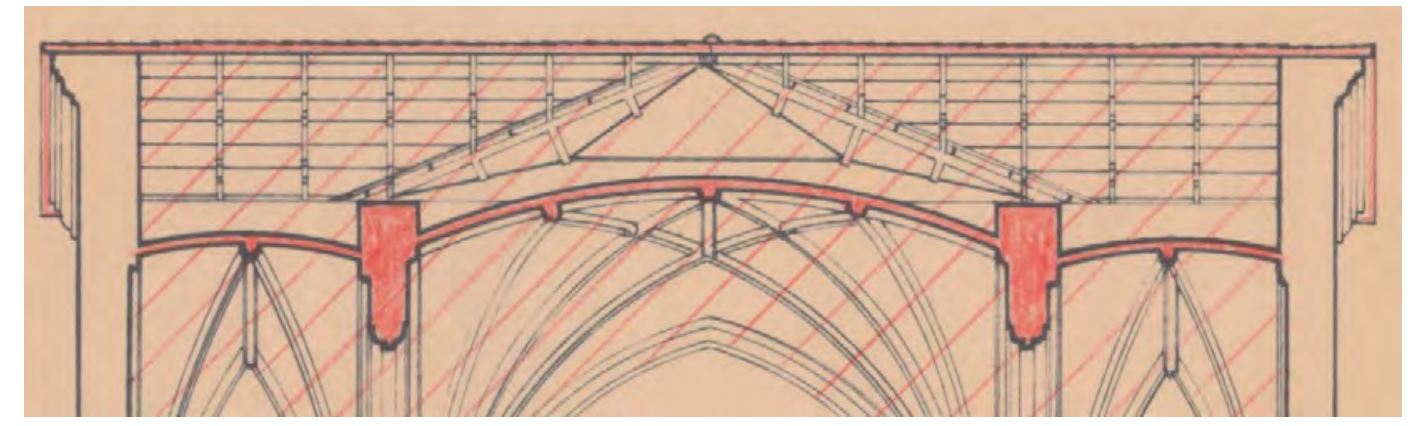

Ilustración 25: sección 1969 Arenillas Asín

Las siguientes imágenes, de un proyecto de 1962, muestran el revestimiento de escamas cerámicas descrito por Arenillas. También podemos apreciar cómo la cumbrera enrasaba con el hastial de piedra de la fachada a los pies, y la teja curva sobre el brazo del crucero a menor altura. (Digitalización AGA) 

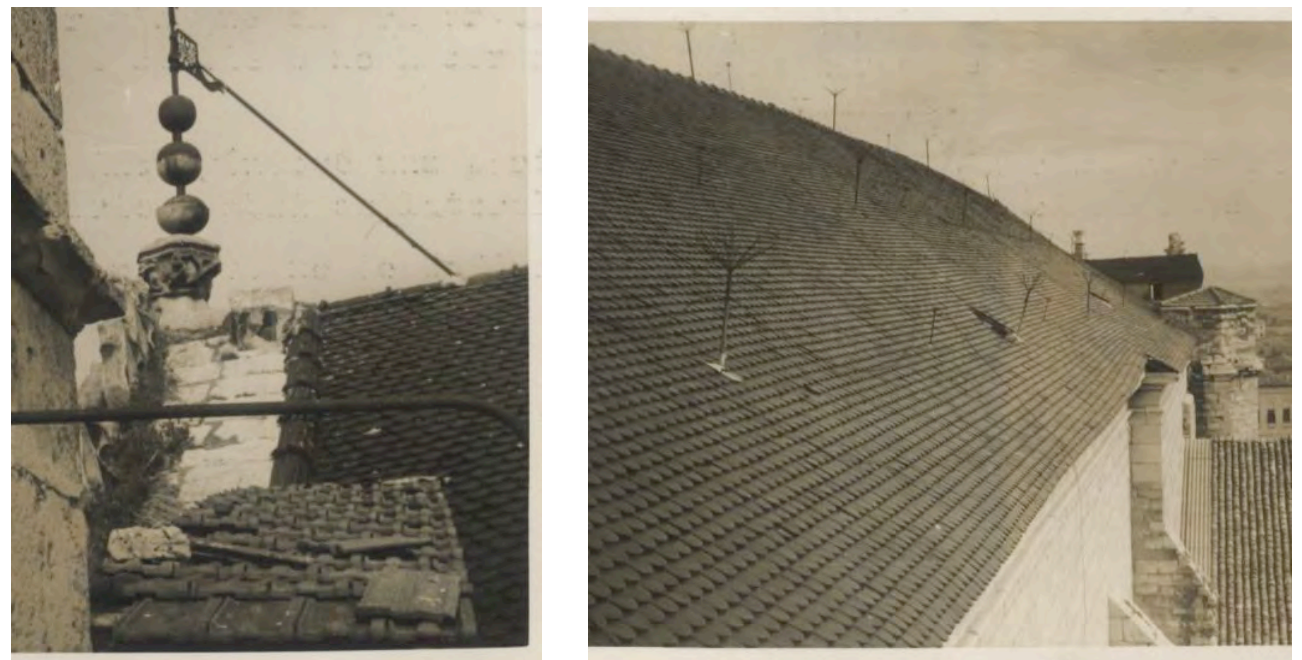

Ilustración 26: digitalización AGA (Arenillas 1962)

En la actualidad, los planos de cubierta se encuentran a menor nivel que el remate del citado hastial. En las secciones se aprecia una pendiente de unos $34^{\circ}$ (35 en el detalle de Arenillas).
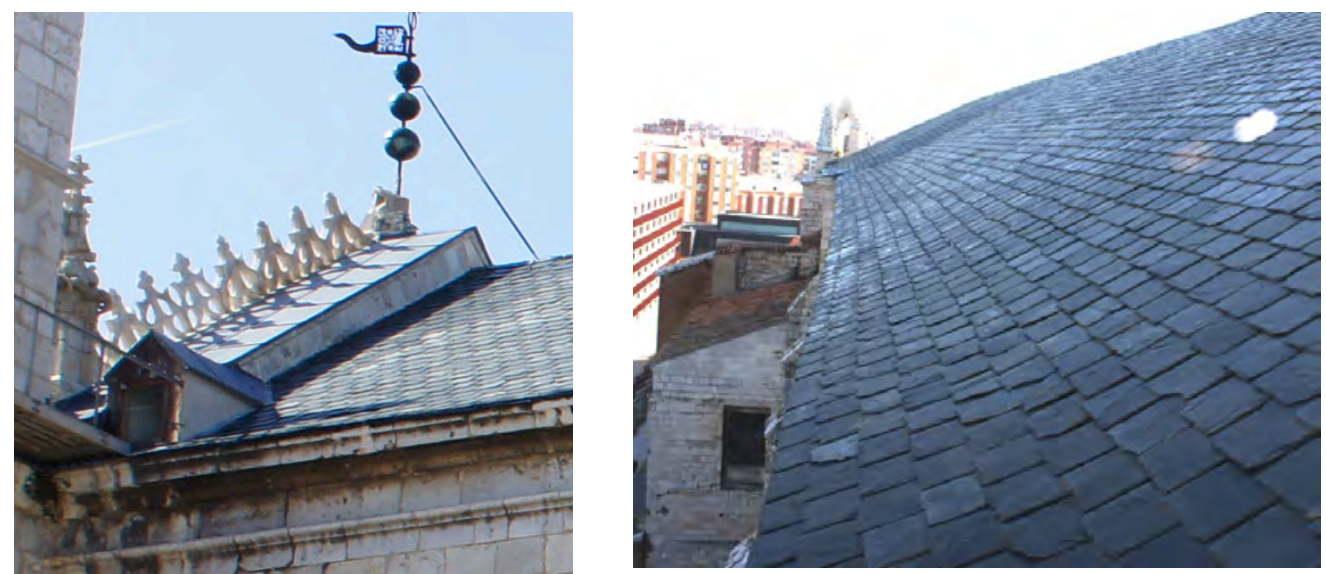

Ilustración 27: vista de la cubierta actual (visita 26/09/2014)

\section{Zunchos}

En la memoria de los proyectos de Arenillas se describe cómo se va a "reparar las cabezas de los muros poniendo sobre ellos un solerón de hormigón armado de $40 \times 30 \mathrm{~cm} "$.

Durante la visita se distingue al menos tres soluciones distintas, fruto de las intervenciones sucesivas: el apoyo de cerchas sobre una repisa de unos $95 \mathrm{~cm}$ con el inter-eje tabicado en el cuerpo de la nave, otra zona contra el paramento sin resalto 
(máximo unos $20 \mathrm{~cm}$ en el encuentro con el quiebro correspondiente al cambio de anchura entre nave y cabecera) en el tramo central y, mediante tramos de perfil de acero laminado recibido con unos $40 \mathrm{~cm}$ de canto de hormigón, en la cabecera.

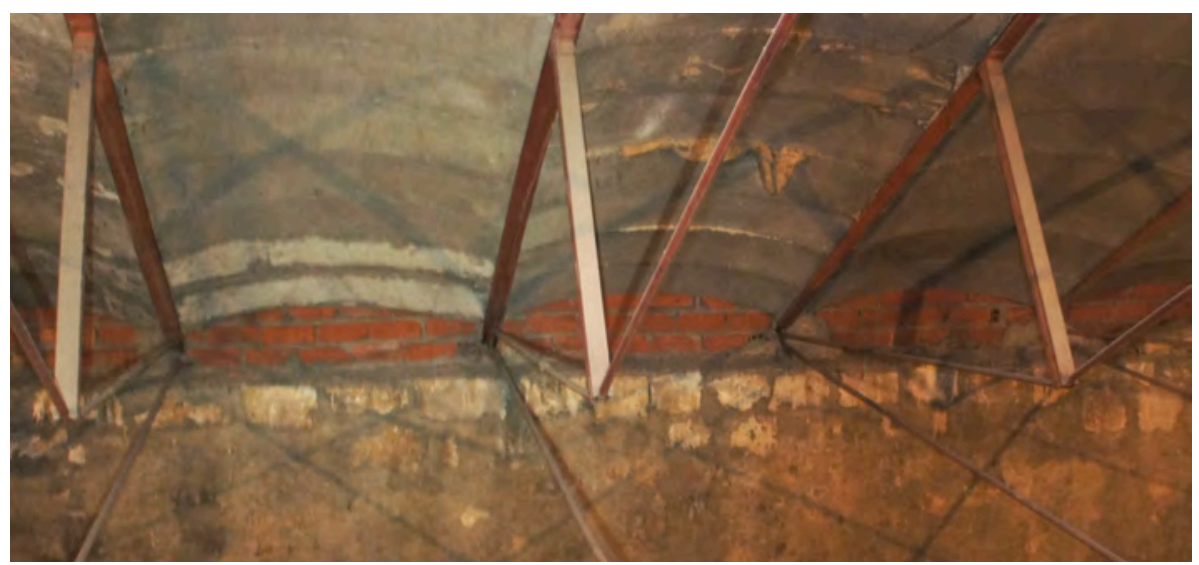

Ilustración 28: vista del resalto en el apoyo de cerchas (visita 26/09/2014)

No se aprecia visualmente estos zunchos (solerones) sobre el paramento en el que deben encontrarse embebidos, ya que el remate de los muros presenta gran homogeneidad $y$ un acabado cementoso, con un cambio de aspecto en las dos últimas hiladas de sillares.

En la cabecera, las cerchas son radiales $\mathrm{y}$ apoyan sobre tramos independientes de perfil de acero laminado embebidos en un zuncho de hormigón de unos $40 \mathrm{~cm}$ de

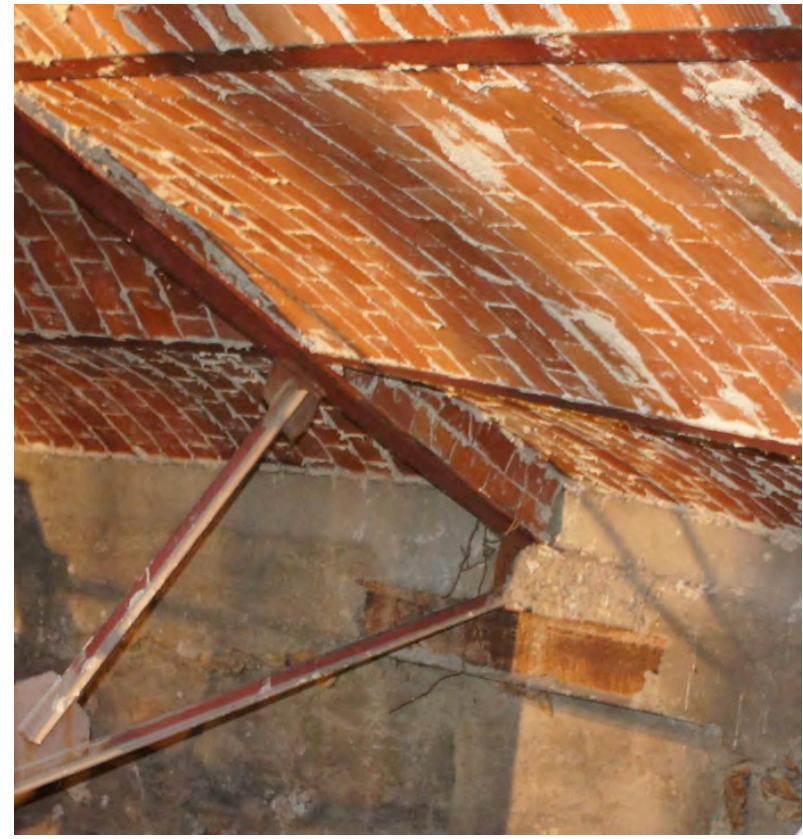

Ilustración 29: detalle en cabecera (visita 26/09/2014) canto.

\section{Conclusiones}

La estructura metálica incorporada a la iglesia en los años 60 es especialmente ligera, con cerchas separadas $1,45 \mathrm{~m}$ atirantadas una a una. Cuenta además con una familia de tensores adicionales que soportan la pasarela central, dispuestos con una modulación transversal de $1,25 \mathrm{~m}$. 
En este edificio es probable que fuera dispuesto un zuncho perimetral rectangular 40x30 embebido en los muros de piedra, aunque no es posible comprobarlo al no quedar expuesto a la vista. La ejecución del reemplazo de estructura de cubierta en tres fases induce a pensar que el elemento puede no presentar continuidad en todo el perímetro.

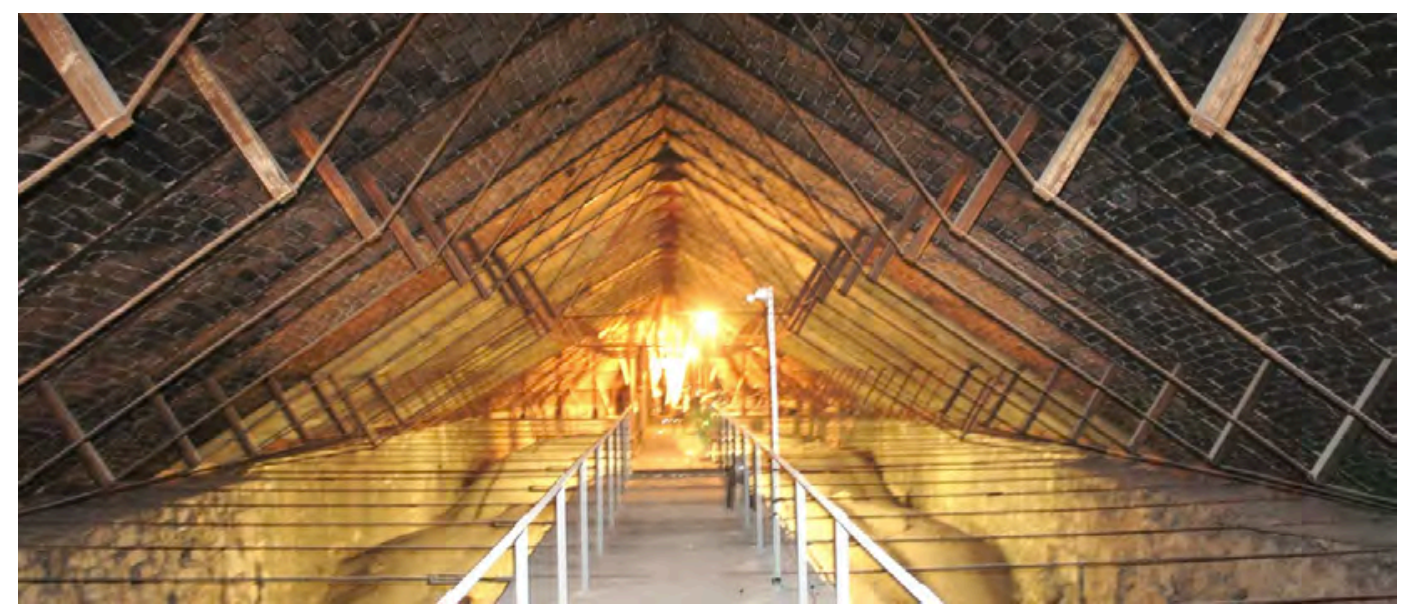

Ilustración 30: vista del espacio bajo cubierta desde la pasarela central (visita 26/09/2014) 


\section{Iglesia de San Pablo en Valladolid}

Intervenciones citadas en la publicación del Ministerio:

1962 - Reparación de la crestería y cubierta - Anselmo Arenillas

1964 - Sustitución de las cubiertas - Anselmo Arenillas

1965 - Cubiertas de las naves bajas y ábside - Anselmo Arenillas

1968 - Restauración de cubiertas - Anselmo Arenillas

1969 - Restauración de bóvedas, cubiertas y pavimentos dañados por incendio - José Antonio Arenillas Asín

1971 - Pavimentación del crucero y ábsides. Restauración de las paredes de la capilla mayor - Felipe Prieto Granda y Manuel Cuadrado Isasa

En la web del IPCE hay cuatro planos: dos del Colegio de San Gregorio y dos plantas de la iglesia, una de 1964 y otra sin fecha.

\section{En el Archivo General de la Administración}

AGA 26/00253

1962 Anselmo Arenillas

Proyecto de reparación de la crestería y cubierta de la iglesia de San Pablo

Memoria (1pag y otra con 4 fotos)

La crestería gótica rematada con florones sobre el frontón que corona la fachada está en estado lamentable. Piedra descompuesta y desplome hacia el exterior, la grieta llena de tierra y vegetación.

La fachada está separada del tejado, que tiene una pendiente exagerada y es de escamas cerámicas que ya no se fabrican. La armadura de madera está apolillada en sus estribos.

El conjunto de grandes goteras y su reparación es difícil, porque no

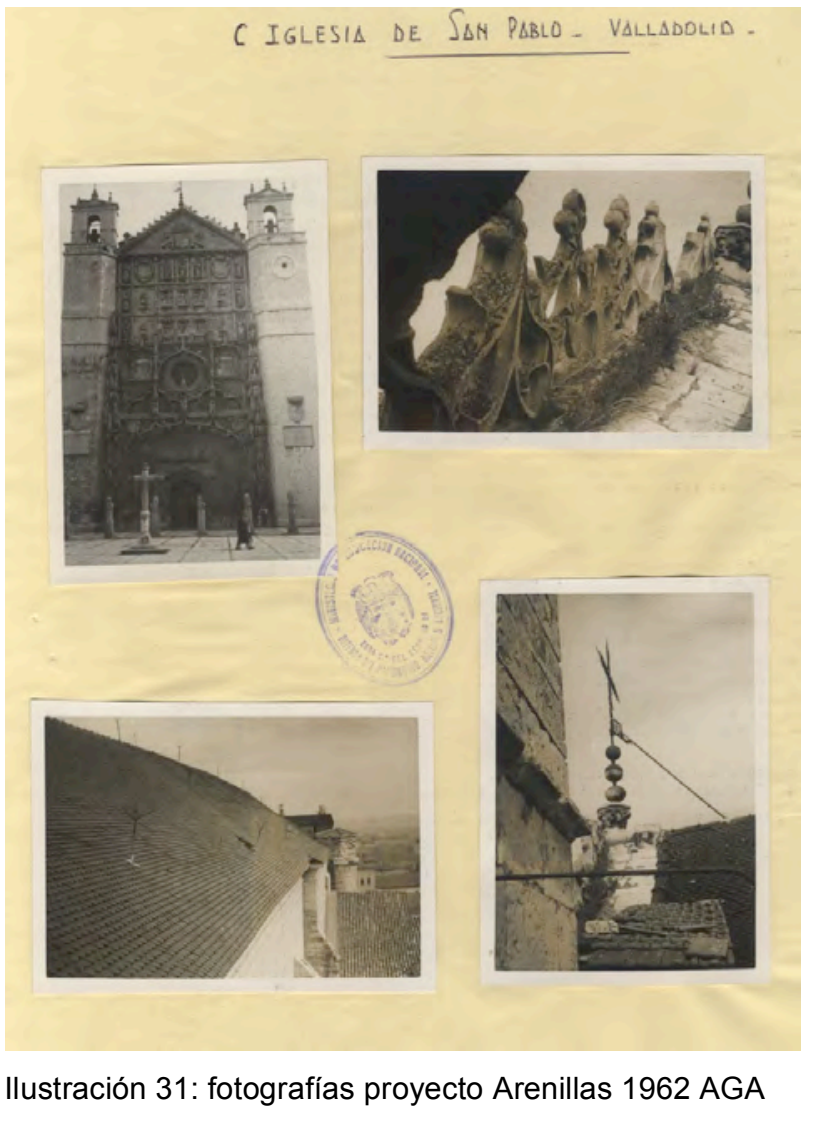


existen tejas y porque su reparación es complicada.

El proyecto comprende: desmontado de la crestería y recolocación aplomada, bien engrapada y recomponiendo piezas que faltan. Rejuntado y engrapado del muro, recubriéndole con capa impermeable.

Se proyecta levantar el tejado y las armaduras de madera de los dos primeros tramos de bóvedas en los pies de la iglesia, rehaciéndolos con tabiquillos y tablero de rasilla y ladrillo hueco en las dos naves bajas. En la nave alta se colocarán cuchillos de hormigón armado prefabricado y sobre ellos tableros de rasilla. En los faldones así formados se tenderá una capa de yeso fuerte de $4 \mathrm{~cm}$ de espesor y sobre ella se clavará pizarra de Bernardos.

Se intentará ejecutar sin andamios especiales.

El resto de la cubierta queda sin restaurar

Plano (1) con dos plantas, baja con línea roja señala dos primeras crujías a los pies y planta de faldones con trama roja esa zona.

\section{Mediciones}

1. Desmontado, reconstrucción y montaje de crestería de piedra dura con labra moldada y calado. Coronación fachada.

$2 \times 9,50 \times 0,40 \times 1,50=11,40 \mathrm{~m} 3$

2. m2Cubierta rehacer, desmontando, poner armadura de hormigón armado con faldones de doble tablero de rasilla y tejado pizarra

Nave alta dos tramos pie $2 \times 8,0 \times 12,0=192$

Nave baja, dos tramos pie $2 \times 6,0 \times 12,0=144$

3. Retejo ligero escamas cerámicas viejas

En resto cubierta $1 \mathrm{ud}$

\section{AGA 26/00370}

Sustitución de las cubiertas de San Pablo de Valladolid

Anselmo Arenillas marzo 1964

Memoria 1pag

"Cumpliendo ordenes superiores, se ha redactado este proyecto cuya finalidad es sustituir las deficientes cubiertas de la Iglesia de San Pablo, cuyo estado es ruinoso.

Es una cubierta de gran endiente, propia para el empleo de pizarra, que tiene armadura de madera con muy amplias luces y esta cubierta con unas escamas de barro cocido, teñidas con alquitrán (fabricadas no hace cincuenta años) y clavadas sobre el enripiado. 
Estas escamas están rotas y faltan en muchos sitios, no siendo posible su reposición porque ya no se fabrican ni existen troqueles. Se han sustituido en parte con medios ocasionales y, como consecuencia, las goteras son grandes y perpetuas.

Debido a las goteras, se han podrido las cabezas de los tirantes y de los pares de sus grandes formas y también las soleras y parte de las correas. Para contener la ruina han ido poniendo puntales y codales que, a su vez, también se han descompuesto, y el conjunto perfectamente construido con maderas escuadradas amenaza una ruina rápida y pone en peligro, además, las bóvedas góticas de esta hermosa iglesia, Monumento Nacional.

Se propone, con caracter de urgencia, desmontar la cubierta y su tejado, cosa no fácil dada su altura y estar rodeada por edificaciones bajas de gran interés artístico.

Se proyecta reconstruir las armaduras con formas prefabricadas de hormigón armado tipo MORSA, CUPRE o similar de las que existen en Valladolid, y sobre ellas, hacer los faldones de doble tablero de rasilla guarnecido con mortero de cemento impermeable. La nueva pendiente de la cubierta será, como máximo, del $40 \%$.

Las formas de la cubierta se colocarán sobre una solera de hormigón armado que regularice la coronación de los muros, trasdose y consolide las cornisas y facilite con el atirantado de los cuchillos la contención del pequeño desplome de las fábricas de sillería.

Sobre los nuevos faldones, de disminuida pendiente, se colocará teja curva normal emboquillada con mortero de cal, por ser un buen tejado en Castilla y de fácil reparación en todo momento.

El sistema empleado hace menos fáciles los peligros de incendio, goteras $\mathrm{y}$ putrefacción y, además, consolida las fábricas existentes.

Como complemento se retejarán todas las naves bajas y se repararán las cornisas y desagües.

En los demás documentos del proyecto: mediciones, planos, pliego de condiciones, cuadros de precios y presupuesto, se definen, dimensionan y ubican los trabajos propuestos con suficiente precisión.

En esta obra se cumplen los preceptos del Decreto del 12 de julio 1962 especialmente lo establecido en sus artículos $1^{\circ}$ y $2^{\circ}$, no obstante no ser operante en ellos por tratarse de reparación de un Monumento Histórico Artístico Nacional.

Se propone la ejecución de las obras por gestión directa de la Administración, de acuerdo con los artículos 57 y 58 de la Ley vigente de Contabilidad (Capítulo V), por tratarse de una reparación en un Monumento Artístico oficialmente declarado y por ahorrarse más del $20 \%$ en su ejecución por reducción de medios auxiliares". 
1 plano: coincide con el escaneado del IPCE en plantas de iglesia y cubiertas y frente de crestería, pero no incluye el detalle de cerchas metálicas que aparece en el digital, en su posición está el pitipié.

Pliego

Mediciones y Presupuesto

Desmontado de tejado y armadura y porte a vertedero

$2 \times 36,00 \times 9,00 ; 2 \times 13,00 \times 9,00 ; 5 \times 4,80 \times 9,00 ; 4 \times 11,00 \times 9,00$ $=1.494,00 \mathrm{~m} 2$

Armaduras de cubierta con hormigón armado y doble tablero de rasilla en faldones, incluido solera y tirantes hormigón armado

En naves desmontadas $\quad 2 \times 36,00 \times 8,00 ; 2 \times 13,00 \times 8,00 ; 5 \times 4,80 \times 8,00 ; 4$ x $11,00 \times 8,00=1.328,00 \mathrm{~m} 2$

Tejado con teja árabe, recibiendo boquillas y asientos con cal y sobre tendido impermeable, incluso este y las limas

$1.328 \mathrm{~m} 2$

Reparación de cornisas, rejuntándolas y regularización de asientos, sobre muros y desagües

Toda la cubierta 1 ud

Retejo en resto de la cubierta vieja

Naves bajas $2 \times 33,00 \times 7,50$

Absides $2 \times 3,00 \times 7,50 ; 3 \times 3,80 \times 7,50=625,50 \mathrm{~m} 2$

\section{AGA 26/00356}

Reparación de cubiertas de las naves bajas y abside de la iglesia de S.Pablo.

Anselmo Arenillas Alvarez, marzo 1965

Memoria 1 folio: La iglesia de San Pablo de Valladolid, es uno de los monumentos góticos platerescos más típicos de la región. Sus cubiertas de tejas en escama hechos a principios de siglo sobre buenas armaduras de madera, dieron mal resultado. Por su gran pendiente requerían el tipo de teja que para ellos habían fabricado, pero la dificultad de hacer nuevas tejas y de repolerlas cuando las había, hizo que no se reparasen adecuadamente las goteras y como consecuencia, que las maderas de su armazón se pudriesen y todo amenazase ruina con peligro de las fábricas. Se cambiaron las cubiertas de la nave principal, mas están sin reparar las naves bajas y los ábsides en los cuales la madera se halla descompuesta, según puede verse en las adjuntas fotografías. 
Dispuesto, en consecuencia, por el Iltmo. Sr. Director General de Bellas Artes, Don Gratiniano Nieto, el arreglo de estas cubiertas con una asignación de 1.000.000,0 pesetas, se ha redactado el presente proyecto que comprende: demoler los tejados viejos indicados con las precauciones debidas para evitar su prematuro derrumbe y daños subsiguientes. Hacer de nuevo las armaduras, con menor pendiente (40\%), para (evitar) poder usar en la cubrición tejas curvas ordinarias, que es lo que requiere el edificio y, finalmente, colocar encima la teja indicada bien recibida con mortero mixto de cal y cemento en previsión de la acción de los vientos, allí fuertes, y sobre todo, de la de los pájaros que anidan debajo de las tejas y las remueven.

Las armaduras de la cubierta se harán con formas de hormigón armado, prefabricadas, con tirantes metálicos, muy ligeras para evitar peso y dificultades de elevación. Estas formas irán a un metro de distancia una de otra y sus cabezas sujetas sobre una solera y una cumbrera de hormigón armado que las mantienen en su sitio y las atiranten. Sobre estas formas se forjará un tablero de dos hojas de rasilla, la primera hecha con yeso y la segunda con mortero de cemento, y sobre este tablero se tenderá una capa de dos centímetros de grueso de mortero impermeable de cemento; quedan así formados los faldones de cubierta impermeables, incombustibles e imputrescibles para en ellos asentar la teja como etapa final de la obra.

Se incluye también acondicionar unos huecos de ventilación e iluminación, abiertos no se sabe cuando, en las naves altas que están hechos rompiendo los muros y sin cerramiento. Se propone recercarlos con vidrieras de madera y cerrarlos.

En los planos, mediciones, precios de jornales y materiales, precios descompuestos, presupuesto, resumen y pliego de condiciones, se detallan dimensionan y ubican las obras a realizar, que son de reparación.

Plano (el del IPCE con detalle cercha en la esquina)

Mediciones

Demolición de tejados y sus armaduras $\quad 1092,25 \mathrm{~m} 2$

AGA 26/00146

1968 - Proyecto de terminación de la restauración de las cubiertas - Anselmo Arenillas

1 plano como digital IPCE pero sólo las dos plantas (iglesia y cubiertas) con trama roja en crucero y cabecera

Memoria 1 folio: La finalidad del proyecto es dar fin a la sustitución de las cubiertas de la iglesia cuyo estado es deplorable. Se llevó a cabo la sustitución de naves alta y baja hasta el crucero en 1964-5 porque las armaduras estaban podridas debido a que tenían mucha pendiente y las tejas eran planas. Se solucionó colocando armaduras de 
hierro y forjados de rasilla en faldones con tendido grueso de yeso y empizarrando como estuvo originalmente. Mas en la nave del crucero y en la cabecera prosiguió el daño, cayendo yesones y nervadura de las bóvedas.

Proyecta sustituir con pizarra 40x20 en crucero y cabecera. Como complemento se repararán las cabezas de los muros poniendo sobre ellos un solerón de hormigón armado de $40 \times 30 \mathrm{~cm}$, reparando los aleros y cornisas de ladrillo existentes.

\section{AGA 26/00332}

Obras de conservación en el conjunto monumental de Valladolid. Iglesia de San Pablo. Mayo de 1971. Felipe Prieto (colaborador: Manuel Cuadrado Isasa)

Memoria (2 páginas) "Hace pocos años y a causa de un incendio se produjo el derrumbamiento de las bóvedas del ábside principal y crucero. Las bóvedas se reconstruyeron con hormigón y la cubierta de esta zona fue sustituida totalmente, quedando solamente por renovar la cubierta de una pequeña zona correspondiente al brazo de la epístola del crucero y la de la primera capilla de la misma zona. Estos dos tramos se encuentran en mal estado a causa de las filtraciones y goteras de la cubierta. Esta zona limita con la Capilla de San Gregorio del contiguo Museo Nacional de Escultura. En el interior del templo nos encontramos con la total inexistencia del pavimento de la zona correspondiente al crucero y capilla mayor. El primitivo pavimento sufrió el lógico deterioro debido al hundimiento de las bóvedas y al tiempo que se mantuvo a la intemperie, así como a causa de los trabajos que hubieron de hacerse (colocación de andamios, carga y descarga de materiales, etc) En las paredes de la capilla mayor y por las mismas causas se produjeron deterioros en la línea de imposta, molduras y tribuna. Se produjo el hundimiento de los hornos de calefacción situados en la cripta bajo el altar mayor.

Criterio de actuación

Se procederá a la pavimentación total del crucero y absides. El pavimento del crucero, que será de madera, la reconstrucción de los hornos de calefacción y la renovación de cubiertas se harán, bajo nuestra dirección facultativa, por cuenta de los propietarios del templo, los Padres Dominicos.

El pavimento de los ábsides será con losas de mármol de las cuales se conserva una parte correspondientes al primer tramo del ábside principal. Se restaurarán las paredes de la capilla mayor para lo cual se procederá a realizar catas a fin de investigar el estado de los paramentos y poder fijar el criterio a seguir.

Por último se procederá a la apertura de los ventanales góticos del ábside principal, hoy cegados, y a la restauración y limpieza de los mismos. 
Incluye 2 planos: Planta 1:100 con esquema de nervaduras de bóveda sólo de la zona de cabecera y crucero delineada sencilla, sin capilla anexa al ábside ni sacristía.

Plano 1:200 con la planta general de la que es trozo el plano anterior) equivale a la de los proyectos de Arenillas y una planta de faldones de cubierta con trama rayada dirección de la pendiente sólo de cabecera y crucero pero que incluye la cubrición de un tramo de bóvedas adicional, el primero adyacente hacia los pies

Pliego estandar

Mediciones y Presupuesto.

$42,67 \mathrm{~m} 3$ transporte $\mathrm{d}$ escombros en ábside y crucero a vertedero

$28,45 \mathrm{~m} 3$ excavación de tierras en apertura de caja para solera

$142,27 \mathrm{~m} 2$ solera de hormigón en masa $0,15 \mathrm{~m}$ de espesor en ábside y crucero

2,37m3 muro de fábrica de ladrillo macizo zócalo de presbiterio $(2 \times 2,20 \times 1,08 \times$ $0,50)$

$62,47 \mathrm{~m} 2$ solado con losas de mármol

Uds limpieza, testigos, andamios, apertura de huecos, fotografías.

AGA 26/00146

Restauración de bóvedas y daños incendio en la iglesia de San Pablo de Valladolid José Antonio Arenillas Asín. Abril 1969

Restauración de los daños producidos en el incendio ocurrido en el verano pasado... En primer lugar se procederá al desescombro cuidadoso de toda la nave del crucero de la Iglesia, apartando todos aquellos elementos de piedra que se puedan utilizar nuevamente en la reconstrucción.

Se procederá también a la demolición de aquellos elementos de cubierta que, aun cuando no quedaron totalmente destruidos por el incendio, hay que demolerlos en previsión de daños posteriores.

Incluido en estas obras de demolición, irá el levantado de los pavimentos rotos, y como en el caso anteriormente expuesto, se procurará aprovechar la mayor parte posible de piezas.

Una vez realizadas todas estas obras, se levantará una cimbra ligera, montada sobre tubo metálico, que nos permita dar forma a todas las nervaduras que vamos a reconstruir. Estas nervaduras se reconstruirán con piezas labradas en piedra caliza, trasdosadas en hormigón armado. 
Entre las nervaduras, la plementería se sustituirá por una bóveda triple tabicada en rasilla, que posteriormente se guarnecerá y revocará interiormente.

Se reconstruirán las cubiertas incendiadas utilizando armaduras ligeras en acero laminado, con tableros de rasilla sobre las correas, y tendido grueso de yeso para clavar la pizarra.

Como obras complementarias de éstas descritas, se procederá a la restauración de los pavimentos y a la reconstrucción de la cubierta de la cripta, hundida por el impacto de las bóvedas al desplomarse.

Finalmente, se procederá a la reparación de la cornisa exterior de piedra y a la restauración de las vidrieras...

Planos (2)

Planta baja y de cubierta con trama roja en crucero y cabecera. Sección constructiva transversal por crucero representa las formas como hormigón en 3 montantes y acero en cordón inferior con tensor entre ambos centros simétricos. (1:200). No menciona ni representa ningún zuncho.

Planta de cabecera y crucero con esquema de estructura de cubierta 1:100 y despiece de las cerchas con perfiles en L.

No menciona ni representa ningún zuncho en la documentación, presupuesto ni planos.

\section{AGA 26/01769}

Es una caja completa con dos carpetas gordas

Proyecto de restauración de la fachada de la iglesia conventual de San Pablo, Valladolid

1982 Adjudicado a la empresa COMSA Constructora de obras municipales SA

Y el Reformado

1985 Arquitecto Ignacio Gárate Rojas (Revisado por Antón Capitel jefe de Servicio de la inspección técnica de monumentos Ministerio de Cultura.) 


\section{En el Archivo Municipal de Valladolid}

\section{Fondo Histórico}

AMVA: 1053-79 Licencia calefacción 1934

El Prior de los Dominicos entrega un plano al Ayuntamiento que ya había aprobado la instalación urgente de calefacción. El ingeniero industrial da el visto bueno. Plano en vegetal con los caloríferos dibujados en rojo en el ábside tras el altar toma de aire a la izquierda de la escalera de acceso y salida de calor a la derecha. Chimenea por el exterior del ábside entre pasillo y sacristía.

\section{Fondo Administrativo}

AMVA: 46/1966 C1252-6

Construcción Colegio Menor (planos)

Es el edificio aparte en diente de sierra.

AMVA: 374/1985

Dominicos obras menores. Permiso sin técnico facultativo.

Arreglo de un tejado en patio interior y nueva cubrición en tronera derrumbada.

AMVA: San Pablo 1243/1999 C4212-1

Caída de cascotes de la fachada de lateral de la nave sur, que tiene sueltos parte del tapial y revestimiento.
AMVA: Exp 176/1999
C4210-7
Órdenes de ejecución

Derrumbamiento de parte del hastial del muro de la sacristía sobre la cubierta de una de las pandas del claustro del museo de escultura. Escrito de la arquitecto municipal Pilar Tirador. (2 fotografías color del muro)

Memoria valorada y compromiso de dirección de Elesio Gatón: obras urgentes de demolición y reconstrucción de muro hastial.

El muro es de tapial y el piñón superior se remata con gruesos muros de adobe y entrepaños de ladrillo. Uno de los entrepaños cayó, el que queda está suelto. Las cubiertas también deben repararse.

En las fotografías de Gatón está cegado con ladrillo hueco el trozo desprendido. 
Restaurado, se archiva el expediente. Incluye fotografía renovado y pintado todo el muro testero, con un pequeño vuelo albardilla de teja horizontal bajo el piñón.

\section{AMVA: C32024-2 822/2002}

Reparación de fachada interior de la residencia de los PP Dominicos, la Sacristía de $18 \mathrm{~m}$ de altura cubierta con bóveda estrellada con ligaduras y combados.

Arq: Elesio Gatón.

La sacristía dividida en cuatro plantas con forjados de madera, las tres primeras para residencia, la cuarta biblioteca.

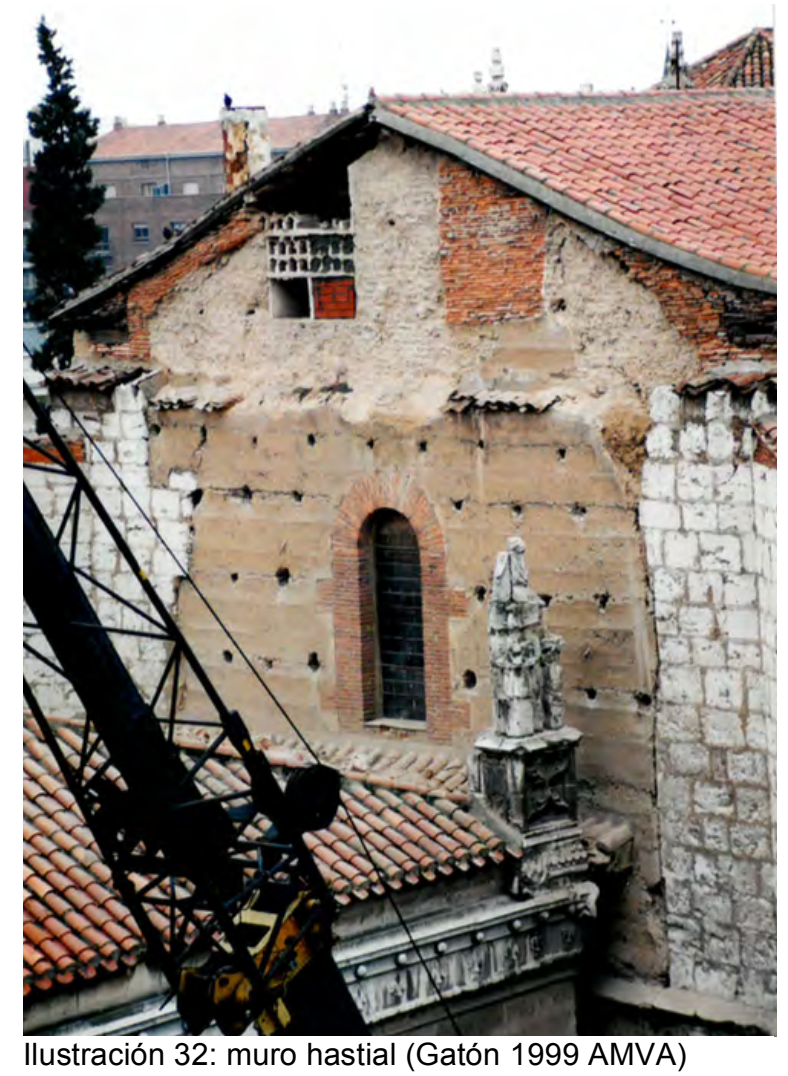

Las zonas de tapial deteriorado se pican y sustituyen por medio pie de ladrillo perforado anclado con tizones y llaves de acero inoxidable. Se empotran nudillos de madera de acacia con una malla de poliéster, enfoscado con mortero bastardo coloreado.

La fábrica de piedra se limpia con cepillo de raíces, reponiendo elementos deteriorados. Rejuntado y reposiciones con Petratex de Tecsa.

Reemplazo de canalones y bajantes con cobre. Detalle sección constructiva 1/50 y 1/10 se aprecia el muro de tapial con remate de adobe revestido. La armadura y el forjado apoyan sobre piezas que parecen durmientes, sin especificar si son madera, no parece que haya zunchos de hormigón. El par apoya en el recrecido del muro y el forjado también sobre la fábrica.

AMVA: 866/2004

Proyecto básico y de ejecución de tratamiento de humedades en la portada de la iglesia de San Pablo. Julio de 2002.

Proyecto y planos en 2 cajas

C34057-2

Memoria y planos. Anexos I

C34058-1

Mediciones y presupuesto, Pliego, Seguridad y salud, Anexos II 
En el anexo 2.c. incluye un dossier con fotocopias de documentación de las intervenciones arquitectónicas recientes:

1972-75 Felipe Prieto Granda Restauración de cubiertas del crucero y ábside 1982 José María Cabrera Garrido y Dionisio Hernández Gil Fachada 1985 Ignacio Gárate Rojas fachada

\section{En el archivo de la Junta de Castilla y León}

Restauración de la fachada (Documentación suministrada en CD)

En el documento final de obra de Proyecto cultural de la restauración de la fachada con fecha octubre de 2010 del arquitecto Eduardo González fraile se incluye un Libro general de la edificación y calendario de actuaciones de mantenimiento (extendidos al conjunto del edificio). También planos y explicación de obras anteriores y futuras en dos anexos.

\section{Libro del edificio}

Según los elementos a inspeccionar descritos en el Libro del edificio se conserva una estructura de madera de par e hilera en la cubierta del crucero. Se incluyen las siguientes imágenes.
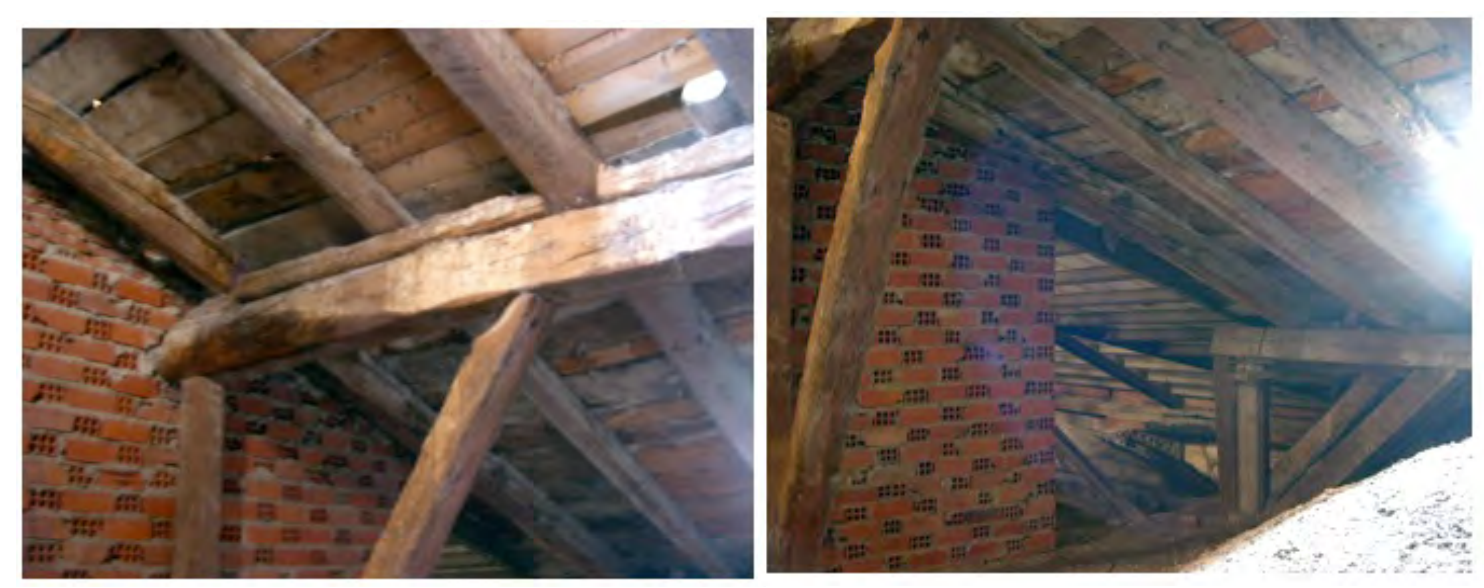

Ilustración 33: imágenes del bajo cubierta (González Fraile 2010 JCyL)

Describe una claraboya de fundición colocada como emergencia en 2003 en la capilla del Rosario que debería inspeccionarse cada 15 días.

En el apartado 3.1 define las actuaciones para VIGAS Y ZUNCHOS DE HORMIGÓN ARMADO: 
"Bajo esta denominación se incluyen los elementos estructurales horizontales de hormigón armado con hierro que reciben las cargas de los techos (Forjados) y las trasladan a los pilares o muros de carga.

Cuando se apoyan en pilares se denominan vigas y si descansan en muros de carga, zunchos o encadenados, aunque, por extensión se denominan zunchos a otros elementos estructurales con misión de atado (por ejemplo en extremos de vuelos). Habitualmente su forma es rectangular pudiendo sobresalir del forjado por su parte inferior (Vigas descolgadas) o hallarse embebidas en él (Vigas planas)

\section{Uso del elemento}

Precauciones:

Se procurará colocar los elementos de mobiliario de gran peso (estanterías, librerías) sobre las vigas $\mathrm{y}$, en lo posible, cercanos a los pilares. Para ello será conveniente conocer su localización lo que puede ser fácil en el caso de vigas descolgadas o exigir disponer de los planos de la estructura del edificio en el caso de vigas planas. En general, los orificios pequeños (tacos para cuelgue de lámparas, etc.) no ocasionan ningún problema. No son recomendables orificios mayores aunque pueden ser realizados con supervisión de Técnico competente. En cualquier caso, se procurará distanciarlos y se evitará dejar al aire hierros de la armadura.

Se evitarán situaciones de humedad persistente que pueden ocasionar corrosión de los hierros.

No es conveniente sobrepasar la sobrecarga de uso ni las hipótesis de carga (Véase la memoria del Proyecto).

Debe ser tenido en cuenta que las fisuras, aún cuando no revistan peligro para la resistencia y estabilidad, pueden ser (sobre todo en vigas a la intemperie) el camino de entrada de la humedad y, en consecuencia, de la corrosión de las armaduras.

\section{Prohibiciones}

Está terminantemente prohibida toda manipulación de las vigas (picado, perforado, etc) que disminuya su sección resistente o deje hierros al descubierto. En este último caso, de producirse, las armaduras deberán protegerse con mortero de cemento, NUNCA CON YESO.

\section{Mantenimiento del elemento}

Usuario. Inspección ocular:

En caso de ser observada la aparición de fisuras o grietas deberá avisarse al Técnico competente (Arquitecto o Arquitecto Técnico) quien dictaminará su importancia y, si es el caso, las medidas a llevar a cabo. 
Debe tenerse en cuenta que la aparición de fisuras en otros elementos no estructurales (muros o tabiques) puede ser indicativo de un incorrecto funcionamiento de la estructura.

La aparición de manchas de óxido es síntoma de corrosión de las armaduras. Deberá avisarse a un Técnico competente.

En vigas descolgadas suelen producirse erosiones por golpes (Plantas bajas, garajes). En general pueden ser reparadas por personal cualificado. Si las lesiones son de consideración deberá ponerse en conocimiento de Técnico competente.

\section{Profesional}

En general la reparación de pequeñas erosiones, desconchones, humedades no persistentes, etc.

Toda manipulación de mayor entidad de estos elementos requiere conocimientos técnicos por lo que no deberán llevarse a cabo sin la supervisión de un Técnico competente.

\section{Calendario}

Periódicamente (por el usuario): Inspecciones oculares antes citadas.

Cada 5 años:

Análisis de las fisuras o grietas, detectándose su origen y analizando su evolución (Técnico competente).

Análisis de deformaciones (flechas), comprobando que no superan las admisibles (Técnico competente)

En el CD que contiene documentación aportada con el final de obra encontramos varias familias de planos, como afecciones al entorno AFE, futuras intervenciones

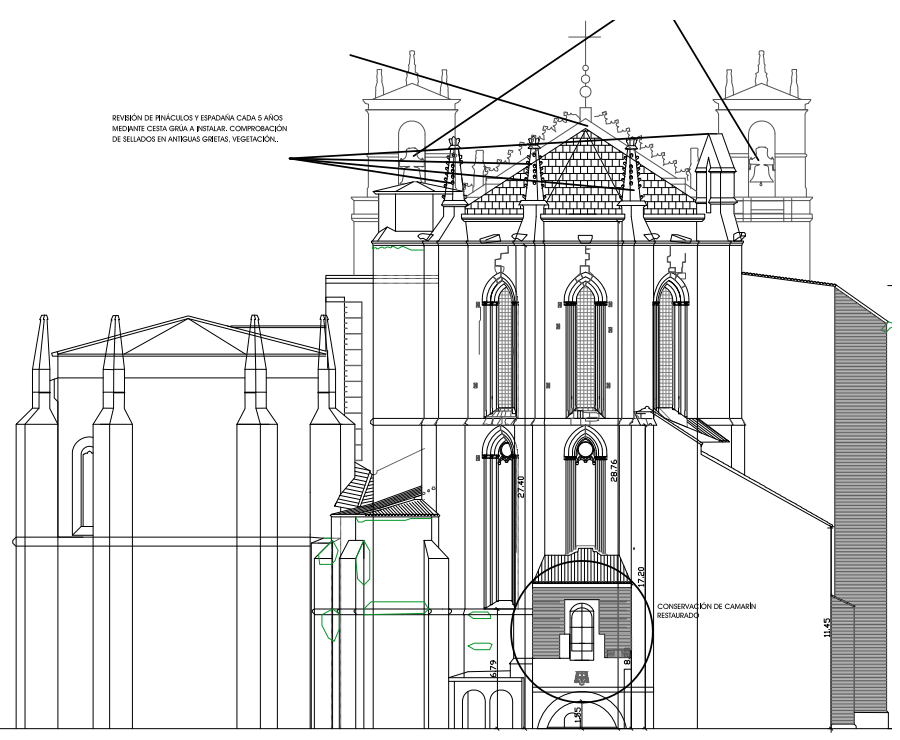
FIE, plan de conservación Ilustración 34: esquema de mantenimiento 2010 González JCyL $\mathrm{PC}$, etc.

En el plano 4A se describe una hipótesis de evolución histórica del monumento: 
30 EL PAPEL DEL ZUNCHO EN LA RESTAURACIÓN MONUMENTAL

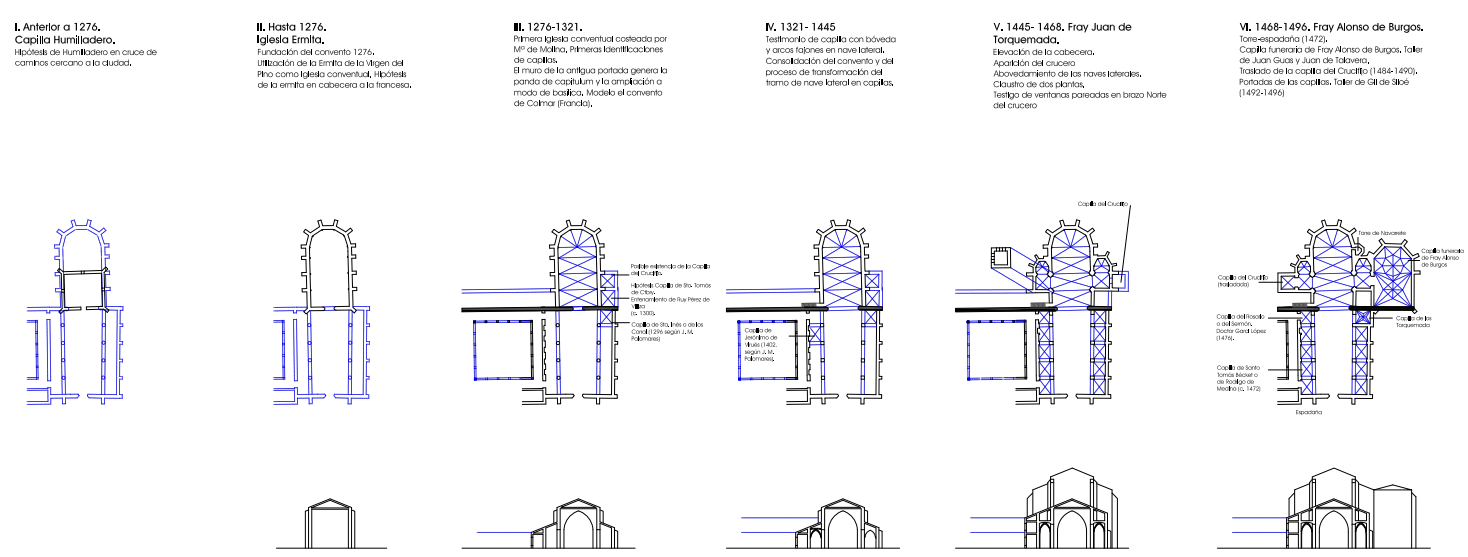

Ilustración 35: evolución histórica 2010 González JCyL 


\section{Visitas realizadas}

$26 / 09 / 2014$

El estado de conservación del monumento es razonable: la fachada a los pies ha sido restaurada recientemente, la cubierta presenta un revestimiento en buen estado y el espacio bajo la misma está iluminado y bastante limpio.

Encontramos, sin embargo, algo de vegetación en los contrafuertes de la nave central $y$, sobre todo, un considerable deterioro de la piedra en la capilla hexagonal adosada al ábside.

La fachada a los pies fue objeto de una restauración integral que finalizó en 2009. Según el material divulgativo de la Fundación Cajamadrid se incorporó un sistema de drenaje bajo rasante exterior e interior y nueva impermeabilización del hastial con baberos de plomo. Limpieza y reposición de elementos escultóricos. Consolidación y barrera electrostática anti palomas. El andamiaje contaba con una plataforma elevadora que se aprovechó para implementar una visita turística durante el tiempo de ejecución de las obras.

La cubierta de la nave central y ambos faldones, a menor cota sobre las capillas laterales, son de pizarra.

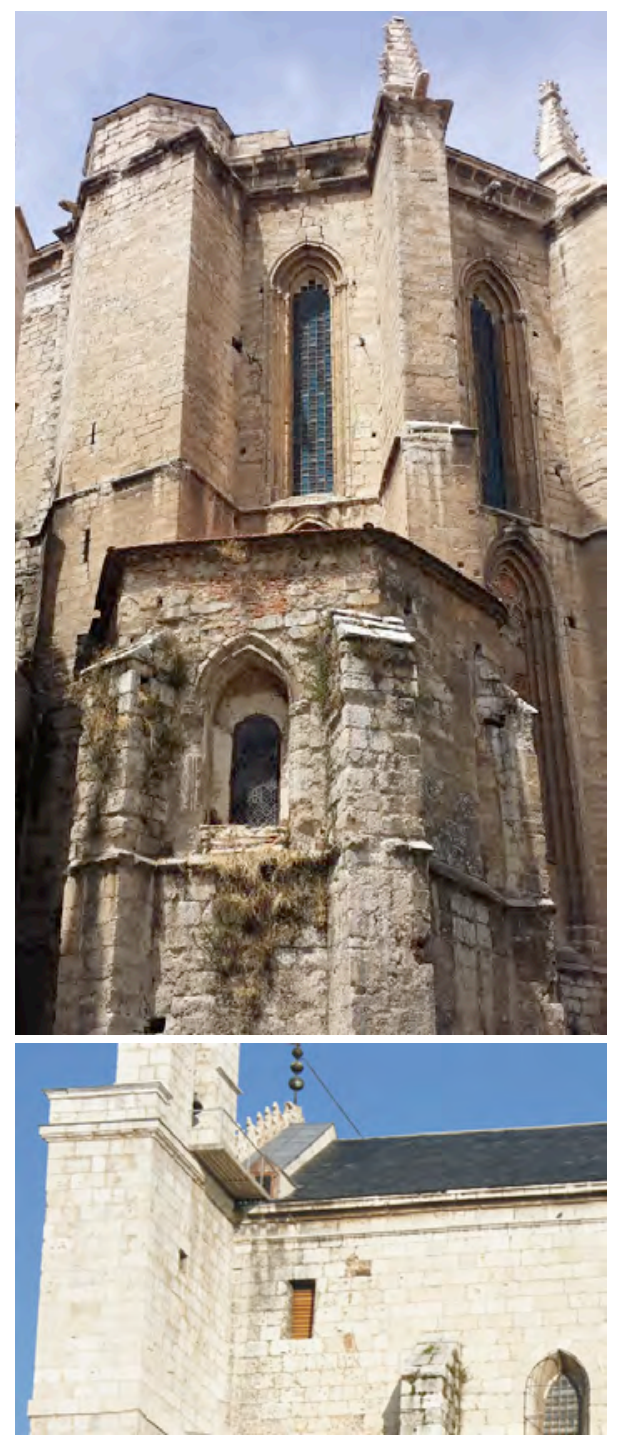

Los brazos del crucero se cubren con ladrillo. El oeste presenta un testero recrecido que no se corresponde con el perfil del faldón, más rebajado. Sobre el paramento de la nave central se aprecia la huella del antiguo encuentro. El brazo este está formado por un faldón a un agua dispuesto transversalmente. 
La entrada al bajo cubierta se realiza desde una escalera de caracol a la que se accede desde la cabecera del templo. Tras el desembarco de la escalera encontramos una pasarela de acero y tablas que, a partir del cuerpo de la nave, está formada por arcos de fábrica de ladrillo hueco doble que apoyan sobre el trasdós de las bóvedas de crucería.

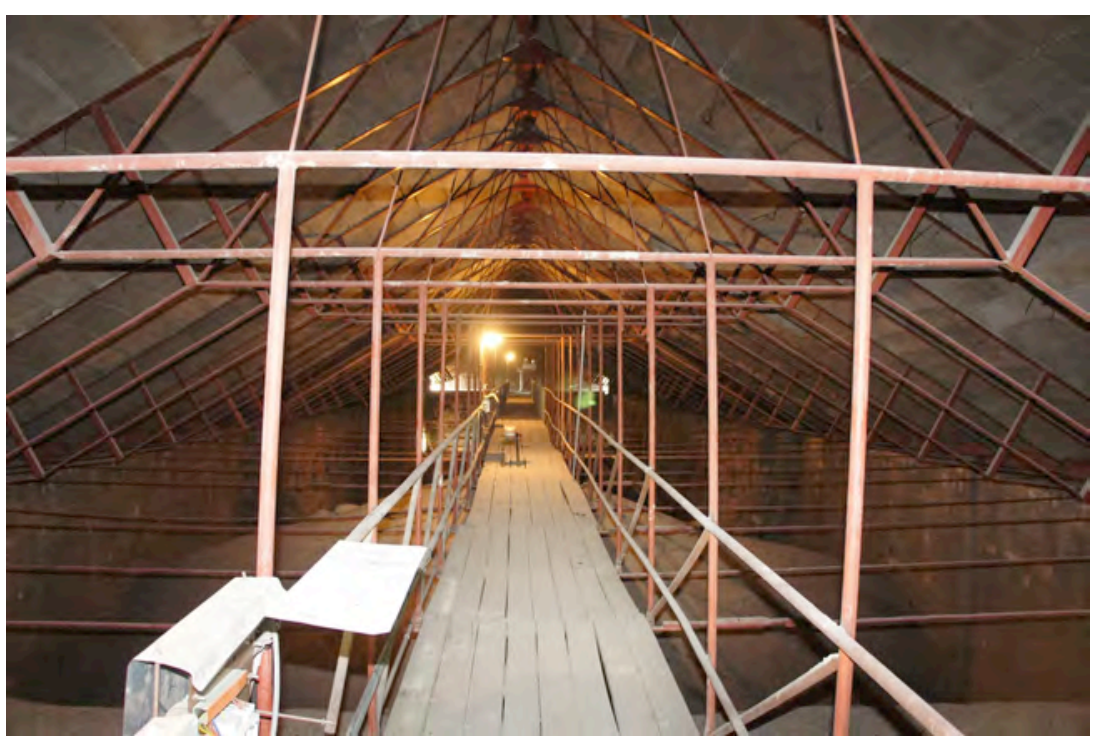

Es posible distinguir las diferentes fases de las intervenciones de Arenillas, especialmente lo anterior al incendio de 1968, que afecta desde los pies hasta el crucero, pues se conservan ennegrecidos sus paramentos.

La estructura metálica no corresponde al diseño reflejado en el plano de 1964. Se trata de piezas muy ligeras armadas con tirantes continuos. Cada elemento cuenta con un tensor.

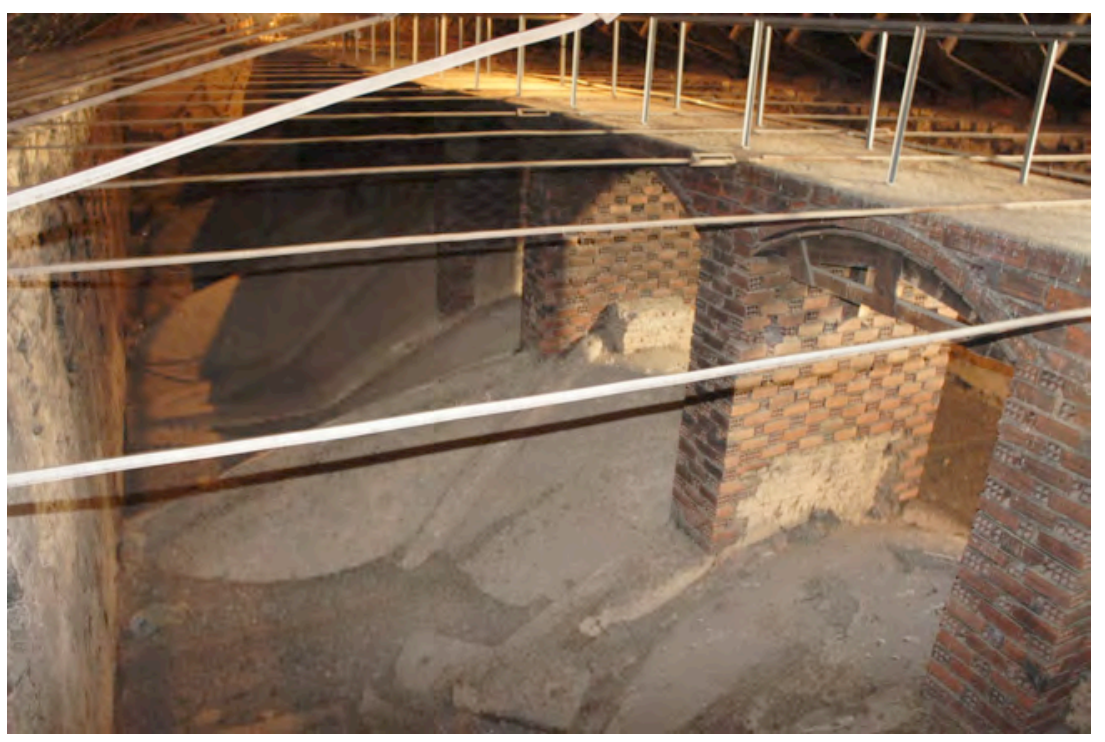

Aunque en los proyectos de 1962 a 1965 se prevé reemplazar la cubierta por una de menor pendiente más adecuada para revestir con teja, finalmente debió 
mantenerse el volumen original y cambiar el material de recubrimiento a pizarra. También se describían formas de hormigón que finalmente se resolvieron con acero. Ambos cambios se incorporaron ya a las descripciones de la memoria del proyecto de terminación de 1968, que citaba además un "solerón de hormigón armado 40x30" sobre las cabezas de los muros.

En la visita se aprecia cómo las cerchas apoyan sobre el remate de la fábrica, con el frente entre apoyos tabicado con ladrillo. En el cuerpo de la nave queda una repisa de unos $90 \mathrm{~cm}$, que se reduce hasta desaparecer en la zona del crucero para absorber la diferencia en el ancho total de la nave. En el encuentro se duplica la cercha, y por el exterior la superficie se alabea irregularmente.

Podemos apreciar cómo las de segunda fase se realizaron con perfiles aún más livianos que las de la primera, y el tablero es de hormigón, mientras que en el cuerpo se resuelve con rasillas. Las formas están dispuestas cada $1,45 \mathrm{~m}$.
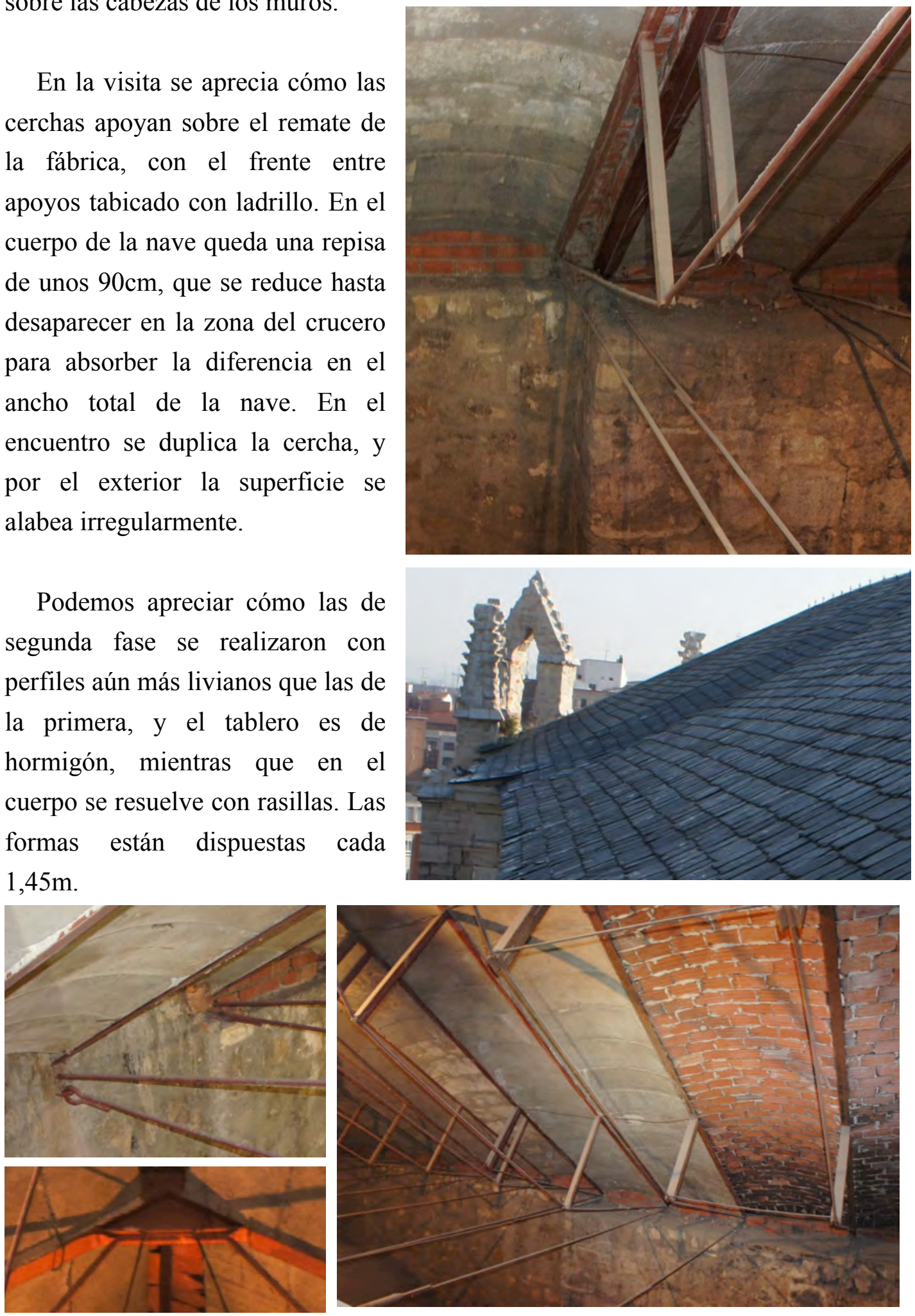

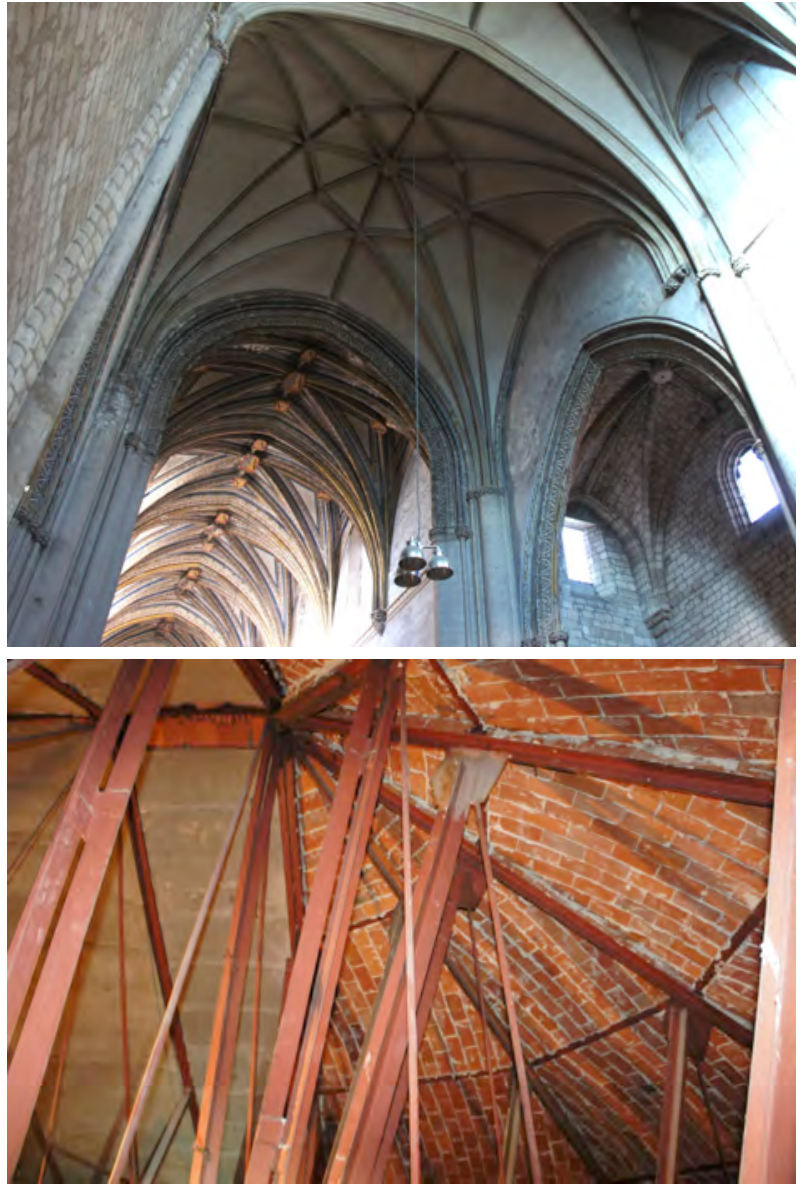

Por el acabado de la superficie del trasdós de las bóvedas parece que todas cuentan con un refuerzo de cemento. Las de crucero y cabecera debieron ser reconstruidas además tras el incendio. Se he incorporado peldañeado para facilitar la circulación sobre las bóvedas de ambas zonas.

El tablero de cubierta es de rasilla también en la zona del ábside, y es soportado por una estructura radial de cerchas, formadas por angulares metálicos soldados y acartelados. El apoyo de cerchas en esta zona se realiza sobre tramos de cargadero metálico embebidos en hormigón.

Se ha podido medir un canto de zuncho, sólo en esta zona, de unos $40 \mathrm{~cm}$. En crucero y cuerpo de la nave no se aprecian las dimensiones del mismo.

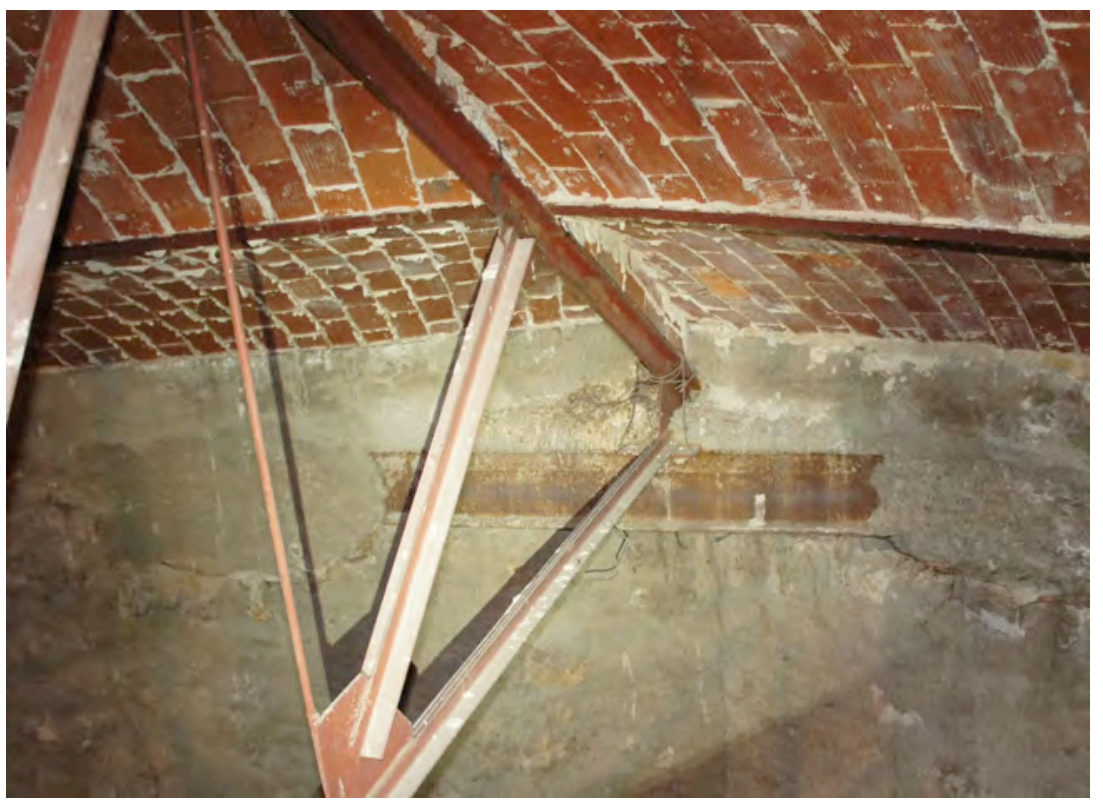




\section{Iglesia de Santa María de la Antigua}

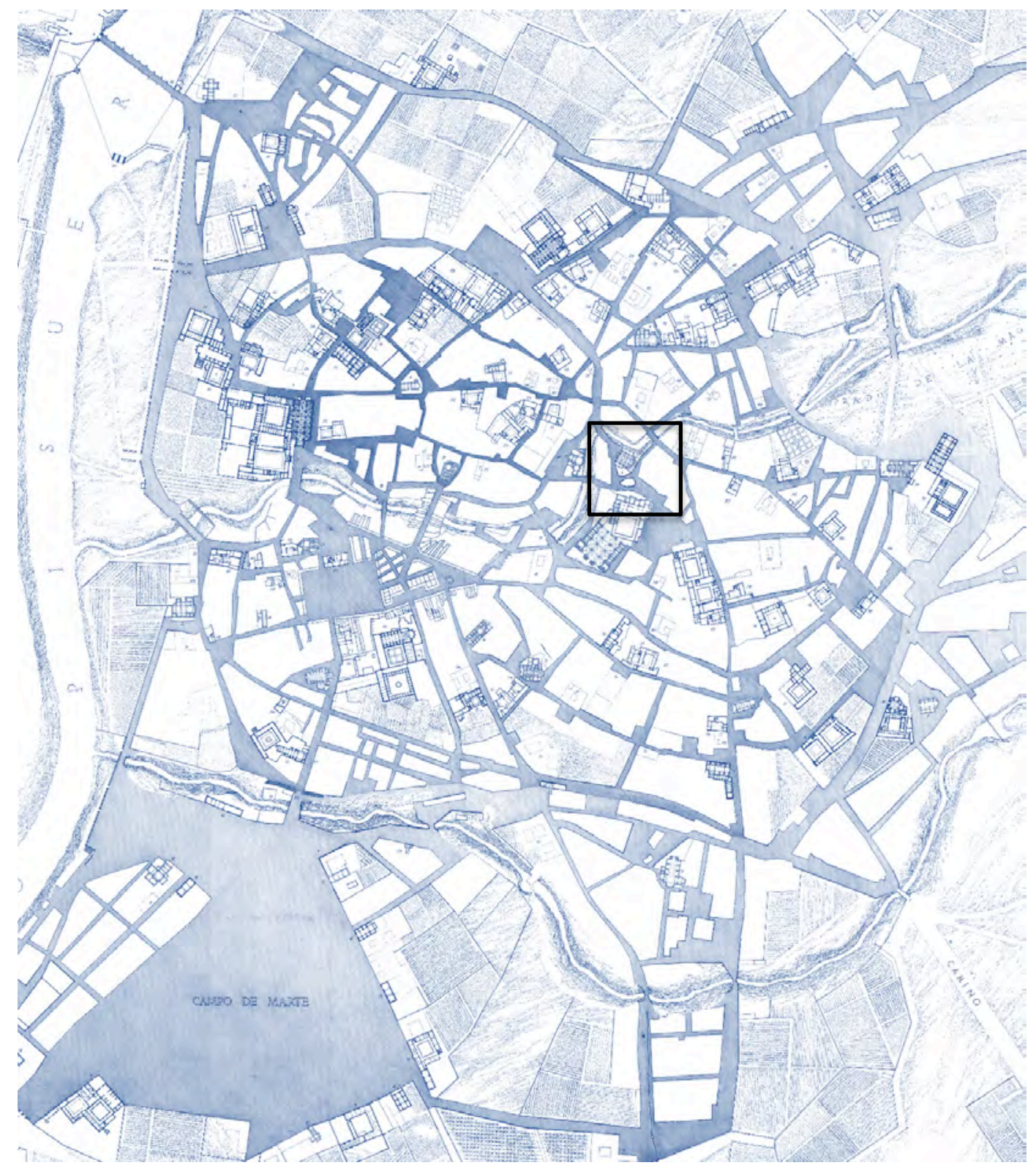



FICHA SÍNTESIS

Código de identificación: FZ-11

Denominación: $\quad$ Iglesia de Santa María de la Antigua

Localidad: $\quad$ Valladolid

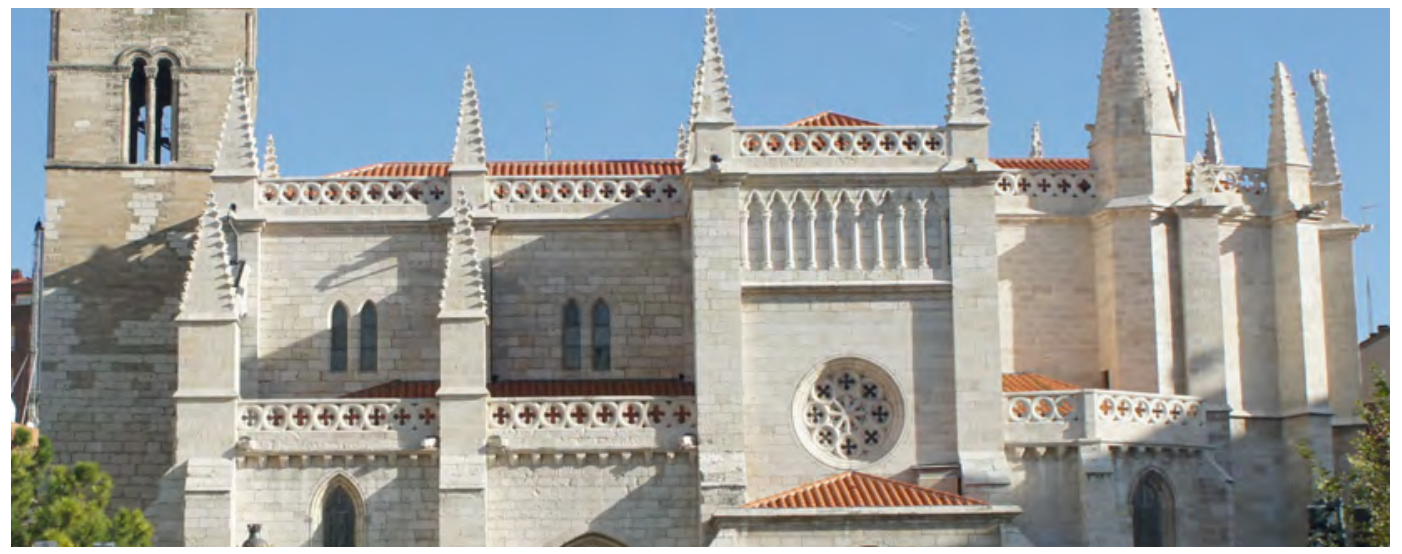

\section{Descripción}

Se trata de una iglesia gótica de tres naves, cubiertas con bóvedas de crucería, rematadas con ábsides poligonales en la cabecera. El templo fue prácticamente reconstruido a principios del siglo XX, excepto cabecera y torre.

\section{Materiales}

Los muros son de sillería de piedra y la cubierta de teja curva (excepto la torre).

\section{Singularidades}

El edificio contaba con un cúmulo de construcciones adosadas a finales del XIX. Ha sufrido múltiples restauraciones, desde sus orígenes y a lo largo del tiempo, llegando a ser completamente desmontado y reconstruido el cuerpo del templo a principios del XX. La torre románica, singularmente esbelta y con cubierta piramidal revestida de escamas, es uno de los símbolos de la ciudad.

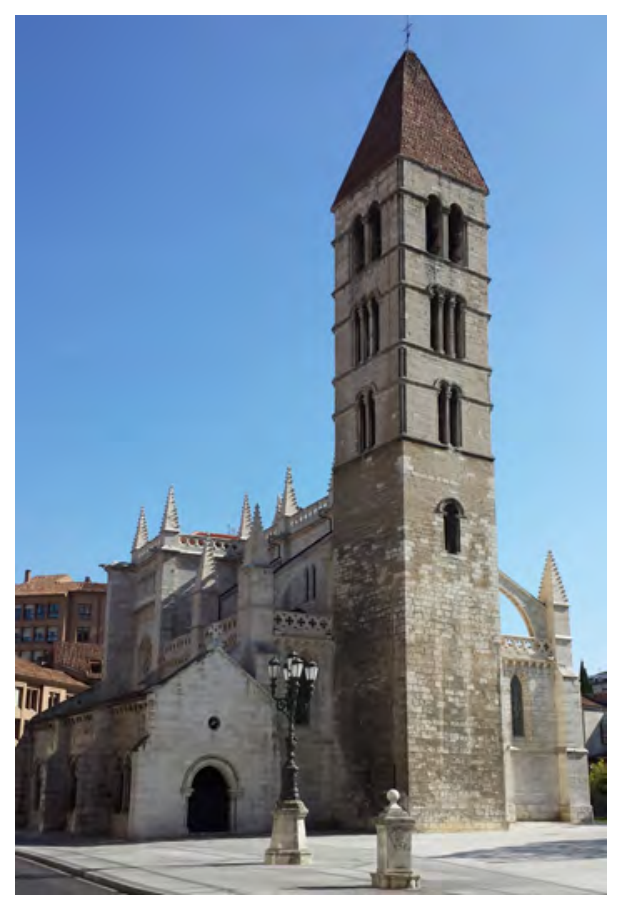

llustración 1: fachada a los pies (visita 26/09/2014) 


\section{Dimensiones básicas del templo}

$\begin{array}{llll} & \text { central } & \text { laterales } & \text { capillas } \\ \text { Ancho de nave } & 7,0 & 3,5 & - \\ \text { Altura } & 15,7 & 9,2 & -\end{array}$

\section{Memoria histórica constructiva}

Según el Catálogo:

La reforma la portada sur en 1494 es la primera obra documentada. En 1531 Diego de Riaño inspecciona daños en dos capillas. En 1492 se refuerzan bóvedas y pilares.

El arranque de la torre se refuerza, posiblemente en 1554, con un encamisado de piedra a cargo del maestro de cantería Pedro del Valle. Hubo intervenciones para reforma $y$ refuerzo sucesivas en el XVI para afianzar un pilar desplomado ${ }^{1}$, reforzar los contrafuertes $^{2}$ del templo y colocar una espadaña.

Juan de Nates traza en 1602 una nueva sacristía. En 1628 de nuevo se refuerzan contrafuertes y en 1649 la torre.

A mediados del XIX, a raíz del encauzamiento del Esgueva, la trasera norte se convierte en fachada transitada por lo que se actúa repetidamente sobre la galería románica.

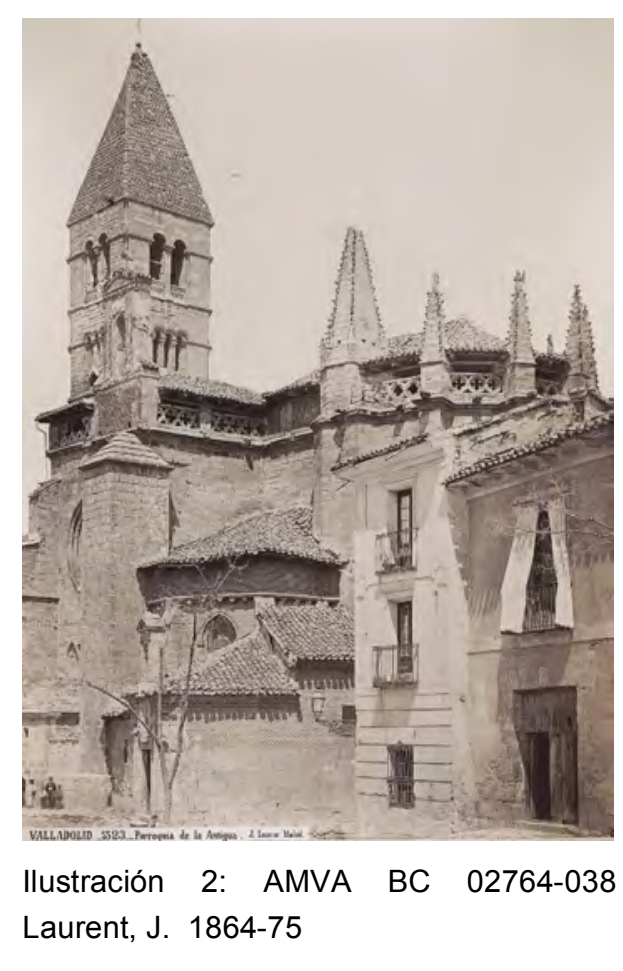

A principios del siglo $\mathrm{XX}$ se desmonta y reconstruye el cuerpo de la nave, interviniendo sucesivamente en la obra varios arquitectos: 1900 Antonio Bermejo, 1901 Vicente Lampérez (que renuncia por considerar inadecuado reparar el tejado de unas naves en riesgo de ruina), 1908-16 Ricardo García Guereta y Fernández Casanovas.

\footnotetext{
${ }^{1}$ En 1576 Francisco del Río y Juan de Mazarredonda afianzan el pilar desplomado con trazas de Rodrigo Gil de Hontañón (González-Echegaray 1991)

2 Juan Lastra en 1566
} 


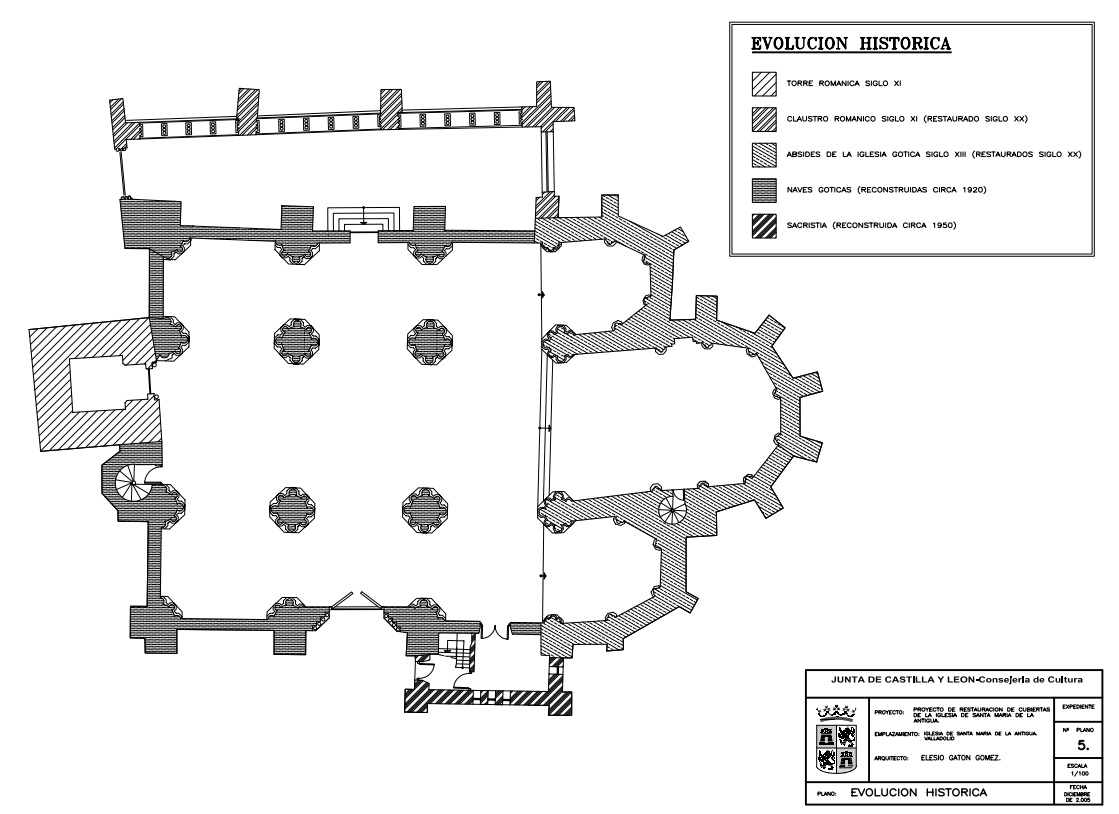

Ilustración 3: plano planta de fases constructivas (Proyecto de cubiertas Gatón 2005)
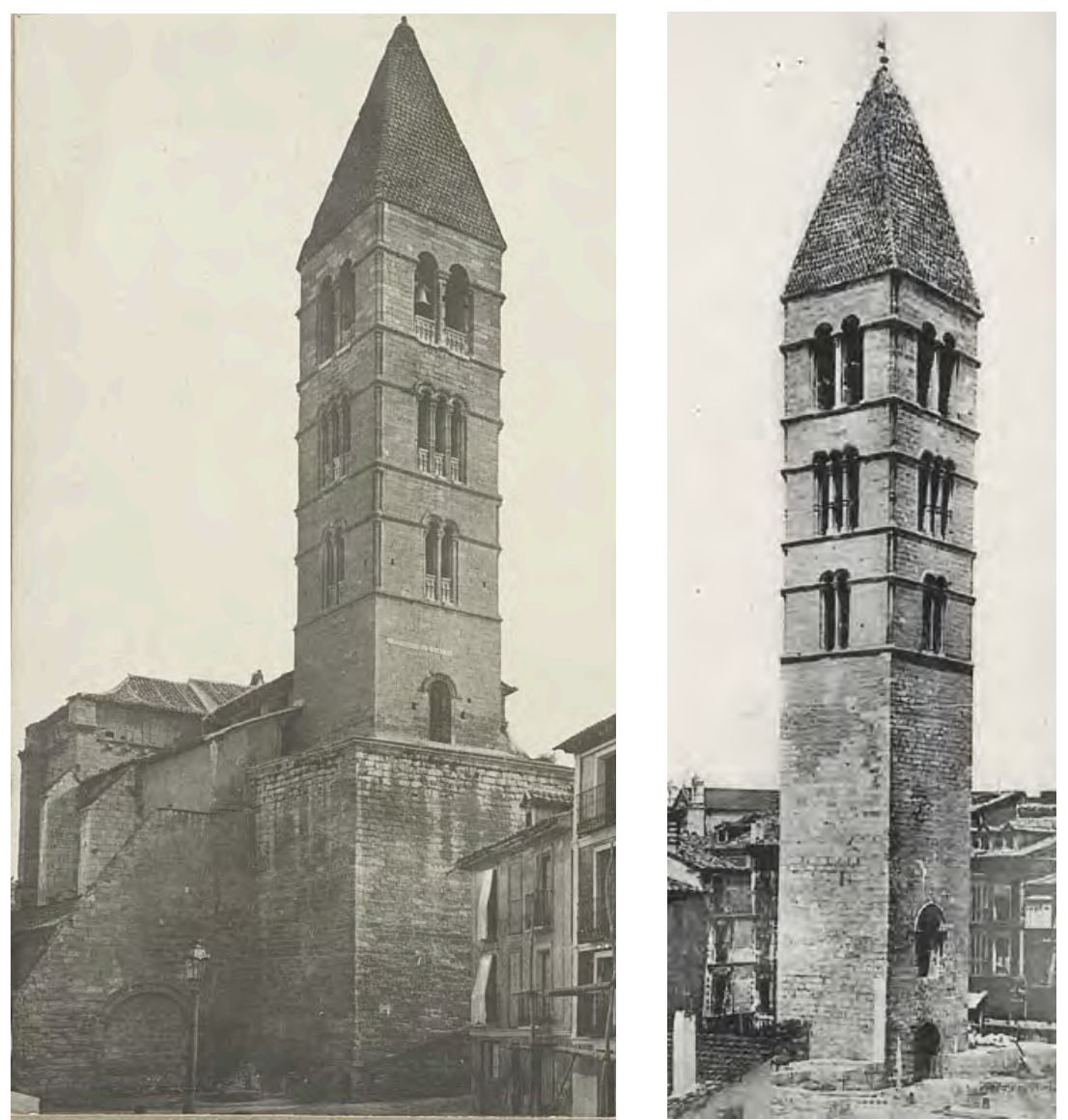

Ilustración 4: vista noroeste antes de la restauración y torre exenta (Casaseca inédito; AMVA CS-059)

En la imagen izquierda de la ilustración anterior podemos apreciar el zunchado de sillares de piedra de más de dos metros de espesor que se había incorporado al arranque de la torre antes de 1578. La imagen de la derecha corresponde a una postal y muestra la torre aislada tras la demolición del cuerpo de la nave, conservando 
ábside y pórtico, y la eliminación de la envolvente de piedra del arranque de la torre, hacia 1912.

En la memoria de su proyecto de restauración de 1944, Anselmo Arenillas explica que la iglesia se encuentra cerrada al culto pues su restauración se inició "antes de la II República y está sin rematar".

\section{Cronología. Fechas clave}

1095-1546- 1952

\section{Intervenciones}

1944 - Proyecto de restauración - Anselmo Arenillas

Repasa solados, puertas, ventanas y altares. Construye un nuevo volumen adosado con el mismo lenguaje goticista que se integra en la fachada sur.

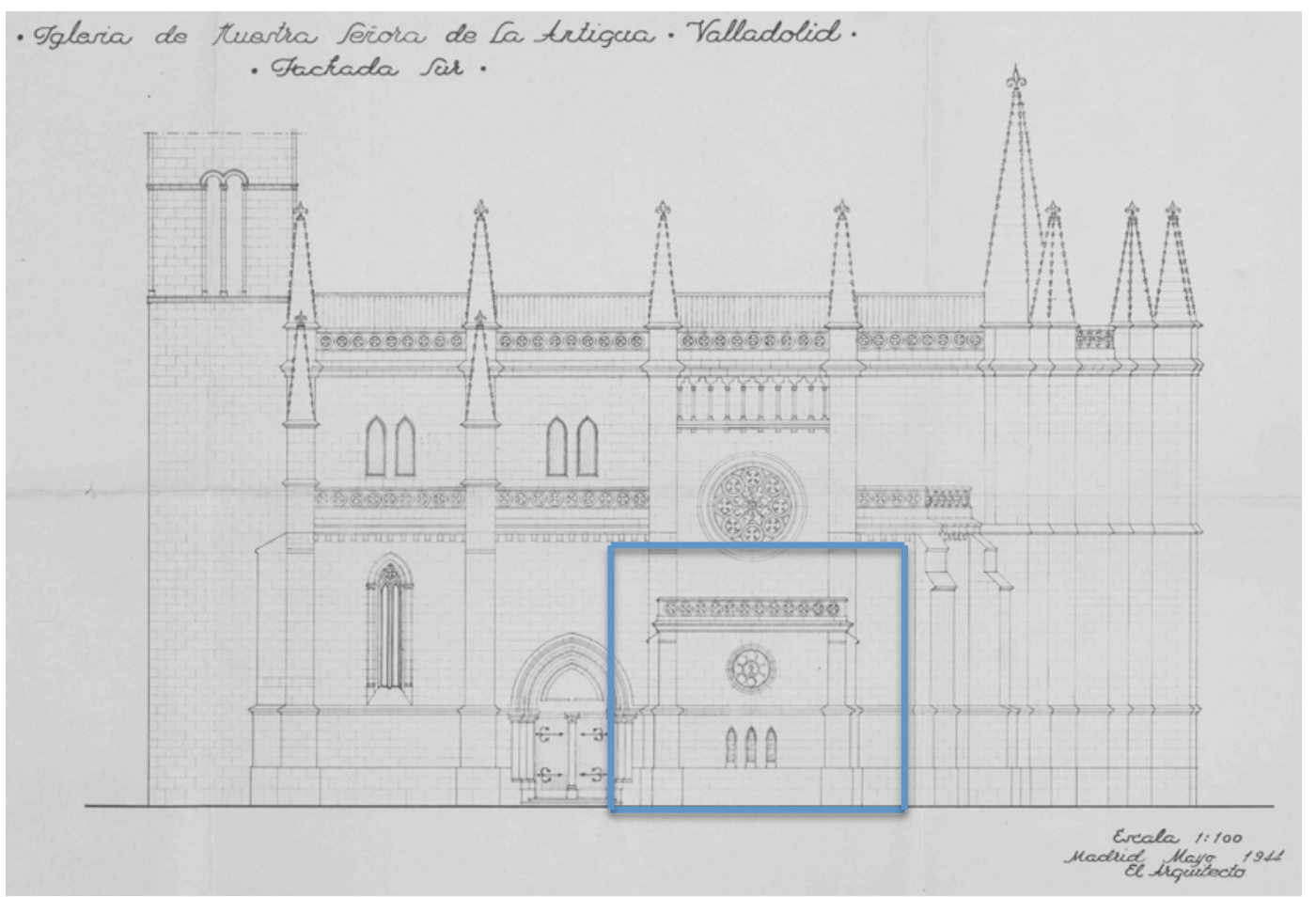

Ilustración 5: alzado sur con volumen adosado (1944 Arenillas IPCE)

1948 - Consolidación y restauración del atrio porticado de la Iglesia de Ntra. Sra. de la Antigua - Anselmo Arenillas

La obra afecta sólo a la zona de atrio porticado, que ya había sido reconstruido por el Arquitecto de Ciudad en el XIX. 
1953 - Proyecto de restauración - Anselmo Arenillas

Se colocan 30 losas de piedra para cubrir huecos destinados a alojar una calefacción no instalada, puerta, rejas y alumbrado.

1965 - Reparación de cubiertas -Anselmo Arenillas

Tras la reconstrucción del templo a principios del siglo $\mathrm{XX}$ se han reiterado las intervenciones destinadas a paliar goteras. Revisa las cubiertas y concluye que muchas gárgolas son macizas y la crestería-balaustrada embolsa las aguas. Se perforan las gárgolas, añadiéndolas nuevas de piedra artificial con tubo incorporado. Repasa el tablero y reteja reponiendo un tercio de las piezas.

La red de recogida de pluviales se dispone en el bajo-cubierta.

2005 - Restauración de cubiertas - Elesio Gatón

2008 - Actualización

En el proyecto se describe la perforación de las gárgolas macizas, que no debió ejecutarse en 1965 según lo previsto. Incorpora bajantes de cobre exentas y canales sobre los arbotantes para evitar su desgaste con la salpicadura. Las tejas se clavan sobre rastreles de madera.

\section{Planos}

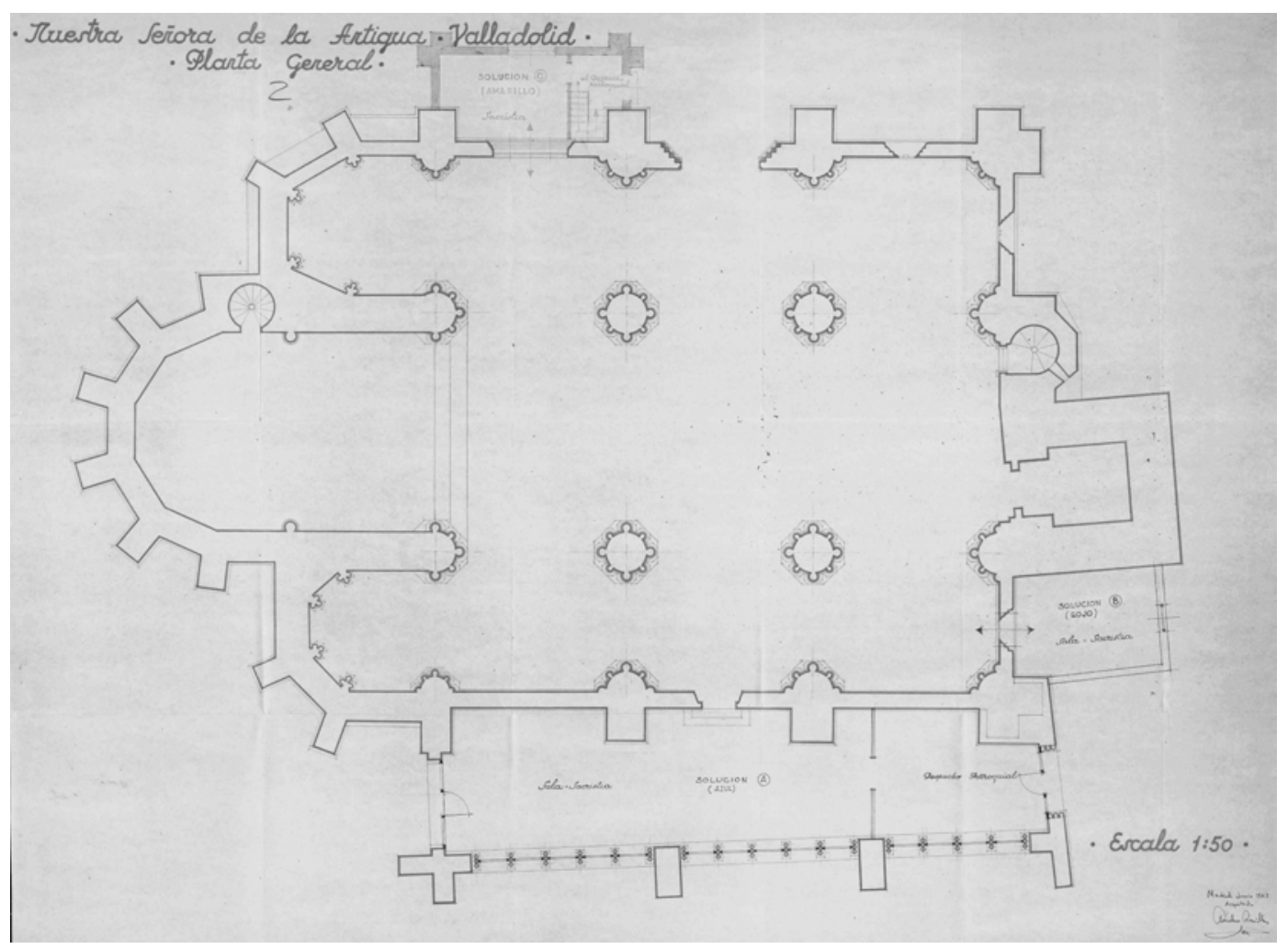

Ilustración 6: planta general (1943 Arenillas IPCE) 


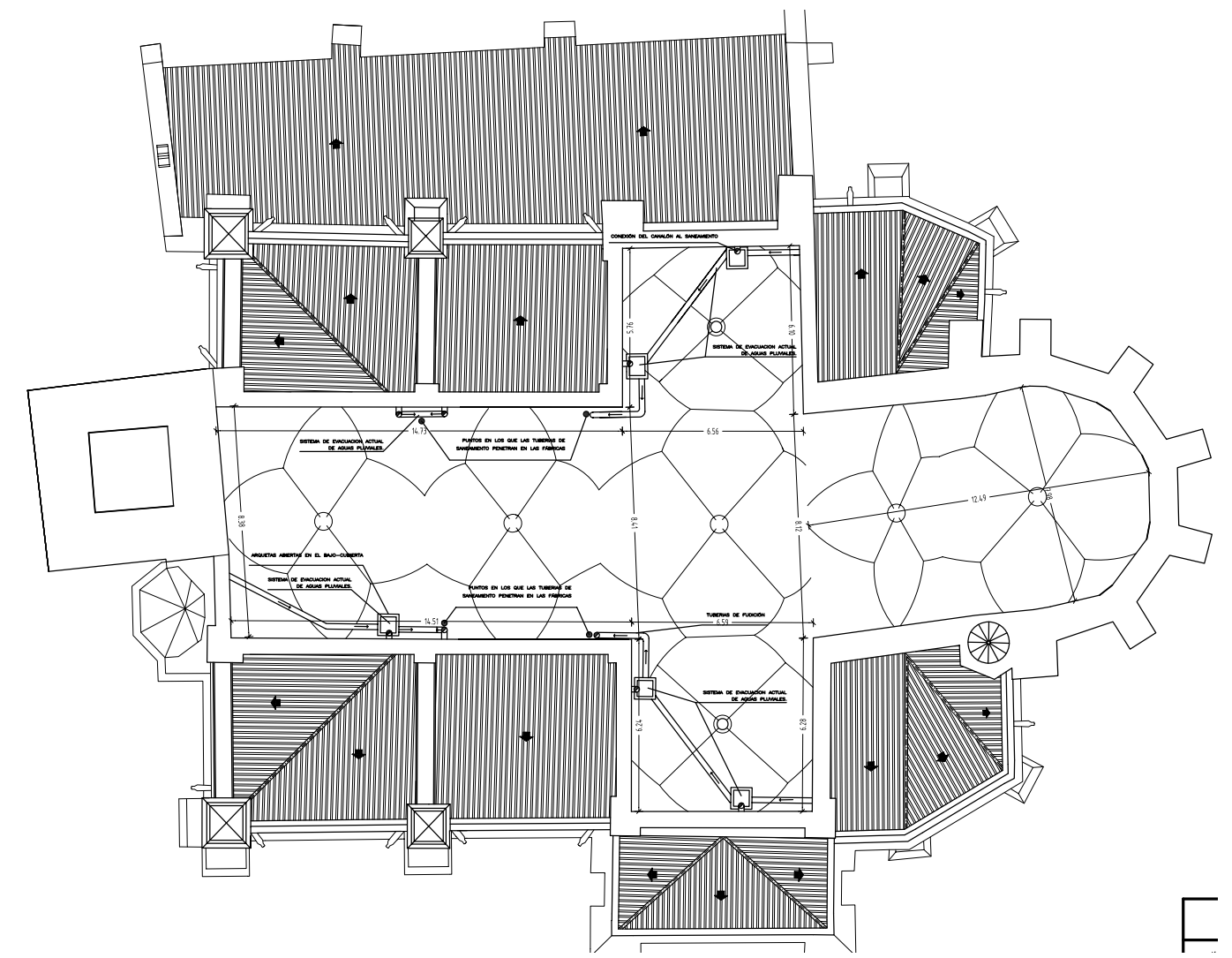

Ilustración 7: planta del bajo-cubierta estado actual 2005 (Gatón JCyL)

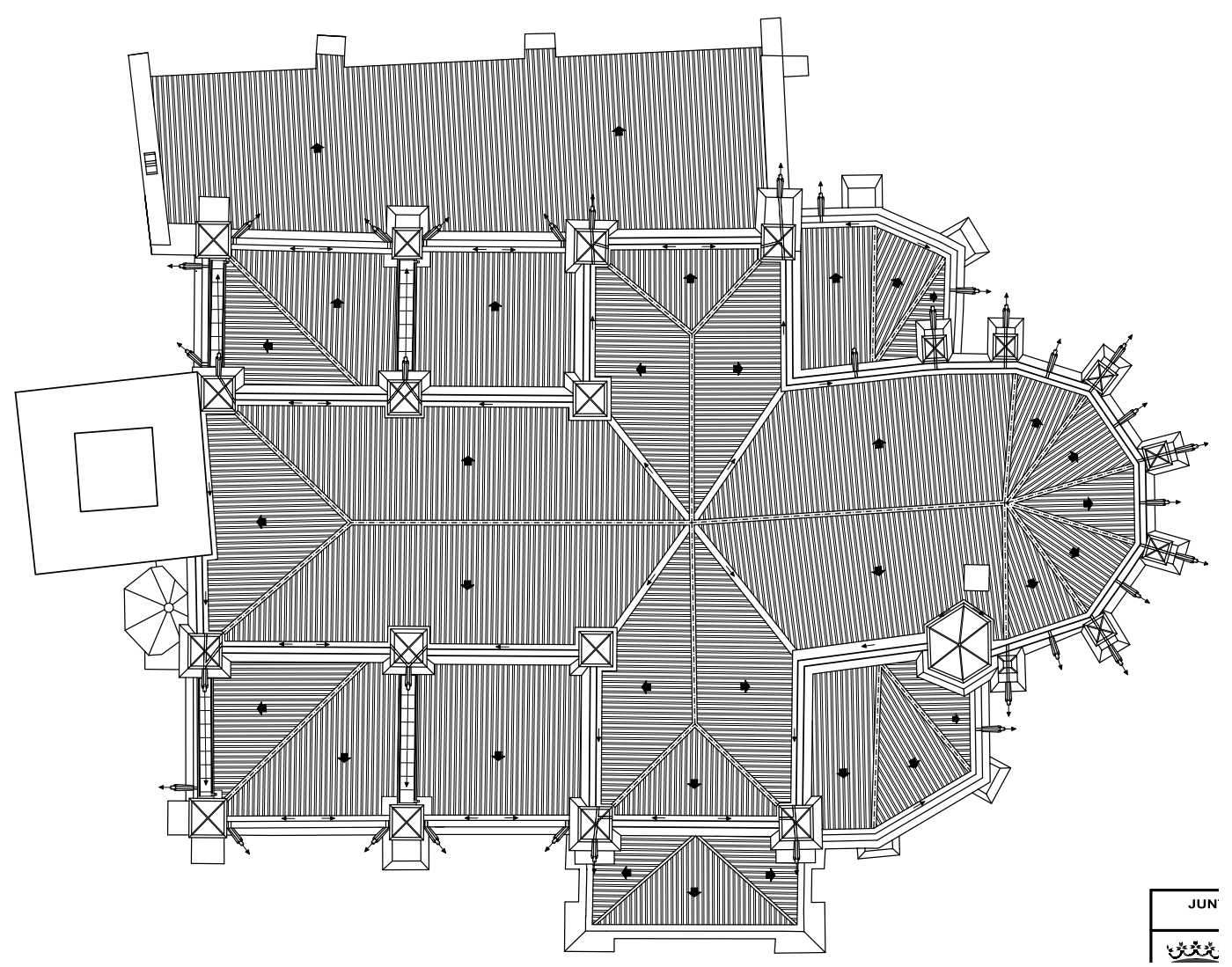

Ilustración 8: planta de cubiertas (Gatón 2005 JCyL) 


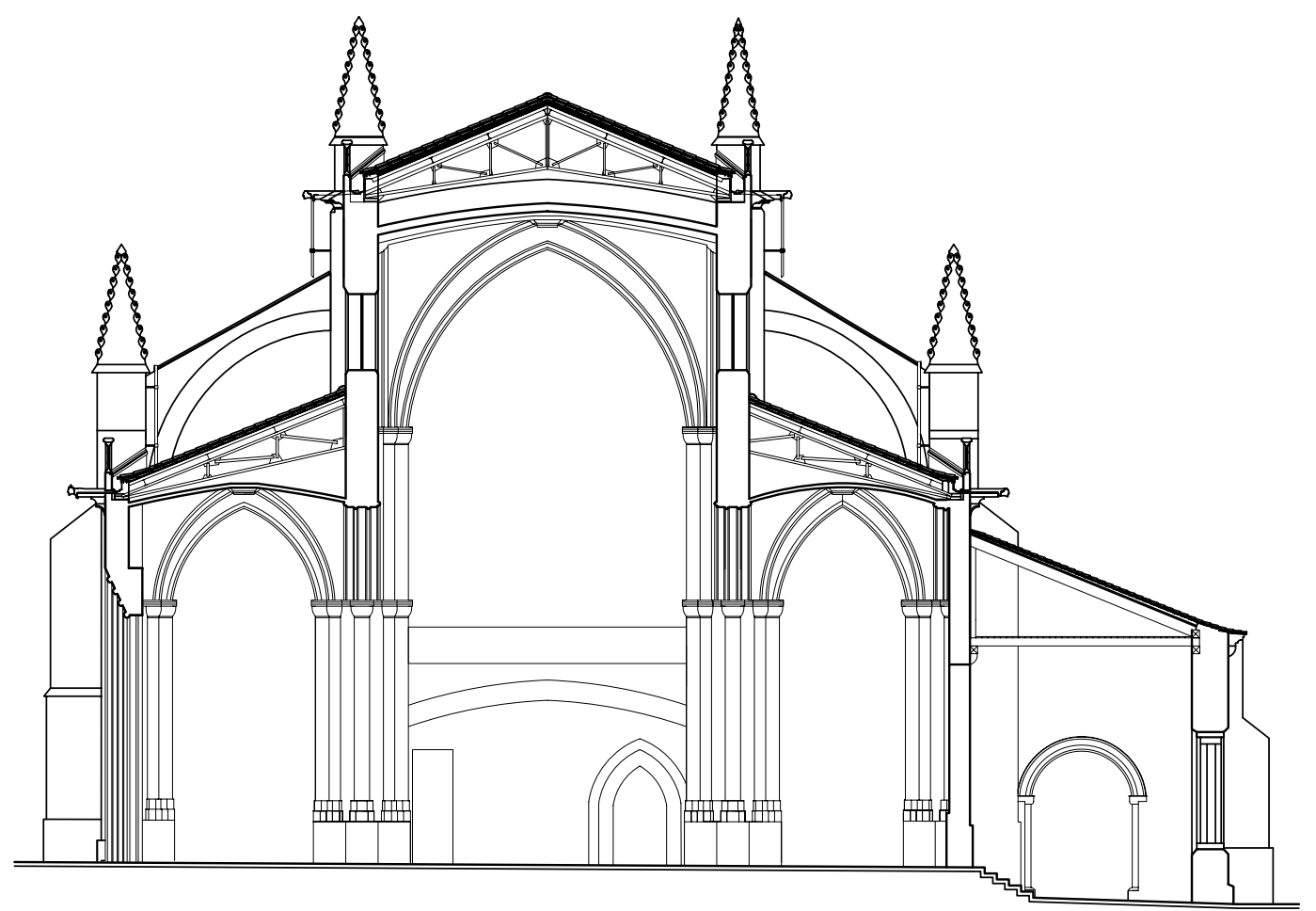

Ilustración 9: sección transversal (Gatón 2005 JCyL)

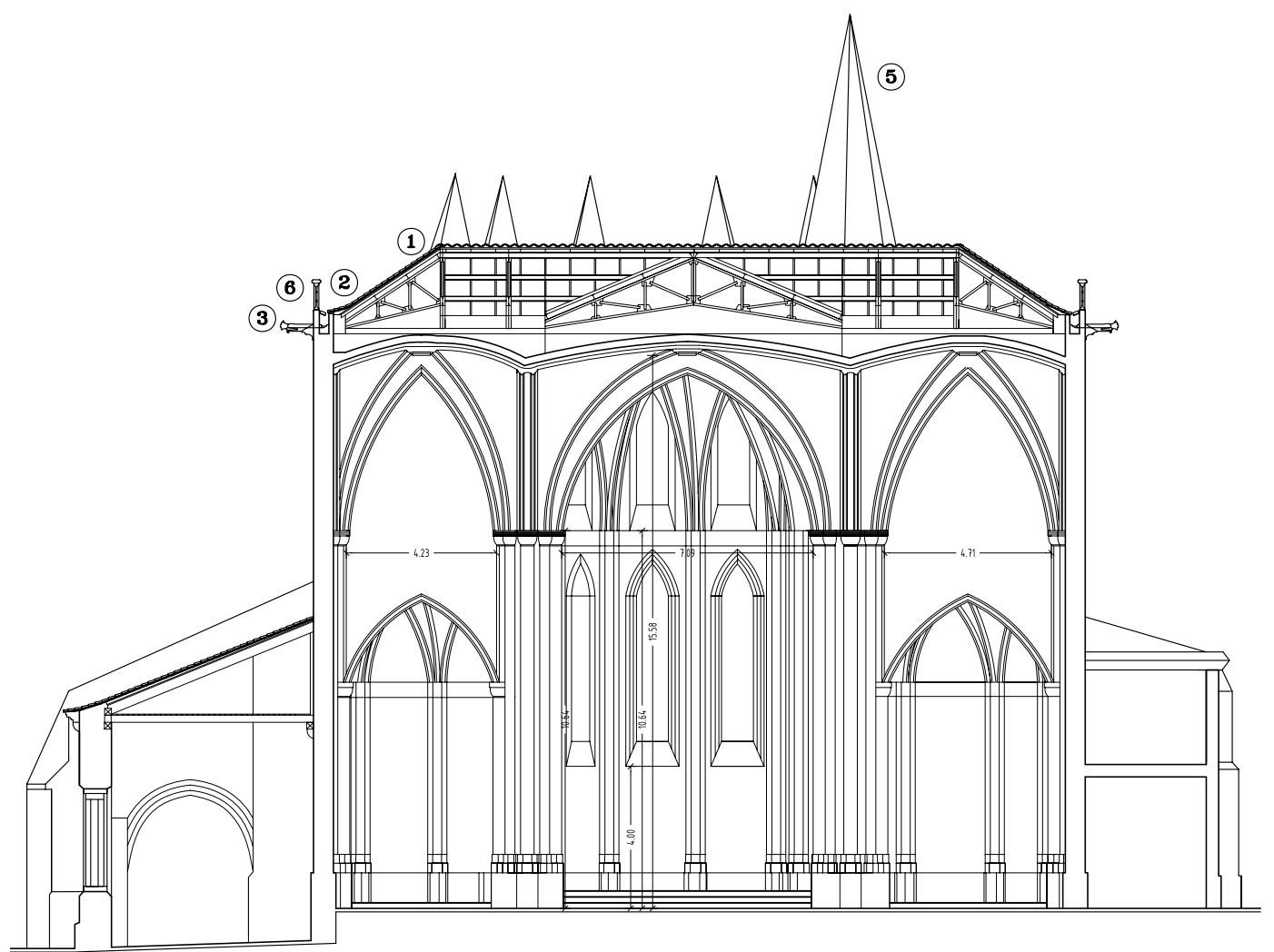

Ilustración 10: sección transversal por crucero (Gatón 2005 JCyL) 


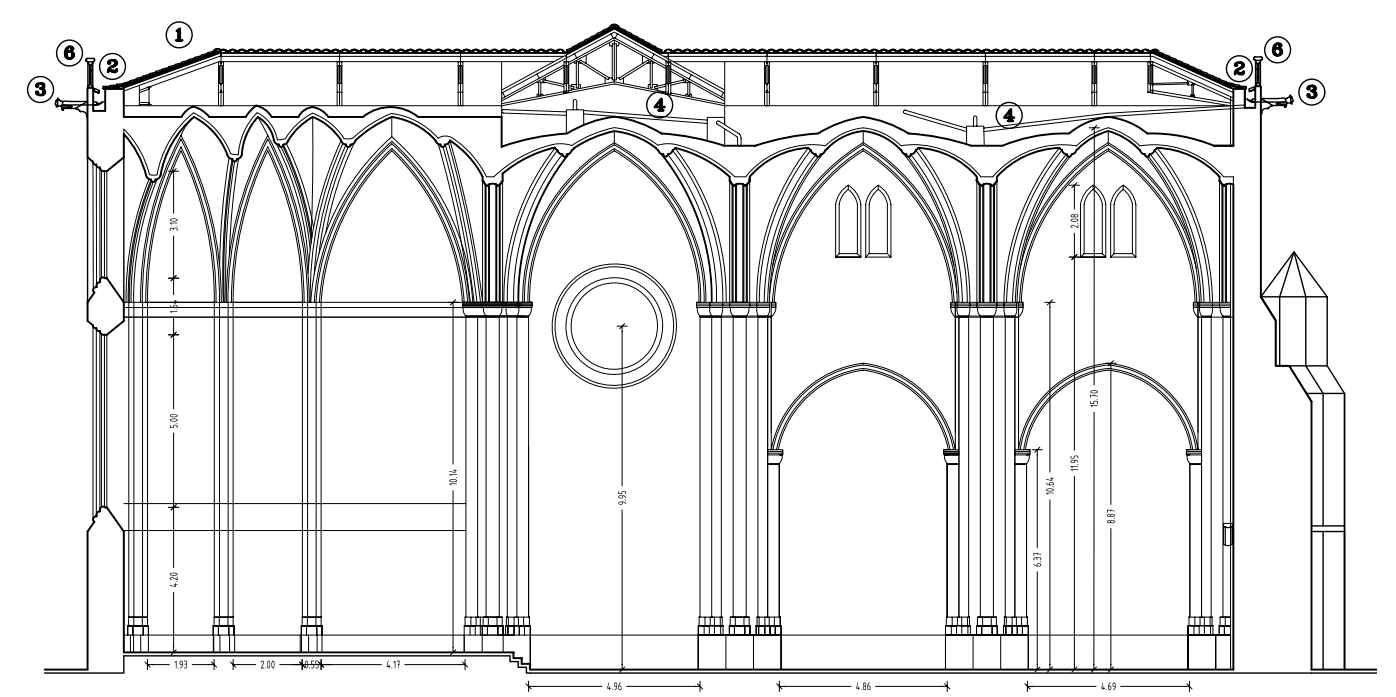

Ilustración 11: sección longitudinal (Gatón 2005 JCyL)
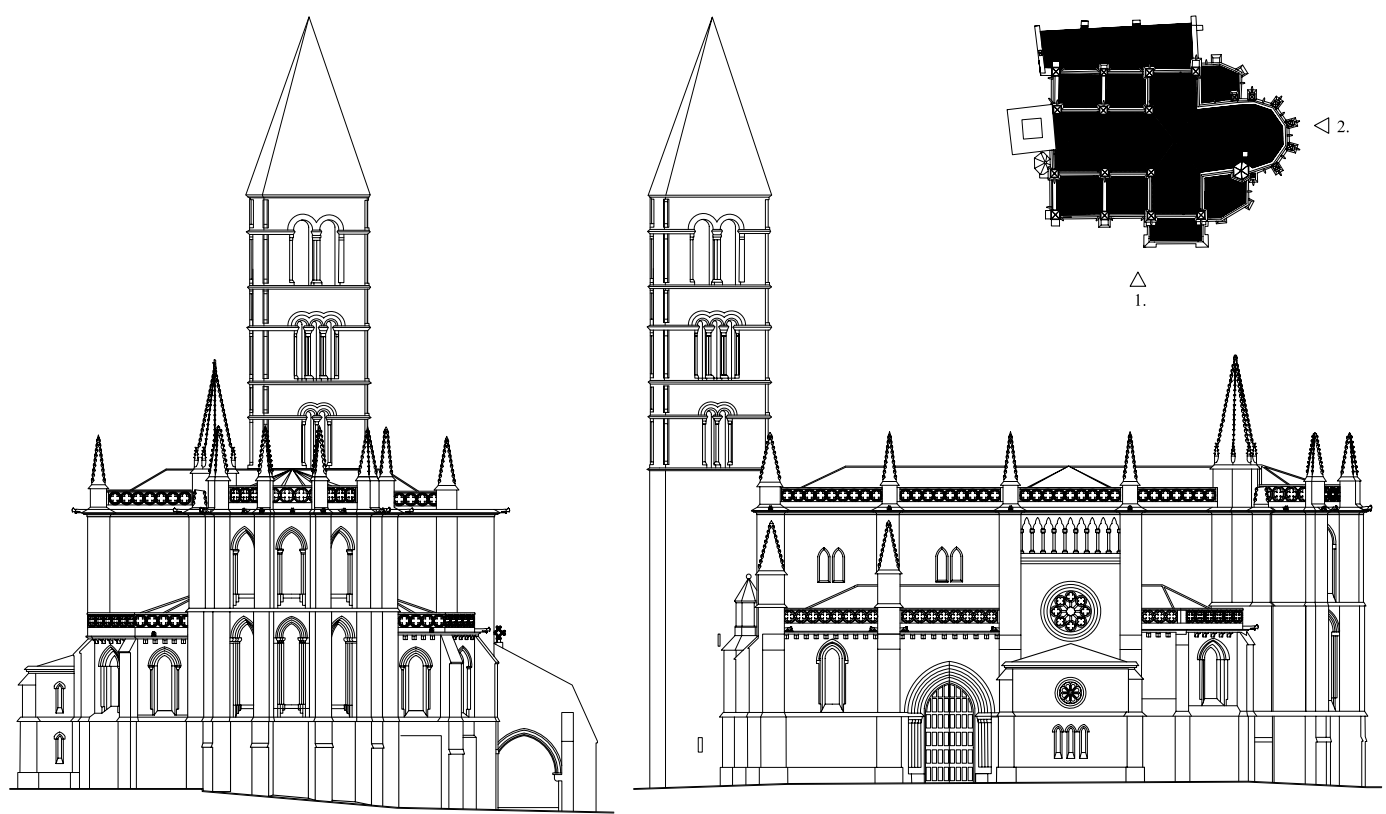

Ilustración 12: alzados (Gatón 2005 JCyL)

\section{Solución constructiva de la cubierta}

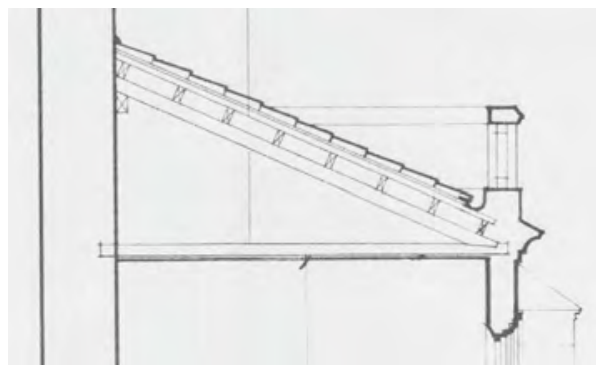

Ilustración 13: detalle 1944 Arenillas IPCE
El volumen adosado a la fachada sur en 1944 se proyectó con una cubierta de teja oculta (tras un acroterio que no llegó a ejecutarse) soportada por estructura de madera según la sección siguiente. 
A principios del siglo XX se desmonta y reconstruye el cuerpo de la nave, disponiendo una estructura metálica de cubierta formada por cerchas.

En las secciones de 2005 se representa los faldones con unos $23^{\circ}$ de inclinación.

En el proyecto de 2008 de Gatón se describe cómo "la cubierta está formada por cerchas y correas de acero laminado sobre los que apoya un tablero cerámico revestido de yeso por su parte inferior, en principio la estructura parece muy bien resuelta, no se observan indicios de ningún tipo de fallo estructural, tan solo se observa una oxidación de su superficie que apenas ha provocado pérdida de la capacidad resistente de los perfiles."

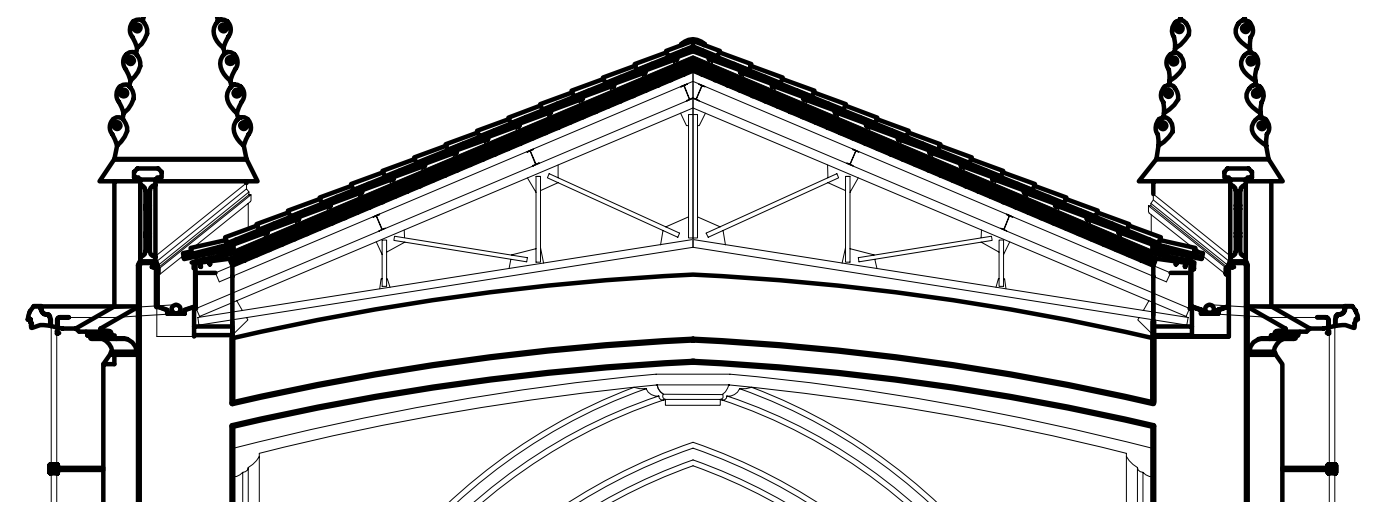

Ilustración 14: sección transversal (Gatón 2008 JCyL)

\section{Zunchos}

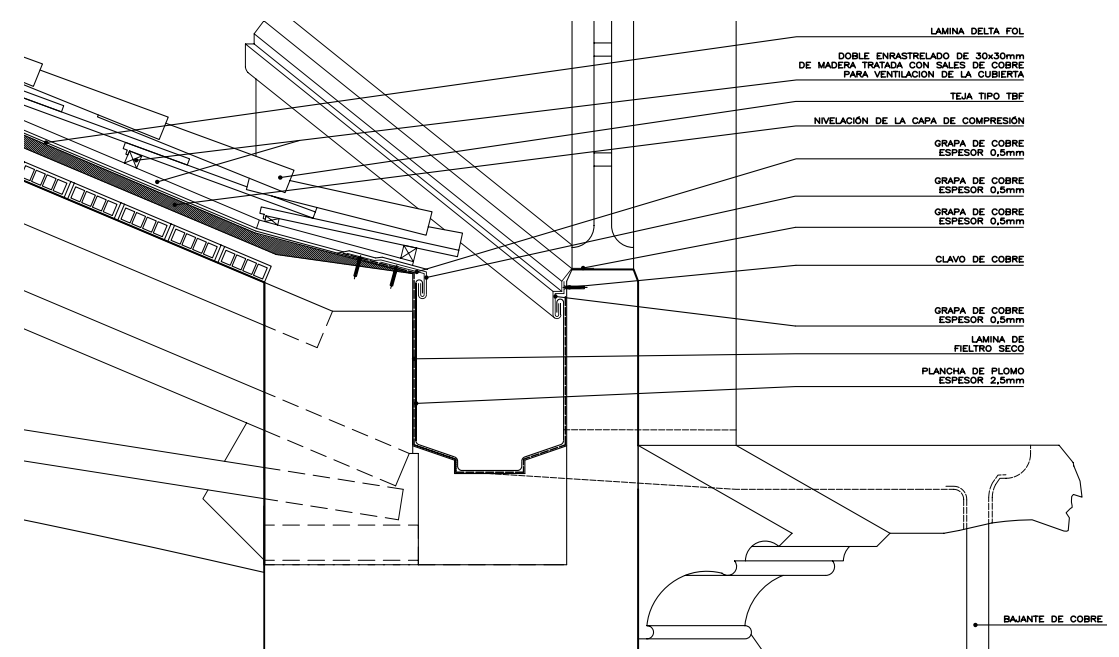

Ilustración 15: detalle cornisa y gárgolas (Gatón 2008 JCyL)

En los planos recopilados no se define la sección del muro con detalle, ni aparece representado cómo se produce el apoyo de la estructura metálica sobre el muro. 
En las cuatro imágenes siguientes, suministradas por la profesora Camino, se aprecia cómo el encuentro de las cerchas incorporadas a principios del siglo XX con el muro de piedra se encuentra tabicado con fábrica de ladrillo revestida.
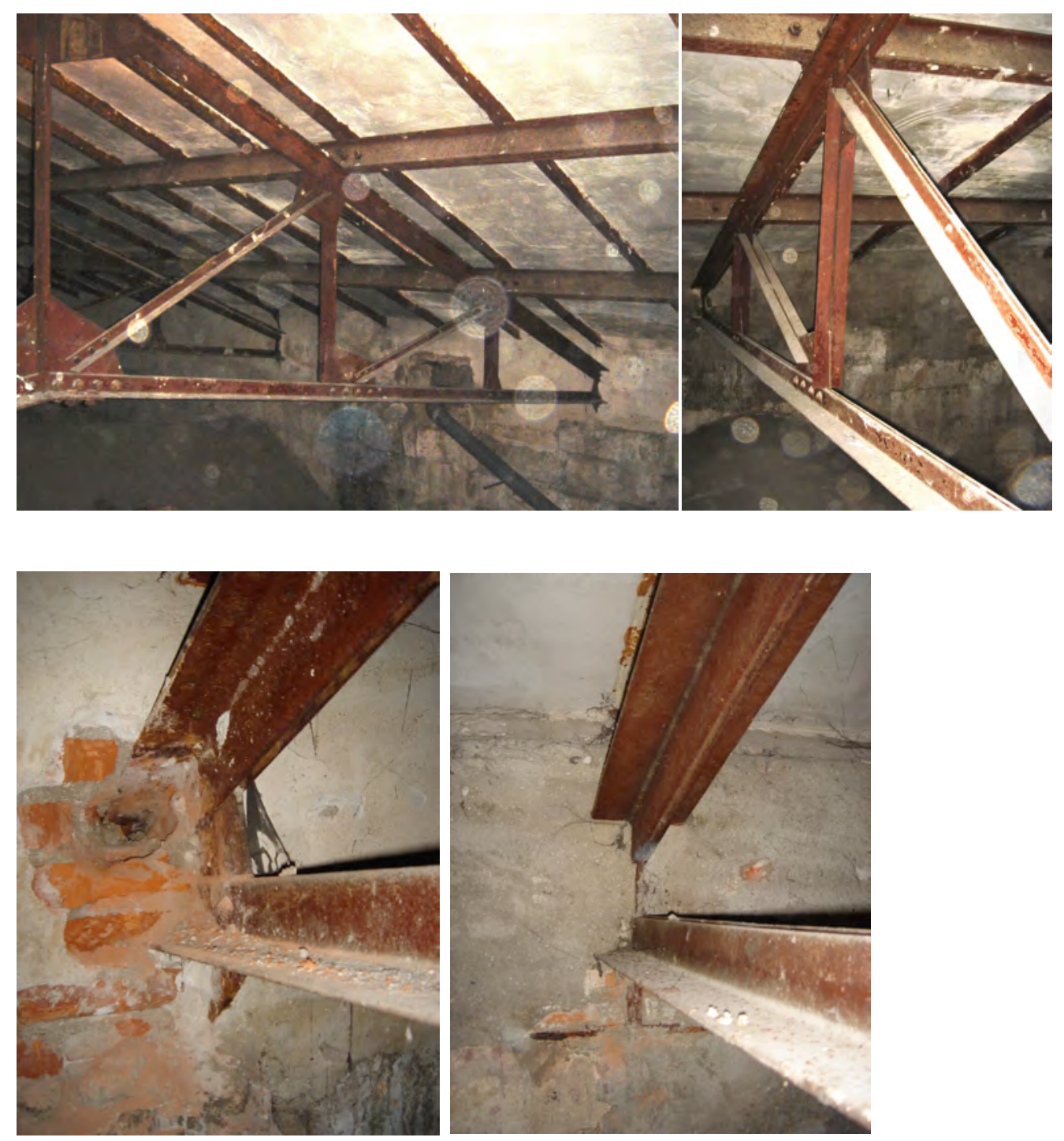

Ilustración 16: fotografías cortesía Ma Soledad Camino

\section{Conclusiones}

No se cuenta con documentación de la obra de reconstrucción llevada a cabo por García Guereta en la primera década del siglo XX. Tampoco ha sido posible obtener permiso del párroco para acceder al espacio bajo cubierta. En las fotografías de catas, practicadas durante la intervención de Elesio Gatón, no se aprecia la existencia de zunchos en el muro. 


\section{Iglesia de Santa María de la Antigua. Valladolid}

Intervenciones citadas en la publicación del Ministerio:

1944 - Obras generales - Anselmo Arenillas

1948 - Consolidación y restauración del atrio porticado - Anselmo Arenillas

1953 - Obras generales - Anselmo Arenillas

1964 - Reparación de las cubiertas del atrio - Anselmo Arenillas

1965 - Cubierta - Anselmo Arenillas

En la web del IPCE hay digitalizados siete planos de 1943-44, dos de 1966 y una perspectiva de 1970 para ordenación de los alrededores.

\section{En el Archivo General de la Administración}

AGA 26/00294 (1)

Proyecto de restauración de Nuestra Señora de la Antigua.

1944. Anselmo Arenillas

Memoria (2pag)

Explica que se inició su restauración antes de la II República y está sin rematar. Debe ser puesta en culto para protegerla.

Proyecta un cuerpo saliente que prolonga la nave del crucero en su fachada sur para alojar Sacristía y despacho parroquial.

Solados, puertas, ventanales, subida al púlpito, altares

Planos

Plantas nuevo pabellón

Alzado y sección (sin zuncho)

Alzado sur iglesia

Planta general 1:50 dibuja en rojo el pabellón encima.

AGA 31/06007

Consolidación y restauración del atrio porticado de la Iglesia de Ntra. Sra. de la Antigua

Anselmo Arenillas Alvarez junio 1948

(Este proyecto contiene el plano con planta y sección del porche sobre los que marca en rojo la reparación del 64)

Memoria (2pag) 
Se refiere sólo al pórtico, no al cuerpo de la iglesia.

Demuele y construye una cubierta nueva con vigas vistas cada $0,40 \mathrm{~m}$.

La última partida de las mediciones es:

Repaso general de cubierta de la iglesia

en nave central $\quad 1 \times 4,00 \times 12,50$

en naves laterales $2 \times 28,00 \times 8,00$

Total $\mathrm{m} 2$ de repaso de tejado $=498,00 \mathrm{~m} 2$

26/00294 (2)

1948 Anselmo Arenillas Álvarez

Proyecto de consolidación y restauración del atrio porticado de la iglesia de Nuestra Señora de la Antigua.

Memoria descriptiva (2pag)

Para completar la restauración total del templo emprendida por el Servicio.

"Por erosión natural al cabo de los tiempos y por defectos de filtración en las alcantarillas y sumideros inmediatos a los muros ha habido un desplome en el contrafuerte de la izquierda afectando también a la inmediación de toda la línea de fachada y los cinco contrafuertes. Igualmente el estado de la cubierta deja mucho que desear por falta de arriostramiento adecuado, dada la excesiva longitud de los pares, necesitándose además sustituir muchos de ellos por encontrarse la madera pasada en sus cabezas.

El orden de las obras será el siguiente: Primeramente se procederá a desmontar la cubierta en su totalidad y a continuación se saneará por puntos a todo lo largo de la fachada izquierda, preeviéndose alcanzar cotas de 2 a 21/2 metros. Una vez consolidada la cimentación haciéndose un relleno con mampostería hidráulica, se levantará en fábrica de sillería con las mismas características que el actual hastial de la izquierda. Se efectuará además un repaso general de toda la sillería taqueando donde haya faltas demasiado notorias, sobre todo en la zona de zócalos y se rejuntará nuevamente la cornisa con sus canecillos. Se armará la cubierta sobre formas o cuchillos, para de esta manera evitar el excesivo empuje en los muros armando un techo raso con vigas vistas separadas $40 \mathrm{cms}$ entre ejes y se efectuarán las obras complementarias en cuanto a limas, etc. La red de saneamiento se efectuará nuevamente haciendo pozos de registro .

Se presupuesta una pequeña partida de repaso general de cubierta en la iglesia, o mejor retejo. Cierre de los huecos del pórtico con cerrajería.

Plano del pórtico 1:50, con trozo de planta y alzado.

Mediciones y presupuesto 
AGA 26/00294 (3)

Proyecto de restauración de la iglesia de Nuestra Señora de la Antigua.

1953. Anselmo Arenillas

Memoria (1pag)

Hay canales en el pavimento para alojar tubos de la inexistente calefacción. Faltan algunas rejas sobre ellos. Se colocan 30 losas de piedra de Campaspero para taparlos $0,80 \times 0,40 \times 0,15$.

Reponer doble puerta de madera al sur, la que hay abre directamente a la nave. Colocar rejas en el claustro exterior.

Alumbrado.

Completar altar mayor.

\section{AGA 31/06007}

Restauración de la Iglesia de Ntra. Sra. de la Antigua

Anselmo Arenillas Alvarez junio 1953

(mismo proyecto revisado en carpeta anterior: huecos de canalización en pavimento, cancel y reja del claustro)

\section{AGA 26/00206}

1965 Anselmo Arenillas Álvarez

Reparación de cubiertas de la iglesia de Nuestra Señora de la Antigua, Valladolid.

Memoria (2 pag)

Se redacta el proyecto por encargo del Director General de Bellas Artes a solicitud del párroco. Fue restaurada a principios de siglo. Desde entonces ha sido preciso reparar sus tejados varias veces, las goteras se reproducen. Ahora hace un reconocimiento a fondo y ve que la mayor parte de las gárgolas no están perforadas (son adornos) y como hay una crestería-balaustrada que corona los muros y las gárgolas no desaguan, se retiene el agua y las goteras dañan cubiertas y bóvedas.

Las dos únicas que funcionan dejan caer el agua sobre la sacristía adosada y dañan su cubierta.

Se decide hacer perforación (o aumentarla en las que la tienen pequeña) de $10 \mathrm{~cm}$ mínimo de diámetro. Se añadirán gárgolas de piedra artificial imitando las antiguas con tubo incluido de hierro o fibrocemento que desagüe y a la vez arme.

Se rehacen limahoyas y canalones con cama de yeso, pintura asfáltica y chapa de cinc con cazoletas que viertan a las gárgolas. No es posible poner bajantes por interior, exterior ni empotradas. Se repasa la cubierta a teja vuelta, reponiendo una tercera parte de ellas, sustituyendo tablas y cabios rotos o podridos.

La sacristía se cubre con tablero de hormigón armado, cartón asfáltico y teja. 
Desmontar reja (tupida impide seguir las ceremonias) nuevo altar cara al público. Limpieza, electricidad.

Planos (3) febrero 1966

Planta General 1:50 (señala línea amarilla supongo reja que se retira)

Fachada sur 1:100 con anotaciones a mano en rojo (parece la ubicación de las nuevas gárgolas)

Altar

\section{En el archivo de la Junta de Castilla y León}

\section{VA-60}

1991 - Consolidación y tratamiento de la fábrica de piedra - Carlos Descalzo Llorente

La caja contiene documentación administrativa: ofertas licitación, certificaciones, contratos, etc)

Se adjudica a TRYCSA y cuenta con reformado y modificado.

Respecto al proyecto original finalmente no se emplea celulosa frente a la costra negra por resultar desfavorables las pruebas, sino productos químicos diluidos en agua. Barras roscadas de acero inoxidable en vez de las de fibra de vidrio tipo ROVI previstas. Se reintegra con espátula sin emplear moldes de látex.

Debido al mal estado del mortero se añade partidas de picado de juntas y rejuntado general de sillares.

No se ejecutan obras de reparación del canalón de cinc, ni aplicación de oxirón.

Se incrementa la medición de limpieza, reintegración, resina y aplicación de pátina.

Incluye un amplio dossier de fotografías en color de interior, exterior y cubierta en que se aprecia la afección de la piedra.

Planos de alzados y plantas 1:100. No hay secciones.

\section{VA-665 Carpeta en el Servicio}

2005 - Restauración de cubiertas de la iglesia de Santa María de la Antigua en Valladolid - Elesio Gatón Gómez

Aparejador: Pedro Luis Baz García

La obra se adjudica a ERCOSA (Especialidades Técnicas de la Restauración y Construcción SA). 
Con sus orígenes documentados desde 1088, el monumento sufrió constantes intervenciones a lo largo de la historia: reemplazo de la nave en el XIV por una de estilo gótico conservándose torre $\mathrm{y}$ pórtico románicos, reforma de la portada sur en 1494, de la tribuna en 1512, supervisión de daños en 1531, rehenchido de bóvedas y aseguramiento de pilares en 1542, Ilustración 17: AMVA digital 00020450

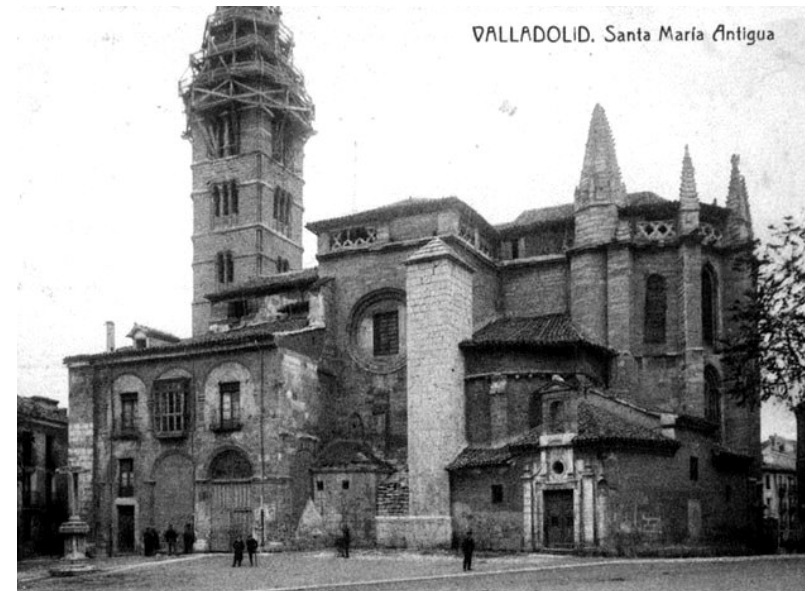
refuerzo de contrafuertes en 1566 y 1628 , del pilar toral desplomado en 1575 , etc.

La torre llega a revestirse hasta $15 \mathrm{~m}$ de altura con un encamisado de más de dos metros de espesor de sillería en el siglo XVI, volviéndose a reparar en el XVII precisamente por el asentamiento del propio refuerzo.

El edificio se desmonta y reconstruye prácticamente en su totalidad en la primera mitad del siglo XX, pero se siguen precisando reparaciones de las cubiertas hasta la actualidad a causa de las humedades.

En este esquema de Arenillas de 1965 se señala por ejemplo las zonas con insuficiente desagüe, problema que debió resolver con una red interna de recogida de pluviales dispuesta sobre el extradós de las bóvedas y bajantes camufladas embebidas en los muros.

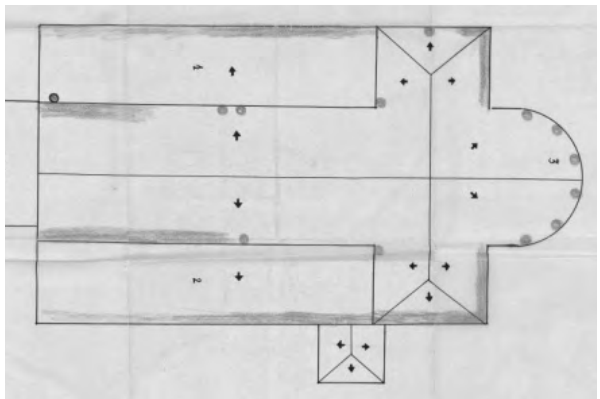

Ilustración 18: cubiertas 1965 Arenillas IPCE

Según la Memoria de su proyecto, Gatón considera muy bien resuelta la estructura de cubierta roblonada, de cerchas y correas en acero laminado con tablero cerámico revestido inferiormente de yeso, destacando sin embargo problemas por falta de estanqueidad.

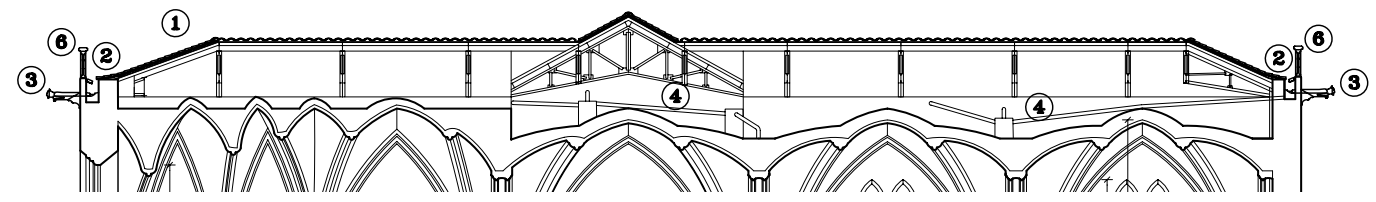

Ilustración 19: sección bajo cubierta 2005 Gatón JCyL 


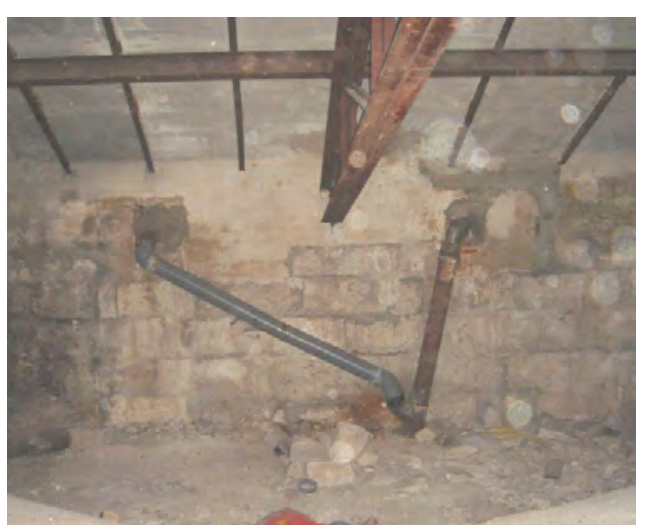

Ilustración 20: dossier 2005 Gatón JCyL

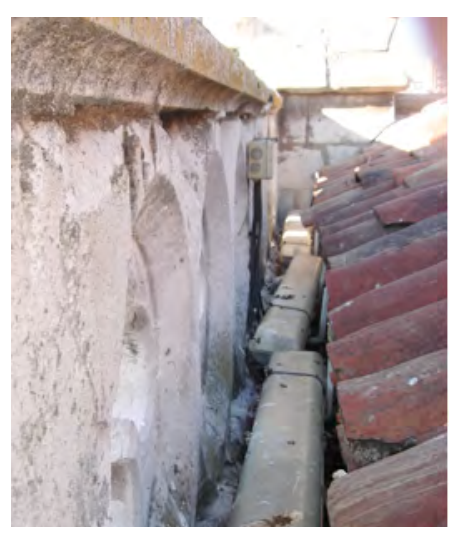

Señala cómo numerosos canalones están prácticamente cegados tras la colocación en ellos de luminarias estancas, que se propone retirar, y la inutilidad de las gárgolas macizas existentes, colocadas como meros adornos, que propone perforar.

En el proyecto se prescribe la retirada de teja, limpieza del tablero e impermeabilización del mismo mediante lámina DeltaFol, y retejado con tejas clavadas sobre rastreles de madera.
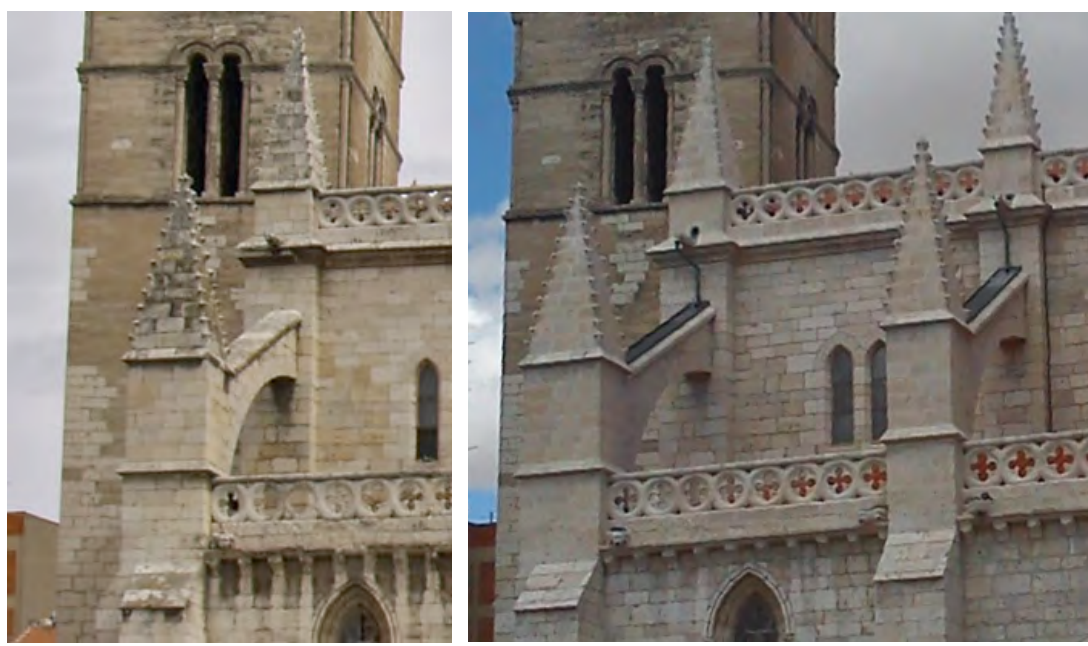

Ilustración 21: detalle arbotantes 2008 wikipedia 20080816 y visita 16/06/2012

Se disponen canales cubriendo los arbotantes con bajantes de cobre exentas que conducen hasta los mismos las aguas que atraviesan las gárgolas para evitar las salpicaduras.

Para la limpieza de las fachadas se aprovecha la experiencia reciente en la Colegiata cercana, construida al tiempo y con el mismo tipo de piedra. Se eliminarán los morteros incorporados a las juntas en anteriores restauraciones, unos de cemento y especialmente los más recientes, con unas resinas que han degenerado.

Los refuerzos y consolidaciones de grietas en la sillería se plantean mediante inyección de resinas epoxídicas de baja viscosidad. 
En la misma carpeta se incluye una solicitud de Modificado con el que se pretende aprovechar los andamios ya montados para limpieza de las cornisas y acometer la de las fachadas completas, advirtiendo además peligro de desprendimiento en embocaduras de ventanales del ábside, muy degradadas. No se acepta.

\section{En el Archivo Municipal de Valladolid}

\section{Fondo Histórico}

\section{AMVA: CH 38347 Licencia de obras 1857}

1. Dossier tamaño cuartilla con queja de arquitecto y contestaciones: "28 Nov 1857. El $\mathrm{Arqt}^{\circ}$ de Ciudad pone en conocimiento del Sr Alcalde que el empresario de las obras que se están ejecutando en la Parroquia de Ntra Sra de la Antigua se construyen faltando en todo a las condiciones del contrato y que habiéndolo reprendido no ha merecido mas que insultos.

Como ampliación a mi anterior oficio fecha 27 del corriente debo manifestar que me personé en la obra que se está egecutando en la Iglesia de nuestra Sra de la Antigüa, por el contratista D Felipe Rablares, y reconocida resultó que por el citado contratista se habían suprimido las formas de armadura que en las condiciones se hallaban indicadas habiendo puesto en su lugar unas tigeras o tornapuntas que según él creía suficientes para la resistencia de la misma armadura. En vista de esto le demostré en primer lugar que no eran suficientes las espresadas tornapuntas y en segundo lugar que bajo ningún concepto podía hacer alteración alguna....." (pido copia)

2. Solicitud de la Junta de Hacienda de la Antigua de Licencia para ejecutar ciertas obras de Reparación de la Iglesia. Informe del Arquitecto de Ciudad ifirmado Vicente Miranda? que no cree oportuno que se conceda el permiso para hacer un cerramiento provisional en los dos costados de la Galería que hoy está en reparación por ser construcciones en mala relación con el precioso monumento. Habría que hacerlas acordes en materiales dimensiones y estilo y encargar los planos a otro arquitecto.

AMVA: CH 412-4 Licencia andamio $1877 \quad$ J. Ortiz de Urbina

Solicita permiso para colocar andamio y hacer algunas pequeñas reparaciones. En el mismo pliego la Comisión de Obras 2a Sección concede la licencia. 
AMVA: CH 352-18 Denuncia ruina cornisa

1. Con membrete del Arzobispado Entrecomillan cómo El arquitecto diocesano Antonio de Iturralde explica que el Expediente de declaración de monumento nacional está pendiente de resolución de la Academia de San Fernando, y que el problema transmitido por el párroco sólo podría remediarse con una restauración de casi la totalidad de las cornisas, cresterías, pináculos y otros muchos puntos que constituyen la parte artística de este templo.

2. Folio doblado con membrete de la Sección de obras del Ayuntamiento

Al jefe de la guardia municipal para que avise al párroco que en tres días debe demoler la cornisa denunciada para evitar desgracias a los transeúntes.

La cornisa de ladrillo del ángulo derecho en la fachada principal de la Iglesia de la Antigua se halla en estado de ruina, así como es de necesidad que se recalcen algunos contrafuertes de la referida iglesia que siendo de piedra franca se hallan por efecto del tiempo con falta de base. Firmado por Santiago Herrero en abril de 1892.

Otros párrafos de enterados y diligencias.

AMVA: CH 382-177 Demolición accesorios 1854-1859

Dossier muy amplio de comunicaciones, expedientes, incumplimientos, etc entre Arquitecto de Ciudad, Junta de Hacienda de la Iglesia. Todos quieren eliminar adherencias de la fachada norte, sobre todo a raíz del cambio del cauce que ha transformado una zona sin paso bañada por el río en una calle importante de mucho transito. Las obras las costea el Ayuntamiento, ya que la superficie que pierde el templo pasa a ser dominio publico. La Junta reclama habiliten espacio para sus reuniones, cambio de escalera, etc. Se discute por la Galería, que debía restaurarse según criterio de la Academia Provincial de Bellas Artes y dejarse libres los arcos pero han instalado habitaciones.

Se definen las condiciones de la licitación. "Cubierta de tejado con atirantado de vigas de 22 pies hechando una cuarta en cada tramo para sobre ellas formar por medio de pendolones la corriente del tejado usando maderas cortas, 1 hechando techos rasos en las salas derecha e izquierda del pórtico y en este. Cubrir de fabrica de ladrillo toda la parte superior que se halla al descubierto estucando e imitando piedra: componer con piedra todos los puntos resentidos y los dos arcos laterales cerrándoles con la misma fabrica. Construir la escalinata que resulta entre los dos estribos centrales....

Recepción 
AMVA: CH 240-30 Licencia atrio 1946

Anselmo Arenillas comunica al Ayuntamiento que va a ejecutar un pequeño pabellón para sacristía en la fachada sur, cierre con verjas de las puertas del atrio aporticado y las obras interiores precisas para la puesta al Culto de la Iglesia.

Le contestan que es preciso presentar la planta de conjunto para poder informar en lo relativo al Plan de Urbanización.

AMVA: C 1098-13 Pavimento accesos 1937

El presidente de la Comisión de obras, visto el proyecto de pavimentación de los accesos a la iglesia confeccionado por un ingeniero de Vías y Obras recomienda ejecutarlas por administración dado que su cuantía no exige concurso.

\section{AMVA: CH 344-31 Informe torre 1903}

El concejal que suscribe apercibido de que el movimiento que ha tenido lugar en la cúpula de la torre de la iglesia de Santamaría de la Antigua viene acentuándose y pudiere en día no muy lejano ocasionar algún día de luto al vecindario de Valladolid, propone á la Corporación Municipal acuerde que el $\mathrm{Sr}$ Arquitecto Municipal acompañado del Provincial practiquen un reconocimiento de dicha torre $\mathrm{y}$ presenten un informe referente al indicado obgeto. Fdo. Eustaquio Sanz

Carta del Alcalde al Gobernador explica lo anterior y solicita que se digne dar órdenes para que el arquitecto provincial reconozca la torre con el municipal.

Informe extenso firmado por Juan Agapito y Revilla y Santiago Guadilla: Han inspeccionado la torre de cuatro cuerpos que alcanza en su terminación treinta y seis metros cincuenta centímetros sobre el pavimento de la calle, el espesor de los muros es de un metro cuarenta centímetros, conservándose esta dimensión en el arranque de la cúpula o flecha. En el exterior los elementos están deteriorados por la intemperie, en el interior hay grietas que pueden deberse a pelos de la piedra que se pongan de manifiesto a causa del peso, o también por las heladas. La bóveda está construida con una mampostería particular formada por piedras irregulares, especie de losas sin desbastar, sentadas por hiladas horizontales y enlazadas con mortero de mediana calidad las juntas tienen tal espesor que es provable que el elemento de unión ocupe más de una cuarta parte del volumen de esta fábrica. No hay elementos de madera en la estructura de la aguja de trece metros, sólo dos ligeros entramados o pisos formados con cuatro tablas para apoyar la escalera de mano. Describe la geometría circular de la bóveda embutida en la sección de caras planas. Desde el 
interior no se justifica la deformación evidente por el exterior, que puede responder sólo a desprendimientos de la argamasa que soporta las escamas de teja. No se puede estudiar bien la parte piramidal. El refuerzo en el arranque de la torre en el XVI es de $3 \mathrm{~m}$ de espesor y 14 de altura. Recomiendan no obstante reparar la torre. Indican que se hallan paralizadas unas obras de reparación de la iglesia por lentas tramitaciones y falta de consignación y la reparación de la cubierta de la flecha de la torre está en el proyecto.

Acuerdo de la Comisión. Insistir al Ministro, pedir que el arquitecto diocesano inspeccione del cuerpo de la iglesia y proponer que se cierre temporalmente si decide que no es segura.

AMVA: CH 379-6 Bóveda ladrillo cauce Esgueva 1851

Acta de contrata de ladrillo para cubrir el trozo de cauce del Rio Esgueva á la parte accesoria de la Iglesia de la Antigua Reunidos en la Secretaria del Ayuntamiento el 2o teniente de alcalde (alcalde accidental) y un oficial de albañil se contrata la ejecución de la rosca o bóbeda de ladrillo a cuenta del Ayuntamiento.

\section{Fondo Administrativo}

AMVA: 2634-20 Iluminación interior 1970

El párroco solicita iluminación interior como se está instalando en otros monumentos

AMVA: 2577-26 Aprobación del proyecto de Anselmo Arenillas 1966

1 hoja

AMVA: 4552-1 Planos cabecera 1988

Proyecto de consolidación, limpieza y tratamiento protector de la fábrica

Sólo un juego de copias de los planos de 1988 plantas y alzados (originales en la Junta)

AMVA: 204-3 Restauración y consolidación del claustro norte 1999

Licencia exp. 6603

Dos planos DinA3 y un A4 de Elesio Gatón, planta, alzado principal y lateral en que señala la zona de "enmugrecimiento" de la piedra. Sin escala. $2^{\text {a }}$ Fase

Constructor Yáñez. 
Fotocopias de fotos y dos hojas a mano de planta y alzado en que acota la zona de actuación.

AMVA: 20-319-3 Reparación pórtico lateral

1998

Licencia, memoria de Elesio Gatón, presupuesto (unos 160m2). croquis y fotos: se interviene sólo sobre la zona del piñón y el primer tramo lateral

AMVA: 39887-1 Solicitud de Licencia de obras

Restauración de cubiertas. Proyecto de Elesio Gatón

Diciembre de 2005. Actualización septiembre de 2008.

Memoria parece más extensa que la del proyecto revisado en la Junta VA-665, (pido copia digital) Incluye dossier fotográfico.

Los planos llevan la fecha 2005 en la carátula.

\section{AMVA: 1831-2-5 1995 Exp. 3075/1995}

Sustitución del sistema de calefacción en c/ Arzobispo Gandásegui sn Arq: Javier Blanco Martín. Hay 2 copias del proyecto, una firmada original visada COACYLE.

En la memoria incluye bibliografía, Castán, Heras, el Catálogo y

García Guinea MA y Wattenberg, F. La iglesia románico-gótica de Sta M ${ }^{\mathrm{a}}$ de la Antigua. BSAA XIII, Valladolid 1945

Mañueco Villalobos, Manuel y Zurita Nieto, José Documentos de la iglesia colegial de Sta $\mathrm{M}^{\mathrm{a}}$ de Valladolid. Valladolid 1920

Dossier de fotografías (fotocopia) de exterior en 1897, etc. Indica imagennes extraidas de publicaciones del Grupo Pinciano.

Describe la actuación: aire caliente obtenido mediante gas natural, aprovechará conductos existentes en el pavimento cegando otros y abriendo nuevos. Sobre una solera de $10 \mathrm{~cm}$ de hormigón en masa.

Se desmantela la cubierta de la sacristía para reemplazar el generador actual. Nueva pendiente de tabiquillos, rasillones y capa de compresión. Lámina asfáltica y teja curva. Salida de humos.

Dosier fotos copias en color: cubierta actual revestida de cemento, chimenea e interior de sacristía, interior del templo describe despiece de pavimento, rejillas de fundición, pavimento alrededor del templo y dos vistas exteriores.

La obra afecta a $250 \mathrm{~m} 2$ construidos.

Planos:

Planta 1:100 con despiece de losas del pavimento en las tres naves. 
Alzados. Secciones transversal y longitudinal 1:100 que muestran una estructura de cubierta con aspecto de gruesas escuadrías de madera?

Planos de sacristía 1:25 y detalles constructivos, arquetas, canalizaciones y esquema de acometida.

AMVA: 17218-2 1988 Exp. 68/2009

Consolidación, limpieza y tratamiento de la fábrica de piedra de la iglesia de Santa María de la Antigua: cabecera y mirador Carlos Descalzo Llorente

Concesión de licencia 1989

La Primera fase corresponde a paramentos exteriores de cabecera (los tres ábsides) y el mirador. Justifica la elección porque es la zona más degradada y si no se corrige habrá pérdida de materia pétrea.

Memoria histórica.

Dossier fotocopias imágenes Antolínez de Burgos, Parcerisa, etc.

Diagnóstico: "La conservación de los Monumentos pétreos, presenta el problema de la aceleración de las degradaciones en los últimos 20-30 años, pues al proceso natural de deterioro del material, se le añade la atmósfera contaminada de los núcleos urbanos. La acción más visible... es forma de COSTRA NEGRA"

Características de la piedra de Campaspero: asepcto, mineralogía, porosidad, absorción de agua, densidad, factores de alteración...

Dosier copias fotos.

Planos (fecha diciembre 1988 visados, los mismos que en JCYL VA-60) plantas y alzados actual y actuación, sin secciones.

\section{AMVA: 2577-26 C-277-25}

Hoja para el Alcalde con membrete del Ministerio, de Orden por la que se aprueba un proyecto de la Antigua de Anselmo Arenillas por 500.000,00 pesetas en abril de 1966.

\section{AMVA: BIBLIOTECA}

Librito (15 pág.) de Adolfo Fernández Casanova a partir del articulo publicado en el Boletín de la Sociedad Española de Excursiones en 1911, Imprenta de San Francisco de Sales, Madrid.

Escribe la monografía porque el inminente estado de ruina en que se encuentra el cuerpo de la iglesia impone la necesidad de derribarlo 
Organismo del templo. La planta de la nave del crucero queda comprendida en las fachadas de las naves menores, acusándose sus brazos solamente en elevación, por hallarse sus embobedamientos a igual altura que la nave mayor, la que, así como las menores, se divide en dos tramos. Cubren los tramos de altas y bajas naves bóvedas de crucería francesa de valientes y bien moldados arcos transversales y formeros apuntados y diagonales de medio punto, conteniendo la mayoría de los tramos ligaduras de espinazo longitudinales.

Galería románica del costado $\mathrm{N}$ del templo. Aparece elevada sobre la rasante de la vía publica, y su estado ruinoso impuso la necesidad de efectuar su restauración, que se ha dejado sin terminar.

La torre es la fábrica más interesante del monumento: mide $55 \mathrm{~m}$ de altura total y está formada por un prisma recto, de sillería de base cuadrada de $6,50 \mathrm{~m}$ de lado y $36 \mathrm{~m}$ de alto, con espesor medio de muros de $1,85 \mathrm{~m}$ y $2,85 \mathrm{~m}$. Su parte inferior, de $15 \mathrm{~m}$ de altura, se halla envuelta por un potente muro de $2,30 \mathrm{~m}$ de espesor refrentado de sillería que se construyó posteriormente para evitar su ruina, y cuatro cuerpos más de unos $5 \mathrm{~m}$ de altura el primero, segundo y último, y cerca de $6 \mathrm{~m}$ el tercero.... Corona el monumento alto chapitel, cubierto de tejas verdes y rojas, de bordes en escama que recibe veleta y cruz.

\section{CAUSAS EFICIENTES DE LA RUINA}

Las causas que han motivado el lamentable estado de descomposición en que se encuentran actualmente las fábricas del cuerpo de la iglesia, son:

$1^{\circ}$ Viciosa disposición mecánica de contrarrestos de la nave mayor

$2^{\circ}$ Defectuosa construcción material

$3^{\circ}$ Obras posteriores de reparación y reforma

$1^{\circ}$ El empuje resultante de cada haz de nervios de alta nave, contrarrestado por contrafuertes exteriores, cargando en falso sobre los riñones del respectivo arco transversal bajo, produjo las naturales consecuencias: depresión de la rama de este arco sometida a su acción; deformación de los arcos transversales altos, hundiéndose de corona y corriéndose en los riñones, según el movimiento de desplome de los contrafuertes; flexión de los pilares sometidos a presiones contrarias, no bien equilibradas y actuando en puntos situados a distintas alturas, y por fin desplome de los muros exteriores. En los siguientes fotograbados se acusan ostensiblemente las grandes deformaciones producidas en las nervaduras, que arrastran consigo la completa dislocación de las plementerías que reciben y la flexión de unos pilares y 
completa descomposición de otros. Las bóvedas de los ábsides de estructura, también articulada, integran sus presiones en los ángulos respectivos y son contrarrestadas por contrafuertes que arrancan del suelo. Su organismo general aparece mejor entendido especialmente en el ábside central.

$2^{\circ}$ Construcción material. Los materiales y la mano de obra son muy defectuosos, principalmente en la cimentación, en que la piedra arenisca empleada es de muy mala clase y el mortero escaso. En las exploraciones que ha practicado el digno arquitecto, director de las obras, D. Ricardo García Guereta, resulta, cual yo mismo tuve ocasión de comprobar en la visita oficial que hice el pasado verano, que las fundaciones del edificio descansan en un banco de cascajo de mediana consistencia con alguna veta de arena, en que apareció el agua por bajo de la capilla absidial del Evangelio. Que se multiplicaron de tal suerte los enterramientos, que, a falta de extensión superficial, se aumentó la profundidad, vaciando el banco de cascajo hasta el plomo mismo de los cimientos a unos dos metros de profundidad por bajo de éstos, con lo cual dicho banco, no encajonado, se va corriendo y aplastando paulatinamente, ocasionando el consiguiente descenso y agrietamiento de los pilares y la descomposición de las fábricas que sustentan. Los cimientos de la torre aparecieron también completamente sueltos, y los muros ofrecen varias quiebras, estando descompuesto el del costado E en su parte inferior.

$3^{\circ}$ Obras posteriores de reparación y reforma En el siglo XVI la iglesia se encontraba ya en tan desfavorables condiciones de estabilidad, que según un escritor coetáneo, "parecía que quería caerse". Entonces se aumentó la sección de algunos contrafuertes, se colocaron otros nuevos, se establecieron arbotantes para contener los empujes hacia afuera de los embovedamientos de la nave mayor, y se acodalaron los pilares de división de naves con muy rebajados arcos escarzanos, para neutralizar los empujes producidos al interior por los embovedamientos de las naves menores. Si bien estas obras contuvieron, por de pronto, los movimientos, no podían, en definitiva, producir el resultado apetecido, puesto que las cabezas de los arbotantes se hallaban muy por cima de la resultante de los empujes altos, según puede observarse en la referida sección transversal. En esta misma centuria se construyó el coro alto ya mencionado, y las poderosas y no bien contrarrestadas presiones oblicuas de su muy rebajado arco agravaron los daños. Posteriormente se abrieron huecos y se colocaron capillas que debilitaron las fábricas, y por último, se elevaron, tal vez en el siglo XVII, las cubiertas del edificio, haciéndolas descansar en toscos machos de fábrica de ladrillo y convirtiendo las bellas losas caladas de antepecho en absurdos ventiladores. Las nuevas armaduras se terminaron en piñón por el costado 
occidental, en vez de peto que tenía la antigua, cual lo justifica la cornisa subsistente. No han sido en verdad menos desafortunadas las obras de consolidación $\mathrm{y}$ de reforma efectuadas en la mencionada torre. En el mismo siglo XVI se ampararon sus tres fachadas de sillería $\mathrm{S}, \mathrm{O}$ y $\mathrm{N}$, no adosadas al templo, con un potente muro revestido de sillería de $2,30 \mathrm{~m}$ de espesor y $15 \mathrm{~m}$ de alto, ampliando para ello convenientemente los primitivos cimientos, y se rellenó de tierra, piedra y cascote esta parte del monumento. El nuevo muro de refuerzo si bien, por de pronto, contuvo los movimientos, resultó, en definitiva, pernicioso para las mismas fábricas que se pretendía conservar; pues simplemente adosado a ellas, al efectuar su natural asiento, se separó ostensiblemente de los antiguos muros, y penetrando las aguas llovedizas entre ambas fábricas, descomponen el mortero de la nueva obra, y lo que es peor, saturadas de humedad las de la parte superior, al ser atacadas por los hielos producen grandes quiebras que las dividen y descomponen.

\section{PLAN DE RESTAURACIÓN}

Declarado el edificio Monumento nacional... el arquitecto Antonio Bermejo en el año 1900 y parte del siguiente efectuó el derribo y reconstrucción del hastial O, atirantó el muro $\mathrm{N}$ y efectuó algunas obras de reparación. Fallece y se nombra a Vicente Lampérez que reconstruye el pórtico $\mathrm{N}$, no terminado por falta de fondos, $\mathrm{y}$ arma el andamio volado del chapitel de la torre. Tras su renuncia le reemplaza Ricardo García Guereta en 1908, que desescombra el interior de la torre para consolidar sus cimientos. Demuele la zona superior de la envolvente en una altura de $3 \mathrm{~m}$, construye un castillete circundante que cargando sobre el resto de la envolvente recibe en firme el andamio volado del chapitel. En su opinión deben conservarse los ábsides, especialmente el central, y la torre, y la galería románica norte. 



\section{Iglesia del Rosarillo}

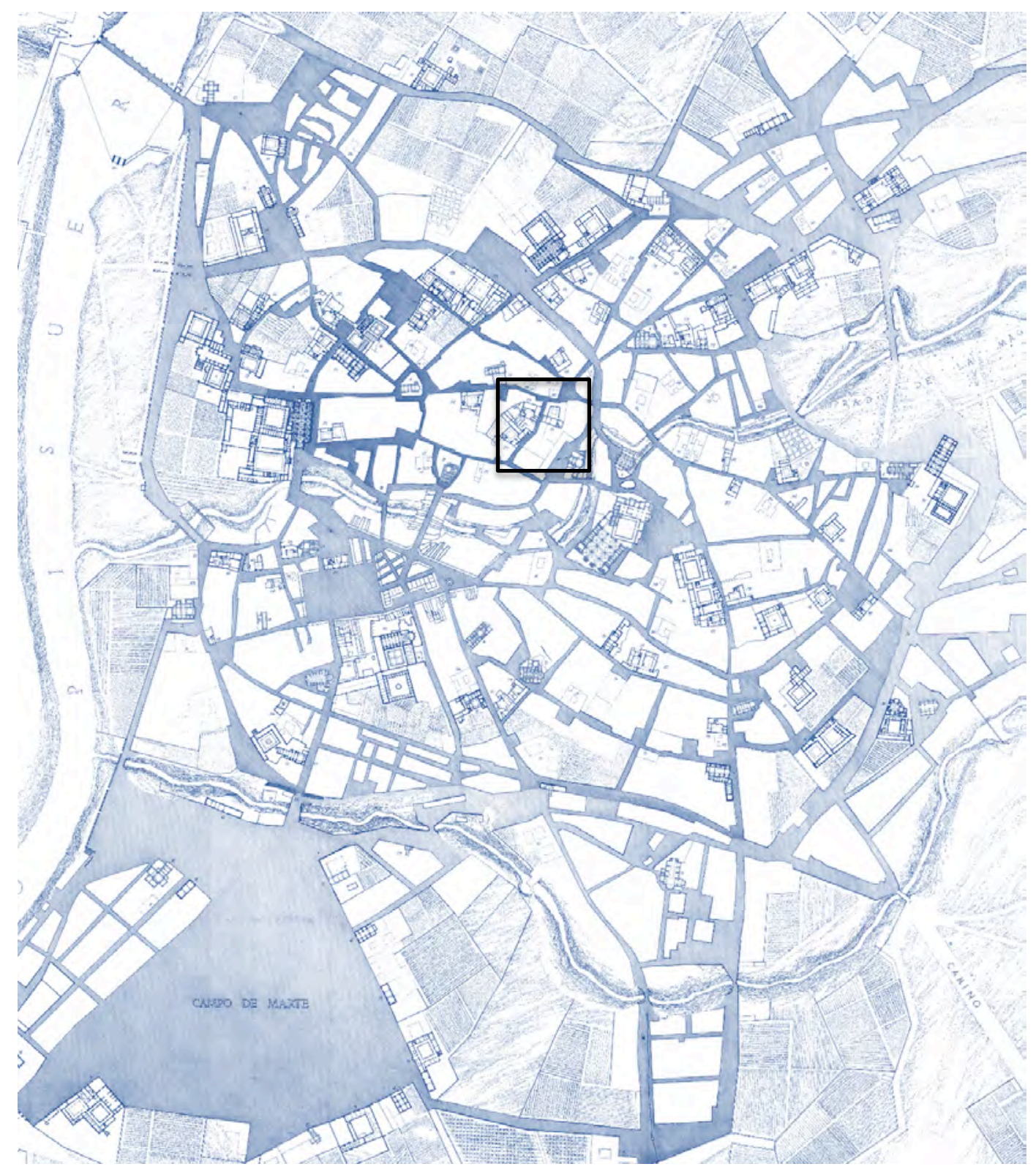



FICHA SÍNTESIS

\section{Código de identificación: FZ-12}

Denominación: Iglesia del Rosarillo

Localidad: $\quad$ Valladolid

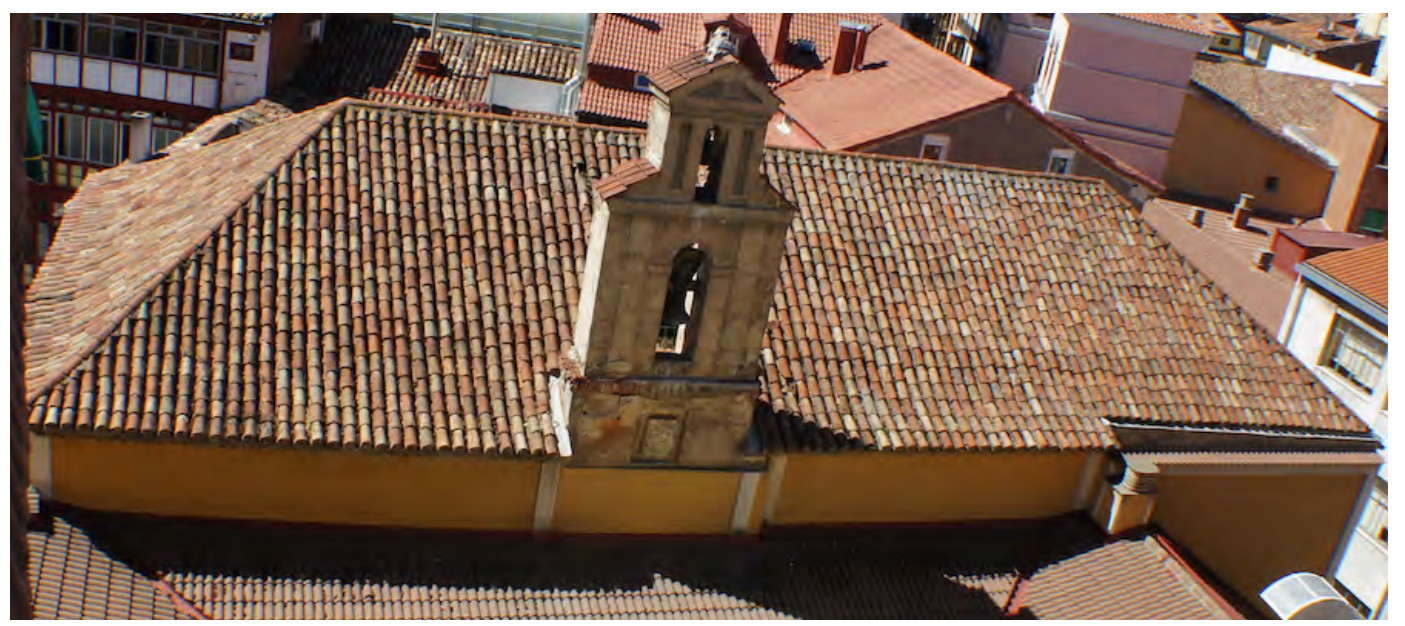

\section{Descripción}

Iglesia de una sola nave sin capillas, tipo cajón, con dos tramos cubiertos por bóveda de arista y capilla mayor cuadrada con cúpula.

\section{Materiales}

Los muros son de tapial, según la memoria de un proyecto de 1980. La cubierta está revestida de teja curva.

\section{Singularidades}

Iglesia originalmente asociada a un Hospital, y adquirida por la Corona en 1601 para convertirla en Capilla Real. Sólo la fachada, muy sencilla con tres ventanas y una puerta con frontón partido, se aprecia desde la calle. Actualmente se encuentra cerrada al culto.

\section{Dimensiones básicas del templo}

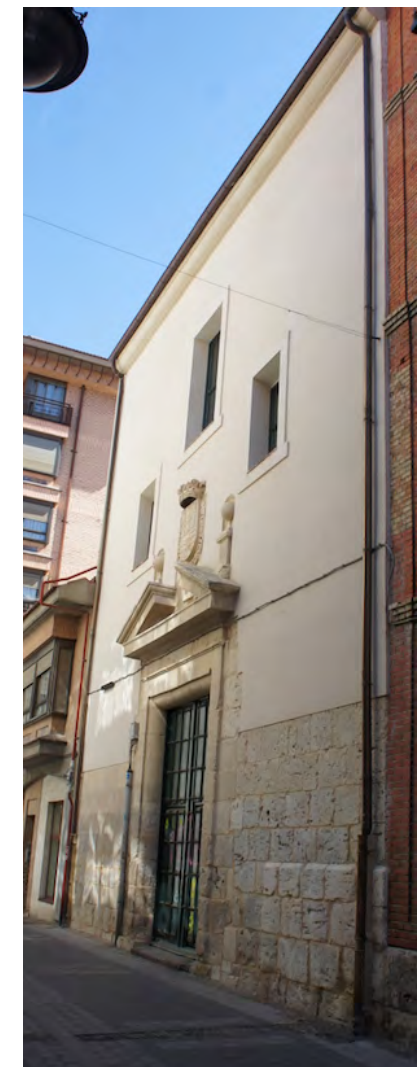

Ilustración 1: fachada visita 19/08/2015

$\begin{array}{llll} & \text { central } & \text { laterales } & \text { capillas } \\ \text { Ancho de nave } & 10,0 & - & \\ \text { Altura } & 12,5 & - & \end{array}$




\section{Memoria histórica constructiva}

Según el Catálogo:

La portada del Hospital (en la actualidad trasladada al edificio de enfrente) es el resto más antiguo, del último decenio del siglo XV. Juan de Nates da condiciones para el claustro en 1604 y también interviene en la iglesia.

\section{Cronología. Fechas clave}

$1499-1604-1980$

\section{Intervenciones}

1980 - Restauración - José Luis Iñiguez de Onzoño

Incorporación de zuncho de acero laminado HEB.

Reemplazo de la cubierta tras el hundimiento de grandes zonas. Se dispone una estructura de cerchas metálicas con correas IPN-100 cubiertas con placas onduladas de fibrocemento revestidas con mortero armado y revestimiento de teja.

- Rehabilitación de fachada - Jesús Manzano Pascual y Rosana Puyo Díaz

\section{Planos}

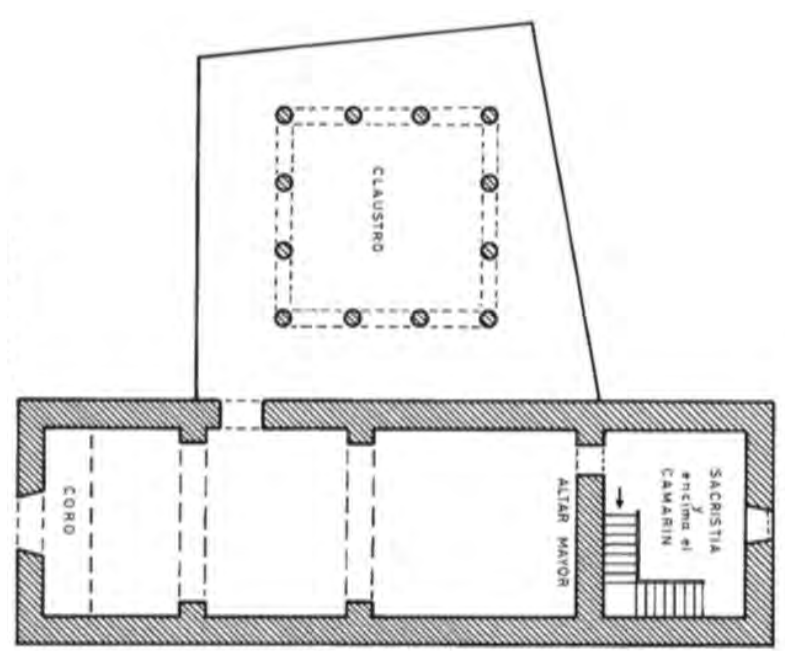

Ilustración 2: planta del Catálogo 


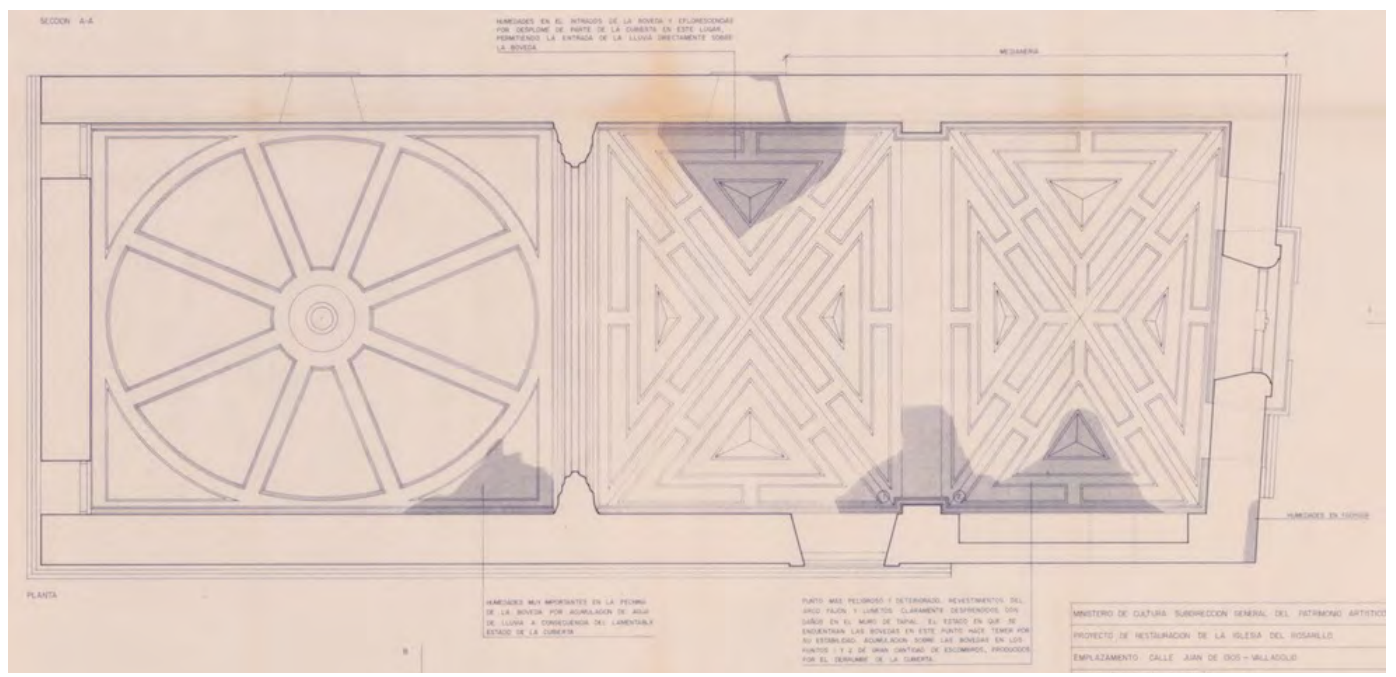

Ilustración 3: planta Rosarillo 1980 Iñiguez AGA

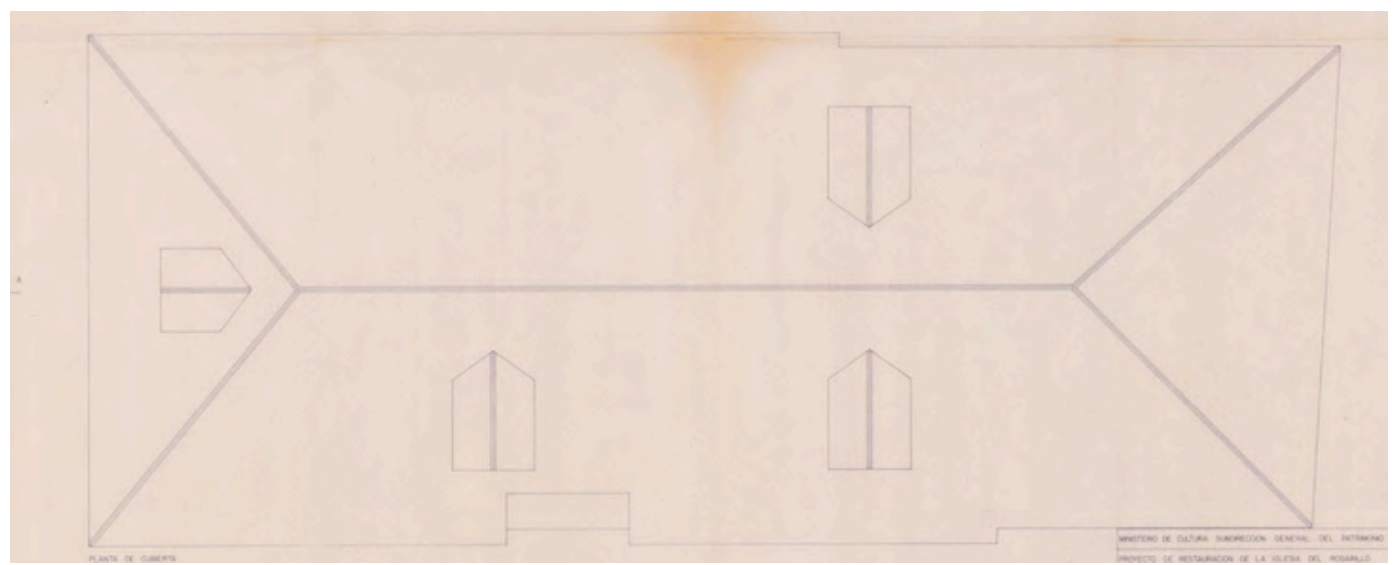

Ilustración 4: planta de cubiertas 1980 Iñiguez AGA

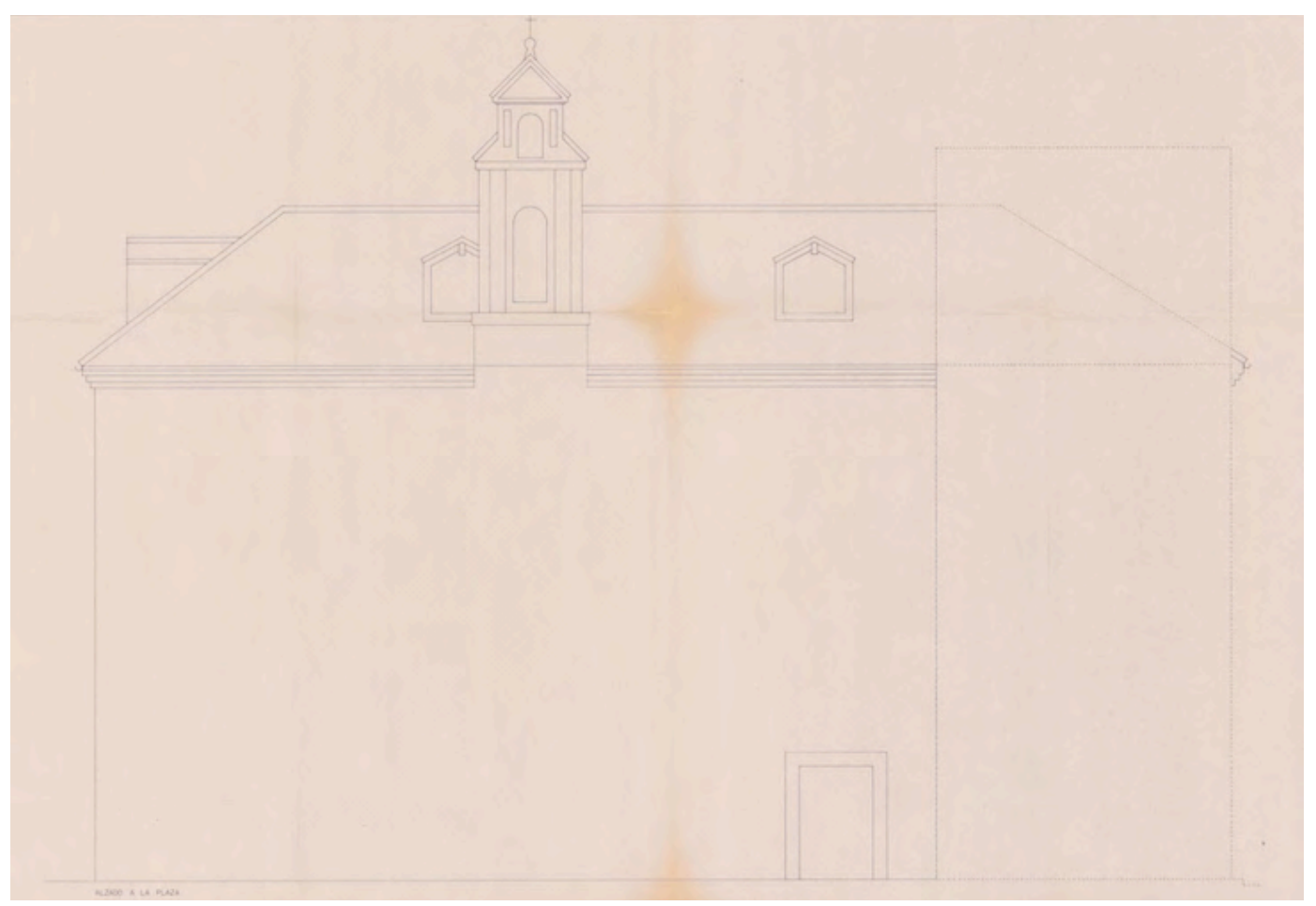

Ilustración 5: alzado lateral 1980 Iñiguez AGA 


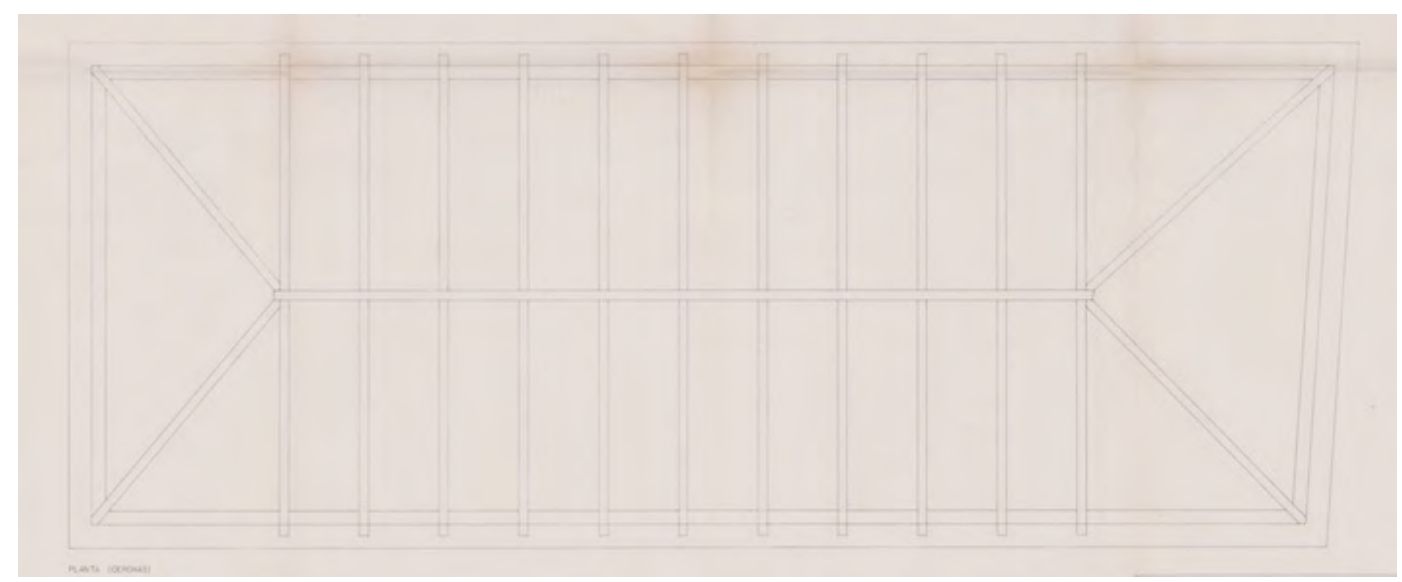

Ilustración 6: planta estructura cubierta actual 1980 Iñiguez AGA

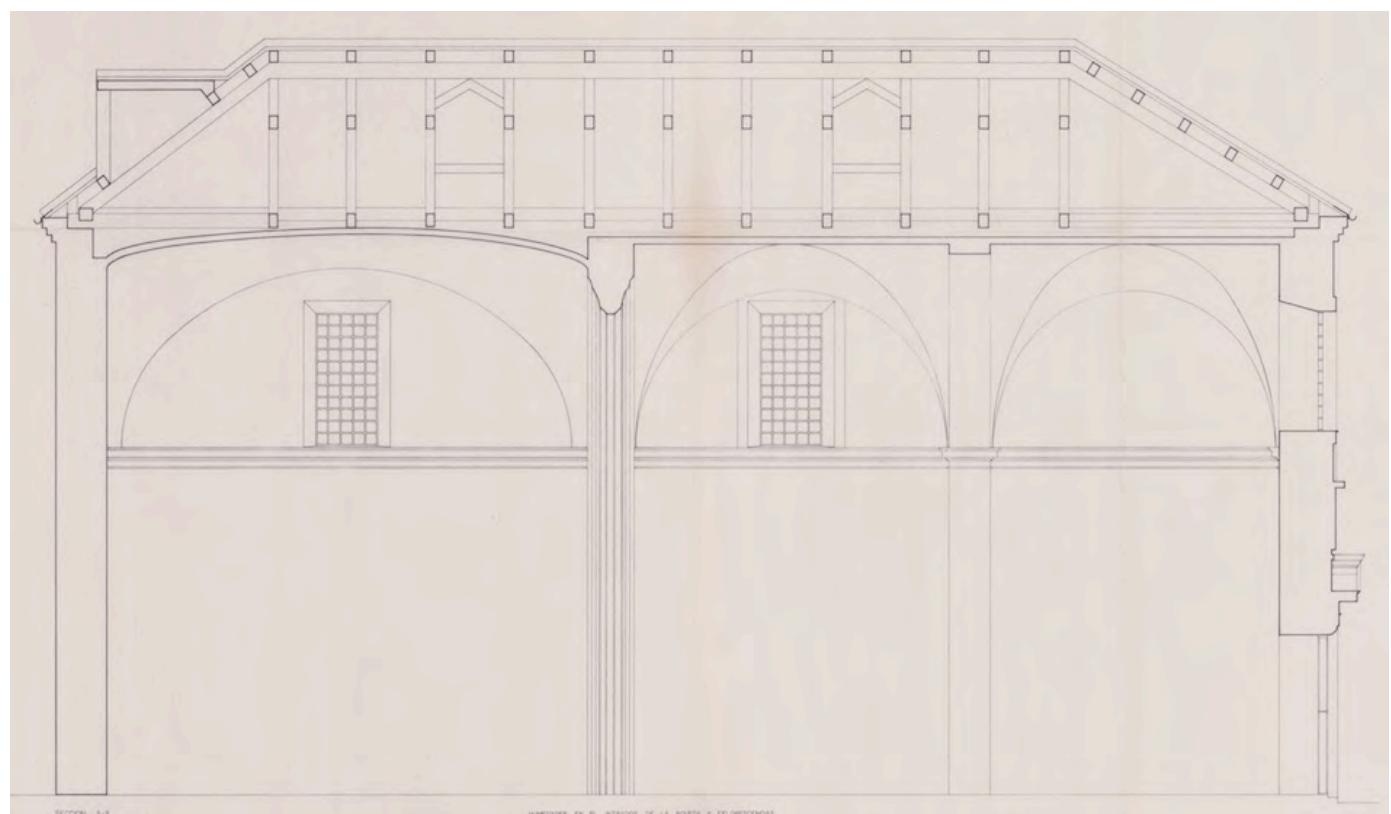

Ilustración 7: sección longitudinal 1980 Iñiguez AGA

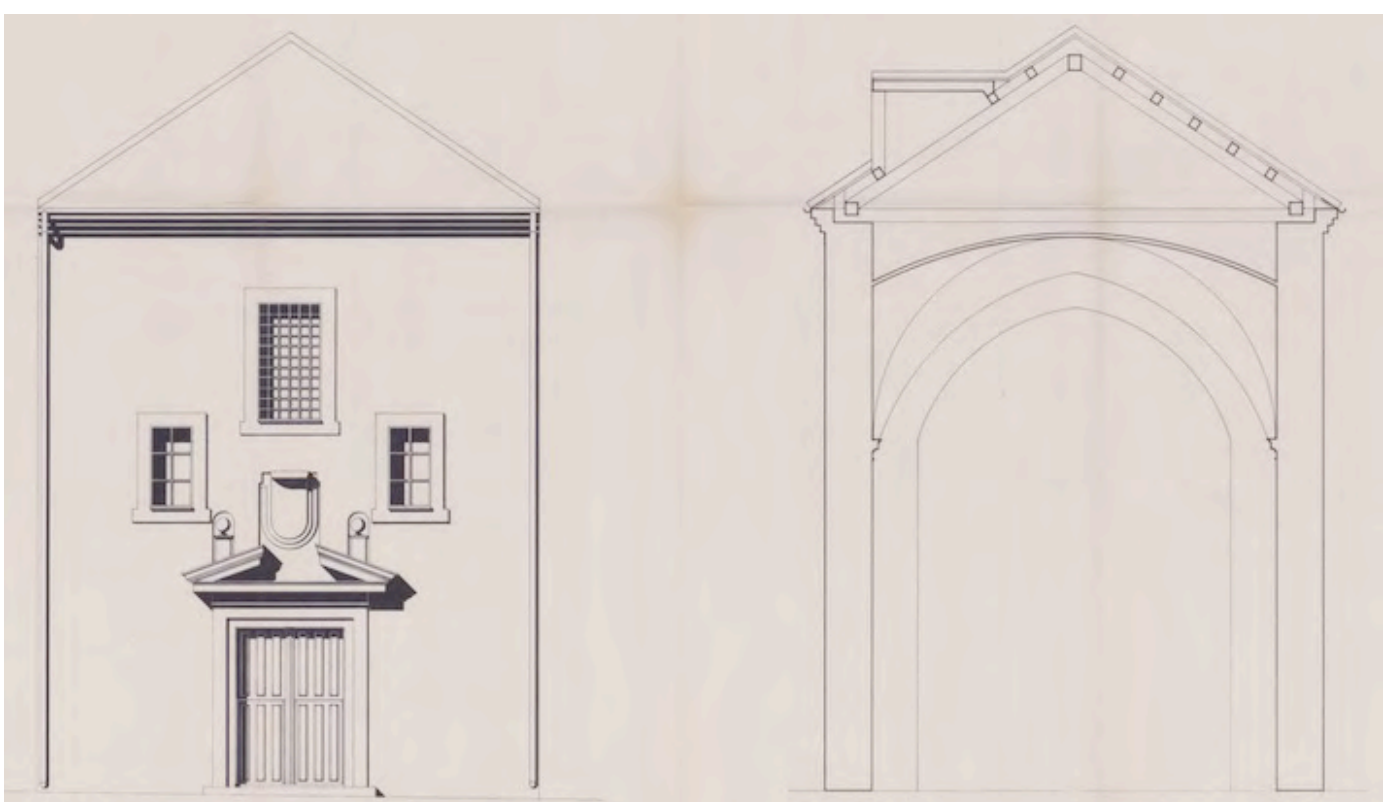

Ilustración 8: fachada y sección transversal actual 1980 Iñiguez AGA 


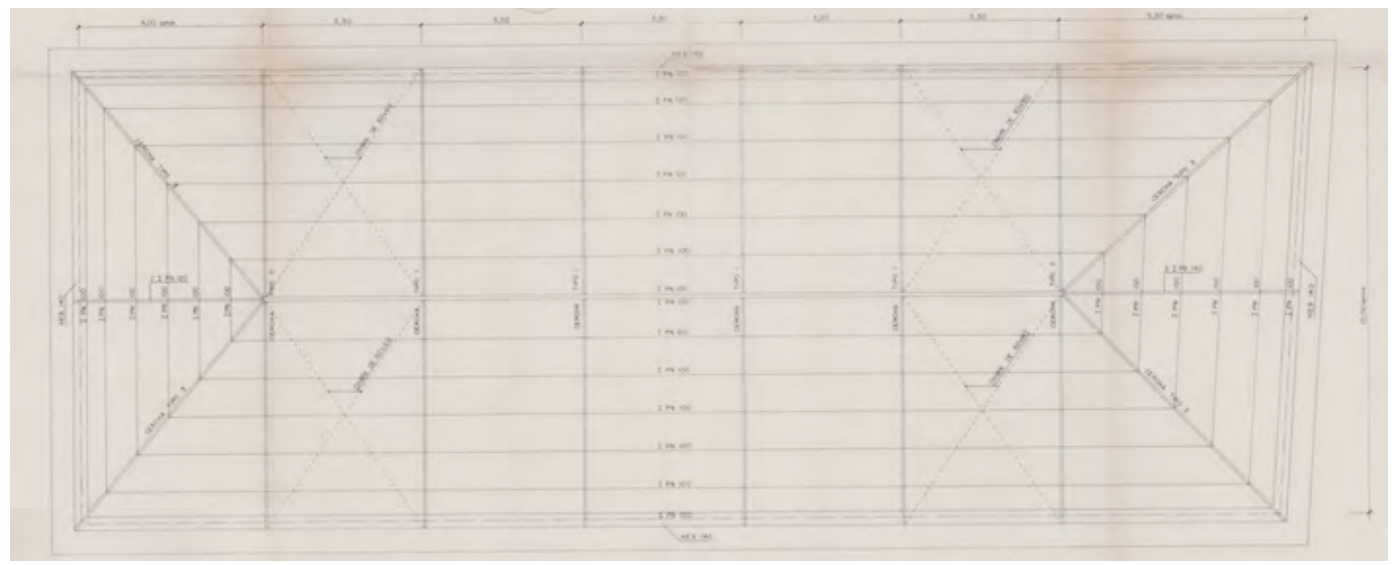

Ilustración 9: planta estructura nueva de cubierta 1980 Iñiguez AGA

\section{Solución constructiva de la cubierta}

En las secciones se aprecia una pendiente de unos $34^{\circ}$ y de $35^{\circ}$ en el detalle de cercha metálica que sustituye a las armaduras formadas con pares de perfiles angulares de acero laminado empresillados.

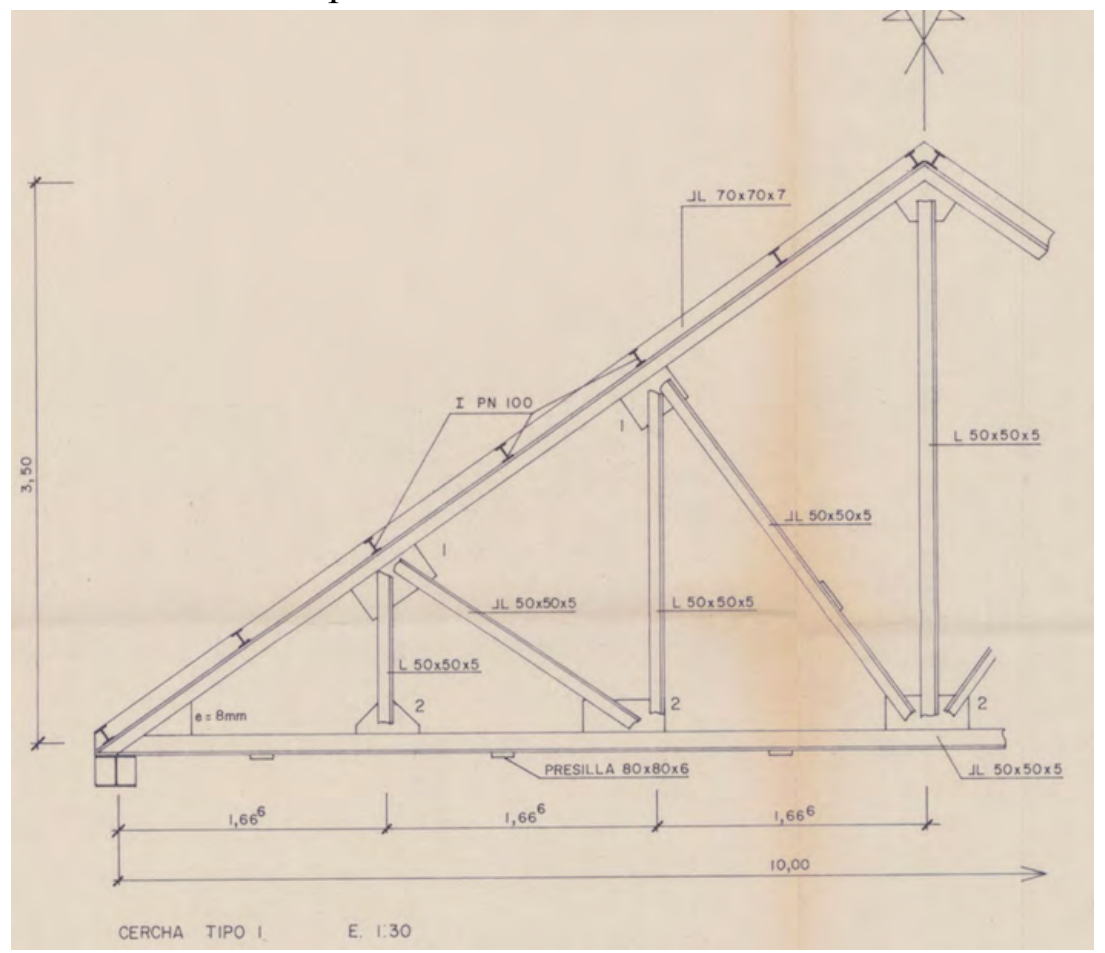

Ilustración 10: detalle de cercha 1980 Iñiguez AGA

\section{Zunchos}

En el plano de estructura se rotula que el apoyo de la cercha, fijo en un extremo y deslizante en el otro, se realiza sobre un perfil corrido tipo HEB como zuncho perimetral. 


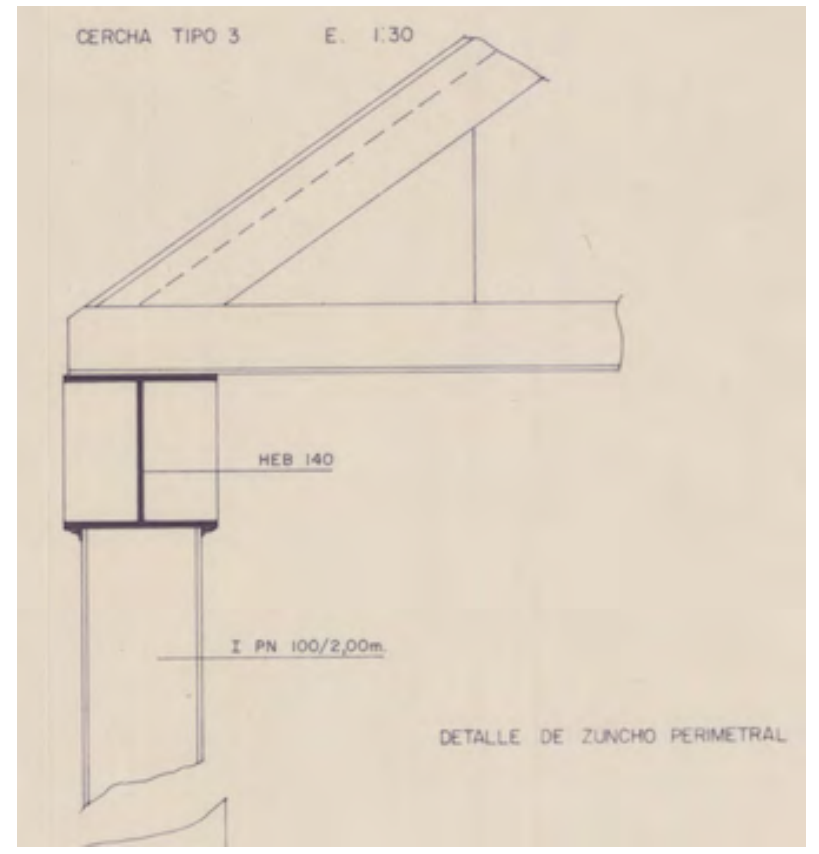

Ilustración 11: detalle 1980 Iñiguez AGA

\section{Conclusiones}

En este edificio se incorporó, según el proyecto de restauración de 1980, un zuncho perimetral de acero laminado HEB-140, anclado al muro mediante perfiles IPN-100 cada dos metros. 


\section{Iglesia del Rosarillo}

Intervenciones citadas en la publicación del Ministerio

1980 - Cubiertas - José L. Iñiguez de Onzoño

No se han localizado planos en la web del IPCE

\section{En el Archivo Municipal de Valladolid}

No se ha localizado documentación

\section{En el archivo de la Junta de Castilla y León}

No se ha localizado documentación

\section{En el Archivo General de la Administración}

AGA 26/1574

1980 - Proyecto de restauración de la iglesia del Rosarillo -José Luis Iñiguez de Onzoño

La cofradía de San Felipe Neri posee un completo archivo de documentación:

La cofradía de San Cosme y San Damián tenía un hospital y una ermita que cedió a los monjes de San Basilio en 1499 por habérseles arruinado la iglesia del otro lado del Pisuerga. Con un legado la reconstruyen (aunque los escudos no son de este benefactor)

En 1602 se une el hospital del rosario, se empieza a llamar el Rosarillo y en 1609 se construye la iglesia nueva en la calle San Juan de Dios.

En 1604 Juan de Nates construye el Claustro.

Como paso previo al comienzo de las obras se demuele ciertas construcciones modernas en las que está embebido.

Iglesia barroca del siglo XVII. Una nave cubierta de arista con yeserías y bóvedas vaídas en los brazos del crucero. Portada a los pies adintelada. 
La obra más urgente y necesaria es la reparación total de la cubierta por el estado de ruina en que se encuentra.

La mayor parte de los elementos resistentes de madera están en condiciones muy precarias.

Las armaduras de par, tirante y nudillo se encuentran rotas en un alto porcentaje y con reparaciones deficientes realizadas en diversas épocas (apeos con puntales de pares partidos, algunos pendolones metálicos, etc.)

La rotura y salida de su sitio de los pares, ha provocado hundimientos de grandes zonas y caídas de escombros sobre las bóvedas de ladrillo, especialmente en las zonas indicadas con sombreado en los planos de estado actual, y la aparición de humedades. Todo ello hace imposible el aprovechamiento de los elementos de cubierta, excepto quizás un $20 \%$ de las tejas.

Se propone con la mayor urgencia y con las debidas precauciones las siguientes obras de restauración y consolidación:

Obras de demolición

Desmontaje de tejas, entablado, pares y armaduras de cubierta. Para ello será preciso trocear (con sierra mecánica) las grandes piezas de la armadura que permita su manejo con la grúa y elimine el riesgo de impacto o carga sobre las delicadas bóvedas.

También será preciso limpiar de escombros las zonas sobrecargadas de las bóvedas, en especial los vacíos del extradós en los arranques o riñones. Todas estas operaciones se realizarán disponiendo protecciones sobre las bóvedas, que apoyan sobre los arcos fajones.

Constituida por cerchas metálicas de perfiles normales laminados apoyadas en un zuncho perimetral de perfil Grey HEB 140 anclado al muro mediante perfiles IPN 100 cada 2 mts. Sobre ellas se dispondrán correas I IPN 100 situadas a distancias entre sí, de $1 \mathrm{mt}$. con objeto de recibir sobre ellas placas de fibrocemento.

Material de cubierta:

Placas de fibrocemento fijadas a las correas, con gancho galvanizado. Sobre ellas se construirá un entramado reticular de redondo D8 revestido de mortero de cemento que sirve a su vez para el recibido de algunas tejas. Estas se sujetarán entre sí mediante ganchos especiales galvanizados para evitar el deslizamiento.

Recogida de las aguas

Se dispondrá un canalón de plancha de zinc de 14 y sección semicircular... 
Ventilación de la cámara de cubierta

Por medio de beatas, para evitar en lo posible dilataciones y empujes. Se dispondrá también un registro practicable de entrada a la cámara accesible desde la cubierta del claustro contiguo.

Obras pendientes para una ulterior fase de cara a una total restauración... restauración de yesos y pinturas.

Madrid a Julio de 1980.

Cálculos a mano

Fotocopias de 8 fotografías. Se ven vigas partidas, cascotes derrumbados y goteras.

\section{Mediciones}

396m2 de levantado de cubierta de teja árabe, tabla ripia, desmantelado de correas de madera,...

$80 \mathrm{ml}$ cajeado perimetral en muros de coronación y asiento de cerchas, de 30x30cms., con saneado de cabeza de madera y regulación de paramentos con mortero de cemento, para posterior asiento de viga GREY de zuncho perimetral. $2 \times 28+2 \times 12$

lud limpieza de bóvedas

4ud desmantelado de huecos de buhardillas con teja, tabla, ripia, correas, armaduras, bajada de materiales, transporte de escombros a vertedero

13 ud placa de anclaje...

$11.980 \mathrm{~kg}$ de hierro colocado en estructura de cubierta

placas de fibrocemento, teja curva, canalón,

6 ud beatas de zinc pintadas a tono de teja

1 ud tronera de acceso a cámara de cubierta, con demolición de muro, cargaderos metálicos, reja practicable con tela metálica tupida, con pintura, totalmente terminada con herrajes de cuelgue y seguridad

Planos (se solicitan copias)

Situación 1:1000

Estado actual, planta y sección 1/50

Sección longitudinal y patología de bóvedas

Planta de cubierta (con 4 buhardillas)

Estructura de cubierta y detalles. (Sólo rotula zuncho perimetral en el detalle de apoyo de la cercha sobre los HEB140) 
AGA 26/00835

Restauración, honorarios

1980 José Luis Iñiguez de Onzoño

Documentación administrativa:

Pagos a Construcciones NORTE SA

Copia del mismo Proyecto de 26/01574 


\section{Iglesia de EI Salvador}

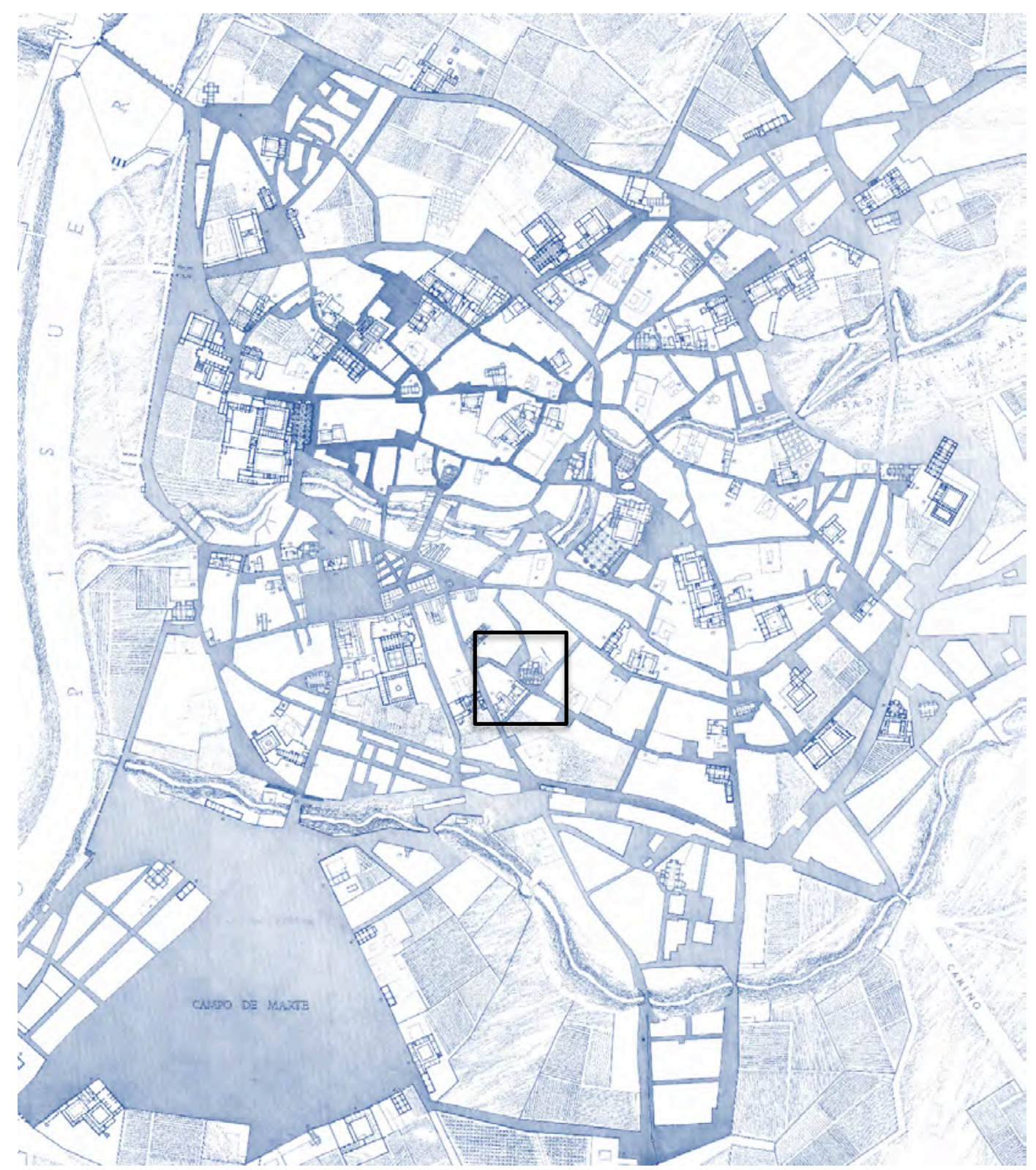





\section{FICHA SÍNTESIS}

\section{Código de identificación: FZ-13}

Denominación: Iglesia de El Salvador

Localidad: $\quad$ Valladolid

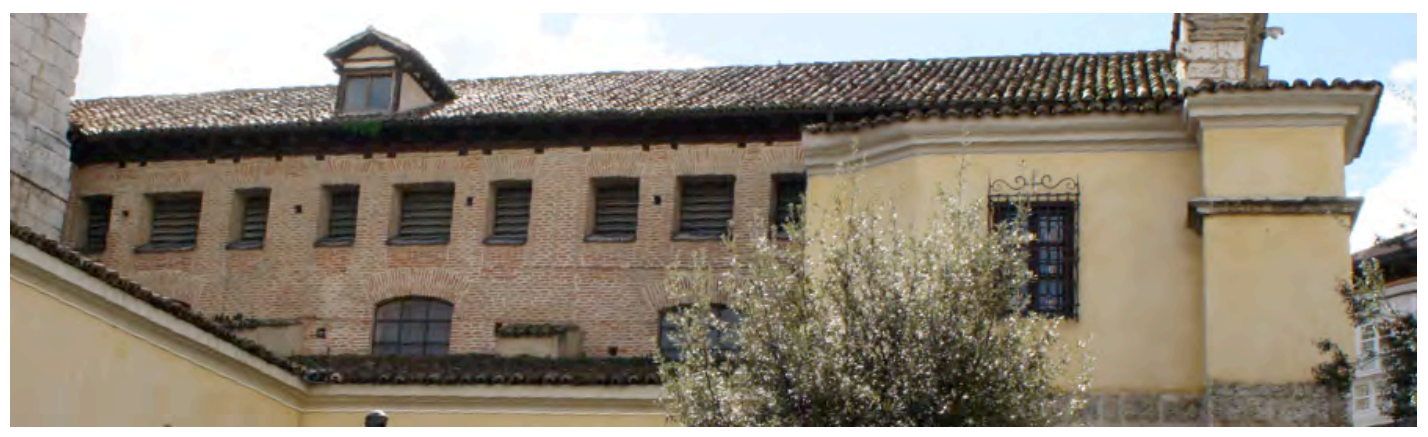

\section{Descripción}

Iglesia de una sola nave, con gran desarrollo de capillas abiertas entre contrafuertes y otras construcciones adosadas, incluso envolviendo la torre, que se ubica en el lado del Evangelio junto al tramo anterior a la cabecera. La nave se cubre con bóveda de cañón apuntado con lunetos, mientras que cabecera y algunas capillas cuentan con bóvedas de crucería estrellada. En el interior hay una característica galería de madera que recorre ambas impostas laterales.

\section{Materiales}

La portada, el ábside y la capilla junto al mismo (4 sobre la planta) están edificados con sillería de piedra, mientras que los muros laterales de la nave son de fábrica de ladrillo visto. Encontramos sillería en el arranque de algunas capillas y los primeros cuerpos de la torre, de planta cuadrada. El remate octogonal de la torre también se resuelve con ladrillo.

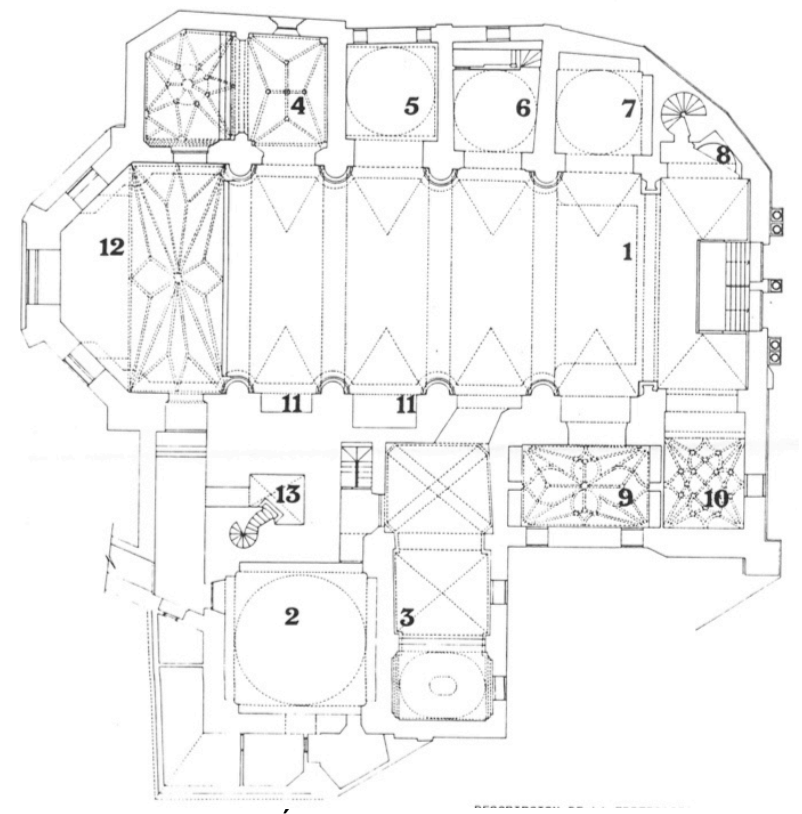

Ilustración 1: 1999 Álvaro Abad JCyL VA-199

Las cubiertas están revestidas de teja curva y cuentan con un alero de madera. 


\section{Singularidades}

El edificio presenta una portada con dos puertas, dos óculos y un remate con balaustrada.

En el costado junto a la torre se ubica la capilla de San Pedro Regalado, que se desarrolla con tres tramos en perpendicular al cuerpo del templo. El contraste de materiales y geometría de la torre son elementos característicos de la ciudad. En el inédito catálogo de Casaseca se afirma sobre El Salvador que el interior del templo es "de ningún interés".

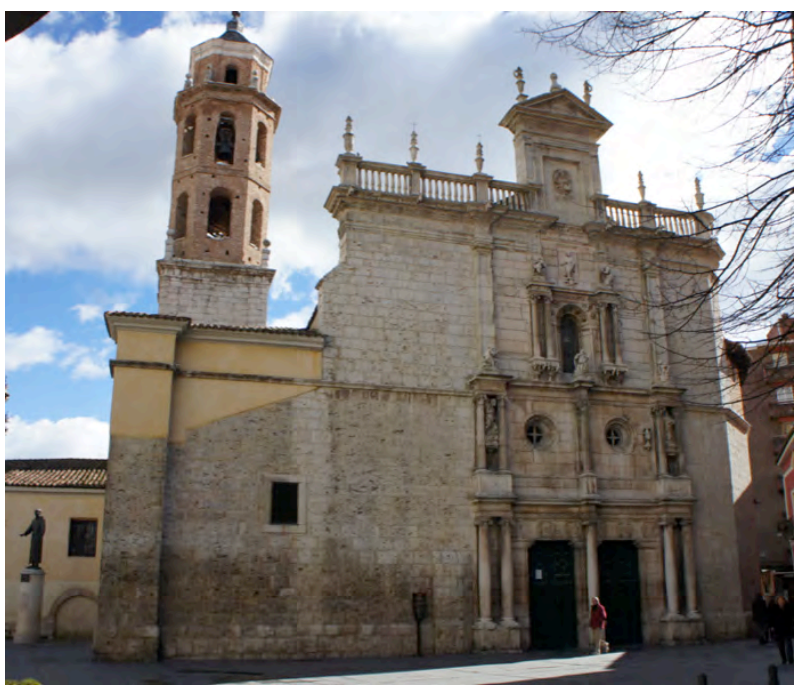

Ilustración 2: portada a los pies (visita 21/02/2015)

\section{Dimensiones básicas del templo}

$\begin{array}{llll} & \text { central } & \text { laterales } & \text { capillas } \\ \text { Ancho de nave } & 12,2 & - & \text { variables } \\ \text { Altura } & 14,0 & & \end{array}$

\section{Memoria histórica constructiva}

Según el Catálogo:

Lo más antiguo debe ser la capilla de San Juan Bautista, que se finaliza en 1487, según la inscripción en el friso de la misma. La portada, del foco clasicista, es obra de Juan de Escalante y se levanta entre 1541 y 1559.

Bartolomé de la Calzada reforma en 1606 la torre que, tras desplomarse arruinando las capillas adyacentes, se reconstruye hacia 1720, colocándose el chapitel ochavado revestido de pizarra actual.

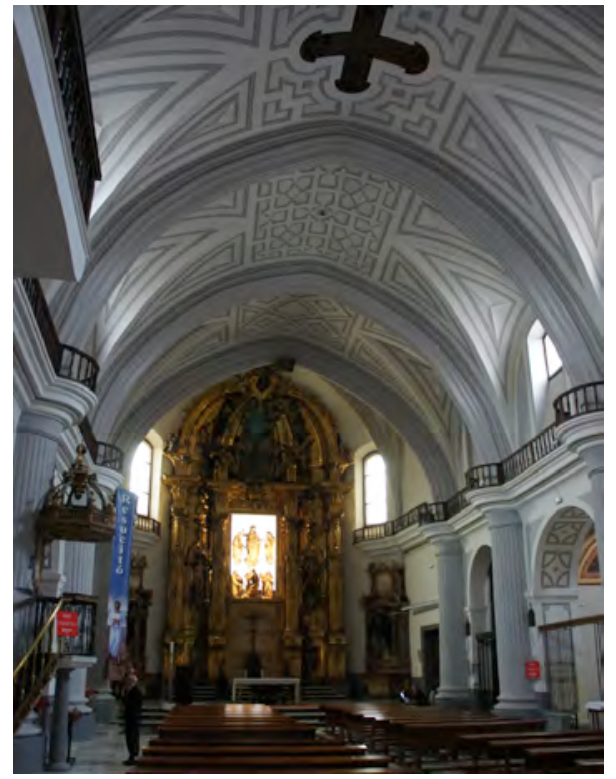

Ilustración 3: interior (visita 03/05/2015) 
A mediados del siglo XVII se reforma las bóvedas, que reemplazan a la estructura original de madera sobre arcos diafragma de piedra. La sacristía actual ( 2 sobre la planta) se construye en 1722 .

En la Memoria del proyecto de la última actuación sobre la iglesia se recoge una hipótesis de proceso constructivo según la cual las bóvedas corresponden a la segunda mitad del XVI. En ella se afirma que durante la construcción de la iglesia se incrementa la altura sobre la marcha y se levanta un grueso muro sobre el arco piñón toral.

\section{Cronología. Fechas clave}

$1487-1875-1999-2006$

\section{Intervenciones}

1968 - Cubiertas, limpieza interior y pavimentación capilla de San Juan Bautista Anselmo Arenillas

1979 - Portada principal - Luis Alberto Mingo

En la memoria afirma que la bóveda de crucería estrellada de la capilla mayor es decorativa, ya que los nervios no trabajan. Limpieza general de paramentos de la portada de sillería e impermeabilización de cornisas.

1999 - Restauración - Álvaro Abad Cabrera

Reforma la estructura de cubierta de madera por encontrarse en mal estado. Reordena durmientes, cuchillos y correas colocando menor número pero de mayores dimensiones. Rehace los aleros con canecillos de madera, excepto algunos de piedra.

Se reordena el volumen del conjunto eliminando algunas construcciones añadidas, como la caseta cubierta con un forjado de vigueta y bovedilla inclinado que se aprecia en la fotografía.

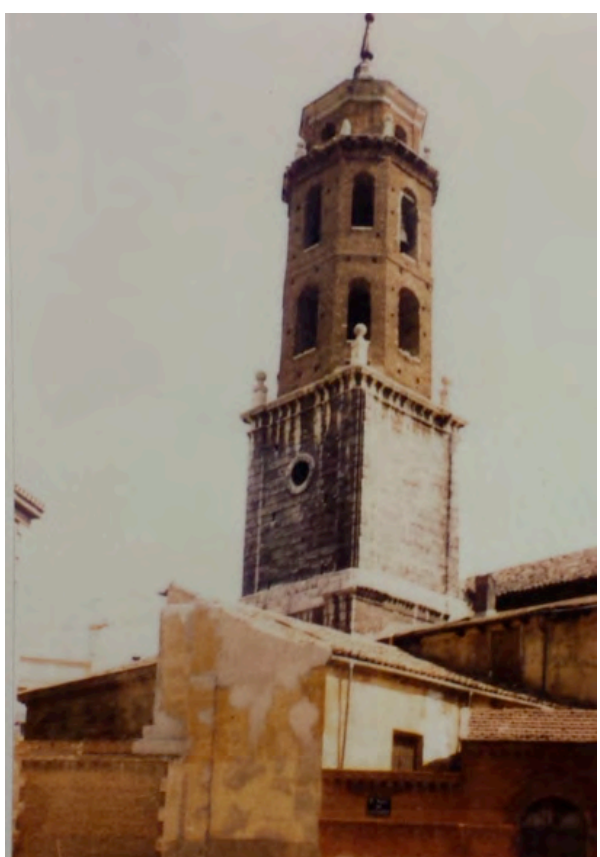

Ilustración 4: fotografía de estado actual en el proyecto de Abad 1997 
Sanea el remate de los muros, demoliendo $75 \mathrm{~cm}$ y rehaciéndolo con ladrillo de tejar (según el presupuesto con aprovechamiento de materiales), para "afianzar las hiladas superiores de los muros".

Los extremos de 10 tirantes se reconstruyen con madera nueva conectada con varillas de fibra de vidrio adheridas con epoxi. No se mencionan zunchos de ningún tipo en los documentos.
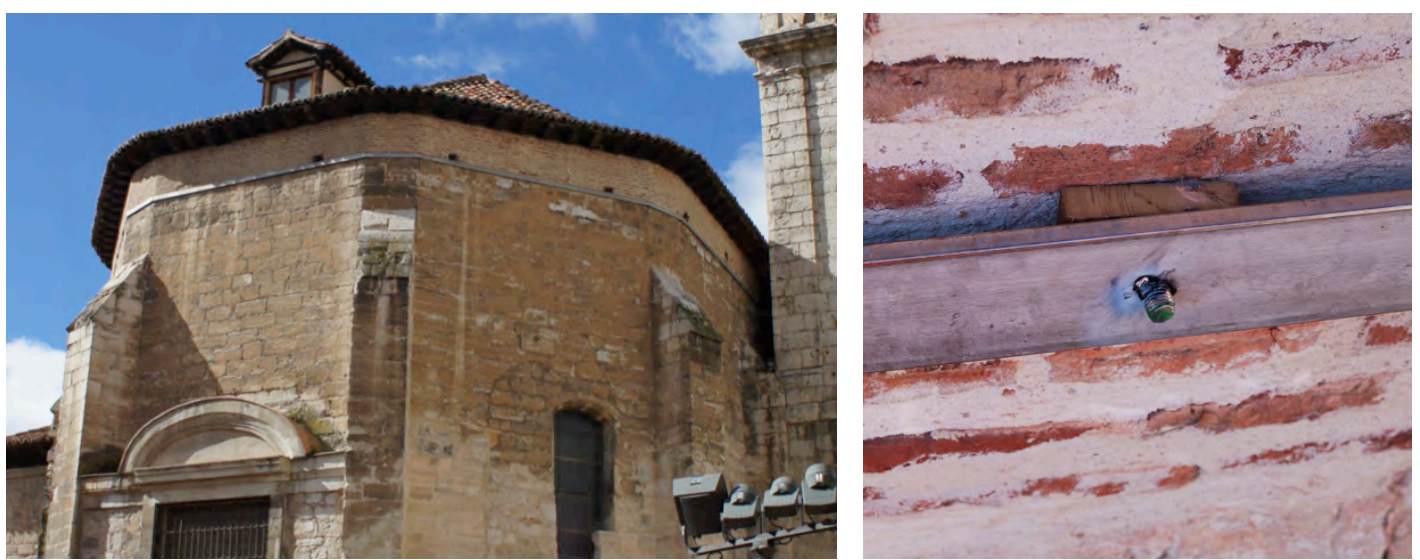

llustración 5: cincha exterior de cabecera (visita 21/03/2015) y detalle (González 2006 Fundación)

2006 - Restauración de capilla de San Juan Bautista - Eduardo González Fraile Aunque el título del proyecto sólo hace referencia a la capilla adyacente, la intervención alcanza la cubierta sobre la cabecera del templo. Para resolver un problema estructural del muro entre ambos espacios se zuncha perimetralmente en coronación (en el cambio de material de sillería a fábrica de ladrillo) ambos volúmenes, atirantándolos mediante una estructura de celosía metálica a la que denominan "brida" por el interior del bajocubierta sobre el presbiterio.

Las platabandas que zunchan la cabecera por el exterior se acuñan, dejando espacio hasta el paramento para no provocar escorrentías. En la capilla, el zuncho consiste en un perfil laminado UPN anclado por la cara interior y triangulado espacialmente.

2008 - Reparación de cubiertas de la iglesia Juan Antonio Huidobro Piriz

No se cuenta con documentación de este proyecto.

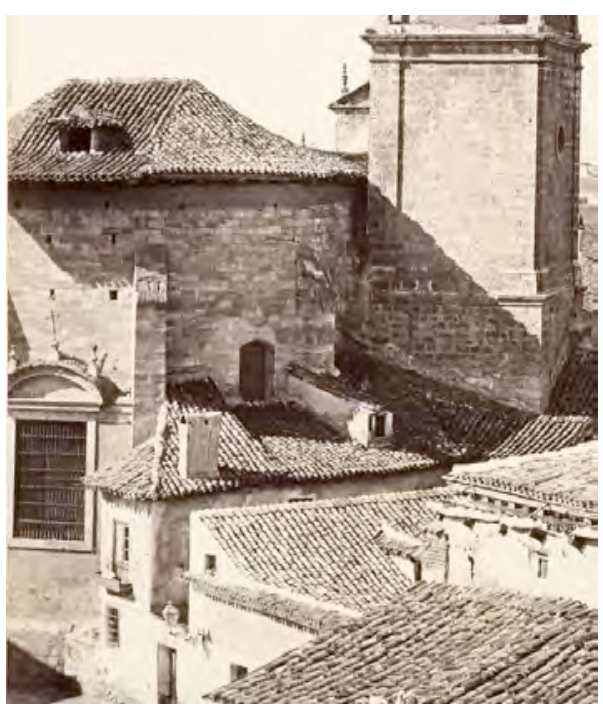

Ilustración 6: fotografía 1864 Muriel BNE 


\section{Planos}

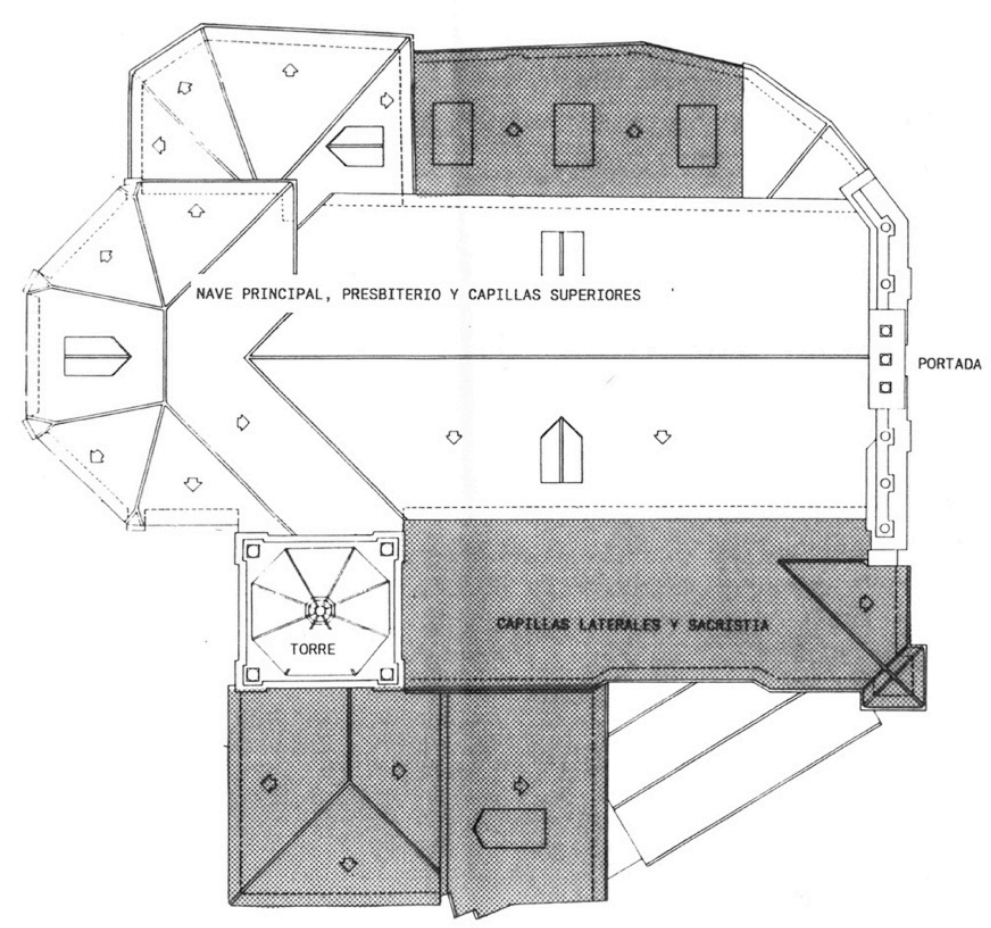

llustración 7: planta de cubiertas Abad 1999 JCyL
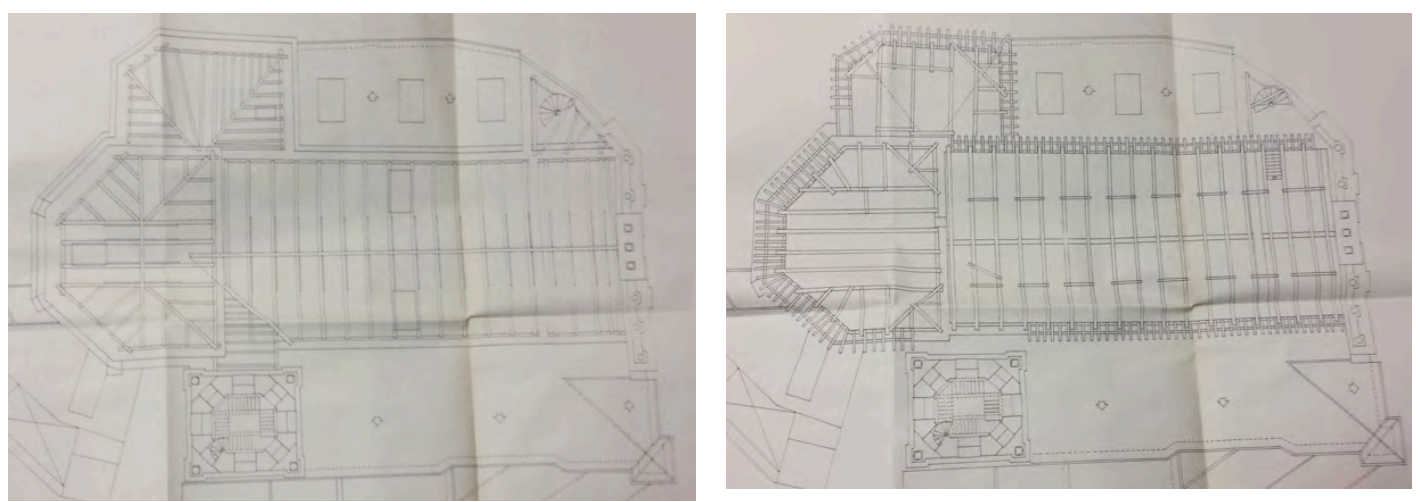

Ilustración 8: planta estructura de cubierta estado actual 1999

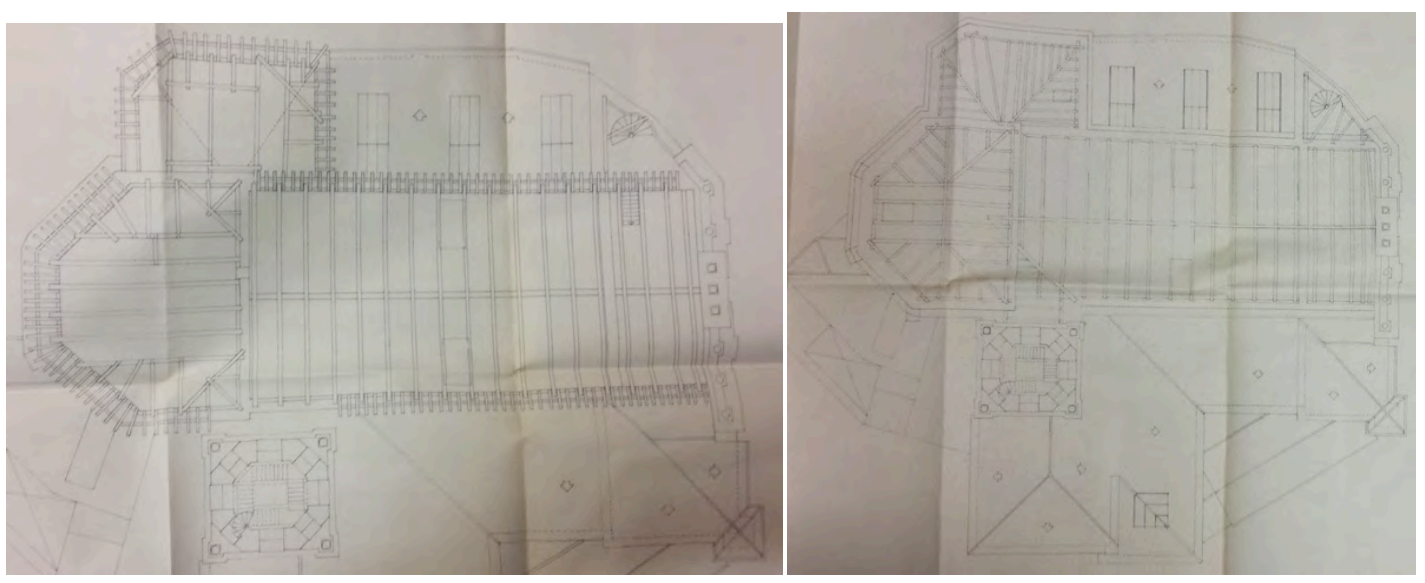

llustración 9: planta estructura de cubierta estado reformado 1999 


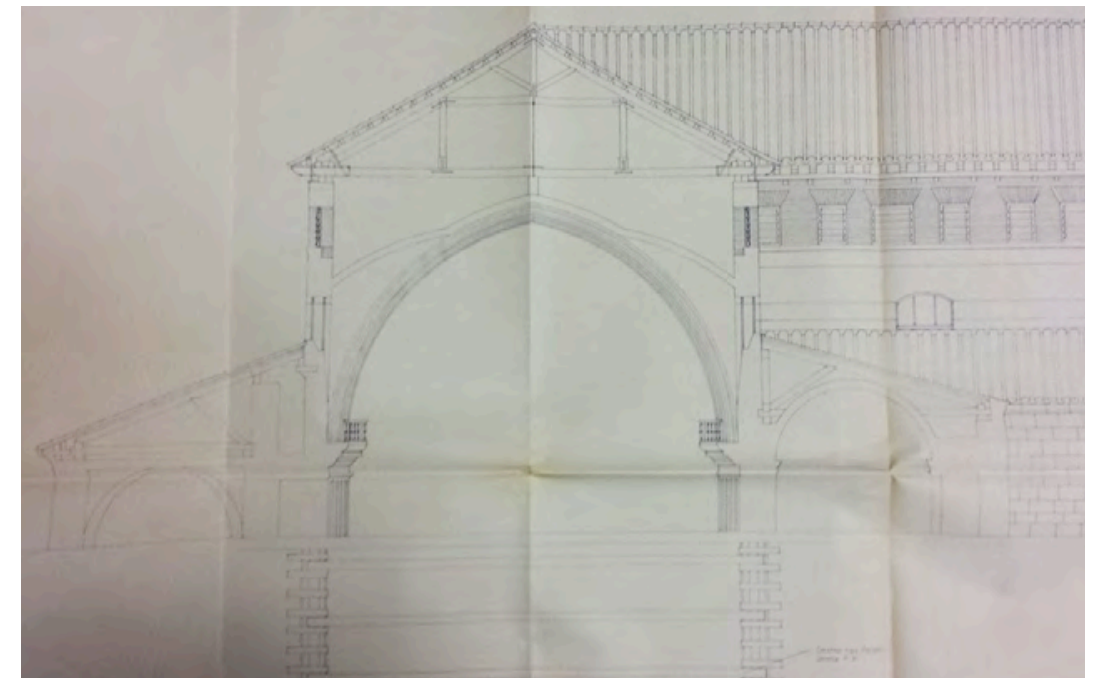

Ilustración 7: sección transversal estado reformado 1999

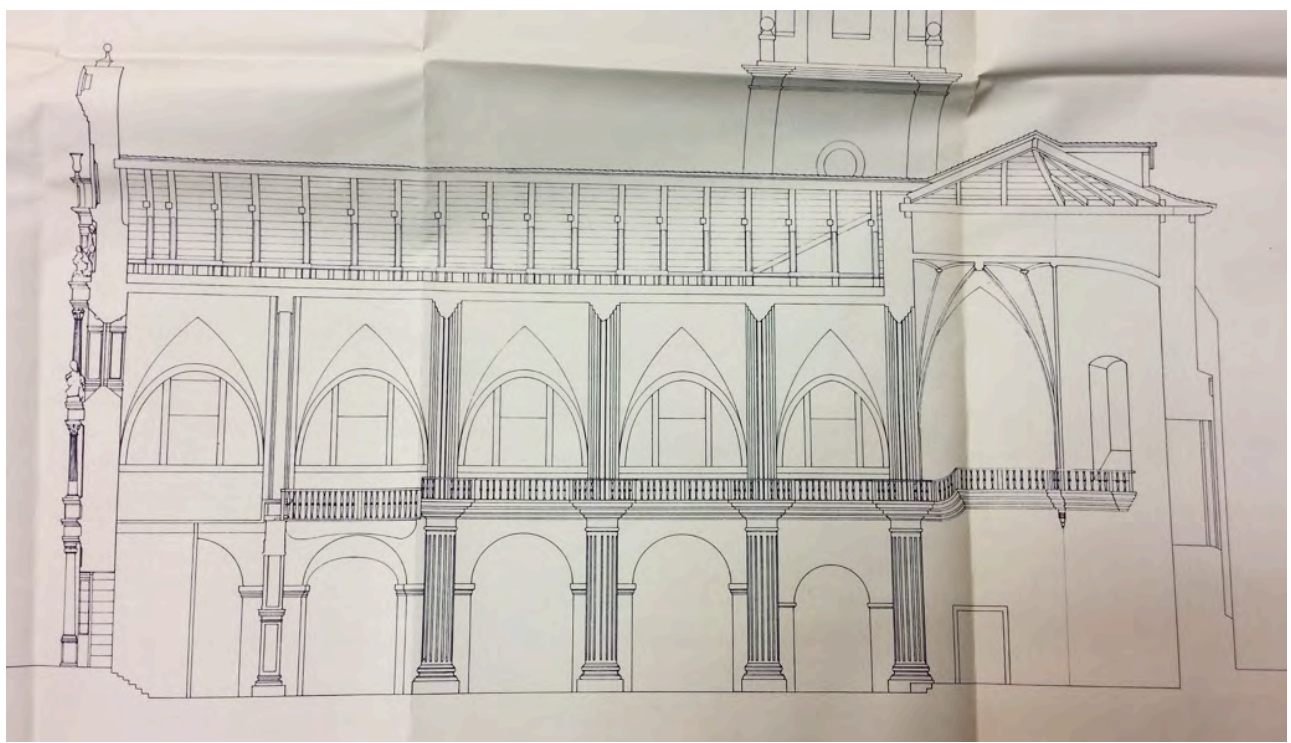

Ilustración 8: sección longitudinal del templo 1999

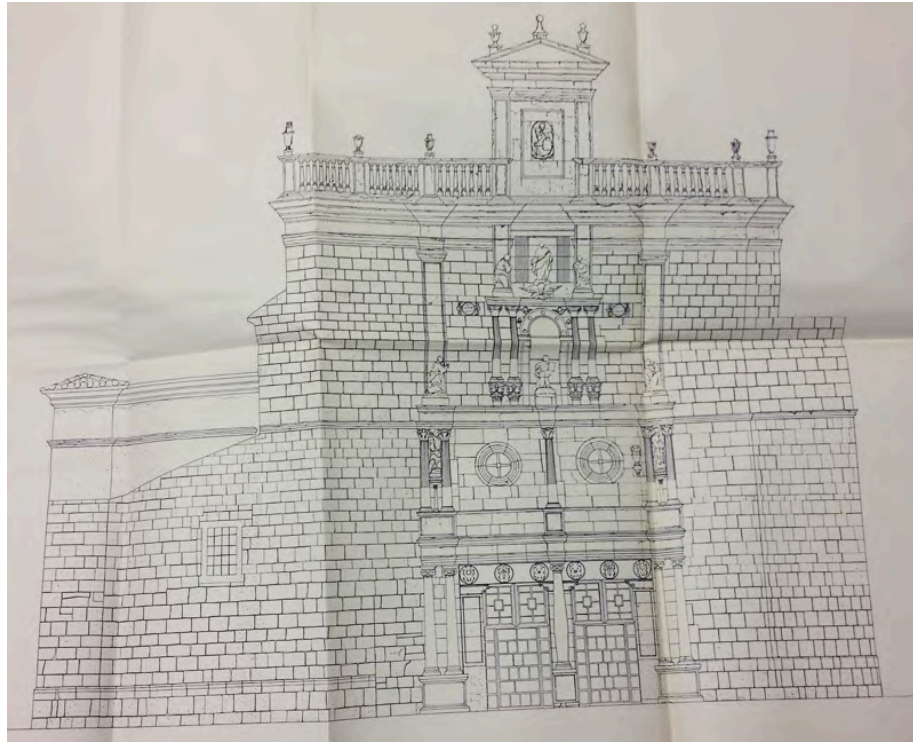

Ilustración 12: fachada a los pies 1999 

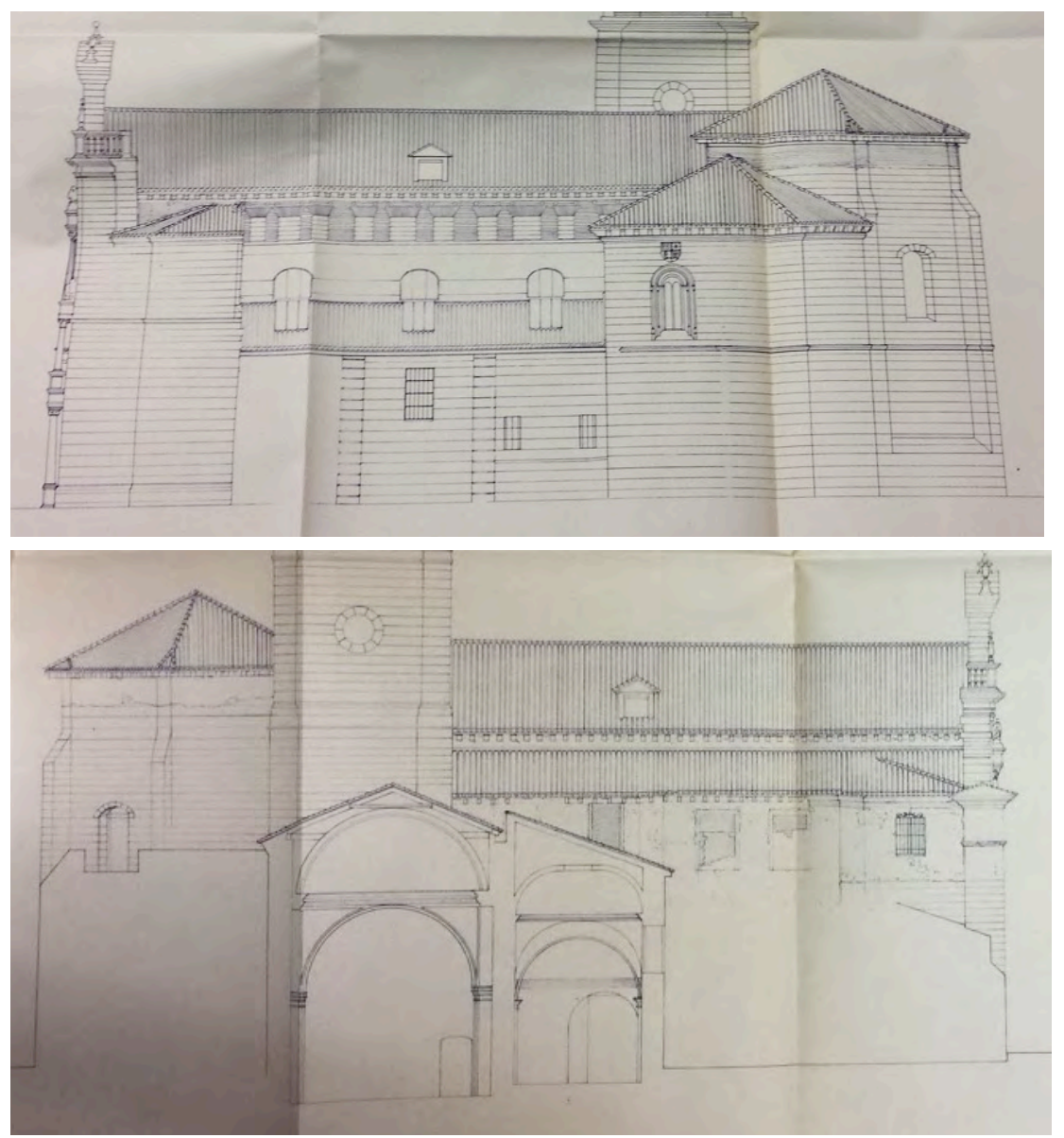

Ilustración 9: alzados laterales 1999

\section{Solución constructiva de la cubierta}

En las siguientes secciones de estado actual y estado reformado de 1999 se aprecia cómo se mantiene el perfil original de la cubierta de la nave.
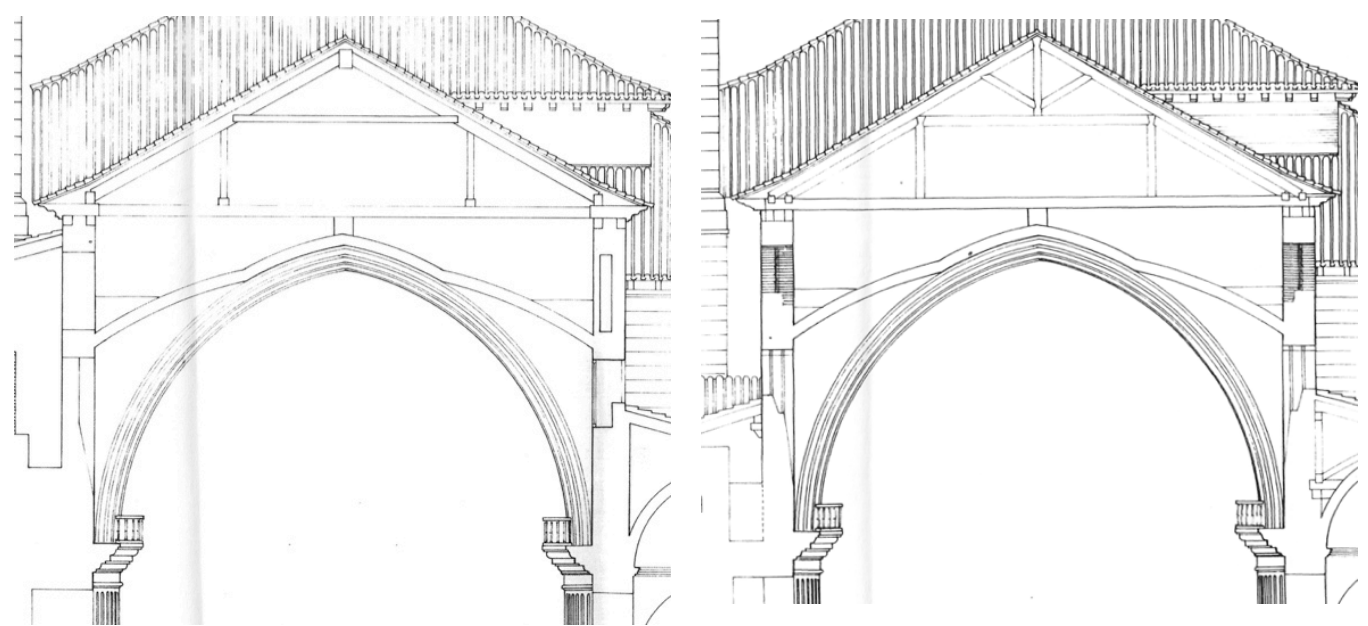

Ilustración 14: sección transversal Abad 1999 JCyL 
Se conservan los tirantes, reemplazando los extremos podridos con madera nueva y modificando el diseño de la estructura y sus encuentros.
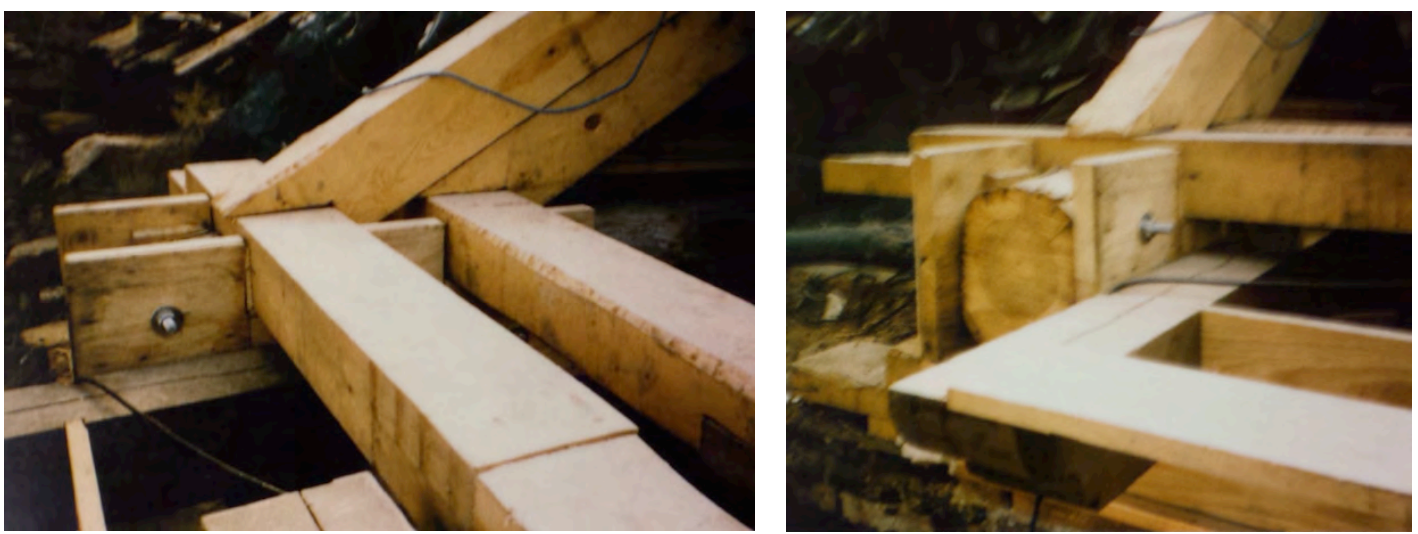

Ilustración 15: fotografías del proyecto de 1999 Abad JCyL

La nueva cercha se define como "cuchillo tipo Palladio de pino del país con pendiente $30^{\circ}$ para $200 \mathrm{~kg} / \mathrm{m} 2$ de sobrecarga formado por pares, tirantes, jabalcones y pendolón, tirantillas $12 \mathrm{~mm}$ de hierro, aprovechando los tirantes existentes".

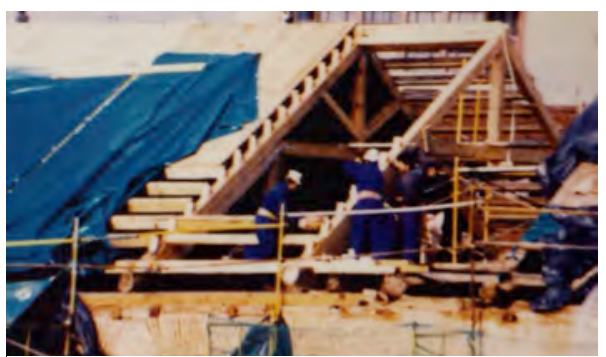

Describe unos aleros de piedra, otros resueltos con ladrillo aplantillado y, la mayor parte, ejecutados con canecillos y tablas de madera.

llustración 16: obra 1999 Abad JCyL

En las fotografías siguientes, también tomadas del dossier del proyecto de Abad, se aprecia las diferencias entre la estructura existente y la ejecutada en la intervención de 1999.
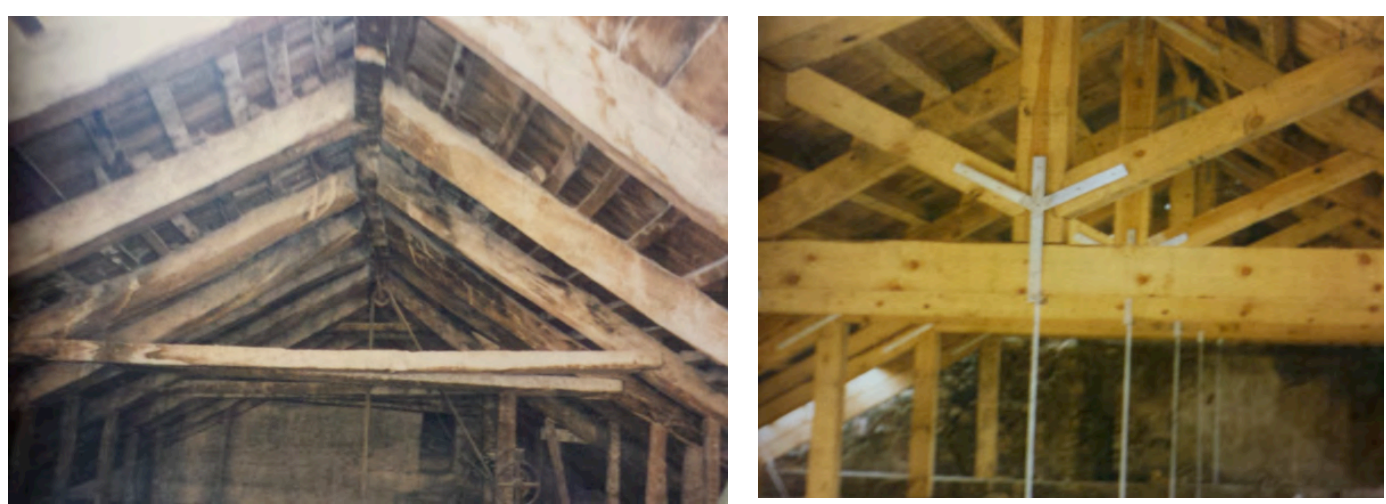

Ilustración 17: empalmes de cerchas antes y después de 1999 Abad JCyL

En la sección siguiente se representa la enorme "brida" metálica introducida sobre el presbiterio en 2006 para evitar la transmisión de empujes del muro diafragma triunfal a la capilla de San Juan Bautista adyacente. 


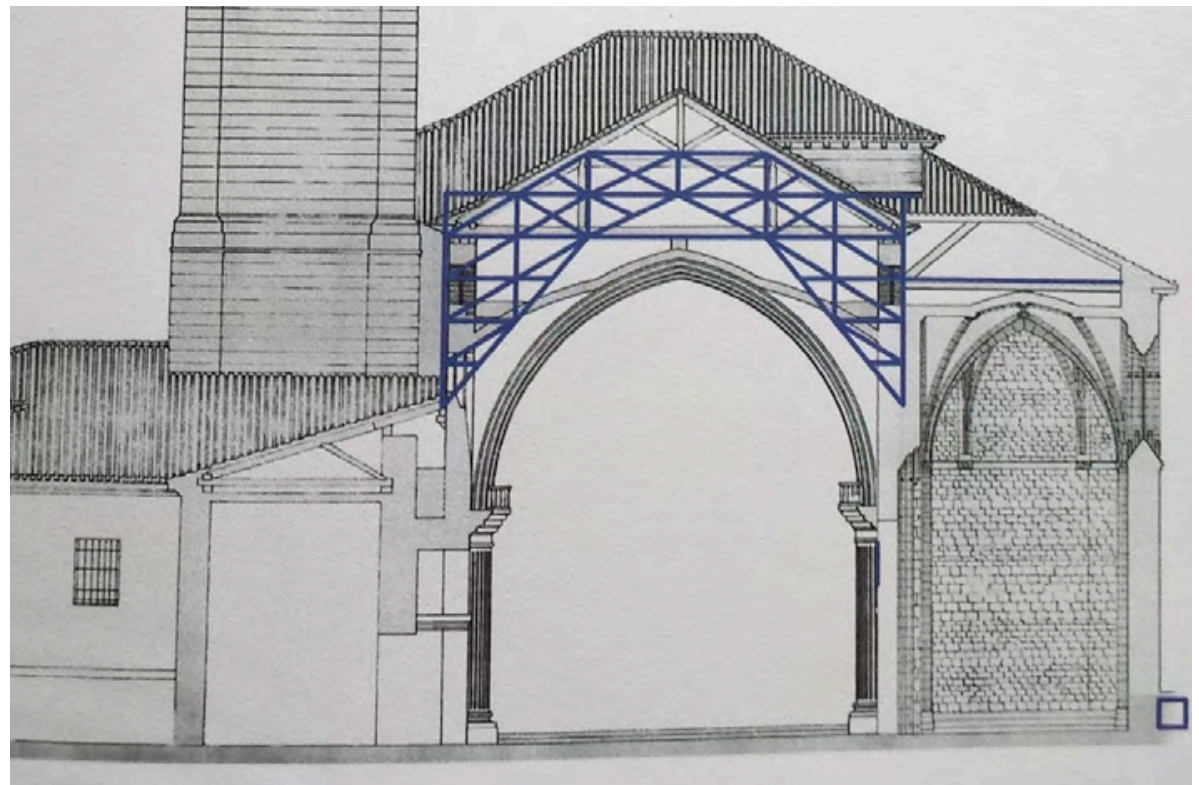

Ilustración 10: brida de atado (González 2006 Fundación)

\section{Zunchos}

En los detalles constructivos siguientes, así como en el resto de documentación del proyecto, se define el apoyo de la estructura, sobre el remate reconstruido del muro de fábrica de ladrillo, resuelto con piezas de madera. Tirante y canecillos apoyan sobre un doble durmiente y este a su vez sobre unos nudillos transversales embebidos en la fábrica. Se desdobla los pares, embridados con pletinas metálicas, duplicando también sus correspondientes estribos de sujeción en la dirección del muro.

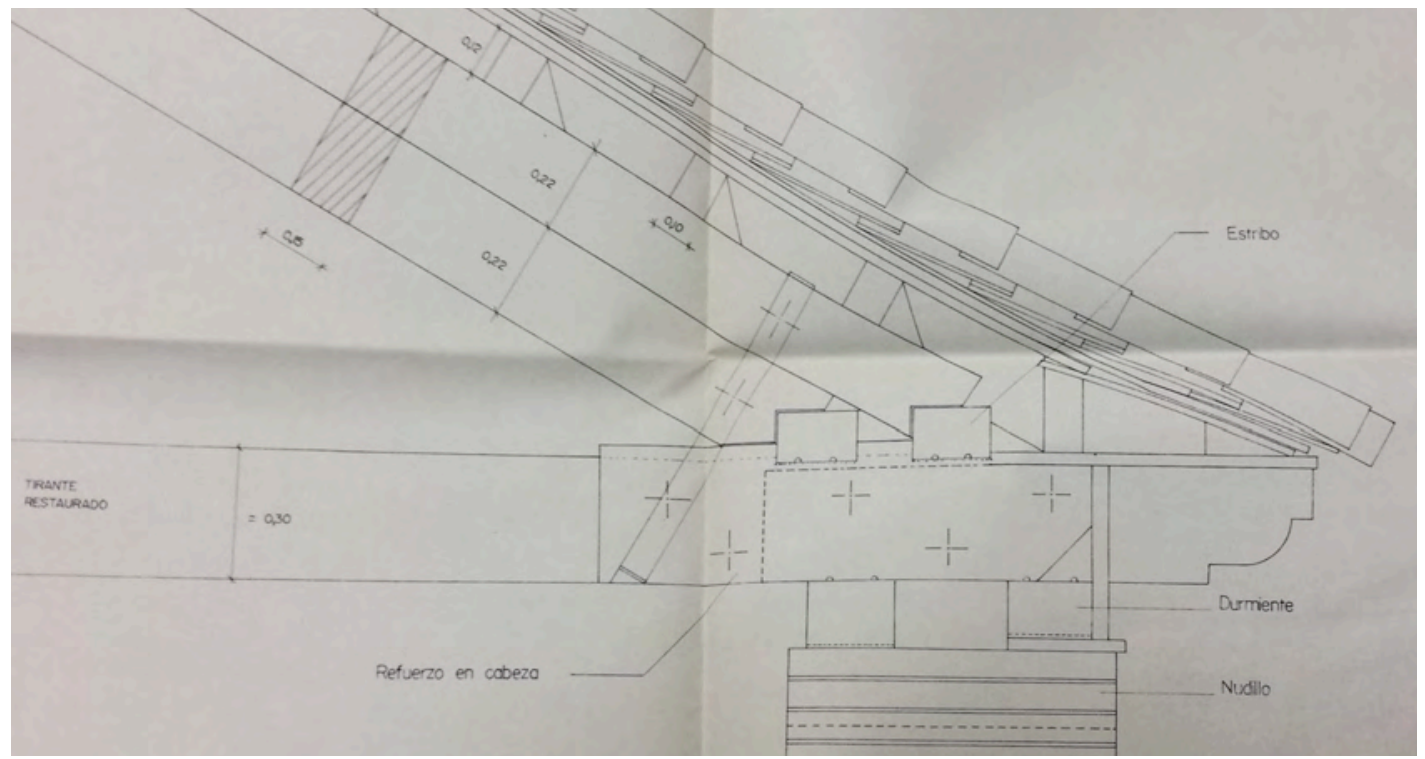

Ilustración 11: detalle cornisa 1999 Abad JCyL

En el detalle del apoyo sobre muro de sillería con cornisa de piedra tampoco de disponen más elementos corridos que los durmientes de madera. 
Toda la intervención de 1999 elude intencionadamente el empleo de zunchos, encomendando a los nudillos "el correcto apoyo y reparto de la carga que transmitirán los nuevos durmientes al muro"

El diseño del encuentro de tirantes y pares con una solera (como denomina al durmiente inferior de madera) y un estribo superior permite según Abad "configurar el necesario contrapeso para la formación de la cornisa".

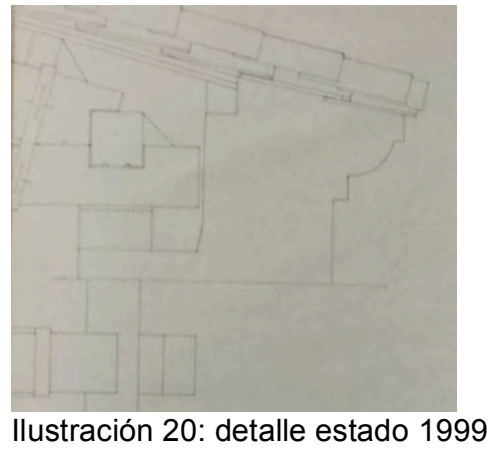

En 2006, sin embargo, González Fraile incorpora una cincha perimetral metálica vista de platabanda de acero inoxidable en la cabecera a la altura del cambio de material y otro anillo perimetral interior UPN en la coronación del muro de la capilla "para zunchar todo el conjunto" que forma con una "gran brida" para atar el muro arco diafragma que, según él, transmite empujes a la capilla.

\section{Conclusiones}

Según la documentación de los proyectos de restauración analizados en este edificio, no se incorporó los habituales zunchos de hormigón en las intervenciones de reemplazo de estructura de cubierta, confiando la homogeneidad del apoyo a la reconstrucción de la banda de remate de fábrica de ladrillo, con nudillos de madera embebidos y un doble durmiente sobre los mismos.

En una obra de restauración de la capilla gótica adyacente a la cabecera, sin embargo, ya en 2006, sí se decide disponer una banda metálica perimetral para zunchar ambos volúmenes, que se atirantan mediante una gran estructura metálica de celosía, insertada en el espacio bajo cubierta descarnando el relleno de los riñones de las bóvedas. Un zuncho metálico UPN está dispuesto por la cara interior del muro de la capilla y otro, de platabanda inoxidable, discurre por la cara exterior del cerramiento de la cabecera.

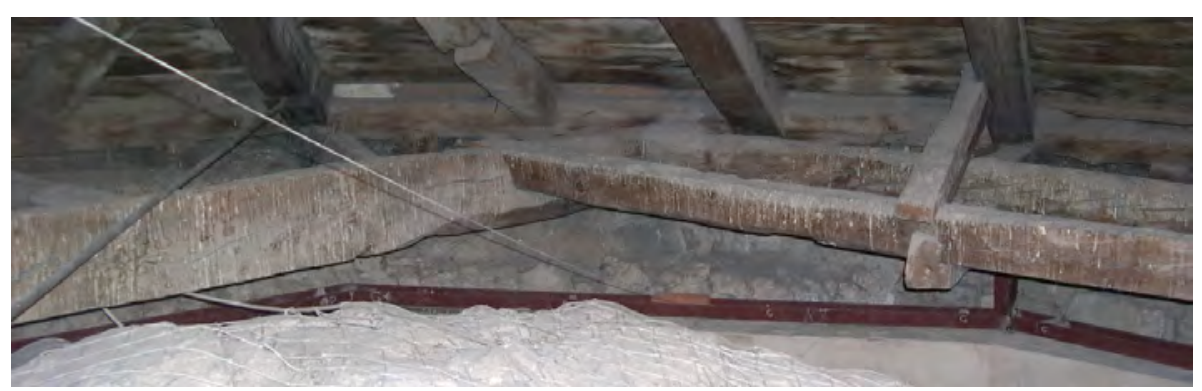

Ilustración 21: zuncho interior UPN, cortesía Fundación 


\section{Iglesia de EI Salvador en Valladolid}

Intervenciones citadas en la publicación del Ministerio:

1968 - Cubiertas, limpieza interior y pavimentación capilla de San Juan Bautista Anselmo Arenillas

1979 - Portada principal - Luis Alberto Mingo Macías

No hay planos en la web del IPCE

\section{En el Archivo General de la Administración}

\section{AGA 26/00131}

1968 - Reparación en la capilla de San Juan Bautista - Anselmo Arenillas

Sus fábricas están en buen estado en general, si bien se observan unas grietas, en su esquina exenta, que acusan que existe un empuje no contrarrestado (hay dos fotografías sobre las que se señala); empuje que se compone del dado por el arco diagonal de la bóveda y el suplementario de la lima del tejado cuya cubierta no está en buen estado, siendo preciso repararla.

Incluye pintura, pavimentación y alumbrado.

No describe en qué consiste esa "reparación de cubiertas y tejado".

No hay planos.

\section{AGA 26/01070}

Documentación administrativa.

Pagos a arquitecto Luis Mingo y aparejador Luciano Suárez Rojo

Contratista Gregorio Toquero por CONSTO SA

Recepción definitiva febrero 1983 (provisional agosto 1981)

Proyecto: Obras de restauración en la iglesia de El Salvador, Valladolid Agosto de 1979

Planos: situación, emplazamiento, planta general 1:100, planta de cubiertas, sección $1: 100$ y 1 alzado principal

Memoria histórica y descriptiva

La iglesia se construye a mediados del siglo XVI (fachada de 1576) bajo dirección del arquitecto Juan de Escalante sobre una ermita del siglo XII dedicada a Santa Elena. 
La torre, en la parte posterior del templo, fue construida en 1618 por Bartolomé de la Calzada. El chapitel actual empizarrado sustituye en 1727 la media naranja que servía de remate

Está formada por una nave central con capillas entre contrafuertes, cubierta de bóveda de cañón apuntado con lunetos decorada con yeserías del XVIII.

Las columnas embebidas en las paredes soportan un entablamento cuya galería cuenta con pasamanos de madera. "Este tipo de interior de único espacio y galería alta es muy similar al llamado "marinero" que se desarrolla en el norte de la península.

Capilla mayor de crucería estrellada gótica del siglo XVI, que es necesariamente decorativa ya que los nervios no trabajan. Una reforma barroca suprimió el resto de la bóveda, disponiéndose la actual decorada con elementos geométricos de yesería

Obras a realizar:

La iglesia se encuentra abierta al culto, por lo que no se encuentra afectada por problemas de tipo estructural o de consolidación

El proyecto afecta a la portada principal de acceso:

Limpieza general de paramentos

Tratamiento individualizado de esculturas exentas y relieves de bultos

Descenso y traslado de esculturas y remates ornamentales para su consolidación mediante tratamiento de inmersión

Impermeabilización de cornisas, aleros y parte superior de cristerías

Presupuesto: limpieza fachada principal 8,50 x 18,00

limpieza de fachada de sillería $11 \times 14+9 \times 10,50$

AGA 26/01574

Iglesia de El Salvador. Mismo proyecto de Luis Mingo agosto de 1979

\section{En el archivo de la Junta de Castilla y León}

\section{VA-199}

Carpeta 5378 (3 cajas)

Restauración de la iglesia de El Salvador en Valladolid.

Documentación administrativa: acta de recepción 29/10/1999, adjudicada el 2/07/1997 a ERCOSA. Arquitecto Álvaro Abad Cabrera. Proyecto Reformado en febrero 1999 y Modificado de 1999. 
Algunas partidas del Presupuesto:

24x8,2m2 demolición de forjados de viguetas pretensadas de hormigón armado, bovedillas cerámicas o de hormigón y capa de compresión de hormigón.

2x27x0,75 m2 "demolición de muros de fábrica de ladrillo en su parte superior y reconstrucción de los mismos con aprovechamiento de los materiales, colocación de nudillos para, según documentación gráfica, colocar material de cubierta, incluso limpieza y retirada de escombros y con pp de medios auxiliares. Se trata de afianzar las hiladas superiores de los muros."

transporte de escombros al vertedero, demolición de cubrición de teja cerámica curva $1077 \mathrm{~m} 2$

$807 \mathrm{~m} 2$ demolición del soporte de la cubrición, formado por entablado de madera sobre entramado de cerchas y correas de madera, sin incluir la demolición del entramado, por medios manuales...

901,5m2 demolición del entramado de cerchas y correas de madera de la estructura de la cubierta, por medios manuales, $\mathrm{i} /$...

$10 \times 10 ; 7,5 \times 10,5 ; 16 \times 7,5 ; 3,5 \times 5,5 ; 27 \times 14,5 ; 16 \times 12$

lud demolición de elementos salientes de todo tipo tales como chimeneas, ventilaciones...

$30,42 \mathrm{~m} 2$ demolición de muros de fábrica de ladrillo de $1 / 2$ pie

$150 \mathrm{~m} 2$ picado de revocos de cal en paramentos verticales con martillo eléctrico

lud apeo de la lámpara situada en la nave central para posterior demolición del entramado de madera

$959 \mathrm{~m} 2$ suministro y colocación de entablado con madera de pino del país de $32 \mathrm{~mm}$ de espesor i/clavado y colocado

$0 \mathrm{ml}$ correa de madera de pino $12 \times 20$ o similar..., $0 \mathrm{ml}$ cuchillo a un agua, ...

$386 \mathrm{ml}$ carrera de madera de pino del país de 15×20 colocada sobre fábrica de ladrillo i/nivelación y colocación de elementos de atado. Precio que incluye tanto el listón de solera como el estribo, ambos en madera. Según documentación gráfica.

2ud formación de buhardillas en cubierta de nave central y presbiterio, según detalle de planos.

$1196 \mathrm{ml}$ de correa de madera de pino del país $10 \times 15 \mathrm{~cm}$ i/pp de ejiones $15 \times 15 \times 10$, nivelación o pendiente y colocación de los elementos de atado y refuerzo. Estas dimensiones se ajustarán a la documentación gráfica adjunta

$300 \mathrm{ml}$ correa de madera de pino del país $11 \times 8 \mathrm{~cm}$, nivelación o pendiente $\mathrm{y}$ colocación de los elementos de atado y refuerzo. 
12ud suministro y colocación de cuchillo a un agua con madera de pino del país luz superior de $6 \mathrm{~m}$, pendiente variable, una sobrecarga de $200 \mathrm{~kg} / \mathrm{m} 2$ formado por pares, tirantes, etc. mismo material y tirantillas de hierro de $12 \mathrm{~mm}$, pp de ensambles, refuerzos y cinchas de hierro o pernos en los nudillos i/nivelación, centrado y colocación.

12 ud suministro y colocación de cuchillo tipo Palladio con madera de pino del país para luz de $12 \mathrm{~m}$ o superior, pend. $30^{\circ}$ y una sobrecarga de $200 \mathrm{~kg} / \mathrm{m} 2$ formado por pares, tirantes, jabalcones y pendolón del mismo material y tirantillas de hierro de $12 \mathrm{~mm}$, pp de ensambles, refuerzos y cinchas de hierro i/nivelación, centrado y colocación, aprovechando los tirantes existentes.

$812,60 \mathrm{~m} 2$ cubierta de teja cerámica curva roja recibida con mortero de cemento y arena de río 1/8 sobre placa Onduline BT-111 clavada a la estructura, i/pp de piezas especiales, caballetes y limas, medios auxiliares y elementos de seguridad.

$592 \mathrm{ml}$ de perforación a roto-percusión de diámetro medio $36 \mathrm{~mm}$ para inyecciones armadas de cosido y consolidación, incluso suministro y colocación de lechada de cemento, incluso suministro y puesta en obra de armadura de redondos de $16 \mathrm{~mm}$ de diámetro de acero inoxidable roscado....

47,50ml de limpieza de cornisa de piedra caliza

Hay varias partidas con medición 0,00 . Por ejemplo creación de ménsulas para el apoyo de carrera en la formación de cubierta.

$24 \mathrm{ml}$ de Alero formado por ladrillo aplantillado especial para alero y tres hiladas de ladrillo cara vista de $25 \times 12 \times 5 \mathrm{~cm}$, recibido con mortero de cemento II-Z/35A y arena de río 1/6 relleno de hormigón ligero Arlita $\mathrm{H}-150 \mathrm{~kg} / \mathrm{cm} 2$ y emboquillado de tejas, i/replanteo, limpieza, medios auxiliares y elementos de seguridad. 2x10; 1x4;

$40 \mathrm{ml}$ de Alero formado por canecillos de madera de 130x20x15mm separados $50 \mathrm{~cm}$ y tabla de madera a media madera de $28 \mathrm{~mm}$ clavada al canecillo con un vuelo de $50 \mathrm{~cm} \mathrm{i} /$ barnizado y recibido al forjado, medios auxiliares y elementos de seguridad según NTE-QTT

$54 \mathrm{ml}$ de Alero formado por canecillos de madera de $130 \times 20 \times 20 \mathrm{~mm}$ separados $50 \mathrm{~cm}$ y tabla de madera a media madera de $28 \mathrm{~mm}$ clavada al canecillo con un vuelo de $50 \mathrm{~cm} \mathrm{i} /$ barnizado y recibido al forjado, medios auxiliares y elementos de seguridad según NTE-QTT 
$5 \mathrm{ml}$ demolición y posterior colocación de nueva cornisa de piedra caliza de Campaspero de 50x22cm de sección, recibido con mortero de cemento II-Z/35A y arena de río 1/6 nivelado y aplomado de piedras s/NTE-EFP

14,1m2 de fábrica de ladrillo con vista de tejar fabricado manualmente y 1 pie de espesor recibido con mortero bastardo

Describe los rejuntados de fábrica de sillería y de ladrillo cara vista "con mortero de cemento de las mismas características que el existente"

lud reparación y renovación de cubierta de torre de pizarra, fijada con clavos a estructura existente

10ud prótesis para sustitución de testa o cabeza de madera deteriorada, mediante corte diagonal de la zona en mal estado y su sustitución por nueva cabeza de igual sección completando el corte, unida mediante resina epoxi y reforzada con varillas de fibra de vidrio tipo Rovin o similar, comprendiendo: apeo de la pieza, apertura del muro, eliminación de la zona deteriorada, taladros de $28 \mathrm{~mm}$ en la zona sana, aporte de madera nueva, encolado con epoxi e introducción de las varillas, mordazas de presión hasta la polimerización y acabado restituyendo la zona del muro demolida i/retirada de escombros

2 lucernarios $5 \times 1,8$ en madera de iroko

\section{Memoria del proyecto reformado.}

Explica las variaciones, como más cosido en la torre por encontrarse en peor estado de los previsto.

Se incrementan las demoliciones al derribar "una serie de muros de mampostería y ladrillo tanto dentro de las cubiertas primitivas de la iglesia como de cara al exterior en el alzado norte que mira hacia la plaza de El Salvador para de esta forma lograr las alturas, cotas y pendientes precisas de las nuevas cubiertas."

"Al comenzar la ejecución de las estructuras de madera en cubierta se comprobó el pésimo estado de conservación de la madera, afectada por la acción de diversos insectos y hongos con el consiguiente peligro para la estabilidad de las estructuras. Esto provocó la reordenación de durmientes, cuchillos y correas de madera, colocándose un menor número de cuchillos pero con unas secciones de mayor 
dimensión. Igualmente se creyó imprescindible el que toda la madera nueva tuviese un tratamiento curativo-preventivo a base de producto insecticida."
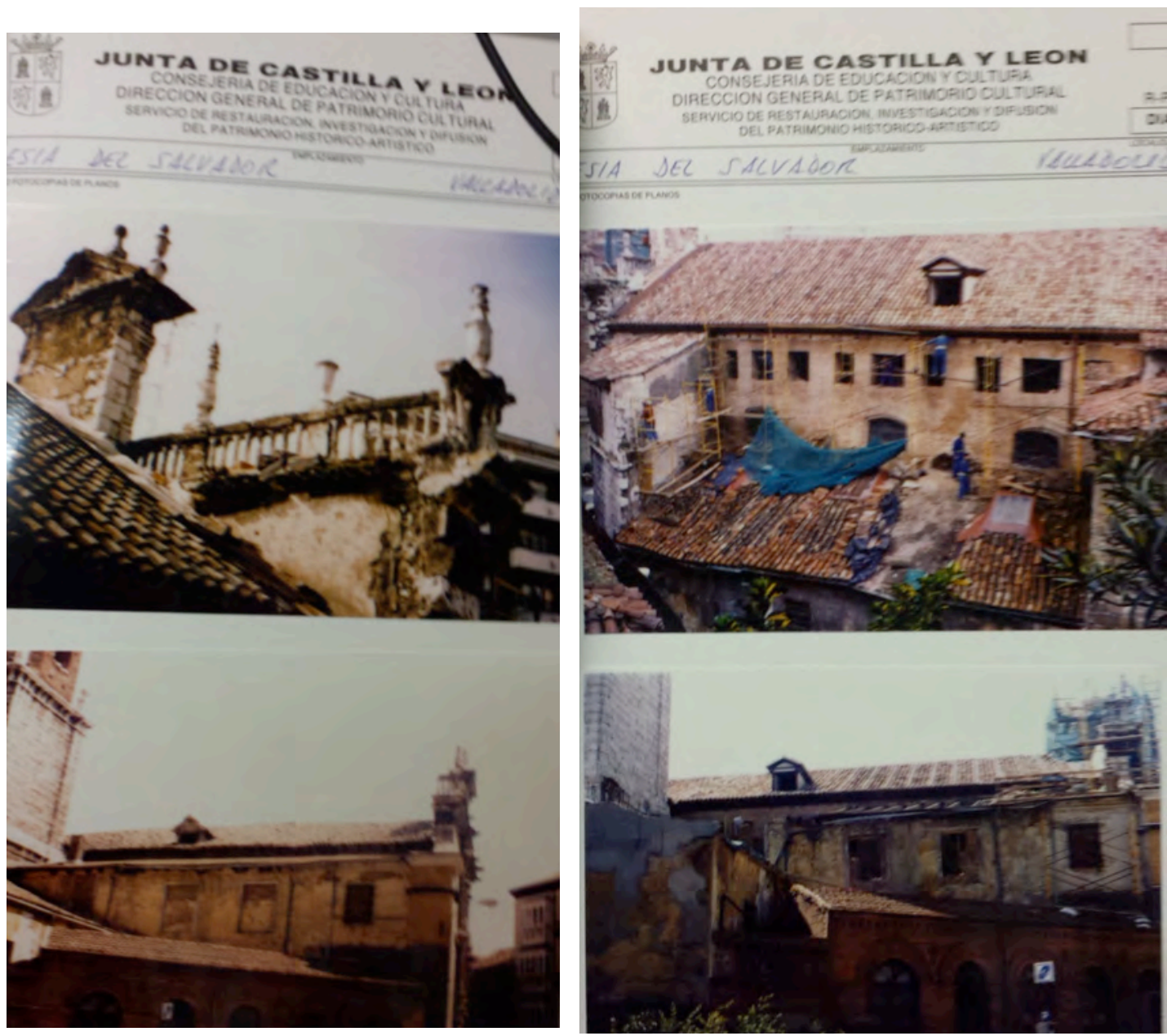

Ilustración 22: dossier 1999 Abad JCyL

"La ejecución de cubiertas de teja y sus correspondientes aleros, ya sean a base de canecillos de madera o de cornisas de piedra en todas las dependencias de la iglesia: nave central, presbiterio, sacristía y capillas laterales. De la misma forma se consideró conveniente recuperar las fachadas primitivas de la iglesia a base de ladrillo antiguo de tejar en la zona superior del presbiterio y en las capillas laterales."

\section{Planos}

Saco foto a casi todos los planos. Los de estado reformado parecen antiguos al emplear cerchas de madera con mayor sección que las antiguas. No hay indicios de zunchos.

Los detalles del plano 31 de abril de 1995 muestran la cercha de madera en que se rotula "tirante restaurado" con $30 \mathrm{~cm}$ de canto, con un refuerzo en cabeza que apoyan en un doble durmiente sobre nudillos. 


\section{En el Archivo Municipal de Valladolid}

\section{Fondo Histórico}

369 - Carp2 - $178 \quad 1934$

Petición de licencia del Cura Párroco del Salvador para instalar calefacción central en dicha iglesia [Hojas: 1 ; Planos: 1]

Incluye una planta con el esquema de red de radiadores desde debajo de la escalera a los pies, firmado por el ingeniero industrial municipal.

\section{Fondo Administrativo}

AMVA 6007/1997

Restauración iglesia. 5 piezas

Proyecto de Álvaro Abad Cabrera

En la memoria plantea el desmonte progresivo de la estructura de cubierta, sin superar en cada fase de trabajo la extensión de un tramo de la nave central, para no modificar sustancialmente el estado de cargas del conjunto ni dejar a la intemperie la totalidad del edificio.

Reseña que "la cubierta de estos edificios es un elemento que se acopla a la estructura que, por decirlo así, va evolucionando y se ve sustituido en numerosas ocasiones. Es necesario que su comportamiento y su concepción sea así; la transmisión de esfuerzos sea repartida, en apoyo (con únicas cargas verticales) sobre los muros y su condición de elemento exento y la libre para absorber sus propios movimientos diferenciales.

La nueva estructura que se plantea en el presente proyecto, pretende un aprovechamiento del máximo número de elementos originales, siendo en este caso reutilizados los tirantes, tirantes que como se detalla más adelante precisarán en ciertos casos unas prótesis del mismo material en sus cabezas, proveeyendo en todos los casos una consolidación de las cabezas solapando a cada lado un tablón, tal y como se refleja en documentación gráfica anexa. También en ciertos tramos de cornisa, se podrán y deberán reutilizar los canecillos originales. 
La intervención pretende la búsqueda de una uniformidad en la distribución de cargas sobre los muros, preveyendo para ello además de un gran número de cerchas estructurales (el mismo número que el existente) unos adecuados durmientes continuos en todo el perímetro, tanto de solera como estribos; es decir, se ha previsto un estribo en el encuentro de los tirantes y pares y una solera por debajo del tirante (según detalle de la documentación gráfica) para así poder entre otras cosas, configurar el necesario contrapeso para la formación de la cornisa.

La cubierta se deberá de desmontar progresivamente, se deberá de consolidar la fábrica de ladrillo en sus hiladas superiores, introduciendo unos nudillos que coincidan con los límites de los machones (situación que se aprecia en documento de estado reformado al efecto) para de esta forma asegurar un correcto apoyo y reparto de la carga que transmitirán los nuevos durmientes al muro.

Se plantea la ejecución de unas cerchas tipo Palladio, dado que la flexión de los pares es grande, por su mucha luz, ejecutando estas cerchas con falso tirante, pendolón principal y dos secundarios. Se ejecutará una cercha de este tipo en aquellos puntos donde existe estructura portante en la actualidad, aprovechando tal y como se cita en la presente memoria los tirantes originales inferiores."

Describe el tratamiento de los tirantes y su empalme con las prótesis. Cerchas de madera de grandes escuadrías, correas, cabios o parecillos, tablero de tabla ripia de una pulgada de espesor, lámina impermeable tipo Onduline y cubrición final de teja cerámica curva recuperada parcialmente, asentada sobre pelladas de mortero bastardo o torta de barro y recibida cada seis hiladas y en cumbrera y aleros.

Se recuperan los huecos, cerrando con hiladas los excesos de apertura, colocando una celosía de lamas de cobre. Recupera así la iluminación de la nave central en el lado del Evangelio, con doble carpintería.

Reestructura los volúmenes demoliendo el cuerpo añadido sobre las capillas sacramental y de los Reyes, con vigueta y bovedilla de hormigón.

Coloca lucernarios con acabado de cobre en cubiertas.

Memoria de instalaciones de electricidad, fontanería, calefacción y saneamiento. No prevé canalones y bajantes salvo si un faldón vuelca sobre otro.

Cálculo de estructura de madera de pino:

Ángulo de cercha $30^{\circ}$, separación entre correas $60 \mathrm{~cm}$, distancia entre apoyos correacercha $2, \mathrm{~m}$. Incluye especificaciones de madera laminada por si llega a emplearse. 
Dossier de fotografías de estado actual, con ventanas cegadas, etc. En las del bajo cubierta se aprecia cómo las cerchas apoyan sobre el muro con fábrica de ladrillo entre el doble durmiente, cabezas podridas, y el volumen a demoler con forjado inclinado sobre perfiles metálicos que apoyan en enanos-pilastras modernas de ladrillo.

Pliego de condiciones, presupuesto y 33 planos (equivalentes a los del reformado en archivo de JCyL) de fecha abril de 1995.

AMVA 503/2006 Digitalizado lo veo en PC

Restauración capilla de San Juan Bautista

Licencia de obras para la Fundación del Patrimonio Histórico

Correspondencia sobre pago del impuesto.

Planta 1:300 en colores señala enterramientos

Proyecto básico. Arq: Eduardo González Fraile

El pavimento de la capilla en su nivel más bajo está $1 \mathrm{~m}$ por debajo de la rasante del terreno, lo que origina humedad en los muros. Carece de contrafuertes al exterior, es un volumen limpio.

Además de la capilla se interviene sobre "el bajocubierta de la cabecera de la iglesia, cuyo perímetro se pretende rigidizar por medio de una estructura metálica, puesto que los problemas estructurales del presbiterio se traducen en empujes sobre la capilla. Estos empujes producen importantes desplomes de los muros de la capilla y han originado aparatosas grietas en los mismos que amenazan la estabilidad del conjunto."

Hace una hipótesis de historia constructiva que resumo:

1. Construcción inicial de ermita en 1245. En 1336 se convierte en parroquia. En el siglo XV se funde con el núcleo urbano.

2. Posible construcción en el siglo XV de una capilla de planta similar a la actual con dos chaflanes en el ábside. Capilla funeraria adosada o ajena a la ermita.

3. Se reconstruye tras posible derrumbe parcial del ábside y del muro lateral del evangelio, simultáneamente a la nueva iglesia. Observa:

Significativa discontinuidad de las hiladas de la fábrica interior en el chaflán del ábside y parte del rincón entre el anterior y el lado frontal del ábside. Da la impresión de que se ha reiniciado la colocación de las hiladas de piedra aun disponiendo de material ya replanteado con dimensiones acordes. 
El aparejo de esta fábrica continúa, en otra supuesta fase de construcción, hasta el contrafuerte del ábside de la iglesia, al cual se adosa.

Los pies (excepto la parte interna de muro que linda con la nave y el lateral derecho de la capilla tienen fábrica exterior e interior más o menos continua, aún cuando existen hiladas donde la nivelación se pierde. La cornisa de coronación de la capilla se introduce en el bajocubierta de la nave central, indicando la existencia anterior de la capilla y la construcción adosada de la iglesia.

La cabecera de la iglesia es un solo cuerpo, como lo demuestra la continuidad de la imposta que recibe el empuje de las bóvedas.

La unidad de labra de la iglesia viene atestiguada por las marcas de cantería.

4. En esos momentos se está construyendo la iglesia de una sola nave con arcos-diafragma y cubrición a dos aguas.

5. Hay indicios de un incremento de altura en pleno proceso de construcción de la iglesia. En un futuro se agravan los problemas al debilitar el muro común a iglesia y capilla y levantar muro de $80 \mathrm{~cm}$ sobre el diafragma de separación para dar mayor altura al presbiterio que a la nave.

6. Ese diafragma es el único $\sin$ contrafuerte.

7. Se abre y cierra una puerta a la capilla.

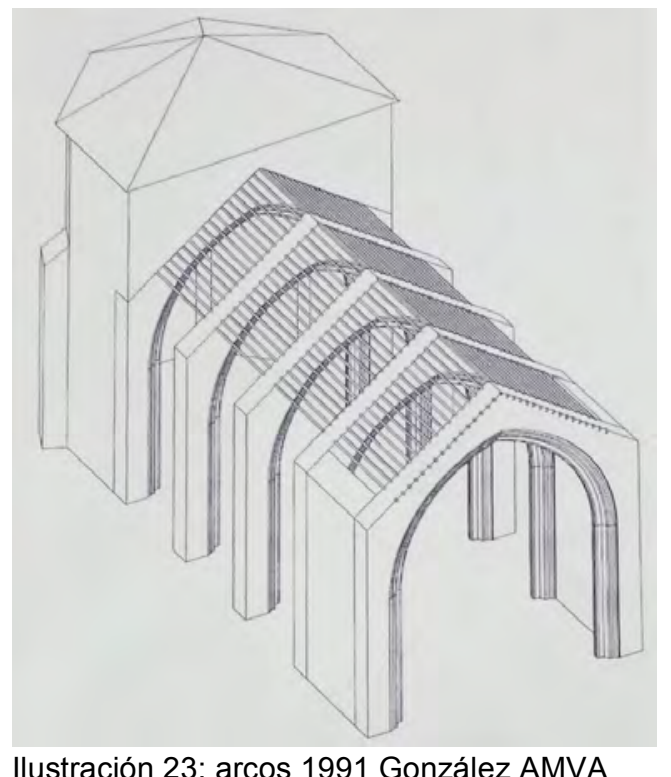

Ilustración 23: arcos 1991 González AMVA

8. La modificación más importante es la sustitución, seguramente en la segunda mitad del siglo XVI, de la cubierta por bóvedas de ladrillo, que obliga a recrecer el apoyo de la nueva estructura de cercha palladiana y cuchillo español sobre paredes de ladrillo.

9. En el Barroco se añaden y modifican capillas, forrando las columnas adosadas a los diafragmas con órdenes monumentales. El arquitecto culpa a este forrado de la ocultación y favorecimiento de las humedades producidas por capilaridad.

Con el paso del tiempo se va incrementando la rasante del terreno en derredor.

10. En la actualidad toda la capilla muestra un desplome hacia el exterior.

Intervenciones recientes: menciona 1875 por inscripción pero desconoce qué se hizo, la obra en la portada en 1981, intervención general en 1995. Restauración de la cubierta en 1992. 
Análisis arquitectónico:

Describe la geometría y cómo la planta rectangular y presbiterio poligonal responden al modelo de iglesias conventuales de la época. La galería corrida a modo de triforio sobre las cornisas de la nave permite el acceso a las ventanas.

Análisis patológico y diagnóstico: humedades y grietas

Las criptas bajo la capilla a su vez sobreexcavadas por enterramientos amenazan la estabilidad del edificio. Las criptas han estado llenas de escombro, sin ventilar.

En la página 51 hace el cálculo de peso del muro de piedra sobre el arco diafragma de separación entre las cabeceras de iglesia y capilla con el resto de la edificación. Suma el la resultante del peso de las bóvedas. Achaca las grietas al empuje de este muro y las bóvedas de la iglesia sobre la pilastra y el muro de separación común a iglesia y capilla. Concluye que la pilastra debiera haber volcado. Recalcula contando con los movimientos.

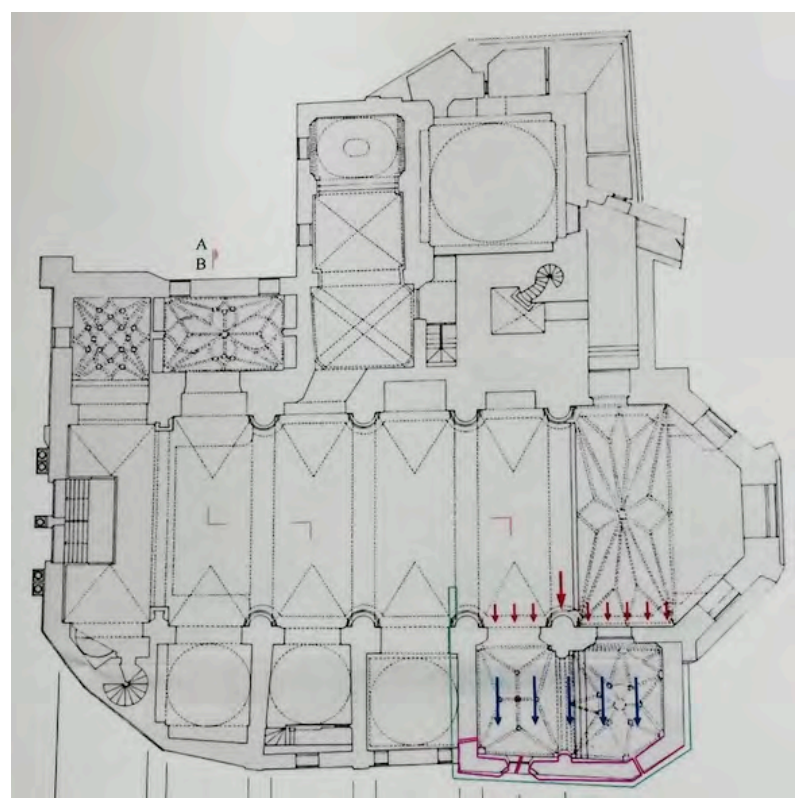

Ilustración 24: planta diagnóstico 1991 González

Propone una "estructura metálica a modo de gran brida que zunche y rigidice todo el muro del arco diafragma y elimine los empujes del mismo".

Recalcula el conjunto, incluyendo un "anillo perimetral metálico en la coronación de los muros de la capilla, de forma que no sólo empuje el muro del arco diafragma, sino que si se produjera cualquier tendencia de empuje o mayor desplome en los paramentos de la capilla, estos tendrían que arrastrar la inercia del muro diafragma y por consiguiente

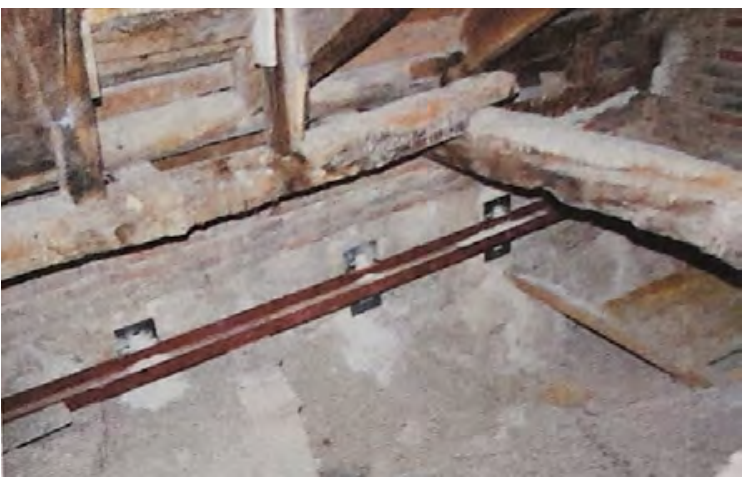

Ilustración 25: zuncho interior de toda la iglesia" 
Solución a los problemas estructurales:

"Una estructura metálica rigidizadora, a modo de gran brida, atará el muro de fábrica de piedra del arco diafragma para que no transmita empujes a la capilla. A su vez, para zunchar todo el conjunto, se realizarán dos anillos perimetrales, uno interior en la coronación del muro de la capilla y otro exterior en el límite de la piedra y el ladrillo de los muros de la cabecera de la iglesia.

El zuncho de coronación de la capilla consistirá en un perfil UPN colocado lo más bajo posible en el paramento interior del muro de piedra con anclajes mecánicos cruzados, a su vez estará triangulado espacial y horizontalmente, de tal forma que trabajará en el plano horizontal como una cercha.

El zunchado de la cabecera se realizará por el exterior, puesto que, debido al estado del muro, con infinidad de grietas existentes, es difícil garantizar la eficacia de los anclajes y no parece conveniente hacerlo por el interior. El zuncho se realizará, a la altura del cambio de piedra a ladrillo, mediante una platabanda de acero inoxidable se sección 1000 x 400mm separada ligeramente de la superficie del muro por chapones o tacos para evitar escorrentías.

Será necesario también en esta zona del presbiterio de la iglesia reparar los acodalamientos y los apoyos de las cerchas que se hallan desencajados por los visibles desplazamientos de los muros."

Describe pavimentos de madera, tratamientos de la fábrica, iluminación y acondicionamiento de los accesos al bajocubierta para hacerlos visitables. Esta última actuación la justifica en un Plan de Gestión que propone habilitar el bajocubierta como visita cultural para pequeños grupos, entre otras actuaciones diversas, como la musealización como necrópolis.

Hay una propuesta de ficha de catálogo arqueológico, En el texto figura que la actual parroquia la fundó hacia 1630 el conde de Gondomar según trazas de Diego de Praves y ejecución de Bartolomé de la Calzada...

Dossier fotográfico. En 13.S se ve una gárgola 32 planos

El segundo archivo tiene 894 páginas. Es el proyecto de ejecución, como anterior archivo pero sin color, con Pliego, Presupuesto, anexos: estudio geotécnico, barreras arquitectónicas, etc. 
En el Presupuesto hay 16t acero en cerchas formadas por 2T80.80.9 horizontales, verticales y diagonales. Anillo perimetral UPN 100.30, y otros perfiles UPN en suelo interior, traveseras, etc

12 placas de anclaje de acero A42b en perfil plano embebidas en cimentación de la estructura de acero de la cámara interior de la capilla, de dimensiones $30 \times 30 \times 1,5 \mathrm{~cm}$ con cuatro garrotas de acero corrugado de $12 \mathrm{~mm}$ de diámetro y $45 \mathrm{~cm}$ de longitud total

Anillo perimetral $2376 \mathrm{~kg}$ de acero inoxidable: $2 \times 14 ; 5 \times 6 ; 5 \times 6$ pletinas para el anillo perimetral de la cabecera con uniones soldadas, incluso parte proporcional de soldaduras, esmerilado de las mismas, cortes, piezas especiales, despuntes, cartelas, presillas, tacos de anclaje a muros, medios auxiliares y plataforma elevadora para su colocación, montado y colocado.

Una de las partidas es "1ud vaciado de los riñones de las bóvedas del presbiterio para la colocación de las cerchas hasta alcanzar el punto más bajo posible, incluso desplazamiento del material de relleno por el bajocubierta, entibados y apeos necesarios, posterior rellenado de los mismos y medios auxiliares.

A partir de pag 367-419 del pdf un documento con fotografías interesantes (aunque está escaneado de copia en blanco y negro) titulado Estudios, ensayos y análisis previos. Incluye un croquis hipótesis del esquema original con arcos-diafragma.

Estudio de seguridad y salud.

Memoria de los trabajos arqueológicos. FORAMEN SL.

Vuelven a escanear el proyecto básico a color.

AMVA 777/2008 Digitalizado lo veo en PC

Reparación cubiertas iglesia

El archivo digitalizado consta de sólo 4 hojas con la Licencia de obras.

En noviembre de 2008 se autoriza la memoria valorada de reparación de cubiertas de la iglesia del Salvador promovido por la parroquia y presentado por el arquitecto redactor del proyecto Juan Antonio Huidobro Piriz.

\section{En la Fundación del Patrimonio Histórico}

Capilla de San Juan Bautista. Arq Eduardo González Fraile Anexo de Estudios Previos (dossier extenso: 69 páginas) 1991 


\section{Levantamiento a 1:20}

Dossier fotográfico en color de gran calidad.

Fin de la obra

Memoria. Concluye que, si sus hipótesis son correctas, los problemas de estabilidad de la capilla han sido originados por los defectos estructurales de la iglesia, concatenados entre sí en la misma época de construcción del conjunto (entre finales del s.XV y principios del XVII) y desde luego son problemas históricos, producidos y conocidos antes de 1618, fecha de construcción de la torre.

Achaca la gravedad de las humedades al forrado de columnas adosadas a los arcos en época barroca.

"La solución dada a los problemas estructurales... una estructura metálica rigidizadora, a modo de gran brida, atará el muro de fábrica de piedra del arco diafragma para que no transmita empujes a la capilla. A su vez, para zunchar todo el conjunto se realizarán dos anillos perimetrales, uno interior en la coronación del muro de la capilla y otro exterior en el límite de la piedra y el ladrillo de los muros de la cabecera de la iglesia".

El zuncho de coronación de la capilla consiste en un perfil UPN.

(La descripción es equivalente a la incluida en el análisis patológico digitalizado en AMVA, redactada con verbos en presente y con diferencias en el caso de la platabanda, que allí era de 1000x400 y aquí se describe como sección 1000x200mm.)

Informes de 29 de febrero de 2008, de González Fraile. Indica en qué unidades de obra se ha producido aumento de medición, entre ellas el acero, ya que "al vaciar los riñones de las bóvedas, la morfología, la triangulación y la afección de las vigas de madera existentes ha obligado a modificar la estructura, que ha diferido de la inicialmente prevista, adaptándose a la realidad geométrica de las bóvedas."

Libro del edificio.

10 Planos enormes de plantas y alzados de capilla, muros con patología y "unidades constructivas" (lectura de paramentos).

Informe arqueológico de la capilla 2008. 


\section{Iglesia del Convento de las Descalzas Reales}

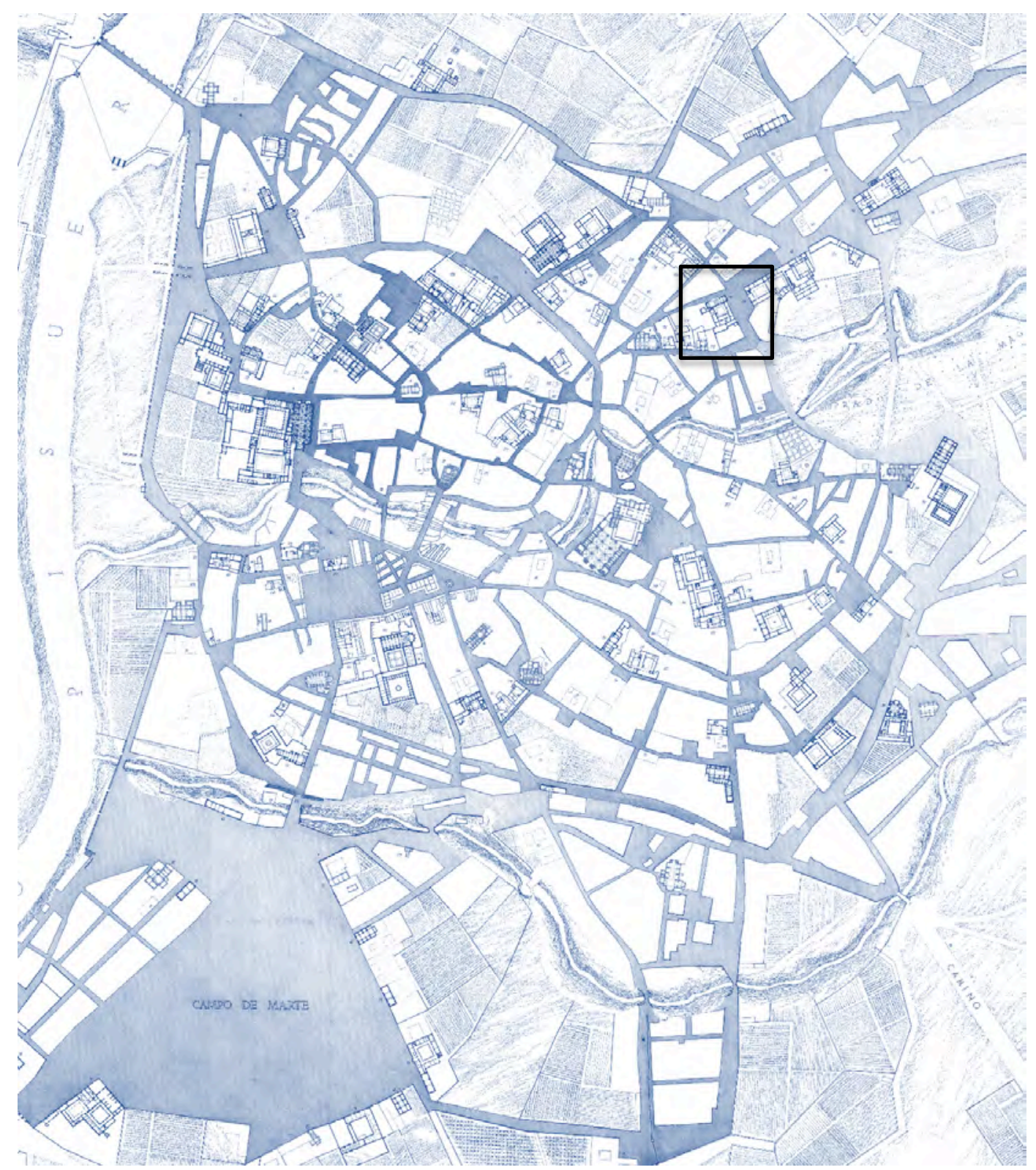



FICHA SÍNTESIS

\section{Código de identificación: FZ-14}

Denominación: Iglesia del convento de las Descalzas Reales

Localidad: $\quad$ Valladolid

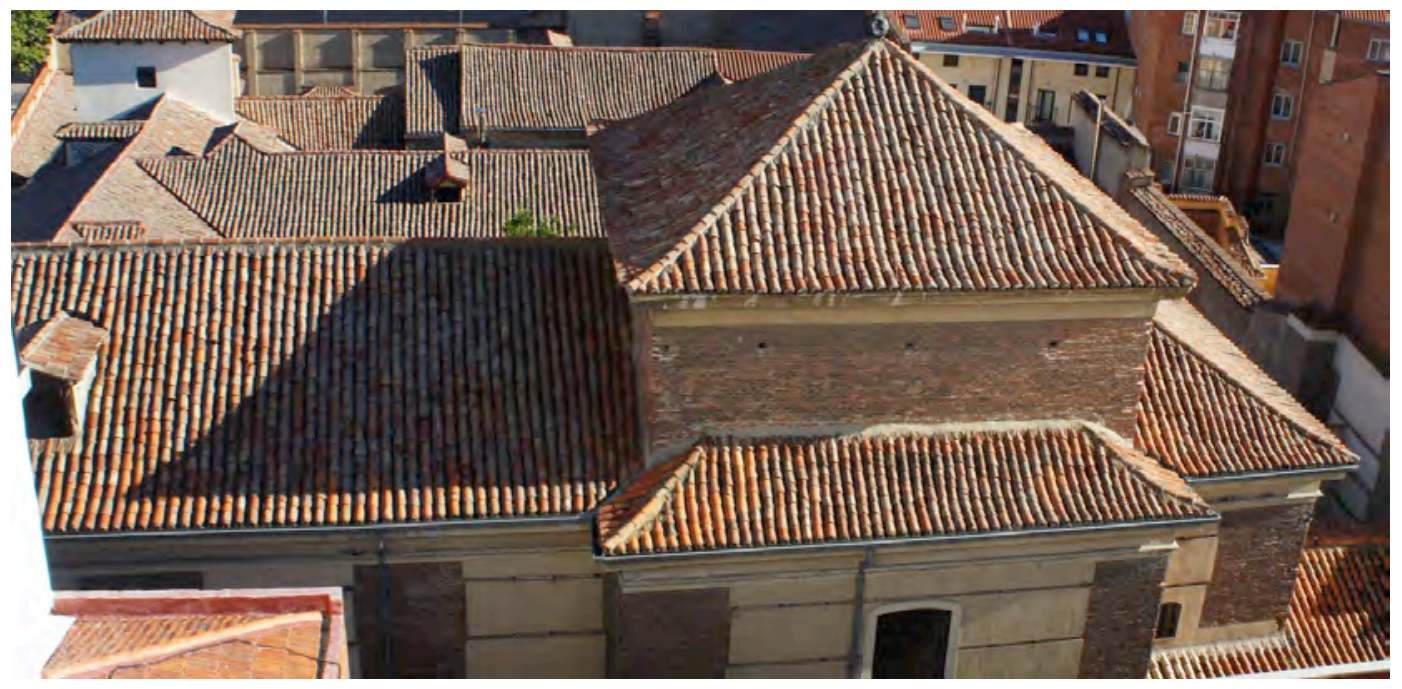

\section{Descripción}

Iglesia de una sola nave con cuatro tramos, crucero poco marcado y cabecera plana. Se cubre con bóveda de cañón con lunetos. Sobre el crucero se levanta un cimborrio cuadrado con una cúpula sobre pechinas.

\section{Materiales}

Los muros son de fábrica de ladrillo y cajones de tapia sobre un zócalo de sillería. La cubierta está revestida de teja curva.

\section{Singularidades}

Sobre el muro del evangelio hacia los pies se levanta una doble espadaña.

\section{Dimensiones básicas del templo}

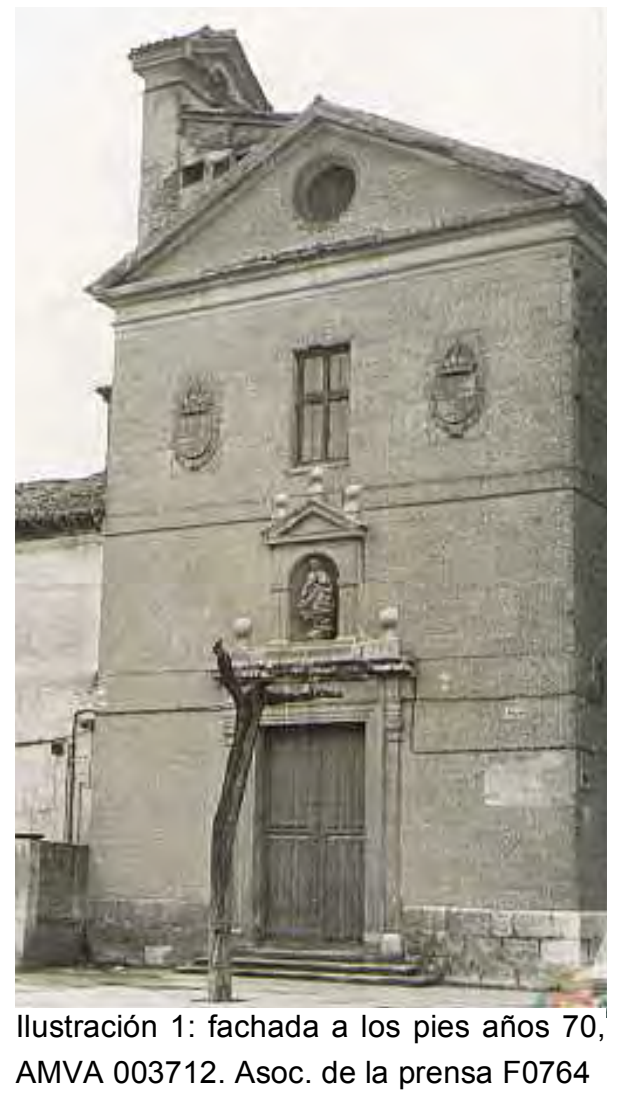

$\begin{array}{llll} & \text { central } & \text { laterales } & \text { capillas } \\ \text { Ancho de nave } & 5,4 & - & - \\ \text { Altura } & 8,8 & - & -\end{array}$




\section{Memoria histórica constructiva}

Según el Catálogo:

El convento va ocupando un conjunto de casas nobles cedidas a partir de 1552 y se ocupa poco después de 1615. Dirige la obra del templo Diego de Praves bajo trazas del arquitecto del Rey Francisco de Mora.

En 1628 se hacen reparaciones, y en 1657 se adquieren nuevas casas para extender los dominios de la congregación.

\section{Cronología. Fechas clave}

$1615-1978$

\section{Intervenciones}

1975 - Restauración - Ana Iglesias

Multiplica y acondiciona las celdas.

1976 - Restauración - Ana Iglesias

Se restaura la zona del claustro.

1978 - Restauración - Ana Iglesias

Repara las cubiertas de la iglesia, consolidando la armadura con herrajes metálicos y reemplazando maderas en mal estado. Incorpora una capa de compresión de hormigón sobre la tabla ripia y reteja.

\section{Planos}

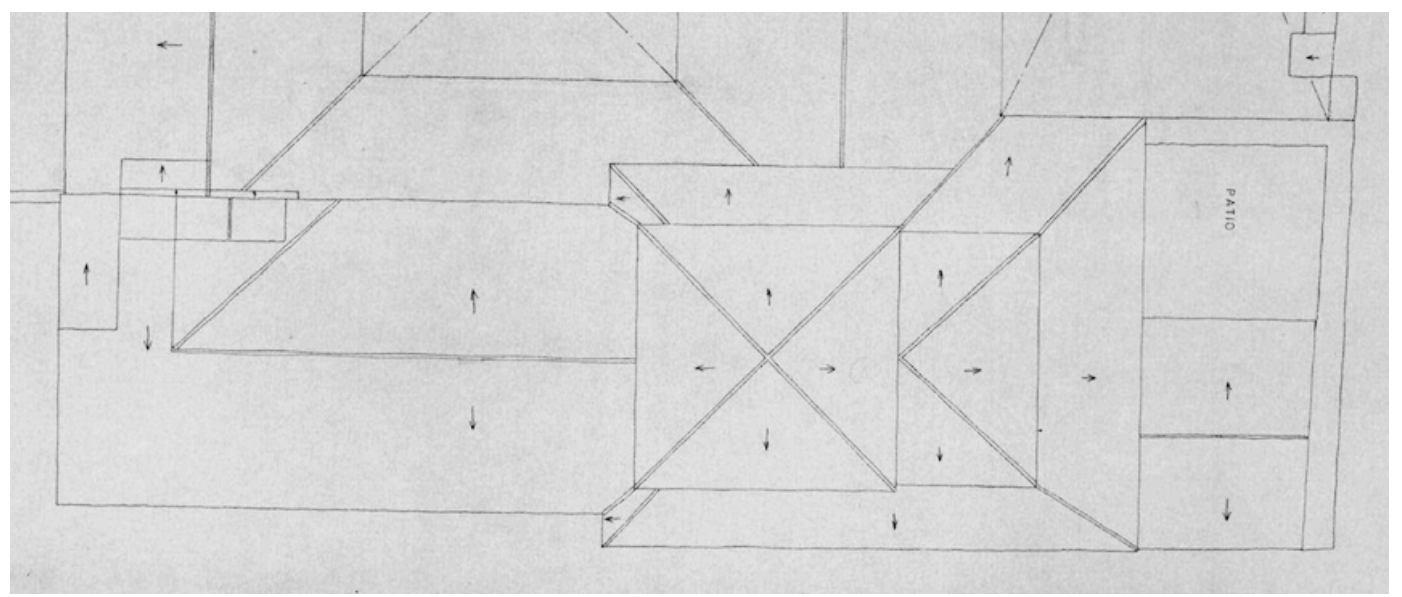

Ilustración 2: planta de cubiertas 1978 Iglesias IPCE 


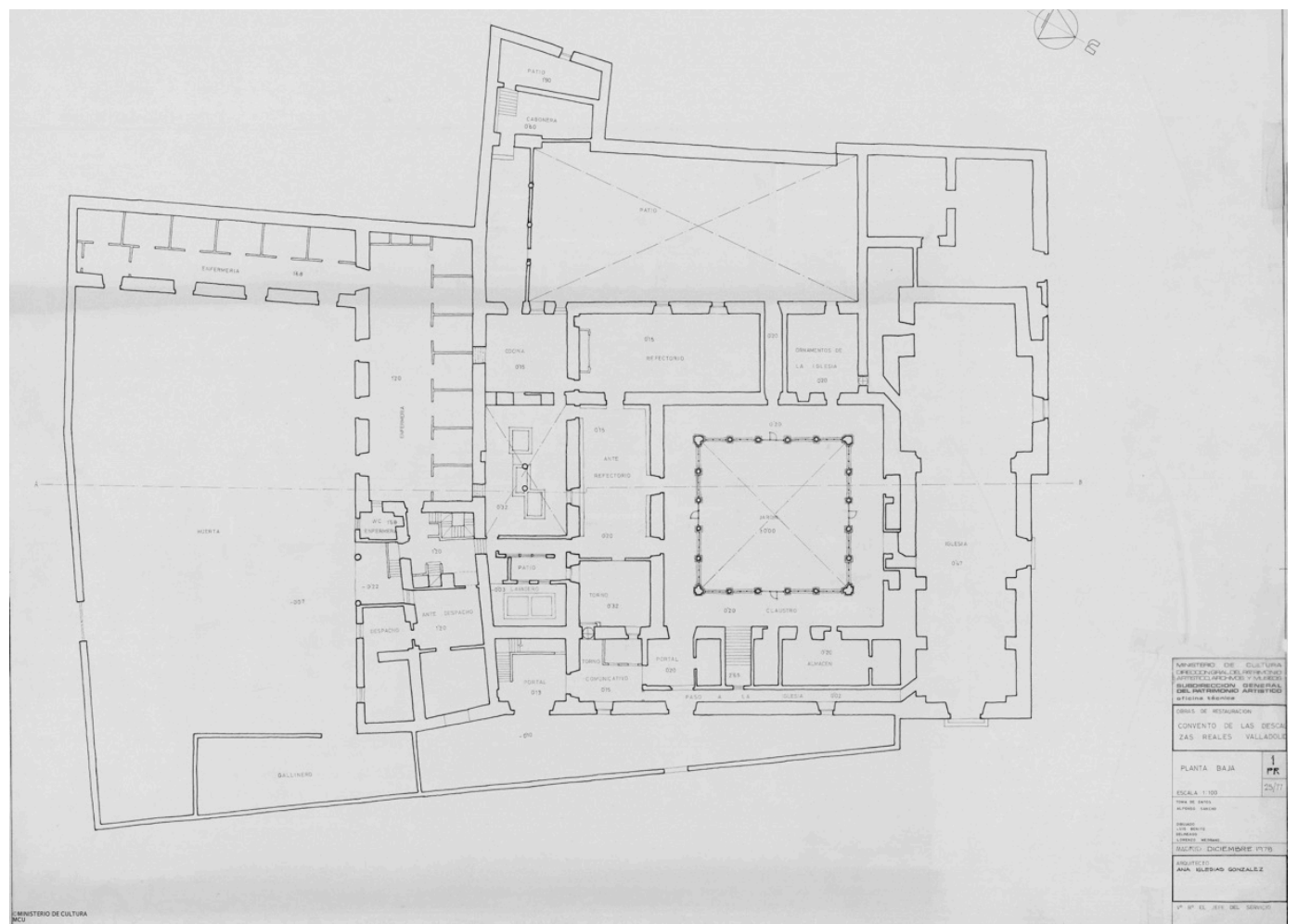

Ilustración 3: planta general 1978 Iglesias IPCE

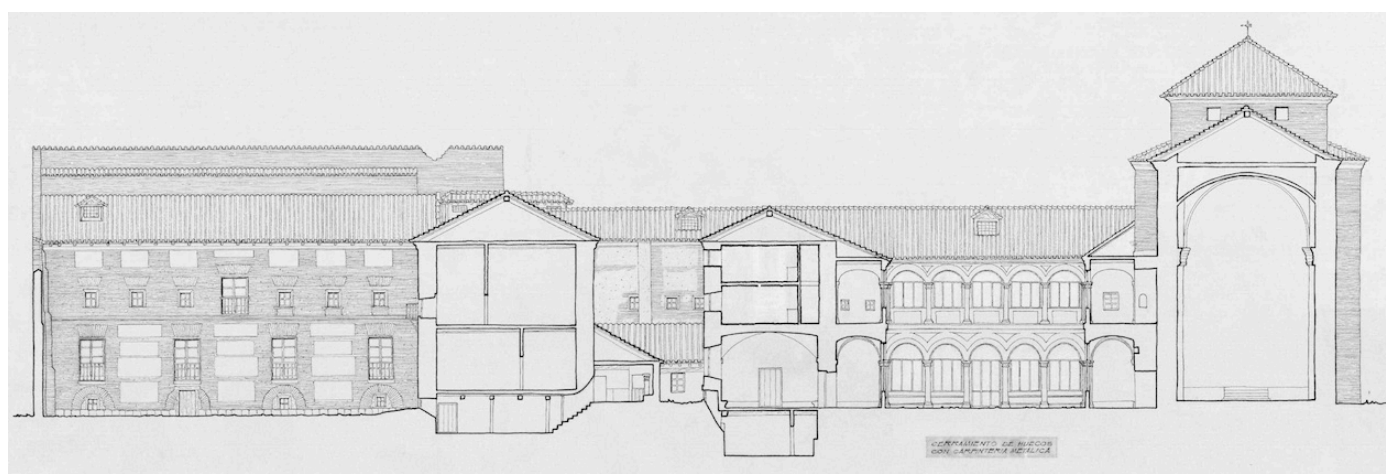

llustración 4: sección general 1978 Iglesias IPCE

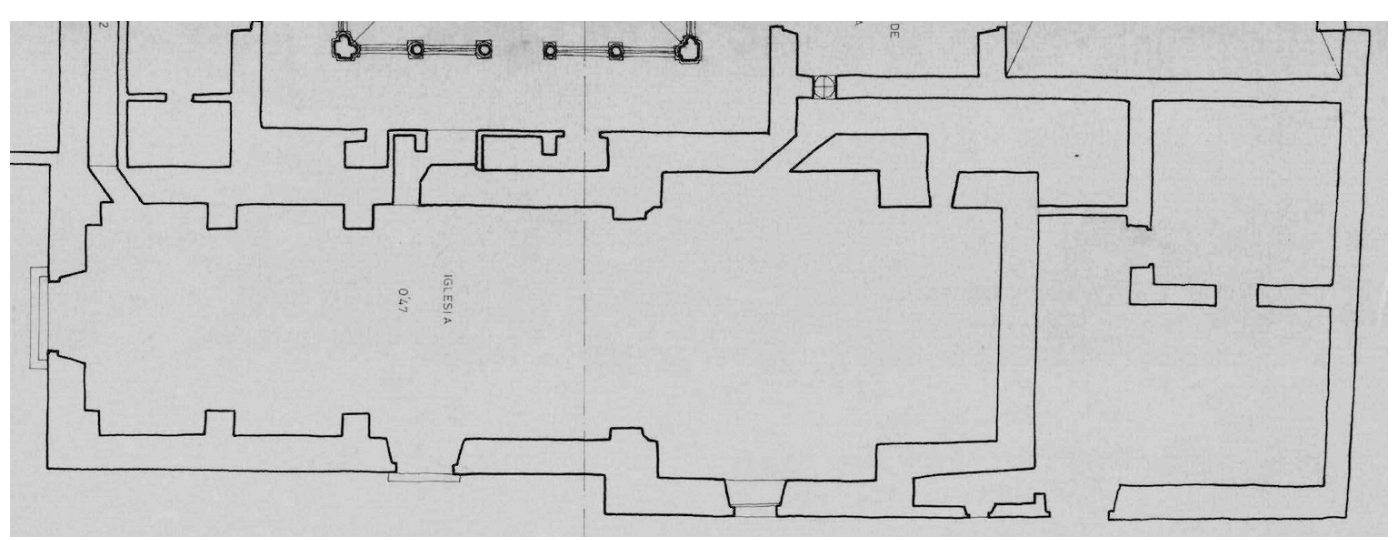

Ilustración 5: iglesia de la planta general 1978 Iglesias IPCE 


\section{Solución constructiva de la cubierta}

En las secciones generales (delineadas por Luis Benito y José María Marcos, sin la calidad del dibujante habitual de los planos de Ana Iglesias, José Sandoval) no se aprecian detalles de la solución estructural de las cubiertas que, según la memoria del proyecto de 1978, se mantiene reforzándose la ripia con una capa de hormigón. Se representa una pendiente de unos $30^{\circ}$.

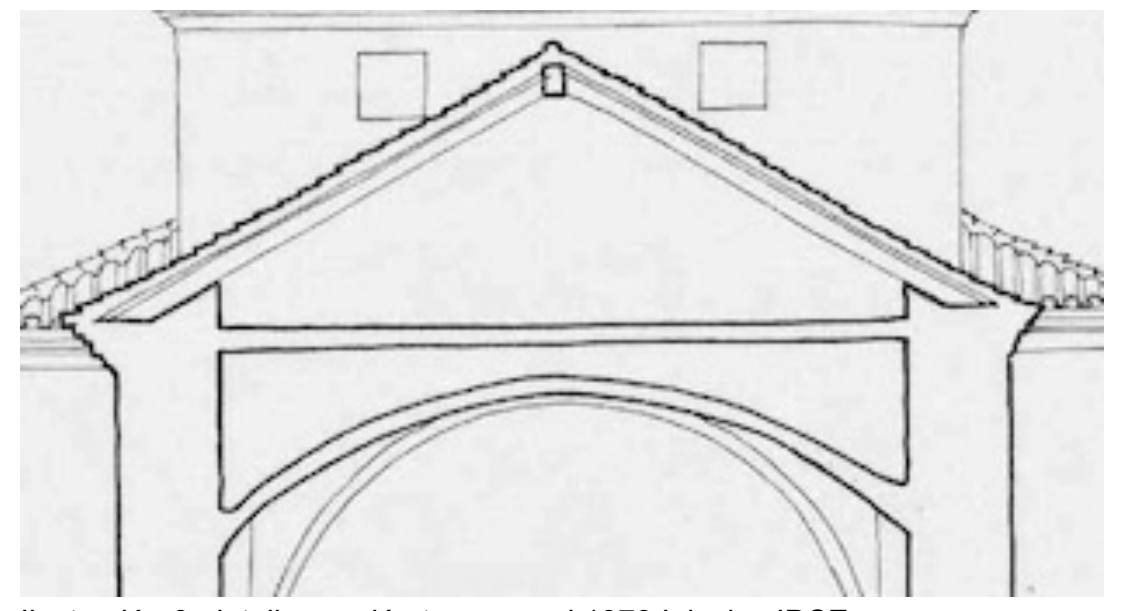

Ilustración 6: detalle sección transversal 1978 Iglesias IPCE

\section{Zunchos}

Aunque en la documentación consultada se describe el vertido de hormigón sobre la ripia existente, no se menciona el empleo de zunchos en los proyectos.

\section{Conclusiones}

No se ha documentado la incorporación de zunchos en este edificio, ni ha sido posible acceder al bajo cubierta. 


\section{Iglesia del convento de las Descalzas Reales}

Intervenciones citadas en la publicación del Ministerio:

1968 - Cubiertas, limpieza interior y pavimentación capilla de San Juan Bautista Anselmo Arenillas

1979 - Portada principal - Luis Alberto Mingo Macías

En la página web del IPCE hay 27 planos de los años 1973, 1975, 1976 y 1978.

\section{En el Archivo Municipal de Valladolid}

\section{Fondo Histórico}

\section{AMVA: CH 321-56 1877}

Expediente de concesión de licencia a Gerónimo Ortiz de Urbina para revocar la fachada del convento de las Descalzas Reales de la calle Prado

\section{AMVA: 280-59 1903}

Expediente por el que la R.M. Superiora del Convento de la Descalzas Reales pide licencia para reconstruir la tapia que cerraba el convento por calle del Prado. Plano de tela plastificada a:100 alzado de $20 \mathrm{~m}$ y sección del muro de $11,80 \mathrm{~m}$ de altura con $1,0 \mathrm{~m}$ de espesor en la parte baja y 070 en la mitad superior. tres hiladas de sillares en zócalo y remate de teja inclinada. Firmado por Antonio Ortiz de Urbina.

\section{AMVA: 1049-53 1932}

Licencia concedida al convento de Descalzas Reales para colocar canalones en su edificio de calle Prado

La superiora solicita licencia exenta de pago para colocar $20 \mathrm{ml}$ de canalón que obliga la orden municipal, la conceden pero obligan a abonarla por ser vivienda, no lugar de culto.

AMVA: 1049-69 1933

Prórroga de licencia, concedida al convento de las Descalzas Reales, para revocar las fachadas del convento en avenida Ramón y Cajal, calle San Martín y calle Prado Dejan un año para conseguir recursos por la fuga de D Joaquín Aragón con su capital. 
AMVA: $395-81 \quad 1941$

Concesión de licencia a la Comunidad de Religiosas Descalzas Reales para modificar huecos en el Convento sito en Calle Prado [Hojas: 1 ; Planos: 1]

Amplían tres ventanas. El plano es un trozo de la fachada 1:100 en que se marcan en rojo los huecos modificados.

\section{AMVA: CH 263-48 1948}

Licencia a la superiora de la comunidad de Descalzas Reales para ejecutar obras de reforma en capilla del convento en avenida Ramón y Cajal

Solicitud y concesión. "Deseando reparar ciento cuarenta y cuatro metros cuadrados de la cubierta correspondiente a la cúpula del Coro de la Capilla, sustituyendo dos pares de la misma."

\section{AMVA: 9261955}

Convento de las Descalzas Reales. Demolición de parte del convento por amenaza de ruina (son las viviendas del capellán y la comendadora) (Exp. 65/1955)

Y solicitan también permiso para construir esas viviendas en unos locales de calle San Martín según proyecto del arquitecto Manuel López Fernández. Plano con plantas alta y baja de las viviendas $1 / 50$ sep1954. Se concede.

\section{AMVA: 464-8 1955}

Expediente sobre construcción muro de cerramiento en el Convento de Descalzas Reales de Avenida Ramón y Cajal. Proyecto de Manuel López Fernández. Alterna fajas de ladillo visto con entrepaños de revoco. Cimientos de hormigón en masa. Planos 1/50: 100ml, con altura $8 \mathrm{~m}, 5 \mathrm{~m}$ y $2 \mathrm{~m}$. Sección variable y contrafuertes.

\section{Fondo Administrativo}

\section{AMVA: $\exp 538 \quad 1976$}

Convento Madres Descalzas Reales. Instalación tanque gas propano en el patio del convento. Proyecto del perito industrial Andres Ceresa. Plano de patio y recorrido de canalización hasta la cocina 1:100. Recorte de prensa para alegaciones. Concesión.

AMVA: $\exp 12 / 20102010$

Orden de ejecución en Convento Descalzas Reales (Exp. CH 12/2010)

Ha habido desprendimiento de piezas cerámicas que conforman la cornisa de la 
fachada a calle San Martín. La causa aparente son filtraciones del agua de lluvia procedente del faldón de cubierta que ha deteriorado las propiedades del mortero de agarre y del propio material.

Certificado final de dirección de obra de cornisas y cubiertas de Elesio Gatón de 30 de junio de 2010. (Aquí no hay copia de ese proyecto)

\section{En el archivo de la Junta de Castilla y León}

No se ha localizado documentación.

\section{En el Archivo General de la Administración}

AGA 26/00088

1975 - Restauración - Ana Iglesias

Las religiosas ya estaban instaladas en el convento en 1615. La fachada es de ladrillo con una sencilla portada de piedra. La iglesia es de una sola nave con crucero. Se cubre con bóveda de cañón con lunetos sobre fajones y en el crucero hay una cúpula sobre pechinas.

En el edificio destaca un claustro de columnas de piedra con arquerías cegadas. Varias estancias del convento se cubren con artesonados de madera y otras con sencillas bóvedas de crucería. El estado de las celdas es ruinoso e insano.

Este proyecto se refiere a las de acondicionamiento de las celdas. Demolición de divisiones actuales, un forjado prefabricado que divida su altura de 4,70m en dos duplicando el número de celdas. Restauración de la cubierta.

AGA 26/00110

1976 - Restauración - Ana Iglesias

Restauración del claustro con apertura de la totalidad de huecos cerrados por ventanas de madera y muros de ladrillo enfoscados que dejan semiocultas las columnas. Cubiertas y pavimentos. (Planos ya en Planoteca, febrero de 1976)

AGA 26/01573

1976 - Restauración - Ana Iglesias 
La carpeta contiene sólo planos del mismo proyecto.

\section{6/01799}

1979 - Proyecto restauración - Ana Iglesias

Documentación administrativa. TRYCSA

Obras de restauración - Ana Iglesias - diciembre 1978

Obras a realizar

Consisten estas en las de restauración de las cubiertas de la iglesia que dado su buen estado en cuanto a la estructura principal, deberán ser realizadas con la sustitución de la tabla necesaria existente para que sirva de encofrado para la formación de una capa de compresión de hormigón, creada sobre lámina de plástico y mallazo, posteriormente se colocará la teja actual completandola con la reposición de la necesaria para su total cubrición.

En el claustro, cuyos huecos han sido liberados en obras anteriores, de sus tabiques y carpinterías, serán segun los planos correspondientes, cerrados estos con carpintería metálica...

\section{Presupuesto}

$392,12 \mathrm{~m} 2$ desmontado de cubierta de teja curva, incluso tabla ripia...

$392,12 \mathrm{~m} 2$ consolidación general de armadura de cubierta mediante la inclusión del herraje preciso y sustitución de elementos leñosos en mal estado $439,17 \mathrm{~m} 2$ formación de faldones de cubierta con tabla ripia $439,17 \mathrm{~m} 2$ capa de compresión formada por mortero de cemento, armado con mallazo metálico, vertido sobre lámina de plástico $439,17 \mathrm{~m} 2$ cubierta de teja curva sentada con mortero bastardo de cal y barro, incluso pate proporcional de caballetes, con aprovechamiento de teja desmontada 40ud recibido de cercos metálicos

Planos (ídem en Planoteca)

\section{AGA 26/01579}

1979 - Restauración cubiertas iglesia, claustro - Ana iglesias

En la caja sólo hay documentación administrativa: acta de recepción de la obra adjudicada a TRYCSA el 20-7-79. 


\section{Iglesia del Convento de San Joaquín y Santa Ana}

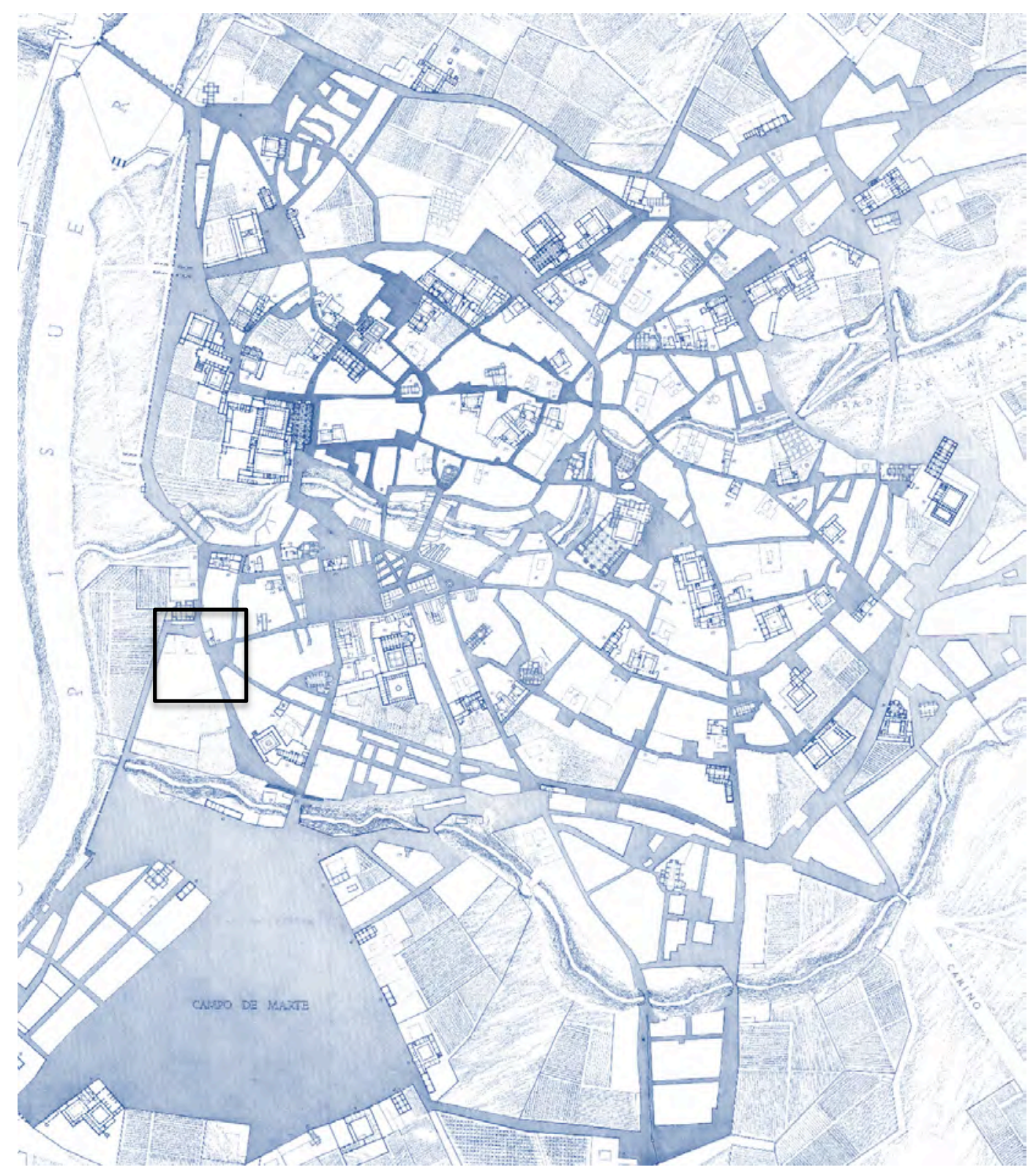



FICHA SÍNTESIS

\section{Código de identificación: FZ-15}

Denominación: $\quad$ Iglesia del Convento de San Joaquín y Santa Ana

Localidad: $\quad$ Valladolid

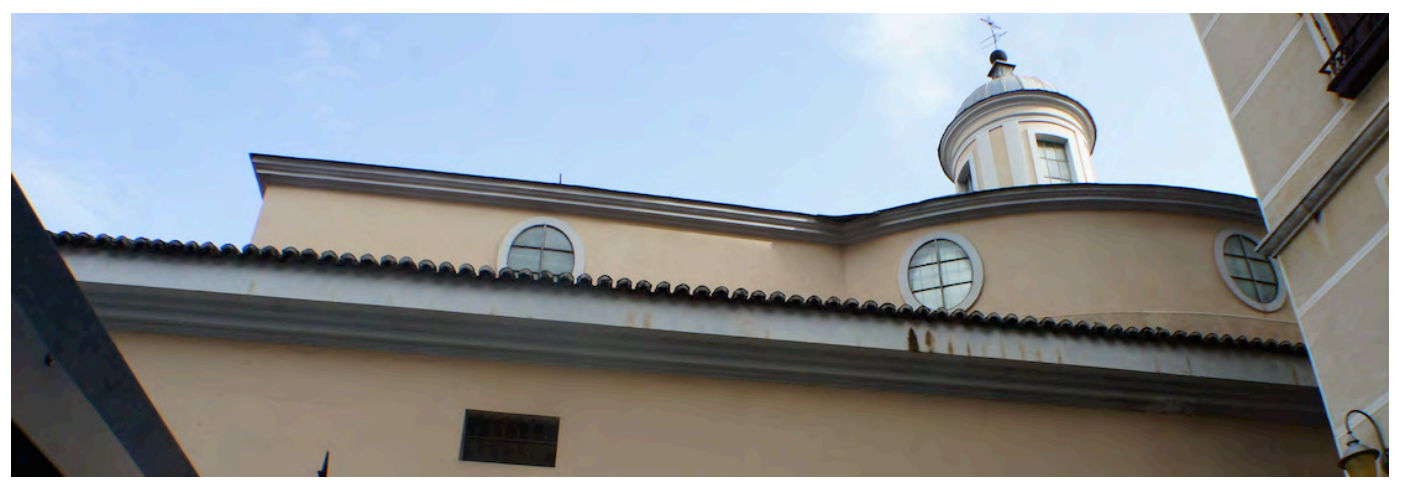

\section{Descripción}

Iglesia conventual barroca de planta ovalada con cúpula y linterna, vestíbulo y capilla mayor profunda. Fachada clasicista con grandes pilastras y frontón.

\section{Materiales}

Los muros son de fábrica de ladrillo enfoscada y pintada, excepto un zócalo con tres hiladas de sillares de piedra. La cubiertas están revestidas de teja curva, excepto la cúpula de pizarra con baberos de plomo.

\section{Singularidades}

El Monasterio forma un conjunto muy amplio, de sobrio estilo neoclásico, con tres claustros.

El templo se engarza en la esquina frente a una plaza, y se compone de una concatenación de espacios centralizados.

\section{Dimensiones básicas del templo}

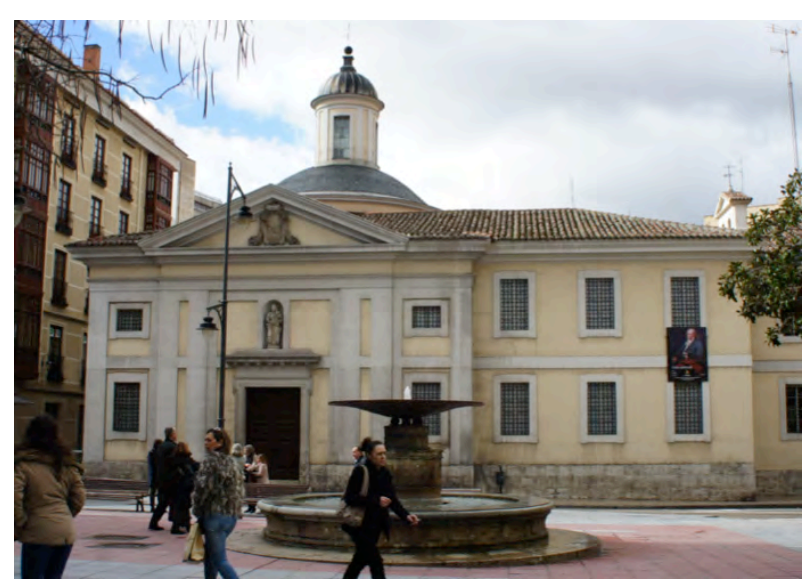

Ilustración 1: fachada a plaza de Santa Ana (visita 21/02/2015)

Ancho de nave $\quad 10,5$

Altura 26

$$
\text { central laterales capillas }
$$




\section{Memoria histórica constructiva}

Según el Catálogo:

El edificio se levanta con trazas y condiciones de Francisco Sabatini sobre otro anterior en estado ruinoso ${ }^{1}$. El arquitecto Francisco Álvarez Benavides coloca la primera piedra en 1781 como "asentista", bajo la dirección de Francisco Valzania y más tarde de Manuel Mariátegui.

En 1971 se aplicaron tratamientos para luchar contra una plaga de termitas, y la naturaleza inflamable de las sustancias favoreció la propagación de un incendio en las cubiertas de una zona del edificio en 1973.

\section{Cronología. Fechas clave}

$1618-1781-1973-1994$

\section{Intervenciones}

1957 - Fachada - Anselmo Arenillas Álvarez

Se sanea la fachada del Monasterio hacia la Plaza.

1958 - Fachada - Anselmo Arenillas Álvarez

Continúa la obra en ambos laterales del conjunto.

1959 - Cubiertas - Anselmo Arenillas Álvarez

Se interviene sobre la iglesia retejando y saneando con cinc los faldones del cimborrio.

1960 - Cubiertas y cornisas - Anselmo Arenillas Álvarez

Repara el tejado sobre la cornisa en la mitad derecha de la fachada a la Plaza.

1961 - Cornisas y tejados - Anselmo Arenillas Álvarez

Renueva el revoco de la fachada lateral. Reparan más de dos mil metros de cubiertas reponiendo maderos y tablas rotas para retejar. Incluye $34 \times 17 \mathrm{~m} 2$ de cubiertas correspondientes a la iglesia.

1962 - Saneamiento de las cubiertas - Anselmo Arenillas Álvarez

Continúan la reparación de cubiertas en nave lateral y zona sur.

1969 - Reparación de las cubiertas de unas salas anexas al coro - Alberto García Gil Se interviene tras el hundimiento de un entramado debido al pésimo estado de conservación. Hay un sillar de cornisa desplazado con riesgo de caída.

\footnotetext{
${ }^{1}$ Fundado el Monasterio en 1596, Francisco de Praves lo remodela en 1618, según el blog http://domuspucelae.blogspot.com.es/2011/05/un-museo-diferente-real-monasterio-de.html
} 
Se zuncha la esquina del edificio con hormigón armado disponiendo forjado de vigueta y bovedilla.

1971 - Obras urgentes de desinsectación de la capilla de Sabatini - Felipe Prieto

1973 - Restauración cubierta afectada por el fuego - Ana Iglesias y Cervantes Martinez Broca

La obra se realiza sobre una superficie de unos $200 \mathrm{~m} 2$ en la esquina opuesta al templo.

1974 - Obras urgentes de desinsectación de la madera - Felipe Prieto Granda Remate del tratamiento anti termes.

1974 - Adaptación de algunas dependencias a museo

1975 - Reforma y consolidación - Ana Iglesias

Recalce de cimientos y formación de contrafuerte en esquina opuesta al edificio del templo, sobre el que no se interviene.

1978 - Obras de restauración - Ana Iglesias (planos en IPCE)

Afecta a la esquina izquierda del conjunto adyacente a la fachada hacia la Plaza.

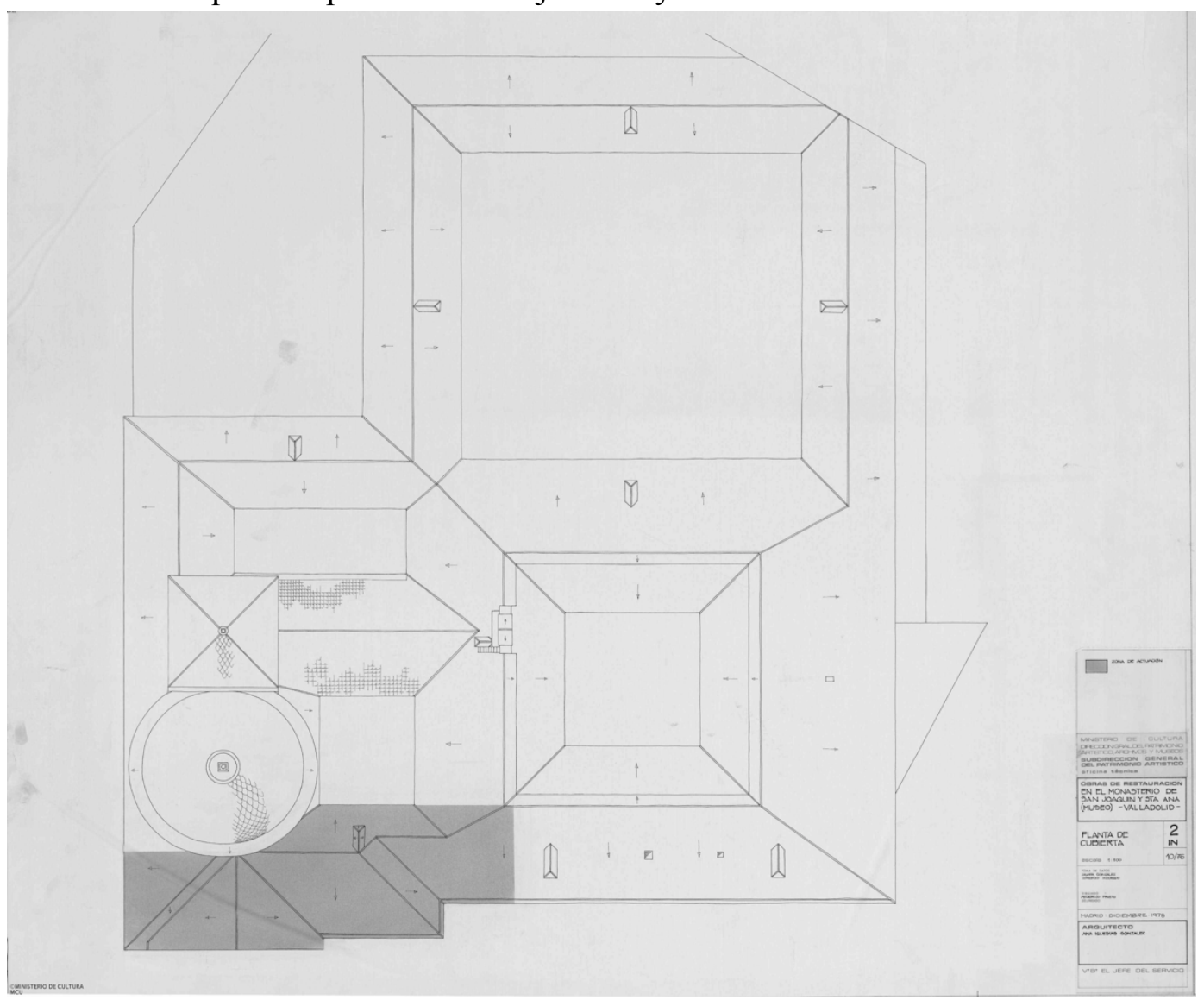

Ilustración 2: planta 1978 Iglesias IPCE 
1993 - Reposición de cubiertas y acondicionamiento del monasterio - Elesio Gatón Se restauran las cubiertas, por encontrarse podridas muchas piezas de la armadura. Hay pares rotos y apeos. Achaca la patología a la colocación de un canalón oculto tras la cornisa de la fachada a la plaza. Hay zonas peor conservadas que otras.

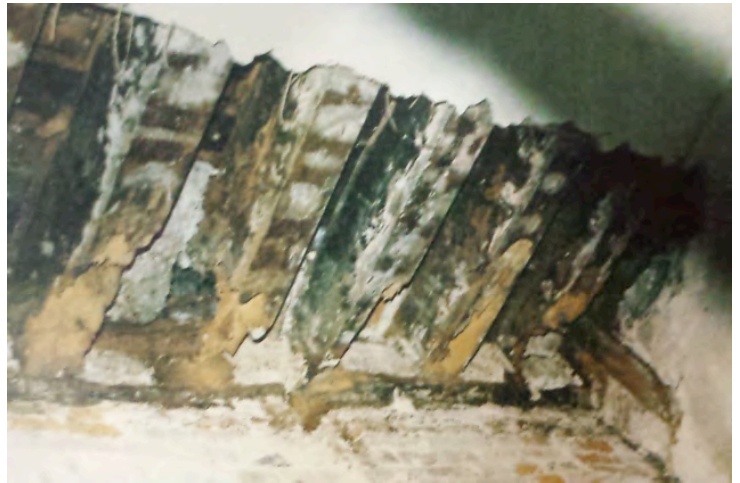

Ilustración 3: dossier proyecto Gatón 1993

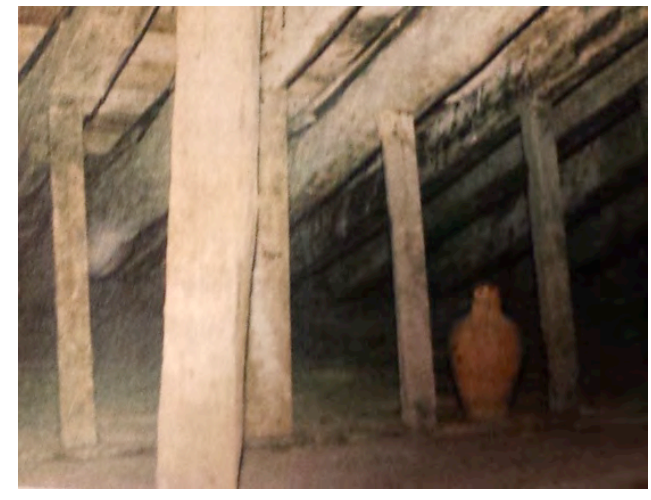

Repara cabezas mediante prótesis de madera de pino unidas con varillas y resina epoxy. Reutiliza la tabla ripia y tejas que se encuentra en buen estado, incorporando $936,84 \mathrm{~m} 2$ de tablero de $22 \mathrm{~m}$ con aislamiento.

Con el Proyecto modificado en 1994 se restauran las fachadas y reconstruyen las cornisas con ladrillo prensado, desmontando previamente $287 \mathrm{ml}$ de rellenos de aleros y coronación de muros, con limpieza de durmientes y cabezas de vigas de madera.

\section{Planos}

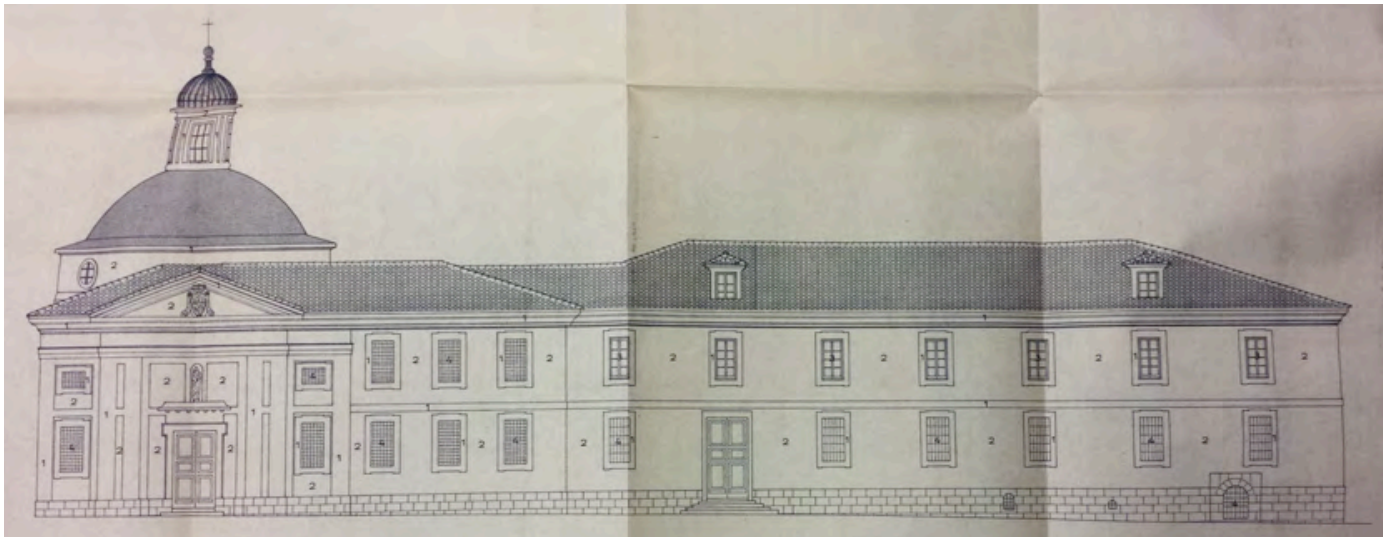

Ilustración 4: alzado del Monasterio a la Plaza, 1993 Gatón JCyL 


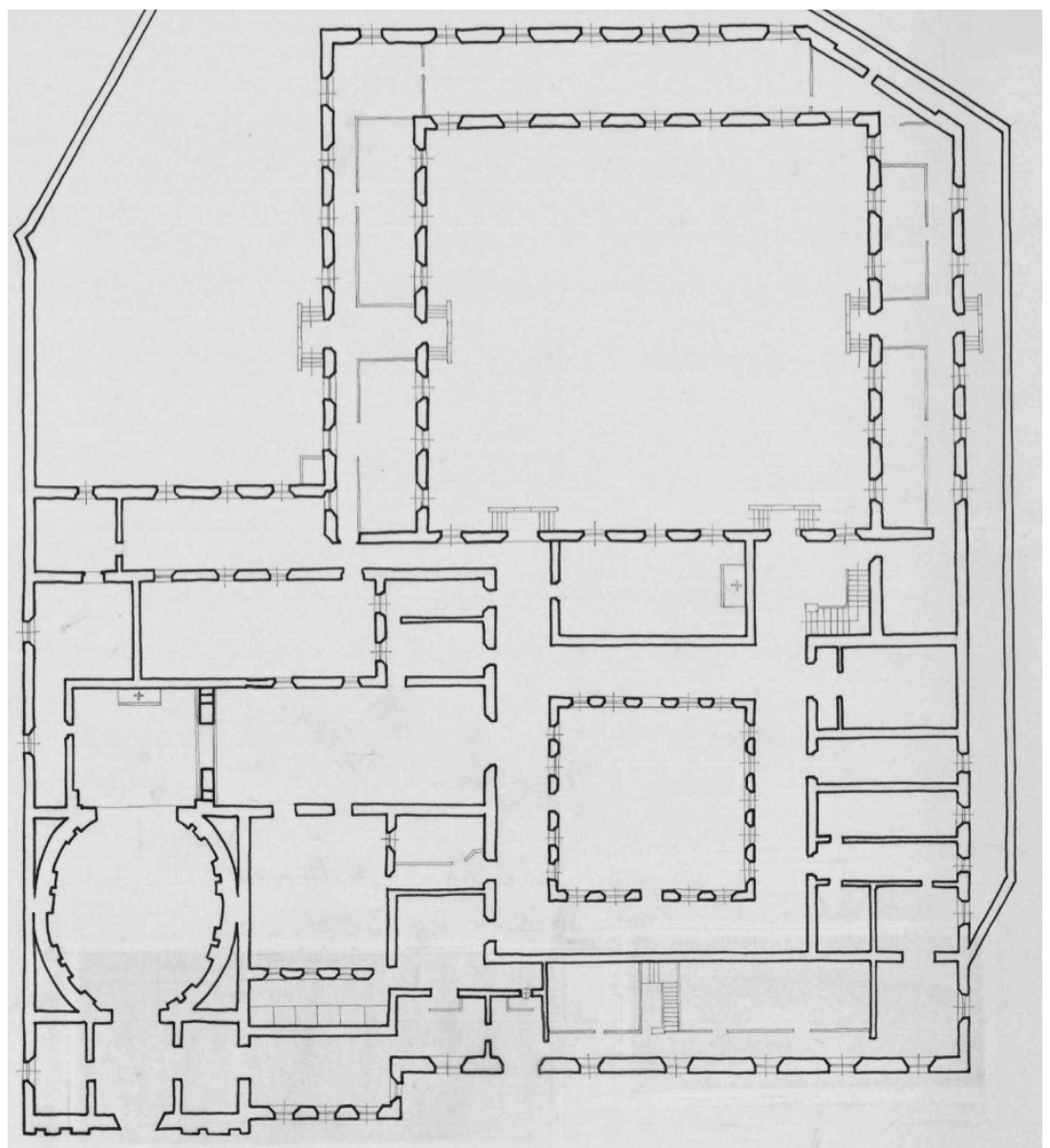

Ilustración 5: planta general del conjunto 1973 Iglesias IPCE

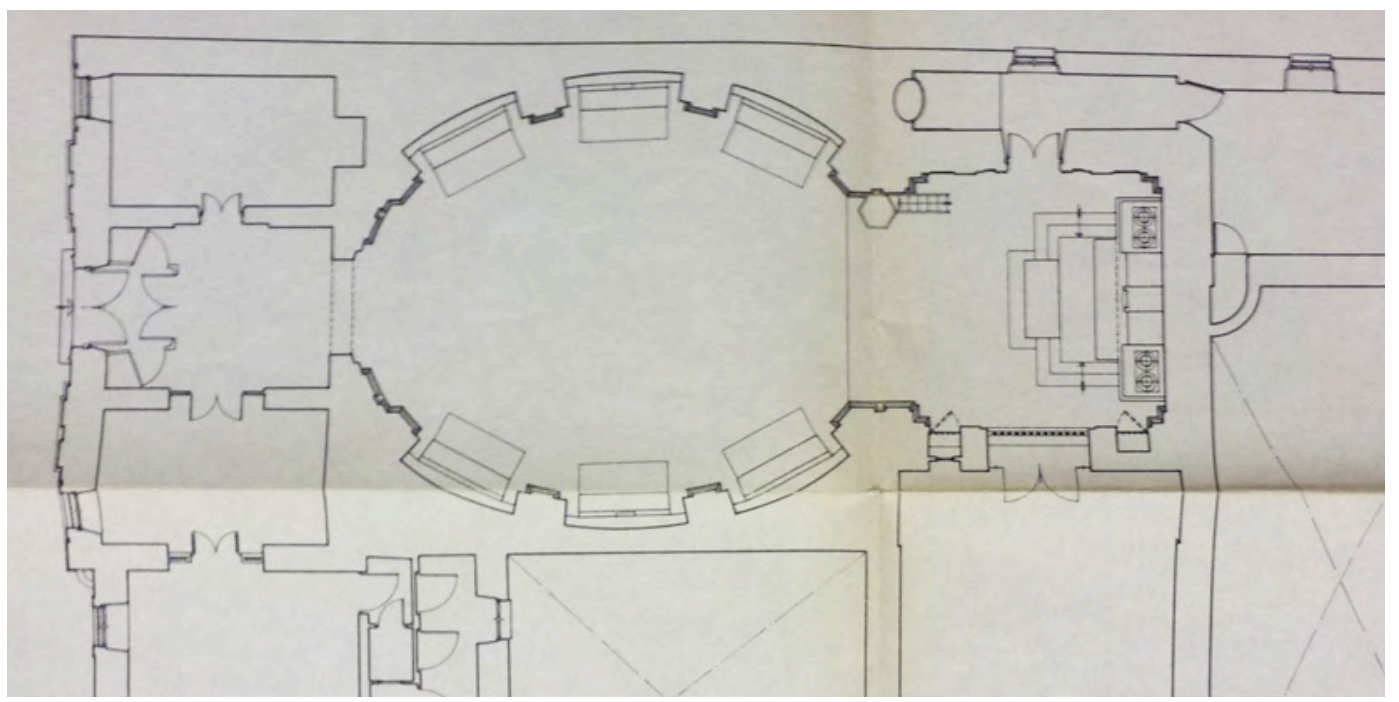

Ilustración 6: planta baja de la iglesia 1993 Gatón JCyL 


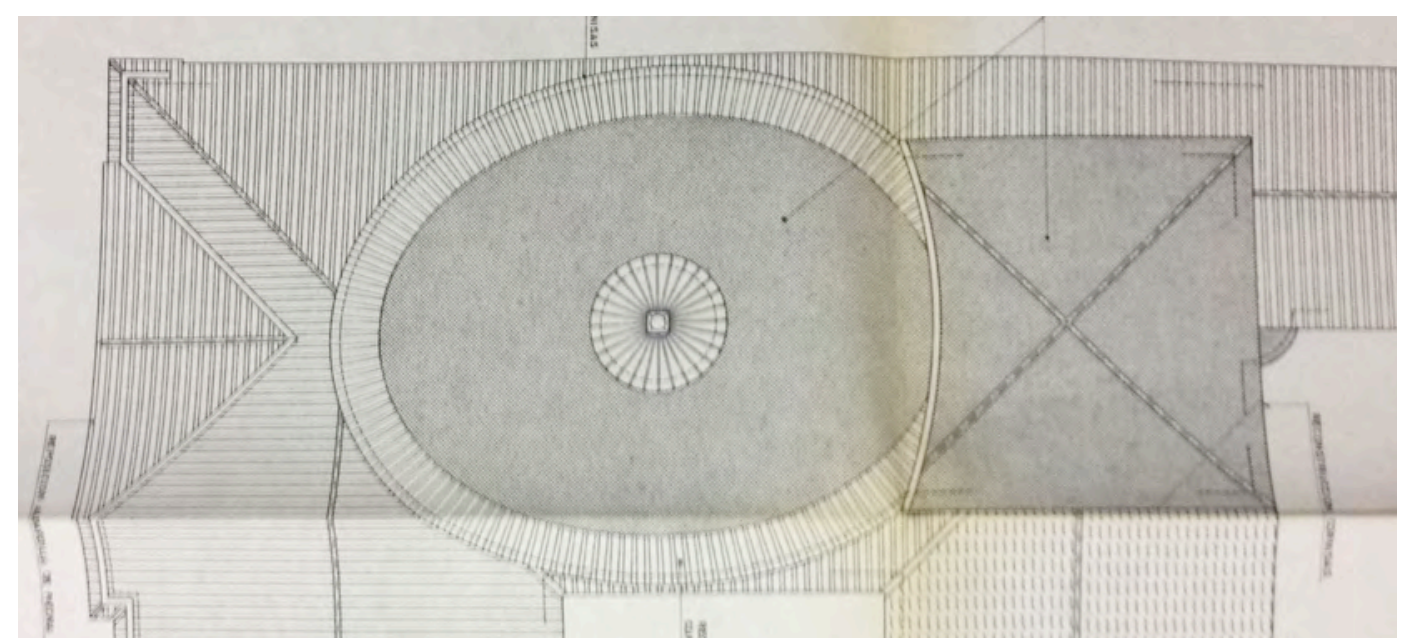

Ilustración 7: planta de faldones de cubierta 1993 Gatón JCyL. Áreas repaso de cubiertas de pizarra

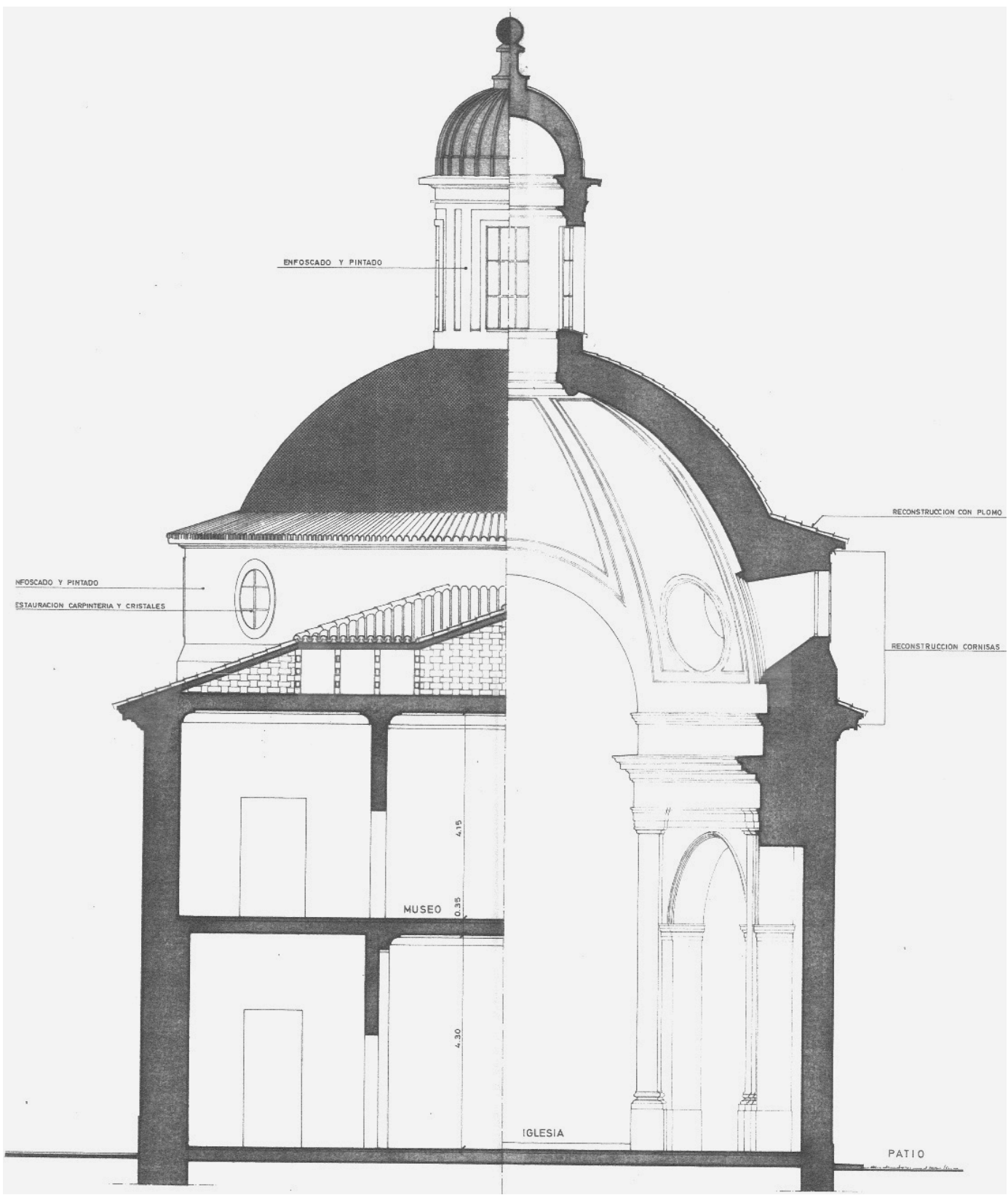

Ilustración 8: sección mixta del cuerpo del templo y salas del museo 1993 Gatón JCyL 


\section{Solución constructiva de la cubierta}

En los planos está representada la pendiente sin acotar, con unos $26^{\circ}$.

La sección de 1993 de Elesio Gatón concuerda con la planta de la actuación de Ana Iglesias de 1978, ya que en ambos documentos se representa la zona de salas sobre los pies del templo con una estructura de cubierta resuelta con tabicones y tabiquillos palomeros.

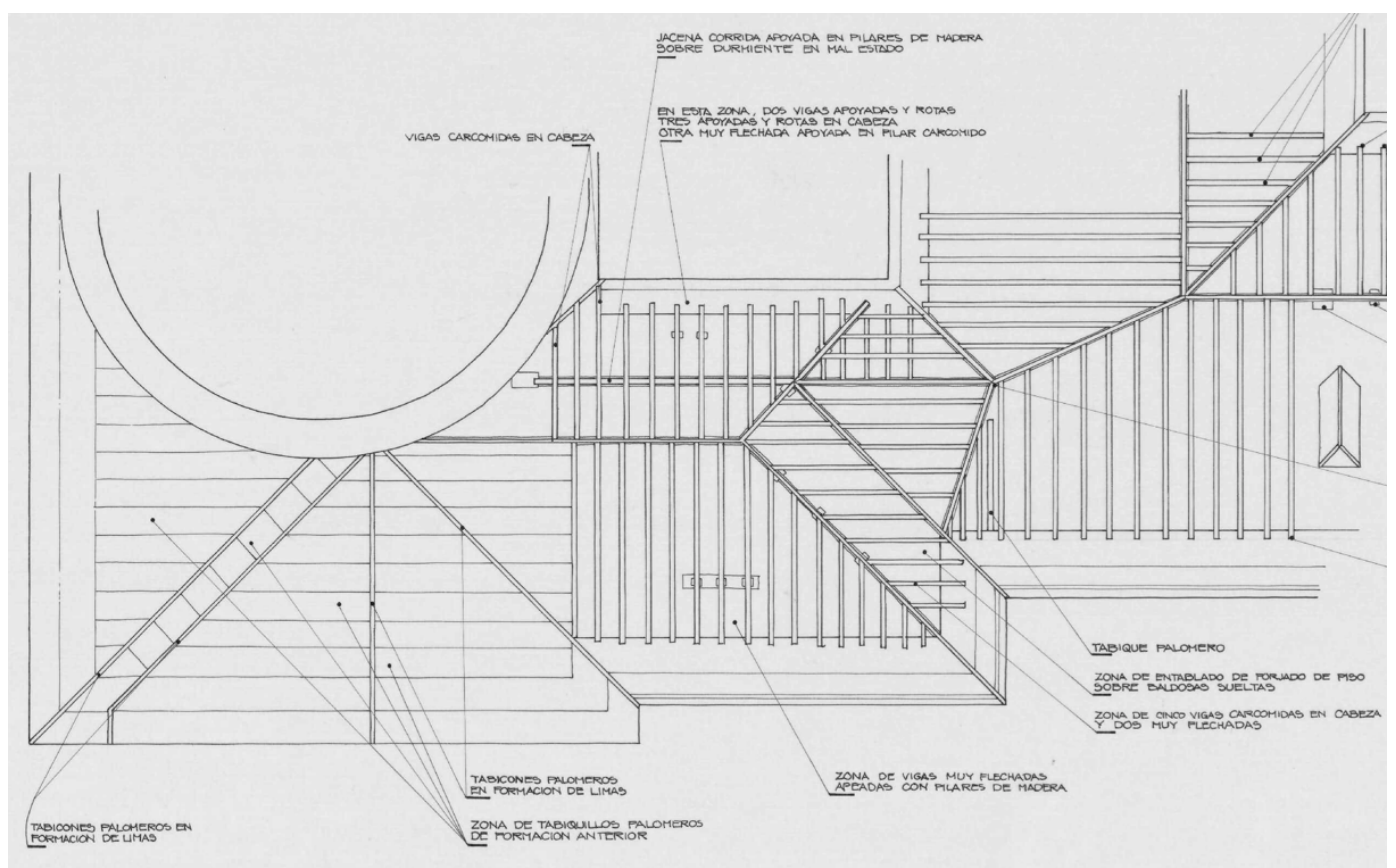

Ilustración 9: Estructura de cubierta en zona de actuación Ana Iglesias 1978 IPCE

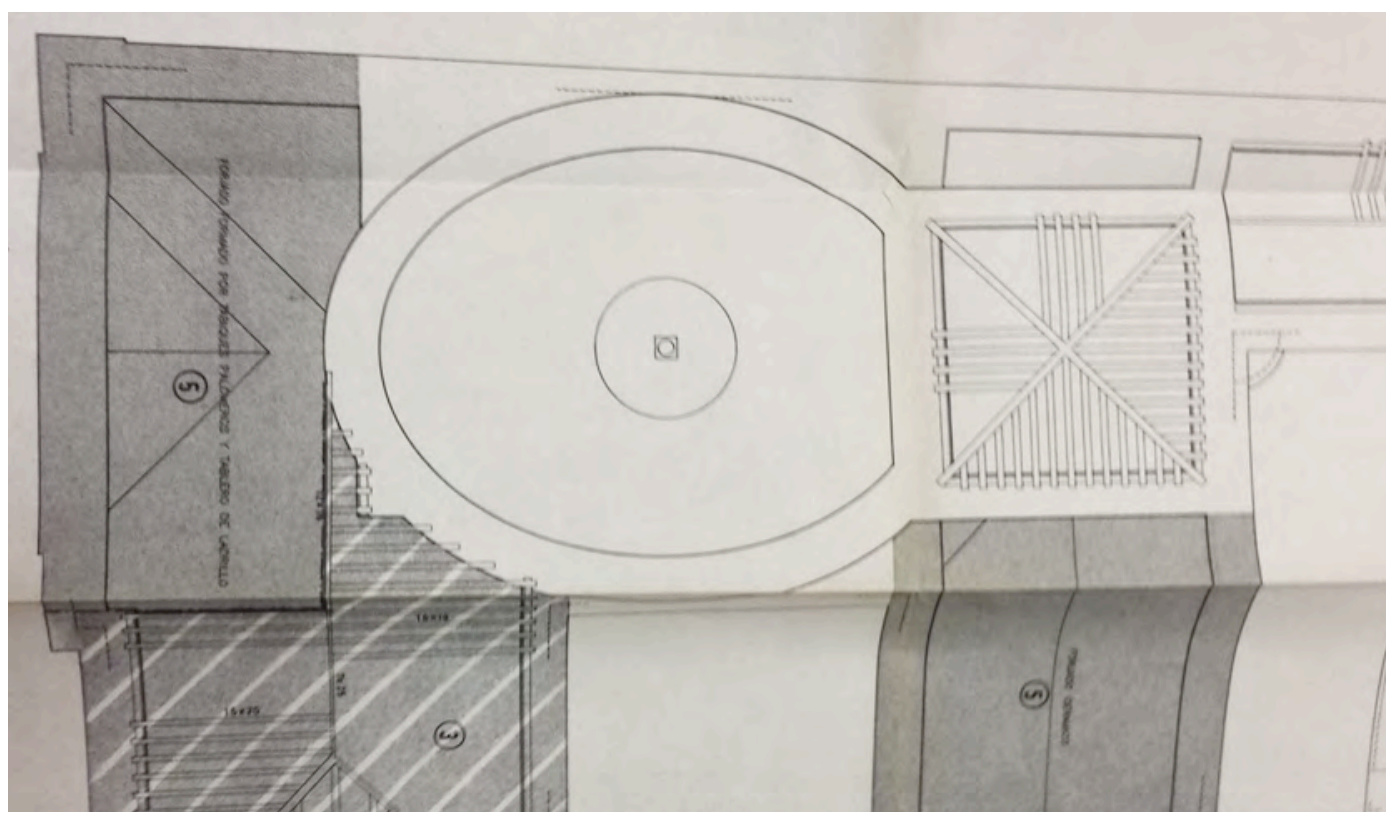

Ilustración 10: planta de cerchas de cubierta y zonas de actuación 1993 Gatón JCyL 
Leyenda del plano de planta Ilustración 10:

3 ) sustitución de durmientes en alero e hileras $100 \%$, pares $50 \%, 10 \%$ prótesis de pares y en cabezas de tirantes en fachada a calle $95 \%$.

5) aislamiento y retejo

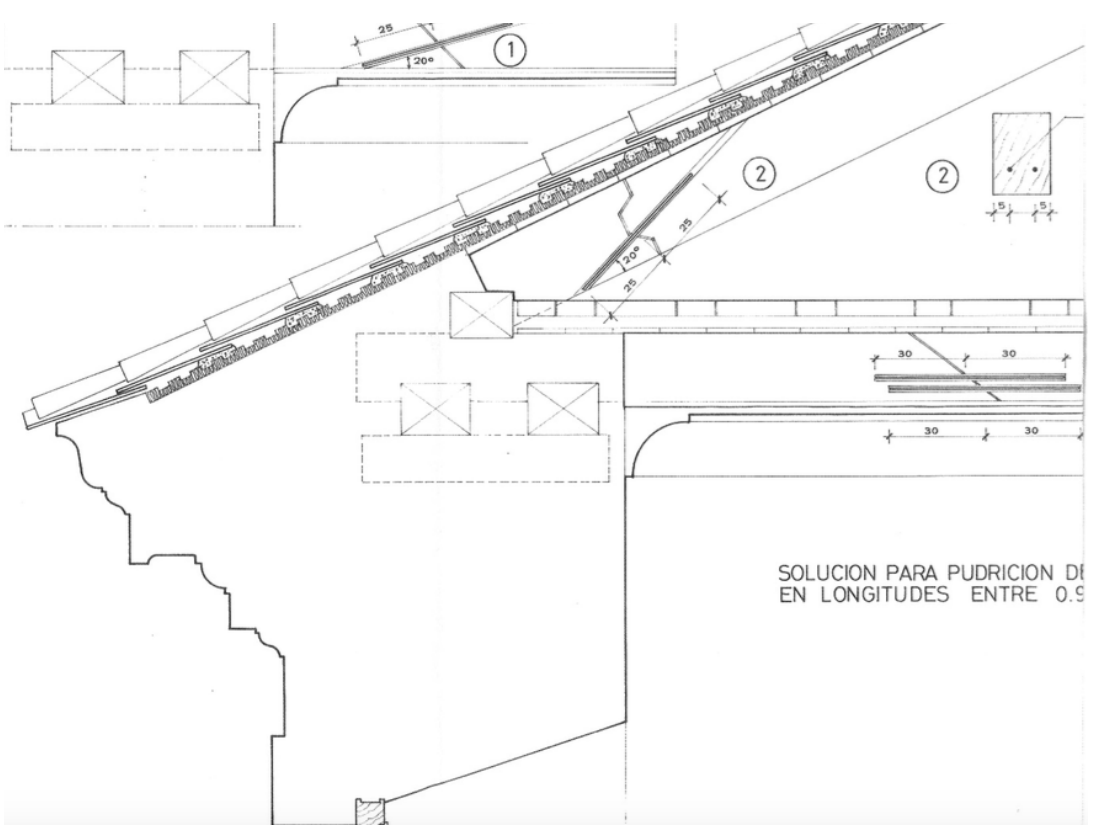

Ilustración 11: detalle cornisa 1993 Gatón JCyL

En los detalles del proyecto de Gatón de 1993 se representa los tirantes de madera con sus cabezas restauradas mediante prótesis, apoyados sobre un doble durmiente de madera que parece embebido en el espesor del muro de fábrica.

\section{Zunchos}

En la documentación de las intervenciones de Iglesias en 1978 y Gatón en 1993 sobre la zona del templo no se representa ni menciona zunchos.

Sólo en el proyecto de 1969, realizado por García Gil tras el hundimiento de una zona de entramado, se incorporan $0,855 \mathrm{~m} 3$ de zuncho de hormigón armado "en arriostramiento de muros de ángulo".

\section{Conclusiones}

En este edificio hay soluciones constructivas diversas según las zonas. Parece que sólo se incorpora un tramo en L de zuncho de hormigón armado para atar la esquina, al incorporar un forjado de vigueta y bovedilla y una cubierta resuelta con tablero de una rosca de ladrillo con $2 \mathrm{~cm}$ de capa de compresión de hormigón apoyado sobre tabiquillos de ladrillo hueco. 


\section{Iglesia de San Joaquín y Santa Ana, en Valladolid}

Intervenciones citadas en la publicación del Ministerio:

1957 - Fachada - Anselmo Arenillas

1958 - Fachada - Anselmo Arenillas

1959 - Cubiertas - Anselmo Arenillas

1960 - Cubiertas y cornisas - Anselmo Arenillas

1961 - Cornisas y tejados - Anselmo Arenillas

1962 - Saneamiento de las cubiertas - Anselmo Arenillas

1969 - Reparación de las cubiertas de unas salas anexas al coro - Alberto García Gil

1971 - Obras urgentes de desinsectación de la capilla de Sabatini - Felipe Prieto Granda

1973 - Restauración cubierta afectada por el fuego - Ana Iglesias González y Cervantes Martínez Brocca

1974 - Obras urgentes de desinsectación de la madera - Felipe Prieto Granda 1974 - Adaptación de algunas dependencias a museo - Ana Iglesias González

En la web del IPCE hay 2 planos de 1973, 9 de 1974, y 3 de 1978.

\section{En el Archivo Municipal de Valladolid}

\section{Fondo Administrativo}

AMVA: exp 30221922 C-19483-62

Comunidad de religiosas del Convento de San Joaquín y Santa Ana ( Yllera del Valle, Leonor ). Sala de exposiciones y reuniones. Solicitud y concesión.

AMVA: exp $349 \quad 1967$ C-2189-3

Illera del Val, Madre Leonor ( Superiora de las religiosas cistercienses del convento de San Joaquín y Santa Ana). Instalación de tanque de fuel-oil de 10.000 litros de capacidad. (contiene planos)

Instalación para abastecer la Lavandería mecánica. Planos con itinerario de camiones de abastecimiento, croquis en planta y detalles de la instalación del tanque.

AMVA: $\exp 342 / 1975 \quad 1975$

Convento cisterciense de San Joaquín y Santa Ana. Reforma y consolidación de dicho convento (Exp. 342/1975) (8 planos) 
Solicitud de permisos para realizar la obra del proyecto de Ana Iglesias.

Pliego. Presupuesto:

Partidas alzadas de demolición de tapia, restos de muro trasero, tabiques actuales de planta primera y rasgado de ventana para puerta.

$6 \mathrm{~m} 3$ de hormigón en consolidación de cimientos y 4,5m3 en cimentación de muro de cerramiento.

$18 \mathrm{~m} 2$ de fábrica de ladrillo perforado de $11 / 2$ pie de espesor en formación de nueva tapia recibido con mortero de cemento $1: 6,25 \mathrm{~m} 2$ de 1 pie incluso contrafuertes, etc

Memoria:

"Trata el presente proyecto de las obras necesarias para consolidar parte del edificio que por falta de cimientos en esa zona, ha sufrido daños. Será por tanto necesario proceder a un recalce de cimientos en la misma, así como a la formación de un contrafuerte que asegure la estabilidad del muro que a él se encuentra trabado."

Nueva alineación de tapia y construcción de escalera.

La obra afecta a la esquina de calle Pedro Niño, alejada del cuerpo de la iglesia.

\section{AMVA: exp 1290/88 1988 Infracción urbanística C23069-26}

Expediente 1290/88. Sancionador: obras no ajustadas a permiso en plaza Santa Ana c/v a Pedro Niño (Convento San Joaquín y Santa Ana). Madre Abadesa

El permiso era para obras menores y se está ejecutando: reducción de nave de servicio, escaleras, nuevo acceso, apertura de huecos, dependencias, nuevas carpinterías, sustitución de vigas, nervios abovedados de piedra e instalaciones.

\section{AMVA: 28193/11 1993}

Licencia de vallas o andamios. Calle Pedro Niño, 1. Leonor Yllena del Valle (Convento San Joaquín y Santa Ana) Croquis

\section{AMVA: $\exp 484 / 2005 \quad 2005$ C-34441-1}

Real Monasterio de San Joaquín y Santa Ana (Voces Sierra, Erundina). Instalación ascensor (Exp. 484/2005) 3 carpetas: documentación administrativa, proyecto y estudio de seguridad.

Proyecto de Elesio Gatón. Contiene dos fotos del patio interior donde se va a instalar el ascensor, ficha de la pintura al silicato, compromiso de intervención arqueológica Planos con plantas y alzados del patio, planta general del convento 1/500 y 1/200 


\section{En el archivo de la Junta de Castilla y León}

\section{VA-132}

Carpeta 5328/1

Reposición de cubiertas y acondicionamiento del Monasterio

1993-1994

Arq: Elesio Gatón

Resumen de la memoria histórica:

En 1594 se funda el monasterio de Santa Ana, con la oposición de la parroquia de San Llorente y el convento de la Santísima Trinidad. En 1777 el edificio se encuentra en muy mal estado. Sabatini propone reedificarlo y la obra comienza en 1781. En Chancillería se conservan quejas del Director de obra Valzania sobre retrasos y mala calidad de los materiales que aportaba el "asentista" (el contratista) Benavides. (E1 primero estuvo dos meses preso por empujar al segundo desde un andamio)

Los aparejadores denuncian y Ballina descubre que la arena era de mala calidad, había abuso en la mezcla del mortero, ladrillos mal cocidos, etc. Ordena demoler lo mal ejecutado.

El edificio se construye en el XVIII a partir del proyecto de Sabatini, no hay evolución constructiva y los pocos restos anteriores son sólo una columna y un pozo.

El estado del edificio no amenaza ruina inminente pero la patología de cubierta puede causar graves daños. En el presente siglo se colocó un canalón oculto tras la cornisa de la fachada a la plaza de santa Ana y sustituyó la cubierta de plomo de la iglesia por otra de pizarra con tres hiladas de tejas

Plano $n^{\circ} 8$ : La solución constructiva y el estado de conservación varía mucho de unas zonas a otras.

Zona 1 resuelta a par y picadero con escuadrías escasas, mal estado de conservación, pares partidos, apeados, etc

Zona 2 estructura de madera de par y picadero, pares próximos de fuerte sección, tabla ripia y teja cerámica curva a canal y cobija. Los pares apoyan en un doble durmiente que a su vez está cajeado en un tirante de madera que sirve para la formación del forjado de la última planta.

Zona 3 similar pero con estructura de madera de par e hilera, secciones más escasas e inferior calidad. La mitad de pares está roto y apeado contra el forjado 
Al fallar el canalón empotrado las zonas 2 y 3 tienen podridas las cabezas.

Zona 4 similar a 2 pero sin el canalón empotrado están menos podridas las piezas

Zona 5 ha sido sustituida recientemente la estructura de cubierta con tableros cerámicos y capa de compresión de hormigón.

El presupuesto es insuficiente para restauración integral. Se propone reparar las cabezas con prótesis de madera unidas con un corte en forma de $\mathrm{V}$, enlazadas por varillas prensadas de $40 \%$ poliester y $60 \%$ fibra de vidrio rellenas con resina epoxy. Hay dos modelos de detalle constructivo para dos longitudes ya que cambian los esfuerzos.

\section{Recomienda cuidado al apuntalar la cornisa para evitar su vuelco.}

Reutilizar tabla y teja en buenas condiciones.

Tablero de tabla ripia de una pulgada de espesor, aislamiento de poliestireno extruido, $4 \mathrm{~cm}$ roofmate y teja sobre pelladas de mortero de cemento, recibida cada seis hiladas en cumbreras y aleros.

Picado y enfoscado con mortero bastardo del tambor y linterna. Rehacer tramo de cornisa desprendido con ladrillo prensado y enfoscarlo.

Pintura y restauración de vidrieras. Entarimado, carpinterías, instalaciones.

Dossier cuatro láminas con fotocopia de fotografías en color.

Memoria de cálculo madera pino Soria. No recalcula lo existente, usará misma escuadría se ve que funciona.

Presupuesto.

En albañilería hay $464 \mathrm{~m} 2$ de falso techo de cañizo, $8 \mathrm{ml}$ de reparación y consolidación de cornisas, ejecutado con ladrillo prensado rojo, recibido con mortero bastardo de cal, cemento y arena de río 1/1/6 y sacado y corrido de cornisa y emboquillado de tejas totalmente terminado...

Reposición de hileras, durmientes. Prótesis: 48ud cabezas pares, 34 de vigas y 199ud más de $90 \mathrm{~cm}$ cabezas de vigas

$936,84 \mathrm{~m} 2$ tabla ripia de $22 \mathrm{~mm}$

Planos febrero 1993. (saco algunas fotos) 
VA-132

Carpeta 5328/1

Reposición de cubiertas y acondicionamiento del Monasterio

1993-1994

Arq: Elesio Gatón

Documentación administrativa, contratos, etc.

Acta de recepción definitiva 8 de enero de 1997. Adjudicada 17/08/1994

Proyecto Modificado mayo de 1994

Aprovechando el montaje de andamios se incluye la restauración de fachadas. Se va a recuperar la forma primitiva de dos huecos rasgados convertidos en balcones en fecha reciente.

En el presupuesto, entre otras, $287 \mathrm{ml}$ desmontado de rellenos de aleros y coronación de muros, con limpieza de durmientes y cabezas de vigas de madera

\section{En el Archivo General de la Administración}

AGA 26/00310

1957 - Restauración de la fachada - Anselmo Arenillas

Se picará a fondo las fachadas... revoco. Se colocará balcón.

La cornisa se correrá de nuevo y se saneará.

Planta general señala en rojo la línea de fachada a la plaza.

AGA 26/00160

1958 - Adecentamiento de la fachada del Convento de Santa Ana - Anselmo Arenillas

Memoria (1 pag)

Ordenado por la Superioridad que se continúe reparando la fachada... No permite el presupuesto disponible colocar los canalones o limas de plomo en la coronación de la fachada, ambas cosas quedan pendientes de ejecución.

Plano 1:250 con dos líneas rojas señalando fachadas laterales.

AGA 26/00262

1959 - Reparación de cubiertas - Anselmo Arenillas

El tejado de la cúpula ... las partes bajas del cimborrio y el frontispicio están mal conservados y producen un sin fín de goteras y daños en sus armaduras y en el interior del templo. Se trata en este proyecto de levantar todo el tejado y rehacerlo 
empleando teja nueva solamente para reponer las rotas y se procurará adquirir teja de derribo sana para evitar la sensación de obra nueva. Al mismo tiempo se harán de cinc fuerte los faldones del cimborrio, la parte alta de la cornisa y todos los canalones que están picados.

Se aprovecha para poner doble techo en el portal.

Plano de la planta habitual, señalado en rojo el perímetro de la iglesia.

\section{AGA 26/00153}

1960 - Reparación de cubiertas y cornisas - Anselmo Arenillas

Proyecto de reparación parcial.

Se proyectó desmontar el tejado sobre la cornisa de la fachada, rehacer ésta con ladrillo y cemento, reponer encima su canal o lima de zinc previo corrido de su moldura con igual perfil pero con mortero de cemento y después de sanear la armadura de la primera nave de tejado paralela a la calle, volverla a tejar con teja nueva en su mayor parte y rehaciendo el tejaron volarlo sobre la cornisa.

En el plano señala la mitad derecha de la fachada a la plaza.

\section{AGA 26/00357}

1961 - Reparaciones - Anselmo Arenillas

Renovar el revoco de la fachada lateral como se hizo con la principal. Rehacer cornisas como estaban, con ladrillo pero con mortero de cemento, revoco pétreo y lima de cinc.

Planta general del conjunto 1:250.

Reparación total de cubiertas reponiendo maderos y tablas rotas y retejando a fondo: Iglesia $34 \times 17$ (suma resto de dependencias hasta $2.345 \mathrm{~m} 2$ totales)

\section{AGA 26/00253}

1962 - Obras de saneamiento - Anselmo Arenillas

En este convento es necesario retejar y reponer las armaduras de parte de sus cubiertas que tienen goteras que no han sido reparadas por falta de medios hace tiempo.

Se necesita también agrandar la puerta trasera, barandilla, zócalos de azulejo.

Son estas obras una compensación a los locales que cede el convento para Museo.

Plano de planta 1/250 de todo el conjunto con rótulos de usos: Iglesia pública, patio, presbiterio, confesionarios... Trama roja señala una zona junto al jardín.

En presupuesto:

Reparación de cubiertas reponiendo maderas rotas

Nave lateral 17x15m y nave jardín sur 27x8 
AGA 26/00146

1969- Obras de restauración en dependencias junto al coro alto - Alberto García Gil Segovia mayo de 1969

En una sala anexa al coro alto principal, en el ángulo izquierdo del edificio, sobre la Plaza de Santa Ana, se ha producido el hundimiento de un entramado de madera originado por el pésimo estado de conservación de la cubierta, la cual es de construcción deficiente.

La disposición de los forjados hace que la fachada lateral, falta de atado, se haya desplazado, empujada por la cubierta, produciendo grieta en la fachada principal.

Por otro lado, una esquina de la cornisa, de piedra de gran volúmen, falta de atado, se encuentra desplazada de su posición con grave peligro de desprendimiento total.

En consecuencia la restauración que se proyecta abarcará:

Desmonte de la cubierta en la zona dañada y de los entramados de madera inservibles.

Zunchado de la esquina del edificio.

Construcción de los forjados a reparar, con viguetas prefabricadas de hormigón pretensado y bovedillas de cemento.

Construcción de cubierta cerámica con tabicas aligeradas y tablero de ladrillo hueco sencillo.

Retejo.

Adecentamiento de paramentos y pavimentos.

Puerta en sitio de la cornisa desprendida.

Reparaciones en la cubierta del edificio hasta completar el total del presupuesto concedido.

Se hace notar que una reparación del total de la cubierta se presenta como obra necesaria a realizar con urgencia, sobre todo en la zona de la iglesia.

Asimismo sería interesante pensar en la instalación de un museo en el Monasterio...

Dossier de fotografías de la zona apeada y hundida. Pido copia de sillar de esquina desprendido.

Presupuesto.

Demoliciones 2 ud apeo de forjados, 54,67m2 desmontado de material de cubrición, $41,76 \mathrm{~m} 2$ desmontado de armadura de madera y 49,77m2 demolición de entramados de piso. 
En albañilería:

0,855 m3 Zuncho de hormigón armado de $350 \mathrm{~kg}$ de cemento y $60 \mathrm{kgs}$. de hierro redondo, elaborado y colocado, incluso encofrado y desencofrado, en arriostramiento de muros de ángulo.

Forjado de piso y cubierta $49,77 \mathrm{~m} 2$ formados por viguetas de hormigón armado prefabricado de $700 \mathrm{~kg} . \mathrm{m}$ entrevigado con bloques de hormigón vibrado aligerado y capa de compresión con mortero de cemento 1:4 y 2 cms. de espesor, incluso apertura de mechinales para carga de vigas.

Formación de cubierta con tabicón de ladrillo h. doble sentado con mortero de cemento colocado en celosía de limas, tabicas de ladrillo hueco sencillo del mismo tipo tomado con mortero de yeso a $50 \mathrm{cms}$. ejes, codales del mismo material y tipo cada 2,5 metros y tablero de rasilla de una rosca con capa de compresión de mortero de cemento 1:4 y $2 \mathrm{cms}$. de espesor (a medir luces)

ReteJado

P.A. Colocación de piedra de cornisa en ángulo posterior del Monasterio, incluso desmontado de tapa y nueva colocación, apeos, anclajes y recibidos a muro.

Solado

Pintura

NO hay planos en este proyecto.

\section{AGA 26/00331}

1971 - Obras urgentes en la capilla de Sabatini - Felipe Prieto

Desinsectación en la zona de capilla y departamentos anejos, tras un estudio de todo el edificio por técnicos de la empresa Corpesa de tratamiento de maderas.

Incluye tres fotos: general, fachada desconchada y sillar desprendido en esquina. Ni planos ni mediciones.

\section{AGA 26/00065}

1974 - Restauración - Ana Iglesias

Diciembre de 1973

Obras para restaurar la parte del edificio afectado por el incendio del 8 de diciembre de 1973.

Dicha zona comprende $200 \mathrm{~m} 2$ y en ella la parte más dañada ha sido su cubierta, cuya estructura construida en madera había sido recientemente tratada contra las termitas con productos químicos altamente combustibles, hecho este que favoreció la propagación del fuego.

Según el plano es la esquina de la fachada a la Plaza contraria a la iglesia. 
AGA 26/00065

1974 - Obras urgentes - Felipe Prieto

( 2 pág memoria y 3 partidas presupuesto)

Recientemente se descubrieron tanto en el templo como en el resto del edificio importantes focos de insectos litófagos (Reticulitermes lucífugus y otros) que ya habían causado grandes daños en las estructuras de madera habiéndose llegado en algunas vigas a la pérdida del $50 \%$ de su resistencia mecánica y en otras a su completa destrucción.

Última parte de los trabajos de desinsectación.

Incluye dos fotografías de la cornisa.

AGA 26/00088

1975 - Restauración - Ana Iglesias

Proyecto para adaptar algunas dependencias al uso de museo. Cambian dos forjados de madera por vigueta y bovedilla. Se refuerza un durmiente de madera.

(Son los planos de la Planoteca IPCE de 1974) 



\section{Iglesia del Monasterio de Santa María de las Huelgas}

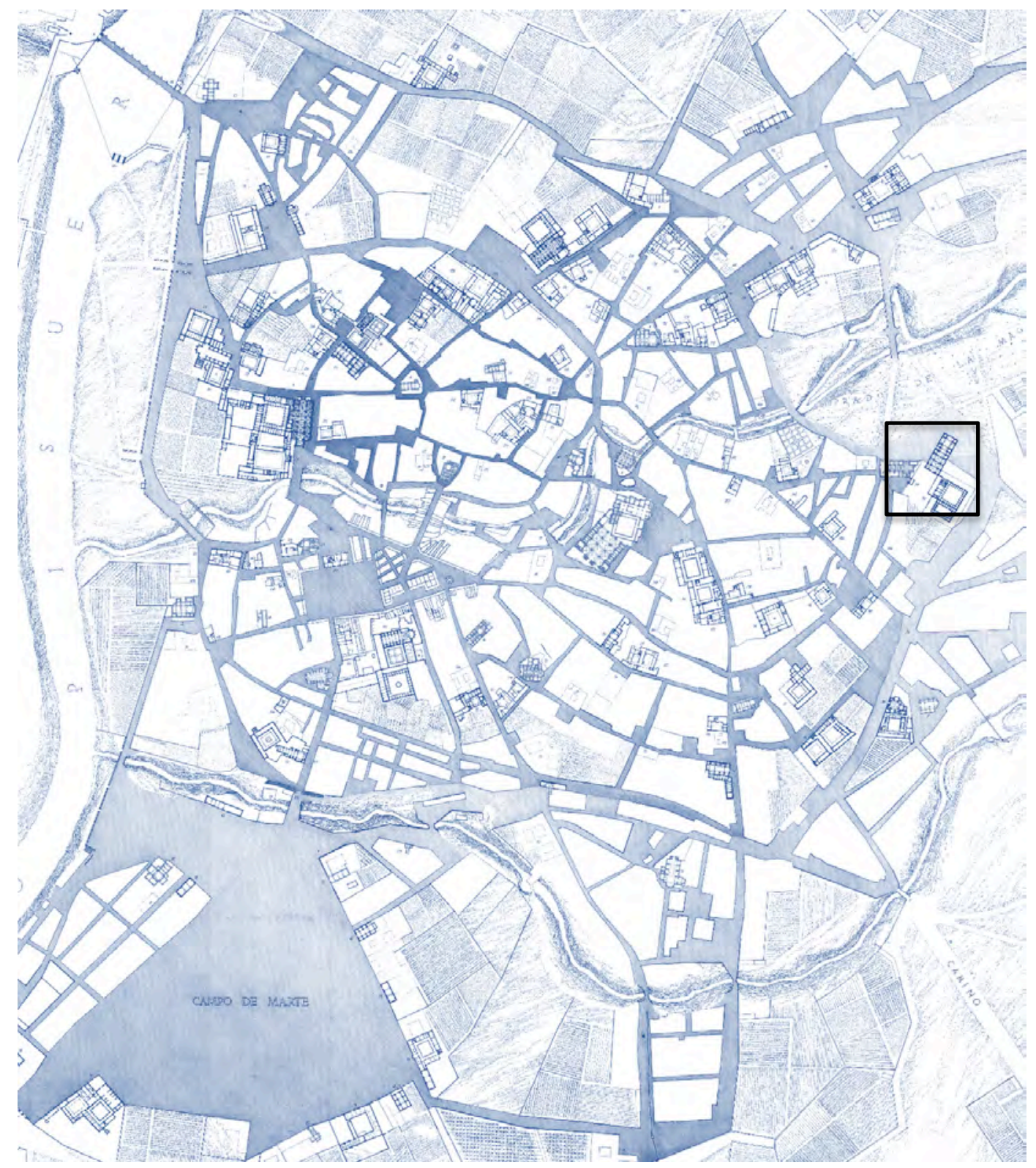





\section{FICHA SÍNTESIS}

\section{Código de identificación: FZ-16}

Denominación:

Iglesia del Monasterio de Santa María de las Huelgas

Localidad: Valladolid

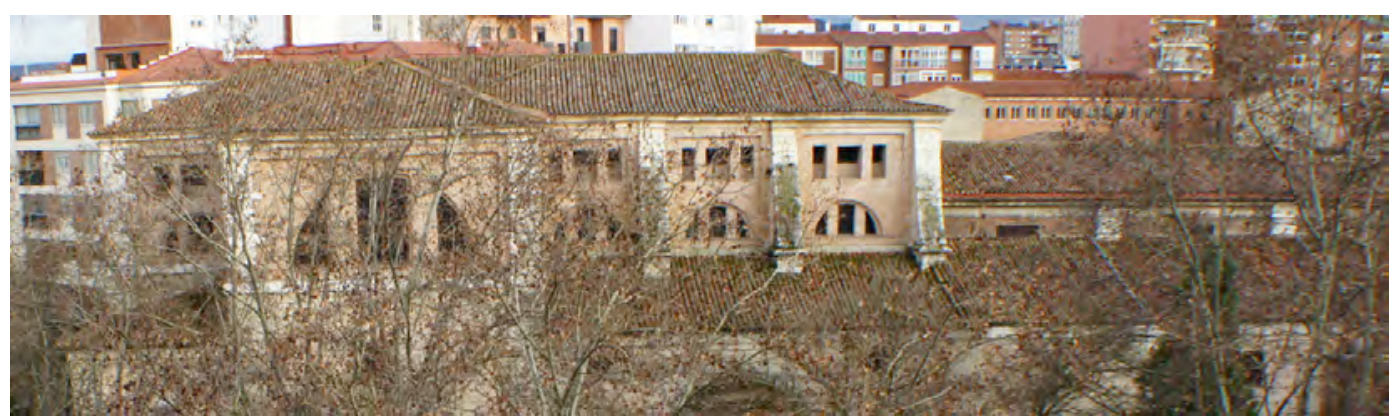

\section{Descripción}

En la zona de clausura, la iglesia adopta un esquema de tres naves con deambulatorio, mientras que el volumen principal del templo presenta planta de cruz latina inscrita en un rectángulo con capillas entre contrafuertes. La primera alcanza menor altura que la segunda. La nave se cubre con una bóveda de cañón dividida en tramos por arcos fajones y sobre el crucero se dispone una cúpula baída ciega.

\section{Materiales}

Los muros son de tapial, con verdugadas y arcos de descarga de ladrillo entre pilastras de piedra, sobre un zócalo de cuatro hiladas de sillería. La cubierta está revestida de teja curva.
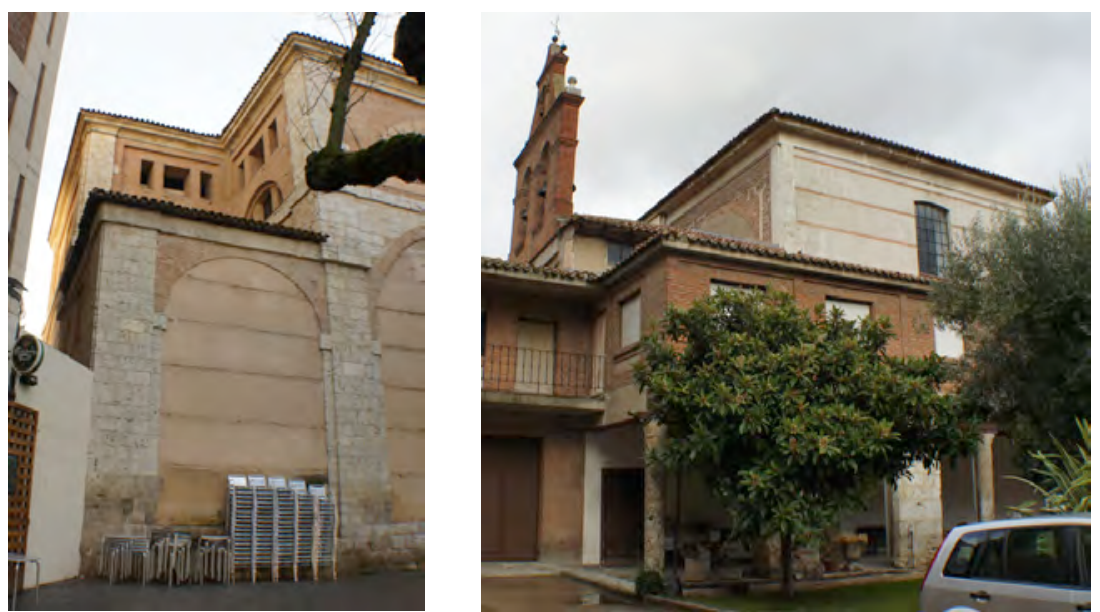

Ilustración 1: vistas desde el patio (visita 01/02/2015) 


\section{Singularidades}

Los edificios que componen convento y colegio se adosan al cuerpo de la nave. Otras construcciones ocultan también la fachada del Evangelio. La cabecera plana presenta el mismo lenguaje descarnado y sólo la parte superior del testero a los pies se aprecia desde un patio interior. El único acceso del público se realiza desde la fachada lateral por una puerta prácticamente sin ornamentación. Cuenta con numerosas ventanas: óculos, rectángulos y huecos termales de varios tamaños.

\section{Dimensiones básicas del templo}

$\begin{array}{llll} & \text { central } & \text { laterales } & \text { capillas } \\ \text { Ancho de nave } & 10,0 & - & 7,0 \\ \text { Altura } & 16,0 & - & \end{array}$

\section{Memoria histórica constructiva}

Según el Catálogo, la construcción arranca en 1579 con trazas de Mateo de Elorriaga, Juan de Ribero Rada y Juan de Nates, con este último a cargo de la ejecución de las obras. El templo se bendice sólo veinte años más tarde. Iglesia y coro se levantan al unísono aunque se rematen a diferentes alturas. (Carreño 1999 proyecto VA-410).

Según Bustamante (pág. 85) fue el primer edificio clasicista que se construyó en la ciudad, las condiciones fueron muy detalladas y en ellas se citaba como modelo el criterio de Palladio para basas, dinteles, etc.

El diseño de la cúpula aún no se trasdosa al exterior, ni cuenta con cimborrio.

\section{Cronología. Fechas clave}
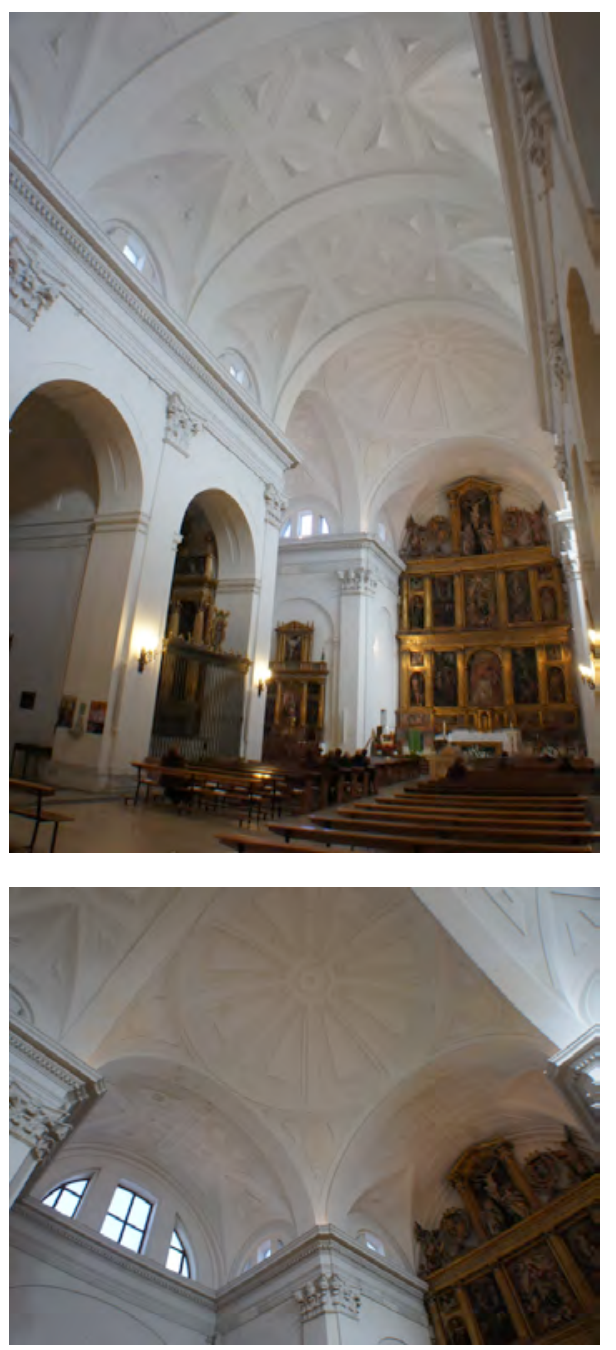

$1599-1972-1975$

Ilustración 2: interior (visita 01/02/2015) 


\section{Intervenciones}

1950 - Obras de saneamiento - Anselmo Arenillas

Se repara zócalos y pavimento de ladrillo dañado durante la guerra. Realiza un retejo general de $594 \mathrm{~m} 2$ de cubierta sustituyendo los maderos podridos.

1951 - Reparaciones - Anselmo Arenillas

Se cierran los pórticos con pies derechos de madera del claustro pequeño con fabrica de ladrillo, imitando la solución constructiva del claustro grande, para configurar cuatro nuevas celdas.

1959 - Reparación de cubiertas de la cabecera - Anselmo Arenillas

La escasez de presupuesto impide reparar la cubierta completa, por lo que reparan sólo la cabecera (ábside, sacristías, brazos del crucero y cimborrio), saneando su entramado de madera. Los usuarios han apuntalado con enanos las piezas de armadura rotas sobre elementos débiles no preparados para ello.

\section{9 - Reparación de cubiertas - Luis Cervera Vera}

La cubierta se encuentra en muy mal estado. El proyecto pretende "dejar la cumbrera general a una misma altura", aportando madera nueva y aprovechando la que quede tras sanear las cabezas. Se reteja sobre entablado de madera y torta de barro.

\section{2 - Reforma coro - Julio González Martín}

El coro es la zona de acceso restringido a los pies del templo que alcanza menor altura que el resto de la iglesia. Presenta tres tramos, con el extremo dividido en dos por un potente pilar.

En la memoria se describe esta zona "en situación ruinosa debido al mal estado de las armaduras de cubierta, algunas de las cuales están descansando sobre las bóvedas." Se propone atirantar los arcos de la nave central en sus arranques y reemplazar la estructura de cubierta por una nueva metálica con "entrevigado de bóvedas de rasilla y enjutado de hormigón de cemento". Incorpora un zuncho al que denomina durmiente: "a fin de conseguir un adecuado asiento de las nuevas armaduras de cubierta se proyecta un durmiente de hormigón armado que reparta sobre el muro continuo de tapial los esfuerzos y cargas de la cubierta. El proceso programado para la realización de todos los trabajos es sencillo, comenzando por atirantar las bóvedas, desmontar la vieja cubierta, construir el durmiente de hormigón y montar la cubierta nueva" 


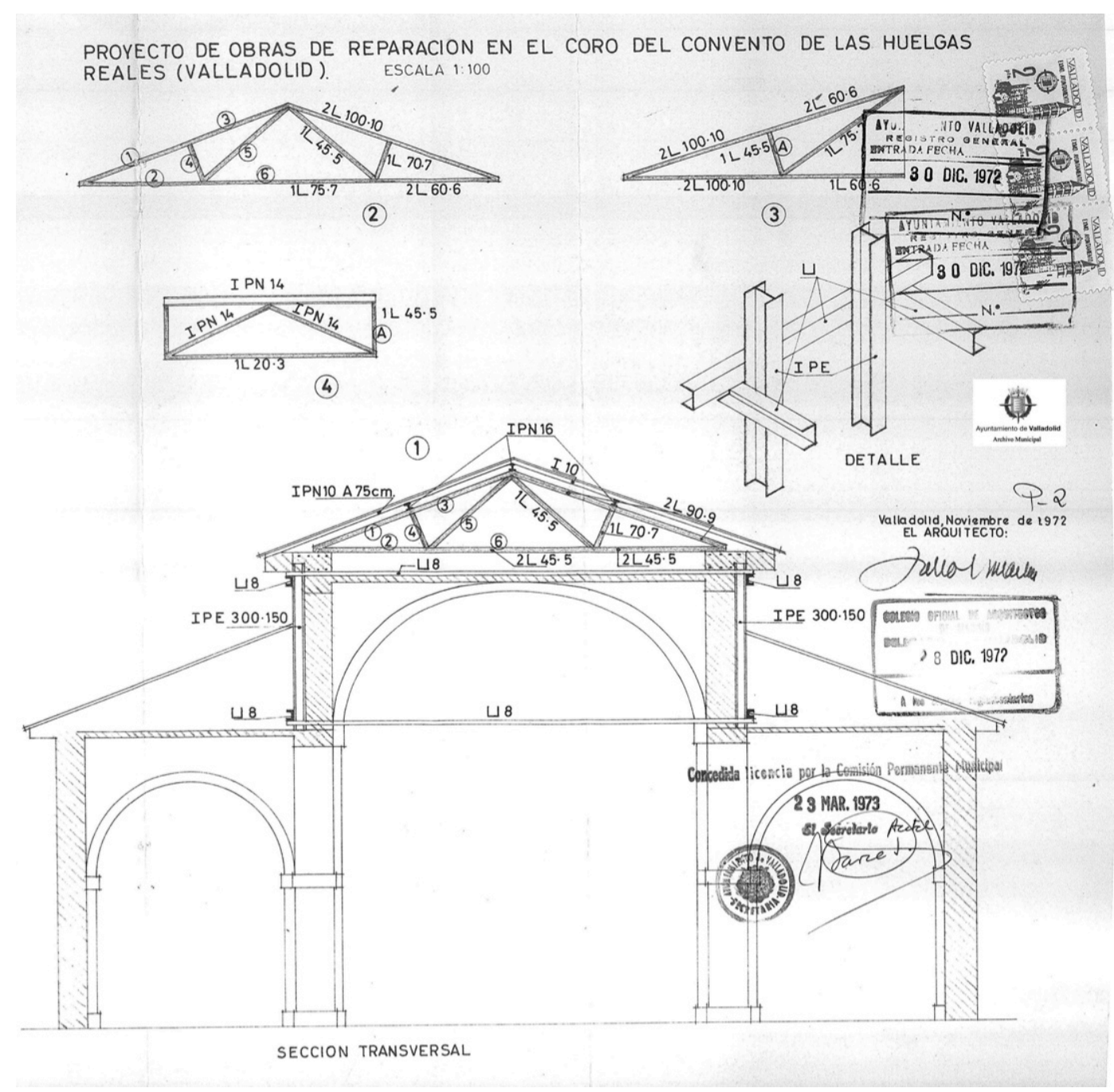

Ilustración 3: detalle en plano de estructura (González 1972 AMVA)

En el archivo digital del IPCE encontramos tres juegos de planos, uno de 1975 que contempla la actuación sobre ábside y crucero, otro de 1976 referido al resto de faldones y planta y sección generales de 1977 .

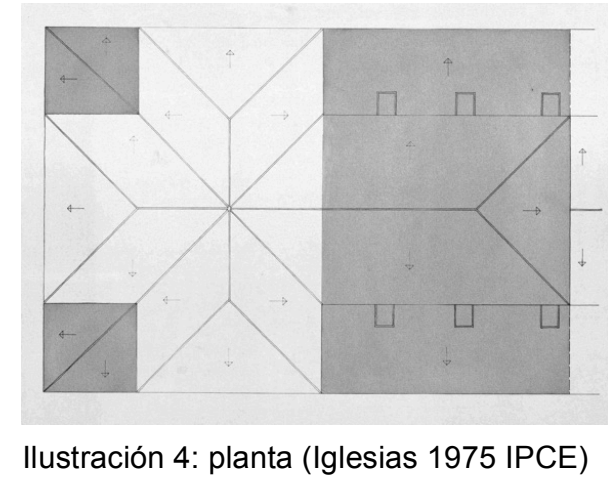

1975 - Restauración - Ana Iglesias

Confirma que el coro ya ha sido restaurado.

En la memoria del proyecto describe cómo se va a conservar la estructura de madera, menos dos pares que se encuentran partidos, incluyendo herraje para reforzarla y formando una capa de compresión de hormigón ligeramente armada con mallazo sobre la tabla ripia existente que, según el presupuesto, sólo reemplaza en un $40 \%$. 


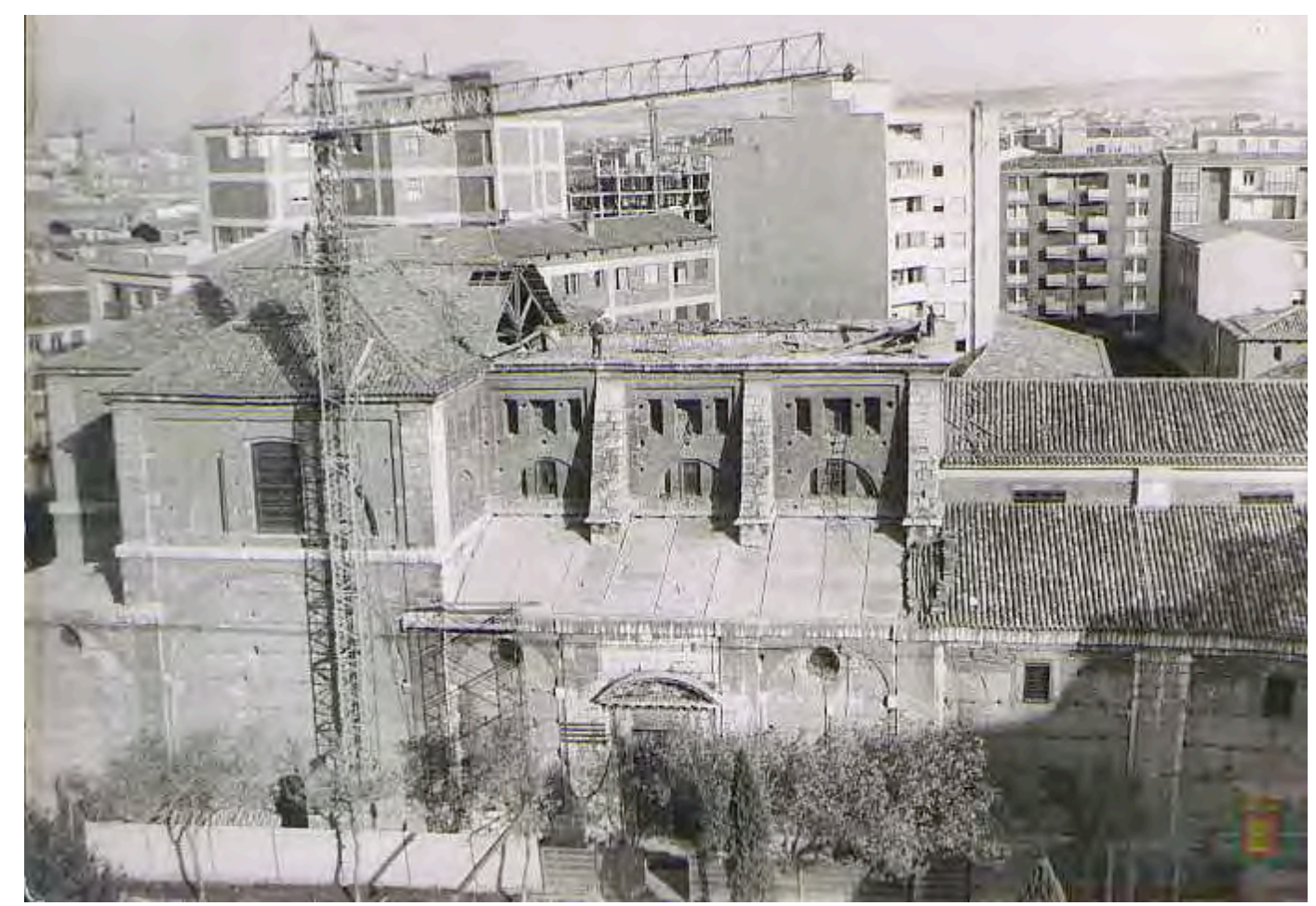

Ilustración 5: obras en Las Huelgas AMVA AUX00195-012 Asociación de la prensa

Sin embargo en la fotografía anterior se aprecia precisamente la ejecución del desmontaje completo y reemplazo de estructura de cubierta tanto del cuerpo de la nave como de las capillas laterales.

\section{6- Restauración $2^{\text {a }}$ fase - Ana Iglesias}

Se completa la intervención anterior desmontando 486,5m2 de estructura de cubierta de madera, que se reemplaza por cerchas metálicas, correas con capa de compresión de hormigón sobre nervometal.

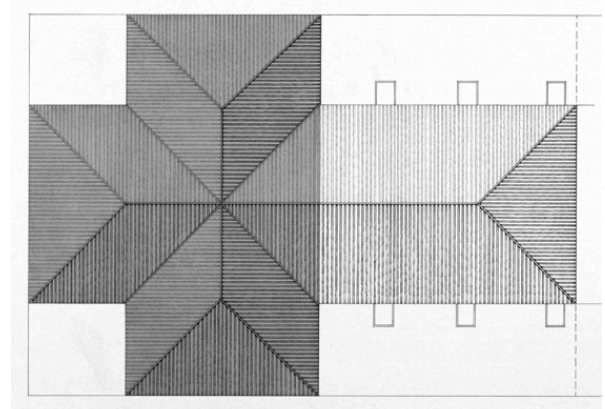

llustración 6: planta (Iglesias 1976 IPCE)

1978 - Paramentos interiores - Ana Iglesias

Limpieza y rejuntado de fábricas con dos manos de pintura plástica. Nuevo pavimento sobre encachado drenado y solera de hormigón en masa tras excavar $25 \mathrm{~cm}$ toda la superficie interior de la iglesia.

1999 - Restauración de fachadas y cubiertas - Pedro Carreño

Desmonta $1070 \mathrm{~m} 2$ de teja curva para recolocarla como cobija sobre canales de teja nueva. Diseña un alero nuevo más volado con tablero fenólico.

Limpia y restaura las fachadas, eliminando fábricas de panderete que cerraban parte de la superficie de los huecos termales. 
Los planos de este proyecto llevan una carátula en que se justifica que se han obtenido a partir de documentación.

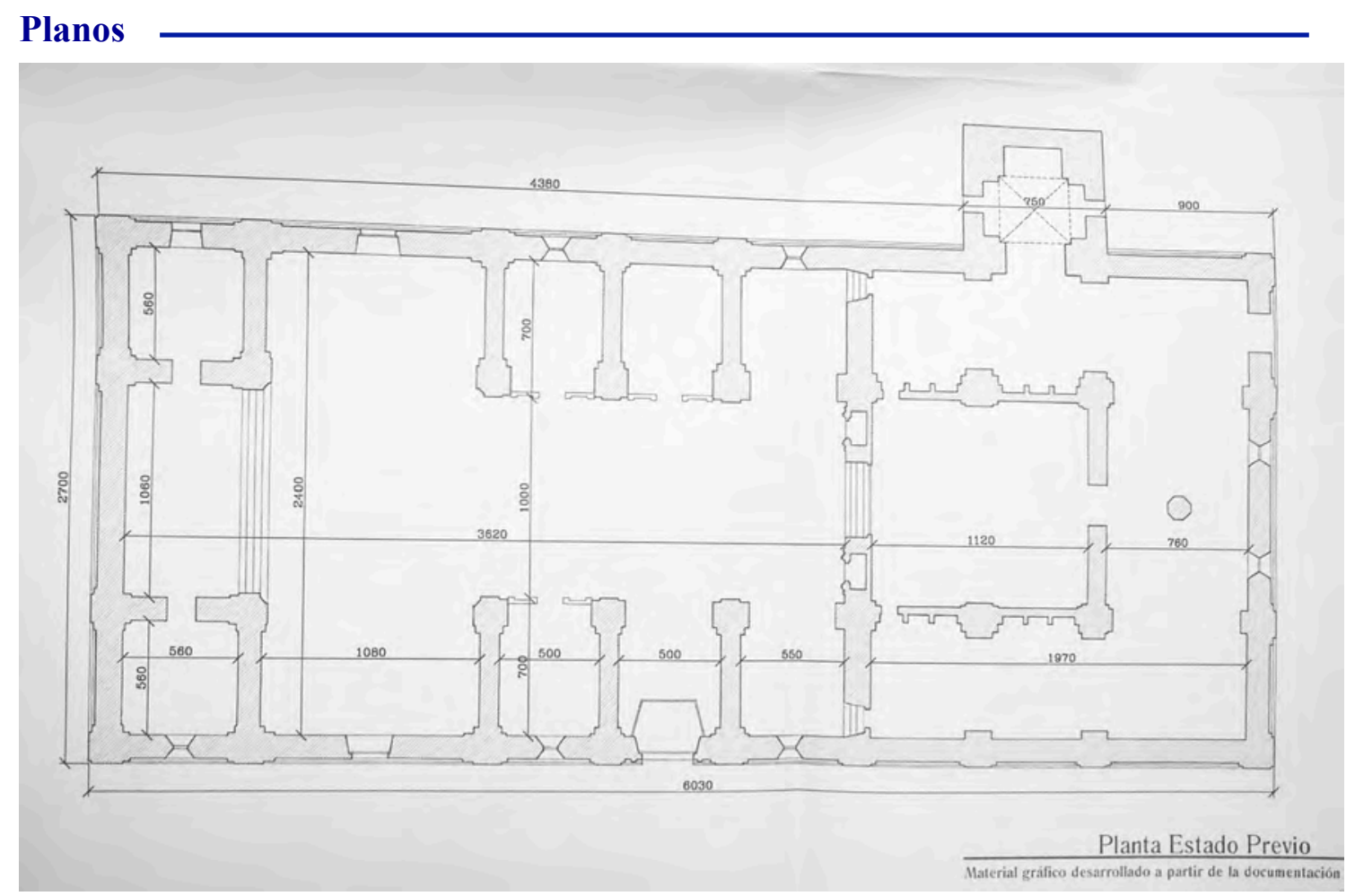

Ilustración 7: planta completa de iglesia y zona del coro con cotas (Carreño 1999 JCyL)

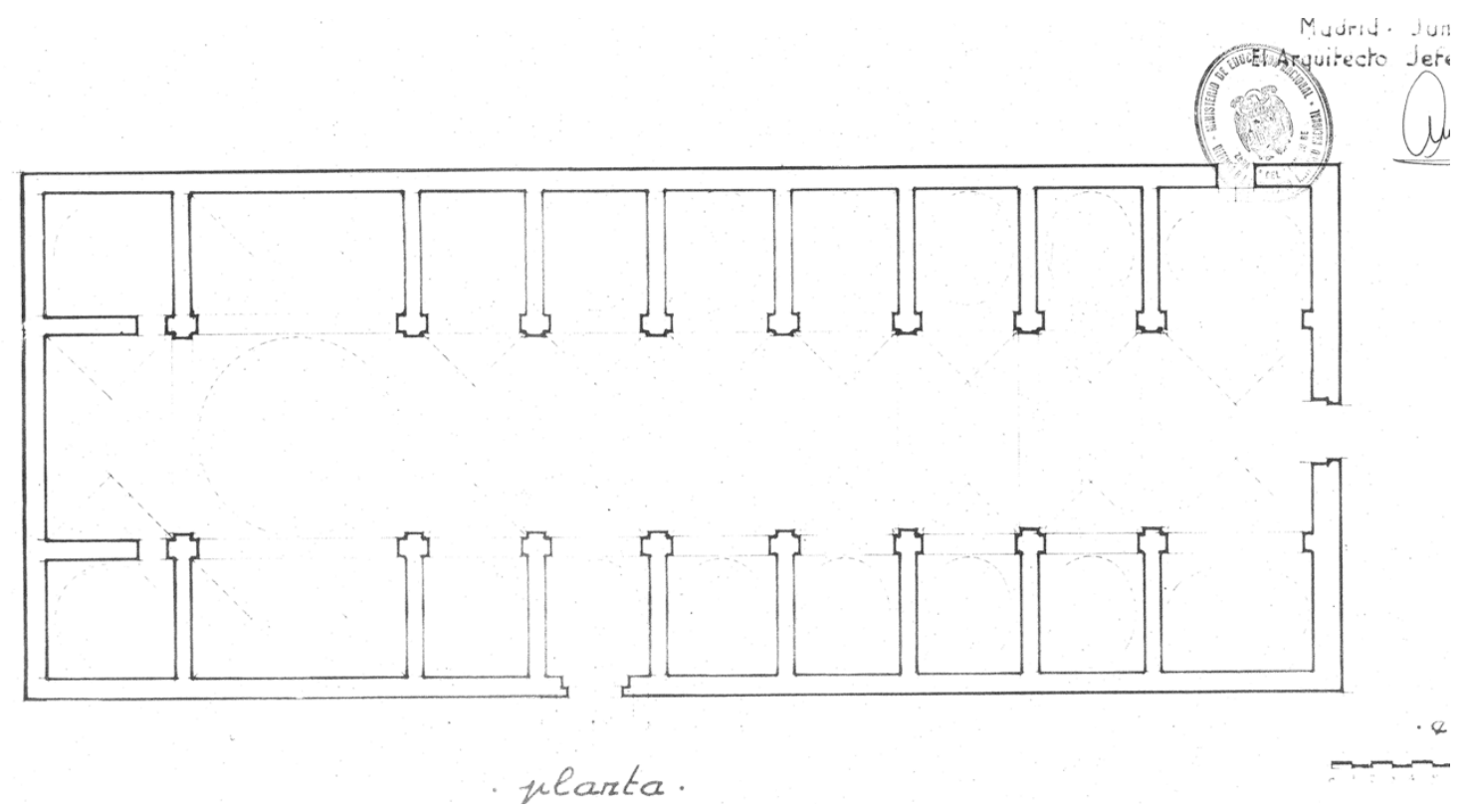

Ilustración 8: planta general (Anselmo Arenillas 1959 AGA) 


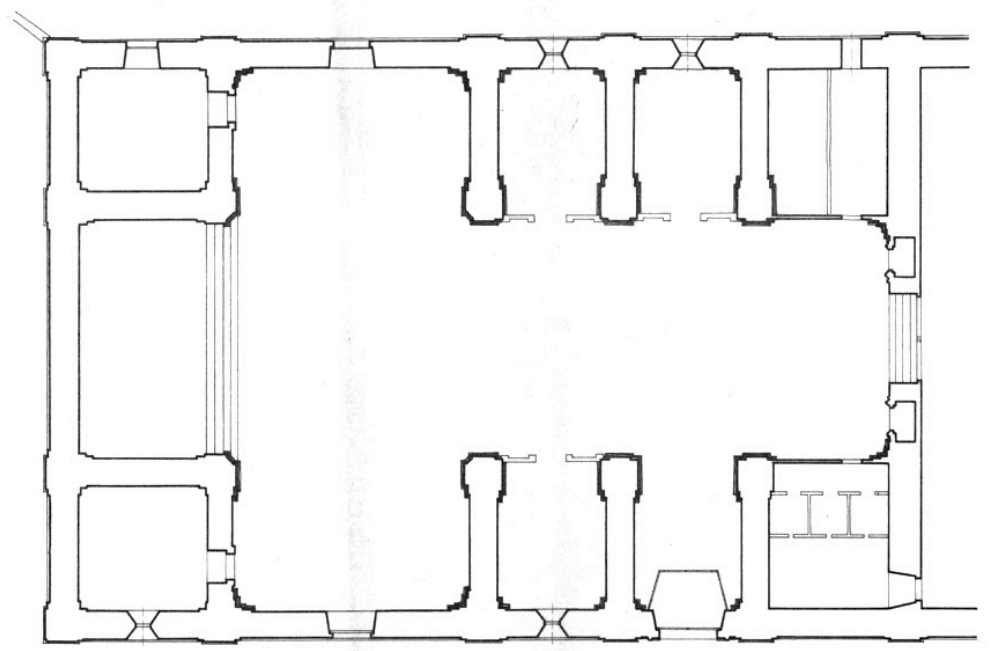

Ilustración 9: planta (Ana Iglesias 1977 IPCE)

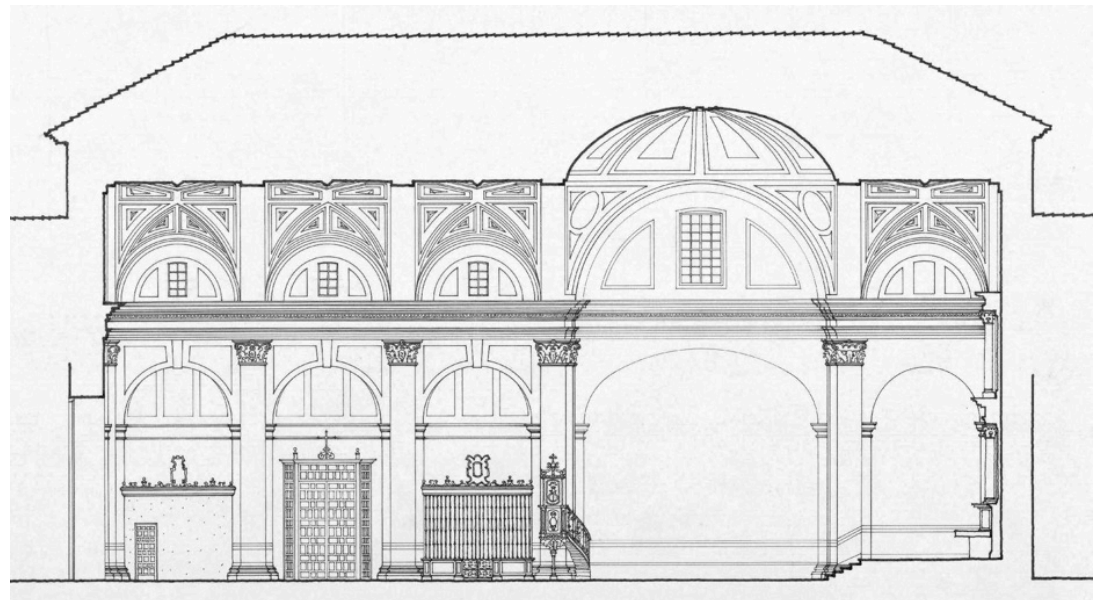

Ilustración 10: sección longitudinal (Ana Iglesias 1977 IPCE)

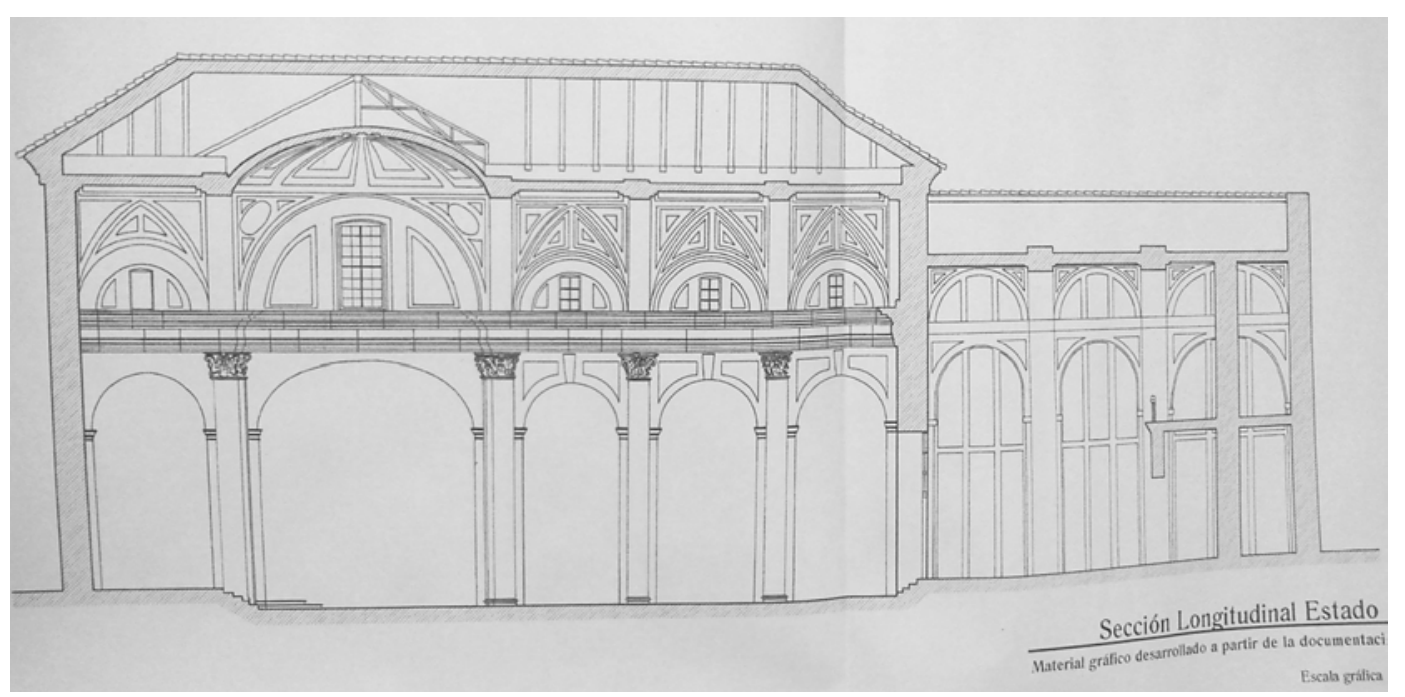

Ilustración 11: sección estado previo con nota "desarrollo a partir de la documentación gráfica de archivo" (Carreño 1999 JCyL) 

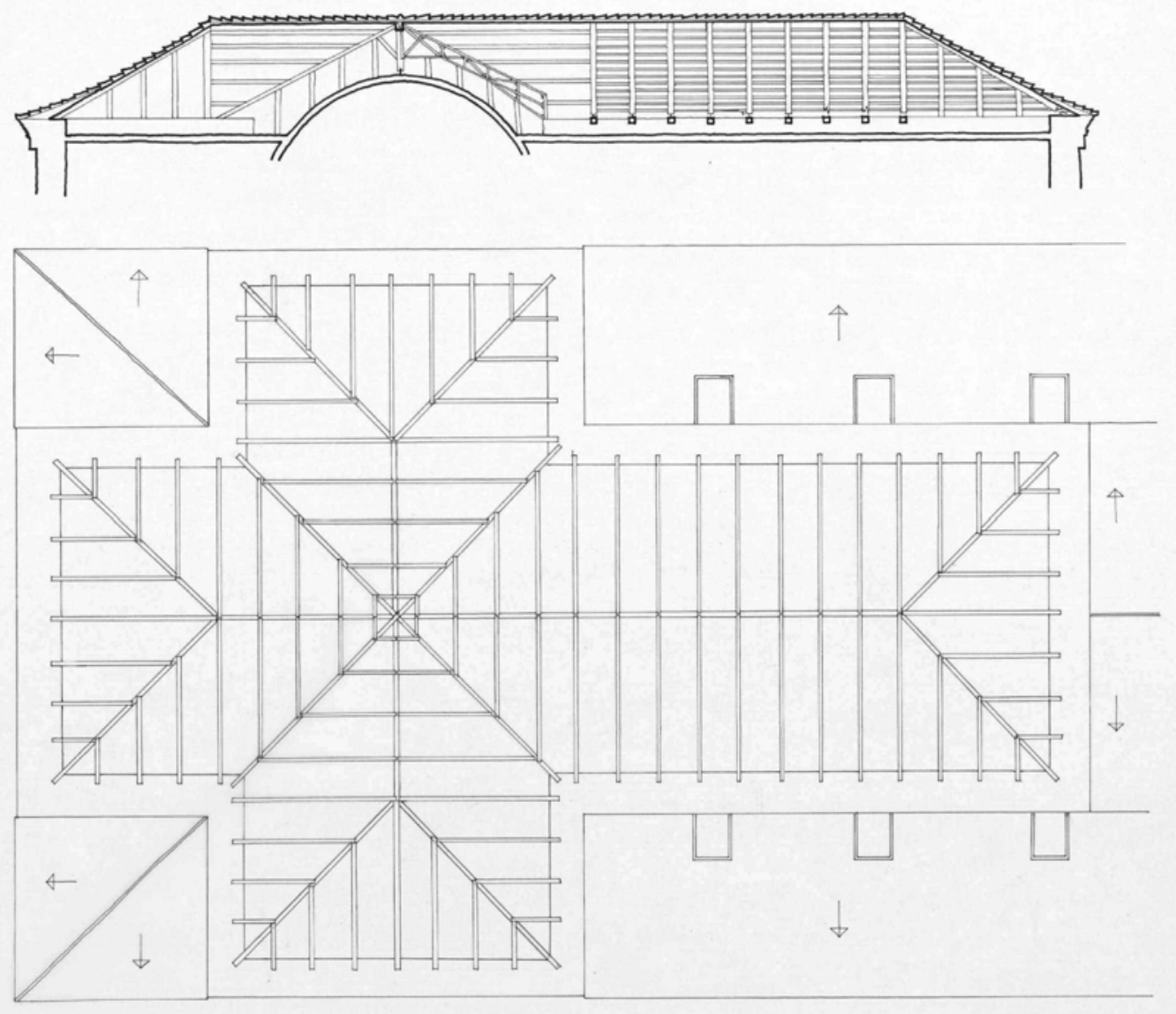

Ilustración 12: sección y planta de estructuras estado actual (Ana Iglesias 1975 IPCE)
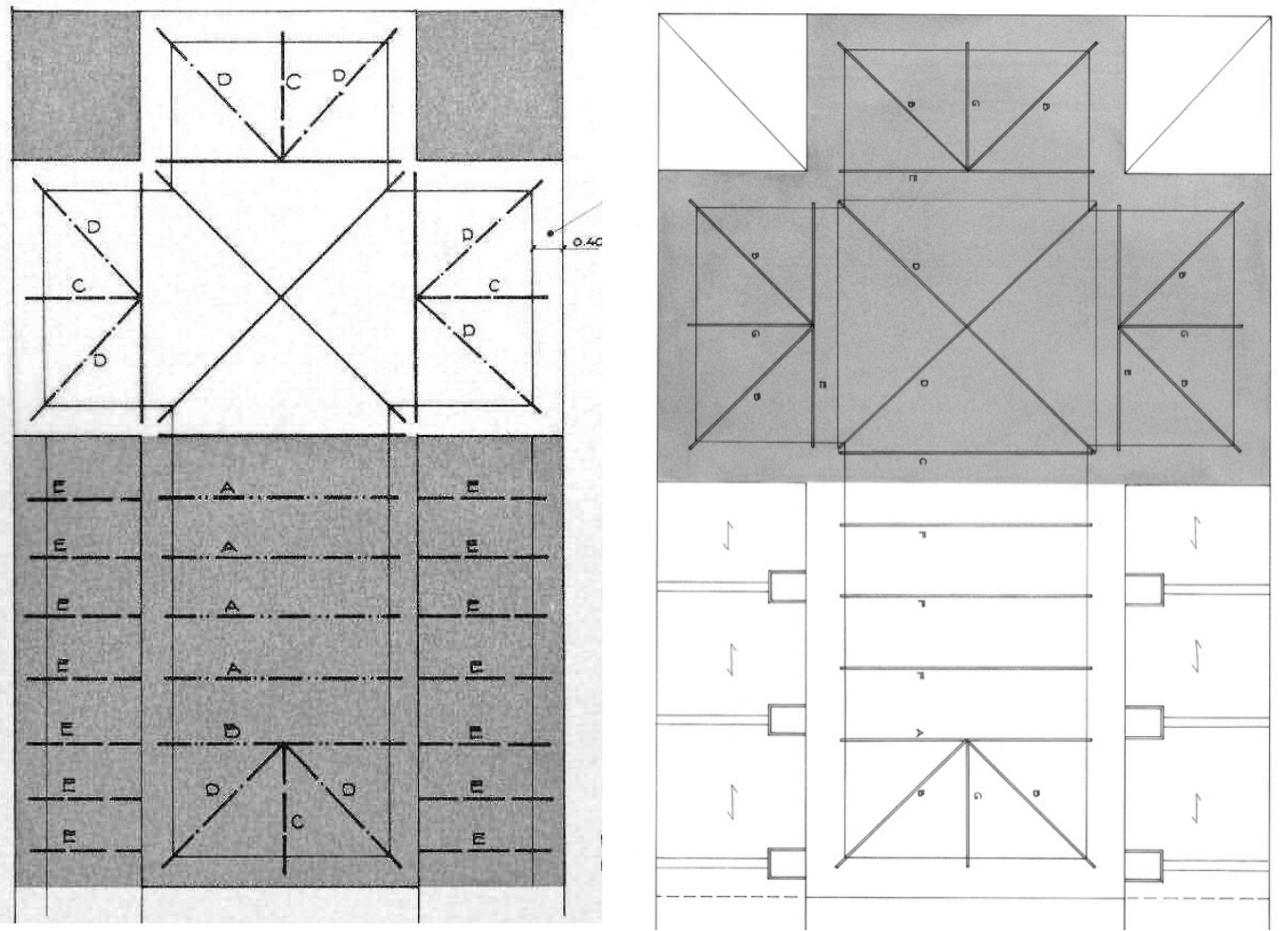

Ilustración 13: plantas de estructuras de 1975 y 1976 (Ana Iglesias IPCE) 


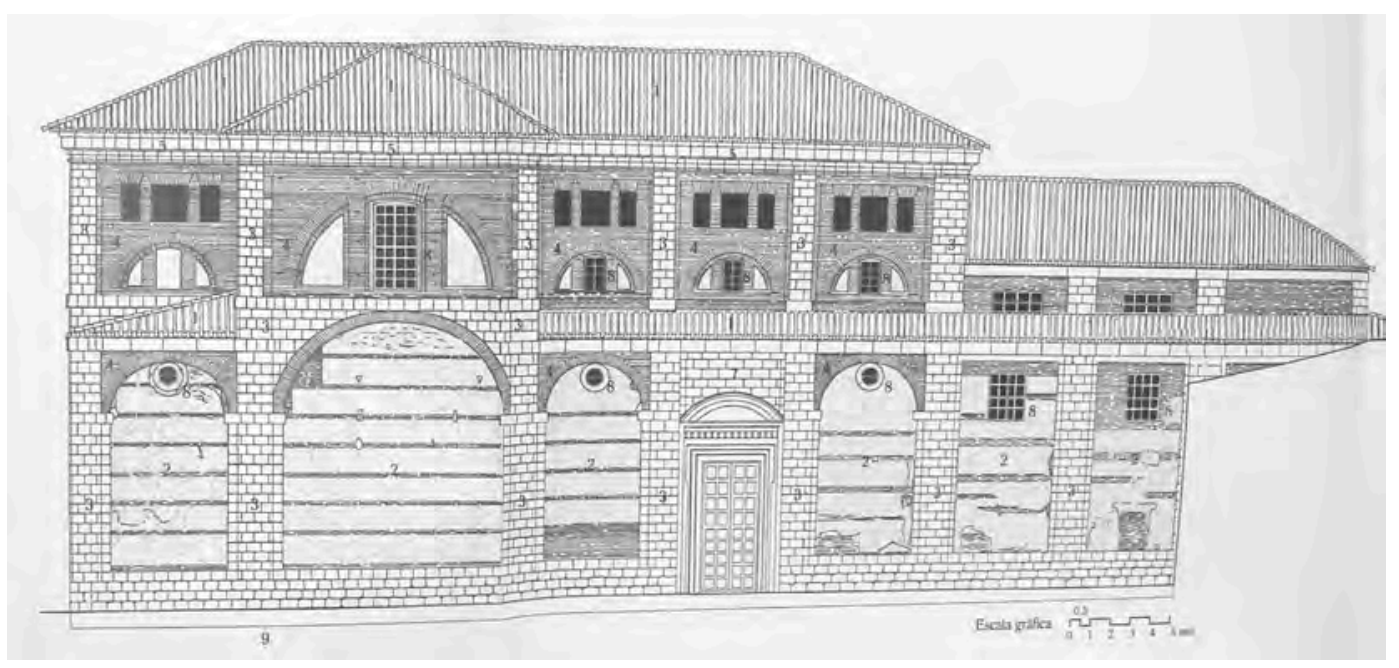

Ilustración 14: alzado antes de abrir vanos extremos de huecos termales (Carreño 1999 JCyL)
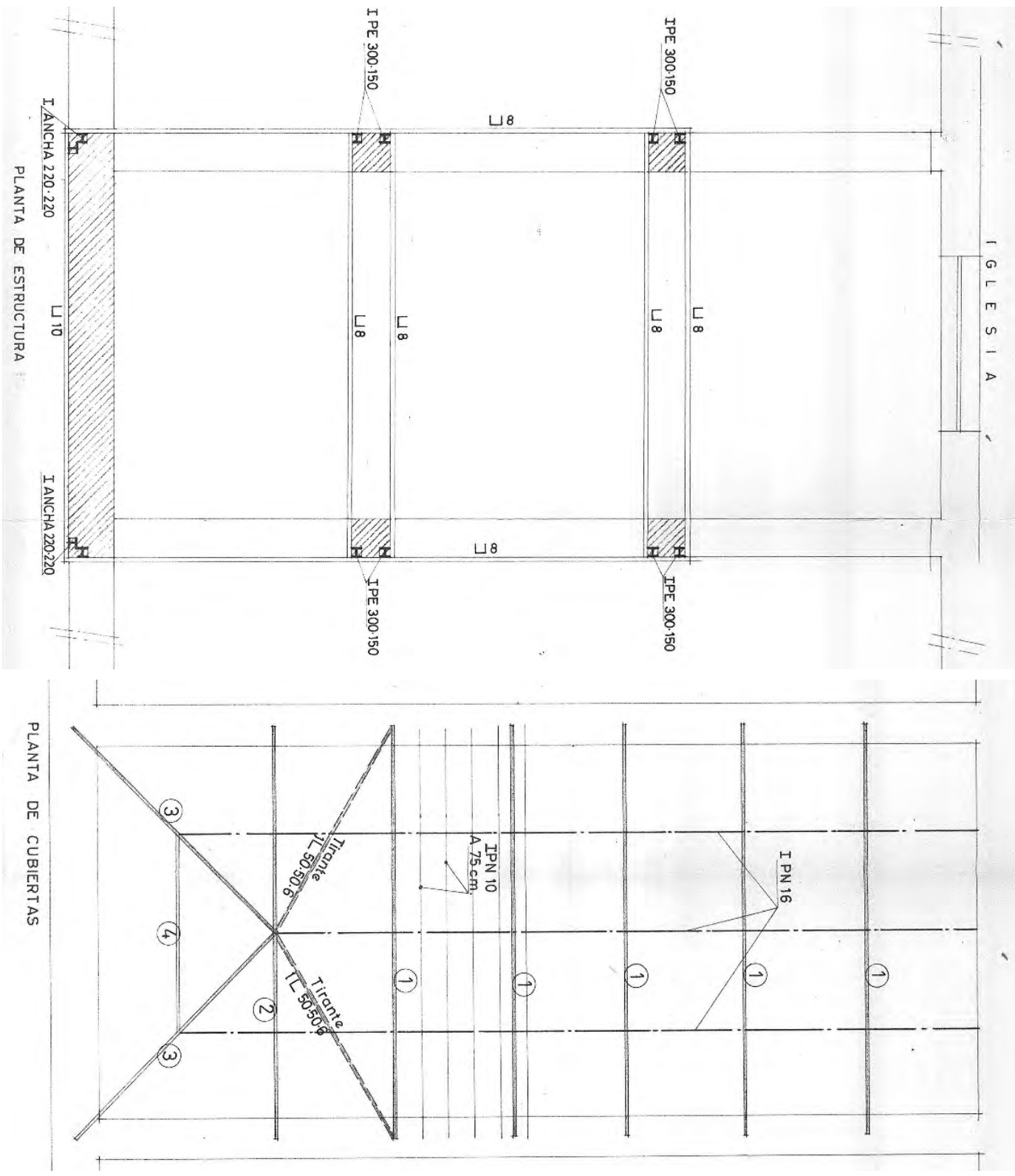

Ilustración 15: plantas de estructura del coro (González 1972 AMVA) 


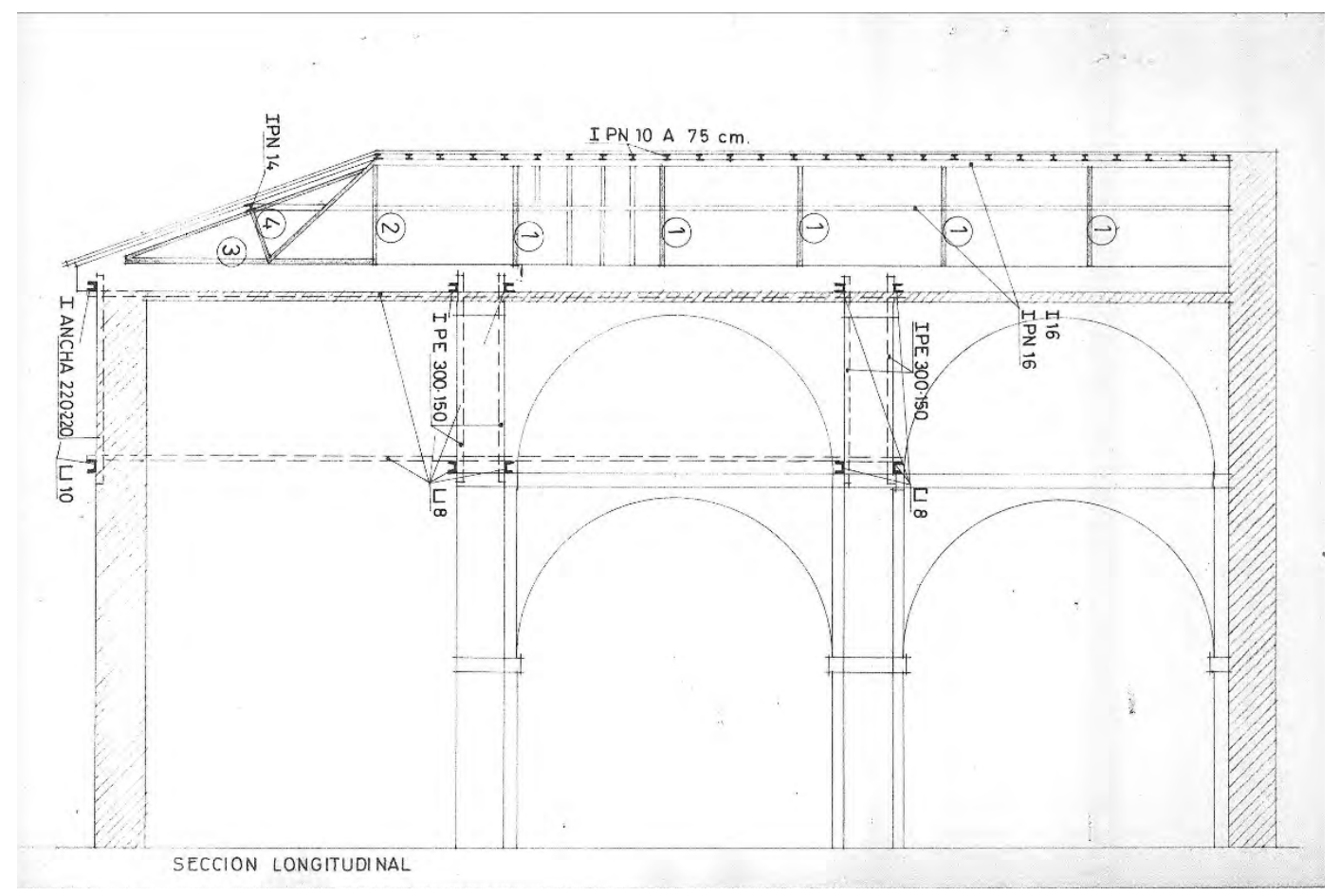

Ilustración 16: sección longitudinal estructura del coro (González 1972 AMVA)

\section{Solución constructiva de la cubierta}

En las plantas de estructura de cubierta reproducidas más arriba, podemos apreciar diferencias entre las cerchas definidas en 1975 y las representadas un año más tarde. En el primer plano no se incluye la zona de cabecera y crucero, y el cuerpo de la nave se resuelve con cuatro elementos rotulados como A. En el segundo plano, ese mismo cuerpo cuenta con tres elementos más separados que se rotulan con la letra $\mathrm{F}$.

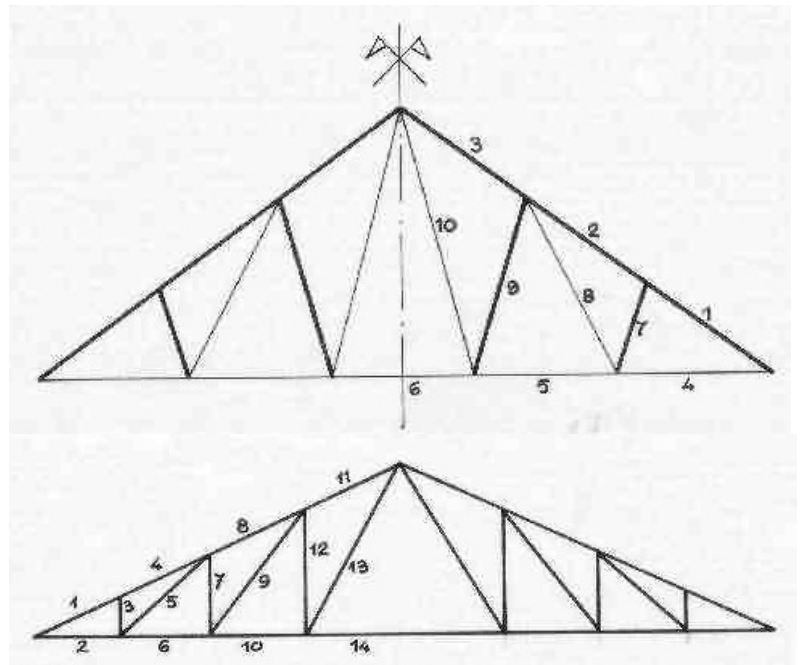

(F)

Ilustración 17: cerchas 1975 y 1976 Iglesias IPCE
Si comparamos ambas cerchas tipo de la nave podemos observar la gran diferencia de pendiente para los $11 \mathrm{~m}$ de luz; con un diseño sólo de diagonales en el primer caso y con montantes $\mathrm{y}$ diagonales en el segundo.

En las tablas que figuran en los planos se representan los perfiles angulares, por parejas, con sus longitudes. 
En la pieza superior A se definen con L12.11 el cordón superior, con L35.6 el inferior y con L50.7 las diagonales. Para la pieza inferior F se adopta L90.9 para el cordón superior, L45.5 el inferior, L35.4 diagonales y L55.5 los montantes. El montante extremo y las diagonales se definen con perfil simple, el resto doble. Si medimos sobre plano la pendiente de ambas cerchas se representa de $36^{\circ}$ en el primer caso y unos $24^{\circ}$ en el segundo.

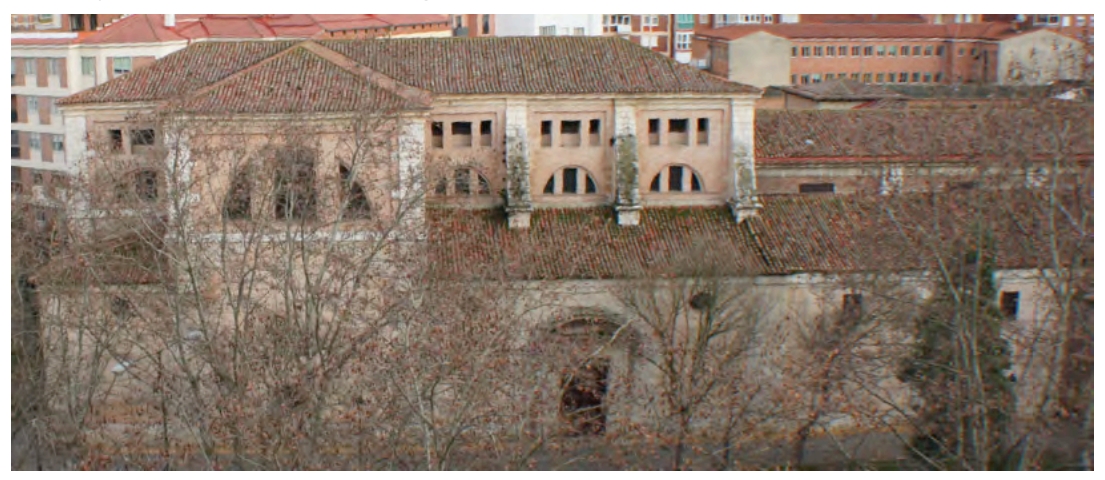

Ilustración 18: vista de la iglesia, $2^{\text {a }}$ visita 02/02/2015

En las fachadas podemos apreciar un nivel superior de huecos rectangulares que corresponden al espacio bajo cubierta, por encima del arranque de las bóvedas. Esta disposición no es habitual en las iglesias del foco clasicista. En la fotografía siguiente, tomada del libro de Bustamante, vemos como no la encontramos en la Colegiata de San Luis en Villagarcía de Campos, antecedente directo de las Huelgas Reales.

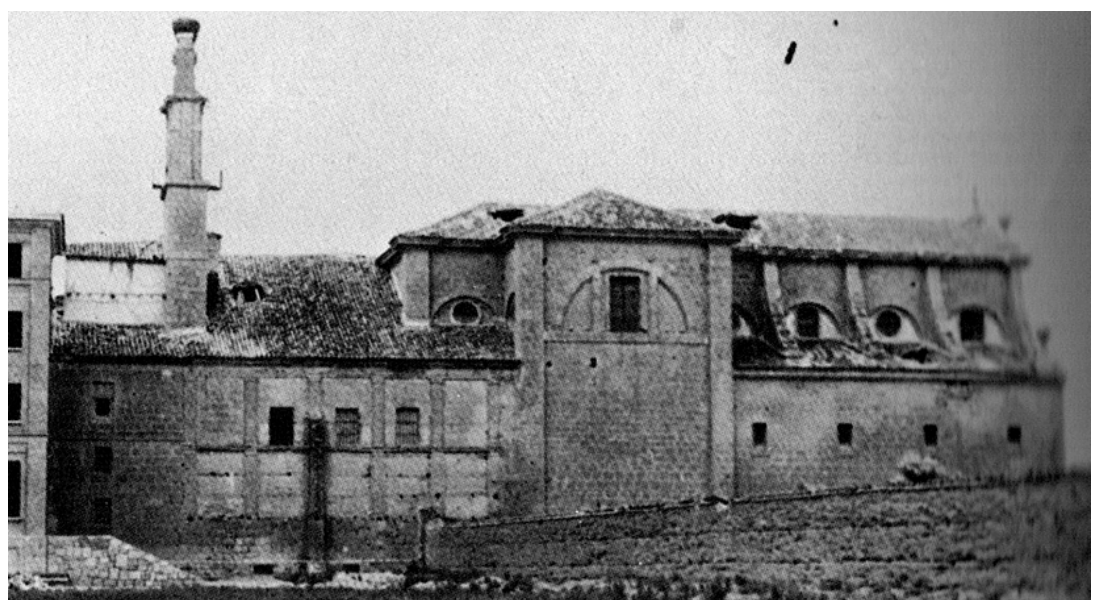

Ilustración 19: Colegiata de San Luis en Villagarcía de Campos (Bustamante 1983)

En la intervención de 1999 se rediseñan los aleros de capillas y sacristías con más vuelo, que según el detalle del proyecto se resuelve recuperando cierto refreno con relleno de mortero sobre un tablero fenólico.

En la fotografía siguiente se aprecia el nuevo alero sobre una de las sacristías y la cornisa de piedra que remata ábside y crucero a cota más alta. 


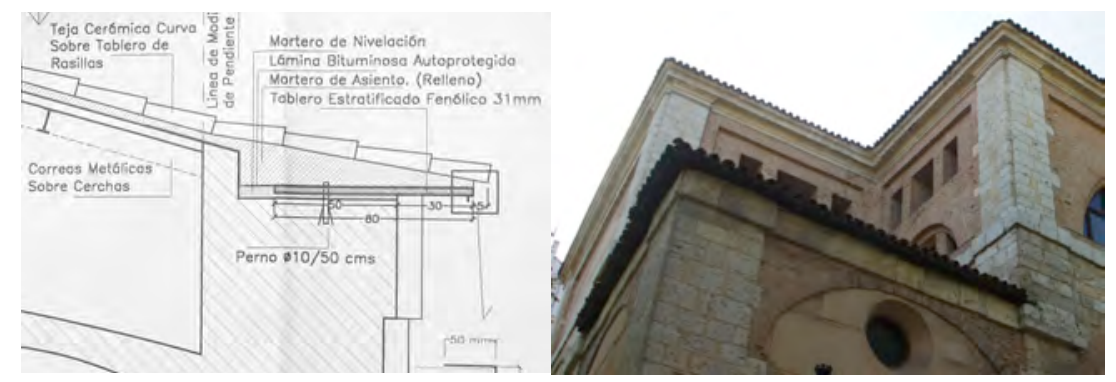

Ilustración 20: detalle alero (Carreño 1999 JCyL) y visita 01/02/2015

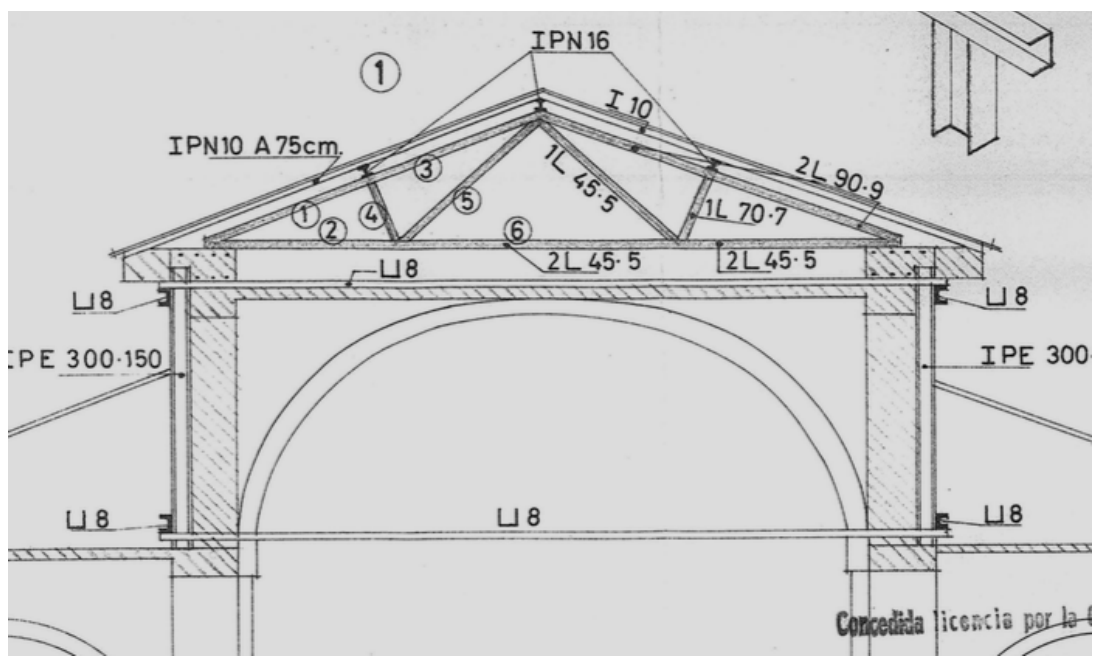

Ilustración 21: sección transversal por el coro (González 1972 AMVA)

\section{Zunchos}

En los planos de Ana Iglesias se define el zuncho con un detalle señalado sobre la planta. Se acotan $40 \mathrm{~cm}$ de espesor de muros con un zuncho de $30 \mathrm{~cm}$ de anchura, sin indicar si se debe colocar a haces interiores o centrado.

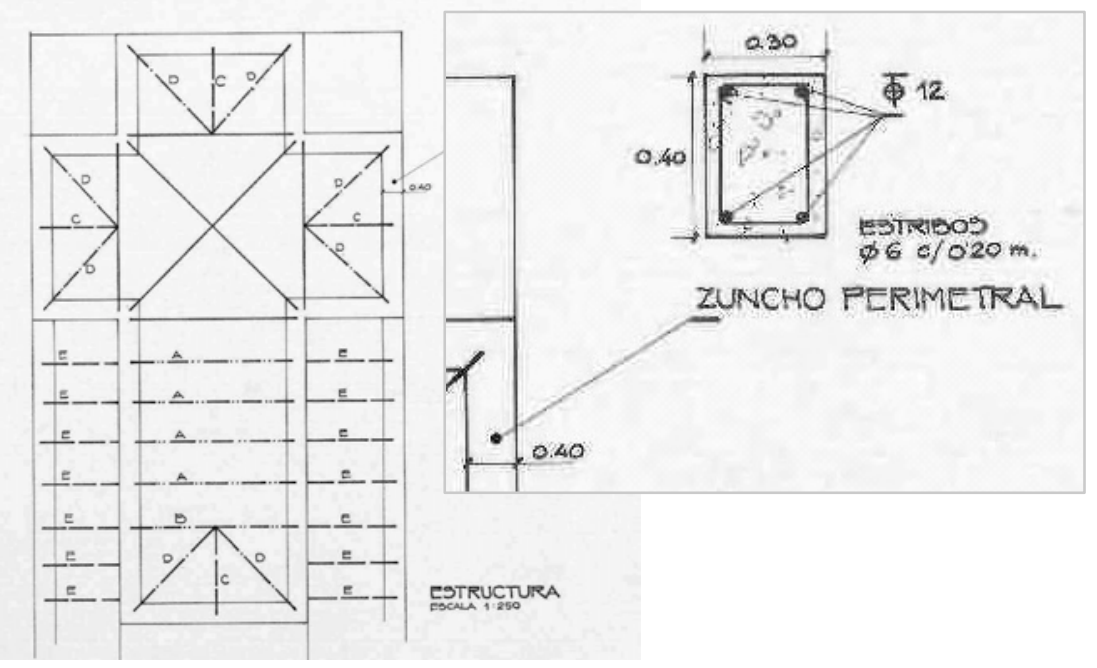

Ilustración 22: estructura (1976 Ana Iglesias IPCE) 
En el plano de Julio González para la cubierta y atirantado de la nave en perímetro del coro, el elemento denominado "durmiente de hormigón" se representa con el mismo ancho del cerramiento y con el canto del borde del alero, en el que se prolonga la trama a modo de macizado sin precisar su naturaleza.
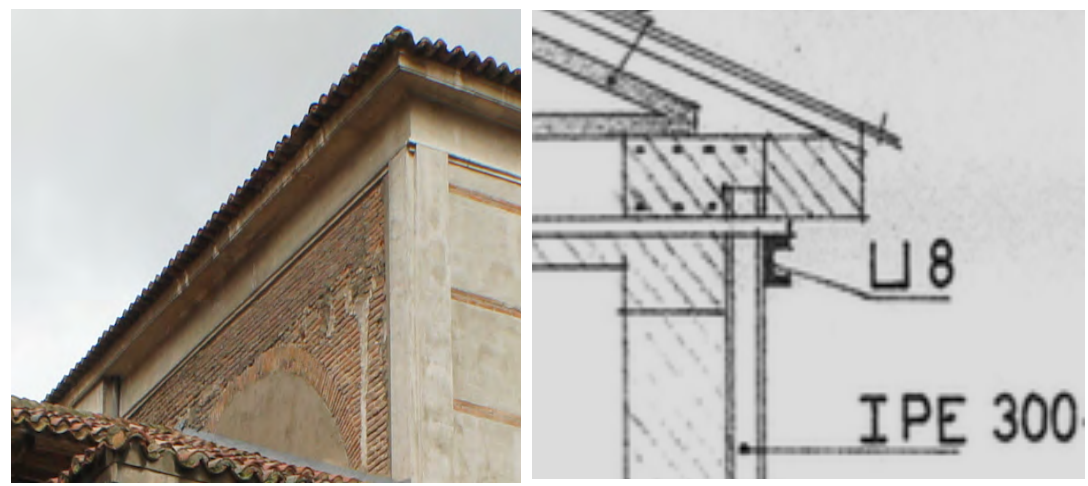

Ilustración 23: detalle zuncho en sección (González 1972 AMVA)

\section{Conclusiones}

No se ha conseguido permiso de la congregación para acceder al bajo cubierta, por lo que no es posible confirmar cómo se ejecutaron las obras correspondientes a los proyectos analizados. 



\section{Monasterio de Santa María de las Huelgas}

Intervenciones citadas en la publicación del Ministerio:

1950 - Obras de saneamiento - Anselmo Arenillas

1951 - Sustitución del cerramiento claustro pequeño - Anselmo Arenillas

1959 - Cubiertas cabecera de la iglesia - Anselmo Arenillas

1960 - Cubiertas - Luis Cervera Vera

1975 - Reparación cubiertas de la nave de la iglesia - Ana Iglesias González

En la web del IPCE se facilitan diez planos del proyecto de Ana Iglesias: tres de 1975, cinco de 1976, dos de 1977 y cinco de 1978.

\section{En el Archivo General de la Administración}

\section{AGA 26/00294}

Proyecto de obras de saneamiento en el Real Monasterio de las Huelgas

Anselmo Arenillas junio de 1950

Memoria (1pag)

"Durante la guerra este Monasterio estuvo dedicado en gran parte a depósitos de la Intendencia Militar y como consecuencia sufrió grandes destrozos su pavimentación, que era de simple ladrilleta, al circular los vehículos de transporte por su interior, se hace por ello preciso rehacer el solado de las partes más averiadas colocándolo sobre firme de hormigón de $12 \mathrm{~cm}$ de grueso y hecho con loseta hidráulica en general y con los pasos de losa de granito.

El zócalo interior de la Iglesia de simple revoco está tan averiado que produce una lamentable impresión y por ello se propone picarlo y rehacerlo en revoco pétreo lo más discretamente disimulado posible, ajustándose al estilo de la fábrica vieja.

Para evitar las humedades existentes se proyecta la construcción de un suplemento de la cimentación y zócalo en unos $25 \mathrm{~cm}$ de espesor en buen hormigón impermeable de cemento.

Finalmente se hará un retejo general y sustitución de maderos podridos en las cubiertas."

Un plano con planta de 9 tramos y sección longitudinal 1:200.

Pliego. 


\section{Mediciones:}

$\mathrm{m} 3$ apertura de zanjas en fachadas $73,60 \mathrm{~m} 3$

$1 \times 33 \times 0,80 \times 1,00 \times 26,40 ; 1 \times 33 \times 0,80 \times 1,00 \times 26,40 ; 1 \times 33 \times 0,80 \times 1,00 \times$ 10,$40 ; 1 \times 33 \times 0,80 \times 1,00 \times 10,40$;

$336 \mathrm{~m} 2$ levantado pavimento interior, ídem solado

73,60 m3 hormigón en zanja de saneamiento y recalzo

$18 \times 33=594 \mathrm{~m} 2$ repaso de tejado

\section{AGA 31/06007}

Obras de saneamiento en el Real Monasterio de las Huelgas

Anselmo Arenillas Alvarez junio de 1950

(mismo proyecto que $26 / 00294$ )

\section{AGA 26/00294}

Proyecto de obras reparaciones en el Monasterio de Huelgas Reales

Anselmo Arenillas junio de 1951

Memoria (1pag)

"El Monasterio... tiene dos amplios claustros inmediatos, pero separados por un gran muro de tapial. La ordenación en planta baja, hecha en cantería, es la misma en ambos, pero no su molduración; la planta alta es de ladrillo y bien compuesta en el claustro mayor, mientras en el pequeño está sin terminar y el tejado sostenido por simples pies derechos de madera. El claustro grande parece ser obra de D.Juan de Herrera y el pequeño de Machuca. En la actualidad uno de los lados del claustro pequeño está cerrado con fábrica moderna de ladrillo de no muy acertada ejecución. Los otros dos tienen los postes en mal estado y con peligro de hundirse uno de ellos dado el estado de putrefacción de varios maderos. Por ello se proyecta ahora la sustitución de estos puntales por fábrica de ladrillo con igual composición que en el viejo claustro de Herrera. Se incluye la distribución en 4 celdas del espacio resultante y como complemento su pavimentación y guarnecido."

Plano con plantas y secciones de los dos patios conjuntos. Señala en rojo tramo donde reemplaza pies de madera por fábrica.

Pliego, mediciones, etc. (18ml)

\section{AGA 31/06007}

Obras de reparaciones en el Monasterio de las Huelgas Reales

Anselmo Arenillas Alvarez junio de 1951)

(mismo proyecto que $26 / 00294$ ) 
AGA 26/00262

Proyecto de reparación de cubiertas de la cabecera de la iglesia del Monasterio de las Huelgas Reales de Valladolid

Anselmo Arenillas Alvarez julio de 1959

Memoria (1pag)

"La iglesia ... tiene grandes goteras que perjudican a sus bóvedas y muros.

El tejado presenta múltiples hundimientos y roturas denunciadas ya hace años y que han ido en aumento, los arreglos hechos por sus usuarios han sido apuntalar las piezas rotas con enanos que transmiten la carga a elementos débiles no preparado para ellos.

La reparación total del tejado, sustituyendo las armaduras costaría 300.000,00 pesetas, pero asignadas por la superioridad 50.000,00 pesetas para estos fines, solo cabe reparar a fondo la cabecera de la Iglesia, dejando su entramado de madera saneado, el resto quedará aún con sus averías hasta nuevo presupuesto como consecuencia evidente de la escasa consignación para atender a la restauración de Monumentos."

Firma como arquitecto conservador de monumentos jefe de la $2^{\mathrm{a}}$ zona.

Un plano de planta sólo muros de planta baja. (pido copia)

Pliego.

Presupuesto con dos partidas:

1. Levantado de teja, sustitución de entablado podrido, reparación y sustitución de maderos apolillados o rotos y tejado de nuevo reponiendo tejas rotas.

Abside presbiterial $1 \times 12,00 \times 8,60$

Sacristías $2 \times 8,00 \times 12,00$

Brazos del crucero $2 \times 13,00 \times 8,00$

Cimborrio $1 \times 13,20 \times 12,00$

total $591,20 \mathrm{~m} 2$

2. Reparación de viseras tapajuntas en muros lud

\section{AGA 26/00153}

Proyecto de reparación de cubiertas del Monasterio de las Huelgas Reales de Valladolid

Luis Cervera Vera junio de 1960

Plano planta de cubiertas (esquema de direcciones de pendiente de faldones, más largo que los planos de 1975 del IPCE) 1:200 
Memoria 1 pág., presupuesto 5 partidas

"En general hay que levantar toda la teja, ya que se encuentra inservible más del 85\% de la totalidad.

Las formas están en muy mal estado, pudiéndose aprovechar muy pocos elementos, sin embargo como se proyecta dejar la cumbrera general a una misma altura, con madera suficiente nueva que se aporte y pudiendo sanear las cabezas de los elementos existentes se pueda formar una armadura suficiente para sanear toda la cubierta.

Una vez que la armadura esté en perfectas condiciones se tejará con teja curva sobre entablado de madera y tortada de barro, construyendo nuevas todas las cumbreras, así como limatesas y limahoyas del tejado a reparar"

Desmontado del tejado en las partes a sanear la madera de las formas $429,70 \mathrm{~m} 2$ $1 / 2 \times 12,00 \times 6,20 ; 2 \times 8,00 \times 6,40 ; 1 \times 13,00 \times 6,10 ; 4 \times 7,00 \times 6,20 ; 1 / 2 \times 12,00 \times$ 6,20

Bajada y transporte del escombro y detritus al vertedero PA

Desmontado de las formas de madera, saneando y cambiando los elementos deteriorados $255,80 \mathrm{~m} 2$

$1 / 2 \times 12,00 \times 6,10 ; 2 \times 8,00 \times 6,50 ; 1 \times 13,00 \times 6,00 ; 1 / 2 \times 12,00 \times 6,20$

Retejado de cubierta cambiando las tejas, por encontrarse en muy mal estado $337,28 \mathrm{~m} 2$

$1 / 2 \times 12,20 \times 6,30 ; 1 \times 13,10 \times 6,20 ; 4$ × 7,00 x 6,40;1/2 x 12,20 x 6,30

Construcción de cumbreras, limatesas y limahoyas 140,60ml

\section{AGA 26/00153}

1960 Luis Cervera Vera (y firma de Arenillas al lado Vº

Hay que levantar toda la teja ya que se encuentra inservible más del $85 \%$. Las formas en muy mal estado, pudiéndose aprovechar muy pocos elementos, sin embargo como se proyecta dejar la cumbrera general a una misma altura, con madera suficiente nueva que se aporte y pudiendo sanear las cabezas de los elementos existentes se pueda formar una armadura suficiente para sanear toda la cubierta.

una vez que la armadura esté en perfectas condiciones se tejara con teja curva sobre entablado de madera y tortada de barro.

\section{AGA 26/00110}

Obras de restauración iglesia de las Huelgas Reales

Ana Iglesias Noviembre 1975

Memoria (2 pág. descripción) 
"Obras a realizar:

Consisten estas en la reparación de las cubiertas de la nave de la iglesia según figura en el plano correspondiente, en el que se ha excluido el coro por estar ya restaurado en su totalidad.

Por conservarse bien su estructura principal de madera en su mayor parte, se conservará la misma y sobre ella y utilizando la tabla ripia como encofrado se formará una capa de compresión de hormigón ligeramente armada con mallazo, sobre esta capa se impermeabilizarán los faldones colocando seguidamente la teja, utilizando todo el material actual servible. Será necesario sustituir los dos pares que ahora se encuentran partidos."

Pliego de condiciones genérico (6pag)

Mediciones:

$862,80 \mathrm{~m} 2$ levantado de tejado, incluso tabla ripia con clasificación de material aprovechable y transporte de escombro a vertedero $1 \times 40,2 \times 15,5 ; 2 \times 14,1 \times 8,5$

PA Limpieza y extracción de escombros acumulados sobre las bóvedas

$862,80 \mathrm{~m} 2$ consolidación de armadura de madera mediante la inclusión del herraje preciso y sustitución de dos pares partidos

$345,12 \mathrm{~m} 2$ sustitución de tabla ripia podrida, $40 \%$ superficie

$96,63 \mathrm{~m} 2$ capa de compresión formada por hormigón de 300kg de cemento armado con mallazo metálico $12 \%$ aumento por formación de pendientes

Impermeabilización de tableros de cubierta mediante extendido de fieltro asfáltico

cubierta de teja curva sentada con torta de cal y barro, incluso parte proporcional de caballete

$14 \mathrm{~m} 2$ reconstrucción de bóveda de ladrillo 1 x 4,0 × 3,5

$\mathrm{Ud}$ andamios, fotografías, tratamiento ignífugo y bactericida, pintura...

Planos

Planta ídem la de web IPCE, planta de bóvedas 1:100, hay una sección longitudinal estado actual no tengo de IPCE pero coincide el detalle con los dos pares rotos.

\section{AGA 26/01573}

Obras de restauración Iglesia de las Huelgas Reales

Ana Iglesias octubre 1976

Memoria (2pag)

Obras a realizar:

Las obras motivo del presente proyecto son las referentes a la segunda fase de la realización de la cubierta, dando así terminación a la misma y quedando completadas 
con la restauración de los huecos de ventilación de la nave central, en el hastial formado en la diferencia de altura de las naves laterales con esta.

Se realiza la cubierta previo desmontado de la todavia de madera existente, sobre estructura metálica compuesta por cerchas y correas según figura en los planos adjuntos, sobre la que se crea la correspondiente capa de compresión formada sobre el nervometal que le sirve de soporte. Finalmente se coloca la teja pudiendo ser utilizada tan solo un $20 \%$ de la existente.

Mediciones

Desmantelado de cubierta... 1 × 14,50 x 7,00; 1 × 27,50 x 14,00 =486,50m2

Demolición de fábricas en apertura de caja para alojamiento de zunchos de atado perimetral de muros

$2 \times 8,00 \times 0,40 \times 0,30 ; 1 \times 12,00 \times 0,40 \times 0,30 ; 2 \times 7,50 \times 0,40 \times 0,30 ; 2 \times 12,50 \times$ $0,40 \times 0,30 ; 1 \times 25,50 \times 0,40 \times 0,30 ; \quad=11,22 \mathrm{~m} 3$

Hormigón de $350 \mathrm{kgs}$ de cemento, garbancillo y arena de rio, armado con $80 \mathrm{~kg}$ de hierro redondo en formación de zunchos de atado perimetral de muros, incluso el encofrado preciso 11,22

Estructura de cubierta formada por cerchas metálicas construidas en perfiles normalizados y correas I. medido en planta 486,50

Forjado de cubierta compuesto por tableros prefabricados de nervometal incluso capa de compresión íd

Cubierta de teja curva vieja con apr..Fotografías, pintura antioxidante sobre estructura metálica 1 ud

4 pág. fotocopia fotografías

Vista exterior, otra muestra un pendolón con abanico de jabalcones radiales (como un paraguas), dos vistas de pares y tirantes y dos negras.

Los planos son los mismos de 1976 de la web del IPCE.

\section{AGA 26/01799}

Carpeta gruesa (impresos de pagos, fianzas, etc)

Copia de Escrituras de contrata a Técnicas para la restauración y construcciones SA, TRYCSA.

Recepción provisional 07/07/81 y definitiva 28/09/88. Adjudicada en octubre de 1979.

Proyecto de Ana Iglesias Noviembre de 1978

Obras de restauración iglesia de las Huelgas Reales.

Memoria 1pag describe. 
Obras a realizar: Consisten estas en la restauración general de los paramentos interiores del templo, limpiando y rejuntando fábricas de sillería y recomponiendo los paramentos de yeso que se encuentran deteriorados. Posteriormente se procederá a la pintura de todos los paramentos enyesados con dos manos de pintura plástica y una de imprimación.

Se levantará todo el pavimento actual de ladrillo que se encuentra en pésimo estado y se procederá a la excavación de toda la iglesia en una profundidad aproximada de veinticinco centímetros bajo el nivel actual del piso.

El nuevo pavimento se asentará sobre una solera de hormigón en masa debajo de la cual irá extendido un encachado de grava gruesa con salidas de drenaje y ventilación para sanear humedades.

Finalmente se procederá a la instalación eléctrica.

AGA 26/01579

Sólo carpetilla documentación administrativa

Obras de restauración Iglesia del convento de las Huelgas Reales

Ana Iglesias

Adjudicada a TRYCSA en octubre de 1979.

Recepción provisional 1981 y definitiva 88.

AGA 26/01720

Proyecto de restauración en el Monasterio de Santa María de las Huelgas Reales

Ana Iglesias noviembre 1978

Memoria (2pag)

Construida esta iglesia a finales del siglo XVI por Juan de Nates ...

Obras a realizar

Consisten estas en la restauración general de los paramentos interiores del templo, limpiando y rejuntando fábricas de sillería y recomponiendo los paramentos de yeso que se encuentran deteriorados, posteriormente se procederá a la pintura de todos los paramentos enyesados con dos manos de pintura plástica y una de imprimación (es el mismo proyecto de 26/01799)

\section{En el archivo de la Junta de Castilla y León}

VA-410 Carpeta en el Servicio

1999 - Restauración de fachadas y cubiertas de la iglesia de Santa María la Real de las Huelgas de Valladolid - Pedro Carreño Aguado 
Aparejador: Ángela Martín Larrañaga

(Aunque en la aceptación del encargo el arquitecto propone a Jesús Herrera Olmedo) La obra se adjudica a Construcciones Río Mayor SL.

Se incluyen informes del arquitecto territorial FP Roldán y del arqueólogo territorial JD Sacristán, que describe cómo en esa ubicación se encontraba el palacio de la reina María de Molina, del que queda la puerta monumental mudéjar que se incorporaba al segundo recinto murado de la ciudad.

En la Memoria del proyecto se describe cómo en 1320 la citada reina ordena en su testamento ser sepultada en el Monasterio, para lo que realiza la correspondiente donación, ya que en 1282 había desaparecido en un incendio el edificio original ubicado en el arrabal. Se empieza a levantar el conjunto actual en 1579, bendiciéndose veinte años después.

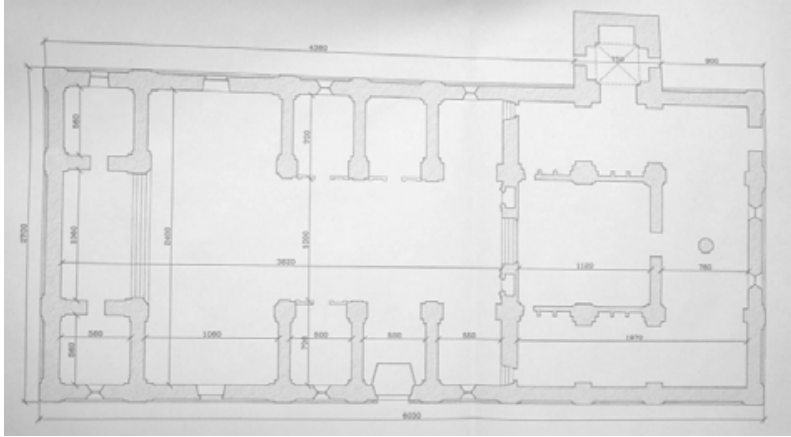

Ilustración 24: planta acotada (Carreño 1999 JCYL)
Se trata de un edificio con planta de cruz latina inscrito en un rectángulo en el que se adosan iglesia y coro, que se levantan al unísono aunque se rematen a diferentes alturas. Cuenta con tríos de capillas laterales sin interconexión, bóveda de cañón en la nave y bóveda baída, sin cimborrio, sobre el crucero.

Los muros exteriores cuentan con pilastras de piedra que marcan cada tramo y arcos sobre relleno de tapial con verdugadas de ladrillo y mechinales.

En el proyecto se menciona cómo hace pocos años se derribó la Sala Capitular del siglo XVI, albergándose la nueva en lo que fue capilla de San Bernardo. En 1622 se levantó claustro y dormitorios y en una reforma reciente se derribó un segundo claustro.

Se afirma que el jardín público que rodea al edificio, cuya rasante ha sido incrementada en unos $30-35 \mathrm{~cm}$, provoca humedades en los zócalos, llegando a verter agua directa al interior del brazo del Evangelio, por lo que propone reestructurarlo en cuanto sea posible, optándose de momento por disponer una zanja de drenaje perimetral. 


\section{Muros}

En la valoración de las actuaciones sobre los muros se incluye la restauración de $760 \mathrm{~m} 2$ de fachada de ladrillo, picado y restitución de revocos de cal y arena 1/3, limpieza de $700 \mathrm{~m} 2$ de sillería. También la restauración de $100 \mathrm{~m} 2$ de muros de tapial y verdugadas, $8 \mathrm{~m} 2$ de sillería y $10 \mathrm{ml}$ de cornisas de cantería con reintegración de masa conectada mediante espigas de fibra de vidrio ROVI y resina epoxídica.

El pavimento interior de mármol sobre solera de hormigón armado está impidiendo la evaporación natural de las humedades en zócalos. Tanto la pilastras y cornisas de piedra como los paños de tapial real presentan erosiones debidas a la acción de las aves, lluvia, viento, escorrentías y salpicaduras.

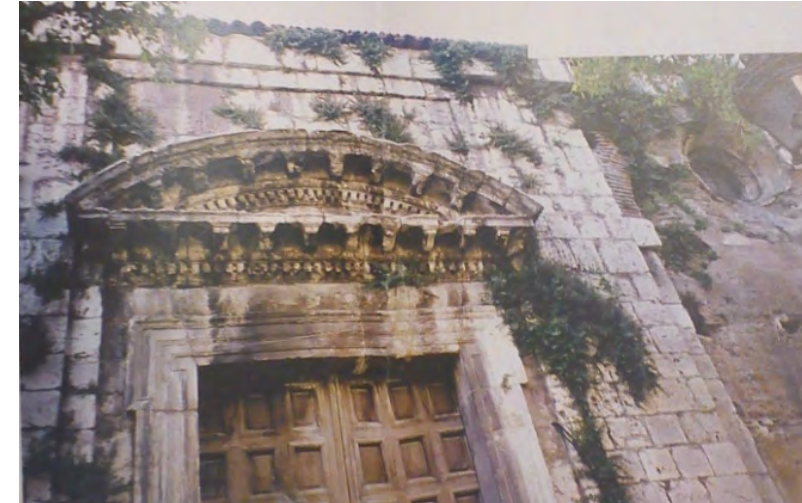

Ilustración 25: dossier proyecto (Carreño 1999 JCyL)

Se plantea la realización de análisis de tapiales y morteros, así como estratigráficos de paramentos, bóvedas, pinturas y encalados.

\section{Cubiertas}

En cubierta se desmonta $1070 \mathrm{~m} 2$ de teja curva, que se recolocará como cobijas sobre canales de teja nueva.

Se diseña un alero más volado con $83 \mathrm{ml}$ de paneles de estratificado lígneo fenólico tipo Batipin de $31 \mathrm{~mm}$ con una chapa de cobre de remate formando goterón.

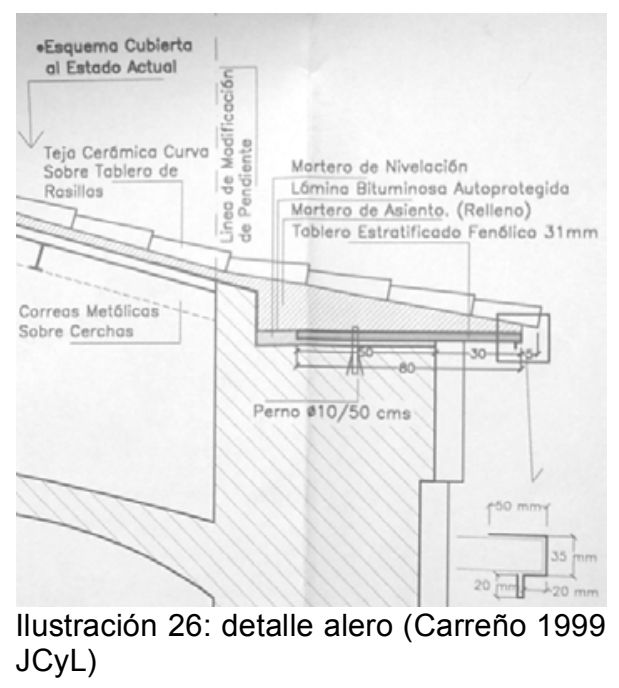

Se demuelen $60 \mathrm{~m} 2$ de cubrición con fibrocemento de la nave de la Epístola, colocándose placas gran onda nuevas pero del mismo material sobre pares de madera de pino estructural $7 \times 20$ cada $60 \mathrm{~cm}$.

La estructura de la cubierta se encuentra al parecer en buen estado.

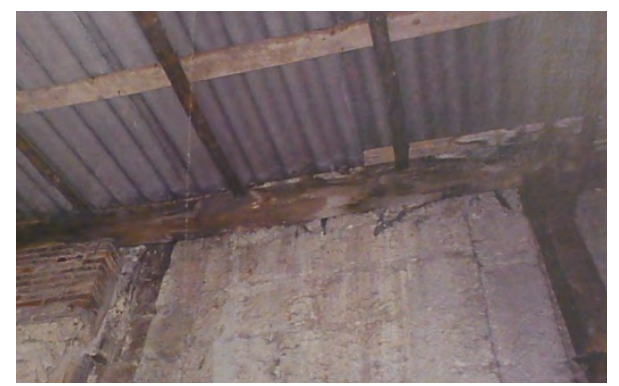

Ilustración 27: dossier proyecto (Carreño 1999 JCyL) 
Se trata de un conjunto de cerchas y correas de acero laminado con tablero de nervometal y hormigón armado, incorporadas por Ana Iglesias en su intervención de 1975 para reemplazar la estructura original de madera, representada en el mismo conjunto de planos (a la izquierda de la ilustración). Sobre los muros se colocó el habitual zuncho perimetral de hormigón armado 30x40.
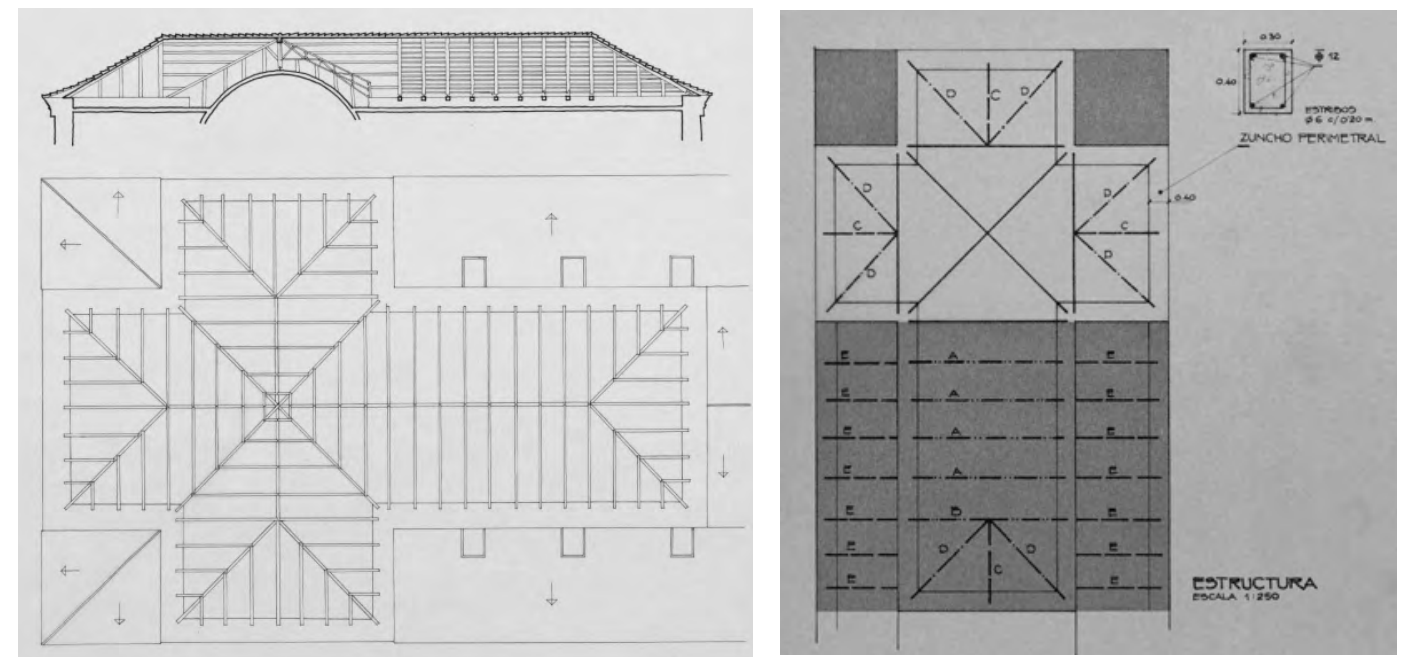

Ilustración 28: planos de estructura actual y reformada (Iglesias $1975 \mathrm{JCyL}$ )

VA-475 Carpeta en el Servicio

2004 - Modificado de la obra Restauración de fachadas y cubiertas de la iglesia de Santa María la Real de las Huelgas de Valladolid - Pedro Carreño Aguado

El modificado se plantea debido a que el nebulizado originalmente previsto no basta para garantizar la limpieza de la piedra, recurriéndose a un tratamiento con microchorro con áridos de sílice que incrementa considerablemente el presupuesto.

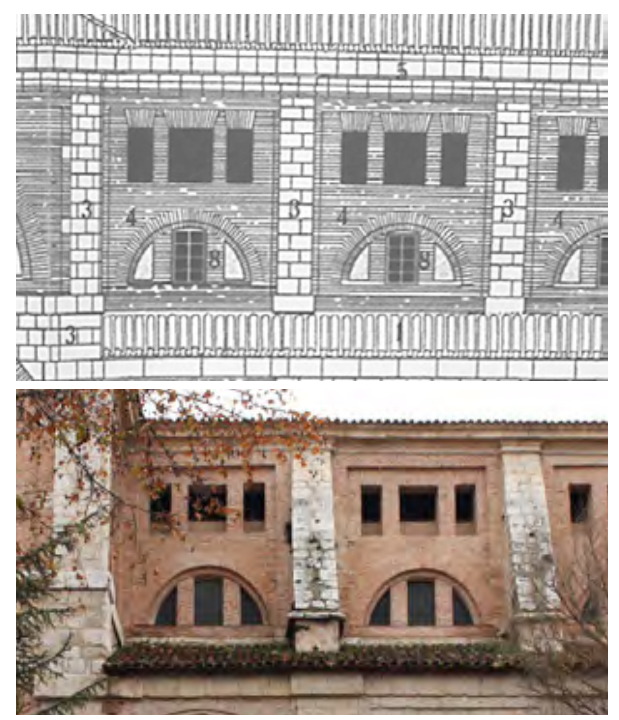

$\mathrm{Al}$ acceder a los huecos termales que albergan las ventanas se descubre que están cegados con ladrillo a panderete en lo que parece una actuación del siglo XIX, por lo que Carreño propone descubrirlos completamente para incrementar la luminosidad de la iglesia.

Se llega a plantear la eliminación de los machones parteluz, formados con el mismo tipo de ladrillo y aparentemente con una unión precaria, opción no aceptada por la Comisión llustración 29: alzado (Carreño 2004 Territorial. JCyL) 


\section{En el Archivo Municipal de Valladolid}

\section{Fondo Histórico}

AMVA: Licencia obras $1926 \quad 1049-71$

1. El Alcalde multa c/ Colón 8 por un parte que remite el arquitecto municipal Juan Agapito del aparejador por estar haciéndose obras sin licencia. 20 Abril 1926

Solicitud de licencia de la Superiora para revocar la fachada, entarimar y hacer cocinas en Colón 8. 21 de abril de 1926

2. 15 julio 1926 la Superiora pide licencia para vallar terreno resultante de derribar un cuerpo de edificio perteneciente al convento. Incluye un plano 1:50 del alzado (un rectángulo con tres molduras de remate) y memoria 1 pag: construcción de una tapia para cerrar el solar partiendo del ángulo posterior de la iglesia de la Magdalena y termina en el murón de la iglesia del convento. Será un zócalo de sillarejo, resto de ladrillo ordinario y albardilla de teja ordinaria.

Conceden $14 \mathrm{~m}$ de pared de cerramiento a $1,50 \mathrm{~m}$

\section{Fondo Administrativo}

\section{AMVA: 78/1964}

García Moreno, María Cruz (Monasterio Cisterciense Santa María la Real de Huelgas ; Huelgas Reales). Construcción colegio de enseñanza media (Planos) (Exp. 78/1964)

Arquitecto Julio González Martín. Enero de 1964.

Se edifica sobre la huerta, en el extremo opuesto a la iglesia.

AMVA: $\exp 2511966$

Monasterio Cisterciense de Santa María la Real (Huelgas Reales). Instalación depósito de fuel oil para el colegio (Contiene planos)

\section{AMVA: 161/1973 C.1936-5}

Reforma coro (2 planos). Arquitecto Julio González Martín. Diciembre de 1972. 


\section{Memoria:}

"El coro está en situación ruinosa debido al mal estado de las armaduras de cubierta, algunas de las cuales están descansando sobre las bóvedas que cierran la nave central del coro, zona a la que se contrae la ruina incipiente.

Por otra parte, el entramado inclinado, que es de madera, como las armaduras, cuenta con muchos elementos podridos, rotos, desencajados de su posición primitiva $\mathrm{y}$ correcta, lo que hace pensar en la necesidad de una sustitución total de sus elementos. Finalmente, la antigüedad de esta situación ha dado lugar a la aparición de grietas de diversa índole pero indicadoras de que el empuje que producen ahora las bóvedas y los arcos que las sustentan es peligroso hasta temer una ruina inminente si no se toman pronto las medidas necesarias para contrarrestar tales empujes.

Por todo ello se propone, para salvar la nave central del coro sin cambiar su configuración y respetando íntegramente su arquitectura, proceder al atirantado de sus arcos en la parte correspondiente a las dos bóvedas más alejadas de la Iglesia, y a sustituir la cubierta por otra nueva compuesta de armaduras, correas y parecillos metálicos, entrevigado de bóvedas de rasilla y enjutado de hormigón de cemento, y teja curva canal y cobija.

Para el atirantado que se realizará en los arranques de los arcos y bajo el vuelo de la cornisa alta, este para corregir los desplomes de los muros en sus cabezas, se proponen perfiles metálicos en la forma expresada gráficamente en los correspondientes planos. $\mathrm{Y}$ a fin de conseguir un adecuado asiento de las nuevas armaduras de cubierta se proyecta un durmiente de hormigón armado que reparta sobre el muro continuo de tapial los esfuerzos y cargas de la cubierta.

El proceso programado para la realización de todos los trabajos es sencillo, comenzando por atirantar las bóvedas, desmontar la vieja cubierta, construir el durmiente de hormigón y montar la cubierta nueva, rematando finalmente con el repaso de paramentos para dejar el edificio con el carácter arquitectónico que hoy tiene.

Como trabajo previo necesario para la seguridad de los operarios, se apeará la bóveda central con una torre de madera apoyada en el suelo, no necesitándola más extrema por contar con un fuerte pilar central.

La obra afecta exclusivamente a parte del coro, no es necesario llegar a la Iglesia, y consolida o refuerza dos bóvedas, con $250 \mathrm{~m} 2$ de superficie y renueva unos $370 \mathrm{~m} 2$ de cubierta, medido en proyección horizontal." (se solicita copia del plano) 


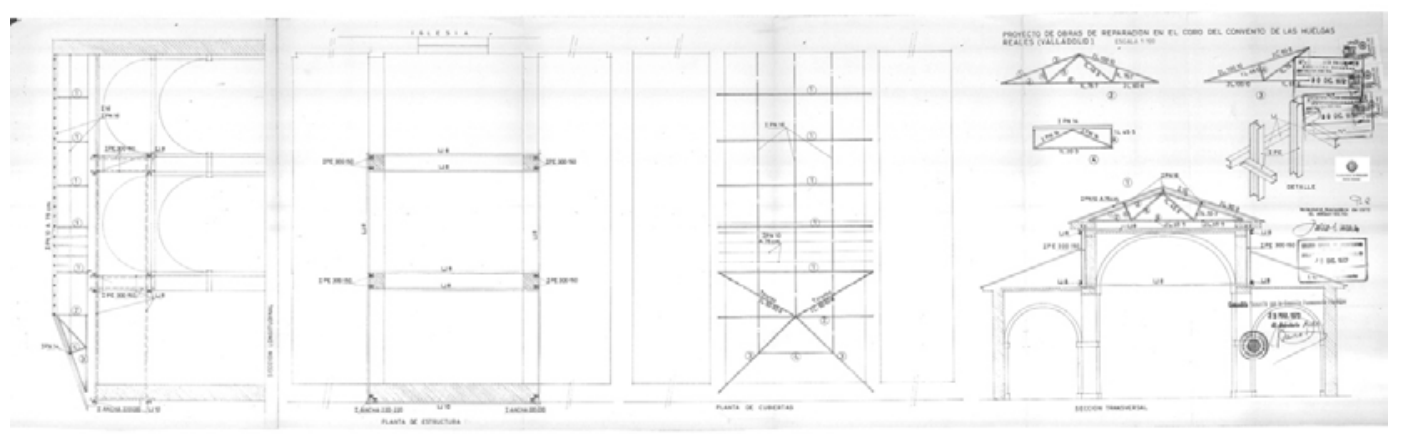

Ilustración 30: plano proyecto reforma del coro (González 1972 AMVA)

La Comisión de protección del patrimonio histórico artístico notifica que el proyecto es correcto, aunque "si las naves laterales no son suficientes para poder efectuar el contrarresto del empuje en la nave central, puede colocarse entonces ese tirante proyectado, sustituyendo la $U$ por un redondo de acero calibrado capaz de soportar las tensiones correspondientes."

AMVA: 457/1976 2717-8

Ministerio de Educación y Ciencia ; Dirección General del Patrimonio Artístico y Cultural. Informe sobre obras en el Monasterio Santa María la Real (Huelgas Reales) (Exp. 457/1976) En septiembre de 1976 envían desde el Ministerio al Alcalde un proyecto que debe devolverse para ser archivado.

Enterado de la Comisión de obras del Ayuntamiento.

AMVA: $\exp 306 / 2000$

Monasterio Santa María la Real (Huelgas Reales). Reforma interior plantas primera y segunda del Colegio (Exp. 306/2000)

AMVA: $665 / 2001 \quad$ C.21051-1

2001 Restauración fachada y cubiertas Construcciones RÍO MAYOR SL (Martínez Muñoz, José María). (mismo proyecto visto en JCyL)

Restauración de fachada y cubiertas de la Iglesia de Santa María la Real de Huelgas Licencia a la Fundación del Patrimonio Histórico de Castilla y León. 



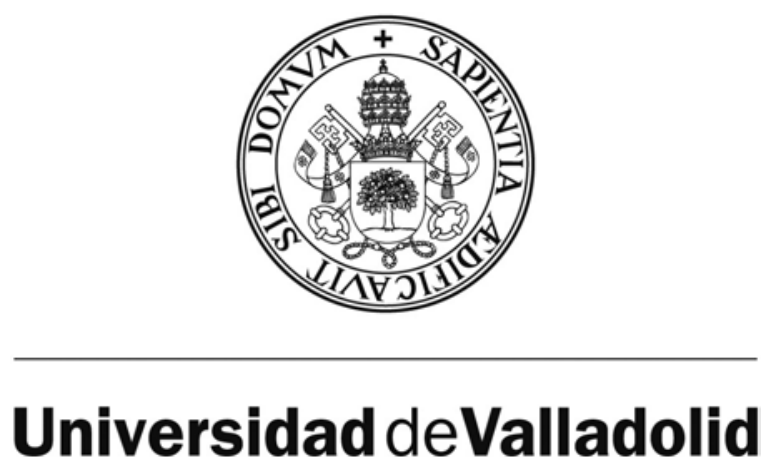

ESCUELA TÉCNICA SUPERIOR DE ARQUITECTURA

DEPARTAMENTO DE CONSTRUCCIONES ARQUITECTÓNICAS, INGENIERÍA DEL TERRENO, MECÁNICA DE LOS MEDIOS CONTINUOS Y TEORÍA DE ESTRUCTURAS

TESIS DOCTORAL:

\section{EL PAPEL DEL ZUNCHO EN LA RESTAURACIÓN MONUMENTAL: ATADO PERIMETRAL DE ESTRUCTURAS DE CUBIERTA EN IGLESIAS DE VALLADOLID}

TOMO III

Presentada por Rosa Bellido Pla para optar al grado de doctor por la Universidad de Valladolid

Dirigida por:

María Soledad Camino Olea

Francisco Javier León Vallejo 



\section{FICHAS: RESUMEN, DOCUMENTACIÓN Y VISITAS}

$\begin{array}{ll}\text { FZ-17 } & \text { Santa María } \\ \text { FZ-18 } & \text { San Juan } \\ \text { FZ-19 } & \text { La Santa Espina } \\ \text { FZ-20 } & \text { Santa María del Castillo } \\ \text { FZ-21 } & \text { Santos Justo y Pastor } \\ \text { FZ-22 } & \text { San Juan } \\ \text { FZ-23 } & \text { Santa María } \\ \text { FZ-24 } & \text { Santa María } \\ \text { FZ-25 } & \text { San Francisco } \\ \text { FZ-26 } & \text { Santa Cruz } \\ \text { FZ-27 } & \text { Santiago } \\ \text { FZ-28 } & \text { San Antolín } \\ \text { FZ-29 } & \text { San Martín } \\ \text { FZ-30 } & \text { Santos Juanes } \\ \text { FZ-31 } & \text { San Juan } \\ \text { FZ-32 } & \text { Santa María } \\ \text { FZ-33 } & \text { San Pablo } \\ \text { FZ-34 } & \text { San Cebrián de Mazote } \\ \text { FZ-35 } & \text { Santa María } \\ \text { FZ-36 } & \text { La Anunciada } \\ \text { FZ-37 } & \text { Santa María } \\ \text { FZ-38 } & \text { Santa María del Castillo } \\ \text { FZ-39 } & \text { Santa María } \\ \text { FZ-40 } & \text { San Pedro }\end{array}$

Alaejos
Arroyo
Castromonte
Castronuño
Cuenca
Fresno
Iscar
Mayorga
Medina de Rioseco
Medina de Rioseco
Medina de Rioseco
Medina del Campo
Medina del Campo
Nava del Rey
Olmedo
Palazuelo
Peñafiel
San Cebrián de Mazote
Tordesillas
Urueña
Valbuena
Villaverde
Wamba
Serrada




\section{MUNICIPIO: VALLADOLID}

- Mapas de la provincia descargados de "Municipios de Valladolid" en wikipedia el 22/07/2015

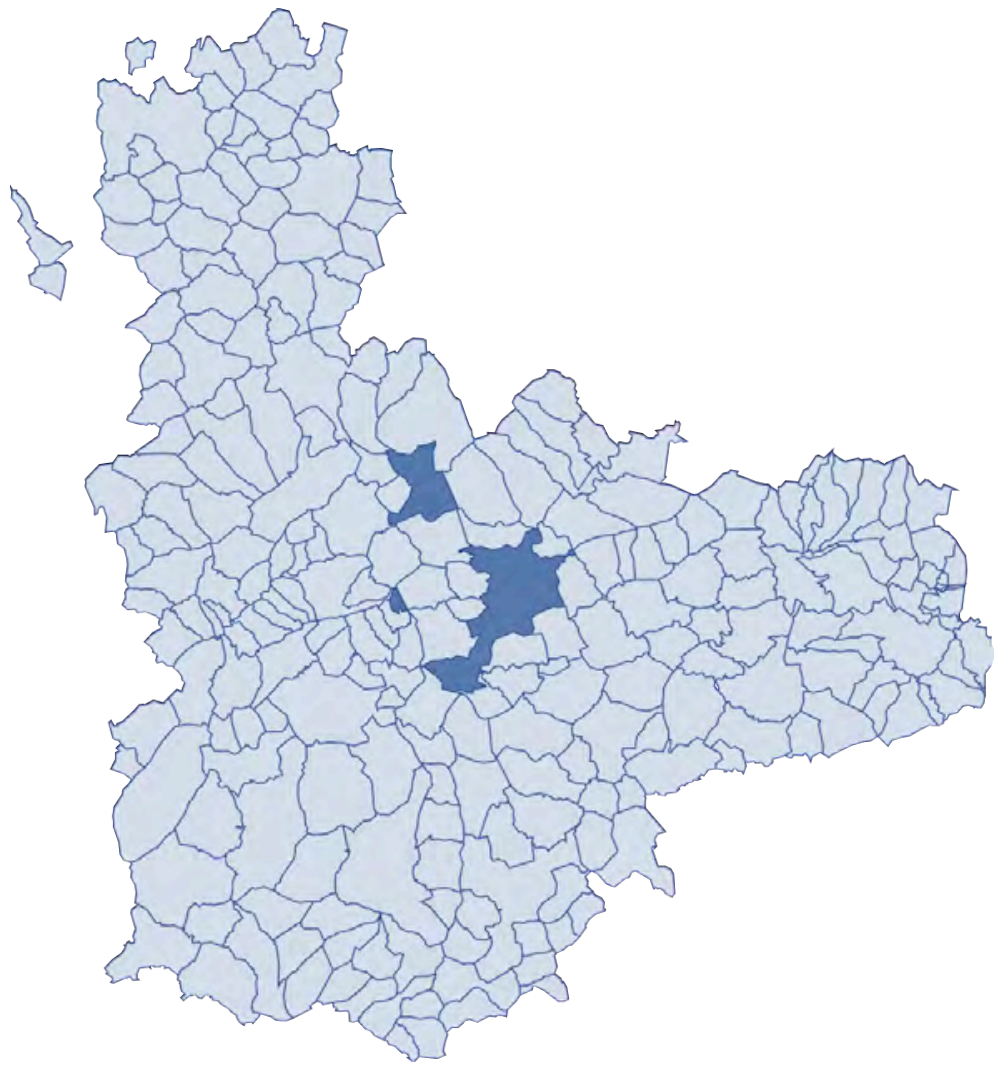




\section{Iglesia de Santa María}

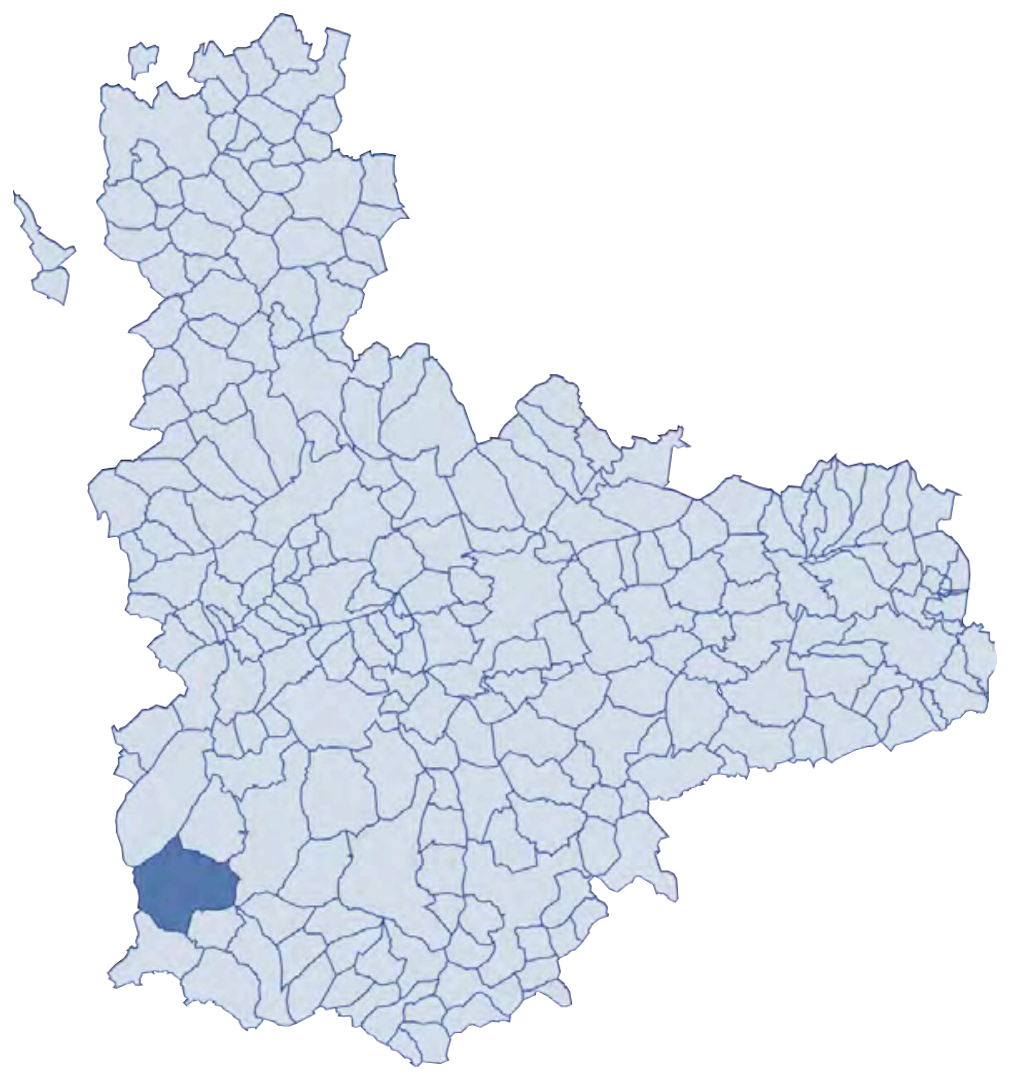



FICHA SÍNTESIS

Código de identificación: FZ-17

Denominación:

Iglesia de Santa María

Localidad:

Alaejos

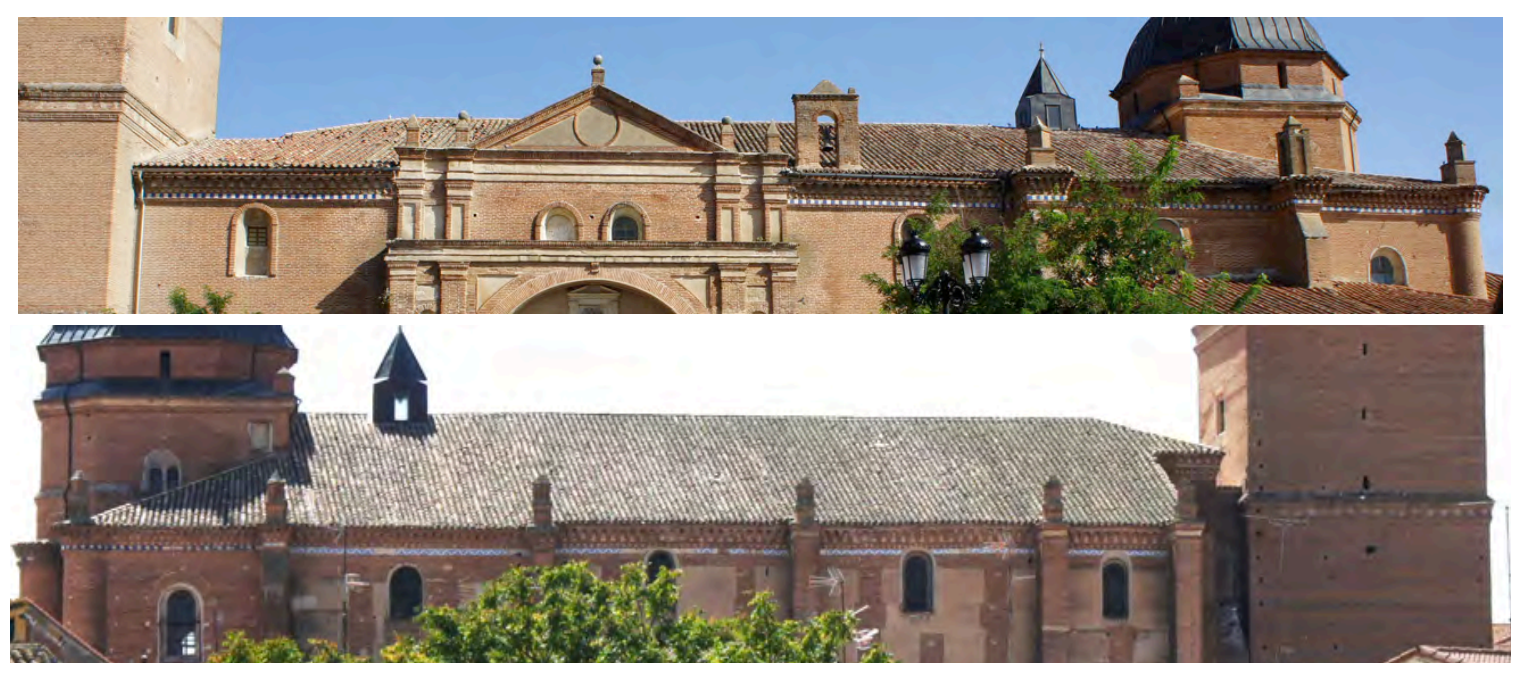

\section{Descripción}

Iglesia de tres naves que, aunque no poseen la misma altura, se integran bajo los dos faldones de cubierta al modo salón. El testero es plano, con dos contrafuertes cilíndricos en las esquinas. Las bóvedas, en los tres tramos hacia los pies, son de arista en nave central y cañón con lunetos en laterales, mientras que a ambos lados de la cabecera y en los brazos del crucero son de crucería estrellada con combados.

En el centro del crucero y sobre la cabecera encontramos bóvedas mudéjares octogonales de madera, la primera embebida en el volumen de la cubierta sobre el que sobresale una linterna, y la segunda coronada con una cúpula sobre tambor. La torre se ubica a los pies, a continuación de la nave de la Epístola.

\section{Materiales}

Los muros son de ladrillo, excepto el del lado del Evangelio, que presenta tapiales encuadrados con ladrillo y tres tramos hacia los pies con sillería de piedra hasta media altura, tal vez restos de una construcción anterior. Los faldones de cubierta están revestidos de teja curva, mientras que cúpula y linterna se recubren con chapa de cobre. 
En algún momento la teja fue de colores formando dibujos, y cúpula y chapitel estuvieron rematados con escamas de cinc (tal vez anteriormente fueron lajas de pizarra según se describe en la memoria de un proyecto de Ana Iglesias en 1974). Bajo la cornisa de ladrillo hay un encintado de azulejos.

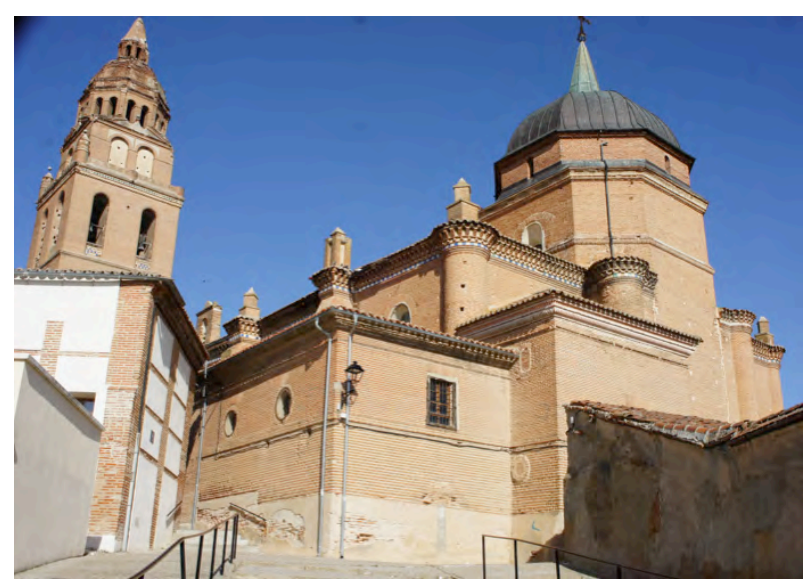

Ilustración 1: vista de la cabecera (visita 01/09/2014)

\section{Singularidades}

En el exterior llama la atención la existencia de las zonas con sillería de piedra, en contraste con la sencillez de la solución constructiva del resto de los paños, con mezcla de ladrillo y cajones de tapial. También la imponente cúpula que corona la cabecera de testero plano, con la linterna del crucero sobresaliendo sobre la cumbrera de la cubierta de la nave.
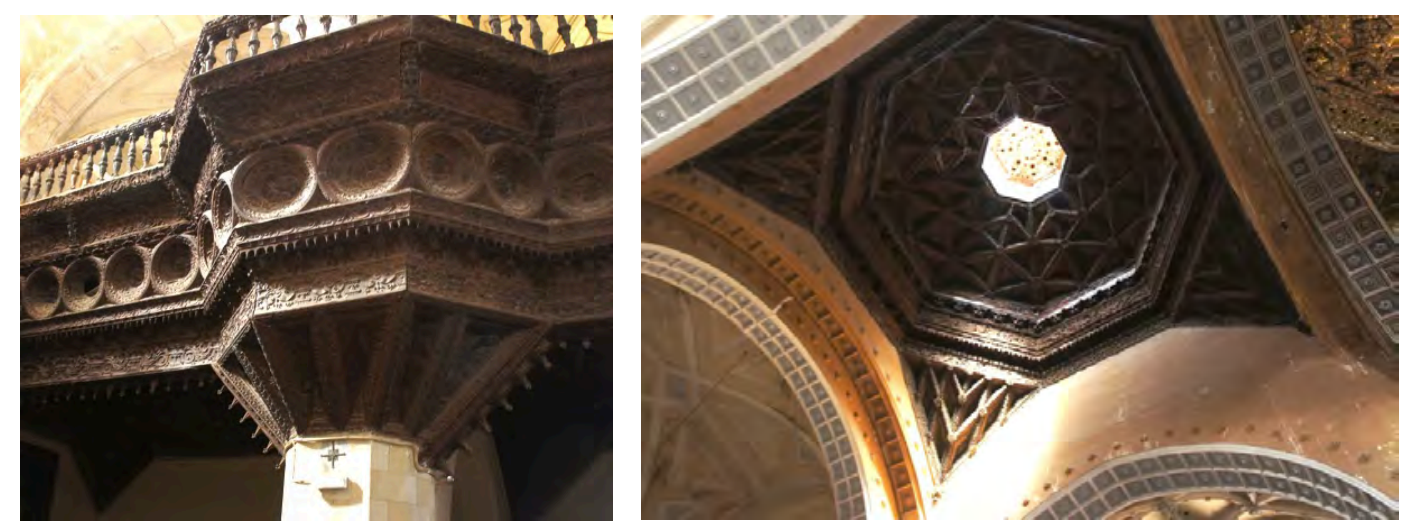

Ilustración 2: coro alto y artesonado crucero (visita 01/09/2014)

En el interior se mezclan arcos semicirculares con formeros apuntados entre las naves. Lo más característico de este edificio son las imponentes armaduras ochavadas de cabecera y crucero, así como el coro alto, también con una destacada labor de carpintería.

\section{Dimensiones básicas del templo}

$\begin{array}{llll} & \text { central } & \text { laterales } & \text { capillas } \\ \text { Ancho de nave } & 7,2 & 5,3 & - \\ \text { Altura } & 13,2 & 11,6 & \end{array}$


Los tramos de crucero y cabecera presentan una anchura ligeramente superior $(1,2 \mathrm{~m})$ a la del resto del templo.

\section{Memoria histórica constructiva}

Información extraída del Catálogo:

La iglesia se cita ya en documentos de 1500 , encontrándose prácticamente acabada tan solo cien años después. En el cuerpo del templo conviven arcos formeros muy apuntados con fajones semicirculares. En el Catálogo se sugiere que la fachada del Evangelio debió presentar problemas de estabilidad desde el principio, por lo que se usó sillares en la base y refuerzo en los contrafuertes, Describe cómo "el estribo más desarrollado, junto a la cabecera, se construyó en 1786 y tuvo un hueco de paso cegado" que hoy encontramos practicable.

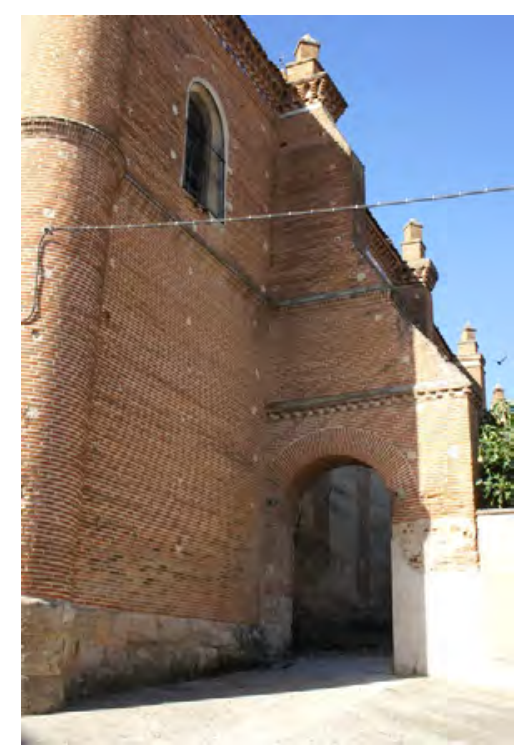

Ilustración 3 (visita 02/09/2014): hueco en estribo

Las informaciones documentadas sobre la historia constructiva de la torre son aparentemente contradictorias, dado que según el Libro de Fábrica se termina en 1605, pero cita la reparación en 1594 de un chapitel de madera que la remataba.

En el proyecto de Ana Iglesias de 1974 se mencionan restos del artesonado que en tiempos cubrió la nave central, arrasado para construir las bóvedas según el gusto de la época. Esta información concuerda con las conclusiones obtenidas al recorrer el trasdós de las bóvedas que se recogen en el anejo resumen de la visita: el templo debió contar con un artesonado de vigas de madera pareadas sobre ménsulas labradas y pendiente a dos aguas a una cota inferior a la actual con la que quedaba exento el cimborrio del crucero, cuya fábrica cuenta con ornamentos hoy ocultos en el bajo cubierta.

En el proyecto de Areizaga de 1989 se describe el templo mencionando que la zona de sillares en el muro del Evangelio puede tratarse de los restos de una construcción anterior.

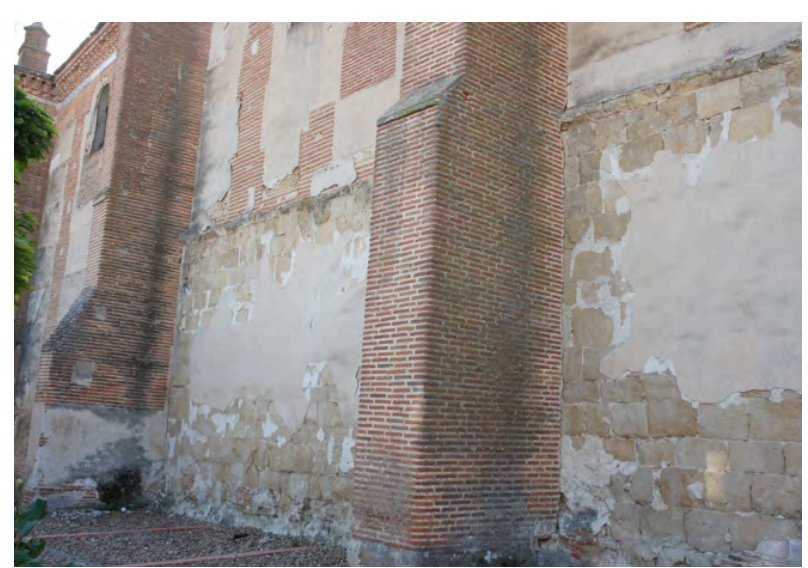

Ilustración 4: muro del evangelio (visita 02/09/2014) 
En enero de 2001 cae parte del muro del Evangelio.

\section{Cronología. Fechas clave}

$1500-1786-1974-1989$

\section{Intervenciones}

1959 - Consolidación de muros y reparación de bóvedas - Luis Cervera

Tras el derrumbe de parte de la bóveda, $6,5 \times 4,0 \mathrm{~m}$, de nave lateral izquierda se recalza los muros con pozos y zanjas de hormigón armado. El tramo de bóveda se reconstruye con dos hojas de ladrillo hueco tabicado.

1974 - Restauración de la iglesia - Ana Iglesias

\section{Incorporación de zuncho de hormigón armado}

Cita en la memoria que algunas bóvedas de ladrillo habían sido reforzadas con una capa de cemento en una restauración anterior.

En el proyecto se contempla reemplazar la estructura de madera de cubierta de las naves laterales por cerchas metálicas, dispuestas cada $3 \mathrm{~m}$, y se describe un tablero prefabricado de hormigón $0,25 \times 3 \mathrm{~m}$, conservando la armadura existente en nave central.

En la planta de estructura reformada se representa con trama las piezas de madera que se prevé conservar. Se define un "zuncho interior perimetral de atado, hormigón armado 40x40".

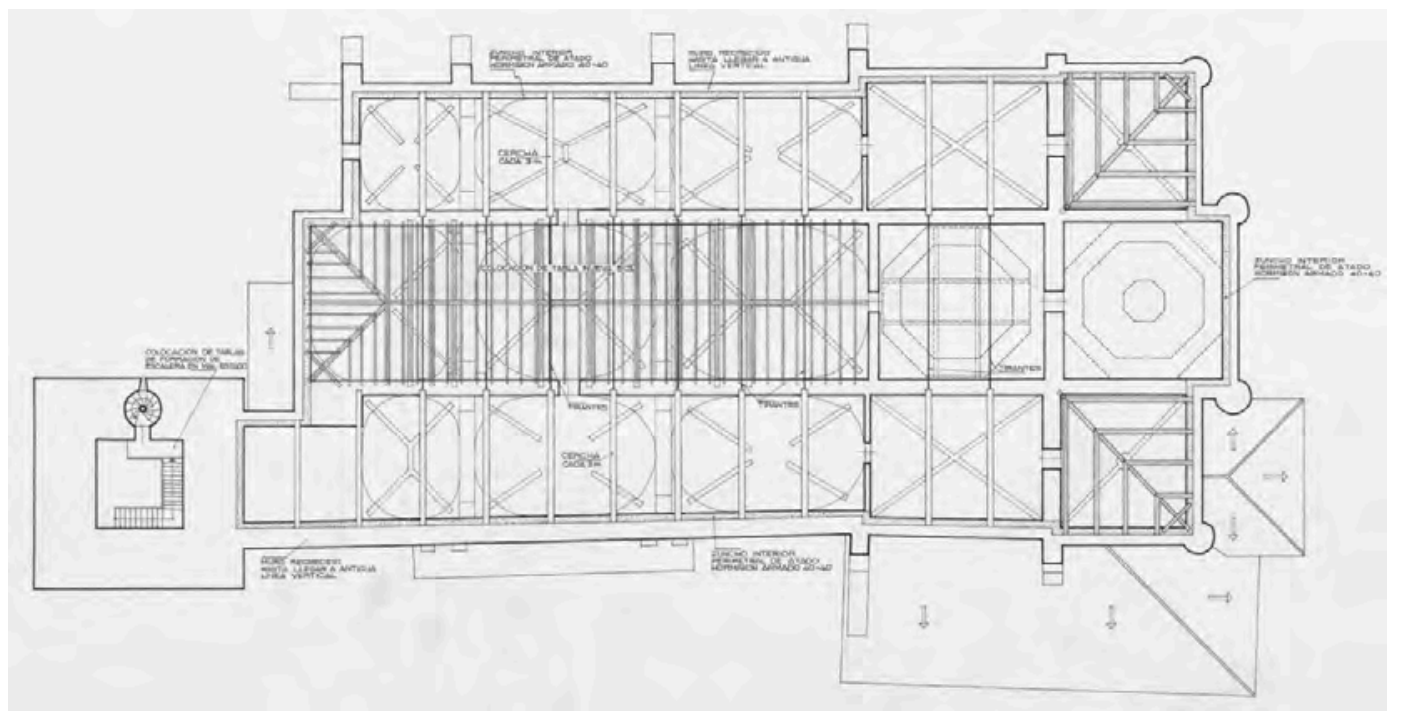

Ilustración 5: planta estructura de cubierta reformada (Ana Iglesias 1974 IPCE) 


\section{7 - Artesonado - REARASA / Enrique Nuere}

Restauración en dos fases de las estructuras de madera mudéjares: bóveda octogonal del crucero con linterna y cúpula sobre el altar.

Encuentran serrado el tirante de la estructura de cubierta con la nave en la zona del crucero, por lo que se atiranta con barras roscadas de acero diámetro $20 \mathrm{~mm}$ provistas de tensor.

1989 - Restauración de cubiertas de crucero y cabecera - Armando Areizaga y Juan Corral

Plantean la eliminación de cuerpos adheridos al volumen del templo para disponer un drenaje perimetral. Consolidación de bóvedas y restauración de cubierta sobre crucero y presbiterio. Restauración de la torre.

En las secciones de estado actual de la zona central del crucero se representa zuncho de hormigón armado en la cara exterior de los tres paramentos que lo separan de las naves del templo.

El tablero sobre naves laterales descrito por Ana Iglesias como prefabricado es de vigueta $\mathrm{y}$ bovedilla.

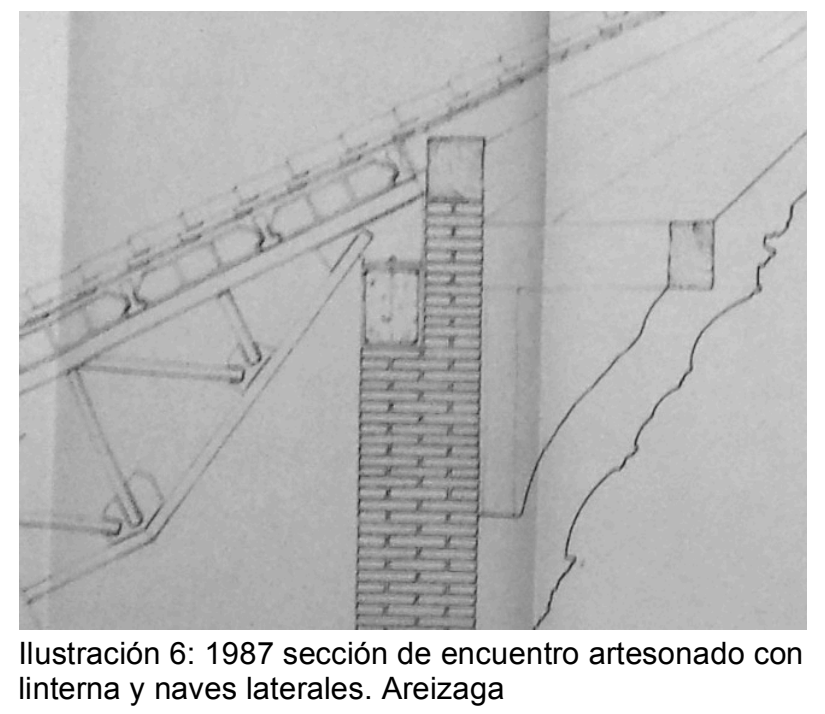

En una zona sobre la nave de la Epístola el tablero se ha realizado con hormigón vertido sobre nervometal. 


\section{Planos}

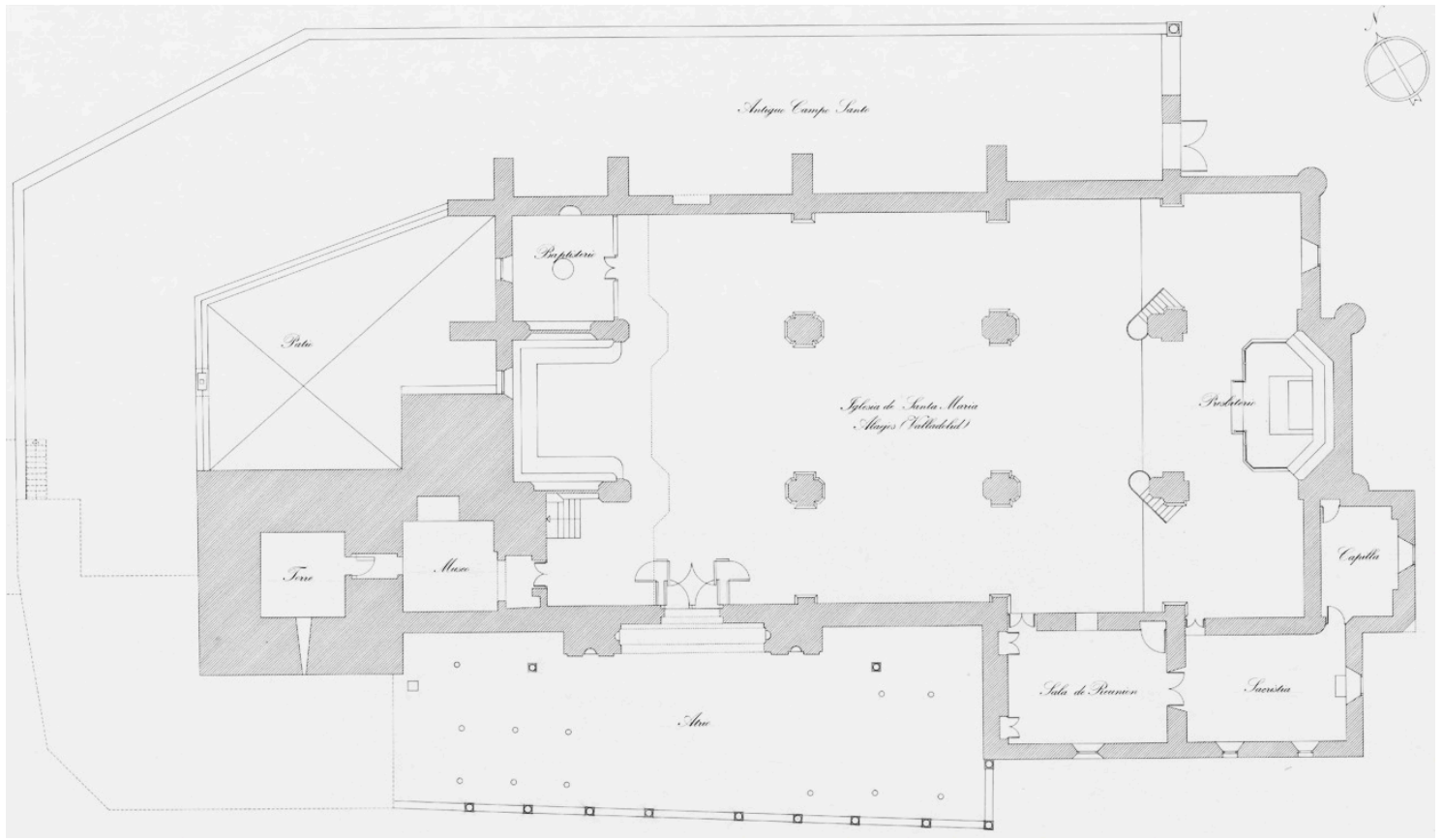

Ilustración 7: planta baja (Villalobos 1983 IPCE)

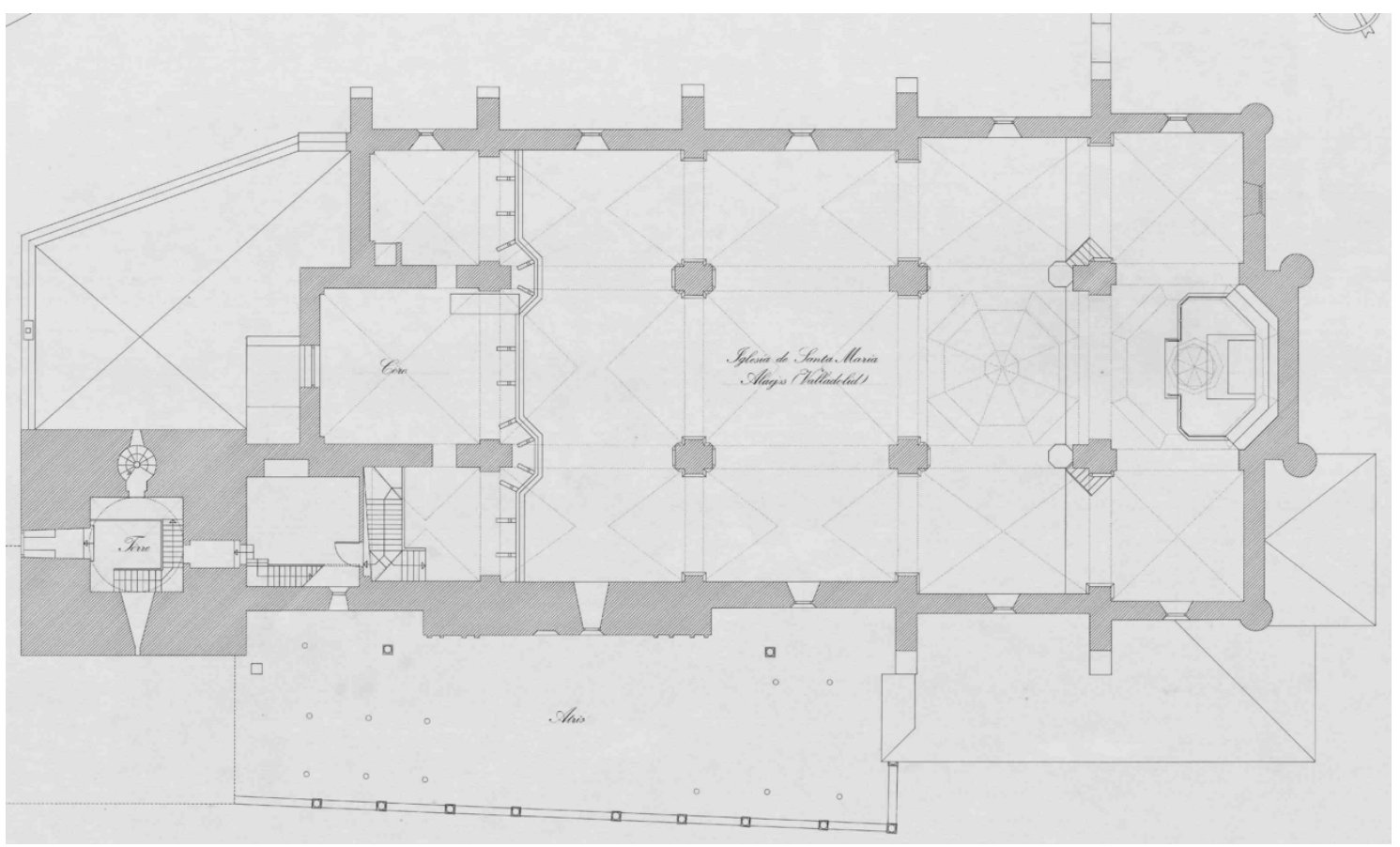

Ilustración 8: planta alta (Villalobos 1983 IPCE) 


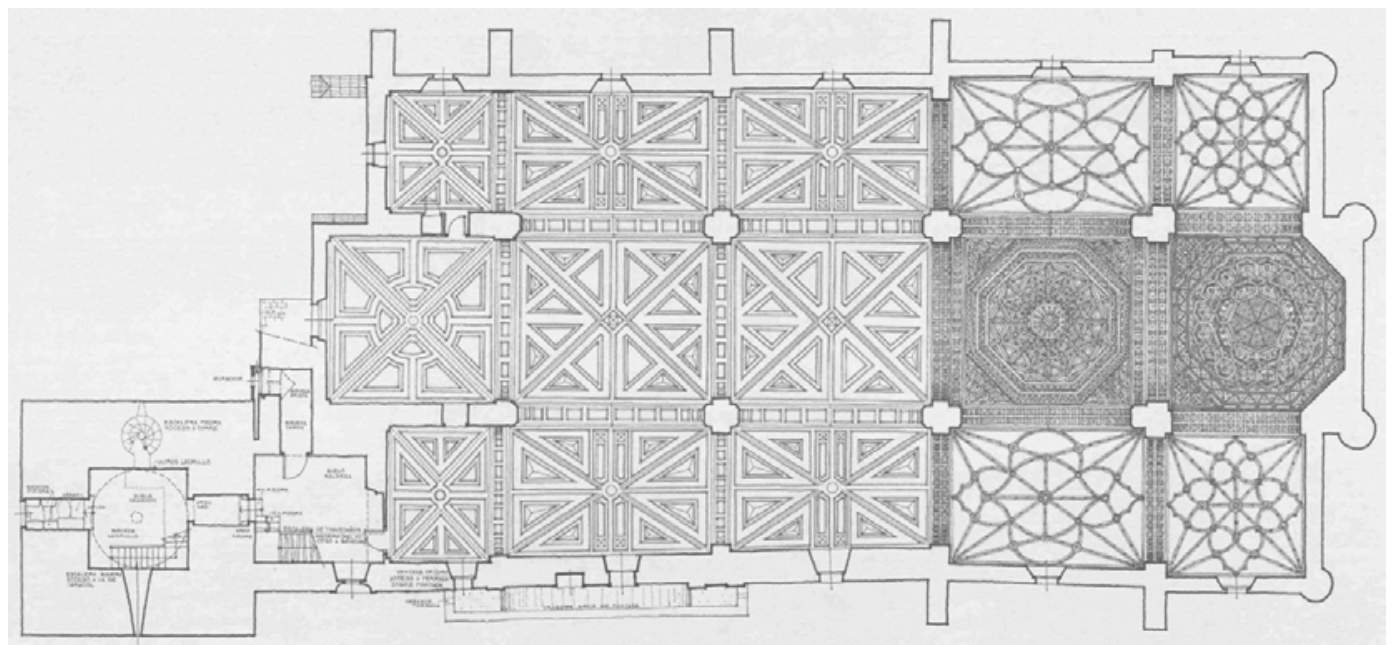

Ilustración 9: planta de bóvedas (Ana Iglesias 1974 IPCE)

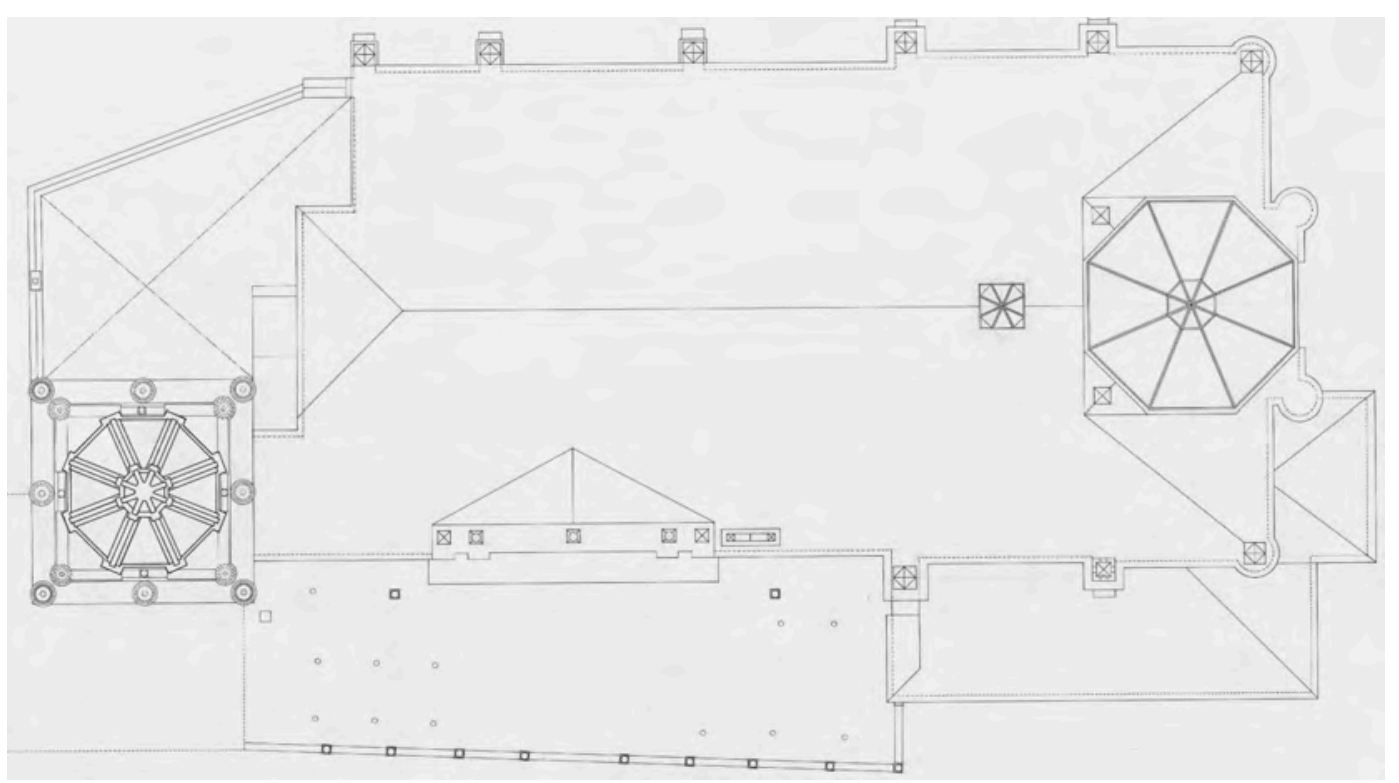

Ilustración 10: planta de cubiertas (Villalobos 1983 IPCE)

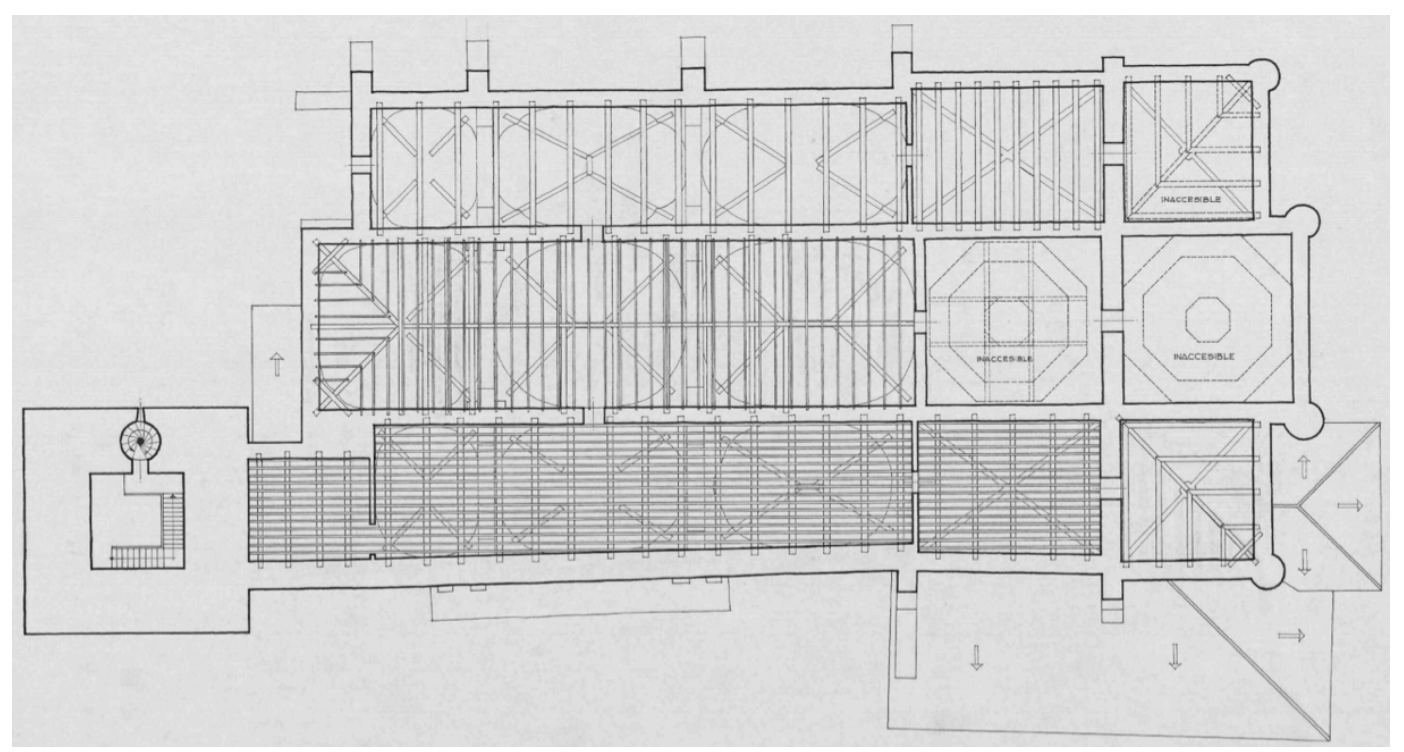

Ilustración 11: planta estructura de cubiertas estado actual (Ana Iglesias 1974 IPCE) 


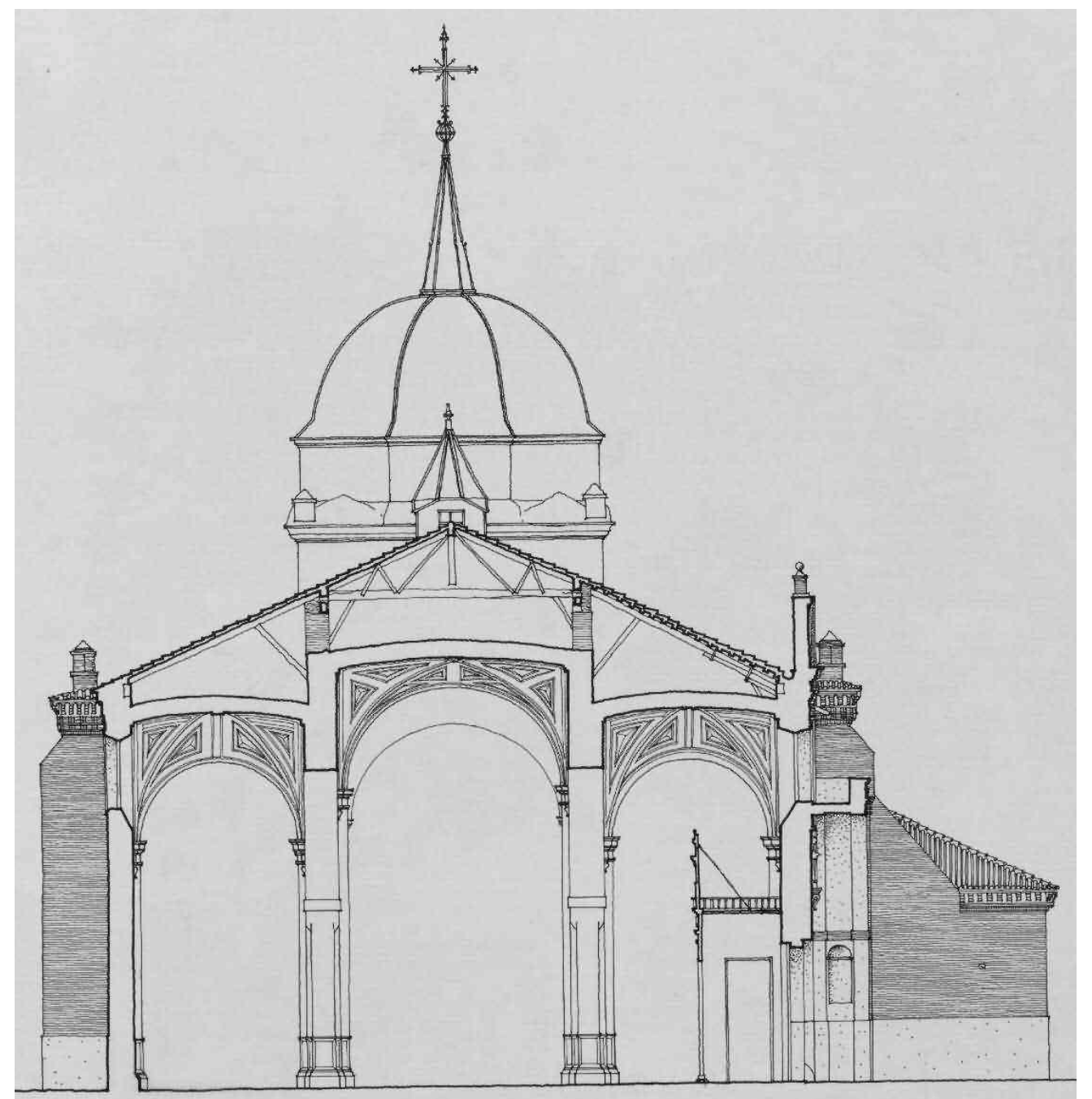

Ilustración 12: sección transversal estado actual (Ana Iglesias 1974 IPCE)

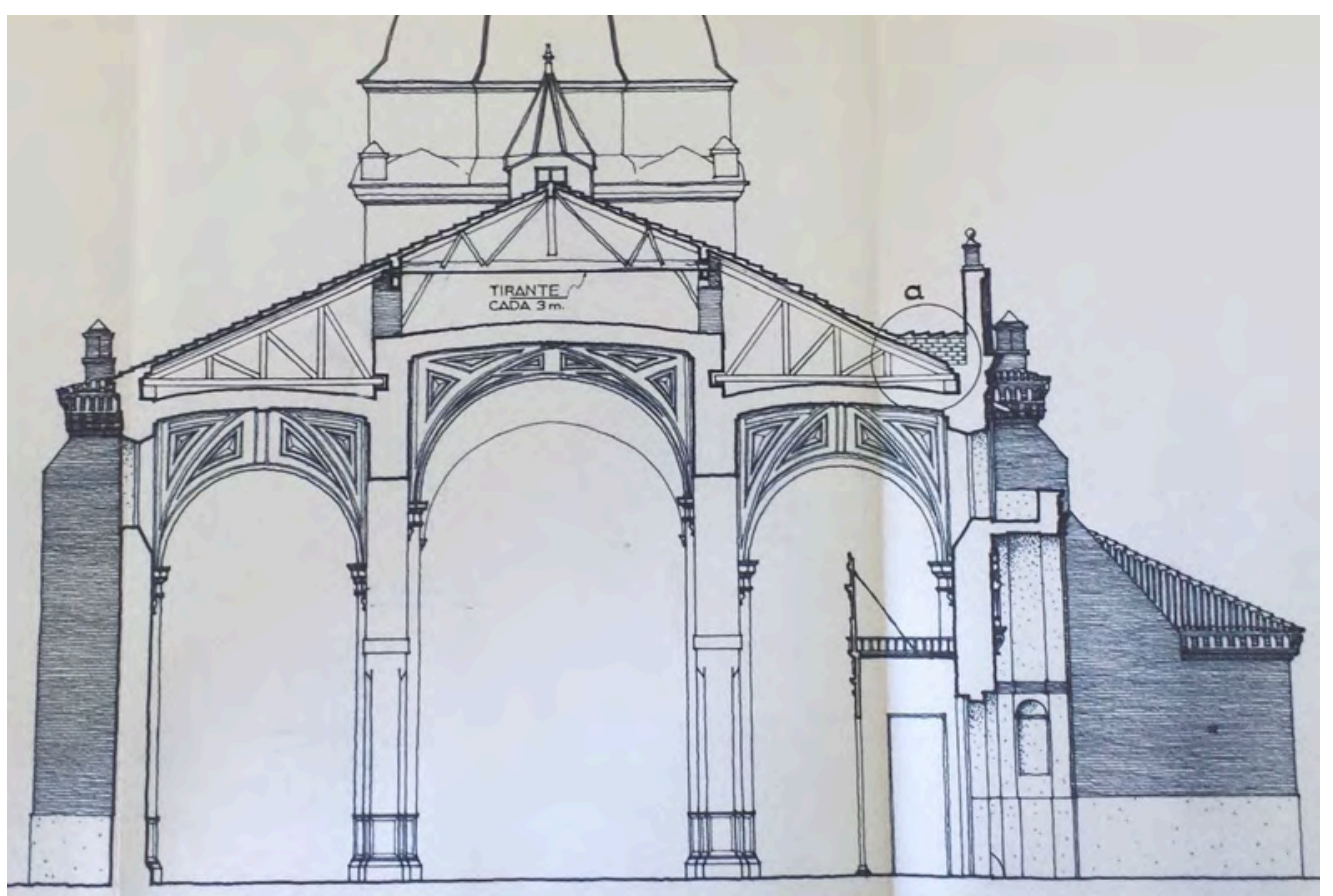

Ilustración 13: sección transversal templo reformado (Ana Iglesias 1974 IPCE) 


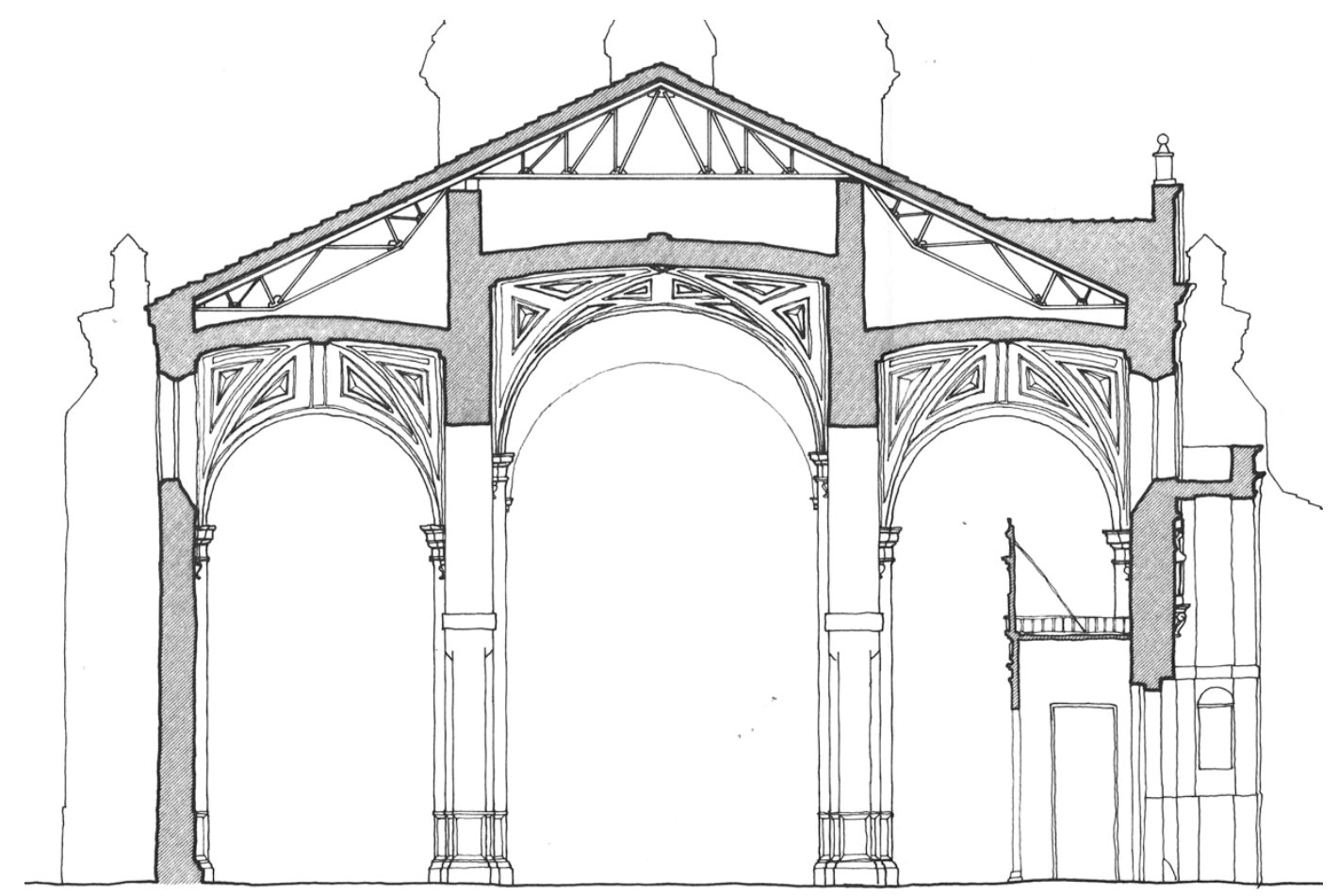

Ilustración 14: sección transversal estado actual (Areizaga 1989 JCyL)

En la visita al edificio se comprueba que la sección realmente ejecutada por Ana Iglesias en los años setenta, con la estructura de cubierta de las tres naves enteramente reemplazada por cerchas metálicas, no coincide con sus planos, sino con la representada en los planos del Proyecto de Areizaga de1989.

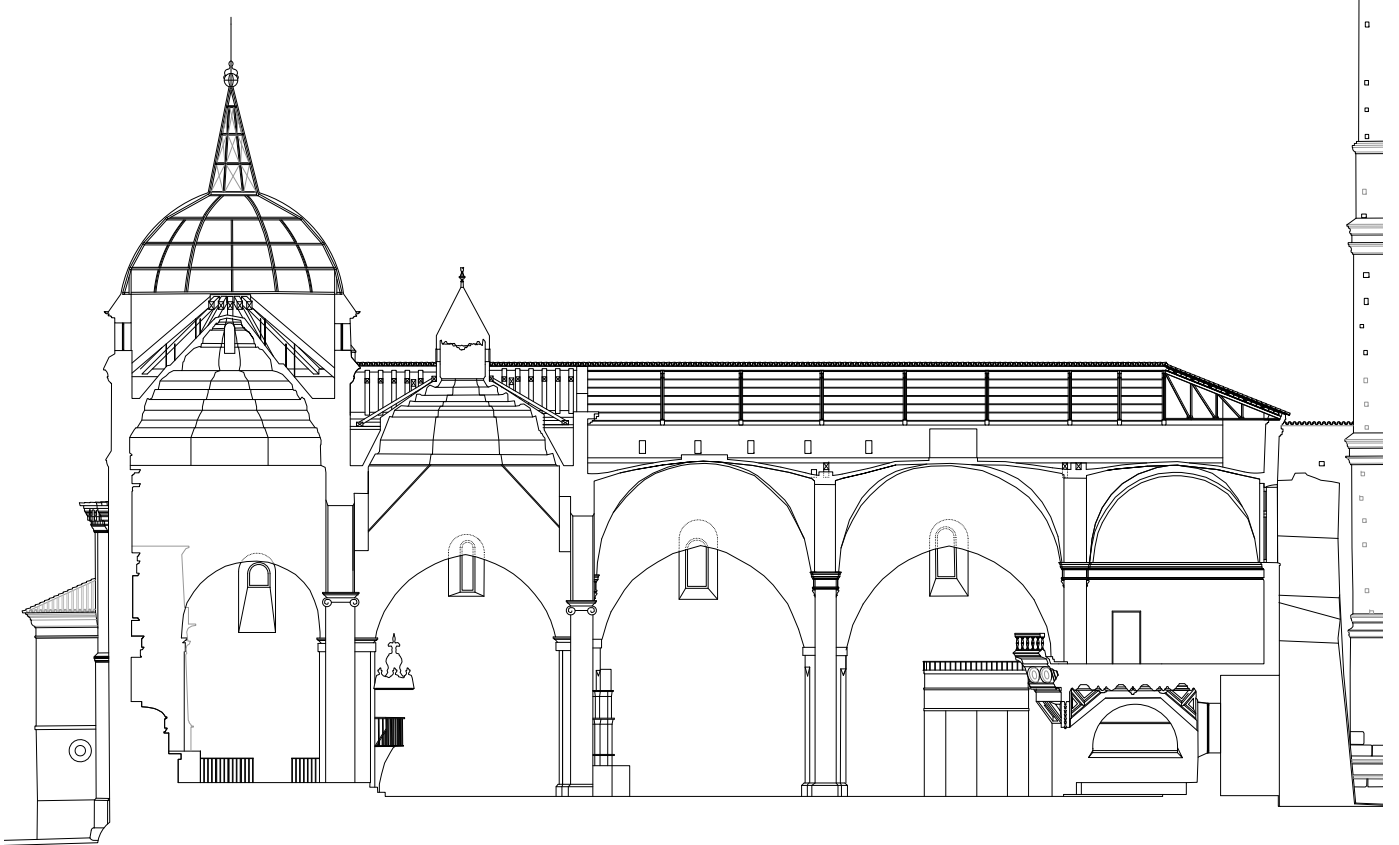

Ilustración 15: sección longitudinal (levantamiento 2011 JCyL) 


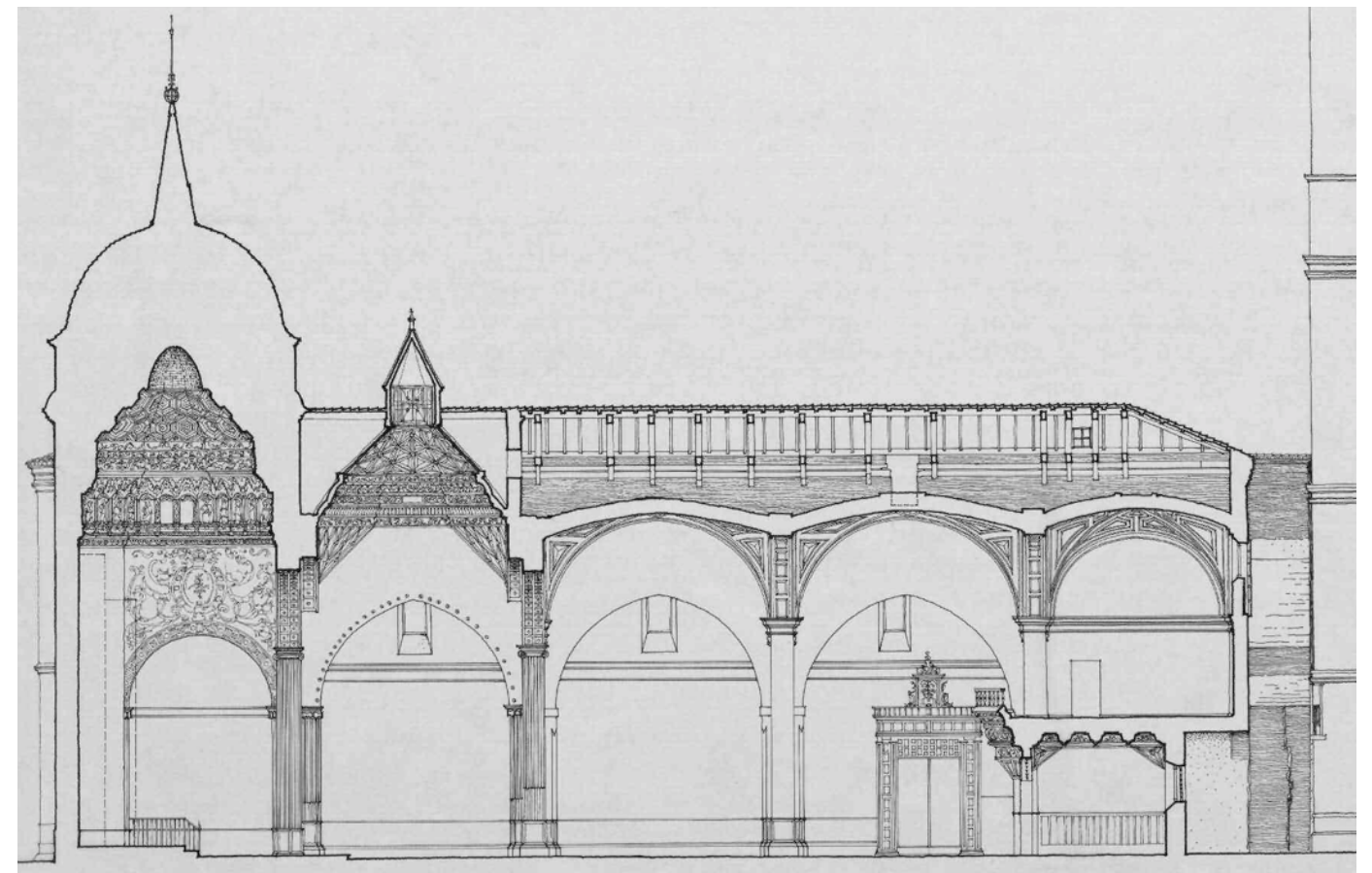

Ilustración 16: sección longitudinal estado actual (Ana Iglesias 1974 IPCE)

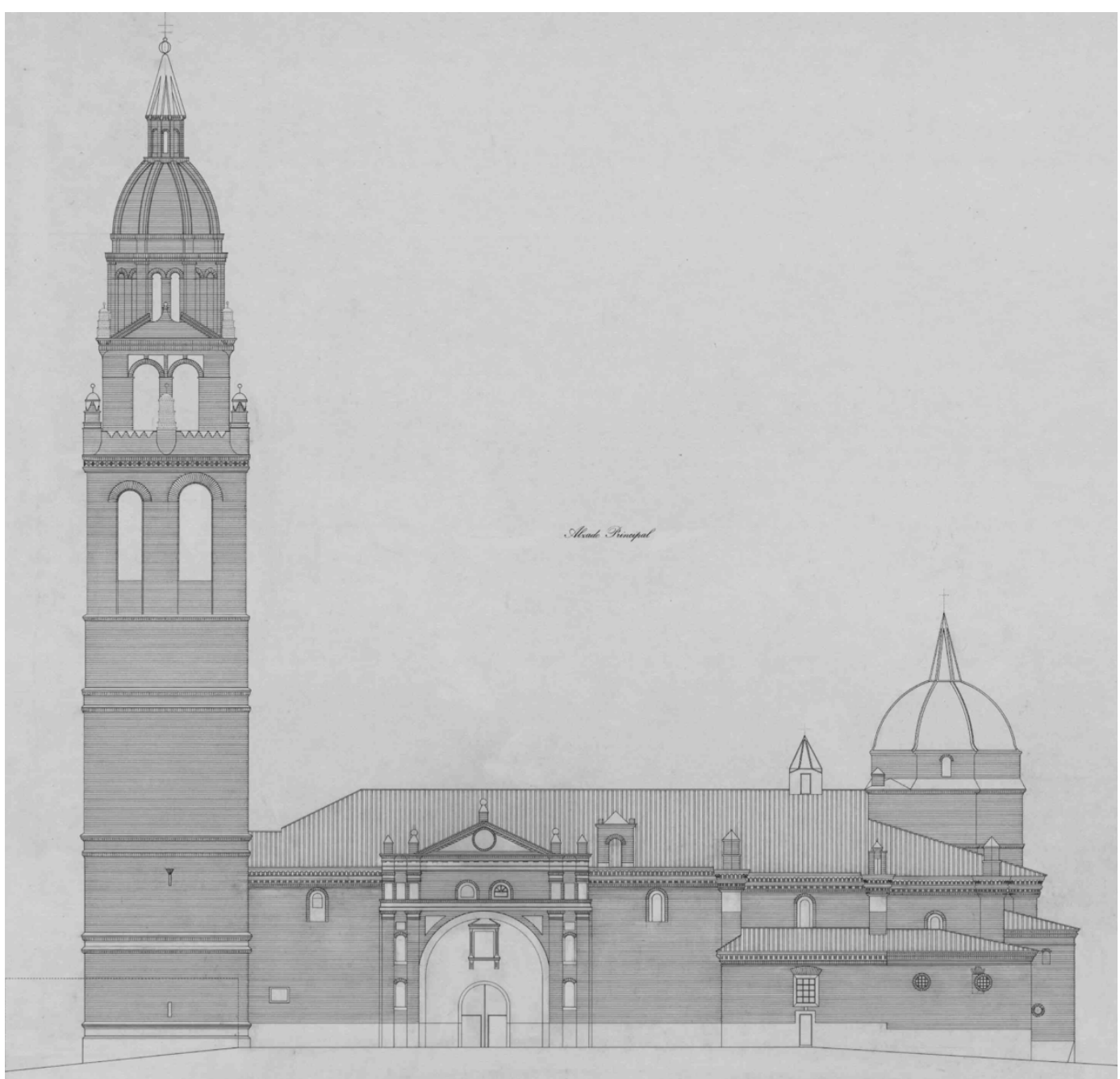

Ilustración 17: alzado principal (Villalobos 1983 IPCE) 


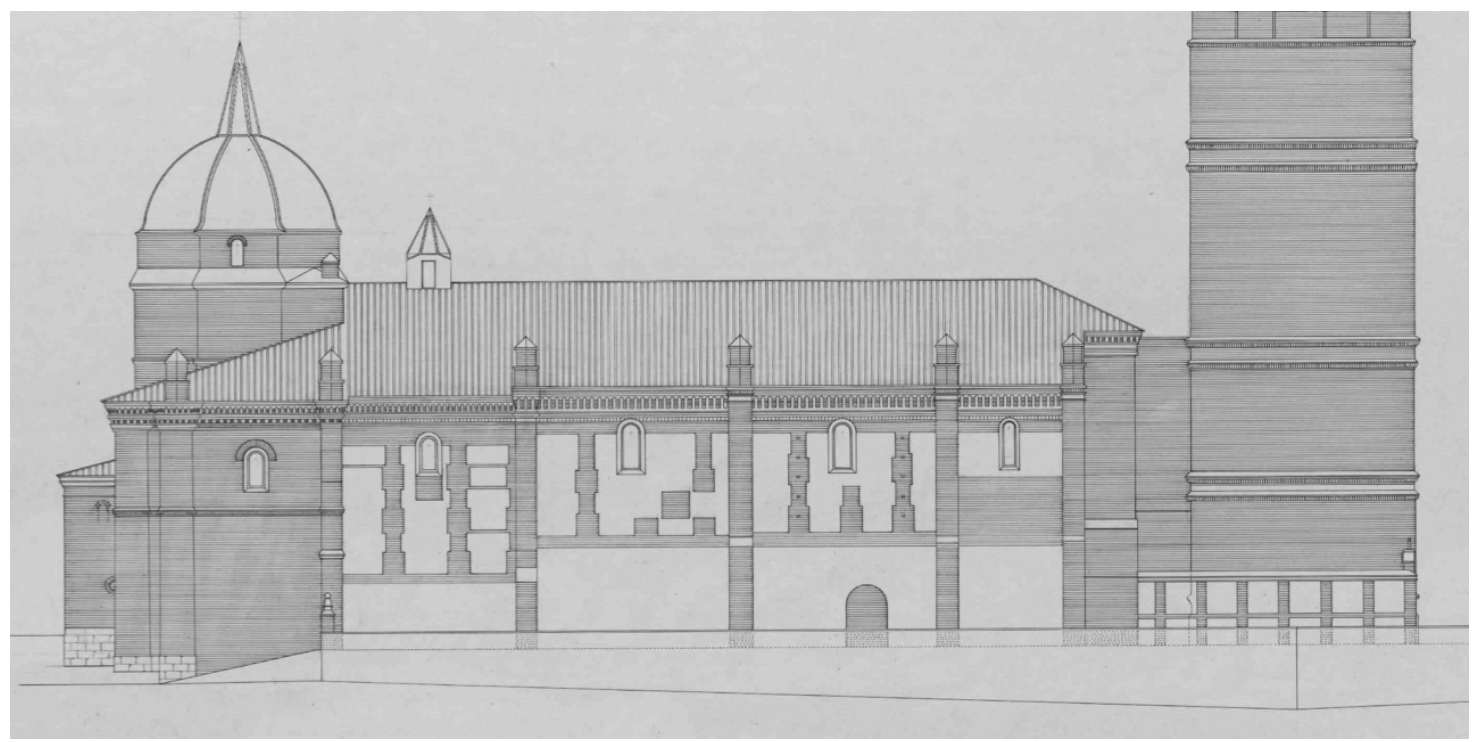

Ilustración 18: alzado trasero (Villalobos 1983 IPCE)

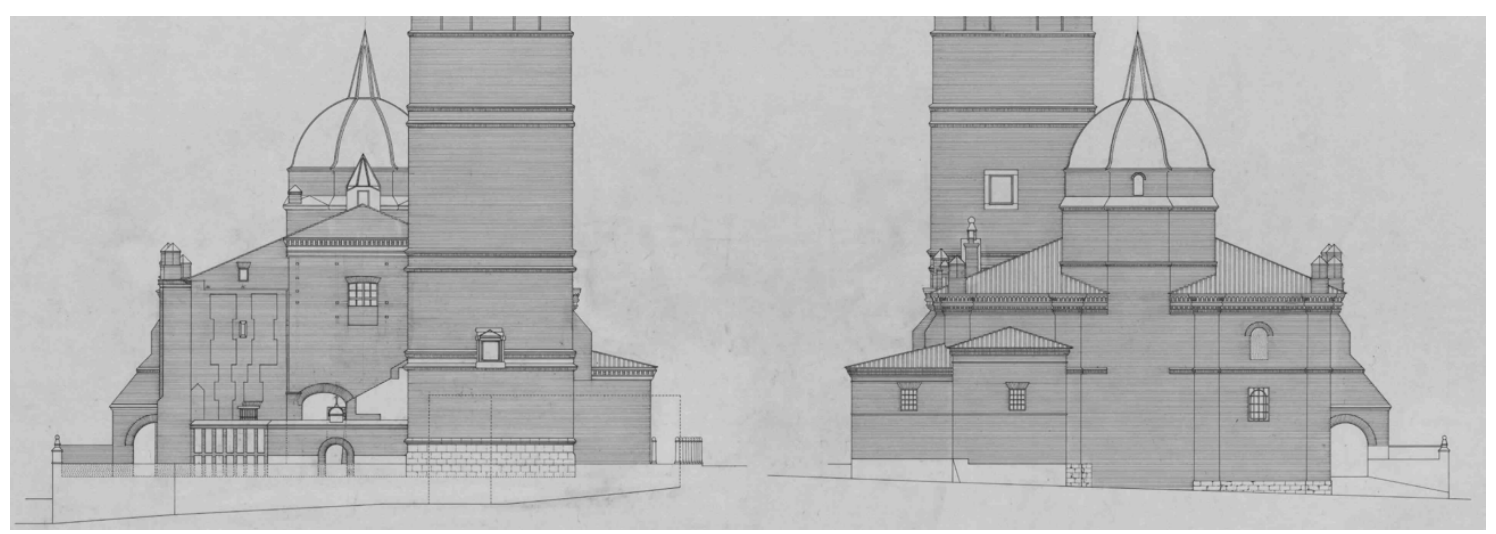

Ilustración 19: fachadas pies y cabecera (Villalobos 1983 IPCE)

\section{Solución constructiva de la cubierta}

En el proyecto de Areizaga de 1989 se describe cómo la estructura general de la cubierta, hasta la anterior restauración, estaba constituida por armaduras de madera de par y nudillo sobre la nave central y pares simples, apoyados en durmientes recibidos en los muros, sobre las naves laterales. Las tejas iban recibidas directamente sobre la tabla ripia, con una cama de barro. Plantea que la cumbrera debió sobre-elevarse en algún momento para conseguir mayor pendiente en los faldones y evitar problemas de penetración de agua, lo que complicó los encuentros con la linterna del crucero. También sospecha que debió existir una cubierta independiente sobre las cúpulas de la nave central, tras descubrir restos de cornisa en el paramento que limitaría los pies del crucero. 
En la imagen se aprecia la estructura de madera que conforma la cubierta del tramo lateral de la cabecera junto al presbiterio, con pares rollizos sin escuadrar, correas y tabla ripia.

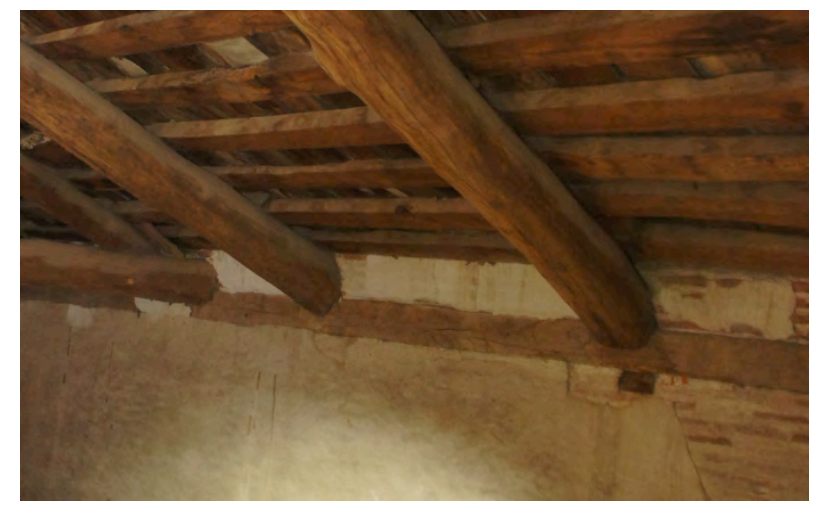

Ilustración 20: apoyo de pares (visita 02/09/2014)

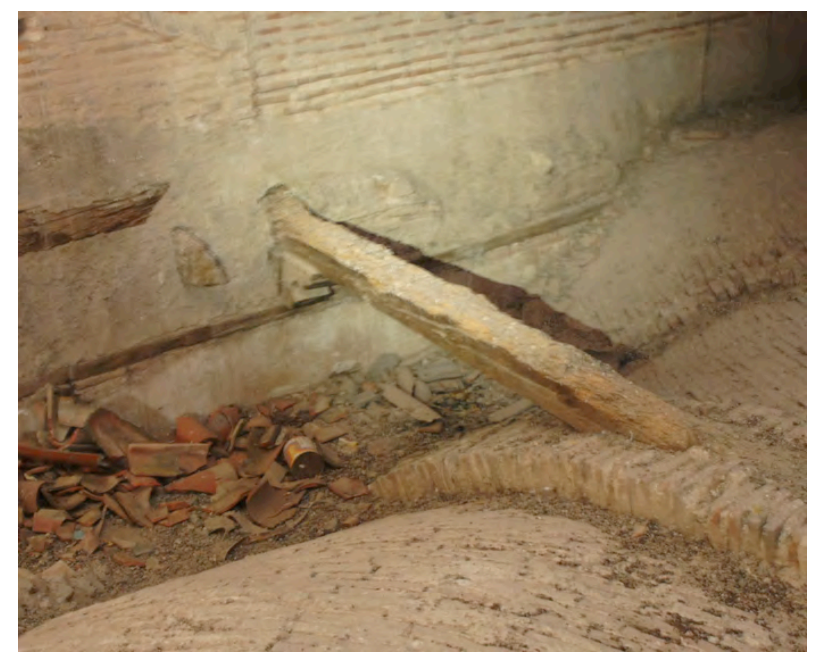

Ilustración 21: restos de ménsulas de madera (visita)
El apoyo se resuelve sobre durmiente de madera embebida y enrasada a cara interior del muro de fábrica de ladrillo. En las esquinas encontramos cuadrales apoyados sobre el mismo durmiente (podemos ver parte de uno a la izquierda de la fotografía 20).

En la visita al bajo cubierta se ha comprobado la existencia de restos de vigas de madera sobre ménsulas labradas, que debieron formar el artesonado del techo de la nave central en su configuración original. Tal vez se trataba de una estructura obra del mismo carpintero que realizó las valiosas cúpulas de crucero y presbiterio y el coro alto labrado a los pies.

Según el Catálogo de Castán, "Felipe Heras cree que podrían atribuirse las tres obras de los años 80 del siglo XVI, perfecta fusión de elementos renacentistas y mudéjares, al carpintero Bartolomé Hernández".

Las bóvedas son de varios tipos: de crucería en laterales de cabecera y crucero, rosca de ladrillo en nave central y del Evangelio, y tabicadas en nave de la Epístola, excepto la primera de menor anchura a los pies, que también parece de rosca.

En las secciones de 1974 se aprecia una pendiente de unos $25^{\circ}$. La antigua pendiente puede estimarse por las huellas dejadas sobre el paramento del antiguo cimborrio, del que sólo sobresale hoy por encima de la cumbrera una linterna. 
En la fotografía siguiente vemos el testero a los pies de la nave del Evangelio, cuyas grietas se citan en la memoria de varias de las intervenciones. Se puede apreciar el encuentro del muro con el contrafuerte lateral, sin enjarje de los ladrillos. Tampoco se traba con el macizado de ladrillo de los paños de tapial.

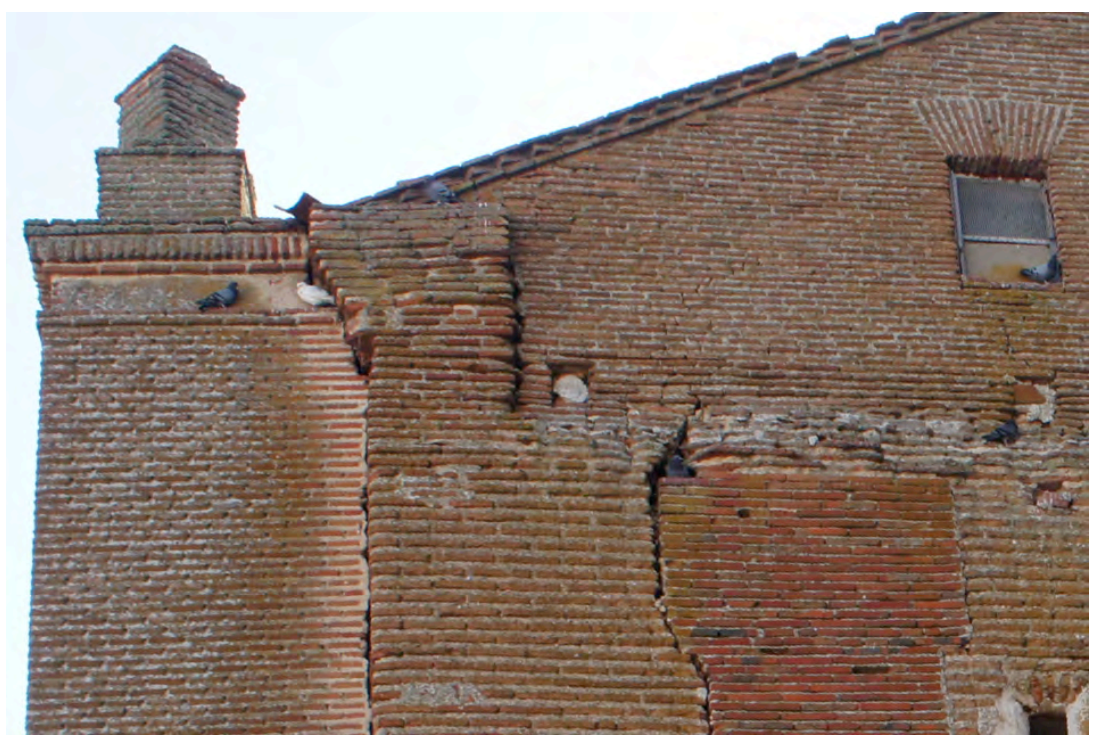

Ilustración 22: detalle encuentro de fábricas sin enjarjes (visita 02/09/2014)

La alteración más importante de la geometría de cubierta no se produjo con el reemplazo por estructura metálica en el siglo XX, sino que debió realizarse con la ejecución de las bóvedas y el desmontaje del artesonado de madera original de la nave central. Se incrementó la altura de los muros de ladrillo sobre los ejes de pilares desde la cota superior del doble durmiente de madera hasta el nivel necesario para resolver el apoyo intermedio de los dos grandes faldones.

\section{Zunchos}

Según se ha señalado más arriba, en 1974 se reemplaza la estructura de cubierta del templo, de madera, por cerchas metálicas. Se mantiene la madera en la zona central de crucero y en los espacios de la cabecera.

Aunque en los planos de Ana Iglesias se representa un zuncho perimetral exterior completo 40x40, finalmente se ejecutaron zunchos longitudinales de $30 \mathrm{~cm}$ de canto enrasados en cara interior de ambas fachadas.

Dichos zunchos reciben el apoyo de las cerchas de naves laterales, que sí se prolongan inclinados en el cerramiento del crucero, pero no se cerró ambos anillos sobre los muros a los pies. 

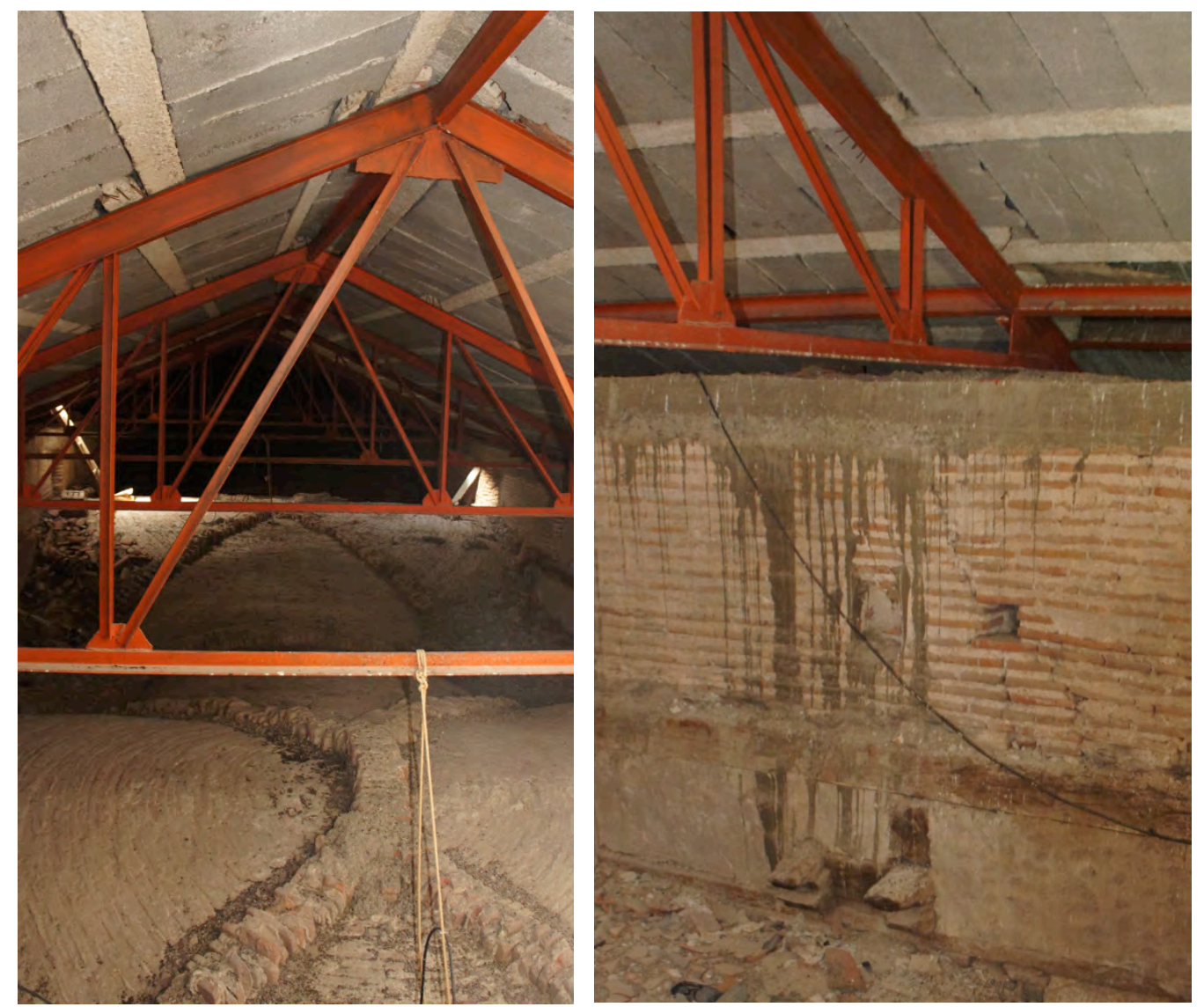

Ilustración 23: cerchas de nave central (visita 02/09/2014)

Sobre la nave central se configura un anillo completo, que se prolonga inclinado sobre los piñones de pies y crucero. Se estima que este elemento cuenta con unos $55 \times 30 \mathrm{~cm}$ de sección.

La estructura de la cúpula sobre el octógono del presbiterio muestra, en el detalle de los planos de Areizaga, un zuncho embebido en el muro de fábrica de ladrillo sobre el que arranca la perfilería, pero en una inspección ocular no es posible confirmar este aspecto.

La zona de cabecera en el lado de la Epístola conserva estructura de madera y no se aprecia ningún zuncho añadido.

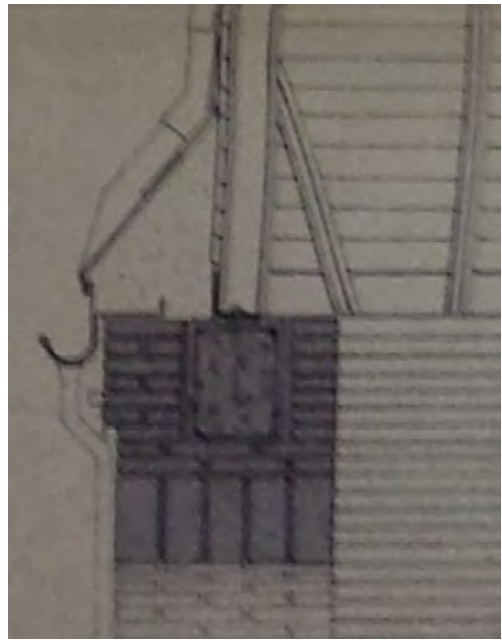

Ilustración 24: detalles de cúpula (Areizaga y Corral $1989 \mathrm{JCyL}$ )

Los espacios que corresponden a los octógonos de madera tampoco cuentan con zunchos añadidos, resolviéndose el encuentro de pares y cuadrales en huecos directamente abiertos en la fábrica. 


\section{Conclusiones}

En este edificio se incorporaron zunchos de hormigón armado en 1974 que, en el presupuesto, la arquitecto Ana Iglesias denomina "de atado perimetral de muros".

En los planos del proyecto, según se describe en el epígrafe anterior y los anexos, se define un único elemento de sección $40 \times 40$ continuo por todo el perímetro exterior. Se ejecuta de 55x30 y cierra un anillo sobre la nave central de la iglesia, con otros dos zunchos lineales en muros de fachada sin continuidad con el testero a los pies.

En este último hay una grieta vertical sin resolver (en rojo sobre el eje 1 del croquis) que ha sido mencionada en varios proyectos.

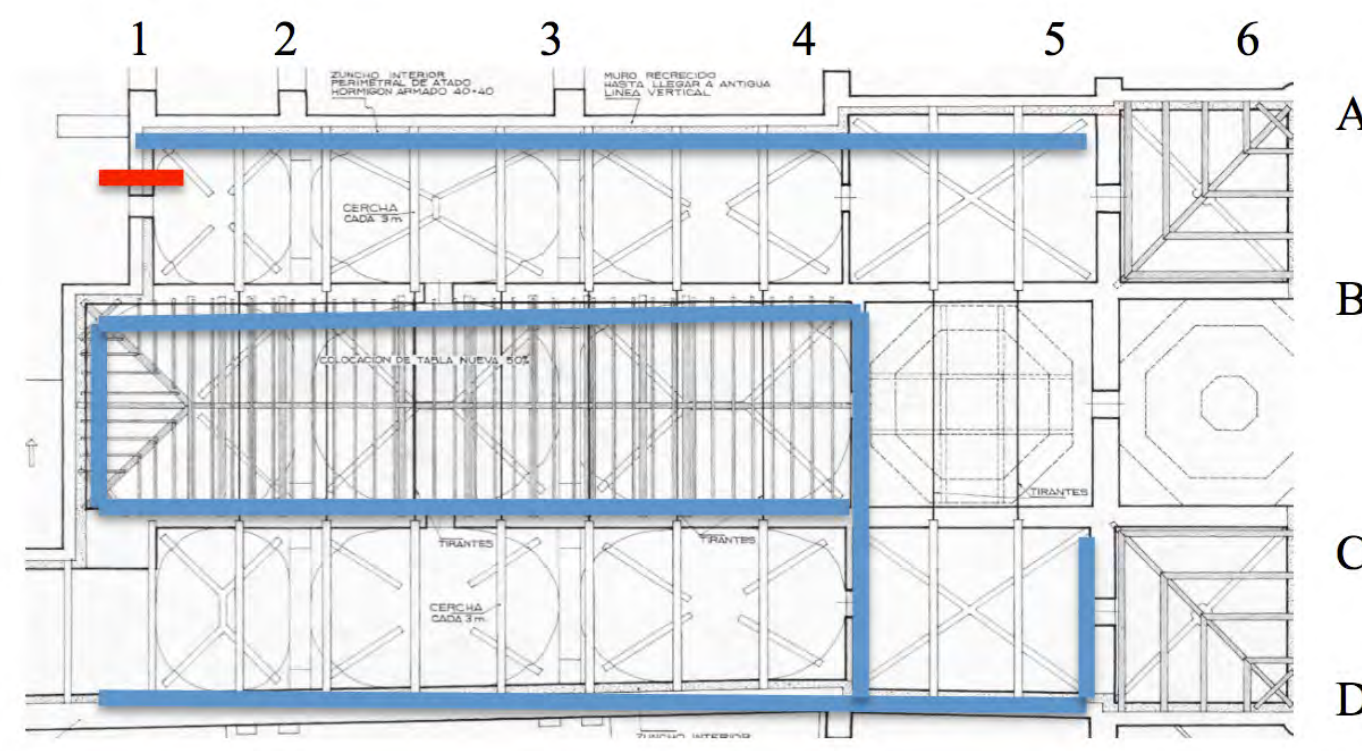

Ilustración 25: esquema de zunchos

Entre los ejes 1 y 2 encontramos restos de tirantes metálicos. No se ha podido acceder a los tramos de fondo de la nave lateral A-B en 4-5-6. Las bóvedas C-D 2-34 presentan un perfil más apuntado y parecen resueltas con el ladrillo dispuesto de forma tabicada, mostrando por su trasdós un revestimiento de hormigón armado. El resto presenta los ladrillos a rosca con nervios resaltados. 
La estructura de cubierta de cerchas metálicas y forjado de vigueta y bovedilla de hormigón incorporados en el siglo XX apoyan sobre estos zunchos, prolongándose los cordones superiores en continuidad a ambos lados (fotografía 26).

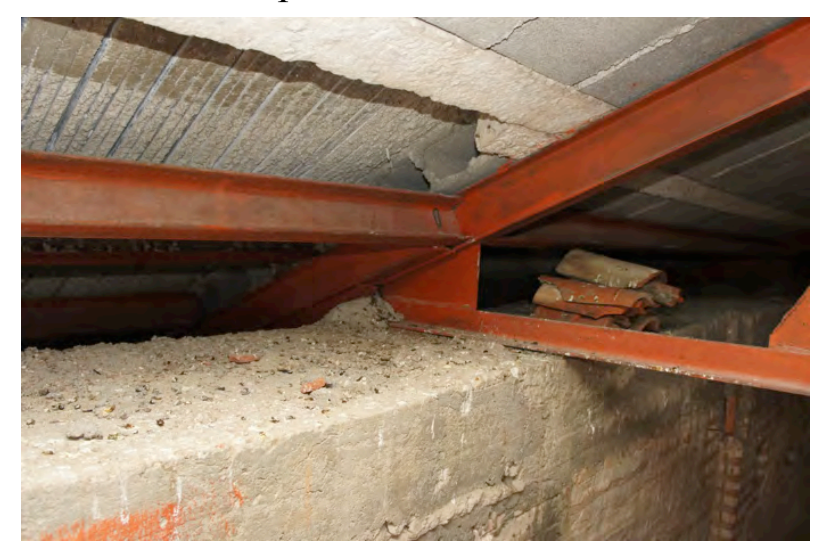

Ilustración 26: apoyo intermedio (visita 02/09/2014)

En el eje de los zunchos hay además un atado de perfiles metálicos, que acodalan entre sí las celosías sobre el punto de apoyo de las mismas (como podemos apreciar en la anterior fotografía 23), tanto sobre los muros exteriores como sobre las fachadas. 


\section{Iglesia de Santa María en Alaejos.}

Intervenciones citadas en la publicación del Ministerio:

1959 - Artesonado y coro - Luis Cervera Vera

1960 - Consolidación muros y reparación bóvedas - Luis Cervera Vera

En la web del IPCE hay 24 planos digitalizados: 12 de 1974, 11 de 1983 y una planta sin datar, posiblemente de 1961.

Los planos de 1983 son de Daniel Villalobos Alonso

Planos extraños, con la sección longitudinal escalonada.

No tienen en IPCE copia de este proyecto, sólo los planos sueltos escaneados. Parece una restauración de bienes muebles porque detalla en planos los retablos de forma exagerada y por el contrario simplifica la arquitectura

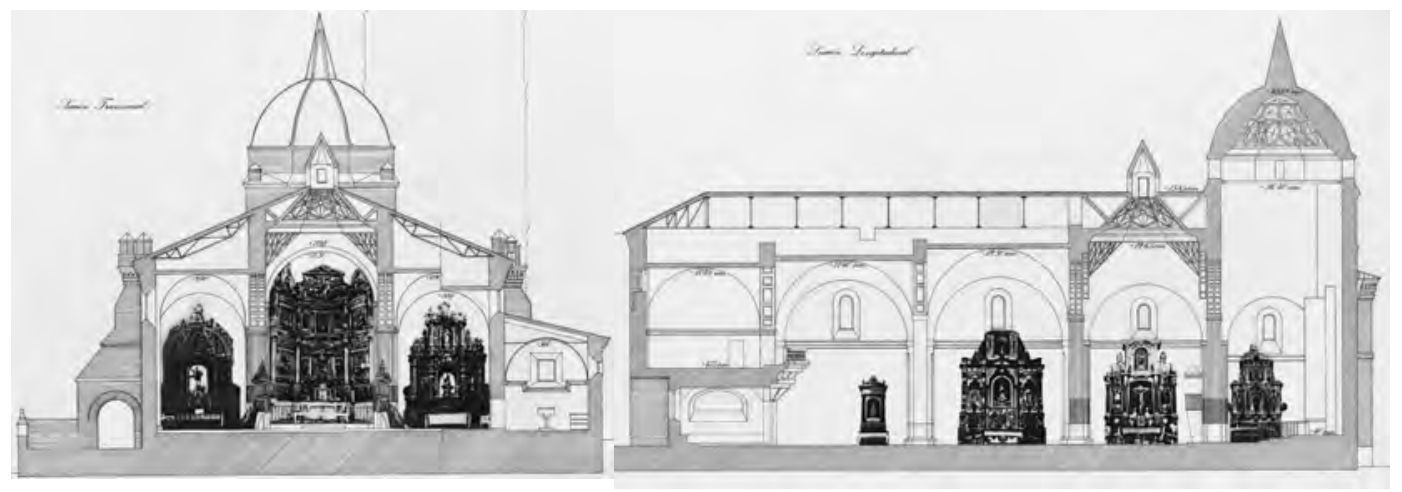

Ilustración 27: secciones 1983 Villalobos IPCE

\section{En el archivo General de la Administración:}

\section{AGA 26/00262}

1959 - Proyecto de consolidación de muros y reparación de bóvedas en la iglesia de Santa María de Alaejos (Valladolid) - Luis Cervera Vera

Memoria descriptiva. (1 página) "En la iglesia de SMA se encuentra derruida la parte de bóveda correspondiente al tramo de nave lateral izquierda señalado en los planos que se adjuntan.

Este derrumbamiento ha tenido su origen a causa del desplome de los muros de cerramiento, debido a una insuficiente cimentación. La cimentación de estos muros está situada sobre terrenos permeables; y la acción continua de lluvias han debido arrastrar tierras de asiento así como atacar los materiales constitutivos del propio cimiento. 
Se proyecta consolidar por pozos y zanjas el muro desplomado, para una vez consolidado proceder a la reconstrucción de la bóveda derruida. Los pozos y zanjas se rellenarán con hormigón una vez encontrado el firme. Las bóvedas se construirán con doblado de ladrillo hueco sencillo, análogas a las existentes; se tenderán de yeso y recubrirán con nuevas molduras, asimismo de yeso, con los perfiles que actualmente se conservan. Madrid, julio 1959."

Mediciones y presupuesto (10 páginas)

Apertura de pozos para recalzo de muro $7 \mathrm{ud} 1 \times 1,5 \times 2,5=26,25$

Apertura de zanjas 4 × 2 × 1,5 x 2,5; 2 × 1 × 1,5 x 2,5; 1 x 0,8 x 1,5 x 2,5=40,5m3

Hormigón en masa... suma las dos anteriores pero en vez de altura $\times 2,5$ pone todo $\mathrm{x} 1,5=40,05$

Manifestado y relleno de grietas 1

Demolición de la bóveda afectada

Reconstrucción de bóveda 6,50 x 4,00 (26m2)

Guarnecido, tendido paramentos.

Molduras

Planos (2)

Planta sin rótulos señala muros con trama

Sección 1:100 bóveda y muro con recalce en rojo

AGA 00357

1961 - Reparaciones de artesonado y coro - Luis Cervera

Parte del forjado del coro ha cedido debido a la rotura de los maderos que forman las vigas de dicho forjado.

Posteriormente se desmontará la parte de artesonado que esté averiada para su reparación y se apeará el forjado para sustituir las vigas de madera que estén rotas por otras nuevas, reforzando todo el forjado con elementos metálicos a ser posible.

\section{AGA 26/01573}

1974 - Restauración cubiertas naves laterales - Ana Iglesias González

Memoria histórica: La iglesia se construye en el siglo XVI y se reforma en el XVII Tres amplias naves sostenidas por columna dórica y cubiertas con bóvedas de crucería. Crucero y altar mayor con cúpulas mudéjares de madera.

"Del artesonado que en tiempos cubrió la nave central quedan escasos restos que fueron en tiempos arrasados para poder construir las bóvedas según el gusto de la época, éstas realizadas en ladrillo o con piezas cerámicas a veces tienen sus nervios 
ocultos por el cemento que como capa de refuerzo se incorporó en una reciente restauración".

Se cubre el total del edificio a dos aguas siguiendo la pendiente de la que corresponde a la nave central, las laterales; esta cubierta de teja presenta unos dibujos realizados con la distinta coloración de la misma y una capa de otro material sobre parte de la cubierta. El altar mayor y el crucero están rematados con cúpula y chapitel ochavados realizadas con lajas de pizarra teniendo iluminación por tambor de distinta importancia ambas cubiertas.

La cubierta exterior de la cúpula de la torre es de ladrillo aplantillado que forma relieves. Todos los paramentos son de ladrillo visto y se nota las épocas de construcción por la falta de traba entre algunos lienzos y la interrupción de ventanas y contrafuertes. El zócalo está enfoscado con cemento.

Obras a realizar: Reparación de la cubierta. La actual con estructura de madera realizada con gruesos pares de escuadrías irregulares y diferentes entre sí con la distribución representada en el plano. El estado de los pares de las naves laterales es pésimo, con las cabezas empotradas en el muro sin ventilación totalmente inservibles y podridas, han sido reforzadas con anterioridad con puntales, troncos, bridas. Por nuevos desplomes sufridos en los muros exteriores de la nave vuelven a quedar prácticamente sin apoyo por lo que "será necesario recrecer sobre las bóvedas y muro desplazado, parte de este, y sustituir la estructura de madera de las naves laterales, por cerchas metálicas sobre las que se colocarán tableros prefabricados de hormigón en los que se recibirá la teja, utilizando al máximo las de derribo".

En fachada se levanta un frontis contra el que desagua parte de la cubierta por lo que éste ha sufrido desplome y las goteras producidas en esta zona son numerosas, será por tanto necesario realizar una variación de pendiente mediante dos faldones nuevos para que de este modo desagüe libremente sin acometer contra el frontis.

En el extremo posterior de la nave de la Epístola, se ha formado una enorme grieta que atraviesa totalmente la altura del templo y que se prolonga por la bóveda de este tramo de nave sobre el lateral del coro, posiblemente producida por un cedimiento del terreno con fallo del cimiento; tendrá que ser investigado previamente con sondeo.

Se modificará la escalera y coloca una con perfiles metálicos de subida a las bóvedas. Pintar zócalo y adecentar fachada. 


\section{Mediciones}

Desmontado de teja

- nave central $45 \times 9=405 \mathrm{~m} 2$

- naves laterales 24,5 x 6,5; 17,5 x 7,5;29,4 x 8,0;16,0 x 7,8 =650,50

demolición fábricas descompuestas

$2 \times 25 \times 0,5 \times 0,90 ; 2 \times 16 \times 0,5 \times 0,90 ; 2 \times 21 \times 0,5 \times 0,50 ; 2 \times 2,5 \times 0,5 \times 0,5 ; 1 \times$ $3,0 \times 0,5 \times 0,5=49,40 \mathrm{~m} 3$

Demolición de fábricas pétreas en apertura de caja para alojamiento de zunchos de atado $25,00 \times 0,30 \times 0,40 \ldots$

1,$0 ; 16,20 ; 7,10 ; 2,00 ; 8,20 ; 2,10 ; 7,50 ; 16,20 ; 30,5 ; 5,20 ; 3,70 ; 10,00 ; 3,50 ; 6,50$

todas ...x0,30x0,40 =17,34m3

Consolidación de armadura de madera con inclusión del herraje preciso y sustitución de palos podridos $405 \mathrm{~m} 2$

Reposición de tabla ripia en faldones de cubierta de nave central con sustitución aproximada de un $50 \%$ de tabla $453 \mathrm{~m} 2$

Estructura de cubierta formada por cerchas metálicas, colocadas a $3 \mathrm{~m}$, incluso correas y tirantes de redondo.

Hormigón de $350 \mathrm{~kg}$ de cemento, garbancillo y arena de río, armado con $80 \mathrm{~kg}$ de hierro al m3 incluso el encofrado preciso en formación de zuncho de atado perimetral de muros $17,34 \mathrm{~m} 3$.

Fábrica de mampostería sentada con mortero de cemento en recrecido de muros $25+$ $1+16+7,1+2+8,2+7,5+16,2 \ldots \times 1,50 \times 0,60$

$+30,5+22,5 \ldots \times 1,50 \times 1,10$

Forjado de cubierta, en formación de faldones, formado por placas de hormigón prefabricado $453,60+650,50+78,06=1182,16 \mathrm{~m} 2$

ídem impermeabilización de tableros con fieltro asfáltico, teja curva sentada con mortero bastardo de cal y barro

Planos

Son los mismos digitalizados en la web del IPCE en papel. La sección reformada se ve mejor que la imagen, aunque debe ser una copia de ese vegetal raspado. 


\section{En el archivo del IPCE:}

Carpeta 636-1

1974/78 - Restauración en la iglesia de Santa María de Alaejos - Ana Iglesias

Certificado de Ana Iglesias 15 octubre 1977 de que bajo su dirección el constructor Alfonso Sancho Miguel domicilio en c/Tenerías de Valladolid, para abonarle, ha realizado las unidades:

- Desmontado de teja y tabla de cubierta

- Demolición de estructura de cubierta

- Formación de zunchos

- Formación de estructura de cubierta

Fotocopia dossier fotos: suelo acceso, fachada, cubiertas, artesonados, bóvedas, sacristías, naves. Se ven poco. Hay 6 fotocopias de fotografías de la estructura de cubierta de madera.

Memoria histórica: Se construye en el XVI, notablemente reformada en XVII y la torre en el XVIII. Crucero y altar mayor se cubren con artísticas cúpulas mudéjares de valioso trazado en madera.

Los planos en papel se ven bien, sin las manchas blancas del raspado del vegetal original que se puede obtener digitalizado en la web.

\section{En el archivo de la Junta de Castilla y León:}

\section{VA-75}

Carpeta 5262

Expedientes de restauración de bienes muebles: Artesonado de la iglesia de Santa María

Contratista: REARASA Restauración de edificios, artesonados y retablos Alonso SA de Zamora.

Las obras comprenden:

Retirada de escombros

Limpieza del artesonado

Eliminación de intervenciones anteriores

Desinfección de la madera por impregnación

Consolidación con resinas

Reposición de elementos tallados y estructurales

Protección final 


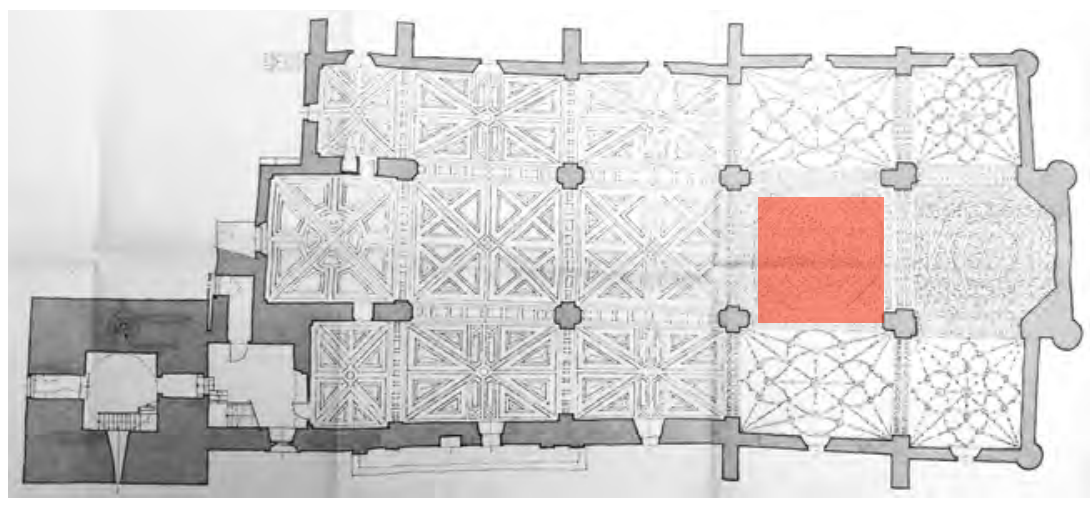

Ilustración 28: artesonado de la nave central (Nuere 1987 JCyL)

Artesonado de la nave central: 80 casetones triangulares, 8 pares, 16 limas, pechinas y linterna en el almizate.

Informe del Consejo Parroquial del 22 de septiembre de 1987.

Piden la reparación urgente de la cúpula que remata el retablo mayor mudéjar renacentista con manchas blanquecinas de hongos debidos a la humedad y vigas de la estructura dañadas. Carcoma en el retablo. En el texto se indica que en el "muro norte del templo se puede apreciar una grieta que sube por el fondo hasta las bóvedas y por éstas se extiende hasta el segundo tramo, afectando también a los arcos que las sostienen. Hace 10 o 12 años el Ministerio de Cultura hizo nueva toda la estructura metálica del tejado, pero al no sujetar las tejas, los aires las mueven de forma caprichosa y esto indudablemente influye en el estado de humedad en que se encuentra buena parte del edificio".

Añaden que incluyen fotografías pero no se encuentran en esta carpeta.

Informe técnico del arquitecto territorial de la Junta Carlos Descalzo Llorente del 27 de noviembre se 1987.

La intervención en la cúpula sobre el altar es inaplazable. La bóveda mudéjar octogonal del crucero requiere saneo pero está menos dañada.

Aprecia carcoma en coro, cajonería de sacristía y retablo mayor.

Detecta humedades de capilaridad en todos los muros hasta alturas considerables.

Recomienda elaborar con urgencia un estudio y evaluación del sistema estructural, aunque hay grietas y desplomes apreciables que parecen asentados.

Escrito remitido por el Ayuntamiento el 18 de septiembre de 1987. Envían informe de un restaurador sobre el estado de cajonera, retablo y puerta en que se pide fumigar. Menciona desplome de una pared. 
Copia de un articulo de prensa anotado como 1986 en que se incide sobre la falta de arreglo del templo tres años después de un informe del técnico de la Diputación.

Documento de REARASA en que se cita que según el experto Enrique Nuere el artesonado sufre daños no recogidos en la intervención prevista: deformaciones y desplazamientos de estribado y linterna.

Firma la documentación como Director de las obras desde la Administración Pío García Escudero, Director General de Patrimonio y promoción Cultural.

Proyecto del arquitecto Enrique Nuere Matauco, especialista en carpintería de lo blanco.

Describe cómo ha entrado en carga la armadura ochavada con linterna debido al fallo de la estructura portante de la cubierta.

"El estribo de la armadura general de la cubierta de la nave perdió su tirante al realizar esta armadura (se puede ver serrado en sus dos extremos) y aunque entonces se tomara alguna medida para sujetar el empuje de la cubierta con los faldones interiores, el equilibrio de la armadura de cubierta es muy precario, por lo que estos estribos se deben atirantar, aunque para ello se utilizarán tirantes de redondo de acero de $20 \mathrm{~mm}$, roscados en sus extremos y provistos de tensor para garantizar su entrada en carga. De esta forma no se interfiere con el conjunto de armaduras existentes".

Incluye fotografías del octógono con avanzada pudrición, carcoma en el retablo y una grieta en un arco, así como dos planos, uno de plantas y otro con secciones de los que tomamos el siguiente detalle:
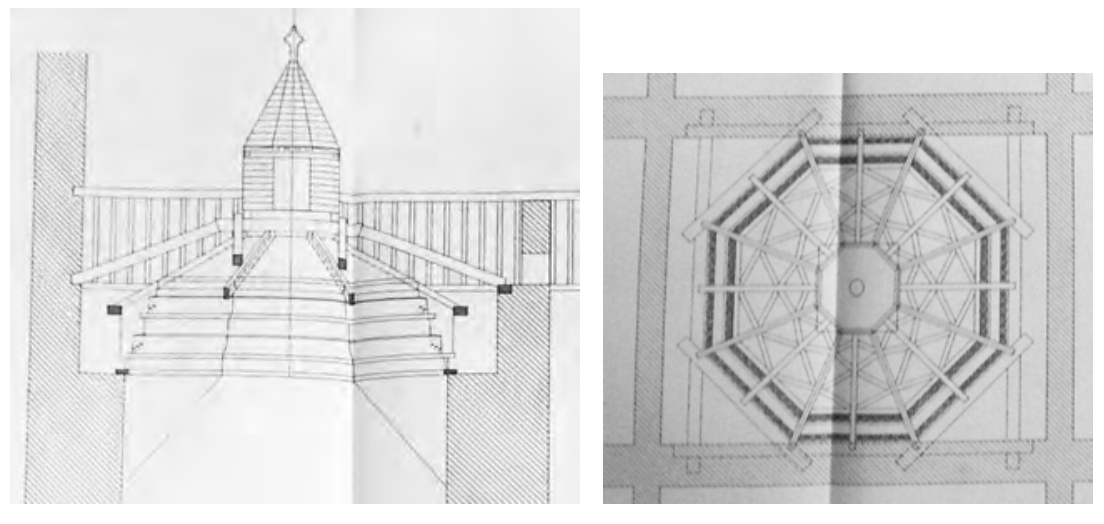

Ilustración 29: planta a nivel del estribo de la ochava y sección (Nuere 1987 JCyL)

\section{VA-94}

Carpeta 5283

Restauración de la $2^{\mathrm{a}}$ fase del artesonado de la iglesia de Santa María de Alaejos.

Proyecto con carátulas de Enrique Nuere y el contratista REARASA. 
En la carpeta se incluye una Ficha del artesonado sobre el altar mayor similar a la del crucero de la carpeta anterior, ambas elaboradas por los mismos técnicos: Donelis Almeida, Carlos Tejedor y Jesús Aragón.

Informe final de ambas fases.

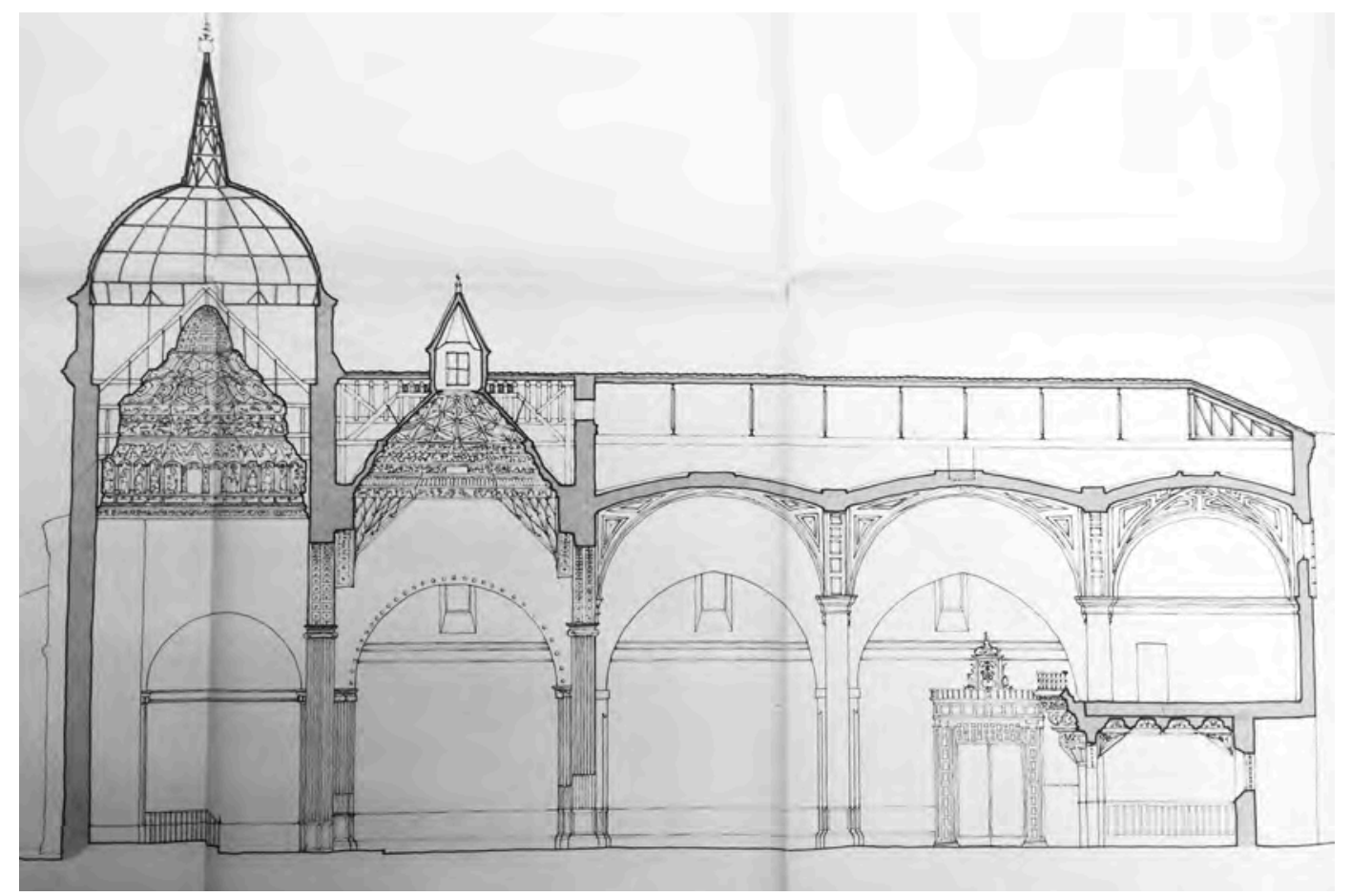

Ilustración 30: sección longitudinal (Nuere sin fecha JCyL)

\section{VA-61}

Carpeta 5246

Restauración de las cubiertas del crucero y cabecera de la iglesia de Sta. María de Alaejos. 11 de septiembre de 1989.

Arquitectos: Armando Areizaga Esteban y Juan Corral Fernández Aparejador: Gregorio Gallo Vallejo

Ficha de diagnóstico modelo R-P1. Aunque la estanquidad de suelo y cerramientos es buena, no lo es la de las cubiertas, con paso directo del agua en muchos puntos. Hay construcciones adosadas al costado izquierdo. Observan desplomes del muro de cerramiento lateral izquierdo achacables a los apoyos de las bóvedas, grietas apreciables en bóvedas de nave lateral izquierda y humedad general por capilaridad en muros y columnas.

Propuesta de actuación modelo R-P4. Se plantea "liberar de elementos distorsionantes" el monumento (construcciones, tapias), disponer un sistema 
perimetral de drenaje, apeo de bóvedas y estabilización de cargas sobre muro costado izquierdo desplomado. Incluye también consolidación de todas las bóvedas y creación de accesos a la parte superior de bóvedas y artesonados para su reparación y estudio. Reposición de pavimento y fajas cerámicas exteriores, restauración de todos los revestimientos interiores. Restauración completa de cubiertas sobre crucero y presbiterio y retejado de naves. Restauración de la torre.

Proyecto.

Los planos parecen tomados del proyecto de Ana Iglesias.

Memoria histórica. Se describe la iglesia con planta de tres naves que aunque no poseen la misma altura se integran bajo dos únicos faldones de cubierta para reivindicar el sistema de planta salón.

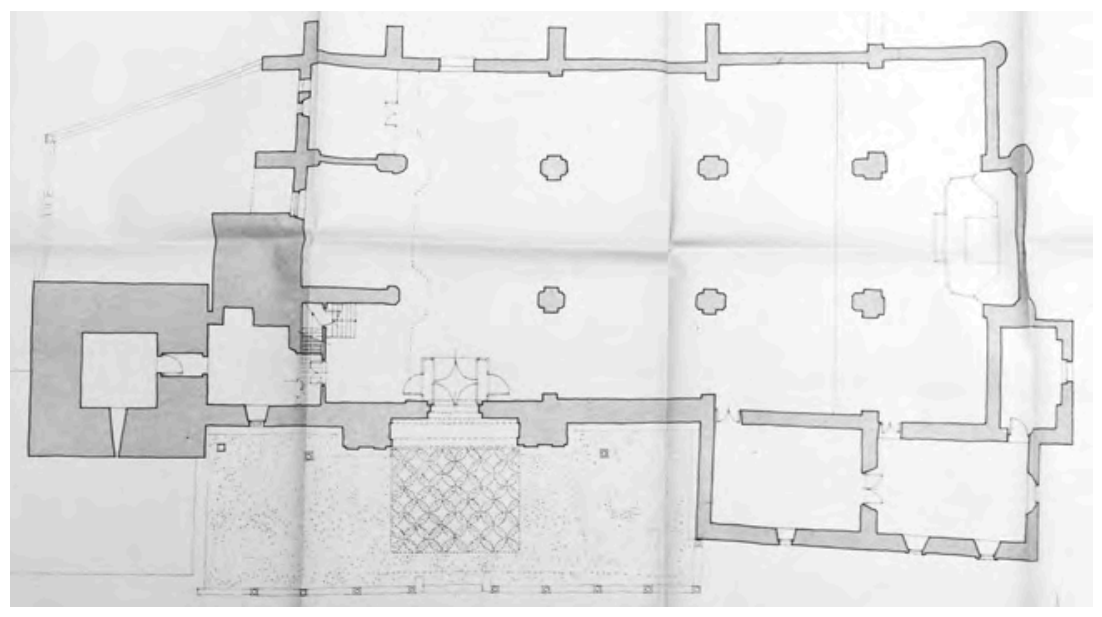

Ilustración 31: planta (Areizaga y Corral 1989 JCyL)

La cabecera presenta testero plano cuyo ábside poligonal sólo destaca por la incorporación de dos potentes contrafuertes cilíndricos a ambos lados del presbiterio.

El edificio se resuelve en ladrillo, excepto el muro del lado del Evangelio con tapiales encuadrados con ladrillo y tres tramos hacia los pies que presentan sillería hasta media altura tal vez resto de una construcción anterior (aunque parece probado que el templo arrancó por la cabecera). Los muros se coronan con lo que Areizaga denomina "cornisa medinense", con ladrillos escalonados a tizón que se unen por medio de tejas curvas formando arquillos, sobre frisos denticulados o en esquinillas. Bajo el friso azulejos en blanco y azul. Describe como, hasta la reforma más reciente, la cubierta general de la iglesia estaba constituida por armaduras de madera. De par y nudillo sobre la nave central y pares simples apoyados en durmientes recibidos en los muros sobre las naves laterales. Sobre tabla de ripia se reciben las tejas directamente con una cama de barro. 
Los dos primeros tramos de naves laterales y estancias adosadas se cubren con bóvedas de crucería estrelladas con combados. El resto de bóvedas son de arista en nave central y cañones con lunetos en laterales. En todo el templo los arcos fajones de medio punto y formeros apuntados.

La torre se sitúa a los pies, del lado de la Epístola, y se remata antes que las bóvedas.

El autor del proyecto afirma que la cumbrera debió sobre-elevarse en algún momento para conseguir mayor pendiente en los faldones y evitar problemas de penetración de agua, de ahí la dificultad de los encuentros con la linterna del crucero. En su visita a la parte superior de las cúpulas de la nave central descubre la existencia de los restos de una cornisa en el paramento que limitaría los pies del crucero, por lo que sospecha que en algún momento existió una cubierta independiente sobre este espacio.

En 1975 se reemplaza la estructura de cubierta existente por cerchas metálicas con forjado inclinado de semi-viguetas pretensadas y bovedillas de hormigón, excepto en el crucero.

También se dispone estructura metálica en la cúpula sobre el presbiterio, revestida con escamas de chapa de zinc. Sustituye los durmientes de madera por zunchos de hormigón.

En cuento al estado del edificio en ese momento es destacable que la humedad sube hasta $2 \mathrm{~m}$ de altura sobre los muros de fábrica. El del Evangelio, expuesto a la orientación noroeste, presenta un considerable desplome hacia el exterior en sus primeros tramos. En la cubierta del crucero se conserva la madera original pero con el vertido superior de una capa de hormigón.

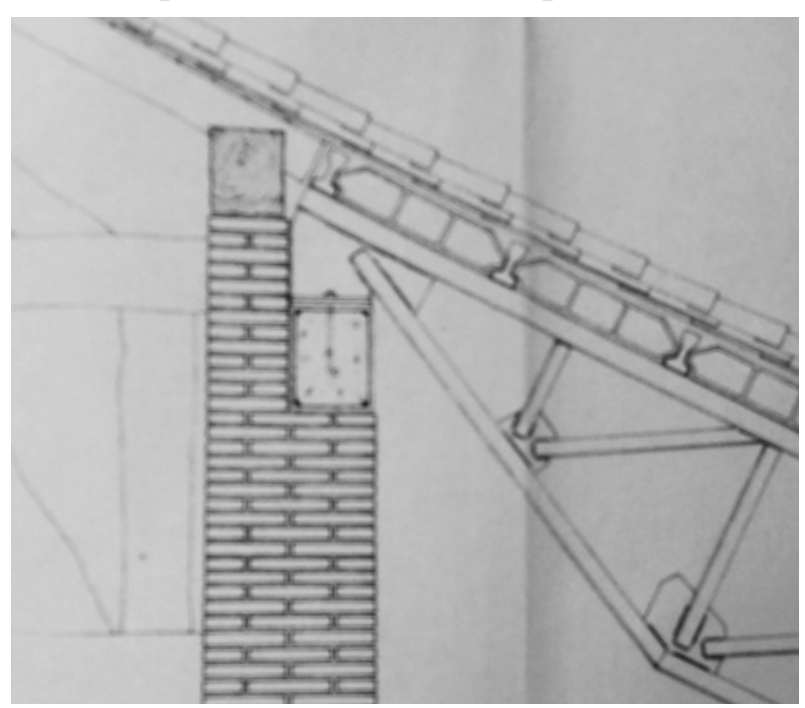

Ilustración 32: detalle (Areizaga y Corral 1989 JCyL)

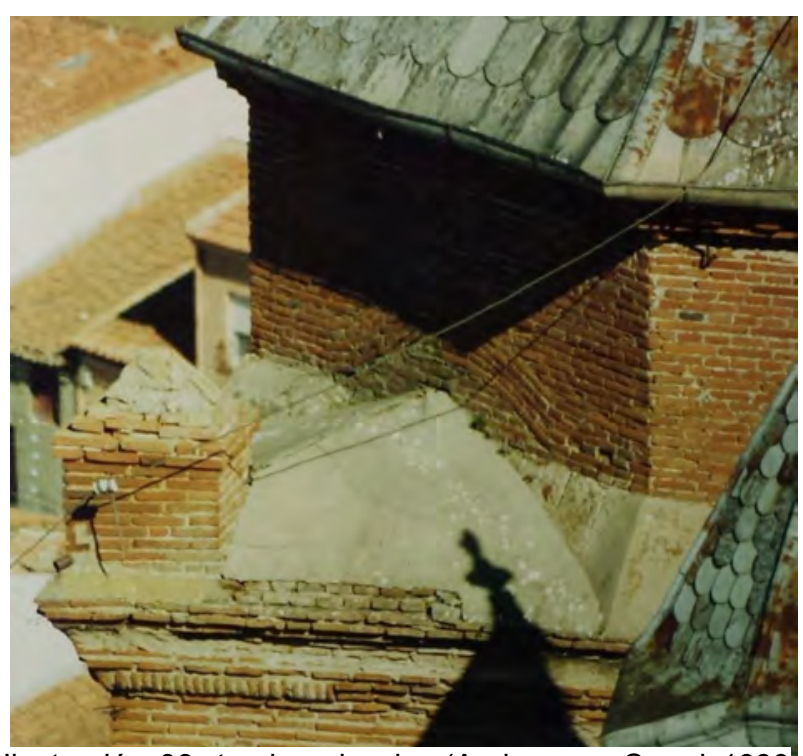

Ilustración 33: tambor dossier (Areizaga y Corral 1989 JCyL) 
La cubierta de la cabecera parece en buen estado, pero la transición de rectángulo a octógono se formaliza con tramos de fábrica enfoscados inclinados sin impermeabilizar. En la carpeta se incluyen fotografías del estado actual de 1988, entre las que se encuentra la reproducida junto a estas líneas.

Actuaciones definidas en el proyecto: levantado de teja, formación de capa asfáltica con onduline sobre el forjado, retejado recibiendo con mortero una de cada cinco hiladas en perpendicular al alero. En el crucero se pretende picar la losa de hormigón, reemplazar la tabla ripia por tablero de pino soria machihembrado $y$ reponer la capa de hormigón sobre malla nervometal. En cabecera y linterna se trata de reemplazar la tablazón deteriorada y colocar hormigón, revestido con chapa de cobre sobre fieltro.

Se incorpora un anejo en que describe las medidas para ventilar el bajo cubierta mediante taladros en el hormigón y colocación de beatas.

Memoria final de la obra.

La ejecución se realizó a la vez que la restauración del artesonado dirigida por García Escudero, debido a la relación entre ambas estructuras.

Finalmente no se coloca la capa de hormigón sobre las cubiertas de cabecera y linterna. Se rejunta fábrica de pináculos y sustituye ventanas.

Además de en cúpula y linterna se dispuso revestimiento de chapa de cobre cubriendo las pendientes de cornisas y elementos de transición cuadrado-ochavo.

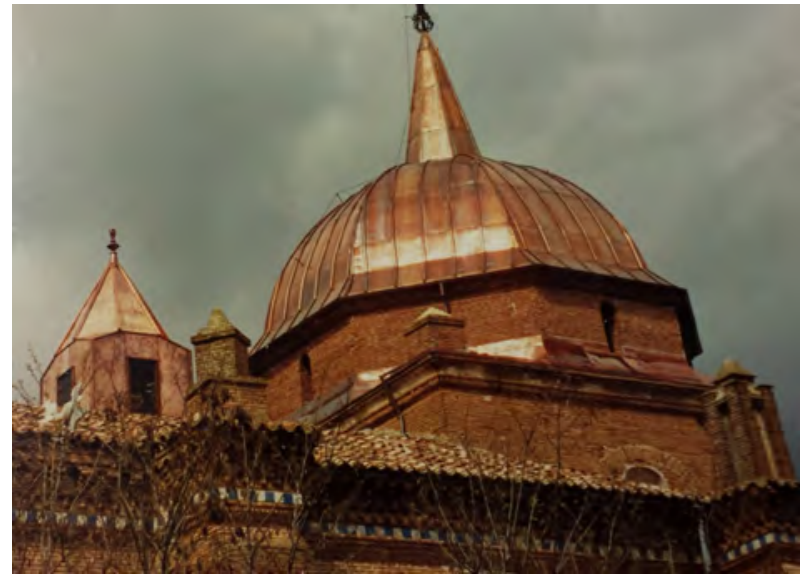

Ilustración 34: dossier (Areizaga y corral 1989 JCyL)

CD: Levantamiento SPC (Soluciones para el Patrimonio cultural) Junio de 2011 Coordinación: Rafael Martín Talaverano

"La iglesia de Santa María está constituida al exterior fundamentalmente por una fábrica de ladrillo formando paramentos esencialmente planos. En algunas zonas la fábrica es de sillería o de ladrillo y mampostería combinada. Salvo en ciertas zonas 
el edificio carece de revestimiento, de modo que las fábricas quedan vistas. Al interior, sin embargo, los paramentos están casi totalmente revestidos, excepto en algunos espacios situados a los pies de la iglesia y en las plantas bajas de la torre, donde se aprecian las fábricas de ladrillo y sillería.

El espacio se cubre con bóvedas de arista, cañones con lunetos y bóvedas de crucería, generalmente de una elevada sencillez formal. Destacan las bóvedas del crucero y del presbiterio, construidas con madera, que sin embargo poseen una complejidad geométrica muy elevada.

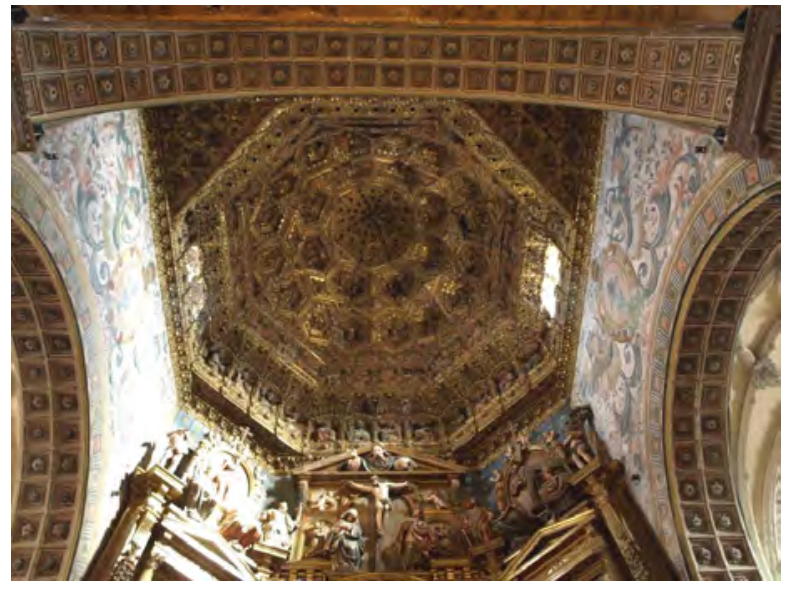

Existen además algunos elementos como el coro o el retablo mayor, de alta singularidad artística.

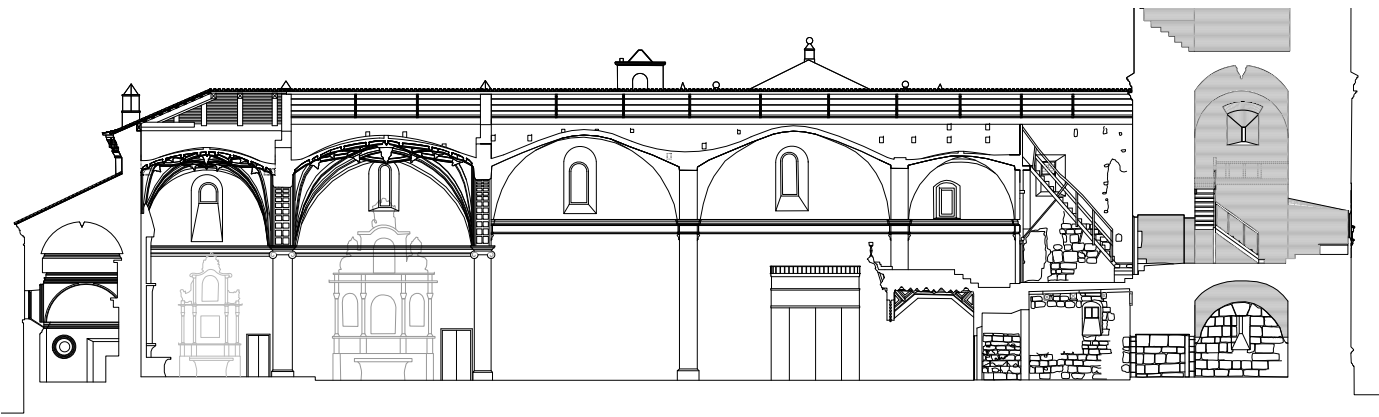

Ilustración 36: sección longitudinal (levantamiento 2011 JCyL)

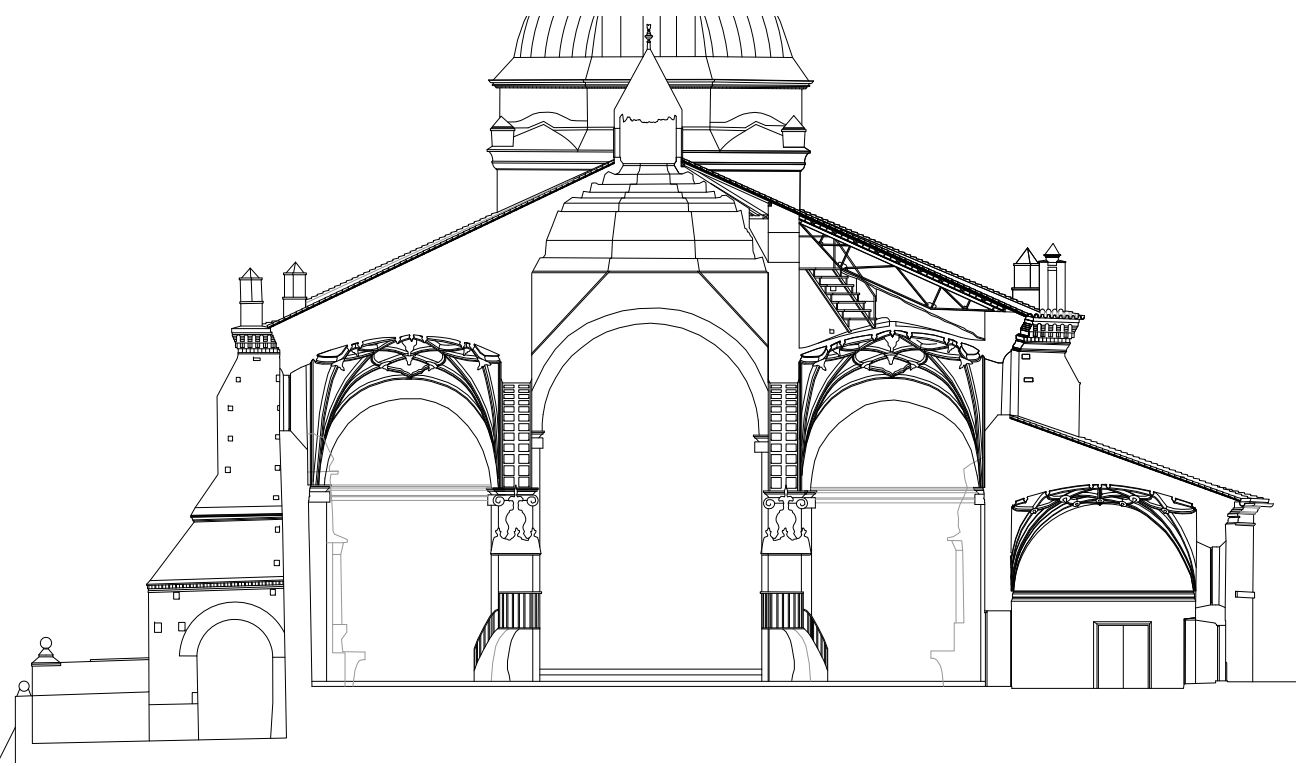

Ilustración 37: sección transversal por el crucero (levantamiento 2011 JCyL) 


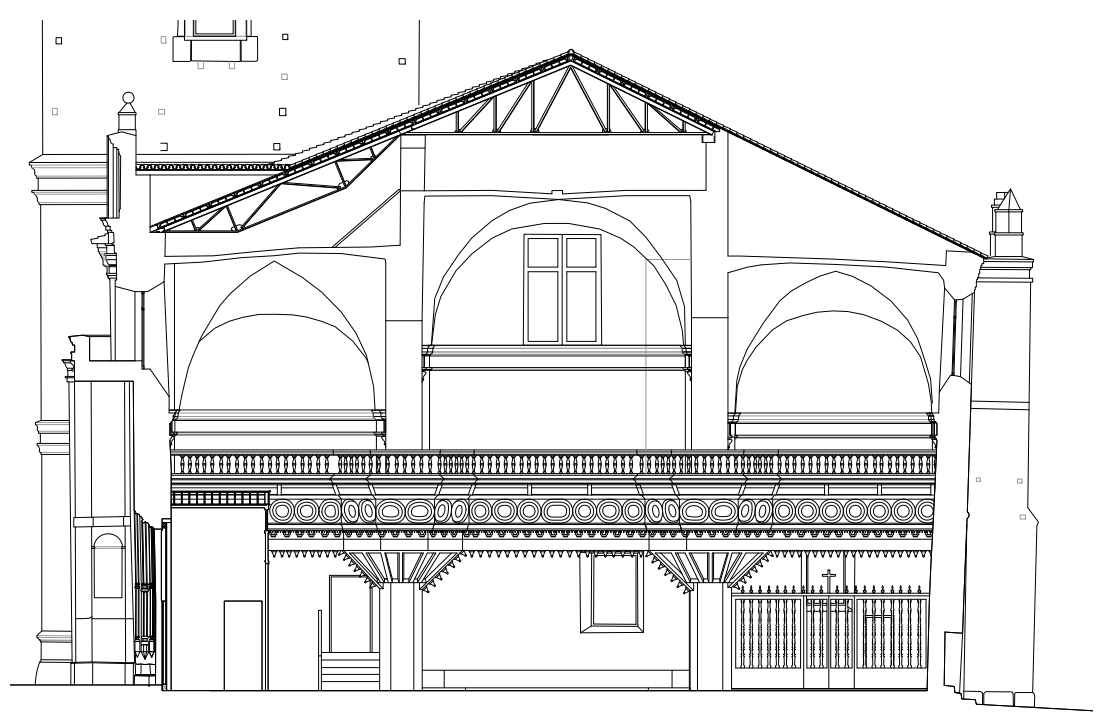

Ilustración 38: sección transversal hacia los pies (levantamiento 2011 JCyL)

Los trabajos posteriores a realizar se centran en la lectura de paramentos y en el proyecto de restauración. Se ha optado por un método de levantamiento que combina dos técnicas: topografía terrestre y rectificación fotográfica".

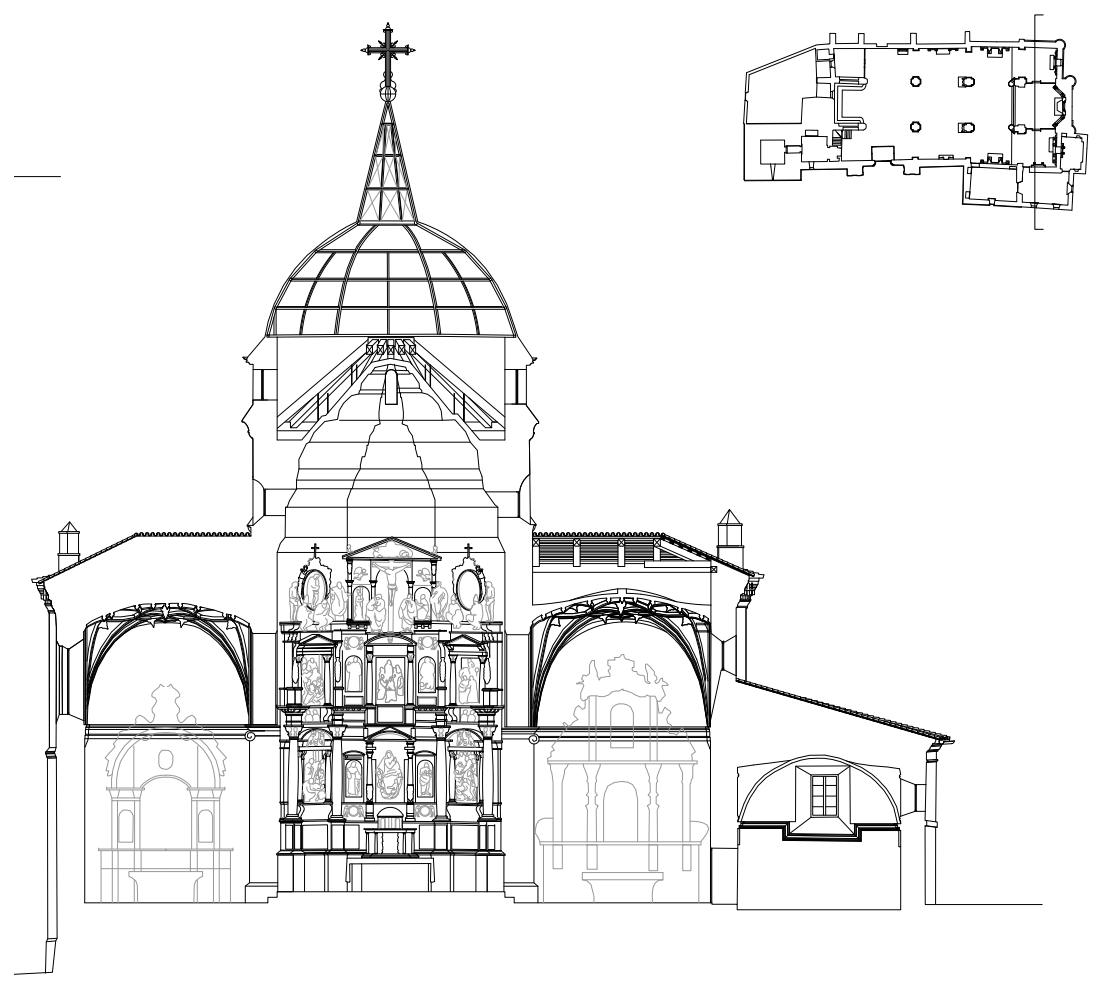

Ilustración 39: sección por cabecera, levantamiento 2011 JCyL 



\section{Visitas realizadas}

$02 / 09 / 2014$

El estado de conservación del monumento es preocupante en varios puntos. El remate de la torre, de fábrica de ladrillo, se encuentra muy deteriorado, con las evidentes pérdidas de rejuntado que se aprecian en la imagen.

La cubierta del cuerpo del templo, sin embargo, aparenta estar en buenas condiciones, con los faldones correctamente revestidos

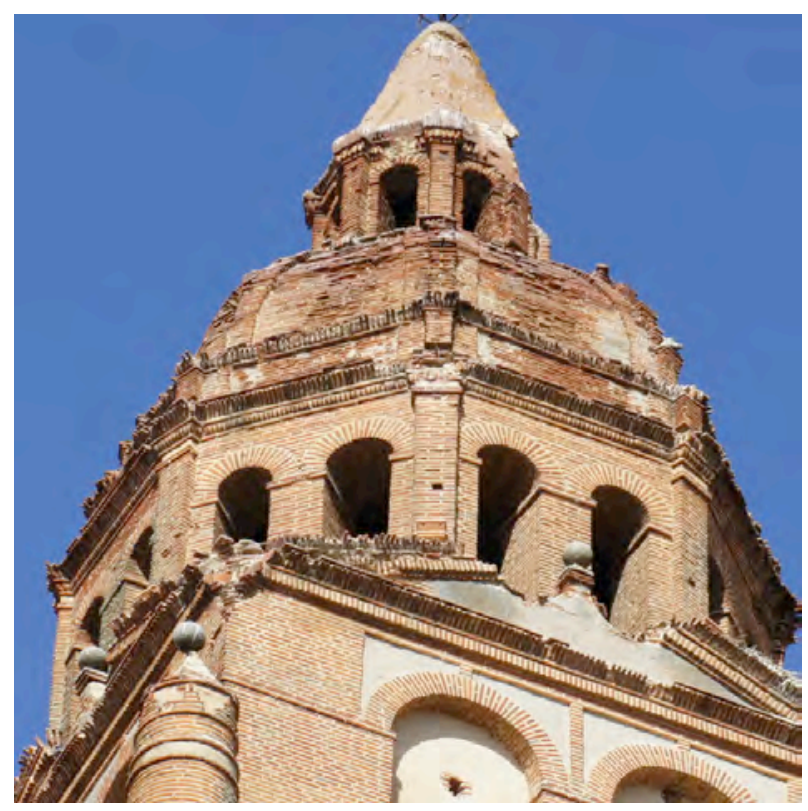
de teja y la fábrica de las cornisas bien retacada. La cúpula del presbiterio y la linterna del crucero también cuentan con revestimientos metálicos recientes. Los muros perimetrales, por el contrario, presentan algunos desconchados y falta de material en su parte baja.
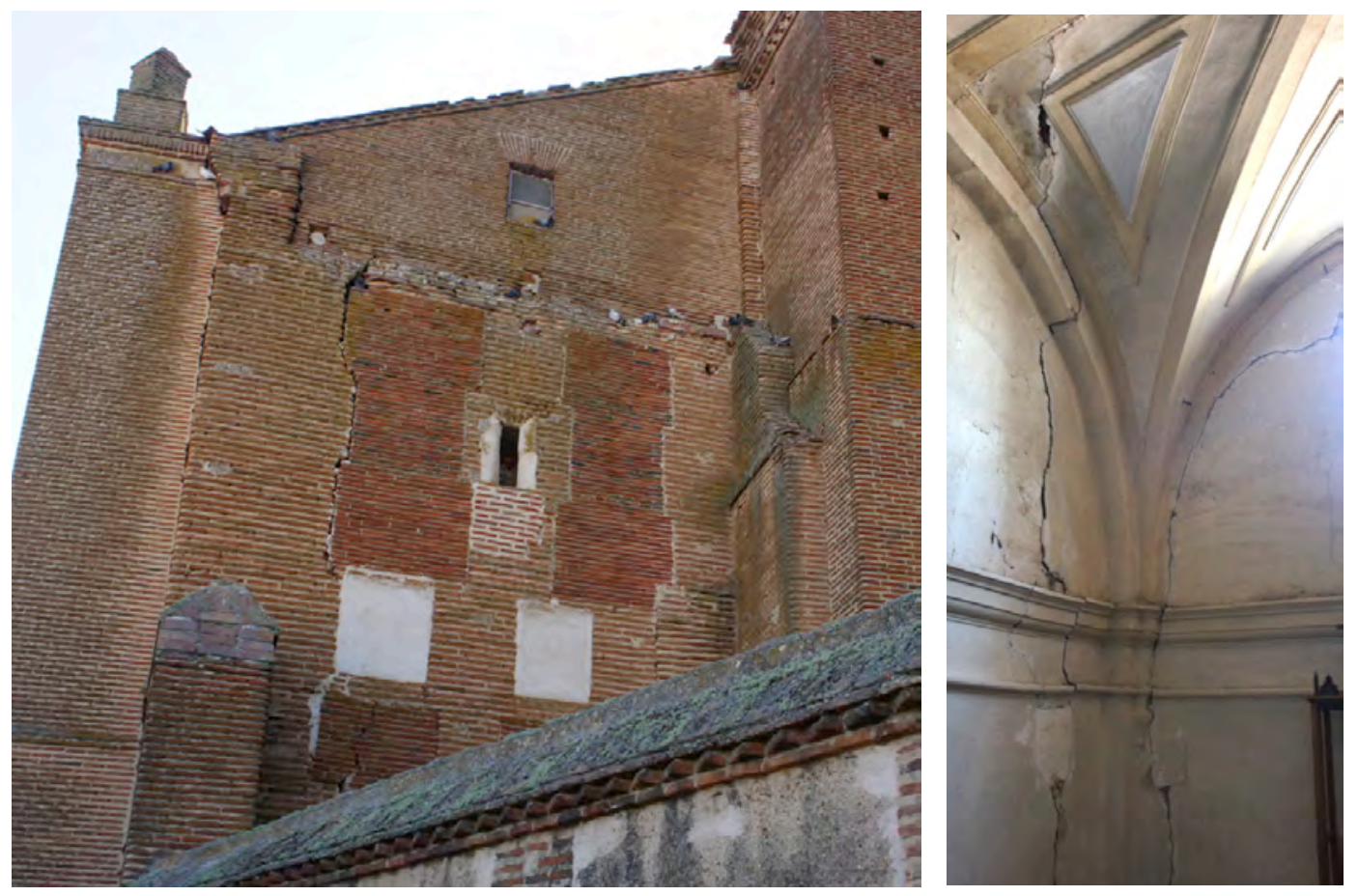

En el intradós de las bóvedas encontramos manchas de humedad y, en algún caso macas y grietas, como las del testero de la nave del Evangelio, que por el exterior corresponde a un encuentro de casetones de tapial reemplazado por ladrillo con el paramento de ladrillo que encadena la esquina. 
La entrada al bajo cubierta se realiza desde el espacio entre el testero de nave de la Epístola y la torre, accediéndose mediante una escalera de madera carcomida.
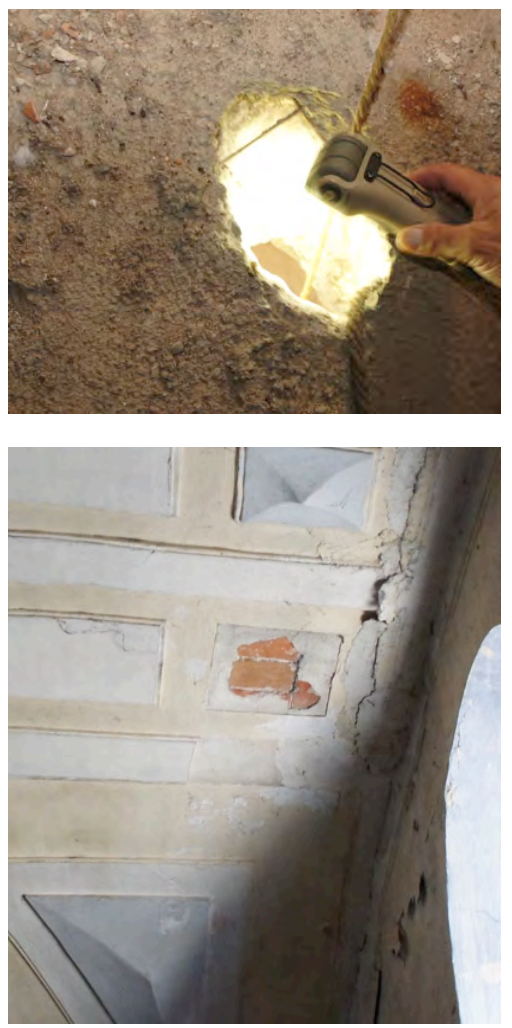

Se aprecia el trasdós de la primera bóveda, resuelta con rosca de ladrillo y nervios resaltados, mientras que las dos siguientes en esa nave lateral presentan un revestimiento de hormigón armado con mallazo sobre un perfil de destacada pendiente, con muy poco grosor.

Desde el interior del templo se aprecia un desconchón en el intradós que deja ver como efectivamente en esta zona los ladrillos están dispuestos de forma tabicada.

En la nave del Evangelio, sin embargo, el trasdós de las bóvedas muestra los ladrillos colocados a rosca, sin incorporación de esa capa adicional de hormigón armado.

El tablero de cubierta sobre ese primer tramo es de vigueta y bovedilla de hormigón, pero a partir de la quinta cercha, en esa nave, es de hormigón vertido sobre nervometal.

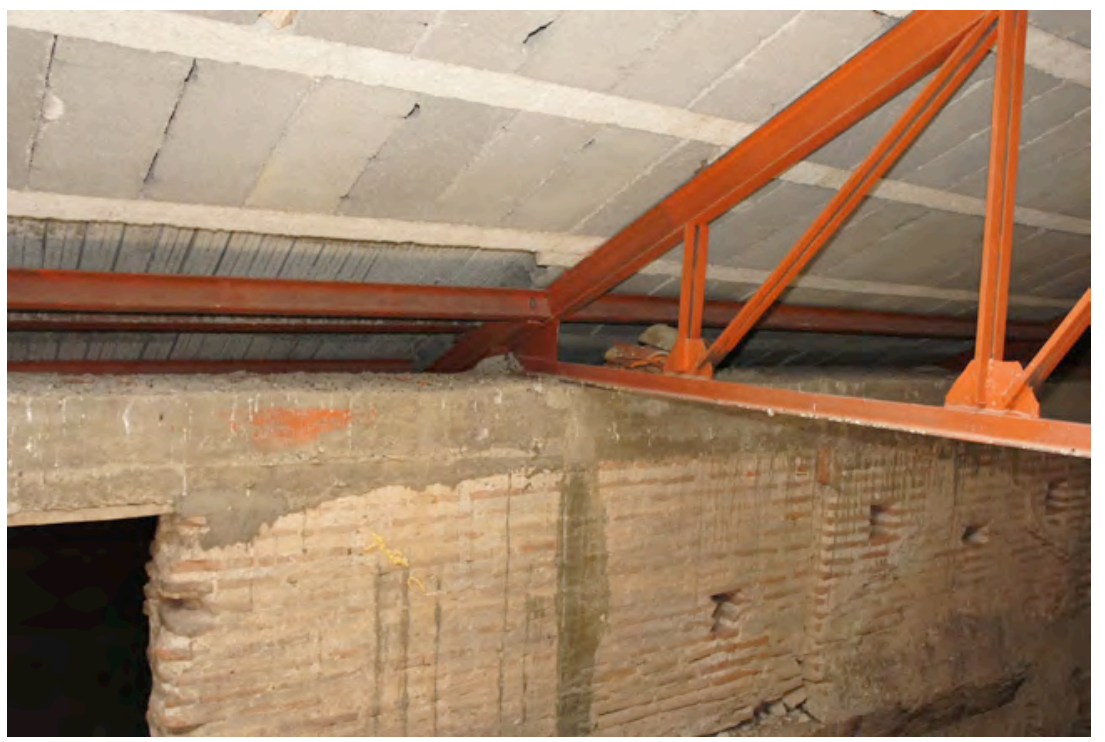

Zuncho sobre muro entre nave central y nave del evangelio 
A grandes rasgos la solución constructiva de cubierta observada coincide con la definida en el plano de sección del proyecto de Ana Iglesias, con el cordón superior de las cerchas metálicas de las naves laterales dispuesto en continuidad con los de la central. Los zunchos de hormigón, sin embargo, adoptan una forma distinta al encadenado continuo en la cara interior del cerramiento perimetral, rotulado como 40x40 que se representó en la planta de estructura de cubierta. En el plano citado se había previsto mantener la estructura de madera en nave central reemplazando sólo el $50 \%$ del tablero pero finalmente se reemplazó la armadura en su totalidad.

En la nave central encontramos un zuncho de hormigón armado de 55x30 enrasado a cara interior sobre ambos muros laterales y cerrado sobre el testero bajo el faldón a los pies donde apoyan las cerchas que conforman ambas diagonales. En el encuentro con el crucero también se prolonga este zuncho sobre el muro adoptando la inclinación de la pendiente para recibir y rematar el forjado de vigueta y bovedilla.

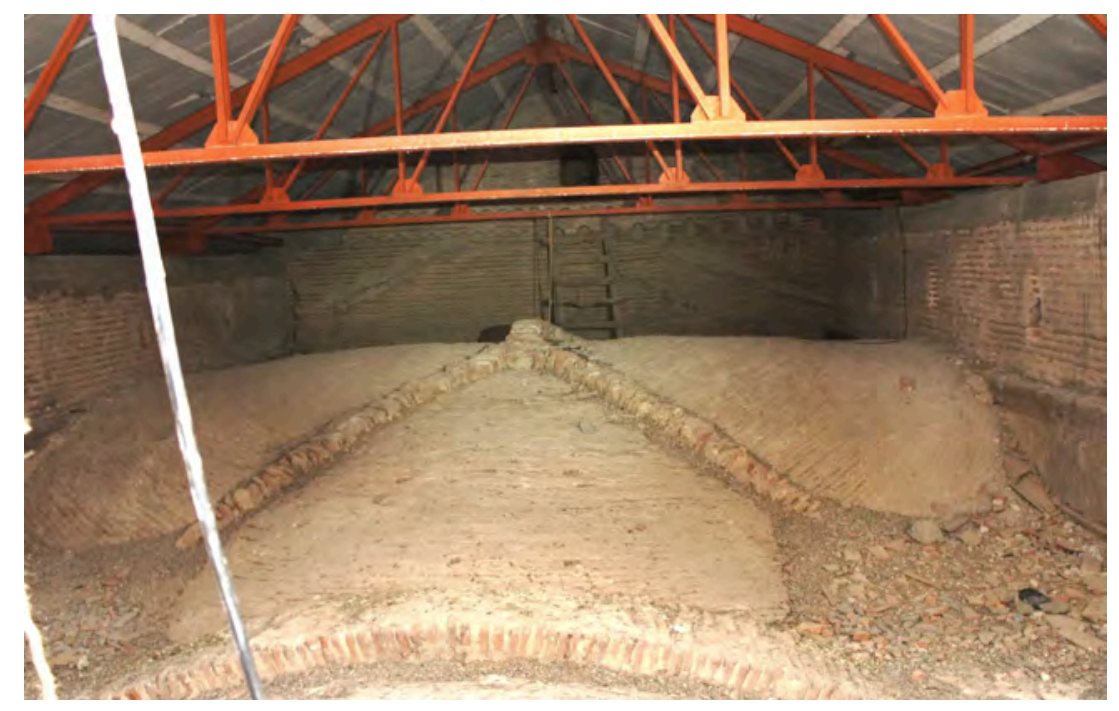

En este cerramiento podemos leer sobre el paramento las trazas de una antigua cubierta a cota inferior, por lo que podemos inferir que el tambor de la cúpula del crucero se alzaba exento por encima de la misma.
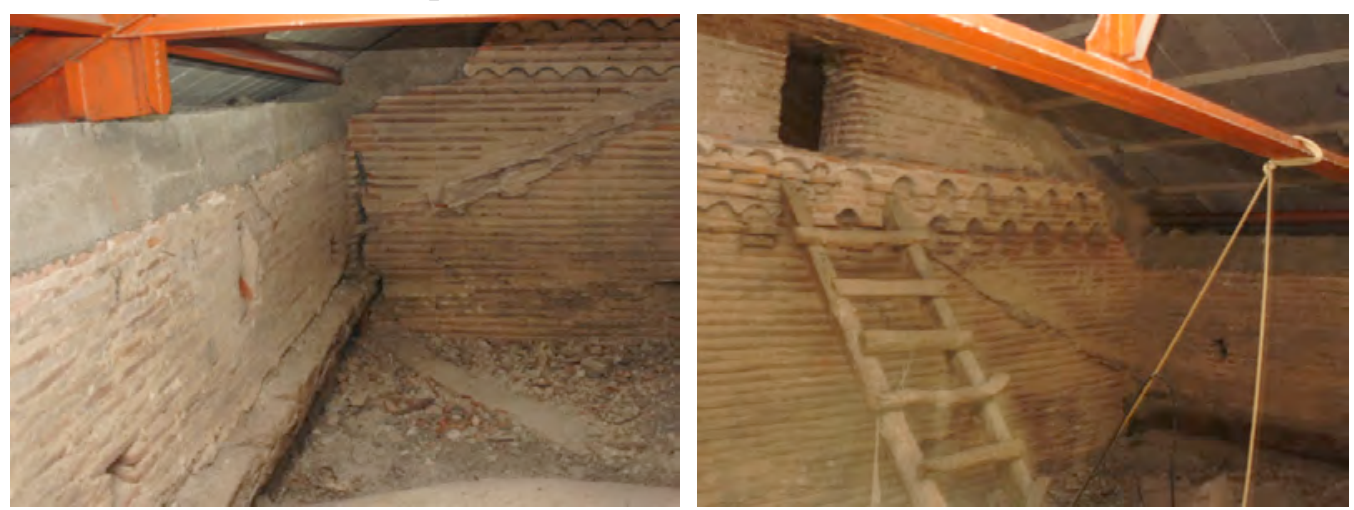
En las fotografías se aprecia la cornisa de cincha que adornaba este muro y la huella del encuentro de los citados faldones. A ambos lados se han mantenido los dobles durmientes de madera de la solución constructiva original.

En cada muro lateral, encajadas entre ambos durmientes, se aprecian restos de ménsulas de madera sobre las que apoyaban pares de tirantes que enlazaban los muros de ambos lados de la nave central. Se conservan algunas de estas piezas, generalmente las que se encuentran semi-embebidas en los arcos fajones.

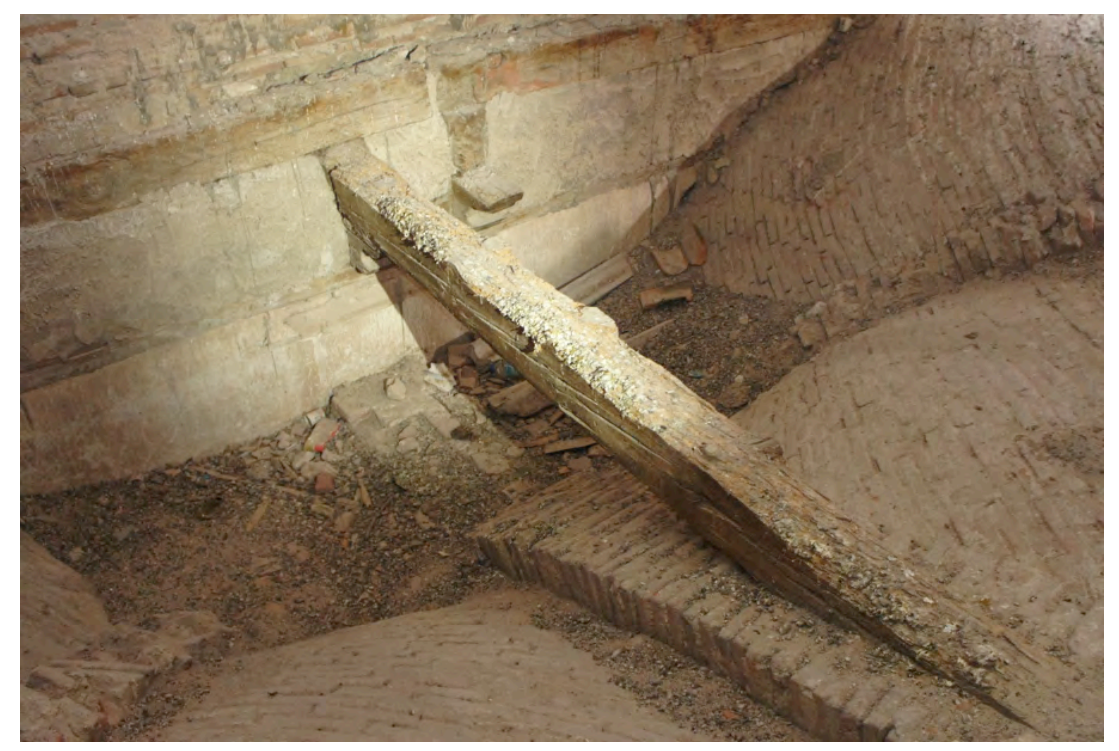

Estos pares de ménsulas labradas nos recuerdan los encontrados en otras iglesias de la zona. Los de Villaverde de Medina, según se describe en la ficha FZ-38, correspondían a un techo artesonado construido para quedar visto, que fue desmontado a los cien años de su construcción para colocar las habituales bóvedas de fábrica de ladrillo. El reemplazo de techos de madera por bóvedas de fábrica de ladrillo, tanto tabicado como a rosca, fue una práctica habitual en estos templos, tanto por adaptación a los cambios de gusto hacia "lo romano" como por considerarse la fábrica un material más seguro frente a la acción del fuego que la madera. (Recordemos el Tratado sobre bóvedas incombustibles en pág. III.16)

Si consideramos la magnífica obra de carpintería que presenta esta iglesia, tanto en la cabecera (cúpula de presbiterio y cimborrio sobre el crucero) como a los pies, con un coro de madera intensamente labrada, es muy probable que en origen contase con una techumbre importante en su nave central. La fábrica por encima del durmiente debió recrecerse en el momento de ejecutar las bóvedas. 
En las naves laterales el zuncho no se ve prolongado sobre los testeros a los pies, mientras que sí se dispone en continuidad sobre el cerramiento que comunica con los brazos del crucero.
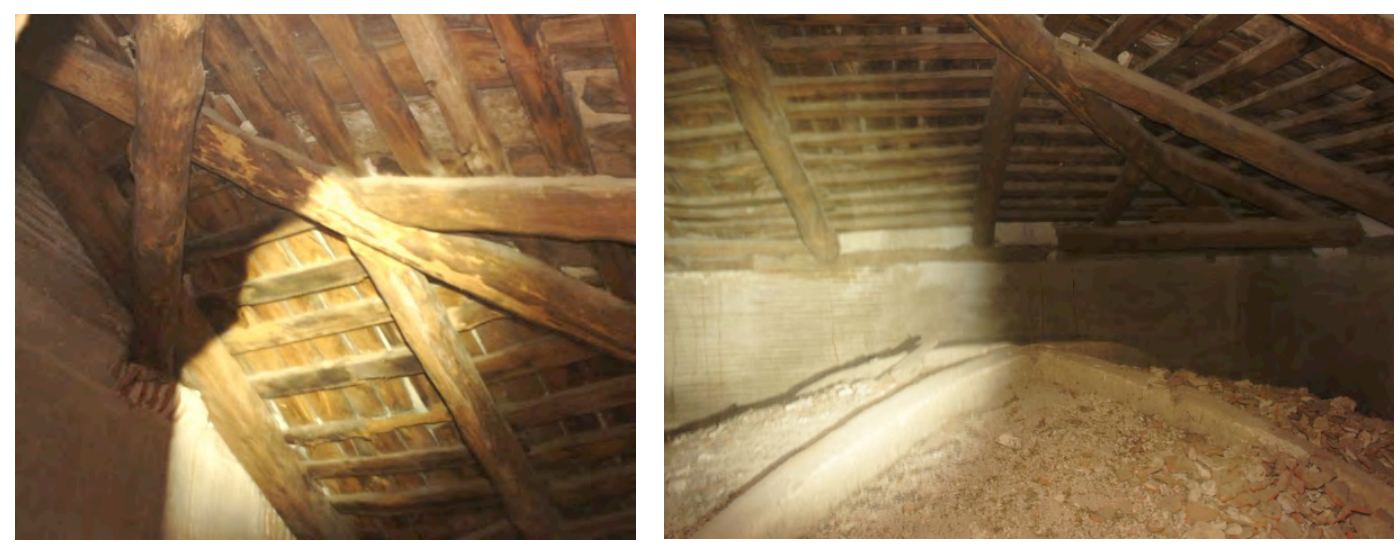

El tablero sobre el brazo del crucero también es de vigueta y bovedilla, mientras que sobre la bóveda de la cabecera lateral al presbiterio se conserva una estructura de madera, con pares de rollizo sin escuadrar, que apoya sobre durmientes de madera embebidos en los muros. En la imagen se aprecia cómo un cuadral descansa sobre una pequeña ménsula de fábrica que sobresale del cerramiento del presbiterio.

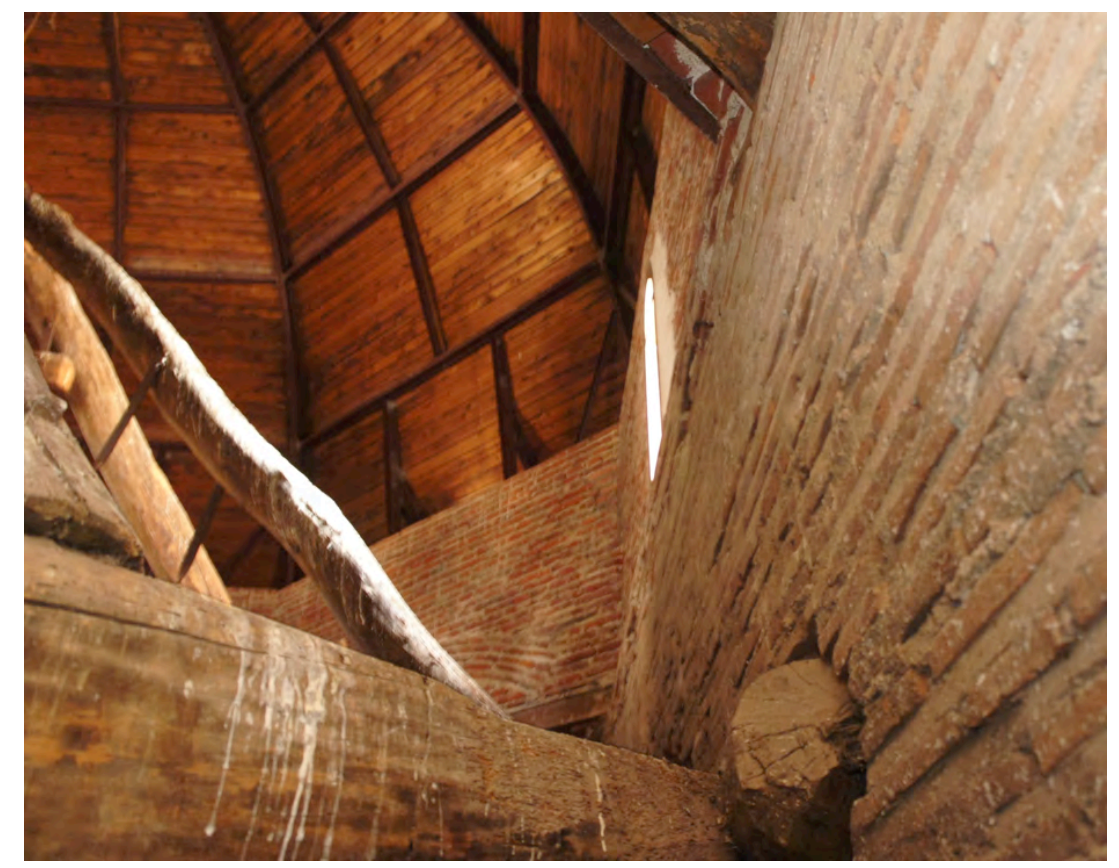

Aunque la intervención más reciente saneó la cúpula sobre el presbiterio y la fábrica de transición del cubo al ochavo es de nueva factura, el artesonado aparece cubierto con plásticos. En la zona del crucero se mezcla madera vieja con piezas de madera nueva, en todos los casos acometiendo directamente sobre huecos en la 
fábrica, no observándose zunchos de hormigón en ninguna de las dos estructuras de carpintería. 


\section{Iglesia de San Juan Evangelista}

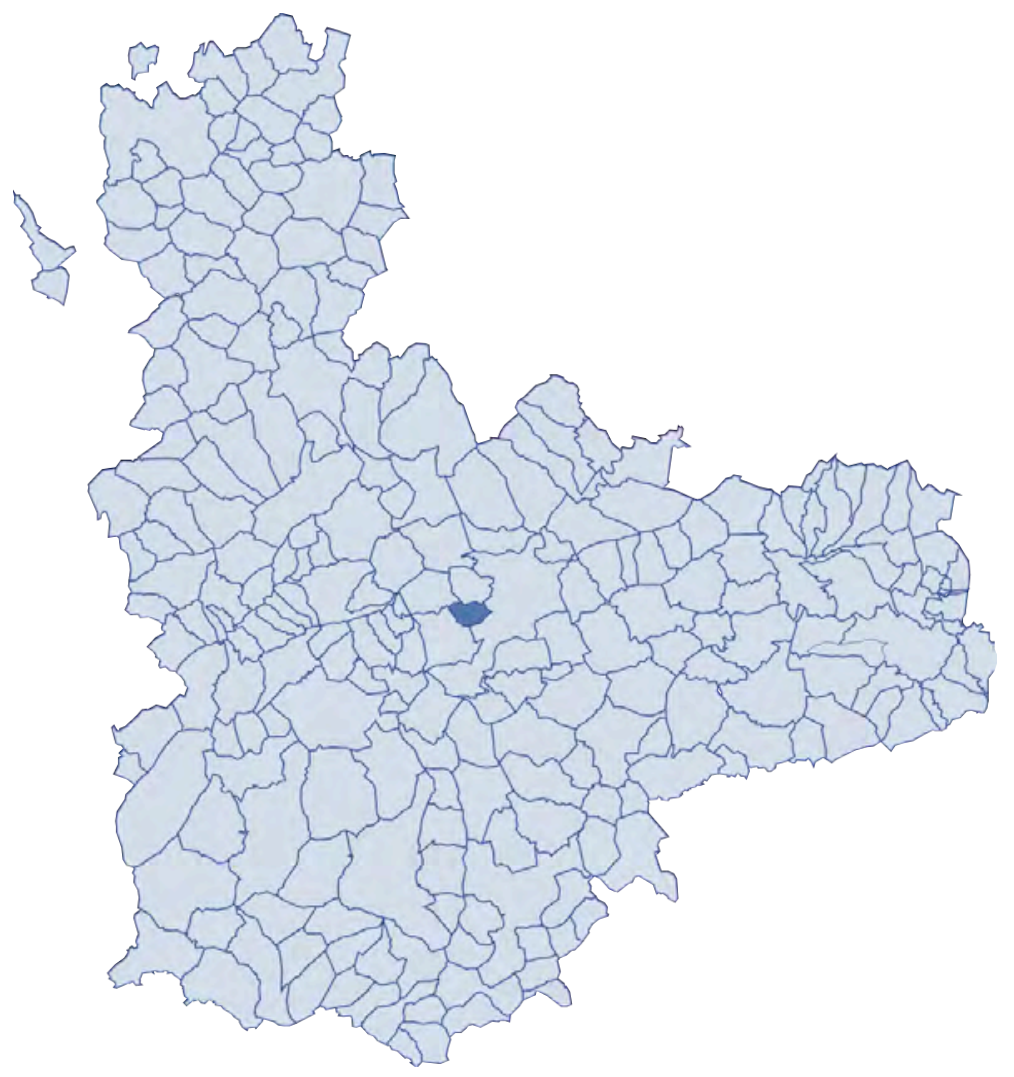



FICHA SÍNTESIS

\section{Código de identificación: FZ-18}

Denominación:

Iglesia de San Juan

Localidad:

Arroyo de la Encomienda

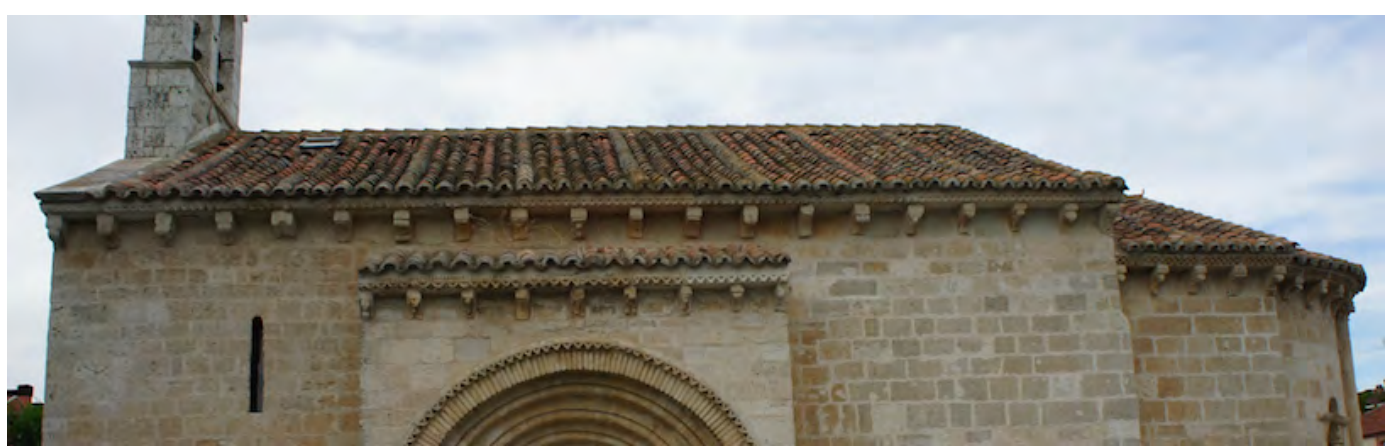

\section{Descripción}

Pequeña iglesia románica sin contrafuertes, de una sola nave cubierta con bóveda de cañón. El ábside semicircular se cierra con bóveda de horno y el presbiterio, más estrecho que la nave, con bóveda de cañón.

\section{Materiales}

Los muros son de sillería de piedra. La cubierta está revestida de teja curva.

\section{Singularidades}

El alero volado se sostiene mediante canes labrados con figuras. El monumento ha sido restaurado recientemente y presenta un exterior muy cuidado. Se aprecian los sillares labrados de la sacristía y otros elementos nuevos de piedra, como canes lisos y columnillas.

\section{Dimensiones básicas del templo}
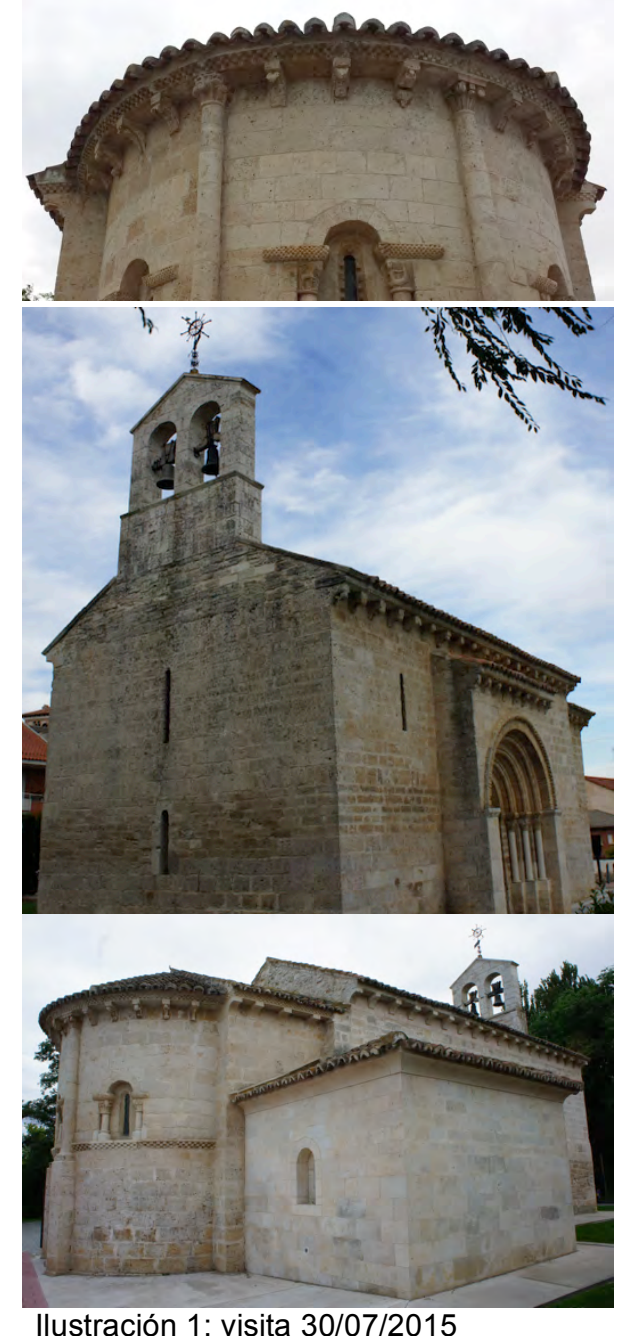
central laterales

Ancho de nave 


\section{Memoria histórica constructiva}

Según la Enciclopedia ${ }^{1}$ de la Fundación Santa María la Real:

La construcción se inicia hacia 1150. El muro septentrional y la sacristía se levantan con posterioridad al resto del perímetro. La bóveda de cañón de ladrillo enlucida de yeso se construye en el curso de una restauración, realizada en 1876 por Segundo Rezola y Ortiz de Urbina, y sustituye a una armadura de madera.

\section{Cronología. Fechas clave}

$1150-1876-1974-2001$

\section{Intervenciones}

1974 - Memoria de obras urgentes - Alberto García Gil

Se desmantela la cubierta formando la nueva con doble tablero de rasilla y $3 \mathrm{~cm}$ de hormigón sobre correas metálicas.

2001 - Restauración - (sin confirmar DF)

En 2011 también se presupuestan obras menores a cargo de la Diputación encaminadas a eliminar las humedades en el interior del templo y goteras en la sacristía.

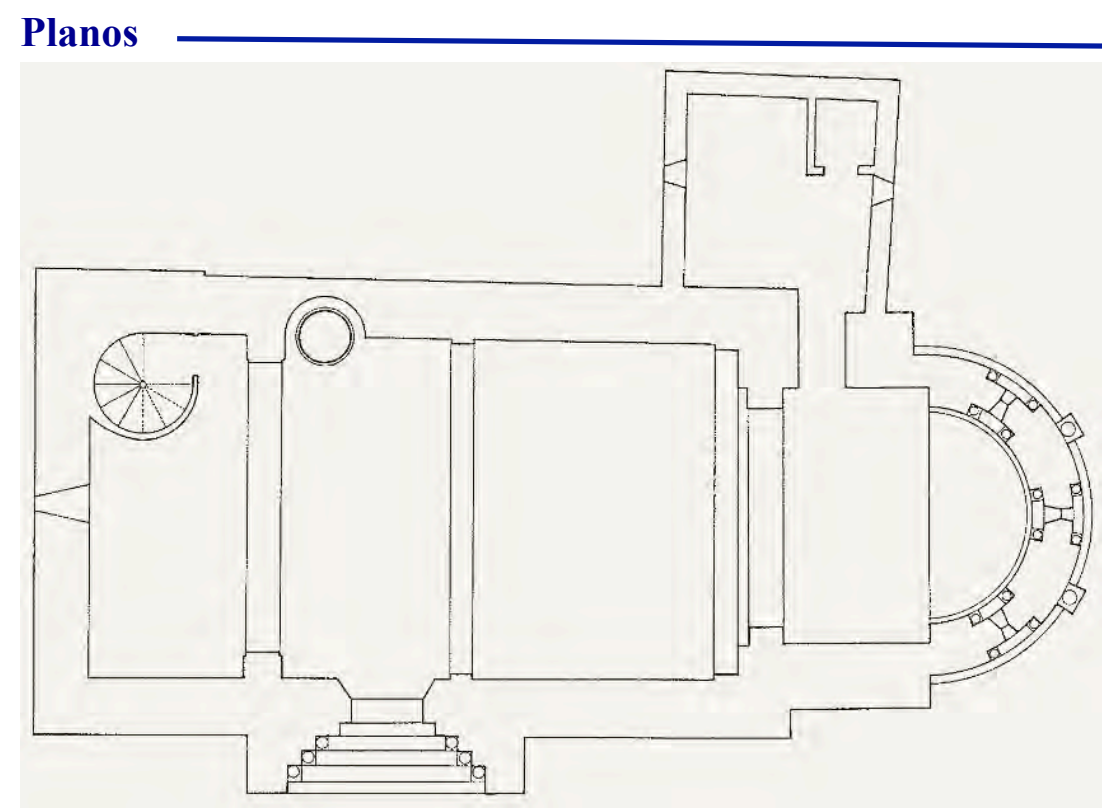

Ilustración 2: planta romanicodigital ${ }^{1}$

\footnotetext{
${ }^{1}$ Castán Lanaspa, J. (2002). Panorama general del Románico en Valladolid. En Enciclopedia del románico en Castilla y León: Valladolid (pp. 43-56). Fundación Santa María la Real. Y Enciclopedia online en www.romanicodigital.com.
} 

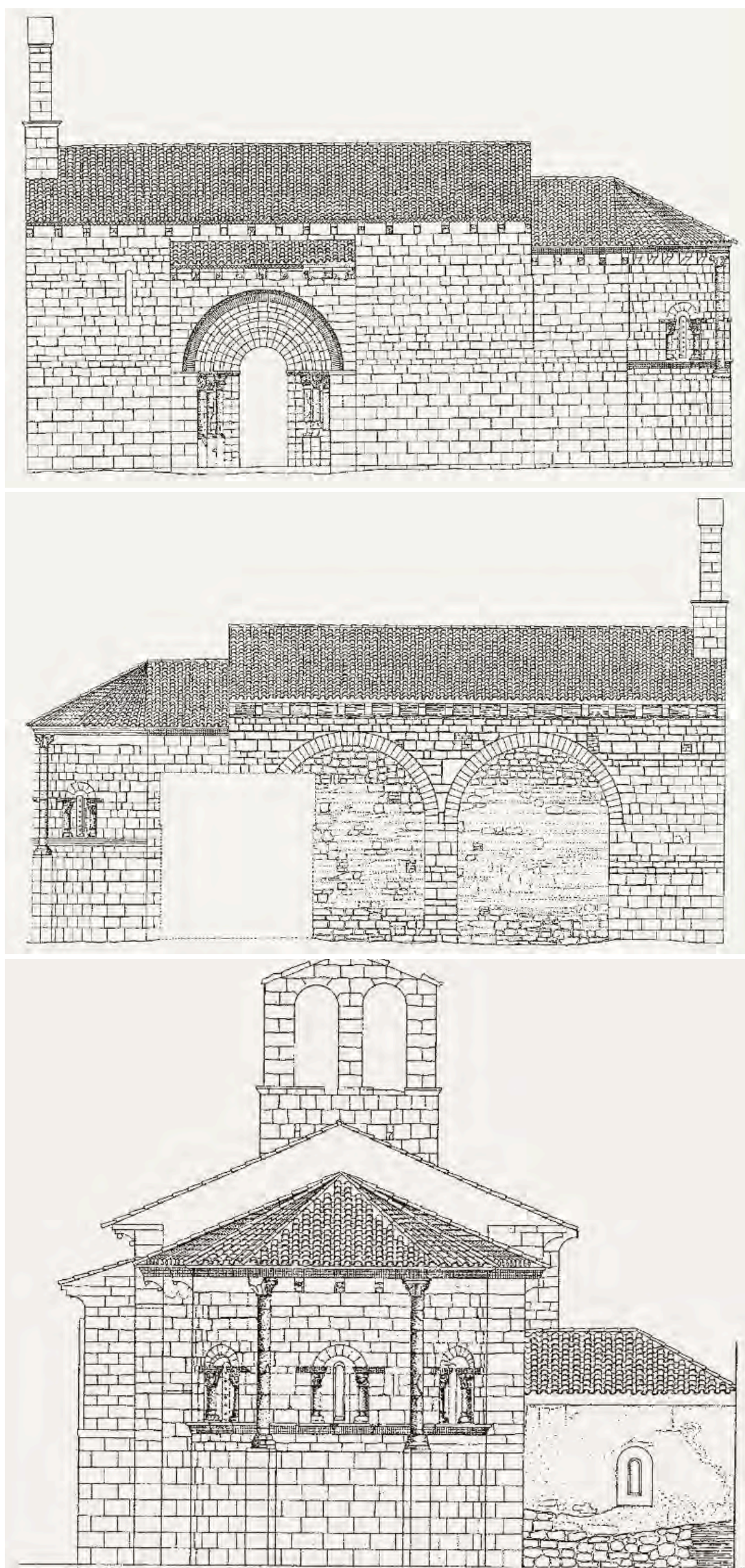

Ilustración 3: alzados y secciones romanicodigital 


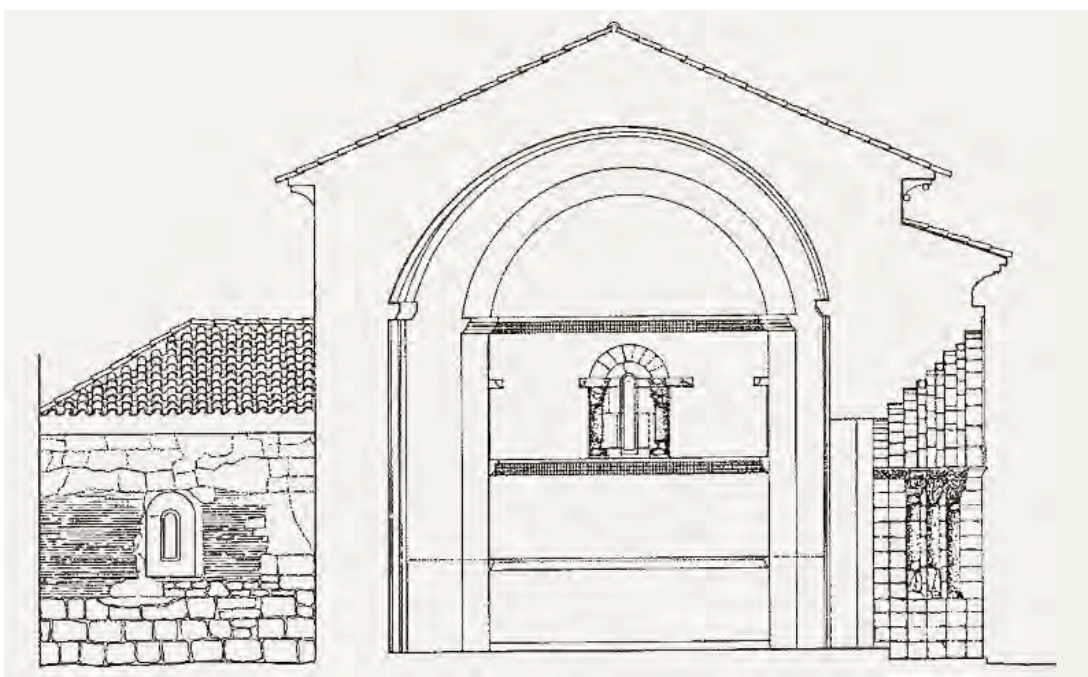

Ilustración 4: sección web romanicodigital

\section{Solución constructiva de la cubierta}

En las secciones se representa una pendiente de unos $24^{\circ}$.

\section{Zunchos}

No se ha podido comprobar la existencia de zunchos.

\section{Conclusiones}

No se ha podido comprobar la existencia de zunchos en este edificio. 


\section{Iglesia de San Juan}

Intervenciones citadas en la publicación del Ministerio

1973 - Obras urgentes: reparación de las cubiertas y rejuntado de la fábrica del ábside - Alberto García Gil

No hay planos en la web del IPCE

\section{En el archivo del IPCE}

\section{Carpeta 1170-17}

1974 - Memoria de obras urgentes - Alberto García Gil

Documentación administrativa y dos copias sólo del texto de la memoria

\section{En el Archivo General de la Administración}

AGA 26/00065

1974 - Memoria de obras urgentes - Alberto García Gil

Cuartilla de Juan José Martín González al Director General de Bellas Artes, en que indica que el edificio está muy necesitado de restauración, como acreditan las fotografías.

Memoria de obras urgentes en la iglesia parroquial de Arroyo de la Encomienda El edificio presenta señales muy claras de haber sido restaurado, sustituyendo la mayor parte de los sillares en la zona baja de sus muros. Igualmente han sido sustituidos todos los canecillos y cornisas de la fachada lateral izquierda.

199,81m2 Desmantelado de cubierta actual con clarificación de material aprovechable, incluso transporte de escombro a vertedero.

íd. Forjado de cubierta formado por doble tablero de rasilla y capa de compresión de $3 \mathrm{cms}$. de espesor apoyado sobre correas metálicas

íd. cubierta formada por teja curva, recibida con mortero bastardo incluso p.p. de caballete y emboquillado

$38,34 \mathrm{~m} 2$ restauración de fábrica de sillería en abside incluso acuñado y rejuntado de $\operatorname{arcos}$. 
Dossier con muchas fotografías en color. La última es un detalle de las armaduras con bridas metálicas y apoyo triangular sobre una especie de machón de ladrillo.

\section{En el archivo de la Junta de Castilla y León}

No se ha localizado documentación.

*Tampoco en la Delegación Diocesana de Patrimonio se ha encontrado documentación de las obras realizadas en 2001. 
Iglesia del Monasterio de la Santa Espina

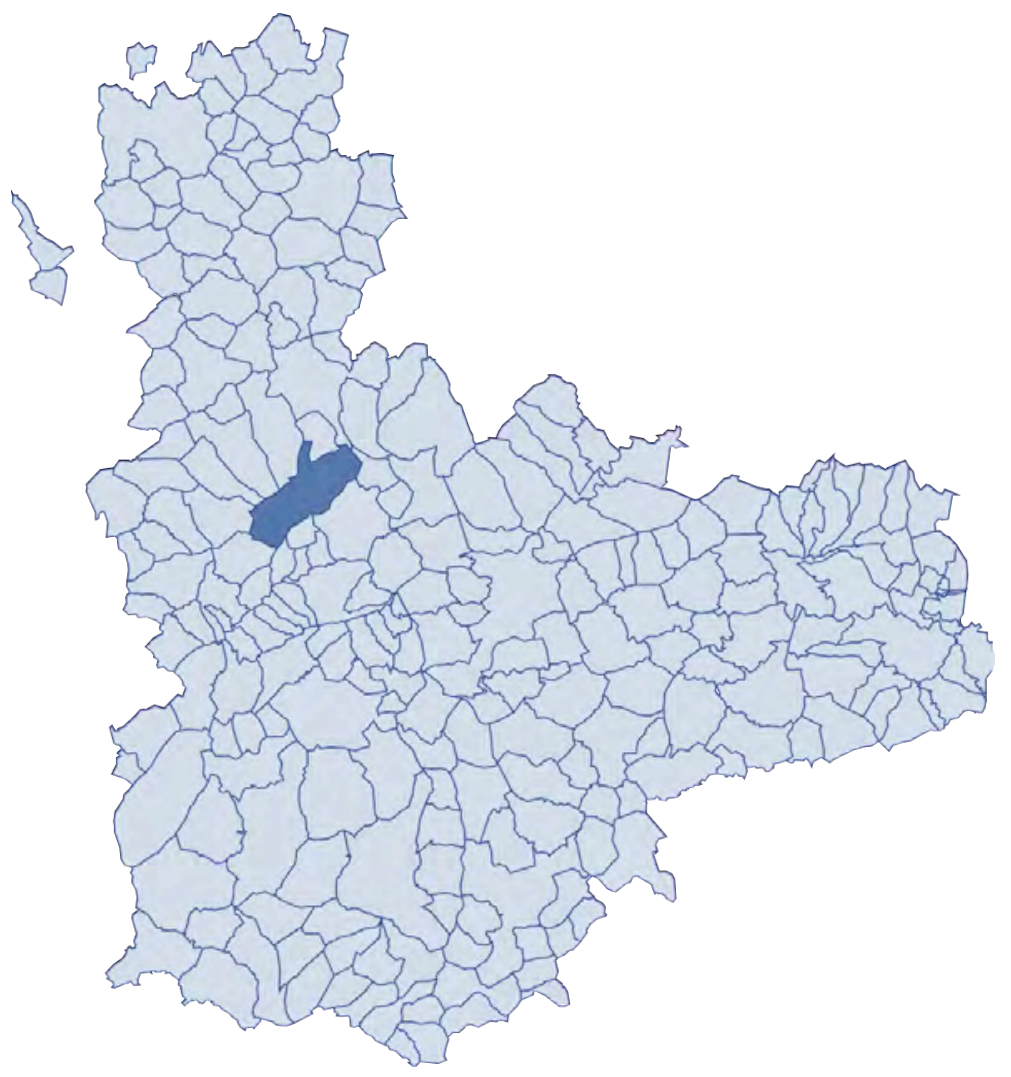



FICHA SÍNTESIS

\section{Código de identificación: FZ-19}

Denominación: $\quad$ Iglesia del Monasterio de la Santa Espina

Localidad: $\quad$ La Santa Espina (Castromonte)
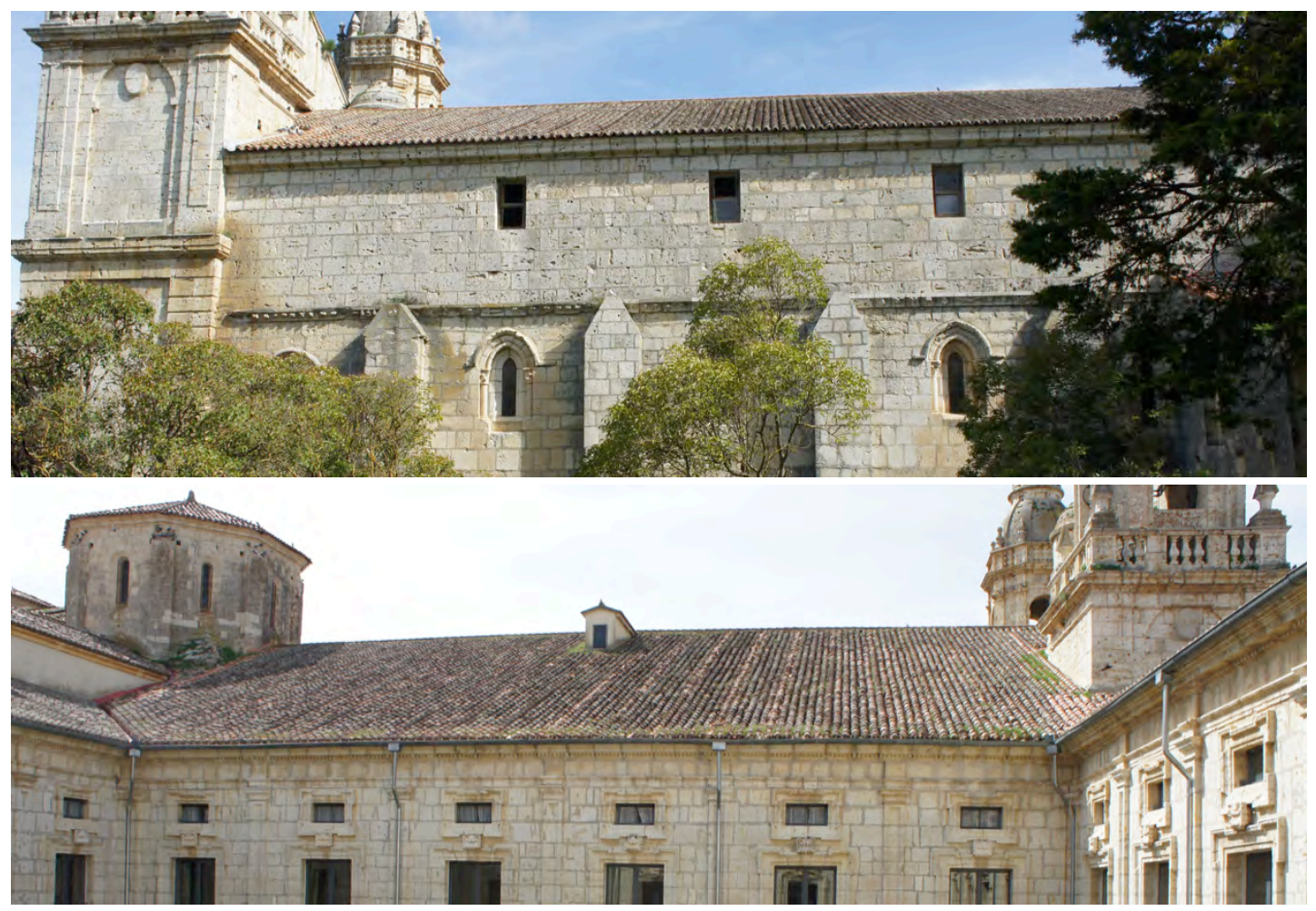

\section{Descripción}

Iglesia de tres naves con crucero sobresaliente en planta y cimborrio. Tuvo cinco capillas de planta rectangular adosadas a la cabecera, de las que se conserva sólo la extrema del lado del evangelio, cubierta con bóveda de cañón apuntado, y algunos muros. Las naves y el crucero se cubren con bóvedas de crucería sencilla, la cabecera con bóveda estrellada sobre trompas y el cimborrio con bóveda de horno avenerada.

\section{Materiales}

Los muros son de cantería, aunque algunos recrecidos no visibles desde el exterior del templo están resueltos con fábrica de ladrillo hueco. Las cubiertas están revestidas de teja curva.

\section{Singularidades}

Se trata de un Monasterio convertido en Escuela de formación agraria prácticamente desde su desamortización en el siglo XIX. 
La iglesia se adosa a uno de los claustros y el faldón de cubierta se prolonga sobre la panda sur del mismo.

La portada a los pies se macla con la fachada de acceso al Monasterio formando un extraño quiebro. Algunos elementos de la misma se encuentran, sin labra, apuntalados sobre pequeñas cuñas de madera, como inconclusos.
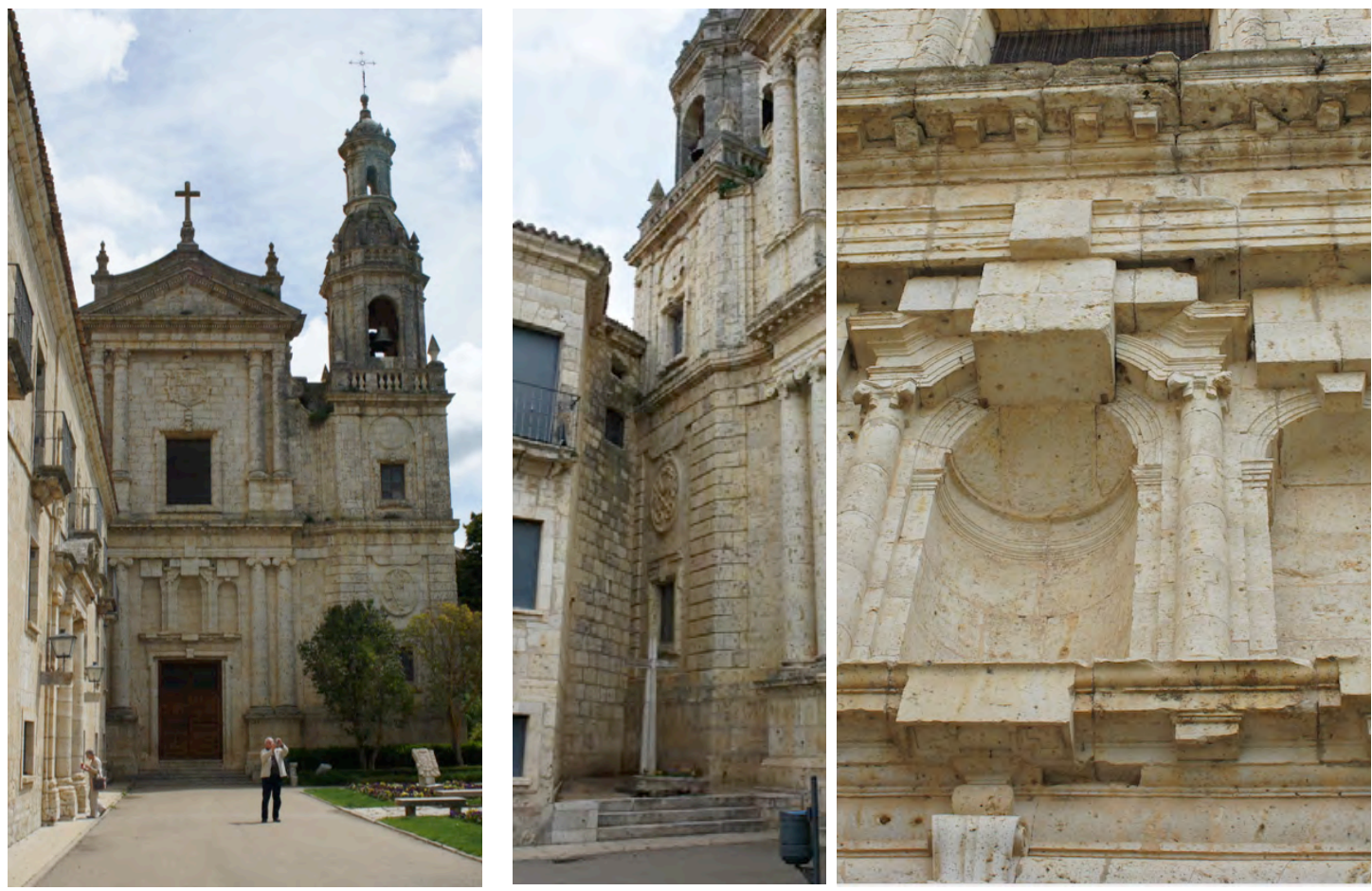

Ilustración 1: detalles de la fachada oeste de la iglesia

\section{Dimensiones básicas del templo}

$\begin{array}{lrcc} & \text { central } & \text { laterales } & \text { capillas } \\ \text { Ancho de nave } & 7,0 & 3,8 & \\ \text { Altura } & 15,3 & 9,4\end{array}$

\section{Memoria histórica constructiva}

Según el Catálogo:

La iglesia se inicia a finales del siglo XII por la cabecera y las obras se paran temporalmente en 1285 a la muerte de D Martín Alonso, hasta que finalmente se rematan las tres capillas que faltaban, naves colaterales del templo y conjunto monacal. Entre 1546 y 1558 se reedifican la Capilla mayor y el cimborrio, disponiéndose linternas sobre ambos espacios. La capilla de la Santa Espina se levanta en 1635 con planos de Francisco de Praves, bajo dirección de Fray Pedro García. La portada del templo se termina hacia 1760-1780. 
En 1835 abandonan el templo los monjes cistercienses, tras la Desamortización de Mendizábal y, a partir de 1866, la Marquesa de Valderas establece en el monasterio un centro docente de enseñanza básica $\mathrm{y}$, posteriormente, una especialización agrícola, con internado para niños sin recursos.

En 1954, tras la firma del convenio entre Patronato y Ministerio, se establece la Escuela de Capataces. Hasta hoy se mantienen los usos como internado y Escuela de Formación Agraria, tras la firma de diferentes convenios y el traspaso de competencias a la Comunidad Autónoma de 1984.

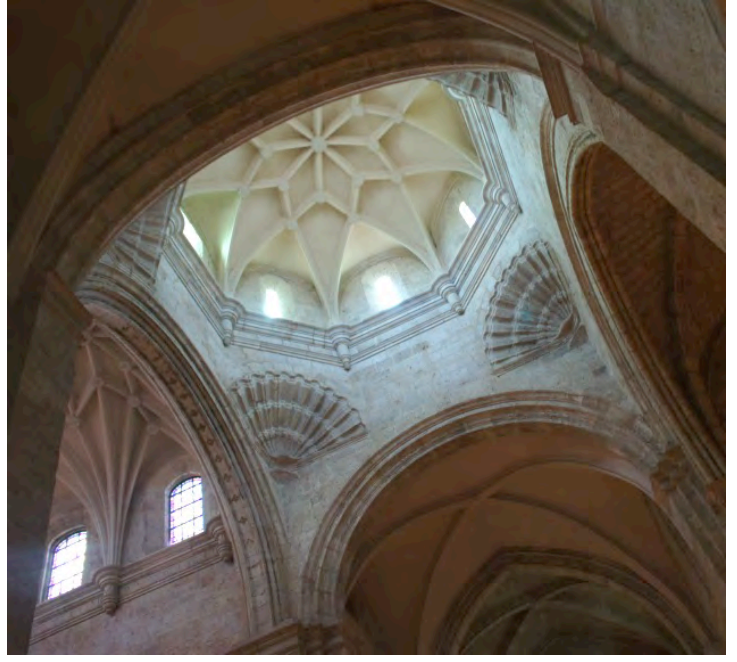

Ilustración 2: Imágenes del interior (visita mayo 2013)

\section{Cronología. Fechas clave}

$1147-1886-1953-2008$

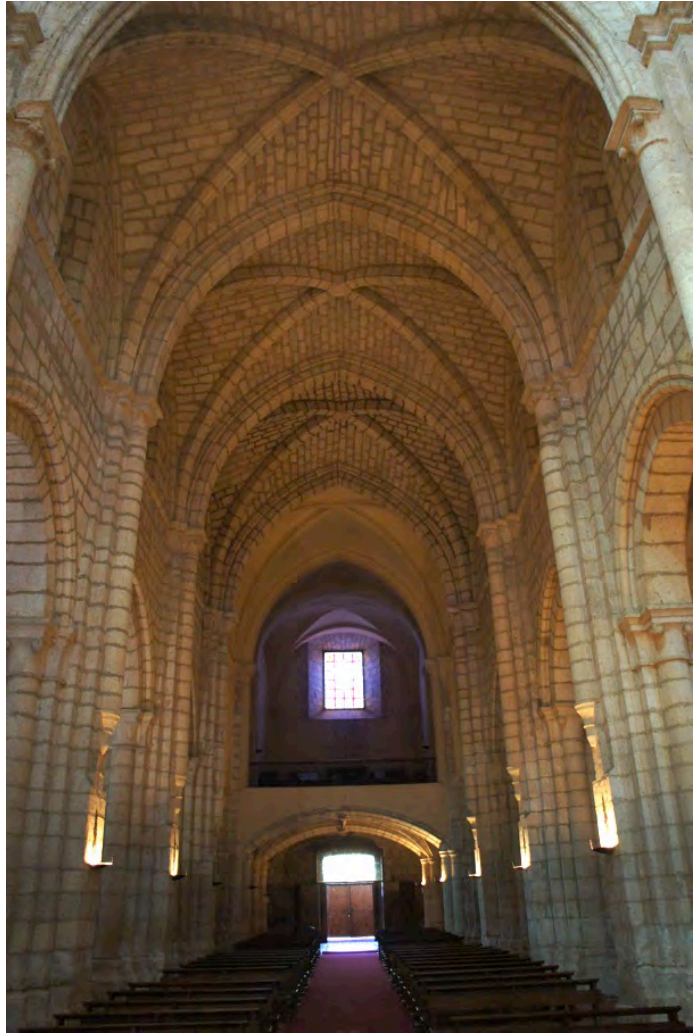

\section{Intervenciones}

Sobre la piedra encontramos grabadas algunas fechas de terminación de reformas: 1661 en la escalera monumental y 1674 sobre la espadaña que corona la residencia.

1952 - Pavimentación de la iglesia - Anselmo Arenillas

2008 - Plan Director - Alberto Martínez, Ángel Rodríguez y Pablo Brezmes Algunas obras planteadas en el Plan Director se ejecutan en 2007, como la restauración de sacristía, el cambio de carpinterías de claustros y el drenaje de la sala capitular.

2010 - Proyecto de restauración de cubiertas - Alberto Sainz de Aja, José Manuel Barrio y José Isidro Cameno. 
En grabados del XIX aparece ya la fachada lateral de la nave de la epístola con la altura incrementada y distribución de huecos con que la encontramos hoy.

Exceptuando la breve memoria del cambio de pavimento de Arenillas conservada en el AGA no se ha localizado documentación sobre la profunda reforma estructural de los años 50. En ese momento debió reconstruirse la práctica totalidad de cubiertas del Monasterio, colocando jácenas prefabricadas de hormigón con entrevigado de rasilla.

\section{Planos}

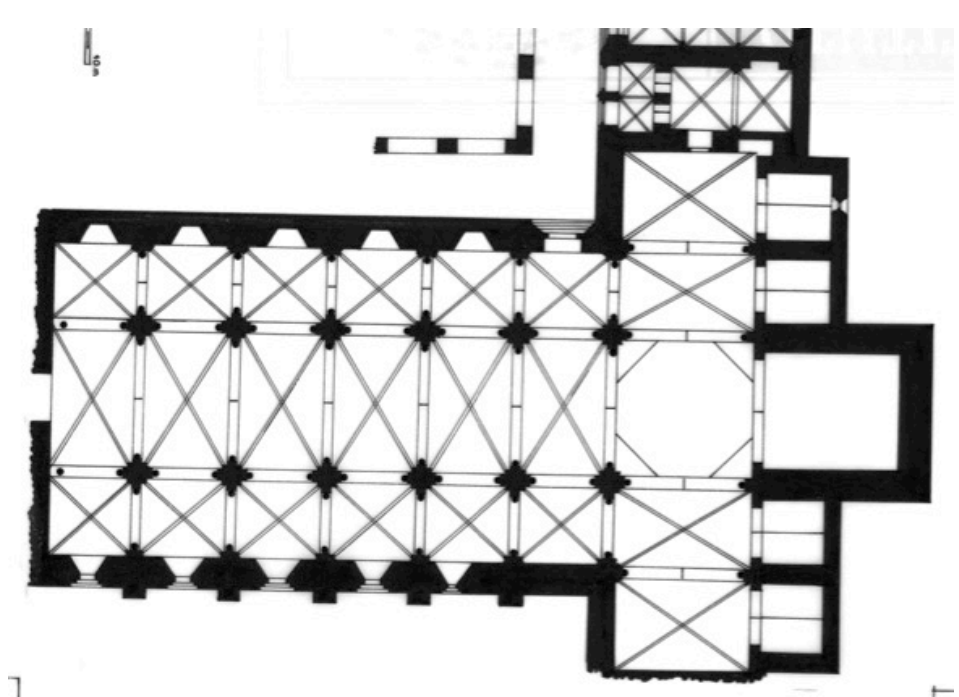

Ilustración 3: planta general sin fecha (web IPCE)

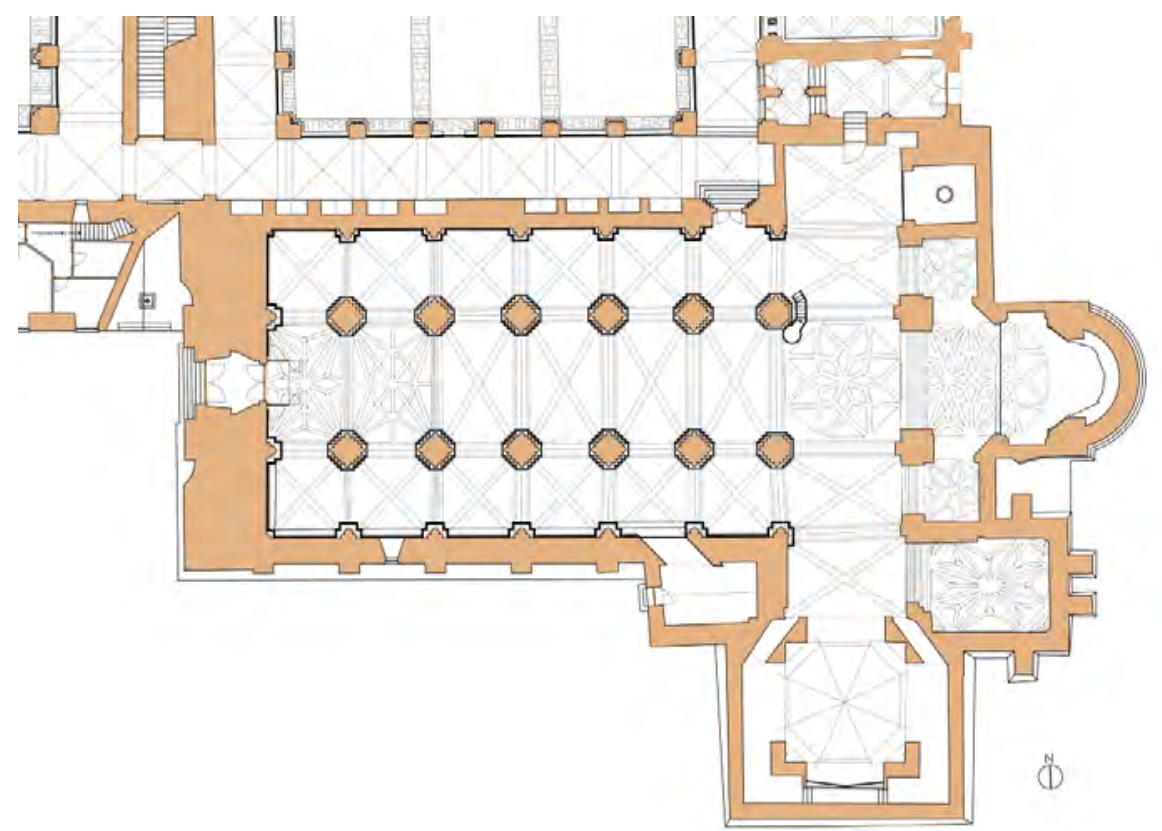

Ilustración 4: planta de la iglesia 2008 (Plan Director) 


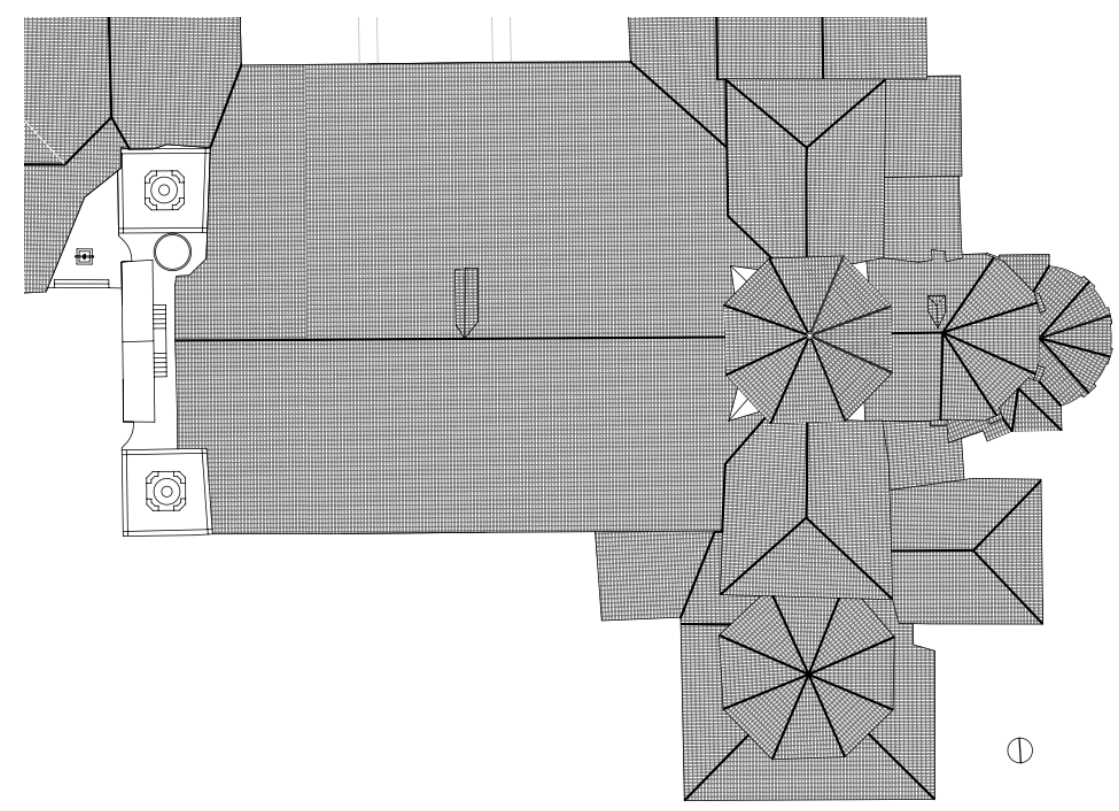

Ilustración 5: plano de cubiertas 2008 (Plan Director)

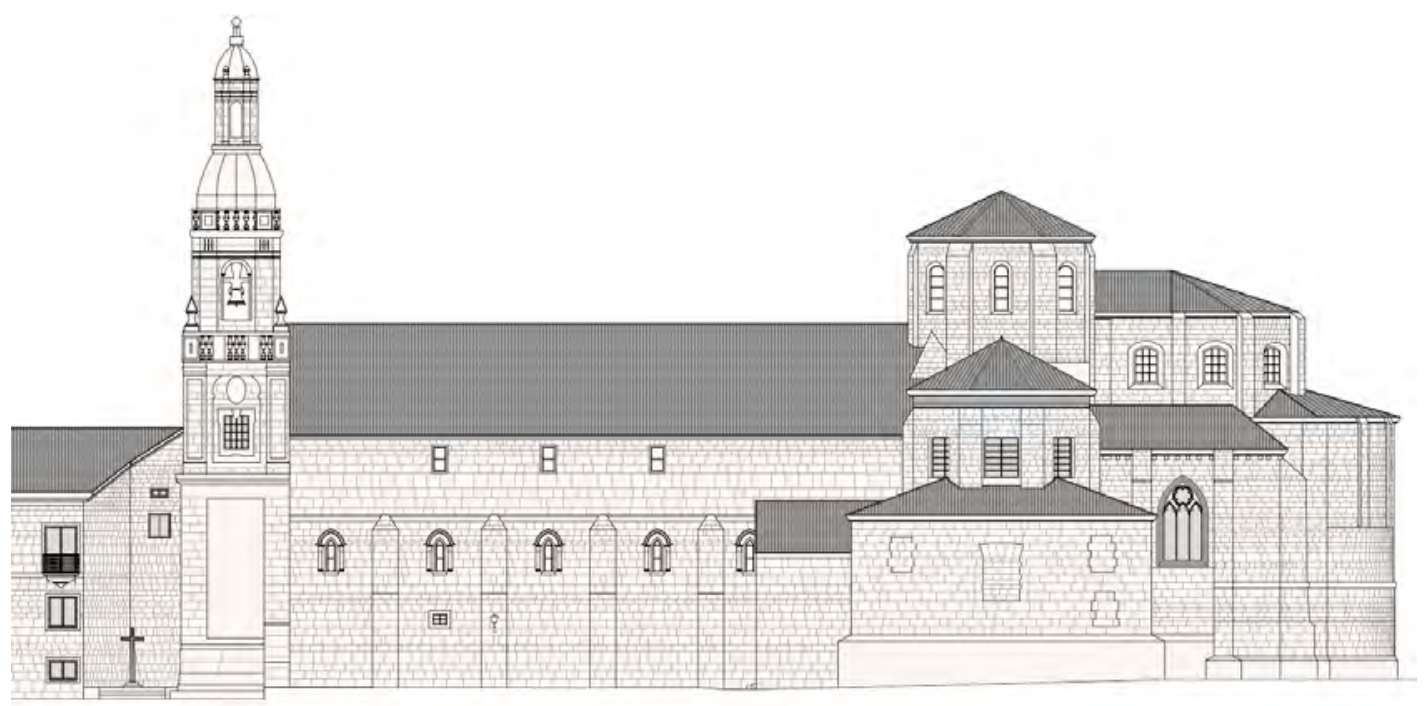

Ilustración 6: alzado sur 2008 (Plan Director)

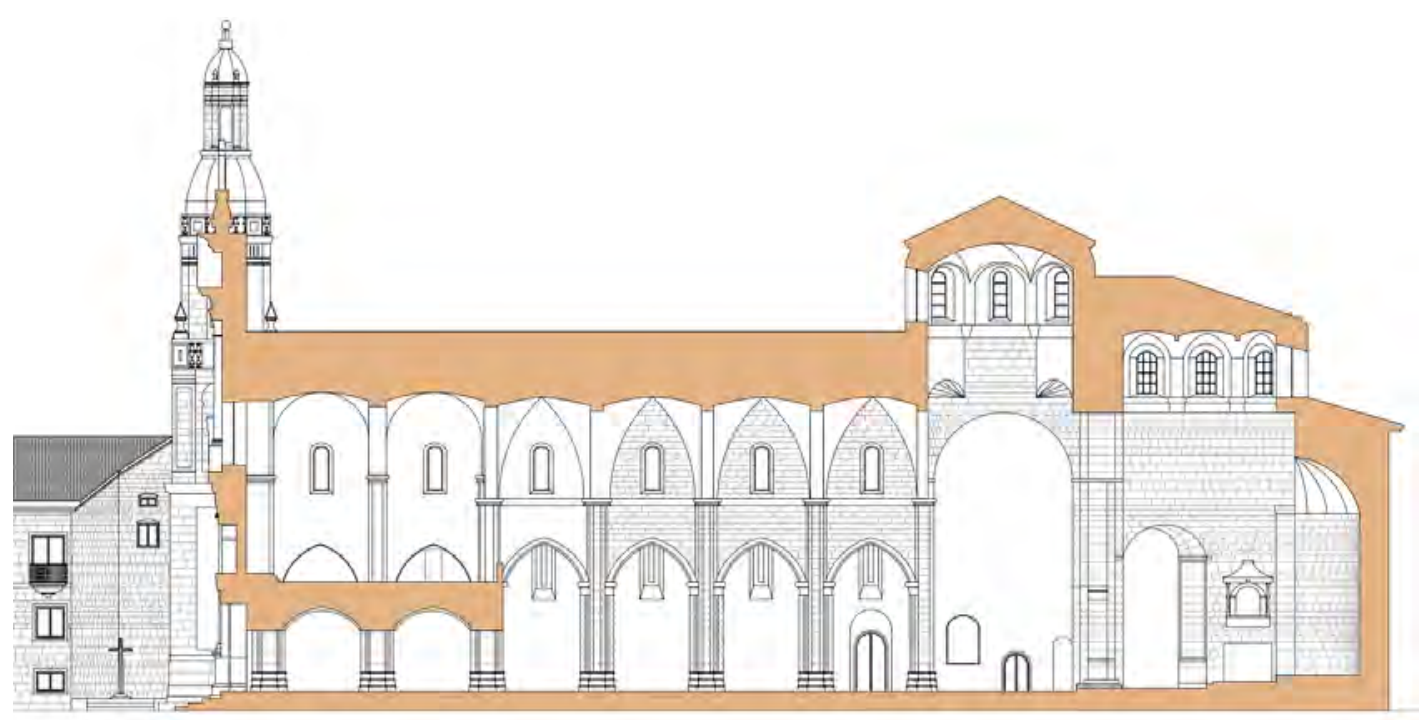



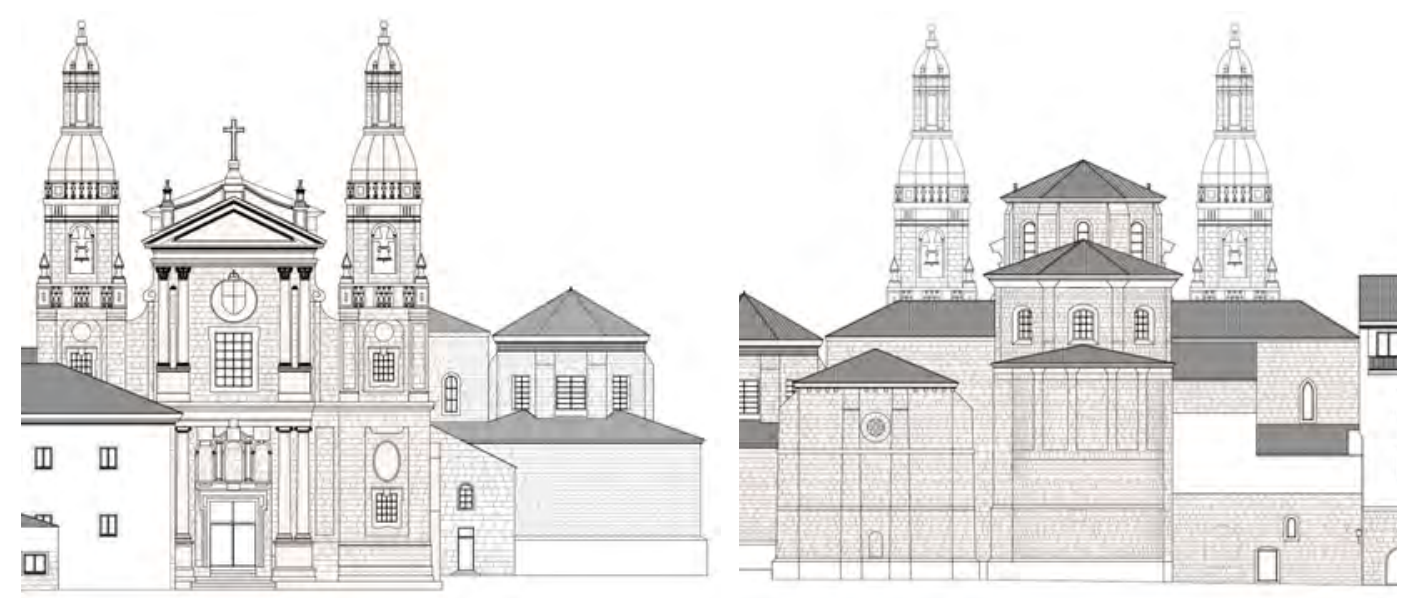

Ilustración 7: alzados este y oeste de la iglesia 2008 (Plan Director)

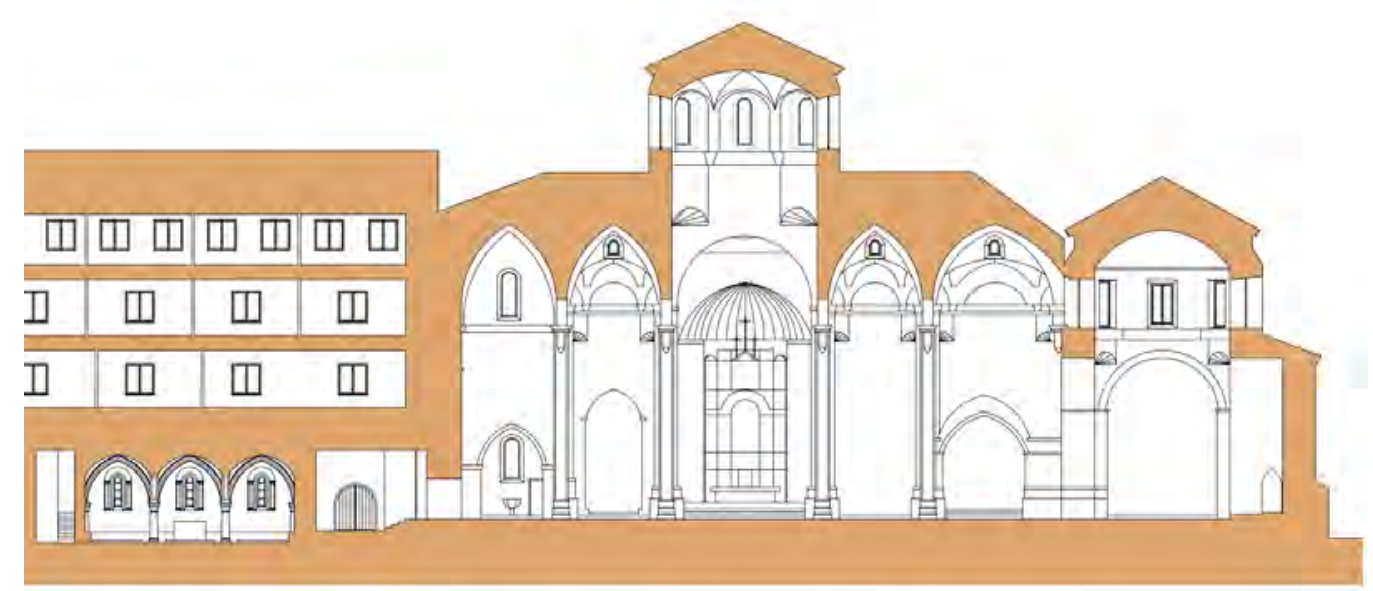

Ilustración 8: sección transversal por crucero y capilla de la Santa Espina 2008 (Plan Director)

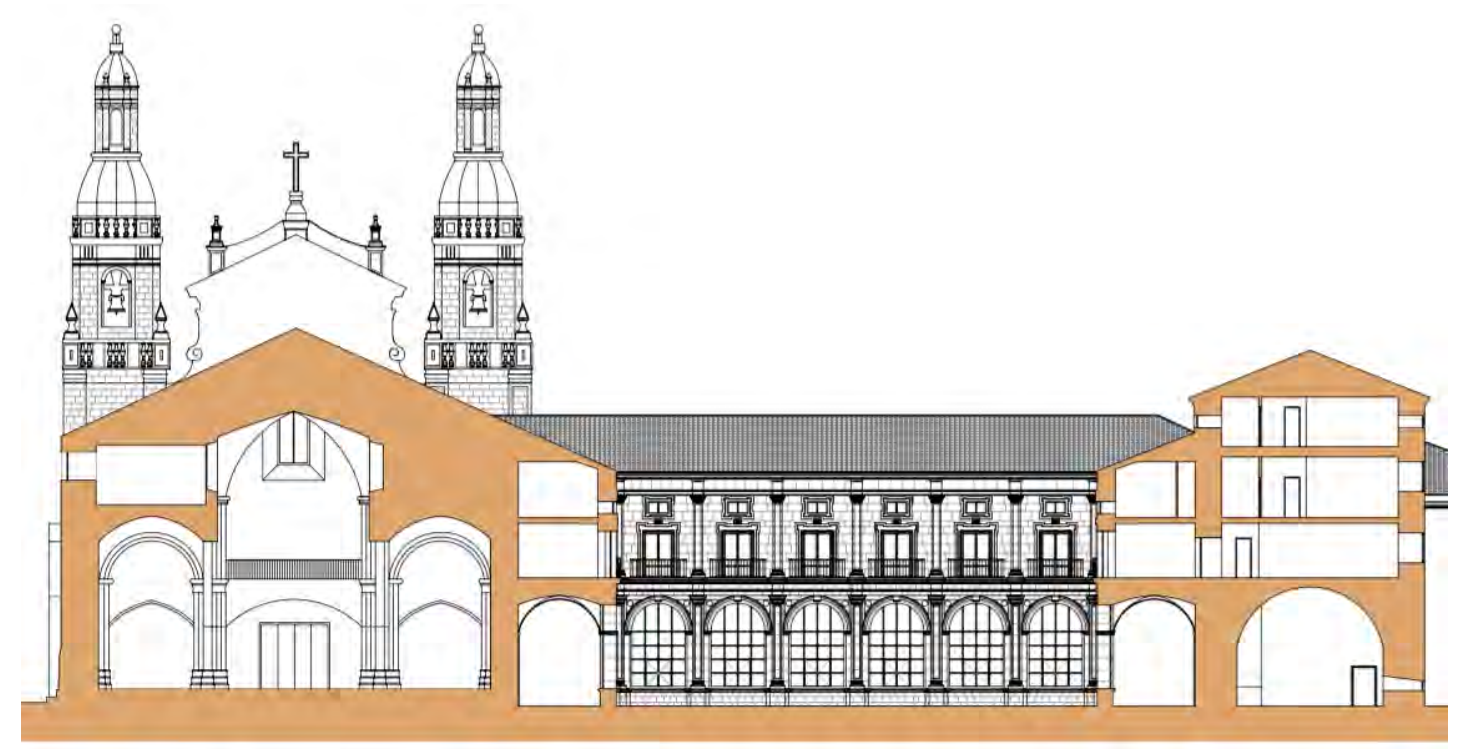

Ilustración 9: sección transversal de claustro y cuerpo del templo hacia los pies 2008 (Plan Director) 


\section{Solución constructiva de la cubierta}

En las secciones del Plan Director se representa una pendiente de unos $24^{\circ}$, aunque no se describe el perfil del edificio (cornisa, espacios diáfanos bajo cubierta, estructura, etc.) con la fidelidad que requiere la escala de representación de los planos.

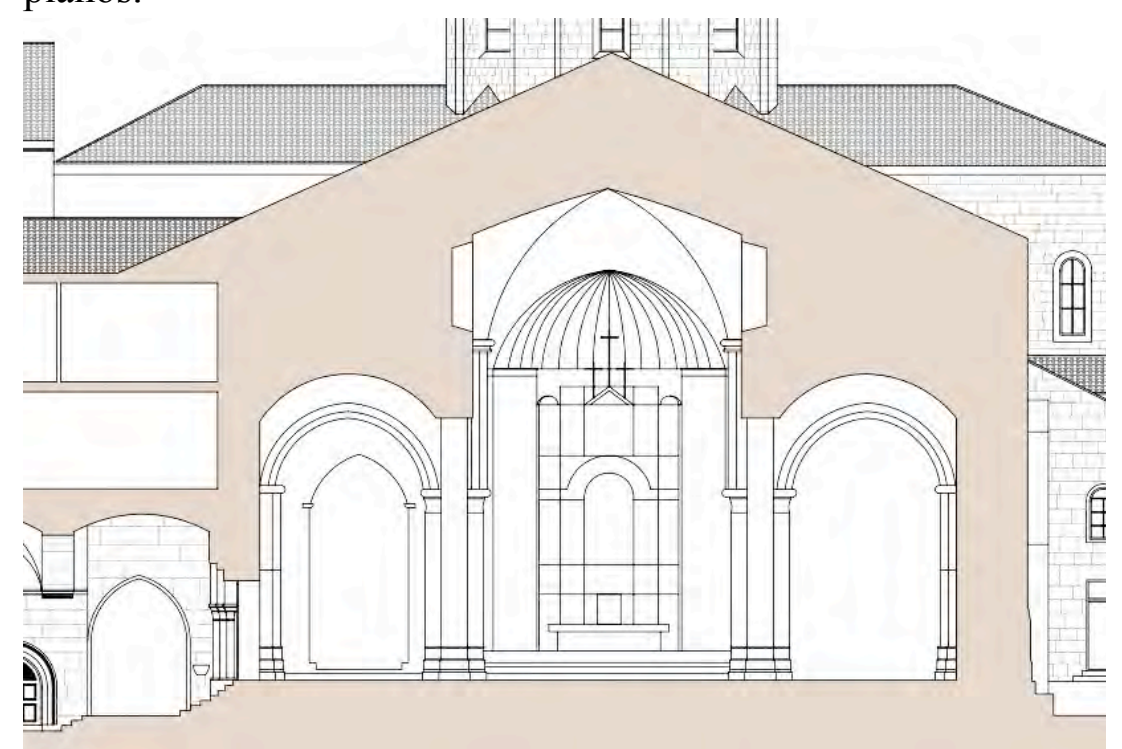

Ilustración 10: sección del cuerpo del templo 2008 (Plan Director)

Según se desarrolla más adelante, en el resumen de la visita, el cuerpo de la nave central cuenta con un recrecido de ladrillo hueco sobre ambos cerramientos longitudinales. Sobre esta fábrica apoyan una vigas prefabricadas de hormigón tipo doble $\mathrm{T}$ dispuestas a dos aguas, con su unión en cumbrera rigidizada mediante una pieza de hormigón armado ejecutado in situ. De este prisma cuelgan unos cables que no están realizando trabajo estructural, destinados a cortar la luz a flexión de unos tensores metálicos engarzados al arranque de las vigas.

\section{Zunchos}

En la visita no se aprecia la existencia de zunchos que recojan el apoyo de las grandes vigas, aunque dado el grosor de los muros, estos podrían existir y encontrarse revestidos con la fábrica de ladrillo hueco.

En la cubierta de la nave de la epístola sí hay un zuncho de hormigón armado visto que recorre el interior de la fachada sur del templo.

\section{Conclusiones}

En este edificio no se ha constatado la existencia de zunchos en la cubierta de la nave central de la iglesia. 



\section{Iglesia del Monasterio de la Santa Espina en Castromonte}

Intervenciones citadas en la publicación del Ministerio:

1952 - Pavimentación de la iglesia - Anselmo Arenillas Álvarez

En la web del IPCE hay una planta del conjunto monástico, sin fecha, "según el plano de F. Antón"

\section{En el Archivo General de la Administración}

AGA 26/00294

Proyecto de pavimentación de la iglesia en el Monasterio de Ntra Sra de la Santa Espina de Castromonte (Valladolid)

Abril de 1953 Anselmo Arenillas

Memoria (1 pag) : Forma parte esta iglesia del Monasterio de la Santa Espina, Monumento Nacional. Recientemente ha sido consolidada y reparadas todas las cubiertas y, en el Monasterio se llevan a cabo actualmente amplias obras de reparación y reconstrucción, todo por gestión de organismos oficiales. La iglesia queda inutilizada para el culto por faltarle los altares y tener todo su pavimento de madera totalmente descompuesto.

Presupuesto: $1210,65 \mathrm{~m} 2$ pavimento de baldosín, $181 \mathrm{~m} 3$ solera de hormigón, $67 \mathrm{~m} 2$ entarimado sobre rastreles,

Planos: 1 planta del monasterio 1:200

\section{En el Colegio Oficial de Arquitectos de Madrid.}

En la Biblioteca Histórica del COAM hay dos publicaciones relativas a la Santa Espina, un libro de 1887 de F. Gillén Robles y un articulo de la revista la Ilustración Española y Americana, de noviembre de 1894. En la revista se explica el origen del Monasterio, fundado en enero de 1147, el incendio de 1731 y el paso de tropas en la Guerra de Independencia. Se subastó en 1837. 


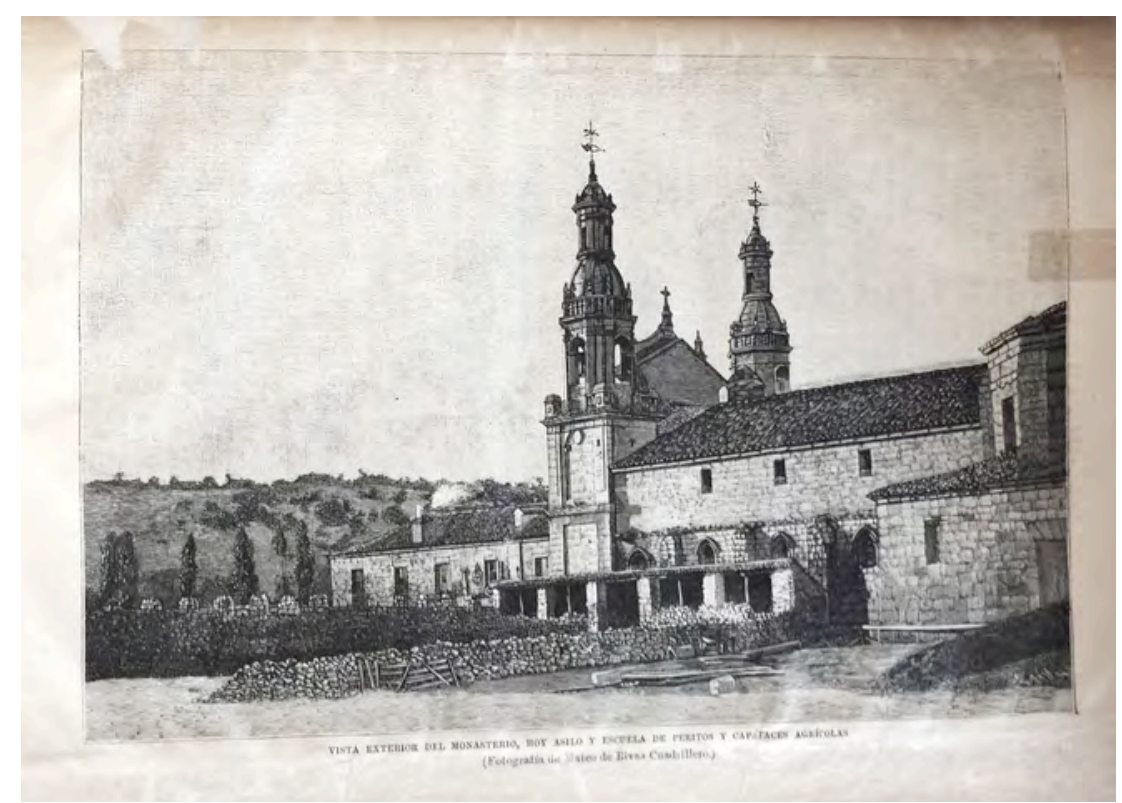

Ilustración 11: ilustración 1887 Gillén COAM

\section{En el archivo de la Junta de Castilla y León}

No se ha localizado documentación en el emplazamiento habitual. La Consejería de Agricultura, Ganadería y Montes tiene asumidas las competencias sobre este monumento por tratarse en la actualidad de una Escuela de Formación Agraria.

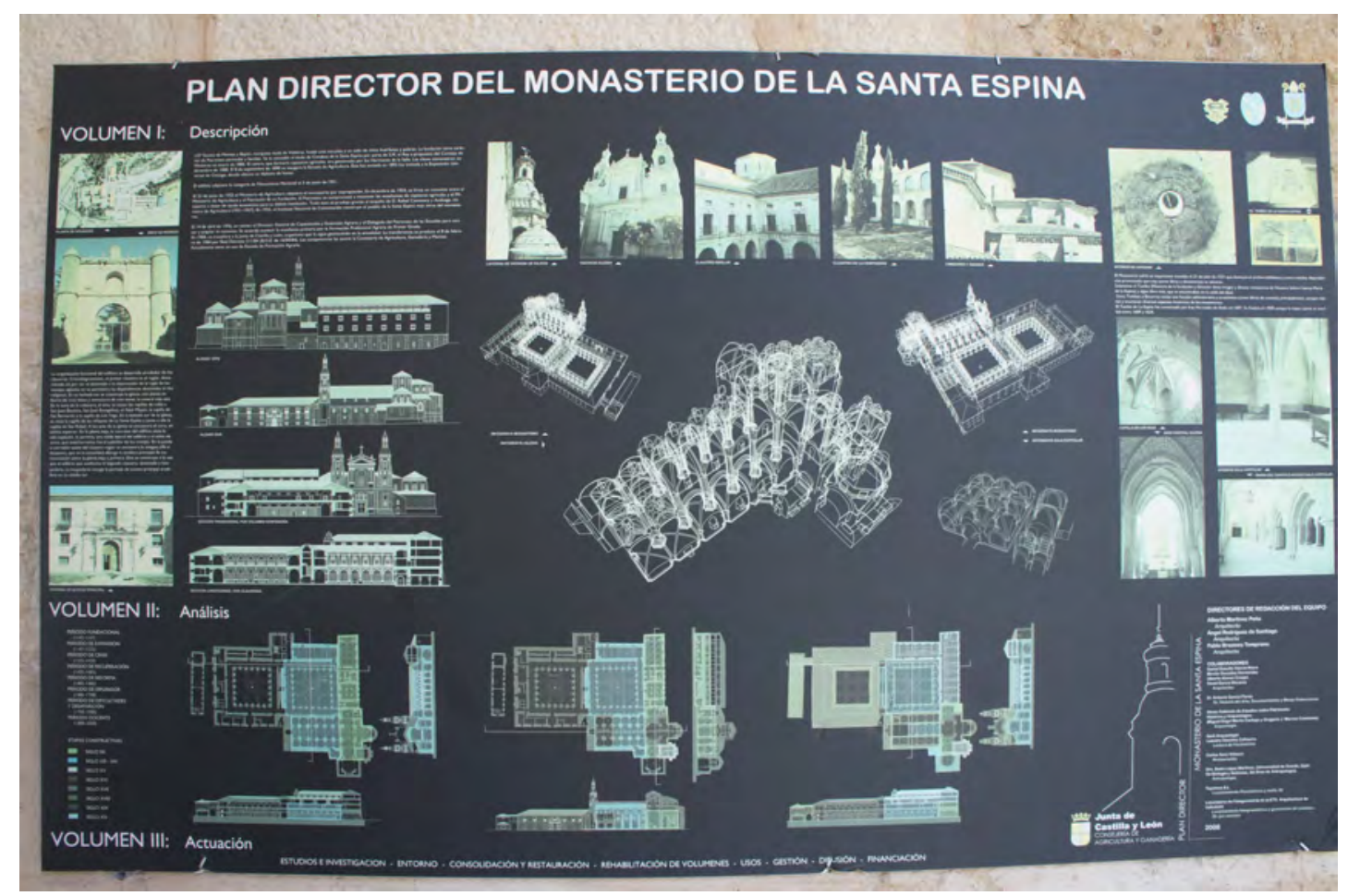

Ilustración 12: panel informativo del Plan Director 2008 
En el edificio hay un panel informativo en el que se describe el Plan Director de 2008, dirigido por los arquitectos Alberto Martínez Peña, Angel Rodriguez de Santiago y Pablo Brezmes Temprano. Figuran colaboradores y equipos de Lectura de paramentos y Fotogrametría.

El edificio es Monumento Nacional desde 1931. En 1890 se inaugura en el mismo la Escuela de Agricultura, y es propiedad del Ministerio de Agricultura desde su expropiación en 1953.

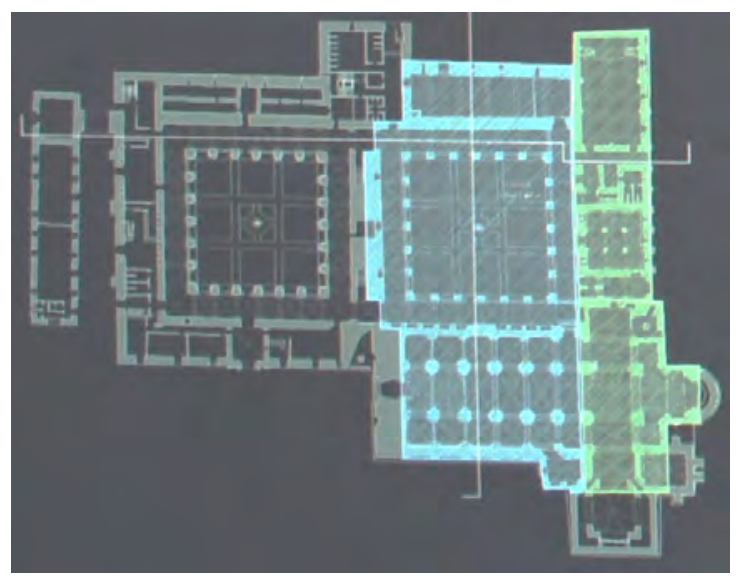

En el panel se señalan 8 periodos:

fundacional 1143-1147

expansión 1147-1225

crisis

$1225-1420$

recuperación 1420-1485

reforma $1485-1486$

esplendor $1486-1708$

dificultades 1708-1888

docente $\quad 1888-2008$

Ilustración 13: detalle fases constructivas

Se marcan las etapas constructivas, con lateral hacia el este, cabecera y crucero del templo levantados hacia el siglo XII, cuerpo de la iglesia y claustro adyacente XIII$\mathrm{XIV}$, y resto del conjunto edificado con posterioridad.

El conjunto se organiza alrededor de dos grandes claustros. La iglesia es de tres naves, la central más alta. En la fachada sur se ubica la capilla que alberga las reliquias de la Santa Espina.

En la sección Licitaciones de la página web de la Junta de Castilla y León puede descargarse en pdf:

Proyecto de Restauración de Cubiertas "Centro de Formación Agraria La Santa espina". Enero de 2010.

Arquitectos: Alberto Sáinz de Aja, José Manuel Barrio y José Isidro Cameno.

Según la Memoria, el proyecto se redacta porque la cubrición del edificio de teja árabe, con canal y cobija, presenta numerosas piezas desplazadas y rotas debido a las inclemencias meteorológicas.

Hay un edificio destinado a aulas externas que ha sido recientemente rehabilitado. 
Se pretende renovar la totalidad de las cubiertas del conjunto con teja similar, montada en seco sobre rastreles de madera manteniendo las pendientes actuales. Se propone eliminar las bajantes y canalones en ambos claustros. En las zonas residenciales se dispondrá aislamiento de $8 \mathrm{~cm}$ de poliestireno extruido (señaladas con trama en el plano).

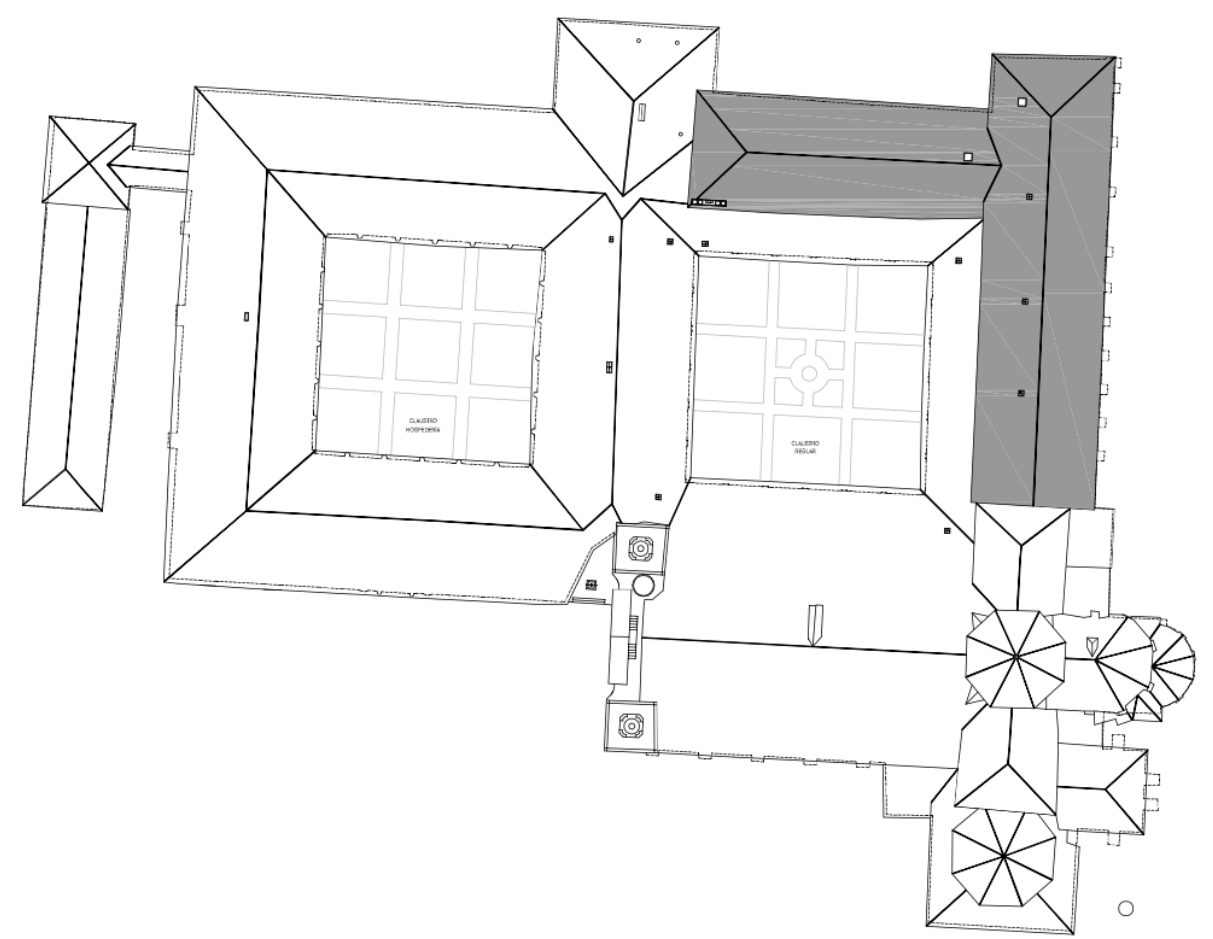

Ilustración 14: planta 2010 Sáinz de Aja y otros

Las actuaciones se corresponden con los principios del Plan Director.

Deficiencias detectadas:

Desplazamientos de hiladas generando zonas descubiertas

Incorrecta impermeabilización en determinados puntos (limas, remates, bordes...)

Acumulación de palomino en distintas zonas

Presencia masiva de suciedad y vegetación en determinados puntos.

El proyecto no afecta a la estructura del edificio ni a las fachadas. Se mantendrá el soporte de la teja existente reparando parcialmente zonas en mal estado para recuperar la planeidad.

Presupuesto:

Reemplazo de $6.275 \mathrm{~m} 2$ de teja cerámica curva y 4 ud de carpintería exterior.

Incluye $1.950 \mathrm{~m} 2$ de reparación de capa de compresión dañada, incluso picado del hormigón deteriorado, relleno con mortero de cemento y terminación con llana.

Limpieza y rejuntado de chimeneas y colocación de pararrayos. 
El proyecto contiene 5 planos.
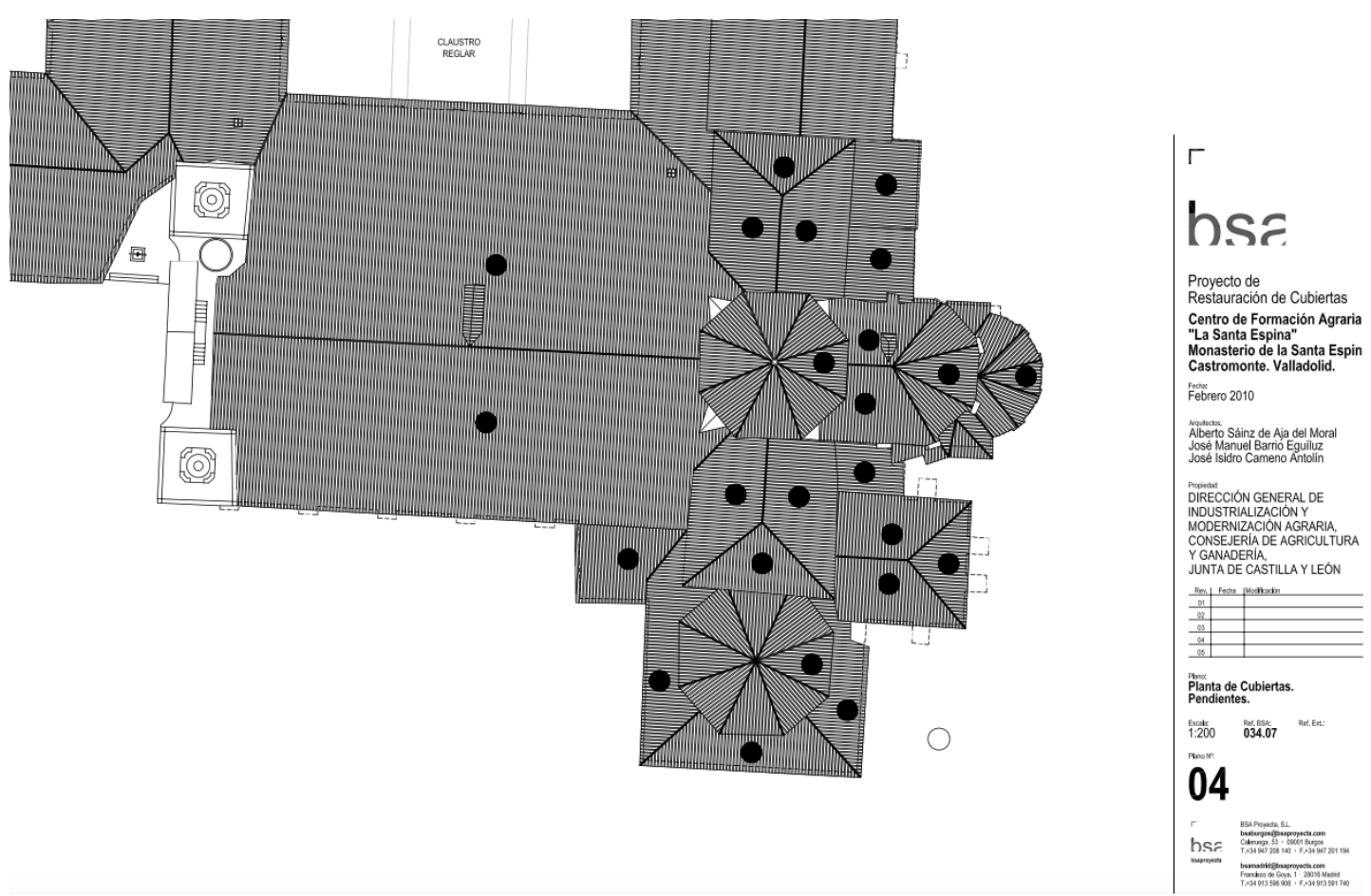

Ilustración 15: planta cubiertas 2010 Sáinz de Aja y otros

Detalle constructivo:

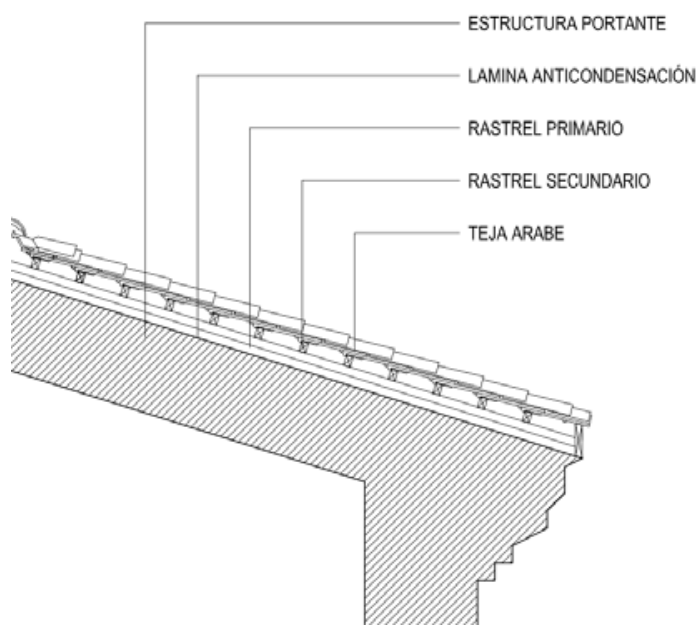

Ilustración 16: detalle 2010 Sáinz de Aja y otros

\section{Plan Director}

Durante la visita al Monasterio se consulta la copia del Plan Director que se conserva en el edificio. El documento se divide en tres tomos: 
I. Planos de planta, alzados y secciones. Perspectivas de líneas producto del levantamiento.

II. Análisis y diagnóstico

III. Propuestas de actuación

Se describe cómo el conjunto monacal se desarrolla alrededor de los dos claustros, el primero reglar con la iglesia adyacente al lado sur. En la cabecera de la iglesia se sitúan las capillas de San Juan Bautista, San Juan Evangelista, San Bernardo y de Los Vega. Hacia el sur se adosa la capilla de las reliquias de la Santa Espina y de San Rafael, esta última con los restos del mentor de las actuaciones del siglo XX Rafael Cavestany.

El edificio alberga aulas de la Escuela de Capacitación Agraria y residencia de internos, con comedores, biblioteca y sala de juegos. El internado es gestionado por la Comunidad religiosa Hermanos de la Salle.

En un disco incorporado a la caja hay documentación adicional no impresa en la copia consultada. Se trata de listados de documentación relacionada con el Monasterio (pleitos, juros, etc) en los archivos de Chancillería, Histórico Provincial, General de Simancas. También transcripciones del libro Tumbo, la única obra de la biblioteca original que se salvó en el incendio de 1731.

En la transcripción del Tumbo podemos leer:

"Reedificacion deste monasterio

Año de 1275. Siendo Sumo Pontifice Gregorio decimo, Emperador de Alemania Rodulfo, Reynando en España Don ALonso decimo llamado el Sabio, siendo Abbad perpetuo desta casa Don Abril, el muy ilustre cavallero Don Martin Alfonso hijo de Don Alfonso Tellez de Alburquerque (que edifico a Palaçuelos) començo a labrar a su costa esta yglesia; y prevenido de la muerte no la pudo acabar, por lo qual mando a sus testamentarios la acabassen a costa de sus bienes; y alcanço licencia del Rey Don Sancho 4o el brabo (que Reinaba en Castilla quando Don Martin hizo su testamento) para que le diessen sepultura en la capilla mayor de la dicha yglesia, y el Abbad y convento le hizieron escriptura dello, y le dieron el renombre de patron della como consta por su testamento retro escripto.

Don Juan Alfonso de Alburquerque hijo del infante de Molina sobrino de Don Martin acabo el edificio de la dicha yglesia y hizo los claustro y oficinas y dormitorio viejo de los bienes que para ello quedo por su testamento Don Martin (segun se collige) por que darle sepultura en la capilla mayor, fue por la martiniega de Villa Garcia y tercias de Grajal que dio a este monasterio segun se 
collige de la executoria de las dichas tercias dadas contra Juan Rodriguez de Escobar (...)

Si el dormitorio viejo se hizo despues de la yglesia (como es verosimil) estuvo el convento en la primera habitacion 166 años, poco más o menos.

(fol.66r-no109

2a reedificacion de la capilla mayor desta yglesia despues de la que hizo Don Martin Alfonso.

Año de 1546 nuestro Reverendo padre fray Lorenço de Horozco siendo Abbad desta Sancta casa y general Reformador hizo derribar la capilla mayor que Don Martin Alfonso avia hecho por ser algo escura y pequeña conforme al cuerpo de la yglesia. Començose a hazer luego de nuevo a costa deste monasterio la que al presente permanece y es el Retablo de alabastro. Hizieronse tambien las dos capilla collaterales de San Joan Baptista y San Juan Evangelista, y la de nuestros padres San Benito y San Bernardo (que son las imagines y figuras de los mismos santos que tuvieron ambos altares al principio de su fundacion) y el zimborrio del cruzero. Acabose todo en doze años que fue el de 1558.

(fol.66v-no110)

Consagracion de la capilla mayor y altares.

Año de 1560 siendo Abbad el padre fray Geronimo de Montesa se consagro esta capilla mayor, y las dos collaterales de San Juan Baptista y Evangelista y la de nuestros padres San Benito y San Bernardo, y la del crucifixo que esta cabe la red, consagro la dicha capilla y altares un obispo de Salamanca

(fol.67r-no111)"

\section{Transcripción del Libro de Obras}

"LIBRO DE OBRAS QUE EMPEZO EL AÑO DE 1735, SIENDO ABAD DE ESTE MONASTERIO EL PADRE MAESTRO FRAY MANUEL PORTOLES, HIJO DE ESTE MONASTERIO. ( A.H.N., Clero, Libro no 17948 Transcripción de Antonio García Flores.

(Fol 1r) Abriose la obra en veinte y dos de marzo de 1735 y se trabajo sin cesar asta diez y seis de diciembre. Repararonse la bobedas, que pudieron servir del Claustro de la Hospedería, hechandoles por arriba estribos, zinchos, recinchos y lechadas; hecharonse doze bovedas nuebas y se guarnecieron de nuebo todas las bobedas y se blanquearon estas y todo el Claustro: Embaldosaronse los dos lienzos de la Sala de Invierno y de la escalera. Hizose la Sala de Invierno y Zelda del Compañero. Hicieronse las despensas alta y baja, zerraronse las puertas la que subia a la cocina, la que mira a la huerta, y la que servia para entrar a la antecocina y en estas dos ultimas y en la bentana de la despensa baja, que mira al 
claustro, se echaron rejas. Abriose una puerta para comunicacion de la antebodega con las bobedas de la panera. Deshizose y se bolbio a hazer de nuebo la escalera que esta fuera del cuarto del Norte, hizose nueba la pared y escalera de piedra que sube desde la panera a la Cocina y Claustro. Hizose todo el Cuarto del Norte sobre la Panera y en el La Sala de Verano con sals, antesala, dos alcobas y lazena: Una celda de hospederia con dos alcobas y lazena: celda para el cillerero con cuerpo de zelda, estudio y alcoba y una sala para la cillerera para la cual se abrio puerta en la pared maestra que divide el lienzo del norte de el de poniente, y lo correspondiente a la cillereria se le añadio abajo a la panera. En el lienzo de poniente se pusieron para las dos terceras partes del piso veinte y seis vigas que se cubrieron de sobradiles medieros; hizose una escalera de madera que baja al Estal $\mathrm{y}$ se hizo un quarto grande para los cocineros y criados; quedaron hechas bobedillas correspondientes a dos celdas para hospederia. deshizose y se bolbio a hacer de nuevo el arco de la puerta de la Iglesia, subiendoles tres quartas, hizose el pavimento y la calzada de guijarro que coje desde dicha puerta toda la fachada de la casa asta los arcos; hizose de nuebo la mesa del altar de la Santa Espina."

15-IV-1764 = 15-Iv-1765

Hospederia

Yglesia Retejo.- Recorriose toda la Yglesia, quitando las goteras y para esto se compraron mil y quinientas tejas a noventa y quatro reales el millar importan ciento y quarenta y un reales. A un oficial que andubo veinte y un dias a cinco reales cada dia importan ciento y cinco reales.

15-IV-1765 = 15-IV-1766

(Fol 101v) Retejo.- Recorriose la Iglesia, quitando las goteras y para esto se compraron mil y quinientas tejas a noventa y seis reales el millar importan ciento y quarenta y quatro reales; y a un oficial por diez y seis dias a cinco reales cada dia llebo ochenta reales. Dos peones para llevar materiales a dos reales y medio cada uno por dia importan ochenta y todo 304.

(Fol 128v)

Carpinteros.- Para deshacer los texados, hacerlos de nuevo, echar piso de madera a todos los lienzos del Claustro Reglar, desarmar los de la Yglesia, Sacristia y Dormitorio, y volverlo a armar, cortar las maderas de los Sotos para ello, y componerlas, y hacer andamios, estuvieron trabajando ocho carpinteros, y ocuparon en esto quatrocientos y veinte dias a seis reales de jornal uno con otro que ymportaron veinte mil ciento y sesenta reales. " 
Diagnóstico: describe los procesos patológicos más importantes.

Desplazamiento de la cobertura de teja hacia la zona inferior de los planos de cubierta por deslizamiento de las placas tipo "bajo-teja" por gravedad, dejando al descubierto la línea de cumbrera de forma generalizada

Escalera de acceso al campanario desplomada

Zonas de planta baja con humedades por capilaridad

Sistema de evacuación de pluviales en claustros deficiente

El rejuntado de mortero de cemento que se generalizó en la actuación de 1953 y posteriores intervenciones daña el estado de la piedra.

Vegetación

Suciedad: palomino

Carpintería exterior de claustros (en la actualidad ha sido renovada)

Lista de últimas obras realizadas:

STOA Construcciones y Rehabilitaciones SL

2005 Arq: Pablo Berzmes

Colocación de canalón y bajante de cobre en fachada este

2007 Arq: Alberto Martinez, Angel Rodriguez y Pablo Brezmes

Zanja de drenaje perimetral y solera en sala capitular

Restauración de Sacristía

Sustitución de carpinterías en claustros 



\section{Visitas realizadas}

28/04/2015

El estado de conservación del conjunto monumental es bueno, sin duda debido a su uso habitual como centro de formación agraria y comunidad monástica.

El hermano Satur actúa como guía durante el recorrido por las bóvedas. Explica las etapas constructivas del edificio y cómo se modificaron sustancialmente las cubiertas de la iglesia para homogeneizar, dentro de lo posible, los volúmenes que forman las dos aguas a ambos lados del eje central de la misma. El faldón hacia el interior se prolonga, más allá de la nave del evangelio, para cubrir los dormitorios ubicados en la planta superior incorporada a la panda del claustro adyacente al cuerpo del templo.

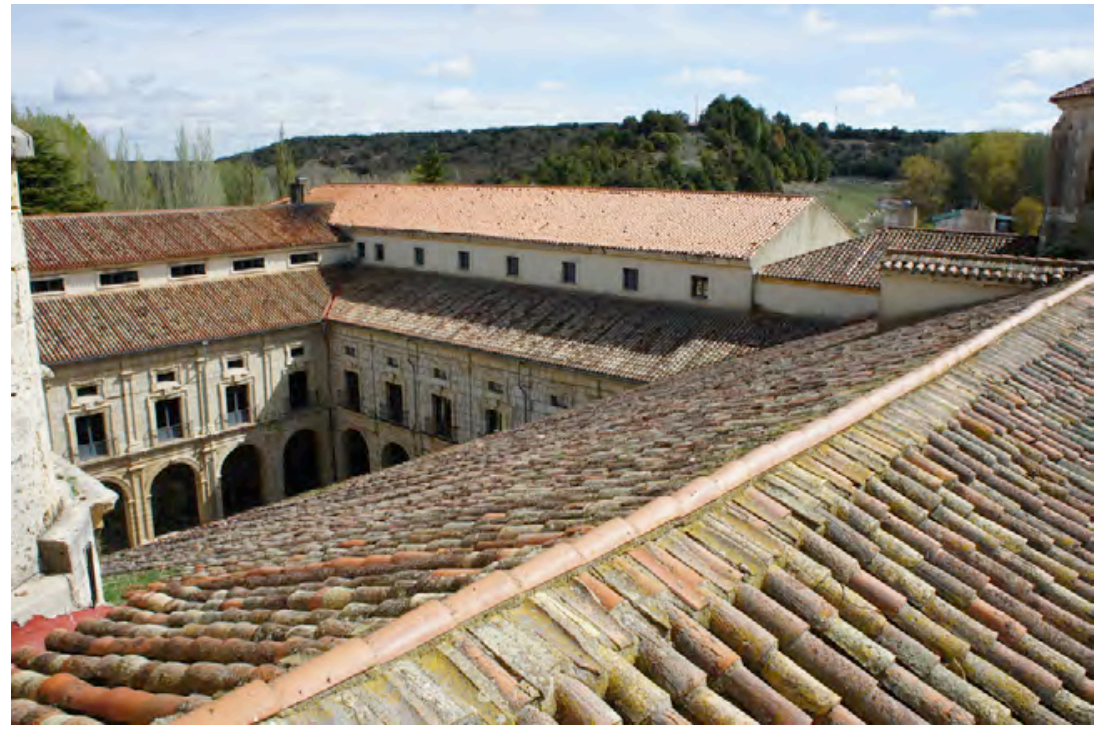

En la imagen desde la cumbrera, sobre la nave central a los pies, se aprecia la zona de cubierta cuyo revestimiento de teja se encuentra aparentemente en peores condiciones, precisamente objeto de una restauración reciente.

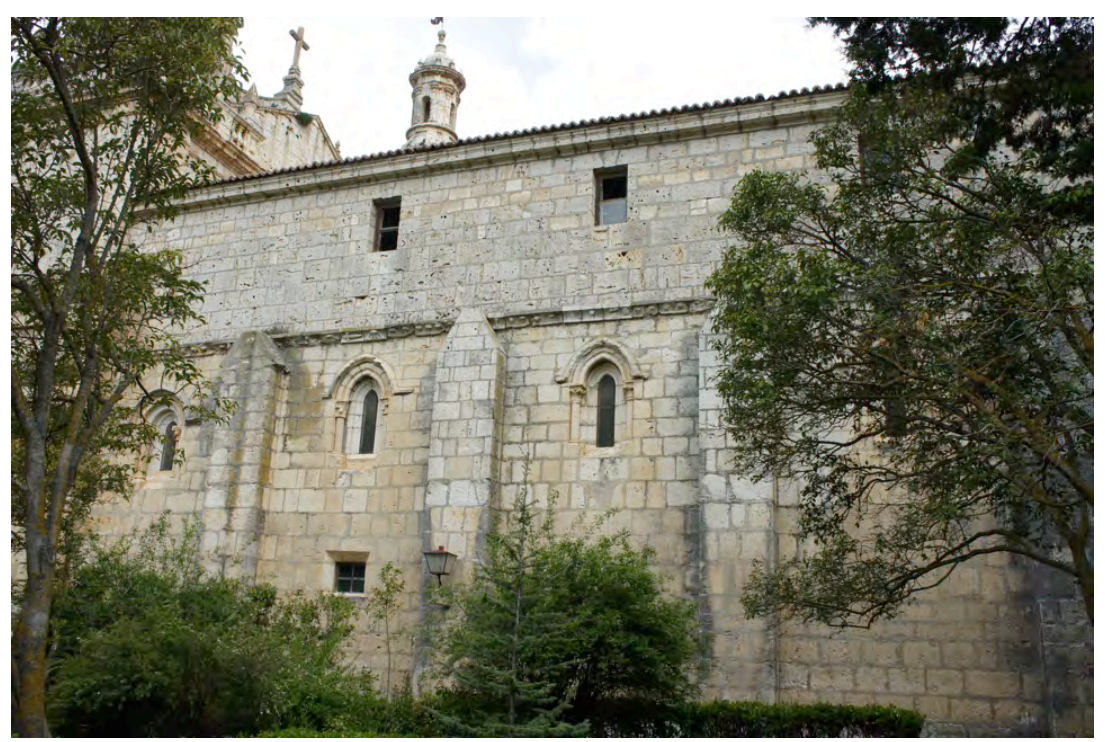


En la fachada exterior de la iglesia podemos leer sobre el paramento la etapa constructiva en que se elevan las naves laterales, con diferente despiece de sillares a partir de una imposta sobre la que aparecen labrados detalles al parecer de los años 50 (como el símbolo de un conocido equipo de futbol gallego).

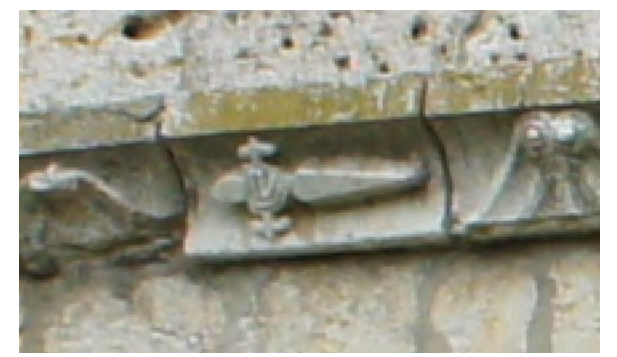

El acceso al espacio sobre las bóvedas de ambas naves laterales se realiza desde el coro alto. El cerramiento que separa el bajo cubierta de la nave del evangelio de la zona residencial del claustro está ejecutado con fábrica de ladrillo hueco doble con unas hiladas de ladrillo hueco sencillo.

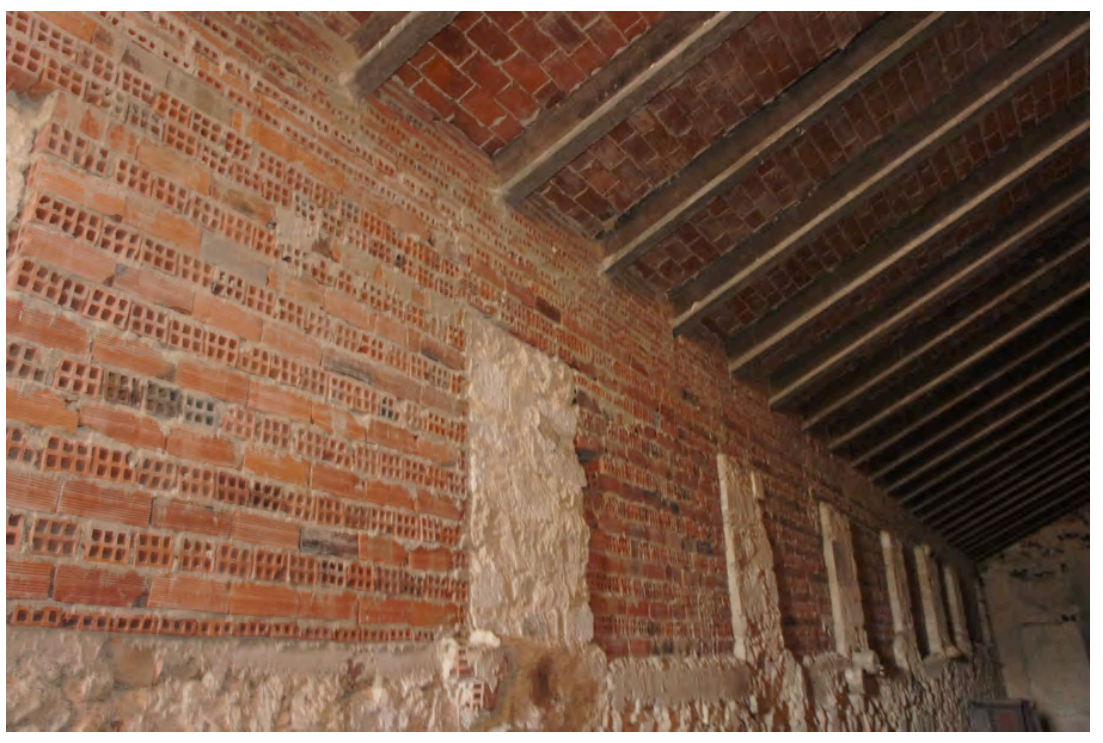

La estructura de cubierta se resuelve con jácenas prefabricadas de hormigón en doble T. No se aprecia la existencia de zunchos de reparto bajo estos elementos y, aunque dado el espesor del muro podrían haberse dispuesto en el interior del mismo, no parece probable que se adoptase una solución semejante para revestirla con ladrillo hueco. El entrevigado es de rasillas.

El muro que separa la nave central y la lateral también muestra el mismo tipo de recrecido de fábrica de ladrillo hueco sin zunchos a la vista.

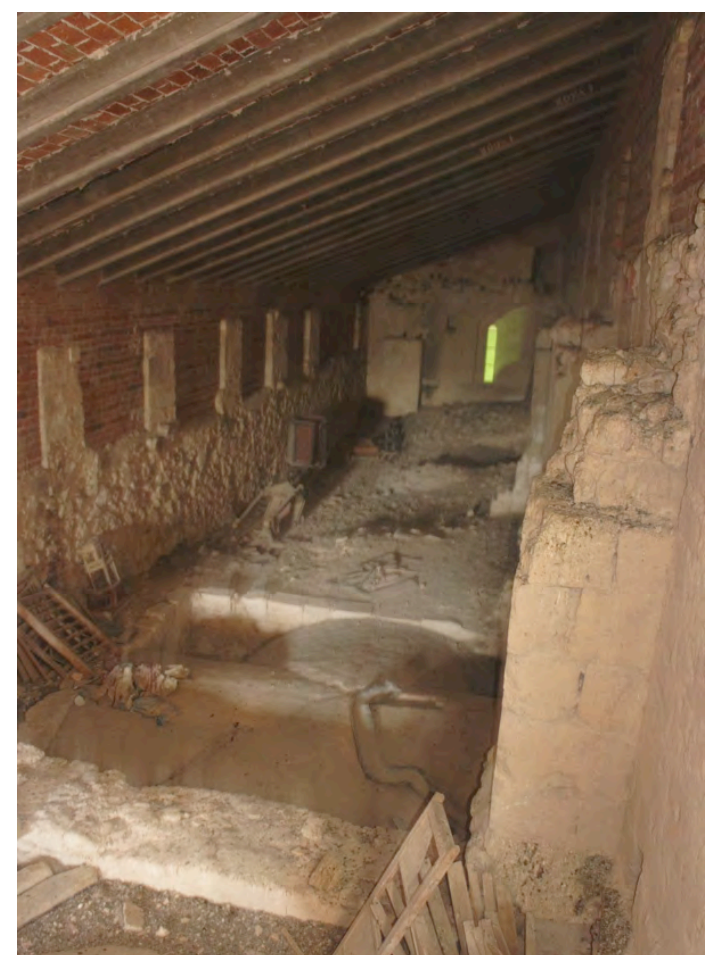




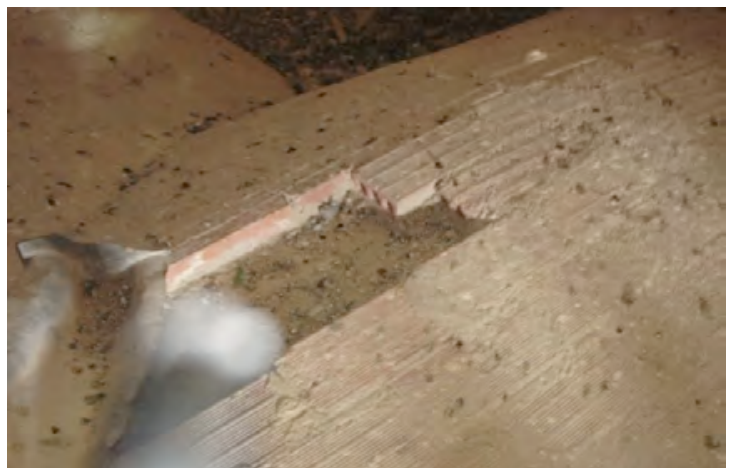

Encontramos bóvedas de distintos materiales, piedra, ladrillo, vistas $\mathrm{y}$ revestidas.

En la imagen se aprecia la falta de algunas piezas en una bóveda moderna resuelta con ladrillo hueco.

La fachada lateral de la nave de la epístola, que aparece con sillares perfectamente escuadrados en la imagen de la página anterior, cuenta hacia el interior con contrafuertes resaltados. En la coronación se dispone un zuncho de hormigón armado sobre el que se remata el paramento con ladrillo hueco. Este zuncho no se prolonga en el testero de piedra a los pies.
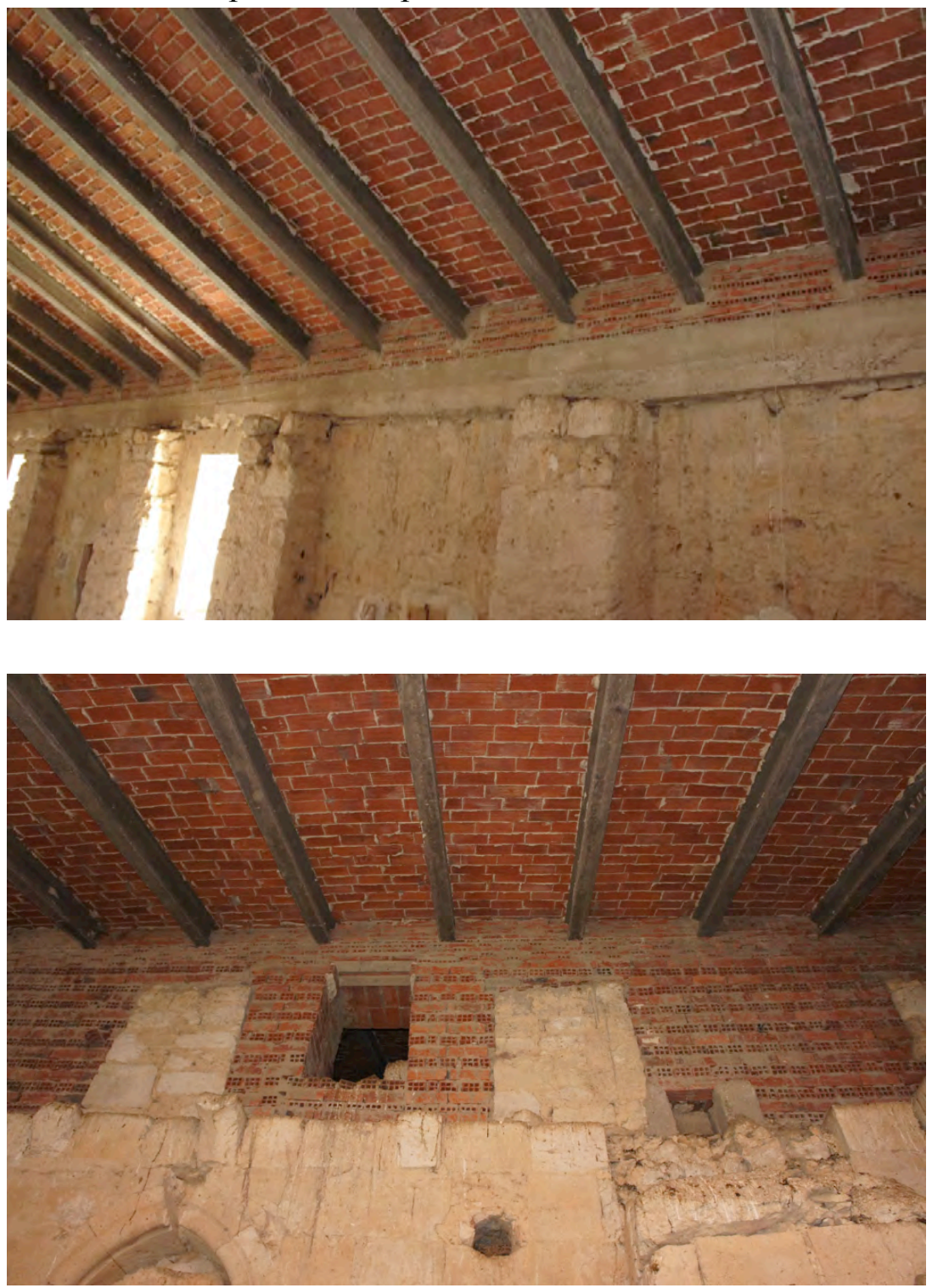
El muro entre este lateral y la nave central también se recrece con ladrillo hueco sin zuncho aparente.

La estructura de cubierta de nave central es también de hormigón, en este caso a dos aguas, con entrevigado de rasilla. El encuentro de las jácenas en cumbrera se rigidiza con unos dados de hormigón, de los que pende un cable hasta los tirantes de acero. Entre los dados se dispone una viga rigidizadora también de hormigón armado.

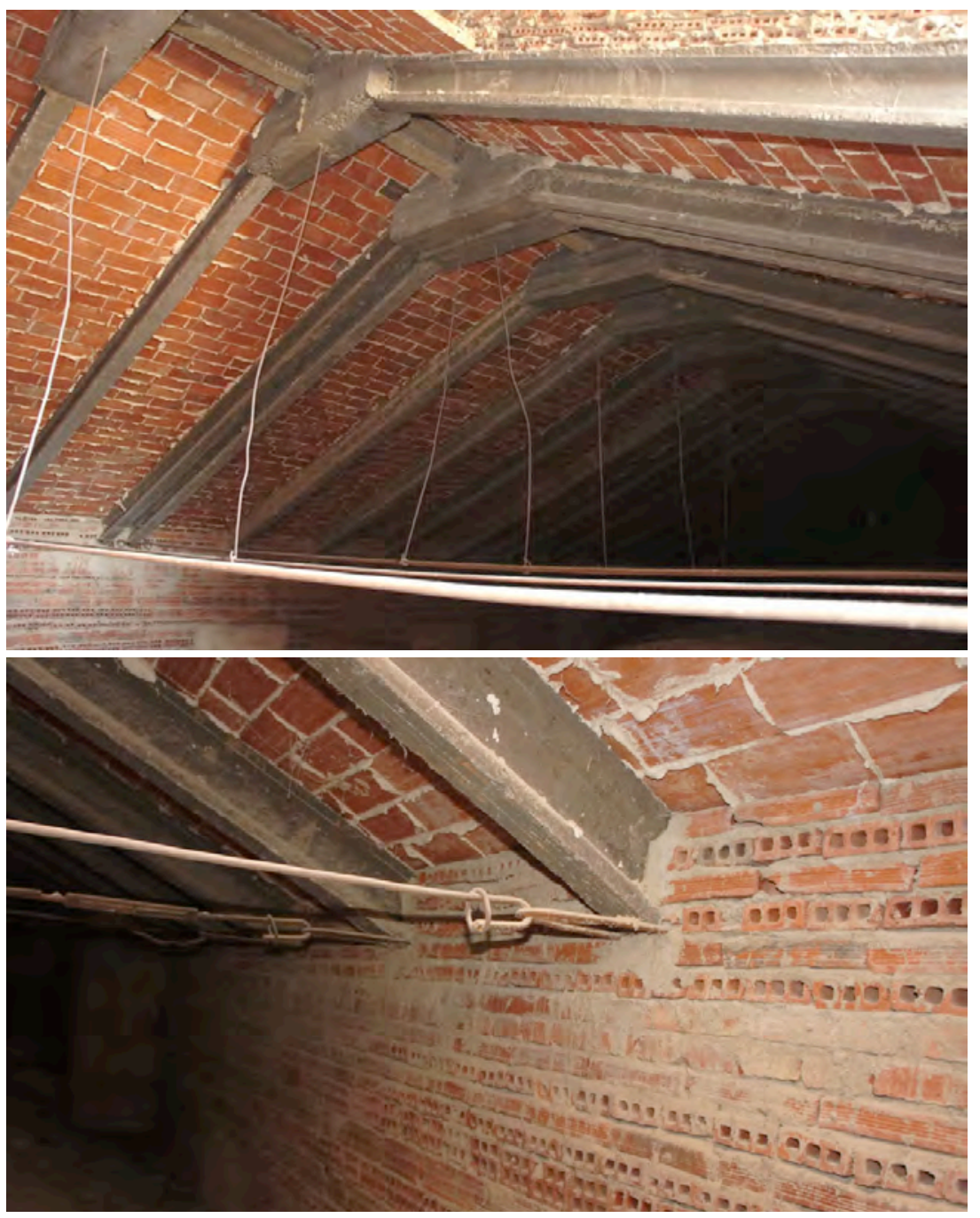

Los tirantes se engarzan con otras piezas dispuestas en el arranque de las vigas y cuentan con tensores.

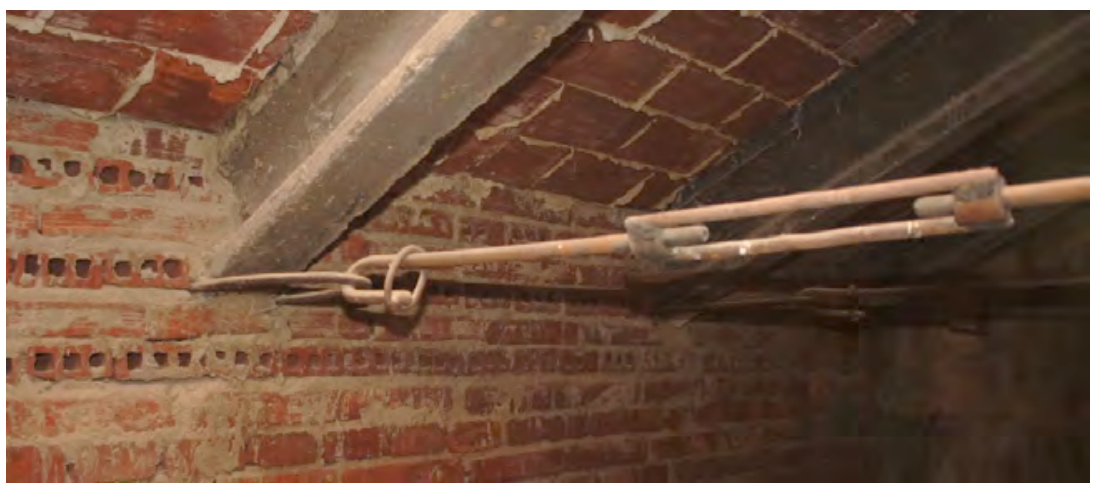


Durante la visita se recorre otras zonas del Monasterio reformadas en la misma época, como la cubierta almacén sobre las cocinas, otra panda del claustro y la escalera monumental, que también cuentan con vigas prefabricadas de hormigón grandes y pequeñas con distintos tipos de cumbreras in situ. En algún caso aparece una especie de zuncho de hormigón en el apoyo de las correas.
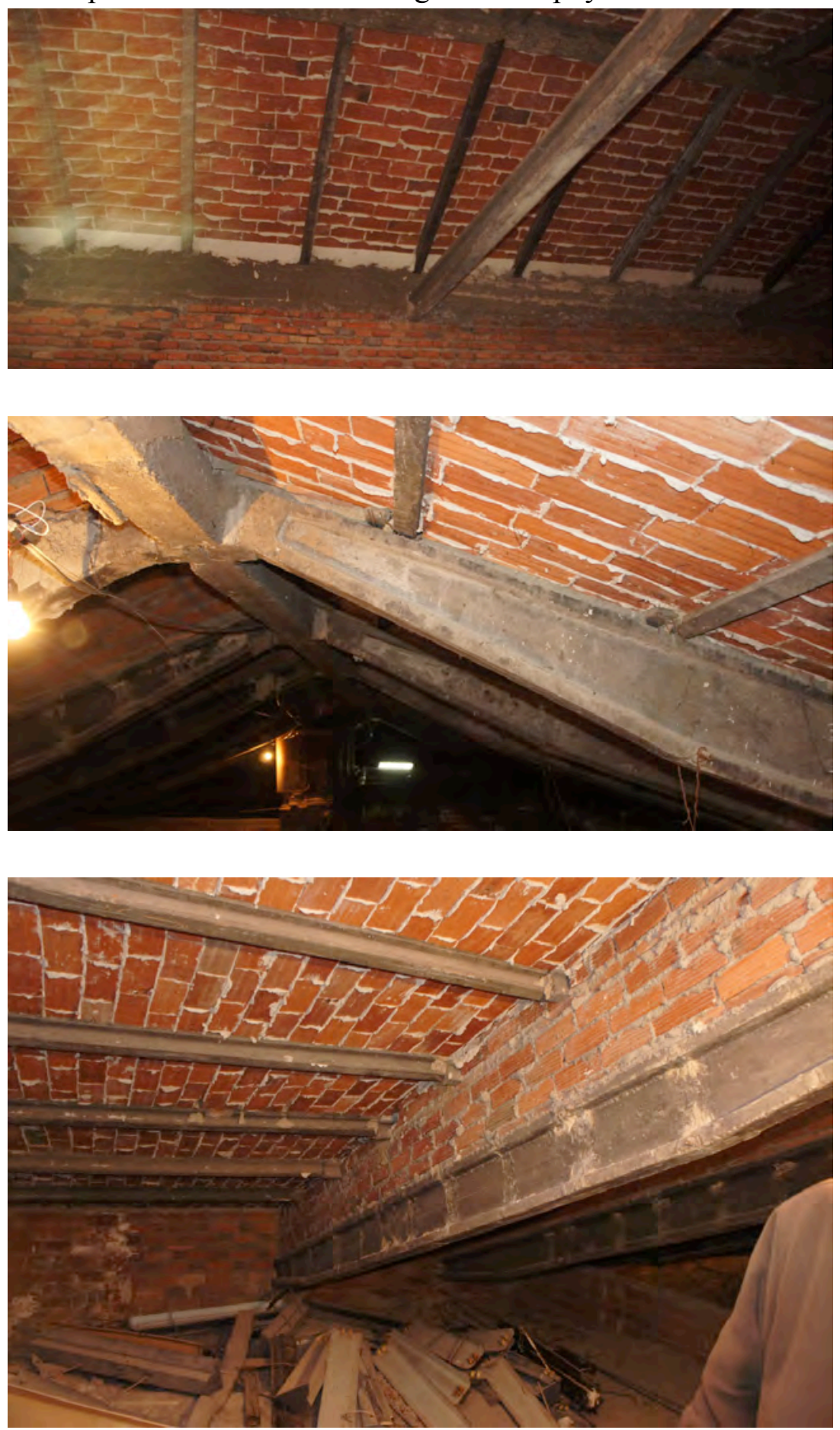

No ha sido posible acceder al bajo cubierta de cimborrio y cabecera. 

Iglesia de Santa María del Castillo

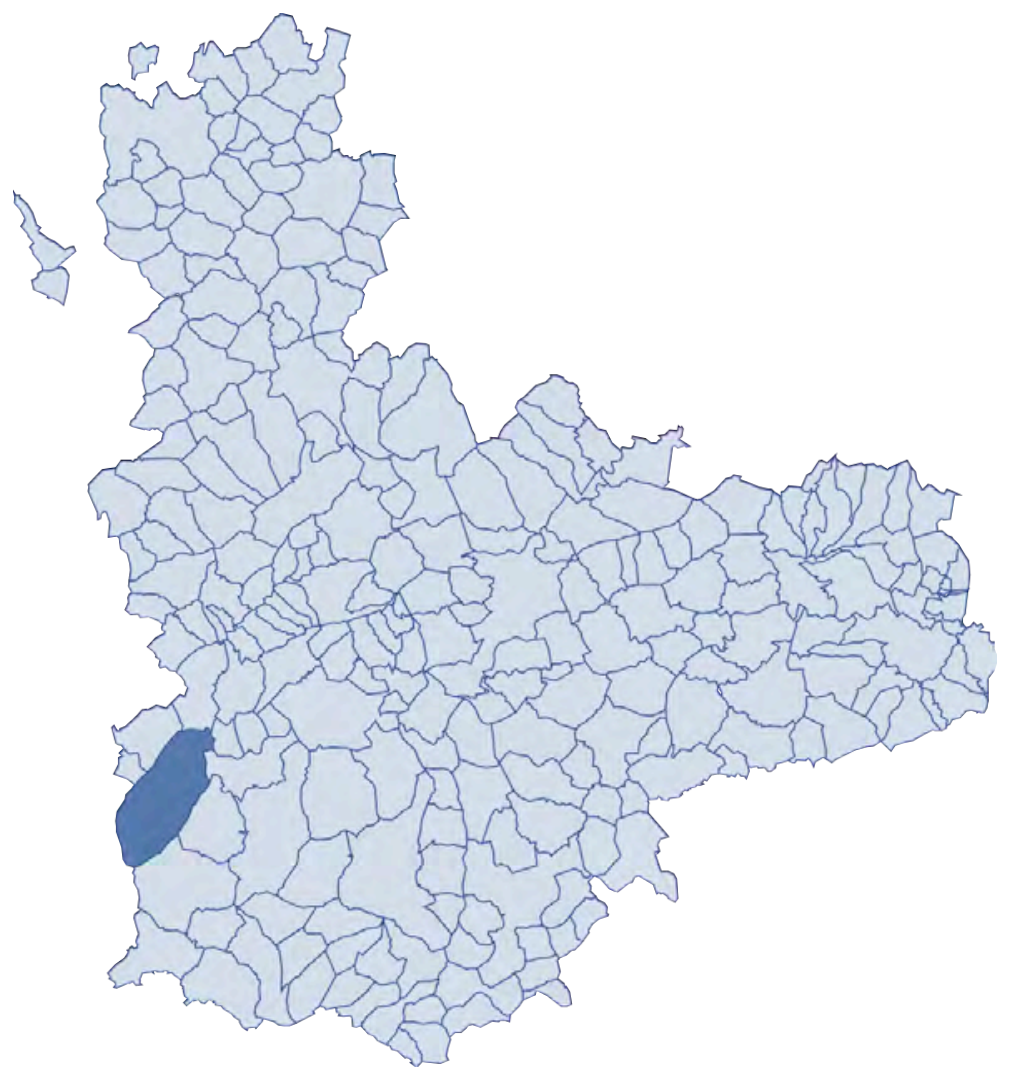



FICHA SÍNTESIS

Código de identificación: FZ-20

Denominación:

Iglesia de Santa María del Castillo

Localidad:

Castronuño

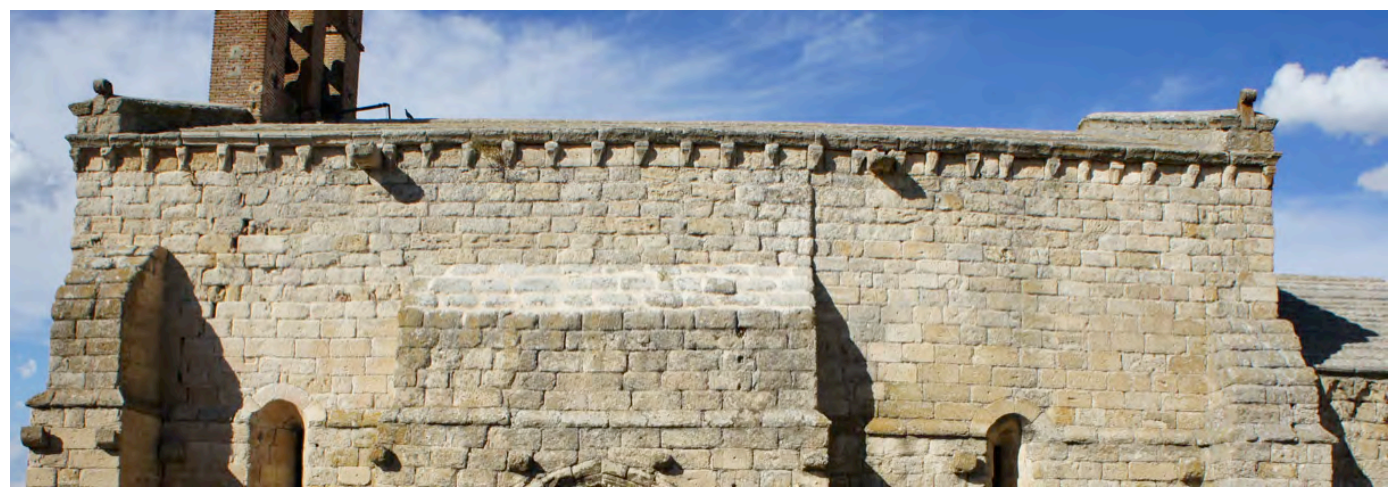

\section{Descripción}

Iglesia fortificada de una sola nave con dos tramos y presbiterio recto. Se cubre con bóvedas de crucería y, en la cabecera, de cañón apuntado rematado en semicírculo, con cubierta de horno.

Muchos de los huecos están cegados. Sobre la portada a los pies se alza una espadaña de ladrillo y en el lado norte de la cabecera se adosa la sacristía, de ladrillo y mampuesto cubierta con una cúpula.

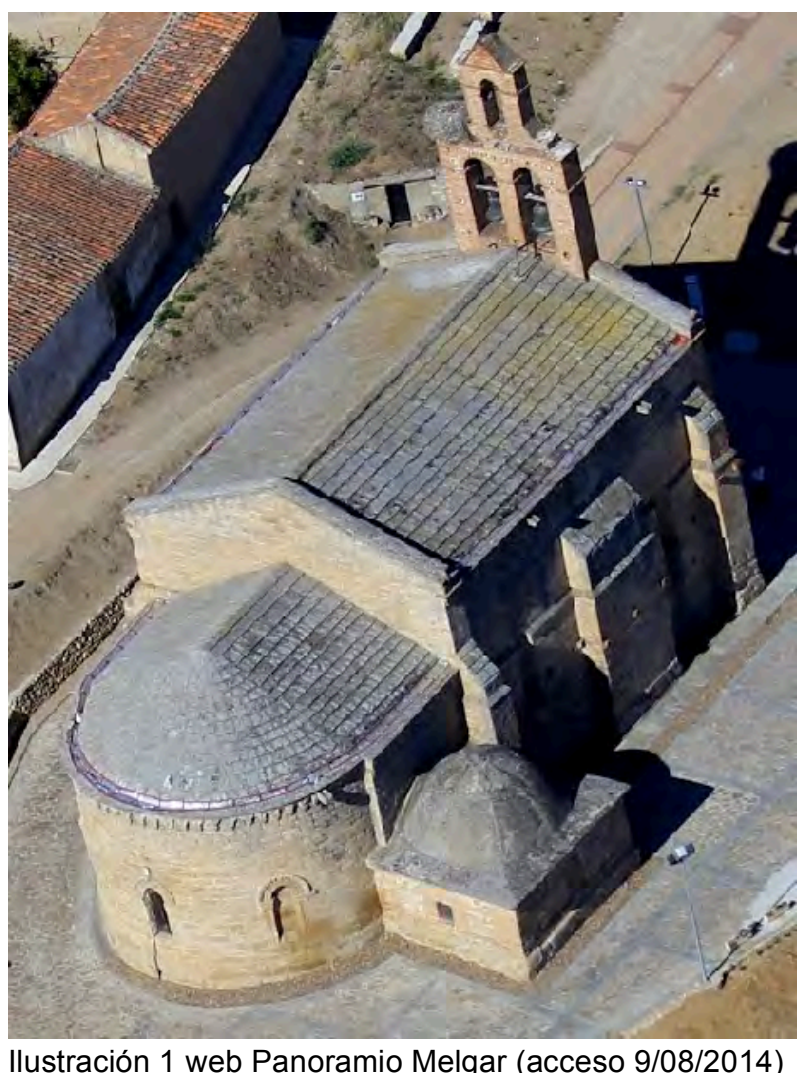

\section{Materiales}

Los muros son de sillería con robustos contrafuertes. Las cubiertas a dos aguas de nave y cabecera están recubiertas con lajas de piedra, mientras que la cúpula de ladrillo de la sacristía parece revestida con mortero. 


\section{Singularidades}

Según el Catálogo, la primitiva iglesia de Santa María del Castillo era un templo de tres naves que se arruinó definitivamente en 1919.

La edificación BIC conocida actualmente con ese mismo nombre es una construcción románica, de comienzos del siglo XIII, denominada originalmente iglesia de San Juan Bautista o Ermita del Cristo y readaptada al uso de iglesia parroquial.

\section{Dimensiones básicas del templo}

$\begin{array}{llll} & \text { central } & \text { laterales } & \text { capillas } \\ \text { Ancho de nave } & 9,5 & - & - \\ \text { Altura } & 11,0 & - & -\end{array}$

\section{Memoria histórica constructiva}

El monumento se levantó a principios del siglo XIII, abriéndose poco más tarde la portada oeste y el rosetón. Algunas fuentes apuntan que los sillares de piedra provienen de la fábrica de un antiguo castillo (Catálogo), según otras (proyecto de Arenillas 1963) se trataba en origen de la capilla del mismo. El profesor Castán afirma, sin embargo, que se trata de una construcción funeraria del prior Fernán Rodríguez de Valbuena y la data entre 1323 y $1333^{1}$.

En algún momento se adosa el volumen de la Sacristía (aún se aprecia la ventana de la cabecera cegada)

En 1798 se ordena incrementar el vuelo de cornisas de la Sacristía y reedificar la espadaña que se encontraba sobre el arco toral disponiéndola en su actual posición a los pies (Catálogo), aunque según la Enciclopedia web Románico Digital está fechada en 1910.

El coro es contemporáneo, con estructura de vigas de cuelgue y losa maciza de hormigón armado.

\footnotetext{
${ }^{1}$ Castán, J. (2006). El buen prior Fernán Rodriguez de Valbuena y la Iglesia funeraria de San Juan Bautista en Castronuño (Valladolid). Codex Aquilarensis, (22), 175-190.
} 

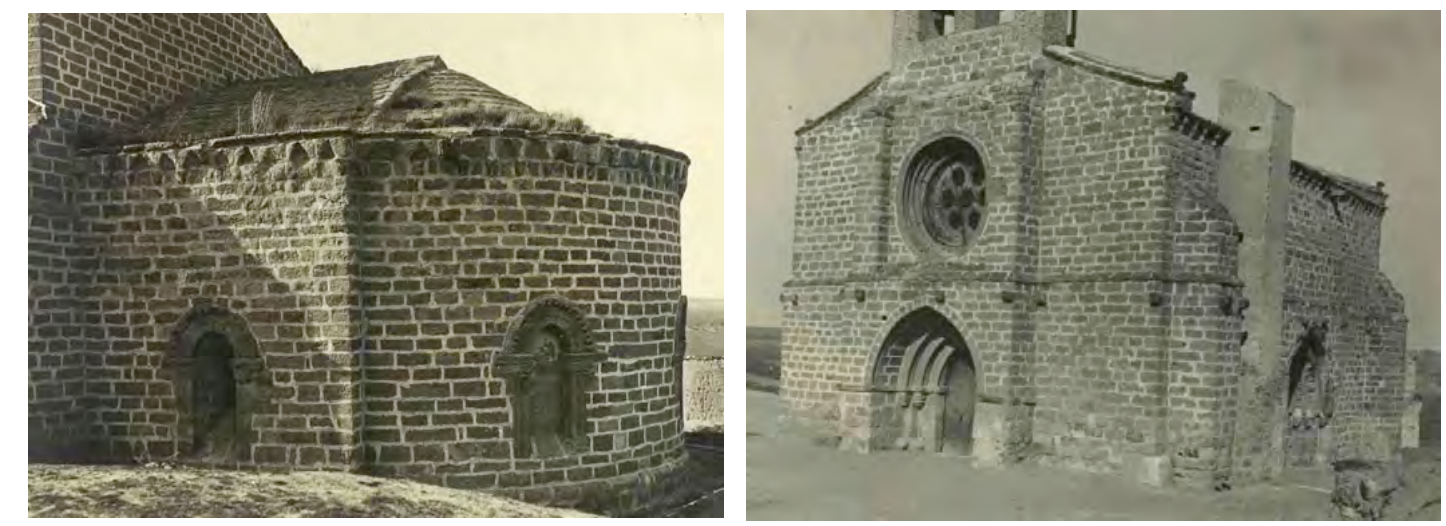

Ilustración 2: Casaseca (facsímil CSIC)
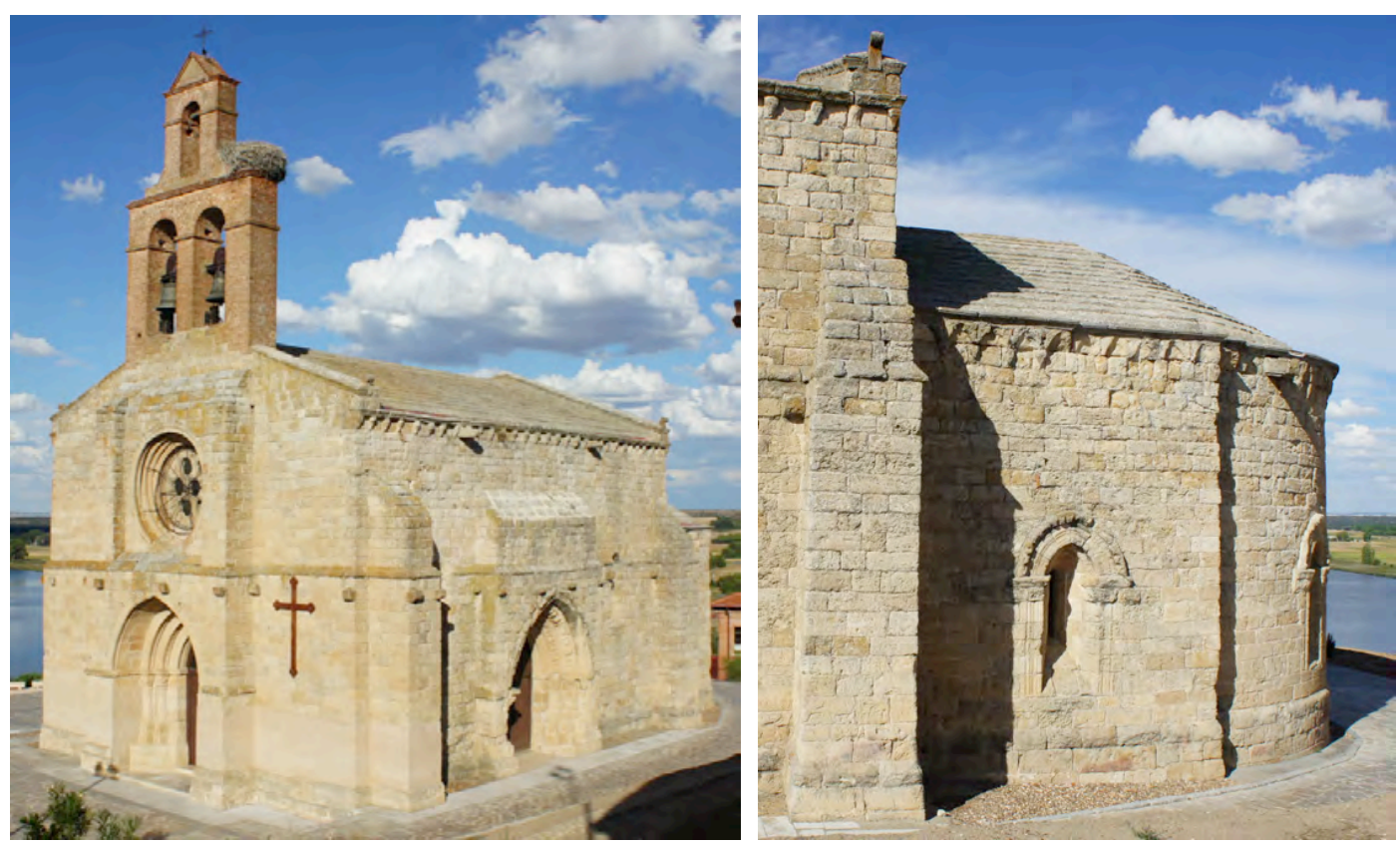

Ilustración 3: vistas actuales (visita 13/09/2014)

Cronología. Fechas clave

$1323-1798-1965$

\section{Intervenciones}

1962 - Anselmo Arenillas

En la carpeta archivada sólo hay dos planos sueltos: planta acotada y planta esquemática de faldones de cubierta. 
1963 - Reparación de la Iglesia Parroquial - Anselmo Arenillas

Se levanta el trasdosado de losas y lajas de piedra, recibido con tierra sobre las bóvedas, que forma los faldones de cubierta, para colocar doble tablero de rasilla sobre tabiquillos de LHD cada $50 \mathrm{~cm}$, reponiendo las losas sobre tendido de mortero de cemento, complementando con piedra nueva las que faltan.

1965 - Restauraciones - Anselmo Arenillas

Se rebaja $25 \mathrm{~cm}$ el nivel general del terreno alrededor de la iglesia para evitar humedades.

1966 - Proyecto de terminación de la restauración de la iglesia románica de Castronuño - Anselmo Arenillas

En el proyecto se describe cómo la restauración se plantea en dos fases. En la primera se reconstruye la cubierta y eliminan construcciones adosadas. En la segunda se pretende incrementar el rebaje del terreno para mejorar el desagüe, chapar zócalos, renovar carpinterías y demoler el coro de hormigón.

No podemos confirmar la ejecución de este proyecto ya que en la intervención siguiente siete años más tarde se plantean de nuevo las mismas propuestas: sustitución de vidrios, demolición del coro, etc.

1973 - Proyecto de obras de restauración - Ana Iglesias

Se trata de repasar la cubierta en la zona del presbiterio, con goteras debido a movimientos de las losas. Se pretende incorporar un acceso al tejado para propiciar que se realicen labores de mantenimiento, añadir revestimiento cerámico a la cúpula y chapado de zócalos con piedra.

Tampoco podemos confirmar la ejecución de las obras definidas, ya que hay planos en que desaparecen espadaña y cúpula $\mathrm{y}$, sin embargo, ambos elementos constructivos se mantienen hoy en pie.

1974 - Obras de restauración - Ana Iglesias

¿Incorporación de zuncho de hormigón armado ?*

Además de las obras descritas en 1973 se define un coro nuevo, con estructura de madera, y describe cómo el templo presenta "un desplome superior en sus paramentos, que tendrá que ser corregido con un zuncho de hormigón armado que ate perimetralmente todo el edificio, para lo cual habrá que desmontar esta parte de la cubierta de piedra y abrir una caja donde se sitúe dicho zuncho". 
* Podemos confirmar que no se ejecutó las obras definidas en 1974: espadaña y cúpula se mantienen en pie, la cubierta de sacristía no cuenta con revestimiento cerámico. También se conserva en uso el coro alto de hormigón armado.

\section{Planos}

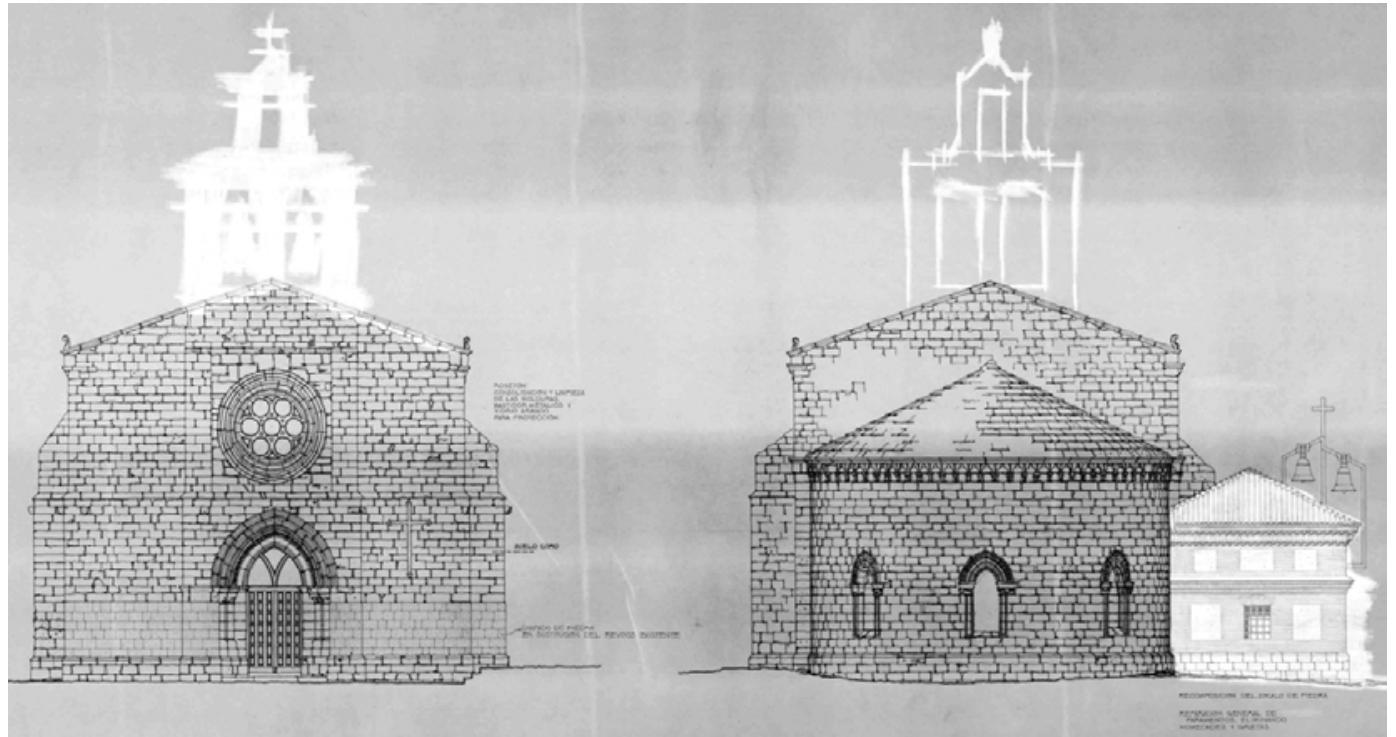

Ilustración 4: proyecto no ejecutado. Ana Iglesias 1973 (IPCE)

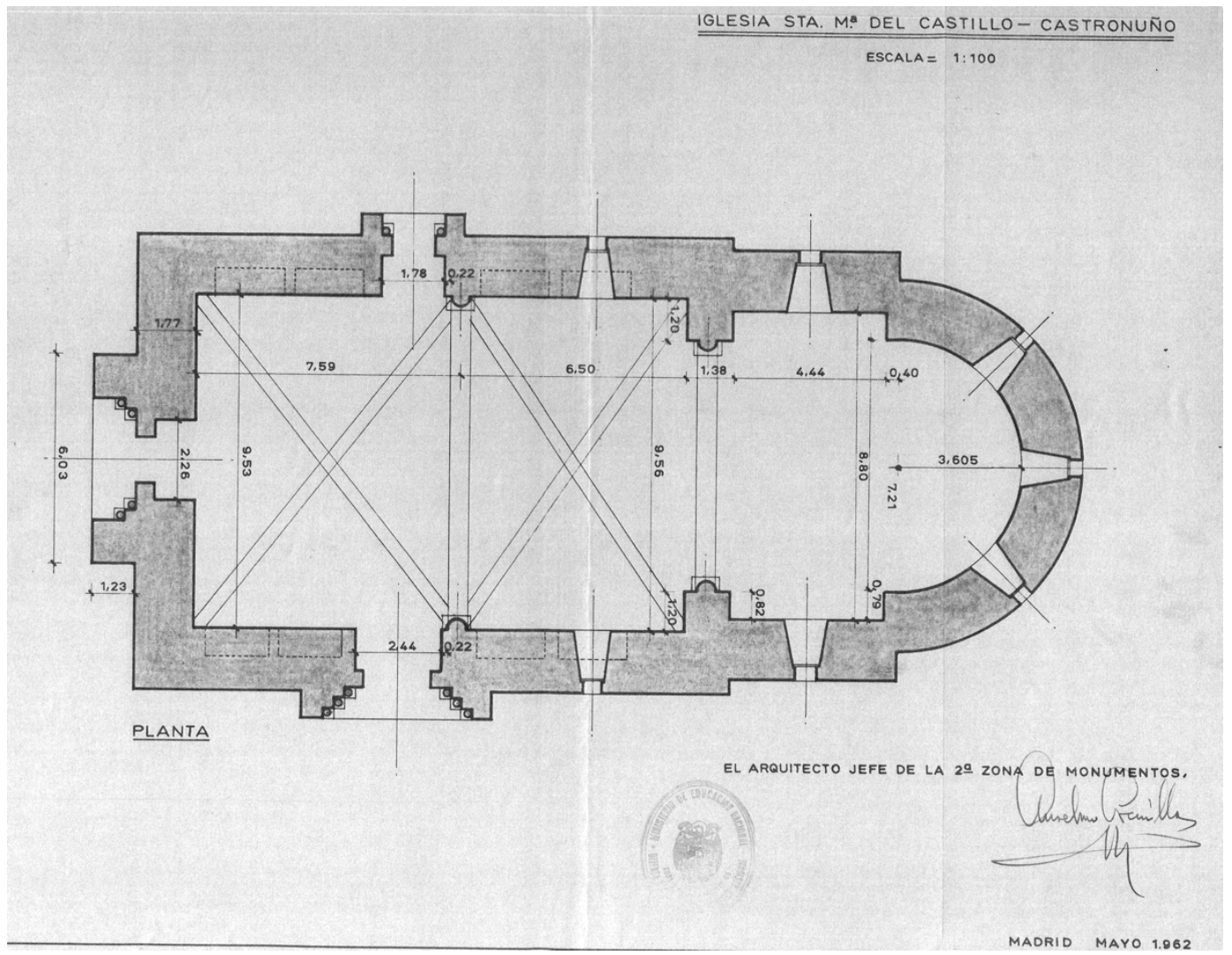

Ilustración 5: planta baja acotada (Arenillas 1962 AGA) 


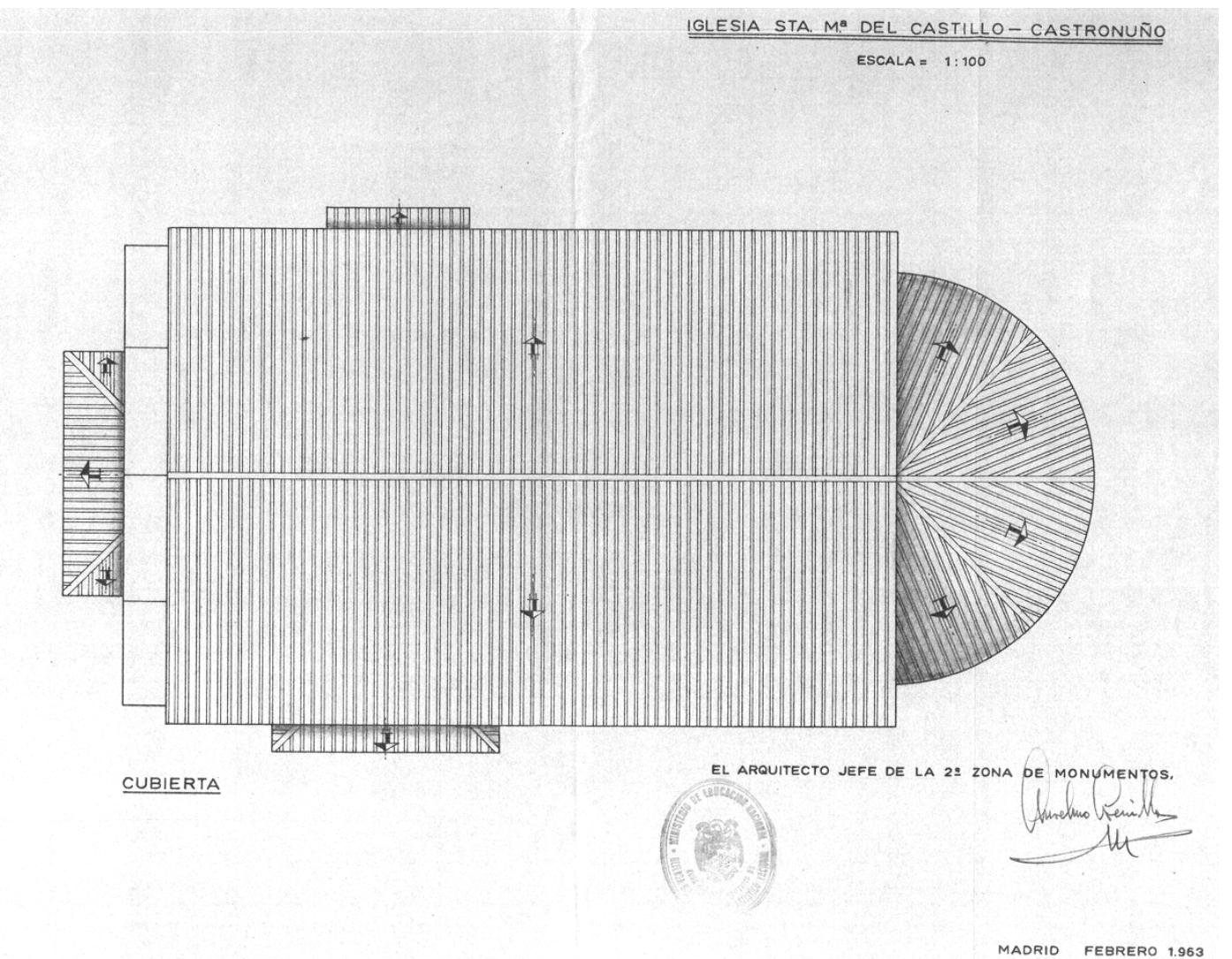

Ilustración 6: planta de cubiertas 1:100, (Anselmo Arenillas 1963 AGA)

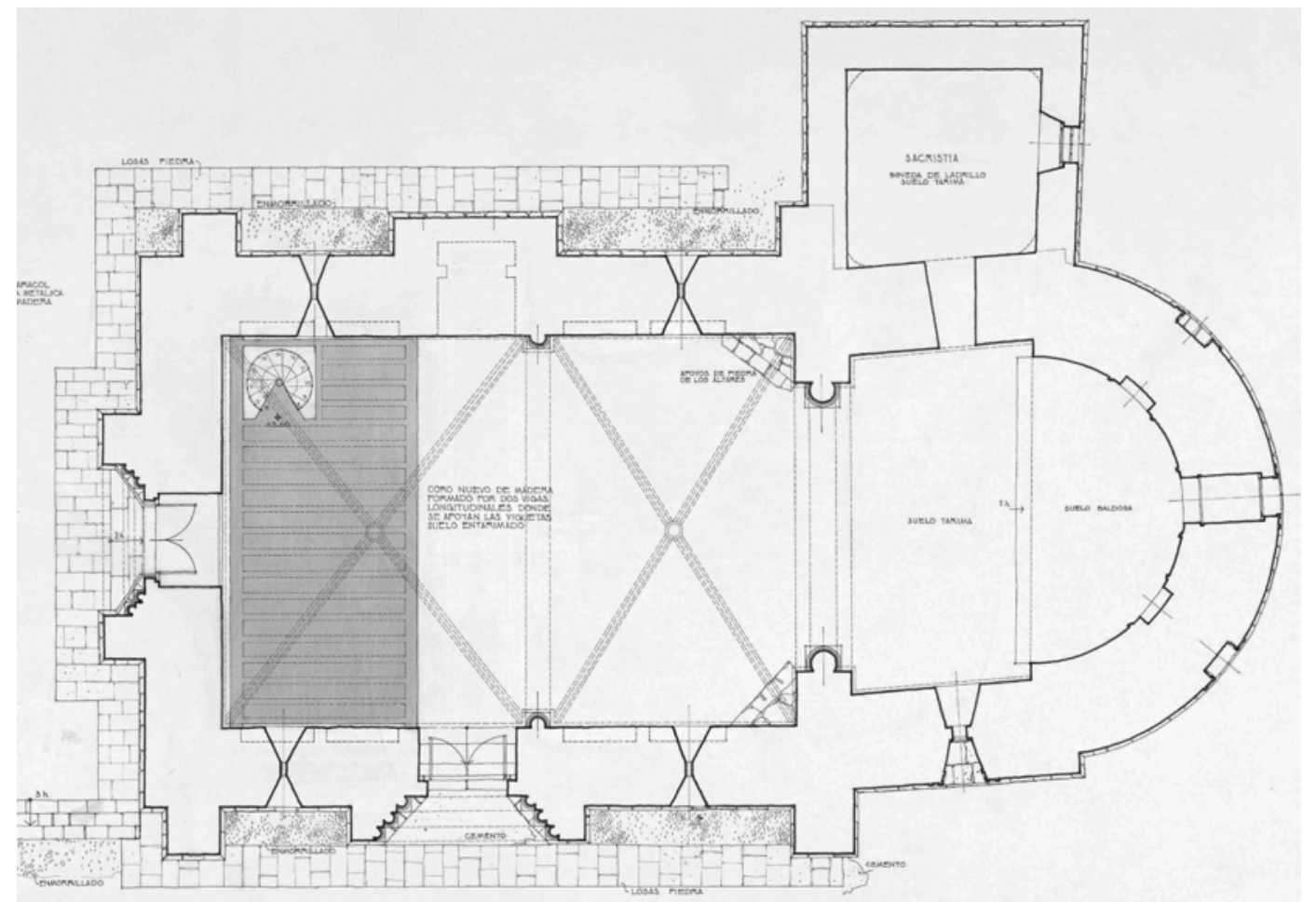

Ilustración 7: planta cota $+3,60$ proyecto. (Ana Iglesias 1974 IPCE) 


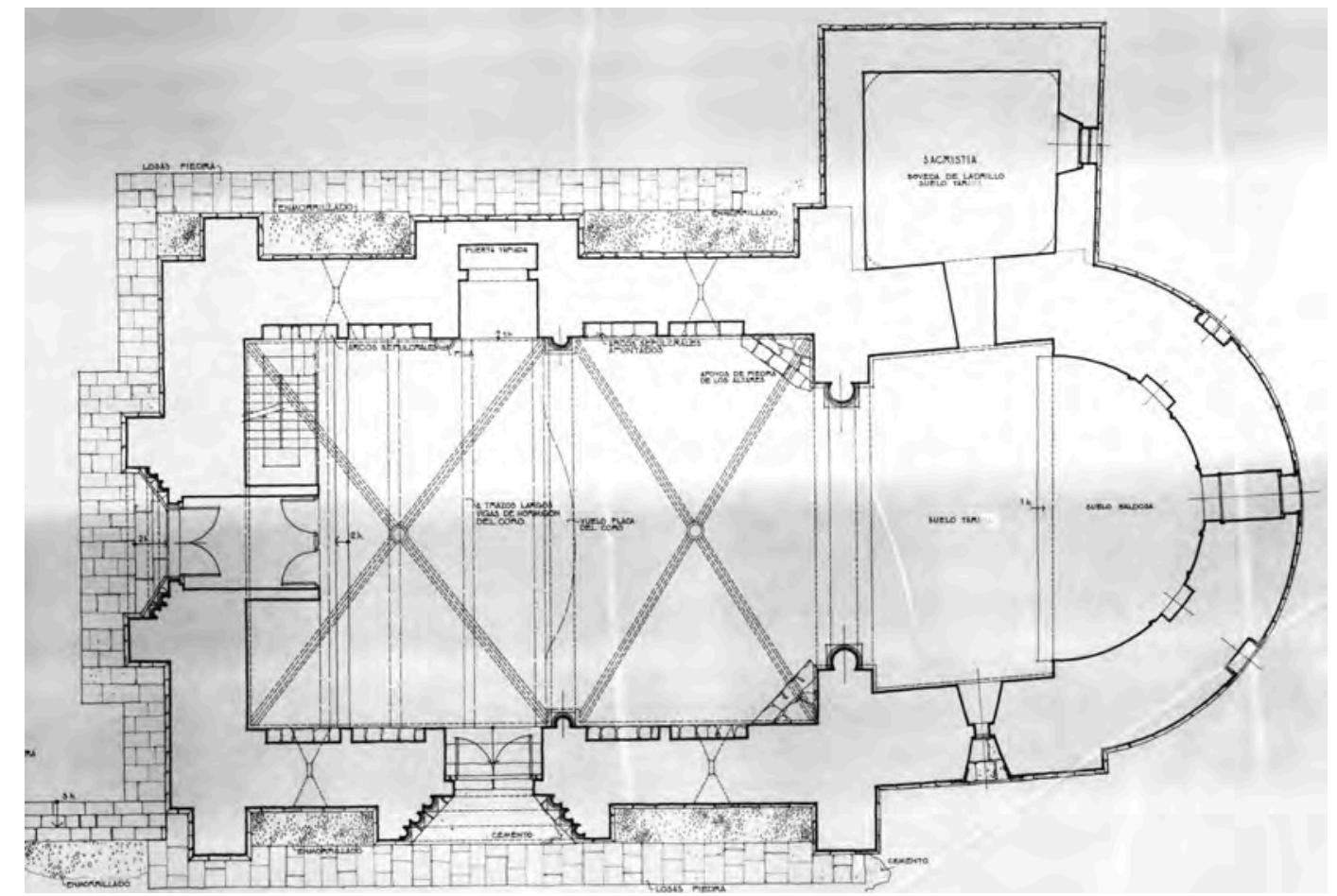

Ilustración 8: planta estado actual (Ana Iglesias 1974 IPCE)

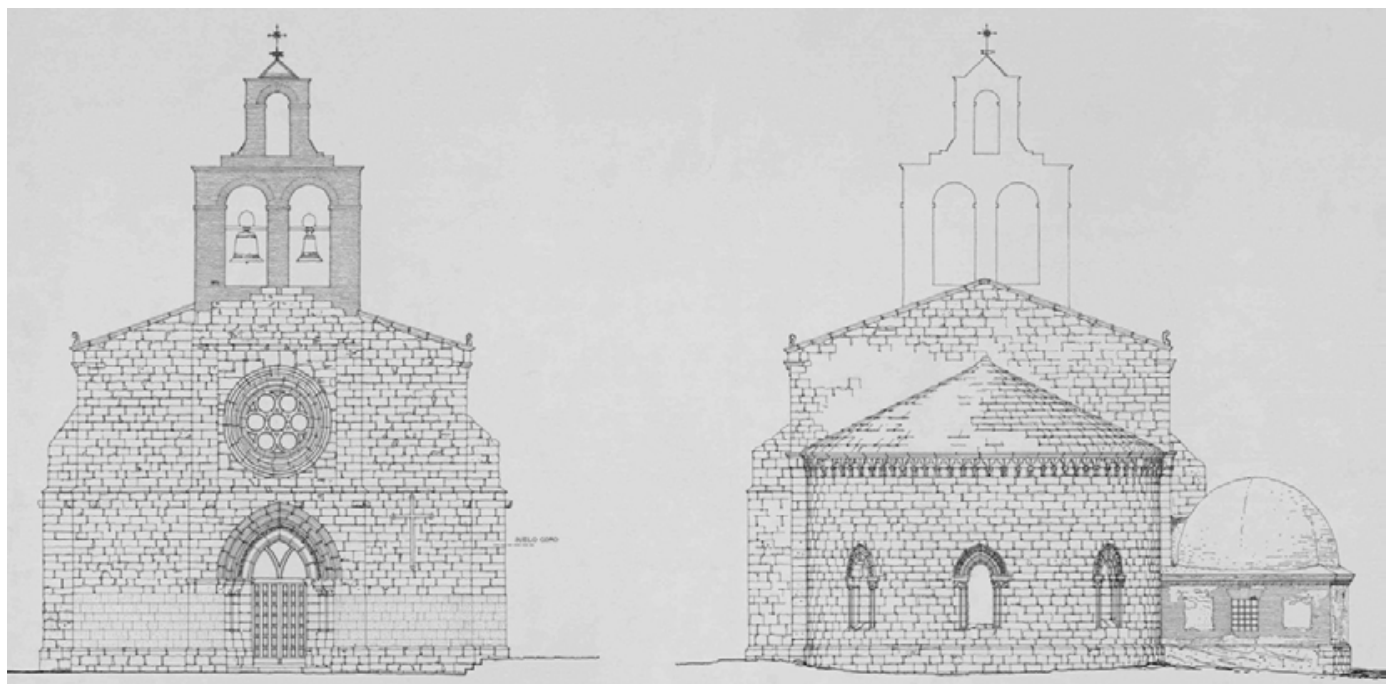

llustración 9: alzados estado actual (Ana Iglesias 1974 IPCE) 


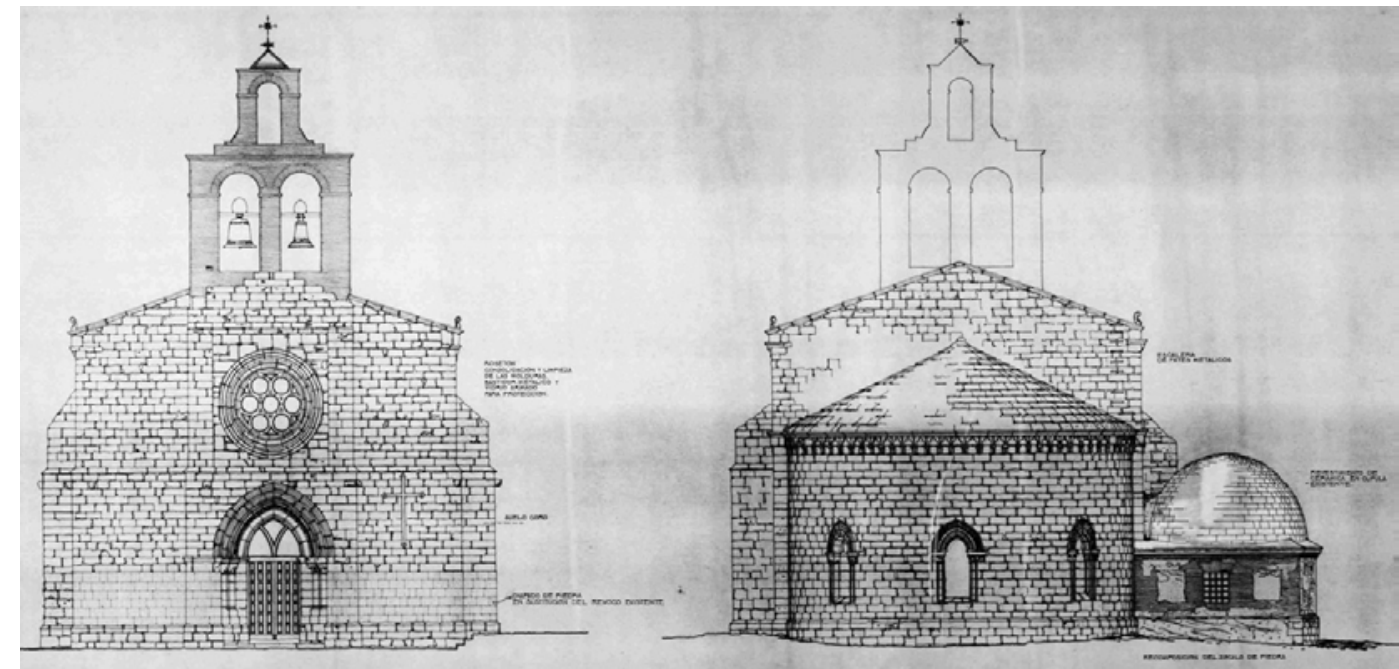

Ilustración 10: alzados primer proyecto de 1974 (Ana Iglesias IPCE)
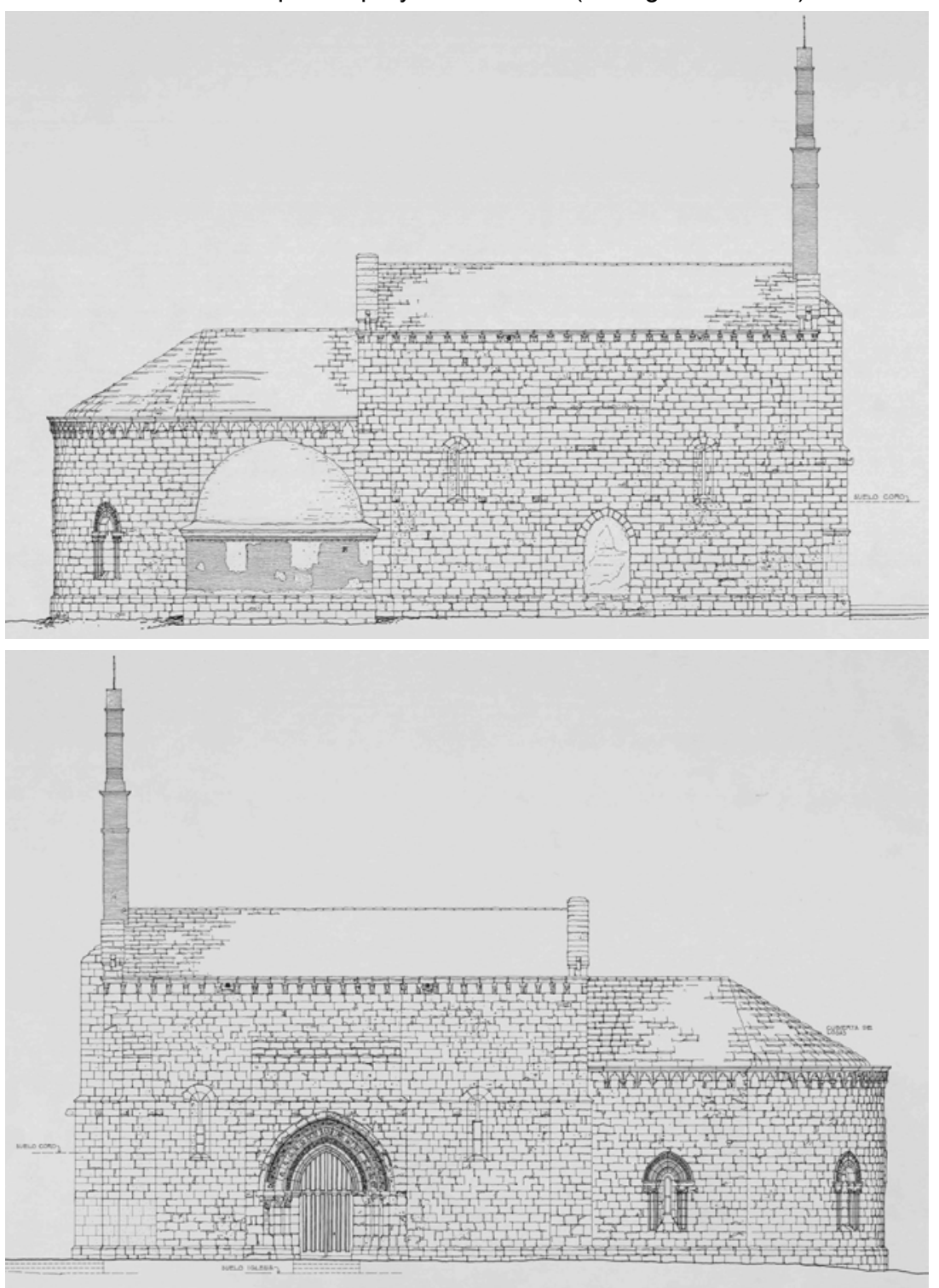

Ilustración 11: alzados laterales (Ana Iglesias 1974 IPCE) 


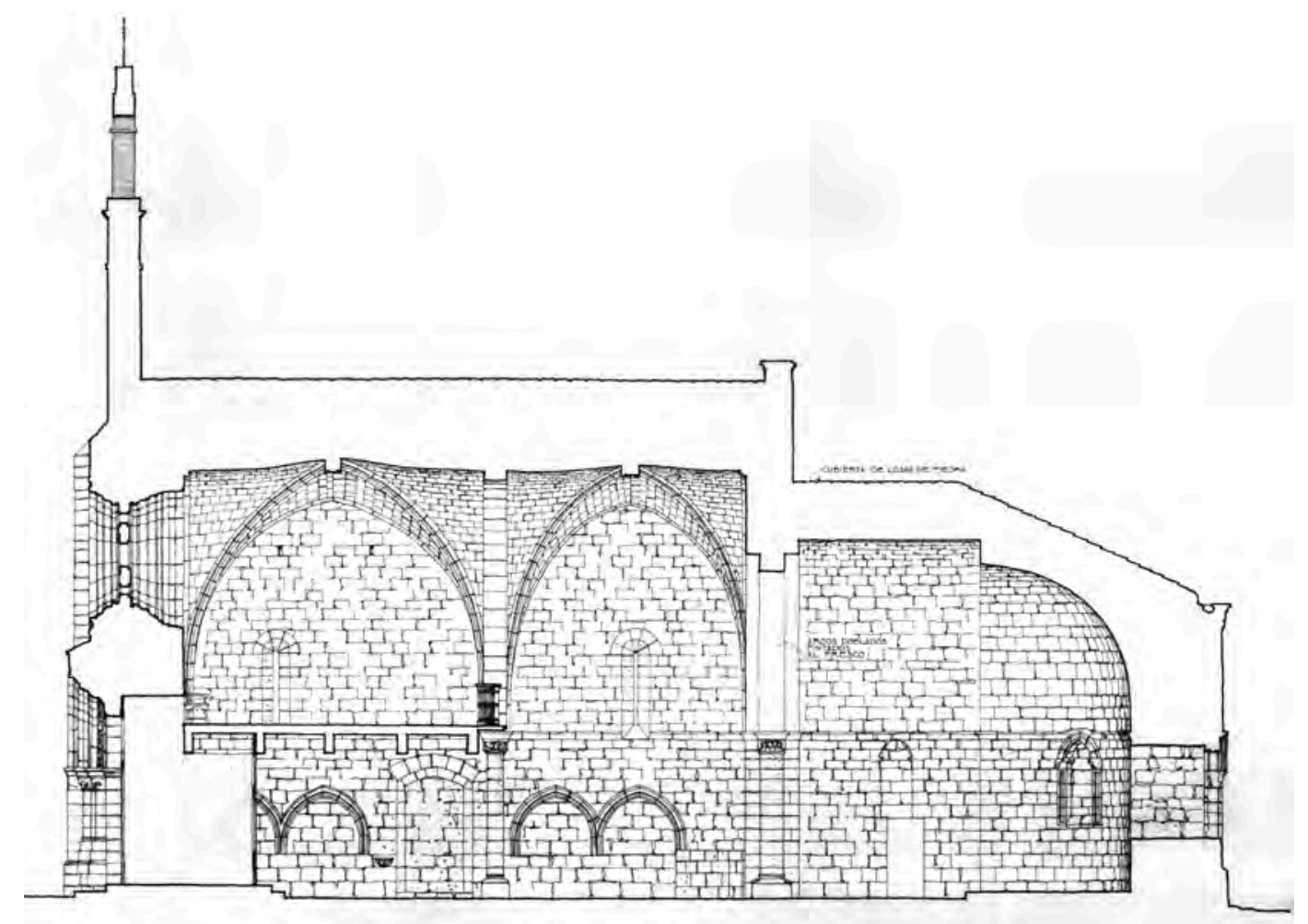

Ilustración 12: sección longitudinal (Ana Iglesias 1974 IPCE)

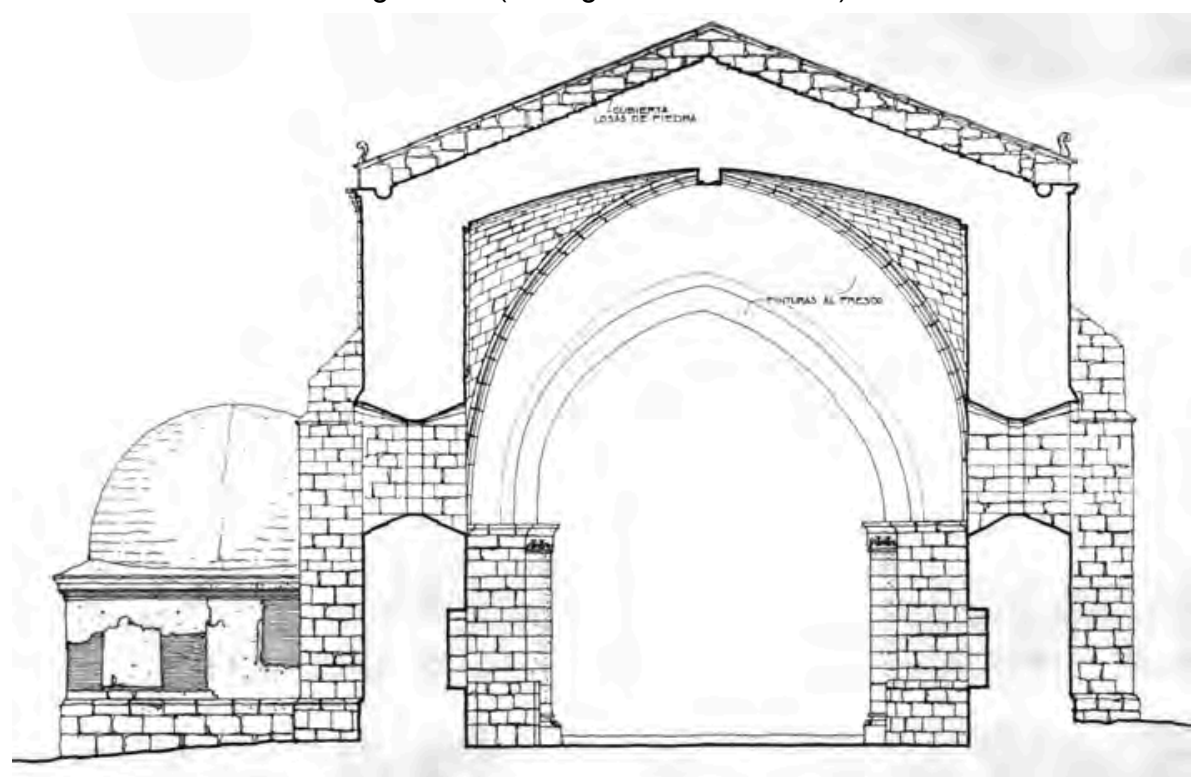

Ilustración 13: sección transversal (Ana Iglesias 1974 IPCE)

\section{Solución constructiva de la cubierta}

Este templo no responde a la tipología habitual de iglesia parroquial de la provincia de Valladolid, ya que se trataba originalmente de una ermita que vio su uso readaptado tras la desaparición del templo del mismo nombre. Se trataba además de una construcción de carácter fortificado perteneciente a la orden militar de San Juan 
de Jerusalén, que fue levantada bajo fundación del prior Hernán Rodríguez de Balboa con el fin de albergar su enterramiento.

En las secciones se aprecia una pendiente de unos $22^{\circ}$ con una sencilla cornisa de piedra de perfil de nacela, con ménsulas y canecillos, algunos decorados. Los faldones a dos aguas revestidos de piedra que trasdosan las bóvedas tuvieron en origen un relleno de tierras que, según la memoria del proyecto de intervención de 1963, iba a ser reemplazado por tabiquillos palomeros de ladrillo con un tablero doble de rasilla, aunque según el testimonio de algunas vecinas del pueblo nunca se realizó esta sustitución.

\section{Zunchos}

Según se indica en el epígrafe Intervenciones, en el proyecto de Ana Iglesias de 1974 Obras de restauración se describe la incorporación de un zuncho de hormigón armado destinado a resolver el "atado perimetral" del templo, que presentaba "un desplome superior en sus paramentos, que tendrá que ser corregido con un zuncho de hormigón armado que ate perimetralmente todo el edificio, para lo cual habrá que desmontar esta parte de la cubierta de piedra y abrir una caja donde se sitúe dicho zuncho".

Sin embargo, no es posible confirmar la ejecución de este proyecto ya que en el mismo se definen, entre otras actuaciones, la demolición de la espadaña de ladrillo que aún podemos contemplar y la reconstrucción de la sacristía sin cúpula.

\section{Conclusiones}

No es posible comprobar si se incorporó a este edificio algún tipo de zuncho. 


\section{Iglesia de Santa María del Castillo en Castronuño}

Intervenciones citadas en la publicación del Ministerio

1963 - Cubierta, encalado muros y reparación de portadas románicas - Anselmo Arenillas Álvarez

1965 - Reparación de fachadas y entradas - Anselmo Arenillas Álvarez

1966 - Saneamiento, demoliciones y arreglo pavimentos - Anselmo Arenillas Álvarez

1973 - Reparación y saneamiento cubiertas. Apertura portadas laterales - Anselmo Arenillas Álvarez

En la web del IPCE hay 14 planos de plantas, alzados y secciones de 1974 firmados por Ana Iglesias.

\section{En el archivo del IPCE}

\section{Carpeta 636-2}

Proyecto de Restauración de cubierta y fachada Iglesia de Sta $\mathrm{M}^{\mathrm{a}}$ del Castillo Memoria: describe una nave dividida en dos tramos por arco perpiaño apuntado.

Obras a realizar: "Presenta el templo un desplome superior en sus paramentos, que tendrá que ser corregido con un zuncho de hormigón armado que ate perimetralmente todo el edificio, para lo cual habrá que desmontar esta parte de la cubierta de piedra y abrir una caja donde se sitúe dicho zuncho."
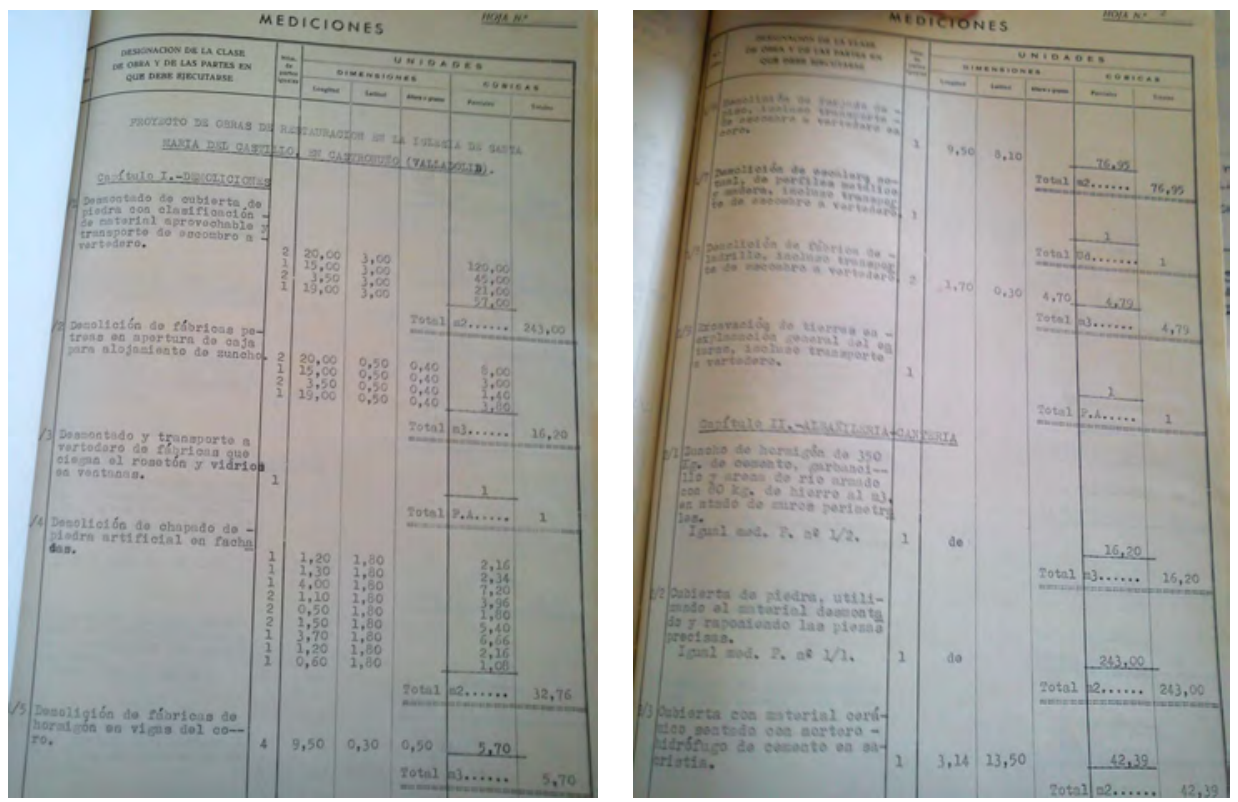

Ilustración 14: mediciones 1974 Iglesias IPCE 
En 1975 había ya un coro de hormigón armado y chapados de piedra artificial en fachadas que demuele y repone análogos.

Planos de estado actual y proyecto de plantas, alzados y secciones 1/50 con fecha 1974. Son copias en papel con la firma original. No hay detalles.

\section{En el Archivo General de la Administración}

\section{AGA 26/01188}

En la carpeta hay sólo dos planos sueltos de Anselmo Arenillas mayo 1962 de Castronuño

(La planta acotada y la de faldones anteriores que he pedido copia)

\section{AGA 26/00370}

Reparación de la Iglesia Parroquial de CASTRONUÑO

Anselmo Arenillas mayo de 1963

Memoria (1pag 2 caras)

"Por orden del Ilmo. Sr. Director General de Bellas Artes, se ha redactado el presente proyecto de reparación de la bella iglesia románica de CASTRONUÑO, recientemente declarada Monumento Nacional.

Este pequeño templo, que se dice fue la capilla del Castillo, que dió nombre al pueblo tenía su cubierta de piedra sentada sobre tierra que rellena las bovedas y forma la pendiente del tejado. Hoy en día ha desaparecido parte de las losas y se han sustituido por lajas y por tejas. El conjunto deja pasar el agua de lluvia que empapa la tierra y produce, además de goteras, un aumento de carga y empuje en las bóvedas.

Se propone en este proyecto quitar los restos de la cubrición y vaciar de tierras todos los trasdos de las bovedas, luego se hará una cuadrícula de tabiques de ladrillo hueco con separación de 0,50m y colocados siempre en las líneas de acción de las cargas ó sea sobre los elementos resistentes de las bovedas; encima se hará un doble tablero de rasilla según los faldones de la cubierta ,o con una hoja recibida con yeso y otra con cemento. Se terminará con un tendido de mortero impermeable de cemento y sobre él se volveran a colocar las losas de piedra de la antigua cubierta, si su estado y cantidad salvada permiten complementar con piedra nueva. esta piedra se recibirá con mortero de cemento. Si la piedra que se logre recuperar no cubre más de la mitad del tejado, entonces se colocará en toda ella pizarra gruesa, clavada sobre capa de 
yeso; ya que la pizarra es más impermeable que la piedra caliza de la zona, empleada anteriormente.

En el interior se picará ó mejor dicho se levantara el revestimiento y encalado de bovedas y muros y se rejuntara con cal su fábrica de piedra, salvo en las zonas con pinturas...."

Planos:

Dos plantas 1:100, una de faldones y la otra de muros con cotas. (Pido copia)

Pliego

Mediciones

Levantado de tejado y quitar tierras relleno bóveda y retirar escombros

Cuerpo central $\quad 1 \times 22,00 \times 14,00 \times 1,50$

Ábside $\quad 0,5 \times 3,14 \times 36 \times 1,00 \quad 518,520 \mathrm{~m} 3$

Faldón de cubierta de doble tablero de rasilla hecho sobre tabiques de ladrillo hueco, enfoscado de cemento e impermeabilizado

$2 \times 21,00 \times 7,70 ; 3 \times 3,14 \times 6,00 \quad 372,22 \mathrm{~m} 2$

Cubierta de pizarra sentada sobre capa de yeso, incluida ésta

En tejado $1 \times$ medición faldones 372,22

En sobre puertas $1 \times 7,00 \times 2,00 ; 1 \times 6,50 \times 0,80 ; 1 \times 4,00 \times 0,80 \quad 394,62 \mathrm{~m} 2$

Limpieza de bóvedas y muros sillería rejuntándolos con mortero de cal

Pies iglesia bóvedas $1 \times 3,14$ × 5,00 x 7,60; 1 × 3,14 x 5,00 x 6,5; 1 x 3,14 x 5,00 x

5,$80 ; 2 \times 20,00 \times 7,00 ; 1 \times 9,50 \times 7,00 ; 4 \times 1,00 \times 7,00 \quad 686,93 \mathrm{~m} 2$

Restauración de cantería moldurada y tallada 1PA

AGA 26/00356

Restauraciones en la iglesia de Castronuño

Anselmo Arenillas Álvarez julio 1965

Memoria 1pag

Reparación parcial de las fachadas e ingresos. Finalidad evitar que las aguas de lluvia entren en la iglesia y recubrir de piedra los zócalos de los muros que quedan al descubierto y en parte están revestidos con mortero de cemento pero en otras estan descompuestos sus fábricas.

Se proyecta rebajar el terreno alrededor de la iglesia $25 \mathrm{~cm}$ con lo que quedará más bajo que el piso de la puerta. Hacer los escalones. Poner la canccela y una escalera de acceso al coro por haber desaparecido en obras anteriores la que había.

Un único plano, el de planta acotada sobre el que señala en lapiz rojo a mano alzada los tres nuevos escalones en la puerta a los pies y la zona de fachada con linea roja . 
AGA 26/00206

1966 - Proyecto de terminación de la restauración de la iglesia románica de Castronuño Anselmo Arenillas

Es sólo una memoria en 1 pag

Es lo único que resta del conjunto que formó la fortaleza que da nombre al pueblo. La restauración se ha llevado a cabo en dos etapas, en la primera se reconstruye la cubierta de losas, quitan los añadidos de las fachadas dejando el templo exento menos en la parte ocupada por la sacristía. Se rebaja el terreno circundante que había llegado a tapar gran parte del conjunto por arrastres dejándolo como semisótano.

Segunda etapa el resto pero por presupuesto se deja pendiente. De algunas obras se prescinde (reabrir la puerta sur, reducir sacristía, poner aceras norte y oriente.)

Obras finales:

$100 \mathrm{~m} 3$ más excavación del terreno para mejor desagüe

45,52m3 demolición hormigón en coro

$10 \mathrm{~m} 2$ chapado de zócalos

$14,80 \mathrm{~m} 2$ carpintería puertas ventanas

$12,80 \mathrm{~m} 2$ vidrio impreso doble con malla

AGA 26/00045

Proyecto de obras de restauración en la iglesia de Santa María del Castillo de Castronuño

Ana Iglesias Julio 1973

Memoria (2 pág.)

Iglesia románica de tres naves con ábside circular de tres ventanales.

"El interior del edificio presenta un excelente estado de conservación ya que en él se realizaron una serie de obras de restauración llevadas a cabo por la Dirección General de Bellas Artes.

El único detalle que desentona de forma poderosa con el resto del conjunto es el coro, construido totalmente en época reciente y soportado por vigas de hormigón armado, de sección bastante considerable.

Las obras necesarias a realizar en el edificio son muy claras y concretas y en principio no parece que revistan grandes dificultades. Es necesario repasar la cubierta en la zona del presbiterio enl la que aparecen algunas goteras, ocasionadas por el corrimiento de alguna de las losas o destrucción parcial del impermeabilizante que se colocó en la restauración anterior. Igualmente, teniendo en cuenta el peculiar material de cubrición del edificio, es necesario realizar frecuentes reparaciones y limpiezas en la cubierta, por lo cual es necesario disponer un acceso a la misma 
desde el exterior, aprovechando el lugar más discreto y sin el menor perjuicio para la estética del edificio.

Se ha pensado también en impermeabilizar la original cubierta de la sacristía, teniendo en cuenta el mismo criterio de no variar su aspecto actual. Se ha previsto igualmente abrir las dos portadas laterales que actualmente se encuentran cegadas."

Hay un dossier con 8 fotografías blanco y negro del exterior. Se aprecian los huecos del ábside cerrados con sillares y los de portada con fábrica de ladrillo.

Presupuesto con cinco partidas sin medición:

- Repaso general de cubierta en zona de ábside y presbiterio

- Impermeabilización de bóveda de sacristía

- Construcción de escalera de acceso a cubierta formada por pates metálicos

- Apertura de huecos cegados, incluso transporte de tierras al vertedero

- Carpintería de madera de gruesas escuadrías

No hay planos.

AGA 26/1182

Castronuño

Fotocopias: Un poco de documentación administrativa y dos hojas memoria Ana Iglesias 1973.

AGA 26/01720

Obras de restauración en la iglesia de Sta. $\mathrm{M}^{\mathrm{a}}$ del Castillo. Castronuño

Ana Iglesias abril 1974

Memoria (3pag descripción)

Obras a realizar (firma con fecha junio de 1974)

Presenta el templo un desplome superior en sus paramentos, que tendrá que ser corregido con un zuncho de hormigón armado que ate perimetralmente todo el edificio, para lo cual habrá que desmontar esta parte de la cubierta de piedra y abrir una caja donde se sitúe dicho zuncho.

En general la iglesia necesita una sustitución y completación de los vidrios así como la apertura del rosetón de la fachada principal.

Una escalera construida con perfiles metálicos desde una altura no accesible sin escalera portátil y colocada para ser vista lo menos posible, servirá para subir a la cubierta sobre la que se construirá un paso hacia la espadaña.

La parte inferior de la iglesia que estuvo sepultada y fue restaurada con piedra artificial falsamente labrada se picará y arreglará chapándola de nuevo al modo adecuado. 
En la sacristía se realizará la colocación del material de cubrición que actualmente no existe y que será cerámico y despiezado según planos.

El coro de hormigón que interrumpe dos de los arcos y el uso de una de las puertas se tirará y será sustituido por otro realizado en madera al cual se accederá por escalera de caracol, tambien de madera según planos.

Pliego tipo.

\section{Mediciones}

Desmontado de cubierta de piedra con clasificación de material aprovechable y transporte de escombro a vertedero

$2 \times 20,00 \times 3,00 ; 1 \times 15,00 \times 3,00 ; 2 \times 3,50 \times 3,00 ; 1 \times 19,00 \times 3,00 \quad=243 \mathrm{~m} 2$

Demolición de fábricas pétreas en apertura de caja para alojamiento de zuncho

$2 \times 20,00 \times 0,50 \times 0,40 ; 1 \times 15,00 \times 0,50 \times 0,40 ; 2 \times 3,50 \times 0,50 \times 0,40 ; 1 \times 19,00 \times$ $0,50 \times 0,40 ; \quad=16,20 \mathrm{~m} 3$

Desmontado y transporte a vertedero de fábricas que ciegan el rosetón y vidrios en ventanas

Demolición de chapado de piedra artificial en fachada, de fábricas de hormigón en vigas del coro, forjados, escalera, ladrillo, etc.

Zuncho de hormigón de $350 \mathrm{Kgs}$ de cemento, garbancillo y arena de río armado con $80 \mathrm{Kg}$ de hierro al $\mathrm{m} 3$ en atado de muros perimetrales $\quad=16,20 \mathrm{~m} 3$

Cubierta de piedra, utilizando el material desmontado y reponiendo las piezas precisas.

Cubierta con material cerámico sentado con mortero hidrófugo de cemento en sacristía

Chapado, restauración de fábricas pétreas, nuevo coro, fotografías, escalera de pates

Planos: los del IPCE en copia (sin las marcas del raspado sobre vegetal original) sólo hay un plano adicional de planta alta en el que se describe el nuevo coro.

\section{AGA 26/1182}

Proyecto de obras de restauración en la iglesia de Santa María del Castillo de Castronuño

Es un dossier de pocas páginas aprueban la memoria de Ana Iglesias de julio de 1973 (repasar la cubierta del presbiterio, disponer un acceso discreto, impermeabilizar la cubierta de la sacristía y abrir las dos portadas laterales cegadas.) 


\section{En el archivo de la Junta de Castilla y León}

\section{VA-287}

Serie inventario en el Servicio, con membrete de la Dirección General de Patrimonio y Promoción Cultural, Consejería de Cultura de la Junta. Documentación básica de edificios declarados monumento de la provincia Valladolid.

Febrero de 1991. Arquitectos: Álvaro Abad, Mario Fernández Pírez. Historiadores: Ana Moreno Martínez y Ma Ángeles Polanco Uya.

Indican que en el Archivo Diocesano hay documentación de la iglesia hasta 1900. Construida por los templarios en el siglo XII en la plaza fuerte en torno a un castillo medieval donde estuvo un alto de cerro romano.

El edificio, entre románico zamorano y gótico, consta de una única nave dividida en dos tramos por arco perpiaño sobre semi-columnas adosadas de base ática. Cabecera más baja y estrecha que la nave. Describen la portada a los pies avanzada entre contrafuertes, la sur muy abocinada y la norte tapiada. La cubierta se resuelve a dos aguas revestida con lajas de piedra sobre largueros de madera y relleno de barro para formación de pendiente. Sobre la nave hay una espadaña de ladrillo moderna.

El coro de piedra lo construyó la Confederación Hidrográfica del Duero para aumentar el aforo del templo.

Cartografía:

Archivo General del Ministerio de Cultura (Pza del Rey, Madrid)

Exp 1192. Proyecto de cubiertas de 1963. Arq. Anselmo Arenillas

Exp. 1175. Proyecto de fachadas de 1965. Arq. Anselmo Arenillas.

Exp. 70989. Proyecto de pavimentos de 1966. Arq. Anselmo Arenillas.

Exp. 70716. Proyecto de 1973. Arq. Ana Iglesias

Instituto de Conservación y Restauración de bienes culturales (c/ Greco, Universitaria, Madrid)

Carpeta 427. Proyecto de 1974. Arq. Ana Iglesias

Carpeta 428. Proyecto de 1976. Arq. Ana Iglesias.

Diputación Provincial de Valladolid

Trabajo sobre las iglesias de Valladolid realizado por el Departamento de Construcciones Arquitectónicas de la ETSAV.

Intervenciones realizadas y estado actual: (1991)

El estado es bueno, con pequeñas patologías: humedades en zonas altas de muros y bóvedas por falta de mantenimiento y limpieza de los canalones ocultos, y de las 
gárgolas de evacuación. El problema es la falta de accesibilidad a la cubierta: basta colocar pates exteriores desde la cubierta de la Sacristía.

La Sacristía cubre con bóveda de ladrillo revestida al exterior con una capa de mortero de cemento. Necesita intervención.

Erosión de piedras con pérdida de vivos por agentes atmosféricos. El forjado brutal del coro con vigas de hormigón armado que apoyan sobre los muros laterales de piedra rompe las proporciones interiores del edificio. La escalera de acceso también está mal diseñada.

Se trata de un edificio con poco uso, sin calefacción ni ventilación. Aunque hay desprendimientos característicos de las pinturas el estado del conjunto es impecable.

Además del forjado hay tres intervenciones hechas en febrero de 1991:

Restaurado de piedra en parte de la fachada

Rejuntado de lajas de piedra en faldones

Tratamiento de los huecos

En los planos de planta, alzados y secciones, con carátula de Pírez, hay una nota aclaratoria: Documento del Proyecto de Restauración realizado por el Ministerio de Cultura en 1974. Arq: Ana Iglesias. Arq. colaborador: Cervantes Brocca.

Fichas de Diagnóstico.

Pequeñas humedades en zonas altas de los muros próximas al encuentro con cubiertas. Causa: filtraciones del canalón oculto. Origen: Falta de mantenimiento y acceso a cubiertas.

Forjado de hormigón del coro con vigas colgadas por debajo de cota de clave de acceso y distorsionante estéticamente. Restauración reciente demasiado forzada. $76 \mathrm{~m} 2$

Forro exterior de cubierta de Sacristía en estado de degradación. Causa: agentes naturales externos. Origen: restauración poco idónea e inacabada. $49 \mathrm{~m} 2$

Cornisas y portadas erosionadas por el agua de rebose del canalón. $30 \mathrm{ml}$

Problemas de adecuación y limitación de los revestimientos interiores de la Sacristía. Origen: Restauración incompleta. $70 \mathrm{~m} 2$

CD Levantamiento planimétrico y diagnóstico. Mayo de 2012. Fo Javier Carbayo $\mathrm{Baz}$

Descripción del edificio de una sola nave con dos tramos separados interior y exteriormente por pilastras o contrafuertes, bóvedas de crucería, tramo recto presbiterial con cubierta de cañón apuntado y cabecera semicircular con bóveda de cuarto de esfera. Construida con sillarejo bien aparejado excepto la espadaña de 
ladrillo. La cubierta de nave, presbiterio y cabecera se realiza mediante lajas de piedra vertiendo en un pesebrón que echa las aguas fuera mediante gárgolas.

El levantamiento se realiza con estación total. El edificio presenta desviaciones en el trazado, hasta $4^{\circ}$ entre la fachada de poniente y el eje longitudinal de la nave, que se desplaza unos $50 \mathrm{~cm}$ hacia el sur respecto al presbiterio. El espesor de muros varía entre 1,6 y $2 \mathrm{~m}$.

Se incluye en el documento un amplio dossier fotográfico sobre el que se señalan las lesiones de los distintos elementos.

"El remate de los hastiales se ha ejecutado mediante una hilera de ladrillo macizo colocado a tabla revestido de una capa de mortero de cemento que, con el tiempo, ha quedado recubierta de una costra y una capa biogénica. En algunos puntos se está desprendiendo tanto el ladrillo como el mortero.

Las juntas entre las lajas de piedra que conforman la cubierta están unidas con mortero de cemento con lo que se consigue impermeabilizar la cubierta. Sin embargo se aprecian desprendimientos de estas juntas sobre casi toda la superficie de la cubierta."
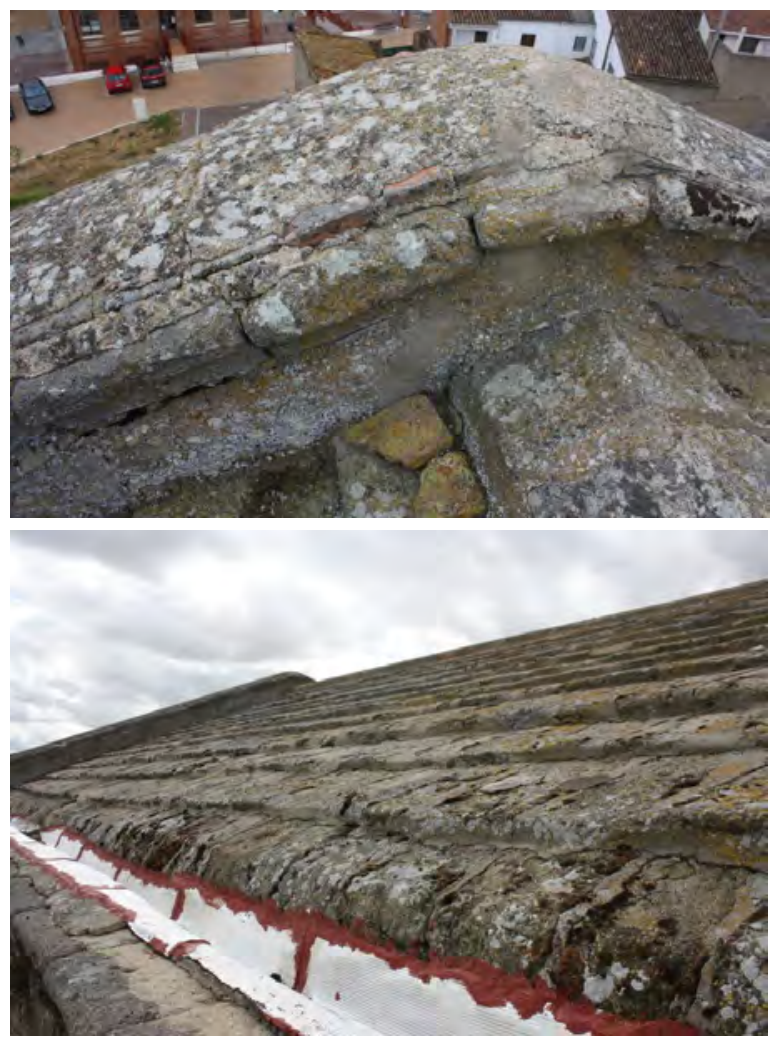

Ilustración 15: remates cubierta, dossier 2012 Carbayo

Realiza un diagnóstico del estado del templo en el que, entre otras afirmaciones, destacan:

"La presencia de grietas tanto en paños exteriores como interiores y de desplazamientos de planos en plementerías pueden denotar movimientos estructurales hasta cierto punto peligrosos para la estabilidad del edificio o de determinados tramos. Puesto que no se ha realizado un estudio de la evolución de los movimientos de los distintos paños mediante la colocación de testigos o, mejor aún, de fisurómetros, no se puede evaluar si las grietas progresan o está detenida su evolución. En muchos casos las grietas aparecen entre las piezas de piedra que se unen a los arcos asociados a los muros en la formación de las bóvedas y las piezas que conforman las plementerías, de modo que inicialmente podrían seguir 
funcionando independientemente unas de otras sin peligro. La ubicación del edificio, en un macizo elevado sobre el río, expuesto a los vientos y humedades de la zona ha hecho que muchos de los relieves o tallas de la piedra se hayan erosionado y perdido su volumetría. Del mismo modo ha provocado el desplacado, desagregación, alveolización y agrietamiento en la práctica totalidad de las fachadas.

La falta de mantenimiento de pesebrones lleva a que periódicamente se provoque el atasco de los mismos y el posterior filtrado de agua hacia los muros, tanto por el exterior como por el interior, con la aparición de manchas de humedad y pátinas biogénicas. Es posible que incluso se haya forzado un reblandecimiento de la estructura que esté asociado con los desplazamientos estructurales existentes. La falta de mantenimiento es así mismo la causa del crecimiento de plantas superiores (herbáceas) en pesebrones y superficies horizontales o con ciertas pendientes (impostas, remates de contrafuertes,...) en los que se acumula tierra y se facilita su desarrollo.

En algunos puntos (fachada norte, ábside) aparecen humedades en el zócalo del muro exterior que pueden aparecer por capilaridad abosorbiéndose del terreno.

La presencia de aves, fundamentalmente palomas y cigüeñas, hace que además de la aparición de nidos que ejercen grandes sobrecargas en algunos puntos, dejen en su entorno restos de plumaje, alimentación y deyecciones y orines, estos últimos causantes del deterioro de la piedra y el ladrillo por su acidez y de la aparición de costra en algunos casos, además de la obturación de canales de desagüe.

Se aprecian en los paños de ladrillo de la espadaña o de los muros de la sacristía deterioros debidos bien a la instalación de elementos adosados y posteriormente retirados (piezas de madera o soportes de campana en la espadaña) o a la acción de agentes meterológicos.

Como modificaciones antrópicas se han localizado tanto en el interior como en el exterior de la iglesia la colocación de morteros de cemento en rejuntados entre sillares, piedras de la cobertura o en el asiento de piezas que se han movido o se han recolocado.

Igualmente usados en remates y revestimientos es particularmente llamativo entre estos últimos el que cubre la franja inferior de la fachada de poniente y parte de la sur en las que, para reponer la falta de la piedra original ya muy erosionada, se proporcionó una capa de mortero de cemento, en tono dorado similar a la piedra, sobre la que se practicó un llagueado a imitación del original.

Entre los planos elaborados encontramos el siguiente conjunto en que se describen las lesiones: 

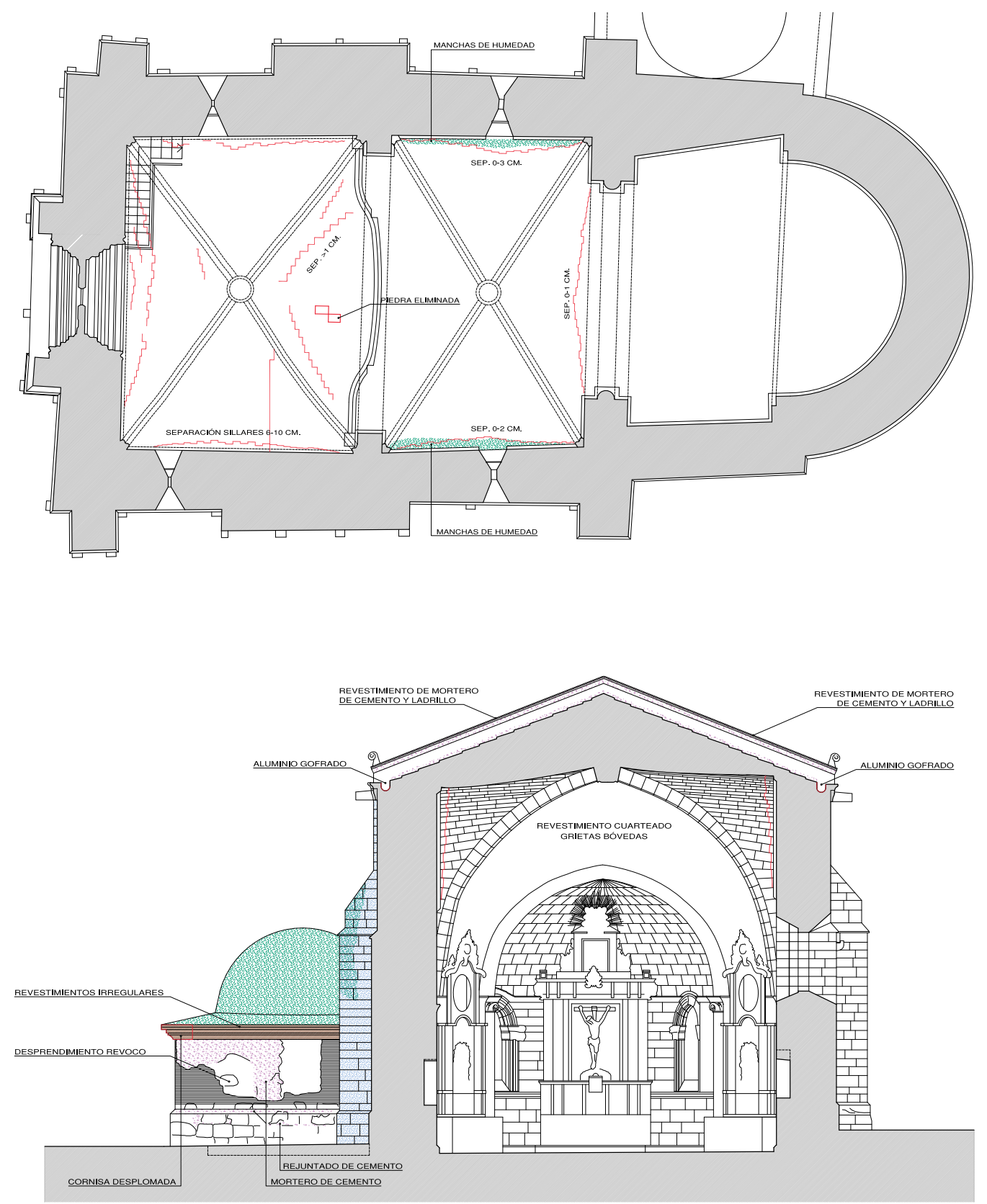

Ilustración 16: planta y sección diagnóstico 2012 Carbayo 

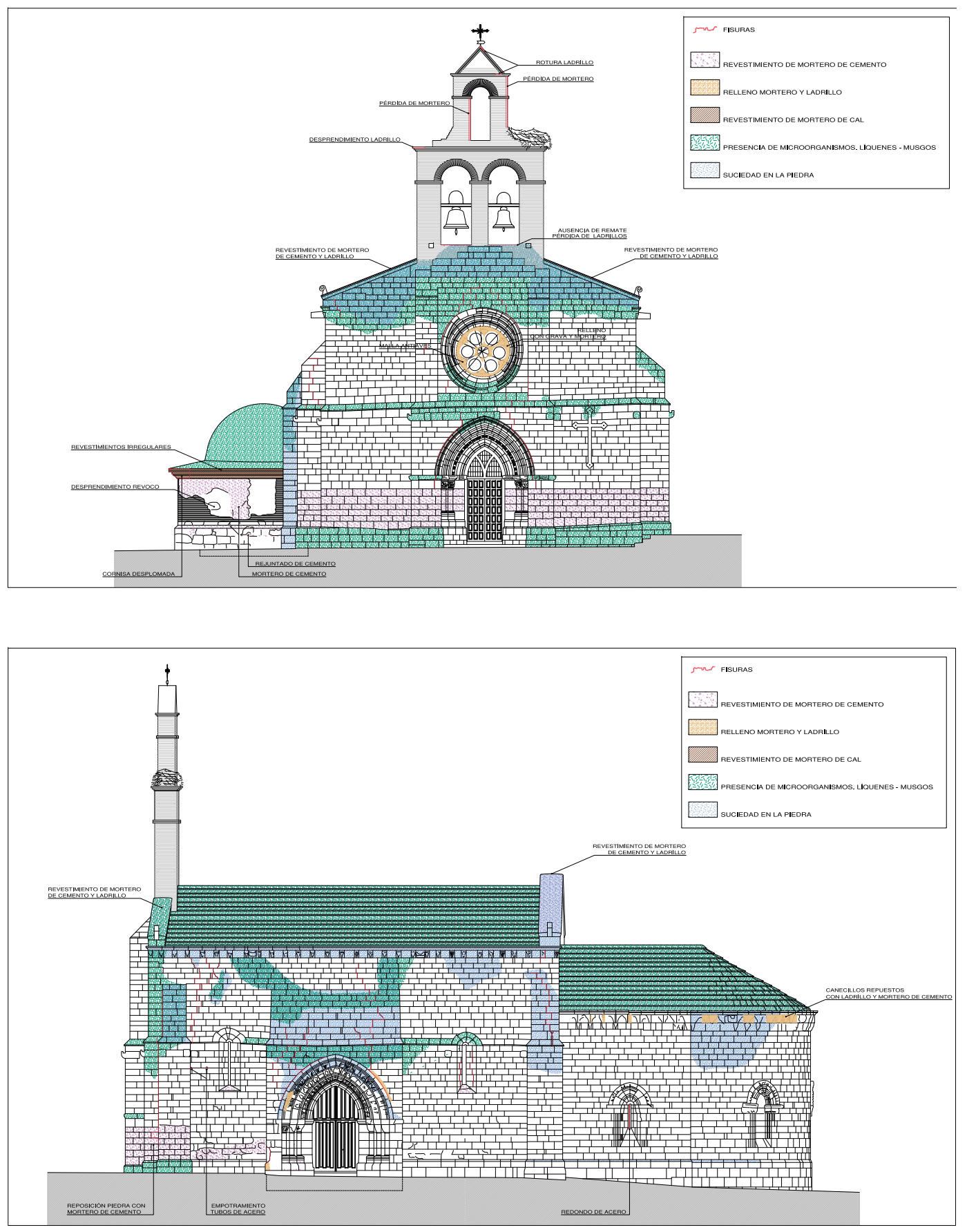

Ilustración 17: diagnóstico alzados 2012 Carbayo 

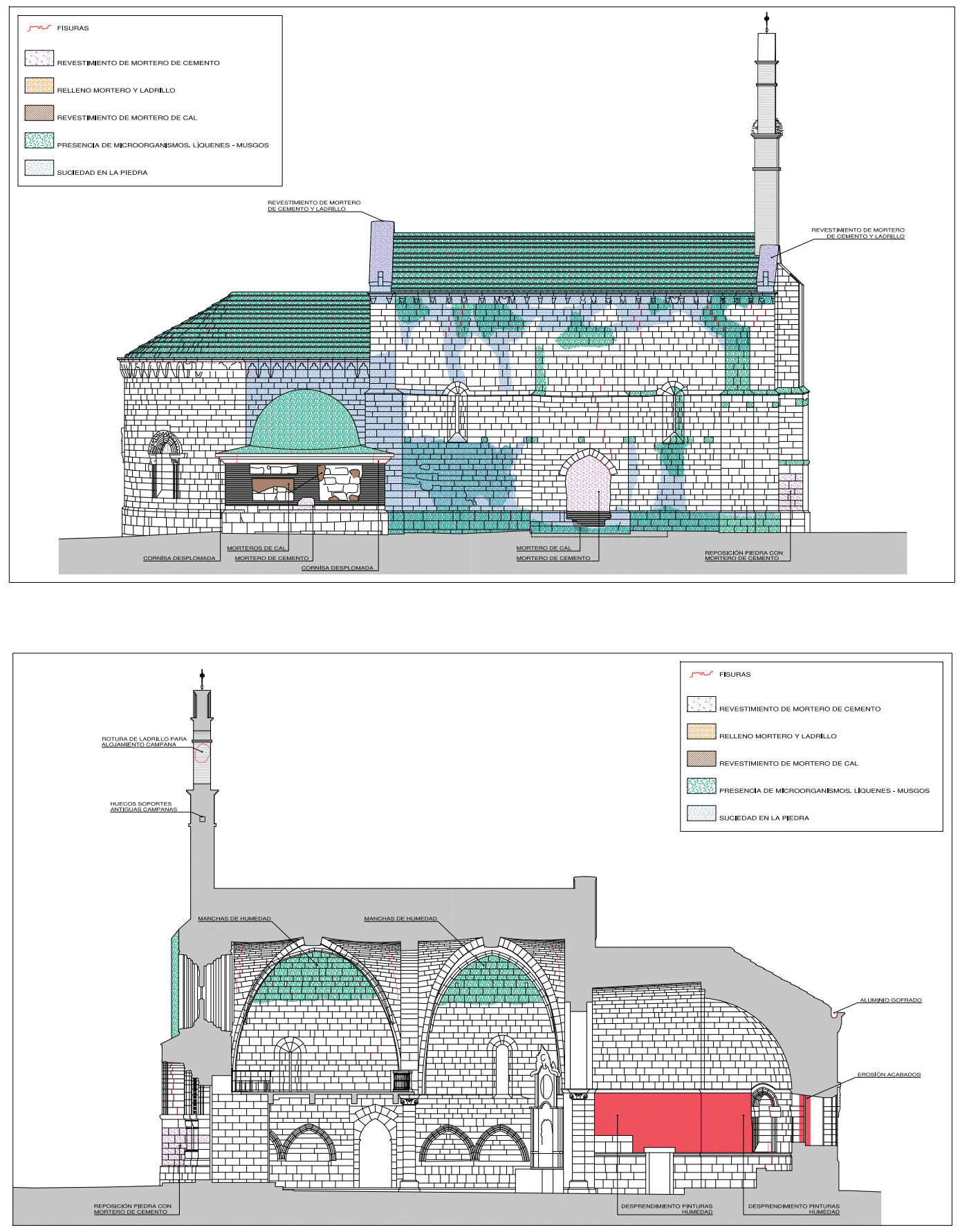

Ilustración 18: diagnóstico sección 2012 Carbayo 



\section{Visitas realizadas}

$13 / 09 / 2014$

El estado de conservación del monumento es aceptable.

El entorno inmediato está acondicionado, con pavimento $\mathrm{y}$ señalética bastante recientes.

La fachada a los pies cuenta con un revestimiento nuevo en la zona baja, y no se aprecian humedades de capilaridad recientes.

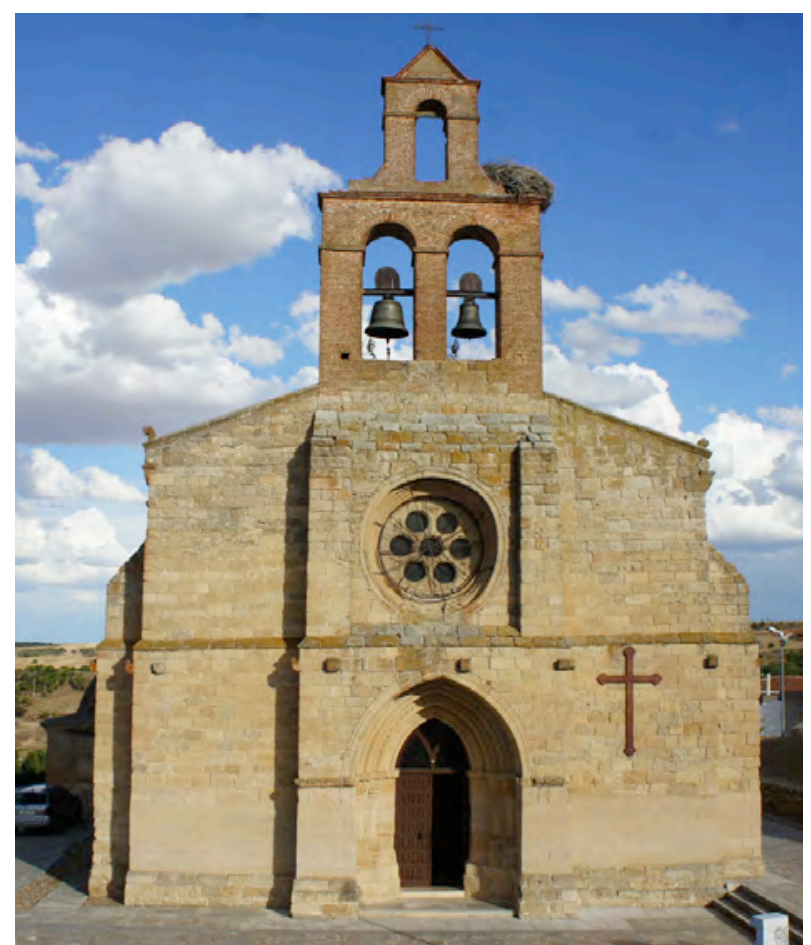

Los remates inclinados sobre contrafuertes y resaltos sí muestran falta de rejuntado con restos de una lechada gris, posiblemente cementosa y, por tanto, factor de aceleración de la degradación de la fábrica. Estos planos se encuentran mejor rematados en la fachada sur, con una coloración blanquecina que hace factible el uso de morteros con cal, más adecuados. Hay cierto crecimiento de vegetación, sin embargo, en la orientada al norte. En este último cerramiento se encuentran cegados con fábrica tanto ventanas como pórtico y, en la fotografía, podemos observar una grieta a $45^{\circ}$ desde el primer contrafuerte de la derecha.
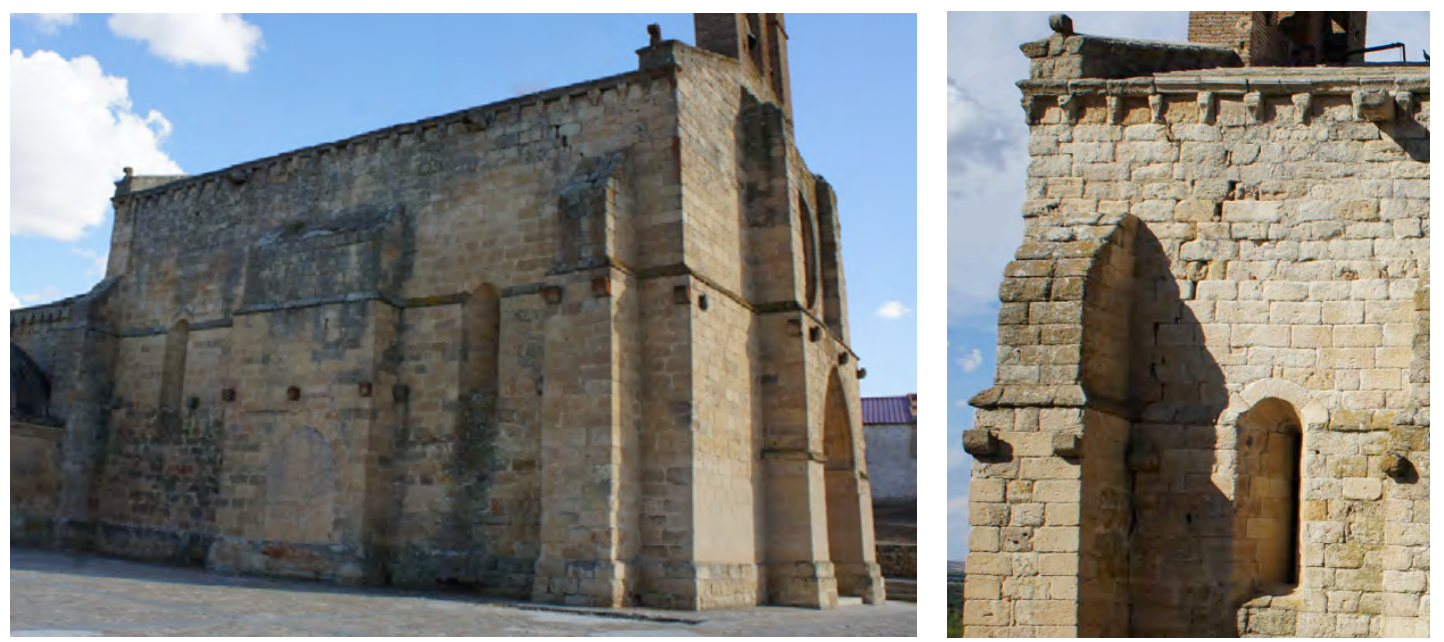

En la fachada opuesta se trata de la zona en que a principios del siglo XX había adosada una escalera que servía de acceso a la espadaña desde el coro alto a través de la ventana hoy cerrada, según podemos comprobar en fotografías de la época y nos 
confirma una feligresa nacida en 1938, que se encontraba en el templo vistiendo un altar durante la visita. En su testimonio explica también cómo se trataba entonces de un coro de madera al que se llegaba por una escalera de caracol, hasta la incorporación del coro de hormigón armado. Afirma que nunca se ha levantado el relleno sobre las bóvedas, sólo recolocado las losas para limpiar canalones y aplicar una imprimación hace unos cuatro años. (Sin duda el revestimiento rojizo que se aprecia en la imagen siguiente)

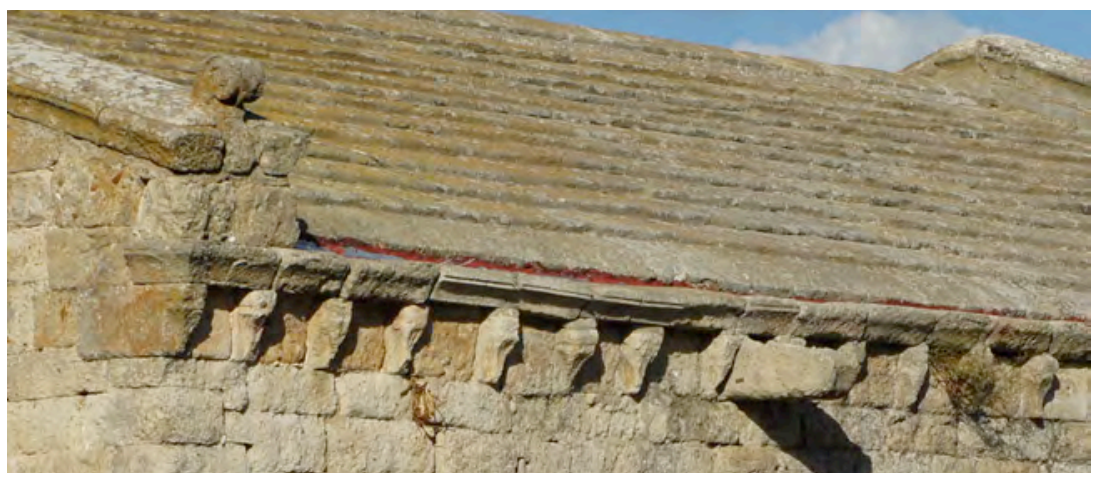

Actualmente no encontramos un acceso practicable a la cubierta.
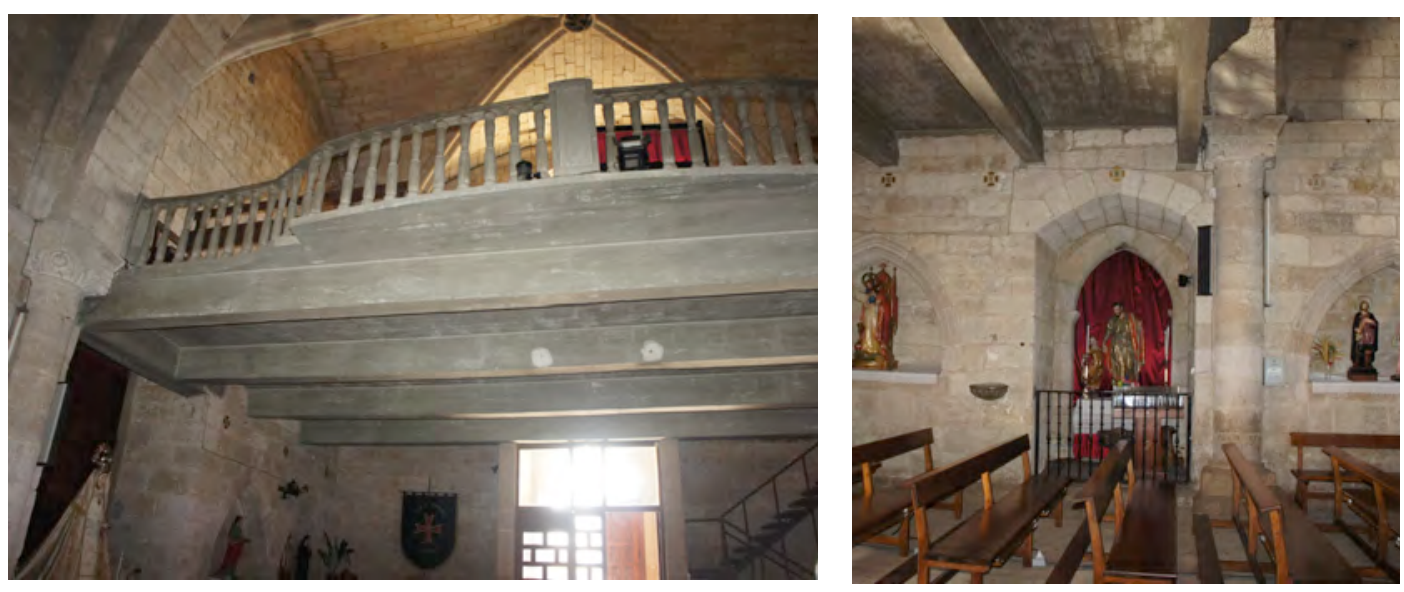

En el interior se mantiene el coro de vigas de canto con losa superior maciza de hormigón armado que mencionan los proyectos de finales del siglo XX.

Aunque se observa suciedad por humedades en la parte superior de los paramentos, puede tratarse de una patología resuelta con la última reparación y saneo de los canalones, ya que puede apreciarse cómo se encuentran selladas bastantes grietas de las bóvedas.

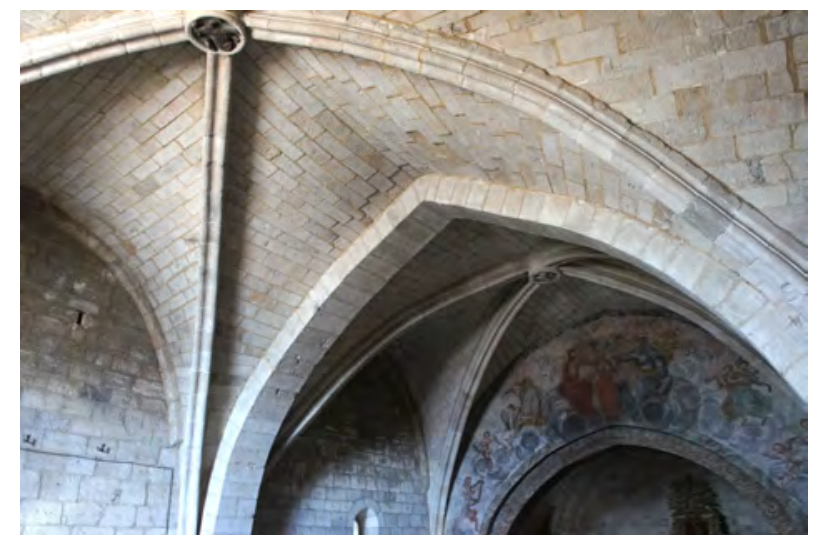


En el intradós de la bóveda de la sacristía podemos apreciar cómo se ha dejado a la vista su geometría, resuelta con rosca de ladrillo.
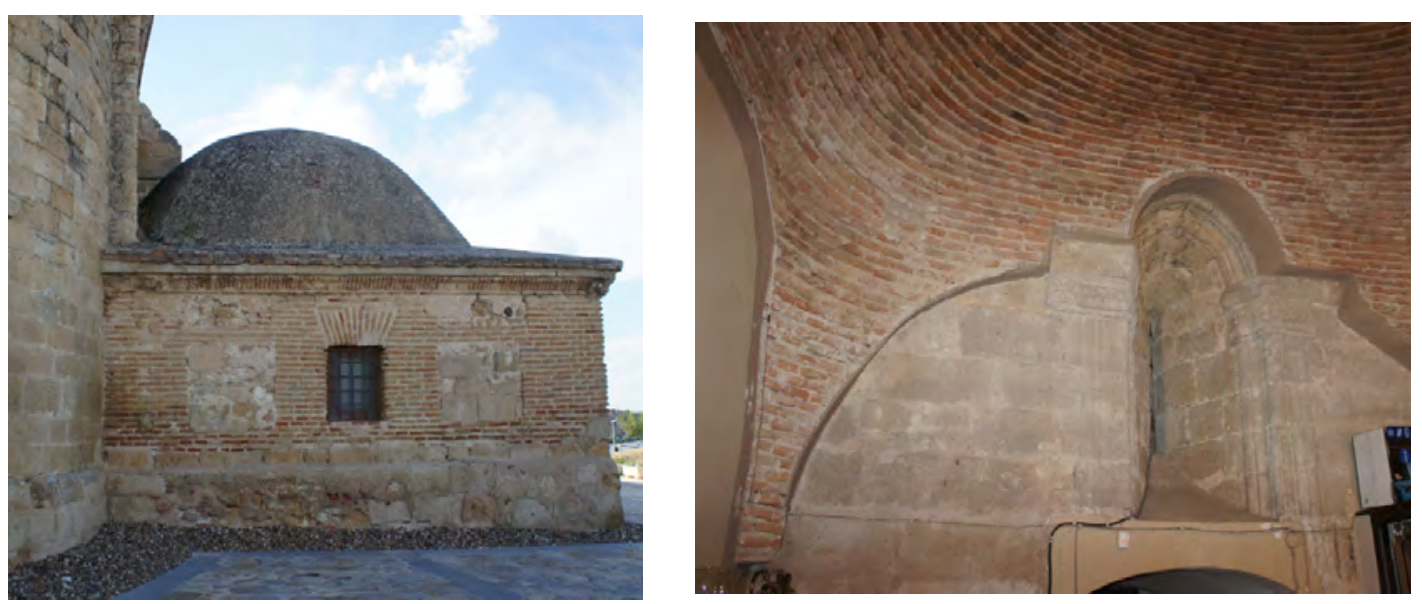

A grandes rasgos la arquitectura observada coincide con la definida en los planos de estado actual del proyecto de Ana Iglesias. La permanencia del coro y la espadaña de ladrillo confirman, sin embargo, que no se llegaron a ejecutar sus proyectos, redactados en los años 70, ya que en todos ellos se incluía la demolición de ambos elementos. No ha debido incorporarse a la cubierta entonces el zuncho perimetral que se contemplaba en los mismos. 



\section{Iglesia de los Santos Justo y Pastor}

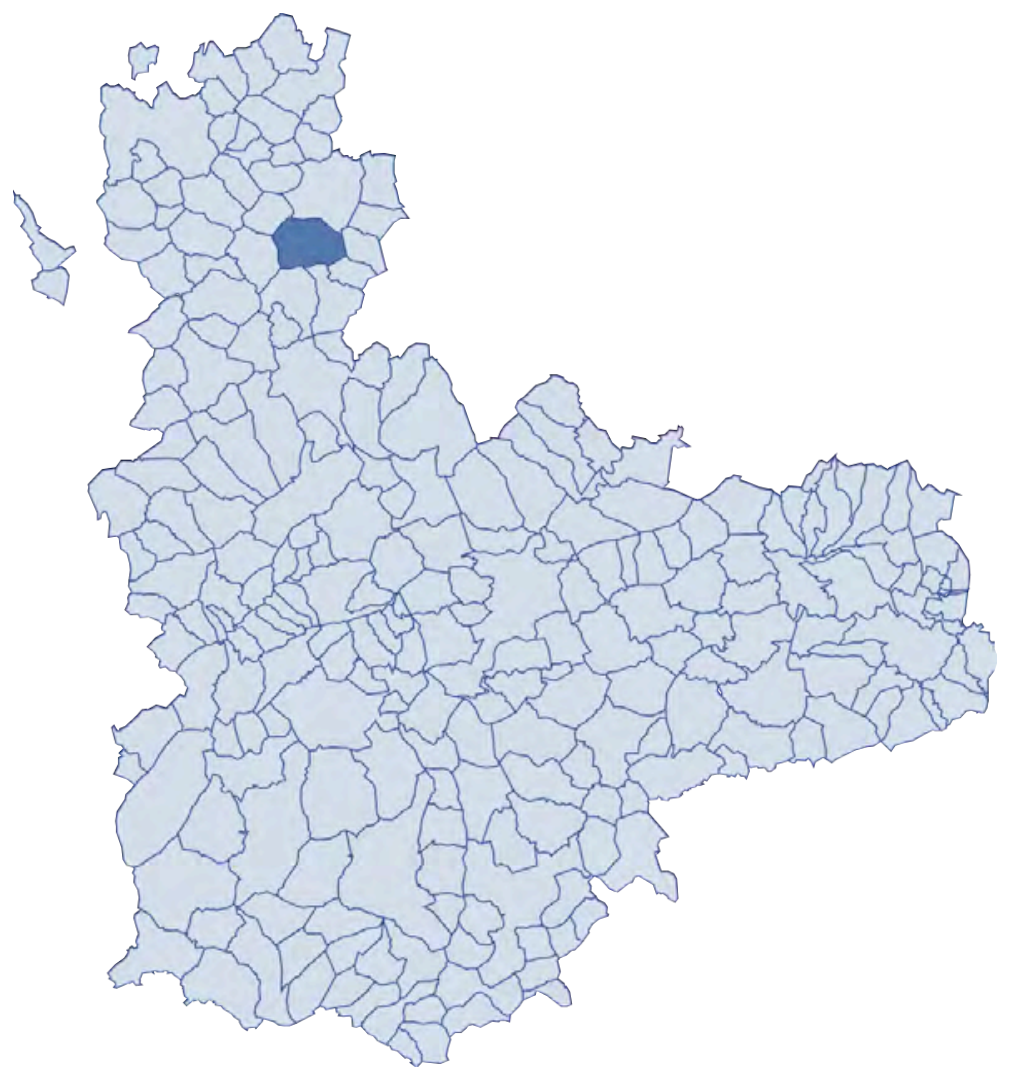



FICHA SÍNTESIS

\section{Código de identificación: FZ-21}

Denominación: $\quad$ Iglesia de los Santos Justo y Pastor

Localidad: Cuenca de Campos

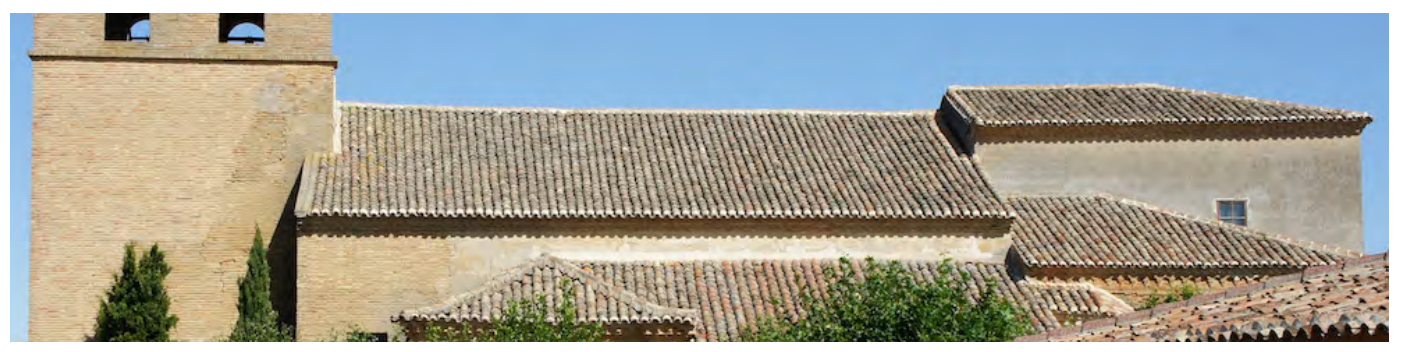

\section{Descripción}

Iglesia mudéjar de tres naves, separadas por columnas y cubiertas por artesonados.

\section{Materiales}

Los muros son de ladrillo visto, con un núcleo de tapial. Cuenta con un zócalo de sillería de piedra. La cubierta está revestida de teja curva.

\section{Singularidades}

El templo estuvo abandonado durante años y sufrió diversos derrumbes, entre ellos gran parte de la torre, que está reconstruida. Las techumbres son de carpintería de lazo policromada y las columnas, esbeltísimas, de "madera revestida de yeso" ${ }^{1}$.

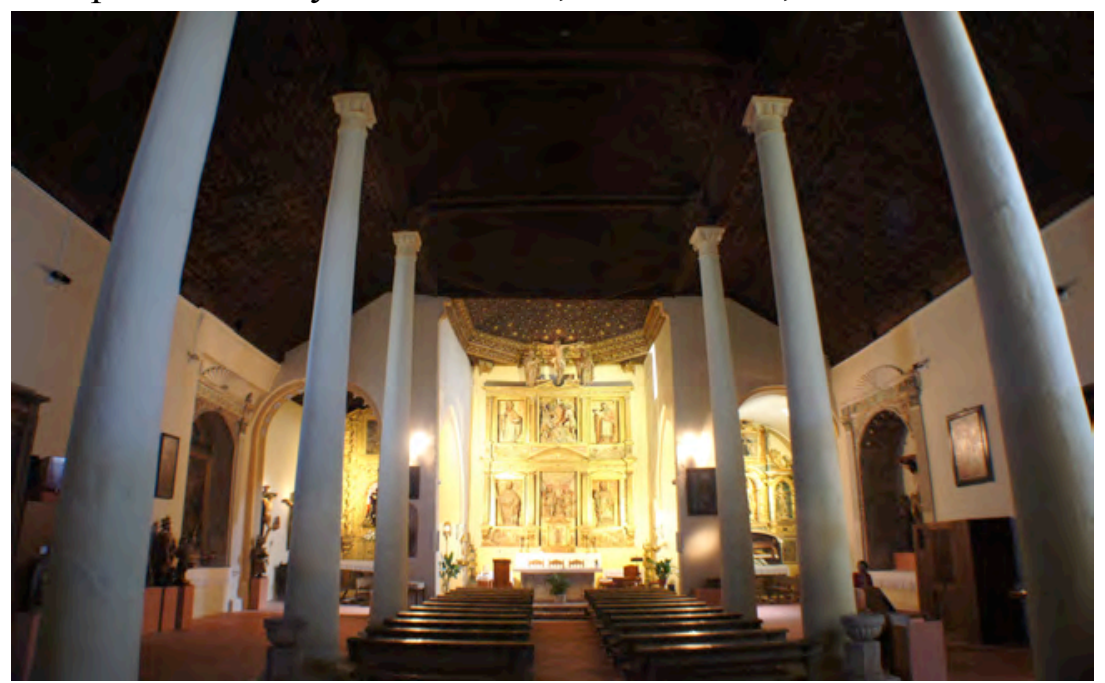

llustración 1: interior del templo, visita 25/08/2015

\footnotetext{
${ }^{1}$ Descripción del material de las columnas en la memoria del proyecto 1967 Arenillas AGA 26/00120.
} 


\section{Dimensiones básicas del templo}

$\begin{array}{llll} & \text { central } & \text { laterales } & \text { capillas } \\ \text { Ancho de nave } & 5,8 & 4,0 & - \\ \text { Altura } & 8,0 & & \end{array}$

\section{Memoria histórica constructiva}

Según el Catálogo el edificio se construye en el siglo XVI.

En el proyecto de 1964 Arenillas indica que la torre es un torreón defensivo de la baja Edad Media, con muros de ladrillo de gran espesor con "el interior macizado con tierra arcillosa hasta unos dos metros bajo el patio de campanas".

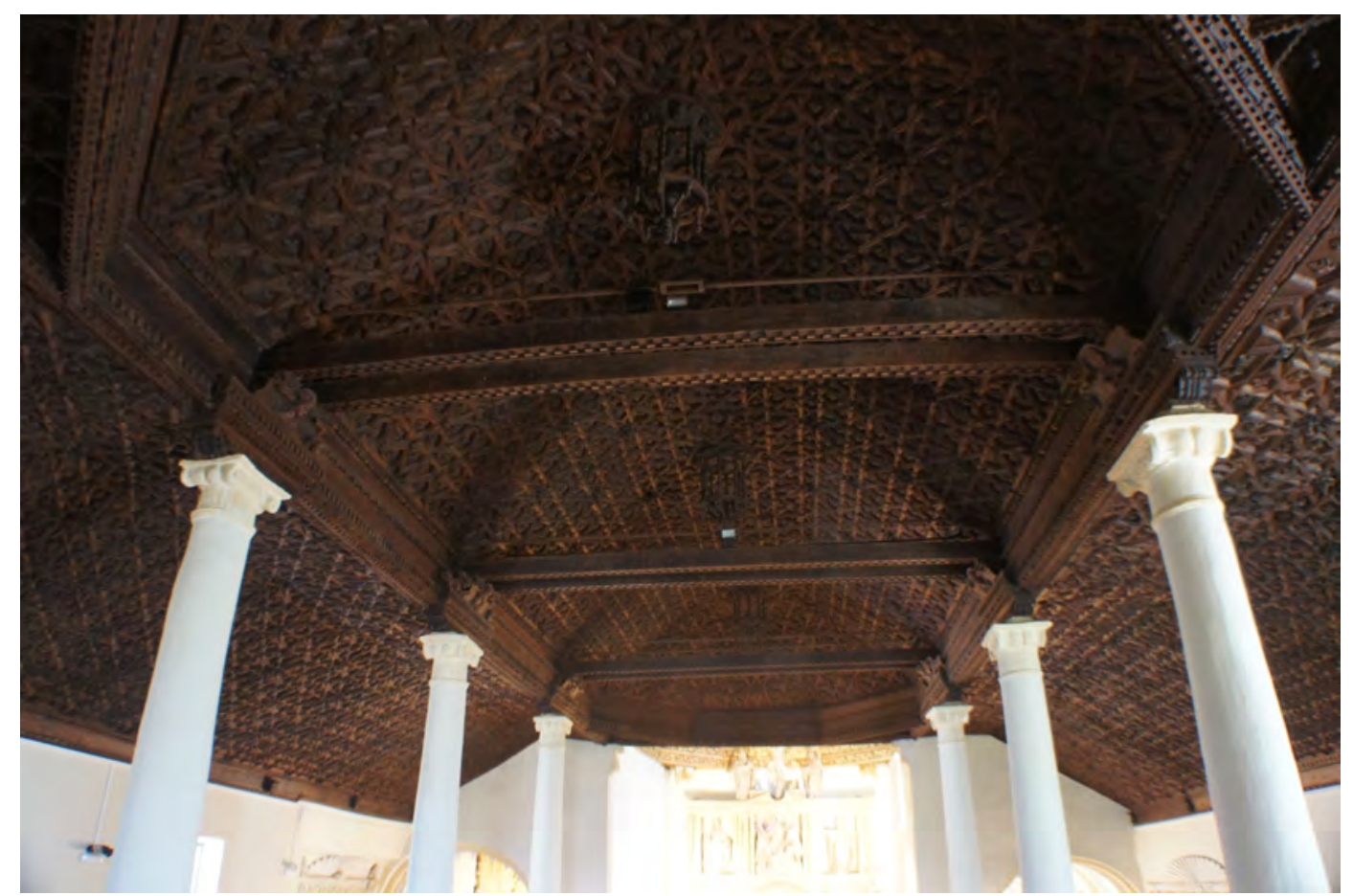

Ilustración 2: artesonado del cuerpo de la iglesia, visita 25/08/2015

\section{Cronología. Fechas clave}

$1962-1969$

\section{Intervenciones}

1962 - Consolidación - Anselmo Arenillas

Tras el hundimiento de torre y parte de fachada en 1961, se pican los muros de tapial de 3,5 astas y recubren con 1 asta de ladrillo por cada cara, tras recalzar sus cimientos. 
Arenillas indica que se reemplaza las columnas por pilares de hormigón armado con jácenas del mismo material sobre los mismos atirantadas transversalmente con redondos.

Los faldones de cubierta se reemplazan por placas de hormigón aligerado con cerámica dejando $80 \mathrm{~cm}$ de espacio bajo cubierta, hasta los artesonados suspendidos con alambres.

1964 - Contención de ruina y reconstrucción de la torre - Anselmo Arenillas

1966 - Restauración del artesonado - Anselmo Arenillas

Limpieza y encalado de muros, solado y reparación del artesonado.

1967 - Reparación de la cubierta de la cabecera - Anselmo Arenillas

\section{Incorporación de zuncho de hormigón armado en cabecera (solerón).}

Tras el hundimiento de una zona de artesonado del presbiterio, debido a la rotura de un par de la cubierta, se reemplaza la estructura de los tres ábsides por cerchas metálicas.

2006 - Restauración de los artesonados. Contratista REARASA

\section{Planos}

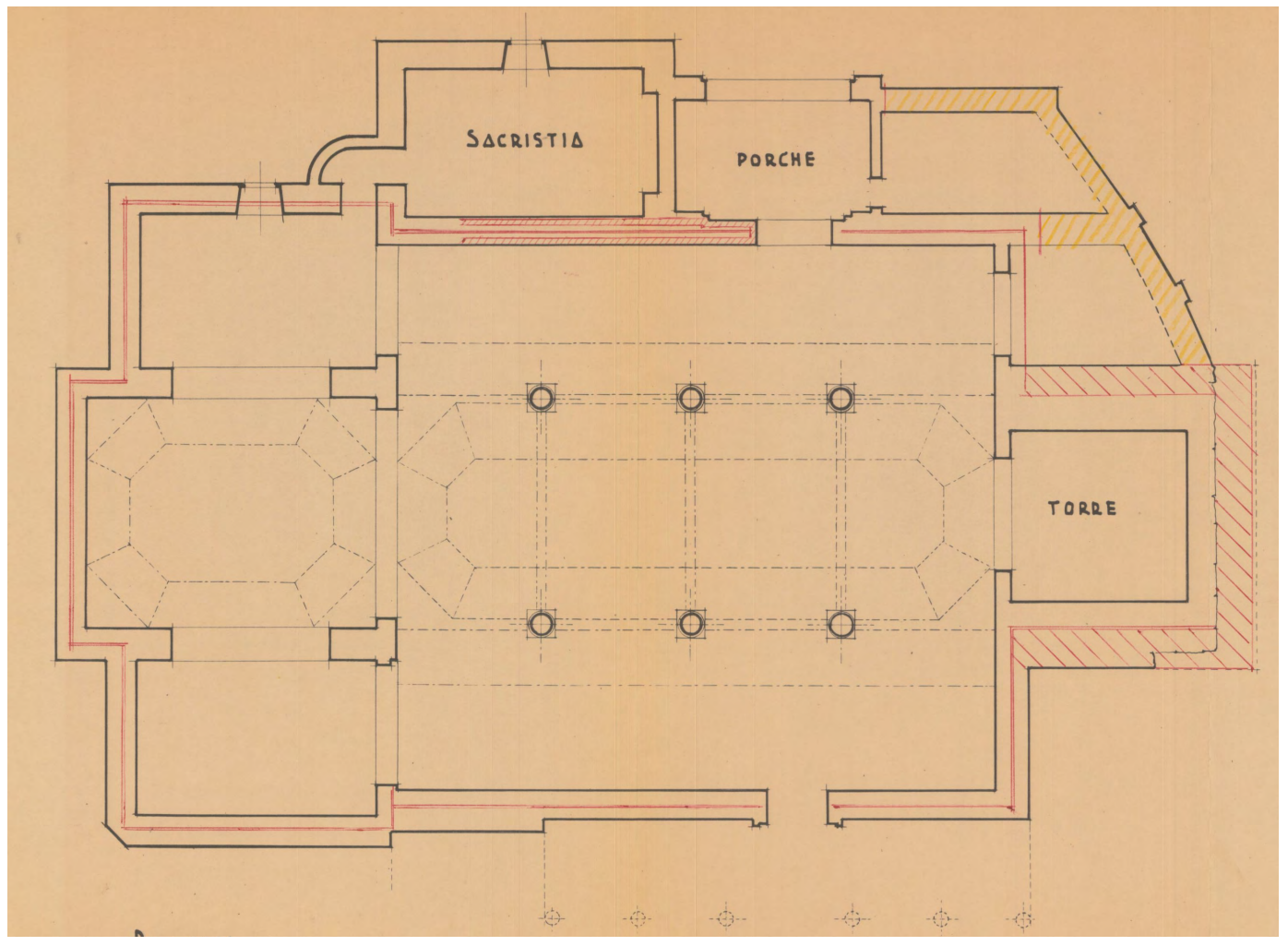

Ilustración 3: planta 1962 Arenillas AGA 


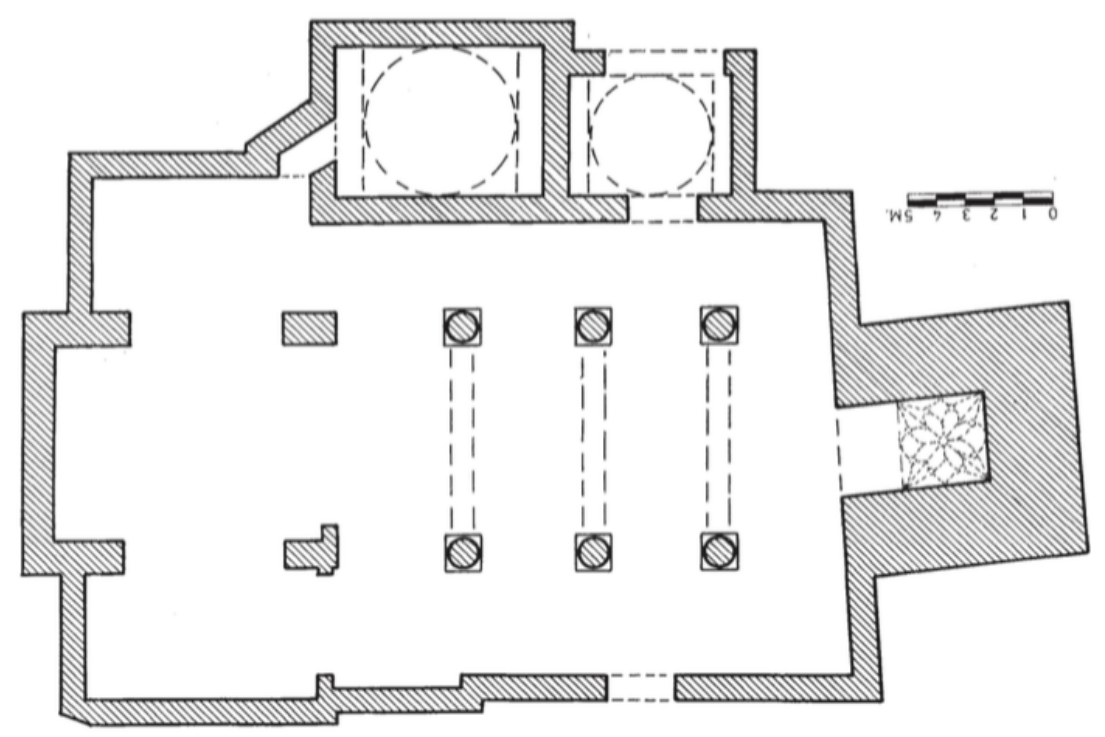

Ilustración 4: planta Catálogo Villalón

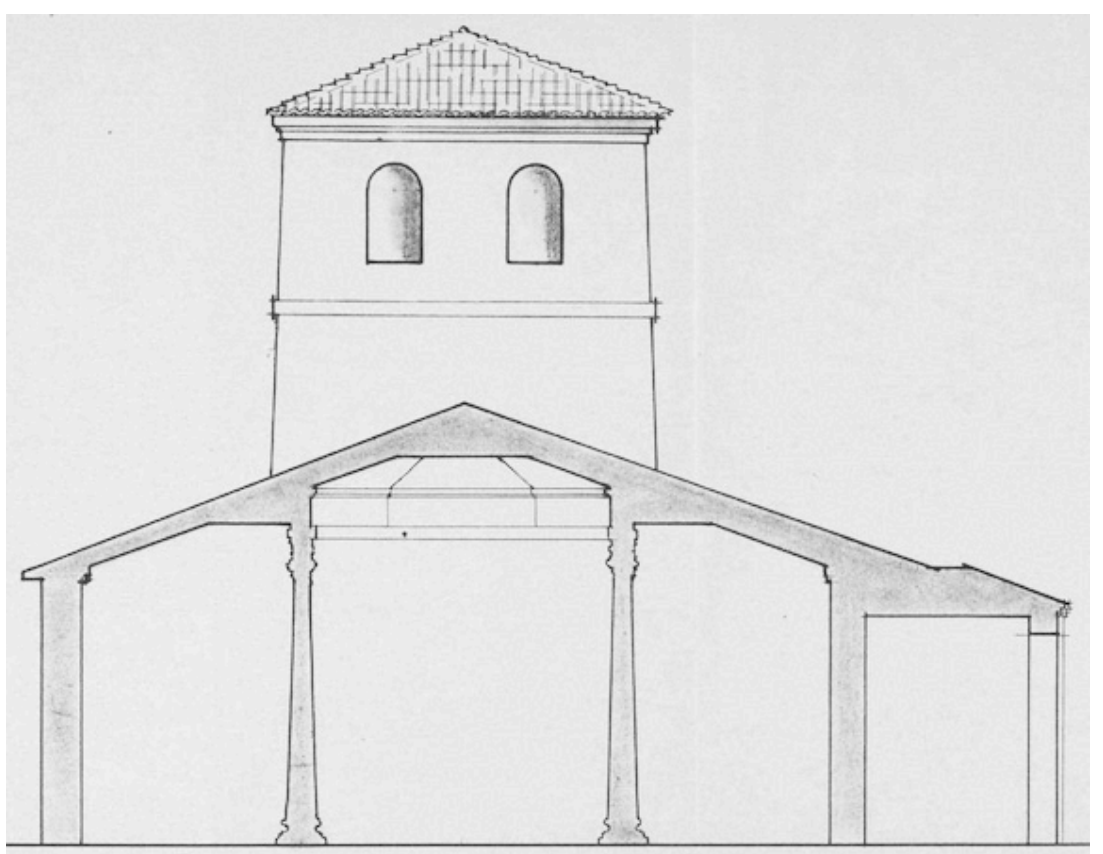

Ilustración 5: sección 1964 Arenillas IPCE

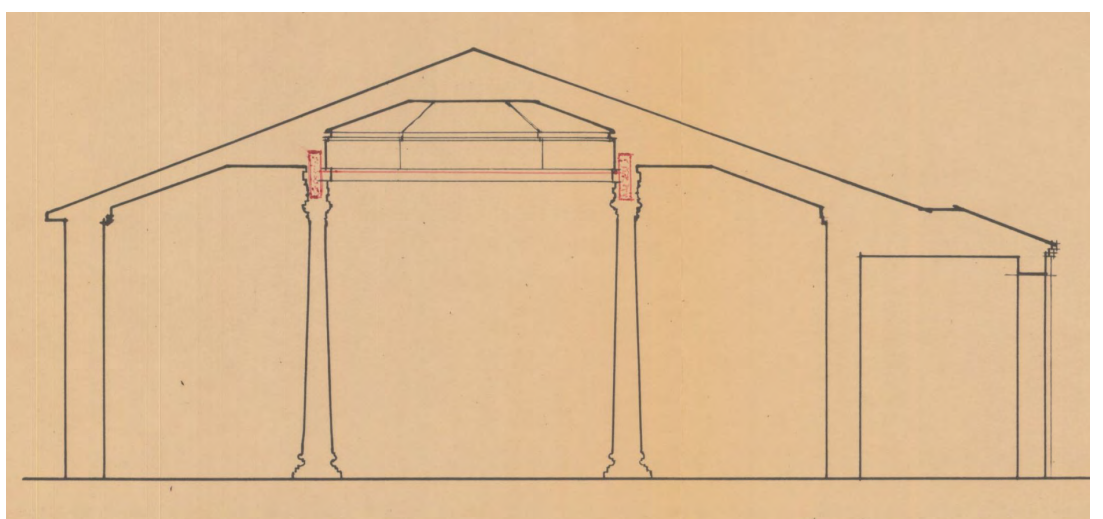

Ilustración 6: sección 1962 Arenillas AGA 


\section{Solución constructiva de la cubierta}

En las secciones de los años 60 se aprecia una pendiente de unos $21^{\circ}$, cubriéndose bajo dos faldones las tres naves. Según el diseño de Arenillas se debió encastrar en el cuerpo de la nave unas vigas de hormigón sobre las columnas, atadas con tensores de acero dispuestos sobre los tirantes del artesonado que se mantuvo como techumbre.

El proyecto del mismo autor de 1967 plantea una estructura metálica, con un zuncho de hormigón armado, para cubrir los tres ábsides tras un hundimiento.

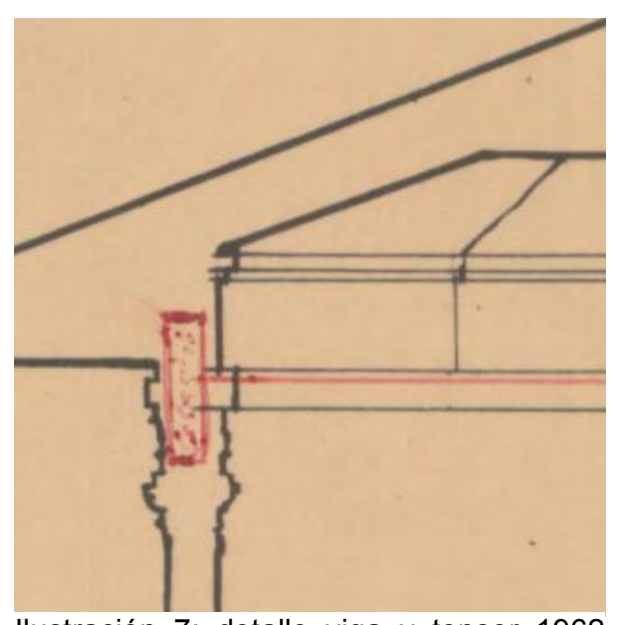

llustración 7: detalle viga y tensor 1962 Arenillas AGA

\section{Zunchos}

En la sección de 1962 se representa en rojo las vigas mencionadas. Los zunchos mencionados sobre la cabecera no se representan en los planos.

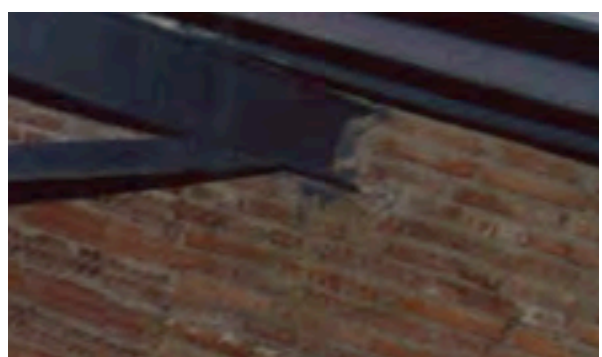

En fotografías cedidas por REARASA, tomadas durante la restauración del artesonado, se aprecia la existencia de un zuncho en L sobre el que apoya la estructura en la esquina, mientras que no se distingue cómo está resuelto el apoyo de las cerchas de las naves.

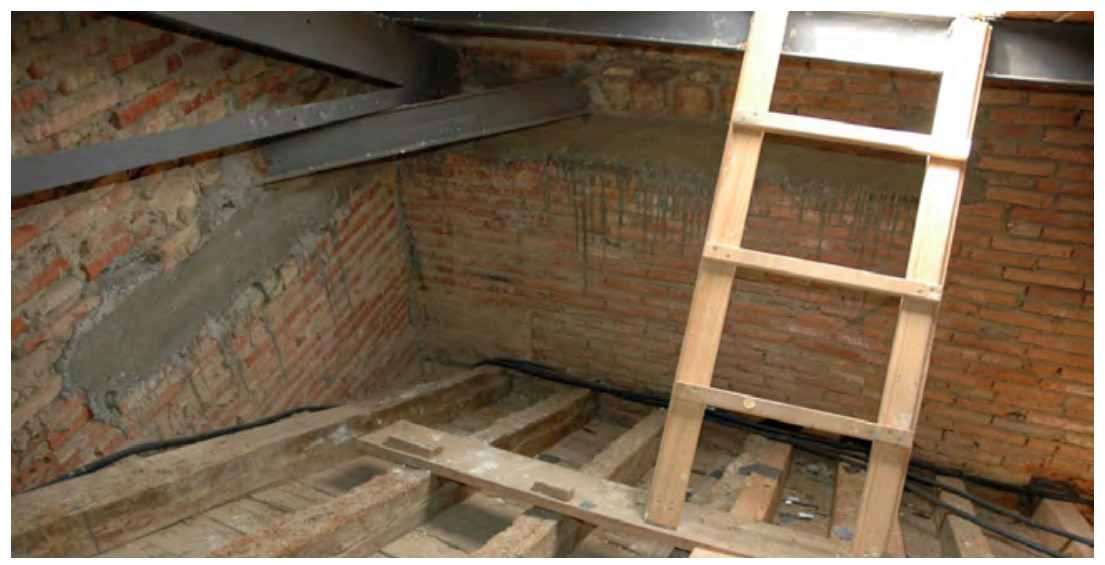

Ilustración 8: fotografías del bajocubierta cedidas por REARASA 


\section{Conclusiones}

En este edificio Arenillas debió incorporar las vigas sobre ejes de pilares que define en su proyecto, ya que en la visita se aprecian los tensores que describe como atado transversal de las mismas.

No ha sido posible acceder al espacio bajo cubierta para comprobarlo.

En imágenes del dossier de la última intervención en el templo se aprecia la existencia de un zuncho de hormigón armado en L en la esquina. 


\section{Iglesia de los Santos Justo y Pastor}

Intervenciones citadas en la publicación del Ministerio:

1962 - Consolidación de muros de la fachada - Anselmo Arenillas Álvarez

1964 - Contención de ruina y reconstrucción de la torre - Anselmo Arenillas Álvarez

1966 - Restauración y limpieza artesonado, pavimentación y carpintería -

Anselmo Arenillas Álvarez

1967 - Reparación de la cubierta de la cabecera - Anselmo Arenillas Álvarez

En la web del IPCE hay un plano con planta y sección transversal 1:100, de 1964, firmado por Anselmo Arenillas.

\section{En el archivo de la Junta de Castilla y León}

No se ha localizado documentación

\section{En el Archivo General de la Administración}

AGA 26/253

Consolidación

1962 Anselmo Arenillas

En la Memoria describe la iglesia "cuyo mérito radica en los espléndidos artesonados moriscos que la cubren, descansando sobre unas esbeltas columnas seguramente de madera recubiertas de espesa capa de yeso.

Mas los muros de este templo son de tapial, que acaso estuvieron recubiertos de fábrica de ladrillo que los protegería contra la acción de los agentes atmosféricos; pero que hoy ha desaparecido y dejado indefensos los gruesos muros de tierra, y por ello amenazan ruina.

Los últimos en caer han sido los chapados (de 2 astas) de ladrillo de la torre, lo que ha traido la ruina de esta...

El proyecto comprende, esencialmente, el recubrimiento de los muros de fachada por su exterior con otro muro de ladrillo de un asta de espesor, calando cada metro de altura el tapial por puntos para la traba con el trasdós. Este trasdós o cara del interior de los muros de fachada, se rozará en otra asta de espesor por puntos ó fajas verticales; y se unirá a el muro exterior por dos hiladas de traba cada metro de altura. 
En resumen, la operación consiste en lograr rehacer o consolidar el muro de tres y media astas que tiene ahora, convirtiendole en un muro de ladrillo con un nucleo de tapial a modo de emparedado. Será operación delicada pero factible.

Previamente se hará el recalce de las cimentaciones...

Después se levantará el tejado y se apearán los artesonados para intentar quitar los soportes que hacen de columnas y sustituirlos por pies derechos de hormigón, que se recubrirán de madera y acaso de yeso, según aparecen hoy. Por encima del artesonado se colocarán jácenas o vigas de hormigón armado, que descansarán en las columnas mediante tacos de hormigón, atirantándose sus cabezas en sentido transversal, con tensores de hierro redondo disimulados sobre los tirantes de madera.

Rehechos así los elementos sustentantes se proyecta reconstruir los faldones de la cubierta en placa de hormigón armado, aligerado con cerámica, que descansará (sin dar empuje a causa de su simetría) sobre los muros y sobre las jácenas de hormigón ya hechas. encima se proyecta colocar la teja árabe normalmente. Entre las placas de los faldones y los artesonados, se dejará un pequeño espacio de unos $80 \mathrm{~cm}$ para permitir visitarlos y colgarlos de la misma placa con alambres fuertes galvanizados.

Con este quedarán protegidos los artesonados y sin cumplir otra misión que la decorativa, puesto que el tejado estará más alto, será impermeable y también incombustible.

En realidad se rehace toda la estructura portante y el tejado de la iglesia para lograr salvar el artesonado dejándolo en su emplazamiento."

\section{AGA 26/00370}

Proyecto de contención de ruina y reconstrucción de la torre de la Iglesia de los Santos Justo y Pastor

1964 Anselmo Arenillas

\section{Memoria}

La torre de la iglesia de los Santos Justo y Pastor de Cuenca de Campos es obra de la baja edad media, está hecha como torreón defensivo, sus muros son de ladrillo con grandes gruesos y el interior está macizado con tierra arcillosa hasta unos dos metros bajo el patio de campanas.

Hace mucho tiempo que su cubierta, con armadura de madera se hundió y arrastró parte de la cabecera. Entonces se limitaron a hacer un astial para las campanas sobre el muro interior y construir un casetón de madera en la torre...

En la memoria hay una foto de la torre, le falta la mitad y tiene una caseta encima. 


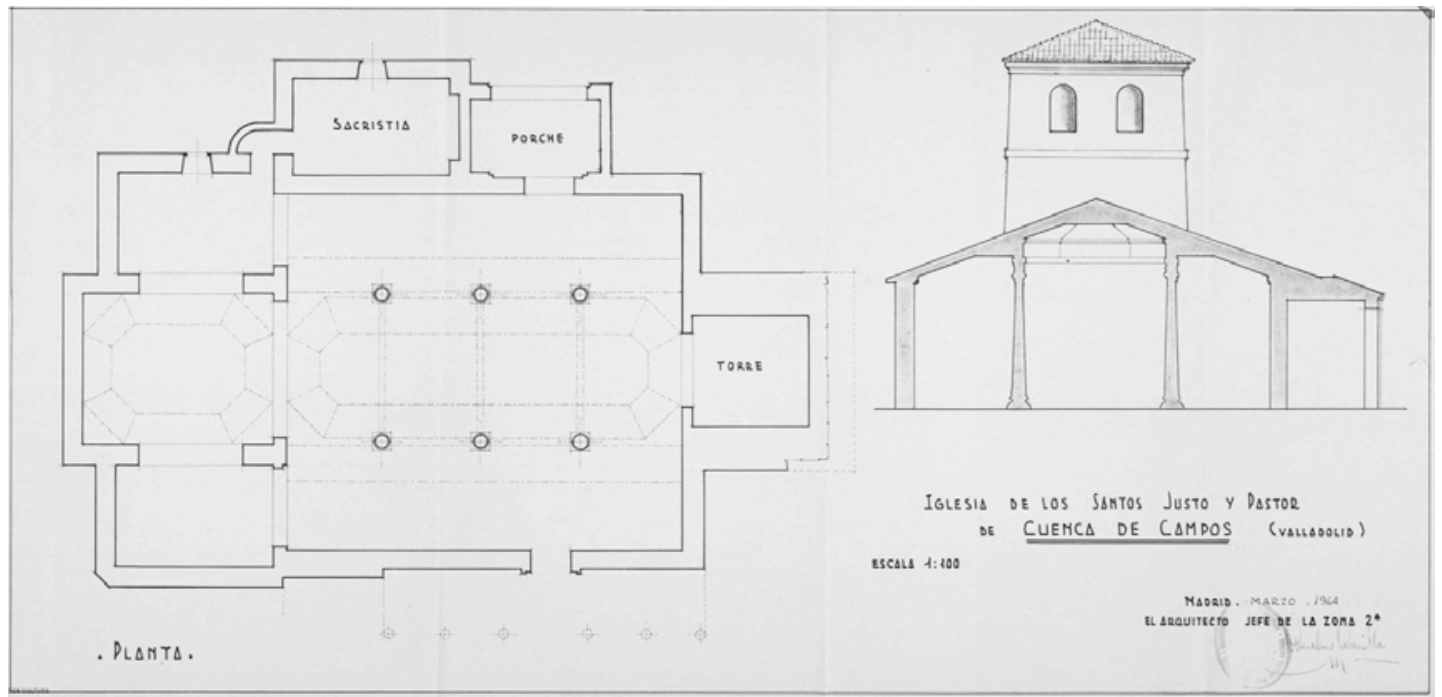

Ilustración 9: plano 1964 Arenillas IPCE

\section{AGA 26/00206}

Restauración del artesonado

1966 Anselmo Arenillas

Memoria

"Su fábrica era de tapial y su cubierta entramada de madera, ambas estaban en muy mal estado y muy descuidadas por haber dejado de celebrar culto en la iglesia. Esto produjo en 1.961 el hundimiento de la torre y parte de los muros de fachada. se acudió a remediar esta situación por la Dirección General de Bellas Artes, ya que los artesonados, origen de la clasificación de Monumento Histórico Artístico, corrían grave riesgo y no podían ser trasladados a otro lugar.

Como consecuencia se rehicieron gran parte de los muros con fábrica de ladrillo y zócalo de piedra, dejando colgada la cubierta y artesonado, se chaparon con fábrica de ladrillo el resto de ellos, se sustituyó la cubierta haciéndola con armadura metálica, dejando entre ella y el artesonado una gran cámara de aire, visitable, lo que obligó a recrecer los muros y hacer las cornisas nuevas y, finalmente se reconstruyó la torre con nueva cimentación, zócalo de piedra y fábrica de ladrillo, vaciándola de tierras y forjando pisos, escaleras y cubierta. Todo quedó consolidado y saneado con cargo a dos proyectos aprobados en 1962 y 1964.

$\cdots$

La iglesia va a volver a ser empleada para el culto general en el pueblo, abandonando otra que está en peor situación".

Quedaba pendiente: Se repara el artesonado 505m2, solado nuevo con baldosa de barro $541 \mathrm{~m} 2$, carpinterías, limpieza de los muros y blanqueo de cal. Se coloca un altar 
Mismo plano de planta y sección (sin los añadidos rojos a mano de los otros proyectos)

Presupuesto

\section{AGA 26/00120}

Proyecto de reparación de la cubierta de la cabecera de la iglesia de Cuenca de Campos

1967 Anselmo Arenillas

Memoria (2 pag)

Iglesia de tipo morisco con bellísimos artesonados.

"Habiéndose derrumbado su torre y amenazando ruina las cubiertas y los muros de las naves, hubo de acudir la Dirección General de Bellas Artes a reconstrucción para salvar el artesonado que no admitía, por su estado, ser desmontado y trasladado a otro emplazamiento.

Con las obras previstas, una vez realizadas, quedó totalmente consolidada la iglesia y con una cubierta de entramado metálico que no sólo hace de tejado, sino que tiene colgado de ella el artesonado de debajo. Esta cubierta nueva comprende las dos naves bajas y la central, pero no los tres ábsides. Fué de dificil ejecución porque no se disponía de apoyo, ya que las columnas de las naves son de madera y yeso.

Se creyó que no era preciso obrar en los tejados y armaduras de los tres ábsides porque al retejar presentaron un buen aspecto y se vió que eran independientes de los artesonados. Más, transcurridos dos o tres años, ha surgido un molesto accidente: se ha roto un madero o par de la armadura de la cubierta del presbiterio, que ha caído sobre el artesón, rompiéndolo y hundiendo una pequeña porción de él, (poco más de un metro cuadrado) y esto nos ha alertado y hecho ver que, por su vejez, la madera de las cubiertas conservadas es preciso sustituirla por entramados metálicos, cosa que se evitó antes por razones económicas y no acusarse la urgencia del caso.

Se apeó el artesonado en la parte deformada y por orden del Iltmo. Sr.Director General se ha redactado el presente proyecto de obras, que comprende:

Desmontar con precaución y por tramos sucesivos los tejados y cubiertas de los tres ábsides y sacristía.

Limpiar bien el trasdós y los entramados de los artesones de madera e impregnarlos de un líquido antiparásito y anticomburente. Reparar estos artesones ligeramente y disponer en ellos alambres de cobre o hierro galvanizado que luego quedarán sujetos a la armadura de la cubierta. 
Recrecer los muros de contorno para recibir la nueva cubierta, que como la anteriormente hecha sobre el cuerpo de la iglesia, quedará separada del artesonado permitiendo su aireación y visita.

La nueva cubierta comprende una cubierta a TRES aguas sobre el presbiterio, dos cubiertas a dos aguas sobre los ábsides laterales y una a un agua sobre la sacristía.

Estas cubiertas se formarán con elementos prefabricados de hormigón y hierro en los pares y limas, con un solerón de hormigón armado con estribo, con sus tirantes de hierro que pasarán sobre los artesonados y con elementos cerámicos que formarán el faldón apoyando en los pares. Sobre todo ello se tenderá una capa de hormigón de $3 \mathrm{~cm}$. y se colocará una tela de plástico de butapropeno. Quedarán recibidos en la masa de hormigón los alambres de sustentación de los artesonados.

Finalmente, se colocará la teja, siendo la nueva empleada como canales y la vieja aprovechable de cabijas.

Plano: Una planta con faldones en rojo sobre la cabecera y sección transversal general 1:100. Arenillas febrero de 1967.

Pliego, Precios y Presupuesto.

$252,80 \mathrm{~m} 2$ de levantado del tejado y armadura

$252,80 \mathrm{~m} 2$ de reparación entablado exterior del artesonado y tratamiento antiparásito $27,86 \mathrm{~m} 3$ de fábrica de ladrillo recocho y cemento en recrecido de muros y cornisas $252,80 \mathrm{~m} 2$ de faldón de cubierta en hormigón armado, incluidas soleras y tirantes, más tela plástica imputrescible tendido de cemento y teja árabe colocada 1 ud de pararrayos 



\section{Visitas realizadas}

$25 / 08 / 2015$

El estado de conservación del monumento es bueno. En el interior del edificio sólo se aprecia una fisura que cruza el pavimento del altar mayor.

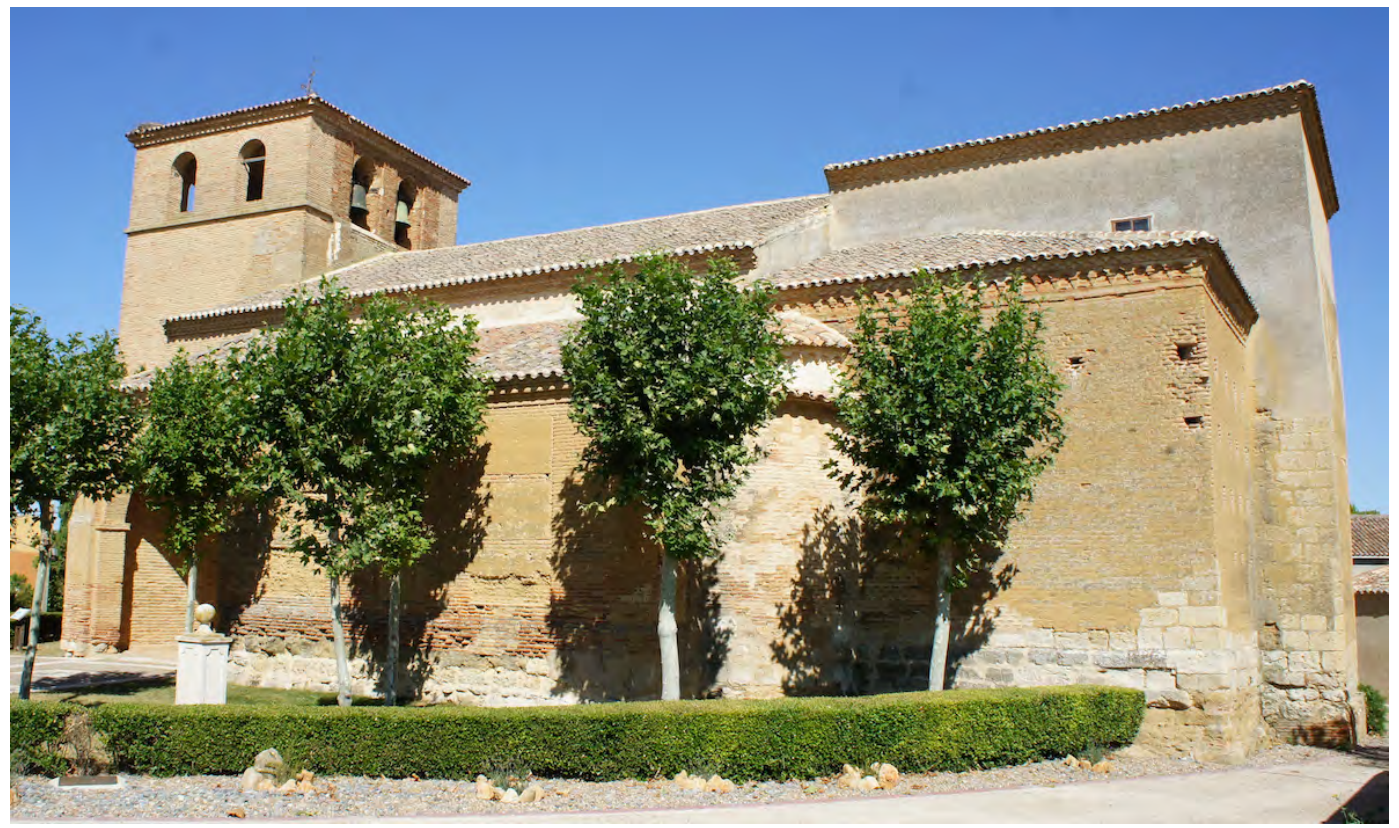

En los paramentos exteriores sí encontramos cierta erosión en la fábrica de sacristía y los testeros de ambas naves a los lados de la cabecera, especialmente erosión de la cornisa de ladrillo y falta de retacado en la parte baja de ladrillo por encima del zócalo de piedra.
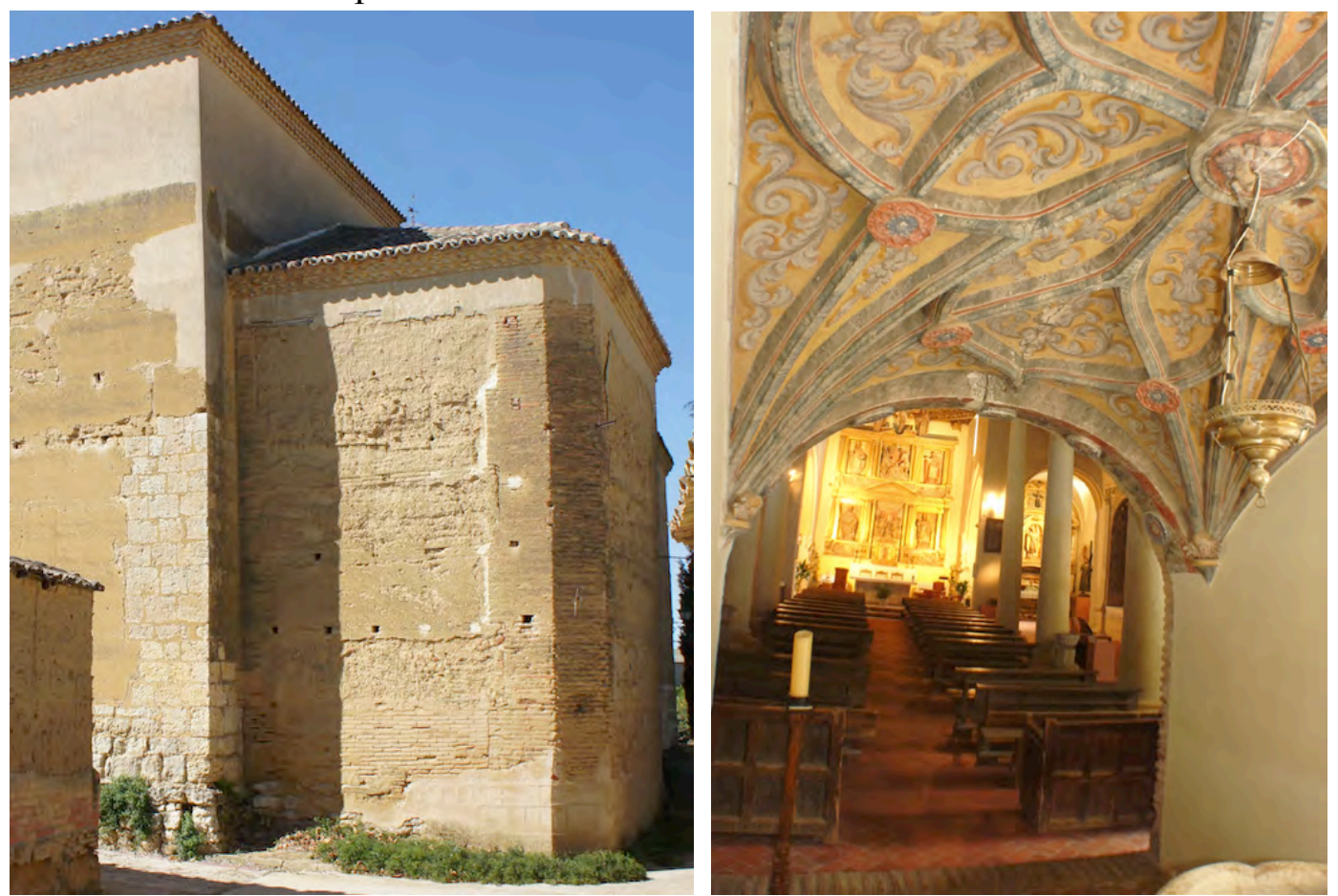
El arranque del núcleo de la torre se cubre con bóveda de crucería gótica. Sobre su trasdós se aprecian los restos del cerramiento original de dicha torre, realizado con ladrillo y un relleno de tapial de gran espesor.

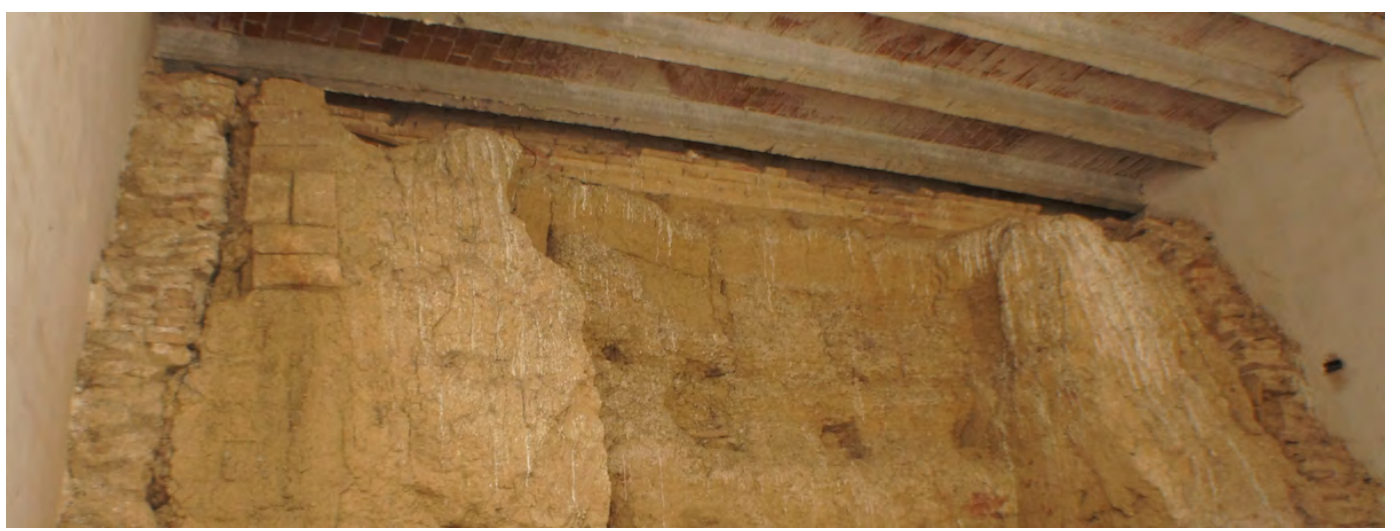

También podemos ver el forjado moderno con que Arenillas cubrió los mismos, bajo el cuerpo de campanas, al llevar a cabo su proyecto de reconstrucción de la torre en 1964 que en la memoria describe como "placa de hormigón armado aligerado con cerámica".
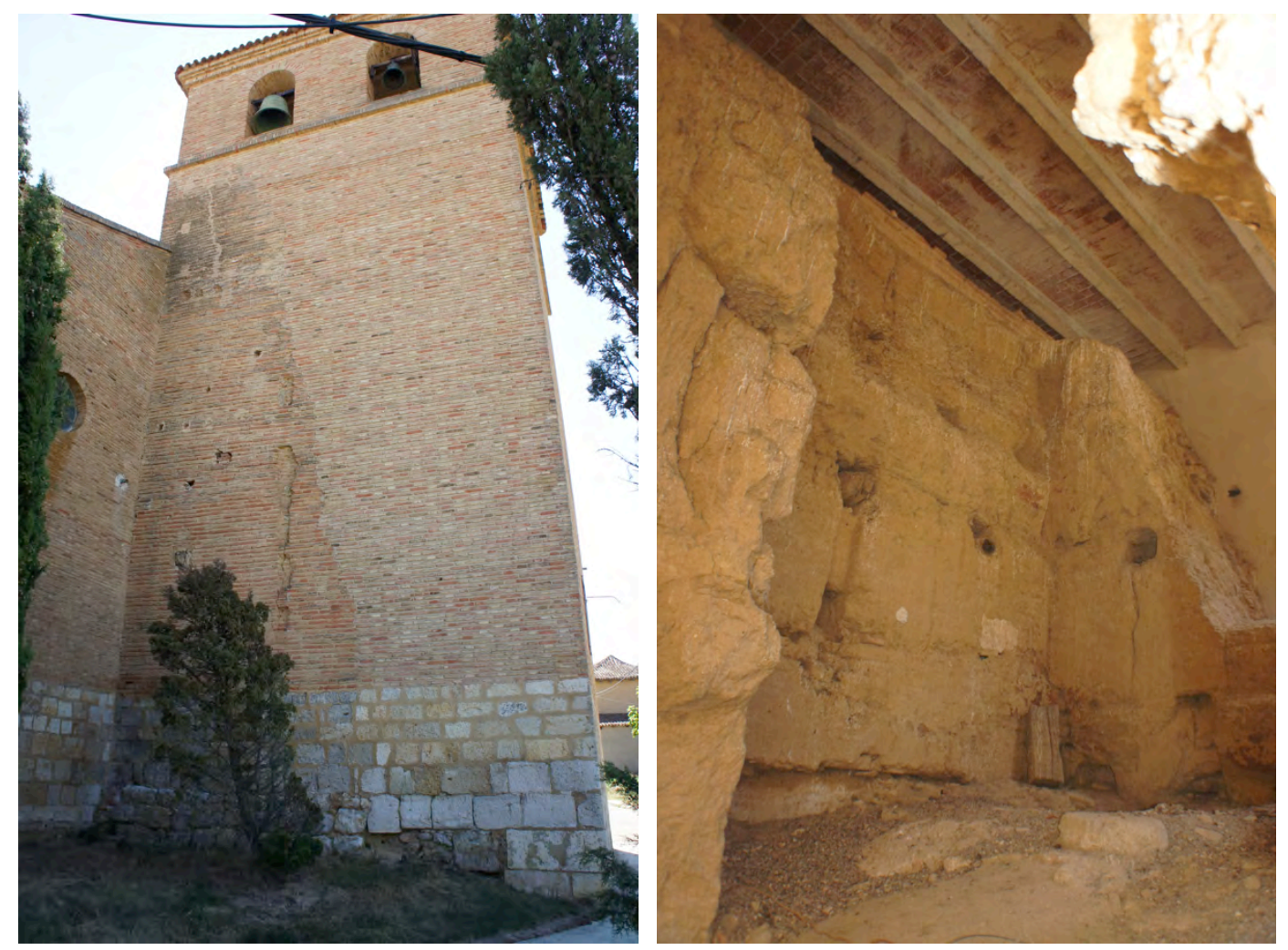

Las soluciones observadas durante la visita coinciden con las descripciones de las memorias de este arquitecto, lo que induce a pensar que dichas obras se ejecutaron tal y como se habían planteado. 
Así, aunque no sea posible acceder al espacio bajo cubierta, ya que según nuestra guía local sería necesario alcanzar una pequeña trampilla cerca de la techumbre, sí se aprecian desde el interior del templo los tensores metálicos dispuestos sobre los tirantes de madera del artesonado que menciona como parte de la nueva estructura de cubierta de la nave.

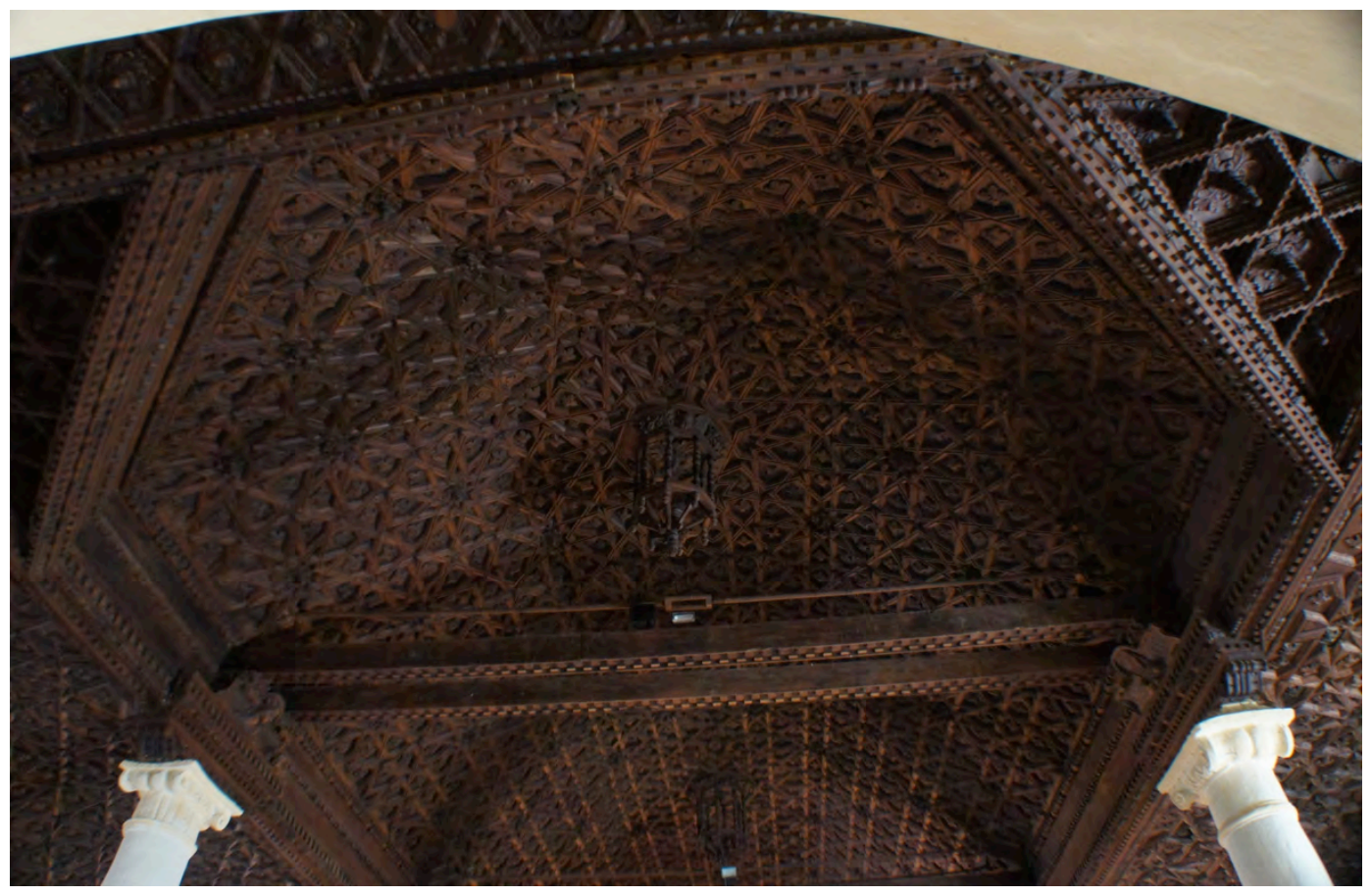

Arenillas describe también cómo pretende reemplazar las esbeltas columnas originales por pilares de hormigón recubiertos de madera y yeso para apoyar sobre ellos las jácenas de hormigón y atirantarlas con los tensores citados.
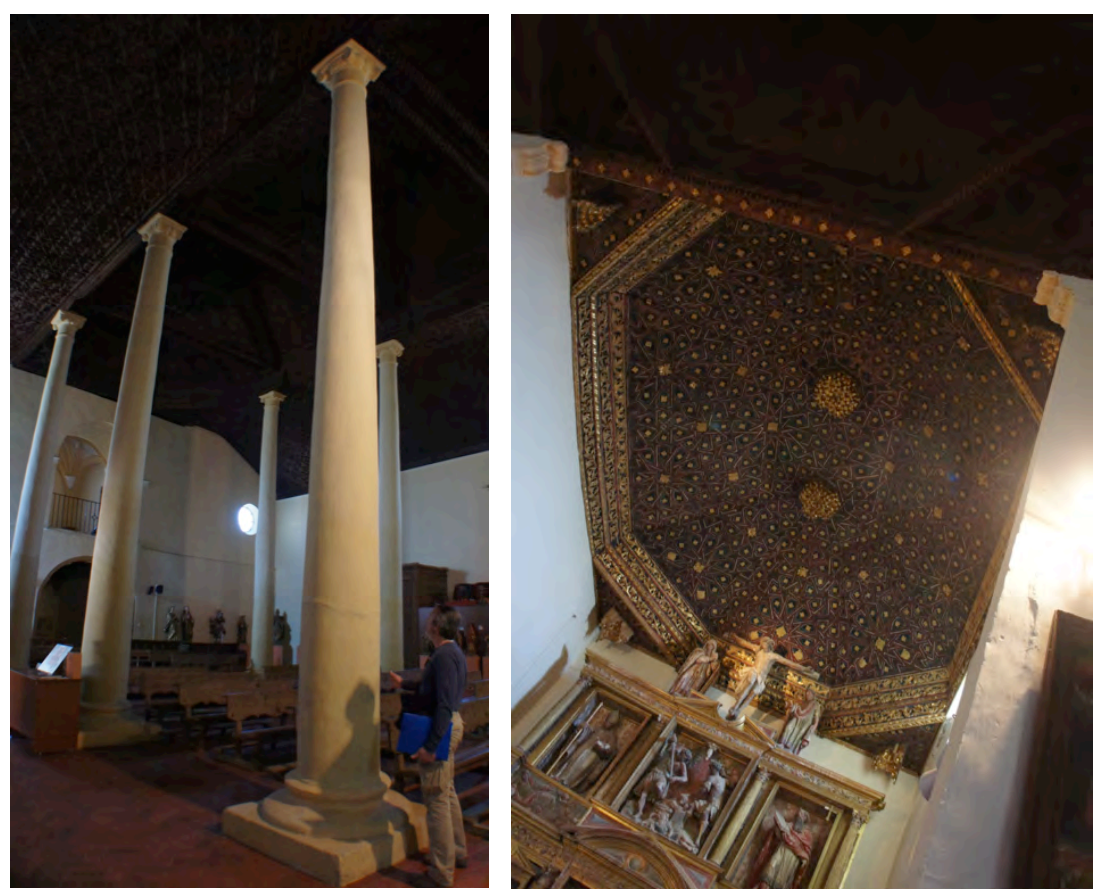
Se cuenta con un dossier de fotografías del trasdós del artesonado proporcionado por la constructora REARASA ${ }^{1}$, responsable de su restauración.

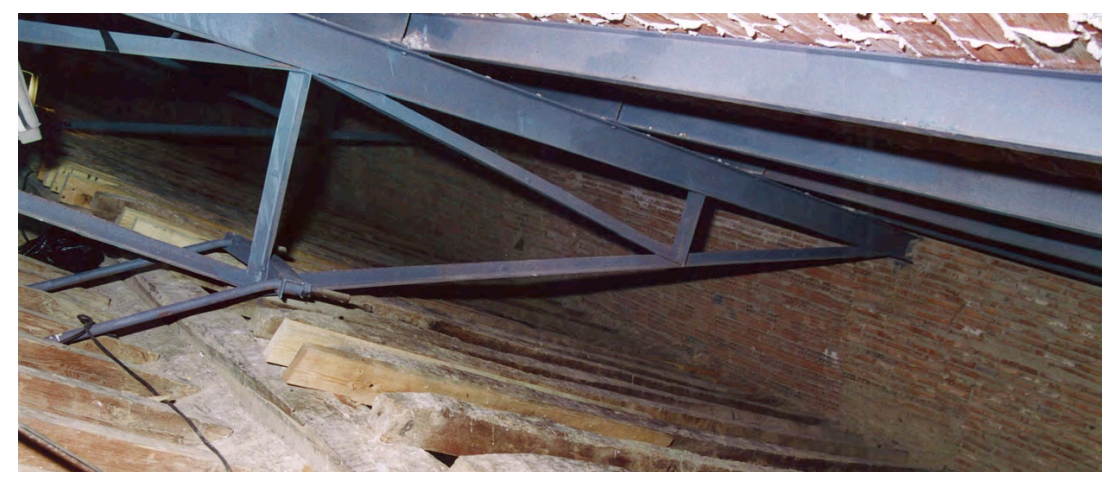

Capilla lateral izquierda

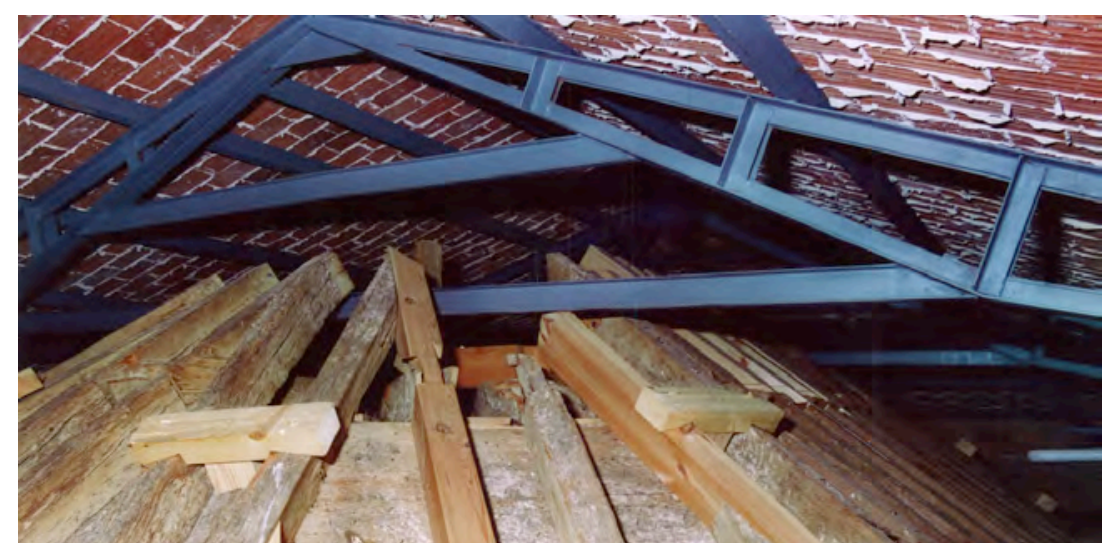

Armadura nave central

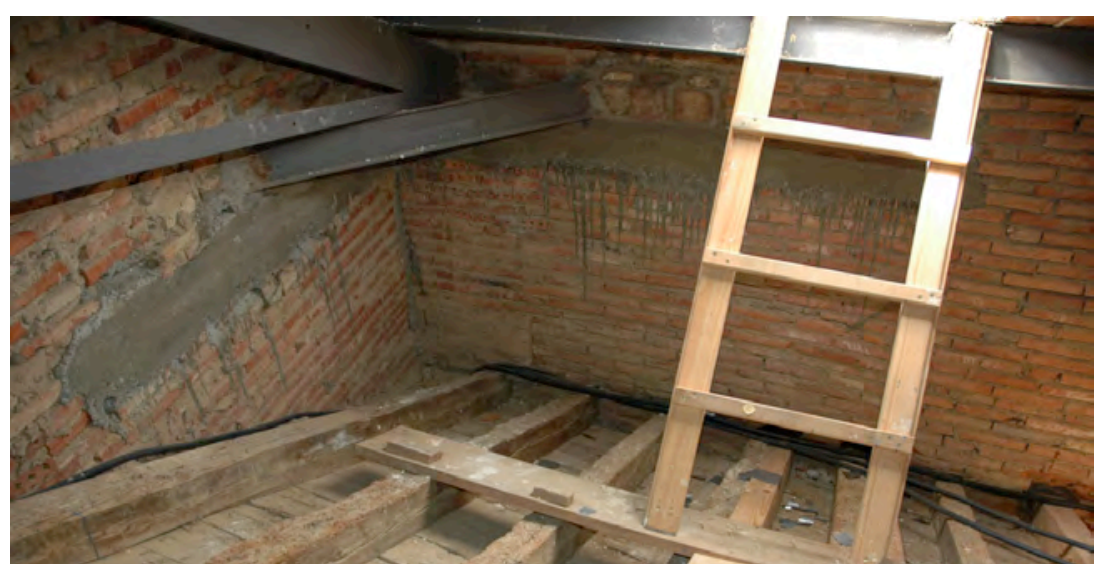

En las imágenes se aprecia un zuncho en L en la esquina sobre el que apoya la estructura de cubierta. No se percibe cómo se resuelve el apoyo de las cerchas de nave lateral sobre los muros.

\footnotetext{
${ }^{1}$ Las imágenes se han suministrado con autorización de la Dirección General de Patrimonio Cultural de la JCyL.
} 


\section{Iglesia de San Juan Bautista}

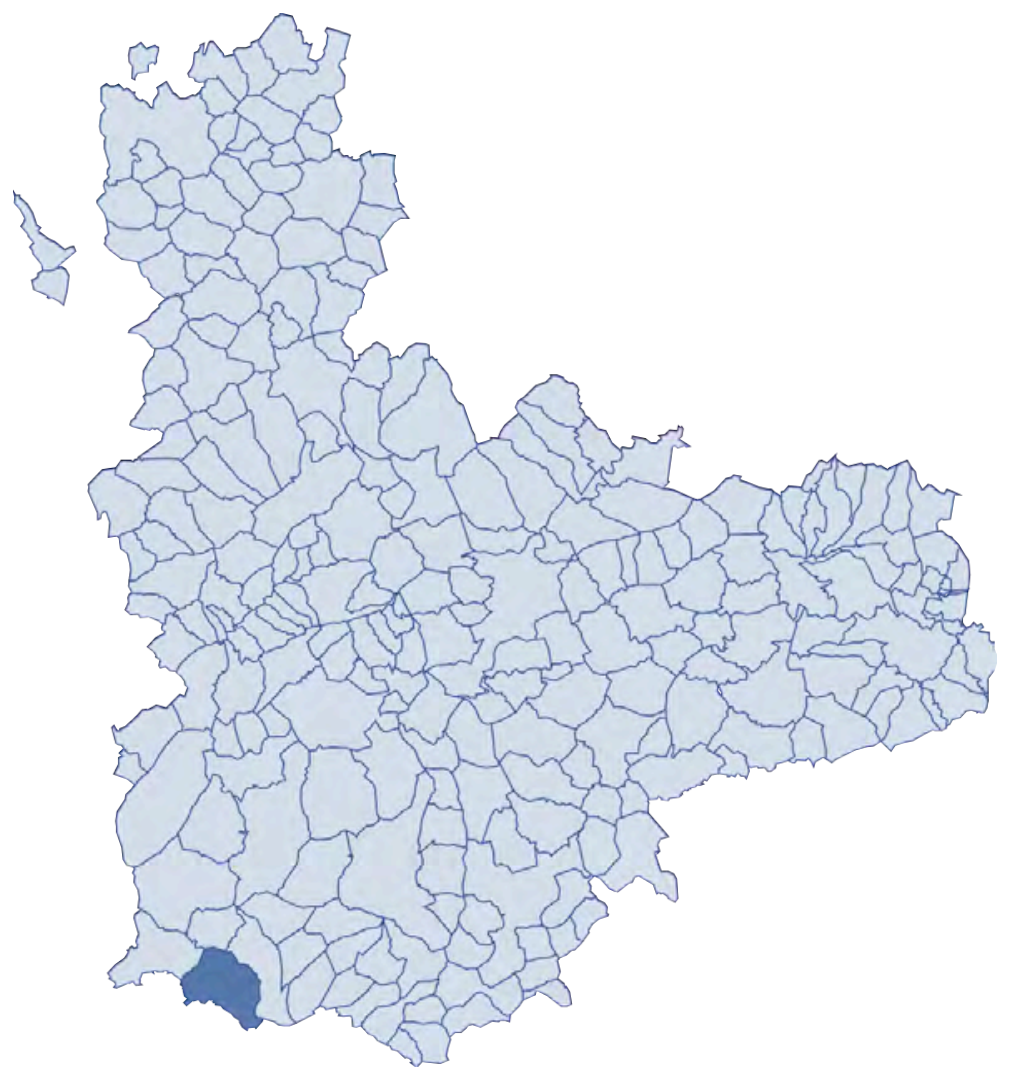



FICHA SÍNTESIS

\section{Código de identificación: FZ-22}

Denominación: $\quad$ Iglesia de San Juan Bautista

\section{Localidad: $\quad$ Fresno el Viejo}
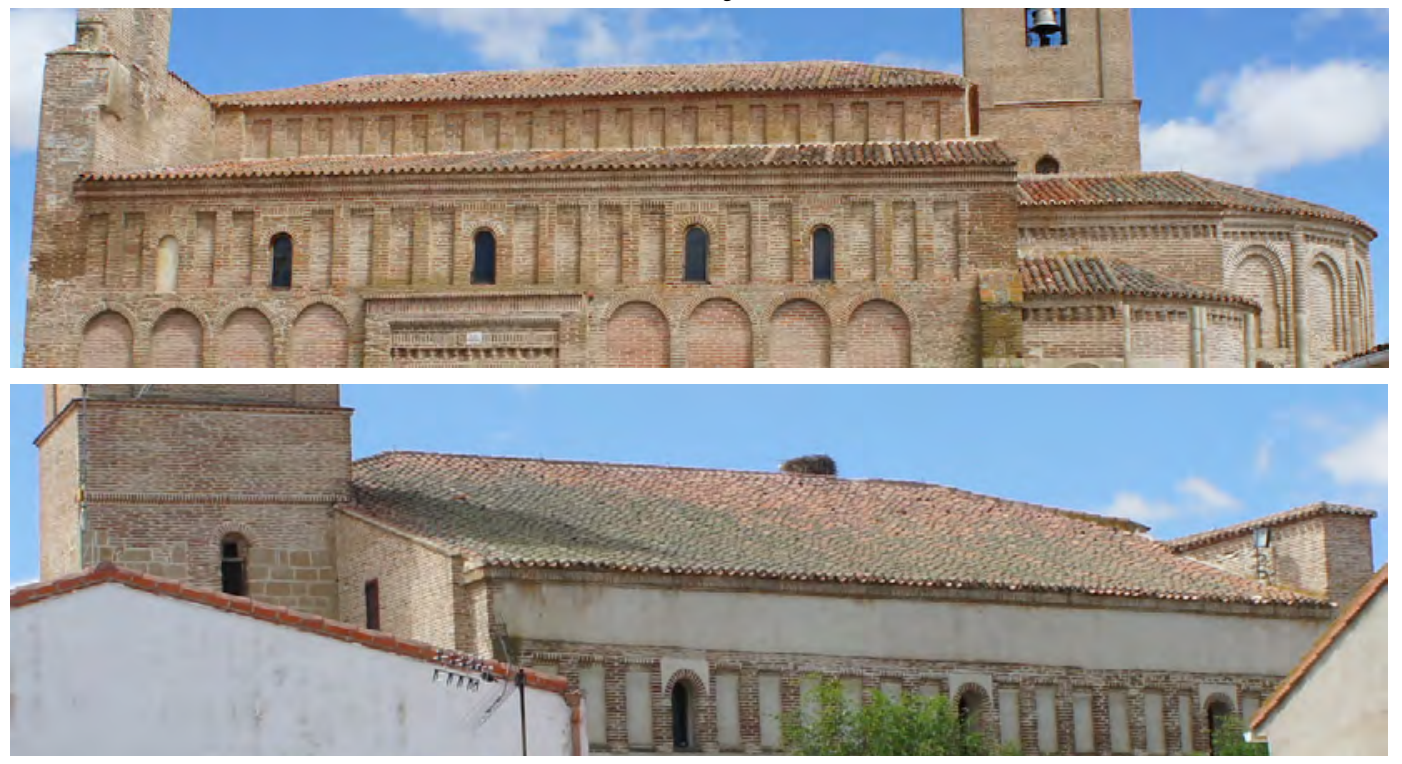

\section{Descripción}

Iglesia basilical de tres naves cubiertas con bóvedas de arista con yeserías. El cuerpo es mudéjar y la cabecera románica forma tres ábsides, cubiertos con bóvedas de cañón apuntado y horno.

\section{Materiales}

Los muros del cuerpo son de ladrillo, mientras que en los ábsides se levanta el cerramiento con sillería de piedra hasta media altura y el resto se remata con fábrica de ladrillo. Las cubiertas están revestidas de teja curva.

\section{Singularidades}

La cabecera arranca en cantería y se remata con fábrica de ladrillo. Las fachadas muestran un juego decorativo con arquerías, recuadros
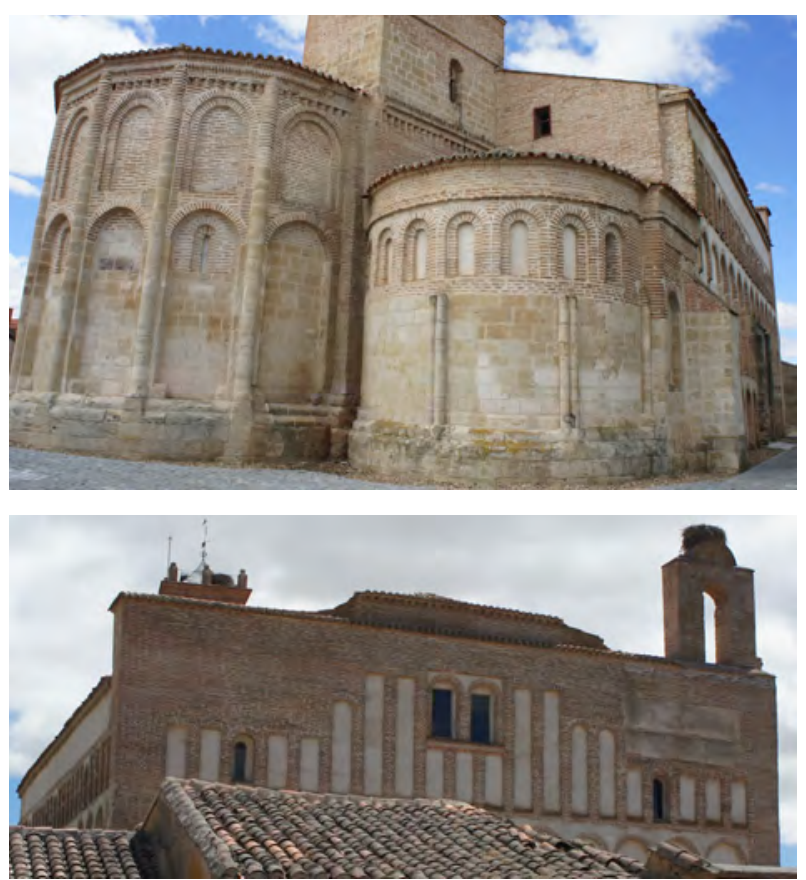

Ilustración 1: ábsides y remate de fachada a los pies (visita 13/08/2015) de ladrillo y entrepaños revestidos. 


\section{Dimensiones básicas del templo}

Ancho de nave $\quad 6,0$

$$
\text { central laterales capillas }
$$

Altura $\quad 13,5$

\section{Memoria histórica constructiva}

Según el proyecto de Carreño (1997 JCyL):

Las obras comienzan a finales del siglo XII y se interrumpen hasta mediados del XIII, cuando se recrecen con ladrillo la cabecera de cantería inacabada y encastra la portada románica en la nueva fachada de ladrillo con arquería mudéjar.

En algún momento se unifican las cubiertas a distinto nivel de nave central y laterales bajo dos únicos faldones.

Se construyen las bóvedas bajo el artesonado mudéjar.

Se añade un coro alto a los pies, hoy demolido, que condenaba la portada románica y dos espadañas. En 1834 se levanta el cuerpo de campanas de la torre.

Tras la última restauración, el tramo del hastial de la nave del evangelio se ha convertido en sacristía con la techumbre mudéjar que había en el coro alto y que procedía de la cubierta original de las naves.

\section{Cronología. Fechas clave}

$1974-1997-2003$

\section{Intervenciones}

1971 - Cubierta - José Ángel Rodrigo García

Desmonte parcial de las cubiertas reponiendo pares, tirantes, correas y tablazón en mal estado. Regulariza la coronación de los muros.

1974 - Memoria final - José A. Rodrigo y Joaquín Roldán

Incorporación de zuncho de hormigón armado.

Nueva cubierta de una nave lateral resuelta a nivel más bajo con tablero de viguetas de hormigón. 


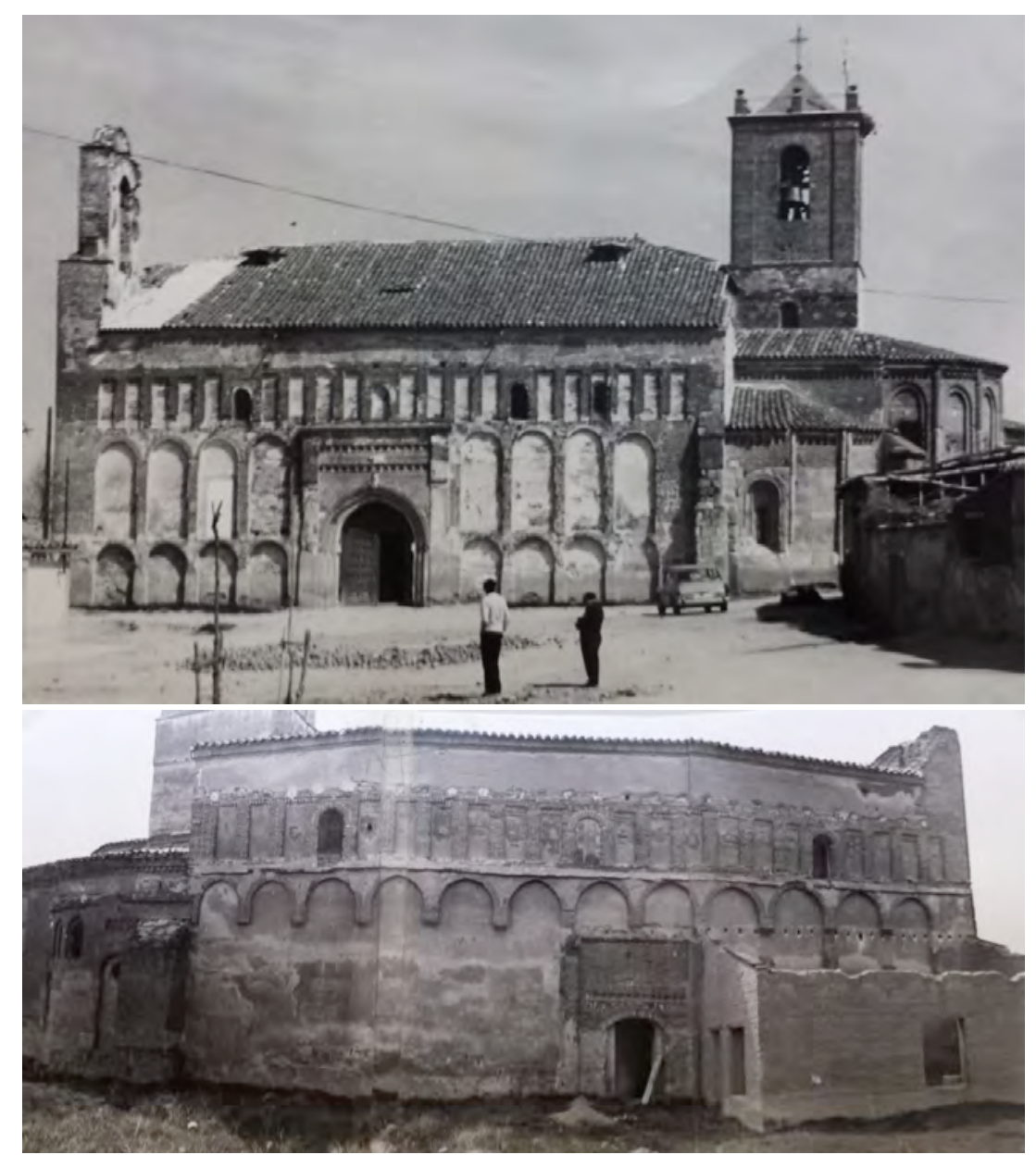

Ilustración 2: vista de los alzados este y oeste en 1971 Rodrigo IPCE

1997 - Proyecto de restauración - Pedro Carreño Aguado

Rebaja 60-70cm la cota base interior y exterior del templo recuperando el nivel original definido por los arqueólogos.

Restaura fábricas de ladrillo y piedra, reponiendo sillares erosionados.

Desmonta y reconstruye con madera de pino las armaduras de cubierta de todo el templo excepto la nave lateral tratada en 1974.

2003 - Restauración - Carreño Tratamiento del entorno de la iglesia.
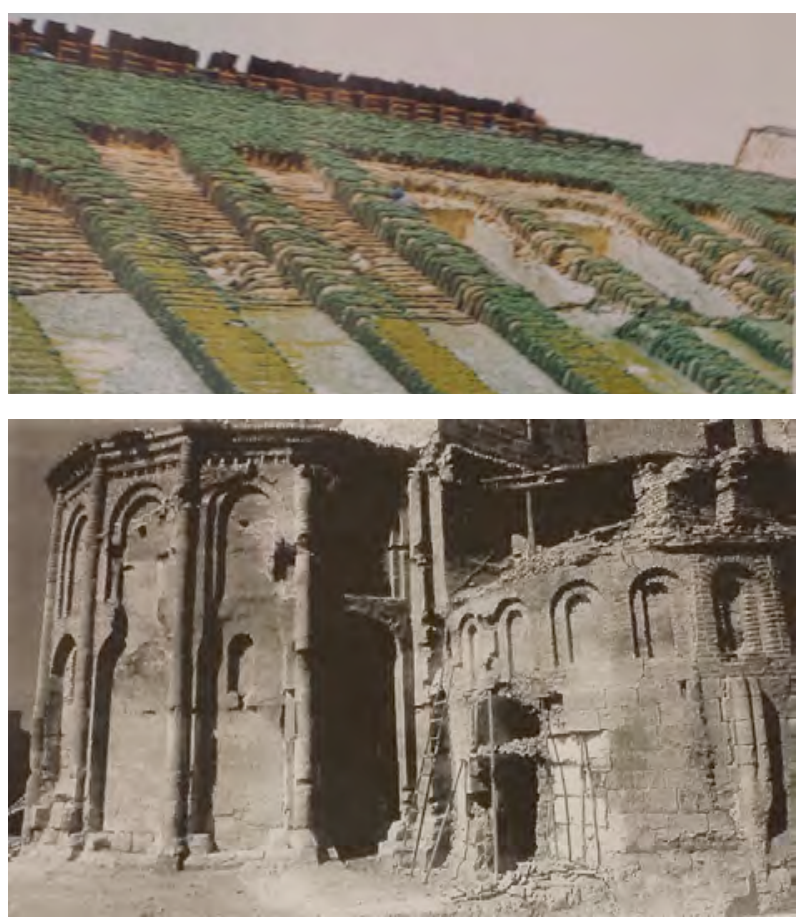

Ilustración 3: Dossier 1997 Carreño JCyL 
Recuperación de la portada románica, reconstrucción del hastial de cabecera.

Recuperación de pinturas en el interior del templo. Desmontaje del coro e instalación de megafonía y alumbrado.

\section{Planos}

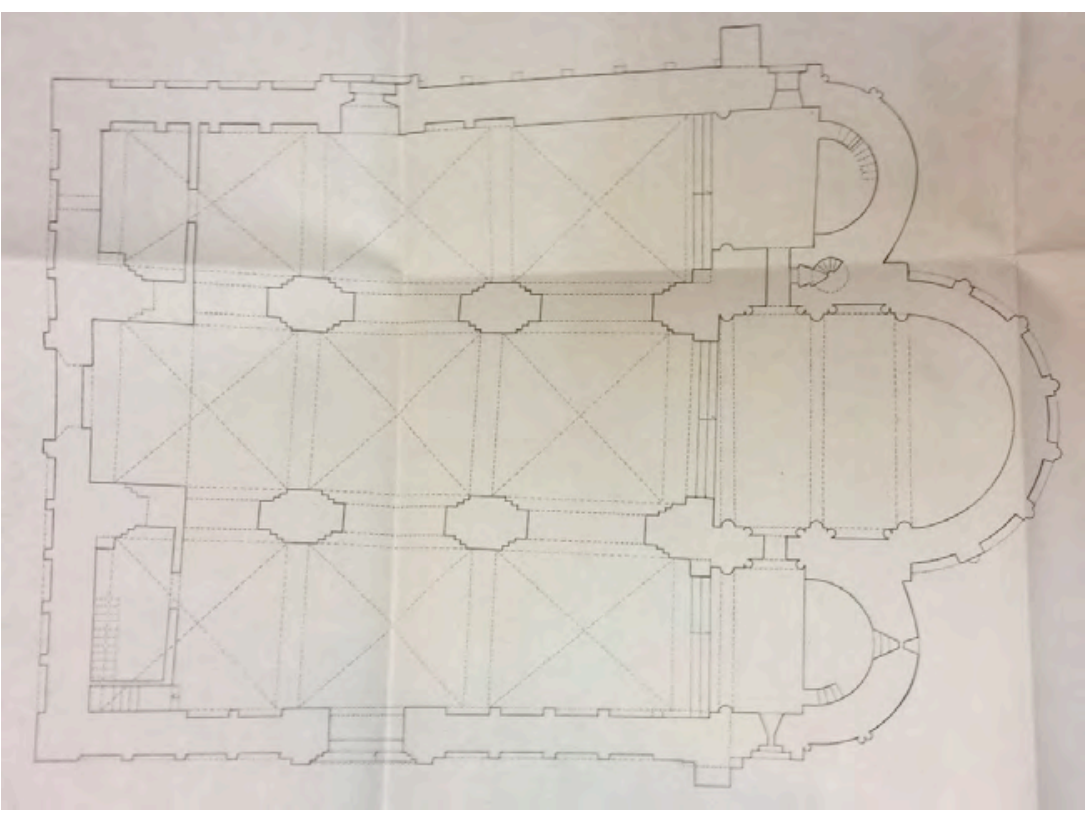

Ilustración 4: planta reformado 1997 Carreño JCyL

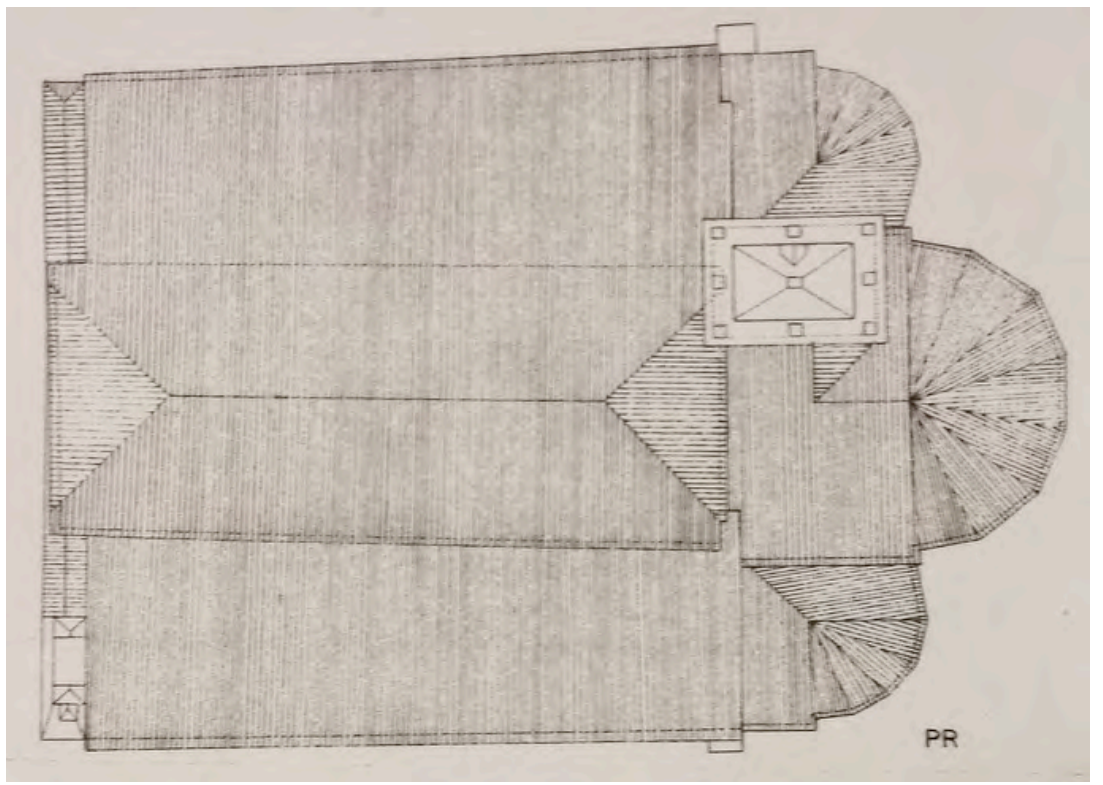

Ilustración 5: planta de cubiertas reformado 1997 Carreño JCyL 


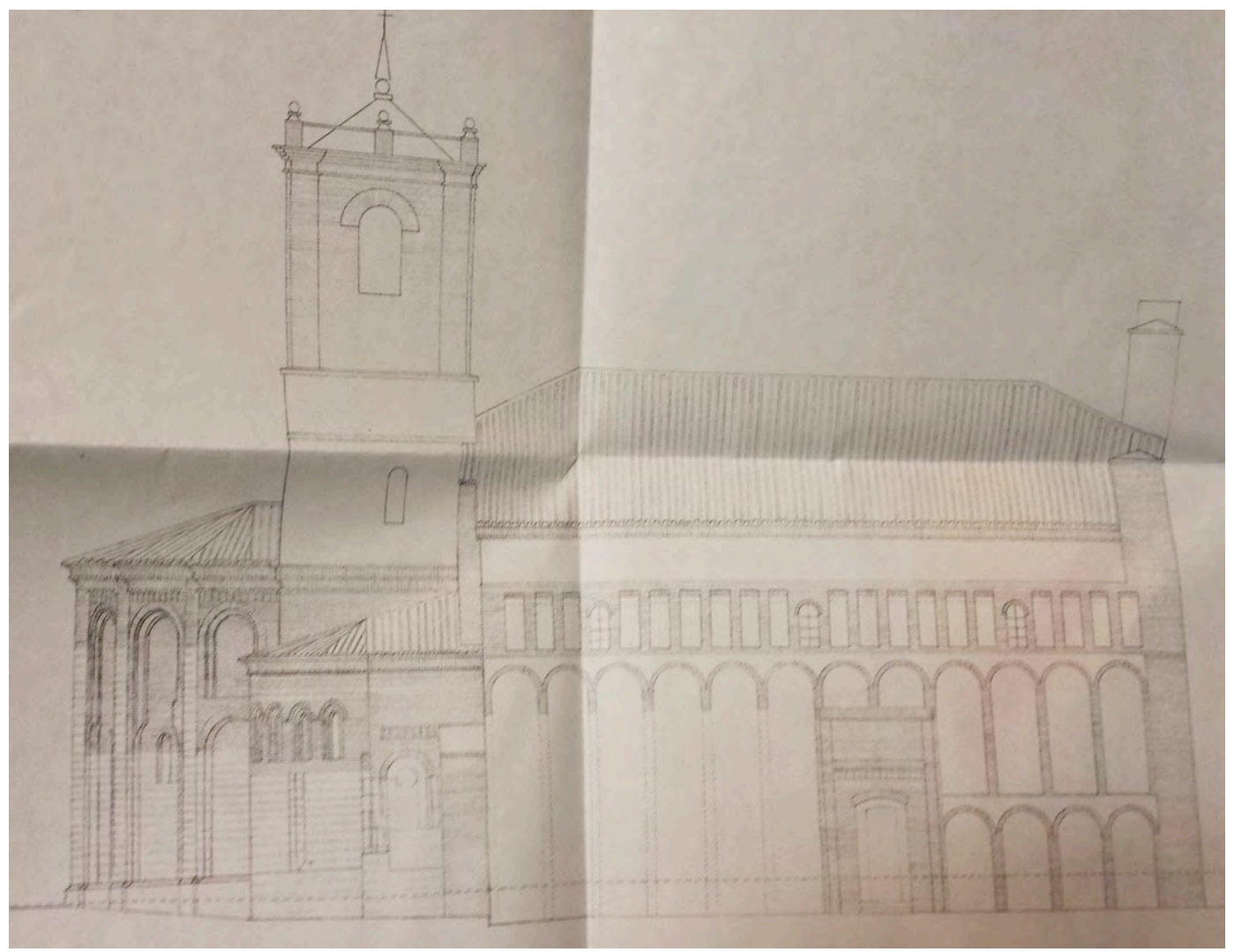

Ilustración 6: alzado del evangelio reformado 1997 Carreño JCyL

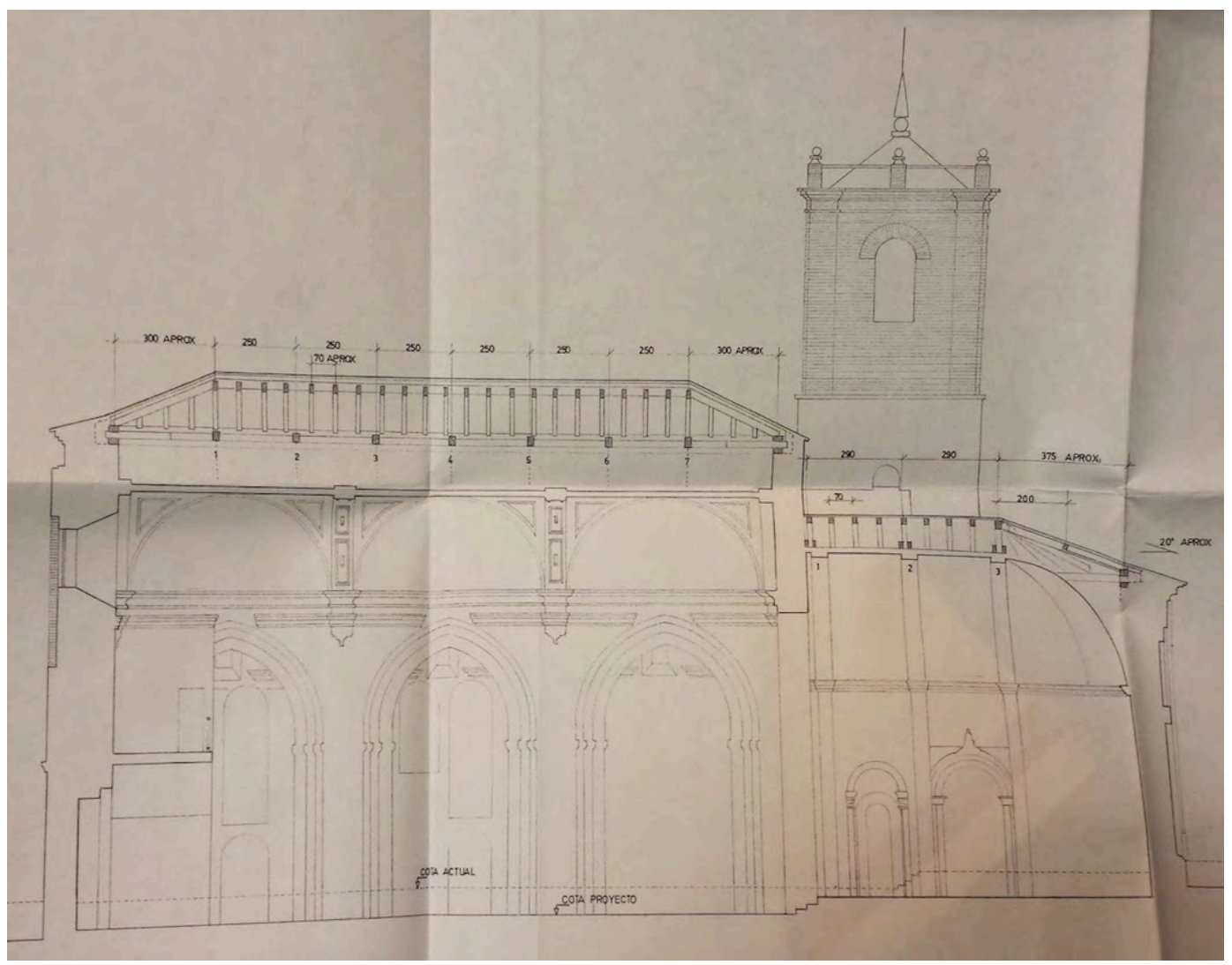

Ilustración 7: sección longitudinal 1997 Carreño JCyL 


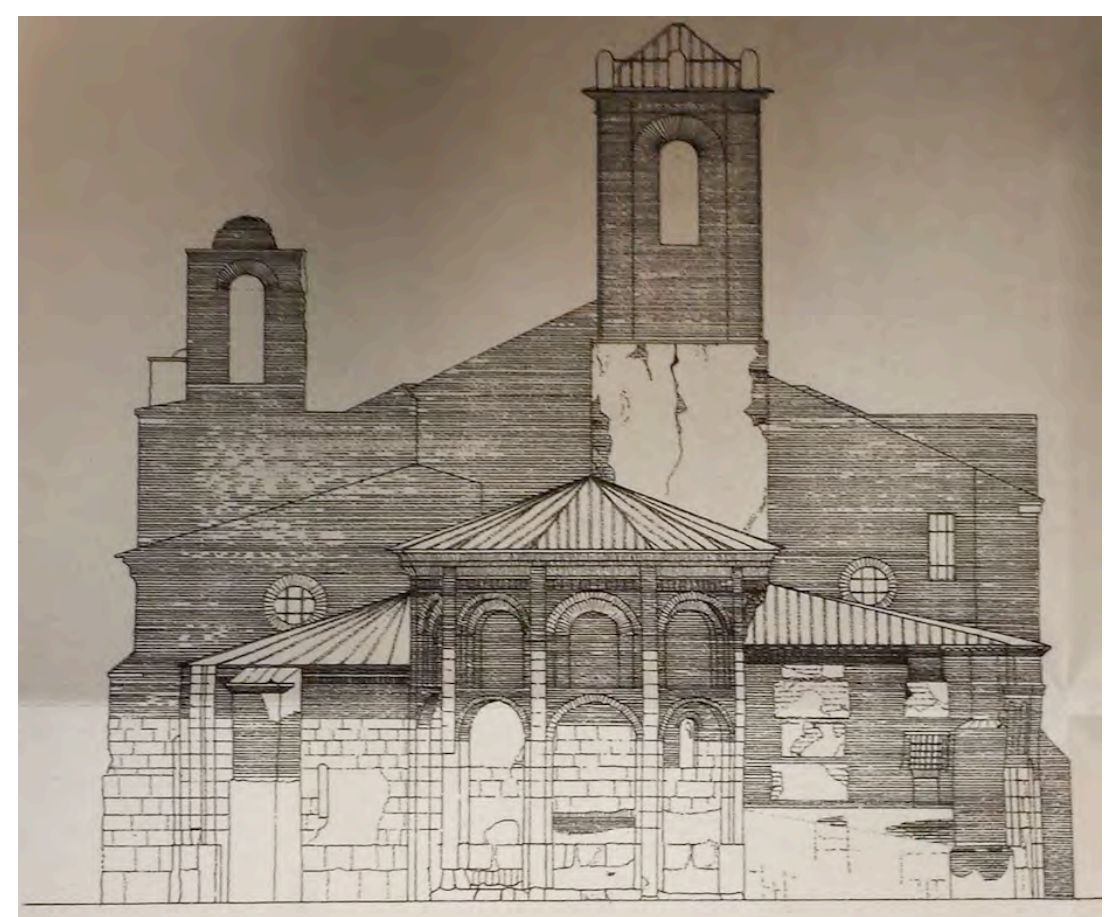

Ilustración 8: alzado de cabecera actual 1997 Carreño JCyL

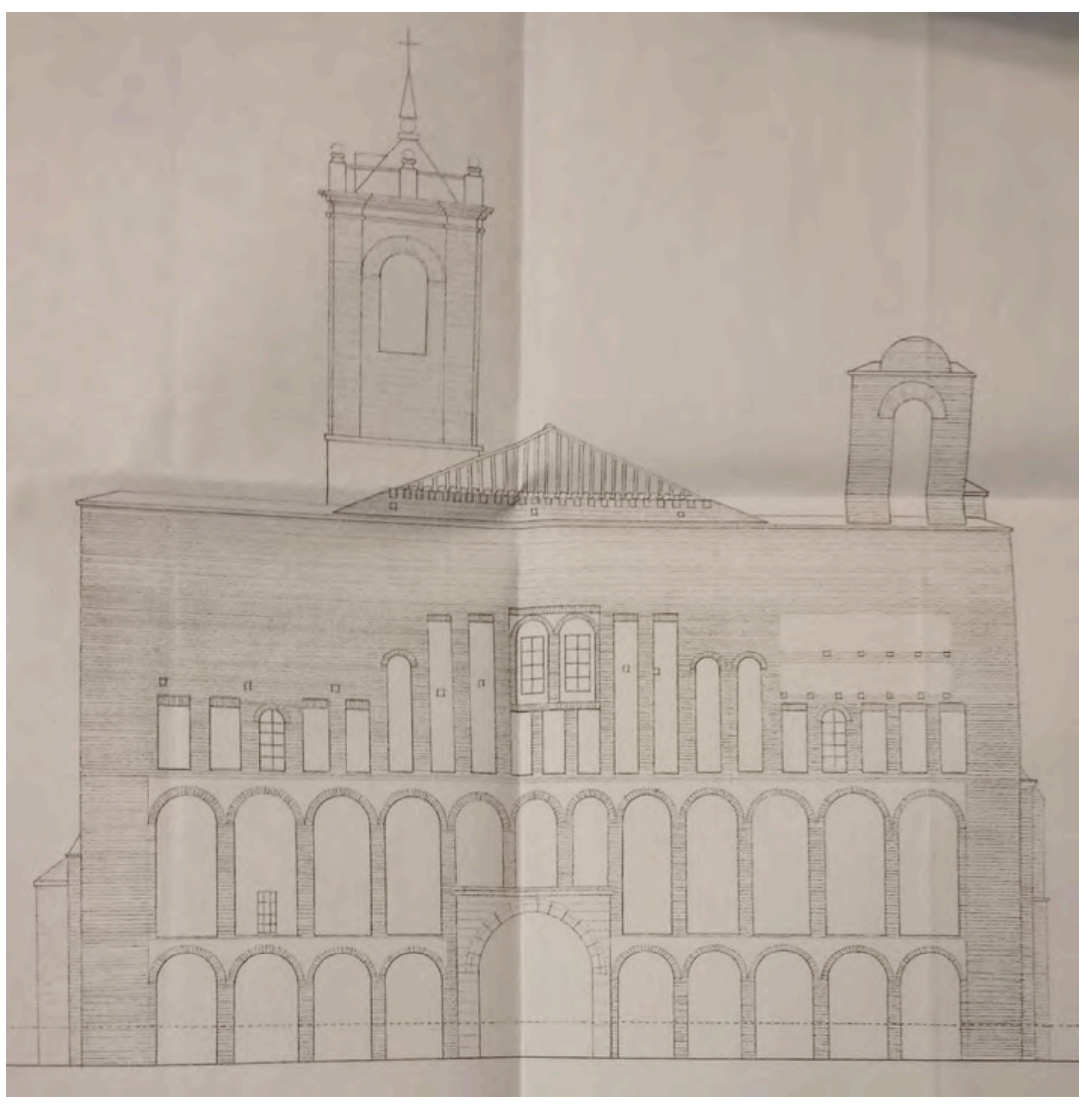

Ilustración 9: fachada a los pies 1997 Carreño JCyL 


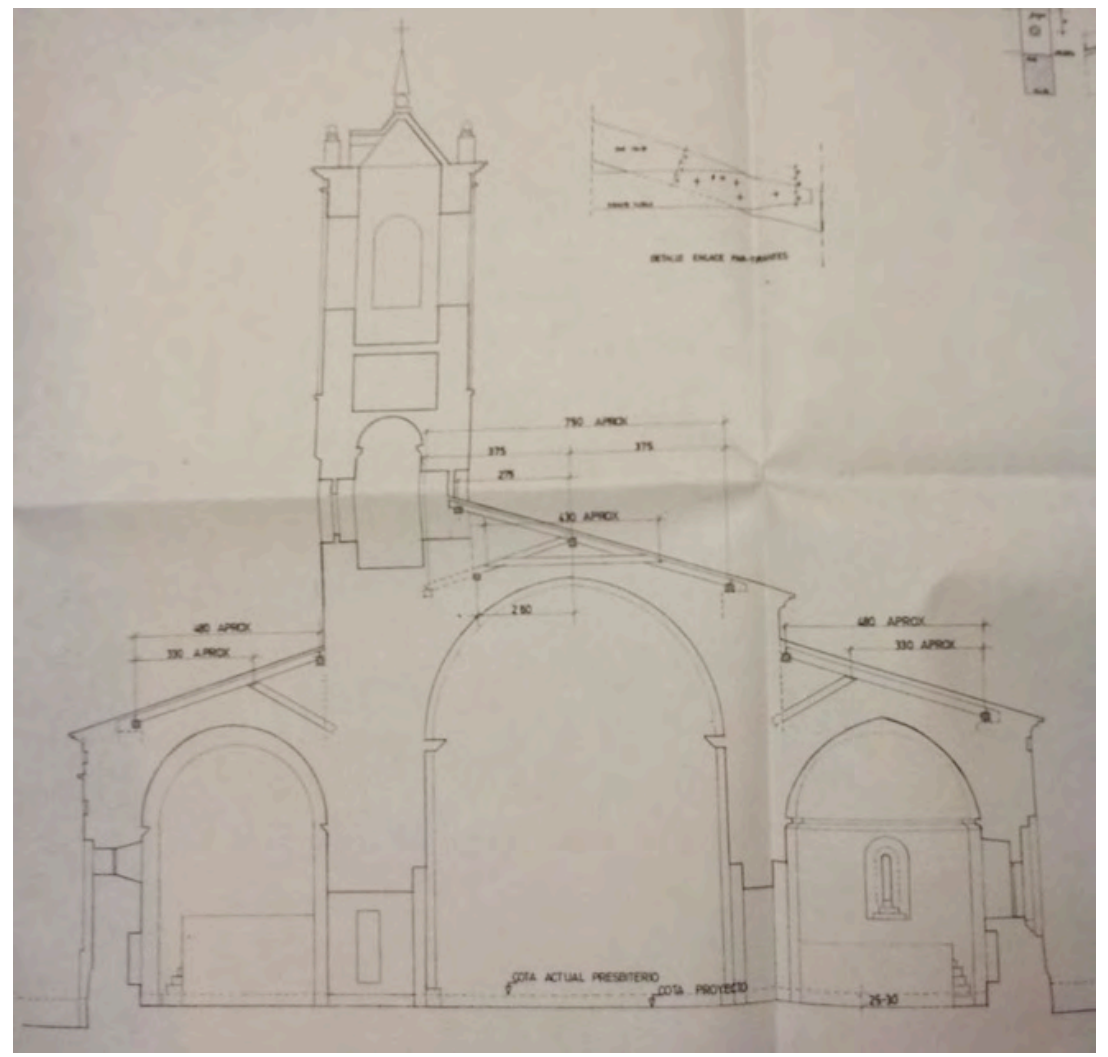

Ilustración 10: sección transversal por cabecera 1997 Carreño JCyL

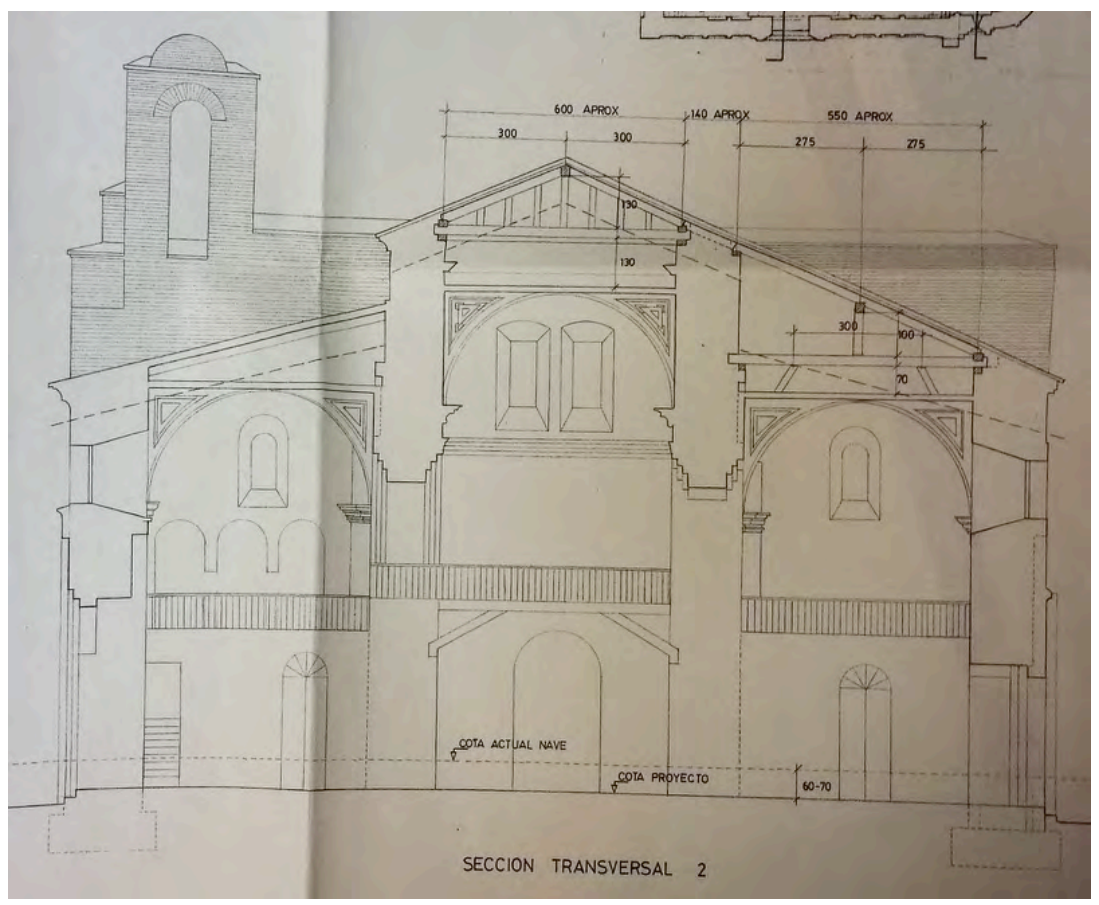

Ilustración 11: sección transversal 1997 Carreño JCyL 


\section{Solución constructiva de la cubierta}

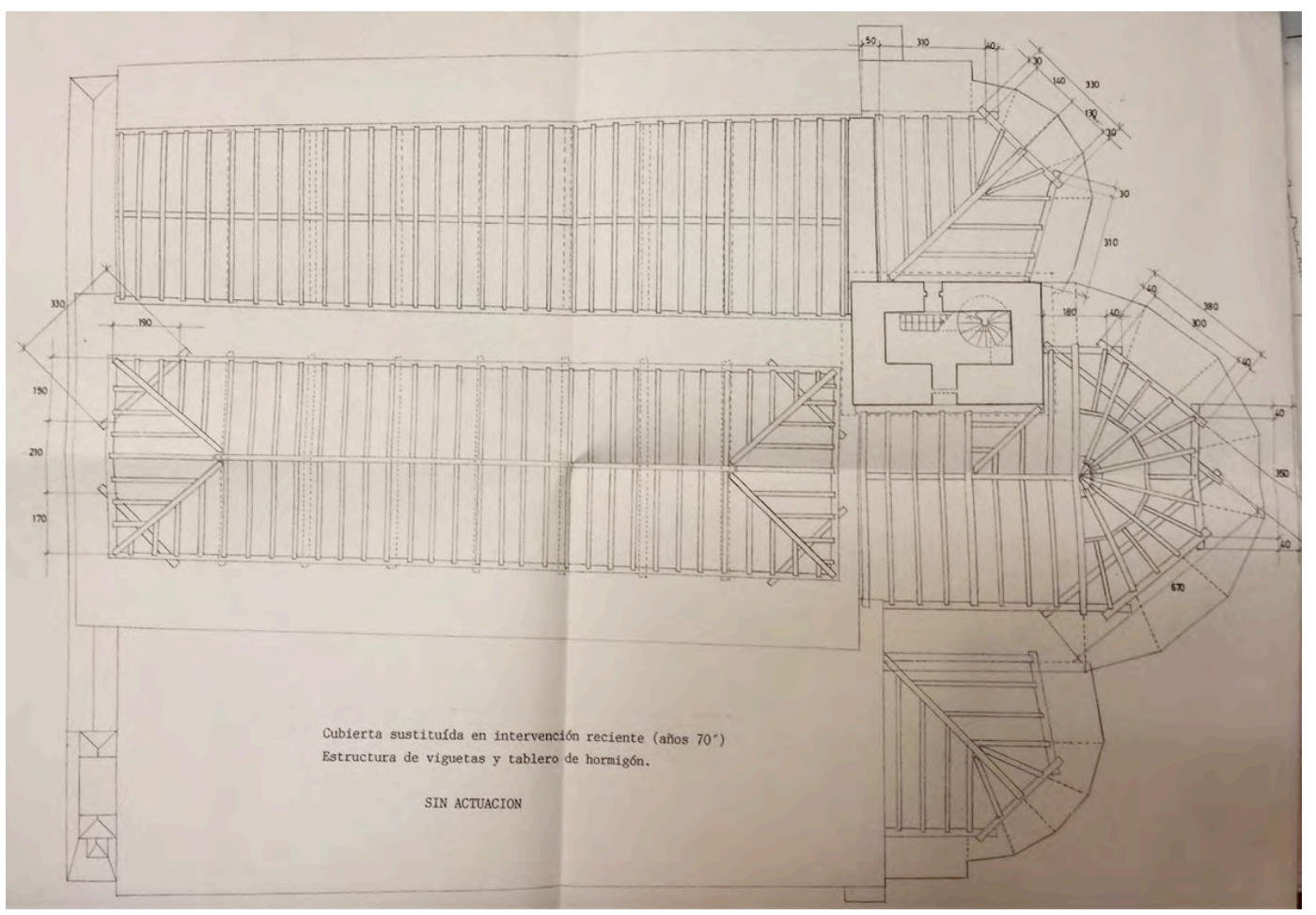

Ilustración 12: planta estructura de cubiertas 1997 Carreño JCyL

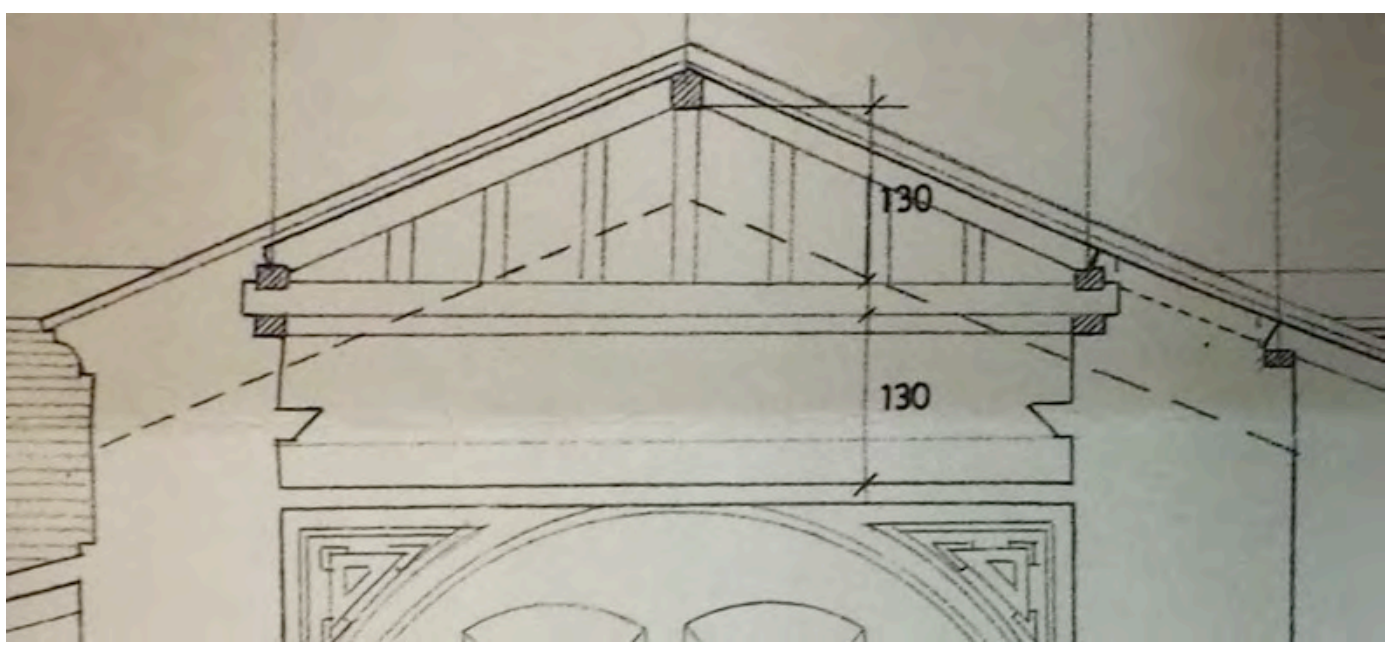

Ilustración 13 de cubiertas 1997 Carreño JCyL: sección estructura

En la sección transversal de la nave central se aprecia una pendiente sin acotar de unos $25^{\circ}$, con un faldón prolongado sobre la nave del evangelio. En la nave lateral de la epístola podemos medir sobre plano una inclinación de unos $15^{\circ}$ para el forjado inclinado de viguetas de hormigón incorporado en 1974.

La estructura de cubierta ejecutada en la intervención de 1997 a 2000 está resuelta con madera aserrada de pino y sus apoyos sobre el muro se definen en planos de forma tradicional. 


\section{Zunchos}

En 1974 se sustituye la cubierta de la nave de la epístola por un forjado, con zuncho de atado de hormigón armado.

Sobre el resto del edificio se interviene en 1997, empleando madera en cerchas y durmientes.

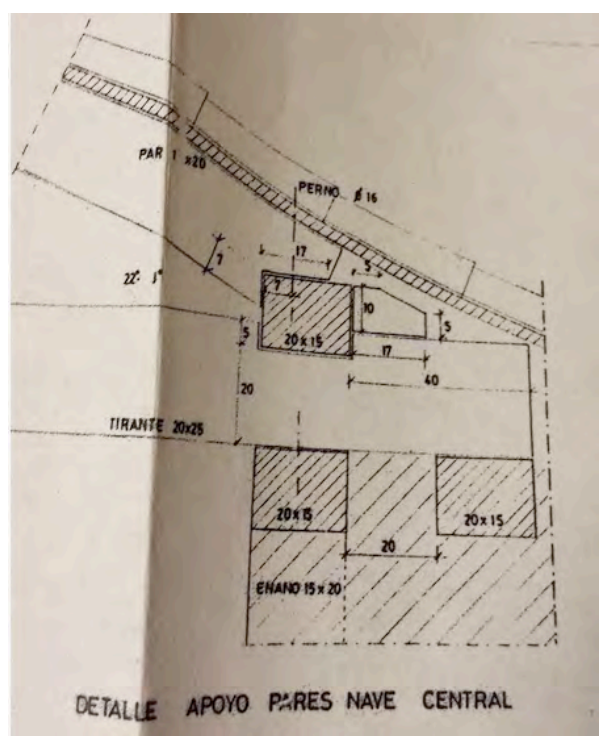

Ilustración 14: detalle apoyo cercha 1997 Carreño JCyL

\section{Conclusiones}

Según la documentación de los proyectos estudiados, en este edificio se incorporó el típico zuncho perimetral rectangular en una nave lateral en 1974.

En las últimas restauraciones, sin embargo, se ha reemplazado las armaduras restantes por estructuras similares de madera aserrada apoyadas sobre las tradicionales piezas de madera, al parecer sin incorporar ningún elemento de hormigón o acero coronando los muros en el resto del templo.

No se ha podido comprobar mediante visita al interior. 



\section{Iglesia de San Juan}

Intervenciones citadas en la publicación del Ministerio:

1971 - Cubierta - José Ángel Rodrigo García y Joaquín Roldán Pascual

En la web del IPCE hay una planta con el rótulo "según plano del arquitecto J.A. Rodrigo (1971)"

\section{En el Archivo General de la Administración}

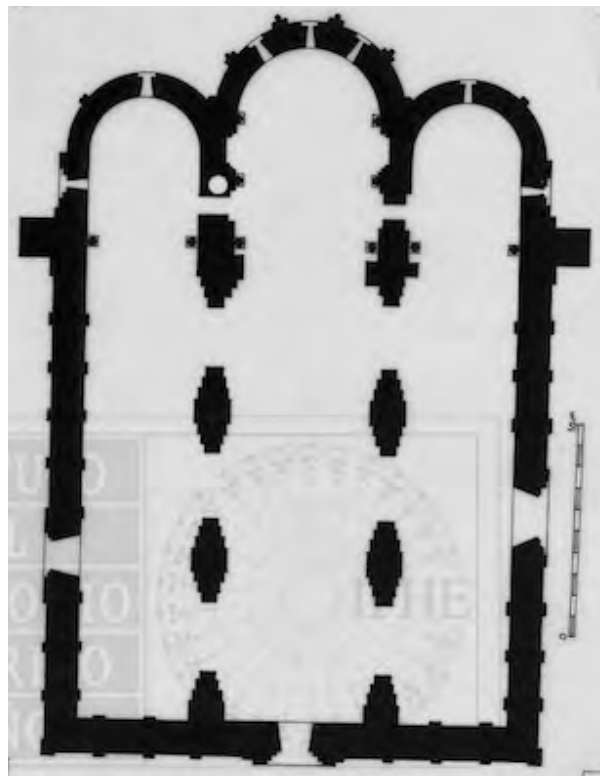

Ilustración 15: planta IPCE

AGA 26/00331

1971 - Restauración de la cubierta - José A. Rodrigo García

La iglesia es románica de la segunda mitad del siglo XII y el resto es mudéjar del siglo XIII, en el interior existen tres naves soportadas por pilares que apean arcos apuntados, cerrándose las bóvedas de aristas y yeserías del siglo XVIII; la Capilla Mayor de cañón apuntado con fajones.

Se procederá al desmonte parcial de las cubiertas, con reposición de los elementos necesarios, tanto estructurales como de cubrición; entre los primeros es necesario reponer pares, tirantes, correas y tablazón, y de los segundos, teja vieja curva, sentada con mortero bastardo, y se regularizarán los muros de apoyo de cubierta con reposición del elemento resistente necesario tanto de piedra como de mortero.

Un plano con planta baja, planta de cubierta y pequeño alzado. Se señala un cuerpo a demoler adosado al ábside. No hay secciones ni detalles.

En el presupuesto aparece $430 \mathrm{~m} 2$ levantado de armadura de cubierta reponiendo pares, tirantes, correas y tablazón en mal estado

1 Ud Regularización de muros de apoyo de cubierta incluso andamio y material necesario.

(NO menciona zunchos) 


\section{En el archivo del IPCE}

\section{Carpeta 636-3}

Memoria final de julio de 1974 - Jose A. Rodrigo y Joaquín Roldán

Se ha considerado como etapa inicial acometer los trabajos de reposición de cubiertas, ya que su mal estado originaba grandes humedades que ponían en peligro la seguridad de sus bóvedas.

La zona más afectada correspondía al faldón que vierte sus aguas a la actual fachada principal y que cubría en el mismo plano, la nave lateral y la mitad de la central. En ella parecían parcheados de Uralita para disminuir estas humedades lo que afeaba grandemente el conjunto y no era suficiente para proteger su armazón de madera ya suficientemente dañado.

Por ello se comenzaron las obras en esta zona con el levantado de teja y desmontado de su estructura de madera, efectuándose el acopio del material que más tarde pudiera ser utilizado.

La nueva cubrición de la nave lateral se ha realizado con arreglo a su estado original, es decir, a nivel inferior del faldón que cubre la nave central. Esta nueva disposición se apreciaba en los restos de apilastrados que existían sobre el muro de la nave central y que antes no aparecían por taparlo la continuidad de la cubierta. Otra prueba era el suplemento de muro que sobre su fachada mudéjar se había levantado para conseguir este plano continuo.

Por esto se procedió a la demolición de este añadido del muro y a la regularización de su paño. La nueva cubierta se construyó en hormigón armado como elemento más eficaz ante posibles incendios y se zunchó con una viga de atado de este material.

También fue preciso reparar la espadaña que debido al nuevo trazado de la cubierta surgía con mayor esbeltez y cuyos paños por el paso del tiempo se encontraban deteriorados.

A continuación se procedió al nuevo retejado aprovechando el material acopiado y reponiendo en gran parte con teja vieja que igualara su color y trazado. Fué preciso efectuar un repaso general del resto de cubierta de la Iglesia, para disminuir en lo posible otros focos de humedad que pudieran dañar sus bóvedas.

Proyecto

Visto en AGA pero original con dossier de fotografías grandes en blanco y negro. 


\section{En el archivo de la Junta de Castilla y León}

\section{VA-256}

Restauración de la Iglesia de San Juan en Fresno el Viejo(4 cajas)

1) Informe preliminar arqueológico de TRESMEDIOS SL: seguimiento de vaciados en el suelo de la iglesia, control de la apertura de zanja perimetral en torno a la iglesia y documentación de posibles enterramientos.

Se añadió un sondeo en el interior de la iglesia.

Memoria final de obra. Pedro Carreño Aguado, mayo de 2000.

Restauración de tipo conservador.

Torre de campanas. Desmontaje de la albarda perimetral en coronación y restitución de la misma. Chapado final de chapitel con paneles de cobre.

Fachada a los pies. Desmontaje previo y restitución de fábricas con recomposición de cornisas en coronación de muro de la fachada oeste. Zanja en la base de los muros. Desmontaje del cegado de la portada, se ordena el apeo posponiendo su restauración... hasta que se pueda abrir la zona con la cesión de la finca colindante.

Fachada del Evangelio. Zanja en la base de los muros hasta cota originaria definida en arqueología. restauración de muros y pilastras hasta ese nivel. Sellado final de zanja con áridos sueltos en espera de otra fase de intervención.

Interior del templo. Sub-base de áridos compactados por capas en toda la zona de intervención donde se sustituyen los solados.

Cubiertas del templo. Se desmontan, en las zonas de actuación, las cubiertas de la iglesia según prescripciones del proyecto. Una vez constatado el estado de conservación de las armaduras desmontadas, se procede a su limpieza, imprimación y clasificación, autorizándose y dando instrucciones para el posterior montaje de algunas de ellas, desechándose las consideradas como no aptas para su reutilización. se ordena control esmerado en la manipulación y puesta en obra de los canes y tirantes policromados, restos procedentes de la antigua armadura mudéjar de la cubierta primitiva de la nave central, cuyo estado de conservación permite así mismo su reutilización.

Con la ayuda de los medios auxiliares de la obra se define con exactitud la traza geométrica de los ábsides de cabecera, produciendo leves variaciones en la organización de los faldones poligonales de las cubiertas en esta zona.

Se desmonta el ábside de la Epístola clasificando los sillares. 
Se restituyen dos arcos ciegos del primer piso de la antigua sacristía.

Al final no coloca el drenaje perimetral por falta de cota.

$907,88 \mathrm{~m} 2$ restauración de fábricas de ladrillo

$78,86 \mathrm{~m} 2$ muro de fábrica de ladrillo de dos astas y relleno de hormigón de cal y canto

90,90 $\mathrm{ml}$ cornisa de remate de coronación

$737,63 \mathrm{~m} 2$ demolición de cubrición de teja curva

id demolición del soporte de la cubrición, formada por entablado de madera sobre entramado de cerchas y correas de madera, sin incluir la demolición del entramado... $72,79 \mathrm{~m} 2$ demolición de entramados de madera con recuperación y acopio de material aprovechable y transporte ...

248,71 m2 formación de estructura de cubiertas, con elementos estructurales de madera de pino Pinaster de $1^{\text {a }}$ calidad...

$640,57 \mathrm{~m} 2$ entablado con tabla de madera machihembrada de $23 \mathrm{~mm}$ de espesor clavada con puntas de acero

demolición y levantado $200 \mathrm{~m} 2$ de pavimento de hormigón en masa de $15 / 25 \mathrm{~cm}$ de espesor

Informe reunión de recepción negativa: permanencia de humedades, restauración incompleta de las fachadas, etc (Garcés, mayo 2000)

Informe de restauración de un capitel (Salazar marzo 2000)

Caracterización de la piedra (CLAR julio de 1999)

2) Proyecto de restauración. Pedro Carreño.

Memoria

Comienza la edificación del templo en los últimos años del siglo XII. Las obras se interrumpen bruscamente cuando apenas si se han levantado los muros de la cabecera y la portada en estilo románico.

Hacia la mitad del siglo XIII se retoman las obras; se completa la obra de la cabecera en ladrillo (aunque se sigue la traza anterior) y, ya en estilo mudéjar, se levantan las naves y se engasta la primitiva portada románica en medio de la arquería mudéjar del gran lienzo de la fachada occidental.

En el Presbiterio, el muro del Evangelio fue modificado en el siglo XVI para emplazar el sepulcro de Fernando de Cadenas. 
A fines del siglo XVI se modifica la portada meridional.

En los siglos XVII y XVIII se realizan varias obras de las que va a derivar en buena medida el aspecto actual del edificio:

En origen se realiza una cubierta a distintos niveles, la centra, a dos aguas, era más alta. Las naves colaterales, cada una con su tejado, desaguaban a una sola vertiente que arrancaba bajo los ventanales que daban luz directa a la nave central. Es posteriormente cuando se realiza la cubierta a dos aguas para todo el edificio y se cubren las tres naves con bóvedas de arista con labores de yesería.

No había bóvedas, sino artesonado mudéjar, del que aun se conservan los modillones, e incluso pares y tirantes y restos de faldones (con los que se decora en el siglo XVIII el intradós del coro actual).

Del mismo modo, en un principio, la fachada occidental mostraba un alzado piramidal, siendo el añadido de las dos espadañas que la franqueaban, obra de este momento.

Se edificó el coro alto a los pies del edificio condenando la portada románica.

Se tapian puertas y ventanas y se recubre todo el edificio, incluso la parte románica, con yeso y cal.

Se edifica la sacristía tapiando el ábside del Evangelio.

Se modifican los niveles de pavimento levantando la primitiva almorrefa de baldosa grande y entarimando el presbiterio...

En 1834 se construye el cuerpo de campanas de la torre.

La sacristía sufre diversos hundimientos que determinan su refuerzo y reparación. El último de ellos, documentado en 1877.

En la década de 1960 se pican parte de las yeserías del interior de la iglesia dejando al descubierto la arquitectura románica y varios tramos de la construcción en piedra de las naves.

En 1972 la Dirección General de Bellas Artes del Ministerio de Cultura realiza diversas obras de restauración:

Reconstruye la cubierta de la nave de la Epístola, convirtiéndola en un tejado independiente a un solo agua y liberando los ventanales de la obra original.

Restaura las fachadas y la portada de esta nave.

En el año 1975 se realizan trabajos de urbanización del entorno de la iglesia.

En 1980 se colocan el actual piso de baldosas en las naves, trasladando algunas lápidas...

En 1985 se realizan labores de acondicionamiento y ajardinamiento superficiales en el terreno del antiguo cementerio. 


\section{Descripción del edificio}

Edificio de tipo basilical con la cabecera románica de mitad del siglo XII y el resto mudéjar del siglo XIII. Cuenta con tres naves, la central más ancha y larga, aparece separada por tres arcos apuntados abocinados que descargan sobre pilastras cruciformes muy sencillas. Se cierran los tres espacios con bóvedas de arista con labores de yesería del siglo XVIII...

... El ábside central tiene una sección poligonal de siete lados ... a partir de los 3,75m se prosigue la obra en ladrillo.

\section{Estado actual. Diagnóstico.}

Grieta pasante vertical en torre de campanas.

Grieta pasante vertical en el hastial de la fachada a los pies del edificio aparentemente por giro del mismo.

Desplome acusado de la hoja exterior del muro frontero del ábside de la Epístola, con abertura de las llagas por posible expansión del relleno por filtraciones desde cubierta.

Erosión en todos los muros de fábrica de ladrillo...

Cubiertas

Defectos de estanqueidad generalizados en nave central, Evangelio, Sacristía y cabecera.

Elementos estructurales y tablazón de madera con caducidad material en dichas zonas; acción de xilófagos y hongos, alabeos de piezas, flechas pronunciadas, roturas $\mathrm{y}$ apeos generalizados. En algunos puntos se constata verdadera urgencia de intervención. Se prevé la sustitución de estos elementos. Esta situación cuenta con la excepción de la nave de la Epístola cuyas cubiertas fueron sustituidas por unas de viguetas y tablero de hormigón en fechas recientes.

\section{Obras a realizar}

Restauración de fábricas de sillares de arenisca con reposición de elementos igualando los existentes... con una profundidad media estimada en $150 \mathrm{~mm} .$.

Restauración de fábricas de ladrillo...

Incluye todas las cubiertas del Elemento, con excepción de la cubierta de la nave de la Epístola.

Se procederá al desmontaje de las tejas, recuperando las piezas servibles. El desmontaje se ejecutará por zonas de faldones opuestos, comenzando por la cumbrera. A continuación se desmontará la tablazón y por último las armaduras en todos sus elementos. Durante el proceso no se dejarán desprotegidas las superficies subyacentes por lo que no se desmontarán las cubiertas en su totalidad y se dispondrá 
una cubrición provisional que garantice una protección suficiente a las zonas afectadas. La sustitución se prevé del 100\%.

Montaje de las estructuras de cubierta, en escuadrías y disposición indicada en planos correspondientes, realizadas en madera estructural aserrada, tratada y seca, utilizando piezas de ensamblaje y utillaje en general de acero galvanizado, según documentación correspondiente. En este apartado se prevé la posibilidad de utilización de armaduras y piezas existentes previa comprobación de su estado de conservación, utilizando si es necesario, barrena para captación y análisis de testigo, y siempre bajo órdenes y criterio de la DF.

Montaje de tablero de cubierta, en nomenclatura según plano, con cubrición de teja cerámica curva con porcentaje de recuperación, y el resto nueva, colocando ésta preferiblemente en canales, recibida cada cinco hiladas con mortero M20 de dosif. 1/6. En los encuentros de faldones con paramentos se dispondrán baberos de cobre, embutidos mediante roza en paramentos, formando canalón o limas, según plano.

Cubierta de torre de campanas en placas de cobre de $1 \mathrm{~mm}$ de espesor instalada según se especifica en medición.

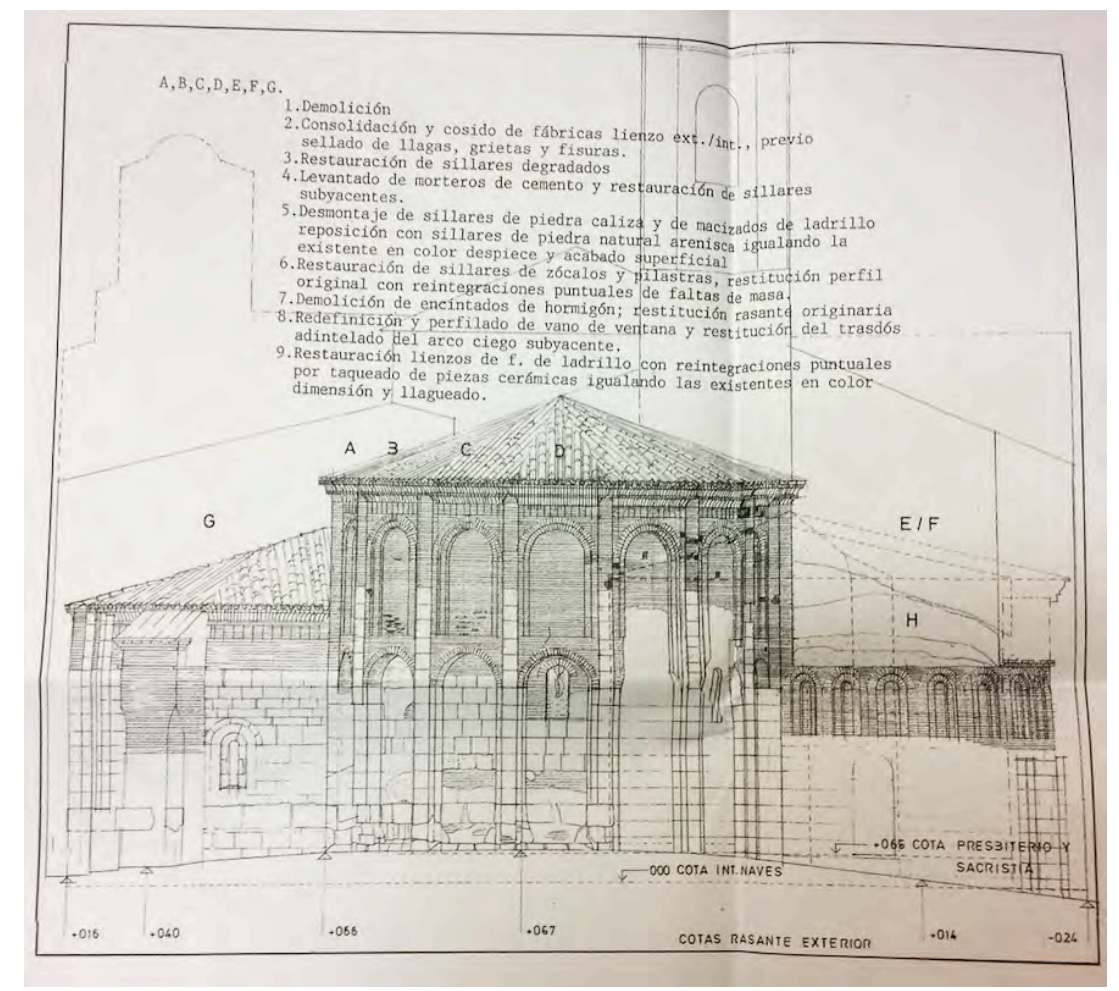

Ilustración 16: plano diagnóstico 1997 Carreño JCyL

Informe geológico de INZAMAC

Planos de 1997 con secciones bastante detalladas 
3) Carpeta con documentación administrativa

4) Copia del Proyecto con el dossier de fotografías impreso en color. CONABSIDE SA

Adjudicación 11/12/1998

Recepción 5/5/2000

\section{En la Fundación del Patrimonio Histórico'}

La edificación del templo comienza en los últimos años del siglo XII. Por razones que nos son desconocidas, las obras se interrumpen bruscamente cuando apenas si se han levantado los muros de la cabecera y la portada de estilo románico.

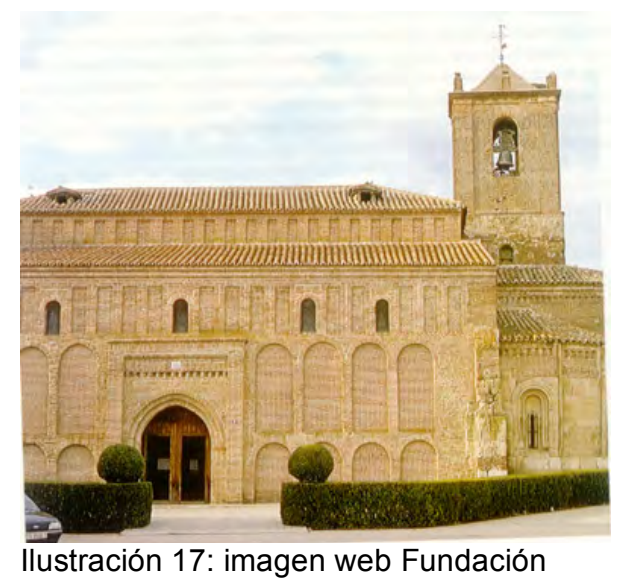

Hacia la mitad del siglo XIII se retoman las obras; se completa la obra de la cabecera en ladrillo, (aunque se sigue la traza de la anterior) y, ya en estilo mudéjar, se levantan las naves y se engasta la primitiva portada románica en medio de la arquería mudéjar del gran lienzo de la fachada occidental.

Se trata de un edificio de tipo basilical, con cabecera románica de mitad del siglo XII y el resto de estilo mudéjar del siglo XIII. Cuenta con tres naves, la central más larga y ancha, aparece separada por tres arcos apuntados abocinados que descargan sobre pilastras cruciformes muy sencillas. Se cierran los tres espacios con bóvedas de arista con labores de yesería en el siglo XVIII.

Los arcos que enjarjan el hastial cubren parte de la obra románica de la cabecera. Esta última la componen tres capillas románicas con los muros del tramo recto articulados por parejas de arcos de medio punto. El conjunto se cubre con cañón apuntado y horno.

Restauración 2002-2003

Los procesos de restauración fueron los siguientes:

\footnotetext{
${ }^{1}$ En la página web se describe esta intervención (consultada 26/07/2015)
} 
1.- Urbanización del entorno inmediato de la Iglesia.

Pavimentación, drenajes y saneamiento. Recuperación de rasantes. Alumbrado. Tratamiento del jardín adyacente. Seguimiento arqueológico. Demolición parcial nave adosada.

2.- Restauración edificio. Elementos exteriores.

Restauración de la Portada Románica, recuperando el acceso. Recuperación portada del Evangelio. Desmontaje y restitución del hastial de cabecera y contrafuerte anexo. Restauración de la ventana románica en el ábside de la Epístola. Retejado de cubiertas de la nave lateral de la Epístola.

\section{3.- Restauración edificio. Elementos interiores}

Vaciado de peanas trasaltares en ábsides laterales de cabecera y restitución de solados. Restitución de muros apilastrados y arcos ciegos en lienzos perimetrales de muros de cerramiento. Desmontaje de los recrecidos de los pilares apilastrados cruciformes del muro de cerramiento a los pies de la nave central. Demolición de tabique de partición del trastero bajo coro y restitución del solado y rasante originaria igualando el nivel con el resto del templo. Desmontado de las estructuras del coro y escaleras de acceso al mismo. Restauración del cuadrante de bóveda $1^{\mathrm{a}}$ a los pies de la nave lateral de la Epístola.

4.- Restauración edificio. Interior de la Iglesia, puesta en valor.

Restauración de pinturas y lienzos en bóvedas y paramentos verticales.

5.- Patrimonio mueble. Diversas intervenciones.

6.- Varios.

Ventanas del cuerpo principal de la iglesia y saeteras de cabecera triabsiada. Instalación de megafonía y de alumbrado interior. Tablado para Culto en presbiterio de Ábside Mayor.

VA-442

Dos carpetas. La primera contiene el mismo proyecto de Carreño visto en JCyL.

En la segunda: proyecto de restauración $2^{\mathrm{a}}$ fase, del mismo arquitecto.

Memoria final:

Restauración del hastial y contrafuerte de cabecera de la nave del Evangelio, sustituyendo ambos elementos según previsión de Proyecto. En la coronación de los muros delimitadores de la nave central se descubren tres ventanas por lado. En el 
lado de la Epístola se recuperan otras tres ventanas. En el ábside Mayor se descubren y recuperan las tres ventanas saeteras ocultas por los tabicados antes descritos.

Retejado de la nave de la Epístola.

Retirada de los revocos de cal y yeso que ocultaban la obra Mudéjar. Se recuperan las pinturas murales.

Restaura las bóvedas de yesería del periodo barroco. 


\section{Visitas realizadas}

\section{$13 / 08 / 2015$}

El estado de conservación del monumento es sólo correcto tras la $2^{\mathrm{a}}$ fase de la restauración.
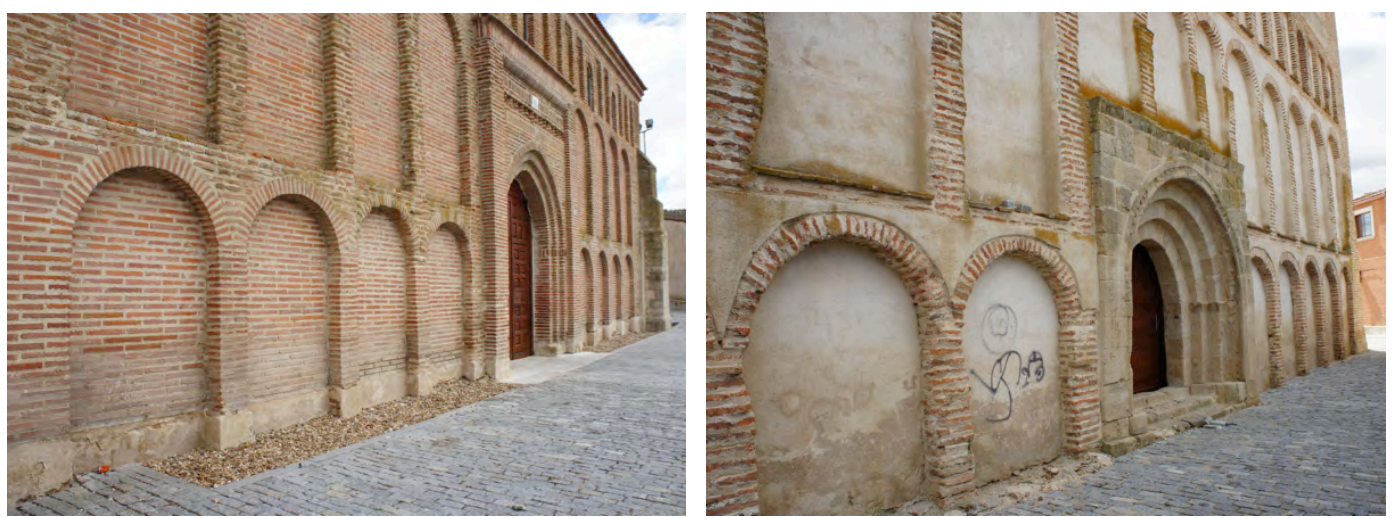

En el exterior se aprecia el ajuste de niveles del entorno y un drenaje perimetral dispuesto por Carreño en 2002.
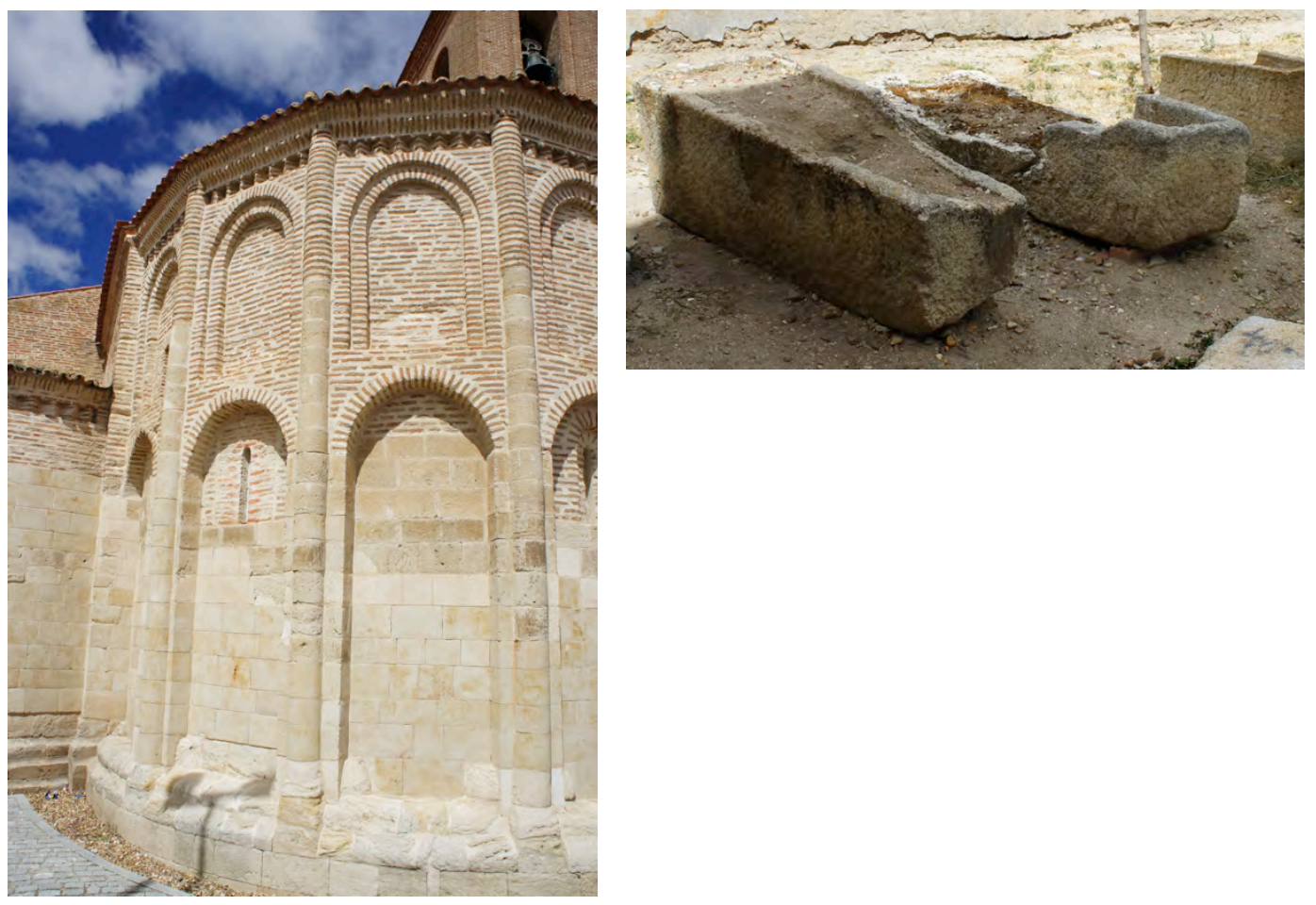

Aunque no se ha visitado el interior del templo, se cuenta con documentación gráfica del estado de las bóvedas en 2013 mostrada en la Fundación. Se ha recuperado pinturas murales y un tramo de artesonado que se dispone en vertical tras el altar a modo de retablo. 
En la documentación gráfica de la Fundación aparece una nueva estructura de cubierta de madera laminada con un singular apoyo sobre el pórtico de madera existente.
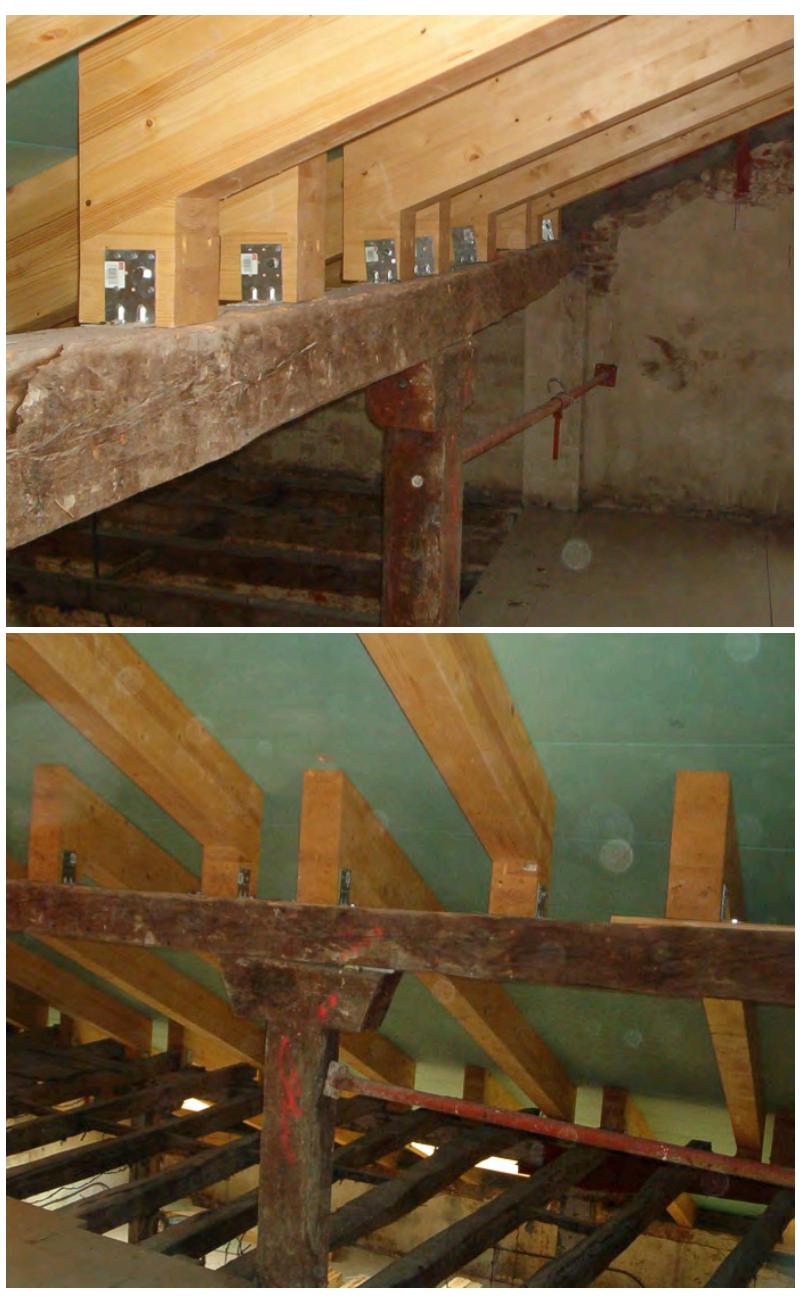


\section{Iglesia de Santa María}

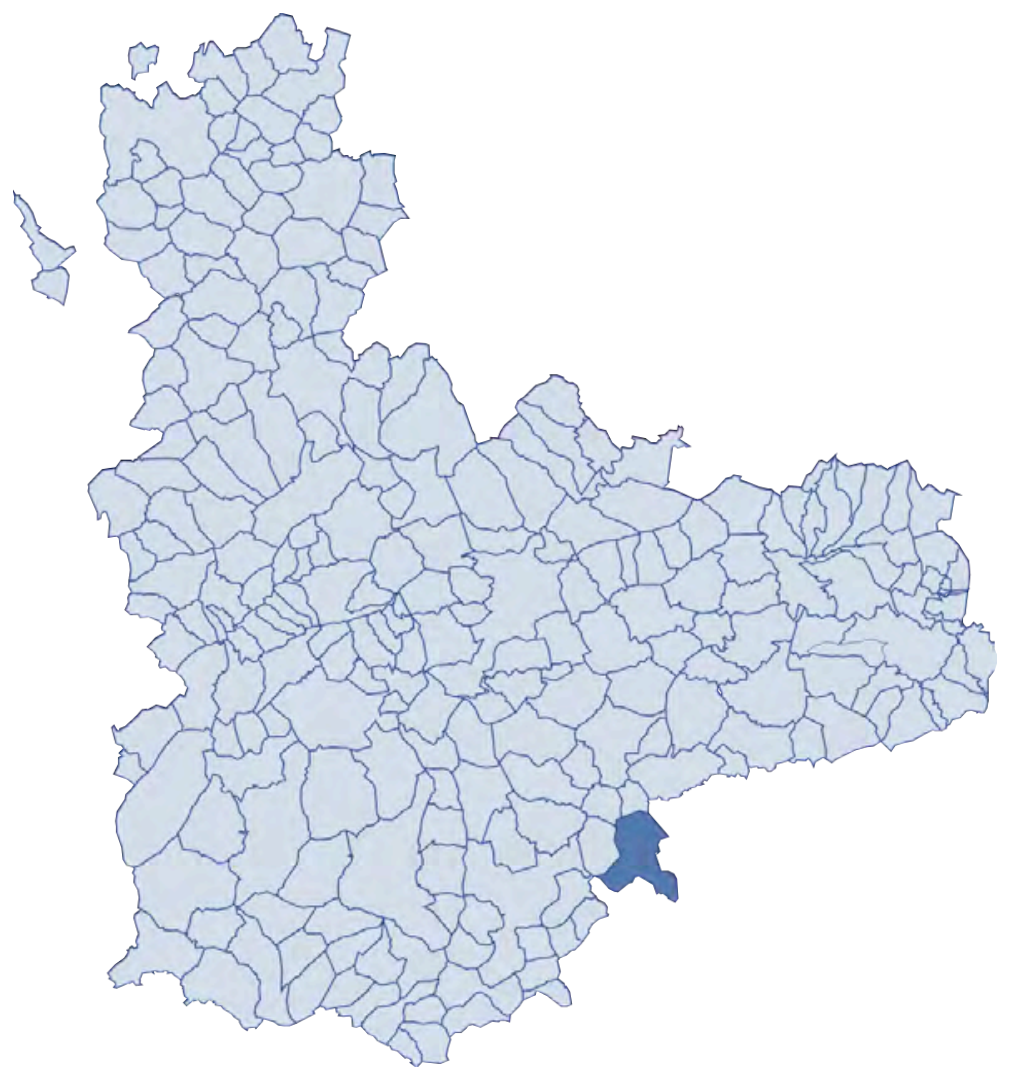



FICHA SÍNTESIS

Código de identificación: FZ-23

Denominación:

Iglesia de Santa María

Localidad: Íscar

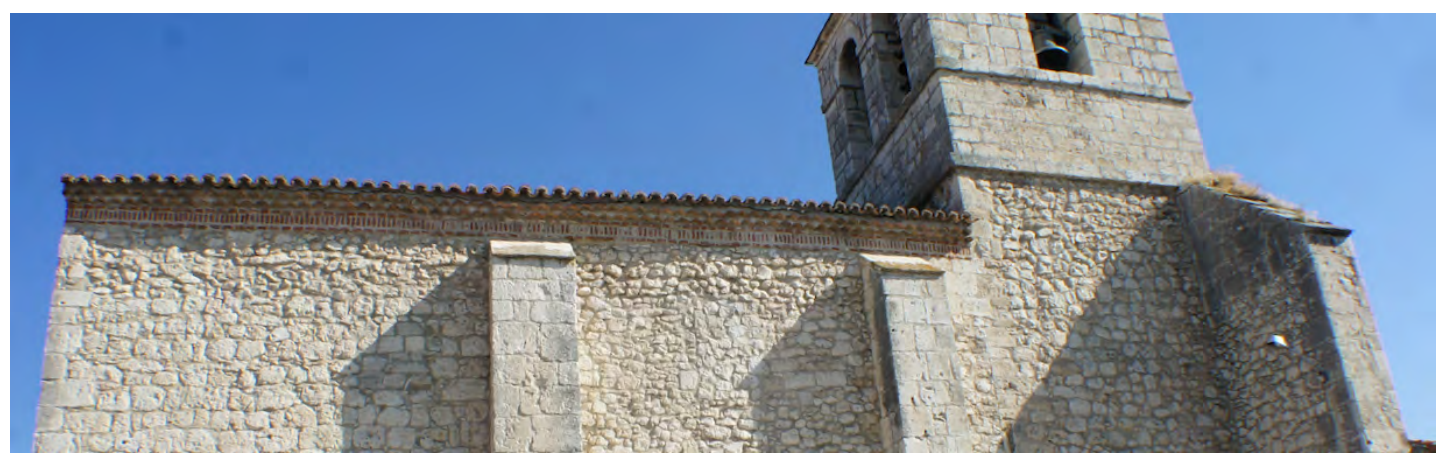

\section{Descripción}

Iglesia de tres naves con pilares cilíndricos y arcos formeros apuntados. El espacio central se cubre con bóveda de cañón, con lunetos, y las naves laterales con bóvedas vaídas decoradas con yeserías, excepto un tramo lateral a los pies con techo de madera. La cabecera se cierra con bóveda de horno. La torre, rematada con chapitel de pizarra, se ubica en el crucero del lado de la epístola.

\section{Materiales}

Los muros del cuerpo del templo son de sillarejo, con contrafuertes exteriores de sillería, mientras que la cabecera está compuesta por arquerías de ladrillo.

La cubierta está revestida de teja curva.

\section{Singularidades}

El espacio interior del templo cuenta con una iluminación natural escasa, desde los tres huecos de la fachada a los pie con sólo uno lateral en el potente ábside mudéjar de ladrillo.
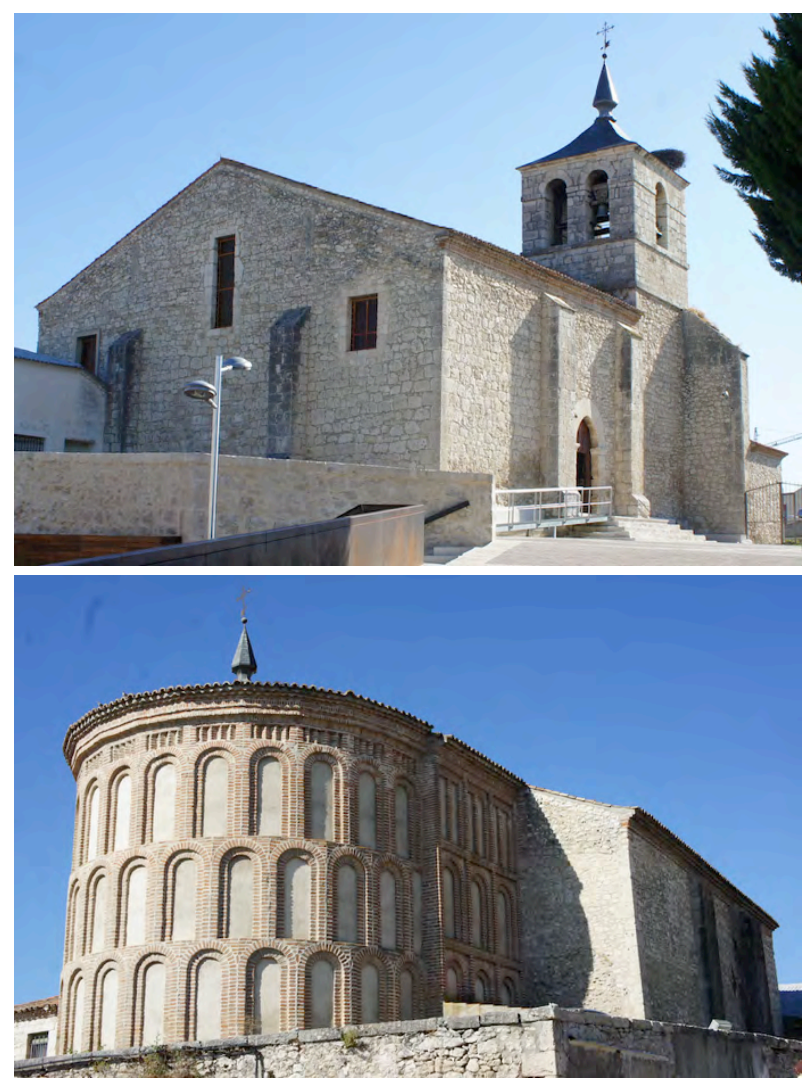

Ilustración 1: pies y cabecera, visita 02/08/2015 


\section{Dimensiones básicas del templo}

$\begin{array}{llll} & \text { central } & \text { laterales } & \text { capillas } \\ \text { Ancho de nave } & 7,0 & 4,0 & - \\ \text { Altura } & & & \end{array}$

\section{Memoria histórica constructiva}

Según la memoria del proyecto de Cembrero y Morante:

La cabecera es románico mudéjar del siglo XIII, mientras que al cuerpo de la nave del XVI se le incorporan las bóvedas en el XVIII.

En el XIX se unifican las cubiertas hasta formar dos aguas que cubren la nave central y las laterales en prolongación, recreciéndose el piñón testero a los pies.
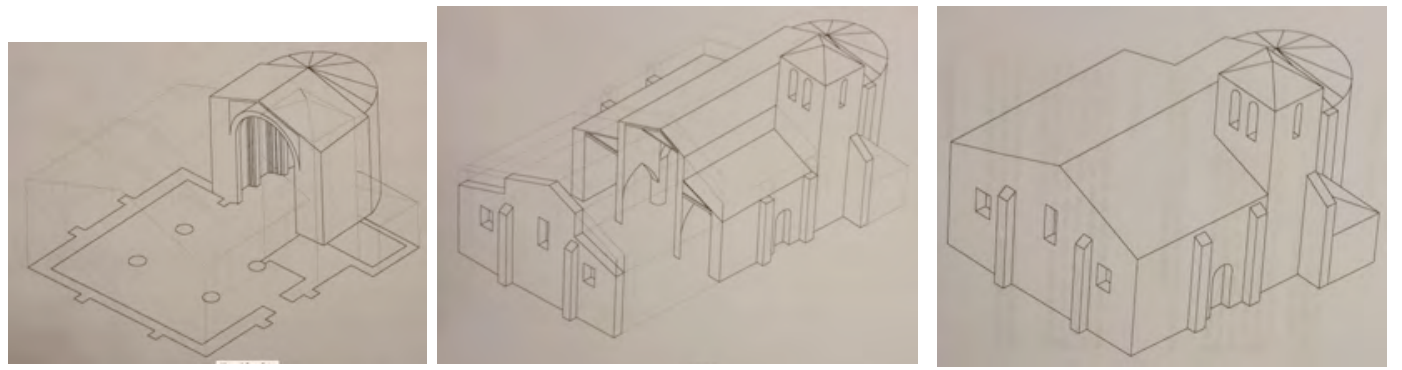

Ilustración 2: proceso constructivo según proyecto de Cembrero y Morante JCyL

Actualmente podemos apreciar en el paramento de fachada a los pies la silueta original basilical y el recrecido para convertir las cubiertas en un único volumen a dos aguas.

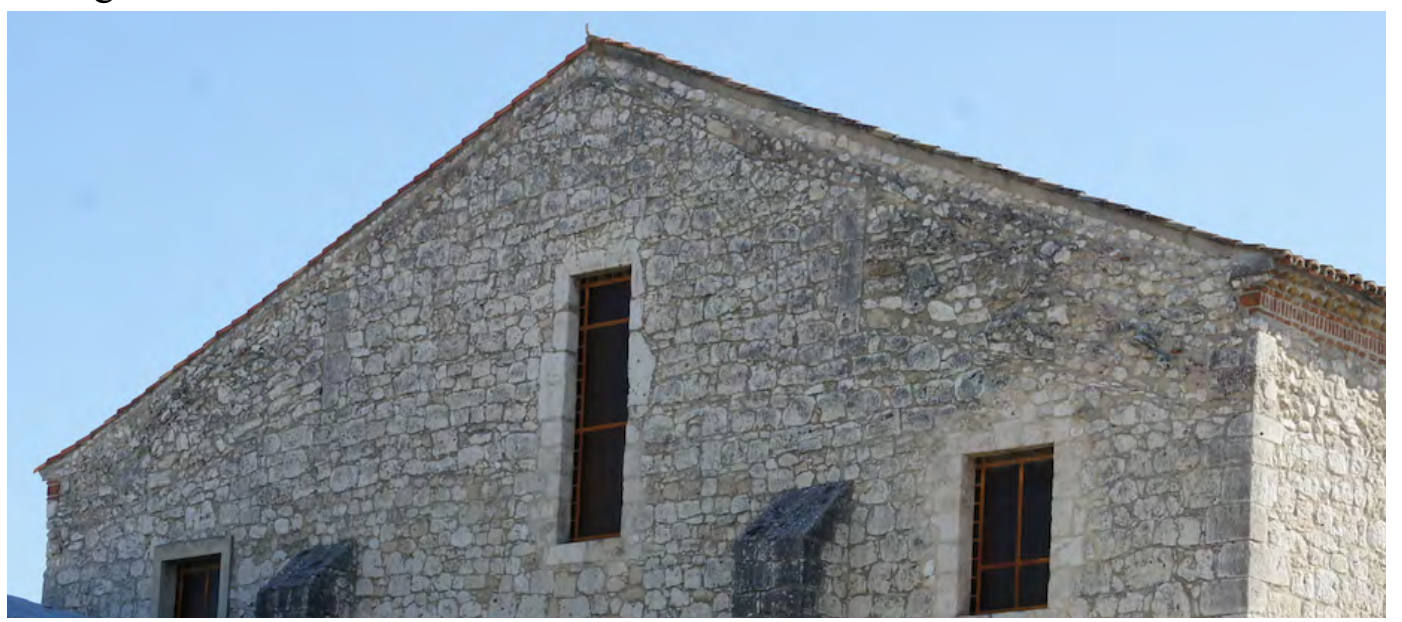

Ilustración 3: testero imagen visita 02/08/2015

\section{Cronología. Fechas clave}

$1978-2000$ 

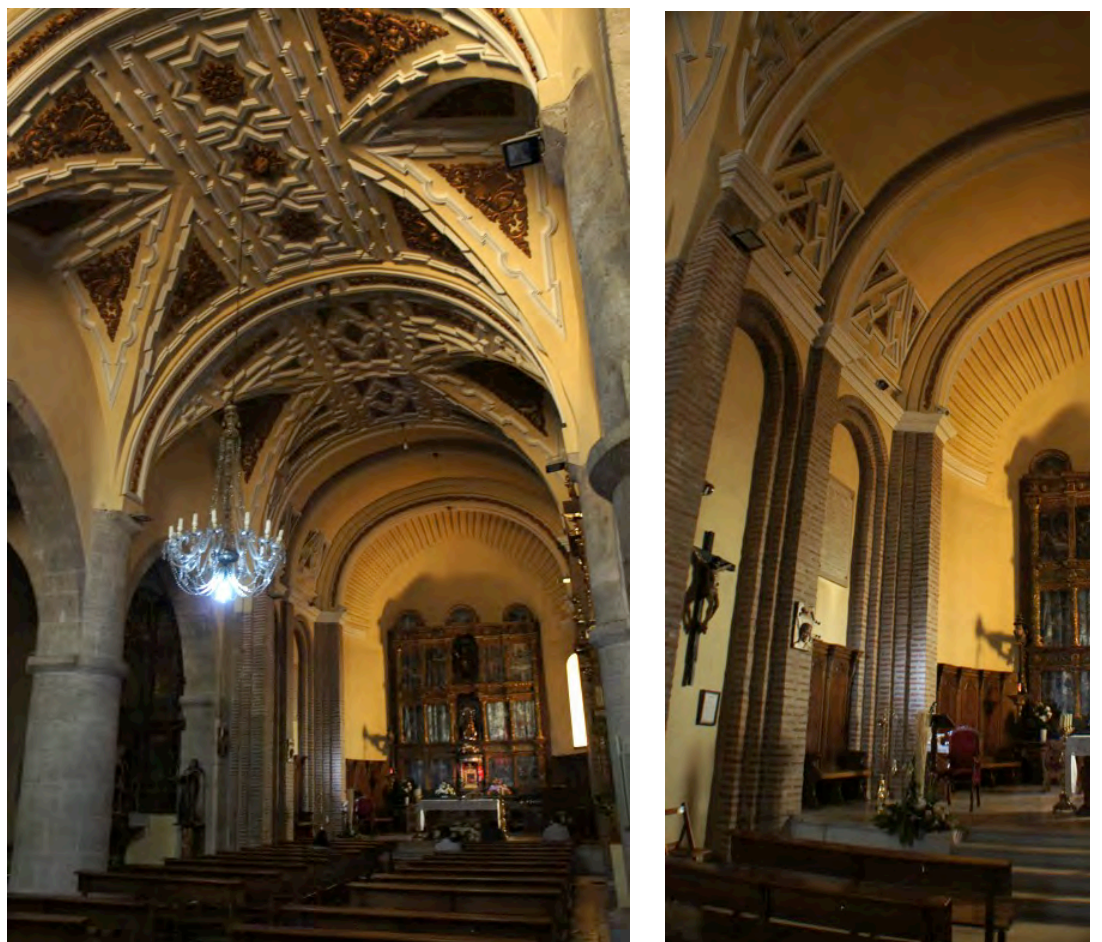

Ilustración 4: vistas del interior con las bóvedas dieciochescas, visita 02/08/2015

\section{Intervenciones}

1978 - Restauración - Ana Iglesias

Levanta toda la cubierta: repara elementos, repone tabla ripia y reteja incorporando cobijas. Pica los revestimientos, para dejar al descubierto las fábricas de piedra, y repara pavimentos.

1979 - Instalación de calefacción - Ana Iglesias

Coloca la caldera sobre el coro alto.

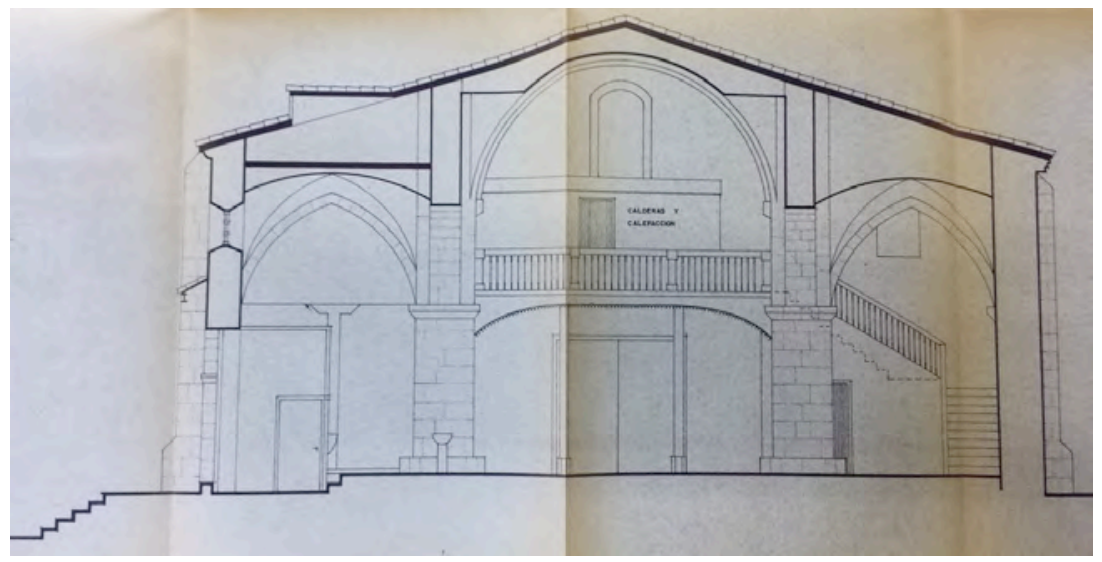

Ilustración 5: sección 1979 Iglesias IPCE

2000 - Restauración - Eduardo Cembrero y Alberto Morante

Retejan el ábside sobre el tablero rematado con hormigón existente. 
Construyen una estructura nueva, manteniendo los restos de artesonados a cota más baja. Eliminan los durmientes sobre los muros, cajeando para disponer piezas nuevas de madera de pino.

\section{Planos}

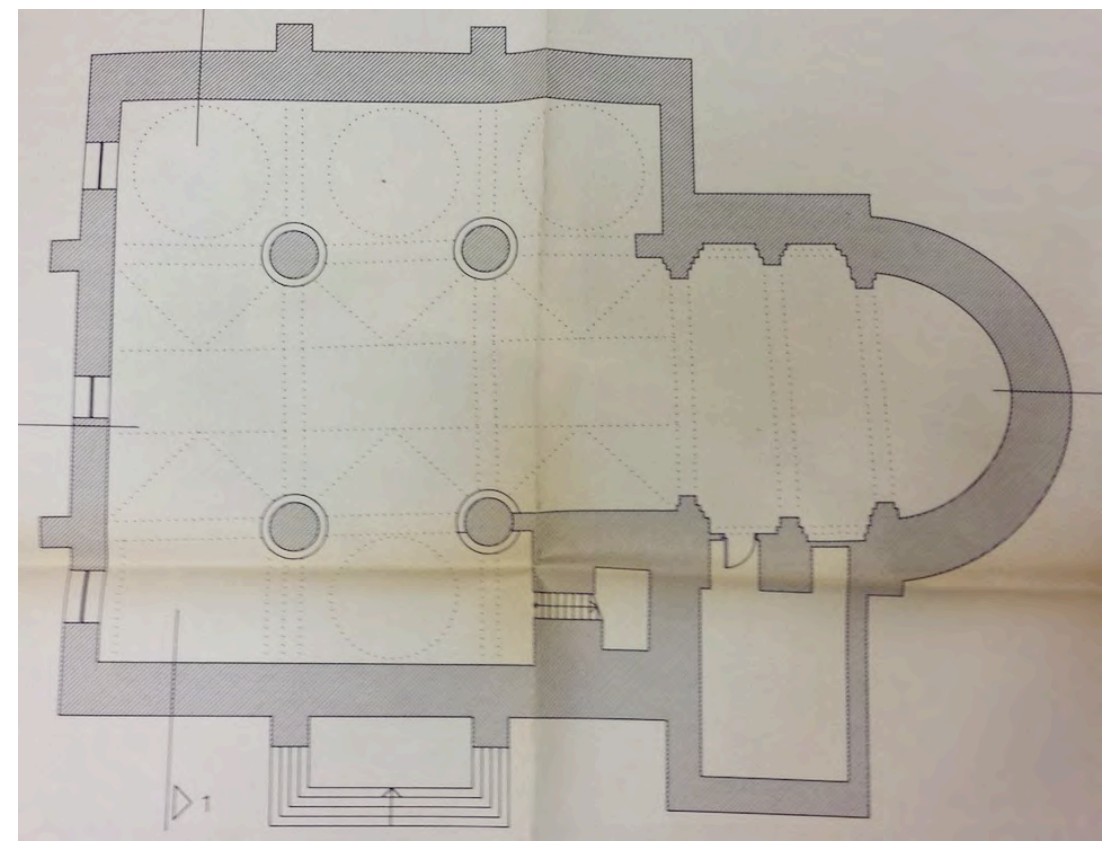

Ilustración 6: planta 2000 Cembrero y Morante JCyL

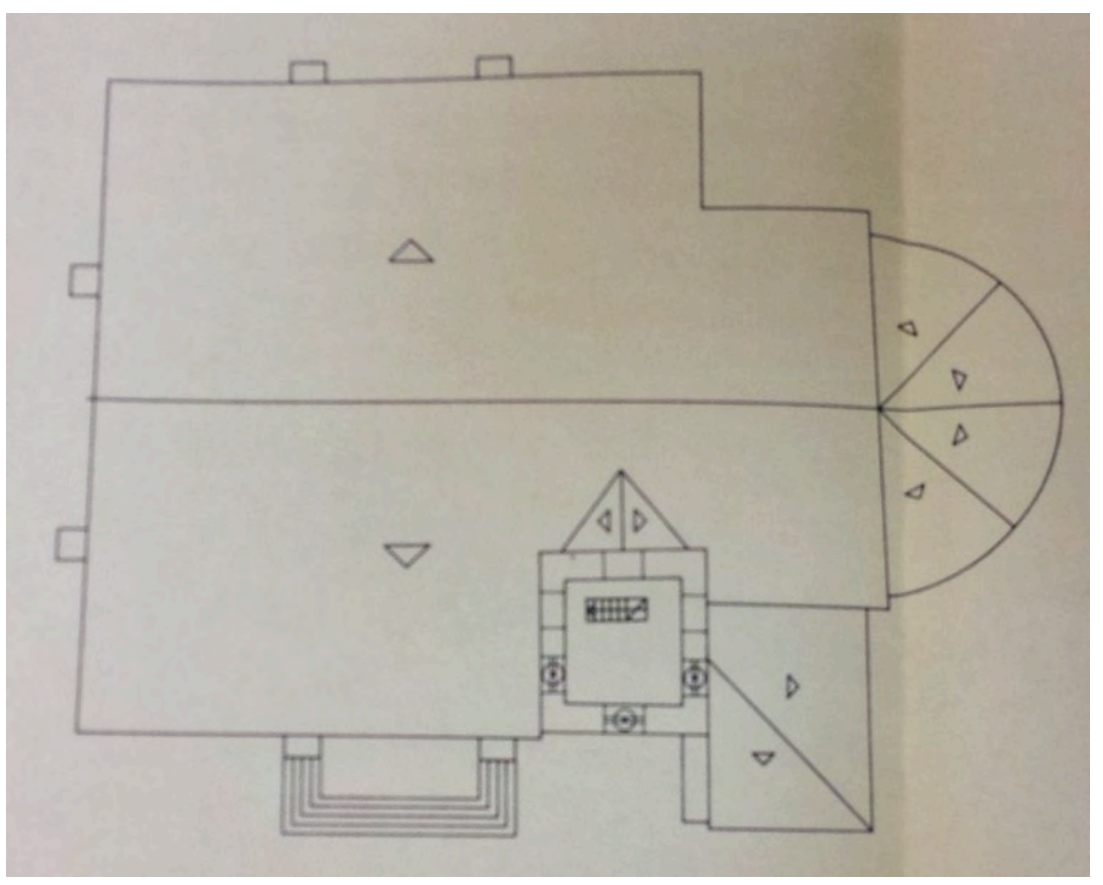

Ilustración 7: planta de cubiertas 2000 Cembrero y Morante JCyL 


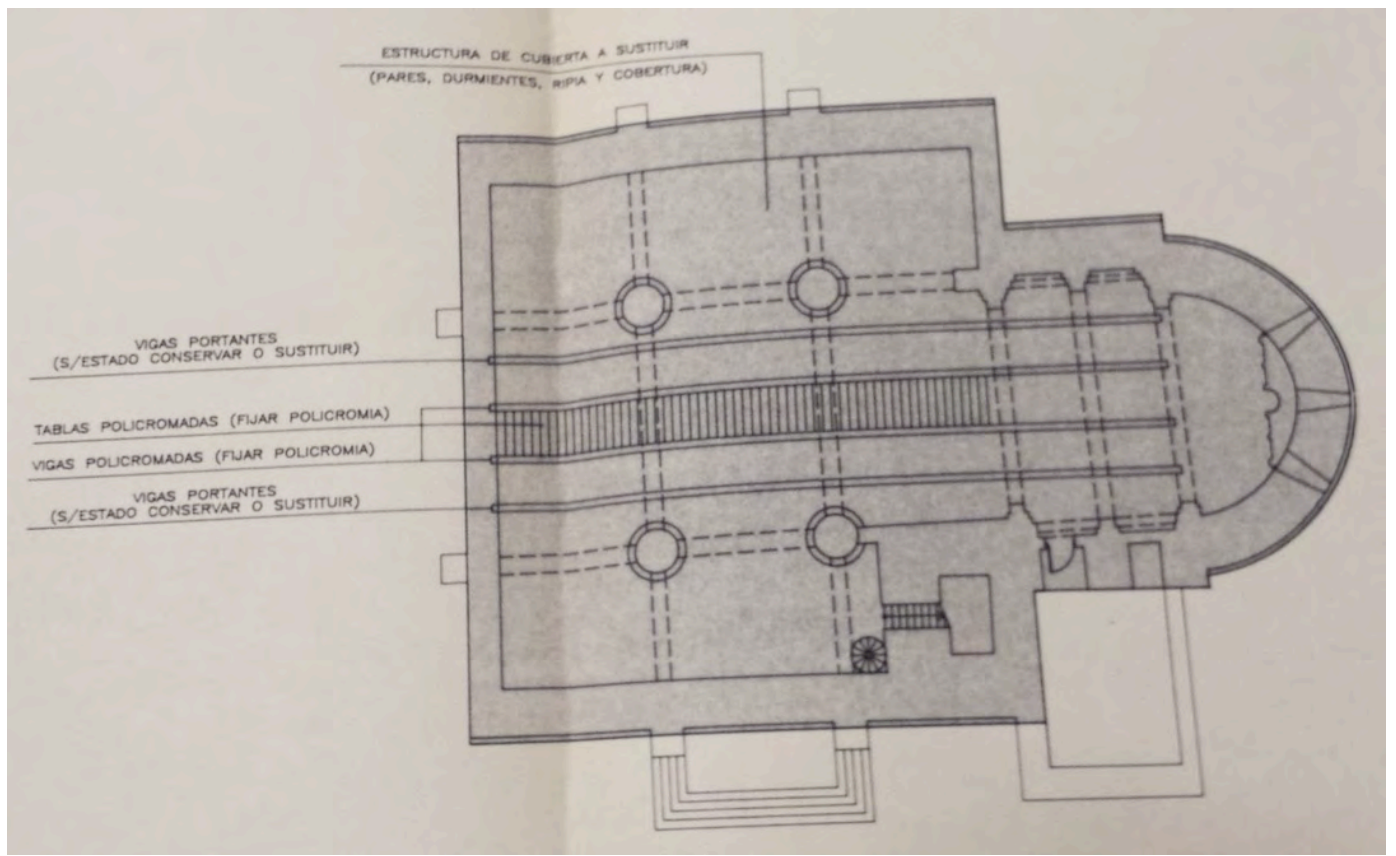

Ilustración 8: planta estructura actual 2000 Cembrero y Morante JCyL
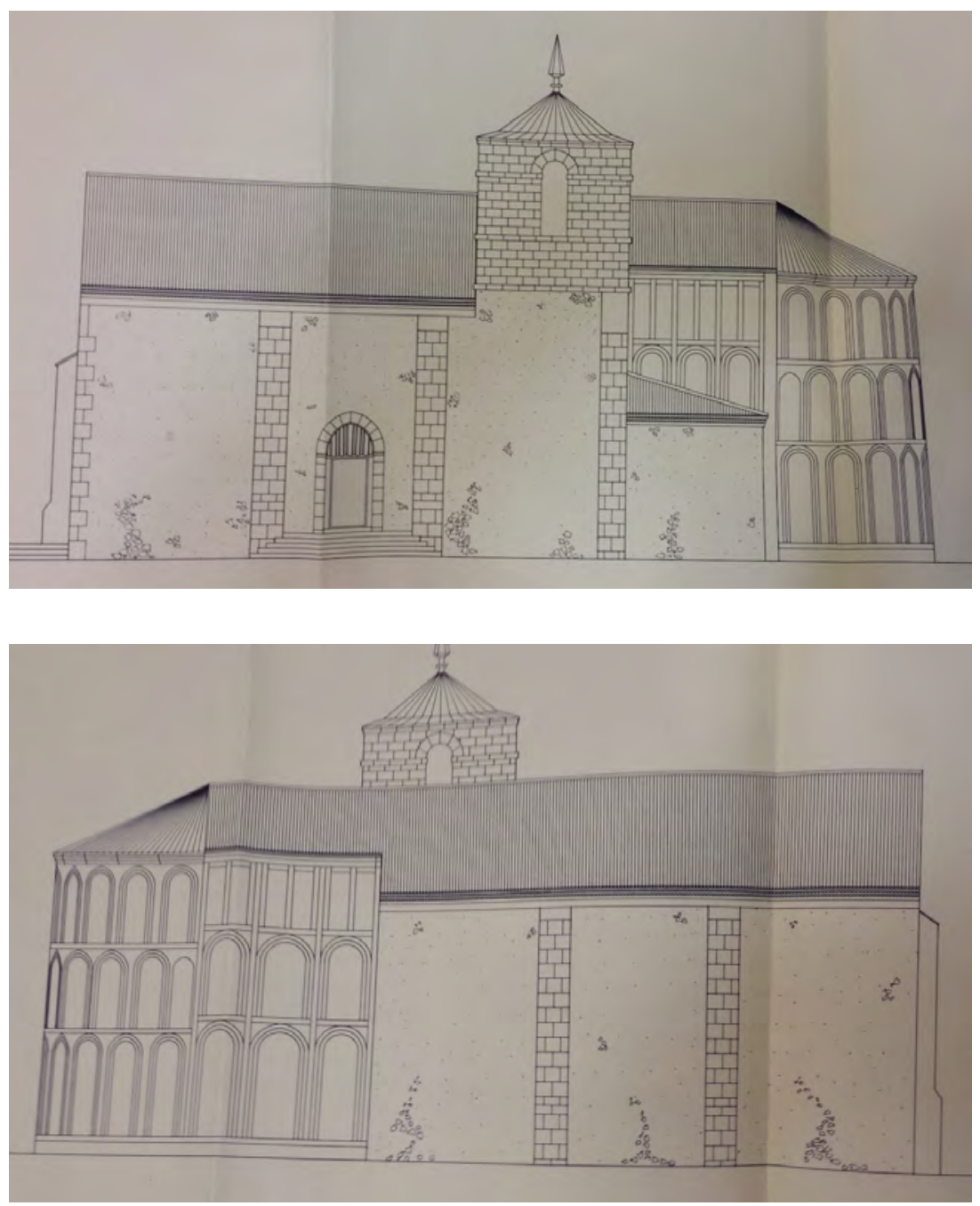

Ilustración 9: alzados laterales 2000 Cembrero y Morante JCyL 


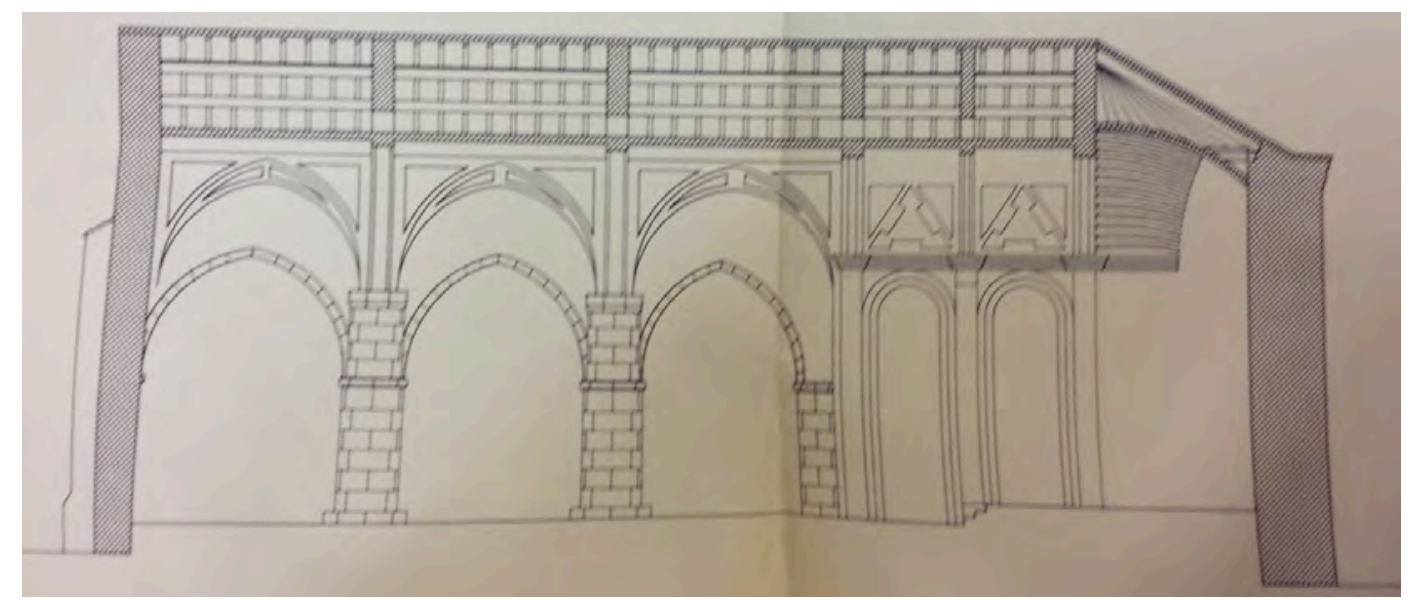

Ilustración 10: sección longitudinal 2000 Cembrero y Morante JCyL

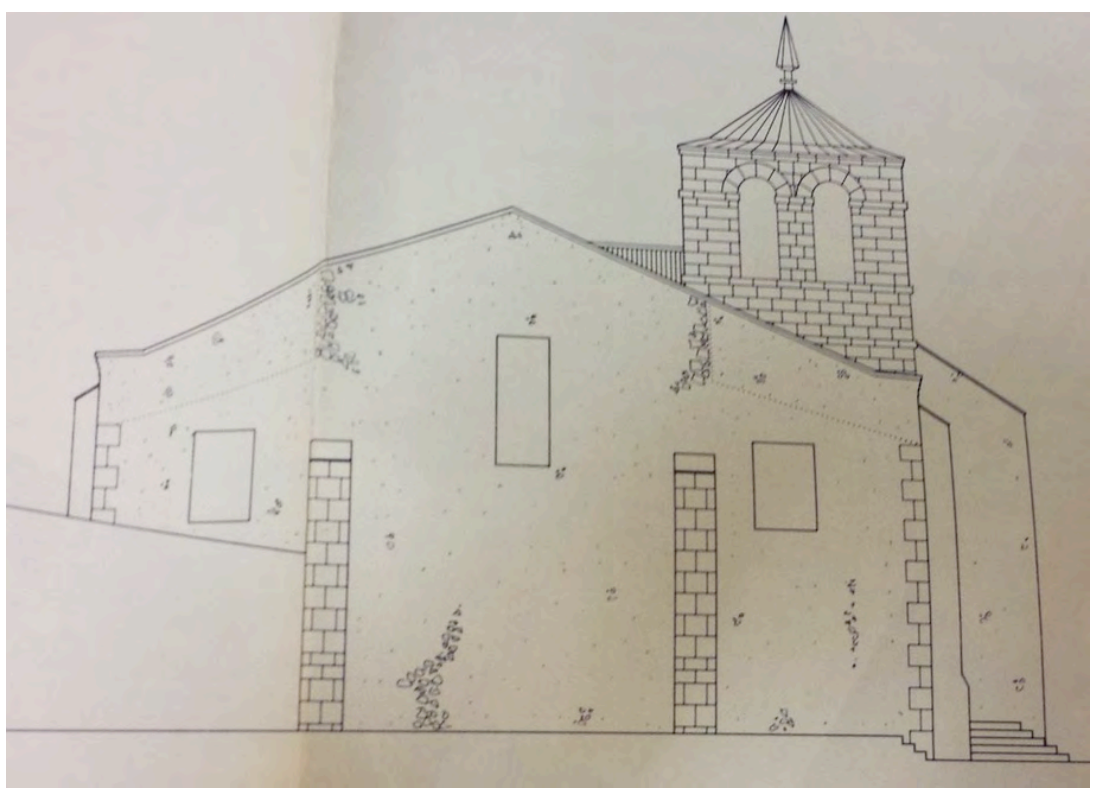

Ilustración 11: fachada a los pies 2000 Cembrero y Morante JCyL

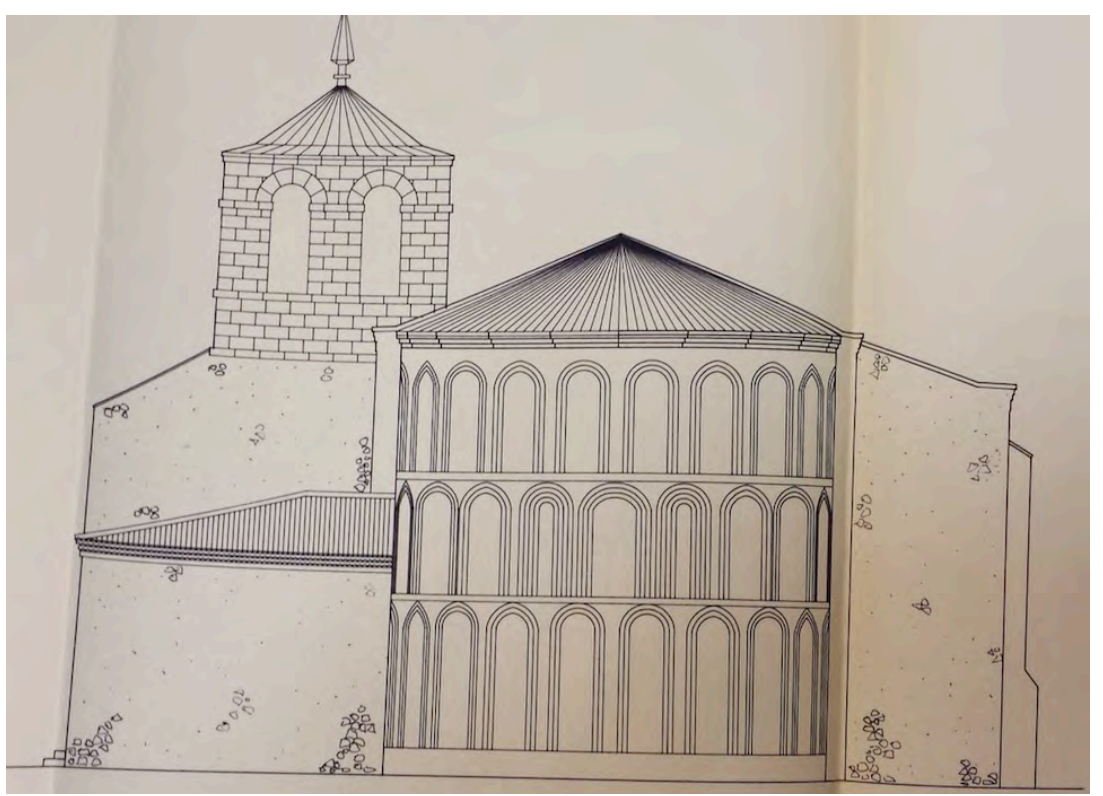

Ilustración 12: alzado de cabecera 2000 Cembrero y Morante JCyL 


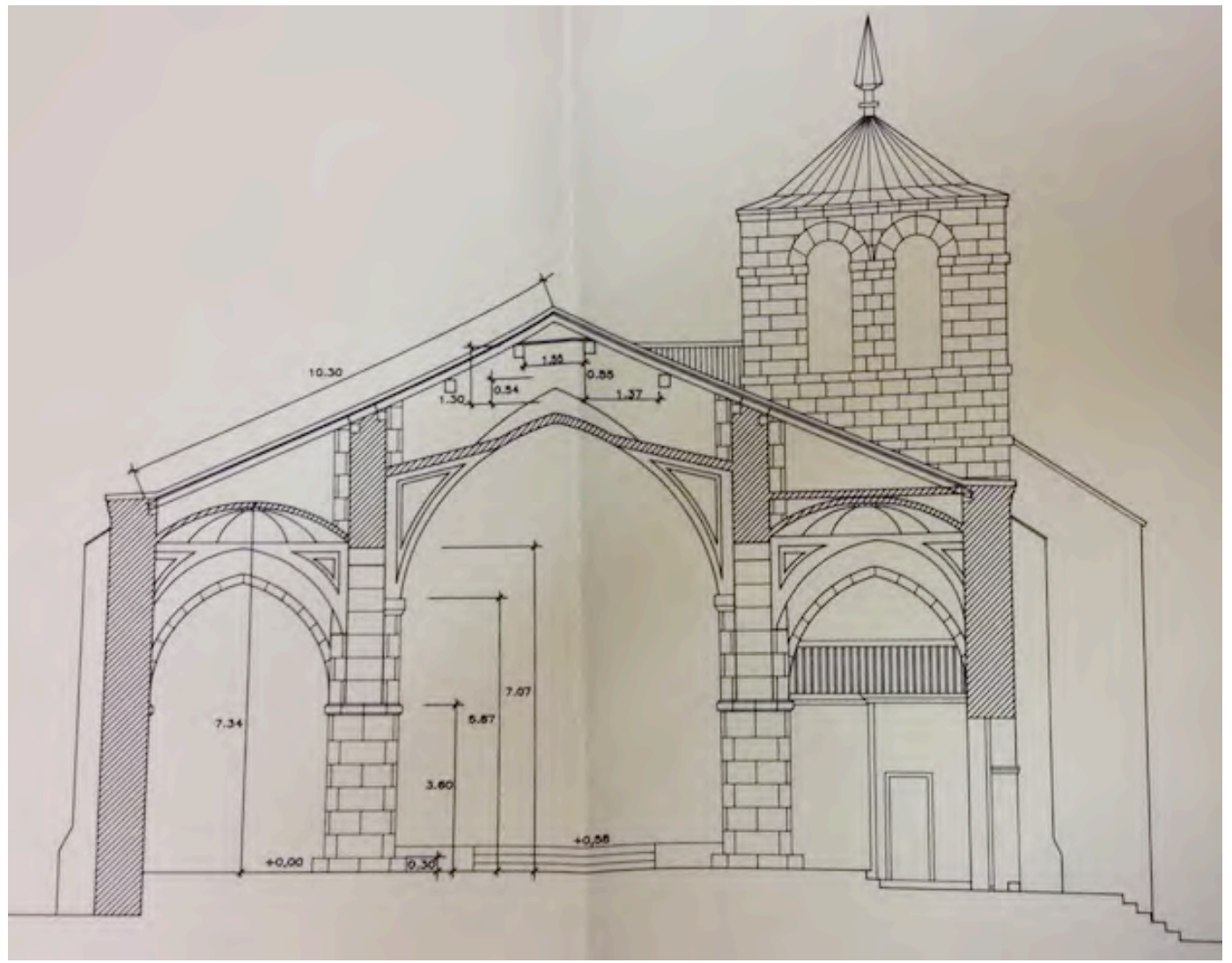

Ilustración 13: sección transversal 2000 Cembrero y Morante JCyL

\section{Solución constructiva de la cubierta}

Según los rótulos del plano de sección del proyecto, se mantienen vigas y tablas originales en buen estado, reemplazando pares, durmientes y ripia a cota inferior.

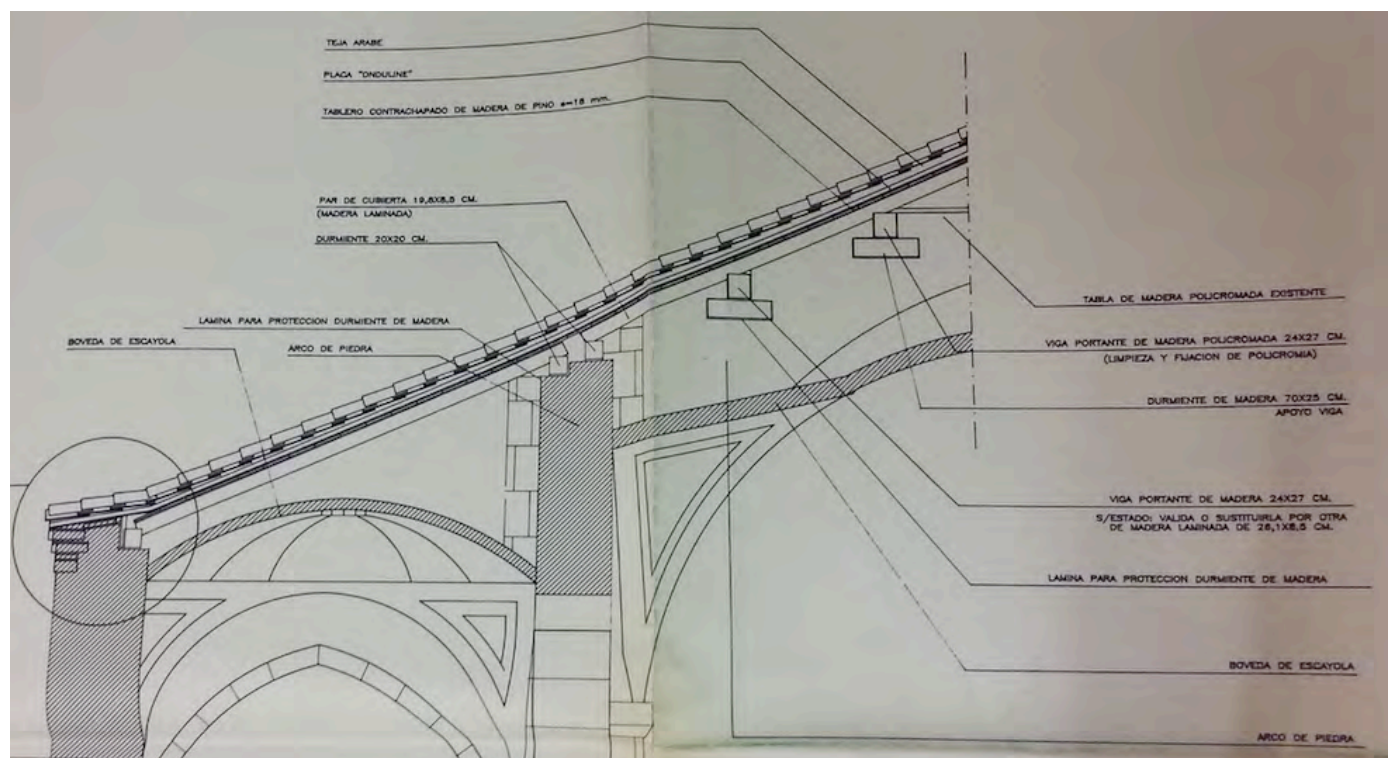

Ilustración 14: sección constructiva de cubierta 2000 Cembrero y Morante JCyL 

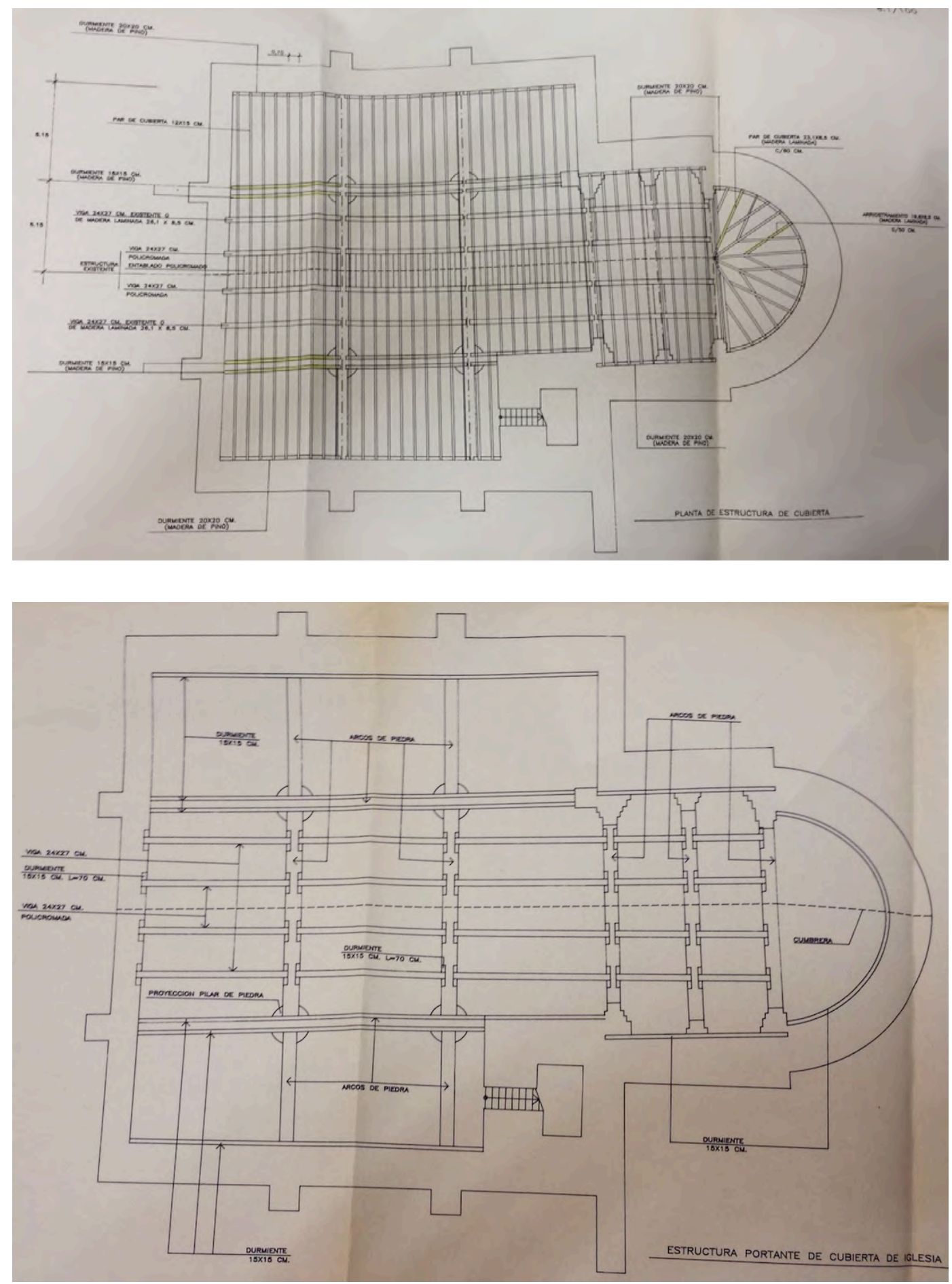

Ilustración 15: estructura de cubierta 2000 Cembrero y Morante JCyL

En las secciones se aprecia una pendiente de unos $25^{\circ}$, con refreno final sobre el ancho del cerramiento. Según los planos de 2000, la estructura de cubierta está formada por vigas $24 \times 27 \mathrm{~cm}$ policromadas, que descansan sobre tramos de $70 \mathrm{~cm}$ de durmiente $15 \times 15$ encastrados en los arcos diafragma de piedra. Se han reemplazado, por secciones iguales de madera laminada de pino, los elementos muy deteriorados. 


\section{Zunchos}

En la documentación analizada no se ha localizado referencias a zunchos. Los durmientes colocados en la restauración de cubiertas de la nave en 2000 son de madera.

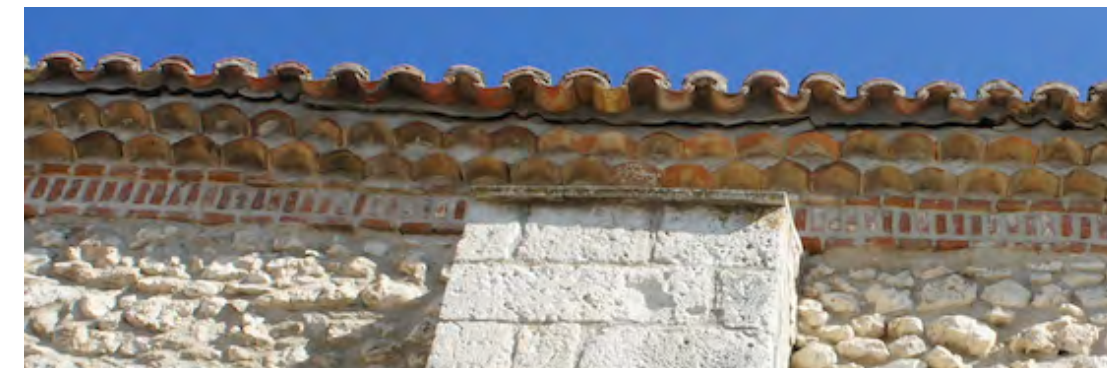

Ilustración 16: cornisa fisurada

En la visita realizada en agosto de 2015 se aprecia una fisura continua en el alero de la fachada de acceso.

\section{Conclusiones}

No se ha podido comprobar la existencia de zunchos en esta iglesia. 



\section{Iglesia de Santa María de Íscar}

Intervenciones citadas en la publicación del Ministerio:

1978 - Obras generales de consolidación, limpieza y embellecimiento - Ana Iglesias González

En la web del IPCE hay un plano en el que aparece sólo el croquis de planta de la zona de cabecera.

\section{En el Archivo General de la Administración}

AGA 26/00397

1978 - Restauración - Ana Iglesias

(Obras adjudicadas en 79, recepción provisional 17-7-80; 9-10-81 definitiva)

Construcciones Alfonso Sancho Miguel

Antiguamente denominada iglesia de San Pedro.

Edificio mudéjar bastante reformado, sobre todo en el XVIII. Muros de piedra. Posee tres naves, entre pilares y arcos apuntados, que se cubren: la central con bóveda de cañón con lunetos y las laterales con bóvedas vaídas, horno en la capilla mayor y arista con yeserías en la sacristía. A mediados del siglo XVIII, se recubrieron las bóvedas con hermosas yeserías barrocas de triángulos mixtilíneos y rameados en su interior.

En el crucero del antiguo lado de la Epístola se dispone la Torre, con remate de chapitel empizarrado; consta de dos cuerpos y basamento, de piedra y mampostería. Lo más importante del templo es el hermoso ábside románico-mudéjar, decorado con arquerías ciegas de ladrillo (siglo XII)

Obras a realizar. Las obras que se pretenden realizar tienen como objetivos primordiales la consolidación, limpieza y embellecimiento del Monumento.

Para ello:

Se levantará toda la cubierta actual, que se encuentra en estado deficiente y es causa de humedades importantes en el interior del edificio; se comprobará el estado actual de la viguería y elementos resistentes y portantes de madera, procediendo a las sustituciones y operaciones que se vean necesarias. Se retejará de nuevo con teja curva similar a la existente, dispuesta por hiladas alternas de canal y cobija, solución 
constructiva que es preferible a la existente en la actualidad (sin cobijas), y que en buena parte ha contribuido a las penetraciones del agua.

En el exterior del templo, se pretende destacar al máximo la imponente categoría del ábside románico-mudéjar. Para ello, además de suprimir los enfoscados que actualmente tapan la fábrica de ladrillo de tejar en los interiores de las arquerías ciegas y de proceder a las pequeñas reparaciones que sean precisas, se picarán además todos los enfoscados actuales de las fachadas... de manera que aparezcan las fábricas de piedra y mamposteria originales.

Planos 1/50. En la carátula pone toma de datos y delineado Estudio Lopez Uribe. (Con mucho detalle pero el grafismo es peor que el de Sandoval)

Cubiertas (esquema de faldones con pendientes), Planta general y Fachada principal.

Otra copia del proyecto. Las obras objeto del contrato son:

Reparación general de cubierta

Restauración general de fachadas

Restauración interior

Reparación de pavimentos

En el presupuesto describe como unidad las partidas:

$1 \mathrm{Ud}$. general para la reparación de estructura de cubierta consistiendo en sustituir maderamen en mal estado y colocación da tabla ripia en zonas deterioradas $1 \mathrm{Ud}$. general para la reparación de alero cornisa consistente en retoques de ladrillo

$597,56 \mathrm{~m} 2$ de cubierta de teja curva $534,97 \mathrm{~m} 2$ de picado de enfoscado... $428,07 \mathrm{~m} 2$ de rejuntado de mampostería con mortero de cemento blanco $287,40 \mathrm{~m} 2$ de rejuntado de fábrica de ladrillo macizo de "tejar" con mortero de cemento blanco

\section{En el archivo del IPCE}

Carpeta 636-5

1979 - Obras de restauración - Ana Iglesias

CONSTRUCCIONES ALFONSO SANCHO MIGUEL

Acta de recepción 9-10-81 


\section{Certificaciones}

Memoria con firma original

Presupuesto (mismo que AGA: 56,44m2 demolición de cubierta de teja curva y entramado de madera, $141,78 \mathrm{~m} 3$ de demolición de mampostería en piedra caliza y mortero de cal incluso clasificación de piedra para posterior utilización en esquina de torre, ...)

Sólo cuatro planos, referidos a la colocación de la calefacción: S1 sección longitudinal, S2 sección transversal ambas de estado actual; A1 fachada sur actual y PL5 planta de coro reformada.

\section{En el archivo de la Junta de Castilla y León}

VA-349 (3 cajas)

1) Proyecto de seguridad

2) Documentación administrativa

3) Proyecto básico y de ejecución.

Eduardo Cembrero Cil y Alberto Morante González

Cabero Edificaciones SA

\section{Proyecto de restauración}

La memoria de daños. Las patologías que presenta el edificio tienen su origen en un mal estado de la construcción y de los elementos estructurales de la cubierta... derivando al resto del edificio

Presenta gran cantidad de tejas desplazadas. La tablazón realizada con ripia de madera esta afectada alabeándose y desplazándose.

Un punto particularmente dañado son los encuentros de los muros con la estructura, donde los durmientes, por las humedades, por carcomas, por el empuje de la estructura, por el mal apoyo de los muros, escasa sección, etc. presentan un grave deterioro, existiendo zonas en que se encuentran totalmente desplazados y girados sin apoyo en el muro, podridos, e incluso en alguna zona el deterioro es tal que han desaparecido, produciendo en los apoyos de las vigas y correas, desplazamientos, giros y rotura de las mismas. 
Criterio de intervención: los elementos que presenten síntomas de ataque de organismos xilófagos con pérdida de sección, en más del $40 \%$ de la superficie en las zonas de encuentro con los muros, si el daño se produce en ambos apoyos la pieza se sustituirá, si solo es en un apoyo se refuerza con prótesis. Las piezas con pérdida de sección en un $10 \%$ a lo largo de la pieza se sustituirán. Las flechas mayores de 1/200L se sustituirán.

Se eliminan los durmientes existentes sobre los muros, limpiando de rellenos y eliminando las piedras suelta, maderas y demás materiales existentes en la coronación de los muros, se colocaran durmiente de madera.

Después de haber ejecutado las obras de acondicionamiento, se procederá a consolidar los muros perimetrales y centrales de la iglesia, igualando sus paramentos con piedra y mortero. Se colocarán los durmientes de madera de pino aserrado que irán protegidos de la humedad por lámina asfáltica impermeable.

La estructura de madera, en la nave central, estará formada por vigas de madera de pino laminado de secciones según planos que apoyan sobre los durmientes en apoyo recto, con herrajes de piezas metálicas, sobre estos irán los pares del mismo material con ensamblajes a boca de perro cajeados....

La parte de los muros entre las bóvedas y la cubierta se revocarán con mortero bastardo de cal y arena.

El encuentro de la cubierta con el muro perimetral se remata con alero construido con hiladas de ladrillo tejar.

En el faldón de las cubiertas se colocaran huecos de ventilación de la misma.

Memoria final noviembre de 2001:

Adjudicación noviembre 2000, inicio de obras enero 2001.

La obra fue lenta por el cambio de aparejador y las condiciones climáticas con fuertes lluvias.

Las obras se iniciaron con el desmontaje del material de cubierta del ábside de la iglesia, que se apoyaba sobre una solera inclinada de hormigón, que se mantuvo en su misma posición, procediendo únicamente a sustituir la teja y el mortero existente por una nueva cubierta de chapa de Onduline y teja cerámica curva, mezclando la nueva y la antigua teja, recibidas ambas con mortero de cemento.

A la vez que se realizaban estas obras se empezó a desmontar la estructura de la cubierta de la torre...

Encadenado con esta obra se desmontaron las cubiertas de la nave de la iglesia, descubriendo que la estructura original era policromada en más superficie y 
elementos que en un primer momento se había considerado y que sobre las naves laterales, tanto de la Epístola y del Evangelio situados entre las bóvedas de yesería y la cubierta existían, en un buen estado de conservación, con excepción de los encuentros con los muros exteriores, unos forjados en dos planos horizontal e inclinado, con entrevigado de artesa y pintura monocroma, que nos indicaban la existencia de una techumbre anterior a las bóvedas y que además de ser un elemento decorativo formaría arte de la cubierta original.

Según se avanzaba en el desmontaje se observa que aún se mantenía parte de la estructura original de la cubierta con muchos elementos del artesonado policromados de la nave central, aunque su estado de conservación era malo. Esto nos llevó a mantener estos elementos como resto de la estructura original, así como los forjados laterales, procediendo solo a la limpieza de los mismos y sanearlos, construyendo la nueva estructura de cubierta por encima de esta, conservando los elementos antiguos independientes de los nuevos, en dos planos diferentes.

En este punto, consideramos oportuno no reponer la bóveda de yeso situada en la zona de la pila bautismal, que estaba en muy malas condiciones y que tenía un escaso valor arquitectónico, colocando la techumbre original en esa zona de la iglesia, forjado en dos planos, de la que aún existen apoyos y canes de piedra, originales.

En todo este proceso constructivo se determinó ejecutar los elementos estructurales vistos de madera aserrada y los elementos ocultos de madera laminada.

Se reforzaron, tanto con cosidos, refuerzos y prótesis, etc. los elementos estructurales que se conservan y se aplicó un tratamiento preventivo contra insectos incluidos termitas...

$598,98 \mathrm{~m} 2$ levantado tendido de teja actual

$565,12 \mathrm{~m} 2$ desmontado de la tablazón de madera de los faldones de la cubierta

$317 \mathrm{ml}$ desmontado por medios manuales de par o alfarda de madera en armadura de cubierta $14 \times 4,9 ; 10 \times 4,40 ; 12 \times 4,10 ; 1 \times 155,20$

214,43 ml cajeado en fábrica de cualquier tipo para colocación de durmiente de asiento para reparto de cargas de la estructura de cubierta

$1,94 \mathrm{~m} 3$ y $113,90 \mathrm{ml}$ durmientes de pino Valsain

$60,40 \mathrm{ml}$ reposición de vigas en madera de pino laminada encolada

$161,80 \mathrm{ml}$ par o alfarda de madera de pino laminada encolada

14,82 ud prótesis de madera

$431,30 \mathrm{~m} 2$ tablero contrachapado en madera de pino de $18 \mathrm{~mm}$ de espesor en formación de faldones de cubierta, sujeto sobre los pares o alfardas con tornillo Spax 
$20 \mathrm{~m} 2$ artesonado de madera aserrada

176,47ml remate de cajeados en cualquier tipo de fábricas, para colocación de piezas estructurales, durmientes, etc. a base de ladrillo tosco y mortero de cemento 103,52 ml nivelado y rejuntado, con mortero de cemento M-60, en zonas de coronación de muros y encuentros de cubiertas

$66,52 \mathrm{ml}$ repaso y saneado de hiladas de ladrillo de remate de muros, colocado a sardinel

Dossier fotocopias de fotografías, informes técnicos y ensayos
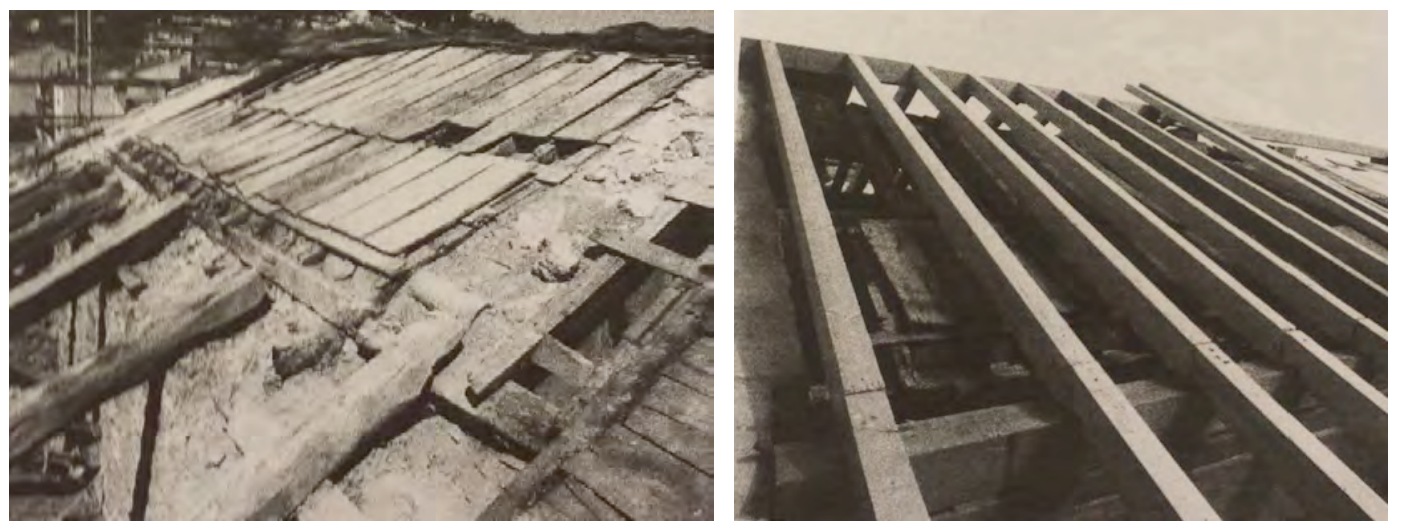

Ilustración 17: cubierta de nave central antes y durante la obra 2000 Cembrero y Morante JCyL 


\section{Visitas realizadas}

$02 / 08 / 2015$

El estado de conservación del monumento es básicamente correcto: los paramentos están limpios y no hay muestras de humedad en el interior. La cornisa, sin embargo, muestra un agrietamiento generalizado.
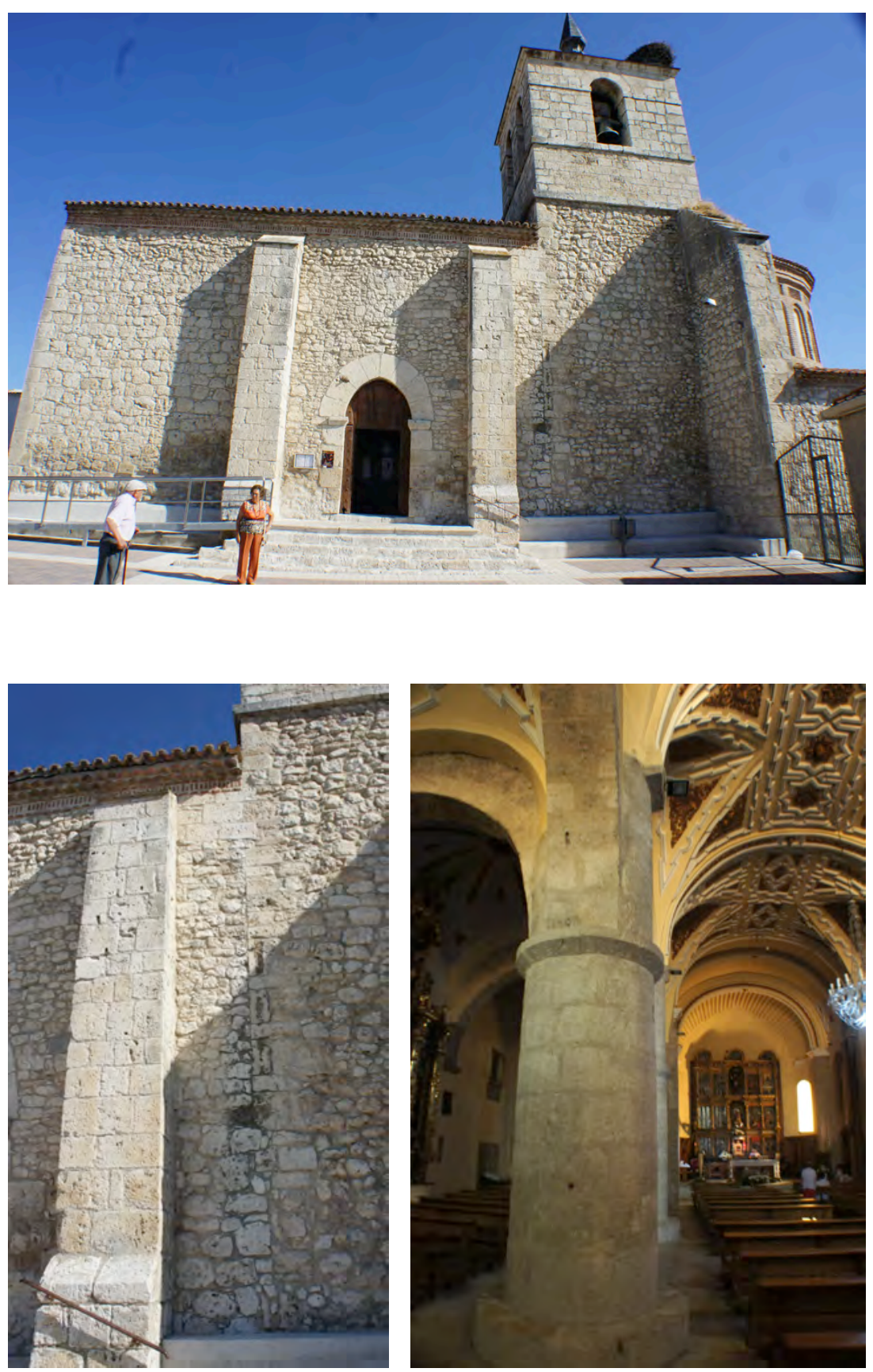
También los dos contrafuertes de cerramiento del lado del evangelio se encuentran oscurecidos y con indicios de vegetación.
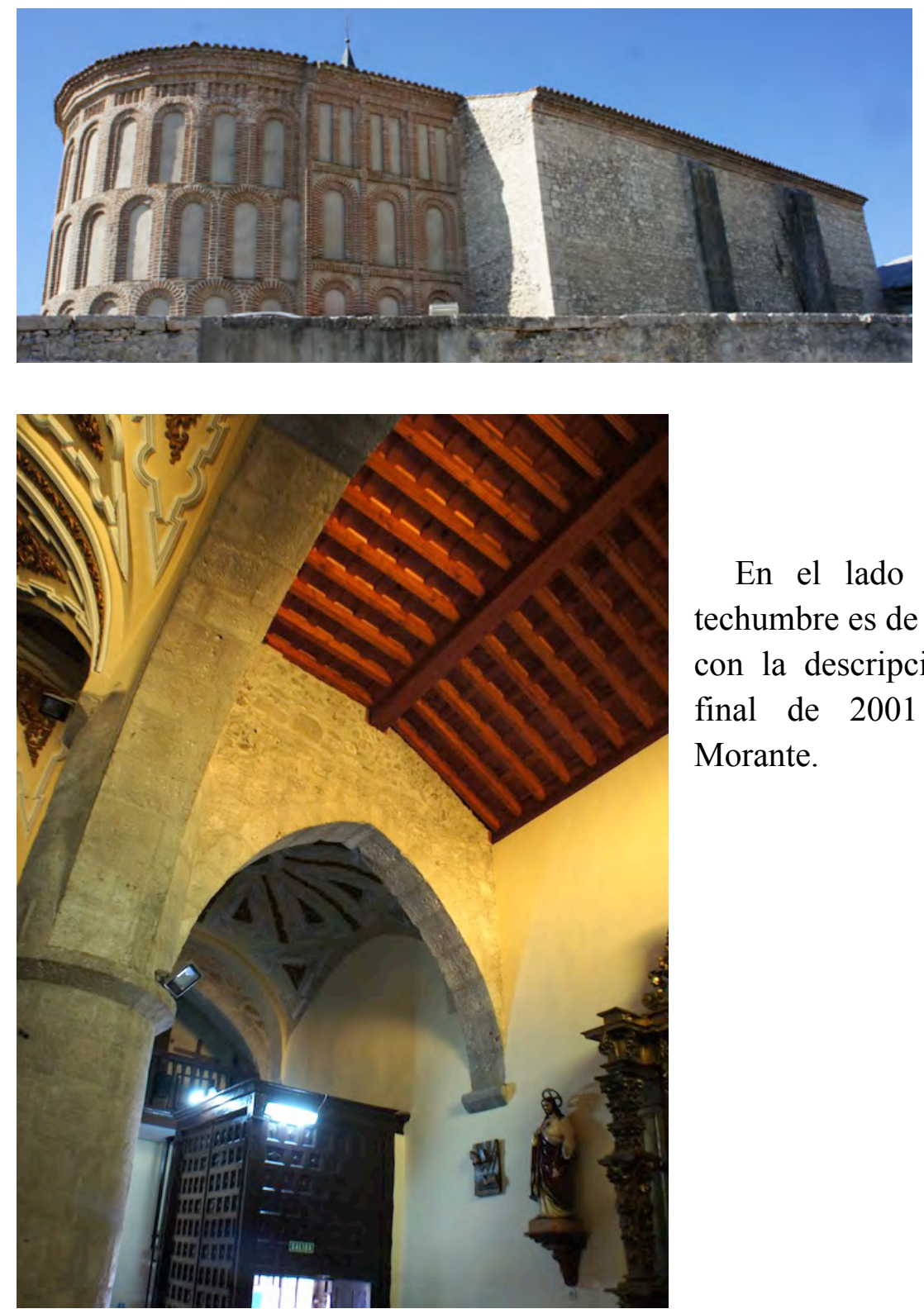

En el lado de la epístola, la techumbre es de madera, de acuerdo con la descripción de la memoria final de 2001 de Cembrero y Morante. 


\section{Iglesia de Santa María de Arbás}

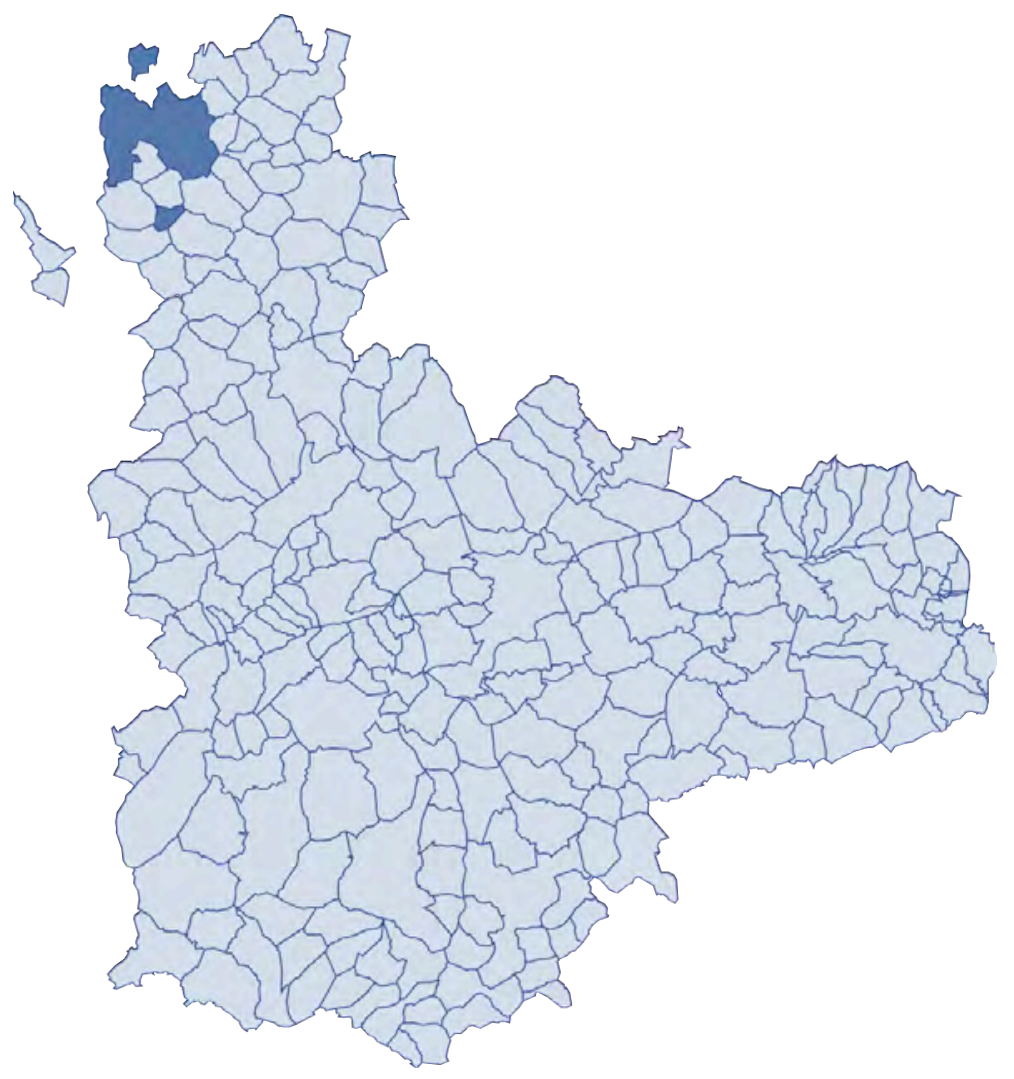



FICHA SÍNTESIS

Código de identificación: FZ-24

Denominación:

Localidad:

Iglesia de Santa María de Arbás

Mayorga

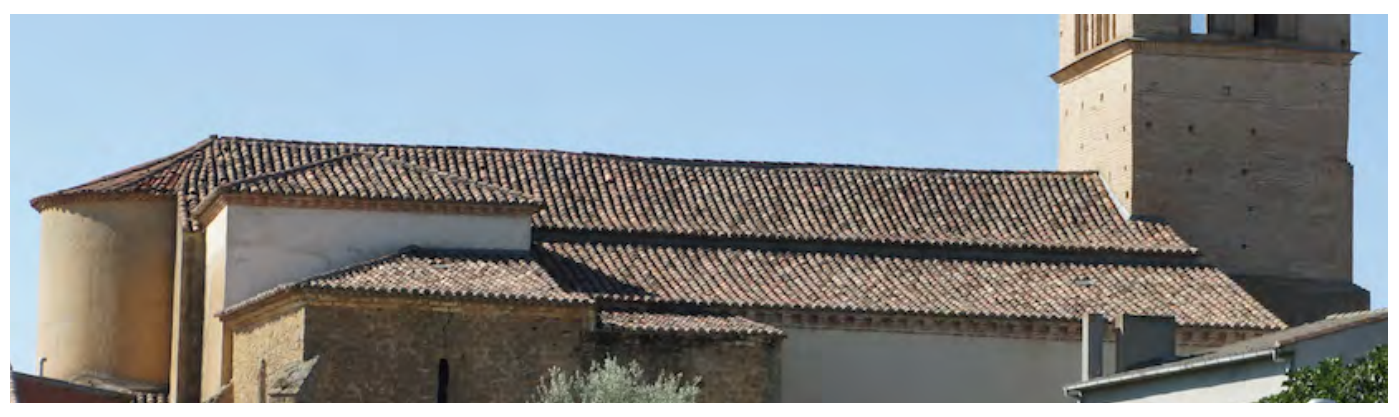

\section{Descripción}

Iglesia mudéjar con dos naves, separadas por pilares con arcos apuntados, la central con cubierta a dos aguas y la única lateral a una.

Cuenta con un único ábside semicircular.

La torre a los pies se levanta escalonada.

\section{Materiales}

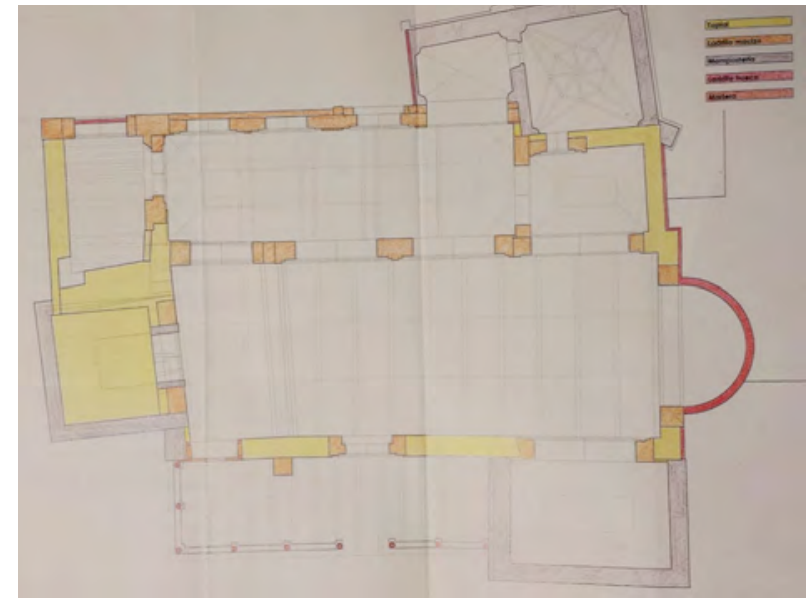

Ilustración 1: planta materiales 1998 Espinosa JCyL

Los muros son de tapial y ladrillo macizo, con adiciones de mampostería y ladrillo hueco. La cubierta está revestida de teja curva.

\section{Singularidades}

El edificio se encontraba ruinoso en 1964. En 1981, cuando se edita el Catálogo de Villalón, aún se mantenía sin uso y, en la actualidad, permanece cerrada.

\section{Dimensiones básicas del templo}

$\begin{array}{llll} & \text { central } & \text { laterales } & \text { capillas } \\ \text { Ancho de nave } & 12,0 & 8,7 & - \\ \text { Altura } & 16,6 & & \end{array}$




\section{Memoria histórica constructiva}

Según la memoria del proyecto de Espinosa:

En 1565 se sustituye el claustro por otro de cantería y en 1567 se dan trazas para construir los cuerpos altos de la torre derribando una parte arruinada. En 1570 se levanta la panera, a los pies de la nave lateral. En los siglos XVII y XVIII hay reparaciones constantes de los tejados. En 1603 se abren las dos ventanas altas del muro sur. En 1825 se coloca la falsa artesa sobre la nave lateral y en 1859 se embaldosa el templo.

\section{Cronología. Fechas clave}

$1964-1989-1971$

\section{Intervenciones}

1965 - Reparación de cubiertas y artesonado - Anselmo Arenillas

El templo se encuentra en muy mal estado. Levanta gran parte de las cubiertas de presbiterio, nave central y nave del evangelio para sustituir los pares rotos y el entablado. Limpia, reteja, coloca ventanas y repara pavimentos.

1971 - Restauración - José Ángel Rodrigo García

Retejo general y reconstrucción del ábside con fábrica de ladrillo y cubierta de madera.

1998 - Restauración - Luis A. Espinosa y José Ma Varona

Incorporación de zuncho de hormigón armado sobre el muro norte de la nave central.

Desmontado y restauración integral de todas las cubiertas, con armadura de par y nudillo, mediante prótesis puntuales y sustitución de elementos deteriorados por madera laminada. El muro se recrece con dos hojas de fábrica de ladrillo y se copia la cornisa escalonada de una capilla.

No se interviene sobre el presbiterio restaurado en 1971. Se pinta de rojo las tablas nuevas del artesonado para distinguirlas de las originales.

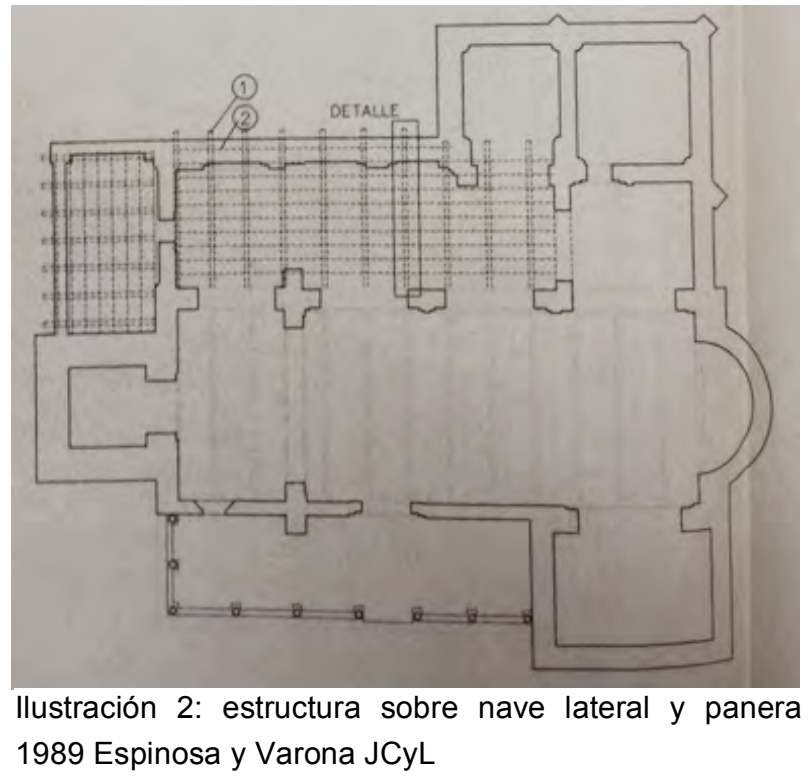


Planos

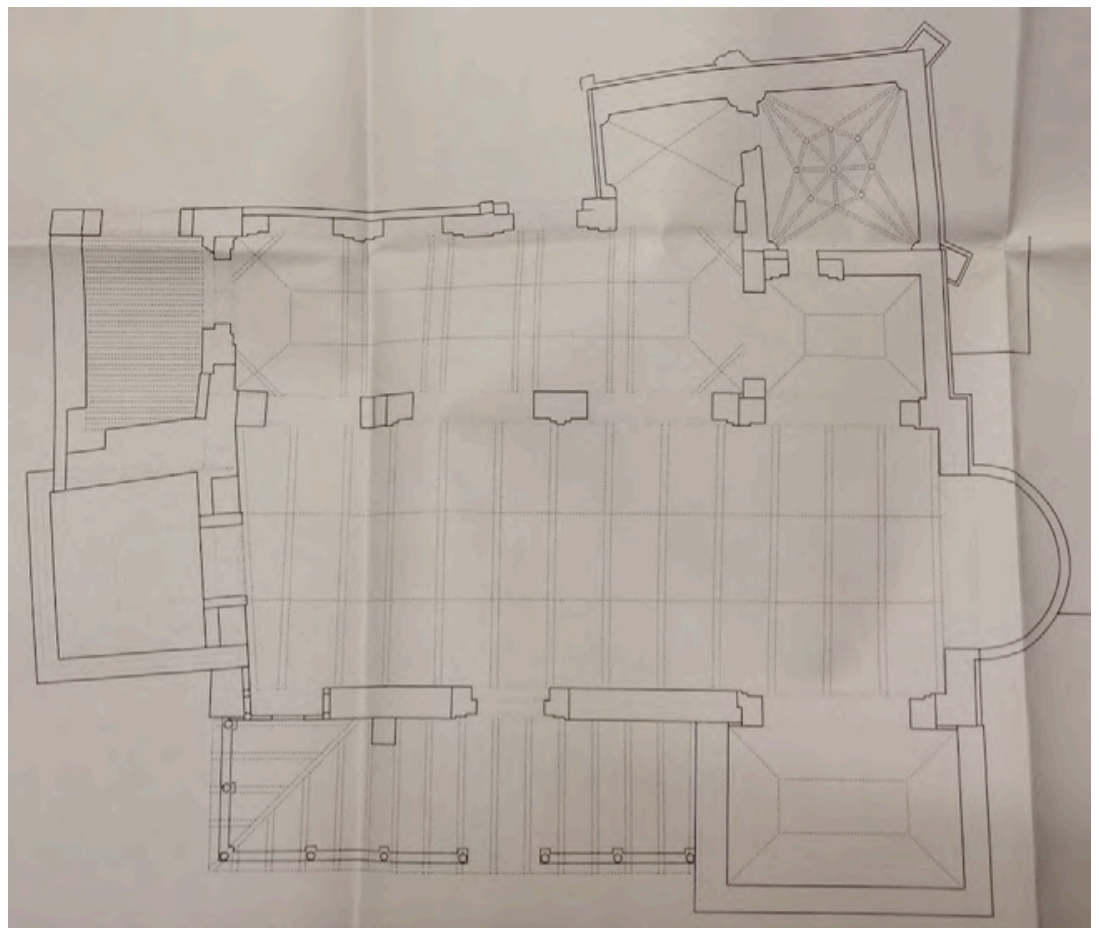

Ilustración 3: planta 1998 Espinosa y Varona JCyL

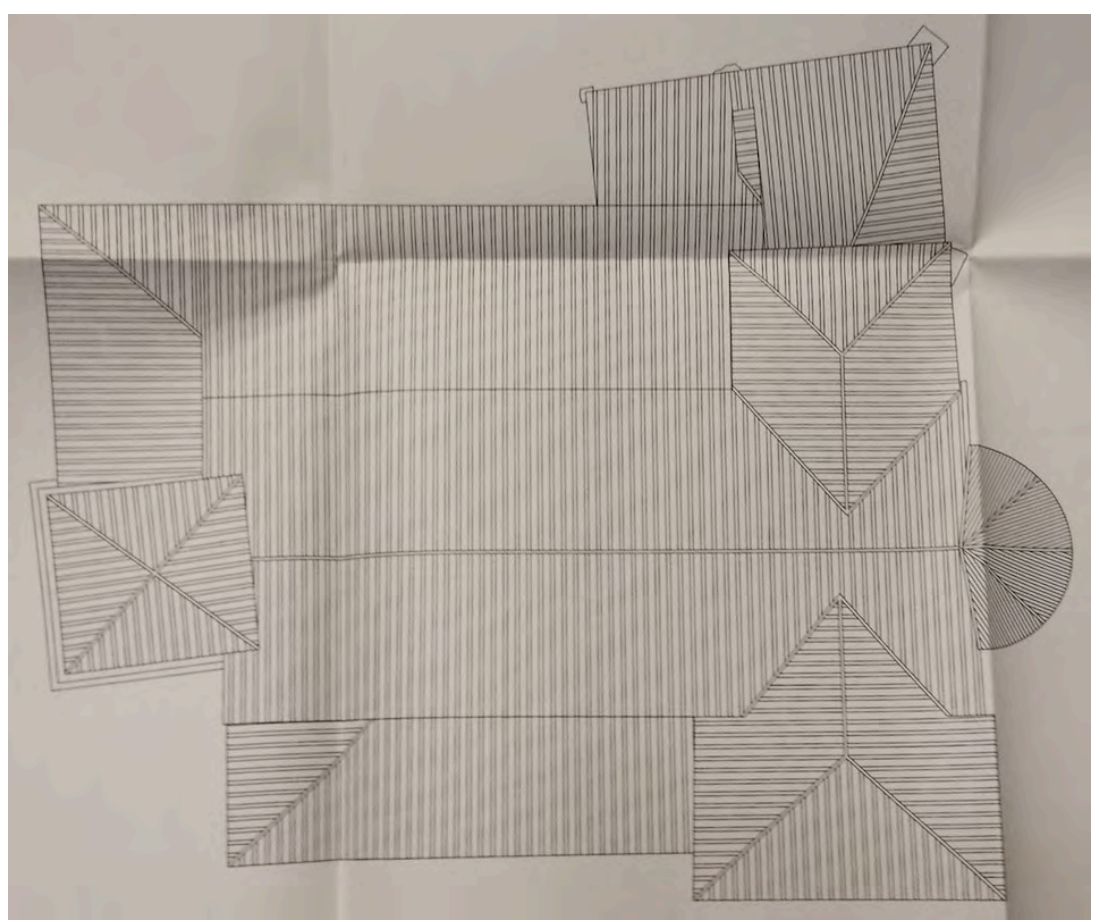

Ilustración 4: planta de cubiertas 1998 Espinosa y Varona JCyL 


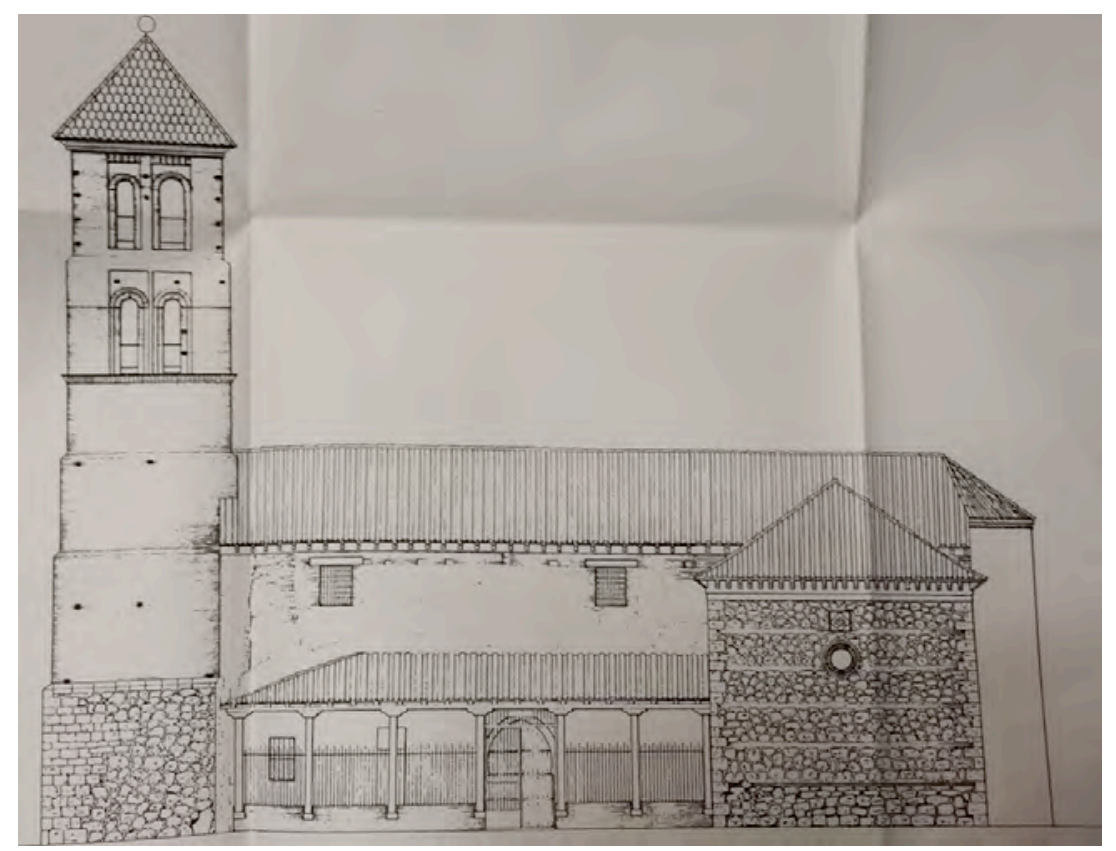

Ilustración 5: fachada de acceso 1989 Espinosa y Varona JCyL

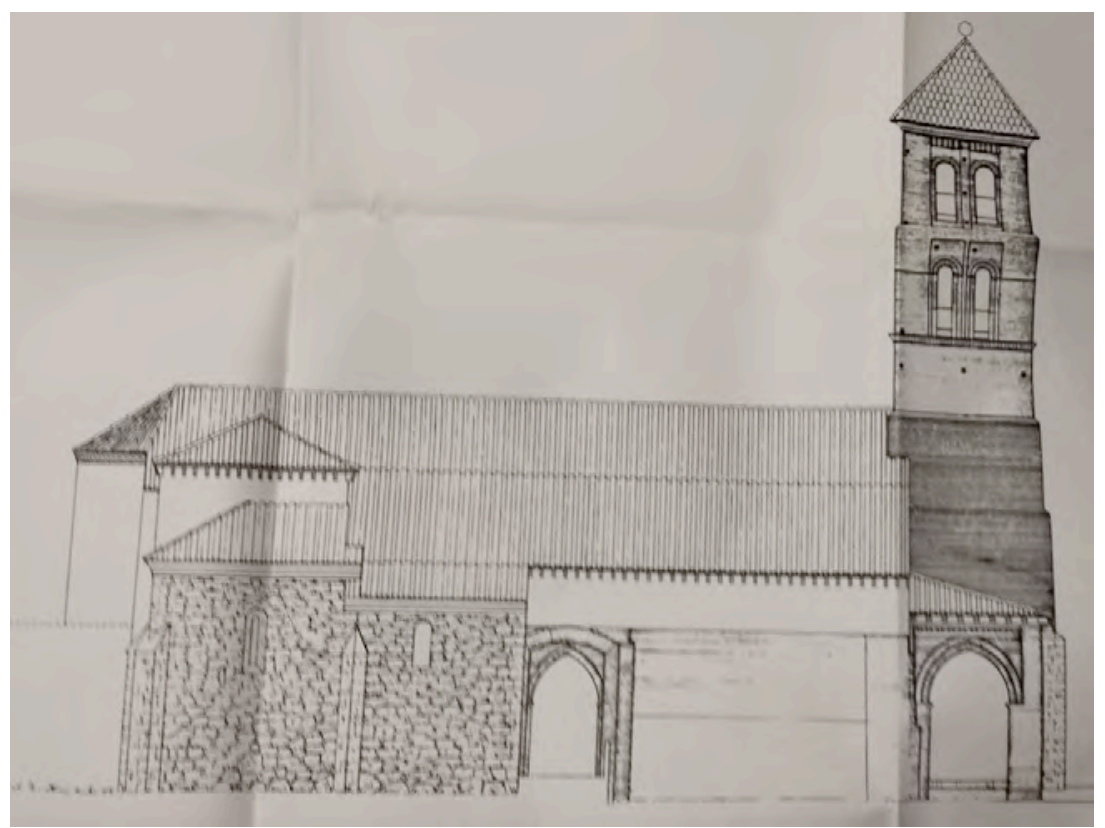

Ilustración 6: alzado del evangelio 1989 Espinosa y Varona JCyL

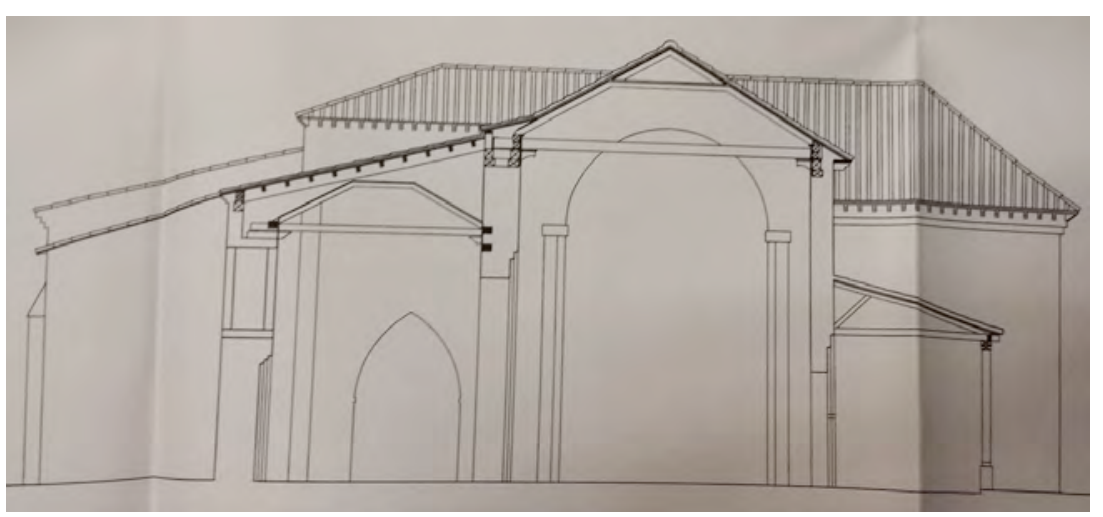

Ilustración 7: sección transversal 1989 Espinosa y Varona JCyL 


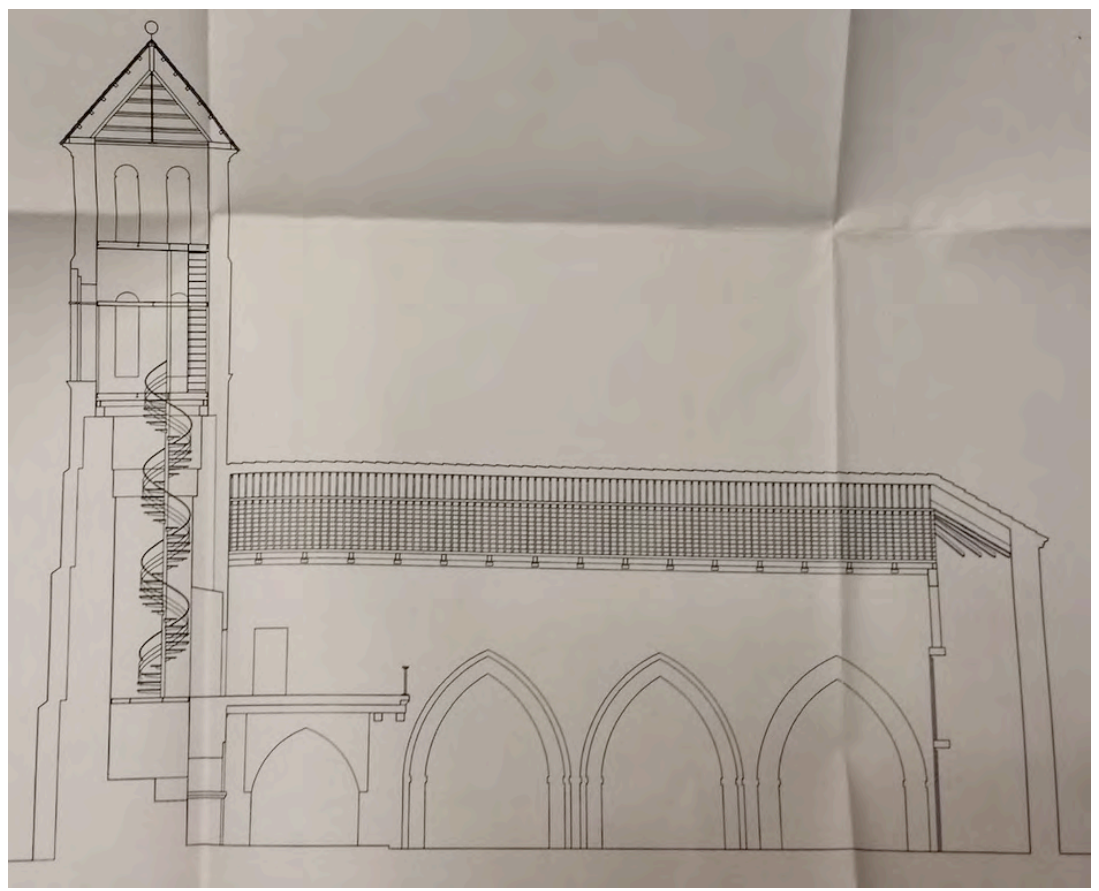

Ilustración 8: sección longitudinal 1989 Espinosa y Varona

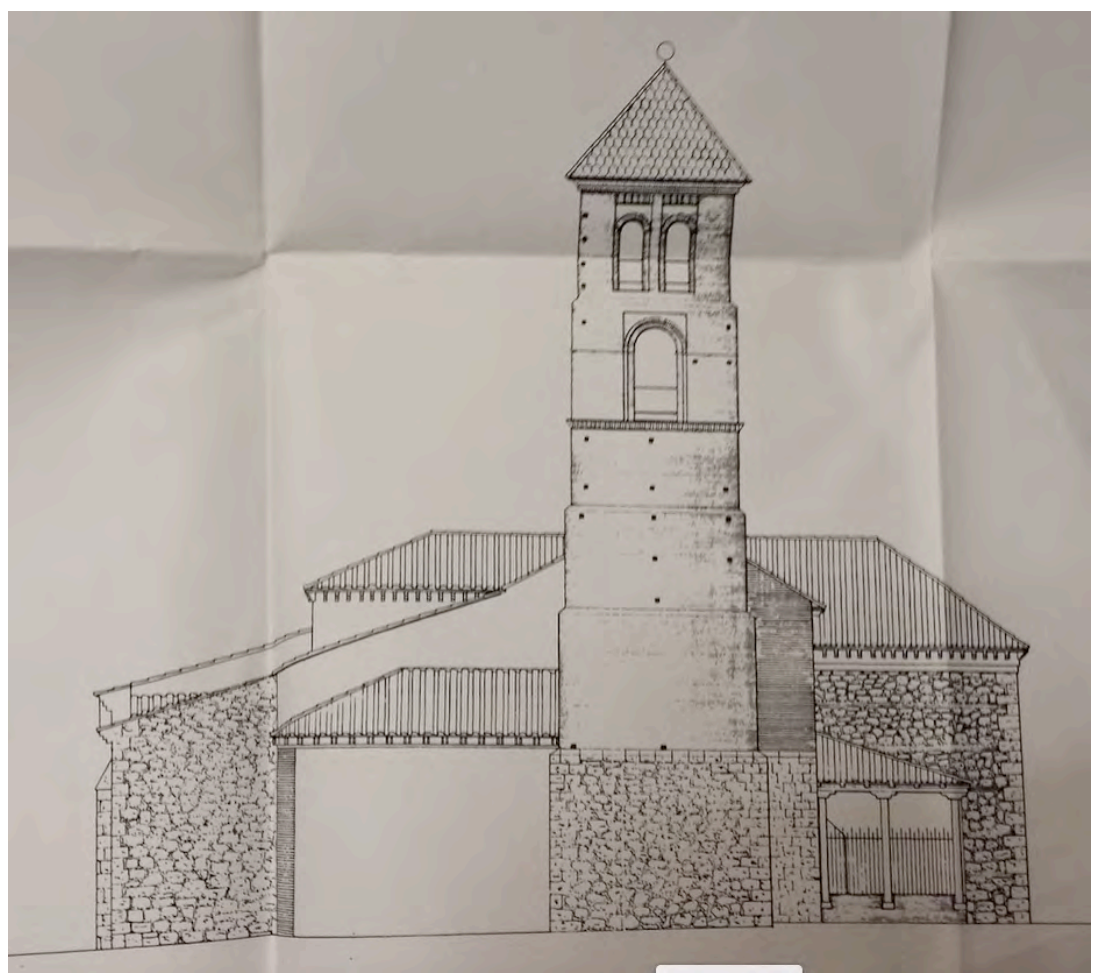

Ilustración 9: alzado a los pies 1989 Espinosa y Varona JCyL 


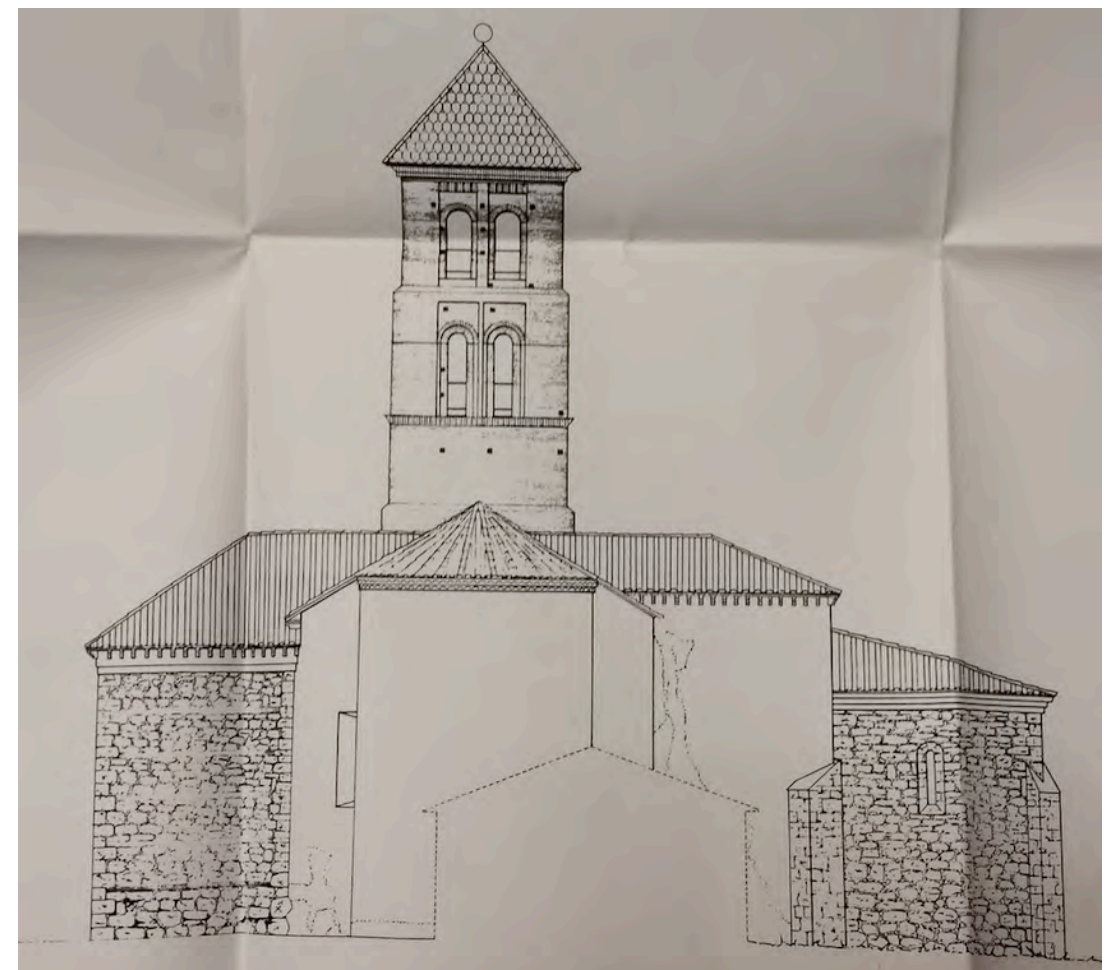

Ilustración 10: alzado por cabecera 1989 Espinosa y Varona JCyL

\section{Solución constructiva de la cubierta}

En las secciones de la cubierta se aprecia una pendiente de unos $30^{\circ}$, con una banda a modo de refreno en el encuentro de ambas naves sobre el muro.

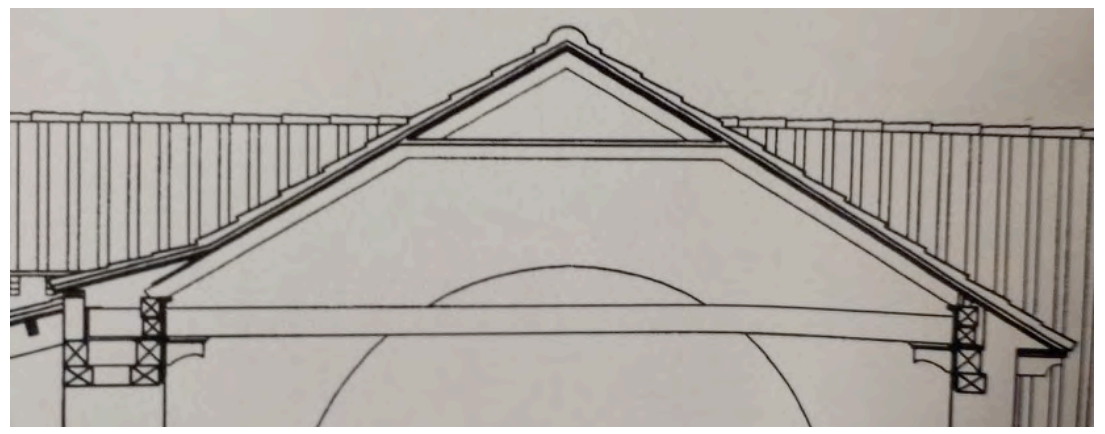

Ilustración 11: sección cubierta nave central 1989 Espinosa y Varona JCyL

En la sección se aprecia cómo se forma la techumbre en artesa de la nave central con tableros dispuestos sobre pares y nudillo.

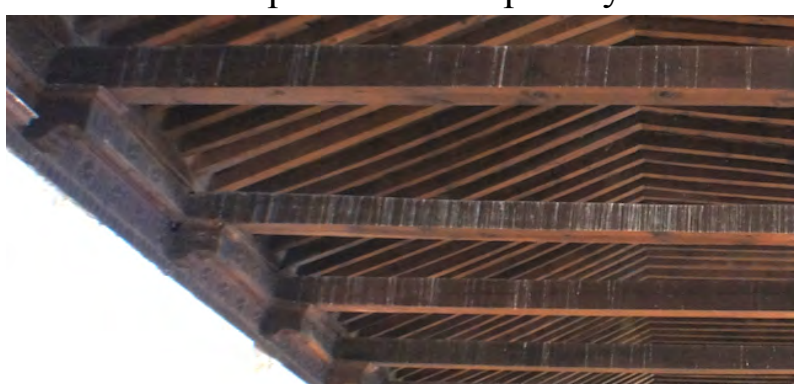

Ilustración 12: vista de los tirantes, visita 25/08/2015 


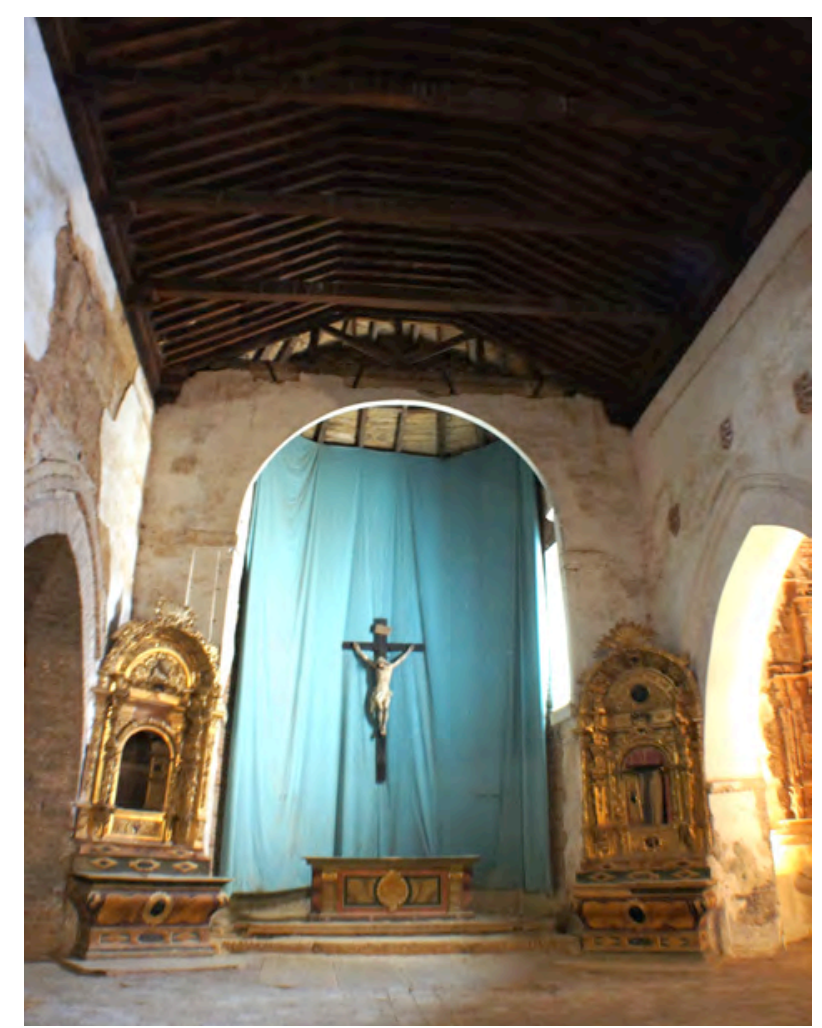

Ilustración 13: imágenes visita 25/08/2015

\section{Zunchos}

En los detalles se incluye una leyenda descriptiva que indica:

1. Par de madera laminada $10 \times 50$

2. Cabios de madera laminada $10 \times 5$

3. Tablero hidrófugo

4. Teja recuperada sobre onduline

5. Funda metálica de apoyo en dilatación

6. Chapón de anclaje

7. Zuncho en L de H.A. sobre coronación de muro

8. Muro de ladrillo perforado de dos hojas de un asta trabadas cada $2 \mathrm{~m}$.

9. Revoco coloreado.

10. Funda metálica de anclaje soldado

11. Chapón metálico en $Z$ para apoyo del par.

12. Armadura de cubierta y arrocabe existente.

No se define las dimensiones del zuncho, que tampoco se acotan, indicándose únicamente que se trata de una sección en L. En el presupuesto se definen dos zunchos en nave lateral, de $24 \mathrm{~m}$ de longitud y sección $80 x 30 \mathrm{~cm}$ (y uno de $8,5 \mathrm{~m}$ con sección de 50x30cm en el espacio denominado panera). 

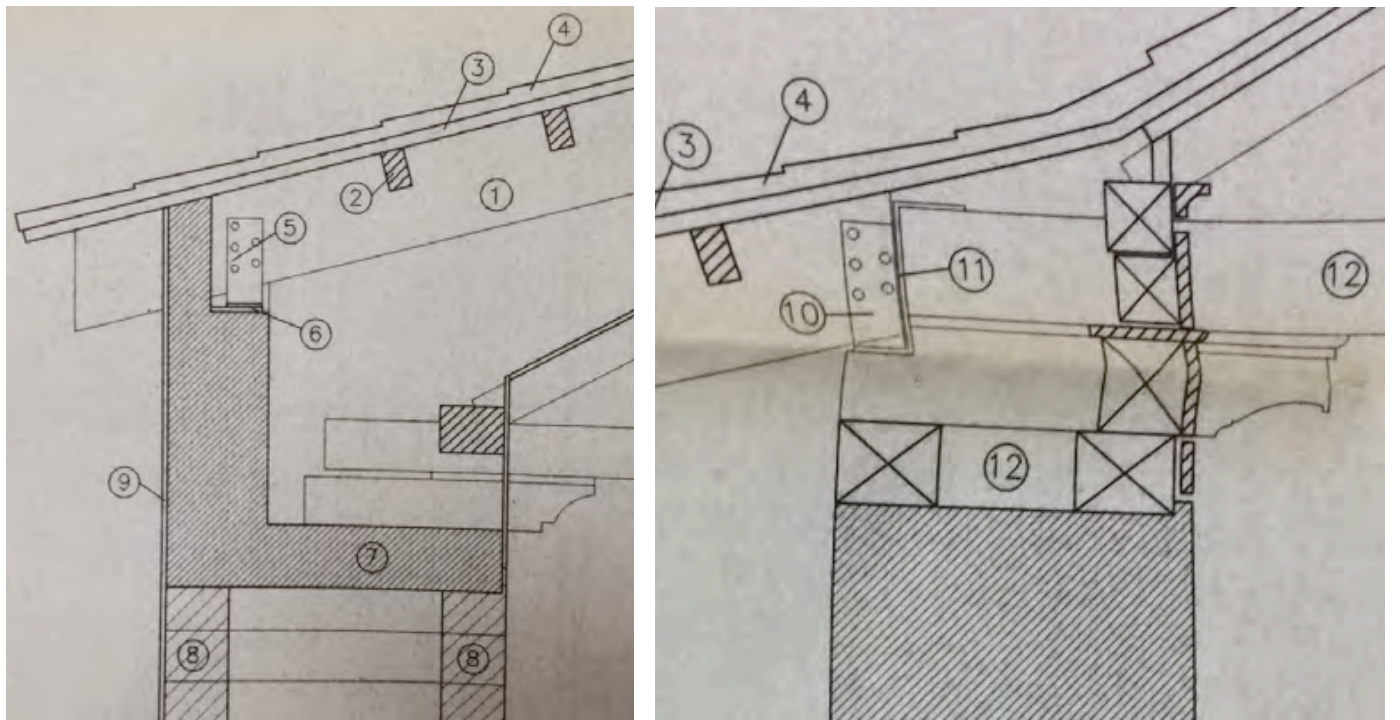

Ilustración 14: detalles borde nave lateral y encuentro con cubierta nave central 1989 Espinosa JCyL

En el detalle de la nave central no se representan zunchos, aunque en la Memoria final de obra de 1999 aparece descrita la "ejecución de zuncho corrido de hormigón en el muro norte" dentro del epígrafe dedicado a la nave mayor, y se repite "zuncho de coronación en hormigón, para apoyo de la cubierta" en el apartado sobre la nave lateral.

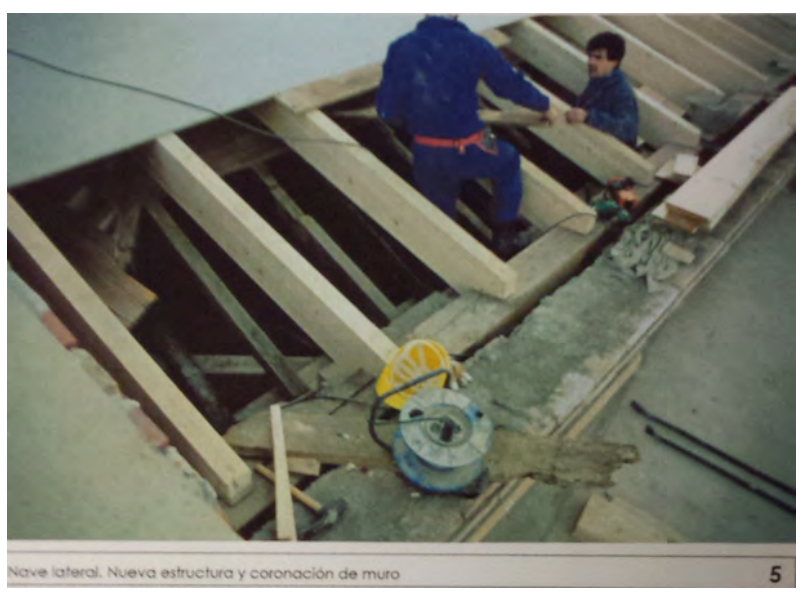

Ilustración 15: dossier Espinosa y Varona JCyL
En una imagen del dossier del proyecto de Espinosa y Varona, titulada "nave central, nueva estructura y coronación de muros", aparecen dos operarios trabajando sobre la cubierta en la que se aprecian los pares de madera nueva y, a cota inferior, unas piezas más oscuras que forman parte del artesonado.

Si la imagen corresponde al remate de la nave lateral, la solución ejecutada no coincide con la representada en el plano de detalles del proyecto (pasante sobre un apoyo en dilatación mediante carcasa metálica).

\section{Conclusiones}

En este edificio parece que se incorporó zuncho de hormigón armado en 1989 en la cubierta de la única nave lateral al reemplazar su estructura por una nueva de madera laminada, aunque no se ha podido confirmar ocularmente. No consta que se haya dispuesto también sobre uno de los muros de nave central, aunque se menciona en una Memoria final de obra. 


\section{Iglesia de Santa María en Mayorga}

Intervenciones citadas en la publicación del Ministerio:

1964 - Cubierta y artesonado - Anselmo Arenillas Álvarez

1971 - Restauración cubierta - José Ángel Rodrigo García y Joaquín Roldán Pascual

En la web del IPCE hay un plano de planta esquemática.

\section{En el archivo del IPCE}

Carpeta 1379-2

1974 - Memoria final de las obras de restauración de la Iglesia de Santa María de Arbás - José Ángel Rodrigo García y Joaquín Roldán Pascual

(Aprobación: diciembre de 1971; Memoria final julio de 1974)

"Dado el estado de ruina del ábside que corona la Capilla Mayor los trabajos se iniciaron con su reconstrucción. Fué preciso para ello proceder al desescombrado del material acumulado y apuntalamiento de las zonas existentes para asegurar su desmantelamiento.

La primera fase fué el levantado de teja curva de su cubrición con acopio del material utilizable y el desmontado de los restos de su armadura de madera.

Después se llevó a cabo la demolición de sus muros de fábrica mixta a base de tapial y ladrillo. En esta fase fué preciso efectuar los apeos necesarios para seguridad de la vivienda colindante que apoya su armado en dicho ábside, ya que en sus días fué edificio anexo y perteneciente a esta iglesia.

La reconstrucción de los muros del nuevo ábside precisó de nueva cimentación para garantizar su levantamiento en fábrica de ladrillo y siguiendo su trazado primitivo original.

Los paños exteriores e interiores se enfoscaron con aditivos hidrófugos para asegurar su impermeabilización y su ejecución a "pasaregla" le daba ese aspecto tosco de su primitivo trazado.

Su cubrición fué realizada con nueva armadura de madera convenientemente atada y distribuida para ser soporte del nuevo entablado. Se reconstruyó sus originales aleros propios de su construcción mudéjar y fué colocada la teja curva que se acopió reponiendo el resto con material de iguales características. La teja fué convenientemente recibida y asegurada cada cinco hiladas en ambos sentidos. 
El acabado de su exterior se consiguió mediante el empleo de pintura a la cal con el aporte de pigmentos naturales, adquiriendo una tonalidad ocre que entonaba con el conjunto.

Por último el edificio colindante fué consolidado en su estructura y rematado en su cubrición".

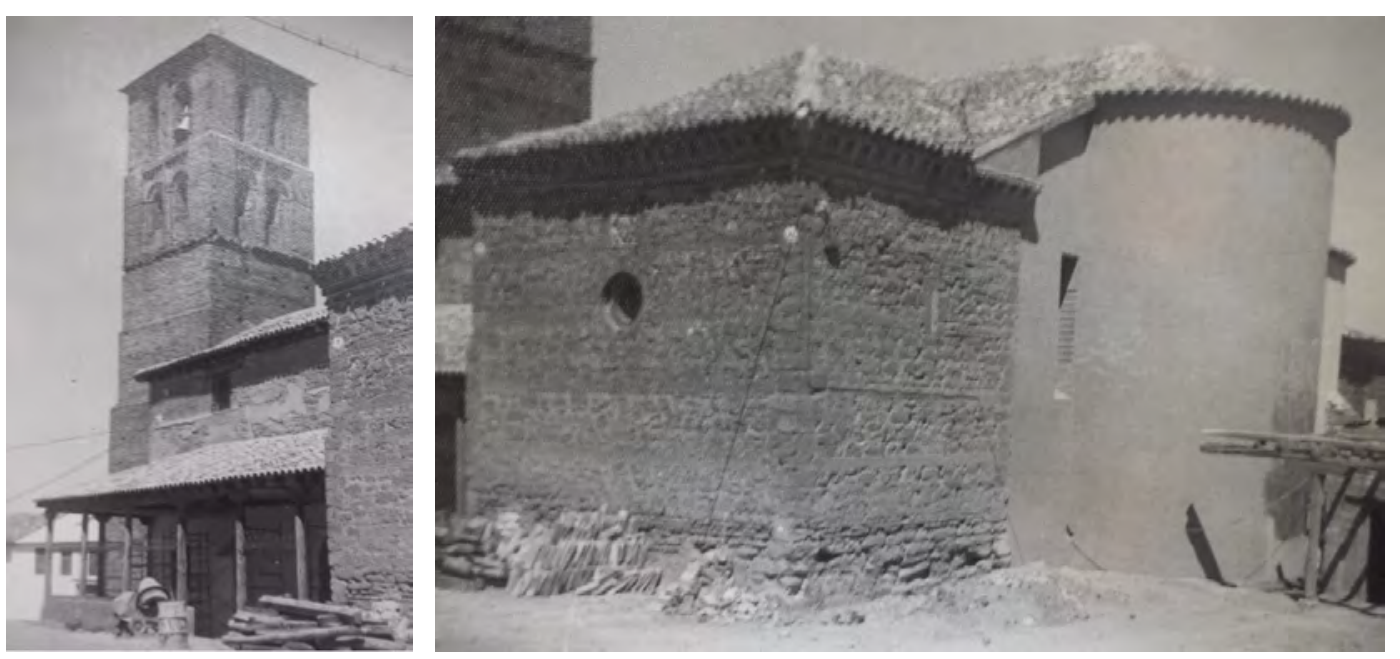

Ilustración 16: dossier 1974 Rodrigo y Roldán IPCE

Dossier 2 hojas con fotografías.

\section{En el Archivo General de la Administración}

\section{AGA 26/00356}

1965 - Reparación de cubiertas y artesonado - Arenillas

Memoria 2 pag. 1964

La iglesia de Santa María de Mayorga de Campos es un pequeño ejemplar de las iglesias moriscas de ladrillo en esta región. Es Monumento Nacional, tenía unos bellos artesonados en el presbiterio y en las dos capillas, que son de bella taracea de tabla moldurada clavada sobre tableros lisos, formando lazos y estrellas. El resto de la iglesia está cubierto con armadura de par e hilera, haciendo artesón visto.

Los artesonados de las capillas están en parte hundidos y en parte desprendidos, teniendo rotos los tejados de ellos y los de parte de la nave mayor y de la lateral. En el presbiterio tambien falta la teja y penetra el agua sobre el retablo. La sensación es de pleno desamparo y ruina; posiblemente se pretendía desmontar los elementos de valor y abandonar el local, nomonstante su calificación. 
... obras de reparación que se agrupan en dos capítulos: en el primero se incluyen las obras de urgente ejecución, precisas para salvar los restos de los artesonados y el retablo; en el segundo se comprenden las obras de restauración y adecentamiento... Como reparación hay que levantar gran parte de las cubiertas, de sencillo artesón de par e hileras, de la nave principal, de la nave del evangelio, del presbiterio y de la capilla del lado de la epístola, para sustituir los pares rotos y el entablado.

Retejo, ventanas. Picado y guarnecido con yeso de los arcos apuntados, reparación de pavimentos de ladrillo delgado muy rotos y desnivelados, limpieza de artesonados...

Planta 1/100.

AGA 26/00331

1971 - Restauración - José Ángel Rodrigo García

Descripción del estado actual

Edificio mudéjar del siglo XV, de ladrillo y mampostería, con dos naves separadas por pilares que sostienen arcos apuntados. Se divide en cuatro tramos, cubriéndose la nave principal de madera, y la lateral, de cubierta también de madera, a una vertiente. La capilla mayor lleva cubierta de madera y arco triunfal de medio punto. Tiene una capilla funeraria, con cubierta de alfarje con decoración de lacería y arrocada de yesos. Coro alto a los pies.

\section{Proyecto}

Se procederá inicialmente al levantado de teja y acopio de la utilizable, sustituyéndose el resto por otra lo más semejante posible; en la parte que corresponde al ábside se desmontará la armadura, reponiéndose los elementos que se encuentren en mal estado y se procurará la restauración parcial del muro del mismo para evitar filtraciones de agua que ponen en peligro el retablo del Altar Mayor, a cuyo desmontaje se procederá previamente.

Se finalizará la obra con el montaje de la armadura restaurada, así como con el retejado completo de cubierta, nuevo montaje del retablo.

Dos planos de planta: general y cubierta 1:100. Rotula tres zonas: cubierta de ábside renovada, aleros que se han de sanear y reposición de formas que están hundidas y retejado. 
AGA 26/01573

1971 - Restauración retablo altar mayor - José Ángel Rodrigo García

Mismo proyecto carpeta anterior

$315,70 \mathrm{~m} 2$ levantado de teja curva con acopio de la utilizable, incluso retirada de escombros a vertedero

315,70m2 demolición de armadura de cubierta con ídem.

475,50 m3 demolición de muros de fábrica mixta de tapial y ladrillo con...

196,25m2 fábrica de ladrillo de dos pies de espesor, tomada con mortero de cemento en muros de ábside

15,70m2 formación de armadura de cubierta en ábside incluso p.p de alero y entablado

15,70m2 colocación de teja curva en cubierta de ábside sentada sobre mortero de cal, y recibida con mortero bastardo cada 5 hiladas en amos sentidos.

Fotografías blanco y negro con grieta en fachada y chamizos adosados. (Pido copia)

\section{En el archivo de la Junta de Castilla y León}

\section{VA-267}

Fichas diagnóstico y propuesta de actuación.

Fábricas. Derrumbe del muro en nave del evangelio, grieta vertical con desplome hacia el exterior de la fachada en nave de la epístola

Grietas en fachada este de nave central.

Estructura de torre en mal estado.

Estructura de cubierta en mal estado con apeos puntuales.

TRYCSA, adjudicada 08/06/1998. Recepción 20/12/1999.

\section{Proyecto de restauración}

Luis A. Espinosa y José M $M^{\text {a }}$ Varona Leguinazabal

En la memoria afirma que "como las estructuras de cubierta no son ahora accesibles en general, se ha estimado un porcentaje de piezas a reparar o sustituir en función de las que sí son conocidas."

En la descripción para nave lateral sí cita ya el zuncho: " Se prevé la demolición de la cubierta de rollizos existente y del muro arruinado, apeando previamente el actual artesonado. se repararán las piezas de madera del apoyo corrido de éste, sustituyendo los tramos irrecuperables. Se levantará un nuevo muro de cerramiento 
sobre los restos del anterior, con un asta de ladrillo por cada cara, para revocar posteriormente, y se rematará con un zuncho de hormigón para el atado de las hojas de ladrillo y el apoyo de la nueva cubierta. Esta cubierta se realizará en madera laminada, dada la luz a salvar y la presencia de la artesa que impide otra solución".

Presupuesto:

851,10 m2 Demolición completa de cubierta formada por cubrición de teja cerámica con recuperación y acopio, barro, entablado de madera y estrucrura de madera en mal estado...

92,80 m2 Demolición de muro de tapial de hasta $100 \mathrm{~cm}$ de grueso por emedios manuales

21,31 m3 Jácena y viga de madera laminada encolada de diferentes secciones, en madera de pino...

$1208 \mathrm{~kg}$ Suministro y colocación de acero laminado A-42b, unido por electrosoldadura en refuerzo de elementos estructurales existentes, $\mathrm{i} / \mathrm{p} . \mathrm{p}$. de presillas, anclajes, cosidos, piezas de apoyo y especiales, pintura de minio de plomo i/p-.p despuntes y recortes: 16,00x75,50 atirantado nave mayor

13,55 m3 Hormigón armado H-175kg/cm2 Tmax $20 \mathrm{~mm}$ elaborado en central en zunchos, i/p.p. de armadura $(75 \mathrm{~kg} / \mathrm{m} 3)$ y encofrado de madera, vertido con plumagrúa: nave lateral $2 \times 24 \times 0,80 \times 0,30 ; 1 \times 8,50 \times 0,50 \times 0,30$

Cosidos, rejuntados, revocos, tratamientos anti-xilófagos. Escalera de caracol.

Plano $\mathrm{n}^{\circ} 16$ de detalles constructivos interesante.

Final de obra. Junio de 1999, Luis A. Espinosa.

Proceso constructivo.

En 1652 se realiza nueva cubierta de la nave principal, que suponemos es la actual.

Hay enterramientos entre los siglos XII y XIII bajo los cimientos.

Lo más antiguo es cabecera y naves excepto los pies.

Pudo construirse entre finales del XIII y principios del XIV.

La planta es románica pero el tramo recto del presbiterio mudéjar.

La intervención planteaba la reparación de cubiertas de toda la iglesia. Se han cumplido las expectativas en cuanto al número de piezas estructurales de las techumbres de par y nudillo que ha sido necesario reconstruir mediante prótesis o sustituir. 
Ha sido necesario renovar íntegramente las estructuras de cubiertas. Todas ellas eran reparaciones de ínfima calidad, relativamente recientes, en estado de ruina o ya colapsadas, y apoyando directamente sobre los artesonados.

La sustitución y nueva definición volumétrica de las cubiertas ha incrementado los trabajos de consolidación de coronaciones de muros, recrecidos, realización de cornisas y aleros, etc.

Se ha restaurado la torre prácticamente en su integridad.

Nave mayor:

Desmontado de tejas, barro de asiento y limpieza.

Desmontado del paño superpuesto sobre el faldón norte y eliminación del recrecido de los apoyos.

Eliminación de las prolongaciones de los faldones que apoyaban sobre las cubiertas de las capillas laterales.

Limpieza y consolidación de coronaciones de muros, con sustitución de canes y alero del muro sur y ejecución de zuncho corrido de hormigón en el muro norte.

Restauración de durmientes y estribos deteriorados, girados, escupidos, etc., con nueva clavazón de pares.

Ejecución de paños de refreno del faldón sobre los muros.

Limpieza y tratamiento anticarcoma y fungicida de la madera.

restauración integral de la armadura de par y nudillo mediante prótesis y sustituciones en pares, tirantes y arrocabe. Se han repuesto las cintas y saetinos deteriorados y se han cerrado las calles de los faldones con tablero hidrófugo pintado de rojo almagre por su cara inferior para distinguir la intervención. El almizate se ha restaurado con piezas desmontadas.

Colocación de onduline y recibido de las tejas.

Se han dejado huecos para ventilación cruzada de los apoyos de la cubierta sobre los muros, protegidos con tela metálica contra la entrada de aves.

No se ha actuado sobre la cubierta del ábside. Existen indicios de que éste puede estar recrecido, y esta operación debería asociarse a la reintegración volumétrica del muro testero de la nave y la recuperación del arco triunfal.

Rejuntado de grieta entre el ángulo suroeste de la nave y la torre.

Eliminación del arco rebajado de apoyo de la tribuna y su contrafuerte en la nave lateral...

Nave lateral:

Desmontado de tejas, barro de asiento, tablazón y estructura de la cubierta completa, pares y tornapuntas de rollizos. 
Picado de tapiales arruinados hasta llegar a la arquería inferior de ladrillo.

Nuevo cerramiento macizo de ladrillo perforado, revocado por ambas caras con mortero de cal.

Zuncho de coronación en hormigón, para apoyo de la cubierta.

Nueva cornisa formada por canecillos de ladrillos escalonados, tomando como modelo la capilla de Villagómez.

Nueva estructura de cubierta en madera laminada sobre durmiente de madera, con tablero hidrófugo, onduline y teja recuperada.

Se realizan huecos para ventilación protegidos con tela metálica y se coloca un tragaluz de acceso al camaranchón.

Restauración estructural de la falsa artesa de par y nudillo y del arrocabe y tirantes originales del XV mediante prótesis y sustituciones.

Limpieza y tratamiento anticarcoma y fungicida de la artesa, arrocabe y tirantes... 



\section{Visitas realizadas}

$25 / 08 / 2015$

El monumento se encuentra a la espera de acometer obras de restauración, aunque por el exterior se aprecia algunas zonas saneadas, como la torre a los pies, con un retejado bicolor, y el volumen prismático junto a la cabecera.

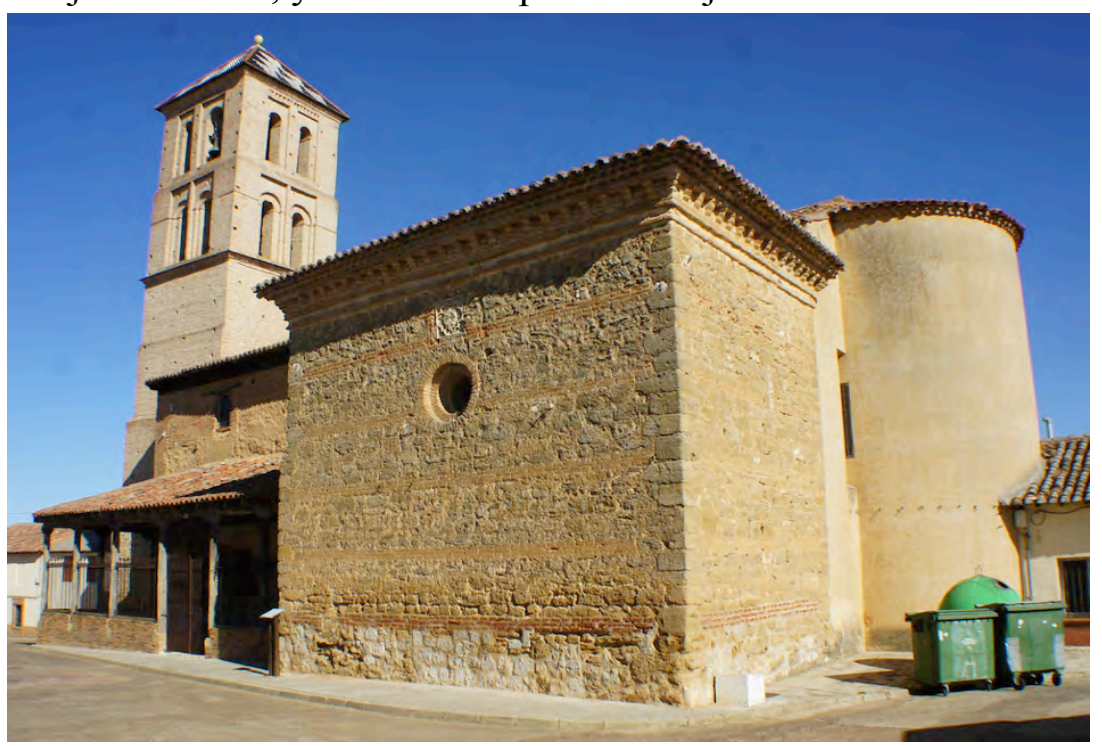

Han sido reparadas las cubiertas hace pocos años y se encuentran en buen estado. También se han repasado los artesonados, reconstruyendo con madera nueva las zonas desaparecidas.

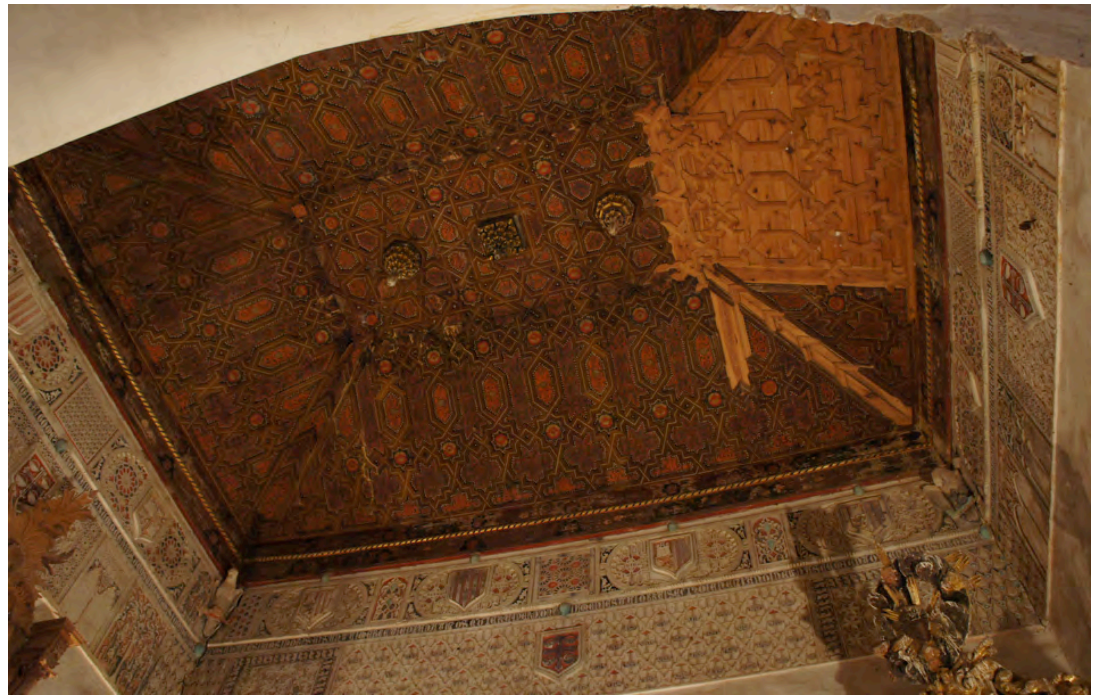

El atrio de acceso se encuentra en muy mal estado, con la cubierta de madera envejecida y los paramentos erosionados.

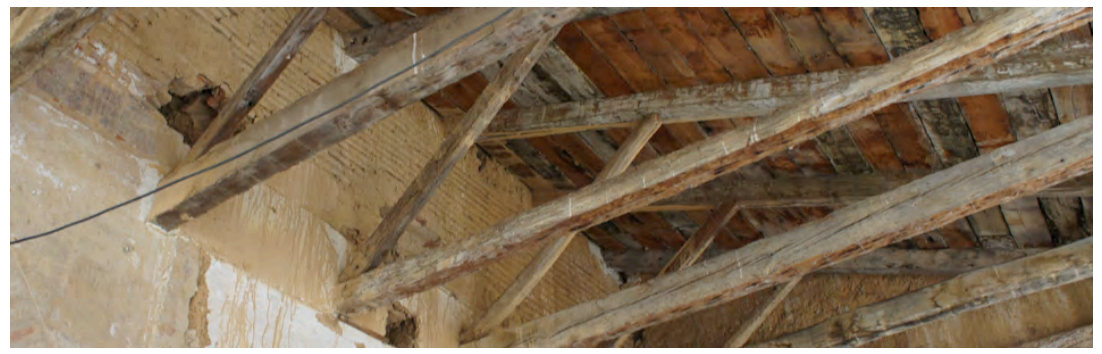


El cuerpo del templo muestra en el interior grandes desconchones, pérdidas de verticalidad y agrietamientos.

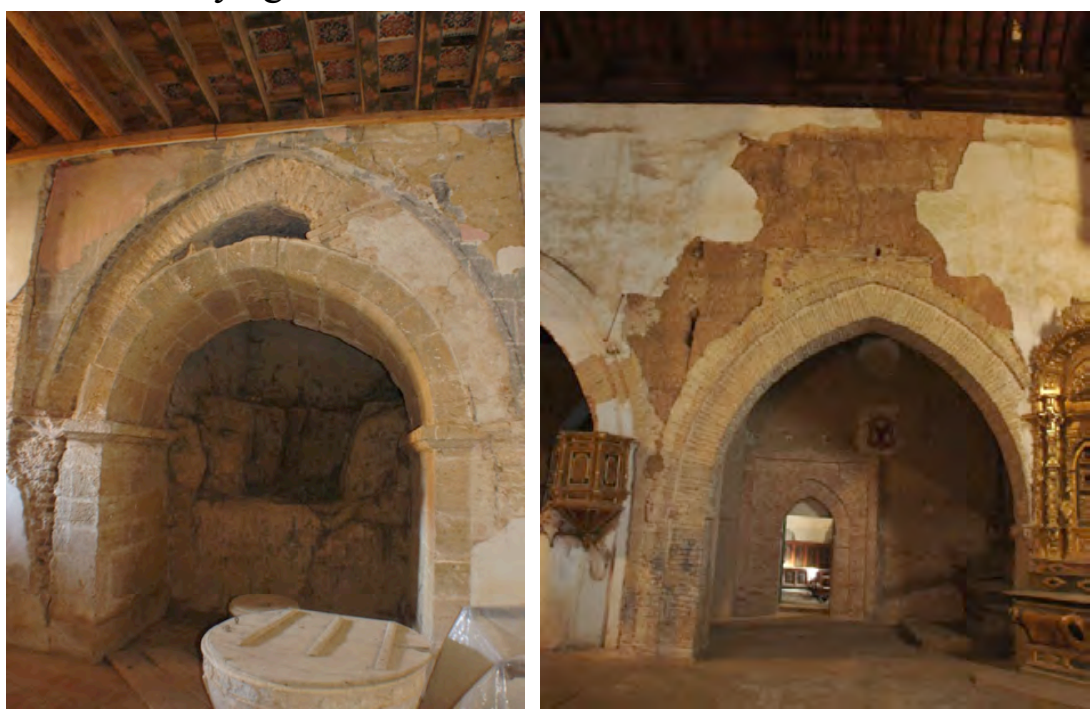

El coro está apuntalado provisionalmente con tablones y pies derechos.

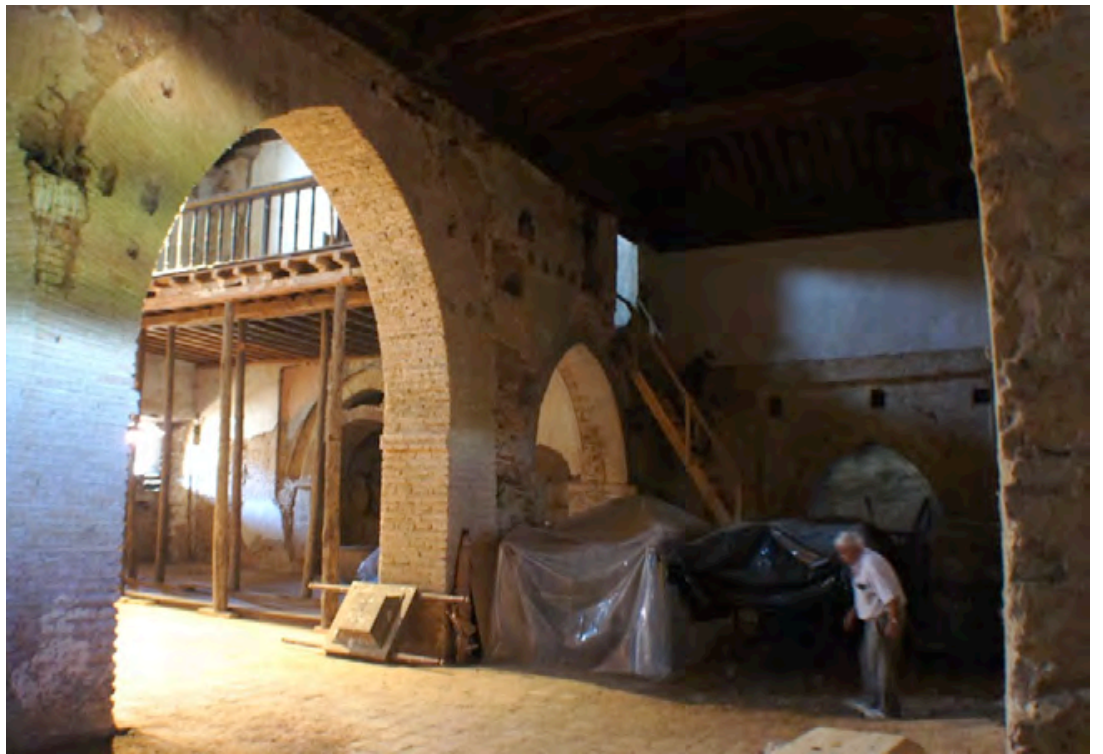

Hay huecos de puertas y ventanas sin carpinterías.

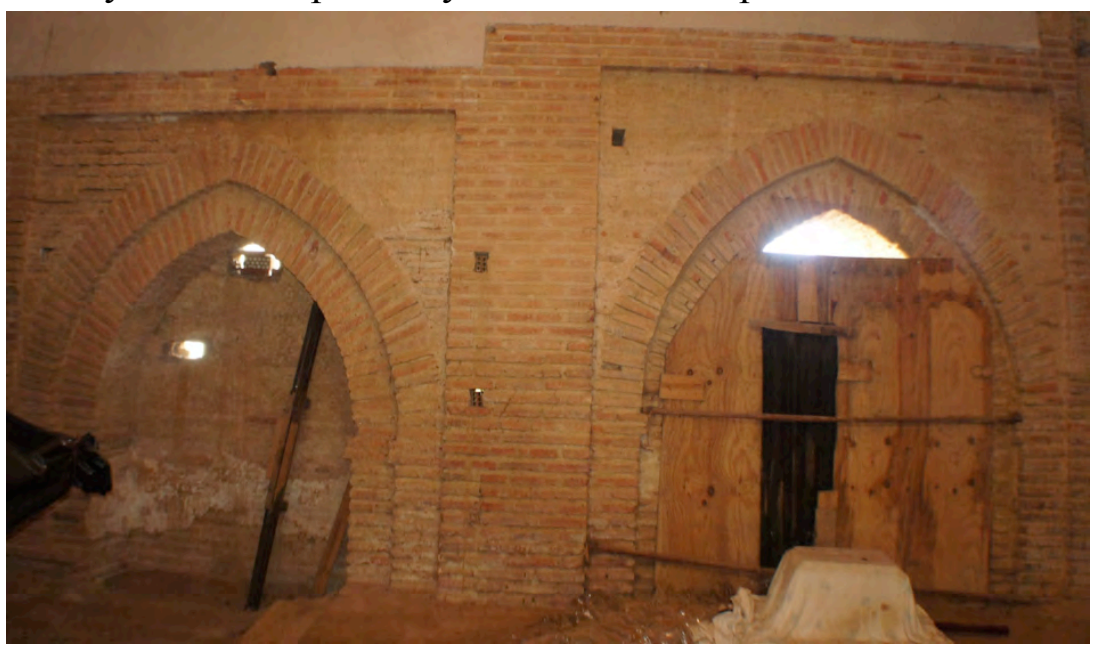



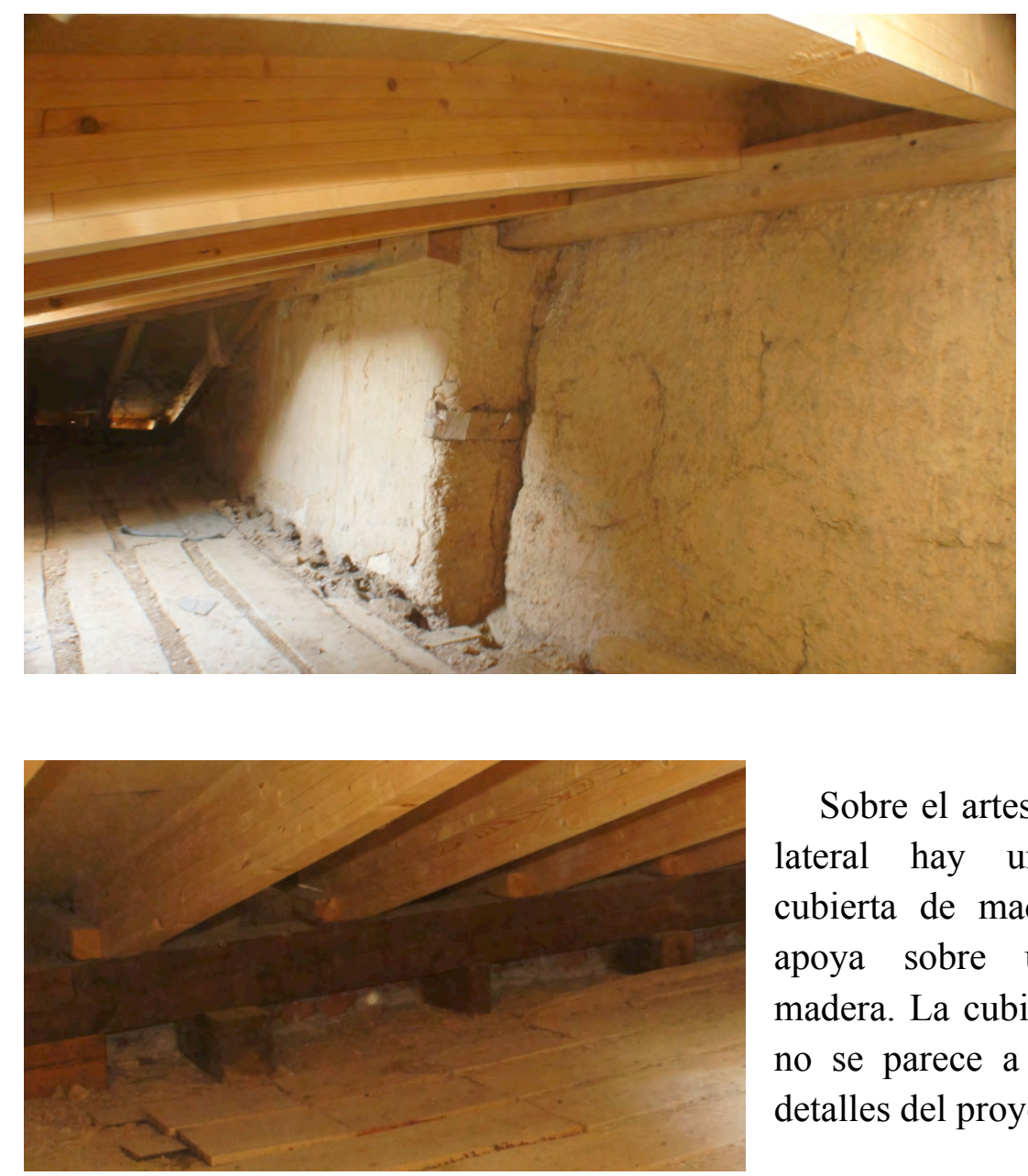

Sobre el artesonado de la capilla lateral hay una estructura de cubierta de madera laminada que apoya sobre un durmiente de madera. La cubierta de nave lateral no se parece a la definida en los detalles del proyecto.

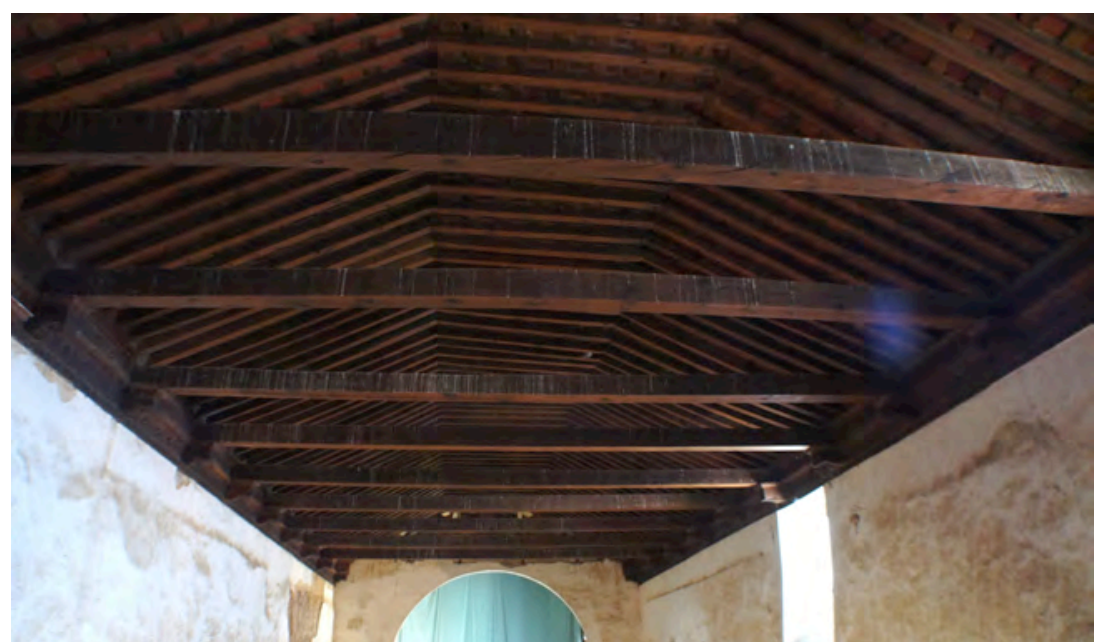

La estructura de madera que cubre la nave central observada sí coincide con la armadura representada en el plano de sección del proyecto de 1989 de Espinosa.

No se ha podido comprobar la existencia de zunchos de hormigón en el edificio. 


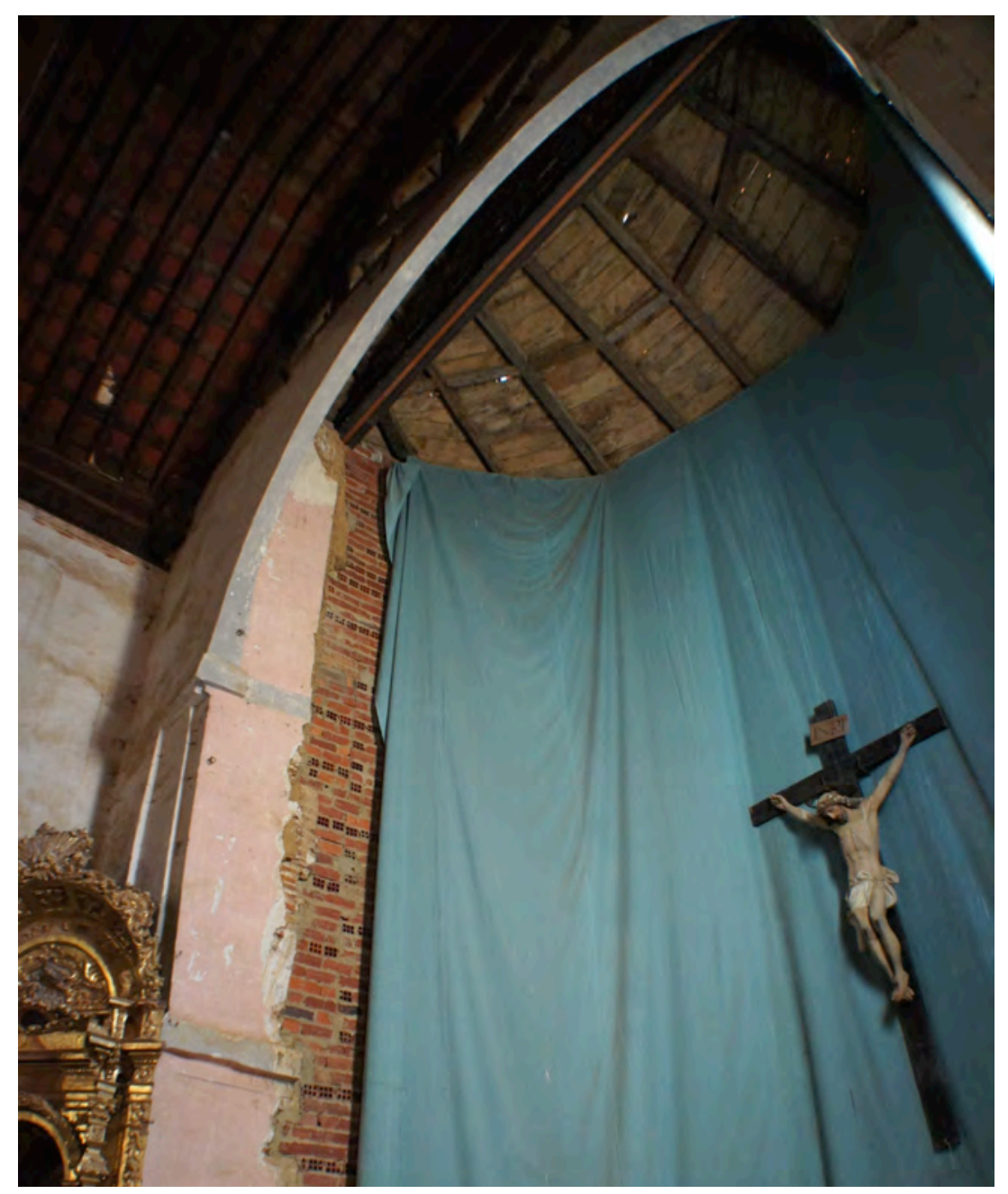

La cabecera, que fue reconstruida en 1971 con ladrillo hueco, aparece actualmente sin rematar hacia el interior y cubierta con una lona. 
Iglesia de San Francisco (Museo de arte sacro)

Iglesia de Santa Cruz (Museo de la Semana Santa)

Iglesia de Santiago Apóstol

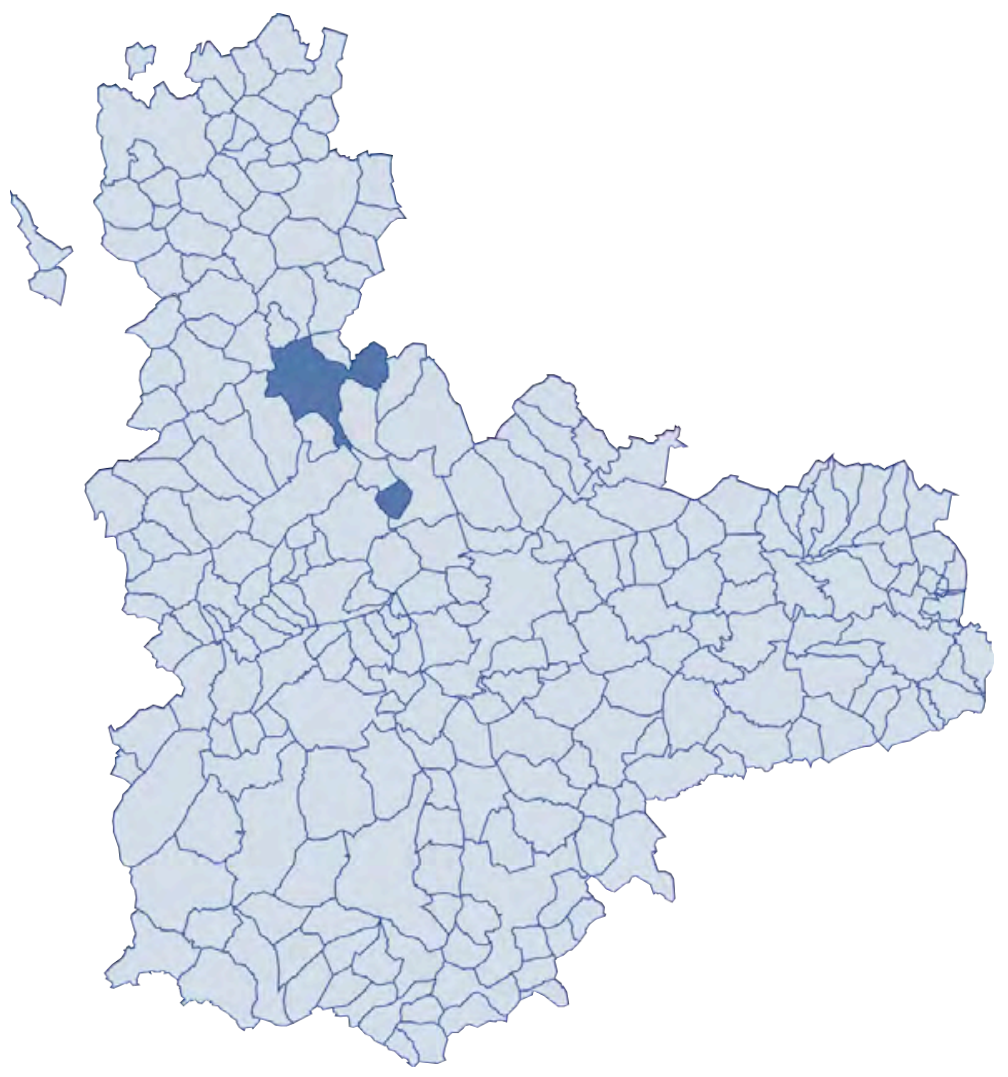



FICHA SÍNTESIS

Código de identificación: FZ-25

Denominación:

Iglesia de San Francisco

Localidad:

Medina de Rioseco

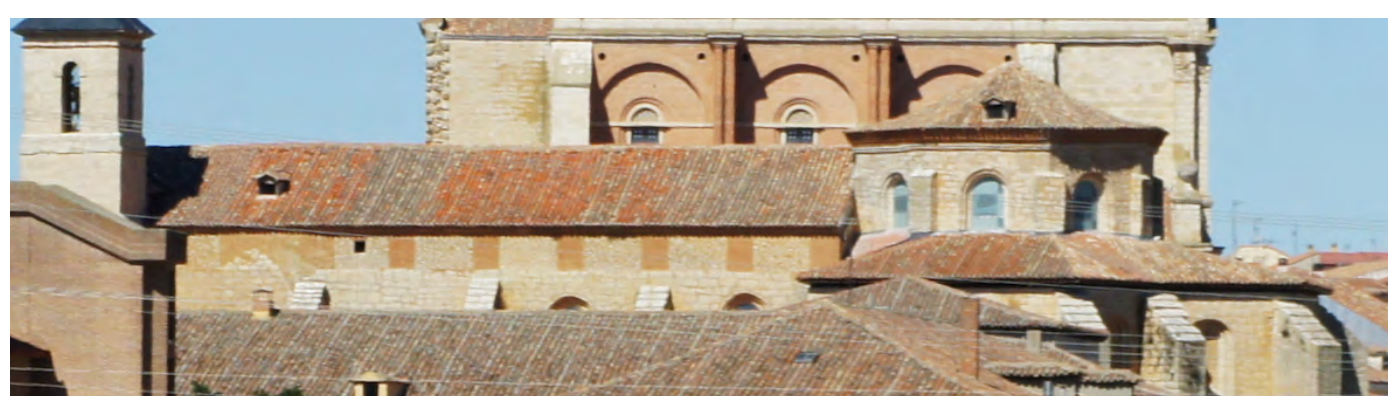

\section{Descripción}

Iglesia transformada en museo. Consta de una sola nave de cuatro tramos con bóvedas de crucería y capillas entre contrafuertes, con un nivel superior de tribuna corrida sobre éstas. En el crucero se levanta, sobre pechinas, una cúpula con cimborrio ochavado.

\section{Materiales}

Los muros son de piedra en cabecera y naves laterales. La nave central, a partir del remate de los contrafuertes exteriores, se remata con mampuesto y fábrica de ladrillo. Las cubiertas están revestidas de teja curva.

\section{Singularidades}

El edificio alberga un museo de arte sacro. Se sitúa en el camino de ronda de la antigua muralla.

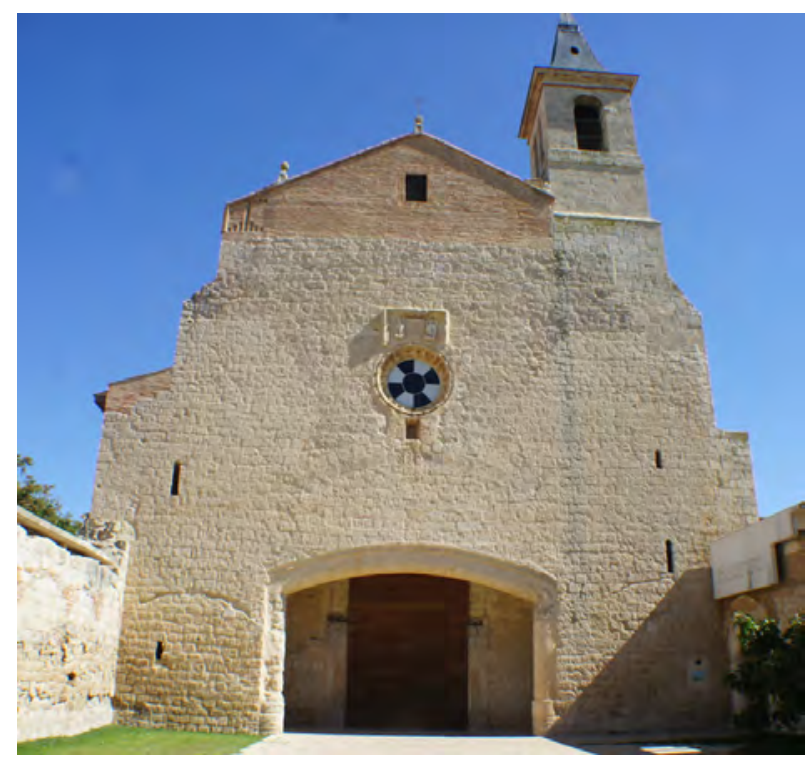

Ilustración 1: fachada, visita 20/09/2015

\section{Dimensiones básicas del templo}

$\begin{array}{llll} & \text { central } & \text { laterales } & \text { capillas } \\ \text { Ancho de nave } & 11,1 & - & 4,4 \\ \text { Altura } & 18,3 & - & 5,3\end{array}$




\section{Memoria histórica constructiva}

Según el Catálogo:

La primera piedra del convento se coloca en 1492, y el templo se inaugura en 1520.

En 1596 Ribero Rada refuerza el cimborrio y sube el nivel de la nave central, cegando los ventanales del crucero colindantes.

En 1677 un rayo daña la torre y Felipe Berrojo la demuele y reconstruye.

En 1725 se acometen obras de reparación den la capilla mayor, y en1730 debido al riesgo de daños se traslada el altar.

Tras la exclaustración se ubican Hospital, Beneficiencia y, más tarde, la cárcel.

Hay documentadas obras de saneamiento en 1935.

\section{Cronología. Fechas clave}

$1520-1596-1955-1986$

\section{Intervenciones}

1955 - Saneamiento - Anselmo Arenillas

1986 - Restauración - Ignacio Gárate y Manuel Manzano

\section{Incorporación de zuncho de hormigón armado.}

Se consolida la estructura de cubiertas existente con reposición de piezas dañadas y refuerzo de ensambles con herrajes. Se desmonta la coronación de los muros y repone, tras ejecutar un zuncho de hormigón con la capa de compresión vertida sobre una nueva tablazón de madera.

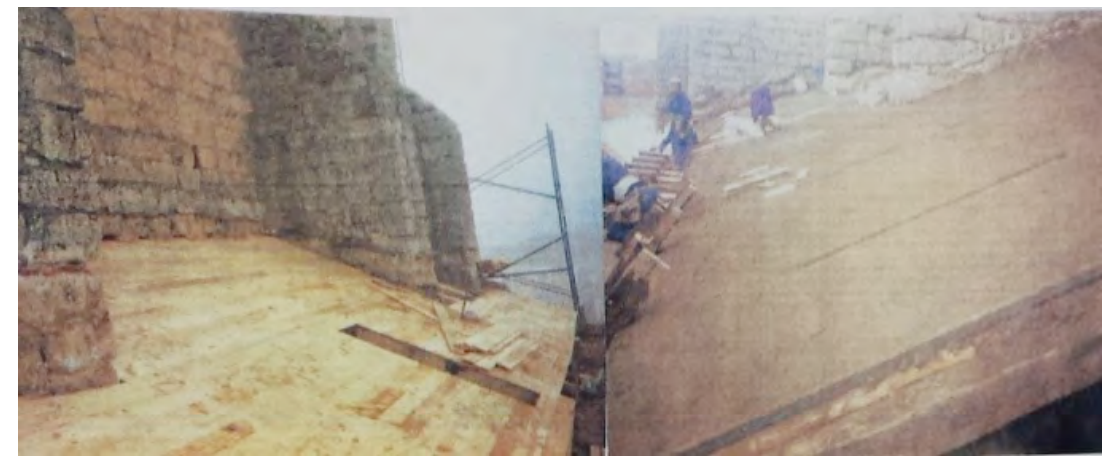

Ilustración 2: dossier imágenes de la obra 1986 Gárate y Manzano JCyL

1990 - Emergencia - Manuel Manzano

Deformación excesiva de arcos torales con rotura en dovela. Se encarga un análisis a Santiago Huerta y José Miguel Ávila, de la ETSAM. Concluyen que la falta de uso ha disparado la humedad y debilitado la fábrica de ladrillo, entrando en carga las vigas de hormigón de los 50. Recomiendan mantener un ambiente interior más seco y reparan la fábrica con resina. 


\section{Planos}

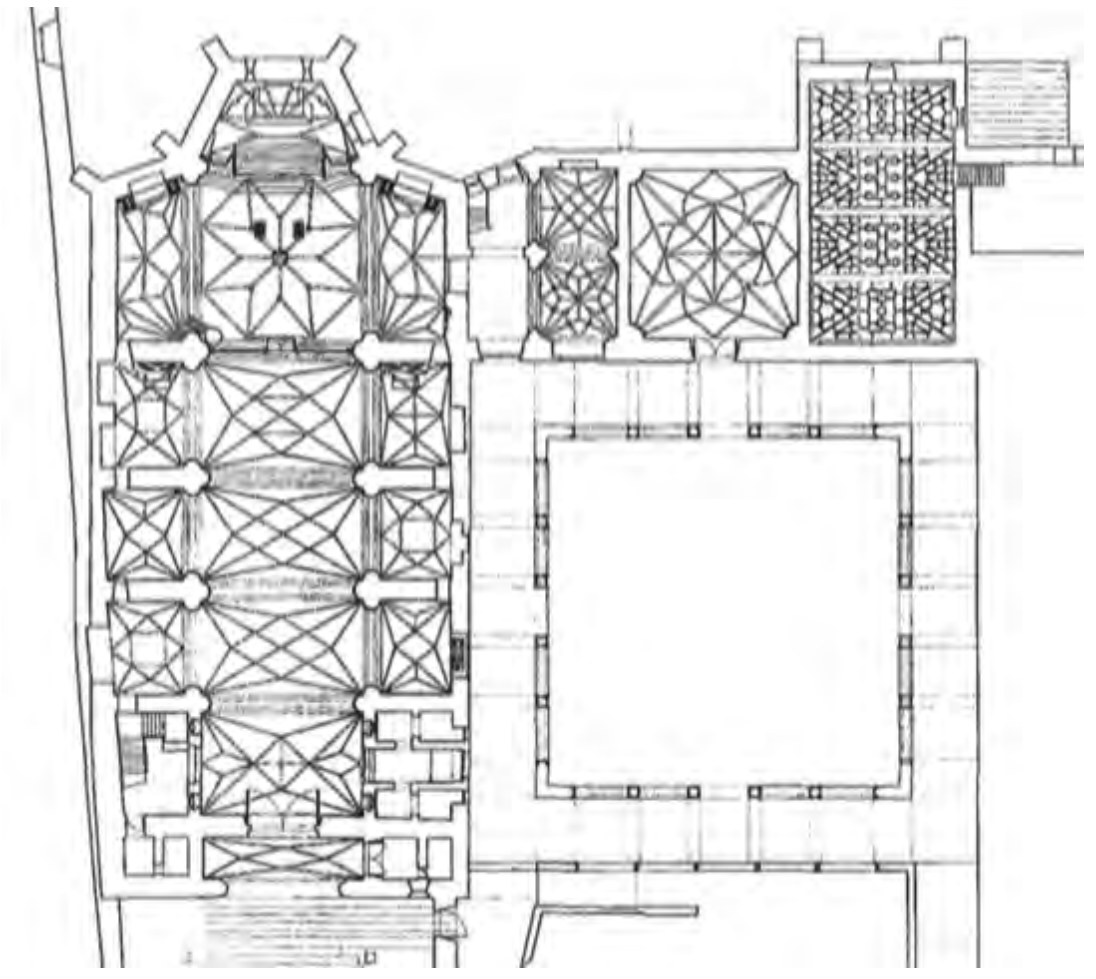

Ilustración 3: planta Catálogo

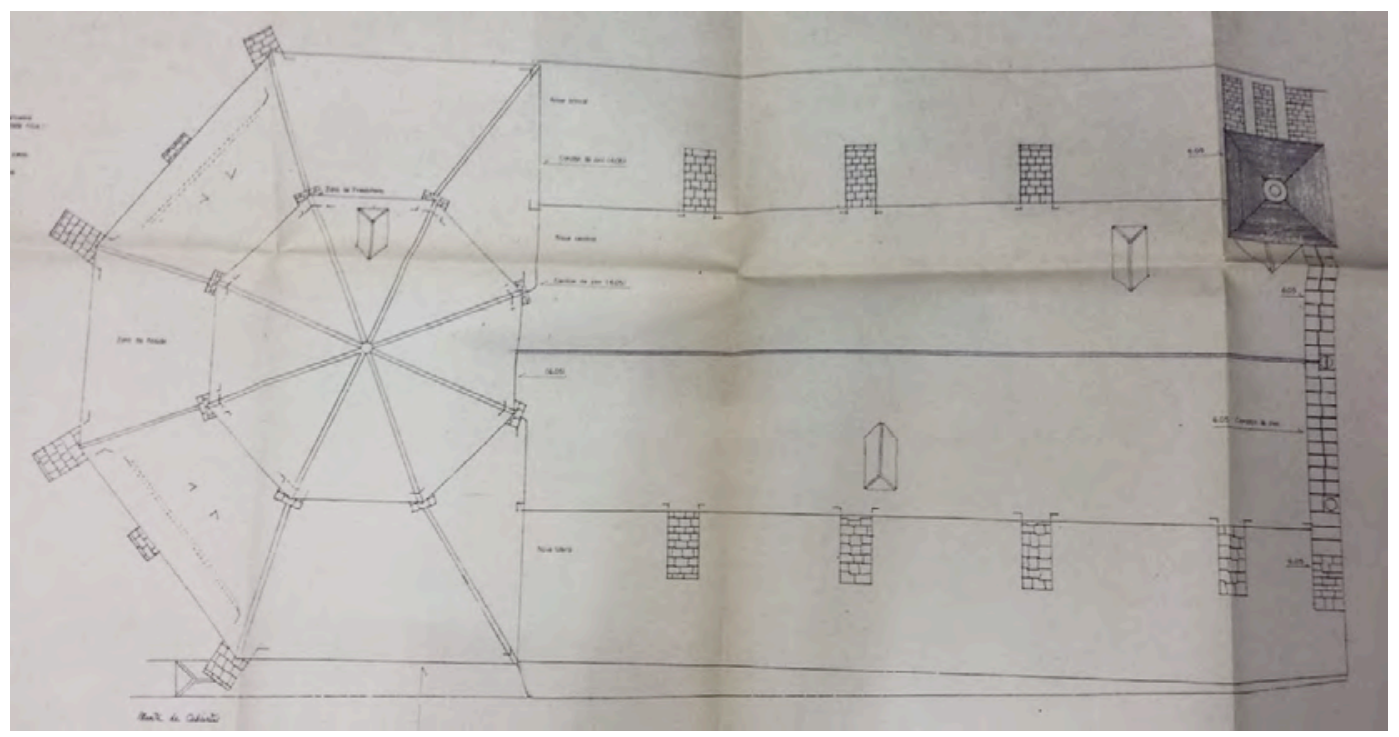

Ilustración 4: planta de cubiertas 1986 Gárate y Manzano JCyL 


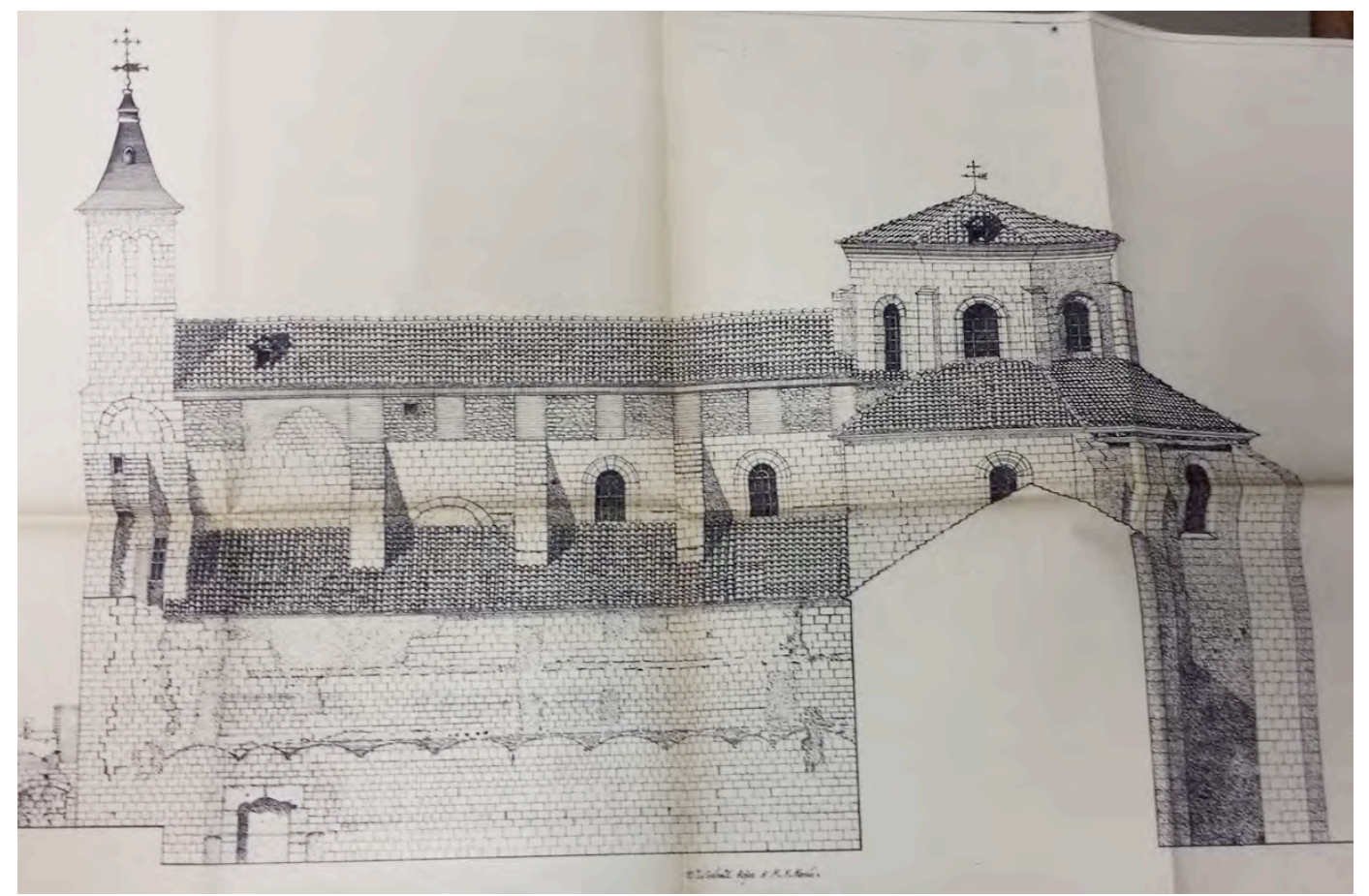

Ilustración 5: alzado lateral 1986 Gárate y Manzano JCyL

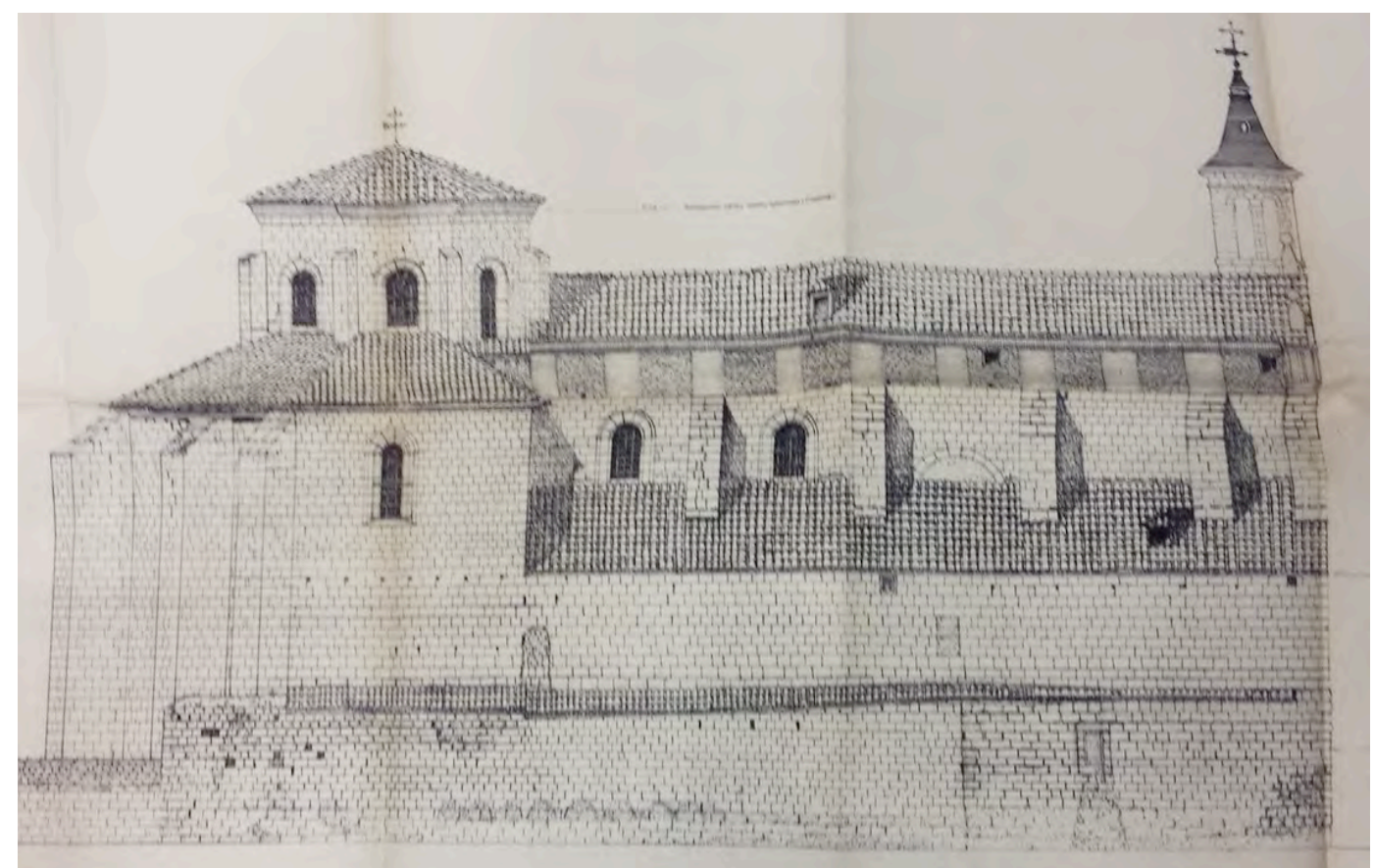

Ilustración 6: alzado lateral 1986 Gárate y Manzano JCyL 


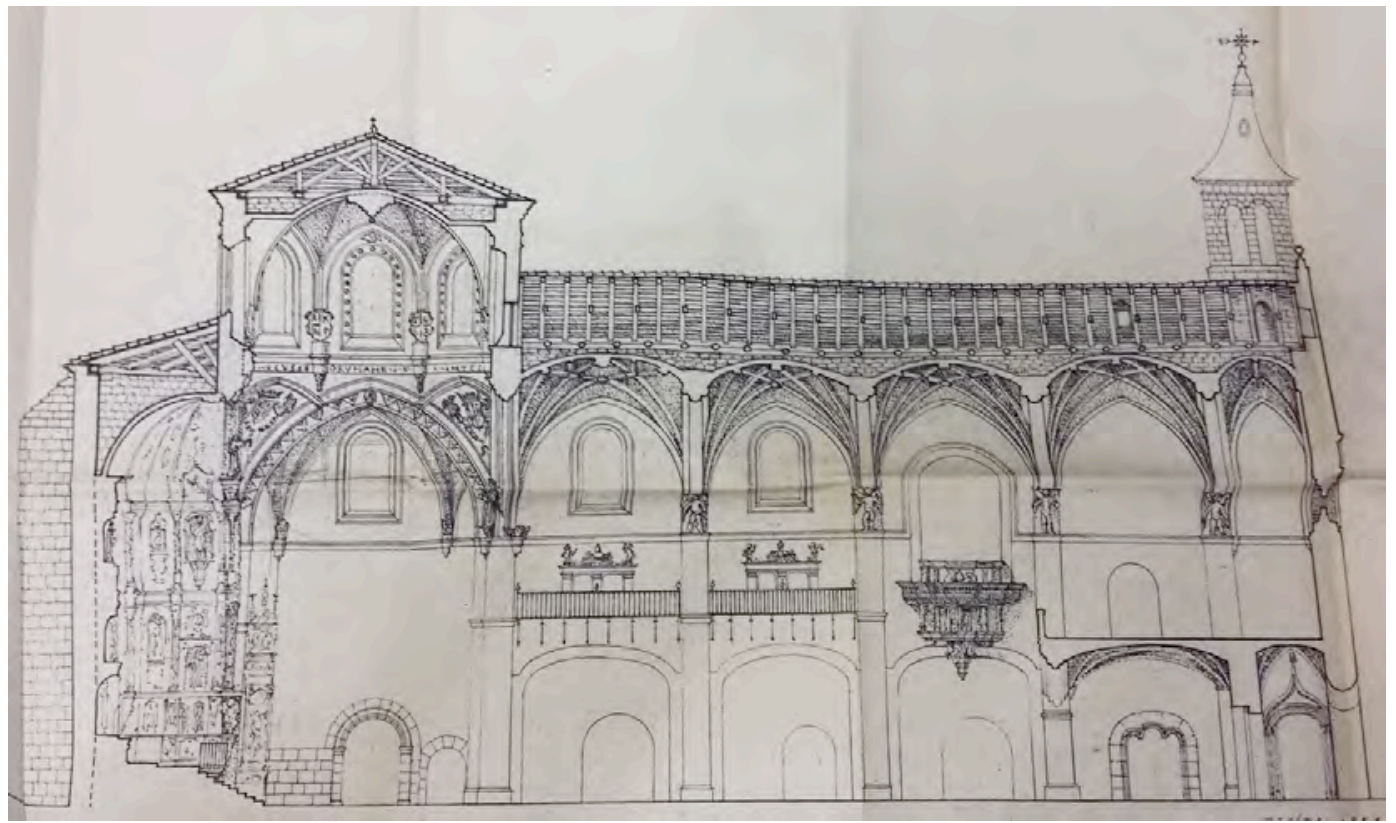

Ilustración 7: sección longitudinal 1986 Gárate y Manzano JCyL

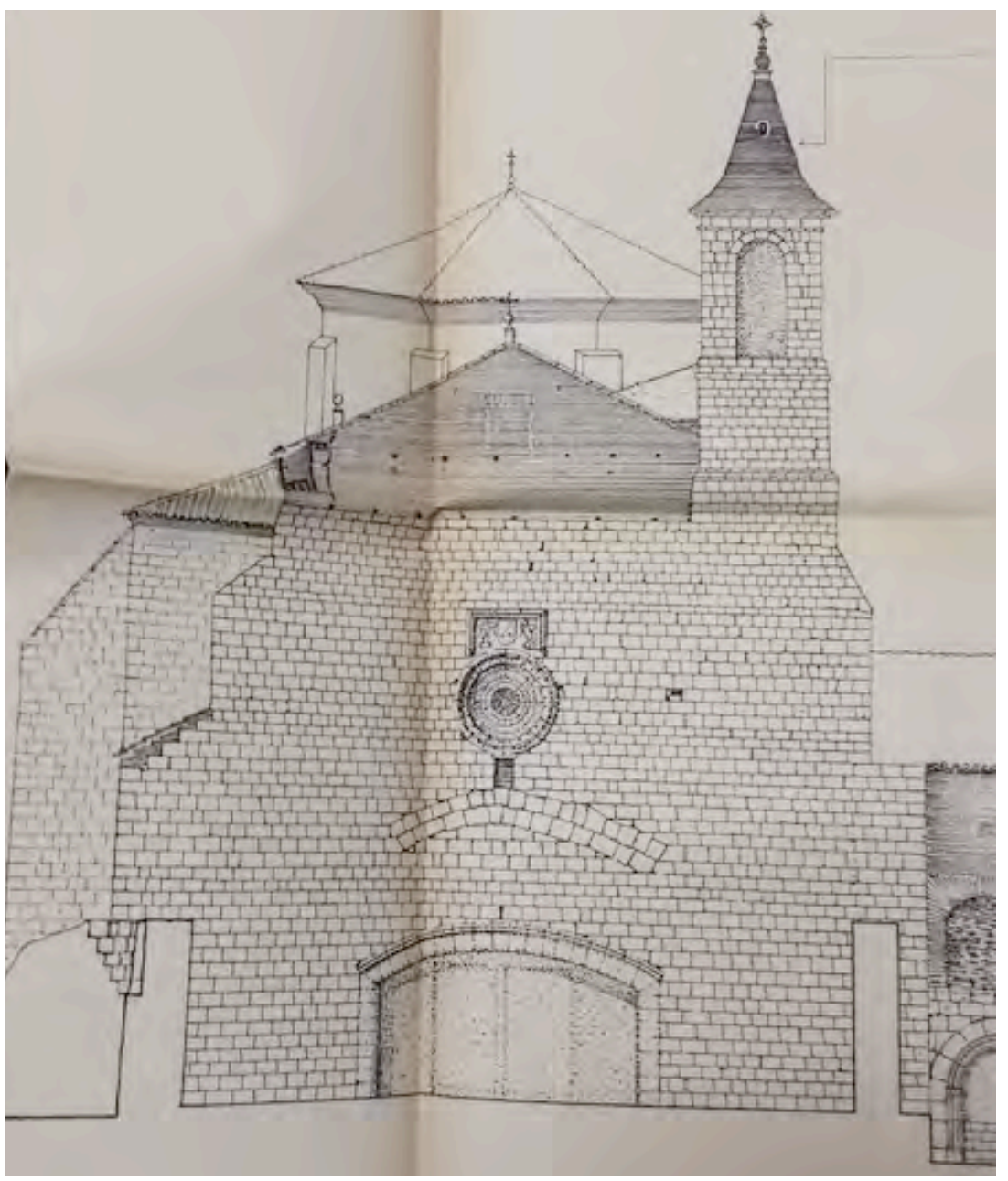

Ilustración 8: fachada a los pies 1986 Gárate y Manzano JCyL 


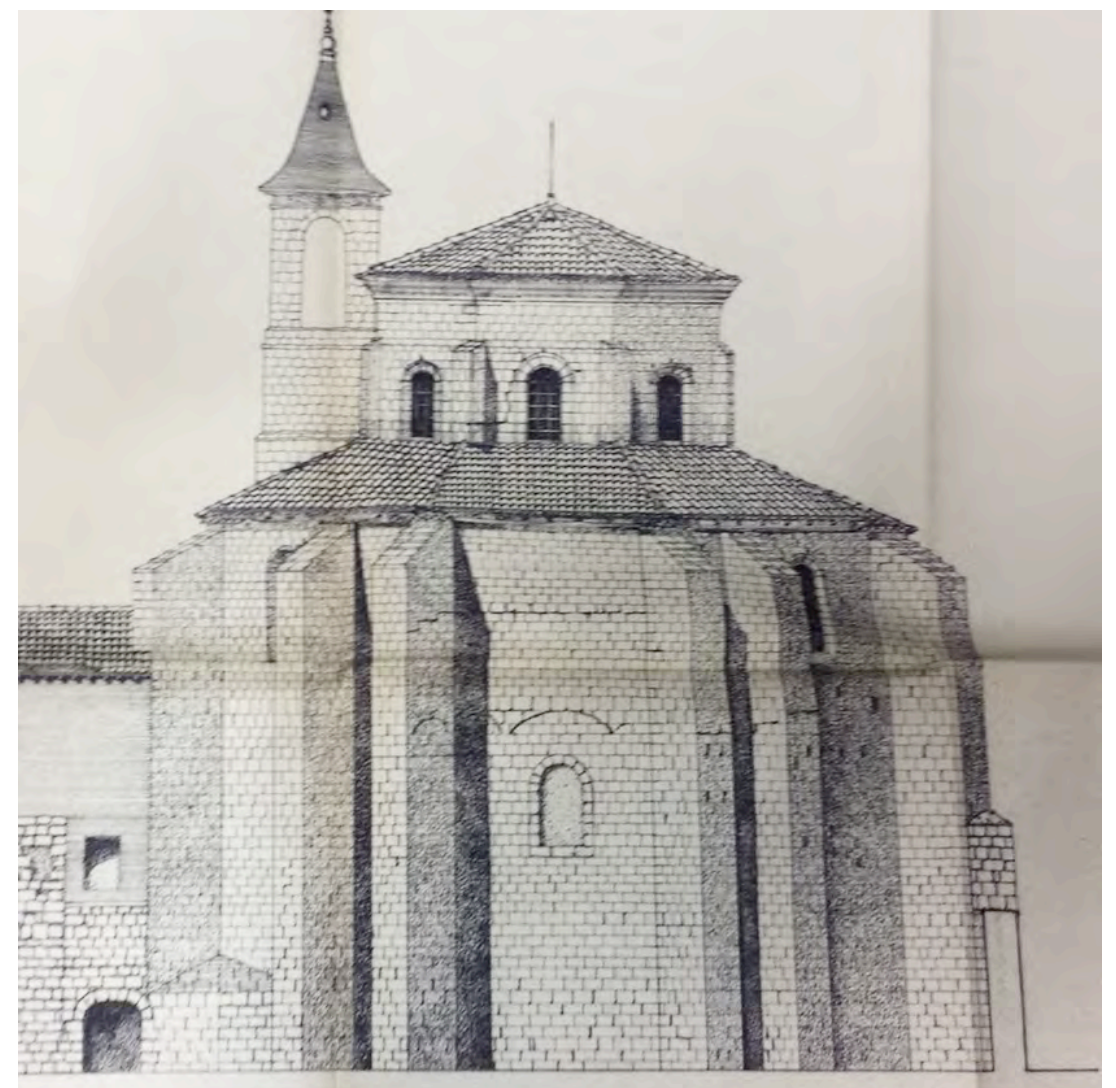

Ilustración 9: alzado cabecera 1986 Gárate y Manzano JCyL

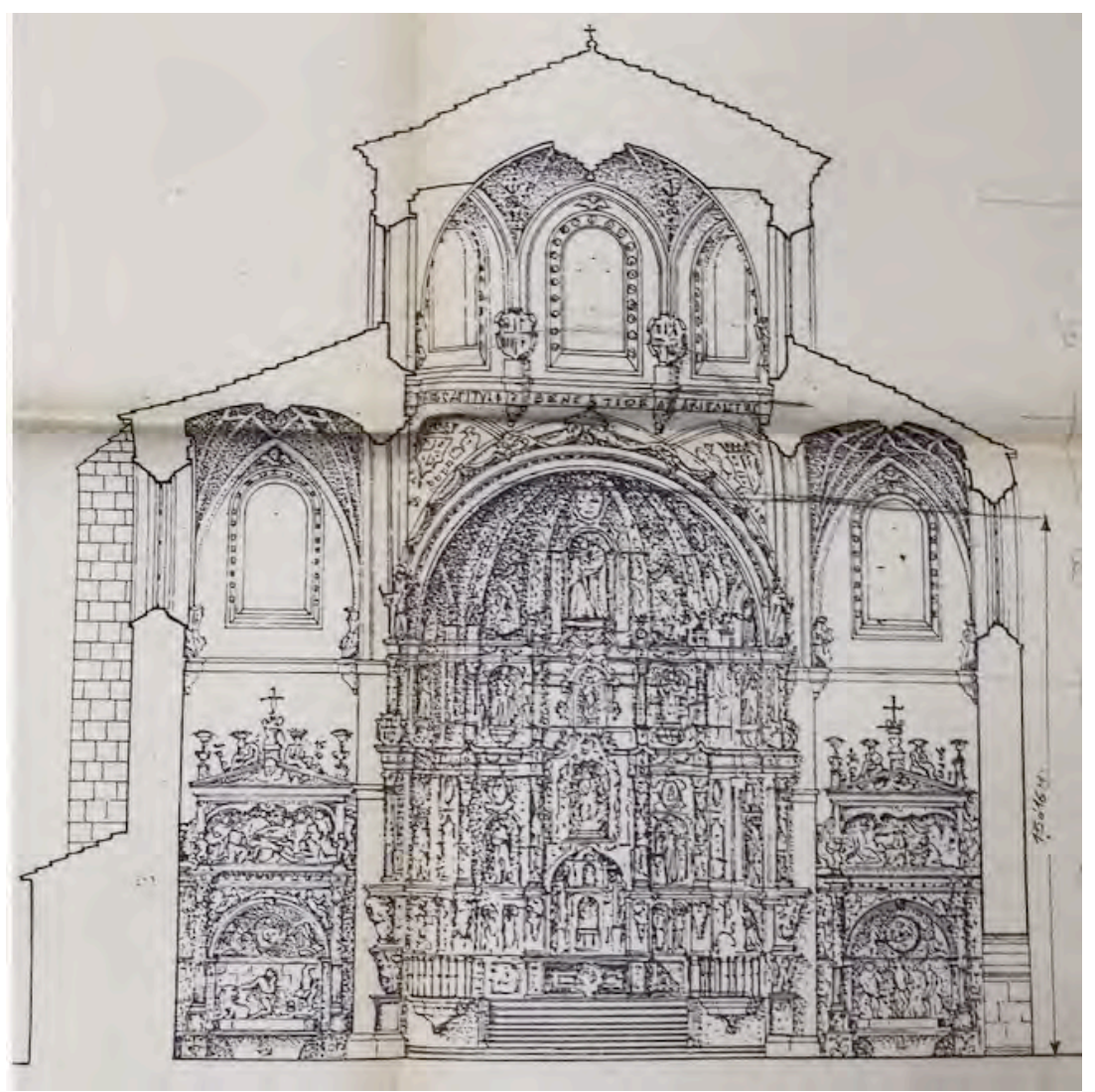

Ilustración 10: sección transversal por crucero 1986 Gárate y Manzano JCyL 


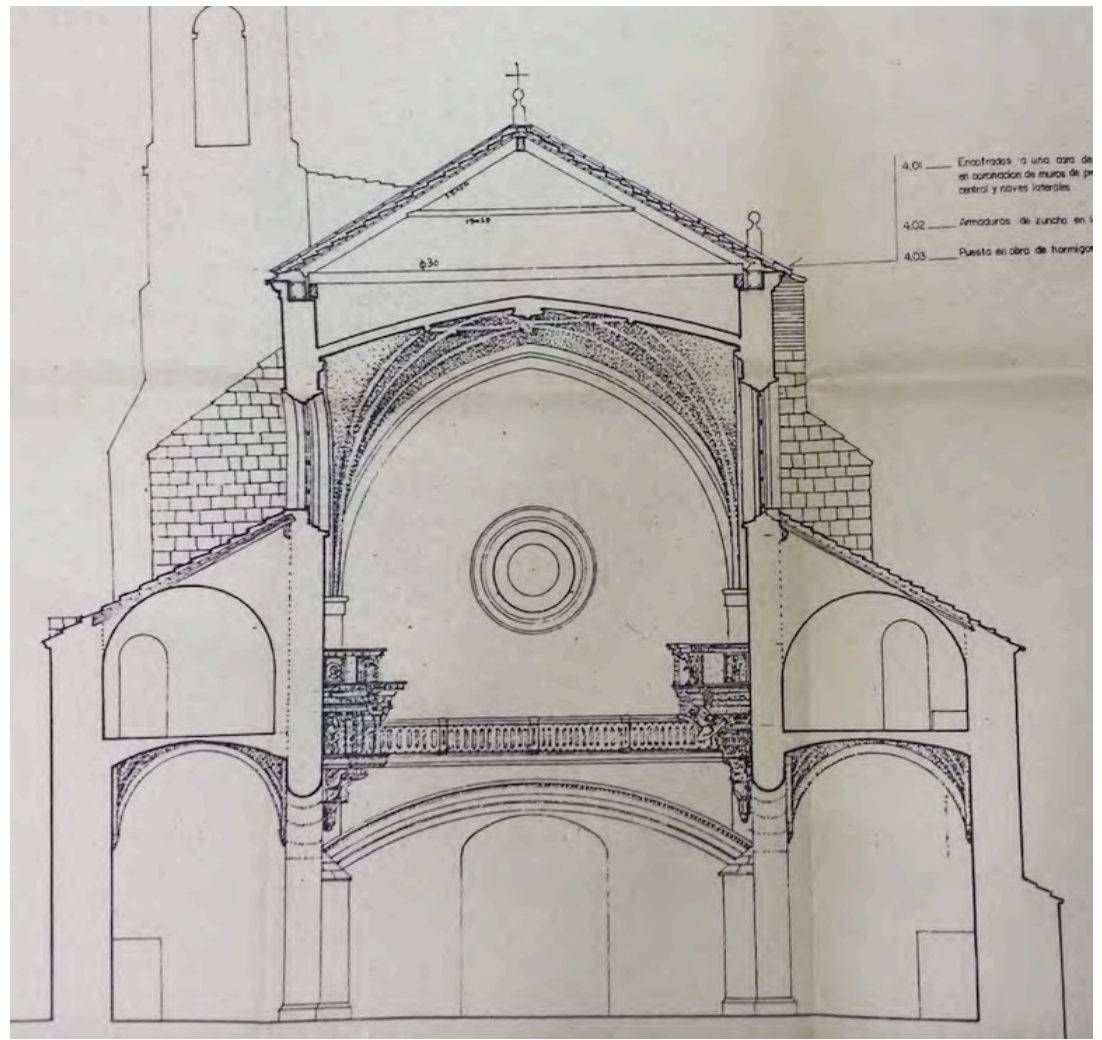

Ilustración 11: sección transversal reformado 1986 Gárete y Manzano JCyL

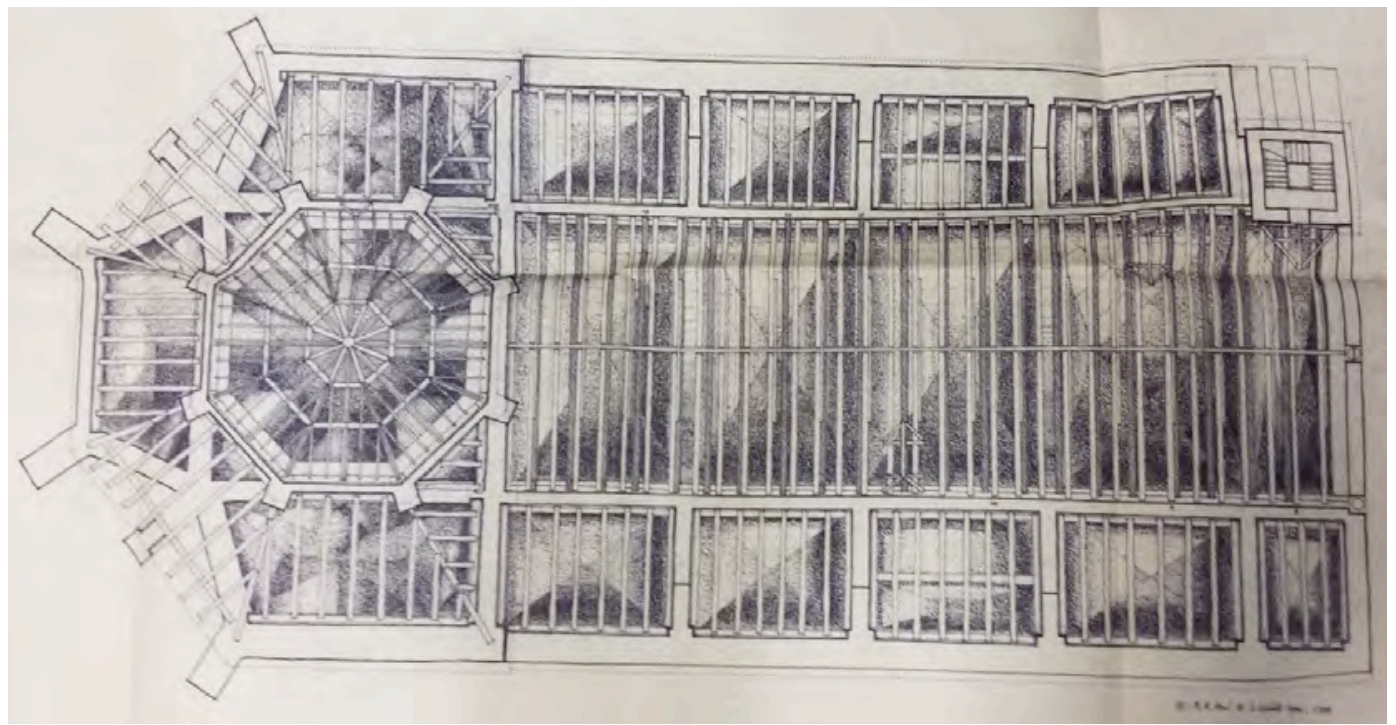

Ilustración 12: planta estructura de cubierta 1986 Gárate y Manzano JCyL

\section{Solución constructiva de la cubierta}

En la restauración de 1986 se conservan las armaduras existentes, tratando de reemplazar únicamente las piezas en mal estado. En las secciones se dibuja una pendiente de unos $29^{\circ}$, que Gárate describe con luz interior de $11,1 \mathrm{~m}$ y flecha de unos $3 \mathrm{~m}$. Los tirantes son rollizo de pino de unos $30 \mathrm{~cm}$ de diámetro y el falso tirante se enlaza a media madera, reforzado con un pasador. 


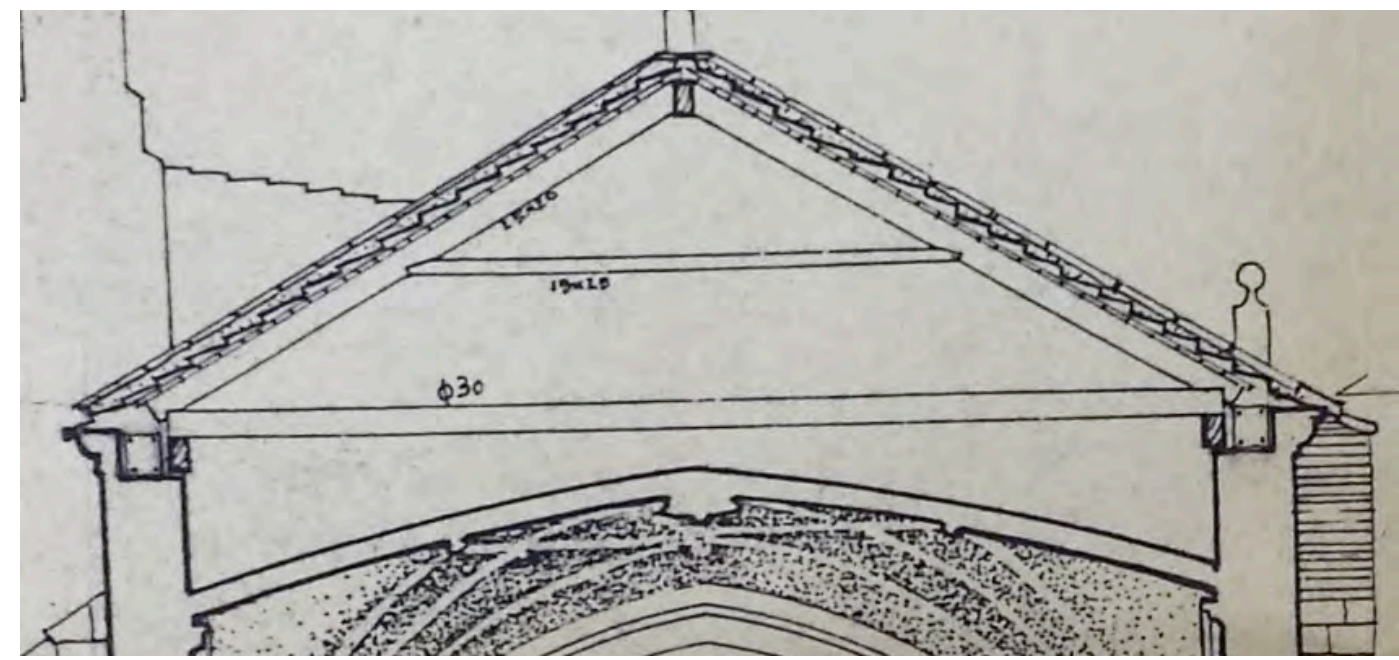

llustración 13: sección 1986 Gárate y Manzano JCyL

\section{Zunchos}

En la fotografía de obra del dossier se aprecia el hormigonado del zuncho con la capa vertida sobre la tablazón de madera.

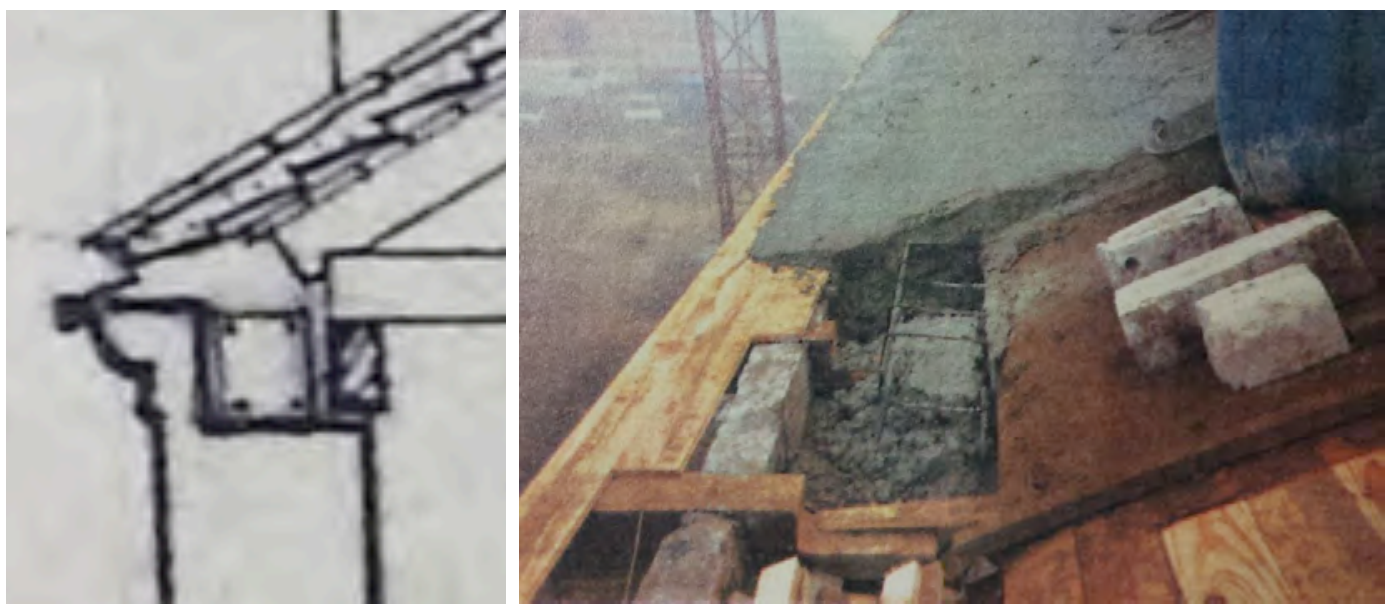

Ilustración 14: detalle de sección e imagen dossier 1986 Gárate y Manzano JCyL

Se van a acometer obras en la actualidad, por lo que se cuenta con documentación gráfica muy reciente. Se han efectuado catas, comprobando que, tras el durmiente de madera, aparece el zuncho de hormigón previsto.

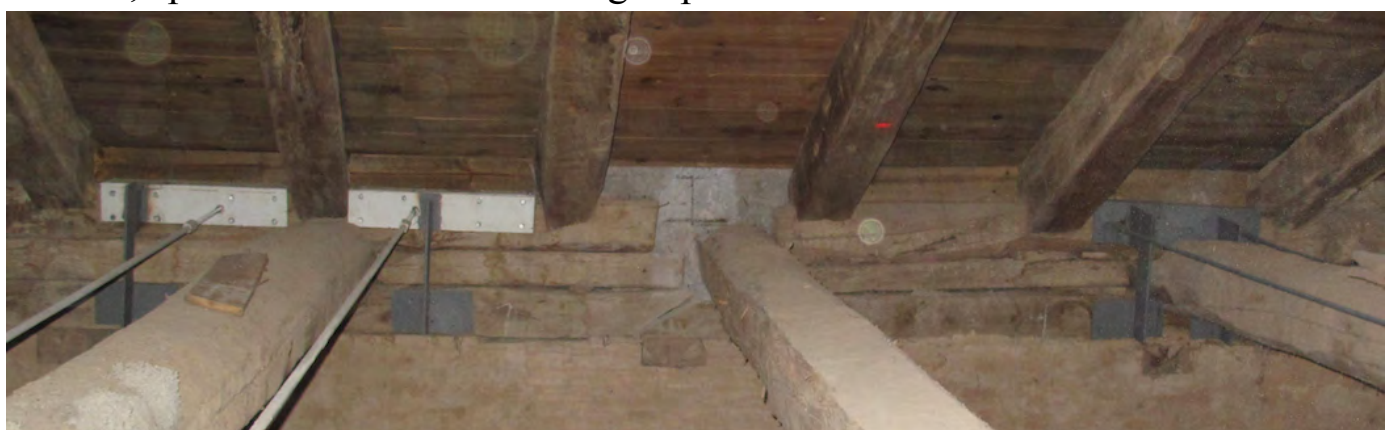

Ilustración 15: fotografía facilitada por Garcés Desmaison 03/06/2015 JCyL 
En las imágenes se aprecia también la existencia de un atirantado metálico.

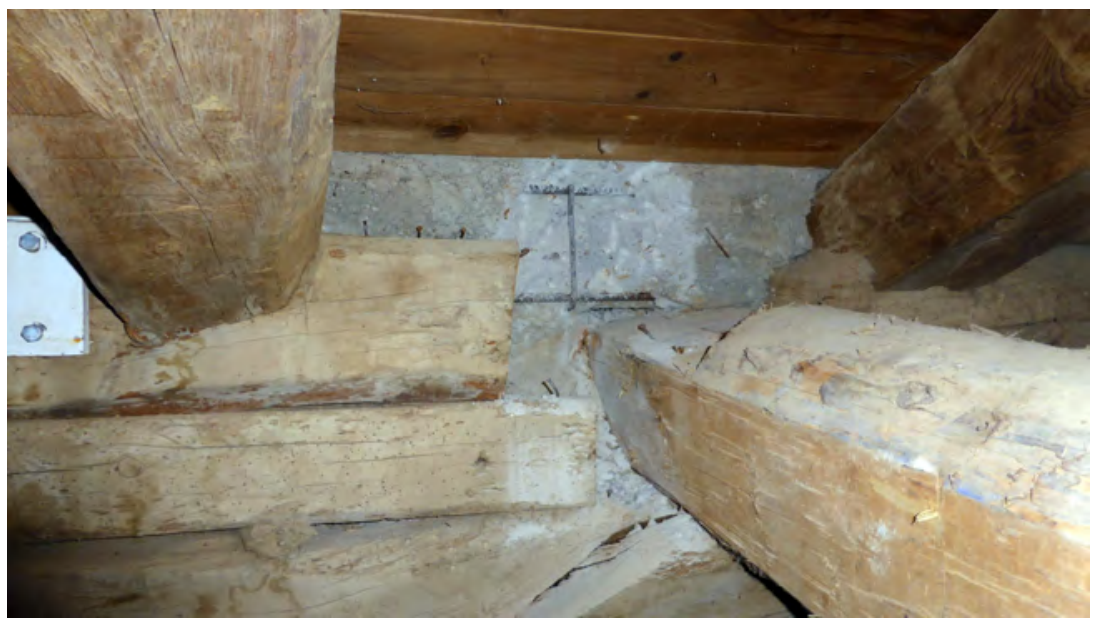

Ilustración 16: imagen de la cata, facilitada por el profesor Basterra 03/06/2015

Según el proyecto de Gárate el zuncho se define con una sección de $50 \times 35 \mathrm{~cm}$, ejecutado con encofrado de madera a una cara y se coloca en todo el perímetro (cita presbiterio, ábside, nave central y naves laterales).

\section{Conclusiones}

En este edificio se incorporó el típico zuncho perimetral rectangular que, en este caso, discurre centrado sobre los muros, en paralelo a un durmiente de madera que sirve de apoyo a los pares de cubierta.

En este caso el zuncho no se emplea como apoyo de la estructura de cubierta, sino únicamente para reforzar la coronación de los muros y dotar de continuidad a la cornisa que los remata. 



\section{Iglesia de San Francisco}

Intervenciones citadas en la publicación del Ministerio:

1955 - Saneamiento y consolidación - Anselmo Arenillas Álvarez

1956 - Saneamiento - Anselmo Arenillas Álvarez

1957 - Saneamiento - Anselmo Arenillas Álvarez

1958 - Saneamiento - Anselmo Arenillas Álvarez

1960 - Saneamiento - Anselmo Arenillas Álvarez

1962 - Saneamiento - Anselmo Arenillas Álvarez

Hay dos planos de planta en la web del IPCE; uno de 1955 de Arenillas y otro similar sin fecha ni autor.

\section{En el archivo del IPCE}

No se ha localizado documentación.

\section{En el Archivo General de la Administración}

AGA 26/00294

1955 - Saneamiento y consolidación - Anselmo Arenillas

AGA 26/00294

1956 - Desecación de humedades - Anselmo Arenillas

AGA 26/00310

1957 - Saneamiento - Anselmo Arenillas

AGA 26/00160

1958 - Cerramiento del patio - Anselmo Arenillas

AGA 26/00357

1961 - Saneamiento del subsuelo - Anselmo Arenillas

AGA 26/00253

1962 - Obras de limpieza - Anselmo Arenillas 


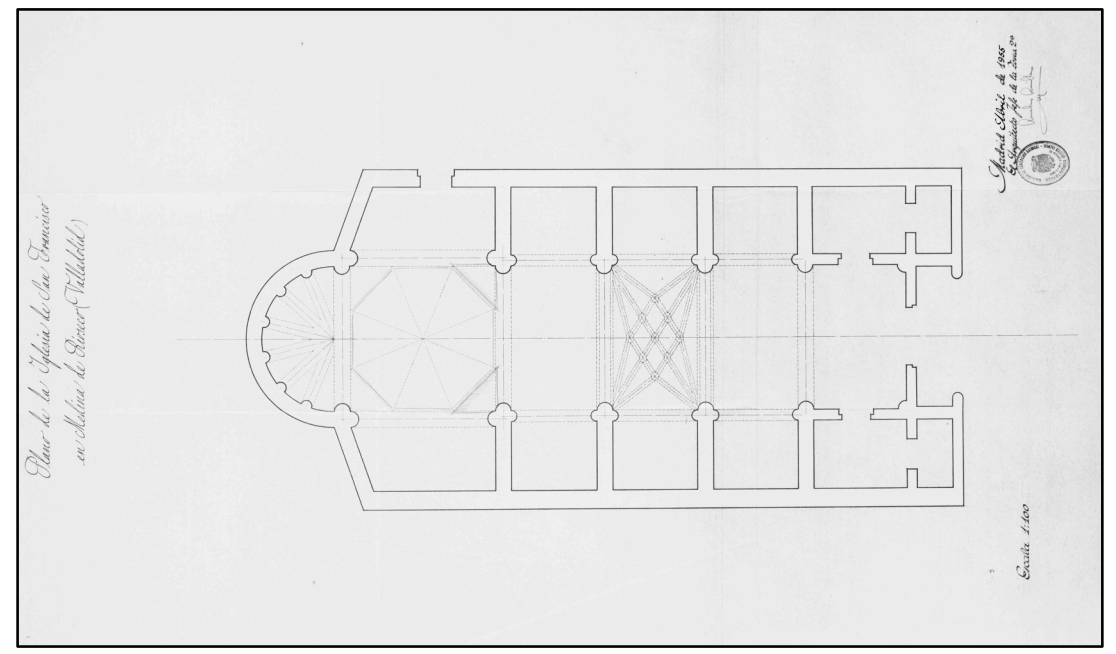

Ilustración 17: planta 1955 Arenillas IPCE

\section{En el archivo de la Junta de Castilla y León}

\section{VA-062}

Carpeta 5247

1986 - Propuesta de actuación para un programa de restauración integral - Ignacio Gárate Roja y Manuel Manzano-Monis

1988 - Proyecto de restauración - Ignacio Gárate Roja y Manuel Manzano-Monis

Dossier fotocopias color

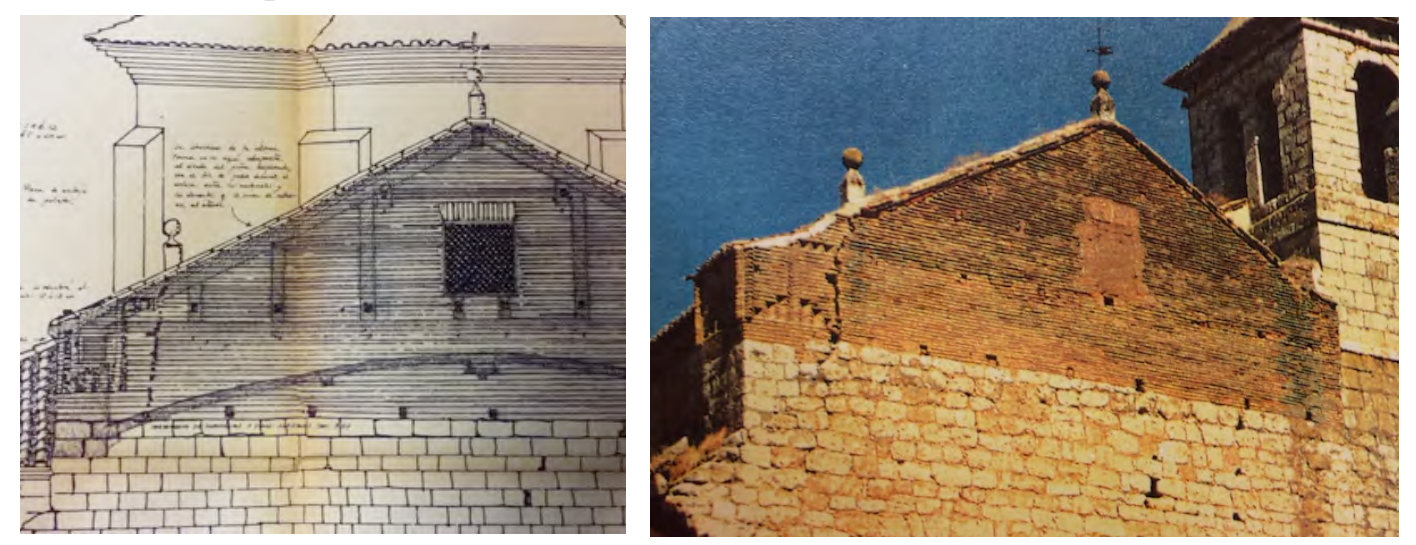

Ilustración 18: fotografías dossier 1988 Gárate JCyL

Ignacio Gárate resuelve sus proyectos de forma singular, con un grafismo especialmente centrado en los detalles y extensas descripciones rotuladas a mano. 
En uno de los planos incluye el siguiente texto manuscrito:

"Análisis y restitución ideal de la estructura de la cubierta.

Nave central.

La cubierta de este elemento queda formada por 34 pares de unas dimensiones canónicas de $20 \times 28 \mathrm{~cm}$.

daños apreciados: $\quad \mathrm{n}^{\circ} 2$ (rotura falso tirante)

$\mathrm{n}^{\mathrm{0}} 7$ (refuerzo inadecuado con herrajes)

$\mathrm{n}^{\mathrm{o}} 11$ (refuerzo y apuntalamiento)

Los muros están atirantados por un conjunto de elementos de rollizo de pino de dimensiones aprox. a D30 cm.

daños apreciados: $\quad \mathrm{n}^{\mathrm{o}} 10$ (se encuentra partido) $\mathrm{n}^{\mathrm{o}} \mathrm{s} 12,14$ y 18 (dañados y/o revirados)

La luz interior es de $11,10 \mathrm{~m}$ con una flecha de $3,00 \mathrm{~m}$. La distancia libre al trasdós de la bóveda es de 4,20m medidas ambas desde la cara inferior del picadero de cumbrera. El enlace entre par y falso tirante es a media madera, reforzado con pasador.

Cobertura antigua: Tabla ripia de pino de $28 \mathrm{~cm}$.

Nota: Para el establecimiento de la estructura de los elementos inaccesibles (crucero y naves laterales) se ha utilizado un criterio analógico por lo que la disposición prevista deberá ser verificada en la obra.

Se encuentra prevista la consolidación y saneado de los elementos leñosos en mal estado. (taqueado, desinsección e imprimación protectora). La sustitución completa de elementos de estructura debe ser considerada excepcional.

Está también prevista la conservación del herraje primitivo que sólo será sustituido en caso de absoluta obsolescencia por herraje industrial moderno. Los elementos subsistentes deberán ser apilados y saneados, tratándose con 3 manos de pintura protectora.

Los Arquitectos.

Se observa en la ampliación como los materiales existentes en la fábrica, se utilizan para atirantamiento del muro desplomado. El enlace entre fábrica y madera se realiza con morteros coloreados de resina de poliéster, bastando esta sujeción, si se encuentra bien ejecutada, para garantizar la estabilidad del conjunto al no superarse el $10 \%$ de la tensión admisible del material". 
En un plano incluye la leyenda siguiente:

4.01- Encofrado de madera a una cara para zunchado de muros en presbiterio, ábside y naves centrales y laterales.

4.02- Armaduras de zuncho de acero $4200 \mathrm{Kgr} / \mathrm{cm} 2$ cuantía $50 \mathrm{Kgr} / \mathrm{m} 3$

4.03- Hormigón para armar de resistencia característica.. en zuncho de 50x35cms.

En el plano de sección transversal los define así:

4.01- Encofrados a una cara de zuncho perimetral en coronación de muros de presbiterio, ábside, nave central y naves laterales.

4.02- Armaduras de zuncho en las mismas zonas

4.03- Puesta en obra de hormigón en zuncho.

Dentro del orden establecido con anterioridad, el proyecto contempla las acciones de mayor urgencia en su resolución como son las referentes a la estructura general y la cubierta del edificio.

La patología de la cubierta de la iglesia responde al ya clásico problema de las estructuras insuficientemente atirantadas y en las que el esquema del recorrido de los empujes no se encuentra satisfactoriamente resuelto en su aspecto constructivo. Esto se debe fundamentalmente a dos causas: por una parte la falta de eficiencia de los tirantes de madera, a base de rollizos de sección excéntrica que hacen problemático el equilibrio de par y tirante, originándose una concentración de esfuerzos excesiva en la zona de borde del muro de apoyo. El segundo motivo que resulta complementario del anterior es el de la diversidad de materiales que configuran esta zona de apoyo, debida sin duda a las sucesivas obras de reforma sufridas a lo largo del tiempo. Esta situación produce una falta de resistencia en el sentido del eje del muro, generando unos agrietamientos en las zonas de mayor debilidad o de menor traba...

Otro tanto puede decirse en lo que se refiere al estado de la cornisa que adolece de una morfología constructiva común. Aquí la solución adoptada que la dota de continuidad es la construcción del ya clásico zuncho de apoyo perimetral que viene a sustituir parcialmente el trabajo de los antiguos durmientes.

\section{Presupuesto}

$1564 \mathrm{~m} 2$ desmontado de cubierta de reja árabe

íd. desmontado de tabla ripia

1181,40m2 desmontado de estructura de cubierta, cerchas, cabios y durmientes con clasificación y acopio del material 
22,43m3 desmontaje manual de fábrica de mampostería de muros de naves laterales, clasificación y acopio del material, retirada de escombros, carga y transporte de los mismos a vertedero

13,80m3 desmontado de sillares de coronación de muros, con clasificación y numeración de las piezas, acopio en almacén, con retirada...

15,70m3 desmontado manual de muros de fabrica de ladrillo macizo, con clasificación, recuperación, limpieza... (alzado principal y contrafuerte)

Cantería:

27,60 m3 restauración de fábrica de sillería en coronación de muros, con el material desmontado anteriormente y aportación del necesario y su labra de similares características al existente. incluso preparación de esta sillería para ser trasdosada con zuncho de hormigón, realizando los mechinales precisos y cajeados para canecillos, sentada y rejuntada con mortero bastardo y árido apropiado. Patinado de superficies y limpieza de paramentos. Aprobado según muestra.

Carpintería de armar:

$829,40 \mathrm{~m} 2$ consolidación de cubierta en ábside y nave central con reposición de piezas deterioradas $\mathrm{o}$ en descomposición, con madera curada, refuerzo $\mathrm{y}$ modificación de ensambles con la inclusión del herraje preciso, nivelación y aplomado de formas.

$352,00 \mathrm{~m} 2$ consolidación de cubierta en naves laterales...

Hormigones:

103,09m2 encofrado y desencofrado de madera a una cara de zunchos perimetrales de coronación de muros, incluso parte proporcional de mechinales para el encaje de cerchas y formas de la estructura

$2513,11 \mathrm{~kg}$ acero corrugado...en armaduras de zunchos perimetrales

$51,55 \mathrm{~m} 3$ hormigón para armar de $175 \mathrm{~kg} / \mathrm{cm} 2$ de resistencia característica en zunchos perimetrales, incluso vertido y vibrado. (Define muchas longitudes para la misma sección, siempre de $0,50 \times 0,35 \mathrm{~m}$ )

40ml Restauración de cornisa de ladrillo aplantillado en coronación muros del Presbiterio

65,00 restauración de alero de ladrillo aplantillado en coronación de muros de nave central, con aportación de las piezas que sean precisas, de similares características y formas a las existentes. Incluso preparación de esta fábrica para ser trasdosada al zuncho perimetral, realizando mechinales y cajeados...

\section{VA-097}

Limpieza de grupos escultóricos 


\section{VA-093}

Emergencia de restauración

Manuel Manzano Monis

Contratista Alejandro Bolado SA, adjudicada 13-11-90

Informe de Manzano con Santiago Huerta y José Miguel Ávila sobre la estabilidad de los arcos que sustentan el ochavo: por razones desconocidas en la década de los 50 se construyen en el trasdós de las pechinas unas vigas de hormigón. La colocación de ventanales de vidrio armado en el ochavo u el cierre de la misma por su falta de uso, ha originado un notable aumento de la humedad relativa interior, que se ha transmitido lentamente a la piedra. Esto ha conducido a una pérdida de rigidez de las fábricas mientras que el hormigón ha mantenido sus características mecánicas.... descargando la pechina y concentrando la carga en el arco.

Recomiendan reducir la humedad en el interior de la iglesia y reparar o sustituir las dovelas

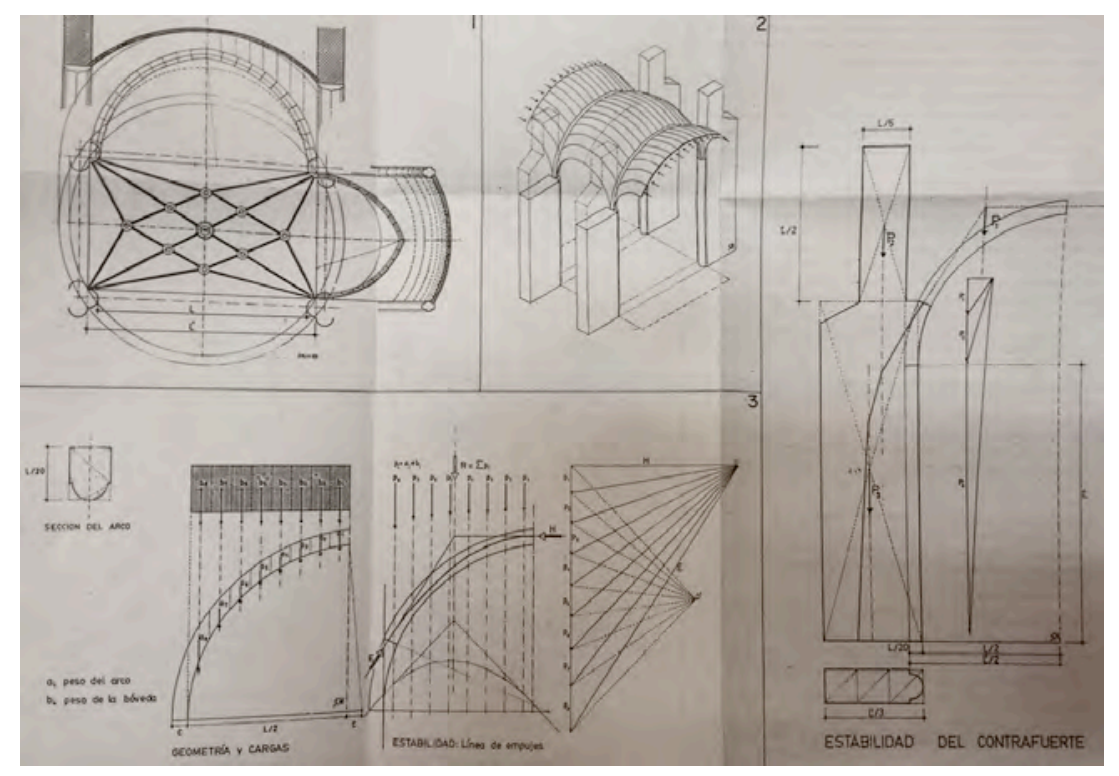

Ilustración 19: práctica académica del cálculo en la ETSAM

Informe de Marco Antonio Garcés, noviembre de 1990:

Tanto el arco que separa la nave del crucero, como los que comunican a éste con sus brazos han sufrido una deformación que, en el primero de los casos citados, ha producido la rotura parcial de una de las dovelas. La estabilidad del cimborrio que apoya sobre este conjunto está seriamente amenazada, con peligro de ruina y caída.

\section{Memoria final}

Han apeado, colocado sistema de control termohigrométrico y reintegrado con morteros de resina epoxi. 
FICHA SÍNTESIS

\section{Código de identificación: FZ-26}

Denominación: Iglesia de Santa Cruz

Localidad: $\quad$ Medina de Rioseco

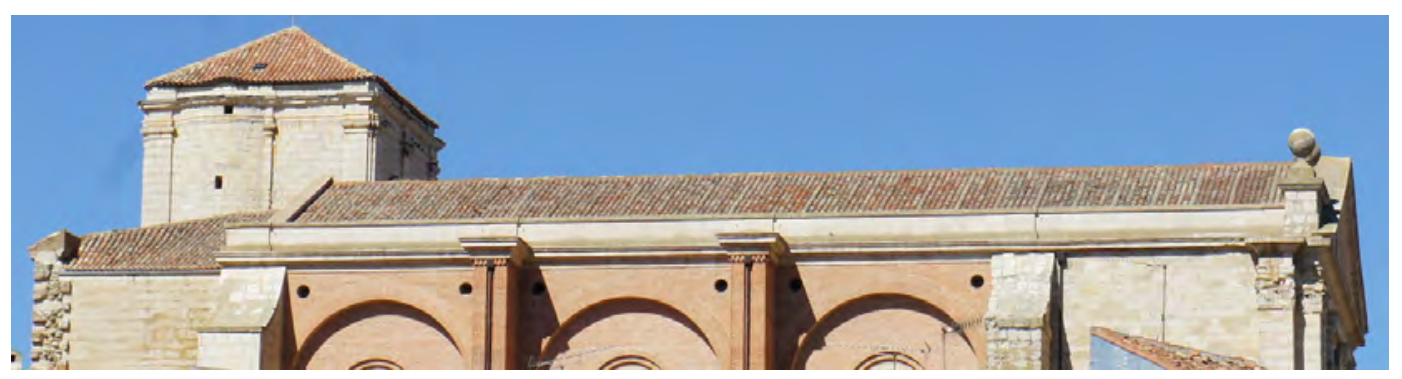

\section{Descripción}

Iglesia rectangular de una sola nave con capillas hornacinas. Se conserva el arco triunfal y la cúpula elíptica del XVIII, pero el resto de las cubiertas es moderno y forma una gran bóveda revestida interiormente con madera.

\section{Materiales}

Los muros son de sillería de piedra, con hormigón armado y fábrica de ladrillo resuelta con un sistema de varias hojas "capuchino" en las zonas reconstruidas tras un colapso. La cubierta está revestida de teja curva.

\section{Singularidades}

El edificio se utiliza en la actualidad como Museo de Semana Santa.

\section{Dimensiones básicas del templo}

$\begin{array}{llll} & \text { central } & \text { laterales } & \text { capillas } \\ \text { Ancho de nave } & 18,2 & - & 7,4 \\ \text { Altura } & 27,0 & - & 14,0\end{array}$

\section{Memoria histórica constructiva}

Según el Catálogo:

Se abren los cimientos desde 1549 hasta 1593. Hasta 1598 se emplean trazas de Rodrigo Gil de Hontañón y desde entonces unas nuevas de Felipe de la Cajiga. Dirigen la obra Mazuecos y posteriormente Cisniega, con el templo en uso ya en 1610. En 1618 se coloca la cruz de remate de la fachada, aunque las obras prosiguen, 
sucediéndose varios maestros. En 1662 Francisco Cillero da trazas y condiciones para cubrir la capilla mayor con media naranja y linterna, edificar un chapitel entre las dos torres y acabar las bóvedas de la iglesia. Felipe Berrojo cierra las tres bóvedas últimas en 1664. En 1718 amenaza ruina el chapitel y se demuele. Según García Chico el terremoto de Lisboa de 1755 provoca grandes hendiduras en las bóvedas e inclinación de la fachada. ${ }^{1}$

Se repara repetidamente la fachada en $1803,1839,1844,1845$ y 1874 , hasta que se hunde el último tramo de la iglesia en 1954. En 1964 se incorporan unos enormes contrafuertes.

En 1971 se emprenden obras para desmontar piedra a piedra y reconstruir la fachada, que se llevan a cabo hasta que en 1977 se derrumba el cuerpo de la nave. En 1987 se culmina una reconstrucción moderna, con cerchas y bóveda de madera laminada revestida en madera.

\section{Cronología. Fechas clave}

$1602-1668-1954-1977-1987$

\section{Intervenciones}

En 1954 se hunde el tramo de bóveda a los pies, tras una inclinación de 1,2m en los años cuarenta que Arenillas achaca al fallo de la cimentación por las aguas procedentes del Canal de Castilla y un cauce mal cegado del río Sequillo.

1968 - Desmontado y cimentado de la fachada - Anselmo Arenillas

Se desmonta y reconstruye tras ejecutar por pozos una cimentación nueva de hormigón. Demuele el primer tramo de cubierta de la nave.

1970 - Fachada - José Ángel Rodrigo García y Joaquín Roldán Pascual

La fachada se levanta por fases hasta 25,5 y $35,5 \mathrm{~m}$ sobre la nueva cimentación, ejecutada como doble muro de dos pies de ladrillo macizo con un pie transversal y sillería engatillada por el paramento exterior. Cada dos metros se dispone un zuncho perimetral de $15 \mathrm{~cm}$ y toda la sección.

1972 y 1974 - Bóvedas, cubiertas y fachadas - José Ángel Rodrigo García y Joaquín Roldán Pascual.

\footnotetext{
${ }^{1}$ En 1726, mucho antes del tereemoto, ya se temía la ruina de la fachada "maliziosa, desluzida y encanchada su piedra hasta una altura de siete pies", y se acomete el refuerzo de sus cimientos.
} 

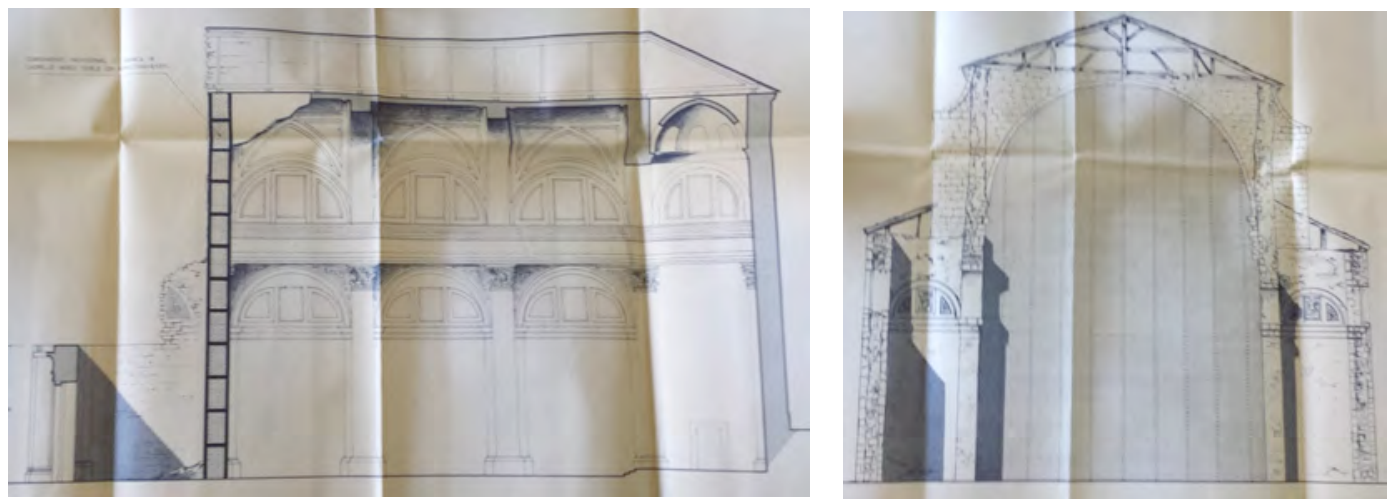

llustración 1: secciones 1972 Rodrigo y Roldán IPCE

Se producen varios hundimientos durante las obras de Rodrigo y Roldán.

1979 - Obras urgentes de consolidación - Ana Iglesias González.

Se encarga el proyecto de reconstrucción a Ana Iglesias y su ejecución a Ángel Espejel que, finalmente redacta un proyecto nuevo. En ambos documentos se define un cajeado en la coronación del muro lateral izquierdo para la formación del zuncho.

Se prevé un zuncho de hormigón armado de $350 \mathrm{~kg} / \mathrm{m} 3$ de resistencia característica $\quad 180 \mathrm{~kg} / \mathrm{cm} 2$ en coronación de muro.

Se diseña una cubierta abovedada de estructura metálica, cubierta con planchas de cobre y, en el centro, policarbonato traslúcido.

1987 - Restauración - José Ignacio Linazasoro y Salvador Mata.

Se diseña una estructura de cubierta doble con cerchas y arcos de madera laminada. Disponen un drenaje perimetral.

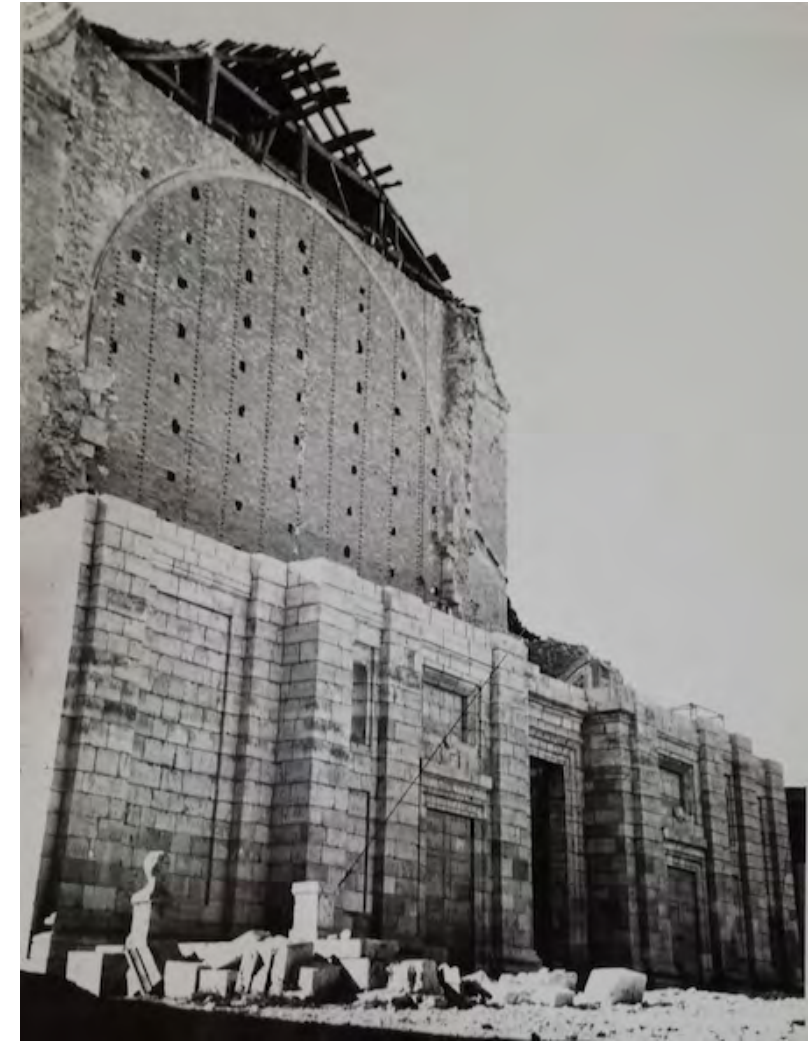

Ilustración 2: dossier 1982 Espejel IPCE

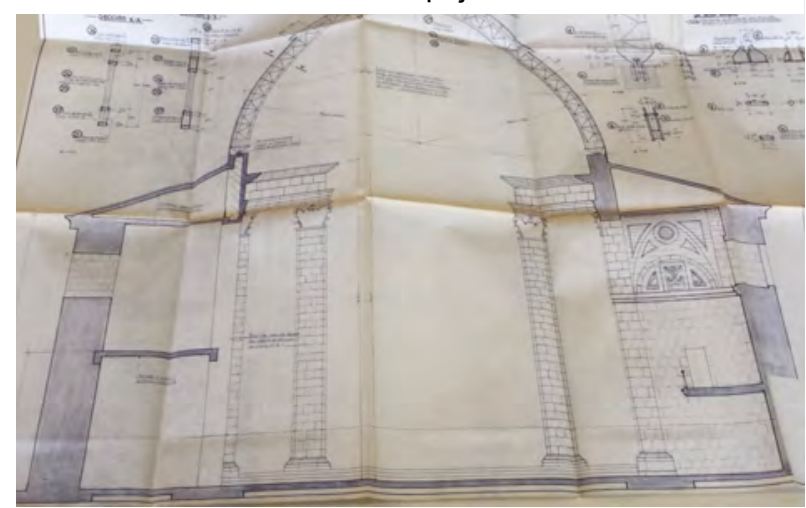

Ilustración 3: sección 1982 Espejel IPCE 
1994 - Rehabilitación y acondicionamiento como Museo de arte sacro- Pablo Puente

\section{Planos}

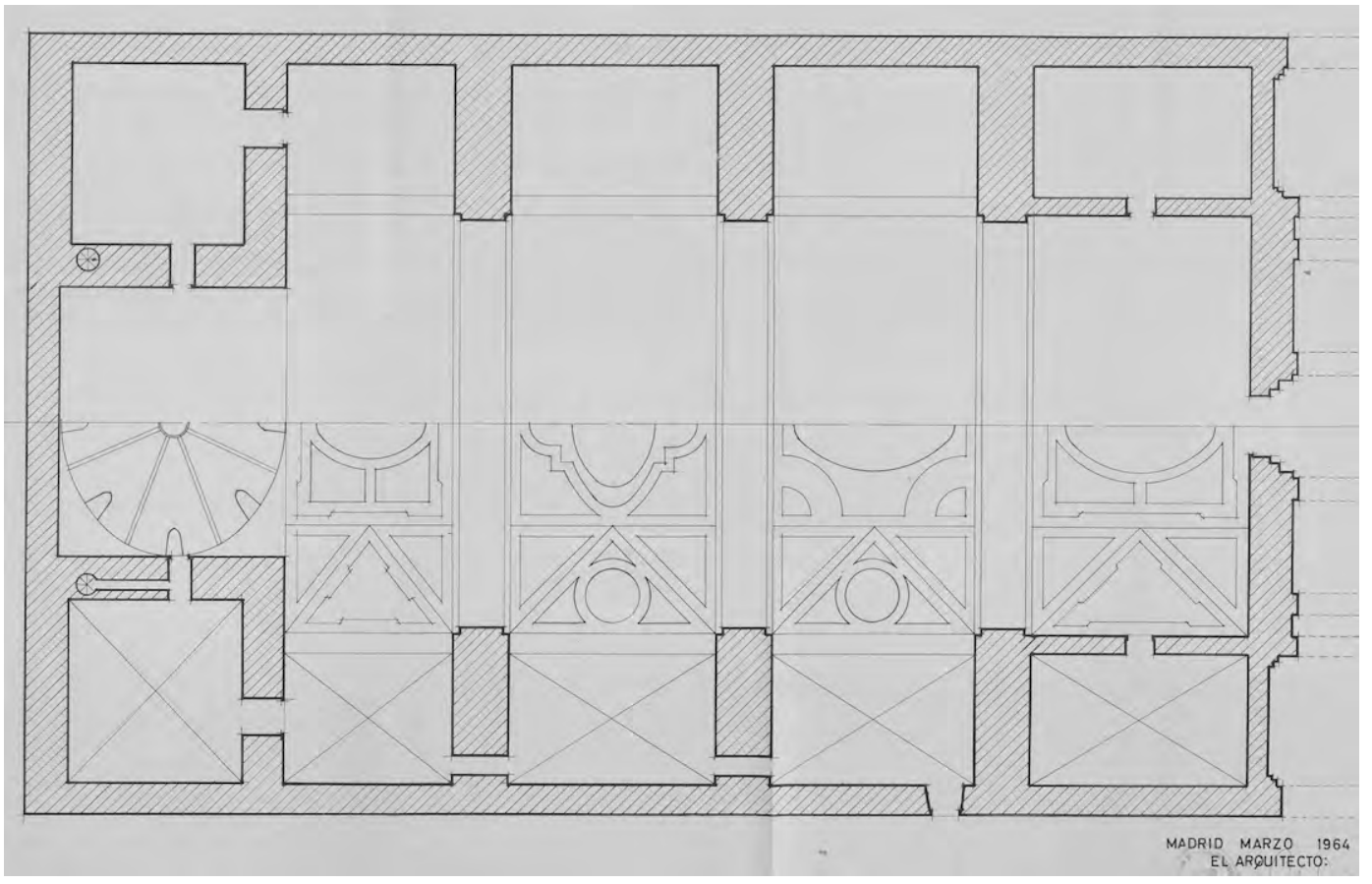

Ilustración 4: planta 1964 Arenillas IPCE

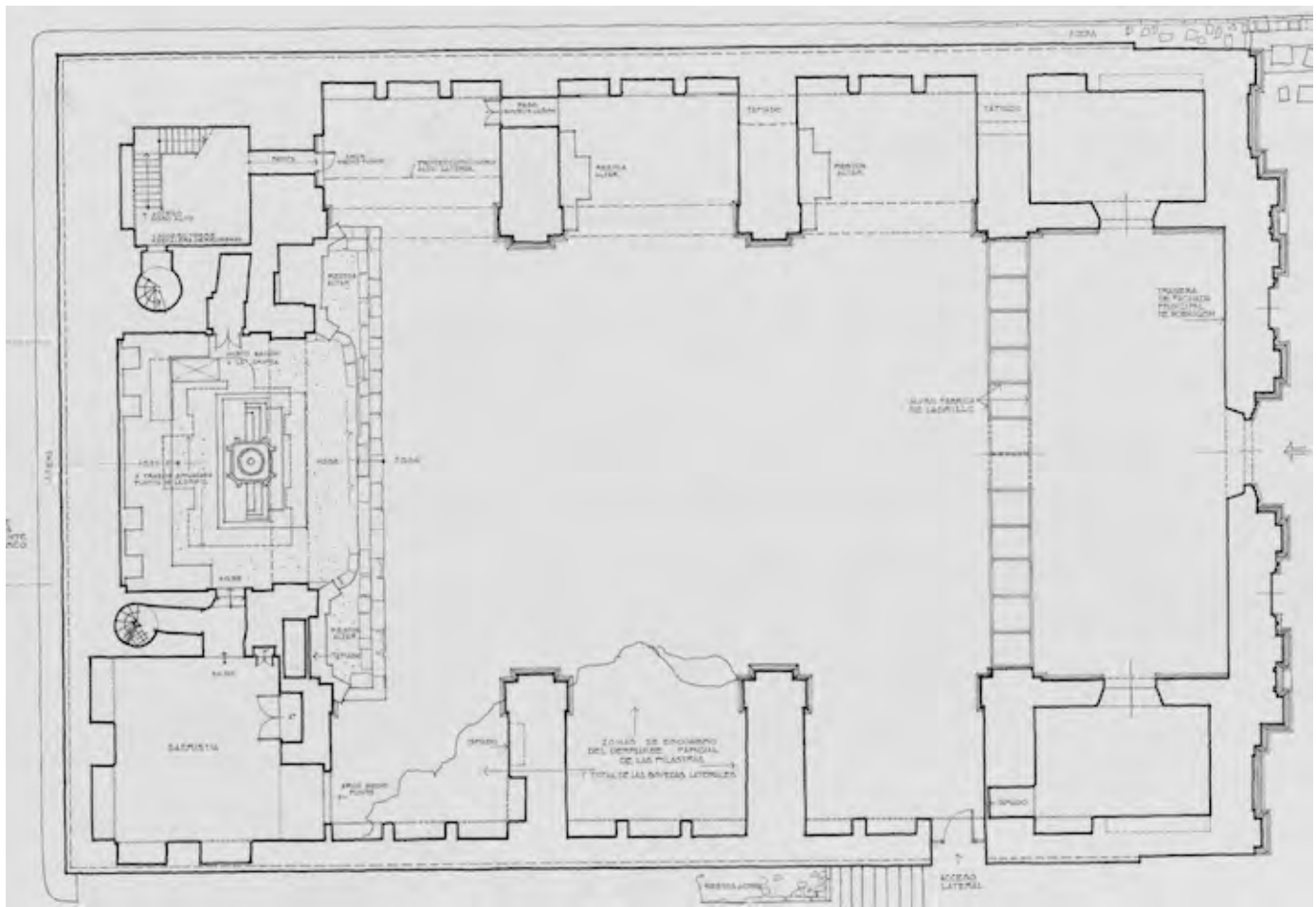

Ilustración 5: planta 1979 Iglesias IPCE 


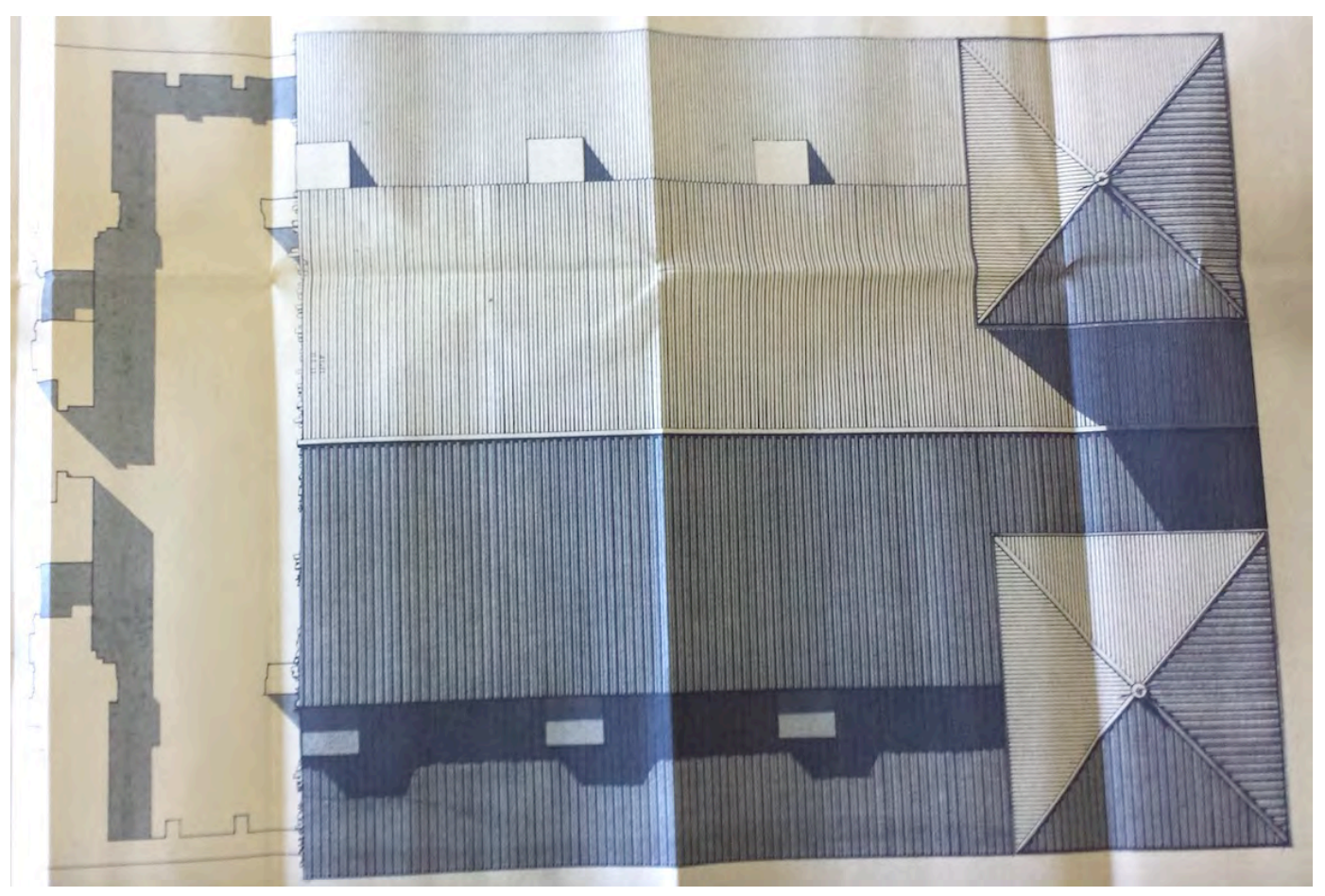

Ilustración 6: planta de cubiertas 1972 Rodrigo y Roldán IPCE

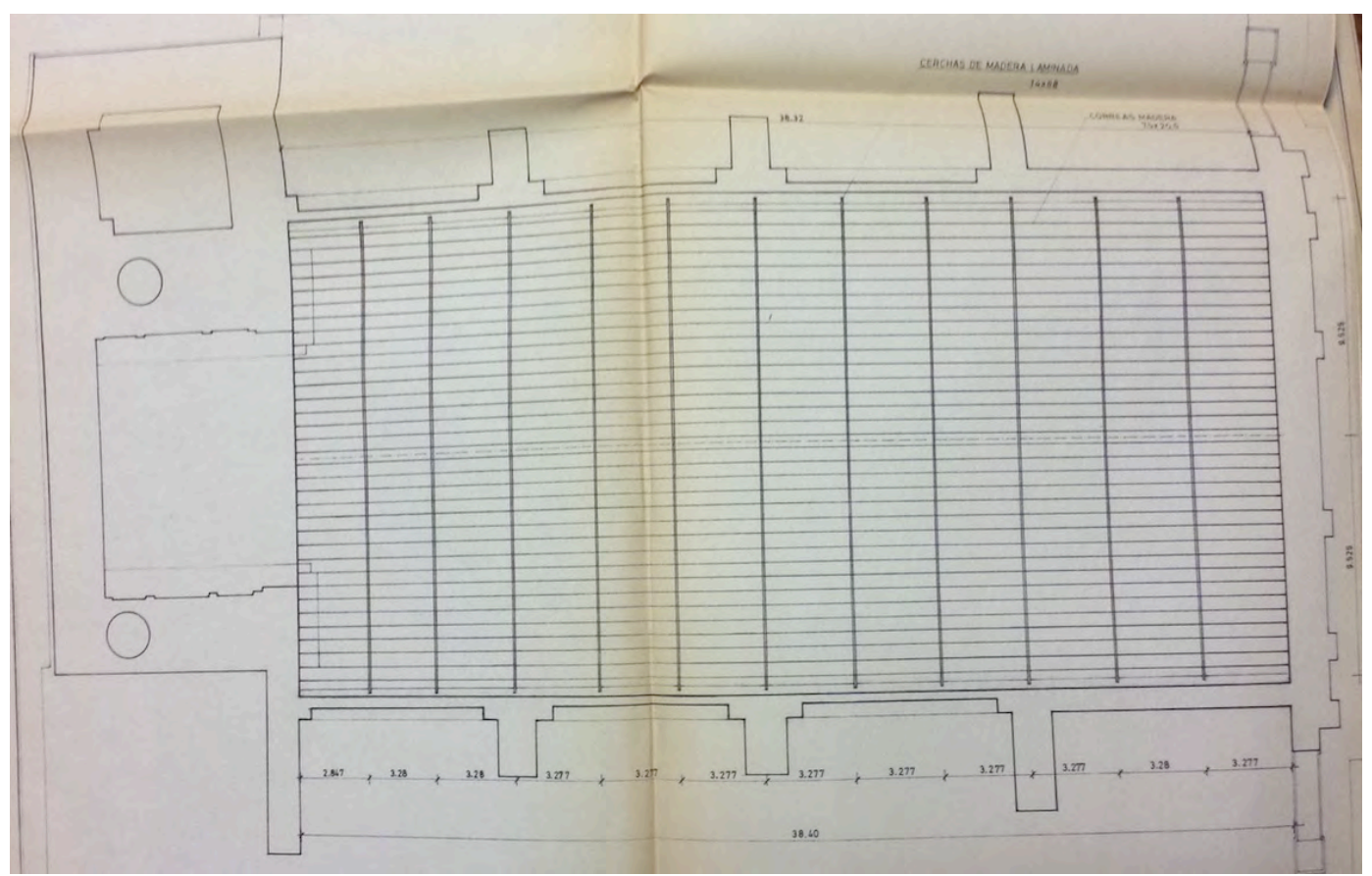

Ilustración 7: planta de cubiertas 1987 Linazasoro JCyL 


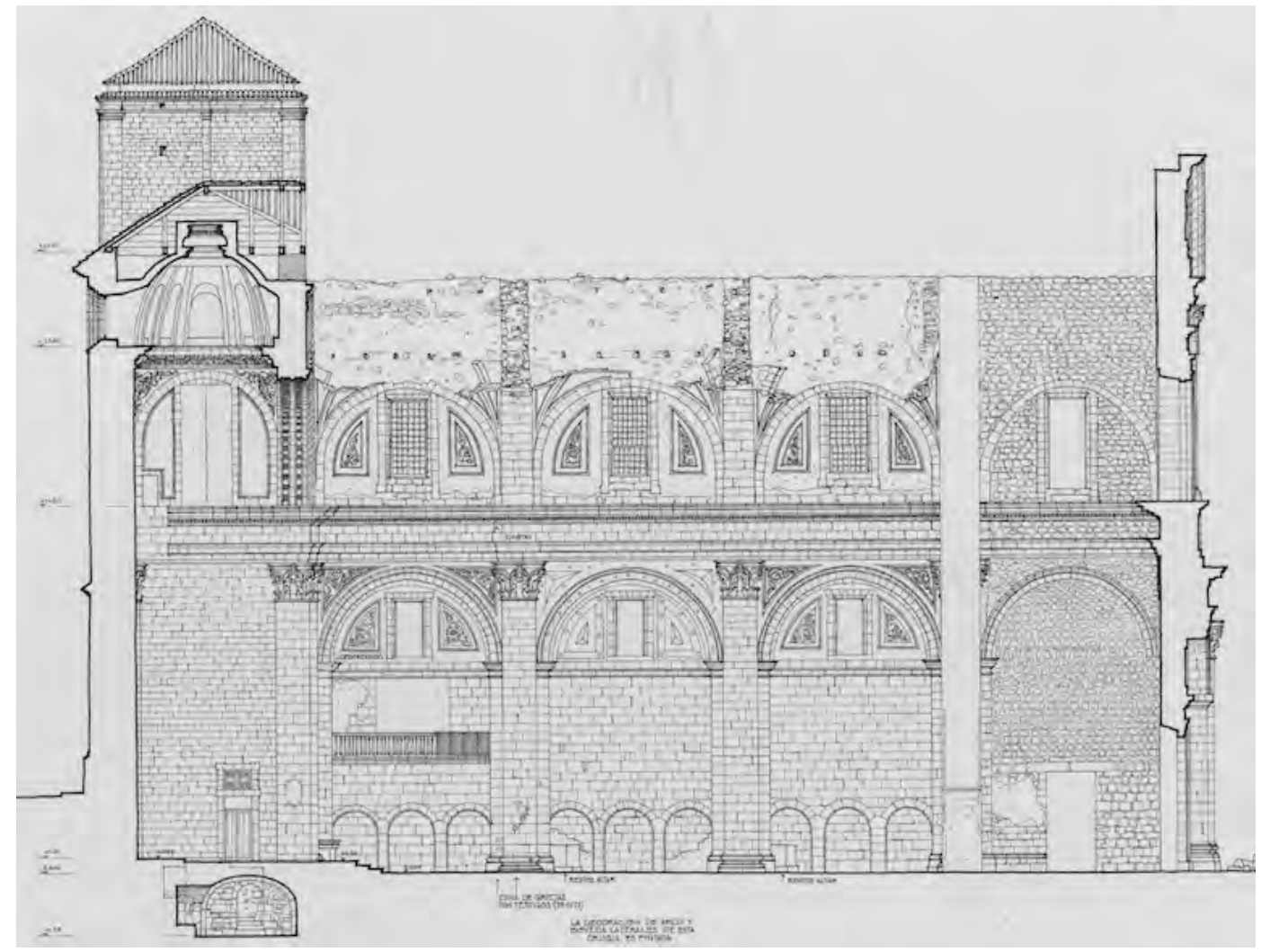

Ilustración 8: sección 1979 Iglesias IPCE

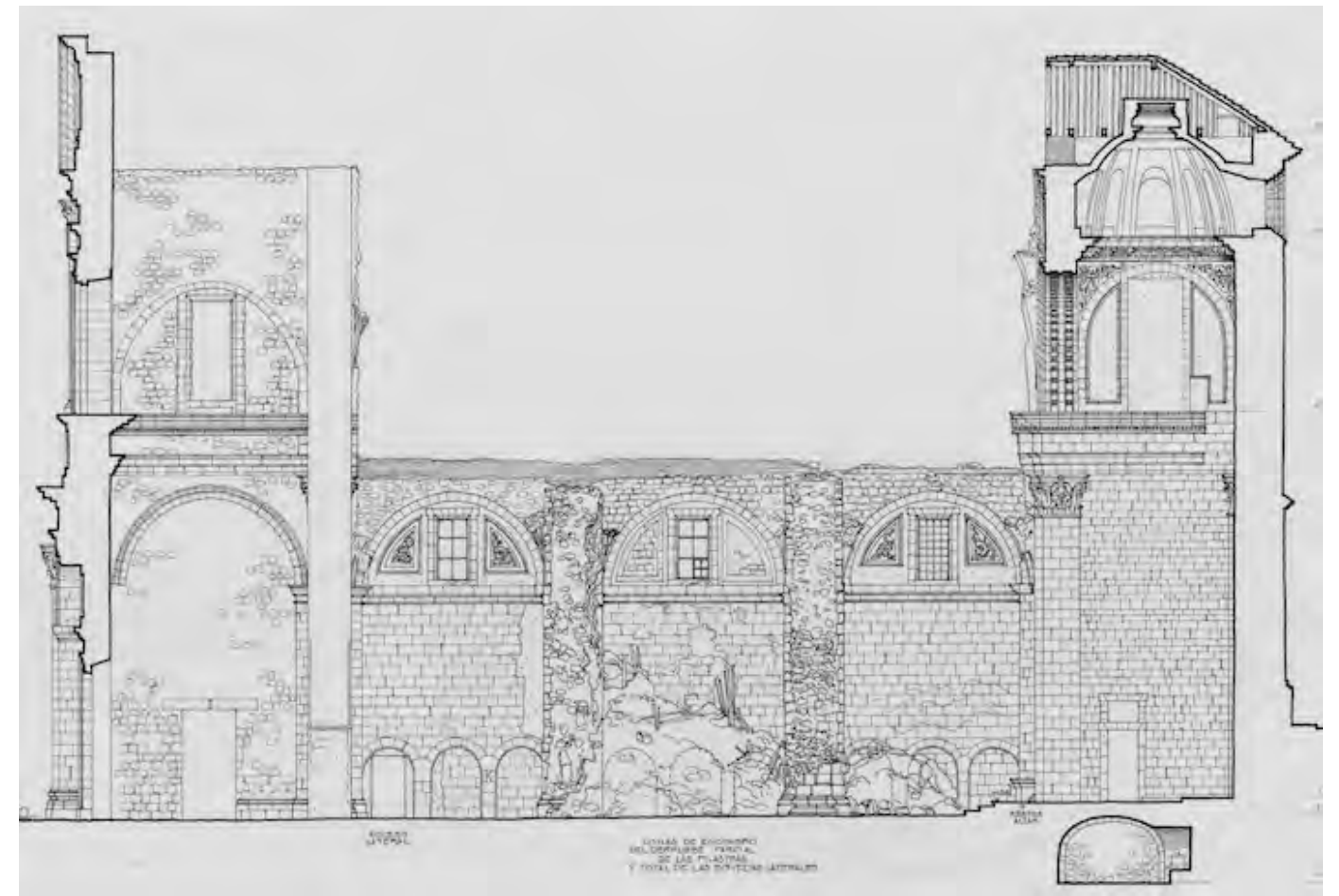

Ilustración 9: sección 1979 Iglesias IPCE 


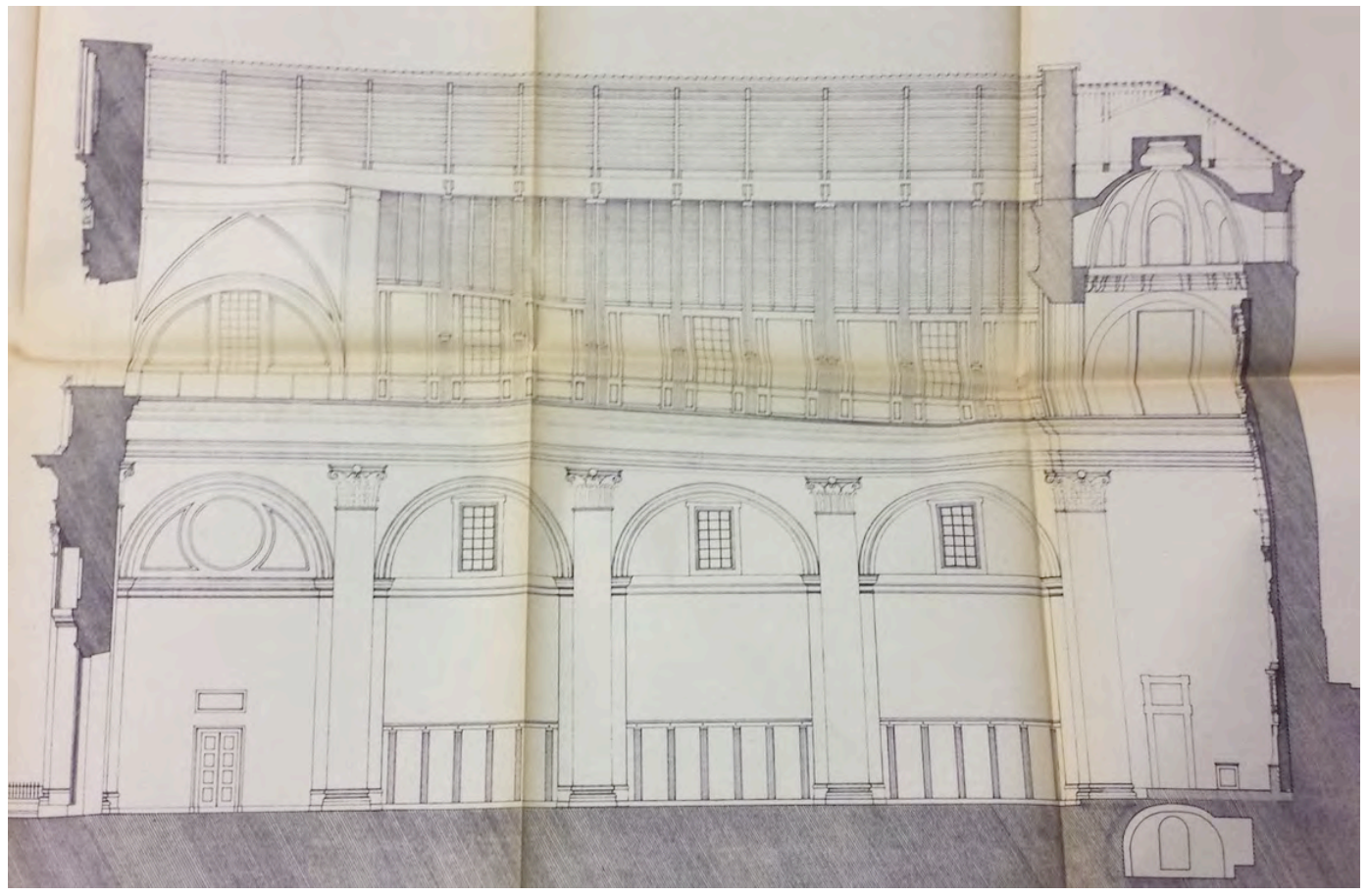

Ilustración 10: sección longitudinal 1987 Linazasoro JCyL

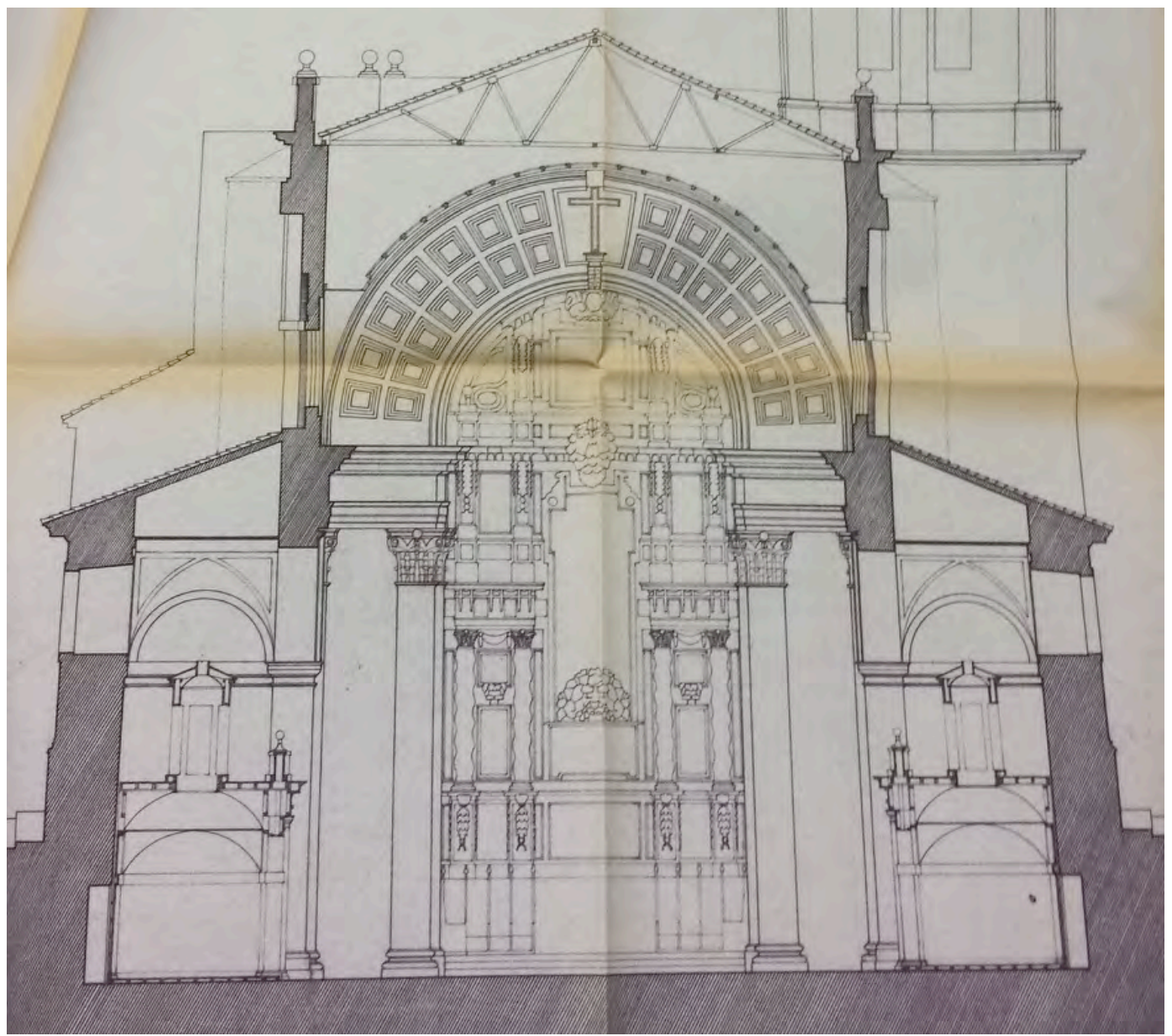

Ilustración 11: sección proyecto 1987 Linazasoro JCyL 


\section{Solución constructiva de la cubierta}

En las secciones de Linazasoro se aprecia una pendiente de unos $22^{\circ}$. En el proyecto reformado aparece una cercha más ligera que la del proyecto inicial, sin diagonales de relleno, con el tirante suspendido de dos tirantillas metálicas.

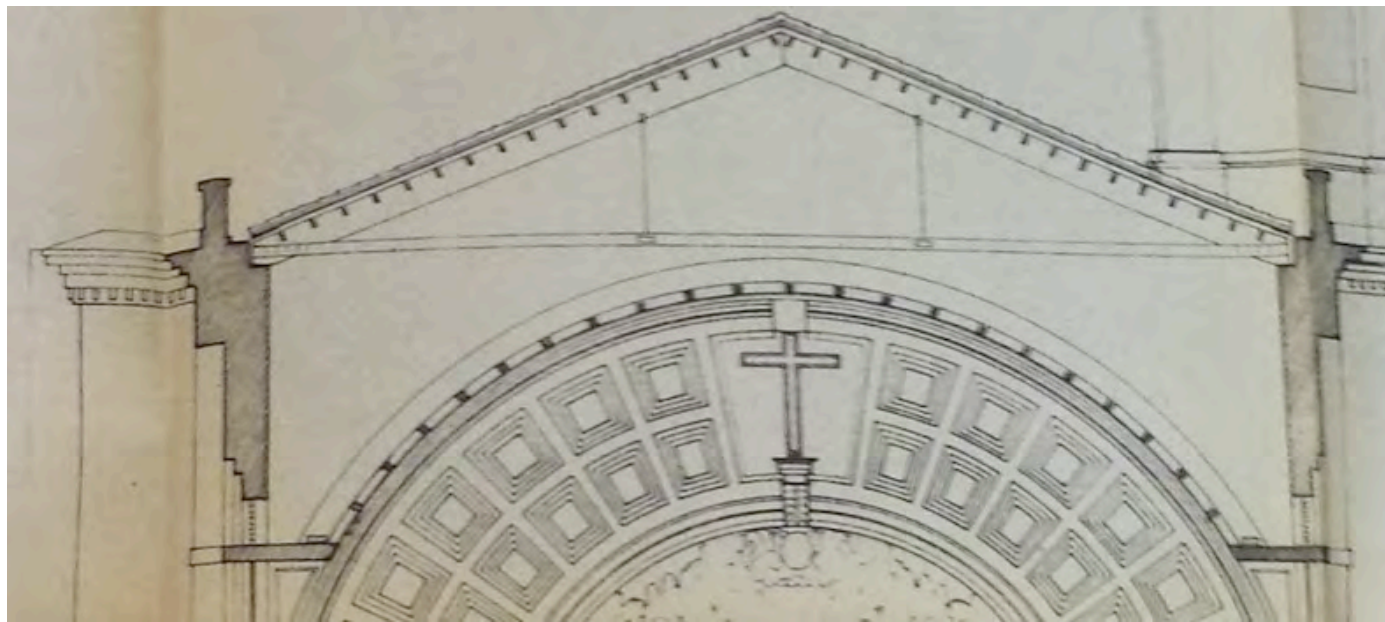

Ilustración 12: sección transversal reformado 1987 Linazasoro JCyL

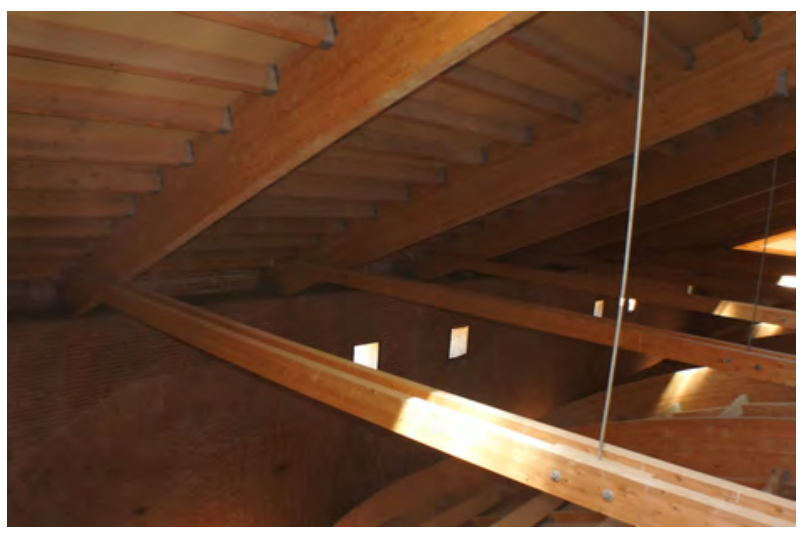

Ilustración 13: bajo cubierta, visita 25/08/2015

La estructura observada en la visita al bajo cubierta coincide con la geometría definida por Linazasoro en el proyecto reformado, de madera laminada con cerchas y tirantillas sobre arcos también de madera laminada.

El zuncho o viga, sin embargo, aparece semiembebido en la fábrica de ladrillo visto, en vez de enrasado con la cara interior de paramento como aparece representado en los planos de detalle del proyecto.

\section{Zunchos}

En los proyectos de Ana Iglesias de 1979 y Espejel de 1982 se definen los zunchos en plantas y secciones.

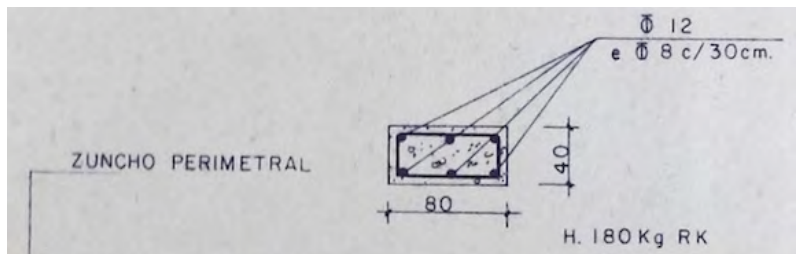

Ilustración 14: detalle 1979 Iglesias IPCE 
En el de Linazasoro de 1987 finalmente adoptado se diseña una pieza en forma de yunque revestida con una cornisa hueca de piedra, y las cerchas apoyan sobre un durmiente de madera colocado en el extremo interior del mismo.

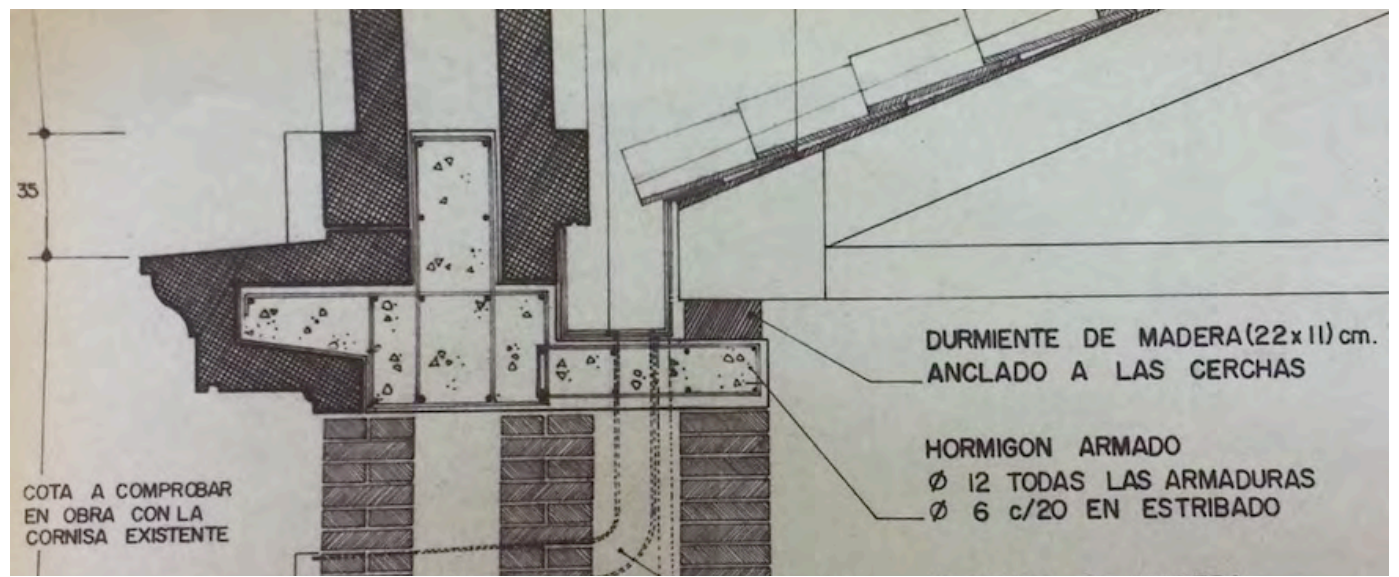

llustración 15: detalle 1987 Linazasoro JCyL

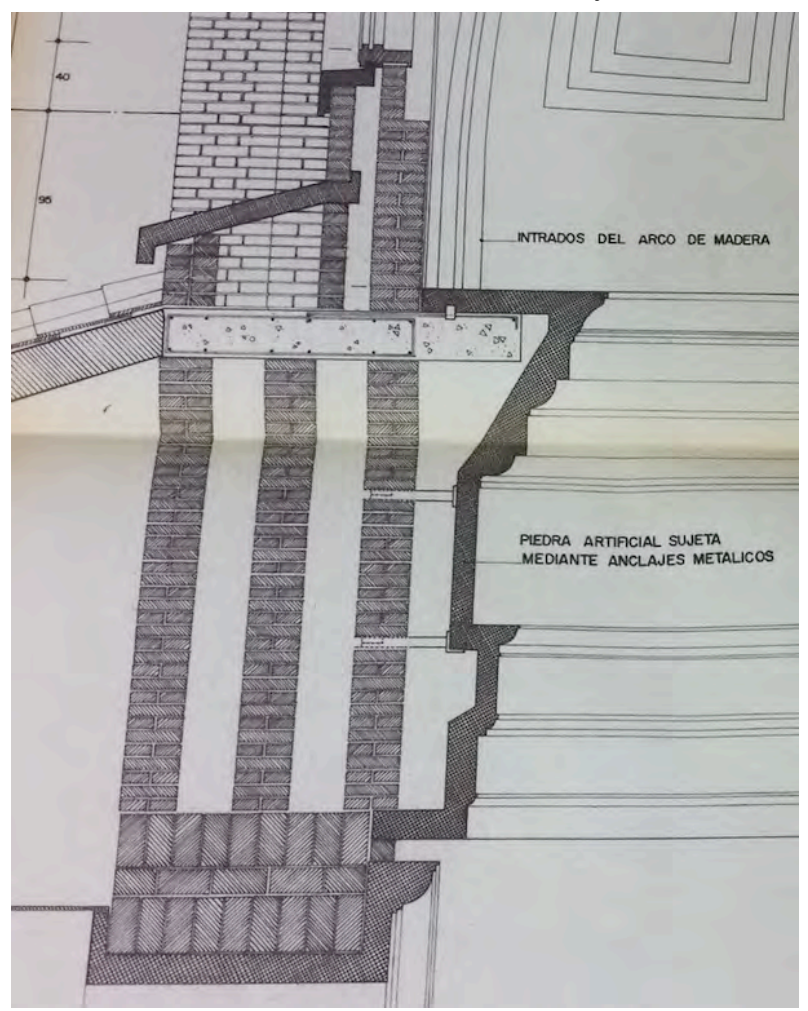

Ilustración 16: detalle 1987 Linazasoro JCyL

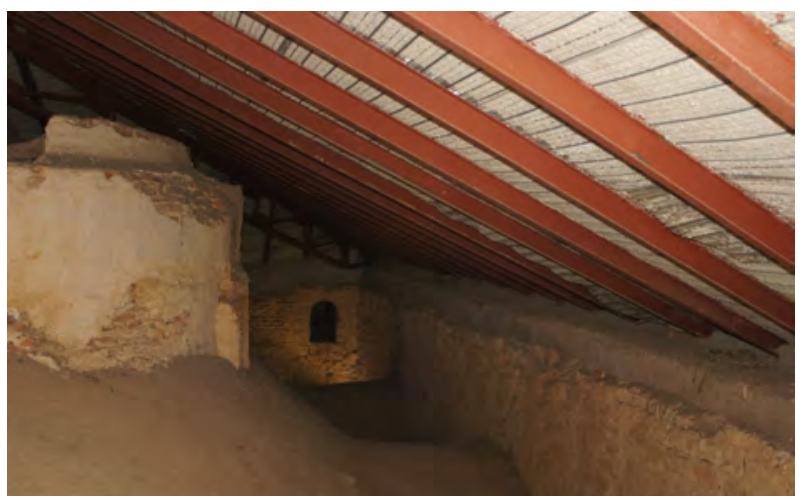

Ilustración 17 : bajo cubierta cabecera 25/08/2015
En la misma sección constructiva donde se define el apoyo de la cercha puede apreciarse cómo el arco de madera que forma el intradós de la nueva cubierta de la nave arranca también sobre una viga plana de hormigón armado que remata la triple hoja de fábrica de ladrillo a la que se ancla la moldura hueca que forma una cornisa interior de piedra artificial.

En la visita se comprueba que en la cabecera se ejecutó la estructura diseñada en 1979 por Ana Iglesias, con una cubierta de hormigón y nervometal sobre perfiles de acero laminado apoyados en un zuncho perimetral de hormigón armado. 


\section{Conclusiones}

En este edificio se incorporó una estructura, embebida en la fábrica hueca de ladrillo y tras las molduras de piedra artificial, que cuenta con vigas de hormigón armado en los dos niveles de apoyo de arcos y cerchas de madera laminada.

El zuncho o viga ejecutado que se observa en la visita no concuerda con el definido en los planos de detalle del proyecto. 


\section{Iglesia de Santa Cruz en Medina de Rioseco}

Intervenciones citadas en la publicación del Ministerio

1964 - Cubiertas - Anselmo Arenillas

1968 - Fachada - Anselmo Arenillas

1970 - Fachada - José Ángel Rodrigo García y Joaquín Roldán Pascual

1971 - Fachada - José Ángel Rodrigo García y Joaquín Roldán Pascual

1972 - Bóvedas, cubiertas y fachadas - José Ángel Rodrigo García y Joaquín Roldán Pascual

1972 - Bóvedas, cubiertas y fachadas - José Ángel Rodrigo García y Joaquín Roldán Pascual

1974 - Fachada - José Ángel Rodrigo García y Joaquín Roldán Pascual

1974 - Fachada - José Ángel Rodrigo García y Joaquín Roldán Pascual

1974 - Fachada - José Ángel Rodrigo García y Joaquín Roldán Pascual

1976 - Cubiertas - José Ángel Rodrigo García

1978 - Retablos - José Ángel Rodrigo García

1979 - Obras urgentes de consolidación - Ana Iglesias González

1979 - Consolidación muros y contrafuertes - Juan Antonio Espejel y Ana Iglesias González

1984 - Consolidación de muros - José Ángel Rodrigo García

En la web del IPCE hay una planta de Arenillas 1964 y diez planos de plantas, alzados y secciones de Ana Iglesias de 1979.

\section{En el Archivo General de la Administración}

AGA 26/00131

1968 - Desmontado y cimentado de la fachada Anselmo Arenillas

Memoria: En los años cuarenta se acusó un serio desplome de esta fachada, que alcanzó 1,20m de desplazamiento de su vertical. Para contener esta ruina, la extinta Dirección General de Regiones Devastadas construyó unos inmensos contrafuertes de fábrica de ladrillo, cuya cimentación parece ser alcanzó $14 \mathrm{~m}$ de profundidad. Así logró inicialmente retardar el vuelco de la fachada, mas últimamente se ha apreciado que el movimiento prosigue, que este gran muro que tiene hasta $3 \mathrm{~m}$ de grueso se está separando del resto de la fábrica e incluso se separa de las bóvedas y esto se acusa sobre todo en la parte alta, allí donde no llegan los contrafuertes. 
De la observación de estos síntomas y de la información adquirida se deduce que el desplome no es debido a empujes de bóvedas ni cubierta, sino a fallo de cimentación que, en el templo no es profunda y en cambio al hacer los contrafuertes sólo encontraron terreno firme a las $14 \mathrm{~m}$ y antes el terreno estaba humedecido. Parece ser que la dársena del Canal de Castilla, situada en la parte alta del pueblo, tiene amplias filtraciones que actualmente discurren por la vaguada natural que constituye la calle Real y por debajo de ella; esta corriente es la que ha afectado a la cimentación. Contribuyó a su mal el relleno del cauce del río Sequillo, ahora ya dragado por la Confederación.

Se desmontará la fachada piedra a piedra, numeradas, los contrafuertes y las bóvedas del primer tramo a los pies. Se hará nueva cimentación con pozos.

Plantas y alzados 1:100 con contrafuertes y sin ellos. Sección longitudinal.

En el presupuesto mide $22 \times 8$ en nave central y $2 \times 10 \times 5$ en laterales $=276 \mathrm{~m} 2$ demolición de primer tramo de bóveda de ladrillo y yeso. 2x11x19_418m2 demolición de primer tramo de nave de cubierta y armaduras.

$26 / 00110$

Santa Cruz 1976

La obras del templo dieron comienzo en los primeros años del siglo XVII.

Dos siglos más tarde, en 1755, a consecuencia del terremoto de Lisboa, se abrieron grandes hendiduras en las últimas bóvedas, y la fachada se inclinó ligeramente.

Para consolidarla, se desmontó el coro cerrando con sillares los arcos de las dos últimas capillas, colocando grapas de hierro en los muros exteriores.

En febrero de 1954 se produce el hundimiento del último tramo de la bóveda con un mayor riesgo de ruina para la fachada.

Posteriormente y ante el riesgo de ruina inminente se colocó un eficaz sistema de contrafuertes muy aparatosos, que si bien resolvía el problema inminente de la consolidación, no era deseable una larga situación con este aspecto anacrónico.

Así, promovida por la Dirección General de Bellas Artes, se procedió en fecha reciente a la supresión de dichos contrafuertes, con el desmontaje casi total de fachada y muros transversales en el ámbito de la primera bóveda, siendo los sillares cuidadosamente clasificados para la posterior reconstrucción. 
En el año 1971 se inician las obras para la reposición de la fachada a su estado primitivo. Para ello se consolidó la cimentación con la formación de una losa armada en todo el ancho de la misma, a partir de la cual se fue levantando la fachada en fases sucesivas, alcanzando las cotas de 25,50, 35,50 metros, y coronación de frontón con sus acróteras, de acuerdo con los proyectos parciales que se confeccionaros.

En el momento presente, y elevada toda la fachada urge la reposición de las zonas de cubierta ausentes entre la primitiva cubierta y la fachada reconstruida, tanto en la nave central como en las capillas laterales.

La estructura portante se realizará en hierro laminado con cerchas y correas de P.N.

Aparte de la estricta cubrición de las zonas ausentes de ella, se prevé una sustitución paulatina de todo el entramado portante de la cubierta, de madera en mal estado, por elementos metálicos, siendo así mismo objeto de este proyecto la sustitución hasta una longitud de 19,50 metros.

Hay una sección transversal del estado actual 1/100 y muchos detalles en planos cuya firma parece de Rodrigo y Roldán

Otro proyecto 1974. Detalles enormes de cornisa. Plano de consolidación hormigón sobre bóvedas.

AGA 26/01799

Restauración y consolidación de retablos

Traslado y recuperación tras los hundimientos del 31 de enero y el 27 de abril de 1977.

Dentro hay un plano con una serie de esquemas en sección "Análisis de hundimiento producido en la iglesia de Santa Cruz ... el 31 de enero de 1977"

AGA 26/00183

1970 - Proyecto de restauración Fachada de la Iglesia de Santa Cruz - Rodrigo y Roldán

Las obras origen y objeto del presente proyecto alcanzan a la consolidación de cimientos, desmontaje y clasificación del perímetro que permanece en la zona de basas de pilastras y la posterior construcción de una altura de 4,11 metros, equivalente a once hiladas sobre la cota del terreno actual. 


\section{Sistema de ejecución}

A fin de lograr un aligeramiento de la nueva fachada, se proyecta la ejecución de un doble muro de dos piés de ladrillo macizo trabados ambos con muro transversal de un pié de ladrillo macizo. El más exterior de dichos muros sirve de trasdós a la sillería de fachada que se irá subiendo al mismo tiempo y debidamente engatillado al mismo.

Cada dos metros aproximadamente de altura, se dispondrá un zuncho perimetral de toda la altura de la sección de fachada, y altura de $15 \mathrm{cms}$. en hormigón armado, que correrá también por los muros de traviesa hasta anclar firmemente en la parte existente de dichos muros.

Hay 6 fotos en un sobre: se ve corte de la antigua armadura y contrafuertes tremendos. También ver si hay plano 7 con detalle cimentación sale zunchos en muro con armadura sólo 1 capa

\section{En el archivo del IPCE}

Carpeta 637-3

1972 - Proyecto de restauración de bóvedas, cubiertas y fachada de la iglesia de Sta. Cruz en Medina de Rioseco (Valladolid) - Rodrigo y Roldán

(Carátula Dirección General de Bellas Artes, julio de 1972)

Memoria

Planos (falta el primer tramo de bóveda)

Carpeta 633-2

Carta del arquitecto Antonio Espejel al Ministerio de Cultura explica en marzo de 1982 sobre el proyecto reformado que:

La iglesia está en proceso de restauración bajo su dirección facultativa desde octubre de 1980 con el proyecto de agosto de 1979 de Ana Iglesias

El estado actual del monumento es de ruina parcial.

Orden de las obras:

Regiones Devastadas levanta cinco grandes contrafuertes en fachada principal, ante su deterioro y extraplome (Arenillas Álvarez)

Se desmonta la fachada, los contrafuertes y la $1^{\mathrm{a}}$ crujía de crucero y se tapia la fachada provisional a base de muro doble de ladrillo hueco con llaves desde el suelo hasta el arco fajón correspondiente (Arenillas Asín). Se desploma entonces, la bóveda de la $2^{\mathrm{a}}$ crujía entre el arco fajón tapiado y el siguiente. 
Desde 1979 se comienza a levantar de nuevo la fachada principal con los primitivos sillares de arenisca y trasdosado de hormigón, hasta su total terminación, así como los muros laterales de cerramiento y los intermedios de arriostramiento, de esta $1^{\text {a }}$ crujía, hasta 1975 (Luis Ángel Rodrigo)

A finales de 1976 se comienza la nueva etapa de restauraciones de la nave y capillas laterales, por presentar la Iglesia, ya en 1976 serios signos de agrietamiento en diversas partes, además de permanecer aún sin cubrir y sin bóveda la $1^{\text {a }}$ crujía y sin bóveda y con la cubierta semideshecha la $2^{\text {a }}$ crujía (Luis Ángel Rodrigo)

Es en esta etapa, y en Enero de 1977, cuando se produce (al cabo de algunas semanas de obras de forjado y retejado de las capillas laterales) el reventado y desplome del contrafuerte del lado del evangelio entre la $3^{\mathrm{a}}$ y $4^{\mathrm{a}}$ crujías, del arco fajón correspondiente, y del muro basilical, bóvedas $3^{\mathrm{a}}$ y $4^{\mathrm{a}}$, tímpanos y cubierta.

A partir de este hundimiento, y por el testimonio de fotografías (testigos de yeso) se comprueba un progresivo agrietamiento en contrafuertes restantes y encuentros de bóvedas de capillas con arcos formeros.

El 16 de Abril se tira el arco fajón (anejo al hundimiento) correspondiente a la $2^{\mathrm{a}}$ y $3^{\mathrm{a}}$ crujías, mediante una tiranta de cable desde la torre.

E1 29 de Abril de 1977, se produce el hundimiento del contrafuerte de ese arco fajón del lado del evangelio, así como el muro basilical, bóveda de capilla correspondiente a la $2^{\text {a }}$ crujía y arco formero de ese lado.

Desde esa fecha hasta la visita efectuada en Diciembre de 1980, por el que suscribe este informe, la Iglesia ha permanecido básicamente en el mismo estado, aunque el agrietamiento en pilastras, arcos formeros y muro basilical del lado de la epístola se ha incrementado, así como el de la cabeza absidal y bóveda elíptica del altar mayor....

Proyecto reformado del realizado el 10-8-79 por Ana Iglesias. A. Espejel. Marzo de 1982

Memoria histórica

Se puede suponer que sea Felipe de la Cajiga el autor de las trazas del templo, las bóvedas por Fray Diego del Castillo y Francisco de cillero. Constructores: Mazuecos, los Gonzalez de Cisniega, Gomez del Rebollar y Berrojo.

La ejecución comienza en 1602 y finaliza en 1668.

La cabecera aun en pie es rectangular cubierta con cúpula elíptica iluminada por tres huecos verticales.

La torre se eleva a la derecha del altar Mayor, la sacristía a la izquierda, con sendas escaleras de caracol. 


\section{Estado actual}

Derrumbamiento de todo el muro basilical de la $2^{\mathrm{a}}, 3^{\mathrm{a}}$ y $4^{\mathrm{a}}$ crujía, y sus contrafuertes correspondientes

Semirruina o agrietamientos en cabeza absidal, torre y contrafuertes, bóvedas y muro basilical del lado de la epístola.

Deterioro del retablo del altar mayor

Permanencia de grandes montones de escombros del último hundimiento

Obras a realizar

Se desmontará la cubierta de la nave lateral derecha, levantando la teja curva existente, para su aprovechamiento posible y la estructura de madera que formaba la cubierta.

Se retira todo el escombro de la nave lateral clasificándose sillares, capiteles y otros materiales.

Se prevee un cajeado en la coronación del muro lateral izquierdo para la formación del zuncho.

Se preveen unos pozos de cimentación para los apeos metálicos frontales.

Se desmontará el muro de sillería y mampuesto del muro basilical derecho así como los contrafuertes.

Se ha previsto un zuncho de hormigón armado de $350 \mathrm{~kg} / \mathrm{m} 3$ de resistencia característica $180 \mathrm{~kg} / \mathrm{cm} 2$ en coronación de muro.

Se reforzarán las bóvedas de la nave lateral derecha con mallazo 30x30 y capa de hormigón de $8 \mathrm{cms}$.

Se atarán las pilastras al muro, mediante taladros y redondos con relleno de resina.

Los apeos se han calculado con perfiles de acero laminado, aprovechando los existentes de las cerchas que estaban previstas para esta fase de restauración antes del hundimiento.

La estructura de la cubierta de la nave lateral derecha será a base de perfiles normalizados.

La formación de la cubierta será con forjado de Nervometal o similar y capa de compresión de $7 \mathrm{cms}$. de hormigón de $\mathrm{Rk}=180 \mathrm{~kg} / \mathrm{cm} 2$ sobre la que se recibirá la teja curva vieja, con mortero bastardo de cal y barro.

Se ha previsto un revestimiento de hormigón de $350 \mathrm{~kg} / \mathrm{m} 3$ y $\mathrm{Rk}=180 \mathrm{~kg} / \mathrm{cm} 2$ de granulometría fina en relleno de pilastras deterioradas por el desplome de la nave lateral izquierda, así mismo se inyectará lechada de cal para el relleno de muros, mediante taladros... 
Presupuesto:

86,20ml cajeado de zuncho de hormigón en coronación de muro de nave lateral.

$86,20 \mathrm{ml}$ zuncho perimetral de 0,80x0,40 de hormigón de $350 \mathrm{~kg}$ de dosificación y 18 $\mathrm{kg} / \mathrm{m} 3$ de redondos en zonas de cubiertas. $\mathrm{Rk}=180 \mathrm{~kg} / \mathrm{cm} 2$.

$6115,39 \mathrm{~kg}$ estructura metálica en perfiles normalizados en estructura de cubierta PNI-220; PNI-80; D100; D16

En los planos señala zuncho con flechas sobre los alzados. (saco fotos)

\section{Carpeta PI-639-1}

Anejo a la memoria con revisión de precios, cuadro de jornales, medición, etc.

Memoria descriptiva de la segunda fase de las obras. Análisis de causa de la ruina.

Propuesta de tercera fase.

Planos de diciembre de 1982.

Proyecto de bóveda moderna de $20 \mathrm{~m}$ de radio resuelta con una celosía metálica ligera.

\section{En el archivo de la Junta de Castilla y León}

\section{VA-005}

Carpeta 5201

Proyecto de Espejel mejor conservado que la documentación del IPCE.

Mayo de 1983.

Cobertura abovedada sobre estructura metálica mediante la extensión de una lámina fijada a la estructura compuesta por planchas de cobre de $2,00 \mathrm{~mm}$ de espesor... en los laterales. Con placas de policarbonato traslúcido en el centro de la bóveda.

Los muros laterales se revisten con teja.

"Será precisa la consolidación de la coronación del muro lateral sobre la que se dispondrá la cornisa de piedra comprendiendo: desmontado de elementos sueltos disgregados y o recrecidos de ladrillo, fijación de la sillería y mampostería con mortero de cal 1:4 nivelando la superficie con relación al nivel del zuncho, reposición de piezas que falten en igual material y limpieza".

Anejo de cálculos a mano de pórticos de hormigón y viga bajo cubierta.

Planos de diciembre de 1982. 


\section{VA-019}

Carpeta 5210

Proyecto Reformado abril 1987

Restauración de la iglesia de Santa Cruz

Arq. redactor JI Linazasoro

Arq colaborador: Salvador Mata Pérez

Varias memorias.

Proyecto modificado anulado.

Final de obra con dossier fotocopias de fotografías y planos en A3.

Documentación administrativa y certificaciones.

\section{Carpeta 5211}

Segundo Proyecto modificado (a cero).

Proyecto Reformado abril de 1987.

José Ignacio Linazasoro.

Colaboradores arq: Barrenechea, Franches, Iriondo, Urbizu. Y asesoría de Pérez Arroyo.

Consolidaciones. Mediante un triple sistema de inyecciones, bastonado y cosido multidireccional se han consolidado la totalidad de muros y contrafuertes...

Estructura. Se ha realizado mediante un sistema de madera laminada y con dos soluciones diferentes para la de cubierta y la de la bóveda. Para la cubierta se empleó un sistema de cerchas de pares únios de gran canto y doble tirante ayudado por dos tensores de acero verticales, $\mathrm{La}$ cubrición se llevó a cabo como estaba previsto reforzándola con un tablero hidrófugo y una lámina impermeabilizante.
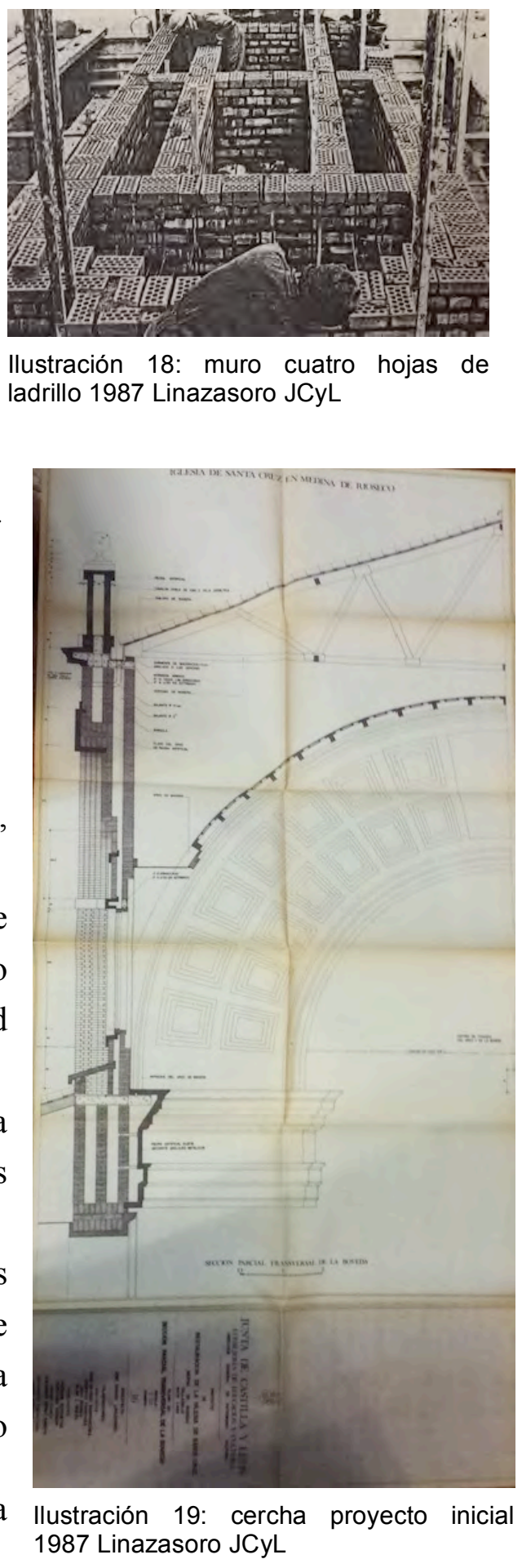

La estructura de la bóveda se realizó mediante un sistema de arcos triarticulados de madera laminada también, con correas de madera y tabla machihembrada. La estructura arranca de nervios de hormigón armado con la forma de la madera a modo de grandes salmeres, que más tarde se forrarán igualmente de madera. 
El resto de los muros de ladrillo se realizó de acuerdo con el sistema de muros capuchinos previsto, modificándose algunos puntos como la traba con la piedra y los desarrollos a la altura de ventanas y petos.

Hay un plano de sección constructiva en gran formato que describe el encuentro de la doble estructura de cubierta cercha-arco con el muro.

\section{VA-102}

\section{Carpeta 5290}

Restauración del atrio y capillas laterales de la iglesia de Sta. Cruz

Carta de salvador Mata pide disculpas por retraso encargado en septiembre de 1989 no ha entregado el proyecto en enero de 1990. Exigen entrega inmediata a Mata y Linazasoro con telegrama.

Proyecto diciembre de 1989. $2^{\text {a }}$ fase.

Memoria

En 1985 hay un proyecto de restauración de Linazasoro con modificado en abril de 1987. Actúa sobre un estado de ruina casi total de la iglesia tras un derrumbamiento en 1977. El proyecto era más una reconstrucción que una restauración.

Dossier fotográfico en color.

Planos.

\section{VA-211 (4 cajas)}

Acondicionamiento y rehabilitación para museo.

Pablo Puente Aparicio. Proyecto modificado de agosto de 1997.

\section{VA-413}

Emergencia en la iglesia de Santa Cruz. Mario Pírez. CYM YAÑEZ SA.

El motivo del expediente es la necesidad de ejecutar unas reparaciones de Urgencia, para solventar unas patologías constructivas aparecidas... de grave incidencia, por lo que el retraso en su ejecución pondría en peligro diversos elementos constructivos a mayores, algunos estructurales, que agravarían el problema a unos niveles peligrosos.

Por otro lado la voluntad de transformar en Museo dicha Iglesia, hace necesario que dichas obras se ejecuten inmediatamente.

Como se sabe la cubrición de la iglesia se ha efectuado mediante dos elementos estructurales independientes que descansan sobre los muros de fábrica de la misma a diferentes cotas. 
Ambos elementos estructurales están formados por maderas laminadas, siendo el interior el que conforma la bóveda de la iglesia, formado por unos grandes arcos fajones que transmiten las cargas a los contrafuertes de la fábrica, y unidos mediante correas longitudinales, con un acabado visto de madera MDF que ocultan las correas dejando vistos los arcos.

El elemento estructural superior que es el que soporta la cubierta, está formado por cerchas igualmente en madera laminada, formadas por dos pares y un tirante, con dos tensores verticales de acero a 1/3 de la luz que evitan la flecha del tirante. Dicha cercha estática, que descansa sobre el muro, como se puede observar en la sección constructiva del proyecto, aportada en el presente informe, no transmite esfuerzos horizontales al muro de fábrica, siendo su carga puramente vertical.

Sobre el conjunto de cerchas igualmente se dispone un sistema de correas de madera apoyadas en los pares... tablero de madera, al parecer también de MDF, colocándose sobre dicha base una lámina de Onduline bajo-teja como impermeabilizante.

El encuentro de dicho faldón con el muro se resuelve mediante una serie de cartabones... listo para desarrollar el pesebrón.

Es primordial y fundamental el levantado de toda la teja de cubierta, así como del pesebrón de plomo y su basamento...

Informe final

Las patologías... consecuencia de las grandes dimensiones de la cubierta,... El gran problema surgido era el deslizamiento de la cubierta de teja sobre la impermeabilización de Onduline debido a la inclinación de la cubierta, y a la falta de recibido suficiente de las tejas a la base no respetándose el recibido cada cinco hiladas.

Este desplazamiento arrastró en su avance a las planchas de plomo en algunas áreas.

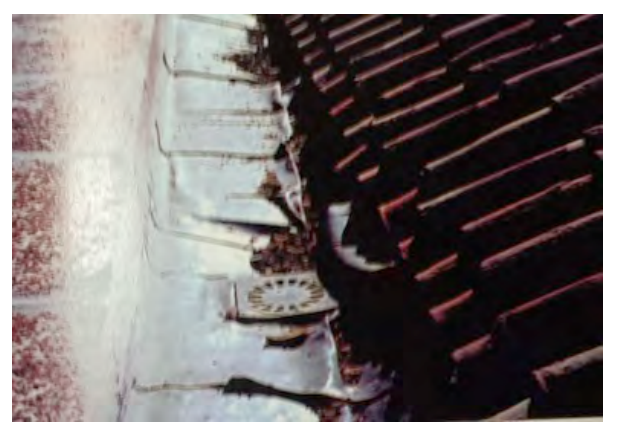

Ilustración 20: patología dossier Pírez 


\section{Visitas realizadas}

$25 / 08 / 2015$

El estado de conservación general del monumento es bueno, aunque hay un problema de diseño de la cubierta $\mathrm{y}$, tras haberse reparado hace pocos años el deslizamiento de teja sobre el onduline y el arrastre de la lámina de plomo del canal, están aflorando humedades producidas por el mal funcionamiento de las bajantes embebidas en los muros.

En el trayecto de subida a la bóveda se ha detectado también cómo los sillares del muro que envuelve la escalera de caracol se están descascarillando, apareciendo fisuras también por la cara exterior de la torre.

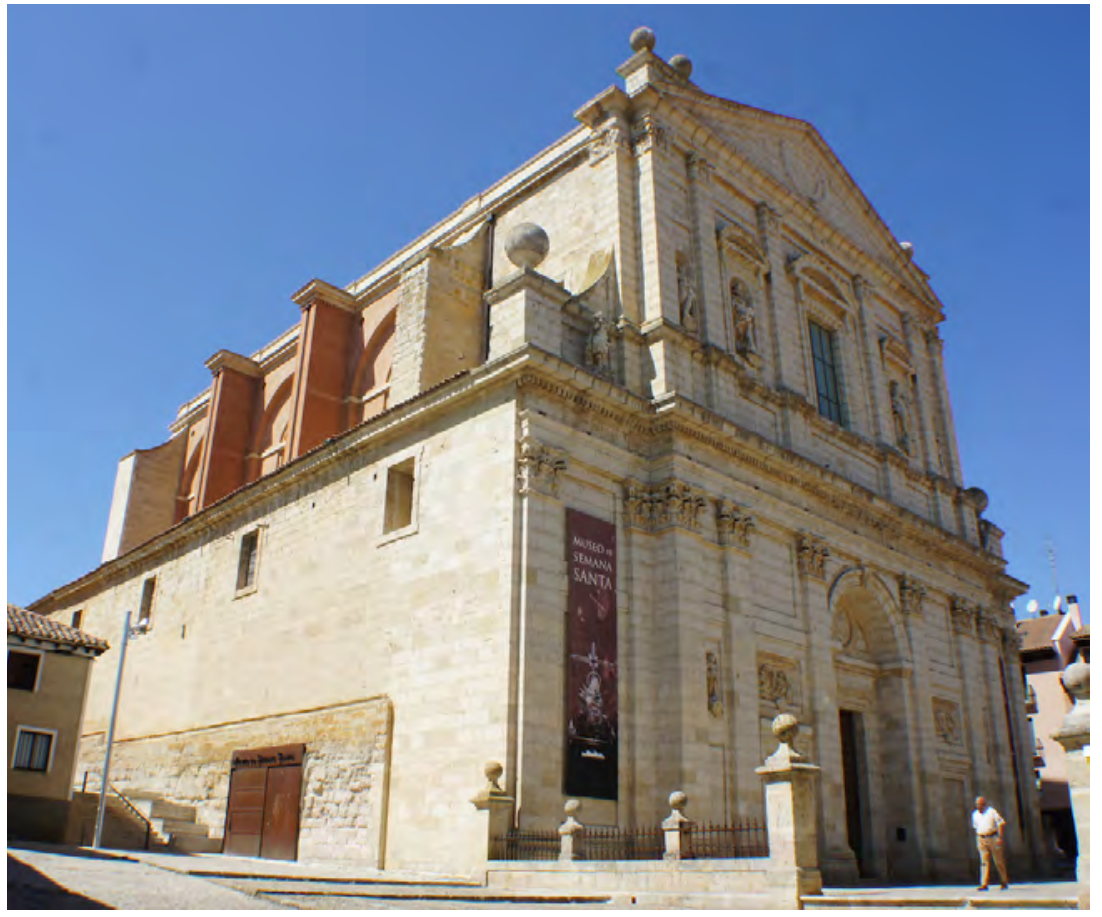

La subida a la torre se cubre con un forjado de perfiles de acero y entrevigado de bovedillas cerámicas.

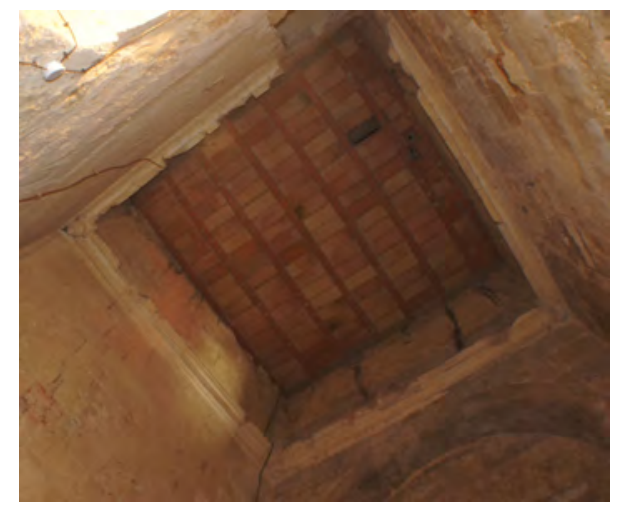

Cúpula y linterna de fábrica de la cabecera se cubren con una estructura metálica con tablero formado por nervometal y hormigón, apoyada sobre zuncho perimetral de hormigón armado y en un cerramiento lateral de tabicón. 

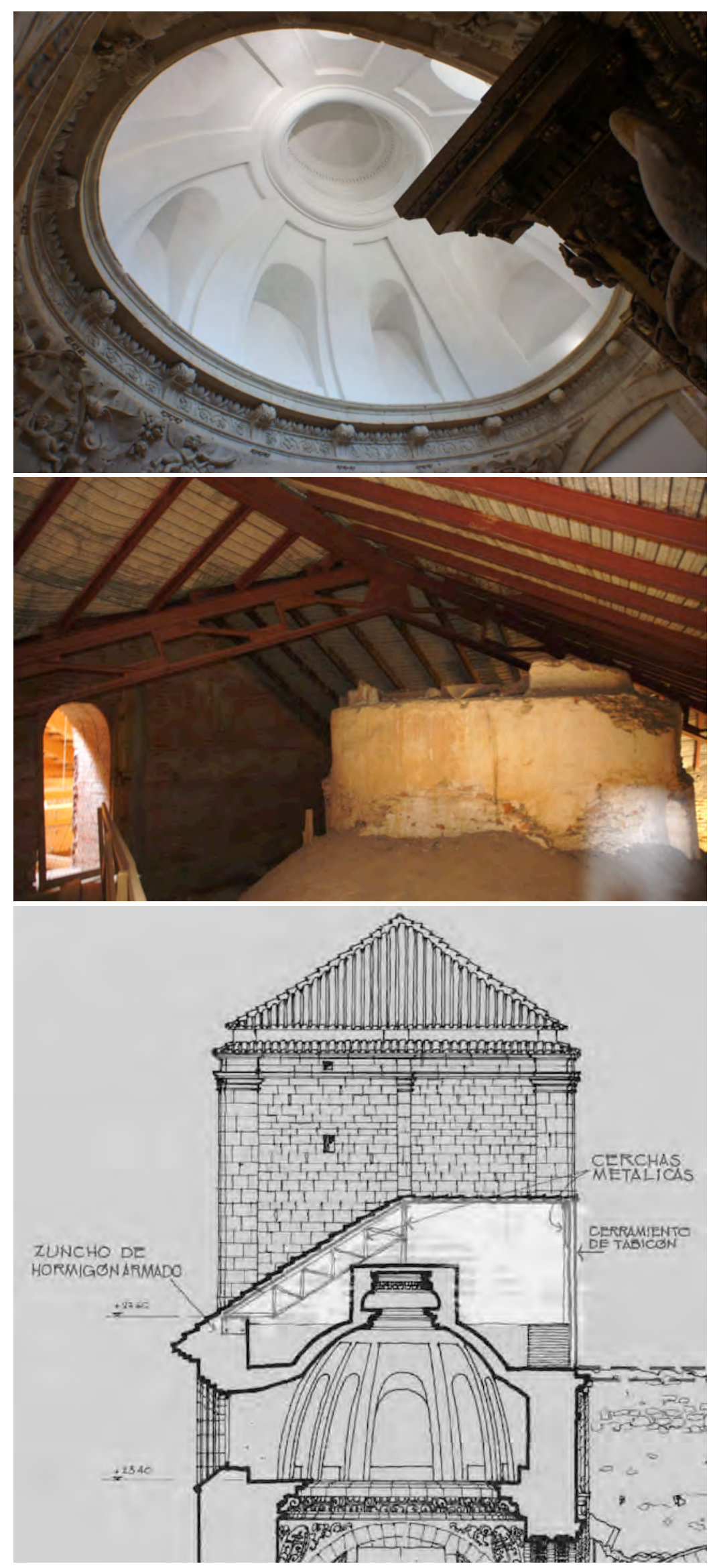
La estructura de cubierta del cuerpo de la nave observada coincide con la definida en el plano de sección del proyecto de Linazasoro, con arcos y cerchas, de madera laminada encolada, con tirantillas.

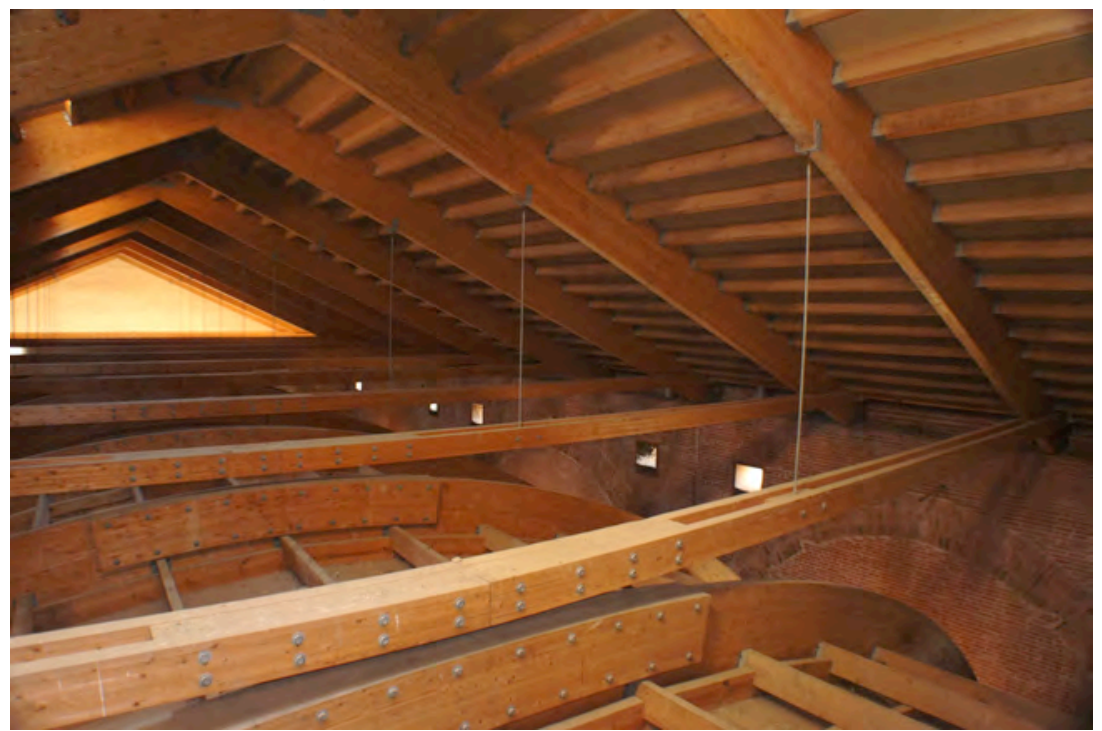

Se aprecia, sin embargo, que las vigas de hormigón sobre las que apoyan las cerchas se encuentran revestidas por fábrica de ladrillo, mientras que según el detalle definido en el proyecto debieran quedar vistas y enrasadas con dicho paramento.

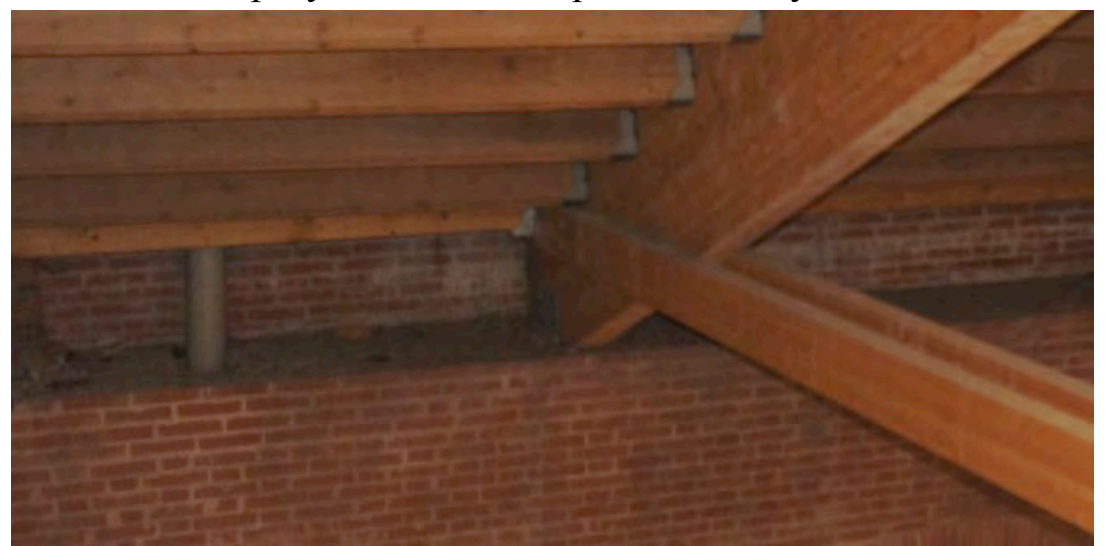

En el interior del museo se interrumpe la bóveda con su intradós revestido de madera, dejando al descubierto las dos primeras cerchas hacia los pies.

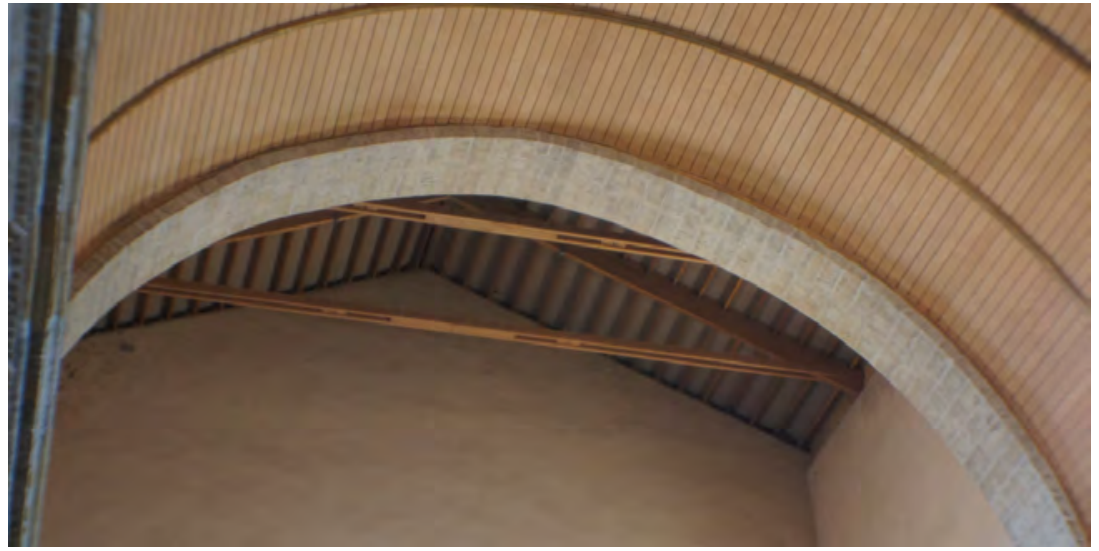



FICHA SÍNTESIS

\section{Código de identificación: FZ-27}

Denominación:

Iglesia de Santiago Apóstol

Localidad:

Medina de Rioseco

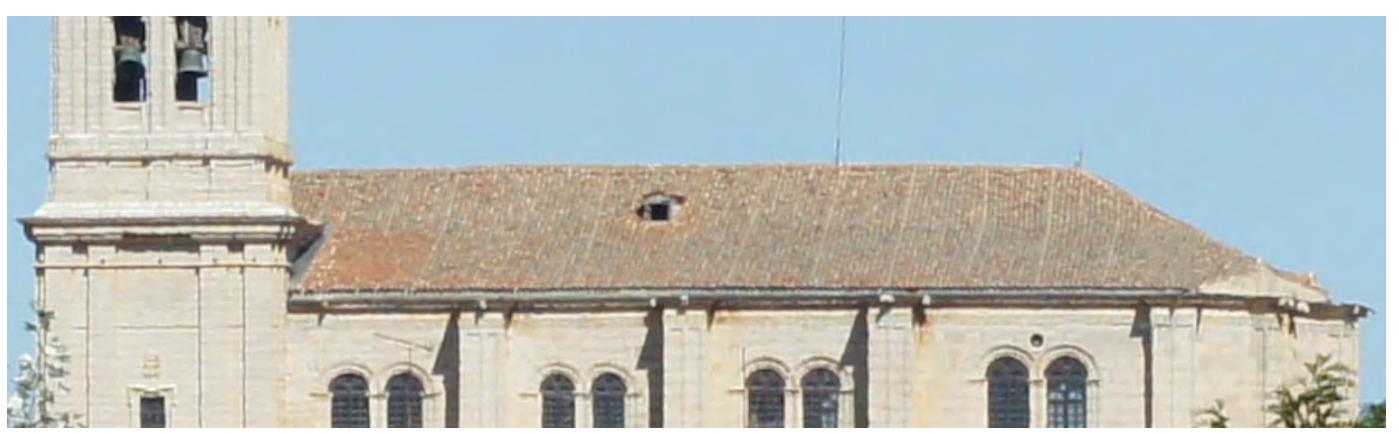

\section{Descripción}

Iglesia de tipo salón, con tres naves de cuatro tramos cubiertas a la misma altura y separadas por pilares cruciformes. Un quinto tramo a los pies alberga el coro, entre el arranque de dos torres, de las que sólo la de la epístola sobresale por encima del cuerpo del templo. La cabecera se remata con tres ábsides semicirculares. Las naves laterales se cubren con bóvedas de arista y la nave central con cúpulas sobre pechinas, elípticas excepto en pies y cabecera, donde son de media naranja gallonada.

\section{Materiales}

Los muros son de cantería. Las cubiertas están revestidas de teja curva.

\section{Singularidades}

La fachada de inspiración herreriana a imagen de la Catedral, en una iglesia salón de gestación gótica, cubierta con bóvedas barrocas policromadas.

\section{Dimensiones básicas del templo}

$\begin{array}{lll} & \text { central } & \text { laterales } \\ \text { Ancho de nave } & 10,5 & 6,7 \\ \text { Altura } & 32,7 & 30,3\end{array}$

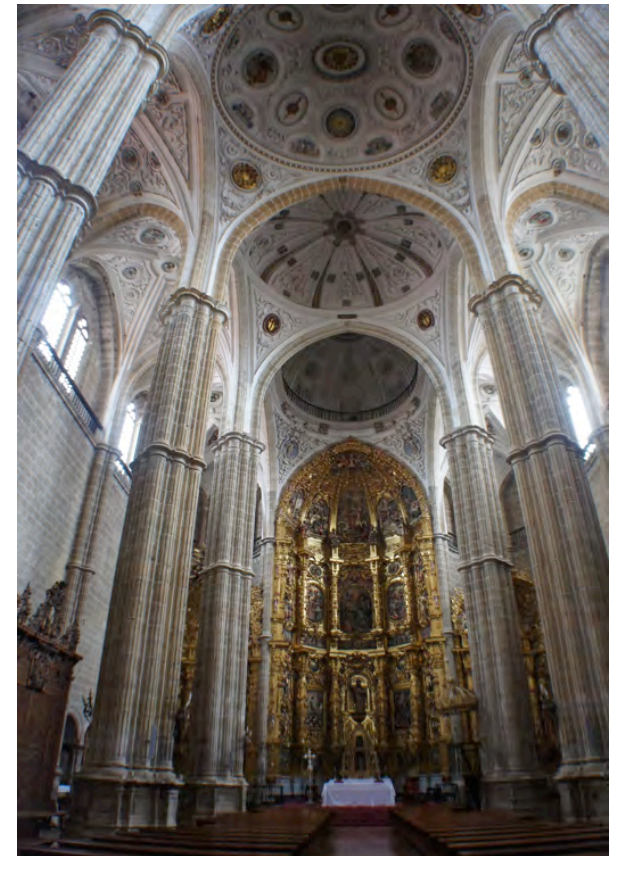

Ilustración 1: interior, visita 20/09/2015 


\section{Memoria histórica constructiva}

\section{Según el Catálogo:}

Templo levantado a partir de 1533 con trazas de Rodrigo Gil de Hontañón. A su muerte en 1577 sigue la obra Juan de Hermosa. En 1586 Alonso de Tolosa da trazas de pies y torre para acabar la iglesia bajo la dirección de Hermosa y otros. A partir de 1612 se derriba la antigua torre de piedra y se levanta, para soportar las campanas, una estructura provisional de madera. En 1642 Cillero da trazas para corregir el diseño de la torre y aumentar su altura, pero en 1660 ésta se arruina.

Las yeserías de bóvedas se realizan en 1673 y hacia 1678 se termina la reconstrucción de la torre. El coro no se remata hasta 1700.

\section{Cronología. Fechas clave}

$1533-1673-1978$

\section{Intervenciones}

1977 /1978 - Restauración - Ana Iglesias

\section{Incorporación de zuncho de hormigón armado.}

Demolición y reemplazo de la estructura de cubierta de madera en mal estado. Define una nueva de cerchas metálicas con correas y tablero de hormigón sobre nervometal.

\section{9 - Restauración - Ana Iglesias}

Interviene sobre la torre, donde define forjados metálicos, estructura, tablero de cubierta de nervometal y cosidos en la parte baja agrietada. Prosigue trabajos del proyecto anterior sobre la nave lateral adyacente a dicha torre y refuerza sus bóvedas.

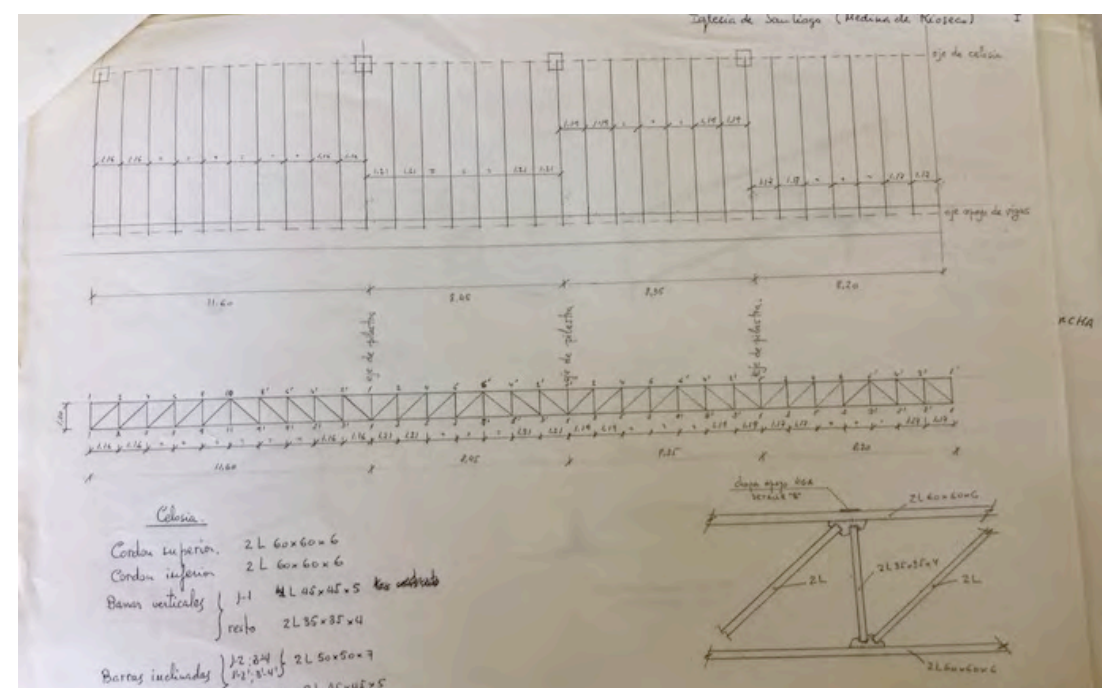

Ilustración 2: celosía metálica sobre ejes de pilares (Ana Iglesias 1979 IPCE) 
Los perfiles se sueldan "sobre la estructura de una gran viga corrida de celosía y sobre las pilastras que suponen la continuación de los pilares que conforman las naves".

1990 - Fachada oeste y torres - Jesús Manzano Pascual

Restaura la fachada principal a los pies con cosidos y reintegraciones mediante morteros de reparación, incorporando una cámara de ventilación junto a la misma para evitar las humedades de capilaridad. Se reteja fachada y torre.

2002 - Restauración de emergencia - Jesús Manzano

Repara sacristía y camarín, muy agrietados tras derrumbarse parte de la cubierta de este último.

\section{Planos}

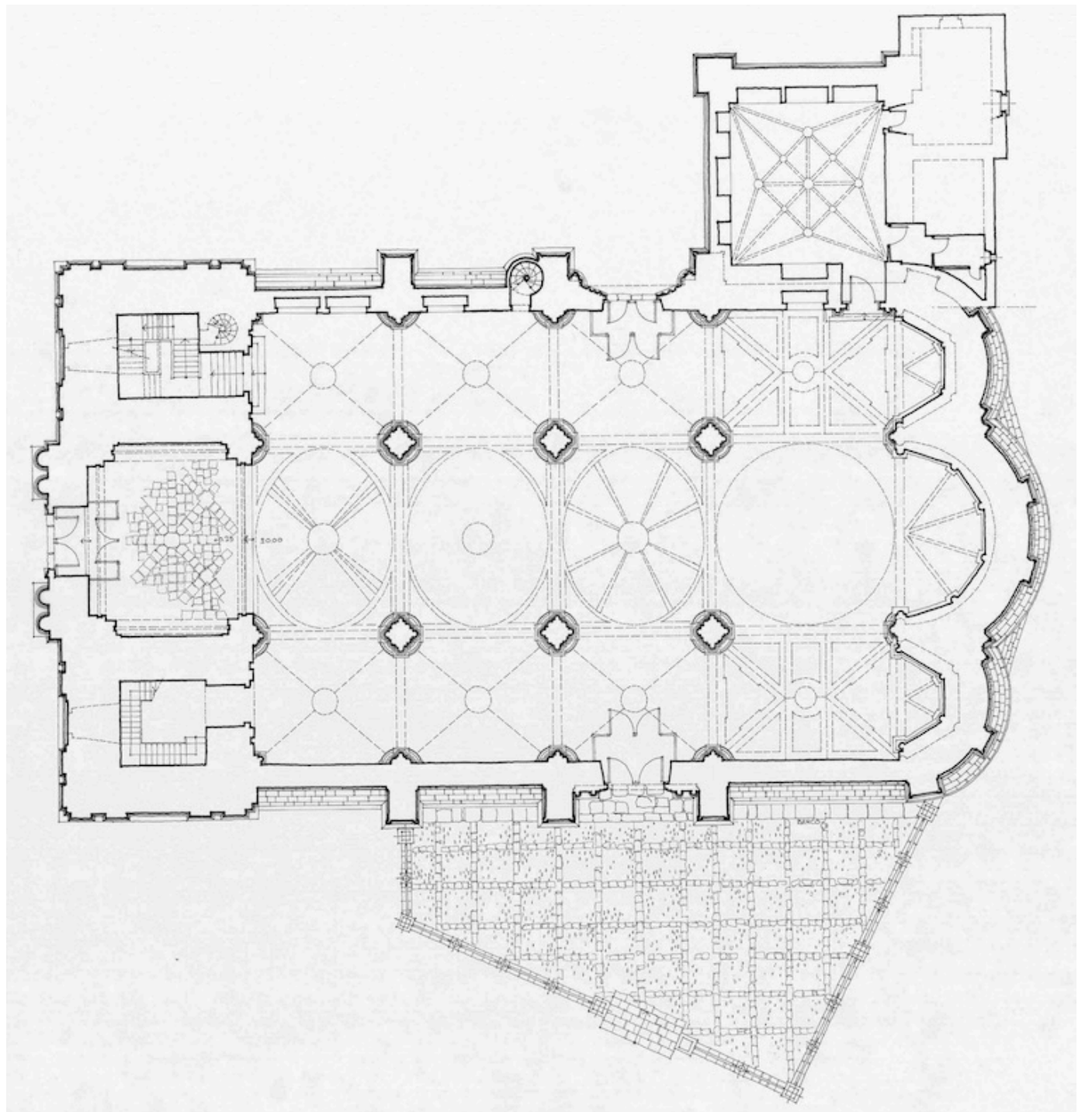

llustración 3: planta general (Ana Iglesias 1978 IPCE) 


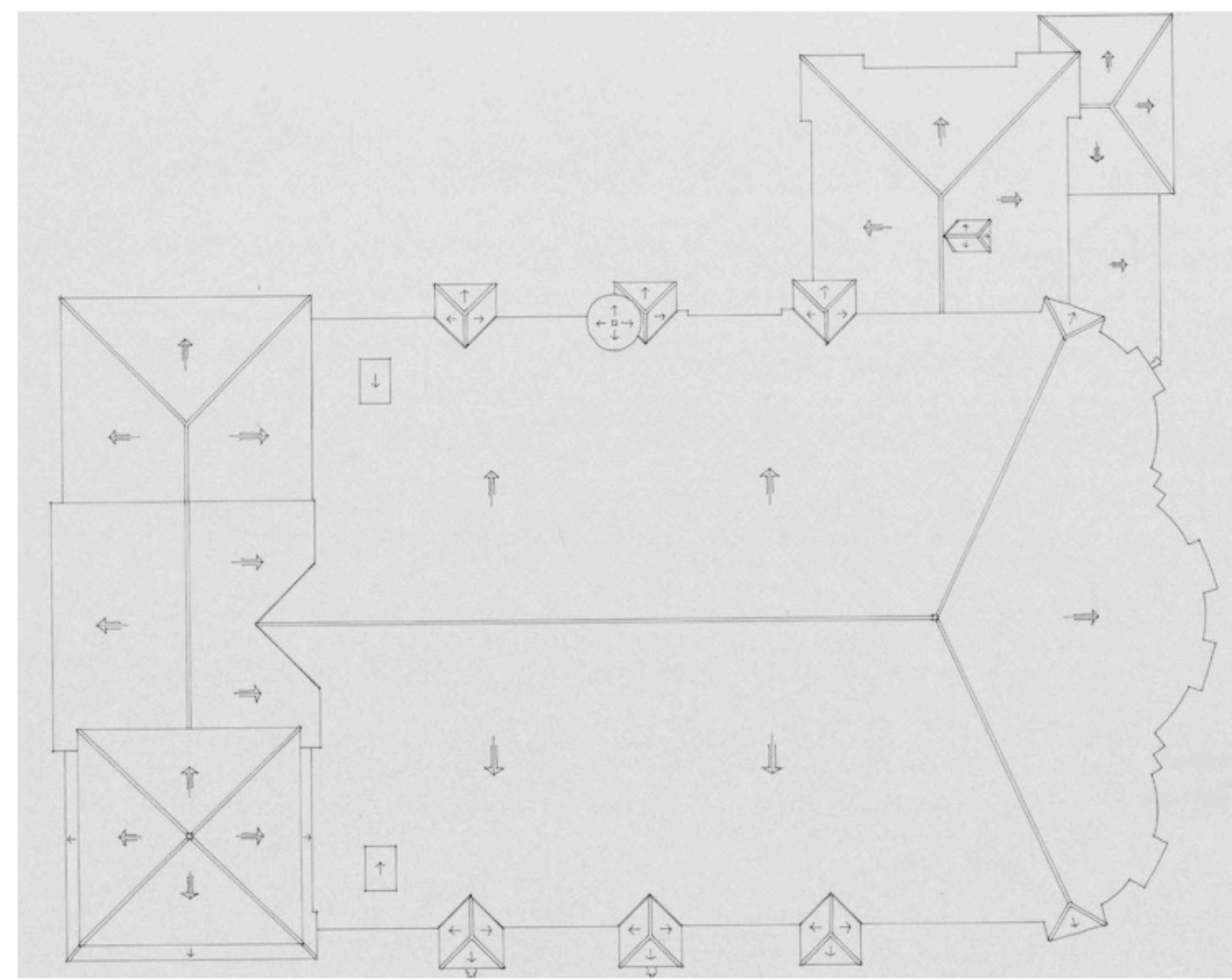

Ilustración 4: planta de cubiertas (Ana Iglesias 1978 IPCE)

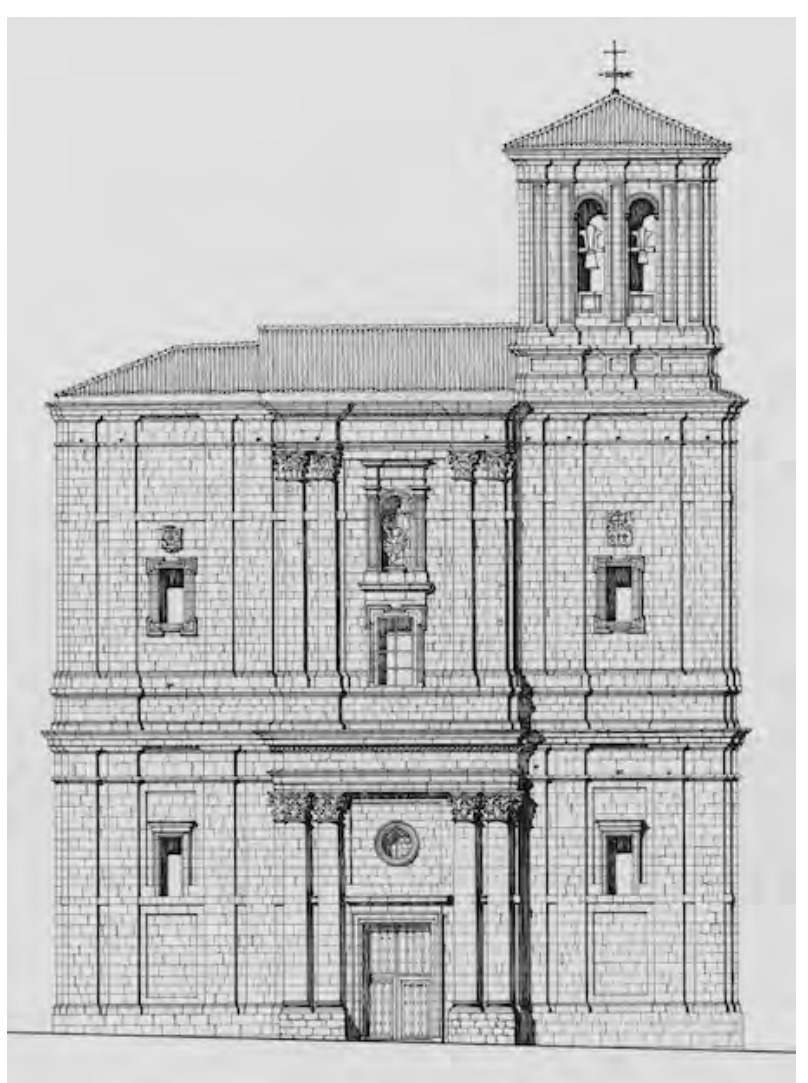

Ilustrac ión 5: fachada principal a los pies (Ana Iglesias 1978 IPCE) 


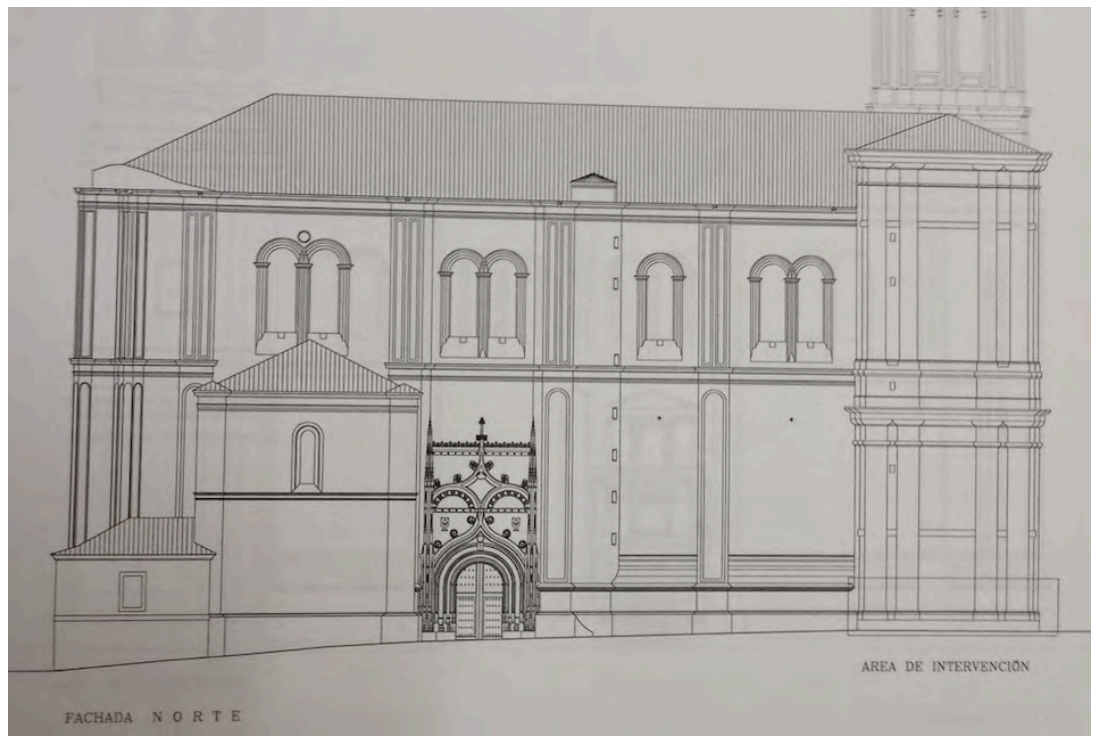

Ilustración 6: fachada norte (Manzano 2002 JCyL)

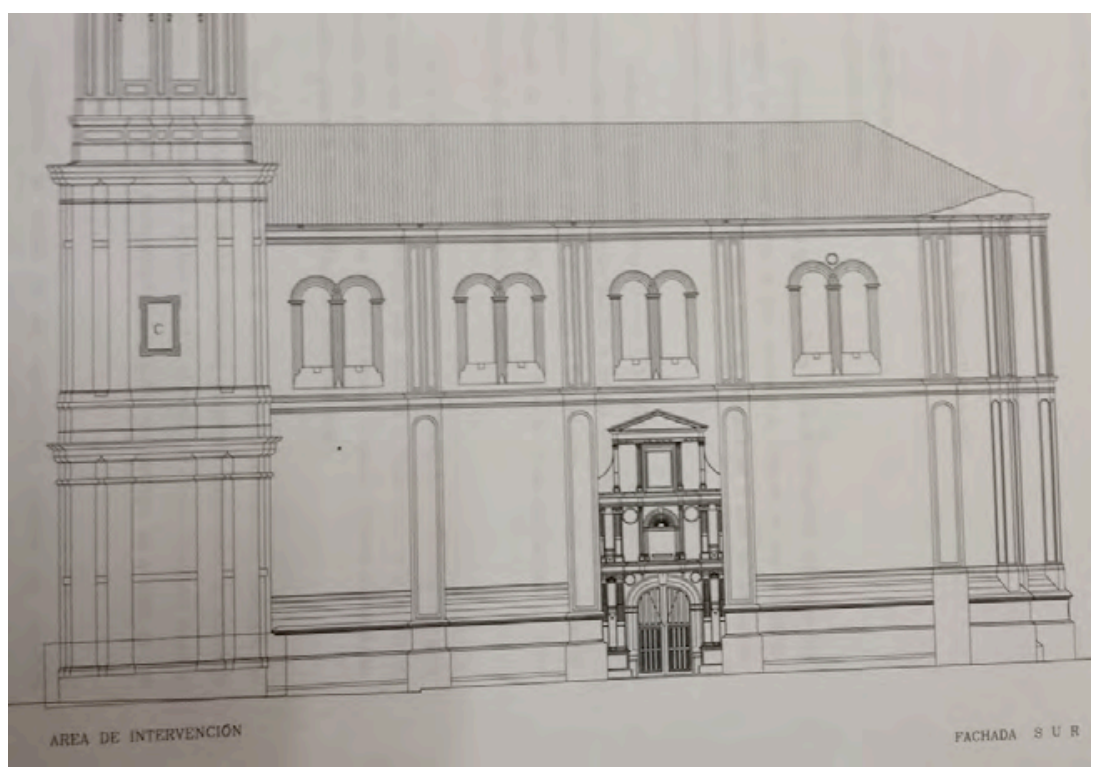

llustración 7: fachada sur (Manzano 2002 JCyL)

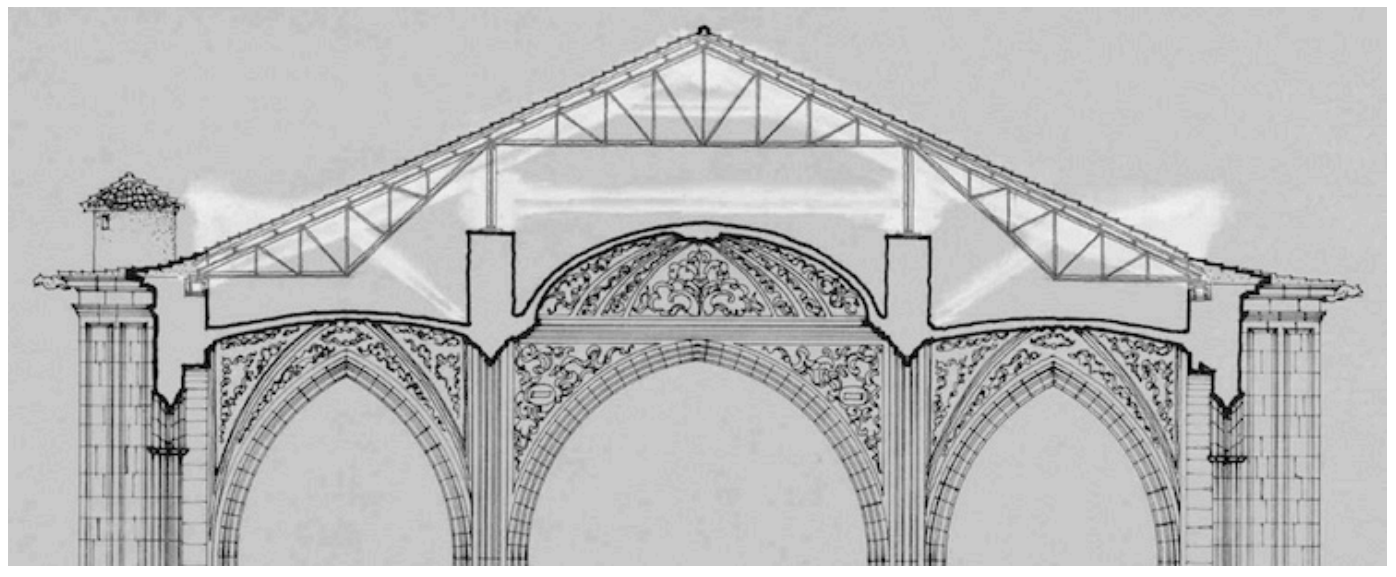

Ilustración 8: sección transversal (Ana Iglesias 1978 IPCE) 


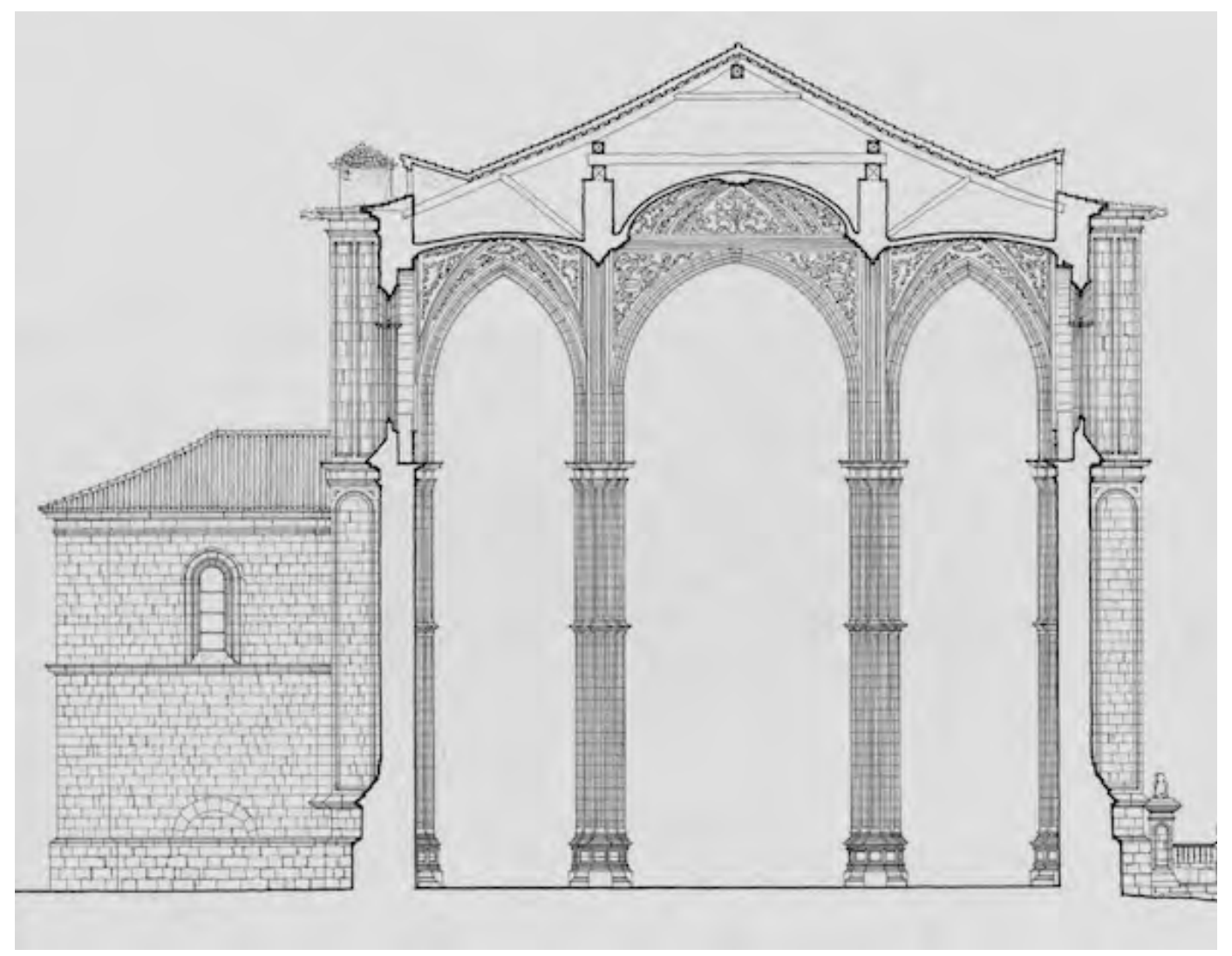

Ilustración 9: sección estado actual antes de la intervención (Ana Iglesias 1978 IPCE)

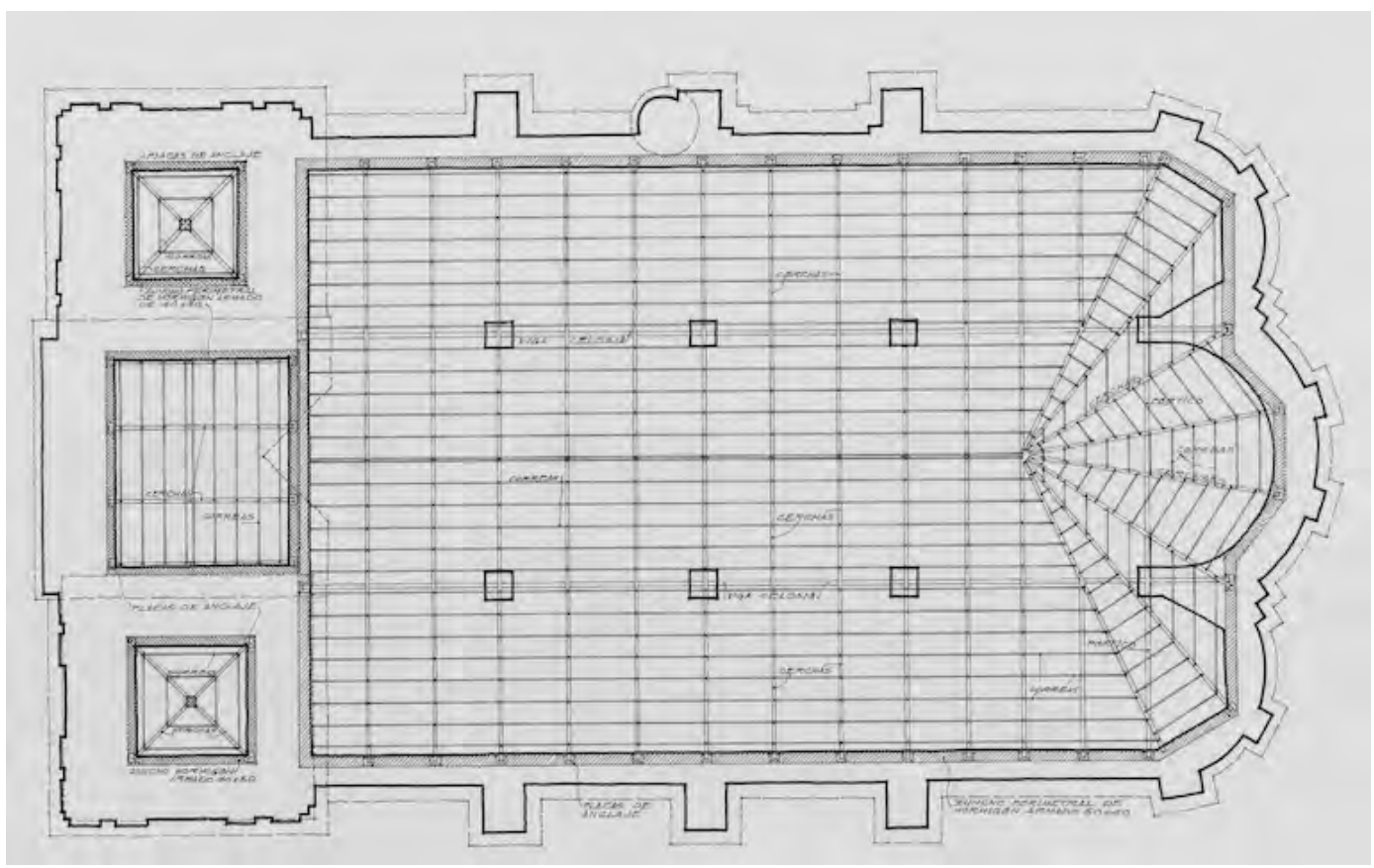

Ilustración 10: estructura de cubierta (Ana Iglesias 1978 IPCE) 


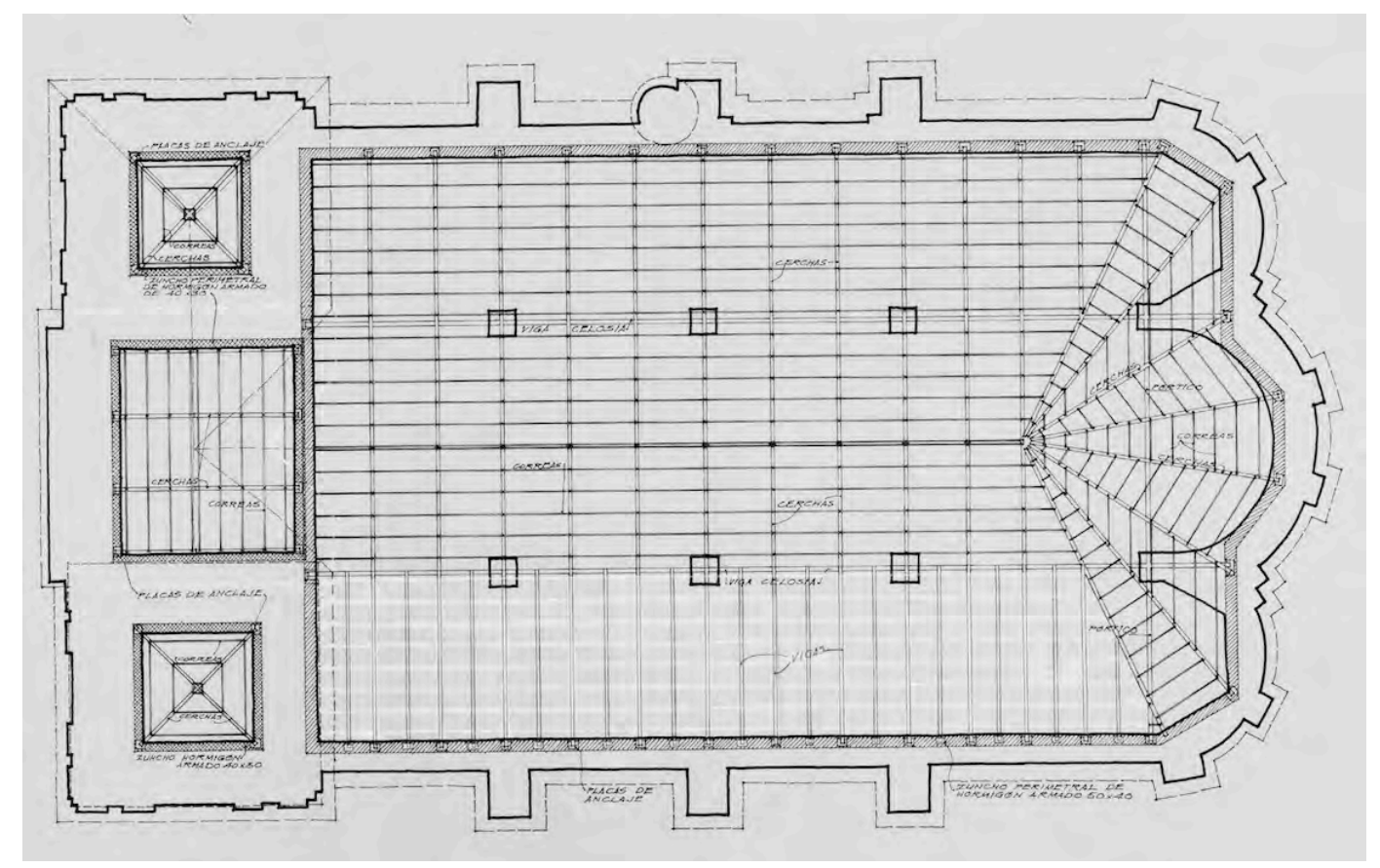

Ilustración 11: estructura de cubierta (Ana Iglesias 1979 IPCE)

\section{Solución constructiva de la cubierta}

En las secciones se aprecia cómo la estructura de cubierta de acero laminado diseñada por Ana Iglesias en 1978 contaba con dos celosías dispuestas en sentido longitudinal y apoyadas sobre los ejes de pilares que, según se ha comprobado en la visita al bajo cubierta, sí se ejecutaron. Según los detalles a mano en la carpeta del IPCE estas celosías se definen con 1,0m de canto. Sobre ellas, sin embargo, aparecen representadas en la sección unas cerchas, con cordones doble T sobre las tres naves, que no llegaron a colocarse.

Según las notas manuscritas, y los croquis que acompañan a los cálculos, en la crujía de la nave lateral del evangelio, ejecutada un año más tarde que el resto de la cubierta, las vigas son perfiles de alma llena IPE-200 dispuestos con la inclinación de la pendiente, solución que concuerda con la observada en la visita.
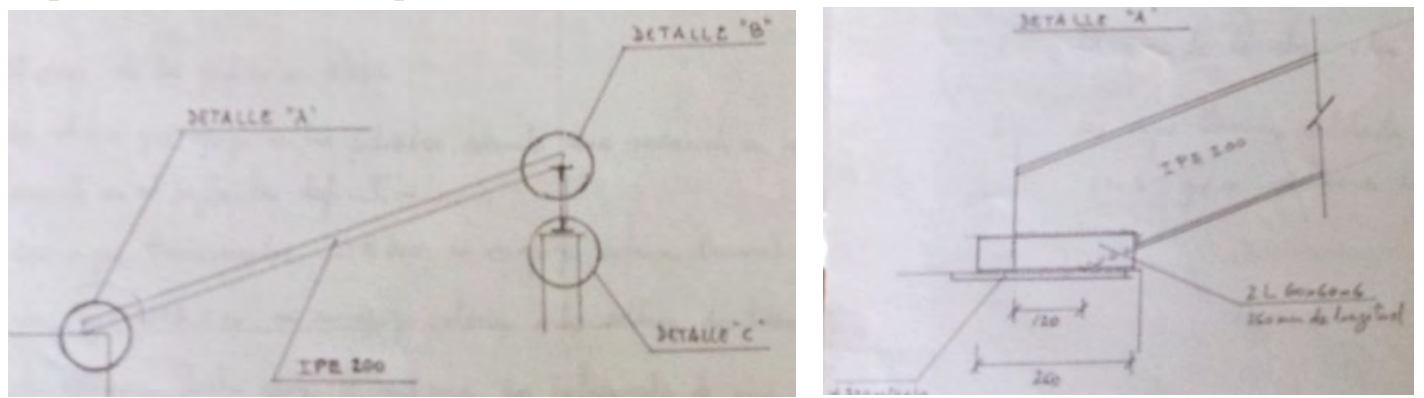

Ilustración 12: croquis 1979 Iglesias IPCE 
Sobre los planos podemos estimar una pendiente de unos $25^{\circ}$.
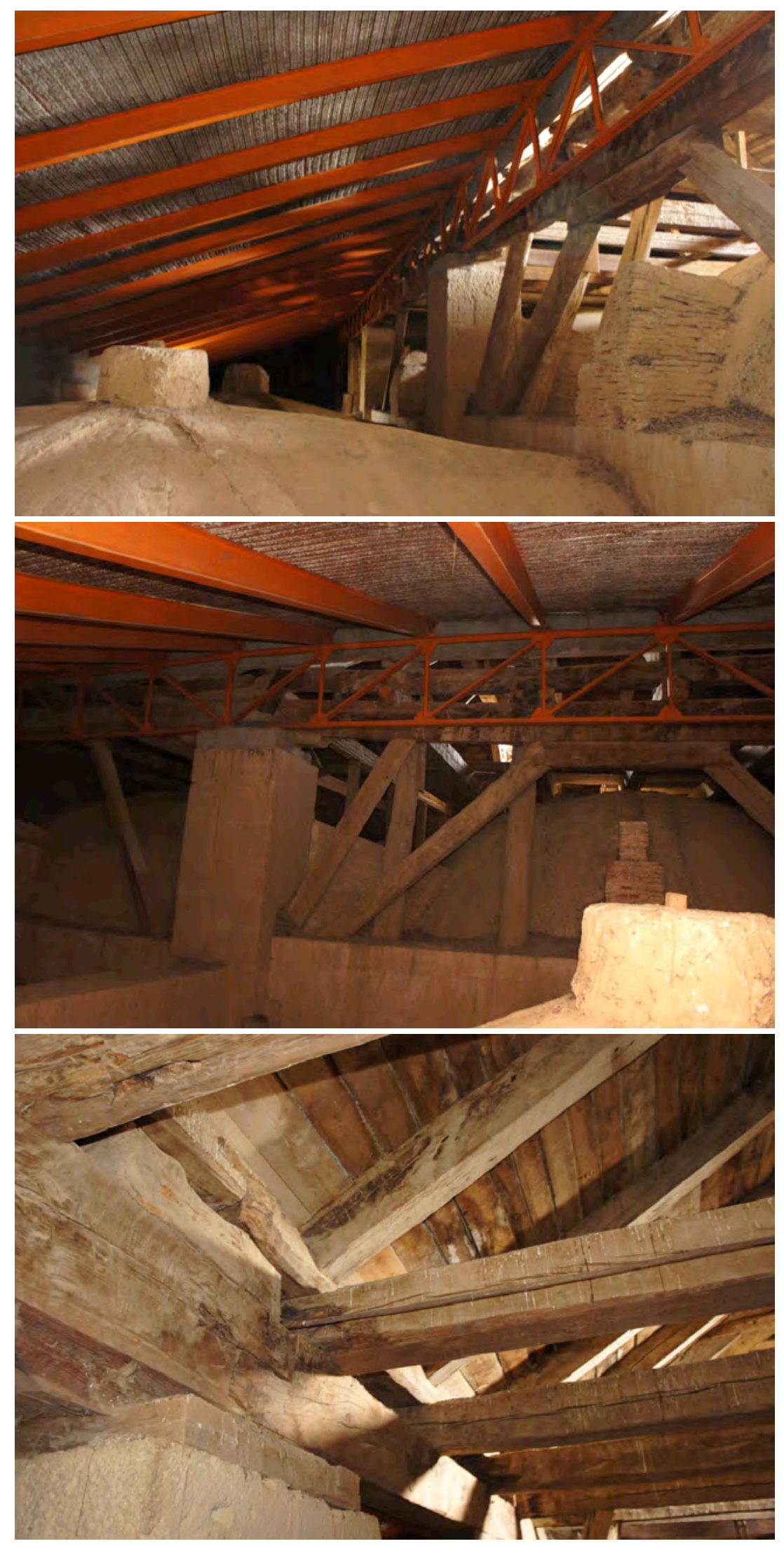

Ilustración 13: imágenes bajo cubierta visita 20/09/2015 
Sobre la nave central se conserva la armadura. En naves laterales se ha sustituido la madera por perfiles de acero laminado, formando el tablero con hormigón sobre nervometal. Una zona a los pies en nave central muestra también nervometal y hormigón en vez de la tabla ripia, con un par de tensores metálicos.

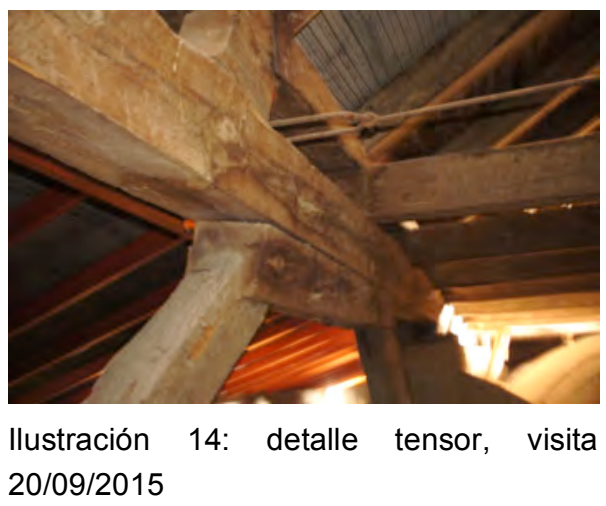

Sobre los machones de sillería en ejes de pilares se apoyan, tanto la nueva celosía metálica, como las antiguas armaduras de madera.

\section{Zunchos}

En los planos de planta de estructura de 1978 y 1979 se rotula "zuncho perimetral de hormigón armado 50x40", señalado sobre un anillo que rodea completamente el cuerpo del templo. Ambas torres y el espacio entre ellas se rotulan como zuncho $40 \times 30$.

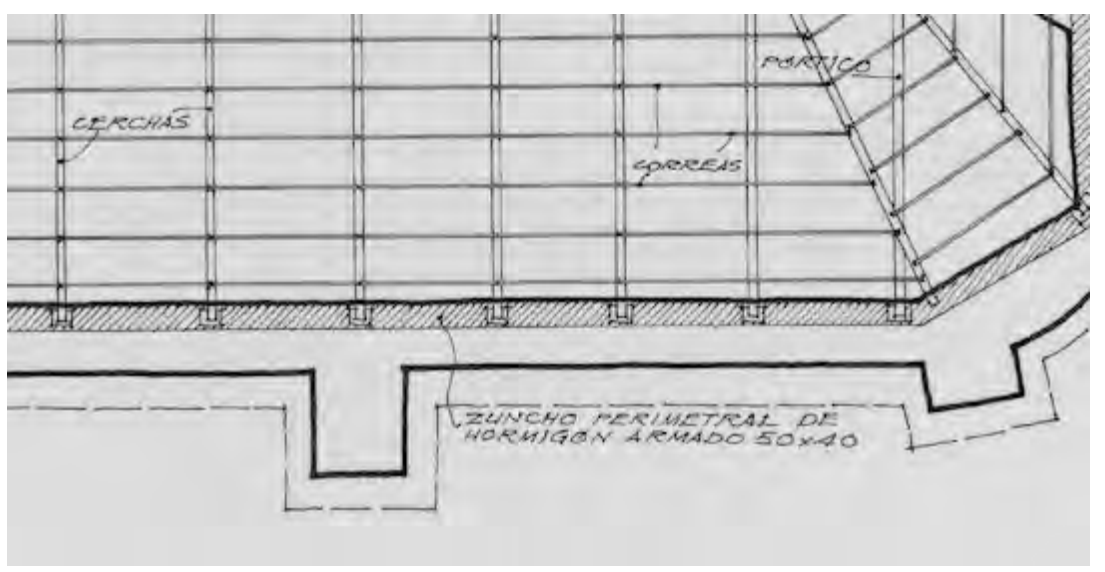

Ilustración 15: detalle de planta 1978 Iglesias IPCE

En el presupuesto de 1977 aparecen las mediciones de zuncho y cajeado con un total de $8,16 \mathrm{~m} 3$ que se desglosan para $0,40 \mathrm{x} 0,30 \mathrm{~m}$, y en el de 1979 encontramos la partida $61,88 \mathrm{ml}$ de zuncho $40 \times 50$, dimensiones que coinciden con los especificado sobre los planos.

En la visita se observa un zuncho corrido bajo ambos apoyos de los perfiles de acero en las naves laterales. En el extremo de los perfiles a menor cota el zuncho se enrasa con el paramento y presenta un canto de unos $45 \mathrm{~cm}$. 
El zuncho a cota superior se forma exento por detrás de la celosía metálica corrida longitudinal. Dicha celosía cuenta con unos dados de hormigón recrecidos sobre los machones de piedra para resolver sus apoyos puntuales.

\section{Conclusiones}

En este edificio se incorporó el típico zuncho rectangular de hormigón armado al reemplazar las armaduras de cubierta de las naves laterales por estructura metálica.

La solución ejecutada no se corresponde con los planos de los proyectos, ya que en éstos se define cerchas en toda la cubierta mientras que las naves laterales cuentan con una cubierta de vigas inclinadas de alma llena y en la nave central aún se conservan las armaduras de madera. 


\section{Iglesia de Santiago en Medina de Rioseco}

Intervenciones citadas en la publicación del Ministerio:

1978 - Cubiertas - Ana Iglesias González

1979 - Cubiertas y consolidación de una de las torres - Ana Iglesias González

En la web del IPCE hay seis planos de 1978, cinco de 1979 y uno sin datar, con plantas, secciones y estructura de cubierta.

\section{En el archivo del IPCE}

\section{Carpeta 639-2}

Obras de restauración en la iglesia de Santiago de Medina de Rioseco

Octubre de 1977 Ana Iglesias

Acta de recepción que definitiva firma ella, Merino de Cáceres por el Ministerio de Cultura y Alfonso Sancho Miguel por la constructora. Adjudicada en 1978 con recepción provisional en 1980 y definitiva en octubre de 1981.

7 pag a mano con los cálculos y detalles de la celosía el original a lápiz.

Memoria

"Obras a realizar: Consisten estas en las de restauración de sus cubiertas previa demolición de las existentes en muy mal estado. La estructura principal de madera ha fallado en algunas zonas, produciéndose un hundimiento notable en las proximidades de la torre con el consabido arrastre de correas, tablas y tejas. Se creará un zuncho perimetral de atado en la coronación de los muros que servirá de apoyo de la estructura que será formada con cerchas metálicas sobre las que se recibirán correas, creando sobre ellas tablero de nervometal que permitirá la construcción de capa de compresión que soportará la teja árabe, empleando el 30\% de la existente."

Mediciones:

Desmantelado de cubierta de teja curva, incluso armadura de madera, con clasificación de material aprovechable y transporte de escombros a vertedero. Medido en planta

$1 \times 28,00 \times 20,00 \quad=560 \mathrm{~m} 2$

Extracción y transporte a vertedero de escombros acumulados sobre las bóvedas 1ud Demolición de fábricas en apertura de cajas para alojamiento de zunchos de atado $2 \times 20,00 \times 0,40 \times 0,30 ; 1 \times 28,00 \times 0,40 \times 0,30=8,16 \mathrm{~m} 3$ 
Hormigón de $350 \mathrm{~kg}$ de cemento, garbancillo y arena de río, armado con $80 \mathrm{~kg}$ de hierro redondo al $\mathrm{m} 3$ en formación de zunchos de atado perimetral de muros. ídem 8,16

Estructura metálica de cubierta, compuesta por dos vigas de celosía en sentido longitudinal, cerchas metálicas construidas con perfiles normalizados y correas doble-T

Forjado de cubierta formado por tablero nervometal, incluso capa de compresión 560 $+12 \%$ aumento por pendientes $=627,20$

Cubierta de teja curva vieja

Planos

Planta general, planta de cubiertas, alzado principal, sección transversal (antes y después) y estructura de cubierta (planta)

Carpeta 639-3

Obras de restauración en la iglesia de Santiago de Medina de Rioseco

Agosto 1978

Ana Iglesias

Originales de memoria y presupuesto del legajo $\mathrm{n}^{\circ} 2$.

Dossier fotocopia fotos: general, fachada, hueco caído en tejado y tres del interior

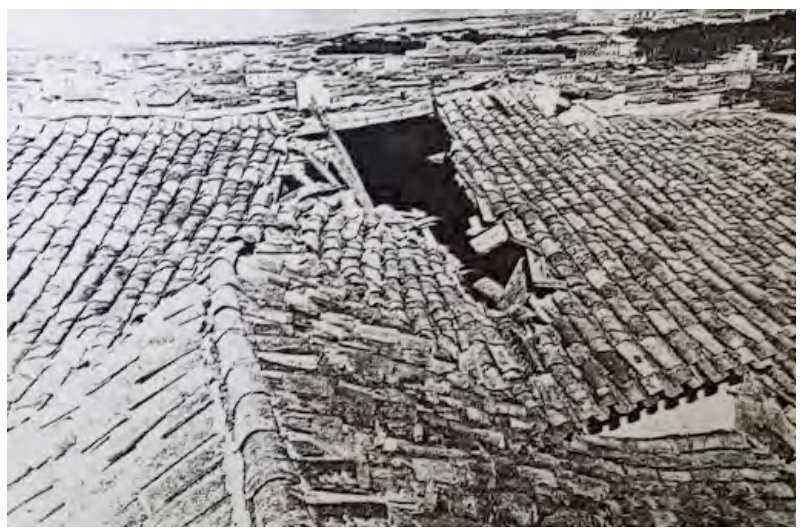

Ilustración 16: hundimiento 1978 dossier Iglesias IPCE

Carpeta 640-1

Obras de restauración en la iglesia de Santiago de Medina de Rioseco

Agosto 1979

Ana Iglesias

La iglesia se encuentra cerrada al culto debido a su mal estado siendo propiedad del pueblo

Planta rectangular salón propio del gótico del último periodo de los Reyes Católicos, de tres naves a igual altura formadas por robustas columnas nervadas y estriadas que 
sostienen los arcos formeros y fajones. Se empezó a construir en el siglo XVI pero las obras duran siglo y medio por lo que se cierran las obras con magníficas yeserías policromadas de Berrojo bajo el influjo barroco. El primer arquitecto del que se conserva documentación en Rodrigo Gil de Hontañón, que trabajó hasta su muerte siendo reemplazado por Alonso de Tolosa.

La parte más antigua corresponde a Sacristía y puerta N. Exterior sencillo sus contrafuertes y muros arrancan de un basamento moldurado.

Obras a realizar: siguiendo los trabajos anteriores se continuará con la formación de la cubierta de estructura metálica tras el levantamiento de la estructura de madera en mal estado. "Sobre la estructura de una gran viga corrida de celosía y sobre las pilastras que suponen la continuación de los pilares que conforman las naves se soldarán los perfiles según figura en la documentación gráfica del proyecto; sobre ellos se formará la capa de compresión necesaria recibida en las planchas de nervometal." Se termina con teja vieja. Se harán cosidos en la torre agrietada en su parte baja. Eliminar la escalera de madera que perjudica a la torre.

Obras definidas en el Pliego:

- Levantamiento de teja

- Demolición de estructura

- Demolición de escalera existente

- Formación de zuncho perimetral

- Colocación de estructura metálica en nave lateral

- Formación de forjados metálicos en torre

- Reposición de estructura y tabla de torre

- Formación de forjado de nervometal en cubierta

- Tendido de teja curva vieja

- Refuerzo de bóvedas de nave lateral

- Pavimentación con cemento ruleteado

- Protección de estructura de madera

- Formación de escalera de caracol metálica en torre

- Tapado de grietas con resinas, acuñado de dovelas de arcos y rejuntado y cegado de mechinales de antigua escalera con sillares

Mediciones:

Levantamiento de teja $\quad 7,5 \times 32,0$

y torre $10,5 \times 10,0$

Demolición de estructura de cubierta $\quad 7,50 \times 32,00$

Apertura de hueco para zuncho perimetral de hormigón 1 × 32; 1 x 7,88; 4 × 5,50 $=61,88$ 
Cajeado para empotramiento de vigas en muro de torre 4 X 28

Demolición de escalera lud

Zuncho perimetral de hormigón de $40 \times 50,350 \mathrm{~kg}$ de cemento por m3 y $30 \mathrm{~kg}$ por ml de hierro $1 \times 61,88$

Estructura metálica de cubierta con $35 \mathrm{~kg} / \mathrm{m} 2$ en la nave lateral derecha, compuesta por cerchas, correas, chapas de anclaje $\quad 1 \times 240,00 \times 35=8.400 \mathrm{~kg}$

IPN-20 en formación de forjados torre

Reposición de madera y tabla en estructura de cubierta

Forjado de cubierta con nervometal $1 \times 362,25 \mathrm{~m} 2$

Tendido de teja curva vieja, sentada con mortero bastardo de cal y barro 362,25

Forjados de torre con nervometal

Refuerzo de bóvedas de nave lateral con mallazo electrosoldado de 30x30 D5mm y capa de compresión de $7 \mathrm{~cm}$ de espesor $\quad 2 \times 8,0 \times 7,0 ; 1 \times 8,25 \times 7,0 ; 1 \times 10 \times 7,0=$ $239,75 \mathrm{~m} 2$ etc.

Dossier fotocopias fotos generales interior y exterior

Planos (En la planta se señala zona de intervención en rojo. Torre y nave lateral)

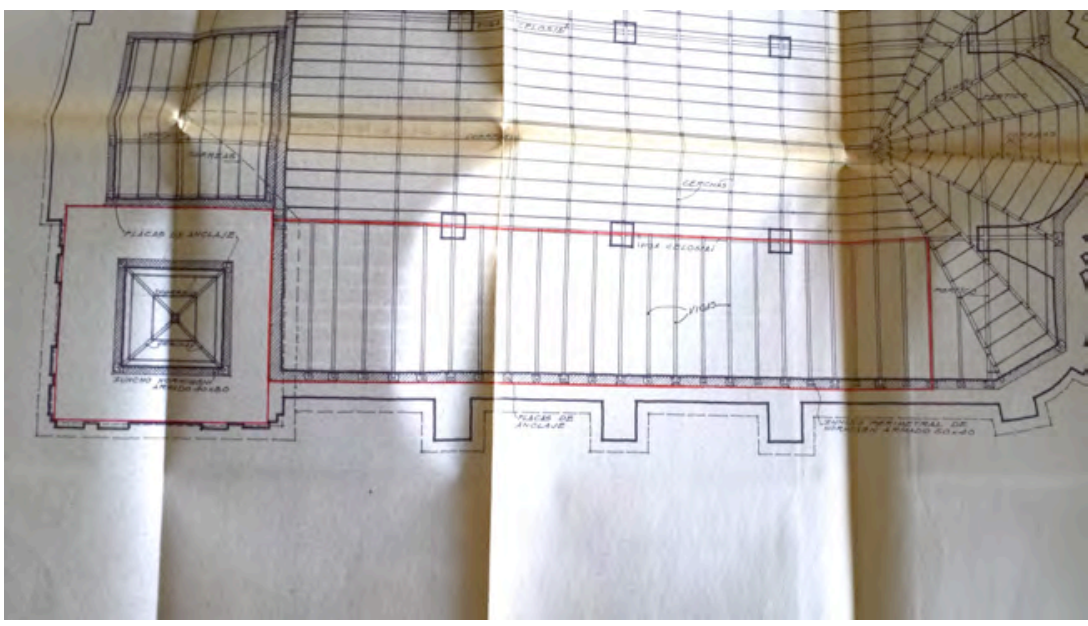

Ilustración 17: planta intervención 1979 Iglesias IPCE

\section{En el Archivo General de la Administración}

\section{AGA 26/00393}

\section{Carpeta gruesa}

Proyecto de Ana Iglesias agosto de 1978 (mismo que IPCE 640)

Obras de restauración en la iglesia de Santiago en Medina de Rioseco.

Dos copias y documentación contable y administrativa 
AGA 26/01097

Carpeta gruesa

Proyecto de Ana Iglesias agosto de 1979

Obras de restauración en la iglesia de Santiago en Medina de Rioseco.

AGA 26/01721

1979 - Restauración sacristía, puerta norte, fachada - Ana Iglesias

Obras a realizar

Siguiendo los anteriores trabajos de restauración se continuará con la formación de la cubierta de estructura metálica según los perfiles que figuran en la documentación adjunta tras el levantamiento de la anterior cubierta de madera que se encuentra en muy mal estado... (Es el mismo proyecto de 1979 ya visto en IPCE)

En la carpeta hay dos cartas de Ana Iglesias fechadas el 18 de abril de 1980. En ambas propone que se contrate la obra a TRYCSA:

En la de Santiago lo justifica: actualmente la torre de dicha iglesia, se encuentra en avanzado estado de deterioro, siendo una obra muy peligrosa por las numerosas grietas que posee en su cuerpo bajo, y las enormes dimensiones de la torre.

En la nota de Santa Cruz expone: en la actualidad dicha Iglesia, después de sufrir dos derrumbamientos se encuentra desde el punto de vista estático en avanzado estado de ruina, con el consecuente peligro de vidas humanas. Por tal motivo, veo necesario, que para esta Obra debería contratarse una empresa con gran experiencia en este tipo de consolidación...

\section{En el archivo de la Junta de Castilla y León}

VA - 086

Memoria de obra de emergencia de restauración de cubierta de Sacristía y Camarín de la iglesia de Santiago en Medina de Rioseco.

Firmado por el Arquitecto Territorial Pizarro el 24 de abril de 1990.

Dossier 4 hojas con fotos.

Memoria: 
En febrero de 1990 se arruinó parte de la cubierta de la Sacristía de la Iglesia de Santiago. Es un cuerpo añadido lateralmente por el exterior de la nave del Evangelio y más bajo que la nave lateral. Cubierta a tres aguas con una limahoya y un cambio de pendiente en uno de los faldones laterales para salvar un contrafuerte de la nave. La estructura es de par e hilera con tirantes.

Ha caído un ángulo, el resto presenta pudrición en cabezas de tirantes y carreras, así como sustitución de algunos pares con piezas de escuadría insuficiente. El encuentro con el cuerpo de la iglesia está mal resuelto con unas piezas de menor tamaño apoyadas en el botaaguas del muro de la nave, situado a media pendiente. Es necesario desmontar y volver a montar toda la cubierta aprovechando un $50 \%$ de las piezas actuales. Sustituir toda la ripia. Colocará onduline. Sustituirá el 70\% de la teja.
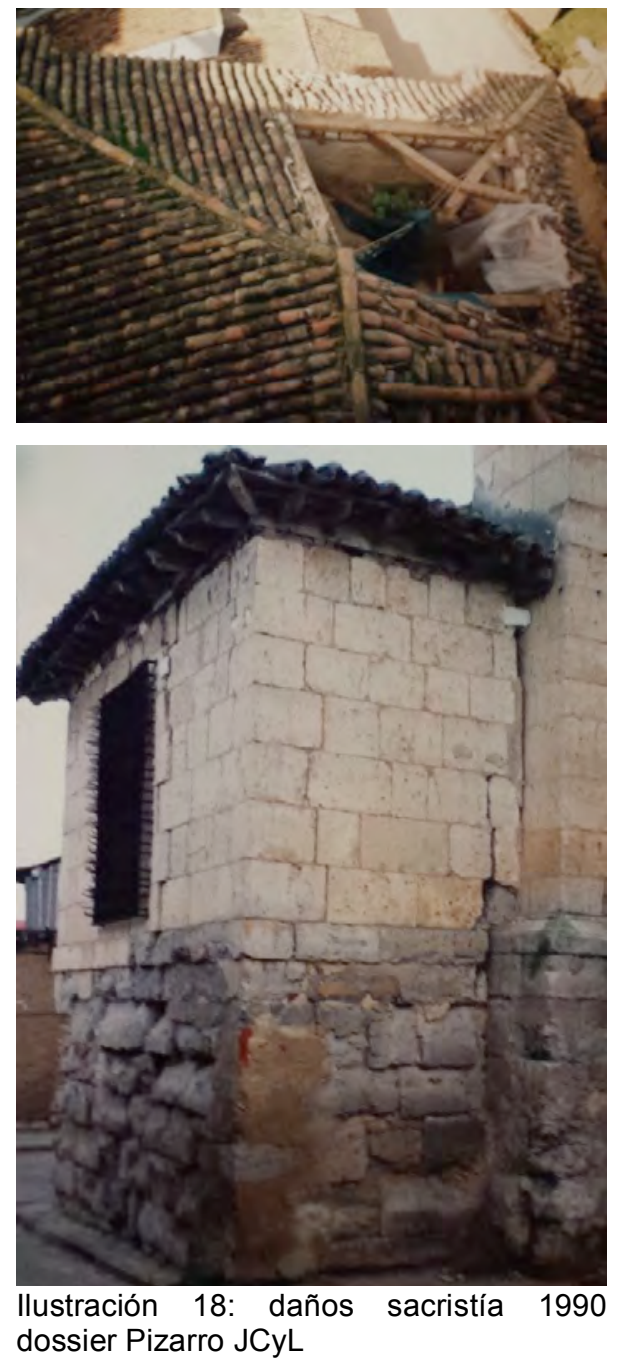

Colocará testigos en las grietas del muro. Cimbrar dos arcos rotos del camarín, testigos y retejar. También el oratorio.

Memoria fotográfica. Es un dossier muy extenso de antes y durante la obra de la sacristía.

Memoria final de obra.

Constructora LEVIGAR SA. Tras demoler la cubierta se decide reducir la pendiente de la nueva desmontando la primera hilada de piedra en la cara interna del muro. Se para la obra y cubre con lonas. Se cede a la empresa TRYCSA que reanuda. Sólo se conservan los tirantes de madera original, el resto se trae de derribos. "La tronera de entrada no se repitió sustituyéndose por una simple claraboya."

El alero de cornisa de la sacristía se ha reintegrado en su totalidad con mortero de resina epoxilica y prestados de piedra de Campaspero añadiendo una protección de plomo en el reborde, rematado a modo de goterón. 
VA- 432 (dos cajas delgadas)

Emergencia para la Restauración de fachada oeste y torres de la iglesia de Santiago de los Caballeros

Arq: Jesús Manzano Pascual

Templo amplio de tres naves planta salón. Detalles de decadencia gótica y notas del Renacimiento. Trazas se atribuyen a Rodrigo Gil de Hontañón en 1533 y reformas a Felipe Berrojo que concluye el templo siglo y medio después cubriendo las naves con doce majestuosas bóvedas de teso y profusa decoración en las pechinas entre arcos.

Tres naves de igual altura pero no anchura. Cabecera conformada por tres ábsides semicirculares escalonados en planta, crucero marcado en planta y coro alto a los pies sobre arco escarzano. Andén de servicio por encima de la imposta.

La fachada sur del edificio ha sido recientemente restaurada.

Patología:

Fuerte alteración de la piedra en zonas inferiores de muros. Propone crear cámara de ventilación como la de la fachada sur. Sustitución de sillares de al menos $20 \mathrm{~cm}$.

Importante pérdida de material que forma cornisa de remate de cuerpo inferior, desaparición del moldurado. Limpiará costras, reconstrucción de sillares labrados, reintegración con morteros pétreos. Babero de cobre, etc.

Presupuesto

Retejado de torre y fachada

$80 \mathrm{~m}$ de Cosido longitudinal de cornisas e impostas realizado por la cara superior y alojado en caja realizada en la piedra formado por pletina de acero A42b galvanizada $100 \times 1 \mathrm{~cm}$ colocada en sentido longitudinal sobre zona de vuelo y transversal cada 1,50 metros hasta muro portante, pegadas con mortero de resina epoxi, anclada sobre la piedra cada 1 metro a base de varilla galvanizada de acero corrugado B500S se $12 \mathrm{~mm}$ de diámetro y $20 \mathrm{~cm}$ de profundidad, sobre taladro de $18 \mathrm{~mm} .$.

Cornisa o imposta en piedra caliza sólido capaz $70 \times 70 \mathrm{~cm}$, rejuntado de cal, etc

Documentación administrativa: acta de recepción 7 de octubre de 2002.

TRYCSA

2a caja:

Estudio básico de Seguridad y Salud. 
Restauración de zócalos de fachada oeste y torres. Documentación final de obra. Septiembre de 2002

TRYCSA. Jesús Manzano Pascual

Informe técnico de resultados Ensayos de piedra y morteros de restauración. Inzamac Asistencias Técnicas SA

Memoria de investigación histórica. Historiadoras Concha Ferrero e Inmaculada Guadalupe. Incluye dossier con la documentación de libros de fábrica.

Dos planos grandes escala $1 / 200$ con zonas reintegradas, morteros, cosidos... señala con colores.

Restauración de emergencia en fachada. Documentación final de obra.

Mayo de 2002.

Incluye lo mismo que la otra, dos planos, análisis de materiales y memoria histórica. 


\section{Visitas realizadas}

20/09/2015

Aunque el estado de conservación del edificio muestra un esfuerzo de mantenimiento notable, se aprecian grietas visibles a ambos lados y en los paramentos de la torre.
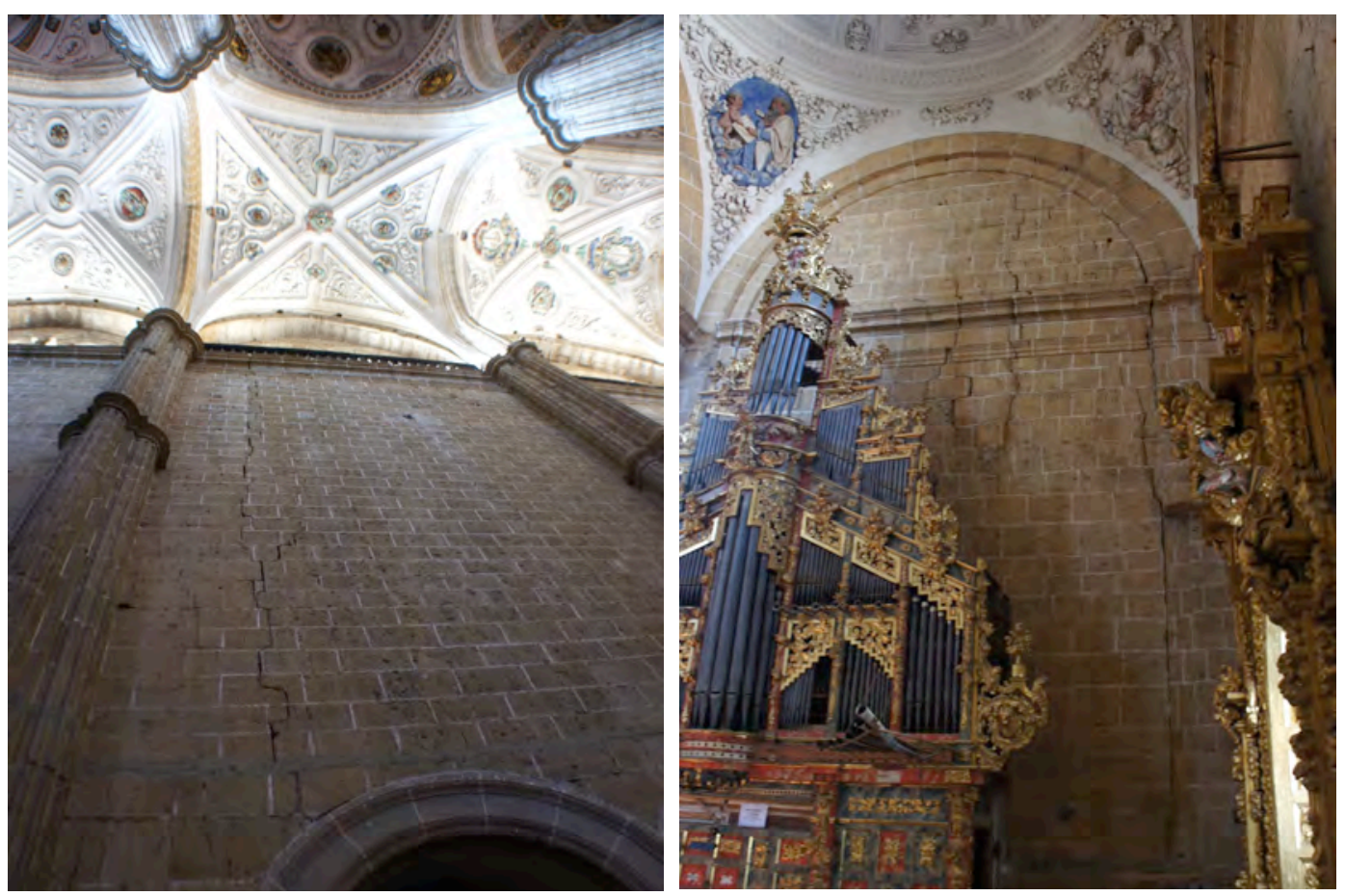

En el encuentro de las bóvedas de nave lateral con el muro perimetral también se aprecian señales de humedad.

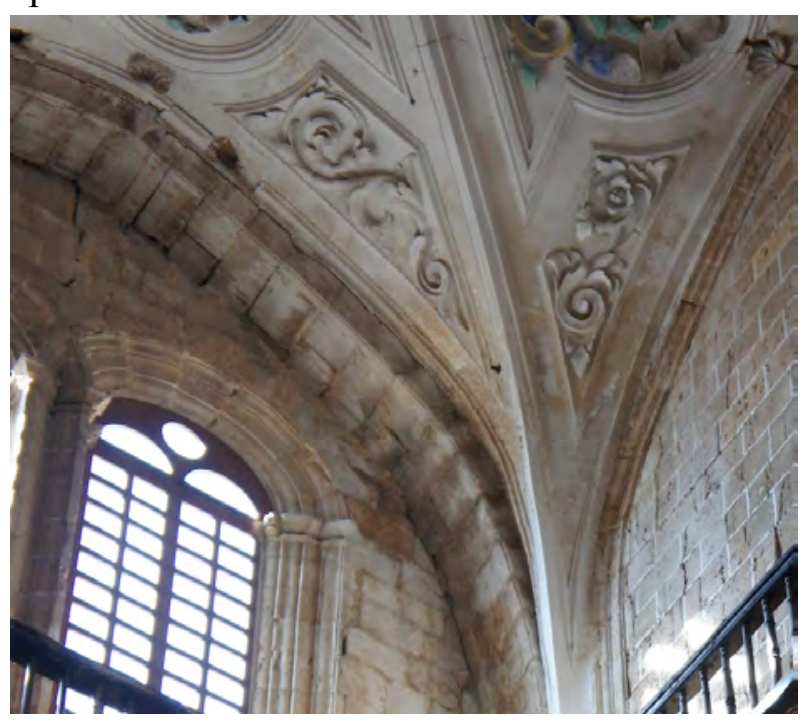

La entrada al bajo cubierta se realiza desde el lado del evangelio, a los pies, mediante una escalera de caracol. 
Entre ambas torres se dispone un forjado de vigueta y bovedilla de hormigón que apoya sobre dos perfiles de acero. Éstos a su vez descansan en la fachada y sobre una cercha de diagonales a base de LPN pareadas empresilladas.

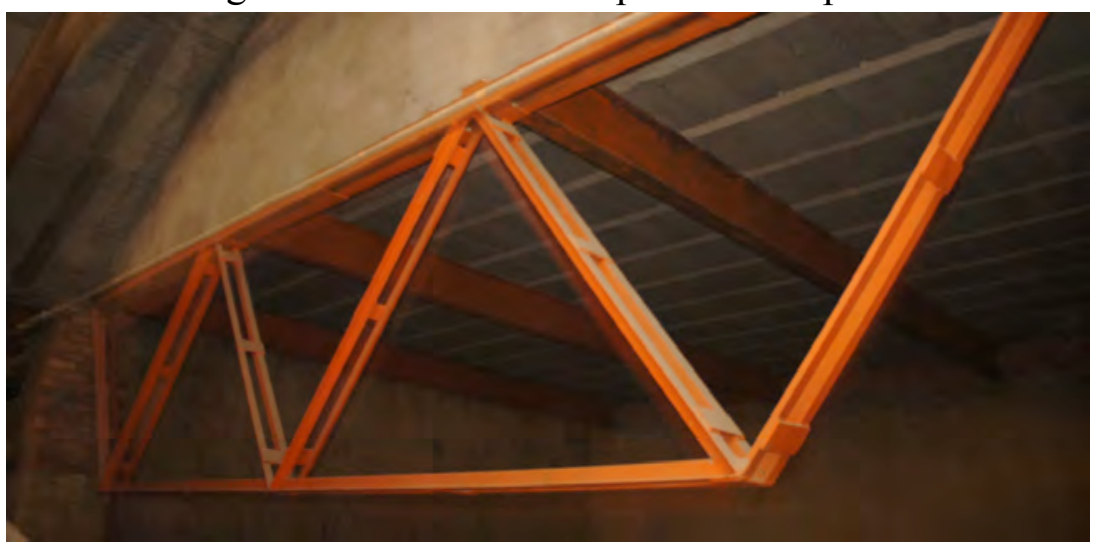

El diseño de este elemento coincide con el plano a mano conservado en el archivo del IPCE.

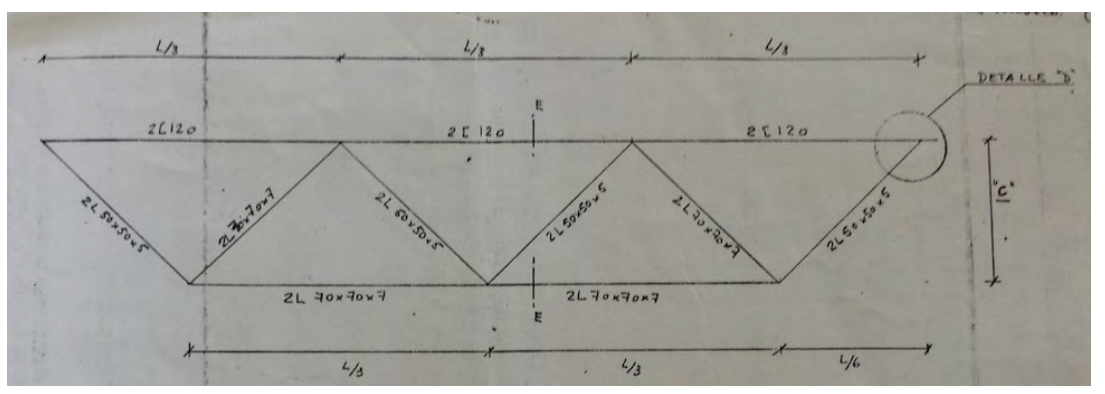

La nave central conserva una armadura de madera mientras que sobre ambas naves laterales se disponen perfiles inclinados de acero laminado con el tablero formado con hormigón sobre nervometal.

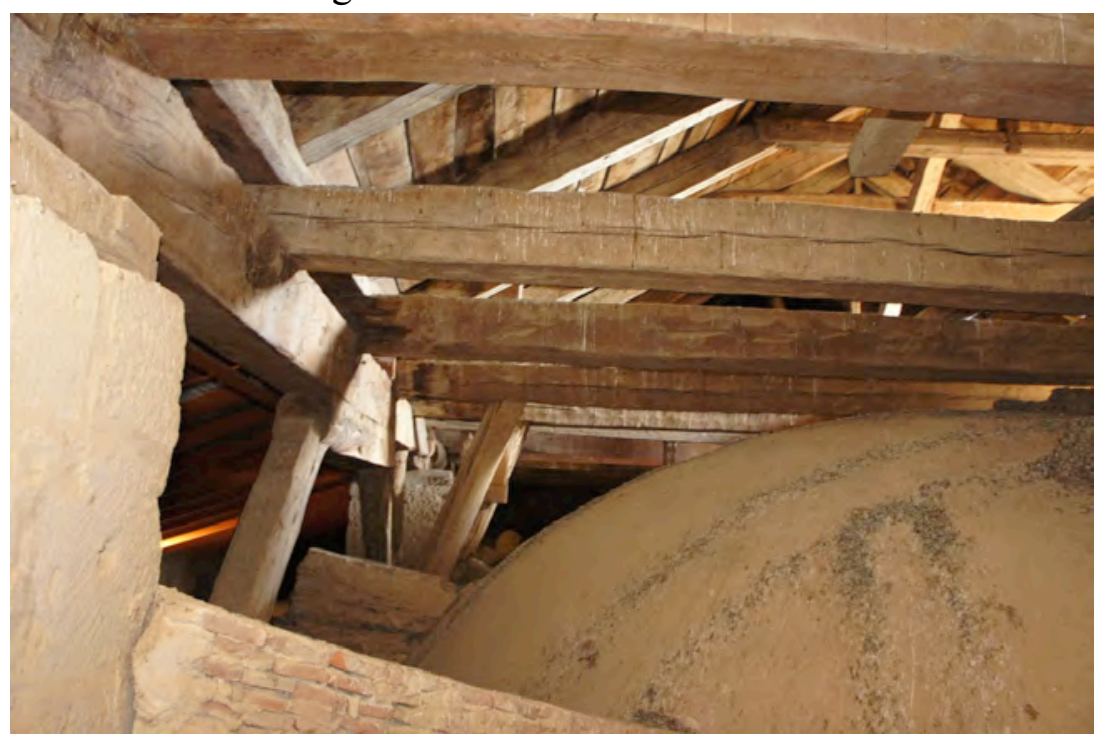

Las bóvedas de nave mayor cuentan con tabiques dispuestos en las diagonales de los recuadros en que se inscriben. 
En su extremo a menor cota, las vigas de naves laterales apoyan sobre un zuncho de hormigón de $45 \mathrm{~cm}$ de canto que no se prolonga sobre los testeros, mientras que su extremo a más altura descansa sobre una celosía corrida, que cuenta con apoyos puntuales sobre los machones de sillería de piedra.

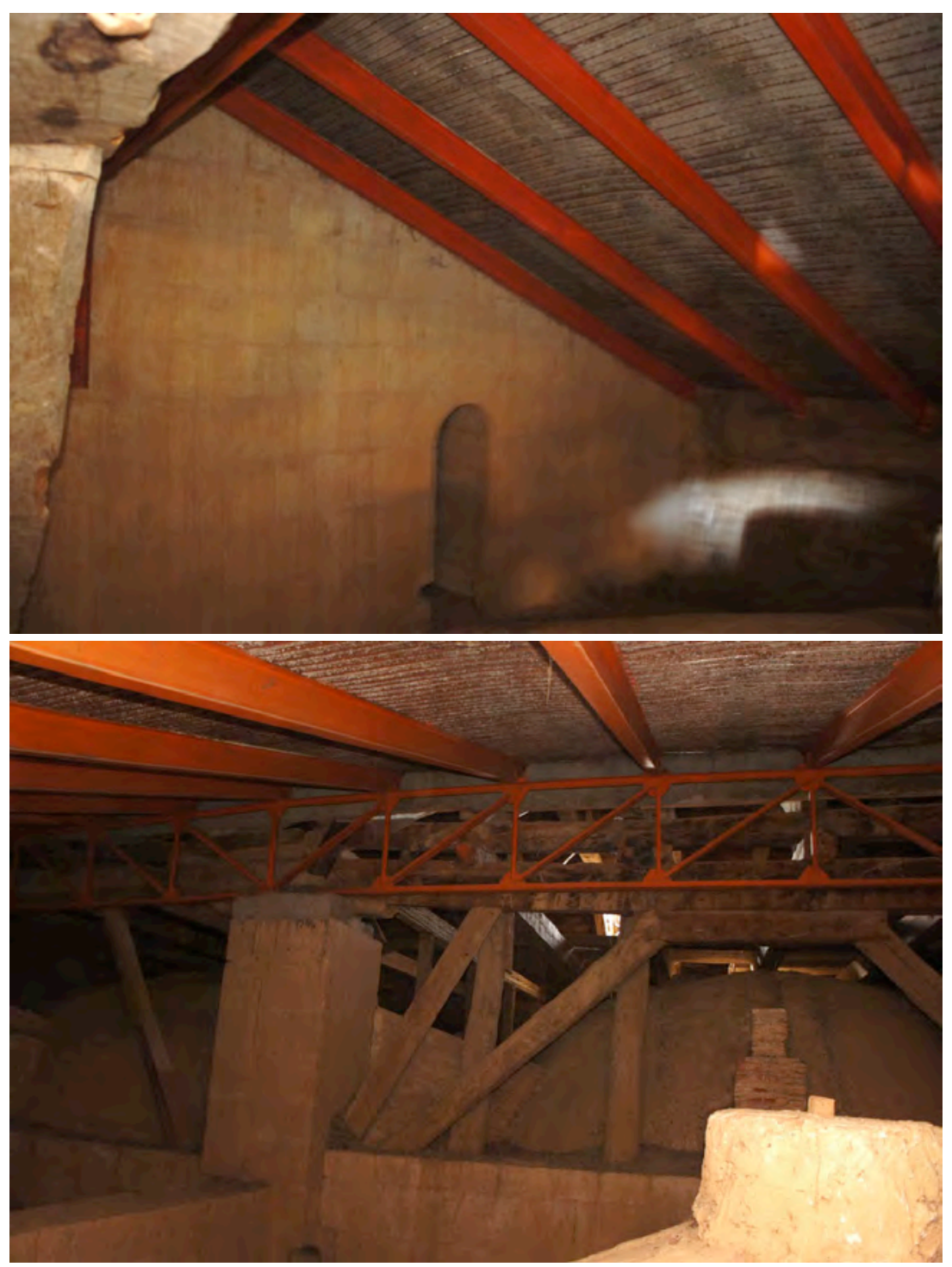

La solución constructiva de cubierta observada no coincide con la definida en el plano de sección del proyecto de 1978 en la que se representaban cerchas metálicas sobre las tres naves, ya que la estructura existente es de madera en nave central y las laterales metálicas se han resuelto con perfiles de alma llena.

Una zona hacia los pies de nave central se cubre con hormigón sobre nervometal y cuenta con tensores de acero, mientras que el resto de la nave conserva la tabla ripia. 

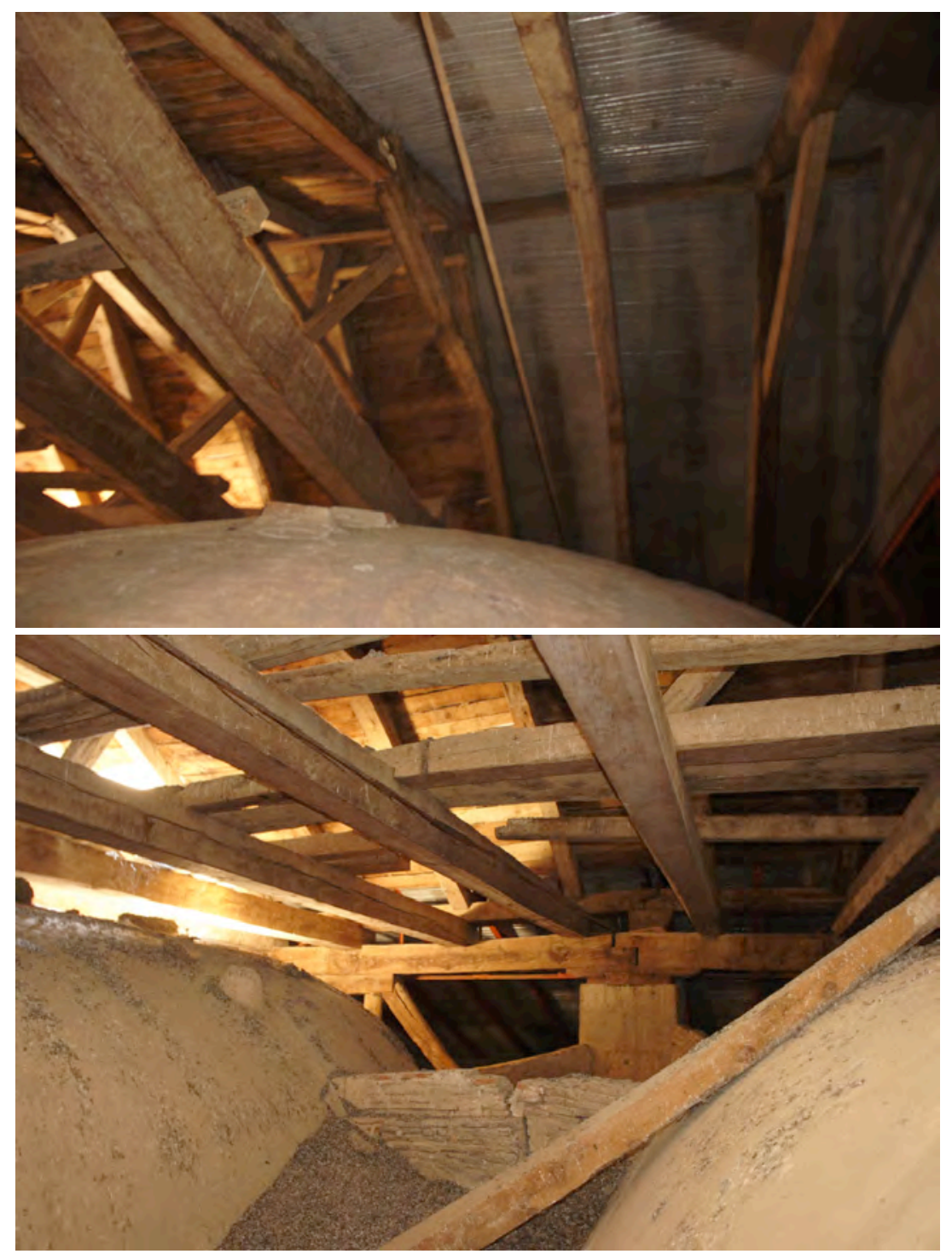

El diseño de la celosía longitudinal coincide también con los croquis a mano del IPCE, incluso el quiebro hacia la cabecera, pero no con los planos contenidos en la misma carpeta.

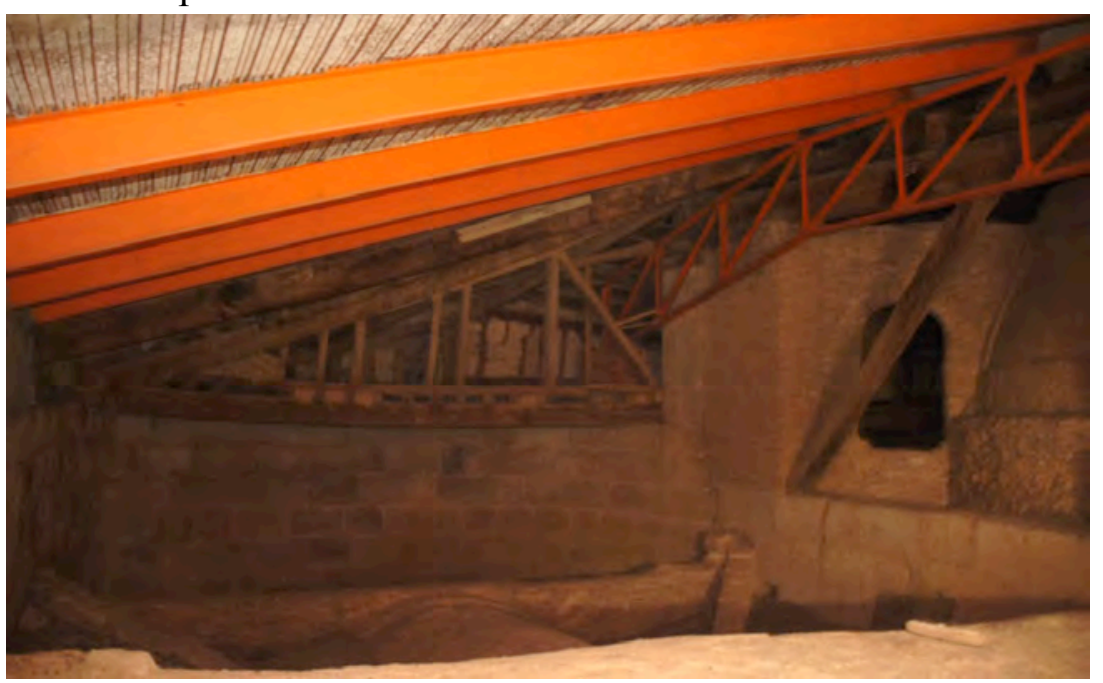



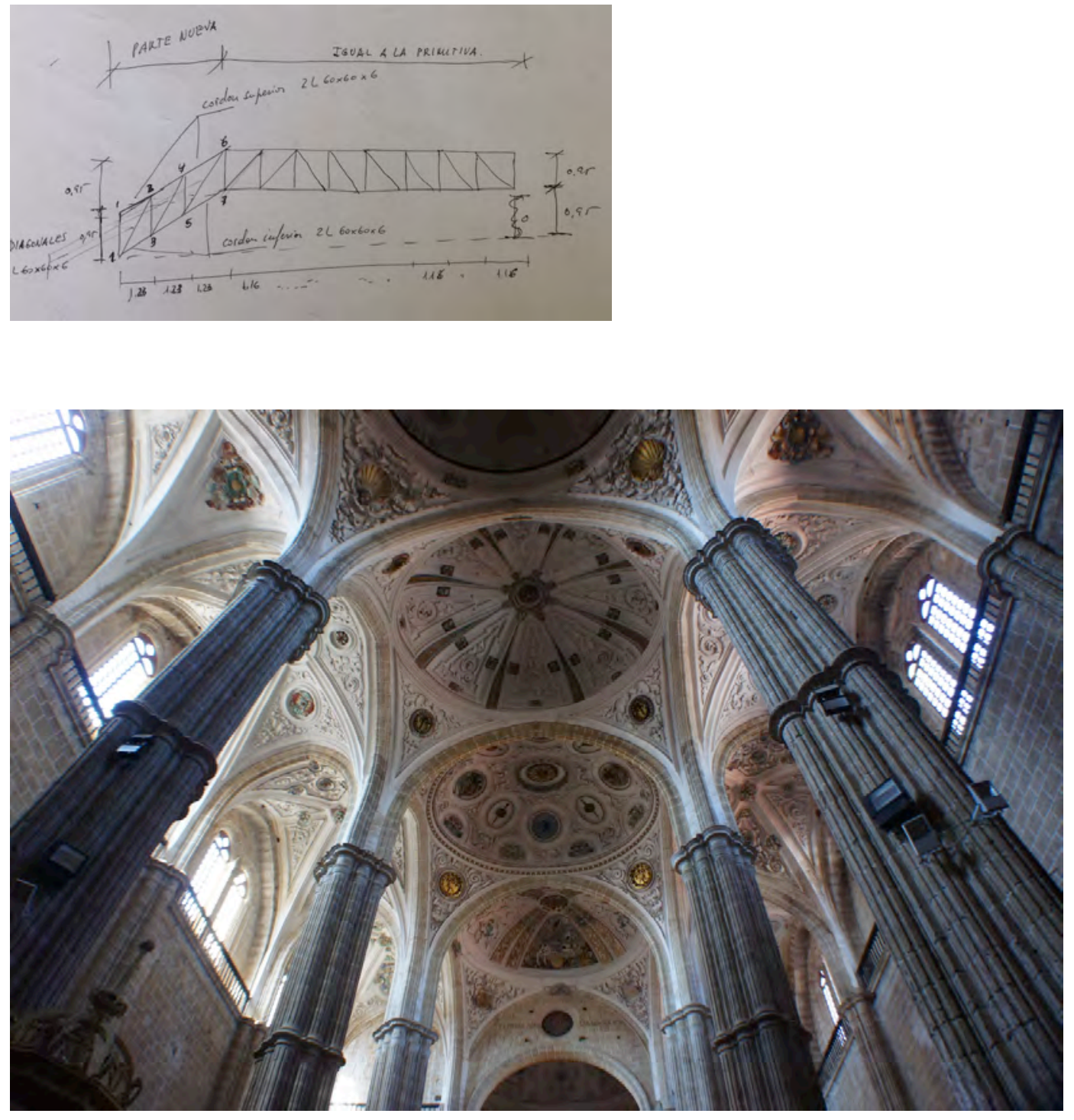

Iglesia de San Antolín

Iglesia de San Martín (Museo de las Ferias)

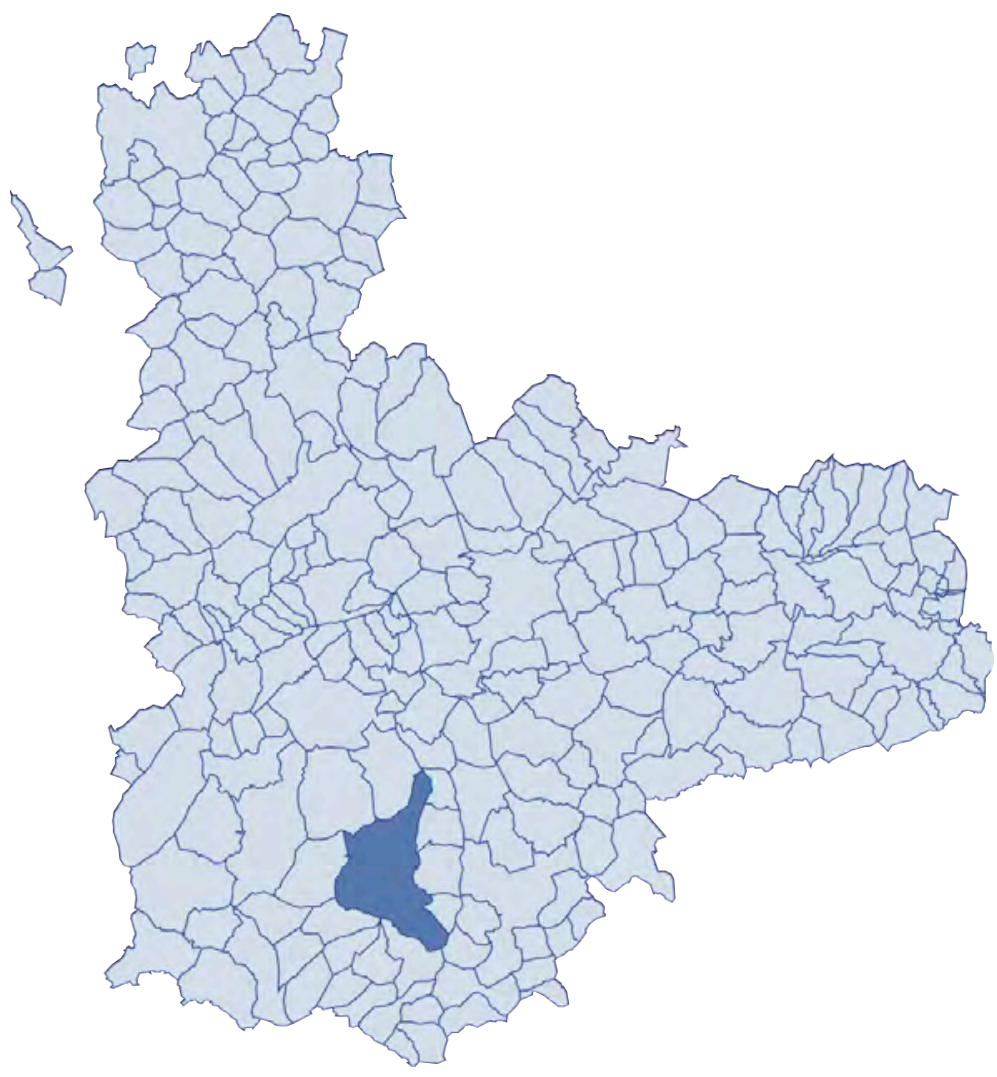



FICHA SÍNTESIS

Código de identificación: FZ-28

Denominación: $\quad$ Iglesia de San Antolín

Localidad: $\quad$ Medina del Campo

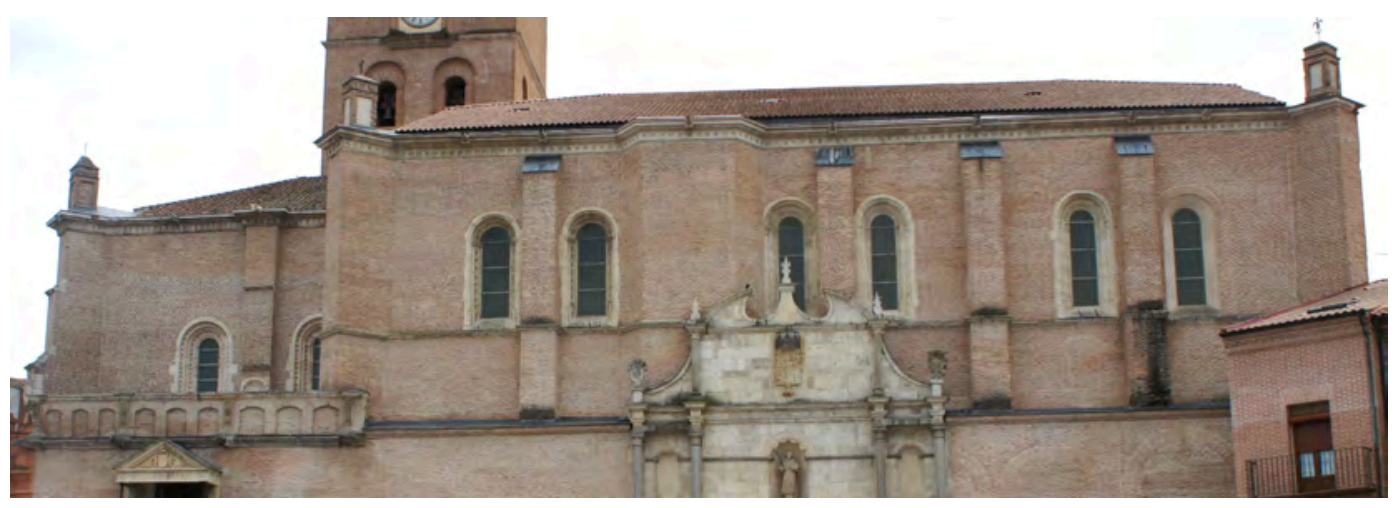

\section{Descripción}

Se trata de una iglesia gótica tipo salón, con tres naves de igual altura cubiertas mediante bóvedas de crucería estrellada con combados, terceletes y ligaduras. Los pilares son cilíndricos, con columnillas adosadas que se prolongan en las nervaduras. La cabecera es rectangular de testero plano. En el centro de la nave se dispone un coro con cerramiento de fábrica.

Al cuerpo del templo se adosa un conjunto de volúmenes interesantes, en especial la capilla de las Angustias, a los pies en diagonal, con una nave cubierta con bóveda de tres tramos, de cañón con lunetos, y cabecera trebolada cubierta con una cúpula sobre tambor octogonal.

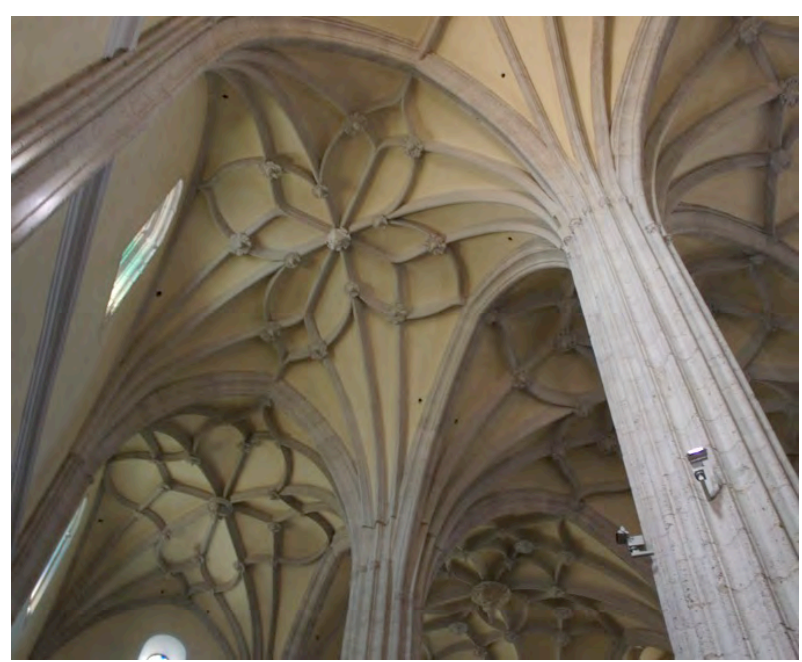

llustración 1: bóvedas (visita 05/05/2014)

\section{Materiales}

Los muros de fachada son de ladrillo, con contrafuertes exteriores y pilastras hacia el interior. En la actualidad los paramentos se encuentran retacados y con acabado homogéneo pero el aparejo de los volúmenes añadidos es en muchos casos tosco y de 
diferentes características. Portadas y capilla exterior se resuelven con piedra. El Cuarto de Canónigos fue revocado en 1996 debido al deterioro irrecuperable de la fábrica pero presenta de nuevo desperfectos en sus acabados.

En el interior, los cuatro pilares centrales son de piedra. Las cubiertas están revestidas de teja curva, con los remates y encuentros de faldones resueltos tras las últimas intervenciones con lámina de cobre.

\section{Singularidades}

El conjunto presenta la fachada lateral del Evangelio orientada hacia el norte como chaflán de la plaza mayor, un espacio urbano singular, especialmente relevante por la celebración en el mismo de ferias internacionales desde principios del siglo XV hasta nuestros días.

En ella destaca una portada central añadida en el XVIII a modo de retablo de piedra, un cuerpo adosado lateralmente con la llamada balconada de los Canónigos y el Balcón del Pópulo. Este último es una capilla abierta, el precedente más antiguo que se conserva de las llamadas capillas de indios típicas de Hispanoamérica, desde la que se podía celebrar misa los días de mercado sin que los feriantes abandonasen sus puestos.

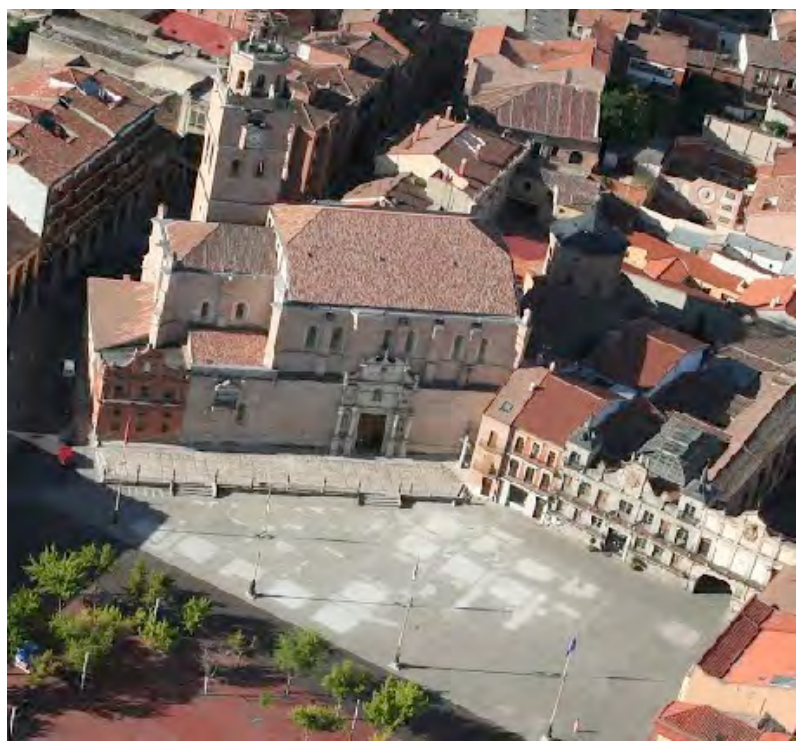

Ilustración 2: web Panoramio Melgar (28/04/2014)

El rango de Colegiata, alcanzado con la bula de Sixto IV para su creación en 1480, se pierde en 1855 .

\section{Dimensiones básicas del templo}

$\begin{array}{llll} & \text { central } & \text { laterales } & \text { capillas } \\ \text { Ancho de nave } & 10,9 & 7,6 & - \\ \text { Altura } & 18 & 18 & -\end{array}$




\section{Memoria histórica constructiva}

Se considera que el monumento arranca en 1503, aunque en todos los escritos relacionados se cita como ampliación sobre una preexistencia, ya documentada en 1177. El contrato para la construcción de la cabecera lo firman el cantero Maestre Felipe y el carpintero Francisco de Çorita, ambos vecinos de Valladolid, con los que surgieron problemas que se recogen en un pleito conservado en la Real Chancillería.

La obra es dirigida por Juan Gil de Hontañón, que firma las condiciones de construcción de los muros del crucero en 1521. En el esquema de planta junto a estas líneas se señala en azul una línea de discontinuidad que se manifiesta en los muros interiores bajo cubierta (observada en la visita de mayo de 2014).

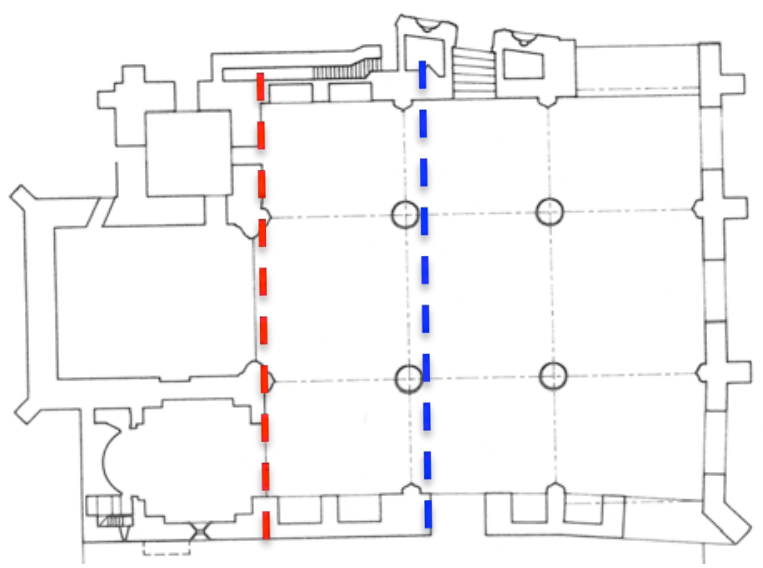

En una de las ilustraciones siguientes, obtenida en la web www.museoferias.net (06/05/2014), aparece representado el templo en construcción idealizado por Miguel Sobrino a partir de documentación de Sánchez del Barrio, por encargo del IPCE. Se está levantando en ese momento el tercer cuerpo de la torre y el cerramiento de la capilla del Pópolo, se encuentran sin cubrir los muros interiores de la nave y la cabecera aparece completa. Esta situación coincidiría con la fase representada con trazos rojos en la planta anterior.
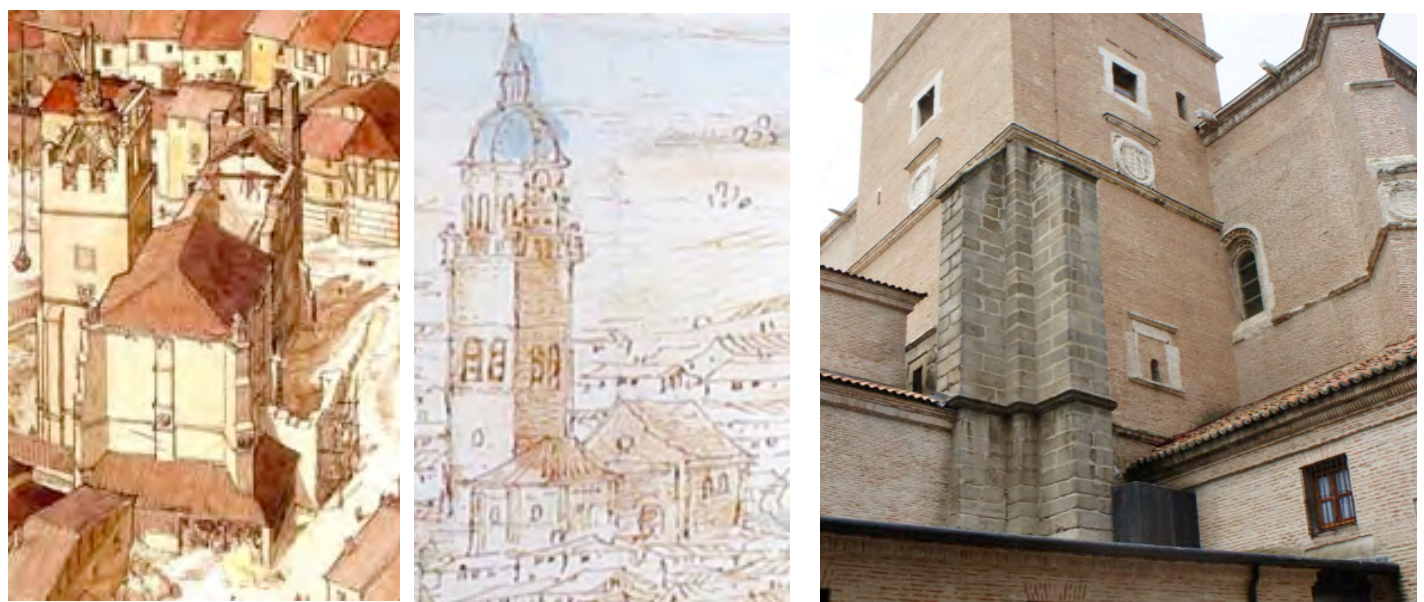

Ilustración 3: idealización Sobrino 2014, Van den Wyngaerde hacia 1570 
Según el Catálogo, se añadió un estribo (de granito) con dos contrafuertes para reforzar los dos primeros cuerpos de la torre en 1538, para contrarrestar los empujes de las naves, que también aparece representado en el dibujo.

La construcción avanza hacia los pies con la construcción de capillas

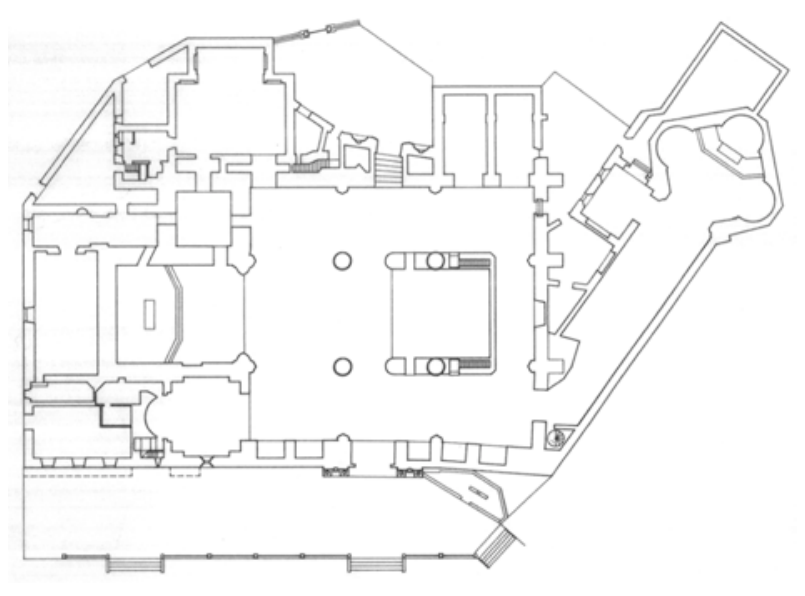
en paralelo hasta la fundación de llustración 4: evolución histórica Plan Director (1994) las Angustias en 1556.

En 1574 se dan las condiciones por las que el maestro carpintero Francisco Martinez construye cuatro de las bóvedas. En ellas se describe cómo se ejecutarán "los cascos de acitara de ladrillo, con una rasa en los arcos perpiaños y arcos cruzados por encima de la bóveda sobresaliendo una cuarta de alto". La crucería se compone por la parte inferior una vez hechos los cascos y las bóvedas. Sobre la parte superior las bóvedas llevarán "una caxa de yeso y arena y cal muy bien bruñida".

El templo se consagra tras el remate de la capilla de las Angustias, realizado en 1749.

\section{Cronología. Fechas clave}

$1503-1574-1749-1982-1999$

\section{Intervenciones}

Siglo XIX: 1857 Obras de conservación diversas - Jerónimo Ortiz de Urbina

1982 - Cubiertas y consolidación de muros y arcos- José María Gómez Santander

\section{Incorporación de zuncho de hormigón armado}

Según la memoria del proyecto se embebe un zuncho, entre los durmientes de madera superior e inferior de la estructura de cubierta de la nave central, sobre los dos muretes interiores y también en el remate de ambos muros de fachada. 


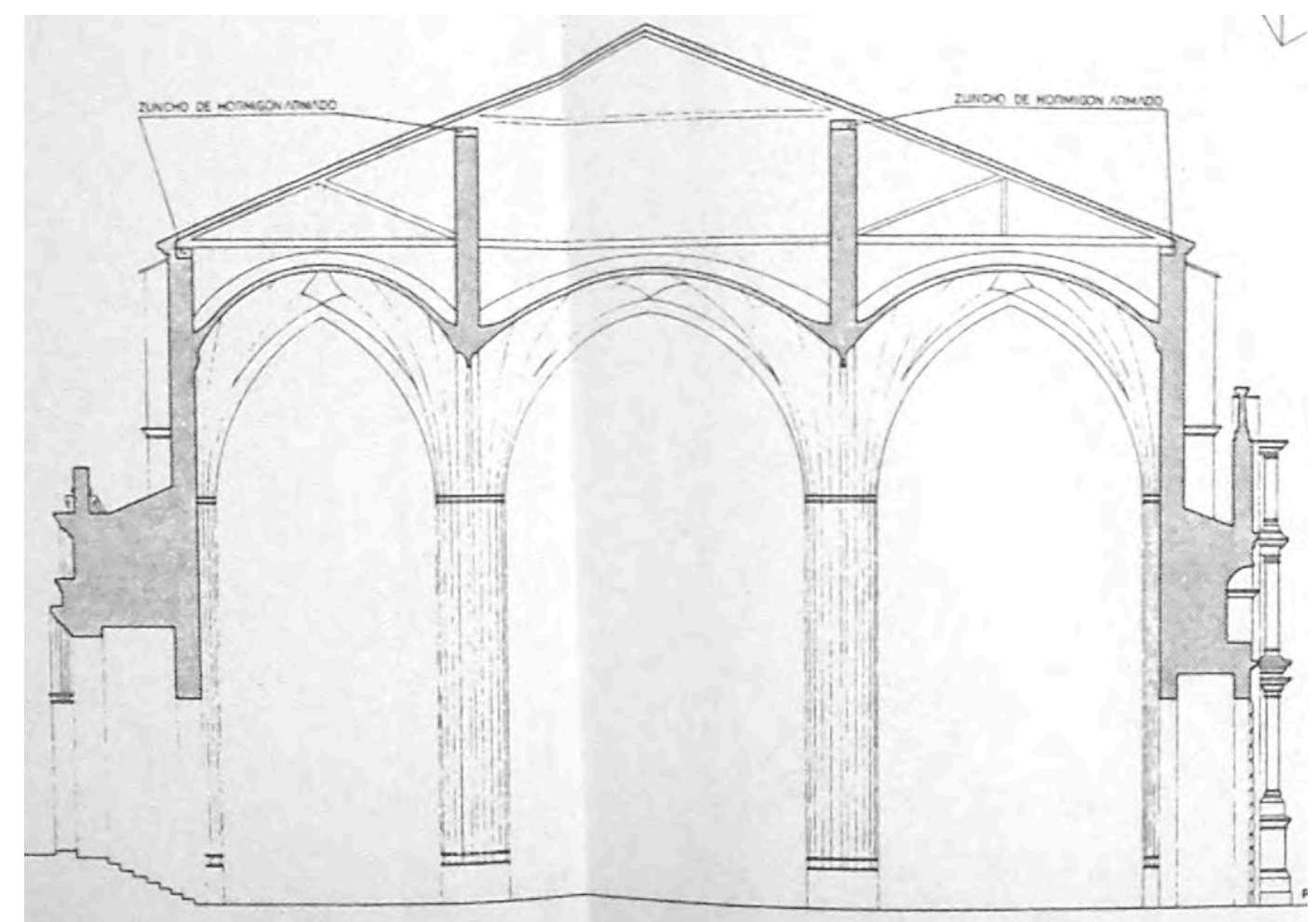

Ilustración 5: sección transversal (Gómez Santander 1982 IPCE)

Dos tramos de zuncho a cota más baja, hacia los pies, en los muros que separan la nave central de las laterales, se anclan mediante tirante metálico a otro zuncho corrido, incorporado en el testero, con el fin de impedir el vuelco de éste hacia el exterior. En el detalle siguiente del plano de Diagnóstico incluido en el Plan Director se aprecia otro tirante en la misma esquina del bajo cubierta a menor altura.

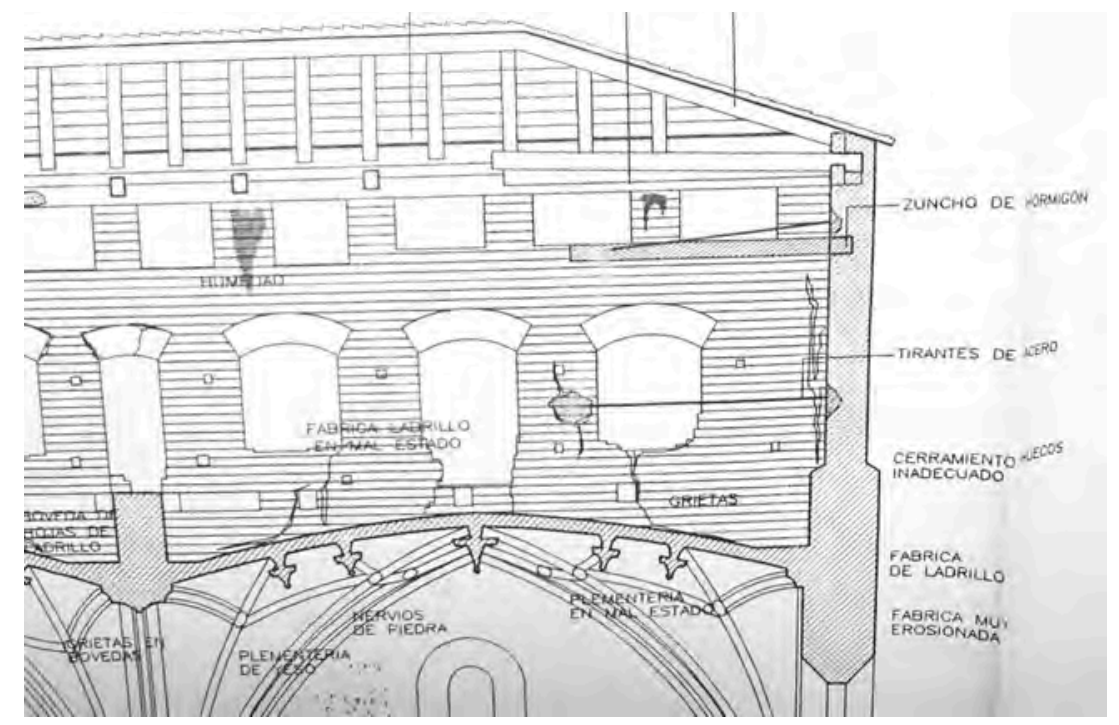

Ilustración 6: detalle planos de Patología Plan Director

1989-90 - Proyecto de acondicionamiento y recuperación - Carlos Descalzo Llorente, Luis Hernández Duque y Jesús Tovar 
1996 - Proyecto de restauración cuarto de canónigos y capilla exterior de la Concepción de la Colegiata de San Antolín - Antonio García Paniagua

1999- Obras de emergencia de las bóvedas y cubiertas de la nave - Antonio García Paniagua

Tras la caída accidental de dos tirantes de cerchas de cubierta de la nave central se decide renovar toda la estructura.

\section{Incorporación de zuncho de hormigón armado}

Se demuele completamente la cubierta de las tres naves, incluso los cuatro zunchos incorporados en la intervención de 1983.

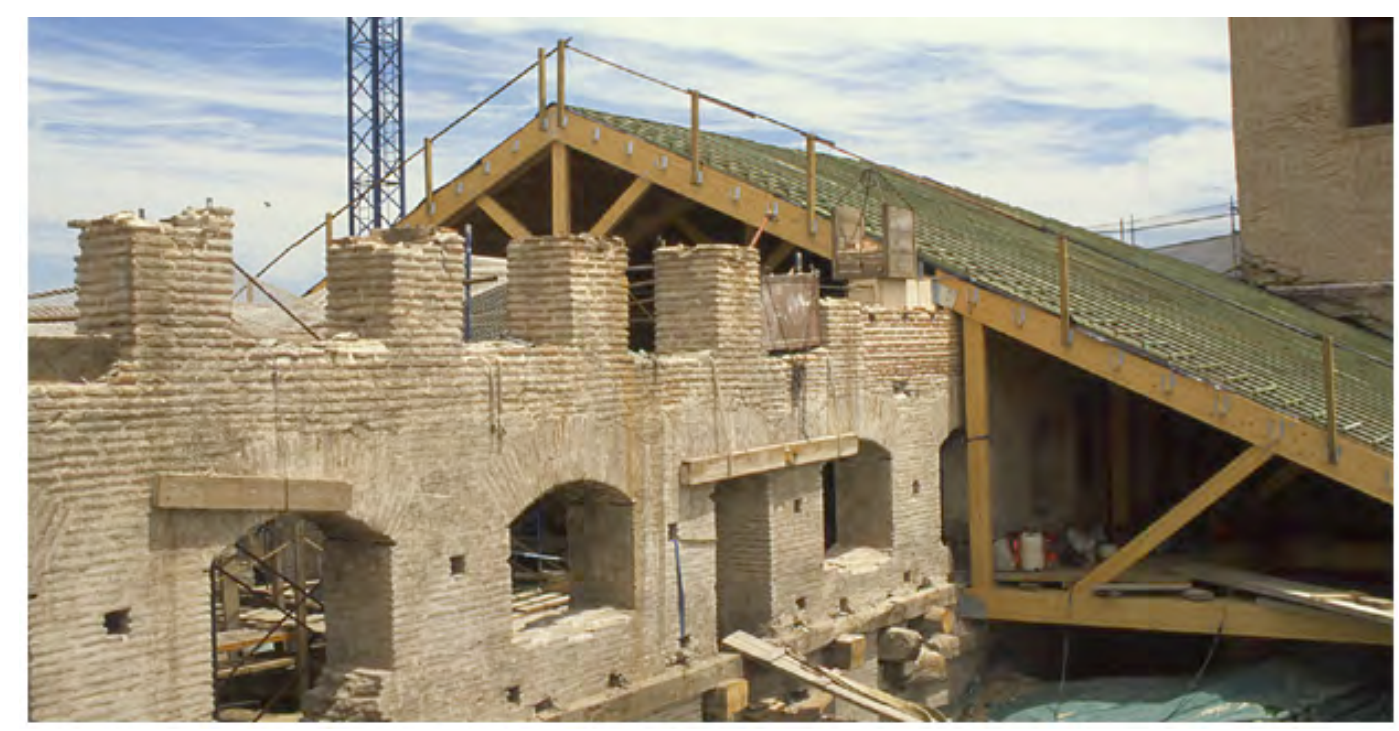

Ilustración 7: nueva cubierta nave central (Paniagua 1999)

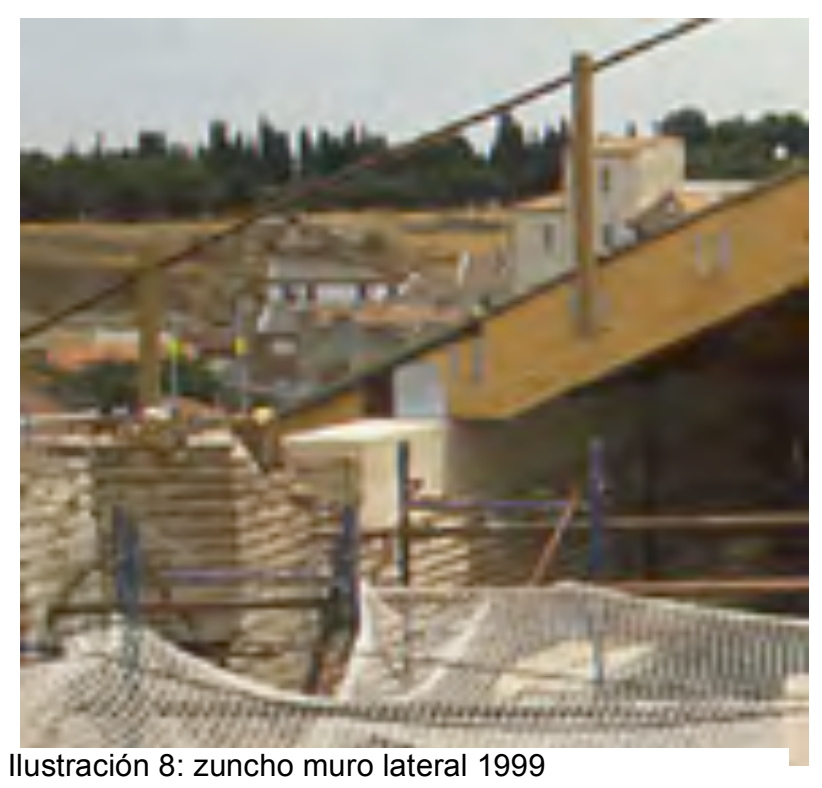

Se dispone una nueva cubierta a dos aguas sin cambio de pendiente entre la nave central y las laterales, según se aprecia en el siguiente conjunto de fotografías obtenidas en la página web del arquitecto (antoniopaniagua.com 25/04/2014)

La nueva estructura de madera laminada se atiranta mediante barras metálicas tipo gewi a dos niveles: en el apoyo de las cerchas y a cota de acceso al bajo cubierta. 


\section{Planos}

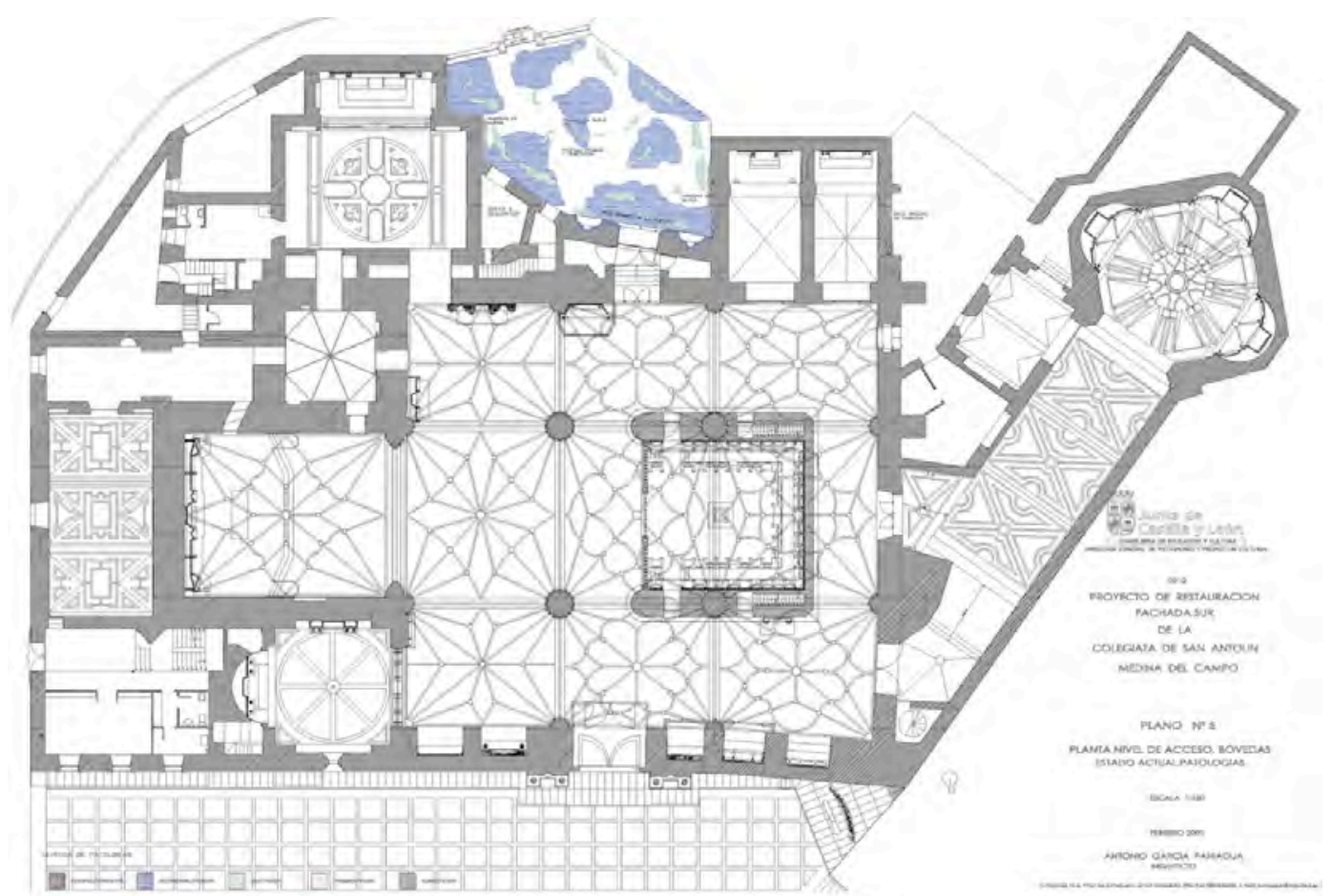

Ilustración 9: planta nivel de acceso. Proyecto restauración fachada sur 2003

Sobre una planta de estructura de cubierta de las tres naves, Paniagua señala a mano los tirantes cuya caída en 1999 justificó el reemplazo de toda la estructura

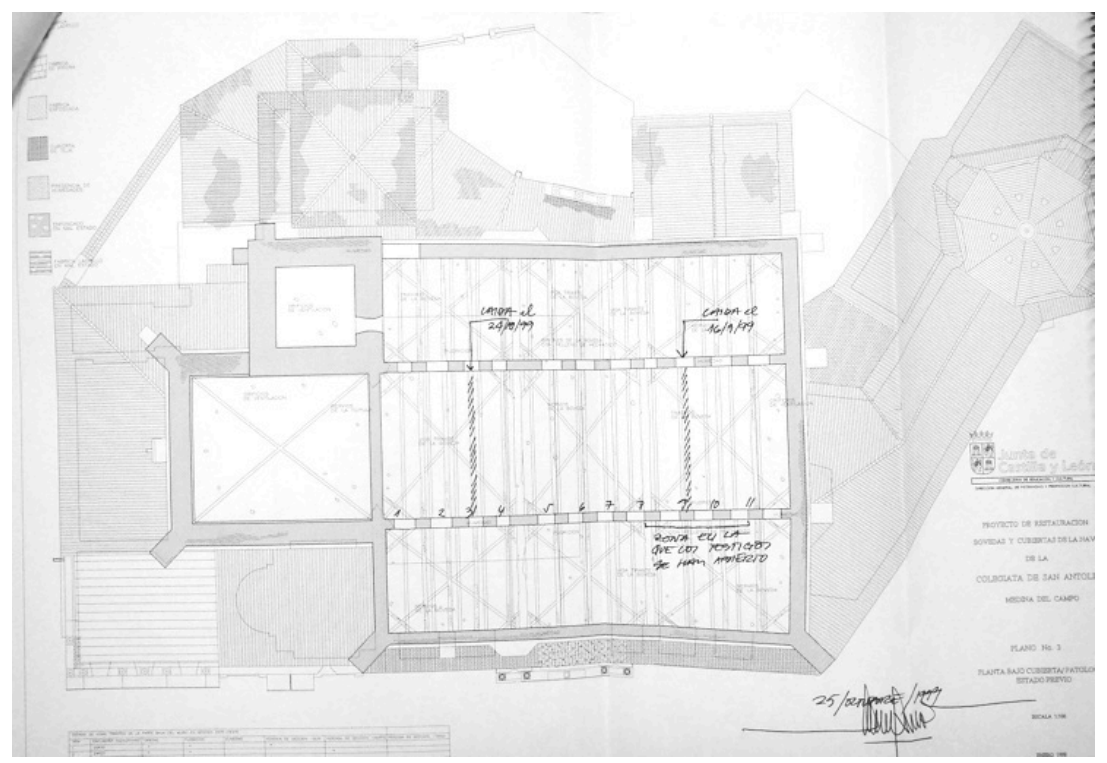

Ilustración 10: plano Paniagua 1999 


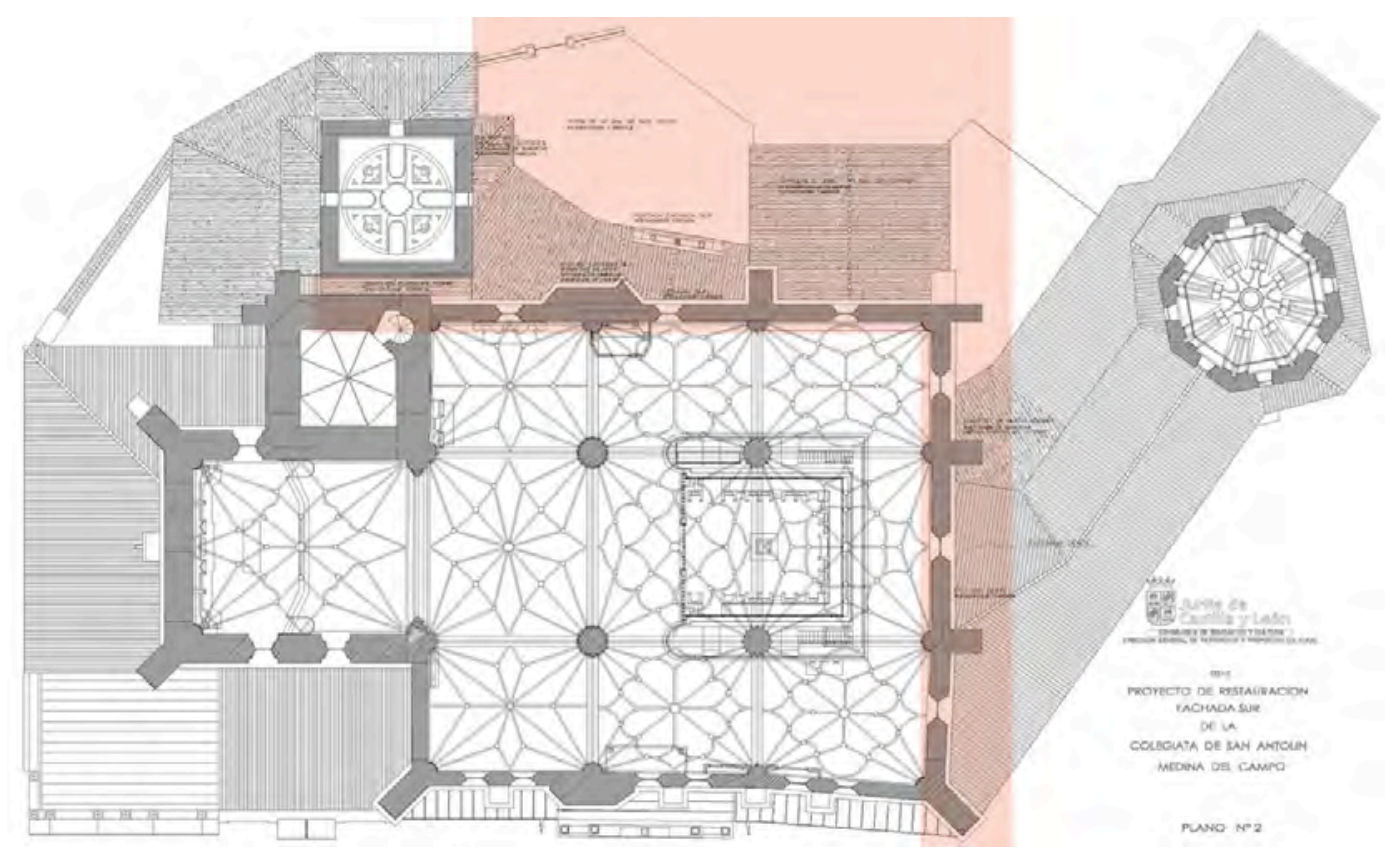

Ilustración 11: planta general de bóvedas (Paniagua 2003 JCyL)

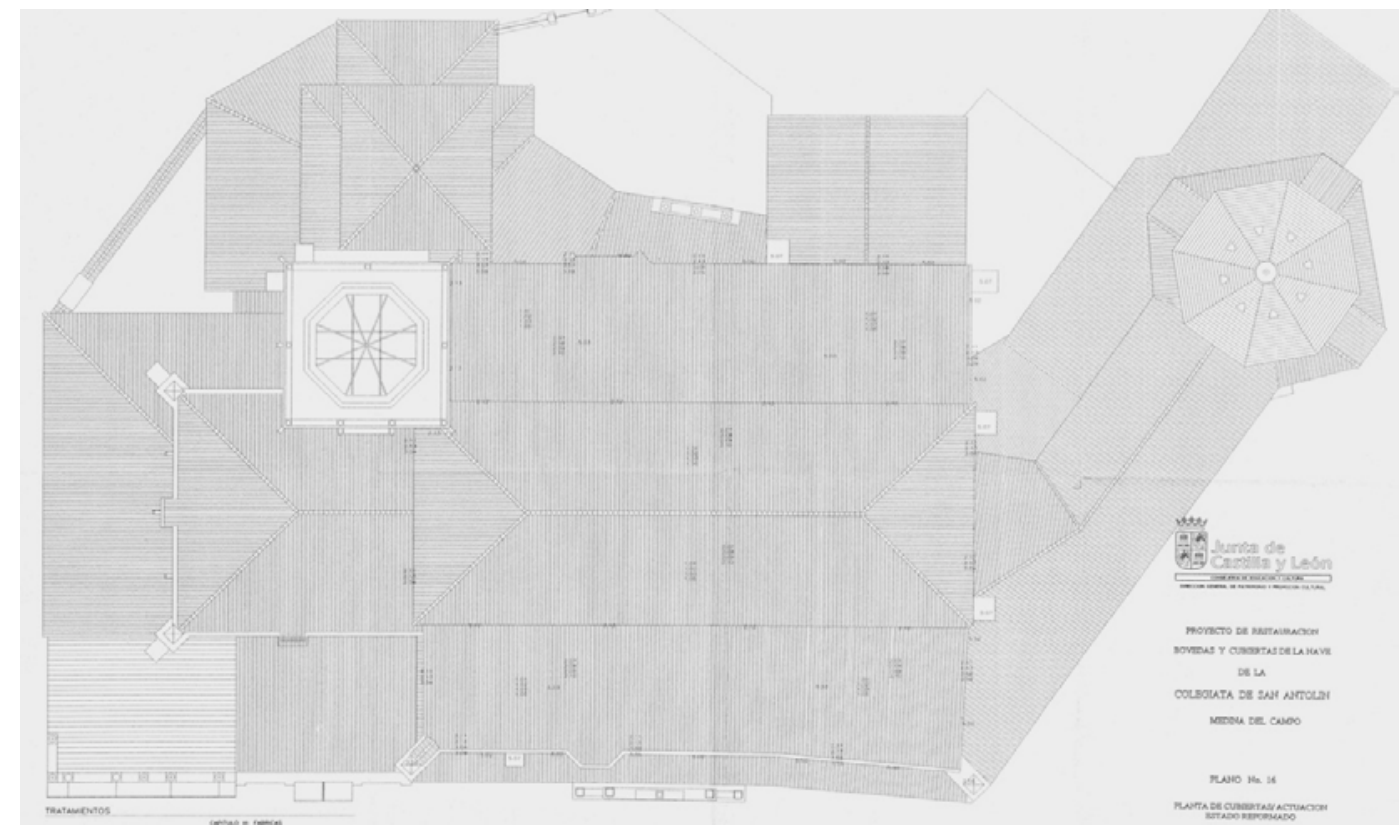

Ilustración 12: planta de cubiertas (Paniagua 2003 JCyL) 


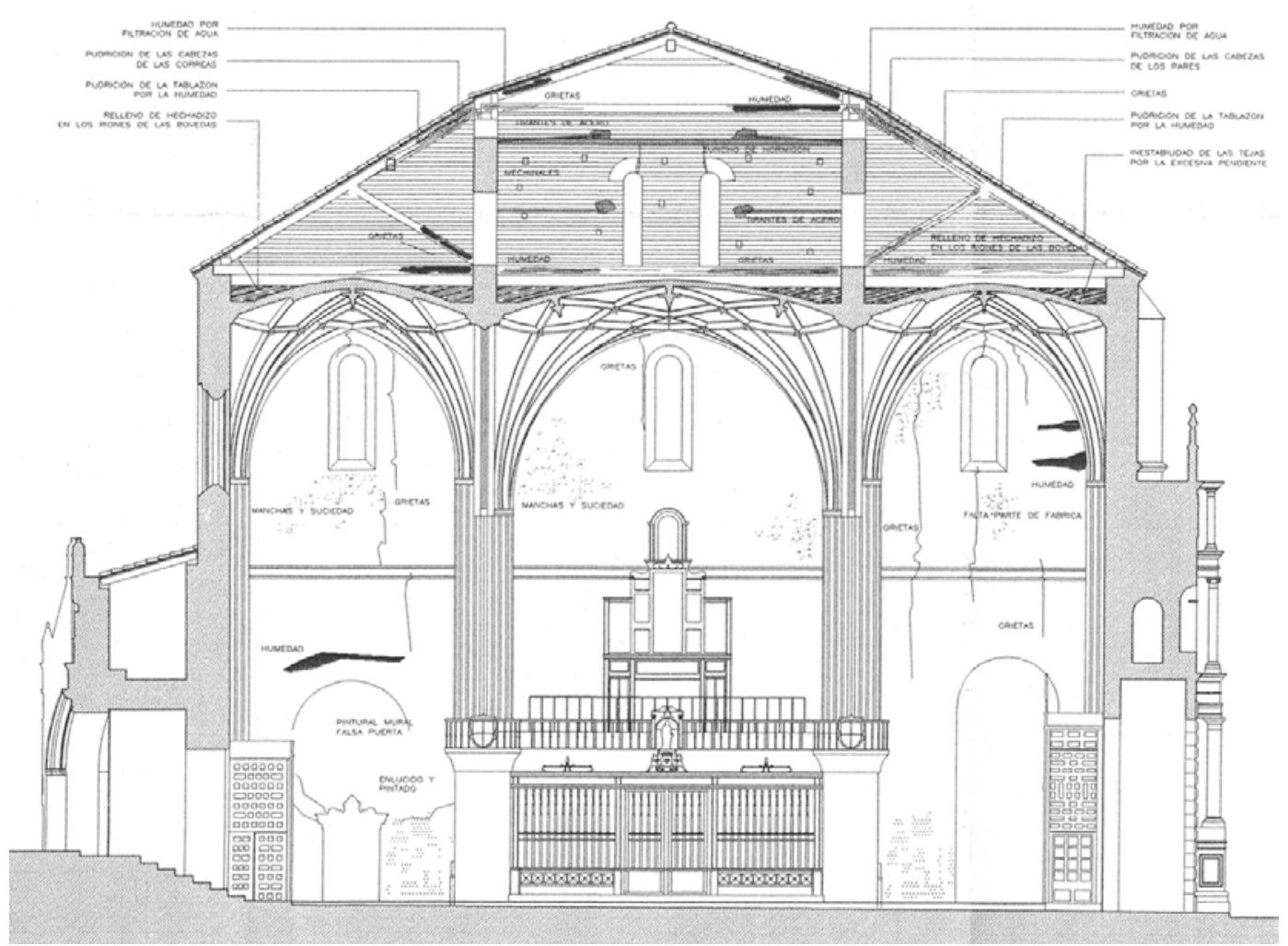

Ilustración 13: sección del cuerpo del templo estado actual de 1999. Plano de diagnóstico

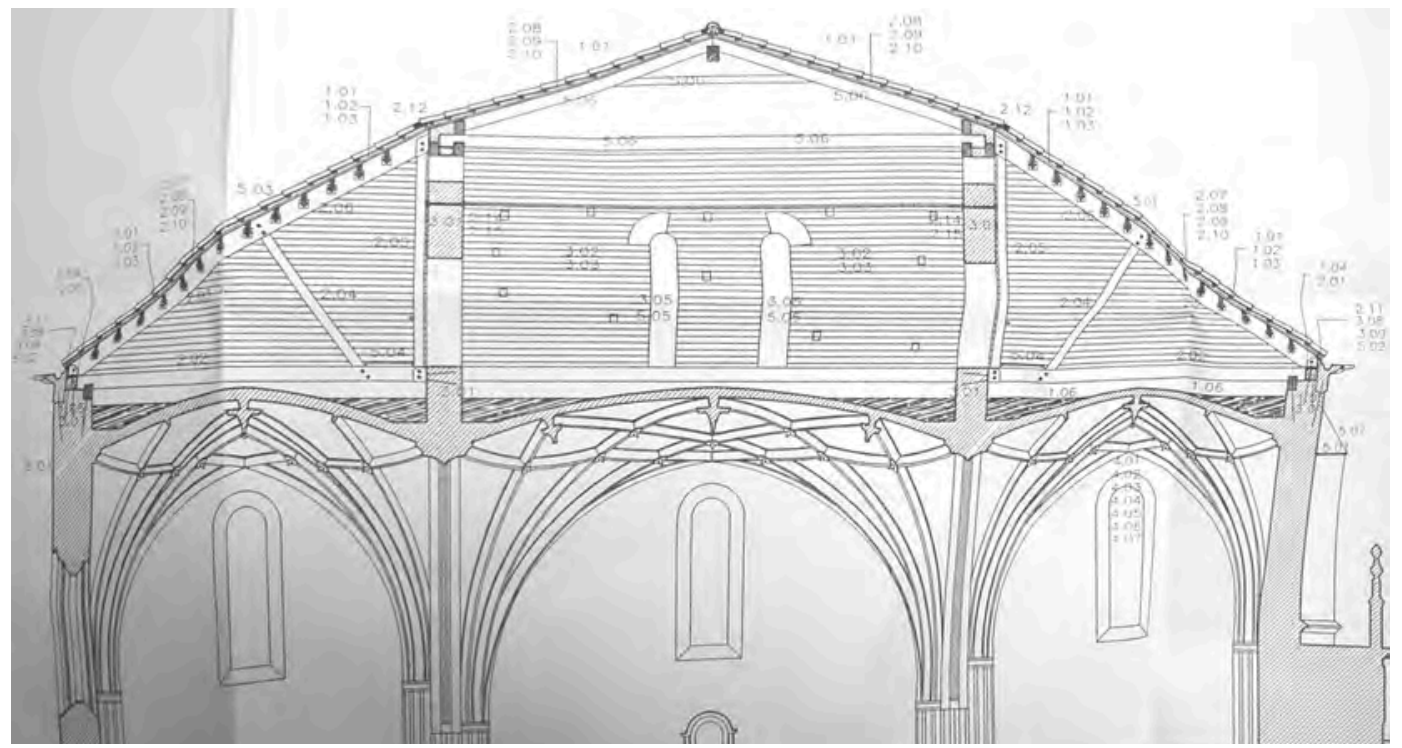

Ilustración 14: sección proyectada en 1999

La anterior sección, proyectada en 1999, no coincide con la solución realmente ejecutada ya que, aunque estaba previsto conservar la armadura de nave central, finalmente se reemplaza también por madera laminada, como en las naves laterales.

Tampoco se mantendrá el quiebro de faldones entre las naves, que finalmente se resuelven en un solo plano. 


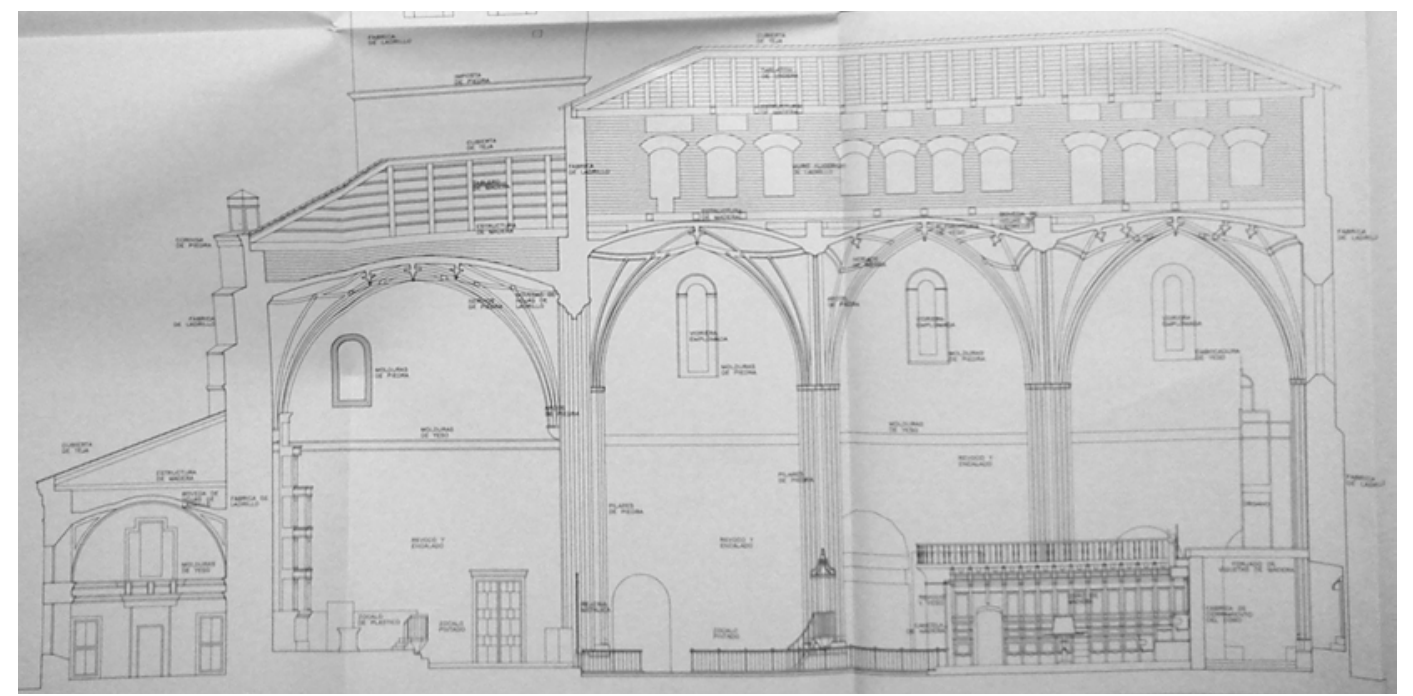

Ilustración 15: sección longitudinal antes del reemplazo de la cubierta (Plan Director)

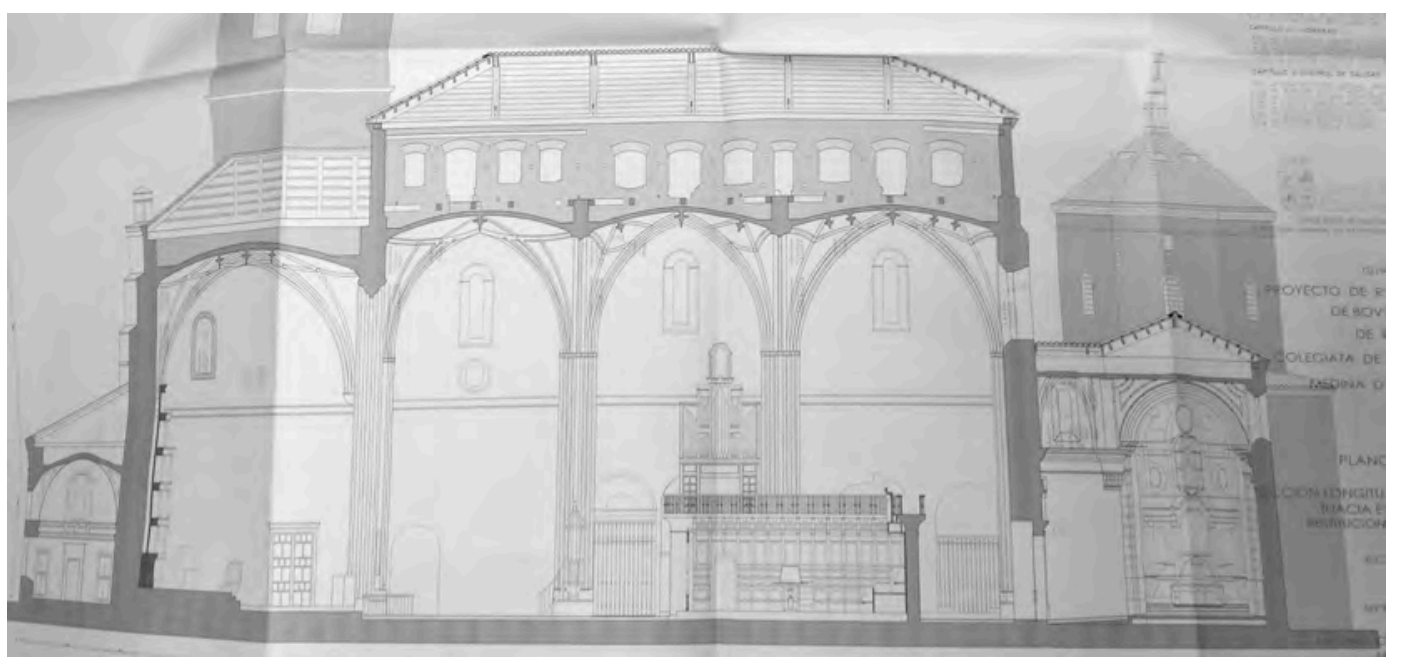

Ilustración 16: sección longitudinal reformada

En el corte anterior, tras las reformas, aparece también representada la capilla de las Angustias con el tambor de la cúpula cubierta de pizarra al fondo.

\section{Solución constructiva de la cubierta}

Las tres naves del templo se cubren a cuatro aguas con una anchura total de más de $25 \mathrm{~m}$. La estructura se resuelve con dos líneas de apoyo intermedio. En un plano de sección transversal estado reformado de 1999 se rotula una pendiente del faldón sobre naves laterales de $31,34^{\circ}$. En el estado original se producía un quiebro del plano de cubierta en ambos ejes de apoyo interiores, incremento de pendiente en ambos extremos, mientras que en la situación actual, tras la intervención realizada a partir del Plan Director, se mantienen los dos grandes faldones planos. 
Sobre los ejes de las cuatro pilas, revestidas de columnillas, que configuran el espacio de la iglesia se disponen dos muros con grandes aberturas, configurando una especie de fila de pilastras. La estructura cuenta con dos niveles de atado, uno inferior, sobre el trasdós de las bóvedas, y otro superior en el apoyo. Los citados muros se remataban antiguamente con doble durmiente de madera, según se aprecia en la imagen siguiente.

En el nivel inferior de estructura bajo cubierta además de las grandes vigas nortesur se contaba con cuadrales reforzando por áreas coincidentes con los tramos de bóveda.

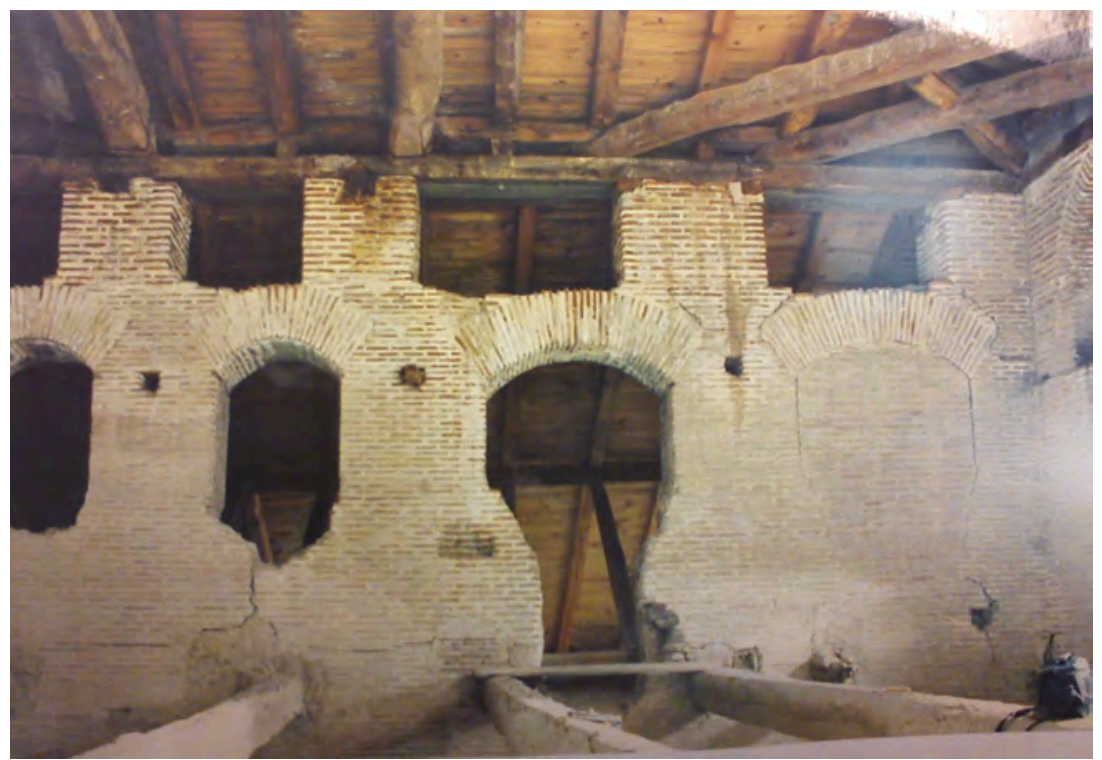

Ilustración 17: detalle muro nave central antes del reemplazo de cubierta

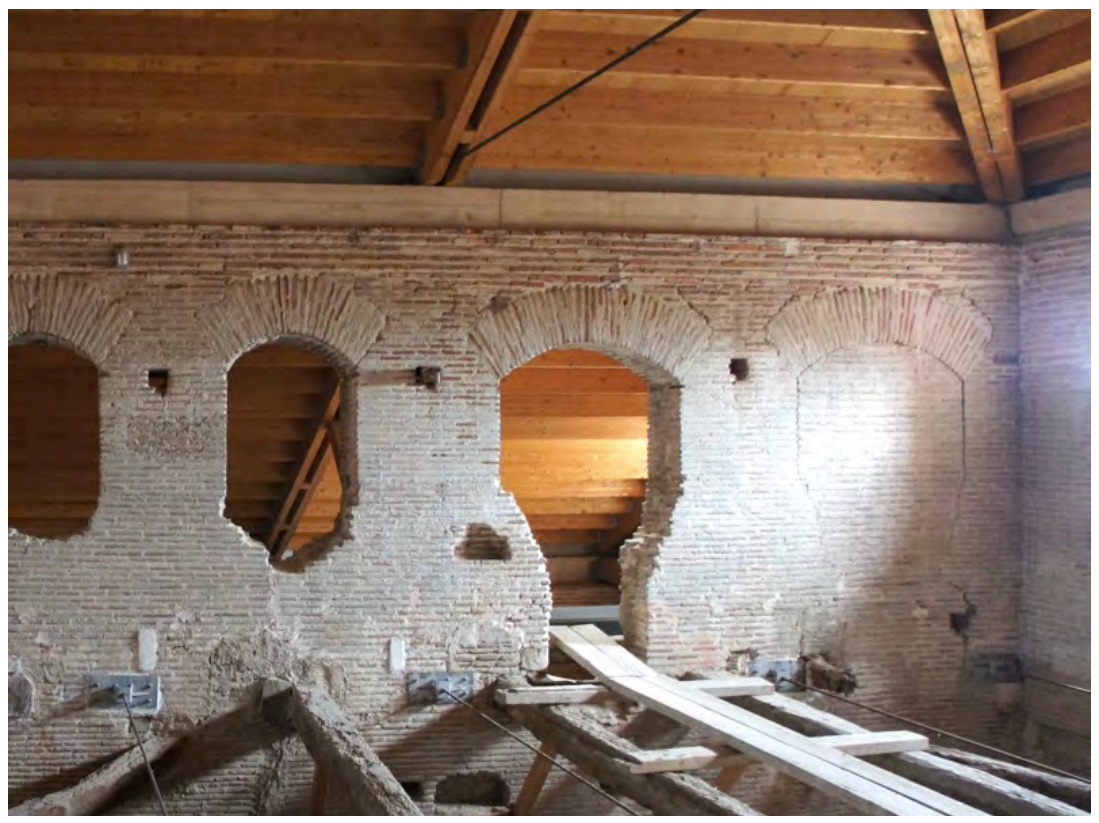

Ilustración 18: detalle muro nave central estado actual (visita 05/05/2014) 
También se disponían cuadrales dobles en las esquinas del nivel superior, según se aprecia en la fotografía 17, del dossier incluido en el Plan Director. En la fotografía general se aprecia los antiguos tirantes, de madera sin escuadrar.

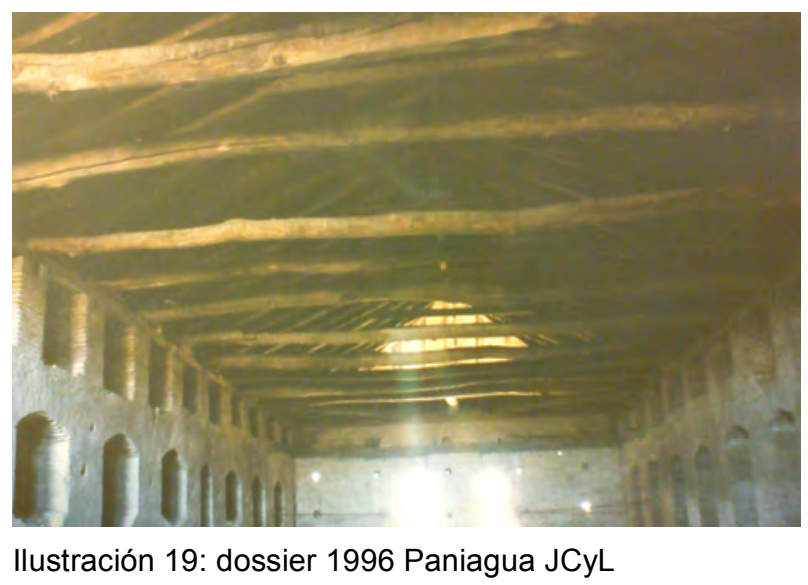

En la vista 18 del actual, se puede observar cómo se ha conservado algunas piezas del nivel inferior, retirando las más deterioradas, tras colocar tensores anclados. Se ha demolido la hilera superior de pilastras reconstruyendo el lienzo de fábrica ciego hasta aproximadamente la mitad de la altura anterior.

En la documentación se afirma que esta estructura se realizó en 1983.

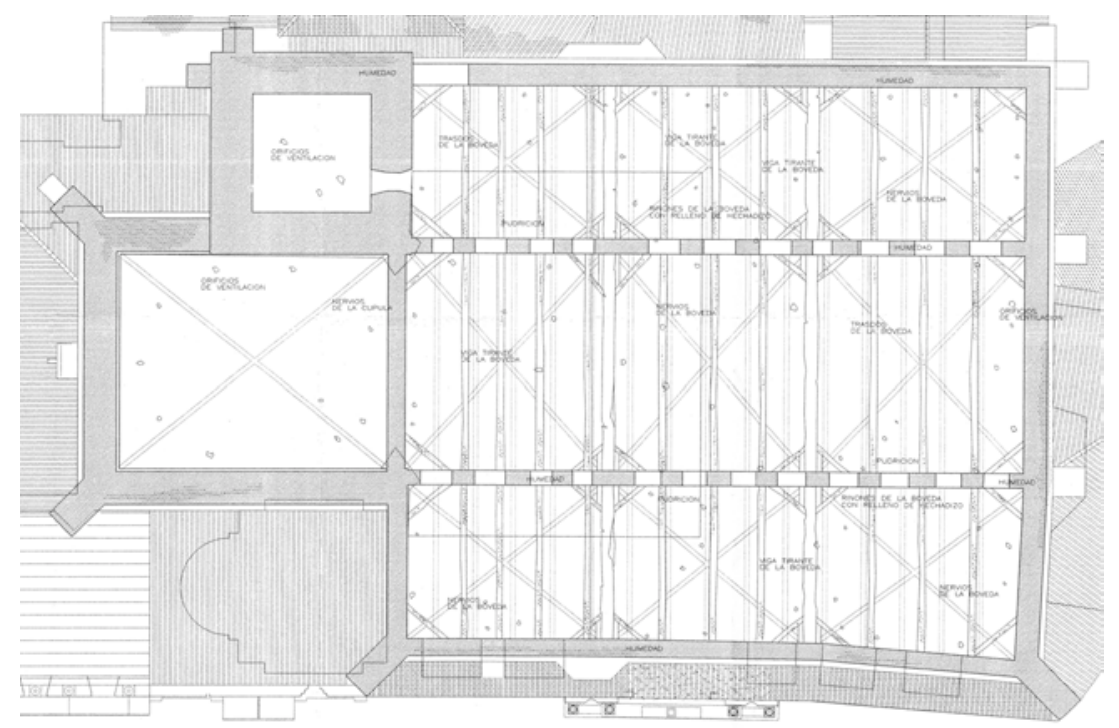

Ilustración 20: estructura de cubierta 1999 Paniagua JCyL

\section{Zunchos}

En las imágenes de estado previo y situación actual de la página anterior podemos observar cómo el doble durmiente de madera se reemplaza por un zuncho de hormigón armado que sirve de apoyo a la nueva estructura de cubierta de madera laminada. 
En el proyecto de emergencia, redactado en 1999, se planteaba reemplazar únicamente la estructura de cubierta de naves laterales, según se ha dicho, manteniendo la madera sin escuadrar sobre la nave central.

En el detalle de la derecha se aprecia la solución de zuncho mantenida desde entonces, con doble durmiente, que finalmente se demuele para reconstruir el muro, según lo explicado en la página anterior. En el detalle de la izquierda tampoco llega a ejecutarse esa pieza que muerde el tirante en la cara interior del muro, aunque se mantienen el zuncho y la cornisa-canalón.

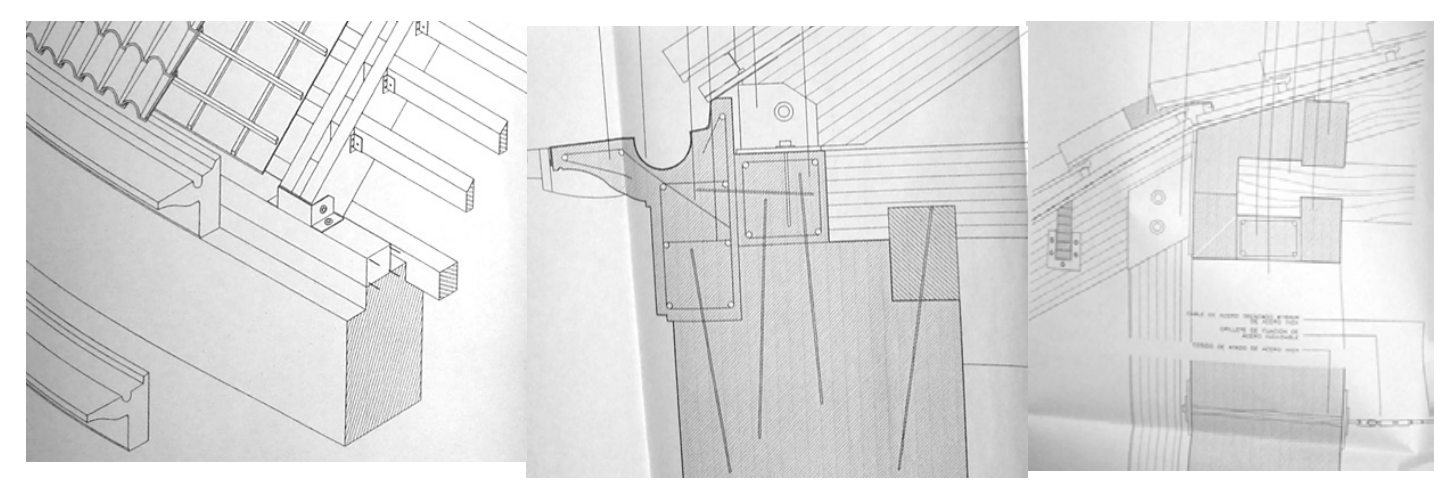

Ilustración 21: detalles zunchos (Paniagua 1999)

Los pares de las naves laterales se anclan a la cara del zuncho interior mediante conectores metálicos y apoyan sobre el zuncho de fachada. Los tirantes se anclan a la cara lateral de este último.
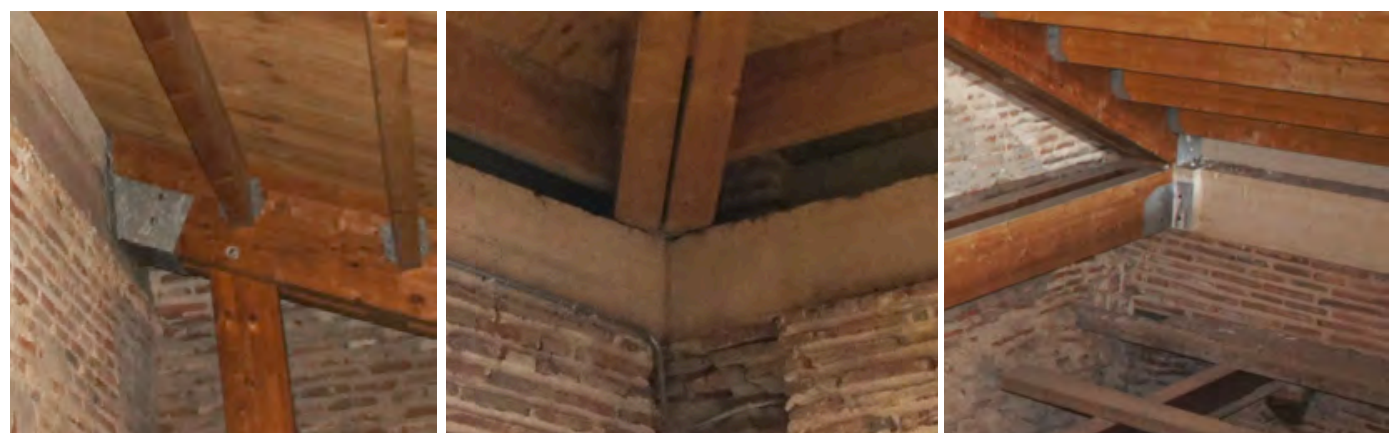

Ilustración 22: detalles nave central y laterales (visita 05/05/2014)

En la nave central, el zuncho configura un anillo perimetral rectangular completo. Los pares apoyan sobre este zuncho perimetral, y sus tirantes acometen directamente a la sección de madera laminada. 


\section{Conclusiones}

En este edificio se incorporaron zunchos de hormigón armado en 1983, pero fueron demolidos en 1999. En esta segunda intervención se reemplaza la estructura de madera por una nueva de madera laminada, dispuesta con un zuncho perimetral rectangular cerrado sobre la nave central y dos en las fachadas norte y sur, engarzados con una pieza de cornisa-canalón también de hormigón. Todos estos elementos se cosen al muro de fábrica. En la cabecera la nueva estructura es de madera aserrada y sus cerchas también apoyan sobre un zuncho de hormigón armado.

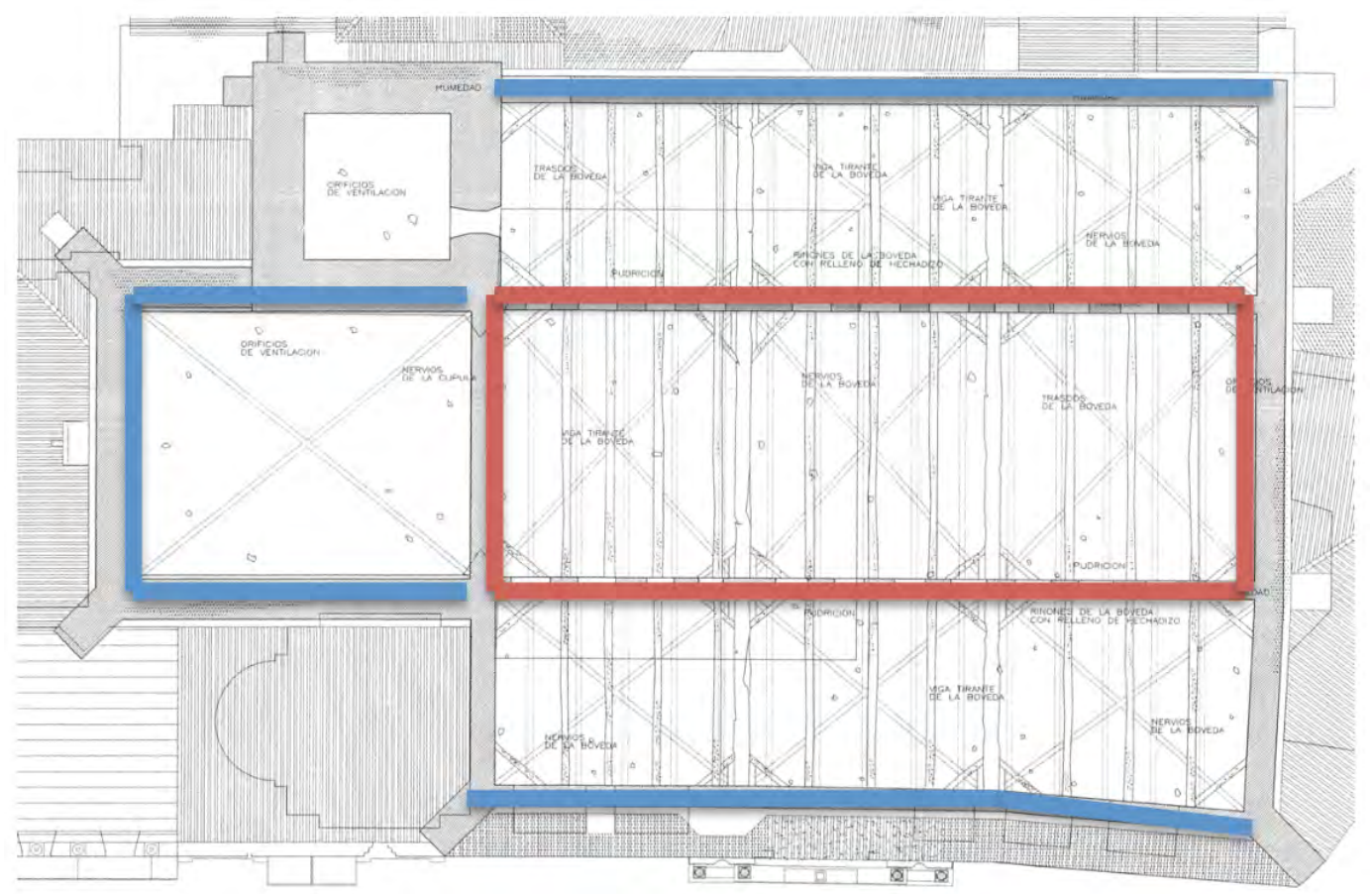

Ilustración 23: esquema zunchos

Otro zuncho del mismo material resuelve el apoyo y anclaje de una estructura de madera laminada que reemplaza a la original en la capilla de las Angustias, según se explica en el resumen de inspección in situ incorporado como anejo.

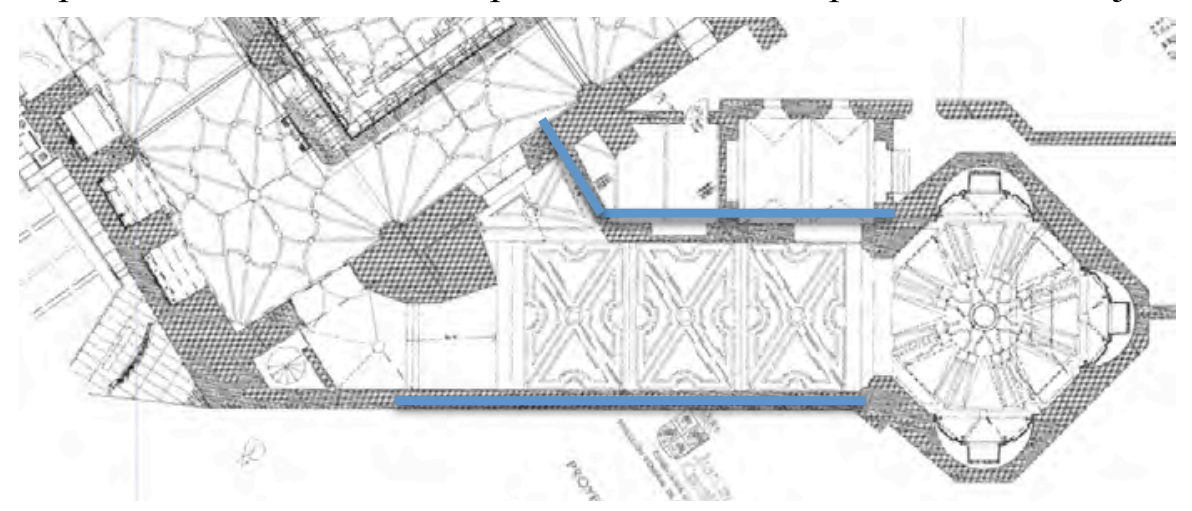

Ilustración 24: esquema zunchos Angustias 


\section{Iglesia de San Antolín. Medina del Campo}

Intervenciones citadas en la publicación del Ministerio

1982 - Cubiertas y consolidación de muros y arcos - José Ma Gómez Santander

En la página web del IPCE no se han encontrado planos digitalizados.

La iglesia cuenta con un cuerpo original compuesto por tres naves de la misma altura y una amplia cabecera rectangular cubiertas con bóvedas de crucería estrellada. Se adosan lateralmente estancias de cierta entidad, como la capilla de Montserrat, la de Quiñones o el cuarto de Canónigos.

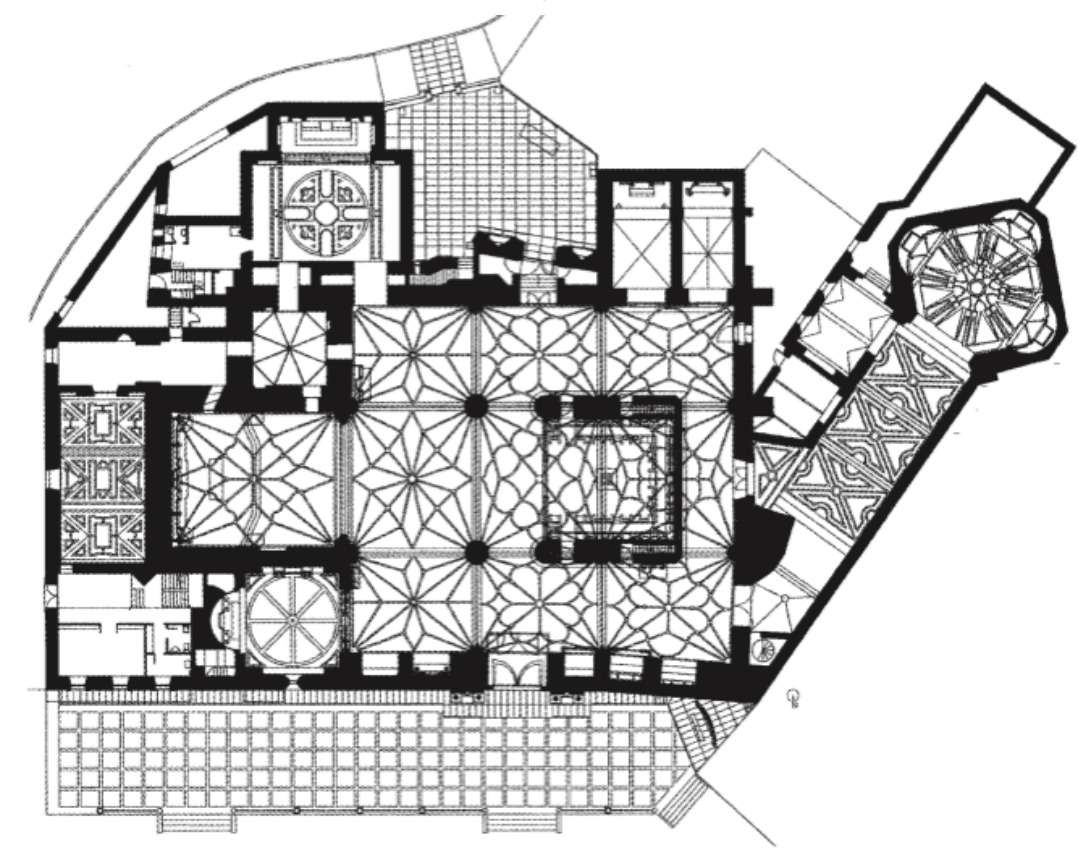

Ilustración 25: planta Catálogo

A los pies se levanta diagonalmente un volumen con remate trebolado barroco que alberga la Capilla de las Angustias.

\section{En el archivo del IPCE}

Carpeta 640-2

1982 - Cubiertas y consolidación de muros y arcos- José María Gómez Santander Memoria del estado de conservación y obras a realizar: La estructura de cubiertas es de formas de madera. En general se encuentran en mal estado, existiendo numerosas goteras. Muchas tienen las cabezas rotas o descompuestas y otras están partidas. Las 
de las naves laterales tienen un enorme desplazamiento por falta de arriostramiento. Están apuntaladas con madera. En la nave central no observa desplazamiento.

Las obras pretenden desmontar la cubierta, construir zunchos perimetrales de nivelación y consolidación y volver a colocar la estructura antigua reparada sustituyendo las formas deterioradas. Se plantea recibir la teja con mortero cada cinco hiladas.

Hay algunas zonas con fibrocemento que se pretende acometer en fases siguientes. El arquitecto afirma que pilares y bóvedas (de varias roscas de ladrillo) están en buen estado. Detecta una intervención anterior en que se atirantó la torre campanario mediante barras de acero.

En la justificación de cálculo de la estructura de madera aserrada de cubierta que contiene el proyecto, exigida en un anexo al informe de supervisión del proyecto realizado en el Servicio de Inspección Técnica del Ministerio, se considera una pendiente de $20^{\circ}$ y pares de $5,70 \mathrm{~m}$ de luz entre cerchas cada $2,50 \mathrm{~m}$.

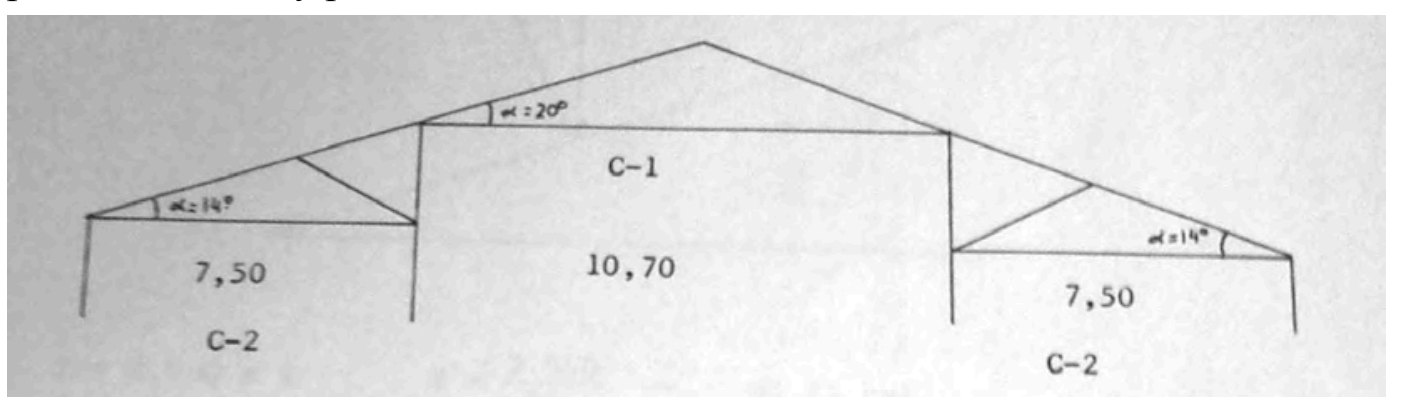

Ilustración 26: esquema estructural (Gómez Santander 1982 IPCE)

El croquis no parece concordar con la geometría real, ya que acota los ángulos de inclinación de los pares en naves laterales como $14^{\circ}$ pero los representa en continuidad con los interiores que acota como $20^{\circ}$. Tampoco cuenta con unas grandes vigas que atan horizontalmente las tres naves a cota de cornisa.

Entre las acciones consideradas para estos cálculos junto al peso propio de tablero $40 \mathrm{~kg} / \mathrm{m} 2$ y teja $50 / \mathrm{kg} / \mathrm{m} 2$ incluye $\operatorname{los} 140 \mathrm{~kg} 7 \mathrm{~m} 2$ de una losa de hormigón armado.

La carpeta contiene una Memoria final sobre la primera fase de las obras de restauración de la Colegiata, consistentes en reparar toda la cubierta principal ya que las "formas de madera se encontraban en mal estado de conservación, o rotas o descompuestas las cabezas en su contacto con la fábrica de ladrillo. Una acción continuada del tiempo junto con otros agentes habían producido el efecto dominio sobre las estructuras de las naves laterales. [] La amenaza de ruina era evidente" 
La ejecución se resolvió en tres etapas, atirantando las formas con tensores de acero.

Se proyectó encajar un zuncho perimetral de hormigón armado entre los durmientes superior e inferior del muro de la nave central. Se desbastó el durmiente superior tras recolocarlo para recibir las formas. (imágenes del plano $\mathrm{n}^{\circ} 9$ julio 82 )

El zuncho continuo se prolonga en toda la coronación del hastial y de los muros longitudinales centrales.

Se cambió el diseño de proyecto de teja sobre tablero fenólico por tabla machihembrada impermeabilizada con Aquaseal y un tendido de arena para evitar el deslizamiento de la teja. Los tirantes abiertos se cosieron con bridas metálicas.

En enero de 1984 cae un trozo de yesón de las nervaduras de bóveda
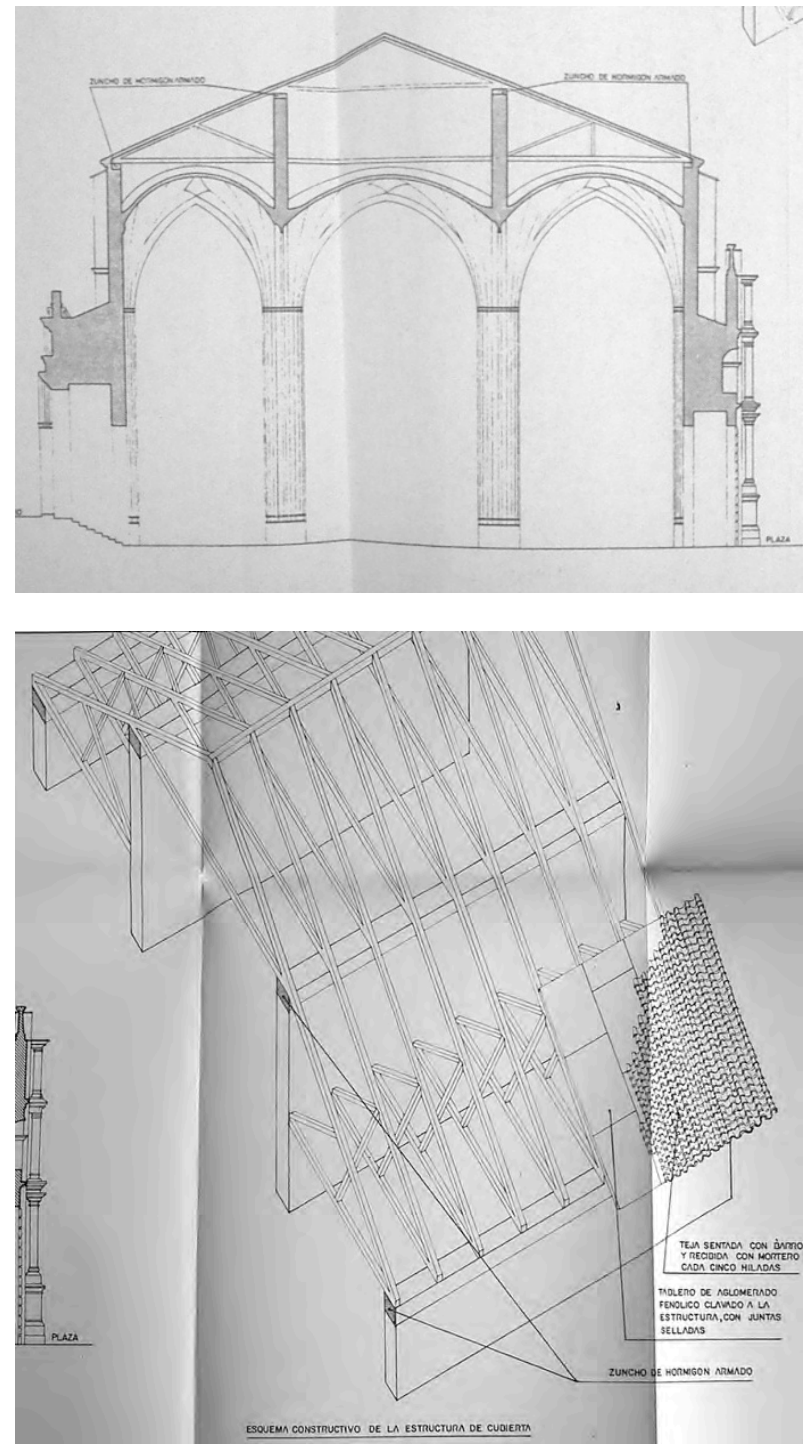
sin connotaciones estructurales.

Según Gómez Santander, el citado efecto dominio ha provocado un desplome tan pronunciado del muro posterior de la bóveda lateral que se debe demoler y reconstruir el hastial de fábrica. Se realiza desde el interior con andamio colgante para no dañar las cubiertas de edificios adyacentes

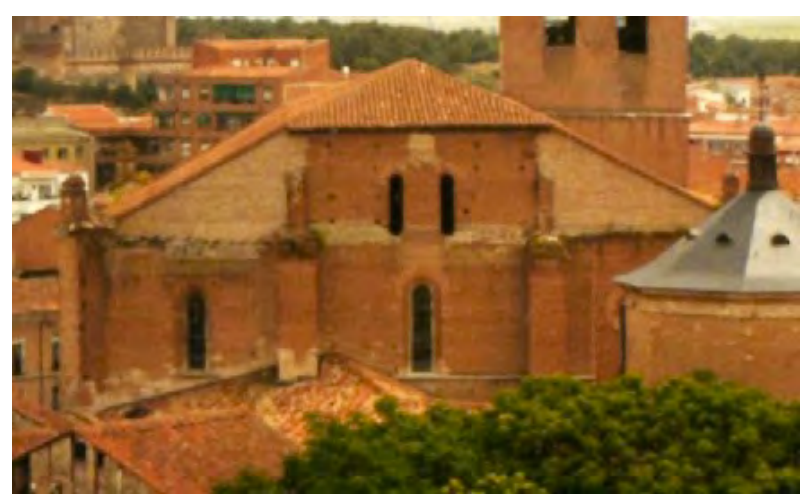
más bajos. 


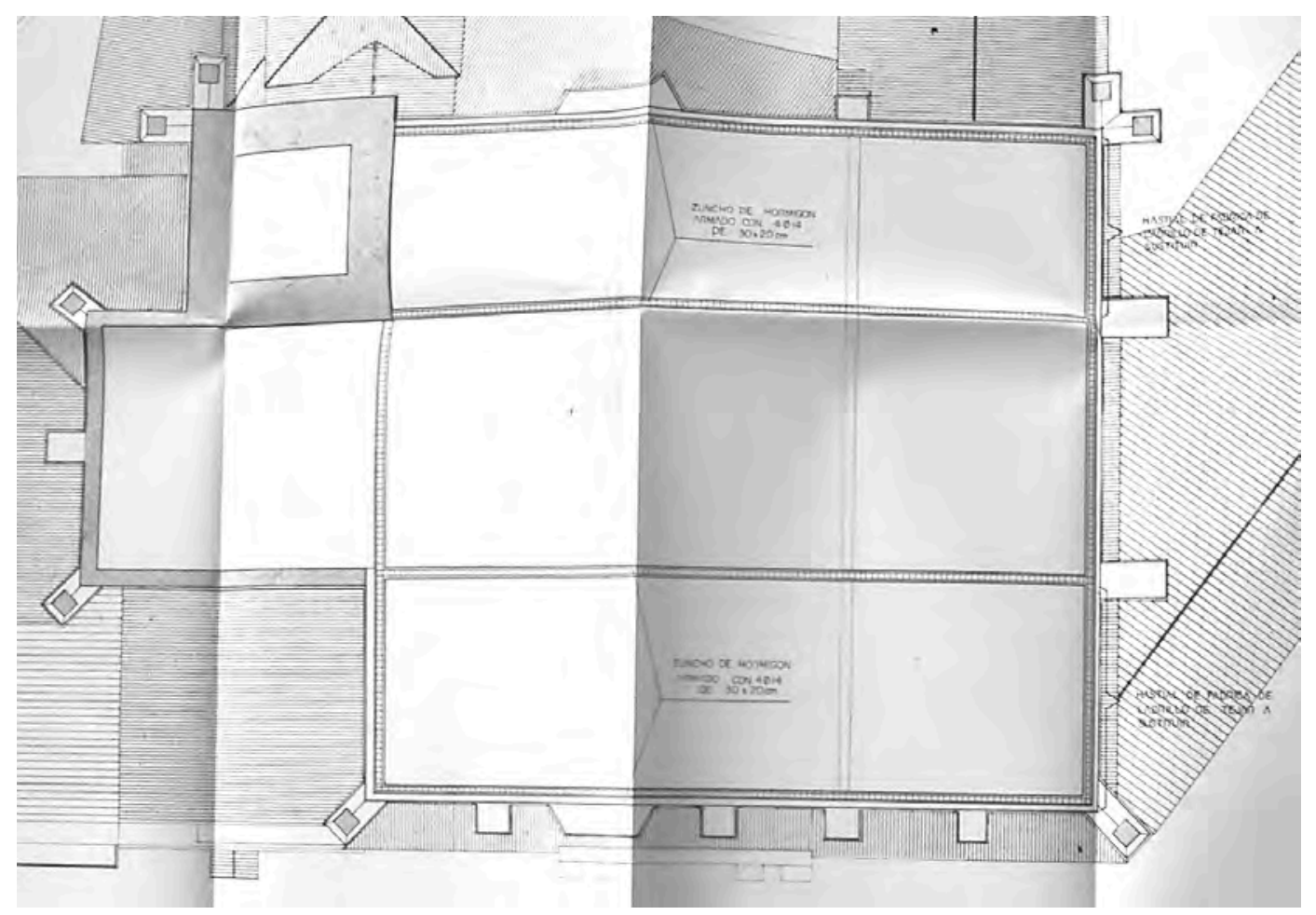

Ilustración 29: planta estructura (Gómez Santander 1982 IPCE)

\section{Notas:}

En la copia de un levantamiento planimétrico de 1991 del archivo de la JCYL también se incluye reproducción a escala reducida de varios de estos planos con la carátula original.

No se ha localizado datos de otras obras para la Consejería de Cultura y Bienestar Social de la Junta citadas en la documentación del Archivo:

1989-90 - Proyecto de acondicionamiento y recuperación - Carlos Descalzo Llorente, Luis Hernández Duque y Jesús Tovar

\section{En el Archivo General de la Administración}

AGA 26/01512

Restauración parcial de la Colegiata de San Antolín, en Medina del Campo

Acta de replanteo julio 1983 José María Gómez Santander

Constructora: Juan Antonio Carrillo Vallejos 
Dossier visado por el Ministerio, en el índice figura: Memoria, Actas, Certificado final, planos, resumen de certificaciones, valoración de obras ejecutadas, liquidaciones (enero 1985) firma de Antón Capitel, pero no hay planos en la carpeta. m2 desmontado de teja curva y tabla de ripia con clasificación de material aprovechable y transporte al vertedero medición proyecto 945; real de obra 1013,27

$\mathrm{m} 2$ desmontado de estructura de cubierta de madera formada por pares y tirantes, con clasificación de material aprovechable para su posterior utilización $\mathrm{m} 2$ demolición de muro de ladrillo macizo de 1 pie en hastiales de naves laterales... $\mathrm{ml}$ zuncho de hormigón de $350 \mathrm{~kg}$ de cemento con una sección de 30x20 armado con $6 \mathrm{~d}$ de 14 , incluso formación de caja en muros encofrado y desencofrado previsto 32 , real $64 \mathrm{~m}$

m2 montaje de estructura de madera aprovechando los elementos desmontados anteriormente (50\%aprox) y reponiendo los necesarios, con formación de tablero de aglomerado fenólico clavado a la estructura y piezas necesarias para su nivelación con tratamiento de protección de la madera y sellado de juntas.

$\mathrm{m} 2$ cobertura de teja curva vieja con mortero bastardo, incluso parte proporcional de limas y caballete

m2 fábrica de ladrillo de tejar de 1 pie de espesor en formación de hastiales de naves laterales incluso formación de andamios

\section{AGA 26/01257 (1)}

Carpeta con documentación administrativa: Pagos en firme, liquidaciones, etc.

Obras de restauración parcial en la Colegiata de San Antolín en Medina del Campo Gómez Santander -

Se adjudicó al constructor Juan Antonio Carrillo Vallejos en junio de 1983

Recepción provisional abril de 1984

Liquidación: medición proyecto--medición obra

m2 desmontado de teja curva y tabla de ripia etc 945--1013,27

$\mathrm{m} 2$ desmontado de estructura de madera formada por pares y tirantes íd $\mathrm{m} 2$ demolición de muro de ladrillo macizo de 1 pie hastiales de naves laterales 32-64 $\mathrm{ml}$ zuncho de hormigón de $350 \mathrm{~kg}$ de cemento con una sección de 30x20 armado con 6D14, incluso formación de caja en muros encofrado y desencofrado 167,20-192,80 m2 montado de estructura de madera aprovechando los elementos desmontados anteriormente (50\% aproximadamente) y reponiendo los necesarios, con formación de tablero de aglomerado fenólico clavado a la estructura y piezas necesarias para su nivelación con tratamiento de protección de la madera y sellado de juntas 
m2 cobertura de teja curva vieja sentada con mortero bastardo incluso parte proporcional de limas y caballete íd

$\mathrm{m} 2$ fábrica de ladrillo de tejar de 1 pie de espesor en formación de hastiales de naves laterales incluso andamios íd

AGA 26/01257 (2)

Carpeta con documentación sólo administrativa: Pagos en firme, liquidaciones, etc.

Restauración parcial de la Colegiata de San Antolín en Medina del Campo

Gómez Santander --

\section{En el archivo de la Junta de Castilla y León:}

\section{VA-182}

\section{Carpeta 5355}

Contiene un Informe de enero de 1994 de Antonio García Paniagua (arquitecto elaborador del Plan Director) sobre el estado de algunas partes de la Colegiata que podían requerir actuación urgente, ya que se habían producido desprendimientos de las fábricas a vía pública recogidos en prensa: humedades en arranque y coronación de fábricas, vegetación en portada, grapas al aire en balcón, cubiertas en muy mal estado, atrio sin drenaje, etc.

La elaboración del Plan Director de la Colegiata arranca en 1991 con una valoración de actuaciones y plazos.

Fase previa (3 meses):

Memoria histórico artística

Levantamiento planimétrico.

Estudio legal

Primera fase (1 mes):

Ficha chequeo según modelo de la Dirección General

Segunda fase (15 meses, es necesario cubrir un ciclo climático completo):

Estudio arqueológico (catas)

Diagnóstico de materiales

Análisis estructural (testigos)

Patología

Fase final (3 meses):

Planes de intervenciones, usos, estudios, gestión y difusión. 
El Levantamiento planimétrico cuenta con 34 planos. También incluye copia de abundantes fotografías y dibujos previos localizados:

1961 Catálogo monumental de Esteban García Chico;

1975 Arquitectura religiosa del sXVI en la primitiva Diócesis de Valladolid de Felipe Heras García;

1982 Levantamiento para el proyecto de restauración de Jose $M^{\mathrm{a}}$ Gómez Santander; 1988-90 Planos del proyecto de Acondicionamiento y recuperación de Carlos Descalzo Llorente.

\section{Carpeta 6297}

Memoria histórico-artística redactada por el historiador Antonio Sánchez del Barrio en 1993.

Según este historiador, la primera mención documentada a una iglesia románicomudéjar de San Antolin en esta población es de 1177. (Coincidente con lo indicado en el Catálogo Monumental)

En 1480 Sixto IV emite la bula de creación de la Colegiata, a raíz de lo cual en 1503 se "alarga" el edificio y ejecuta el grueso de la obra que perdura en la actualidad. En una escritura se cita a Juan Gil de Hontañón como artífice de los muros del crucero, dándose instrucciones para la mezcla del migajón (mortero para aparejar el ladrillo) 4 de arena e 2 de cal en botaletes, 5 e 2 en paredes, se define un ancho 4 pies para paredes de ladrillo blanco al interior colorado al exterior, etc. Por las anotaciones en el Libro de Bezerro conocemos también las diferentes intervenciones y levantamiento de capillas, con la nueva sacristía en el XVII y la consagración de la capilla de las Angustias, levantada en dos fases, en 1749.

En 1841 se coloca un entramado metálico sobre la torre tras quedar destruido el antiguo chapitel ochavado por la caída de un rayo.

El atrio suscitó controversia al ser mal ejecutado por Juan de Ornedo, debiendo desmontarse gran parte del mismo.

La cimentación de la capilla de las Angustias tuvo que ser reforzada durante su construcción al aparecer bodegas antiguas y afloramiento de aguas.

La techumbre de dependencias de la sacristía se derrumbó en 1966.

En 1983 se acomete una renovación casi total de las cubiertas de las tres naves, y en 1985 la de la capilla del Pópolo. 
Esta capilla abierta es el antecedente más antiguo de las capillas exteriores o "de indios" extendidas por Hispanoamérica. Se realizan así para celebrar misa hacia la plaza en días de mercado y que los feriantes puedan seguirla sin abandonar sus tenderetes.

En los noventa se lleva a cabo una consolidación de la capilla mayor.

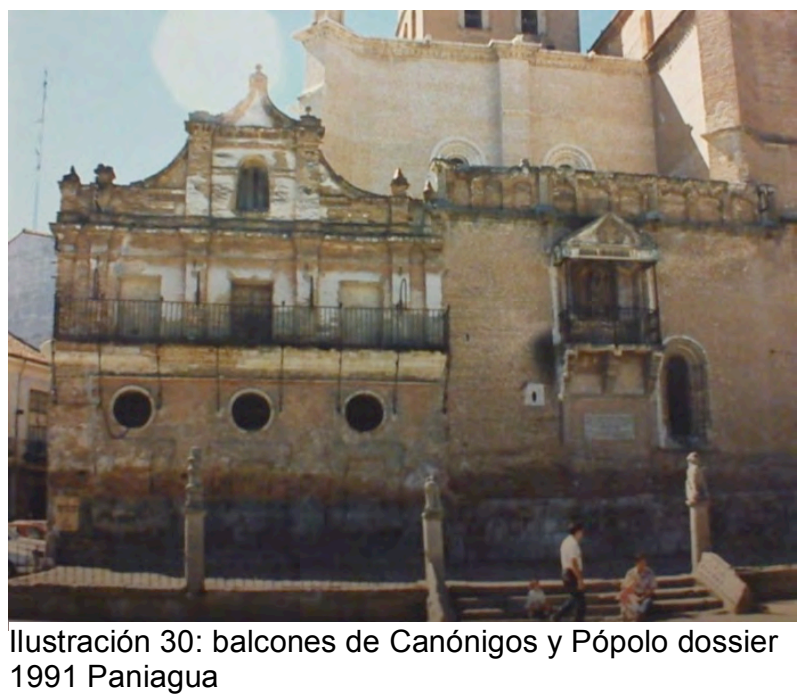

Se incluye en este archivador un Estudio termográfico del Instituto Torroja, para localización de humedades en edificios del Patrimonio Histórico, según el cual no se aprecia acumulación de las mismas, aunque en la propia memoria se advierte de que se trata de un método que no detectaría un problema por condensación homogénea en el paramento.

\section{Plan Director}

Encargado al arquitecto Antonio García Paniagua por la Dirección General de Patrimonio en agosto de 1991, sus objetivos son la restauración, consolidación y puesta en valor de la Colegiata, gran parte de la cual encuentra en un estado lamentable.

\section{Materiales:}

De la cimentación arranca un zócalo de sillería de piedra caliza de altura variable, rematado con moldura en la fachada norte. Las fábricas son de ladrillo macizo de tejar con mortero de cal y están reforzadas con contrafuertes del mismo material con pináculos de remate, excepto los de la torre, que se resuelven con granito. La cornisa es de piedra caliza en unos casos y de ladrillo en otros.

Las bóvedas son de ladrillo tabicado con nervios de piedra. En la capilla de las Angustias bóveda y arcos perpiaños son de ladrillo.

La estructura de cubierta es de madera maciza, aunque en la capilla de las Angustias ha sido reemplazada por madera laminada, con correas de madera maciza, y en la zona de Canónigos fue sustituida por estructura metálica. 
La cobertura general de las cubiertas es de teja árabe, empleándose pizarra en la cubrición de la capilla de las Angustias y fibrocemento en la del cuerpo de Canónigos.

En el Plan se repite la enumeración cronológica de obras del estudio histórico, que hace evidente la reiteración de intervenciones (1645 capilla de Quiñones, 1676 reforma de portada, 1691 construcción de balconada de Canónigos, etc). Se describe cómo en 1895 se acometieron importantes obras de saneamiento y drenaje, sobre todo en la parte sur, y en 1982 Gómez Santander sustituyó las cubiertas de nave central y laterales, incorporando una nueva estructura de madera con tablero aglomerado y teja sobre un zuncho de atado de hormigón armado.

Entre 1988 y 1990 Descalzo sustituye las cubiertas de Capilla Mayor y Sacristía y en 1992 se lleva a cabo la Restauración de la Capilla de las Angustias.

La Colegiata fue declarada Monumento Histórico Artístico en el Decreto de 1931, y catalogada con Protección Integral Bien de Interés Cultural Existente en el PGOU de Medina.

Análisis del estado de conservación:

En muchos casos está sin resolver el encuentro de las cubiertas con las fábricas, incluso con ausencia de alero, lo que provoca el lavado continuado de los muros. Las fábricas se encuentran significativamente erosionadas y alteradas. En la fachada oeste falta remate en el muro, lo que produce aspecto inacabado, con rejuntados inapropiados y huecos del bajo cubierta sin controlar. Hay soluciones constructivas inadecuadas, como en el engarce de fábricas de capilla de Quiñones y acceso a la torre. Las grietas en bóvedas denotan, según Paniagua, la existencia de movimientos en algún momento. La plementería se encuentra en mal estado, aprecia deformaciones de arcos y bóvedas.

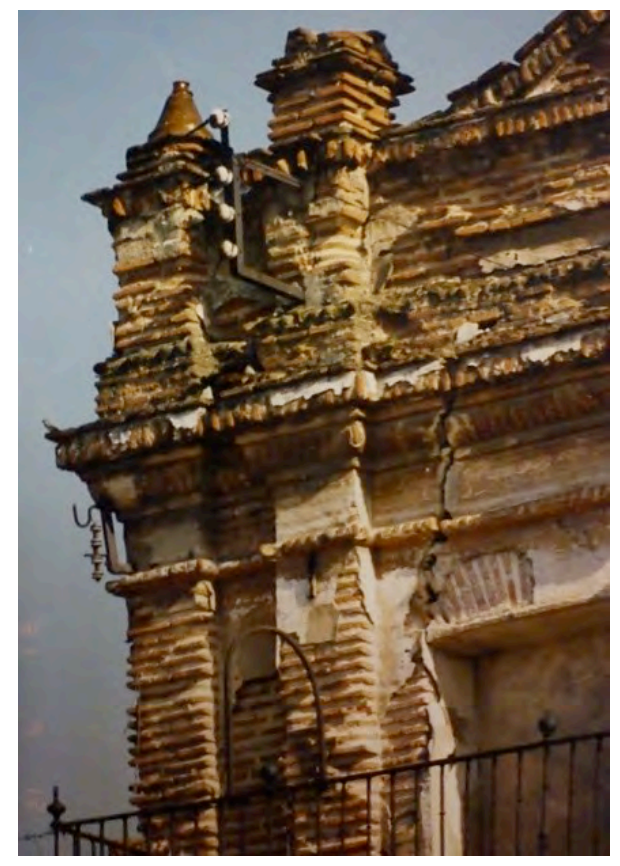

Ilustración 31: fotografías dossier patología Plan Director

En la intervención más reciente se consolidaron por el extradós las bóvedas de las Angustias y su cúpula sufrió una restauración integral. Paniagua indica que el diseño 
de la estructura de cubierta de madera de la capilla Quiñones (afectada además por pudrición) es inapropiado, con un pendolón central que transmite empujes a la bóveda.

En la cubierta restaurada en 1982 de naves central y laterales no se resolvió de forma definitiva los aleros, y la evacuación de aguas está provocando notables patologías en las fachadas. En algún momento se produjeron desprendimientos en la ruinosa balconada de los Canónigos que aparecieron en prensa.

El autor del Plan remarca cómo los enfoscados sucesivos de cemento han incrementado el deterioro de las fábricas. En el interior destacan los intentos fallidos de tapar humedades, como el zócalo de plástico de $1,5 \mathrm{~m}$ de altura en la zona del altar de la Capilla mayor, otro de contrachapado hasta $1,3 \mathrm{~m}$ en la de Quiñones, y de 1,8m en la del Carmen.

Tampoco en las Angustias funciona la cámara de ventilación del zócalo de la nave.

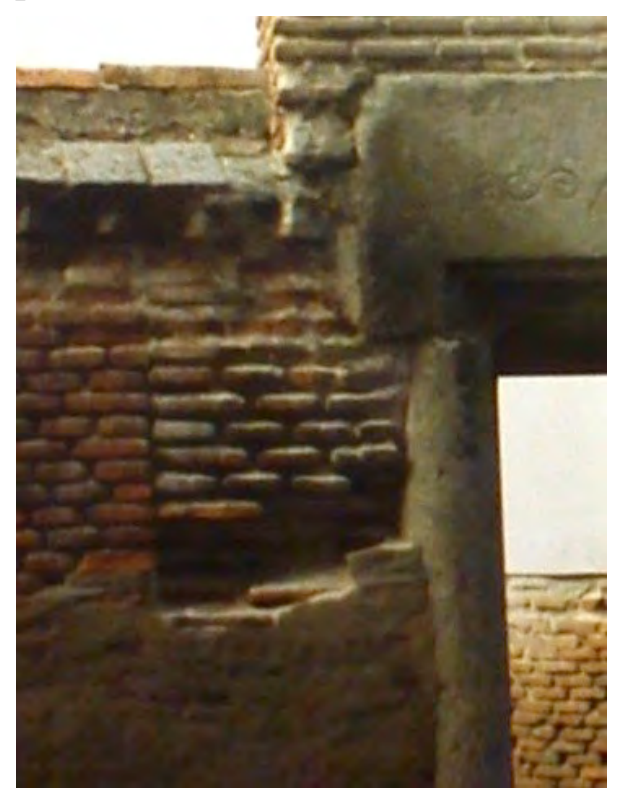

Ilustración 32: dossier Plan Director

El pavimentado con una solera de hormigón sobre el solado original del Atrio de $\mathrm{N}^{\mathrm{a}}$ $\mathrm{S}^{\mathrm{a}}$ de San Julián además de no resolver las recogidas de aguas evita la ventilación del subsuelo, por lo que ha agravado los problemas de capilaridad de las fábricas.

En el archivo fotográfico de la Oficina de Obras de la Diócesis de Valladolid se documentan las distintas intervenciones realizadas en la Colegiata. Cita como fuentes además el Catálogo monumental de Medina de 1961 de García Chico y el archivo de Antonio Sánchez del Barrio.

\section{Diagnóstico:}

El origen de las patologías se debe al agua, la falta de mantenimiento y el envejecimiento de los materiales. La catequesis se impartía en la capilla de Quiñones pero ésta se cerró tras un desprendimiento en la bóveda. En general el estado de conservación de las bóvedas es bueno, las grietas parecen estacionarias y no ha sido necesario intervenir sobre las mismas. La plementería de las naves sí ha perdido su adhesión al soporte, produciéndose pequeños desprendimientos continuos. 
Los Planes de actuación definidos en el Plan Director comprenden un periodo de 8 años, con dos tipos de intervenciones, unas de restauración y consolidación, y otras de mantenimiento. Para aprovechar de forma rentable los medios auxiliares se complementan obras a corto plazo (en los cuatro primeros años) con las de urgencia. Se intenta además acometer las fases por piezas completas.

\section{Corto plazo:}

Consolidar y restaurar bóvedas y forjados (arriostramiento horizontal), fábricas y balaustradas de la torre. Se diseña una cúpula como la original.

Instalar redes horizontales de saneamiento y ventilación a lo largo de toda la fachada. Desmontado y reconstrucción del balcón del Pópulo.

Sustitución de las cubiertas de Canónigos y Quiñones rediseñando la pendiente.

Se incorporan forjados para albergar el centro parroquial en el cuerpo de Canónigos.

Restauración de portadas norte y sur.

Restauración de bóvedas de naves y recuperación del pavimento original.

Instalación de suelo radiante.

Medio plazo:

Atrios, sacristía, resolución de aleros y cornisas de fachada oeste e instalación de una zona de exposición de la obra de la Colegiata (con una temporal sobre la restauración) en el espacio bajo cubierta de la nave central.

\section{Largo plazo:}

Recuperar acceso principal a las Angustias y colocar en ésta suelo radiante, traslado del Órgano mayor a su ubicación original, solados de capillas y remate del resto de paramentos.

Plan de mantenimiento con inspección anual para limpieza de desagües y limahoyas, retejados, repasos, etc. Se recomienda contratar a una empresa calificada.

Recomienda realizar en el futuro estudios complementarios de los materiales para caracterizar la piedra, el ladrillo y los morteros que permitan tratar más eficazmente sus alteraciones.

Propone crear un "Consejo de Fábrica" como órgano encargado de la Gestión y la figura de Arquitecto-conservador como responsable de las obras y el control del mantenimiento anual futuro. Se incluye medición y valoración de las diferentes partidas que suponen la obras previstas, que alcanzarían 300 millones (por el orden de magnitud se supone estas cuantías expresadas en pesetas, que aunque no se 
indican unidades en el documento, fechado en agosto de 1994) a corto plazo, 600 totales y 1,5 millones al año para mantenimiento.

En el Plan Director se incluye un reportaje fotográfico de 78 imágenes ordenadas según recorridos. En las mismas se aprecia el estado de degradación de las fábricas en muchos puntos, descarnadas y con humedades debidas principalmente a la falta de alero.

Se cuenta con una serie de planos de Diagnóstico sobre los que se marca las manchas, grietas, etc. En el $n^{0} 5$ se representa la evolución histórica del conjunto, incluyéndose las adiciones por fases. Las intervenciones a corto, medio y largo plazo se definen también sobre plantas, alzados y secciones longitudinales, con una planta de cubiertas en la que se señalan las futuras tareas de mantenimiento.

A partir del Plan Director se desarrollan diferentes proyectos de intervención sobre el conjunto realizados por el mismo arquitecto: restauración bóvedas, reparación de cubiertas, restauración de Cuarto de Canónigos y del Balcón del Pópolo, etc.

\section{VA-238}

1996 - Proyecto de restauración cuarto de canónigos y capilla exterior de la Concepción de la Colegiata de San Antolín - Antonio García Paniagua

Se incluye una descripción general del conjunto y sus patologías equivalente a la desarrollada en el Plan Director, del mismo autor, del que este proyecto emana. Se aborda específicamente:

Incorporación de redes horizontales de saneamiento y ventilación a lo largo de la fachada.

Restauración del Altar del Pópolo, desmontaje de piedra, reemplazo de grapas, reparación de muretes, gárgolas y cornisa.

Consolidación y tratamiento de fachada exterior del cuarto de canónigos. Sustitución de su cubierta rediseñando pendientes y con otros materiales. Incorporación de forjados y distribuciones para uso centro parroquial.

Cuarto de Canónigos

Se pretende recuperar la imagen original de la fachada, redefiniendo líneas de cornisa, huecos, impostas y frontón. Se incorpora una gran superficie acristalada en el lateral para resolver la transición hasta el cuerpo de la sacristía.

Los paramentos se revocan para proteger las maltrechas fábricas y favorecer la lectura compositiva. Para resolver el revestimiento se aplican $2 \mathrm{~cm}$ de enfoscado con 
mortero bastardo de cal y cemento 1:1:4 y $5 \mathrm{~mm}$ de revoco también de mortero bastardo, con mármol y tierras coloreadas.

La nueva estructura de cubierta inclinada es de madera laminada y apoya sobre un angular metálico anclado a la fábrica. Se cubre con panel doble de madera con aislante interior rematado con chapa de cobre engatillada. Se incorpora una zapata aisladas de hormigón armado para soportar un pilar central y otra corrida para la Ilustración 33: plano n¹1 Paniagua 1996 estructura tubular de la escalera.

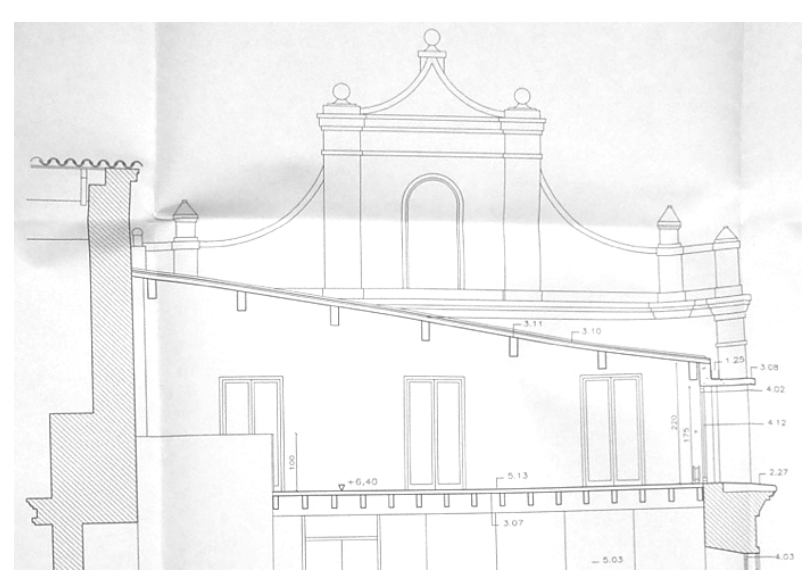

Los nuevos forjados combinan viguetas de madera laminada y tablero contrachapado de $14 \mathrm{~mm}$ con una capa de compresión de hormigón armado con mallazo.

El pavimento en planta baja es de $3 \mathrm{~cm}$ de caliza apomazada a hueso, y continuo de PVC en el resto de plantas. Las carpinterías se fabrican en madera de iroko. Sobre las molduras se fija lámina de plomo clavada. En el frente se incorpora la viga de hormigón armado blanco visto a modo de visera que aparece en la ilustración.

En la carpeta se conserva un informe del Arquitecto Territorial del 6 de noviembre de 1996 en el que advierte que en el proyecto no queda justificado que en esa zona la altura de la edificación llegase hasta la cota proyectada, ya que oculta parte de la cornisa del campanile.
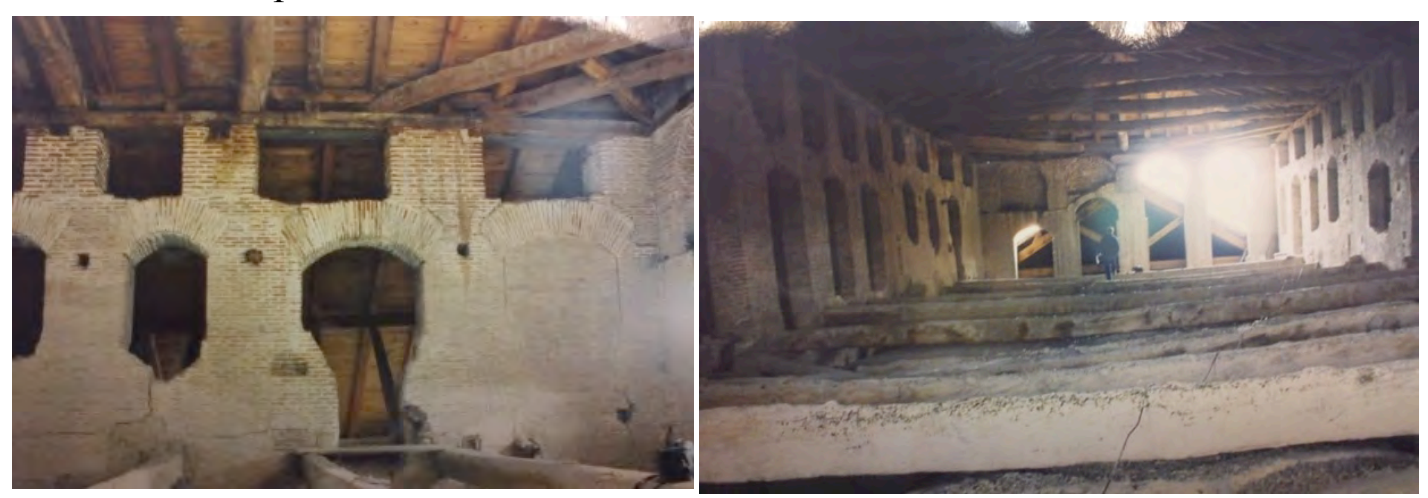

Ilustración 34: bajo cubierta dossier 1996

Capilla exterior de la Concepción

Restauración, consolidación y reintegración. Se trata de recuperar el trazado de la pieza, aplicar fungicida, cepillado, apertura de juntas, desmontado de piezas sueltas y 
cerrajerías, eliminación de grapas de metal. Reconstrucción de faltas de volumen con morteros pétreos o piedra tallada, grapas nuevas de fibra de vidrio, incorporación de cerrajerías restauradas o repuestas, tratamiento consolidante e hidrófugo y patinado final.

\section{VA-398}

1999- Obras de emergencia de las bóvedas y cubiertas de la nave.

Constructora: Técnicas para la restauración y construcciones SA TRYCSA

Arquitecto: Antonio García Paniagua

Aparejador: Alfonso Burgueño Rioja

En el proyecto se describe la actuación sobre la estructura de cubierta de las naves laterales como sustitución, mientras que la central se pretende restaurar. Tras el inicio de la obra se aprecia el mal estado de esta última, por lo que se decide su sustitución. Los planos conservados en la carpeta son los del proyecto original, por lo que en ellos no se define la nueva estructura sobre la nave central. En un informe para la Junta de consejeros se puntualiza que hay que desmontar la cubierta ya que un tirante de la nave central ha caído sobre la bóveda debido a la lluvia.

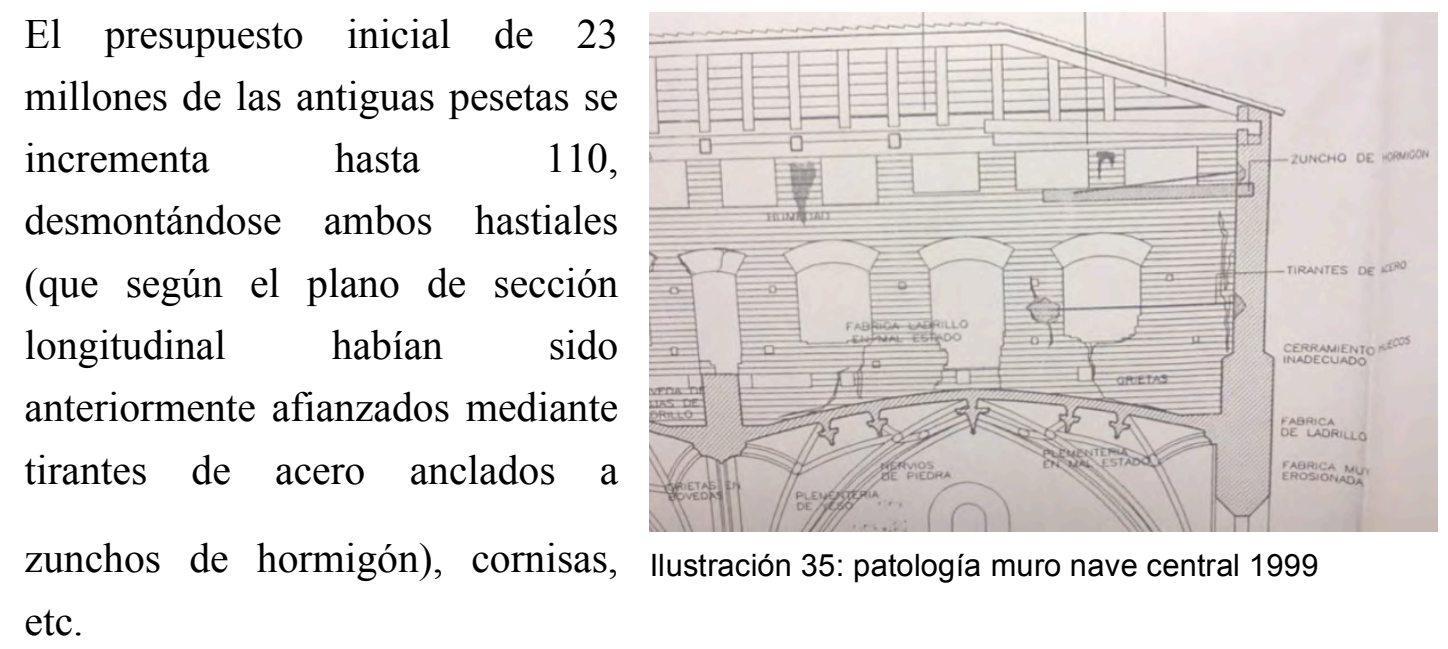

Los planos del proyecto incluyen una pormenorizada descripción de las patologías del estado actual, representándose localizadas las humedades, grietas, erosiones, manchas y pudrición.

Se demuelen mil metros cuadrados de cubiertas correspondientes a las tres naves, con $13 \mathrm{~m} 3$ de apertura de cajas para zuncho y vigas sobre muro de ladrillo con retirada de durmientes y desmontaje de $93 \mathrm{ml}$ de cornisas de ladrillo aplantillado en coronación de muros. 
Demolición con compresor de $24 \mathrm{~m} 3$ de zunchos de hormigón armado 40x30, 40x60 y $45 \times 35$ y ejecución de $39 \mathrm{~m} 3$ de zuncho nuevo visto. En el proyecto se describe un problema de excesiva pendiente de la cubierta de naves laterales, barajando la posibilidad de modificar el diseño escalonándolas, aunque se descarta la misma por la falta de coherencia con el espacio de planta salón que supondría la aparición de parte del muro bajo cubierta en fachada.

La nueva estructura en naves laterales es de medias cerchas de madera laminada con tirantes dobles $320 / 100 \quad y \quad$ tablero contrachapado sobre las correas $80 / 280$ que se describen en el detalle. Se diseñan 30 tirantes de cable de acero Gewi D16mm de $12 \mathrm{~m}$ de longitud.

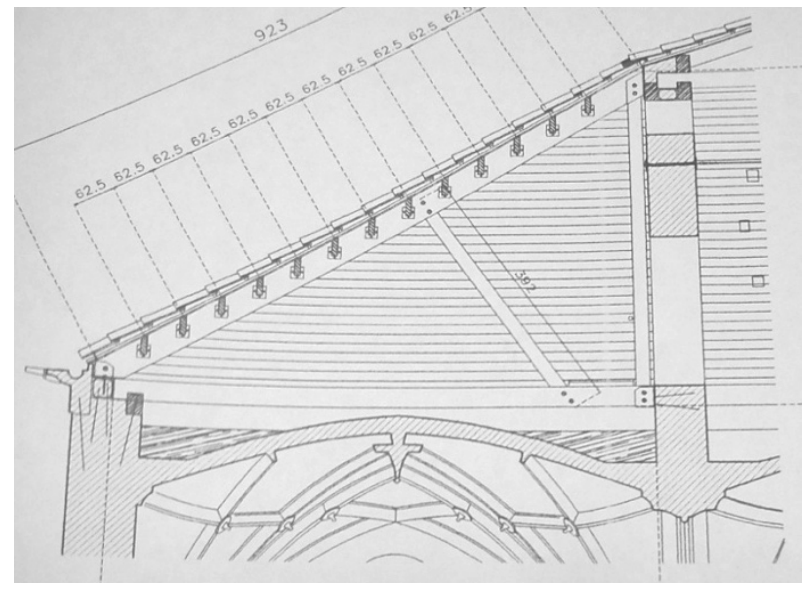

Ilustración 36: detalle cubierta nave lateral

Según el presupuesto se acomete el rejuntado de $157 \mathrm{~m} 2$ de fábrica de ladrillo con mortero bastardo de cal y cemento 1/1/6 y la colocación de $50 \mathrm{~m}$ de cornisa de ladrillo aplantillado con $75 \mathrm{~cm}$ de desarrollo (similar a la existente), la restauración de $20 \mathrm{~m}$ de cornisa de piedra y la realización de $60 \mathrm{~m}$ nuevos en hormigón armado al que denomina "de piedra artificial".

Durante la intervención sobre las cubiertas de la naves se mantiene en uso la Capilla de las Angustias, para lo que se dispone en el interior del templo un pasadizo de acceso temporal cubierto de chapa de $4 \mathrm{~m}$ de ancho y $6 \mathrm{~m}$ de altura.

Memoria final (encontrada suelta el 2 /05/2014, se incorpora a la caja VA-398)

En un documento fechado el 23 de enero de 2001 se resumen las obras realizadas a partir de la actuación de emergencia de 1999, que "se circunscriben a cubiertas de nave central y laterales de la planta salón y a sus muros de cierre a nivel de cubierta"

- Sustitución de estructura y cobertura. Nueva teja colocada en seco sobre rastreles. Cubierta de pendiente única a ambos faldones.

- Reperfilado de las fábricas interiores entre naves con desmontaje de pilastras de ladrillo, ejecución de zuncho corrido para arriostramiento con cosido de fábricas verticales

- Restauración, consolidación y tratamiento de las cornisas de piedra, incorporación de cornisas en piedra artificial en sustitución de las de ladrillo, en fachadas norte y sur 
- Restauración, consolidación y tratamiento de las cornisas y pináculos de ladrillo, en testeros y fachadas norte y sur

- Restauración, consolidación y en algunos casos sustitución de los muros testeros en bajo cubierta

Se colocaron faldones de plomo para resolver los encuentros de cubiertas con paramentos verticales. Los hastiales de fachada este se desmontaron y volvieron a levantar.

Incluye un dossier de fotografías de antes y después de la intervención.

En el presupuesto se describe detalles de la nueva estructura:

Zuncho visto con cosidos a la fábrica de ladrillo de $35 \times 40 \mathrm{~cm}$ en el perímetro $(2 \times 31,0$ $+2 \times 16,3 \mathrm{~m})$ y de $70 \times 60$ sobre ambos muros interiores $(2 \times 31,0 \mathrm{~m}), 14$ pares de madera con escuadría $2 \times 10 / 40$ y $2 \times 10 / 44$ de $9,25 \mathrm{~m}$ de luz y 14 tirantes $2 \times 10 / 32$ de 7,65m en naves laterales.

En las partidas de demolición podemos obtener información sobre la estructura de cubierta existente en el momento de la intervención, formada por pares de sección media 25/20, enanos, pies derechos, arriostramientos y tirantes. La superficie desmontada cubre $31 \times 6,30$ por dos faldones en nave central y dos naves laterales con $31 \times 10 \mathrm{~m}$.

También se retiran 93,10m de cornisas existentes de ladrillo aplantillado con un desarrollo medio de $50 \mathrm{~cm}$.

En la demolición del remate de muros de fábrica marca el espesor de los mismos como $70 \mathrm{~cm}$ en pilastras interiores y $120 \mathrm{~cm}$ las fachadas este y oeste.

El zuncho incorporado en la obra de 1983 que se retira aparece referido de 40x30 en caras este, norte y sur de nave central, de $45 \times 35$ en cara sur de nave sur y 40x30 en cara oeste de nave sur.

\section{VA-428}

2000-Proyecto de Restauración Fachada Norte - Antonio Paniagua

Una caja con documentación administrativa: certificaciones, informes financieros, etc.

En otra caja se encuentra el proyecto y una propuesta de nuevas vidrieras decorativas fechada en octubre de 2001.

Encontramos dos planos de patología de la fachada: ausencia de alero, humedades, erosión, grietas. Se cubre las capillas hornacina con bandejas de plomo, y se dispone a los pies del muro drenaje y atarjea de ventilación. 
En la memoria se describe cómo en ese momento se está realizando la sustitución total de cubierta de las tres naves del templo con estructura de madera laminada y herrajes metálicos.

Ya se encuentran "restauradas" Capilla Mayor y Sacristía, con madera maciza sobre zunchos de atado, así como la capilla de las Angustias y Cuarto de Canónigos con madera laminada.

En las secciones a escala 1:50 aparece sólo el tramo de fachada con su patología.

\section{VA-508}

2002-Proyecto de restauración de bóvedas-Antonio Paniagua

Superficies de cubierta tratadas: cuerpo principal 1495m2; capillas laterales adosadas $125 \mathrm{~m} 2$; sacristía y anejos cabecera 192m2; cuarto de canónigos $110 \mathrm{~m} 2$; capilla Quiñones 268m2 y capilla Angustias 605m2.

Obras a realizar:

- Restauración, consolidación y reintegración de paramentos verticales por encima del nivel de imposta en nave

- Restauración, consolidación y reintegración de bóvedas con nervaduras, pinjantes, etc.

- Restauración, consolidación y reintegración de huecos por el interior con la inclusión de vidrieras artísticas e incorporación de protecciones a las mismas

En la memoria del proyecto se describe la erosión y alteración de las fábricas debidas a las agresiones climáticas. El encuentro de las cubiertas con las fábricas sin resolver en muchos casos, incluso con ausencia de alero, motiva el continuo lavado de los muros.

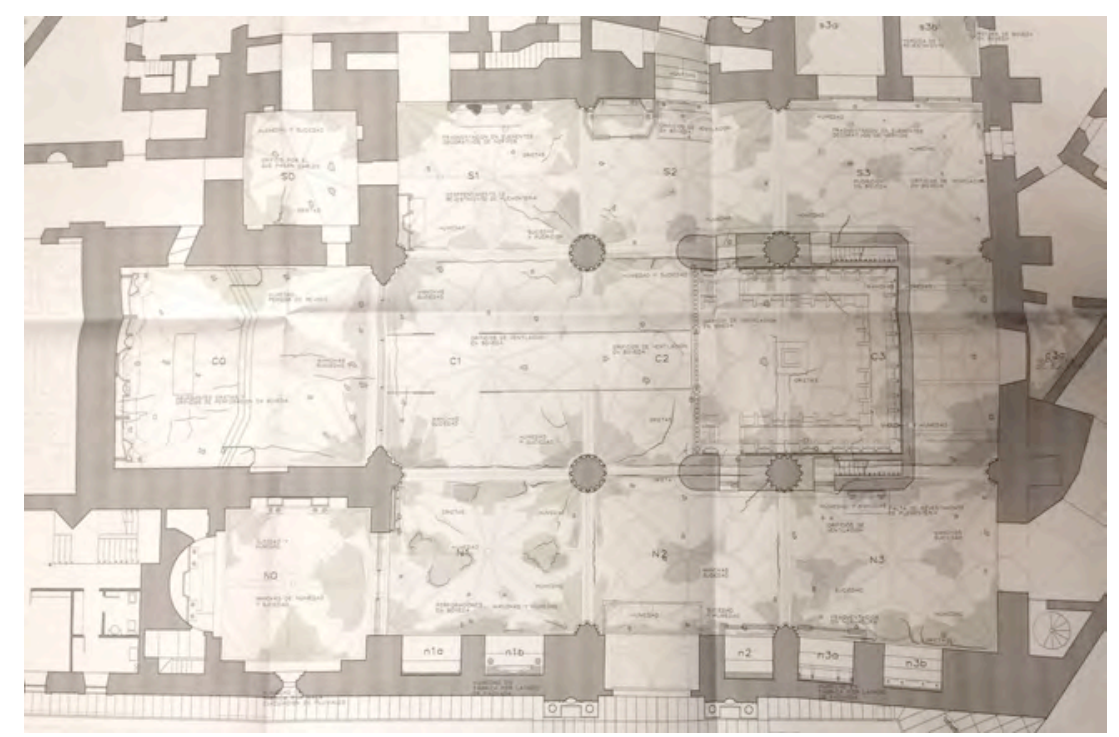

Ilustración 37: patología en bóvedas 
En cuanto a las bóvedas destaca la existencia de grietas en las correspondientes a los cuerpos de la torre. Es reseñable el estado de las de nave norte, en concreto la del último tramo que presenta una pérdida importante de plementería y desprendimientos parciales del revestimiento.

Menciona deformaciones de arcos y bóvedas de nave central y laterales. Hay un "arco de descarga a modo de muleta en uno de los arcos formeros de la nave del evangelio".

Las piezas sueltas en los plementos producen continuos desprendimientos. Ha caído un fragmento de un florón que se encuentra girado y agrietado en el anclaje, y otro trozo de nervadura de los terceletes del lobulado central.

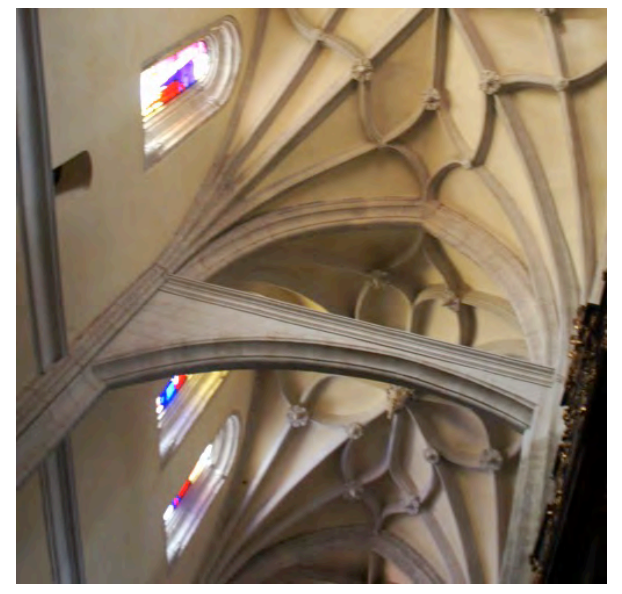

llustración 38: arco codal en nave del evangelio

En la capilla de Quiñones Paniagua observa humedad debida a filtraciones de agua desde la cubierta, así como deformación producida por la transmisión de empujes de la estructura de cubierta.

Para ejecutar la obra se colocó un andamio completo en el interior. Los paramentos verticales se raspan, picando hasta la base de ladrillo. Las grietas se restauran mediante zurcido con varillas de acero inoxidable y relleno con mortero bastardo 11/6. Tras esta consolidación se coloca una base de revoco armado con mortero de cal y malla de fibra de vidrio. El remate se realiza con tres capas de estuco liso.

El revestimiento de las bóvedas se pica también, cosiendo las grietas o sellándolas con consolidante tipo Fetadit In vertido con bebedero o boquilla de inyección (para lo que se enmasilla temporalmente con látex). Se aplica pintura a la cal.

Nervios y arcos se cosen o anclan con espigas de fibra de vidrio tipo Rovi con resina epoxídica. Las pérdidas se reconstruyen con mortero tipo Sicof EM-392.

Se restauran los florones, de madera.

Elimina los escombros almacenados en el extradós.

Se repasan las juntas y aplica estuco sobre la plementería.

En la memoria se incluye un dossier fotográfico del estado de las diferentes bóvedas antes de la intervención, con manchas de humedad y grietas abiertas apreciables en el 
encuentro de plementos y nervios. Hay toberas de ventilación sin rematar o cegadas en los plementos.

\section{VA-509}

2002-Proyecto de restauración de paramentos interiores-Antonio Paniagua

Se actúa sobre capillas y paredes por debajo de la línea de imposta, como desarrollo de lo previsto en el Plan Director aprobado en agosto de 1994.

Se renueva la instalación de electricidad.

\section{VA-504}

Restauración de la Capilla de Quiñones

Proyecto que también emana del Plan Director. Se restaura el volumen y sus cuerpos adosados. La estructura de su cubierta se sustituye por madera laminada con cobertura de teja mixta sobre rastreles. Se restaura las fábricas, reconstruye las bóvedas, reemplaza pavimentos e incorpora una nueva escalera de caracol.

\section{VA-536}

2002-Proyecto de restauración de la Fachada Sur-Paniagua

El Servicio de Patrimonio facilita copia de la documentación en pdf: 23 planos y memoria. También un archivo bc3 del presupuesto.

Las obras consisten en

Restauración, consolidación, limpieza y rejuntado de paramentos exteriores, incluyendo cornisas intermedias, zócalos y jambas. Restauración, restitución y consolidación de la Portada de San Julián. Desmontaje y adecuación del cuerpo anexionado a la Capilla de Quiñones cara oeste y al acceso a la torre. Restauración de paramentos exteriores, correspondientes al cuerpo de acceso a la torre y a los lienzos bajos oeste de la Capilla de Quiñones. Sustitución de las cubiertas que afectan a: la Capilla del Carmen y San José, portada de San Julián, cuerpo acceso a torre y cuerpo bajo oeste de la Capilla de Quiñones. Saneamiento

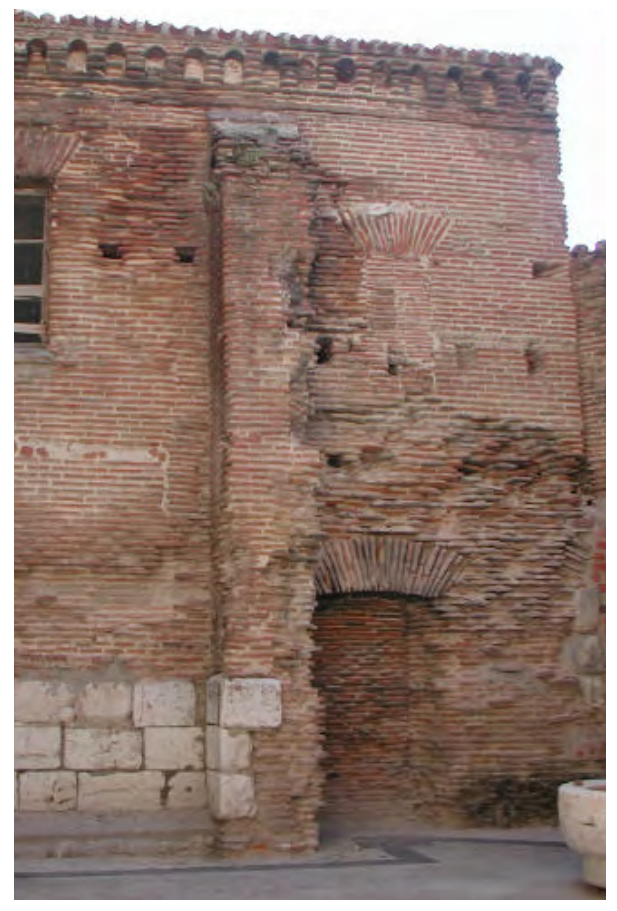
y pavimentación del atrio de San Julián, que Ilustración 39: patología Paniagua 2002 se cierra con reja. 
En un dossier con 9 fotografías (en la imagen lateral una de ellas, de la capilla $\mathrm{N}^{\mathrm{a}}$ Sra del Carmen) se confirma el grado de deterioro de las fábricas.
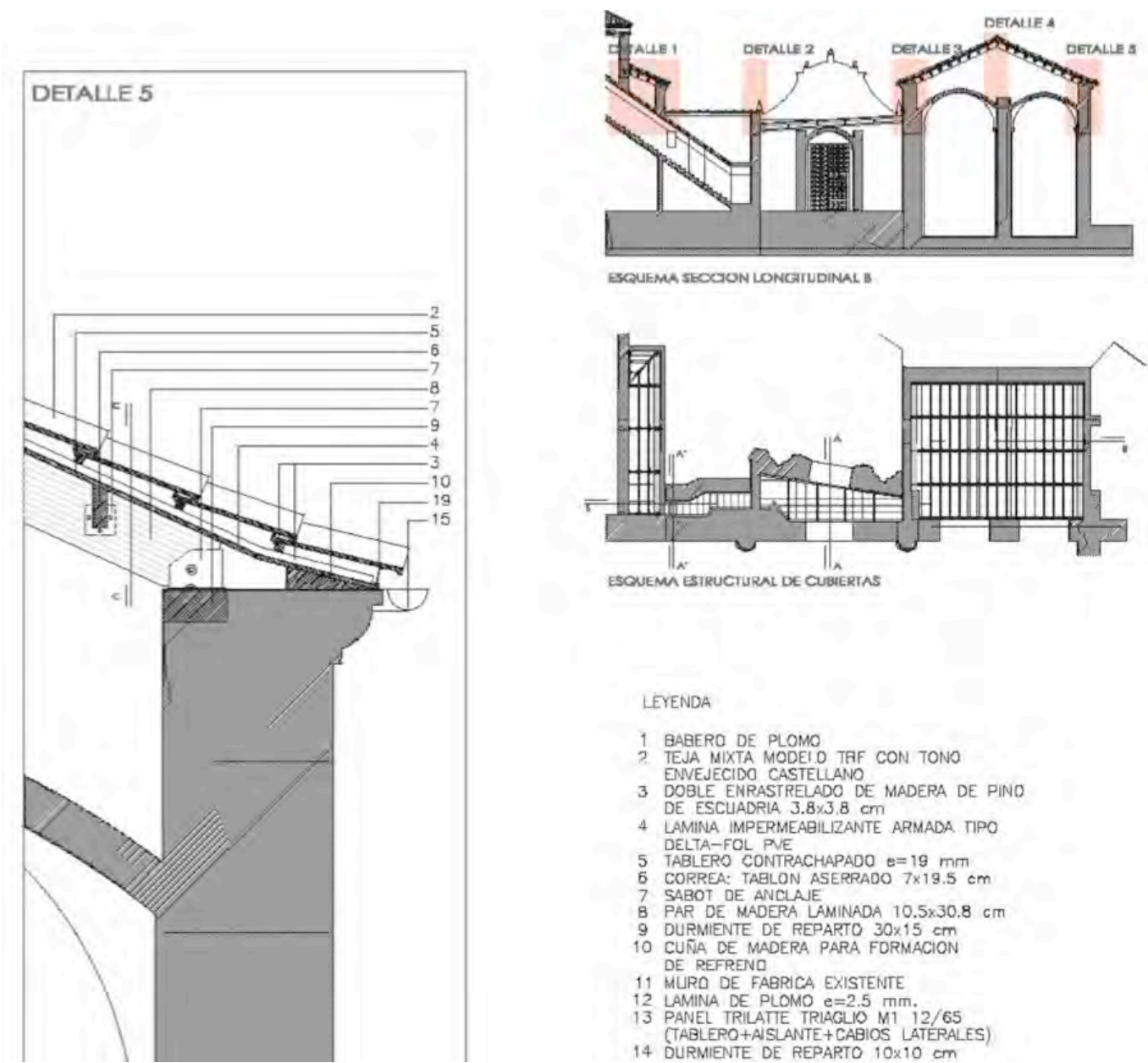

ESQUEMA SECCION LONGITUDINAL B
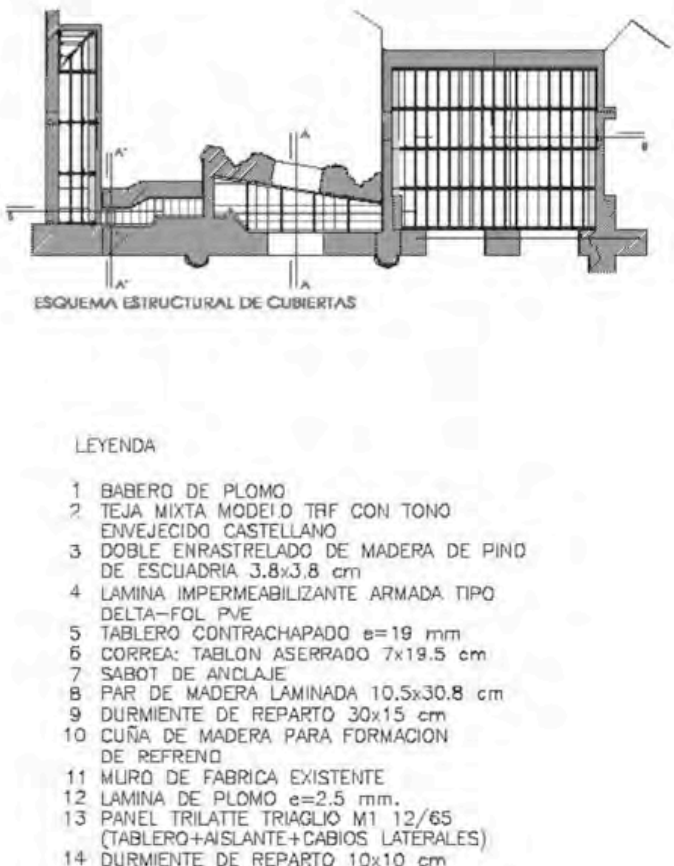

Ilustración 40: detalles constructivos fachada sur (Paniagua 2002 JCyL)

En los detalles del plano 23 se define la nueva estructura de cubierta de esta última capilla resuelta con madera laminada. En la imagen se aprecia el apoyo de los pares anclados mediante sabot metálico sobre un durmiente de reparto 30x15, según se especifica en la leyenda.

(Podemos inferir que no se ha incorporado zunchos de hormigón en esta intervención) 


\section{Visitas realizadas}

\section{$05 / 05 / 2014$}

En el exterior del conjunto monumental se aprecia ya el deterioro progresivo de algunas fachadas restauradas hace pocos años. El edificio de Canónigos, revocado a raíz de una degradación irreversible de la fábrica de ladrillo visto, presenta desconchones en arranque y esquinazo. También hay indicios de humedad en el cerramiento de la capilla del Carmen.
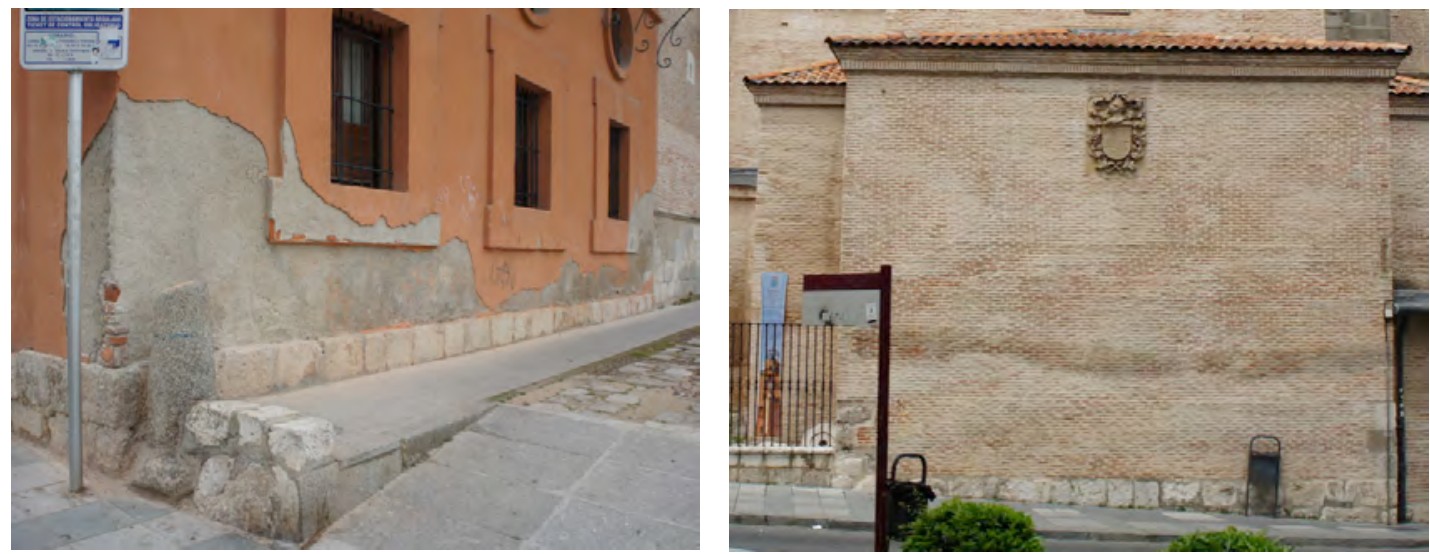

La cubierta de la nave presenta en la actualidad dos faldones homogéneos, sin el quiebro original producido por el incremento de la pendiente sobre las naves laterales. Todos los rebordes y encuentros están protegidos con chapa de plomo para mejorar la estanqueidad, cubriéndose además con este material la cara superior de contrafuertes, aleros y gárgolas.

Durante la visita se está interviniendo de urgencia sobre el volumen adosado a la cabecera trebolada de la capilla de las Angustias, con el hundimiento parcial de su cubierta que se aprecia a la izquierda de la fotografía tomada desde la torre, que se encuentra abierta al público.

También la cabecera cuenta con una cobertura bastante reciente, aunque en ambos casos se puede apreciar rotura puntual de algunas tejas, en especial alrededor de las
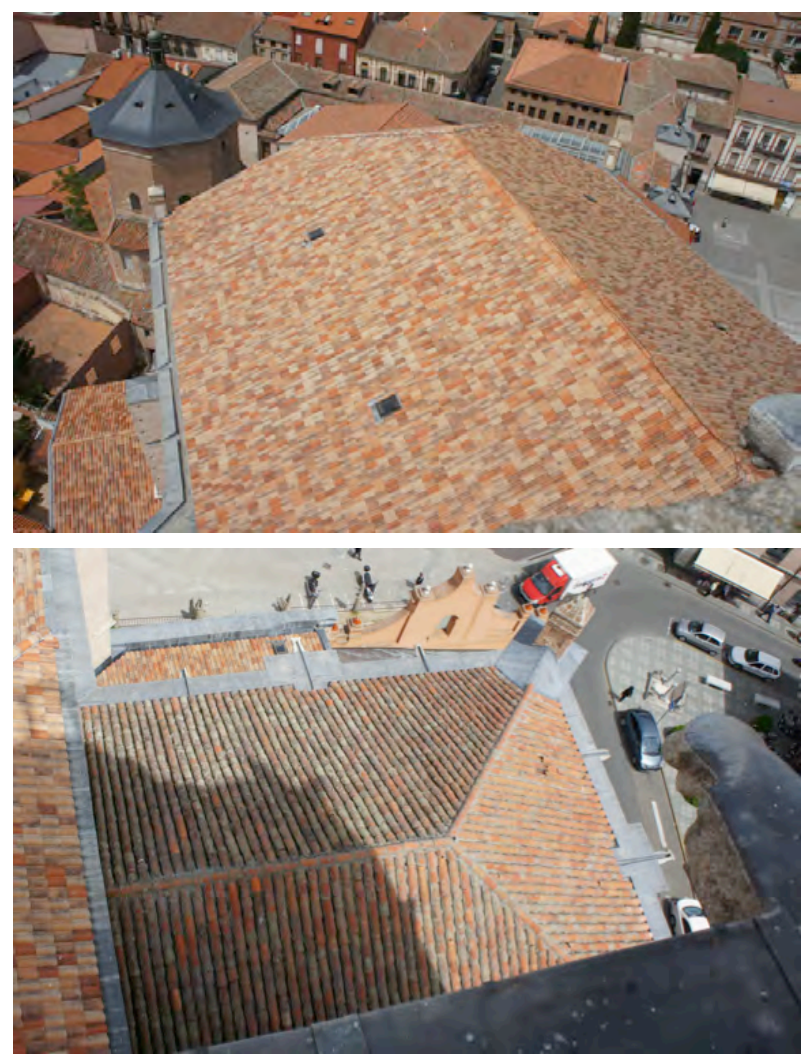
ventanas tipo velux, que debería ser tenida en cuenta según lo estipulado en el Plan de Mantenimiento del Monumento.
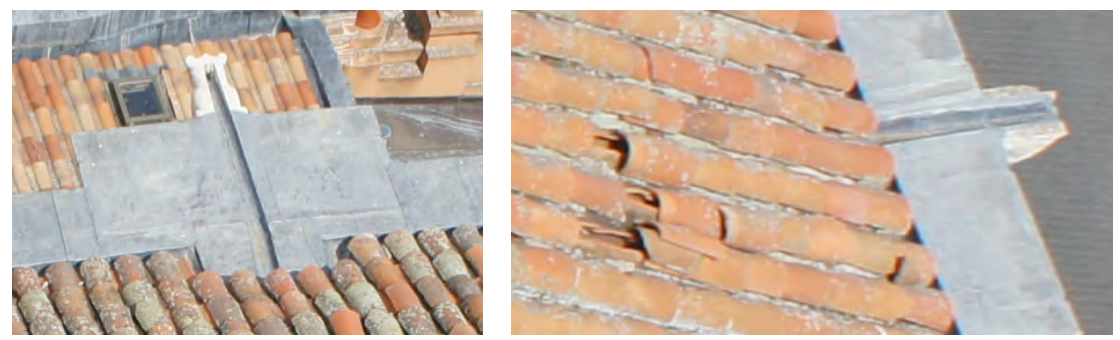

La geometría ejecutada se corresponde con las únicas secciones de pendiente sin quiebro representadas en dos planos sueltos en la carpeta de la JCYL, según las cuales se ejecuta dos familias de zunchos: sobre muros de fachada A e interiores entre naves sobre las pilas B.

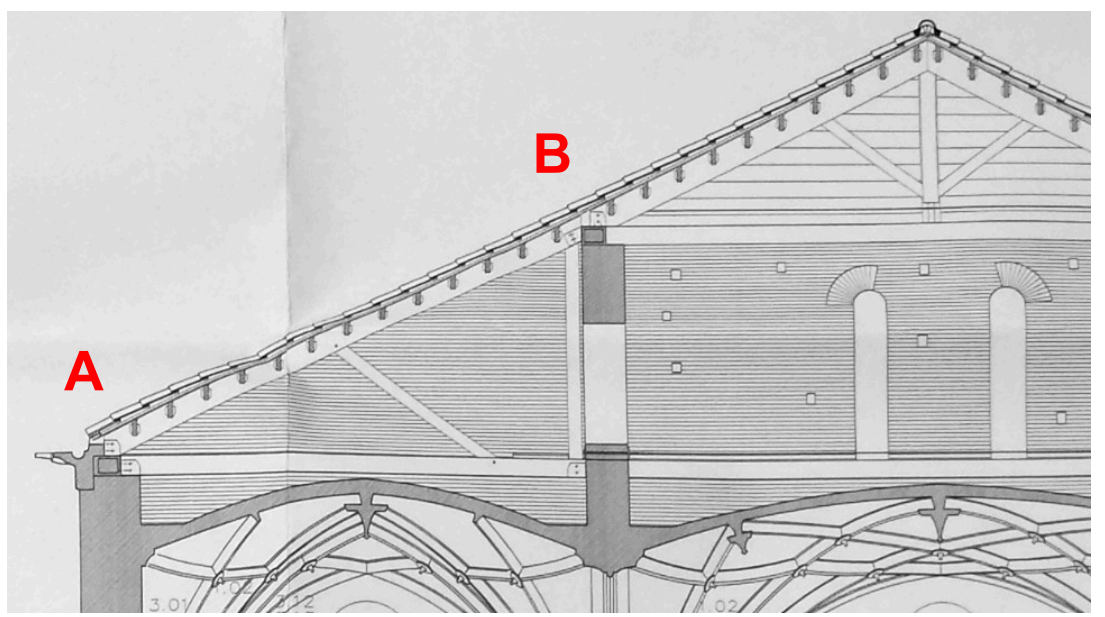

Naves laterales

En la visita se ha podido comprobar que el zuncho sobre las fachadas laterales presenta una cara superior libre de unos $24 \mathrm{~cm}$ y un canto de 36 , retranqueado $48 \mathrm{~cm}$ del paramento interior. Parece un elemento lineal que no se prolonga en los testeros, aunque en el presupuesto de la memoria final del proyecto se desglosaba como zuncho visto de $35 \times 40$ en el perímetro en $2 \times 31,0 \mathrm{~m}+2 \times 16,3 \mathrm{~m}$ de longitud.
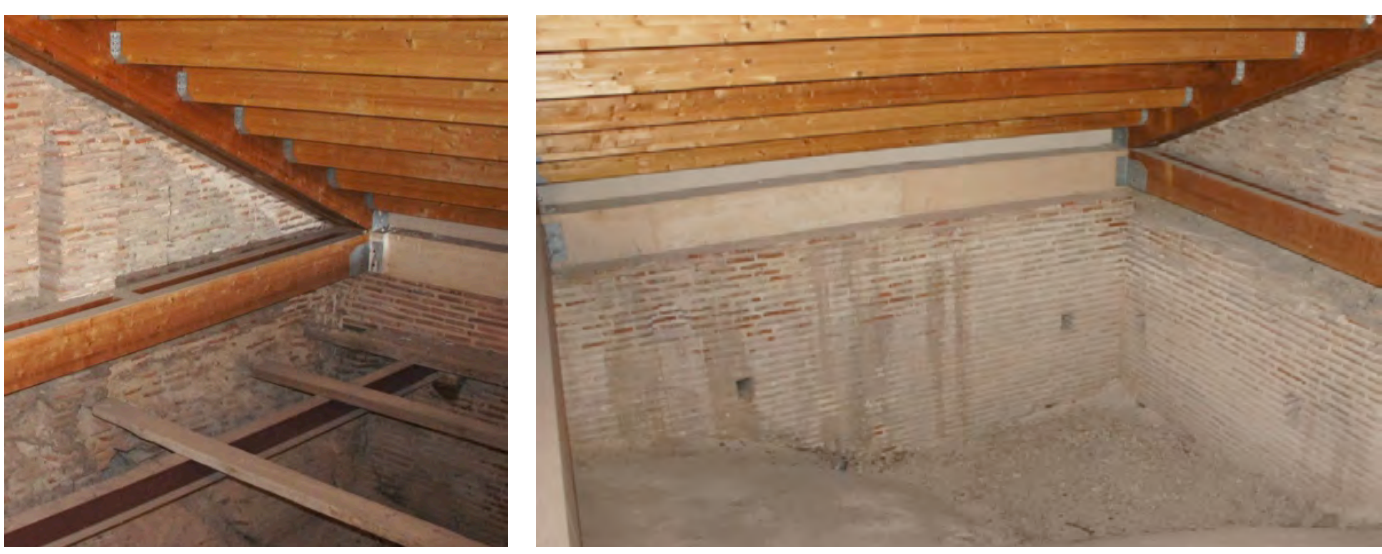

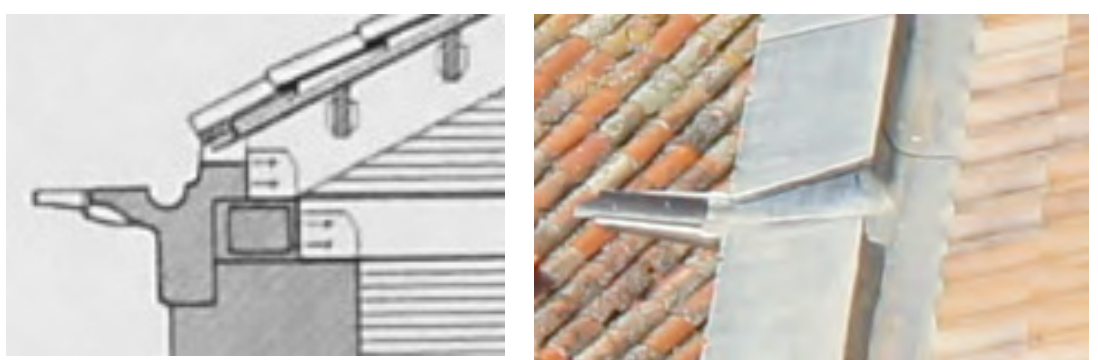

El remate de teja del faldón se aleja de la línea de cornisa para resolver la recogida de aguas de la cubierta mediante una hilera de piezas moldeadas en forma de canalón que vierten a una serie de gárgolas del mismo material, todo ello revestido con chapa de plomo.

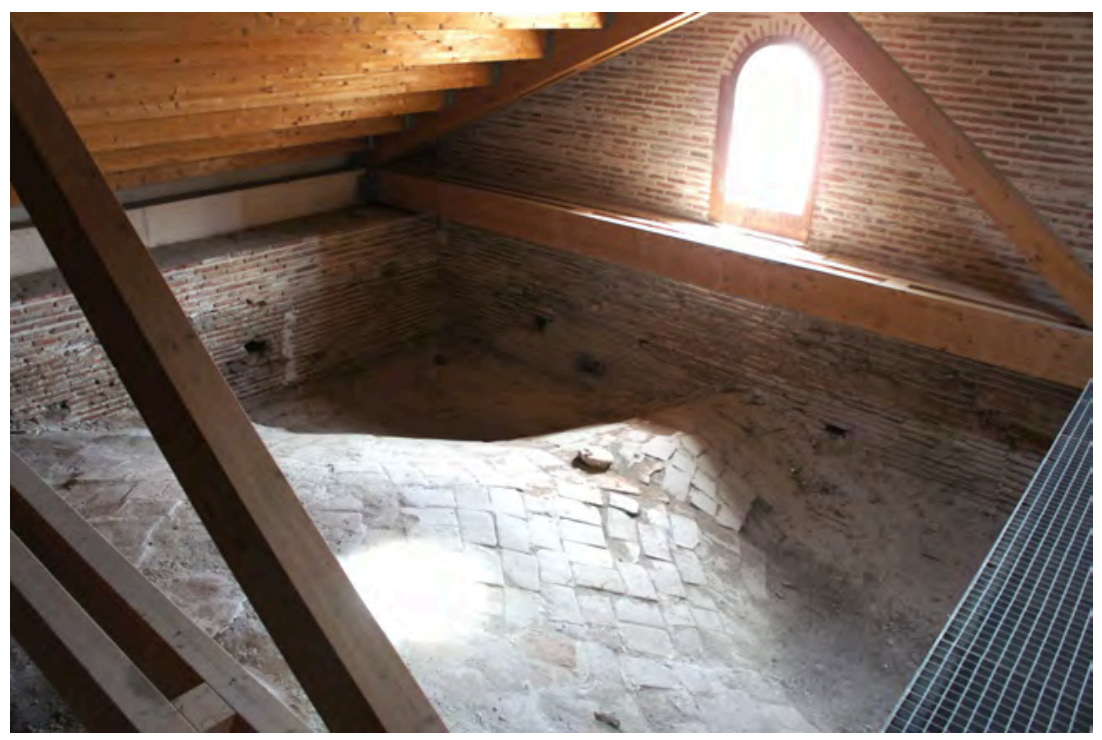

Las bóvedas de las tres naves en el tramo más próximo a la cabecera presentan desprendimientos en la superficie de trasdós.

En la imagen superior se aprecia la disposición de los ladrillos en horizontal, de forma tabicada, en estos tres elementos.

En el resto de bóvedas parecen resueltos según el sistema a rosca, más habitual en la región, con los ladrillos colocados en vertical.

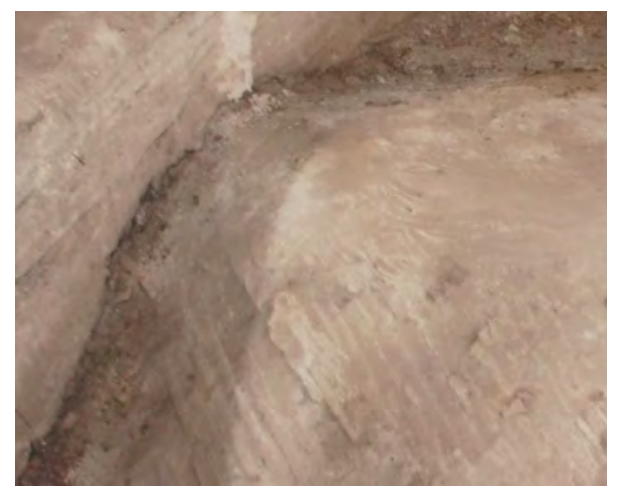

\section{Nave central}

El zuncho de coronación sobre los muros de la nave central recorre también el testero a los pies y el cerramiento sobre el arco triunfal que comunica con la cabecera. Se configura así en planta un rectángulo perimetral completo, cerrado a modo de anillo. 
Durante la visita se comprueba que el grosor de los muros interiores en el bajo cubierta, de $70 \mathrm{~cm}$, coincide con el citado en la partida que define la demolición de su remate como "de pilastras interiores". La sección de este zuncho representada en el plano cubre poco más de la mitad del espesor del muro y cuenta con una altura menor que su ancho, por lo que no parece concordar con los 70x60cm desglosados en

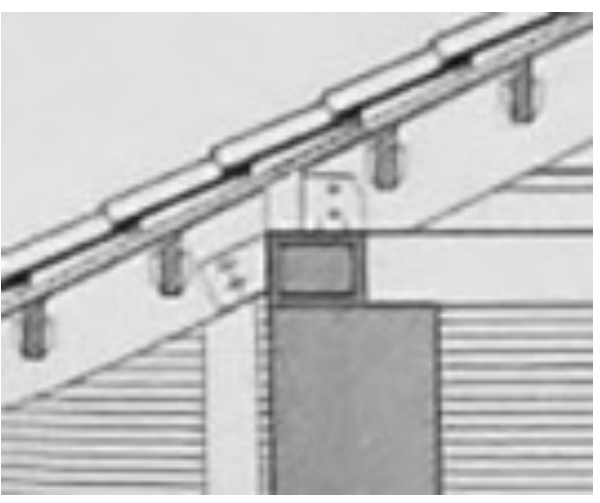
dicho presupuesto.

En el muro testero a los pies se ha conservado bajo el nuevo zuncho uno anterior, con planta en $U$ y tensores anclados en las esquinas para impedir el vuelco del hastial.
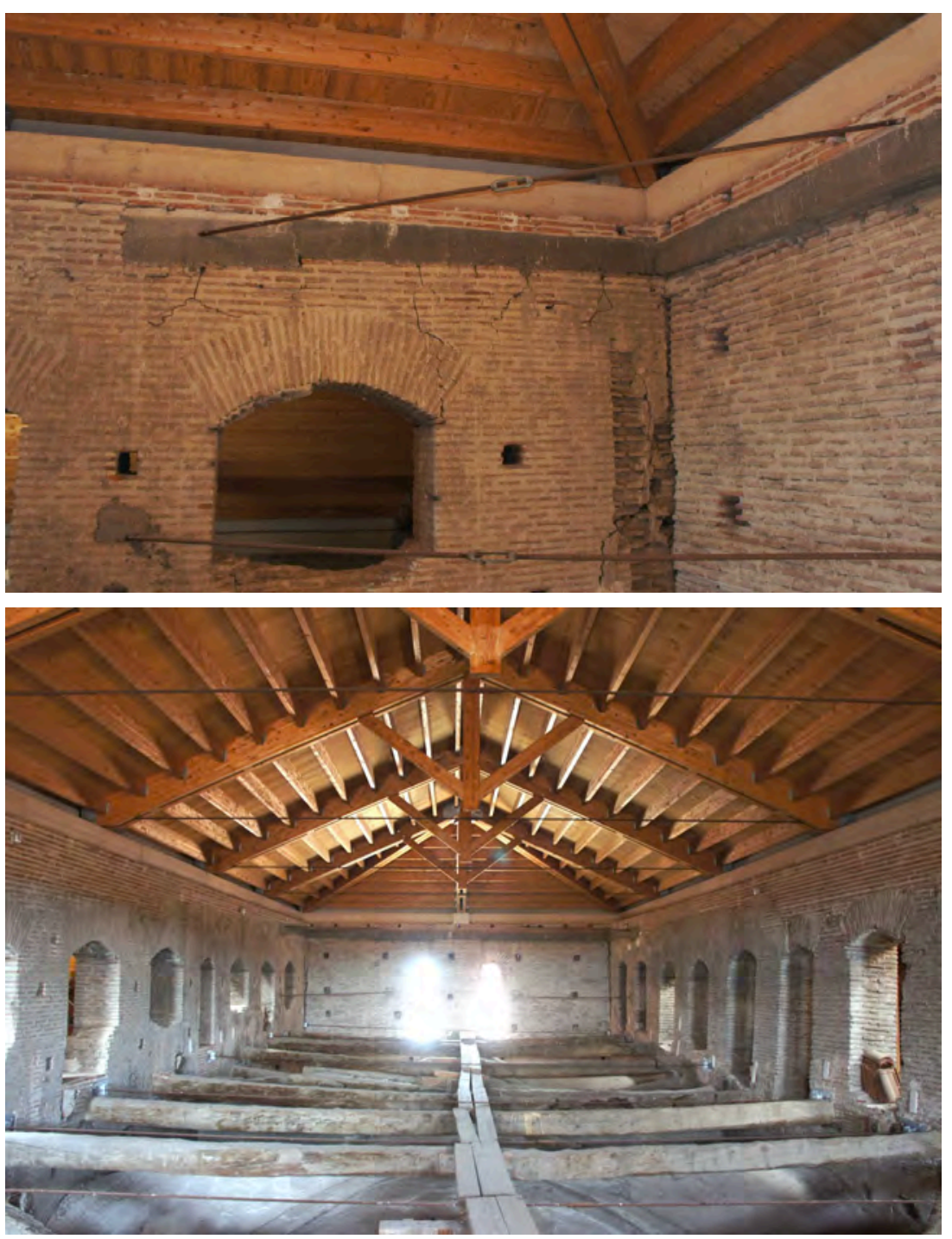
La estructura original de madera bajo cubierta, sobre el trasdós de las bóvedas, contaba con arriostramientos diagonales en cada tramo, a modo de cuadrales.

Algunas piezas se conservan, mientras que en otros casos han sido cortadas y retiradas. Encontramos una hilera de tensores para mantener el atado a ese nivel de los muros interiores.

\section{Cabecera}

La nueva estructura en este caso se ha resuelto con madera aserrada, reforzando los encuentros entre par, pendolón y tirantes con embridados metálicos. El apoyo de los cuchillos se produce también sobre un zuncho corrido.

No se ha podido comprobar en la visita si además de en ambos lados hay zuncho en el testero, dada la dificultad de acceder al bajo cubierta en esta zona por la diferencia de cotas.

\section{Angustias}

La nave de la capilla cuenta con una bóveda de cañón dividida en tres tramos sobre la que se ha colocado una estructura de cubierta de madera laminada a dos aguas atirantada con tensores metálicos. (sección obtenida en web Paniagua
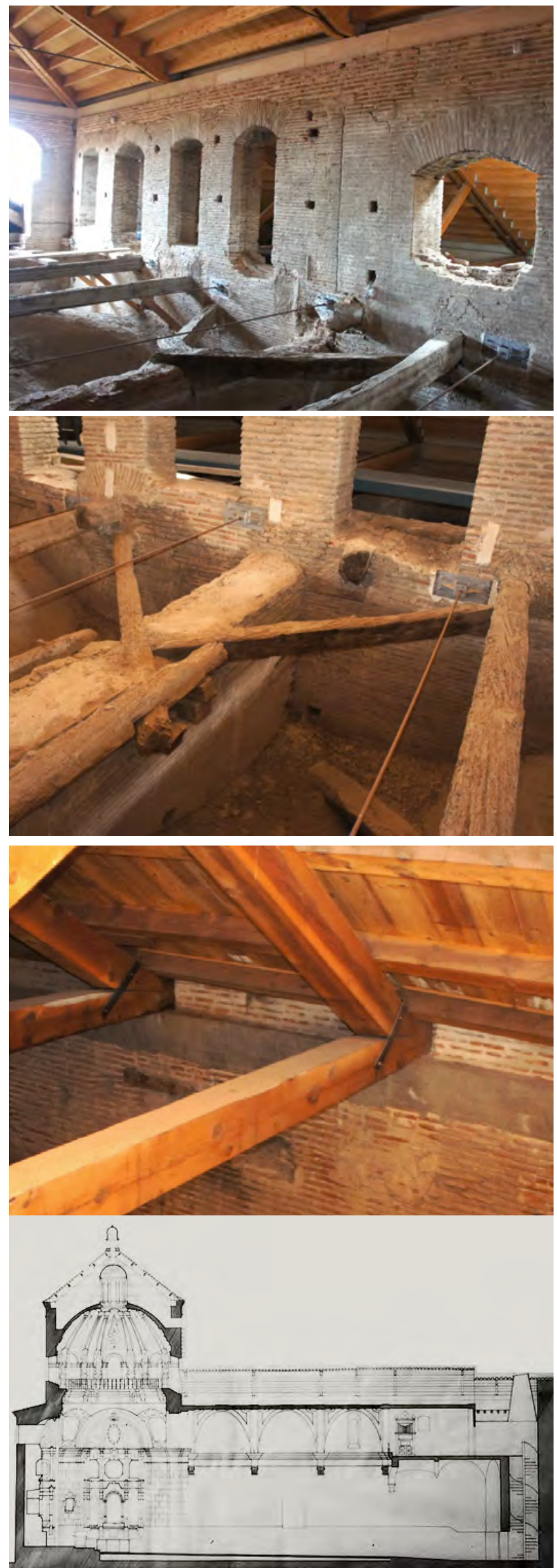
11/05/2014) 
El apoyo de los pares se produce sobre un zuncho de hormigón armado a ambos lados, que se quiebra en ángulo adoptando en planta la forma de la embocadura por la que se accede a la nave central de la iglesia.
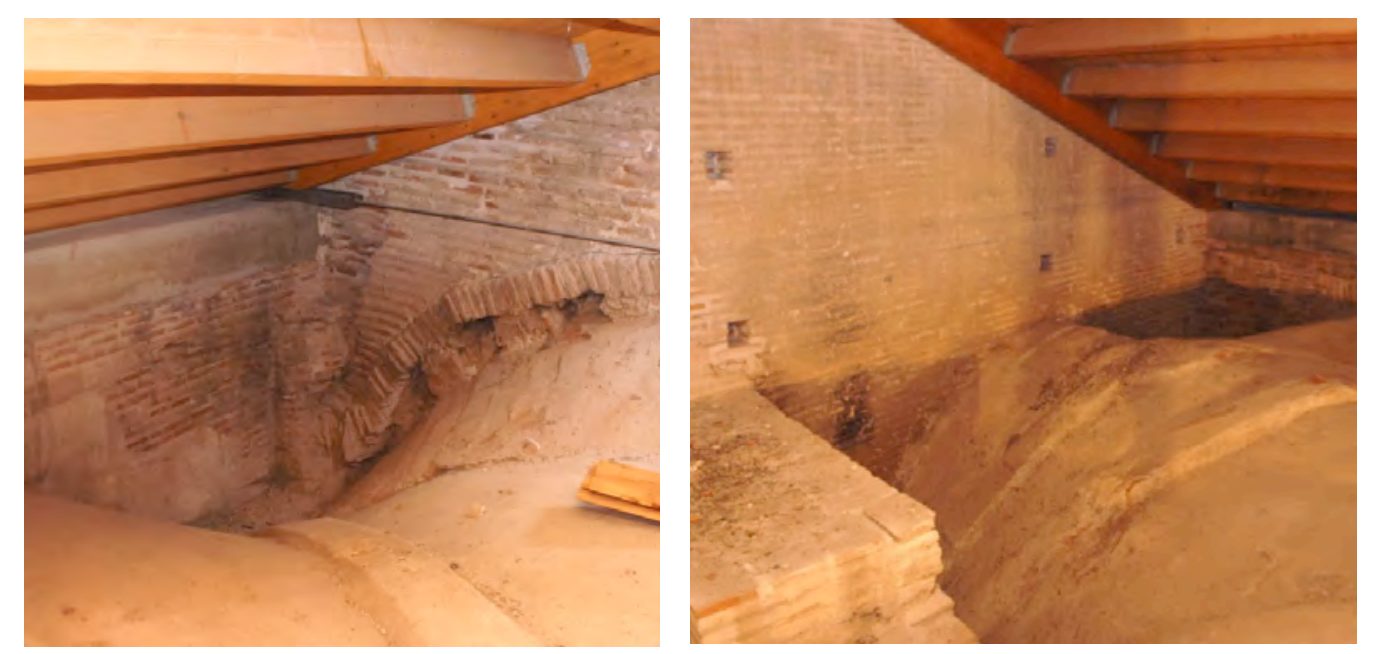

No se prolonga sobre el arco triunfal que separa la nave de la capilla trebolada, ni en el piñón de fábrica entre ambas entradas.

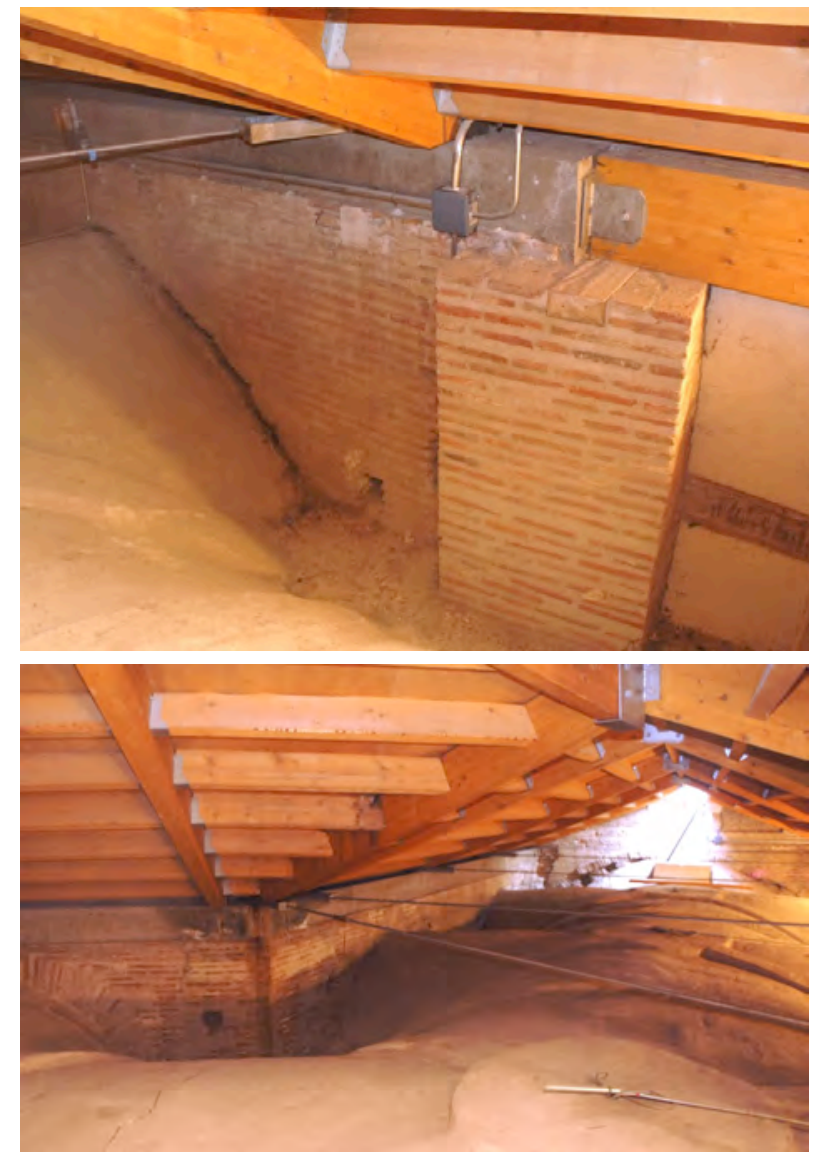

En el muro este se interrumpe el zuncho sobre un machón de fábrica y se empalma con una viga de madera laminada en la zona donde se ubica el órgano. 
FICHA SÍNTESIS

\section{Código de identificación: FZ-29}

Denominación:

Iglesia de San Martín

Localidad:

Medina del Campo

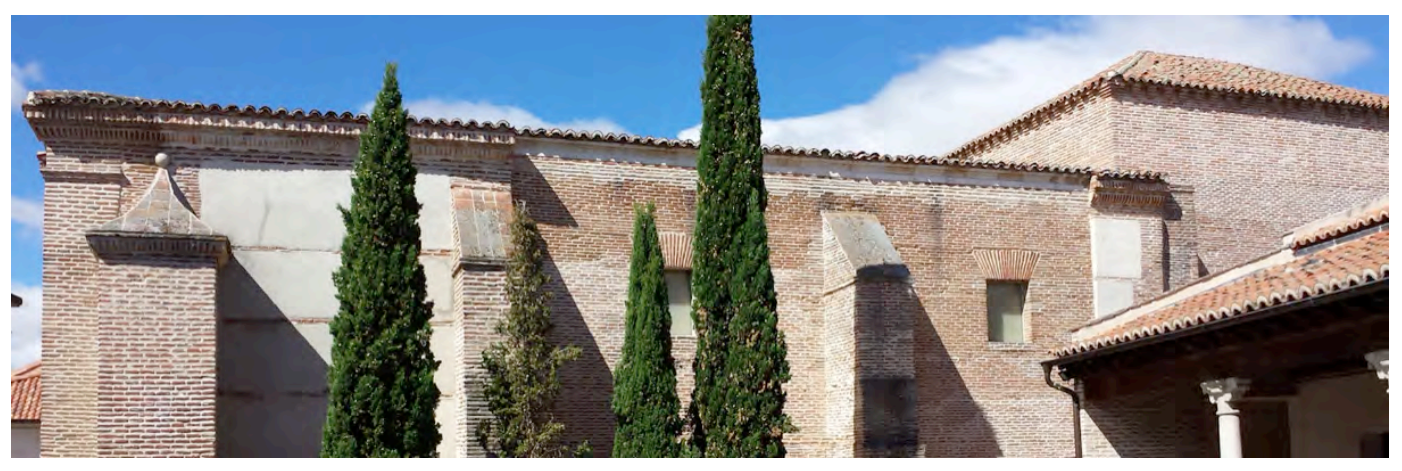

\section{Descripción}

Iglesia transformada en museo. Consta de una sola nave, cubierta con bóveda de cañón con lunetos. La capilla mayor se cubre con un artesonado octogonal mudéjar sobre trompas.

\section{Materiales}

Los muros son de fábrica de ladrillo visto, con un pequeño zócalo de piedra en la base. La cubierta está revestida de teja curva.

\section{Singularidades}

La fachada principal presenta una portada de medio punto con dovelas almohadilladas y, a ambos lados, medias columnas apoyadas sobre ménsulas.

La armadura mudéjar es de lacería estrellada, con madera dorada y policromada.
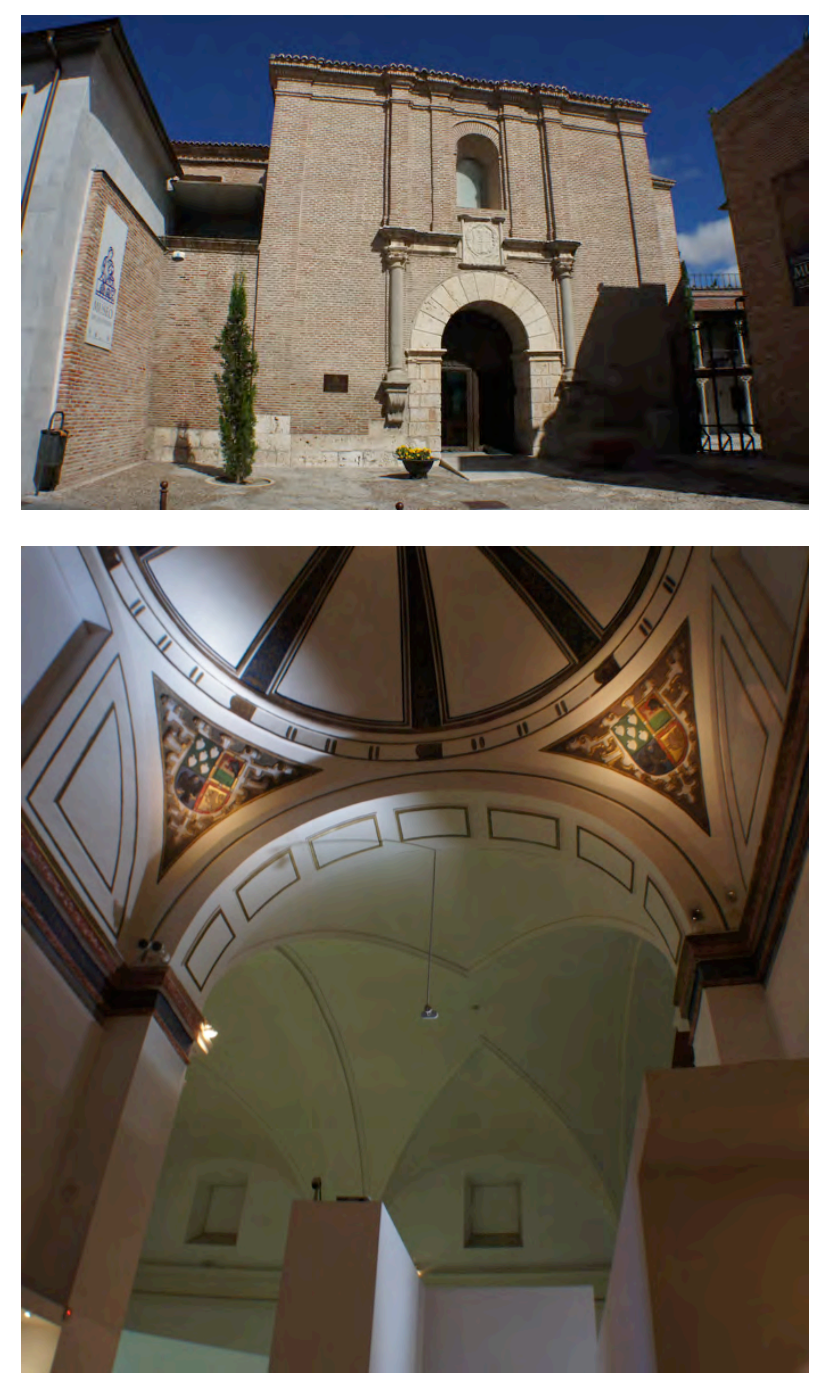

Ilustración 1: fachada y bóvedas, visita 13/08/2015 


\section{Dimensiones básicas del templo}

$\begin{array}{lll} & \text { central } & \text { laterales } \\ \text { Ancho de nave } & 9,8 & - \\ \text { Altura } & 17,0 & -\end{array}$

\section{Memoria histórica constructiva}

Según el Catálogo (221-):

En 1512 está construida la cabecera, según figura en una inscripción de la armadura.

En 1570 se rehace el coro de madera y en 1598 los maestros Alonso García y Melchor de Riberos reparan el arco triunfal, que estaba agrietado en la clave.

En 1675 se dan trazas para levantar la torre.

La bóveda de cañón con lunetos sobre la nave y una espadaña sobre la fachada se ejecutan en 1801 .

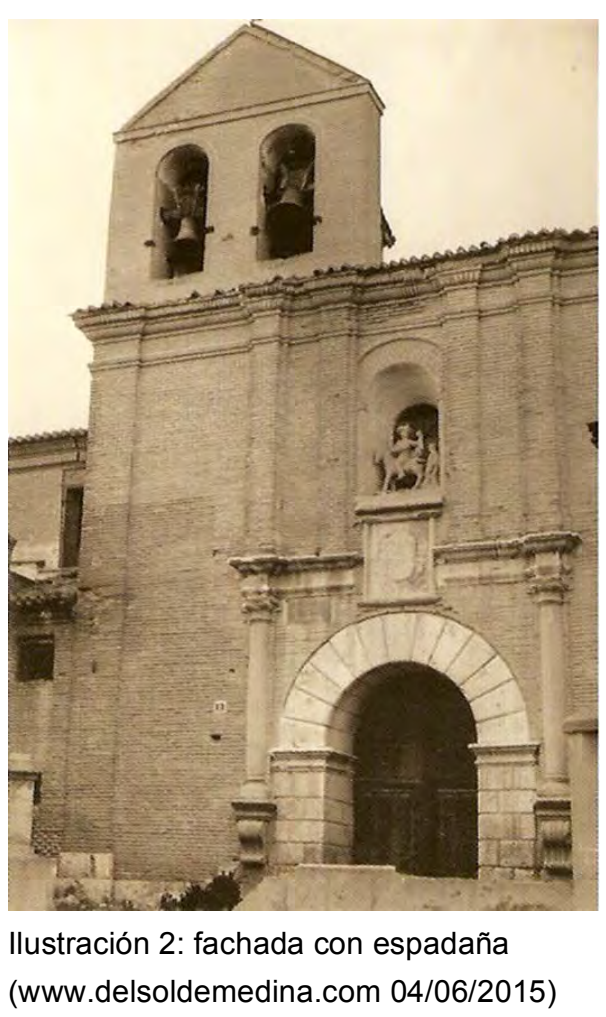

En 1990 se rehabilita el edificio para uso cultural, tras encontrarse abandonado y en condiciones lamentables, según se aprecia en las siguientes fotografías de 1988 suministradas por el profesor Sánchez del Barrio, director del museo.

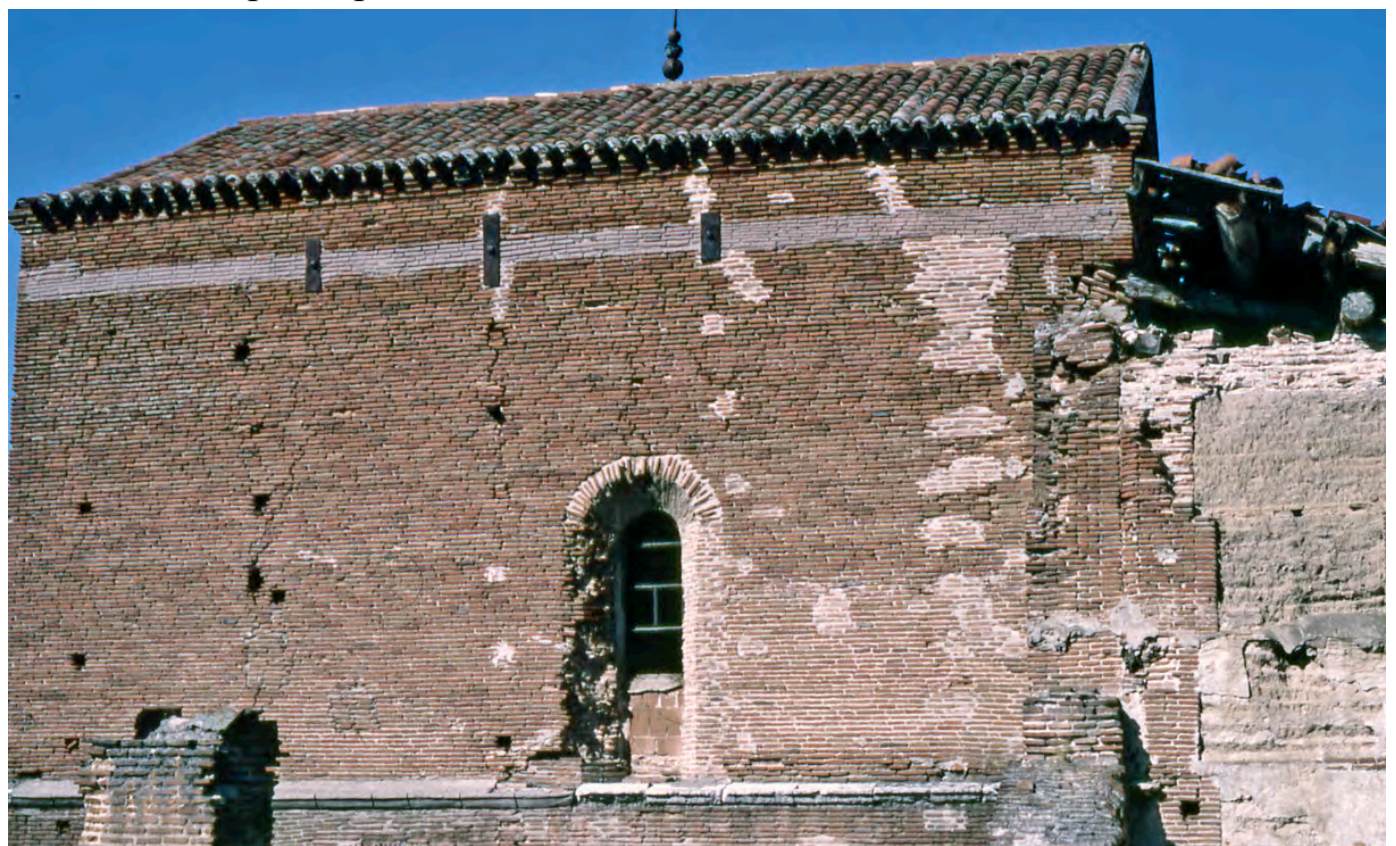

Ilustración 3: lateral de la cabecera 1989 Museo 
En las imágenes se aprecia un hundimiento de la cubierta de la nave y cómo la cabecera se encontraba atirantada con tensores metálicos que atravesaban el artesonado, que muestra grandes manchas de humedad.
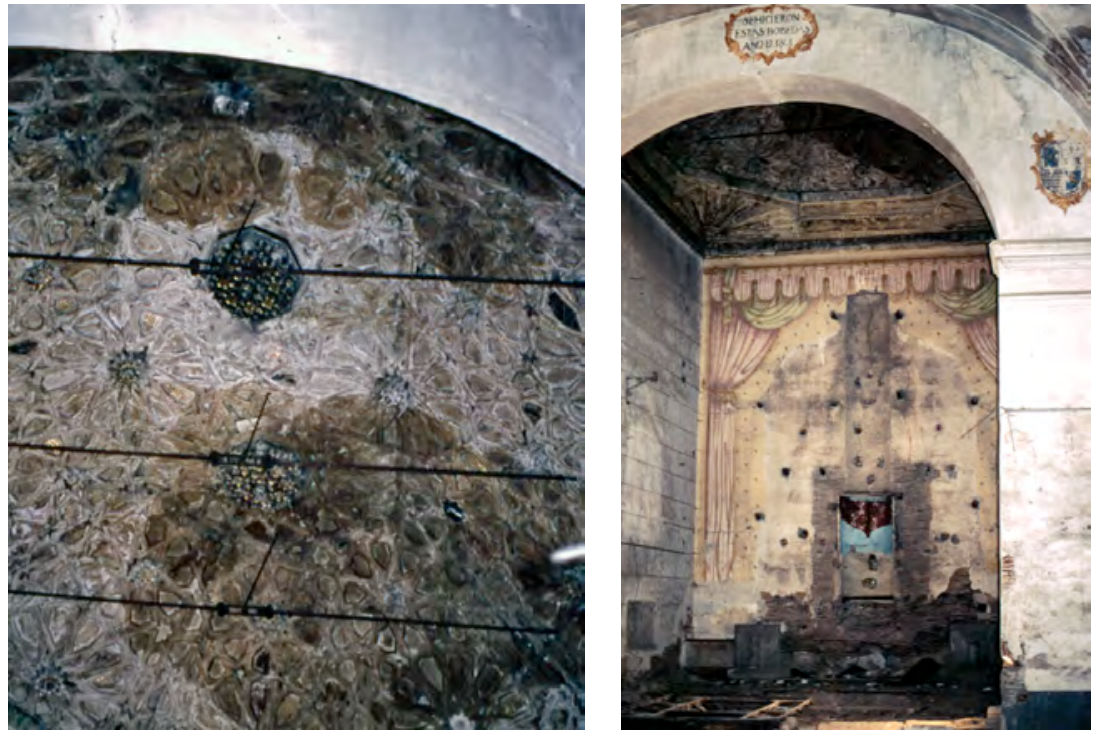

Ilustración 4: interior 1989 Museo

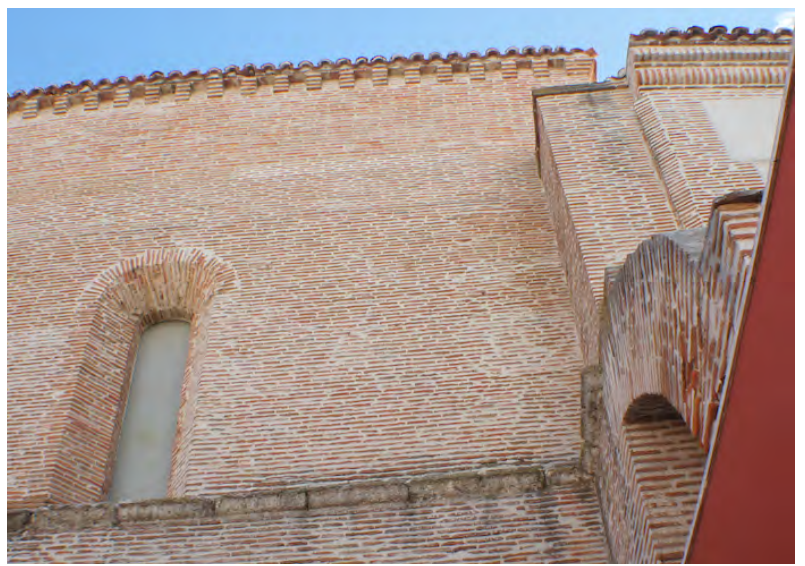

En una imagen actual podemos apreciar como el lateral de la cabecera presenta una fábrica diferente, reconstruida a partir del remate del contrafuerte. También el muro de la nave se sanea en 1989 y se remata con una cornisa de ladrillo. En 2000 se instala el actual Museo de las Ferias.

Ilustración 5: visita 13/08/2015

\section{Cronología. Fechas clave}

$1512-1598-1968-1990$

\section{Intervenciones}

1968 - Cubiertas - Anselmo Arenillas

\section{Incorporación de zuncho de hormigón armado.}

Se proyecta retejar la nave principal, reemplazando el resto de cubiertas (presbiterio, sacristía vieja y capilla baptisterio) con tableros de hormigón aligerado Ceramex apoyados sobre un zuncho de hormigón armado $30 \times 30 \mathrm{~cm}$. Se atiranta con redondos de acero $20 \mathrm{~mm}$ colocados sobre los tirantes de madera existentes. 
Se limpia y repara el artesonado de cabecera, eliminando su revestimiento blanqueador y tiñéndose con un producto antiparásitos.

1989 - Casa de cultura - José Luis Fernández y Fernando M. Inglés

En el archivo central de la Junta hay varios planos de la Casa de Cultura sin carátula y algunas hojas sueltas de este proyecto. Se cuenta con copias parciales de algunos planos del mismo, y de la adecuación como Museo de las Ferias, conservados en la propia institución.

\section{Planos}

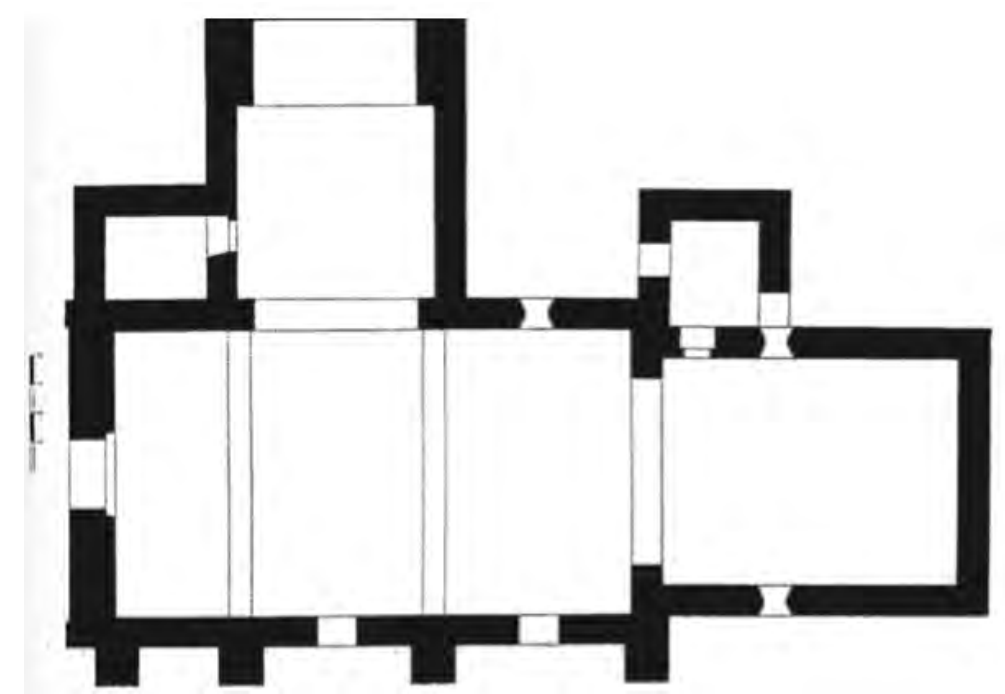

Ilustración 6: planta (Catálogo)

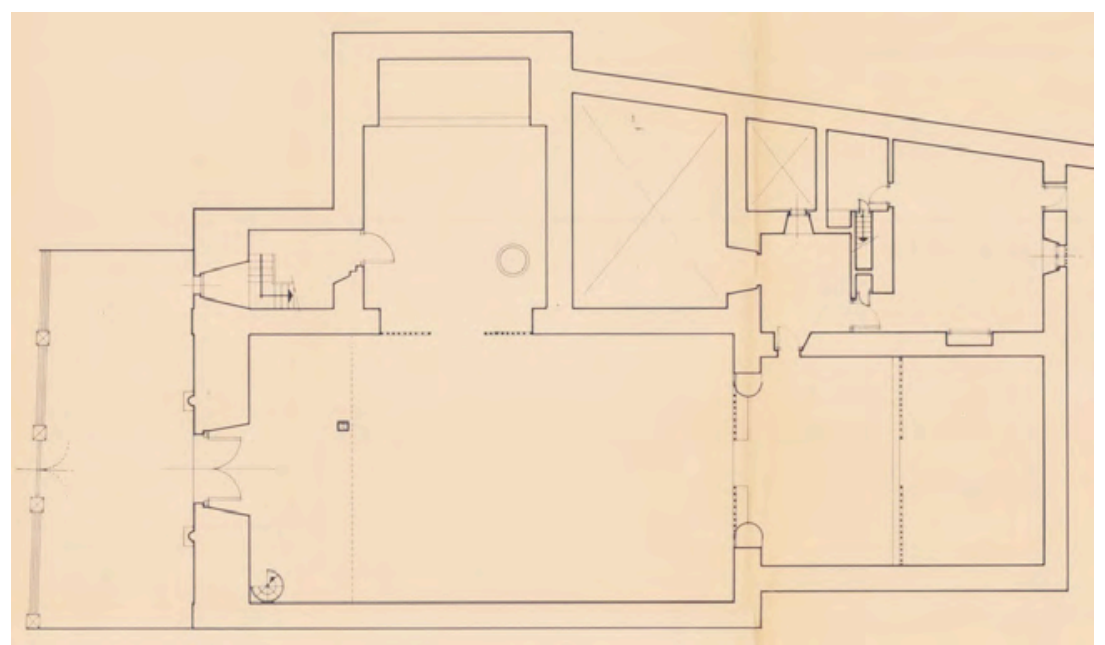

Ilustración 7: planta baja 1968 Arenillas AGA 


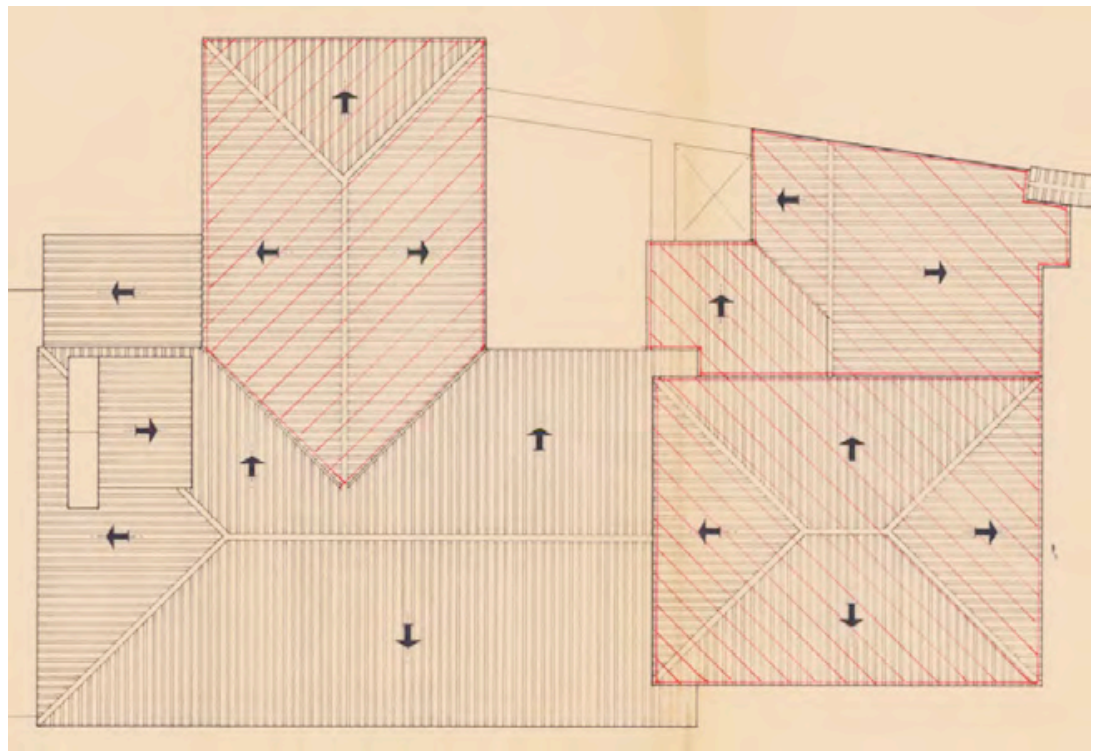

Ilustración 8: planta de cubiertas 1968 Arenillas AGA

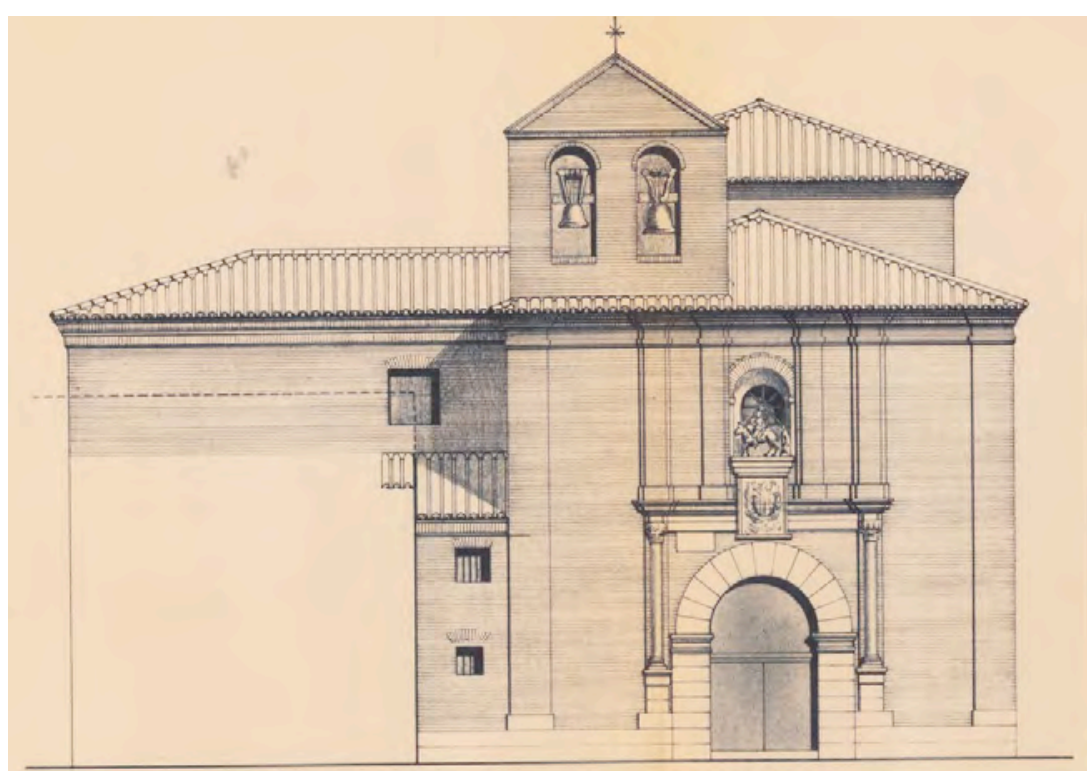

Ilustración 9: alzado 1968 Arenillas AGA

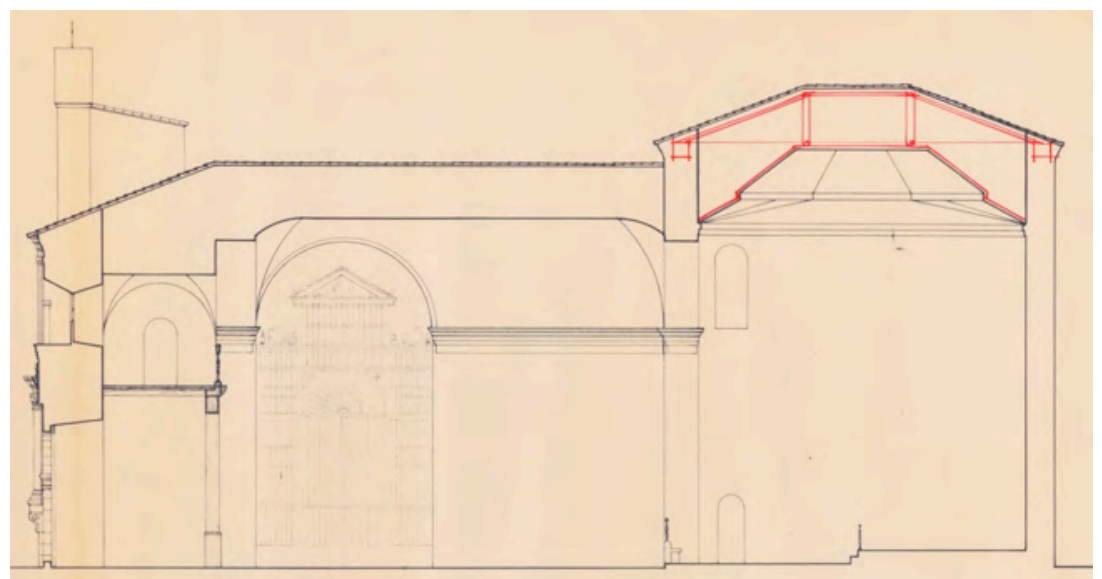

llustración 10: sección longitudinal 1968 Arenillas AGA 


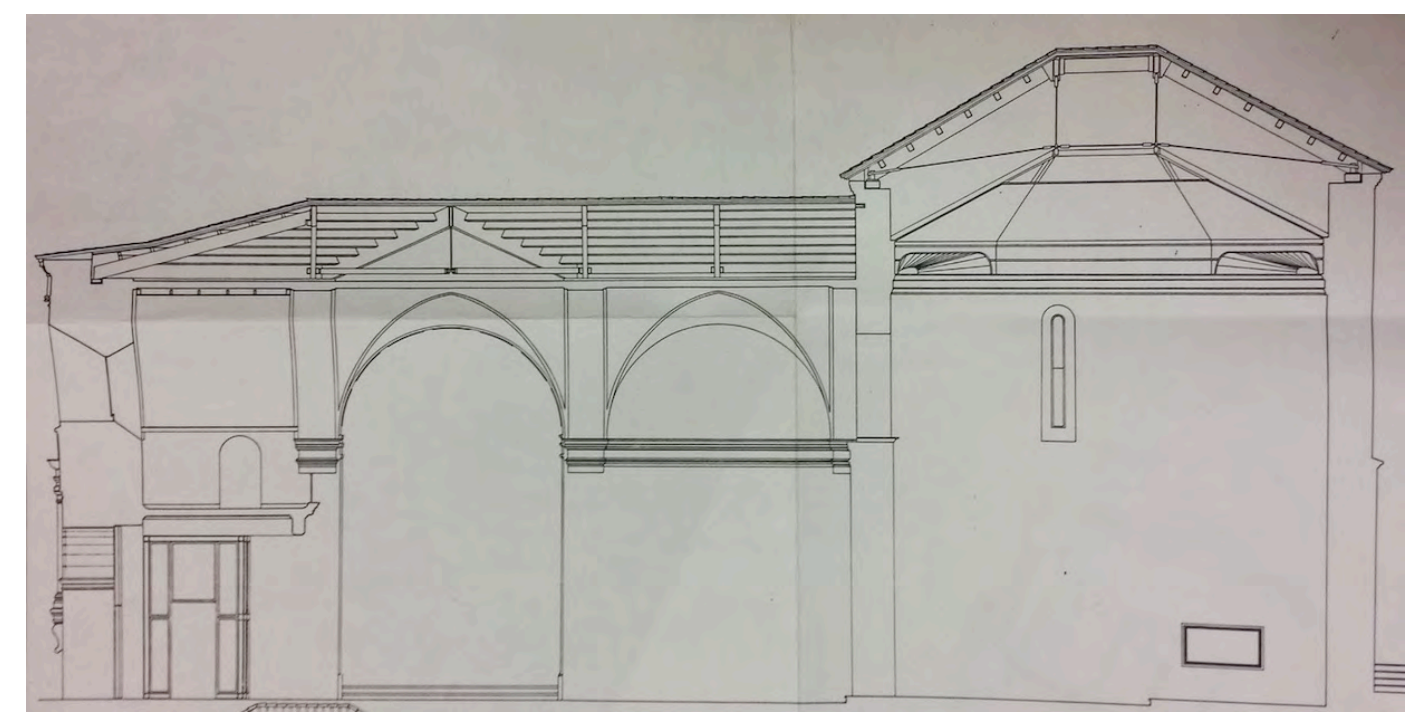

Ilustración 11: sección longitudinal sin carátula JCyL

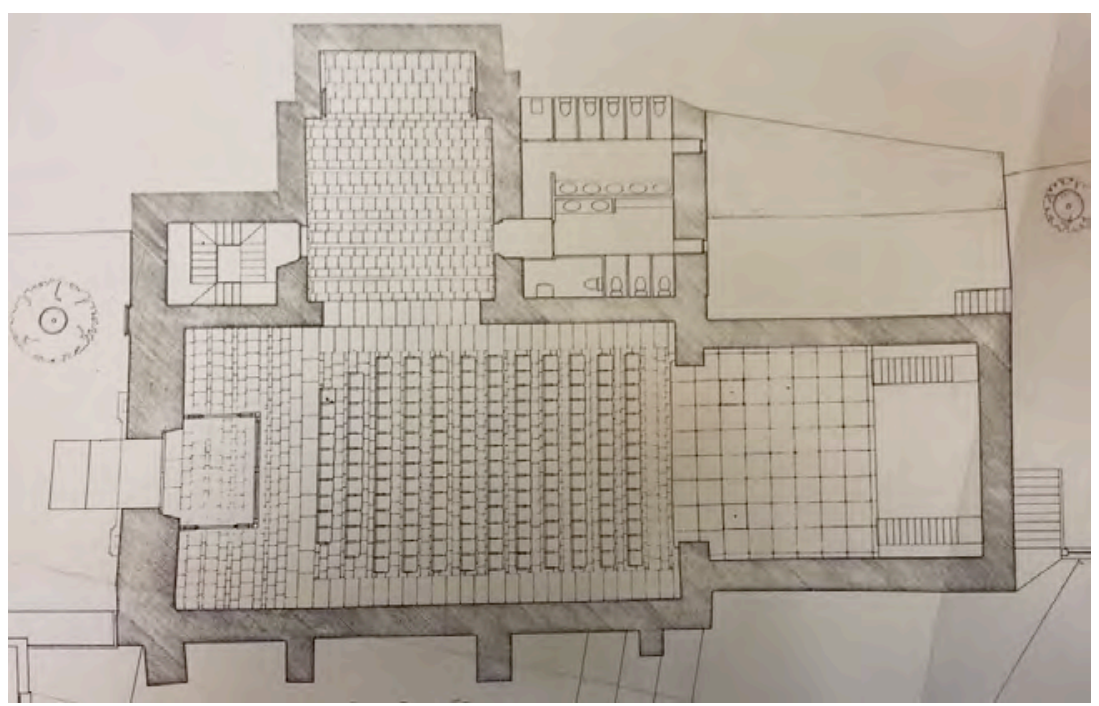

Ilustración 12: planta sin carátula JCyL

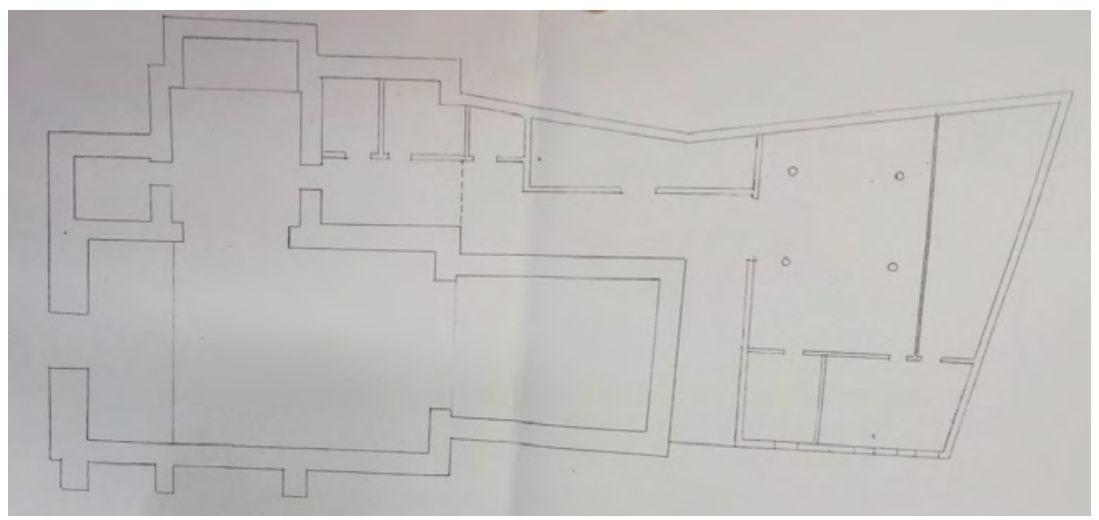

Ilustración 13: planta sin carátula Museo 


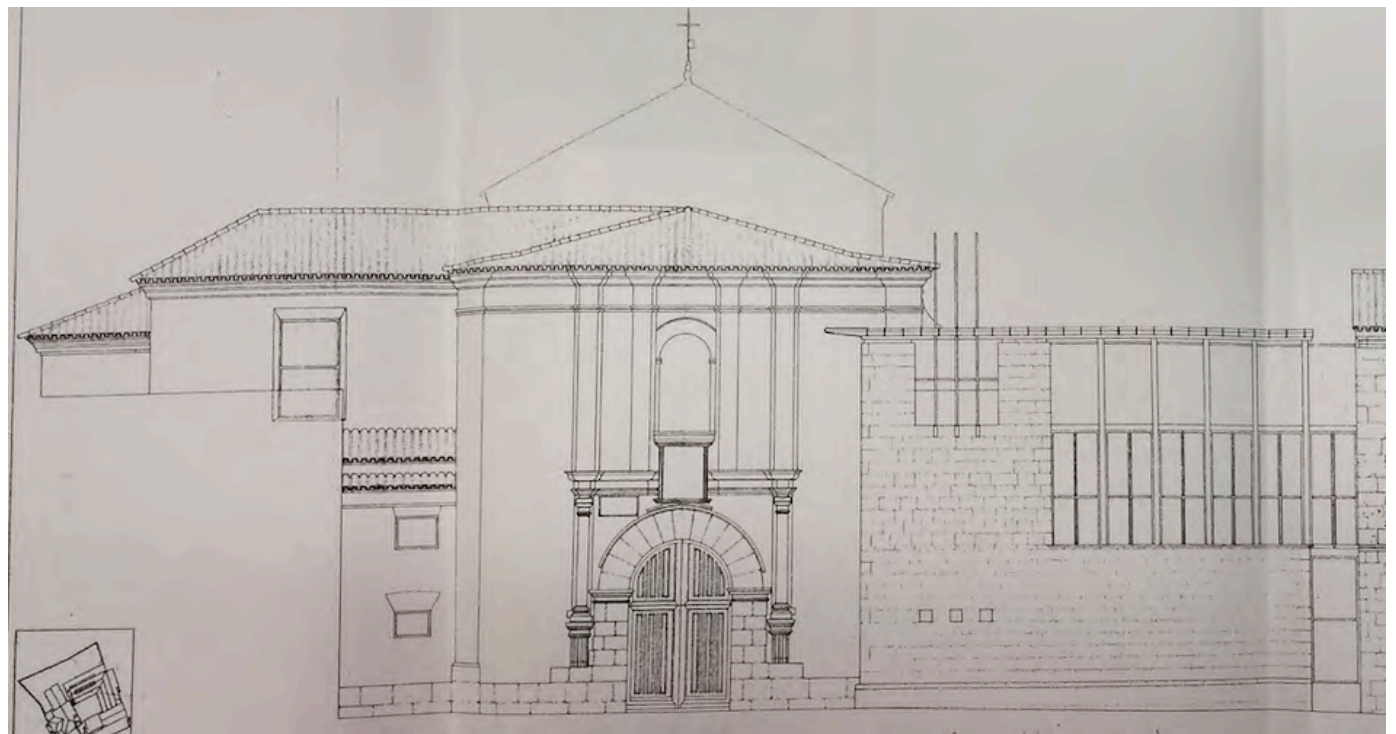

Ilustración 14: alzado principal 1989 Fernández e Inglés Museo

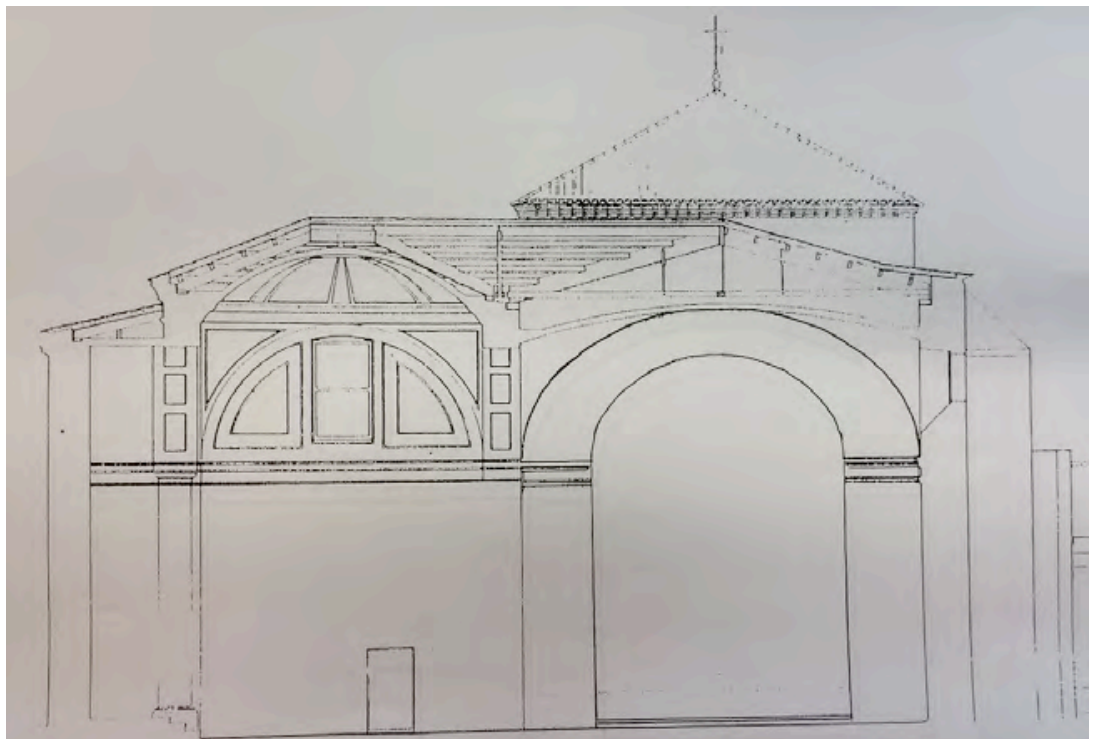

Ilustración 15: sección transversal Museo

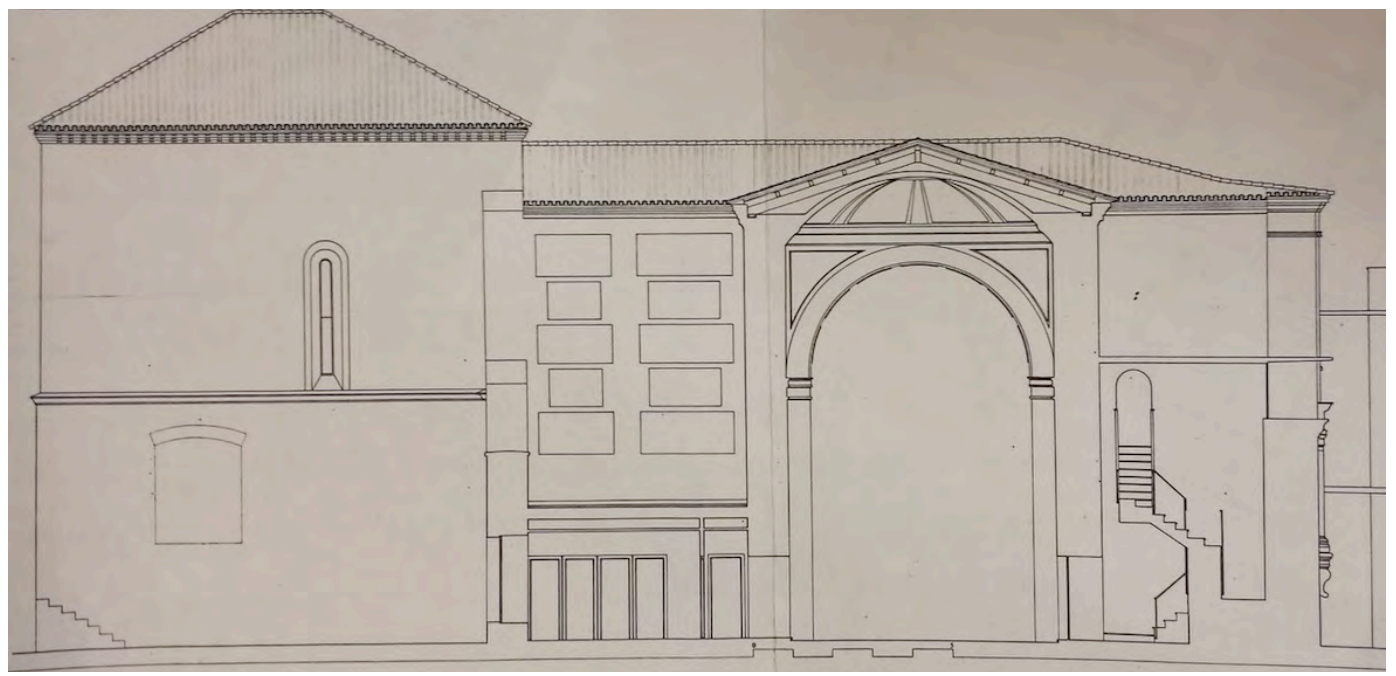

Ilustración 16: sección sin carátula JCyL 


\section{Solución constructiva de la cubierta}

Tras el estado de abandono sufrido hasta 1989, se renovaron las cubiertas de la iglesia, incorporando estructuras de madera laminada.

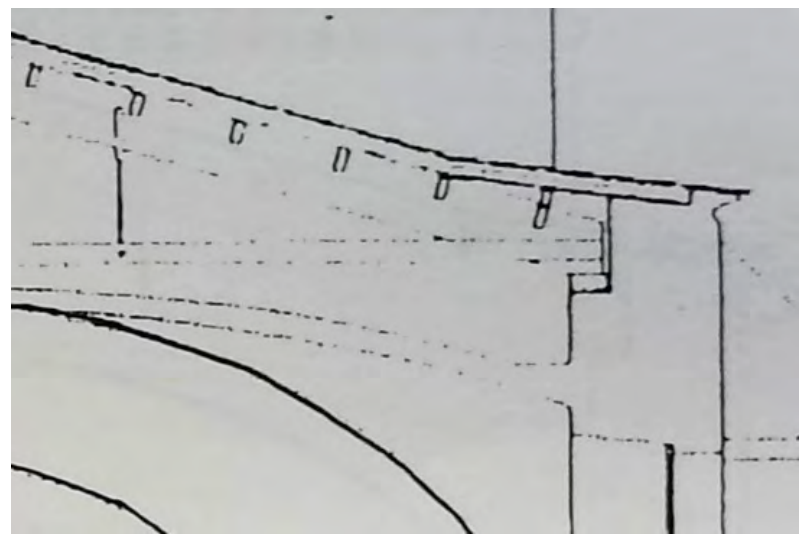

Ilustración 17: detalle sección Museo
En los planos se aprecia cómo el diseño de la cabecera respeta la solución adoptada por Arenillas en 1968, con tensores metálicos y el artesonado suspendido. Aunque la única copia obtenida de una sección por el cuerpo de la nave es de baja calidad, podemos apreciar cómo en ella se representa la cubierta con una pendiente de unos $16^{\circ}$ y dotada de un apreciable refreno.

\section{Zunchos}

A pesar de que en las secciones de 1989 se representa las vigas de cubierta apoyadas sobre un durmiente corrido, en las fotografías del trasdós de las armaduras de la cabecera, tomadas durante un tratamiento de desinsectación y suministradas por el Director del museo, se aprecia la existencia de un zuncho continuo de hormigón armado enrasado con el paramento interior de ladrillo.
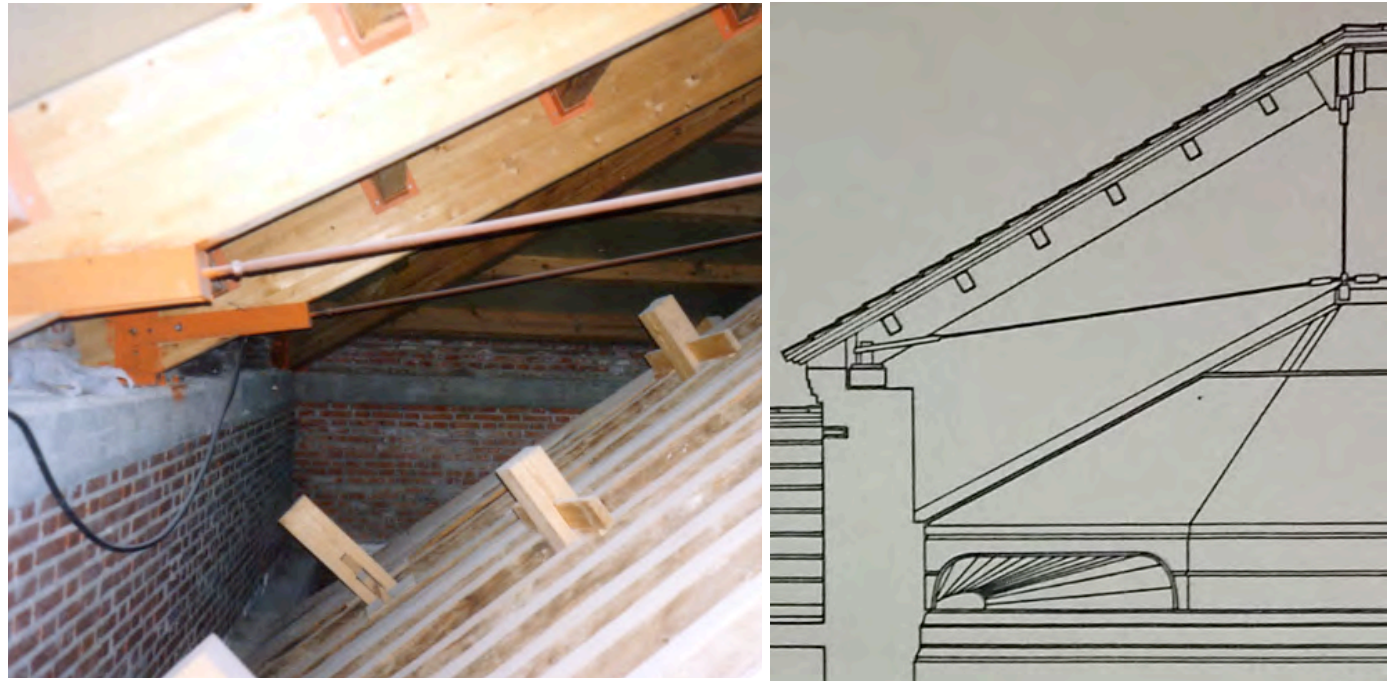

Ilustración 18: zuncho, cortesía Museo

\section{Conclusiones}

Aunque no se recoge en los planos de las intervenciones más recientes, en este edificio se incorporó el típico zuncho perimetral rectangular de hormigón armado. 


\section{Iglesia de San Martín en Medina del Campo}

Intervenciones citadas en la publicación del Ministerio

1968 - Cubiertas - Anselmo Arenillas

No hay planos en la web del IPCE

\section{En el Archivo General de la Administración}

\section{AGA 26/00131}

"Se halla en mal estado de conservación general, pero sobre todo sus cubiertas llenas de goteras y roturas amenazan ruina en muchas partes, con lo que el artesonado morisco de su presbiterio y las bóvedas peligran.

En el presente proyecto se incluyen únicamente las obras precisas para retejar a fondo la nave principal, desmontar y rehacer de nuevo las cubiertas del resto de la iglesia y limpiar el enjabelgado que tiene el artesonado del presbiterio, reparar su tracería de lazos y teñirlo y protegerlo con un antiparásitos "Proimate".

Las nuevas cubiertas se forjarán con tableros de hormigón aligerado "Ceramex" que apoyarán en un solerón de hormigón armado de $30 \times 30 \mathrm{~cm}$ y se atirantarán con redondos de acero de $20 \mathrm{~mm} \mathrm{D}$ colocados sobre los tirantes de madera. Sobre estas placas se tenderá una capa de hormigón fino impermeable de $3 \mathrm{~cm}$ y encima se colocará la teja árabe emboquillada con mortero de cal cada 5 hiladas."

Dossier con 4 fotografías blanco y negro de portada, cornisa de ladrillo y espadaña, interior con artesonado y manchas de humedad en bóveda.

Presupuesto:

Demolición de tejados y sus armaduras

Sobre presbiterio, sacristía vieja y capilla baptisterio:

$2 \times 7,5 \times 5,8 ; 2 \times 5 \times 5,8 ; 7,5 \times 8,3 ; 6 \times 5 ; 4 \times 3,5 ; 2 \times 10,6 \times 5 ; 4,6 \times 5=380,25 \mathrm{~m} 2$

Reconstrucción de armaduras en placa de hormigón aligerado, placa de compresión y tejado. En sustitución de cubiertas demolidas 380,25m 2

Retejo a teja vuelta y reposición tablas y tejas rotas $255,94 \mathrm{~m} 2$

En nave de la iglesia $6,3 \times 7,0 ; 2 \times 18,0 \times 7,0$

Sobre subida al coro $4 \times 6$

Sobre subida al campanario $4,4 \times 3,6$ 
Eliminación del blanqueo, reparación madera y teñido del artesonado. En presbiterio $13 \times 10=130 \mathrm{~m} 2$

Regularización de coronación de muros con solerón de hormigón armado y reparación lima. En cubiertas nuevas 1Ud.

Planos: planta 1:100, cubierta con faldones señalados en rojo y sección en rojo a mano la estructura. (Pido copias)

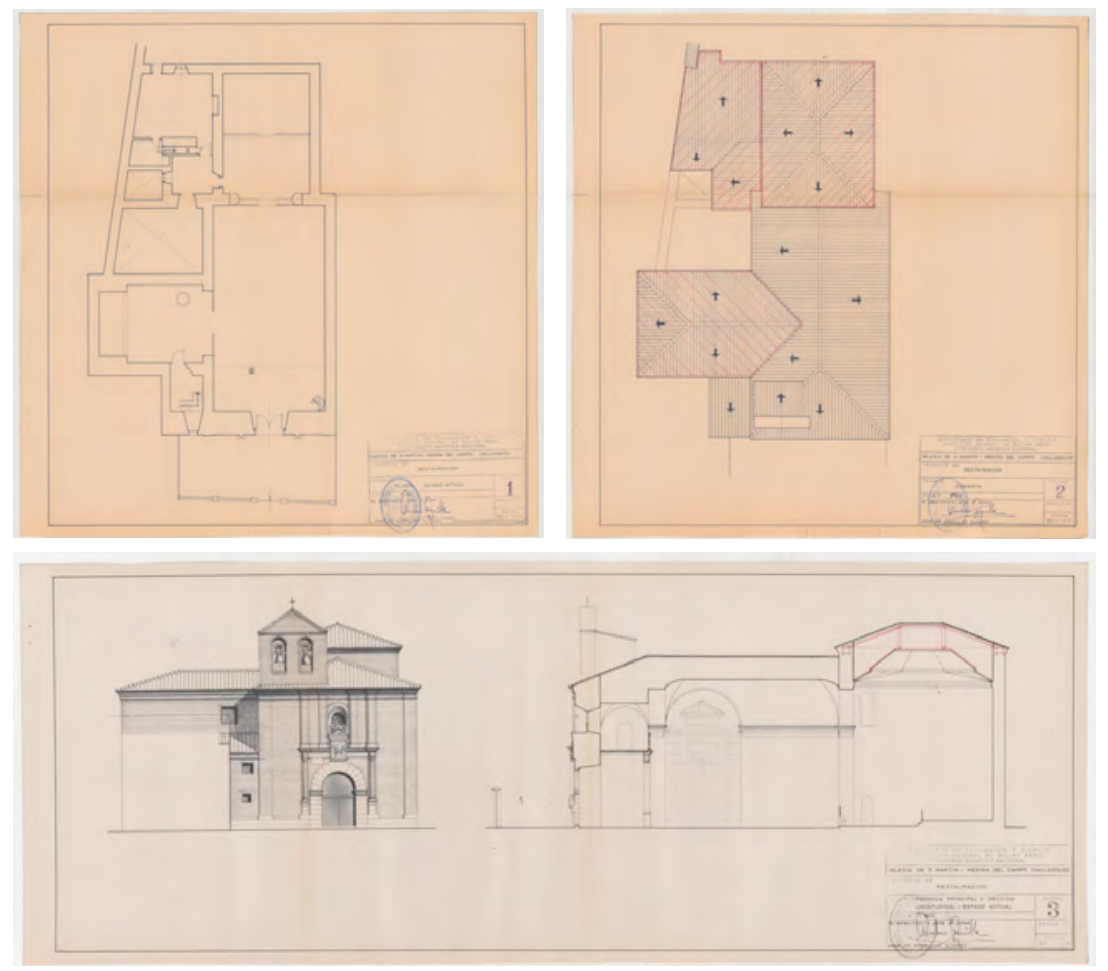

Ilustración 19: planos 1968 Arenillas AGA

\section{En el archivo de la Junta de Castilla y León}

VA-362

La carpeta contiene sólo cuatro planos sin carátula con el título Centro Cultural en los que se define el conjunto formado por la iglesia y un palacio adyacente con el templo rehabilitado como auditorio.

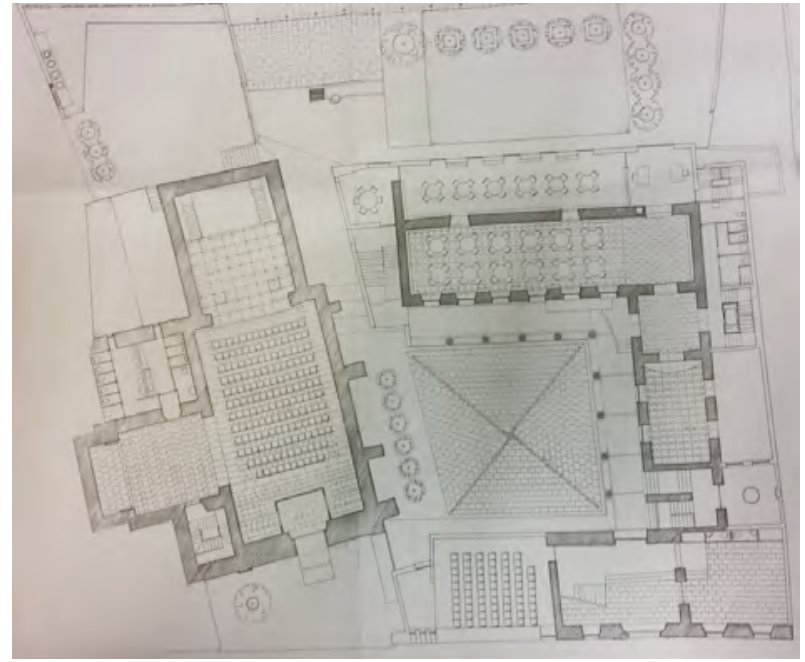

Ilustración 20: planta sin carátula JCyL 
En otras carpetas de documentación administrativa y certificaciones en el Archivo Central de la Junta hay algunas páginas sueltas del proyecto de Casa de Cultura.

Estudio BR arquitectos

Memoria histórica (Ana Manso y Carlos Parrado)

\section{Estado actual}

Más que arruinado cabría afirmar que la iglesia y el palacio han sido saqueados... se ha producido además un relleno de espesor variable entre 60 y $80 \mathrm{~cm}$.

Alteraciones formales y tipológicas. Las dos bóvedas centrales, reconstruidas en 1801, debieron sustituir a una armadura de madera que tenía su culminación en el magnífico artesonado de la cabecera.

Acudiendo a paliar los problemas originados por el hundimiento de aquella cubierta, los contrafuertes se instalaron sin demasiadas preocupaciones respecto de la existente. Se altera de este modo la limpieza del alzado lateral al claustro, además de producirse una molesta fragmentación de tratamientos al sustituirse la fábrica de ladrillo y tapial por otra completamente cerámica.

En la cabecera se sustituye también la primitiva cubierta a cuatro aguas por otra a dos, aunque, afortunadamente, no se destruye la cornisa perimetral de apoyo que hoy nos proporciona los datos para una posible reconstrucción.

La desaparición de todos los elementos ornamentales de la iglesia nos lo muestra hoy en un contexto de desolación... Pero es sin duda el arruinamiento de sus cubiertas lo que ha puesto definitivamente en peligro su estabilidad. La pudrición de una cabeza del tirante de la cercha más próxima a la cabecera arruinó todo este tramo de la estructura que pasó a descansar directamente sobre la bóveda y produjo su fisuración y colmatación de humedades.

También el hundimiento de la estructura de la cabecera debió producir fuertes empujes sobre los muros que aun hoy invisibles en la gran grieta del muro posterior y en la deformación y hundimiento parcial de zonas del artesonado. La solución detuvo el proceso pero a costa de emplazar unos tirantes metálicos que perforan el artesonado y atan las cabezas de los muros. En éstos unos zunchos que cajean exteriormente las fábricas reciben unas no menos poco afortunadas placas de anclaje de indiferente dimensionado. El tablero de la nueva cubierta a dos aguas se ejecuta en rasillones sobre perfiles de acero laminado. 
Finalmente una gran espadaña añadida a la fachada principal no sólo entorpece la pequeña escala de ésta sino que su acceso provoca una difícil solución sobre el coro...

Certificaciones del modificado. YAÑEZ SA

Consolidación cabecera de iglesia:

lud Demolición cuidadosa de fábricas de ladrillo macizo de $0,80 \mathrm{~m}$ de espesor y una altura media de 2,90m; ejecución de mechinales por debajo de zuncho de hormigón perimetral existente de sección $0,65 \times 0,70 \mathrm{~m}$., corte de sierra de disco de diamante en tramos de longitud aprox. de 1,50m., levantado con camión grúa móvil de 40m de brazo y descenso a nivel de suelo. La demolición de las fabricas existentes es en el fondo el perímetro de la cabecera de la Iglesia inc. los astiales.

77,95m3 Demolición de muro de ladrillo macizo

1Ud Apeo de arco de separación entre Nave Central y Cabecera

$1 U d$ Consolidación de arco interior de Iglesia consistente en cajeado lineal de ambas aristas del arco, suministro y colocación de perfilería metálica laminada conformada en obra... tensores a viga superior de hormigón ejecutada anteriormente...

40,60ml Formación de cornisa con ladrillo macizo de tejar con dos hiladas a base voladas a tizón sobre el paramento del muro y última hilada a sardinel tomadas con mortero bastardo

20,24m2 Reposición de muro 


\section{Visitas realizadas}

$13 / 08 / 2015$

El estado de conservación del monumento es bueno y corresponde a su funcionamiento actual como Museo de las Ferias.
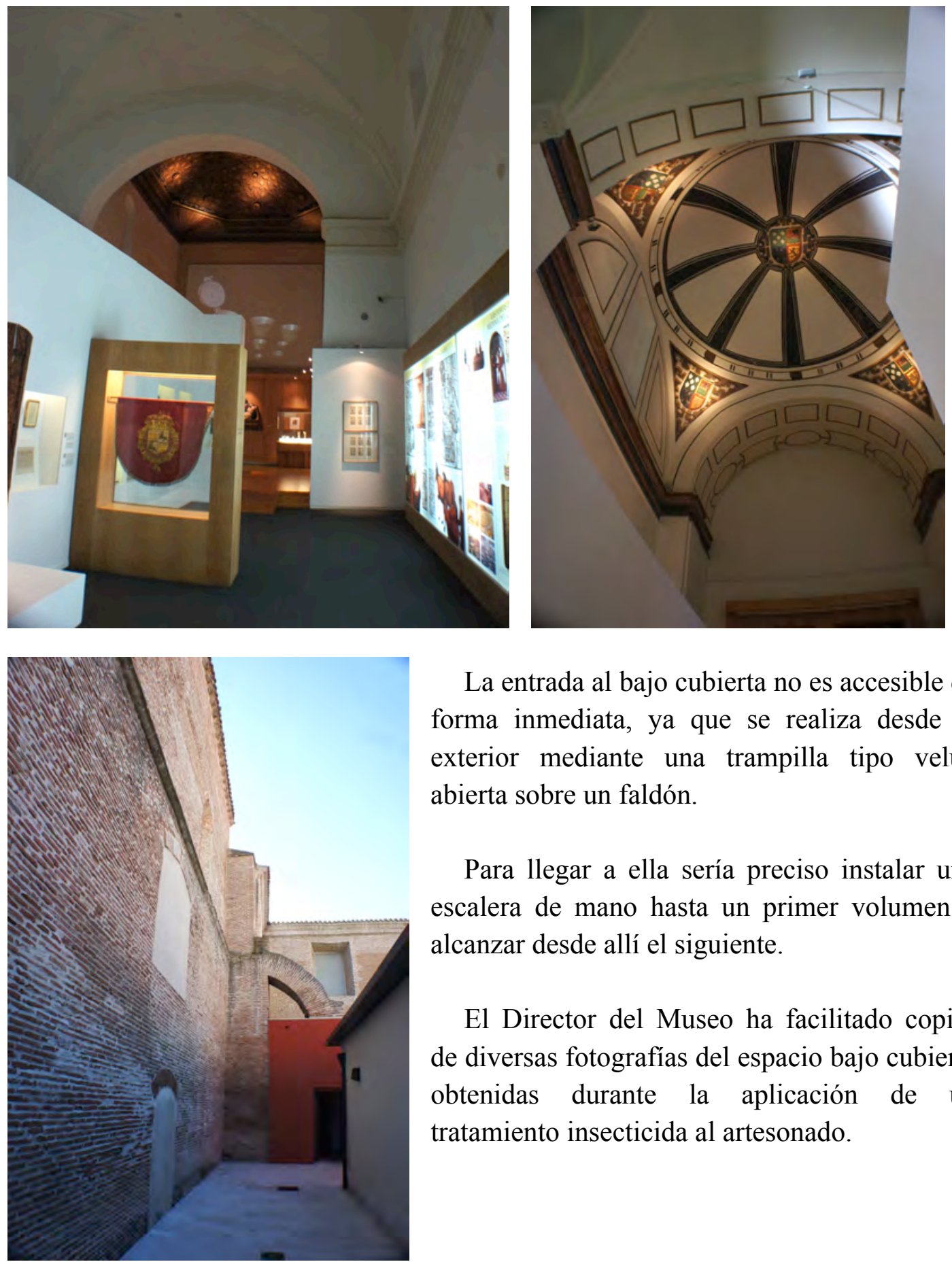

La entrada al bajo cubierta no es accesible de forma inmediata, ya que se realiza desde el exterior mediante una trampilla tipo velux abierta sobre un faldón.

Para llegar a ella sería preciso instalar una escalera de mano hasta un primer volumen y alcanzar desde allí el siguiente.

El Director del Museo ha facilitado copias de diversas fotografías del espacio bajo cubierta obtenidas durante la aplicación de un tratamiento insecticida al artesonado.

En las imágenes se aprecia la existencia de un zuncho de hormigón armado, enrasado a cara interior con el paramento de fábrica de ladrillo. Sobre este elemento apoyan pares de madera laminada con tensores anclados a los mismos mediante 
aparatos metálicos. Dichos tensores confluyen en un pendolón central, también resuelto con acero. Entre los pares se disponen correas de madera, fijadas con piezas metálicas, y sobre ellas un tablero.
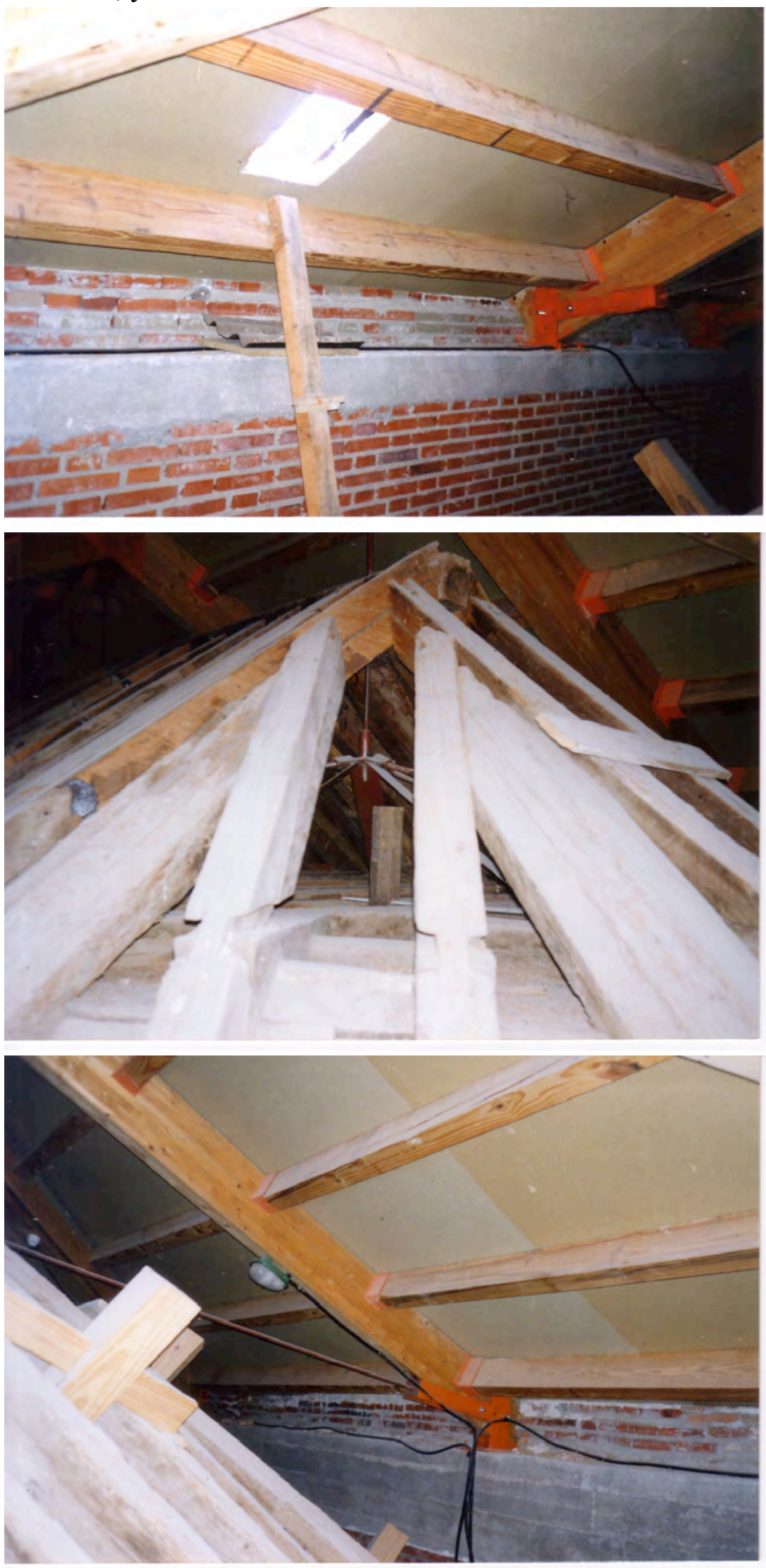
A grandes rasgos, la solución constructiva de cubierta observada coincide con la definida en el plano de sección del proyecto de 1989.

En la cabecera encontramos un zuncho de hormigón armado continuo enrasado a cara interior sobre los muros.

En el paramento se aprecian los diferentes materiales empleados en las sucesivas intervenciones. La cornisa del primer módulo a los pies es de ladrillo, mientras que en los dos tramos centrales de la nave se resuelve con piedra.
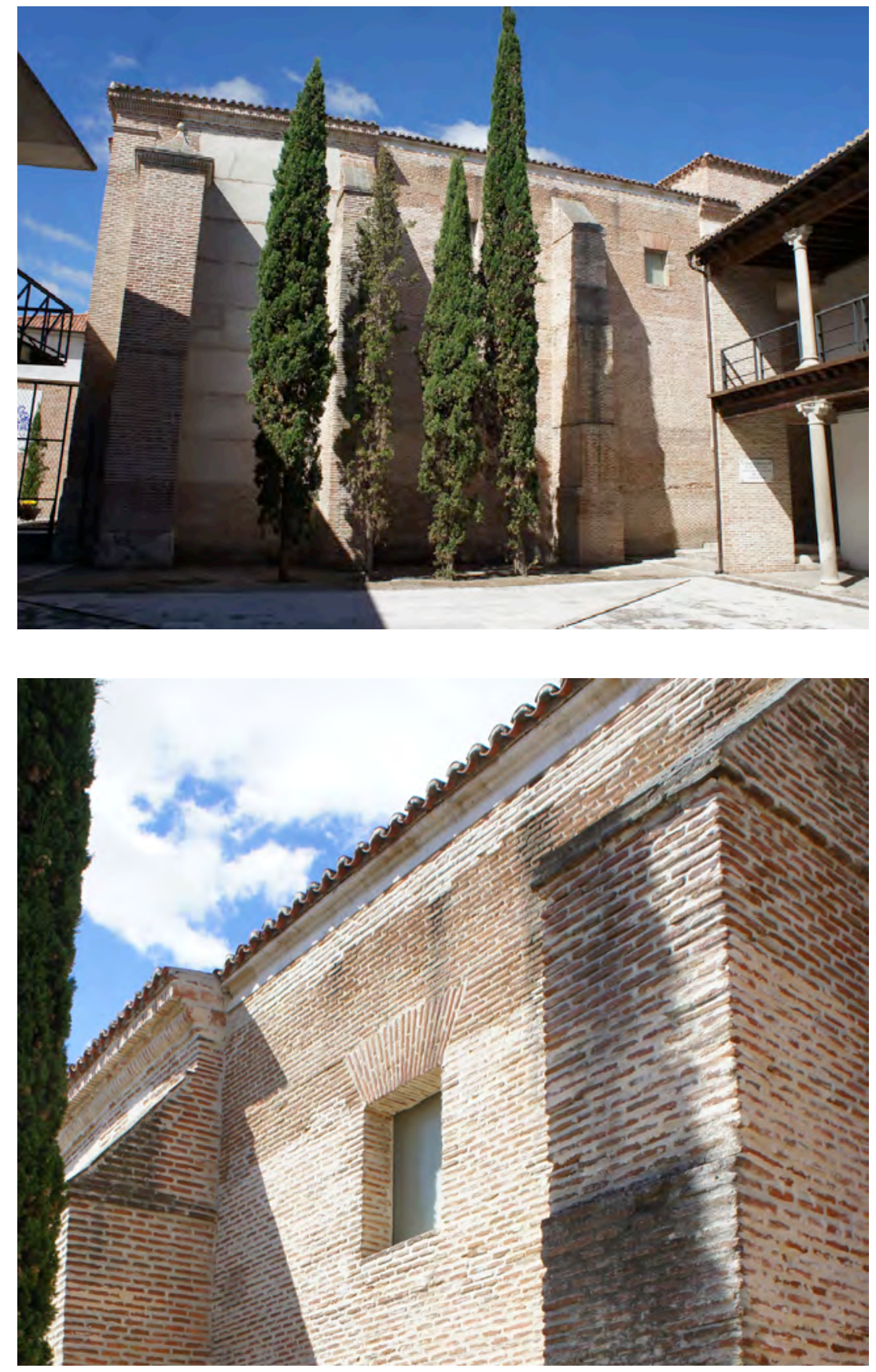



\section{Iglesia de los Santos Juanes}

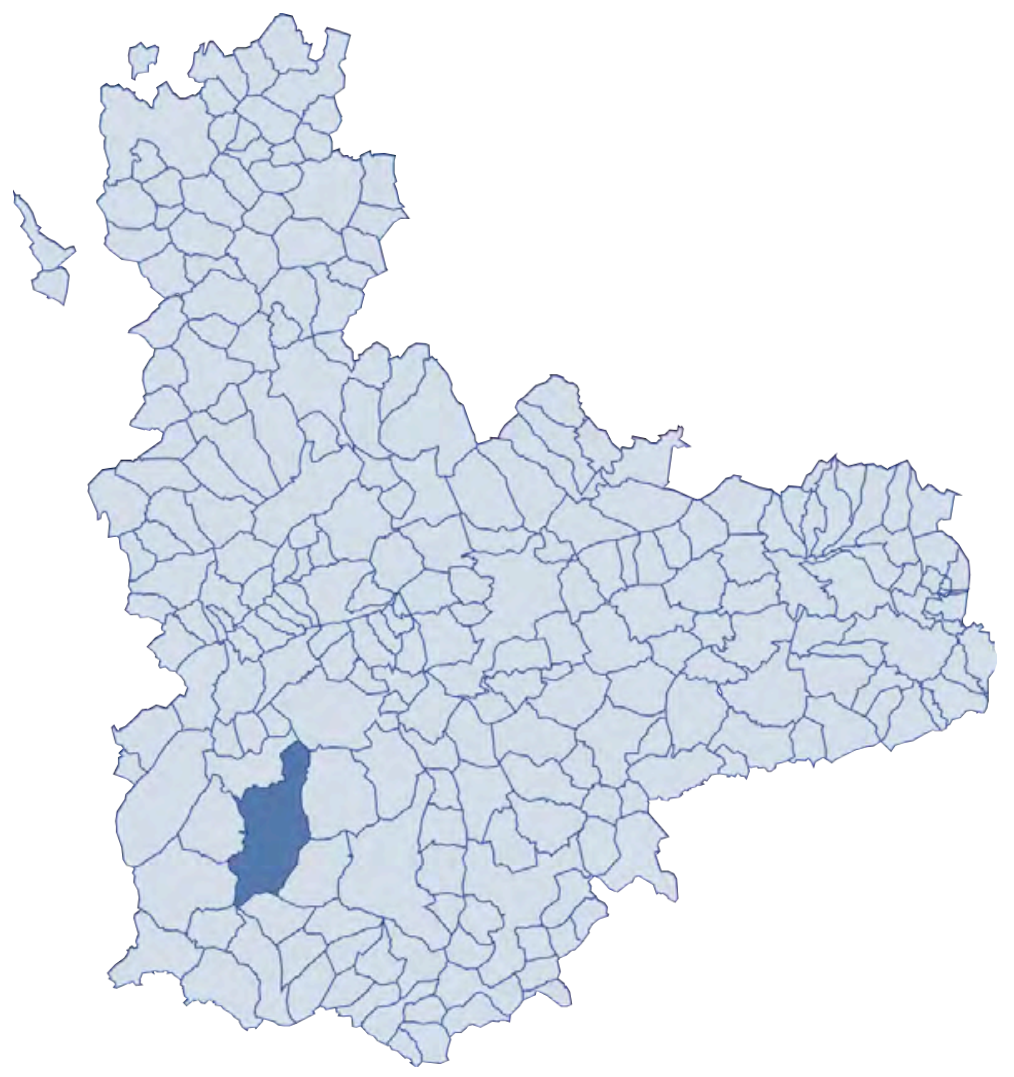



FICHA SÍNTESIS

Código de identificación: FZ-30

Denominación: Iglesia parroquial de los Santos Juanes

Localidad: $\quad$ Nava del Rey

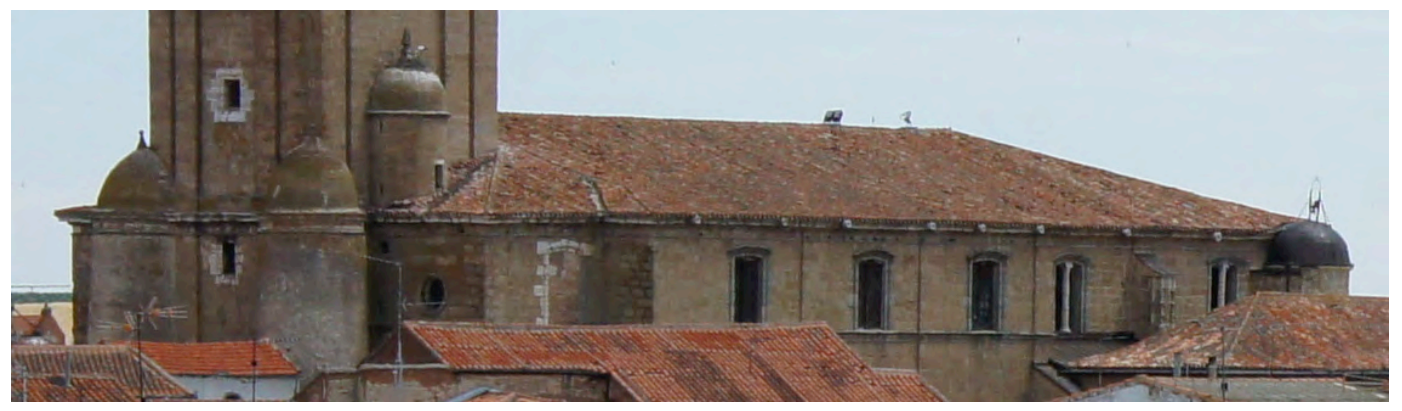

\section{Descripción}

Iglesia con tres naves de igual altura, tipo salón, cubiertas mediante bóvedas de cañón con lunetos, excepto tres de los espacios en la nave central, dos hacia la cabecera y otro a los pies, rematados con cúpula. Cuenta con capillas poco profundas entre contrafuertes, y otras más amplias cubiertas con bóveda de crucería. La torre campanario se ubica a los pies, encastrada en el centro.

\section{Materiales}

Los muros son de sillería arenisca sobre tres hiladas de zócalo de caliza. La cubierta está revestida de teja curva. Algunos espacios presentan en la actualidad un nuevo revestimiento de chapa de cobre sobre sus cubiertas.

\section{Singularidades}

El acceso principal al conjunto se realiza desde una plaza, a través de un doble lienzo de muro o "profundis" barroco, adosado entre cabecera y Sacristía.

\section{Dimensiones básicas del templo (aproximadas en metros)}

$\begin{array}{llll} & \text { central } & \text { laterales } & \text { capillas } \\ \text { Ancho de nave } & 9,4 & 6,2 & 2,8 \\ \text { Altura } & 17,5-19,5 & 17,5 & 17\end{array}$




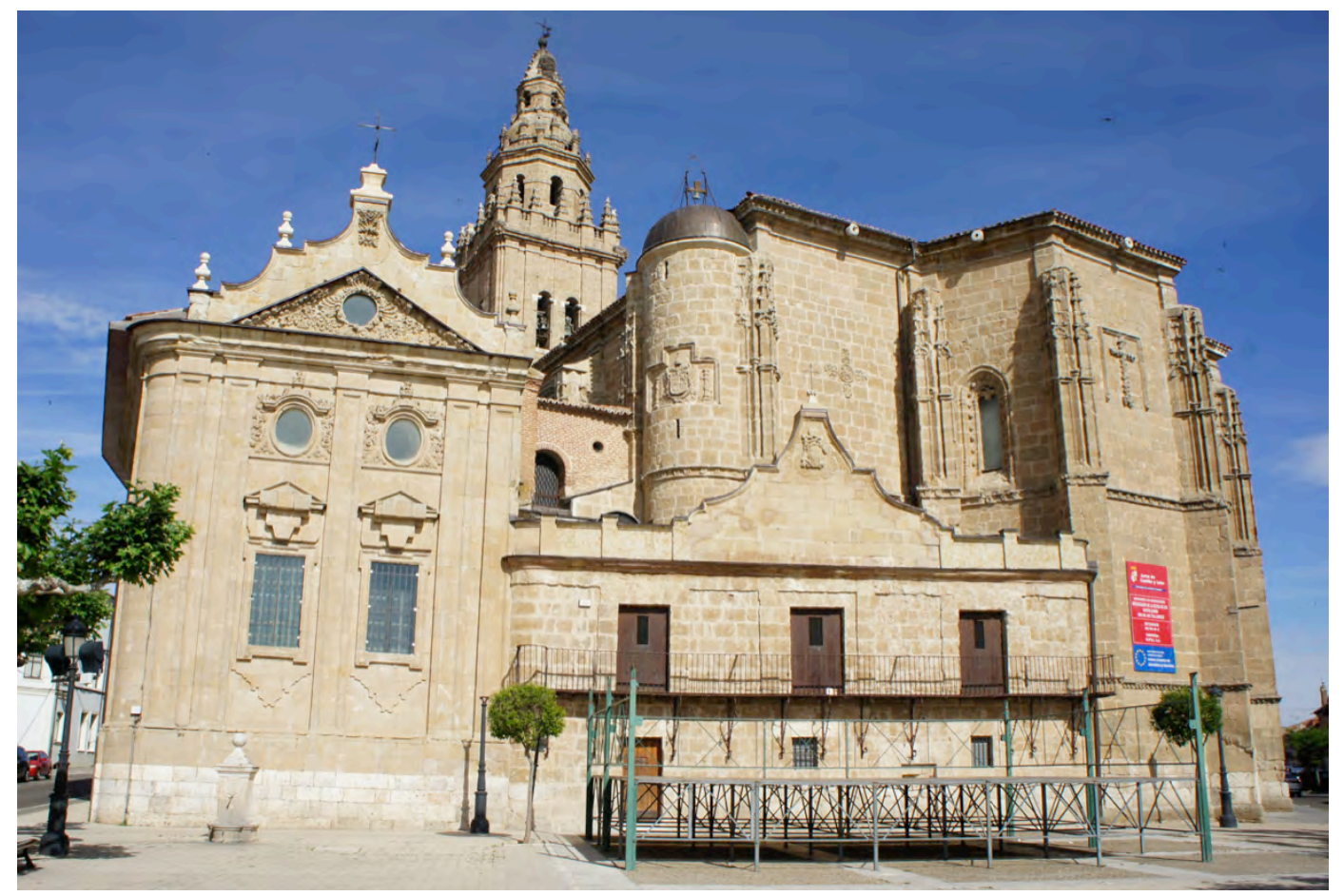

Ilustración 1: cabecera, profundis y sala de canónigos fachada a la plaza (20/06/2012)

\section{Memoria histórica constructiva}

El monumento arranca en 1553 con trazas de Rodrigo Gil de Hontañón, a partir de unas preexistencias góticas. El proceso prosigue con la construcción de capillas entre contrafuertes datadas en 1578, la coronación de fábricas murarias y el abovedamiento del templo hacia 1589 bajo la dirección de Felipe de la Cajiga. En 1635 se produce el hundimiento de la primera torre, que levanta de nuevo Juan de Revilla, y en 1702 se cubre con un chapitel barroco.

Etapas (según planos del Proyecto de Luis Navarro)
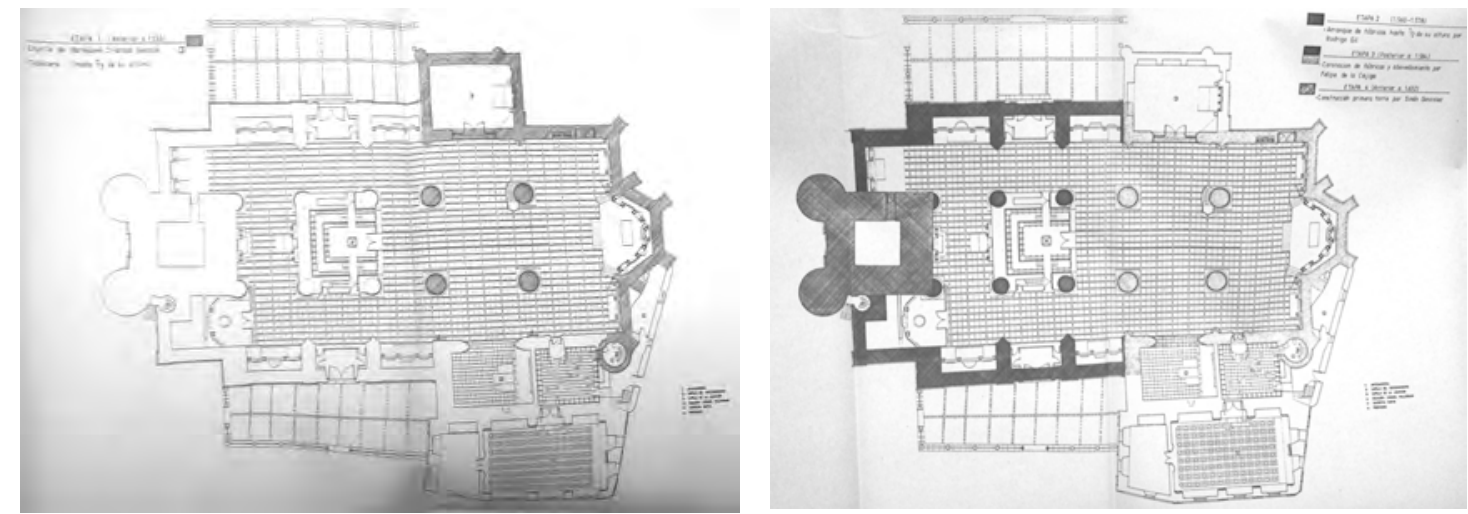

Ilustración 2: etapas primera y segunda (Navarro)

En la primera etapa la cabecera se levanta hasta $2 / 3$ de su altura (antes de 1553) 
En la segunda Rodrigo Gil arranca las fábricas de nave y capillas entre contrafuertes hasta media altura. (1560-1578). Y en la tercera Felipe de la Cajiga las corona y resuelve el abovedamiento. (Posterior a 1584)

Según el pleito divulgado por Javier Castán (1990) el edificio cubrió aguas en 1595 y un año después se construyeron las bóvedas.
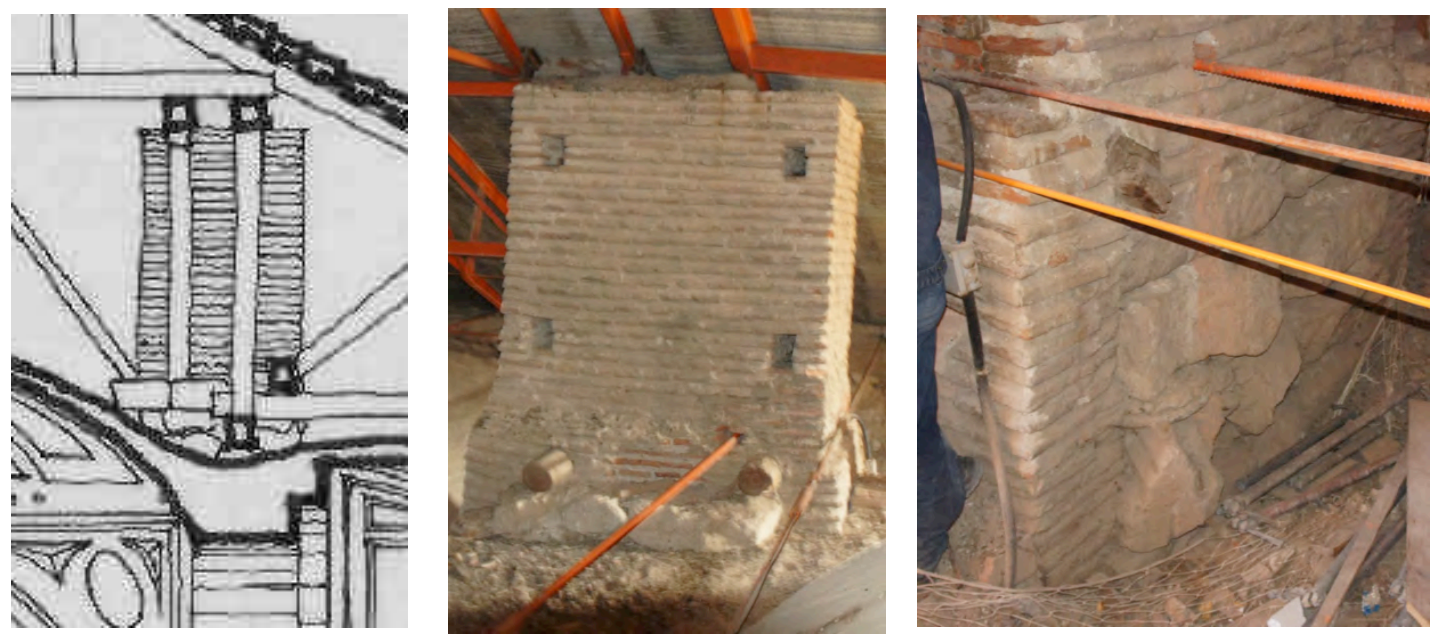

Ilustración 3: machones de fábrica en ejes de pilares (plano Iglesias 1974; visitas 20/06/2012 y 2013)

Sobre el trasdós de las bóvedas, las grandes columnas del templo se prolongan mediante machones de fábrica de ladrillo con un arranque de mampuesto de piedra sin escuadrar. Encontramos en ellos retacados de diversas épocas, incluso fragmentos de piedras labradas que parecen restos de nervaduras.

La armadura de madera original presentaba dos niveles, con jabalcones hoy desaparecidos. Encontramos restos de durmientes y tirantes de madera cortados embebidos en el arranque de los machones en ambas direcciones.

\section{Cronología. Fechas clave}

$1553-1584-1979$

\section{Intervenciones}

\section{7 - Ortiz de Urbina}

Se trata de uno de los primeros proyectos del arquitecto decimonónico. Refuerza el primer cuerpo de la torre incorporando contrafuertes cilíndricos y retaca con fábrica de ladrillo el arranque de los muros. 
En un informe menciona una mejora de la bóveda del crucero incorporando nuevas piezas a la armadura de cubierta. Vuelve a actuar sobre el conjunto cuarenta años más tarde.
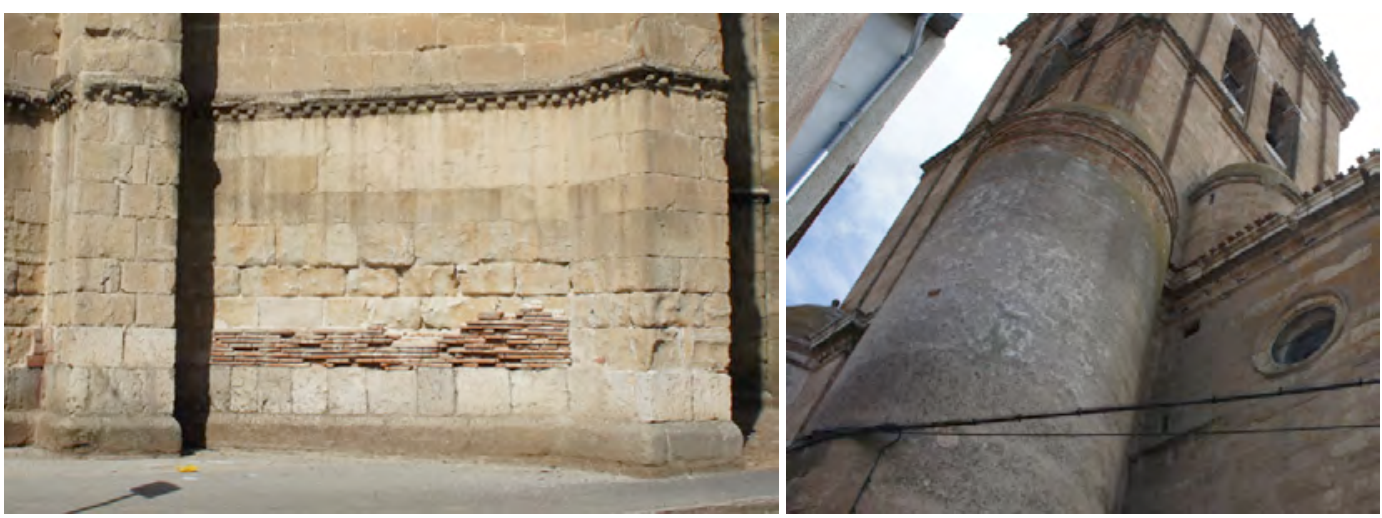

Ilustración 4: retacado de ladrillo y contrafuertes cilíndricos (20/06/2012)

En algún momento antes del siglo $\mathrm{XX}$ se reorganizan los huecos del profundis $\mathrm{y}$ unas escaleras nuevas eliminan la subida por la escalera de caracol de piedra. En los años cuarenta se suprimen revocos y forrados de fábrica de las columnas. También se desmontan y recolocan nervios y plementos de la bóveda de Antesacristía degradados por la humedad.

1964 - Cubierta - Anselmo Arenillas

1971 - Cubierta - José Ángel Rodrigo García

1978 y 1979 - Cubiertas - Ana Iglesias González

\section{Incorporación de zuncho de hormigón armado.}

Desmonta la estructura original de "cerchas leñosas tipo paladiano con tirante ajabalconado en la nave central y semicerchas en cubrición de naves laterales".

En la cabecera se sustituye por estructura metálica de IPN atirantados con un perfil de sección circular roscado y en la nave por cuchillo belga sobre vigas tipo Warren compuesta y Howe. La cubrición de las cerchas la resuelve con una losa de hormigón y nervometal.

Hacia 1985 se pican los paramentos de la capilla del Descendimiento y se rejuntan las fábricas de plementos y nervaduras de bóvedas. 
1988 - Jose V. Rodriguez Hernández

Proyecto para actuar sobre la torre, que presentaba un hueco practicado para retirar las campanas sin cerrar, y el profundis, cuerpo adosado al templo en el siglo XVIII con una balconada desde la que asistir a festejos taurinos populares. Se reconstruye la bóveda de la torre, con dos roscas de ladrillo hueco sencillo con mortero de cemento.

\section{1 - Luis Navarro García}

Se repara cubrición y fachada este de la Sacristía nueva, sustituyendo cubiertas, incluso estructura, de antesacristía y capilla del Descendimiento

1994-1998 - Emergencia en estructura de cubierta y apeo preventivo de bóveda en la Iglesia de los Santos Juanes - Luis Navarro García. Se sustituye la bóveda sobre el coro copiando la contigua, con rosca de ladrillo y mortero de cal.

En 1994 y 1995 se lleva a cabo diversos estudios técnicos sobre el edificio: sondeos, análisis hidrogeológico, de humedades, inspección de soldaduras de estructura de cubierta. GEOCISA lleva a cabo también a lo largo de un año un control instrumentado de las fisuras existentes, que simplemente responden a las variaciones térmicas medioambientales.

\section{1- Alfonso González Gaisán}

Restaura la zona del profundis, antesacristía y capilla del descendimiento, reponiendo molduras y sillares dañados. Incorpora una pasarela y escaleras de diseño moderno en esta zona. Sustituye la teja por chapa de cobre en las áreas problemáticas, para mejorar la estanqueidad.

\section{3 - Marcelino Hurtado Acebes y Pedro Andrés Nieto Mongil}

Tras dos años con el templo clausurado se repara y refuerza la estructura metálica de cubierta incorporada en 1979. Se duplican las celosías intermedias longitudinales de apoyo de las cerchas tipo. Se colocan además dos grandes cerchas para apeo intermedio de las diagonales de la cabecera.

Los zunchos a ambos lados de la nave se atirantan entre sí mediante cuatro pares de tensores anclados al muro mediante cerchas dispuestas en horizontal que reparten el atado. 


\section{Planos}

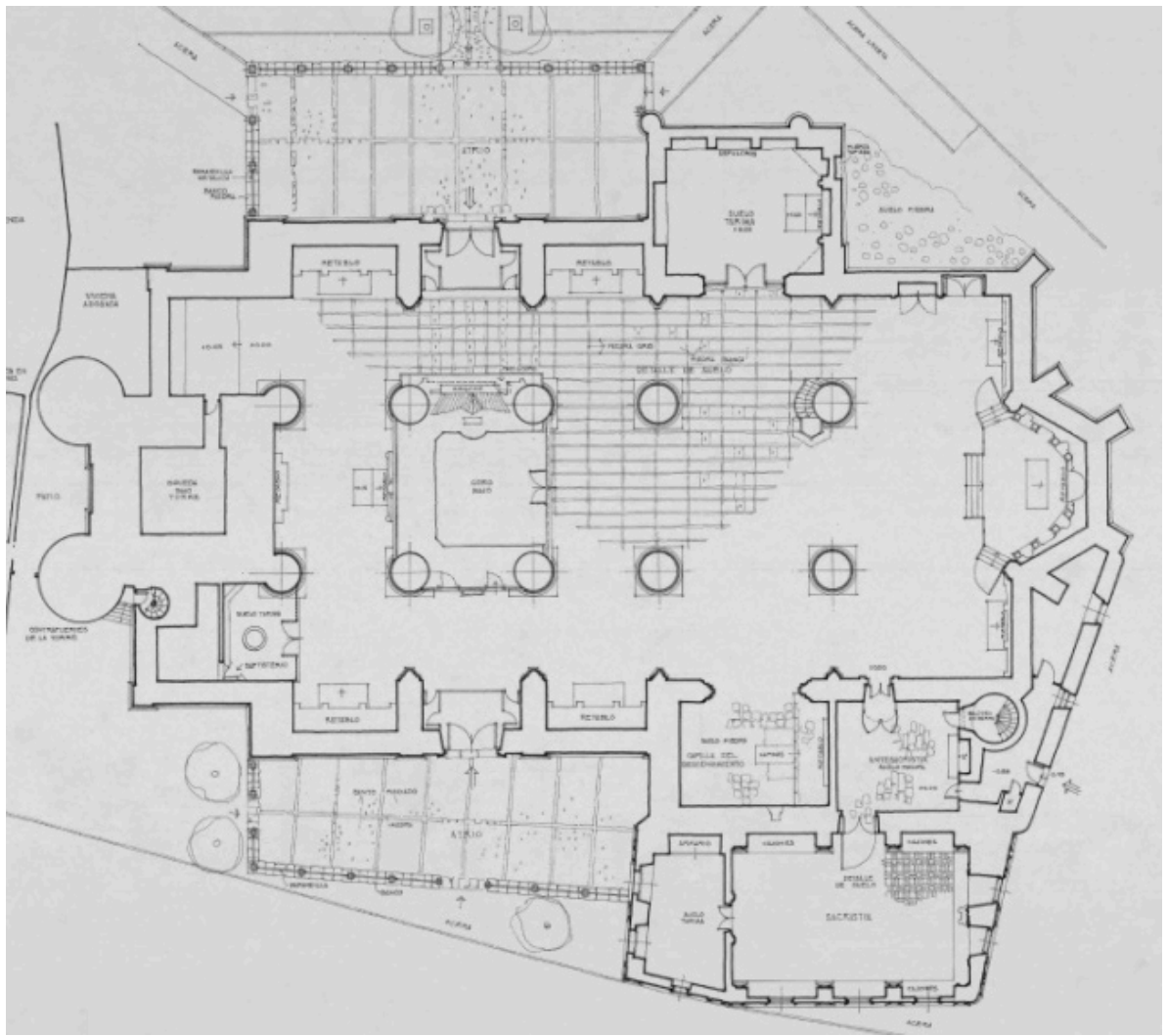

Ilustración 5: planta (Ana Iglesias 1978 IPCE)

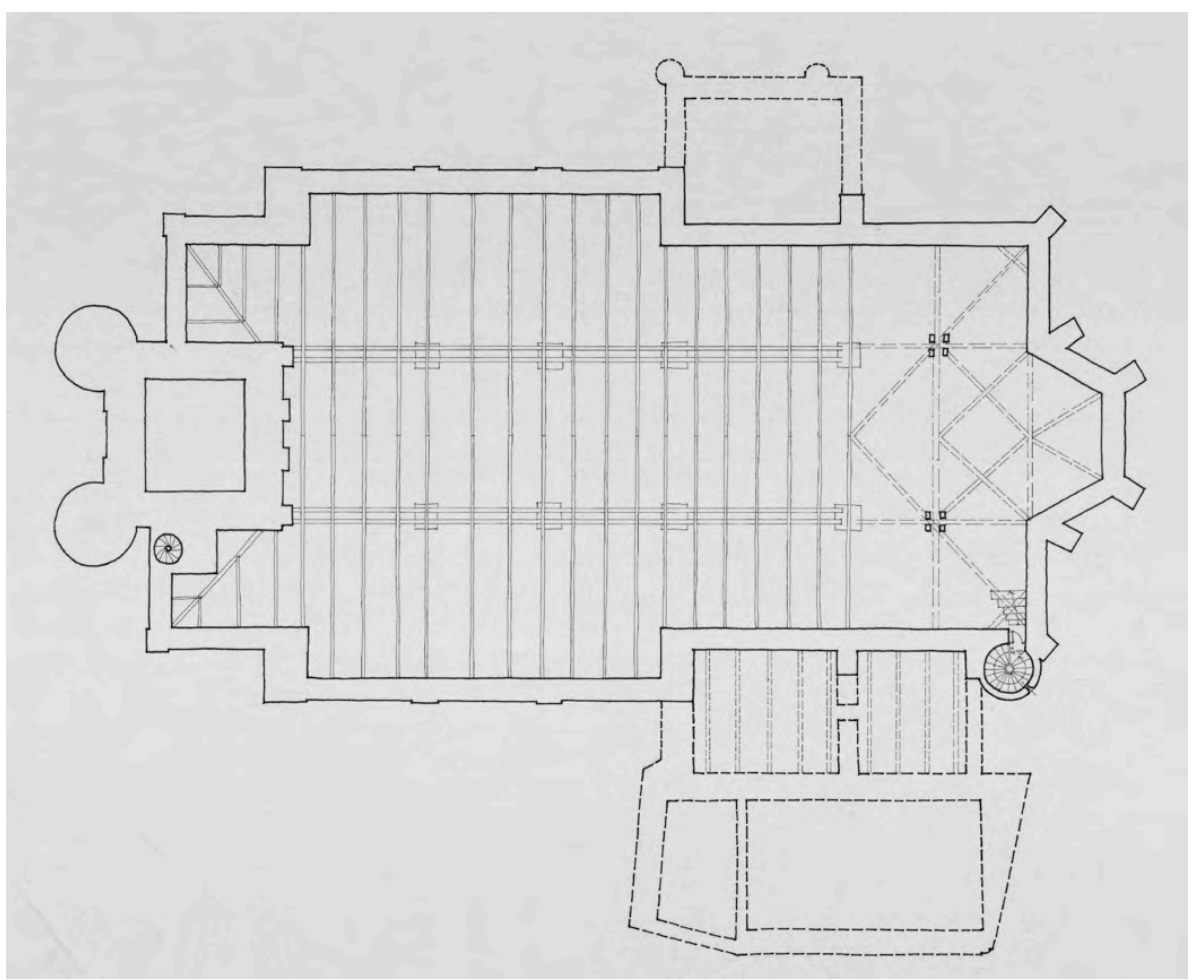

Ilustración 6: plano cerchas de cubierta (Ana Iglesias 1978 IPCE) 


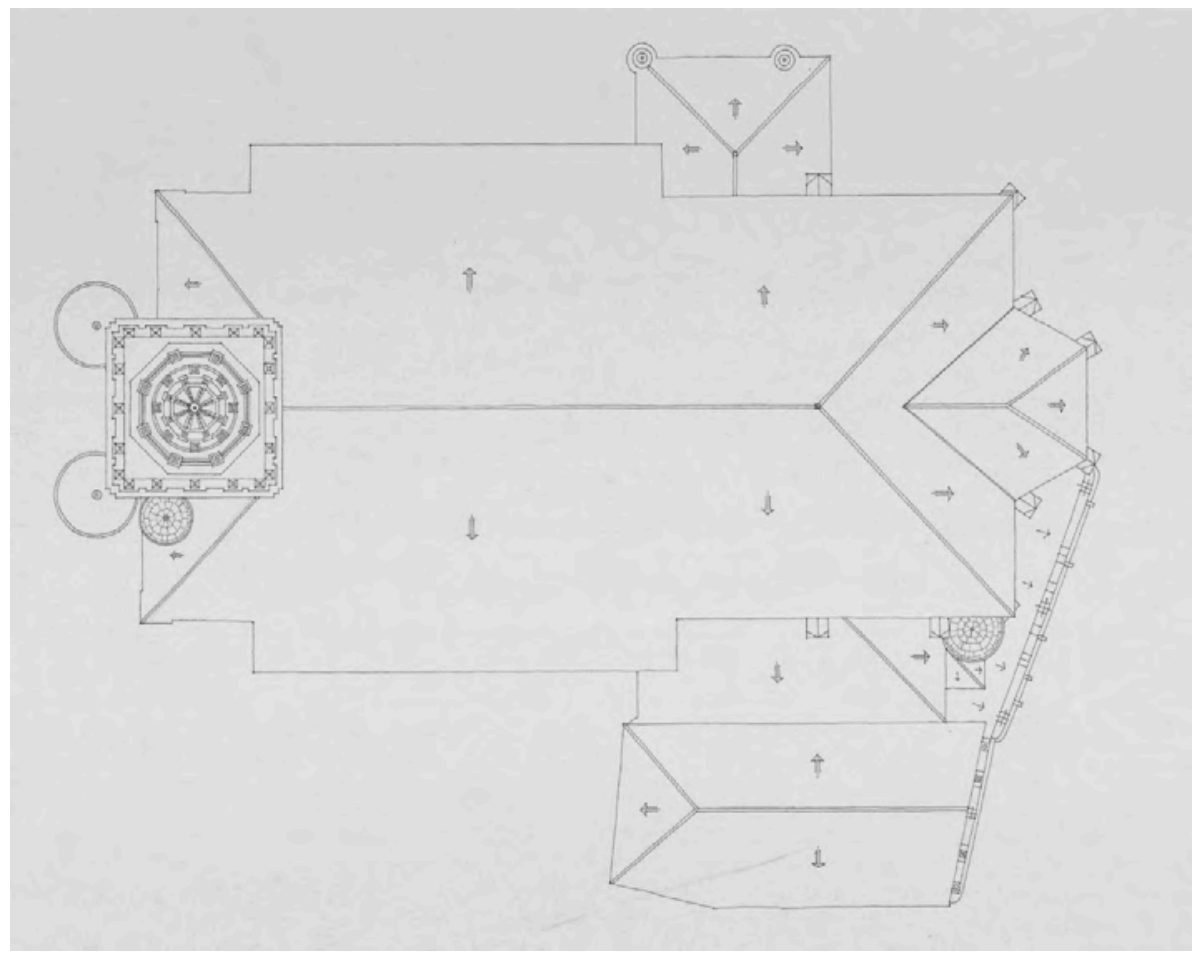

Ilustración 7: faldones de cubierta (Ana Iglesias 1978 IPCE)

Secciones del estado antes de 1980:

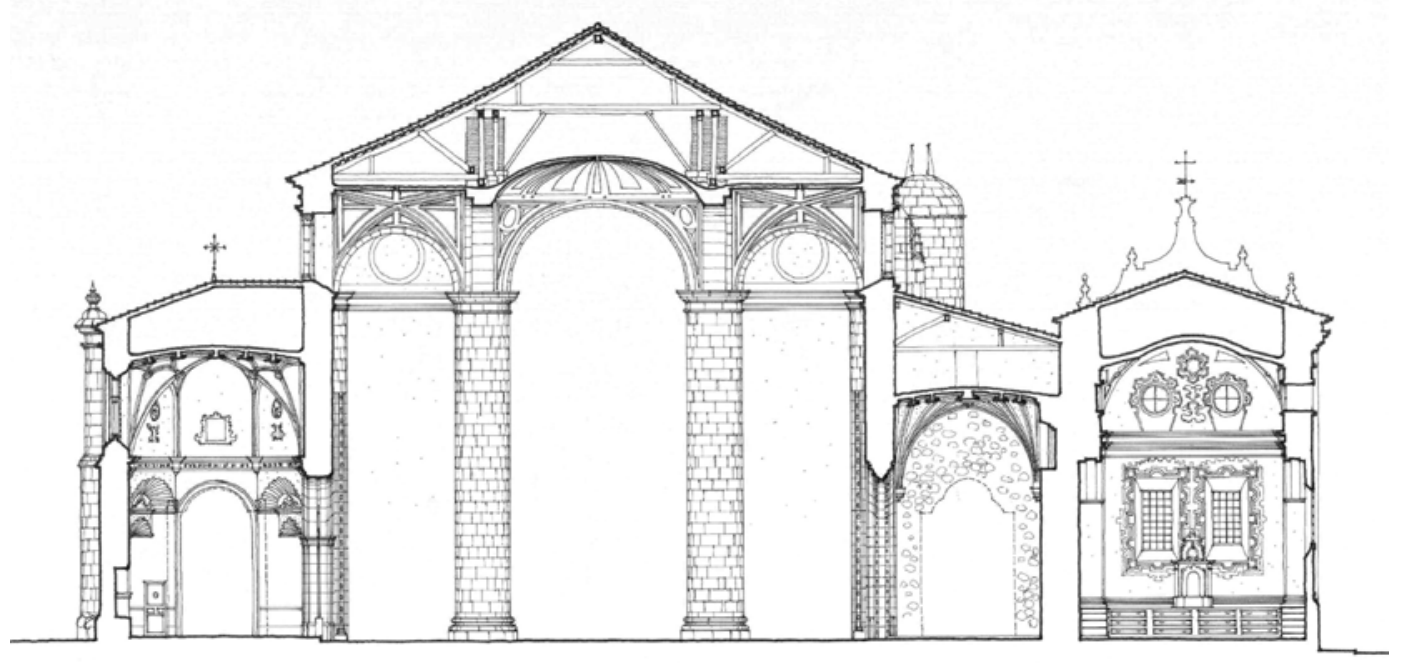

Ilustración 8: sección por crucero y sacristía (Ana Iglesias 1978 IPCE) 


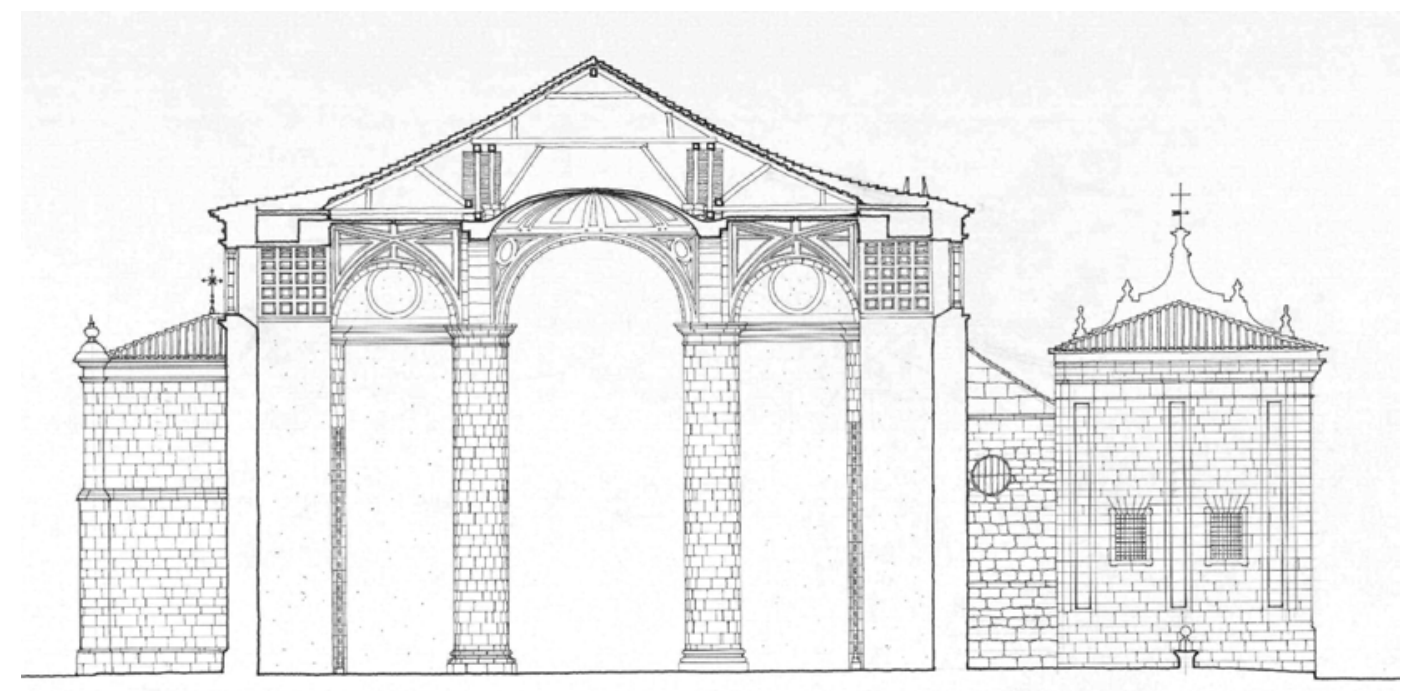

Ilustración 9: sección del cuerpo del templo hacia los pies (Ana Iglesias 1978 IPCE)

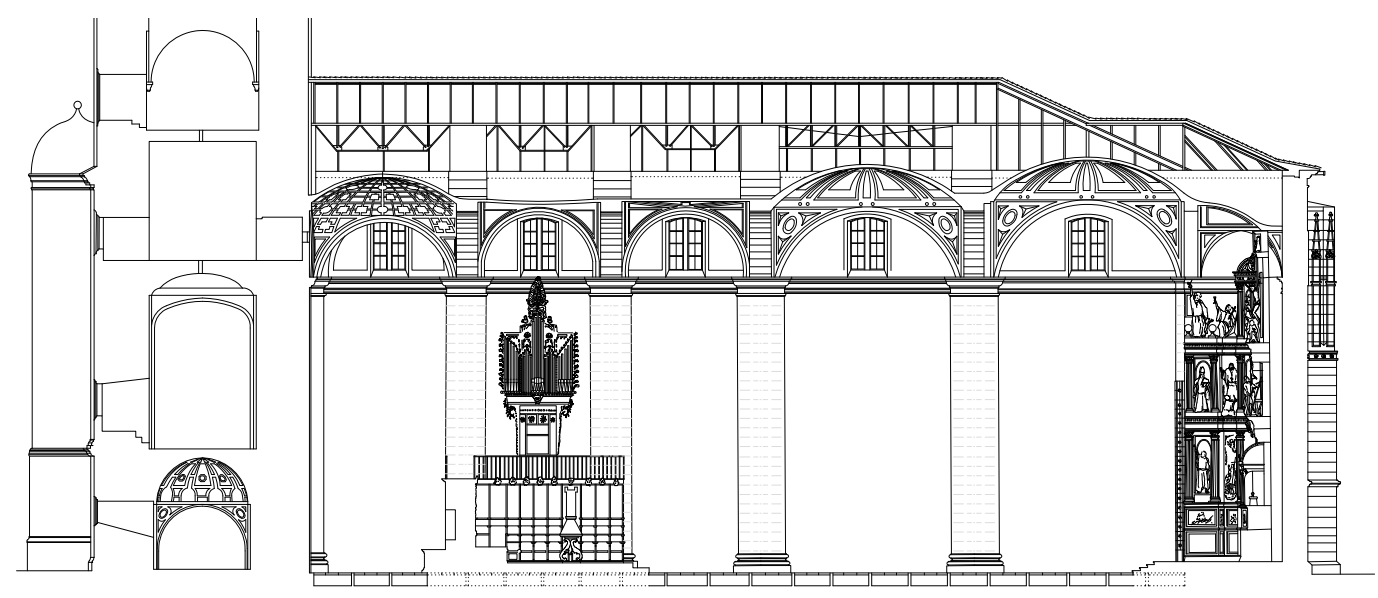

Ilustración 10: sección longitudinal 2001 (Gonzalez Gaisan)

\section{Solución constructiva de la cubierta}

En las secciones transversales anteriores se aprecia cómo era la monumental cubierta original a dos aguas: una estructura de cerchas de madera de "tipo paladiano con tirante ajabalconado" y pendiente de $31^{\circ}$, más tendida en la prolongación sobre las capillas laterales de ambos extremos.

En el reemplazo por estructura metálica del siglo XX se disminuye la pendiente hasta unos $20^{\circ}\left(21,8^{\circ}\right.$ según la Memoria del proyecto de

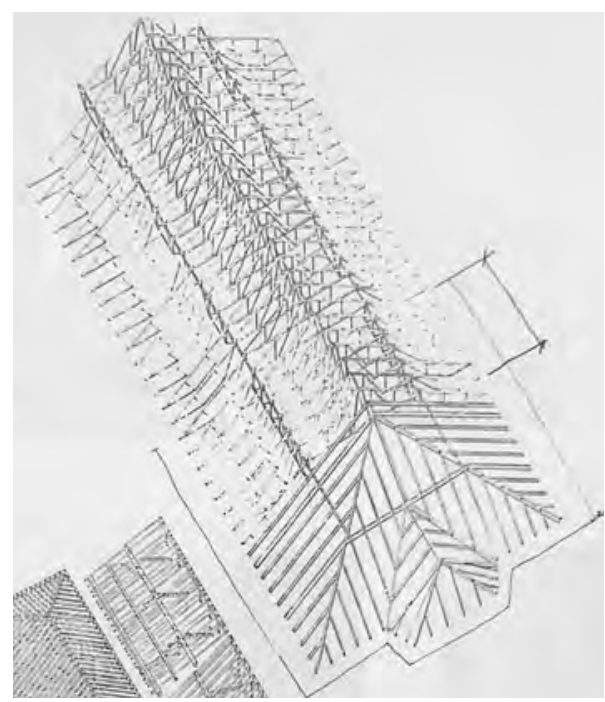

Ilustración 11: estructura de cubierta (Navarro 1994-98) 
Hurtado). El cuerpo de la nave se resuelve con tres cerchas combinadas (ilustración del proyecto de Hurtado), que apoyan de forma intermedia sobre celosías que discurren longitudinalmente y son soportadas por los machones de fábrica de ladrillo.

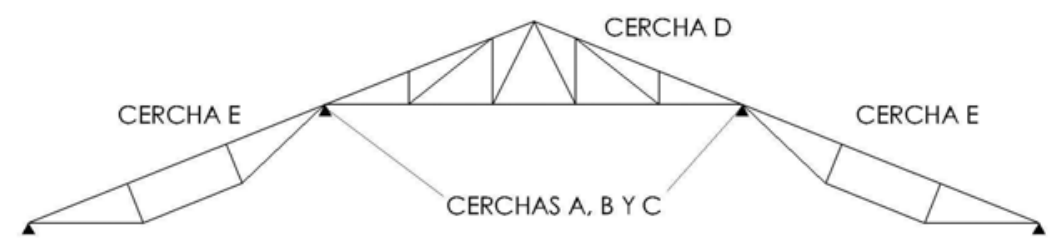

Ilustración 12: esquema de cálculo comprobación de cerchas (Hurtado 2013)

El testero se configura, escalonado a tres aguas, mediante una estructura espacial en la que juegan un papel importante las diagonales. El reciente refuerzo estructural duplica las celosías longitudinales e incorpora grandes aparatos de apoyo preventivo bajo ambas diagonales.

\section{Zunchos}

En la copia de un croquis a mano de la DF conservada en el Archivo del Servicio de Patrimonio de la Junta de Castilla y León se representa la estructura metálica incorporada en 1979 superpuesta a la original de madera más inclinada. Las celosías de naves laterales cuentan con una luz homogénea, por lo que el "zuncho perimetral" de hormigón se dispone cerrando un rectángulo y en realidad apoya sobre los arcos que cubren las capillas laterales, no sobre el cerramiento, dejando en ambos extremos zonas huecas no resueltas e inaccesibles.

Según el esbozo superior y el detalle siguiente de la intervención de 1979, al no disponerse el zuncho perimetral sobre el cerramiento en toda su longitud, sólo se cuenta con la prolongación de la capa de hormigón y nervometal para arriostrar entre sí ambas fachadas. En el proyecto de Navarro se menciona como espesor de esta lámina de hormigón $17 \mathrm{~cm}$ mientras que, tras las catas de GEOCISA, se confirma que varía desde 5,5 hasta $24 \mathrm{~cm}$.

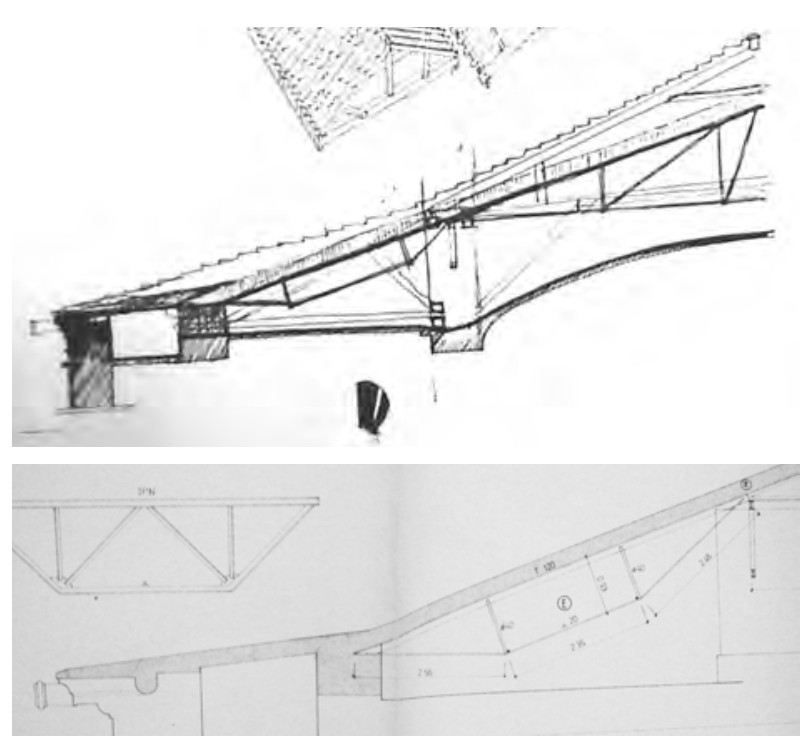

Ilustración 13: detalle 1979 zona prolongada hasta la cornisa 
En la documentación del proyecto de 1994-98 su autor, Luis Navarro, describe un "cizallamiento del zuncho debido al desplazamiento de las fábricas hacia el exterior".

Sin embargo, en la Instrumentación de fisuras llevada a cabo por GEOCISA desde enero de 1994 hasta febrero de 1995, se comprueba que se trata de una grieta estable, $\sin$ apenas movimiento longitudinal y con el mínimo transversal acorde a las variaciones térmicas medioambientales.

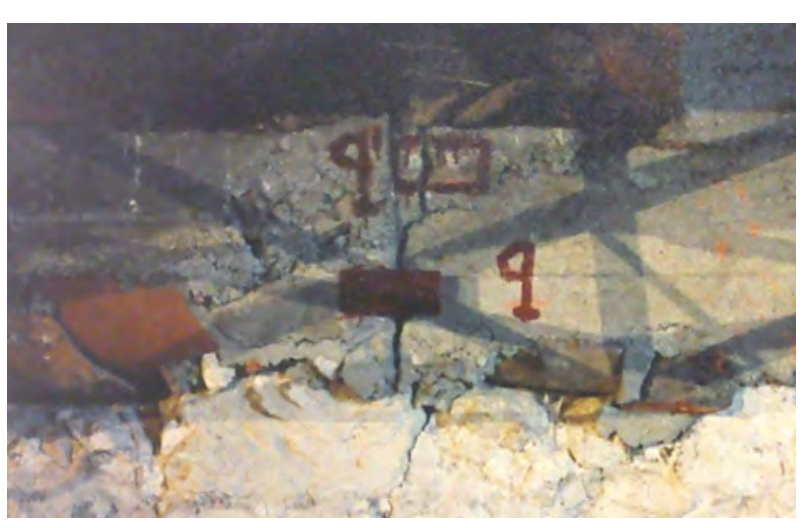

Ilustración 14: grieta en zuncho dossier GEOCISA

\section{Conclusiones}

En la iglesia de los Santos Juanes en Nava del Rey se incorporó hacia 1979 el típico zuncho perimetral rectangular de hormigón armado sobre el que apoya una nueva estructura metálica, que reemplaza a la original de madera aserrada. La principal singularidad de este elemento es que, si bien en ambos testeros y crucero el templo cuenta con tres naves, en su zona central se incorporan unas capillas laterales, y el zuncho discurre sobra la embocadura B de las mismas, en vez de sobre el muro A de fachada.

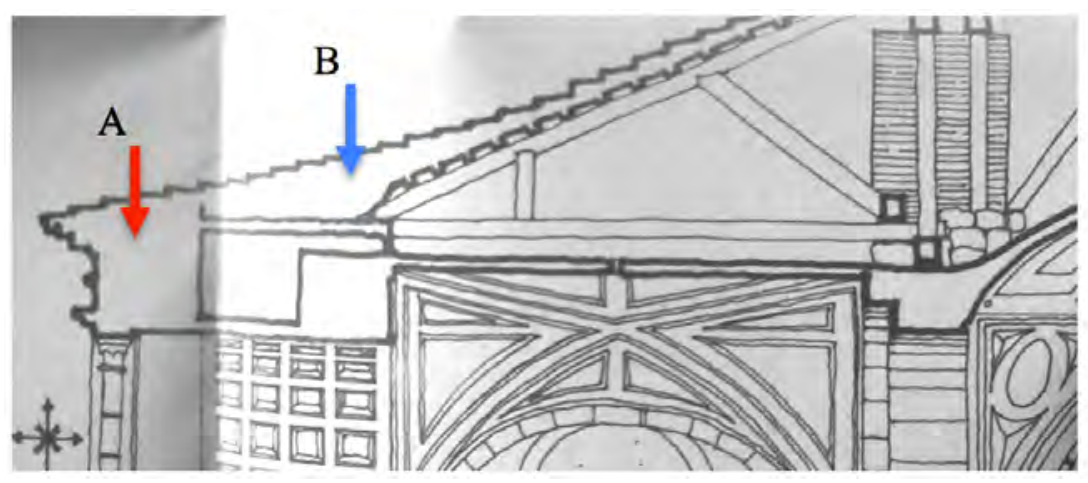

Ilustración 15: alineación B del zuncho en la sección

El tablero de cubierta se prolonga así sobre dichas capillas, con una solución constructiva anómala que, según los planos de 1978, ya se encontraba en la geometría original. 
En resumen: el zuncho perimetral de hormigón armado no llega a conformar un anillo completo, interrumpido por la macla de la torre a los pies. Tampoco ata en cabeza ambas fachadas laterales, ya que discurre como viga continua, sobre apoyos puntuales, en la línea de embocadura de las capillas. Ambas fachadas sólo cuentan para su atado transversal con la prolongación del tablero de hormigón sobre nervometal (de espesor variable entre 5 y $24 \mathrm{~cm}$ ).

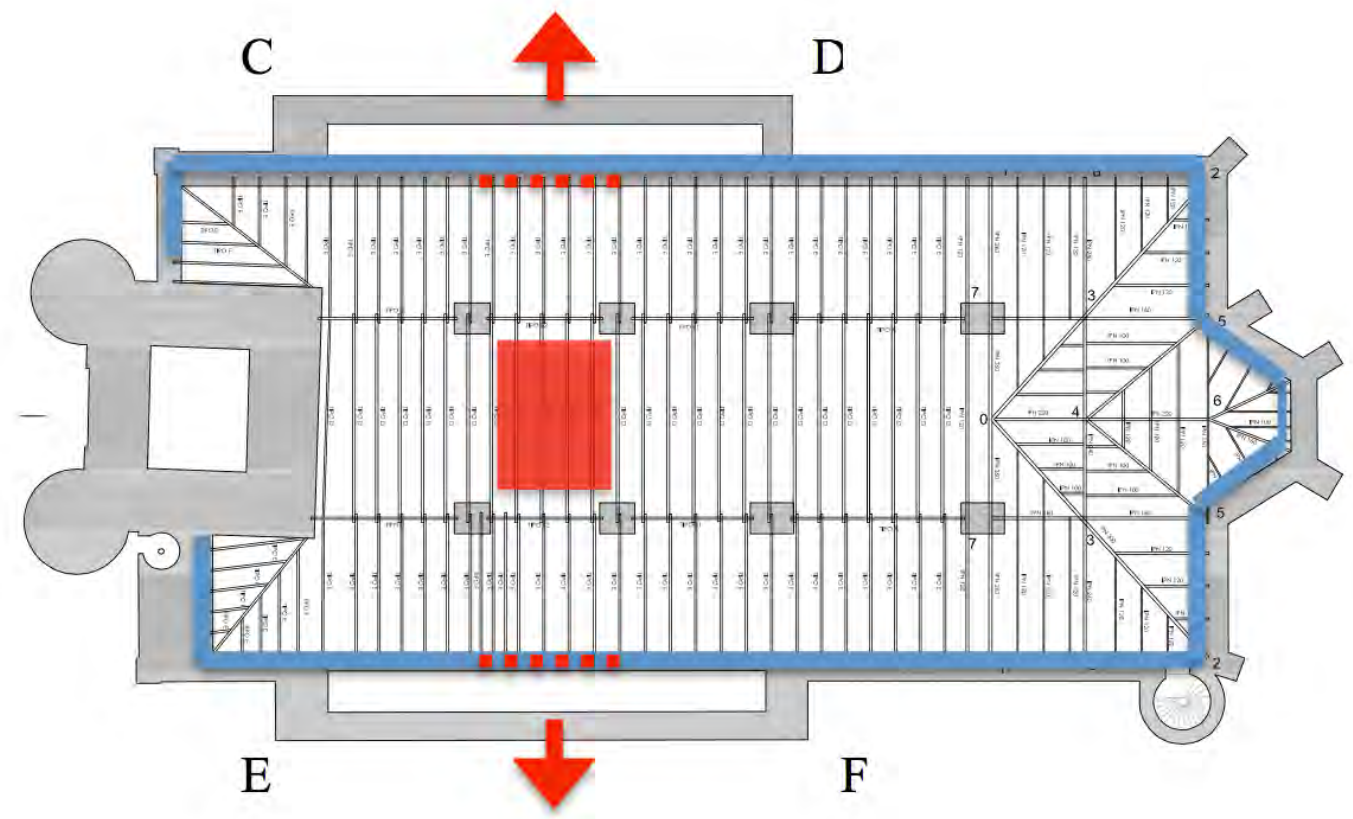

Ilustración 16: esquema de zunchos y bóveda reconstruida

Sobre el croquis de estructura de cubierta en el estado actual del proyecto de Hurtado se señala la zona de bóveda sobre el coro reconstruida en 1994 por Navarro, y las grietas (marcadas a trazos) en el encuentro con los frentes de capillas de las bóvedas de naves laterales, que coinciden con el centro de los tramos en los cuales el zuncho no discurre sobre los muros de fachada C-D y E-F. 



\section{Iglesia de los Santos Juanes en Nava del Rey}

Intervención citada en la publicación del Ministerio:

1964 - Cubierta - Anselmo Arenillas

En la web del IPCE encontramos digitalizada una planta suelta con carátula de Anselmo Arenillas fechada en 1956 sólo del templo, sin sacristía ni profundis.

\section{En el Archivo General de la Administración:}

AGA 26/00294

Proyecto de reparación de la iglesia de los Santos Juanes de Nava del Rey Anselmo Arenillas Álvarez mayo de 1955

En la memoria explica que la iglesia fue afectada por el terremoto de Lisboa: en los huecos que existen en la parte alta de la fachada sur se abrieron los arcos y descendieron las claves. Pusieron un parteluz en cada hueco que sostuviese la clave. Se opusieron sin saberlo al normal trabajo del arco y en el transcurso de los siglos se acentuó su deformación, se asentaron las fábricas y se abrieron las juntas de las cornisas dejando penetrar el agua.

El proyecto sustituye $4 \mathrm{ml}$ de cornisa erosionada, quita los parteluces elevando a su sitio las dovelas, colocando un cargadero de hormigón en su interior si ello es preciso.

Incluye una planta general 1:100 y no dibuja alzados "por falta de medios".

\section{AGA 26/00294}

Proyecto de obras de reparaciones varias en la iglesia de los Santos Juanes de Nava del Rey.

Anselmo Arenillas Álvarez marzo de 1956

Memoria (1pag)

"Esta iglesia, Monumento Nacional, es un espléndido templo gótico-plateresco que se encuentra deteriorado como consecuencia del intenso terremoto de Lisboa. Los daños que sufrió entonces fueron reparados, no siempre con acierto, y ello ha hecho que en el transcurso de los siglos se acentúen. Indudablemente es necesario acudir en su remedio y así lo ha ordenado la Superioridad.

Reparadas, ha poco, cuatro ventanas y la cornisa que sobre ellas descansaban, se hace preciso reponer en ellas los cierres metálicos y la cristalería, que se hará con 
vidrio de catedral y junquillo de aluminio en sustitución del emplomado, hoy tan caro, que resulta de imposible empleo en nuestras económicas reparaciones.

Otra obra consiste en la limpieza y rejuntado de las bóvedas de crucería, reponiendo las dovelas de la plementería que se han caído o fueron quitadas para dejar paso a las cuerdas de suspensión de gran cantidad de lámparas, ya no existentes. Se dejará aparente la piedra sana y en su trasdós se revestirán con una capa de hormigón aquellas partes que aparezcan descompuestas.

La cornisa, que tiene sus juntas descarnadas, se rejuntarán aproximadamente la mitad de su longitud (no hay más posibilidades ahora) y se tenderá de cemento en su parte alta para evitar las filtraciones, reponiendo encima el tejaroz.

Finalmente se limpiará alguno de los paños interiores, quitando el revoco y blanqueo para ver cómo está el paramento de la sillería y en consecuencia proponer o quitar revocos y rejunta, o una reparación de los guarnecidos agrietados y desconchados." 1 plano de planta señala en rojo trama ambas capillas y 4 trazos ventanas a acristalar. Pliego.

Mediciones:

Carpintería 4 ventanales 2 × 4

Bóvedas naves laterales, central, capillas y presbiterio $2462,80 \mathrm{~m} 2$

Cornisa cubierta general, lado sur $86,17 \mathrm{ml}$

Guarnecidos interiores 1 PA

\section{AGA 26/00310}

Proyecto de adecentamiento de la Iglesia Parroquial de Nava del Rey

Anselmo Arenillas 1957

Memoria (1pag)

Monumento de sillería bien labrada. Siguiendo la moda del siglo XIX fue encalado su interior y luego no se limpió adecuadamente, por lo que ha llegado a nuestros días con un aspecto de suciedad impropio de un templo. Se proyecta levantar el encalado sin dañar la piedra allí donde esta presente buen aspecto, rejuntándola y lavándola con agua, y donde la fábrica sea de peor calidad se revocará con mortero de cal por paños o elementos completos y se tenderá luego en color casi blanco a tono con la piedra. No se incluyen otros trabajos.

Plano de planta de siempre.

Mediciones una partida de raspado $5755,14 \mathrm{~m} 2$ y otra alzada para limpieza de suelo naves. 
AGA 26/00370

Obras de reparación del tejado de la iglesia de los Santos Juanes de Nava del Rey

Anselmo Arenillas febrero de 1964

Sólo 1 pag y 1 plano

Memoria (1pag)

"Esta Iglesia, Monumento Nacional tiene sus viejas cubiertas de teja sobre armadura de madera en mal estado debido a que se hallan apolilladas muchas de sus piezas de madera. Sería conveniente rehacer toda la cubierta en forma definitiva e incombustible pero esto sería operación costosa en exceso y por ello la Superioridad me ha dado orden de proceder a la reparación sustituyendo las maderas que ofrezcan peligro y retejando. Toda la iglesia para que las goteras no destruyan la bella estructura gotica de sus bovedas de piedra caliza.

Como la superficie a reparar es de unos $1.600 \mathrm{~m} 2$, según se aprecia en el plano adjunto, y cifrando el coste de la ligera reparación en 57,50 pts m2 serían ....92.000,00 Pts mas para ayuda de otros oficios y gestiones generales ....7.900,00 Pts. Se precisan en total ... 99.900 Pts. Cantidad que ruego se conceda sin las formalidades de redacción de un proyecto, de acuerdo con las normas vigentes, por cuanto su importe no alcanza las 100.000 Pts."

1 plano: la planta1:100 (exacta que la de 1965 digitalizada web IPCE pero con fecha 1964 en vez de 1956 y sin trama en ambas bóvedas)

AGA 26/00110

Memoria de obras urgentes en la iglesia de los Santos Juanes, de Nava del Rey

Ana iglesias junio 1976

2 pág con breve descripción artística del conjunto

dos pág más con descripción y presupuesto sin mediciones

"Obras a realizar:

Es en la capilla adosada a la cabecera y en el lado opuesto a la sacristía donde se han producido importantes goteras que han deteriorado sus policromadas decoraciones efectuadas en la bóveda y de esta son las mayores las de la pechina del interior por producirse sobre ella y en la cubierta una gotera al verter el agua del faldón correspondiente directamente sobre el paramento del crucero, por lo que habrá que formarse una nueva limahoya que recoja y desvíe el agua de lluvia. Se procederá por tanto a levantar esta parte del tejado y formar la nueva solución cambiando los maderos y tabla necesaria, posteriormente se formará una capa de compresión sobre la totalidad de la cubierta procediendo seguidamente a colocar la teja vieja." 


\section{AGA 26/01720}

Obras de restauración en la iglesia de los Santos Juanes de Nava del Rey

Ana Iglesias setiembre 1978

Memoria con:

Etapas constructivas y estilos;

Descripción del exterior acompañada por un dossier fotocopias de 19 fotos, "construcción en sillería, de tres naves, cabecera ochavada de tres paños con contrafuertes rematados en pilares recambiados que se coronan por pilares mortidos y estribo redondo en ángulo F2. El muro va recorrido por doble imposta, la inferior de bolas y la superior de rosetas F3. Las ventanas llevan también decoración de bolas. En el muro norte, sobresale en planta el bloque de la Capilla de la Asunción, con estribos redondos en los ángulos y ventana central amainelada con lazo en forma de cruz F4 y F5. Junto a la Capilla...."

Descripción del interior también muy desarrollada y con las fotos correspondientes.

\section{"Obras a realizar}

Son estas, las referentes a la restauración de las cubiertas que debido a su estado producen innumerables goteras. La tabla es quizas junto con las estructuras secundarias (correas y pares) los peores elementos de la totalidad del soporte de la cubierta, la armadura principal en sus cerchas y vigas, presenta un imponente aspecto debido a la gruesa escuadría de sus secciones y a la profusión de estos elementos. De la inspección realizada se ha llegado a la conclusión de que si bien, el estado de esta estructura es bueno, su interesante disposición y el hecho de la paulatina desaparición de estas estructuras por la sustitución inevitable por otras realizadas con medios más modernos, aconsejan la conservación de la misma aunque para ello haya que sustituir algunos elementos de los que la componen. De este modo realizaremos el proyecto con el fin de conservar la estructura principal, siempre que sea posible y reponer las correas y parecillos, procediendo posteriormente a impermeabilizar el conjunto mediante la colocación de capa de plástico y mallazo que refuerce la capa de compresión finalmente colocada para el posterior recibido de las tejas."

Encargo a Construcciones Alfonso Sancho Miguel Restauraciones

Pliego tipo

Mediciones (y presupuesto):

Desmontado de cubierta de teja curva, incluso tabla ripia, con clasificación de material aprovechable y transporte de escombros a vertedero

$1 \times 8,50 \times 4,50 ; 1 \times 25,00 \times 21,00=563,25 \mathrm{~m} 2$ 
Extracción y transporte a vertedero de escombros acumulados sobre las bóvedas 1ud Consolidación de armadura de cubierta mediante la inclusión del herraje preciso y sustitución de elementos leñosos en mal estado $\quad=563,25$

Formación de faldones de cubierta con tabla ripia íd $+12 \% \quad=630,84$

Capa de compresión formada por mortero de cemento, armado con mallazo metálico Cubierta de teja curva sentada con mortero bastardo de cal y barro...

Andamios

Tratamiento ignífugo y antibactericida de las maderas de cubierta lud

Planos: los 6 digitalizados en web del IPCE.

AGA 26/01721 (1)

Obras de restauración en la iglesia de los Santos Juanes

Ana Iglesias septiembre 1979

Memoria con fotocopias de fotos como la de 1978.

Obras a realizar:

"Consisten estas en las de restauración de la parte de cubierta que figura en los planos y que viene así a finalizar la totalidad de la misma. Como en la fase anterior se procedera al levantamiento de las primitivas formas de madera y demolición de las fábricas que albergan los durmientes para proceder así a la formación del necesario zuncho de atado de hormigón armado, que a su vez sirva de apoyo y anclaje a la nueva estructura, esta se formará con perfiles metálicos y sobre las formas principales de ella se soldaran las correas sobre las que ira el nervometal que soportara la capa de compresión. Finalmente se procedera a la colocación de teja árabe vieja, con lo que quedara así finalizada la obra, tras el necesario traslado de escombros a vertedero y limpieza de esta zona de actuación del monumento. Madrid, agosto de 1979."

Los planos son los de estado actual. No detalla nada de la intervención, solo trama sobre la planta de faldones.

En las mediciones

Levantamiento de teja $\quad 787,79 \mathrm{~m} 2$

desmontado de estructura $\quad 750,28$

Apertura de hueco para colocación de zuncho perimetral $86,40 \mathrm{ml}$

2 x 3,00; 1 x 24,40;6,50;7,20;7,40; 5,50;2,70;23,70;3,00 
AGA 26/01721 (2)

Obras de restauración en la iglesia de los Santos Juanes

Ana Iglesias septiembre 1979

Copia del mismo proyecto (pone "contratista")

\section{AGA 26/01721 (3)}

Obras de restauración en la iglesia de los Santos Juanes

Ana Iglesias septiembre 1979

Copia del mismo proyecto (pone "repetido")

\section{AGA 26/01097}

Obras de restauración en la iglesia de los Santos Juanes

Ana Iglesias septiembre 1979

ídem 26/01721 con documentación administrativa (escrituras, contratos)

\section{En el archivo del IPCE:}

\section{Carpeta 642-3}

1971 - Restauración de Cubierta, Sacristía y Capilla - José Ángel Rodrigo García y Joaquín Roldán. Se elimina un edificio de ladrillo adherido a la nave lateral cerca de la cabecera, dejando una huella que aún se aprecia sobre la fachada actual. La cubierta se encuentra arruinada en bastantes zonas, lo que produce humedades en el templo.

La memoria del proyecto incluye un dossier con bastantes fotografías y dos planos de planta, una de cubiertas y otra general con adherencias.

Presupuesto: colocación de teja curva sentada sobre barro aprovechando la utilizable y reponiendo la que falte incluso parte proporcional de caballete, limas, y recibido con mortero bastardo cada cinco hiladas. Regularización de muros perimetrales de apoyo de cubierta engrapando elementos de cornisa, incluso andamios y demás medios auxiliares.

Y también en el archivo IPCE hay cuatro carpetas de proyectos, todos a cargo de la arquitecto Ana Iglesias González:

\section{Carpeta 1170-18}

Memoria de obras urgentes en la iglesia de los Santos Juanes, de 1976, que afecta sólo a la capilla adosada a cabecera y goteras en el lado opuesto a sacristía. 
Carpeta 642-4

1978 y 1979 - Cubiertas - Ana Iglesias González

Memoria de 1977 en que describe historia del monumento y obras a realizar, explicando que quiere mantener la armadura por ser "imponente". En el presupuesto recoge desmontado y reposición de tabla de ripia e incorporación de capa de compresión de $630,84 \mathrm{~m} 2$ con mortero de cemento y mallazo. Cubierta de teja curva sentada con mortero bastardo de cal y barro. Consolidación de armadura mediante la inclusión de herrajes.

Planos de planta general, de bóvedas, de cerchas y de cubierta. Alzado este y sección transversal.

\section{Carpeta 642-5}

Copia del anterior documento con fecha 1978 y la inclusión adicional de 19 fotografías.

\section{Carpeta 642-6}

En la última carpeta hay una copia con la misma fecha 1979 en la tapa, idéntico dossier de fotos y sección transversal, pero en esta se incluye una descripción de la obra diferente: "restauración de la parte de la cubierta que figura en los planos como en la fase anterior, levantar las primitivas formas de madera, demolición de fábricas que albergan los durmientes para necesario zuncho de atado de hormigón armado".

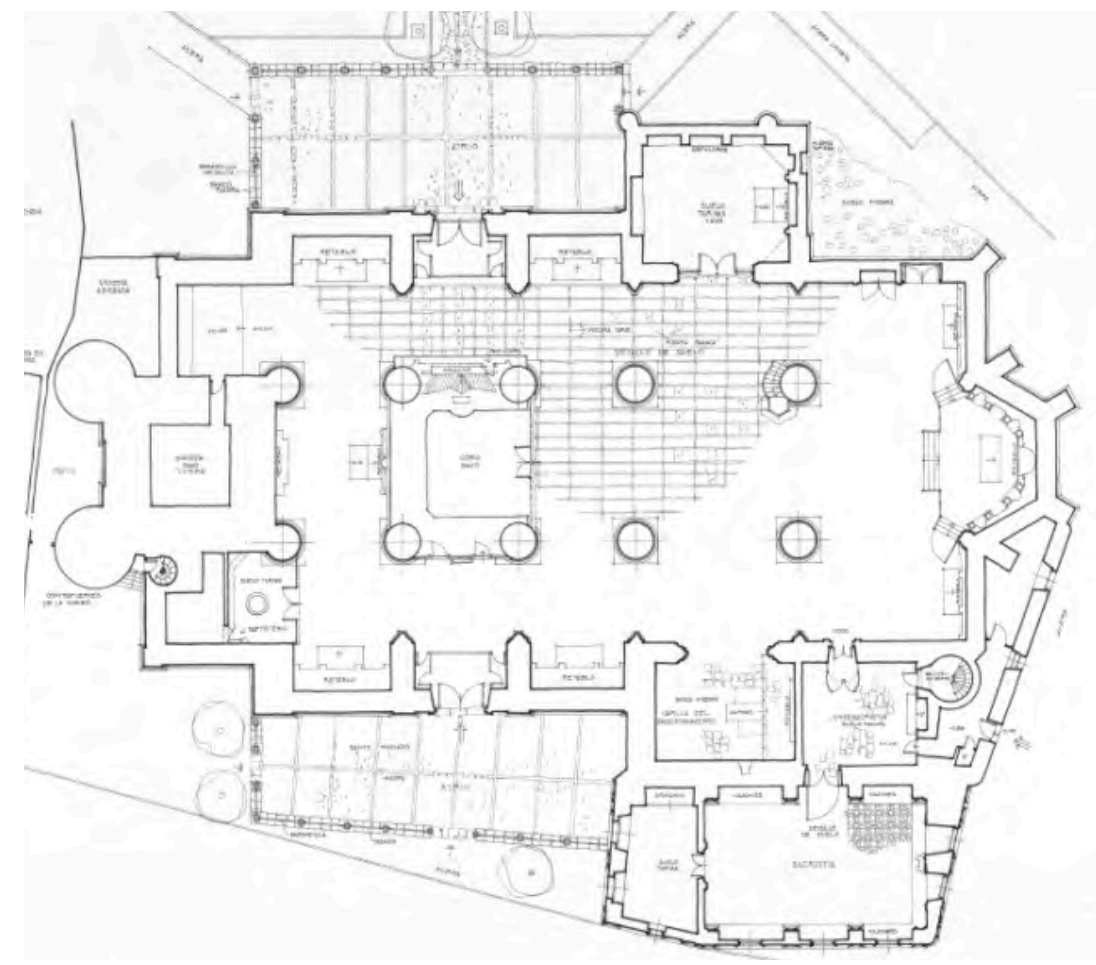

Ilustración 17: planta (Ana Iglesias 1978 IPCE) 
En la web del IPCE se cuenta con seis planos escaneados de las intervenciones fechados en 1978 y dos más de 1979.

\section{En el archivo de la Junta de Castilla y León:}

\section{VA-108}

Carpeta 5305

Se incluye en esta caja la documentación administrativa y dos proyectos de Restauración diferentes, uno de 1988 y otro de 1991.

\section{Documentación administrativa}

El primer documento es la resolución del contrato de 1992 a la constructora Alejandro Bolado SA en 1995 por retraso continuado en la ejecución de las obras de Restauración de la iglesia. En realidad la citada extinción se produce a solicitud del propio adjudicatario a causa de sus problemas financieros y tras la paralización de las obras.

En las certificaciones del arquitecto Luis Navarro García se desglosa el desmontado de $348 \mathrm{~m} 2$ de entramado de cercha y correas y desmontado de teja curva de las cubiertas, picado de una escalera de hormigón armado y desmontado manual de $4,9 \mathrm{~m} 2$ de bóveda de ladrillo galletero de $3 \mathrm{~cm}$ a sardinel previo atirantado y apuntalamiento con retirada de ladrillos a almacén para su limpieza y reutilización. Se incluyen $83 \mathrm{~m} 2$ de entramado de nuevas cerchas de madera de pino con luces hasta $8 \mathrm{~m}, 108$ unidades de actuación puntual en la estructura de madera existente para reponer piezas deterioradas y $275 \mathrm{~m} 2$ de tabla machihembrada de haya de $40 \mathrm{~mm}$ de espesor sobre estructura metálica con su tratamiento protector. En el capítulo correspondiente a una Cubierta de cobre aparece la regularización del trasdós de la bóveda de ladrillo con $5 \mathrm{~cm}$ de mortero de cal, $48 \mathrm{~m} 2$ de panel Cutec, un lucernario de pino, $38 \mathrm{ml}$ de carreras $7 \times 10$ y $41 \mathrm{ml}$ de correas 9x7 de pino.

Se estiman $8 \mathrm{~m} 3$ de inyección de lechada de cal en muro de fachada y grapado con varillas de acero inoxidable, $311 \mathrm{~m} 2$ de limpieza manual del muro y de rejuntado de piedra con mortero de cal y arena ligeramente cementado y la limpieza de otros $155 \mathrm{~m} 2$ previa consolidación. La restauración de cerrajería de balcón y $774 \mathrm{~kg}$ de estructura metálica de perfiles laminados en una pasarela. También incorpora una solera de hormigón armado de $15 \mathrm{~cm}$. 
Se propone continuar las obras con una nueva empresa constituida por el antiguo gerente de Construcciones Bolado, Miguel Ángel Rodríguez. El aparejador es Ignacio Pinedo Calvo.

En septiembre de 1992 el Párroco solicita modificar el Proyecto que se va a ejecutar ya que desaparecen dos salas de reuniones y se produce un estrechamiento que complica el acceso desde la plaza a la antesacristía. Desde el Servicio se comunica a los interesados que la solución a estas discrepancias se acordará el día del inicio de obra transcribiéndose como observaciones en el Acta, aunque el arquitecto propone redactar un Proyecto modificado con estos cambios sin variación de presupuesto.

El alcalde solicitaba ya en junio de 1989 la restauración de la iglesia, en estado lamentable. En ese momento, el Técnico del Servicio detecta los principales problemas en la Capilla anexa, así como la descomposición de sillares en el perímetro exterior.

En otra carta anterior, de julio de 1985, el entonces párroco Francisco Massé pide a Ignacio Represa que se repare una gran gotera en la Capilla de la Asunción. Explica cómo se había obtenido recientemente una aportación de los feligreses de casi dos millones de pesetas invertida en arreglo de vidrieras y limpieza de altares y paredes.

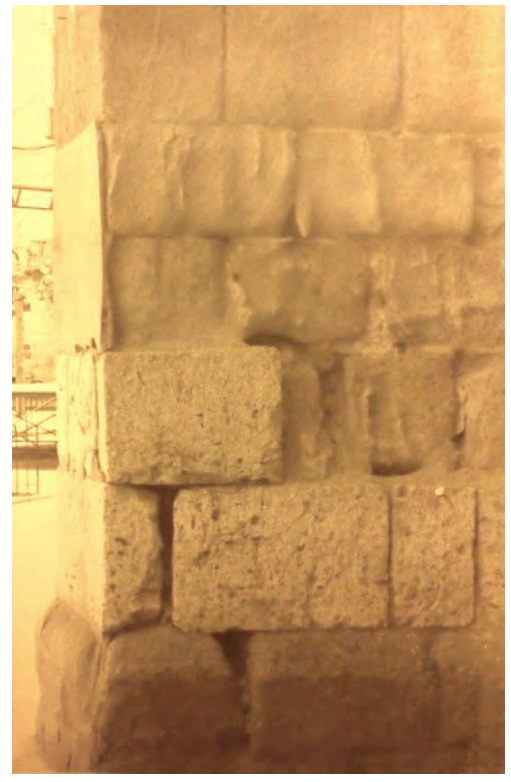

Ilustración 18: sillares erosionados

El 20 de mayo de 1991 el citado arquitecto Luis Navarro entrega 6 ejemplares del Proyecto, tras las Fichas de Diagnóstico y Propuesta de Actuación realizadas en junio de 1990 con la aceptación del encargo. En estas fichas proponía realizar un Estudio hidrogeológico, reponer elementos ornamentales en falsa fachada desplomada y descompuesta y consolidar las fábricas, reponer o reparar la estructura de madera de cubierta de la sacristía y colocar testigos para seguir la evolución del deterioro de elementos de la estructura metálica de cubierta de la nave salón. Mencionaba también el deterioro de bóvedas, la posibilidad de una pérdida de capacidad portante en algún punto de la cimentación y la falta de aireación del suelo en el perímetro tras la colocación en algún momento de una pavimentación estanca.

En la caja se conservan diversas indicaciones para corregir y completar el Proyecto, tanto desde el Servicio (falta de plan de obra, detalles de encuentros y remates, 
planos de evolución histórica en planta, identificación de mediciones, etc) como del Arquitecto Territorial (que recomienda prever enterradas las acometidas de luz y teléfono, ajustarse a fotografías antiguas para reproducir el remate del profundis, contactar con el Departamento de geología de Oviedo para investigar un tratamiento para la piedra, analizar la necesidad de atirantar la estructura de cubierta, confirmar impermeabilización de cúpula de remate de la escalera)

Proyecto de 1988

Restauración del Monumento denominado de los Santos Juanes - José V. Rodríguez Hernández.

La Consejería de Fomento encarga un Proyecto para actuar sobre la torre y "el cuerpo adosado" al templo en el siglo XVIII con una balconada desde la que asistir a festejos taurinos populares. En proyectos venideros se denomina a esta pieza "falsa fachada" o "profundis". Se trataba de un bloque cubierto con una bóveda de cañón muy deteriorada por la filtración de agua a Ilustración 19: profundis dossier Rodriguez 1988

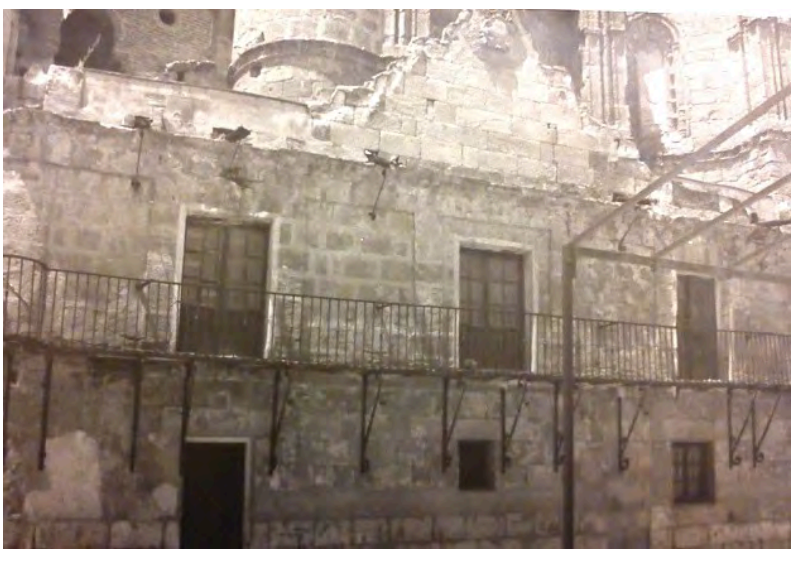
través de la misma.

En esta intervención se demuele la cubierta existente para colocar $36 \mathrm{~m} 2$ de forjado unidireccional de vigueta autoportante y bovedilla de hormigón con una capa de

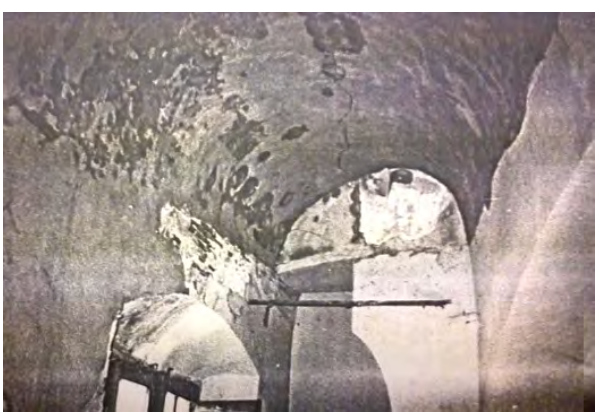
compresión de $3 \mathrm{~cm}$ con mallazo y zuncho. La pendiente se incorpora con hormigón celular impermeabilizado con lámina SBS. La cornisa de piedra caliza se desmonta y repone con mortero bastardo 1:1:4. A ambos lados se rehace el peto de ladrillo macizo demolido con $1 / 2$ pie llustración 20: interior del profundis 1988 de ladrillo hueco doble enfoscado.

La torre presentaba un hueco, practicado para retirar las campanas, sin posterior cierre o protección. Se reconstruye la bóveda de la torre con dos roscas de ladrillo hueco sencillo con mortero de cemento 1:8, el mismo que se aplica para enfoscarla superiormente. 
Proyecto de 1991

Navarro enumera en su Memoria a varios arquitectos colaboradores, cita a CESECO y agradece su apoyo a los técnicos del Servicio de Restauración: Garcés, Pizarro y Represa.

El proyecto se centra en reparar cubrición y fachada este de la Sacristía nueva, sustituir cubiertas, incluso estructura, de antesacristía y capilla del Descendimiento. También se propone restaurar fachada, resolver la cubrición y adecuar el interior del profundis, reparar el acceso a la escalera de caracol y supervisar humedades de fábricas y cubiertas.

Describe las etapas que atraviesa el monumento que arranca en 1553 con trazas de Rodrigo Gil de Hontañón a partir de unas preexistencias góticas. El proceso prosigue con la construcción de capillas entre contrafuertes datadas en 1578, la coronación de fábricas murarias y abovedamiento del templo hacia 1589 por Felipe de la Cajiga.

En esta Memoria no se mencionan los pleitos mantenidos por este arquitecto, acusado de incumplimiento de plazos y modificación de las trazas, ya que había sido contratado para continuar una obra gótica de Gil de Hontañón "a lo moderno" y la transformó en un templo salón "a lo romano", según se expone en la Tesis del profesor Javier Castán Lanaspa.

En 1635 se produce el hundimiento de la primera torre, que levanta de nuevo Juan de Revilla, y en 1702 se cubre con un chapitel barroco.

En algún momento antes del siglo XX se reorganizan los huecos del profundis y unas escaleras eliminan la subida por el caracol de piedra. En los años cuarenta se eliminan revocos y forrados de fábrica de las columnas. También se desmontan y recolocan nervios y plementos de la bóveda de Antesacristía degradados por la humedad.

Navarro describe cómo “en 1979-80 Ana Iglesias desmonta la estructura original de cerchas leñosas tipo paladiano con tirante ajabalconado en la nave central y semicerchas en cubrición de naves laterales". En la cabecera se sustituye por estructura metálica de IPN atirantados con un perfil de sección circular roscado y en la nave por cuchillo belga sobre vigas tipo Warren compuesta y Howe. La cubrición de las cerchas la resuelve con $17 \mathrm{~cm}$ de losa de hormigón y nervometal.

Hacia 1985 se pican los paramentos de la capilla del Descendimiento y rejunta las fábricas de plementos y nervaduras de bóvedas. Se reemplaza la base de arena del 
pavimento de los atrios de canto rodado a cemento y el solado de la plaza de España por baldosa de mortero.

Patología de las cubiertas

Perfiles de acero laminado en nave del templo: corrosiones puntuales, torsiones y pandeo lateral de barras de celosías del lado de la Epístola. En la fotografía siguiente, incluida en el proyecto de 1988, se aprecia ya esta deformación.

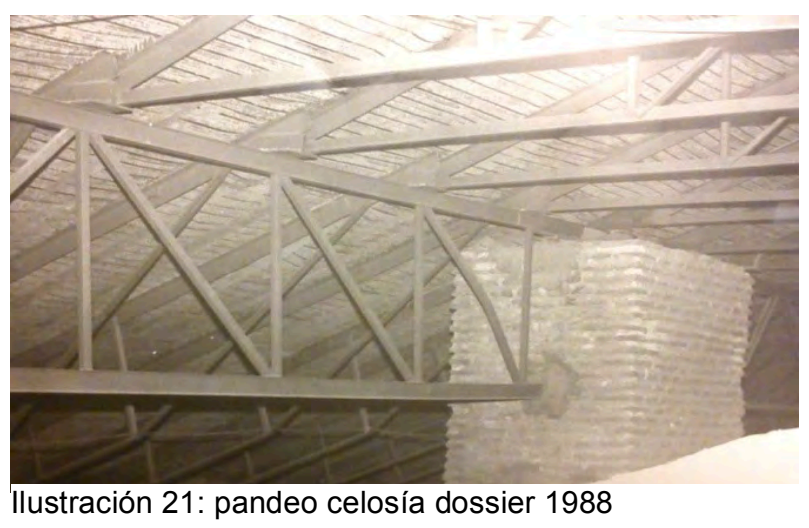

Antesacristía: Roturas y flechas de cabios en faldón de antesacristía, pudrición del tablero.

Capilla del Descendimiento: Par e hilera de gran escuadría reforzados con apeos que cargan sobre la propia bóveda y tablero deteriorado.

Profundis: Mal estado de la bóveda de una rosca de ladrillo a sardinel. La superficie total de recogida de pluviales que vierte sobre el tramo es de unos $900 \mathrm{~m} 2$, ya que recoge media nave central, faldón de Sacristía nueva y dos tramos de nave del Evangelio, por eso continúan las filtraciones tras la intervención de 1988.

Zona con fibrocemento y falta de acceso a la Asunción.

\section{Patología en muros}

Fisuras encadenadas, deformación de cornisas y deterioro en coronación de contrafuertes. La degradación superficial de la primera hilada de sillería arenisca sobre el zócalo de granito llega a seis con parcheados de distintos materiales en la cabecera.

Deterioro de tinglados de madera de chapitel y campanario de la torre. Erosión y desplome del remate ornamental del profundis. Descenso de la bóveda central sobre el coro. Fisuras de yesos generalizadas cerca de las claves de bóvedas.

\section{Diagnóstico y conclusiones}

Deterioro generalizado del sistema de cubrición original (tablazón, torta de mortero de cal y teja) en antesacristía, descendimiento y sacristía.

Deformaciones en un elemento de la estructura metálica de cubierta de naves. 
Sobrecarga en coronación de lienzos de fábrica causada por la cubierta.

Fisuras encadenadas en varios muros y deterioro de la piedra arenisca.

Proyecto

Propuesta de estudios de humedades de CESECO para analizar el deterioro de la arenisca, y de instrumentación de GEOCISA, para controlar movimientos de cubierta metálica y muros. Estudio geotécnico con dos sondeos.

Reemplazar cerchas de par e hilera por otras análogas en las cubiertas de antesacristía y descendimiento.

Restituir el remate del profundis según imágenes antiguas, reemplazar el forjado por una pasarela y su cubierta por una ligera de plancha de cobre en tablero de hormigón con tabiquillos palomeros sobre la bóveda.

Desmontado de pináculos y crestería. Limpieza manual con cepillos, rasquetas y espátulas, desengrasantes, o bifloruro en pasta de celulosa para grandes suciedades. Pegado de piezas rotas con morteros epoxídicos, marmolina, pigmento litopón y arena de cuarzo. Cosido con varilla de acero y mortero epoxi o con vástagos gruesos roscados de acero inoxidable sellados con mortero de cal.

\section{VA-166}

\section{Carpeta 5359}

El proyecto descrito más arriba se centraba en la zona oeste del conjunto, abarcando Profundis, Sacristía, Antesacristía y capilla. Esta caja contiene un proyecto del mismo arquitecto Luis Navarro denominado "Emergencia en estructura de cubierta y apeo preventivo de bóveda en la Iglesia de los Santos Juanes" entregado en agosto de 1994. El aparejador es Félix Martín Valero y la obra se adjudica a GEOCISA en noviembre de 1995, reflejándose el final en una Memoria de marzo de 1996, aunque el acta de recepción no se cumplimenta hasta marzo de 1998.
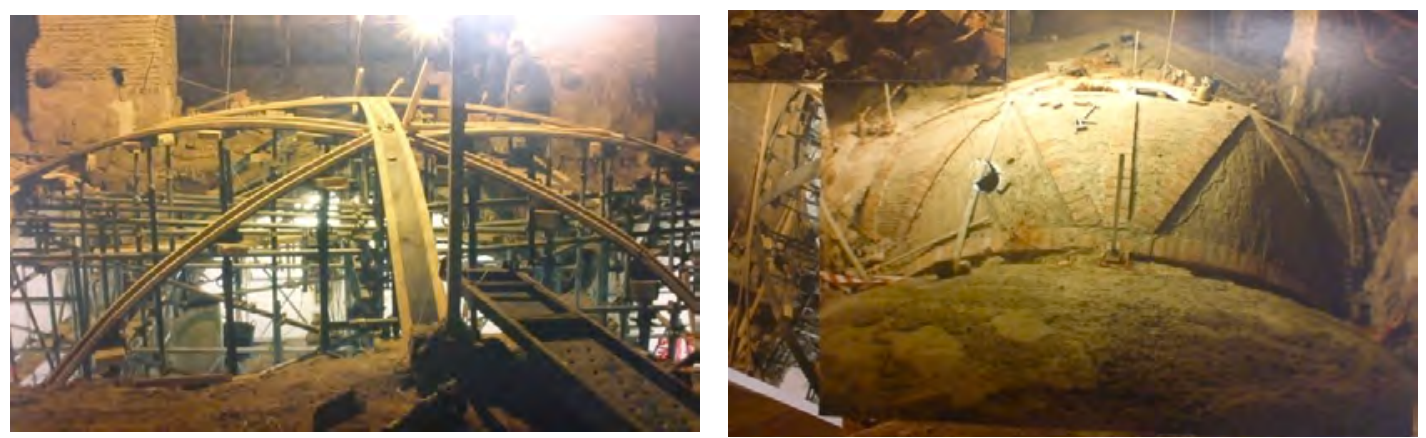

Ilustración 22: reconstrucción de bóveda (dossier Navarro 1995 
La obra se acomete tras detectarse la entrada en carga del apeo de la bóveda sobre el coro. Se sustituye ésta copiando la contigua con ladrillo recibido con mortero de cal y ejecutada sobre cimbra.

En los proyectos de 1988 y 1995 se incluye una foto en que se aprecia la evolución del descenso de esta bóveda desde el mismo punto de vista:
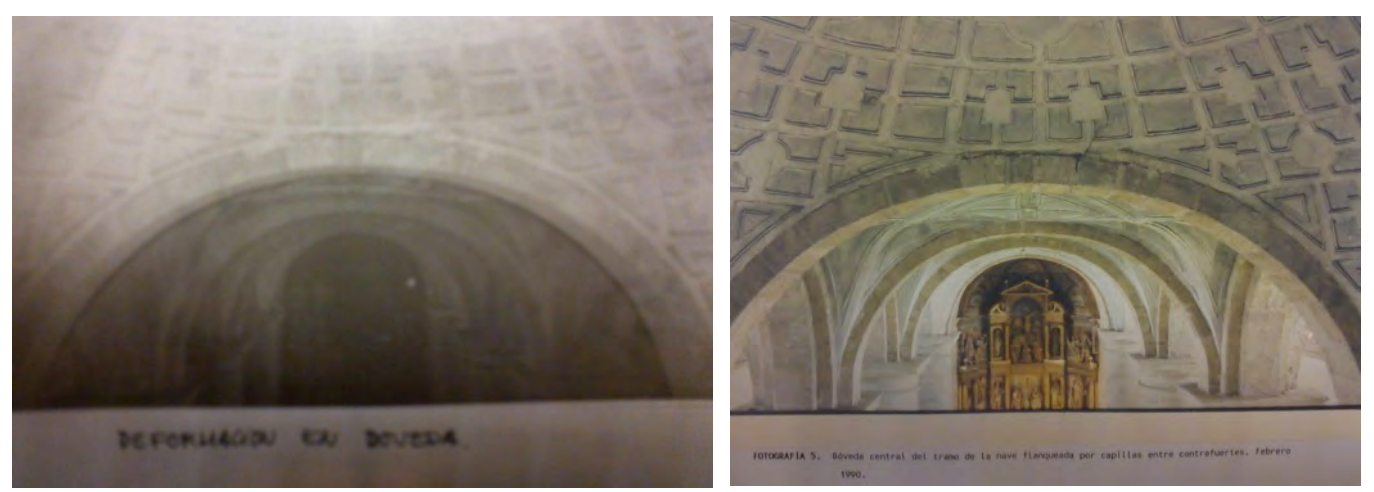

Ilustración 23: bóveda desde ventana a los pies (1988 y 1995)

La cercha metálica insuficiente, según el arquitecto por el espesor excesivo de la losa de hormigón sobre nervometal en esta zona, que alcanza $24 \mathrm{~cm}$ frente a $10 \mathrm{~s}$ $12 \mathrm{~cm}$ previstos en el cálculo, se refuerza disponiendo dos piezas adicionales paralelas a ambos lados.

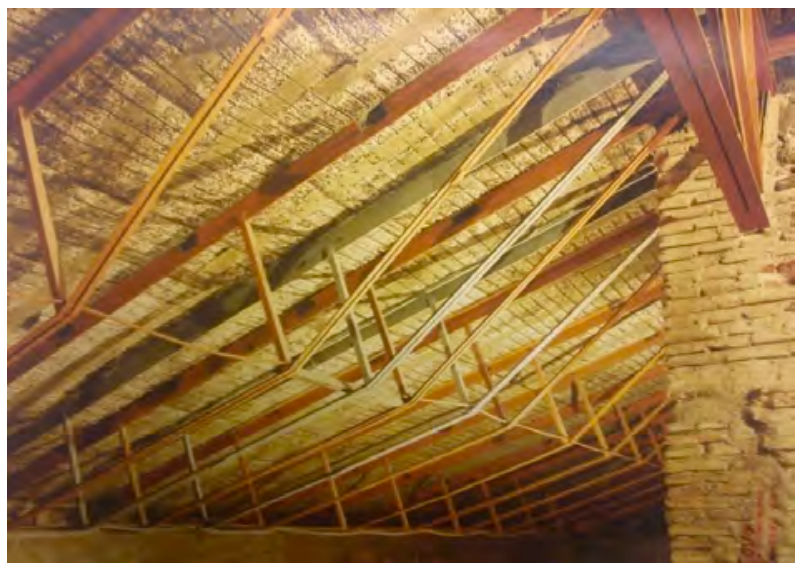

Ilustración 24: nuevas celosías de refuerzo 1995

\section{VA-220}

La carpeta contiene varios documentos:

Informe del arquitecto territorial Francisco P. Roldán Morales del 28 de mayo de 1993 en que explica que es necesario adoptar medidas de refuerzo de la viga celosía Vierendeel que presenta exceso de deformación. 


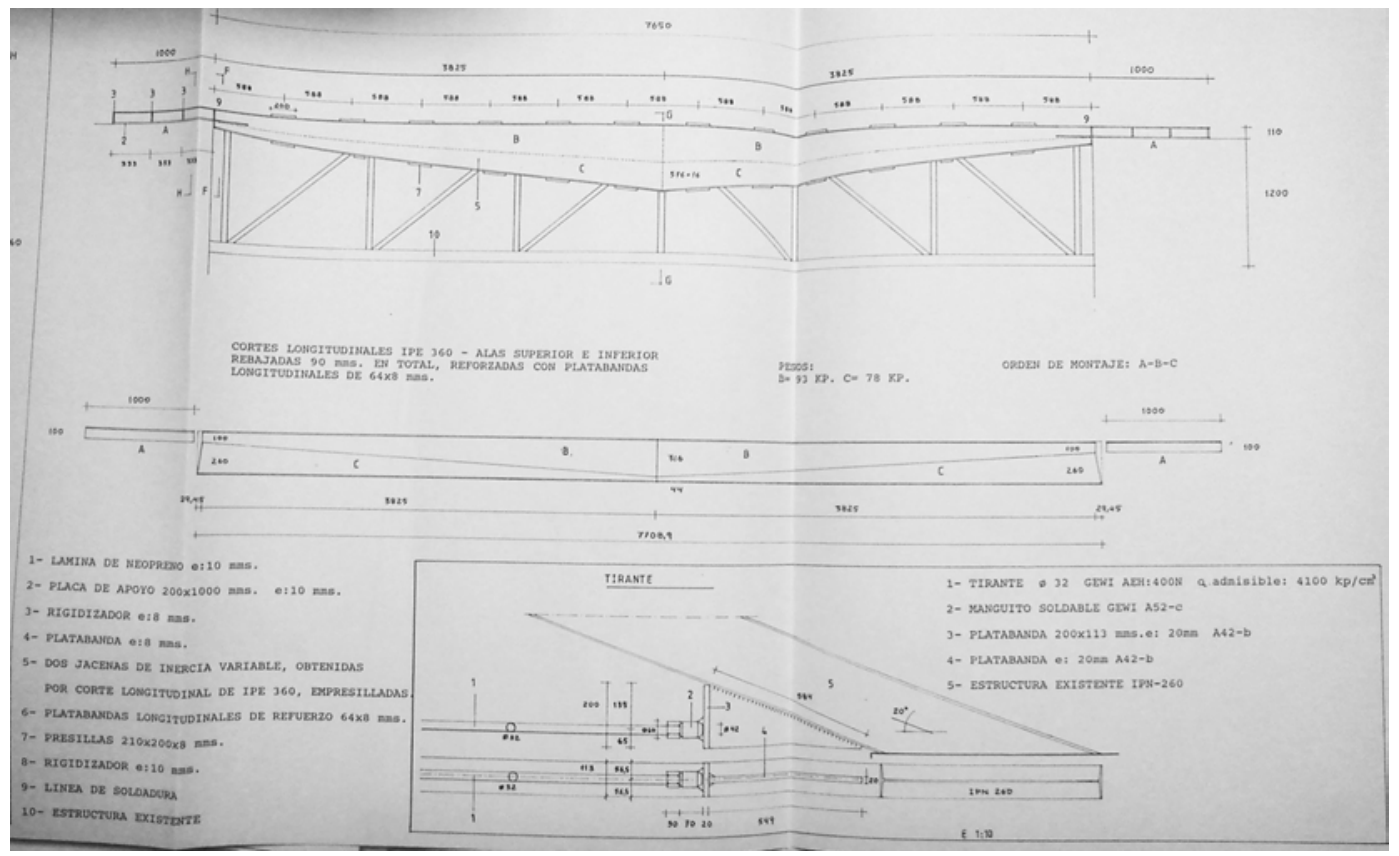

Ilustración 25: plano detalles refuerzo de celosía (Roldán 1993)

Memoria valorada de las obras necesarias para la terminación de la restauración. El arquitecto Luis Navarro paraliza las obras bajo su dirección el 29 de noviembre de 1993. Coloca una viga de refuerzo doble a ambos lados de la citada celosía y un tensor adicional con su conexión al perfil que atraviesa el machón de fábrica a través de un taladro.
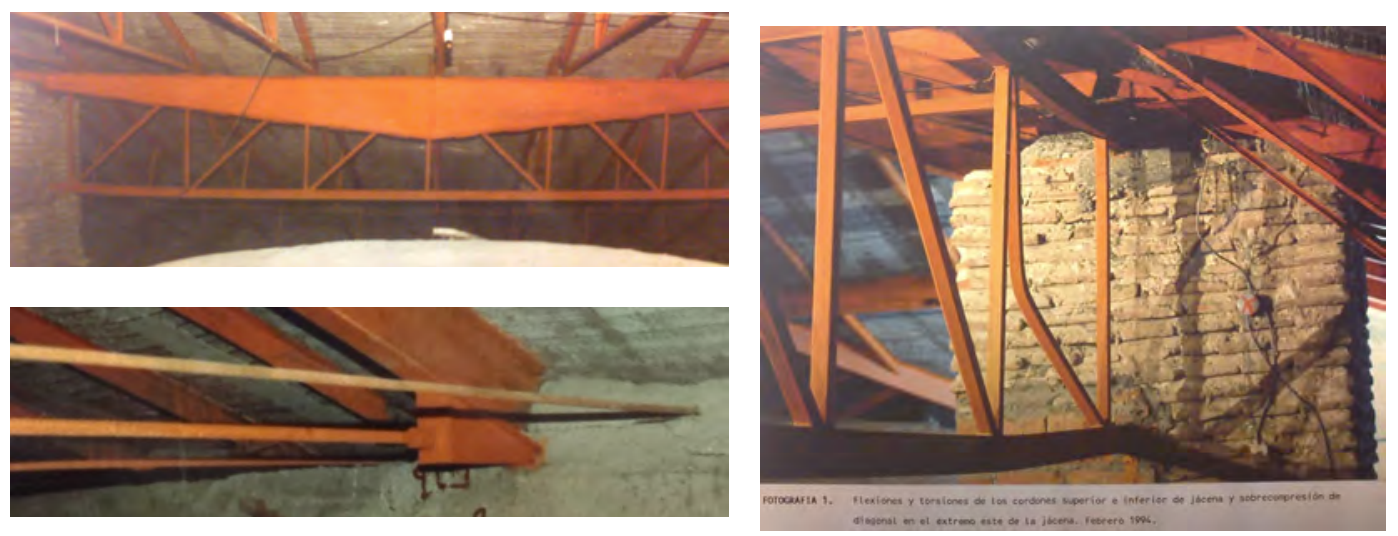

Ilustración 26: refuerzo Navarro 1993

Seguimiento de Instrumentación. GEOCISA.

Se lleva a cabo una exhaustiva medición de movimientos en numerosos puntos del edificio a lo largo de un año, desde el 4 de enero de 1994 hasta el 20 de febrero de 1995. Tras los informes de seguimiento realizados en septiembre, junio, marzo y noviembre de 1994 se entrega un documento final en marzo de 1995 en el que se concluye que los "movimientos en paramentos exteriores son exclusivamente térmicos y sus remanentes nulas excepto dos fisuras de $0,16 \mathrm{~mm}$ y $0,13 \mathrm{~mm} "$. 
En el informe se describe los puntos de control, entre ellos dos en una grieta existente "en el zuncho de atado de cerchas y de soporte de correas de la estructura de cubierta, en la fachada norte" que no varía longitudinalmente y en transversal lo hace acompañando la variación térmica. Según los técnicos de GEOCISA "podría ser una junta de dilatación natural" del zuncho.

En el informe achacan el origen de la fisuración del monumento al terremoto de Lisboa.

Hidrogeológico, geotécnico y estudio de humedades. CESECO.

Realizaron dos sondeos hasta 9,5 y $10 \mathrm{~m}$ de profundidad junto a la fachada principal (muro norte). No se detecta presencia de agua en el subsuelo.

Según una campaña de registro de humedades en muros se aprecian éstas hasta una altura de 2,5m tanto en exterior como por el interior.

Recomiendan ejecutar una zanja de drenaje perimetral rellena de árido grueso (por bataches para no descalzar el muro) o preferiblemente disponer una malla de drenes verticales interior y $5 \mathrm{~m}$ alrededor del edificio, con $15 \mathrm{~m}$ de profundidad. Aconsejan también practicar taladros de ventilación en los muros con pendiente hacia el exterior.

Anejo estudio de sillares en diferente estado de arenización: la resistencia varía mucho entre la piedra sana con más de $200 \mathrm{kp} / \mathrm{cm} 2$ y la alterada, menos de $50 \mathrm{kp} / \mathrm{cm} 2$.

Informe de inspección de soldaduras de la estructura de cubierta metálica. GEOCISA en agosto de 2002 concluye que en general el aspecto es aceptable pero recomienda el reemplazo total tras realizar el cálculo teórico de todo el conjunto de cerchas.

Cálculo de estructura de cubierta. Modelizan de forma independiente la cabecera y el resto de estructura, empleando el programa de cálculo matricial de barras STAAD-III (¿versión educacional?). Para afinar la hipótesis de cargas realizan varias catas en el tablero de nervometal, detectando espesores del hormigón que varían entre 5,5 y $24 \mathrm{~cm}$, por lo que

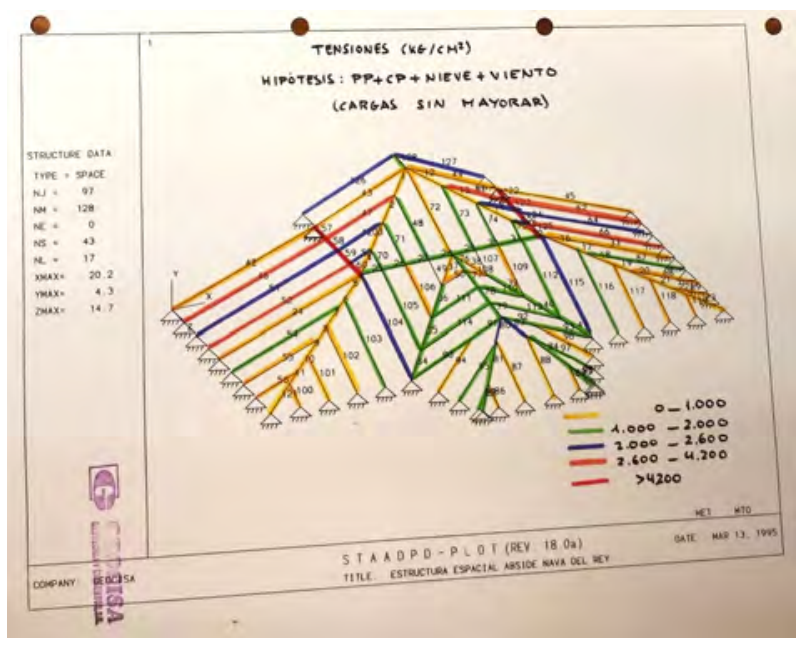

Ilustración 27: esquema de cálculo GEOCISA 
consideran una media de $6,5 \mathrm{~cm}$ en la cabecera y $8,5 \mathrm{~cm}$ para el resto de la nave. Estiman un grosor de muros de $120 \mathrm{~cm}$.

Según los resultados del programa de cálculo algunas barras estarían sometidas a una tensión superior a la admisible según a norma NBE-MV-103. En las conclusiones indican que "hay un considerable número de elementos en situación próxima al colapso" y que "el colapso de algún elemento puede provocar la ruina completa de la cubierta".

\section{VA-262}

Carpintería

La documentación siguiente se encuentra en formato electrónico, suministrándose desde el Servicio de Restauración la copia digital de los proyectos más recientes promovidos por la Dirección General de Patrimonio Cultural de la Junta de Castilla y León en pdf.

\section{VA-474}

Restauración de la iglesia de los Santos Juanes. El proyecto se circunscribe al remate de las obras inconclusas desde 1993.

Arquitecto: Alfonso González Gaisán

En el proyecto se incluye una memoria de las etapas constructivas del edificio desde su inicio hasta la intervención de Navarro en 1991, que describe sin finalizar.

Estudio de Patologías desglosada en las siguientes zonas del monumento: cubierta de madera de antesacristía y del profundis, muros de fachada y caracol. Concluye que la teja árabe es inadecuada para la pendiente y la plaga de palomas cuyos excrementos incrementan el peso propio de la cubierta. Deterioro de la fábrica en diversos puntos: arranque de muros de cabecera por capilaridad, remate de contrafuertes por escorrentía y en lienzos de muro lavado de morteros.

Reemplaza la teja por chapa de cobre engatillado sobre fieltro y refuerza localmente la armadura de madera con piezas de acero galvanizado. El frente de fachada de nave de la Epístola sobre antesacristía se limpia con diversos medios, cosiéndose las grietasy reposición de mampuestos con varilla corrugada de acero inoxidable recibida con epoxi.

El profundis se restaura reponiendo las acróteras mediante molde sacado de una en buen estado. Reposición de tirantes de la bóveda con Dywidag y construcción de escalera, pasarela y altillo de perfiles de acero con paneles Prodema y tramex. 


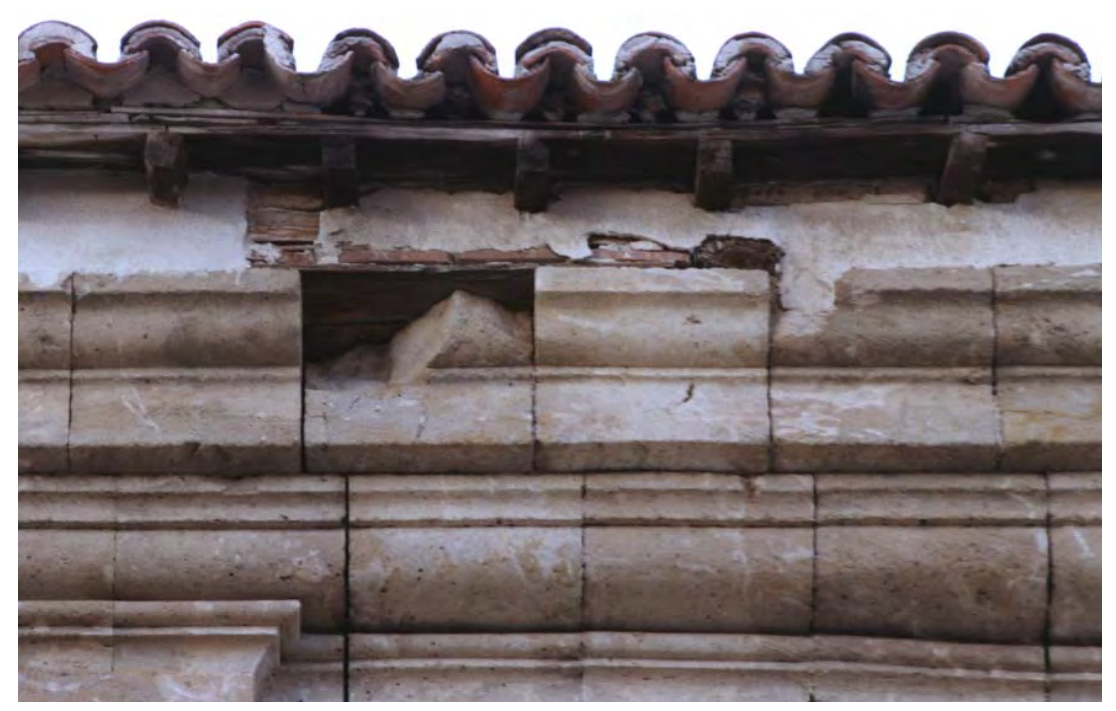

Ilustración 28: detalle de durmiente en cornisa (Gonzalez Gaisan 1993)

\section{VA-453}

Proyecto básico y de ejecución de reparación estructural de la armadura de cubierta de la iglesia de los Santos Juanes, en Nava del Rey (Valladolid) Arquitectos: Marcelino Hurtado Acebes y Pedro Andrés Nieto Mongil. Aparejador: José Antonio Santos García
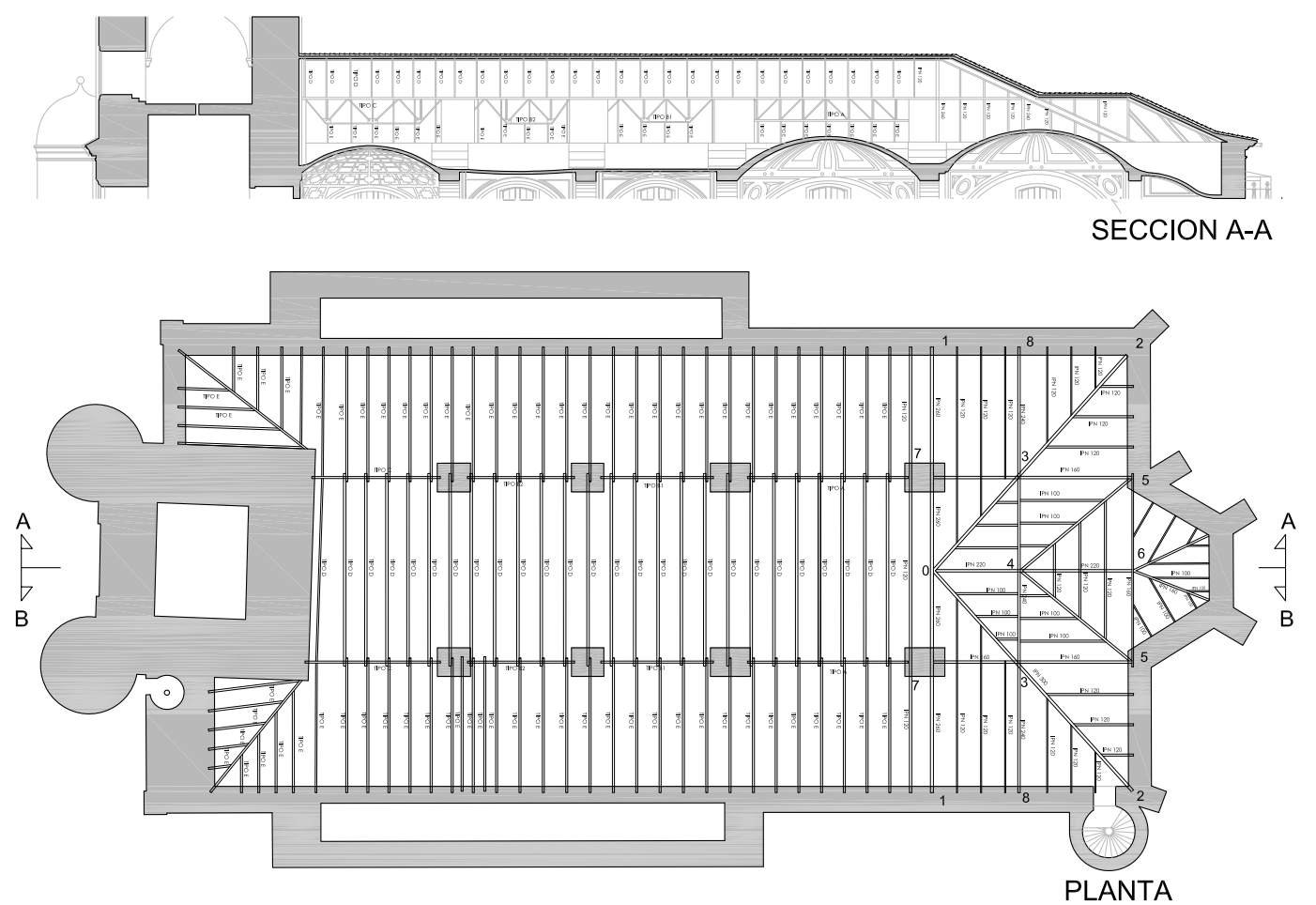

Ilustración 29: estructura de cubierta (Hurtado 2013)

En la Memoria cita un informe previo del propio Marcelino Hurtado de 13 de abril de 2010 sobre el estado de la estructura de la cubierta redactado para corroborar el 
dictamen del informe de GEOCISA en el que se planteaba la posibilidad de reforzar la estructura en mal estado frente a la opción más aconsejable del reemplazo total.

Los nuevos cálculos se realizan considerando las cargas: Peso propio del tablero $228 \mathrm{kP} / \mathrm{m} 2$, nieve $40 \mathrm{kp} / \mathrm{m} 2$ y viento $40 \mathrm{kp} / \mathrm{m} 2$ presión más succión (afinadas frente a las hipótesis del cálculo de GEOCISA 289, 80). Se concluye que el dimensionado original de las cerchas tipo de nave central y laterales resulta suficiente, aunque deben repararse roturas en cordones y soldaduras defectuosas. Las celosías transversales sobre las que estas apoyan deben ser reforzadas. Se considera inaceptable el estado de la estructura de la cabecera, con perfiles insuficientes deformados y trabajando de forma anómala, por lo que no se puede garantizar su estabilidad. Según los cálculos se están produciendo empujes hacia el exterior en la coronación de los muros de fábrica y hacia las naves laterales en los puntos de apoyo intermedios.

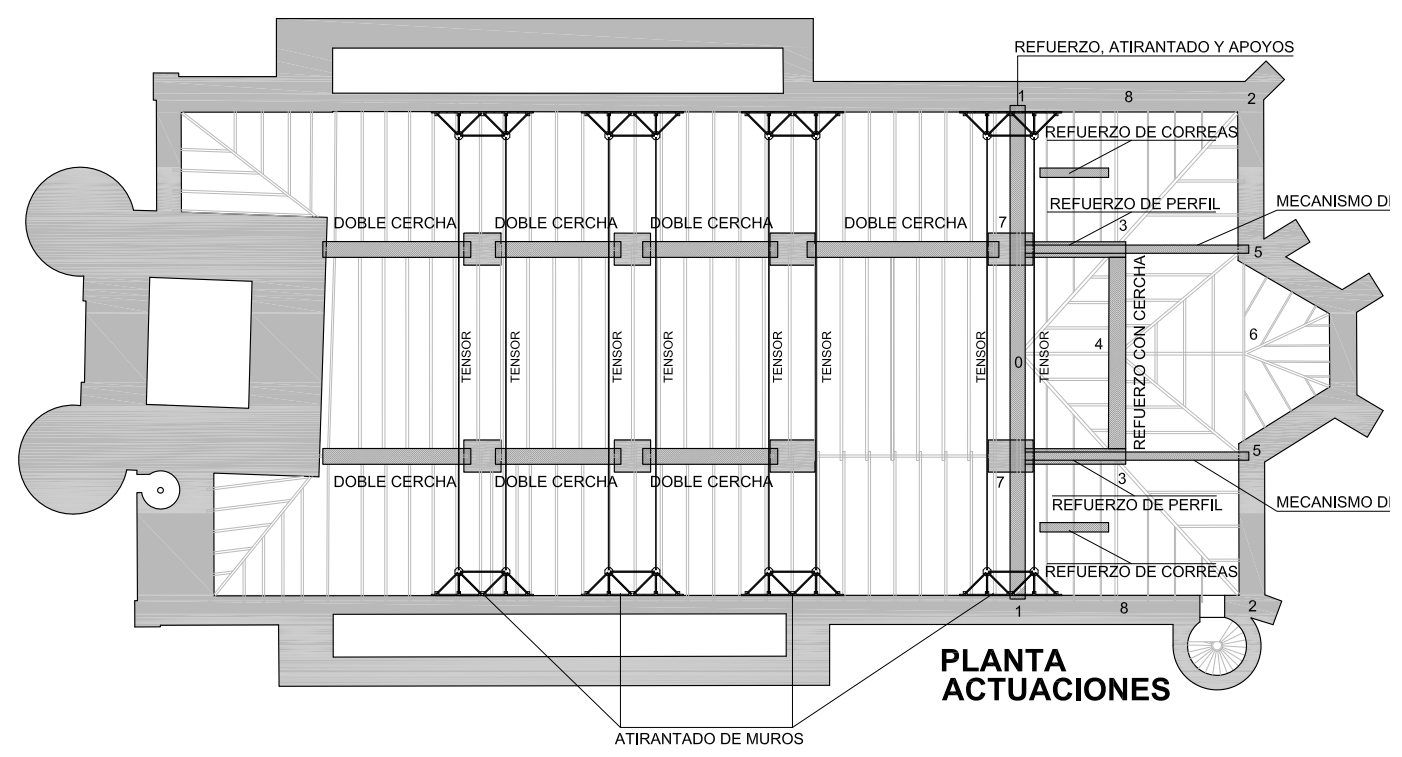

Ilustración 30: refuerzo de estructura de cubierta (Hurtado 2013) 



\section{Visitas realizadas}

20/Junio/2012

El templo se encuentra cerrado al público.

Podemos observar en los cerramientos de la iglesia grietas selladas y degradación de sillares sobre el zócalo. los restos de ladrillo parecen corresponder al "socalce" efectuado por Ortiz de Urbina en el XIX.

Llama la atención al acceder al interior el proceso de arenización de los sillares de arenisca también en el cerramiento de la zona de cabecera tras el profundis. Ese pasillo ha sido recientemente restaurado con criterios y materiales contemporáneos.
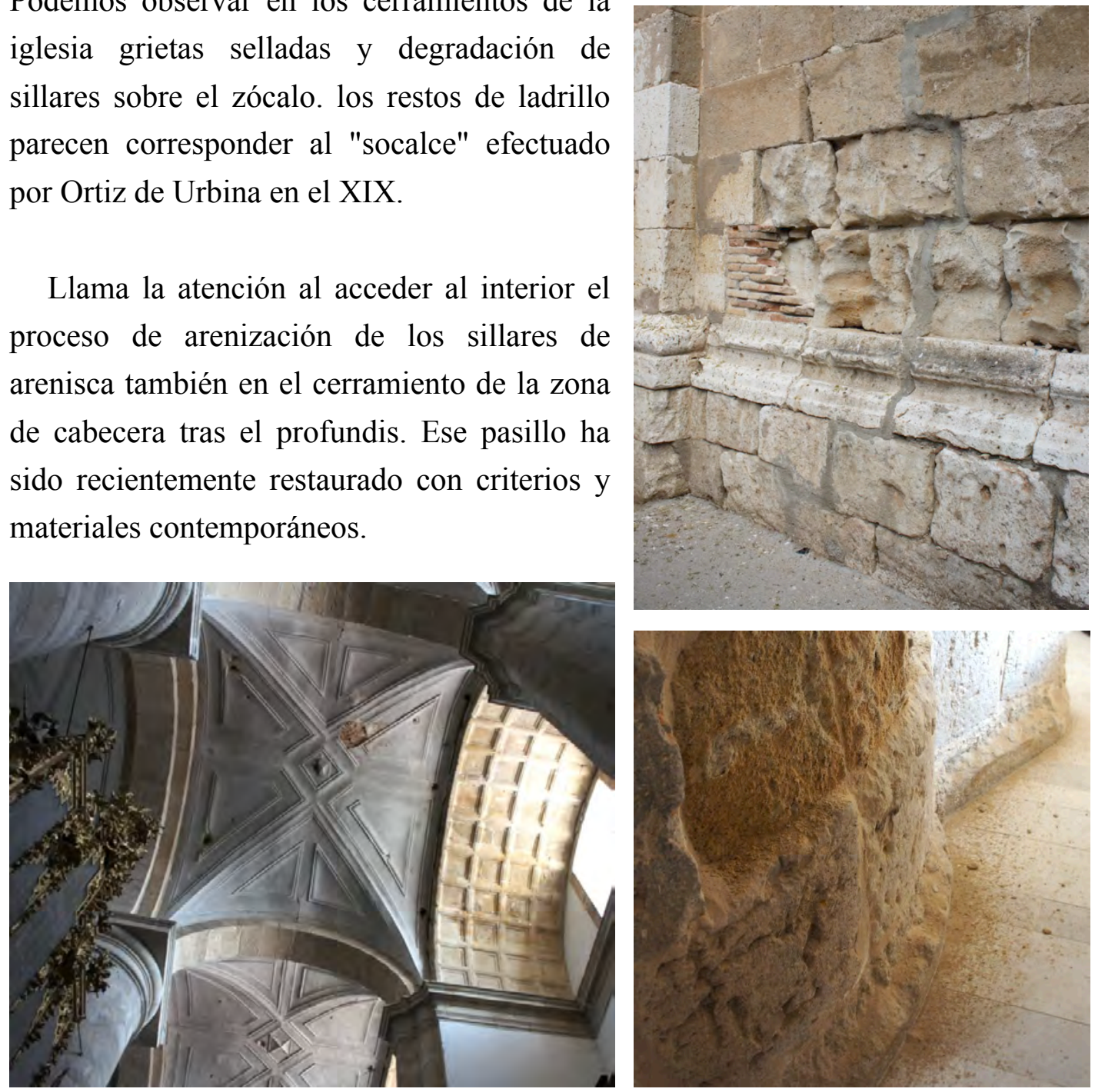

Se aprecian fisuras y desconchados en algunas bóvedas.

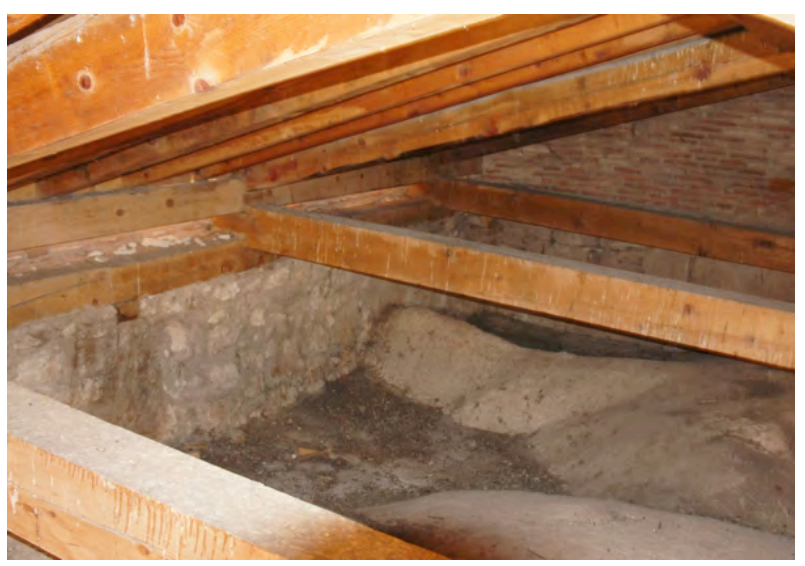

La cubierta de la Sacristía ha sido restaurada con madera respetando criterios tradicionales, por lo que no se ha añadido zunchos de hormigón y los pares apoyan sobre ménsulas y durmientes dobles de madera. 
La subida al bajo cubierta se realiza a través del caracol de mallorca de piedra. La desembocadura se encuentra muy desgastada, con el último peldaño prácticamente desaparecido.

El trasdós de las bóvedas muestra el relieve de los ladrillos dispuestos a rosca. En algunas se ha incorporado peldaños para facilitar el tránsito. En la imagen se aprecia una de las fisuras radiales de las bóvedas de nave central.

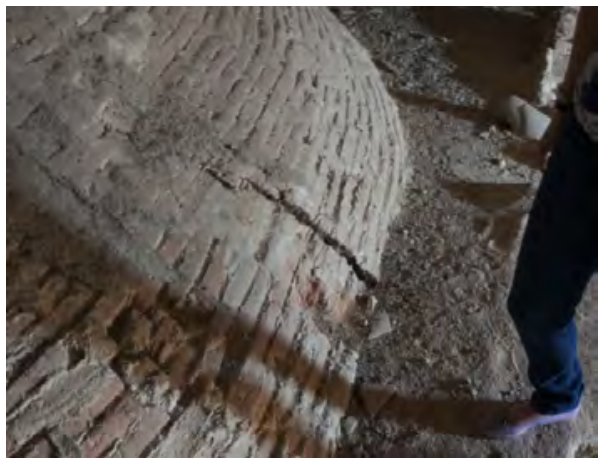

La estructura de cubierta coincide con la representada en los planos de 1978 de Ana Iglesias, con cerchas metálicas ligeras. El tablero es una capa de hormigón sobre nervometal. Hay algunos tirantes que atraviesan los grandes machones de ladrillo. Las deformaciones son evidentes en algunos elementos de la estructura metálica de cubierta.

25/Junio/2013

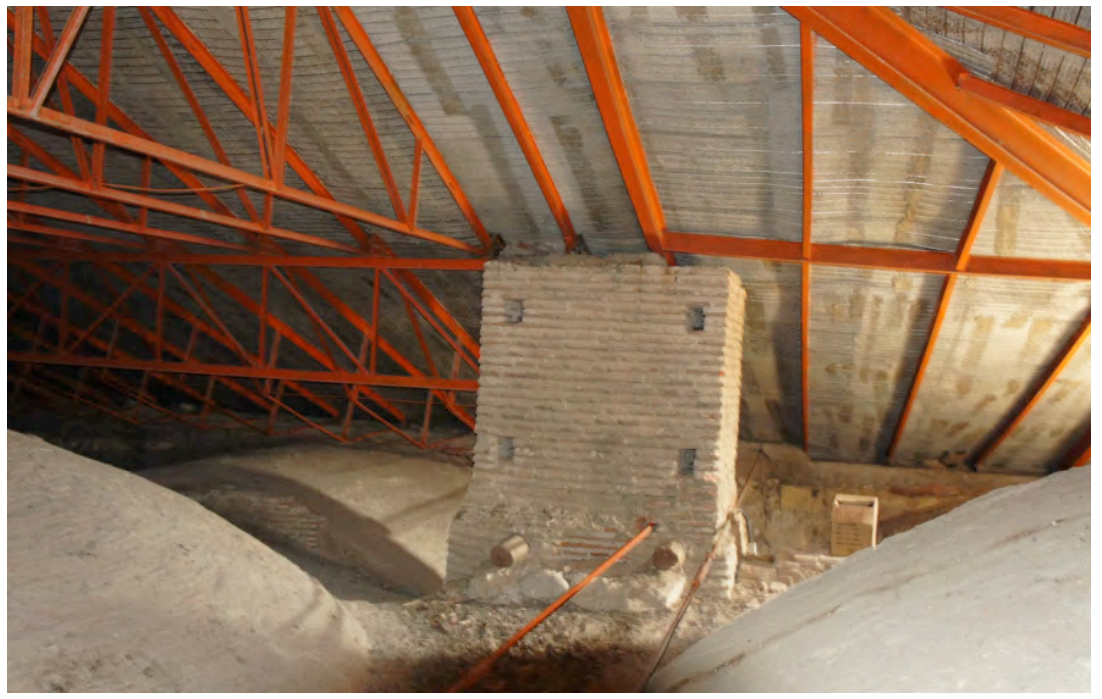

Se está rematando una obra de refuerzo de la estructura metálica de cubierta montada en 1979 y reforzada localmente en 1996. El arquitecto autor del proyecto Marcelino Hurtado, presente durante la visita, describe el sistema empleado en las distintas zonas, explicando como se anclan perfiles al zuncho perimetral sobre los ejes de pilas, disponiéndose tirantes de lado a lado de las tres naves con la intención de atar los cerramientos en cabeza.

En las zonas con capillas laterales los zunchos en realidad están funcionando como pórticos de vigas, sobre apoyos puntuales en el extremo de los machones de separación entre capillas, por lo que este atirantado no llega a atar ambas fachadas, según se aprecia en la planta que plasma las actuaciones reproducida en la Ficha. 

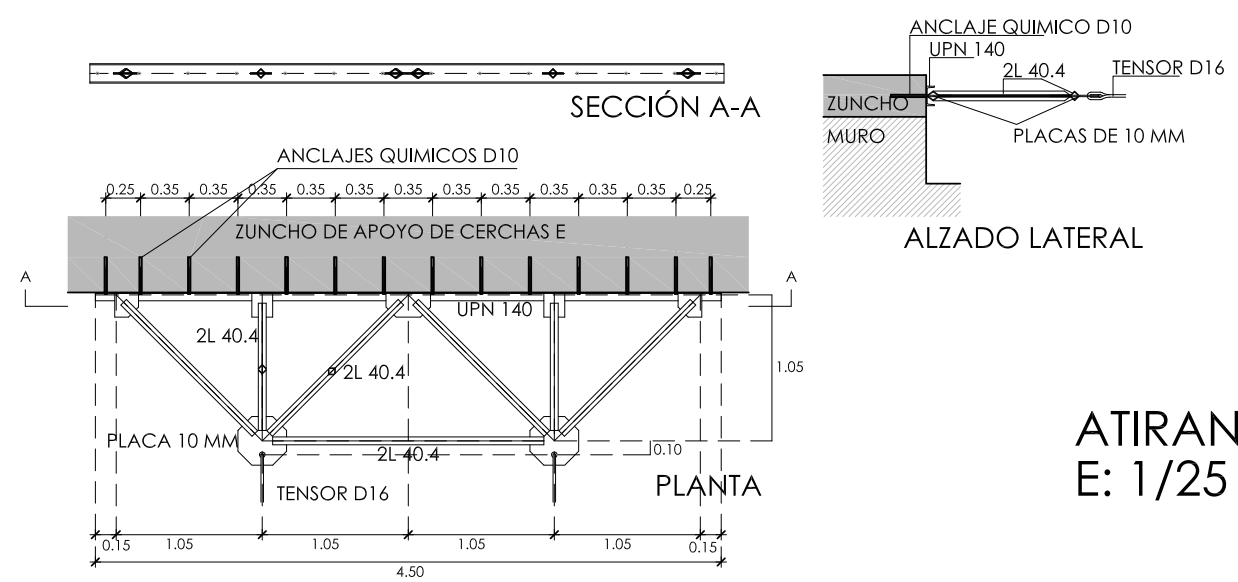

ALZADO LATERAL
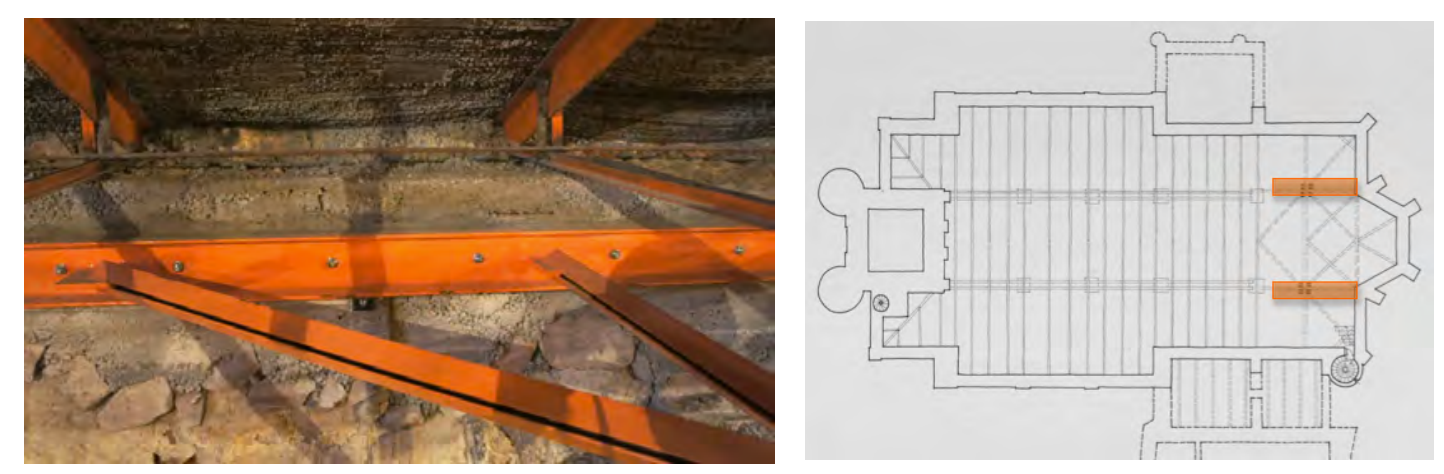

Se incorpora una cercha para permitir el apoyo de las diagonales en su punto medio en el caso de que sufran excesiva deformación. El apoyo de dicha cercha se encastra en un hueco abierto en el machón de ladrillo.
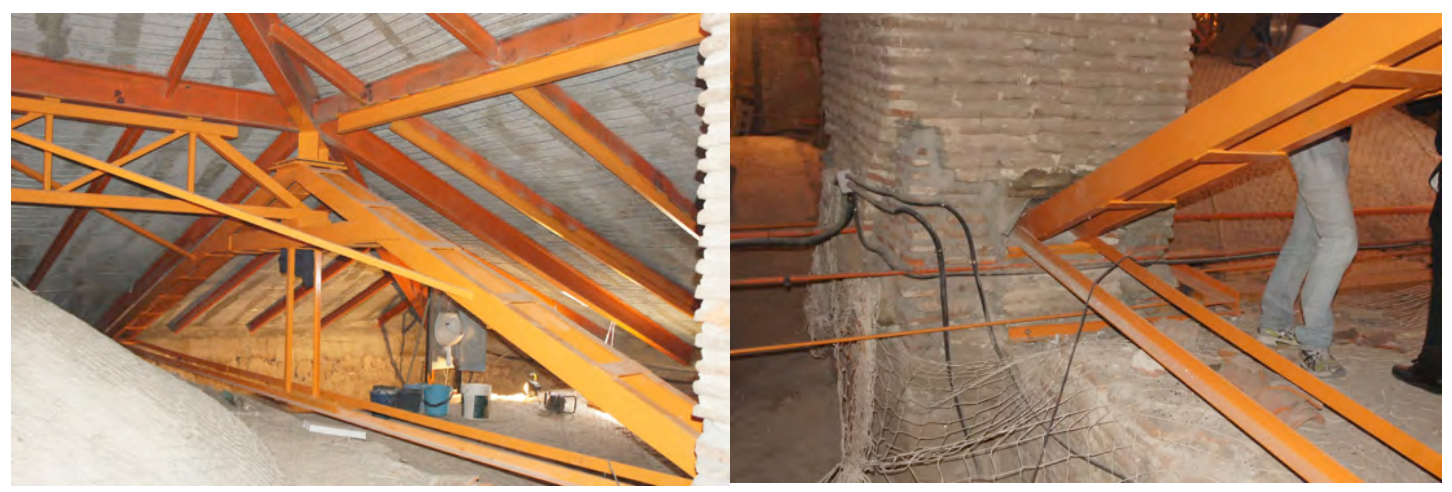

Encontramos tejas curvas en el fondo del zuncho y algún trozo de tabla, mientras que el frente visto ha sido encofrado. El canto presenta un perfil irregular, no se mantiene una línea clara.

El encuentro laterales-cabecera se resuelve con bastante continuidad. 

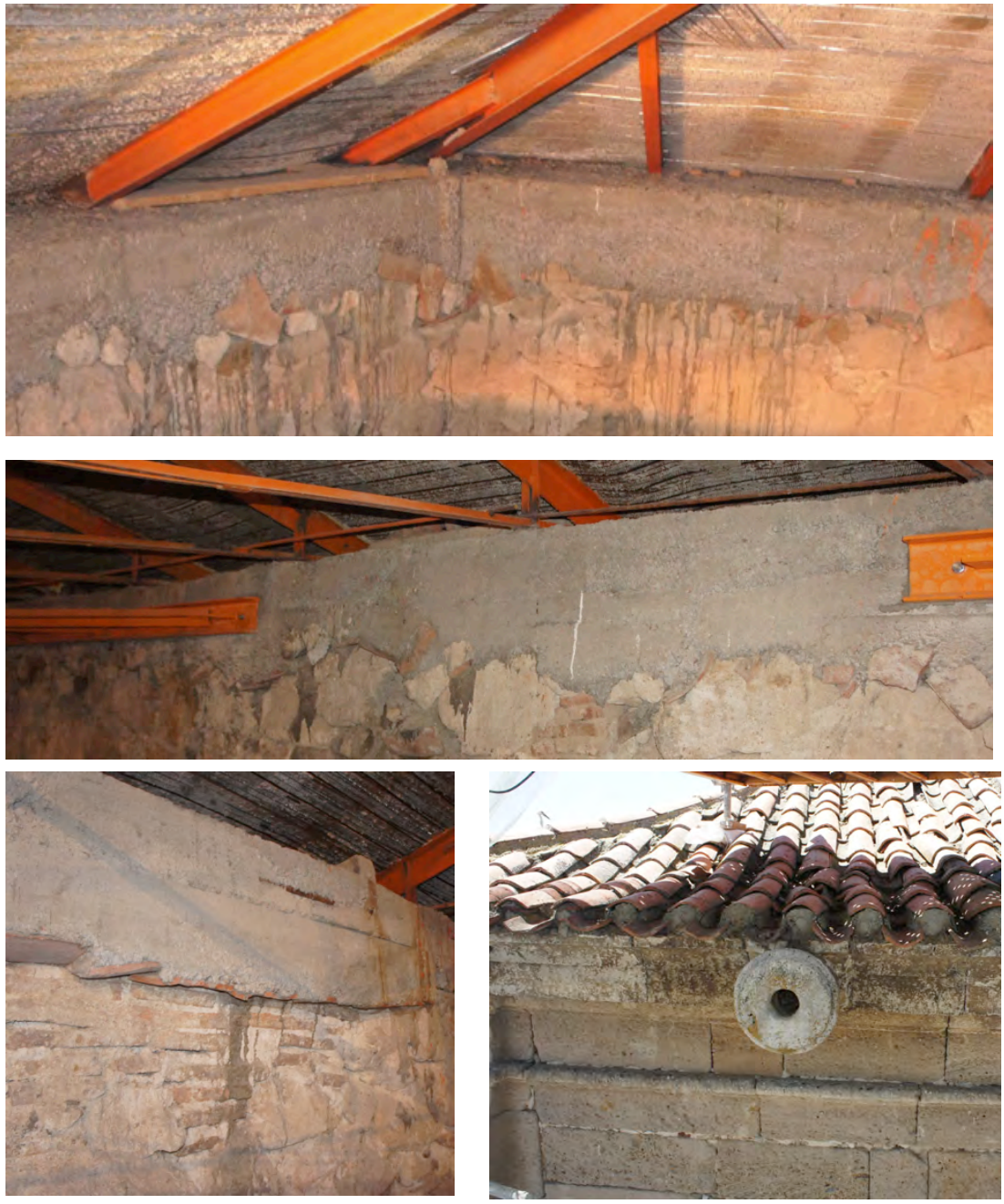

En algunas zonas el remate de piedra se recrece hasta la altura necesaria con fábrica de ladrillo.

Detalle de cornisa con los restos de gárgolas-cañón originales.

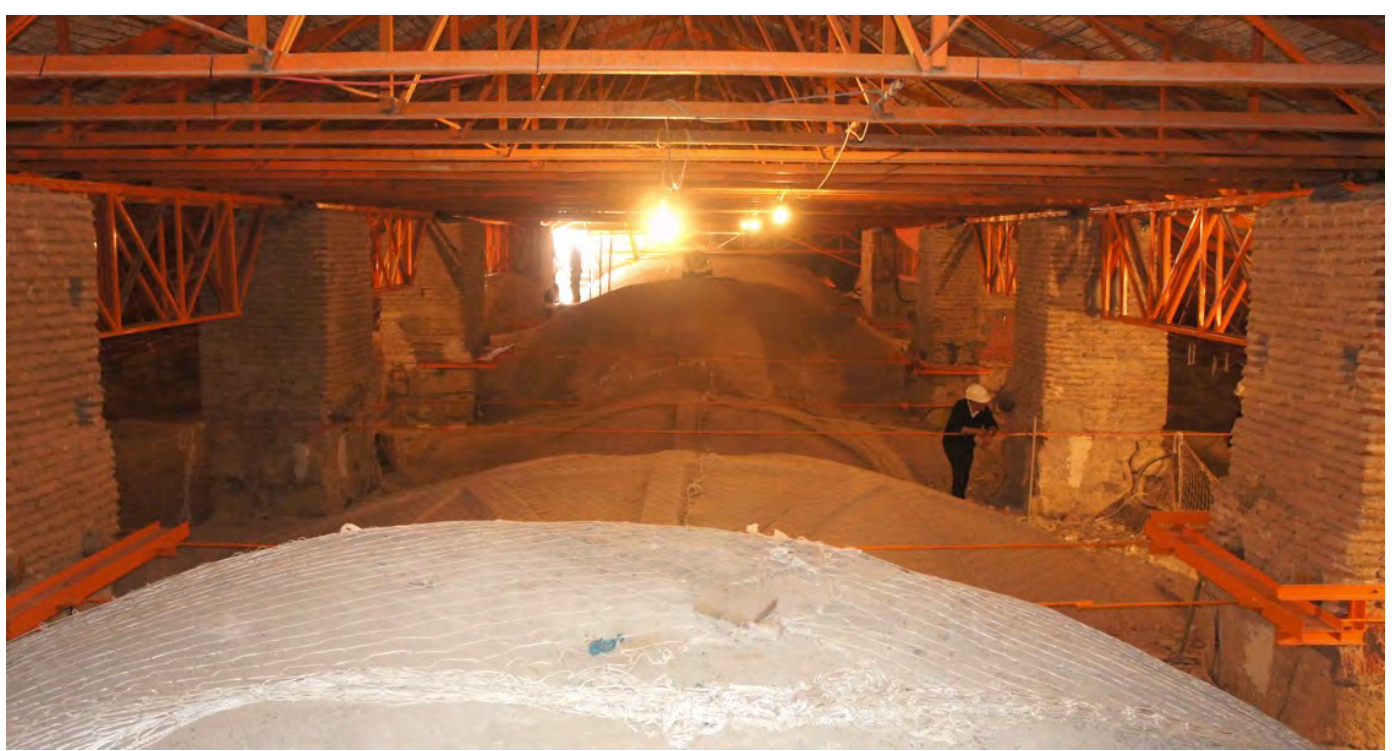




\section{Iglesia de San Juan}

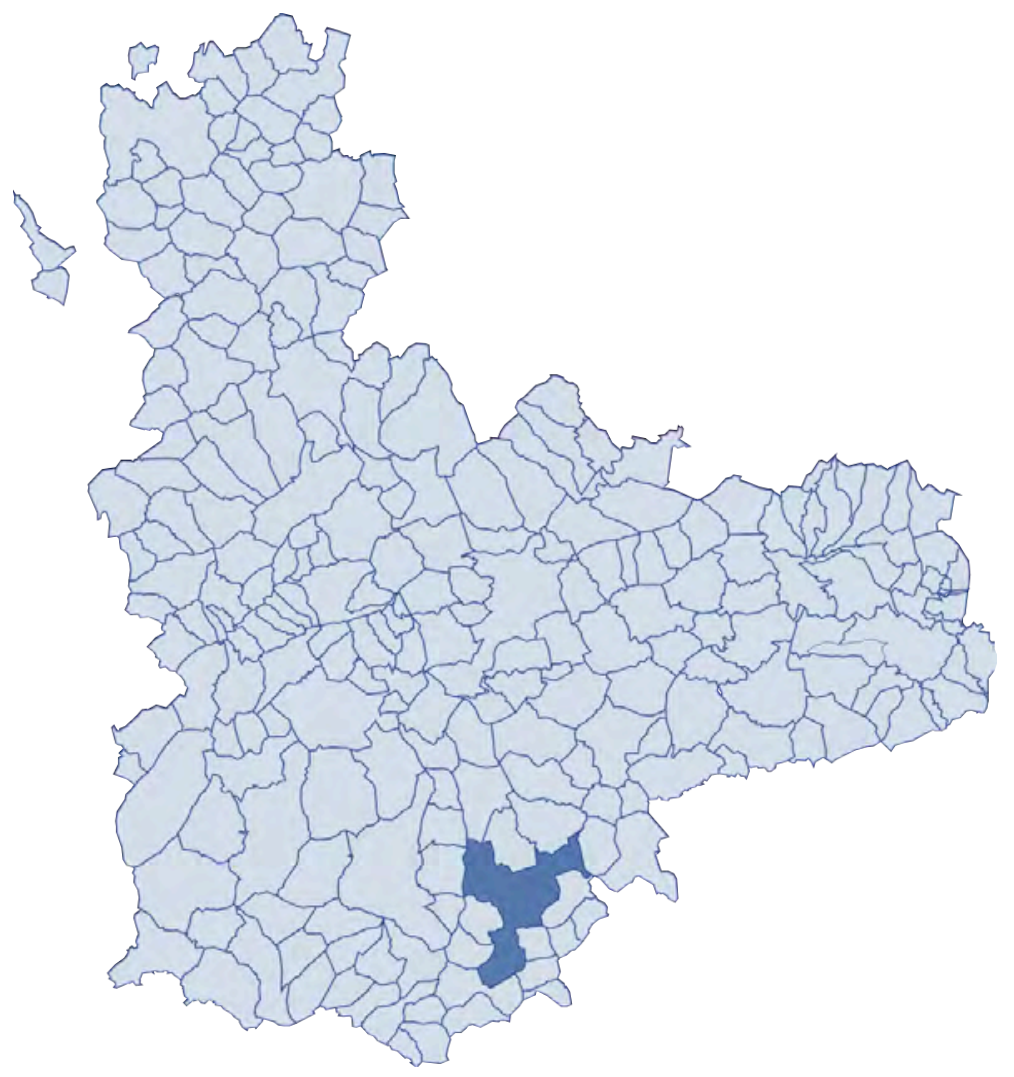



FICHA SÍNTESIS

\section{Código de identificación: FZ-31}

Denominación:

Iglesia de San Juan

Localidad:

Olmedo
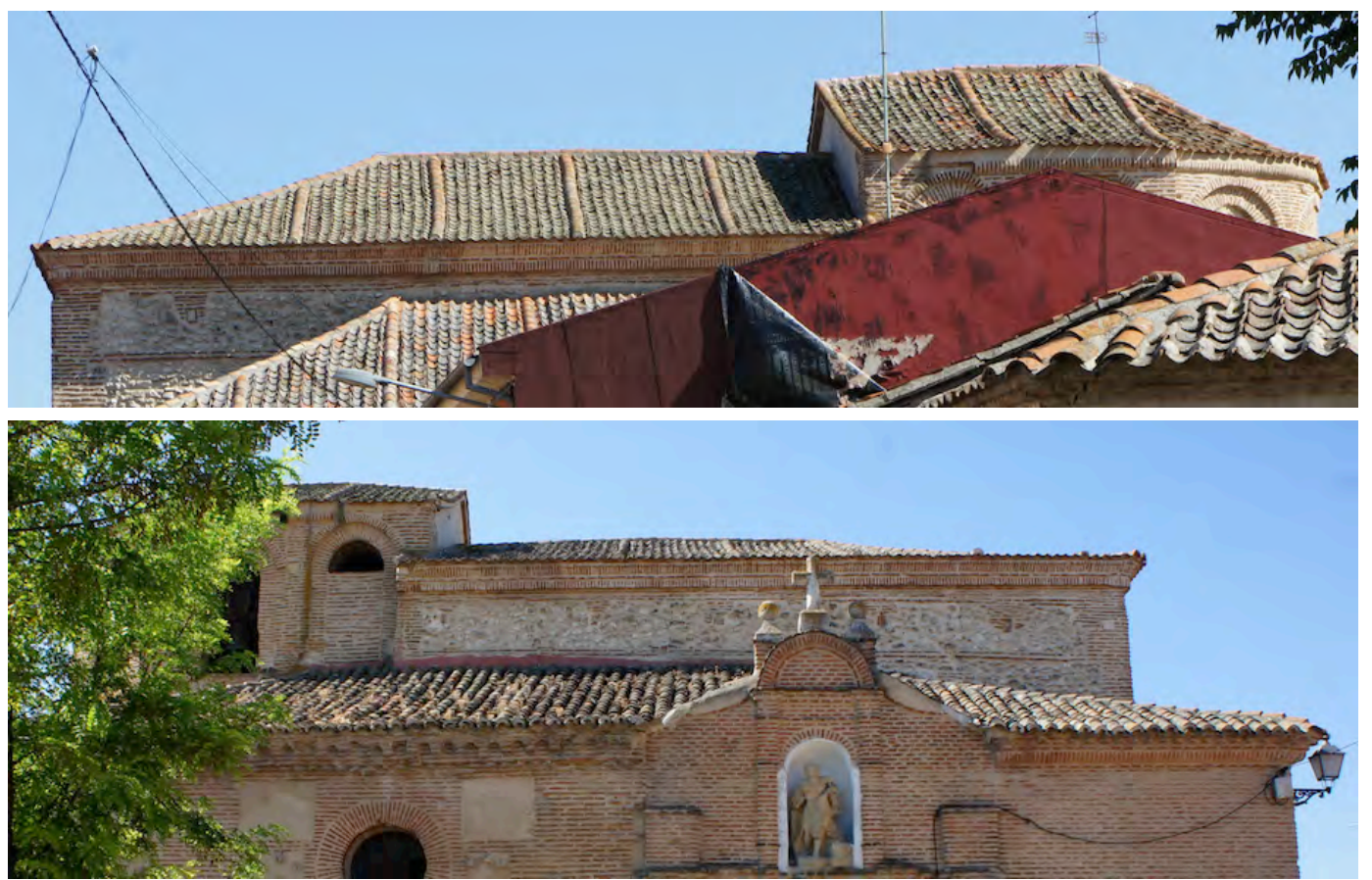

\section{Descripción}

Iglesia gótico-mudéjar de una sola nave cubierta con bóveda de medio cañón apuntado. Hay adosados volúmenes a ambos lados. La torre, de ladrillo, se levanta sobre el ábside.

\section{Materiales}

Los muros del cuerpo del templo están ejecutados con mampuesto encintado, con las esquinas, cornisa y remate de la cabecera resueltas con fábrica de ladrillo. Cuenta con grandes cuerpos adosados, sacristía y capilla funeraria, con tramos de muro construidos con fábrica de ladrillo, cajones de tapial y algunos paños de mampuesto.

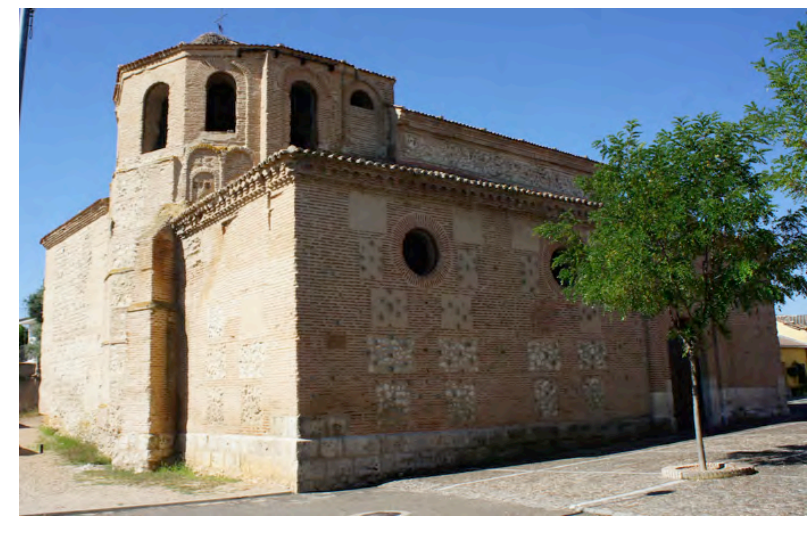

Ilustración 1: visita 02/08/2015 
Las cubiertas están revestidas de teja curva, dispuesta sólo con canales en nave central y cabecera.

\section{Singularidades}

El edificio se encuentra cerrado al culto desde hace décadas, aunque se emplea ocasionalmente en determinadas procesiones.

En 1967 se trasladaron los elementos valiosos al Museo Nacional de Escultura en Valladolid.

\section{Dimensiones básicas del templo}

Ancho de nave

$$
\text { central laterales capillas }
$$

Altura

\section{Memoria histórica constructiva}

Según el Catálogo:

El edificio, gótico-mudéjar, se construye en los siglos XIII y XIV y es reedificado en el XVI.

\section{Cronología. Fechas clave}

1967

\section{Intervenciones}

1967 - Traslado de elementos - Anselmo Arenillas

Dado el estado ruinoso del templo, se llevan al Museo de Escultura de Valladolid un sepulcro y una escultura de Berruguete que corrían riesgo de deteriorarse en su emplazamiento.

Se cuenta con un documento elaborado por Ingrid Amorette, Diana Muñoz y Marta Fernández en la Escuela de Arquitectura de Valladolid, dentro de la asignatura Rehabilitación, conservación y construcción de los edificios antiguos del que se reproducen a continuación plantas y alzados. 


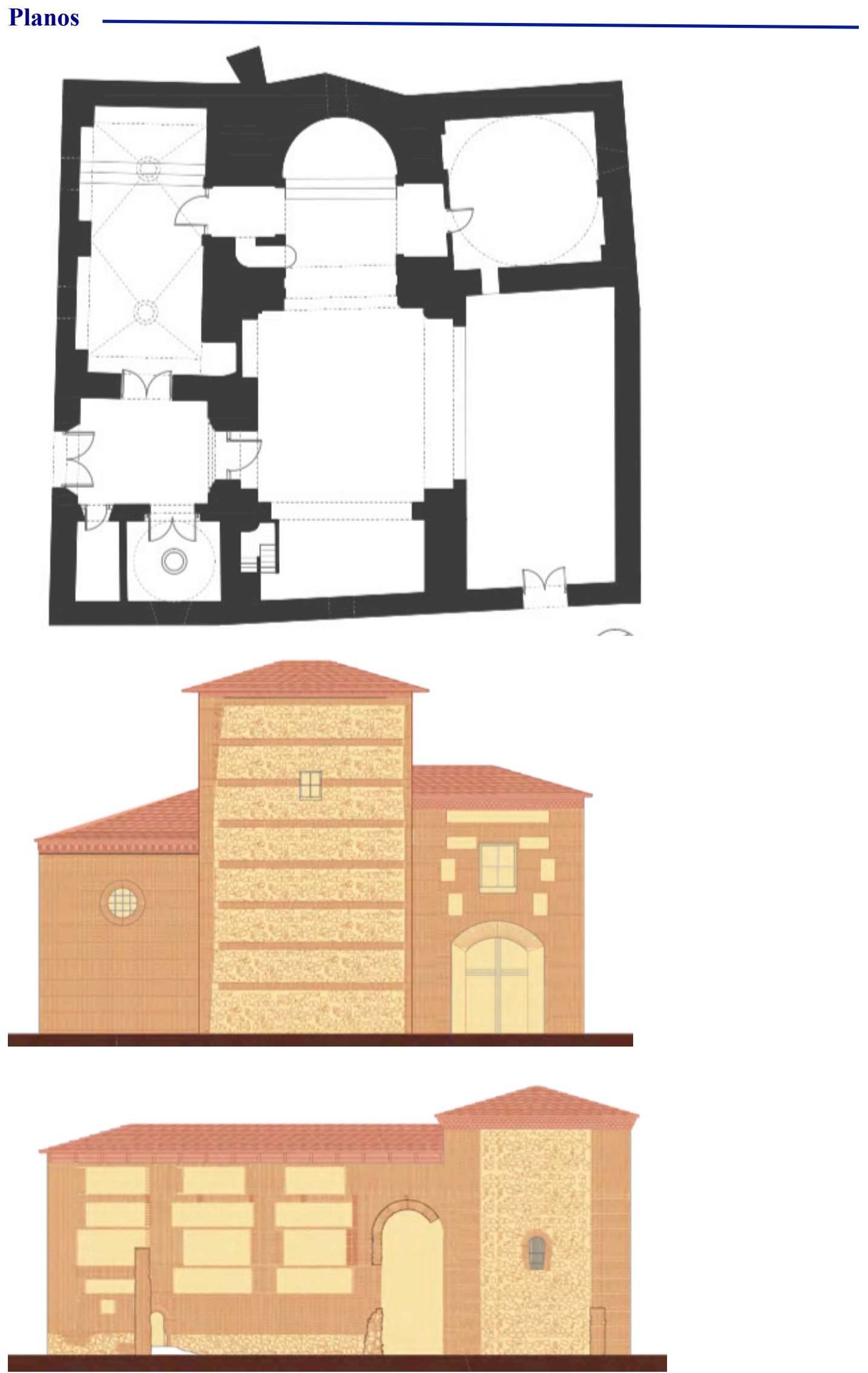



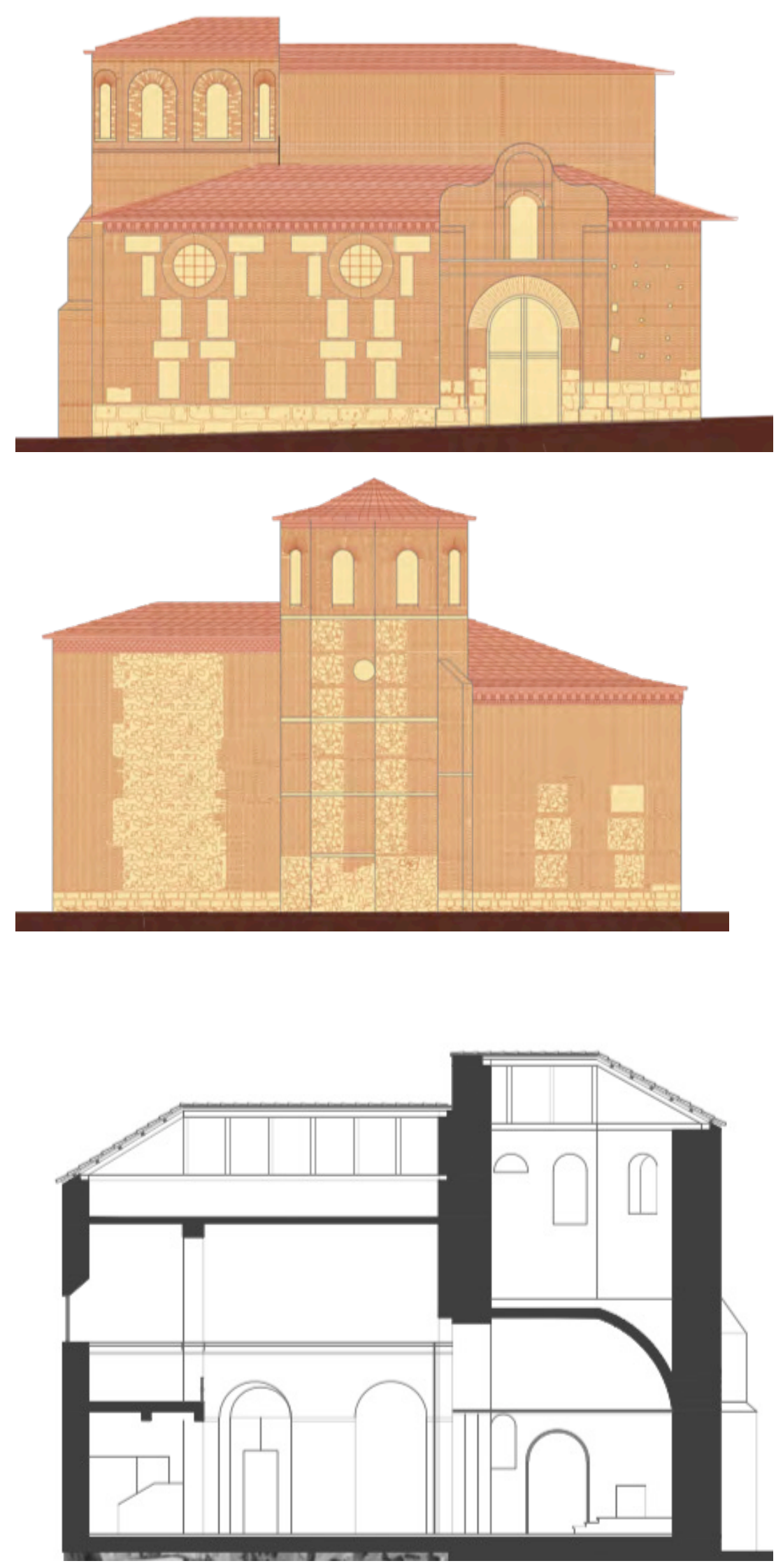


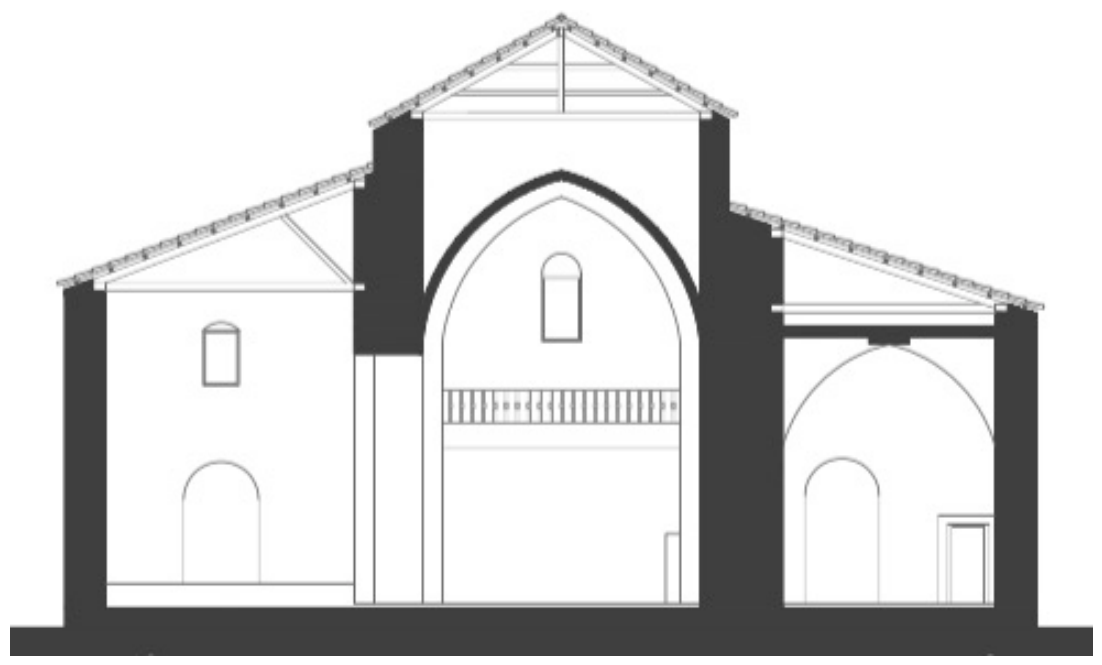

Ilustración 2: planos del trabajo de curso Amorette, Muñoz y Fernández

\section{Solución constructiva de la cubierta}

En las secciones se aprecian cubiertas inclinadas, con pendientes diversas y estructura de madera.

\section{Zunchos}

No se cuenta con documentación de las obras que hayan podido realizarse en esta iglesia.

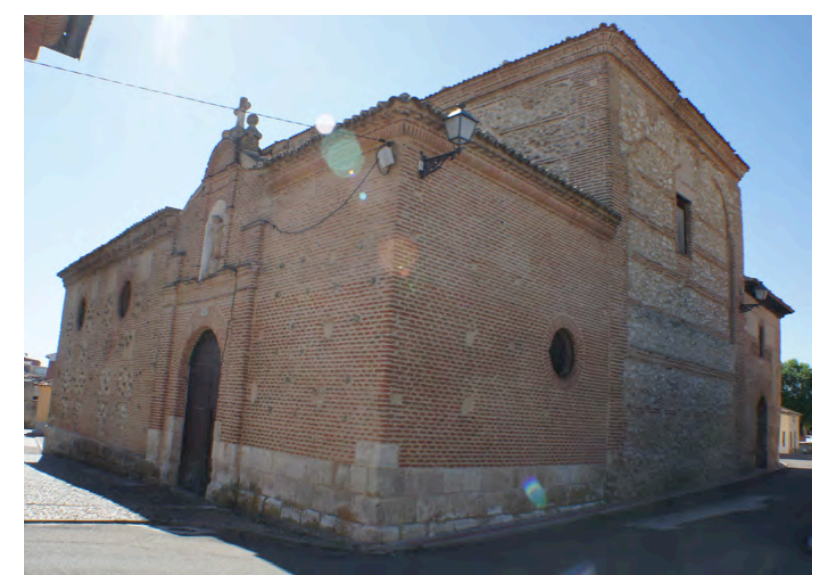

Ilustración 3: visita 02/08/2015

\section{Conclusiones}

No se ha localizado proyectos de obras realizadas en el edificio. 



\section{Iglesia de San Juan en Olmedo}

Intervenciones citadas en la publicación del Ministerio

1967 - Traslado de elementos al Museo Nacional de Escultura - Anselmo Arenillas

No hay planos en la web del IPCE

\section{En el archivo de la Junta de Castilla y León}

No se ha localizado documentación

\section{En el Archivo General de la Administración}

AGA 26/00120

Proyecto de obras de desmontado, traslado y nuevo montage de diversos elementos arquitectónicos de gran valor, desde la iglesia de San Juan de Olmedo al Museo Nacional de Escultura Policromada de Valladolid.

1967 Arenillas

La iglesia de San Juan se encuentra en la actualidad en absoluto estado de ruina, conservando algunos elementos arquitectónicos de gran valor artístico, que de no ser trasladado a un lugar mejor acondicionado se destruirán como el resto de la iglesia.

Dos sepulcros, arcosolios y un Ecce Homo de Berruguete. Transporte y colocación en el Museo.

Plano de planta de la Capilla del Museo de Escultura 1:100. 



\section{Visitas realizadas}

$02 / 08 / 2015$

El estado de conservación del monumento corresponde a su condición de iglesia cerrada al culto, aunque exteriormente no se aprecian grandes señales de patología.

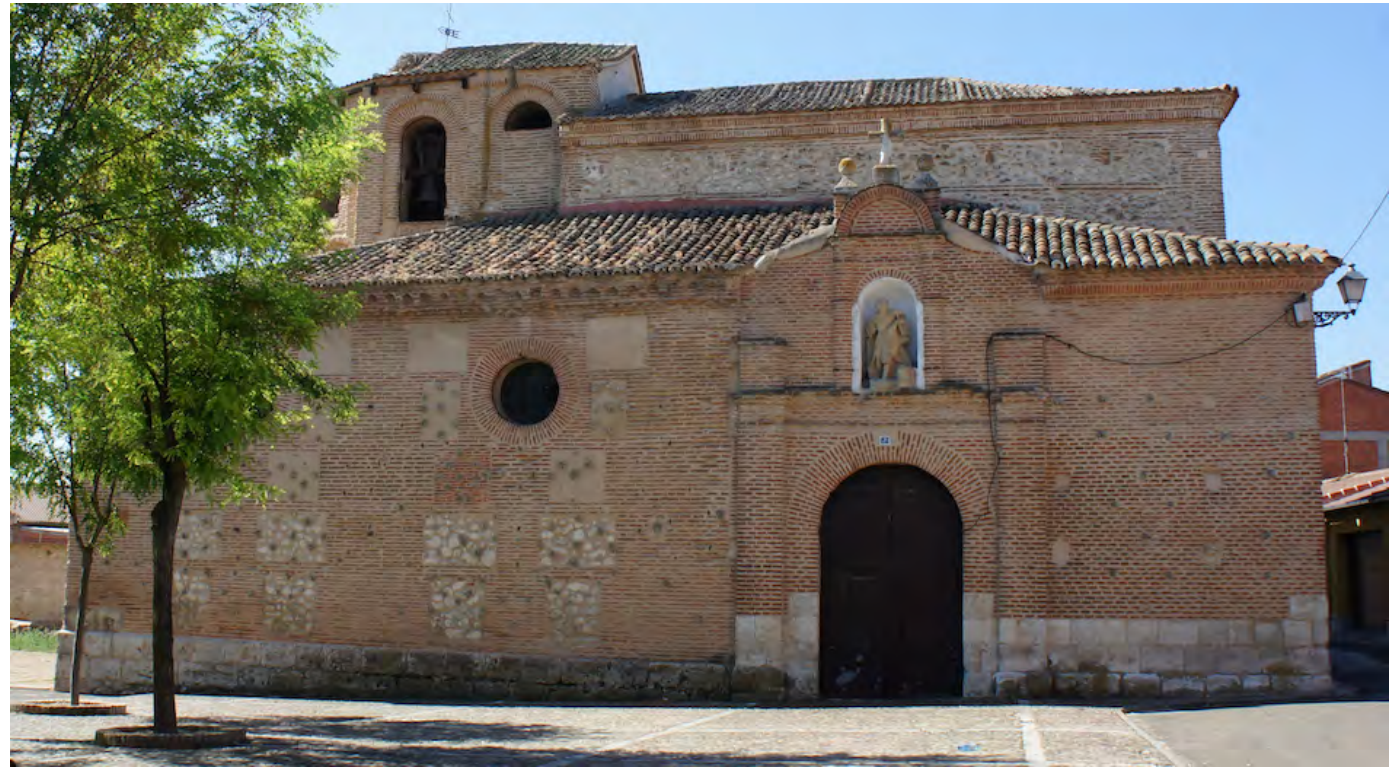

Las cubiertas se encuentran revestidas de teja curva, dispuesta sólo a canal en nave central y presbiterio. La cabecera carece de cornisa y muestra algunos tramos con maderos vistos y otros revestidos.

El cuerpo del templo cuenta con grandes volúmenes adosados, uno de ellos de cajones de mampuesto y fábrica de ladrillo, otro de mampuesto con las esquinas de ladrillo, y un tercero formado con cajones de tapial encintado con verdugadas de ladrillo visto.

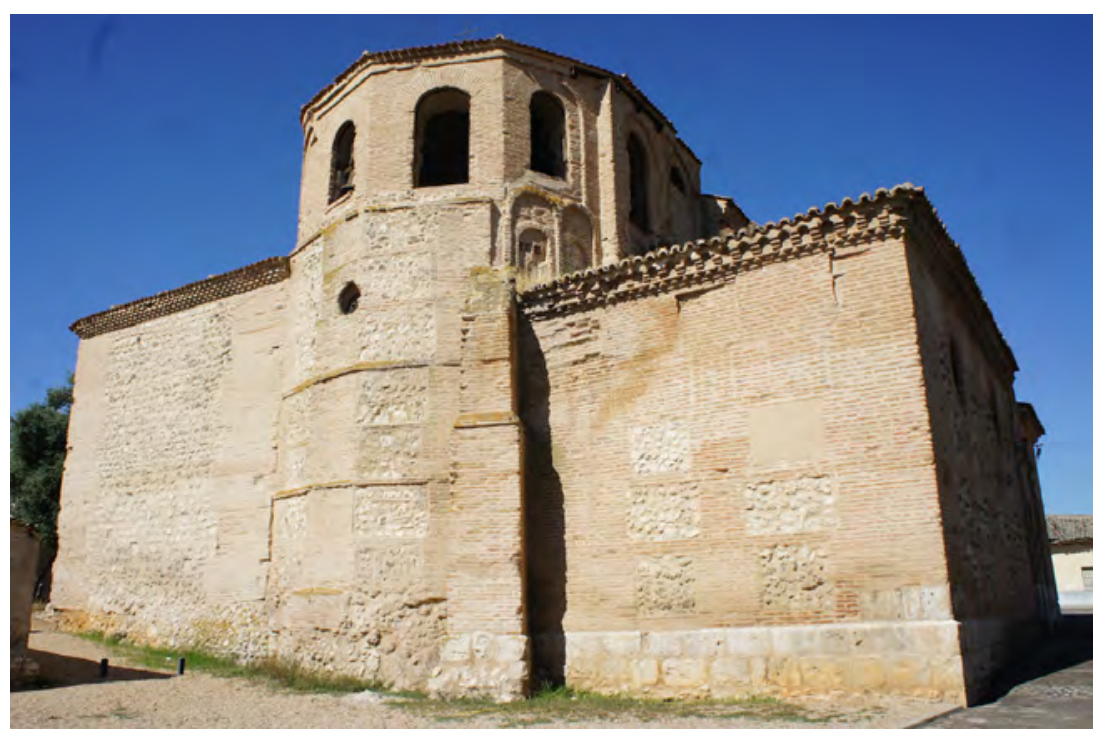



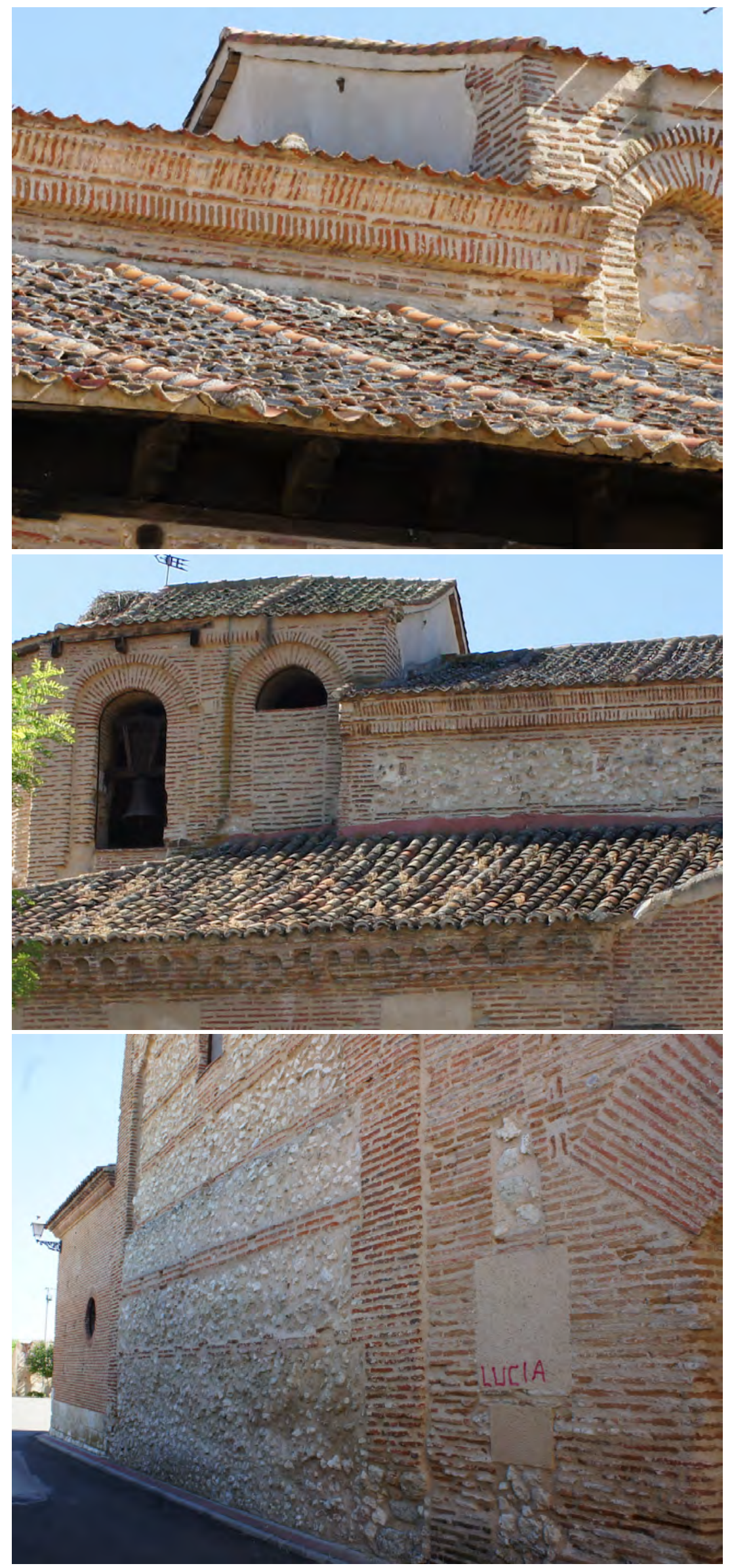
Iglesia del Monasterio de Santa María de Palazuelos

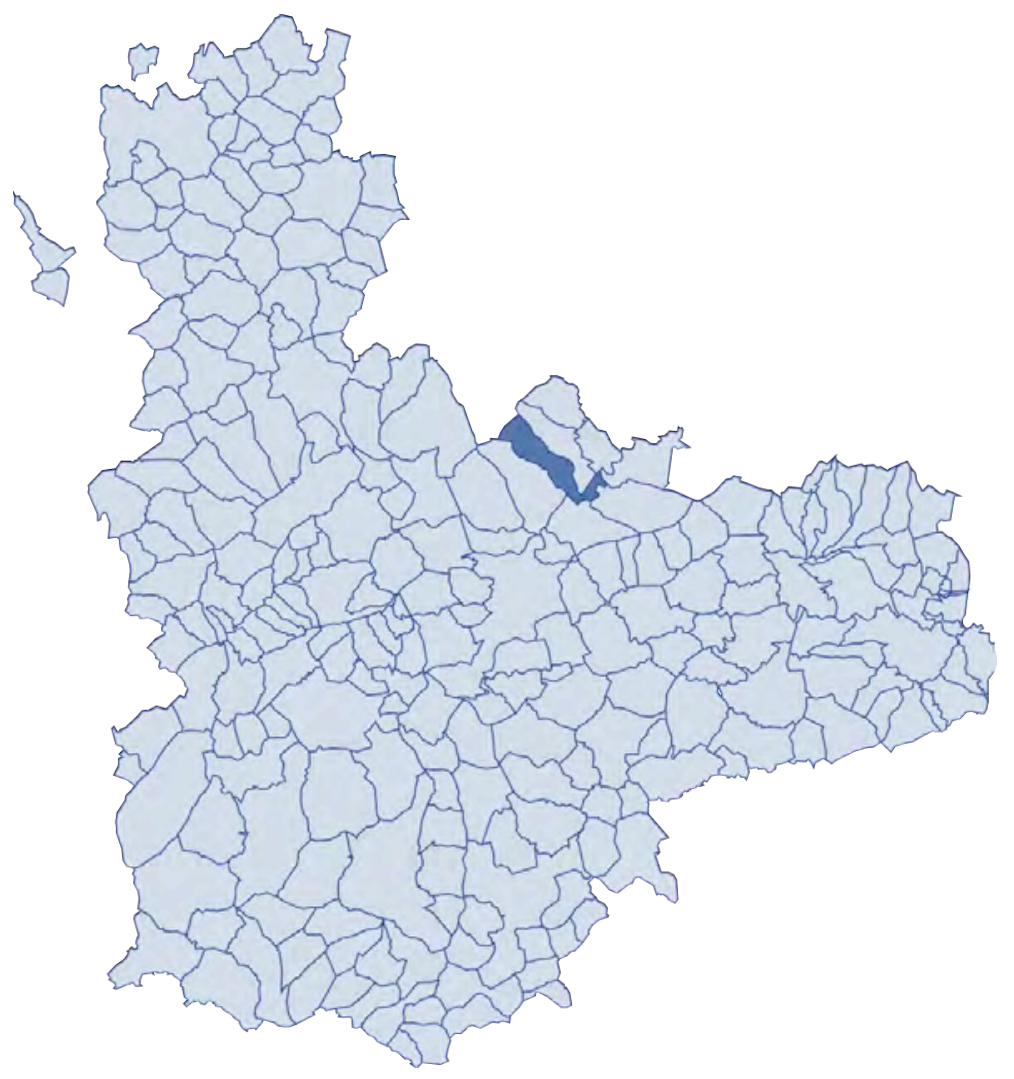



FICHA SÍNTESIS

\section{Código de identificación: FZ-32}

Denominación:

Localidad:

Iglesia del Monasterio de Santa María de Palazuelos Corcos del Valle

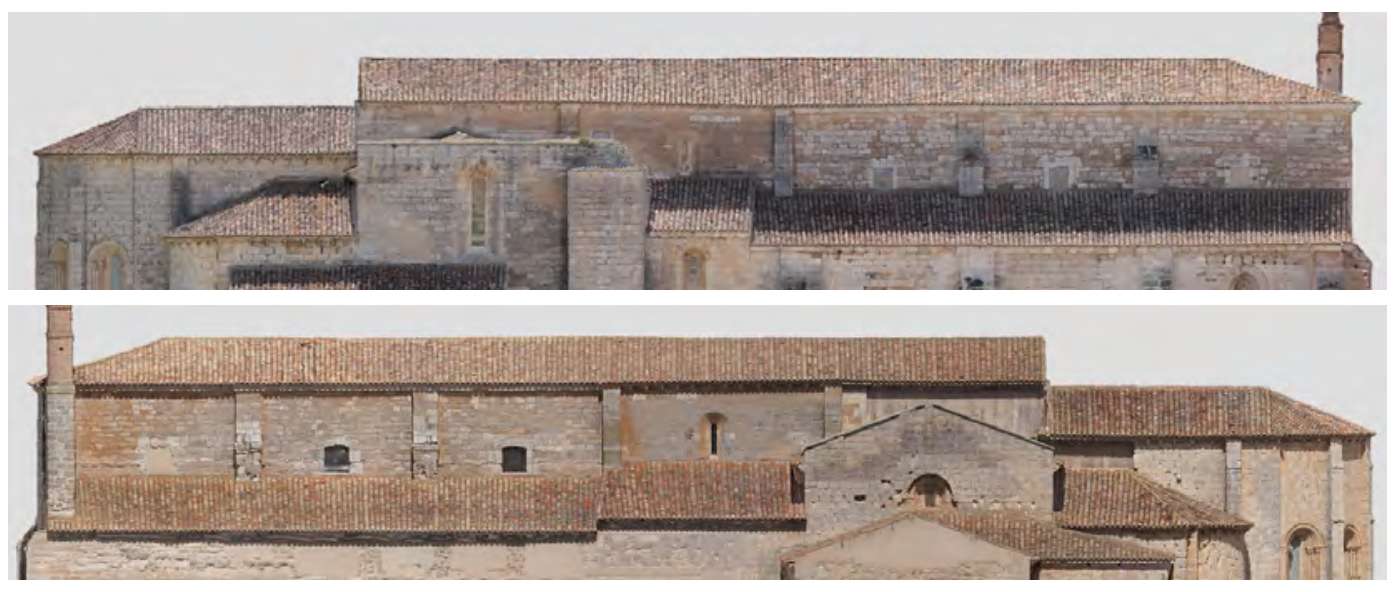

Ilustración 1: levantamiento 2014 JCyL

\section{Descripción}

Iglesia desacralizada de tres naves, rematadas con ábsides laterales semicirculares y el central poligonal, con un crucero marcado en alzado aunque no en planta. Sobre la nave se disponen bóvedas de crucería, de cañón con lunetos hacia los pies y de cañón apuntado en el crucero. La bóveda sobre los absidiolos es de horno.

\section{Materiales}

Los muros son de sillería de piedra. Las cubiertas están revestidas de teja curva.

\section{Singularidades}

El edificio ha permanecido muchos años abandonado, sin uso, sufriendo hundimientos parciales de las cubiertas, que han sido restauradas con una solución moderna y empleo madera laminada.

\section{Dimensiones básicas del templo}

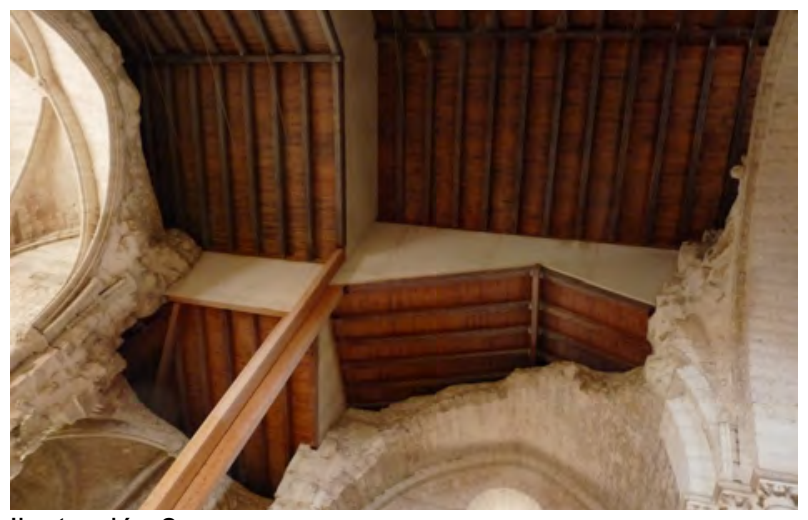

llustración 2:

https://inarqadia.files.wordpress.com/2013/07/p1040555.

$\begin{array}{llll} & \text { central } & \text { laterales } & \text { capillas } \\ \text { Ancho de nave } & 9,5 & 5,9 & \\ \text { Altura } & 15,3 & 13,4\end{array}$




\section{Memoria histórica constructiva}

Según el Catálogo:

En 1226 se consagra el altar y la comunidad se traslada en 1254

Hacia 1580 se hunden las bóvedas de las nueve primeras capillas de los pies, que reconstruye Juan de Nates.

El monasterio desaparece tras la Desamortización de Mendizábal en 1835, aunque se conserva la iglesia.

En 1998 se desplomaron parte de las bóvedas, la cubierta y una espadaña, que se reconstruyen un año más tarde a expensas del Ayuntamiento.

\section{Cronología. Fechas clave}

$1226-1580-2000$

\section{Intervenciones}

1966 - Reparación de la cubierta - Anselmo Arenillas

Repaso de la cubierta con reposición de ripia dañada y retejo.

1986 - Emergencia - Ignacio Represa

Tras la entrada de saqueadores que causan destrozos en los sepulcros se repara la cubierta, tapiando ventanas y colocando puertas blindadas en el recinto.

2000 - Intervención de emergencia en la cubierta - Ana Montoya y José Manuel Horno

Se renueva la cubierta colocando una nueva estructura de par e hilera.

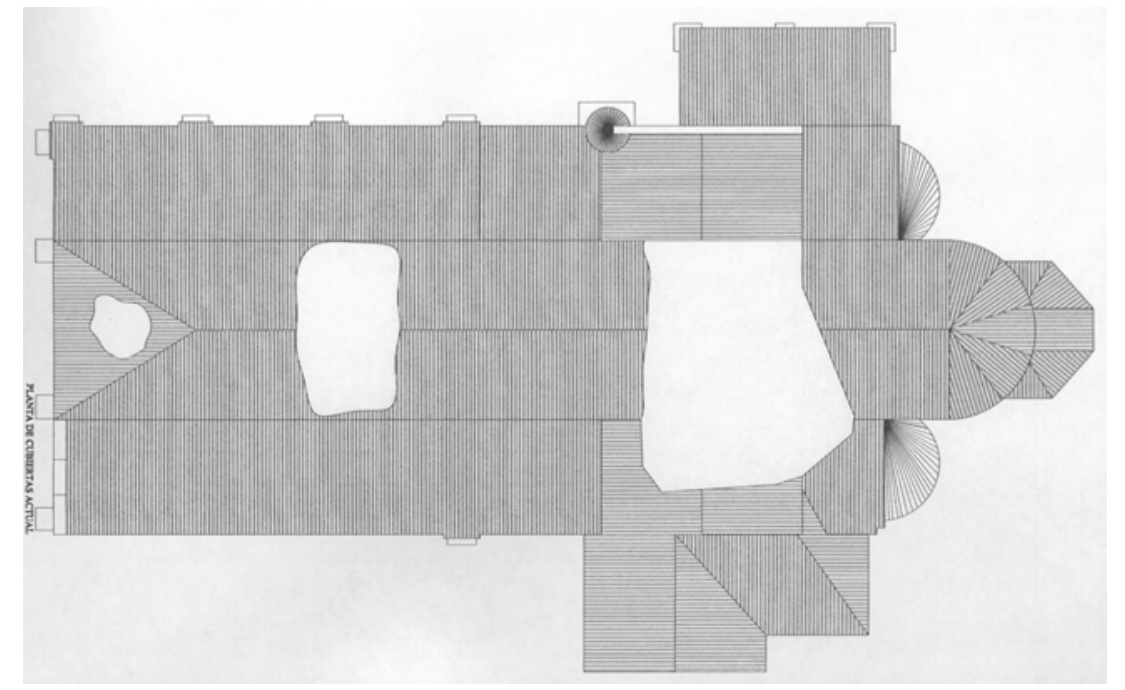

Ilustración 3: planta estado 1999 Montoya y Horno JCyL 
En la parte derrumbada del crucero se incorpora un pilar y vigas de madera laminada para soportar la nueva cubierta, cuya cara interior queda vista.

2001 - Restauración de los cuerpos bajos - Ana Montoya y José Manuel Horno Se prosigue la obra anterior en naves y capilla. También se reconstruye la espadaña.

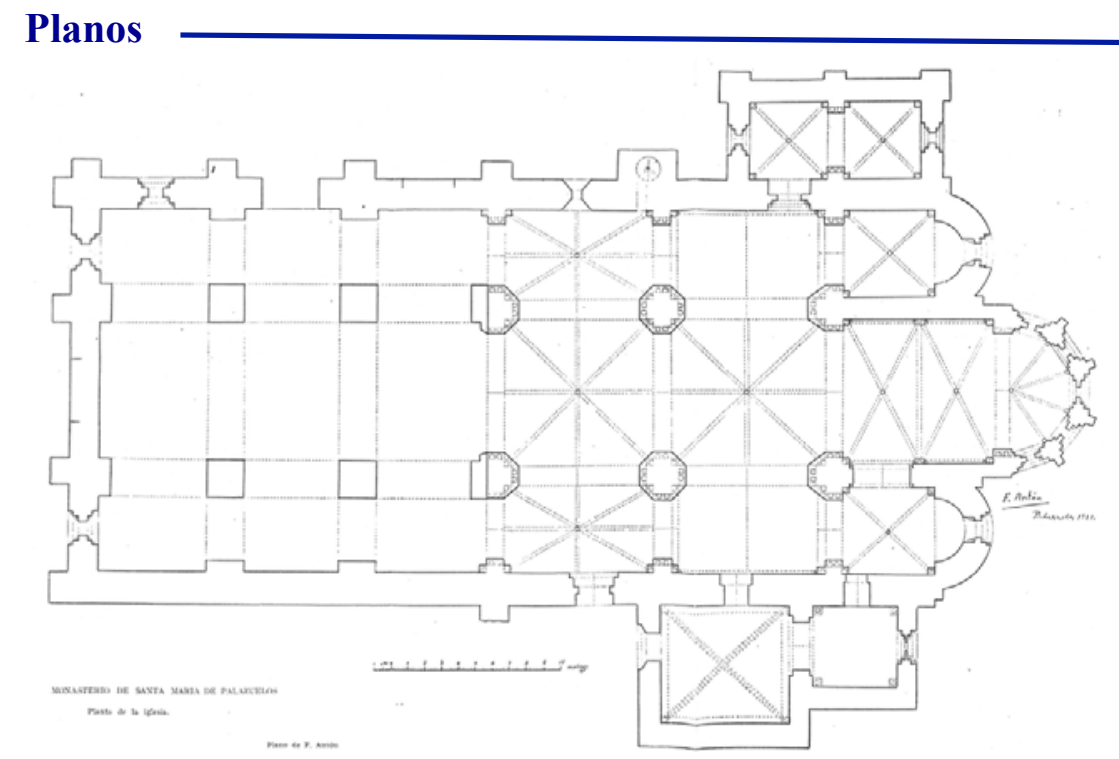

Ilustración 4: planta Antón (1986 Represa JCyL)

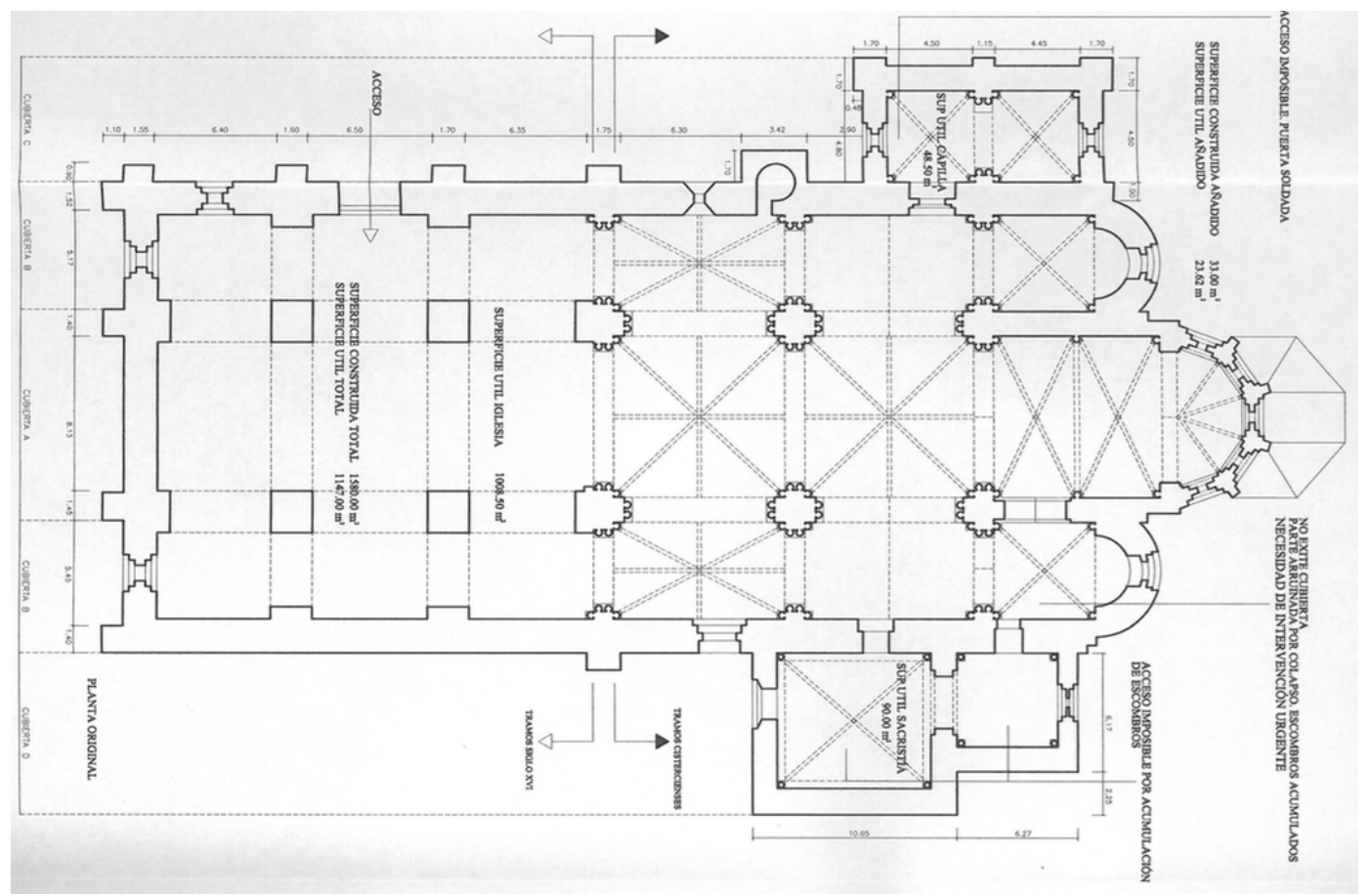

Ilustración 5: planta 1999 Montoya y Horno JCyL 


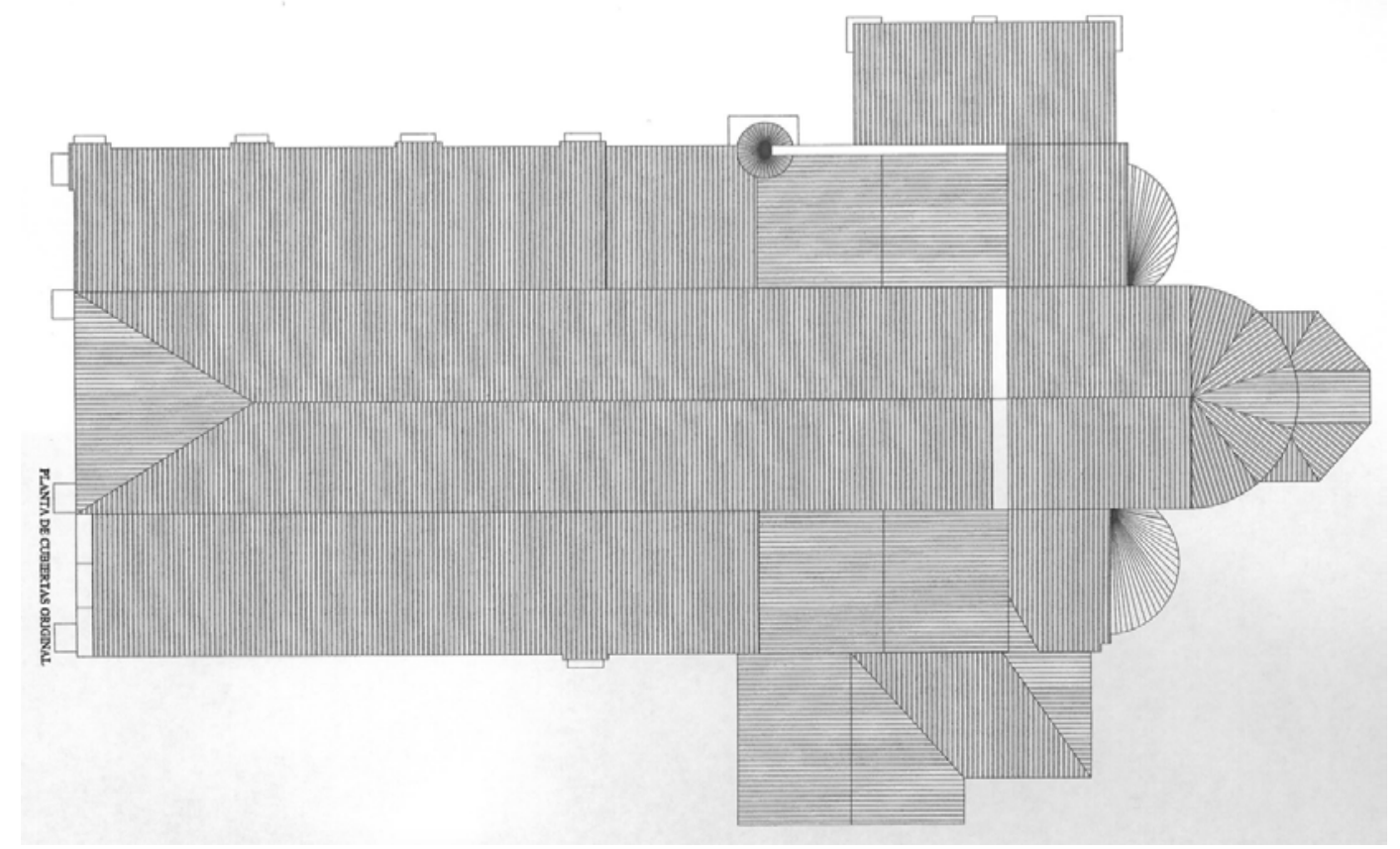

Ilustración 6: planta de cubiertas 1999 Montoya y Horno JCyL

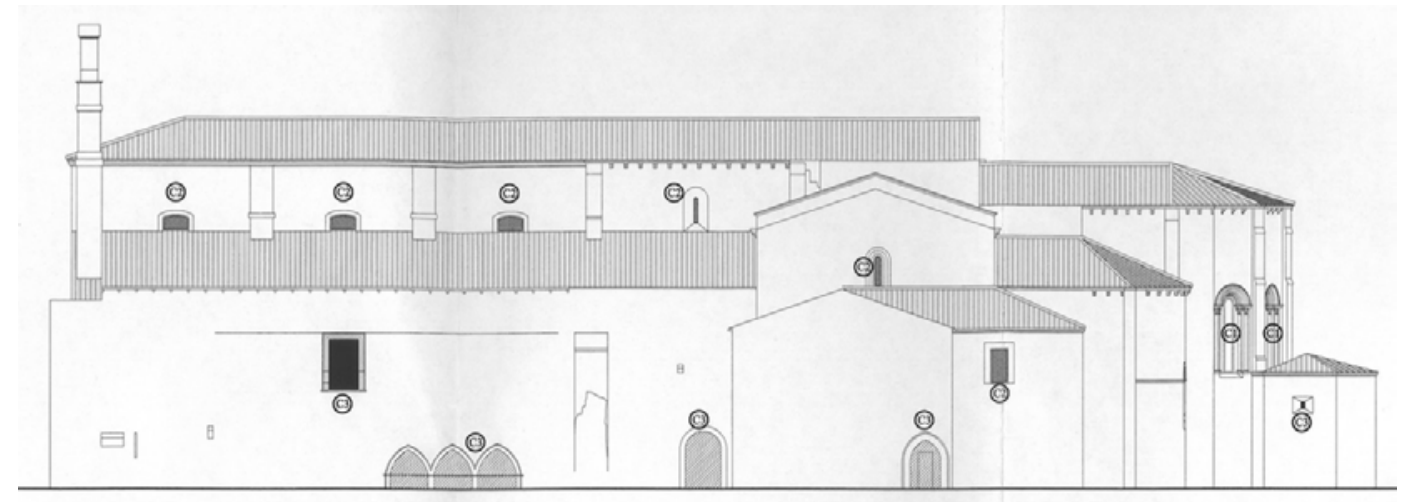

Ilustración 7: alzado sur 2000 Montoya y Horno JCyL

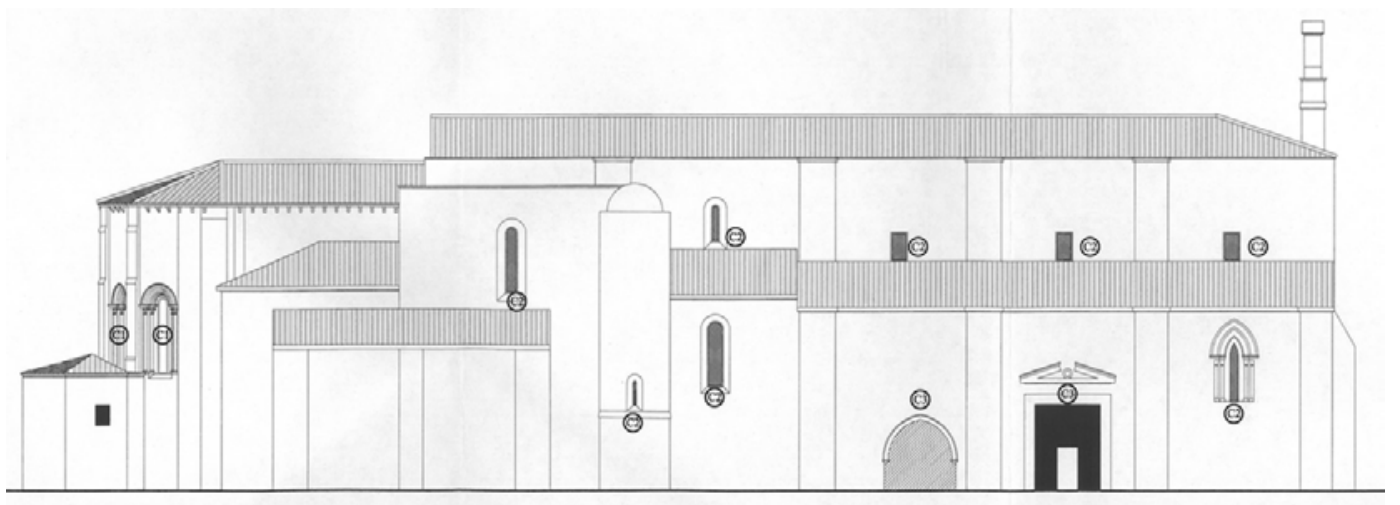

Ilustración 8: alzado norte 2000 Montoya y Horno JCyL 


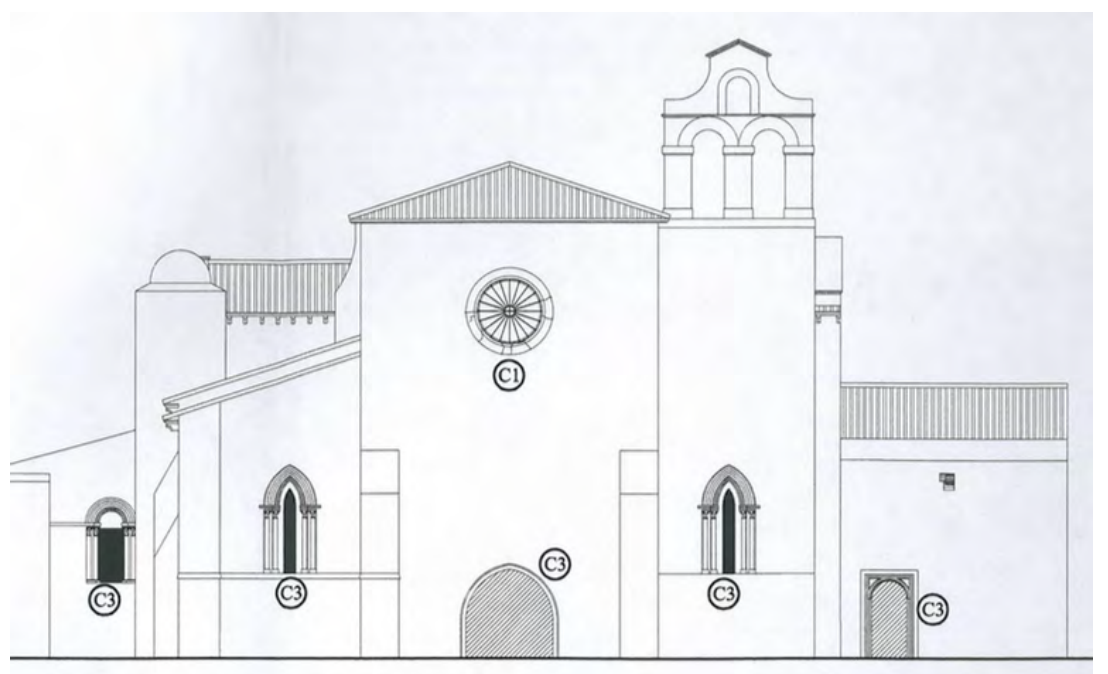

Ilustración 9: alzado oeste Montoya y Horno JCyL

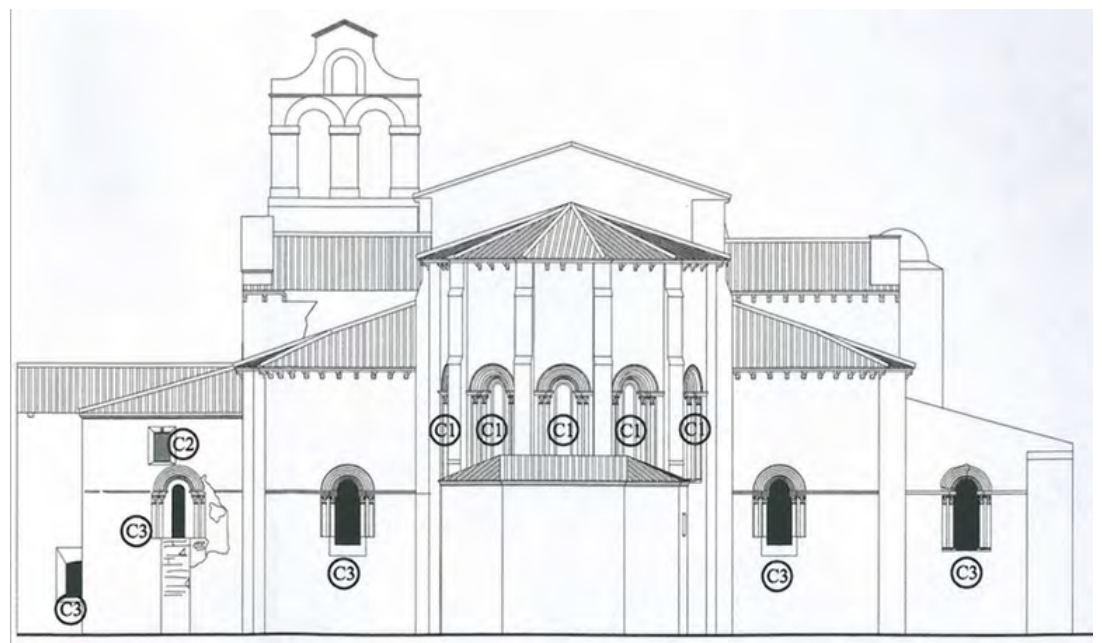

Ilustración 10: cabecera Montoya y Horno JCyL

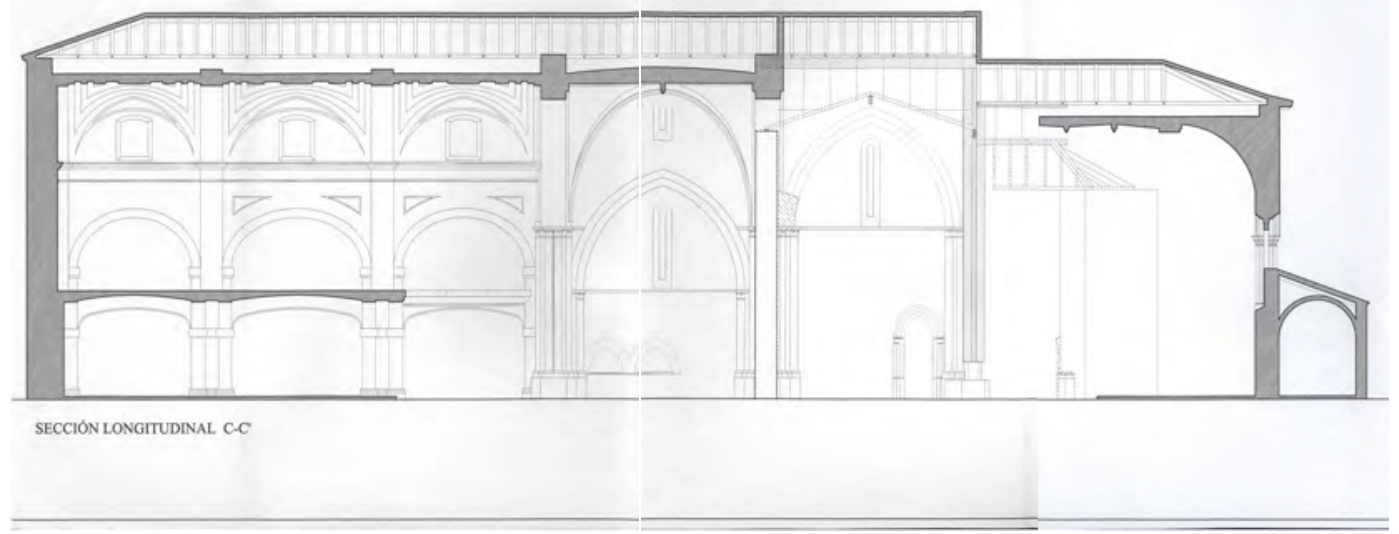

Ilustración 11: sección longitudinal 2000 Montoya y Horno JCyL 


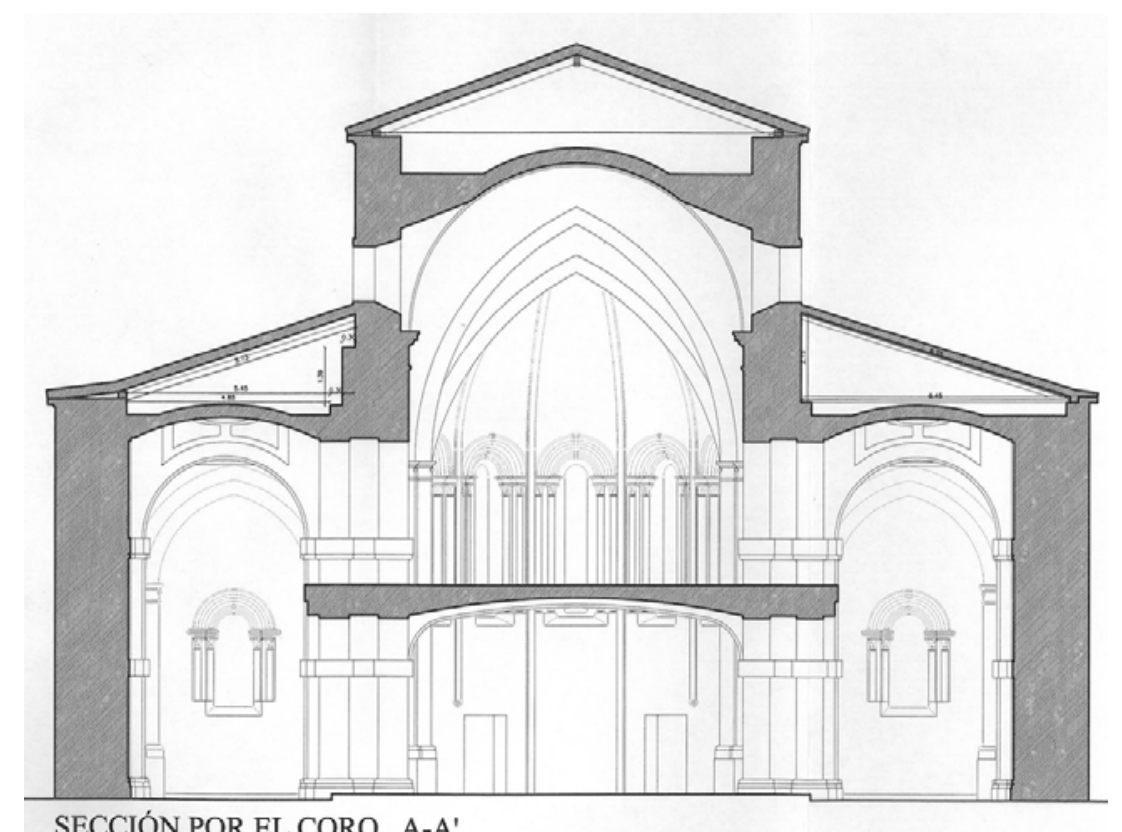

SECCIÓN POR EL CORO A-A'

Ilustración 12: sección transversal 2000 Montoya y Horno JCyL

\section{Solución constructiva de la cubierta}

En las secciones aparece representada una pendiente de ambas aguas sobre la nave central más alta de unos $19^{\circ}$.

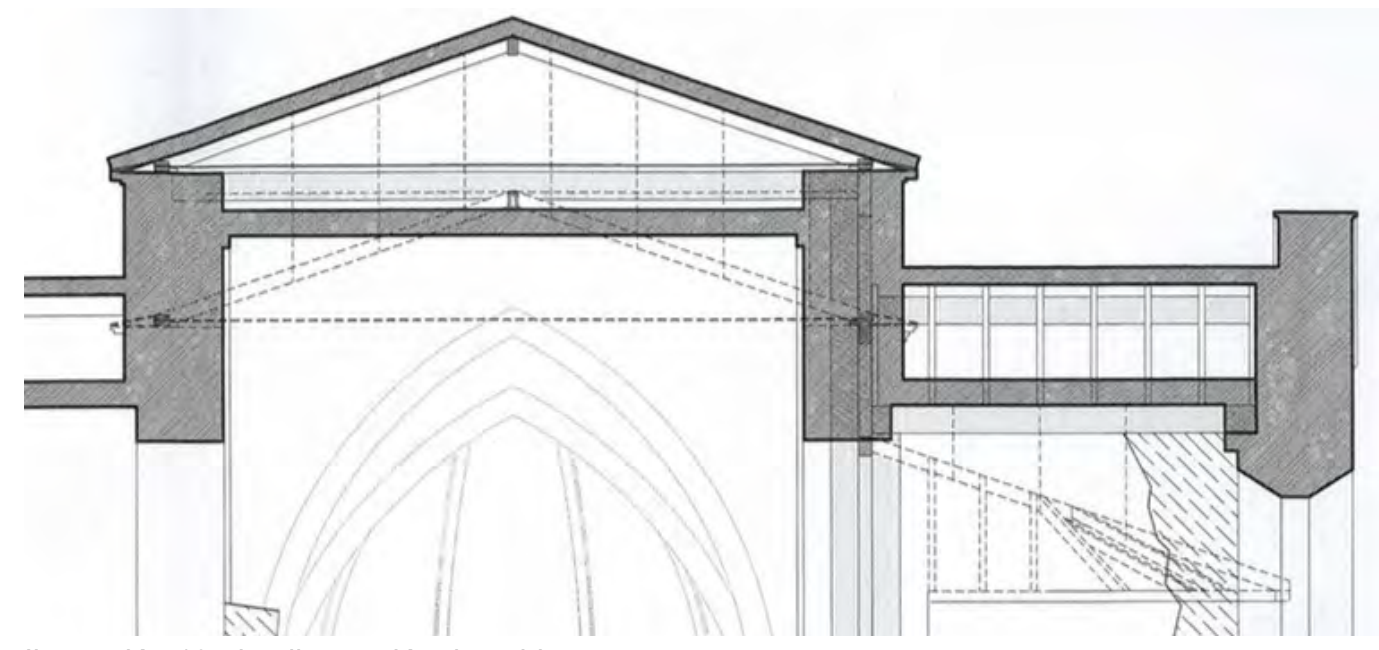

Ilustración 13: detalle sección de cubiertas

La nueva estructura de cubierta incorporada en el año 2000 es de par e hilera de madera con un tirante metálico.

La estructura se interrumpe en el crucero, donde se ha instalado un sistema de jácenas de madera laminada, apoyadas sobre un nuevo soporte del mismo material, para salvar el gran hueco producido por el derrumbamiento. (Ver fotografía 2 al principio de la ficha) 


\section{Zunchos}

Los pares de madera de $15 \times 25 \mathrm{~cm}$ de escuadría, que forman la estructura de cubierta de la nave, apoyan sobre un durmiente continuo de madera de $20 \times 15 \mathrm{~cm}$ dispuesto sobre ambos muros laterales.

Según los detalles de aleros y cornisas de los cuerpos bajos definidos en el proyecto de 2001, el remate de la cubierta se organiza mediante distintas piezas de madera, un durmiente 20x15, cuñas tableros y canes. En algunas zonas sin embargo se forma el ángulo de refreno con un relleno de fábrica de ladrillo hueco doble.

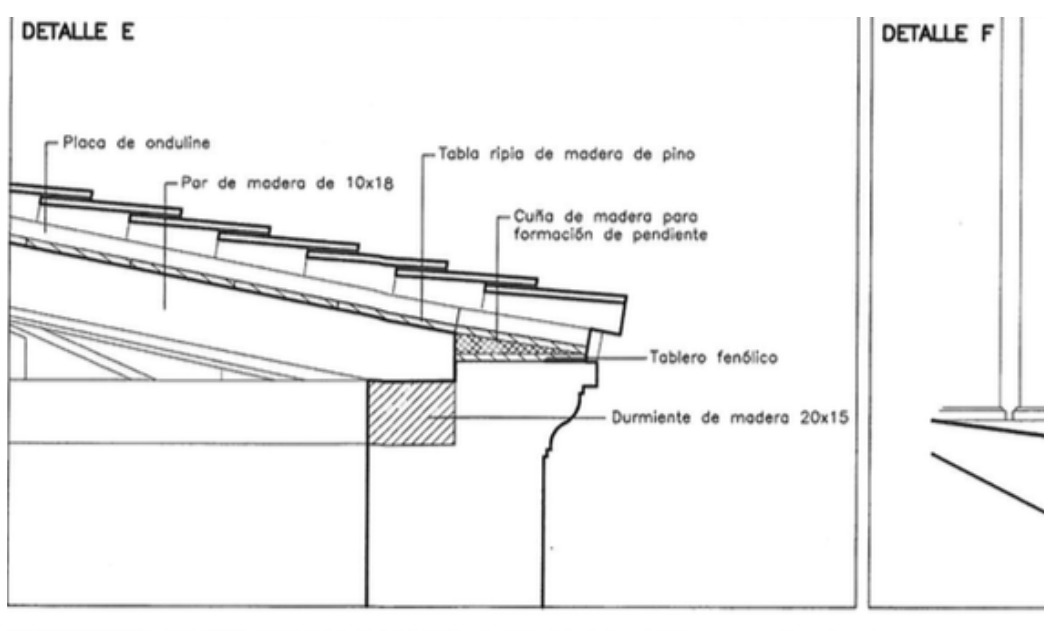

DETAUE C

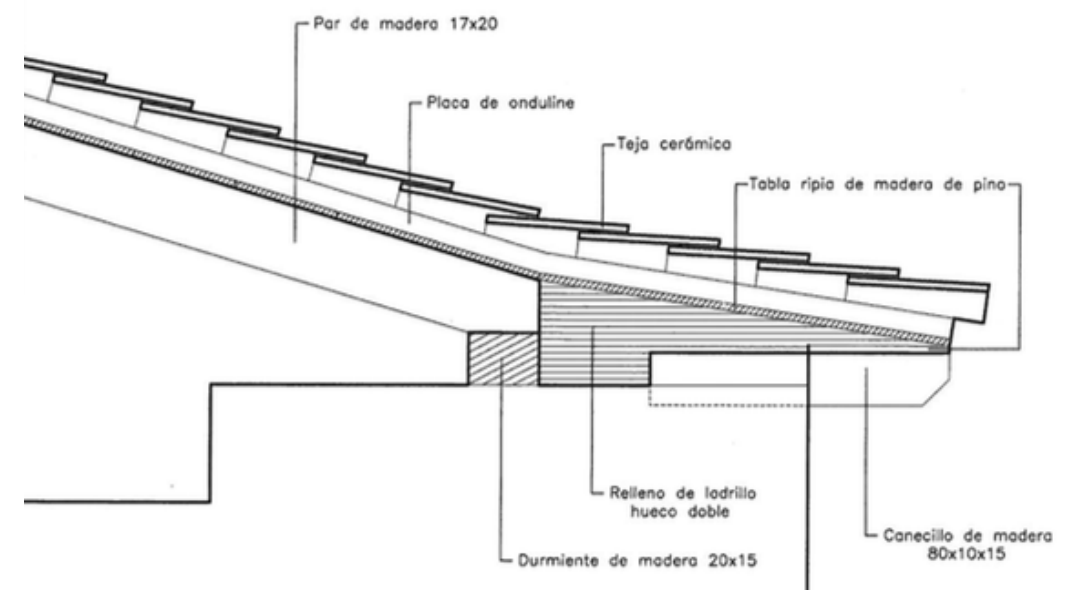

Ilustración 14: detalles aleros 2000 Montoya y Horno JCyL

\section{Conclusiones}

En este edificio no se han incorporado los típico zunchos perimetrales de hormigón armado. Se diseña en su lugar durmientes de madera corridos para recibir la nueva estructura de madera, que se dispone en 2000. Ambos durmientes se atirantan mediante tensores metálicos. 



\section{Iglesia de Santa María de Palazuelos*}

Intervenciones citadas en la publicación del Ministerio

1966 - Cubierta - Anselmo Arenillas Álvarez

* Aunque en la base de datos ANDREA del AGA aparece definido este edificio como una iglesia sita en Palazuelo de Vedija, al revisar el Proyecto de Arenillas de 1966 en su Memoria se especifica que se trata de la iglesia de Santa María de Palazuelos, resto único del Monasterio Cisterciense.

No se han localizado planos en la web del IPCE

\section{En el Archivo General de la Administración}

AGA 26/00206

Proyecto-Memoria de reparación de la cubierta de la iglesia de Santa María de Palazuelos

Madrid, 15 de diciembre de 1966. Anselmo Arenillas

El expediente es sólo 1 hoja mecanografiada a una cara.

"La iglesia de Santa María de PALAZUELOS, Monumento Nacional, catalogado con el $n^{\circ} 1.190$, es una iglesia, resto único del Monasterio Cisterciense que allí hubo; actualmente está alejada de los centros urbanos próximos y enclavada en la finca particular en que se convirtió el cenobio en la Desamortización.

Fué iniciada su construcción a principios del siglo XII y completada o reformada en el XVII.

Nuestro Servicio de Defensa del Patrimonio Artístico Nacional, reparó las cubiertas y restauró algunos muros de esta iglesia hace veinte años.

Actualmente su tejado se halla en malas condiciones, dá goteras y tiene algunos maderos de su armadura en mal estado, consecuencia de no haber sido atendido adecuadamente en estos años...

La superficie del tejado viene a ser de unos 800 a 1.000 metros cuadrados y por ello se cifra en 25.000 pesetas el importe de su reparación, es decir, reposición de la tabla en mal estado en algunos espacios, retejo de los sitios con goteras y repaso general del resto del tejado.

No se incluye croquis, ni datos gráficos, porque dada su situación en campo llano, no es posible conseguir fotografías del tejado, salvo desde muy lejos y esto sin detalle y en cuanto a plano general está reproducido en el catalogo de Monumentos en su pagina 357 del tomo tercero". 


\section{En el archivo de la Junta de Castilla y León}

\section{VA-30}

Carpeta 5222

1986 - Emergencia - Memoria firmada por el arquitecto Ignacio Represa.

Septiembre de 1986. Monasterio en Corcos

Empresa TRYCSA

Gran deterioro agravado por la entrada de saqueadores, con tres sepulcros profanados, uno despiezado.

La cubierta se encuentra en un lamentable estado: zonas de maderámen totalmente destruido, caballetes inexistentes, tejas rotas y removidas, acumulación de detritus de aves y presencia de arbustos...

Se proponen medidas protectoras contra saqueadores (ventanas, puertas blindadas) y para prevenir la entrada de agua: Colocación de placas transparentes en aquellas partes hundidas y sin tejas: en nave central y campanario. Reparación de cubierta, desmontando tejas y tablas, levantando machones de madera y reponiendo ripia $\mathrm{y}$ retejado: en capilla lateral izquierda y sacristía. Retirada de arbustos en cubierta de capilla lateral izquierda.

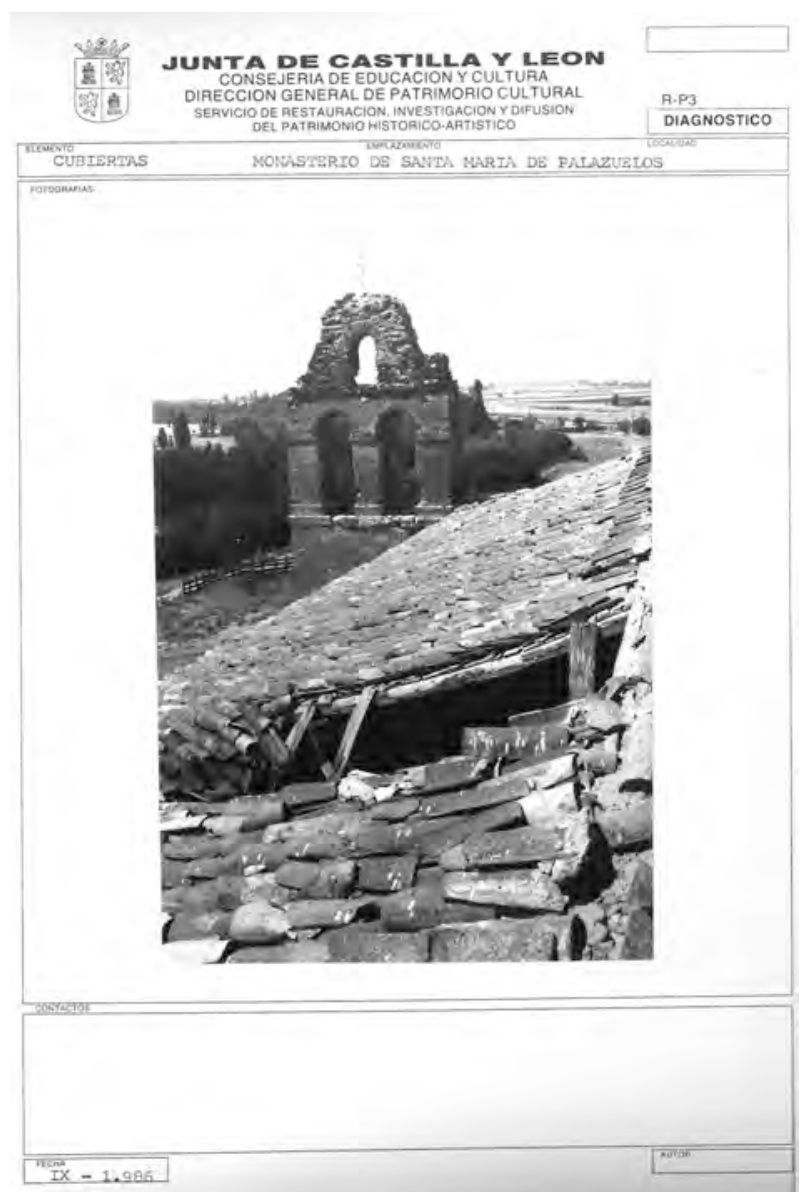

Ilustración 15: fotografía diagnóstico 1986 Represa JCyL

Datos históricos: fotocopias del libro "Monasterios medievales en la provincia de Valladolid", Antón 1942.

Dossier fotográfico muy amplio en blanco y negro del estado del edificio y los sepulcros expoliados. 
VA-386

2000 - Intervención de emergencia en la cubierta de la iglesia del monasterio de Santa María de Palazuelos - Ana Montoya García y José Manuel Horno Hernández Iglesia de tres naves sin acusarse el crucero en planta, con cabecera de capilla mayor poligonal, tramo anteabsidal y dos absidiolas semicirculares.

La cornisa es alero con borde cóncavo, sobre canes perfilados en nacela curva y aguzados en su frente.

La mitad de las naves fue rehecha hacia los pies en el siglo XVI, dotándole al tramo nuevo de ventanas cuadradas y alero moderno. El aparejo es grande, de sillares.

En la actualidad, la bóveda que cerraba en altura el crucero ha desaparecido al precipitarse la cubierta, arruinando pilares, muros, bóvedas del interior, y arrastrando capiteles.

Del antiguo Monasterio sólo queda la iglesia de grandes dimensiones construida en piedra en a primera mitad del siglo XIII, el altar mayor se consagra en 1226. En el XVI se construye la espadaña.

La iglesia está sin uso y cerrada. Su situación es preocupante. La envergadura del volumen de la primera espadaña de piedra existente en esta parte, al desplomarse sobre la cubierta provocó el impacto por colapso de la misma. Al caer arrastró bóvedas, arcos y pilares de esa zona.

Actualmente, la propia cubierta del edificio es su mayor enemigo, provocando filtraciones y acumulación de agua en puntos concretos que aceleren el desplome de la cubierta sobre las bóvedas.

Tras la demolición de elementos inestables, el desescombro y montaje de andamios y apeos:

Ejecución de una estructura primaria para cerrar el borde de los muros en la zona del crucero y apoyar la nueva estructura de cubierta. Serán dos vigas cruzadas de madera laminada de sección variable, como aparece en plano y diseñada en obra.

Desmontaje por tramos de toda la cubierta del inmueble...

Montaje de una nueva estructura de cubierta, con similares elementos a los existentes. Se sustituirá completamente. Al desmontar se observará y analizará detenidamente el estado real de todas las piezas y se decidirá en obra si puede aprovecharse algún elemento. 
La estructura será un entramado de cerchas de madera a diseñar en obra. Sobre las cerchas se colocarán correas igualmente de madera.

Sobre la estructura se colocará tabla nueva, sobre ésta, planchas tipo "onduline", y sobre ellas, el elemento de cobertura de remate, que será teja cerámica curva tipo árabe.

Se cerrará con un pie de ladrillo hueco doble y acabado con revoco de mortero de cemento la parte de los muros que se arruinó...

Se repondrán los bordes de aleros y cornisas que por su estado o por el deterioro sufrido durante la ejecución de la obra puedan quedar en condiciones de inseguridad con riesgo de desprendimiento y caída.

Cosido de grietas longitudinales de arcos y bóvedas en los tramos del siglo XVI.

Dossier fotocopias de fotos.

Presupuesto:

$1551,86 \mathrm{~m} 2$ entramado de cerchas de madera de $2^{\mathrm{a}}$ con secciones de 4x9" y 6x9", correas y durmientes para luces de hasta $8 \mathrm{~m}$, medios auxiliares y elementos de seguridad

12,12m3 jácena de madera laminada de sección variable i/nivelación y colocación de los elementos de atado y refuerzo. Incluido tratamiento para exteriores.

$1 \times 17,0 \times 0,15 \times 1,50 ; 2 \times 7,0 \times 0,15 \times 0,70 ; 2 \times 10,0 \times 0,15 \times 1,0$

\section{Memoria final}

El criterio de intervención... ejecutar los trabajos imprescindibles para mantener en pie el edificio. El propósito era que ni la intervención general ni las intervenciones parciales resultaran irreversibles.

Memoria histórica.

En 1832 se celebró el último capítulo en el monasterio y se produjo la enajenación... junio de 1888 nos describen como la ruina avanzaba ya en la iglesia del monasterio a finales del siglo XIX.

La gran diferencia de altura entre la nave central y las laterales permite abrir ventanas en la primera, detalle no muy frecuente en este tipo de arquitectura. Las naves se valoran $21,34,21$ pies (pies castellanos de valor $27,86 \mathrm{~cm}$ ). La altura de bóvedas es de 48 pies. Las bóvedas de la nave central tienen 55 pies de altura.

Se cree que fue hacia 1580 cuando se produjo el hundimiento de las bóvedas de las primeras capillas de los pies del templo. La orden encargó entonces al arquitecto 
Juan de Nates la reconstrucción de las partes hundidas. Da las trazas para levantar cuatro pilares y nueve capillas el 8 de febrero de 1585 ante escribano. Nates se muestra como un consumado maestro en la ejecución de todas las partes de la obra y particularmente en la de estas bóvedas (baídas utilizadas en las naves laterales) por la dificultad que su trazado encierra al ser su superficie un elipsoide circular.

Se ejecutó una cubierta de par e hilera con tirantes de tetracero, aproximadamente al doble de la distancia de los que existían en madera. La hilera, que recorre de este a oeste la iglesia tiene una escuadría de $15 \times 25$. los pares, de 20x15, van desde la hilera hasta los muros laterales de piedra apoyados en un durmiente continuo de madera de 20x15, que recorre toda la nave central. Previamente se niveló el apoyo de los muros laterales de piedra.

La estructura de cubierta quedó limpia, sin apoyos intermedios y de esta manera se despejó el bajocubierta de modo que ahora se puede circular libremente en su interior. Al llegar a la parte del crucero, no existía posibilidad de apoyo directo en los muros laterales y hubo que montar una estructura auxiliar de madera laminada para apoyar los pares. Entre cada dos pares, se atirantó la estructura con cable de tetracero a una altura que permitiera salvar la altura de las bóvedas.

Las vigas cruzadas apoyaban en un pilar, también de madera laminada.

En todo el perímetro del alero se colocó tablero hidrófugo sobre la cornisa existente para regularizar la superficie de apoyo del elemento de cobertura.

En la parte donde no existía cornisa, consecuencia del hundimiento, el tablero se apoyó sobre canes de madera de $14 \times 9 \mathrm{~cm}$, apoyados en cuna metálica... El refreno superior se formó con piezas trapezoidales a cuña de pino Soria cada $84 \mathrm{~cm}$ aproximadamente y con una sección máxima de 130x90mm. Onduline, dejando tejas de ventilación cada ciertas hiladas.

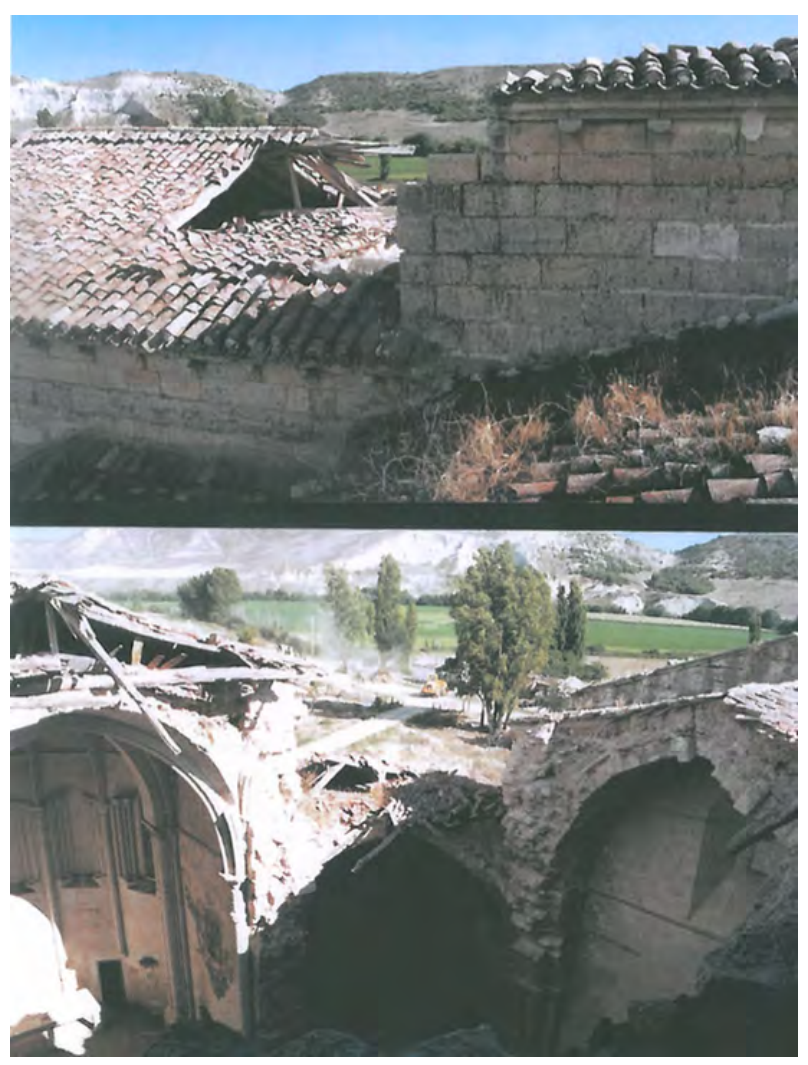

Ilustración 16: dossier 1986 Represa JCyL 
Memoria de cálculo.

Fichas de los sepulcros.

Dossier de fotografías.

VA-444

2001 - Restauración de los cuerpos bajos e intervenciones puntuales de recuperación de elementos - Ana Montoya y José Manuel Horno

VA-446

2014 - Escaneado y levantamiento 
Iglesia del convento de San Pablo

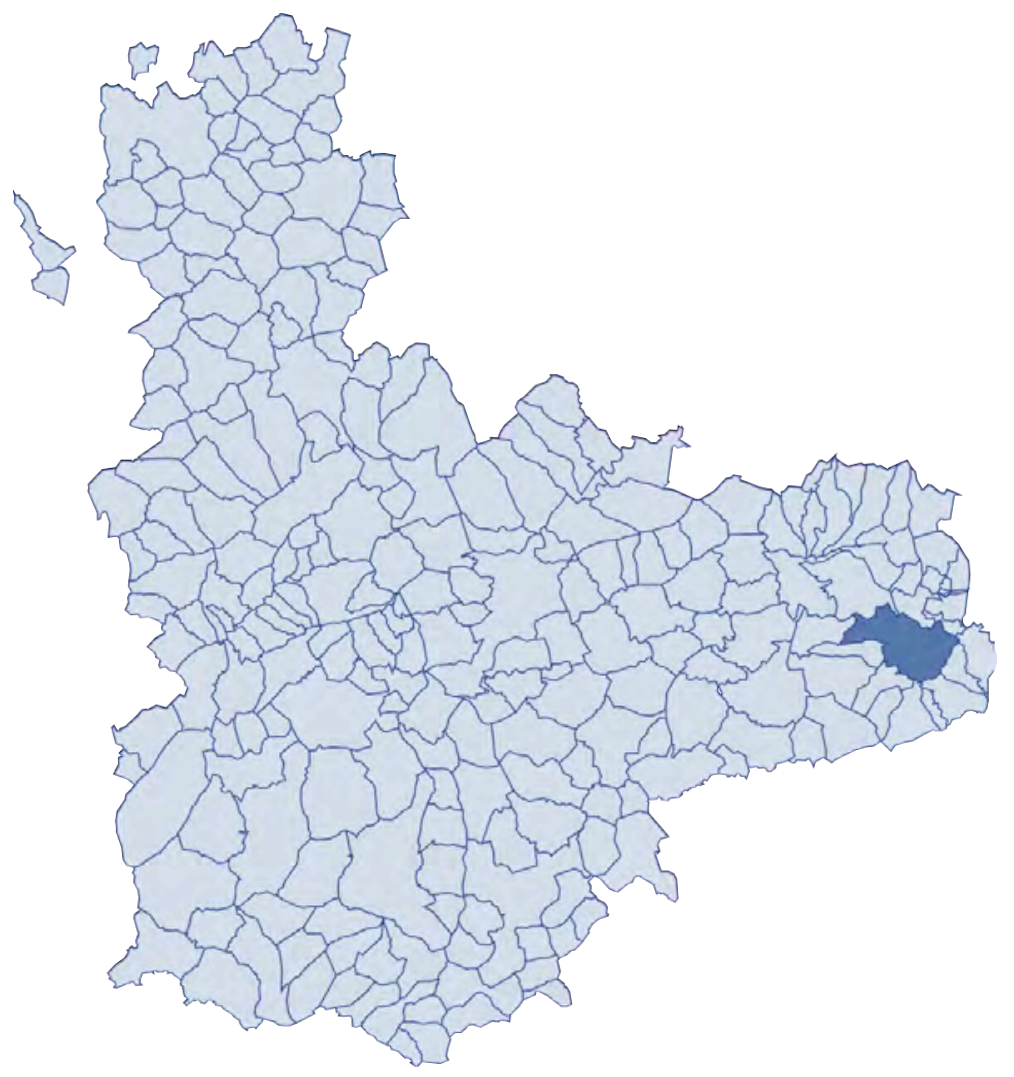



FICHA SÍNTESIS

\section{Código de identificación: FZ-33}

Denominación:

Iglesia del Convento de San Pablo

Localidad: Peñafiel

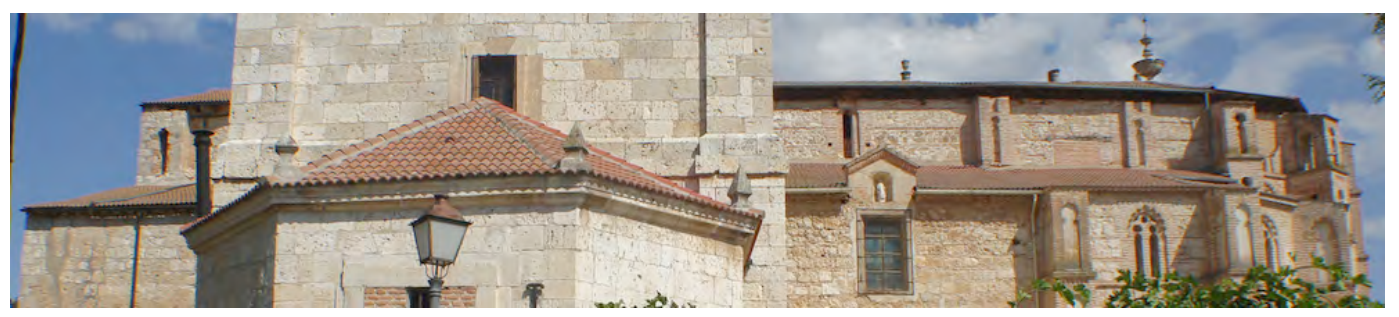

\section{Descripción}

Iglesia gótico-mudéjar de tres naves con cuatro tramos. La nave central llevó en origen una cubierta de madera sobre arcos diafragma apuntados apoyados sobre pilares, mientras que hoy se cubre con un falso techo de madera en forma de artesa. Las naves laterales se cierran mediante bóvedas de crucería y la sacristía con bóveda estrellada.

\section{Materiales}

Los muros del ábside son de fábrica de ladrillo visto con arquerías lobuladas sobre un potente zócalo de sillería. Las capillas adosadas son de piedra, mientras que el cuerpo alto de la nave muestra un mampuesto encintado entre verdugadas de ladrillo.

Las cubiertas están revestidas con tejas de hormigón.

\section{Singularidades}
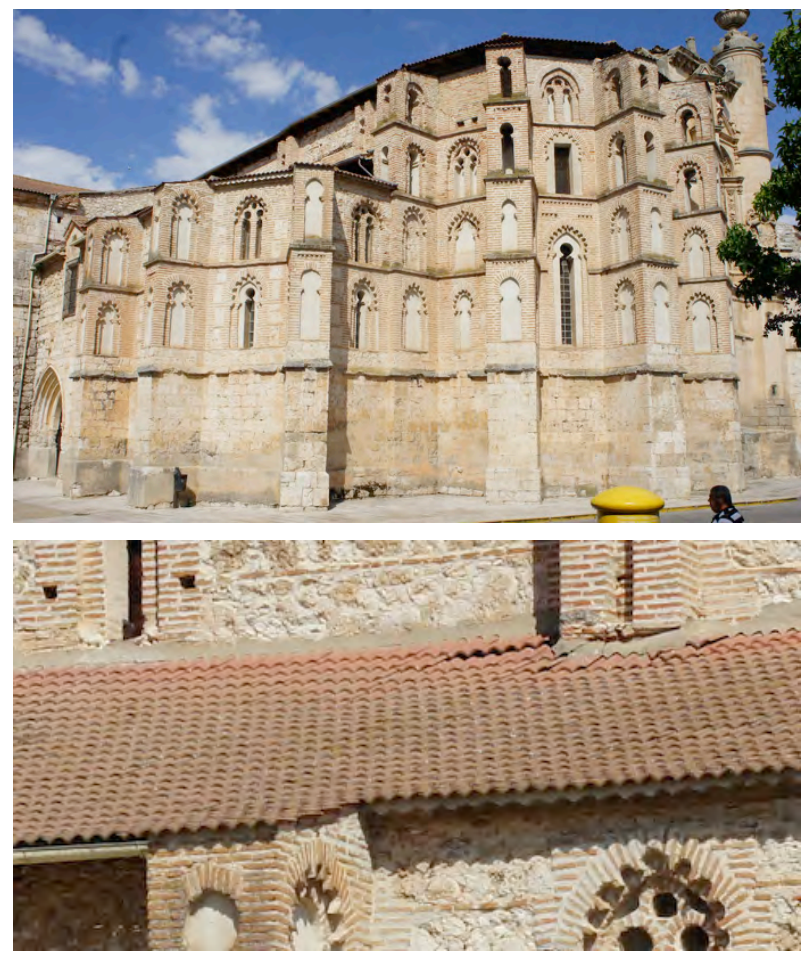

Ilustración 1: cabecera, visita 21/08/2015

Cuenta con un vistoso ábside

mudéjar con arcos de herradura y poli-lobulados escalonados. El ábside del Evangelio ha sido reemplazado por una gran capilla funeraria rectangular plateresca. El edificio se localiza en el casco urbano, con los pies del templo junto al borde exterior de un meandro del río Duratón. 


\section{Dimensiones básicas del templo}

$\begin{array}{lccc} & \text { central } & \text { laterales } & \text { capillas } \\ \text { Ancho de nave } & 7,8 & 5,8 & \\ \text { Altura } & 13,3 & \end{array}$

\section{Memoria histórica constructiva}

Según Araceli de la Torre ${ }^{1}$, fue fundada en 1324 como residencia de Padres Dominicos para albergar la tumba del Infante Don Juan Manuel. La cabecera corresponde a esta época. Un artesonado mudéjar de la nave central desapareció, seguramente a causa del incendio sufrido en 1398.

La escalera de piedra se construye en 1500 y la Capilla del Príncipe en 1536.

Según el Becerro en 1682 una noche se hundió la bóveda de la iglesia al haberse retirado por orden del prior unos pesos que tenía. Se reedifica en estilo clásico. Los dominicos levantan por detrás el camarín en 1720.

En 1749 hubo otro incendio devastador y se reconstruye el conjunto monástico bajo directrices del maestro Juan Francisco de la Peña. Según un informe del maestro Antonio Delgado para el rey en 1778, la techumbre de la iglesia, estribos, paredes y Capilla Real peligran.

El edificio fue saqueado durante la Guerra de la Independencia. El convento se abandona en 1836 por la Desamortización y en 1882 se cede a los Padres Pasionistas que aún lo gestionan.

\section{Cronología. Fechas clave}

$1324-1682-1749-1836$

\section{Intervenciones}

La Capilla de los Manuel se restauró en 2005.

1966 - Reparaciones en la iglesia de San Pablo de Peñafiel - Anselmo Arenillas Repara los remates de los seis contrafuertes mudéjares de ladrillo, también se lleva a cabo el rejuntado y reparación de las grietas de la fachada. Repone dos ventanales y restaura la capilla del infante Don Juan Manuel.

\footnotetext{
${ }^{1}$ De la Torre Yubero, A. (2009). San Juan y San Pablo en Peñafiel. ARGAYA Revista de Cultura, (39).
} 
1993 - Restauración: Fase I - Álvaro Abad Cabrera

Se actúa en varias zonas del conjunto monástico, como refectorio y claustro.

En el proyecto se prevé el recalzo de la cimentación del muro testero a los pies, dañado por la proximidad del río, sobre el que también se planea intervenir. Se diseña un atirantado con perfiles metálicos de la parte alta del muro.

Durante la visita no se aprecia señales del cosido ni de la intervención sobre el cauce.

El Padre Teodoro que guía durante el recorrido afirma que no se llevó a cabo la actuación descrita en esta zona.

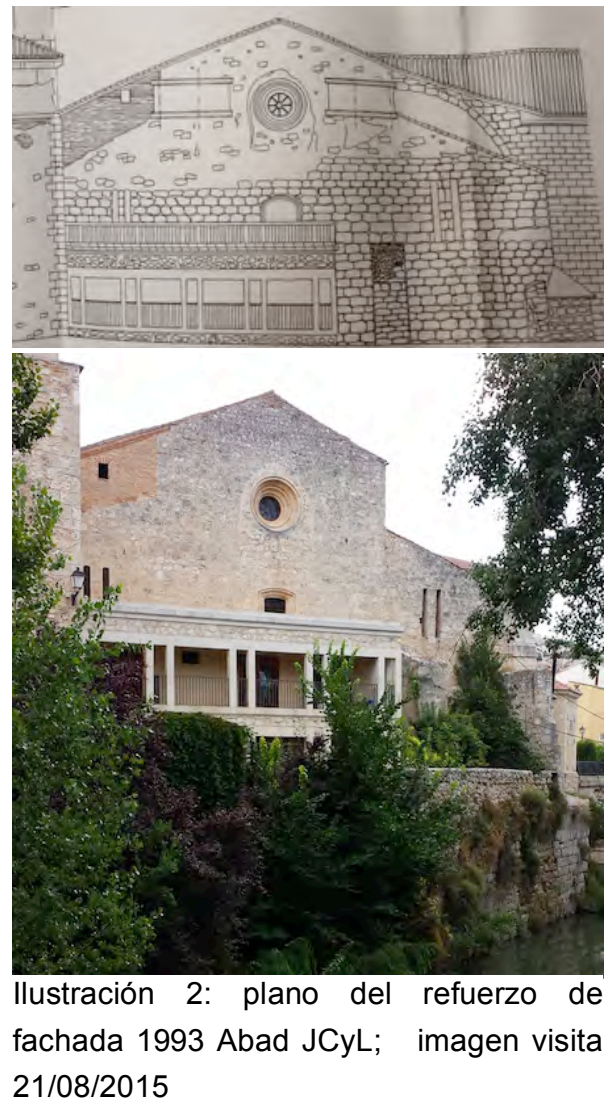

\section{Planos}

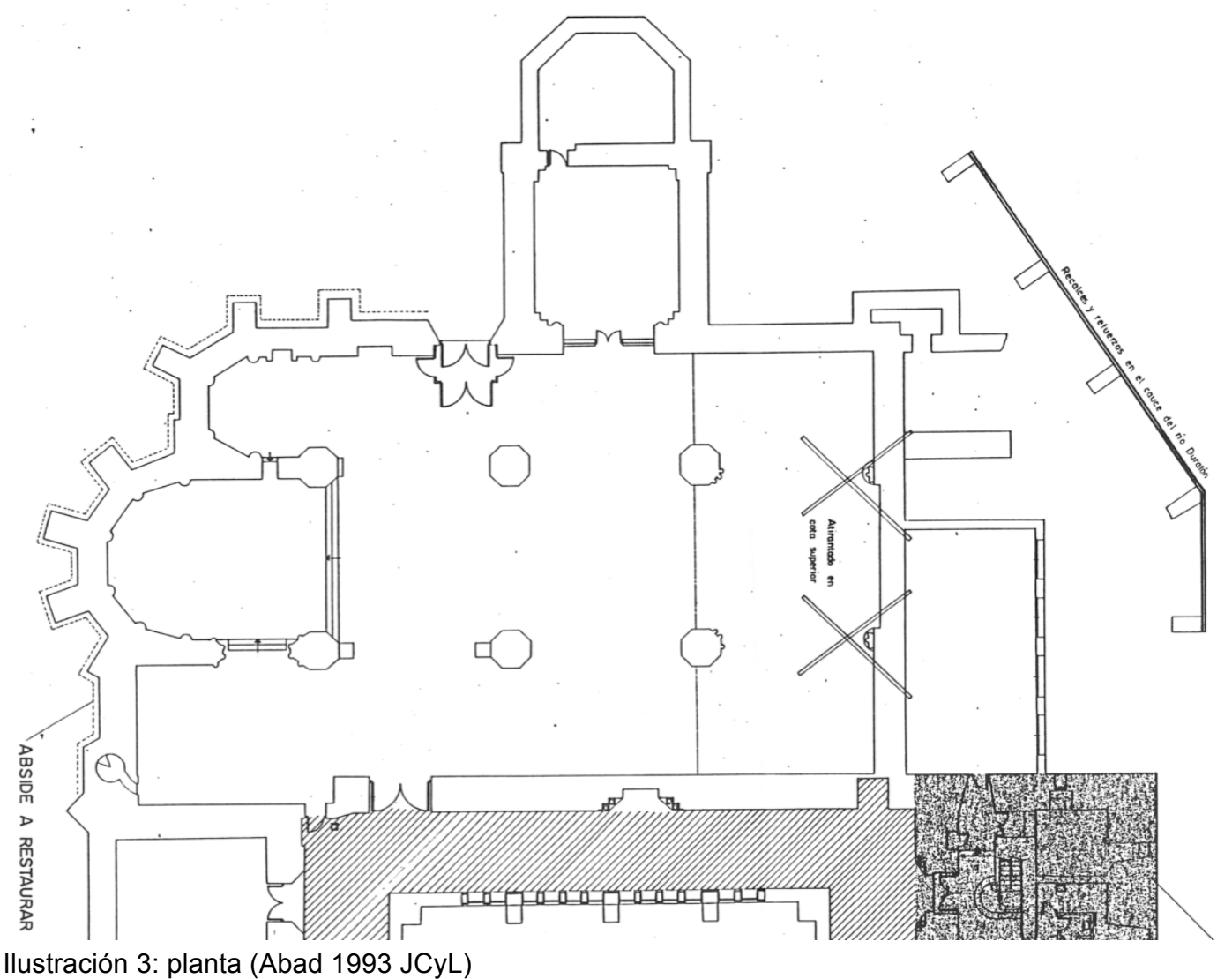




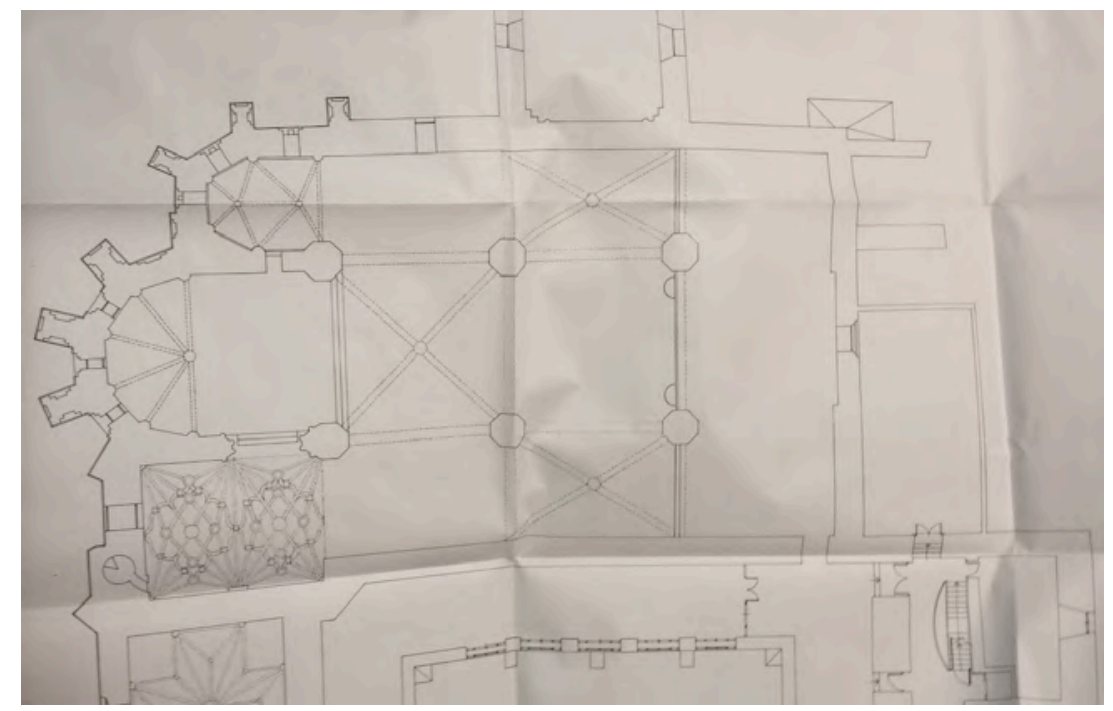

Ilustración 4: planta alta (Abad 1993 JCyL)

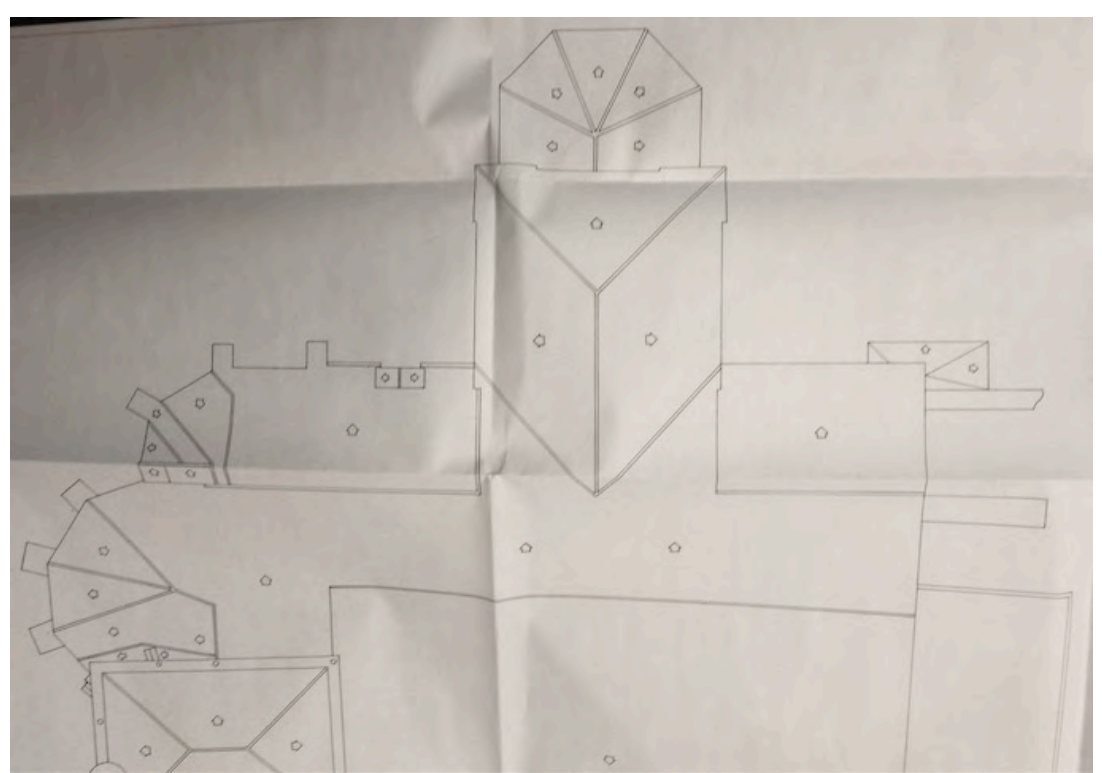

Ilustración 5: cubiertas (Abad 1993 JCyL)

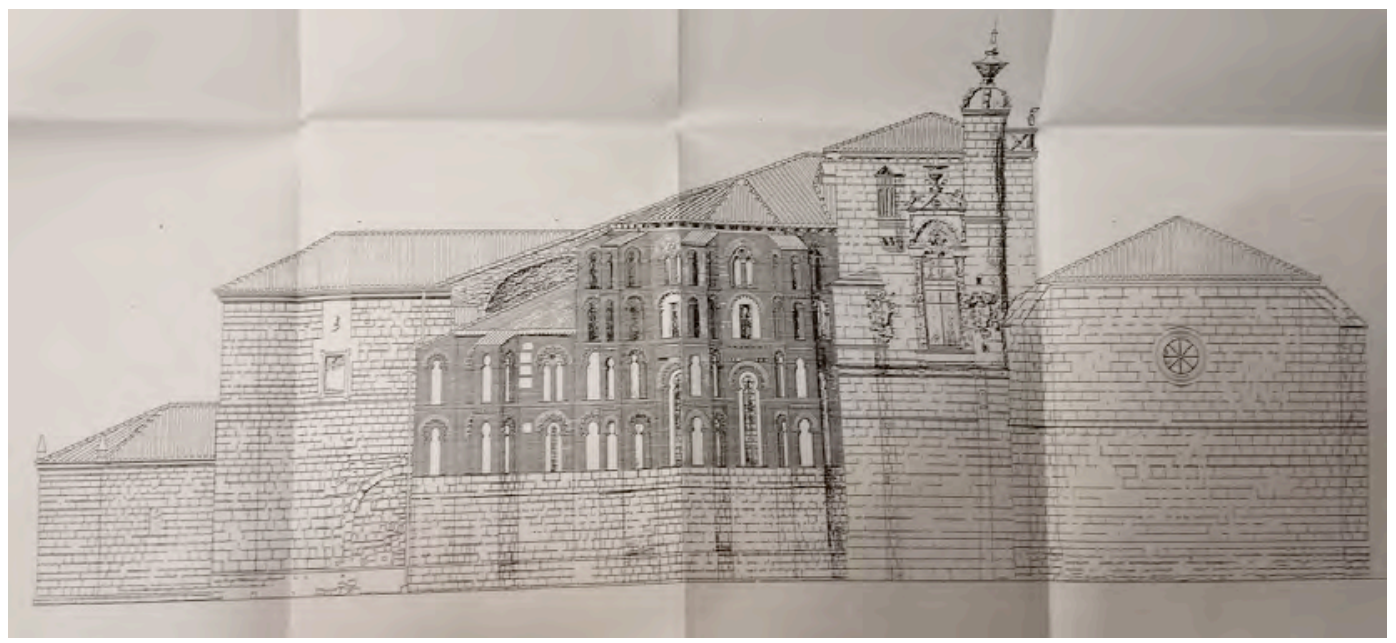

Ilustración 6: alzado de cabecera (Abad 1993 JCyL) 


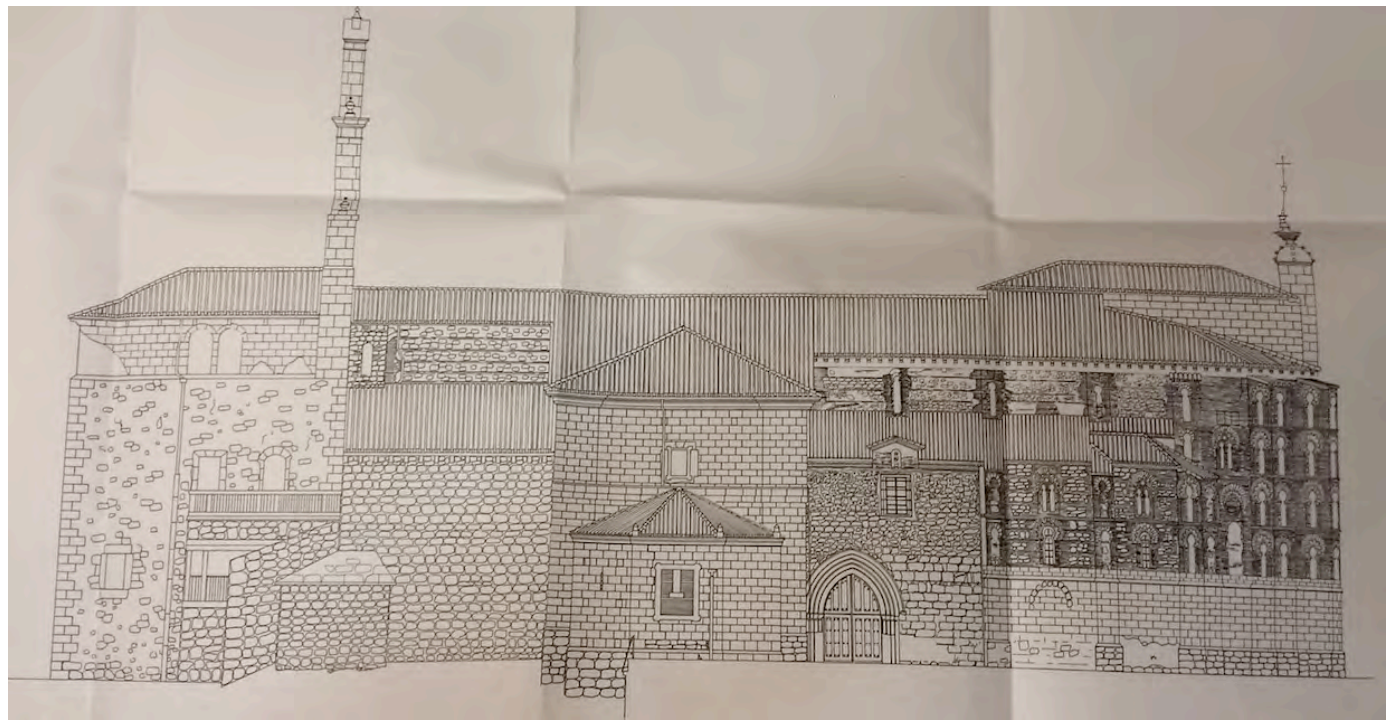

Ilustración 7: alzado lado de la epístola (Abad 1993 JCyL)

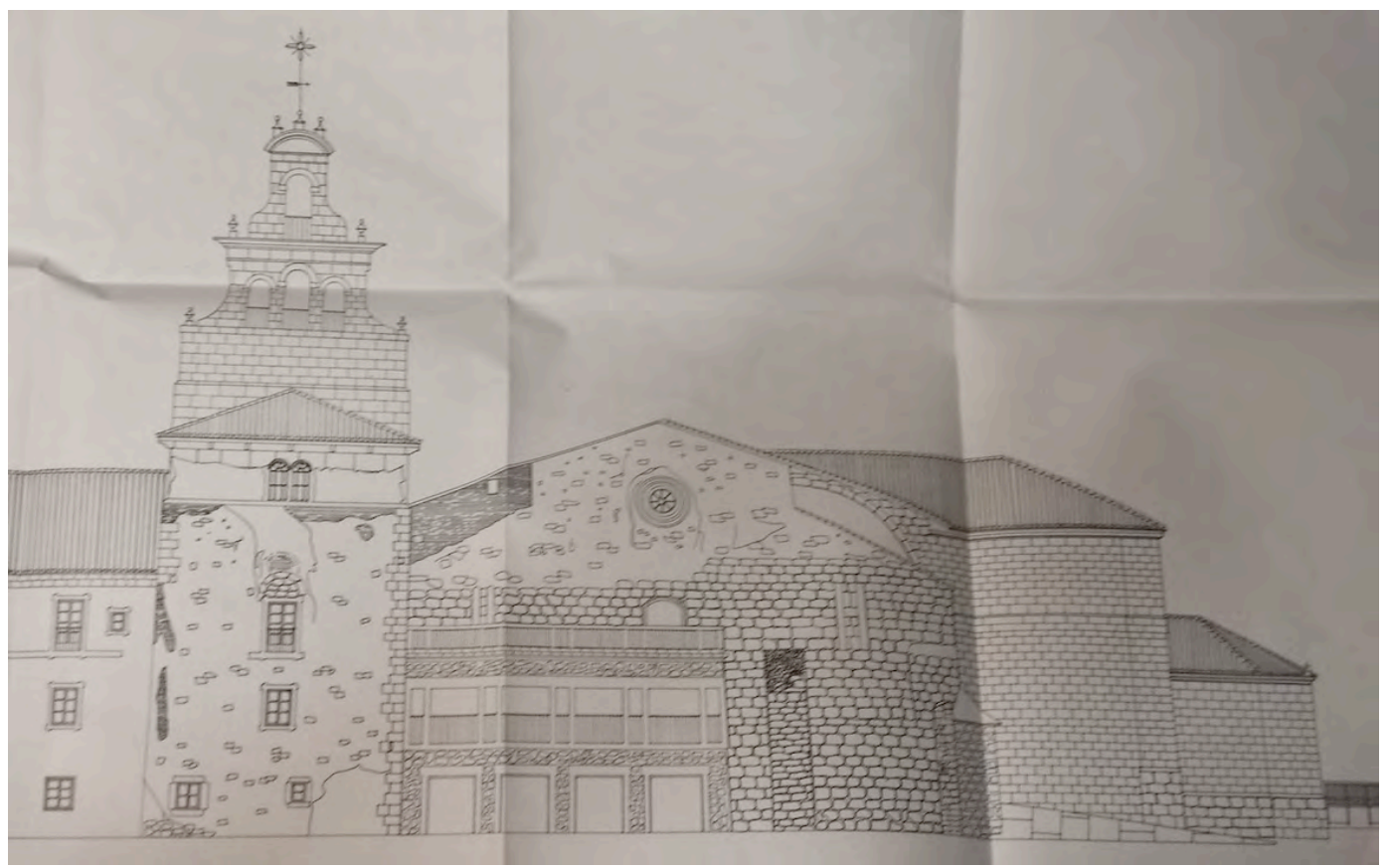

Ilustración 8: alzado a los pies (Abad 1993 JCyL)

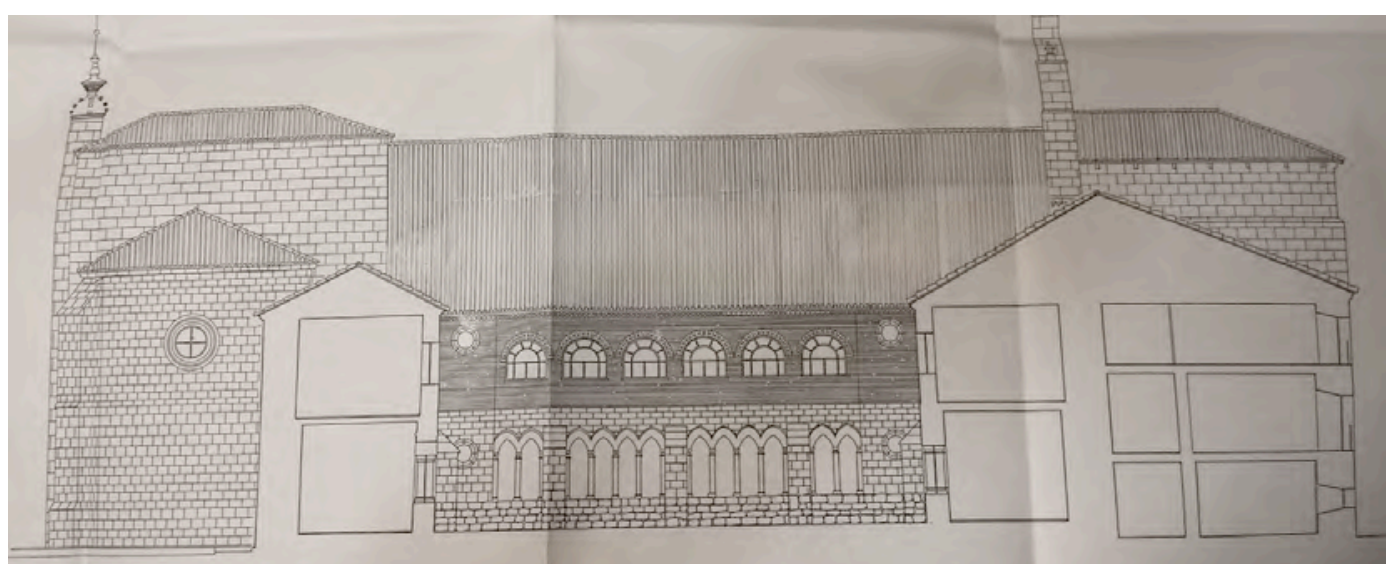

Ilustración 9: sección por el claustro lado del evangelio (Abad 1993 JCyL) 


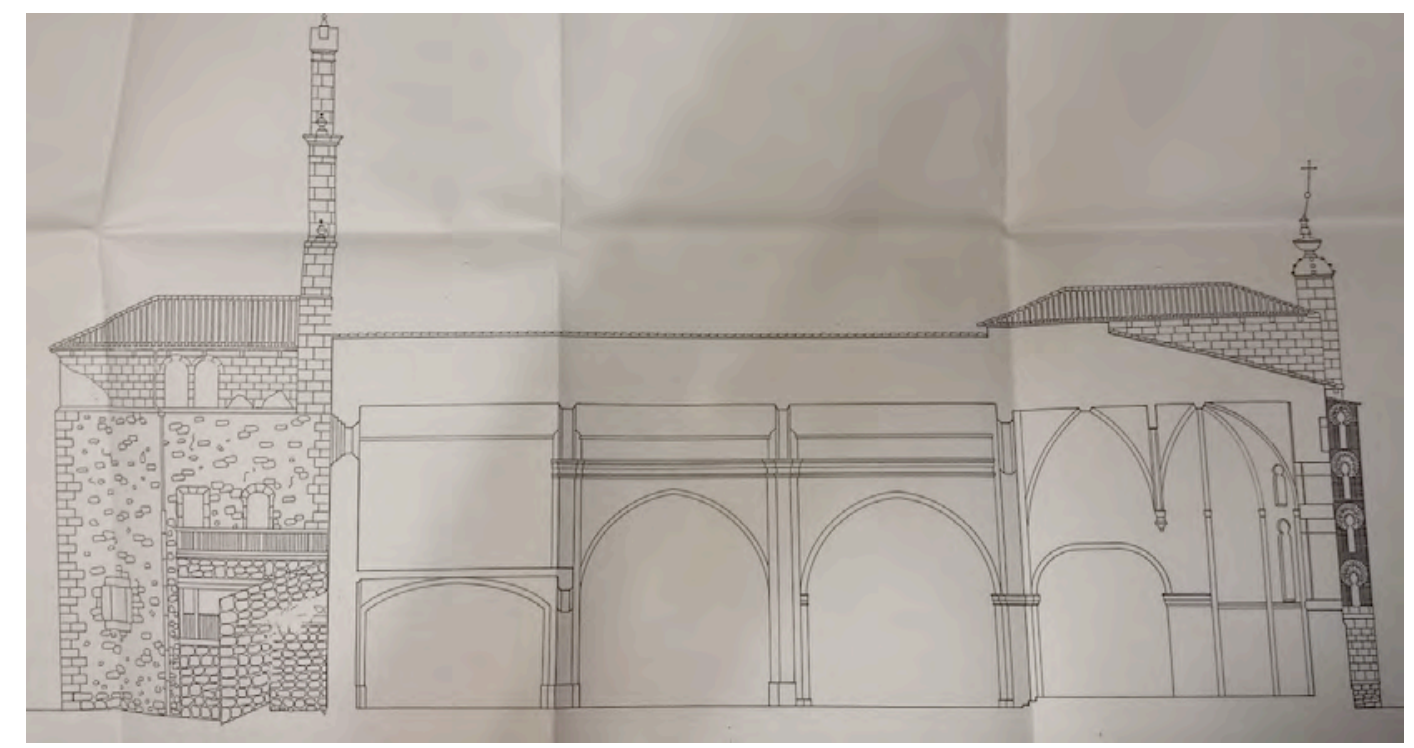

Ilustración 10: sección longitudinal del templo (Abad 1993 JCyL)

\section{Solución constructiva de la cubierta}

En los proyectos de 1966 y 1993 no se incluyen obras que afecten a la cubierta del templo. En la sección longitudinal de Abad no se detalla el corte del espacio sobre las bóvedas y tampoco se cuenta con una sección transversal del cuerpo de la iglesia.

La nave central se cubre con una armadura cuyos tirantes soportan un falso techo en forma de artesa.

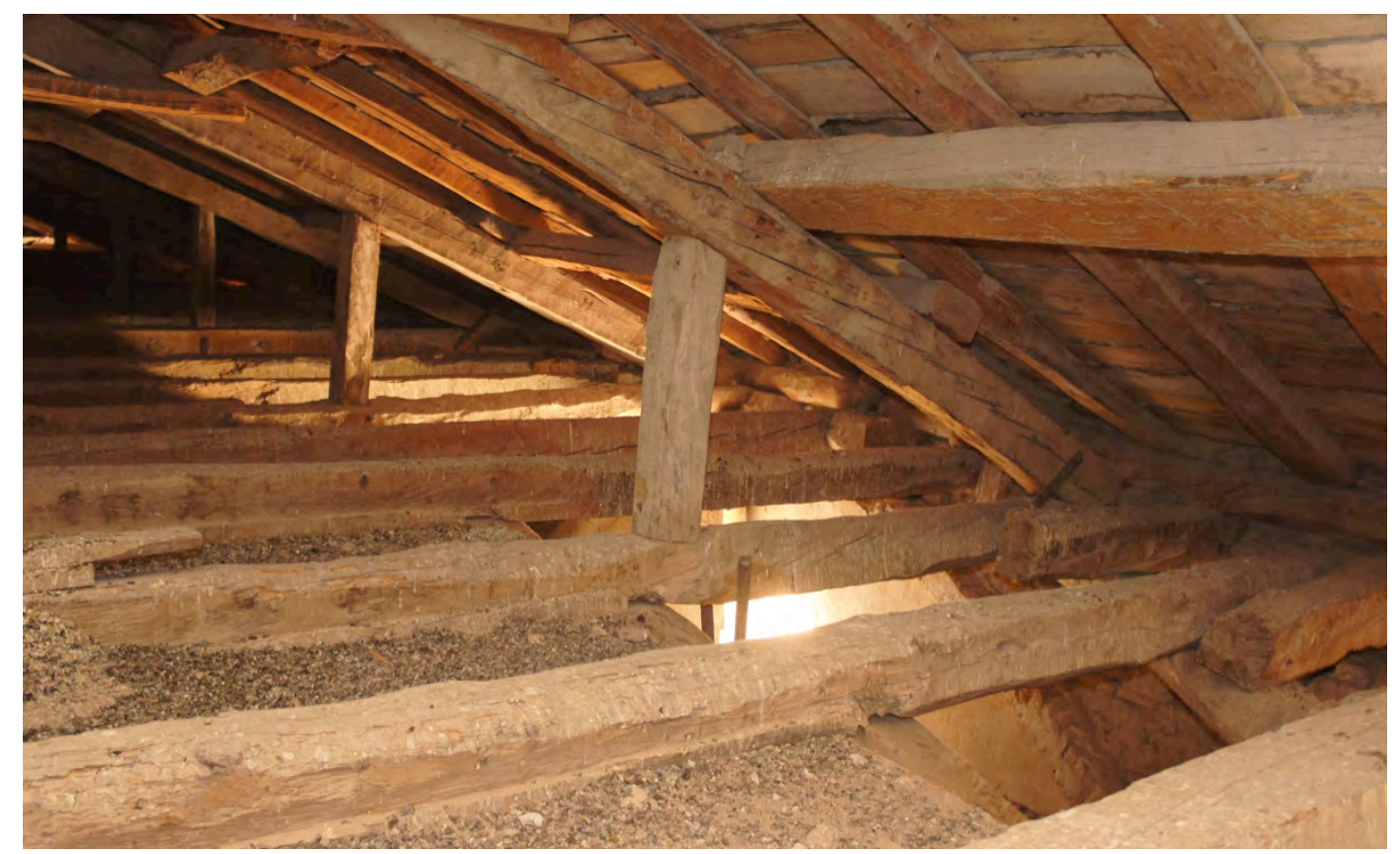

Ilustración 11: tramo horizontal central del falso techo cubierto de palomina y quiebro de la artesa. 
En el plano de fachada a los pies de Abad de 1993 se representa una pendiente de unos $18^{\circ}$.

Uno de los faldones a dos aguas de la cubierta de la nave central se prolonga sobre la nave lateral del evangelio y cubre una de las pandas del claustro. Por el lado de la epístola, sin embargo, la nave lateral se remata a cota más baja, dejando libres los huecos de ventana laterales de la nave central, excepto en el tramo de intersección con la sacristía.

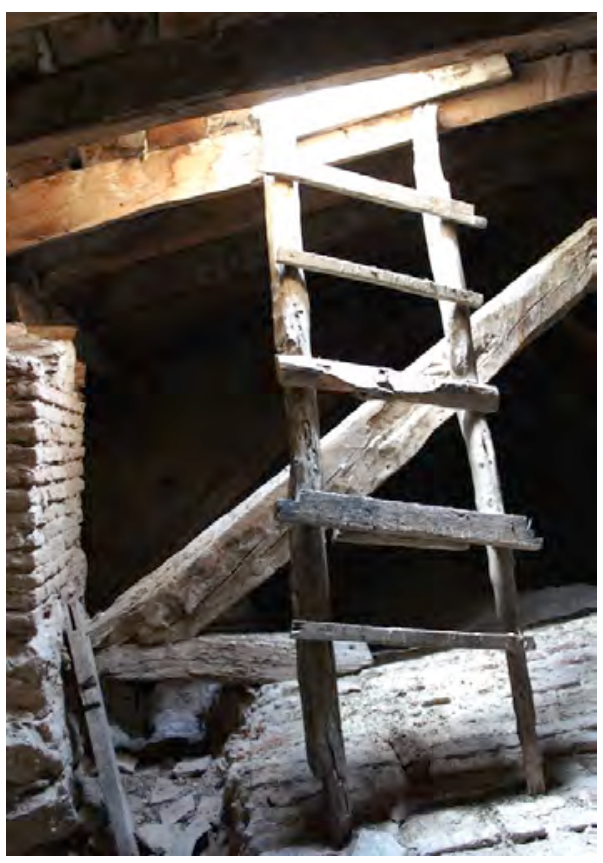

Ilustración 13: escalera visita 21/08/2015

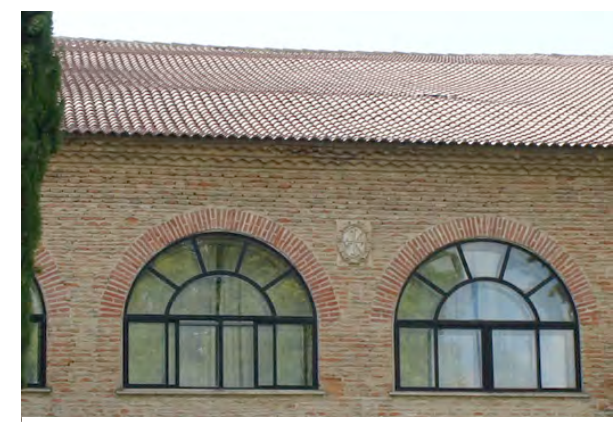

Ilustración 12: vista del faldón que cubre nave central, lateral y panda del claustro.

En el muro a los pies se aprecia claramente el cambio de material entre la fachada de piedra y el recrecido de fábrica de ladrillo que cierra el espacio bajo cubierta de la nave lateral del evangelio.

En ese espacio encontramos los arbotantes y dos niveles de cerchas, la actual peraltada sobre fábrica de ladrillo para permitir la prolongación del tablero sobre la panda, y otro sin uso, con mayor pendiente y apoyo sobre la fábrica de piedra, que en la imagen de la escalera de salida al exterior junto a estas líneas muestra los restos de su tirante cortado descansando sobre el trasdós de la bóveda.

\section{Zunchos}

En las cubiertas de la iglesia no se ha localizado zunchos de hormigón, resolviéndose el apoyo de la estructura contra el muro de forma tradicional con nudillos, durmiente y estribo de madera.

Según se comenta en la visita en el conjunto monástico sí se ha incorporado zunchos de hormigón en zonas renovadas con estructura de madera laminada.

\section{Conclusiones}

En esta iglesia se mantiene la cubierta de madera y no se ha detectado la incorporación de zunchos. 



\section{Iglesia del Convento de San Pablo en Peñafiel}

Intervenciones citadas en la publicación del Ministerio:

1966 - Obras generales en la iglesia - Anselmo Arenillas Álvarez

No hay planos en la web del IPCE

\section{En el Archivo General de la Administración}

AGA 26/00206

Reparaciones en la iglesia de San Pablo de Peñafiel (Valladolid)

1966 Anselmo Arenillas Álvarez

Sólo contiene la Memoria (2 pag)

Tiene diversidad de estilos: fachada parte morisca, gótica y otra plateresca. Se propone reparar los remates de los seis contrafuertes mudéjares de ladrillo, rejuntar y taquear las grietas de esta fachada morisca y reponer los dos ventanales de la misma. También restaurar la capilla del infante Don Juan Manuel.

\section{En el archivo de la Junta de Castilla y León}

VA-162

Proyecto de Restauración Convento de San Pablo, Peñafiel

Arquitecto: Álvaro Abad Cabrera Julio de 1993

Sellos de entrada y aprobado 29-12-93

Incluye 46 planos

Intervenciones programadas fase I. Describe cómo el documento es un proyecto guía. La fase I comprende:

Intervención en el Claustro

Reparación de cubiertas del Refectorio

Recalce en cimentación a los pies de la iglesia, con el encauzamiento del río Duratón. Tratamiento de fisuras en las partes altas de los muros.

Restauración parcial del ábside de la iglesia en su cara exterior reponiendo albardillas y vierteaguas

Pequeña intervención en la terraza de la Capilla de D. Juan Manuel 


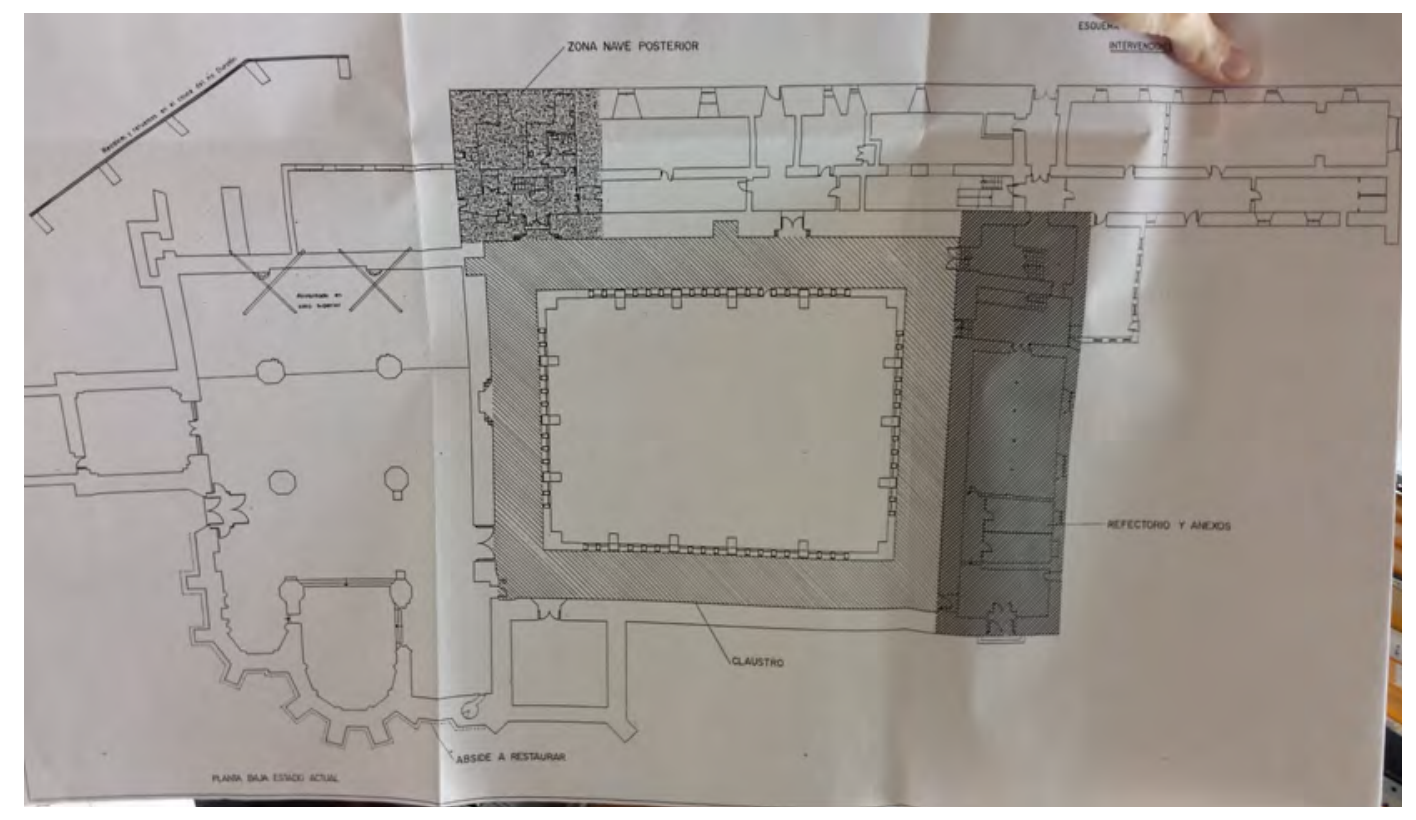

Ilustración 14: zonas de actuación (Abad 1993 JCyL)

Anexo dos hojas responde a informe de la Comisión del 18 de noviembre de 1993. Justifica que faltan detalles de estructura de cubierta, saneamiento, etc porque no se ejecutan en esta $1^{\text {a }}$ fase. El plano de cubiertas actual y reformada es el mismo porque no cambia diseño ni pendientes.

No coinciden alzados sureste 9 y 10 . Se precisa el ábside con más detalle.

Dice que adjunta documentación detalles de cornisas (pero no la veo)

El monasterio pertenece a la comunidad de padres Pasionistas y se utiliza como seminario menor (uso residencial y docente). Edificio románico-mudéjar ubicado en el casco urbano de Peñafiel. Iglesia fundada por Infante Don Juan Manuel. Primera piedra en 1324. Posible obra del maestro local Juan Picardo.

Arcos apuntados con ábside mudéjar típico toledano y acceso en el lado de la Epístola. Capilla funeraria plateresca. Iglesia de tres naves con cuatro tramos. Las naves laterales llevan bóvedas de crucería estrellada y la central tenía un artesonado que fue consumido por el fuego. Se reconstruyó un falso techo de madera en forma de artesa de escaso valor estético. Coro alto y espadaña de piedra de dos cuerpos a los pies.

\section{Patología:}

El edificio se localiza en el borde exterior de un meandro del río que ha ido erosionando la base del muro a los pies. Han aparecido grietas en la parte superior de los muros. Además hay humedades ascendentes. 
El ábside mudéjar sufre fuerte erosión, ausencia de morteros y disgregación de fábricas. La inexistencia de baberos, vierteaguas y canalones expone el ladrillo a los agentes meteorológicos. En muchos puntos del monasterio hay ausencia o deterioro de bajantes.

Ha habido un cedimiento de una cercha del refectorio. La cubierta se encuentra apuntalada provisionalmente.

Describe las obras a realizar en varias zonas del conjunto. En la iglesia:

Recalce de cimentación, con el encauzamiento del río, que evite la erosión en la base del edificio.

Cosido del muro de los pies de la iglesia, estableciendo en primer lugar unos testigos en las fisuras, que nos reflejen el posible movimiento de esta estructura. Para llevar a cabo este cosido, se desmontarán todas las cargas posibles antes de llevar a cabo el cosido y atirantado de esta fisura.

Presupuesto. Capítulos 1 a 12 claustro; 14 a 19 refectorio, 21 a 28 nave posterior, 34 capilla. El recalce y tratamiento de fisuras corresponde al capítulo 32. No incluye el 30, que indica m2 eliminación de tela en paramentos de ábside.

Demolición de $51 \mathrm{~m} 2$ de solera, excavación de zanjas $15 \times 4 \times 1,20$ y $80 \mathrm{~m} 3$ de hormigón en relleno de recalces. 



\section{Visitas realizadas}

$21 / 08 / 2015$

El conjunto tiene un uso residencial y docente gestionado por los Padres Pasionistas y cuenta con cierto nivel de mantenimiento.

La obra más reciente ha sido la reconstrucción del Camarín, cuya cubierta había sufrido un derrumbamiento.

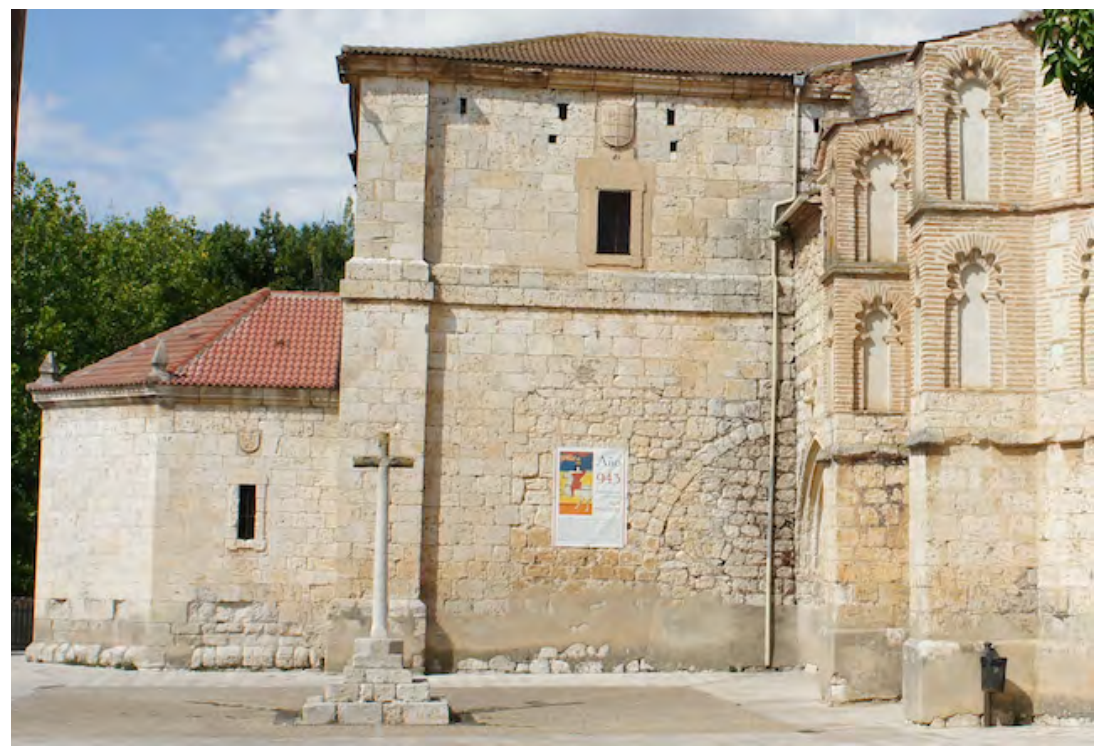

El forjado, paredes y suelos del claustro también parecen fruto de una restauración, aunque menos reciente, puesto que ya han aparecido algunas muestras de ensuciamiento.
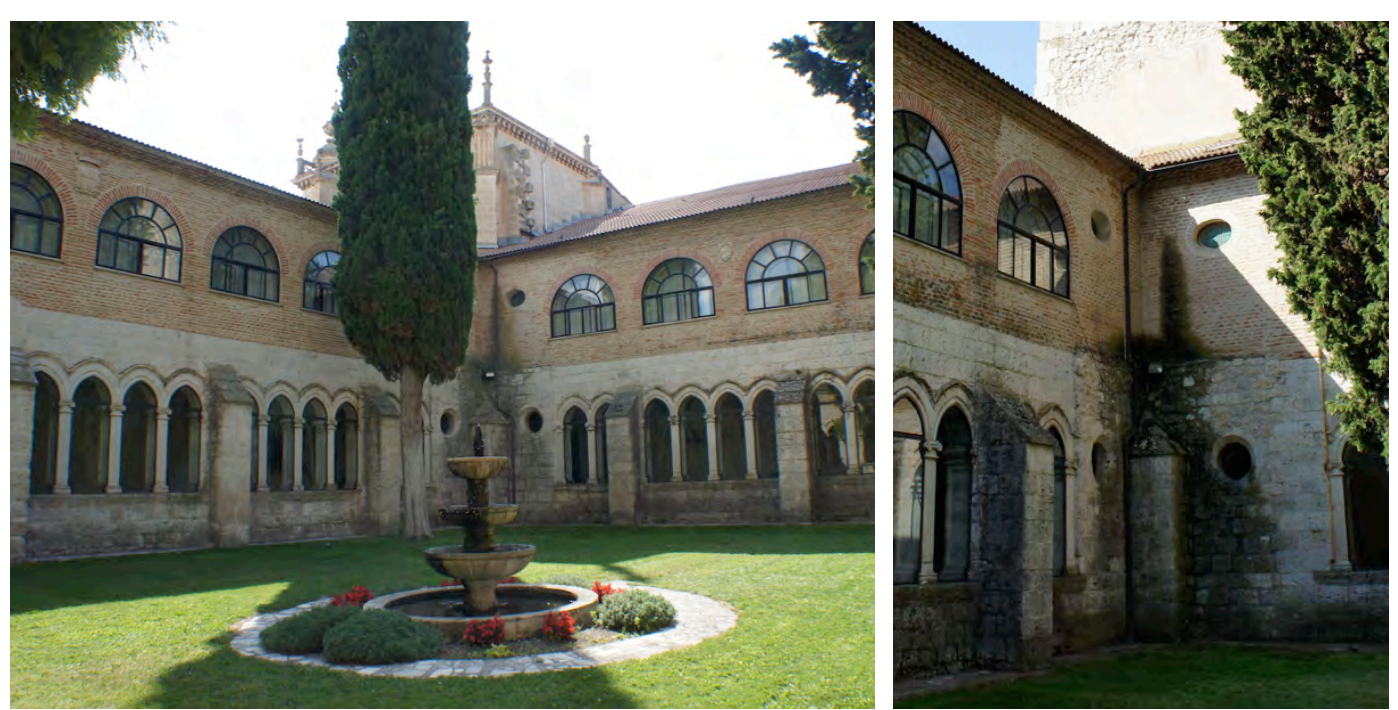

El acceso al espacio bajo cubierta del templo se realiza a través de su prolongación sobre las dependencias del Monasterio, donde se sitúan diversas instalaciones y conductos de acondicionamiento de aire. 

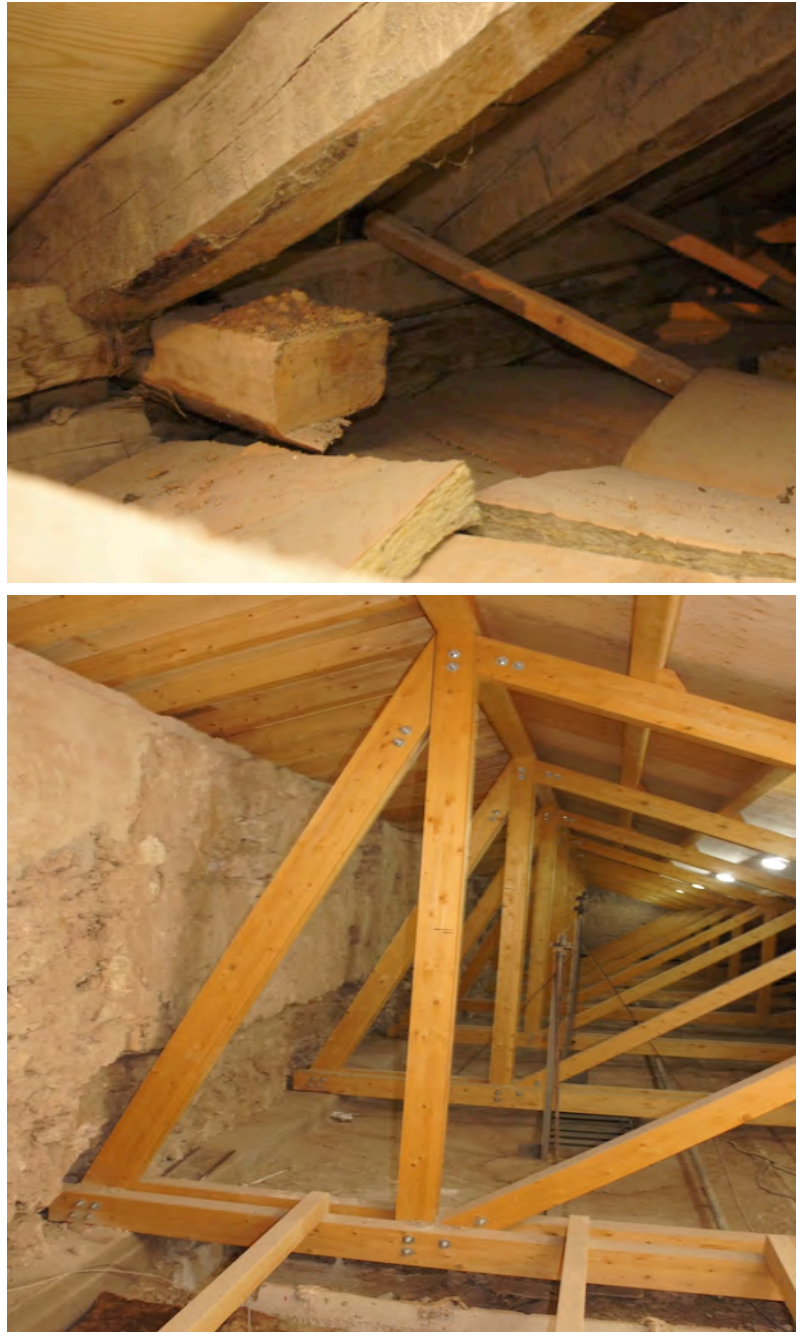

Sobre las bóvedas que cubren estancias habitadas encontramos extendidas planchas sueltas de material aislante, que dificultan el recorrido y la identificación de los espacios.

En general se mantiene la estructura de madera, aunque hay zonas donde se ha reemplazado por cerchas de madera laminada apoyadas sobre zuncho de hormigón armado.

En las zonas renovadas se ha instalado un sistema de iluminación.

En el resto de cubiertas conviven ambos materiales, con reemplazos locales de tirantes, correas y tablazón.

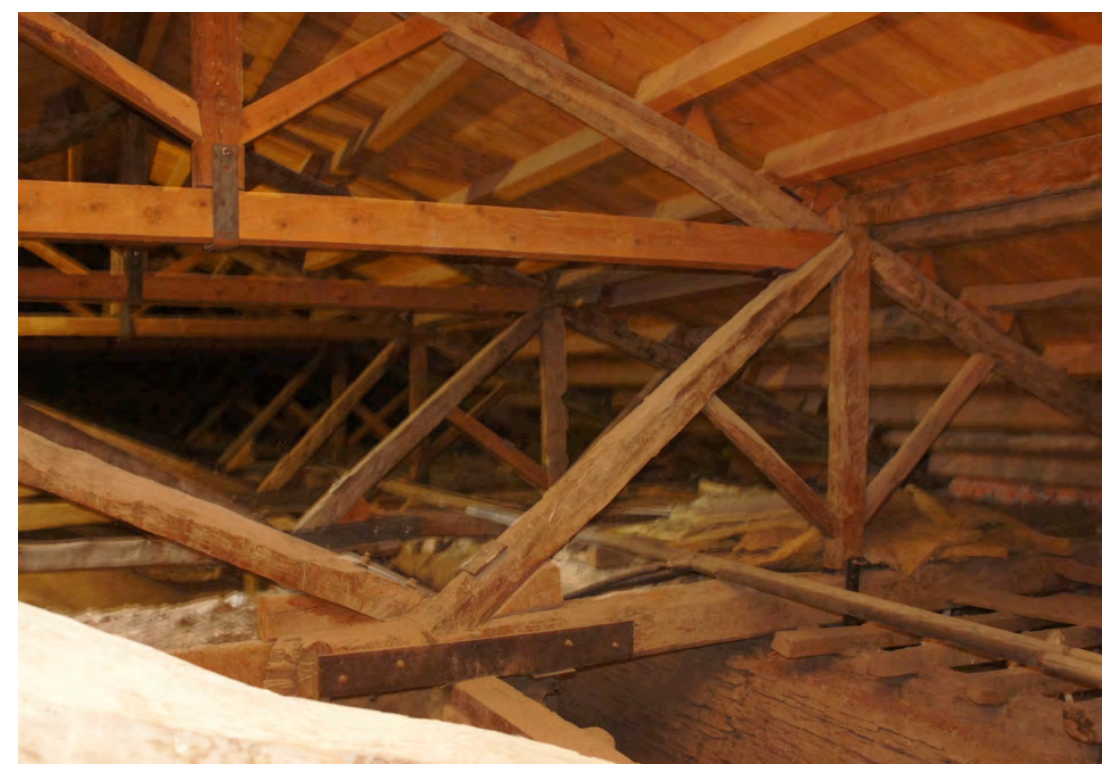

Una vez sobre el trasdós de las bóvedas de ladrillo que cubren la nave lateral a los pies, se aprecia la incorporación de acodalamientos de la armadura que acometen directamente contra el muro de mampuesto encintado y ladrillo de la nave central. 


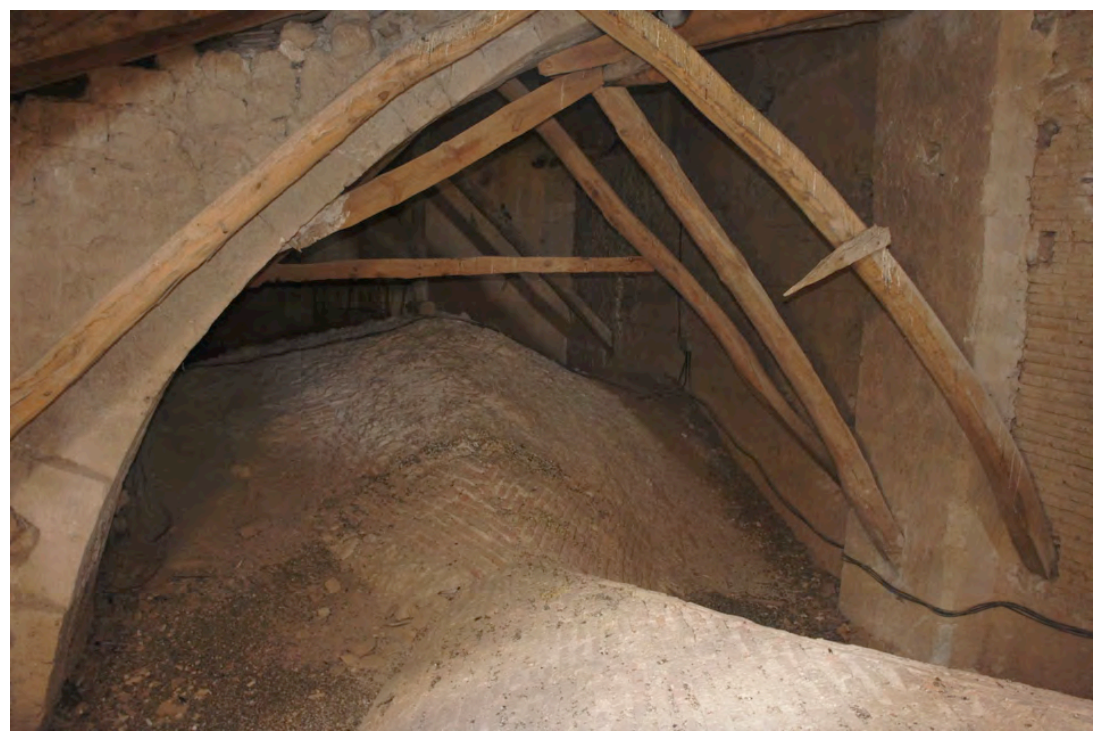

Ocultos bajo cubierta podemos apreciar los arbotantes de la nave del evangelio.

La nave central se cubre con un falso techo en forma de artesa.
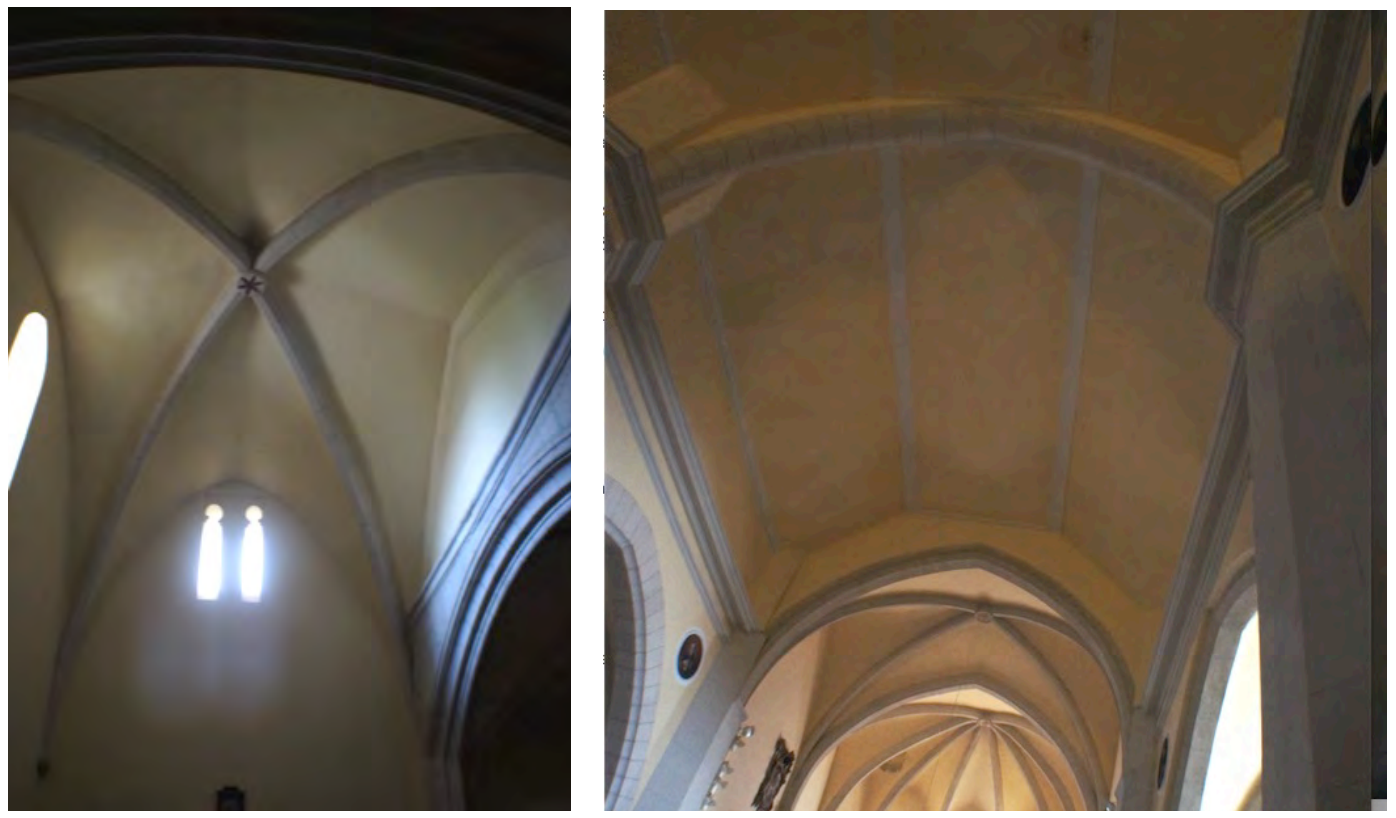

El trasdós de dicha techumbre se resuelve con tablas cosidas mediante cañizo y sujetas a la armadura de cubierta.

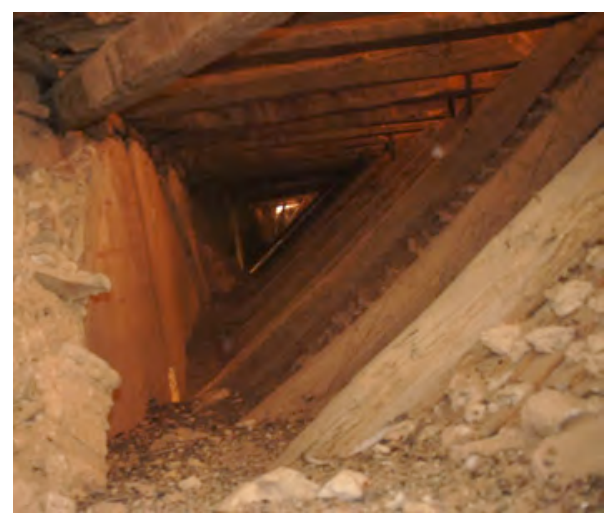

En la visita no se detecta incorporación de elementos modernos en esta zona del templo.

Las cerchas acometen al muro con una solución tradicional de estribo y durmiente de madera sobre nudillos. 

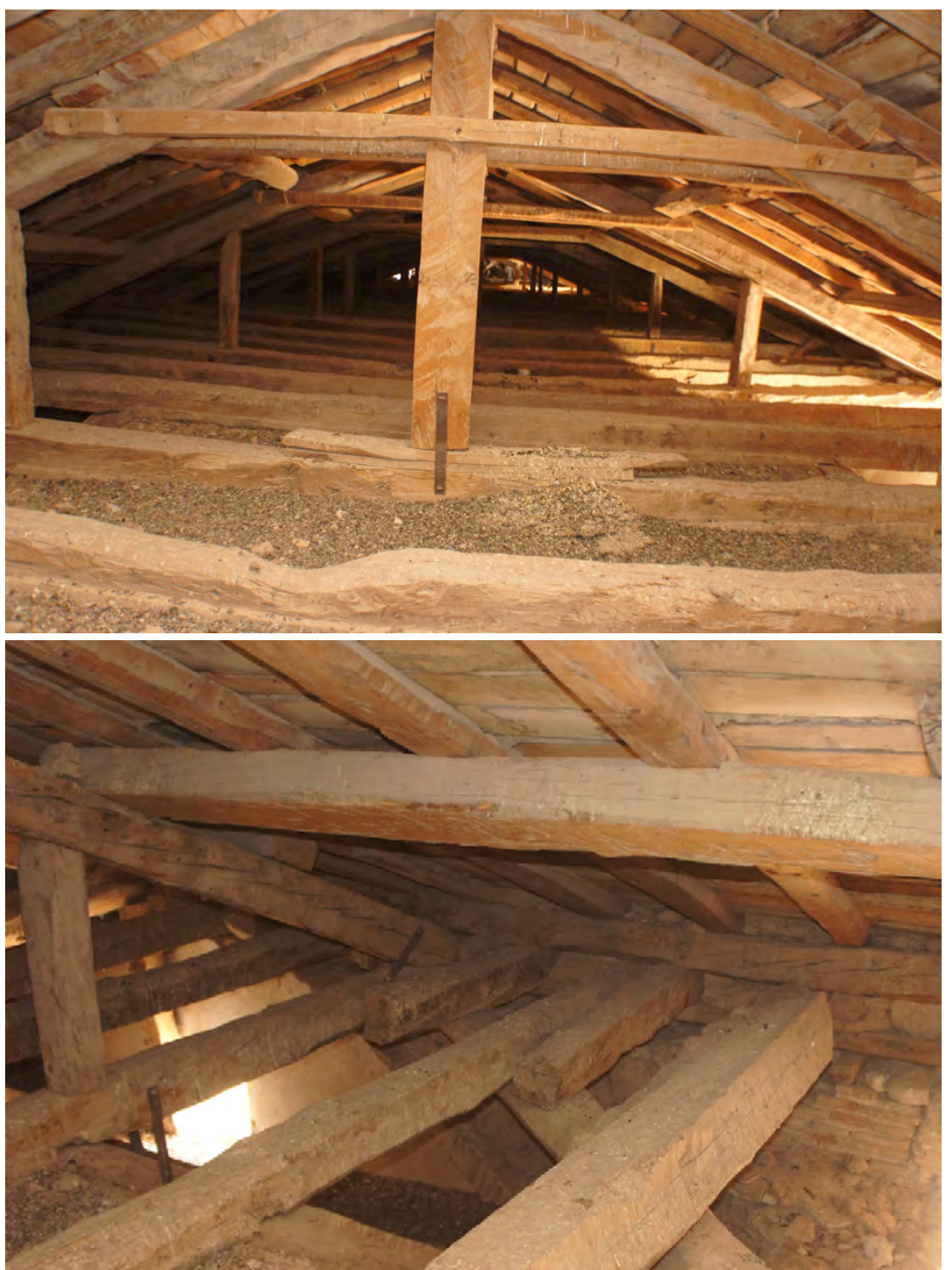

Hacia el exterior la cubierta de nave central y cabecera cuenta con un potente alero de madera.

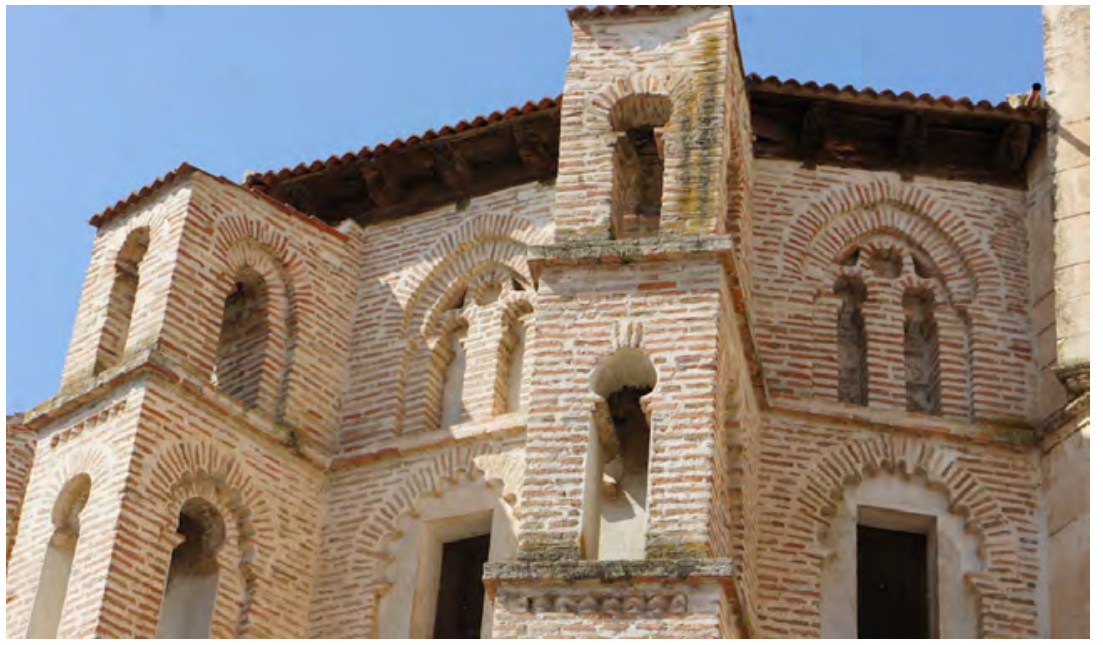

En algunas zonas se ha incorporado canalones, cazoletas y bajantes, por ejemplo en el lateral de la nave central para evitar la caída de agua sobre la nave lateral más baja de la epístola. Ésta se remata con cornisa de ladrillo. 


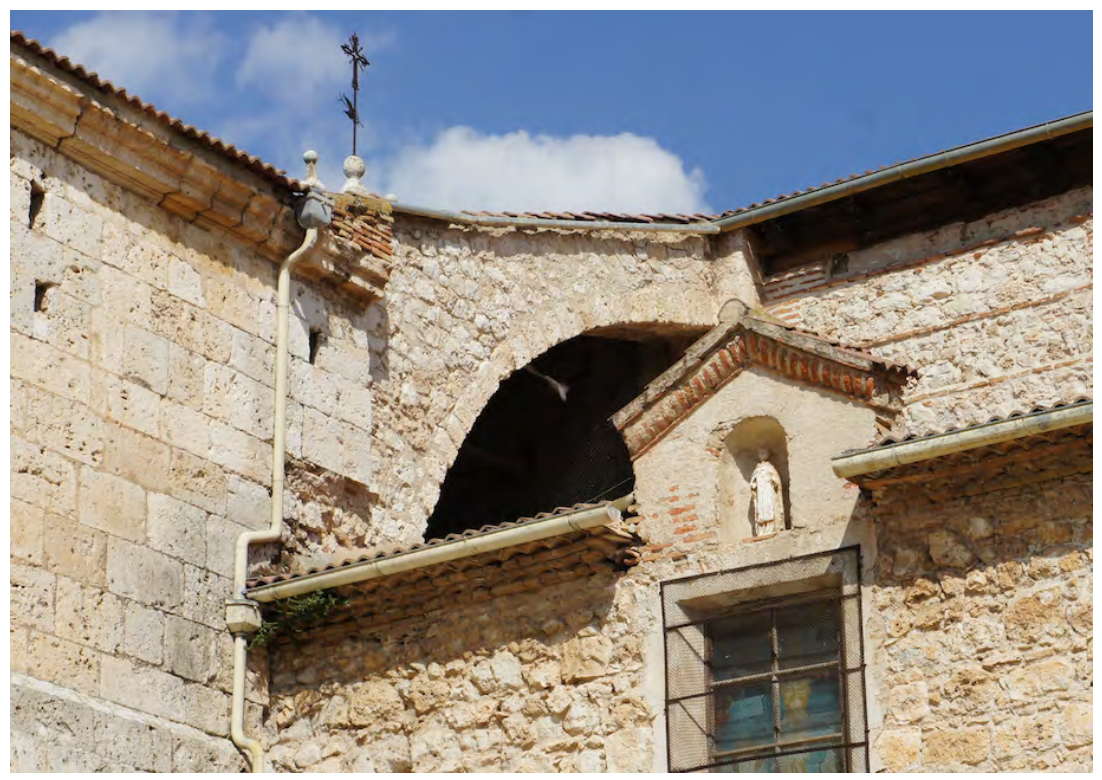

Por último, en la fachada a los pies no se aprecian señales de la intervención de cosido recogida en los planos del proyecto de Abad de 1993.

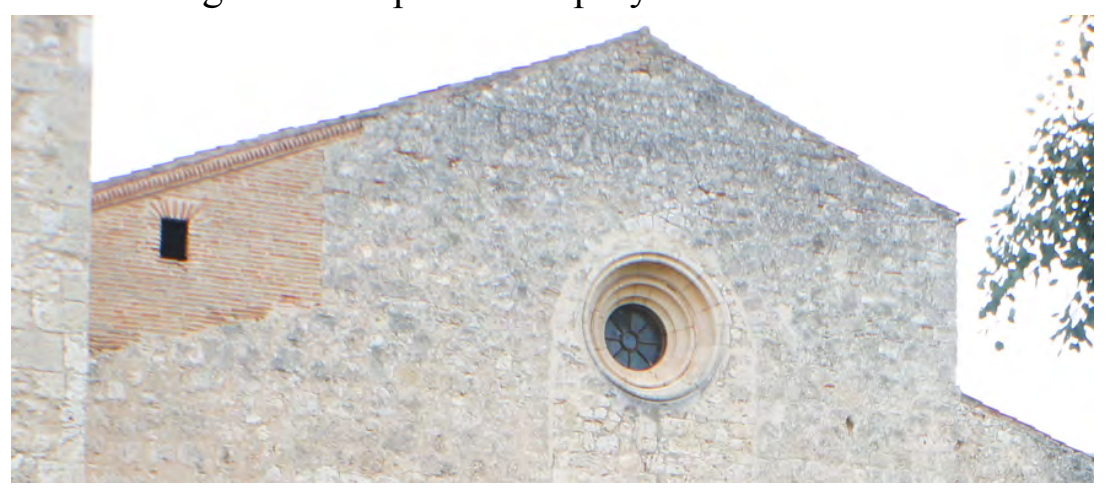

Desde el bajo cubierta de nave lateral puede apreciarse una grieta en el muro del evangelio de la nave central, hacia los pies, que muestra una serie de testigos en buen estado.

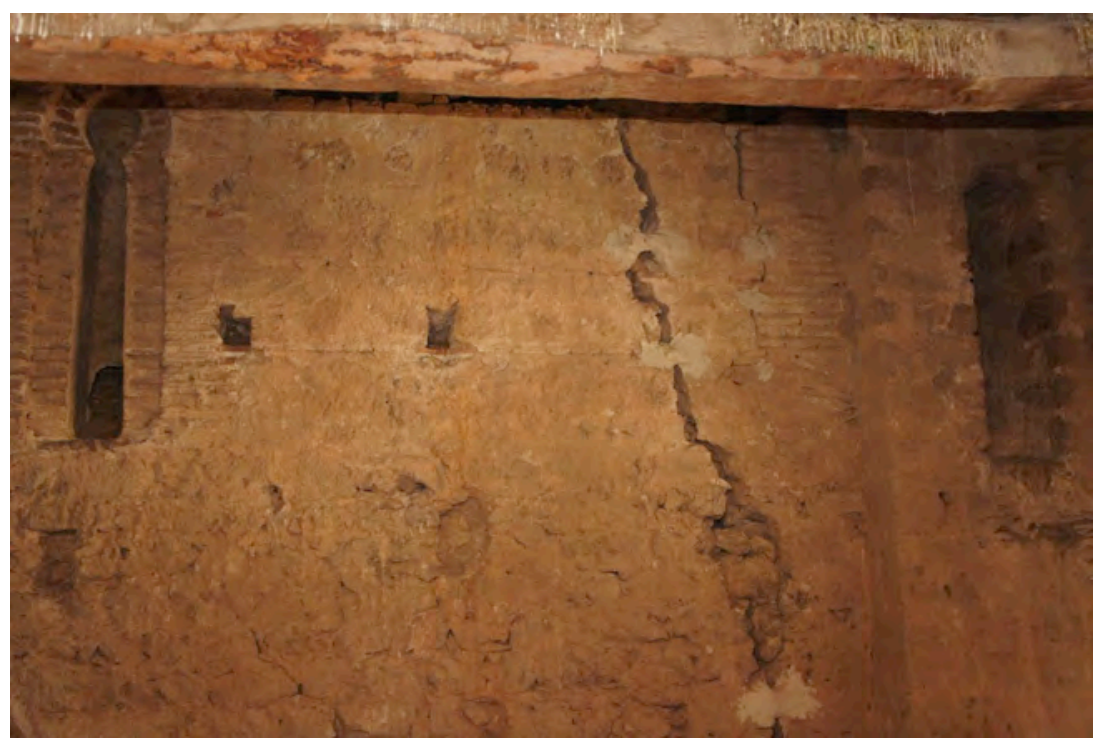





\section{Iglesia de San Cebrián}

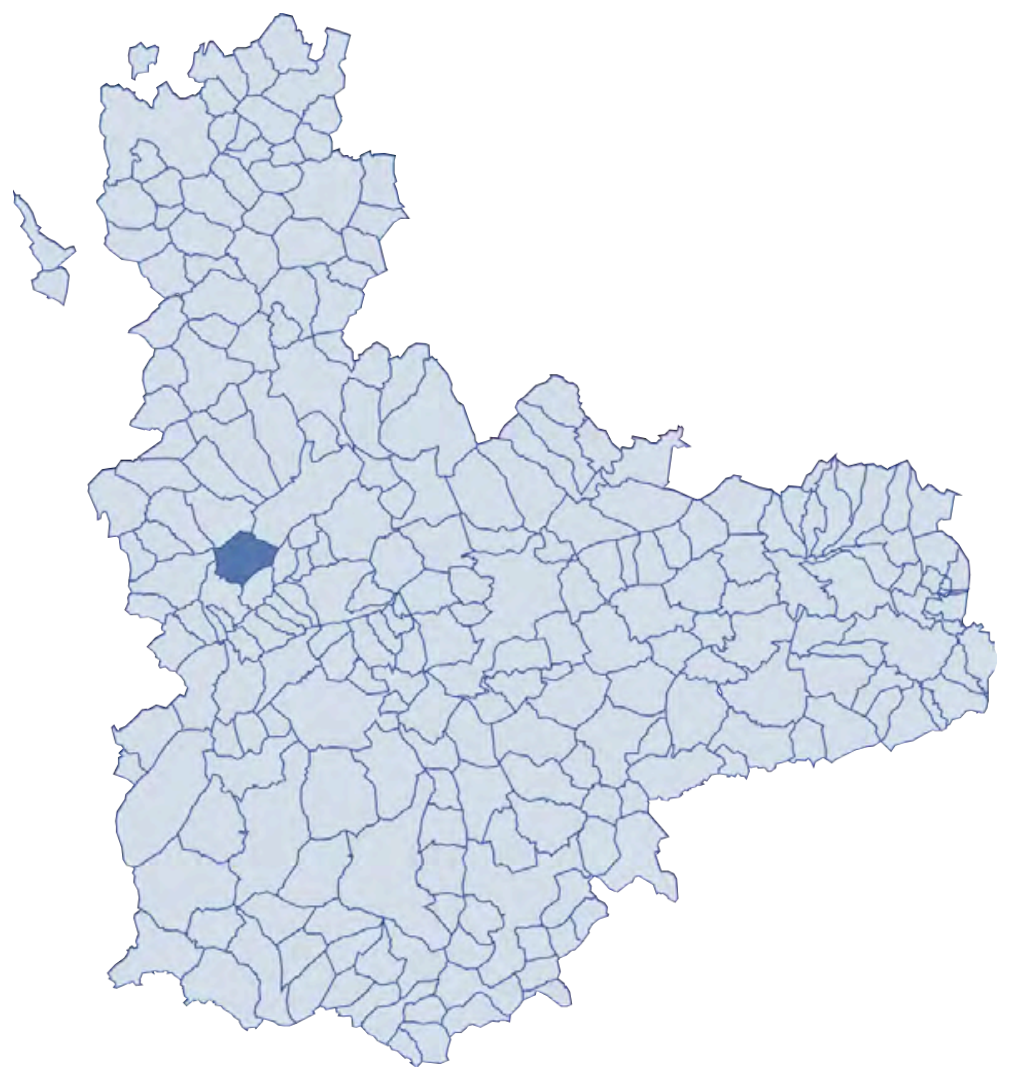



FICHA SÍNTESIS

\section{Código de identificación: FZ-34}

Denominación:

Iglesia de San Cebrián

Localidad:

San Cebrián de Mazote

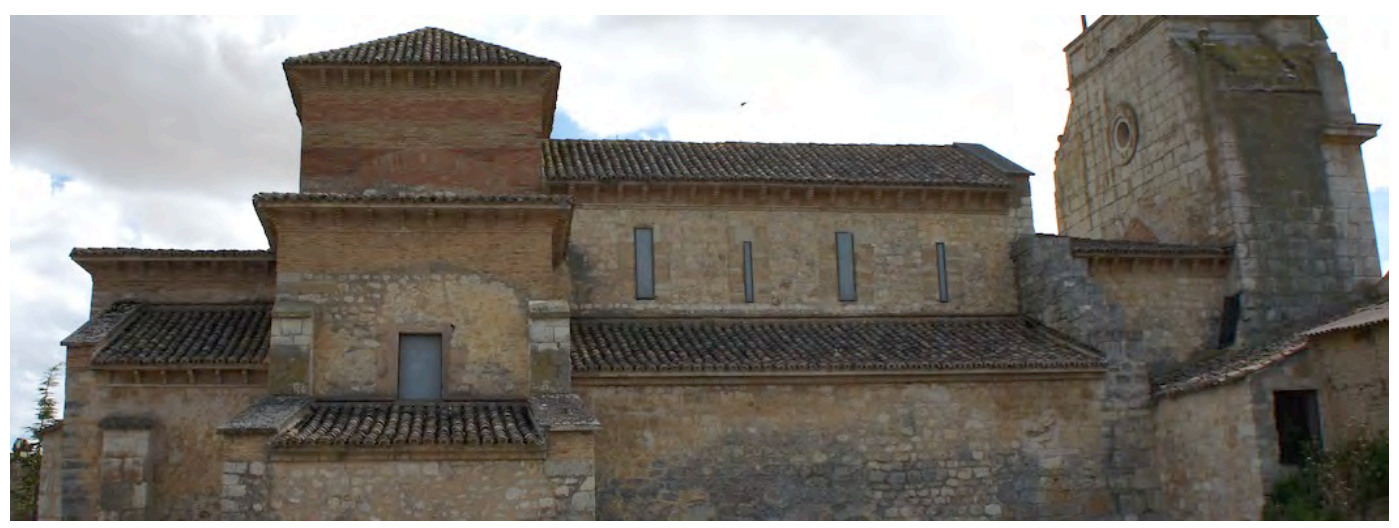

\section{Descripción}

Iglesia de planta basilical de tres naves con un crucero rematado con ábsides y exedras simétricas en pies y cabecera. Cuenta a los pies con una gran espadaña.

La nave central, con amplios arcos de herradura sobre columnas, se cubre mediante un artesonado de madera policromada.

\section{Materiales}

Los muros son de mampuesto de piedra, con refuerzos de sillería en contrafuertes y esquinas, fábrica de ladrillo en la parte alta de la nave y del cimborrio. La cubierta está revestida de teja curva.

\section{Singularidades}

Se trata de una construcción mozárabe que ha sufrido varias restauraciones integrales a lo largo del siglo XX.
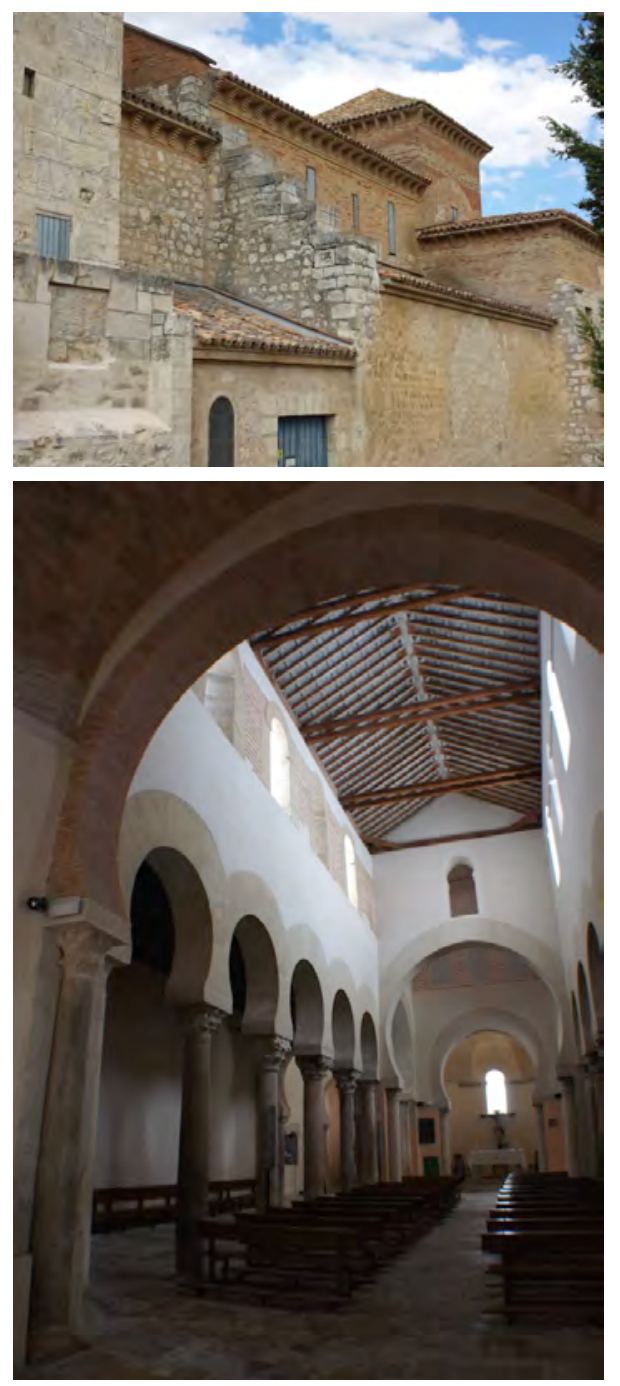

Ilustración 1: visita 30/07/2015 


\section{Dimensiones básicas del templo}

$\begin{array}{llll} & \text { central } & \text { laterales } & \text { capillas } \\ \text { Ancho de nave } & 3,7 & 3,2 & \\ \text { Altura } & 12,4 & \end{array}$

\section{Memoria histórica constructiva}

El monasterio se funda hacia el año 915. La iglesia mozárabe cuenta con tres naves y un crucero rematado con ábsides.

En la cúpula sobre pechinas del crucero estaba pintado 1778 , fecha en la que debieron incorporarse unas bóvedas de ladrillo hoy desaparecidas. En las imágenes de principios del XX vemos también las columnas sin basa, ocultas bajo un metro de rellenos del recrecido del pavimento.

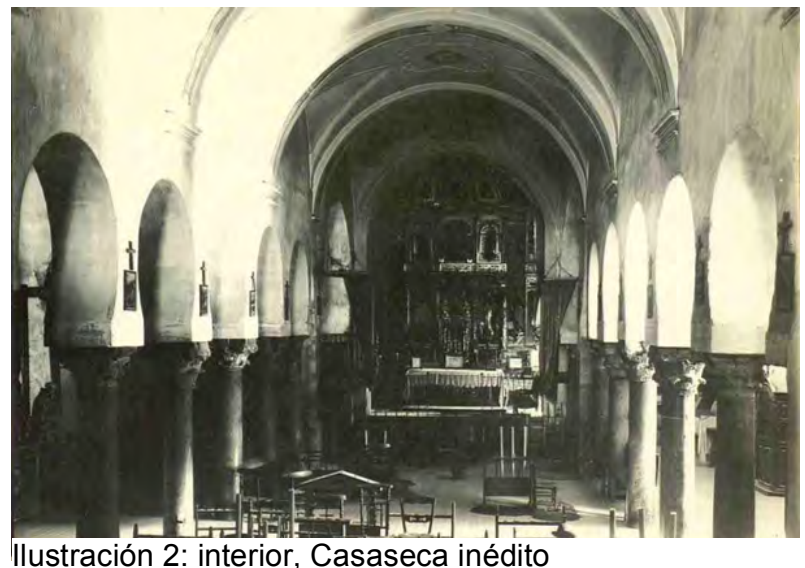

Lampérez publica los planos del templo en 1930. Moya y Candeira eliminaron todo lo que consideraron añadidos, como las bóvedas y el recrecido interior, e incorporaron el contra-ábside a partir de unos restos de curvatura reconocibles en la zona inferior.
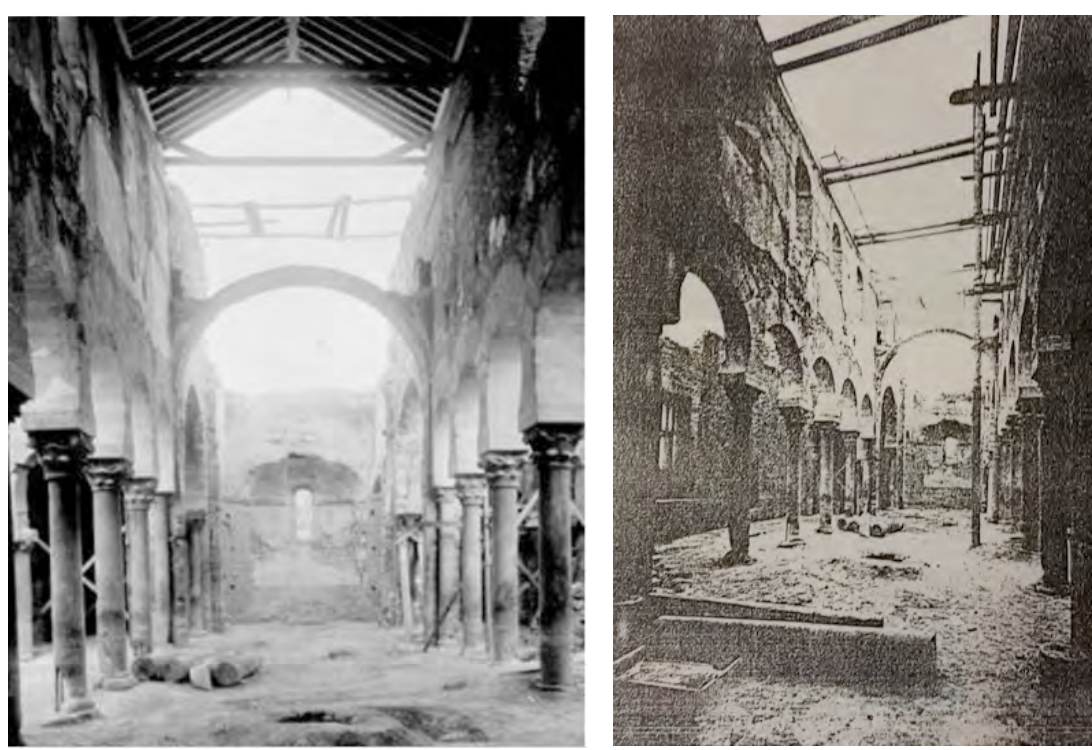

Ilustración 3: fotos Candeira web Salvador Mata (15/07/2015); dossier Mata1990 JCyL

Iñiguez añade posteriormente el cimborrio. Las pendientes de cubierta han sido modificadas en varias ocasiones. 
Cronología. Fechas clave

$915-1902-1932-1944-1988$

\section{Intervenciones}

1941-1944 - Demolición de agregados y reconstrucción de elementos originales Francisco Iñiguez Almech.

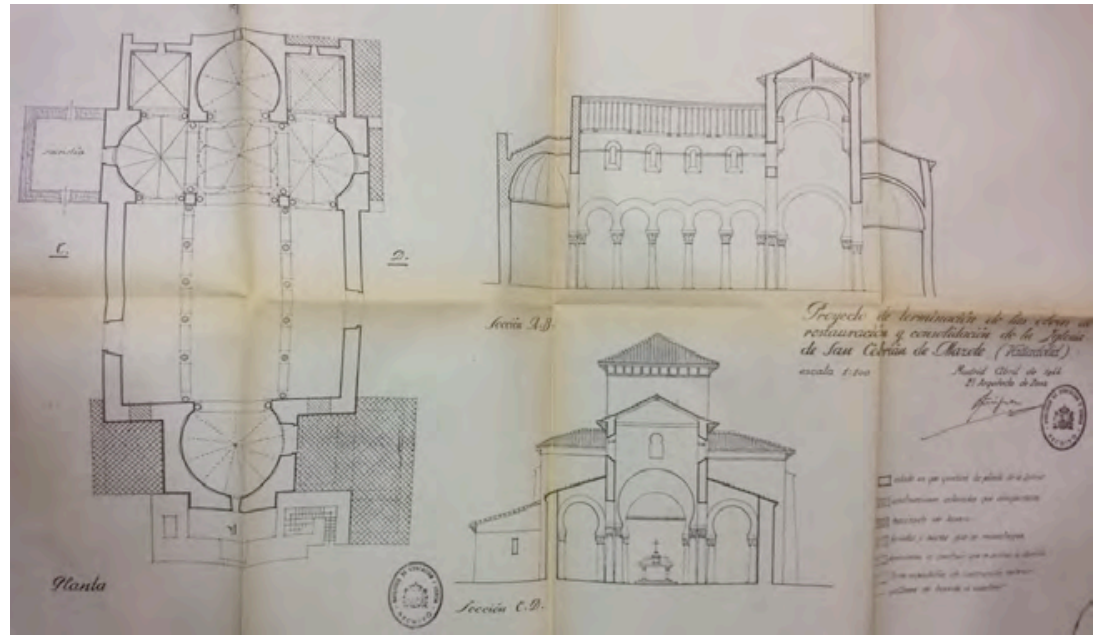

Ilustración 4: plano de Iñiguez en el dossier de Mata 1990 JCyL

1965 - Obras - Anselmo Arenillas

Excavación del terreno en lado norte, picado y enlucido de paramentos, retejo.

1973 - Obras urgentes en la cubierta - Manuel Cuadrado Isasa

Se restaura la cubierta tras el hundimiento de varios pares.

1977 - Ana Iglesias

Colocación de rasilla y capa de compresión sobre la tabla ripia.

1983 - Mariano Benito

Levantamiento de planos

1988 - Restauración - Salvador Mata

Restauración de lesiones, cosido de piedras sueltas. Drenajes. Demolición de un refuerzo de hormigón en un contrafuerte.

Saneado de la cubierta, que levanta totalmente reaprovechando la estructura.

Decoración escenográfica del interior con revestimientos en rojo y blanco con fingido de ladrillo. 


\section{Planos}

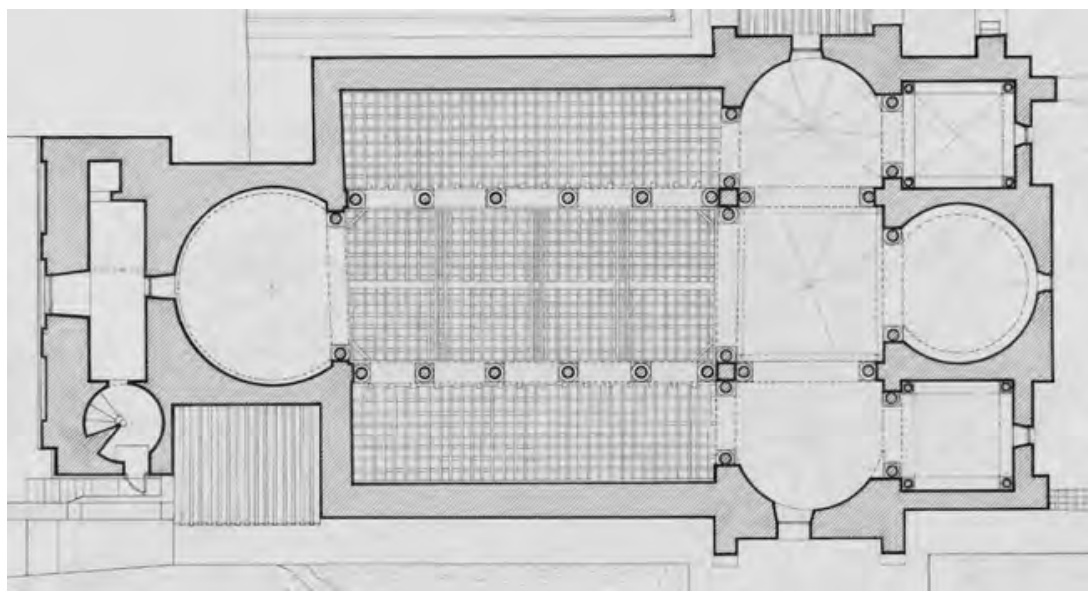

Ilustración 5: planta de techos Benito 1983 IPCE

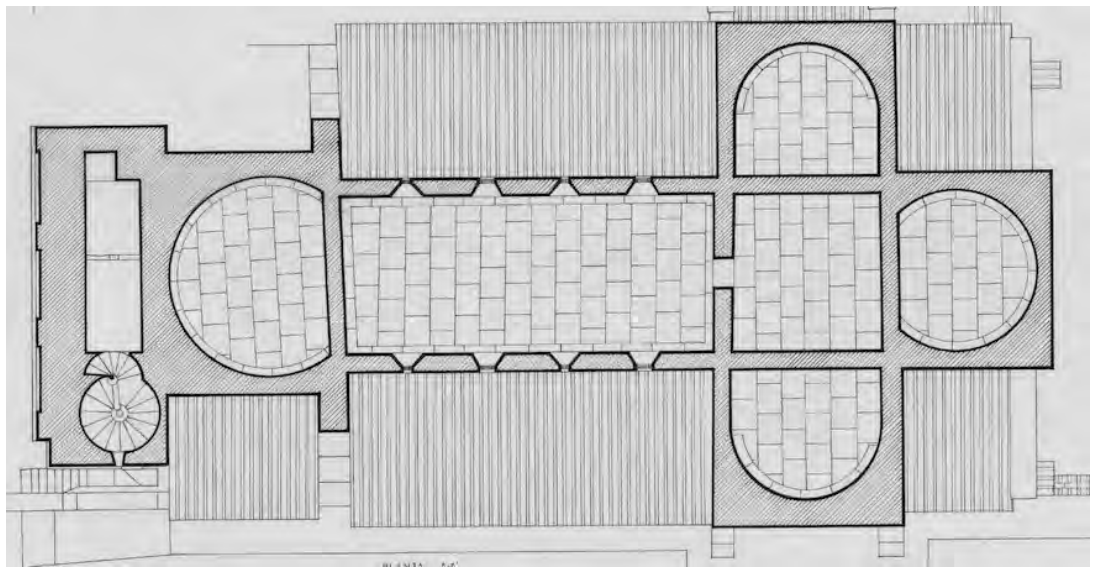

Ilustración 6: planta alta Benito 1983 IPCE

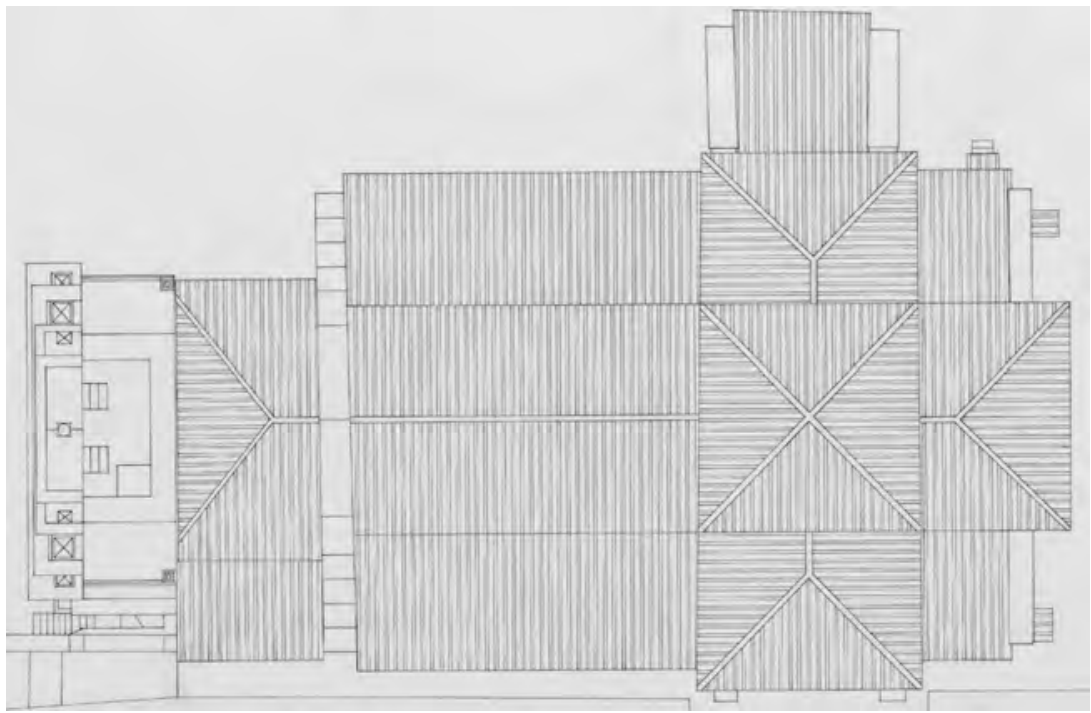

Ilustración 7: planta de cubiertas Benito 1983 IPCE 


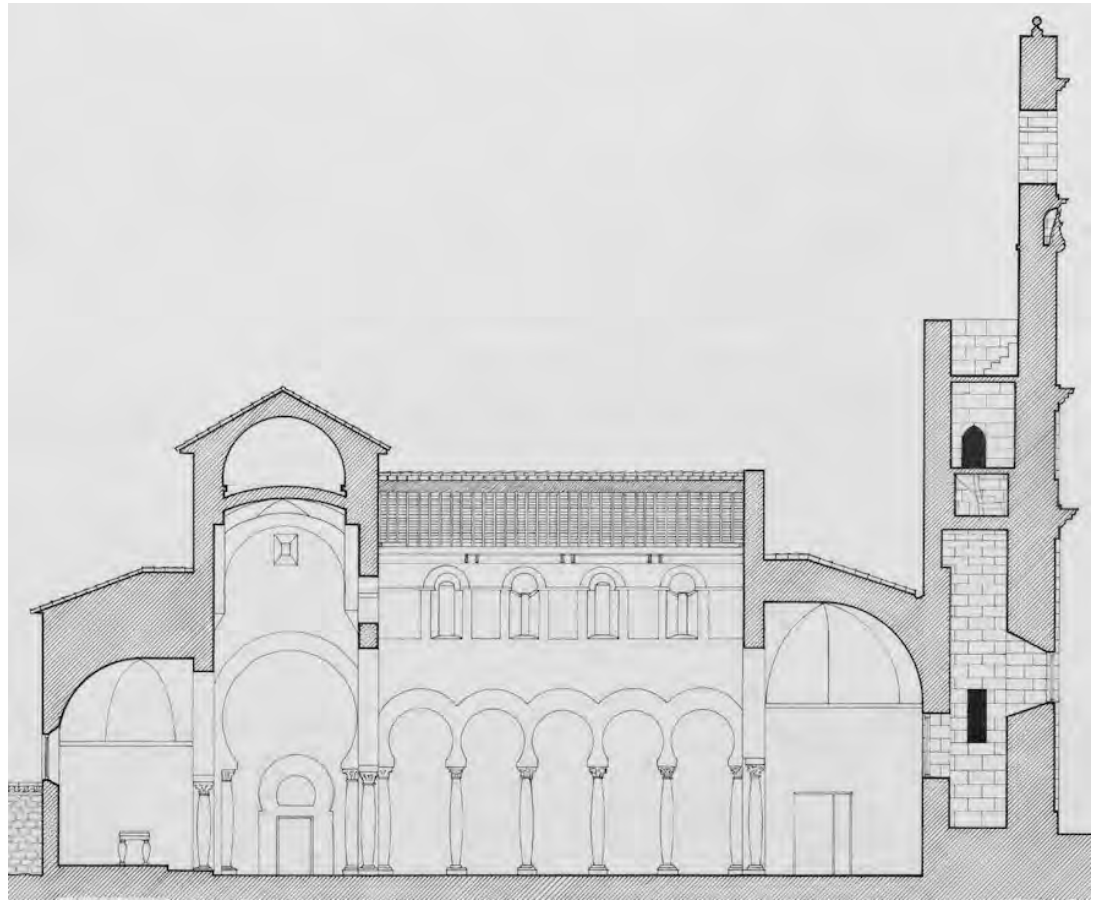

Ilustración 8 sección longitudinal 1983 Benito IPCE

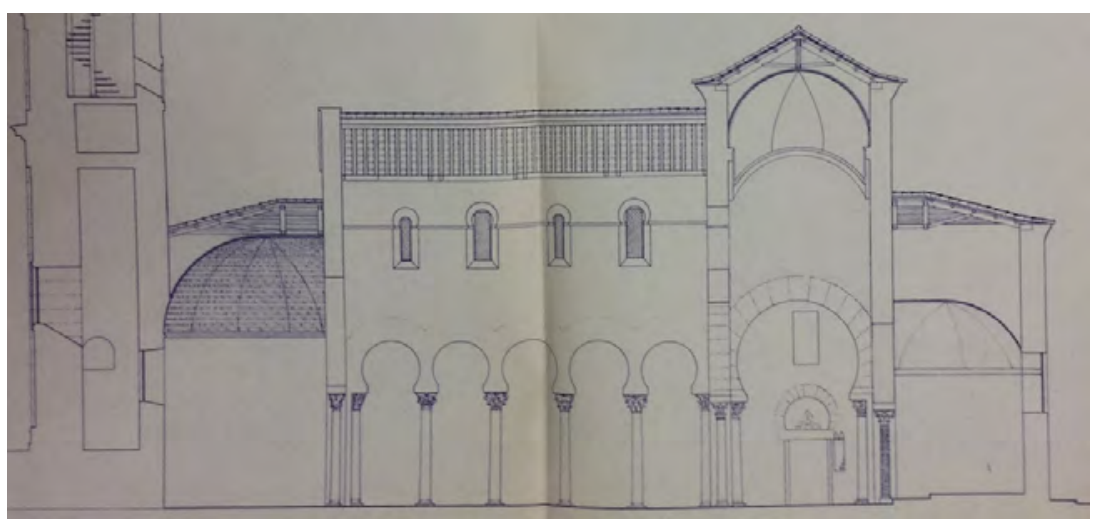

Ilustración 9: sección longitudinal 1988 Mata JCyL
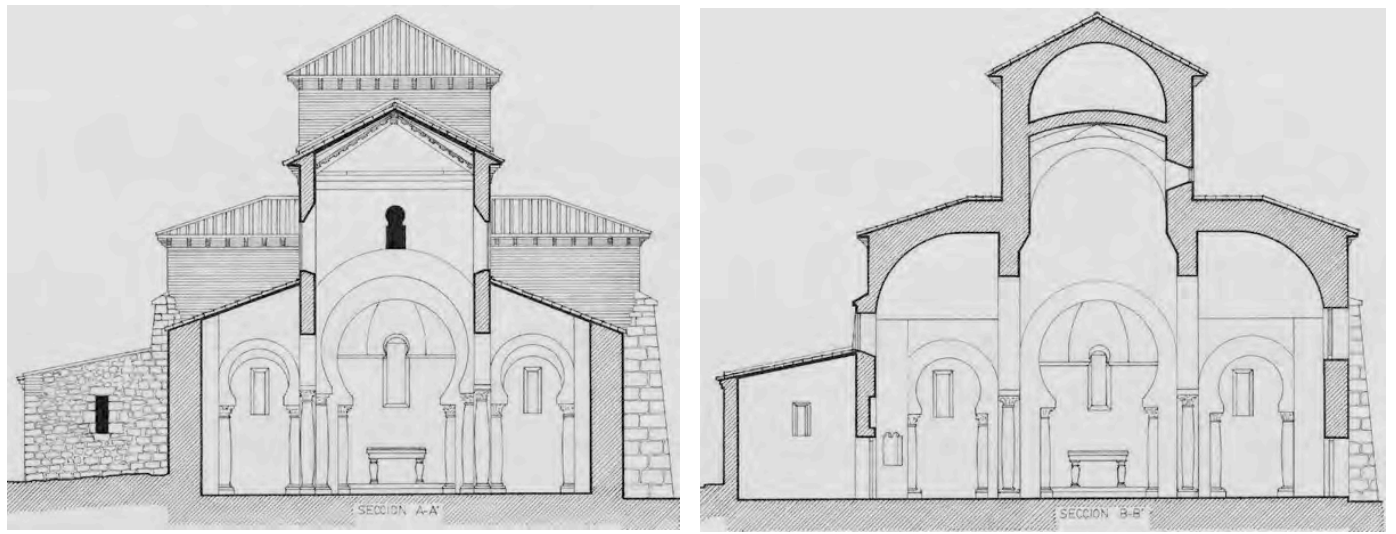

Ilustración 10: secciones 1983 Benito IPCE 


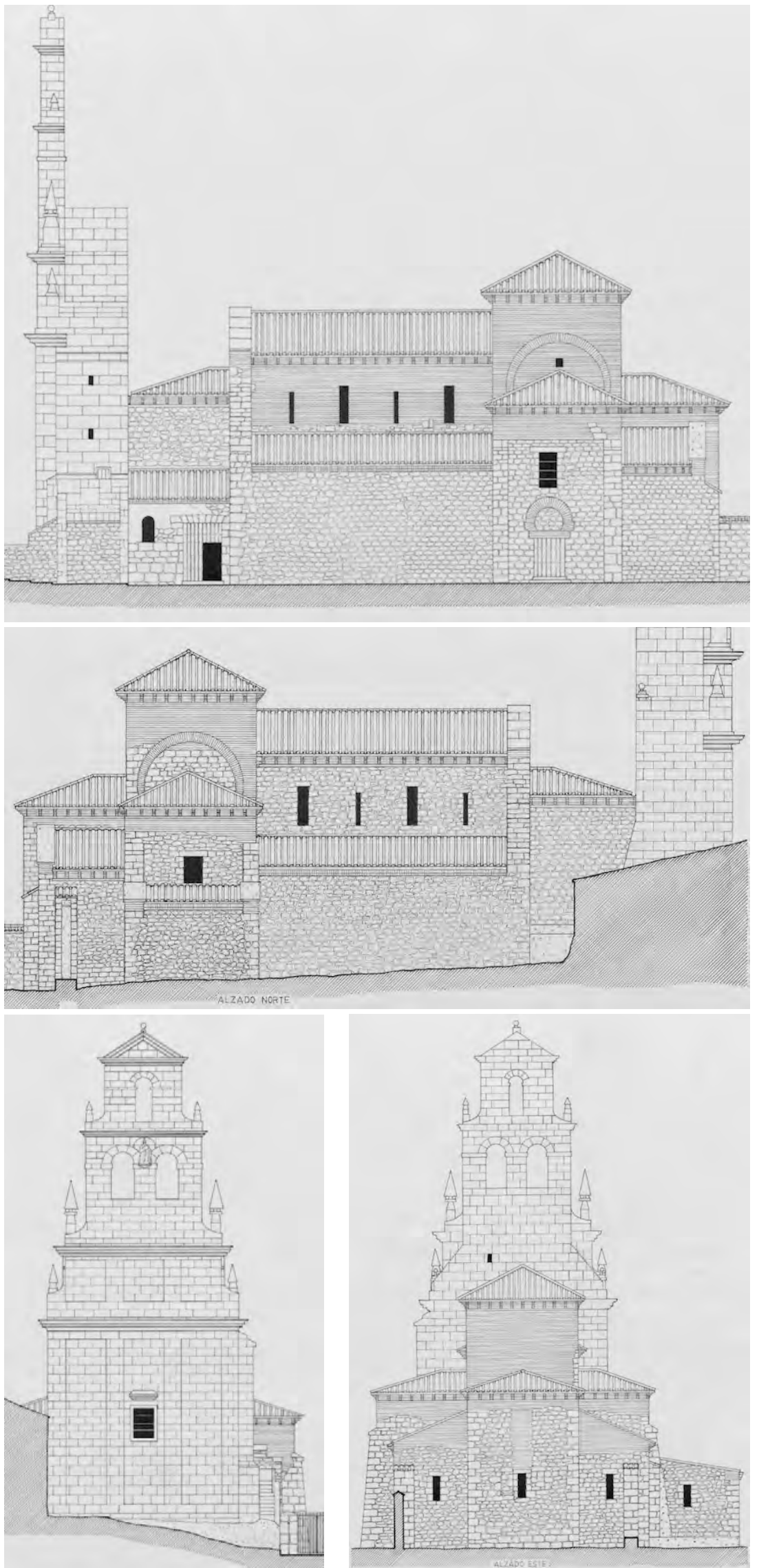

Ilustración 11: alzados Benito 1983 IPCE 


\section{Solución constructiva de la cubierta}

En 1983 se levanta un completo juego de planos, entre los que se incluye un detalle de la sección transversal de la cubierta con durmientes de madera.

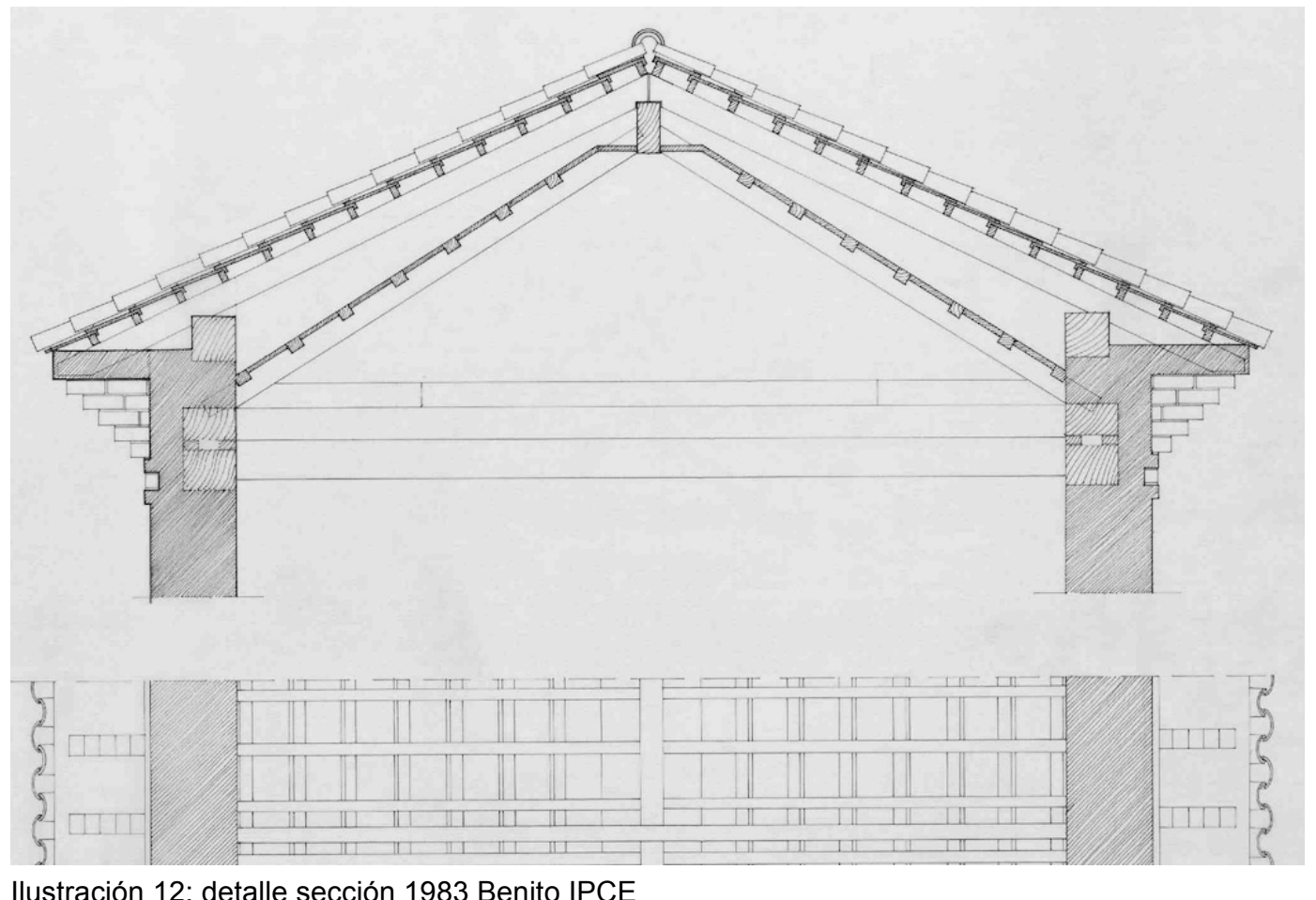

Ilustración 12: detalle sección 1983 Benito IPCE

En 1988 Salvador Mata modifica el perfil de la cubierta, por considerar que el refreno de la intervención anterior es excesivo y provoca la entrada de agua y las consiguientes lesiones. En la sección se representa los faldones de nave central con unos $33^{\circ}$ de inclinación. Traza un nuevo perfil de cubierta que une el caballete con el extremo del alero, formándose con rastreles sobre la antigua tablazón, rastreles que han de ser progresivamente más altos, sobre los que posteriormente se clava la placa de recubrimiento bituminoso para el posterior recibido de la teja.

\section{Zunchos}

En la documentación revisada no se ha encontrado mencionados zunchos.

\section{Conclusiones}

La iglesia de San Cebrián se reconstruye en los años 40, colocándose una cubierta nueva que se restaura en el 73 , el 77 y el 88 sin mencionarse zunchos en los proyectos revisados. 



\section{Iglesia de San Cebrián de Mazote}

Intervenciones citadas en la web del Ministerio:

1941 - Demolición de agregados y reconstrucción de elementos originales Francisco Iñiguez Almech

1944 - Demolición de agregados y reconstrucción de elementos originales Francisco Iñiguez Almech

1965 - Picado y enlucido paramentos, retejo general y reparación escalera de la torre - Anselmo Arenillas Álvarez

1973 - Obras urgentes en la cubierta - Manuel Cuadrado Isasa

En la web del IPCE hay 9 planos de 1983 con la firma del arquitecto Mariano Benito Duque, dos plantas de 1977 de Ana Iglesias y varios planos de los años cuarenta.

\section{En el Archivo General de la Administración}

AGA 26/00356

1965 - Obras - Anselmo Arenillas

No hace muchos años que se restauró este templo, inicialmente por el arquitecto Sr. Candeira y finalmente por D. Francisco Iñiguez, ambos con el consejo del Arqueólogo D. Manuel Gómez Moreno. Quedó en esta restauración sin escavar parte del terreno, antiguo cementerio, al que por el lado norte está adosada la iglesia y que tiene una altura de tres ó cuatro metros de tierra sobre el nivel del piso de la misma. Esto produce grandes humedades en los muros de contorno y los guarnecidos de cal y yeso están desprendidos.

También quedo cortada la escalera de subida a la torre y sin cubrir, lo que es otro origen de humedades. Tinalmente una descarga eléctrica ha roto el remate de la torre, cuyos cascotes al caer sobre el tejado han roto varias tejas y producido unas goteras mas.

Las obras previstas son:

Excavación de terreno en zanja, lado Norte de la iglesia, estudiando y recogiendo los restos arqueológicos

Picado y nuevo guarnecido y enlucido paramentos

Retejo general y repaso entablado

Reparación escalera torre y su cubrición

Andamios 
Un plano 1/100 proyecto de terminación de las obras (está en Planoteca)

\section{AGA 26/00045}

1973 - Obras urgentes. Memoria - Manuel Cuadrado Isasa

El estado de conservación de las fachadas exteriores puede considerarse como bueno, apreciándose el haber recibido atención restauradora no hace muchos años. Es la cubierta la que necesita más urgentemente una reparación, sobre todo en la parte correspondiente al supuesto coro, que se encuentra en estado de ruina por hundimiento de varios de los pares de madera, sin que hasta la fecha, afortunadamente hayan sufrido las bóvedas.

Restauración total de la cubierta dañada

Retejo general del edificio

Saneamiento del acceso a la espadaña

Tres fotografías, una de una zona de faldón hundido.

No hay presupuesto ni planos.

\section{En el archivo del IPCE}

Carpeta-643-4

1977 - Obras de restauración - Ana Iglesias.

"El proyecto comprende las obras del levantamiento en su totalidad de la teja para la formación de un tablero de ladrillo sobre el que será tendida la capa de comprensión y seguidamente a su impermeabilización de cubiertas finalizandolo con la colocación de Teja árabe, siendo recibida con mortero de cal ó paja y barro; Posteriormente se limpiarán los paramentos interiores y su posterior pintado".

\section{Proyecto. Memoria}

Es iglesia de planta basilical y de tres naves y tres ábsides, con crucero formado con nave transversal que se manifiesta exteriormente resaltando su cimborrio con capillas gallonadas que contrarrestan su empuje.

Actualmente se encuentra reforzada por estribos construidos durante sus fases de restauración. Sus primitivas coberturas desaparecieron y las bóvedas de cañón que cubrieron sus capillas solo quedan manifiestas en uno de los laterales.

Varios refuerzos en totalidad de paños de muro recubrieron estos como en el cimborrio que fué forrado interiormente. En los piés de la iglesia debió existir asi 
como en la cabecera un contraabside circular en su interior y cuadrado al exterior, es donde ahora vemos la espadaña...

Obras a realizar

Debido a la actual colocación de la teja se encuentra el interior de sus enfoscados muros y su techumbre lleno de manchas producidas por sus numerosas goteras. sera por tanto necesario proceder al levantamiento de la totalidad de la teja para proceder a la formación de un tablero de ladrillo sobre el que será tendida la capa de compresión ...

Presupuesto

$650 \mathrm{~m} 2$ desmantelado de tejado con clasificación de material aprovechable y transporte de escombro a vertedero

PA picado de revocos y enlucidos en zonas afectadas por la humedad

$250 \mathrm{~m} 2$ demolición de cielo raso de cañizo en acceso

$550 \mathrm{~m} 2$ solera de rasilla recibida con mortero de yeso y apoyada sobre la tabla ripia

$425 \mathrm{~m} 2$ capa de compresión formada por mortero de cemento, armada con mallazo metálico

$850 \mathrm{~m} 2$ impermeabilización de tableros de cubierta mediante extendido de fieltro asfáltico enarenado por su cara superior

$1200 \mathrm{~m} 2$ cubierta de teja curva sentada con mortero bastardo de cal y barro, incluso p.p. de caballetes, con aprovechamiento de material desmontado.

PA repaso de enfoscados en zonas de humedad

PA repaso general de los aleros

Dos planos, de planta baja y cubiertas.

\section{En el archivo de la Junta de Castilla y León}

\section{VA-158}

Carpeta 5349

Restauración de un Cristo Yacente

VA-033

Caja 5224

Restauración de la iglesia Arquitecto: Salvador Mata Pérez

Modificado aceptado en 1990 
Contrato de 1988 con la empresa CPA SA y el arquitecto Salvador Mata con su colaborador García Paniagua

Carta de Mata al Director General de Patrimonio de diciembre de 1988:

Explica que está "perplejo ante un reciente artículo aparecido en el periódico local El Norte de Castilla con el título de "Polémica restauración de un templo mozárabe" que supone un verdadero alarde en cuanto a la falta de rigor, desinformación y desconocimiento total del Proyecto..." La obra lleva en marcha tres meses en los que se ha ejecutado:

- consolidación y reparación del conjunto de la espadaña de los pies de la iglesia, con la completación de la escalera interna de subida al campanario, el óculo practicado sobre el inacabado muro posterior y el tejaroz que cubre el balcón del campanario - desmontado y sustitución de la totalidad de las cubiertas de las naves principal, laterales y cimborio con impermeabilización de las mismas y reposición de más de un sesenta por ciento de la teja

- drenaje perimetral del edificio, operación ésta en la que fueron encontrados restos arqueológicos superficiales, que provocaron una excavación inmediata

- operación de excavación de restos arqueológico bajo la supervisión de los servicios técnicos de la Delegación de Valladolid, durante el verano de 1988, estando pendiente actualmente del informe final del director de la excavación.

- levantado de cemento y parches del mismo material en el interior de la nave principal y naves laterales, con estudio de los restos de pinturas ya documentadas anteriormente, para su posterior reintegración en la fase de estucado

- picado y levantado de todos los añadidos de cemento en basas y fustes de columnas de la nave principal, reparación de las armaduras existente y posterior preparación de estas zonas para su marmoleado final

- picado y levantado de los yesos y cales de las superficies de las bóvedas para su posterior tratamiento

- limpieza y fijado del artesonado de la nave principal y tratamiento del mismo

- paleteado de los muros interiores con morteros especiales de cal, sobre el mampuesto irregular descubierto para su posterior acabado con sucesivas capas de estuco de cal con polvo de mármol

- recalce de todo el perímetro exterior y reparación de dos contrafuertes de la cabecera

- limpieza y desescombrado, siempre bajo la supervisión del arqueólogo de la zona posterior o cara norte del edificio, donde han sido encontrados pequeños restos de modillones entre los escombros que han sido clasificados y documentados 
Con el Modificado hay una nota de Mata de abril de 1990 en que pide disculpas por el retraso en la redacción motivado por haber sufrido una grave y prolongada afección gripal.

Recepción provisional 21 noviembre de 1990

(cont. VA-033)

Caja 5225

Memoria

Fundación del monasterio de San Cebrián hacia 915 por monjes cordobeses.

Iglesia de mayor tamaño que las del mismo siglo, con originalidad notable. Planta basilical de tres naves con crucero, con exedras al modo armenio o sirio. Durante la reconstrucción de los años treinta se recupera un ábside que comunicaba dos capillas laterales cuadradas. Con el levantamiento previo al proyecto se completa la planta con la torre adosada a los pies de la nave de finales del XVIII, la pequeña sacristía en la cara norte y el pequeño baptisterio en la sur que sirve de vestíbulo de entrada.

El estado actual de la iglesia corresponde al proyecto de reconstrucción iniciado en los años treinta por los arquitectos Constantino Candeira y Luis Moya, finalizado en los cuarenta por Francisco Iñiguez. En los cuarenta se reconstruyen las exedras y capillas a ambos lados del ábside. Más tarde se cubre el cimborrio con bóveda de gallones.

La estructura de madera de la nave central policromada parece de la primera mitad del XVI. A finales del XVIII se cubrió las naves con bóvedas de medio cañón con lunetos barrocas y el crucero con cúpula sobre pechinas decoradas. Portada y gigantesca espadaña se añaden en el XIX.

En los años treinta se descubren basas y arranques de las columnas, ocultos bajo casi un metro de relleno.

Fotocopia de dossier de fotografías de Candeira de 1932 a 1936 que usa para recuperar el espacio interior primitivo.

Muros de mampuesto de piedra reforzadas con pequeños contrafuertes y esquinales de sillería. Grandes arcos de herradura sobre columnas de mármol, alabastro o granito. El cimborrio original sería de madera, Iñiguez copió el gallonado de Santiago de Peñalba. 
Las capillas se cubrían con bóvedas de arista y las exedras con semi-cúpulas de gallones, de los que quedan restos originales.

Justificación de la obra propuesta.

Una primera parte atiende a la restauración de patologías y lesiones, como el saneamiento del tejado, que se levanta totalmente aprovechando su estructura, rehaciéndolo con tableros hidrófugos.

Drenajes

Consolidación y cosido de elementos sueltos de piedra

La segunda parte es la recuperación del ambiente interior con los dos espacios separados por el muro del iconostasio. Simularán fingidos de ventanales con aparejo de ladrillo rojo en las paredes del cimborrio, decoración anastilósica en el arco toral, $\mathrm{y}$ aparejos de ladrillo fingidos en rojo y blanco en exedras y cabecera.

Planos

Plantas, alzados y secciones 1:50. Copia de los planos de 1941 y 1944

(ancho de nave 5,5m? laterales 3,3)

Presupuesto. Cap.1 Restauración cubiertas

$555 \mathrm{~m} 2$ levantado de teja curva, 495 de enripiado

desmontado de 55,65 $\mathrm{m} 2$ armadura de par e hilera (contraabside 8,50x2,15; $2 \times 3,25 \times 2,90$; contraab. $4,63 \times 4,00$ )

155,80ml de Formación de alero de cubierta de teja, recreciendo regazos o ensillados con mortero de cemento.

Limpieza de 183,40m2 de maderamen del artesonado, pulverización con xylamon, etc.

Cap. VIII Cantería

$1,53 \mathrm{~m} 3$ de labra y montaje de cornisa $(1 \times 6,20 \times, 30 \times, 50 ; 2 \times 2,00 x, 30 x, 50)$

Carpeta Reformado

Diciembre de 1989

Descripción de las nuevas partidas, entre ellas:

"Modificación del perfil de la cubierta, que al ser descubierta su tablazón, se comprobó una patología producida al formar en la anterior restauración el nuevo alero, de manera que se producía un refreno excesivo.

Se hace necesario el trazado de un nuevo perfil de cubierta que una el caballete con el extremo del alero, formándose con rastreles sobre la antigua tablazón, rastreles que 
han de ser progresivamente más altos, sobre los que posteriormente se clavará la placa de recubrimiento bituminoso, para el posterior recibido de la teja."

Desmontado de un grosero contrafuerte de hormigón armado con tacón del mismo material sobre el antiguo contrafuerte de piedra, realizado durante la anterior restauración, y la comprobación del mal estado del antiguo, conlleva el necesario recalce de la base donde se asienta.

La actuación sobre la torre de la espadaña descubrió ciertas irregularidades, como un forjado de viguetas de hormigón, que debe demolerse, siendo sustituido por otro más ligero, metálico perforado, que permita el paso de la luz.

El picado de la bóveda del ábside de los pies, descubrió un aparejo muy interesante de dos hojas de ladrillo claro, que consideramos como aceptable al interior, siendo necesario su rejuntado y entonado.

\section{Carpeta Memoria final}

"En primer lugar y cumpliendo los objetivos propuestos en el proyecto original, los trabajos de restauración han resuelto los dos graves problemas que la iglesia tenía en aquel momento, como eran la entrada de agua por el refreno del tejado y la humedad por capilaridad de la cara norte y ábside de los pies.

El desmontado de la tablazón del total de la cubierta y la rectificación del perfil de su plano mediante la aportación de rastreles graduales hasta el extremo del alero, para la posterior colocación de lámina bituminosa y teja, solucionaron definitivamente la patología de la cubierta anterior". 



\section{Visitas realizadas}

$30 / 07 / 2015$

El estado de conservación del monumento es aceptable, aunque no se ha rematado el acondicionamiento del entorno, que parece una solución provisional.

Las cubiertas presentan una aspecto saneado. En los muros se mezclan gran variedad de materiales, desde grandes sillares a sillarejos, mampuesto y fábricas de ladrillo visto.
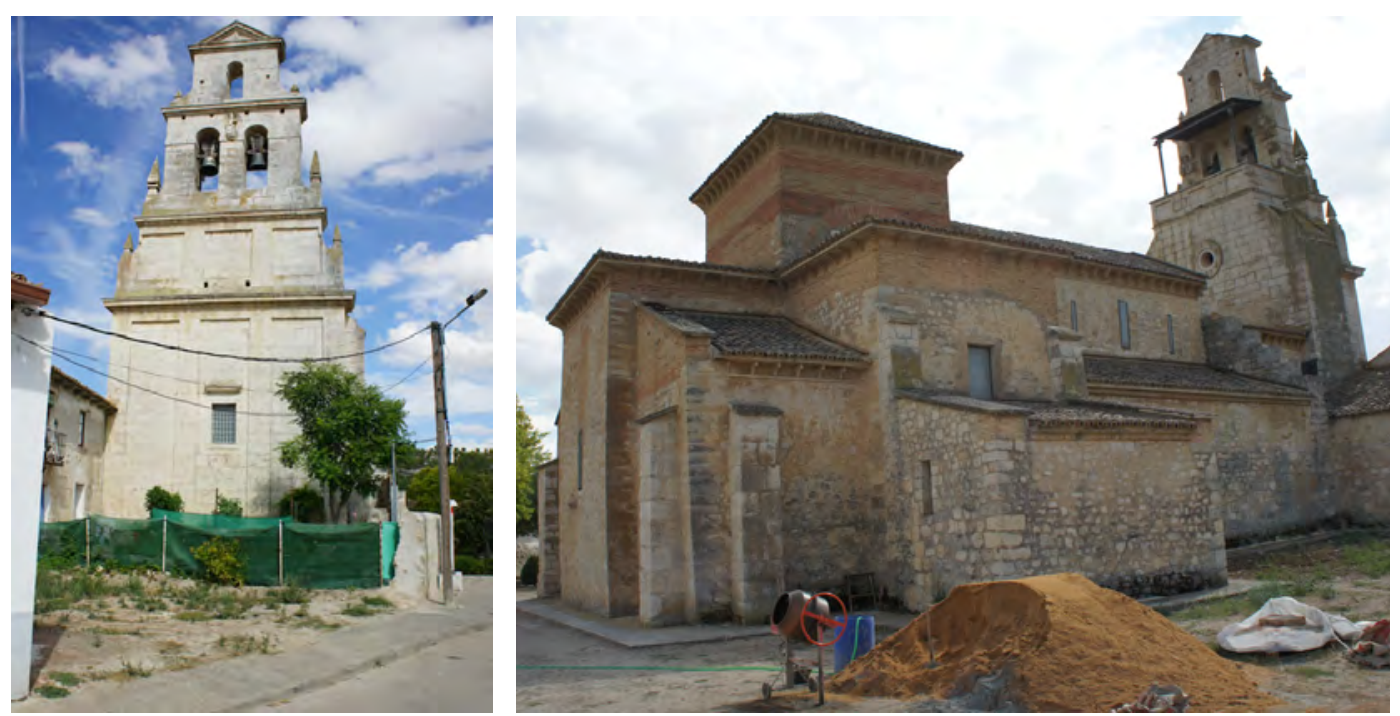

El espacio interior de la nave se cubre con una estructura de madera adornada con motivos pintados. El guía del monumento afirma que no hay acceso a espacios o cámaras bajo cubierta, y que la estructura de la misma está resuelta con madera incluso en su apoyo sobre los muros.

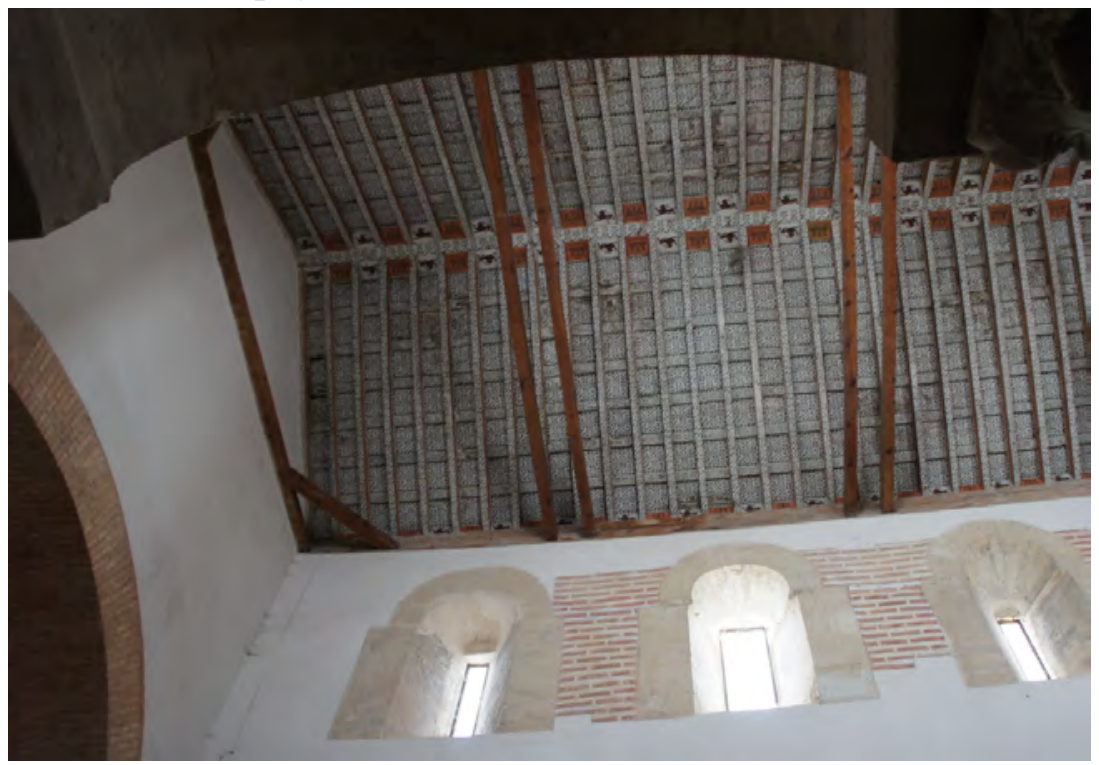




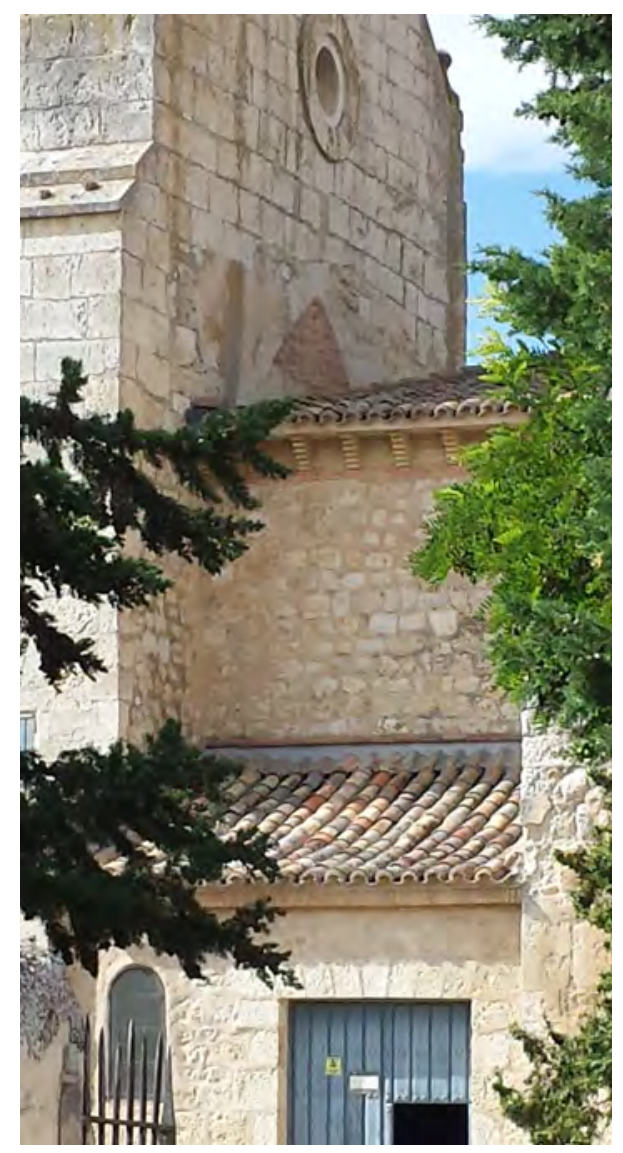

A grandes rasgos la solución constructiva de cubierta observada coincide con la definida en el plano de sección de Mariano Benito fechado en 1983.

No se ha podido confirmar la existencia de zunchos. 


\section{Iglesia de Santa María}

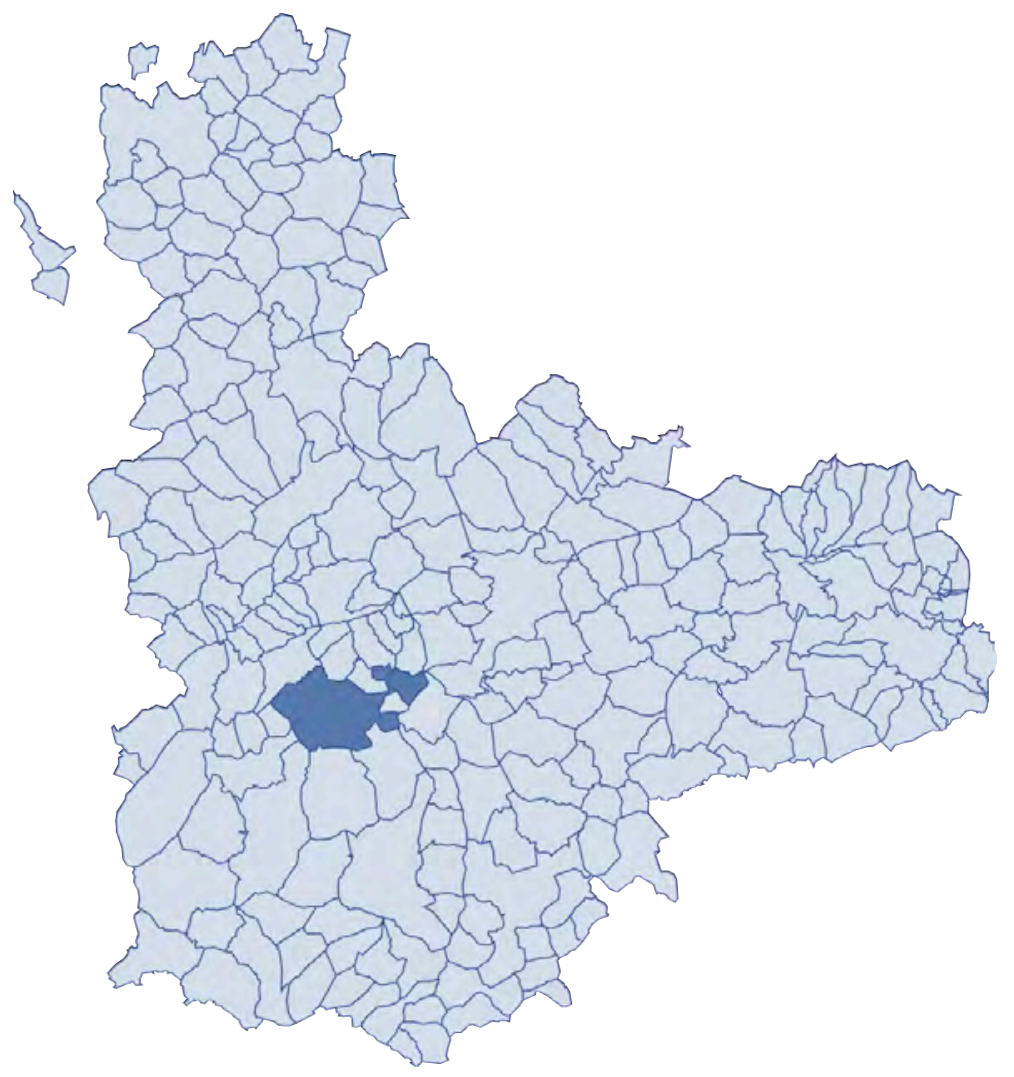



FICHA SÍNTESIS

Código de identificación: FZ-35

Denominación:

Iglesia de Santa María

Localidad:

Tordesillas

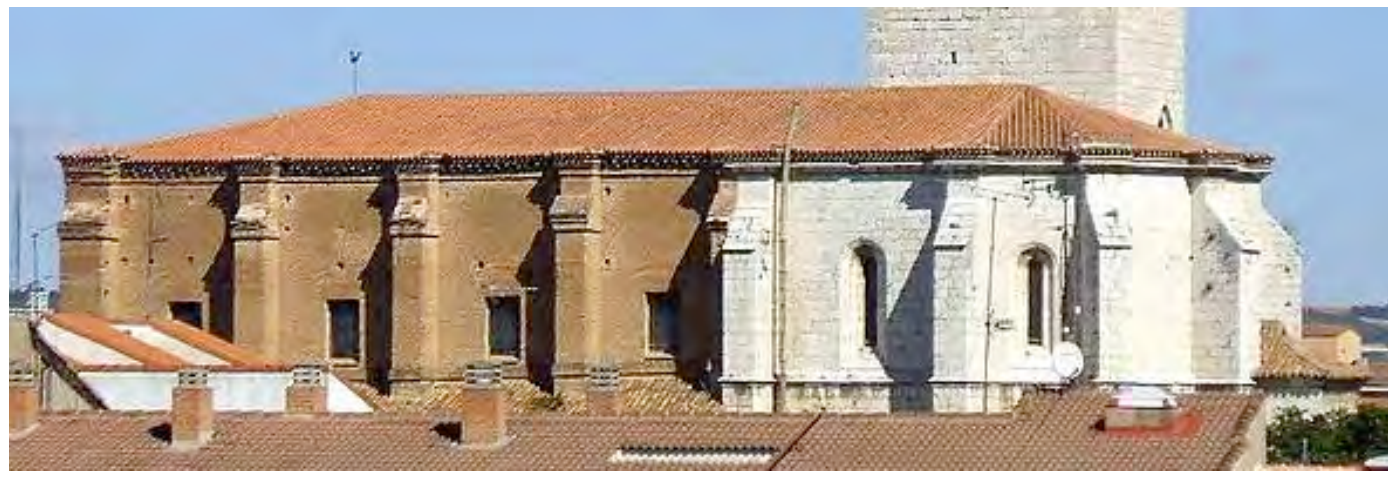

Ilustración 1: foto wikipedia (14/12/2013)

\section{Descripción}

Iglesia de una sola nave y capillas entre contrafuertes, cubierta con bóveda de cañón con lunetos. La construcción dio comienzo por la capilla mayor, ochavada, de factura gótica. Cuenta con una torre cuadrada que se remata mediante cúpula y linternón. Un coro bajo se añade en 1693, y tras el ábside se adosa un camarín con transparente a finales del XVIII.

\section{Materiales}

Cabecera y torre están resueltas en sillería de piedra. La nave central es de fábrica de ladrillo desde la altura de la clave de los arcos embocadura de las capillas laterales, que también presentan fachada exterior de sillería, según se aprecia en las imágenes.
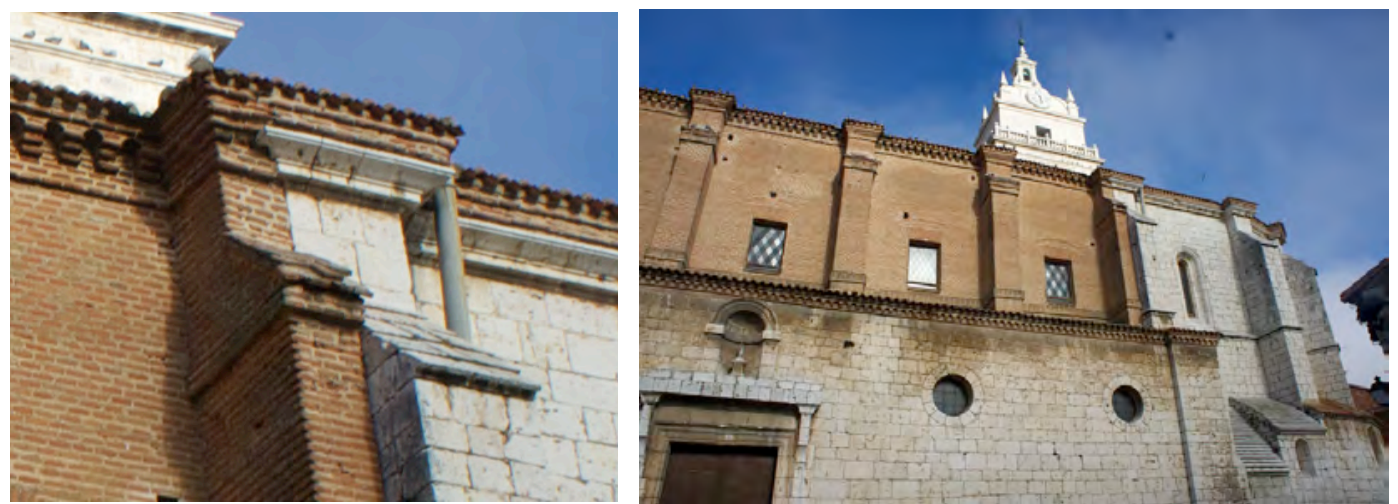

Ilustración 2: vista lateral y detalle enlace ladrillo-piedra (visita 16/12/2013) 
Todas las cubiertas están revestida de teja curva, excepto dos capillas de la cabecera recuperadas en la última intervención llevada a cabo sobre el templo que se rematan con piedra.

\section{Singularidades}

La reanudación de la fábrica de piedra con ladrillo se resuelve en planta, exteriormente, mediante la duplicación del contrafuerte a ambos lados del encuentro.

Por el interior se manifiesta intercalando el arco triunfal entre la primera pilastra y su fajón, que arranca sobre la extraña ménsula resaltada que se aprecia en la fotografía.

Desde el bajo cubierta se pueden observar en los muros de la cabecera restos de arcos apuntados de la solución original. En alzado se homogeneiza la cornisa de las dos zonas con un remate de ladrillo, recrecido sobre el preexistente de piedra.

En el catálogo monumental inédito de Casaseca de 1916 se describía este monumento como un edificio de escaso interés y "sin gracia alguna".
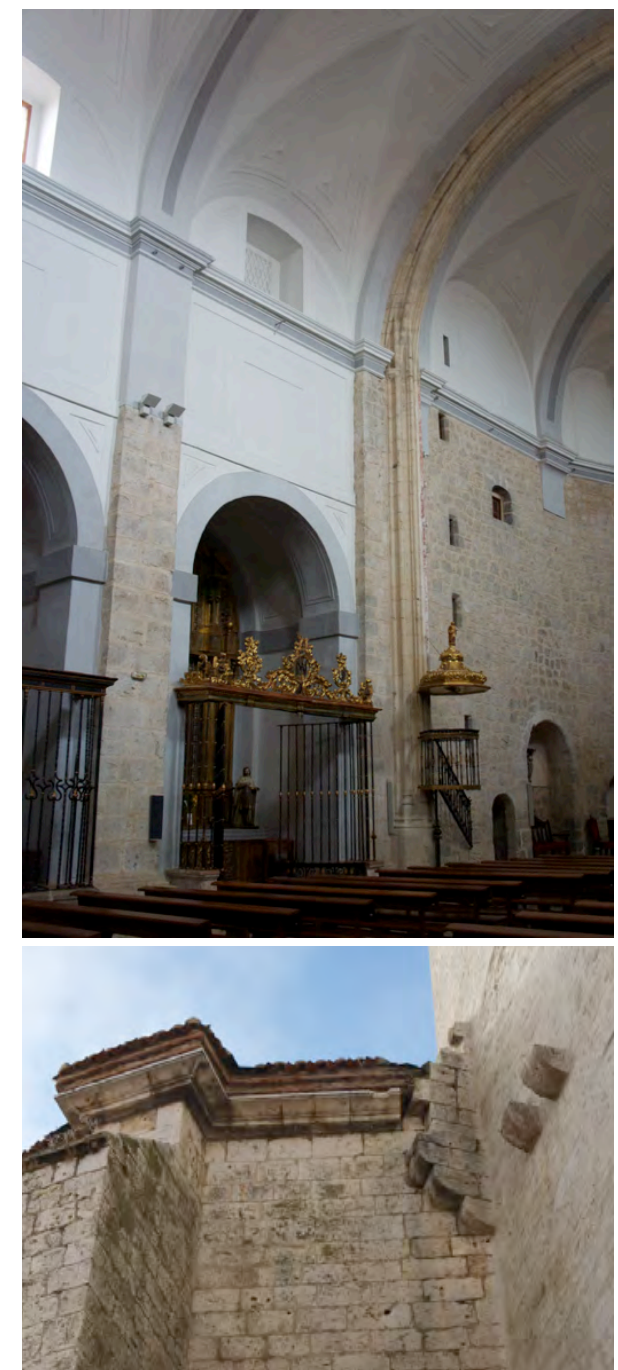

Ilustración 3: interior y enlace cabeceratorre (visita 16/12/2013)

El enjarje del cuerpo del templo con el volumen de la torre presenta aspectos sin resolver, como el encuentro con la cornisa del ábside o una ventana medieval, con asientos de piedra, cegada.

\section{Dimensiones básicas del templo (aproximadas)}

central laterales capillas

Ancho de nave $\quad 12$

Altura 


\section{Memoria histórica constructiva}

El monumento arranca en 1513 y se rehace en estilo neoclásico en el XVII. Hay trazas y condiciones para este templo dadas en 1595 por Felipe de la Cajiga, que no está al frente de la ejecución (Parrado 1990). Dirigen las obras Diego de Hano, Juan de la Puente y Pacual Carrera. La iglesia estaba dispuesta para su cubrición en 1613.

\section{Cronología. Fechas clave}

$1513-1613-1980$

\section{Intervenciones}

1980 - Cubiertas - Luis Alberto Mingo Macías

\section{Incorporación de zuncho de hormigón armado.}

Desmantela la cubierta reemplazando la armadura de madera por una estructura de perfiles de acero laminado IPN-140 que forman simples pórticos a dos aguas cada $1,2 \mathrm{~m}$ con correas IPN-100. Para el atirantado del sistema se dispone cuatro tensores D20. El arquitecto cajea la coronación de los muros para disponer un zuncho de hormigón armado perimetral $50 \times 40 \mathrm{~cm}$ con $4 \mathrm{r} 16$ y estribos $\mathrm{r} 8 / 25$. El tablero se resuelve con nervometal y capa de compresión de hormigón de $7 \mathrm{~cm}$ de espesor.

1981 - Obras urgentes: cubierta nave lateral derecha - Luis Alberto Mingo Macías

1989 - Restauración de la sacristía - Luis de la Riva de la Peña

Tras el hundimiento de un tercio de la cubierta, que arrastra dos tercios de bóvedas, se coloca una nueva estructura de madera de pino sobre durmientes atados a un zuncho de hormigón sobre el remate de los muros. Se refuerza la fachada desplomada con un contrafuerte de hormigón armado.

1993 - Se encarga una nueva intervención a Luis de la Riva de la Peña al detectarse rotura localizada del hormigón del zuncho en puntos de anclaje de tirantes. El refuerzo consiste en la incorporación de diez pares de nuevos tensores D10 (cada tres pórticos)

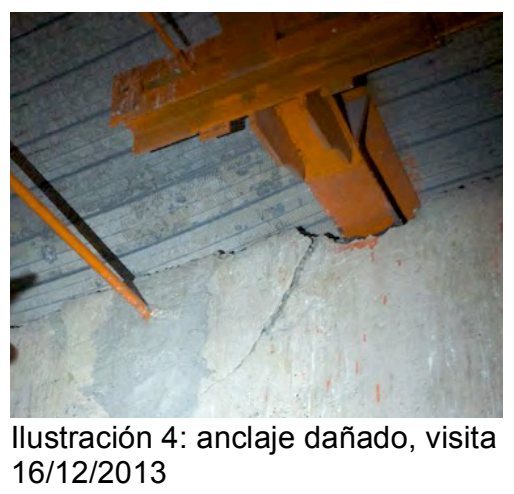
1997 - Proyecto de Restauración de la Iglesia de Santa María - Elesio Gatón Gómez Afecta sólo a revestimientos e instalaciones. 


\section{Planos}

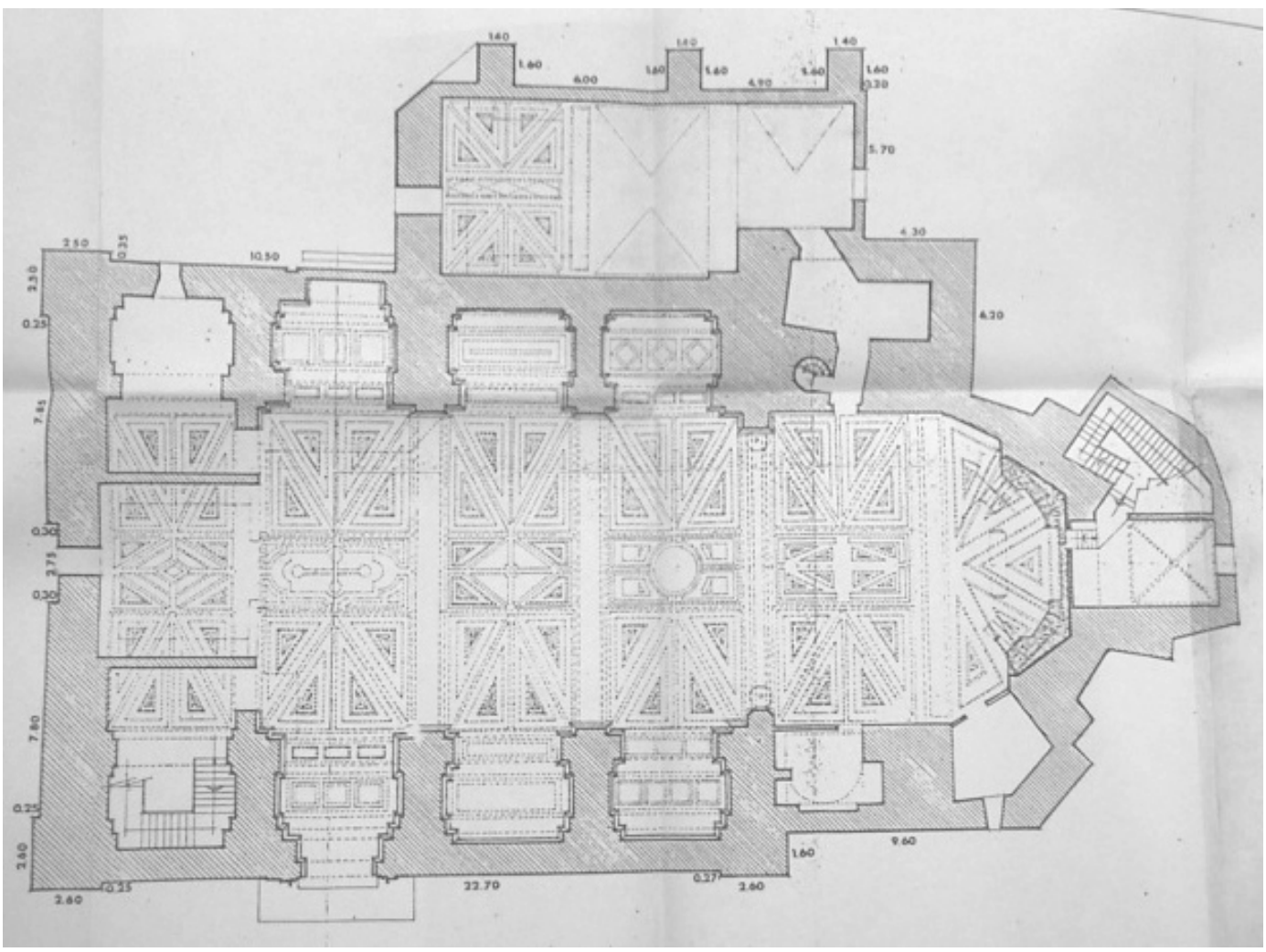

Ilustración 5: planta general (Mingo 1980 IPCE)

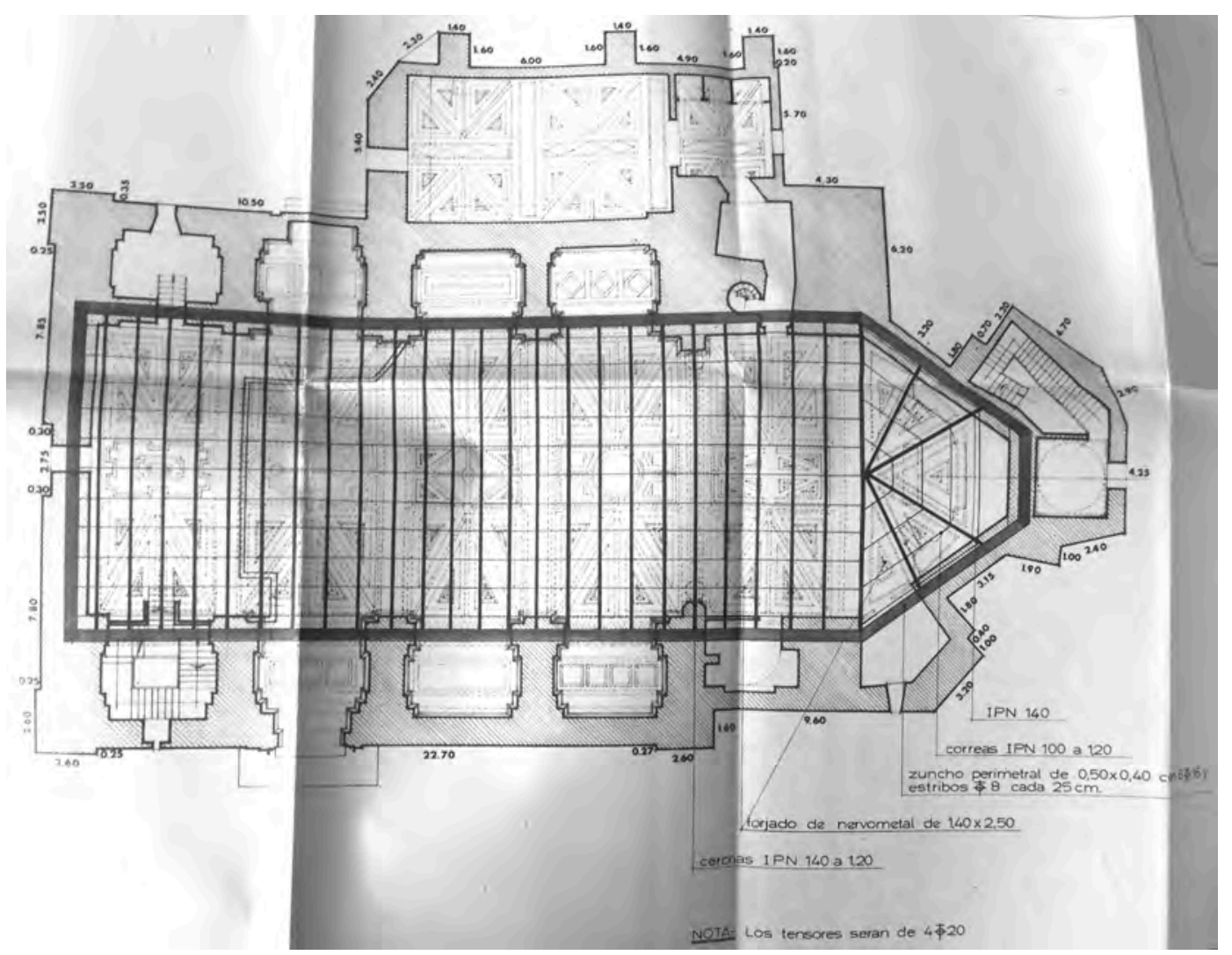

Ilustración 6: estructura de cubierta proyectada (Mingo 1989) 


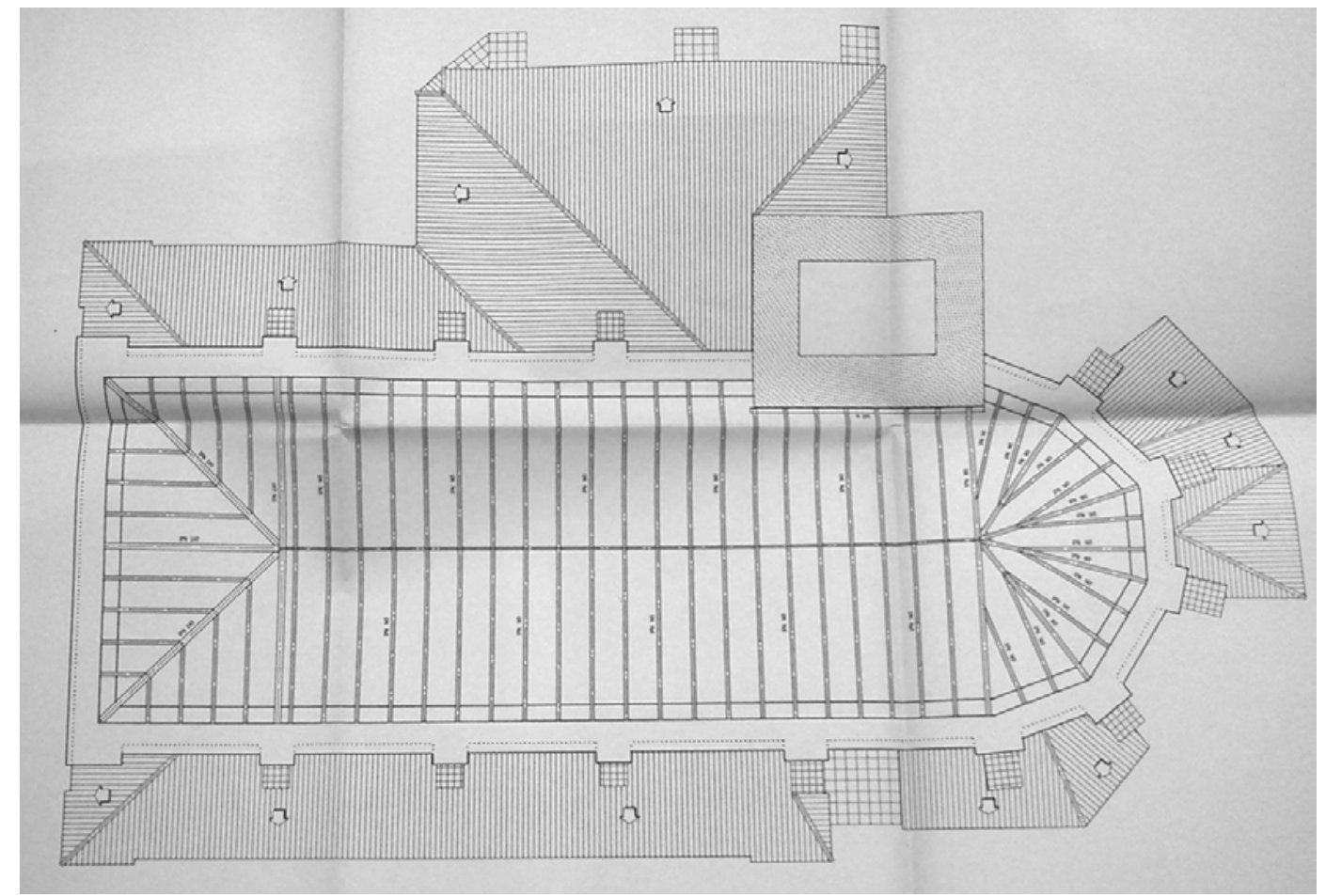

Ilustración 7: estado actual (de la Riva $1993 \mathrm{JCyL}$ )

La geometría reflejada en la planta de estructura de cubierta en estado actual de 1993 se ajusta más a lo realmente ejecutado que el anterior plano del propio proyecto en el que ésta se ejecuta.

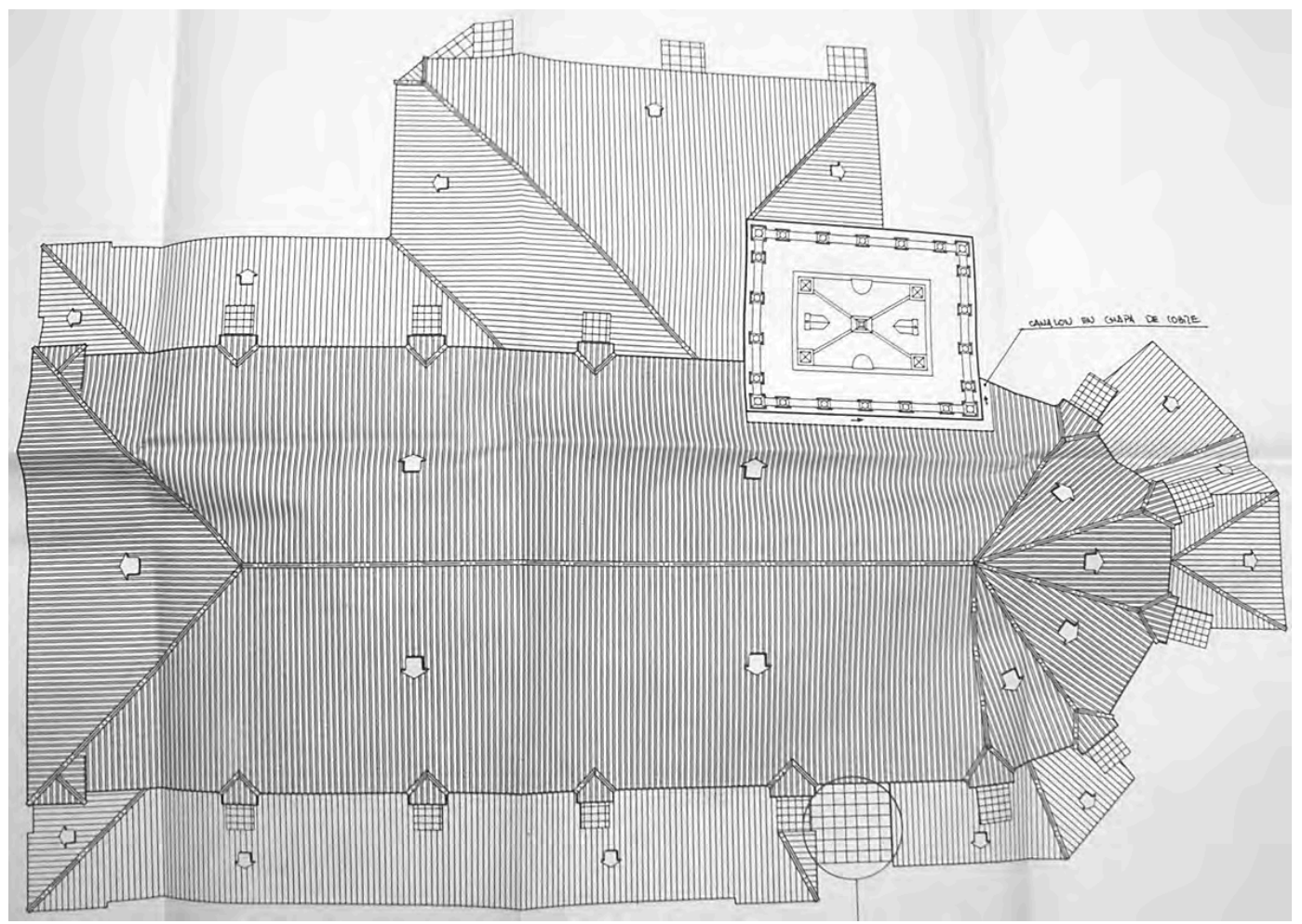

Ilustración 8: planta de cubiertas (de la Riva 1993 JCyL) 


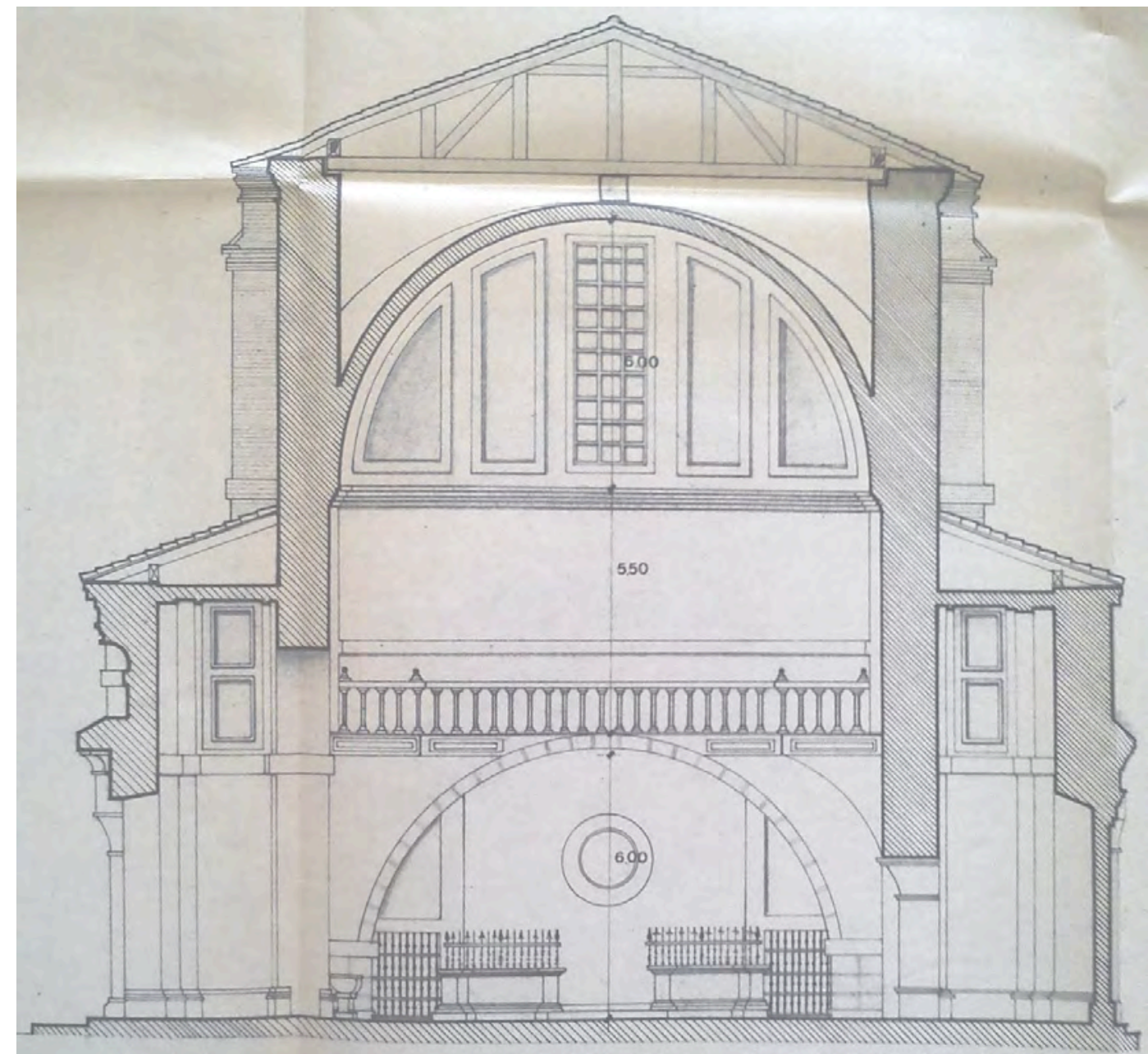

Ilustración 9: sección transversal antes del reemplazo de cubierta (Mingo 1980 IPCE)

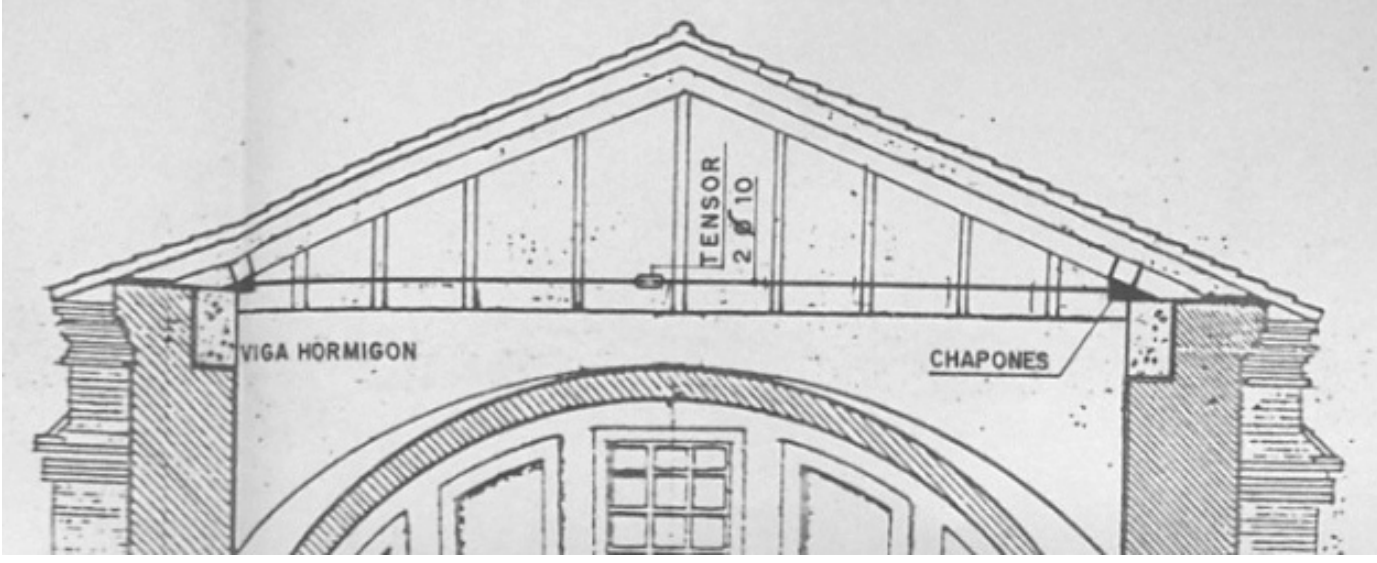

Ilustración 10: sección de nueva estructura según el Proyecto (Mingo 1980 IPCE)
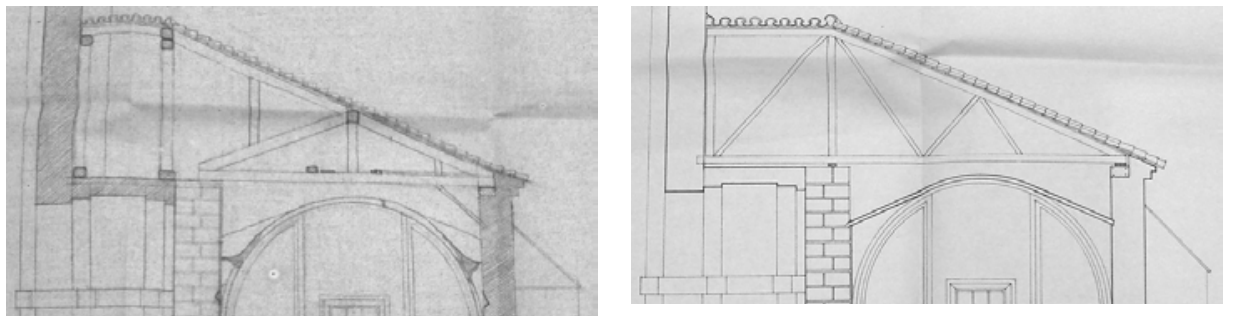

Ilustración 11: sección de sacristía antes y después de 1993 (de la Riva JCyL) 


\section{Solución constructiva de la cubierta}

En las secciones del estado de la cubierta en 1980 se aprecia un extraño dado de apeo central de la cercha de madera sobre la clave de la bóveda. Sobre estos planos podemos medir una inclinación de la cubierta de $23^{\circ}$.

En el proyecto de 1993 se indica que la pendiente de los IPN que forman los faldones de cubierta es de $19^{\circ}$. No se ha encontrado en la documentación de los proyectos mención alguna a cambios de pendiente.

No es frecuente en rehabilitación monumental el diseño de este tipo de pórticos metálicos a dos aguas que hacen necesario el uso de tirantes adicionales para contrarrestar los empujes horizontales producidos por la propia geometría de los elementos. Habitualmente se reemplazan las armaduras de madera por cerchas trianguladas, precisamente con el fin de evitar empujes horizontales, no compensados, sobre la coronación de los muros de fábrica.

\section{Zunchos}

En dos detalles del arquitecto Luis Mingo se define la nueva estructura de perfiles de acero laminado anclados a un zuncho de hormigón armado 40x50. El tablero se diseña con $7 \mathrm{~cm}$ de hormigón sobre nervometal y cobertura de teja árabe recibida con mortero.
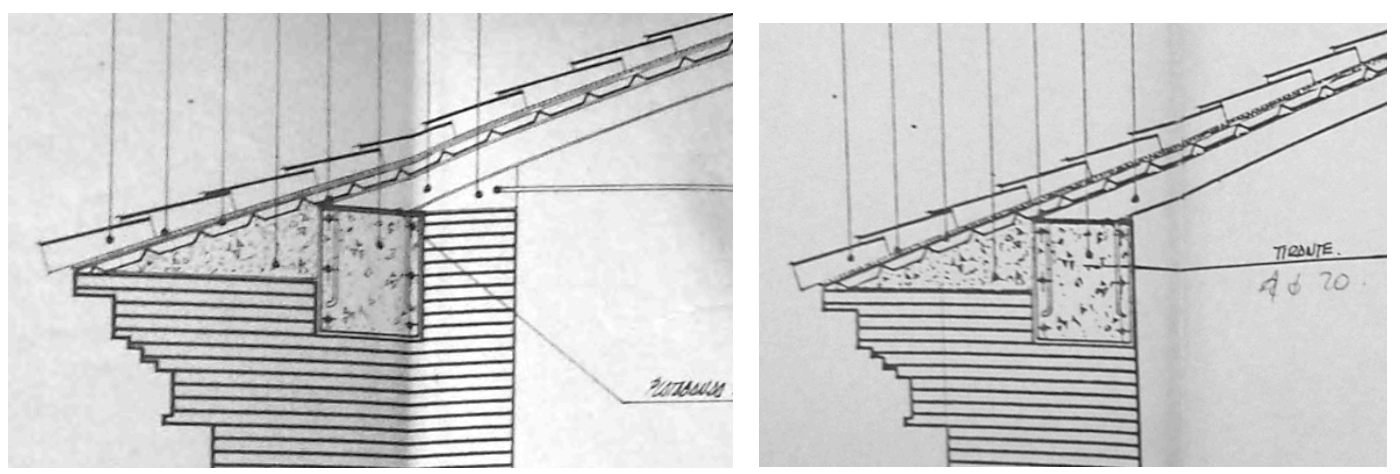

Ilustración 12: detalles de Proyecto y Obra (Mingo 1980)

En el detalle del plano 08 del Proyecto conservado en el archivo del IPCE, a la izquierda de la ilustración anterior, se representa los tirantes anclados a una cartela triangular soldada al ala inferior del perfil. En el de la derecha, sin embargo, tomado de un plano suelto con el mismo grafismo, localizado en la carpeta del proyecto de refuerzo llevado a cabo trece años después y más en concordancia con las fotografías de 1993, el tirante acomete contra el zuncho de hormigón. 
Podemos considerar probable entonces que el diseño del anclaje de los tirantes se modificase durante el transcurso de las obras. En el dibujo con la leyenda 4r20 señalada a mano, se representa el arranque del tirante embebido hasta aproximadamente el centro de la sección del zuncho, pero no se acota la longitud que debe profundizarse ni a qué altura sobre la cara del zuncho.

Años después se produjo una patología con arrancamiento de cuña del anclaje más próximo a los pies que motivó la incorporación de tirantes adicionales, esta vez anclados a perfiles corridos y pletinas soldadas a ambos lados de las cartelas.

\section{Conclusiones}

En este edificio se incorporó un zuncho rectangular de hormigón armado 40x50 en la coronación de los muros de la nave central durante las obras de rehabilitación llevadas a cabo en 1980. Se sustituyó la estructura de madera original de la cubierta por una metálica, formada por pórticos a dos aguas de acero laminado y tablero de nervometal con una capa de $7 \mathrm{~cm}$ de hormigón.

Los empujes sobre el remate de los muros, debidos al diseño de los pórticos como simples vigas quebradas a dos aguas, se intentaron contrarrestar mediante cuatro tirantes de acero anclados al zuncho en B, C y D. El cuarto se dispuso entre los muretes $\mathrm{E}$ y $\mathrm{F}$ que acodalan en el tramo de la torre, en cuyo encuentro se interrumpe el zuncho de hormigón. En el tramo corto A el canto zuncho se reduce drásticamente, produciéndose además el encuentro con los zunchos a ambos lados con su remate a distinto nivel.

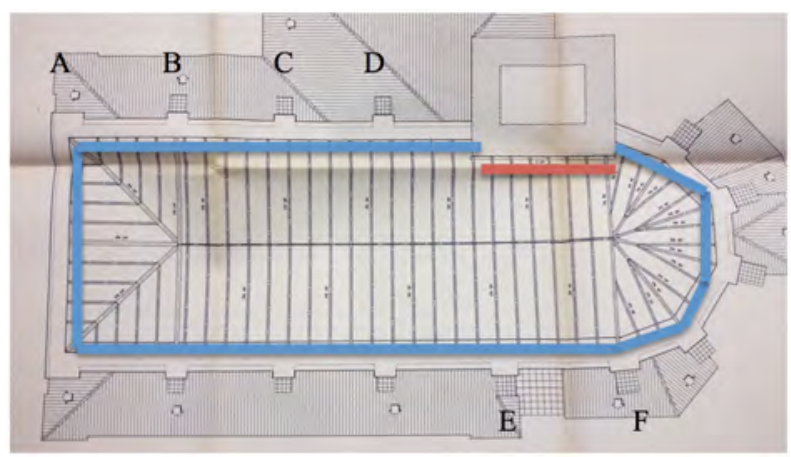

Ilustración 13: esquema de zunchos
Se produjo el arrancamiento del anclaje extremo, correspondiente al eje $B$, que recibe los esfuerzos de las vigas diagonales que forman el frente a cuatro aguas sobre la fachada a los pies. En los apoyos A se manifiestan las grietas verticales a ambos lados de las aristas descritas en la página anterior.

En 1993 se realizó una intervención de refuerzo incorporando diez pares de tirantes adicionales. Los testigos colocados entonces se mantienen inalterados. 


\section{Iglesia de Santa María. Tordesillas}

Intervenciones citadas en la publicación del Ministerio:

1980 - Cubiertas - Luis Alberto Mingo Macías

1981 - Obras urgentes: cubierta nave lateral derecha - Luis Alberto Mingo Macías

En la página web del IPCE no se localizan planos digitalizados

\section{En el Archivo General de la Administración}

AGA 26/01124

Proyecto

Obras de restauración en la iglesia de Santa María de Tordesillas

Luis Alberto Mingo mayo 1980

Memoria (2 pag)

Introducción histórica y descripción.

"En el segundo decenio del siglo XVI se verificaban obras en la iglesia de Santa María, bajo la dirección de Gonzalo de Bueña. Pero Felipe de la Cajiga trazó en 1595 una reforma total, de la cual fue ejecutor Diego de Hano. La iglesia es de una sola nave, conservando la cabecera gótica."

Indica que en ese momento se encuentra abierta al culto.

En una hoja de Anexo explica que si durante el desmontaje se observa que se puede salvar parte de la armadura se hará para ahorrar formas metálicas y transferir esa cuantía a restaurar las capillas.

En la medición el zuncho figura como:

m3 zunchado perimetral $0,50 \times 0,50 \times 0,40$ de hormigón armado de 350Kgs de dosificación y $60 \mathrm{Kgs} / \mathrm{m} 3$ de $6 \mathrm{~d} 16$ y estribos d 8 cada $25 \mathrm{~cm}$.

Planos:

Plano 08 de detalles constructivos 1:20. La leyenda está rotulada a mando: cobertura de teja árabe, mortero de agarre, capa de compresión de $7 \mathrm{~cm}$ de espesor, hormigón para formación de alero, placas de nervometal de 1,40 x 2,50, zuncho perimetral de $0,40 \mathrm{x} 0,50$ con $6 \mathrm{~d} 16$ y estribos d 8 cada $25 \mathrm{~cm}$, cercha metálica formada por IPN 140, cartela, platabanda de unión.

Es el detalle en que los tensores acometen a la cartela de la cercha.

Documentación administrativa, pagos en firme, escrituras de contrata, etc. 


\section{AGA 26/01501}

Carpeta con documentación sólo administrativa: Pagos en firme, liquidaciones, etc.

Obras menores de conservación en la iglesia de Santa María en Tordesillas

Luis Alberto Mingo Macías --

Se adjudicó a TRYCSA en abril de 1982; recepción provisional mayo de 1982 y definitiva en octubre de 1983.

m2 levantamiento de teja curva con aprovechamiento, limpieza y transporte de productos a vertedero $156,32 \mathrm{~m} 2$

$\mathrm{ml}$ de desmonte de cornisas y transporte a vertedero así como cajeado de zuncho $35 \mathrm{ml}$

m3 de retirada de escombros acumulados sobre bóveda y transporte de productos sobrantes a vertedero $121,41 \mathrm{~m} 3$

$\mathrm{ml}$ de zuncho perimetral de hormigón armado incluso encofrado $35,50 \mathrm{ml}$

$\mathrm{kg}$ de hierro en perfiles incluso placas de anclaje $1557,52 \mathrm{~kg}$

$\mathrm{ml}$ de cornisa de ladrillo macizo tipo Navas de Oro y teja $35,50 \mathrm{ml}$

m2 de capa de hormigón con nervometal 130,64ml

$\mathrm{m} 2$ de colocación y reposición de teja curva tomada con mortero $156,32 \mathrm{~m} 2$

\section{En el archivo del IPCE:}

\section{Carpeta 643-7}

Obras de restauración en la iglesia de Santa María de Tordesillas

Mayo 1980

Luis Alberto Mingo

El presenta proyecto de restauración afecta al tema de cubiertas con problemas de goteras producido por corrimiento de tejas, irregularidades en cubierta, fisuración en remates de cornisas y pudrición de armaduras de madera.

Desglose de los trabajos:

- Desmantelamiento de cubierta, consistente en desmontado de teja y armaduras de madera. Limpieza superior de bóveda en general

- Apertura de cajas para alojamiento de zunchos de atado con hormigón de 350kgs

- Estructura de cubierta metálica consistente en formas IPN 140 y 4 tensores D20

- Formación de cubierta constituida por tableros de nervometal y capa de compresión de $7 \mathrm{cms}$ y tendido de teja vieja

- Reparación de cornisa exterior igualando con la existente 
Mediciones y presupuesto

$\mathrm{m} 2$ desmontado de teja curva... $1 \times 46 \times 17=782 ; 66 \quad=848$

$\mathrm{m} 2$ desmontado de estructura de cubiertas con aprovechamiento de tabla $=848$

Cajeado para zuncho perimetral... 105ml

lud limpieza de escombros sobre bóvedas

Zunchado perimetral 0,50 x 0,50 x 0,40 de hormigón armado de $350 \mathrm{kgs}$ de dosificación y $60 \mathrm{kgs} / \mathrm{m} 3$ de $6 \mathrm{D} 16$ y estribos D8 cada $25 \mathrm{~cm}$

$105 \times 0,50 \times 0,40=21,0 \mathrm{~m} 3$

perfiles laminados en formación de estructuras de cubierta, incluso presillas, cartelas, placas de anclaje, tirantes, tensores, etc. totalmente colocado, cerchas a $1,20 \mathrm{~m}$ de separación

IPN-140 4397,0; IPN-120 302,0; IPN-100 512,0

Formación de cubierta constituida por tablero de nervometal, capa de compresión de $7 \mathrm{cms}$ incluso encofrado y desencofrado $\quad 848 \mathrm{~m} 2$

Tendido de teja curva vieja recibida con mortero bastardo de cal y barro

Formación de cornisa de ladrillo tejar igual a la existente $105 \mathrm{ml}$

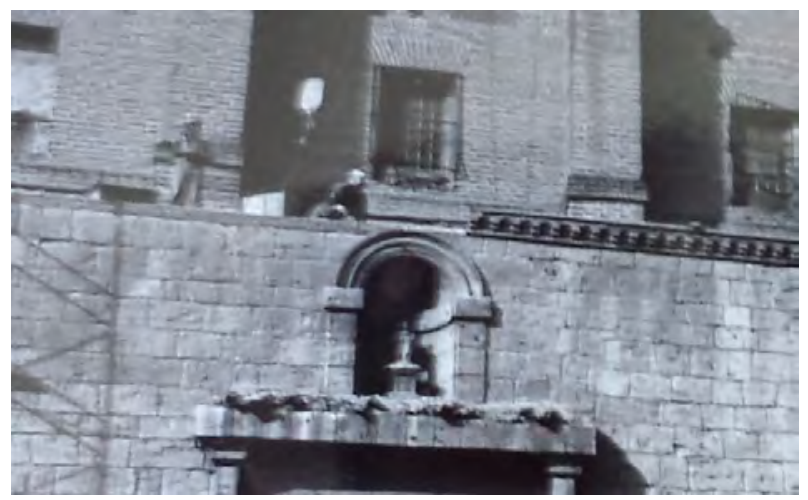

Ilustración 14: dossier de obra, rehaciendo cornisa (Mingo 1980 IPCE)

Dossier 19 págs. con fotografías blanco y negro, con tres fotos de obra.

Hoja firmada por Mingo el 24 de marzo 1983 en que describe obras realizadas mediante una lista igual a la de previstas añadiendo distribución interior de tabiquería.

\section{En el archivo de la Junta de Castilla y León}

\section{VA-47}

Carpeta 5239-1

1988 - Se anula un crédito por imposibilidad de empezar la obra. - José Urrutia Landa entrega su Proyecto en octubre 1988. 
La Comisión Territorial de Patrimonio Cultural acuerda en noviembre no aprobarlo "al ser la solución constructiva presentada totalmente inadecuada a la arquitectura del edificio". Se recomienda reponer la bóveda con el mismo sistema constructivo de la existente, respetar la madera para la nueva cubierta y aplicar revoco de cal en vez de enfoscado en las fachadas. En diciembre el arquitecto renuncia a las obras (incluso cobro de honorarios por lo presentado)

\section{VA-64}

Carpeta 5249

1989 - Restauración de la sacristía - Luis de la Riva de la Peña

En la correspondiente Ficha de diagnóstico el arquitecto refleja la ruina en la totalidad de la cubierta de la sacristía, así como el mal estado de la cubierta del camarín de la Virgen, humedades de capilaridad y grietas en esquinas de muros.

Se adjudica a la constructora segoviana EDOPSA SA y se cuenta con un Modificado.

*En esta carpeta hay varios documentos sueltos que supongo pertenecen al VA47 y se han traspapelado, ya que en ellos aparece que en el proyecto de Urrutia de plantea recomponer bóveda con estructura metálica y de hormigón y se anota a mano que "la solución de arcos formeros con estructura metálica espacial vista parece un poco atrevida".

En la revisión del proyecto del Servicio de junio del 89 se señala oportunamente que “deberá sustituir el refuerzo de la bóveda existente con capa de hormigón armado por otro procedimiento que no sea irreversible y permita respirar a la bóveda." Aunque en las certificaciones incluidas más adelante parece que se sigue incluyendo dicha partida con 71,62m 2 reforzados con capa de compresión de $4 \mathrm{~cm}$ de espesor.

En esta medición se describen $267,42 \mathrm{~m} 2$ de entramado de madera y $116,57 \mathrm{~m} 2$ de bóveda con lunetos tabicada resuelta con tres hojas, la primera de rasilla y dos de ladrillo hueco. También 89,33 m2 de rejuntado de la piedra con mortero de cemento.

Según la memoria del Proyecto de de la Riva se encuentra caída la cubierta en un $30 \%$, y el resto movida, con dos tercios de la bóveda con lunetos arruinada. Describe como "en la coronación del muro y, al objeto de atar todo su perímetro, se proyecta colocar un zuncho corrido de hormigón H-175 armado. Las armaduras se anclarán en los muros de la iglesia de tal forma y manera que permita una unión rígida” 

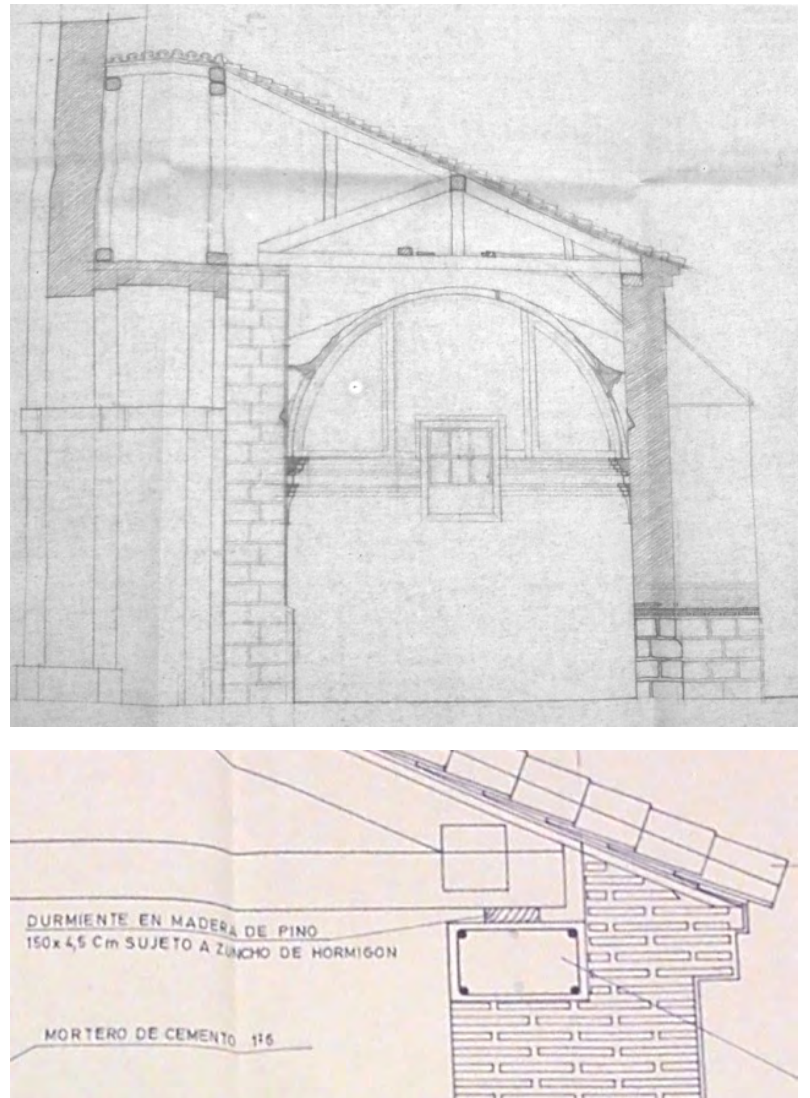

Ilustración 15: planos de sacristía antes y después de la intervención (de la Riva 1989 JCyL)
Para resolver la nueva estructura de cubierta "se proyecta un entramado de madera compuesto por cerchas sobre durmientes de madera ancladas éstas al zuncho de hormigón”.

La Restauración de la Sacristía cuenta con un proyecto Modificado en el que se incluye el refuerzo de la fachada desplomada $15 \mathrm{~cm}$ mediante un contrafuerte en ménsula de $6,2 \mathrm{~m}$ de altura de hormigón armado de $35 \times 70 \mathrm{~cm}$ que se reviste con ladrillo macizo. Se dispone sobre una zapata también de hormigón H-175 de $3 \times 1 \times 1,5 \mathrm{~m}$.

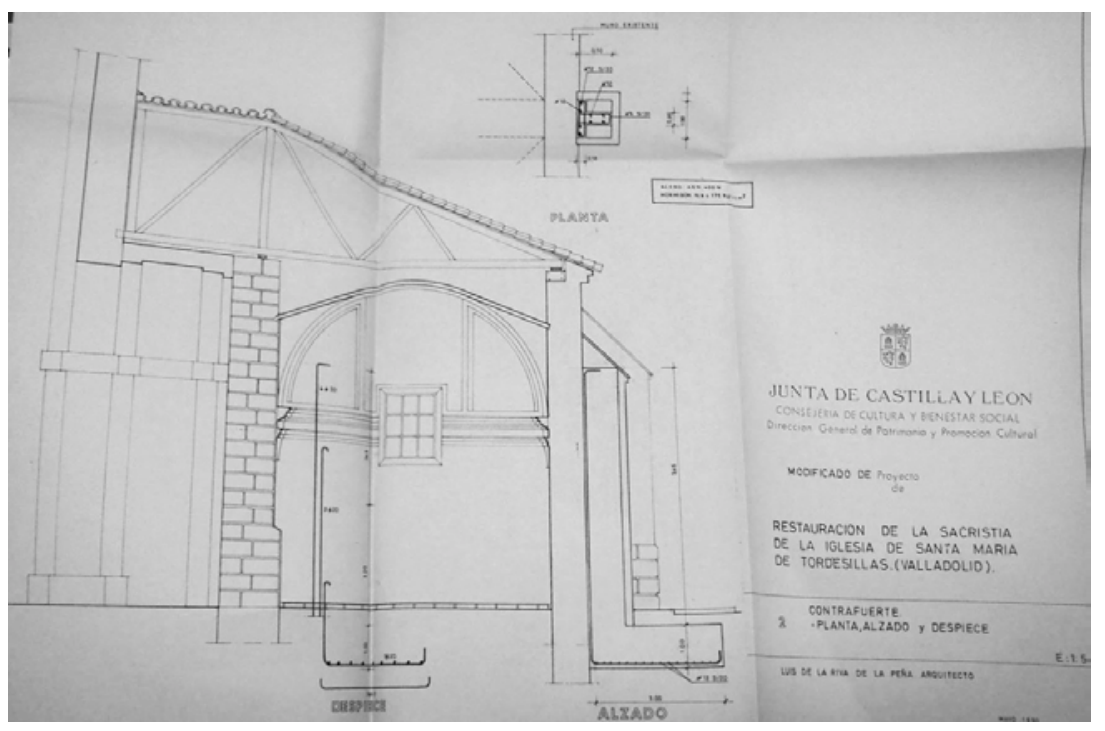

Ilustración 16: detalle contrafuerte sacristía (de la Riva 1989 JCyL)

Según se aprecia en las imágenes anteriores, aunque las nuevas cerchas se resuelven con madera de pino, su diseño en celosía es completamente distinto del existente. 


\section{VA-135}

\section{Carpeta 5328}

En 1993 se encarga una nueva intervención a Luis de la Riva de la Peña, esta vez sobre la cubierta de la nave, al detectarse el "fallo en los tirantes que contrarrestan el empuje de los faldones de cubierta y flexión en el tablero".

La obra se ejecuta con cargo a fondos FEDER y se contrata a Restauración de edificaciones Yañez SA.

Según la descripción del estado actual de la cubierta en 1993, de la memoria del proyecto, ésta estaba "formada por un pórtico a dos aguas en perfiles de acero a una separación de 1,22m, empotrados en un zuncho perimetral de hormigón armado colocado en la coronación del muro de cerramiento de la iglesia. Los empujes horizontales generados por este sistema estructural se contrarrestan con 4 tirantes de acero de D20mm anclados en el zuncho de hormigón. Sobre ellos se encuentra colocada una malla de nervacero con una capa de compresión de hormigón de $5 \mathrm{~cm}$. El anclaje de los tirantes en el zuncho de hormigón ha fallado por lo que los empujes horizontales mencionados con anterioridad no quedan contrarrestados".
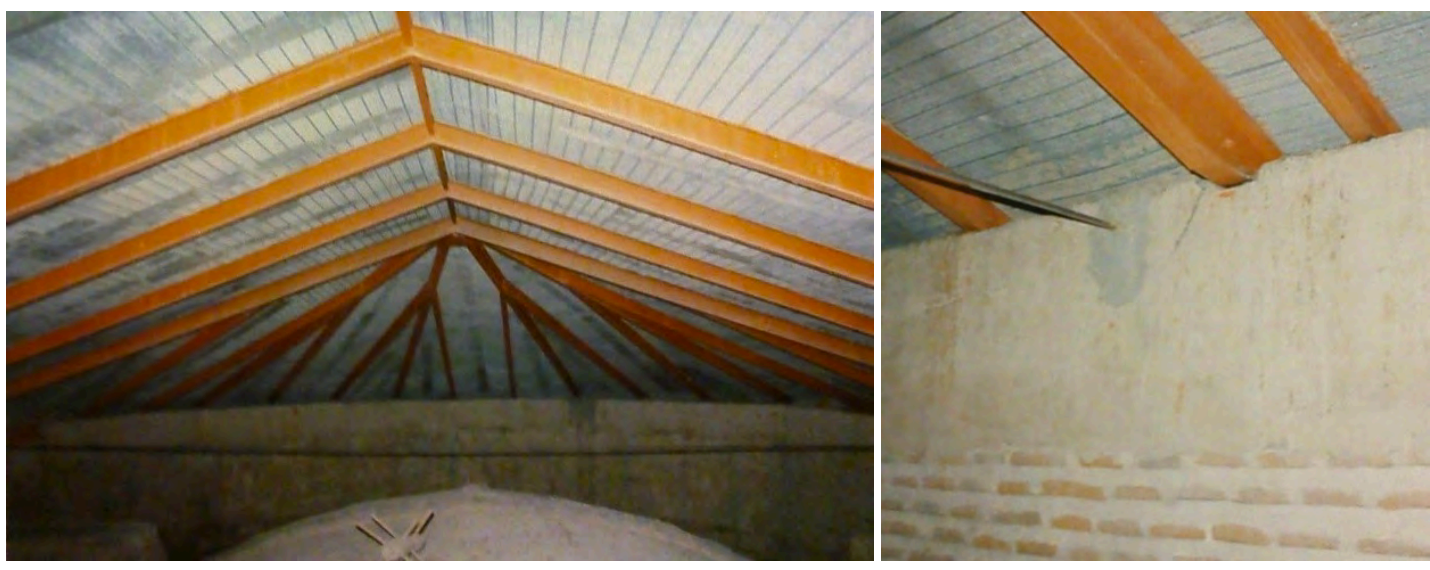

Ilustración 17: dossier patología, rotura del hormigón en anclaje de tirante (de la Riva 1993 JCyL)

"Se proyecta un sistema estructural para atirantar los pórticos creando una viga continua de acero, que los una, soldada sobre una cartela. Esa viga se atiranta cada tres pórticos mediante dos redondos de $\mathrm{D} 10 \mathrm{~mm}$. Estos tirantes van dotados de tensores, que pondrán en estado de solicitación los tirantes."

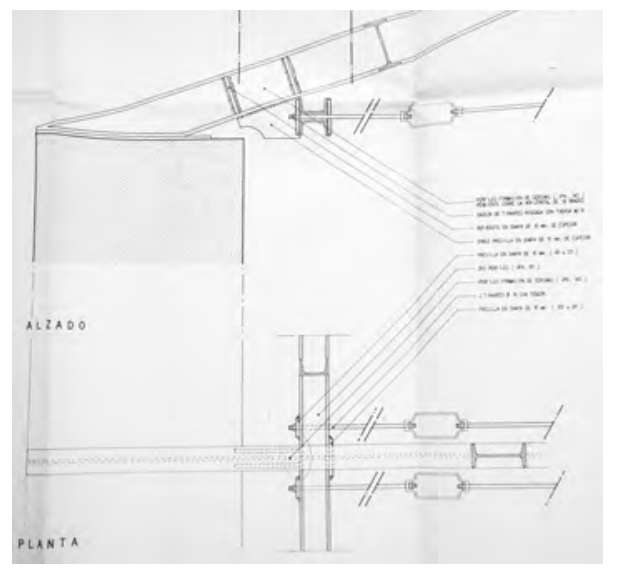

Ilustración 18: detalle refuerzo con anclaje (de la Riva 1993) 


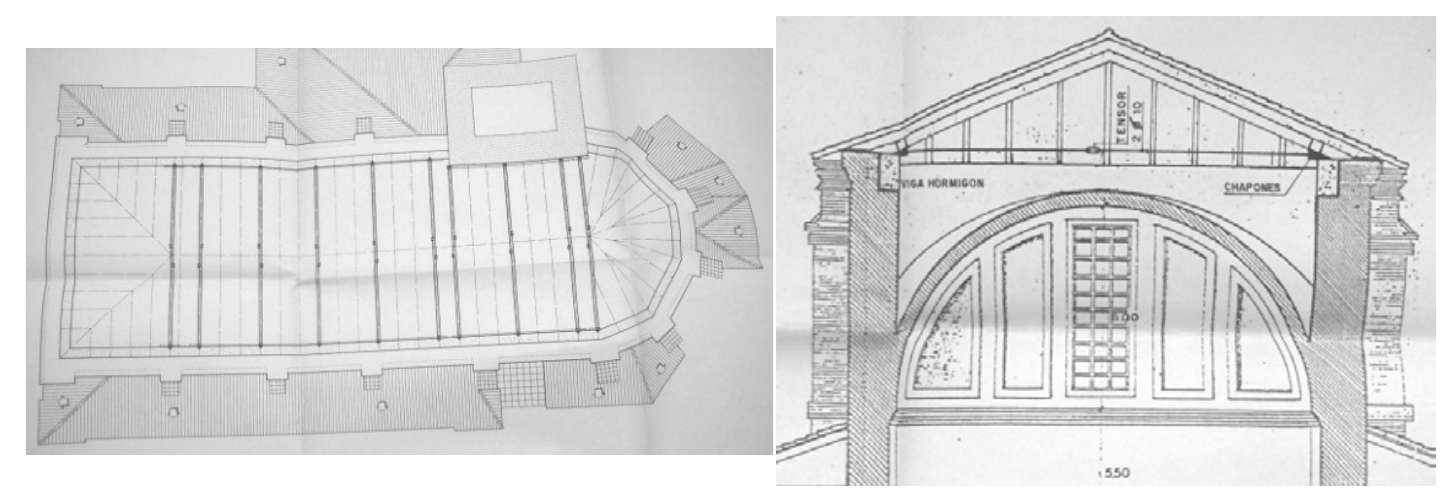

Ilustración 19: planta y sección de anclajes de refuerzo (de la Riva 1993)

Desde el Servicio de restauración el técnico Marco Antonio Garcés recomienda en otro documento:

El tablero hidrófugo no es necesario.

El mecanismo de solidarización de los nuevos tensores se puede confiar a pletina anclada a las viguetas en vez de a la soldadura.

Incluir cartela en los nudos superiores.

Enfoscar por debajo el nervometal.

\section{VA-239}

1997- Proyecto de Restauración de la Iglesia de Santa María. Tordesillas.

Arquitecto: Elesio Gatón Gómez

Aparejador: Pedro Julio Baz

Constructora: Cabero Edificaciones SA

La obra se financia a medias entre la Junta de Castilla y León y la Parroquia mediante un Convenio de colaboración.

La fecha de Recepción definitiva de las obras es junio de 1999.

En el modelo de Ficha propuesta actuación se aclara que no es necesario seguimiento arqueológico por tratarse de obras que afectan sólo a revestimientos: saneo de humedades en capilla, ventilación y drenaje, pavimentos. Se aclara que las cubiertas han sido ya restauradas recientemente. Se repasan las carpinterías de madera, picado y rejuntado de fábrica en ábside y pilastras, emplastecido y pintura. Nuevas instalaciones de electricidad, alarma, etc.

Se cuenta con un Modificado de 1998, que se justifica al localizarse en una cata el solado de piedra original bajo la tarima actual que se iba a repasar. Se propone eliminar ésta y la cama de arena bajo la misma porque según el arquitecto sólo sirve para acumular humedad. En el proyecto se pretende resolver las humedades en una capilla realizando un cajeado de $30 \mathrm{~cm}$ y colocando un encachado, lámina de 
polietileno, solera de $10 \mathrm{~cm}$ de hormigón y sobre la misma tabiquillos de $1 / 2$ pie cada metro sobre los que apoyar un tablero cerámico con capa de compresión de hormigón armado con mallazo. Se recoloca sobre este conjunto la tarima confiando la ventilación de la cámara a la junta abierta del encuentro con los paramentos.

El interior de la iglesia se encontraba pintado en tonos pasteles, típicos de mediados del siglo XX, según Gatón. Se adopta un criterio binario que respete la jerarquía de los elementos, con fondo blanco y molduras gris perla, todo con pintura plástica. Si apareciesen restos de cromatismo original se consolidarán con Paraloid.

\section{VA-298}

Documentación básica de edificios declarados monumento de la provincia. Valladolid II. Iglesia de Santa María de Tordesillas. Abril de 1991.

Arquitectos: Álvaro Abad Cabrera y Mario Fernández Pírez.

Se trata de una recopilación de datos e informe sobre el estado del edificio en ese momento, que los autores afirman haber visitado mientras se encuentra en obras. Describen la estructura como "muro de carga perimetral de sillería con contrafuertes al interior dividiendo la nave única en cuatro tramos y generando las capillas laterales. En la parte superior muro remetido perimetral de carga de ladrillo con contrafuertes al exterior. Ábside de sillería con contrafuertes exteriores. Bóveda de cañón con lunetos sobre la nave y de cascos con lunetos sobre la capilla mayor. En la torre un caracol conduce hasta la cubierta de la nave principal, con el resto de escalera de madera nueva aunque se conserva la anterior en estado lamentable. Cubierta restaurada recientemente, las tejas son de tipo árabe apoyadas sobre un tablero de nervo-metal, sustentado a su vez por unos perfiles IPE-140 dispuestos cada 1,20 y cuatro tirantes para todo el edificio, redondo del 20. Todo ello descansa sobre una viga de hormigón de coronación del muro. La cubierta de las naves laterales y sacristía son de madera".
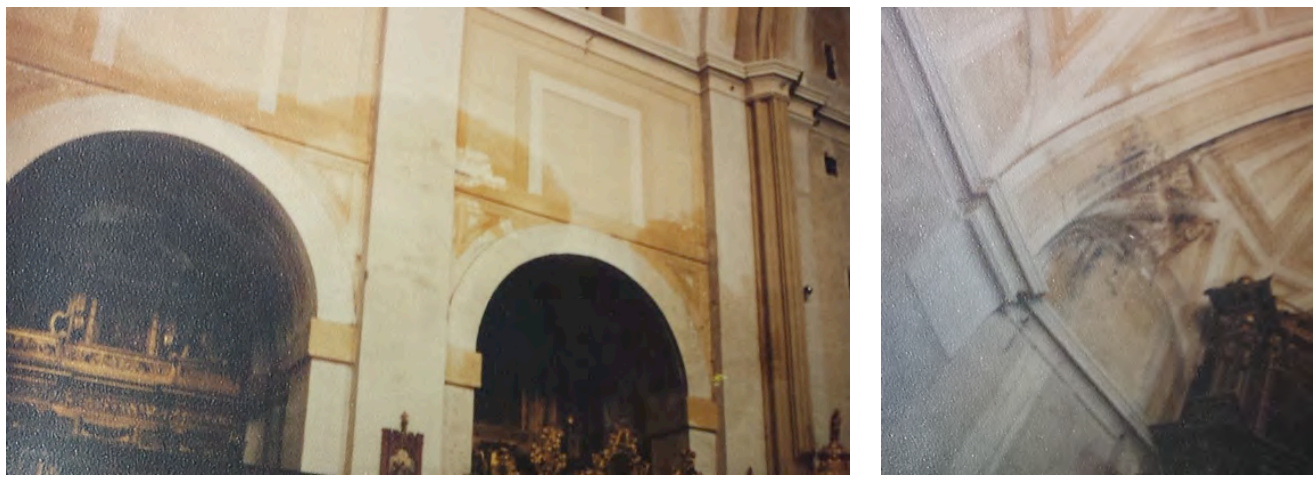

Ilustración 20: dossier informe (Abad 1991) 
En el estudio identifican diversas patologías y soluciones inadecuadas, como la escasa pendiente del tejado y cornisas pequeñas. Proponen sustituir la cubierta de la nave central por una isostática de mayor pendiente con aleros mayores y resolución del encuentro con la torre a dos aguas, según ellos mal resuelto y que produce el impacto directo de aguas contra la torre.

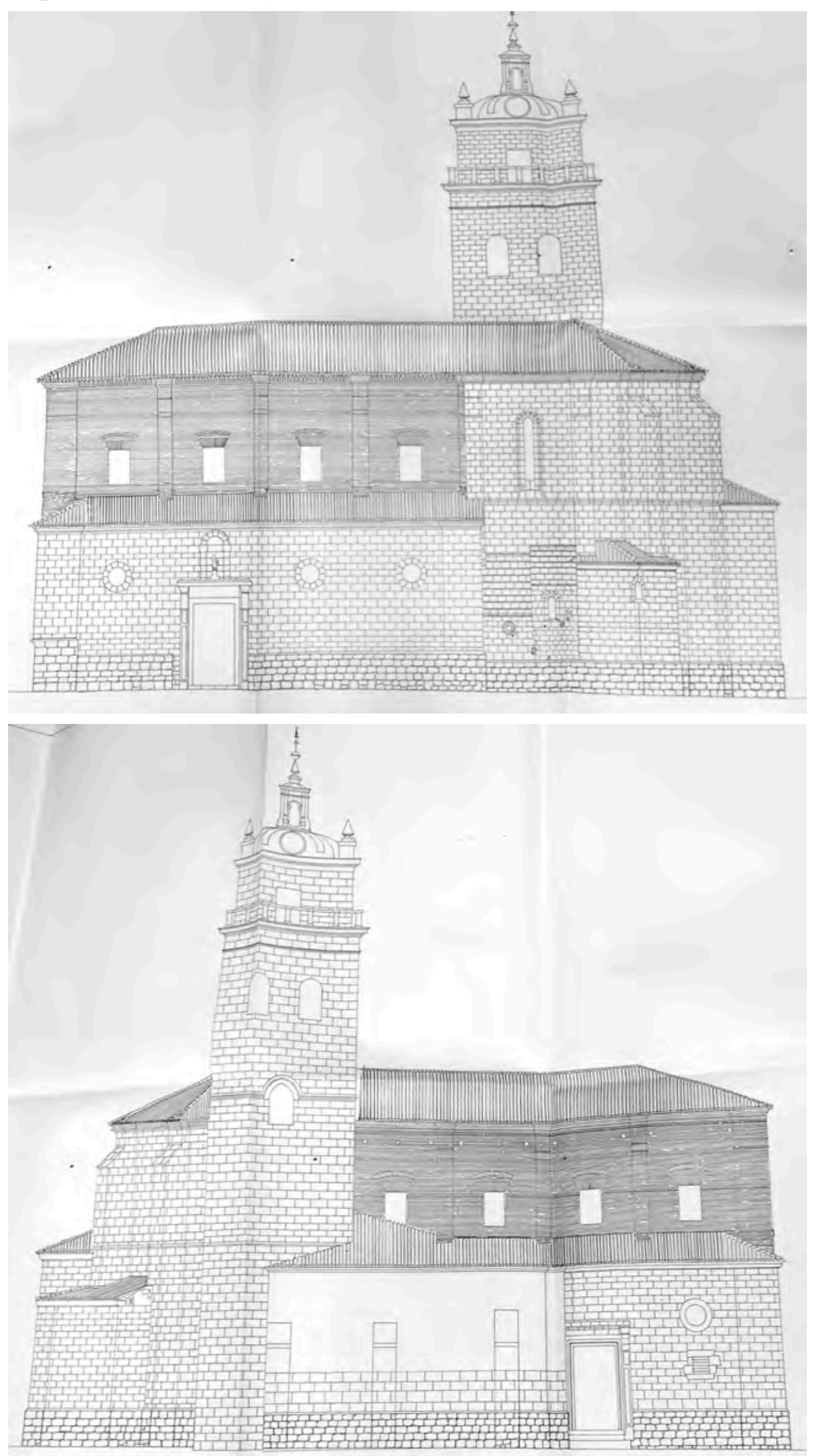

Ilustración 21: alzados laterales (Abad 1991 JCyL) 


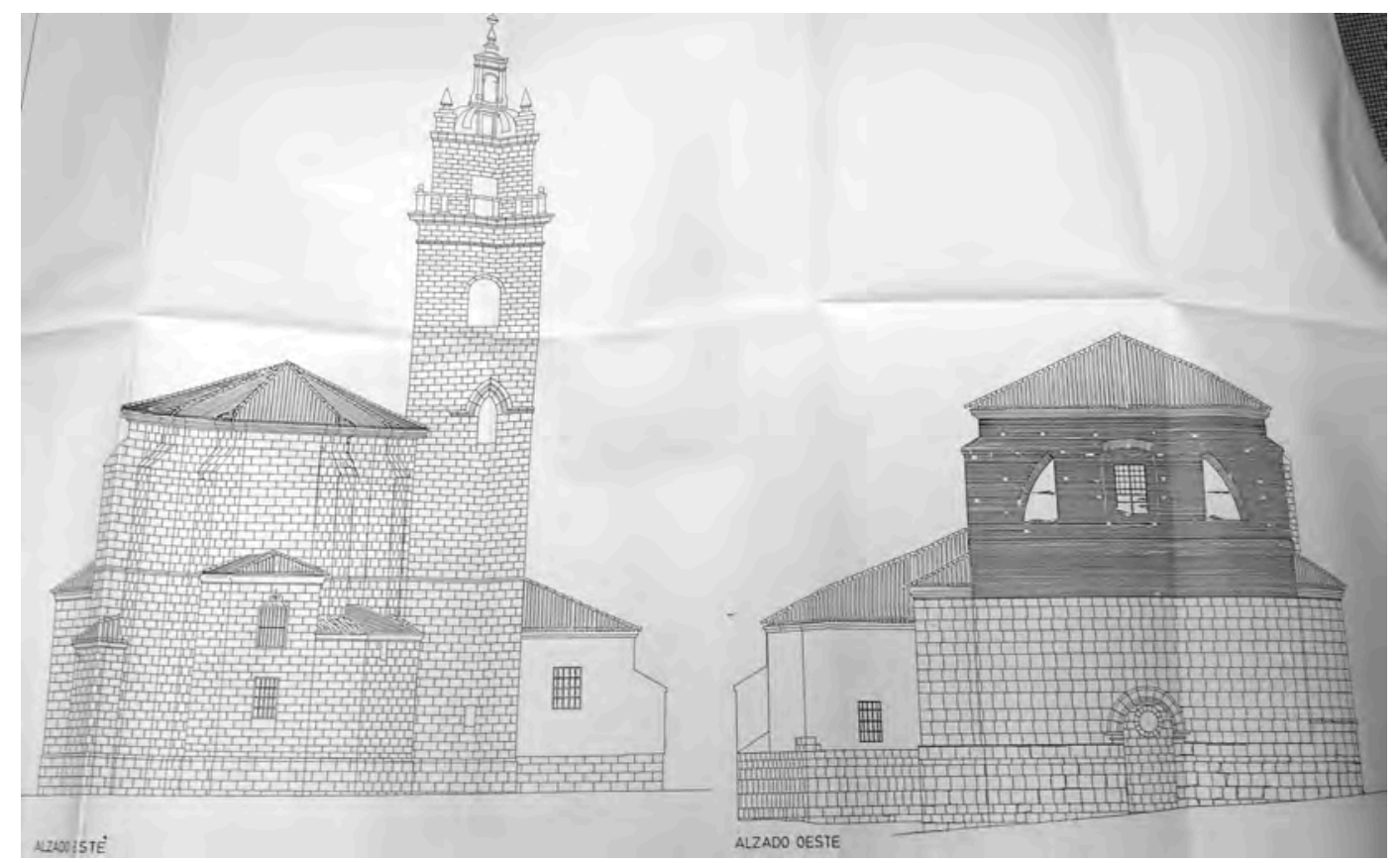

Ilustración 22: alzados pies y cabecera (Abad 1991 JCyL)

Estos planos son mera copia de los contenidos en el proyecto de Luis Mingo, excepto una sección longitudinal esquemática en la que no figuran elementos básicos del bajo-cubierta como los muretes sobre arcos de la cabecera o huecos de acceso desde la torre.

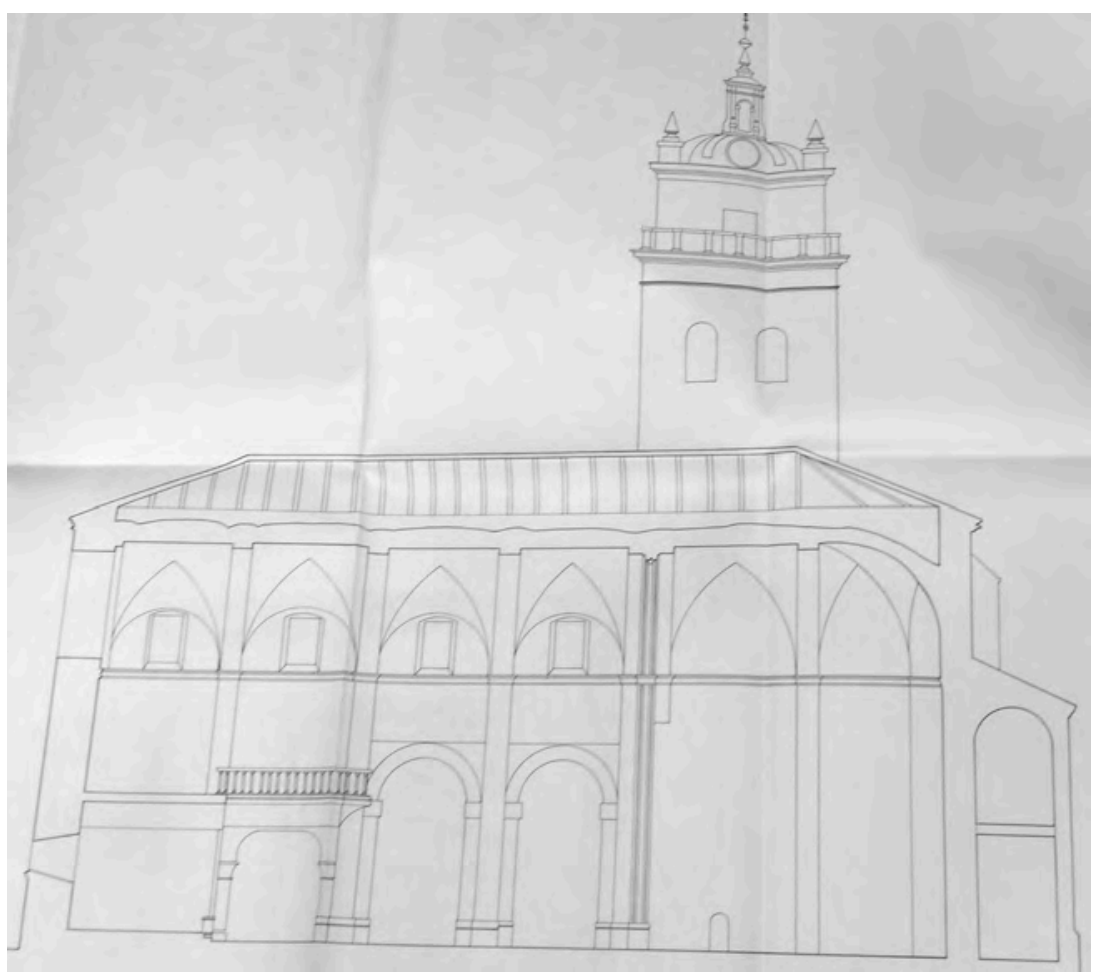

Ilustración 23: sección longitudinal (Abad 1991) 
En el plano de sección longitudinal del Proyecto de acabados interiores de 1997 de Elesio Gatón, tampoco se define correctamente la geometría de las cubiertas.

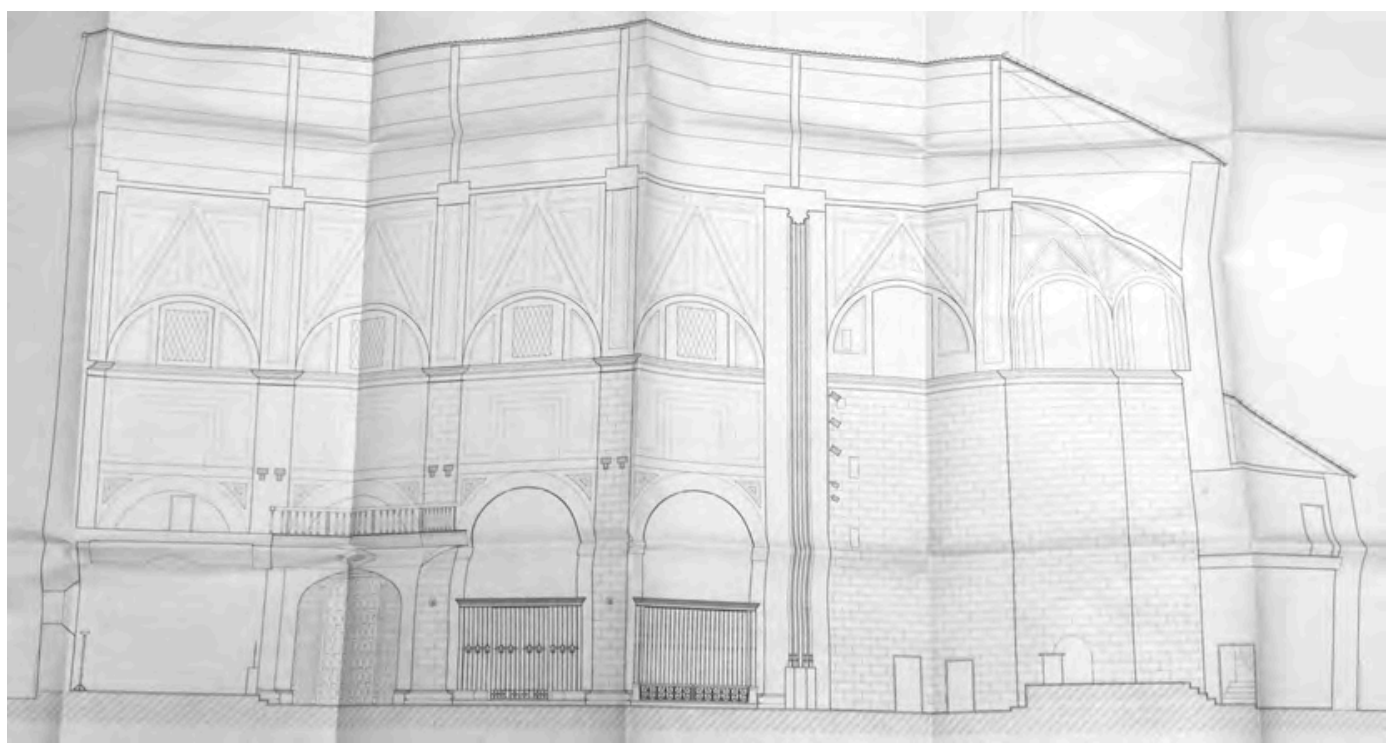

Ilustración 24: sección longitudinal (Gatón 1997) 



\section{Visitas realizadas}

\section{$16 / 12 / 2013$}

En la visita al edificio realizada en diciembre de 2013 se aprecia el estado del conjunto tras la última reparación, llevada a cabo veinte años atrás.

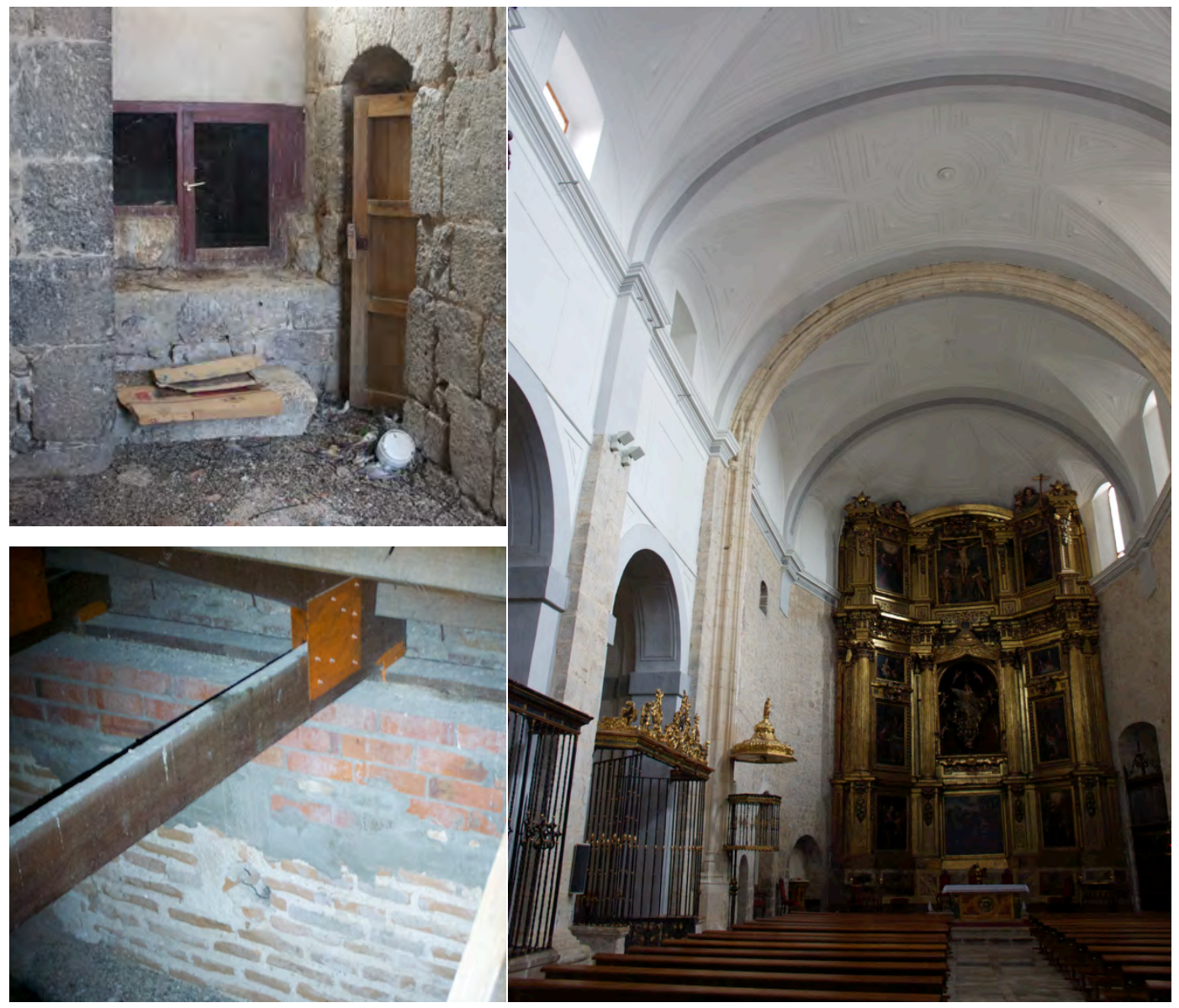

El monumento se encuentra en unas condiciones aceptables, pero el espacio bajo cubierta y el recorrido de acceso hasta el mismo se encuentran llenos de excrementos y restos de palomas, a pesar de los cierres con malla metálica dispuestos en todos los huecos.

La estructura nueva de la sacristía es de madera aserrada, con empalmes metálicos, y el apoyo de ésta sobre el muro presenta un revestimiento de fábrica de ladrillo recibido con mortero de cemento. Hay un durmiente de madera corrido dispuesto bajo los apoyos.

La estructura de cubierta del templo es de perfiles de acero laminado con entrevigado de hormigón sobre nervometal. 
El espacio bajo cubierta queda dividido en dos ámbitos por un murete de cantería que se levanta sobre el arco triunfal gótico, de separación entre el presbiterio y el cuerpo de la nave. La piedra es del mismo tipo que la que forma el paramento de la torre.

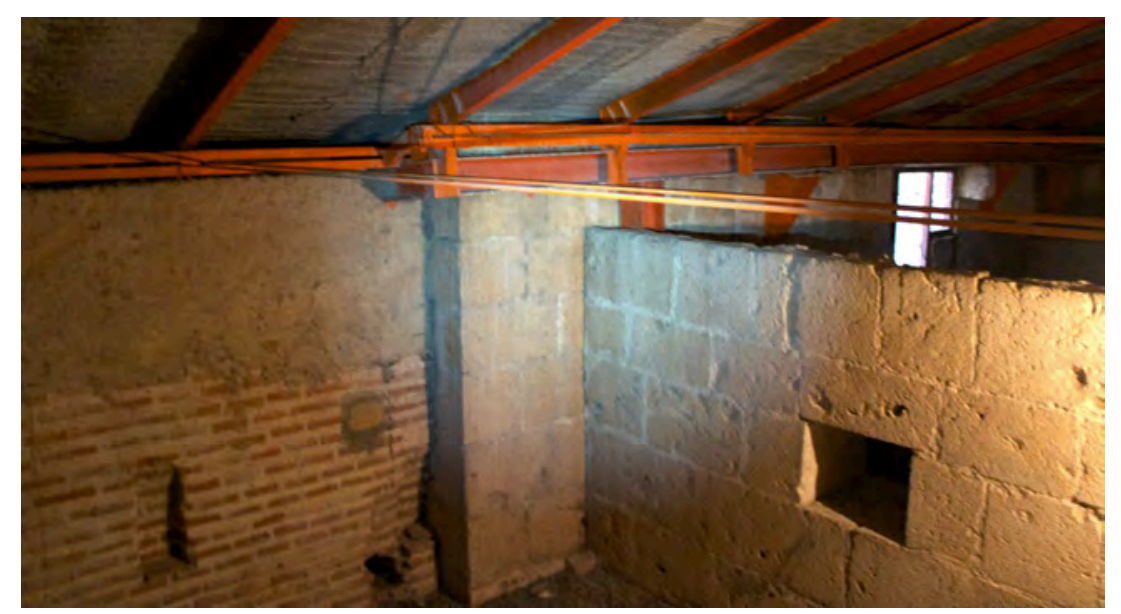

El acceso al bajo cubierta se produce desde la torre, entre este murete y otro de ladrillo cuya ubicación corresponde a la nervadura central del ábside. En este tramo, el zuncho de apoyo de la moderna estructura de cubierta se resuelve con perfiles de acero laminado sobre aparatos de apoyo del mismo material.

En la fotografía pueden verse éstos junto a dos ménsulas de piedra en forma de pecho de paloma, similares a las localizadas a la misma altura en el exterior de la torre que aparecen en la fotografía del encuentro con la cornisa de la Ficha. Otro apoyo se realiza a través de un enano de acero laminado que arranca sobre el murete de fábrica.

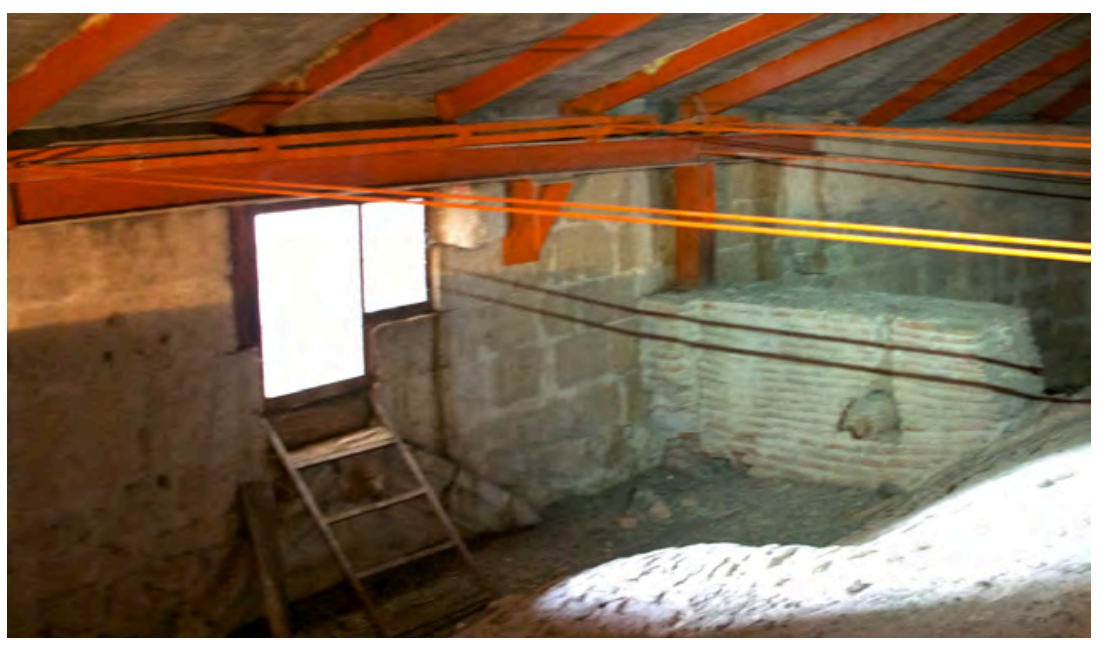

En varias zonas del bajo cubierta se aprecian restos de jácenas de madera recortadas tanto en sentido longitudinal, entre ambos muretes, como transversal. El remate de muros que conforman el cuerpo de la nave cuenta con un zuncho de hormigón armado. 
Se aprecia el trasdós de la bóveda de cañón con lunetos resuelta con rosca de ladrillo.

El zuncho presenta un revestimiento en buen estado que dificulta su revisión, aunque se aprecia a simple vista que los anclajes iniciales se dispusieron de forma no homogénea y sólo a unos $10 \mathrm{~cm}$ o $20 \mathrm{~cm}$ del borde superior.
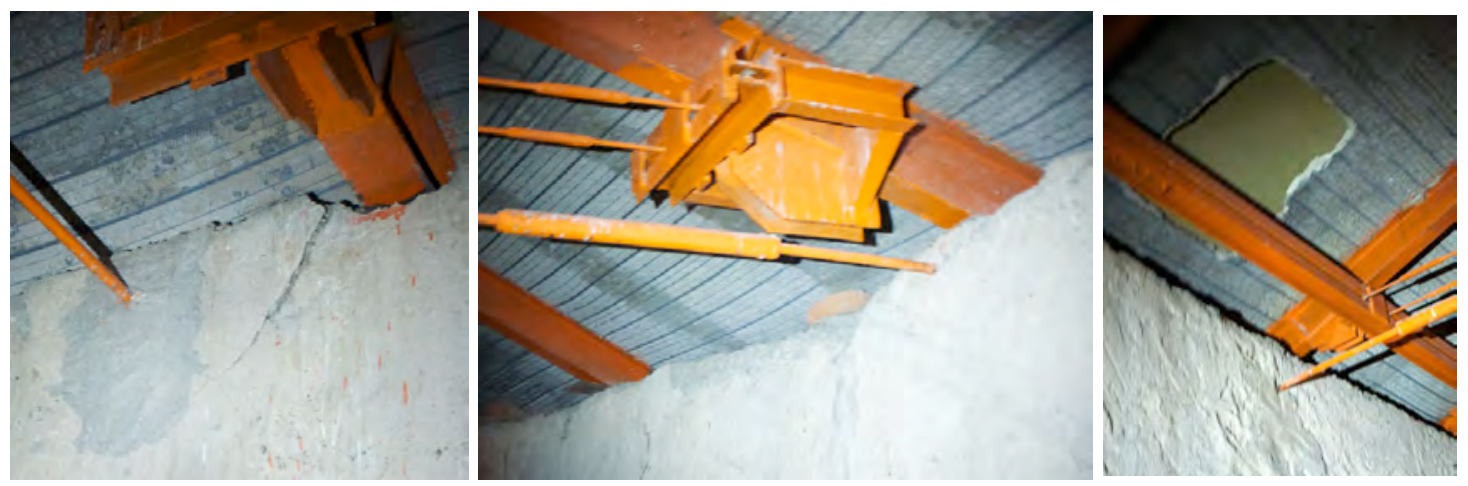

En una cata cuadrada (imagen de la derecha), abierta posiblemente para disponer una ventana tipo velux posteriormente desestimada, se puede apreciar la delgadez de la capa de hormigón armado dispuesta sobre el nervometal en ese punto.

El zuncho de hormigón es de unos $40 \times 50 \mathrm{~cm}$ y no llega a conformar un anillo perimetral completo, ya que su desarrollo se interrumpe en el encuentro con la torre campanario maclada, que forma la mocheta apreciable en las fotografías anteriores.

En el testero a los pies se dispone el zuncho de hormigón con una sección menor, de unos $35 \mathrm{~cm}$ de canto, y escalonado en el encuentro, con su cara superior a cota más alta que los de ambos muros laterales.
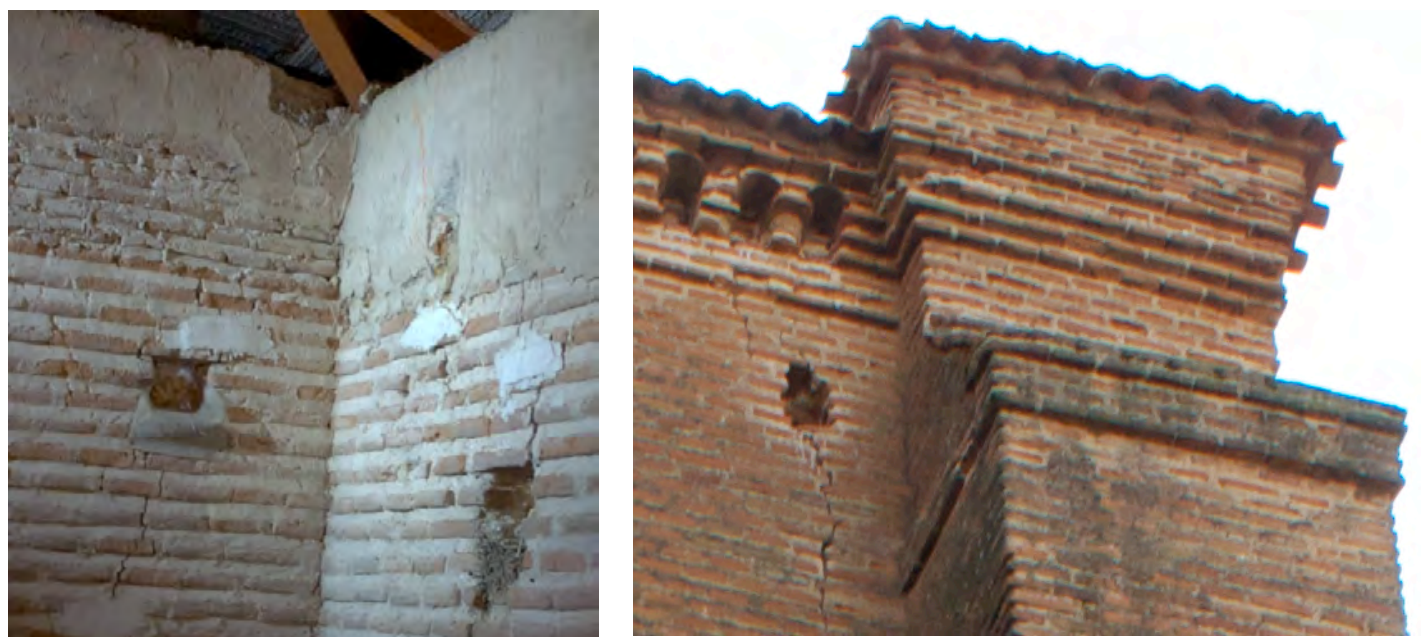

En las esquinas encontramos testigos en buen estado, colocados sobre grietas de recorrido vertical que se manifiestan a ambos lados de cada arista. Estas grietas son 
patentes también por la cara exterior de los paramentos, junto al contrafuerte que forma el remate de la fachada a los pies.

La fábrica de ladrillo que se levanta desde el nivel inferior de los zunchos laterales hasta el arranque del zuncho testero es diferente a la que se puede observar por debajo, con llagas más gruesas y claras.

Por el exterior, el cuerpo del edificio presenta sillería de piedra hasta el nivel de remate de las capillas laterales, mientras que la nave central se levanta en fábrica de ladrillo visto con contrafuertes hacia el exterior.

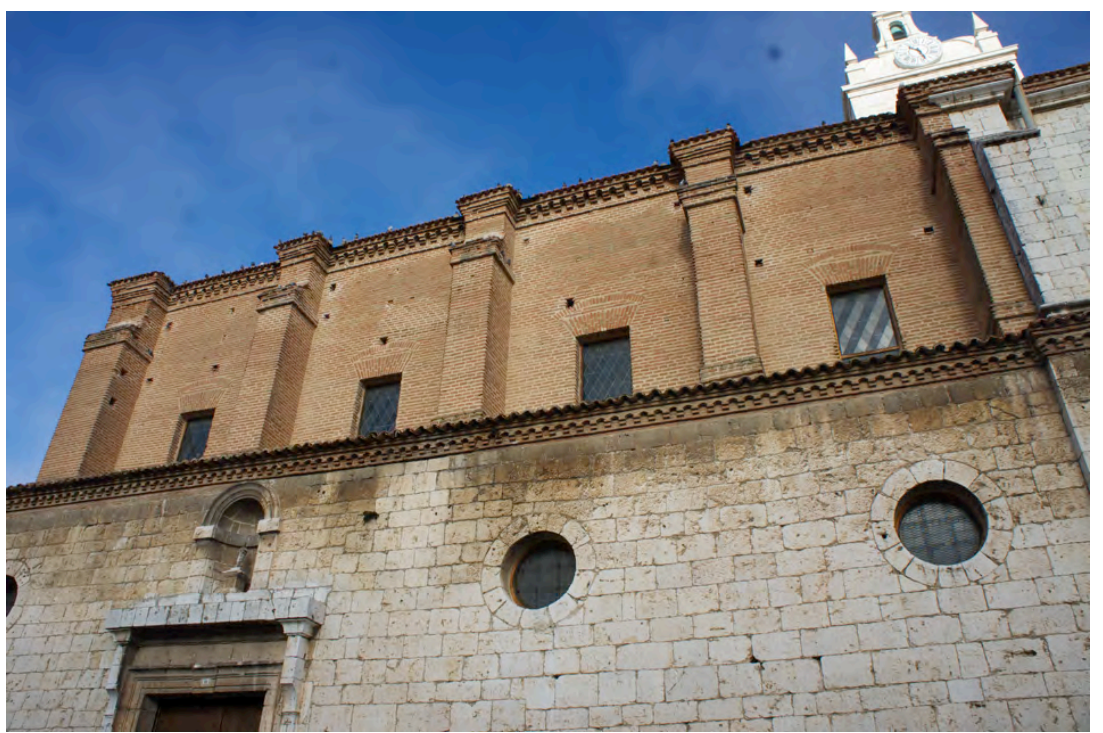

El testero a los pies presenta su hueco de acceso cegado con piedra. También aparecen ciegos los huecos laterales de la ventana termal, que cuenta con una abertura rectangular similar a las dispuestas en ambos muros laterales.
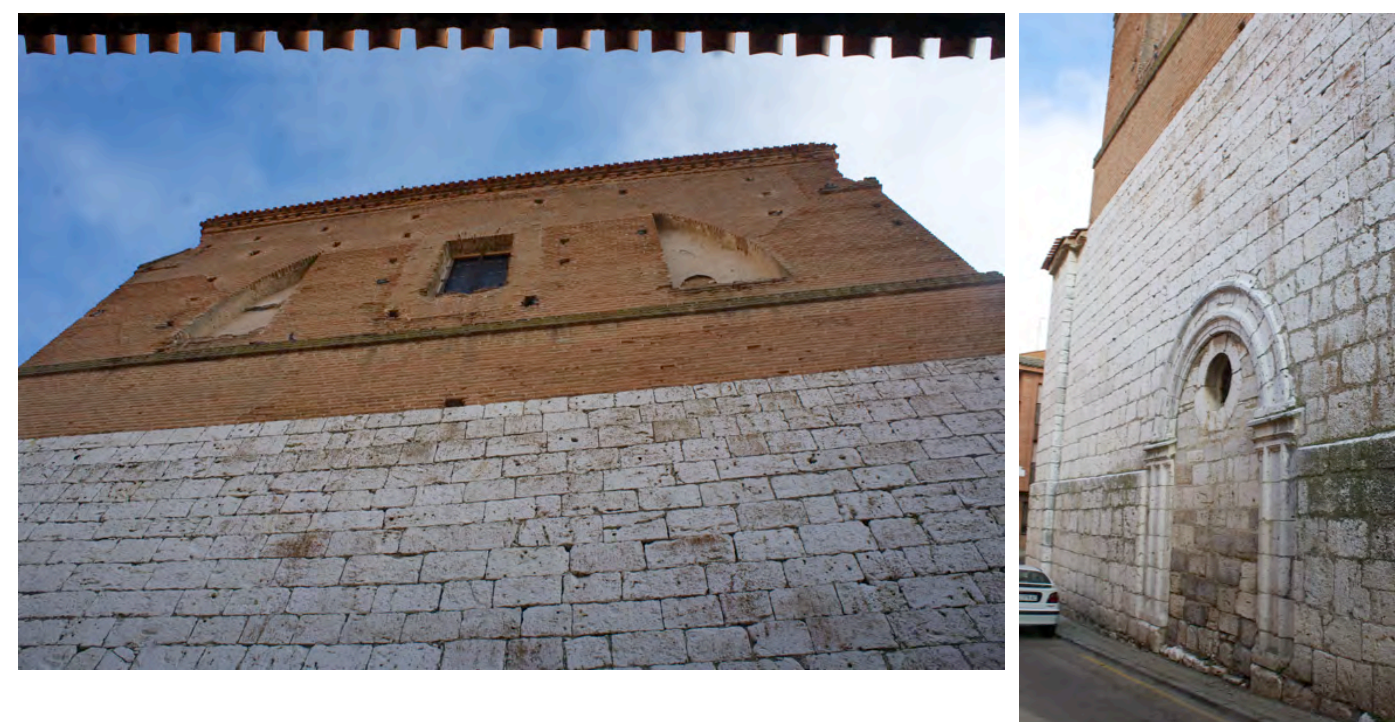

A grandes rasgos la solución constructiva de cubierta observada coincide con la definida en los planos de sección del proyecto de 1993. 


\section{Iglesia de la Anunciada}

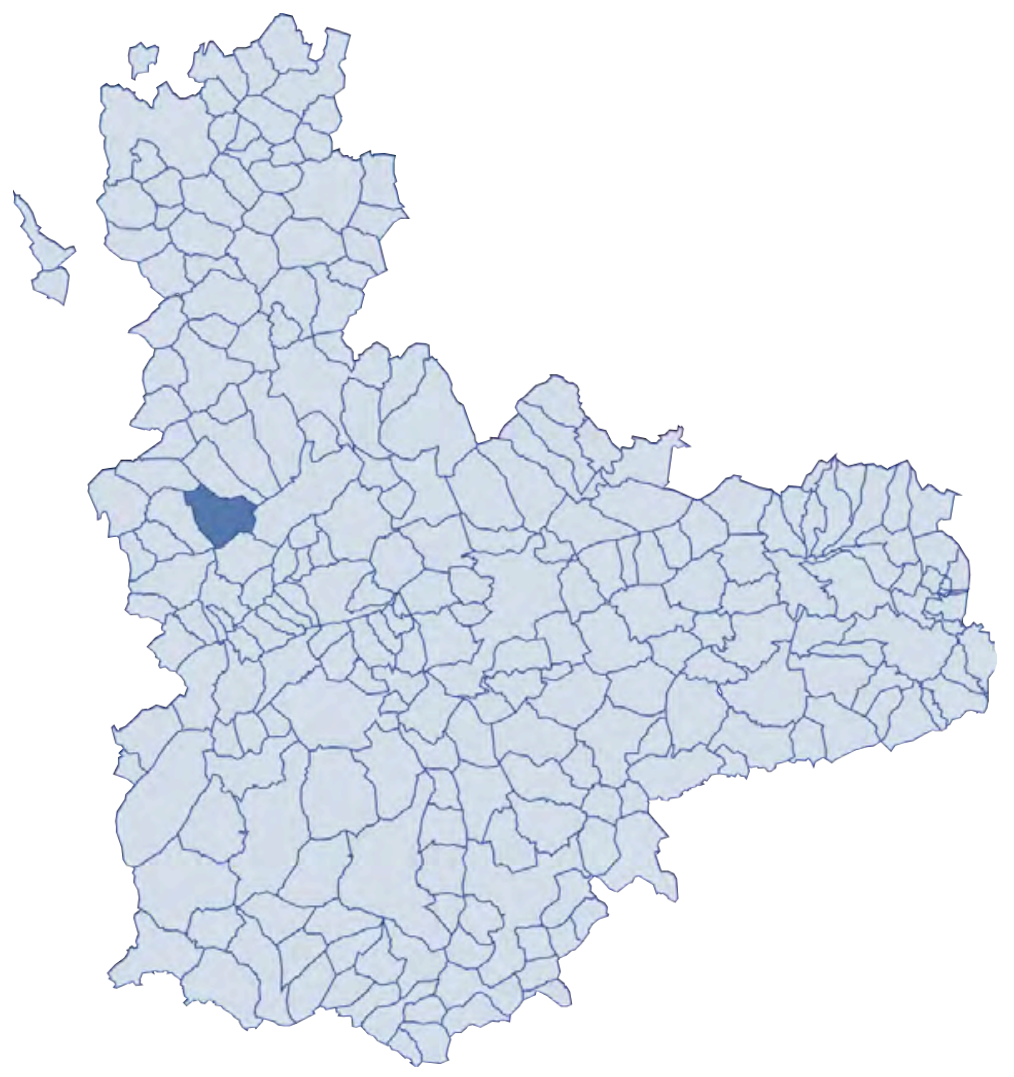



FICHA SÍNTESIS

\section{Código de identificación: FZ-36}

Denominación:

Iglesia de la Anunciada

Localidad:

Urueña
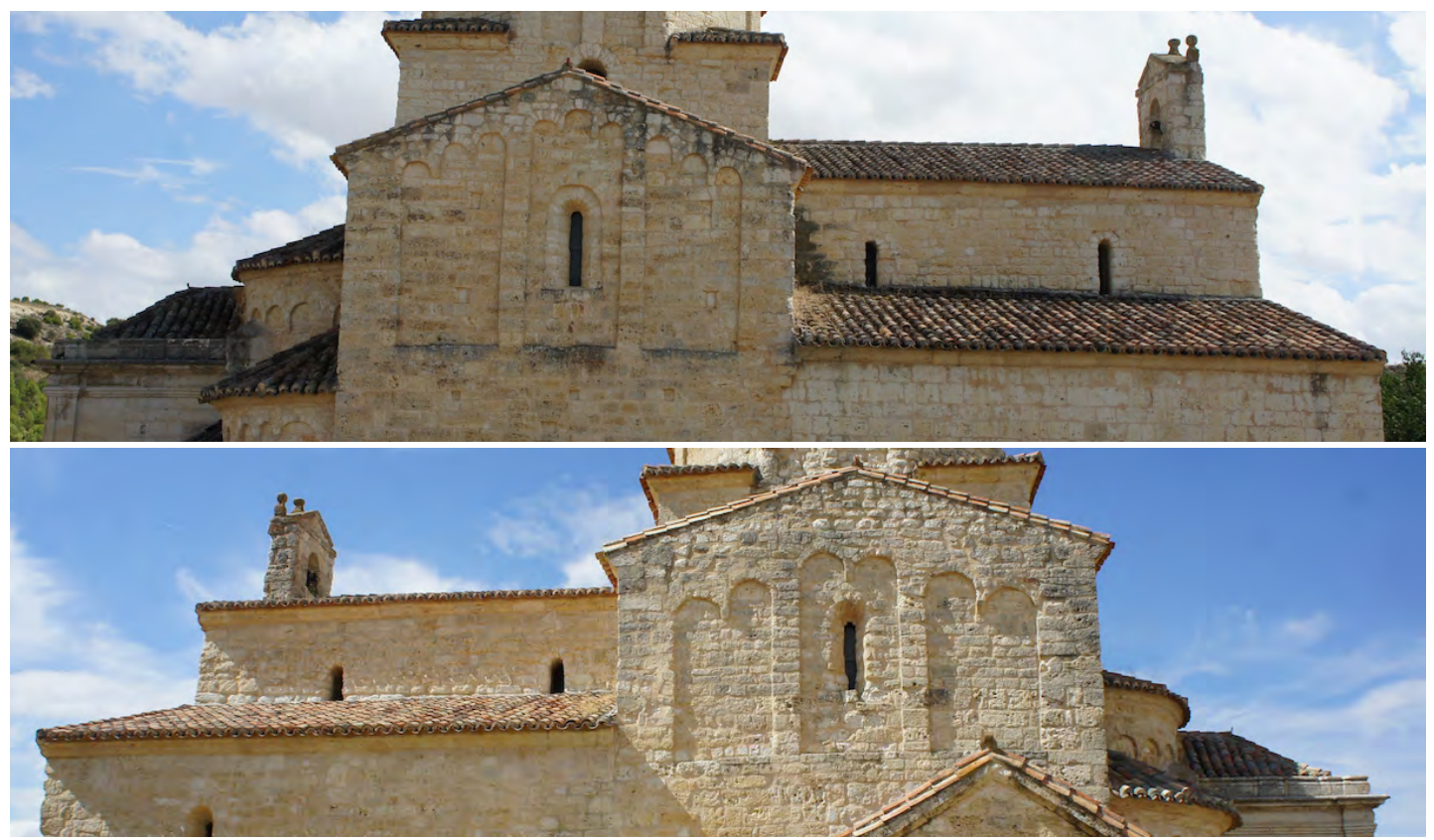

\section{Descripción}

Ermita románica del siglo XII de tres naves cubiertas con bóvedas de cañón y un crucero no marcado en planta. La cabecera se remata en tres ábsides semicirculares cubiertos con bóvedas de horno, deambulatorio en anillo y camarín. Cuenta con un cimborrio octogonal sobre trompas cubierto con una cúpula no trasdosada al exterior.

\section{Materiales}

Los muros son de sillería de piedra. Las cubiertas están revestidas de teja curva.

\section{Singularidades}

El edificio ha sufrido diversas adiciones a lo largo del tiempo que han configurado un peculiar volumen escalonado. Desde el punto de vista artístico se trata de un caso singular de románico lombardo en plena meseta.

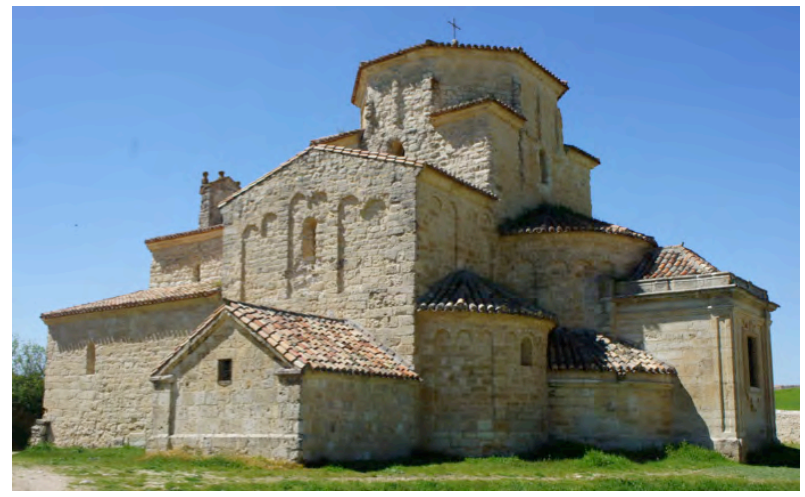

Ilustración 1: vista general, visita 11/05/2013 


\section{Dimensiones básicas del templo}

$\begin{array}{llll} & \text { central } & \text { laterales } & \text { capillas } \\ \text { Ancho de nave } & 5,5 & 3,6-3,8 & - \\ \text { Altura } & 9,4 & 5,6 & \end{array}$

\section{Memoria histórica constructiva}

Según la memoria histórica del proyecto de Paniagua (1990):

La ermita del siglo XII se reforma en 1677 , cuando se rehacen los soportes del arco toral, espadaña y sacristía. En la intervención del XVII también se remata todo el edificio con una cornisa.

En la primera mitad del XVIII se construye el camarín barroco y el deambulatorio en torno al ábside principal.

En 1975 se suprime un cuerpo adosado y el coro. En 1990 se suprime un porche sobre la entrada a los pies.

\section{Cronología. Fechas clave}

$1677-1978-1990$

\section{Intervenciones}

1978 - Sustitución de cubiertas - Ana Iglesias Se reemplazan las armaduras de cubierta por un tablero rematado con cemento y apoyado sobre tabiquillos palomeros de ladrillo hueco.

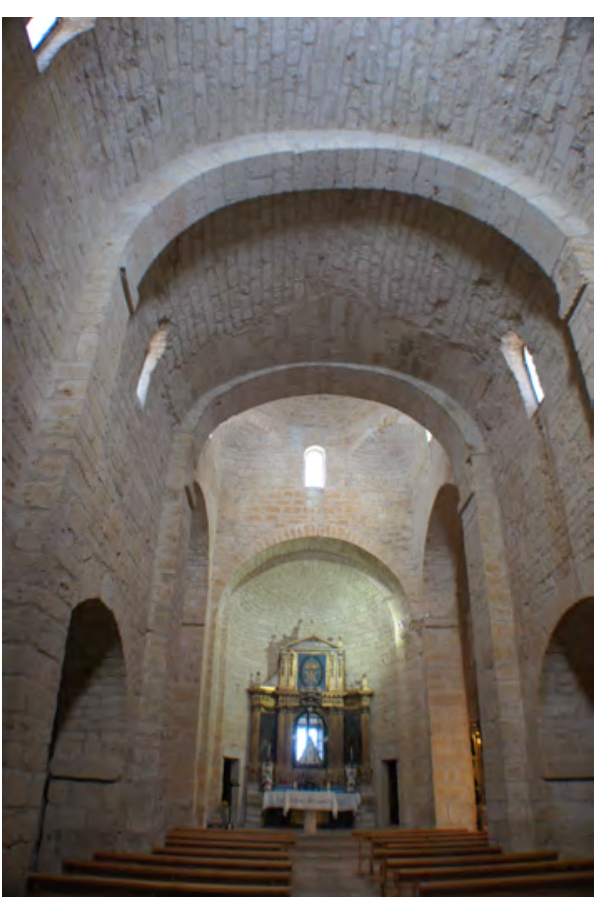

llustración 2: interior visita 30/07/2015

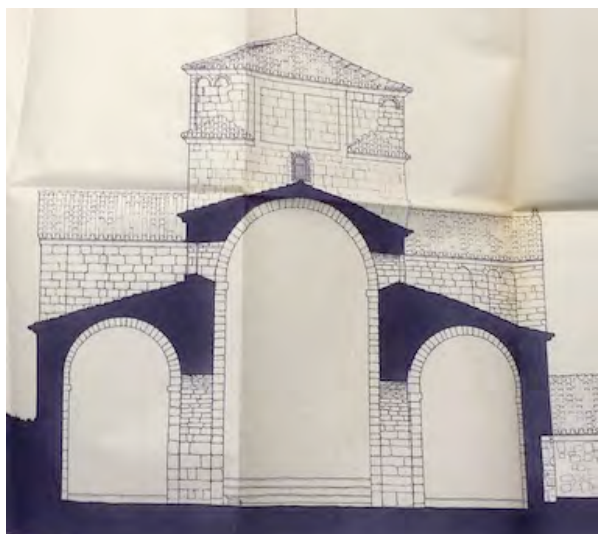

Ilustración 3: sección transversal 1990 Paniagua JCyL

1990 - Restauración $1^{\text {a }}$ fase. Cubiertas y adaptación interior - Antonio García Paniagua

Retejo general y colocación de onduline bajo teja sobre la tabla ripia existente.

Restauración de fábricas y reemplazo de pavimento. Demolición del porche y sustitución de carpinterías.

"No se puede acceder al extradós de las bóvedas para revisar el estado del bajo cubierta". 
1992 - Restauración 2a fase. Adecuación del exterior - Antonio García Paniagua Drenaje perimetral

\section{Planos}

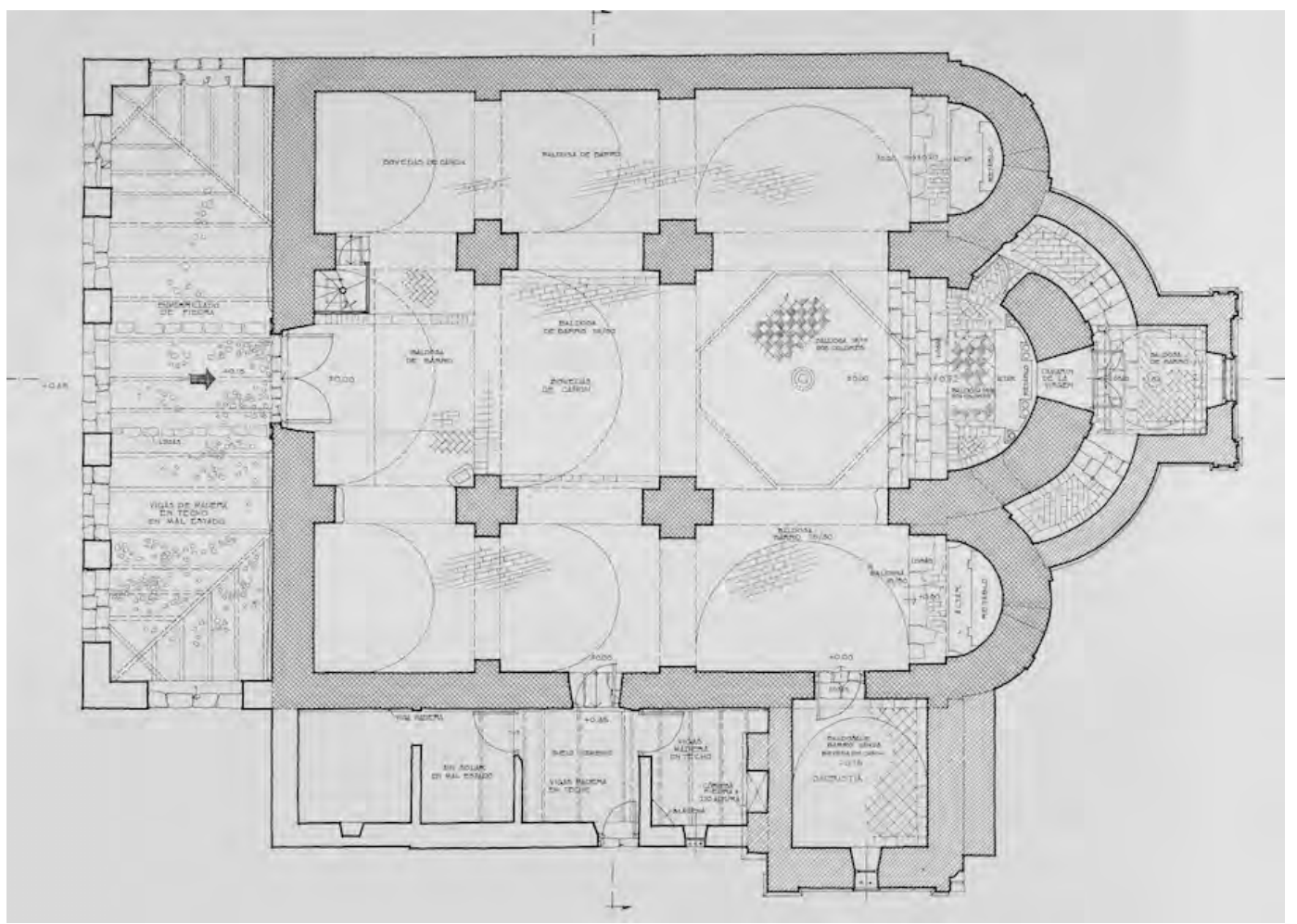

Ilustración 4: planta estado actual 1978 Iglesias IPCE

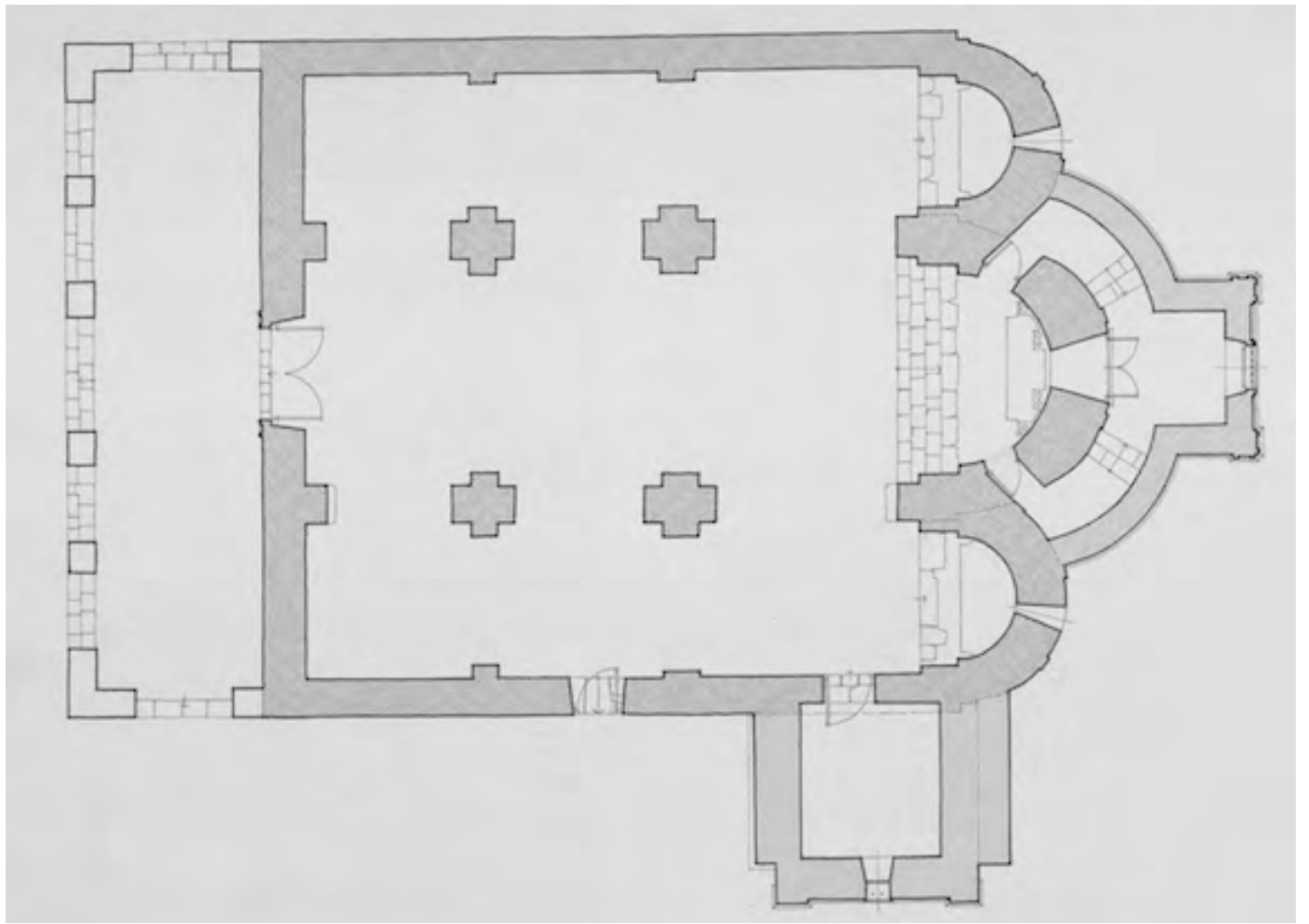

Ilustración 5: planta proyecto 1978 Iglesias IPCE 


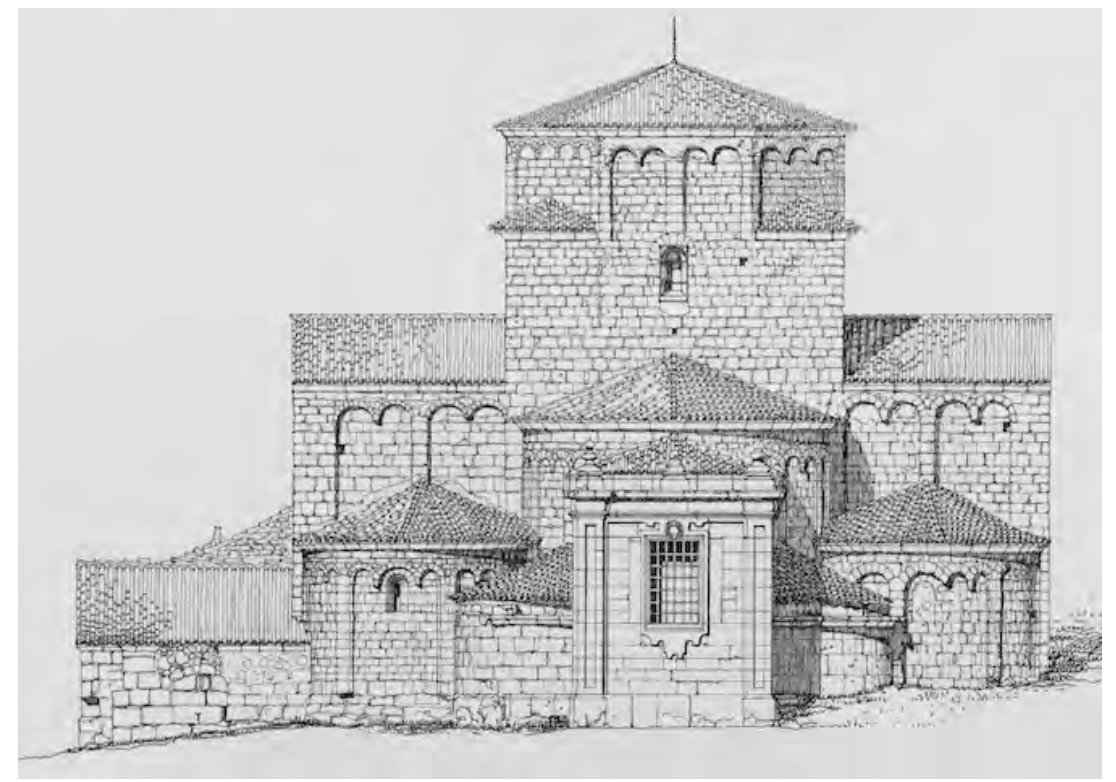

Ilustración 6: alzado este, cabecera actual 1978 Iglesias IPCE

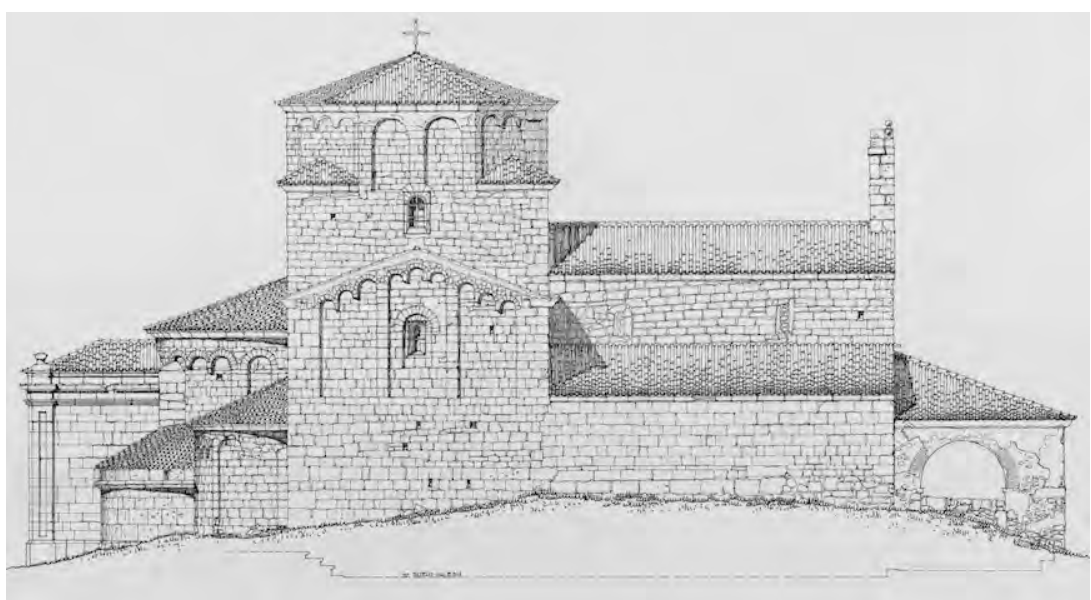

Ilustración 7: alzado norte actual 1978 Iglesias IPCE

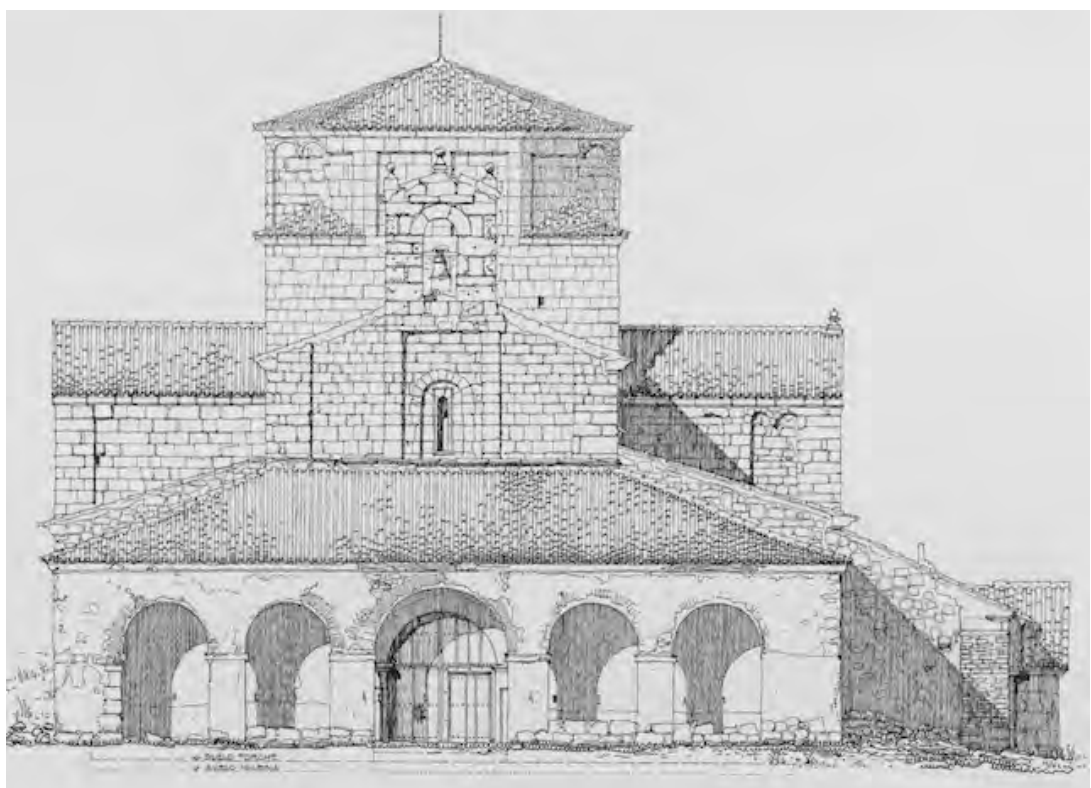

Ilustración 8: alzado oeste con porche 1978 Iglesias JCyL 


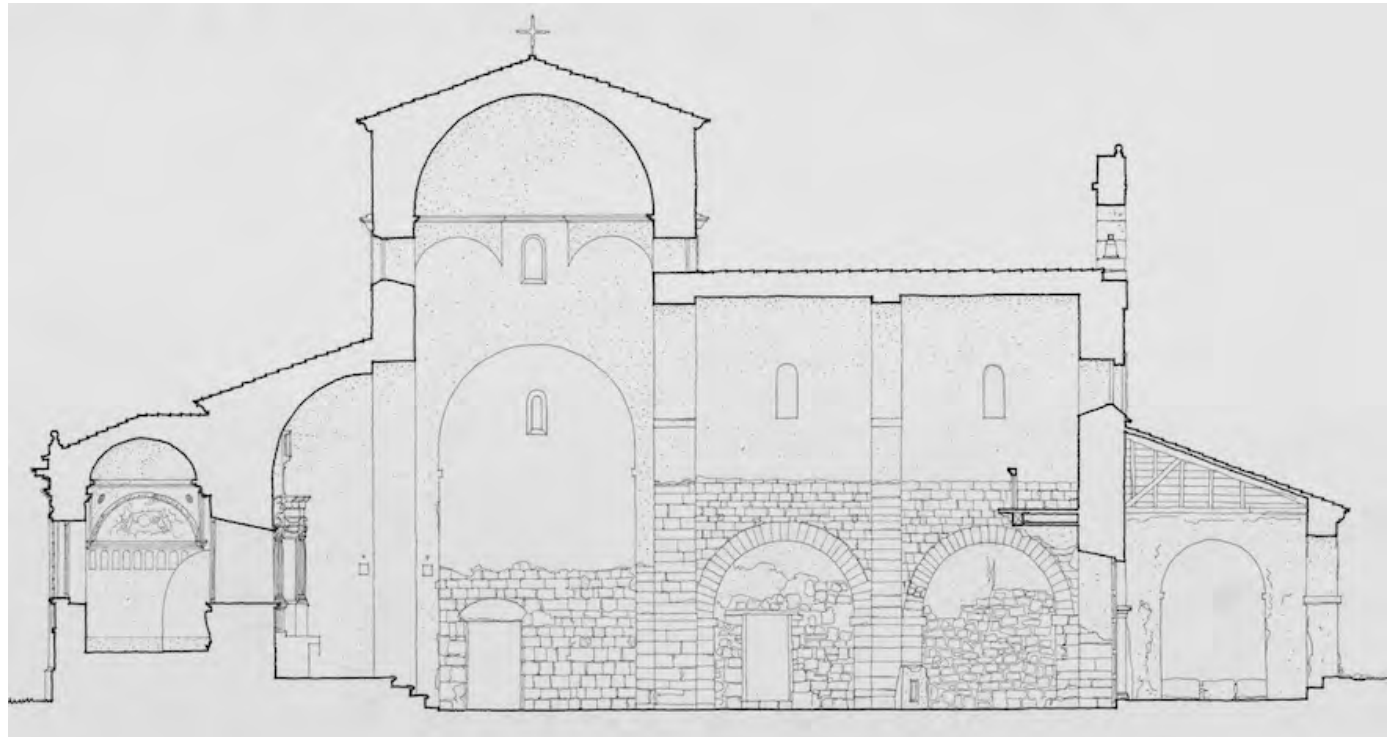

Ilustración 9: sección longitudinal actual 1978 Iglesias IPCE

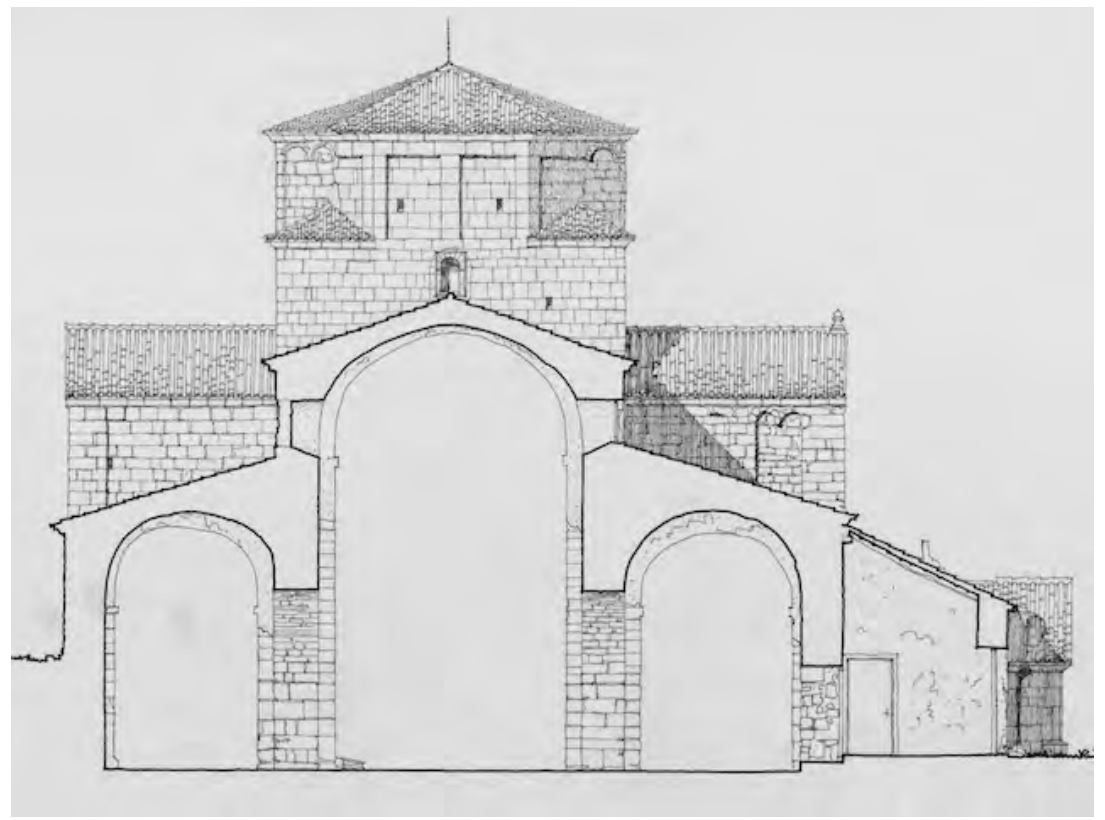

Ilustración 10: sección transversal actual 1978 Iglesias IPCE

\section{Solución constructiva de la cubierta}

En el proyecto de Ana Iglesias de 1978 se describe la nueva cubierta, formada por un tablero doble de rasilla sobre tabiquillos a la palomera, de ladrillo hueco sencillo, ejecutados sobre el trasdós de las bóvedas.

En la memoria de Paniagua de 1993 se describe ésta con el tablero resuelto con nervometal y hormigón, pero en el texto de la misma lamenta que no ha sido posible acceder al bajo cubierta para verlo.

En las secciones generales se representa, sin acotar, una pendiente de unos $20^{\circ}$. 


\section{Zunchos}

Aunque en 1978 se reemplaza la armadura por una estructura de cubierta nueva, resuelta con tabiquillos de ladrillo con tableros de rasilla, en la documentación revisada no se ha encontrado ninguna referencia a zunchos.

\section{Conclusiones}

No se ha podido confirmar la existencia de zunchos en esta iglesia. 


\section{Iglesia de la Anunciada en Urueña}

Intervenciones citadas en la publicación del Ministerio:

1978 - Sustitución de cubiertas - Ana Iglesias González

En la web del IPCE hay 8 planos de plantas, alzados y secciones de 1978 firmados por Ana Iglesias.

\section{En el archivo del IPCE}

\section{Carpeta 644-3}

1976 - Restauración - Ana Iglesias

"El proyecto comprende las obras de nueva cubierta, procediendo a su desmonte y clasificado de teja para en lo posible volver a utilizarla. Se procederá a la excavación del entorno de la Iglesia que se encuentra en sus frente Norte y Oeste parcialmente enterrada con la consiguiente aportación de humedades que se dejan ver en el interior, sacándose seguidamente las pendientes hacia el exterior del edificio".

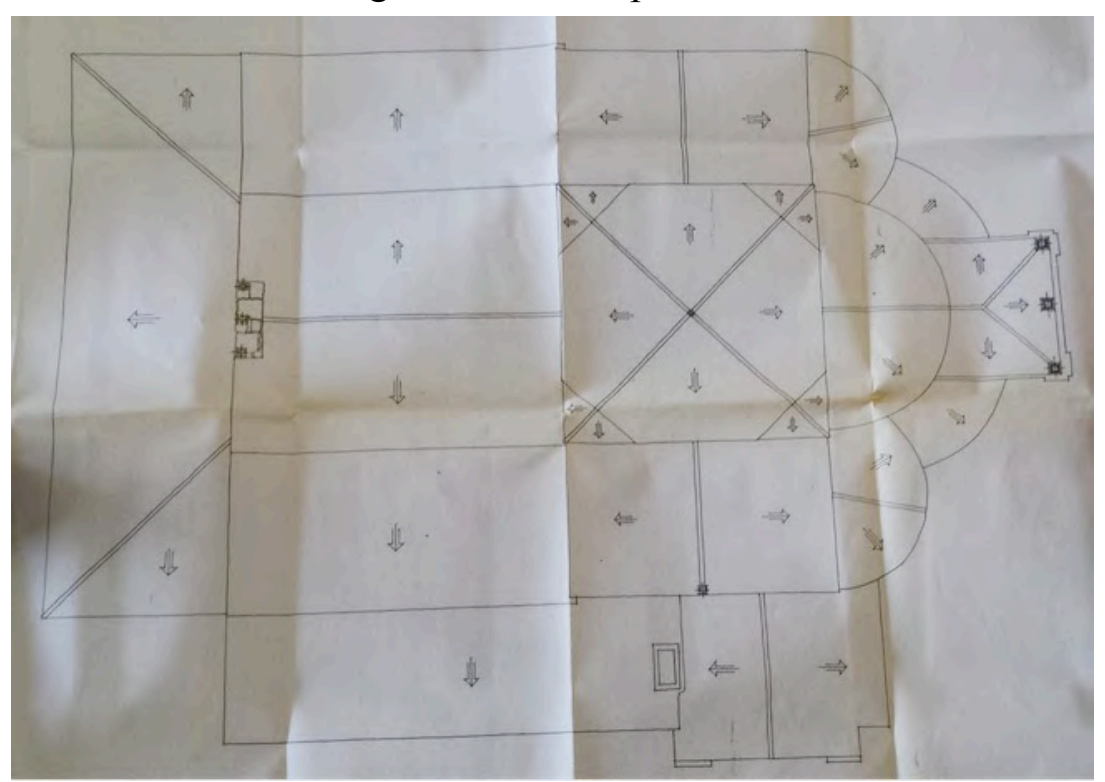

Ilustración 11: planta de cubiertas 1976 Iglesias IPCE

Memoria igual que la de 1978 vista en AGA. Planos algunos como los del IPCE pero con fecha 1976. Además hay sólo una planta de cubiertas. 


\title{
En el Archivo General de la Administración
}

\author{
AGA 26/00422 \\ 1978 - Restauración - Ana Iglesias \\ Documentación administrativa: \\ Construcciones Alfonso Sancho Miguel, de Valladolid
}

Memoria descriptiva y Obras a realizar.

"En la actualidad las cubiertas de la iglesia se encuentran en mal estado, siendo necesario por tanto la sustitución de todas ellas (con excepción del pórtico de acceso), procediendo a su desmonte y clasificando su teja para en lo posible volver a utilizarla; sobre las bóvedas de piedra existentes y mediante el rejuntado y refuerzo superior de ellas, si en su limpieza se viera su necesidad, se crearán los tabiquillos con ladrillo que darán a las pendientes actuales sobre las que se formarían dos tableros de rasilla para finalmente recibir la teja con barro y paja. Seguidamente se procederá a la excavación del entorno de la Iglesia que se encuentra en sus frentes Norte y oeste parcialmente enterrada con la consiguiente aportación de humedades que se dejan ver en el interior, sacándose seguidamente las pendientes hacia el exterior del edificio",

Trabajo complementario estudio arqueológico, picado de paramentos interiores descubiertos sólo hasta la mitad, rejuntado y tapado de grietas en bóvedas de los ábsides. Demoler el coro de nulo valor y su escalera.

Pliego y Presupuesto.

426,64 m2 desmantelado de cubiertas, incluso armaduras de madera con clasificación de material aprovechable y transporte de escombros a vertedero

Extracción escombros sobre bóvedas 1 ud, excavación de tierras, picado de enlucidos $444,60 \mathrm{~m} 2$.

Demolición de edificación adosada en fachada sur. Demolición de coro interior...

Consolidación de bóvedas previa limpieza de las mismas, rejuntando sus plementos y taqueando los huecos por su parte superior $263,30 \mathrm{~m} 2$

Estructura de cubierta formada por tabiquillos de ladrillo hueco sencillo a la palomera 
Forjado de cubierta compuesto de doble tablero de rasilla incluso capa de compresión de mortero de cemento

Cubierta de teja curva sentada con barro y paja, incluso parte proporcional de caballete.

444,60 m2 restauración de fábricas pétreas, taqueando y rejuntando las mismas en paramentos interiores

Dossier fotocopias descoloridas de fotos.

Planos: los mismos 8 de la Planoteca del IPCE. (Todos de estado actual, sólo una planta general del reformado...)

(No menciona zunchos)

\section{En el archivo de la Junta de Castilla y León}

\section{VA-101}

Carpeta 5288

Restauración de la ermita de la Virgen de la Anunciada en Urueña (Cubiertas y adaptación interior $1^{\text {a }}$ fase)

Adjudicada a COHEROSA en enero de 1993

Documentación administrativa. Certificaciones

Memoria final de obra

Arquitecto: Antonio García Paniagua

Proyecto de 1990. Se desdobla en dos en 1992 para tramitarse como Proyecto Piloto de Conservación en la Comunidad Europea. La fase $2^{\mathrm{a}}$ es la Adecuación del espacio exterior. La $1^{\text {a }}$ fase recepción provisional en marzo de 1994.

Se ha procedido a:

Reparación de las cubiertas mediante la incorporación de placas tipo onduline bajo teja.

Restauración de las fábricas y de los cerramientos exteriores.

Sustitución del pavimento existente por otro flotante a base de piezas de piedra, resolviendo la ventilación del terreno.

Desmontado del porche de acceso y recuperación del paño de fachada principal. Sustituido carpinterías.

No incluye planos en la memoria final por ser válidos los del proyecto original. 
Dossier fotográfico antes y después de las obras.

$524,71 \mathrm{~m} 2$ levantado de teja curva a reutilizar, limpieza del entablado, emulsión bituminosa caucho

Borde de teja libre 44,4 $\mathrm{ml}$ y canalón oculto de zinc.

Restauración de molduras y vivos de cantería, rejuntado de fábrica de sillería.

$4,71 \mathrm{ml}$ de labra y montaje de cornisas según sección transversal y molduración idénticas a las existentes, recibida con mortero bastardo 1:2:8 y anclada con varillas de fibra y mortero epoxi, incluso posterior rejuntado.

Labra y montaje de gárgolas, pavimentos, etc.

\section{VA-125}

Carpeta 5320

Adecuación del exterior

Propuesta de intervención arqueológica, pues la ejecución de la zanja de drenaje perimetral del edificio podría afectar a la necrópolis.

Proyecto de Paniagua, fase $2^{\text {a }} .1992$

Memoria histórica de María Alonso-Pimentel

Templo románico catalán singular (fuera de su área de expansión y único ejemplo en Castilla y León) del siglo XII. Pudo ser ejecutado por una cuadrilla que vino con el Conde de Urgel al casarse con la hija del Conde Ansúrez.

En 1677 se repara la ermita y traslada la imagen. Se realiza el arco toral que separa la nave del cimborrio rehaciendo sus soportes. Se coloca una cornisa en forma de gola, se levantan muro y bóveda de la nave del evangelio y parte de la cubierta de la nave mayor, por encontrarse hundidas. Se levanta la espadaña, construye la sacristía adosada al testero del crucero y se encala.

En la primera mitad del XVIII se construye el camarín barroco adosado a la cabecera. Se perforan los ábsides laterales para arbitrar un deambulatorio, cubierto con bóveda rampante, en torno al ábside principal, que comunicaba con el camarín.

Más tarde se añadiría el pórtico y un cuerpo adosado al muro sur. En 1975 se declara la villa de Urueña conjunto Histórico-Artístico y se interviene desde el Ministerio. Suprimen el cuerpo adosado y la cubierta del pórtico. Se pican los muros y demuele el coro con su escalera. 
Planta rectangular dividida en tres naves, la central más alta y ancha que las laterales, con un crucero que no se acusa en planta. La cabecera se remata en tres ábsides semicirculares cubiertos con bóvedas de horno. Las naves se dividen en dos tramos. Se cubre con bóvedas de cañón y en el centro del crucero una cúpula de cascos cubre un octógono sobre trompas. Edificio de piedra con sillarejos muy bien labrados.

\section{Diagnosis}

Los cerramientos exteriores no se encuentran excesivamente descompuestos. Los aleros del cimborrio no restaurados en 1677 más erosionados.

Las cubiertas del edificio fueron reparadas en el año 1977 adoptando como solución la de levantar tabiquillos sobre las bóvedas y forjando un tablero armado con placas de nervometal y capa de compresión, que se impermeabilizó con pintura asfáltica, recibiendo la teja con mortero de cemento.

La cubierta del camarín se resuelve de manera semejante, pero al no tener el alero libre se recogen las aguas con una canaleta formada con una lámina asfáltica muy deteriorada por las inclemencias del tiempo, siendo esta patología la más perjudicial de la cobertura del edificio.

"En general y considerando que no se ha podido acceder al extradós de las bóvedas en el bajo cubierta para comprobar el estado en que se encuentra el nervometal que pudiera estar deteriorado, en una inspección visual se encuentran en un estado tal que requieren una pequeña actuación (limpieza, impermeabilización y retejo) y puntualmente una intervención mayor (zona del camarín)."

Planos

Evolución histórica, plantas y secciones generales $1 / 50$ antes y después. No hay detalles.

(aprox ancho nave central 5,5; laterales 3,8 y 3,6; altura 9,4; 5,6) 



\section{Visitas realizadas}

$30 / 07 / 2015$

El monumento se mantiene en buenas condiciones tras la última restauración, llevada a cabo en 1992.

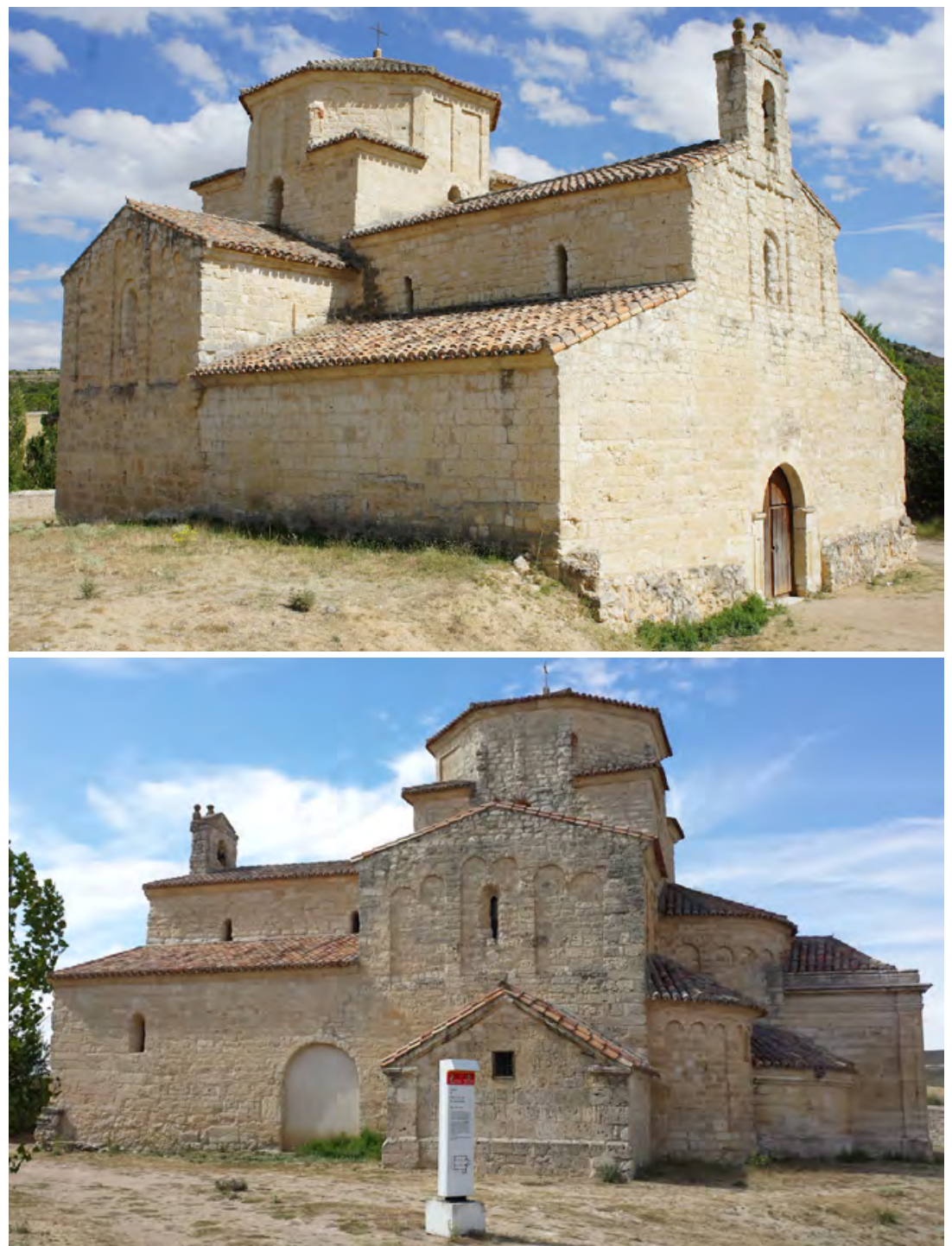

Sólo puntualmente se aprecian algunos indicios de deterioro, debido a la escorrentía.
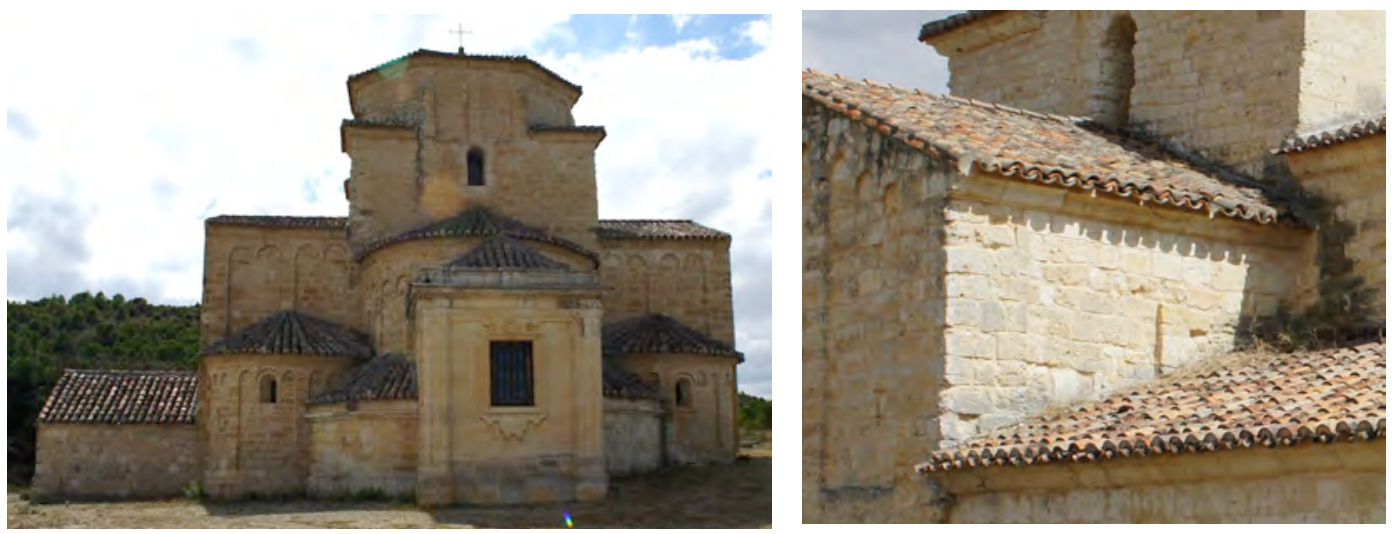
Según la guía, no hay acceso a ningún espacio o cámara sobre las bóvedas de piedra. En los paramentos de su intradós se aprecian las huellas de las distintas intervenciones llevadas a cabo en el templo, ya que la piedra se encuentra despojada de revestimientos.

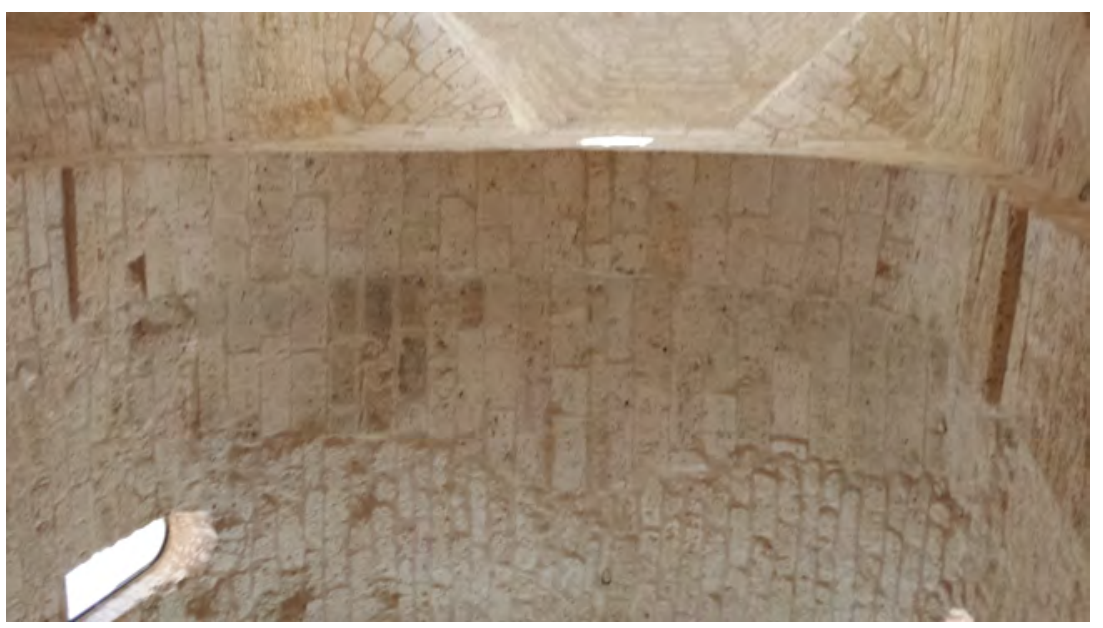

Encuentro de arco toral y bóveda de la nave con distinto tipo de sillares.

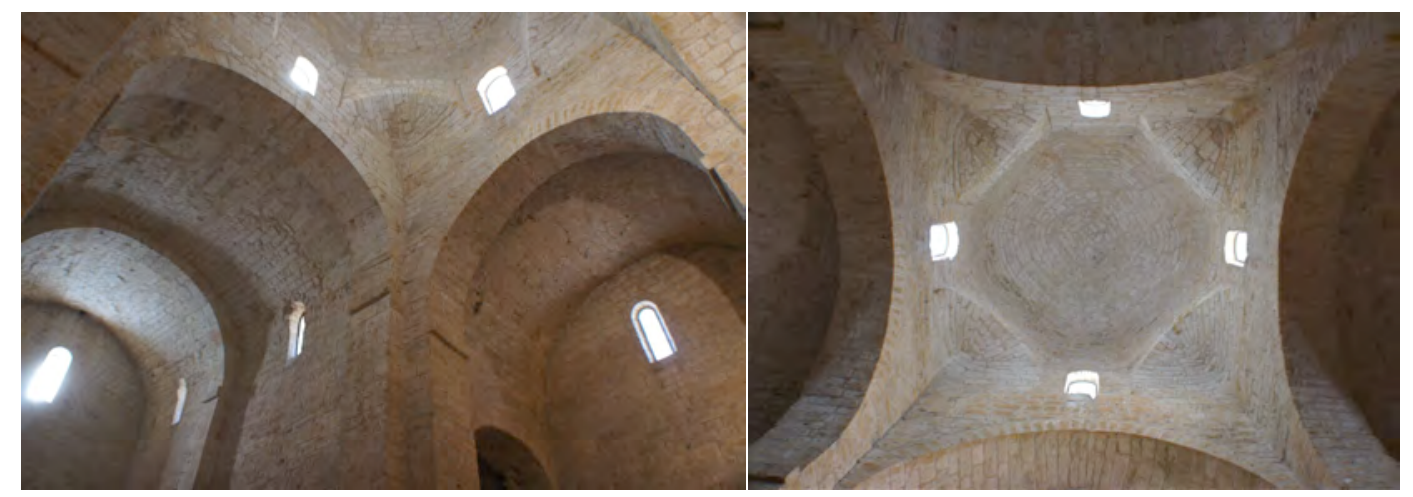

Apoyo del cimborrio sobre trompas

A grandes rasgos la geometría observada coincide con la sección del proyecto de Ana Iglesias de 1978, aunque en la misma no se detalla la solución constructiva empleada para resolver la cubierta. 
Iglesia del Monasterio de Santa María de Valbuena

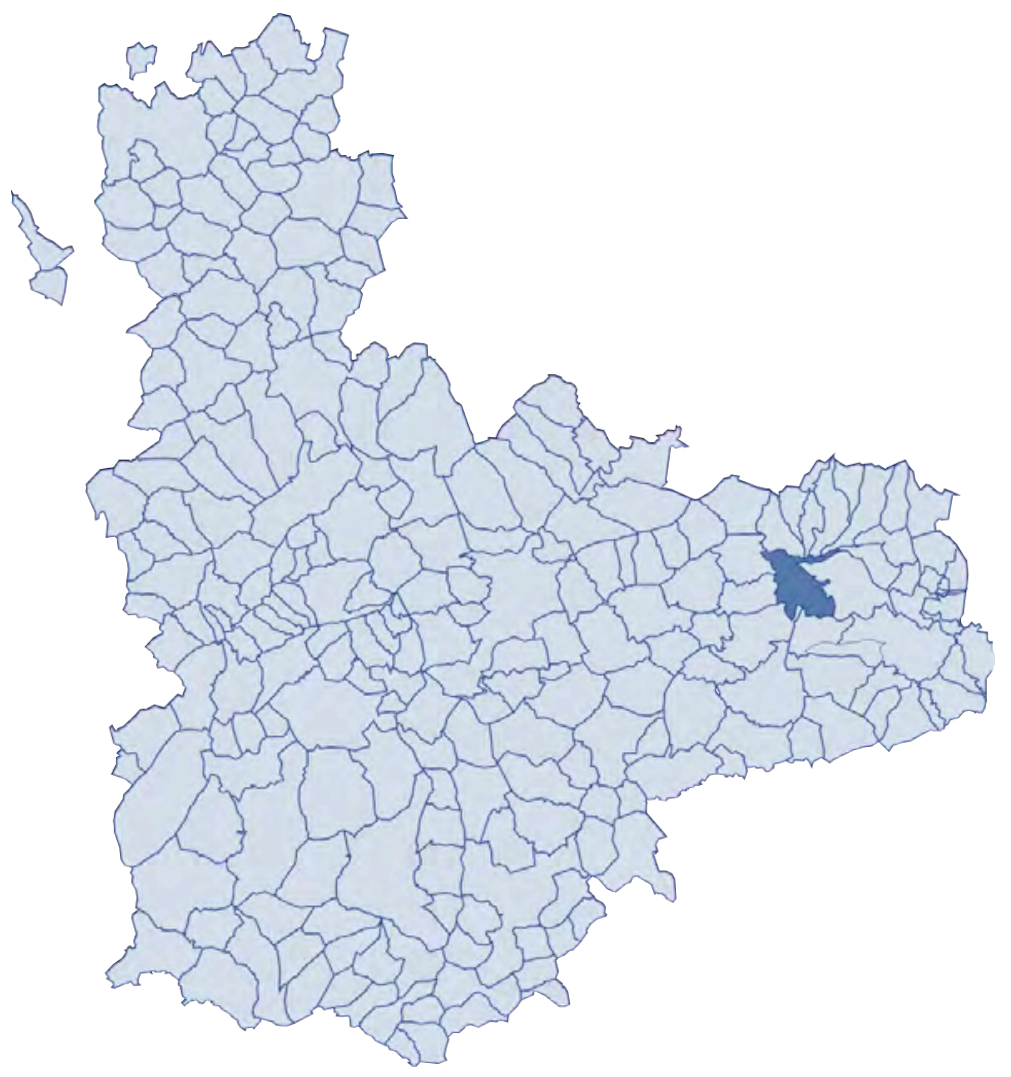



FICHA SÍNTESIS

\section{Código de identificación: FZ-37}

Denominación:

Iglesia del Monasterio de Santa María

Localidad: Valbuena de Duero

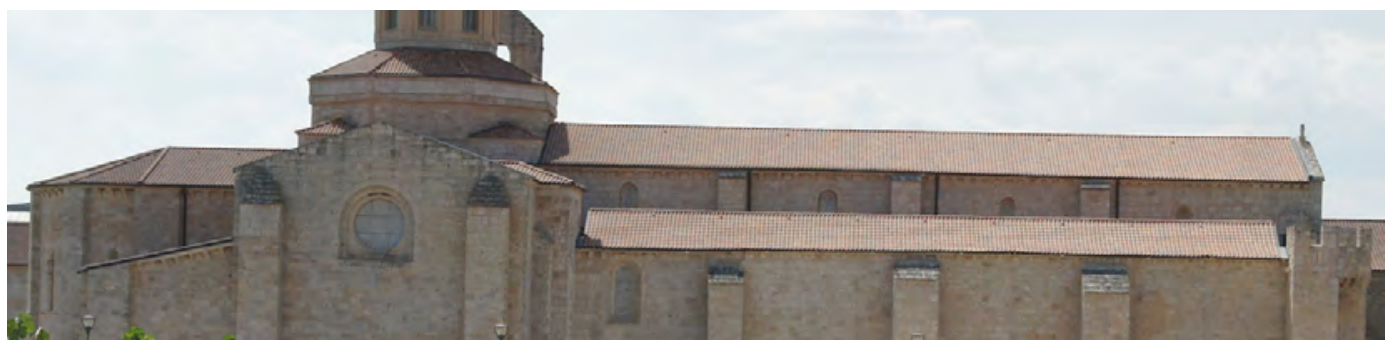

\section{Descripción}

Iglesia del Monasterio cisterciense del mismo nombre ${ }^{1}$, de tres naves con cuatro tramos y crucero de cinco, marcado en planta, con un cimborrio ochavado sobre trompas rematado con cúpula y linterna. Crucero y capilla mayor se cubren con bóvedas de cañón apuntado, las naves con crucería sencilla y el ábside con bóveda de horno.

\section{Materiales}

Los muros son de cantería. La cubierta está revestida de teja curva.

\section{Singularidades}

El testero oeste se remata con piñón a dos aguas, y presenta almenado y contrafuertes propios de la arquitectura fortificada.

\section{Dimensiones básicas del templo}

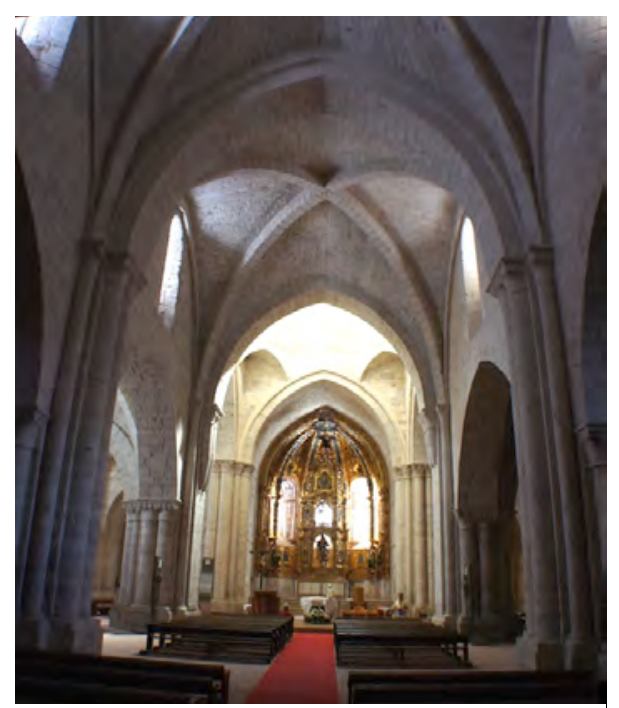

$\begin{array}{llll} & \text { central } & \text { laterales } & \text { capillas } \\ \text { Ancho de nave } & 9,0 & 5,6 & \\ \text { Altura } & 14,0 & 9,4\end{array}$

\footnotetext{
${ }^{1}$ En Valbuena hay además una iglesia parroquial bajo la advocación de Santa María del Castillo edificada en el siglo XVI, al margen del universo de muestra definido para la investigación.
} 


\section{Memoria histórica constructiva}

Según el Catálogo y la memoria del proyecto de Cañedo y otros (1988 JCyL):

La cabecera y el crucero se levantan a finales del siglo XII y el resto del edificio a principios del XIII (antes de 1235). En el XVI se levanta el coro alto a los pies y un cuerpo superior sobre la Capilla del Tesoro.

Tras la Desamortización de 1835 el Barón de Kessel compra el Monasterio en 1848 y lo vende a un vecino de Madrid. En junio de 1951 el INC compra la finca, excepto iglesia, sacristía y casa del curato.

En 1954 se desmantelan muros del Monasterio para emplear el material en la construcción de un poblado. En 1957 el Arzobispado coloca canaletas de recogida de aguas en las cubiertas de las naves laterales.
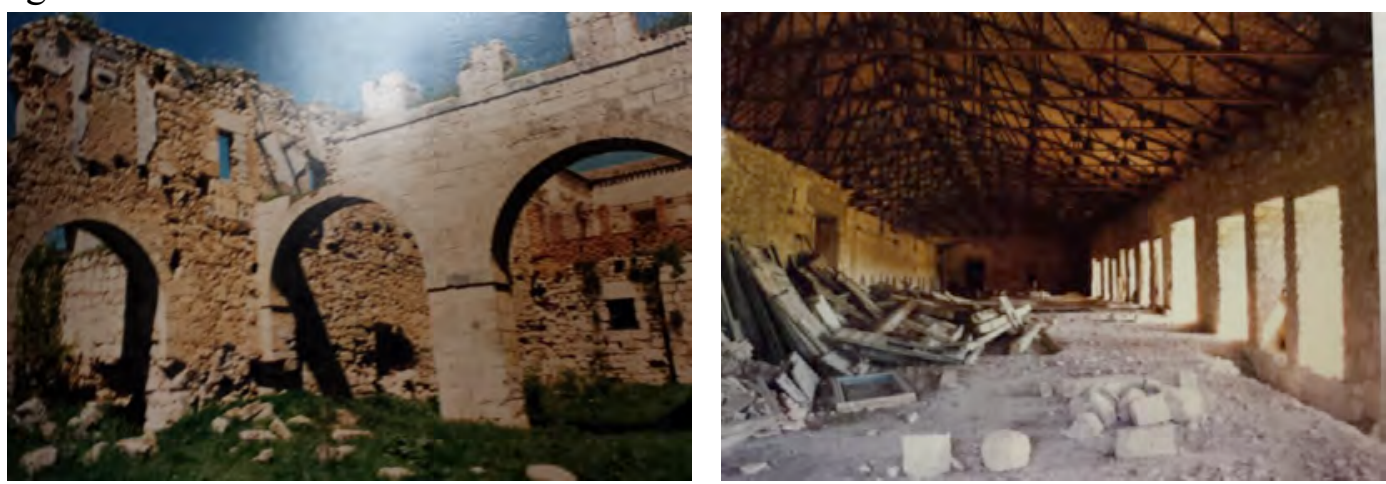

Ilustración 2: estado del conjunto a finales del siglo XX (Cañedo y otros 1993 JCyL)

En 1961 se desmontan todas las cubiertas del conjunto y se rehacen algunas con cerchas metálicas, ejecutando las obras sin dirección facultativa ${ }^{2}$. Se pican las paredes del templo eliminando las yeserías barrocas del XVIII.

En los ochenta vuelve a actuarse sobre la recogida de aguas de las cubiertas.

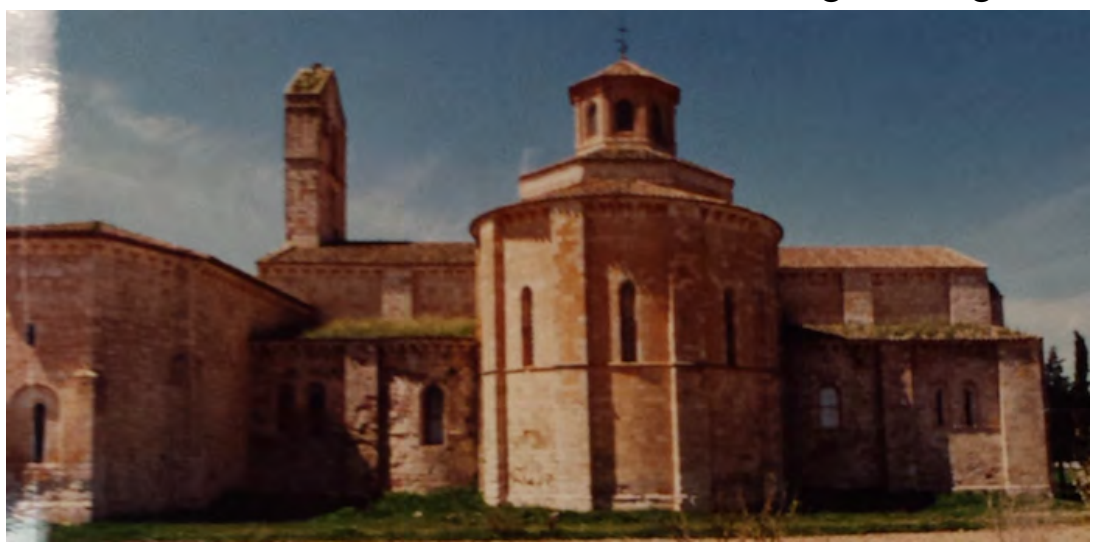

Ilustración 3: vista de la cabecera (Cañedo y otros 1993 JCyL)

\footnotetext{
${ }^{2}$ En el proyecto de 1999 de Puente se especifica que la obra de 1961 es dirigida por Arenillas, primero con García Mesalles y más tardes con Leal. En ella se disponen los tableros sobre tabiquillos.
} 


\section{Cronología. Fechas clave}

$1235-1848-1961-2015$

\section{Intervenciones}

1982 - Restauración en el Monasterio - Javier López de Uribe

Consolidación de claustros y pinturas murales. Instalación de galerías de drenaje perimetral.

1993 - Consolidación del Monasterio de Santa María - José M. Cañedo, José M. Varona y Luis A. Espinosa

Dentro de la consolidación del conjunto monumental se incluye el retejo de la cabecera de la iglesia, con reemplazo de entablado de madera y restauración de zonas deterioradas de estructura de cubierta con madera de pino.

1999 - Revitalización del Monasterio - Pablo Puente Aparicio

Demolición generalizada de las cubiertas existentes y sustitución por nuevas. Se habilita el Monasterio como Sede permanente de la Fundación las Edades del Hombre. En 2015 se ha inaugurado en el complejo un hotel balneario de lujo.

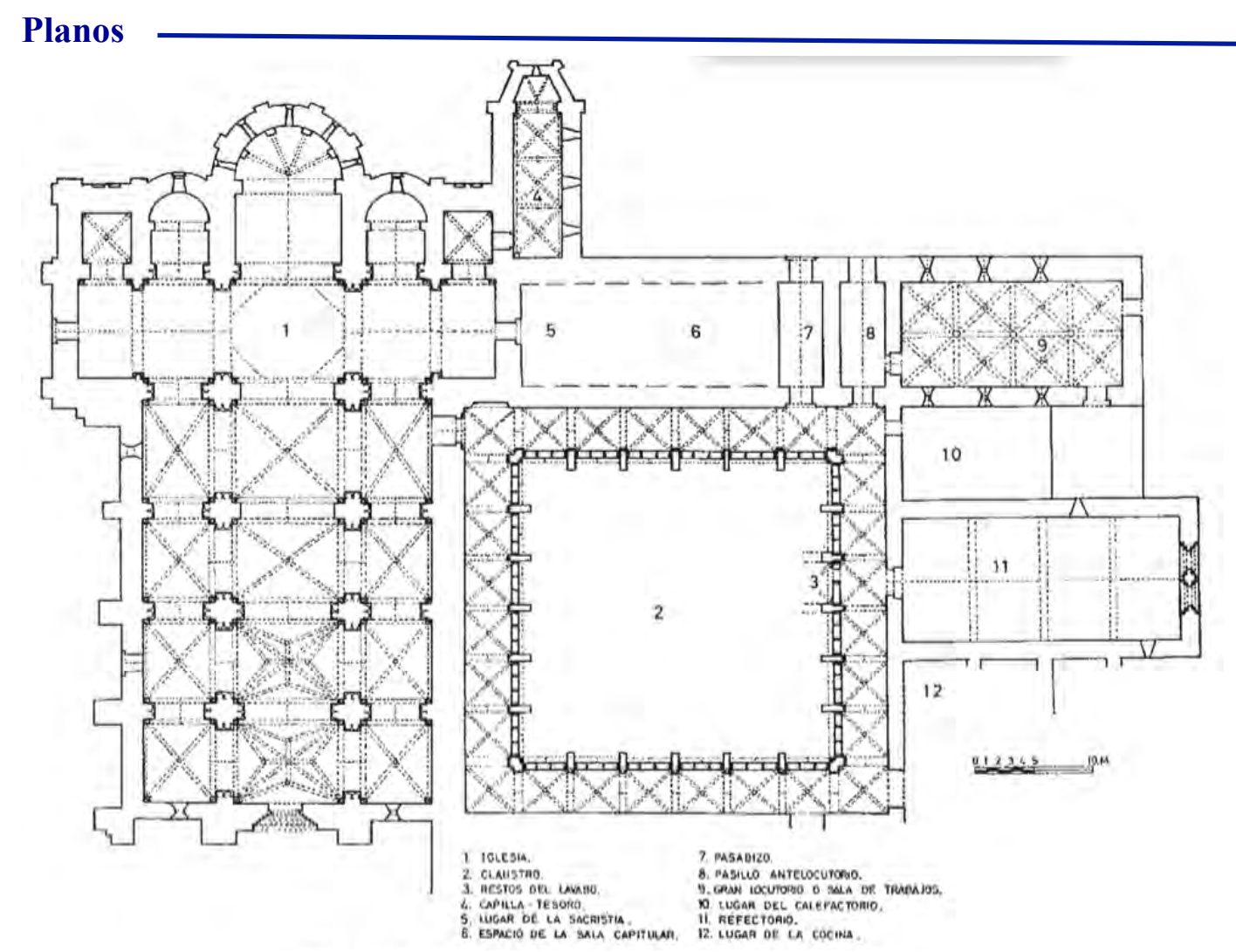

Ilustración 4: planta general de iglesia y Monasterio, del Catálogo 

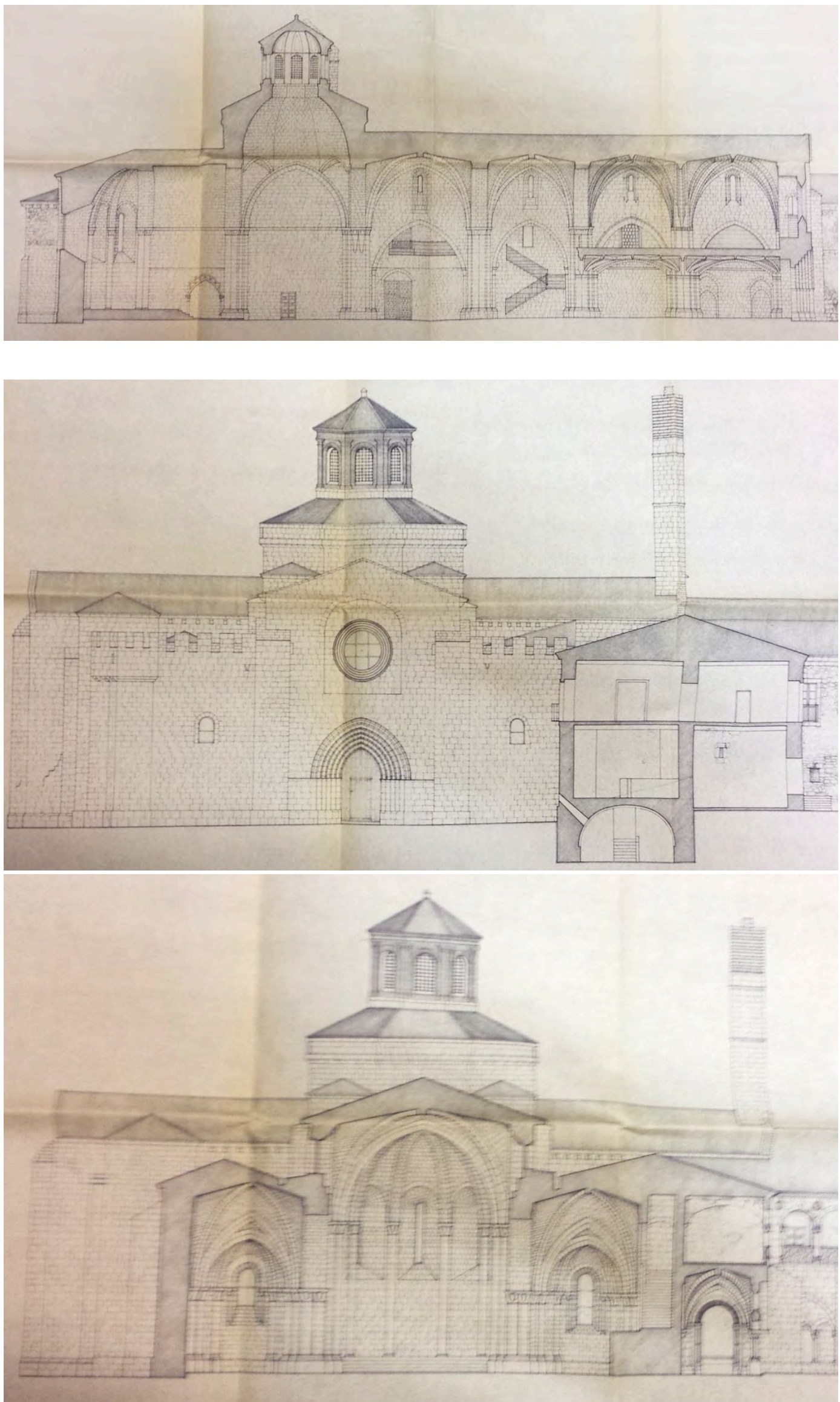

Ilustración 5: secciones 1993 Cañedo JCyL 


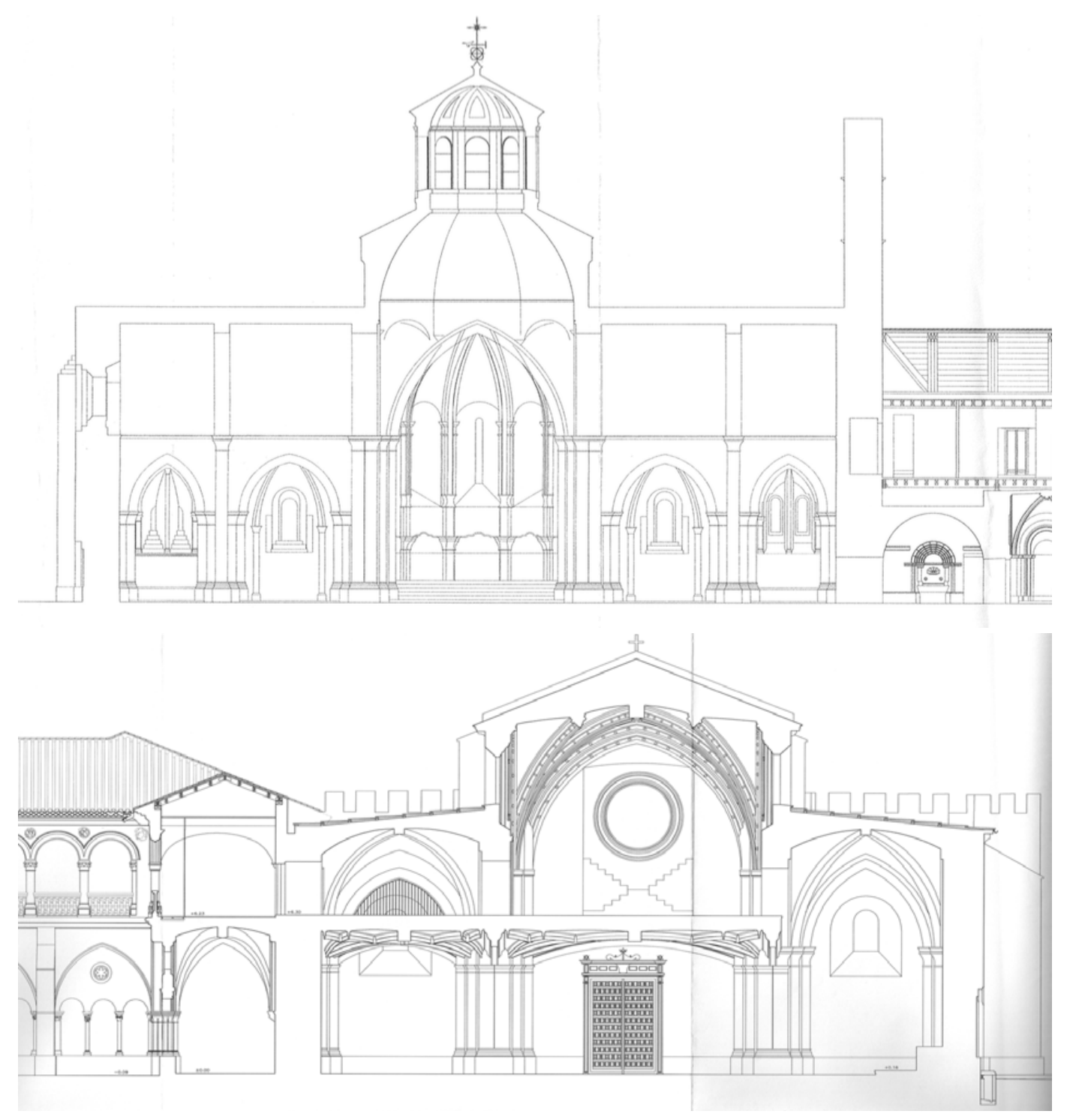

Ilustración 6: secciones transversales SF Puente Las Edades del Hombre JCyL

\section{Solución constructiva de la cubierta}

Hasta la ejecución del Proyecto de Revitalización de Pablo Puente era imposible acceder al espacio bajo cubierta de la iglesia. La estructura, según la memoria del mismo, estaba formada por forjados inclinados de hormigón sobre tabiquillos de ladrillo.

Se decide entonces el reemplazo total de cubiertas del templo. Para las naves laterales se diseña una cubierta aterrazada de paneles de GRC sobre correas y cerchas metálicas, con la menor pendiente posible que permitan los huecos de ventana de la nave central.

En las secciones de Puente se representa una pendiente de nave central de unos $21^{\circ}$ y con unos $5^{\circ}$ las laterales. 


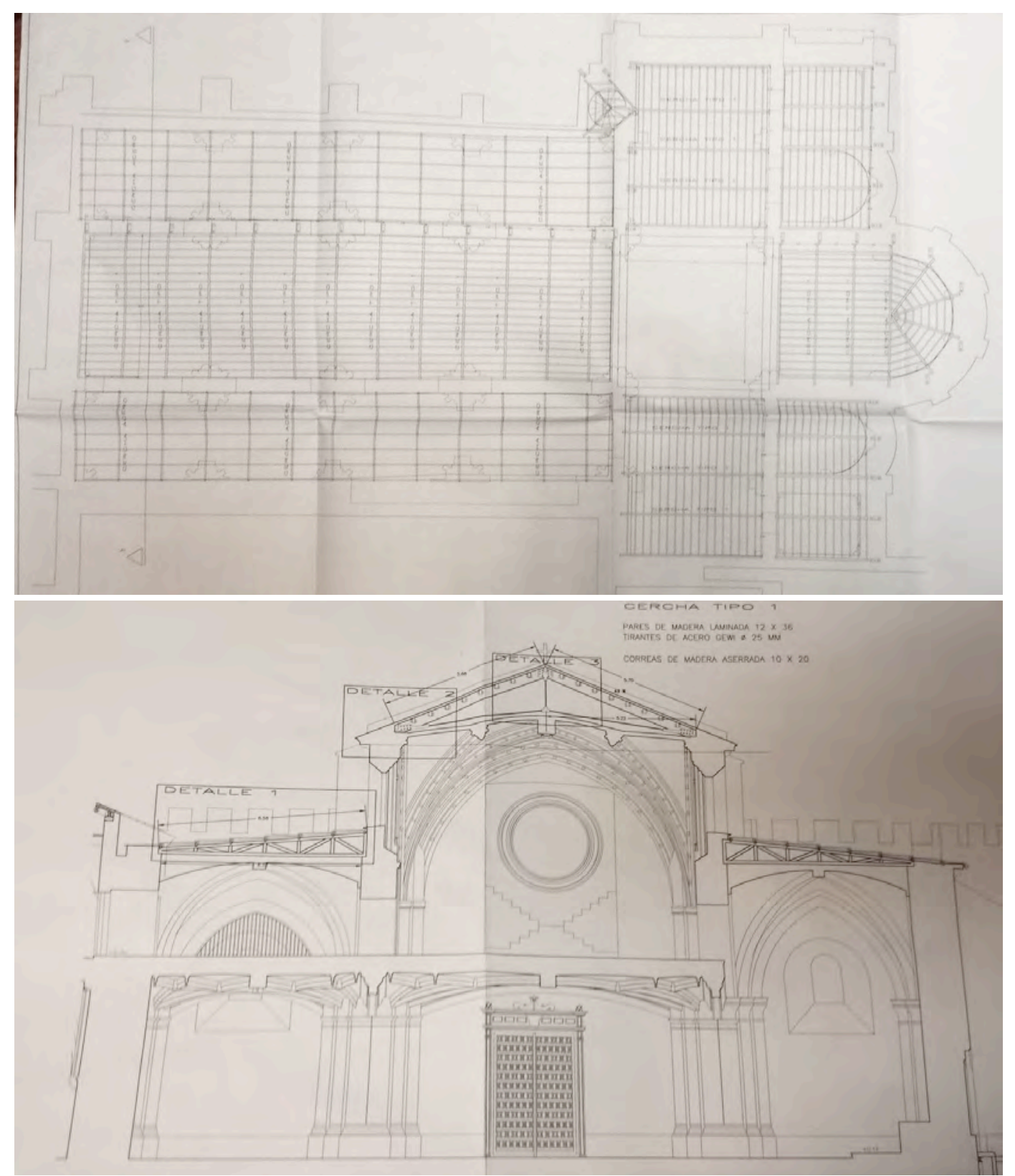

Ilustración 7: estructura de cubierta SF Puente Las edades del Hombre JCyL

\section{Zunchos}

La nueva estructura de cubierta de la nave central se resuelve con pares de madera laminada y tirantes con pendolón de acero Gewi cada $3 \mathrm{~m}$. Sobre estas cerchas se disponen correas de madera aserrada y tablero contrachapado hidrófugo.

En la memoria se describe cómo dicha estructura apoya sobre un zuncho de hormigón armado. 
En el presupuesto, sin embargo, aparecen medidos $76 \mathrm{ml}$ de zuncho 30x40 descritos como $2 \times 38,00 \mathrm{~m}$ en naves laterales, no apareciendo referencias de esta partida relacionadas con la nave central.

En la partida referente a labor de cajeado sí aparece "nave central $2 \times 39$ y $2 \times 13,50 "$, lo que implica la apertura de cajas en la fábrica en todo el perímetro. El texto sin embargo no confirma que se trate de zuncho de hormigón, ya que indica "apertura de caja en muros... para alojamiento de los durmientes de la estructura de cubierta".
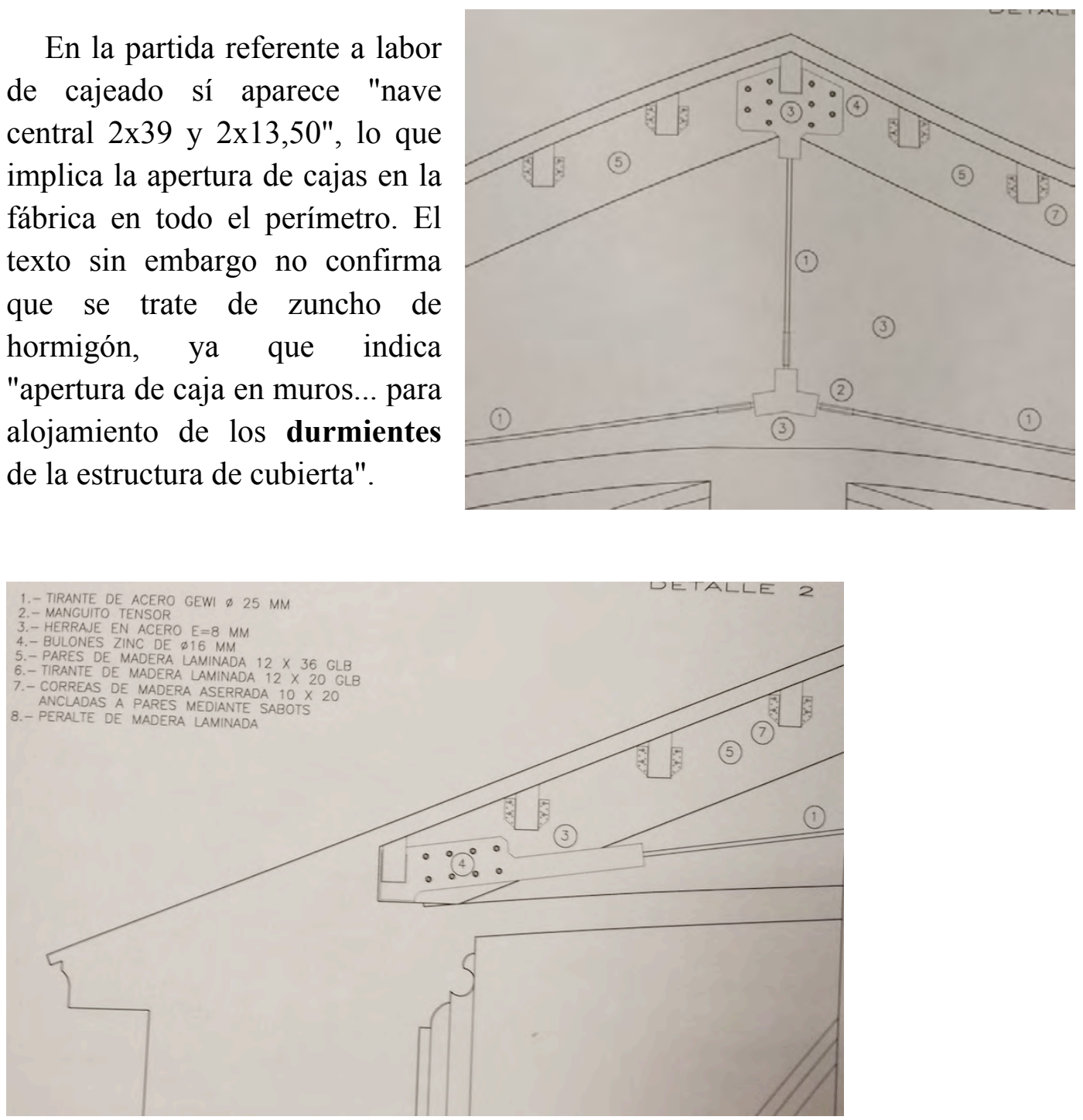

Ilustración 8: detalles cerchas SF Puente Las Edades del Hombre JCyL

En los planos no se ha localizado referencias a estos zunchos y tampoco aparecen representados en el detalle del apoyo.

\section{Conclusiones}

Según el último proyecto ejecutado, en este edificio se incorporó zunchos de hormigón, aunque no se ha podido confirmar accediendo al espacio bajo cubierta si se llegaron a colocar, y si fue en la nave central o sólo en las laterales. 



\section{Iglesia del Monasterio de Santa María de Valbuena}

Proyectos citados en la publicación del Ministerio:

1981 - Protección de los muros de la nave central y consolidación y pavimentación de la galería claustral - Javier López de Uribe

En la web del IPCE sólo hay digitalizado un plano de planta sin fecha.

\section{En el archivo del IPCE}

Carpeta 644-6

1981 - López de Uribe

Memoria de obra finalizada, marzo de 1984.

1. Consolidación y resanado de la infraestructura del subsuelo de la galería Este del claustro

2. Reparación de tejado

Con esta actuación se eliminaron las humedades de penetración a la iglesia, a lo largo de los encuentros de los faldones ce cubierta de las naves laterales con el muro correspondiente a la nave central.

Se realizó un levantamiento de todo el sector afectado: corredores a modo de pasillos, sirviendo de limahoya, viseras de teja rematando el encuentro con los muros de la iglesia, de contrafuerte a contrafuerte, y remate de los aleros del tejado de las naves laterales....

Excavación arqueológica.

\section{Memoria}

Por una parte se propone la seguridad de la iglesia abacial, en cuanto a lo que a las grandes humedades y abundantes recalos se refiere, a causa de las penetraciones de aguas de lluvia que de un modo persistente van paulatinamente degradando los muros de sillería de la nave central, en su encuentro con los faldones de cubierta de las naves laterales...se construirá una correcta limahoya de fábrica.

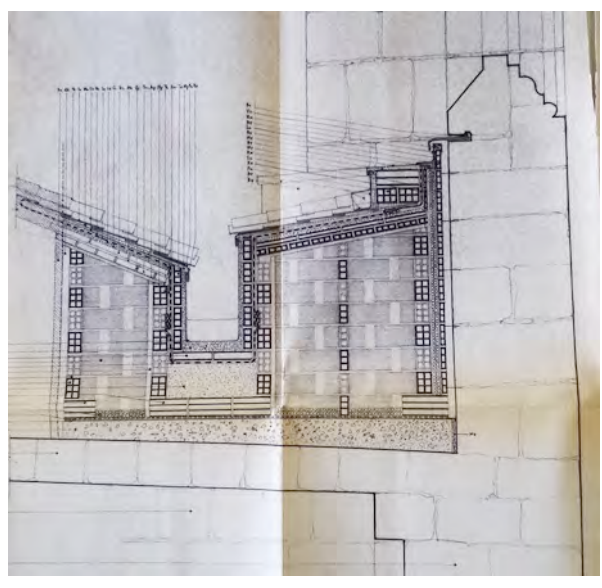

Ilustración 9: detalle limahoya 1984 

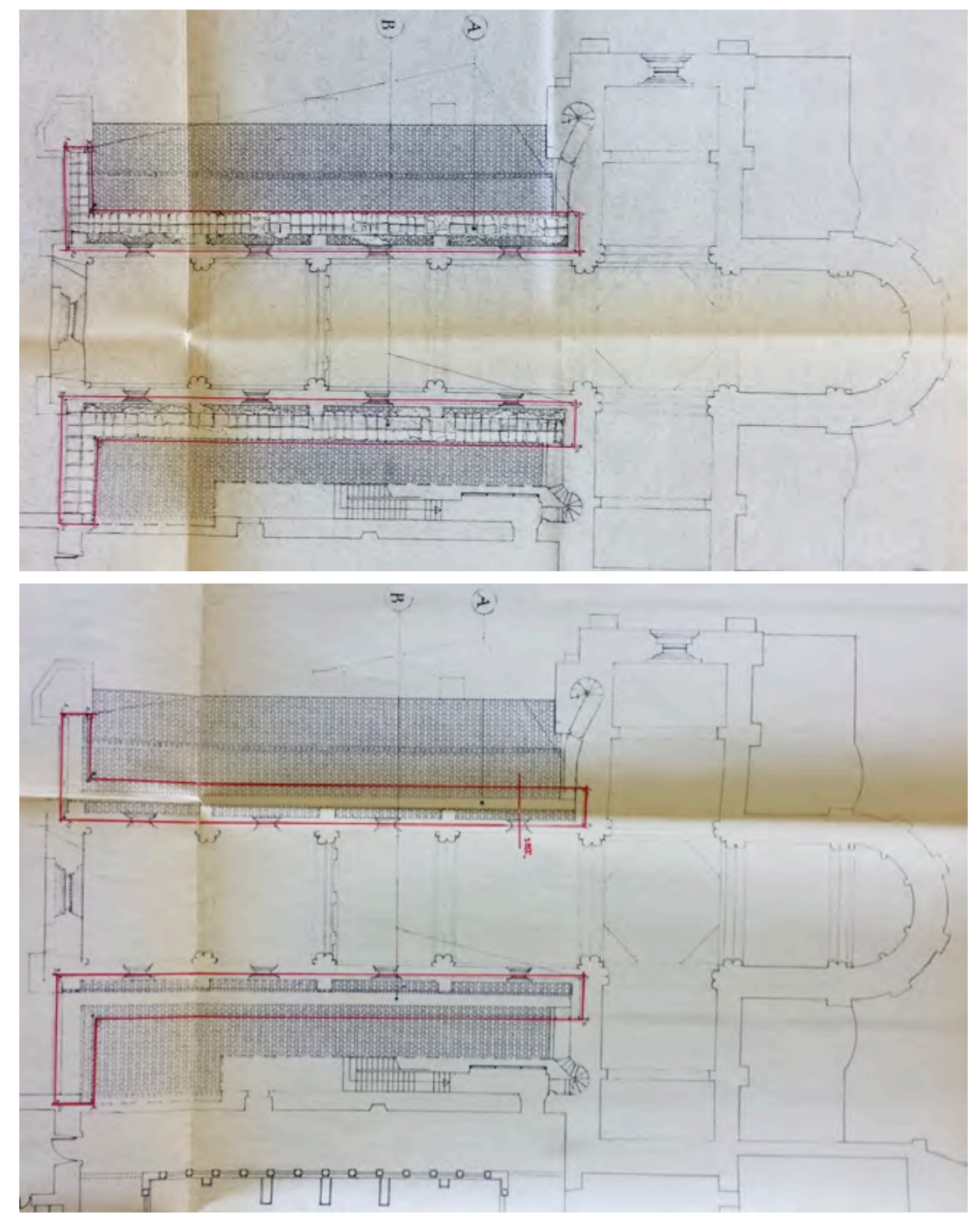

Ilustración 10: área de intervención, encuentro de faldones laterales 1981 López de Uribe

Planos y fotografías del encuentro con los corredores embaldosados y su reemplazo por un canal revestido con lámina de plomo.

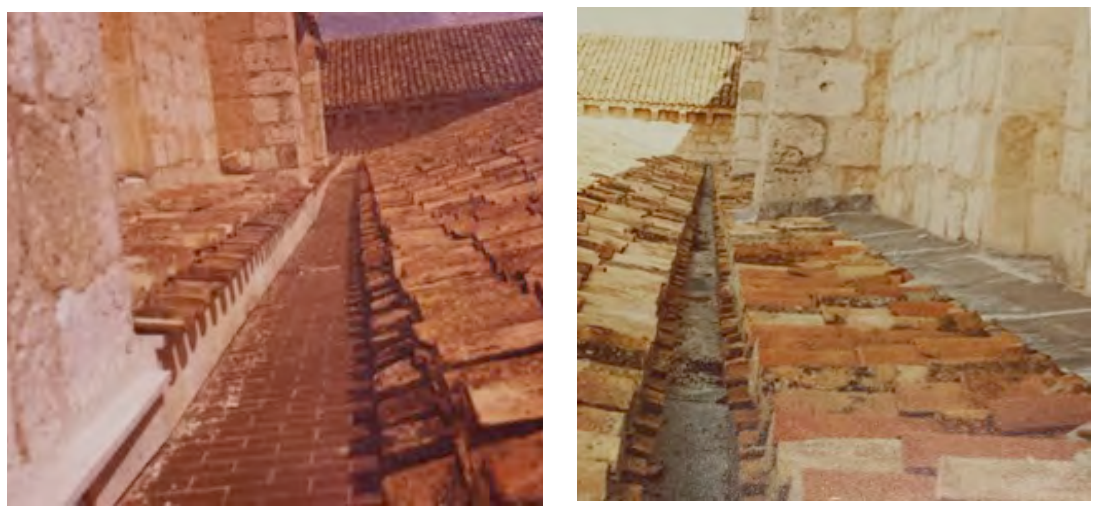

Ilustración 11: antes y después 1981 López de Uribe IPCE 
Carpeta 645-1

Carta de José Luis Velasco: pide que se ejecute urgente el segundo proyecto.

Dossier de fotografías. (Sobre todo de las pinturas de la capilla)

Planos de capilla, generales, drenajes.

\section{En el Archivo General de la Administración}

AGA 26/01721

1981 - Restauración galería claustral, muros - Javier López de Uribe y Laya.

Memoria anejo de la ordenación de los pavimentos del ala este del claustro; con especificación de sus despieces; calidades y tonos. Septiembre de 1981.

Protección de los muros de la nave central de la Iglesia en cubiertas. se programa esta actuación en el monumento, con caracter de urgencia máxima sobre la protección de los citados muros, para evitar que las aguas de lluvia y humedades y hielos penetren al interior de los mismos y se pasen a las bóvedas e interior de la iglesia por lo que sin mas dilación se prevee la eliminación de las perniciosas viseras actuales y corredores longitudinales existentes.

Se construirá una correcta limahoya de fábrica, que deberá ir apoyada sobre una solera de hormigón armada con mallazo ó (membrana de hormigón, según convenga), de modo que los aleros de teja tanto el de los faldones de cubiertas laterales como el de encuentro con los muros de la nave central rematen con goterón...

Plano 1/200 de planta extraño en rojo a mano sobre los muros laterales de la nave. En otra planta señala en rojo los solados de una panda del claustro.

Planos de detalle hasta la última piedrecilla y una sección del canalón en el encuentro.

AGA 26/00999

1981 - Nave central y galería claustral - Javier López de Uribe y Laya. 


\section{En el archivo de la Junta de Castilla y León}

\section{VA-017}

Carpeta 5205

Proyecto de obras de restauración en el Monasterio de Santa María de Valbuena de Duero. Diciembre de 1982

Arquitecto: Javier López de Uribe

"Dada la progresiva agresividad de las humedades existentes por sus zonas Norte y del Saliente desde el exterior inmediato al monumento, habiendo penetrado a su interior y alcanzado incluso en los estratos inferiores del subsuelo a las galerías claustrales y por supuesto a las dependencias anejas a las fachadas de las antedichas orientaciones citadas incluídas las del Panteón fundacional donde se encuentran las magníficas pinturas murales góticas, (que ya se hallan gravemente atacadas por la humedad); es por lo que sin más demora se propone urgentemente este programa enmarcado en tres ámbitos concretos:

$1^{\text {o: }}$ Consolidación de la zona de Claustros

$2^{\text {o: }}$ Restauración y consolidación de las pinturas murales del Panteón

$3^{\text {a }}$ : Eliminación de las humedades mediante la construcción de un concienzudo drenaje de circunvalación..."

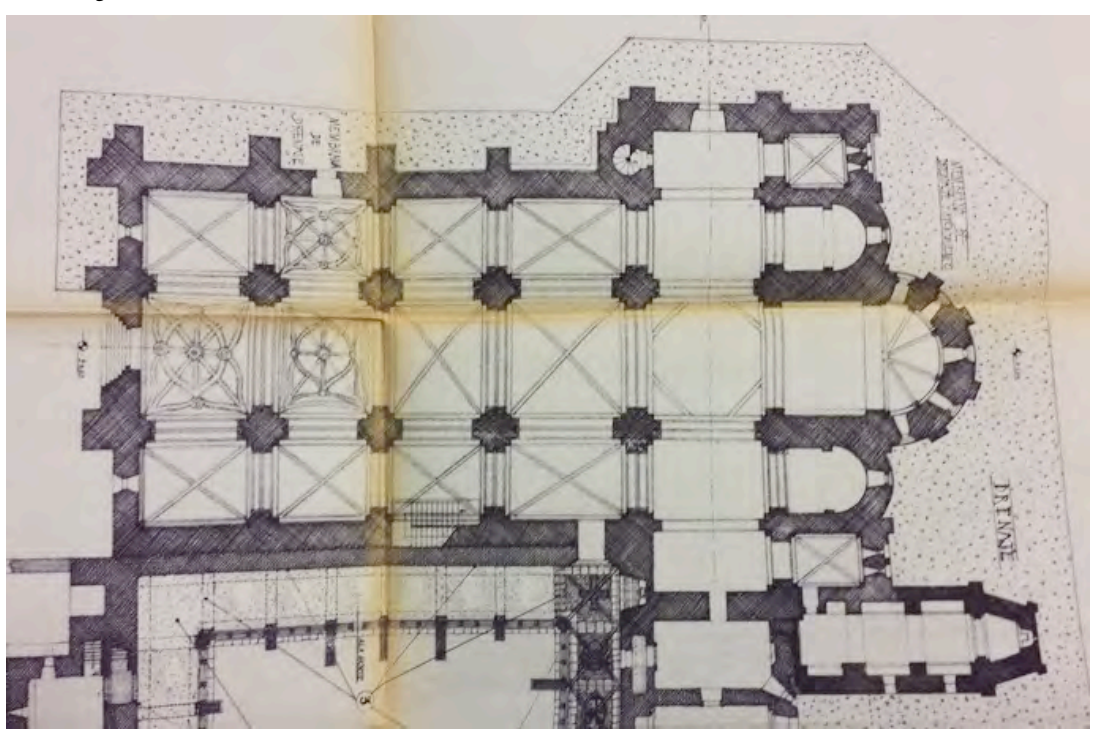

Ilustración 12: planta del área con drenaje (López de Uribe 1982)

Memoria histórica muy extensa con la historia del Cister.... Fundación con la Villa en 1143

Planos enormes 1:100 plantas del Monasterio baja y alta (no cabe la iglesia, no aparece). Otros generales 1:200. Detalles de drenajes y zona arqueológica. 


\section{VA-40}

Carpeta 5232

Restitución planimétrica, diagnóstico y propuesta de intervención en el Monasterio de San Bernardo, en Valbuena de Duero.

Prórroga en marzo de 1988 de dos meses para los tres arquitectos COAM domiciliados en Valladolid José Manuel Cañedo Muñoz, Luis Alberto Espinosa Escudero y José María Varona Leguinazabal

Planos enormes: planta, alzados y secciones 1:100

Diagnóstico con 84 fotografías a color.

Dice que no existen libros de fábrica, cuentas, ni publicaciones del XVIII.

Solo F.Antón lo estudia en el XX. (Vacío historiográfico)

Etapas constructivas:

Salvo detalles se remata antes de 1235 .

En el XVI se levanta el coro alto a los pies y un cuerpo alto sobre la Capilla.

En 1954 se aprovechan materiales para construir una población. Se emplean dependencias como silos y almacenes. Modifican huecos y arruinan pavimentos.

En 1961 el Iryda (Instituto para la Reforma y Desarrollo agrario encarga a la empresa Topesán "reparaciones" sin dirección facultativa. Se desmontan todas las cubiertas del Monasterio salvo la Hospedería. Se rehacen algunas con cerchas metálicas. Se reteja parte con material del Archivo de Simancas, también en obras en ese momento.

Se sustituyen forjados de madera por hormigón, desnuda piedra de la iglesia. "Con el paso de una a dos aguas de las cubiertas de las naves laterales se descubren las ventanas de la nave mayor, que se encontraban tapiadas."

En 1957 el Arzobispado compra el Monasterio y hace reparaciones también sin arquitecto. Coloca canaletas de recogida de aguas en las cubiertas de las naves laterales de la iglesia.

Desde los ochenta, cuando se reforman de nuevo las recogidas de agua de las cubiertas de la iglesia, no ha habido más intervenciones.

Descripción.

Es el Monasterio cisterciense más completo y valioso de la Comunidad. 


\section{VA-128}

Carpeta 5322

"Consolidación del Monasterio de Santa María (San Bernardo)" 1993

Arquitecto: José Ma Cañedo Muñoz, José M. Varona y Luis A. Espinosa

Documentación administrativa

Acta de recepción definitiva de las obras 4 de julio de 1996 (provisional 24 octubre 1994)

Observaciones al Proyecto en junio de 1993 de Garcés, falta documentación de sobre dormitorio de monjes, refectorio, etc. Sobre la Cabecera de la iglesia pide "planos de estado actual de la estructura de cubierta y de la intervención propuestas (detalles)"

Certificaciones.

Sobre la cabecera de la iglesia hay 500,41 m2 desmontaje y montaje de material de cubierta, consistente en: desmontaje de teja curva, i/apilado para posterior utilización, desmontaje de tabla, i/retirada a vertedero, nuevo entablado con tabla machihembrada $23 \mathrm{~mm}$. nueva colocación de teja curva procedente de demolición con reposición del 20\%. medición en p. Horizontal.

Placa bituminosa.

$125,10 \mathrm{~m} 2$ de restauración y colocación de estructura de madera, con reparación de zonas deterioradas, saneamiento de estribos, caballete, solera y durmiente, considerando un $25 \%$ de repercusión en toda la estructura, incluso parte proporcional de pequeño material y desescombro a vertedero.

20,02 m3 madera de pino norte, exenta de nudos y faltas, en vigas, correas y elementos de estructura, trabajada y colocada, incluso parte proporcional de material auxiliar y pérdidas por cortes, p.p. de tratamiento antixilofago de la madera.

\section{Informes}

Un informe de los tres arquitectos actualiza el emitido en julio de 1988.

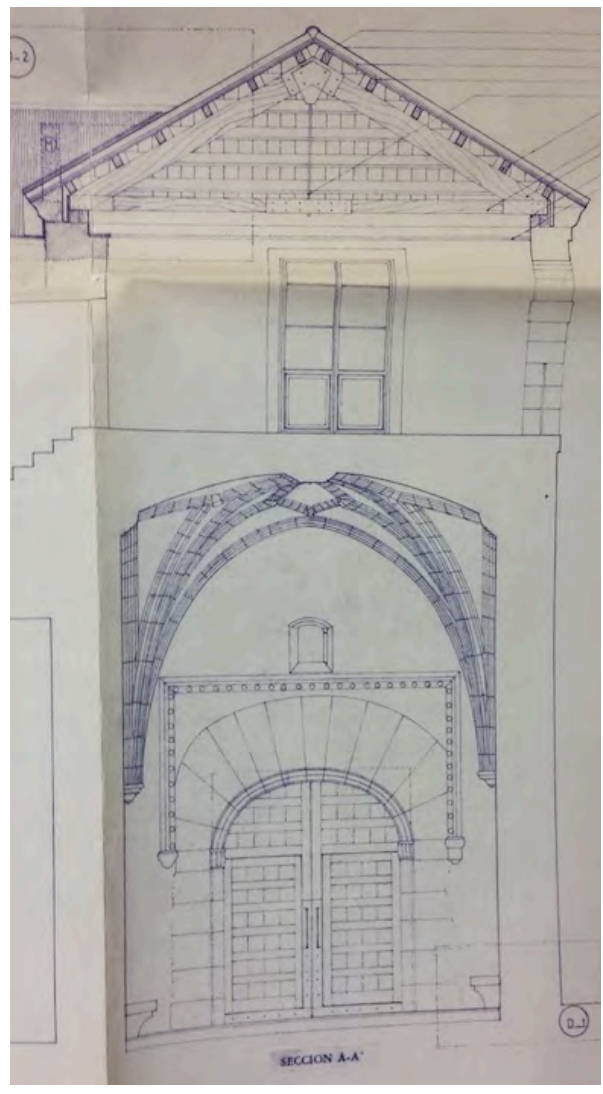

Ilustración 13: nueva estructura de madera en portería 
Intervenciones previstas en iglesia:

restauración de pinturas de la capilla del Tesoro, retejado e impermeabilización de la cabecera, revisión y restauración de la estructura de las cubiertas, eliminación de las humedades de capilaridad.

\section{PROYECTO}

Memoria histórica. En 1820 un indiano, el Barón de Kessel, compra las propiedades del Monasterio mediante terceros y en 1848 tras la Desamortización de 1835, el edificio del Monasterio.

La iglesia consta de tres naves, con crucero destacado en planta respecto de las naves laterales pero no de la cabecera, que tiene su misma longitud.

Por la cabecera, compuesta de cinco capillas, comienza la construcción. La mayor y adyacentes son de ábside semicircular cubierto con bóveda de cuarto de esfera y con nervios concurrentes junto al arco fajón que las separa del tramo rectangular precedente, cubierto con bóveda de cañón apuntado.

La bóveda del crucero, de cinco tramos, es de cañón apuntado. El tramo central se cubre con cimborrio de cúpula ochavada del siglo XVI montada sobre trompas antiguas. Se remata con una linterna barroca de ladrillo ochavada.

El acceso a las cubiertas se realiza a través de una escalera de caracol en el muro del crucero junto a la nave lateral.

El cuerpo de la iglesia consta de tres naves de cuatro tramos. Relación ancho-alto de 1:1,5 en nave mayor y 1:1,7 en laterales, proporción cercana al románico. Todas las bóvedas originales son de crucería sencilla, con nervios planos y plementería francesa.

Los pilares estaban preparados desde el principio para este tipo de cubrición.

El remate del testero oeste presenta un piñón almenado entre dos potentes contrafuertes, con carácter defensivo. El exterior muestra pureza de volúmenes.

Todos los cuerpos de la iglesia se apoyan sobre zócalo corrido rematado en chaflán y se coronan con cornisa de perfil en nacela apoyada sobre canes alargados, con perfil también de nacela o achaflanados, si bien las sucesivas modificaciones los han deformado en los dos últimos tramos de la nave mayor.

Toda la iglesia está realizada en sillería de labra excelente. 
Fundación "Las Edades del hombre":

1991/1999 - Proyecto de revitalización del Monasterio - Pablo Puente Aparicio

Se acomete una campaña de estudios arqueológicos y documentación de los restos. El Monasterio se convierte en sede permanente de la Fundación.

En el verano de 2015 se ha inaugurado en el recinto un hotel-balneario de cinco estrellas.

Memoria anexo

Ni en el proyectos de López de Uribe ni en el de Espinosa y Varona se documenta la estructura de cubierta de la iglesia.

Proceso constructivo:

En el siglo XIII se termina la elevación de los hastiales y muros occidentales del transepto, así como los de cierre septentrional y meridional del primer tramo de naves.

El cambio del sistema estructural de cubrición, mediante bóvedas de crucería en sustitución de las bóvedas de cañón con las que se inició la obra de la iglesia, obligó a reformar los planes constructivos originales con la consiguiente adaptación de los soportes para recibir las ojivas del nuevo abovedamiento gótico. Al tiempo que se ejecutaron los pilares exentos y los muros laterales de los dos primeros tramos de la nave central, se comenzaron a cubrir con bóvedas, al menos, los tres tramos de la nave del evangelio, todos los de la epístola y el primero de la central. También se terminaron los muros de cierre Norte y Sur de las naves y, más tarde, se completaron los sobreelevados muros de la nave central, cerrándose con bóveda al menos el segundo tramo.

En la primera mitad del siglo $\mathrm{XV}$, entre otras cosas, se retejó. A finales, comienzos del XVI, se llevó a cabo la construcción de las bóvedas de los dos últimos tramos de la nave central, de terceletes y ligaduras. En el XIX Espinosa repara las armaduras. El Monasterio sirvió de cárcel durante la Guerra Civil.

En 1942 se reparan con urgencia los tejados del templo en el cual se habían abierto dos hundideros.

En 1961 Construcciones Topesan SL acomete obras de restauración dirigidas por Anselmo Arenillas, primero con García Mesalles y luego con Leal. Eliminan yeserías de muros y bóvedas. Se lleva a cabo una reconstrucción general de cubiertas: 
demolición de las preexistentes, desescombro del trasdós de las bóvedas y nueva cubierta con forjado de hormigón sobre tabiquillos.

Demolición de habitaciones sobre las capillas del lado de la epístola.

Reposición de cornisa, especialmente en la zona de la cabecera y transepto.

En 1981 López de Uribe trata de corregir los problemas de humedades que producían los canalones interiores de naves laterales.

Entre 1988 y 1993 intervinieron los arquitectos Cañedo, Espinosa y Varona. Restauración y sustitución parcial de la estructura de la cubierta y del material de cobertura e impermeabilización.

Diagnosis, a partir del Estudio constructivo de Javier León, Soledad Camino y Roberto García:

La cimentación está ejecutada con rellenos de bolos y bloques... Los muros se componen de 3 hojas de piedra caliza: sillería/mampostería/sillería con zócalos sobresalientes, tanto al exterior como al interior... Las bóvedas carecen de revestimiento, pues en 1963-64 se picaron las yeserias clasicistas que las recubrían, al igual que a los muros y pilares. Son diferentes según su ubicación, y época de ejecución:

Ábside central y absidiolos adyacentes: de cañón apuntado y semicúpulas en remate de cabecera.

Crucero: formado por cuatro tramos de cañón apuntado separados con arcos a perpiaño.

Cúpula central esquifada octogonal sobre trompas con óculo cenital, sobre el que se dispuso una linterna octogonal de ladrillo revestido al interior y arcos de medio punto en cada paño.

Cuatro tramos de la nave central: los dos tramos próximos al crucero son de crucería, siendo los otros dos de bóvedas nervadas con terceletes.

Naves laterales de crucería.

En el coro las bóvedas que soportan el suelo son estrelladas muy rebajadas.

La cubierta es de teja cerámica, árabe o lomuda, vieja... el sistema constructivo actual corresponde a la actuación de los años sesenta del Instituto Nacional de Colonización (Arqo. $\mathrm{G}^{\mathrm{a}}$ Mesalles y Arenillas), cuando se eliminaron los entramados de madera y se ejecutó una cubierta a base de tabiquillos de ladrillo, entre un pie y hueco sencillo, sobre las bóvedas, con tablero cerámico y repobladura de teja vieja. 


\section{Cubiertas}

La solución dada por el INC en su momento, a base de faldones de ladrillo sobre tabiques que apoyan en las bóvedas, si bien ha preservado el monumento, evitando el deterioro de sus bóvedas, se considera inadecuado por desvirtuar el sistema constructivo tradicional de hacer trabajar a los muros perimetrales, concentrando las cargas en sus secciones ampliadas por pilastras interiores y contrafuertes exteriores, incrementando de esta forma la componente vertical y contrarrestar el empuje horizontal de las bóvedas.

La propia ejecución de la cubierta actual, de poca inercia, su difícil acceso, y la ausencia de ventilación, ha dado como consecuencia la corrosión y disolución de los materiales.

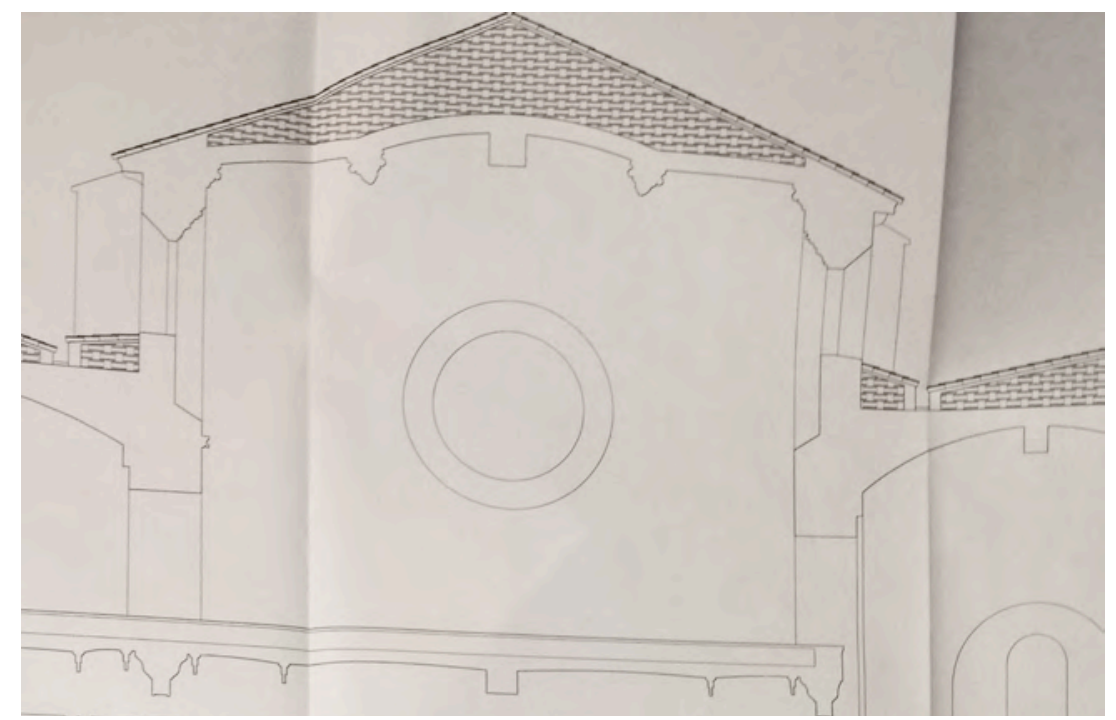

Ilustración 14: sección actual con tabiquillos 1991 Puente JCyL

Propuestas:

Operación generalizada de demolición de las cubiertas actuales y sustitución por nuevas. Para lo que se desmontará la teja y se demolerán los faldones y tabiques de ladrillo, saneando el extradós de las bóvedas.

La falta de documentación sobre la estructura existente, así como la carencia de documentación al respecto en los proyectos de intervención anteriores, unido a la imposibilidad de acceder al espacio bajo cubierta, a hecho que en la documentación del estado actual nos limitáramos a reflejar la geometría fundamental, con excepción de aquellas secciones de las que disponíamos datos...

En las naves laterales se proyecta la ejecución de una cubierta aterrazada como las existentes en los monasterios de Poblet o de Santes Creus con el sistema de losas cabalgando unas sobre otras. se realizará con perfilería zincada tomando la pendiente que permita el nivel inferior de los ventanales de la nave central y el del alero, sobre 
la que se embrochalarán correas del mismo material cada $1,25 \mathrm{~m}$ para apoyo de paneles prefabricados de GRC.

Se ejecutarán armaduras de madera de pino, apoyadas en zuncho perimetral, sobre las que se dispondrán correas del mismo material y tablero contrachapado hidrófugo, con ventilaciones en cumbreras, que soportará una lámina impermeabilizante previa a la pobladura con teja cerámica lomuda envejecida de nueva factura.

Demolición teja estructura: Nave central 39x13,50; naves laterales 37,0 x8,50 y $37,0 \times 8,00 \ldots$

ML apertura de caja en muros...para alojamiento de los durmientes de la estructura de cubierta: nave central 2x39; $2 \times 13,50$

$757,46 \mathrm{~m} 2$ estructura a 2 aguas $<10 \mathrm{~m}$ : formada por cerchas conformadas por pares de madera laminada y tirantes peraltados con pendolón de acero gewi, colocadas a $3 \mathrm{~m}$ a ejes y correas de madera aserrada...

76,00ml Ejecución de zuncho de hormigón armado para atirantados y atados de fábricas de todo tipo. Previa labor de su cajeado cuidadoso en fábricas pétreas o de cualquier tipo, de sección aproximada de $0,30 \times 0,40 \mathrm{~m}$., realizado con hormigón armado HA-40/P/40/IIa preparado en central y con una cuantía de acero AEH-500s de $60 \mathrm{Kgs} . / \mathrm{m} 3$., incluso encofrado... $\quad$ Naves laterales $2 \times 38,00$ 



\section{Visitas realizadas}

21/08/2015

El Monasterio ha sido inaugurado recientemente como hotel balneario. La iglesia permanece abierta al culto y es gestionada por la institución Las edades del Hombre, que cobra la entrada y proporciona un servicio de audio-guía.

Han sido restaurados claustros y capillas, recuperándose policromías.
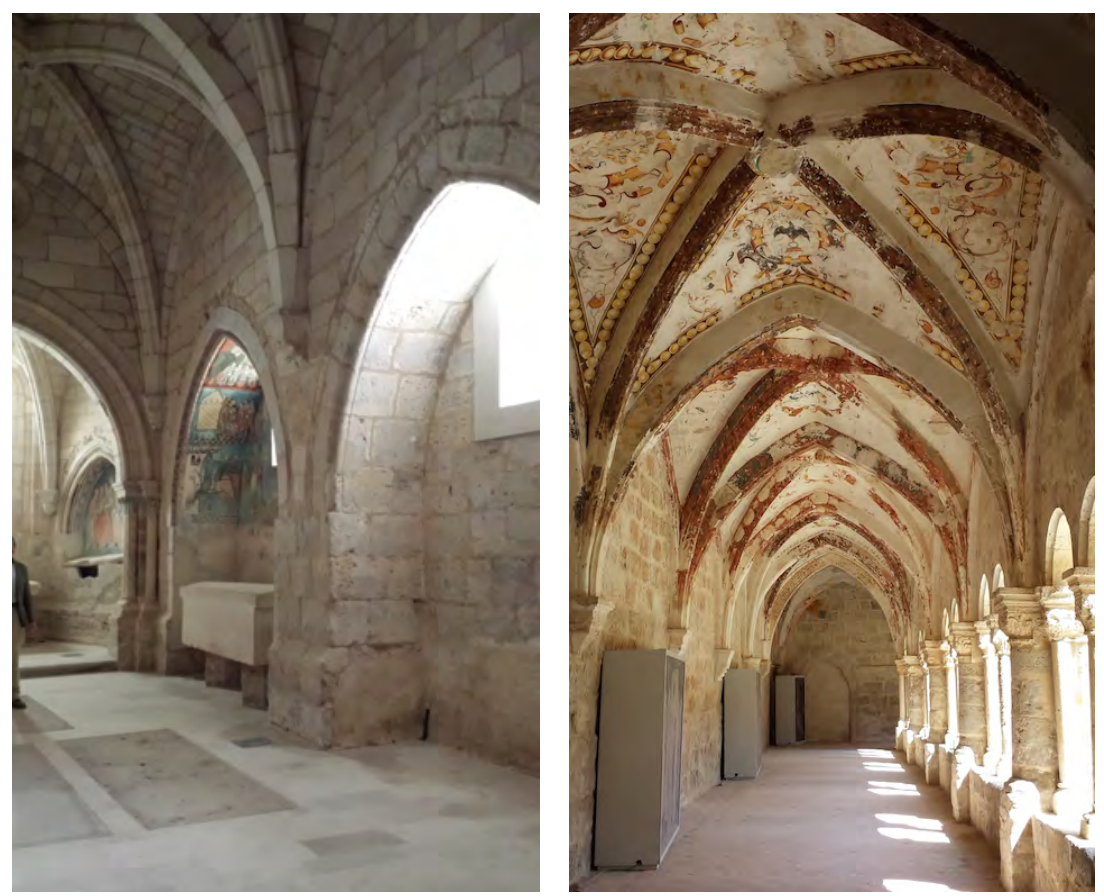

Algunas zonas del conjunto permanecen en obras, aunque la iglesia se encuentra totalmente restaurada con sus fábricas recién rejuntadas.

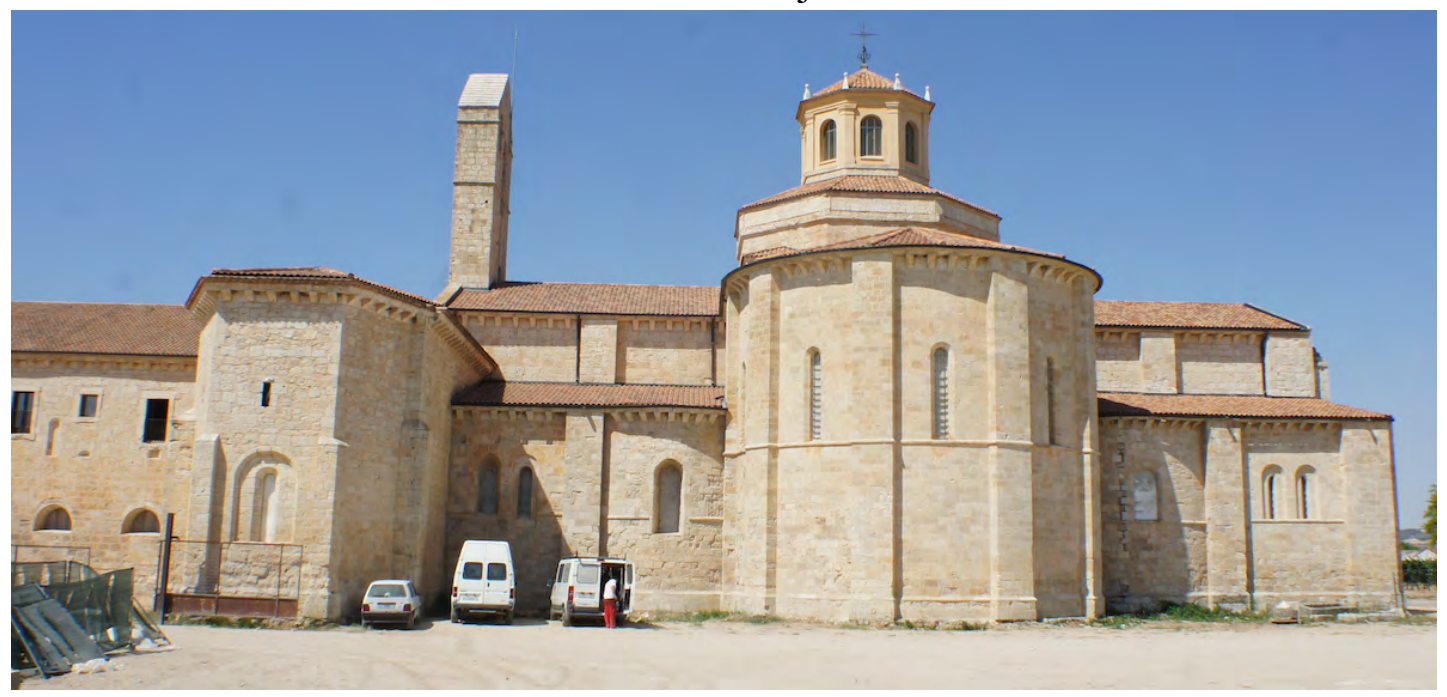

No se ha obtenido permiso para acceder a los espacios bajo cubierta. 

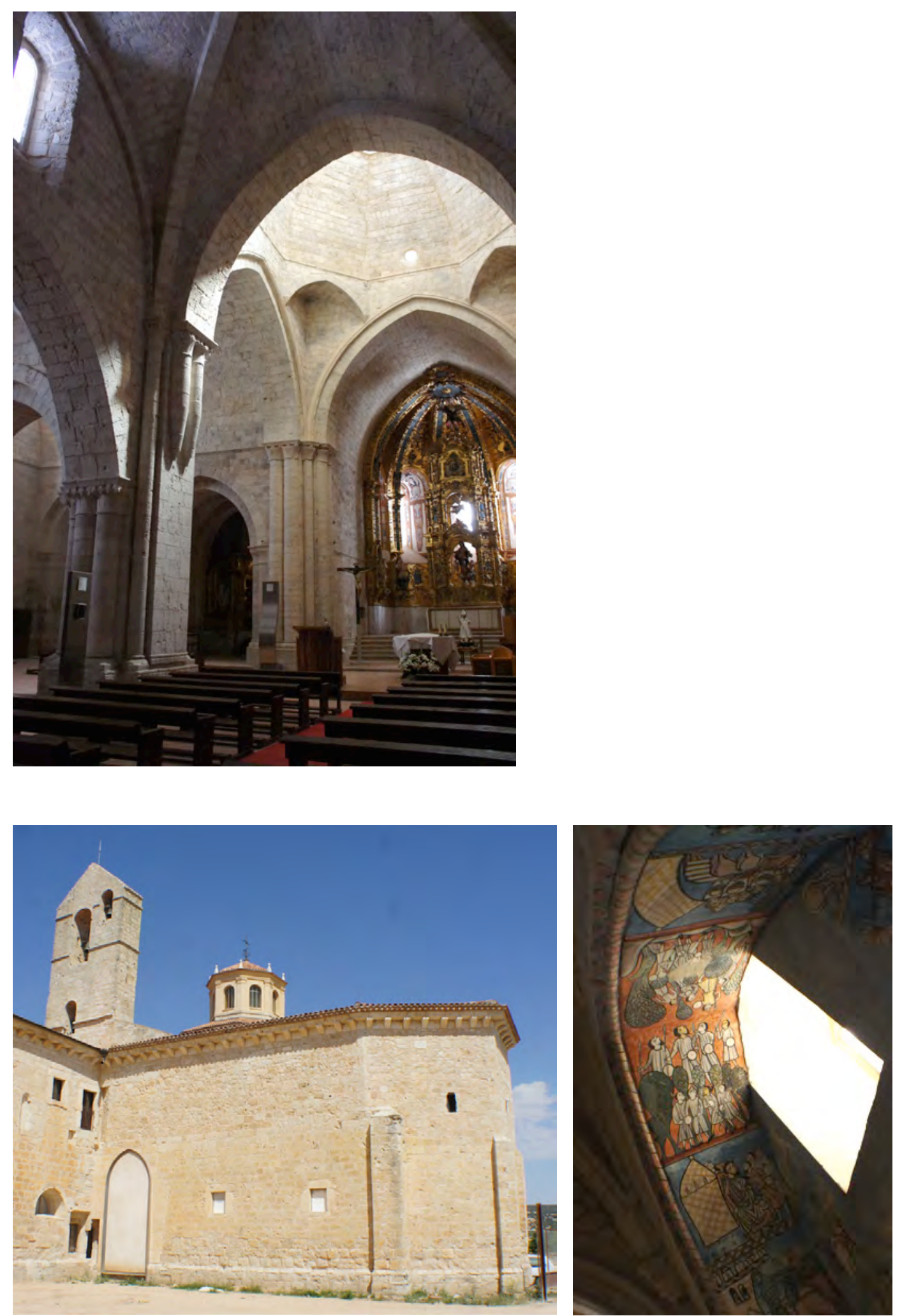

Capilla del Tesoro visita 21/08/2015 


\section{Iglesia de Santa María del Castillo}

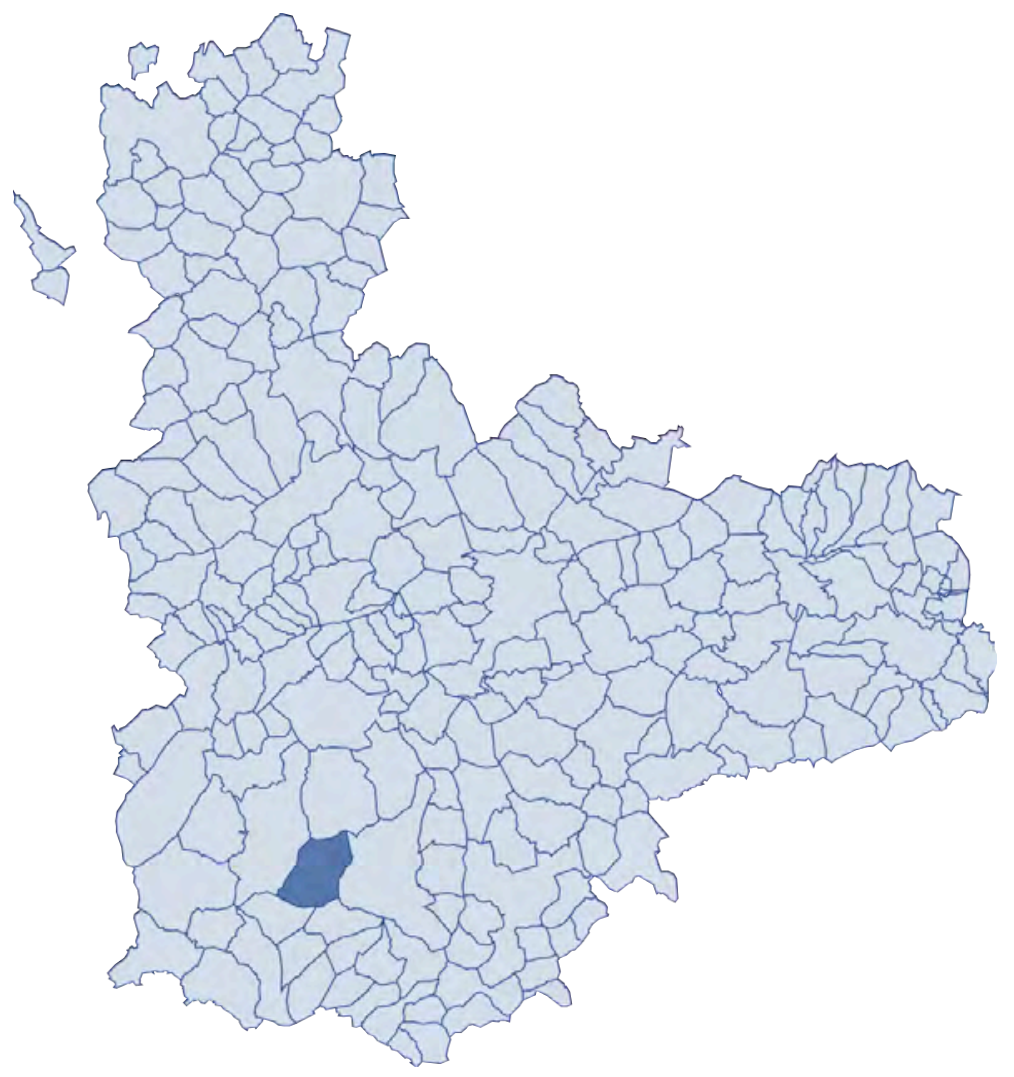



FICHA SÍNTESIS

Código de identificación: FZ-38

Denominación: Iglesia de Santa María del Castillo

Localidad: $\quad$ Villaverde de Medina

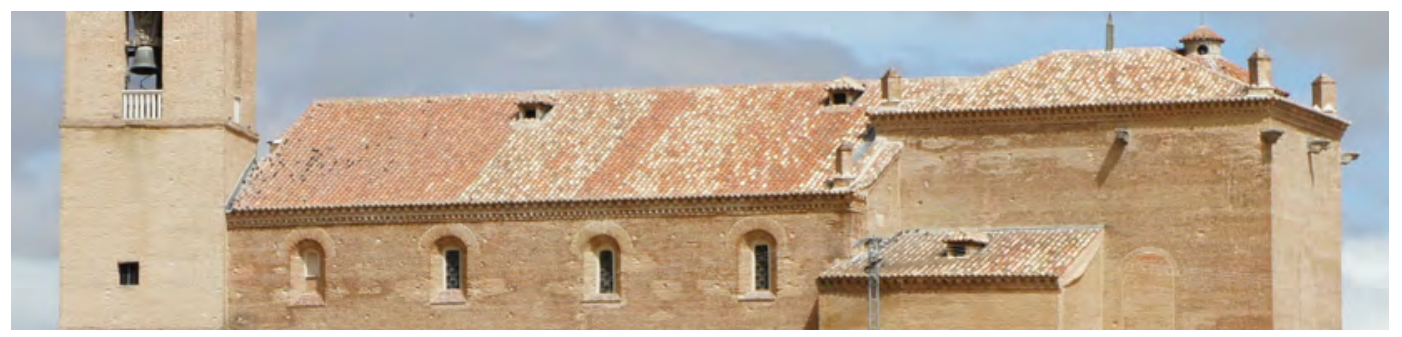

\section{Descripción}

Iglesia de una sola nave con capillas entre contrafuertes. Cubierta con bóveda de cañón, con lunetos sobre la nave y en perpendicular sobre las capillas. La cabecera gótica se cierra, a menor altura, con bóveda de crucería estrellada con combados profusamente decorada.

\section{Materiales}

Todos los muros son de fábrica de ladrillo y cuentan sólo en parte con un pequeño zócalo formado por tres hiladas de sillería de piedra. La cubierta está revestida de teja curva.

\section{Singularidades}

En la última intervención se ha incorporado a la torre, además de un segundo cuerpo de campanas, un remate singular consistente en un estilizado tambor adicional rematado con cúpula y linterna, todo ello revestido con acero corten

La cabecera es de grandes dimensiones y presenta ventanales cegados en sus tres fachadas. En la parte alta de los muros sobresalen gárgolas de piedra encastradas en la fábrica.

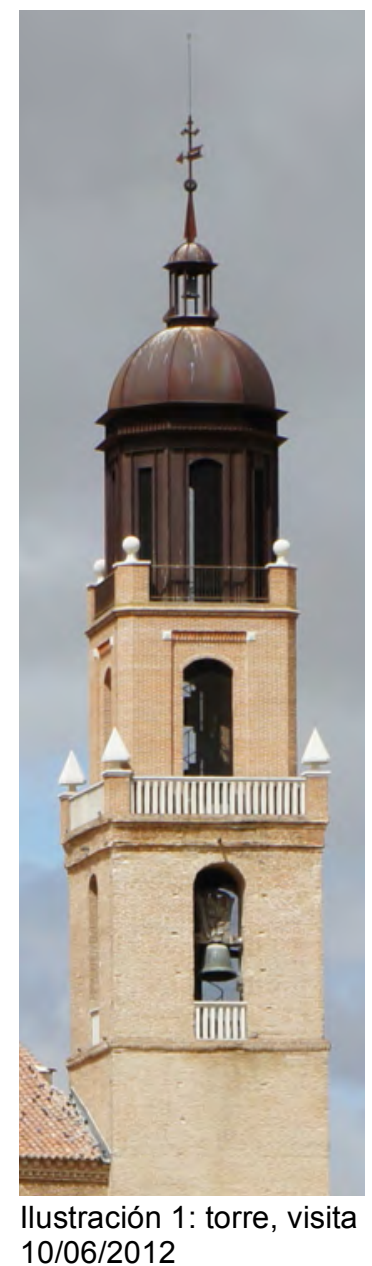




\section{Dimensiones básicas del templo}

$\begin{array}{llll} & \text { central } & \text { laterales } & \text { capillas } \\ \text { Ancho de nave } & 12,4 & - & 2,8 \\ \text { Altura } & 17,7 & & 15,0\end{array}$

\section{Memoria histórica constructiva}

La construcción del monumento arranca por la cabecera a mediados del siglo XVI, no acometiéndose la ejecución del cuerpo hasta 1570, a cargo del maestro de cantería Hernando del Río. La nave permanece algún tiempo sin cubrir hasta que en 1585 está documentado que el carpintero francisco de la Vega adquiere "bigas y tablas para el casco de la yglesia" que dispone según trazas del maestro Diego García.

Se realizó un socalce de los muros en 1658 y ya en 1703 se contratan las bóvedas, que construyen los maestros de obras Francisco de Castander y Pedro Portela con trazas de este último. Al parecer se produjo el derrumbe de una de las cuatro bóvedas durante la construcción, por lo que tuvo que ser reconstruida.

Condiciones de Francisco Castander para ejecutar dos de las bóvedas en 1703 según trazas y Condiciones dadas por Pedro Portela, que se encargará de las otras dos a los pies ${ }^{1}$ :

Se describe cómo harán rozas de cuatro dedos en los arcos torales para que quede una mocheta de medio pie donde apoyar las bóvedas tabicadas dobladas. La cornisa dórica en todo el perímetro interior se clavará con clavijas de hierro de una vara (si no se pudiesen meter nudillos de madera). Se blanqueará todo el cuerpo de la iglesia. Para entrar desde el caracol a la bóveda se deben romper cinco huecos de paso ajustados al paso de un hombre.

Si revisamos el enunciado de las condiciones reproducidas en el Catálogo y descritas en el Anejo de esta Ficha, llama la atención que las bóvedas incorporadas en los albores del XVIII no habían sido previstas en el diseño original del edificio. Eso explica la labra de las ménsulas que sostenían las vigas de madera, diseñadas como parte de una techumbre a la vista. Para sostener la doble hoja de ladrillo se decide hacer rozas de cuatro dedos en los arcos existentes y dejar una mocheta de

\footnotetext{
${ }^{1}$ Concierto reproducido en el Catálogo pág. 502
} 
medio pie donde apoyarlas. Se abren también en ese momento los huecos de paso que comunican los tramos de bóvedas en el espacio bajo cubierta. Podemos encontrar otros casos similares, por ejemplo la iglesia del salvador en la ciudad de Valladolid, cubierta originalmente con artesonados de madera sobre arcos diafragma que se transforman posteriormente en los fajones de una bóveda de cañón con lunetos.

\section{Cronología. Fechas clave}

$1570-1585-1703-1989$

\section{Intervenciones}

1972 - Cubierta, fachada y vidrieras - José Ángel Rodrigo García y Joaquín Roldán Pascual

Se reteja la cubierta de la nave renovando la tablazón en mal estado. La estructura de madera sobre la cabecera se reemplaza por cerchas metálicas con forjado.

\section{Incorporación de zuncho de hormigón armado.}

Se dispone un zuncho $70 \times 50 \mathrm{~cm}$ perimetral, de coronación, sobre los muros repicados.

1988 - Torre - Carlos Descalzo Llorente

1989 - Restauración de la iglesia parroquial - Jesús Tovar Casales

Se reemplaza la estructura de madera que aún cubre nave y sacristía por madera laminada. Se cambia la dirección de vigas principales en longitudinal con correas transversales por un orden único longitudinal de piezas 9x32 con $6,1 \mathrm{~m}$ de luz apoyadas sobre los arcos fajones. Mantiene la pendiente inicial de $26^{\circ}$.

\section{Incorporación de zuncho de hormigón armado.}

Se incorpora más zunchos de hormigón "para sanear" los muros y cinco ménsulas.

\section{8 - Reparación de cubiertas - José Luis Pardo Castañeda}

Tras la caída de un tramo considerable de la cornisa, se reemplaza el mortero que recibe las tejas por otro armado con malla galvanizada y rastreles. Se cambia la solución de 1989, con tejas a la segoviana, por canal y cobija. Se dispone un murete de fábrica de ladrillo recrecido sobre el muro con una cuña, para mejorar el apoyo del tablero. 


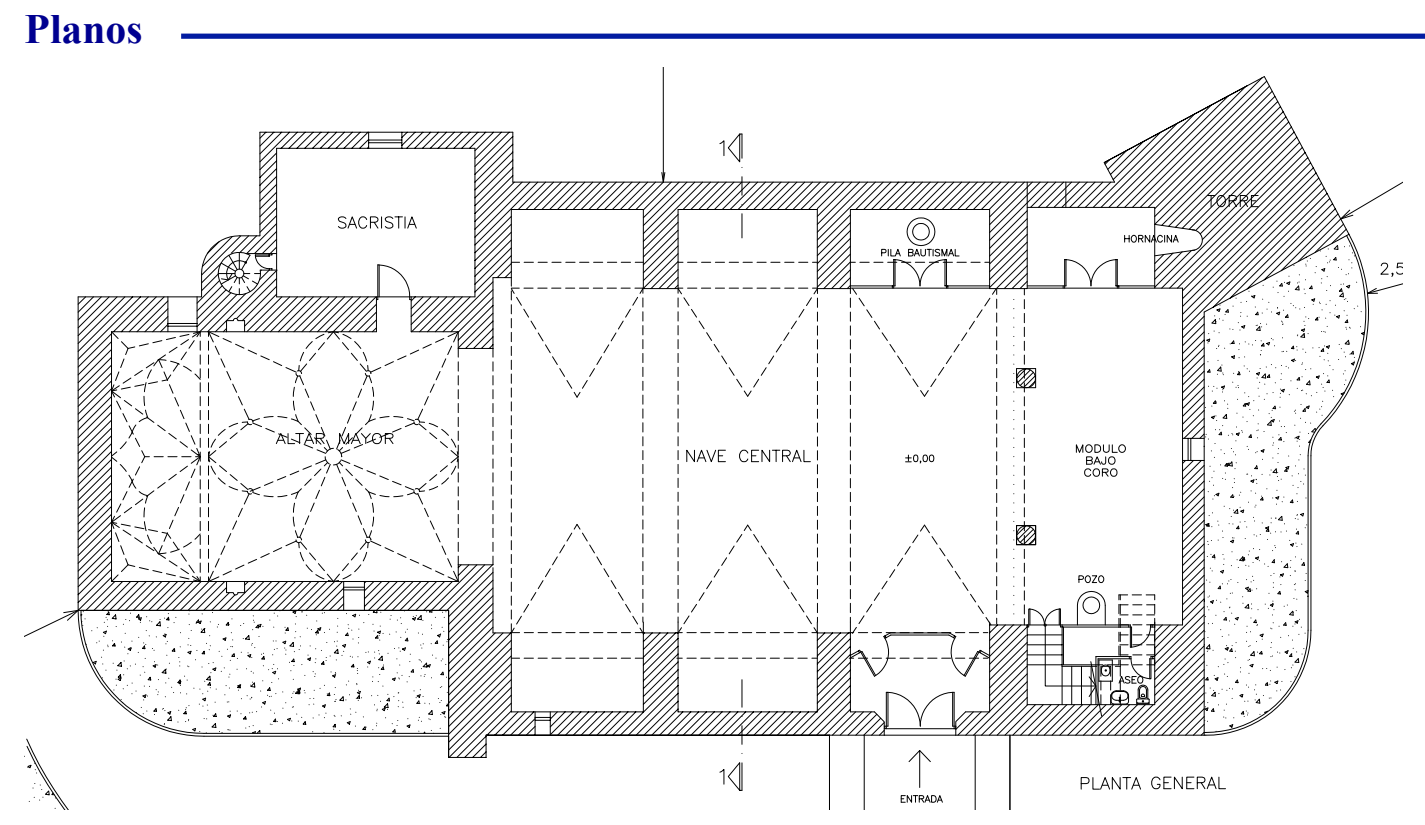

Ilustración 2: planta general (Pardo 2008 JCyL)

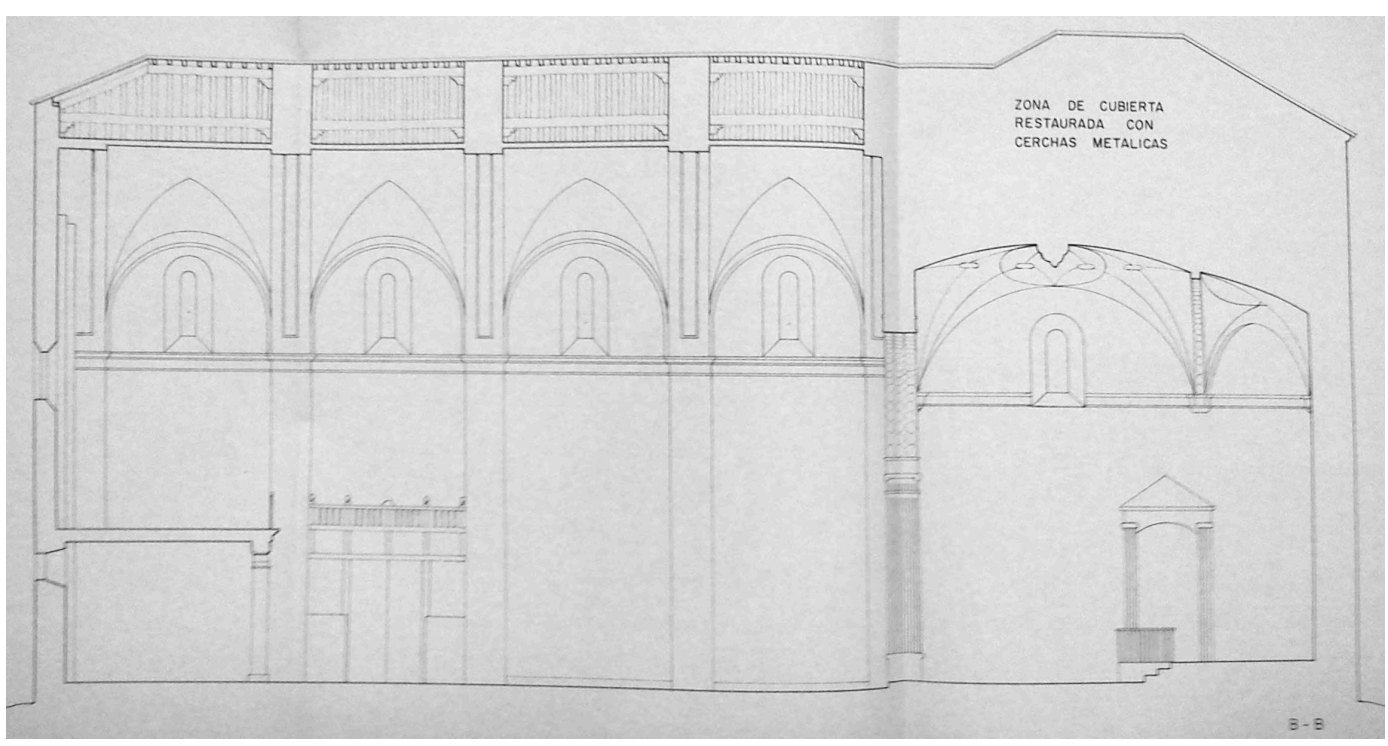

Ilustración 3: sección longitudinal estado actual (Descalzo 1989 JCyL)

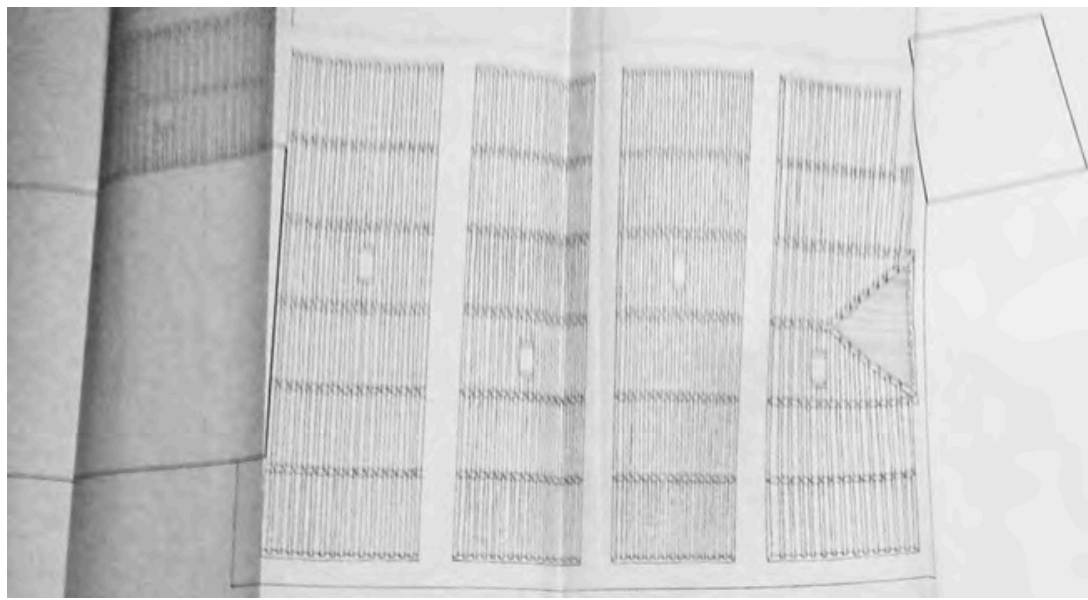

Ilustración 4: planta de estructura original (Tovar 1989 JCyL) 
En la planta de estructura de madera de cubierta de la nave en su estado actual de 1989 se aprecia la disposición original de las vigas, apoyadas en ménsulas encastradas en los arcos-diafragma con las correas orientadas en la dirección de la pendiente. En la proyectada, se colocan las piezas de madera laminada en el mismo sentido, pero distribuidas para repartir la carga a lo largo de los piñones diafragma.

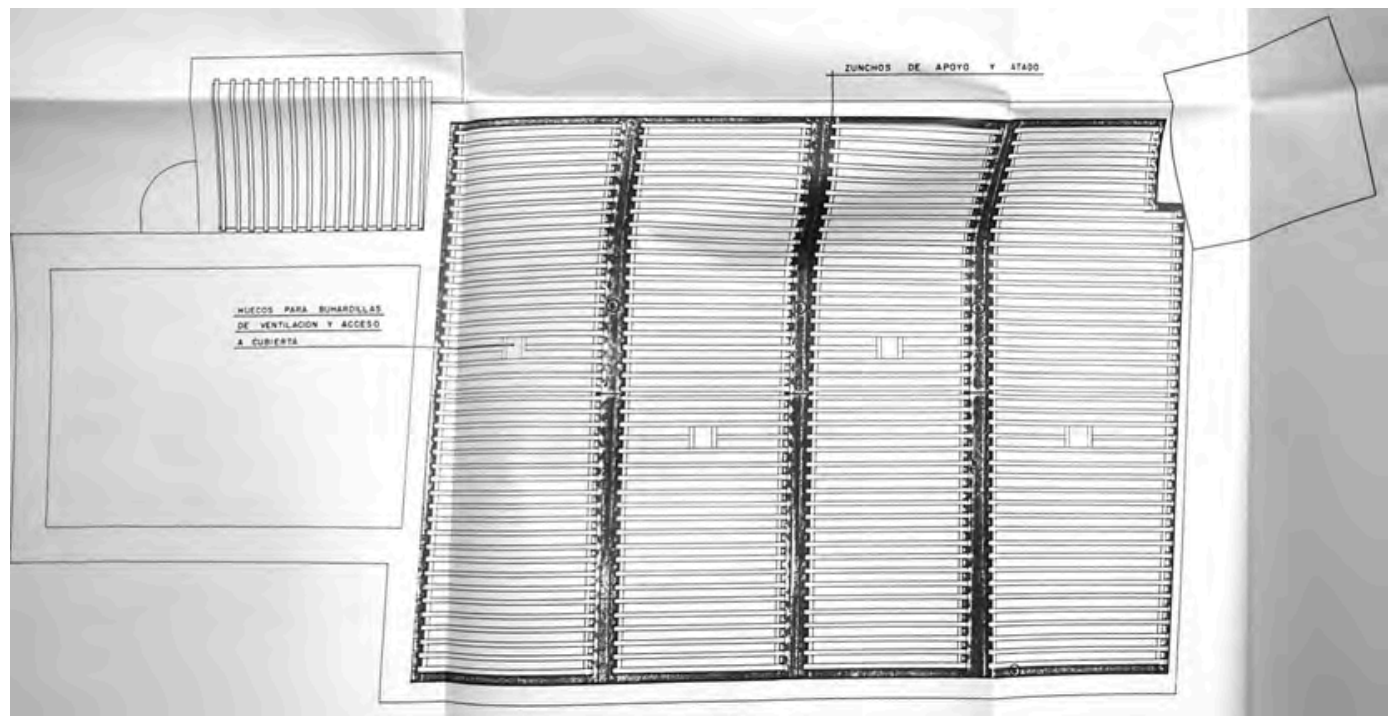

Ilustración 5: planta de nueva estructura de madera laminada (Tovar 1989 JCyL)

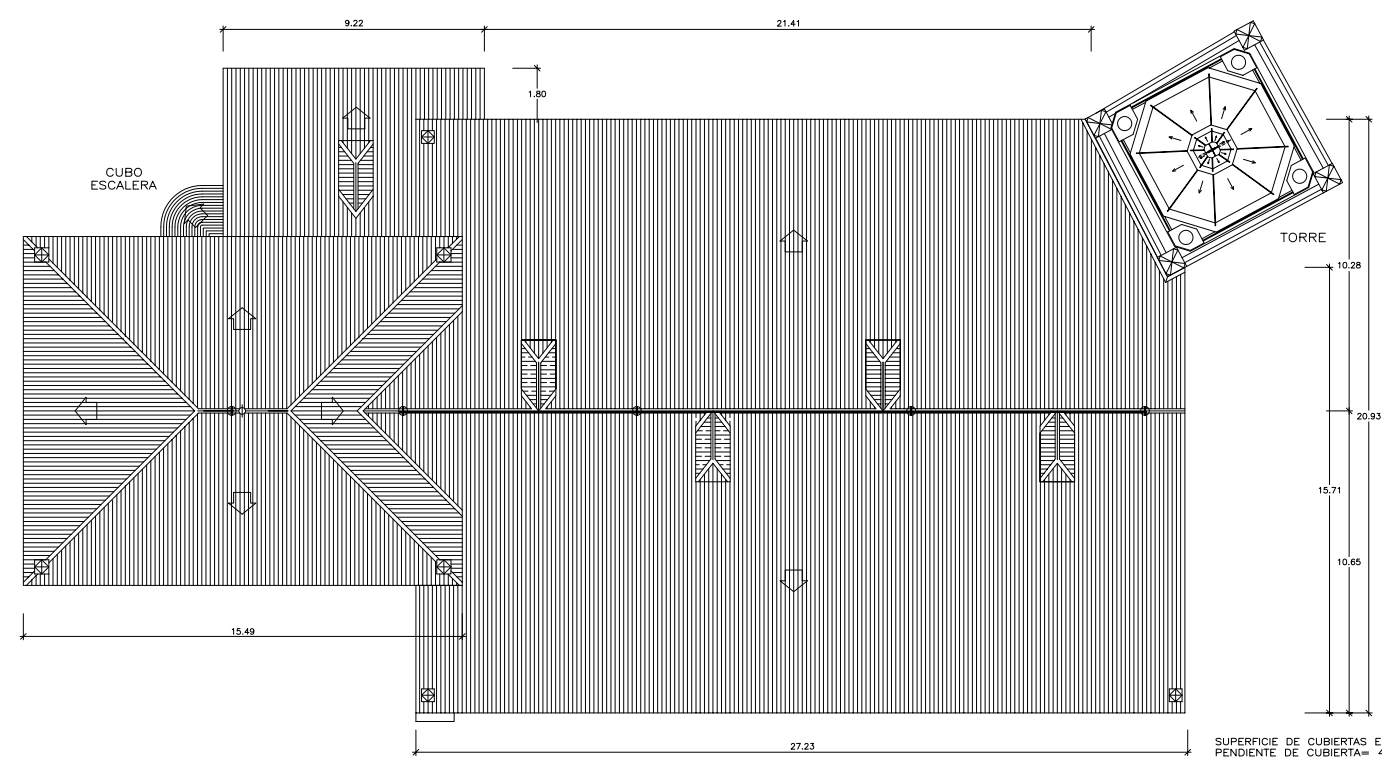

Ilustración 6: planta de cubiertas (Pardo 2008 JCyL) 


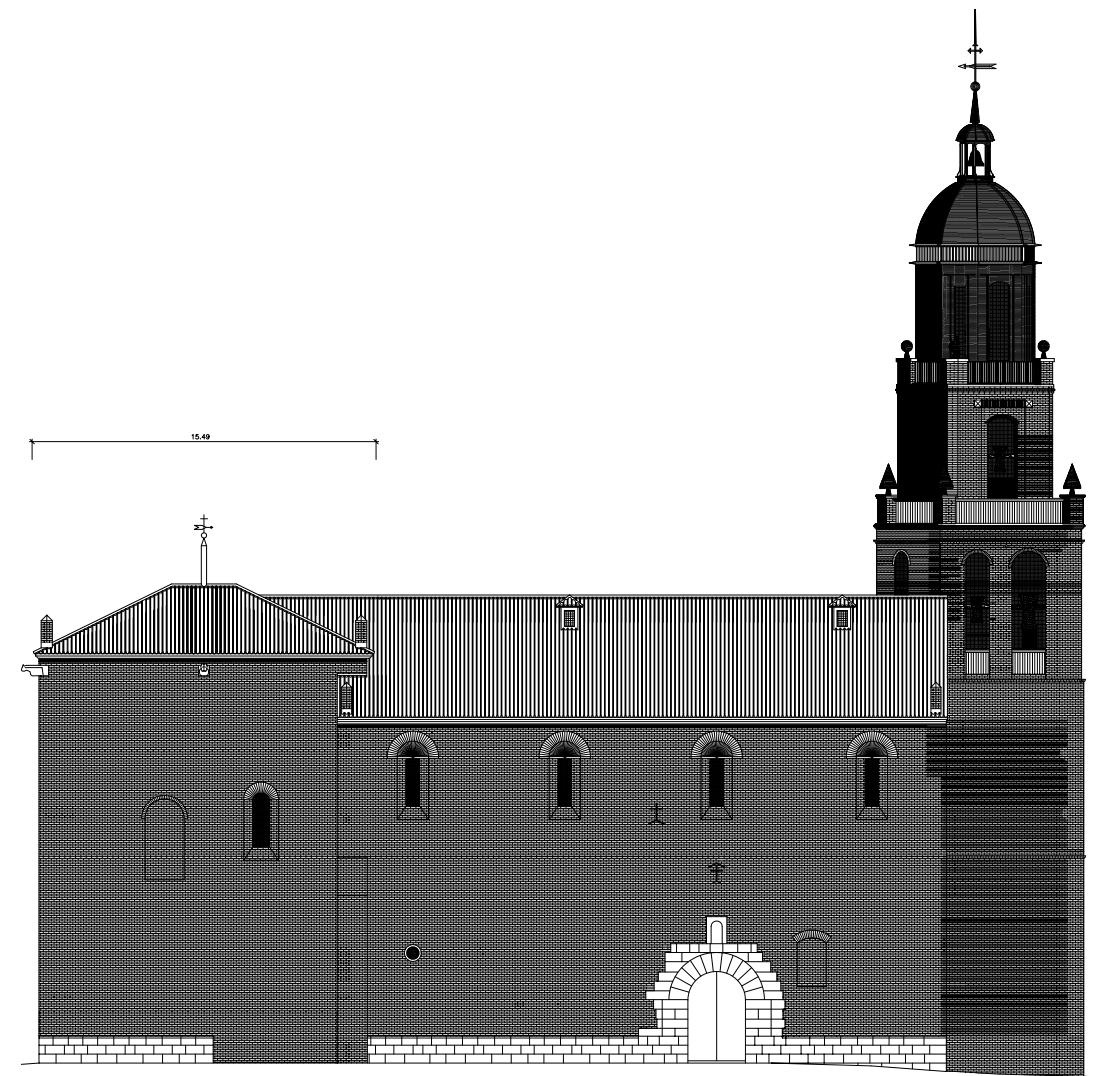

Ilustración 7: fachada de acceso (Pardo 2008 JCyL)

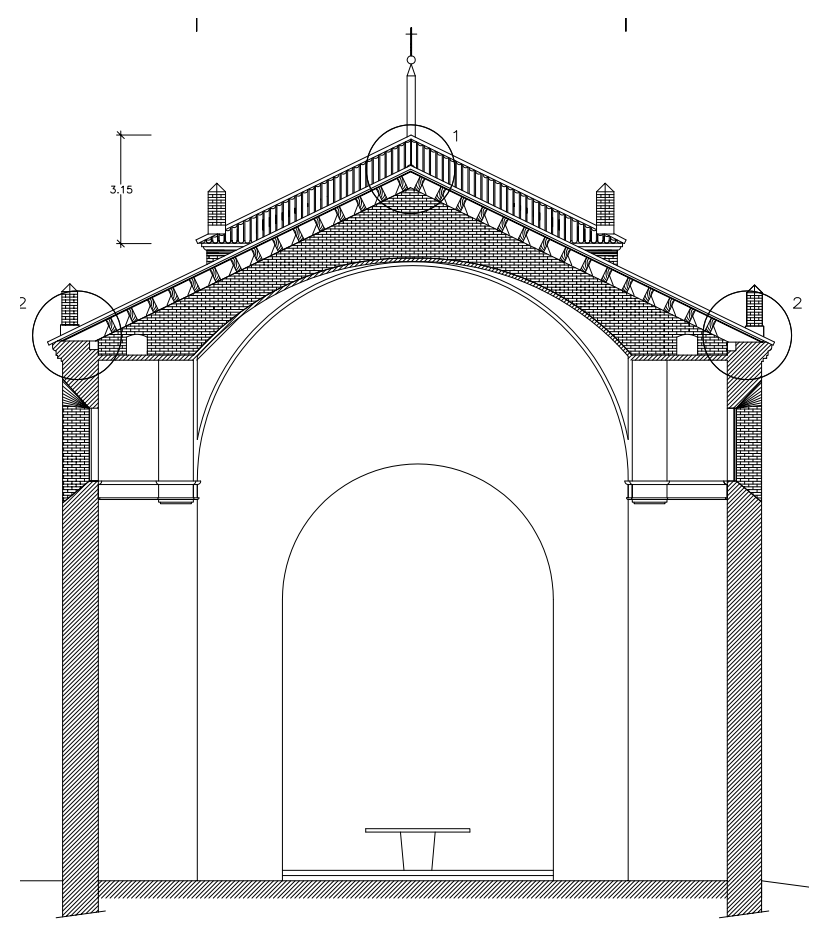

Ilustración 8: sección transversal (Pardo 2008 JCyL) 


\section{Solución constructiva de la cubierta}

En la reforma de 1972 se reemplazó la estructura existente por metálica en la cabecera.

En las secciones de 1989 se aprecia la antigua estructura, con grupos de cinco vigas de madera en cada tramo de bóveda, apoyadas sobre ménsulas labradas encastradas en los muretes rematados superiormente a dos aguas que forman los arcos fajones.
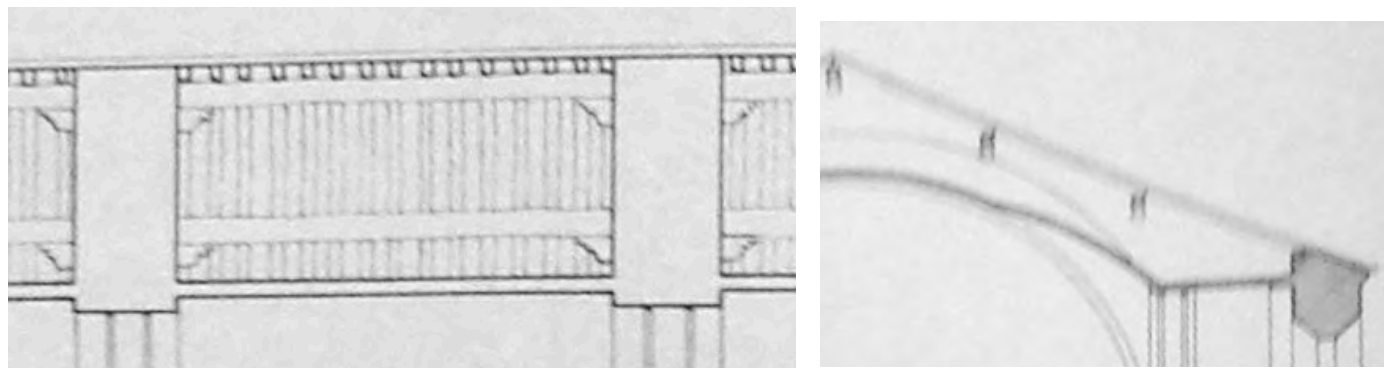

Ilustración 9: detalles sección estado actual de 1989 (Tovar JCyL)

Fotos del dossier contenido en el proyecto de 1989 citado donde se aprecia el estado de la armadura de la nave antes de su reemplazo.
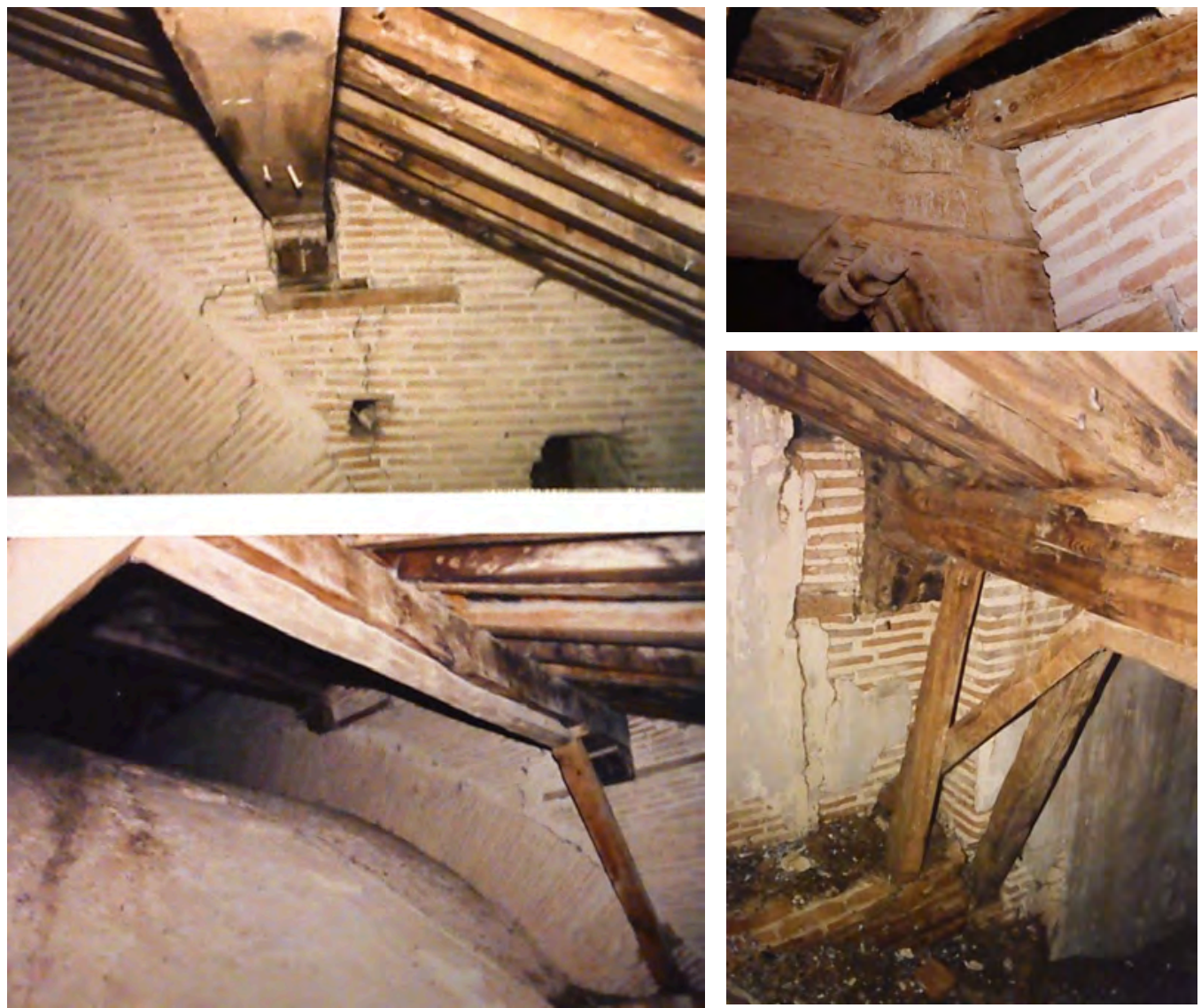

Ilustración 10: dossier imágenes estructura de cubierta en 1989 (Tocar JCyL) 
Algunas vigas se encontraban reforzadas mediante apoyos intermedios, resueltos con jabalcones y codales. Según estas imágenes, la fábrica alrededor de las ménsulas presentaba marcados agrietamientos.

En 1990 el arquitecto territorial justifica cambiar el sentido de la estructura de cubierta de la nave por el mal funcionamiento estructural de la misma. En realidad, si prestamos atención al proceso constructivo descrito en páginas anteriores, podemos llegar a pensar que el agrietamiento pudo deberse, no al mal funcionamiento del entablado original, sino del sistema completo de cubierta tras la incorporación en 1703 de las bóvedas de fábrica no previstas en el dimensionado de los arcos. Se trata de un importante peso propio que incide sobre rozas de medio pie practicadas casi a ras de la cara inferior de los diafragmas. Esta carga se incrementa además en 1989 con el recubrimiento de las bóvedas con una capa "de consolidación" de hormigón armado. Los muretes habían sido debilitados durante la construcción de las bóvedas con la apertura de los huecos de paso.

Según Pardo la pendiente de los faldones es del $26^{\circ}$.

\section{Zunchos}

En los planos de 1972 se define la incorporación de un zuncho perimetral 70x50cm sobre el cuerpo de la nave, para "consolidación", junto al reemplazo de armadura por estructura metálica en cabecera y torre. Se desconoce si se llegó a ejecutar el zuncho previsto en esta actuación, ya que en fotografías de 1988 aún encontramos la torre cubierta con estructura de madera y el zuncho observado durante la visita presenta dimensiones mucho menores.

En el proyecto de 1989 se contempla el hormigonado de $21 \mathrm{~m} 3$ de zuncho "para saneamiento de los muros". En los planos se representa el detalle del encuentro de la cubierta con el muro reproducido junto a estas líneas. Para acodalar lateralmente las vigas de madera laminada, muy esbeltas y con su sección dispuesta con la inclinación de la pendiente, se representan bloques de fábrica de ladrillo a modo de ejiones.

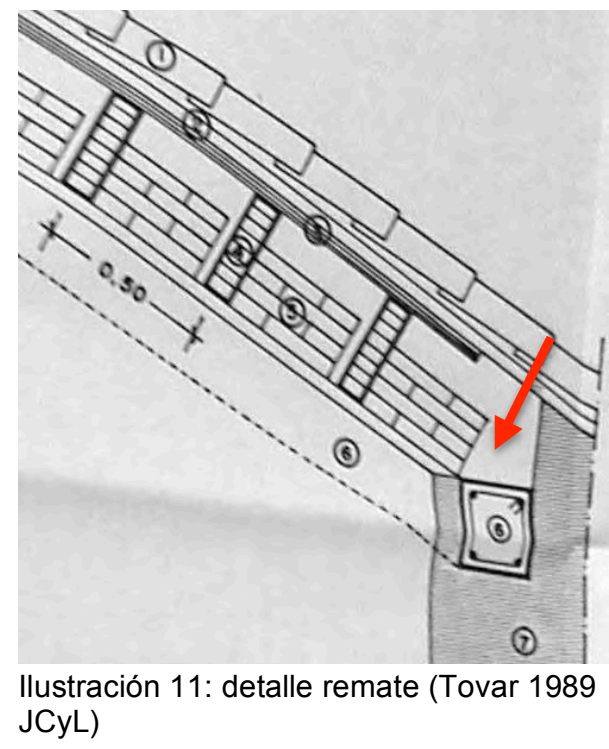


En la leyenda se define el armado del zuncho perimetral pero no sus dimensiones, y se representa embebido en la fábrica. Se define en $37 \mathrm{~cm}$ la zona de muro interior a demoler para colocar zuncho.

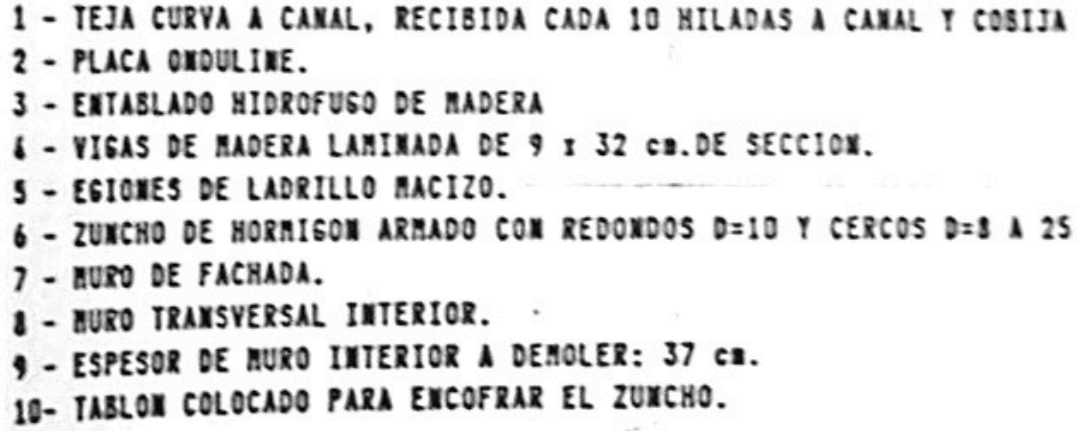

En el detalle anterior se representa el entablado interrumpido nada más adentrarse en la sección del muro de fachada (señalado con una flecha en rojo) y sin aclararse hasta dónde se prolonga el onduline, ya que el dibujo se interrumpe a mitad de la sección de muro. No se define el remate del faldón ni su encuentro con la cornisa, punto crucial para la grave patología producida precisamente a raíz de esta obra que obligó a volver a intervenir urgentemente sobre la cubierta en 2008.

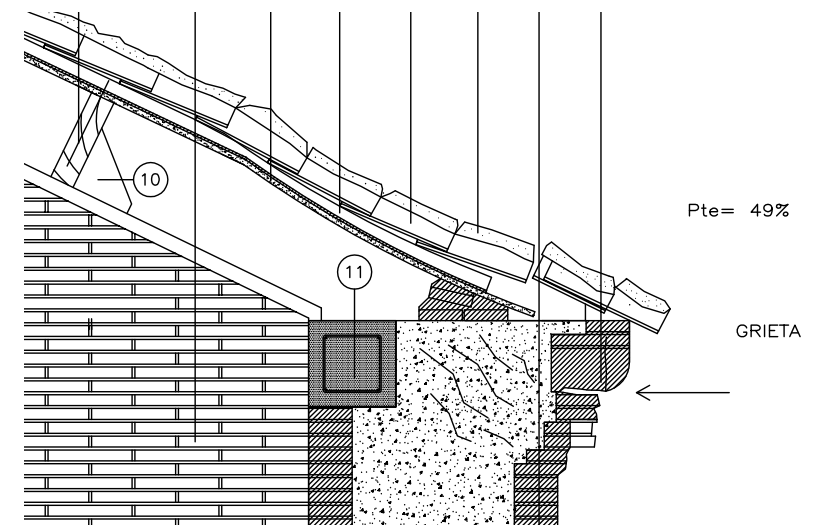

Ilustración 12: patología cornisa 2008 Pardo JCyL

En el plano estado actual de este último año se representa el mismo detalle con el remate del onduline sin sobrepasar el espesor del muro, el zuncho enrasado a cara interior y ejiones metálicos.

En un apartado titulado Consideraciones finales del proyecto modificado, Tovar describe que

"se contempla una nueva disposición de zunchos de atado que varían en cuanto a sección y colocación, y que es una consecuencia de observar in situ la obra que se está ejecutando. Se han previsto unos zunchos adicionales colocados en la coronación de los muros de fachada para unir de forma continua los zunchos transversales sobre los que se apoyan las vigas de madera. A la vez estos últimos han aumentado de sección ya que aunque esto supone un mayor volumen de hormigón, el acabado y ejecución de un solo zuncho en lugar de los dos previstos inicialmente, ofrece una mayor facilidad de ejecución así como un mejor acabado y remate." 
Según el plano de 1989 sobre los arcos fajones se coloca zuncho plano de $90 \times 25 \mathrm{~cm}$.
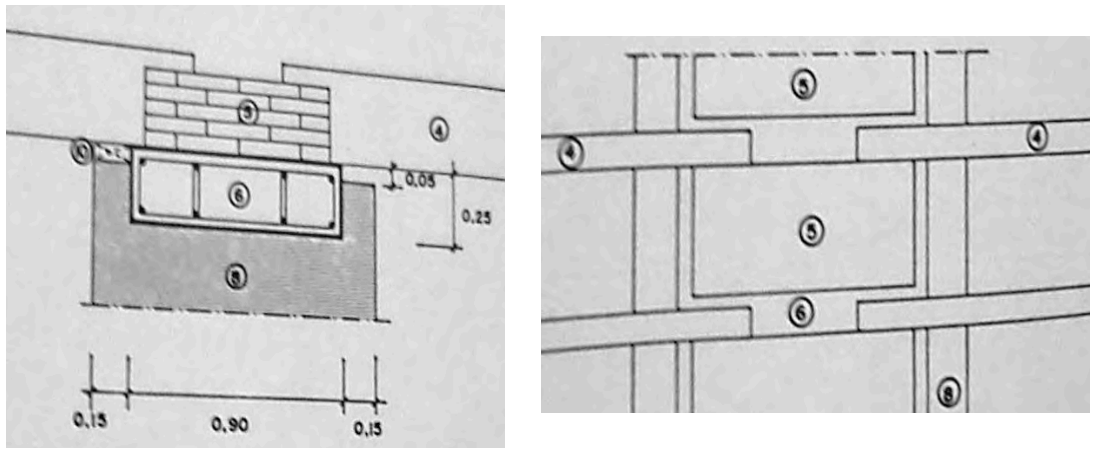

Ilustración 13: zunchos 1989 Tovar JCyL

El zuncho no llega a completar un anillo perimetral cerrado sobre el cuerpo de la nave con capillas ya que, aunque sí se prolonga sobre el murete correspondiente al arco triunfal, en el testero a los pies queda interrumpido en los $6 \mathrm{~m}$ centrales.

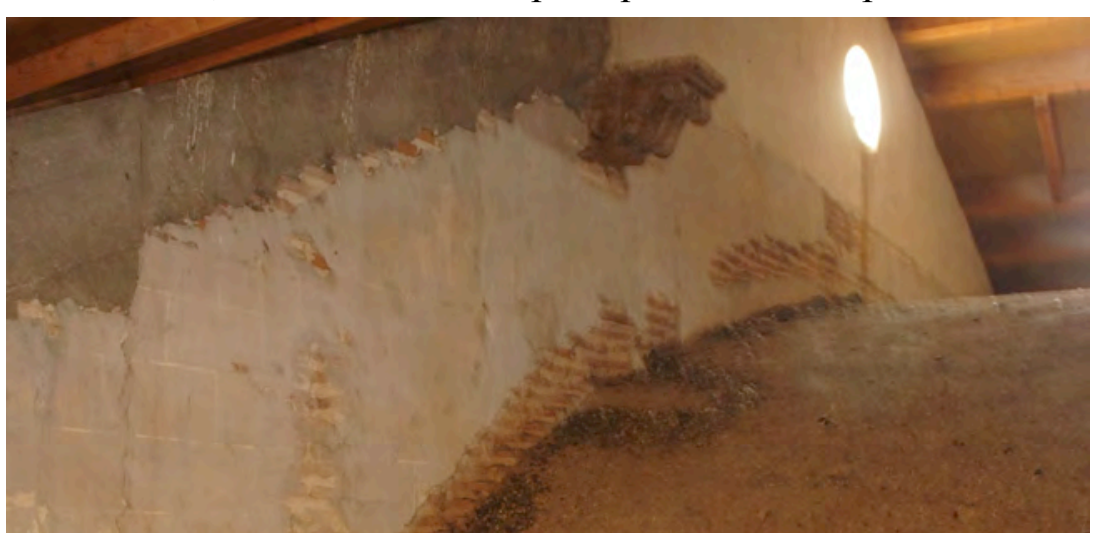

Ilustración 14: interior del muro a los pies, visita 10/06/2012

\section{Conclusiones}

En 1989 se sustituye la estructura de madera existente, de cinco vigas por tramo apoyadas sobre ménsulas empotradas en los muros-diafragma, originalmente a la vista y ocultas tras la ejecución de las bóvedas en 1703.

Sobre ambos muros laterales se dispone entonces un zuncho perimetral de sección rectangular, con su cara vista hacia el interior. Este elemento se prolonga con pendiente a dos aguas sobre ambos testeros de la nave, aunque interrumpe su recorrido en la parte central recrecida del piñón de la fachada a los pies. Sobre los tres muros-diafragma que forman los arcos fajones intermedios hay además zunchos de sección plana, embebidos en el remate de la fábrica de ladrillo, sobre los que apoya la estructura de cubierta nueva de madera laminada. 


\section{Iglesia de Santa María del Castillo en Villaverde de Medina}

Intervenciones citadas en la publicación del Ministerio:

1971 - Torre y cubiertas - José Ángel Rodrigo García y Joaquín Roldán Pascual

1972 - Cubierta, fachada y vidrieras - José Ángel Rodrigo García y Joaquín Roldán

Pascual

En la web del IPCE no se han localizado planos digitalizados.

\section{En el Archivo General de la Administración}

\section{AGA 26/01573}

1971 - Restauración de cubierta en la iglesia de Villaverde de Medina - José Ángel Rodrigo García y Joaquín Roldán Pascual

Hay un dossier con fotografías en blanco y negro pero sólo del exterior y bóvedas.

En un plano de planta de cubiertas 1:100 se representa el ábside señalado como "zona de cubierta objeto de reparación con reposición de formas en mal estado y retejado."

AGA 26/0201, 26/00332 y 26/0066

En las tres cajas se guarda copia del mismo proyecto de 1972 que se conserva también en el IPCE y se describe en el apartado siguiente.

\section{En el archivo del IPCE:}

\section{Carpeta $657-7$}

En la carpeta hay una página firmada por los arquitectos en julio de 1974 en que se consigna como Memoria de la obra de 1971 tres párrafos de texto en los que se justifica que en el mismo se pretendía sólo paliar las humedades de la cabecera. Se reparó localmente el maderamen con retejado y limpieza de canales, a la espera de acometer una reparación en profundidad en próximas fases.

1972 - Cubierta, fachada y vidrieras - José Ángel Rodrigo García y Joaquín Roldán Pascual 
En la Memoria se explica que la iglesia se encuentra en obras, acometidas con urgencia y bajo presupuesto, desde 1970.

El proyecto "Restauración de la cubierta, fachadas y vidrieras de la Iglesia de Villaverde de Medina (Valladolid)" se redacta a petición del arquitecto jefe de la sección de monumentos de la Dirección General de Bellas Artes para acometer las siguientes tareas que se consideran urgentes:

1. Retejar reutilizando las tejas en buen estado sobre mortero de cal,

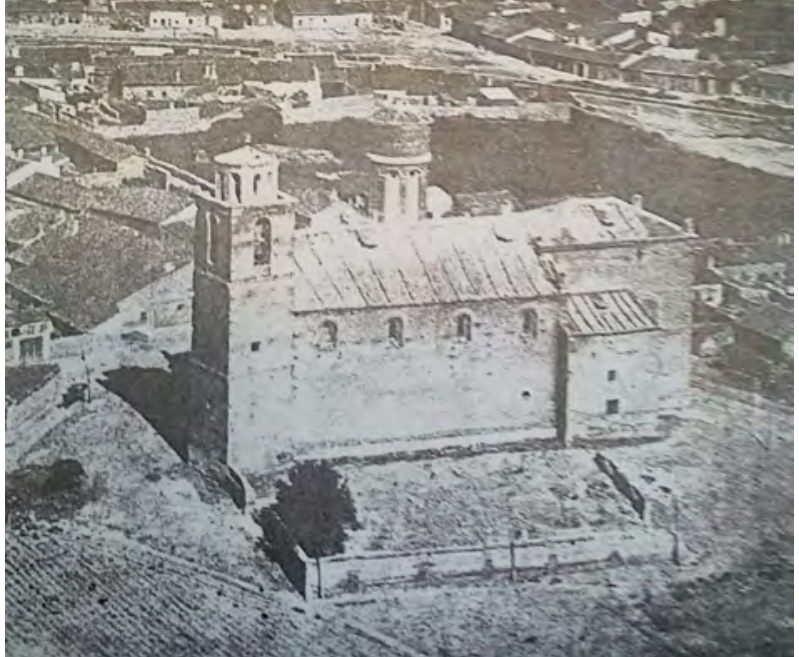

Ilustración 15: foto portada proyecto 1972 recibidas cada cinco hiladas.

Reemplazo de tabla ripia clavada y pares de madera en mal estado.

2. Sustitución de estructura de madera de ábside y campanario por metálica con forjado.

3. Reconstrucción parcial de fachadas de ladrillo con grietas y roturas. Colocación de vidrios dobles y protección metálica en ventanas.

No debió ejecutarse la actuación prevista en el campanario que se describe en este proyecto, ya que en documentación posterior aún figuran imágenes de una antigua estructura de madera que no se sustituye por metálica hasta 1988.

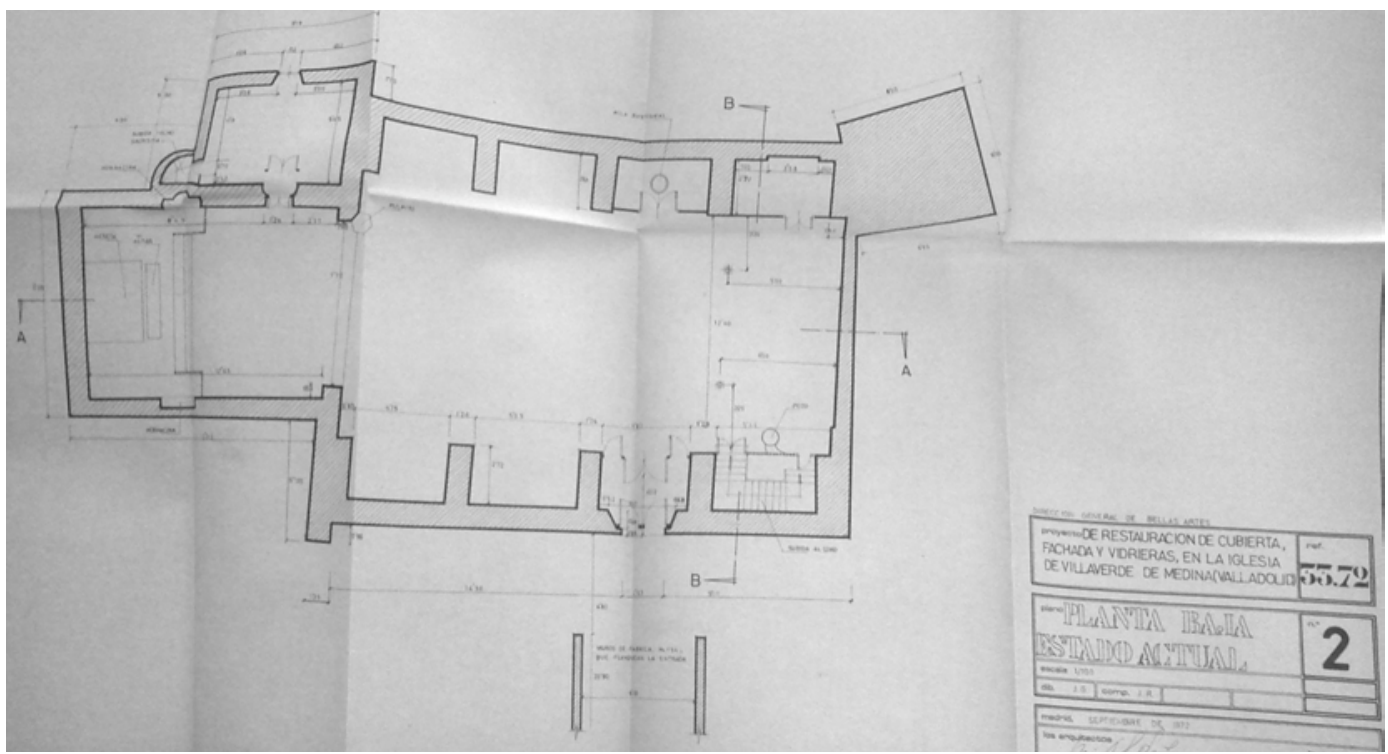

Ilustración 16: planta baja estado actual (Rodrigo y Roldán 1972) 


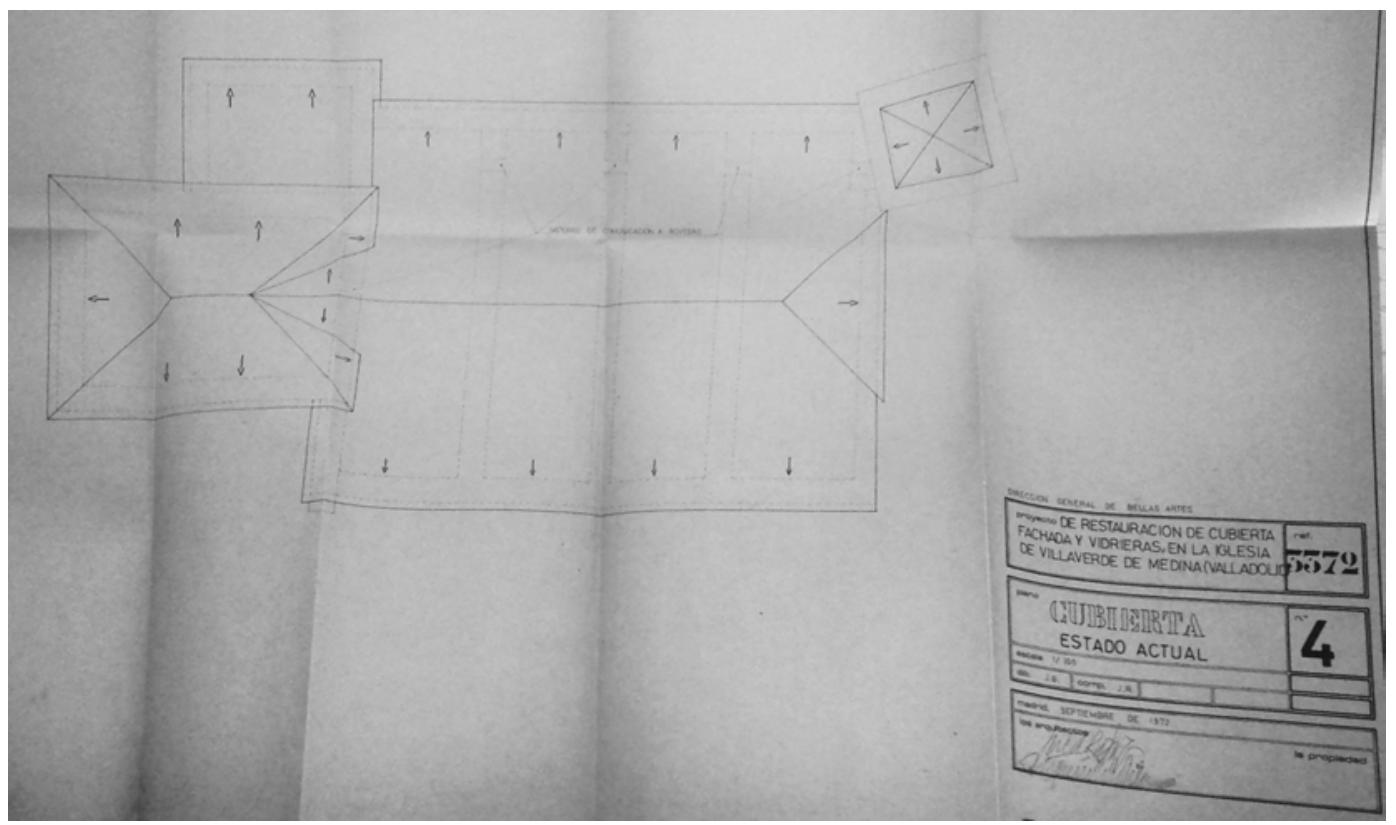

Ilustración 17: planta de cubiertas estado actual (Rodrigo y Roldán 1972)

En el presupuesto se desglosa 70ml de consolidación de coronación de muros con zuncho perimetral de hormigón armado de una sección media de 0,70x0,50 previa demolición y enrasado para su asiento.

En el plano 7 se representa con una trama el área de ábside, sacristía y torre "a restaurar con perfiles metálicos, forjado, entablado de madera y cubierta con teja árabe" y con otra la zona "de consolidación en coronación de muros con zunchos de hormigón armado".

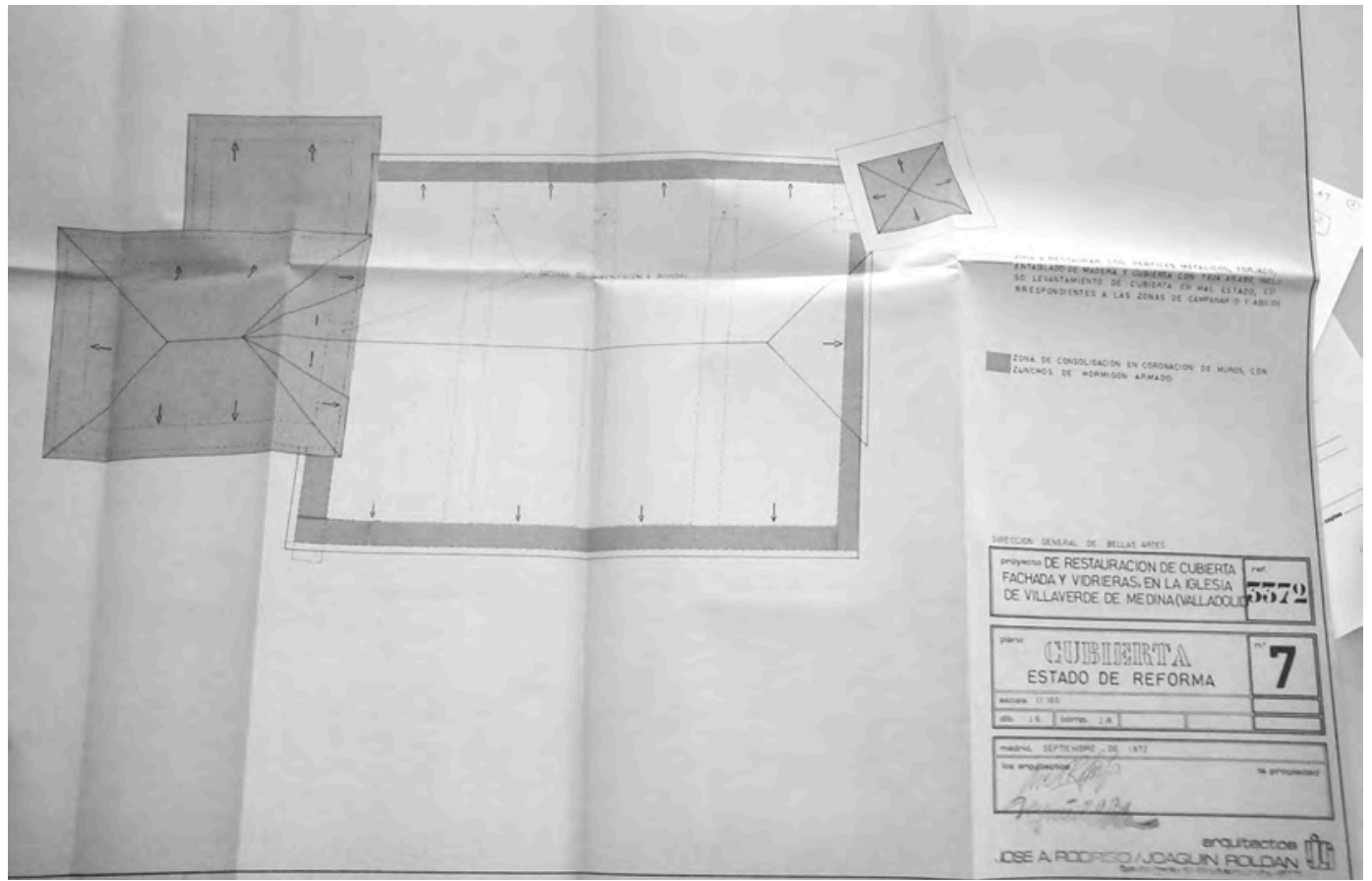

Ilustración 18: plano 7 (Rodrigo y Roldán 1972) 


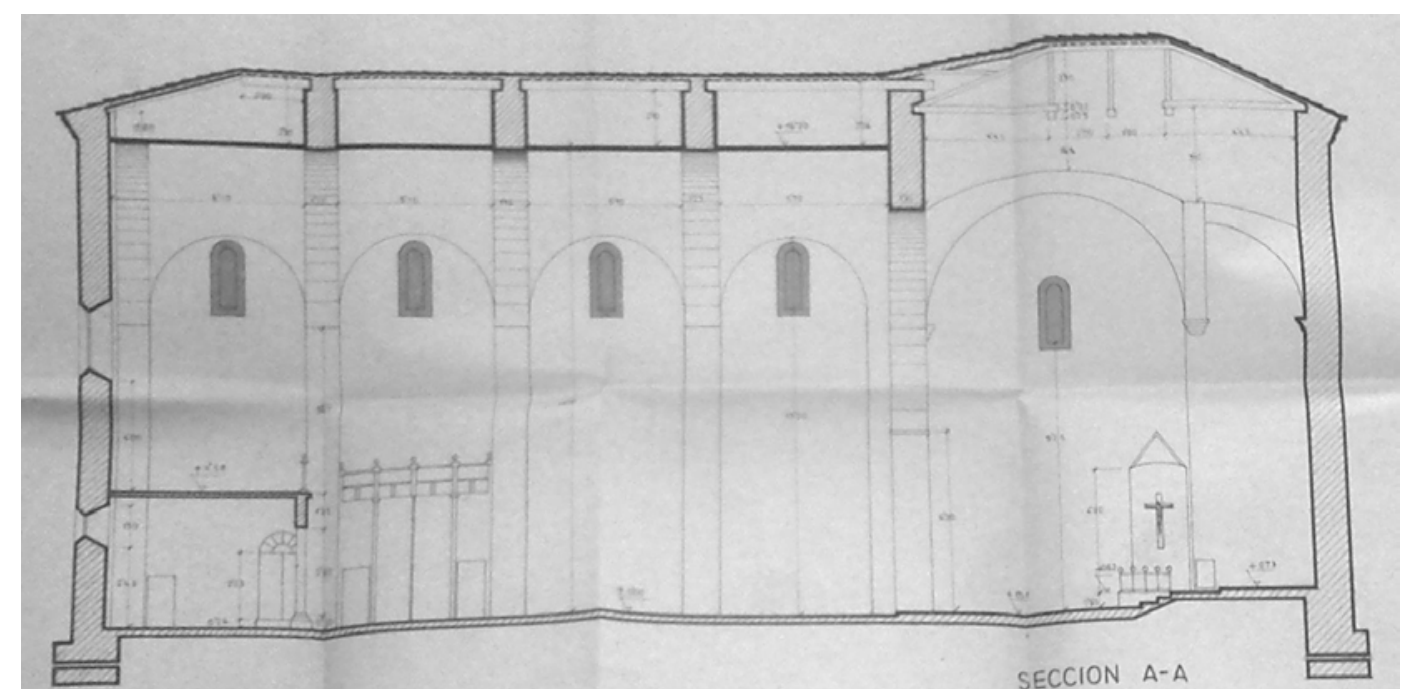

Ilustración 19: sección longitudinal estado reformado (Rodrigo y Roldán 1972)

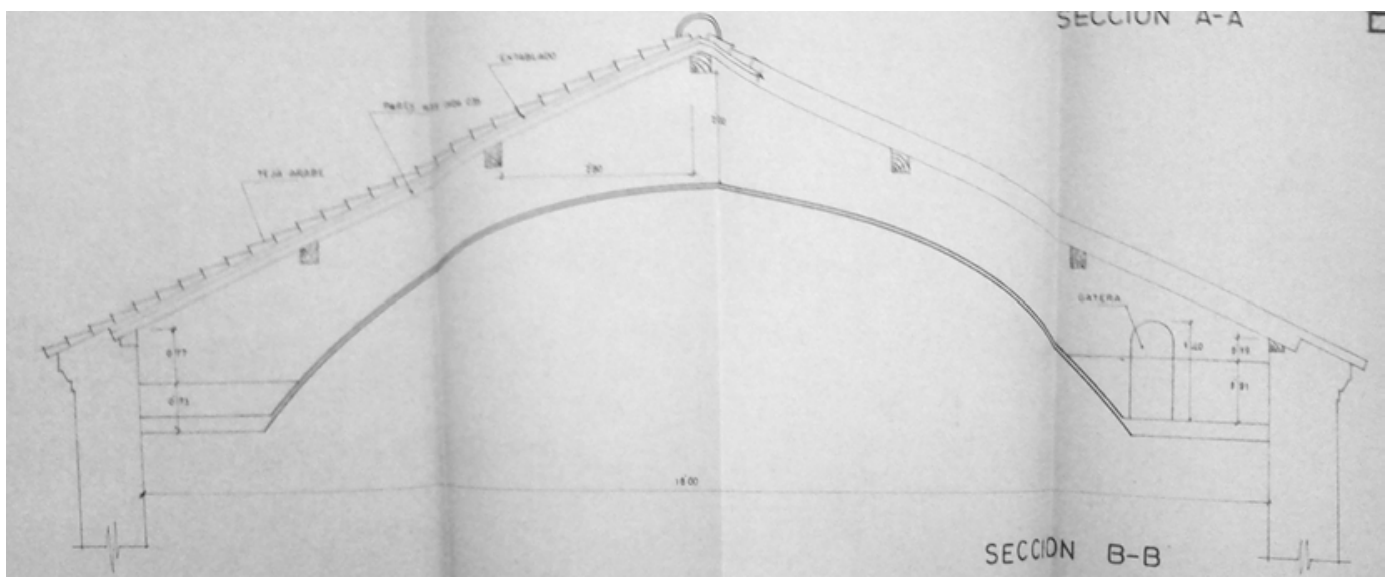

Ilustración 20: sección transversal (Rodrigo y Roldán 1972)

En los planos del proyecto se representa exactamente iguales las secciones de estados actual y reformado, excepto en el grafismo de las ventanas.

No hay en la carpeta ningún plano que defina la nueva estructura metálica de la cabecera.

\section{En el archivo de la Junta de Castilla y León:}

\section{VA-49}

Carpeta 5239

1988 - Obras de emergencia tras arruinarse la cubierta de la linterna sobre la torre. Proyecto del Servicio de Restauración. - Carlos Descalzo Llorente dirige la obra Aparejador: Julio Villuela Fernández 
En noviembre de 1984 el "cura regente" pide por escrito al Consejero actuar de forma preventiva sobre cubierta, torre y retablo, insistiendo el alcalde una semana después en solicitud dirigida al Director de Patrimonio. En agosto de 1987 se da el informe favorable pero un año más tarde, en agosto de 1988, otra carta del párroco indica que no se ha intervenido y ha caído la cubierta de la linterna.

En la documentación se incluye una Memoria final de las obras desarrollada a modo de proyecto, ya que según el arquitecto director éste había consistido sólo en una "Memoria valorada". Se describe las actuaciones realizadas y cómo la torre presenta dos grietas verticales en caras este y oeste, manifestando tendencia a partirse en dos, lo que no se detecta hasta el montaje de los andamios. También se expone que la linterna arruinada (sin valor artístico según anotaciones del propio Servicio) es una sobre-torre octogonal irregular con un corredor perimetral lleno de escombro y excrementos de aves que obstruyen los desagües, con unos pretiles agrietados y descarnados por la meteorización del mortero, y cuatro pináculos sueltos.

Aunque en la valoración del Servicio se proponía la colocación de una estructura de madera de pino en los $33 \mathrm{~m} 2$ de cubierta de la torre, con faldones de tablero hidrófugo, finalmente se reemplazó la estructura de madera original que cubría la linterna por semicerchas de tubo cuadrado de acero con pendolón central y tableros de rasilla con capa de compresión de mortero de cemento. El revestimiento consistía en tégola sobre lámina asfáltica.

En el propio Informe del arquitecto de julio de 1989 se lamenta que por falta de medios, penosas condiciones de trabajo de los operarios y otros motivos el resultado de la intervención es pobre, habiéndose dejado por ejemplo el arco de cara oeste con un trazado incorrecto tras desmontarse en tres ocasiones.
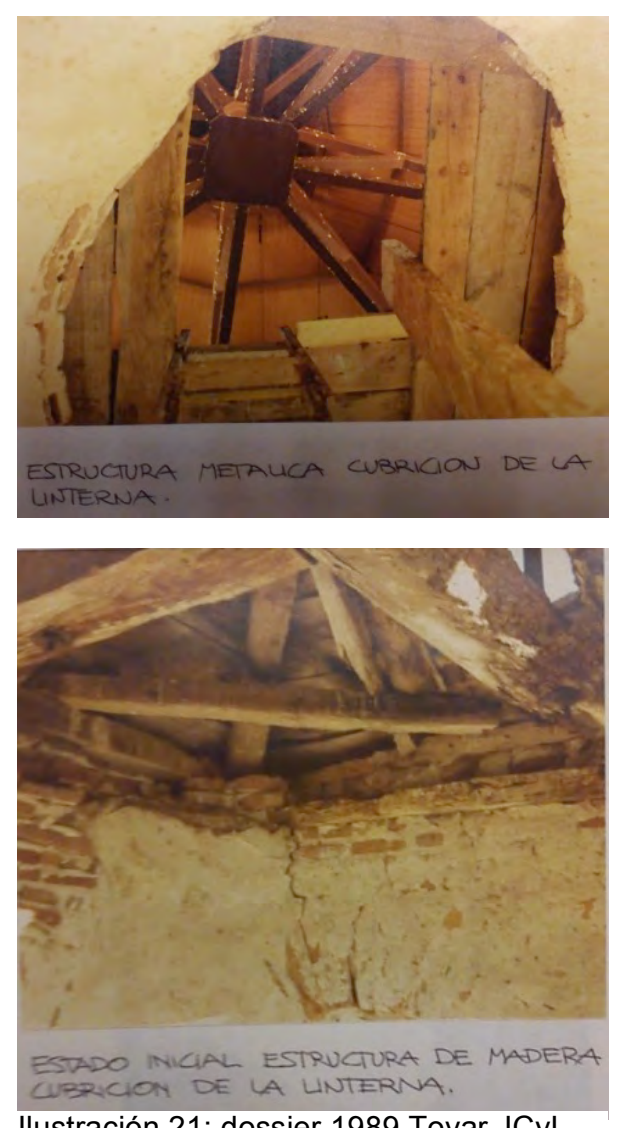

Ilustración 21: dossier 1989 Tovar JCyL 
En las imágenes junto a estas líneas, tomadas del reportaje fotográfico de Descalzo, se aprecia el estado de la torre antes y después de la obra.

\section{VA-87}

Carpeta 5273

Se cuenta con un Modificado de 1991.
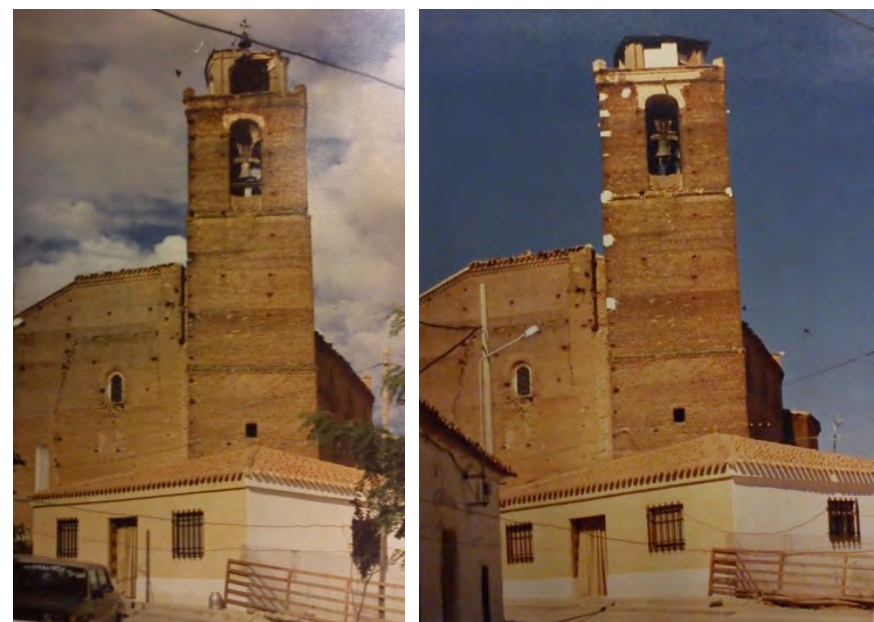

Ilustración 22: torre antes y después, dossier 1989 Tovar JCyL

1989 - Restauración de la Iglesia parroquial - Jesús Tovar Casales.

En esta carpeta se incluye una ficha de Diagnóstico previa de Carlos Descalzo cumplimentada en julio de 1989 en la que pide recalzar la torre y que se encargue la obra a su socio Luis Hernández Duque al encontrarse él contratado por la Diputación. En la carátula de los planos de Tovar aparecen como colaboradores estos dos últimos.

Se contrató un Informe históricoarqueológico al gabinete Anthica. En éste se describe los distintos documentos localizados en catálogos y archivos sobre el desarrollo de la Tierra de Medina, la más occidental de las 42 Comunidades de Villa y Tierra. Villaverde contaba en 1587 con 230

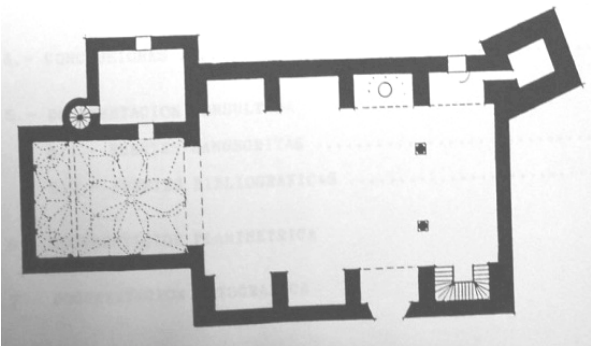

llustración 23: planta portada documento de Anthica vecinos.

En el Catálogo Monumental de Esteban García Chico de 1964 se recopila los libros de cuentas del Archivo Episcopal y en ellos figura el testero de 1561 como lo más antiguo de esta iglesia, lo pagado al albañil en 1577 para cerrar el arco, o la remodelación de los 4 tramos de bóvedas de cañón de la nave en 1706.

Aquí la torre se adosa al muro del coro cuando lo habitual es disponerla junto a la cabecera del lado de la Epístola. Presenta continuas reparaciones ya en el XVI y el XVII. La linterna se levantó tras el informe de un visitador en 1605 donde se explica que hay que ampliar la torre ya que no se oyen la campanas y algunos vecinos faltan a misa. 
En la liquidación de la $2^{\mathrm{a}}$ fase se incluye una Memoria descriptiva de la ejecución, según la cual consiste en la renovación de cubiertas de la nave central y sacristía. En los planos se señala que las cubiertas de cabecera fueron reemplazadas recientemente por estructura metálica, en referencia la actuación de los años 70 que se cita en el encabezamiento.

Tras el desmontaje de la cubierta se ejecuta $21 \mathrm{~m} 3$ de zuncho de hormigón en coronación de muros "para su saneamiento" y 5 ménsulas también de hormigón. "Consolida" las bóvedas con una capa de compresión en su parte superior y relleno de senos con $17 \mathrm{~m} 3$ de hormigón $\mathrm{H}-100$, ligeramente armada con $430 \mathrm{~m} 2$ de mallazo 6.30.30.

El proyecto Modificado consiste en el cambio de la cubierta de madera aserrada prevista por piezas de madera laminada encolada, dada la dificultad que presenta el suministro de piezas de las dimensiones y escuadrías necesarias. A la izquierda se aprecian las jácenas de madera con jabalcones dispuestas en el sentido longitudinal de la nave que, según un Informe del arquitecto territorial Julio Pizarro en 1990 tenían un mal funcionamiento que justificaba el cambio de sentido de la nueva estructura. Se puntualiza que estos pares quedarán acopiados en un depósito de la Junta.

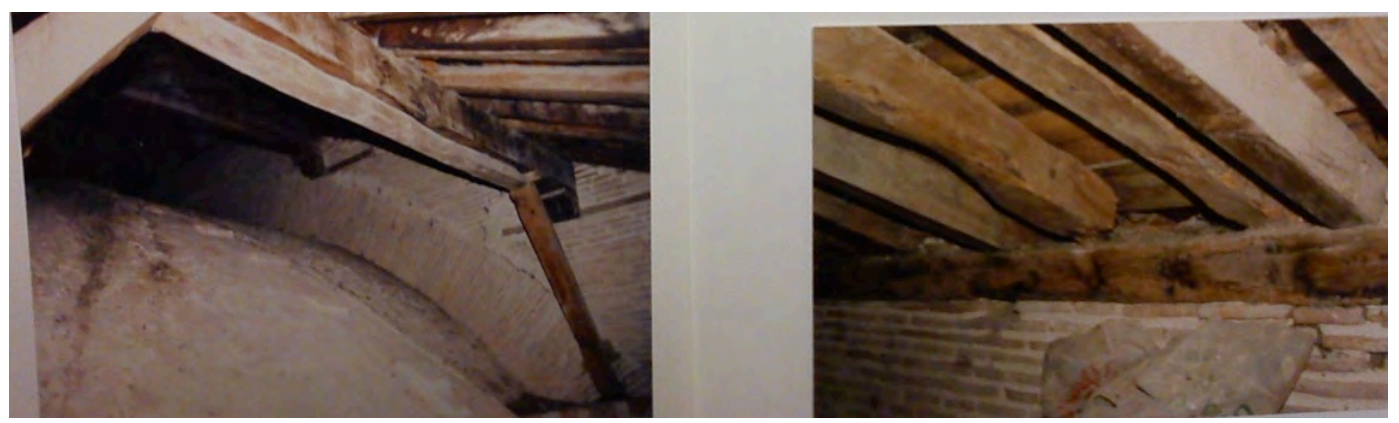

Ilustración 24: antiguas armaduras, dossier 1989 Tovar JCyL

Como solución definitiva se coloca $568,8 \mathrm{~m} 2$ de vigas de madera laminada $9 \times 32 \mathrm{~cm}$ de $6,1 \mathrm{~m}$ de luz, dispuestas cada $50 \mathrm{~cm}$ con una pendiente de $26^{\circ}$.
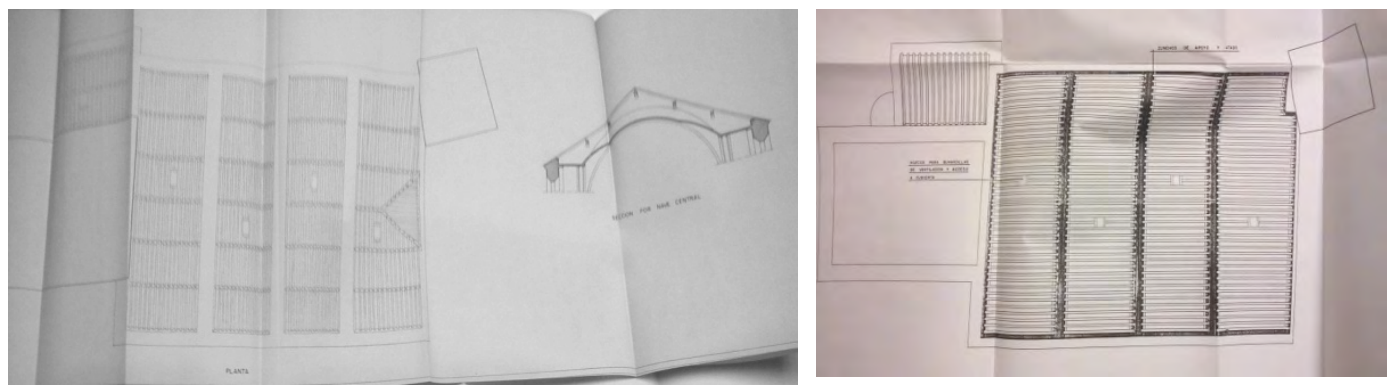

Ilustración 25: planos de estructura actual y reformada 1989 Tovar JCyL 


\section{VA-663}

2008 - Reparación de cubiertas de la iglesia de Santa María del Castillo en Villaverde de Medina - José Luis Pardo Castañeda.

Aparejador: Miguel Ángel Rodriguez Asensio. La obra, dotada con fondos FEDER, se adjudica a Cabero Edificaciones SA.

La carpeta contiene documentación administrativa pero no hay una copia en papel del Proyecto, que se facilita de forma digital desde el Servicio de Restauración.

En la Memoria del proyecto se indica que el encargo del mismo se produce en 2006 a raíz de unos desprendimientos en los aleros. Se describe los muros existentes considerándose un espesor medio de $80 \mathrm{~cm}$ formados por dos hojas de ladrillo macizo de tejar con relleno interior de tierra y piedra. La cubierta consta de tablero aglomerado $19 \mathrm{~mm}$ con onduline bajo teja cerámica curva dispuesta a la segoviana (sólo canales) recibida con mortero.

Los faldones tienen $26^{\circ}$ o un $49 \%$ de inclinación.

La intervención prevé instalar rastreles de pino cada $30 \mathrm{~cm}$ con una malla galvanizada clavados al tablero, y retejar con canal y cobija recibidas sobre mortero bastardo.

Enumera las últimas obras llevadas a cabo, ampliación y remate de la torre con acero corten, restauración de algunas fachadas y reparaciones puntuales sobre el alero de la fachada principal en 1999.

En el proyecto se culpa de los problemas actuales a la sustitución de cubierta llevada a cabo hacia 1980 :

"La inexistencia de elementos suficientes para el apoyo del tablero de madera en el encuentro con los aleros, produce pandeos tanto en el tablero como en el panel flexible onduline existente sobre el mismo, lo que provoca la rotura y disgregación del mortero rígido de asiento de la teja, así como la correspondiente rotura de la misma en la zona en que termina el panel onduline. Igualmente se produce deslizamiento de los materiales indicados debido a la enorme pendiente que presenta la cubierta.

Por otra parte, la deficiente ejecución y puesta en obra de ciertos elementos como el panel onduline, que no se prolongó hasta el exterior del alero sino que termina en el centro de la coronación de los muros de cerramiento, vertiendo en el mismo el agua que recoge, han motivado la existencia de patologías nefastas que finalmente han provocado el desplome de una zona del alero de ladrillo y agrietado buena parte del resto" 
El alero es de ladrillo macizo decorado por medio del uso de impostas con modillones recortados formados por tres ladrillos a sardinel con perfil de cuarto bocel sobre doble hilada arpada enmarcada con doble hilada saliente.

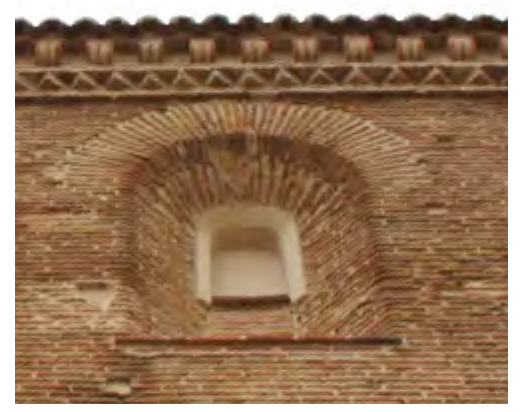

Ilustración 26: dossier 2008 Pardo

La cubierta de la nave central, a dos aguas, está formada por vigas de madera laminada que descansan sobre los arcos de ladrillo que conforman los cuatro cuerpos que se muestran en el interior de la bóveda. La zona superior de las bóvedas sólo es accesible desde la escalera de caracol que comunica los distintos niveles de la torre. Confirma el buen funcionamiento de un tubo drenante instalado en 1999 en el extradós del muro sur, con las humedades estabilizadas frente a las detectadas en el resto de paramentos. Recomienda extender el drenaje a todo el perímetro del edificio.

En la memoria se incluye un dossier con 16 fotografías de la patología: caída de tramo de alero, fisura longitudinal en otras zonas del mismo y agrietamiento de la cumbrera por deslizamiento del tablero.
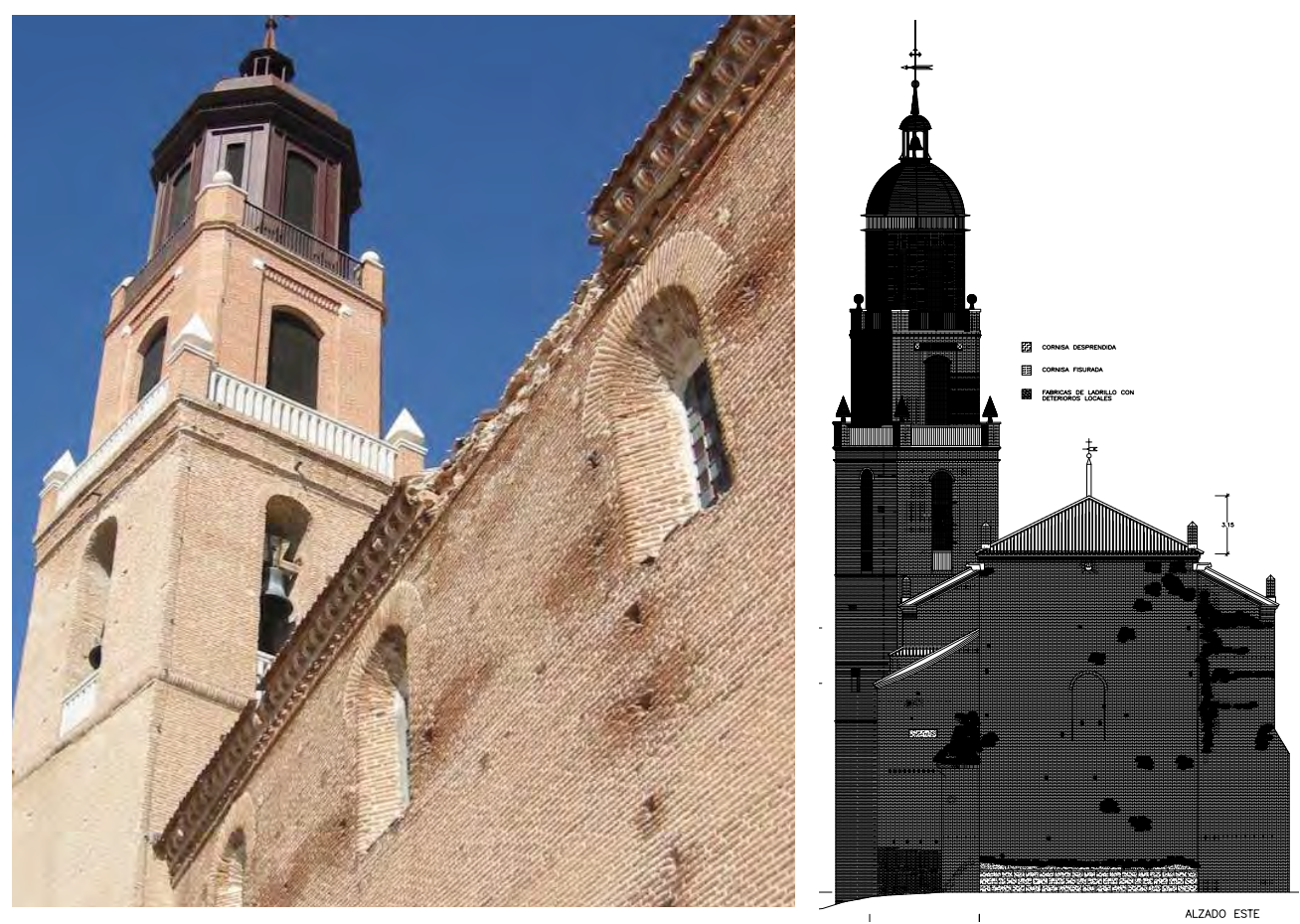

Ilustración 27: lesiones, dossier 2008 Pardo JCyL 


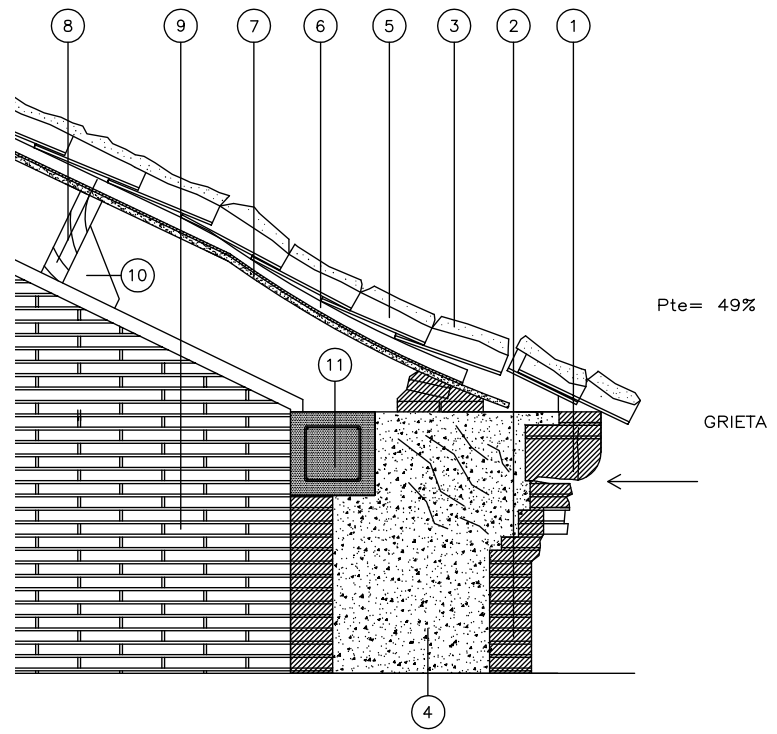

DETALLE CONSTRUCTIVO "2" CUBIERTA Y ALERO ESTADO ACTUAL

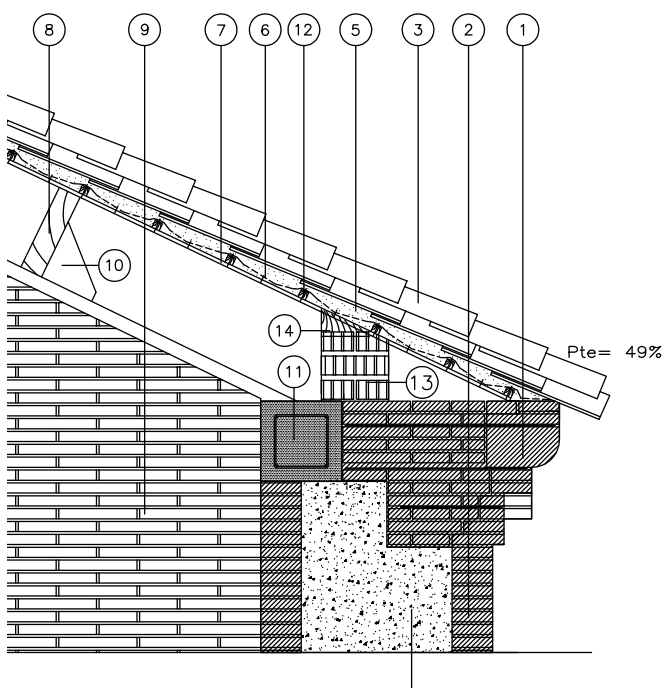

(4)

DETALLE CONSTRUCTIVO "2" CUBIERTA Y ALERO ESTADO REFORMADO

1.- CORNISA DE LADRILLO VIEJO DE TEJAR RECONSTRUIDA.

2.- FACHADA DE LADRILLO VIEJO DE TEJAR.

3.- TEJA CERAMICA CURVA VIEJA (CANAL Y COBIJA).

4.- RELLENO DE MURO

5.- MORTERO DE CEMENTO BASTARDO.

6LAVADA A TABLERO Y CORREAS DE CUBIERTA.
CLAVA

CLAVADA A TABLERO Y CORREAS DE CUBIERTA
7.- TABLERO AGLOMERADO DE $19 \mathrm{~mm}$.
8.

8.- VIGAS DE MADERA LAMINADA

10.- ARCO DE LADRILLO MACIZO.

11.- ZUNCHO DE HORMIGON ARMADO.

12.- RASTREL DE MADERA DE PINO DE $30 \times 30 \mathrm{~mm}$. TRATADO CON XILAMON Y SEPARADO $30 \mathrm{~cm}$. ENTRE EJES

13.- 1 ASTA DE LADRILLO PERFORADO EN CORONACIÓN

DE MURO DE $40 \mathrm{~cm}$. DE ALTURA APROXIMADA.

14.- CUÑA DE MADERA PARA APOYO DE TABLERO AGLOMERAD

15. - CUMBRERA DE TEJA CERAMICA CURVA VEJA.

6. - GANCHO GALVANIZADO DE SERVICIO EN CUBIERTA PARA PASO DE CABLE DE ACERO TRENZADO.

Ilustración 28: planos 2008 Pardo JCyL 


\section{Visitas realizadas}

$10 / 06 / 2012$

En las siguientes fotografías, tomadas en junio de 2012, se aprecia el estado exterior del edificio, con grietas selladas y fábricas rejuntadas
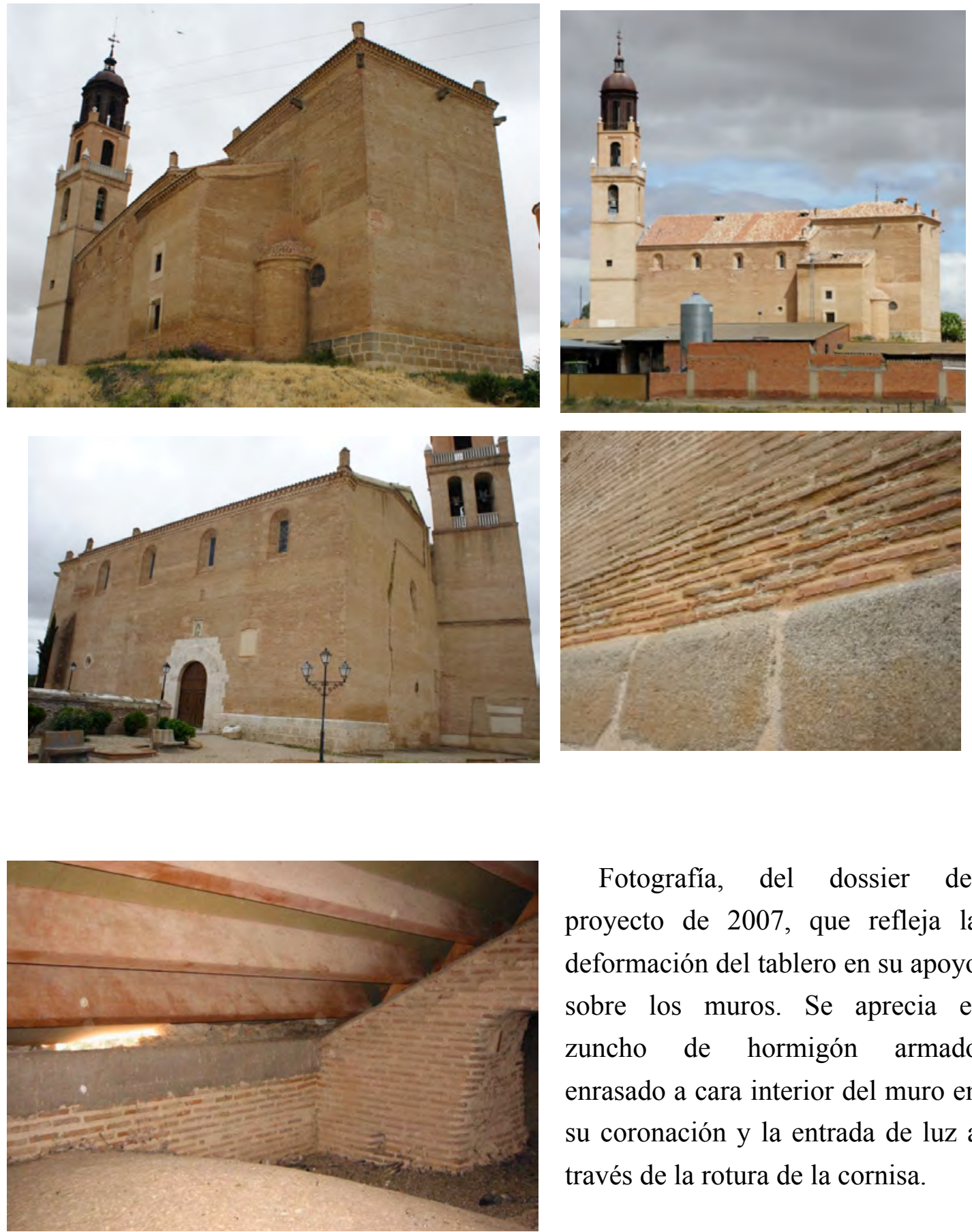

Fotografía, del dossier del proyecto de 2007, que refleja la deformación del tablero en su apoyo sobre los muros. Se aprecia el zuncho de hormigón armado enrasado a cara interior del muro en su coronación y la entrada de luz a través de la rotura de la cornisa. 


\section{$27 / 04 / 2014$}

La fuerte pendiente de la cubierta se corresponde con lo empinado de las bóvedas. Sobre todas ellas aparecen peldaños a ambos lados (suponemos serían incorporados al disponer la capa de hormigón armado sobre el trasdós en 1989).

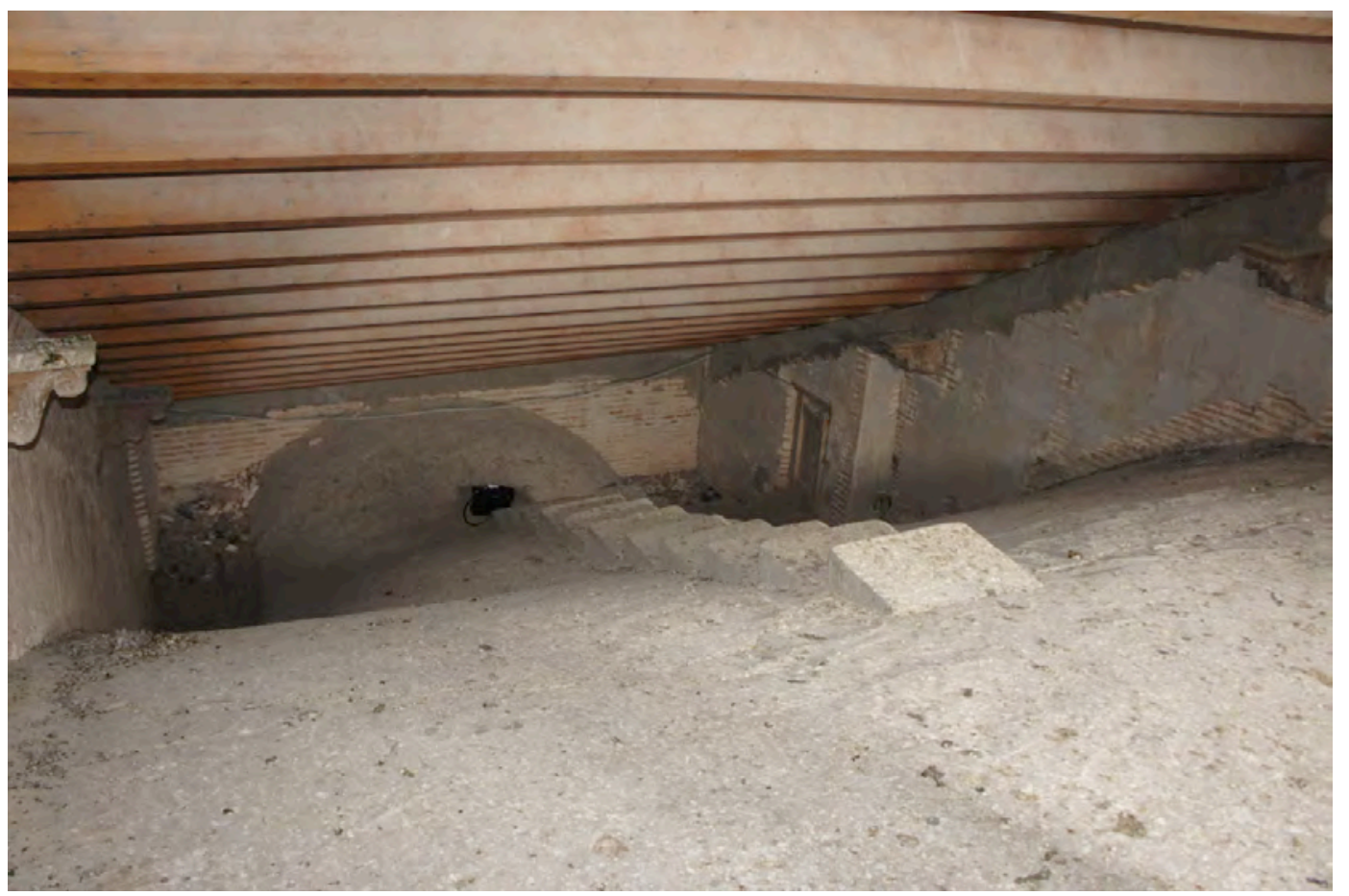

En la imagen anterior se aprecia el suave resalto a modo de luneto y su encuentro con la bóveda de cañón transversal que cubre las hornacinas entre contrafuertes. Los riñones de éstas se encuentran rellenos con palomina, a distinta cota, según la facilidad del acceso de palomas que ocupan, sobre todo la zona adyacente a la cabecera.

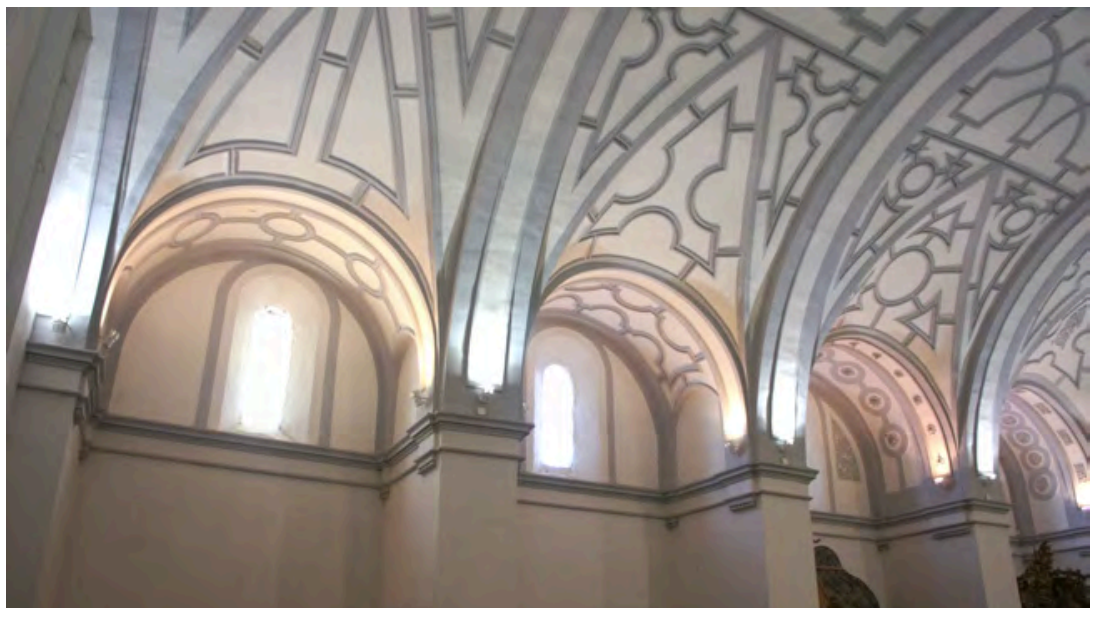

En ambos laterales encontramos zuncho, de unos $30 \mathrm{~cm}$ de canto, enrasado a cara interior de los muros. 
En la imagen siguiente se aprecia el encuentro con el testero a los pies, que tiene también zuncho de coronación inclinado pero interrumpido en el centro a lo largo de $6,36 \mathrm{~m}$, coincidiendo con una zona de fábrica más reciente a modo de piñón. En fotografías antiguas se puede comprobar que la cubierta en este punto contaba originalmente con un chaflán.

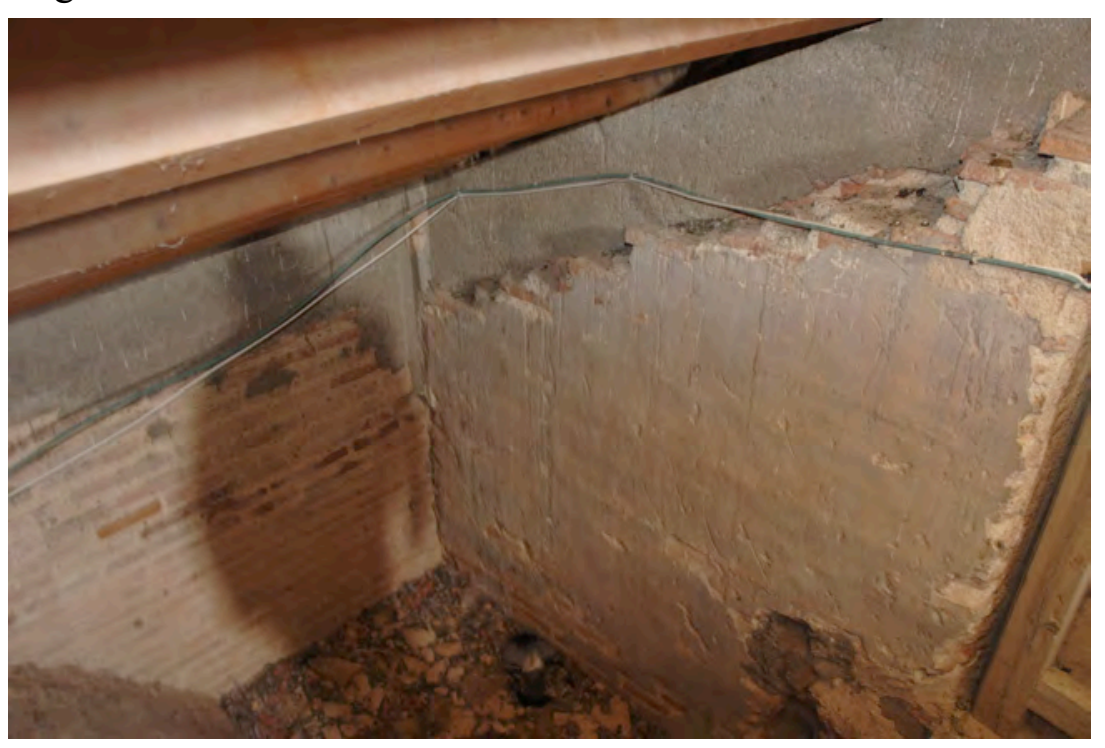

Además de sobre el testero, se dispone zuncho inclinado sobre la fábrica de $76 \mathrm{~cm}$ de grosor del arco triunfal. En la fotografía siguiente destaca el hueco que comunica el bajo cubierta de la cabecera con el de la nave.

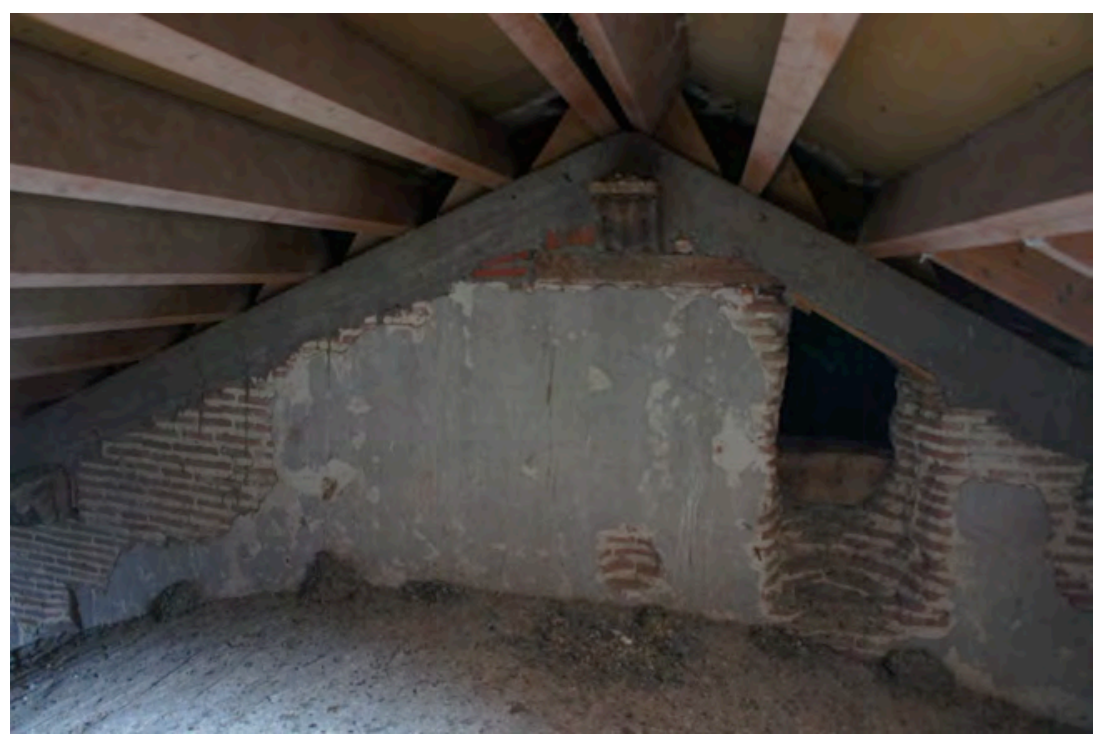

Se han mantenido todas las ménsulas labradas de 28 de canto, 25 de frente y $38 \mathrm{~cm}$ de vuelo de los diferentes diafragmas, incluso en este caso con una difícil intersección. 
En el testero encontramos machones de refuerzo en ambos extremos. También hay recrecidos de la fábrica junto al arco triunfal, que se manifiestan al exterior como grandes contrafuertes, prolongados sobresaliendo respecto al paramento de la fachada de acceso.
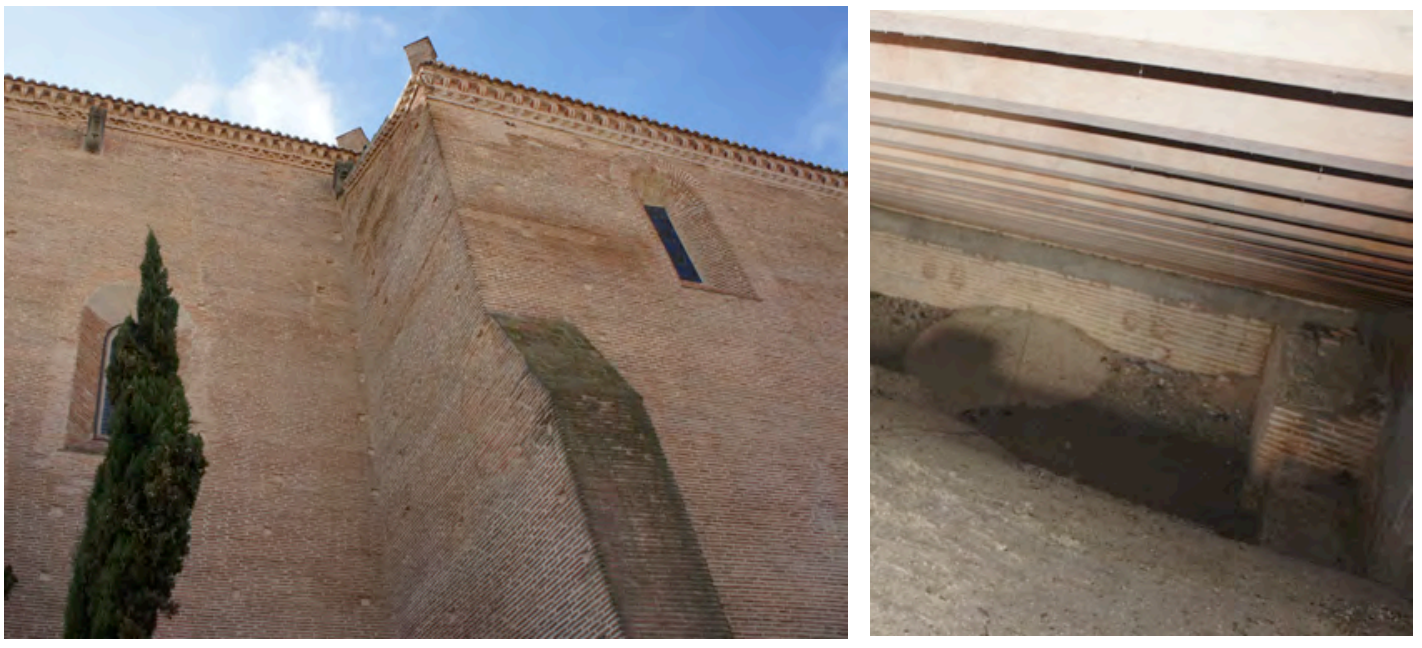

Sobre estas líneas: imagen del tramo de trasdós de la bóveda adyacente a la cabecera. A la derecha se aprecia el machón de refuerzo que al exterior se corresponde con el cerramiento de la nave rematado en la esquina con un contrafuerte.
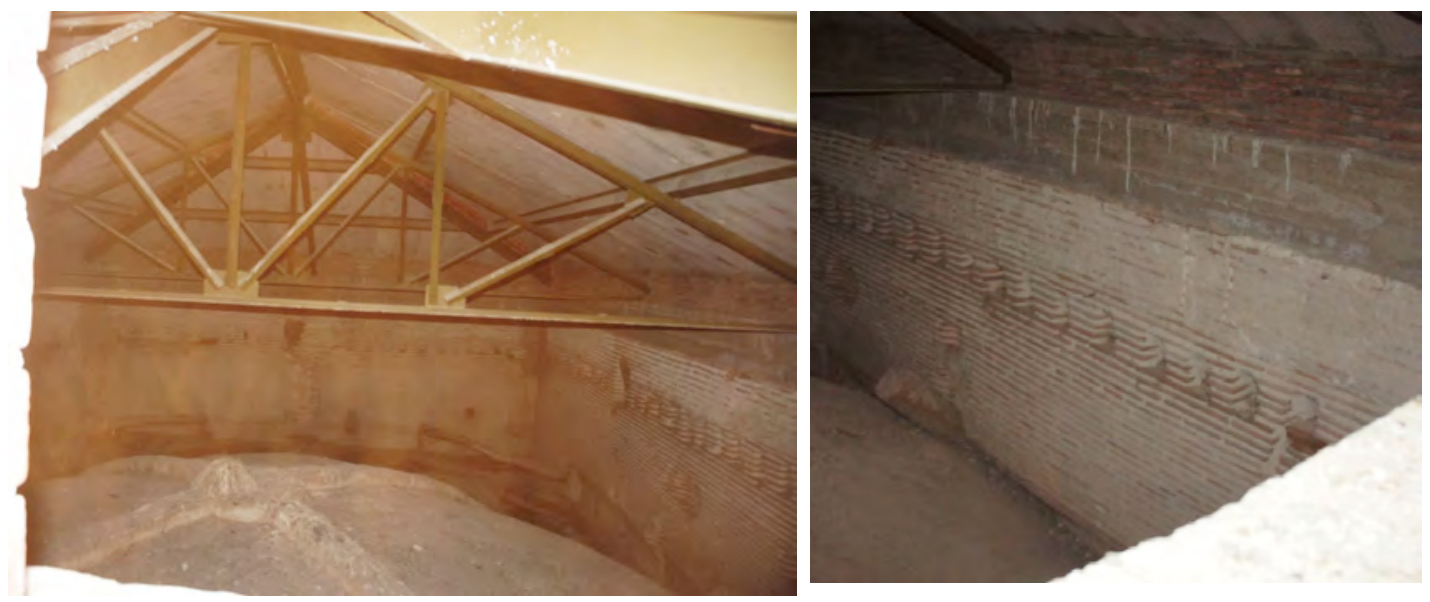

La estructura de cubierta de la cabecera es de cerchas metálicas, que también apoyan sobre un zuncho de hormigón. Se pueden observar restos de las piezas que debieron formar parte de la armadura original, rollizos diagonales recortados y cuadrales que parecen sin escuadrar.

Sobre el remate a dos aguas de los tres muros-diafragma interiores, el zuncho se embebe en la fábrica con un ligero resalto. En algún caso invade ligeramente los ajustados huecos de paso (la altura libre es de aproximadamente un metro) y 
podemos apreciar el fondo de ladrillo a modo de encofrado perdido. En el detalle se puede observar cómo el acodalado lateral de la nueva estructura de vigas de madera laminada se resuelve mediante calzos o ejiones también de madera.
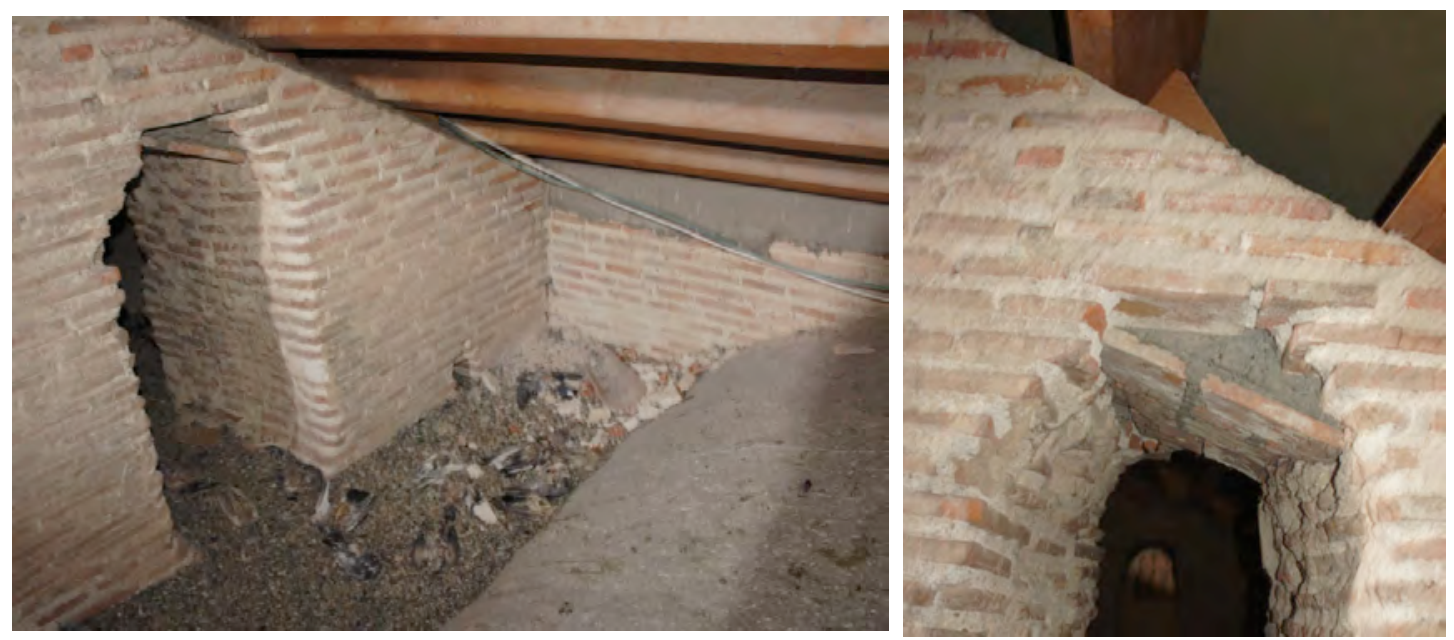

Vista de las bóvedas desde el presbiterio.

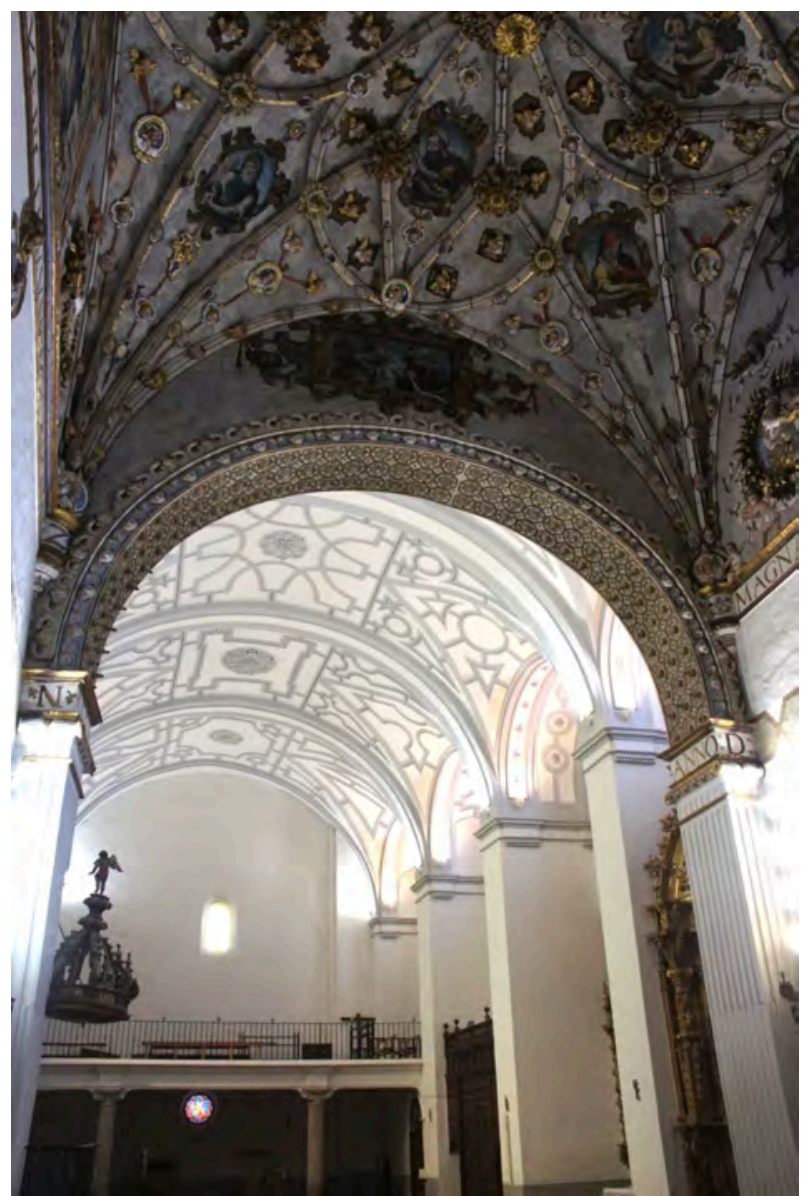





\section{Iglesia de Santa María}

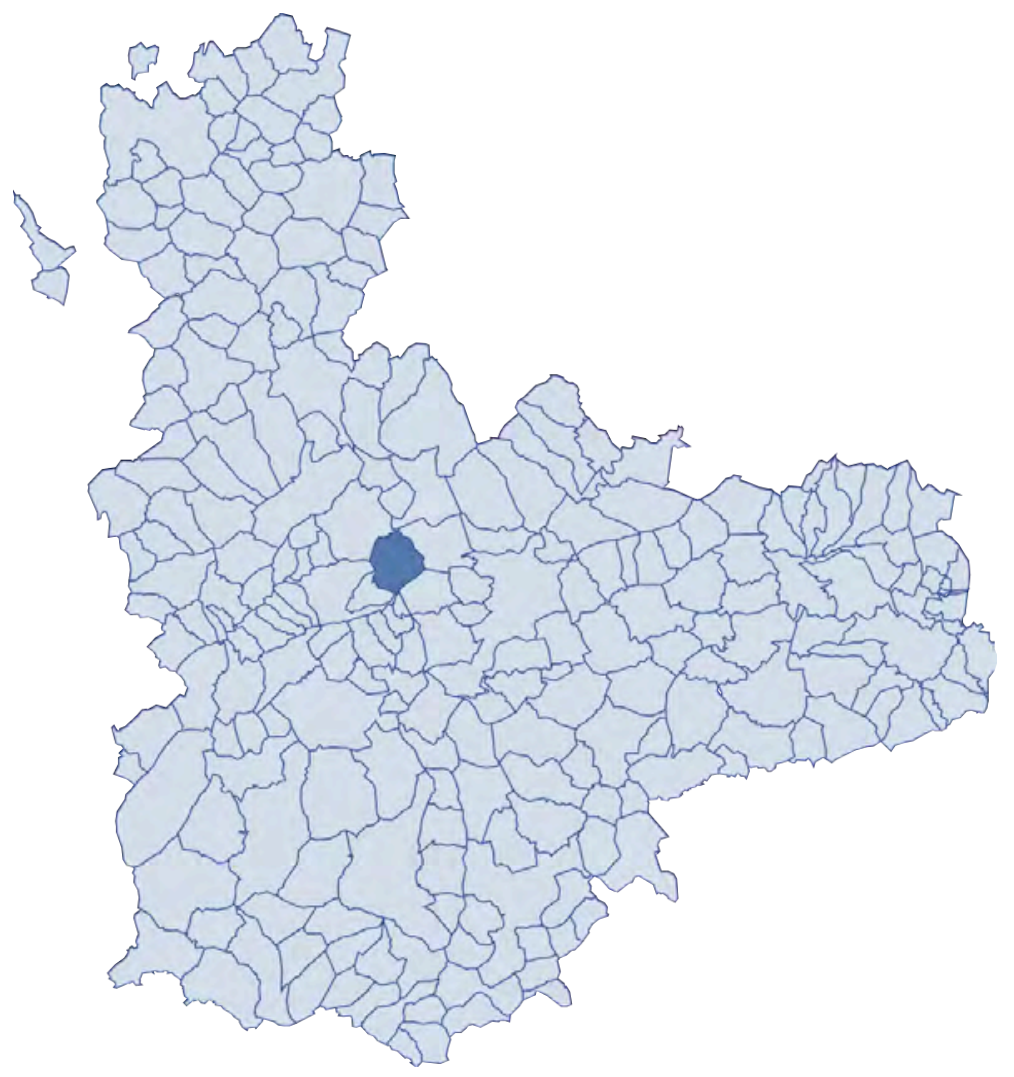



FICHA SÍNTESIS

\section{Código de identificación: FZ-39}

Denominación: Iglesia de Santa María

Localidad: Wamba
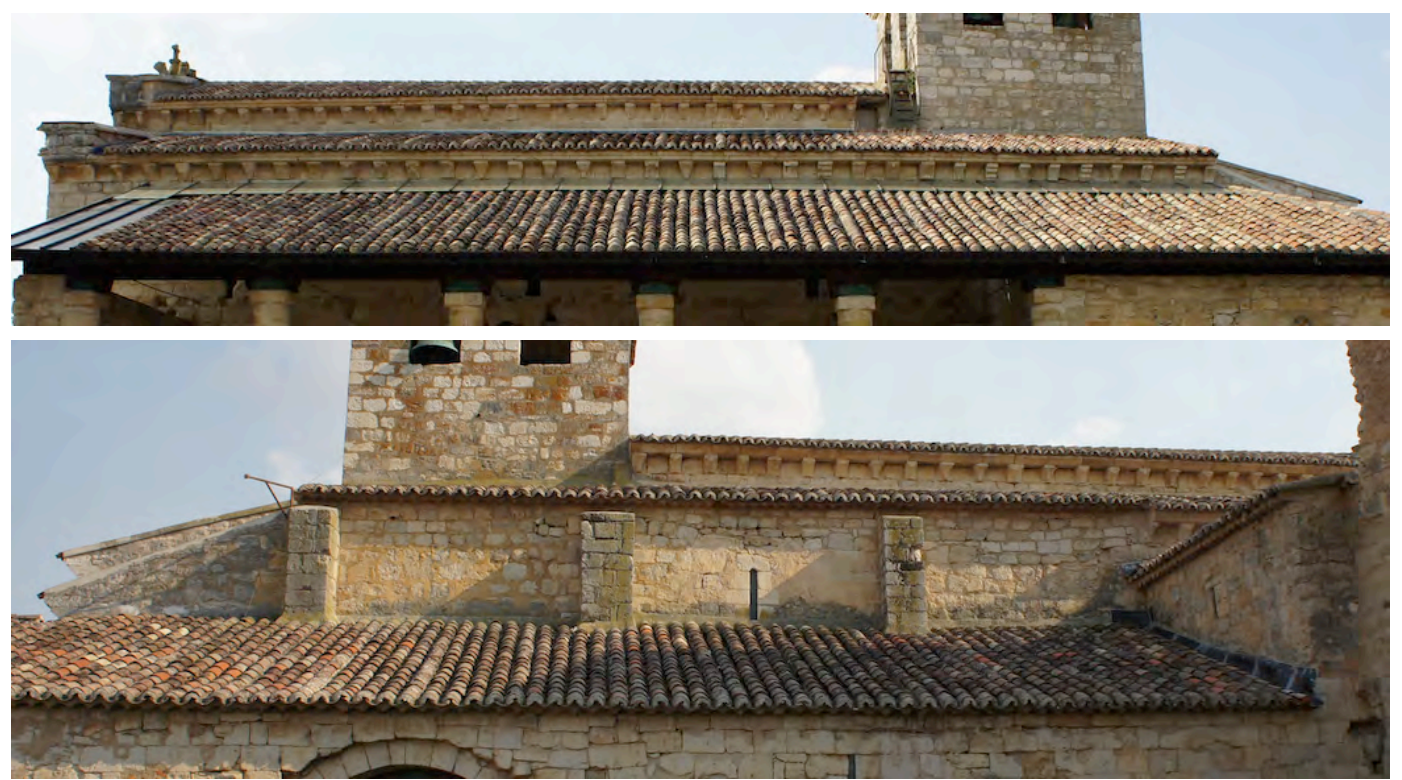

\section{Descripción}

Iglesia de tres naves con crucero no señalado en planta y capillas rectangulares en la cabecera. El campanario se levanta en medio del crucero. La cabecera es mozárabe y el cuerpo románico. El espacio se cubre con bóvedas en cabecera y techumbres de madera en el cuerpo del templo.

\section{Materiales}

Los muros son de piedra, alternando mampostería y sillares. Las cubiertas están revestidas de teja curva.

\section{Singularidades}

El edificio ha sido reformado en diversas ocasiones. La cubierta actual presenta una inclinación distinta de la original y la torre fue demolida y reconstruida en 1962. La cabecera cuenta con pequeños espacios abovedados a distintas alturas.

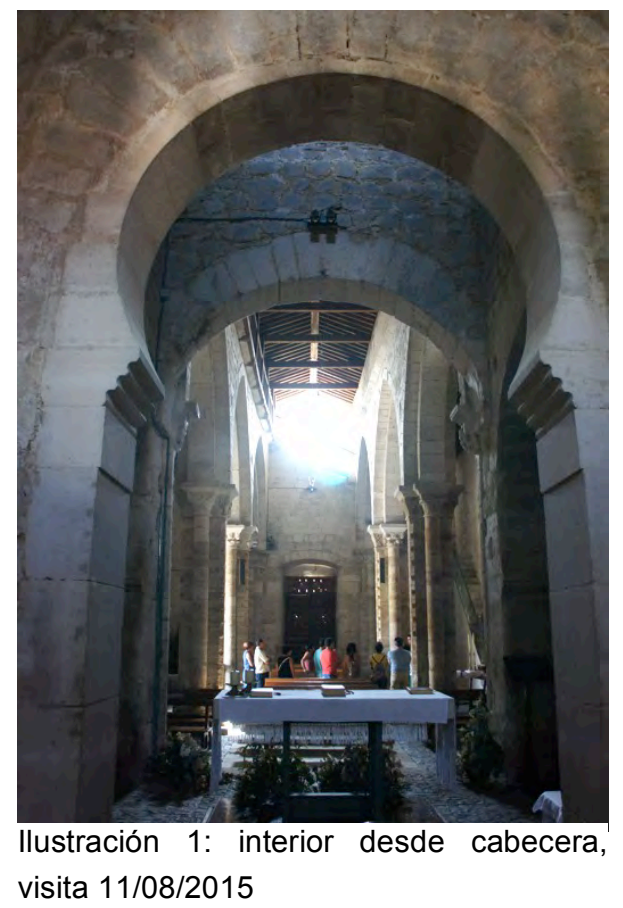




\section{Dimensiones básicas del templo}

$\begin{array}{llll} & \text { central } & \text { laterales } & \text { capillas } \\ \text { Ancho de nave } & 3,5 & 2,4 & \\ \text { Altura } & 10,1 & 7,0\end{array}$

\section{Memoria histórica constructiva}

Según la Memoria de Represa (JCyL):

La iglesia mozárabe puede datarse hacia el año 928, mientras que el cuerpo románico debió reemplazar al original y levantarse, junto con la torre, a comienzos del siglo XIII. En el XVIII se incorporan sacristía y atrio. En el XIX se produce la exclaustración y el expolio de materiales del Monasterio, aunque se conserva el edificio del templo por mantenerse su uso diario.

En 1985 se promueve una rehabilitación integral (mediante soluciones reversibles) con tratamiento de humedades, consolidación de estructuras, estudio arqueológico, etc. Se asignan usos dotacionales a las dependencias restauradas.

\section{Cronología. Fechas clave}

$928-1960-1985$

\section{Intervenciones}

1955 - Consolidación del Coro - Anselmo Arenillas

1957 - Portada románica a los pies del templo - Anselmo Arenillas

Descubre la portada románica oculta.

1958 - Reparación cubierta y consolidación de la portada - Anselmo Arenillas Retejo y saneo de cerchas de madera y entablado.

1959 - Reparación cubierta y construcción muro de separación - Anselmo Arenillas Continuación de la obra anterior.

1960 - Apertura puerta a los pies de la iglesia - Anselmo Arenillas Se realiza más a fondo el saneo de cubierta de los dos proyectos anteriores, al descubrir un estado de las armaduras peor del previsto. 
1961 - Fachada del poniente y atrio - Anselmo Arenillas

Demolición del atrio.

1962 - Refuerzo de los pilares del crucero, repaso artesonados y cubiertas - Anselmo Arenillas

\section{Posible incorporación de zuncho de hormigón armado (no referenciado)}

Incorpora viguetas de hormigón armado, a modo de par e hilera, con entrevigado de bovedillas y cuelga de ellas los artesonados. Retejo.

Demuele la torre cimborrio y la reconstruye con materiales más ligeros.

1964 - Cimentación de los pilares, pavimentación y limpieza paramentos - Anselmo Arenillas. Baja los tejados de las naves laterales dejando exenta la central más alta. Reconstruye la coronación de los muros con nuevas cornisas, semejantes a los restos de las antiguas.

1971 - Obras generales - José Ángel Rodrigo y Joaquín Roldán

1987 - Restauración - Quintana y Boned

Repaso de estructura de las tres naves con tratamiento antixilófagos y retejo de un $30 \%$ de la superficie. Picado de paramentos interiores y apertura de huecos cegados. Restauración de pinturas y vidrieras. recalce de cimentaciones con hormigón.

1990 - Emergencia en el ala poniente del monasterio - José Lis de la Quintana

Tras derrumbarse la cubierta de la cabecera (de madera rematada con tablero de rasilla) sobre la bóveda, coloca una cubierta provisional similar a la anterior revestida de tablero de madera, onduline y teja.

Se reemplaza la cubierta de la panda que se conserva del claustro, con zuncho perimetral en coronación de muros cajeado en el mampuesto.

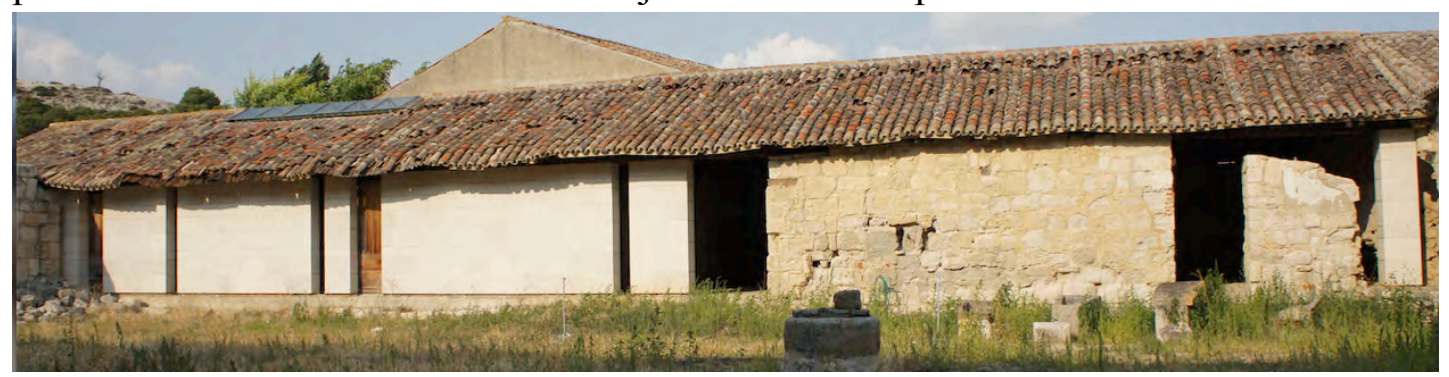

Ilustración 2: ala poniente visita 11/08/2015

En la visita se observa cómo esta construcción adyacente se encuentra muy deteriorada, con deformaciones de la estructura de cubierta inadmisibles y deslizamiento de las tejas sobre las planchas de onduline. 


\section{Planos}

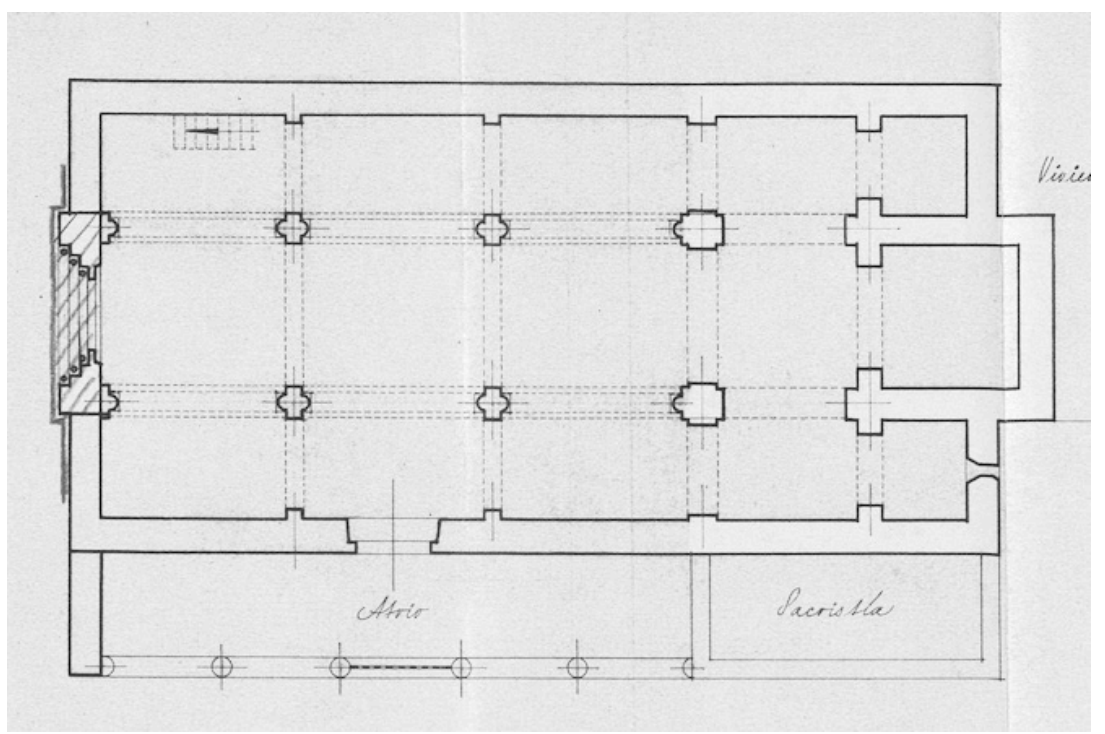

Ilustración 3: planta, 1957 Arenillas IPCE

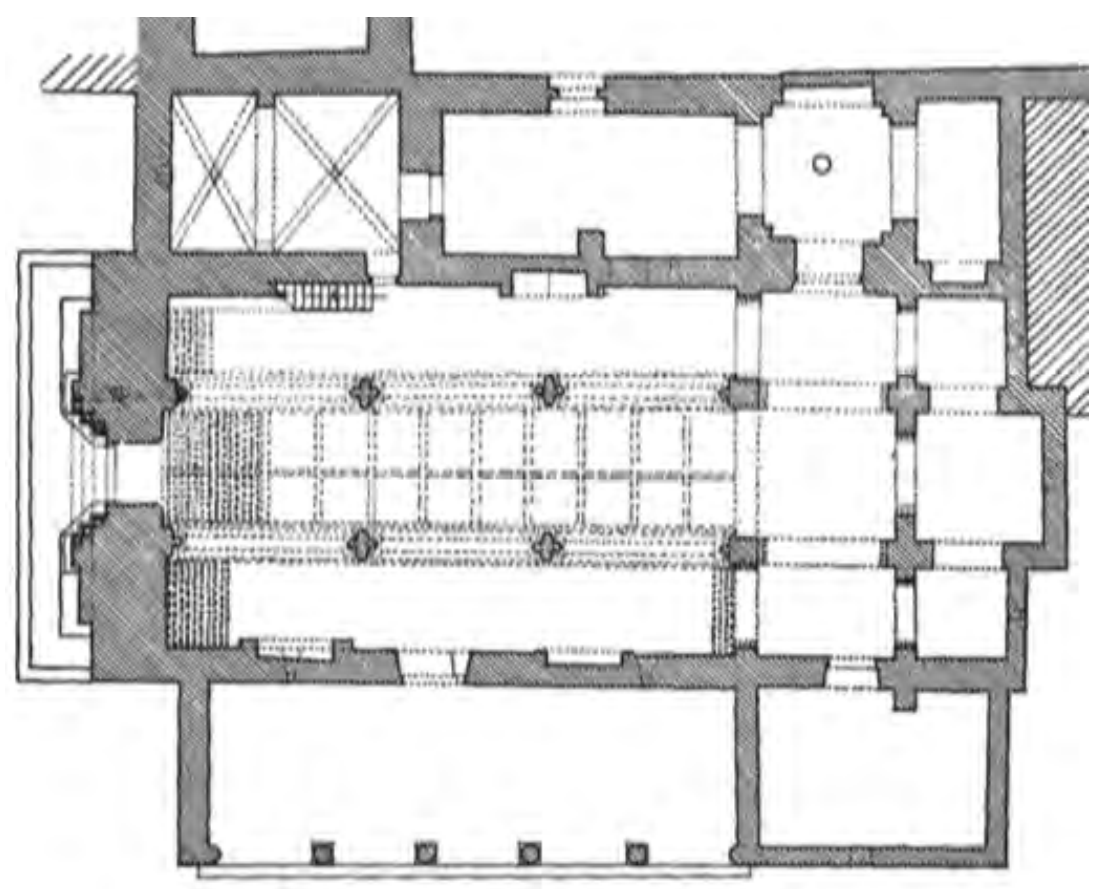

Ilustración 4: planta del Catálogo 1980 


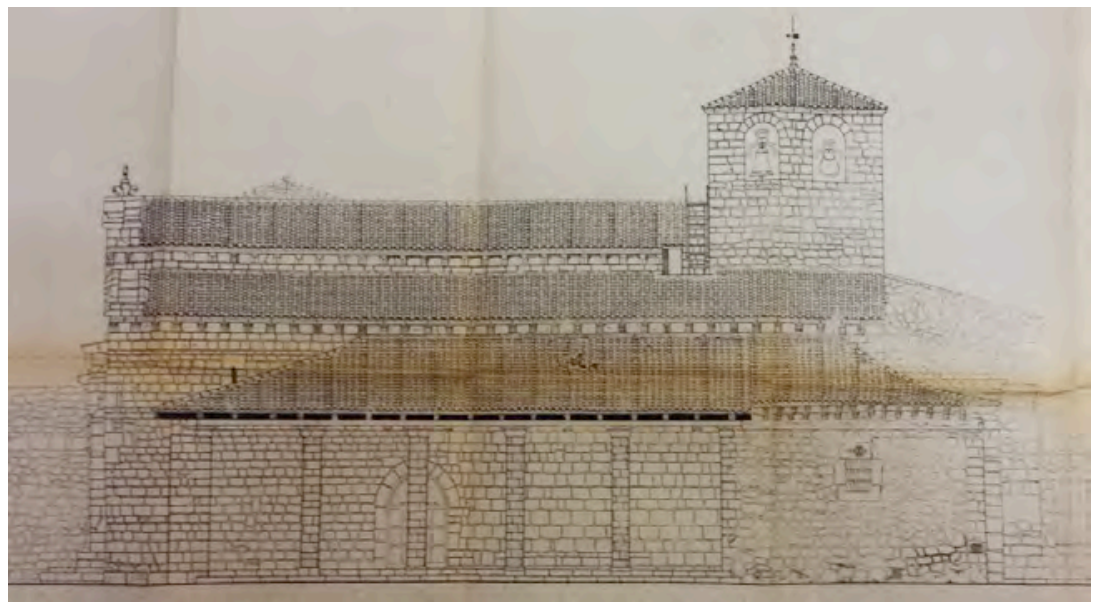

Ilustración 5: alzado1985 Quintana y Boned JCyL

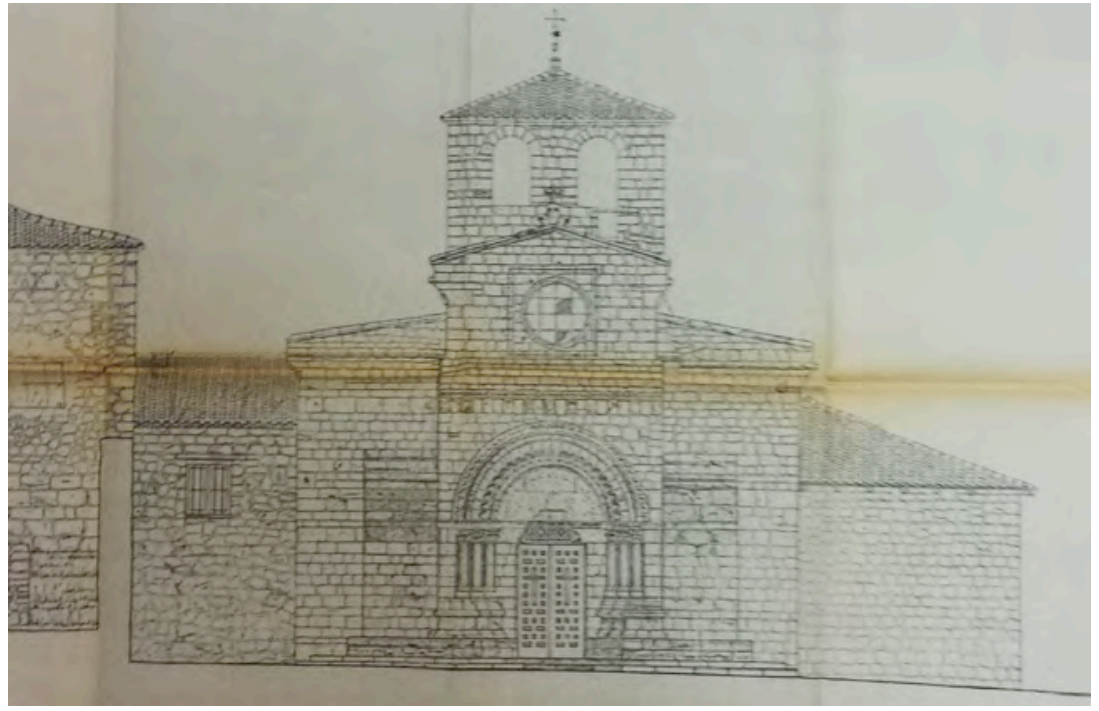

Ilustración 6: alzado1985 Quintana y Boned JCyL

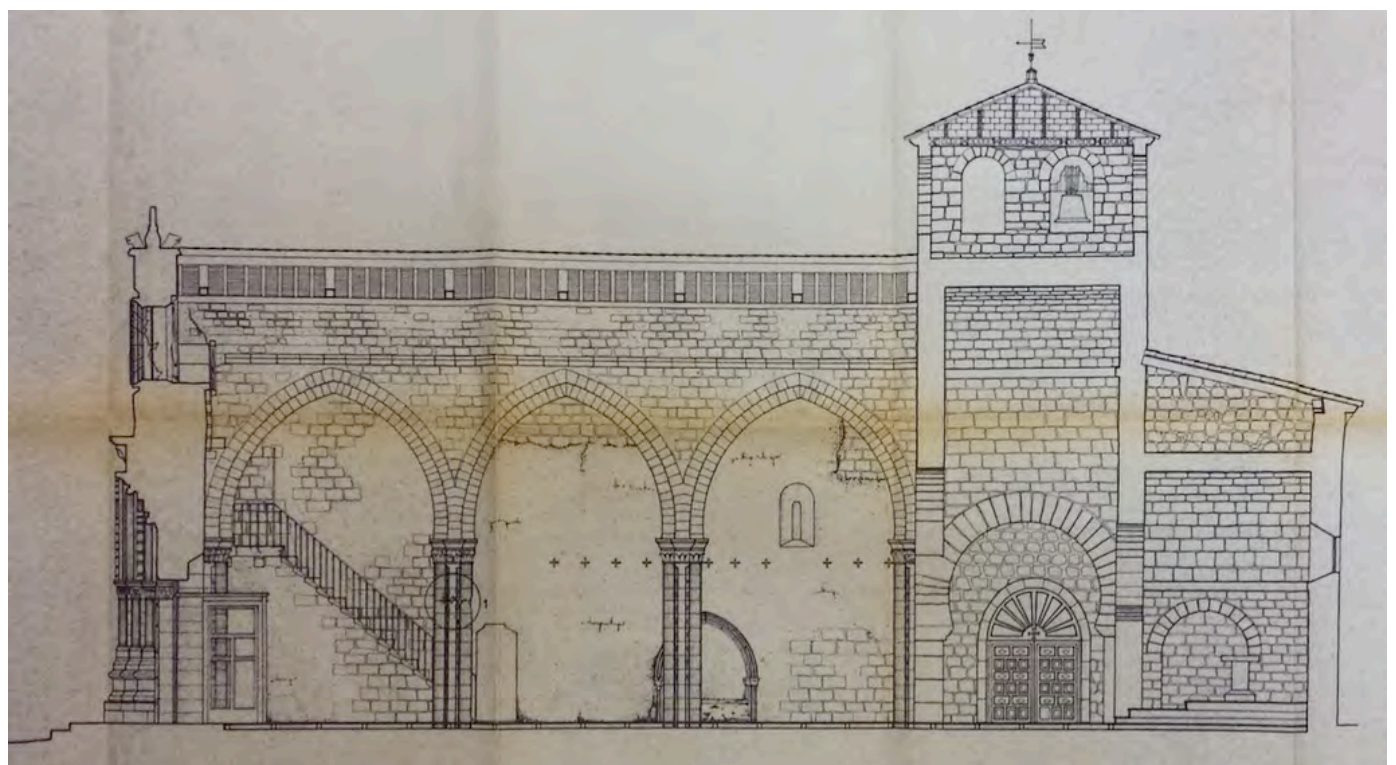

Ilustración 7: sección longitudinal 1985 Quintana y Boned JCyL 


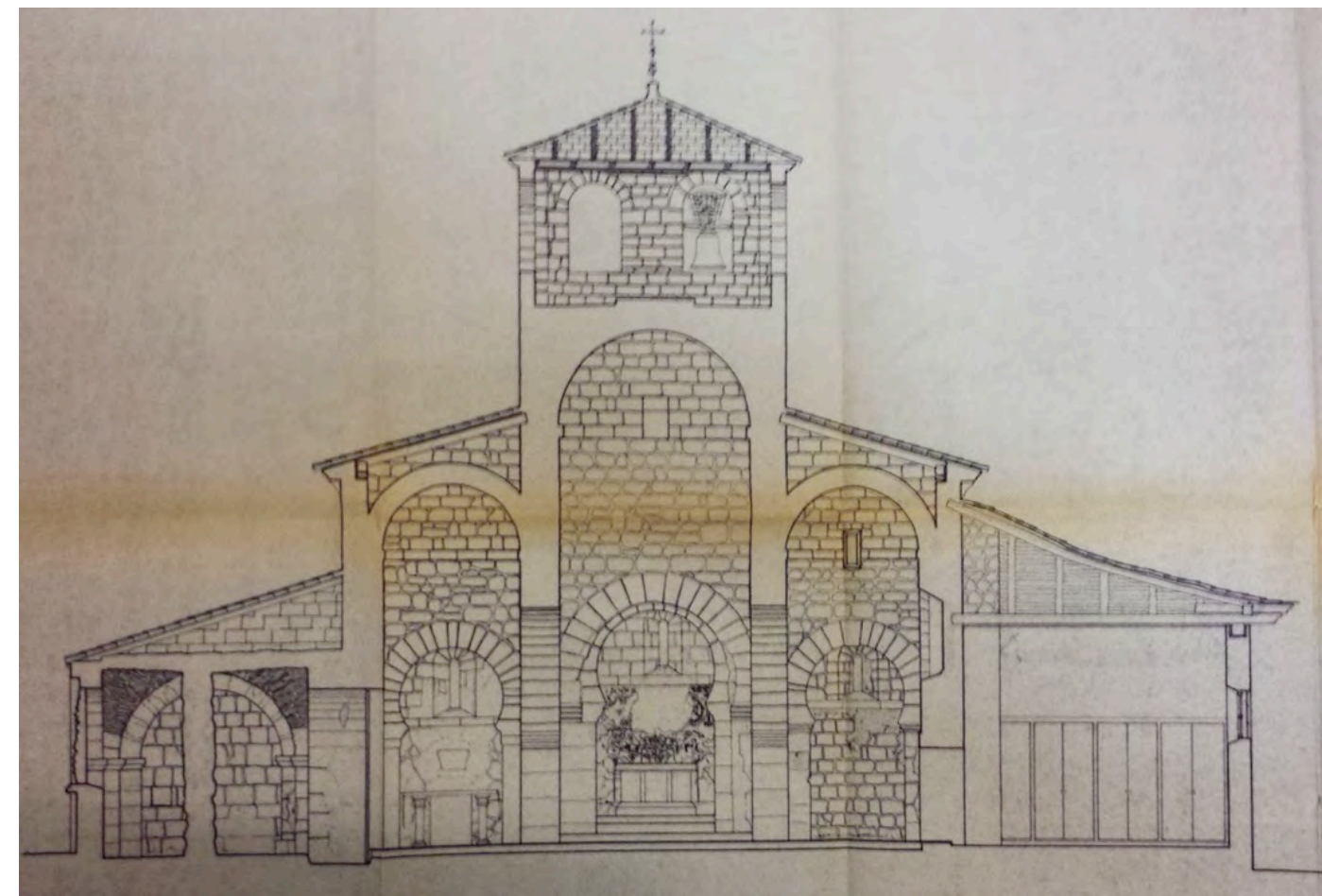

llustración 8: sección transversal 1985 Quintana y Boned JCyL

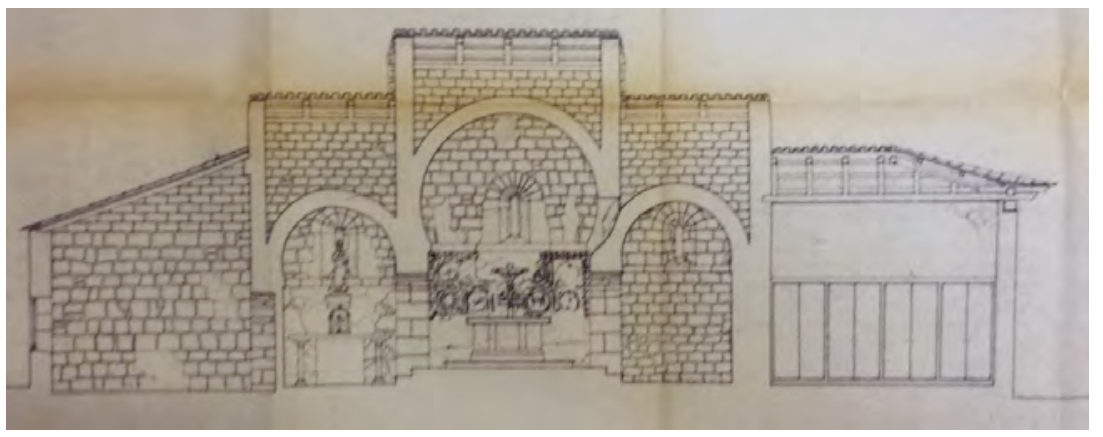

Ilustración 9: sección transversal1985 Quintana y Boned JCyL

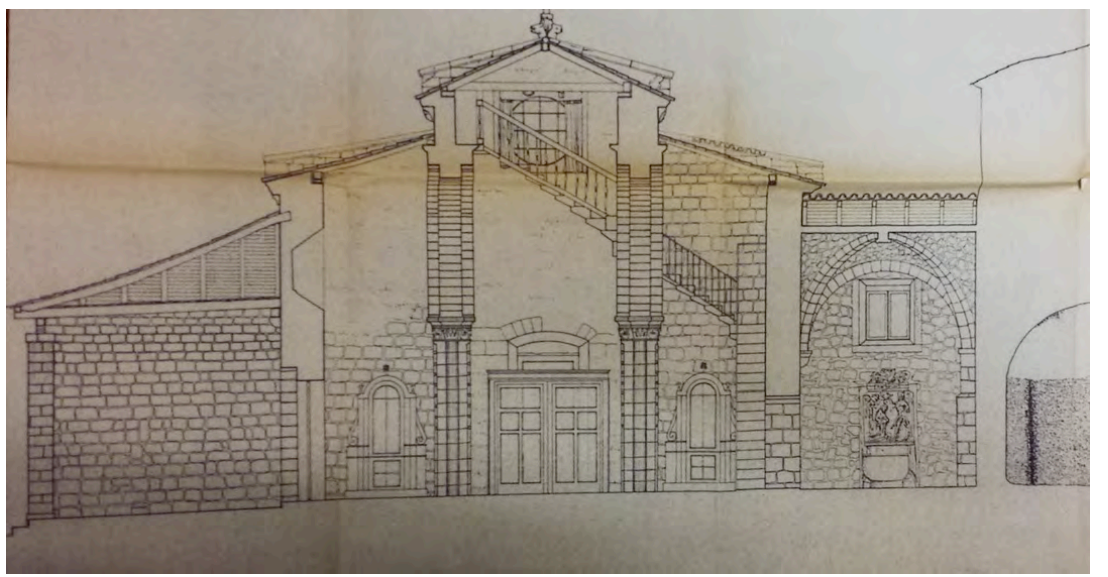

llustración 10: sección interior del muro a los pies 1985 Quintana y Boned JCyL 


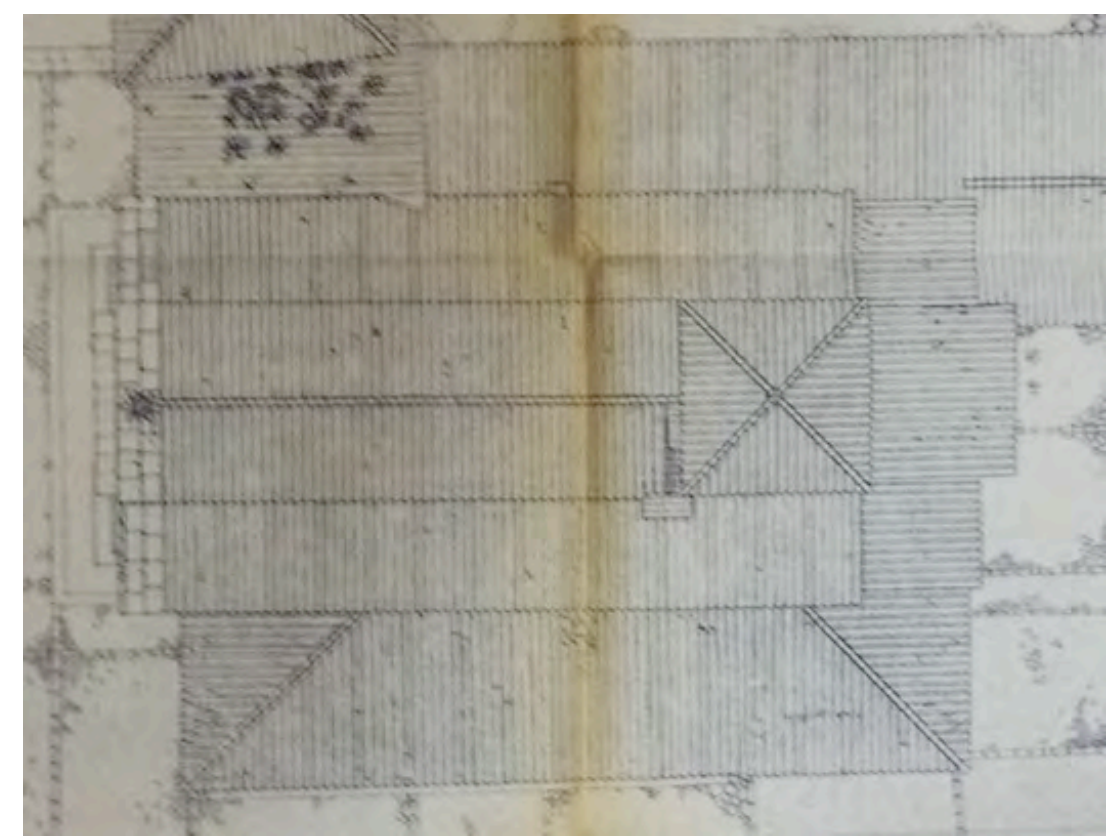

Ilustración 11: planta de cubiertas 1985 Quintana y Boned JCyL

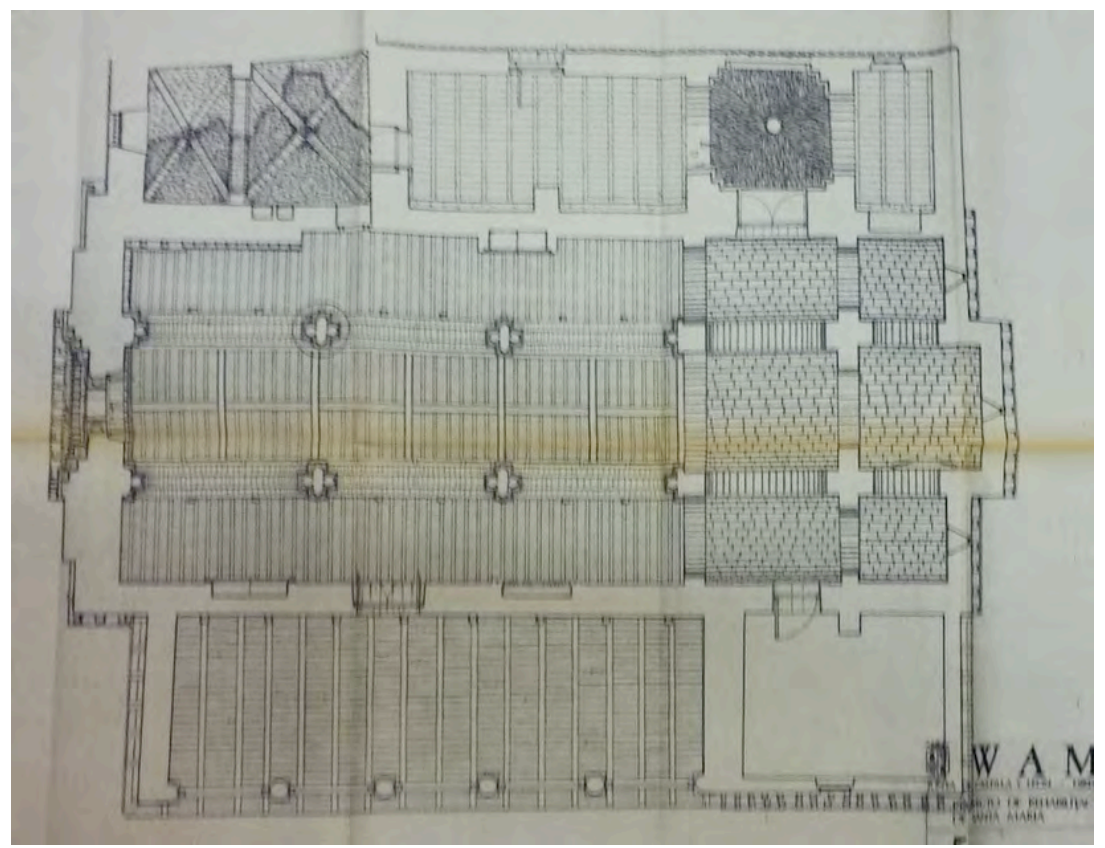

Ilustración 12: planta de bóvedas y entramados 1985 Quintana y Boned JCyL

\section{Solución constructiva de la cubierta}

En la planta de bóvedas se aprecia el despiece de las dovelas de la cabecera. También aparecen representadas las estructuras de madera que cubren el cuerpo de las tres naves del templo. Sobre estos entramados Arenillas incorporó en 1964 una nueva estructura de cubierta, formada por viguetas de hormigón armado a dos aguas con entrevigado de bovedillas (cerámicas o de cemento) y remate de teja sobre la superficie de cemento. Los entramados cuelgan de dicha estructura, según la memoria del proyecto. 


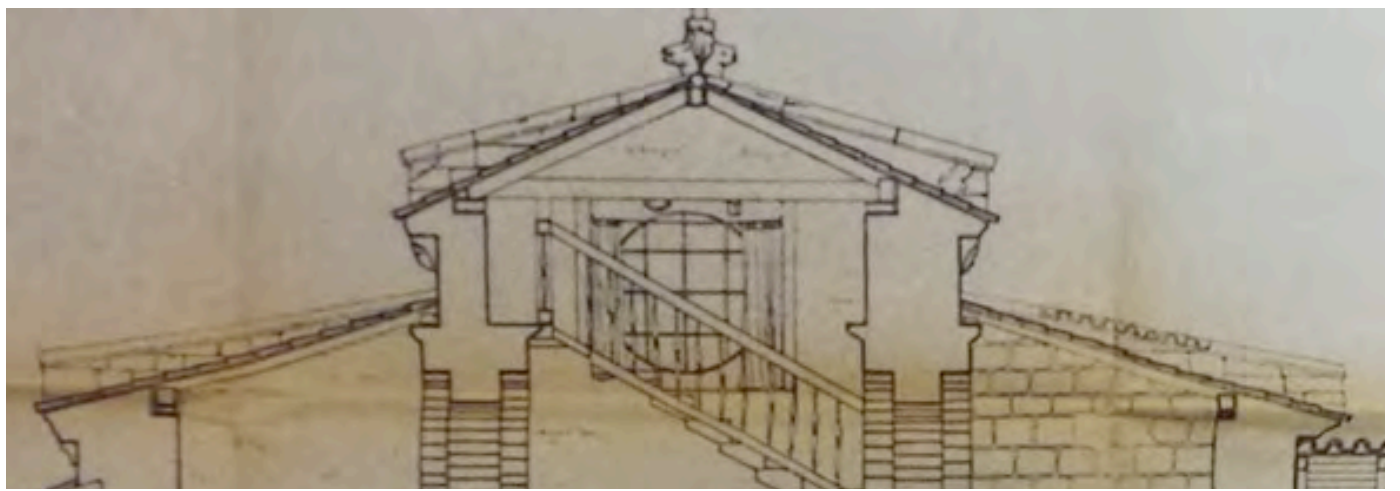

Ilustración 13: sección transversal 1985

La pendiente de ambos faldones de la nave central aparece representada con unos $25^{\circ}$ en la sección transversal. La cubierta de las naves laterales se modifica en 1964, dejando exento el remate de la nave central, antes oculto, por lo que se incorporaron unas cornisas a imagen de las que, según Arenillas, debieron formar parte del edificio original.

También la cabecera ha sido reconstruida tras su derrumbe en 1990 por la pudrición de la viga de madera que soportaba un tablero de rasilla.

\section{Zunchos}

Aunque se reemplazó en el siglo XX la estructura de cubierta de la nave central por forjados inclinados de hormigón en la documentación no se cita expresamente la existencia de zunchos. Durante la visita, sin embargo, se aprecia la existencia de un elemento de hormigón armado entre el durmiente de madera y la cornisa de piedra que queda a la vista sobre el hueco de acceso a cubierta al final del corredor.

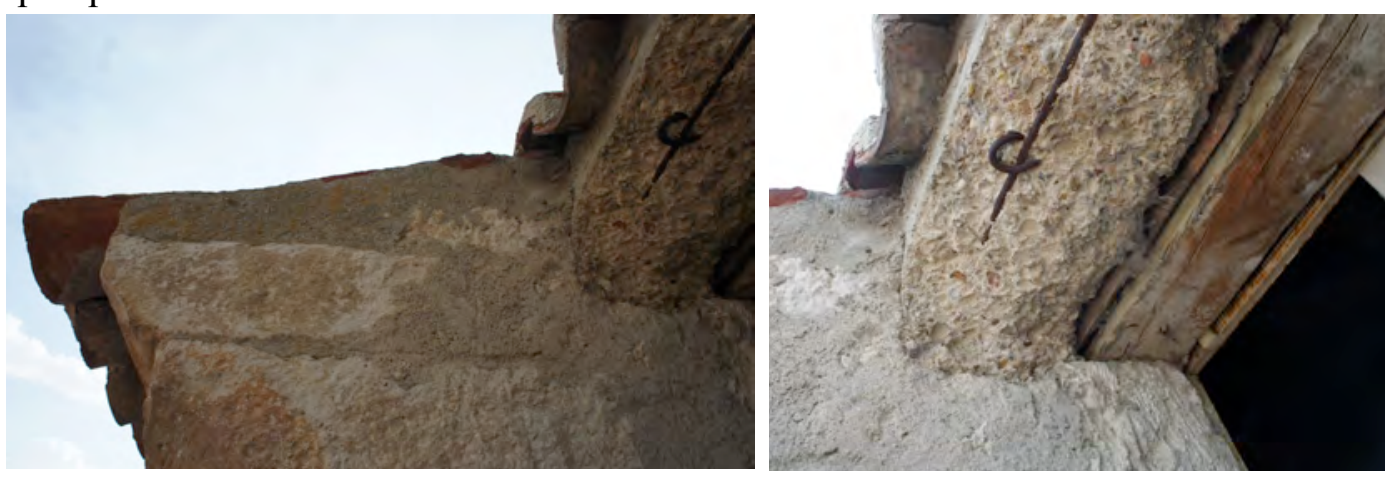

Ilustración 14: detalle zuncho y cornisa visita 11/08/2015

\section{Conclusiones}

No se cuenta con documentación que mencione zunchos, aunque en la visita se ha detectado un tramo de este elemento sobre el hueco de acceso a la cubierta, por lo que es probable que se incorporase en la intervención de Arenillas que en los años 1962-1964 restaura las cubiertas y reconstruye la coronación de los muros. 


\section{Iglesia de Santa María de Wamba}

Intervenciones citadas en la publicación del Ministerio:

1955 - Consolidación del Coro - Anselmo Arenillas Álvarez

1957 - Portada románica a los pies del templo - Anselmo Arenillas Álvarez

1958 - Reparación cubierta y consolidación de la portada - Anselmo Arenillas Álvarez

1959 - Reparación cubierta y construcción muro de separación - Anselmo Arenillas Álvarez

1960 - Apertura puerta a los pies de la iglesia - Anselmo Arenillas Álvarez

1961 - Fachada del poniente y atrio - Anselmo Arenillas Álvarez

1962 - Refuerzo de los pilares del crucero, repaso artesonados y cubiertas - Anselmo Arenillas Álvarez

1964 - Cimentación de los pilares, pavimentación y limpieza paramentos - Anselmo Arenillas Álvarez

1971 - Obras generales - José Ángel Rodrigo García y Joaquín Roldán Pascual

En la web del IPCE hay tres planos de planta de 1957, 1964 y sin datar.

\section{En el Archivo General de la Administración}

AGA 26/00294

1955 - Consolidación del coro - Anselmo Arenillas

AGA 26/00310

1957 - Restauración de la entrada de los pies de la iglesia - Anselmo Arenillas

Descubrir la portada románica hoy tapiada, que existe a los pies del templo, buscando de paso el pavimento antiguo... encontrar las basas y arranques de las primitivas columnas.

AGA 26/00160

1958 - Obras de restauraciones y retejo de la Iglesia Parroquial de Bamba - Anselmo Arenillas

"Se proyectan sencillas obras de reparaciones en la cubierta que tiene en muy mal estado la armadura de cubierta, siendo preciso sanear formar, sustituir pares y entablado, etc. y esto sin desmontarla. Como complemento se propone hacer un amplio retejo. 
En la portada de los pies que fué descubierta en anteriores obras y reclazada se precisa quitar el cierre ó macizado de piedra que le añadieron en épocas anteriores y para ello es necesario hacer un amplio apeo"

Sólo 1 plano de planta (como el del IPCE del 57) con distintas marcas en la entrada y la firma de Luis Cervera como ayudante además de la de Arenillas.

En presupuesto hay $223,45 \mathrm{~m} 2$ retejado y $199,27 \mathrm{~m} 2$ reparación de las formas de madera, en cubierta, saneando y cambiando los elementos deteriorados.

\section{AGA 26/00262}

1959 - Reparación de tejados y aislamiento del atrio - Anselmo Arenillas

La iglesia de Bamba, Monumento Nacional, tenía entre otras averías el tejado deshecho y en sucesivas reparaciones y restauraciones se llevó a cabo la reparación de $199,27 \mathrm{~m} 2$. según proyecto realizado hace tiempo quedando el resto sin arreglar y en muy mal estado, acusando más aún al hacer la anterior obra.

Plano de planta habitual.

En presupuesto el desmontado de cubierta y su reconstrucción $207,83 \mathrm{~m} 2$.

AGA 26/00153

1960 - Reparación - Anselmo Arenillas

Se trató de hacer un buen retejo y reposición de tablas podridas, pero entonces se acusó la descomposición de sus armaduras, en gran parte apolilladas y rotas. Acúdese por ello con este proyecto a recomponer estas armaduras con una reparación hecha a fondo, cumpliendo las órdenes recibidas de la Superioridad.

Como complemento se trata de abrir la puerta de los piés de la iglesia, que ahora está tabicada con sillería, quitando este muro que la ciega y reponiendo las hojas de carpintería.

Plano de planta habitual

Presupuesto dos partidas, 407,10m2 de reparación de armadura de madera de la cubierta y P.A. apertura de hueco cantería y reparación.

\section{AGA 26/00357}

1961 - Reparaciones - Anselmo Arenillas

En esta Parroquia hay adosado un gran muro al de cierre del atrio que sirve de frontón... Se proyecta su demolición.

Se proyecta recalzar por puntos la fachada a poniente con hormigón a fin de evitar movimientos de la fábrica y retacar la fábrica. 
Plano habitual, señala en rojo la fachada a los pies.

\section{AGA 26/00253}

1962 - Obras de reparación de ruina grave - Anselmo Arenillas

Conserva gran parte de su primitiva estructura visigoda y el resto es románico. Toda su cabecera, visigoda, incluido el crucero, se cubre con fuertes bóvedas de sillería. Carga toda esta pesada fábrica sobre los muros de contorno y sobre los cuatro pilares del crucero, que son bastante ligeros.

En el transcurso de los siglos elevaron sobre el crucero una torre de planta cuadrada, inicialmente de un piso, luego de dos y, finalmente, de tres. Hecha con gruesos muros, con dos plantas entramadas y otra sobre el relleno de la bóveda del crucero cubierta con tejado de teja árabe y con seis u ocho campanas. Todo este enorme peso actuando sobre los cuatro pilares centrales debió acusarse por deformación o quebranto del arco triunfal o de embocadura del ábside central y en épocas anteriores, más allá de nuestra guerra reforzaron este arco suplementándole con otro que sólo la gravedad del daño podía justificar.

Al ir a quitar el refuerzo del arco triunfal se observó que los cuatro pilares presentan deformaciones y grietas propias de rotura por aplastamiento.... síntoma de ruina muy grave. ..se ordenó el apeo.

Se intentará retaquear, inyectar de cemento, reforzar con varillas de hierro y zunchos encastrados los cuatro pilares y si ello no fuese suficiente... sustitución uno a uno.

Se incluyen también en este proyecto las obras que se pensaban realizar este año, que esencialmente consisten en desmontar la teja de los tejados que están encima de los artesonados de madera. Repasar estos artesonados, poner encima de ellos unas viguetas de hormigón armado a modo de par e hilera, estribando sobre los muros y colgando de ellos las vigas de madera del artesonado donde estos existen; forjar con bovedilla de rasilla o de cemento los faldones resultantes, tender una capa de hormigón impermeable sobre el faldón y colocar de nuevo la teja, reponiendo la que falte.

Plano de planta con cuadrado en rojo entre los pilares torales.

Presupuesto:

$81,78 \mathrm{~m} 2$ de encimbrado de arcos con dobles cerchas y puntales

$132,8 \mathrm{~m} 3$ desmontado de muros de mampostería, en altura

$126 \mathrm{~m} 2$ de repaso y sujeción del artesonado de madera

4ud de zunchado y consolidación de pilares 
$357 \mathrm{~m} 2$ de cubierta de teja árabe incluyendo entramado de hormigón armado y forjado de faldones de rasilla y mortero de cemento

\section{AGA 26/00370}

1964 - Terminación de la restauración - Anselmo Arenillas

Memoria marzo de 1964

La iglesia de Wamba que es Monumento Nacional acusó una ruina progresiva por descomposición de los cuatro pilares del crucero y hubo de acudirse en años anteriores a su urgente reparación apeandolos sustituyendole algún pilar y enlechando con cemento su descompuesto nucleo que era de mala mamposteria. Previamente se procedió a aligerar las cargas que sobre ellos actuaban demoliendo la gran torre o linterna por muros de mamposteria de $0,80 \mathrm{~cm}$. de grueso que habian ido recreciendo en diversas etapas de su vida y alcanzaba una altura de unos $10 \mathrm{~m}$.

Ahora una vez consolidados los pilares se proyecta rehacer sus cimentaciones que casi no existen, recalzándolos por puntos perimetrales y haciendo unas grandes vigas invertidas de hormigón armado... Una vez todo consolidado se proyecta levantar la linterna... Tanto en la nueva torre como en la cabecera de los ábsides y en la nave alta que ahora es exenta por haberse bajado a su ser los tejados de las naves bajas es preciso reponer las cornisas de las cuales quedan vestigios suficientes para repetirlos.

Plano igual que el del IPCE pero en color rojo la trama entre pilares torales y una línea a ambos lados de la nave.

$65,60 \mathrm{ml}$ de cornisa de piedra con canes repuesta.

AGA 26/01573

1971 - Restauración altar mayor, columnas - José Ángel Rodrigo García

AGA 26/00332; AGA 26/01573

1971 - Restauración de la iglesia de Wamba - José Rodrigo García y Joaquín Roldán Obras a realizar:

Se desmontará una pieza de columna que se encuentra en mal estado dada su naturaleza caliza, que ha sufrido los efectos del tiempo, sustituyéndola posteriormente por otra nueva (según plano la primer izquierda entrando a los pies) Se repondrá el entarimado del Altar Mayor y capillas adyacentes

Desmontará el púlpito

Exterior y atrio 


\section{En el archivo del IPCE}

Carpeta 1379-3

Memoria final de restauración

"Fué objetivo de estas obras conseguir un mayor realce de esta joya mozárabe con una urbanización acorde a su ubicación.

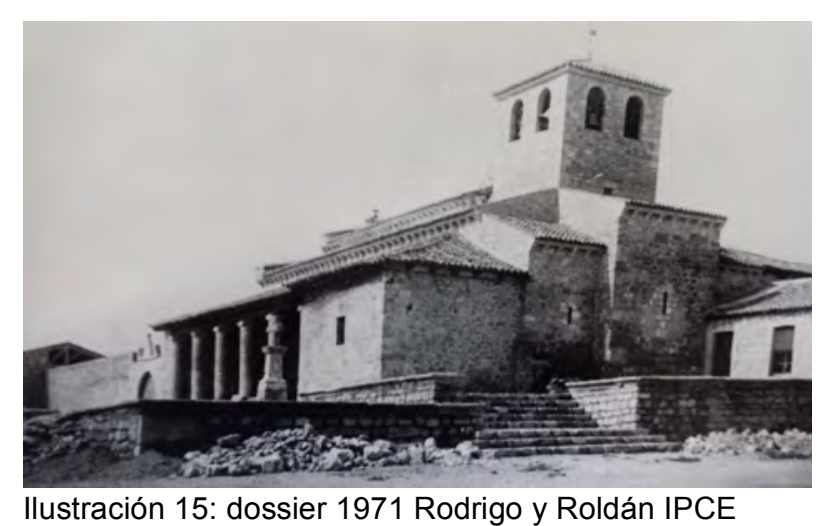

Se han cuidado detenidamente sus accesos respetando el trazado de la carretera que la circunda y sus paseos discurren entre zonas ajardinadas.

Uno de los obstáculos a vencer era la falta de perspectiva de la Iglesia desde sus proximidades, ello era motivado por la excesiva altura de su muro perimetral.

Se hizo un estudio de niveles donde se aunaban niveles de carretera, de coronación de muros, de paseos y de los diversos accesos, iniciándose los trabajos con el desmontado de la albardilla de coronación y demoliendo con arreglo a las nuevas cotas los muros de mampostería...

Otra zona que precisó de cuidados especiales fué su atrio.

Fue necesario desmontar una de sus columnas y tratar su cimentación y fuste.

Reponer las bases del resto por encontrarse deterioradas. Paños de sillarejo fueron rehechos y el enlosado hubo de reponer en su totalidad dado su descomposición, así como el arco de piedra caliza de su puerta que da a la nave lateral necesitó de cuidadosa reparación.

\section{En el archivo de la Junta de Castilla y León}

VA-070

Caja 5260

Obra de Emergencia de Restauración del Ala Poniente del Monasterio de Sta María de Wamba

Recepción provisional 17/12/1990

Arquitecto: José Luis de la Quintana

Contratista: Alejandro Bolado López, adjudicada en diciembre de 1989. 


\section{Memoria}

En fecha 14 de noviembre de 1990 se produjo el derrumbe sobre la bóveda de la cubierta de la cabecera de la nave central de la iglesia de referencia.

Una vez reconocido se observó que la cubierta de unos treinta metros cuadrados a un agua, estaba organizada con tres vigas, dos adosadas a los muros superior e inferior y otra central paralelas al alero, sobre ellas se situaban parecillos, tablero de rasilla y cubierta de teja árabe. La ruina se debió a pudrición de la viga central y parecillos que se rompieron; no se acusó deformación previamente al exterior a causa del tablero rígido de rasilla que se arruinó súbitamente por rotura frágil.

Bajo esta cubierta arruinada se encuentra la cabecera mozárabe de gran valor, que puede deteriorarse, por lo que es precisa una actuación de emergencia.

La obra a efectuar consiste en la colocación de una cubierta provisional organizada con tablones a modo de correas y piezas de onduline como cubierta. Con esta cubierta colocada se procederá al desescombro y limpieza de la bóveda, preparando una nueva estructura de organización similar a la anterior, sustituyendo las vigas y ménsulas de apoyo en mal estado, así como la totalidad de los parecillos que serán un tablero de madera, onduline, la teja con aportación de las piezas nuevas que sean necesarias. La nueva estructura se montará en un solo día retirando solo entonces la cubierta provisional.

Informe de trabajos arqueológicos de 1988.

En la zona oeste comprueban la existencia de un tirante de hormigón realizado durante la restauración de los años sesenta.

C-2. Quitado el entarimado moderno, previa documentación del pavimento de piedra que apareció, escaso, pudimos apreciar un zuncho de hormigón que rodeaba toda la zona, atando los cuatro arcos torales. Este zuncho fue realizado en la restauración de los años sesenta, paralelamente al desmonte del segundo tramo de la torre. Este zuncho resultó bastante negativo para nuestra investigación ya que destruyó toda referencia a la existencia o no de un iconostasio (citado por Gómez Moreno).

Permuta de una zona del claustro de un particular al Ayuntamiento.

Informe sobre el estado de la nave de planta alta del ala poniente del claustro románico del Monasterio de Santa María en Wamba. Septiembre de 1989.

Arq: JL de la Quintana Gordon y JR Boned Colera.

Factura

345,070 m2 desmontado teja curva seleccionándola y apilándola... 
203,28 m2 demolición de falso techo de escayola y cañizo...

$345,070 \mathrm{~m} 2$ demolición de estructura de cubierta formada por entablado de ripia, pares y tirantes formando el alero, incluso medios...

$88,00 \mathrm{ml}$ Saneado de coronación muro desmontando la mampostería suelta y el relleno cajeandolo para la realización de un zuncho perimetral, recolocandolo y retacando con mampuesto los elementos desaparecidos, así como rejuntando según las indicaciones de la DF en una altura no mayor de $0,75 \mathrm{~m}$. incluso p.p. de retirada de escombros, carga y retirada a vertedero.

$92,40 \mathrm{ml}$ suministro y colocación de ladrillos macizos formando pilar de $25 \times 25 \mathrm{~cm}$...

$345,070 \mathrm{~m} 2$ suministro y colocación de cubierta de caracteristicas similares a pabellon nuevo del claustro, formada por: pares y durmientes dobles de escuadría $30 \times 10 \mathrm{~cm}$ hilera, tablones machihembrados de $20 \times 5 \mathrm{~cm}$ todo ello en madera de pino soria de primera calidad y modulados a tres metros. Tirantes y piexzas de anclaje metálico. Faldones con tablero de aglomerado hidrófugo tipo Ebanel con 19mm de espesor, planchas de poliestireno expandido de $60 \mathrm{~mm}$ placa impermeabilizante onduline incluso p.p de canalon y bajantes de cobre, completamente acabada $80,35 \mathrm{ml}$ retacado de ladrillo macizo en formación de zuncho

$88,00 \mathrm{ml}$ suministro, vertido con bomba y vibrado de hormigón prefabricado para zuncho perimetral en coronación del muro. Resistencia característica Fck $200 \mathrm{Kg} / \mathrm{cm} 2$. árido rodado Dmax $20 \mathrm{~mm}$. Cuantia de hierro: $600 \mathrm{Kg} / \mathrm{M} 3$. Cemento Portland. se incluye p.p. de encofrado de madera. Sección $45 \times 35 \mathrm{~cm}$. (Ojo es el claustro perpendicular a la iglesia)

\section{VA-195}

Carpeta 5374

Restauración de las pinturas murales del presbiterio del testero de la nave lateral izquierda de la iglesia parroquial de Santa María de Wamba.

\section{VA-034}

Caja 5226

Rehabilitación del Monasterio de Santa María de Wamba

Documentación administrativa

Dossier de la Restauración: (saco fotos está desencuadernado)

Certificaciones:

Demolición de zunchos para colocación del solado a la altura de la solera de hormigón

4ud zunchado y collarín de pilastras 


\section{Caja 5227}

Documentación administrativa:

Informe de Javier León de la Riva

La obras de Restauración del Monasterio de Sta. María de Wamba, se inscriben en el Programa de Restauraciones que la D.G. de PPC desarrolla anualmente en el extenso patrimonio monumental de nuestra Comunidad Autónoma. Es objetivo prioritario de este Programa el rescatar y poner en valor aquellos elementos de nuestro patrimonio que han entrado en fases de deterioro que amenazan su reconocimiento y supervivencia... Ejemplo de recuperación completa de un conjunto... investigación arqueológica.

Trabajos de restauración desde la eliminación de humedades, hasta la recuperación y sustitución de cubiertas, pasando por la reposición de pavimentos, limpieza de muros y restauración de campanario y elementos de acceso.

Incorporación al uso público y la visita.

El proyecto de restauración fue redactado entre 1986 y 1987, por los arquitectos Quintana y Boned, año a finales del cual la Consejería adjudicó las obras a la empresa Alejandro Bolado. La restauración ha sufrido dos interrupciones: una motivada por la importante campaña arqueológica realizada, entre marzo y abril de 1988, y otra, derivada de la necesaria modificación del proyecto, que supuso una pausa entre septiembre y diciembre de 1988.

La Consejería contrató además y por el procedimiento de emergencia la restauración del cuerpo superior del ala oeste en abril de 1990.

\section{Certificaciones}

Proyecto de rehabilitación

Modificado 1989 de Quintana y Boned

\section{Proyecto diciembre de 1985}

Características y tipología de esta iglesia mozárabe

Del monasterio no quedan restos visibles. La iglesia, construida a lo largo del siglo $\mathrm{X}$ tendría un carácter muy unitario. De este momento sólo se conservan el muro norte, transepto y cabecera (tripartita).

Contraste entre la pesantez de los arcos, relativamente bajo, y la esbeltez de las bóvedas que llegan a triplicar la anchura de las naves. 


\section{Materiales}

Aparejo de los muros: de mampostería.

Bóvedas y soportes: ritmo alternante de hiladas a diferentes alturas, con sillares estrechos, o más gruesos.

Cabecera: aparejo regular en la parte inferior del paramento y opus incertius et minus en la parte alta: reconstrucciones medievales.

Capillas: piedra caliza basta.

Estribos y pilares: sillería bien labrada y careada. Alternan sin orden previo hiladas de $64 \mathrm{~cm}$ con otras de unos 20 .

Seis bóvedas de cañón, arcos de herradura.

Las primitivas cubiertas tendrían unas vertientes de diferente inclinación. Por estar muy reformadas (en el siglo XVII tenemos documentados, además de continuos retejos, una sustitución de la estructura de madera, al menos en una parte importante del conjunto del edificio, y posiblemente en los finales del XII o en el XIII se procediera a una intervención sustitutoria total, en el momento de actuar en la torre), no queda ningún vestigio de su aspecto en época mozárabe.

La torre, evidentemente posterior, se levantaría en los ss. XII-XIII, con materiales aprovechados de la reforma de la iglesia.

Dossier con documentación histórica, copia de varios manuscritos del Archivo AHN sección Órdenes Militares, y su transcripción.

NAVES: Los artesonados eran de madera, y la estructura de la techumbre, de vigas de madera con cubierta de teja. En la visita de 1629 se pide que "sea repasado el tejado de la nave de la dicha capilla del Santísimo-nave central- y en la zona de dicha iglesia sea hecho todo el tejado nuevo así de maderas como de teja" (AHN.Secc.OM. $\left.7441 \operatorname{leg} .13 \mathrm{n}^{\mathrm{o}} 17\right)$

Por otra parte en esta misma visita se confirma que fué "adecentada y reparada la nave de S. Juan de dicha iglesia, un pedazo de tejado y puesto una viga de madera nueva con el que está segura".

Dossier fotocopias de fotos.

Estado actual. No han localizado los proyectos de los últimos 80 años.

Se ha analizado la estructura con un programa de cálculo matricial, asimilando la piedra a un entramado de barras considerando uniones articuladas en los apoyos.

"Realmente, esta forma de análisis, no es el modelo más completo, puesto que un análisis de una estructura estatíca debería haberse analizado piedra a piedra considerando articulaciones entre ellas y efecto de rozamiento, lo que hubiera llevado a una modelización más compleja por método de elementos finitos". 


\section{Cubiertas}

En la zona de las tres naves de la iglesia que han sido restauradas recientemente, la estructura de madera presenta algunos ataques de xilófagos.

Las cubiertas de las capillas D1, C1 e I1 presentan los mismos problemas en el estado de sus tejas, encuentros y aleros. LD4 presenta panzas. La cubierta de LD1, LD2 y LD3 tiene estructura de viguetas semiresistentes de hormigón armado.

En el interior los muros encalados ocultan huecos tabicados en su día.

Las cubiertas correspondientes a las tres naves de la iglesia han sido restauradas, por lo que su estado general es correcto. Sin embargo es preciso actuar en ellas de la forma siguiente:

Repaso de la estructura, incluso tratamiento antixilófagos.

Retejo puntual (Aprox. 30\% de la superficie)

Tratamiento de encuentros entre faldón y muro mediante baberos de plomo.

Emboquillado de aleros mediante mortero.

Capillas D1, C1 e I1.Será necesario construir nuevas cubiertas. La estructura actual se conservará.

En el interior, entre otras actuaciones, se realizará el picado integral de los muros del templo. Se procederá a la apertura de los huecos tabicados.

Planos de octubre de 198: Alzados estado actual 1/50, plantas... 1:100

\section{Caja 5228}

Proyecto sin encuadernar. Varios.

\section{Caja 5229}

Inventario artístico. (Dossier de fotografías a color de capiteles y canes)

Proyecto reformado

Memoria final de las obras. Noviembre de 1990.

Dossier de fotografías.

Estimación del coste de obras pendientes. 


\section{Visitas realizadas}

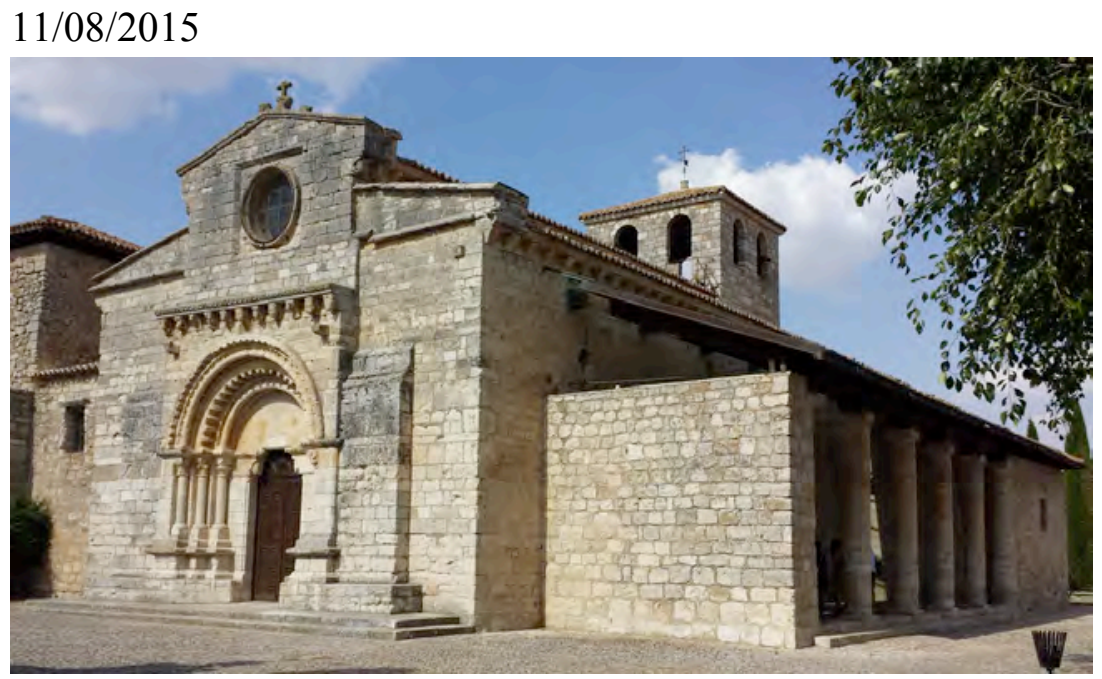

El estado de conservación del monumento es, en general, aceptable, excepto en el edificio anejo del claustro, que muestra una grave patología, con deformaciones excesivas y deslizamiento de las tejas.
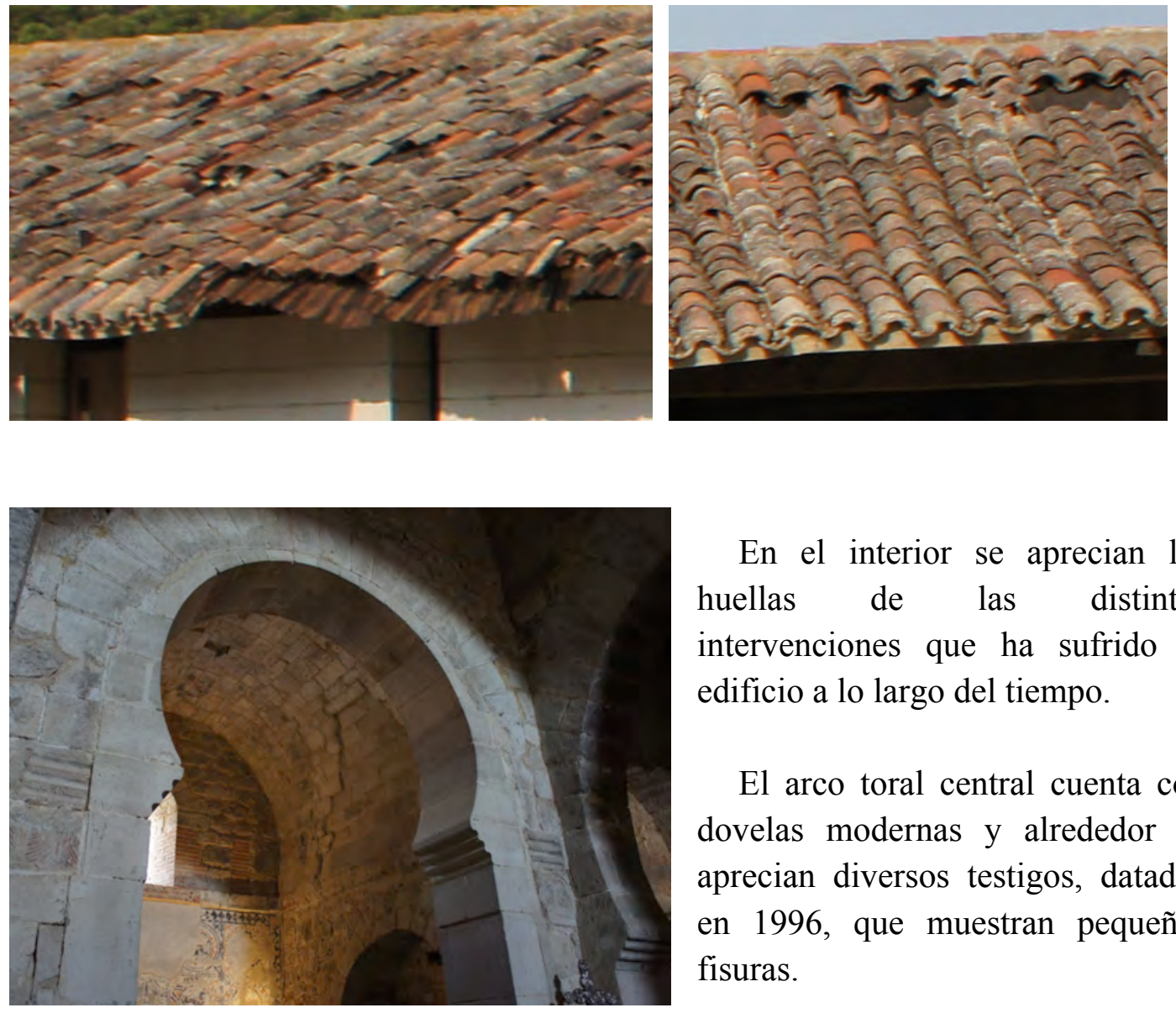

En el interior se aprecian las huellas de las distintas intervenciones que ha sufrido el edificio a lo largo del tiempo.

El arco toral central cuenta con dovelas modernas y alrededor se aprecian diversos testigos, datados en 1996, que muestran pequeñas fisuras.

El templo cuenta con una escalera de piedra, que desemboca en una pasarela corrida con barandilla de madera, que permite un acceso a cubierta inmediato muy eficaz. 


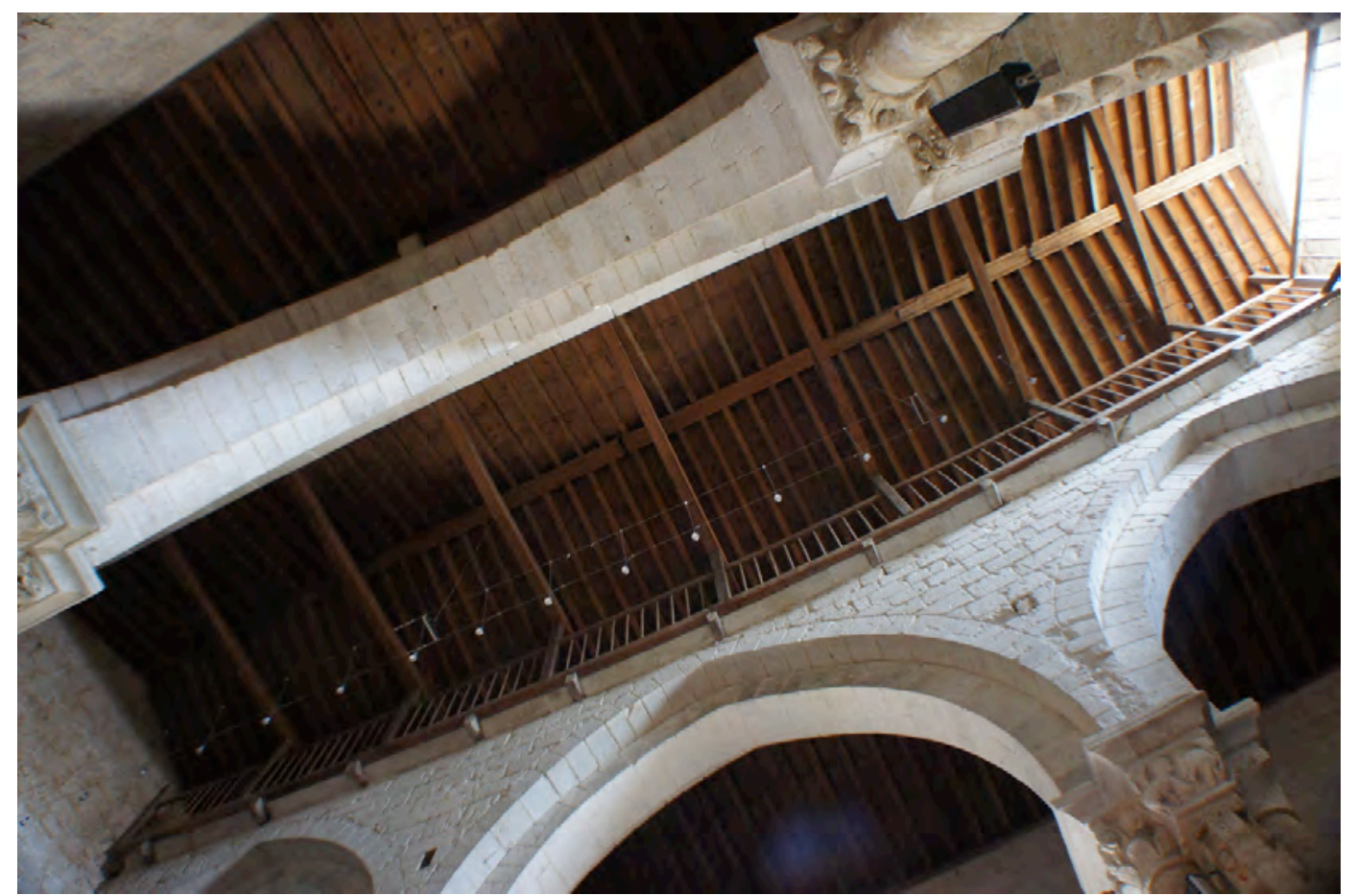

Las entregas de los pares de madera al muro cuentan con una tapeta de madera que cubre el encuentro. En la siguiente imagen se aprecia el detalle del durmiente de madera.
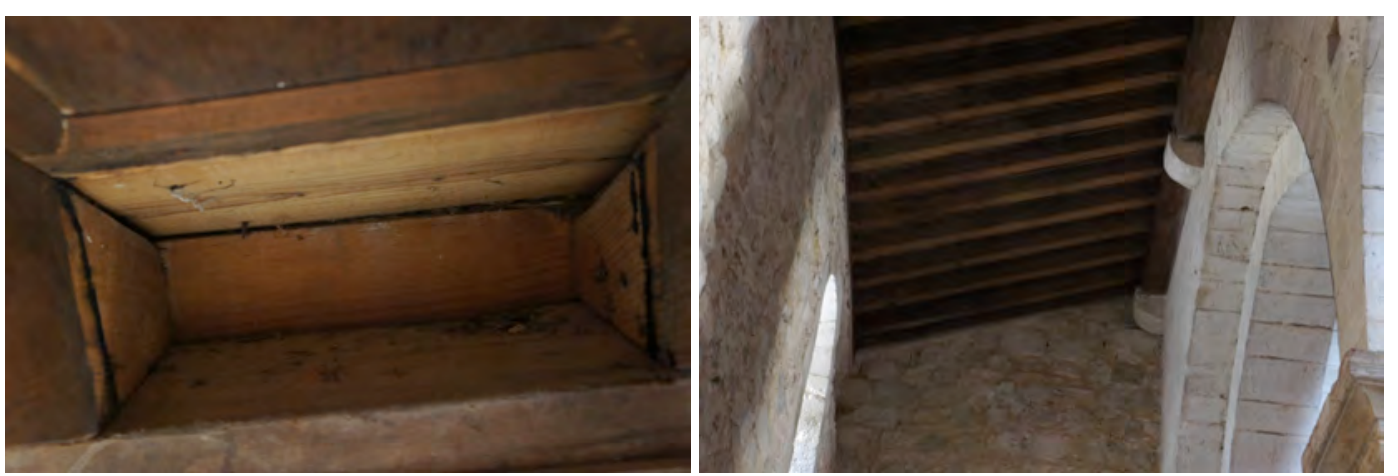

Aunque, a grandes rasgos, la solución constructiva de cubierta observada coincide con la definida en el plano de sección del proyecto de Boned de 1985, al observar detenidamente las piezas de madera dispuestas como hilera y tirantes es posible apreciar cómo no se trata de escuadrías macizas sino de elementos recubiertos con tablas a ambos lados y en cara inferior.

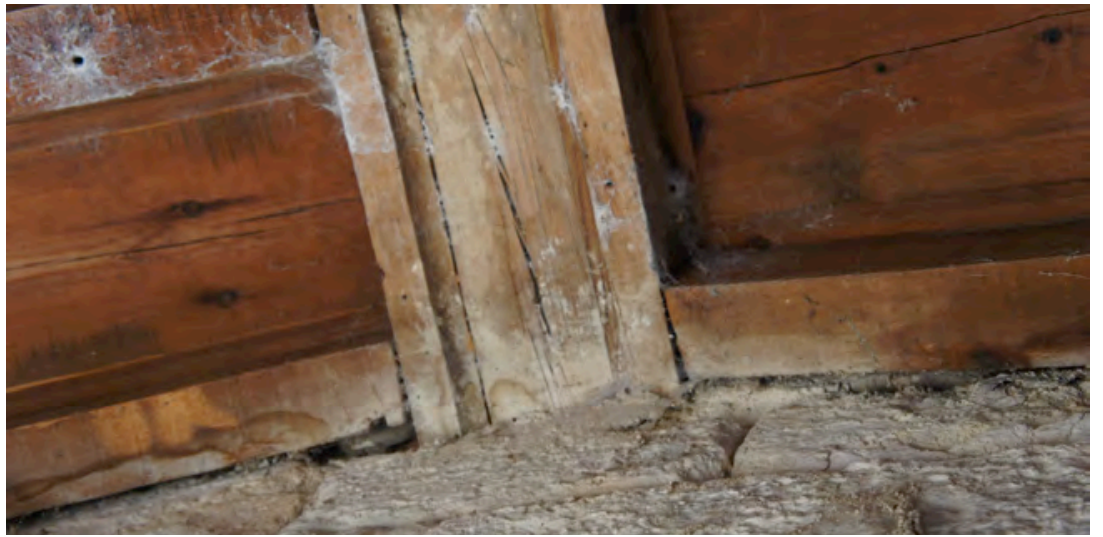



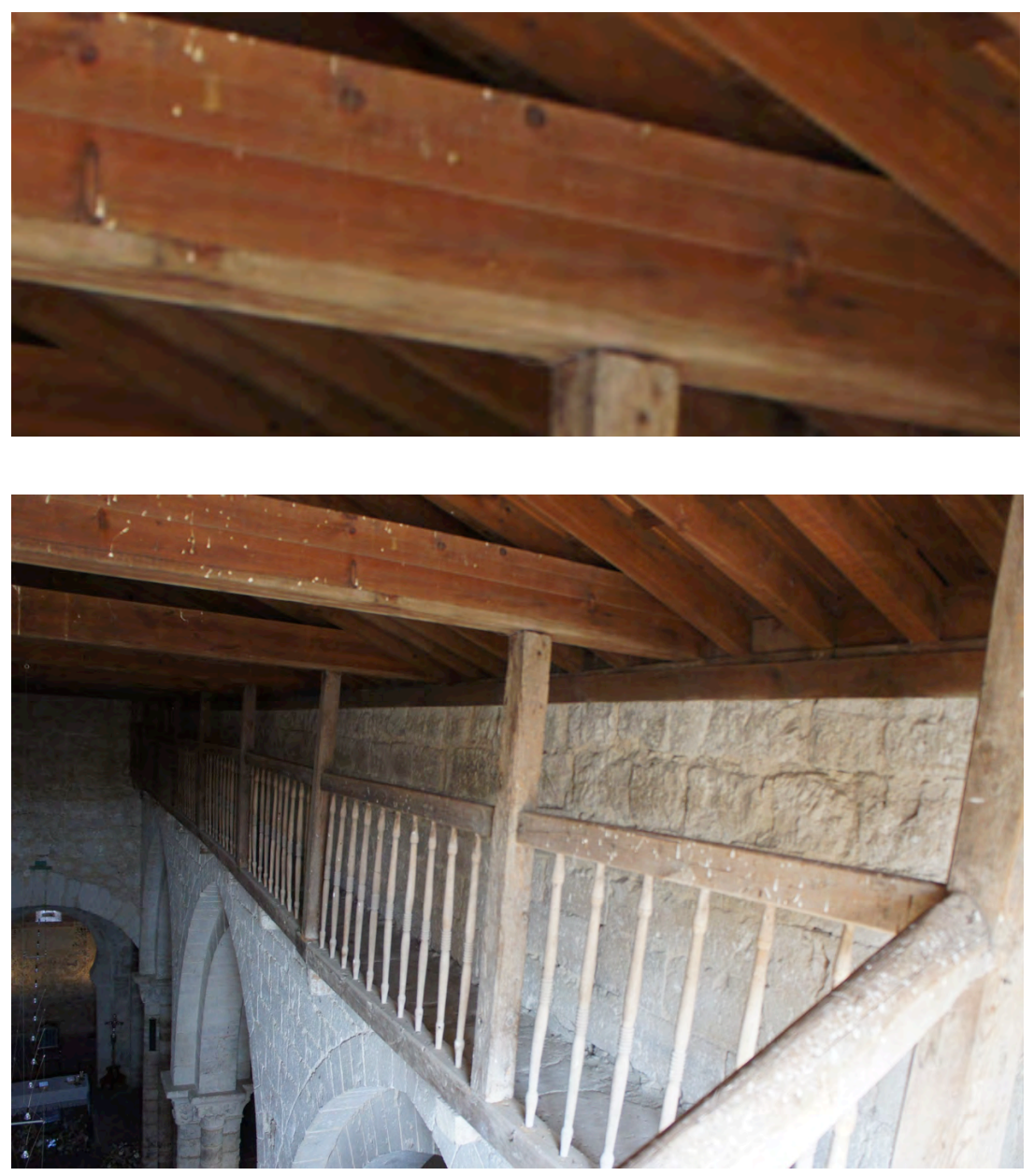

En las capillas anejas encontramos una cubierta de vigueta y entrevigado de rasilla que apoya sobre un potente zuncho de hormigón armado y una columna muy afectada por la erosión.
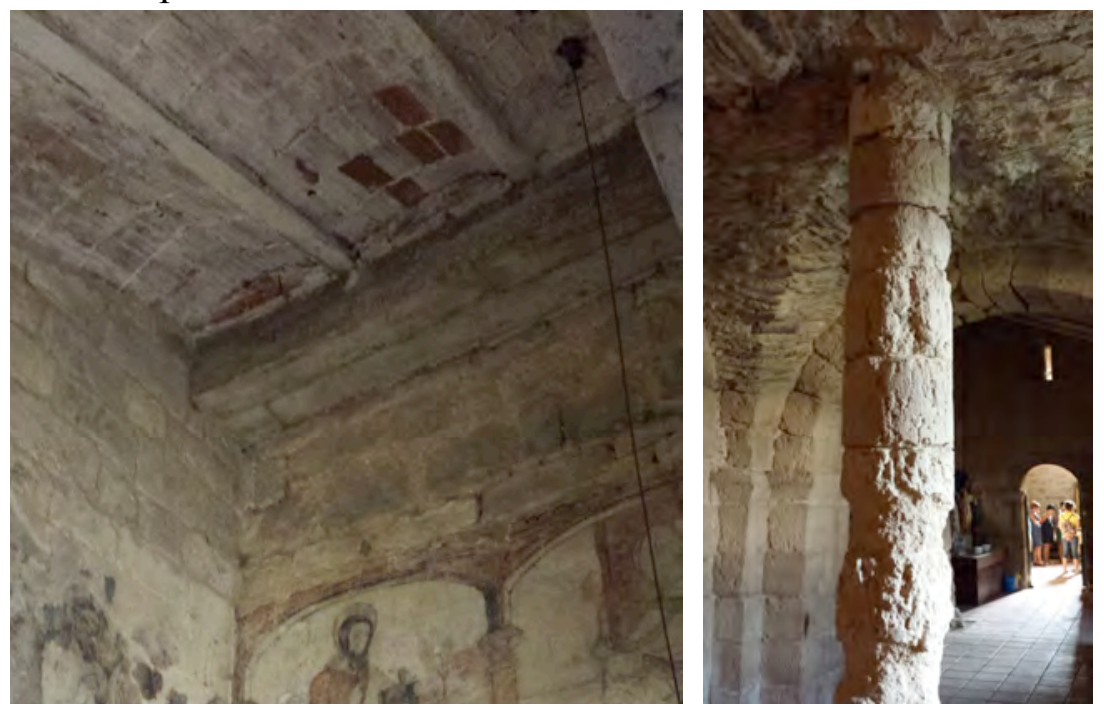
En la desembocadura del corredor se abre una compuerta para acceder a la cubierta sobre la nave de la epístola, junto a la torre. En ese punto se aprecia como, tras el durmiente de madera, discurre un elemento de hormigón en el que asoman una barra longitudinal inferior central cosida con estribos, por lo que podemos considerar que es muy probable que se trate de un zuncho corrido sobre la coronación de los muros incorporado por Arenillas cuando reconstruye las cubiertas entre 1962 y 1964.
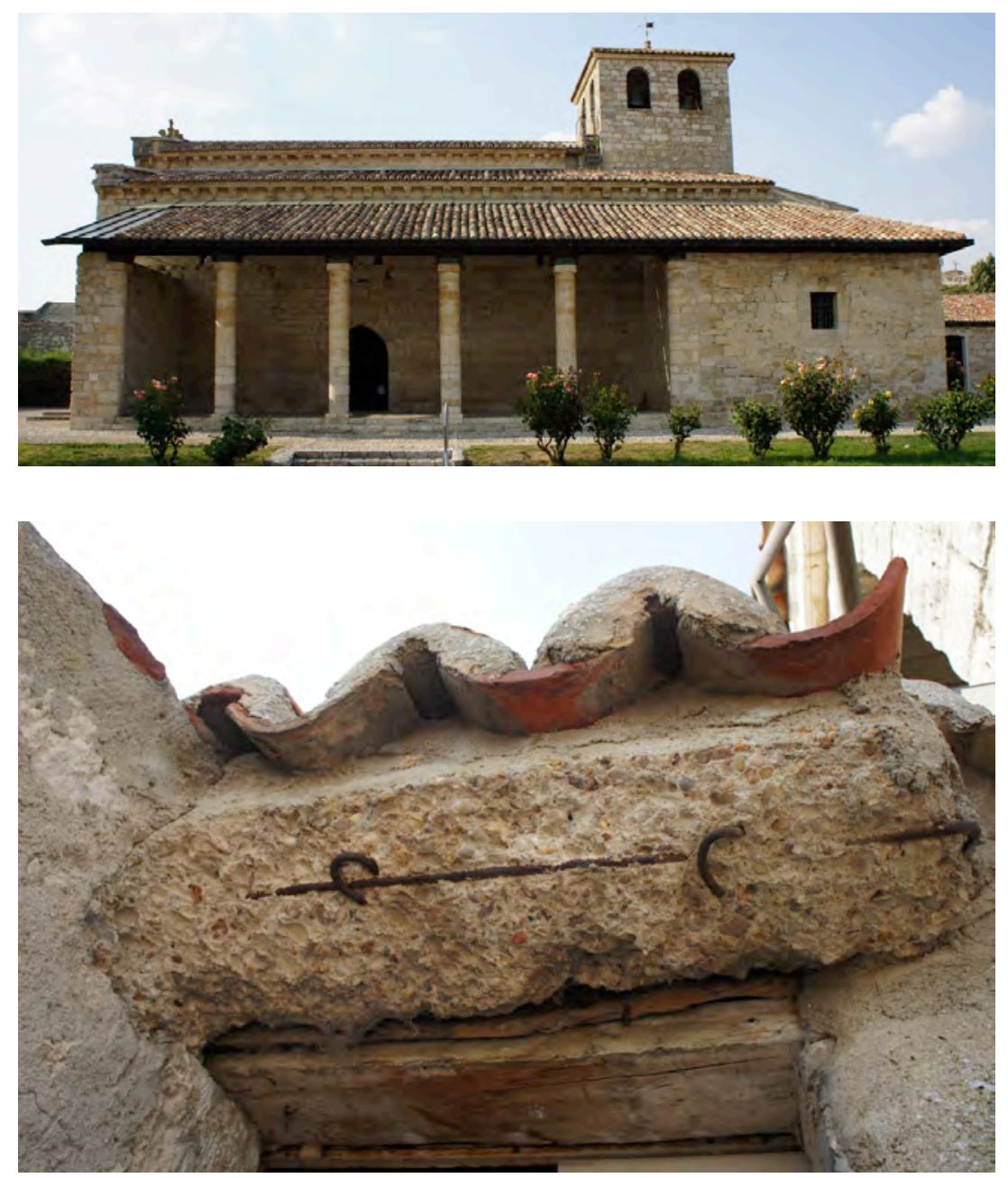


\section{Iglesia de San Pedro}

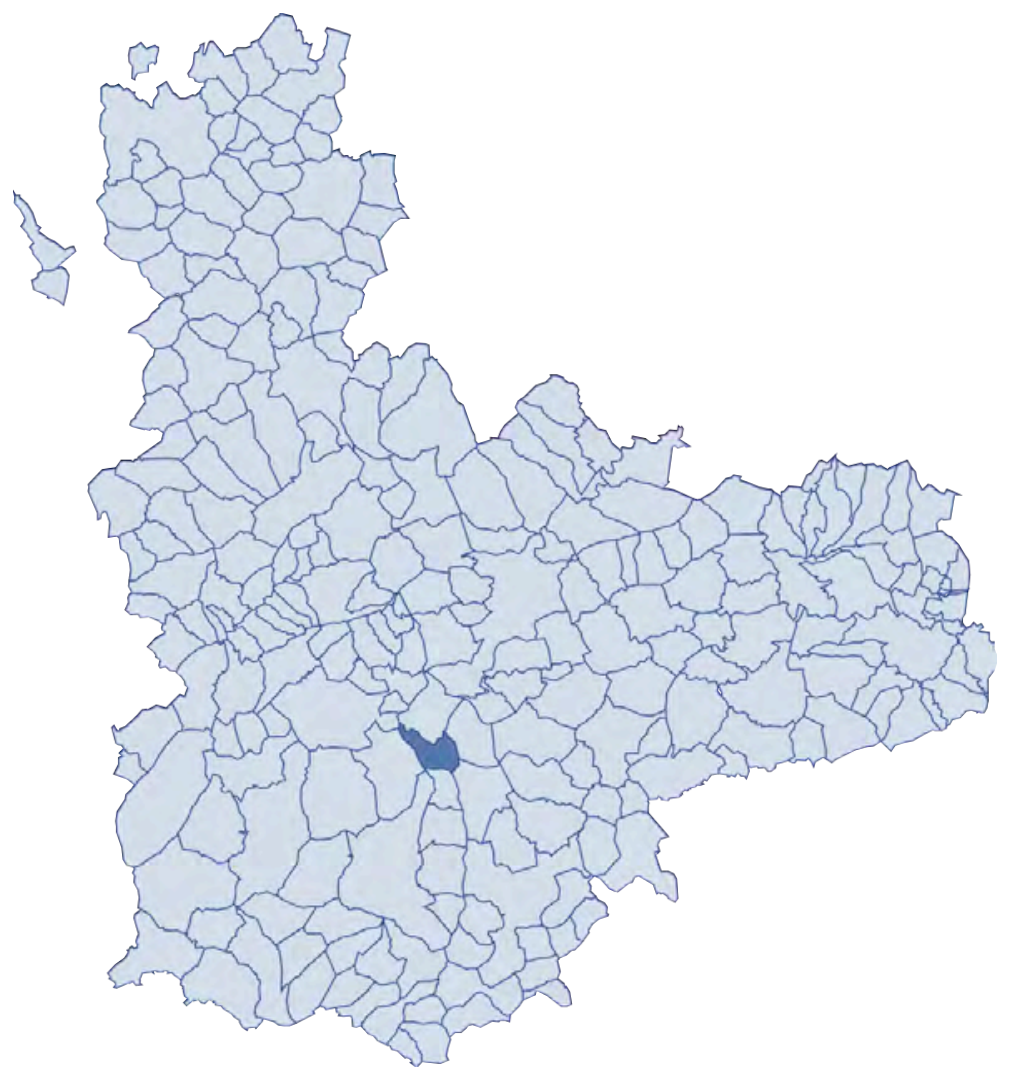



FICHA SÍNTESIS

Código de identificación: FZ-40

Denominación:

Iglesia de San Pedro

Localidad:

Serrada

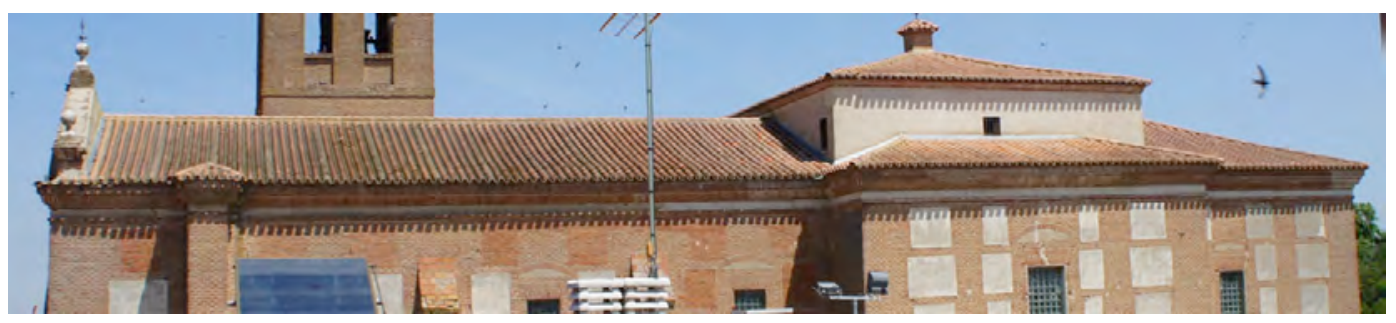

\section{Descripción}

Iglesia de una sola nave con contrafuertes y arco triunfal de medio punto. Se cubre con cuatro tramos de bóvedas de cañón, con lunetos sobre el cuerpo principal y la capilla mayor de cabecera plana. En el crucero se dispone una cúpula vaída sobre pechinas. La torre se ubica a los pies, adosada al muro norte junto a sacristía y dependencias auxiliares.

\section{Materiales}

Los muros de fachada son de ladrillo con entrepaños de tapial. La torre es de fábrica de ladrillo con un zócalo de sillería hasta $2,4 \mathrm{~m}$ de altura, muy superior a la del resto del templo. En los anejos laterales se arranca la fábrica de ladrillo desde el terreno. Las cubiertas se revisten con teja curva.

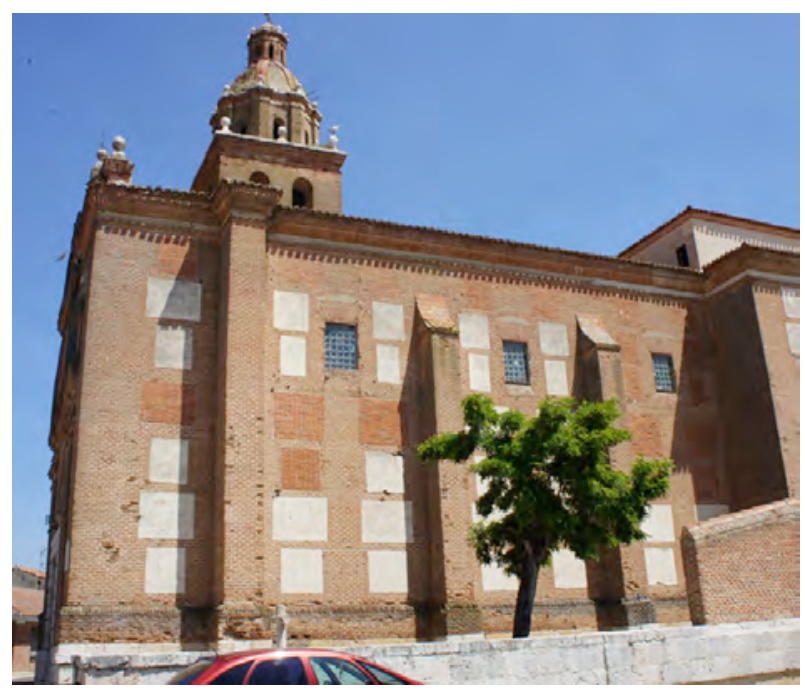

Ilustración 1: fachada epístola, visita 16/05/2014

\section{Singularidades}

Según los anejos del Catálogo, el edificio se reedifica en varias ocasiones. La cubierta sufre hundimientos y las fábricas se agrietan. Encontramos descritos problemas de incumplimiento de condiciones como las dimensiones de estribos de cuatro pies de la torre diseñadas con nueve y medio en diversos pleitos. En los 
informes también se resalta la malísima calidad del ladrillo y cómo se elaboró los morteros con insuficiente proporción de cal.

Dimensiones básicas del templo ( 80 x 32 pies; 30 pies altura de cornisa)

central laterales capillas

Ancho de nave $\quad 10,2$

Altura $\quad 12,3$

* Los muros enrasan a cara exterior y disminuyen su sección hacia el interior desde la altura de arranque del arco.

\section{Memoria histórica constructiva}

El monumento sufre numerosas reedificaciones $\mathrm{y}$ conflictos legales por incumplimiento de las condiciones dadas, mala calidad de la ejecución y de los materiales.

Los libros de fábrica comienzan en 1639 (catálogo) y muestran que aunque el tejado de la iglesia se repara entonces, de nuevo se está hundiendo hacia 1645. El maestro de obras Antonio Cillero reforma en 1654 la capilla mayor, a pesar de que ya había sido reparada cuatro años antes. Ejecuta la media naranja y, poco después, la cubierta de la nave. El maestro de obras Tomás Alonso repara el tejado de la capilla mayor, por estar hundiéndose, y socalza los muros, en 1683.

En 1723 se acomete una reforma integral, según trazas y condiciones del arquitecto Matías Machuca. La obra es ejecutada por el maestro Andrés Cillero hasta $1725 \mathrm{y}$, tras la intervención de otros maestros y diversos pleitos, la remata el propio Machuca.

En 1772 vuelve a acometerse una reforma integral, que se interrumpe por la mala calidad de los materiales y disconformidad con la traza. Llega a demolerse la parte de torre ejecutada y no se concluyen las obras hasta 1799. En 1887 rehace el tejado el arquitecto Teodosio Torres.

\section{Cronología. Fechas clave}

$1639-1723-1772-1877-1992$ 


\section{Intervenciones}

1867 - Reparación de chapitel dañado por un rayo - Santiago Gutiérrez Zurro

1877 - Proyecto de armadura y cubierta y reparación de muros - Teodosio Torres

1992 - Restauración - Armando Areizaga Esteban y Juan Corral Fernández

\section{Incorporación de zuncho de hormigón armado}

En el momento de la intervención la cubierta del edificio se encuentra en un estado lamentable de falta de conservación. Hay zonas sin recubrimiento de teja, quiebros entre faldones sin impermeabilizar, la tablazón de ripia sufre pudrición generalizada. Hay instalados unos jabalcones para apear las cerchas que tienen sus cabezas podridas y que, según el técnico autor del proyecto, provocan el agrietamiento de las fachadas.

Se reemplaza la estructura de cubierta por una nueva, también de madera aserrada. Las uniones entre las piezas de las cerchas se refuerzan con platabandas, porque su montaje se realizó encolando con resorcina bajo condiciones atmosféricas adversas.

Según el proyecto se coloca dos tipos de zuncho de hormigón armado:

$25 \times 40$ para rigidizar a la altura de los arcos torales la traba de los muros demolidos que se vuelven a levantar sobre los mismos

50x45 zuncho perimetral a la altura de las cornisas para consolidarlas, redistribuir las cargas transmitidas por las cerchas y aumentar la carga en cabeza para aplomar el muro

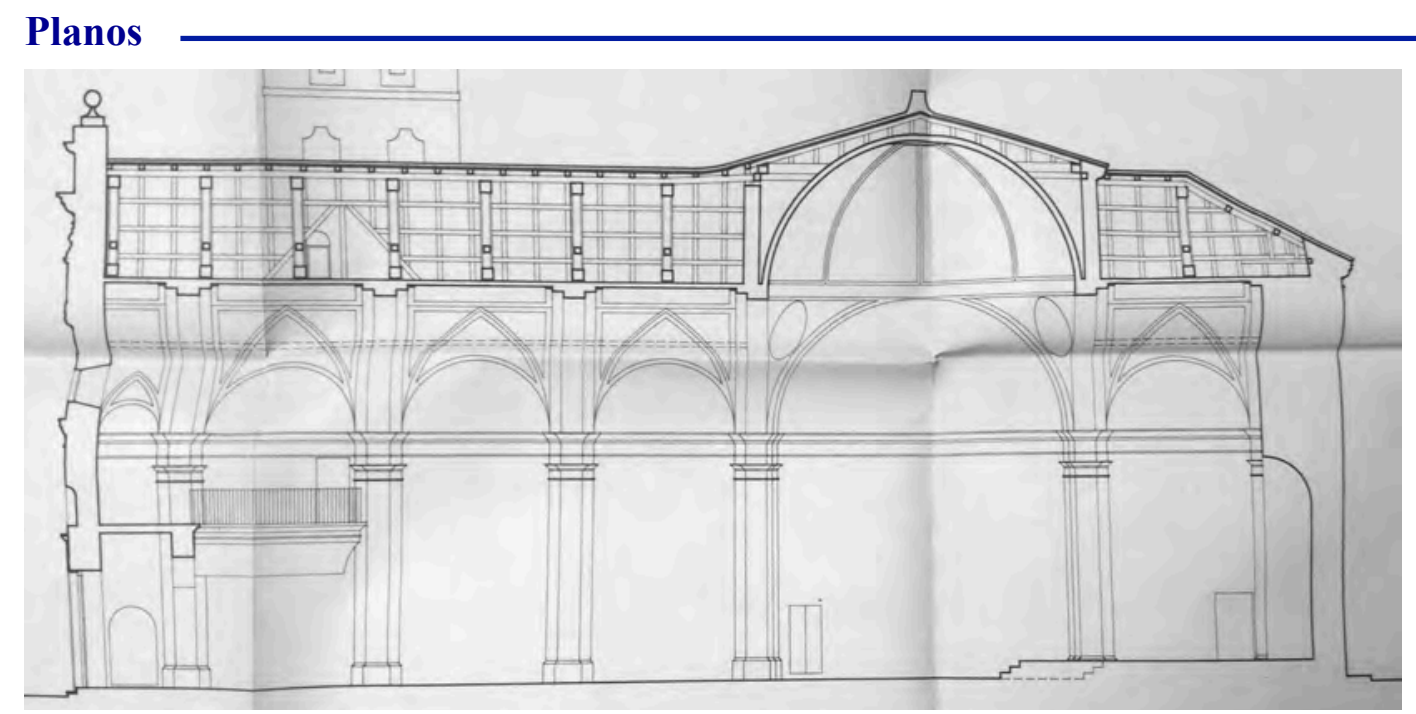

Ilustración 2: sección longitudinal (Areizaga y Correa 1992 JCyL) 


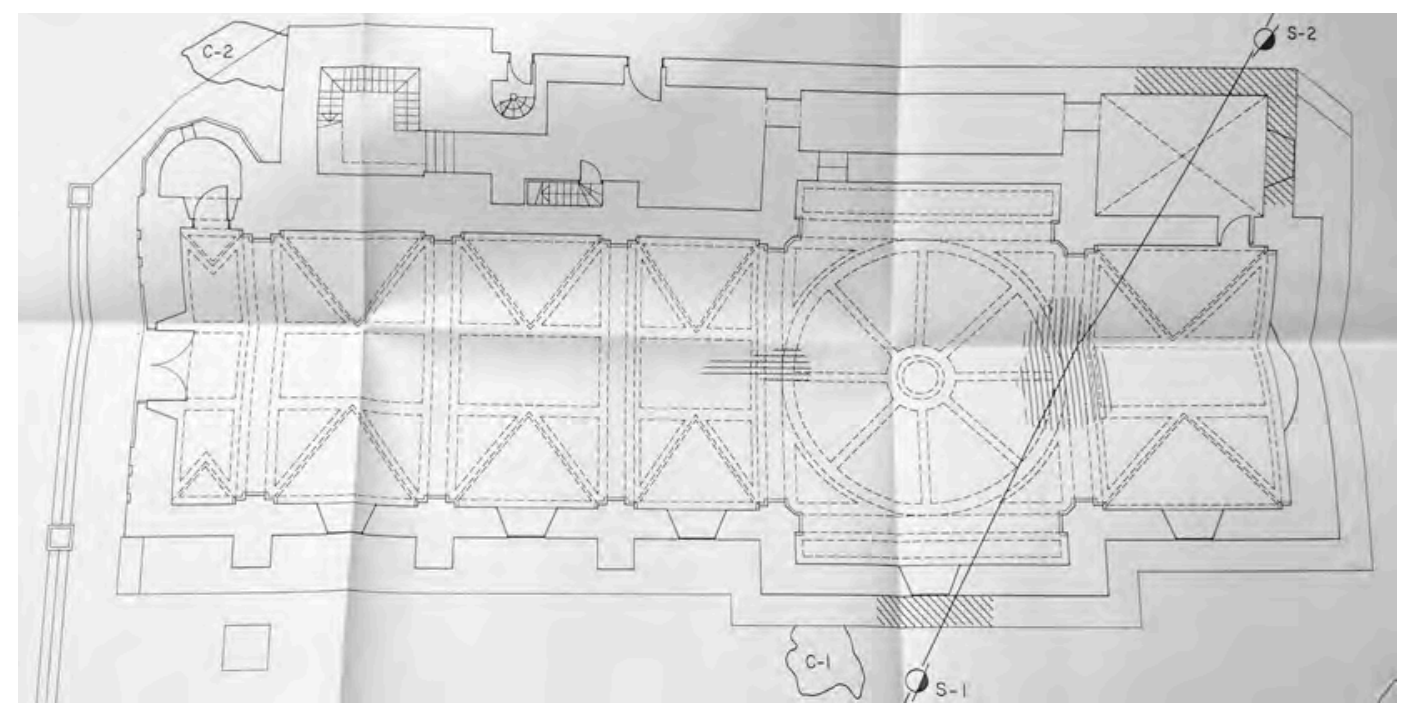

Ilustración 3: planta baja (Areizaga y Correa 1992 JCyL)

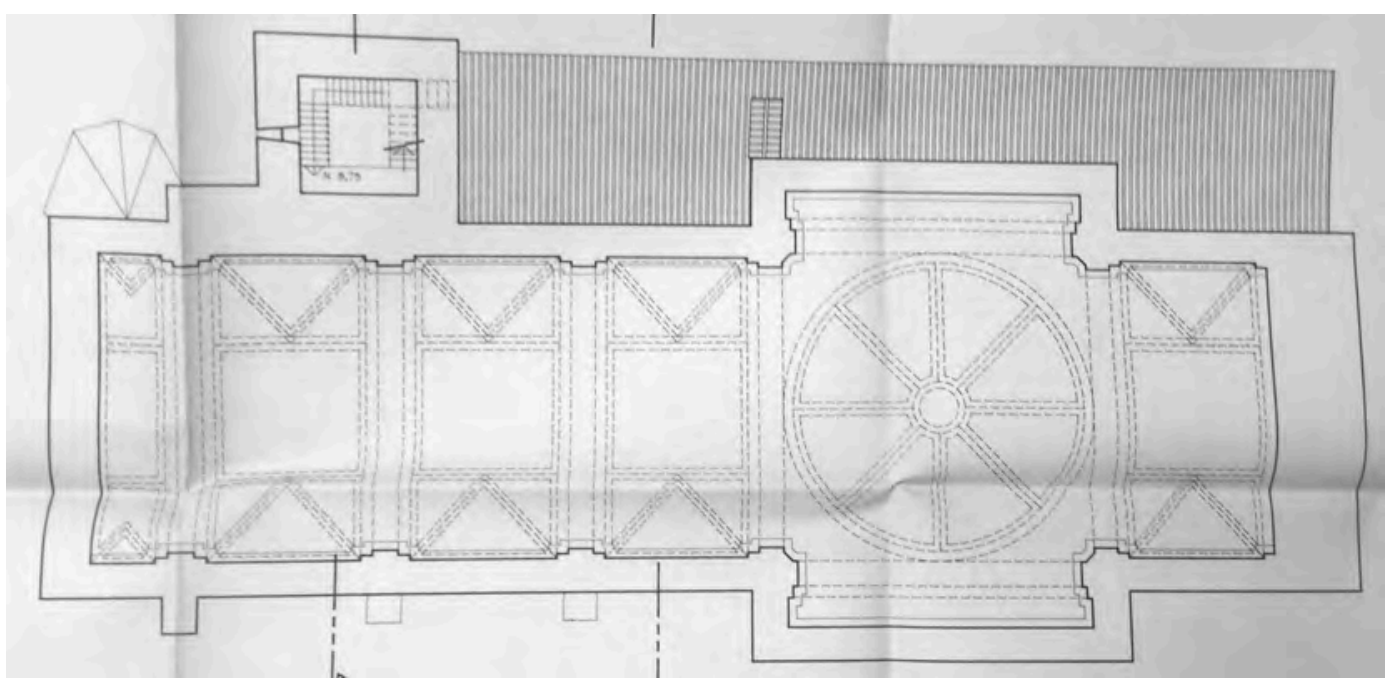

Ilustración 4: planta de bóvedas (Areizaga y Corral 1992 JCyL)

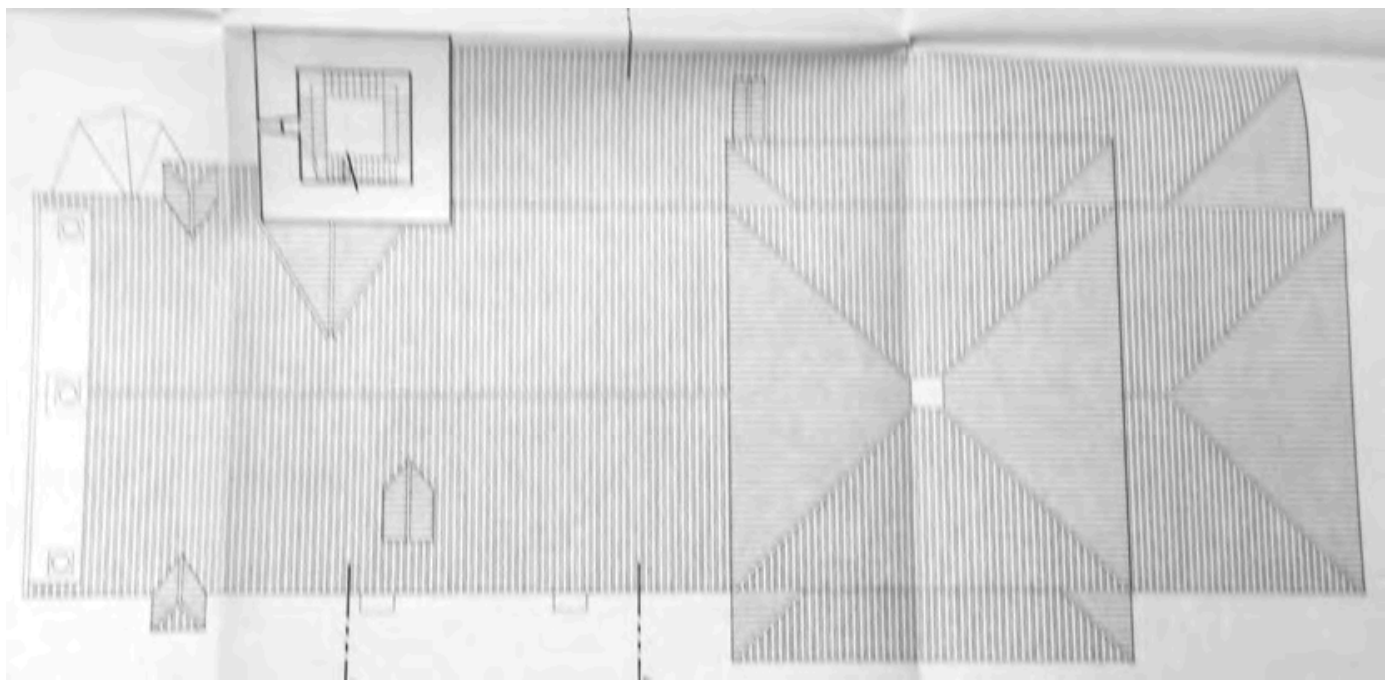

Ilustración 5: planta de cubiertas (Areizaga y Corral 1992 JCyL) 


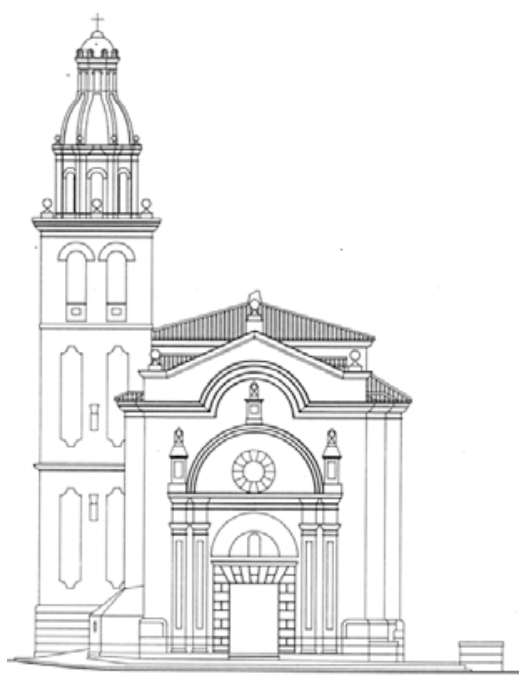

ALZADO DE LA PORTADA

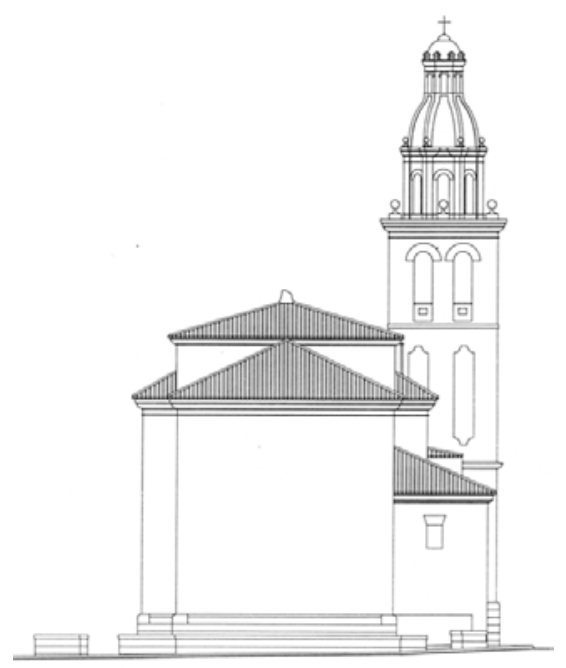

ALZADO DE LA CABECERA

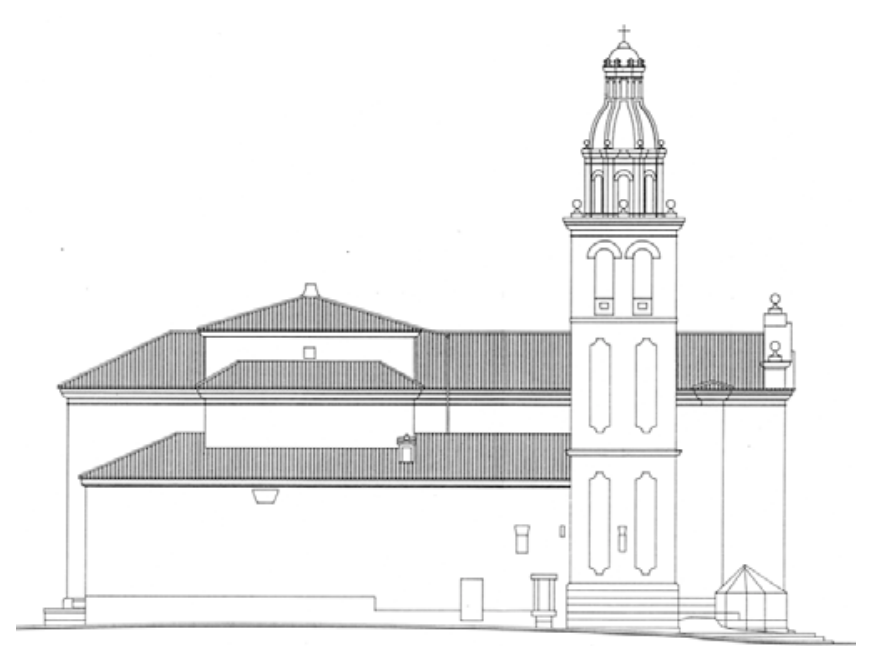

ALZADO DEL EVANGELIO

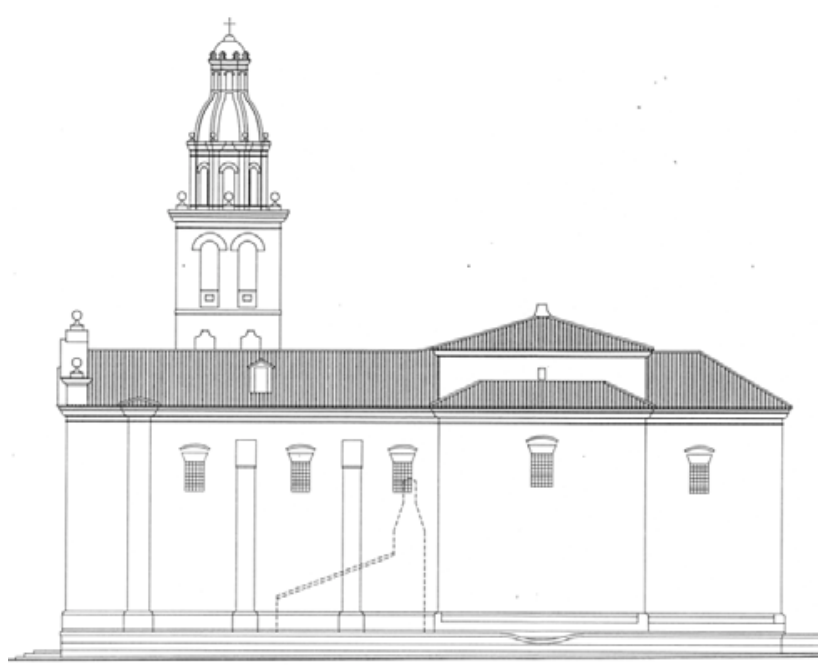

ALZADO DE LA EPISTOLA 

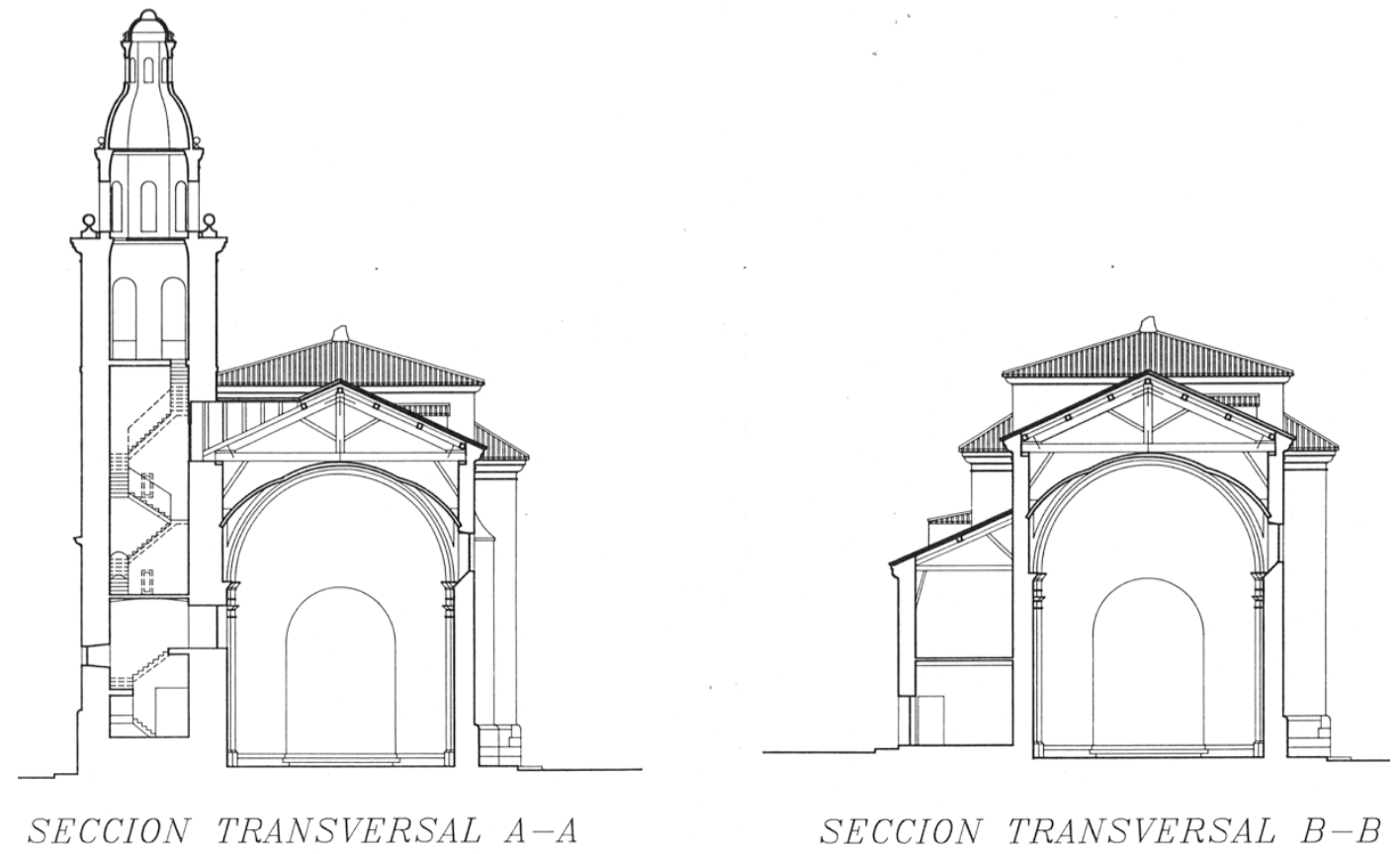

Ilustración 6: secciones de estado antes de la obra (Areizaga y Corral 1992 JCyL)
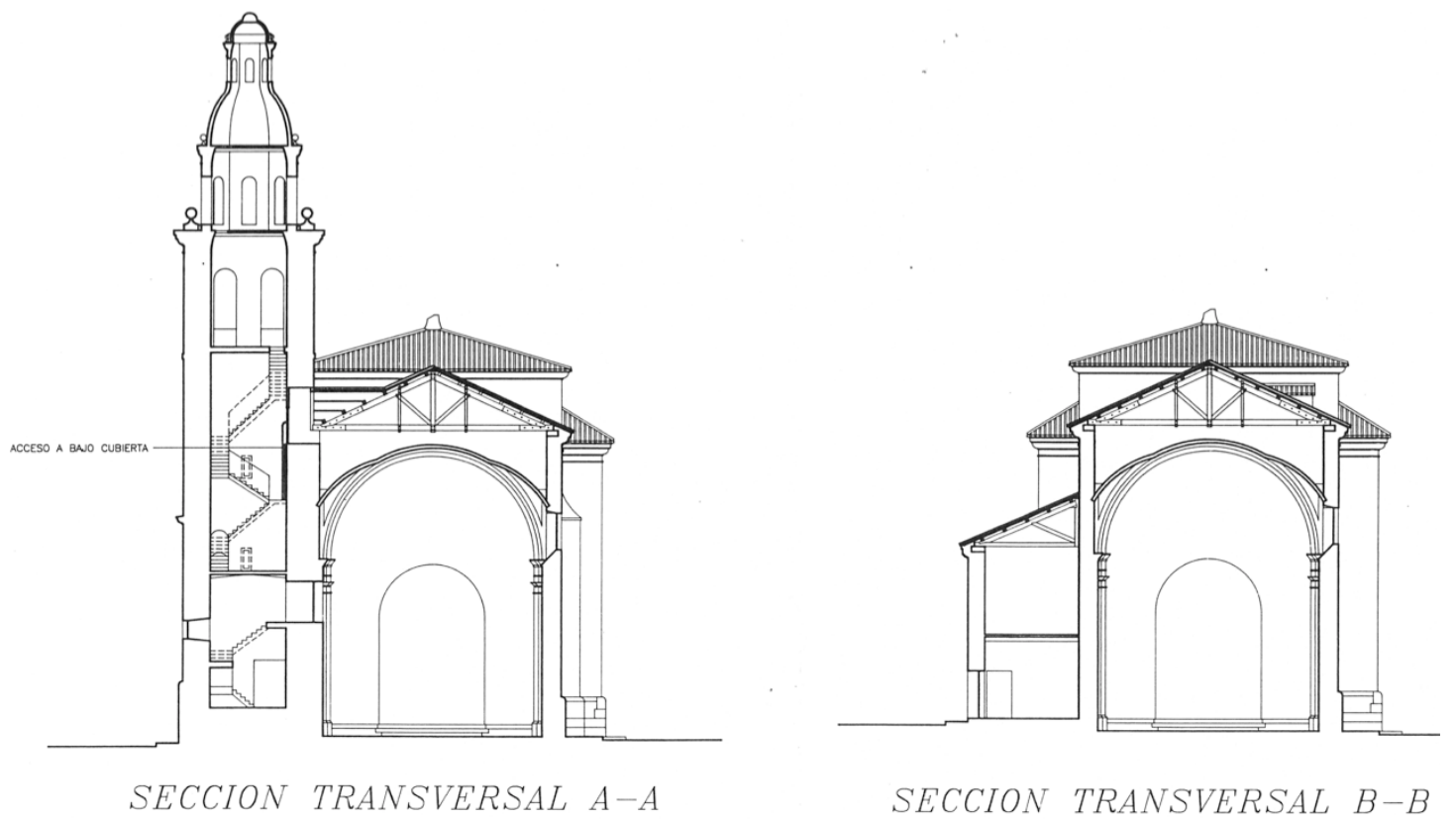

Ilustración 7: secciones estado final (Areizaga y Corral 1992 JCyL) 


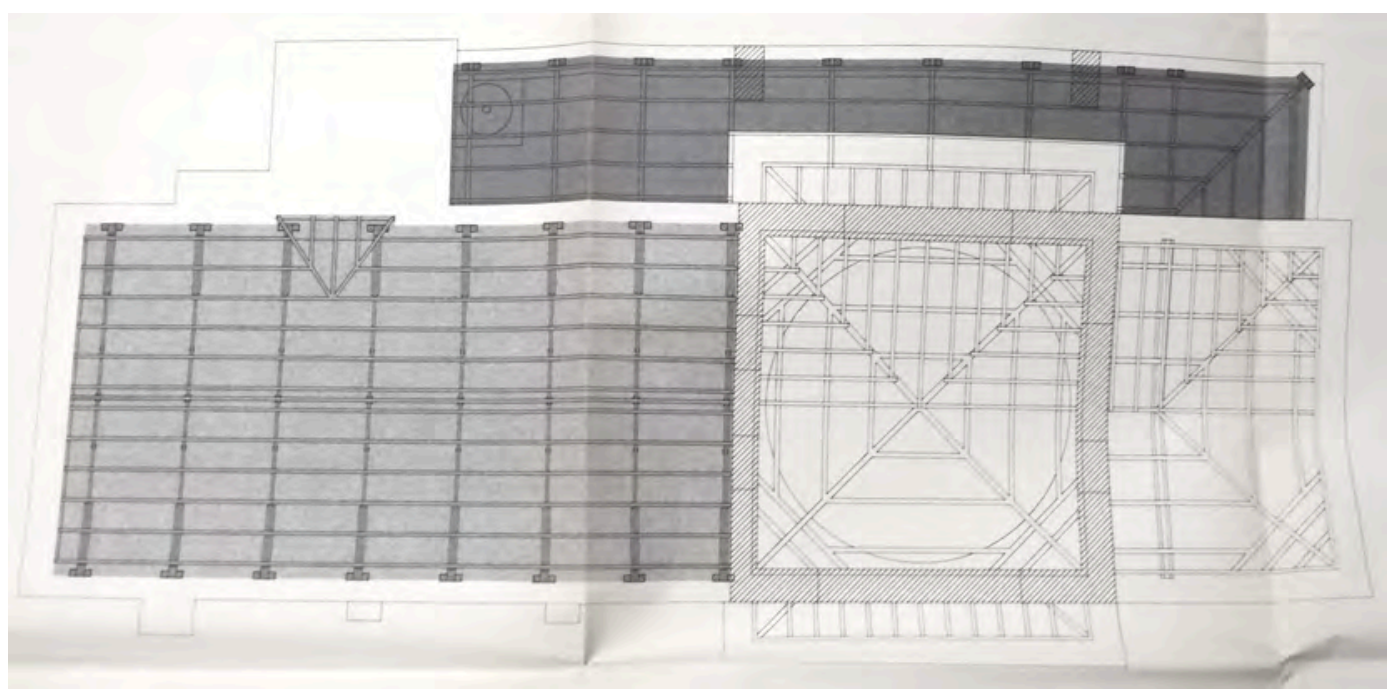

Ilustración 8: planta estructura de cubierta (Areizaga y Corral 1992 JCyL)

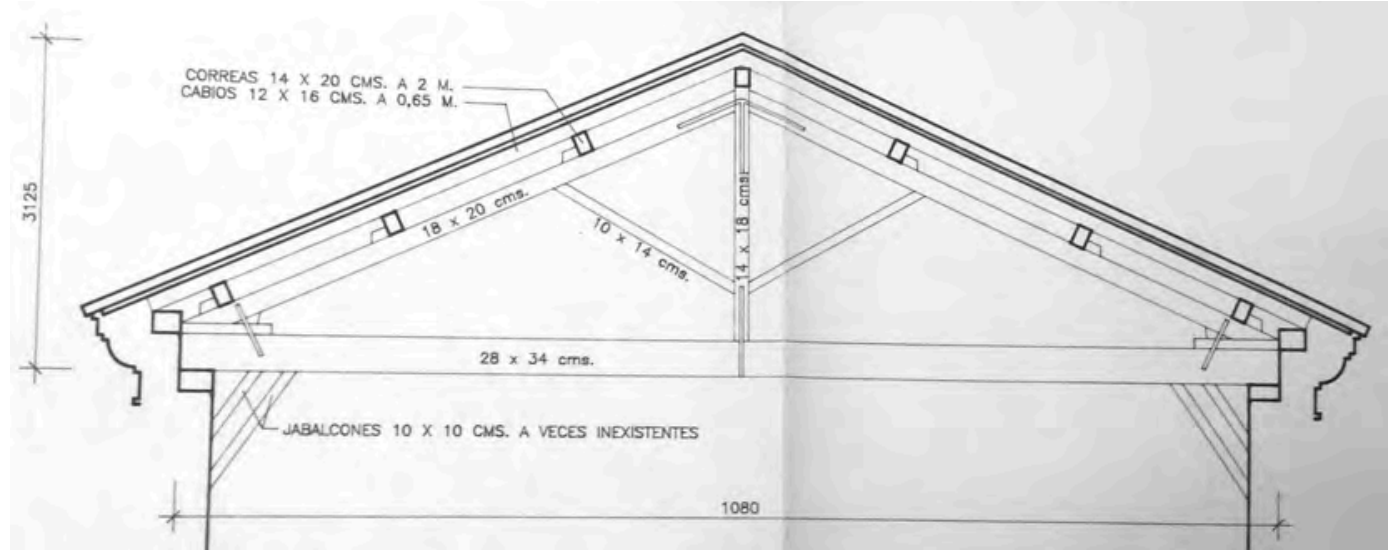

Ilustración 9: sección de la cubierta antes de la obra (Areizaga y Corral 1992 JCyL)

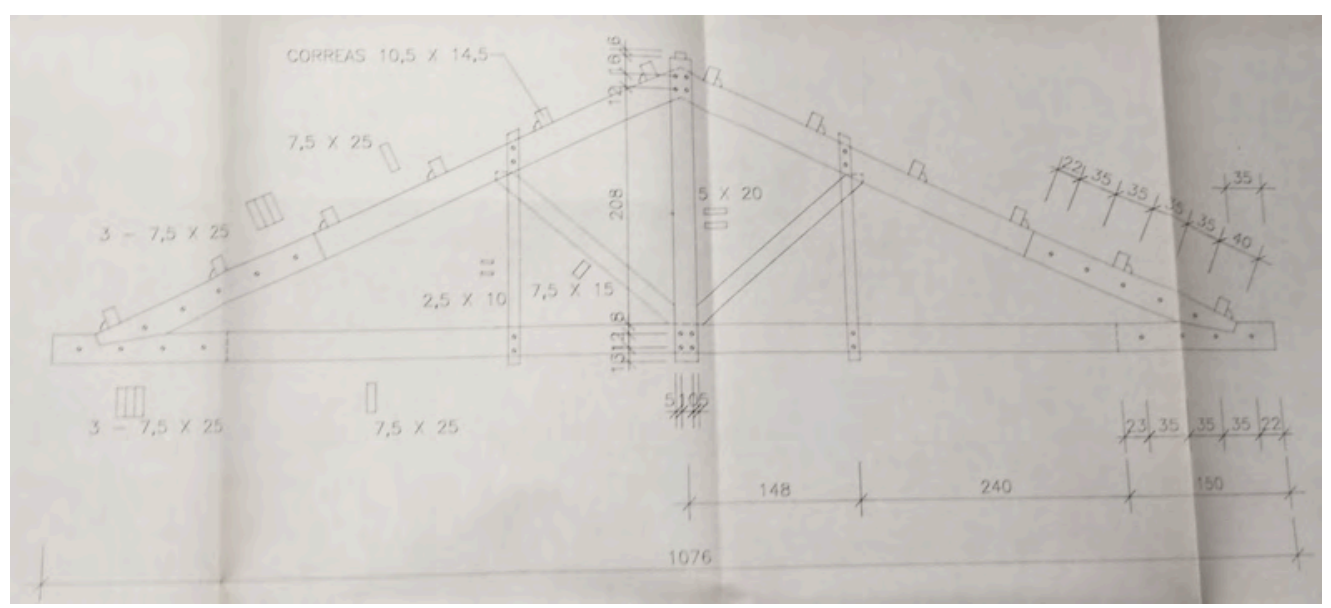

Ilustración 10: cerchas nuevas de madera (Areizaga y Corral 1992 JCyL) 


\section{Solución constructiva de la cubierta}

En las secciones del proyecto podemos medir una pendiente de unos $24^{\circ}$ sobre detalles del plano, aunque en las condiciones del siglo XVIII se definió como patrón para la misma el cartabón de 6 , que supone $30^{\circ}$ de inclinación.

Condiciones dadas por Bernabé Domínguez que se reproducen en 1775 en un Pleito contra el mismo según transcripción del Catálogo pag.437:

" $21^{\mathrm{a}}$ - Yten es condizion que enrasadas que sean dhas paredes se sentaran nudillos a nibel y encima soleras de terzia hachadas para formar su armadura la que se hara sujeta al cartabon de a seis su favrica estrivada paralela en la que se pondran tirantes de pie y quarto de grueso y de treinta y nuebe pies de largo con cajas bien axustdas en estribos y soleras clavadas con clavijas de a media bara de largas con cavezas de bellote y los pares de la armadura seran de terzias y quartas de a veinte y tres pies de largas axavalconadas con su oreja y clavadas con clavos trabajaderos de bellote y se pondran de quatro en trama de sobradiles de a diez pies de largo con los que se entablara dha armadura y se clavara con clavos de medios imprentones y llevaran cada uno quatro.

$22^{\mathrm{a}}$ - Yten es condizion que en todas las paredes y a nivel se pondran cornisas de quarto bozel de ladrillo con dos filetes, uno avajo y otro arriva y las cornisas han de ser de quarta de ancha y media bara de ancha con dos dedos y medio de grueso y hecha la armadura y sentadas las cornisas se texara su texado a texa doble techando cavalletes y bocas canales de cal y todo el resto del texado de varro bien sentadas y encascotadas y despaldadas con el mismo varro".

En 1992 se reemplaza la clásica cercha cuchillo español simple de pendolón y dos tornapuntas por una con pendolón, dos tornapuntas y dos montantes o péndolas.

\section{Zunchos}

Al reemplazar la armadura de cubierta por una nueva estructura de madera, en 1992, se reconstruye el encuentro faldón - muro, definido mediante el detalle siguiente: 


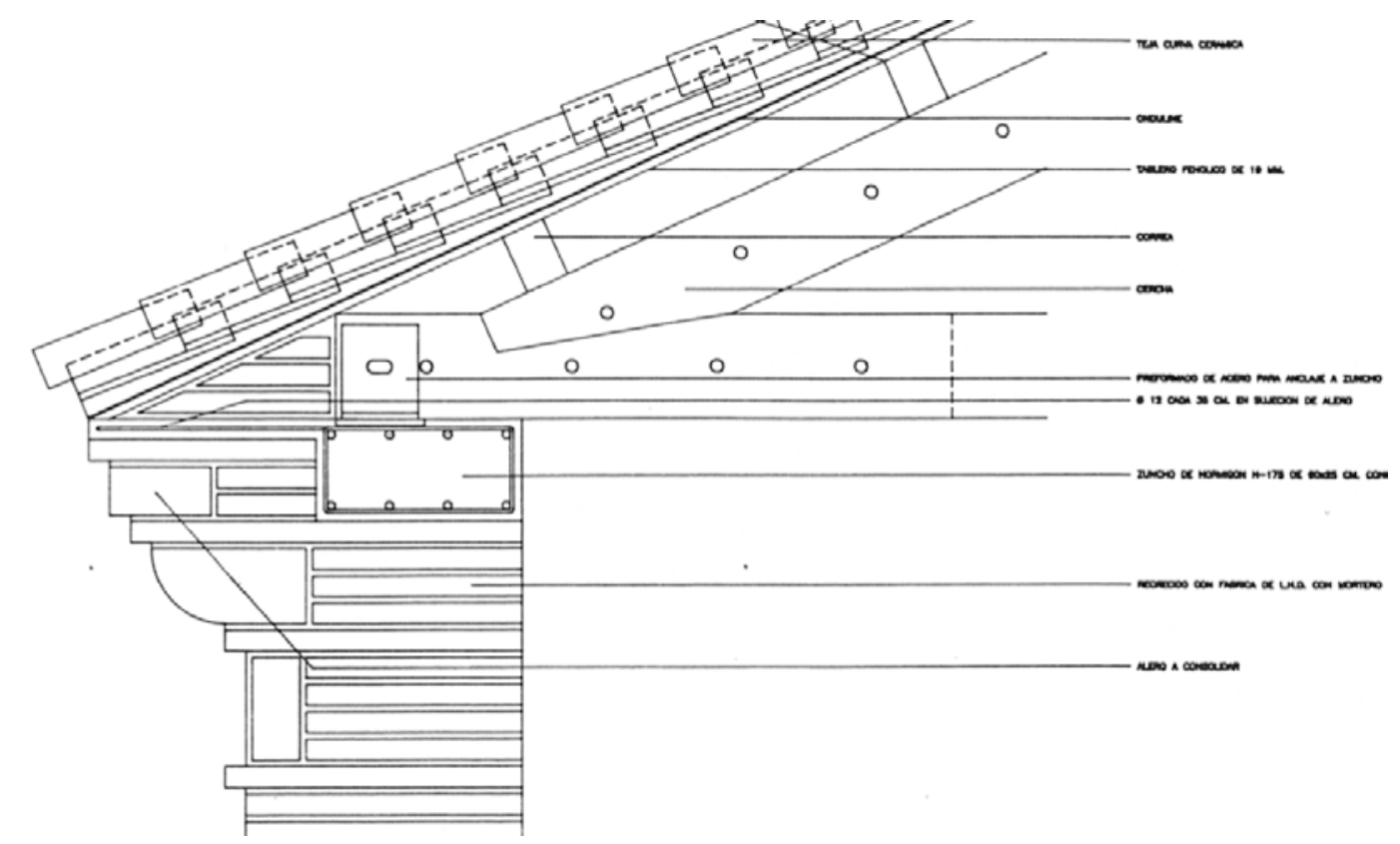

Ilustración 11: detalle cornisa (Areizaga y Corral 1992 JCyL)

En la leyenda se desglosa: teja curva cerámica, onduline, tablero fenólico de $19 \mathrm{~mm}$, correa, cercha, preformado de acero para anclaje a zuncho, D12 cada $35 \mathrm{~cm}$ en sujeción de alero, zuncho de hormigón H-175 de 60x25cm con 8D12 y cercos de D8 cada $10 \mathrm{~cm}$, recrecido con fábrica de LHD con mortero de cemento M-40A, alero a consolidar.

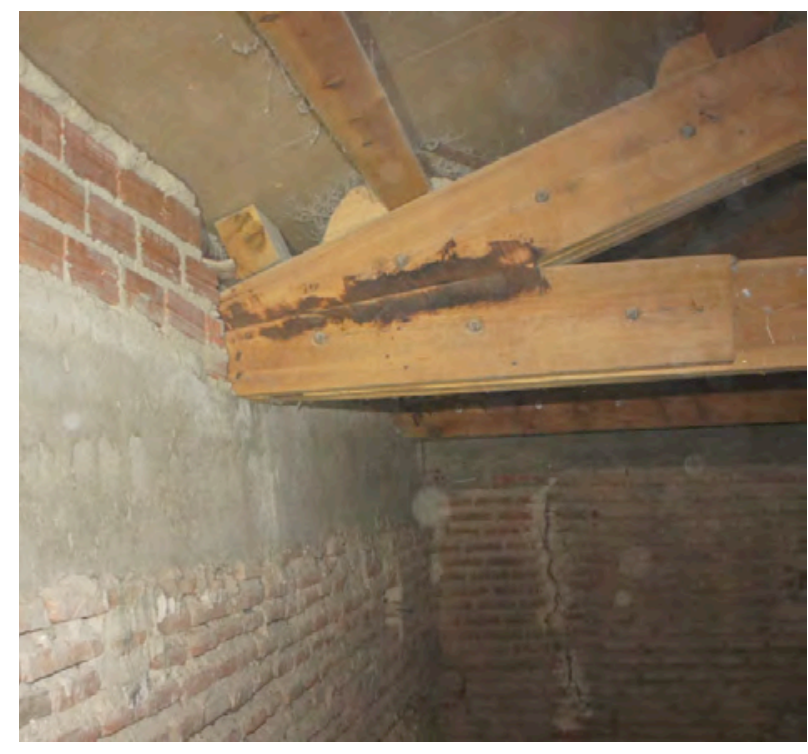

Ilustración 12: visita 16/05/2014
En la visita se ha comprobado que el canto del zuncho es de al menos $40 \mathrm{~cm}$, por lo que el citado detalle de planos de proyecto no se corresponde con lo realmente ejecutado. Sobre este zuncho se dispone, además, un cerramiento de ladrillo hueco doble hasta el entablado que no permite apreciar el estado de las cabezas de los tirantes en el apoyo, que debería contar con holgura para permitir ventilar y evitar los habituales procesos de pudrición. 
Según las certificaciones oficiales que se custodian en el archivo de la Junta (Carpeta 5324, caja VA-131), el zuncho se abona con las dimensiones 110,8 x 0,50 x $0,45 \mathrm{~m}$, más en consonancia con las apreciadas durante la visita.

\section{Conclusiones}

En este edificio se incorporó en 1992 un zuncho de hormigón armado de unos 40cm de canto. El zuncho A discurre enrasado a cara interior, sobre los cerramientos de la nave y testeros del crucero, sin continuidad en el muro a los pies. No se ha comprobado su existencia en la cabecera.

Según la Memoria del proyecto se trata de un zuncho perimetral con doble función: redistribuir uniformemente las cargas transmitidas por las cerchas y aplomar los muros con su peso propio. Se describe otro zuncho B que no se aprecia a simple vista, éste de atado, sobre los arcos torales, ejecutado para rigidizar los cerramientos nuevos sobre los mismos.

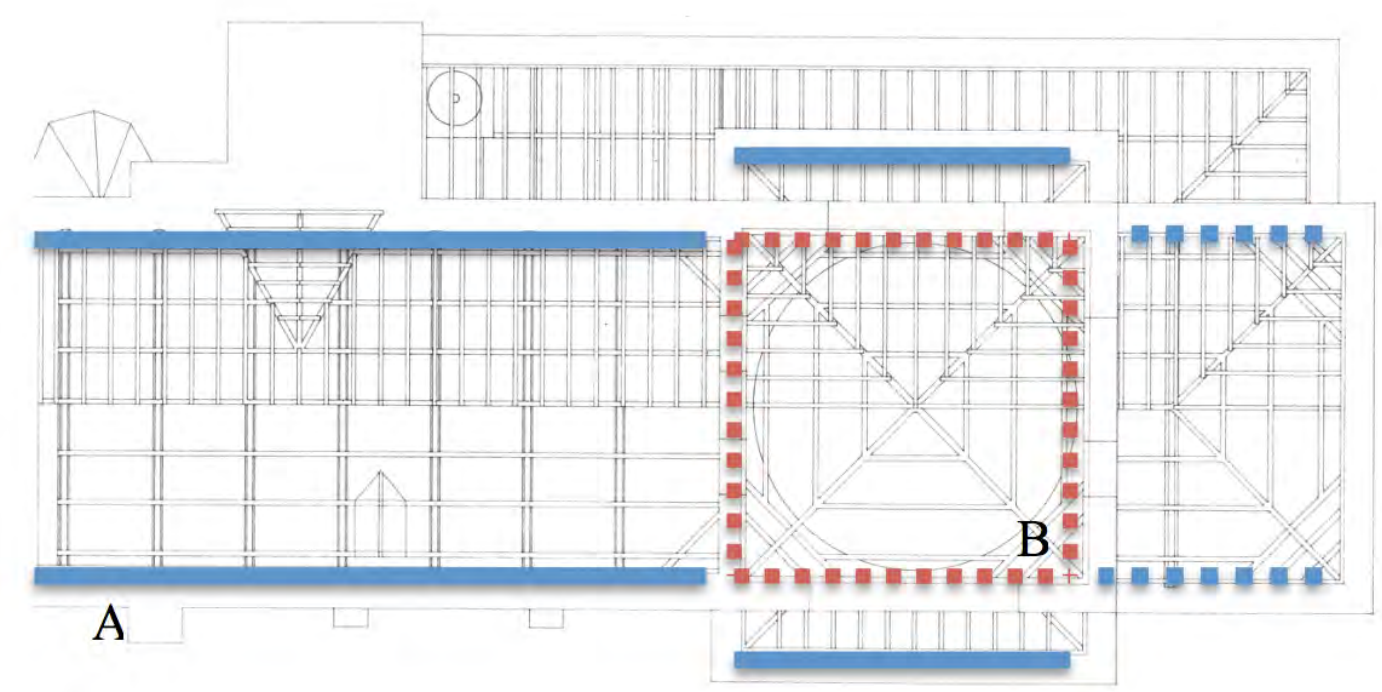

Ilustración 13: esquema de zunchos 


\section{Iglesia de San Pedro. Serrada}

La iglesia parroquial de San Pedro en Serrada no forma parte del conjunto de monumentos referenciados en la publicación del Ministerio, pero se ha incorporado a la muestra por contarse con facilidades para acceder a la misma.

\section{En el archivo de la Junta de Castilla y León}

\section{VA-131}

Carpeta 5324

Restauración de la iglesia de San Pedro en Serrada- Armando Areizaga Esteban y Juan Corral Fernández.

Documentación administrativa:

Contrato para la redacción del proyecto de restauración por la sociedad Areizaga y Corral SL.

\section{$\underline{\text { R-P1 Ficha de diagnóstico }}$}

Existe un frontón colindante con el cerramiento perimetral de piedra.

Baptisterio adosado a los pies de la torre en pésimo estado y sin relación con el resto de la iglesia.

No aparecen síntomas producidos por mala estanquidad en suelos ni en cerramientos verticales.

Huecos sin cerramiento de ningún tipo en torre.

Nula estanquidad en cubiertas.

Ausencia generalizada de cubrición de teja estable.

Pudrición de toda la tablazón de ripia.

Encuentros de faldones sin solución constructiva adecuada.

estado de deterioro generalizado de bajantes y canalones colocados con posterioridad.

No existen síntomas de asentamientos achacables a la capacidad portante del suelo. Un estudio geotécnico somero puede confirmar la existencia o no de bodegas subterráneas.

Los entrepaños de tapial sufren de manera más acusada los movimientos generales de los muros de cerramiento en su función estructural.

El tercio inferior de la fachada del evangelio ha sido enfoscado para tapar el posible deterioro de las fábricas de ladrillo.

Deterioro generalizado de las cornisas. 
Desplazamiento horizontal de los muros de carga y cerramiento en su tercio superior, debido a la existencia de jabalcones en la cercha de madera de la cubierta que, modificando la reacción vertical de la carga de la misma y tras la pudrición de las cabezas de apoyo, producen la patología más generalizada y llamativa, grietas en arcos y bóvedas, etc.

Yesos muy deteriorados y afectados por los esfuerzos de compresión de las fibras superiores de arcos y bóvedas provocados por la circunstancia anterior.

Pintura general sin reposición.

Los accesos a la torre y su situación general a partir del segundo cuerpo son lamentables y aunque no parece correr un peligro de pérdida de estabilidad sí son posibles desprendimientos puntuales de material sumamente peligrosos por su altura. La reciente colocación de piezas de pavés coloreado en sustitución de posibles vidrieras es atentatoria contra cualquier concepción del gusto.
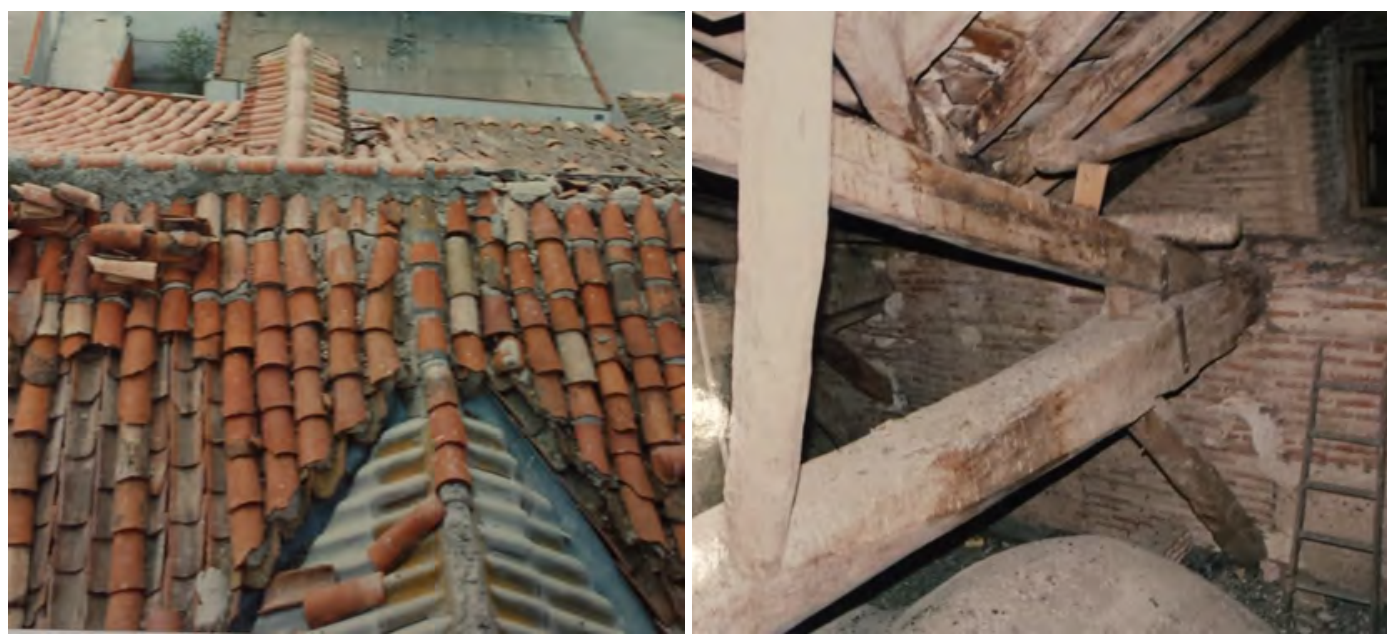

Ilustración 14: dossier Areizaga y Corral JCyL

\section{R-P4 Propuesta de intervención}

Desmontaje de toda la estructura de cubiertas, incluyendo muros de formación de la del crucero.

Consolidación y reposición de la estructura de cubierta.

Consolidación arcos torales de la cúpula del crucero.

Cosido de grieta en muro de la epístola del crucero.

Reposición general de la cubierta.

Reparación, consolidación y reposición último cuerpo de la torre.

Reparación, consolidación y reposición de cornisas.

En esta carpeta podemos encontrar copia de la Supervisión del proyecto realizada en el servicio, según la cual éste consiste en:

1. Arreglo de cubiertas en general con recuperación de teja 
2. Desmontaje de cerchas en cuatro tramos

3. Nueva estructura de madera

4. Zuncho de atado

5. Picado de fábricas en cornisa y reposición con ladrillo tejar

6. Refuerzo con cáscara de hormigón en cúpula

Acta de recepción definitiva de las obras de fecha 29 de marzo de 1993.

La adjudicación se produjo en junio del 93 a la empresa ERCOSA SA, bajo dirección del arquitecto Armando Areizaga y supervisión de Francisco P Roldán Morales.

Certificaciones de obra:

m2 desmontaje de armaduras (cuchillos, correas, cabios y tablazón)

$15 \times 21,15 \times 7,15 \times 11,36 \times 4$ y 2 de $2 \times 11$

$\mathrm{m} 3$ descarnado de muro de fábrica macizo para empotramiento de zuncho

en naves $110,80 \times 0,50 \times 0,50$

en crucero $47,20 \times 0,25 \times 0,50$

$\mathrm{m} 3$ demolición muro adobe

en crucero $32,0 \times 0,50 \times 3,00$

$\mathrm{m} 3$ demolición ladrillo

$16,00 \times 0,80 \times 3,00$

$\mathrm{m} 2$ picado revestimiento

cúpula $3,50 \times 3,14 \times 5,00$

aleros $55,00 \times 0,50 \times 1,00$

m2 fábrica de un pie de ladrillo hueco doble $9 \mathrm{~cm}$ y verdugada de ladrillo macizo cada cinco hiladas

en crucero $42,00 \times 3,00 ; 26,00 \times 3,00$

naves $91,00 \times 0,50$

$\mathrm{m} 2$ encofrado de pino en zunchos para revestir

en naves $110,80 \times 0,45$

en crucero $47,20 \times 0,40$

m3 hormigón H-175 en zunchos

en naves $110,80 \times 0,50 \times 0,45$

en crucero $47,20 \times 0,25 \times 0,40$

m3 hormigón en losas o rosca de mortero de cal para consolidación de la bóveda del crucero a juicio de la DF

en cúpula $50 \times 3,14 \times 0,12$ 
$\mathrm{ml}$ formación de cornisa (reposición de la actual) con ladrillo aplantillado de tejar, en formato especial, recibido con mortero bastardo M40 (1:1:7) incluso sujección con alambre de acero galvanizado

en naves 150,00

en crucero 63,00

$\mathrm{m} 2$ reposición de paramentos mixtos de ladrillo aplantillado de tejar

en linterna 3,50 x $3,14 \times 5,00$

en aleros $105,00 \times 0,50 \times 1,00$

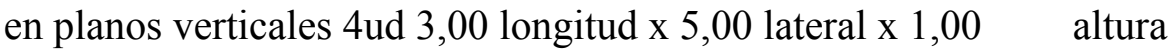

ud cercha de madera de pino Melis de $2^{\mathrm{a}}$ calidad 10,50

ud semicercha de madera de pino de recuperación 10,00

m2 consolidación de estructura de madera existente con reposición de pares, correas, viguetas, durmientes, cabios, etc... 15,00 x 12,00

$\mathrm{m} 2$ tablero fenólico $19 \mathrm{~mm}$, onduline y teja curva asentada sobre mortero de cemento M-20 (1:8) recibido cada cinco hiladas

$16 \times 21,16 \times 7,16 \times 11,2 \times 3 \times 11,36 \times 5$

Se reutiliza madera de la armadura para reparar la escalera de la torre.

\section{Memoria final}

Contiene fotos y copia A3 de los planos 7, 8, 9, 10, 14 y 15 .

El arquitecto explica cómo pidió tres meses de prórroga por lluvia y viento, ya que se paraliza temporalmente la obra por seguridad en septiembre y octubre.

Finalmente no se recupera tejas dado el mal estado general. Sí almacenan las correas no deterioradas.

No estaba previsto pero se desmontan todas las cerchas en presbiterio. También las de nave principal y lateral del evangelio.

La cubierta del crucero estaba apoyada en la clave de la cúpula. Demuele los muros del crucero para disminuir la carga sobre los arcos torales.

"Aprovechando los desmantelamientos descritos a la altura de los arcos torales, se ejecutó un zuncho de atado en hormigón armado que rigidizará la traba de los muros, distribuirá más uniformemente la carga e impedirá el agravamiento de las grietas existentes en las claves de dichos arcos.

De la misma manera se procedió a la demolición de las fábricas existentes a la altura de las cornisas, con el fin de proceder a la ejecución de un zuncho perimetral de hormigón armado que, mediante la armadura superior, consolide además las cornisas. Dicho zuncho perimetral tiene dos funciones fundamentales: redistribuir 
uniformemente las cargas que le trasladará la estructura y actuar como elemento de sobrecarga vertical que aplome los muros de cerramiento y corrija el desplazamiento horizontal al que han sido sometidos hasta el momento".

Se constituye una rosca doble de ladrillo sobre la cúpula para reforzarla e impedir el avance de la grieta.

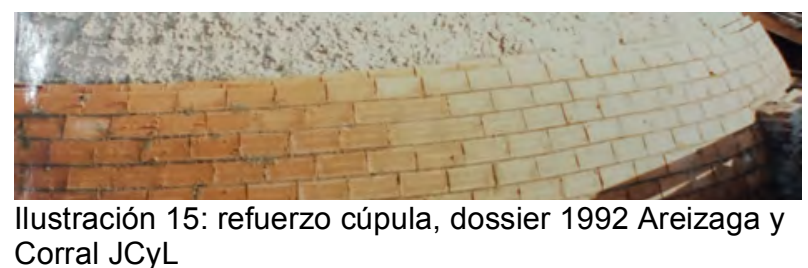

Nuevas cerchas, correas, tablero fenólico, onduline y teja árabe recibida cada cinco hiladas. Las cerchas se refuerzan con platabandas metálicas tras ejecutarse con malas condiciones ambientales las uniones con resorcina. Se reponen las cornisas con ladrillo de tejar. Se reemplaza la estructura de cubierta también en la cabecera.

\section{Estudio Geotécnico}

Realizado por la empresa GENOC SA constó de 2 sondeos a 9 y $11 \mathrm{~m}$ de profundidad, con 8 ensayos de penetración estándar y dos calicatas.

No se detecta nivel freático. Hay $1,1 \mathrm{~m}$ de rellenos antrópicos sobre arcillas arenosas firmes hasta $3 \mathrm{~m}$, arenas finas limpias compactas de 3 a $5 \mathrm{~m}$ y por debajo arcillas duras.

Proyecto

Contiene 15 planos de fecha diciembre de 1992.

"El geotécnico libera de responsabilidad, tanto a la cimentación como a la naturaleza del suelo, en la apertura de grietas existentes en la bóveda del crucero así como en el primer tercio del muro lateral que limita aquel por el lado de la epístola".

La iglesia de San Pedro se empezó a edificar en el último tercio del siglo XVII y fue emplazada en el mismo lugar que una anterior. Se enmarca en la tradición mudejar de toda la zona sur del Duero: cerramientos de ladrillo tomado con mortero de cal y arena y entrepaños de tapial en encuadramientos de diferentes dimensiones.

Una sola nave con tres tramos de idéntico tamaño, que coincide con el de la capilla mayor, cubiertos por bóveda de cañón. Sobre el crucero ligeramente ensanchado hay una cúpula. La decoración es barroca de yesos. La sacristía, sin basamento de piedra, se adosa a la cabecera. 
Datos de construcción recogidos en las Libros de cuentas de la misma iglesia:

Gran parte del templo se debe al maestro de obras de Tordesillas Andrés Cillero y su oficial mayor Agustín Pellón. Matías Machuca decora el presbiterio barroco, Carlos Verde se encarga de la porteda y Bernabé Dominguez levanta los últimos cuerpos de la torre en 1773.

El edificio se encuentra en un ángulo de la plaza. El baptisterio sin uso manifiesta un pésimo estado. En el muro de la epístola tres contrafuertes de los arcos de la nave, el primero como pilastra, se rematan en la línea de cornisa mientras que en los dos restantes se resuelve a un nivel más bajo. Las ventanas cuentan con dinteles de ladrillo incluso en el crucero.

La fachada del evangelio es similar pero sin huecos y de ejecución posterior, ya que se aprecia ausencia de traba de su fábrica con los muros perpendiculares del crucero. La estructura de cubrición es deficiente y falta el basamento de sillares de las demás fachadas. A los pies de la misma se alza la torre de tres cuerpos. Sus sillares de arranque alcanzan más altura que los del resto. La torre se remata con cúpula y linterna ochavada.

En el interior de la nave los tramos se enmarcan mediante pilastras, los arcos fajones surjen desde la cornisa y el crucero se cubre con una cúpula esférica.

El arquitecto describe cómo un zuncho $25 \times 40$ rigidiza la trabazón de los muros perimetrales del crucero a la altura de los arcos torales, distribuye más uniformemente la carga e impide el agravamiento de las grietas que se han producido en las claves de dichos arcos.

Otro zuncho de hormigón armado 50x25 sujeta además por la parte superior las cornisas existentes y las que ha sido necesario reponer. (Se cita en este documento con idénticas palabras las dos funciones fundamentales del mismo recogidas en la Memoria)

En el proyecto se define una rosca de hormigón armado con mallazo sobre la cúpula para reforzar y evitar el avance de la grieta que finalmente debió reemplazarse por la capa de ladrillo descrita en la Memoria final.

Se incluye en el proyecto una memoria de cálculo que en realidad es una transcripción del manual del profesor Argüelles con sus fórmulas pero sin incluir los datos de la estructura ni resolver operación alguna que justifique el dimensionado. 
Carpeta 322

Diagnóstico del grupo de monumentos: Valladolid IV.

Arquitecto: Pedro Carreño Aguado.

Iglesia barroca de una sola nave en ladrillo y tapial sobre zócalo de sillería. Planta alargada con volumen emergente en el crucero, testero plano y contrafuertes laterales. Capilla mayor y nave se cubren con bóveda de cañón con lunetos. En el crucero hay cúpula sobre pechinas.

En el momento de la visita de inspección el edificio se encontraba en obras. Se encuentra desmontada la cubierta de la nave hasta el crucero.

Se agrupan en un único plano de fecha 2/9/93 planta, alzados y secciones sobre las que se rotula las patologías detectadas.

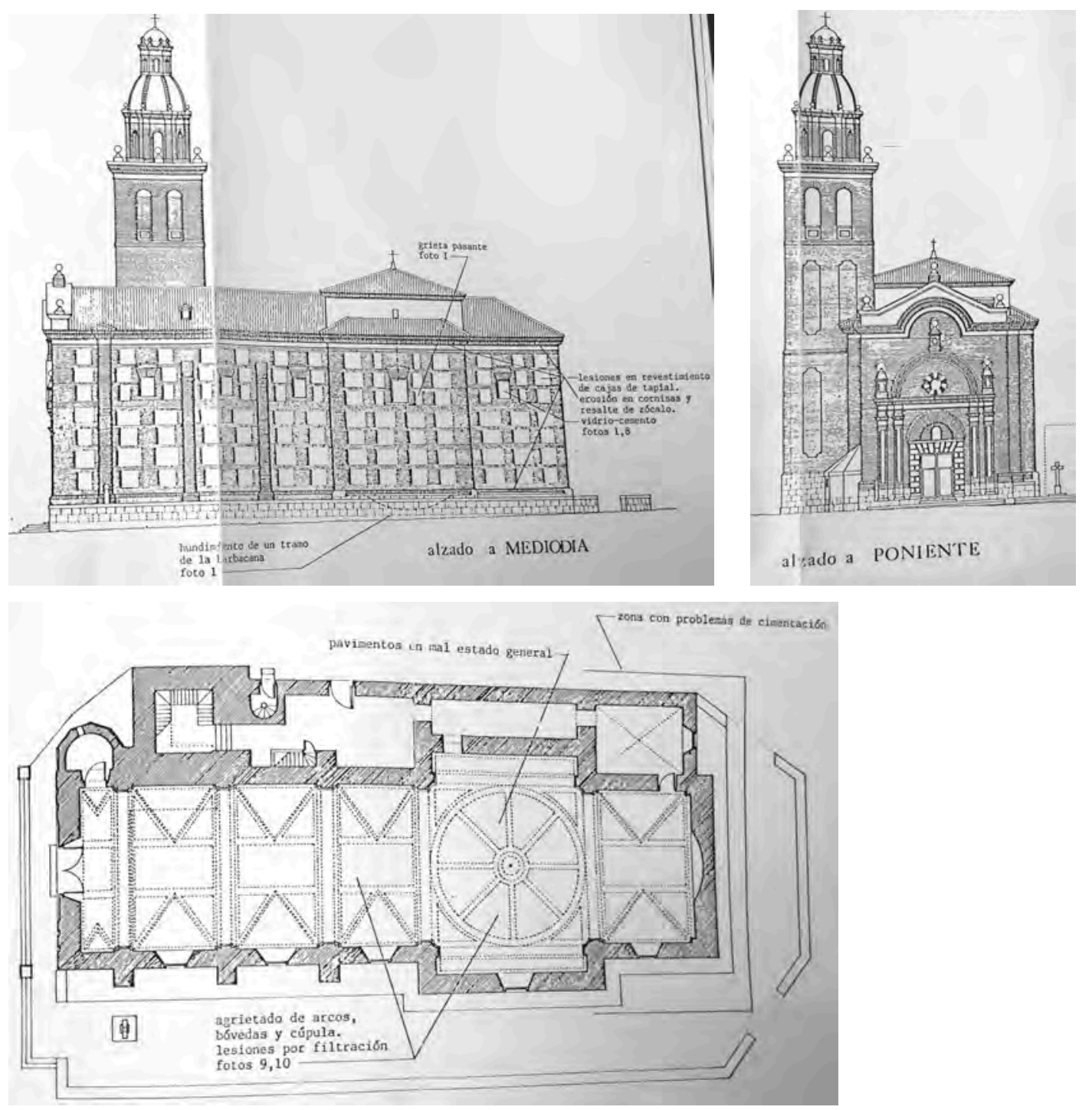



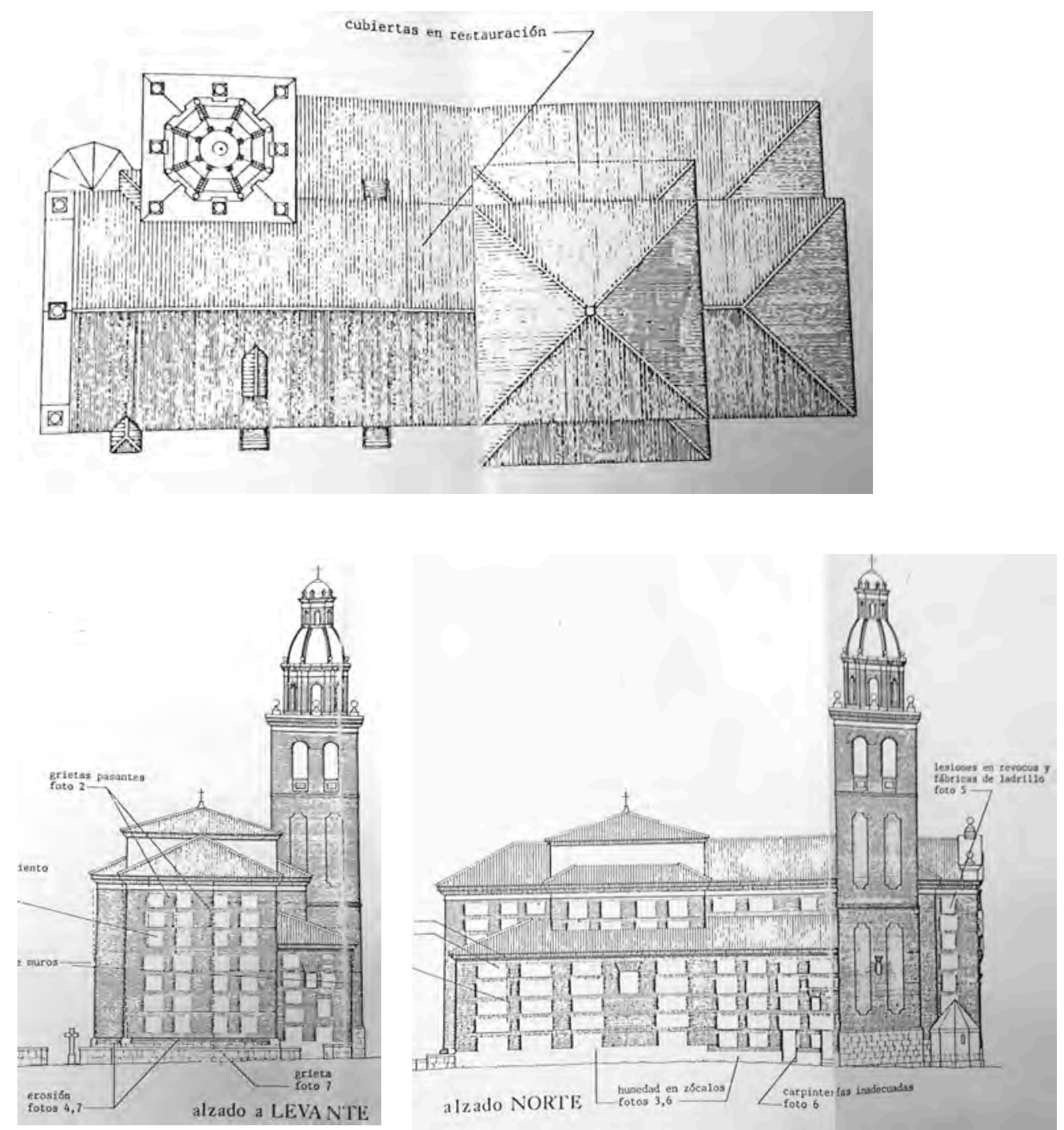

Ilustración 16: planos diagnóstico Carreño

En la carpeta se incluye un dossier de fotografías.

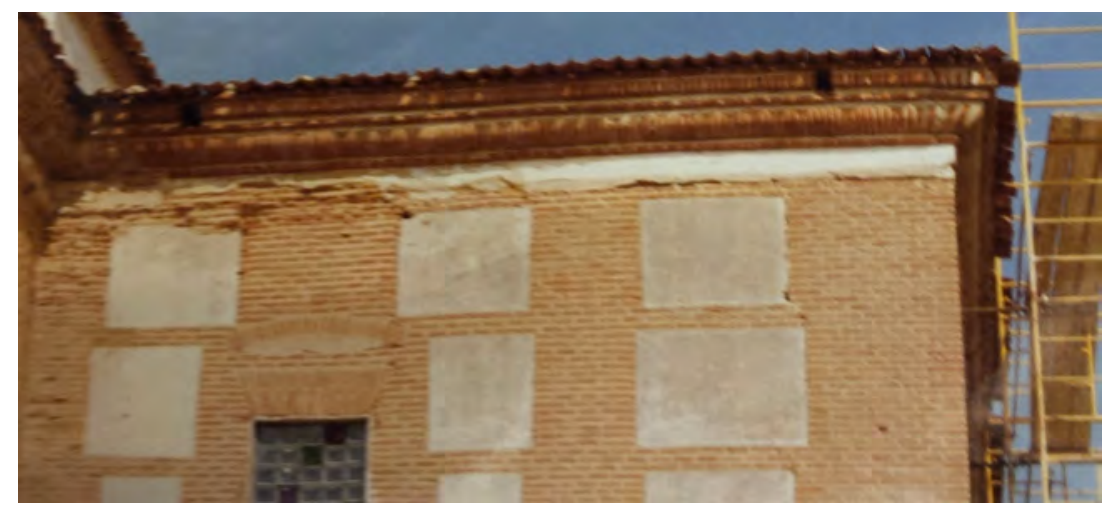

Ilustración 17: dossier Carreño JCyL

Imagen del diagnóstico en que se aprecia la erosión de cornisa y el pavés que remataba los huecos de ventana en 1993, durante la intervención. 


\section{Visitas realizadas}

\section{$16 / 05 / 2014$}

El monumento presenta un estado de conservación aceptable, teniendo en cuenta que la última restauración documentada se llevó a cabo en 1992, por lo que han transcurrido más de veinte años.
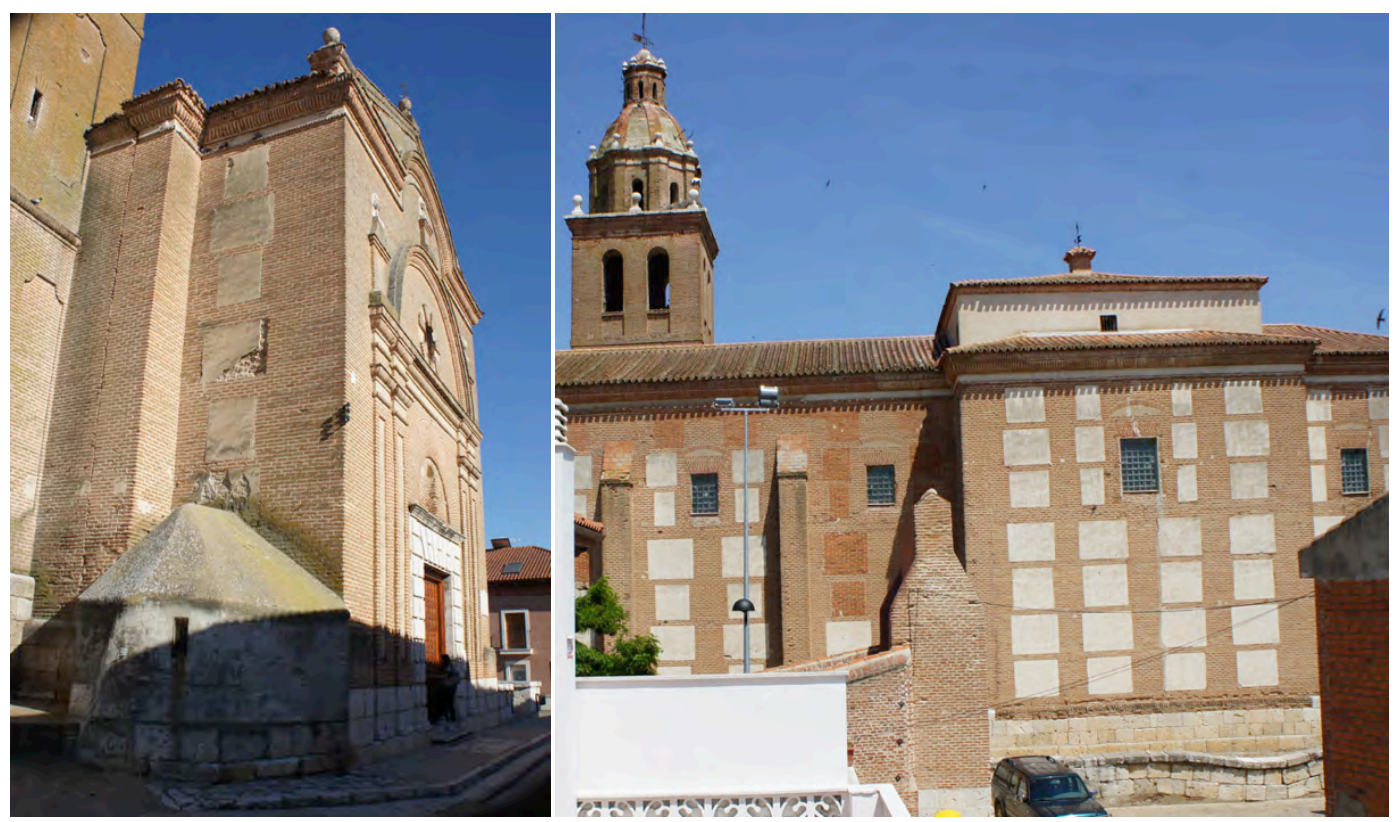

Se puede observar cierta pérdida de material en el sellado de grietas, como la de recorrido vertical en medio del testero del crucero que se aprecia en las imágenes.

También encontramos rotura de varias piezas de pavés de las ventanas y desperfectos puntuales en el revestimiento de algunos recuadros de tapial.

\section{$02 / 06 / 2014$}

La entrada al bajo cubierta se realiza desde la torre, a la que se accede mediante una escalera de caracol que desciende hasta el nivel de calle, sin comunicación con las dependencias laterales ni con una sala ubicada en el arranque de la citada torre.

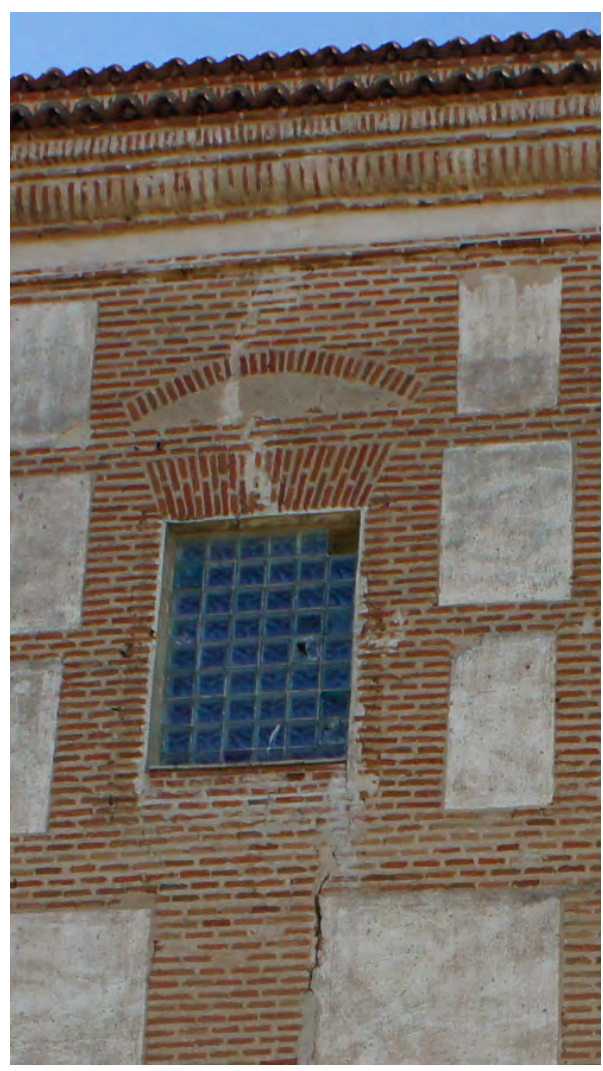




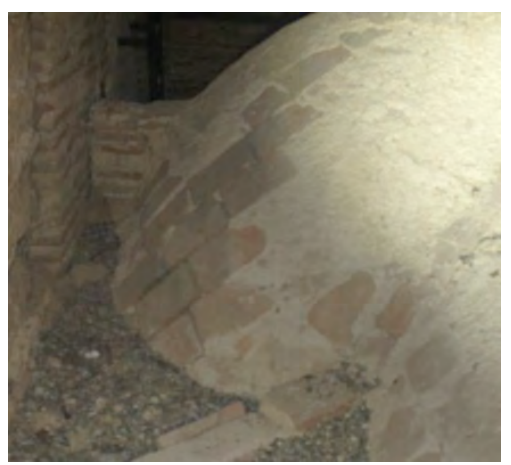

El trasdós de las bóvedas de cañón muestra los ladrillos colocados a rosca en las bandas de refuerzo que se corresponden con los arcos fajones del intradós, mientras que los cascos de las mismas y sus lunetos parecen resueltos con los ladrillos dispuestos de forma tabicada.

El espacio que cubre la cúpula sobre el crucero cuenta con una ventana por la que se introducen las palomas, que invaden todo el recinto y están llenando de desperdicios tanto la torre como el bajo cubierta.
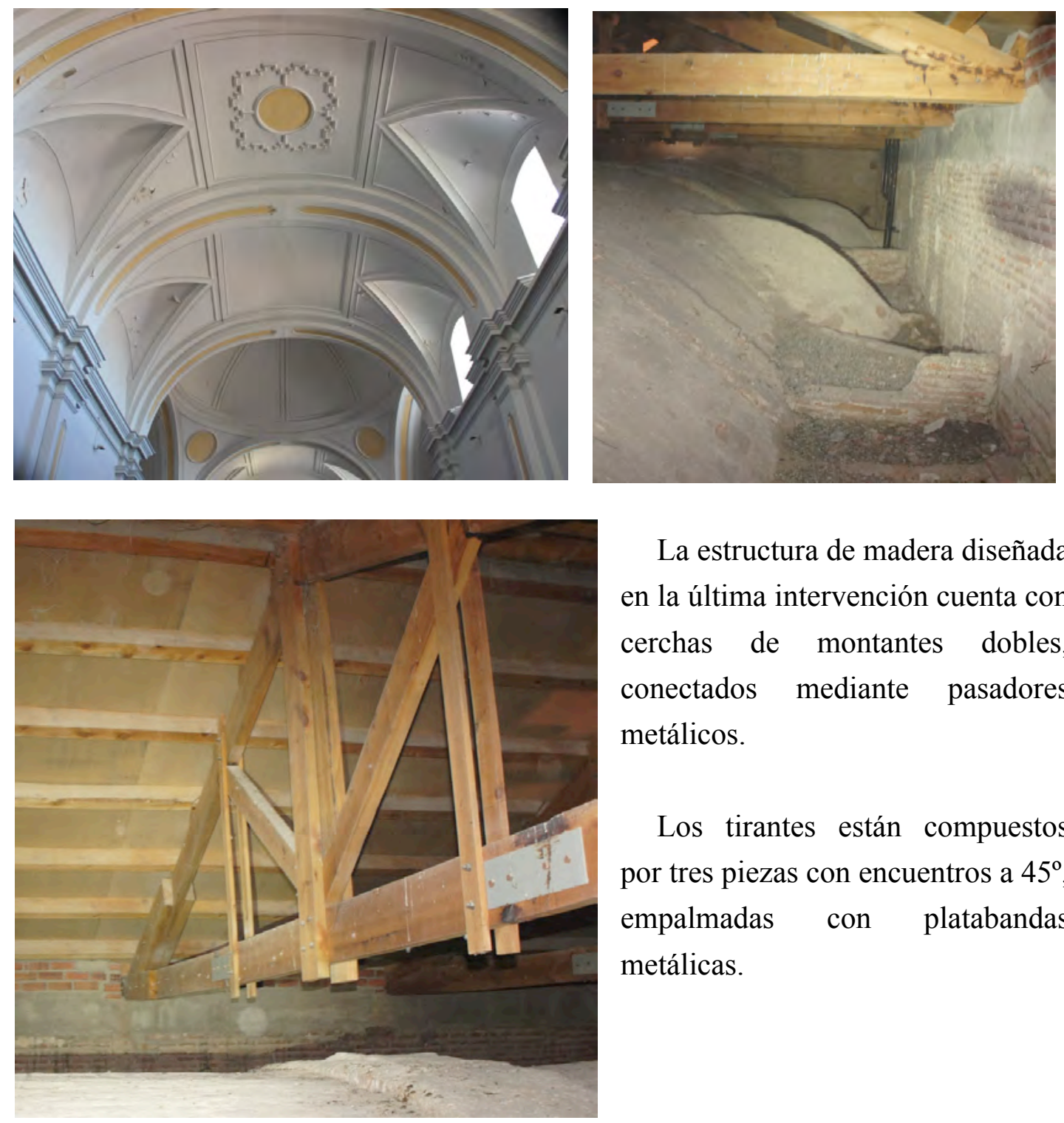

La estructura de madera diseñada en la última intervención cuenta con cerchas de montantes dobles, conectados mediante pasadores metálicos.

Los tirantes están compuestos por tres piezas con encuentros a $45^{\circ}$, empalmadas con platabandas metálicas. 
En algún caso es posible apreciar que se han producido movimientos en estas uniones.
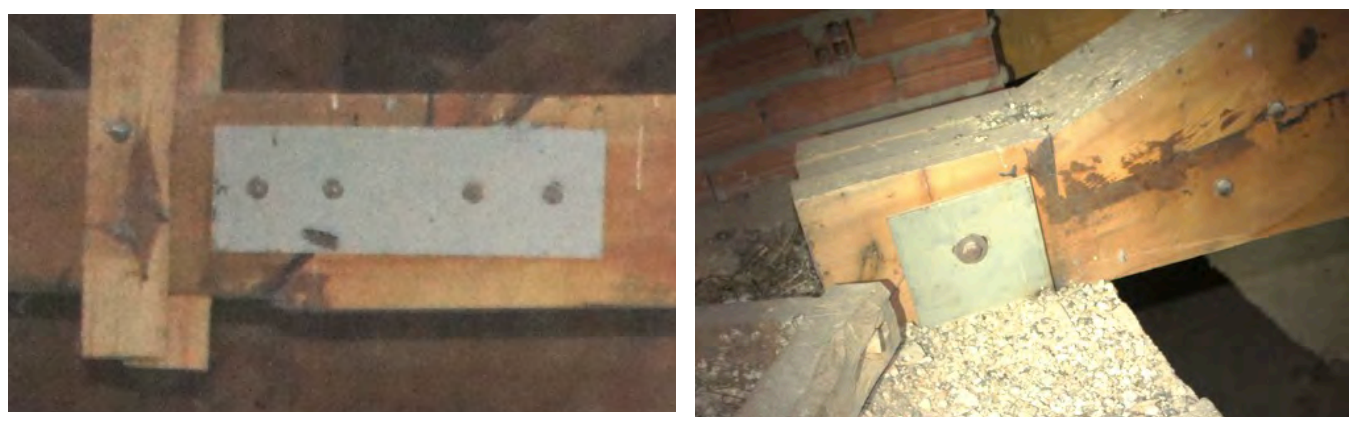

El apoyo de las cerchas más próximas al hueco de acceso desde la torre sobre el zuncho de hormigón armado muestra fijaciones de platabanda metálica. En los demás casos las cabezas quedan ocultas por un cierre tabicado con ladrillo hueco doble.

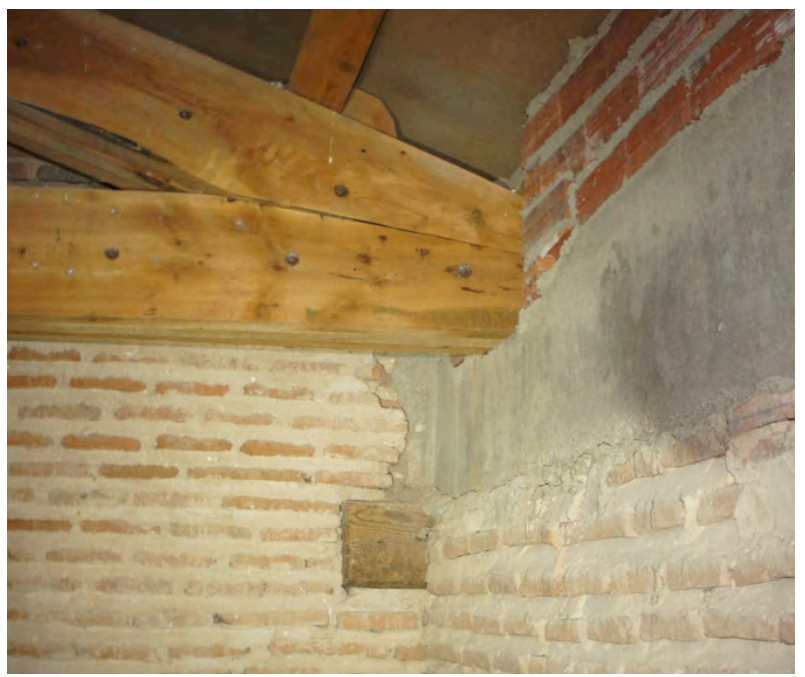

En el pequeño tramo de entrada, el zuncho presenta una anchura de $84 \mathrm{~cm}$. El canto visto a ambos lados de la nave, enrasado con la cara interior del cerramiento, es de unos $40 \mathrm{~cm}$.

El canto de hormigón aparece ligeramente rebajado bajo algunos de estos apoyos.

El zuncho de hormigón armado se dispone sobre ambos cerramientos laterales, pero no se prolonga en el testero de fachada a los pies.

Tampoco se aprecia que se haya colocado zuncho sobre el arco que separa la nave del crucero, aunque el muro sobre el mismo es de fábrica moderna y se encuentra revestido por ambas caras.

En el recinto sobre la cúpula este revestimiento impide apreciar si se cuenta con zuncho sobre el tambor. La cubierta de este prisma presenta una disposición peculiar, con vigas nuevas embridadas que descansan sobre los antiguos cuadrales pareados que se aprecian en la imagen siguiente. 


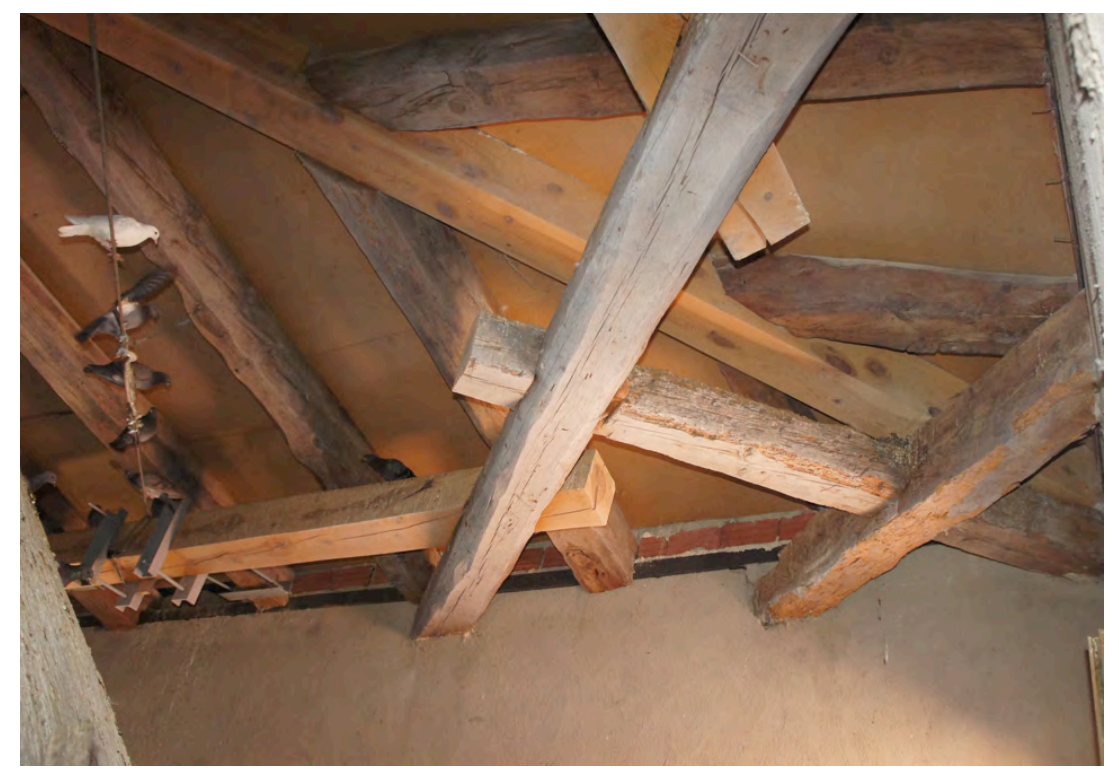

Se ha accedido al brazo del crucero del lado de la Epístola (fachada a la plaza), comprobándose la existencia de zuncho de hormigón armado también en el testero.

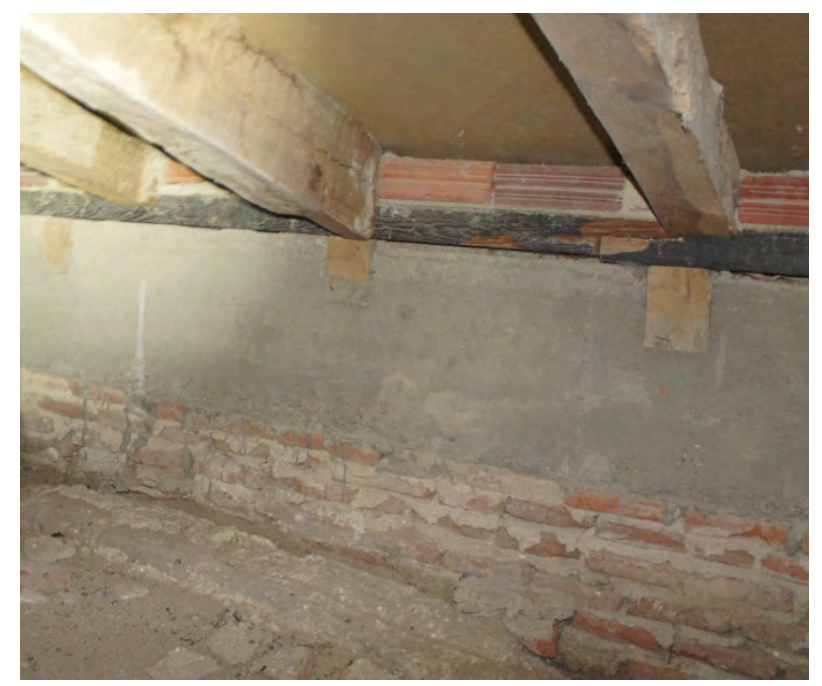

Se aprecian secciones de madera enrasadas con la cara del zuncho que no se corresponden con la distribución de los pares sobre el mismo. Encima del zuncho hay una especie de durmiente de madera sobre el que se levanta una hilada de fábrica de ladrillo que remata la cara interior del cerramiento del crucero.

No ha sido posible llegar hasta la cabecera para comprobar la existencia de zunchos en la misma. 
